
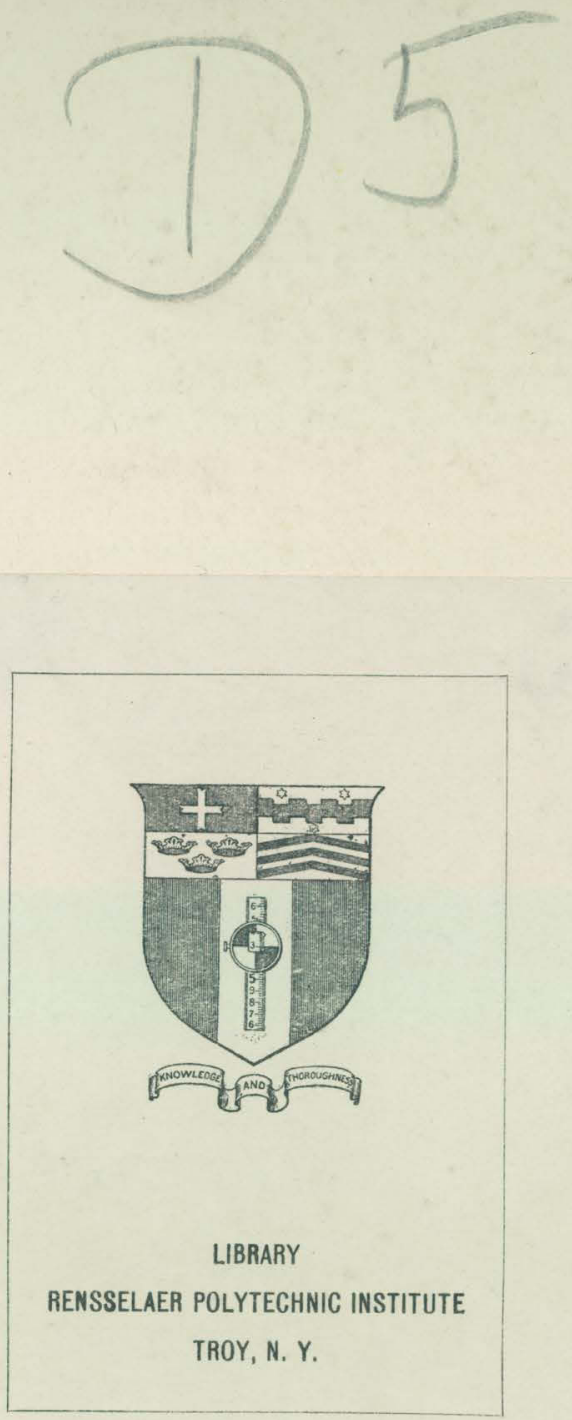
TWENTIETH ANNUAL REPORT

OF THE

\title{
United States Geological Survey TO THE
}

\author{
SECRETARY OF THE INTERIOR
}

$$
\text { 1898-99 }
$$

\section{CHARLES D. WAICOTT DIRECTOR}

IN SEVEN PARTS

PART IV-HYDROGRAPHY

F. H. Newell, Chief of Division

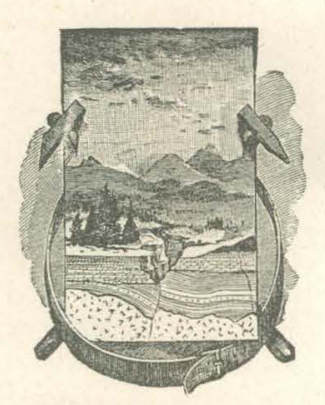

W A SHI NGTON GOVERNMENT PRINTING OFFICE 1900 

TWENTIETH ANNUAL REPORT

OP THE

\section{UNITED STATES GEOLOGICAL SURVEY}

PART IV-HYDROGRAPHY 



\section{O NT E N T S.}

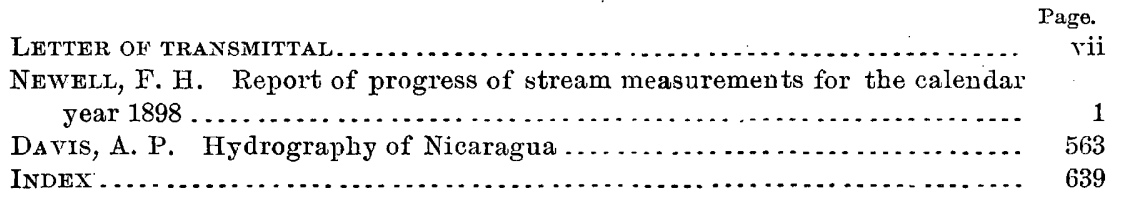





\title{
LETTER OF TRANSMITTAL.
}

\author{
Departiment of the Interior, \\ United States Geological Survey, \\ DIVISION OF HYDROGRAPHY, \\ Washington, June 1, 1899.
}

SIR: I have the honor to transmit herewith the manuscript for a volume on hydrography, prepared for publication as one of the parts of the Twentieth Annual Report of the Survey. The greater portion of this material consists of the results of investigations carried on during the calendar year 1898. The first paper discusses the results of measurements of the flow of various streams in different parts of the United States, the data being presented in diagrammatic form as well as by statistical tables. The arrangement adopted for this progress report is a geographic one, beginning in the extreme northeastern part of the United States and ending in the extreme southwestern. Extracts from a number of papers independently prepared have been incorporated in this report, after such modification as was necessary to bring them into accord with the scheme. A considerable amount of data concerning stream flow has been obtained from various sources, particularly from the engineer officers of the Army and from individuals or corporations. All of these facts have been included and reference made to the sources of information. The great body of facts, however, are those resulting from the field work of the hydrographers of the Geological Survey or from engineers cooperating with them.

Following the report of stream measurements is a paper prepared by Mr. Arthur P. Davis upon the hydrography of Nicaragua, giving the results of observations and measurements made by Mr. Davis during the year 1898. Mr. Davis was detailed to the Nicaragua Canal Commission of the Department of State, as expert in hydrographic investi. gations, and left Washington on December 5,1897, returning on October 21,1898 . He has already prepared for the commission such facts as were desired for its report, and has written the accompanying paper in order to put on record in the publications of the Survey the general results of his work.

Very respectfully,

Hon. Charles D. Walcot't,

F. H. Newell, Hydrographer in Charge.

Director United States Geological Survey. 

REP0RT OF PROGRESS OF STREAM MEASUREMENTS FOR THE CALENDAR YEAR 1898

BY

F. H. NEWELL

20 GEOL, PT $4-1$ 



\section{CONTENTS.}

. $\dot{\text { Page }}$

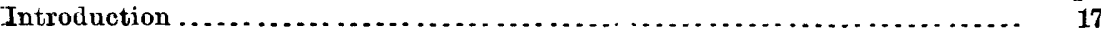

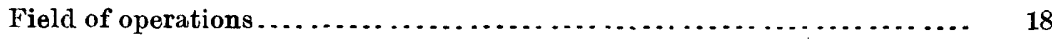

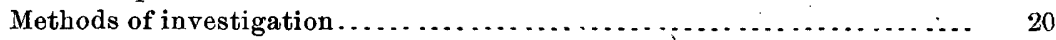

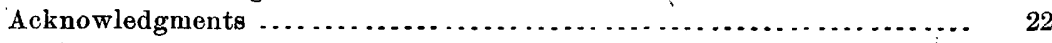

Reservoir surveys. . . . . . . . . . . . . . . . . . . . . . . . . . . . . . . . .

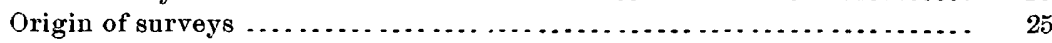

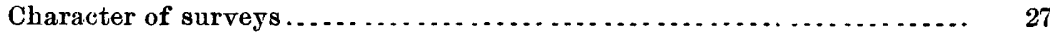

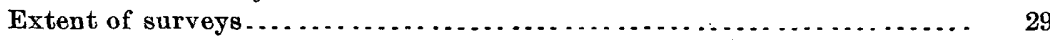

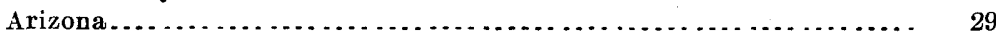

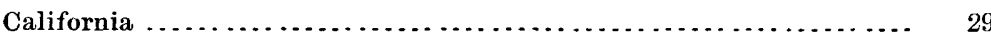

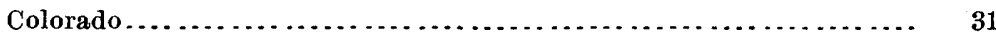

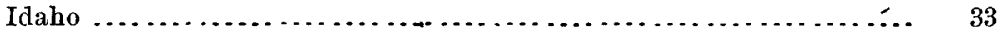

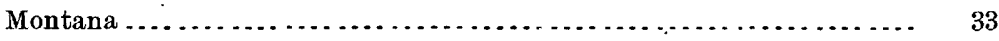

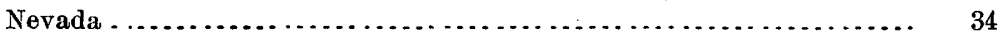

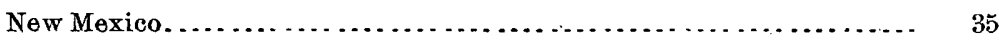

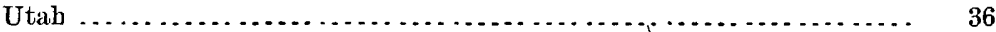

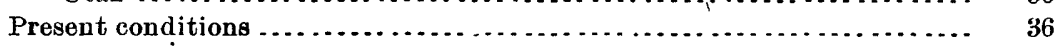

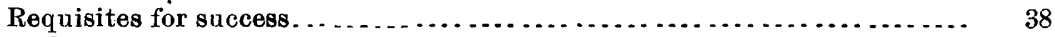

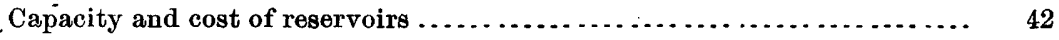

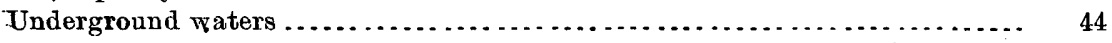

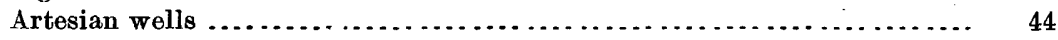

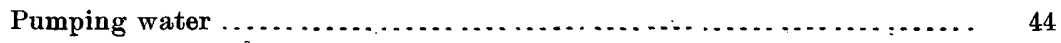

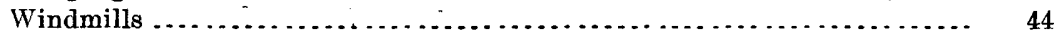

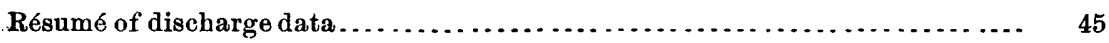

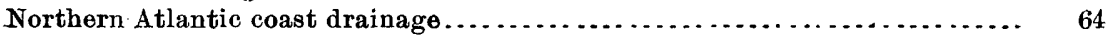

Kennebec River........................................... 64

Androscoggin River.......................................... 66

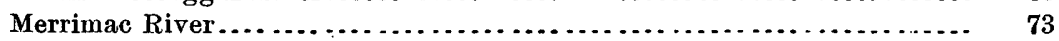

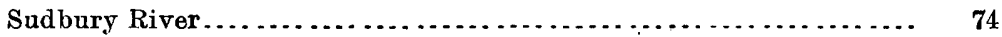

Connecticut River ....................................... 76

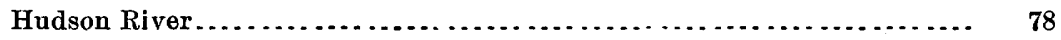

Croton River .......................................... 81

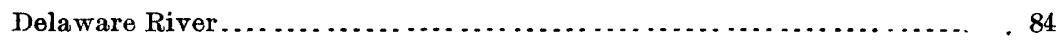

Lehigh River ......................................... 86

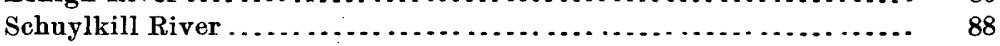

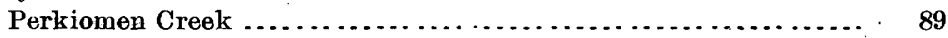

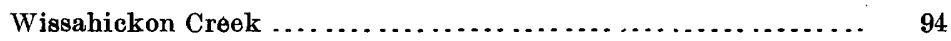

Schuylkill River near Philadelphia ...................... 96

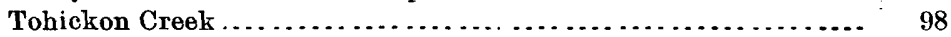

Neshaminy Creek ................................... 103

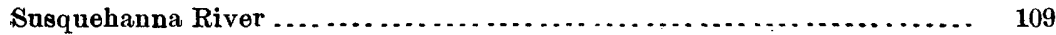

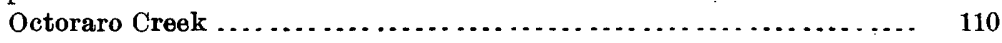

Patapsco and Patuxent rivers .............................. 112

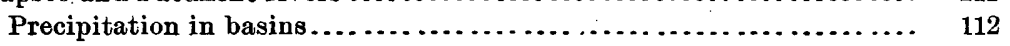


Northern Atlantic coast drainage-Continued. . • Page.

Potomac River.......................................... 117

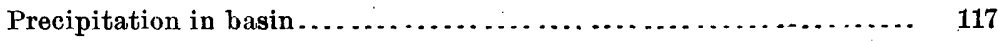

Antietam Creek........................................ 122

Shenandoah River ....................................... 123

North River ....................................... '123

South River ...................................... 125

Shenandoah River at Millville ........................... 127

Monocacy River ...................................... 129

Potomac River at Point of Rocks............................ 130

Park station, on Rock Creek ............................. 132

James River ............................................. 132

Precipitation in basin ...................................... 132

North (of James) River .................................. 135

James River at Buchanan, Va............................ 136

Southern Atlantic coast drainage.............................. 137

Roanoke River.......................................... 137

Precipitation in basin .................................. 137

Tar River....................................................... 143

Neuse River ............................................. 144

Cape Fear River ................................................ 145

Haw River........................................... 146

Deep River ............................................. 146

Yadkin River............................................. 146

Santee River............................................ 148

Catawba River ...................................... 149

Broad River (of Carolinas) ................................. 151

Saluda River........................................... 153

Savannah River.......................................... 154

Precipitation in basins of Savannah and Altamaha rivers........... 158

Tugaloo River ......................................... 162

Broad River (of Georgia) ............................... 163

Savannah River at Calhoun Falls, s. C ....................... 164

Savannah River at Augusta, Ga .......................... 165

Altamaha River............................................... 166.

Oconee River ......................................... 170

Ocmulgè River......................................... 171

Eastern Gulf drainage ....................................... 172

Chattaboochee River......................................... 172

Apalachicola Basin ..................................... 175

Precipitation in basins of Chattahoocheo and Coosa rivers.......... 177

Flint River.............................................. 184

Alabama River.............................................. 184

Coosa River ............................................ 184

Etowah River ........................................... 188

Oostanaula River ................................... 190

Coosawattee River................................. 191

Tallapoosa River...................................... 192

Black Warrior River..................................... 194

Ohio River drainage ............................................. 195

Allegheny River ........................................... 195

Mahoning River and French Creek ........................... 197

Youghiogheny River ........................................ 199

Kanawha River . . . . . . . . . . . . . . .

Precipitation in basin..................................... 199

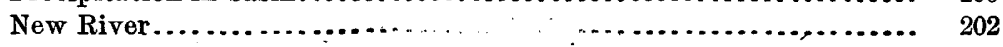


Ohio River drainage-Continued.

Kanawha River-Continued.

Greenbrier River.

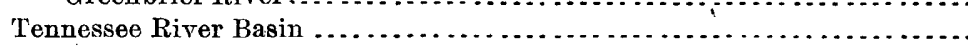

French Broad River .........................................

Tuckasegee River .......................................

Little Tennessee River.....................................

Hiwassee River

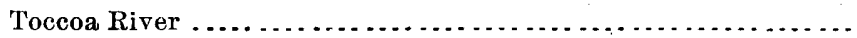

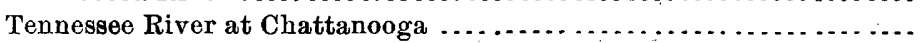

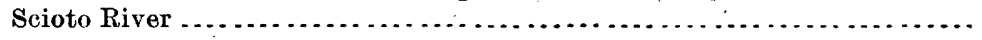

Olentangy River.............................................

Menominee River

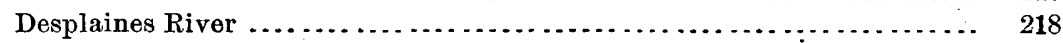

Maumee River .............................................. 223

Sandusky River ................................................. 223

Niagara River ............................................. 224

Genesee River ............................................ 225

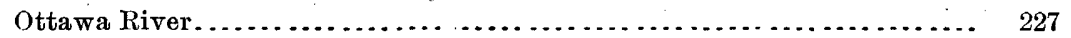

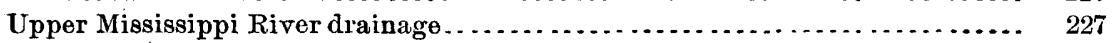

Mississippi River in Minnesota ............................... 227

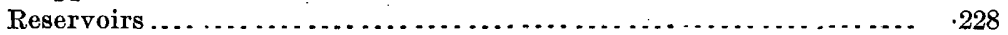

Mississippi River at St. Paul ............................... 230

Upper Missouri River drainage................................. 232

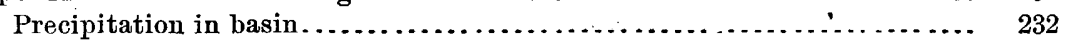

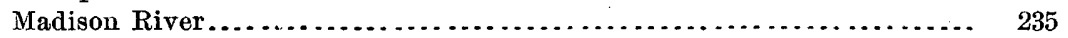

Jefferson River ............................................ 237

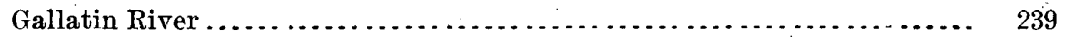

West Gallatin River .................................. 241

Middle Creek ......................................... ${ }_{242}$

Missouri River below Threeforks............................ 243

Milk River............................................. 245

Yellowstone drainage basin ....................................... 246

Yellowstone River ............................................... 246

Shoshone River .......................................... 249

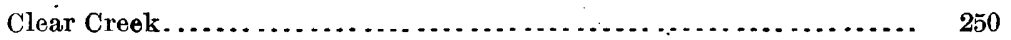

Cheyenne River. .............................................. 251

White River ......................................................... 253

Niobrara River .............................................. 255

Platte River drainage .......................................... 255

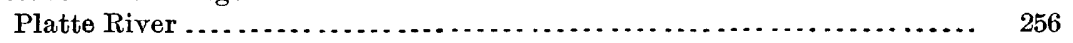

Precipitation in basin..................................... 256

North Platte River....................................... 266

Horseshoe Creek ...................................... 270

Reservoir sites............................................ 270

Laramie River ...................................... 274

Reservoir sites ............................................ 276

South Platte River...................................... 277

Cherry Creek .............................................. 280

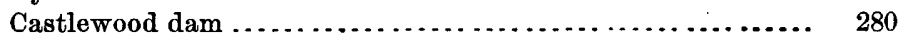

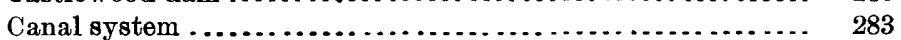

Bear Creek .......................................... 284

St. Vrain Creek . ......................................... 285

Boulder Creek ......................................... 286

South Boulder Creek ................................ 287 
Platte River drainage-Continued. . . $\quad$ Page. Platte River-Continued.

South Platte River-Continued.

Big Thompson Creek................................ 288

Seepage measurements ............................. 289

Cache la Poudre River ................................. $\quad 290$

South Platte River at Orchard, Colo...................... 293

Loup River . . . ........................................... 294

Platte River at Columbus, Nebraska ...................... 295

Elkhorn River .......................................... 296

Miscellaneous measurements in Nebraska........................ 297

Kansas River drainage . . . . . . . . . . . . . . . . . . . . . . . . . . . . . . . . . . 304

Kansas River . . . ......................................... 304

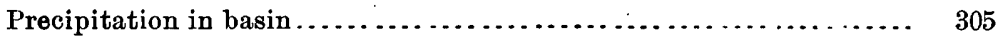

Solomon River......................................... 314

Smoky Hill River ...................................... 315

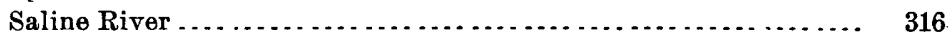

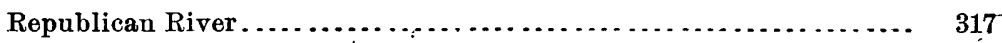

Blue River................................................ 319

Kansas River at Lawrence, Kansas........................ 320 .

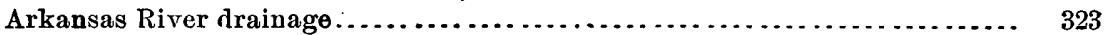

Arkansas River ..............................................

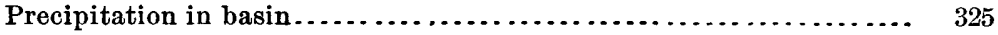

Laguna Canal ............................................ 339

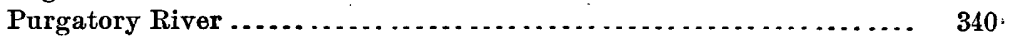

Arkansas River at Las Animas, Colorado . . . . . . . . . . . . . . . . . . . . 342

Arkansas River at Hutchinson, Kansas ........................ 342

Verdigris River......................................... 344

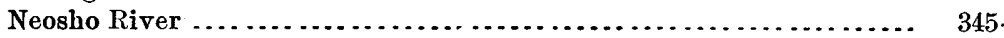

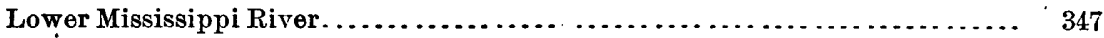

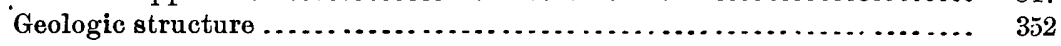

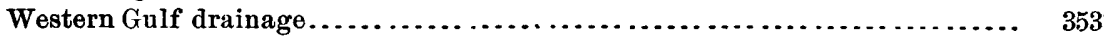

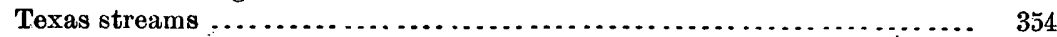

Rio Grande .............................................. 355

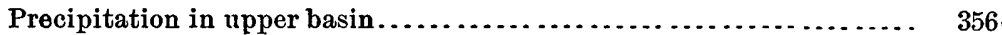

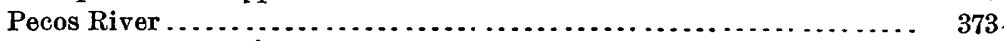

Colorado River drainage ........................................ 373

Colorado River.......................................... 373

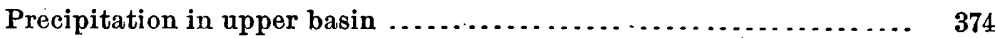

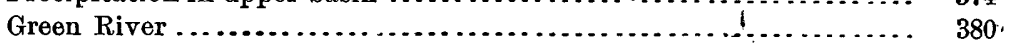

Black Fork of Green River. . . . . . . . . . . . . . . . . . . . . . . 381

Yampa and White rivers ............................... 383

Green River at Blake, Utah ........................... 387

Grand River ................................................. 388

Gunnison River .................................... 390 .

Uncompahgre River............................... 391

Dolores River...................................... 392

San Miguel River ................................. 395

Variations in precipitation in southwestern Colorado . . . . . . . . . . 396

San .Juan River ......................................... 400

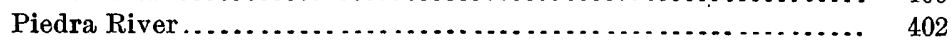

Animas River...................................... 403

Mancos River......................................... 404

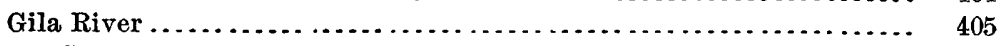

Salt River .......................................... 405

Verde River ................................ 407 
Colorado River drainage-Continued. Page.

Investigations of water supply for the Southern Ute Indian Reservation. 408

Topography and hydrography........................... 409

Geology and underground waters.......................... 412

The Southern Utes...................................... 412

Montezuma Valley Canal............................... 417

Surveys of reservoir sites .................................... 419

Storage capacity of proposed system ........................ 426

Summary ............................................. 433

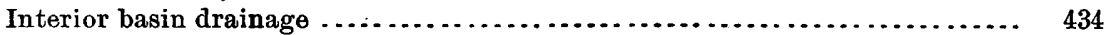

Humboldt River ............................................. 434

Rock Creek storage system................................ 441

Rock Creek reservoir site ............................ 442

Proposed dam ........................................ 444

Canals ............................................... 445

Head gates and diverting dams $\ldots \ldots \ldots \ldots \ldots \ldots \ldots \ldots \ldots \ldots \ldots, \quad 447$

Lower Humboldt storage system ........................... 448

Reservoirs .......................................... 448

Supply canal........................................ 452

Lands to be irrigated ................................. 453

Precipitation in basin of Great Salt Lake........................ 454

Bear River ............................................... 459

Logan River ............................................ 462

Bear Lake reservoir....................................... 463

Ogden and Weber rivers ........................................ 464

Utah Lake .................................................. 467

Provo River .......................................... 468

American Fork River................................... 469

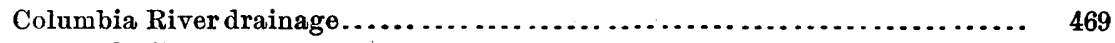

Snake River .................................................. 469

Precipitation in basin................................... 469

Portneuf River ........................................... 475

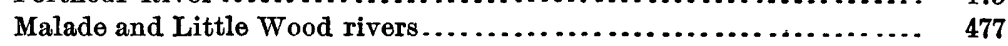

Longtom reservoir sites.................................. 477

Bruneau River......................................... 481

Boise River.......................................... 483

Seepage measurements in Boise Valley ....................... 484

Weiser River ........................................ 488

Palouse River .......................................... 489

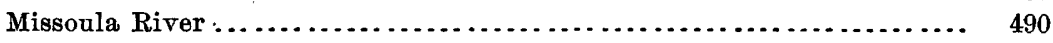

Blackfoot River. ........................................ 491

Bitterroot River ......................................... 492

Lake Chelan................................................. 495

Yakima River......................................... 496

Precipitation in basin .................................... 496

Naches River . ........................................ 503

Wenas Creek ......................................... 504

Reservoir sites in Yakima County ............................ 505

Artesian wells ........................................ 508

Spokane River .............................................. 510

Wallawalla River ........................................... 512

Precipitation in basins of Palouse and Wallawalla rivers.......... 512

Umatilla River............................................... 514

Deschutes River ............................................ 516

Hood River ............................................. 516

Northern Pacific coast drainage $\ldots \ldots \ldots \ldots \ldots \ldots \ldots \ldots \ldots \ldots \ldots \ldots \ldots \ldots \ldots . \ldots \ldots$ 
Northern Pacific coast drainage-Continued. - Page.

Cedar River . . . . . . . ..................................... 516

Dungeness River ........................................... 518

Elwha River.................................................. 519

Calowa River.............................................. 522

Solduck River .............................................. 523

San Francisco Bay drainage. ..................................... 52

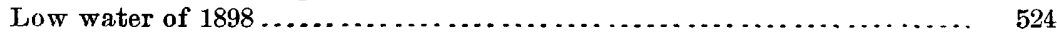

Sacramento River......................................... 527

Clear Lake ............................................ . 528

San Joaquin River ................................... 529

Stanislaus River ..................................... 530

Tuolumne River.................................... 531

Kings River .................................... 534

Kern River ....................................... 536

Southern California drainage..................................... 538

Littlerock Creek......................................... 540

Santa Clara River......................................... 540

Los Angeles River ..................................... 541

Underground water from the bed of the Arroyo Seco and the Pasadena

Mesa ................................................ 543

San Gabriel River....................................... 549

San Antonio and Cucamonga creeks ........................... 552

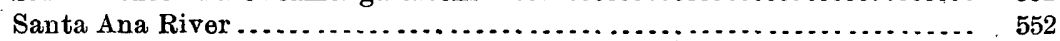

Lytle Creek ............................................ 555

Twin, City, and Plunge creeks .......................... 557

Mill Creek .............................................. 558

. Warm Creek ............................................... 558

Wells in San Bernardino Valley ............................... 559

Precipitation on California mountains ............................... 560

Whitewater River........................................... 561 


\section{ILLUSTRATIONS.}

Page.

Prate I. Relative location of gaging stations, $1898 \ldots \ldots \ldots \ldots \ldots \ldots \ldots \ldots . \ldots 18$

II. $A$, Rumford Falls, Maiue, looking downstream toward Middle Canal; $B$, Upper dam at Rumford Falls, Maine................

III. $A$, Merrimac River at Lawrence, Massachusetts; $B$, Croton River .

IV. $A$, Steel barges in Erie Canal, New York; $B$, Barges passing through locks on Erie Canal ...........................

V. $A$, Weir and nilometer on Tohickon Creek at Point Pleasant, Pennsylvania; $B$, Suspension bridge and nilometer on Perkiomen Creek at Frederick, Pennsylvania

VI. $A$, Weir on Neshaminy Creek; $B$, Suspension bridge at station on Neshaminy Creek, Rush Valley, Pennsylvania ................

VII. High-water gage on Little Neshaminy Creek, Rush Valley, Penn-

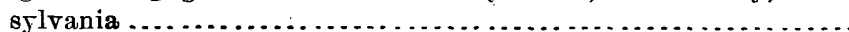

VIII. $A$, Dam across Deep River near Lockville, North Carolina; $B$, Canal from Broad River to Henrietta Cotton Mill No. 1, Rutherford

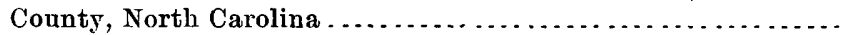

IX. A, Measurement of Tugaloo River from ferryboat near Fort Madison, South Carolina; $B$, Broad River near Carlton, Georgia.........

X. A, Savannah River near Calhoun Falls, South Carolina; $B$, Oconee River at Carey, Georgia .................................

XI. $A$, Oconee River near Dublin, Georgia; $B$, Ocmulgee River at Macon, Georgia ......................................

XII. $A$, Proctors Creek near Oakdale, Georgia; $B$, Etowah River at

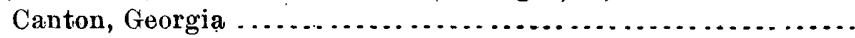

XIII. Tallassee Falls on Tallapoosa River, Alabama; $B$, Tallapoosa River at Milstead, Alabama .....................................

XIV. Junotion of Allegheny and Monongahela rivers at Pittsburg, Pénnsylvania ...........................................

XV. A, Hiwassee River at Reliance, T'ennessee; $B$, Tennessee River at Chattanooga, Tennessee.................................

XVI. Head gate of canal of the West Gallatin Irrigation Company, Gal-

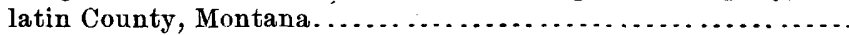

XVII. Flume and trestle across Rocky Canyon, Montana...............

XVIII. A, Measuring Middle Creek above Bozeman, Montana; $B$, Gaging station on West Gallatin River, 6 miles above Salesville, Mon-

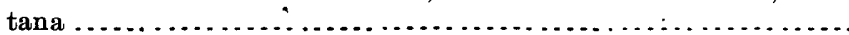

XIX. $A$, Gaging station on Clear Creek, Wyoming; $B$, Bighorn River,

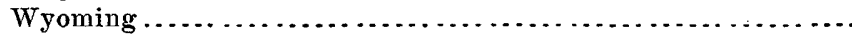

XX. A, Falls of Cheyenne River, Fall River County, South Dakota; $B$, Dakota sandstone at cascades of Fall River near Evan's quarry, Black Hills, South Dakota.............................

XXI. Fall River one-fourth of a mile above Evan's quarry, Black Hills,

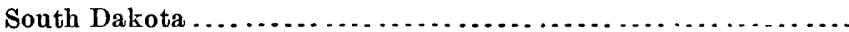

XXII. A, Looking up White River from Tibbitts's ranch, opposite Pumpkin Creek, South Dakota; $B$, Looking down White River from near mouth of Medicine Root Creek, South Dakota............. 
PLATe XXIII. A, Gorge of Horseshoe Creek in upper reservoir site, Albany County, Wyoming; $B$, Ranch on Horseshoe Creek, Wyoming.

XXIV. $A$, Dam site of small reservoir on Horseshoe Creek; $B$, McFarlane's ranch on Horseshoe Creek .........................

XXV. $A$, Measuring Laramie River at Uva, Wyoming; $B$, Laramie River near Uva, Wyoming .............................

XXVI. $A$, Castlewood dam during construction; $B$, Castlewood Lake and dam, Douglas County, Colorado.....................

XXVII. $A$, Sky Line ditch-diverting water from Laramie River to Cache la Poudre River; $B$, Cachela Poudre River 1 mile north of Greeley, Colorado.

Page.

XXVIII. $A$, Head gates of canal of the Farmers and Merchants Irrigation Company on Platte River, near Cozad, Nebraska; $B$, Looking down North Platte River from the Nebraska-Wyoming line..

XXIX. A, Gage on Kansas River at Lecompton, Kansas; $B$, Dam on Kansas River at Lawrence, Kansas........................

XXX. $A$, Dam on Delaware River near Valley Falls, Kansas; $B$, Cottonwood River at Cottonwoud Falls, Kansas ...............

XXXI. $A$, New diverting dam at Canyon, Colorado; $B$, Arkansas River below Main street bridge, Pueblo, Colorado ................

XXXII. $A$, Dam of Amity Canal in Arkansas River, Colorado; $B$, Head gate of A mity Canal.

XXXIII. $A$, Nita Crevasse, Mississippi River, Louisiana; $B$, Back water from Nita Crevasse ..................................

XXXIV. $A$, Topped levee revetted against storms at Greenville, Mississippi; $B$, Wharves at New Orleans during flood ............

XXXV. $A$, Dam at Austin, Texas, during flood; $B$, San Antonio River

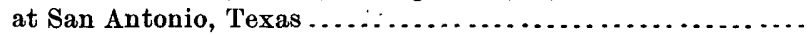

XXX VI. $A$, Brush dam in Rio Grande, New Mexico; $B$, Head of ditch on Rio Grande, New Mexico ..............................

XXXVII. $A$, Measuring Green River near Green River, Wyoming; $B$, Green River near Blake, Utah.......................

XXXVIII. $A$, Hayden, Colorado; $B$, Valley above Hayden, Colorado.....

XXXIX. $A$, Steamboat Springs, Colorado; $B$, Road to Fish Creek Falls.

XL. $A$, Gaging station on Dolores River near Dolores, Colorado; $B$, Looking up Los Pinos River from near head gate of Spring Creek ditch, 6 miles above Ignacio, Colorado................

XLI. $A$, Home Supply dam near Arkins, Colorado; $B$, Gaging station on San Miguel River at Fallereek, Colorado ............

XLII. $A$, Gaging station on San Juan River at Arboles, Colorado; $B$, Gaging station on Piedra River at Arboles, Colorado .........

XLIII. $A$, Dam site at Buttes, Arizona, looking downstream; $B$, Dam site below Riverside, Arizona, looking downstream..........

XLIV. $A$, Subagency of Southern Utes at Navajo Springs, Colorado, with Mesa Verde in background; $B$, Canyon of recent formation below subagency

XLV. A, Flume carrying water to the town of Cortez, in Montezuma Valley, Colorado; B, Portion of western escarpment of Mesa Verde

XLVI. Map of canals and irrigated lands in Montezuma Valley .......

XLVII. $A$, Head gate of Montezuma Canal at Dolores River, Colorado; $B$, Entrance to tunnel at head of Montezuma Canal.........

XLVIII. $A$, Diversion works below tunnel, Montezuma Canal; $B$, Deep eut of main canal No. 2 
Plate XLIX. A, Looking through canyon into Narraguinnep reservoir site; $B$, Wall of canyou, Narraguinnep reservoir site.............

L. $A$, Head waters of Dolores River, showing upper drainage basins near Mount Wilson and the Lizard Head; $B$, Horse Creek, one of the tributaries of Dolores River..............

LI. $A$, Measuring Bear River at Collinston, Utah; $B$, Dam of Bear River Canal, Utah................................

LII. Tunnel for Bear River Canal in canyon, Utah ...............

LIII. A, Gaging station on Blackfoot River, Montana; $B$, Missoula

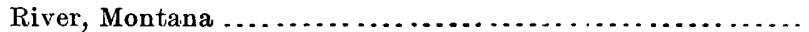

LIV. $A$, Looking east across Bitterroot Valley, Montana; $B$, Bitterroot River near Missoula, Montana ......................

LV. $A$, Mill Creek Canyon on west side of Bitterroot Valley, Montana; $B$, Lake Como, Montana .........................

LVI. $A$, Gaging station on Cedar River, Washington; $B$, Bridges across Elwha River at McDonald, Washington .............

LVII. $A$, Blue Lake dam, Alpine Count,y, California; $B$, Method of construction of the Blue Lake dam ........................

LVIII. $A$, Lake Tenaya, California, looking south ; $B$, Tuolumne Meadows, California, looking south

Page.

428

432

458

462

488

492

496

LIX. $A$, Lagrange dam, California, nearing completion; $B$, Lagrange dam at time of high water..........................

LX. $d$, Kingsburg gaging station on Kings River, California; $B$, Lumber flume at Sanger, California ....................

LXI. $A$, Church ditch, near Centerville, California; $B$, Effect of high velocities on Fowler Switch Canal, California..............

LXII. $A$, Kern River, California, looking downstream from canyon; $B$, Kern River 2 miles below canyon, looking upstream......

LXIII. A, Gaging station on Santa Ana River at Warmsprings, California; $B$, Flume across Santa Ana River ................

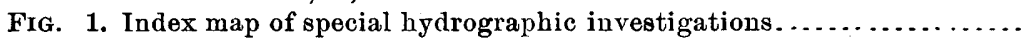

2. Method of attaching stay line to meter by use of a pole .............

3. Method of using stay line from small cable.....................

4. Comparison of depth and capacity of various reservoirs ............

5. Comparison of depth and capacity of various reservoirs ............

6. Comparison of depth and capacity of large reservoirs..............

7. Discharge of Kennebec River at Waterville, Maine, 1893-1898........

8. Relative location of dams and canals at Rumford Falls, Maine.......

9. Discharge of Androscoggin River at Rumford Falls, Maine, 1893-1898.

10. Discharge of Merrimac River at Law rence, Massachusetts, 1891-1898.

11. Discharge of Connecticut River at Holyoke, Massachusetts, 1891-1898.

12. Relative location of river observations in basin of Mohawk and adja-

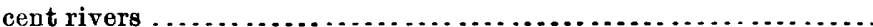

13. Discharge of Hudson River at Mechanicsville, New York, 1889-1898..

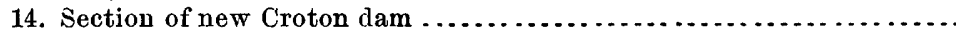

15. Discharge of Delaware River at Lambertville, New Jersey, 1897 and 1898 .

16. Relative location of river and rainfall observations in basins of Tohickon, Perkiomen, Neshaminy, and Wissahickon creeks, 1885.....

17. Discharge of Perkiomen Creek at Frederick, Pennsylvania, 1891-1898.

18. Discharge of Wissahickon Creek $100 \mathrm{~J}$ ards above month, 1897 and 1898.

19. Discharge of Schuylkill River at Fairmount dam, near Philadelphia, 1898.

20. Discharge of Tohickon Creek at Point Pleasant, Pennsylvania, 18911898. 
FIG. 21. Discharge of Neshaminy Creek below forks, 1891-1898 ............ Page.

22. Discharge of Susquehanna River at Harrisburg, Pennsylvania, 1891-1898

23. Discharge of Octoraro Creek at Rowlandsville, Maryland, 1898 ......

24. Relative location of river and rainfall observations in basins of

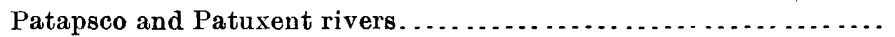

25. Discharge of Patapsco River at Woodstock, Maryland, 1898 .........

26. Discharge of Patuxent River at Laurel, Maryland, 1896-1898 ........

27. Relative location of river and rainfall observations in basin of Potomac River

28. Discharge of Antietam Creek at Sharpsburg, Maryland, 1898 ....... 122

29. Discharge of North River at Port Republic, Virginia, 1895-1898...... 124

30. Discharge of South River at Port Republic, Virginia, 1895-1898..... 126

31. Discharge of Shenandoab River at Millville, West Virginia, 1897 and 1898

32. Discharge of Monocacy River at Frederick, Maryland, 1897 and 1898.

33. Discharge of Potomac River at Point of Rocks, Maryland, 1895-1898 .

34. Relative location of river and rainfall observations in basin of James River

35. Discharge of North (of James) River at Glasgow, Virginia, 1898....

36. Discharge of James River at Buchanan, Virginia, 1898..............

37. Relative location of river and rainfall observations in basin of Roanoke River

39. Dische of Roanoke River at Roanoke, Virginia, 1897 and $1898 \ldots .$.

40. Discharge of Tar River at Tarboro, North Carolina, 1898 .......... 143

41. Discharge of Neuse River at Selma, North Carolina, 1898 ........... 144

42. Discharge of Cape Fear River at Fayetteville, North Carolina, 1898. 145

43. Discharge of Yadkin River at Salisbury, North Carolina, 1898 ...... 147

44. Discharge of Yadkin River at Norwood, North Carolina, 1898 ........ 148

45. Discharge of Catawba River at Catawba, North Carolina, 1898 ...... 149

46. Discharge of Cataw ba River at Rockhill, South Carolina, 1898...... 150

47. Discharge of Broad River at Alston, South Carolina, 1897 and $1898 \ldots .152$

48. Discharge of Saluda River at Waterloo, South Carolina, 1897 and 1898.154

49. Relative location of river and rainfall observations in basins of Savan-

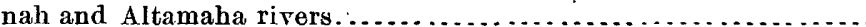

50. Discharge of Tugaloo River at Madison, South Carolina, 1898 ........

51. Discharge of Broad River at Carlton, Georgia, $1898 \ldots \ldots \ldots \ldots \ldots . .$.

52. Discharge of Savannah River at Calhoun Falls, South Carolina, 1898.

53. Discharge of Savannah River at Augusta, Georgia, 1898 ............

54. Discharge of Oconee River at Dublin, Georgia, 1898 ..............

55. Discharge of Ocmulgee River at Macon, Georgia, 1893-1898 ..........

56. Relative.location of river and rainfall observations in basins of Chattahoochee and Coosa rivers.

57. Discharge of Chattahoochee River at Oakdale, Georcia, 1895-1898

58. Discharge of Chattahoochee River at West Point, Georgia, 1898 ....

59. Discharge of Coosa River at Rome, Georgia, 1897 and $1898 . \ldots . . . . .$.

60. Discharge of Coosa River at Riverside, Alabama, 1898 .............

61. Discharge of Etowah River at Canton, Georgia, 1898 ..............

62. Discharge of Oostananla River at Resaca, Georgia, $1898 \ldots \ldots \ldots \ldots$.

63. Discharge of Coosawattee River at Carters, Georgia, 1898 ..........

64. Discharge of Tallapoosa River at Milstead, Alabama, 1898 .........

65. Discharge of Black Warrior River at. Tuscaloosa, Alabama, 1889-1898.

66. Relative location of river and rainfall observations in basin of Kanawha River 
Page.

FIG. 67. Discharge of New River at Fayette, West Virginia, $1898 \ldots \ldots \ldots \ldots .203$

68. Discharge of Greenbrier River at Alderson, West Virginia, 1898.... 204

69. Discharge of French Broad River at Asheville, North Carolina, 1895-1898

70. Discharge of Tuckasegee River at Bryson, North Carolina, 1898.....

71. Discharge of Little Tennessee River at Judson, North Carolina, 1897 and 1898

72. Discharge of Hiwassee River at Murphy, North Carolina, 1898 .......

73. Discharge of Tennessee River at Chattanooga, Tennessee, 1891-1898..

74. Relative location of river and rainfall observations in basin of Scioto River above Columbus, Ohio.

75. Discharge of Olentangy River at Columbus, Ohio, December, 1892, to May, 1893

76. Discharge of Desplaines River at Riverside, Illinois, 1893-1898 .......

77. Discharge of Genesee River at Mount Morris, New York, 1893-1896 ..

78. Lakes and reservoirs at sources of Mississippi River ..............

79. Relative location of river and rainfall observations in basin of Upper Missouri River

80. Discharge of Madison River at Redbluff, Montana, $1898 . . . . . . . . .$.

81. Discharge of Jefferson River at Sappington, Montana, 1898.........

82. Discharge of Gallatin River at.Logan, Montana, 1898 . ...........

83. Discharge of West Gallatin River at Salesville, Montana, 1898......

84. Discharge of Missouri River at Townsend, Montana, 1898 ...........

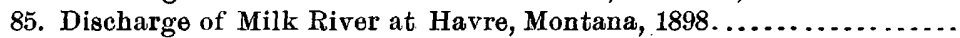

86. Discharge of Yellowstone River at Livingston, Montana, 1898 .......

87. Discharge of Shoshone River at Lovell, Wyoming, 1898............

88. Discharge of Clear Creek at Buffalo, Wyoming, 1898 .............

89. Relative location of river and rainfall observations in basin of Platte River.

90. Discharge of North Platte River at Orin Junction, Wyoming, 1898...

91. Discharge of North Platte River at Gering, Nebraska, 1898..........

92. Discharge of North Platte River at Camp Clarke, Nebraska, 1898.....

93. Ditches diverting water from Horseshoe Creek, Wyoming ...........

94. Proposed reservoir No. 1 on Horseshoe Creek, Wyoming .............

95. Sketch of gorge at dam site on Horseshoe Creek, Wyoming..........

96. Small reservoir on Horseshoe Creek, Wyoming ....................

97. Discharge of Laramie River at Woods Landing, Wyoming, 1896-1898. .

98. Discharge of Laramie River at Uva, Wyoming, 1895-1898.

99. Proposed reservoir of Wyoming Development Company on Laramie River

100. Discharge of South Platte River at Denver, Colorado, 1898 ......... . 280

101. Discharge of Bear Creek at Morrison, Colorado, 1898 ............. 285

102. Discharge of St. Vrain Creek at Lyons, Colorado, $1898 \ldots \ldots \ldots \ldots \ldots . .286$.

103. Discharge of Boulder Creek at Boulder, Golorado, $1898 \ldots \ldots \ldots \ldots \ldots .287$

104. Discharge of South Boulder Creek at Marshall, Colorado, 1898 ...... 288

105. Discharge of Big Thompson Creek at Arkins, Colorado, 1898........ 289

106. Average discharge of Cache la Poudre River, 1884-1898........... 291

107. Discharge of Cache la Poudre River, 1883-1890................ 292

108. Discharge of Cache la Poudre River, 1891-1894................. 293

109. Discharge of South Platte River at Orchard, Colorado, 1898......... 294

110. Discharge of Louṕ River at Columbus, Nebraska, 1898 ........... . 295

111. Discharge of Platte River at Columbus, Nebraska, 1895-1898........ 296

112. Discharge of Elkborn River at Norfolk, Nebraska, 1897 and $1898 \ldots \ldots .297$

113. Relative location of river and rainfall observations in basin of Kansas River. 
Fig. 114. Discharge of Solomon River at Niles, Kansas, 1898 . ............ 314

115. Discharge of Smoky Hill River at Ellsworth, Kansas, 1895-1898.... 315

116. Discharge of Saline River at Salina, Kansas, $1898 \ldots \ldots \ldots \ldots \ldots \ldots .316$

117. Discharge of Republican River at Superior, Nebraska, 1898........ 317

118. Discharge of Republican River at Junction City, Kansas, 1898..... 318

119. Discharge of Blue River at Manhattan, Kansas, 1895-1898........ 319

120. Relation of gage height to solids carried in suspension by Kansas River at Lawrence, Kansas .............................. $\quad 320$

121. Discharge of Kansas River at Lawrence, Kansas, 1895-1898........ 322

122. Relative location of river and rainfall observations in basin of Arkansas River

123. Discharge of Arkansas River at Canyon City, Colorado, 1889-1898... 336

124. Discharge of Arkansas River at Pueblo, Colorado, 1898......... 337

125. Discharge of Arkansas River at Nepesta, Colorado, $1898 \ldots \ldots \ldots \ldots .338$

126. Discharge of Arkansas River at Rockyford, Colorado, 1897 and 1898 . 339

127. Discharge of Purgatory River at Trinidad, Colorado, 1898....... 341

128. Discharge of Arkansas River at Hutchinson, Kansas, 1895-1898 .... 343

129. Discharge of Verdigris River at Liberty, Kansas, 1895-1898 ........ 344

130. Discharge of Neosho River at Iola, Kansas, 1896-1898 ... ......... 346

131. Relative location of observation stations along Lower Mississippi River ............................................... 348

132. Extent of levee system .................................... 351

133. Geologic section of the Lower Mississippi Valley, according to McGee. 352

134. Irrigation system near Del Rio, Texas....................... 354

135. Relative location of river and rainfall observations in basin of upper

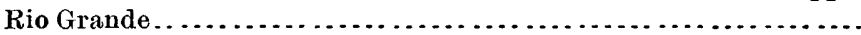

136. Discharge of Rio Grande at Del Norte, Colorado, 1889-1898 . ........

137. Discharge of Rio Grande at Embudo, New Mexico, 1889-1898.......

138. Discharge of Rio Grande at San Marcial, New Mexico, 1898........

139. Relative location of river and rainfall observations in upper basin of Colorado River.

140. Discharge of Green River at Green River, Wyoming, 1898 ........ 381

141. Discharge of Black Fork of Green River at Granger, Wyoming, 1898 . 382

142. Discharge of Green River at Blake, Utah, 1898................ 388

143. Discharge of Grand River at Grand Junction, Colorado, 1898 ..... 389

144. Discharge of Gunnison River at Grand Junction, Colorado, 1898.... 390

145. Discharge of Uncompahgre River at Fort Crawford, Colorado, 1898. 392

146. Discharge of Dolores River at Dolores, Colorado, 1895-1898....... 394

147. Discharge of San Miguel River at Fallereek, Colorado, 1898....... 396

148. Comparison of annual rainfall at Santa $\mathrm{Fe}$, New Mexico, Fort Wingate, New Mexico, and Salt Lake City, Utah . ............. 400

149. Discharge of San Juan River at Árboles, Colorado, 1895-1898....... 401

150. Discharge of Piedra River at Arboles, Colorado, 1895-1898 ........ 402

151. Discharge of Animas River at Durango, Colorado, 1898........... 403

152. Discharge of Salt River at McDowell, Arizona, 1898............ 406

153. Discharge of Verde River at McDowell, Arizona, 1898.......... 407

154. Map of Narraguinnep reservoir site, Colorado ................... 420

155. Map of Narraguinnep dam site, Colorado.................... 421

156. Map of Morton Lake reservoir site, Colorado .................... 423

157. Map of Morton Lake dam site, Colorado ................... 425

158. Comparison of flow of Dolores River and available storage in Morton Lake, 1895

159. Comparison of flow of Dolores River and avaidable storage in Morton Lake, 1896 
Fig. 160. Comparison of flow of Dolores River and available storage in Morton Lake, 1897 ...........................................

161. Comparison of flow of Dolores River and available storage in Morton I,ake, 1898

162. Relative location of river and rainfall observations in basin of Humboldt River.

Page.

163. Discharge of North Fork of Humboldt River at Peko, Nevada, 1898.. 437

164. Discharge of Humboldt River at Elko, Nevada, 1897 and $1898 \ldots \ldots . .437$

165. Discharge of Humboldt River at Golconda, Nevada, 1897 and $1898 . .439$

166. Discharge of Humboldt River at Oreana, Nevada, 1897 and $1898 \ldots . .440$

167. Discharge of South Fork of Humboldt River at Mason's ranch, Nevada, 1898

168. Map of Rock Creek reservoir, Lander County, Nevada..............

169. Plan of dam site of Rock Creek reservoir, Lander County, Nevada..

170. Map of proposed reservoir, canals, and irrigable land in Humboldt Valley, between Battle Mountain and Winnemucca, Nevada......

171. Map of Lower Humboldt Valley above Humboldt Lake . . . . . . . . . . . .

172. Map of proposed reservoir and supply canal in Humboldt County, Nevada.

173. Relative location of river and rainfall observations in basin of Great Salt Lake ............................................

174. Discharge of Bear River at Battle Creek, Idaho, $1898 \ldots \ldots \ldots \ldots . .$.

175. Discharge of Bear River at Collinston, Utah, 1889-1898 ............

176. Discharge of Logan River at Logan, Utah, 1898 . . . . . . . . . . . . . . .

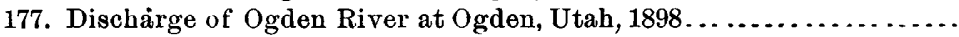

178. Discharge of Weber River at Uinta, Utah, 1898

179. Relative location of Mount Nebo reservoir and canal..............

180. Discharge of Provo River at Provo, Utah, 1889-1898 ..............

181. Relative location of river and rainfall observations in basin of Snake

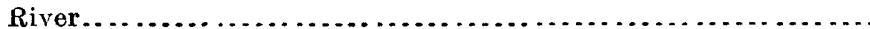

182. Discharge of Snake River at Montgomery Ferry, Idaho, 1898....... 183. Discharge of Portneuf River at Pocatello, Idaho, 1897 and 1898......

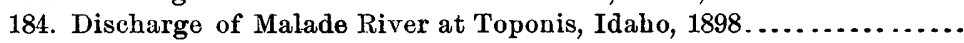

185. Upper Longtom reservoir site, Elmore County, Idaho . . . ............

186. Lower Longtom reservoir site, Elmore County, Idaho ..............

187. Discharge of Bruneau River at Grand View, Idaho, 1895-1898. . . . . .

188. Discharge of Boise River at Boise, Idaho, 1895-1898 ................

189. Relative location of principal irrigation canals between Boise and Caldwell, Idaho ........................................

190. Discharge of Weiser River at Weiser, Idaho, 1898 ................ 191. Discharge of Palouse River at Hooper, Washington, 1897 and $1898 .$.

192. Principal streams and ditches in Bitterroot Valley ...............

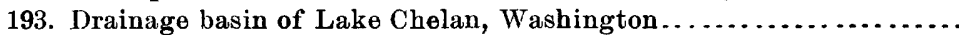

194. Relative location of river and rainfall observations in basin of

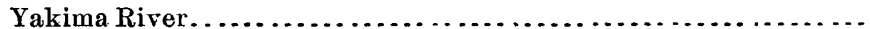

195. Discharge of Yakima River at Union Gap, Washington, 1897 and 1898 ,

196. Discharge of Yakima River at Kiona, Washington, 1898 ...........

197. Discharge of Naches River at North Yakima, Washington, 1898......

198. Reservoir site on Wenas Creek, Washington...................

199. Map of Cowiche reservoir, Washington........................

200. Relative location of point of discharge measurements and of fall of Spokane River. .......................................

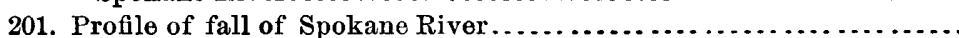
201. Disharge of Spotane River at Spokane, Wagington, $1898 \ldots \ldots . . .$.

\section{1}


FIG. 203. Relative location of river and rainfall observations in basins of

Palouse and Wallawalla rivers ........................ 513

204. Discharge of Umatilla River at Gibbon, Oregon, $1898 \ldots \ldots \ldots \ldots \ldots .515$

205. Discharge of Cedar River at Clifford's bridge, Washington, 1895-1898. 516

206. Discharge of Dungeness River at Seguin, Washington, 1897 and 1898.519

207. Discharge of Elwha River at McDonald, Washington, $1898 \ldots \ldots \ldots . \quad 521$

208. Discharge of Calowa River at Forks, Washington, 1898 ........... 522

209. Discharge of Solduck River at Quillayute, Washington, $1898 \ldots \ldots .523$

210. Discharge of Sacramento River at .Jellys Ferry, California, 1895-1898. 527

211. Discharge of San Joaquin River at Herndon, California, 1898...... 530

212. Discharge of Stanislaus River at Oakdale, California, 1898........ 531

213. Discharge of Tuolumne River at Lagrange, California, 1895-1898.... 532

214. Discharge of Kings River at Red Mountain, California, 1898....... 535

215. Location of measurement on South Fork of Kern River.......... 537

216. Discharge of Kern River at Bakersfield, California, 1894-1897...... 538

217. Map showing location of artesian wells in the vicinity of Pasadena,

California ....................................... 545

218. Discharge of Santa Ana River at Warmsprings, California, 1898.... 555 


\title{
REPORT OF PROGRESS OF STREAM MEASUREMENTS FOR THE CALENDAR YEAR 1898.
}

\author{
By F. H. NEWELL. \\ INTRODUCTION.
}

During the year 1898 measurements of streams and investigations of the water resources of the United States have been carried on in a manner similar to that of preceding years, as described in the annual reports and bulletins of this Survey. These investigations were initiated in the fall of 1888, and the results herewith given are therefore those of the tenth field season. For convenience of reference to earlier publications the following list is given:

1889. Eleventh Annual Report, Part II, Irrigation.

1890. Twelfth Annual Report, Part II, Irrigation.

1891. Thirteenth Annual Report, Part III, Irrigation. ,

1892. Fourteenth Annual Report, Part II, Accompanying Papers.

1893. Bulletin No. 131, Report of Progress of the Division of Hydrography.

1894. Bulletin No. 131, Report of Progress of the Division of Hydrography; also Sixteenth Annual Report, Part II.

1895. Bulletin No. 140, Report of Progress of the Division of Hydrography for the Calendar Year 1895; also Seventeenth Annual Report, Part II.

1896. Eighteenth Annual Report, Part IV, Hydrography; also Water-Supply and Irrigation Paper No. 11.

1897. Nineteenth Annual Report, Part IV, Hydrography; also Water-Supply and Irrigation Papers Nos. 15 and 16.

1898. Twentieth Annual Report, Part IV (present volume); also Water-Supply and Irrigation Papers Nos. 27 and 28.

For the last three years-1896, 1897, and 1898-the discussion of results of river measurements has been given systematically in two series of publications, the material being divided between them in order to insure, on the one hand, prompt publication of engineering details, and, on the other, to put the results in graphic as well as numerical form. As soon as possible after the close of the year the tables of heights of water for that year and list of discharge measurements, with related data, are sent without illustrations to the printer as WaterSupply and Irrigation Papers. For the year 1898 these were numbered 27 and 28 . At the same time computations are made of the daily discharge of various rivers, and the results are plotted to form diagrams showing the fluctuations throughout the year. The subject-matter is also further illustrated by small maps and views. The compiling and 20 GEOL, PT $4 \longrightarrow 2$ 
assembling of these data and illustrations require considerable time, so that the material has usually not been completed before the end of the fiscal year, June 30, thus allowing its incorporation in the annual report of that period. From the details given in the Water-Supply and Irrigation Papers are deduced the results given in the annual reports. On the other hand, in order to obtain the results herewith presented, it is necessary to refer to the fundamental measurements given in the papers just noted. Under each table of river discharge printed in the follow. ing pages reference has been made to the original data in Water-Supply Paper No. 27 or No 28.

The results of investigations of artesian or underground waters, and of methods of utilizing the water resources, are also given in the series of Water-Supply and Irrigation Papers, of which thirty have been printed. The operations of the Division of Hydrography, in condensed form, are also noted in the administrative statements of the Director of the Geological Survey in his annual report.

\section{FIELD OF OPERATIONS.}

The operations of the Division of Hydrography may be divided into a number of classes, the principal of these being the measuring of streams, the survey of reservoir sites, the investigation of the geologic conditions governing underground water, and the preparation of reports. In order . to show at a glance the distribution of the work the accompanying illustrations (Pl. I and fig. 1) have been prepared, showing the relative location of the points where measurements of the rivers have been made during 1898. Pl. I is similar to, but more condensed than, the map accompanying the administrative statement of the Director in this and preceding annual reports. The principal drainage lines of the country have been outlined, and upon these are shown by small dots the river stations maintained by this Survey or the localities from which hydrographic data have been obtained through the aid or cooperation of various individuals or corporations.

In addition to the measurements of rivers at specific points, general investigations have been made of the water resources throughout considerable areas. In order to exhibit this in a broad way the following illustration (fig. 1) has been inserted. This shows the years for which detaile: information is available concerning the surface or underground water supply. The letters on the small map refer to the following explanation, and the shading indicates the portion of country under consideration. The large area in the western part of the United States covered by the diagonal lines indicates the country of which special study was made for the Eleventh Census, the results of which were published in the monograph entitled "Agriculture by Irrigation." In several instances the same year has been covered by two or more reports, this being indicated by the overlapping of the crosshatching. Where this is the case, usually one of the reports was general in character and the other more specific. 


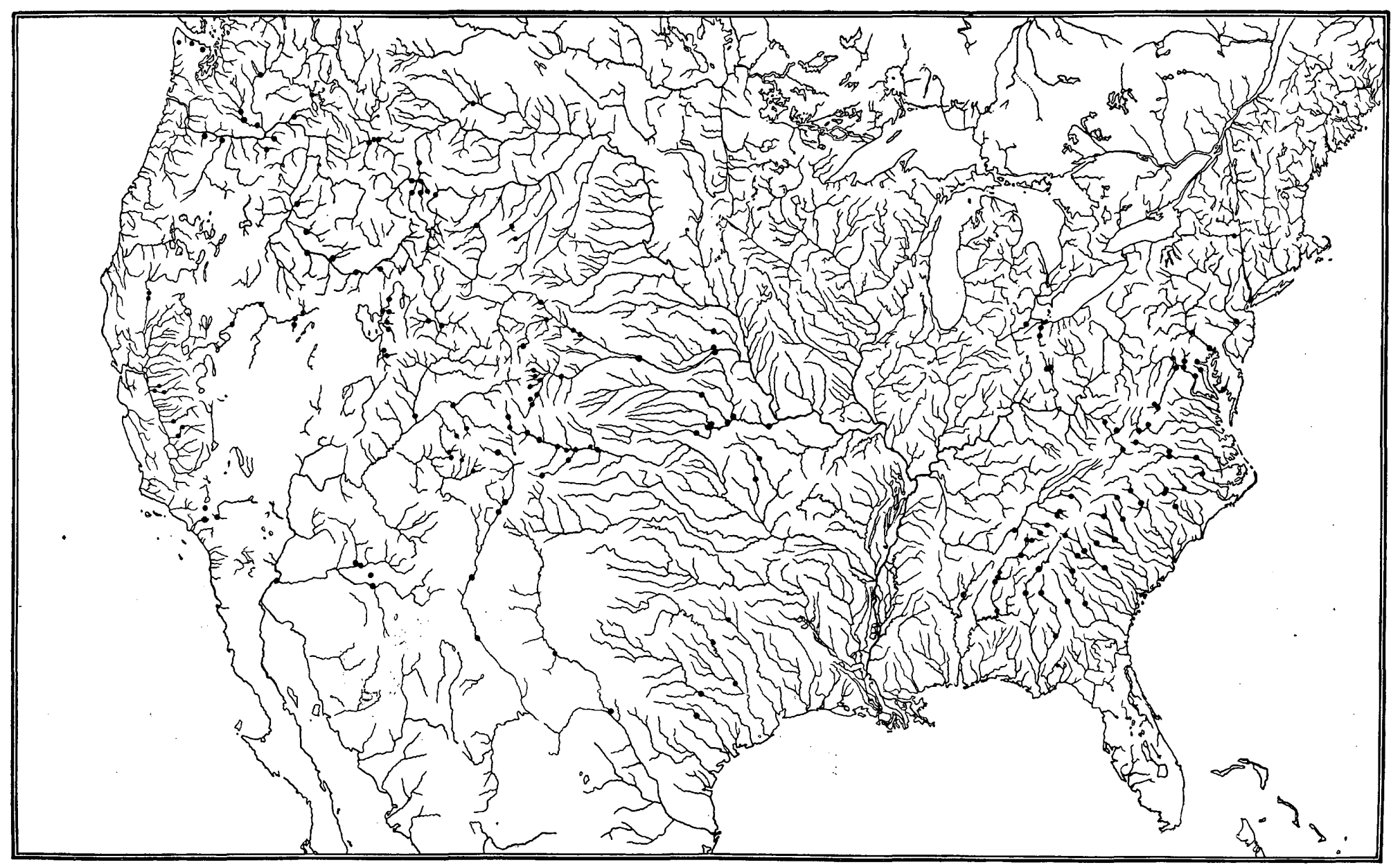

RELATIVE LOCATION OF GAGING STATIONS IN 1898 


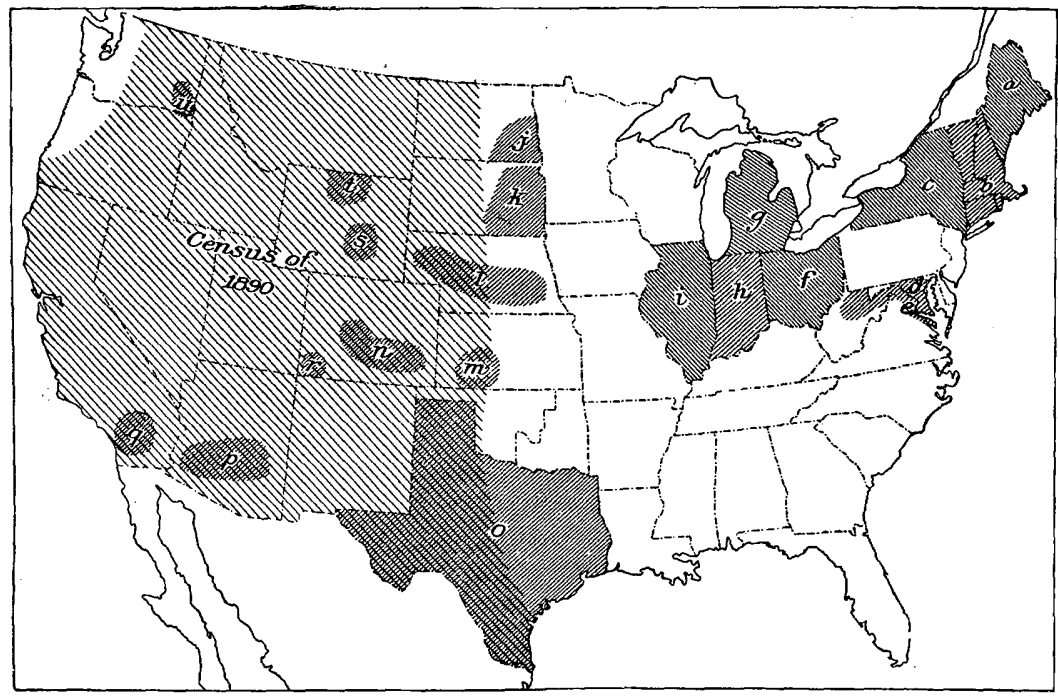

FrG. 1.-Index map of special hyddrographic investigations.

a. Water Powers of Maine, discussed by Dwight Porter in Nineteenth Annual Report, Part IV, p. 34

b. Water Powers of New England, discussed by Dwight Porter, in preparation.

c. Water Powers of New York, discussed by George W. Rafter, in Water-Supply and Irrigation Papers Nos. 24 and 25.

a. Reconnaissance of the Potomac Basin, by Arthur P. Davis and others, Nineteenth Annual Report, Part IV, p. 132.

e. Underground Waters of a Portion of Maryland and Virginia, described by N. H. Darton, in the Nomini Geologic Folio, No. 23.

f. Rock Waters of Ohio, by Edward Orton, Nineteenth Annual Report, Part IV, p. 633; see also The Water Resources of Indiana and Ohio, by Frank Leverett, Eighteenth Annual Report, Part IV, p. 419.

g. Water Resources of the Lower Peninsula of Michigan, by Alfred C. Lane, Water-Supply and Irri. gation Paper No. 30.

h. The Water Resources of Indiana and Ohio, by Frank Leverett, Eighteenth Annual Report, Part IV, p. 419.

i. Water Resources of Illinois, by Frank Leverett, Seventeenth Annual Report, Part II, p. 702.

$j$. Preliminary Report on the Artesian Waters of a Portion of the Dakotas, by N. H. Darton, Seventeenth Annual Report, Part II, p. 609.

k. New Developments in Well Boring and Irrigation in South Dakota, by N. H. Darton, Eighteenth Annual Report, Part 1V, p. 561.

l. Water Resources of Southeastern Nebraska, by N. H. Darton, Water-Supply and Irrigation Paper No. 12.

$m$. Underground Water of Southwestern Kansas, by Erasmus Haworth, Water-Supply and Irrigation Paper No. 6.

$n$. Underground Waters of the Arkansas Valley in Eastern Colorado, by G. K. Gilbert, Seventeenth Annual Report, Part II, p. 557; also Pueblo Geologic Folio, No. 36, by G. K. Gilbert.

o. Artesian Conditions near San Antonio, Texas, by R. 'I. Hill, Eighteenth Annual Report, Part Ir p. 193; see also Irrigation Systems in Texas, by W. F. Hutson, Water-Supply and Irrigation Paper No. 13.

p. Irrigation near Phœnix, Arizona, by Arthur P. Davis, Water-Supply and Irrigation Paper No. 2.

q. Water Supply of San Bernardino Valley, by J. B. Lippincott, Nineteenth Annual Report, Part IV, p. 540.

r. Water Supply for the Southern Utes, Twentieth Annual Report, Part IV.

s. Surveys of Horseshoe Creek, by Clarence T. Johnson, Twentieth Annual Report, Part IV.

$t$. Water-Right Problens of the Bighorn Mountains, by Elwood Mead, Water-Supply and Irrigation Paper No. 23.

u. A Reconnaissance in Southeastern Washington, by Israel C. Russell, Water-Supply and Irrigation Paper No. 4; also a Geological Reconnaissance in Central Washington, by Israel C. Russell, Bullotin No. 108. 
METHODS OF INVESTIGATION.

The methods employed in river measurement have been described in considerable detail in the Nineteenth Annual Report, Part IV, on pages 18 to 30 , and a number of illustrations have been given showing the instruments and the ways of handling them. One of the matters which was not entered upon with any considerable degree of detail was that

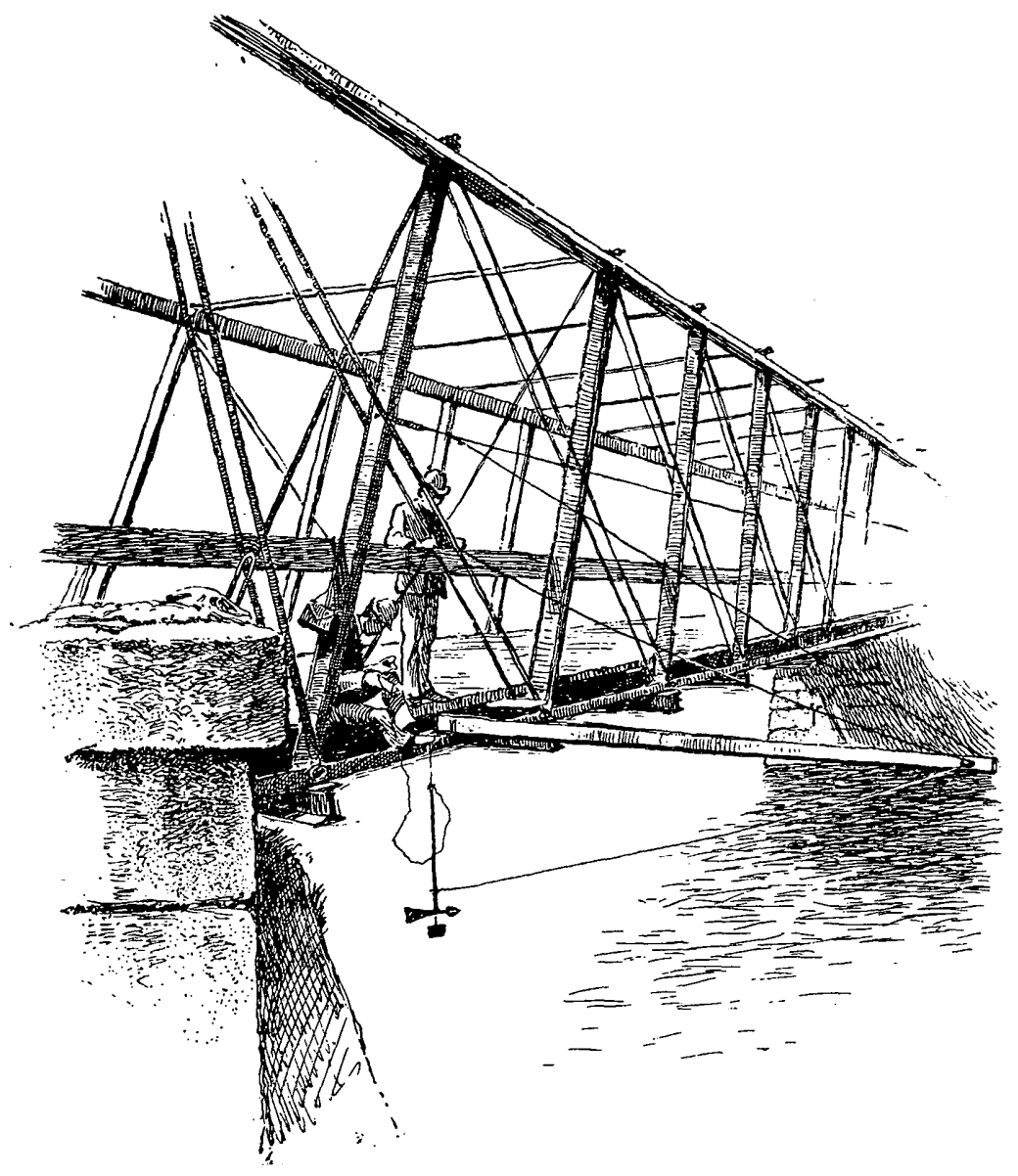

Fra. 2.-Method of attaching stay line to meter by use of a pole.

of holding the meter in swift waters. In ordinary stages of the river the meter can be forced beneath the surface and held in place by means of lead weights, but when the velocity increases in time of floods to over 7 or 8 feet per second, the weights are themselves swept downstream and additional lead does not prove effective. At such times it is necessary to provide a stay line of some character, attached immediately above or below the meter and running diagonally upstream to a point of support. By using this stay line weights can be dispensed with, and 
the meter forced to the bottom and held fairly well in position. The use of such a stay line is illustrated by fig. 2 .

In this case, a long, light timber or pole is placed against a bridge beam or brace, and the outer end is raised or lowered by means of a cord running up over a pulley attached to the bridge. On the upper or outer end of this pole is another pulley, over which runs the stay line from the meter. The instrument is raised and lowered in the ordinary

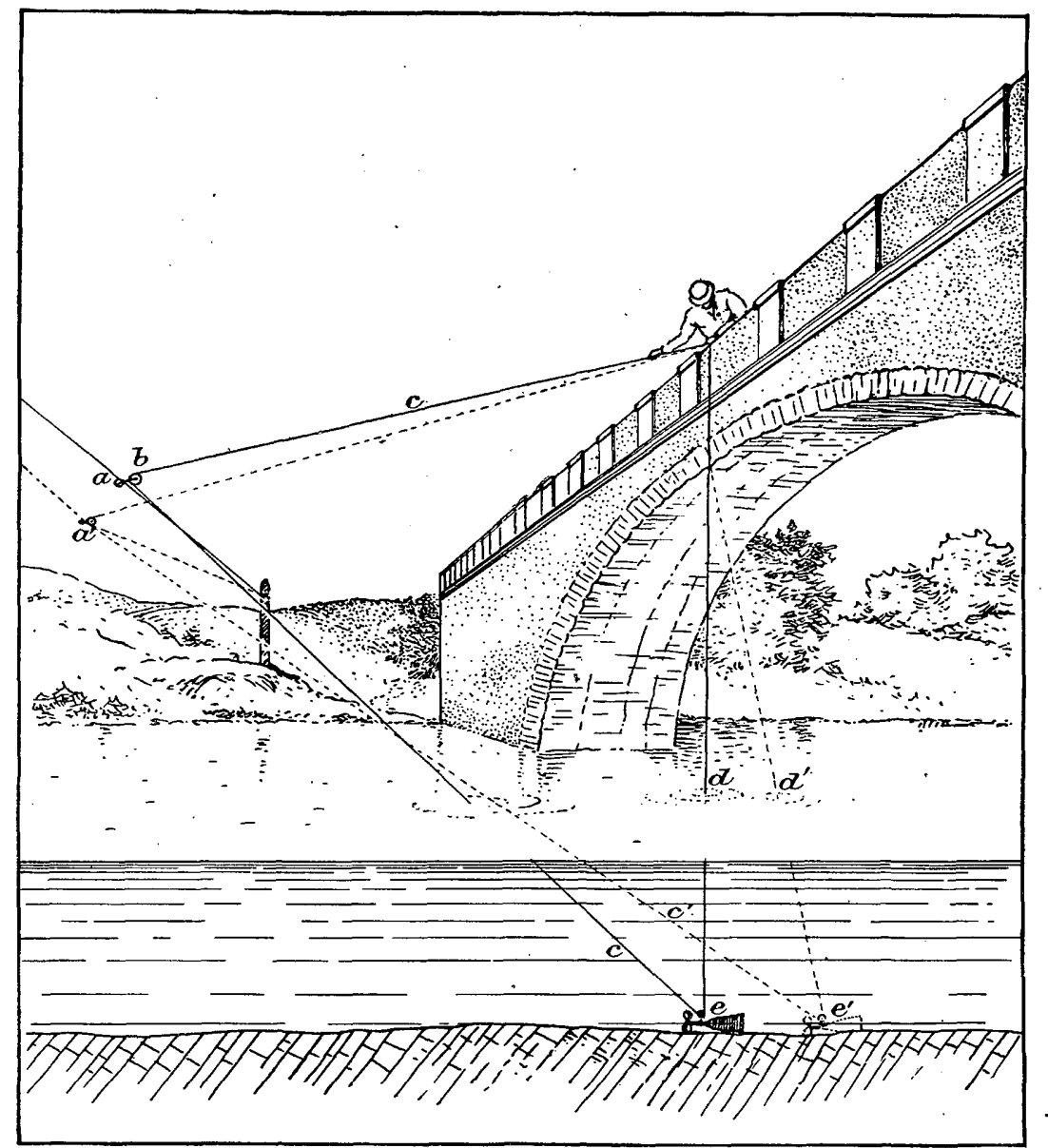

FrG. 3.-Method of using stay line from small.cable.

way by a vertical cord, and is held from being swept downstream by the stay line, which passes out over the end of the pole. This device may be used in the reverse position, on the lower side of a bridge, by lowering the meter from the end of the pole and manipulating the stay line directly from the bridge.

Another method of using this stay line from a bridge is shown in the next illustration (fig. 3). In this case a small cable or stay wire has been stretched across the river above the bridge and a trolley or double 
pulley $(a, b)$ placed on this. The stay line $c$ runs from the bridge to this small trolley $(b)$ and back $(c)$ to the meter $e$. As the instrument is moved along the bridge the trolley on the cable follows the movement. The meter is raised or lowered by the cord $d$. When the meter is immersed in the swift water it will be swept downstream and the cords stretched to the position $a^{\prime}, c^{\prime}, d^{\prime}, e^{\prime}$, but by slight adjustment the meter can be drawn to the desired spot. This device is similar in some respects to the one described in the Eleventh Annual Report, Part II, on pages 16 and 17 , the difference being that in the latter instance the hydrographer works from shore and operates the meter from a second cable.

\section{ACKNOWLEDGMENTS.}

Most of the results presented in this volume have been obtained through local hydrographers, a comparatively small part of the work having been conducted directly from the Survey office at Washington. Acknowledgment is therefore due to each of these persons, and thanks are extended to individuals and corporations who have assisted the local hydrographers, or who have cooperated in various ways, either by furnishing records of height of water or by assisting in transportation. The following list, arranged alphabetically by States, gives the names of the resident hydrographers:

Arizona: W. A. Farish, civil engineer, Phœnix; Albert T. Colton, civil engineer, Florence.

California: J. B. Lippincott, civil engineer, Los Angeles.

Colorado: A. L. Fellows, deputy State engineer, Denver.

Georgia and Alabama: B. M. Hall, civil engineer, Atlanta, Georgia.

Idaho: Frank S. Shirley, civil engineer, Boise.

Kansas: W. G. Russell, Russell; E. C. Murphr, State University, Lawrence.

Maryland: W. B. Clark, State geologist, Baltimore.

Montana (Eastern): S. M. Emery, director experiment station, Bozeman; and Roe

Emery, Bozeman.

Montana (Western): Fred D. Smith, Missoula.

Nebraska: O. V. P. Stout, State University, Lincoin, assisted by Adna Dobson and Glenn E. Smith.

Nevada: L. H. Taylor, civil engineer, Golconda.

New Mexico: P. E. Harroun, civil engineer, Albuquerque.

North and South Carolina: J. A. Holmes, State geologist, Chapel Hill, North Carolina, assisted by E. W. Myers.

Texas: Thomas U. Taylor, State University, Austin.

Utah: Samuel Fortier, civil engineer, Corinne.

Virginia and West Virginia: D. C. Humphreys, Washington and Lee University, Lexington, Virginia.

Washington: Sydney Arnold, civil engineer, North Yakima; William J. Ware, civil engineer, Port Angeles.

Wyoming: Clarence T. Johnston, civil engineer, Cheyenne.

In a number of instances in this report results of computations of . daily flow at milldams, received from local engineers, and figures of river heights obtained from the United States Weather Bureau or Corps of Engineers, have been used. Acknowledgment is therefore 
due for these facts, and particularly to the Weather Bureau for the figures of precipitation which are frequently quoted. The various local hydrographers have asked that thanks be exteuded to the individuals or organizations named in the following paragraphs:

In California assistance in transportation has been rendered by $\mathrm{Mr}$. William Hood, chief engineer of the Southern Pacific Company, and he has also secured the assistance of bridge watchmen in observing the height of water in the rivers. Mr. Walter James, chief engineer of the Kern County Land Company, has supplied records of Kern River, and Mr. A. K. Warren, assistant engineer, has also furnished information. Mr. Burt Cole, engineer of the South Antelope Valley Irrigation Company, has given records of the flow of Littlerock Creek. Mr. H.F. Parkinson, superintendent of canals taking water from the San Gabriel River above Azusa, furnished records of that stream. Mr. J. H. Caruthers, manager of the Anglo-American Canaigre Company, furnished records of Lytle Creek; Mr. W. B. Clapp, city engineer, Pasadena, has furnished records of the Arroyo Seco; Mr. F. H. Olmstead, city engineer of Los Angeles, and Mr. K. Sanborn, engineer of the Riverside Water Company, have rendered valuable assistance in making low-water measurements during the summer of 1898. Mr. W. G. Nevin, general manager Southern California Railroad, has also furnished trans. portation over the Santa Fe lines in California.

In Colorado the State engineering department has continued to cooperate fully, and valuable assistance has been given by the Denver and Rio Grande, the Union Pacific, the Denver and Gulf, the Rio Grande Southern, and the Colorado Midland railroads. Special thanks are also due to the officers and employees of the Great Plains Water Storage Company, the Amity Land and Canal Company, the Buffalo Canal Company-whose engineers, Messrs. Porter J. Preston and C. W. Beach, have made many measurements on the Arkansas-and to Messrs. J. H. Hodgson, S. W. Cressy, J. M. Wolaver, C. W. Reece, and L. H. Dickson, water commissioners in various parts of the State, as well as to many others who have furnished valuable information.

For the accuracy and completeness of work in Georgia and Alabama acknowledgments are due not only to Prof. B. M. Hall, the resident hydrographer, but also to his principal assistant, Mr. Max Hall, who has entered into all the details and management of the work, much of the success being the result of his energy and enthusiasm. Thanks are also due to Prof. W. S. Yeates, State geologist, who has paid the observers at Macon, Oakdale, West Point, Canton, Carey, Molena, Carlton, Madison, Dublin, and Blue Ridge; also to Dr. Eugene A. Smith, State geologist of Alabama, who has paid observers at Riverside and Milstead, Alabama. The officials of the United States Weather Bureau have also rendered assistance, particularly Messrs. J. B. Marbury, D. Fisher, F. P. Chaffee, and L. M. Pindell. 'This organization has main- 
tained stations at Chattanooga, Tennessee; Albany and Rome, Georgia; and for part of the year at Dublin, Resaca, and Canton, Georgia. Mr. W. M. Towers, the observer at Rome, Georgia, is paid by the United States Weather Bureau for half of the year and keeps the record the remainder of the year without charge. Mr. W. S. Weems maintains observations at Carters, Georgia, without charge. The city of Augusta maintains the station at Augusta, and Mr. R. C. McCalla, jr., United States assistant engineer, keeps a record of river height at Tuscaloosa, Alabama, and has rendered valuable assistance in many ways. Prof. C. S. Wilkins, of the Alabama University, has made a series of discharge measurements at Tuscaloosa. The United States engineer corps at Montgomery, Alabama, has furnished records of water heights at Lock No. 4, Lock No. 5, and at Wetumpka, on Coosa River.

Transportation has been furnished to Prof. B. M. Hall, through the kindness of Mr. C. E. Spalding, vice-president, and Mr. Joseph McWilliams, general manager, Atlanta, Knoxville and Northern Railway; Mr. George C. Smith, president and general manager of the Atlanta and West Point Railroad and of the Western Railway'of Alabama; Mr. E. St. John, vice-president and general manager of the Seaboard Air Line; Mr. James T. Wright, general manager of the Macon, Dublin and Savannah Railroad; Mr. W. W. Finley, second vice-president, and Mr. J. S. B. Thompson, superintendent, Southern Railway Company; Mr. Thomas $\mathrm{K}$. Scott, general manager Georgia Railroad; Maj. J. L. McCollum, superintendent Western and Atlantic Railroad; Mr. B. Dunham, general superintendent Plant System; Mr. D. E. Maxwell, general manager Florida Central and Peninsular Railroad, and Mr. J. R. Parrott, vice president Florida East Coast Railway.

In Nebraska a most cordial reception has been accorded the work by the various agencies which are interested in its advancement. Continued and substantial cooperation has been furnished by the agricultural experiment station, the State board of agriculture, and the State board of irrigation; also by the Burlington and Missouri River, Union Pacific, and Fremont, Elkhorn and Missouri Valley railroad companies. Frequent courtesies in the way of information and special facilities for work bave been granted by the owners of irrigation canals and water-power plants:

In Texas the work of Prof. Thomas U. Taylor has been materially assisted by courtesies extended by the Missouri, Kansas and Texas Railway Company.

Thanks are due to the Chesapeake and Ohio Railway and to the Norfolk and Western Railway for annual passes over all lines in Virginia and West Virginia, issued to Prof. D. C. Humphreys.

Thanks are due to Mr. Thomas Cooper, western land agent of the Northern Pacific Railway, for pass for the year 1898 for the State of Washington, issued to Mr. Sydney Arnold, to assist in the work of river measurement. 


\section{RESERVOIR SURVFYS.}

The surveys of reservoirs made during 1898 have been described in geographic order in connection with the river measurements. The field work has been done by Mr. Cyrus C. Babb and Mr. Gerard H. Matthes, as described on later pages of this volume. The necessity of water storage is being more and more appreciated, and the demand for this work has taken more definite form during 1898 than in previous years. For convenience of reference to the subject, a compilation has been made of the results of earlier surveys, which has been published as Senate Document No. 16, Fifty-fifth Congress, third session. The following statements have been taken from this document:

\section{ORIGIN OF SURVEYS.}

The origin of the reservoir investigations carried on by the Geological Survey may be traced to the early work of Maj. J. W. Powell, and particularly to the report prepared by him on the Lands of the Arid Region, transmitted April 1, 1878. On page 12 of this report he calls attention to the increase of irrigable area possible by flood storage, and notes that there are two methods of conserving the waste waters: first, in the upper valleys, among the mountains and foothills, and, second, in ponds withir or adjacent to farms where irrigation is being carried on. At that time both of these classes of reservoir sites were practically untouched, but since then many of the smaller reservoir sites adjacent to cultivated lands have been put in use in whole or in part. At the present time the public is concerned mainly with the larger and more expensive storage propositions within the upper catchment areas of the streams.

Major Powell's early report, while discussing conditions throughout the arid West, brought out details particulariy concerning Utah. He showed, for example, that near the sources of the Sevier River reservoirs could be constructed in the broad basins drained by narrow gorges cut through volcanic sheets. He pointed out particularly Panguitch Lake, in a broad basin 15 miles southwest of the town of the same name. By throwing a dam 30 feet high and 50 or 60 feet long across the outlet a lake would be formed with an area of 6 or 7 square miles. Other reservoirs could be formed by dams across the upper part of East Fork Canyon, also in Grass Valley, upon Fish Lake Plateau, upon the Sevier Plateau, and in the valleys drained by Salina Creek and its tributaries. The Sevier River itself can be cheaply dammed at several gorges, notably at the head of Marysvale Canyon. Since the time of the publication of this report several of these reservoirs have been built, while others now needed are waiting for necessary funds. It was not until ten years after the publication of this report-namely, in 1888-that Congress took definite action in authorizing reservoir surveys. 
Shortly after the publication of Powell's report on the Lands of the Arid Region, the survey of which he was the head was abolished, with other similar organizations, and in the place of these the existing United States Geological Survey was created. This present Survey is concerned with the water resources of the country primarily through what is known as the "organic law" contained in the act of Congress of March 3,1879 (Stat. L., vol. 20, p. 394). To the paragraph creating the office of Director of the Geological Survey the proviso was attached that this officer shall make " the classification of the public lands and examination of the geological structure, mineral resources, and products of the national domain." The first requisite in such classification and examination has been found to be a topographic map for guidance and for exhibiting the results. Since the organization of the Survey, therefore, a large part of its energies has been concentrated on the preparation of such a map, showing all elevations of land surface by means of contours, also the location of streams, towns, roads, railroads, and canals for irrigation or transportation, isolated houses, and boundaries of States, counties, and towns. This map exhibits the drainage area of streams, the relative elevations of catchment basins and irrigable lands, the topographic features favorable to water conservation, the Land Office lines, the slopes of valleys, and many other details of importance in the development of water powers and in the irrigation or the reclamation of the arid lands.

In 1887 the Director of the Geological Survey was called upon by Congress to consider the question of Federal recognition of the irrigation subject. A resolution was passed (Stat. L., vol. 25, pp. 618, 619) requiring the Secretary of the Interior, by means of the Director of the Geological Survey, to make an investigation of that portion of the arid region of the United States where agriculture is carried on by means of irrigation. This was followed by the passage of an act (Stat. L., vol. 25 , pp. 526, 527, 960) containing an appropriation for the purpose of investigating the extent to which the arid region of the United States can be redeemed by irrigation. A portion of the law of October 2, 1888, was repealed by a provision in the act approved August 30, 1890 (Stat. L., vol. 26, p. 391). Under this latter law the Survey selected and mapped a large number of reservoir sites, which have been noted on the records of the General Land Office and are now reserved from entry or settlement. Descriptions of these sites may be found in the Tenth, Eleventh, Twelfth, and Thirteenth Annual Reports of this Survey.

It appears that the portion of the original law approved October 2, 1888, which effected the withdrawal of the public lands from entry, occupation, and settlement was repealed, but that the remaining portions of the law were unaffected by the act of repeal, and that there is still in the statutes authority for making an examination of the arid region of the United States, for ascertaining the capacity of the 
streams, and "for the selection of sites for reservoirs and other hydraulic works necessary for the storage and utilization of water for irrigation and the prevention of floods and overflows, and to make the necessary maps." It is specifically provided that the reservoir sites shall remain segregated for such use, and in a law entitled "An act to repeal timber culture laws, and for other purposes," approved March 3,1891, it is provided that reservoir sites shall be restricted to and shall contain only so much land as is actually necessary for the construction and maintenance of reservoirs, excluding so far as practicable lands occupied by actual settlers at the date of the location of said reservoirs. (Stat. L., vol. 26, p. 1101.)

\section{CHARACTER OF SURVEYS.}

In making surveys and estimates for storage reservoirs the operations fall naturally into two classes or steps: first, the ascertaining of the natural conditions, and, second, the preparation of estimates based upon these and upon the existing artificial limitations. In most of the work of this character conducted by the Geological Survey the operations have extended only to the first class-the ascertaining of the physical facts; but in some cases the investigations and estimates have been further elaborated up to the point of preparing detailed plans and estimates based upon certain assumptions.

The natural conditions to be ascertained in the case of storage reservoirs are primarily those which fall within the observations of the topographers in the preparation of the map of the United States. These are the area, outlines, slopes, and character of the catchment basin tributary to the reservoir, and the capacity at various heights of water. Closely joined with this are the operations of the hydrographers in measuring the flow of the stream and in ascertaining the volume which can be depended upon for filling the reservoir, or the extreme floods against which provisions must be made. Having ascertained the facts as to the probable water supply, it is then necessary to ascertain the conditions at the proposed dam site, such as the character of the foundation, the materials available, and the length, height, and other dimensions of the necessary structure. These facts have been ascertained from time to time concerning many scores of reservoir sites within the arid region, the work on a large or small scale being systematically carried forward year by year.

The artificial conditions to which reference has been made, and which must be taken into consideration in preparing detailed esti. mates, are not susceptible of measurement and final estimates, since they are changing from time to time. These are chiefly land ownership and acquired rights to water, transportation. facilities, cost of materials, and, more than all, the capital available toward the construction of the proposed dam. With unlimited funds at hand, the engineer would plan and build a dam entirely different in material and method 
of construction from one which he must erect when called upon to produce the desired result with an exceedingly small amount of money. In the first case he would look mainly to stability and thoröughness of workmanship; in the second he would adopt the cheapest devices and assume certain risks, under the belief that from year to year the ternporary imperfections might be remedied until a time when larger funds might be available. In the first case he might, and probably would, construct the dam of solid masonry; in the second he might make it of earth or loose rock, or even largely of wood, with the intention of renewing parts in five or ten years, whenever portions of the material showed signs of decay.

From what has been said it is evident that reservoir surveys can be carried on widely to great advantage up to the point of making estimates of cost, and that to go beyond this assumptions must be made founded on a knowledge as to whether the dams are to be built by individuals for limited use, by associations or corporations for larger purposes, or by the community-the county, State, or nation-to supply the largest possible quantity of water and to have unlimited length of life. Without some such fundamental assumption it is of course impossible to make estimates for construction purposes. The Geological Survey has in some instances attempted to overcome this difficulty by making estimates based upon different types of dam, such as earth. work, dry rock with wooden face, masonry, etc. But the laborious estimates prepared upon various assumptions are largely wasted efforts, and will continue to be until it is apparent whether these reservoirs will be constructed by individuals or associations to a small capacity or by the community to the maximum use and stability.

It was early recoguized that detailed estimates of the cost of construction of dams were to a large extent useless until some definite decision had been reached as to probable construction by the Government. The preparation of these estimates was therefore discontinued and efforts were concentrated on ascertaining the natural conditions. These - are of prime importance, and no valid criticism can be brought against the expending of funds in ascertaining where reservoir sites are located, their size and value. Data of this kind are the foundation for any broad classification of the public domain, and for ascertaining the extent to which the arid lands can be redeemed by irrigation. They are inseparably connected with questions concerning flow of streams and quantity of water available. The acquisition of the facts does not in any way depend upon assumptions as to how the reservoirs are to be constructed, and the results are equally valuable whether the work is ultimately performed by individuals, by associations, or by the State. They enable each citizen to determine for himself where reservoir sites exist, and in a general way whether a dam can be constructed to financial advantage.

The method of survey has been that developed by experience as being 
most expeditious and economical. The plane table is used almost exclusively, elevations being checked by precise leveling. In this way results of accuracy are obtained in one-half or one-fourth the time consumed in the usual way of transit location and of plotting notes. The scale employed has been dependent upon the size of the reservoir, the attempt usually being made to complete the map upon the plane table in ordinary use. The contour interval has usually been 10 feet, although in special cases a 5 -foot vertical distance has been used.

At the dam sites it has usually been the custom to prepare a map still more detailed than that of the reservoir, in order to show minor inequalities of surface. The scale employed has been governed by the size of the proposed site, and the contour interval has ranged from 1 to 5 feet, thus bringing out minor inequalities of surface and affording means of computing the cubical contents of the dam above the original surface. Wherever practicable, notes have been made as to the probable amount of earth or loose rock to be removed in preparing foundations.

The resulting plane-table sheets have been carefully completed for preservation and placed among the records of the office of the Geological Survey. Photographs of these are made at once, and in most instances the drawings have been reproduced in generalized form in the annual reports of the Survey.

\section{EXTENT OF SURVEYS.}

The extent of reservoir surveys can best be shown by reference to the annual reports of the Survey, beginning with the Eleventh, Part II. In order to assemble these data in concise form the following tables have been prepared, reference being given to the volume and page where additional facts can be found. A few of the principal details have been assembled in the table, to afford a general conception of the character of the reservoirs examined.

\section{ARIZONA.}

In Arizona the principal reservoir surveys have been those made on the Gila River and its tributaries, and described in Senate Document No. 27, Fifty-fourth Congress, second session; also in less detail in the Eighteenth Annual Report, Part IV, on pages 291 to 297. Detailed estimates have been prepared for the construction of two dams, under the assumption that one of these may ultimately be built by the Government, mainly for the purpose of supplying water to the Indians. Private parties have carried on other surveys of reservoirs on the head waters of the Salt and Verde rivers, which are described in a general way in the Senate document above noted.

\section{CALIFORNIA.}

In this State most of the reservoir surveys have been made within the high Sierras in the vicinity of Lake Taboe, these being on the head waters of Truckee River, flowing from California into Nevada; 
also on the head waters of Stanislaus, Tuolumne, and Merced rivers, flowing into San Joaquin Valley. A general description of these is given in the Eleventh Annual Report, Part II, on pages 150 to 168. The engineering details and estimates are more fully discussed in the Thirteenth Annual Report, Part III, on pages 398 to 409. The following table gives in condensed form the principal facts concerning the reservoirs examined or surveyed in this State. In the secoud column is given the page reference to the Annual Reports, where additional facts may be found; in the next column is given the arbitrary number, and in the fourth column is given the name of the reservoir or stream to which the reservoir is tributary. The drainage area above the reservoir site is also given and the approximate altitude of water surface. An assumed height of dam is also stated, and the area of the water surface in acres which will be formed by a dam of this height; also the total capacity of the reservoir in acre-feet.

Surveys of reservoir sites in California.

\begin{tabular}{|c|c|c|c|c|c|c|c|c|}
\hline 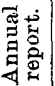 & Page. & No. & Name. & $\begin{array}{c}\text { Drainage } \\
\text { area. }\end{array}$ & Altitude. & $\begin{array}{l}\text { Height } \\
\text { of dam. }\end{array}$ & $\begin{array}{c}\text { Area of } \\
\text { reser. } \\
\text { voir. }\end{array}$ & $\begin{array}{c}\text { Capacity } \\
\text { of reser- } \\
\text { voir. }\end{array}$ \\
\hline 13 & 405 & 1 & Clear Lake $a \ldots . . . .$. & $\begin{array}{r}\text { Sq. miles. } \\
413\end{array}$ & $\begin{array}{c}\text { Feet. } \\
\ldots\end{array}$ & $\begin{array}{c}\text { Feet. } \\
\ldots . . .\end{array}$ & $\begin{array}{l}\text { Acres. } \\
46,080\end{array}$ & $\begin{array}{c}\text { Acrefeet. } \\
435,300\end{array}$ \\
\hline 13 & 391 & 2 & Independence Lake $b$. & ............. & 6,997 & 40 & 984 & 23,707 \\
\hline 13 & 392 & 3 & Webber Lake $b . . .$. & 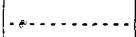 & 6,769 & 29 & 778 & 11,152 \\
\hline 13 & 389 & 4 & Donner Lake $a$. & & 6,095 & 26 & 1,337 & 22,205 \\
\hline & & & & & & 98 & 2,006 & 42,827 \\
\hline 12 & 10 & 5 & Yuba River.. & 6 & $6,700-8,300$ & 20 & 320 & 2,400 \\
\hline 12 & 12 & 6 & Squaw Creek ....... & 12 & $6,100-9,000$ & 16 & 225 & 1,350 \\
\hline 13 & 400 & 7 & Little Yosemite a... & & 5,980 & 115 & 841 & 45,195 \\
\hline 13 & 400 & 8 & Lake Tenaiya $a . . . .$. & $\ldots$ & 7,990 & 59.5 & 597 & 23,082 \\
\hline 13 & 400 & 9 & Tuolumne Meadows $a$ & & 8,339 & 75 & 1,081 & 43,185 \\
\hline 13 & 400 & 10 & Lake Eleanor $a \ldots \ldots \ldots$ & $\ldots$ & 4,561 & 89 & 1,127 & 93,060 \\
\hline 13 & 400 & 11 & Kennedy Meadow a... & & 6,911 & 55 & 348 & 6,817 \\
\hline 13 & 400 & 12 & Kennedy Lake $a . . . . .$. & $\cdots$ & 8,009 & 31 & 110 & 2,018 \\
\hline 13 & 400 & 13 & Bear $\nabla$ alley on Bloods Creek $a$ & & 6,182 & 81 & 128 & 4,608 \\
\hline 12 & 13 & 14 & Red Lake.................. & Small. & $7,850-9,500$ & 35 & 80 & 1,050 \\
\hline 12 & 14 & 15 & Markleeville Creek.. & Small. & $5,900-8,500$ & $c 35$ & 60 & 790 \\
\hline 12 & 16 & 16 & East Carson River... & & $6,000-11,000$ & 65 & 40 & 975 \\
\hline 12 & 17 & 17 & Deer Creek ........ & Indefinite. & 8,000 & 22 & 20 & 160 \\
\hline 12 & 17 & 18 & Heenan Lake...... & Small. & $7,100-8,000$ & 30 & 130 & 1,460 \\
\hline 12 & 19 & 19 & Silver Creek ....... & & $6,400-11,000$ & 60 & 255 & 5,740 \\
\hline 12 & 20 & 20 & Wolf Creek........ & & $6,500-11,000$ & 65 & 190 & 4,630 \\
\hline 12 . & 21 & 21 & East Carson ......... & Extensive. & $6,600-11,000$ & 65 & 225 & 5,480 \\
\hline 12 & 23 & 22 & Mokelumne River.... & & $7,000-10,000$ & 40 & 75 & 1,120 \\
\hline 12 & 24 & 23 & .... do ............... & - ......... & $6,800-10,000$ & 38 & 30 & 430 \\
\hline 12 & 25 & 24 & Pacific Valley Creok.... & Small. & $7,500-9,500$ & 35 & 75 & 980 \\
\hline 12 & 26 & 25 & Big Canyon Creek .. & & $5,500-7,500$ & 60 & 280 & 6,300 \\
\hline 12 & 27 & 26 & ..... do .............. & 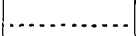 & $5,000-8,000$ & 35 & 175 & 2,200 \\
\hline 12 & 28 & 27 & Hull Creek .... & & $5,000-6,000$ & 50 & 115 & 2,160 \\
\hline 12 & 30 & 28 & Granite Creek ... & & 5,000 & 40 & 220 & 3,300 \\
\hline
\end{tabular}

$a$ See also Eleventh Annual Report, Part II, pp. 150-168.

$b$ See also Eleventh Annual Report, Part II, p. 174 .

$c$ Consists of two sites with separate dams of same height. 
Surveys of reservoir sites in California-Continued.

\begin{tabular}{|c|c|c|c|c|c|c|c|c|}
\hline 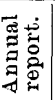 & Page. & No. & Name. & $\begin{array}{c}\text { Drainage } \\
\text { area. }\end{array}$ & Altitude. & $\begin{array}{l}\text { Height } \\
\text { of dam. }\end{array}$ & $\begin{array}{c}\text { Area of } \\
\text { reser- } \\
\text { voir. }\end{array}$ & $\begin{array}{l}\text { Capacity } \\
\text { of reser- } \\
\text { voir. }\end{array}$ \\
\hline 12 & 31 & 29 & Cherry River.. & Sq. miles. & $\begin{array}{c}\text { Feet. } \\
4,500-11,000\end{array}$ & $\begin{array}{c}\text { Feet. } \\
40\end{array}$ & $\begin{array}{r}\text { Acres. } \\
165\end{array}$ & $\begin{array}{c}\text { Acre-feet. } \\
2,500\end{array}$ \\
\hline 12 & 33 & 30 & Lake Vernon........ & $\ldots . . .$. & 6,500 & 30 & 480 & 5,700 \\
\hline 12 & 34 & 31 & Big Meadow site $a . \ldots \ldots$ & Small. & 7,500 & 30 & 980 & 11,000 \\
\hline 12 & 35 & 32 & Errarars Meadow site $b . . . .$. & Small. & 5,000 & 30 & 95 & 1,070 \\
\hline 12 & 36 & 33 & Tuolomne River ......... & Large. & $1,500-12,000$ & 100 & 680 & 25,500 \\
\hline 12 & 38 & 34 & Little Truckee River ..... & ......... & $6,500-9,000$ & 60 & 450 & 10,100 \\
\hline 12 & 39 & 35 & 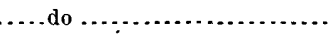 & $\ldots .$. & $5,800-9,000$ & 50 & 120 & 2,250 \\
\hline 12 & 40 & 36 & Prosser Creek ........... & 12 & $6,200-9,000$ & 30 & 310 & 3,480 \\
\hline 12 & 42 & 37 & Little Truckee River.... & ......... & $4,500-9,000$ & 50 & 350 & 6,500 \\
\hline 12 & 43 & 38 & Monument Peak site $b . . . . .$. & Small. & $7,700-10,000$ & 80 & 160 & 4,800 \\
\hline 12 & 45 & 39 & Near East Carson River... & ........ & $5,200-11,000$ & 60 & 150 & 3,370 \\
\hline 12 & 46 & 40 & Grass Lake ................... & Small. & $7,800-9,500$ & 30 & 350 & 4,000 \\
\hline 12 & 47 & 41 & West Fork Carson River ..... & Large. & $5,000-12,000$ & 150 & 2,400 & (c) \\
\hline 12 & 51 & 42 & Near West Fork Carson River. & Small. & $5,500-6,300$ & 40 & 40 & 600 \\
\hline 12 & 52 & 43 & Silver Fork American River.. & Small. & 7,800 & 47 & 135 & 2,400 \\
\hline 12 & 53 & 44 & 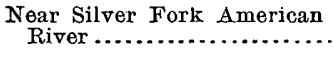 & & 7,900 & 30 & 420 & 4,700 \\
\hline
\end{tabular}

$a$ On small creek in Tuolumne County. $\quad b$ In Tuolumne County.

$c$ Not estimated.

COLORADO.

Most of the reservoir surveys in Colorado have been confined to the head waters of Arkansas River. A general description is given in the Eleventh Annual Report, Part II, on pages 133 to 144, and the engineering details are noted in the Thirteenth Annual Report, Part III, on pages 357 to 370 . The relative location of the reservoirs and of the streams into which their waters empty is shown on a large folded map accompanying the volume. The following list gives the principal details concerning the sites examined:

Surveys of reservoir sites in Colorado.

\begin{tabular}{|c|c|c|c|c|c|c|c|c|}
\hline خ & Page. & No. & Name. & $\begin{array}{l}\text { Drainage } \\
\text { area. }\end{array}$ & $\begin{array}{l}\text { Altitude } \\
\quad(a)\end{array}$ & $\begin{array}{l}\text { Height } \\
\text { of dam. }\end{array}$ & $\begin{array}{c}\text { Area of } \\
\text { reser- } \\
\text { voir. }\end{array}$ & $\begin{array}{c}\text { Capacity } \\
\text { of reser- } \\
\text { voir. }\end{array}$ \\
\hline 13 & 365 & 1 & Twin Lakes $b . .$. & $\begin{array}{c}\text { Sq. miles. } \\
387\end{array}$ & $\begin{array}{l}\text { Feet. } \\
9,240\end{array}$ & $\begin{array}{r}\text { Feet. } \\
73\end{array}$ & $\begin{array}{r}\text { Acres. } \\
3,475\end{array}$ & $\begin{array}{c}\text { Acre feet. } \\
103,500\end{array}$ \\
\hline 13 & 365 & 2 & East Fork Arkansas River.. & $\ldots$ & 10,000 & 105 & $\therefore$ & 8,875 \\
\hline 13 & 365 & 3 & Clear Creek. & & & & & 7,000 \\
\hline 13 & 365 & 4 & Hayden.... & & 9,240 & 120 & & 45,000 \\
\hline 13 & 365 & 5 & Sugar Loaf ............ & $\ldots$ & 10,000 & 105 & - & 8,875 \\
\hline 12 & 55 & 6 & Sevenmile Creek........... & 30 & 8,400 & 100 & 160 & 4,550 \\
\hline 13 & 365 & 7 & Tennessee Fork Arkansas River . & $\ldots$ & $9 ; 870$ & 68 & & 37,000 \\
\hline 12 & 56 & 8 & Grape Creek. & 380 & 8,000 & 140 & 2,540 & 119,100 \\
\hline 12 & 58 & 9 & Pine Creek ................ & 30 & 7,900 & 100 & 80 & 1,520 \\
\hline 12 & 59 & 10 & Slate Creek......................... & 25 & 8,100 & 86 & 560 & 8,570 \\
\hline 12 & 61 & 11 & West Oil or Tenmile Creek. & 20 & 8,500 & 67 & 200 & 2,250 \\
\hline
\end{tabular}

$a$ Elevations refer to approximate altitude of reservoirs. $b$ See Eleventh Annual Report, Part II, p. 135. 
Surveys of reservoir sites in Colorado-Continued.

\begin{tabular}{|c|c|c|c|c|c|c|c|c|}
\hline 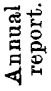 & Page. & No. & Name. & $\begin{array}{c}\text { Drainage } \\
\text { area. }\end{array}$ & A ltitude. & $\begin{array}{l}\text { Height } \\
\text { of dam. }\end{array}$ & $\begin{array}{c}\text { Area of } \\
\text { reser- } \\
\text { voir. }\end{array}$ & $\begin{array}{l}\text { Capacity } \\
\text { of reser- } \\
\text { voir. }\end{array}$ \\
\hline & & & & Sq. miles. & Feet. & Feet. & Acres. & Acrefeet. \\
\hline 12 & 62 & 12 & Oil Creek & 160 & 8,500 & 159 & 1,400 & 56,200 \\
\hline 12 & 64 & 13 & West Beaver Creek. & 60 & 9,000 & 96 & 1,320 & 28,450 \\
\hline 12 & 66 & 14 & Beaver Creek....... & 25 & 9,000 & 63 & 50 & 620 \\
\hline 12 & 67 & 15 & Oil Creek. & 270 & 5,800 & 100 & 167 & 4,300 \\
\hline 12 & 69 & 16 & Wilson Creek..... & 35 & 5,900 & 90 & 80 & 2,900 \\
\hline 12 & 70 & 17 & Sand Creek...... & 30 & 5,450 & 84 & 115 & 1,950 \\
\hline 12 & 72 & 18 & Sixmile Creek .... & $a 180$ & 5,500 & 100 & 50 & 3,100 \\
\hline 12 & 73 & 19 & Eightmile Creek. & 50 & 5,500 & 70 & 210 & 4,540 \\
\hline 12 & 74 & 20 & Beaver Creek...... & 130 & 5,100 & ... & 215 & 7,100 \\
\hline 12 & 76 & 21 & Turkey Creek .... & 70 & 5,400 & 80 & 520 & 9,800 \\
\hline 12 & 78 & 22 & ....do .................. & 70 & 5,000 & 60 & 90 & 1,920 \\
\hline 12 & 79 & 23 & Arkansas River.. & $\cdots$ & 4,900 & 90 & 1,920 & 359,000 \\
\hline 12 & 83 & 24 & Rush Creek........ & 10 & 5,400 & 50 & 335 & 2,100 \\
\hline 13 & 365 & 25 & Cottonwood Lake... & $\therefore$ & -..... & 110 & ..... & 8,400 \\
\hline 12 & 84 & 26 & St. Charles River & 180 & 4,980 & 27 & 170 & 2,640 \\
\hline 12 & 85 & 27 & ....do do ........... & 65 & 6,300 & 77 & 200 & 3,340 \\
\hline 12 & 87 & 28 & Graneros Creek...... & $b 50$ & 6,000 & 165 & 760 & 27,200 \\
\hline 12 & 88 & 29 & Huerfano River.............. & 500 & 6,895 & 49 & 115 & 1,960 \\
\hline 12 & 89 & 30 & Cucharas River... & 40 & 7,800 & 132 & 130 & 4,125 \\
\hline 12 & 91 & 31 & Arapahoe River.... & 25 & 7,200 & .139 & 450 & 13,300 \\
\hline 12 & 92 & 32 & Santá Clara River.. & 45 & 6,700 & 142 & 420 & 10,150 \\
\hline 12 & 94 & 33 & Apishapa River .... & 100 & 6,850 & 115 & 440 & 12,790 \\
\hline 12 & 96 & 34 & Purgatory River............ & 320 & 6,620 & 120 & 450 & 6,200 \\
\hline 12 & 97 & 35 & In Stonewall Valley ............. & 50 & 8,300 & 135 & 240 & 11,200 \\
\hline 12 & 98 & 36 & Purgatory River............ & 65 & 8,200 & 142 & 760 & 22,700 \\
\hline 12 & 100 & 37 & Apishapa River ............... & 420 & 5,600 & 31 & 250 & 3,840 \\
\hline 13 & 365 & 38 & Monument Creek & & 6,950 & 47 & & 5,630 \\
\hline 13 & 365 & 39 & Pring................ & ... & $\ldots .$. & 83 & & \\
\hline 12 & 101 & 40 & Smith Canyon Creek. . . . . . . . . . . . & 220 & 4,700 & 98 & 1,400 & 34,230 \\
\hline 12 & 103 & 41 & Rule Creek ........... & 140 & 4,250 & 68 & 1,560 & 32,780 \\
\hline 12 & 105 & 42 & Cottonwood Creek........ & 110 & 4,300 & 58 & 1,000 & 25,680 \\
\hline 12 & 106 & 43 & Two Butte Creek.......... & 250 & 4,500 & 50 & 480 & 5,900 \\
\hline 12 & 107 & 44 & Supplied from Arkansas River $c .$. & None. & 4,250 & 20 & 700 & 14,720 \\
\hline 12 & 109 & 45 & Supplied from Arkansas River $d . .$. & Small. & 4,150 & None. & 1,680 & 21,470 \\
\hline 12 & 111 & 46 & Supplied from Arkansas River e... & Small. & 4,150 & None. & 4,160 & 73,300 \\
\hline 12 & 113 & 47 & Tennessee Fork Arkansas River ... & 20 & 10,600 & 50 & 420 & 9,600 \\
\hline 12 & 115 & 48 & East Fork Arkansas River........ & 30 & 10,100 & 45 & 250 & 4,100 \\
\hline 12 & 116 & 49 & Pine Creek ............. & 20 & 8,545 & 60 & 130 & 2,500 \\
\hline 12 & 117 & 50 & $\ldots$ do $\ldots \ldots \ldots \ldots$ & 25 & 8,600 & 70 & 90 & 1,500 \\
\hline 12 & 119 & 51 & Arkansas River ......... & 600 & 8,000 & 120 & 420 & 11,940 \\
\hline 12 & 120 & 52 & 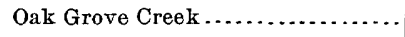 & 30 & 6,425 & 84 & 80 & 1,310 \\
\hline 12 & 122 & 53 & Rock Creek......... & 30 & 5,200 & 70 & 300 & 6,600 \\
\hline 12 & 124 & 54 & Timpas Creek . . . . . . . & 75 & 4,950 & 88 & 840 & 13,640 \\
\hline 12 & 125 & 55 & Las Animas River................. & 2,400 & 4,450 & 108 & 2,360 & 43,330 \\
\hline
\end{tabular}

$a$ Includes drainage of Eightmile and Beaver creeks.

$\checkmark$ Includes drainage of Greenhorn Creek.

$c$ Depression on the open plains, 6 miles east of Rocky Fork.

$d$ Depression on the open plains, 8 miles south of Kilburn.

$e$ Depression on the open plains, 10 miles southeast of Arlington. 


\section{IDAHO.}

In this State reservoir surveys have been made on the headwaters of Snake River, and to a less extent on streams flowing into this river from the north, in the southwestern part of the State. A general description is given in the Eleventh Annual Report, Part II, on pages 190 to 200 , and the engineering features are discussed in the Thirteenth Anuual Report, Part III, on pages 422 to 427 . Later surveys of reser-. voir sites on Blackfoot River are given in the Eighteenth Annual Report, Part IV, on pages 330 to 333 . Other reservoir surveys are described in this report.

\section{MONTANA.}

In Montana the most extensive surveys were made of Sun River, as described in the Eleventh Annual Report, Part II, on pages 113 to 133, and also in the Thirteenth Annual Report, Part III, on pages 371 to 386. The principal details concerning other reservoir sites are given in the following table, with reference to the volume where additional facts may be had:

Survey of reservoir sites in Montana.

\begin{tabular}{|c|c|c|c|c|c|c|c|c|}
\hline 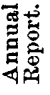 & Page. & No. & River. & $\begin{array}{c}\text { Drainage } \\
\text { area. }\end{array}$ & Altitude. & $\begin{array}{l}\text { Height } \\
\text { of dam: }\end{array}$ & $\begin{array}{c}\text { Area of } \\
\text { reser- } \\
\text { voir. }\end{array}$ & $\begin{array}{c}\text { Capacity } \\
\text { of reser. } \\
\text { voir. }\end{array}$ \\
\hline & & & & Sq. miles. & Feet. & Feet. & Acres. & Acre-feet. \\
\hline 13 & 374 & 1 & North Fork Sun River $a \ldots \ldots$ & 1,172 & & & 275 & 5,250 \\
\hline 13 & 375 & 2 & Sun River ..... & 1,136 & & 99 & 370 & 13,105 \\
\hline 13 & 376 & 3 & North Fork Sun River.... & 668 & & 121 & 1,100 & 51,400 \\
\hline 13 & 377 & 4 & {$[\ldots$ do $\ldots \ldots \ldots \ldots \ldots \ldots \ldots$} & 318 & & 113 & 581 & 20,315 \\
\hline 13 & 378 & 5 & Willow Creek . & 87 & & 84 & 1,600 & 38,600 \\
\hline 13 & 379 & 6 & .... do & 37 & & 22 & 378 & 6,550 \\
\hline 13 & 380 & 7 & Near Willow Creek $b . .$. & Small. & ... & 41 & 293 & 5,590 \\
\hline 13 & 381 & 8 & 1 mile north of reservoir No. 7 . & Small. & & 23 & 140 & 2,091 \\
\hline 13 & 382 & 9 & Below canal No. $2 \ldots \ldots \ldots$ & None. & & 35 & 72 & 812 \\
\hline 13 & 382 & 10 & Benton Lake........... & $\ldots$. & 3,610 & None. $c$ & 9.130 & 140,000 \\
\hline 12 & 127 & 11 & Flat in Meagher County $d$. & 10 & 5,000 & 15 & 30 & 160 \\
\hline 12 & 128 & 12 & Near Martinsdale $e . . . .$. & & $4,900-7,600$ & 40 & 40 & 800 \\
\hline 12 & 129 & 13 & Daisy Dean Creek .............. & 40 & $5,000-8,000$ & 15 & 20 & 105 \\
\hline 12 & 131 & 14 & East Branch Daisy Dean Creek & 18 & $4,800-8,000$ & 35 & 30 & 390 \\
\hline 12 & 132 & 15 & North Fork Musselshell River & 60 & $5,400-8,000$ & 35 & 40 & 520 \\
\hline 12 & 133 & 16 & South Fork Musselshell River & 95 & $5,000-8,500$ & 55 & 100 & $\cdots$ \\
\hline 12 & 133 & 17 & .....do do ....................... & $\therefore$ & $5,100-8,500$ & 20 & 25 & .......... \\
\hline 12 & 134 & 18 & Sixteenmile Creek. ........... & 90 & $5,500-7,000$ & 50 & 1,055 & 19,781 \\
\hline 12 & 137 & 19 & South Fork Smith River...... & 12 & $5,600-7,000$ & 25 & 120 & 1,125 \\
\hline 12 & 139 & 20 & .....do & 50 & $5,300-7,000$ & 30 & 110 & 1,230 \\
\hline 12 & 140 & 21 & Basin in Meagher County $f$... & $\ldots \ldots$ & 4,000 & 10 & 15 & \\
\hline 12 & 141 & $22-23$ & Basin on Mitchell Creek . & & & 15 & 50 & \\
\hline
\end{tabular}

$a$ See also Eleventh Annual Report, Part II, pp. 123-125.

$b 2$ miles west of reservoir No. 5 .

$c$ To be drained by a cut $1 \frac{1}{4}$ miles long and 35 feet maximum depth.

$d 2$ miles above Martinsdale.

$e$ Near North Fork Musselshell River.

$f 3$ miles west of Confederate Gulch.

20 GEOL, PT $4-3$ 
Survey of reservoir sites in Montana-Continued.

\begin{tabular}{|c|c|c|c|c|c|c|c|c|}
\hline 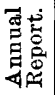 & Page. & No. & River. & $\begin{array}{c}\text { Drainage } \\
\text { area. }\end{array}$ & Altitude. & $\begin{array}{l}\text { Height } \\
\text { of dam. }\end{array}$ & $\begin{array}{c}\text { Area of } \\
\text { reser- } \\
\text { voir. }\end{array}$ & $\begin{array}{l}\text { Capacity } \\
\text { of reser- } \\
\text { voir. }\end{array}$ \\
\hline 12 & 142 & 24 & Big Hole River & sq. miltes. & $\begin{array}{c}\text { Feet. } \\
5,000-10,000\end{array}$ & $\begin{array}{l}\text { Feet. } \\
\quad 100\end{array}$ & $\begin{array}{l}\text { Acres. } \\
11,800\end{array}$ & Acre-feet. \\
\hline 12 & 147 & 25 & Blacktail Deer Creek.. & & $6,000-10,000$ & 40 & 600 & \\
\hline 12 & 148 & 26 & Beaver Head River ........ & & $5,400-10,000$ & 125 & 1,400 & \\
\hline 12 & 150 & 27 & Red Rock River ........ & - & $\ldots \ldots \ldots \ldots \ldots$ & 40 & 1,200 & $\ldots$ \\
\hline 12 & 152 & 28 & Ruby Rirer............. & & $5,300-10,000$ & 35 & 400 & \\
\hline 12 & 153 & 29 & Alkali Basin $a \ldots \ldots .$. & $\ldots$ & . & 20 & 2,800 & \\
\hline 12 & 155 & 30 & Dry Lake $a \ldots . . . . . .$. & & $\ldots \ldots \ldots \ldots$ & 15 & 200 & …..... \\
\hline 12 & 156 & 31 & Boxelder Creek............... & 85 & $3,600-7,000$ & 46 & 180 & 3,000 \\
\hline 12 & 158 & 32 & West Fork Otter Creek....... & ....... & $5,000-7,000$ & 66 & 70 & 1,500 \\
\hline 12 & 159 & 33 & Sage Creek ................. & 25 & $\$, 900-8,000$ & 21 & 30 & 250 \\
\hline 12 & 160 & 34 & Middle Fork Judith River.... & 120 & $5,000-8,000$ & 76 & 100 & 3,000 \\
\hline 12 & 161 & 35 & Dry Basin in Fergus County $b$ & & 4,900 & & 35 & 200 \\
\hline 12 & 162 & 36 & 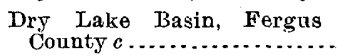 & & 4,900 & 3 & 55 & 350 \\
\hline 12 & 168 & 37 & Lebo Lake. ................... & ... & $5,000-9,000$ & 10 & ... & \\
\hline 12 & 164 & 38 & Flat in Meagher County $d . .$. & $\therefore$ & $6,000-8,000$ & 35 & 250 & \\
\hline
\end{tabular}

NEVADA.

The principal reservoir sites examined for the benefit of this State lie in California, on or near the headwaters of the Truckee, Carson, and other streams flowing from California into Nevada. These have been described under the heading "California." The details can be found in the Eleventh Annual Report, Part II, on pages 168 to 182, and in the Thirteenth Anuual Report, Part III, on pages 387 to 397. Reference should also be made to the surveys by Mr. L. H. Taylor noted on later pages of this report.

Surveys of reservoir sites in Nevada.

\begin{tabular}{|c|c|c|c|c|c|c|c|c|}
\hline 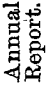 & Page. & No. & River. & $\begin{array}{c}\text { Drainage } \\
\text { area. }\end{array}$ & Altitude. & $\begin{array}{l}\text { Height } \\
\text { of dam. }\end{array}$ & $\begin{array}{l}\text { Area of } \\
\text { reservoir. }\end{array}$ & $\begin{array}{l}\text { Capacity } \\
\text { of reser- } \\
\text { voir. }\end{array}$ \\
\hline 12 & 209 & 1 & Truckee River............ & $\begin{array}{l}\text { Acres. } \\
\cdots 1,000\end{array}$ & $\begin{array}{c}\text { Feet. } \\
4,200-10,800\end{array}$ & $\begin{array}{l}\text { Feet. } \\
50\end{array}$ & $\begin{array}{r}\text { Acres. } \\
400\end{array}$ & $\begin{array}{c}\text { Acre.feet. } \\
7,500\end{array}$ \\
\hline 12 & 210 & 2 & $\therefore$. do $\ldots . . . \ldots \ldots \ldots \ldots$ & 1,000 & $4,200-10,800$ & 60 & 395 & 7,400 \\
\hline 13 & 394 & 17 & Long Valley Creek & & & $\begin{array}{r}60 \\
100\end{array}$ & 1,086 & 34,425 \\
\hline 13 & $\cdot 395$ & 18 & West Carson River. & $\ldots$ & 7,050 & .163 & 1,800 & 90,810 \\
\hline
\end{tabular}




\section{NEW MEXICO.}

A considerable number of small reservoir sites have been examined in this Territory, but comparatively few of these have been surveyed in detail. The results are given in the Eleventh Annual Report, Part II, on pages 145 to 150, and in the Twelfth Annual Report, Part II, on pages 165 to 208 .

Surveys of reservoir sites in New Mexico.

\begin{tabular}{|c|c|c|c|c|c|c|c|}
\hline 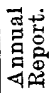 & Page. & No. & River. & Altitude. & $\begin{array}{l}\text { Height } \\
\text { of dam. }\end{array}$ & $\begin{array}{c}\text { Area } \\
\text { of reser- } \\
\text { voir. }\end{array}$ & $\begin{array}{c}\text { Capacity } \\
\text { of reser- } \\
\text { voir. }\end{array}$ \\
\hline 12 & 165 & 1 & $\begin{array}{c}\cdot \quad \cdot \quad \vdots \\
\ldots \ldots \ldots \ldots \ldots \ldots \ldots\end{array}$ & $\begin{array}{c}\cdot \quad \text { Feet. } \\
\ldots\end{array}$ & $\begin{array}{l}\text { Feet. } \\
40\end{array}$ & $\begin{array}{r}\text { Acres. } \\
1,120\end{array}$ & $\begin{array}{c}\text { Acre-feet } \\
21,000\end{array}$ \\
\hline 12 & 166 & 2 & Boulder Lake.... & 7,500 & 100 & 2,250 & 51,000 \\
\hline 12 & 168 & 3 & Stinking Lake... & 7,500 & 50 & 3,630 & 125,000 \\
\hline 12 & 169 & 4 & Vallecitos Creek & $7,000-8,000$ & 100 & 100 & 3,500 \\
\hline 12 & 169 & 5 & Near El Rito.. & $7,000-8,000$ & 150 & 60 & 3,000 \\
\hline 12 & 170 & 6 & Rio Vallecitos. & 7,000 & 80 & 60 & 1,800 \\
\hline 12 & 171 & 7 & Rio Caliente... & $7,000-8,000$ & 80 & 330 & 10,000 \\
\hline 12 & 173 & 8 & Rio Hondo..... & $\ldots \ldots \ldots \ldots$ & 100 & 50 & 1,000 \\
\hline 12 & 173 & 9 & Rio Colorado & $\cdots 8,000$ & 100 & 270 & 9,000 \\
\hline 12 & 174 & 10 & Rio Picuris ..... & $7,000-8,000$ & 60 & 62 & 1,200 \\
\hline 12 & 175 & 11 & Rio Picuris and Rio Lusio & $7,000-8,000$ & 80 & 236 & 6,000 \\
\hline 12 & 175 & 12 & Rio Grande.... & $6,000-13,000$ & 50 & 1,500 & 30,000 \\
\hline 12 & 177 & 13 & East Fork of Rio J & $\ldots \ldots \ldots \ldots$ & $\cdots$ & 4,030 & 18,000 \\
\hline 12 & 177 & 14 & Rio Jemez :....... & $9,000-10,000$ & $53 \frac{1}{2}$ & 256 & 5,000 \\
\hline 12 & 178 & 15 & $\ldots .$. do $\ldots . . . .$. & $8,500-11,000$ & 57 & 212 & 4,500 \\
\hline 12 & 179 & 16 & ....do ..... & $8,500-11,000$ & 58 & 575 & 13,000 \\
\hline 12 & 180 & 17 & ..... do ......... & ! & 70 & 1,046 & 32,000 \\
\hline 12 & 180 & 18 & Rio Salado.'. & $7,000-9,000$ & 60 & 155 & 3,700 \\
\hline 12 & 181 & 19 & Rio Jemez . . . . . & ...........: & $\therefore \quad 90$ & . 1,640 & 60,000 \\
\hline 12 & 182 & 20 & Santa Fe Creek .. & $8,000-12,000$ & 72 & $\therefore 40$ & 1,100 \\
\hline 12 & 183 & 21 & Rio Medio and Rio Frijo!e. & $6,000-10,000$ & 50 & 45 & 800 \\
\hline 12 & 183 & 22 & Rio Mora ....... & $7,000-10,000$ & --60 & $\cdot 620$ & 5,400 \\
\hline 12 & 184 & 23 & $\ldots \ldots$ do $\ldots . . . . .$. & $7,000-11,000$ & 90 & 1,770 & 38,000 \\
\hline 12 & 185 & 24 & Manuelitos and Las Tusas creek & $6,700-10,000$ & 100 & 1,037 & 41,000 \\
\hline 12 & 186 & 25 & Supplied from Rio Mora . ........ & $6,000-10,000$ & None. & 800 & 15,000 \\
\hline 12 . & 188 & 26 & Rio Gallinas ... & $6,000-7,000$ & 100 & 170 & 5,800 \\
\hline 12 & 189 & 27 & "Rio Pecos...... & $7,000-12,000$ & 75 & $\therefore 370$ & 8,800 \\
\hline 12 & 190 & 28 & ...... do ........ & $7,000-11,000$ & 82 & 250 & $\because 7,800$ \\
\hline 12 & 191 & 29 & Rio Grande .... & $6,000-12,000$ & 31 & 4,452 & 87,000 \\
\hline 12 & 192 & 30 & Rio San Jose .... & $6,000-8,000$ & 46 & 900 & 20,000 \\
\hline 12 & 193 & 31 & San Mateo Creek & $6,000-8,000$ & $43 \frac{1}{2}$ & 380 & $\cdot 5,500$ \\
\hline 12 & $19 \dot{4}$ & 32 & Bluewater Creek & 7,000 & 19 & 490 & 3,000 \\
\hline 12 & 195 & 33 & .....do . . . . . . & $7,000 \rightarrow 9,000$ & $74 \frac{1}{2}$ & 1,900 & 53,000 \\
\hline & & & · & . & & 82 & 680 . \\
\hline 12 & 198 & 34 & A gua Fria, Creek & $7,000-9,000$ & & 83 & 660 \\
\hline $12^{\prime}$ & 199 & 35 & Rio Colorado. & $6,000-7,000$ & $\begin{array}{r}36 \\
\because \quad 72 .\end{array}$ & $\begin{array}{r}128^{\circ} \\
\quad 420^{\circ}\end{array}$ & $\begin{array}{l}1,400 \\
1 ; 100\end{array}$ \\
\hline 12 & 200. & 36 & - Rio Salado .... & $6,000-8,000$ & $\because 68$ & 2,800 . & 63,000 \\
\hline 12 & 202 & 37 & Rio Alamosa........ & $6,000-7,000$ & 125 & 1,185 & 59,000 \\
\hline 12 & 203 & 38 & Rio Grande.. & & 80 & 5,540 & $175,000^{\circ}$ \\
\hline 12 & 208 & 39 & $\therefore \ldots$ do ${ }^{\prime} . . . .$. & 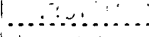 & $\because 40$ & 6,380 & 102,000 \\
\hline 13 & 410 & $\ldots$ & ...... do ......... & $\therefore \quad, 3,778$ & $\therefore 65$ & $26 ; 000$ & 537,000 \\
\hline
\end{tabular}




\section{UTAH.}

Reservoir surveys in this State have been made on the two great fresh-water lakes, Bear and Utah. The results of the survey of Utah Lake are given in the Eleventh Annual Report; Part II, on pages 70 to 74 and 183 to 184 . The conditions are also discussed in the Twelfth Annual Report, Part II, on pages 334 to 339. The survey of Bear Lake is described in the Twelfth Annual Report, Part II, on pages 327 to 329 , and in the Thirteenth Annual Report, on page 452. In addition to these, examinations have been made of reservoir sites mainly along the Sevier and its tributaries, as described in the Thirteenth Annual Report, Part III, on pages 451 to 478.

Surveys of reservoir sites in Utah.

\begin{tabular}{|c|c|c|c|c|c|c|c|c|}
\hline 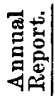 & Page. & No. & River. & $\begin{array}{c}\text { Drainage } \\
\text { area. }\end{array}$ & Altitude. & $\begin{array}{l}\text { Height } \\
\text { of dam. }\end{array}$ & $\begin{array}{c}\text { Area } \\
\text { of reser. } \\
\text { voir. }\end{array}$ & $\begin{array}{l}\text { Capacity } \\
\text { of reser- } \\
\text { voir. }\end{array}$ \\
\hline 13 & 452 & 1 & Bear Lake............ & $\begin{array}{r}\text { Acres. } \\
\quad 250\end{array}$ & $\begin{array}{c}\text { Feet. } \\
6,000-10,000\end{array}$ & $\begin{array}{l}\text { Feet. } \\
\ldots \ldots .\end{array}$ & $\begin{array}{l}\text { Acres. } \\
69,120\end{array}$ & $\begin{array}{l}\text { Acre-feet. } \\
208,000\end{array}$ \\
\hline 13 & 458 & 2 & Silver Lake..................... & 3 & 8,600 & 52 & 140 & 2,500 \\
\hline 13 & 460 & 3 & Twin Lakes .............. & 8 & 9,000 & 20 & 25 & 450 \\
\hline 13 & 460 & 4 & Marys Lake ............... & $\frac{3}{4}$ & 9,000 & 25 & 25 & 550 \\
\hline 13 & 461 & 5 & Sevier River............. & 5,000 & 4,600 & 16 & 940 & 10,000 \\
\hline 13 & 463 & 6 & San Pete River... & 500 & 5,100 & 22 & 830 & 9,000 \\
\hline 13 & 465 & 7 & Sevier River...... & 2,500 & 5,700 & 10 & 290 & 1,600 \\
\hline 13 & 466 & 8 & East Fork Sevier River... & 700 & 6,200 & $12 \frac{1}{2}$ & 460 & 3,000 \\
\hline 13 & 468 & 9 & Otter Creek $\ldots . . . \ldots \ldots \ldots$ & 500 & 6,200 & 15 & 1,860 & 14,000 \\
\hline 13 & 470 & 10 & East Fork Sevier Rirer......... & 575 & 7,000 & 50 & 3,050 & 76,000 \\
\hline 13 & 473 & 11 & $\ldots \ldots$. do $\ldots \ldots \ldots \ldots \ldots \ldots \ldots$ & 300 & 7,200 & 10 & 770 & 3,500 \\
\hline 13 & 475 & 12 & Panguitch Lake ...... & 80 & 8,100 & 10 & 1,280 & 10,700 \\
\hline 13 & 477 & 13 & Blue Spring $a \ldots \ldots \ldots \ldots \ldots \ldots$ & 25 & 8,200 & 48 & 440 & 13,000 \\
\hline
\end{tabular}

$a$ Two miles southwest of Panguitch Lake.

PRESENT CONDITIONS.

From the foregoing statements and tables it appears that a large number of reservoir sites have been discovered, many of these surveyed, and for some of them definite estimates prepared, based upon certain assumptions as to the character of dam needed. The bringing of these to public attention has resulted in much correspondence regarding their use and in discussion, both public and private, as to the opportunities for water conservation. In a few instances the dams have been constructed and the reservoirs are now supplying the needed water to lands under irrigation, but in the majority of cases no action has resulted. This is particularly true with the larger or more valuable sites, the water from which must be distributed among a number of ditches or communities. The great cost involved and the doubts as to methods of equable distribution of the water are such as to cause indefinite delay. 
One fact has come prominently forward during the last ten years, since the inauguration of the reservoir work, and that is that water storage on a large scale can rarely be made profitable to individuals or corporations. Water conservation is expensive at best, and existing conditions, laws, and customs are such that the person who builds a dam on the headwaters of a stream is rarely in a position to be benefited financially by the water which he impounds. The capitalists who have put their money into such enterprises have involuntarily become philanthropists-benefactors of their fellow-men, but not gainers themselves to a notable degree. The community as a whole is unquestionably enriched, directly or indirectly, to an extent many times the first cost of the works, but these benefits can not redound wholly to the constructors. When the reservoir surveys were begun it was believed by many persons that the sites would be eagerly seized upon and that construction would immediately follow; but out of many possible localities very few have been found to be so favorably situated as to attract the investors; nevertheless, the discovery of these few is undoubtedly worth the expenditure.

While reservoirs in general can not be made sources of profit to the investors, there is no gainsaying the fact that they are indispensable to the community. They may be classed with light-houses and other works of internal improvement, which under existing laws and customs can not be made sources of private gain, and yet must be had if a full development of the natural resources is to be attained.

The one great demand of the western half of the United States is for more water during times of scarcity. This has been particularly accentuated by the droughts of 1898, when millions of dollars were lost through lack of ordinary supply. It is highly probable that the aggregate losses to the communities, if these could have been put in the form of works for conserving water, would have repaid the cost of all such works. Such losses are so distributed and far-reaching that it is, of course, impossible to segregate them or to indicate definitely the individuals most deeply concerned. They are, moreover, of such character that only the community as a whole is competent to guard against them, individual or even corporate action not being possible. The State or the nation must in some way provide the means by which disasters of this kind may in the future be avoided.

The most remarkable change has taken place in public opinion within the last decade. Ten years ago it was commonly asserted that every acre of the arid land could be reclaimed. When it was first shown that the water supply, if conserved to its utmost, would only suffice for the utilization of a small part of the arid land, the facts would not be accepted by the people of the West. Now there is no longer talk of irrigating every acre of the fertile lands of the arid region, and comparatively little interest is displayed as to whether 10 or 15 per cent of these lands can be reclaimed. Public sentiment is now concentrated 
on the question as to how the relatively small quantity of water can be conserved for the largest use, it being apparent that by such conservation a population of millions can be directly or indirectly sustained.

The stream measurements carried on at various typical localities have been so diffused as to afford as much data as possible concerning the water resources of the country. They have shown that for many locali. ties there has been sufficient water flowing at times of floods, and inferentially that similar conditions exist elsewhere. There is thus no question as to the fact that in general a large quantity of water exists during spring, and that this can be held in certain reservoirs at least until time of need, but the question still unanswered is; By what means can this water conservation be brought about?

To sum up the present conditions of reservoir surveys, it may be stated that at scattered localities throughout the great arid region numerous reservoir sites have been surveyed and that some of these have been constructed; others still more important may be built, but probably this can not be done with direct financial profit. The great body of the public lands has not yet been examined in detail; but as fast as means will permit, reservoir surveys are being conducted on a small scale. These should be extended whenever practicable. The United States is still the owner of one-third of its whole area, exclusive of Alaska, an area three times as great as the thirteen original States. This one-third contains not only great resources in minerals and grazing, but also immense tracts of rich agricultural land capable of supporting a population of many millions wherever sufficient water can be had. The utilization of this public land, or any considerable portion of it, and the development of the resources of the western half of the country are practically at a standstill owing to the lack of water conservation. The measurements of this survey have shown that during each year great volumes of water run to waste, much of which could be held by storage in natural reservoir sites already surveyed or believed to exist among the high mountains and upon Government land. In order that these sites may be utilized, whether by the individual or by the community, it is necessary to continue and extend accurate surveys and to obtain correct information as to the location, capacity, and probable cost of construction.

\section{REQUISITES FOR SUCCESS.}

In determining the possible use or value of various reservoir sites there are many considerations which must be borne in mind. Some of these modify, if they do not completely prevent, the utilization of the reservoir. Remarks have already been made upon the fact that financial failure is not incompatible with the success of a reservoir in other ways; that is to say, a reservoir may be of very great benefit, returning to the community many times its first cost, and yet not pay its owners. Without dwelling upon this detail it is necessary to consider 
some of the conditions which must be fulfilled in order to result in the reclamation of arid lands.

In almost every locality a number of places are pointed out as being suitable for water conservation. Hundreds of these have been examined and comparatively few found worthy of survey. As a rule, inspection shows that the capacity of the basin is too small for the height of the proposed dam, or, in other words, that the slope of the bottom of the reservoir is too great. This is the most common source of error, as very few people properly note the rapid slope of upland valleys. To hold water in some of these would require a dam so high as to be entirely out of the question. The relation of depth and capacity of several of the best-known reservoirs of the country is shown graphically in figs. 4, 5, and 6. The data upon which these diagrams have been based have been obtained largely from the paper by Mr. James D. Schuyler upon Reservoirs for Irrigation, printed in the Fourteenth Annual Report, Part IV. Additional facts have also been had from the report by Colonel Chittenden, mentioned below. In each of these diagrams the vertical distance represents the depth in feet and the horizontal distance the capacity in acre-feet. In figs. 4 and 5 the same values have been given for the horizontal spaces, but in fig. 6 these are greatly increased. For convenience of comparison of these two scales the curve representative of the proposed reservoir at Warner's ranch, in southern California, has been plotted both on fig. 4 and on fig. 6 .

Favorable conditions for the erection of a dam are also necessary. It occasionally happens that in order to inclose a basin of sufficient capacity the length of darn will be so enormous as to be impracticable; in other cases the foundations must be placed in unconsolidated or fractured material, necessitating excavations of great depth. Some of the gorges draining valleys have been at a previous time excavated below their present surface, and the filling of sand and gravel extends to extraordinary depths.

Where the combination of ample capacity and a good locality for a dam exists, it may happen that there is not sufficient tributary watershed to furnish supply enough to fill the reservoir each year. Many of the best open valleys or marshes exist so near the summits of the mountains that there is not a sufficient eatchment area. In such cases it is sometimes possible to divert water from one or more upper drainage basins, and, by flumes and tunnels, to concentrate this into the desired reservoir site.

On the other hand, the reservoir may be so situated as to have a catchment area too great for safety. This is particularly the case where a dam is located upon a main drainage line receiving storm waters from many square iniles. A cloudburst or general storm may send down a flood of such dimensions as to fill the reservoir and overtop the dam, washing it away, if of earth, as was the case at the time of the Johnstown flood. To meet such emergencies there must be opportunity for 
40 PROGRESS OF STREAM MEASUREMENTS FOR 1898.

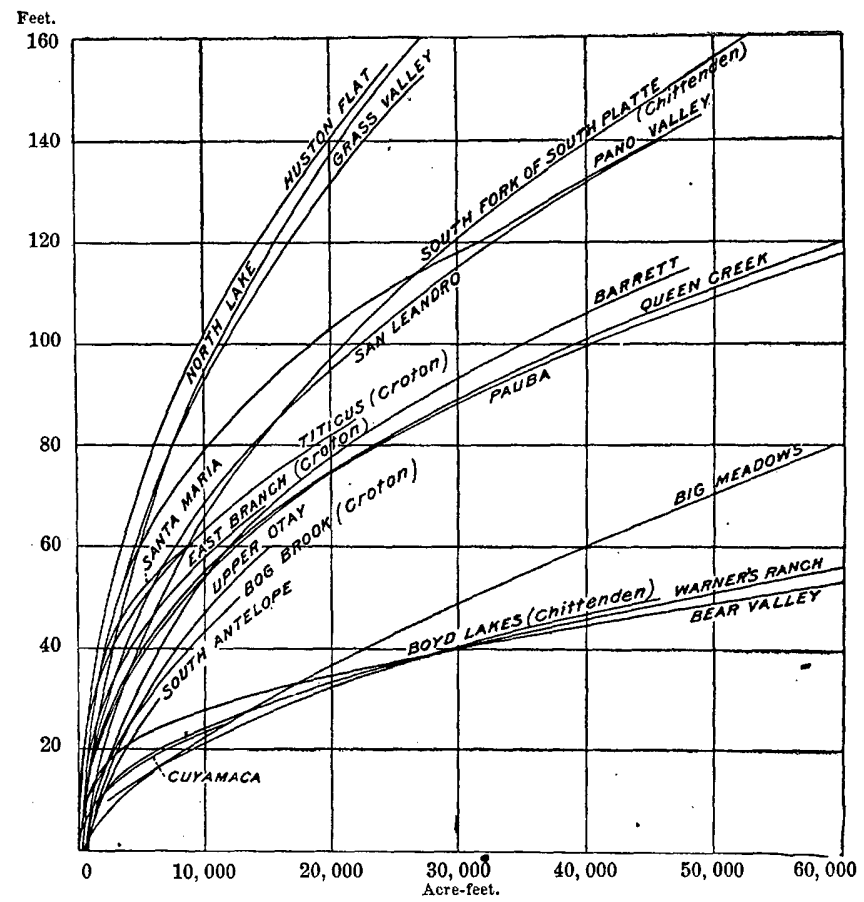

Fig. 4.-Comparison of depth and capacity of various reservoirs.

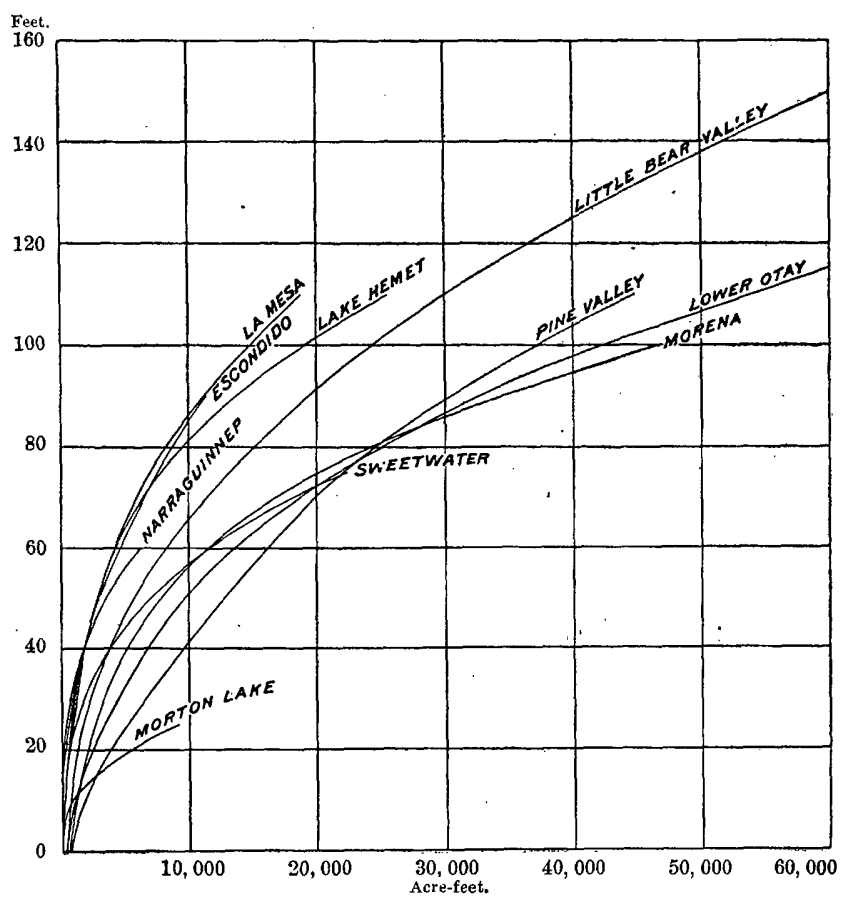

Fig. 5.-Comparison of depth and capacity of various reservoirs. 
the construction of enormous wasteways around the dam, or if these can not be built the dam itself must be made of such substantial masonry that water can pour over its top, as has been the case with the Sweetwater dam of southern California.

Although the dam and the wasteways may be of such character as to withstand the onset of any flood, yet there is still another danger to be guarded against-the bringing down of vast quantities of sand, gravel, and clay, which are dropped in the comparatively still water behind the dam, thus gradually filling the reservoir and destroying its usefulness. There is no economical method of cleaning out a reservoir of large size, and when once filled it must probably be abandoned or the dam raised to a still greater height.

As a safeguard against floods and against silting up the reservoir, attempts are made wherever practicable to find sites upon smaller tributaries and to conduct water to these from the main stream by

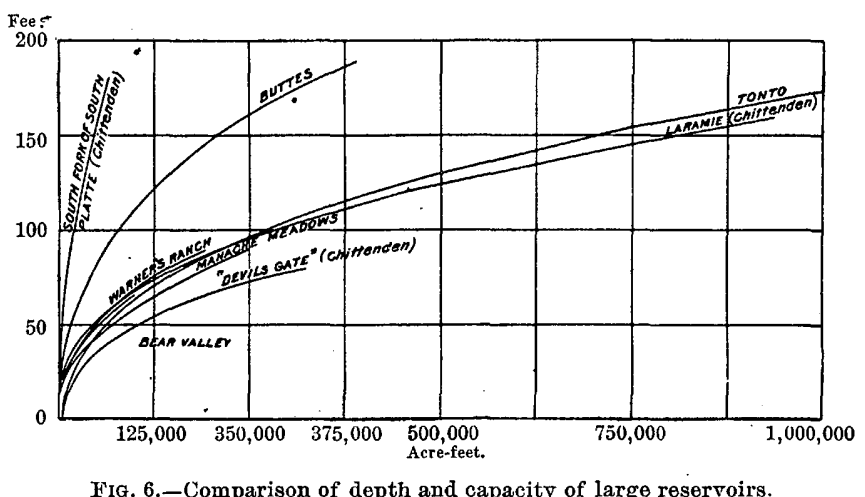

means of large diversion canals. In this way the flood waters can be received with safety, as their quantity is restricted by the capacity of the canal and the silt is in large part dropped on the way and disposed of by means of various well-known engineering devices.

From a consideration of these and other qualifications it is apparent that out of the large number of reservoirs examined very few can be expected to possess the elements of success. Thus it is necessary to go over the country with considerable thoroughness and to consider many questions before it is possible to point out the localities where the largest results can be obtained with a reasonable exṕenditure. It is this fact that good reservoir sites are scarce that renders it imperative to push forward the reconnaissance map of the West, and to follow this by detailed examinations by which it is possible to point out the localities where construction work may be attempted with reasonable assurance of success. 


\section{CAPACITY AND COST OF RESERVOIRS.}

In previous pages reference has been made to estimates of the cost of reservoir construction. For convenience of comparison it is important to have in mind not only the total expenditure but also the cost per unit of capacity. The most convenient unit for this purpose is the acre-foot, or 43,560 cubic feet, as this gives immediately the useful efficiency of a reservoir with respect to its ability to supply water for irrigation purposes. It is often assumed that 1 acre-foot of stored water will irrigate an acre of ground. Tables of cost have been prepared by various persons, particularly by Mr. H. M. Wilson ${ }^{1}$ and by Col. Hiram M. Chittenden. ${ }^{2}$ The data obtained by the latter are combined in the following table. From this it is apparent that the cost per acre-foot varies widely, from the expensive masonry construction of foreign countries and of southern California to the cheaper projects, such as those at the head of the Mississippi River. In the case of the latter, water storage has been provided by closing or raising the outlet of existing lakes or marshes.

Cost of reservoir construction per acre-foot. ${ }^{2}$

\begin{tabular}{|c|c|c|c|c|}
\hline Name. & Kind of dam. & $\begin{array}{c}\text { Capacity in } \\
\text { acre-feet. }\end{array}$ & Cost. & $\begin{array}{l}\text { Cost per } \\
\text { acre-foot. }\end{array}$ \\
\hline AMERICAN. & & & & \\
\hline Escondido, California......... & Rockfill .... & 3,500 & $\$ 110,059$ & $\$ 31.44$ \\
\hline Cuyamaca, Califorvia........ & Earth ..... & 11,410 & 56,400 & 4. 94 \\
\hline Pecos River, Texas: & & & & \\
\hline Lowe. reservoir .......... & ..... do ........ & 6,300 & 176,000 & 27.93 \\
\hline Üpper reservoir, or Lake & & & & \\
\hline Mèillan :- & $\ldots$ do .... & 89,000 & 200,000 & 2.25 \\
\hline Tyler, Texas............... & Hydraulic..... & 24,000 & 1,140 & .05 \\
\hline Sweetwater, California ....... & Masonry ...... & 22,566 & 264,074 & 11. 70 \\
\hline Bear Valley, California . . . . & $\ldots$ do ... & 40,000 & 75,000 & 1.87 \\
\hline Cache la Poudre, Colorado .... & Dike.... & 5,654 & 125,000 & 22.00 \\
\hline Larimer and Weld, Colorado & .....do .. & 7,461 & 90,000 & 12.00 \\
\hline . & Timber and & $2,146,463$ & 678,842 & .32 \\
\hline Upper Mississippi reservoirs & earth. & & & \\
\hline & .... do .. & $a 920,000$ & 678,842 & .74 \\
\hline FOREIGN. & & & & \\
\hline Couzon, France............. & Masonry...... & 1,297 & 247,600 & 190.00 \\
\hline Gouffre d'Enfer, France & $\therefore$ do & 1,297 & 318,000 & 245.00 \\
\hline
\end{tabular}

1 Manual of Irrigation Engineering, by Herbert M. Wilson, second edition, 1897, p. 377.

${ }^{2}$ Preliminary examination of reservoir sites in Wyoming and Colorado, by Col. Hiram M. Chitten den, Fifty-fifth Congress, second session, House of Representatires, Doc. No. 141, 1898, p. 28.

$a$ Capacity of the Upper Mississippi reservoirs on a basis of the estimated average annual storage. 
Cost of reservoir construction per acre-foot-Continued.

\begin{tabular}{|c|c|c|c|c|}
\hline Name. & Kind of dam. & $\begin{array}{l}\text { Capacity in } \\
\text { acre-feet. }\end{array}$ & Cost. & $\begin{array}{l}\text { Cost per } \\
\text { acre-foot. }\end{array}$ \\
\hline FOREIGN-continued. & & & & \\
\hline Ternay, France .......... & Masonry ...... & 2,433 & $\$ 204,372$ & $\$ 84.00$ \\
\hline Ban, France ........... & $\ldots \ldots$ do $\ldots . . .$. & 1,499 & 190,000 & 127.00 \\
\hline Pas du Riot, France .... & $\ldots .$. do $\ldots .$. & 1,054 & 256,000 & 243.00 \\
\hline Chartrain, France ....... & $\ldots . .$. do $\ldots . . . .$. & 3,243 & 420,000 & 129.00 \\
\hline Lake Oredon, France.... & Earth ..... & 5,894 & 142,000 & 24.00 \\
\hline Mouche, France........ & ....do..... & 7,011 & $1,003,657$ & 143.00 \\
\hline Liez, France....... & ..... do ........ & 13,051 & 598,418 & 46.00 \\
\hline Wassy, France......... & $\ldots$ do ........ & 1,740 & 138,942 & 80.00 \\
\hline Patas, India ............. & ....do do.... & 325 & 15,925 & 49.00 \\
\hline Ekruk, India............ & $\begin{array}{l}\text { Earth aud ma- } \\
\text { sonrý. }\end{array}$ & 76,175 & 359,000 & 4.70 \\
\hline $\begin{array}{c}\text { Sixteen reservoirs in Bomba } \\
\text { PROPOSED. }\end{array}$ & & 235,812 & $2,593,932$ & $a 11.00$ \\
\hline Manacbe Meadows, California. & Rockfill ....... & 248,850 & 150,000 & .61 \\
\hline Lake, California.......... & $\ldots$ do ...... & 46,600 & 225,000 & 4.83 \\
\hline Big Meadows, California... & . ... do ........ & 31,150 & 80,000 & 2.57 \\
\hline Riverside County, California & Masonry ...... & 61,500 & 400,000 & 6.50 \\
\hline $\begin{array}{l}\text { Upper Narrows Mojave River, } \\
\text { California. }\end{array}$ & $\ldots .$. do $\ldots . .$. & 390,000 & $1,742,000$ & 4.50 \\
\hline Alpine, California ......... & $\begin{array}{l}\text { Natural basin } \\
\text { and dike. }\end{array}$ & 5,500 & 100,000 & 18.00 \\
\hline Rio Verde system, Arizona. & Rockfill. ...... & $1,618,093$ & $4,000,000$ & 2.47 \\
\hline Buttes, Arizona .......... & Masonry ... & 207,795 & $2,244,000$ & 11.00 \\
\hline Queen Creek, Arizona ..... & Rockfill... & 59,665 & 221,000 & 3.70 \\
\hline $\begin{array}{l}\text { Little Colorado River system, } \\
\text { Arizona. }\end{array}$ & $\begin{array}{l}\text { Earth and rock- } \\
\text { fill. }\end{array}$ & 353,500 & 357,000 & 1.00 \\
\hline Rock Creek, Nevada..... & Rockfill... & 80,000 & 80,000 & 1.00 \\
\hline Antero, Colorado ....... & Earth ..... & 50,640 & 140,000 & 2.76 \\
\hline Great Miami, Ohio .... & & 68,870 & 690,000 & 10.00 \\
\hline Big Cuyahoga, Ohio... & & 66,587 & 600,000 & 9.00 \\
\hline Big Scioto, Ohio.......... & & 114,784 & $1,500,000$ & 13.00 \\
\hline Laramie, wyoming....... & & 414,000 & $1,416,254$ & 3.42 \\
\hline Do............... & & $b 46,000$ & 416,254 & 9.05 \\
\hline Sweetwater, Wyoming .. & & 326,965 & 276,484 & .85 \\
\hline Do................... & & $b 100,000$ & 276,484 & 2.76 \\
\hline South Platte, Colorado ....... & & 67,211 & 540,000 & 8.04 \\
\hline Do... & & $b 41,320$ & 540,000 & 13.07 \\
\hline
\end{tabular}

a Average.

$b$ Revised estimate of capacity based upon aunual supply immediately in sight, with allowance for evaporation. 


\section{UNDERGROUND WATERS.}

Investigations of the conditions covering the distribution and availability of underground waters have been carried on in various localities during 1898. The most important work of this class has been that done by Mr. N.H. Darton in the area immediately east of the Black Hills, in South Dakota, extending into the Bad Lands. Mr. Darton has made an extended reconnaissance of the adjacent area and a special study of the Hermosa quadrangle, with the intention of preparing a geological folio similar in many respects to the Pueblo folio, prepared by Mr. G. K. Gilbert.

In eastern South Dakota Prof. J. E. Todd, State geologist, has been mapping the artesian waters, this work being carried on in cooperation with Mr. Darton. Upon the Parker and Olivet topographic atlas sheets Professor Todd has not only shown the surface geology by colors, but has indicated by conventional lines the depth to the principal water-bearing horizon. The phenomena of artesian supply are thus being examined in the Black Hills region, from which the water is supposed to come, and in the James River Valley, where the wells have greatest economic importance.

\section{ARTESIAN WELLS.}

In addition to the detailed studies of artesian conditions above mentioned, facts have been accumulated concerning the artesian wells in various parts of the West. These have considerable importance in the development of certain localities, although in comparison with gravity supply from streams they sink into insignificance. On later pages will be found reference to some of the important wells of the State of Washington. A catalogue of all deep borings of this character is being prepared by Mr. Darton, with a view to early publication.

Developments of known artesian areas have been proceeding rapidly, especially when reliable facts as to the depth and quality of the water have been made matters of record.

\section{PUMPING WATER.}

The wells from which water must be had.by pumping have in the aggregate far greater importance in the development of the arid region than the flowing wells, from the fact that water can be had at moderate depth in most valleys, especially near the gravel-filled drainage channels. Various forms of power are being utilized for operating pumps raising water for irrigation purposes. Steam and gasoline are thus employed, and in some cases animal power, but the most efficient and economical device and the one in greatest use is the windmill.

\section{WINDMILLS.}

On account of the great importance of windmills in raising water for irrigation considerable attention has been given to studies of their efficiency and adaptability for local conditions. A number of publications 
were issued in 1898 bearing upon this subject. One of these, known as Water-Supply and Irrigation Paper No.14, gives the results of tests of various pumps and water lifts used in irrigation. Another (No. 20) gives the results of experiments with various forms of wind wheels, these being carried on by Mr. Thomas O. Perry. In addition, data has been accumulated by Prof. E. C. Murphy for windmills operating under conditions prevailing in Kansas, while for Nebraska Prof. E. H. Barbour, State geologist, has brought together facts concerning the wells and windmills, this material being printed in Water-Supply and Irrigation Paper No. 29.

Throughout the Great Plains region, from Texas to Montana, water is found in many places at moderate depth beneath the surface, but in small quantities. In order to raise this to the surface innumerable small pumping plants must be employed; in other words, power must be widely distributed. The cheapest power, and one existing almost continually throughout the year, is the wind. The extended use of the windmill in irrigation is therefore in a large way one of the most important steps toward the development of the resources of this great section of the United States. Its adaptation to various local requirements is a matter which may well engage the attention of inventors and citizens concerned in the prosperity of the country.

\section{RÉSUMÉ OF DISCHARGE DATA.}

For convenience of comparison of the volume and fluctuations of the various streams measured during 1898 and preceding years the following table has been prepared, giving the maximum, minimum, and mean discharge for each year during which measurements were made. The quantities of discharge are given in cubic feet per second, or second-feet. The table gives first the name of the river and next the locality at which measurements were made, and adjacent to this the volume and page from which the data have been taken, and by reference to which more complete information can be had. This reference is abbreviated. For example, "19-75" is intended to mean the Nineteenth Annual Report, Part IV, Hydrography, page 75; "20-100" means the Twentieth Annual Report, Part IV, Hydrography (this volume), page 100. In the column next to the reference is given the year during which measurements were made, and next to this the drainage area in square miles. The maximum discharge is the greatest estimated discharge for the year, extending usually throughout the day or a considerable portion of the day; the minimum discharge is the lowest flow for any one day during the year, and the mean is the average for all of the days in the year, including both the highest and the lowest. This mean is obtained by averaging the means for the several months. The run-off is stated in two ways, first in cubic feet per second per square mile, and next in depth in inches over the whole drainage basin; in other words, the quantity of water discharged by the stream throughout the whole year would cover a plain of equal size to a depth of the number of inches 
given. After this, for convenience of comparison, are given figures of estimated or approximate annual rainfall as derived from one or more points of observation in the drainage basin. These have been obtained mainly through the courtesy of Hon. Willis L. Moore, Chief of the Weather Bureau, cr of his assistants.

Résumé of discharge data.

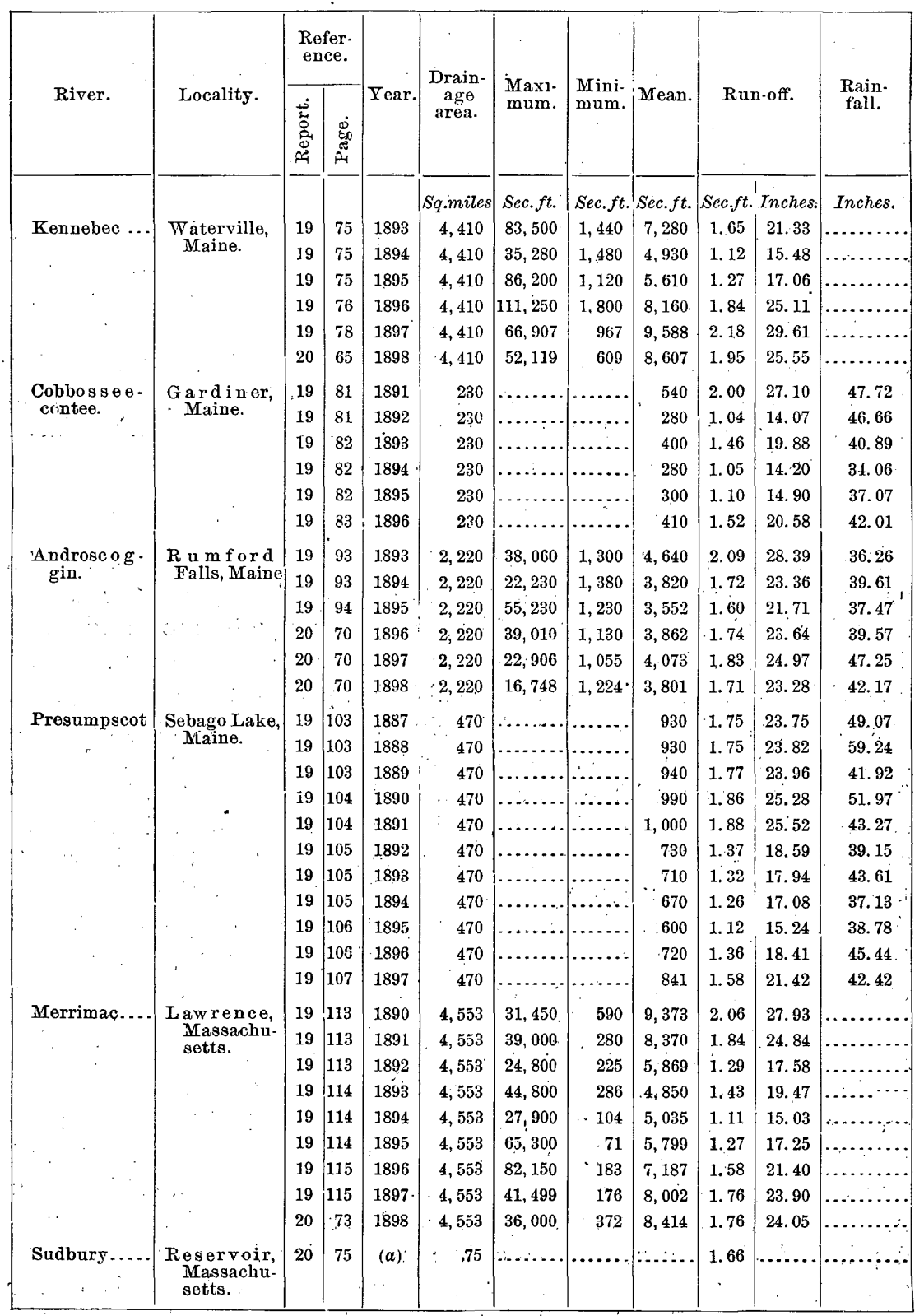

a Mean of twenty-four years' observations, 1875 to 1898 inclusive. 
Résumé of dịscharge data-Continued.

\begin{tabular}{|c|c|c|c|c|c|c|c|c|c|c|c|}
\hline \multirow{2}{*}{ River. } & \multirow[b]{2}{*}{ Locality. } & \multicolumn{2}{|c|}{$\begin{array}{l}\text { Refer- } \\
\text { ence. }\end{array}$} & \multirow[b]{2}{*}{ Year. } & \multirow{2}{*}{$\begin{array}{l}\text { Drain- } \\
\text { age } \\
\text { area. }\end{array}$} & \multirow{2}{*}{$\begin{array}{l}\text { Maxi- } \\
\text { mum.. }\end{array}$} & \multirow{2}{*}{$\begin{array}{l}\text { Minj- } \\
\text { mum. }\end{array}$} & \multirow[b]{2}{*}{ Mean. } & \multirow{2}{*}{\multicolumn{2}{|c|}{ Run-off. }} & \multirow[b]{2}{*}{ Rainfall. } \\
\hline & & & & & & & & & & & \\
\hline & & & & & Sq.miles & Sec.ft. & Sec.ft. & Sec.ft. & Sec.ft & Inches. & Inches. \\
\hline Connecticut . & Hartford, & 14 & 141 & $a 1871$ & 10,234 & 87,460 & 5,520 & 17,433 & 1.70 & 21.11 & 37.70 \\
\hline . & 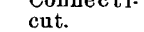 & 14 & 141 & 1872 & 10,234 & 98,100 & 6,250 & 19,335 & 1.89 & 26.71 & 46.71 \\
\hline & & 14 & 142 & 1873 & 10,234 & 109,800 & 5,390 & 23,061 & 2.25 & 30.62 & 43.85 \\
\hline . $\quad$. & & 14 & 142 & 1874 & 10,234 & 134,000 & 5,210 & 23,340 & 2.28 & 30.81 & 43.24 \\
\hline & & 14 & 142 & 1875 & 10,234 & 90,100 & 5,700 & 18,114 & 1.77 & 23.95 & 43.07 \\
\hline & & 14 & 142 & 1876 & 10,234 & 120,800 & 5,360 & 22,080 & 2.15 & 29.15 & 48.18 \\
\hline$\therefore$ & & 14 & 142 & 1877 & 10,234 & 128,200 & 5,700 & 16,683 & 1.63 & 22.09 & 42.92 \\
\hline & & 14 & 143 & 1878 & 10,234 & 89,350 & 5,350 & 20,766 & 2.02 & 27.51 & 50.20 \\
\hline & & 14 & 143 & 1879 & 10,234 & 116,400 & 5,550 & 18,852 & 1.81 & 24.91 & 47.24 \\
\hline & & 14 & 143 & 1880 . & 10,231 & 65,550 & 5,200 & 13,720 & 1.34 & 18.25 & 40.02 \\
\hline & & 14 & 143 & $1881^{\circ}$ & 10,234 & 74,000 & 5,250 & 18,026 & 1.76 & 23.88 & 46.93 \\
\hline & & 14 & 143 & 1884 & 10,234 & 74,700 & 5,150 & 19,861 & 1.94 & 27.30 & 45.15 \\
\hline & & 14 & 144 & 1885 & 10,234 & 88,600 & 5,300 & 17,775 & 1.73 & 23.45 & 43.62 \\
\hline Connecticut. & Ho l $\mathrm{y}$ o k e, & (b) & 38 & 1880 & 8,660 & 44,100 & 300 & 8,343 & 0.96 & 89 & \\
\hline & $\begin{array}{l}\text { Massachu- } \\
\text { setts. } b\end{array}$ & & 38 & 1881 & 8,660 & 49,050 & 450 & 9,818 & 1.13 & 15.53 & \\
\hline & & & 38 & 1882 & 8,660 & 45,000 & 250 & 10,018 & 1.14 & 15.40 & \\
\hline & & & 38 & 1883 & 8,660 & 68,300 & 250 & 8,107 & 0.94 & 12.70 & \\
\hline .. & & & 38 & 1884 & 8,660 & 71,900 & 500 & 13,084 & 1.51 & 20.46 & \\
\hline . & & & 39 & 1885 & 8,660 & 63,950 & 2,950 & 12,635 & 1.46 & 19.65 & \\
\hline$\cdots$ & & & 39 & 1886 & 8,660 & 80,150 & 550 & 11,387 & 1. 31 & 17.73 & \\
\hline$\cdots$ & & & 39 & 1887 & 8,660 & 85,500 & 3,300 & 14,329 & 1. 65 & 32 & \\
\hline$\cdots \cdots$ & & & 39 & 1888 & 8,660 & 99,750 & 1,100 & 17,320 & 2.00 & 27.15 & \\
\hline$\cdots \cdots$ & & & 39 & 1889 & 8,660 & 37,650 & 1,350 & 13,903 & 1.59 & 21.50 & \\
\hline & & & 40 & 1890 & 8,660 & 46,750 & 550 & 15,556 & 1.78 & 24.12 & \\
\hline . . & $\therefore$ & & 40 & 1891 & 8,660 & 67,300 & 900 & 13,190 & 1.51 & 21.48 & \\
\hline.$\quad$. & & & 40 & 1892 & 8,660 & 63,100 & 1,860 & 12,273 & 1.48 & 20.15 & \\
\hline 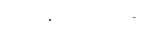 & & & 40 & 1893 & 8,660 & 94,3 & 750 & 10,295 & 1.19 & 16.19 & \\
\hline & & & 40 & 1894 & 8,660 & 43,300 & 150 & 8,397 & 0.97 & 13.17 & \\
\hline & & & 41 & 1895 & 8,660 & 115,000 & 350 & 10,214 & 1.20 & 16. 19 & \\
\hline & & 19 & 116 & 1896 & 8,660 & 112,050 & 450 & 12,394 & 1.43 & 19.41 & \\
\hline${ }^{\circ}$ & & 19 & 116 & 1897 & 8,660 & 75 , & 1,300 & 15,373 & 1. 78 & 24.17 & \\
\hline$\ldots$. & & 20 & 76 & 1898 & 8,660 & 76,150 & 600 & 13,844 & 1.60 & 1.70 & \\
\hline . Hudson... & Mec & 19 & 119 & 1890 & 4,500 & 26,000 & 1,030 & 8,749 & 1.94 & 26. 38 & \\
\hline$\ldots . .$. & & 19 & 119 & 1891 & 4,500 & 33,100 & . 850 & 7,302 & 1.62 & 21.90 & \\
\hline & & $19^{-}$ & 120 & 1892 & 4,500 & 43,910 & 2,440 & 10,532 & 2.34 & 31.87 & \\
\hline & & 19 & 120 & 1893 & 4,500 & 54,060 & 1,380 & 7,562 & 1.68 & 22.85 & \\
\hline & & 19 & 120 & 1894 & 4,500 & 26,560 & 1,170 & 6,170 & 1:37 & 18.62 & \\
\hline & 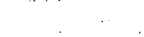 & 19 & 121 & 1895 & 4,500 & 49,630 & 540 & 6,345 & 1.41 & 19.08 & \\
\hline & & 19 & 121 & 1896 & 4,500 & 59,393 & 1,770 & 7,487 & 1.66 & 22.62 & \\
\hline & & 19 & 122 & 1897 & 4,500 & 35,706 & 2,150 & 9,352 & 2.08 & 28.28 & \\
\hline$\therefore$ & 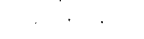 & 20 & 81 & 1898 & 4,500 & 39,389 & 1,763 & 8,244 & 1.33 & 24.90 & \\
\hline Croton........ & $\underset{\text { York. }}{\text { Dam, }}$ & 20 & 83 & (d) & & & & & & 24.65 & 48.58 \\
\hline
\end{tabular}

a January lacking

$b$ Bulletin U. S. Geol. Survey No. 140, pages 37 to 41 .

$c$ See also report by Geo. W. Rafter on Water Resources of the State of New York: Water-Supply and Irrigation Papers Nos. 24 and 25.

$d$ Mean of twenty-nine years' observations, 1870 to 1898 inclusive. 
Résumé of discharge data-Continued.

\begin{tabular}{|c|c|c|c|c|c|c|c|c|c|c|c|}
\hline \multirow{2}{*}{$\begin{array}{c}\text { ' } \\
\text { River. }\end{array}$} & \multirow{2}{*}{ Locality. } & \multicolumn{2}{|c|}{$\begin{array}{l}\text { Refer- } \\
\text { ence. }\end{array}$} & \multirow{2}{*}{ Year. } & \multirow{2}{*}{$\begin{array}{c}\text { Drain. } \\
\text { age } \\
\text { area. }\end{array}$} & \multirow{2}{*}{$\begin{array}{l}\text { Maxi- } \\
\text { mum. }\end{array}$} & \multirow{2}{*}{$\begin{array}{l}\text { Mini. } \\
\text { mum. }\end{array}$} & \multirow{2}{*}{ Mean. } & \multirow{2}{*}{\multicolumn{2}{|c|}{ Run-off. }} & \multirow{2}{*}{ Rainfall. } \\
\hline & & & & & & & & & & & \\
\hline \multirow{10}{*}{ Perkiomen .. } & \multirow{10}{*}{$\begin{array}{l}\text { Frederick, } \\
\text { Pennsyl- } \\
\text { vania. }\end{array}$} & & & & Sq.miles & Sec. ft. & Sec. ft. & Sec. ft. & Sec,ft. & Inches. & Inches. \\
\hline & & 20 & 90 & 1890 & 152 & 4,048 & 37 & 290 & 1.90 & , 25.79 & \\
\hline & & 20 & 90 & 1891 & 152 & 4,803 & 20 & 286 & 1.89 & 25.44 & \\
\hline & & 20 & 91 & 1892 & 152 & 3,769 & 4 & 214 & 1.41 & 19.46 & \\
\hline & & 20 & 91 & 1893 & 152 & 5,139 & 13 & 259 & 1.70 & 22.95 & \\
\hline & & 20 & 91 & 1894 & 152 & 8,769 & 14 & 269 & 1.78 & 24.10 & \\
\hline & & 20 & 92 & 1895 & 152 & 4,203 & 4 & 177 & 1.16 & 16.82 & \\
\hline & & 20 & 92 & 1896 & 152 & 6,789 & 17 & 191 & 1.31 & 17.04 & \\
\hline & & 20 & 93 & 1897 & 152 & 4,747 & 8 & 221 & 1.45 & 19.63 & \\
\hline & & 20 & 93 & 1898 & 152 & 5,552 & 12 & 242 & 1.98 & 24.50 & \\
\hline \multirow[t]{2}{*}{ Wissahickon } & \multirow{2}{*}{$\begin{array}{l}\text { Atmouth, } \\
\text { Pennsyl- } \\
\text { vania. }\end{array}$} & 20 & 95 & 1897 & 646 & 2,817 & & & & & \\
\hline & & 20 & 95 & 1898 & 646 & 1,512 & 15 & $\ldots$ & $\cdots$ & $\cdots$ & \\
\hline Schuylkill... & $\begin{array}{l}\text { Fairmount, } \\
\text { Pennsyl- } \\
\text { vania. }\end{array}$ & 20 & 97 & 1898 & 1,915 & 23,271 & 25 & & & $\cdots$ & \\
\hline \multirow[t]{9}{*}{ Tohickon.... } & \multirow{9}{*}{$\begin{array}{l}\text { Point Pleas- } \\
\text { ant, Penn- } \\
\text { sylvania. }\end{array}$} & 20 & 98 & 1890 & 102 & 2,942 & 4 & 204 & 2.00 & 27.09 & \\
\hline & & 20 & 99 & 1891 & 102 & 2,858 & 3 & 226 & 2.21 & 30.06 & \\
\hline & & 20 & 99 & 1892 & 102 & 3,158 & 4 & 167 & 1.64 & 22.33 & \\
\hline & & 20 & 100 & 1893 & 102 & 2,994 & 3 & 227 & 2.22 & 29.71 & \\
\hline & & 20 & 100 & 1894 & 102 & 8,650 & 2 & 235 & 2.30 & 31.12 & \\
\hline & & 20 & 101 & 1895 & 102 & 3,857 & 2 & 142 & 1.39 & 18.81 & \\
\hline & & 20 & 101 & 1896 & 102 & 6,515 & 3 & 150 & 1.47 & 19.83 & \\
\hline & & 20 & 102 & 1897 & 102 & 3,683 & 3 & 183 & 1.79 & 24.29 & \\
\hline & & 20 & 102 & 1898 & 102 & 4,160 & 3 & 206 & 2.01 & 27.21 & \\
\hline \multirow[t]{9}{*}{ Neshaminy.. } & \multirow{9}{*}{$\begin{array}{l}\text { Below Forks, } \\
\text { Pen n syl- } \\
\text { vania. }\end{array}$} & 20 & 104 & 1890 & 139 & 2,990 & 10 & 204 & 1.47 & 19.88 & \\
\hline & & 20 & 104 & 1891 & 139 & 3,276 & 12 & 251 & 1.81 & 24.36 & \\
\hline & & 20. & 105 & 1892 & 139 & 3,584 & 3 & 169 & 1.09 & 14.91 & \\
\hline & & 20 & 105 & 1893 & 139 & 3,154 & 5 & 264 & 1.90 & 25.53 & \\
\hline & & 20 & 106 & 1894 & 139 & 9,012 & 5 & 240 & 1.72 & 23.50 & \\
\hline & & 20 & 106 & 1895 & 139 & 3,234 & 4 & 167 & 1.19 & 16.18 & \\
\hline & & 20 & 107 & 1896 & 139 & 8,707 & 8 & 176 & 1.27 & 12.02 & \\
\hline & & 20 & 107 & 1897 & 139 & 4,677 & 10 & 218 & 1.56 & 21.23 & \\
\hline & & 20 & 107 & 1898 & 139 & 5,076 & 6 & 229 & 1.65 & 22.16 & \\
\hline \multirow[t]{2}{*}{ Delaware.... } & \multirow{2}{*}{$\begin{array}{c}\text { L a mbert- } \\
\text { ville, New } \\
\text { Jersey. }\end{array}$} & 20 & 85 & 1897 & 6,855 & 66,540 & 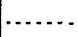 & & . & & \\
\hline & & 20 & 85 & 1898 & 6,855 & 61,260 & 2,500 & 18,619 & 2.72 & 36. 77 & \\
\hline Susquehanna & Harrisburg, & 19 & 125 & 1891 & 24,030 & 302,300 & 10,750 & 52,619 & 2.19 & 29.39 & \\
\hline & $\begin{array}{l}\text { Pennsyl- } \\
\text { vania. }\end{array}$ & 19 & 125 & 1892 & 24,030 & 224,475 & 4,000 & 37,641 & 1.57 & 21.33 & \\
\hline & & 19 & 125 & 1893 & 24,030 & 257,590 & 3,400 & 41,073 & 1.71 & 23.15 & \\
\hline & & 19 & 126 & 1894 & 24,030 & 454,900 & 3,000 & 38,747 & 1.61 & 21.92 & \\
\hline & & 19 & 126 & 1895 & 24,030 & 206,575 & 2,200 & 29,680 & 1.24 & 16.66 & \\
\hline & & 19 & 127 & 1896 & 24,030 & 223,580 & 3,000 & 34,900 & 1.45 & 19. 71 & \\
\hline & & 19 & 127 & 1897 & 24,030 & 168,090 & 4,000 & 32,132 & 1.34 & 18.13 & \\
\hline & & 20 & 109 & 1898 & 24,030 & 242,375 & 5,250 & 40,812 & 1.70 & 23. 06 & \\
\hline Octoraro & Rowlands- & 19 & 128 & 1897 & 217 & 6,150 & 130 & 310 & 1.43 & 19.07 & \\
\hline & $\begin{array}{l}\text { ville, Mary- } \\
\text { land. }\end{array}$ & 20 & 111 & 1898 & 217 & 3,320 & 180 & 399 & 1.84 & 24.95 & 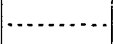 \\
\hline Patapsco .... & Woodstock, & 19 & 130 & 1897 & 251 & 7,250 & 65 & 422 & 1.68 & 22.67 & 48.42 \\
\hline & & 20 & 115 & 1898 & 251 & 2,050 & 58 & 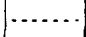 & & 15.06 & 39.97 \\
\hline
\end{tabular}


Résumé of discharge data-Continued.

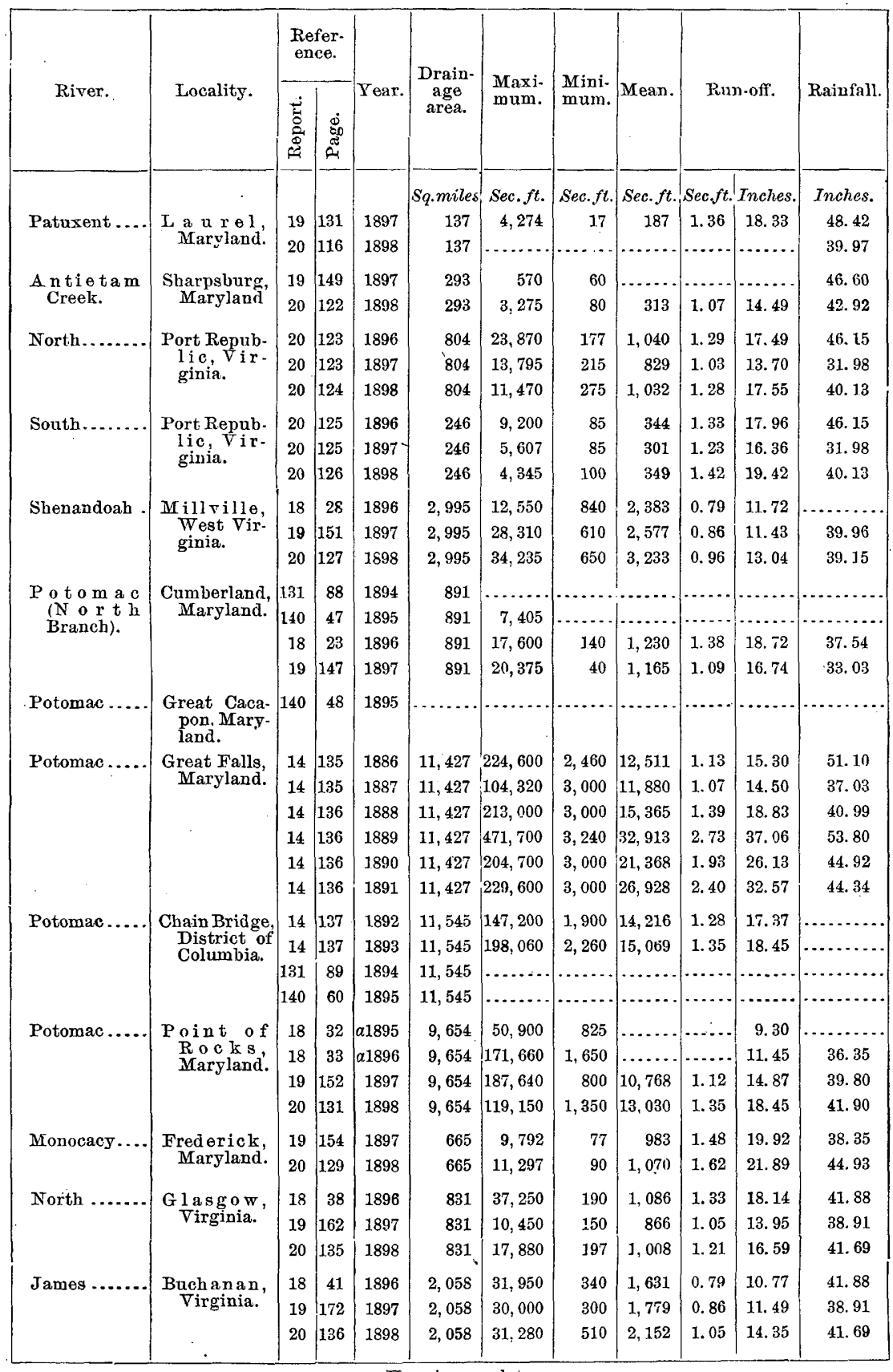

20 GEOL, PT $4-4$

a $\bar{Y}$ ear is complete. 
Résumé of discharge data-Continued.

\begin{tabular}{|c|c|c|c|c|c|c|c|c|c|c|c|}
\hline \multirow{2}{*}{ River. } & \multirow{2}{*}{ Locality. } & \multicolumn{2}{|c|}{$\begin{array}{l}\text { Refer- } \\
\text { ence. }\end{array}$} & \multirow{2}{*}{ Year. } & \multirow{2}{*}{$\begin{array}{l}\text { Drain. } \\
\text { age } \\
\text { area. }\end{array}$} & \multirow{2}{*}{$\begin{array}{l}\text { Maxi- } \\
\text { mum. }\end{array}$} & \multirow{2}{*}{$\begin{array}{l}\text { Mini- } \\
\text { mum. }\end{array}$} & \multirow{2}{*}{ Mean. } & \multirow{2}{*}{\multicolumn{2}{|c|}{ Run-off. }} & \multirow{2}{*}{ Rainfall. } \\
\hline & & $\dot{t}$ & & & & & & & & & \\
\hline \multirow{3}{*}{ Roanoke.... } & \multirow{3}{*}{$\begin{array}{c}\text { Roanoke, } \\
\text { Virginia. }\end{array}$} & & & & Sq.miles & Sec.ft. & Sec.ft. & Sec.ft. & Sec,ft. & Inches. & Inches. \\
\hline & & 20 & 140 & 1897 & 388 & 11,550 & 33 & 467 & 1.20 & 15.99 & 36.91 \\
\hline & & 20 & 140 & 1898 & 388 & 5,700 & 30 & 545 & 1.40 & 19.15 & 39.00 \\
\hline \multirow[t]{2}{*}{ Dan ............ } & \multirow{2}{*}{$\begin{array}{c}\text { Clarksville, } \\
\text { Virginia. }\end{array}$} & 18 & 45 & 1896 & 3,700 & 33,000 & 825 & 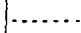 & $\cdots$ & 10.96 & 42.11 \\
\hline & & 19 & 179 & 1897 & 3,798 & 27.044 & 400 & 3,026 & 0.80 & 10.68 & 34.44 \\
\hline \multirow[t]{2}{*}{ Staunton ... } & \multirow{2}{*}{$\begin{array}{c}\text { Clarksville, } \\
\text { Virginia. }\end{array}$} & 18 & 47 & 1896 & 3,450 & 36,000 & 645 & $\ldots$. & $\ldots$ & 10.56 & 42.11 \\
\hline & & 19 & 180 & 1897 & 3,546 & 29,326 & 550 & 3,560 & 1.00 & 13.46 & 34.44 \\
\hline \multirow{2}{*}{ Roanoke...; } & \multirow{2}{*}{$\begin{array}{l}\text { Neal, North } \\
\text { Carolina. }\end{array}$} & 19 & 182 & 1897 & 8,717 & 64,300 & 2,000 & 8,077 & 0.93 & 12.37 & 35.21 \\
\hline & & 20 & 142 & 1898 & 8,717 & 34,274 & 2,060 & 6,485 & 0.74 & 10.11 & 41.21 \\
\hline \multirow[t]{2}{*}{$\operatorname{Tar} . . . . .}$. & \multirow{2}{*}{$\begin{array}{l}\text { Tarboro, } \\
\text { North Car. } \\
\text { olina. }\end{array}$} & 19 & 184 & 1897 & 2,290 & 14,600 & 170 & 1,990 & 0.87 & 11.64 & \\
\hline & & 20 & 143 & 1898 & 2,290 & 8,680 & 360 & 1,872 & 0.82 & 11.12 & \\
\hline \multirow[t]{2}{*}{ Neuse...... } & Selma, North & 19 & 186 & 1897 & 1,175 & 7,856 & 75 & 881 & 0.75 & 10.10 & \\
\hline & & 20 & 144 & 1898 & 1,175 & 6,350 & 185 & 1,032 & 0.78 & 11.95 & \\
\hline Cape Fear & Fayetteville, & 18 & 56 & 1896 & 4,493 & 52,340 & 489 & 4,019 & 0.55 & 11.49 & \\
\hline & $\begin{array}{l}\text { North Car- } \\
\text { olina. }\end{array}$ & 19 & 193 & 1897 & 4,493 & 35,708 & 340 & 4,167 & 0.93 & 12.44 & \\
\hline & & 20 & 115 & 1898 & 4,493 & 24,072 & 489 & 2,945 & 0.66 & 8.90 & \\
\hline Yadkin & Sal is bury, & 18 & 59 & 1896 & 3,399 & 64,200 & 1,000 & 4,844 & 1.42 & 19.31 & \\
\hline & $\begin{array}{l}\text { Norts Car- } \\
\text { olina. }\end{array}$ & 19 & 201 & 1897 & 3,399 & 34,924 & 900 & 5,354 & 1.58 & 21.13 & \\
\hline & & 20 & 146 & 1898 & 3,399 & 79,998 & 1,100 & 3,569 & 1.05 & 14.30 & \\
\hline Yadkin. & Norwood, & 19 & 202 & 1897 & 4,614 & 50,120 & 1,310 & 6,193 & 1.34 & 18.05 & \\
\hline & olina. & 20 & 147 & 1898 & 4,614 & 63,260 & 1,380 & 5,484 & 1.19 & 16.18 & \\
\hline Catawba.. & Catawba, & 19 & 212 & 1897 & 1,535 & 40,525 & 850 & 2,683 & 1.75 & 23.47 & \\
\hline & olina. & 20 & 149 & 1898 & 1,535 & 52,600 & 1,000 & 3,229 & 2.10 & 28.67 & \\
\hline Catawba..... & Rockfill, & 18 & 63 & 1896 & 2,987 & 62,500 & 1,330 & 3,274 & 1.10 & 14.88 & \\
\hline & ar- & 19 & 214 & 1897 & 2,987 & 65,650 & 1,575 & 3,916 & 1.31 & 17.61 & \\
\hline & & 20 & 150 & 1898 & 2,987 & 36,500 & 1,800 & 4,850 & 1.62 & 22.13 & \\
\hline Broad. & $\begin{array}{l}\text { G a ff n } \in \bar{y} \\
\text { South Car- } \\
\text { olina. }\end{array}$ & 19 & 220 & 1897 & 1,435 & 18,736 & 790 & 2,970 & 1.99 & 28.01 & \\
\hline Broad. & A lston, & 20 & 151 & 1897 & 4,609 & 47,375 & 1,900 & 5,976 & 1.30 & 17.36 & \\
\hline & $\begin{array}{l}\text { south Car. } \\
\text { olina. }\end{array}$ & 20 & 151 & 1898 & 4,609 & 28,500 & 1,815 & 5,024 & 1.09 & 14.83 & \\
\hline Saluda... & Waterloo, & 20 & 153 & 1897 & 1,056 & 12,730 & 335 & 1,779 & 1.68 & 22.78 & \\
\hline & olina. & 20 & 153 & 1898 & 1,056 & 8,230 & 290 & 1,573 & 1.49 & 20.34 & \\
\hline Savannall. & Callo oun & 19 & 224 & 1896 & 2,712 & 26,000 & $\ldots$ & & & ....... & 45.86 \\
\hline & Carolina. & 19 & 224 & 1897 & 2,712 & 18,000 & 1,405 & $\cdots$ & $\ldots .$. & 20.13 & 48.59 \\
\hline & & 20 & 164 & 1898 & 2,712 & 23,750 & $\ldots \ldots$ & $\cdots \cdot$ & $\ldots \ldots$ & 19.52 & 54.43 \\
\hline Savannah.. & Augusta, & 14 & 147 & 1884 & 7,294 & 75,890 & 1,980 & 10,640 & 1.46 & 19.84 & \\
\hline & Georgra. $\alpha$ & 14 & 147 & 1885 & 7,294 & 61,050 & 2,460 & 9,857 & 1.35 & 18.24 & \\
\hline & & 14 & 147 & 1886 & 7,294 & 114,800 & 3,020 & 12,560 & 1.72 & 23.41 & \\
\hline & & 14 & 148 & 1887 & 7,294 & 143,450 & 3,200 & 9,731 & 1.33 & 18.14 & \\
\hline & & 14 & 148 & 1888 & 7,294 & 309,930 & 3,500 & i 6,821 & 2.31 & 31.07 & \\
\hline & & 14 & 148 & 1889 & 7,294 & 119,600 & 3,960 & 12,445 & 1.71 & 23.02 & \\
\hline & & 14 & 148 & 1890 & 7,294 & 79,600 & 2,700 & 8,728 & 1.20 & 16. 26 & \\
\hline & & 14 & 148 & 1891 & 7,294 & 116,000 & 3,100 & 13,928 & 1. 79 & 25.66 & \\
\hline
\end{tabular}

$a$ Additional data are given in Water-Supply and Irrigation Paper No. 27, pages 28-30. 
Résumé of discharge data-Continued.

\begin{tabular}{|c|c|c|c|c|c|c|c|c|c|c|c|}
\hline River. & Locality. & 莣 & $\begin{array}{l}\text { fer- } \\
\text { ice. }\end{array}$ & Tear. & \begin{tabular}{|} 
Drain- \\
age \\
area.
\end{tabular} & $\begin{array}{l}\text { Maxi. } \\
\text { mum. }\end{array}$ & $\begin{array}{l}\text { Mini- } \\
\text { mum. }\end{array}$ & Mean & \multicolumn{2}{|c|}{ Run-off. } & Rainfall \\
\hline . & & & & & Sq.miles & Sec.ft. & Sec. ft. & sec. ft. & Sec.ft. & Inches. & Inches. \\
\hline Savannah. & A $\underset{\text { Georgia. }}{\text { gusta. }}$ & 20 & 165 & 1898 & 7,294 & 88,160 & 2,084 & 11,373 & 1.56 & 21.28 & 54.43 \\
\hline \multirow{2}{*}{$\begin{array}{l}\text { Broad. } \\
\text {, }\end{array}$} & \multirow{2}{*}{$\begin{array}{c}\text { Carlto } n, \\
\text { Georgia. }\end{array}$} & 19 & 227 & 1897 & 762 & 3,671 & 315 & & . & & 48.77 \\
\hline & & 20 & 163 & 1898 & 762 & 16,937 & 300 & 1,197 & 1.57 & 21.40 & 60.10 \\
\hline Oconee. & $\begin{array}{l}\text { Cares, Geor- } \\
\text { gia. }\end{array}$ & 19 & 228 & 1897 & 1,346 & 10,000 & 381 & .... & 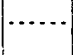 & 10.40 & \\
\hline Oconee $\ldots$ & $\begin{array}{l}\text { Dublin, Geor- } \\
\text { gia. }\end{array}$ & 20 & 170 & 1898 & 4,182 & 27,904 & 865 & & & & 49.31 \\
\hline Yellow .... & $\begin{array}{l}\text { Almon, Geor- } \\
\text { gia. }\end{array}$ & 19 & 230 & 1897 & 379 & 450 & 85 & & & & \\
\hline \multirow[t]{6}{*}{ Ocmulgee.... } & \multirow{6}{*}{$\begin{array}{c}\text { Macon, } \\
\text { Georgia. }\end{array}$} & 18 & 82 & 1893 & 2,425 & 18,550 & 855 & 2,575 & 1.06 & 13.18 & \\
\hline & & 18 & 83 & 1894 & 2,425 & 20,075 & 1,113 & 2,666 & 1.10 & 14.85 & \\
\hline & & 18 & 83 & 1895 & 2,425 & 30,715 & 842 & 3,402 & 1.40 & 19.16 & $\ldots$ \\
\hline & & 18 & 83 & 1896 & 2,425 & 36,200 & 380 & 2,469 & 1.02 & 13.87 & 43.55 \\
\hline & & 19 & 232 & 1897 & 2,425 & 28,700 & 442 & 2,521 & 1.04 & 14.04 & 41.59 \\
\hline & & $2 \theta$ & 171 & 1898 & 2,425 & 31,640 & 388 & 2,749 & 1.13 & 15.44 & 62.54 \\
\hline \multirow[t]{2}{*}{ Flint . ........ } & \multirow{2}{*}{$\underset{\text { Georgia. }}{\text { Mol i n a }}$} & 19 & 234 & 1897 & 892 & 4,439 & 55 & 419 & 0.47 & 3.77 & \\
\hline & & 20 & 184 & 1898 & 892 & 6,580 & & . & 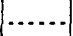 & $\cdots$ & \\
\hline \multirow{3}{*}{$\begin{array}{l}\text { Chattaboo- } \\
\text { chee. }\end{array}$} & \multirow{3}{*}{ Oakdale, } & 18 & 89 & 1896 & 1,560 & 24,600 & 745 & 1,785 & 1.14 & 15.56 & 40.88 \\
\hline & & 19 & 236 & 1897 & 1,560 & 21,890 & 675 & 2,520 & 1.62 & 21.86 & 48.62 \\
\hline & & 20 & 182 & 1898 & 1,560 & 33,975 & 730 & 3,256 & 2.09 & 28.48 & 57.22 \\
\hline \multirow{2}{*}{$\begin{array}{l}\text { Chattahoo. } \\
\text { chee. }\end{array}$} & \multirow{2}{*}{$\begin{array}{c}\text { West Point, } \\
\text { Georgia. }\end{array}$} & 19 & 239 & 1897 & 2,300 & 28,868 & 830 & 4,875 & 1.48 & 20.01 & 48.62 \\
\hline & & 20 & $18^{3}$ & 1898 & 3,300 & 57,350 & 950 & 5,311 & 1.61 & 21.89 & 57.22 \\
\hline \multirow[t]{3}{*}{ Etowah...... } & Canton, & 18 & 96 & 1895 & 604 & 19,000 & 510 & 1,339 & 2.34 & 31.79 & \\
\hline & & 19 & 242 & 1897 & 604 & 9,786 & 244 & 1,134 & 1.87 & 25.35 & 55.76 \\
\hline & & 20 & 189 & 1898 & 604 & 11,695 & 310 & 1,337 & 2.21 & 30.16 & 71.77 . \\
\hline Coosawattee. & Carters, & 19 & 244 & 1897 & 532 & & & & & 20.03 & 52.45 \\
\hline & Geo & 20 & 191 & 1898 & 532 & 8,070 & 313 & 863 & 1.62 & 22.06 & 52.49 \\
\hline Oostanaula. & $R$ es & 19 & 245 & 1897 & $.1,527$ & & & & & 14.77 & 52.45 \\
\hline & & 20 & 190 & 1898 & 1,527 & 22,150 & 594 & 2,838 & 1.86 & 25.24 & 52.49 \\
\hline Coosa.. & River & 19 & 248 & 1897 & 6,850 & 47,624 & 1,350 & 9,282 & 1.35 & 18.27 & 48.08 \\
\hline & & 20 & 189 & 1898 & 6,850 & 72,160 & 2,140 & 9,329 & 1.34 & 18.20 & \\
\hline Coosa... & Rome, Geor- & 20 & 185 & 1897 & 4,001 & 44,910 & 900 & 6,070 & 1.52 & 20.52 & \\
\hline & gia. - & 20 & 185 & 1898 & 4,001 & 45,885 & 1,900 & 6,111 &, 2.22 & 29.20 & \\
\hline Tallapoosa. & Milstead, & 19 & 250 & 1897 & 3,840 & 12,440 & 350 & & & & \\
\hline & & 20 & 193 & 1898 & 3,840 & 36,420 & 540 & 3,902 & 1.02 & 13.85 & \\
\hline Black War. & Tuscaloosa, & 18 & 108 & 1895 & & 190,000 & 140 & 7,991 & 1.63 & 22.31 & \\
\hline & & 18 & 108 & 1896 & $\ldots \ldots$ & 52,600 & 120 & 4,823 & 0.98 & 13.23 & 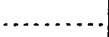 \\
\hline & & 19 & 251 & 1897 & $-4,900$ & 120,080 & 90 & 7,277 & 1.48 & 20.27 & \\
\hline & & 20 & 194 & 1898 & 4,900 & 75,000 & 130 & 4,221 & 0.86 & 11.69 & . \\
\hline Greenbrier. & Alderson, & 18 & 114 & 1896 & 1,344 & 24,400 & 125 & 1,795 & 1.34 & 18.11 & 43.13 \\
\hline & ginia. & 19 & 254 & 1897 & 1,344 & 55,850 & 55 & 2,027 & 1.51 & 20.12 & 42.38 \\
\hline & & 20 & 204 & 1898 & 1,344 & 48,700 & 155 & 2,414 & 1.80 & 24.47 & 49.07 \\
\hline New. & Fay ette, & 18 & 115 & 1896 & 6,200 & 74,200 & 2,615 & 8,671 & 1.40 & 18.46 & 43.13 \\
\hline & $\begin{array}{l}\text { West Vir- } \\
\text { ginia. }\end{array}$ & 19 & 256 & 1897 & 6,200 & 83,574 & 1,170 & 8,530 & 1. 38 & 18.42 & 42.38 \\
\hline & & 20 & 203 & 1898 & 6,200 & 61,080 & 1,850 & 8,401 & 1.36 & 18.47 & 49.07 \\
\hline
\end{tabular}


Résumé of discharge data-Continued.

\begin{tabular}{|c|c|c|c|c|c|c|c|c|c|c|c|}
\hline \multirow{2}{*}{ River. } & \multirow{2}{*}{ Locality. } & \multicolumn{2}{|c|}{$\begin{array}{l}\text { Refer- } \\
\text { ence. }\end{array}$} & \multirow{2}{*}{ Year. } & \multirow{2}{*}{$\begin{array}{l}\text { Drain- } \\
\text { age } \\
\text { area. }\end{array}$} & \multirow{2}{*}{$\begin{array}{l}\text { Maxi- } \\
\text { mum. }\end{array}$} & \multirow{2}{*}{$\begin{array}{l}\text { Mini- } \\
\text { mum. }\end{array}$} & \multirow{2}{*}{ Mean. } & \multirow{2}{*}{\multicolumn{2}{|c|}{ Run-off. }} & \multirow{2}{*}{ Rainfall. } \\
\hline & & $\dot{0}$ & & & & & & & & & \\
\hline & & & & & & & & & & & \\
\hline \multirow{4}{*}{$\begin{array}{c}\mathrm{F} \\
\text { Broad. }\end{array}$} & \multirow{4}{*}{$\begin{array}{c}\text { Asheville, } \\
\text { Nort h } \\
\text { Carolina. }\end{array}$} & 19 & 257 & 1895 & 987 & $\ldots \ldots$ & $\ldots$. & & & & \\
\hline & & 19 & 257 & 1896 & 987 & 7,780 & 672 & 1,244 & 1.26 & 17.14 & \\
\hline & & 19 & 258 & 1897 & 987 & 5,830 & 652 & 1,518 & 1.54 & 20.75 & \\
\hline & & 20 & 205 & 1898 & 987 & 6,030 & 675 & 1,680 & 1.70 & 23.21 & \\
\hline \multirow[t]{2}{*}{ Tuckasegee. } & \multirow{2}{*}{ 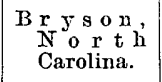 } & 20 & 206 & 1897 & 662 & ........ & $\cdots$ & $\ldots . .$. & $\therefore .$. & ….... & \\
\hline & & 20 & 206 & 1898 & 662 & 26,050 & 400 & 2,042 & 3.08 & 42.24 & \\
\hline \multirow{2}{*}{$\begin{array}{l}\text { Little Ton - } \\
\text { nessee. }\end{array}$} & \multirow{2}{*}{$\begin{array}{l}\mathrm{J} \text { ud son } \\
\mathrm{N} \text { o r t } \mathrm{h} \\
\text { Carolina. }\end{array}$} & 20 & 207 & 1897 & 675 & 16,950 & 407 & 2,623 & 3.89 & 52.53 & \\
\hline & & 20 & 207 & 1898 & 675 & 38,100 & 275 & 2,623 & 3.89 & 53.26 & \\
\hline \multirow[t]{2}{*}{ Hiwasseo... } & \multirow{2}{*}{$\begin{array}{c}\mathrm{Murphy}, \\
\mathrm{N} \text { or th } \\
\text { Caroling. }\end{array}$} & 19 & 260 & 1897 & 410 & 2.470 & 237 & $\cdots$ & $\cdots \cdot$ & & \\
\hline & & 20 & 209 & 1898 & 410 & 9,520 & 315 & 1,073 & 2.62 & 35.60 & \\
\hline \multirow[t]{9}{*}{ 'Tennessee... } & \multirow{9}{*}{$\begin{array}{c}\text { Chattanooga, } \\
\text { Tennessee. }\end{array}$} & 18 & 121 & 1890 & 21,418 & 445,120 & 19,500 & 48,275 & 2.26 & 30.57 & \\
\hline & & 18 & 122 & 1891 & 21,418 & 381,040 & 17,440 & 54,309 & 2.54 & 34.08 & \\
\hline & & 18 & 122 & 1892 & 21,418 & 363,240 & 17,220 & 45,835 & 2.15 & 29.17 & \\
\hline & & 18 & 122 & 1893 & 21,418 & 283,140 & 18,410 & 41,861 & 1.96 & 26.24 & \\
\hline & & 18 & 122 & 1894 & 21,418 & 151,095 & 16,360 & 31,395 & 1.53 & 19.77 & \\
\hline & & 18 & 122 & 1895 & 21,418 & $261,780^{\circ}$ & 16,360 & 36,603 & 1. 71 & 23.27 & \\
\hline & & 19 & 261 & 1896 & 21,418 & 409,520 & 8,426 & 33,825 & 1.58 & 21.39 & \\
\hline & & 19 & 261 & 1897 & 21,418 & 3643,240 & 4,268 & 46,055 & 2.15 & 29.07 & \\
\hline & & 20 & 210 & 1898 & 21,418 & 174,500 & 10,245 & 35,584 & 1.66 & 22.52 & \\
\hline Desplaines .. & $\begin{array}{l}\text { Rirers i d e, } \\
\text { Illinois. } a\end{array}$ & 20 & 219 & 1898 & 630 & 8,960 . & 0 & 509 & 0.81 & 10.92 & \\
\hline Genesee.... & Mount Morris & 20 & 225 & 1894 & 1,070 & 16,142 & 100 & 1,386 & 1.47 & 20.01 & \\
\hline & New York.b & 20 & 226 & 1895 & 1,070 & 11,220 & 100 & 580 & 0.62 & 8.38 & \\
\hline & & 20 & 226 & 1896 & 1,070 & 15,220 & 100 & $\ldots$. & $\cdots$ & . & \\
\hline Mississippi & st. P & 19 & 268 & 1887 & 36,085 & 28,855 & 2,780 & & & & \\
\hline & $\mathrm{Mi}$ & 19 & 268 & 1888 & 36,085 & 53,095 & 4,580 & & & & \\
\hline & & 19 & 268 & 1889 & 36,085 & 9,150 & 3,200 & & $\ldots \ldots$ & & \\
\hline & & 19 & 268 & 1890 & 36,085 & 17,900 & 2,500 & & & & \\
\hline & & 19 & 269 & 1891 & 36,085 & 15,620 & 1,980 & & & & \\
\hline & & 19 & 269 & $18: 2$ & 36,085 & 44,005 & 3,060 & 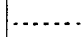 & & & \\
\hline & & 19 & 269 & 1893 & 36,085 & 54,610 & 2,500 & & & & $\cdots$ \\
\hline & & 19 & 269 & 1894 & 36,085 & 39,965 & 1,980 & & & & 23.55 \\
\hline & & 19 & 270 & 1895 & 36,085 & 9,380 & 2,100 & & 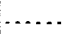 & & 22.05 \\
\hline & & 19 & 270 & 1896 & 36,085 & 34,410 & 1,640 & -- & $\cdots \cdots$ & & 31.65 \\
\hline . & & 19 & 270 & 1897 & 36,085 & 71,275 & 5,060 & & & & \\
\hline We $t$ Galla & Sales & 14 & 102 & 1889 & 850 & & & & & & \\
\hline & & 14 & 102 & 1890 & 850 & $3,800^{\circ}$ & 280 & 871 & 1.03 & 13.94 & \\
\hline & & 14 & 102 & 1891 & 850 & 2,975 & 370 & 880 & 1.03 & 14.05 & \\
\hline & & 14 & 102 & 1892 & 850 & 6,800 & 400 & 1,123 & 1.32 & 18.02 & \\
\hline & & 14 & 102 & 1893 & 850 & ….... & ….... & & $\cdots$ & & \\
\hline & & 131 & 16 & 1894 & 850 & & ........ & & $\cdots$ & & \\
\hline & & 140 & 88 & 1895 & 850 & & $\ldots .$. & $\cdots .$. & ...... & & \\
\hline & & 18 & 126 & 1896 & 860 & 10,750 & 100 & 1,132 & i. 31 & 17.66 & \\
\hline & & 19 & 276 & 1897 & 860 & 5,780 & 350 & 993 & 1.15 & 15.71 & \\
\hline & & 20 & 241 & 1898 & 860 & 7,226 & 560 & 1,328 & 1.55 & 20.96 & \\
\hline
\end{tabular}

$a$ Results for years 1886 to 1898; see also Water Supply and Irrigation Paper No. 24, p. 64. $b$ See also Water Supply and Irrigation Paper No. 24, p. 72. 
Résumé of discharge data-Continued.

\begin{tabular}{|c|c|c|c|c|c|c|c|c|c|c|c|}
\hline \multirow{2}{*}{ River. } & \multirow{2}{*}{$\begin{array}{c}\cdot \\
\text { Locality. } \\
i\end{array}$} & \multicolumn{2}{|c|}{$\begin{array}{l}\text { Refer- } \\
\text { ence. }\end{array}$} & \multirow{2}{*}{ Year. } & \multirow{2}{*}{$\begin{array}{c}\text { Drain- } \\
\text { age } \\
\text { area. }\end{array}$} & \multirow{2}{*}{$\begin{array}{l}\text { Maxi- } \\
\text { mum. }\end{array}$} & \multirow{2}{*}{$\begin{array}{l}\text { Mini- } \\
\text { mum. }\end{array}$} & \multirow{2}{*}{ Mean. } & \multirow{2}{*}{\multicolumn{2}{|c|}{ Run-off. }} & \multirow{2}{*}{ Rainfall. } \\
\hline & & 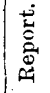 & $\begin{array}{c}\dot{D} \\
\mathbb{D}_{0}^{\infty} \\
\ddot{D}_{1}\end{array}$ & & & & & & & & \\
\hline \multirow{4}{*}{ Gallatin . } & \multirow{4}{*}{$\begin{array}{l}\text { Logan, Mon- } \\
\text { tana. }\end{array}$} & - & & & Sq.miles & Sec.ft. & Sec. ft. & Sec. ft. & Sec.ft. & Inches. & Inches. \\
\hline & & 18 & 130 & 1896 & 1,620 & 6,550 & 630 & 1,085 & 0.67 & 9.06 & 17.16 \\
\hline & & 19 & 278 & 1897 & 1,620 & 6,460 & 400 & 1,105 & 0.68 & 9.28 & 16.98 \\
\hline & & 20 & 240 & 1898 & 1,620 & 6,107 & 370 & 1,226 & 0.76 & 10.24 & 16.89 \\
\hline \multirow[t]{5}{*}{ Madison ...... } & \multirow{5}{*}{$\begin{array}{l}\text { Red bluff, } \\
\text { Montana. }\end{array}$} & 14 & 103 & 1890 & 2,085 & 6,420 & 1,285 & 2,068 & 0.99 & 13.48 & \\
\hline & & 14 & 103 & 1891 & 2,085 & 4,620 & 1,070 & 1,872 & 0.90 & 12.19 & \\
\hline & & 14 & 103 & 1892 & 2,085 & 5,940 & 1,240 & 1,844 & 0.89 & 12.02 & \\
\hline & & 131 & 20 & 1893 & 2,420 & & & & & & \\
\hline & & 131 & 20 & 1894 & 2,420 & ......... & $\ldots \ldots$ & and & & & \\
\hline \multirow[t]{2}{*}{ Madison.... } & \multirow{2}{*}{$\begin{array}{l}\text { Throeforks } \\
\text { Montana. }\end{array}$} & 140 & 92 & 1895 & 2,420 & 3,880 & 1,440 & 2,065 & 0.86 & 11.59 & \\
\hline & & 18 & 133 & 1896 & 2,420 & 8,175 & 1,385 & 2,078 & 0.86 & 11.63 & 17.16 \\
\hline \multirow[t]{2}{*}{ Madison..... } & \multirow{2}{*}{$\begin{array}{l}\text { Red l l u ff } \\
\text { Montasa. }\end{array}$} & 19 & 280 & 1897 & 2,085 & $8,613^{\circ}$ & 1,450 & 2,239 & 1.07 & 13.66 & 16.98 \\
\hline & & 20 & 236 & 1898 & 2,085 & 8,000 & 2,150 & ….... & ....... & & 16.89 \\
\hline \multirow[t]{3}{*}{ Jefferson .... } & \multirow{3}{*}{$\begin{array}{l}\text { Sappington, } \\
\text { Montana. }\end{array}$} & 18 & 135 & 1896 & 8,984 & …..... & $\cdots \cdot$ & & & & \\
\hline & & 19 & 282 & 1897 & 8,984 & 11,040 & 550 & 2,357 & 0.26 & 3.58 & \\
\hline & & 20 & 238 & 1898 & 8,984 & 10,130 & 1,000 & 2,659 & 0.30 & 0.34 & 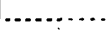 \\
\hline \multirow[t]{3}{*}{ Missouri..... } & Craig, Mon. & 14 & 104 & 1890 & 17,615 & 12,500 & 1,742 & 4,307 & 0.24 & 3.33 & \\
\hline & & 14 & 104 & 1891 & 17,615 & 16,355 & 1,742 & 5,503 & 0.31 & 4.27 & \\
\hline & & 14 & 104 & 1892 & 17,615 & 28,650 & ......... & $\cdots \ldots$ & $\cdots \cdot$ & $\cdots \cdots$ & \\
\hline Missouri. & Townsend, & 131 & 25 & 1893 & 14,500 & & & & & & \\
\hline & Montana. & 131 & 25 & 1894 & 14,500 & .......... & $\cdots$ & & $\cdots$ & & \\
\hline & & 140 & 94 & 1895 & 14,500 & ......... & ........ & ...... & ...... & $\cdots \cdots$ & $\ldots$ \\
\hline & & 19 & 284 & 1896 & 14,500 & 32,500 & 3,300 & 6,440 & 0.36 & 5.71 & 17.16 \\
\hline & & 19 & 285 & 1897 & 14,500 & 21,300 & 2,200 & 5,304 & 0.37 & 5.00 & 16.98 \\
\hline & & 20 & 244 & 1898 & 14,500 & 25,010 & 2,100 & 5,472 & 0.38 & 5.11 & 16.89 \\
\hline Sun. & A ugusta, & 12 & 347 & 1889 & 1,175 & 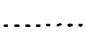 & 180 & , & $\cdots$ & & \\
\hline • & na, $a$ & 13 & 93 & 1890 & 1,175 & 4,085 & 160. & 715 & 0.60 & 8.29 & \\
\hline Milk . & Havre, Mon. & 20 & 245 & 1897 & 7,300 & & & & & & \\
\hline & . & 20 & 245 & 1898 & 7,300 & 2,546 & 0 & $\cdots$. & & & \\
\hline Yellowstone & Horr, Mon- & 12 & 347 & 1889 & 2,700 & & .... & $\cdots$ & $\cdots$ & & \\
\hline & & 12 & 347 & 1890 & 2,700 & 11,915 & 510 & 3,181 & 1.18 & 16.08 & \\
\hline & & 13 & 93 & 1891 & 2,700 & 8,975 & 285 & 2,421 & 0.90 & 12.24 & \\
\hline & & 13 & 93 & 1892 & 2,700 & 15,500 & 470 & 3,202 & 1.19 & 16.15 & \\
\hline Yellowstone. & Livingston, & 19 & 289 & b1897 & 3,580 & 26,820 & 1,650 & & & & \\
\hline & & 20 & 248 & 1898 & 3,580 & 23,239 & 1,608 & 4,394 & 1.23 & 16.66 & \\
\hline Shoshone.... & Lovell, Wy- & 19 & 292 & $b 1897$ & 2,720 & 9,440 & 350 & & & & \\
\hline & & 20 & 249 & 1898 & 2,720 & 12,340 & 150 & & & & \\
\hline Grey Bull. & $\begin{array}{l}\text { Meeteetse, } \\
\text { Wy oming. }\end{array}$ & 19 & 294 & $b 1897$ & 870 & 1,608 & 65 & & & & \\
\hline $\begin{array}{l}\text { Little Goose } \\
\text { Creek. }\end{array}$ & $\begin{array}{l}\text { Sheridan, } \\
\text { Wyoming. }\end{array}$ & 19 & 297 & $b 1897$ & 128 & 207 & 8 & & & & \\
\hline $\begin{array}{l}\text { Big Goose } \\
\text { Creek. }\end{array}$ & $\begin{array}{l}\text { Sheridan, } \\
\text { Wyoming. }\end{array}$ & 19 & 297 & $b 1897$ & 320 & 595 & 17 & & & & \\
\hline Clear Creek.. & Buffalo, Wy & 19 & 298 & $b 1897$ & 118 & 657 & 26 & & & & \\
\hline & & 20 & 250 & $b 1898$ & 118 & 853 & 17 & 132 & 1.12 & 15.20 & \\
\hline
\end{tabular}

$a$ See Report on Agriculture by Irrigation, Eleventh Census, 1890, pp. 163 and 174. $b$ Year incompléte. 
Résumé of discharge data-Continued.

\begin{tabular}{|c|c|c|c|c|c|c|c|c|c|c|c|}
\hline \multirow{2}{*}{ River. } & \multirow[b]{2}{*}{ Locality. } & \multicolumn{2}{|c|}{$\begin{array}{l}\text { Refer- } \\
\text { ence. }\end{array}$} & \multirow[b]{2}{*}{ Year. } & \multicolumn{3}{|c|}{ ! } & \multirow[b]{2}{*}{ Mean. } & \multicolumn{2}{|l|}{ - } & \multirow[b]{2}{*}{ Rainfall } \\
\hline & & 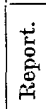 & 帛 & & $\begin{array}{l}\text { age } \\
\text { area. }\end{array}$ & $\begin{array}{l}\text { Maxi- } \\
\text { mum. }\end{array}$ & $\begin{array}{l}\text { Mini- } \\
\text { mum. }\end{array}$ & & \multicolumn{2}{|c|}{ Run-oft'. } & \\
\hline & & & & & Sq.miles & Ser. ft. & Sec. ft. & Sec. ft. & Sec.ft. & Inches. & Inches. \\
\hline White ........ & $\begin{array}{l}\text { Craw ford, } \\
\text { Nebraska. }\end{array}$ & 19 & 299 & 1897 & 270 & 18 & 9 & & & & \\
\hline Laramie..... & Woods Land- & 19 & 301 & 1897 & 435 & 3,425 & 60 & 374 & 0.86 & 11.61 & 12.16 \\
\hline v & $\begin{array}{l}\text { ing, Wy- } \\
\text { oming. }\end{array}$ & 20 & 274 & 1898 & $\cdots$ & 1,572 & 40 & & & & 7.63 \\
\hline Laramie.... & Ura, wyom- & 19 & 302 & 1897 & $3,1.79$ & 2,570 & 8 & 296 & 0.09 & 1.27 & 12.46 \\
\hline & ing. & 20 & 275 & 1898 & 3,179 & 1,220 & 1 & 105 & 0.03 & 0.45 & 7.63 \\
\hline North Platte. & Orin Junc- & 19 & 307 & 1897 & 14,828 & 19,160 & ... & 308 & 0. 21 & 2.79 & 13.75 \\
\hline & $\begin{array}{l}\text { tion, Wy. } \\
\text { oming. }\end{array}$ & 20 & 266 & 1898 & 14,828 & 15,635 & $\ldots$. & 1,662 & 0.11 & 1.51 & 12.96 \\
\hline North Platte. & Gering, Ne- & 19 & 308 & 1897 & 24,340 & & & & & & \\
\hline & & 20 & 267 & .1898 & 24,340 & 18,500 & 50 & & & & \\
\hline North Platte. & Camp Clarke, & 19 & 309 & 1897 & 24,830 & 11,400 . & 350 & 2,564 & 0.10 & 1.39 & \\
\hline & . Nebraska. & 20 & 268 & 1898 & 24,830 & 17.000 & 60 & & & & \\
\hline North Platte. & North Platte, & 19 & 310 & 1897 & 28,517 & 23,720 & 422 & 5,509 & 0.19 & 2.61 & 12.66 \\
\hline & Nebr & 20 & 269 & 1898 & 28,517 & 14,646 & 50 & 2,919 & 0.10 & 1.38 & 12.81 \\
\hline South Platte. & Deansbury, & 13 & 93 & 1887 & 2,600 & & & & & & \\
\hline & Colo & 13 & 93 & 1888 & 2,600 & 780 & 90 & & & & \\
\hline & & 13 & 93 & 1889 & 2,600 & 788 & $\cdots$ & & & & \\
\hline & & 13 & 93 & 1890 & 2,600 & 875 & $\cdots$ & $\ldots$ & & & \\
\hline & & 140 & 103 & 1895 & 2,600 & & $\ldots$. & $\cdots$ & & & \\
\hline & & 18 & 162 & 1896 & 2,600 & 982 & 83 & 235 & 0.09 & 1.22 & .. \\
\hline & & 19 & 312 & 1897 & 2,600 & 1,550 & 67 & 444 & 0.17 & 1.15 & 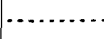 \\
\hline South Platte. & Denver, Col- & 18 & 165 & 1896 & 3,840 & 444 & 42 & 178 & 0.05 & 0.62 & 11.84 \\
\hline & orad & 19 & 314 & 1897 & 3,840 & 2,425 & 55 & 402 & 0.10 & 1.43 & 15.37 \\
\hline & & 20 & 279 & 1898. & 3,840 & 2,308 & 50 & 448 & 0.12 & 1.58 & 12.98 \\
\hline South Platte. & Orchard, Col. & 19 & 315 & 1895 & 12,260 & & & & & & \\
\hline & orad & 19 & 315 & 1896 & 12,260 & $\ldots \ldots$ & $\ldots$ & $\cdots$ & & & \\
\hline & & 19 & 315 & $b 1897$ & 12,260 & 5,520 . & 61 & 934 & 0.07 & 1.029 & \\
\hline & & 20 & 293 & 1898 & 12,260 & 3,214 & 0 & 791 & 0.07 & 0.90 & \\
\hline Bear Creek... & Morrison, & 19 & 317 & $b 1897$ & 170 & 737 & 5 & & & & \\
\hline & Cold & 20 & 284 & 1898 & 170 & 208 & 20 & & & & \\
\hline South Boul- & Marshall. & 19 & 318 & $b 1897$ & 125 & 554 & 18 & & & & \\
\hline ek. & . & 20 & 287 & 1898 & 125 & 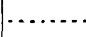 & & & & & \\
\hline Bonlder Creek & Boulder, & 13 & 93 & 1887 & 102 & & & & & & \\
\hline & & 13 & 93 & 1888 & 102 & 320 & & & & & \\
\hline & & 13 & 93 & 1889 & 102 & 785 & & & & & \\
\hline & & 13 & 93 & 1890 & 102 & 1,200 & & & & & \\
\hline & & 18 & 171 & 1895 & 179 & & & & & & \\
\hline & & 18 & 171 & 1896 & 179 & & & & & & \\
\hline & & 19 & 319 & $b 1897$ & 102 & 745 & 23 & & & & \\
\hline & & 20 & 286 & $\cdot 1898$ & 102 & 566 & 3 & *- & & & \\
\hline St. Vrain & Lyyons, Col- & 19 & 320 & $b 1897$ & 209 & 980 & 28 & & & & \\
\hline C & $\begin{array}{l}\text { orado. } \\
.\end{array}$ & & 285 & 1898 & 209 & 551 & 6 & & & & \\
\hline
\end{tabular}

$a$ Estimates from diagrams in Fourth Biennial Report of State Engineeer of Colorado, 1887-88, Pl. XVII; figures also from Fifth Biennial Report, 1889-90, pp. 24, 25.

$b$ Year incomplete. 
Résumé of discharge data-Continued.

\begin{tabular}{|c|c|c|c|c|c|c|c|c|c|c|c|}
\hline \multirow{2}{*}{ River. } & \multirow{2}{*}{ Locality. } & \multicolumn{2}{|c|}{$\begin{array}{l}\text { Refer- } \\
\text { ence. }\end{array}$} & \multirow{2}{*}{ Year. } & \multirow{2}{*}{$\begin{array}{l}\text { Drain. } \\
\text { age } \\
\text { area. }\end{array}$} & \multirow{2}{*}{$\begin{array}{l}\text { Maxi. } \\
\text { mum. }\end{array}$} & \multirow{2}{*}{$\begin{array}{l}\text { Mini- } \\
\text { mum. }\end{array}$} & \multirow{2}{*}{ Mean. } & \multirow{2}{*}{\multicolumn{2}{|c|}{ Run-off. }} & \multirow{2}{*}{ Rainfall. } \\
\hline & & 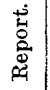 & 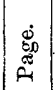 & & & & & & & & \\
\hline \multirow{5}{*}{$\begin{array}{l}\text { St. Vrain } \\
\text { Creek. }\end{array}$} & \multirow{5}{*}{$\begin{array}{l}\mathrm{L}_{\text {yous, }} \text { Colo. } \\
\text { rado. }\end{array}$} & & & & Sq.miles & Sec.ft. & Sec. ft. & Sec.ft. & Sec.ft. & Inches. & Inches. \\
\hline & & 13 & 93 & 1887 & 209 & & & & & & \\
\hline & & 13 & 93 & 1888 & 209 & 490 & & & & & \\
\hline & & 13 & 93 & 1889 & 209 & 423 & & & & & \\
\hline & & 13 & 93 & 1890 & 209 & 57!) & & & & & \\
\hline \multirow{8}{*}{$\begin{array}{l}\text { Big Thomp- } \\
\text { son Creek. }\end{array}$} & \multirow{8}{*}{$\begin{array}{l}\text { Arkins, Col- } \\
\text { orado. } a\end{array}$} & 13 & 93 & 1.888 & 305 & 860 & & & & & \\
\hline & & 13 & 93 & $1889 !$ & 305 & 546 & & & & & \\
\hline & & 13 & 93 & 1890 & 305 & 1,603 & & & & 10 & \\
\hline & & & $\cdots$ & 1891 & 305 & 1,182 & & & & & \\
\hline & & & $\ldots$ & 1892 & 305 & 1,182 & & $\therefore$ & & & \\
\hline & & 140 & 111 & 1895 & 305 & .... & & & & & \\
\hline & & 19 & 322 & $c 1897$ & 305 & 850 & 6 & & & $\cdots$ & \\
\hline & & 20 & 288 & 1.898 & .305 & 605 & 2 & & & & \\
\hline \multirow{9}{*}{$\begin{array}{l}\text { CachelaPou- } \\
\text { dre. }\end{array}$} & \multirow{9}{*}{$\begin{array}{r}\text { Fort Collins, } \\
\text { Colorado. } b\end{array}$} & 13 & 94 & 1884 & 1,060 & & & & & & \\
\hline & & 13 & 94 & 1885 & 1,060 & & & & & & \\
\hline & & 13 & 94 & 1886 & 1,060 & & & & & & \\
\hline & & 13 & 94 & 1887 & 1,060 & & & & & & \\
\hline & & 13 & 94 & 1888 & 1,060 & $\cdots$ & & $\cdots$ & $\ldots$ & $\ldots$. & \\
\hline & & 13 & 94 & 1889 & 1,060 & 1,960 & 33 & 283 & 0.26 & 3.62 & \\
\hline & & 13 & 94 & 1890 & $1 ; 060$ & 1,804 & 37 & 335 & 0.32 & 4. 32 & \\
\hline & & 13 & 94 & 1891 & 1,060 & 5,060 & 32 & 390 & 0.37 & 5.03 & \\
\hline & & 13 & 94. & 1892 & 1,060 & & & & & & \\
\hline South Platte . & $\begin{array}{c}\text { North Platte, } \\
\text { Nebraska. }\end{array}$ & 19 & 323 & $c 1897$ & 23,294 & 4,427 & 0 & & & & \\
\hline North Loup.. & $\begin{array}{c}\text { St. Paul, Ne- } \\
\text { braska. }\end{array}$ & 19 & 329 & 1897 & 4,024 & 4,880 & 575 & 996 & 0.23 & 3.38 & \\
\hline Middle Loup. & $\begin{array}{c}\text { St. Paul, Ne- } \\
\text { braska. }\end{array}$ & 19 & 330 & 1897 & 6,849 & 2,800 & 585 & 1,208 & 0.18 & 2.39 & \\
\hline \multirow[t]{2}{*}{ Loup ......... } & \multirow{2}{*}{$\begin{array}{r}\text { Col tim bus, } \\
\text { Nebraska. }\end{array}$} & 19 & 332 & $c 1897$ & 13,542 & 27,000 & 670 & 2,961 & 0.22 & 1. 73 & 17.70 \\
\hline & & 20 & 294 & 1898 & 13,542 & 6,675 & & $\cdots$ & & ....... & 18.18 \\
\hline \multirow[t]{2}{*}{ Platte........ } & \multirow{2}{*}{$\begin{array}{l}\text { Col umbus, } \\
\text { Nebraska, }\end{array}$} & 19 & 334 & $c 1897$ & 56,867 & 31,000 & 990 & & & & 21.55 \\
\hline & & 20 & 295 & 1898 & 56,867 & 24,600 & & $=\ldots \ldots$. & & |..... & 17.84 \\
\hline \multirow[t]{2}{*}{ Elkhorn ..... } & \multirow{2}{*}{$\begin{array}{l}\text { Norfolk, Ne- } \\
\text { braska. }\end{array}$} & 19 & 335 & 1897 & 2,474 & & & 257 & 0.10 & 0.94 & 26.13 \\
\hline & & 20 & 296 & 1898 & 2,474 & . . . . . . . . & & & & . & 20.37 \\
\hline Republican .. & $\begin{array}{c}\text { Superior, } \\
\text { Nebraska. }\end{array}$ & 19 & 339 & 1897 & 22,347 & 4,310 & 0 & 600 & 0.02 & 0.27 & \\
\hline \multirow[t]{3}{*}{ Republicarf.. } & \multirow{3}{*}{$\begin{array}{c}\text { Junction, } \\
\text { Kansas. }\end{array}$} & 18 & 205 & 1896 & 25,837 & 37,500 & 326 & 1,150 & 0.04 & 0.60 & \\
\hline & & 19 & 340 & 1897 & 25,837 & 6,360 & 85 & 966 & 0.03 & 0.50 & \\
\hline & & 20 & 318 & 1898 & 25,837 & 7,175 & 69 & 759 & 0.03 & 0.39 & $\cdots$. \\
\hline Solomon ...... & Beloit, Kan- & 18 & 210 & 1896 & 5,539 & 21,800 & 5 & 451 & 0.08 & 11.02 & \\
\hline & & 19 & 341 & 1897 & 5,539 & 7,470 & 16 & . & ... & & \\
\hline
\end{tabular}

$a$ See biennial reports of State engineer of Colorado: Fourth, Pls. XVII-XX; Fifth, pp. 24-30; Sixth 1891-92, pp. 22-39.

$b$ Figures of daily fow are given in Water Supply and Irrigation Paper No. 8, pp. 20-26.

$c$ Year incomplete. 
Résumé of discharge data-Continued.

\begin{tabular}{|c|c|c|c|c|c|c|c|c|c|c|c|}
\hline \multirow{2}{*}{ River. } & \multirow{2}{*}{ Locality. } & \multicolumn{2}{|c|}{$\begin{array}{l}\text { Refer- } \\
\text { ence. }\end{array}$} & \multirow{2}{*}{ Year } & \multirow{2}{*}{$\begin{array}{c}\text { Drain- } \\
\text { age } \\
\text { area. }\end{array}$} & \multirow{2}{*}{$\begin{array}{l}\text { Maxi- } \\
\text { mum. }\end{array}$} & \multirow{2}{*}{$\begin{array}{l}\text { Mini- } \\
\text { mum. }\end{array}$} & \multirow{2}{*}{ Mean. } & \multirow{2}{*}{\multicolumn{2}{|c|}{ Run·off. }} & \multirow{2}{*}{ Rainfall. } \\
\hline & & & & & & & & & & & \\
\hline \multirow{3}{*}{ Solomon .... } & \multirow{3}{*}{$\begin{array}{l}\text { Niles, Kan- } \\
\text { sas. }\end{array}$} & & & & Sq.miles & Sec. ft. & Sec. $f t$ & Sec. ft. & Sec.ft & Inches. & Inches. \\
\hline & & 19 & $343^{\circ}$ & $a 1897$ & 6,815 & 5,380 & 60 & .350 & 0.05 & 0.47 & 27.56 \\
\hline & & 20 & 314 & 1898 & 6,815 & 1,175 & 35 & 162 & 0.02 & 0.29 & $2 \dot{4} .87$ \\
\hline \multirow[t]{2}{*}{ Saline ....... } & \multirow{2}{*}{$\begin{array}{c}\text { Bererly, } \\
\text { Kansas. }\end{array}$} & 18 & 212 & 1896 & 2,730 & 16,000 & 26 & 313 & 0.11 & 1.52 & \\
\hline & & 19 & 344 & a 1897 & 2,730 & 11,000 & 17 & 159 & 0.05 & 0.39 & \\
\hline \multirow[t]{2}{*}{ Saline ........ } & \multirow{2}{*}{$\begin{array}{l}\text { Salina, Kan- } \\
\text { sas. }\end{array}$} & 19 & 346 & $a 1897$ & $3,3.1$ & 4,400 & 16 & 88 & 0.02 & 0.24 & \\
\hline & & 20 & 316 & 1898 & 3,311 & 1,100 & 6 & 83 & 0.03 & 0.33 & \\
\hline \multirow[t]{3}{*}{ Smoky Hill. . } & \multirow{3}{*}{$\begin{array}{l}\text { Ellswo r th } \\
\text { Kansas. }\end{array}$} & 18 & 215 & 1896 & 7,980 & 1,713 & 14 & 95 & 0.01 & 1.61- & \\
\hline & & 19 & 347 & 1897 & 7,980 & 385 & 10 & 77. & 0.01 & 0.13 & \\
\hline & & 20 & 315 & 1898 & 7,980 & 1,000 & 14 & 70 & 0.01 & 0.12 & \\
\hline \multirow[t]{2}{*}{ Blue....... } & \multirow{2}{*}{$\begin{array}{c}\text { Manhattan, } \\
\text { Kansas. }\end{array}$} & 19 & 348 & 1897 & 9,490 & 32,256 & 210 & 1,964 & 0.21 & 2.82 & \\
\hline & & 20 & 319 & 1898 & 9,490 & 10,774 & 207 & 1,336 & 0.14 & 1.90 & \\
\hline \multirow[t]{8}{*}{ Kansas ....... } & \multirow{8}{*}{$\begin{array}{c}\text { Lawrence, } \\
\text { Kansas. }\end{array}$} & 140 & 151 & 1891 & 59,841 & 35,750 & 967 & 7,228 & 0.12 & 2.19 & \\
\hline & & & 152 & 1892 & 59,841 & ....... & 787 & 7,222 & 0.12 & 1.54 & \\
\hline & & & & 1893 & 59,841 & 21,440 & 787 & 3,617 & 0.06 & 0.79 & \\
\hline & & & & 1894 & 59,841 & $\ldots \ldots$ & $\cdots$ & 2,326 & 0.04 & 0.51 & \\
\hline & & & & 1895 & 59,841 & ........... & ..... & 3,008 & 0.05 & 0.69 & \\
\hline & & 18 & 222 & 1896 & $\mathbf{5 9}, 841$ & 53,308 & 825 & 6,814 & 0.11 & 1.54 & 28.38 \\
\hline & & 19 & 350 & 1897 & 59,841 & 58,000 & 562 & 4,628 & 0.08 & 1.04 & 26.13 \\
\hline & & 20 & 322 & 1898 & 59,841 & 28,990 & 507 & 3,831 & 0.06 & 0.87 & 25.41 \\
\hline Arkansas. & $\begin{array}{l}\text { Granite, Col- } \\
\text { orado. }\end{array}$ & 19 & 354 & $a 1897$ & 425 & 2,058 & 114 & 519 & 1. 22 & 11.10 & 15. 32 \\
\hline Arkansas. & $\begin{array}{l}\text { Salida, Colo- } \\
\text { rado. }\end{array}$ & 19 & 355 & $\alpha 1897$ & 1,160 & 2,907 & 287 & 784 & 0.68 & 6.17 & \\
\hline Arkansas... & Canyon, Col- & 14 & 108 & 1888 & 3,060 & 2,760 & 430 & 860 & 0.28 & 3.80 & \\
\hline & & 14 & 108 & 1889 & 3,060 & 2,620 & 190 & 433 & 0.14 & 1.92 & \\
\hline & & 14 & 108 & 1890 & 3,060 & 3,270 & 180 & 874 & 0.28 & 3.88 & \\
\hline & & 14 & 109 & 1891 & 3,060 & 4,230 & 325 & 1,012 & 0.35 & 4.49 & \\
\hline & $\vdots$ & $1 \dot{4}$ & 109 & 1892 & 3,060 & 4,750 & 345 & 889 & 0.29 & 3.95 & \\
\hline & & .20 & 333 & 1893 & 3,060 & 4,750 & 200 & 857 & 0.27 & 3.80 & 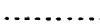 \\
\hline . & & 20 & 334 & 1894 & 3,060 & 4,400 & 245 & 845 & 0.28 & 3.74 & \\
\hline & & 18 & 227 & 1895 & 3,060 & 2,588 & 256 & 837 & 0.27 & 3.71 & .. \\
\hline & . & 18 & 227 & 1896 & 3,060 & 2,876 & 124 & 544 & 0.18 & 2.41 & 11.96 \\
\hline & & 19 & $35 \overline{6}$ & 1897 & 3,060 & 3,395 & 230 & 757 & 0.25 & 3.33 & 11.13 \\
\hline & . & 20 & 335 & 1898 & 3,060 & 3,245 & 160 & 640 & 0.21 & 2.83 & 11.45 \\
\hline Arkansas. . . & Pueblo, Col- & 13 & 94 & 1885 & 4,600 & & & & & & \\
\hline & do & 13 & 94 & 1886 & 4,600 & & & & & & \\
\hline & & 13 & 44 & 1887 & 4,600 & $\ldots$ & . & .... & ... & $\ldots$. & \\
\hline & & 18 & 230 & 1895 & 4,600 & 5,000 & 301 & 914 & 0.20 & 2.72 & \\
\hline & & 18 & 230 & 1896 & 4,600 & 3,438 & 203 & 517 & 0.11 & 1. 54 & \\
\hline & & 19 & 357 & 1897 & 4,600 & 3,750 & 146 & 670 & 0.14 & 1.98 & \\
\hline & & 20 & 336 & 1898 & 4,600 & 5,385 & 31 & 614 & 0.13 & 1.82 & \\
\hline
\end{tabular}

$a$ Year incomplete. 
Résumé of discharge data-Continued.

\begin{tabular}{|c|c|c|c|c|c|c|c|c|c|c|c|}
\hline \multirow{2}{*}{ River. } & \multirow{2}{*}{ Locality. } & \multicolumn{2}{|c|}{$\begin{array}{l}\text { Refor- } \\
\text { ence. }\end{array}$} & \multirow{2}{*}{ Year. } & \multirow{2}{*}{$\begin{array}{l}\text { Drain- } \\
\text { age } \\
\text { area. }\end{array}$} & \multirow{2}{*}{$\begin{array}{l}\text { Maxi- } \\
\text { mum. }\end{array}$} & \multirow{2}{*}{$\begin{array}{l}\text { Mini- } \\
\text { mum. }\end{array}$} & \multirow{2}{*}{ Mean. } & \multirow{2}{*}{\multicolumn{2}{|c|}{ Run-off. }} & \multirow{2}{*}{ Rainfall } \\
\hline & & 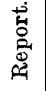 & 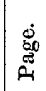 & & & & & & & & \\
\hline \multirow{3}{*}{ Arkansas.... } & \multirow{3}{*}{$\begin{array}{l}\text { Nepesta, Col- } \\
\text { orado. }\end{array}$} & & & & Sq.miles & Sec. ft. & Sec. ft. & Sec. ft. & Sec.ft. & Inches. & Inches. \\
\hline & & 19 & 358 & 1897 & & & & & & & \\
\hline & & 20 & 337 & 1898 & & & & & & & \\
\hline Arkansas.... & $\begin{array}{l}\text { Rockyfor d, } \\
\text { Colorado. }\end{array}$ & 20 & 338 & 1898 & $\mathbf{i 1}, 440$ & 3,832 & 34 & 546 & 0.49 & 0.68 & \\
\hline \multirow[t]{3}{*}{ Purgatory ... } & \multirow{3}{*}{$\begin{array}{c}\text { Trinidad, } \\
\text { Colorado. }\end{array}$} & 19 & 359 & 1896 & 742 & 4,600 & 0 & .... & $\cdots$ & $\ldots$. & \\
\hline & & 19 & 359 & 1897 & 742 & 2,023 & 10 & 184 & 0.25 & 3.38 & \\
\hline & & 20 & 341 & 1898 & 742 & 1,282 & 31 & ....... & . & $\cdots \cdot$ & \\
\hline \multirow[t]{3}{*}{ Arkansas.... } & \multirow{3}{*}{$\begin{array}{c}\text { Hutchinson, } \\
\text { Kansas. }\end{array}$} & 18 & 234 & 1896 & 34,000 & 1,138 & 16 & 150 & 0.01 & 0.06 & 20.40 \\
\hline & & 19 & 361 & 1897 & 34,000 & 2,270 & 0 & 175 & 0.01 & 0.07 & 18.39 \\
\hline & & 20 & 343 & 1898 & 34,000 & 2,830 & 4 & 316 & 0.09 & 0.12 & 25.10 \\
\hline \multirow[t]{3}{*}{ Neosho...... } & \multirow[t]{3}{*}{ Iola, Kansas. } & 18 & 240 & $i 896$ & 3,670 & 45,560 & 0 & 1,322 & 0.36 & 4.92 & \\
\hline & & 19 & 362 & 1897 & 3,670 & 4,840 & 0 & 422 & 0.11 & 1.52 & \\
\hline & & 20 & 346 & 1898 & 3,670 & 27,875 & 1 & 1,745 & 0.48 & 6.58 & \\
\hline \multirow[t]{4}{*}{ Verdigris.... } & \multirow{4}{*}{ 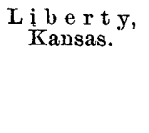 } & 19 & 370 & 1895 & 3,067 & $3 \pi, 000$. & 20 & ........ & & $\cdots$ & \\
\hline & & 19 & 370 & 1896 & 3,067 & 19,900 & 5 & 1,022 & 0.33 & 4.54 & \\
\hline & & 19 & 371 & 1897 & 3,067 & 26,100 & 2 & 813 & 0.27 & 3.57 & \\
\hline & & 20 & 344 & 1898 & 3,067 & 30,690 & 2 & 1,255 & 0.41 & 5.57 & \\
\hline Brazos... & Lewis, Texas & 20 & 354 & 1898 & & & & & & & \\
\hline Guadalupe... & $\begin{array}{l}\text { New Braun- } \\
\text { fels, Texas. }\end{array}$ & 20 & 354 & 1898 & & & & & & & \\
\hline Pecos... & Pecos, Texas & 20 & 354 & 1898 & & & & & & & \\
\hline \multirow[t]{10}{*}{ Rio Grande.. } & \multirow{10}{*}{$\begin{array}{c}\text { Del Norte, } \\
\text { Colorado. }\end{array}$} & 20 & 360 & 1889 & 1,400 & .. & 200 & . & $\ldots . .$. & $\ldots$ & \\
\hline & & 20 & 360 & 1890 & 1,400 & 5,930 & 307 & 1,242 & 0.89 & 12.06 & \\
\hline & & 20 & 360 & 1891 & 1,400 & 5,650 & 290 & 1,403 & 1.00 & 13.56 & \\
\hline & & 20 & 361 & 1892 & 1,400 & 4,710 & 243 & 812 & 0.58 & 7.92 & \\
\hline & & 20 & 361 & 1893 & 1,400 & 3,320 & 214 & 714 & 0.51 & 6.93 & \\
\hline & & 20 & 362 & 1894 & 1,400 & 2,850 & 200 & 652 & 0.46 & $6: 29$ & \\
\hline & & 20 & 362 & 1895 & 1,400 & 3,804 & 322 & 1,044 & 0.75 & 10.14 & \\
\hline & & 20 & 363 & 1896 & 1,400 & 3,579 & 214 & 884 & 0.63 & 8.58 & \\
\hline & & 20 & 365 & 1897 & 1,400 & 5,234 & 354 & 1,346 & 0.96 & 13.05 & \\
\hline & & 20 & 364 & 1898 & 1,400 & 5,266 & 220 & 1,517 & 1.08 & 14.66 & \\
\hline Rio Grande.. & $\mathbf{E} \mathrm{m} b \mathrm{ud}$ & 20 & 364 & 1889 & 7,000 & 5,660 & 181 & 1,032 & 0.15 & 1.99 & \\
\hline & $\begin{array}{l}\text { New Mex. } \\
\text { ico. }\end{array}$ & 20 & 365 & 1890 & 7,000 & 6,071 & 260 & 1,467 & 0.21 & 2.84 & \\
\hline & & 20 & 365 & 1891 & 7,000 & 8,550 & 225 & 1,855 & 0.26 & 3.61 & \\
\hline & & 20 & 367 & 1892 & 7,000 & 6,665 & 140 & 1,240 & 0.18 & 2.40 & $\ldots$ \\
\hline & & 20 & 367 & 1893 & 7,000 & 5,105 & 140 & 841 & 0.12 & 1.66 & \\
\hline & 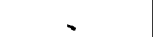 & 20 & 367 & 1895 & 7,000 & 4,985 & 420 & 1,222 & 0,17 & 2.36 & $\ldots$ \\
\hline & & 20 & 368 & 1896 & 7,000 & 2,980 & 210 & 645 & 0.09 & 1.25 & 10.28 \\
\hline & & 20 & 368 & 1897 & 7,000 & 8,745 & 285 & 1,497 & 0.22 & 2.97 & 13. 72 \\
\hline & & 20 & 368 & 1898 & 7,000 & 4,700 & 265 & 1,157 & 0.17 & 2.28 & 9.05 \\
\hline Chama....... & $\begin{array}{l}\text { Abiquiu, } \\
\text { New Mex. } \\
\text { ico. }\end{array}$ & 19 & $\ldots$ & 1897 & 2,300 & & & & & & \\
\hline
\end{tabular}

$a$ See Report on Agriculture by Irrigation, Eleventh Census, 1890, pp. 117, 118. 
Résumé of discharge data-Continued.

\begin{tabular}{|c|c|c|c|c|c|c|c|c|c|c|c|}
\hline River. & Locality. & \multicolumn{2}{|c|}{$\begin{array}{l}\text { Refer- } \\
\text { ence. }\end{array}$} & Year. & $\begin{array}{l}\text { Drain- } \\
\text { age } \\
\text { area. }\end{array}$ & $\begin{array}{l}\text { Maxi. } \\
\text { mum. }\end{array}$ & $\begin{array}{l}\text { Mini- } \\
\text { mum. }\end{array}$ & Mean. & \multicolumn{2}{|c|}{ Run-off. } & Rainfall. \\
\hline \multirow{5}{*}{ Rio Grande.. } & \multirow{5}{*}{$\begin{array}{l}\text { Rio Grande, } \\
\text { New Mex- } \\
\text { ico. }\end{array}$} & & & & Sq.miles & Sec. ft. & Sec.ft. & Sec. ft. & Sec.ft. & Inches. & Inches. \\
\hline & & 140 & 176 & 1895 & 11,250 & & $\cdots$ & $\ldots$ & $\ldots .$. & K... & \\
\hline & & 18 & 254 & 1896 & 11,250 & $\ldots \ldots$ & $\cdots \cdots$ & $\ldots$. & $\ldots$. & ...... & \\
\hline & & 19 & 386 & 1897 & 11,250 & 15,340 & 200 & 2,610 & 0.23 & 3.00 & \\
\hline & & 20 & 370 & 1898 & 11,250 & 8,020 & 230 & 1,501 & 0.16 & 2. 15 & \\
\hline \multirow[t]{2}{*}{ Rio Grande... } & \multirow{2}{*}{$\begin{array}{l}\text { San Marcial, } \\
\text { New Mex. } \\
\text { ico. }\end{array}$} & 19 & 388 & 1897 & 28,067 & 21,750 & 5 & 3,045 & 0.11 & 1.48 & \\
\hline & & 20 & 371 & 1898 & 28,067 & 16,775 & 27 & 1,335 & 0.05 & 0.64 & \\
\hline \multirow[t]{10}{*}{ Rio Grande.. } & \multirow{10}{*}{$\begin{array}{c}\text { E } 1 \underset{\text { Pa s o, }}{\text { Texas }(a)}\end{array}$} & 14 & 114 & 1889 & 30,000 & 4,705 & 0 & ....... & $\cdots \cdot$ & ...... & \\
\hline & & 14 & 114 & 1890 & 30,000 & 7,200 & 40 & 1,327 & 0.04 & 0.60 & \\
\hline & & 14 & 114 & 1891 & 30,000 & $16,6 \approx 0$ & 0 & 2,653 & 0.08 & 1.20 & \\
\hline & & 14 & 144 & 1892 & 30,000 & 10,050 & 0 & $.1,285$ & 0.04 & 0.58 & \\
\hline & & 131 & 47 & 1893 & 30,000 & $\ldots$. & & & $\ldots$ & -. & \\
\hline & & 131 & 47 & 1894 & 30,000 & & & & $\cdots$ & & \\
\hline & & 140 & 179 & 1895 & 30,000 & 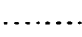 & & & & & \\
\hline & & 18 & 259 & 1896 & 30,000 & $\ldots \ldots$ & $\cdots$ & $\ldots$ & …... & $\cdots$ & 10.28 \\
\hline & & 19 & 390 & 1897 & 30,000 & 17,000 & 0 & 1,871 & 0.06 & 0.84 & 13. 72 \\
\hline & & 20 & 372 & 1898 & 30,000 & 9,900 & 0 & 922 & 0.03 & 0.42 & 9.05 \\
\hline \multirow[t]{2}{*}{ Black Fork.. } & \multirow{2}{*}{$\begin{array}{c}\text { Gran g e r } \\
\text { Wy yoming. }\end{array}$} & 19 & 393 & 1897 & 2,400 & 5,375 & 150 & 690 & 0.29 & 3.94 & \\
\hline & & 20 & 381 & 1898 & 2,400 & ......... & $\cdots$ & 727 & 0.30 & 4.09 & \\
\hline \multirow[t]{2}{*}{ Green ........ } & \multirow{2}{*}{$\begin{array}{l}\text { Green River, } \\
\text { Wyoming. }\end{array}$} & 19 & 395 & 1897 & 7,450 & 17,860 & 400 & 2,676 & 0.36 & 4. 89 & \\
\hline & & 20 & 380 & 1898 & 7,450 & 15,120 & 160 & & & & \\
\hline \multirow[t]{4}{*}{ Green ........ } & \multirow[t]{4}{*}{ Blake, Utah. } & 18 & 278 & 1895 & 38,200 & 21,460 & 610 & 6,372 & 0.17 & 2.25 & \\
\hline & & 18 & 278 & 1896 & 38,200 & 28,950 & 1,100 & 7,005 & 0.18 & 2.49 & 9.09 \\
\hline & & 19 & 398 & 1897 & 38,200 & 68,800 & 1,040 & 10,434 & 0.27 & 3.70 & 12.19 \\
\hline & & 20 & 387 & 1898 & 38.200 & 35,550 & 1,080 & 7,621 & 0.27 & 3.69 & 7.36 \\
\hline Grand ........ & Grand Junc- & 19 & 401 & 1897 & 8,644 & 37,950 & 1,280 & 6,693 & 0.77 & 10.56 & \\
\hline & $\begin{array}{l}\text { tion, Colo- } \\
\text { rado. }\end{array}$ & 20 & 389 & \begin{tabular}{|l|}
1898
\end{tabular} & 8,644 & 17,262 & .. & 3,555 & 0.42 & 5. 63 & \\
\hline Uncompahgre & Fort Craw. & 19 & 404 & 1897 & 497 & 1,467 & 55 & 319 & 0.64 & 8.71 & \\
\hline & $\begin{array}{l}\text { ford, Colo- } \\
\text { rado. }\end{array}$ & 20 & 391 & 1898 & 497 & 985 & & & & & \\
\hline Gunnison.... & Grand Junc- & 19 & 405 & 1897 & 7,935 & 20,730 & 160 & & & & \\
\hline & $\begin{array}{l}\text { tion, Colo- } \\
\text { rado. }\end{array}$ & 20 & 390 & 1898 & 7,935 & 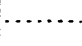 & & & & & \\
\hline San Miguel.. & Fall Creek, & 19 & 407 & 1897 & 327 & 997 & 52 & 243 & 0.74 & 10.09 & \\
\hline & & 20 & 395 & 1898 & 327 & 1,335 & 22 & & & & \\
\hline Dolores....... & Dolores, Col- & 20 & 393 & 1895 & 524 & & & & & & \\
\hline & & 20 & 393 & 1896 & 524 & 1,578 & 8 & 306 & 0.58 & $7.90^{\circ}$ & \\
\hline & & 20 & 393 & 1897 & 524 & 2,944 & 76 & 631 & 1.20 & 16. 37 & \\
\hline & & 20 & 394 & 1898 & 524 & 2,030 & 34 & 432 & 0.82 & 11.17 & 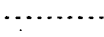 \\
\hline San Juan .... & Arboles, Col- & 19 & 410 & 1897 & 1,320 & 4,423 & 182 & 975 & 0.70 & 9.47 & \\
\hline & orado. & 20 & 401 & 1898 & 1,320 & 3,255 & 83 & & & . & ......... \\
\hline Piedra........ & Arboles, Col- & 19 & 413 & 1897 & 650 & 2,398 & 68 & 605 & 0.93 & 12.66 & 24.93 \\
\hline & & 20 & 403 & 1898 & 670 & 1,599 & 27 & & $\cdot$ & $\cdots$ & 16.27 \\
\hline
\end{tabular}

$a$ See also Report on Agriculture by Irrigation, Eleventh Census, 1890, p. 197. 
Résumé of discharge data-Continued.

\begin{tabular}{|c|c|c|c|c|c|c|c|c|c|c|c|}
\hline \multirow{2}{*}{ River. } & \multirow{2}{*}{ Locality. } & \multicolumn{2}{|c|}{$\begin{array}{l}\text { Refer- } \\
\text { ence. }\end{array}$} & \multirow{2}{*}{ Year. } & \multirow{2}{*}{$\begin{array}{l}\text { Drain- } \\
\text { age } \\
\text { area. }\end{array}$} & \multirow{2}{*}{$\begin{array}{l}\text { Maxi- } \\
\text { mum. }\end{array}$} & \multirow{2}{*}{$\begin{array}{l}\text { Mini. } \\
\text { mum. }\end{array}$} & \multirow{2}{*}{ Mean. } & \multirow{2}{*}{\multicolumn{2}{|c|}{ Run-off. }} & \multirow{2}{*}{ Rainfall. } \\
\hline & & 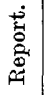 & 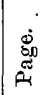 & & & & & & & & \\
\hline \multirow{3}{*}{ Animas...... } & \multirow{3}{*}{$\begin{array}{c}\text { D u rango, } \\
\text { Colorado. }\end{array}$} & & & & Sq.miles & Sec.ft. & Sec.ft. & Sec. ft. & Sec.ft. & Inches. & Inches. \\
\hline & & 19 & 414 & $189 \vec{t}$ & 812 & 5,870 & 275 & 1,349 & 1. 66 & 22.61 & 24.93 \\
\hline & & 20 & 404 & 1898 & 812 & 4,677 & 125 & 851 & 1.05 & 14.25 & 16.27 \\
\hline San Pedro ... & $\begin{array}{c}\text { Dudleyville, } \\
\text { Arizona. }\end{array}$ & 12 & 305 & 1890 & 2,819 & 507 & $I$ & 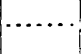 & 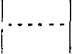 & 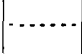 & \\
\hline \multirow[t]{5}{*}{ Gila ........... } & \multirow{5}{*}{$\begin{array}{l}\text { Buties, Ari- } \\
\text { zona. }\end{array}$} & 18 & 290 & 1889 & 13,750 & 890 & 90 & & & & \\
\hline & & 18 & 290 & 1890 & 13,750 & 6,330 & 11 & & & & \\
\hline & & 18 & 290 & 1895 & 13,750 & .. & & $\ldots$. & & $\ldots$. & \\
\hline & & 18 & 290 & 1896 & 13,750 & 11,793 & 1 & 842 & 0.06 & 0.84 & \\
\hline & & 19 & 416 & 1897 & 13,750 & 5,590 & 0 & 838 & 0.06 & 0.68 & \\
\hline \multirow{3}{*}{ Salt........... } & \multirow{3}{*}{$\begin{array}{l}\text { Arizona } \\
\text { dam, Ari- } \\
\text { zona. }\end{array}$} & 13 & 95 & 1888 & 12,260 & 43,489 & & $\ldots$ & 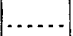 & & \\
\hline & & 13 & 95 & 1889 & 12,260 & 33,794 & 319 & 2,576 & 0.21 & 2.86 & \\
\hline & & 13 & 95 & 1890 & 12,260 & 143,288 & 397 & 3,771 & 0.31 & 4.14 & \\
\hline \multirow[t]{3}{*}{ Salt........... } & \multirow{3}{*}{$\begin{array}{c}\text { Mc Dowell, } \\
\text { Arizona. }\end{array}$} & 18 & 298 & 1895 & 6,260 & 49,796 & 145 & 1,409 & 0.22 & 3.05 & \\
\hline & & 19 & 420 & i 897 & 6,260 & 4,580 & 83 & 787 & 0.13 & ....... & \\
\hline & & 20 & 406 & 1898 & 6,260 & 1,275 & 137 & 429 & 0.07 & 0.92 & \\
\hline \multirow[t]{3}{*}{ Verde ........ } & \multirow{3}{*}{$\begin{array}{c}\text { Mc Dowell, } \\
\text { Arizona. }\end{array}$} & 18 & 297 & 1895 & 6,000 & 33,000 & 116 & 1,051 & 0.18 & 2.36 & \\
\hline & & 19 & 423 & 1897 & 6,000 & 5,000 & 90 & 409 & 0.06 & ....... & \\
\hline & & 20 & 407 & 1898 & 6,000 & 1,890 & 115 & 313 & 0.05 & 0.70 & \\
\hline \multirow[t]{2}{*}{ Prosser Creek } & \multirow{2}{*}{$\begin{array}{l}\text { Boca, Cali- } \\
\text { fornia. }\end{array}$} & 13 & 95 & 1889 & 55 & & & & & & \\
\hline & & 13 & 95 & 1890 & 55 & & & & & & \\
\hline LittleTruckee & $\begin{array}{l}\text { Boca, Cali- } \\
\text { fornia. }\end{array}$ & 13 & 95 & 1890 & 186 & 2,867 & 70 & & & & \\
\hline Truckee ...... & $\begin{array}{l}\text { Boca, Cali- } \\
\text { fornia. }\end{array}$ & 13 & 95 & 1890 & 887 & & & & $\ldots$ & & \\
\hline Truckee..... & Vista, $\mathrm{Ne}-$ & 13 & 95 & 1890 & 1,519 & 7,510 & 400 & -. & $\cdots$ & ....... & \\
\hline & vada. & 13 & 95 & 1891 & 1,519 & 3,285 & 370 & 980 & 0.63 & 8.69 & \\
\hline & & 13 & 95 & 1892 & 1,519 & 1,120 & 210 & & & & \\
\hline EastCarson.. & Rodenbahs, & 14 & 116 & 1890 & 414 & 4,260 & 375 & 970 & 2.34 & 31.89 & \\
\hline & & 14 & 117 & 1891 & 414 & 1,884 & 377 & 619 & 1.50 & 20.31 & \\
\hline & & 14 & 117 & 1892 & 414 & 5,540 & 290 & 610 & I. 47 & 20.07 & \\
\hline & & 14 & 117 & 1893 & 414 & 3,230 & $382^{\circ}$ & 843 & 2.04 & 27. 71 & \\
\hline West Carson. & Wood for d, & 14 & 118 & 1890 & 70 & 1,284 & 42 & 206 & 2.95 & 40.08 & \\
\hline & California. & 14 & 118 & 1891 & 70 & -740 & 34 & 128 & 1.83 & 24.89 & \\
\hline & & 13 & 96 & 1892 & 70 & $\cdots$ & . & $\cdots$ & & & \\
\hline Fumboldt ... & $\begin{array}{l}\text { Peko, } \mathrm{Ne} \text { - } \\
\text { vada. }\end{array}$ & 20 & 436 & 1898 & 1,020 & 257 & 1 & & & & \\
\hline Humboldt ... & Elko, Neva- & 18 & 301 & 1896 & 2,840 & 1,848 & 10 & 276 & 0.10 & 1.29 & \\
\hline & & 19 & 424 & 1897 & 2,840 & 2,396 & 5 & 449 & 0.15 & 2.16 & \\
\hline & & 20 & 437 & 1898 & 2,840 & 565 & 1 & 130 & 0.05 & 0.62 & \\
\hline Humboldt ... & Battle Moun- & 18 & 303 & 1896 & 7,800 & 3,001 & 11 & 584 & 0.07 & 0.64 & \\
\hline & $\begin{array}{l}\text { tain, Neva- } \\
\text { da. }\end{array}$ & 19 & 426 & 1.897 & 7,800 & 3,131 & 5 & 718 & 0.09 & 1. 24 & \\
\hline Humboldt... & Golconda, & 18 & 306 & 1896 & 10,780 & 1,614 & 14 & 226 & 0.02 & 0.28 & \\
\hline & & 19 & 427 & 1897 & 10,780 & 3,100 & 5 & 649 & 0.06 & 0.81 & \\
\hline . & & 20 & 438 & 1898 & 10,780 & 485 & 1 & 130 & 0.01 & 0.16 & \\
\hline
\end{tabular}


Résumé of discharge data-Continued.

\begin{tabular}{|c|c|c|c|c|c|c|c|c|c|c|c|}
\hline \multirow{2}{*}{ River. } & \multirow{2}{*}{ Locality. } & \multicolumn{2}{|c|}{$\begin{array}{l}\text { Refer- } \\
\text { ence. }\end{array}$} & \multirow{2}{*}{ Year. } & \multirow{2}{*}{$\begin{array}{c}\text { Drain- } \\
\text { age } \\
\text { area. }\end{array}$} & \multirow{2}{*}{$\begin{array}{l}\text { Maxi. } \\
\text { mum. }\end{array}$} & \multirow{2}{*}{$\begin{array}{l}\text { Mini- } \\
\text { mum. }\end{array}$} & \multirow{2}{*}{ Mean. } & \multirow{2}{*}{\multicolumn{2}{|c|}{$\begin{array}{c}\text { liun-off. } \\
\text {. }\end{array}$}} & \multirow{2}{*}{ Rainfall. } \\
\hline & & 范 & 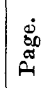 & & & & & & & & \\
\hline \multirow{4}{*}{ Humboldt... } & \multirow{4}{*}{$\begin{array}{l}\text { Oreana, Ne- } \\
\text { vada. }\end{array}$} & & & & Sq.miles & Sec.ft. & Sec. ft. & Sec. ft. & Sec.ft. & Inches. & Inches. \\
\hline & & 18 & 308 & 1896 & 13,800 & $\ldots$ & $\cdots$ & 214 & 0.01 & 0.17 & \\
\hline & & 19 & 428 & 1897 & 13,800 & 3,047 & 26 & 641 & 0.04 & 0.63 & \\
\hline & & 20 & 439 & 1898 & 13,800 & $\ldots .$. & & & $\cdots$ & & \\
\hline Rock Creek.. & $\begin{array}{l}\text { Battle Moun- } \\
\text { tain, Neva- } \\
\text { da. }\end{array}$ & 18 & 310 & 1896 & 750 & 1,102 & 9 & 208 & 0.28 & 1.55 & \\
\hline \multirow{3}{*}{$\begin{array}{l}\text { South Hum- } \\
\text { boldt. }\end{array}$} & \multirow{3}{*}{$\begin{array}{c}\text { M a s o n's } \\
\text { ra n c h, } \\
\text { Nevada. }\end{array}$} & 19 & 430 & 1896 & 1,150 & …... & $\cdots$ & & -. & & \\
\hline & & 19 & 430 & 1897 & 1,150 & 1,327 & 2 & 224 & 0.19 & 2.66 & \\
\hline & & 20 & 440 & 1898 & 1,150 & 473 & 0.1 & 114 & 0.10 & 1.34 & \\
\hline \multirow[t]{5}{*}{ Bear . .......... } & \multirow{10}{*}{$\begin{array}{l}\text { Battle Creek, } \\
\text { Idaho. }\end{array}$} & 14 & 119 & 1889 & 4,500 & ..... & $\ldots$. & $\ldots$ & ....... & $\cdots \cdot$ & \\
\hline & & 14 & 119 & 1890 & 4,500 & 5,980 & 270 & 1,751 & 0.42 & 5.27 & \\
\hline & & 14 & 119 & 1891 & 4,500 & 3,030 & 690 & 1,224 & 0.27 & 3.70 & \\
\hline & & 14 & 119 & 1892 & 4,500 & 5,260 & 600 & 1,537 & 0.34 & 4.64 & \\
\hline & & 14 & 119 & 1893 & 4,500 & 3,960 & 690 & 1,452 & 0.32 & 4.38 & \\
\hline \multirow{5}{*}{ ' } & & 131 & 55 & 1894 & 4,500 & …... & $\cdots$ & …... & …... & $\cdots \cdots$ & \\
\hline & & 140 & 227 & 1895 & 4,500 & 3,637 & 612 & 1,207 & 0.27 & 3.63 & - \\
\hline & & 18 & 315 & 1896 & 4,500 & 5,205 & 580 & 1,397 & 0.31 & 4.25 & 14.09 \\
\hline & & 19 & 432 & 1897 & 4,500 & 6,100 & 780 & 1,707 & 0.38 & 5.16 & 10.84 \\
\hline & & 20 & 459 & 1898 & 4,500 & 3,483 & 535 & 1,174 & 0.26 & 3.54 & 11.73 \\
\hline Bear..... & $\begin{array}{l}\text { SodaSprings, } \\
\text { Idaho. }\end{array}$ & 18 & 313 & 1896 & 3,940 & & & & & & \\
\hline \multirow[t]{3}{*}{ Logan ........ } & \multirow[t]{3}{*}{ Logan, Utah. } & 18 & 318 & 1890 & 218 & 1,860 & 193 & 465 & 2.15 & 17.20 & \\
\hline & & 19 & 434 & 1897 & 218 & $1,823^{\circ}$ & 150 & 400 & 1.83 & 25.02 & $\cdots$ \\
\hline & & 20 & 462 & 1898 & 218 & 778 & 108 & 268 & 1.23 & 16.68 & .... \\
\hline \multirow[t]{10}{*}{ Bear .......... } & Collinston, & 14 & 120 & 1889 & 6,000 & $\cdots$ & $\ldots$ & $\ldots$. & $\cdots$ & & \\
\hline & Utah. & 14 & 120 & 1890 & 6,000 & 8,220 & 1,000 & 2,945 & 0.49 & 6.68 & \\
\hline & . & 14 & 120 & 1891 & 6,000 & 5,000 & 825 & 1,847 & 0.31 & 4.19 & $\cdots \cdots$ \\
\hline & & 14 & 120 & 1892 & 6,000 & 6,260 & 1,000 & 2,097 & 0.35 & 4.76 & \\
\hline & & 14 & 120 & 1893 & 6,000 & 6,470 & 675 & 1,938 & 0.32 & $4.40^{\circ}$ & \\
\hline & & 131 & 57 & 1894 & 6,000 & …... & $\cdots$ & c.en. & n..... & ...... & \\
\hline & & 140 & 229 & 1895 & 6,000 & 4,990 & 540 & 1,842 & 0.31 & 4. 16 & $\ldots$ \\
\hline & & 18 & 320 & 1896 & 6,000 & 7,415 & 1,100 & 2,187 & 0.36 & 4.92 & 13.06 \\
\hline & & 19 & 435 & 1897 & 6,000 & 10,590 & 990 & 2,863 & 0.48 & 6.46 & 15.20 \\
\hline & & 20 & 460 & 1898 & 6,000 & 5,315 & 718 & 1,973 & 0.33 & 4.44 & 12.14 \\
\hline Ogden ... & Ogden, Utah. & 13 & 96 & 1889 & 360 & , nen & 40 & & . & & \\
\hline & & 13 & 96 & 1890. & 360 & 2,178 & 195 & 663 & 1.84 & 24.97 & $\cdots$ \\
\hline & & 140 & 230 & 1895 & 360 & …….. & $\cdots$ & $\cdots$ & $\cdots$ & & $\cdots$ \\
\hline & & 18 & 322 & 1896 & 360 & ……. & $\cdots$ & $\ldots .$. & $\ldots .$. & $\ldots .$. & 13.95 \\
\hline & & 19 & 439 & $a 1897$ & 360 & 2,433 & 30 & 193 & 0.88 & 6.44 & 16.24 \\
\hline & & 20 & 465 & 1898 & 360 & 517 & 30 & 91 & 0.25 & 3.43 & 13. 68 \\
\hline Ogden ........ & Eden, Utah.. & 18 & 322 & 1896 & 360 & …. & . & & & & \\
\hline Weber........ & Uinta, Utah. & 14 & 122 & 1889 & 1,600 & & $\cdots$ & $\cdots$ & ...... & 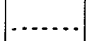 & \\
\hline & & 14 & 122 & 1890 & 1,600 & 5,465 & 200 & 1,070 & 0.67 & 9.09 & \\
\hline & & 14 & 123 & 1891 & 1,600 & 4,655 & 240 & 880 & 0.55 & 7.49 & \\
\hline & & 14 & 123 & 1892 & 1,600 & 5,755 & 100 & 907 & 0.57 & 7.71 & $\cdots$ \\
\hline & & 14 & 123 & 1893 & 1,600 & & & $\cdots$ & & & \\
\hline & & 131 & 58 & 1894 & 1,600 & & & & & & \\
\hline
\end{tabular}

a Year incomplete. 
Résumé of discharge data-Continued.

\begin{tabular}{|c|c|c|c|c|c|c|c|c|c|c|c|}
\hline \multirow{2}{*}{ River. } & \multirow{2}{*}{ Locality. } & \multicolumn{2}{|c|}{$\begin{array}{l}\text { Refer- } \\
\text { ence. }\end{array}$} & \multirow{2}{*}{ Xear. } & \multirow{2}{*}{$\begin{array}{l}\text { Drain- } \\
\text { age } \\
\text { area. }\end{array}$} & \multirow{2}{*}{$\begin{array}{l}\text { Maxi- } \\
\text { mum. }\end{array}$} & \multirow{2}{*}{$\begin{array}{l}\text { Mini- } \\
\text { mum. }\end{array}$} & \multirow{2}{*}{ Mean. } & \multirow{2}{*}{\multicolumn{2}{|c|}{ Run-off. }} & \multirow{2}{*}{ Rainfall. } \\
\hline & & & & & & & & & & & \\
\hline \multirow{5}{*}{ Web̄er........ } & \multirow{5}{*}{ Uinta. Utah . } & & & & Sq.miles & Sec.ft. & Sec. ft. & Sec. ft. & Sec.ft & Inches. & Inches. \\
\hline & & 140 & 233 & 1895 & 1,600 & 2,400 & 90 & 534 & 0.33 & 4.77 & $\ldots$ \\
\hline & & 18 & 325 & 1896 & 1,600 & 7,980 & 155 & 1,044 & 0.67 & 9.08 & 17.55 \\
\hline & & 19 & 440 & 1897 & 1,600 & 5,342 & 160 & 856 & 0.54 & 7.28 & 21.44 \\
\hline & & 20 & 466 & 1898 & 1,600 & 2,118 & 65 & 532 & 0.33 & 4.52 & \\
\hline \multirow{2}{*}{$\begin{array}{c}\text { American } \\
\text { Fork. }\end{array}$} & \multirow{2}{*}{$\begin{array}{l}\text { American } \\
\text { F o r k } \\
\text { Utah. }\end{array}$} & 13 & 96 & 1889 & 66 & ...... & 6 & & & $\cdots$ & \\
\hline & & 13 & 96 & 1890 & 66 & 885 & 6 & 146 & 2.21 & 30.02 & \\
\hline \multirow{10}{*}{ Provo........... } & \multirow[t]{10}{*}{ Provo, Utah } & 14 & 123 & $a 1889$ & 640 & ......... & $\cdots \cdots$ & $\ldots$. & $\ldots \ldots$ & ….. & \\
\hline & & 14 & 124 & 1890 & 640 & 2,260 & 200 & 572 & 0.89 & 12.13 & \\
\hline & & 14 & 124 & 1891 & 640 & 1,704 & 200 & 503 & 0.79 & 10.71 & \\
\hline & & 14 & 124 & 1892 & 640 & 1,780 & 174 & 469 & 0.73 & 9.96 & \\
\hline & & 14 & 124 & 1893 & 640 & 2,340 & 240 & 530 & 0.83 & 11.. 25 & \\
\hline & & 131 & 60 & a.1894 & 640 & . n. & & & & n....... & \\
\hline & & 140 & 235 & 1895 & 640 & 1,760 & 192 & 423 & 0.66 & 9.07 & 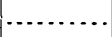 \\
\hline & & 18 & 327 & 1896 & 640 & 4,150 & 292 & 544 & 0.85 & 11.53 & 17.82 \\
\hline & & 19 & 442 & 1897 & 640 & 2,600 & 225 & 571 & 0.89 & 12.12 & 19.40 \\
\hline & & 20 & 468 & 1898 & 640 & 1,212 & 146 & 386 & 0.60 & 8.19 & 14.96 \\
\hline \multirow[t]{2}{*}{ Spanish Fork } & \multirow{2}{*}{$\begin{array}{l}\text { S panish } \\
\text { For } \mathrm{k}, \\
\text { Utah. }\end{array}$} & 13 & 97 & $\alpha 1889$ & 670 & & & & $\cdots$ & & \\
\hline & & 13 & 97 & 1890 & 670 & 1,040 & 50 & 172 & 0.25 & 3.50 & \\
\hline Sevier ........ & Joseph, Utah & 12 & 342 & $a$ & & & & & & & \\
\hline \multirow{5}{*}{ Sevier ........ } & \multirow{5}{*}{$\begin{array}{c}\text { Leamington, } \\
\text { Otah. }\end{array}$} & 14 & 126 & a1889 & 5,595 & & $\ldots$ & $\ldots$ & $\ldots$ & 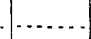 & \\
\hline & & 14 & 126 & 1890 & 5,595 & 2.329 & 150 & 625 & 0.11 & 1.49 & \\
\hline & & 14 & 126 & 1891 & 5,595 & 1,386 & 140 & 535 & 0.10 & 1.20 & \\
\hline & & 14 & 126 & 1892 & 5,595 & 1,222 & 48 & 401 & 0.07 & 0.97 & \\
\hline & & 14 & 126 & 1893 & 5,595 & 1,304 & 35 & 379 & 0.07 & 0.92 & \\
\hline Henry Fork & Near mouth, & 13 & 97 & 1890 & 931 & 7,710 & 1,120 & 1,719 & 1.85 & 25.16 & \\
\hline & Idah & 13 & 97 & $\alpha 1891$ & 931 & 3,180 & 1,280 & $\ldots . .$. & $\ldots a$ & $\cdots$ & \\
\hline Falls. & Near mouth, & 13 & 97 & $a 1890$ & 591 & 4,440 & 480 & $\ldots \ldots$ & $\cdots$ & 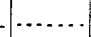 & \\
\hline & & 13 & 97 & 1891 & 594 & 2,790 & 450 & 773 & 1.31 & 17.75 & \\
\hline Teton. & Wilford, & 14 & 127 & 1890 & 967 & 4,445 & 450 & 1,021 & 1. 05 & 14.41 & \\
\hline & & 14 & 128 & 1891 & 967 & 2,360 & 425 & 696 & 0.72 & 9.75 & \\
\hline & & 14 & 128 & 1892 & 967 & 5,270 & 450 & 1,084 & 1.12 & 15.26 & \\
\hline & & 14 & 128 & 1893 & 967 & $\cdots$ & $\cdots$ & 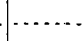 & & & \\
\hline Snake ... & Idabo Falls, & 13 & 97 & 1889 & 10,100 & & & & & & \\
\hline & & 13 & 97 & 1890 & 10,100 & 50,450 & 2,000 & 10,365 & 1.05 & 14.47 & \\
\hline & & 13 & 97 & 1892 & 10,100 & 54,300 & 2,250 & 10,025 & 1.00 & 13.50 & \\
\hline & & 131 & 65 & 1893 & 10,100 & $\cdots$ & & & & $\cdots$ & \\
\hline & & 131 & 65 & 1894 & 10,160 & & & & & & $\cdots$ \\
\hline Snake... & Montgom. & 18 & 336 & 1895 & 22,600 & & & & & & \\
\hline & $\begin{array}{l}\text { ery Ferry, } \\
\text { Idaho. }\end{array}$ & 18 & 336 & 1896 & 22,600 & $\ldots \ldots \ldots$ & $\ldots$ & $\ldots$. & $\cdots \cdots$ &..... & 17.67 \\
\hline & & 19 & 447 & 1897 & 22,600 & 47,480 & 4,800 & 10,064 & 0.44 & 6.02 & 15.24 \\
\hline & - & 20 & 474 & 1898 & 22,600 & 26,360 & 4,350 & $\cdots$ & & ...... & 10.72 \\
\hline Portneuf .... & Pocatello, & 20 & 475 & 1897 & & & & & & & \\
\hline & Idaho. & 20 & 475 & 1898 & & 336 & 14 & & & & \\
\hline
\end{tabular}

$a$ Year incomplete. 
Rósumé of discharge data-Continued.

\begin{tabular}{|c|c|c|c|c|c|c|c|c|c|c|c|}
\hline \multirow[b]{2}{*}{ River. } & \multirow[b]{2}{*}{ Locality. } & \multicolumn{2}{|c|}{$\begin{array}{l}\text { Refer- } \\
\text { ence. }\end{array}$} & \multirow[b]{2}{*}{ Year. } & \multirow{2}{*}{$\begin{array}{l}\text { Drain- } \\
\text { age } \\
\text { area. }\end{array}$} & \multirow{2}{*}{$\begin{array}{l}\text { Maxi- } \\
\text { mum. }\end{array}$} & \multirow{2}{*}{$\begin{array}{l}\text { Mini- } \\
\text { mum. }\end{array}$} & \multirow[b]{2}{*}{ Mean. } & \multirow{2}{*}{\multicolumn{2}{|c|}{ Run-off. }} & \multirow[b]{2}{*}{ Rainfall. } \\
\hline & & $\mid \frac{\dot{0}}{0}$ & : & & & & & & & & \\
\hline \multirow{3}{*}{ Malade ....... } & \multirow{3}{*}{$\begin{array}{l}\text { Top o n is } \\
\text { Idaho. }\end{array}$} & & & & Squmiles & Sec. fl. & See.ft. & Sec.ft. & Sec.ft. & Inches. & Inches. \\
\hline & & 19 & 449 & 1897 & 2,190 & 2,360 & 0 & 307 & 0.21 & $\cdots$ & \\
\hline & & 20 & 477 & 1898 & 2,190 & 1,590 & 2 & & & & \\
\hline \multirow[t]{2}{*}{ Little Wood } & \multirow{2}{*}{$\begin{array}{c}\text { Topon is } \\
\text { Idaho. }\end{array}$} & 19 & 449 & 1897 & 1,270 & 481 & 1 & 84 & 0.06 & & \\
\hline & & 20 & $\ldots$ & 1898 & 1,270 & & 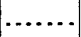 & & & & \\
\hline \multirow{3}{*}{ Bruneau..... } & \multirow{3}{*}{$\begin{array}{l}\text { Grandviow, } \\
\text { Idaho. }\end{array}$} & 18 & 340 & 1896 & 1,800 & 3,630 & 40 & 405 & 0.47 & 3.05 & \\
\hline & & 19 & 450 & 1897 & 1,800 & 3,840 & 30 & 513 & 0.29 & 3.88 & \\
\hline & & 20 & 482 & 1898 & 1,800 & 1,040 & 15 & 229 & 0.13 & 1.74 & \\
\hline \multirow[t]{7}{*}{ Owyhee } & \multirow{7}{*}{$\begin{array}{l}\text { Nyssa, Ore. } \\
\text { gon. }\end{array}$} & 14 & 131 & 1890 & 9,875 & 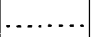 & & $\cdots$ & $\ldots$ & ...... & \\
\hline & & 14 & 121 & 1891 & 9,875 & 10,000 & 200 & 1,332 & 0.14 & 1.83 & \\
\hline & & 14 & 131 & 1892 & 9,875 & 18,000 & 320 & 3,268 & 0.33 & 4. 51 & \\
\hline & & 14 & 131 & 1893 & 9,875 & & & $\ldots .$. & & & \\
\hline & & 131 & 66 & 1894 & 9,875 & ........ & $\ldots$ & .... & $\ldots . .$. & $\ldots .$. & \\
\hline & & 18 & 347 & 1895 & 9,875 & 6,760 & 32 & 866 & 0.09 & 1.19 & \\
\hline & & 18 & 347 & 1896 & 9,875 & 14,905 & $\cdots$ & & $\cdots$ & $\cdots$ & \\
\hline \multirow[t]{4}{*}{ Mrilheur..... } & \multirow[t]{4}{*}{ Vale, Oregon } & 13 & 98 & 1890 & 9,900 & & & & & & \\
\hline & & 13 & 98 & 1891 & 9,900 & $\ldots \ldots$ & $\ldots$ & $\ldots$ & ...... & - & \\
\hline & & 18 & 349 & 1895 & 9,900 & 2,490 & 4 & 268 & 0.03 & 0.36 & \\
\hline & & 18 & 349 & 1896 & 9,900 & & & & 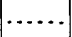 & & \\
\hline Boise........ & Boise, Irlaho. & 18 & 343 & 1895 & 2,450 & 7,095 & 620 & 2,082 & 0.85 & 11.56 & \\
\hline & & 18 & 343 & 1896 & 2,450 & 40,130 & 620 & 4,189 & 1.78 & 24.16 & \\
\hline & & 19 & 454 & 1897 & 2,450 & 28,572 & 570 & 3,957 & 1.62 & 17.17 & \\
\hline & & 20 & 483 & 1898 & 2,450 & 8,245 & 550 & 2,134 & 0.87 & 11.85 & \\
\hline Payette. & Payette, & 18 & 352 & 1895 & 3,565 & & & & & & \\
\hline & & 18 & 352 & 1896 & 3,565 & $\ldots \ldots$ & $\ldots$ & . & $\ldots \ldots$ & ...... & \\
\hline & & 19 & 455 & 1897 & 3,565 & 25,570 & 2,080 & 11,157 & 3.60 & $\ldots . . .$. & \\
\hline Weiser ....... & Weise $x$ & 13 & 98 & 1890 & 1,670 & 11,220 & 140 & & 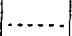 & & \\
\hline & & 13 & 98 & 1891 & $1, \dot{6} 70$ & 9,300 & 190 & & $\cdots \cdots$ & . . . . & \\
\hline & & 18 & 354 & 1895 & 1,670 & 6,125 & 40 & 782 & 0.47 & 6.35 & $\cdots$ \\
\hline & & 18 & 354 & 1896 & 1,670 & 17,940 & 165 & 1,877 & 1.13 & 15.29 & 29.38 \\
\hline & . & 19 & 457 & 1897 & 1,670 & 17,175 & 80 & 1,133 & 1.34 & 13.63 & 20.53 \\
\hline . & & 20 & 488 & 1898 & 1,670 & 3,875 & 10 & 673 & 0.40 & 5.49 & 16.53 \\
\hline Yakima.. & $\begin{array}{l}\text { Selah, Wash- } \\
\text { ington. }\end{array}$ & 19 & 478 & 1897 & 1,960 & 19,811 & $644^{\circ}$ & 3,052 & 1.56 & 10.21 & \\
\hline Yakima ..... & Union Gap, & 19 & 480 & 1896 & 3,300 & 45,550 & 840 & & $\ldots .$. & & \\
\hline & $\begin{array}{l}\text { Washing. } \\
\text { ton. }\end{array}$ & 19 & 480 & 1897 & 3,300 & 27,550 & 705 & 5,058 & 1.53 & 20.76 & \\
\hline & & 20 & 500 & 1898 & 3,300 & 22,246 & 685 & 4,538 & 1.37 & 18.56 & \\
\hline Naches... & $\begin{array}{c}\text { North Yaki- } \\
\text { ma, Wash. } \\
\text { ington. }\end{array}$ & 20 & 503 & 1898 & 1,000 & 7,480 & 225 & 1,845 & 1.85 & 24.89 & \\
\hline Takima ... & Kiona, Wash- & 19 & 485 & 1896 & 5,230 & 30,000 & & & 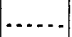 & $\ldots .$. & \\
\hline & & 19 & 485 & 1897 & 5,230 & 25,266 & 643 & 5,361 & 1.03 & 13.90 & \\
\hline & & 20 & 502 & 1898 & 5,230 & 21,786 & 612 & 4,828 & 0.93 & 12.45 & 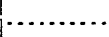 \\
\hline Palouse... & H $о \circ p$ er, & 19 & 458 & 1897 & 2,210 & & & & & & 22.59 \\
\hline & $\begin{array}{l}\text { W ashing. } \\
\text { ton. }\end{array}$ & 20 & 489 & 1898 & 2,210 & 7,070 & 20 & 850 & 0.39 & 5.12 & 17.09 \\
\hline Blackfoot. & $\begin{array}{l}\text { B onner, } \\
\text { Montana. }\end{array}$ & 20 & 491 & 1898 & 2,465 & & & & & & \\
\hline Bitterroot ... & $\begin{array}{c}\text { Miss oula, } \\
\text { Montana. }\end{array}$ & 20 & 495 & 1898 & 3,260 & 7,930 & 875 & & & & \\
\hline
\end{tabular}


Résumé of discharge data-Continued.

\begin{tabular}{|c|c|c|c|c|c|c|c|c|c|c|c|}
\hline \multirow{2}{*}{ River. } & \multirow{2}{*}{ Locality. } & \multicolumn{2}{|c|}{$\begin{array}{l}\text { Refer- } \\
\text { ence. }\end{array}$} & \multirow{2}{*}{ Year. } & \multirow{2}{*}{$\begin{array}{l}\text { Drain- } \\
\text { age } \\
\text { area. }\end{array}$} & \multirow{2}{*}{$\begin{array}{l}\text { Maxi- } \\
\text { mum. }\end{array}$} & \multirow{2}{*}{$\begin{array}{l}\text { Mini. } \\
\text { mum. }\end{array}$} & \multirow{2}{*}{ Mean. } & \multirow{2}{*}{\multicolumn{2}{|c|}{ Run-off. }} & \multirow{2}{*}{ Rainfall. } \\
\hline & & & & & & & & & & & \\
\hline & & & & & Sq.miles & Sec.ft. & Sec. ft. & Sec.ft. & Sec.ft. & Inches. & che \\
\hline Missoula .... & $\begin{array}{l}\text { Missocla, } \\
\text { Montana. }\end{array}$ & 20 & 491 & 1898 & 5,960 & 7,300 & 1,620 & & & $\ldots$ & \\
\hline Wenache.... & $\begin{array}{l}\text { Wenache, } \\
\text { Washing. } \\
\text { ton. }\end{array}$ & 19 & 489 & 1897 & 1,527 & . & $\ldots$ & 1,285 & 0.84 & 2.86 & \\
\hline \multirow[t]{2}{*}{ Wallawalla.. } & \multirow{2}{*}{$\begin{array}{l}\text { Whitman, } \\
\text { Washing- } \\
\text { ton. }\end{array}$} & 19 & 492 & 1897 & 310 & 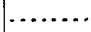 & & & & & 21.67 \\
\hline & & 20 & 512 & 1898 & 310 & 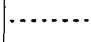 & & & $\cdots$ & $\cdots$ & 16.34 \\
\hline \multirow[t]{3}{*}{ Spokane.... } & \multirow{3}{*}{$\begin{array}{l}\text { Spoka ne } \\
\text { Washing- } \\
\text { ton. }\end{array}$} & 19 & 488 & 1896 & 4,005 & & $\ldots$ & & & & \\
\hline & & 19 & 488 & 1897 & 4,005 & 32,875 & 1,972 & 9,344 & 2.33 & 31.68 & \\
\hline & & 20 & 511 & 1898 & 4,005 & 27,510 & 2,436 & 9,455 & 2.06 & 31.98 & \\
\hline \multirow[t]{3}{*}{ Jmatilla..... } & \multirow{3}{*}{$\begin{array}{l}\text { Gibbon, Ore- } \\
\text { gon. }\end{array}$} & 19 & 494 & 1896 & 353 & . . . . . & & $\mid . . . . .$. & & & \\
\hline & & 19 & 494 & 1897 & 353 & 4,217 & 75 & 612 & 1.74 & 23.46 & \\
\hline & & 20 & 515 & 1898 & 353 & 3,730 & 74 & 440 & 1.25 & 16.74 & \\
\hline \multirow{2}{*}{ Deschutes... } & \multirow{2}{*}{$\begin{array}{c}\text { Moro, Ore- } \\
\text { gon. }\end{array}$} & 19 & 498 & 1897 & & & & & & & \\
\hline & & 20 & 516 & $\mid 1898$ & & & $\cdots$ & - & $\cdots$ & $\cdots$ & \\
\hline \multirow{2}{*}{ Hood ......... } & \multirow{2}{*}{$\begin{array}{l}\text { Tucker, Ore- } \\
\text { gon. }\end{array}$} & 19 & 498 & 1897 & 350 & & & ....... & $\cdots$ & & 46.87 \\
\hline & & 20 & 516 & 1898 & 350 & $\cdots$ & & & $\cdots$ & & \\
\hline \multirow[t]{4}{*}{ Cede } & Seattle, & 19 & 502 & 1895 & 143 & $\ldots$ & & & ... & $\cdots$ & \\
\hline & $\begin{array}{l}\text { Washing- } \\
\text { ton. }\end{array}$ & 19 & 502 & 1896 & 143 & 4,695 & 150 & 1,047 & 7.32 & 99.49 & \\
\hline & & 19 & 502 & 1897 & 143 & 3,601 & 294 & 1,089 & 7.61 & 103.22 & \\
\hline & & 20 & 517 & 1898 & 143 & 3,318 & 71 & …… & $\ldots \ldots$ & $\cdots$ & \\
\hline Dungeness .. & $S$ e $g$ un, & 19 & 505 & 1897 & 145 & & & & & $\cdots$ & \\
\hline & $\begin{array}{l}\text { Washing. } \\
\text { ton. }\end{array}$ & 20 & 518 & 1898 & 145 & 1,177 & 150 & 286 & 1.97 & 26.73 & \\
\hline Elwha ........ & McDon ald, & 19 & 508 & 1897 & 188 & 7.075 & 170 & ...... & ........ & $\cdots$ & \\
\hline & $\begin{array}{l}\text { Washing- } \\
\text { ton. }\end{array}$ & 20 & 521 & 1898 & 188 & 3,310 & 330 & 1,444 & 7.68 & 103.89 & \\
\hline Calowa ...... & & 20 & 522 & 1897 & 213 & 19,040 & $\ldots$ & & . & ... & \\
\hline & $\begin{array}{l}\text { Washing. } \\
\text { ton. }\end{array}$ & 20 & 522 & 1898 & 213 & 8,976 & 40 & 1,006 & 4. 72 & 63.25 & \\
\hline Solduck ..... & Quillayu te, & 20 & 523 & 1897 & 272 & 12,262 & .... & $\cdots \cdots$ & .... & $\cdots \cdots$ & \\
\hline & $\begin{array}{l}\text { Washing- } \\
\text { ton. }\end{array}$ & 20 & 523 & 1898 & 272 & 5,398 & 200 & 1,298 & 4.77 & 64.27 & \\
\hline Sacramento.. & Jellys Ferry, & 18 & 369 & 1896 & 9,134 & 130,050 & 6,000 & 18,109 & 1.98 & 27.08 & \\
\hline & & 19 & 509 & 1897 & 9,134 & 89,100 & 4,600 & 12,480 & 1.36 & 18.26 & \\
\hline & & 20 & 527 & 1898 & 9,134 & 33,600 & 4,250 & 6,349 & 0.70 & 9.38 & \\
\hline Stanislaus... & Oakdale, & 18 & 374 & 1896 & 1,051 & 13,050 & 150 & 1,935 & 1.85 & 25.05 & \\
\hline & & 19 & 511 & 1897 & 1,051 & 10,580 & 140 & 1,835 & 1.74 & 23.55 & \\
\hline & & 20 & 530 & 1.898 & $\mathfrak{I}, 051$ & 3,920 & 27 & 466 & 0.44 & 6.00 & \\
\hline Tuolumne... & Lagrange & 18 & 383 & 1896 & 1,501 & 11,798 & 75 & 2,342 & 1.56 & 21.21 & \\
\hline & in & 19 & 513 & 1897 & 1,501 & 14,700 & 28 & 3,364 & 2.24 & 30.26 & \\
\hline & & 20 & 532 & 1898 & 1,501 & 7,800 & ...... & 1,182 & 0.79 & 10.54 & \\
\hline San Joaquin . & $\mathrm{H}_{\ominus \mathrm{r}} \mathrm{ndon}$, & 140 & 291 & 1895 & 1,637 & 19,960 & 260 & 3,791 & 2.34 & 31.09 & \\
\hline & aia. & 18 & 389 & 1896 & 1,637 & 18,800 & 80 & 2,756 & 1. 69 & 22.96 & \\
\hline & & 19 & 51.5 & 1897 & 1,637 & 18,600 & 60 & 3,105 & 1.90 & 25.75 & \\
\hline & & 20 & 529 & 1898 & 1,637 & 5,846 & 220 & 1,190 & 0.73 & 9.84 & \\
\hline Kings ........ & Red Moun- & 18 & 393 & 1896 & 1,775 & 22,100 & 310 & 2,582 & 1.48 & 20.11 . & \\
\hline & $\begin{array}{l}\text { tain, Cali- } \\
\text { fornia. }\end{array}$ & 19 & 519 & 1897 & 1,775 & 22,732 & 250 & 2,933 & 1.65 & 22.47 & \\
\hline & & 20 & $j^{535}$ & .1898 & 1,775 & 7,820 & 145 & 1,116 & 0.63 & 8.53 & \\
\hline
\end{tabular}


Résumé of discharge data-Continued.

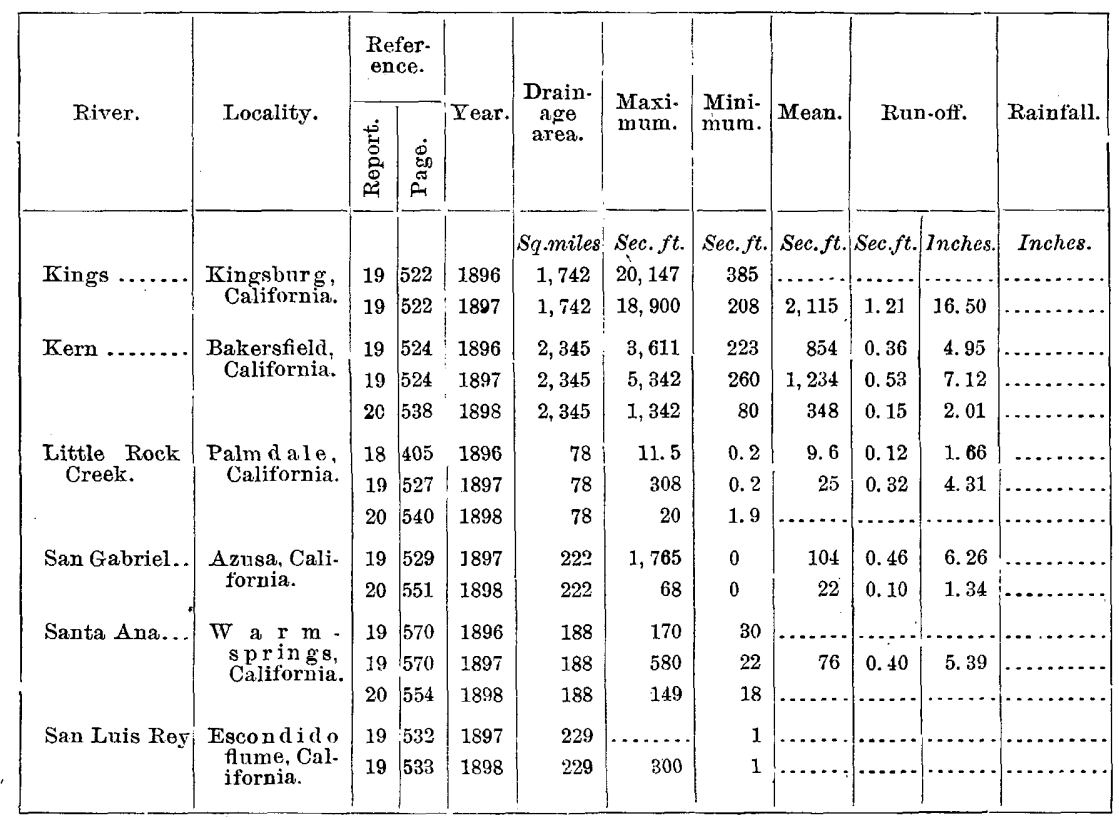

\section{NORTHERN ATLANTIC COAST DRAINAGE.}

Under this heading have been included data concerning the rivers entering the Atlantic Ocean from Maine to Virginia, inclusive, an arbitrary line being drawn between the James River and the Roanoke River, the latter being included under Southern Atlantic Coast Drainage.

A study of the rivers of New England was begun by Prof. Dwight Porter, the results for Maine being printed in the Nineteenth Annual Report, Part IV, while those for the remainder of New England, not being yet complete, are held for subsequent publication. Data of discharge of the Kennebec and Androscoggin rivers, supplementing those previously published, have been obtained and are given below; also additional facts concerning the Merrimac, Connecticut, and Hudson rivers, these being obtained mainly from resident engineers or waterpower companies.

\section{KENNEBEC RIVER.}

Figures of the daily discharge of Kennebec River at Waterville, Maine, furnished by Mr. Sumner Hollingsworth, have been printed in Water-Supply Paper No. 27, on pages 11 to 14, relating to the years 1892 to 1898. The fluctuations of the stream are graphically shown on fig. 7 . An analysis of the discharge is given in tabular form on page 75 of the Nineteenth Annual Report; Part IV. The following table is a continuation of that on page 78 of the volume mentioned.. The figures up to and including July have been revised by Mr. Hollingsworth. Since his death, which occurred on June 27, 1899, additional figures have been obtained from Mr. James L. Dean, engineer of the Hollingsworth 
\& Whitney Company. These, however, have not been revised, and may be subject to correction.

Monthly discharge of Kennebec River at Waterville, Maine, for the year 1898.

[Drainage area, 4,410 square miles.]

\begin{tabular}{|c|c|c|c|c|c|c|}
\hline \multirow[b]{2}{*}{ Month. } & \multicolumn{3}{|c|}{ Discharge in second-feet. } & \multirow[b]{2}{*}{$\begin{array}{l}\text { Total in acre- } \\
\text { feet. }\end{array}$} & \multicolumn{2}{|c|}{ Run-off. } \\
\hline & $\begin{array}{l}\text { Maxi. } \\
\text { mum. }\end{array}$ & $\begin{array}{l}\text { Mini- } \\
\text { mum. }\end{array}$ & Mean. & & $\begin{array}{l}\text { Depth in } \\
\text { inches. }\end{array}$ & $\begin{array}{l}\text { Second. } \\
\text { feet per } \\
\text { square } \\
\text { mile. }\end{array}$ \\
\hline 1898. & & & & & & \\
\hline January & 5,434 & 1,738 & 3,213 & 197,559 & 0.84 & 0.73 \\
\hline February .. & 4,387 & 2,133 & 3,402 & 188,938 & 0.80 & 0.77 \\
\hline March ...... & 27,432 & 2,997 & 11,287 & 694,010 & 2.95 & 2.56 \\
\hline April ...... & 52,119 & 6,563 & 29,833 & $1,715,682$ & 7.54 & 6.76 \\
\hline -May ..... & 39,372 & 14,611 & 25,120 & $1,544,568$ & 5.61 & 5.70 \\
\hline June.... & 14,311 & 4,326 & 9,983 & 594,030 & 2.52 & 2.26 \\
\hline July ....... & 5,464 & 1,745 & 3,908 & 240,294 & 1.02 & 0.89 \\
\hline August..... & 4,188 & 609 & 2,797 & 171,980 & 0.74 & .0 .64 \\
\hline September & 5,443 & 1,437 & 2,618 & 155,782 & 0.65 & 0.59 \\
\hline October.... & 15,319 & 961 & 3,689 & 226,827 & 0.97 & 0.84 \\
\hline November.. & 10,037 & 2,758 & 5,145 & 306,149 & • 1.31 & 1.17 \\
\hline December .. & 3,752 & 1,723 & 2,294 & 141,052 & 0.60 & 0.52 \\
\hline The year. & 52,119 & 609 & 8,607 & $6,176,871$ & 25.55 & 1.95 \\
\hline
\end{tabular}

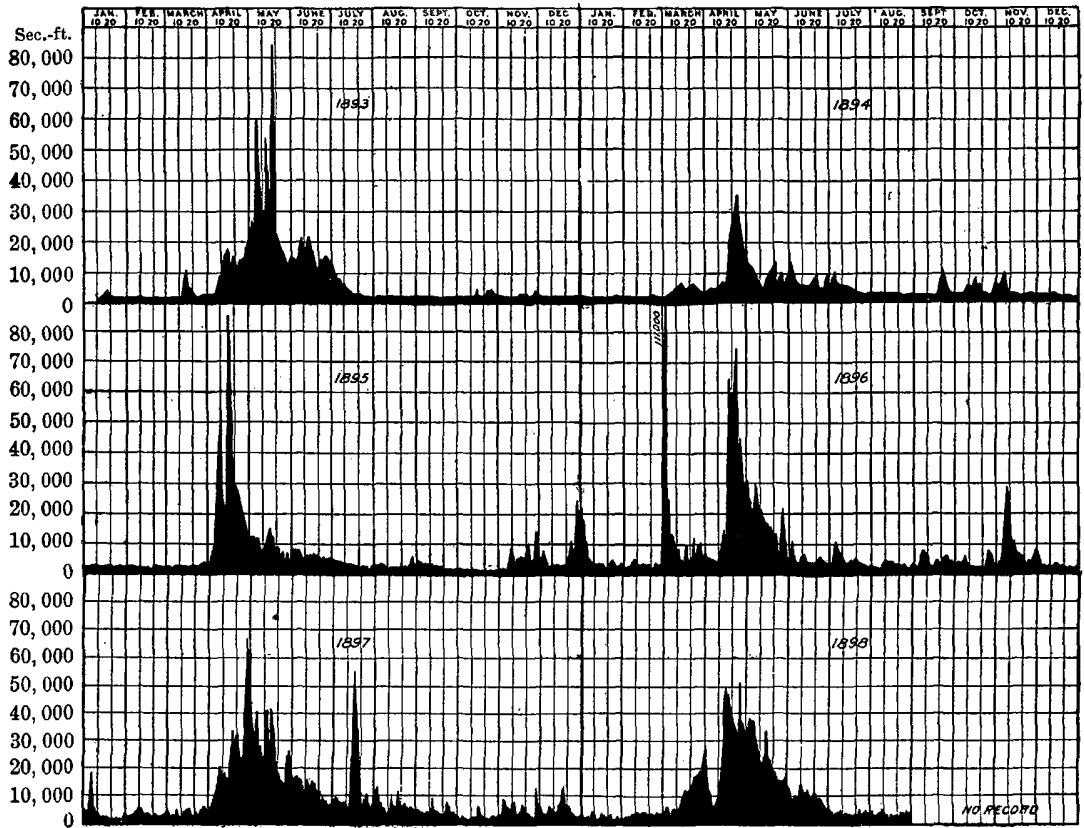

Frc. 7.-Discharge of Kennebec River at Waterville, Maine, 1893-98.

20 GEOL, P' $4-5$ 


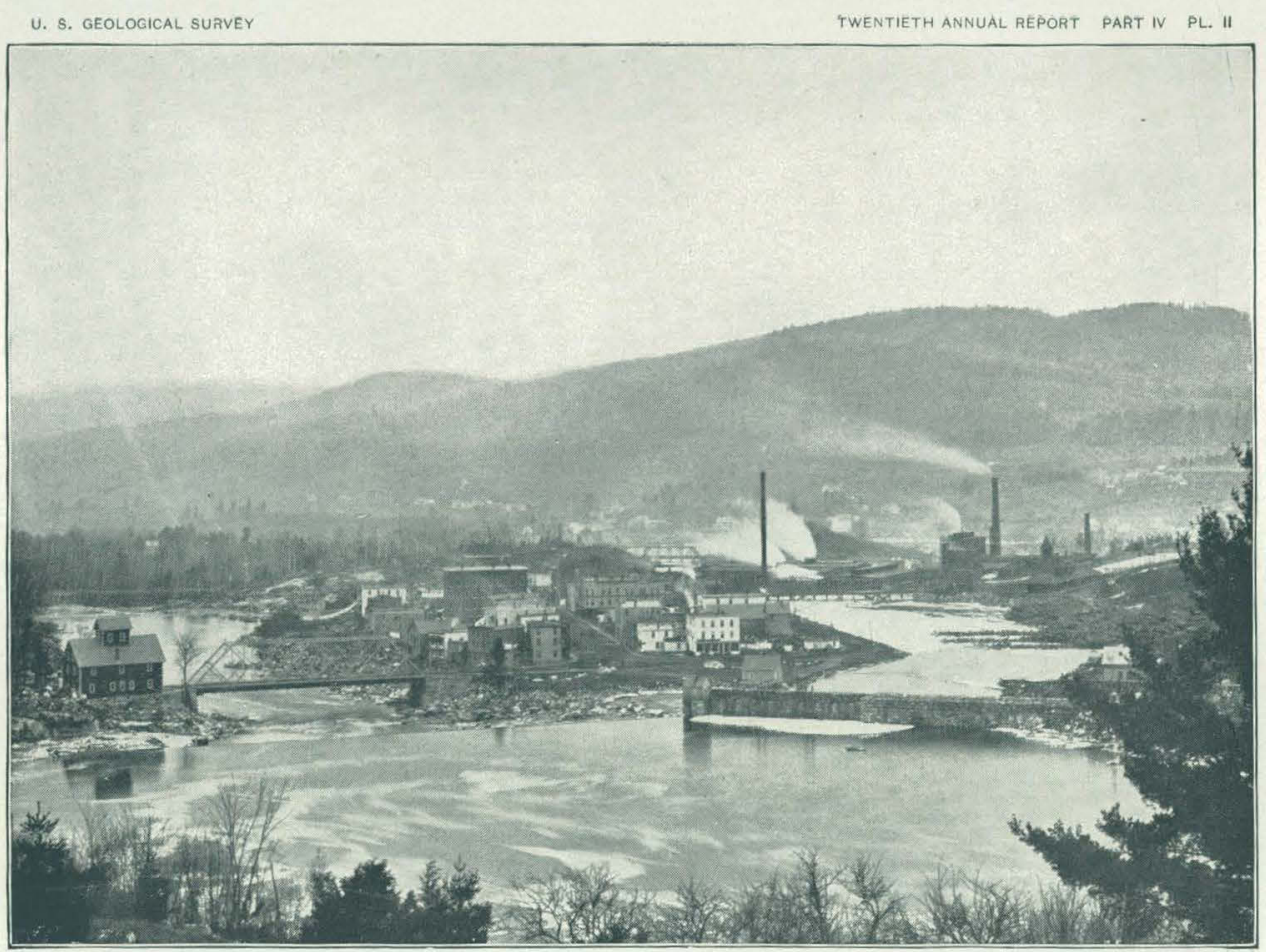

A. RUMFORD FALLS, MAINE. LOOKING DOWNSTREAM TOWARD MIDDLE CANAL.

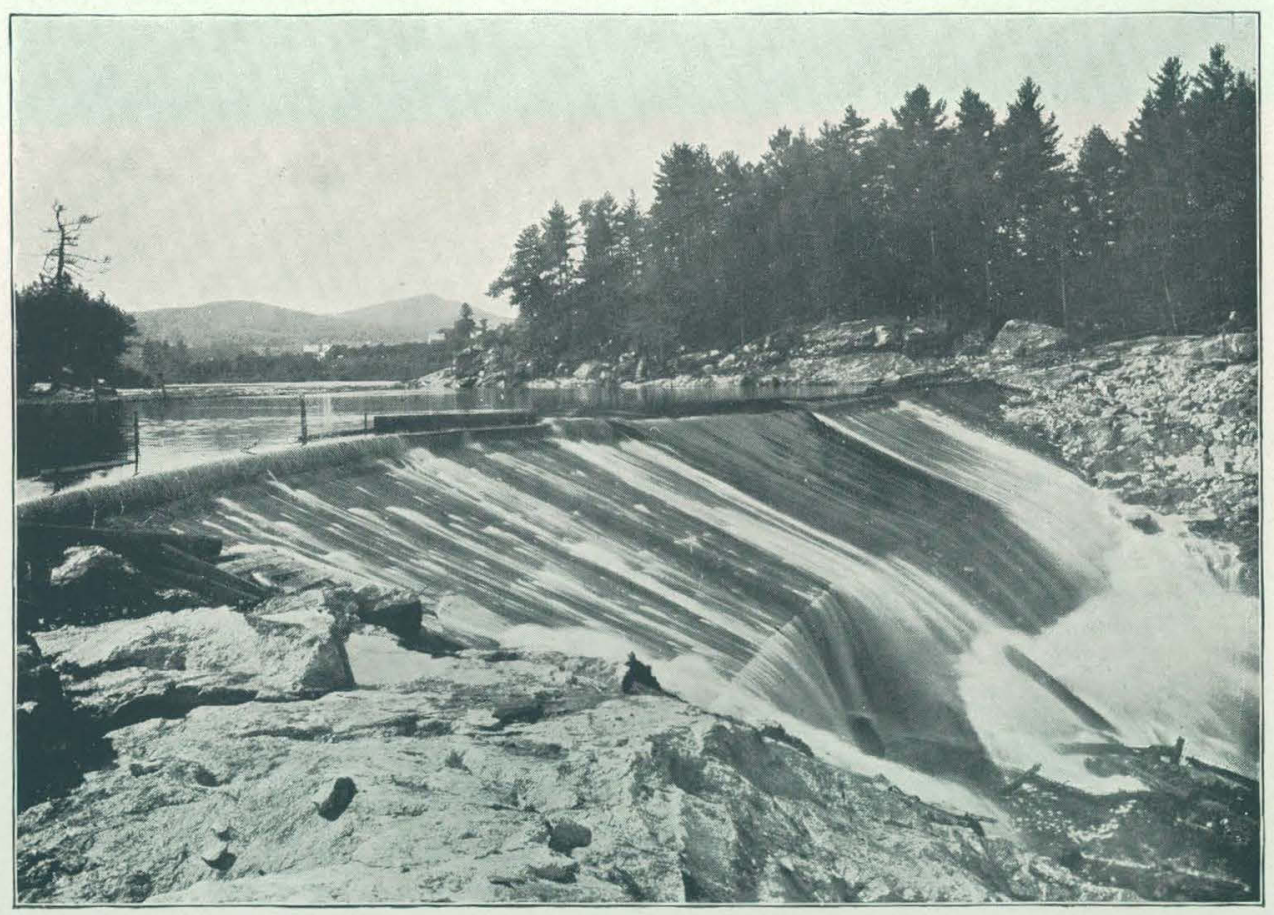

B. UPPER DAM AT RUMFORD FALLS, MAINE. 


\section{ANDROSCOGGIN RIVER.}

Androscoggin River has been described by Prof. Dwight Porter in the Nineteenth Annual Report, Part IV, on pages 84 to 97. The water power at Rumford Falls has also been discussed and a general description given of the canal system for utilizing the fall of the water. The following small diagram (fig. 8) sbows the relative location of the upper dams and canals, and the accompanying illustrations (Pl. II, $A, B$ ) afford a general conception of the topographic condition.

Plate II, $A$, is a view looking down the river from a point located near the upper left.hand corner of the small map (fig. 8). The straight line in the water at the left side is the crest of the middle dam, a view of which, taken from the opposite direction, is shown in the Nineteenth Annual Report, Pl. XV, A. At the right are the head gates and wall, and beyond these the middle canal. This has a head of 50 feet and dis-

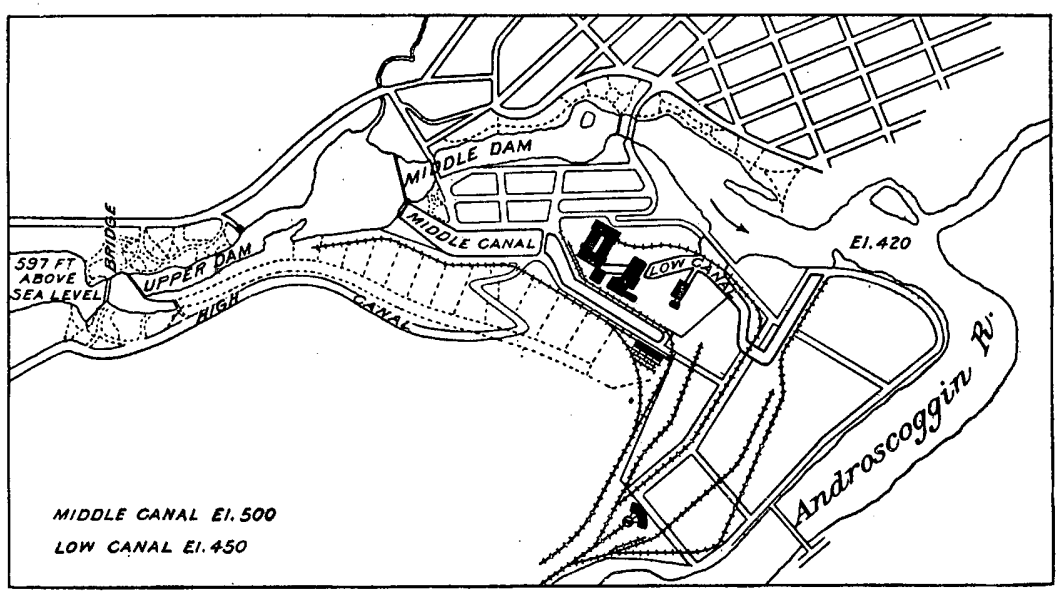

FIG. 8.-Relative location of dams and canals at Rumford Falls, Maine.

charges into a low-line canal, as shown by the small map. Pl。II, $B$, is a view of the upper dam. This is 100 feet above the middle dam. It is a log structure, built primarily to provide boomage for logs and to prevent trouble from anchor ice. A timber sluiceway (shown at the extreme right of $\mathrm{Pl}$. II, $A$ ) has been constructed from the point above this dam down the right bank to the middle-level canal, for the purpose of sluicing down logs for the mills. The bigh-level canal has not yet been built, and no water power is used in connection with the upper dam.

The flow of the river at Rumford Falls from May, 1892, to April 31, 1895, is graphically exhibited by diagrams (figs. 16 and 17) in the Nineteenth Annual Report, Part IV, pages 94 and 95. Figures of daily discharge for the years 1892 to 1895 , obtained from $\mathrm{Mr}$. Charles A. Mixer, resident engineer of the Rumford Falls Power Company, have been given on pages 14 to 16 of Water-Supply Paper No. 27, and later figures for the years 1896 to 1898 are given below. The accompanying diagram (fig. 9) shows all the fluctuations in quantity of water from 1893 to 1898 , as given in detail in these tables. 


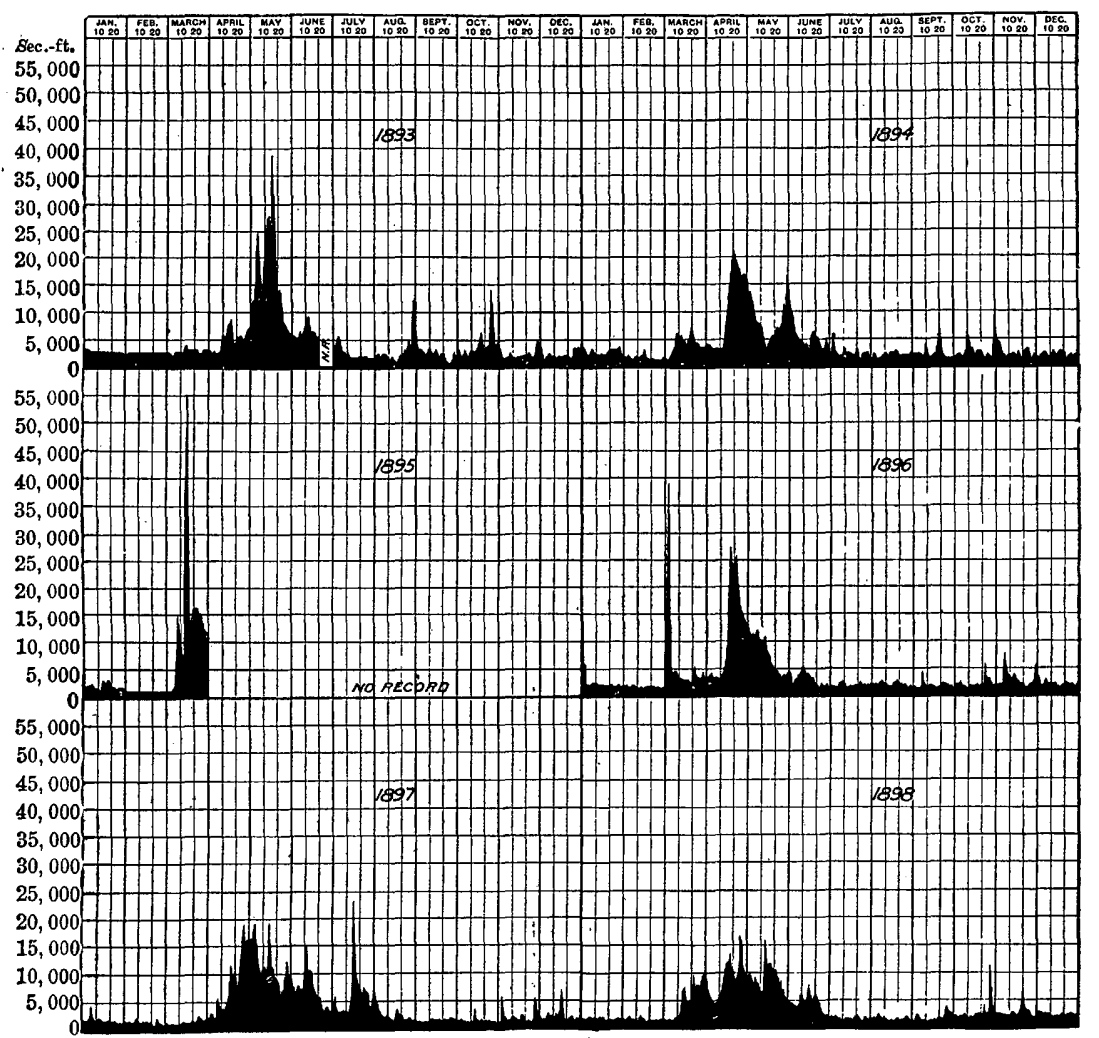

Fra. 9.-Discharge of Androscoggin River at Rumford Falls, Maine, 1893-98.

Daily discharge of Androscoggin River at Rumford Falls, Maine.

[Cubic feet per second.]

\begin{tabular}{|c|c|c|c|c|c|c|c|c|c|c|c|c|}
\hline Day. & Jan. & Feb. & Mar. & Apr. & May. & June. & July. & Aug. & Sept. & Oct. & Nov. & Dec. \\
\hline 1896. & & & & & & & & & & & & \\
\hline $1 \ldots$ & 21,540 & 1,650 & 10,630 & 3,660 & 12,140 & 4,530 & 1,820 & 1,820 & 1,620 & 1,950 & 1,970 & 3,240 \\
\hline 2. & 5,470 & 1,850 & 39,010 & 4,050 & 11,440 & 4,000 & 1,840 & 1,690 & 1,470 & 1,910 & 2,110 & 1,850 \\
\hline $3 \ldots$ & 5,220 & 1,690 & 16,680 & 4,300 & 11,380 & 2,300 & 1,840 & 1,970 & 1,390 & 1,910 & 2,040 & 1,700 \\
\hline 4. & 3,460 & 1,640 & 6,510 & 3,720 & 11,540 & 2,270 & 1,740 & 1,680 & 1,480 & 2,230 & 1,970 & 1,710 \\
\hline $5 .$. & 2,110 & 1,620 & 4,580 & 3,390 & 11,070 & 3,080 & 1,680 & 1,630 & 1,490 & 1,890 & 2,140 & 2,310 \\
\hline $6 \ldots$ & 2,020 & 1,810 & 4,120 & 3,370 & 12,180 & 3,110 & 1,500 & 1,970 & 1,570 & 1,740 & 8,100 & 3,040 \\
\hline $7 \ldots$ & 2,100 & 1,840 & 4,440 & 3,280 & 11,460 & 3,530 & 2,310 & 2,100 & 4,760 & 1,610 & 6,480 & 2,470 \\
\hline $8 \ldots$ & 2,320 & $i, 860$ & 4,430 & 3,350 & 10,340 & 3,570 & 2,080 & 2,310 & 2,830 & 1,540 & 4,830 & 2,220 \\
\hline $9 .$. & 2,310 & 1,770 & 4,030 & 3,180 & 10,200 & 4,500 & 2,490 & 1,970 & 2,170 & 1,460 & 3,610 & 2,210 \\
\hline 10. & 2,310 & 1,530 & 3,340 & 3,420 & 10,020 & 5,760 & 2,390 & 1,980 & 1,520 & 1,530 & 3,250 & 2,340 \\
\hline $11 .$. & 2,320 & 1,560 & 3,230 & 3,900 & 10,000 & 5,230 & 2,140 & 1,760 & 2,000 & 1,700 & 3,040 & 2,060 \\
\hline 12. & 2,240 & 1,620 & 3,070 & 4,800 & 10,860 & 4,710 & 1,810 & 1,660 & 1,930 & 1,590 & 3,320 & 1,910 \\
\hline $13 .$. & 2,190 & 1,720 & 3,000 & 6,770 & 9,490 & 4,020 & 1,800 & 1,620 & 1,830 & 1,590 & 3,720 & 1,930 \\
\hline 14. & 2,230 & 1,560 & 2,780 & 12,310 & 8,310 & 3,980 & 1,960 & 1,660 & 1,750 & 1,600 & 3,320 & 2,210 \\
\hline $15 \ldots$ & 2,160 & 1,730 & 2,810 & 14,880 & 7,690 & 3,620 & 1,770 & 1,710 & 1,640 & 1,590 & 2,740 & 1,630 \\
\hline $16 \ldots .$. & 2,030 & 1,880 & 2,600 & 23,180 & 7,110 & 3,260 & 1,940 & 2,240 & 1,420 & 1,730 & 2,690 & 1,620 \\
\hline $17 \ldots \ldots$ & 2,040 & 1,840 & 2,630 & 27,390 & 5,910 & 3,190 & 1,960 & 2,230 & 1,560 & 1,660 & 2,490 & 1,130 \\
\hline
\end{tabular}


Daily discharge of Androscoggin River at Rumford Falls, Maine-Continued.

[Cubic feet per second.]

\begin{tabular}{|c|c|c|c|c|c|c|c|c|c|c|c|c|}
\hline Day. & Jan. & Feb. & Mar. & Apr. & May. & June. & July. & Aug. & Sept. & Oct. & Nov. & Dec. \\
\hline & & & & & & & & & & & & \\
\hline 18 & 2,090 & 1,920 & 2,310 & 25,020 & 5,470 & 2,700 & 1,980 & 2,450 & 1,730 & 1,380 & 2,460 & 1,680 \\
\hline 19. & 2,180 & 1,910 & 2,310 & 23,660 & 5,220 & 2,650 & 2,050 & 2,270 & 1,740 & 1,810 & 2,300 & 1,820 \\
\hline 20. & 2,190 & 1,920 & 2,780 & 24,550 & 4,860 & 2,530 & 1,890 & 2,050 & 1,820 & 2,180 & 2,370 & 1,940 \\
\hline 21. & 2,180 & 1,800 & 5,570 & 25,340 & 4,760 & 2,040 & 2,300 & 2,260 & 2,450 & 2,100 & 1,690 & 2,190 \\
\hline 22. & 1,860 & 1,940 & 4,680 & 22,450 & 4,550 & 2,220 & 2,760 & 1,900 & 2,390 & 5,710 & 1,990 & 2,150 \\
\hline 23. & 1,930 & 1,730 & 4,050 & 19,550 & 4,080 & 2,530 & 2,190 & 2,300 & 2,360 & 3,720 & $1,7 \overline{5} 0$ & 2,080 \\
\hline 24. & 1,840 & 1,440 & 3,690 & 18,090 & 3,970 & 2,250 & 2,080 & 2,190 & 2,130 & 3,160 & 2,280 & 1,920 \\
\hline 25. & 1,790 & 1,650 & 3,270 & 16,240 & 3,680 & 2,100 & 2,190 & 1,960 & 2,180 & 3,280 & 2,390 & 2,040 \\
\hline 26. & 1,540 & 1,620 & 3,220 & 15,500 & 3,940 & 1,850 & 1,680 & 1,680 & 1,960 & 2,450 & 2,360 & 1,950 \\
\hline 27. & 1,750 & 1,600 & 3,540 & 14,360 & 3,870 & 1,990 & 2,100 & 1,660 & 1,830 & 2,260 & 2,380 & 1,640 \\
\hline 28. & 1,830 & 1,680 & 3,830 & 13,720 & 4,370 & 2,130 & 1,940 & 1,690 & 1,810 & 2,060 & 2,820 & 1,580 \\
\hline 29. & 1,680 & 1,810 & 4,430 & 13,170 & 4,310 & 1,630 & 2,040 & 1,870 & 1,440 & 1,960 & 5,670 & 1,650 \\
\hline 30. & 1,600 & . & 3,610 & 12,750 & 4,610 & 1,770 & 2,030 & 1,600 & 1,500 & 1,900 & $3, \mathbf{5 8 0}$ & 1,990 \\
\hline 31. & 1,870 & ........ & 3,560 & 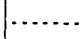 & 4,660 & & 1,750 & 1,570 & & 2,030 & & 2,030 \\
\hline Mear & 3,303 & 1,731 & 5,443 & 12,444 & 7,532 & 3,102 & 2,002 & 1,718 & 1,926 & 2,070 & 3,062 & 2,008 \\
\hline 189 & & & & & & & & & & & & \\
\hline & 2,062 & 1,787 & 1,816 & 2,043 & 16,440 & 8,023 & 5,943 & 5,726 & 1,291 & 1,596 & 1,085 & 2,180 \\
\hline 2. & 1,851 & 1,806 & 1,645 & 2,290 & 15,312 & 7,641 & 4,956 & 4,829 & 1,383 & 1,455 & 1,443 & 1,846 \\
\hline 3. & 1,812 & 1,766 & 1,618 & 2,871 & 17,981 & 6,787 & 3,941 & 4,428 & 1,217 & 1,800 & 5,686 & 1,921 \\
\hline $4 .$. & 1,820 & 1,793 & 1,554 & 2,634 & 19,266 & 7,235 & 3,231 & 3,423 & 1,234 & 1,435 & 3,617 & 1,877 \\
\hline 5. & 2,257 & 1,636 & 1,694 & 1,914 & 14,649 & 7,952 & 3,271 & 3,013 & 1,143 & 1,328 & 2,450 & 2,609 \\
\hline 6. & 4,623 & 1,653 & 1,661 & 2,377 & 12,818 & 8,200 & 3,282 & 2,798 & 1,249 & 1,413 & 1,780 & 3,450 \\
\hline 7. & 2,729 & 1,623 & 1,652 & 4,639 & 11,576 & 7,379 & 3,304 & 2,289 & 1,298 & 1,359 & 1,506 & 2,784 \\
\hline 8 & 2,022 & 1,911 & 1,637 & 5,573 & 10,739 & 7,331 & 3,483 & 2,086 & $\mathfrak{l}, 146$ & 1,441 & 1,776 & 2,368 \\
\hline 9. & 1,753 & 2,228 & 1,660 & 4,580 & 10,104 & 6,687 & 3,197 & 2,240 & 1,355 & 1,297 & 1,820 & 2,350 \\
\hline 10. & 1,612 & 2,016 & 1,673 & 3,768 & 11,178 & 10,523 & 3,260 & 2,271 & 1,375 & 1,360 & 2,410 & 2,357 \\
\hline 11. & 1,814 & 1,817 & 1,707 & 3,891 & 11,528 & 14,764 & 3,011 & 2,061 & {$[1,765$} & 1,414 & 2,353 & 2,232 \\
\hline 12. & 1,787 & 1,635 & 1,748 & 3,683 & 10,359 & 10,817 & 2,727 & 1,993 & 1,873 & 1,360 & 2,090 & 2,905 \\
\hline 13. & 1,589 & 1,679 & 1,814 & 4,199 & 11,447 & 8,982 & 5,660 & 1,924 & 1,596 & 3,757 & 1,992 & 2,382 \\
\hline 14. & 1,574 & 1,799 & 1,917 & 4,737 & 19,220 & 10,500 & 17,505 & 1,669 & 1,695 & 2,363 & 1,663 & 2,926 \\
\hline 15. & 1,644 & 1,644 & $\mathbf{1}, 570$ & 5,181 & 15,333 & 10,118 & 22,906 & 1,385 & 1,691 & 1,894 & 1,653 & 3,302 \\
\hline 16. & 1,680 & 1,755 & 1,688 & 8,221 & 11,690 & 8,414 & 12,781 & 2,390 & 1,543 & 1,606 & 1,610 & 7,462 \\
\hline 17 & 1,706 & 1,790 & 1,568 & 11,435 & 10,709 & 7,763 & 10,015 & 3,672 & 1,649 & 1,610 & 2,620 & 5,699 \\
\hline 18. & 1,661 & 1,694 & 1,587 & 9,546 & 10,469 & 7,068 & 8,800 & 2,828 & 1,764 & 1,873 & 2,717 & 4,221 \\
\hline 19. & 1,742 & 1,777 & 1,732 & 9,746 & 9,565 & 6,303 & 8,121 & 2,255 & 1,395 & 1,480 & 2,607 & 1,965 \\
\hline 20. & 1,320 & 1,597 & 1,829 & 10,736 & 9,230 & 5,841 & 7,380 & $' 2,103$ & 1,448 & 1,619 & 1,259 & 1,622 \\
\hline 21. & 1,552 & 1,055 & 1,712 & 7,802 & 8,771 & 5,839 & 6,786 & 1,994 & 1,867 & 1,683 & 1,223 & 2,051 \\
\hline 22. & 1,545 & 1,150 & 1,688 & 6,415 & 8,338 & 4,917 & 6,709 & 1,420 & 1,961 & 1,491 & 1,665 & 2,129 \\
\hline 23. & 1,680 & 1,571 & 2,102 & 8,230 & 6,724 & 4,098 & 7,657 & 1,452 & 1,776 & 1,544 & 1,373 & 2,241 \\
\hline 24. & 1,709 & 1,604 & 2,516 & $11,8 \dot{0} 0$ & 7,338 & 3,634 & 6,982 & 1,619 & 1,768 & 1,664 & 1,218 & 2,258 \\
\hline 25. & 1,567 & 1,738 & 2,387 & 16,082 & 7,526 & 4,345 & 7,030 & 1,651 & 1,833 & 1,409 & 1,245 & 1,797 \\
\hline 26. & 1,400 & 1,680 & 2,253 & 18,986 & 9,732 & 4,469 & 6,721 & 1,852 & 2,001 & 1,504 & 1,573 & 1,736 \\
\hline 27. & 1,459 & 1,516 & $.2,061$ & 17,272 & 8,895 & 3,493 & 5,327 & 1,755 & 1,997 & 1,506 & 5,295 & 2,149 \\
\hline 28. & 1,662 & 1,501 & 1,883 & 15,440 & 12,432 & 3,405 & 4,242 & 1,472 & 1,941 & 1,506 & 5,149 & 2,086 \\
\hline 29. & 1,476 & & 1,791 & 15,912 & 11,383 & 3,420 & 4,016 & 1,368 & 1,891 & 1,489 & 3,039 & 1,894 \\
\hline 30. & 1,541 & & 1,938 & 15,359 & 10,095 & 4,007 & 5,560 & 1,400 & 1,605 & 1,336 & 2,545 & 1,781 \\
\hline & 1,812 & $\ldots$ & 1,995 & $\cdots$ & 9,397 & & 6,940 & 1,342 & 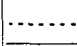 & 1,190 & $\cdots$ & 1,886 \\
\hline Mean. & 1,821 & 1,686 & 1,810 & 7,913 & 11,614 & 6,998 & 6,605 & 2,345 & 1,592 & 1,606 & 2,282 & 2,605 \\
\hline
\end{tabular}


Daily discharge of Androscoggin River at Rumford Falls, Maine-Continued.

[Cubic feet per second.] .

\begin{tabular}{|c|c|c|c|c|c|c|c|c|c|c|c|c|}
\hline Day. & Jan. & Feb. & Mar. & Apr. & May. & June. & July. & Aug. & Sept. & Oct. & Nov. & Dec. \\
\hline 18 & & & & & & & & & & & & \\
\hline & 2,142 & 1,823 & 1,641 & 8,582 & 9,925 & 5,001 & 2,067 & 1,601 & 1,421 & 2,080 & 2,508 & 2,507 \\
\hline 2 & 1,905 & 1,584 & $\cdot 1,601$ & 7,370 & $\mathbf{9}, 963$ & 4,643 & 2,280 & 1,858 & 1,493 & 2,149 & 2,514 & 2,519 \\
\hline 3. & 1,815 & 1,822 & 1,565 & 6,772 & 9,422 & 4,384 & 2,192 & 1,912 & 1,713 & 1,961 & 2,500 & 2,556 \\
\hline 4. & 1,938 & 1,949 & 1,615 & 6,221 & 8,941 & 4,743 & 2,152 & 1,588 & 2,638 & 1,871 & 2,463 & 2,448 \\
\hline 5. & 1,909 & 2,193 & 1,573 & 5,693 & 8,086 & 4,462 & 2,209 & 2,025 & 2,151 & 2,151 & 2,286 & 2,290 \\
\hline 6. & 1,952 & 1,960 & 1,470 & 5,262 & 9,414 & 4,352 & 2,132 & 2,459 & 1,815 & 2,122 & 2,233 & 2,233 \\
\hline 7. & 2,095 & 1,741 & 1,397 & 4,977 & 8,591 & 4,298 & 2,010 & 1,974 & 1,707 & 2,288 & 2,155 & 2,443 \\
\hline 8. & 2,130 & 1,635 & 1,462 & 4,833 & 8,423 & 4,694 & 2,003 & 1,890 & 1,776 & 2,408 & 2,150 & 2,196 \\
\hline 9 & 2,118 & 1,655 & 1,817 & 4,962 & 7,669 & 6,200 & 1,960 & 1,805 & $1,801^{\circ}$ & 2,038 & 2,265 & 2,115 \\
\hline 10. & 2,048 & 1,606 & 1,859 & 5,639 & 6,746 & 6,139 & 1,721 & 1,639 & 1,742 & 1,949 & 2,203 & 2,030 \\
\hline 11. & 1,974 & 1,602 & 2,147 & 6,710 & 6,426 & 4,669 & 1,645 & 1,635 & 1,440 & 1,800 & 2,341 & 1,910 \\
\hline 12. & 1,858 & 1,728 & 2,606 & 8,243 & 7,264 & 4,790 & 1,808 & 1,560 & 1,302 & 1,889 & 2,856 & 1,796 \\
\hline 13. & 1,953 & 2,109 & 3,583 & 10,102 & 15,566 & 5,243 & 1,710 & 1,495 & 1,484 & 1,929 & 2,715 & 1,829 \\
\hline 14. & 2,185 & 1,778 & 6,894 & 10,933 & 13,245 & 5,662 & 1,728 & 1,487 & 1,509 & 1,772 & 2,807 & 1,940 \\
\hline 15. & 2,041 & 1,724 & 7,501 & 11,849 & 11,295 & 7,980 & 1,736 & 1,577 & 1,457 & 1,803 & 2,614 & 2,022 \\
\hline 16. & 2,113 & 1,758 & 6,052 & 12,349 & 11,882 & 6,475 & 1,677 & 1,567 & 1,524 & 2,466 & 2,569 & 2,016 \\
\hline 17. & 1,887 & 1,443 & 5,055 & 11,623 & 11,763 & 5,964 & 1,710 & 1,465 & 1,595 & 2,273 & 2,460 & 2,007 \\
\hline 18. & 1,854 & 1,224 & 4,983 & 13,272 & 11,196 & 5,587 & 1,463 & 1,562 & 1,352 & 2,415 & 2,731 & 2,053 \\
\hline 19. & 1,751 & 1,577 & 4,987 & 11,594 & 10,996 & 5,025 & 1,673 & 1,583 & 1,789 & 2,075 & 3,720 & 2,382 \\
\hline 20. & 1,977 & 1,673 & 5,195 & 10,268 & 10,594 & 6,596 & 2,031 & 2,033 & 1,893 & 2,269 & 6,903 & 2,107 \\
\hline 21. & 1,927 & 1,574 & 9,617 & 8,504 & 10,386 & 5,844 & 2,194 & 1,448 & 1,842 & 2,600 & 4,754 & 1,992 \\
\hline 22. & I, 977 & 1,577 & 8,231 & 7,899 & 9,216 & 5,384 & 2,013 & 1,517 & 1,667 & 2,588 & 3,698 & 2,215 \\
\hline 23. & 1,778 & 1,545 & 7,365 & 9,075 & 9,000 & 4,914 & 1,969 & 1,616 & 1,555 & 4,039 & 3,165 & 2,319 \\
\hline 24. & 1,764 & 1,608 & 8,041 & 10,057 & 8,377 & 3,888 & 1,526 & 1,557 & 2,433 & 2,312 & 2,923 & 2,454 \\
\hline 25. & 1,878 & 1,549 & 7,826 & 16,748 & 8,666 & 3,095 & 1,684 & 1,560 & 4,245 & 2,742 & 2,816 & 2,580 \\
\hline 26. & $1,93 t$ & 1,640 & 7,442 & 15,881 & 7,281 & 2,837 & 1,930 & 1,888 & 3,534 & 2,662 & 2,011 & 2,290 \\
\hline 27 & 2,038 & 1,764 & 7,631 & 13,083 & 6,033 & 2,672 & 2,261 & 1,981 & 2,610 & 11,529 & 1,971 & 2,260 \\
\hline 28. & 1,928 & 1,763 & 8,032 & 11,292 & 7,243 & 2,508 & 1,904 & 1,744 & 2,456 & 6,698 & 1,840 & 2, 201 \\
\hline 29. & 1,918 & & 9,585 & 10,266 & 5,650 & 2,116 & 1,599 & 1,668 & 2,399 & 4,585 & 1,741 & 1,939 \\
\hline & 1,832 & & 10,096 & 9,217 & 5,459 & 2,117 & 1,569 & 1,501 & 2,077 & 3,228 & 2,486 & 2,047 \\
\hline 31. & 1,764 & and & 10,857 & ....... & 5,085 & .......... & 1,812 & 1,595 & . & 2,776 & ....... & 2,176 \\
\hline & 1 & 0 & 2 & 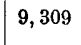 & 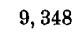 & 4,743 & 1,873 & 1,750 & 1,961 & 2,821 & 2,813 & 2,189 \\
\hline
\end{tabular}

Note.-The figures for 1892 to 1895 are given in Water-Supply and Irrigation Paper No. 27, pages 14 tc. 16

The monthly and annual totals are given in the following table in the conventional form adopted in this report. These tables are a continuation of those published in the Nineteenth Annual Report, Part IV, page 93, the latter being slightly different in arrangement. The totals for the year $1895^{1}$ have been inadvertently omitted.

The diagram of discharge for 1895 , shown in fig. 9 , is in error in stating that there is no record since April. The data for 1895 have been published in Water-Supply Paper No. 27, on page 16. The omission in the latter part of June, 1893, has also been supplied, as shown by the table on page 15 of the same publication. 
Estimated monthly discharge of Androscoggin River at Rumford Falls, Maine.

[Drainage area, 2,220 square miles.]

\begin{tabular}{|c|c|c|c|c|c|c|}
\hline \multirow[b]{2}{*}{ Month. } & \multicolumn{3}{|c|}{ Discharge is. second-feet. } & \multirow[b]{2}{*}{$\begin{array}{c}\text { Total in acre- } \\
\text { feet. }\end{array}$} & \multicolumn{2}{|c|}{ Run-off. } \\
\hline & $\begin{array}{l}\text { Maxi. } \\
\text { mum. }\end{array}$ & $\begin{array}{l}\text { Mini- } \\
\text { mum. }\end{array}$ & Mean. & & $\begin{array}{l}\text { Depth in } \\
\text { inches. }\end{array}$ & $\begin{array}{c}\text { Second- } \\
\text { feet per } \\
\text { square } \\
\text { mile. }\end{array}$ \\
\hline 1896. & & & & & & \\
\hline January ............ & 21,540 & 1,540 & 3,303 & 203,095 & 1. 72 & 1. 49 \\
\hline February ........... & 1,940 & 1,440 & 1,731 & 96,135 & 0.81 & 0.78 \\
\hline March ......... & 39,010 & 2,310 & 5,443 & 334,679 & 2.83 & 2.45 \\
\hline April . . . . . . . . . & 27,390 & 3,180 & 12,444 & 740,468 & 6.26 & 5.61 \\
\hline May .............. & 12,180 & 3,680 & 7,532 & 463,128 & 3.91 & 3.39 \\
\hline June .............. & 5,760 & 1,630 & 3,102 & 184,581 & 1.56 & 1.40 \\
\hline July . . . . . . . . & 2,760 & 1,500 & 2,002 & $\mathbf{1 2 3}, 099$ & 1.04 & 0.90 \\
\hline August . . . . . . . . . & 2,450 & 1,570 & 1,718 & 105,636 & 0.89 & 0.77 \\
\hline September ........ & 4,760 & 1,390 & 1,926 & 114,605 & 0.97 & 0.87 \\
\hline October ............ & 5,710 & $1, \overline{5} 30$ & 2,070 & 127,280 & 1.07 & 0.93 \\
\hline November .......... & 8,100 & 1,690 & 3,062 & 182,201 & 1.54 & 1. 38 \\
\hline Decomber . . . . . . . & 3,240 & 1,130 & 2,008 & 123,468 & 1.04 & 0.90 \\
\hline The year ... & 39,010 & 1,130 & 3,862 & $2,798,375$ & 23.64 & $1 . ' 74$ \\
\hline 1897. & & & & & & \\
\hline January & 4,623 & 1,320 & 1,821 & 111,970 & 0.94 & 0.82 \\
\hline February ....... & 2,228 & 1,055 & 1,686 & 93,080 & 0.79 & 0.76 \\
\hline 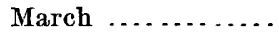 & 2,516 & 1,554 & 1,810 & $\mathbf{1 1 1}, 293$ & 0.93 . & 0.81 \\
\hline 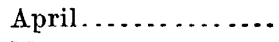 & 18,986 & 1,914 & 7,913 & 470,855 & 3.97 & 3.56 \\
\hline May .... & 19,266 & 6,724 & 11,614 & 714,122 & 6.04 & 5.23 \\
\hline June ............... & 14,764 & 3,405 & 6,998 & 416,409 & 3.51 & 3.15 \\
\hline July .... & 22,906 & 2,727 & 6,605 & 406,128 & 3.44 & 2. 98 \\
\hline August.......... & 5,726 & 1,342 & 2,345 & 144,189 & 1.22 & 1.06 \\
\hline September ...... & 2,001 & 1,143 & 1,592 & 94,730 & 0.80 & 0.72 \\
\hline October ............ & 3,757 & 1,190 & 1,606 & 98,750 & 0.83 & 0.72 \\
\hline November. & 5,686 & 1,085 & 2,282 & 135,788 & 1.15 & 1.03 \\
\hline December ....... & 7,462 & 1,622 & 2,605 & 160,176 & 1.35 & 1. 17 \\
\hline The year. . & 22,906 & 1,055 & 4,073 & $2,957,490$ & 24.97 & 1.83 \\
\hline 1898. & & & & & & \\
\hline January ... & 2,185 & 1,751 & 1,947 & 119,717 & 1. 01 & 0.88 \\
\hline February ...... & 2,193 & 1,224 & 1,700 & 94,413 & 0.80 & 0.77 \\
\hline 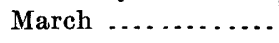 & 10,857 & 1,397 & 5,152 & 316,786 & 2. 68 & 2.32 \\
\hline April... & 16,748 & 4,833 & 9,309 & 553,923 & 4.67 & 4.19 \\
\hline May .... & 15,566 & 5,085 & 9,348 & 574,790 & 4.86 & 4.21 \\
\hline June.... & 7,980 & 2,116 & 4,743 & 282,227 & 2.39 & 2.14 \\
\hline July .... & 2,280 & 1,463 & 1,873 & 115,067 & 0.97 & 0.84 \\
\hline August. . . . . . . & 2,459 & 1,465 & 1,750 & 107,604 & 0.91 & 0.79 \\
\hline September ........ & 4,245 & 1,302 & 1,961 & 116,687 & 0.98 & 0.88 \\
\hline October ............... & 11,529 & 1,772 & 2,821 & 173,458 & 1.46 & 1. 27 \\
\hline November.......... & 6,903 & 1,741 & 2,813 & 167,385 & 1. 42 & 1.27 \\
\hline .December . . . . . . & 2,580 & 1,796 & 2,189 & 134,597 & 1.13 & 0.98 \\
\hline The year.... & 16,748 & 1,224 & 3,801 & $2,756,654$ & 23.28 & 1. 71 \\
\hline
\end{tabular}


Yield of Androscoggin River at Rumford Falls, Maine, in cubic feet per second per square mile.

\begin{tabular}{|r|r|r|r|r|r|r|r|r|}
\hline $\begin{array}{c}\text { Month } \\
\text { (order of } \\
\text { dryness). }\end{array}$ & 1893. & 1894. & 1895. & 1896. & 1897. & 1898. & Total. & Average. \\
\hline $1 \ldots$ & 1.162 & 0.852 & 0.451 & 0.759 & 0.703 & 0.751 & 4.678 & 0.780 \\
\hline $2 \ldots$ & 1.188 & 0.879 & 0.552 & 0.765 & 0.709 & 0.773 & 4.866 & 0.811 \\
$3 \ldots$ & 1.237 & 0.923 & 0.784 & 0.851 & 0.745 & 0.827 & 5.367 & 0.895 \\
$4 \ldots$ & 1.321 & 0.994 & 0.799 & 0.884 & 0.799 & 0.860 & 5.657 & 0.943 \\
$5 \ldots .$. & 1.352 & 1.099 & 0.803 & 0.887 & 0.804 & 0.866 & 5.811 & 0.969 \\
$6 \ldots$ & 1.405 & 1.099 & 0.878 & 0.914 & 1.008 & 0.967 & 6.271 & 1.045 \\
$7 \ldots .$. & 1.418 & 1.201 & 1.121 & 1.352 & 1.036 & 1.242 & 7.370 & 1.228 \\
$8 \ldots .$. & 1.449 & 1.343 & 1.269 & 1.370 & 1.151 & 1.246 & 7.828 & 1.305 \\
$9 \ldots$ & 1.687 & 1.780 & 1.575 & 1.459 & 2.917 & 2.095 & 11.513 & 1.919 \\
$10 \ldots$ & 2.222 & 2.244 & 1.846 & 2.404 & 3.091 & 2.276 & 14.083 & 2.347 \\
$11 \ldots .$. & 2.491 & 3.639 & 3.369 & 3.327 & 3.495 & 4.113 & 20.434 & 3.406 \\
$12 \ldots$ & 7.787 & 4.179 & 5.305 & 5.496 & 5.130 & 4.129 & 32.026 & 5.338 \\
\hline
\end{tabular}

Androscoggin River at Rumford Falls, Maine, minimum flow in each month in order of dryness, in cubic feet per second per square mile.

\begin{tabular}{|r|r|r|r|r|r|r|r|r|}
\hline $\begin{array}{r}\text { Month } \\
\text { (order of } \\
\text { yness). }\end{array}$ & 1893. & 1894. & 1895. & 1896. & 1897. & 1898. & Total. & Average. \\
\hline $1 \ldots$ & & & & & & \\
\hline $2 \ldots$ & 0.839 & 0.543 & 0.375 & 0.499 & 0.466 & 0.541 & 3.131 & 0.522 \\
$3 \ldots$ & 0.839 & 0.610 & 0.543 & 0.614 & 0.505 & 0.617 & 3.728 & 0.621 \\
$4 \ldots$ & 0.936 & 0.645 & 0.543 & 0.663 & 0.526 & 0.640 & 3.953 & 0.659 \\
$5 \ldots$ & 0.950 & 0.693 & 0.587 & 0.676 & 0.583 & 0.646 & 4.135 & 0.689 \\
$6 \ldots$ & 0.998 & 0.693 & 0.596 & 0.680 & 0.593 & 0.769 & 4.329 & 0.722 \\
$7 \ldots$ & 1.215 & 0.742 & 0.698 & 0.693 & 0.686 & 0.773 & 4.807 & 0.801 \\
$8 \ldots .$. & 1.215 & 0.742 & 0.724 & 0.720 & 0.716 & 0.783 & 4.900 & 0.817 \\
$9 \ldots$ & 1.299 & 0.941 & 0.764 & 0.746 & 0.845 & 0.793 & 5.388 & 0.898 \\
$10 \ldots$ & 1.321 & 1.369 & 0.821 & 1.020 & 1.205 & 0.935 & 6.671 & 1.112 \\
$11 \ldots$ & 1.396 & 1.458 & 0.835 & 1.405 & 1.504 & 2.135 & 8.733 & 1.456 \\
$12 \ldots$ & 2.257 & 2.009 & 1.590 & 1.625 & 2.970 & 2.246 & 12.697 & 2.116 \\
\hline
\end{tabular}


In connection with these data, Mr. Mixer calls attention to the fact that during the year there are two low-water seasons-one in February and the other in September. The two periods of low water are each short, thus reducing the requirements for storage and resulting in rapid increase of efficiency of every storage project. The amount of power utilized at Rumford Falls has increased from about 9,000 horsepower in 1897 to about 11,000 horsepower at the end of 1898. There has never been any anchor ice noted in tie river, and thus in quality of water and reliability of power the conditions at Rumford Falls are notable.

Observations of rainfall have been made at Rumford Falls, giving the results shown in the following table. These figures, which include rain and melted snow, can not be considered as strictly representative of the precipitation upon the whole catchment basin, as the elevation of the rain gage is 512 feet, while the catchment surface is higher, ranging from 600 feet and upward in the portion of the drainage basin without storage. This portion aggregates about one-half of the entire area. The other half of the drainage basin, within which are the lakes and other facilities for storage, averages in elevation about 1,450 feet.

Precipitation, in inches, at Rumford Falls, Maine.

\begin{tabular}{|c|c|c|c|c|c|c|c|c|c|c|c|c|c|}
\hline Year. & Jan. & Feb. & Mar. & Apr. & May. & June. & July. & Aug. & Sept. & Oct. & Nov. & Dec. & Total. \\
\hline 1.893. & & & & & & & & & & & & 3.00 & \\
\hline $1894 \ldots$ & 2.40 & 1.85 & 1.57 & 1.20 & 5.55 & 3.20 & 5.15 & 4. 30 & 4.35 & 3.95 & 4. 25 & 2.70 & 40.47 \\
\hline 1895. & 3.50 & 0.60 & 1.06 & 5.60 & 4.40 & 2. 30 & 2. 15 & 3.10 & 2.05 & 1. 60 & 5.40 & 5.71 & 37.47 \\
\hline $1896 \ldots$ & 1.10 & 5.85 & 9.75 & 1.65 & 2.07 & 1. 75 & 2.75 & 3.15 & 4.40 & 3. 20 & 2.95 & 0.95 & 39.57 \\
\hline $1897 \ldots$ & 3.80 & 2.70 & 4.05 & 3.35 & 4.25 & 6.20 & 9.44 & 2.15 & 1. 93 & 0.63 & 5. 35 & 3.40 & 47.25 \\
\hline 1898. & 3.85 & 7.25 & 1.08 & 2.87 & 2.55 & 3. 05 & 2. 70 & 3.39 & 3.96 & 4.52 & 5.00 & 1.95 & 42.17 \\
\hline
\end{tabular}

In addition to the annual water storage in lakes there is another form resulting from the prevailing low temperature on the drainage basin. The winter precipitation is nearly all retained for a period of weeks or months, and by melting in spring is rapidly added to the rainfall of that season. Thus the ratio between rainfall and run-off during winter and spring means little or nothing. By yearly periods the comparison as given in the following table is of interest.

Comparison of rainfall with run-off, in inches, at Kumford Falls, Maine.

\begin{tabular}{|c|c|c|c|c|c|}
\hline & Normal. & 1895. & 1896. & 1897. & 1898. \\
\hline Rainfall.. & 41.64 & 37.47 & 39.57 & 47.25 & 42.17 \\
\hline 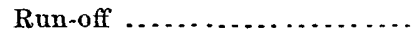 & 23.41 & 21.71 & 23.64 & 24.97 & 23.28 \\
\hline Percentage of rainfall ......... & 56.22 & 57.94 & 59.74 & 52.85 & 55.21 \\
\hline
\end{tabular}


MERRIMAC RIVER.

The figures of monthly discharge of Merrimac River at Lawrence, Massachusetts, for 1898 have been obtained from Mr. R. A. Hale, of Lawrence, Massachusetts, these being a continuation of the table in the Nineteenth Annual Report, Part IV, page 113. These are based upon the quantity passing through the canal and wheels of the various mills and wastiug over the dam in the river. The minimum flow has little connection with the natural discharge of the stream, as this is regulated by pondage. A view of Merrimac River at Lawrence, Massachusetts, is shown on Pl. III, $A$. This gives the method of holding back water in the river by means of flashboards placed on top of the dam.

Estimated monthly discharge of Merrimac River at Lawrence, Massachusetts.

[Drainage area 4,553 square miles.]

\begin{tabular}{|c|c|c|c|c|c|c|}
\hline \multirow{2}{*}{ Month. } & \multicolumn{3}{|c|}{ Discharge in second-feet. } & \multirow[b]{2}{*}{$\begin{array}{l}\text { Total in acre- } \\
\text { feet. }\end{array}$} & \multicolumn{2}{|c|}{ Run-off. } \\
\hline & $\begin{array}{l}\text { Maxi- } \\
\text { mum. }\end{array}$ & $\begin{array}{l}\text { Mini. } \\
\text { mum. }\end{array}$ & Mean. & & $\begin{array}{c}\text { Depth in } \\
\text { inches. }\end{array}$ & $\begin{array}{l}\text { Second- } \\
\text { feet per } \\
\text { square } \\
\text { mile. }\end{array}$ \\
\hline 1898. & & & & & & \\
\hline January ........... & 11,480 & 4,246 & 7,394 & $4.54,639$ & 1.87 & 1.62 \\
\hline February........... & 10,790 & 5,000 & 7,797 & 433,023 & 1.78 & 1.71 \\
\hline 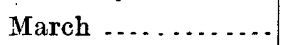 & 36,000 & 6,850 & 18,612 & $1,144,407$ & 4.72 & 4.09 \\
\hline April...... & 30,362 & 9,529 & 15,229 & 906,188 & 3.71 & 3.34 \\
\hline May ....... & 16,279 & 6,160 & 10,996 & 676,118 & 2.79 & 2.42 \\
\hline June..... & 9,964 & 3,908 & 6,464 & 384,635 & 1.58 & 1.42 \\
\hline July ..... & 4,516 & 1,018 & 2,660 & 163,558 & 0.67 & 0.58 \\
\hline August...... & 6,261 & 1,893 & 3,799 & 233,592 & 0.95 & 0.83 \\
\hline September. & 6,075 & 372 & 2,910 & 173,156 & 0.71 & 0.64 \\
\hline October .... & 14,473 & 2,077 & 6,429 & 395,304 & 1.63 & 1.41 \\
\hline November ........... & 19,785 & 5,204 & 9,887 & 588,317 & 2.42 & 2.17 \\
\hline December ... & 17,398 & 5,792 & 8,779 & 540,414 & 2.22 & 1.93 \\
\hline The year ... & 36,000 & 372 & 8,413 & $5,092,341$ & 25.05 & 1.85 \\
\hline
\end{tabular}

In the above table the maximum and minimum amounts are the greatest and least disclarges in each month for one full day, while the mean is the average 24-hour flow for the total number of days in the month. The following figure (10) shows in graphic form the fluctuations in discharge of Merrimac River for eight years, from 1891 to 1898, inclusive. The time of occurrence and relative importance of the spring floods are particularly noticeable. 


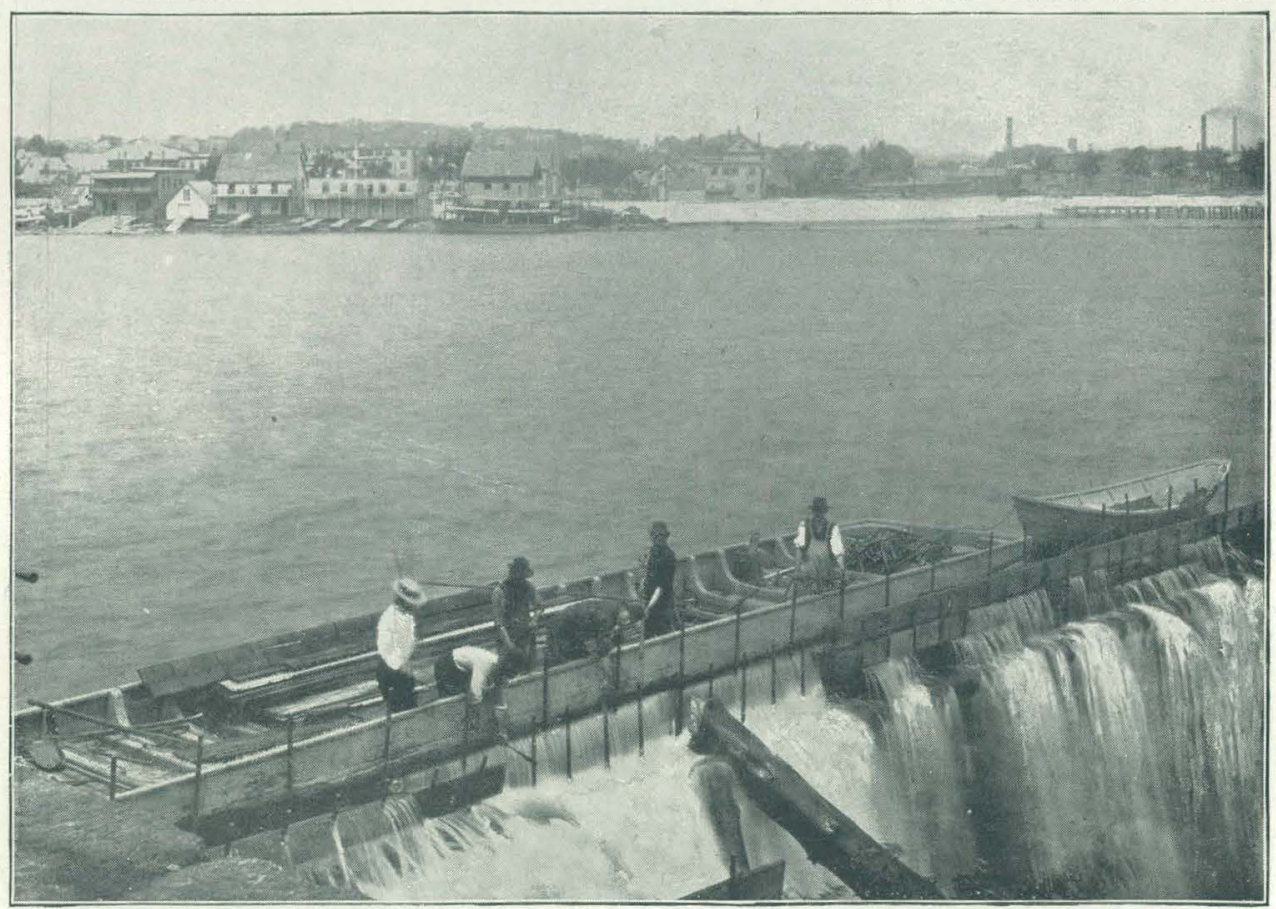

A. MERRIMAC RIVER AT LAWRENCE, MASSACHUSETTS.

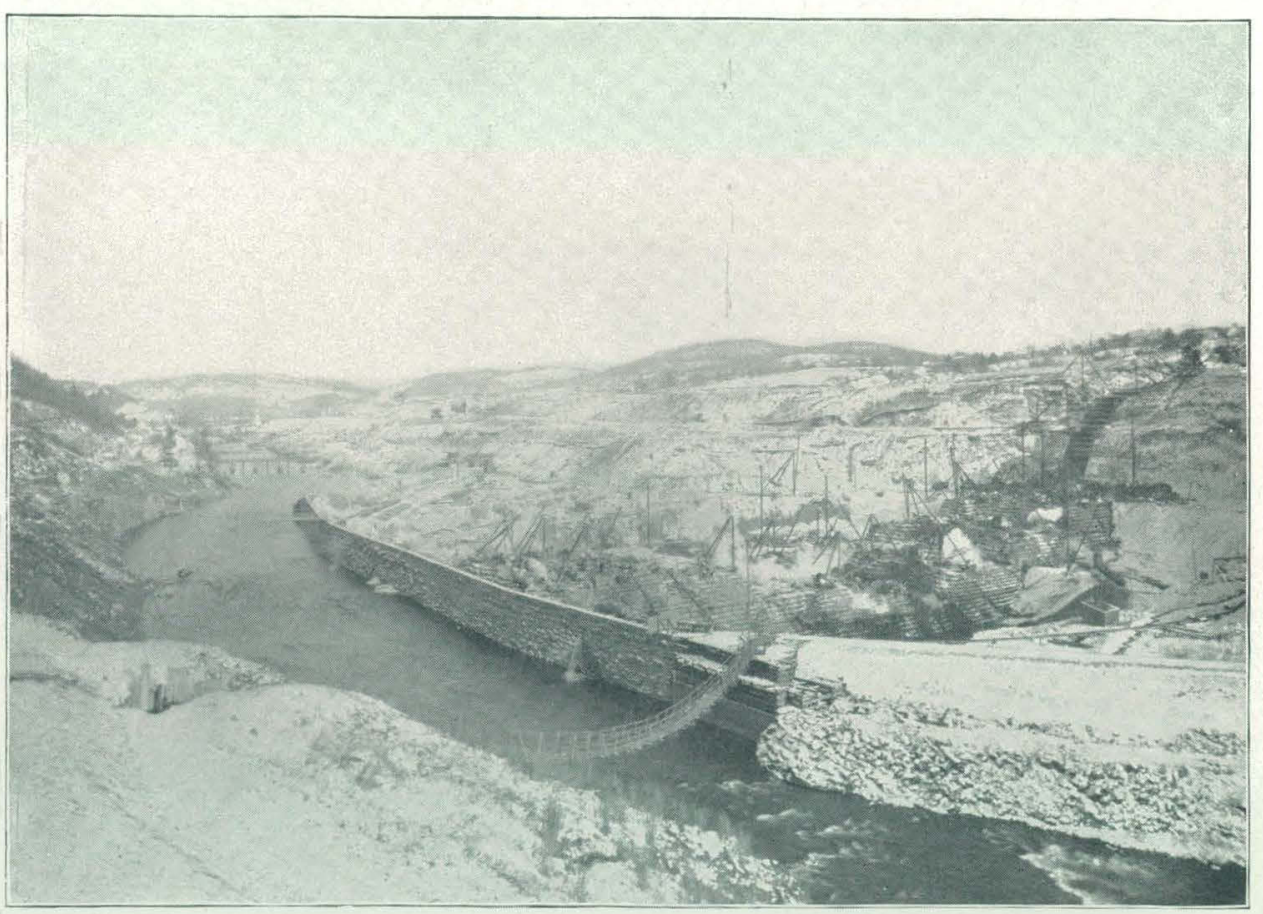

B. CROTON RIVER. 


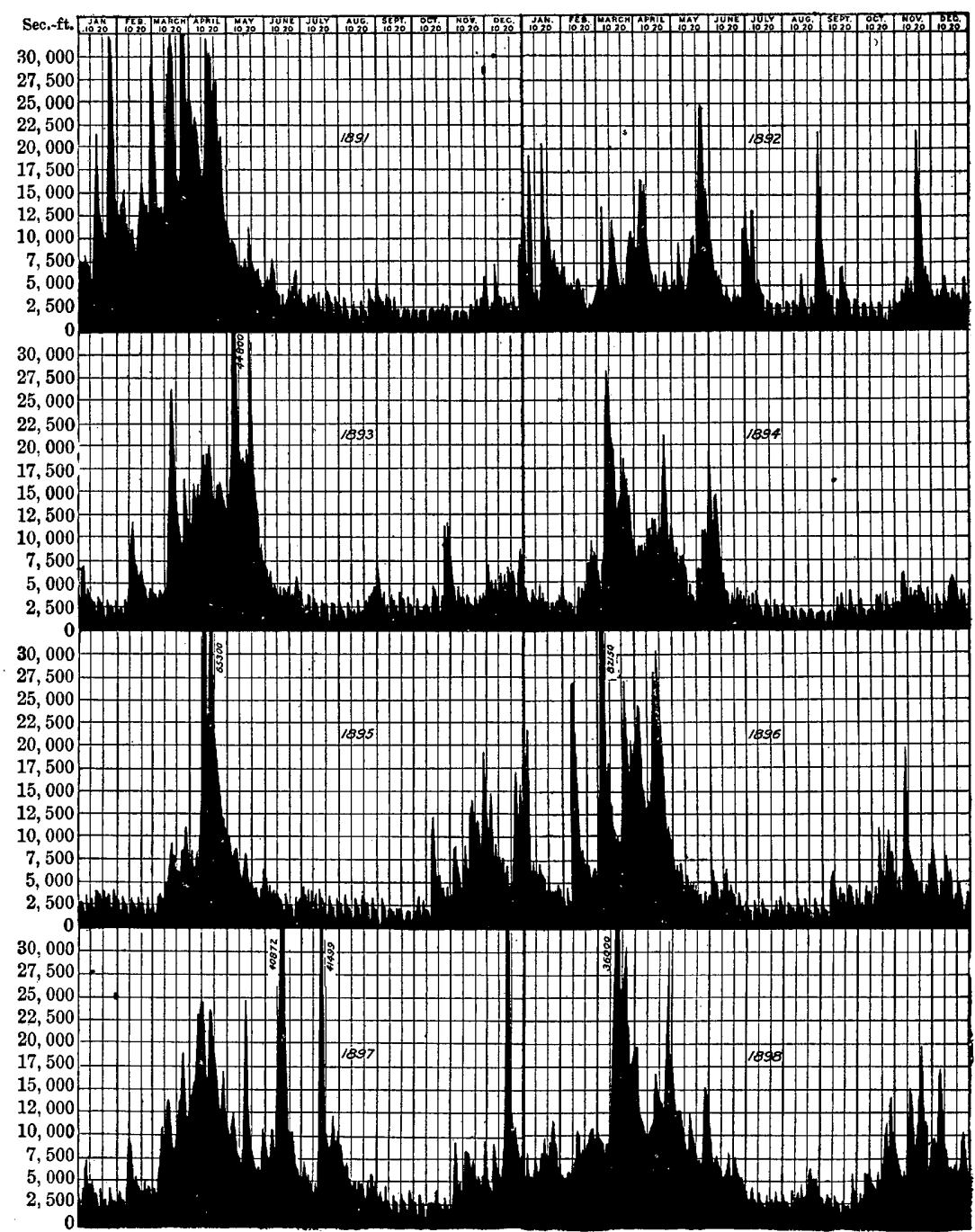

FIG. 10.-Discharge of Merrimac River at Lawrence, Massachusetts, 1891-98.

\section{SUDBURY RIVER.}

Sudbury River is a small stream of eastern Massachusetts which, receiving water from an area west-of Framingham, flows thence in a northerly course through meadows and swamps and joins Assabet River to form Concord River. This in turn continues northerly, entering Merrimac River immediately below the city of Lowell. Storage reservoirs, to the number of seven, have been constructed from time to time, the yield of the entire catchment basin in this vicinity being controlled for municipal water supply. The available water has been 
systematically measured and studied by Mr. Desmond FitzGerald, the records beginning in 1875 .

The stream is so thoroughly reservoired that the flow by days would be very difficult of computation and would have little practical value. The results, however, are obtained by months, and have been printed in various forms, particularly in a discussion by Mr. FitzGerald in Vol. XXVII of the Transactions of the American. Society of Civil Engineers, September, 1892. The following table gives the results in cubic feet per second per square mile, this being considered to be the most convenient unit for comparison with data obtained for other catchment areas.

Run-off of Sudbury River watershed.

[Drainage area 75.2 square miles. Cubic feet per second per square mile.]

\begin{tabular}{|c|c|c|c|c|c|c|c|c|c|c|c|c|c|}
\hline & an. & eb. & Mar. & Apr. & May. & June. & July. & Aug. & Sept. & Oct. & Nov. & Dec. & Mea \\
\hline 18 & 159 & 2.315 & $2.482 \mid$ & 4.718 & 1.838 & 1.346 & 0.497 & 0.612 & 0.321 & 1.000 & 2.015 & 0.908 & .504 \\
\hline 18 & 995 & 116 & 6.862 & 5.094 & 1.761 & 0.343 & 0.283 & 0.627 & 0.285 & 0.361 & 1.683 & 0.702 & 1. 756 \\
\hline $187 J$ & 019 & 1.469 & 7.448 & 3.703 & 2.153 & 0.924 & 0.312 & 0.187 & 0.092 & 0.977 & 2.193 & 1. 995 & 878 \\
\hline 1878 & 2.800 & 3.814 & 5.426 & 2.516 & 2.158 & 0.782 & 0.199 & 0.736 & 0.249 & 0.799 & 2.619 & 4.916 & 246 \\
\hline $187 \mathrm{~s}$ & 1.083 & 2. 647 & 3.605 & 4.821 & 1.723 & 0.640 & 0.243 & 0.611 & 0.218 & 0.109 & 0.318 & 0.716 & 1. 383 \\
\hline 18 & 1.733 & 2.765 & 2.126 & 1. 808 & 0.796 & $0.27 \mathrm{i}$ & 0.273 & 0.184 & 0.124 & 0.157 & 0.318 & 0.271 & 895 \\
\hline 188$]$ & 0.642 & 2. 392 & 6.195 & 2.392 & 1.493 & 2.070 & 0.428 & 0.229 & 0.305 & 0.287 & 0.611 & 1.199 & 1. 515 \\
\hline 188 & 1.920 & 3.718 & 4. 392 & 1. 342 & 1.998 & 0.818 & 0.133 & 0.086 & 0.474 & 0.463 & 324 & 0.487 & 334 \\
\hline 18 & 0.518 & 1.598 & 2.492 & 2.088 & 1.450 & 0.464 & 0.178 & 0.122 & 0.141 & 0.288 & 0.317 & 0.299 & 824 \\
\hline 188 & 1.540 & 4.397 & 5.857 & 4.415 & 1.594 & 0.644 & 0.346 & 0.397 & 0.068 & 0.129 & 0.271 & 1. 431 & .747 \\
\hline 18 & 910 & 2.095 & 2.433 & 2.808 & 2.067 & 0.659 & 0.096 & 0.372 & 0.187 & 0.519 & 1.822 & 1.816 & 1. 393 \\
\hline 188 & 2.260 & 7.428 & 3.185 & 3.013 & 1.114 & 0.314 & 0.179 & 0.146 & 0.182 & 0.225 & 1.041 & 1.578 & .682 \\
\hline & 4.006 & $|4.377|$ & 4.437 & 4. 053 & 1.561 & 0.640 & 0.178 & 0.331 & 0.172 & 0.294 & .0 .570 & 0.995 & 785 \\
\hline 188 & 1.629 & 3.011 & 5.009 & 4. 093 & 2.526 & .652 & 0.182 & 0.587 & 1. 786 & 3.093 & 4. 267 & 4.708 & 626 \\
\hline & 4.305 & 1.850 & 2.071 & 2.182 & 1.361 & 1.011 & 0.980 & 2.216 & 1.274 & 1.903 & 3.003 & 3.467 & 140 \\
\hline 1890 & 1.941 & 2.366 & 5.636 & 2.900 & 2.114 & 0.878 & 0.166 & 0.204 & 0.708 & 3.515 & 1.879 & 1.541 & .989 \\
\hline & 4.669 & 5.393 & 6.891 & 3.709 & 0.901 & 0.639 & 0.231 & 0.252 & 0.314 & 0.325 & 0.472 & 0.842 & 034 \\
\hline 189 & 2.893 & 1.454 & 3.025 & 1. 348 & 1. 947 & 0.662 & 0.331 & 0.433 & 0.355 & 0.195 & 1.079 & 0.750 & .209 \\
\hline 1893 & 0.671 & 2.386 & 5.021 & 3.288 & 4.461 & 0.680 & 0.244 & 0.280 & 0.167 & 0.343 & 0.493 & 1. 232 & 604 \\
\hline & 1.072 & 1.533 & 3.463 & 2.538 & 1.299 & 0.648 & 0.249 & 0.324 & 0.231 & 0.579 & 1.293 & 1.108 & .192 \\
\hline 1895. & 1.600 & 0.837 & 3.728 & 3.892 & 0.984 & 0.269 & 0.357 & 0.354 & 0.138 & 2.134 & 4.296 & 2.757 & .782 \\
\hline & 1.677 & 4.140 & 5.933 & 2.312 & 0.557 & 0.617 & 0.147 & 0.088 & 0.600 & 0.916 & 1.020 & 1.017 & .576 \\
\hline 1897. & 1.307 & 1.651 & 3.968 & 2.344 & 1.416 & 1.488 & 1.018 & 0.914 & 0.282 & 0.145 & 1. 407 & 2.451 & 1.533 \\
\hline 1898. & 2.535 & 4.676 & 4.029 & 2.830 & 1.927 & 0.880 & 0.357 & 1. 712 & 0.571 & 1. 795 & 3.073 & 2. 783 & 2. 248 \\
\hline $\mathbf{M}$ & 1.871 & 2.935 & 4.405 & 3. 091 & 1.717 & 0.761 & 0.317 & 0.500 & 385 & 0.856 & 1.516 & $|1.665|$ & 561 \\
\hline
\end{tabular}

There are also available records of yield of water from the drainage basin of Lake Cochituate, with area of 18.87 square miles, including 7.6 per cent of water surface, and from the watershed of Mystic Lake, with watershed of 26.9 square miles and about 3 peri cent of surface. The figures of yield from these are considered to be somewhat less precise, but of sufficient accuracy for practical purposes. 


\section{CONNECTICUT RIVER.}

The figures of the monthly discharge of Connecticut River at Holyoke, Massachusetts, for 1898 bave been obtained from Mr. A. F. Sickman, these being a continuation of the table in the Nineteenth Annual Report, Part IV, page 116.

Estimated monthly discharge of Connecticut River at Holyoke, Massachusetts.

[Drainage area, 8,660 square miles.]

\begin{tabular}{|c|c|c|c|c|c|c|}
\hline \multirow[b]{2}{*}{ Month. } & \multicolumn{3}{|c|}{ Discharge in second-feet. } & \multirow[b]{2}{*}{$\begin{array}{c}\text { Total in acre- } \\
\text { fect. }\end{array}$} & \multicolumn{2}{|c|}{ Run-off. } \\
\hline & $\begin{array}{l}\text { Maxi- } \\
\text { mum. }\end{array}$ & $\begin{array}{l}\text { Mini. } \\
\text { mumm. }\end{array}$ & Mean. & & $\begin{array}{l}\text { Depth in } \\
\text { inches. }\end{array}$ & $\begin{array}{c}\text { Seroud- } \\
\text { feet per } \\
\text { square } \\
\text { mile. }\end{array}$ \\
\hline 1898. & & & & & & 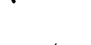 \\
\hline January - & 16,050 & 7,500 & 10,339 & 635,724 & 1.37 & 1.19 \\
\hline February ........ & 12,450 & 6,350 & 8,673 & 481,674 & 1. 04 & 1.00 \\
\hline March .. & 76,150 & 6,950 & 35,482 & $2,181,717$ & 4.72 & 4.09 \\
\hline April ........ & 50,450 & 16,050 & 29,245 & $1,740,198$ & 3.77 & 3.38 \\
\hline May ... & 26,800 & 12,350 & 19,079 & $1,173,122$ & 2.53 & 2.19 \\
\hline June. . & 17,900 & 7,550 & 11,395 & 678,048 & 1.46 & 1.31 \\
\hline July . & 6,050 & 600 & 3,798 & 233,531 & 0.52 & 0.45 \\
\hline August... & 7,550 & 3,150 & 4,958 & 304,857 & 0.66 & 0.57 \\
\hline September ..... & 12,550 & 650 & 5,423 & 322,690 & 0.70 & 0.63 \\
\hline October.... & $.23,000$ & 4,650 & 12,207 & 750,168 & 1. 61 & 1.40 \\
\hline November... & 29,150 & 8,850 & 15,840 & 942,543 & 2.03 & 1.82 \\
\hline December ... & 15,250 & 5,800 & 9,689 & 595,757 & 1.29 & 1. 12 \\
\hline The year ....... & 76,150 & 600 & 13,844 & $10,040,029$ & 21.70 & 1. 60 \\
\hline
\end{tabular}

The daily fluctuations of Connecticut River are shown in fig. 11, on the opposite page, for the eight years from 1891 to 1898 , inclusive. The figures by months for the years 1880 to 1895 have been given in Bulletin No. 140, on pages $37-41$, but the details of daily flow have not been printed. The quantities given represent the average daily amount drawn on the pond above the dam, and show the discharge of the river except at such times as the surface falls below the crest of the dam when water is ponded over night and during Sunday; 


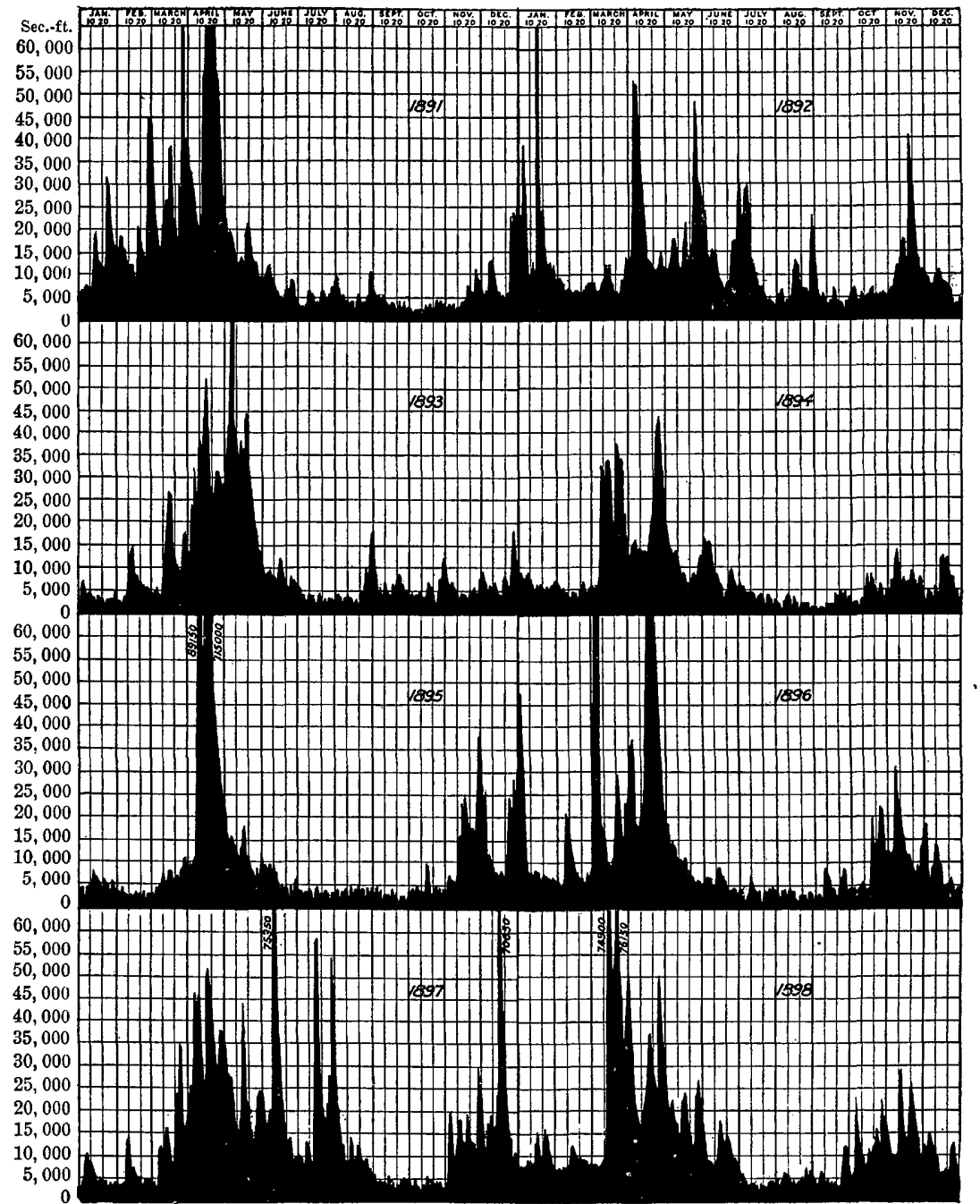

FIG. 11.-Discharge of Conuecticut River at Holyoke, Massachusetts, 1891-1898.

Observations of the height of Connecticut River have been maintained at a point near Hartford, on what is known as the "tollhouse gage," this being placed at the same elevation as the old gage established by the Engineer Corps, U. S. A., about 1872. Daily readings made by the Connecticut River Bridge and Highway district, of which Mr. Edwin D. Graves is the chief engineer, have been obtained there, beginning February 8, 1896. The bed of the river at this point probably changes very little, if at all, from year to year. During the extreme low water in the summer the height may be affected by the tide coming up the river from Long Island Sound. On some days this tidal aifference is not perceptible, it depending largely on the direction and force of the 
wind. In the Report of the Chief of Engineers for 1878, pages 348 to 391 , the matter of extending navigation north of Hartford was discussed, and at that time the original gage was established and the discharge of the river at Hartford computed. From the figures given in this report and from other data, computations of the discharge of Connecticut River at Hartford from 1871 to 1886 , inclusive, were prepared and published in Part II of the Fourteenth Annual Report of this Survey, on pages 140 to 146.

In 1897 a further survey of the river was made, the results being given by Maj. Smith S. Leach in the Report of the Chief of Engineers, U.S. A., for 1898 , on pages 976 to 988 . The extremely high gage readings occasionally reported on this section of the river are probably due to the narrowing of the river a short distance below Middletown, Connecticut, the water being held back by the gorge at this point. In this connection Mr. Edwin D. Graves states that this explanation of the extreme high water is open to doubt in that if the water were held back by the gorge its surface would be more nearly level than at low water. At the latter time there is probably not more than 4 or 5 inches fall from Hartford to the narrows below Middletown, but at high water Mr. Graves states that he has seen a fall of 5 feet between the tide gage at Hartford and the tide gage at Middletown, indicating that instead of water being held back below Middletown it is banked up somewhere near Hartford and falls more rapidly from Hartford down in freshet time than on days of low water.

\section{HUDSON RIVER.}

Computations of discharge of Hudson River and its tributaries, especially the Mohawk, have been made during 1898 by the WaterSupply Division of the United States Board of Engineers on Deep Waterways. The work in New York has been under the direction of Mr. George W. Rafter, the object being to determine the amount of water available for supplying a canal of sufficient size to accommodate vessels navigating on the Great Lakes, or even on the ocean. The principal factor in furnishing sufficient water has been found to be Black River, which has its source on the western slope of the Adirondacks, flowing from these mountains in a general northwesterly course, and emptying into Lake Ontario near its outlet into St. Lawrence River. It is proposed to divert water from Black River by means of a large feeder canal skirting the foothills at a distance of from 10 to 15 miles from the lake. Measurements of the amount of water in Black River and of various streams to be crossed have therefore been made, as well as of the run-off from adjacent drainage areas. These for convenience of reference are here included under the head of Hudson River, although tributary to the Great Lakes drainage. The following list gives the name of the river and locality, together with numbers which refer to a small index map, fig. 12. 


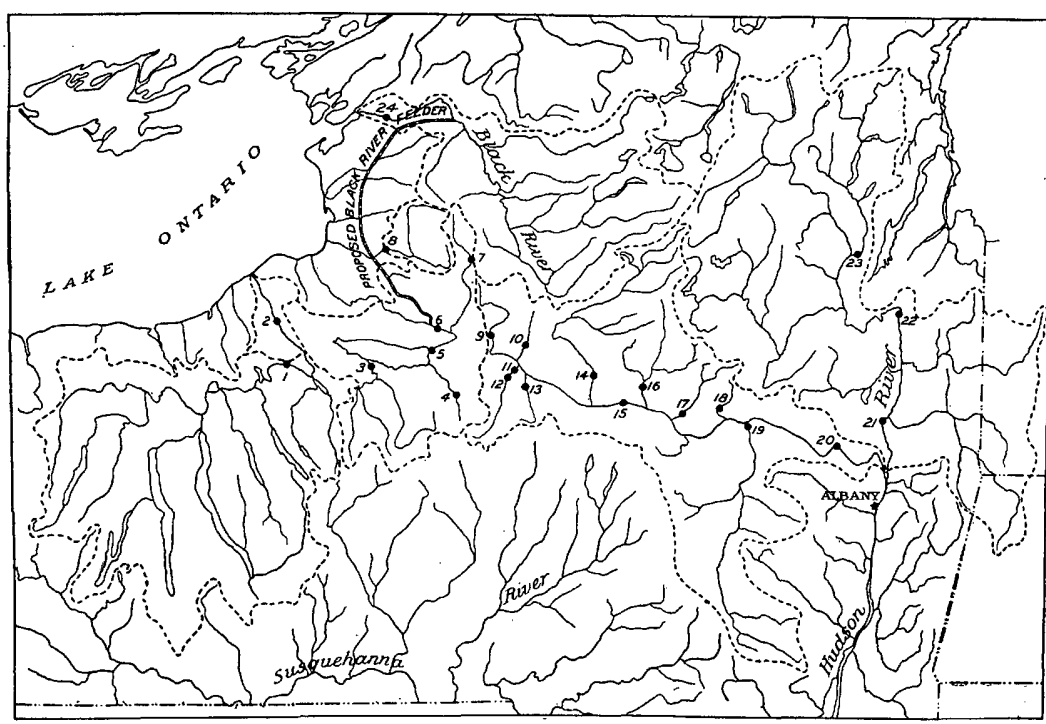

Fig. 12. Relative location of river observations in basin of Mohawk and adjacent rivers.

Streams measured by United States Board of Engineers on Deep Waterways.

\begin{tabular}{|c|c|c|}
\hline Number. & Stream. & Locality. \\
\hline $1 .$. & Seneca River.... & Baldwinsville. \\
\hline $2 .$. & Oswego River ..... & Fulton. \\
\hline 3. & Chittenango Creek .. & Bridgeport. \\
\hline 4. & Oneida Creek ...... & Kenwood. \\
\hline $5 \ldots$ & Wood Creek............ & Near mouth. \\
\hline $6 \ldots$ & Fish Creek, west branch..... & McConnellsville. \\
\hline $7 \ldots$ & Fish Creek, east branch & Above Point Rock. \\
\hline $8 \ldots$ & Salmon River & About 1 mile above falls. \\
\hline $9 .$. & Mohawk River .. & Ridge Mills. \\
\hline $10 .$. & Ninemile Creek ..... & 1 mile below Stittville. \\
\hline $11 .$. & Oriskany Creek ............. & State Dam, Oriskany. \\
\hline $12 \ldots$ & $\ldots$ do $\ldots . . . . . . . . . .$. & Coleman. \\
\hline $13 \ldots$ & Saquoit Creek......... & New York Mills. \\
\hline 14 & West Canada Creek . & Middleville. \\
\hline $15 \ldots$ & Mohawk River ...... & Little Falls. \\
\hline $16 \ldots$ & East Canada Creek... & Dolgeville. \\
\hline $17 \ldots \ldots$. & Garoga Creek .......... & 3 miles above the Mohawk. \\
\hline $18 \ldots \ldots \ldots$ & Cayadutta Creek....... & Below Johnstown. \\
\hline $19 .$. & Schoharie Creek....... & State Dam, Fort Hunter. \\
\hline $20 \ldots$ & Mohawk River ......... & State Dam, Rexford Flats. \\
\hline $21 \ldots$ & Hudson River ........... & Mechanicsville. \\
\hline $22:$ & $\ldots$ do $\ldots . . . . . . . .$. & Fort Edward. \\
\hline 23. & Schroon River.......... & Warrensburg. \\
\hline $24 \ldots$ & Black River ................... & Watertown. \\
\hline
\end{tabular}




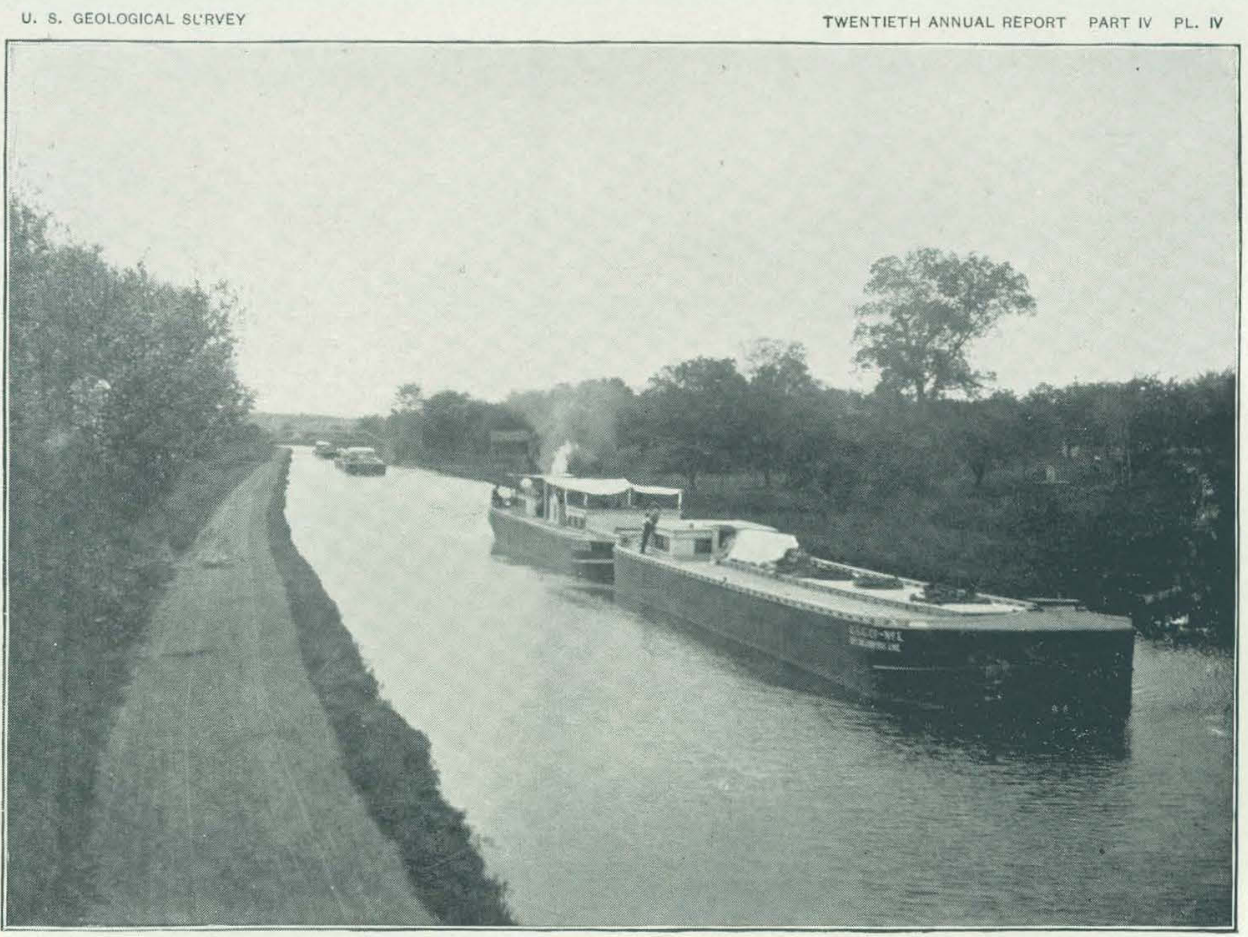

A. STEEL BARGES IN ERIE CANAL, NEW YORK.

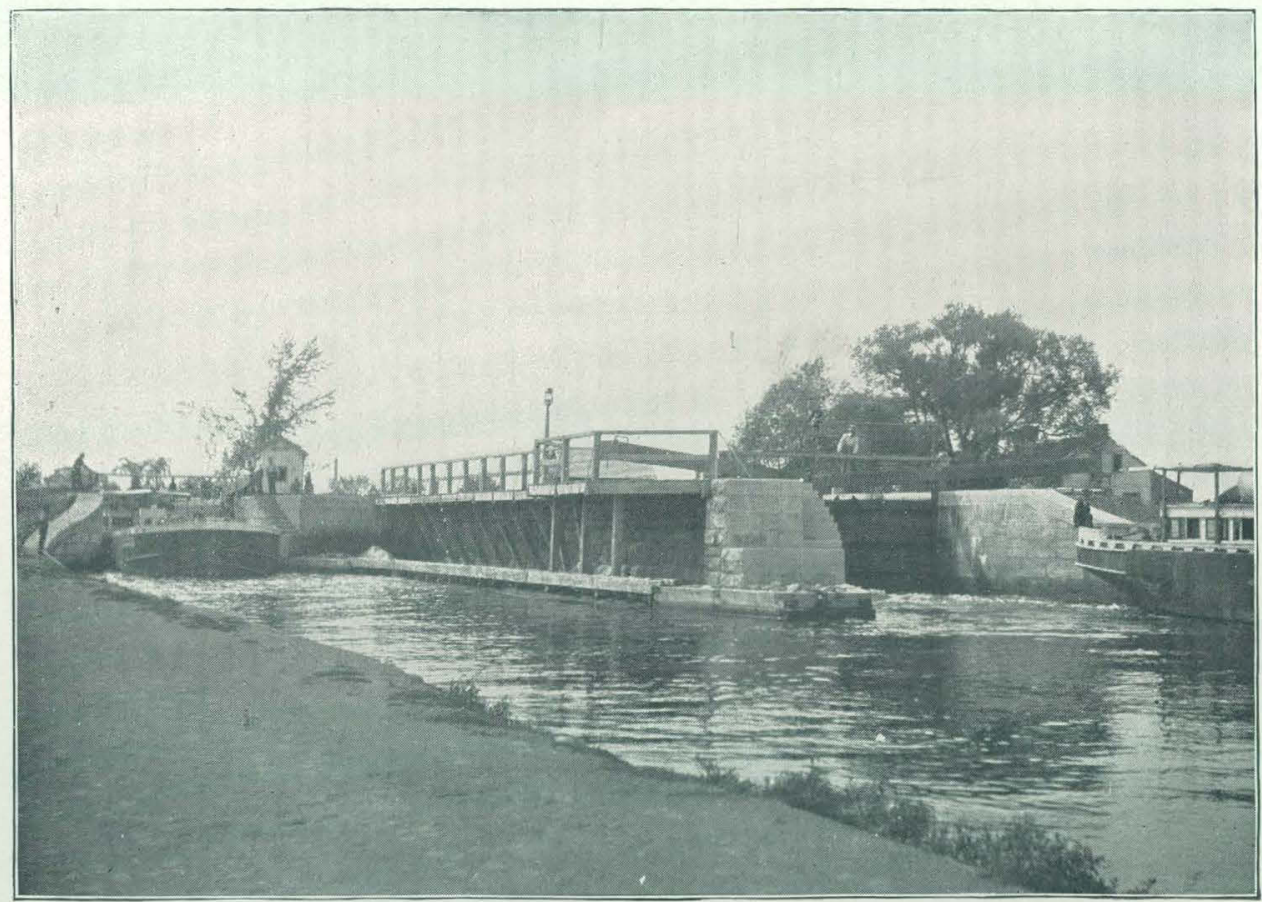

R RARGES PASSING THROUGH LOCKS ON ERIE CANAL. 

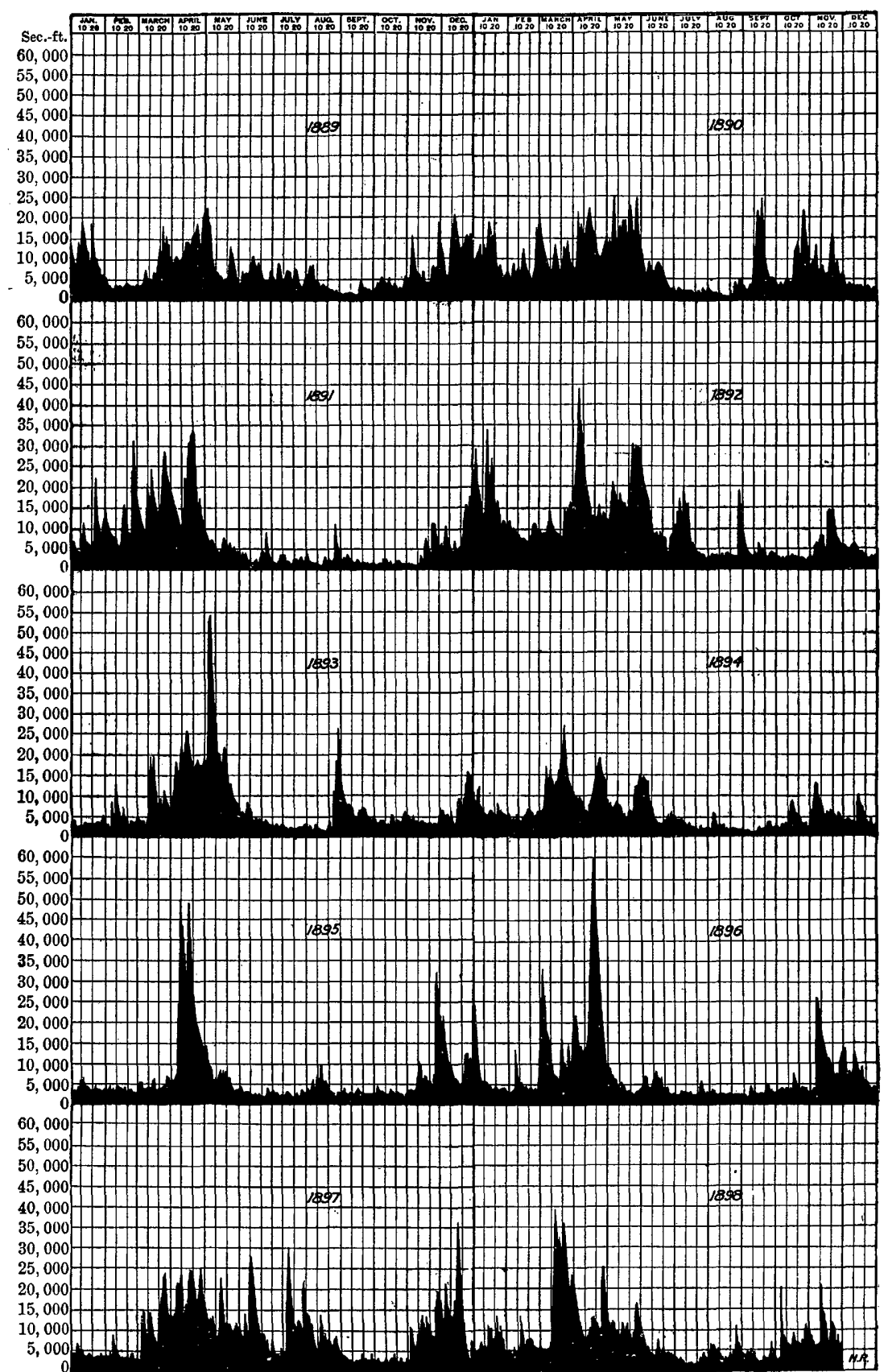

FIa. 13. Discharge of Hudson River at Mechanicsville, New York, 1889-1898.

Canal transportation has been discussed by Mr. Rafter in WaterSupply and Irrigation Papers Nos 24 and 25, where reference is made to the deep-waterways projects designed to supplement or replace the 
Erie Canal, whose importance has declined in spite of attempts made to enlarge it. Some of the recent improvements in methods of transportation on the Erie Canal are shown. on Pl. IV. On Pl. IV, $A$, is a view of six steel barges in sets of two each, all of these being pro. pelled by steam power in the second barge, the first being pushed in advance and the remainder being towed by a long line. On Pl. IV, $B$, is shown the locks of the Erie Canal below Schenectady and the steel barges passing through these. The following table is a continuation of that given in the Nineteenth Annual Report, Part IV, page 122.

Estimated monthly discharge of Hudson River at Mechanicsville, New York.

[Drainage area 4,500 square miles.]

\begin{tabular}{|c|c|c|c|c|c|c|}
\hline \multirow[b]{2}{*}{ Month. } & \multicolumn{3}{|c|}{ Discharge in second-feet. } & \multirow[b]{2}{*}{$\begin{array}{l}\text { Total in acre- } \\
\text { feet. }\end{array}$} & \multicolumn{2}{|c|}{ Run-off. } \\
\hline & $\begin{array}{l}\text { Maxi. } \\
\text { mum. }\end{array}$ & $\begin{array}{l}\text { Mini- } \\
\text { mum. }\end{array}$ & Mean. & & $\begin{array}{l}\text { Depth in } \\
\text { inches. }\end{array}$ & $\begin{array}{l}\text { Second. } \\
\text { feet per } \\
\text { square } \\
\text { mile. }\end{array}$ \\
\hline 1898. & & & $\cdot$ & & & \\
\hline January ............. & 13,757 & 4,689 & 7,723 & 474,872 & 1. 98 & 1. 72 \\
\hline February .......... & 13,042 & 4,151 & 6,754 & 375,098 & 1. $\overline{5} 6$ & 1.50 \\
\hline March.......... & 39,389 & 5,186 & 20,225 & $1,243,595$ & 5.18 & 4.49 \\
\hline April.......... & 25,150 & 7,389 & 13,719 & 816,335 & 3.40 & 3.05 \\
\hline May ........ & 16,206 & 7,162 & 11,081 & 681,349 & 2.84 & 2.46 \\
\hline June ......... & 10,118 & 3,100 & 5,280 & 314,181 & 1. 31 & 1.17 \\
\hline July & 4,425 & 1,163 & 2,570 & 158,024 & 0.66 & 0.57 \\
\hline August ........ & 12,058 & 2,417 & 5,133 & 315,618 & 1.31 & 1. 14 \\
\hline September .. & 7,359 & 1,782 & 3,869 & 230,221 & 0.95 & 0.86 \\
\hline October ........ & 20,948 & 2,417 & 7,895 & 485,448 & 2.02 & 1.75 \\
\hline November ... & 21,100 & 5,209 & 9,243 & 549,995 & 2.29 & 2.05 \\
\hline December... & 8,690 & 3,560 & 5,436 & 334,246 & 1. 40 & 1.25 \\
\hline The yeax..... & 39,389 & $\mathbf{1}, 763$ & 8,244 & $5,978,982$ & 24.90 & 1.83 \\
\hline
\end{tabular}

CROTON RIVER.

The Croton River watershed is the principal source of the water supply of the city of New York. A number of reservoirs have been built within the basin, and a new and larger dam is being constructed near the lower end, at what is known as the Cornell site. This new Croton dam (shown on Pl. III, $B$ ) will be one of the largest and most notable masonry structures in the country. It will raise the water to a height sufficient to submerge the old Croton dam. In order to lay the foundation, Croton River has been diverted around the dam site through an artificial channel, as shown in the view. Figures of yield of this watershed have been published by Mr. Alphonse Fteley, in the report of the 20 GEOL, PT $4-6$ 
Aqueduct Commissioners of January 1, 1895. The following table of rainfall is taken from that report, with additional figures up to 1898, furnished by Mr. Fteley.

Precipitation, in inches, at Boyds Corners, in. Croton River basin, for each month from 1870 to 1898 .

\begin{tabular}{|c|c|c|c|c|c|c|c|c|c|c|}
\hline Months. & 1870. & 1871. & 1872. & 1873. & 1874. & 1875. & 1876. & 1877. & 1878. & $18 \pi 9$ \\
\hline January . & 4.51 & 3.80 & 1.44 & 5.66 & 6.96 & 2.74 & 1.42 & 2.68 & 4.49 & 2.52 \\
\hline February & 6.40 & 3.81 & 1. 22 & 3. 09 & 2.78 & 3.47 & 4.91 & 0.80 & 3.65 & 2.85 \\
\hline March ... & 3.80 & 4.27 & 2.59 & 3.08 & 1.57 & 4.99 & 6.33 & 7. 66 & 3.10 & 4.96 \\
\hline April ... & 5.45 & 3.01 & 3.04 & 3. 77 & 6.31 & 3.04 & 4.43 & 2.35 & 2.85 & 5.10 \\
\hline May .... & 2.30 & 3.45 & 3.69 & 2.91 & 1.99 & 1.08 & 3.99 & 0.85 & 4.97 & 2.45 \\
\hline June..... & 2.06 & 5.73 & 4.00 & 0.71 & 3.57 & 3.02 & 2.52 & 4.95 & 4.65 & 5.29 \\
\hline July ... & 3.43 & 5.07 & 4.34 & 2.21 & 5.98 & 3.10 & 3.42 & 4.65 & 4.28 & 5.95 \\
\hline August. . & 5. 10 & 5.24 & 5.99 & 5. 73 & 2.75 & 10.33 & 1.20 & 2.54 & 2.66 & 5.83 \\
\hline September . & 2.85 & 1.44 & 3.69 & 3. 73 & 3.56 & 2.11 & 5.21 & 1.49 & 6.61 & 3.43 \\
\hline October...... & 4. 73 & 6.18 & 2.15 & 5.13 & 2.40 & 3.61 & 1.50 & 8.38 & 3. 78 & 0.95 \\
\hline November & 2.51 & 4.35 & 4.91 & 3.72 & 2. 72 & 4.61 & 3.40 & 8.16 & 4. 36 & 2.49 \\
\hline December ... & 1.49 & 2.59 & 3.68 & 4.13 & 1. 78 & 1.56 & $2.35^{\circ}$ & 1.52 & 8. 74 & 4.26 \\
\hline Total & 44.63 & 48.94 & 40.74 & 43.87 & 42.37 & 43.66 & 40.68 & 46.03 & 54.14 & 46.08 \\
\hline Flow of river: & & & & & & & & & & \\
\hline Inches & 21.38 & 21.19 & 19.19 & 27.88 & 26.85 & 27.67 & 24.89 & 22.23 & 28.86 & 22.87 \\
\hline Per cent.. & 48 & 43 & 47 & 64 & 63 & 63 & 61 & 48 & 53 & 50 \\
\hline Months. & 1880. & 1881. & 1882. & 1883. & 1884. & 1885. & 1886. & 1887. & 1888. & 1889 \\
\hline January & 4.00 & 4.19 & 4.41 & 2.80 & 5.07 & 5.59 & 5. 24 & 5. 68 & 5. 56 & 5.14 \\
\hline February & 2.92 & 5. 28 & 5.96 & 5.21 & 6. 31 & 4.66 & 5.20 & 6.01 & 5.07 & 2.33 \\
\hline March & 4.51 & 6.14 & 4.58 & 1. 67 & 4.82 & 1. 29 & 3.86 & 3.60 & 6.44 & 1.86 \\
\hline April .... & 3.99 & 1.67 & 1.36 & 3.94 & 2.96 & 2.09 & 3.61 & 3.47 & 2.68 & 4.42 \\
\hline May .... & 1.17 & 3.74 & 6.30 & 2.86 & 4.33 & 2.44 & 4.54 & 0.32 & 6.27 & 3.22 \\
\hline June.. & 1.28 & 5.72 & 3.04 & 5.64 & 2.04 & 1. 19 & 3.09 & 7. 70 & 2.00 & 4.51 \\
\hline July ..... & 5.65 & 2.45 & 3.63 & 4.26 & 6.54 & 5.27 & 4.40 & 13.32 & 2.43 & 7.74 \\
\hline August.... & 3. 60 & 1.71 & 3.92 & 2. 09 & 4.50 & 7.35 & 3.21 & 7.06 & 6.87 & 2.90 \\
\hline September & 2.69 & 0.75 & 14.33 & 2.45 & 1.69 & ·1. 09 & 2.30 & 2.00 & 10.77 & 6.13 \\
\hline October.. & 3.25 & 3.65 & 3.33 & 6.99 & 3. 74 & 5.19 & 2.28 & 3.12 & 4.80 & 4.85 \\
\hline November... & 2.97 & 4.50 & 1. 66 & 1. 79 & 4.37 & 5.99 & 5.57 & 2.69 & 4.49 & 8.45 \\
\hline December & 2.49 & 6.53 & 2.68 & 3.45 & 7.34 & 3.84 & 4.29 & 6.71 & 6.13 & 2.94 \\
\hline Total & 38.52 & 46.33 & 55.20 & 43.15 & 53.71 & 45.99 & 47.59 & 61.68 & 63.51 & 54.49 \\
\hline Flow of river: & & & & & & & & & & \\
\hline Inches & 15.32 & 20.16 & 25.35 & 15.95 & 25.41 & 19.48 & 22.24 & 28.28 & 37.81 & 33.86 \\
\hline Per cent. & 40 & 44 & 46 & 37 & 47 & 42 & 47 & 46 & 60 & 62 \\
\hline
\end{tabular}


Precipitation, in inches, at Boyds Corners, in Croton River basin, etc.-Continued.

\begin{tabular}{|c|c|c|c|c|c|c|c|c|c|c|}
\hline Months. & 1890 & 1891. & 1892. & 1893. & 1894. & 1895. & 1896. & 1897. & 1898. & $\begin{array}{c}\text { A verage } \\
1870 \text { to } \\
1898 .\end{array}$ \\
\hline January ..... & 2.03 & 9.76 & 5.95 & 3.29 & 3.40 & 3.63 & 1.52 & 4.07 & 5.82 & 4.25 \\
\hline February ... & 4.94 & 6.02 & 1. 22 & 4.60 & 5.01 & 3.34 & 6.65 & 3.14 & 5.56 & 4.22 \\
\hline March ...... & 5.66 & 3. 36 & 2.90 & 4.52 & 1. 62 & 1.88 & 8.20 & 3.68 & 2.64 & 3.99 \\
\hline April ....... & 3.03 & 3. 77 & 1.08 & 3.55 & 3. 07 & 5.63 & 0.96 & 2. 78 & 4.32 & 3.37 \\
\hline May .... & ๖. 74 & 1. 36 & 5.74 & 8.18 & 6.67 & 2.41 & 3.09 & 5.54 & 7.07 & 3.75 \\
\hline June .... & 3.56 & 1.81 & 3.84 & 2.43 & 1.69 & 1.89 & 3.79 & 2.89 & 1.50 & 3.31 \\
\hline July & 5.46 & 2.97 & 5.05 & 2.38 & 1.75 & 3.95 & 3.98 & 13.03 & 4.58 & 4.87 \\
\hline August. & 4.70 & 5.61 & 6.12 & 7.06 & 1.45 & 3.10 & 4.56 & 5.63 & 8.51 & 4.74 \\
\hline September & $6.86^{\circ}$ & 1.87 & 2.65 & 2.65 & 7.49 & 1. 16 & 6.50 & 1. 74 & 1.97 & 3.83 \\
\hline October... & 7.63 & 2.15 & 0.92 & 6.42 & 5.94 & 3.55 & 2.17 & 1.94 & 4.84 & 3.99 \\
\hline November. & 1. 12 & 3.86 & 7.85 & 3.32 & 4.44 & 2.91 & 3.96 & 6.44 & 6.81 & 4.29 \\
\hline December . & 3.71 & 5.65 & 1.11 & 5.34 & 4.43 & $4.88^{\circ}$ & 2.72 & 6.56 & 2.20 & 3.97 \\
\hline Total & 54.44 & 48.19 & $\overline{44.43}$ & 53.74 & 46.96 & 38.33 & 48.10 & 57.44 & 55.82 & 48.58 \\
\hline $\begin{array}{r}\text { Flow of river: } \\
\text { Inches ... }\end{array}$ & 27.86 & 25.71 & 17.22 & 31.29 & 23.39 & 18.04 & 25.40 & 26.42 & 32.76 & 2465 \\
\hline Per cent. & 51 & 53 & 39 & 58 & 50 & 48 & 53 & 46 & 59 & 50.62 \\
\hline
\end{tabular}

Discharge of Croton River in second-feet.

[Drainage area, 338 square miles.]

\begin{tabular}{|c|c|c|c|c|c|c|c|c|c|c|c|c|c|}
\hline Year. & Jan. & Feb. & Mar. & Apr. & May. & June. & July. & Aug. & Sept. & Oct. & Nov. & Dec. & Mean. \\
\hline 1870. & 1,170 & 1,388 & 1,039 & 1,242 & 543 & 250 & 150 & 149 & 107 & 124 & 190 & 187 & 538 \\
\hline 1871. & 173 & 715 & 1,030 & 611 & 604 & 433 & 214 & 249 & 190 & 563 & 1,031 & 617 & 534 \\
\hline 1872. & 610 & 391 & 511 & 942 & 376 & 369 & 180 & 481 & 376 & 329 & 808 & 424 & 483 \\
\hline 1873. & 1,258 & 557 & 1,180 & 2,155 & 641 & 165 & .144 & 209 & 156 & 424 & 548 & 990 & 702 \\
\hline 1874 & 2,407 & 907 & 886 & 1,097 & 934 & 280 & 419 & 261 & 176 & 238 & 223 & 286 & 677 \\
\hline 1875. & 191 & 1,327 & 948 & 1,690 & 546 & 178 & 170 & 1,700 & 272 & 249 & 620 & 538 & 698 \\
\hline 1876. & 466 & 1,143 & 2,096 & 1,934 & 595 & 213 & 161 & 148 & 113 & 111 & 215 & 348 & 626 \\
\hline 1877. & 241 & 503 & 2,013 & 914 & 260 & 189 & 150 & 144 & 103 & 332 & 1,265 & 576 & 560 \\
\hline 1878 & 834 & 1,273 & 1,140 & 512 & 461 & 461. & 217 & 199 & 644 & 272 & 631 & 2,118 & 727 \\
\hline 1879 & 425 & 898 & 1,261 & 1,550 & 518 & 283 & 213 & 435 & 331 & 196 & 248 & 592 & 576 \\
\hline 1880. & 806 & 936 & 883 & 631 & 288 & 158 & 158 & 152 & 152 & 150 & 181 & 158 & 386 \\
\hline 1881. & 223 & $1,4 \mathrm{C} 2$ & 1,782 & 569 & 405 & 504 & 168 & 153 & 153 & 153 & 143 & 506 & 509 \\
\hline 1882 & 704 & 1. 372 & 1,388 & 431 & 645 & 516 & 203 & 153 & 985 & 665 & 291 & 376 & 639 \\
\hline 1883. & 311 & 1,235 & 885 & 825 & 405 & 191 & 153 & 153 & 153 & 192 & 207 & 186 & 402 \\
\hline 1884 & 626 & 1,549 & 1.468 & 908 & 559 & 210 & 236 & 345 & 216 & 165 & 297 & 1,106 & 639 \\
\hline $1885 \ldots$ & 1,206 & 789 & 600 & .784 & 461 & .179 & 151 & 168 & 128 & 162 & 663 & 611 & 491 \\
\hline $1886 .$. & 1,001 & 1,587 & 732 & 1,366 & 629 & 237 & 178 & 170 & 154 & 153 & 266 & 348 & 560 \\
\hline 1887. & 801 & 1,614 & 1,081 & 987 & 381 & 351 & 769 & 1,043 & 271 & 301 & 288 & 727 & 713 \\
\hline 1888. & 1,174 & $\mathrm{i}, 547$ & 1,374 & 1,468 & 781 & 421 & 195 & 325 & 911 & 755 & 919 & 1,539 & 951 \\
\hline 1889 & 1,290 & 764 & 614 & 780 & 515 & 432 & 477 & 1,182 & 688 & 565 & 1,601 & 1,332 & 854 \\
\hline 1890. & 687 & 1,034 & 1,382 & 996 & 801 & 464 & 207 & 175 & 616 & 984 & 631 & 483 & 702 \\
\hline $1891 \ldots$ & 2,005 & 1,860 & 1,282 & $\delta 77$ & 261 & 190 & 117 & 92 & 114 & 120 & 195 & 480 & 625 \\
\hline 1892. & 1,485 & 498 & 614 & 429 & 474 & 348 & 206 & 263 & 155 & 48 & 478 & 432 & 452 \\
\hline $1893 \ldots$ & 497 & 1,064 & 2,114 & 1,080 & 1,776 & 29] & 118 & 212 & 160 & 343 & 629 & 1,206 & 790 \\
\hline $1894 \ldots$ & 519 & $6 \dot{97}$ & 1,529 & 740 & 550 & 448 & 133 & 209 & 173 & 220 & 1,022 & 753 & 583 \\
\hline 1895 & 1,001 & 338 & 1,133 & 1,277 & 390 & 149 & 128 & 182 & 28 & 118 & 250 & 382 & 448 \\
\hline 1896 & 604 & 1,357 & 2,315 & 923 & 255 & 292 & 251 & 224 & 198 & 258 & 525 & 396 & 630 \\
\hline 1897 & 591 & 817 & 1,038 & 749 & 794 & 451 & 845 & 889 & 295 & 165 & 423 & 824 & 657 \\
\hline 1898. & $\cdot 1,107$ & 1,558 & 971 & $6 \pi 1$ & 1,492 & 564 & 198 & 830 & 297 & 289 & 736 & $|1,089|$ & 816 \\
\hline
\end{tabular}


The above figures of monthly and yearly yield of Croton River at Croton dam for the years 1870 to 1890 , inclusive, have been taken from Table No. 12, following page 96 of the Report of the Aqueduct Commissioners, the additional figures being furnished by Mr. Fteley. This table gives the flow in thousands of gallons, and includes the delivery through the aqueduct. Mr. Fteley states that until 1891, the total volume of storage being comparatively small, its fluctuations were not taken into account: From 1891 to 1898 inclusive, however, as new reservoirs were being added, allowance has been made for the amount of storage drawn down or gained during each month.

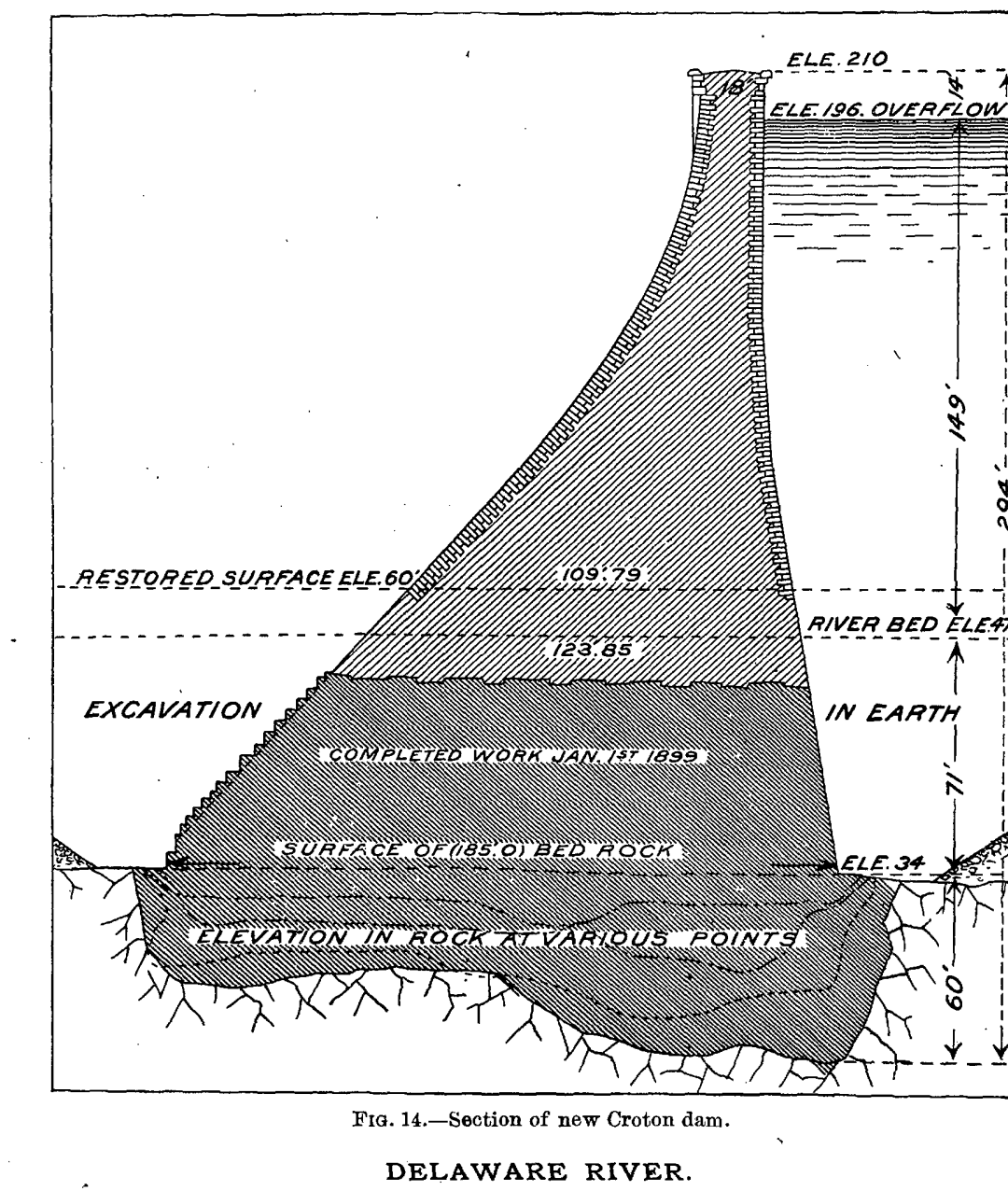

Measurements of Delaware River have been made at Lambertville, New Jersey, as described in prévious publications, this point being about 30 miles below the mouth of Lehigh River, at Easton, Pennsylvania. Conditions at this locality have been found most fayorable for 
obtaining the entire discharge of the river above the influence of the tide. Results of computations for 1898 are shown in the following table:

Estimated monthly discharge of Delaware River at Lambertville, New Jersey.

\begin{tabular}{|c|c|c|c|c|c|c|}
\hline \multirow[b]{2}{*}{ Month, } & \multicolumn{3}{|c|}{ Discharge in second.feet. } & \multirow{2}{*}{$\begin{array}{l}\text { Total in acre. } \\
\text { feet. }\end{array}$} & \multicolumn{2}{|c|}{ Run-off. } \\
\hline & $\begin{array}{l}\text { Maxi- } \\
\text { mum. }\end{array}$ & $\begin{array}{l}\text { Mini- } \\
\text { mum. }\end{array}$ & Mean. & & $\begin{array}{l}\text { Depth in } \\
\text { inches. }\end{array}$ & $\begin{array}{c}\text { Second- } \\
\text { feet per } \\
\text { square } \\
\text { mile. }\end{array}$ \\
\hline 1897. & & & & & & \\
\hline July 23-31 . . . . . & $\ldots \ldots$ & $\ldots \ldots \ldots$ & 28,406 & $\ldots \ldots \ldots \ldots$ & 1.39 & 4.14 \\
\hline August.......... & 33,420 & 7,125 & 15,440 & 949,369 & 2.59 & 2.25 \\
\hline September .... & 9,550 & 2,600 & 5,120 & 304,662 & 0.83 & 0.75 \\
\hline October..... & 5,475 & 2,350 & 2,948 & 181,265 & 0.49 & 0.43 \\
\hline November... & 30,060 & 2,462 & 13,214 & 786,109 & 2.15 & 1.93 \\
\hline December .......... & 66,540 & 10,300 & 24,845 & $1,527,657$ & 4.17 & 3.62 \\
\hline 1898. & 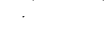 & $\cdot$ & & & & \\
\hline January ....... & 49,740 & 8,100 & 21,455 & $1,319,216$ & 3.61 & 3.13 \\
\hline February ... & 61,260 & 11,900 & 28,538 & $1,584,920$ & 4.33 & 4. 16 \\
\hline March ..... & 48,780 & 12,700 & 27,676 & $1,701,731$ & 4. 66 & 4.04 \\
\hline April ... & 39,660 & 9,125 & 18,233 & $1,084,938$ & 2.96 & 2.66 \\
\hline May ........ & 45,420 & 19,050 & 29,336 & $1,803,798^{-}$ & 4.94 & 4.28 \\
\hline June....... & 23,820 & 5,750 & 10,746 & 639,430 & 1.75 & 1.57 \\
\hline July ....... & 10,300 & 2,500 & 4,894 & 300,920 & 0.82 & 0.71 \\
\hline August .... & 38,700 & 8,450 & 18,192 & $1,118,587$ & 3.06 & 2.65 \\
\hline September .. & 18,575 & 4,350 & 8,459 & 503,345 & 1.37 & 1. 23 \\
\hline October ........ & 26,220 & 3,500 & 12,154 & 747,324 & 2.04 & 1.77 \\
\hline November... & 42,060 & 11,100 & 23,131 & $1,376,387$ & 3.76 & 3.37 \\
\hline December .... & 34,860 & 12,700 & 20,619 & $1,267,811$ & 3.47 & 3.01 \\
\hline The year. & 61,260 & 2,500 & 18,619 & $13,448,407$ & 36.77 & 2.72 \\
\hline
\end{tabular}

Note.-Gage heights for 1898 are given in Water-Supply and Irrigation Paper No. 27, page 16; measurements, page 23 ; rating table, page 24; results for 1897 in Water-Supply and Irrigation Paper No. 15, page 7, and in the Nineteenth Annual Report, Part IV, page 122. 


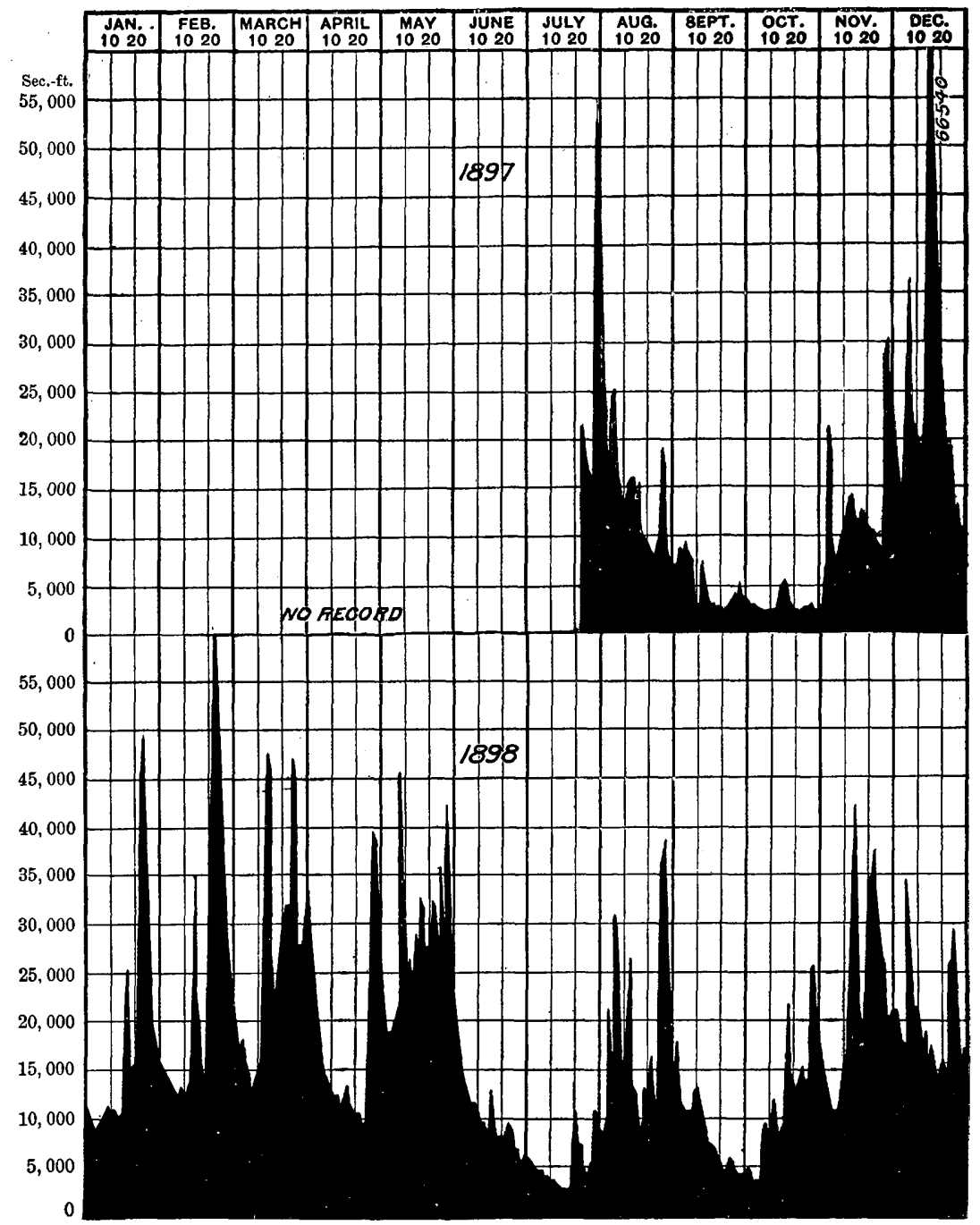

FiG. 15.-Discharge of Delaware River at Lambertville, New Jersey, 1897 and 1898.

LEHIGH RIVER.

Measurements of Lehigh River have been made at Bethlehem, Pennsylvania, by students of Lehigh University, under the direction of Mansfield Merriman, professor of civil engineering. The results have been recorded in various these ${ }^{1}$ on file in the civil engineering depart-

\footnotetext{
1 The authors and titles are as follows:

No. 74. John B. Price, A Formula for the Discharge of Lehigh River, 1885.

No. 103. William Bradford, Discharge and Mean Velocity of the Lehigh River, 1888.

No. 178. James U. Boyd, The Amount of Sediment Transported by Lehigl River, 1891.

No. 200. Philip L. Cobb, Utilization of Water Power of Lehigh River, 1892.

No. 239. Emott D. Buel, Gaging Lehigh River above Calypso Island, 1894.

No. 245. James D. Ferguson, Gaging Lehigh River below the New Street Bridge, 1894.
} 
ment of this university. In these theses the data have been discussed in relation to various practical applications.

The various measurements were made by means of floats of different kinds, both surface and submerged. The height of water was noted, usually, upon temporary gages located near the places of measurement and referred to the Lehigh Valley Railroad datum and also to a per. mawent gage located at the north end of the old wooden highway bridge across the river near the railroad station. This gage is fastened to the masonry foundation of a building immediately east of the north end of the bridge and can be easily seen in passing. At low stages the water does not reach the bottom of the gage.

The following list gives the date and estimated height of water on this gage and also the computed discharge, based on float measurements. The figures for 1862 and 1869 were obtained by leveling to the high-water marks made during those years and by estimating the probable velocity of the water passing through the section. The measurement on October 10,1881, gave a discharge of 338 cubic feet per second, being the lowest observed at Bethlehem; this was believed to be the driest season for fourteen years. The two measurements of 1888 depend upon a few observations of surface floats and are liable to considerable error.

Estimated discharge of Lehigh River at Bethlehem, Pennsylrania.

\begin{tabular}{|c|c|c|c|c|c|}
\hline Date. & $\begin{array}{c}\text { Gage } \\
\text { height. }\end{array}$ & $\begin{array}{l}\text { Discharge } \\
\text { per second. }\end{array}$ & Date. & $\begin{array}{c}\text { Gage } \\
\text { height. }\end{array}$ & $\begin{array}{l}\text { Discharge } \\
\text { per second. }\end{array}$ \\
\hline & Feet. & Cubic feet. & & Feet. & Cubic feet. \\
\hline Flood of $1862 \ldots$ & 21.52 & 93,132 & May 11,1885 . & 3.79 & 3,359 \\
\hline Flood of $1869 \ldots$ & 20.62 & 87,012 & Oct. $15,1885 \ldots$ & 2.01 & 797 \\
\hline Oct. $10,1881 \ldots$ & 1.81 & 338 & Oct. 22,1885 & 2. 61 & 1,336 \\
\hline Apr. $7,1885 \ldots$ & 5.72 & 8,458 & Oct. $14,1887 \ldots$ & 2.15 & 881 \\
\hline Apr. 10, 1885 . . . & 4.69 & 4,922 & Oct. $21,1887 \ldots$ & 2.40 & 1,142 \\
\hline Apr. $13,1885 \ldots$ & 4.09 & 4,171 & Feb. $21,1888$. & 5.88 & 15,923 \\
\hline Apr. $16,1885 \ldots$ & 3.94 & 3,452 & Mar. 22, 1888. & 7.75 & $\cdot 29,837$ \\
\hline Apr. $18,1885 .$. & 3.67 & 2,826 & May $4,1894 \ldots \ldots$ & 2.82 . & 1,711 \\
\hline Apr. $20,1885 \ldots$ & 3.39 & 2,618 & May $5,1894 \ldots \ldots$ & 2.82 & 1,774 \\
\hline Apr. $27,1885 \ldots$ & 3.84 & 2,923 & Мaj 11, 1894 & 2.60 & 1,139 \\
\hline May $9,1885 \ldots$ & 4.51 & 4,495 & 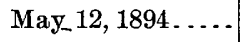 & 2.68 & 1,450 \\
\hline
\end{tabular}

The elevation of the zero of the gage, referred to the datum of the Lehigh Valley Railroad (practically the same as the datum of the United States Coast and Geodetic Survey), is 213.45 feet, and this is locally understood to indicate the lowest stage of water. The gage was established prior to 1878 , probably 1870 or earlier, but since 1878 a rude dam, built about 200 yards lower down the stream, has caused at low stages a backwater rise of about 1.5 feet at the gage. The above 
gage heights; which are less than 4 or 5 feet, do not represent actual heights of water level above low water or the gage heights that would have been observed in the absence of the dam. At stages greater than 6 or 7 feet the dam has probably no influence on the gage readings.

Mr. John Ruddle, general supervisor of the Lehigh Coal Navigation Company, states that he does not know of any systematic record that has been kept of the flow of Lehigh River, and the only source of information is the common report of the inhabitants along the streams. It is believed that the extreme low water is less than it was years ago, and that the river is more subject to sudden rises, due to showers.

Occasional measurements of discharge of Lehigh River have been made at Easton, above the dam at the mouth of the Lehigh, these being under the direction of J. M. Porter, professor of civil engineering at Lafayette College.

\section{SCHUYLKILL RIVER.}

The Schuylkill River receives the drainage of that part of southeastern Pennsylvania lying between the Lehigh River on the north and the Susquehanna River on the south. It flows in a general southeasterly course and enters Delaware River, the city of Philadelphia being located at the junction of these streams. Early in the century a canal was constructed along Schuylkill River for the purpose of transporting coal to tide water, and a number of dams for diverting water into the canal were built at frequent intervals. From above one of these the city of Philadelphia has for many years taken its principal water supply, and observations have been made of the flow of the stream at this point. The comparatively dense population on the drainage basin of Schuylkill River and the development of various industries has resulted in pollution of the waters of the stream. Sewage from towns of considerable size is discharged directly into the stream, also manufacturing refuse and coal washings, rendering the water disagreeable and even unwholesome. Many plans for improving the water supply have been considered, and as a preliminary to projects for storing water of other streams careful measurements have been made of a number of creeks entering the Schuylkill and Delaware rivers near their junction. These are the Tohickon, Perkiomen, Neshaminy, and Wissahickon. These measurements were begun by Mr. Rudolph Hering and carried on by Mr. John E. Codman, in charge of hydrographic work, burean of water of the city of Philadelphia. Results are given in the annual reports of the chief engineer of the Philadelphia water department, beginning with that for the year of 1886. The accompanying map, fig. 16, gives the relative location of the points of river and rainfall observations in the basins of these streams, this being taken from Pl. II of the report of the Philadelphia.water department for 1885. 


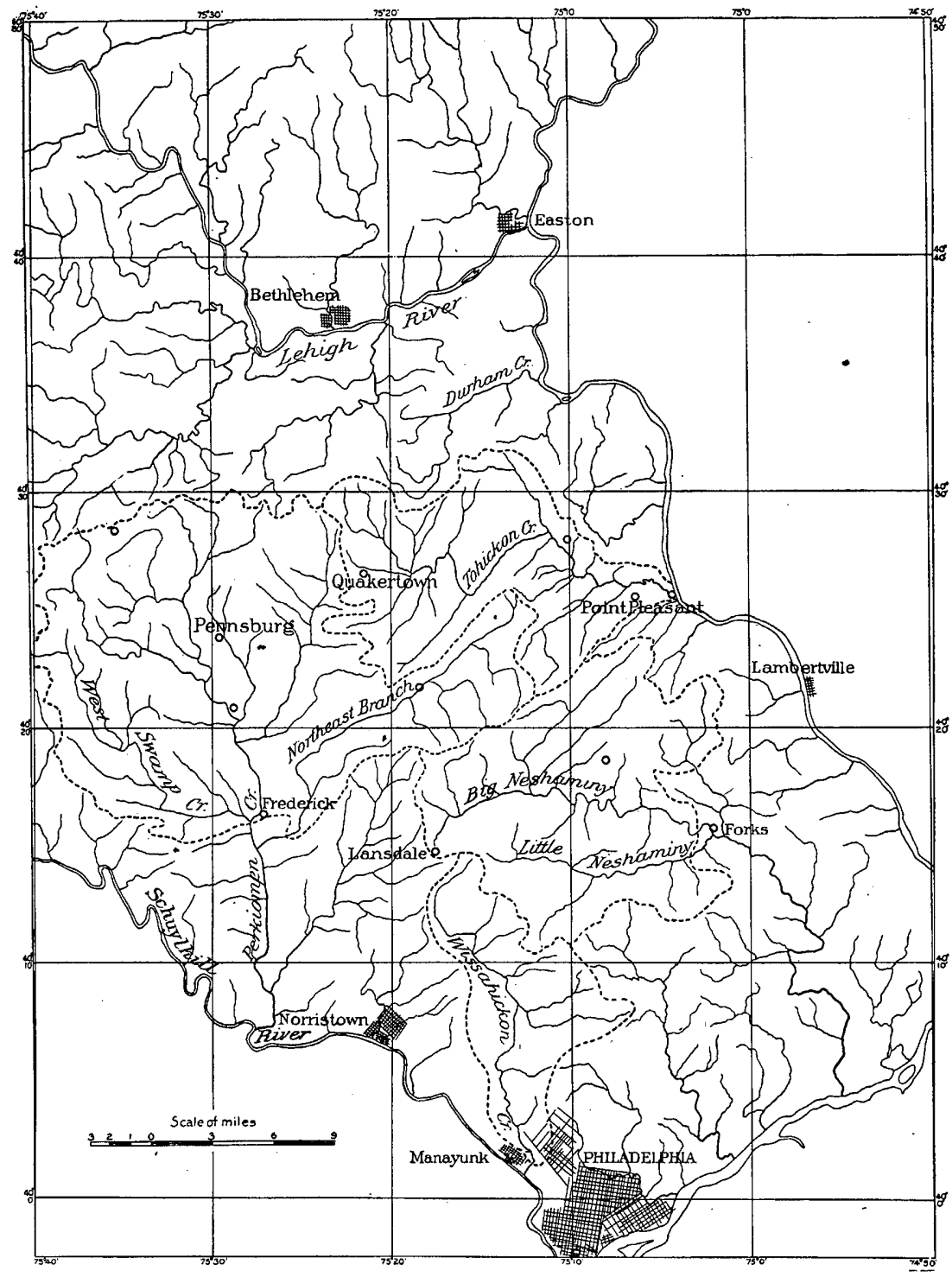

FIG. 16.-Relative location of river and rainfall obserrations in basins of Tohickon, Perkiomen, Neshaminy, and Wissahickon creeks.

\section{PERKIOMEN CREEK.}

Perkiomen Creek drains an area lying northwest of the city of Philadelphia, as shown on fig. 16. It flows in a southerly direction, emptying into Schuylkill River about 7 miles above Norristown and about 18 miles above Philadelphia. The point of measurement of discharge is located at Frederick, this being about 12 miles above the mouth. This point is also above two large tributaries known as West Swamp 


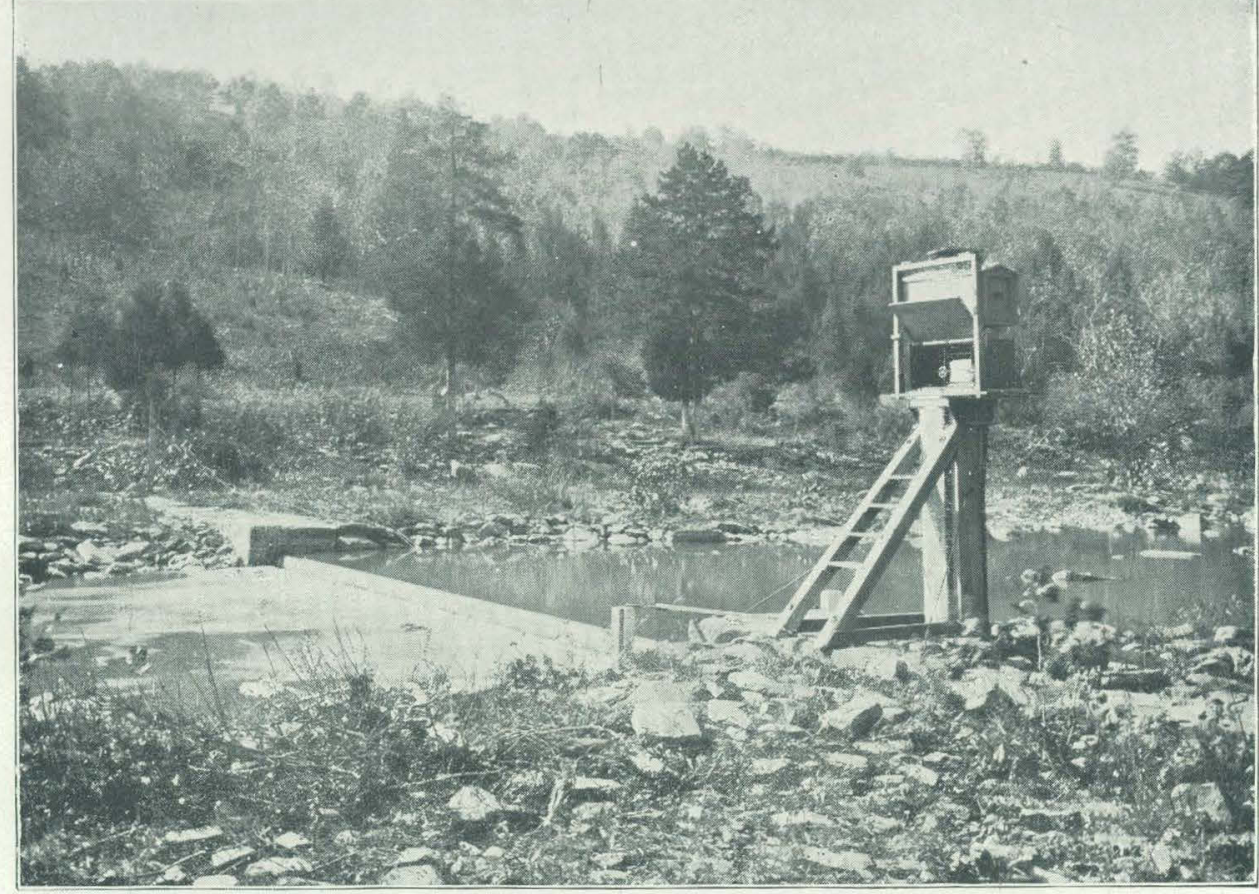

A. WEIR AND NILOMETER ON TOHICKON CREEK AT POINT PLEASANT, PENNSYLVANIA.

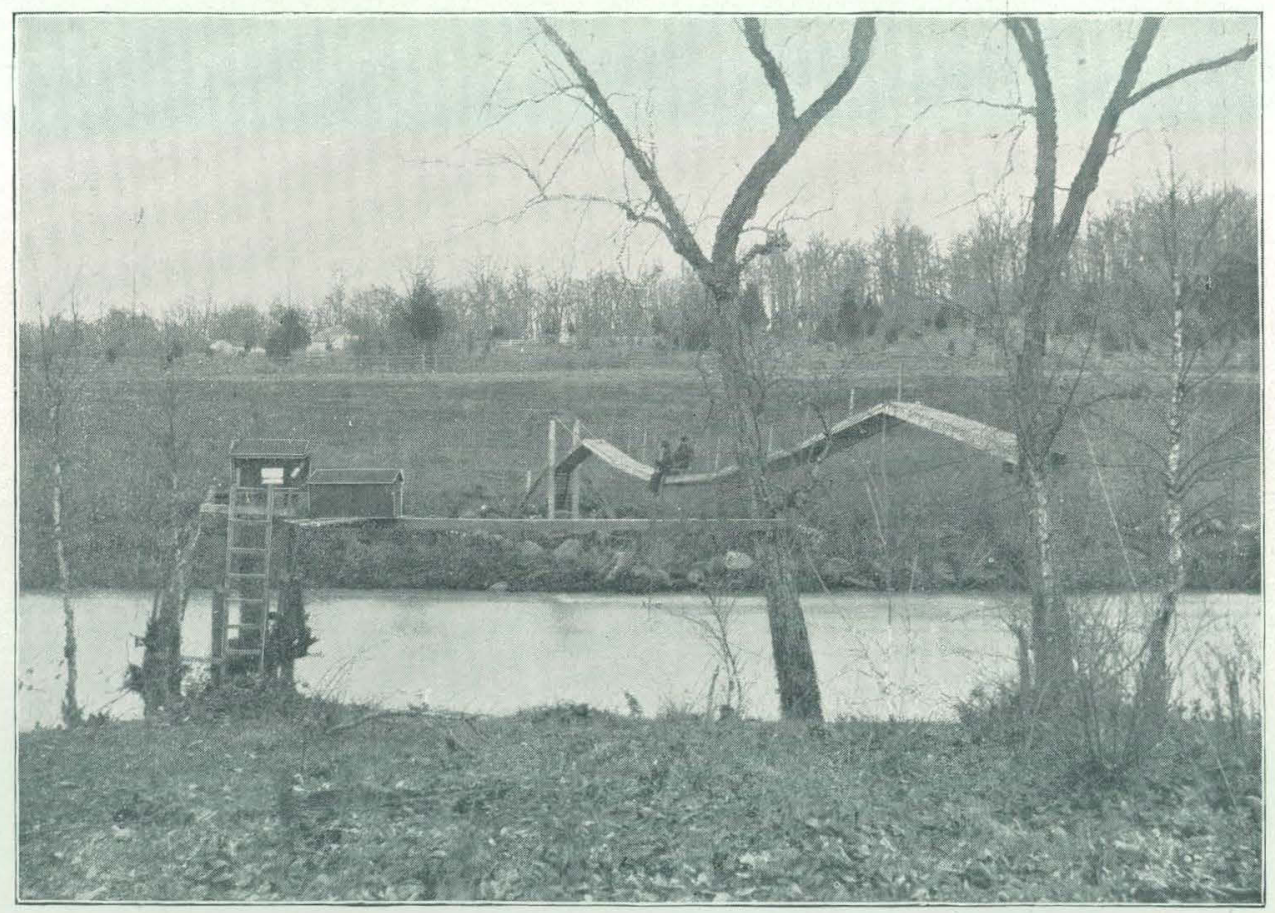

B. SUSPENSION BRIDGE AND NILOMETER ON PERKIOMEN CREEK AT FREDERICK, PENNSYLVANIA. 
Creek and Northeast Branch of Perkiomen. Both of these tributaries have been measured-the first at Zieglerville, and the second near Schwenkville. The drainage area of the Perkiomen above the point of measurement is given by Mr. Rudolph Hering as 152 square miles, of which 111 are cultivated and improved, and 41 untillable and wooded. A view of the point of measurement is shown on Plate $V, B$. The following tables give the discharge of this stream since 1890.

Estimated monthly discharge of Perkiomen Creek at Frederick, Pennsylvania.

[Drainage area, 152 square miles.]

\begin{tabular}{|c|c|c|c|c|c|c|}
\hline \multirow{2}{*}{ Month. } & \multicolumn{3}{|c|}{ Discharge in second-feet. } & \multirow[b]{2}{*}{$\begin{array}{l}\text { Total in acre- } \\
\text { feet. }\end{array}$} & \multicolumn{2}{|c|}{ Run-off. } \\
\hline & $\begin{array}{l}\text { Maxi- } \\
\text { mum. }\end{array}$ & $\begin{array}{l}\text { Mini- } \\
\text { mum. }\end{array}$ & Mean. & & $\begin{array}{l}\text { Depth in } \\
\text { ivches. }\end{array}$ & $\begin{array}{l}\text { Second. } \\
\text { feet per } \\
\text { square } \\
\text { mile. }\end{array}$ \\
\hline 1890. & . & & & & & \\
\hline January .............. & 1,368 & 129 & 271 & 16,663 & 2.05 & 1. 78 \\
\hline February $\ldots . . . .$. & 3,699 & 147 & 524 & 29,101 & 3.59 & 3.45 \\
\hline March .............. & 4,048 & 165 & 735 & $4 \overline{5}, 19 \overline{3}$ & 5.59 & 4.84 \\
\hline 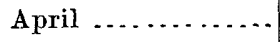 & 1,246 & 139 & 355 & 21,123 & 2.61 & 2.34 \\
\hline 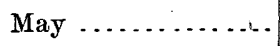 & 2,510 & 117 & 422 & 25,947 & 3.18 & 2.76 \\
\hline June............... . & 664 & 48 & 127 & 7,557 & 0.93 & 0.84 \\
\hline July ................ & 1,018 & 37 & 142 & 8,731 & 1.07 & 0.93 \\
\hline August............. & 803 & 45 & 146 & 8,977 & 1. 10 & 0.95 \\
\hline September ........ & 876 & 54 & 178 & 10,591 & 1. 30 & 1. 17 \\
\hline October ........... & 1,754 & $5 \overline{5}$ & 309 & 18,999 & 2.34 & 2.02 \\
\hline November ......... & 308 & 71 & 119 & 7,080 & 0.87 & 0.78 \\
\hline December $\ldots . . . .$. & 1,006 & 64 & 149 & 9,161 & 1.13 & 0.98 \\
\hline The year. & 4,048 & 37 & 290 & 209,123 & 25.76 & 1.90 \\
\hline 1891. & & & & & & \\
\hline January ............ & 3,945 & 75 & 699 & 42,980 & 5.31 & 4.60 \\
\hline February ........... & 1,917 & 181 & 612 & 33,988 & 4. 18 & 4.02 \\
\hline 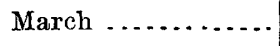 & 4,803 & 199 & 615 & 37,815 & 4.66 & 4.04 \\
\hline April . . . . . . . . & 870 & 103 & 247 & 14,697 & 1.82 & 1.63 \\
\hline May ........... & 243 & 51 & 88 & 5,410 & 0.66 & 0.58 \\
\hline June ........... & 117 & 20 & 49 & 2,915 & 0.36 & 0.32 \\
\hline July $\ldots . . . . . . .$. & 812 & 23 & 111 & 6,825 & 0.84 & 0.73 \\
\hline August .............. & 1,915 & 45 & 270 & 16,601 & 2.05 & 1. 78 \\
\hline September ......... & 2,367 & 40 & 209 & 12,436 & 1.54 & 1. 38 \\
\hline October................ & 275 & 31 & 74 & 4,550 & 0.56 & 0.49 \\
\hline November.......... & 303 & 27 & 80 & 4,760 & 0.59 & 0.53 \\
\hline December ......... & $\mathbf{1}, 225$ & 51 & 379 & 23,303 & 2.87 & 2.49 \\
\hline The year.... & 4,803 & 20 & 286 & 206,280 & 25.44 & 1.89 \\
\hline
\end{tabular}


Estimated monthly discharge of Perkiomen Creek at Frederick, Pennsylvania-Continued.

[Drainage area, 152 square miles.]

\begin{tabular}{|c|c|c|c|c|c|c|}
\hline \multirow[b]{2}{*}{ Month. } & \multicolumn{3}{|c|}{ Diseharge in second-feet. } & \multirow[b]{2}{*}{$\begin{array}{c}\text { Total in acre- } \\
\text { feet. }\end{array}$} & \multicolumn{2}{|c|}{ Run-off. } \\
\hline & $\begin{array}{l}\text { Maxi- } \\
\text { mum. }\end{array}$ & $\begin{array}{l}\text { Mini- } \\
\text { mum. }\end{array}$ & Mean. & & $\begin{array}{l}\text { Depth in } \\
\text { inches. }\end{array}$ & $\begin{array}{c}\text { Second. } \\
\text { feet per } \\
\text { square } \\
\text { mile. }\end{array}$ \\
\hline 1892. & & & & & & \\
\hline January .......... & 3,769 & 158 & 634 & 38,983 & 4.82 & 4.17 \\
\hline February ......... & 217 & 96 & 160 & 9,203 & 1. 12 & 1.05 \\
\hline 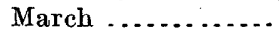 & 2,073 & 145 & 536 & 32,957 & 4.07 & 3.53 \\
\hline April . . . . . . . . & 265 & 87 & 158 & 9,401 & 1. 16 & 1.04 \\
\hline 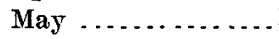 & 1,491 & 71 & 241 & 14,818 & 1.83 & 1. 59 \\
\hline June .............. & 479 & 41 & 124 & 7,378 & 0.91 & 0.82 \\
\hline July ............ & 557 & 18 & 101 & 6,210 & 0.76 & 0.66 \\
\hline August. . . . . . . . . . & 571 & 24 & 100 & 6,148 & 0.76 & 0.66 \\
\hline September ......... & $\cdot 90$ & 20 & 44 & 2,618 & 0.32 & 0.29 \\
\hline October ......... & 43 & 4 & 27 & 1,660 & 0.21 & 0.18 \\
\hline November .......... & 2,836 & 26 & 288 & 17,137 & 2.11 & 1.89 \\
\hline Decomber .......... & 550 & 33 & 156 & 9,592 & 1.19 & 1.03 \\
\hline The year.... & 3,769 & 4 & 214 & 156,105 & 19.46 & 1. 41 \\
\hline 1893. & & & & & & \\
\hline January ............ & 1,169 & 93 & 192 & 11,805 & 1.45 & 1.26 \\
\hline February .......... & 3,247 & 147 & 592 & 32,877 & 4.05 & 3.89 \\
\hline 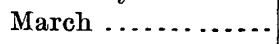 & 3,546 & 168 & 649 & 39,905 & 4.93 & 4.27 \\
\hline 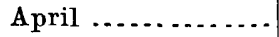 & 1,537 & 101 & 317 & 18,862 & 2.32 & 2.08 \\
\hline 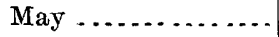 & 5,139 & 84 & 428 & 26,316 & 3.24 & 2.81 \\
\hline June............... & 197 & 37 & 72 & 4,284 & 0.53 & 0.47 \\
\hline July ............... & 118 & 14 & 39 & 2,398 & 0.30 & 0.26 \\
\hline August $\ldots \ldots \ldots \ldots$ & 1,166 & 13 & 129 & 7,931 & 0.98 & 0.85 \\
\hline September ......... & 978 & 21 & 84 & 4,998 & 0.61 & 0.55 \\
\hline October........ & 1,939 & 24 & 114 & 7,010 & 0.86 & 0.75 \\
\hline November......... & 1,470 & 41 & 250 & 14,876 & 1.83 & 1. 64 \\
\hline December ... & 1,091 & 98 & 241 & 14,818 & 1. 83 & 1.59 \\
\hline The year. - & 5,139 & 13 & 259 & 186,080 & 22.93 & 1. 70 \\
\hline 1894. & & & & & & \\
\hline January ......... . & 168 & 55 & 93 & 5,718 & 0.70 & 0.61 \\
\hline February ........... & 1,284 & 68 & 355 & 19,715 & 2.43 & 2.34 \\
\hline March . . . . . . . . . . & 1,045 & 126 & 314 & 19,307 & 2.39 & 2.07 \\
\hline April...... & 1,119 & 93 & 233 & 13,864 & 1. 71 & 1.53 \\
\hline May........ & 8,769 & 36 & 885 & 54,416 & 6.72 & 5.82 \\
\hline June .... & 509 & 60 & 154 & 9,163 & 1.13 & 1. 01 \\
\hline July ....... & 571 & 23 & 77 & 4,734 & 0.59 & 0.51 \\
\hline August............ & 154 & 14 & 45 & 2,766 & 0.35 & 0.30 \\
\hline September.......... & 2,490 & 14 & 236 & 14,042 & 1. 73 & 1.55 \\
\hline October .... & 2,335 & 36 & 219 & 13,465 & 1.66 & 1. 44 \\
\hline November.......... & 908 & 70 & 252 & 14,995 & 1.85 & 1.66 \\
\hline December .......... & 4,132 & 78 & 374 & 22,996 & 2.84 & 2.46 \\
\hline The year ..... & 8,769 & 14 & 269 & 195,181 & 24.10 & 1. 78 \\
\hline
\end{tabular}


Estrmated monthly discharge of Perkiomen Creek at Frederick, Pennsylvania-Continued.

[Drainage area, 152 square miles.]

\begin{tabular}{|c|c|c|c|c|c|c|}
\hline \multirow[b]{2}{*}{ Month. } & \multicolumn{3}{|c|}{ Discharge in second-feet. } & \multirow[b]{2}{*}{$\begin{array}{l}\text { Total in acre } \\
\text { feet. }\end{array}$} & \multicolumn{2}{|c|}{ Run-off. } \\
\hline & $\begin{array}{l}\text { Maxi. } \\
\text { mum. }\end{array}$ & $\begin{array}{l}\text { Mini- } \\
\text { mum. }\end{array}$ & Mean. & & $\begin{array}{l}\text { Depth in } \\
\text { inches. }\end{array}$ & $\begin{array}{c}\text { Second- } \\
\text { feet per } \\
\text { square } \\
\text { mile. }\end{array}$ \\
\hline 1895. & & & & & & \\
\hline January ............. & 2,372 & 80 & 404 & 24,841 & 3.07 & 2.66 \\
\hline February .......... & 820 & 86 & 182 & 10,107 & 1.25 & 1.20 \\
\hline March ................ & $1, \overline{528}$ & 161 & 516 & 31,727 & 3.91 & 3.39 \\
\hline April ................. & 4,203 & 126 & 475 & 28,264 & 3.49 & 3.13 \\
\hline 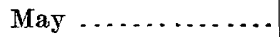 & 348 & 59 & 129 & 7,931 & 0.98 & 0.85 \\
\hline June.............. & 140 & 28 & 59 & 3,510 & 0.44 & 0.39 \\
\hline July $\ldots \ldots \ldots \ldots$ & 667 & 21 & 93 & 5,718 & 0.70 & 0.61 \\
\hline August.............. & 133 & 18 & 37 & 2,275 & 0.28 & 0.24 \\
\hline September . ......... & 38 & 4 & 23 & 1,368 & 0.17 & 0.15 \\
\hline October $\ldots \ldots \ldots$ & 177 & 5 & 32 & $\mathbf{1}, 967$ & 0.24 & 0.21 \\
\hline November.......... & 131 & 18 & 51 & 3,034 & 0.38 & 0.34 \\
\hline December .......... & 1,191 & 25 & 120 & 7,378 & 0.91 & 0.79 \\
\hline The year ....... & 4,203 & 4 & 177 & 128,120 & 16.82 & 1.16 \\
\hline 1896. & & & & & & \\
\hline January $\ldots \ldots \ldots$ & 379 & 20 & 78 & 4,796 & 0.59 & 0.51 \\
\hline February .......... & 6,789 & 52 & 490 & 28,185 & 3.46 & 3.22 \\
\hline 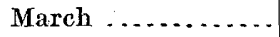 & 3,150 & $5 \overline{5}$ & 504 & 30,989 & 3.83 & 3.32 \\
\hline April ....... & 351 & 66 & 132 & 7,854 & 0.97 & 0.87 \\
\hline May .......... & 300 & 23 & 61 & 3,750 & 0.46 & 0.40 \\
\hline June............ & 177 & 28 & 65 & 3,867 & 0.48 & 0.43 \\
\hline July .............. & 1,938 & 23 & 264 & 16,232 & 2.01 & 1. 74 \\
\hline August.............. & 123 & 17 & 40 & 2,459 & 0.30 & 0.26 \\
\hline September ......... & 758 & 20 & 88 & 5,236 & 0.64 & 0.58 \\
\hline October ......... & 2,711 & 33 & 195 & 11,990 & 1.48 & 1.28 \\
\hline November........... & 2,439 & 42 & 274 & 16,304 & 2.01 & 1.80 \\
\hline December ... & 236 & 36 & 107 & 6,579 & 0.81 & 0.70 \\
\hline The year..... & 6,789 & 17 & 191 & 138,241 & 17.04 & 1.31 \\
\hline
\end{tabular}


Estimated monthly discharge of Perkiomen Creek at Frederick, Pennsylvania-Continued.

[Drainage area, 152.square miles.]

\begin{tabular}{|c|c|c|c|c|c|c|}
\hline \multirow{2}{*}{ Montb. } & \multicolumn{3}{|c|}{ Discharge in second-feet. } & \multirow[b]{2}{*}{$\begin{array}{c}\text { Total in acre: } \\
\text { feet. }\end{array}$} & \multicolumn{2}{|c|}{ Run-off. } \\
\hline & $\begin{array}{l}\text { Maxi. } \\
\text { mum. }\end{array}$ & $\begin{array}{l}\text { Mini- } \\
\text { mum. }\end{array}$ & Mean. & & $\begin{array}{l}\text { Depth in } \\
\text { inches. }\end{array}$ & $\begin{array}{l}\text { Second- } \\
\text { feet per } \\
\text { square } \\
\text { mile. }\end{array}$ \\
\hline 1897. & & & & & & \\
\hline January ......... & 1,291 & 38 & 156 & 9,592 & 1.17 & 1.02 \\
\hline February ........ & 4,083 & 46 & 429 & 23,825 & 2.93 & 2.82 \\
\hline March ........... & 730 & 98 & 241 & 14,818 & 1.82 & 1.58 \\
\hline April ................. & 1,643 & 61 & 224 & 13,328 & 1.64 & 1.47 \\
\hline May & 4,747 & 82 & 525 & 32,281 & 3.98 & 3.45 \\
\hline June....... & 899 & 35 & 126 & 7,497 & 0.92 & 0.83 \\
\hline July ........ & 1,901 & 29 & 205 & 12,605 & 1.55 & 1.35 \\
\hline August..... & 213 & 26 & 78 & 4,796 & 0.60 & 0.52 \\
\hline September & 159 & 8 & 39 & 2,320 & 0.29 & 0.26 \\
\hline October .... & 89 & 8 & 29 & 1,783 & 0.22 & 0.19 \\
\hline November.. & 3,089 & 34 & 238 & 14,161 & 1. 74 & 1.57 \\
\hline December $\_-$ & 2,561 & 71 & 365 & 22,443 & 2.77 & .2 .40 \\
\hline The jear..... & 4,747 & 8 & 221 & 159,449 & 19.63 & 1.45 \\
\hline 1898. & & & & & & \\
\hline January . ........ & 2,758 & 37 & 338 & 20,782 & 2.56 & 2. 22 \\
\hline February ... & 5,552 & 114. & 487 & 27,046 & 3.33 . & 3.20 \\
\hline March ................. & 899 & 74 & 206 & 12,666 & 1.57 & 1.36 \\
\hline April .... & 658 & 95 & 229 & 13,626 & 1.68 & 1.51 \\
\hline May .... & 3,493 & 131 & 505 & 31,051 & 3.83 & 3.32 \\
\hline June.... & 113 & 36 & 57 & 3,391 & 0.43 & 0.38 \\
\hline July .... & 115 & 18 & 44 & 2,705 & 0.33 & 0.29 \\
\hline August... & 393 & 24 & 83 & 5,103 & 0.62 & 0.54 \\
\hline September ..... & 61 & 12 & 31 & 1,844 & 0.22 & 0.20 \\
\hline October ........ & 475 & 18 & 78 & 4,796 & 0.59 & 0.51 \\
\hline November.. & 3,808 & 45 & 419 & 24,932 & 3.07 & 2.76 \\
\hline December ........ & 3,406 & 70 & 428 & 26,316 & 3.25 & 2.82 \\
\hline The year .... & 5,552 & 12 & 242 & 174,258 & 21.48 & 1.98 \\
\hline
\end{tabular}




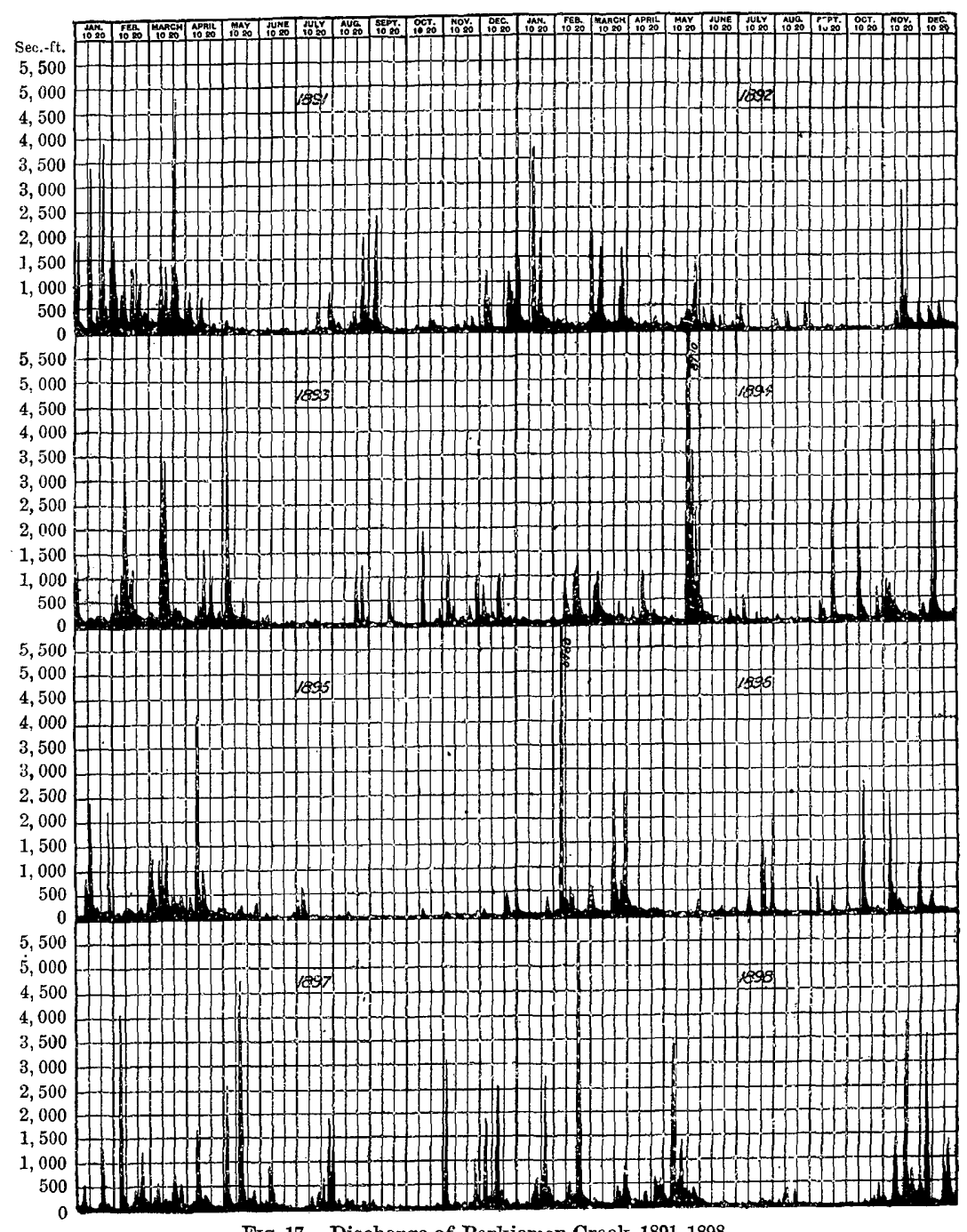

Fia. 17._Discharge of Perkiomen Creek, 1891-1898.

、

WISSAHICKON CREHK.

This stream receives water from an area southeasterly from that drained by the Perkiomen, and between the latter and the Little Neshaminy. It enters Schuylkill River a short distance above Philadelphia. Measurements of flow were begun in April, 1897, the work being done under the direction of Mr. John E. Codman, in charge of hydrographic work for the bureau of water of Philadelphia. A suitable locality for making current meter measurements was found about 100 yards above the mouth, and a sufficient number of observations were taken to plot a curve of flow. These data were compared with the computed discharge over a stone dam. In August, 1897, an auto. 
matic recording stream gage or nilometer was established. Results have been computed as given in the annual report of the bureau of water of Philadelphia for the year ending December 31; 1897.

Estimated monthly discharge of Wissahickon Creek, 100 yarás above mouth.

[Drainage area, 64.6 square miles.]

\begin{tabular}{|c|c|c|c|c|c|c|}
\hline \multirow[b]{2}{*}{ Month. } & \multicolumn{3}{|c|}{ Discharge in second-feet. } & \multirow[b]{2}{*}{$\begin{array}{l}\text { Total in acre } \\
\text { feet. }\end{array}$} & \multicolumn{2}{|c|}{ Run-off. } \\
\hline & $\begin{array}{l}\text { Maxi- } \\
\text { mum. }\end{array}$ & $\begin{array}{l}\text { Mini- } \\
\text { mum. }\end{array}$ & Mean. & & $\begin{array}{l}\text { Depth in } \\
\text { inches. }\end{array}$ & $\begin{array}{c}\text { Second- } \\
\text { feet per } \\
\text { square } \\
\text { mile. }\end{array}$ \\
\hline 1897. & & . & & & & \\
\hline May................ & 345 & 69 & 95 & 5,841 & 1. 69 & 1. 47 \\
\hline June .............. & 1,384 & 67 & 148 & 8,806 & 2.54 & 2.28 \\
\hline July $\ldots \ldots \ldots \ldots$ & 2,817 & 32 & 204 & 12,543 & 3.67 & 3.16 \\
\hline August $\ldots \ldots \ldots \ldots$ & $5 \check{5} 0$ & 78 & 147 & $\ddot{9}, 038$ & 2.62 & 2.27 \\
\hline September ......... & 102 & 29 & 47 & 2,796 & 0.81 & 0.73 \\
\hline October .............. & 89 & 24 & 32 & 1,967 & 0.58 & 0.50 \\
\hline November ......... & 432 & 28 & 71 & 4,224 & 1.22 & 1.09 \\
\hline December ...... & 833 & 65 & 127 & 7,808 & 2.26 & 1.96 \\
\hline 1898. & & & & & & \\
\hline January .......... & 751 & 64 & 139 & 8,546 & 2.48 & 2.15 \\
\hline February ......... & $1, \overline{\mathbf{5}} 12$ & 92 & 176 & 9,774 & 2.84 & 2.73 \\
\hline March ........... & 357 & 78 & 110 & 6,763 & 1.96 & 1.70 \\
\hline April ............ & 235 & 75 & 103 & 6,128 & 1. 79 & 1. 60 \\
\hline May $\ldots \ldots \ldots \ldots$ & 744 & 73 & 162 & 9,961 & 2.90 & 2.51 \\
\hline June .............. & 125 & $46^{\circ}$ & 71 & 4,224 & 1.23 & 1.10 \\
\hline July ....... & 243 & 26 & 43 & 2,643 & 0.77 & 0.67 \\
\hline August............ & 858 & 26 & 111 & 6,825 & 1.98 & 1.72 \\
\hline September ........ & 33 & 19 & 22 & 1,309 & 0.39 & 0.35 \\
\hline October ......... & 70 & 15 & 28 & 1,721 & 0.51 & 0.44 \\
\hline November......... & 918 & 23 & 118 & 7,021 & 2.04 & 1. 83 \\
\hline December .......... & 923 & 75 & 163 & 10,022 & 2.91 & 2.52 \\
\hline The year.... & 1,512 & 15 & 104 & 74,937 & 21.80 & 1.61 \\
\hline
\end{tabular}




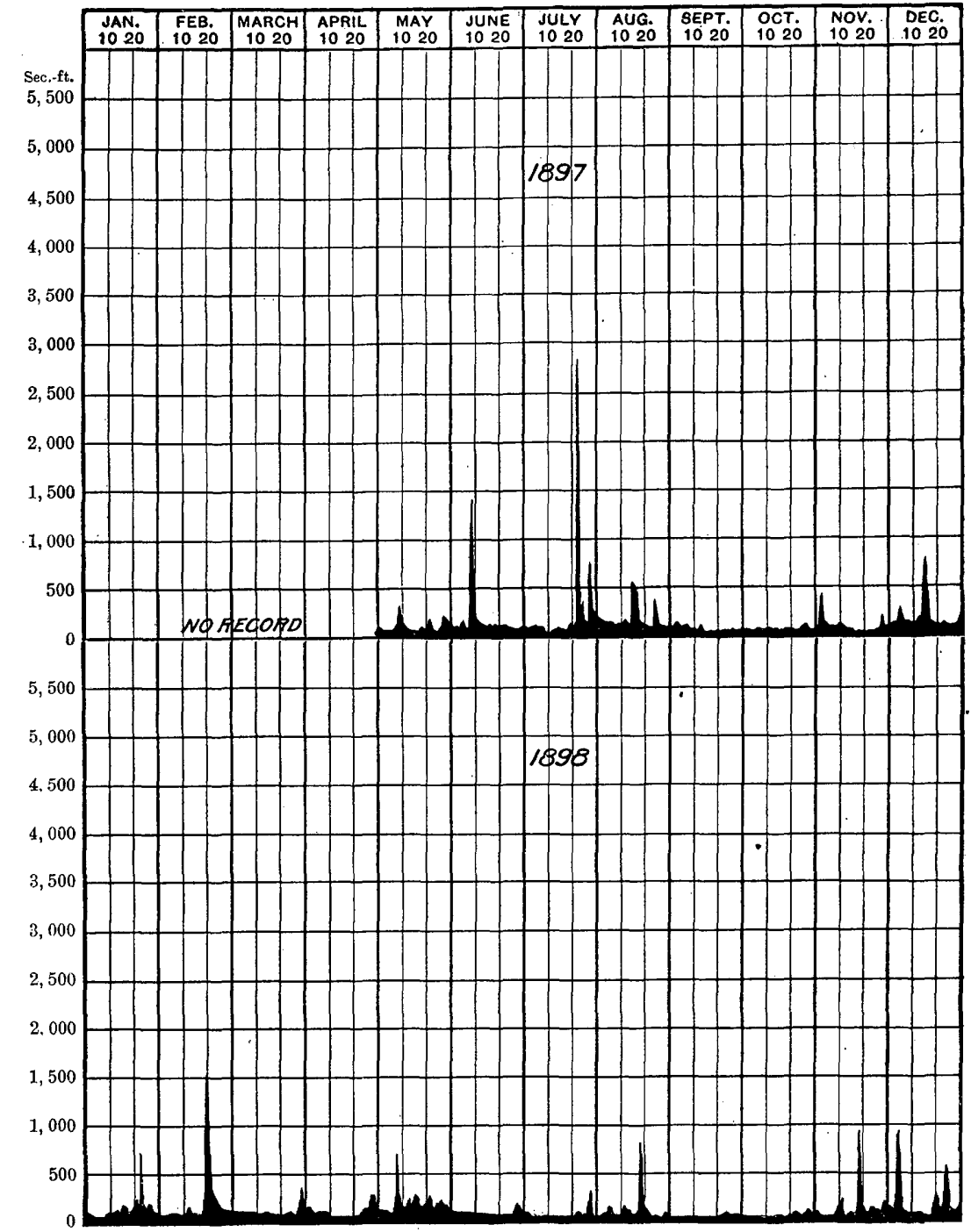

Fig. 18.-Discharge of Wissahickon Creek, 1897 and 1898.

SCHUYLIKILL RIVER NEAR PHILADELPHIA.

Records of the height of Schuylkill River have been kept at Fairmount Pool for many years, but these have been in such form as to be incapable of being interpreted into daily discharges. In 1898, however, careful estimates were prepared by Mr. John E. Codman showing the total flow of Schuylkill River at this point, the results being given in the following table.

The quantity of low-water flow has been of especial importance in considerations of supply for the city of Philadelphia. The matter has been discussed by Mr. Edwin F. Smith in a paper before the Engineers' 
Club of Philadelphia, in 1896. The data contained in this discussion have been reprinted in the annual report of the bureau of water of Philadelphia for the year ending December 31, 1898, page 78.

Estimated monthly discharge of Schuylkill River at Fairmount dam.

[Drainage area, 1,915 square miles.]

\begin{tabular}{|c|c|c|c|c|c|c|}
\hline \multirow[b]{2}{*}{ Montì. } & \multicolumn{3}{|c|}{ Discharge in second-feet. } & \multirow{2}{*}{$\begin{array}{l}\text { Total in acre- } \\
\text { feet. }\end{array}$} & \multicolumn{2}{|c|}{ Run-off. } \\
\hline & $\begin{array}{l}\text { Maxi- } \\
\text { mum. }\end{array}$ & $\begin{array}{l}\text { Mini- } \\
\text { mum. }\end{array}$ & Mean. & & $\begin{array}{l}\text { Depth in } \\
\text { inclies. }\end{array}$ & $\begin{array}{l}\text { Second- } \\
\text { feet per } \\
\text { square } \\
\text { wile. }\end{array}$ \\
\hline 1898. & & & & & & \\
\hline 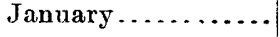 & 14,539 & 238 & 3,391 & 208,504 & 2.04 & 1.77 \\
\hline February ........ & 23,271 & 25 & 3,015 & 167,444 & 1.62 & 1.56. \\
\hline March ..... & 6,283 & 62 & 1,712 & 105,267 & 1.02 & 0.89 \\
\hline April . . . . . . . . . & 7,650 & 780 & 2,352 & 139,954 & 1.37 & 1.23 \\
\hline May ................. & 19,543 & 978 & 4,815 & 296,063 & 2.91 & 2.52 \\
\hline June............ & 1,177 & $\ldots \ldots$ & 483 & $a 28,740$ & $a 0.28$ & $a 0.25$ \\
\hline July & 1,430 & $\ldots$ & $a 531$ & $a 32,650$ & $a 0.32$ & $a 0.28$ \\
\hline August. . . . . . & 11,678 & 206 & 4,129 & 253,882 & 2.48 & 2.15 \\
\hline September & & & -0 & 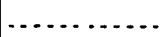 & & $\ldots$ \\
\hline October.... & 1,588 & $\ldots$. & $a 643$ & $a 39,536$ & $a 0.38$ & $a 0.33$ \\
\hline November... & 17,200 & 112 & 3,175 & 188,926 & 1.85 & 1. 66 \\
\hline December .......... & 21,722 & 56 & 2,072 & 127,402 & 1.25 & 1.08 \\
\hline
\end{tabular}

a Approximate.

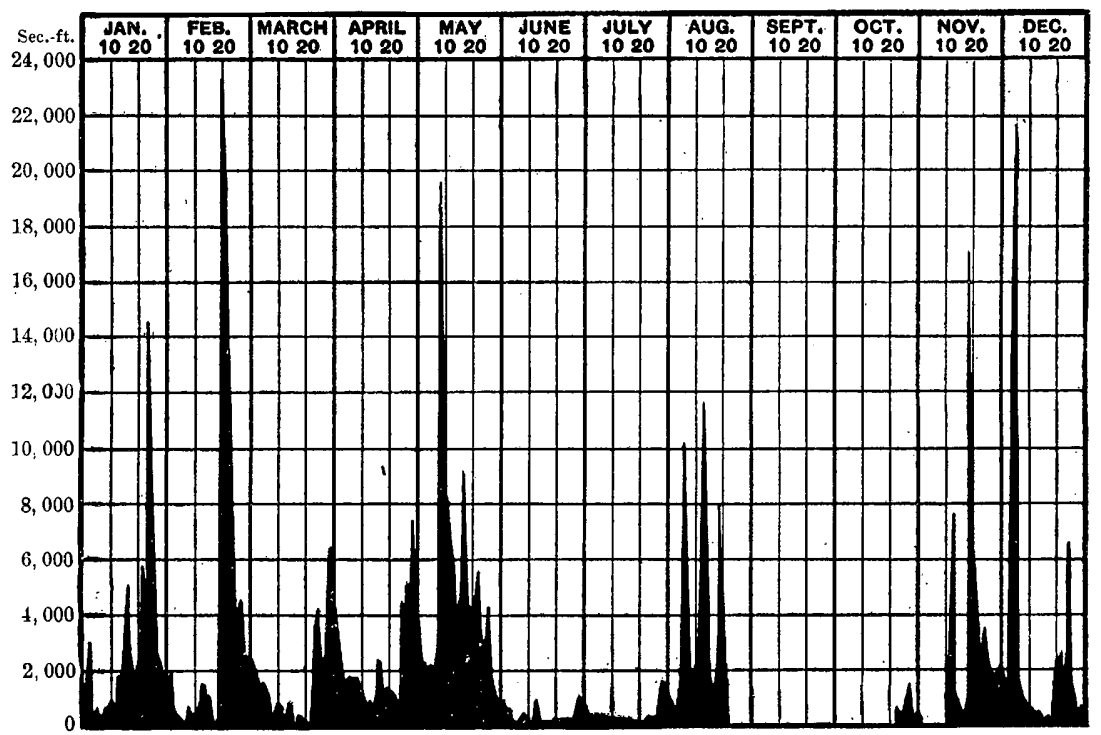

Frt. 19.-Discharge of Schuylkill River at Fairmount dam, near Philadelphia, 1898. 20 GEOL, PT $4-7$ 
TOHICKON CREEK.

Tohickon Creek drains an area of 102 square miles in Bucks County, north of Philadelphia. It flows in an easterly course, entering Delaware River about 8 miles above Lambertville, New Jersey. In a statement by Mr. Rudolph Hering, printed in the report of the Philadelphia water department for 1885 , on page 350 , is given a classification of the drainage area of Tohickon Creek, from which it appears that 76 square miles is cultivated and improved and 26 square miles untillable and wooded. Measurements of the discharge of the creek are made near its.mouth at Point Pleasant. Rain gages are located within the drainage basin at Quakertown, also at a point about 3 miles north of Bedminster, and near Point Pleasant. The following table gives the estimated monthly discharge since 1890.

The accompanying plate $(\mathrm{Pl} . \mathrm{V}, A)$ shows the weir and nilometer on Tohickon Creek at Point Pleasant. By means of this instrument an automatic record is kept of the height of water passing over the weir. From this the average daily height is computed, and the corresponding discharge. Plate $\mathrm{V}, B$, is a view of a similar nilometer on Perkiomen Creek, at Frederick, Pennsylvania. This also shows the suspension bridge from which discharge measurements are made.

Estimated monthly discharge of Tohickon Creek at Point Pleasant, Pennsylvania.

[Drainage area, 102.2 square miles.]

\begin{tabular}{|c|c|c|c|c|c|c|}
\hline \multirow[b]{2}{*}{ Month. } & \multicolumn{3}{|c|}{ Discharge in second-feet. } & \multirow[b]{2}{*}{$\begin{array}{l}\text { Total in acre- } \\
\text { feet. }\end{array}$} & \multicolumn{2}{|c|}{ Run-off. } \\
\hline & $\begin{array}{l}\text { Maxi- } \\
\text { mum. }\end{array}$ & $\begin{array}{l}\text { Mini. } \\
\text { num. }\end{array}$ & Mean. & & $\begin{array}{l}\text { Depth in } \\
\text { inches. }\end{array}$ & $\begin{array}{c}\text { Second. } \\
\text { feet per } \\
\text { square } \\
\text { mile. }\end{array}$ \\
\hline 1890. & & & & & & \\
\hline January .... & 1,586 & 45 & 181 & 11,129 & 2.04 & 1.77 \\
\hline February & 2,512 & 75 & 371 & 20,604 & 3.79 & 3.64 \\
\hline March .. & 2,942 & 64 & 602 & 36,954 & 6.80 & 5.89 \\
\hline April ...... & 778 & 36 & 165 & 9,818 & 1.81 & 1.62 \\
\hline May & 1,967 & 24 & 270 & 15,601 & 3.06 & 2.65 \\
\hline June...... & 485 & 16 & 68 & 4,046 & 0.74 & 0.67 . \\
\hline July & 687 & 4 & 79 & 4,857 & 0.89 & 0.77 \\
\hline August.... & 478 & 9 & 81 & 4,980 & 0.91 & 0.79 \\
\hline September & 797 & 10 & 112 & 6,664 & 1.23 & 1.10 \\
\hline October .............. & 2,624 & $\cdot 18$ & 320 & 19,676 & 3.61 & 3.13 \\
\hline November... & 249 & 21 & 63 & 3,748 & 0.69 & 0.62 \\
\hline December. & 1,044 & 28 & 135 & 8,300 & 1.52 & 1.32 \\
\hline The year & 2,942 & 4 & 204 & 146,377 & 27.09 & 2.00 \\
\hline
\end{tabular}


Estimated monthly discharge of Tohickon Creek at Point Pleasant, Pennsylvania-Cont'd.

[Drainage area, 102.2 square miles.]

\begin{tabular}{|c|c|c|c|c|c|c|}
\hline \multirow[b]{2}{*}{ Month. } & \multicolumn{3}{|c|}{ Discharge in second-feet. } & \multirow[b]{2}{*}{$\begin{array}{l}\text { Total in acre- } \\
\text { feet. }\end{array}$} & \multicolumn{2}{|c|}{ Run-off. } \\
\hline & $\begin{array}{l}\text { Maxi. } \\
\text { mum. }\end{array}$ & $\begin{array}{l}\text { Mini- } \\
\text { mum. }\end{array}$ & Mean. & & $\begin{array}{l}\text { Depth in } \\
\text { inches. }\end{array}$ & $\begin{array}{c}\text { Second. } \\
\text { feet per } \\
\text { square } \\
\text { mile. }\end{array}$ \\
\hline 1891. & & & & & & \\
\hline January . $\therefore . . . . .$. & 2,451 & 57 & 545 & 33,511 & 6.15 & 5.33 \\
\hline February .......... & 1,726 & 97 & 540 & 29,990 & 5.50 & 5.28 \\
\hline March ............. & 2,858 & 79 & 446 & 27,423 & 5.03 & 4.36 \\
\hline April ............. & 814 & 27 & 144 & 8,568 & 1.57 & 1.41 \\
\hline May .................... & 61 & 12 & 25 & 1,537 & 0.28 & 0.24 \\
\hline June................ & 35 & 6 & 17 & 1,011 & 0.19 & 0.17 \\
\hline July .............. & 611 & 3 & 81 & 4,980 & 0.91 & 0.79 \\
\hline August............. & 3,159 & 14 & 349 & 21,459 & 3.93 & 3.41 \\
\hline September & 598 & 7 & 85 & 5,057 & 0.92 & 0.83 \\
\hline October.... & 212 & 5 & 39 & 2,398 & 0.44 & 0.38 \\
\hline November.......... & 386 & 7 & 58 & 3,451 & 0.63 & 0.57 \\
\hline December ............ & 1,670 & 33 & 379 & 23,303 & 4.29 & 3.71 \\
\hline The year..... & 2,858 & 3 & 226 & 162,688 & 29.84 & 2.21 \\
\hline 1892. & & & & & & \\
\hline January ............ & 3,158 & 79 & 580 & 35,663 & 6.55 & 5.68 \\
\hline February $\ldots . . .$. & 237 & 35 & 116 & 6,672 & 1.22 & i. 15 \\
\hline March .... & 1,645 & 65 & 433 & 26,624 & 4.89 & 4.24 \\
\hline April...... & 191 & 33 & 77 & 4,581 & 0.83 & 0.75 \\
\hline May .... & 1,333 & 39 & 188 & 11,559 & 2.12 & 1.84 \\
\hline June .... & 555 & 14 & 65 & 3,867 & 0.71 & 0.64 \\
\hline July .... & 455 & $\mathbf{5}$ & 45 & 2,766 & 0.51 & 0.44 \\
\hline August ............. & 101 & 8 & 29 & 1,783 & 0.32 & 0.28 \\
\hline September .- & 227 & 5 & 24 & 1,428 & 0.27 & 0.24 \\
\hline October ......... & 17 & 4 & 8 & 491 & 0.09 & 0.08 \\
\hline November ........... & 2,962 & 6 & 292 & 17,375 & 3.18 & 2.86 \\
\hline December ........... & 623 & 49 & 148 & 9,100 & 1.67 & 1.45 \\
\hline The year.... & 3,158 & 4 & 167 & 121,909 & 22.36 & 1. 64 \\
\hline
\end{tabular}


Estimated monthly discharge of Tohickon Creek at Point Pleasant, Pennsylvania-Cont'd.

[Drainage area, 102.2 square miles.]

\begin{tabular}{|c|c|c|c|c|c|c|}
\hline \multirow[b]{2}{*}{ Month. } & \multicolumn{3}{|c|}{ Discharge in second-feet. } & \multirow[b]{2}{*}{$\begin{array}{l}\text { Total in acre- } \\
\text { feet. }\end{array}$} & \multicolumn{2}{|c|}{ Run-off. } \\
\hline & $\begin{array}{l}\text { Maxi- } \\
\text { mum. }\end{array}$ & $\begin{array}{l}\text { Mini. } \\
\text { mum. }\end{array}$ & Mean. & & $\begin{array}{c}\text { Depth in } \\
\text { inches. }\end{array}$ & $\begin{array}{l}\text { Second- } \\
\text { feet per } \\
\text { square } \\
\text { mile. }\end{array}$ \\
\hline 1893. & & & & & & \\
\hline January .............. & 1,406 & 53 & 197 & 12,113 & 2.22 & 1.93 \\
\hline February & 2,597 & 73 & 655 & 36,376 & 6.66 & 6.41 \\
\hline March .... & 2,400 & 78 & 402 & 24,718 & 4.53 & 3.93 \\
\hline April....... & 1,903 & 41 & 293 & 17,434 & 3. 20 & 2.87 \\
\hline May & 2,994 & 31 & 333 & 20,475 & 3.76 & 3.26 \\
\hline June..... & 217 & 9 & 40 & 2,380 & 0.44 & 0.39 \\
\hline July .... & 25 & 3 & 10 & 615 & 0.12 & 0.10 \\
\hline August.... & 1,814 & 3 & 139 & 8,546 & 1.57 & 1.36 \\
\hline September ..... & 834 & 13 & 76 & 4,522 & 0.82 & 0.74 \\
\hline October ............... & 506 & 10 & 55 & 3,381 & 0.62 & 0.54 \\
\hline November . ........... & 1,288 & 46 & 244 & 14,518 & 2.67 & 2.39 \\
\hline December....... & 1,593 & 75 & 275 & 16,909 & 3. 10 & 2. 69 \\
\hline The year . & 2,994 & 3 & 227 & 161,987 & 29.71 & 2.22 \\
\hline 1894. & & & & & & \\
\hline January ............ & 137 & 41 & 71 & 4,365 & 0.79 & 0.69 \\
\hline February ... & 1,606 & $6 \overline{3}$ & 373 & 20,715 & 3.79 & 3.65 \\
\hline March .............. & 1,174 & 61 & 275 & 16,910 & 3: 12 & 2.70 \\
\hline April.......... & 1,283 & 47 & 209 . & 12,436 & 2.29 & 2.05 \\
\hline 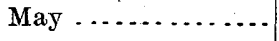 & 8,650 & 16 & 760 & 46,730 & 8.58 & 7.44 \\
\hline June....... & 267 & 6 & 49 & 2,915 & 0.54 & 0.48 \\
\hline July $\ldots \ldots \ldots \ldots \ldots$ & 68 & 3 & 17 & 1,045 & 0.20 & 0.17 \\
\hline August............. & 35 & 4 & 10 & 614 & 0.12 & 0.10 \\
\hline September. & 3,556 & 2 & 306 & 18,208 & 3.34 & 3.00 \\
\hline October .... & 1,674 & 7 & 186 & 11,436 & 2.10 & 1.82 \\
\hline November. & 1,193 & 39 & 245 & 14,578 & 2.68 & 2.40 \\
\hline December ... & 3,342 & 42 & 316 & 19,430 & 3.57 & 3.09 \\
\hline The year. & 8,650 & 2 & 235 & 169,382 & 31.12 & 2.30 \\
\hline
\end{tabular}


Estimated monthly discharge of Tohickon Creek at Point Pleasant, Pennsylvania-Cont'd.

[Drainage area, 102.2 square miles.]

\begin{tabular}{|c|c|c|c|c|c|c|}
\hline \multirow[b]{2}{*}{ Month. } & \multicolumn{3}{|c|}{ Discharge in second feet. } & \multirow[b]{2}{*}{$\begin{array}{c}\text { Total in acre. } \\
\text { feet. }\end{array}$} & \multicolumn{2}{|c|}{ Run-off. } \\
\hline & $\begin{array}{l}\text { Maxi. } \\
\text { mum. }\end{array}$ & $\begin{array}{l}\text { Mini. } \\
\text { mum. }\end{array}$ & Mean. & & $\begin{array}{l}\text { Depth in } \\
\text { inches. }\end{array}$ & $\begin{array}{c}\text { Second- } \\
\text { feet per } \\
\text { square } \\
\text { mile. }\end{array}$ \\
\hline 1895. & & & & & & \\
\hline January . . . . . . . . & 2,942 & 62 & 351 & 21,582 & 3.97 & 3.44 \\
\hline February $\ldots \ldots \ldots$ & 902 & 35 & 167 & 9,274 & 1. 70 & 1. 64 \\
\hline 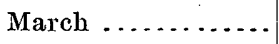 & 1,519 & 114 & 476 & 29,268 & 5.37 & 4.66 \\
\hline 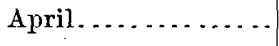 & $3,8 \overline{57}$ & 41 & 426 & 25,348 & 4.65 & 4.17 \\
\hline May ................. & 351 & 23 & 62 & 3,812 & 0.70 & 0.61 \\
\hline June........... & 58 & 7 & 25 & 1,487 & 0.28 & 0.25 \\
\hline July $\ldots \ldots \ldots \ldots$ & 648 & 7 & 71 & 4,365 & 0.81 & 0.70 . \\
\hline August.............. & 310 & 4 & 32 & 1,967 & 0.36 & 0.31 \\
\hline September ........ & - 6 & 2 & 3 & 178 & 0.03 & 0.03 \\
\hline October ${ }^{\prime} . . . .$. & 27 & 2 & 8 & 491 & 0.09 & 0.08 \\
\hline November. . . . . . . & 78 & 9 & 20 & 1,190 & 0.22 & 0.20 \\
\hline December .. & 420 & 6 & 59 & 3,628 & 0.67 & 0.58 \\
\hline The jear & 3,857 & 2 & 142 & 102,590 & 18.85 & 1.39 \\
\hline 1896. & & & & & & \\
\hline January ............ & - 327 & 4 & 48 & 2,951 & 0.54 & 0.47 \\
\hline February .......... & 6,515 & 47 & 435 & 25,021 & 4.58 & 4.26 \\
\hline March ................ & 3,343 & 35 & 486 & 29,883 & 5. 49 & 4.76 \\
\hline 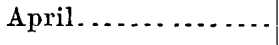 & 297 & 20 & 67 & 3,986 & 0.73 & 0.66 \\
\hline May $\ldots \ldots \ldots \ldots$ & 145 & 7 & 27 & 1,660 & 0.30 & 0.26 \\
\hline June.... & 35 & 4 & 16 & 952 & 0.18 & 0.16 \\
\hline July ................. & 2,417 & 5 & 225 & 13,388 & 2.54 & 2.21 \\
\hline August................ & 113 & 3 & 16 & 983 & 0.18 & 0.16 \\
\hline September ........ & 1,665 & 3 & 102 & 6,069 & 1.11 & 1 \\
\hline October ............ & 1,130 & 10 & 94 & 5,779 & 1.06 & 0.92 \\
\hline November........... & 1,851 & 19 & 214 & 12,733 & 2.33 & 2.09 \\
\hline December .... & 289 & 27 & 71 & 4,365 & 0.79 & 0.69 \\
\hline 'The year ..... & 6,515 & - 3 & 150 & 107,770 & 19.83 & 1.47 \\
\hline
\end{tabular}


Estimated monthly discharge of Tohickon Creek at Point Pleasant, Pennsylvania-Cont'd.

[Drainage area, 102.2 square miles.]

\begin{tabular}{|c|c|c|c|c|c|c|}
\hline \multirow[b]{2}{*}{ Month. } & \multicolumn{3}{|c|}{ Discharge in second-feet. } & \multirow[b]{2}{*}{$\begin{array}{l}\text { Total in acre- } \\
\text { feet. }\end{array}$} & \multicolumn{2}{|c|}{ Run.off. } \\
\hline & $\begin{array}{l}\text { Maxi. } \\
\text { mum. }\end{array}$ & $\begin{array}{l}\text { Mini. } \\
\text { mum. }\end{array}$ & Mean. & & $\begin{array}{l}\text { Depth in } \\
\text { inches. }\end{array}$ & $\begin{array}{c}\text { Second. } \\
\text { feet per } \\
\text { square } \\
\text { mile. }\end{array}$ \\
\hline 1897. & & & & & & \\
\hline January ............ & 1,221 & 23 & 160 & 9,838 & 1.81 & 1.57 \\
\hline February .......... & 2,312 & 49 & 287 & 15,939 & 2.92 & 2.81 \\
\hline March ................ & 927 & 47 & 194 & $\mathbf{1 1}, 928$ & 2.19 & 1. 90 \\
\hline 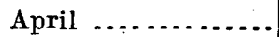 & 1,454 & 15 & 142 & 8,449 & 1.55 & 1. 39 \\
\hline May .............. & 3,683 & 20 & 411 & 25,271 & 4.63 & 4. 02 \\
\hline June . . . . . . . . . . . & 2,389 & 9 & 157 & 9,342 & 1.72 & 1.54 \\
\hline July .............. & 1,817 & 4 & 238 & 14,634 & 2.68 & 2.32 \\
\hline Angust............... & 745 & 8 & 65 & 3,996 & 0.72 & 0.63 \\
\hline September ......... & 42 & 4 & 11 & - 654 & 0.12 & 0.11 \\
\hline October............. & 21 & 3 & 7 & 430 & 0.07 & 0.07 \\
\hline November ......... & 1,400 & 6 & 163 & 9,699 & 1.79 & 1.60 \\
\hline December .......... & 3,135 & 49 & 362 & 22,258 & 4.09 & 3.54 \\
\hline The year . & 3,683 & 3 & 183 & 132,438 & 24.29 & 1.79 \\
\hline 1898. & & & & & & \\
\hline January ............ & 2,890 & 36 & 328 & 20,168 & 3.70 & 3.21 \\
\hline February ........ & 4,160 & 65 & 397 & 22,048 & 4.05 & 3.89 \\
\hline March $\ldots . . .$. & 1,078 & 39 & 162 & 9,961 & 1.83 & 1.59 \\
\hline April............... & 810 & 53 & 195 & 11,603 & 2.13 & 1.91 \\
\hline 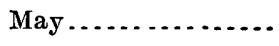 & 2,940 & 69 & 447 & 27,485 & 5.05 & 4.37 \\
\hline 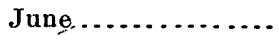 & 65 & 4 & 17 & 1,011 & 0.19 & 0.17 \\
\hline July ........... & 20 & 2 & 7 & 430 & 0.08 & 0.07 \\
\hline August ............. & 574 & 5 & 66 & 4,058 & 0.75 & 0.65 \\
\hline September.......... & 15 & 4 & 8 & 476 & 0.09 & 0.08 \\
\hline October ............ & 512 & 3 & 54 & 3,320 & 0.61 & 0.53 \\
\hline November .......... & 3,451 & 27 & 412 & 24,515 & 4.49 & 4.03 \\
\hline December ... & 2,932 & 23 & 375 & 23,058 & 4.24 & 3.67 \\
\hline The year. & 4,160 & 3 & 206 & 148,133 & 27.21 & 2.01 \\
\hline
\end{tabular}




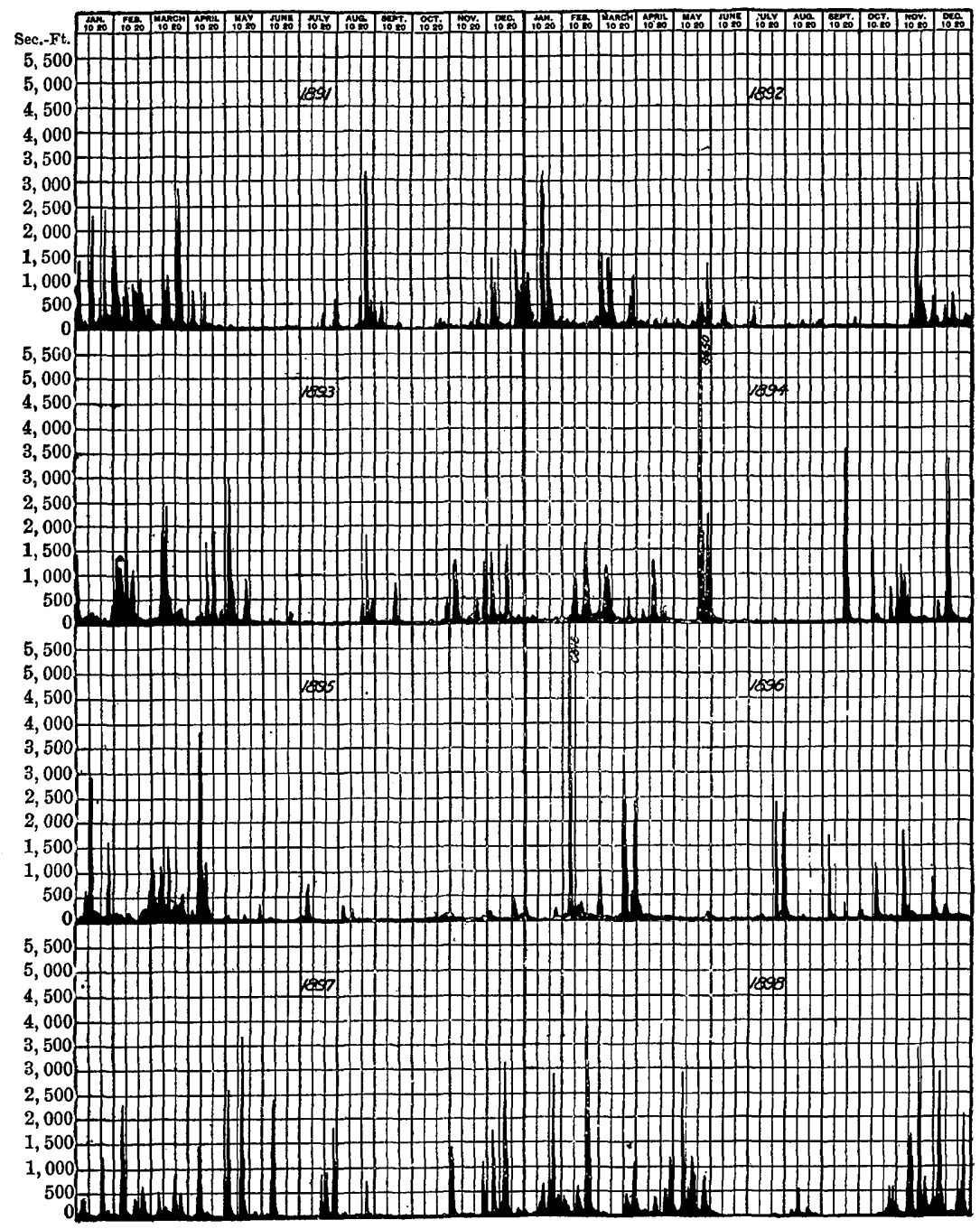

FiG. 20.-Discharge of Tohickon Creek, 1891-1898.

NESHAMINY CREEK.

The drainage basin of Neshaminy Creek is immediately south of that of Tohickon Creek and of a portion of that of Perkiomen Creek. The stream flows in a general southeasterly and southerly course, entering Delaware River at a point about 12 miles above $P$ hiladelphia. The point of measurement is at the forks of Big and Little Neshaminy creeks. The drainage area at this point is 139.3 square miles, of which 128.2 are cultivated and improved and 11.1 miles untillable and wooded. The accompanying view (Pl. VI, $A$ ) shows the weir on Neshaminy Creek, in Rush Valley, and Plate VI, $B$ shows the suspended bridge at the point of measurement, also in Rush Valley. Another view, on Plate VII, shows 


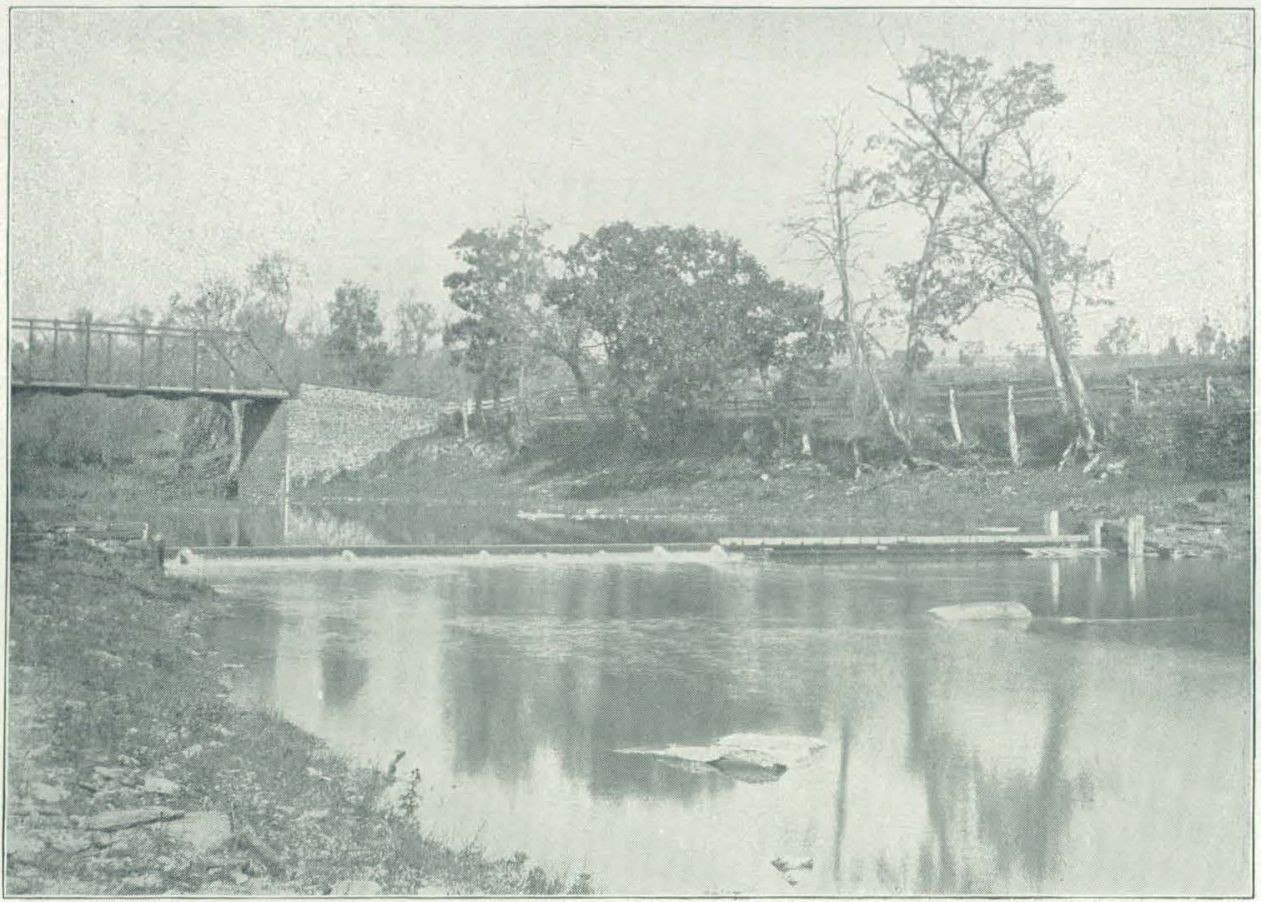

A. WEIR ON NESHAMINY CREEK.

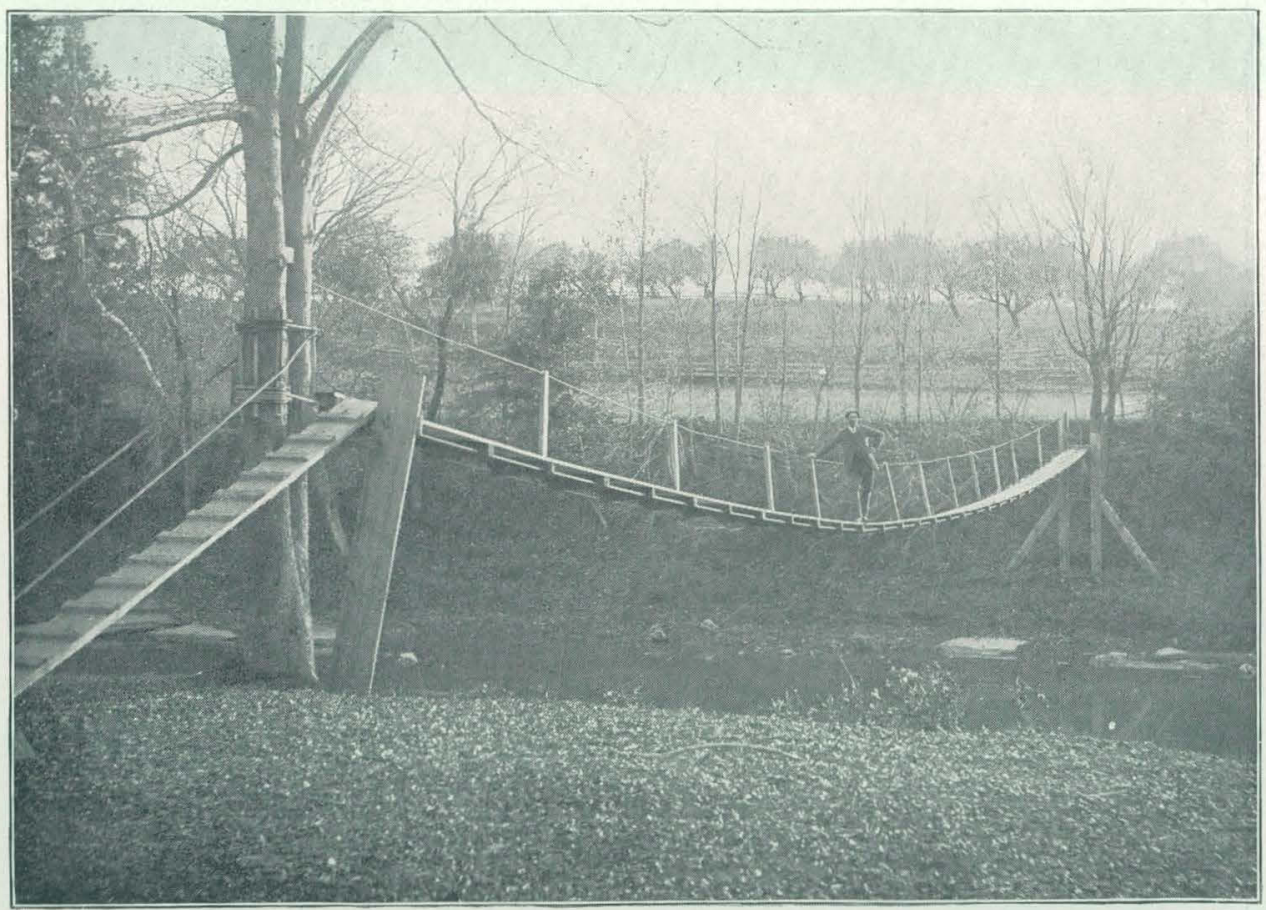

B. SUSPENSION BRIDGE AT STATION ON NESHAMINY CREEK, RUSH VALLEY, PENNSYLVANIA. 


\section{PROGRESS OF STREAM MEASUREMENTS FOR 1898.}

the high-water gage on the Little Neshaminy at the forks, this having been located for the purpose of obtaining the automatic record of the height of water during the sudden floods which occur within this area. The gage is so arranged that a metal float is raised by the water, but is provided with a catch, so that it can not fall until released by hand.

Estimated monthly discharge of Neshaminy Creek below forks.

[Drainage area, 139.3 square miles.]

\begin{tabular}{|c|c|c|c|c|c|c|}
\hline \multirow[b]{2}{*}{ Month. } & \multicolumn{3}{|c|}{ Disclıarge in second-feet. } & \multirow[b]{2}{*}{$\begin{array}{l}\text { Total in acro- } \\
\text { feet. }\end{array}$} & \multicolumn{2}{|c|}{ Run-off. } \\
\hline & $\begin{array}{l}\text { Maxi- } \\
\text { mum: }\end{array}$ & $\begin{array}{l}\text { Mini- } \\
\text { mam. }\end{array}$ & Mean. & & $\begin{array}{l}\text { Depth in } \\
\text { inches. }\end{array}$ & $\begin{array}{c}\text { Second- } \\
\text { feet per } \\
\text { square } \\
\text { mile. }\end{array}$ \\
\hline 1890. & & & & & & \\
\hline January .......... & 1,391 & 80 & 201 & 12,359 & 1. 67 & 1.45 \\
\hline Feliruary .... & 2,818 & 111 & 397 & 21,993 & 2.97 & 2.85 \\
\hline March .... & 2,990 & 132 & 620 & 38,122 & 5. 14 & 4.45 \\
\hline April ... & 666 & 61 & 222 & 13,209 & 1.77 & 1.59 \\
\hline May .. & 1,086 & 47 & 181 & 11,129 & 1.50 & 1. 30 \\
\hline June ............ . . & 1,150 & 27 & 133 & 7,914 & 1.07 & 0.96 \\
\hline July $\ldots \ldots \ldots \ldots$ & 566 & 15 & 73 & 4,488 & 0.60 & 0.52 \\
\hline August......... & 670 & 10 & 63 & 3,874 & 0.52 & 0.45 \\
\hline September ..... & 180 & 18 & 39 & 2,320 & 0.31 & 0.28 \\
\hline October... & 2,400 & 28 & 262 & 16,109 & 2. 17 & 1.88 \\
\hline November.... . & 231 & 52 & 98 & 5,831 & 0.79 & 0.71 \\
\hline December ...... & 848 & 56 & 165 & 10,145 & 1. 37 & 1. 19 \\
\hline The year. & 2,990 & 10 & 204 & 147,493 & 19.88 & 1. 47 \\
\hline 1891. & & & & & & \\
\hline January & 3,257 & 128 & 703 & 43,226 & 5.82 & 5.05 \\
\hline February & 1,5585 & 193 & 600 & 32,322 & 4.48 & 4.31 \\
\hline March .... & 3,046 & 182 & 525 & 32,281 & 4.35 & 3.77 \\
\hline April ... & 931 & 55 & 182 & 10,829 & 1. 46 & 1.31 \\
\hline May ... & 83 & 26 & 39 & 2,398 & 0.32 & 0.28 \\
\hline June. & 126 & 15 & 31 & 1,844 & 0.24 & 0.22 \\
\hline July ....... & 214 & 14 & 40 & 2,459 & 0.33 & 0.29 . \\
\hline August..... & 3,276 & 17 & 235 & 14,449 & 1.95 & 1. 69 \\
\hline September & 1,939 & 22 & 157 & 9,342 & 1. 26 & 1. 13 \\
\hline October .......... & 340 & 12 & 65 & 3,996 & 0.54 & 0.47 \\
\hline November.......... & 261 & 29 & 73 & 4,343 & 0.58 & 0.52 \\
\hline December: ... & 1,622 & 50 & 366 & 22,504 & 3.03 & 2.63 \\
\hline The year..... & 3,276 & 12 & 251 & 180,993 & 24.36 & 1.81 \\
\hline
\end{tabular}


Estimated monthly discharge of Neshaminy Creek below forks-Continued.

[Drainage area, 139.3 square miles.]

\begin{tabular}{|c|c|c|c|c|c|c|}
\hline \multirow{2}{*}{ Month. } & \multicolumn{3}{|c|}{ Discharge in second-feet. } & \multirow[b]{2}{*}{$\begin{array}{l}\text { Total in acre. } \\
\text { feet. }\end{array}$} & \multicolumn{2}{|c|}{ Run-off: } \\
\hline & $\begin{array}{l}\text { Maxi- } \\
\text { mun. }\end{array}$ & $\begin{array}{l}\text { Mini- } \\
\text { mum. }\end{array}$ & Mean. & & $\begin{array}{l}\text { Depth in } \\
\text { inches. }\end{array}$ & $\begin{array}{c}\text { Second- } \\
\text { feet per } \\
\text { square } \\
\text { mile. }\end{array}$ \\
\hline 1892. & & & & & & \\
\hline January .......... & 3,584 & 144 & 627 & 38,552 & 5.20 & 4.50 \\
\hline February ......... & 191 & 77 & 125 & 7,190 & 0.97 & 0.90 \\
\hline March ............. & 2,582 & 114 & 431 & 26,501 & 3.57 & 3.09 \\
\hline April $\ldots . . . . . .$. & 193 & 87 & 126 & 7,497 & 1. 00 & 0.90 \\
\hline May ................... & 492 & 50 & 194 & 11,928 & 1. 60 & 1. 39 \\
\hline June ............. & 140 & 26 & 71 & 4,225 & 0.56 & 0.50 \\
\hline July $\ldots \ldots \ldots \ldots$ & 519 & 14 & 66 & 4,058 & 0.54 & 0.47 \\
\hline August.... & 69 & 10 & 24 . & 1,476 & 0.20 & 0.17 \\
\hline September ......... & 96 & 3 & 13 & 774 & 0.10 & 0.09 \\
\hline October............ & 8 & 4 & 5 & 307 & 0.04 & 0.04 \\
\hline November......... & 2,346 & 5 & 220 & 13,091 & 1. 76 & 1.58 \\
\hline December .......... & 559 & 47 & 127 & 7,809 & 1.05 & 0.91 \\
\hline The year.... & 3,584 & 3 & 1.69 & 123,408 & 16.59 & 1.21 \\
\hline 1893. & & - & & & & \\
\hline January.............. & 1,678 & 90 & 242 & 14,880 & 2.01 & 1.74 \\
\hline February .......... & 2,727 & 179 & 661 & 36,710 & 4.94 & 4.76 \\
\hline 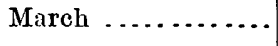 & 2,436 & 133 & 565 & 34,740 & 4.69 & 4.06 \\
\hline April. ................. & 2,448 & 85 & 363 & 21,599 & 2.91 & 2. 61 \\
\hline 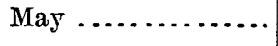 & 3,154 & 63 & 358 & 22,012 & 2.97 & 2.57 \\
\hline June $\ldots . . . . . . .$. & 284 & 24 & 56 & 3,332 & 0.46 & 0.41 \\
\hline July $\ldots \ldots \ldots \ldots$ & 25 & 8 & 16 & 983 & 0.14 & 0.12 \\
\hline 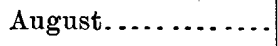 & 1,692 & 5 & 132 & 8,116 & 1. 09 & 0.95 \\
\hline September ......... & 749 & 27 & $\because 72$ & 4,284 & 0.58 & $0.5 \overline{2}$ \\
\hline October ............. & 481 & 18 & 70 & 4,304 & 0.58 & 0.50 \\
\hline November......... & 759 & 59 & 322 & 19,160 & 2.58 & 2.31 \\
\hline December ........ & 1,938 & .102 & 316 & 19,430 & 2.62 & 2.27 \\
\hline The year .... & 3,154 & 5 & 264 & 189,550 & 25.57 & 1. 90 \\
\hline
\end{tabular}




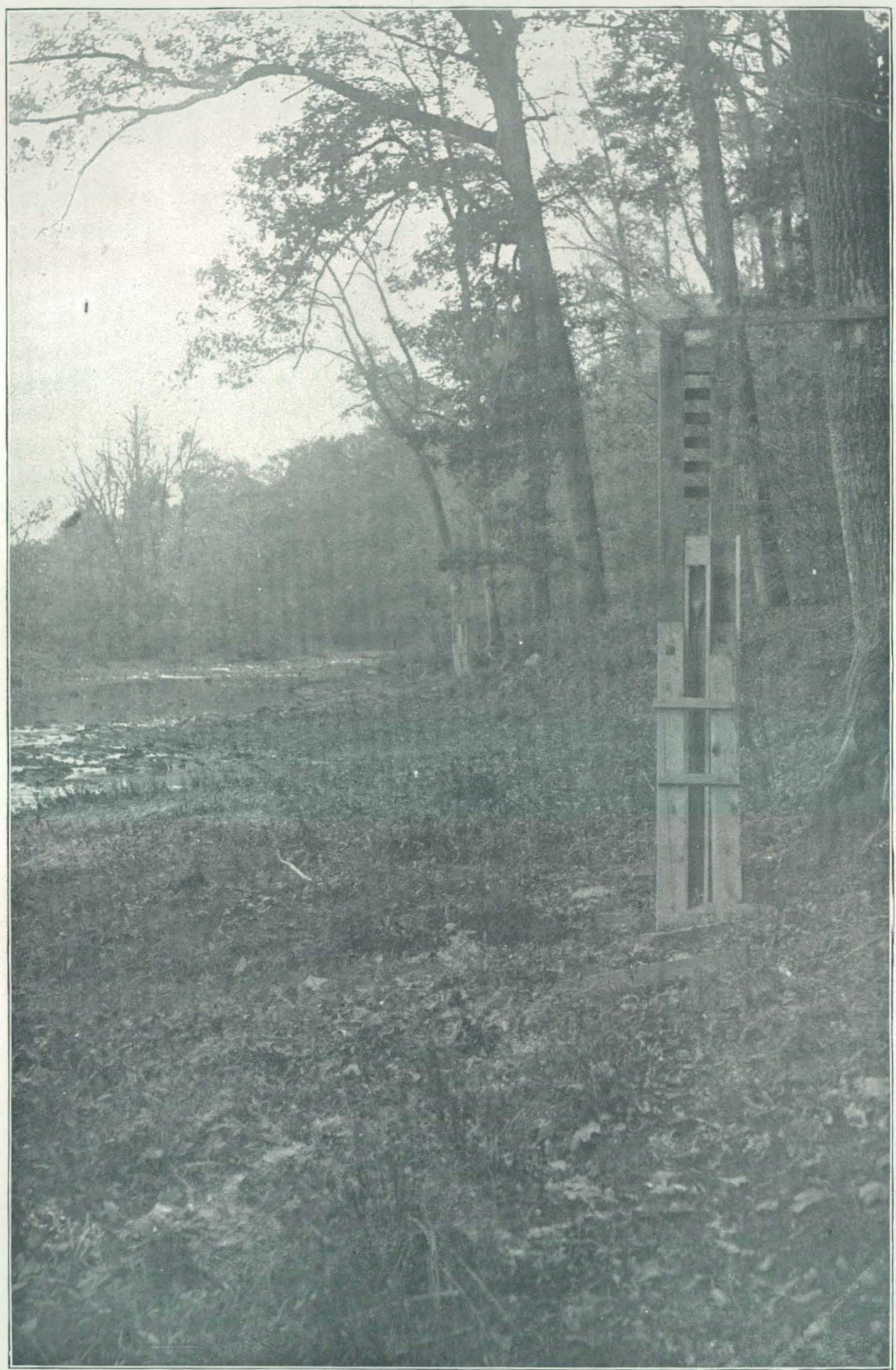

HIGH-WATER GAGE ON LITTLE NESHAMINY CREEK, RUSH VALLEY, PENNSYLVANIA. 
Estimated monthly discharge of Neshaminy Creek below forks-Continued.

\begin{tabular}{|c|c|c|c|c|c|c|}
\hline \multirow[b]{2}{*}{ Month. } & \multicolumn{3}{|c|}{ Discharge in second.feet. } & \multirow[b]{2}{*}{$\begin{array}{l}\text { Total in acre. } \\
\text { feet. }\end{array}$} & \multicolumn{2}{|c|}{ Run-off. } \\
\hline & $\begin{array}{l}\text { Maxi- } \\
\text { mum. }\end{array}$ & $\begin{array}{l}\text { Mini- } \\
\text { mum. }\end{array}$ & Mean. & & $\begin{array}{l}\text { Depth in } \\
\text { inches. }\end{array}$ & $\begin{array}{l}\text { Second. } \\
\text { feet per } \\
\text { square } \\
\text { mile. }\end{array}$ \\
\hline 1894. & & & & & & \\
\hline January............ & 188 & 67 & 95 & 5,841 & 0.78 & 0.68 \\
\hline February .......... & 1,090 & 6 & 37 & 2,054 & 0.28 & 0.27 \\
\hline March ... & 934 & 131 & 323 & 19,799 & 2.69 & 2.32 \\
\hline April . . . . . . . & 1,521 & 97 & 250 & 14,876 & 2.00 & 1.79 \\
\hline May ........... & 9,012 & 36 & 895 & 55,031 & 7.39 & 6.42 \\
\hline June ........ & 368 & 45 & 143 & 8,792 & 1.16 & 1.04 \\
\hline July ....... & 212 & 19 & 52 & 3,197 & 0.43 & 0.37 \\
\hline August ..... & 400 & 7 & 41 & 2,521 & 0.33 & 0.29 \\
\hline September & 3,197 & 5 & 284 & 16,899 & 2.27 & 2.04 \\
\hline October..... & 1,715 & 34 & 180 & 11,067 & 1.49 & 1.29 \\
\hline November........... & 1,371 & 96 & 296 & 17,613 & 2.37 & 2.13 \\
\hline December ...... & 1,824 & 110 & 279 & 17,155 & 2.31 & 2 \\
\hline The year. & 9,012 & 5 & 240 & 174,845 & 23.50 & 1.72 \\
\hline 1895. & & & - & & & \\
\hline January ..... & 2,289 & 98 & 412 & 25,333 & 3.41 & 2.96 \\
\hline February ...... & 903 & 98 & 237 & 13,162 & 1.76 & 1.70 \\
\hline March............. & 1,635 & 149 & 515 & 31,666 & 4.26 . & 3.70 \\
\hline April........... & 3,234 & 101 & 417 & 24,813 & 3.33 & 2.99 \\
\hline May ........ & 225 & 39 & 84 & 5,164 & 0.69 & 0.60 \\
\hline June....... & 202 & 25 & 68 & 4,046 & 0.54 & 0.48 \\
\hline July ....... & 664 & 18 & 106 & 6,517 & 0.87 & 0.76 \\
\hline August ................ & 1,225 & 9 & 81 & 4,980 & 0.67 & 0.58 \\
\hline September...... & 11 & 4 & 7 & 4,165 & 0.06 & 0.05 \\
\hline October......... & 34 & 4 & 10 & 614 & 0.08 & 0.07 \\
\hline November ........... & 34 & 7 & 14 & 833 & 0.11 & 0.10 \\
\hline December .......... & 573 & 6 & $\cdot 49$ & 3,012 & 0.40 & 0.35 \\
\hline The year. & 3,234 & 4 & 167 & $124 ; 305$ & 16. 18 & 1.19 \\
\hline
\end{tabular}


Estimated monthly discharge of Neshaminy Creek below forks-Continued.

[Drainage area, 139.3 square miles.]

\begin{tabular}{|c|c|c|c|c|c|c|}
\hline \multirow[b]{2}{*}{ Month. } & \multicolumn{3}{|c|}{ Discharge in second.feet. } & \multirow[b]{2}{*}{$\begin{array}{l}\text { Total in acre- } \\
\text { feet. }\end{array}$} & \multicolumn{2}{|c|}{ Run-off: } \\
\hline & $\begin{array}{l}\text { Maxi- } \\
\text { mum. }\end{array}$ & $\begin{array}{l}\text { Mini- } \\
\text { mum. }\end{array}$ & Mean. & & $\begin{array}{l}\text { Depth in } \\
\text { inches. }\end{array}$ & $\begin{array}{c}\text { Second- } \\
\text { feet per } \\
\text { square } \\
\text { mile. }\end{array}$ \\
\hline 1896. & & & & & & \\
\hline January .............. & 565 & 14 & 71 & 4,365 & 0.59 & 0.51 \\
\hline February $\ldots . . .$. & 8,707 & 39 & 611 & $, 35,146$ & 4.73 & 4.39 \\
\hline March ............. & 5,408 & 57 & 528 & 32,465 & 4.38 & 3.79 \\
\hline April ............ & 286 & 81 & 133 & 7,914 & 1.07 & 0.96 \\
\hline 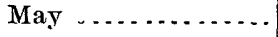 & 135 & 23 & 46 & 2,828 & 0.38 & 0.33 \\
\hline June............. & 236 & 17 & 50 & 2,975 & 0.40 & 0.36 \\
\hline July $\ldots \ldots \ldots \ldots$ & 1,373 & 13 & 126 & 7,747 & 1.04 & 0.90 \\
\hline August........... & 71 & 10 & 25 & 1,537 & 0.21 & 0.18 \\
\hline September ........ & 765 & 8 & 120 & 7,140 & 0.95 & 0.86 \\
\hline October................. & 1,480 & 19 & 112 & 6,886 & 0.92 & 0.80 \\
\hline November .......... & 1,305 & 28 & 190 & 11,305 & 1.52 & 1.36 \\
\hline December ............... & 306 & 30 & 106 & 6,519 & 0.87 & 0.76 \\
\hline The year.... & 8,707 & 8 & 176 & 126,827 & 17.06 & 1.27 \\
\hline 1897. & & & & & & \\
\hline January .... & 1,856 & 31 & 156 & 9,776 & 1.29 & 1.12 \\
\hline February .......... & 2,973 & 41 & 339 & 18,494 & 2.53 & 2.43 \\
\hline 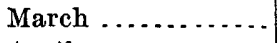 & 700 & 88 & 210 & 12,912 & 1.73 & 1.50 \\
\hline 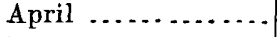 & 1,750 & 65 & 191 & 11,365 & 1.53 & 1. 37 \\
\hline May $\ldots . . . . . . . .$. & 2,215 & 74 & 331 & 20,352 & 2.75 & 2.38 \\
\hline June.............. . & 4,677 & 48 & 307 & 18,267 & 2.45 & 2.20 \\
\hline July $\ldots \ldots \ldots \ldots$ & 3,083 & 27 & 258 & 22,012 & 2.96 & 2.57 \\
\hline August $\ldots \ldots \ldots \ldots$ & 1,075 & 49 & 130 & 7,993 & 1.07 & 0.93 \\
\hline September ........ & 43 & 19 & 27 & 1,606 & 0.22 & 0.20 \\
\hline October $\ldots . . . . .$. & 85 & 10 & 20 & 1,229 & 0.16 & 0.14 \\
\hline November......... & 1,354 & 36 & 147 & 8,747 & 1.17 & 1.05 \\
\hline December ........ & 2,696 & 91 & 395 & 24,288 & 3.26 & 2.83 \\
\hline The year.... & 4,677 & 10 & 218 & 157,041 & 21.12 & 1.56 \\
\hline 1898. & & & & & & \\
\hline January ........ & 2,985 & 88 & 374 & 22,996 & 3.09 & 2.68 \\
\hline February ..... & 5,076 & 105 & 469 & 26,046 & 3.50 & 3.37 \\
\hline March ..... & 1,232 & 77 & 199 & 12,236 & 1.65 & 1.43 \\
\hline April ... & 782 & 77 & 211 & 12,555 & 1.70 & 1.52 \\
\hline 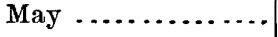 & 3,153 & 129 & 459 & 28,222 & 3.81 & 3.30 \\
\hline June ................ & 117 & 28 & 55 & 3,272 & 0.45 & 0.40 \\
\hline July .... . & 66 & 14 & 23 & 1,414 & 0.20 & 0.17 \\
\hline August.. & 1,615 & 22 & 128 & 7,870 & 1.06 & 0.92 \\
\hline September ........ & - 24 & 6 & 12 & 714 & 0.10 & 0.09 \\
\hline October ................ & 176 & 6 & 27 & 1,660 & 0.22 & 0.19 \\
\hline November.......... & 3,529 & 17 & 376 & 22,373 & 3.00 & 2.70 \\
\hline December ...... & 3,059 & 85 & 418 & 25,701 & 3.47 & 3.01 \\
\hline 'The year... & 5,076 & 6 & 229 & 165,059 & 22.25 & 1.65 \\
\hline
\end{tabular}




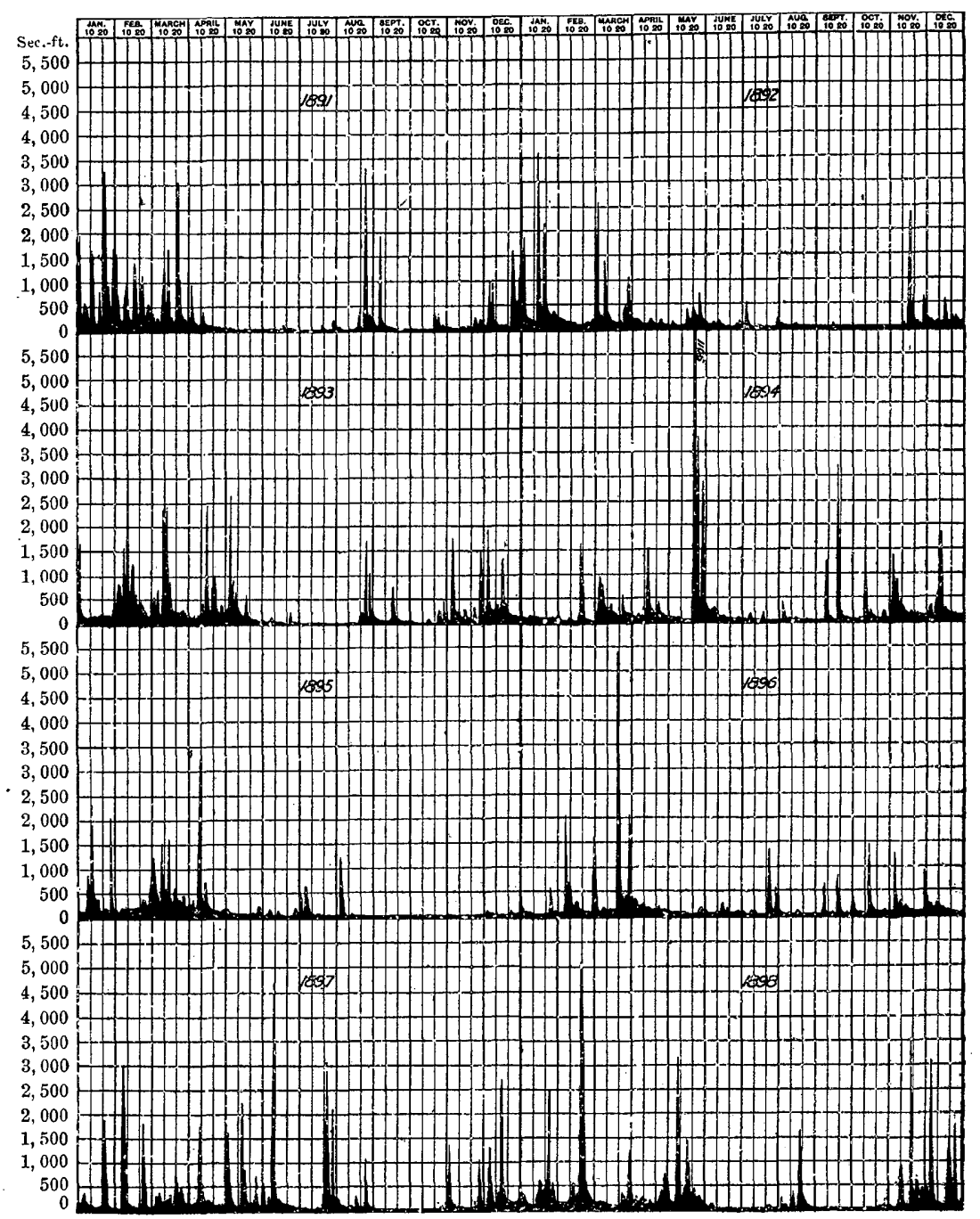

FIG. 21.-Discharge of Neshaminy Creek, 1891-1898.

The above diagram shows flnctuations of discharge of Neshaming Creek from 1891 to 1898 , inclusive. The figures for daily discharge for this and for similar diagrams for Perkiomen Creek (fig. 17) and Tohickon Creek (fig. 20) were obtained from Mr. John E. Codman, who for many years has been hydrographer for the bureau of water of the city of Philadelphia. The sudden fluctuations of these streams and the irregularity in occurrence of the floods are particularly noticeable. Most of these, as might be expected, are in February and March, but, as shown by the diagram, floods have occurred in nearly every other month, taking the series as a whole. 


\section{SUSQUEHANNA RIVER.}

Susquehanna River receives the drainage from the greater portion of eastern Pennsylvania and from a part of southern New York. Measurements have been made of the flow of the stream at Harrisburg, as described in preceding reports. Additional stations have also been established on Juniata River, the principal tributary from the west, entering a shortdistance above Harrisburg; also on the West Branch, above Sunbury, and on the main river above Sunbury, at Wilkesbarre. The results of the measurements at Harrisburg are shown in the following table:

Estimated monthly discharge of Susquehanna River at Harrisburg, Pennsylvania.

[Drainage area, 24,030 square miles.]

\begin{tabular}{|c|c|c|c|c|c|c|}
\hline \multirow[b]{2}{*}{ Month. } & \multicolumn{3}{|c|}{ Discharge in second-feet. } & \multirow{2}{*}{$\begin{array}{l}\text { Total in acre- } \\
\text { feet. }\end{array}$} & \multicolumn{2}{|c|}{ Run.off. } \\
\hline & Maximum. & $\begin{array}{l}\text { Mini- } \\
\text { mum. }\end{array}$ & Mean. & & $\begin{array}{l}\text { Depth in } \\
\text { inches. }\end{array}$ & $\begin{array}{l}\text { Second } \\
\text { feet per } \\
\text { square } \\
\text { mile. }\end{array}$ \\
\hline 1898. & & & & & & \\
\hline January ... & 150,190 & 13,100 & 59,481 & $3,657,368$ & 2.86 & 2.48 \\
\hline February ......... & 108,275 & 19,800 & 52,435 & $2,912,092$ & 2.27 & 2.18 \\
\hline March ....... & 242,375 & 27,225 & 89,331 & $5,492,785$ & 4.29 & 3.72 \\
\hline April $\ldots \ldots \ldots \ldots$ & 147,505 & 23,400 & 53,420 & $3,178,704$ & 2.47 & 2.22 \\
\hline May.......... & 87,790 & 35,400 & 59.761 & $3,674,584$ & 2.87 & 2.49 \\
\hline June.............. & 40,400 & 11,125 & 20,117 & $1,197,042$ & 0.93 & 0.84 \\
\hline July $\ldots \ldots \ldots \ldots$ & 15,000 & 5,250 & 8,499 & - 522,587 & 0.40 & 0.35 \\
\hline August. . . . . . . . . & 58,313 & 9,450 & 25,887 & $1,591,740$ & 1.25 & 1.08 \\
\hline September ........ & 23,400 & 5,725 & 11,657 & 693,638 & $0.5 \overline{5}$ & 0.49 \\
\hline October . . . . . . . . . & 111,955 & 5,250 & 33,475 & $2,058,311$ & 1. 60 & 1. 39 \\
\hline November... & 118,965 & 18,300 & 40,848 & $2,430,619$ & 1.90 & 1. 70 \\
\hline December . & 102,955 & 13,100 & 34,836 & $2,141,996$ & 1.67 & 1. 45 \\
\hline The year & 242,375 & 5,250 & 40,812 & $29,551,466$ & 23.06 & 1.70 \\
\hline
\end{tabular}

NotE.-Gage heights for 1898 are given in Water-Supply and Irrigation Paper No. 27, page 17; measurements, page 23 ; rating table, page 24 ; results for 1897 , in Water-Supply and Irrigation Paper No. 15, page 8, and in the Nineteenth Annual Report, Part IV, pages 122 to 127.

The measurements of Susquehanna River and its tributaries have been made by Mr. Edwin G. Paul, assistant hydrographer, who has carried on the work from the Washington office. Assistance has been rendered by Mr. Thomas 'T. Wierman, chief engineer of the Pennsylvania Canal Company, who has supplied gage readings and furnished transportation. 


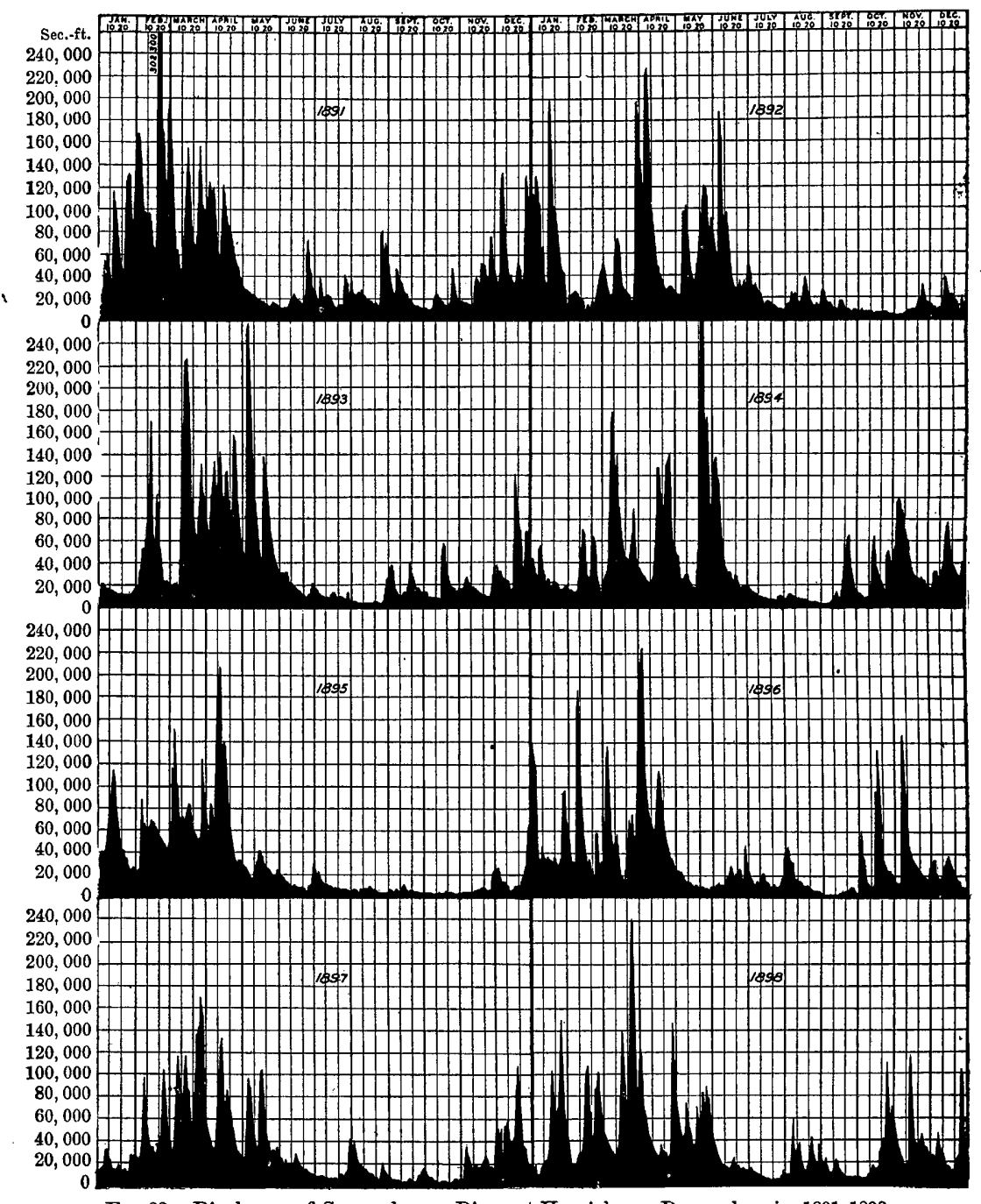

Fra. 22.-Discharge of Susquehanna River at Harrisburg, Pennsylvania, 1891-1898.

\section{OCTORARO CREEK.}

Octoraro Creek is a small stream of southeastern Pennsylvania flow ing across the State line into Maryland and entering Susquehanna River from the north side at a point about 10 miles above Chesapeake Bay. Measurements of discharge of this stream have been made for several years at Rowlandsville, Maryland, as described in preceding reports. The work has been carried on by Mr. Hugh W. Caldwell. The results for 1898 are given in the following table: 
Estimated monthly discharge of Octoraro Creek at Rowlandsville, Maryland.

[Drainage area, 217 square miles.]

\begin{tabular}{|c|c|c|c|c|c|c|}
\hline \multirow[b]{2}{*}{ Month. } & \multicolumn{3}{|c|}{ Discharge in second-feet. } & \multirow[b]{2}{*}{$\begin{array}{l}\text { Total in acre- } \\
\text { feet. }\end{array}$} & \multicolumn{2}{|c|}{ Run-off. } \\
\hline & $\begin{array}{l}\text { Maxi- } \\
\text { mum. }\end{array}$ & $\begin{array}{l}\text { Mini- } \\
\text { mum. }\end{array}$ & Mean. & & $\begin{array}{l}\text { Depth in } \\
\text { inches. }\end{array}$ & $\begin{array}{l}\text { Second- } \\
\text { feet per } \\
\text { square } \\
\text { wile. }\end{array}$ \\
\hline 1898. & & & & & & \\
\hline January .......... & 705 & 220 & 306 & 18,815 & 1.57 & 1.41 \\
\hline February ......... & 985 & 220 & 325 & 18,050 & 1.56 & 1.50 \\
\hline March ................. & 985 & 245 & 315 & 19,369 & 1.67 & 1.45 \\
\hline 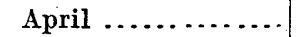 & 535 & 245 & 322 & 19,160 & 1.65 & 1.48 \\
\hline May ........ & 1,070 & 300 & 523 & 32,158 & 2.78 & 2.41 \\
\hline June....... & 562 & 220 & 282 & 16,780 & 1.45 & 1.30 \\
\hline July ....... & 375 & 200 & 230 & 14,142 & 1.22 & 1.06 \\
\hline August..... & 1,687 & 200 & 415 & 25,518 & 2.20 & 1.91 \\
\hline September ... & 480 & 180 & 243 & 14,459 & 1.25 & 1.12 \\
\hline October ........ & 375 & 200 & 225 & 13,835 & 1.20 & 1.04 \\
\hline November...... & 1,605 & 220 & 650 & 38,677 & 3.34 & 3.00 \\
\hline December ......... & 3,320 & 245 & 951 & 58,475 & 5.06 & 4.38 \\
\hline The year. & 3,320 & 180 & 399 & 289,438 & 24.95 & 1.84 \\
\hline
\end{tabular}

Note.-Gage heights for 1898 are given in Water-Supply and Irrigation Paper No. 27, page 17, measurements, page 23; rating table, page 24; results for 1897 in Water-Supply and Irrigation Paper No. 15, page 12, and in the Nineteenth Annual Report, Part IV, page 128.

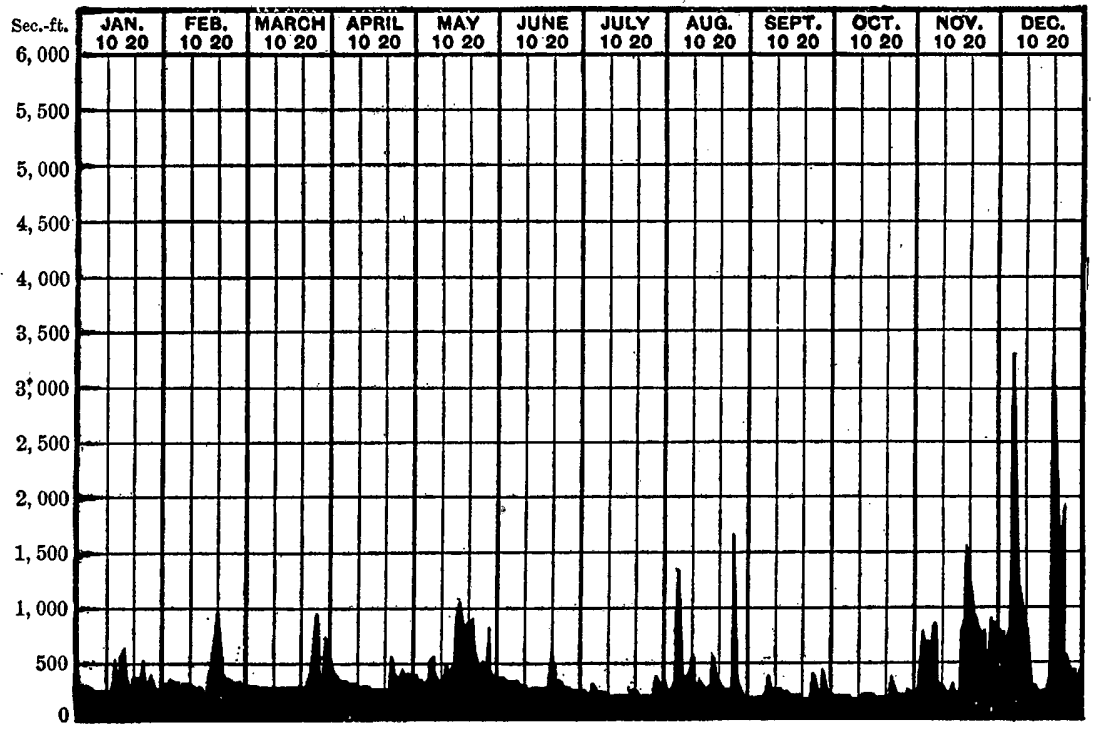

FiG. 23.-Discharge of Octoraro Creek at Rowlandsville, Maryland, 1898. 


\section{PATAPSCO AND PATUXENT RIVERS.}

Patapsco and Patuxent rivers receive the drainage of a portion of central Maryland lying north and west of the city of Baltimore and between it and the Potomac River. The discharge of these streams has been measured at points near where they cross the fall line between Baltimore and Washington. To the northwest of these is the drainage area of Monocacy Creek, which flows into Potomac River.

\section{PRECIPITATION IN BASINS OF PATAPSCO AND PATUXEN'T RIVERS.}

The principal observations of rainfall made within or near the basius of the Patapsco and Patuxent rivers are at Bachmans Valley, near Westminster, Woodstock, Baltimore, Laurel, and Annapolis. The relative location of these places is shown on fig. 24 , in connection with the points of river measurement, which are also at Woodstock and Laurel. The record at most of these localties is broken. The following table gives the names and locations of the stations, the elevations, and the lengths of the records:

Location of rainfall stations.

\begin{tabular}{|c|c|c|c|c|c|c|}
\hline Station. & County. & State. & Latitude. & $\begin{array}{l}\text { Longi- } \\
\text { tude. }\end{array}$ & $\begin{array}{l}\text { Eleva- } \\
\text { tion. }\end{array}$ & $\begin{array}{l}\text { Record be } \\
\text { gins. }\end{array}$ \\
\hline & & . & $\circ$, & $\circ \quad$, & Feet. & \\
\hline $\begin{array}{l}\text { Bachmans } \\
\text { Valley. }\end{array}$ & Carroll... & Maryland . & 3937 & 7655 & 860 & 1893 \\
\hline Woodstock. & .....do .... & ....do .... & 3920 & $76 \quad 52$ & 392 & 1870 \\
\hline Baltimore.. & Baltimore......... & .....do .... & $\begin{array}{ll}39 & 18\end{array}$ & 7637 & 142 & 1836 \\
\hline Laurel ..... & Prince George..... & ..... do .... & $\begin{array}{ll}39 & 6\end{array}$ & 7652 & 150 & 1895 \\
\hline Annapolis.. & Anne Arundel.... & .....do .... & 3859 & 7630 & 20 & 1857 \\
\hline
\end{tabular}

In the following tables are given the figures of normal or average monthly precipitation from the time of the beginning of the record to and including 1898, together with the total precipitation by months for the years 1896,1897 , and 1898 , and also the amount by years. In obtaining the normal precipitation the average is taken for all of the months during which observations were made.

Precipitation at stations in drainage basins of Patapsco and Patuxent rivers.

BACHMANS VALLEY.

\begin{tabular}{|c|c|c|c|c|c|c|c|c|c|c|c|c|c|}
\hline Year. & Jan. & Feb. & Mar. & Apr & May. & June. & $J$ uly. & Aug. & Sept. & Oct. & Nov. & Dec. & Annual \\
\hline $\begin{array}{r}\text { Normal }(1893- \\
1898)\end{array}$ & $\begin{array}{l}I n . \\
2.55\end{array}$ & $\begin{array}{l}\text { In. } \\
3.82\end{array}$ & $\begin{array}{l}\text { In. } \\
4.23\end{array}$ & $\begin{array}{l}I n . \\
3.95\end{array}$ & $\begin{array}{l}\text { In. } \\
6.91\end{array}$ & $\begin{array}{l}\text { In. } \\
2.89\end{array}$ & $\begin{array}{l}\text { In. } \\
3.98\end{array}$ & $\begin{array}{l}\text { In. } \\
3.8 \overline{5}\end{array}$ & $\begin{array}{l}\operatorname{In} . \\
3.61\end{array}$ & $\begin{array}{l}\text { In. } \\
3.45\end{array}$ & $\begin{array}{l}\text { In. } \\
4.32\end{array}$ & $\begin{array}{l}\text { In. } \\
3.32\end{array}$ & $\begin{array}{r}I n . \\
46.88\end{array}$ \\
\hline $1896 \ldots$ & 1.40 & 6.19 & 6.18 & 1.63 & 2. 67 & 5.09 & 4. 42 & 1.85 & 2.58 & 2.06 & 3. 70 & 1.27 & 39.04 \\
\hline 1897. & 2.20 & 7.18 & 5.50 & 3.37 & 7.52 & 3.71 & 5. 10 & 5.62 & 2.08 & 2.22 & 8.43 & 3.59 & 56.52 \\
\hline 1898. & 3.74 & 1.91. & 4. 75 & 4.87 & 12.29 & 0.86 & 4. 62 & 4.98 & 1.83 & 6.10 & 5.52 & 6.02 & 57.49 \\
\hline
\end{tabular}


Precipitation at stations in drainage basins of Patapsco and Patuxent rivers-Continued. WOODSTOCK.

\begin{tabular}{|c|c|c|c|c|c|c|c|c|c|c|c|c|c|}
\hline \\
\hline Year. & Jan. & Feb. & Mar. & Apr. & May. & June. & July. & Aug. & Sept. & Oct. & Nov. & Dec. & Annual. \\
\hline $\begin{array}{r}\text { Normal }(1870 \\
\quad 1898)\end{array}$ & 3.51 & 3.41 & 3.98 & 3.05 & 4. 14 & 3.52 & 3.64 & 4.10 & 3.57 & 3.39 & 3.34 & 2. 68 & 42.33 \\
\hline $1896 \ldots \ldots$ & 1.76 & 5. 65 & 6. 12 & 1. 20 & 1.85 & 2.50 & 3.64 & 1.25 & 2.83 & 1.00 & 3.40 & 1.00 & 32.20 \\
\hline 1897. & 1.78 & 5.51 & 2.74 & 2.63 & 6. 64 & 3.81 & 3.64 & 4.47 & 1.88 & 2.35 & 6.50 & 4.17 & 46.12 \\
\hline $1898 \ldots \ldots \ldots$ & 2.28 & 1.31 & 2.48 & 1.87 & 4.46 & 1.80 & 3.15 & 6.03 & 1.55 & 4. 21 & 3.79 & 3.87 & 36.80 \\
\hline \multicolumn{14}{|c|}{ - BALTIMORE. } \\
\hline $\begin{array}{r}\text { Normal }(1836 \\
1898) . . . .\end{array}$ & 2.99 & 3.46 & 4.02 & 3.30 & 4.00 & 3.70 & 4.66 & 4. 09 & 3.56 & 3.12 & 3. 29 & 3.15 & $43.34^{\circ}$ \\
\hline $1896 .$. & 2.62 & 7.07 & 4.70 & 1.44 & 1.61 & 3. 94 & 6.32 & 1.93 & 4.14 & 1.11 & 3.34 & 0.37 & 38.59 \\
\hline $1897 \ldots$ & 2.05 & 5.13 & 2.40 & 3.19 & 6. 88 & 2.57 & 6.93 & 4.71 & 2.17 & 3.67 & 4. 39 & 3.40 & 47.49 \\
\hline $1898 \ldots$ & 2.99 & 1. 32 & 2.58 & 1.84 & 3. 86 & 1.06 & 3.51 & 6. 09 & 1. 56 & 3. 97 & 4. 34 & 3.34 & 36.46 \\
\hline \multicolumn{14}{|c|}{ LAUREL. } \\
\hline $\begin{array}{r}\text { Normal }(1895 \\
1898)\end{array}$ & 2.68 & 3.22 & 2.74 & 3.03 & 4. 24 & 2.72 & 4.80 & 3.72 & 2.29 & 2.76 & 3. 07 & 2.37 & 37.64 \\
\hline $1896 \ldots$ & 2.68 & 3.22 & 2.60 & 1.30 & 3.20 & 3.15 & 7.89 & 3.76 & 3.93 & 0.55 & 2.60 & 0.20 & 35.08 \\
\hline $1897: \ldots$ & 2.05 & 5.51 & 3.08 & 3.29 & 5.62 & 2.40 & 6.70 & 2.33 & 1.55 & 4. 54 & $5: 15$ & 3.75 & 45.97 . \\
\hline 1898. & 3.30 & 0.92 & 2.54 & 2.07 & 4.70 & 0.65 & 1. 72 & 7.20 & 0.98 & 3.65 & 2. 97 & 4.39 & 35.09 \\
\hline \multicolumn{14}{|c|}{ ANNAPOLIS. } \\
\hline $\begin{array}{c}\text { Normal (1857 } \\
1898)\end{array}$ & 3.20 & 3.64 & 4.27 & 3.90 & 4. 70 & 3.95 & 4.75 & 4.55 & 3.72 & 3.84 & 4.31 & 3.38 & 48.21 \\
\hline $1896 \ldots$ & 2.70 & 7.48 & 4.53 & 1.25 & 2.25 & 3.11 & $\ldots .$. & $\ldots .$. & …... & ....... & 2.41 & 0.77 & ….... \\
\hline $1897 \ldots$ & 3.20 & 4.68 & 2.46 & 2.80 & 6.67 & 1.73 & 5.76 & 4.39 & 2,17 & 3.69 & 4.98 & 3.48 & 46.01 \\
\hline $1898 \ldots$ & 2.37 & 1.40 & 1.44 & 1.11 & 3.28 & 0.88 & 3.17 & 2.81 & 1.35 & 8.13 & 4.69 & 3.38 & 34.01 \\
\hline \multicolumn{14}{|c|}{ AVERAGE. } \\
\hline Normals & 2.99 & 3.51 & 3.86 & 3.45 & 4.80 & 3.36 & 4. 37 & 4. 06 & 3.35 & 3.31 & 3. 67 & 2. 98 & 43.68 \\
\hline $1896 \ldots$ & 2.23 & 5.92 & 4.83 & 1.36 & 2.32 & 3.56 & 5.57 & 2.20 & 3.37 & 1.18 & 3.09 & 0.72 & 36.23 \\
\hline $1897 \ldots$ & 2.26 & 5.60 & 3.24 & 3.06 & 6.67 & 2.84 & 5.64 & 4. 30 & 1.97 & 3.29 & 5.89 & 3.68 & 48.42 \\
\hline $1898 \ldots$ & 2.94 & 1.37 & 2.76 & 2.35 & 5. 72 & 1.05 & 3.23 & 5.42 & 1.45 & 5.21 & 4.26 & 4. 20 & 39.97 \\
\hline
\end{tabular}

Depth of run-off, in inches, from Patapsco and Patuxent basins.

PATAPSCO AT WOODSTOCK.

\begin{tabular}{|c|c|c|c|c|c|c|c|c|c|c|c|c|c|}
\hline Tear. & Jan. & Feb. & Mar. & Apr. & May. & June. & July. & Aug. & Sep. & Oct. & Nov. & Dec. & Annual \\
\hline $1896 a \ldots$ & & $\cdots$ & $\cdots$ & & $\cdots$ & c...... & … & 0.53 & 0.52 & 0.69 & 0.93 & 0.74 & \\
\hline $1897 b \ldots \ldots \ldots$ & 1. 52 & 3.25 & 1.52 & 1.48 & 2. 17 & 1.15 & 2.70 & 2.75 & 0.57 & 0.63 & 2.62 & 2.31 & 22.67 \\
\hline $1898 c \ldots \ldots \ldots$ & 1.79 & 1.51 & 1.58 & 1.44 & 2.09 & 0.91 & 0.71 & 1.52 & 0.47 & 0.77 & 1.11 & 2.34 & 16.24 \\
\hline A verage. & 1.66 & 2.38 & 1.55 & 1.46 & 2.13 & 1.03 & 1.71 & 1.60 & 0.52 & 0.70 & 1.55 & 1.79 & 19.45 \\
\hline \multicolumn{14}{|c|}{ PATUXENT AT LAUREL: } \\
\hline $1896 a$. & & $\ldots$ & .. & $\ldots$ & ...... & $\ldots$. & ...... & 0.98 & $0.80^{-}$ & 0.83 & 1.04 & 1.18 & \\
\hline $1897 b \ldots$. & 1.01 & 3.04 & 1. 36 & 1.20 & 1. 71 & 0.91 & 2.70 & 1.22 & 0.70 & 0.77 & 2.04 & 1.67 & 18.33 \\
\hline $1898 c \ldots \ldots . .$. & 1.56 & 1.23 & 1.09 & 0.94 & 1.49 & 0.73 & 0.41 & …... & ....... & & ....... & ...... & ........ \\
\hline Average. & 1.29 & 2.14 & 1.23 & 1.07 & 1.60 & 0.82 & 1.56 & 1.11 & 0.75 & 0.80 & 1.54 & 1.43 & 15.34 \\
\hline
\end{tabular}


PROGRESS OF STREAM MEASUREMENTS FOR 1898.

Annual rainfall and run-off.

\begin{tabular}{|c|c|c|c|c|}
\hline Station. & Normal. & 1896. & 1897. & 1898. \\
\hline \multirow{6}{*}{ 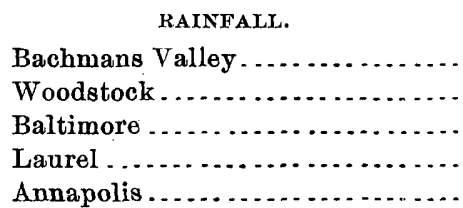 } & Inches. & Inches. & Inches. & Inches. \\
\hline & 46.88 & 39.04 & 56.52 & 57.49 \\
\hline & 42.33 & 32.20 & 46.12 & 36.80 \\
\hline & 43.34 & 38.59 & 47.49 & 36.96 \\
\hline & 37.64 & 35.08 & 45.97 & 35.09 \\
\hline & 48.21 & $\ldots$ & 46.01 & 34.01 \\
\hline \multirow{2}{*}{$\begin{array}{l}\text { Average } \ldots \ldots \ldots \\
\text { RUN-OFF. }\end{array}$} & 43.68 & 36.23 & 48.42 & 39.97 \\
\hline & & & & \\
\hline \multirow{4}{*}{$\begin{array}{l}\text { Patapsco } \ldots \ldots \ldots \\
\text { Patuxent..... } \\
\quad \begin{array}{l}\text { Average } \ldots \\
\text { Per cent of rainfall } \ldots \ldots\end{array} \\
\end{array}$} & 17.66 & $\ldots$ & 22.67 & 16.24 \\
\hline & 15. 34 & & 18.33 & $\ldots \ldots \ldots$ \\
\hline & 16.50 & $\ldots \ldots$ & 20.50 & $\ldots \ldots \ldots$ \\
\hline & 37.77 & \#. & 42.34 & 40.63 \\
\hline
\end{tabular}

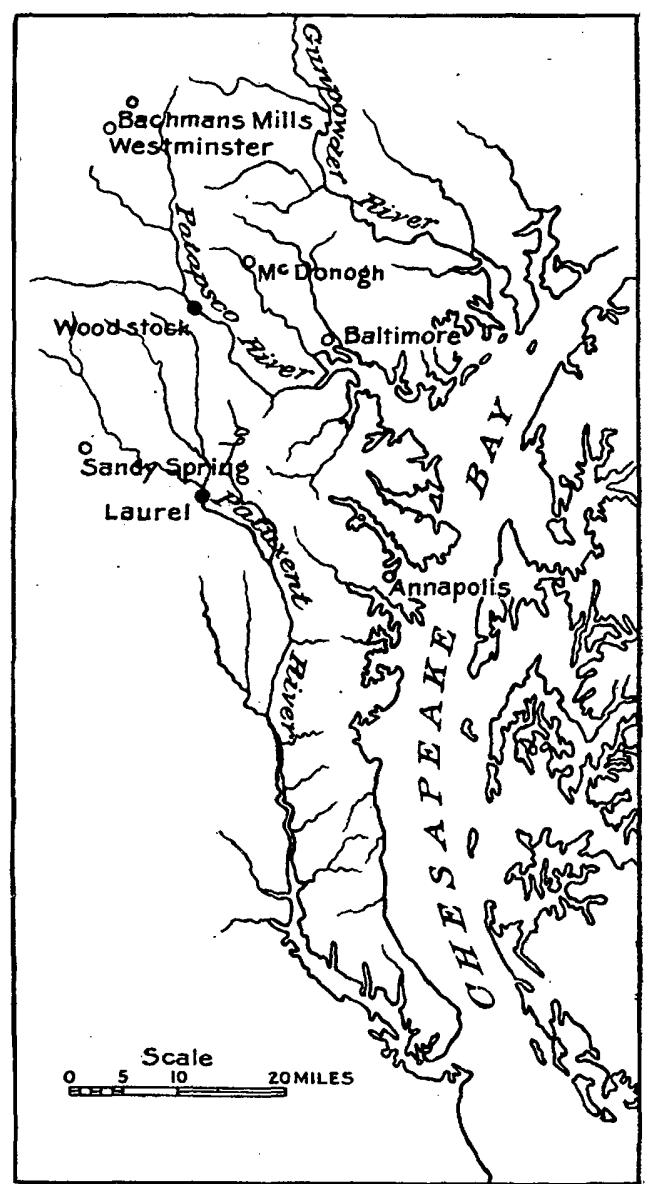

Fra. 24.-Relative location of river and rainfall observations in basins of Patapsco and Patuxent rivers. 
Estimated monthly discharge of Patapsco River at Woodstock, Maryland.

[Drainage area, 251 square miles.]

\begin{tabular}{|c|c|c|c|c|c|c|}
\hline \multirow[b]{2}{*}{-Month. } & \multicolumn{3}{|c|}{ Discharge in second-feet. } & \multirow{2}{*}{$\begin{array}{l}\text { Total in acre- } \\
\text { feet. }\end{array}$} & \multicolumn{2}{|c|}{ Run-off. } \\
\hline & $\begin{array}{l}\text { Maxi- } \\
\text { mum. }\end{array}$ & $\begin{array}{l}\text { Mini- } \\
\text { mum. }\end{array}$ & Mean. & & $\begin{array}{c}\text { Depth in } \\
\text { inches. }\end{array}$ & $\begin{array}{c}\text { Second- } \\
\text { feet per } \\
\text { square } \\
\text { mile. }\end{array}$ \\
\hline 1898. & & & & & & \\
\hline January ............ & 1,000 & 161 & 388 & 23,857 & 1.79 & 1.55 \\
\hline February ......... & 1,200 & 148 & 365 & 20,271 & 1.51 & 1.45 \\
\hline March ............. & 835 & 253 & 344 & 21,152 & 1.58 & 1.37 \\
\hline April .............. & 590 & 148 & 324 & 19,279 & 1. 44 & 1. 29 \\
\hline May ............... & 1,100 & 235 & 454 & 27,916 & 2.09 & 1.81 \\
\hline June..... & 425 & 122 & 207 & 12,317 & 0.91 & 0.82 \\
\hline July $\ldots \ldots \ldots \ldots$ & 355 & 75 & 156 & 9,592 & 0.71 & 0.62 \\
\hline August......... & 2,050 & 122 & 331 & 20,353 & 1.52 & 1.32 \\
\hline September ......... & 173 & 58 & 106 & 6,307 & 0.47 & 0.42 \\
\hline October ............. & 450 & 83 & 174 & 10,699 & 0.77 & 0.69 \\
\hline November......... & 1,150 & 111 & 250 & 14,876 & 1.11 & 1.00 \\
\hline December 1-14 ..... & 1,950 & 270 & 509 & a 31,297 & a 2.34 & $a 2.03$ \\
\hline The year....... & 2,050 & 58 & 300 & 217,916 & 16.24 & 1. 20 \\
\hline
\end{tabular}

a Estimated for whole month.

Noтк.-Gage heights for 1898 are given in Water-Supply and Irrigation Paper No. 27, page 18; measurements, page 23 ; rating table, page 24; results for 1897 in Water-Supply and Irrigation Paper No. 15, page 13, and in the Nineteenth Aunual Report, Part IV, page 129.

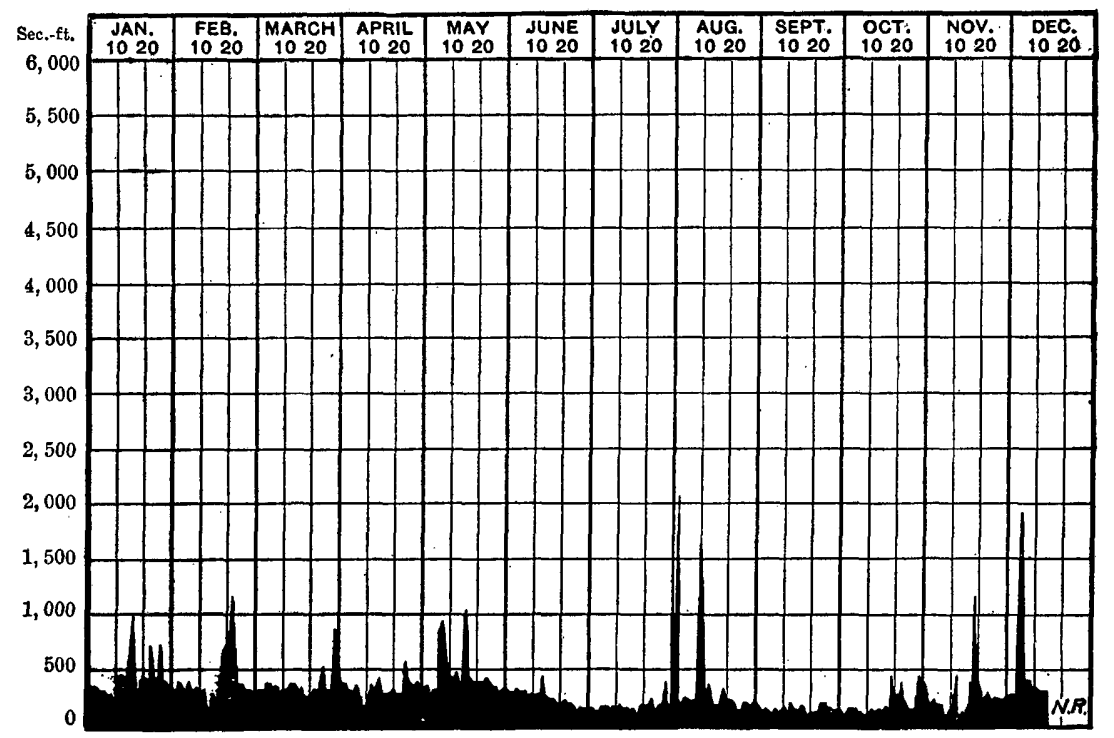

FIG. 25.-Discharge :ะ ?atapsco River at Woodstock, Maryland, 1898. 
PROGRESS OF STREAM MEASUREMENTS FOR 1898.

Estimated monthly discharge of Patuxent River at Laurel, Maryland.

[Drainage area, 137 square miles.]

\begin{tabular}{|c|c|c|c|c|c|c|}
\hline \multirow[b]{2}{*}{ Month. } & \multicolumn{3}{|c|}{ Discharge, in second-feet. } & \multirow[b]{2}{*}{$\begin{array}{c}\text { Total in acre } \\
\text { feet. }\end{array}$} & \multicolumn{2}{|c|}{ Run-off. } \\
\hline & $\begin{array}{l}\text { Maxi- } \\
\text { mum. }\end{array}$ & $\begin{array}{l}\text { Mini- } \\
\text { mum. }\end{array}$ & Mean. & & $\begin{array}{c}\text { Depth in } \\
\text { inches. }\end{array}$ & $\begin{array}{l}\text { Second- } \\
\text { feet per } \\
\text { square } \\
\text { mile. }\end{array}$ \\
\hline 1898. & & & & & & \\
\hline January . . . . . . . . & 341 & 194 & 185 & 11,375 & 1.56 & 1.35 \\
\hline February........... & 323 & 110 & 161 & 8,942 & 1.23 & 1.18 \\
\hline March ............... & 347 & 90 & 130 & 7,994 & 1.09 & 0.95 \\
\hline April.... & 162 & - 94 & 117 & 6,962 & 0.94 & 0.85 \\
\hline May............. & 630 & 78 & 177 & 10,884 & 1.49 & 1.29 \\
\hline June . . . . . . . . . & 272 & 59 & 91 & 5,415 & 0.73 & 0.66 \\
\hline Jüly ....... & 255 & 6 & 50 & 3,074 & 0.41 & 0.36 \\
\hline August 1-10 ....... & 1,586 & 56 & 272 & $a 16,725$ & $a 2.29$ & $a 1.99$ \\
\hline
\end{tabular}

$a$ Estimated for whole month.

Note.-Gage heights for 1898 are given in Water-SupplJ and Irrigation Paper No. 27, page 18; measurements, page 23 ; rating table, page 24; results for 1897 in Water-Supply and Irrigation Paper No. 15 page 14; and in the Nineteenth A nnual Report, Part IV, page 131.

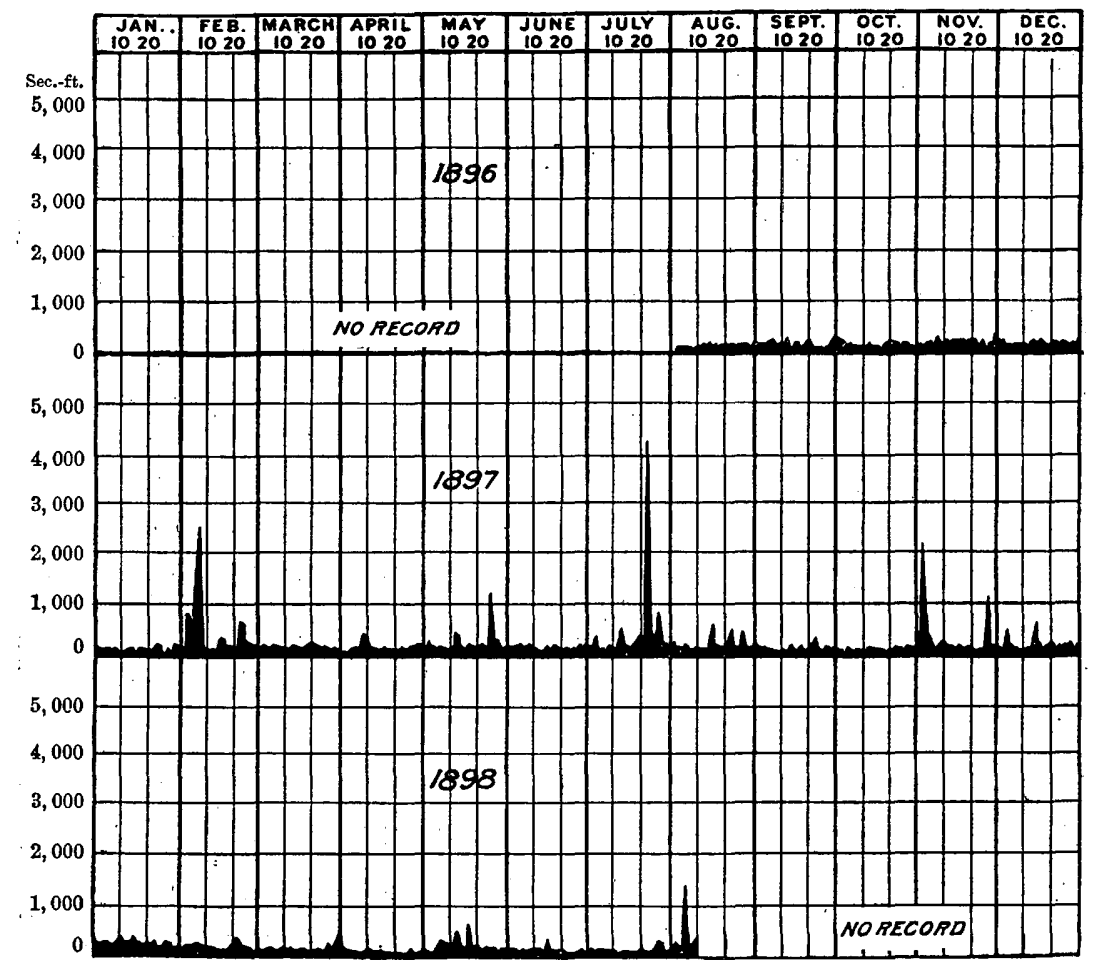

Fig. 26.-Discharge of Patuxent River at Laurel, Maryland, 1896-1898. 


\section{POTOMAC RIVER.}

A number of measurements have been made in the drainage basin of Potomac River, and also a general reconnaissance of its headwaters, the results being published in preceding annual reports. Observations have been continued at most of the stations hitherto established, giving figures of flow for 1898, as shown in the following tables.

\section{PRECIPITATION IN BASIN OF POTOMAC RIVER.}

The principal observations of rainfall made within the Potomac Basin are at Cumberland, Martinsburg, Staunton, Dale Enterprise, Woodstock, Harpers Ferry, Emmitsburg, Frederick, Newmarket, and Washington. The relative location of these points is shown on fig. 27, in connection with the points of river measurement which are located at Cumberland, Springfield, Port Republic, Millville, Point of Rocks, Frederick, Sharpsburg, and Washington.

The following table gives the names and location of the stations, the elevations, and the number of years during which the observations have been made, or rather the number of complete monthly observations used in computing the normals :

Location of rainfall stations.

\begin{tabular}{|c|c|c|c|c|c|c|}
\hline Station. & County. & State. & Latitude. & $\begin{array}{l}\text { Longi. } \\
\text { tude. }\end{array}$ & $\begin{array}{l}\text { Elera- } \\
\text { tion. }\end{array}$ & $\begin{array}{l}\text { Length of } \\
\text { record. }\end{array}$ \\
\hline Cumberland. & Allegany ... & Marvland. & $\begin{array}{cc}\circ & 1 \\
39 & 39\end{array}$ & $\begin{array}{cc}\circ \\
78 \\
78 & 45\end{array}$ & $\begin{array}{l}\text { Feet. } \\
700\end{array}$ & $\begin{array}{l}\text { Years. } \\
25-27\end{array}$ \\
\hline Martinsburg & Berkeley ... & West Virginia & 3927 & 7758 & 435 & $4-6$ \\
\hline Staunton..... & Augusta .... & Virginia. & 3809 & 7904 & 1,340 & $9-12$ \\
\hline $\begin{array}{l}\text { Dale Enter- } \\
\text { prise. }\end{array}$ & Rockingham & .....do. & 3840 & 7845 & 850 & 18 \\
\hline Wocdstock.. & Shenandoah. & .... do. & 3853 & 7831 & 927 & $5-7$ \\
\hline Harpers Ferry & Jefferson.... & West Virginia & 3919 & 7742 & 277 & $8-9$ \\
\hline Emmitsburg & Frederick ... & Maryland. & 3943 & 7720 & 498 & $17-26$ \\
\hline Frederick .... & .... do $\ldots$ do & ..... do... & 3924 & 7724 & 400 & $19-22$ \\
\hline Newmarket & ..... do & ..... do........... & 3910 & 7715 & 500 & $9-12$ \\
\hline Washington... & $\ldots$. & $\begin{array}{l}\text { District of Co- } \\
\text { lumbia. }\end{array}$ & 3854 & 03 & 112 & 42 \\
\hline
\end{tabular}




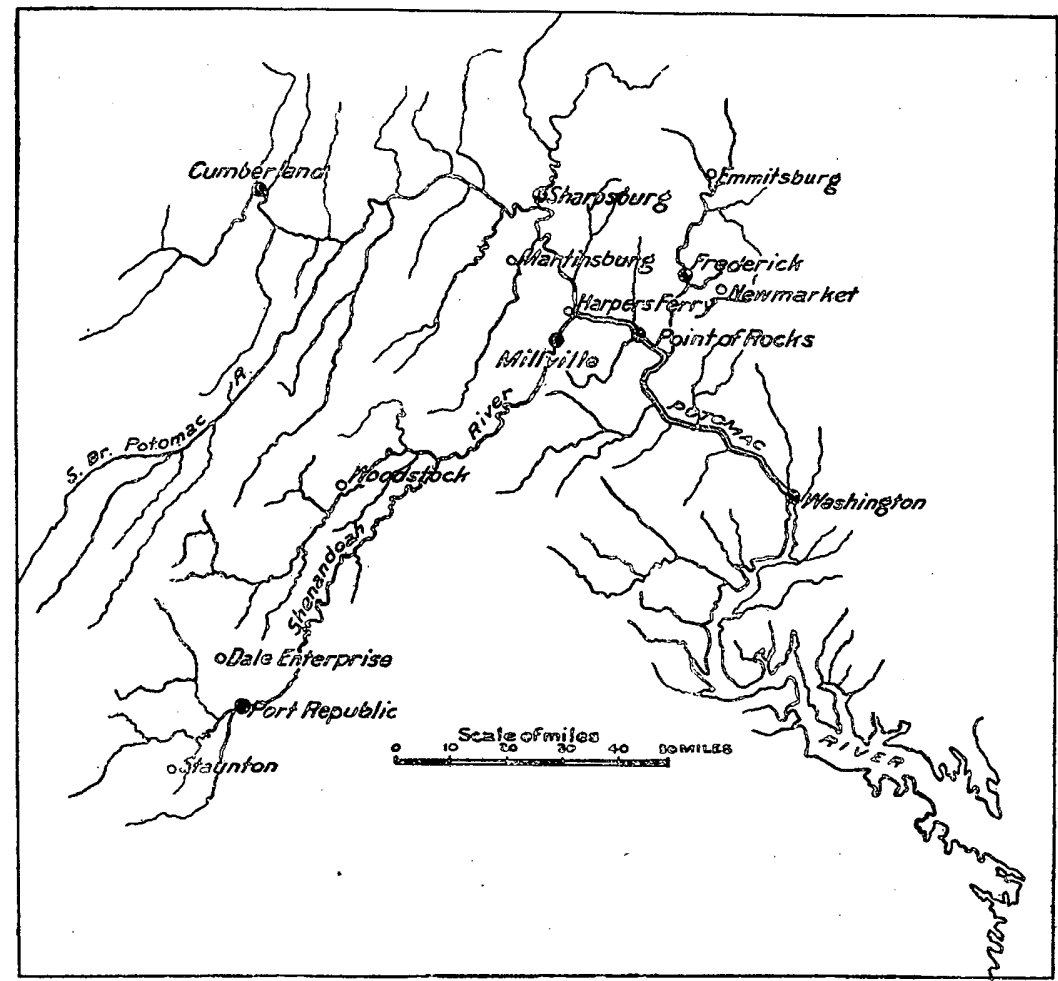

FIG. 27.-Relative location of river and rainfall observations in basin of Potomac River

The following table gives the figures of normal or average monthly precipitation from the beginning of the record to and including 1897, together with the total precipitation by months for the years 1896, 1897, and 1898; and also the amount by years. In obtaining the normal precipitation the average is taken for all of the months during which observations were made.

Precipitation at stations in drainage basin of Potomac River.

CUMBERLAND.

\begin{tabular}{|c|c|c|c|c|c|c|c|c|c|c|c|c|c|}
\hline Year. & Jan. & Feb. & Mar. & Apr. & May. & June. & July. & Aug. & Sept. & Oct. & Nov. & Dec. & Annual. \\
\hline Normal & 2.10 & 2.7 & 2.90 & 2.50 & 3.40 & 3.70 & 3.40 & 3.20 & 2.80 & 2.20 & 2.30 & 2.10 & 33.20 \\
\hline $1896 \ldots$ & 1.41 & 3.01 & 3.59 & 1.88 & 5.09 & 4.22 & 5.16 & 1.71 & 5.56 & 1.32 & 3.68 & 0.91 & 37.54 \\
\hline $1897 \ldots$ & 1.80 & 5.81 & 2.94 & 3.00 & 3.47 & 1.88 & 4.41 & 2.26 & 1.50 & 0.81 & 4.85 & 3.30 & 36.03 \\
\hline $1898 .$. & 4.57 & 1.15 & 5. 58 & 2.45 & 4.21 & 1.66 & 1.50 & 6.17 & 1.33 & 6.92 & 2.34 & 3.45 & 41.33 \\
\hline \multicolumn{14}{|c|}{ MARTINSBURG. } \\
\hline Norma & 1.96 & 2.88 & 2.56 & 2.68 & 4.66 & 3.78 & 4.16 & 1.96 & 2.39 & 2.33 & 2.58 & 2.10 & 34.04 \\
\hline 1896 & 1.60 & 2.97 & 2.58 & 1.30 & 1.26 & 7.54 & 5.64 & 1.03 & 3.50 & 1.13 & \begin{tabular}{|l|}
2.48 \\
\end{tabular} & 0.75 & 31.78 \\
\hline 1897 & 1.05 & 4.90 & 2.63 & 2.20 & 5.00 & 3.18 & 2.85 & 2.78 & 1.80 & 1.15 & 4.70 & 3.10 & 35.34 \\
\hline $1898 .$. & 3. 15 & 1.29 & 3. 35 & 1.87 & 4.51 & 1.42 & 3.20 & 7.00 & 1.31 & 5.09 & 2.91 & 3.50 & 38.60 \\
\hline
\end{tabular}


Precipitation at stations in drainage basin of Potomac River-Continued. STAUNTON.

\begin{tabular}{|c|c|c|c|c|c|c|c|c|c|c|c|c|c|}
\hline Year. & Jan. & Feb. & Mar. & Apr. & May. & June. & July. & Aug. & Sept. & Oct. & Nov. & Dec. & Annual. \\
\hline Normal. & 2.51 & 3.17 & 3.17 & 2.50 & 4.41 & 4.15 & 3.23 & 2.94 & 4.05 & 2.66 & 2.39 & 2.27 & 37.45 \\
\hline $1896 .$. & 2.55 & 3.81 & 4.41 & 1.33 & 4.13 & 6.58 & 6. 10 & 3.92 & 8.08 & 0.23 & 5.01 . & T. $a$ & 46. 15 \\
\hline 1897. & 0.92 & 3.99 & 2.56 & 1.56 & 5.75 & 2.18 & 3.70 & 2.30 & 0.73 & 2.84 & $2.14^{\circ}$ & 3.31 & 31.98 \\
\hline 1898. & 2.89 & 0.55 & 3.10 & 2.95 & 4.82 & 2.16 & 4.41 & 5.16 & 2.22 & 7.13 & 1.74 & 3.00 & 40.13 \\
\hline \multicolumn{14}{|c|}{ DALE ENTERPRISE. } \\
\hline Normal & 2.75 & 3.38 & 3.13 & 3.23 & 5.08 & 4. 93 & 4.29 & 3.62 & 4.06 & 2.81 & 2.51 & 2.52 & 42.31 \\
\hline 1896. & 1.75 & 3.40 & 3. 70 & 1.19 & 1.99 & 5.17 & 5.69 & 1.55 & 7.85 & 0.16 & 4. 30 & T. $a$ & 36.73 \\
\hline 1897. & 1.56 & 5.64 & 2.40 & 1.70 & 5.37 & 2.88 & 4.15 & 0.68 & 0.43 & 2.55 & 2.40 & 3.23 & 32.99 \\
\hline 1898. & 2.37 & 0.61 & 3.90 & 2.91 & 4.94 & 4.83 & 6.24 & 9.54 & 2.23 & 7. 39 & 1.82 & 3.60 & 50.38 \\
\hline \multicolumn{14}{|c|}{ WOODSTOCK. } \\
\hline Normal & 1.86 & 3.93 & 3.15 & 2.44 & 4.00 & 4.82 & 3.35 & 3.30 & 3.12 & 2.95 & 2.66 & 2.20 & 37.78 \\
\hline $1896 \ldots$ & ...... & $\ldots$ & $\ldots$. & $\ldots \ldots$ & ...... & $\ldots .$. & ...... & $\ldots \ldots$ & 8.74 & 0.82 & 3.20 & 0.35 & ......... \\
\hline 1897. & 1. 46 & 7.65 & 1.81 & 2.30 & 5.41 & 3.37 & 4.38 & 2.74 & 1.38 & 2.94 & 2.20 & 3. 72 & 39.36 \\
\hline $1898 \ldots \ldots \ldots$ & 3. 30 & 0.60 & 3. 79 & 2.75 & 4.85 & 1.12 & 3.56 & 7.31 & 0.95 & 6.23 & 2.08 & 2.61 & 39.15 \\
\hline \multicolumn{14}{|c|}{ HARPERS FERRY. } \\
\hline Normal & $2: 03$ & 2.92 & 2. 79 & 2.60 & 4. 67 & 3.66 & 3.13 & 2.66 & 2.83 & 2.45 & 2.66 & 1.98 & 34.38 \\
\hline $1896 .$. & 1.94 & 4.19 & 2.48 & 1.64 & 4.60 & 5.25 & 5.08 & 0.88 & 4.29 & 0.88 & 2.06 & 1.04 & 34. 33 \\
\hline 1897. & 1.44 & 5.76 & 3.12 & 2.14 & 5.67 & 3.20 & 4.12 & 4. 50 & 1.57 & 2.27 & 5.56 & 3.90 & 43.25 \\
\hline $1898 .$. & 4. 15 & 1.49 & 4.36 & 1.87 & 6.51 & 1.08 & 2.12 & 5.64 & 1.47 & 8.50 & 3.60 & 3.69 & 44.48 \\
\hline \multicolumn{14}{|c|}{ EMMITTSBURG. } \\
\hline Normal & 3.11 & 3.09 & 4.05 & 3.48 & 4.61 & 3.90 & 3. 36 & 3.29 & 3.77 & 3.85 & 3.79 & 3. 05 & 43.29 \\
\hline 1896. & 0.96 & 5.16 & 5.75 & 1.40 & $b 4.61$ & 4.00 & 6.07 & 1.70 & 3.16 & 1.06 & 4.63 & 0.56 & $b 42.50$ \\
\hline $1897 .$. & 2.26 & 3.53 & 3.04 & 2.90 & 5.97 & 3.52 & 7.99 & 3.23 & $2: 65$ & 2.24 & 6.15 & 3.12 & 46. 60 \\
\hline $1898 \ldots$ & 3.78 & 1.41 & 3.68 & 1.43 & 4.64 & 1.95 & 3.17 & 8. 92 & 1.17 & 5.98 & 3.75 & 3.04 & 42.92 \\
\hline \multicolumn{14}{|c|}{ FREDERICK. } \\
\hline Normal. & 3.11 & 3.05 & 3.01 & 3.57 & 4.25 & 4.39 & 3.77 & 2.58 & 3.60 & 2.37 & 2.85 & 2.88 & 39.43 \\
\hline 1896. & 2.09 & 6.15 & 4.04 & 1.27 & 1.40 & 3.83 & 4.67 & 0.77 & 3.08 & 0.80 & 3.12 & 0.59 & 31.81 \\
\hline 1897. & 1.39 & 4.77 & 2.72 & 2.32 & 3.71 & 2.06 & 7.33 & 2.25 & 1.63 & 1.42 & 5.01 & 3.74 & 38.35 \\
\hline 1898. & 4.05 & 1.49 & 3.40 & 1.53 & 5.10 & 0.74 & 1.64 & 6.34 & 1.37 & 5.82 & 3.99 & 3.46 & 44.93 \\
\hline \multicolumn{14}{|c|}{ NEWMARKET. } \\
\hline Normal & 2.46 & 3.44 & 3.73 & 3.52 & 4.05 & 3.72 & 4.26 & 4.12 & 3.99 & 2.60 & 4. 75 & 2.32 & 42.96 \\
\hline 1896. & 2.58 & 5.97 & 5.91 & 1. 30 & 1. 27 & 3.57 & 3.87 & 1.77 & 4.10 & 0.86 & 3.43 & 0.50 & 35.13 \\
\hline $1897 \ldots$ & 1.66 & 5.99 & 3.28 & 3.15 & 5.31 & 2.76 & $9: 48$ & 4.11 & 1.61 & 2.21 & 6.69 & 3.31 & 49.56 \\
\hline $1898 \ldots$ & 3.14 & 1.97 & 3.29 & 2.59 & 5.20 & 0.63 & 2.41 & 5.80 & 1.28 & 4.98 & 4.70 & 3.39 & 39.38 \\
\hline \multicolumn{14}{|c|}{ WASHINGTON. } \\
\hline Normal. & 3.40 & 3.20 & 3.90 & 3.40 & 4.20 & 3.90 & 4.50 & 4.00 & 3.50 & 3.30 & 2.70 & 3.10 & 42.90 \\
\hline 1896. & 2.27 & 5.31 & 5.16 & 1.07 & 2.26 & 2. 39 & 3.96 & 2.65 & 3.18 & 0.34 & 2.54 & 0.30 & 31.16 \\
\hline $1897 \ldots$ & 1.98 & 6.47 & 2.66 & 3.02 & 6.97 & 2.60 & 5.78 & 3.35 & 1.54 & 3.55 & 3.31 & 3.35 & 44.58 \\
\hline 1898. & 3.54 & 1.64 & 2.52 & 2.36 & 3.60 & 1.33 & 2.86 & 8.76 & 0.89 & 3.54 & 3.12 & 3.56 & 37.72 \\
\hline \multicolumn{14}{|c|}{ AVERAGE. } \\
\hline Normal & 2.53 & 3.18 & 3.24 & 2.99 & 4.33 & 4.10 & 3.75 & 3.17 & 3.41 & 2.75 & 2.92 & 2.45 & 38.77 \\
\hline 1896. & 1.91 & 4.44 & 4.18 & 1.38 & 2.96 & 4. 73 & 5.14 & 1.78 & 5.15 & 0.76 & 3.45 & 0.50 & 36.35 \\
\hline $1897 \ldots$ & 1.55 & 5.45 & 2.72 & 2.43 & 5.26 & 2.76 & 5.42 & 2.82 & 1.48 & 2.20 & 4.30 & 3.41 & 39.80 \\
\hline 1898.. & 3.49 & 1.22 & 3.70 & $2.27 \mid$ & 4.84 & 1.69 & 3. 11 & 7.06 & 1.42 & 6.16 & 3.01 & 3.33 & 41.90 \\
\hline
\end{tabular}


Depth of run-off, in inches, from Potomac drainage basin. SOUTH BRANCH, NEAR SPRINGFIELD.

\begin{tabular}{|c|c|c|c|c|c|c|c|c|c|c|c|c|c|}
\hline Year. & Jan. & Feb. & Mar. & Apr. & May. & June. & July. & Aug. & Sept. & Oct. & Nor. & Dec. & Annual. \\
\hline 1894. & & & & & & 0.61 & 0.25 & 0.18 & 0.30 & 0.40 & & & \\
\hline 1895 & ....... & ... & & 1.28 & 1.76 & 0.47 & 0.40 & & & & & & \\
\hline 1896. & 0.68 & 1.51 & ..... & $\cdots \cdots$ & . & $\mid \cdots \cdots$ & ....... & ........ & ....... & ........ & & . & \\
\hline Average. & 0.68 . & 1.51 & $\ldots$. & 1.28 & 1.76 & 0.54 & 0.33 & 0.18 & 0.30 & 0.40 & .... & & \\
\hline \multicolumn{14}{|c|}{ NORTH BRANCH, NEAR CUMBERLAND. } \\
\hline 1895. & 2.39 & 1. 32 & 4.12 & 2.35 & 1.13 & 0.45 & 0.55 & $\cdots$ & & & & & \\
\hline 1896. & 0.56 & 1.81 & 2.57 & 2.24 & 1. 75 & 1.75 & 2.77 & 085 & 1.07 & $1.12^{\circ}$ & 1.39 & 0.84 & 18.72 \\
\hline 1897. & 1.08 & 4.21 & 3.55 & 1.96 & 2.79 & 0.21 & 0.25 & 0.33 & 0.09 & 0.04 & a1. 39 & $a 0.84$ & $\ldots .$. \\
\hline Average. & 1.34 & 2.45 & 3.41 & 2.18 & 1.89 & $0.80 \mid$ & 1.19 & 0.59 & 0.58 & 0.58 & 1.39 & 0.84 & 17.24 \\
\hline \multicolumn{14}{|c|}{ SHENANDOAH, NEAR MILLVILLE. } \\
\hline 1896. & 0.94 & 1.34 & 1.45 & 1.02 & 0.79 & 0.79 & 1.07 & 0.47 & 0.48 & 0.79 & 0.72 & 0.86 & 11.72 \\
\hline 1897. & 0.46 & 3.51 & 1. 76 & 0.88 & 2.14 & 0.52 & 0.48 & 0.35 & 0.24 & 0.26 & 0.29 & 0.54 & 11.43 \\
\hline 1898. & 0.59 & 0.34 & 0.57 & 1.17 & 1.64 & 0.37 & 0.32 & 3.15 & 0.45 & 1.91 & 0.94 & 1.59 & 13.04 \\
\hline Average. & 0.66 & 1.73 & 1. 26 & 1.02 & 1.52 & 0.56 & 0.62 & 1.32 & 0.39 & 0.99 & 0.65 & 1.00 & 12.06 \\
\hline \multicolumn{14}{|c|}{ ANTIETAM CREEK, NEAR SHARPSBURG. } \\
\hline $189 ?$ & & & & & & & 0.63 & 0.66 & 0.43 & 0.41 & 0.56 & 0.98 & \\
\hline $18998 .$. & 1.27 & 1.18 & 1. 33 & 1.31 & 1.54 & 0.97 & 0.68 & 1.34 & 0.71 & 0.83 & 1.04 & 2.29 & 14.49 \\
\hline Average. & 1.27 & 1.18 & 1. 33 & 1.31 & 1.54 & 0.97 & 0.66 & 1.00 & 0.57 & 0.62 & $0.8 \mathrm{C}$ & 1.61 & 12.86 \\
\hline \multicolumn{14}{|c|}{ MONOCACY, AT FREDERICK. } \\
\hline 1896 & & & & & & …. & 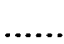 & 0.19 & 0.18 & 0.24 & 0.53 & 0.33 & \\
\hline 1897 & 0.56 & 3. 15 & 2.47 & 1.56 & 2.77 & 0.85 & 1.27 & 1.61 & 0.32 & 0.23 & 1. 70 & 3.43 & 19.92 \\
\hline $1898 \ldots$ & 4. 02 & 2.29 & 2.34 & 1.20 & 2.69 & 0.72 & 0.40 & 1.61 & 0.21 & 1.20 & 1.91 & 3.30 & 21.89 \\
\hline Average. & 2.29 & 2. 72 & 2.41 & 1.38 & 2.73 & 0.79 & 0.84 & 1.14 & 0.27 & 0.56 & 1.38 & 2.35 & 18.86 \\
\hline \multicolumn{14}{|c|}{ POTOMAC, AT POINT OF ROCKS. } \\
\hline 1895. & 0.77 & 2.62 & 1.55 & 1.45 & 0.43 & 0.46 & 0.22 & 0.17 & 0.12 & 0.13 & 0.25 & a1. 13 & 9.30 \\
\hline 1896. & 0.67 & 1.23 & a1. 95 & a1. 60 & 0.27 & 0.69 & 1.15 & 0.49 & 0.31 & 1.61 & 0.84 & 0.64 & 11.45 \\
\hline 1897. & 0.60 & 4.50 & 2.41 & 1.43 & 2. 70 & 0.72 & 0.64 & 0.43 & 0.16 & 0.12 & 0.31 & 0.85 & 14.87 \\
\hline 1898. & 2.84 & 0.96 & 1.90 & 1.93 & 2.26 & 0.50 & 0.30 & 2.78 & 0.30 & 1.72 & 1.05 & 1.91 & 18.45 \\
\hline Average. & 1.22 & 2.33 & 1.95 & 1.60 & 1.42 & 0.59 & 0.58 & 0.97 & 0.22 & 0.90 & 0.61 & 1.13 & 13.52 \\
\hline \multicolumn{14}{|c|}{ POTOMAC, AT GREAT FALLS AND CHAIN BRIDGE. } \\
\hline 1886. & 1.43 & 2.20 & 0.58 & 4.46 & 2.52 & 0.30 & 0.55 & 0.63 & 0.34 & 0.35 & 0.80 & 1.14 & 15.30 \\
\hline $1887 \ldots \ldots$ & 1.27 & 2.28 & 2.84 & 1. 42 & 2. 62 & 1.43 & 0.64 & 0.37 & 0.37 & 0.35 & 0.33 & 0.58 & 14.50 \\
\hline 1888 & 1.33 & 2. 70 & 3.01 & 1.82 & 1.11 & 0.88 & 1. 94 & 0.51 & 1. 70 & 0.74 & 1.66 & 1.43 & 18. 83 \\
\hline $1880 \ldots$ & 3.26 & 1. 77 & 3.95 & 3.61 & 1. 98 & 4.65 & 1.00 & 1.71 & 2.57 & 3. 08 & 6.58 & 2.90 & 37.06 \\
\hline $1890 \ldots$ & 1.01 & 3.68 & 5.09 & 2.56 & 5.26 & 2.07 & 0.67 & 0.71 & 0.80 & 2.46 & 0.94 & 0.88 & 26.13 \\
\hline $1891 \ldots$ & 4.25 & 7.54 & 6.23 & 7. 22 & 0.65 & 2.23 & 1.22 & 0.74 & 0.61 & 0.41 & 0.46 & 1.01 & 32.57 \\
\hline $1892 \ldots$ & 3.18 & 0.98 & 4. 79 & 3.56 & 1.13 & 1.36 & 0.35 & 0.39 & 0.46 & 0.31 & 0.34 & 0.52 & 17.37 \\
\hline $1893 \ldots$ & 0.54 & 1.67 & 2.72 & 1.61 & 3.44 & 1.10 & 0.46 & 0.57 & 1.40 & 3.14 & 1.24 & 0.56 & 18.45 \\
\hline Average & 2.03 & 2.85 & 3.65 & 3.28 & 2.34 & 1. 75 & 0.85 & 0.70 & 1.03 & 1.36 & 1.54 & 1.13 & 22.53 \\
\hline
\end{tabular}


Depth of run-off, in inches, from Fotomac drainage basin-Continued.

NORTH, AT PORT REPUBLIC.

\begin{tabular}{|c|c|c|c|c|c|c|c|c|c|c|c|c|c|}
\hline Year. & Jan. & Feb. & Mar. & Apr. & May. & June. & July. & Ang. & Sept. & Oct. & Nor. & Dec. & Annual. \\
\hline 1895. & & & & & & & $\cdots$ & 0.46 & 0.49 & 0.31 & .33 & 0.36 & \\
\hline 1896. & 1.14 & 1: 93 & 2.37 & 2.21 & 1.18 & 0.89 & 1.56 & 0.66 & 1.70 & 1. 34 & 1.51 & 1.00 & 17.49 \\
\hline 1897. & 0.55 & 4.06 & 1.79 & 0.89 & 3.17 & 0.68 & 0.67 & 0.41 & 0.32 & 0.35 & 0.36 & 0.45 & 13.70 \\
\hline $1898 \ldots$ & 0.70 & 0.53 & 0.80 & 1.54 & 2.05 & 0.81 & 1.18 & 4. 35 & 0.72 & 2. 61 & 0.70 & 1.56 & 17.55 \\
\hline Average & 0.80 & 2.17 & 1.65 & J. 55 & 2.13 & 0.79 & 1.14 & 1.47 & 0.81 & 1.15 & 0.73 & 0.84 & 16.25 \\
\hline \multicolumn{14}{|c|}{ SOUTH, AT PORT REPUBLIC. } \\
\hline 1895. & & & & & & & & 0.38 & 0.43 & 0.40 & 0.43 & 0.63 & \\
\hline 1896. & 1.43 & 2.19 & 1.28 & 1. 70 & 1.02 & 1.16 & 1.51 & 0.58 & 2.71 & 1.69 & 1.71 & 0.98 & 17.96 \\
\hline $1897 .$. & 0.61 & 4.54 & 2.16 & 0.95 & 3.74 & 0.69 & 0.59 & 0.48 & 0.41 & 0.55 & 0.87 & 0.77 & 16.36 \\
\hline $1898 .$. & 0.82 & 0.69 & 0.83 & 1.85 & 2.63 & 0.69 & 0.67 & 3.23 & 0.55 & 3.91 & 1.28 & 2.27 & 19.42 \\
\hline Average. & 0.95 & 2.47 & 1.42 & 1.50 & 2.46 & 0.85 & 0.92 & 1.17 & 1.03 & 1.64 & 1.07 & 1.16 & 16.64 \\
\hline
\end{tabular}

Annual rainfall and run-off.

\begin{tabular}{|c|c|c|c|c|}
\hline Station. & Normal. & 1896. & 1897. & 1898. \\
\hline RAINFALL. & Inches. & Inches. & Inches. & Inches. \\
\hline Cumberland.... & 33.20 & 37.54 & 36.03 & 41.33 \\
\hline Martinsburg $\ldots \ldots \ldots \ldots \ldots \ldots \ldots \ldots$ & 34.04 & 31. 78 & 35.34 & 38.60 \\
\hline Staunton................... & 37.45 & 46.15 & 31.98 & 40.13 \\
\hline Dale Enterprise..$\ldots \ldots \ldots \ldots \ldots \ldots$ & 42.31 & 36.73 & 32.99 & 50.38 \\
\hline Woodstock................... & 37.78 & $\ldots \ldots \ldots$ & 39.36 & 39.15 \\
\hline Harpers Ferry ................. & 34.38 & 34.33 & 43.25 & 44.48 \\
\hline Emmitsburg $\ldots \ldots \ldots \ldots \ldots \ldots$ & 43.29 & 42.50 & 46. 60 & 42.92 \\
\hline Frederick .................. & 39.43 & 31.81 & 38.35 & 44.93 \\
\hline Newmarket $\ldots \ldots \ldots \ldots \ldots \ldots \ldots$ & 42.96 & 35.13 & 49.56 & 39.38 \\
\hline 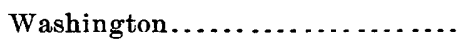 & 42.90 & 31. 16 & 44.58 & 37.72 \\
\hline Average.... & 38.77 & 36. 35 & 39.80 & 41. 90 \\
\hline RUN-OFF. & & & & \\
\hline 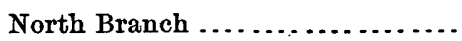 & 17.24 & 18.72 & 16.74 & \\
\hline North (Port Republic) ............ & 16.25 & 16.61 & 13.70 & 17.55 \\
\hline South (Port Republic)............. & 16.64 & 17.96 & 16. 36 & 19.42 \\
\hline Shenandoah . ........ & 12.06 & 11. 72 & 11.43 & 13.04 \\
\hline Antietam Creek .............. & 12.86 & ........... & $\ldots \ldots$ & 14.49 \\
\hline Monocacy ......... & 18.86 & . & 19.92 & 21.89 \\
\hline Potomac $\ldots \ldots \ldots \ldots \ldots \ldots \ldots$ & 13.52 & 11.45 & 14.87 & 18.45 \\
\hline$\ldots \ldots \ldots \ldots \ldots \ldots$ & 22.53 & $\ldots \ldots$ & $\ldots \ldots \ldots$ & $\ldots \ldots \ldots$ \\
\hline Average. & 16.24 & 15.47 & 15.50 & 17.47 \\
\hline Percentage of rainfall.... & 41.89 & 42.56 & 38.94 & 41. 69 \\
\hline
\end{tabular}




\section{ANTIETAM CREEK.}

Estimated monthly discharge of Antietain Creek at Sharpsburg, Maryland.

[Drainage area, 293 square miles.]

\begin{tabular}{|c|c|c|c|c|c|c|}
\hline \multirow[b]{2}{*}{ Month. } & \multicolumn{3}{|c|}{ Discharge in second-feet. } & \multirow[b]{2}{*}{$\begin{array}{l}\text { Total in acre- } \\
\text { feet. }\end{array}$} & \multicolumn{2}{|c|}{ Run.off. } \\
\hline & $\begin{array}{l}\text { Maxi- } \\
\text { mum. }\end{array}$ & $\begin{array}{l}\text { Mini. } \\
\text { mum. }\end{array}$ & Mean. & & $\begin{array}{l}\text { Depth in } \\
\text { inches. }\end{array}$ & $\begin{array}{c}\text { Second- } \\
\text { feet per } \\
\text { square } \\
\text { mile. }\end{array}$ \\
\hline 1898. & & & & & & \\
\hline January . . . . . . . . . & 618 & 80 & 321 & 19,738 & 1.27 & 1. 10 \\
\hline February .......... & 510 & 233 & 331 & 18,383 & 1.18 & 1.13 \\
\hline March........... & 673 & 233 & 336 & 20,660 & 1.33 & 1.15 \\
\hline April ....... & 479 & 264 & 344 & 20,469 & 1.31 & 1. 17 \\
\hline May ........ & 673 & 233 & 393 & 24,165 & 1. 54 & 1.34 \\
\hline June ...... & 356 & 171 & 256 & 15,233 & 0.97 & 0.87 \\
\hline July & 294 & 138 & 173 & 10,637 & 0.68 & 0.59 \\
\hline Angust. . . . . & $1 ; 708$ & 171 & 340 & 20,906 & 1. 34 & 1.16 \\
\hline September .. & 264 & 138 & 188 & 11,187 & 0.71 & 0.64 \\
\hline October ..... & 510 & 80 & 212 & 13,035 & 0.83 & 0.72 \\
\hline November ... & 417 & 138 & 276 & 16,423 & 1.04 & 0.94 \\
\hline December ......... & 3,275 & 233 & 584 & 35,909 & 2.29 & 1.99 \\
\hline .. The year ..... & 3,275 & 80 & 313 & 226,745 & . 14.49 & 1.07 \\
\hline
\end{tabular}

NoTE.-Gage heights for 1898 are given in Water-Supply and Irrigation Paper No. 2i, page 19, measurements, page 23; rating table, page 24; results for 1897 in Water-Supply and Irrigation Paper No. 15, page 16, and in the Nineteenth Annual Report, Part IV, page 148.

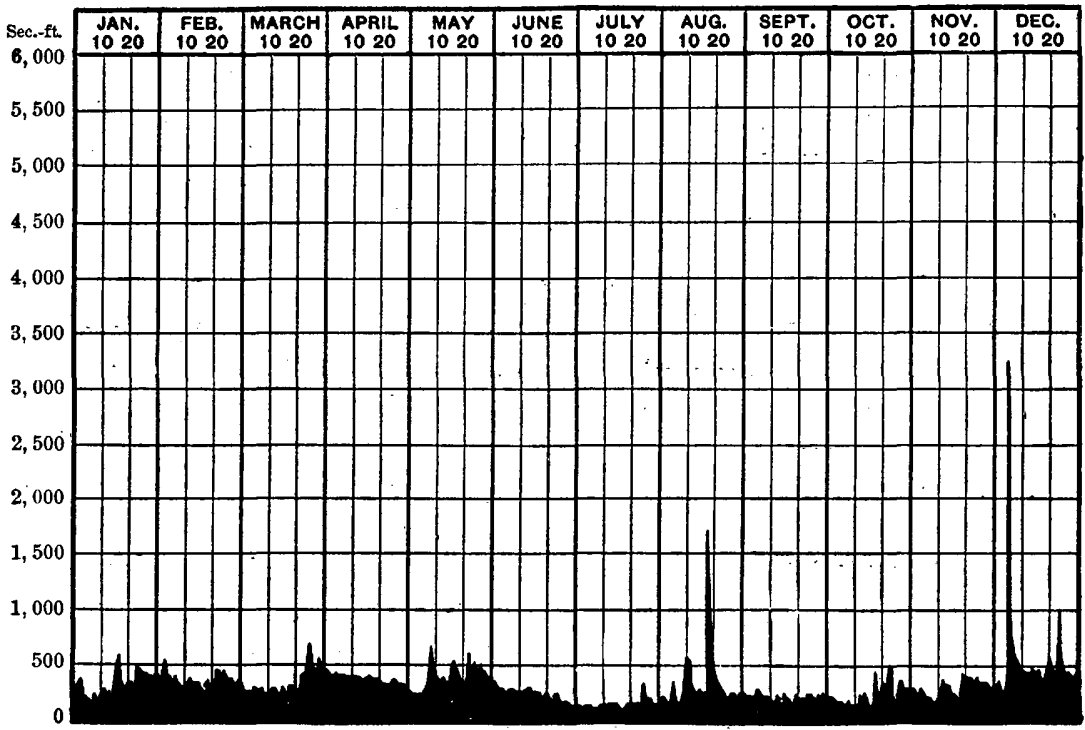

Frg. 28.-Discharge of Antietam Creek at Sharpsburg, Máryland, 1898. 
SHENANDOAH RIVER.

NORTH RIVER.

Estimated monthly discharge of North River at Port Republic, Virginia.

[Drainage area, 804 square miles.]

\begin{tabular}{|c|c|c|c|c|c|c|}
\hline \multirow[b]{2}{*}{ Month. } & \multicolumn{3}{|c|}{ Discharge in second-feet. } & \multirow[b]{2}{*}{$\begin{array}{l}\text { Total in acre- } \\
\text { feet. }\end{array}$} & \multicolumn{2}{|c|}{ Run-off. } \\
\hline & $\begin{array}{l}\text { Maxi- } \\
\text { mum. }\end{array}$ & $\begin{array}{l}\text { Mini- } \\
\text { mum. }\end{array}$ & Mean. & & $\begin{array}{l}\text { Depth in } \\
\text { inches. }\end{array}$ & $\begin{array}{l}\text { Second- } \\
\text { feet per } \\
\text { square } \\
\text { mile. }\end{array}$ \\
\hline 1895. & & & & & & \\
\hline August $6-31$. & $\cdot 445$ & 292 & 319 & a 19,614 & $a 0.46$ & a 0.40 \\
\hline September .... & 2,635 & 245 & 346 & 20,588 & 0.49 . & 0.44 \\
\hline October...... & 245 & 202 & 219 & 13,466 & 0.31 & 0.27 \\
\hline November... & 275 & 202 & 239 & 14,222 & 0.33 & 0.30 \\
\hline December ....... & 500 & 215 & 251 & 15,433 & 0.36 & 0.31 \\
\hline 1896. & & & & & & \\
\hline January . & 5,502 & 275 & 799 & 49,129 & 1.14 & 0.99 \\
\hline February .. & 4,805 & 500 & 1,488 & 82,639 & 1.93 & 1.85 \\
\hline March .......... & 7,130 & 445 & 1,653 & 101,640 & 2.37 & 2.05 \\
\hline April 1-15, 28-30... & 4,340 & 350 & 1,594 & 94,849 & 2.21 & 1.98 \\
\hline May ........ & 4,960 & 395 & 824 & 50,666 & 1. 18 & 1.02 \\
\hline June......... & 2,945 & 350 . & 642 & 38,202 & 0.89 & 0.80 \\
\hline July ..... & 7,595 & .472 & 1,085 & 66,714 & 1.56 & 1.35 \\
\hline August. ..... & 1,550 & 310 & 458 & 28,162 & 0.66 & 0.57 \\
\hline September . & 23,870 & 177 & 1,224 & 72,833 & 1.70 & 1.52 \\
\hline October..... & $7, \overline{5} 95$ & 420 & 931 & 57,245 & 1.34 & 1.16 \\
\hline November..... & 5,270 & 420 & 1,088 & 64,740 & 1.51 & 1.35 \\
\hline December ... & 2,790 & 420 & 699 & 42,980 & 1.00 & 0.87 \\
\hline The year. & 23,870 & 177 & 1,040 & 749,799 & 17.49 & 1.29 \\
\hline 1897. & & & & & & \\
\hline January ... & 420 & 372 & 388 & 23,857 & 0.55 & 0.48 \\
\hline February ..... & 11,237 & 420 & 3,138 & 174,276 & 4.06 & 3.90 \\
\hline March ......... & 2,015 & 625 & 1,250 & 76,860 & 1.79 & 1.55 \\
\hline April ..... & 865 & 445 & 642 & 38,202 & 0.89 & 0.80 \\
\hline May ....... & 13,795 & 445 & 2,212 & 136,011 & 3.17 & 2.75 \\
\hline June.......... & 865 & 420 & 489 & 29,097 & 0.68 & 0.61 \\
\hline July .......... & 1,420 & 330 & 463 & 28,469 & 0.67 & 0.58 \\
\hline August ........ & 330 & 275 & 292 & 17,954 & 0.41 & 0.36 \\
\hline September & 275 & 215 & 234 & 13,924 & 0.32 & 0.29 \\
\hline October ............ & 310 & 215 & 250 & 15,372 & 0.35 & 0.31 \\
\hline November......... & 555 & 215 & 256 & 15,233 & 0.36 & 0.32 \\
\hline December ......... & 590 & 230 & 319 & 19,615 & 0.45 & 0.39 \\
\hline The year. & 13,795 & 215 & 829 & 588,870 & 13.70 & 1.03 \\
\hline
\end{tabular}

$a$ Estimated. 


\section{PROGRESS OF STREAM MEASUREMLNTS FOR 1898.}

Estimated monthly discharge of North River at Port Republic, Virginia-Continued.

[Drainage area, 804 square miles.

\begin{tabular}{|c|c|c|c|c|c|c|}
\hline \multirow[b]{2}{*}{ Month. } & \multicolumn{3}{|c|}{ Discharge in second-feet. } & \multirow[b]{2}{*}{$\begin{array}{l}\text { Total in acre- } \\
\text { feet. }\end{array}$} & \multicolumn{2}{|c|}{ Run-off. } \\
\hline & $\begin{array}{l}\text { Maxi- } \\
\text { mum. }\end{array}$ & $\begin{array}{l}\text { Mini- } \\
\text { mum. }\end{array}$ & Mean. & & $\begin{array}{c}\text { Depth in } \\
\text { inches. }\end{array}$ & $\begin{array}{c}\text { Second- } \\
\text { feet per } \\
\text { square } \\
\text { mile. }\end{array}$ \\
\hline 1898. & & & & . & & \\
\hline January.... & 700 & 275 & 491 & 30,191 & 0.70 & 0.61 \\
\hline February .. & 625 & 310 & 414 & 22,992 & 0.53 & 0.51 \\
\hline March .... & 2,480 & 310 & 581 & 35,725 & 0.80 & 0.72 \\
\hline April .... & 4,030 & 555 & 1,110 & 66,049 & 1.54 & 1.38 \\
\hline May ...... & 7,207 & 445 & 1,430 & 87,928 & 2.05 & 1.78 \\
\hline June ....... & 2,480 & 275 & 585 & 34,810 & 0.81 & 0.73 \\
\hline July ....... & 3,720 & 275 & 822 & 50,543 & 1.18 & 1.02 \\
\hline August..... & 9,920 & 555 & 3,030 & 186,309 & 4.35 & 3.77 \\
\hline September & 662 & 445 & 520 & 30,942 & 0.72 & 0.65 \\
\hline October..... & 11,470 & 275 & 1,814 & 111,539 & 2.61 & 2.26 \\
\hline November ........... & 865 & 330 & 507 & 30,169 & 0.70 & 0.63 \\
\hline December $\because$ & 6,820 & 395 & 1,089 & 66,960 & 1.56 & 1.35 \\
\hline The year. & 11,470 & 275 & 1,032 & 754,157 & 17.55 & 1.28 \\
\hline
\end{tabular}

Note.-Gage heights for 1898 are given in Water-Supply and Irriration Paper No 27 , page 19; rat ing table, page 25; results for 1897 in Water-Supply and Irrigation Paper No. 15, page 18, and in the Eighteenth Annual Report, Part IV, page 25.

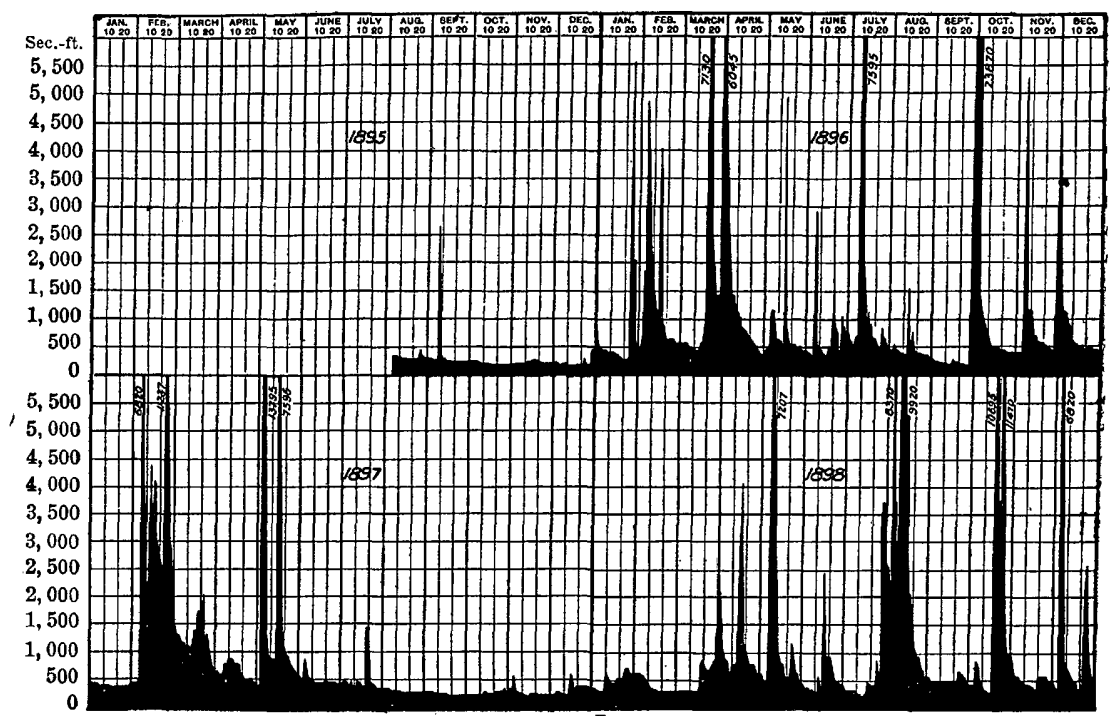

Fig. 29.-Discharge of North River at Port Republic, Virginia, 1895-1898. 
SOUTH RIVER.

Estimated monthly discharge of South River at Port Republic, Virginia.

[Drainage area, 246 square miles.]

\begin{tabular}{|c|c|c|c|c|c|c|}
\hline \multirow[b]{2}{*}{ Month. } & \multicolumn{3}{|c|}{ Discharge in second-feet. } & \multirow[b]{2}{*}{$\begin{array}{c}\text { Total in acre. } \\
\text { feet. }\end{array}$} & \multicolumn{2}{|c|}{ Run-off. } \\
\hline & $\begin{array}{l}\text { Maxi- } \\
\text { mum. }\end{array}$ & $\begin{array}{l}\text { Mini- } \\
\text { mum. }\end{array}$ & Mean. & & $\begin{array}{c}\text { Depth in } \\
\text { inches. }\end{array}$ & $\begin{array}{c}\text { Second- } \\
\text { feet per } \\
\text { square } \\
\text { mile. }\end{array}$ \\
\hline 1895. & & & . & & & \\
\hline August $6-31 \ldots \ldots \ldots$ & 105 & 70 & 80 & 4,919 & 0.38 & 0.33 \\
\hline September ......... & 112 & 85 & 94 & 5,593 & 0.43 & 0.38 \\
\hline October ............ & 85 & 85 & 85 & 5,226 & 0.40 & 0.35 \\
\hline November . . . . . . . . & 95 & 85 & 93 & 5,534 & 0.43 & 0.38 \\
\hline December ........... & 290 & 95 & 136 & 8,362 & 0.63 & 0.55 \\
\hline 1896. & & & & & & \\
\hline January............ & 2,350 & 85 & 305 & 18,754 & 1. 43 & 1.24 \\
\hline February ........... & 1,390 & 250 & 517 & 28,713 & 2.19 & 2. 10 \\
\hline 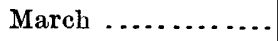 & 1,905 & 195 & 473 & 29,084 & 1.28 & 1.11 \\
\hline April ................. & 1,090 & 160 & 375 & 22,314 & 1.70 & 1. 52 \\
\hline May ................ & 945 & 140 & 218 & 13,404 & 1. 02 & 0.89 \\
\hline June............. & 570 & 120 & 255 & 15,174 & 1.16 & 1.04 \\
\hline July .............. & 2,275 & 120 & 322 & 19,799 & 1.51 & 1.31 \\
\hline August. . . . . . . . . . & 250 & 105 & 123 & 7,563 & 0.58 & 0.50 \\
\hline September .......... & 9,200 & 90 & 597 & 35,524 & 2.71 & 2.43 \\
\hline October .............. & 2,425 & 140 & 362 & 22,258 & 1. 69 & 1. 47 \\
\hline November... & $\mathbf{1}, 760$ & 140 & 376 & 22,374 & 1.71 & 1.53 \\
\hline December . . . . . . . & 720 & 112 & 208 & 12,790 & 0.98 & 0.85 \\
\hline The year & 9,200 & 85 & 344 & 247,751 & 17.96 & 1. 33 \\
\hline 1897. & & & & - & & \\
\hline January . . . . . & 195 & 112 & 131 & 8,055 & 0.61 & 0.53 \\
\hline February .. & 3,717 & 195 & 1,072 & 59,536 & 4.54 & 4.36 \\
\hline March ..... & 720 & 250 & 459 & 28,223 & 2.16 & 1.87 \\
\hline April $\ldots \ldots \ldots \ldots$ & 290 & 170 & 211 & 12,555 & 0.95 & 0.86 \\
\hline 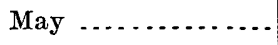 & 5,607 & 170 & 797 & 49,006 & 3.74 & 3.24 \\
\hline June . . . . . . . . . . . & 210 & 120 & 152 & 9,045 & 0.69 & 0.62 \\
\hline July ........ & 160 & 105 & 125 & 7,686 & 0.59 & 0.51 \\
\hline August. . . . . . . . . & 120 & 85 & 103 & 6,333 & 0.48 & 0.42 \\
\hline September ..... & 95 & 85 & 91 & 5,415 & 0.41 & 0.37 \\
\hline October ............. & 250 & 95 & 119 & $7, \mathbf{3 1 7}$ & 0.55 & 0.48 \\
\hline November... & 795 & 120 & 192 & 11,425 & 0.87 & 0.78 \\
\hline December ............ & 495 & 112 & 166 & 10,207 & 0.77 & 0.67 \\
\hline The year.... & 5,607 & 85 & 301 & 214,803 & 16.36 & 1.23 \\
\hline
\end{tabular}


Estimated monthly discharge of South River at Port Republic, Virginia-Continued.

[Drainage area, 246 square miles.]

\begin{tabular}{|c|c|c|c|c|c|c|}
\hline \multirow[b]{2}{*}{ Month. } & \multicolumn{3}{|c|}{ Discharge in second-feet. } & \multirow[b]{2}{*}{$\begin{array}{l}\text { Total in acre- } \\
\text { feet. }\end{array}$} & \multicolumn{2}{|c|}{ Run-off. } \\
\hline & $\begin{array}{l}\text { Maxi- } \\
\text { mum. }\end{array}$ & $\begin{array}{l}\text { Mini- } \\
\text { mum. }\end{array}$ & Mean. & & $\begin{array}{l}\text { Depth in } \\
\text { feet. }\end{array}$ & $\begin{array}{l}\text { Second. } \\
\text { teet per } \\
\text { square } \\
\text { mile. }\end{array}$ \\
\hline 1898. & & & & & & \\
\hline January ........... & 250 & 130 & 175 & 10,760 & 0.82 & 0.71 \\
\hline February .......... & 250 & 120 & 162 & 8,997 & 0.69 & 0.66 \\
\hline March ..... & 350 & 120 & 177 & 10,883 & 0.83 & 0.72 \\
\hline April ..... & 945 & 250 & 408 & 24,278 & 1.85 & 1.66 \\
\hline May ....... & 2,425 & 180 & 561 & 34,495 & 2.63 & 2.28 \\
\hline June ....... & 195 & 120 & 153 & 9,104 & 0.69 & 0.62 \\
\hline July ........ & 290 & 105 & 142 & 8,731 & 0.67 & 0.58 \\
\hline August...... & 3,605 & 140 & 690 & 42,427 & 3.23 & 2.80 \\
\hline September .. & 150 & 100 & 121 & 7,200 & 0.55 & 0.49 \\
\hline October..... & 4,345 & 100 & 835 & 51,342 & 3.91 & 3.39 \\
\hline November .......... & 570 & 195 & 282 & 16,780 & 1.28 & 1.15 \\
\hline December ........... & 1,685 & 180 & 484 & 29,760 & , $\quad 2.27$ & 1.97 \\
\hline The year. & 4,345 & 100 & 349 & 254,757 & 19.42 & 1.42 \\
\hline
\end{tabular}

NoTE.-Gage heights for 1898 are given in Water-Supply and Irrigation Paper No. 27, page 20; rating table, page 25; results for 1897 in Water.Supply and Irrigation Paper No. 15, pago 18, and in the Eighteenth Annual Report, Part IV, page 25.

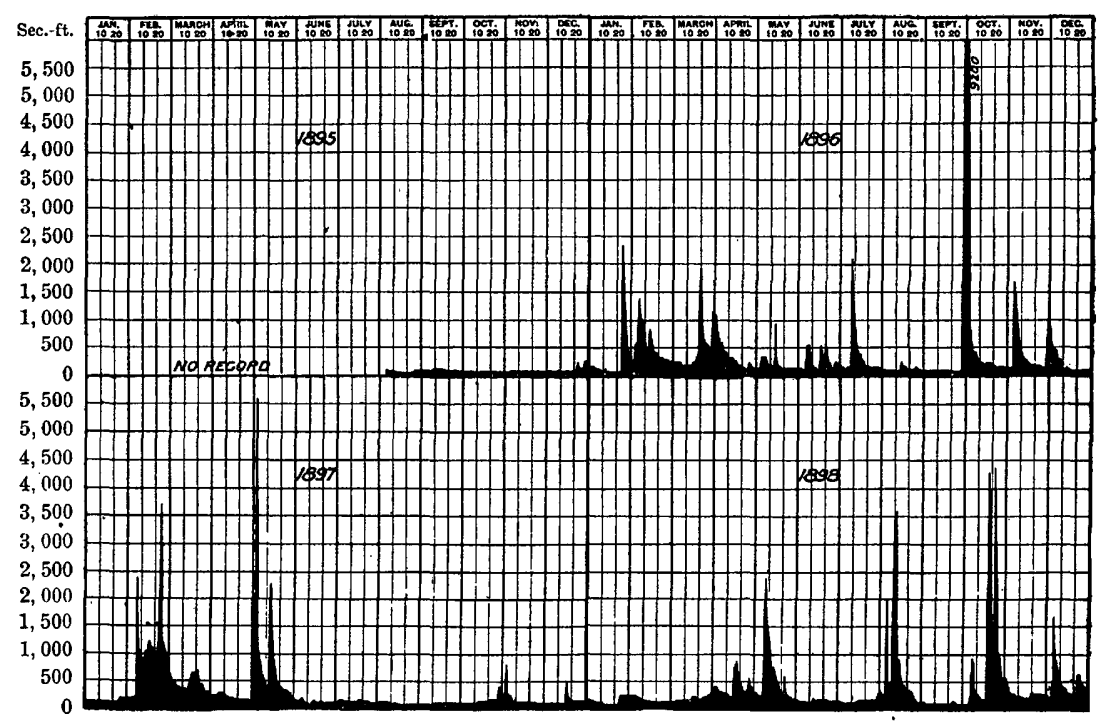

Fia. 30.-Discharge of South River at Port Republic, Virginia, 1895-1898. 
SHENANDOAF RIVER AT MILLVILLE.

The foregoing tables, beginning on page 123, give the discharge of a relatively small portion of the head waters of Shenandoah River. The main stream has been measured at Millville, West Virginia, about 4 miles above the junction with Potomac River. The results giv́e practically the entire flow from the Shenandoah Valley and tributary country. These measurements, as well as those along Potomac River, have been made by Mr. Edwin G. Paul, assistant hydrographer. The daily fluctuations for $\mathbf{1 8 9 8}$ are shown graphically on the next page, fig. 31 , together with those for the preceding year. In the case of 1897 the greater part of the discharge occurred during the late winter or early spring, while in 1898 the greatest flows were in August and October.

Estimated monthly discharge of Shenandoah River at Millville, West Virginia.

[Drainage area, 2,995 square miles.]

\begin{tabular}{|c|c|c|c|c|c|c|}
\hline \multirow[b]{2}{*}{ Month. } & \multicolumn{3}{|c|}{ Discharge in second-feet. } & \multirow{2}{*}{$\begin{array}{c}\text { Total in acre- } \\
\text { feet. }\end{array}$} & \multicolumn{2}{|c|}{ Run-off. } \\
\hline & $\begin{array}{l}\text { Maxi- } \\
\text { mum. }\end{array}$ & $\begin{array}{l}\text { Mini. } \\
\text { mum. }\end{array}$ & Mean. & & $\begin{array}{l}\text { Depth in } \\
\text { inches. }\end{array}$ & $\begin{array}{l}\text { Second- } \\
\text { feet per } \\
\text { square } \\
\text { mile. }\end{array}$ \\
\hline 1898. & & - & & & & \\
\hline January ............. & 4,840 & 650 & 1,594 & 98,012 & 0.59 & 0.53 \\
\hline February......... & 1,650 & 650 & 988 & 54,871 & 0.34 & 0.33 \\
\hline 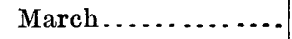 & 4,370 & 650 & 1,520 & 93,462 & 0.57 & 0.51 \\
\hline April..... & 10,530 & 1,270 & 3,136 & 186,605 & 1.17 & 1.05 \\
\hline May ....... & 22,555 & 1,160 & 4,239 & 260,648 & 1.64 & 1. 42 \\
\hline June..... & 1,520 & 710 & 1,000 & 59,504 & 0.37 & 0.33 \\
\hline July ..... & 1,800 & 650 & 833 & 51,220 & 0.32 & 0.28 \\
\hline August..... & 34,235 & 780 & 8,173 & 502,541 & 3.15 & 2.73 \\
\hline September .. & 1,800 & 990 & 1,188 & 70,691 & 0.45 & 0.40 \\
\hline October ............. & 24,745 & 920 & 9,464 & 305,226 & 1.91 & 1. 66 \\
\hline November... & 3,930 & 1,800 & 2,557 & 152,152 & 0.94 & 0.85 \\
\hline December ....... & 13,430 & 2,130 & 4,130 & 253,945 & 1.59 & 1. 38 \\
\hline The year..... & 34,235 & 650 & 3,233 & $2,088,877$ & 13.04 & 0.96 \\
\hline
\end{tabular}

NoтE.-Gage heights for 1898 are given in Water-Supply and Irrigation Paper No. 27, page 20; measurements, page 23; rating table, page 25; results for 1897 in Water-Supply and Irrigation Paper No. 15, page 19, and in the Nineteenth Anuual Report, Part IV, page 150. 


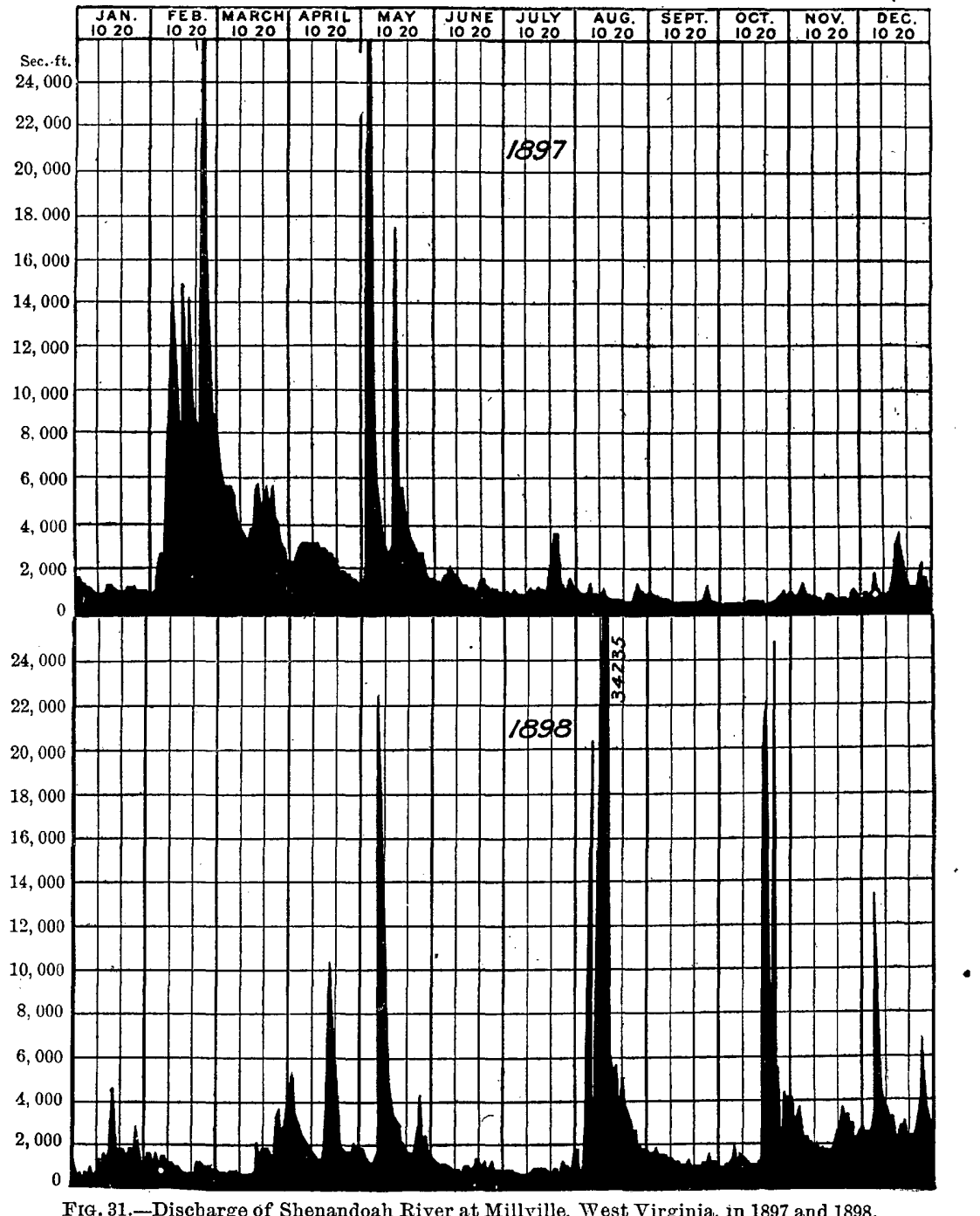

Observations at Millville were begun on April 15, 1895, as described in Bulletin No. 140, page 53. The fluctuations of discharge for the years 1895 and 1896 are shown graphically in form similar to the above, fig. 31, in the Eighteenth Annual Report, Part IV, on page 29. 


\section{MONOCACY RIVER.}

Monocacy River is a tributary of the Potomac entering below Point of Rocks, where the main stream is measured, and above the Great Falls of the Potomac. It has not been found practicable to make accurate measurements of discharge near the falls, and in order to obtain data regarding the water power available a river station has been established at Point of Rocks and on the Monocacy. The total discharge obtained by adding the results secured at these two places represents fairly well the flow above the city of Washington, although there is a small area drained below the points of measurement and above the head works of possible water-power plants. The results for 1898 are shown in the following table, and are graphically compared with those for 1897 in fig. 32 , on the next page.

Estimated monthly discharge of Monocacy River at Frederick, Maryland.

[Drainage area, 665 square miles.]

\begin{tabular}{|c|c|c|c|c|c|c|}
\hline \multirow[b]{2}{*}{ Month. } & \multicolumn{3}{|c|}{ Discharge in second-feet. } & \multirow[b]{2}{*}{$\begin{array}{l}\text { Total in acre- } \\
\text { feet. }\end{array}$} & \multicolumn{2}{|c|}{ Run-off. } \\
\hline & $\begin{array}{l}\text { Maxj. } \\
\text { mum. }\end{array}$ & $\begin{array}{l}\text { Mini- } \\
\text { mum. }\end{array}$ & Mean. & & $\begin{array}{l}\text { Depth in } \\
\text { inches. }\end{array}$ & $\begin{array}{l}\text { Second. } \\
\text { feet per } \\
\text { square } \\
\text { mile. }\end{array}$ \\
\hline 1898. & & & & 、 & & - \\
\hline January ............ & 6,825 & 600 & 2,315 & 142,345 & 4.02 & 3.48 \\
\hline February .......... & 8,588 & 500 & 1,466 & 81,418 & 2.29 & 2.20 \\
\hline 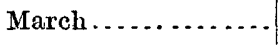 & 5,105 & 460 & 1,348 & 82,886 & 2.34 & 2.03 \\
\hline 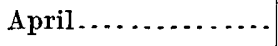 & 1,966 & 420 & 717 & 42,664 & 1. 20 & 1.08 \\
\hline 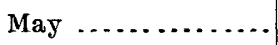 & 7,384 & 340 & 1,550 & 95,306 & 2.69 & 2.33 \\
\hline June . . . . . . . . . . . . & 750 & 270 & 429 & 25,527 & 0.72 & 0.65 \\
\hline July $\ldots . . . \ldots \ldots$ & 700 & 120 & 235 & 14,450 & 0.40 & 0.35 \\
\hline August............ & 6,524 & 150 & 933. & 57,368 & 1.61 & 1. 40 \\
\hline September ......... & 210 & 90 & 128 & 7,616 & 0.21 & 0.19 \\
\hline October ............... & 5,793 & 90 & 689 & 42,365 & 1. $20^{\circ}$ & 1.04 \\
\hline November............ & 6,481 & 270 & 1,134 & 67,478 & 1.91 & 1.71 \\
\hline December ........... & 11,297 & 500 & 1,899 & 116,766 & 3.30 & 2.86 \\
\hline The year..... & 11,297 & 90 & 1,070 & 776,189 & 21.89 & 162 \\
\hline
\end{tabular}

Note.-Gage heights for 1898 are given in Water-Supply and Irrigation Paper No. 2i, pàge 21; measurements, page 24; rating table, page 25; results for 1897 in Water-Supply and Irrigation Paper No. 15, page 20, and in the Nineteentl Annual Report, Part IV, page 153.

$$
20 \text { GEOL, PT } 4 \longrightarrow 9
$$




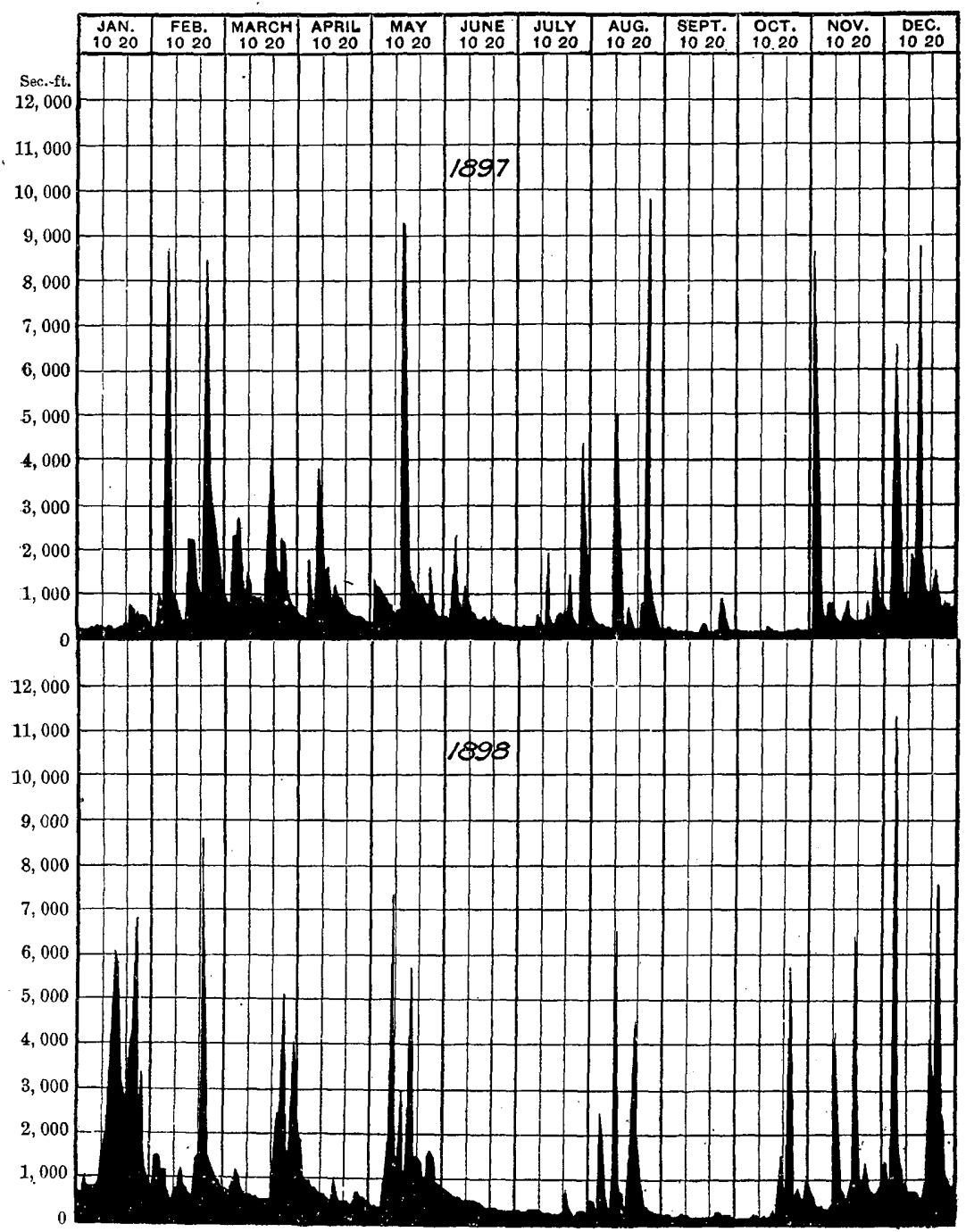

FIG. 32.-Discharge of Monocacy River at Frederick, Maryland, 1897 and 1898.

POTOMAC RIVER AT POINT OF ROCKS.

The nearest point above the city of Washington at which the flow of Potomac River can be economically and accurately measured has been found to be Point of Rocks, Maryland. The principal tributary entering below this point is Monocacy River, as stated on page 129 . The results obtained at this lattel locality added to those at Point of Rocks give approximately the total discharge above Great Falls: 
Estimated monthly discharge of Potomac River at Point of Rocks, Maryland.

[Drainage area, 9,654 square miles.]

\begin{tabular}{|c|c|c|c|c|c|c|}
\hline \multirow[b]{2}{*}{ Month. } & \multicolumn{3}{|c|}{ Discharge in second-feet. } & \multirow[b]{2}{*}{$\begin{array}{l}\text { Total in acre } \\
\text { feet. }\end{array}$} & \multicolumn{2}{|c|}{ Run-off. } \\
\hline & Maximum. & $\begin{array}{l}\text { Mini- } \\
\text { mum. }\end{array}$ & Mean. & & $\begin{array}{c}\text { Depth in } \\
\text { inches. }\end{array}$ & $\begin{array}{l}\text { Second- } \\
\text { feet per } \\
\text { square } \\
\text { mile. }\end{array}$ \\
\hline 1898. & & & & & . & \\
\hline January..... & 59,300 & 12,300 & 23,716 & $1,458,249$ & 2.84 & 2. 46 \\
\hline February ... & 18,850 & 6,250 & 8,896 & 494,059 & 0.96 & 0.92 \\
\hline March .... & 69,200 & 4,900 & 15,898 & 977,536 & 1.90 & 1.65 \\
\hline April ..... & 55,700 & 9,600 & 16,702 & $.993,835$ & 1.93 & 1. 73 \\
\hline May ...... & 74,150 & 6,700 & 18,897 & $1,161,939$ & 2.26 & 1.96 \\
\hline June..... & 8,600 & 1,700 & 4,383 & 260,806 & 0.50 & 0.45 \\
\hline July ...... & 6,250 & 1,350 & 2,497 & 153,536 & 0.30 & 0.26 \\
\hline Angust... & 119,150 & 4,000 & 23,255 & $1,429,903$ & 2.78 & 2.41 \\
\hline September . & 4,000 & 2,050 & 2,627 & 156,317 & 0.30 & 0.27 \\
\hline October.... & 92,600 & 1,700 & 14,350 & 882,353 & 1.72 & 1. 49 \\
\hline November.. & 16,000 & 5,800 & 9,148 & 544,343 & 1.05 & 0.95 \\
\hline December .... & 57,500 & 7,600 & 15,989 & 983,132 & 1.91 & 1.66 \\
\hline The year... & 119,150 & 1,350 & 13,030 & $9,496,008$ & 18.45 & 1.35 \\
\hline
\end{tabular}

Note.-Gage heights for 1898 are given in Water-Supply and Irrigation Paper Ro. 27, page 21; measurements, page 24; rating table, page 25; results for 1897 in Water-Supply and Irrigation Paper No. 15, page 21. and in the Nineteentl Annual Report, Part IV, page 153

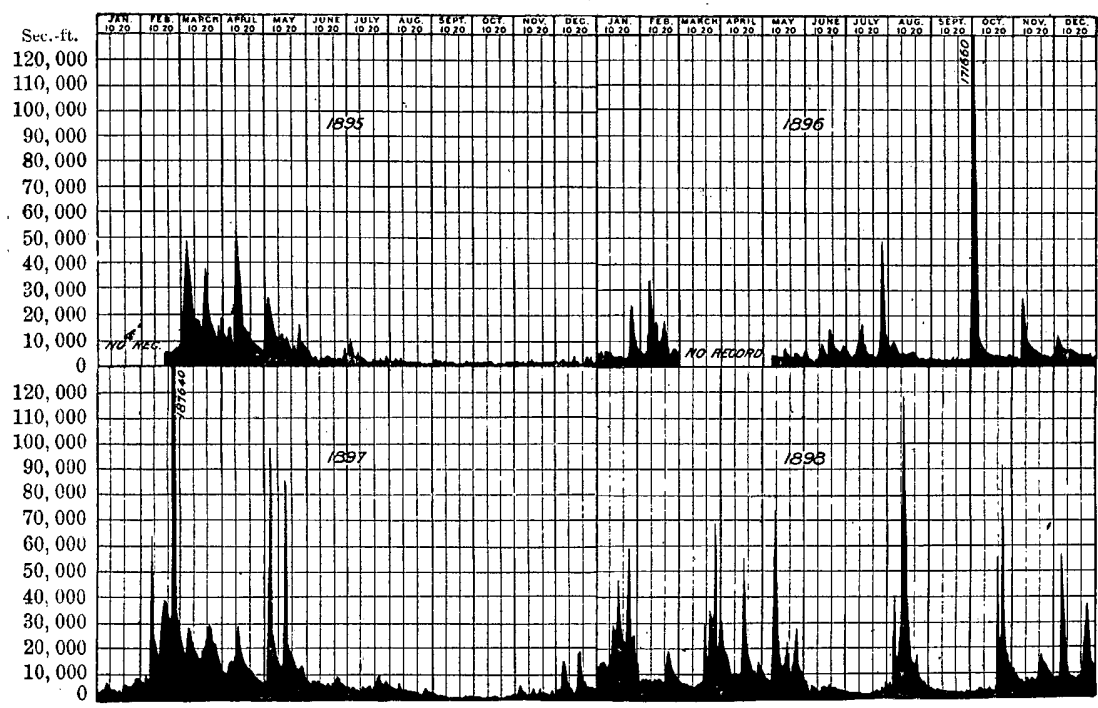

FIG. 33.-Discharge of Potomac River at Point of Rocks, Maryland, 1895-1898. 


\section{PARK STATION, ON ROCK CREEK.}

Gage heights for 1898 are given in Water-Supply and Irrigation Paper No. 27, page 22; measurements, page 24: results for 1897 in Water-Supply and Irrigation Paper No. 15, page 22, and in the Nineteenth Annual Report, Part IV, page 155.

\section{JAMES RIVER.}

Measurements on the headwaters of James River have been continued during 1898; the work being under the direction of Prof. D. C. Humphreys, of Lexington, Virginia. The results at special points have been shown in earlier reports, together with a general description of the water powers along the James, for which reference should be made to the Nineteenth Annual Report, Part IV.

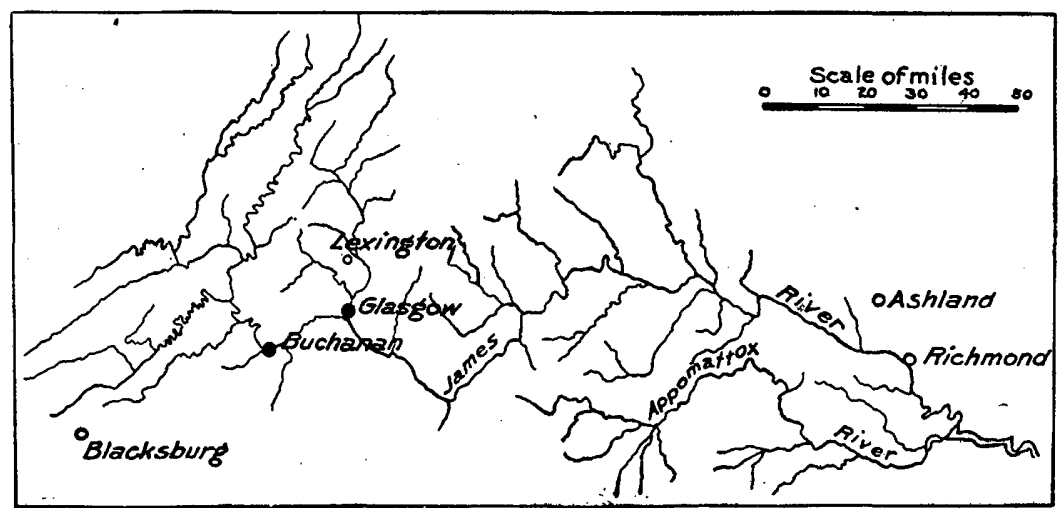

FIG. 34.- Relative location of river and rainfall observations in basin of James River.

PRECIPITATION IN THE BASIN OF. JAMES RIVER.

The principal observations of rainfall made within or near the basin of James River are at Lexington, Blacksburg, Ashland, Richmond, and Buckingham. The relative location of these places is shown on fig. 40, in connection with the points of river measurements which are at Buchanan and Glasgow. The following table gives the names and locations of the stations, and the lengths of the records:

Location of rainfall stations.

\begin{tabular}{|c|c|c|c|c|c|}
\hline Station. & County. & State. & Latitude. & $\begin{array}{l}\text { Longi- } \\
\text { tude. }\end{array}$ & $\begin{array}{l}\text { Length of } \\
\text { record. }\end{array}$ \\
\hline Lexington . & Rockbridge ... & Virginia & $\begin{array}{cc}\circ & , \\
37 & 46\end{array}$ & $\begin{array}{cc}\circ & \prime \\
79 & 28\end{array}$ & $\begin{array}{l}\text { Fears. } \\
24-26\end{array}$ \\
\hline Blacksburg . . . . . . & Montgomery & $\ldots .$. do .... & 3718 & 8027 & - \\
\hline Ashland ... & Hanover ....... & .....do .... & 3744 & 7736 & \\
\hline Richmond & Henrico....... & $\ldots$....do ... & 3731 & 7728 & 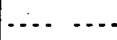 \\
\hline Buckingham............. & Buckingham & $\mid \ldots \ldots$ do .... & 3734 & 7839 & \\
\hline
\end{tabular}


In the following tables are given the figures of normal or average monthly precipitation from the time of the beginning of the record to and including 1897 ; together with the total precipitation by months for the years 1896, 1897, and 1898, and also the amount by years. In obtaining the normal precipitation the average is taken for all of the months during which observations were made.

Precipitation at stations in the drainage basin of James River.

LEXINGTON.

\begin{tabular}{|c|c|c|c|c|c|c|c|c|c|c|c|c|c|}
\hline Year. & Jan. & Feb. & Mar. & Apr. & May. & June. & July. & Aug. & Sept. & Oct. & Nov. & Dec. & Annual. \\
\hline Normal & 3.40 & 3.34 & 3.21 & 3.04 & 3.67 & 3.48 & 4.03 & 3.67 & 4.06 & 2.75 & 3. 11 & 2.60 & 40.36 \\
\hline $1896 \ldots$ & 2.93 & 4.21 & 4.97 & 1.11 & 1.55 & 4. 31 & 8.10 & 5.65 & 5.88 & 0.31 & 5.35 & 0.15 & $\dot{4} 4.52$ \\
\hline 1897. & 1.76 & 5.79 & 3.44 & 1.58 & 4. 63 & 3.33 & 3.99 & 3.03 & 1.09 & 2.56 & 2.44 & 3. 42 & 37.06 \\
\hline $1898 .:$ & $/ 2.58$ & 0.77 & 3.47 & 2.59 & 5.81 & 4.72 & 4.44 & 6.24 & 3.61 & 7.83 & 2.10 & 2.90 & 47.06 \\
\hline \multicolumn{14}{|c|}{ BLACKSBURG. } \\
\hline \multicolumn{14}{|l|}{ Normal ...... } \\
\hline 1896. & 1.51 & 3.65 & 6.53 & 3. 71 & 2.08 & 5.38 & 7.18 & 3.84 & 4.83 & 1.16 & 4.52 & 0.50 & 44.89 \\
\hline $1897 \ldots$ & 1.65 & 6.93 & 3.87 & 1.69 & 4.23 & 2.34 & 6.17 & 3.49 & 1.19 & 3.54 & 1.34 & 3.67 & 40.11 \\
\hline $1898 \ldots \ldots \ldots$ & 2.96 & 0.88 & 3.99 & 1.96 & 5.83 & 3.13 & 3.70 & 3.49 & 3.42 & 5.21 & 1.89 & 2.68 & 39.14 \\
\hline \multicolumn{14}{|c|}{ ASHLAND. } \\
\hline \multicolumn{14}{|l|}{ Normal ...... } \\
\hline $1896 \ldots$ & 2.35 & 3.56 & 4.12 & 2.00 & 3.37 & 3.67 & 6.64 & 1.46 & 5.49 & 0.56 & 2.42 & 0.51 & 36.15 \\
\hline $1897 \ldots$ & 1.52 & 6.26 & 4.56 & 2.82 & 3.01 & 3.64 & 4.93 & 2.28 & 0.80 & 6.93 & 3.47 & 2.67 & 42.89 \\
\hline $1898 \ldots \ldots \ldots$ & 1.61 & 0.78 & 4.18 & 5.09 & 6.05 & 3.94 & 4.42 & 4.82 & 2.86 & 4.33 & 1.93 & 3.33 & 43.34 \\
\hline \multicolumn{14}{|c|}{ RICHMOND. } \\
\hline \multicolumn{14}{|l|}{ Normal } \\
\hline $1896 \ldots \ldots \ldots$ & 2.98 & 4. 21 & 3.98 & 2.22 & 4.21 & 6.11 & 7.13 & 1.26 & 4.61 & 0.89 & 3.27 & 1.27 & 41.94 \\
\hline $1897 \ldots$ & 1.90 & 4.35 & 5.00 & 2.62 & 2.46 & 2.11 & 3.74 & 1.73 & 0.86 & 6.62 & 4.37 & 4.01 & 39. 77 \\
\hline $1898 \ldots$ & 1.72 & 0.81 & 3.43 & 4.71 & 6.95 & 2.34 & 3.50 & 4.74 & 3.22 & 4.89 & 2.93 & 3.25 & 42.49 \\
\hline \multicolumn{14}{|c|}{ BUCKINGHAM. } \\
\hline \multicolumn{14}{|l|}{ Normal ....... } \\
\hline 1896. & 3.30 & 3.74 & ..... & 2.02 & 4.96 & 4.41 & 6.09 & 2.27 & 4.83 & 0.29 & 3.79 & $\mathrm{~T}$. & $\ldots \ldots$ \\
\hline $1897 \ldots$ & 0.92 & 6.70 & 3.56 & 2.95 & 3.02 & 1.90 & 2.92 & 0.73 & 1.05 & 4. 72 & 3.47 & 2.77 & 34.71 \\
\hline $1898 \ldots$ & 2.00 & 0.40 & 2.23 & 3.20 & 3.53 & 1.75 & 5.00 & 3.90 & 2.08 & 6.60 & 2.17 & 3.56 & 36.42 \\
\hline \multicolumn{14}{|c|}{ AVERAGE. } \\
\hline Normal ... & 3.40 & 3.34 & 3.21 & 3.04 & 3.67 & 3.48 & 4.03 & 3.67 & 4.06 & 2. 75 & 3.11 & 2.60 & 40.36 \\
\hline $1896 \ldots$. & 2.61 & 3.87 & 4.90 & 2.21 & 3.23 & 4.78 & 7.03 & 2.90 & 5. 13 & 0.64 & 3.87 & 0.49 & 41.66 \\
\hline $1897 \ldots$ & 1.55. & 6.01 & 4.09 & 2.33 & 3.47 & 2.66 & 4.35 & 2.25 & 1.00 & 4.87 & 3.02 & 3.31 & 38.91 \\
\hline $1898 \ldots$ & 2.17 & 0.73 & 3.46 & 3.51 & 5.63 & 3. 19 & 4.21 & 4.64 & 3.04 & 5.77 & 2.20 & 3.14 & 41.69 \\
\hline
\end{tabular}


Run-off, in inches, from James drainage basin.

JAMES, AT BUCHANAN.

\begin{tabular}{|c|c|c|c|c|c|c|c|c|c|c|c|c|c|}
\hline Year. & Jan. & Feb. & Mar. & Apr. & May. & June. & July. & Aug. & Sept. & Oct. & Nov. & Dec. & Annual \\
\hline 1895. & & & & & & & & & 0.19 & 0.20 & 0.26 & 0.49 & \\
\hline $1896 \ldots$ & 0.56 & 1.31 & 1.88 & 0.98 & 0.55 & 0.61 & 1.29 & 0.54 & 0.84 & 0.60 & 0.72 & 0.89 & 10.77 \\
\hline 1897. & 0.48 & 3.75 & 1.90 & 0.88 & 1.86 & 0.52 & 0.54 & 0.36 & 0.23 & 0.23 & 0.20 & 0.54 & 11.49 \\
\hline 1898. & 1.06 & 0.55 & 1.29 & 1.93 & 1.98 & 0.48 & 0.47 & 1.84 & 0.49 & 1.98 & 1.08 & 1.20 & 14.35 \\
\hline Average. & 0.70 & 1.87 & 1.69 & 1.26 & 1.46 & 0.54 & 0.73 & 0.91 & 0.44 & 0.75 & 0.57 & 0.76 & 11.68 \\
\hline \multicolumn{14}{|c|}{ NORTH, AT GLASGOW. } \\
\hline 1895: & & & $\ldots$ & $\cdots$ & .... & - & 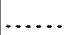 & ... & 0.15 & 0.15 & 0.21 & 0.38 & \\
\hline 1896. & 0.98 & 2.15 & 2.63 & 1.45 & 0.98 & 0.64 & 2. 04 & 0.75 & 2.14 & 1.22 & 1.67 & 1.48 & 18.14 \\
\hline 1897. & 0.63 & 3. 99 & 2. 32 & 1.19 & 2.83 & 0.62 & 0.51 & 0.31 & 0.23 & 0.28 & 0.32 & 0.72 & 13.95 \\
\hline $1898 \ldots$ & 0.99 & 0.53 & 1.28 & 2.00 & 2.38 & 0.80 & 0.72 & 2.38 & 0.41 & 2. 48 & 1.23 & 1. 39 & 16.59 \\
\hline Average. & 0.83 & 2.22 & 2.08 & - 1.55 & 2.06 & 0.69 & 1.09 & 1.15 & 0.73 & 1.03 & 0.86 & 1.00 & 15. 29 \\
\hline
\end{tabular}

Annual rainfall and run-off.

\begin{tabular}{|c|c|c|c|c|}
\hline Station. & Normal. & 1896. & 1897. & 1898. \\
\hline RAINFALL. & Inches. & Inches. & Inches. & Inches. \\
\hline 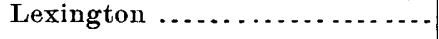 & 40.36 & 44.52 & 37.06 & 47.06 \\
\hline 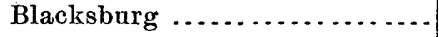 & 41.38 & 44.89 & 40.11 & 39.14 \\
\hline Ashland....... & 40.79 & 36.15 & 42.89 & 43.34 \\
\hline Richmond....... & 41.40 & 41.94 & 39. 77 & 42.49 \\
\hline Buckingham .... & $35.57^{\circ}$ & $\ldots \ldots$ & 34.71 & 36.42 \\
\hline Average. & 39.90 & 41.88 & 38.91 & 41.69 \\
\hline RUN-OFF. & & & & \\
\hline 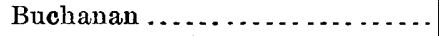 & 11. 68 & 10. 77 & 11. 49 & 14.35 \\
\hline Glasgow .. & 15.29 & 18. 14 & 13.95 & 16.59 \\
\hline Average.... & 13.44 & 14.46 & 12.72 & 15.47 \\
\hline Percentage of rainfall .... & 33.68 & 34.53 & 32.69 & 37.11 \\
\hline
\end{tabular}

The results of measurements at the two points on the head waters of James River-namely, Glasgow and Buchanan-are shown in the tables on pages 135 and 136. Occasional observations of river flow have also been made, under the direction of Mr. J. Turner Morehead, at Holcomb Rock, Virginia, where the power is being used by the restoration of Pedlar dam, described in the Nineteenth Annual Report, Part IV, page 169 . 
NORTH (OF JAMES) RIVER.

Estimated monthly discharge of North (of .Tames) River at Glasgow, Virginia.

[Drainage area, 831 square miles.]

\begin{tabular}{|c|c|c|c|c|c|c|}
\hline \multirow[b]{2}{*}{ Month. } & \multicolumn{3}{|c|}{ Discharge, in second-feet. } & \multirow[b]{2}{*}{$\begin{array}{l}\text { Total in acre- } \\
\text { feet. }\end{array}$} & \multicolumn{2}{|c|}{ Run-off. } \\
\hline & $\begin{array}{l}\text { Maxi- } \\
\text { mum. }\end{array}$ & $\begin{array}{l}\text { Mini- } \\
\text { mum: }\end{array}$ & Mean. & & $\begin{array}{l}\text { Depth in } \\
\text { inches. }\end{array}$ & $\begin{array}{c}\text { Second- } \\
\text { feet per } \\
\text { square } \\
\text { mile. }\end{array}$ \\
\hline 1898. & & & & & & \\
\hline January,$\ldots \ldots \ldots$ & 2,610 & 250 & 718 & 44,148 & 0.99 & 0.86 \\
\hline February ........ & 730 & 220 & 420 & 23,326 & 0.53 & 0.51 \\
\hline March. . & 4,465 & 375 & 920 & 59,569 & 1. 28 & 1. 11 \\
\hline April. ............... & 3,940 & 775 & 1,487 & 88,482 & 2.00 & 1. 79 \\
\hline May.... & 6,210 & 640 & 1,711 & 105,206 & 2.38 & 2.06 \\
\hline June.......... & 1,285 & 340 & 595 & 35,405 & 0.80 & 0.72 \\
\hline July .......... & 1,810 & 250 & 521 & 32,035 & 0.72 & 0.63 \\
\hline 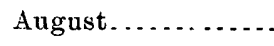 & 14,275 & $250^{\circ}$ & 1,716 & 105,513 & 2.38 & 2. 06 \\
\hline September .. & 1,810 & 197 & 302 & 17,970 & 0.41 & 0.36 \\
\hline October ........ & 17,880 & 220 & 1,786 & 109,818 & 2.48 & 2.15 \\
\hline November .......... & 2,070 & 560 & 911 & 54,208 & 1.23 & $1: 10$ \\
\hline December ........... & 3,640 & 410 & 1,007 & 61,918 & 1.39 & 1. 21 \\
\hline The year:... & 17,880 & 197 & 1,008 & 737,598 & 16.59 & 1. 21 \\
\hline
\end{tabular}

Note.-Gage heights 'for 1898 are given in Water-Supply and Irrigation Paper No. 27, page 22; mensurements, page 24; resilits for 1897 in Water-Supply and Irrigation Paper No. 15, page 23, and in the Nineteenth Annual Report, Part IV, page 162.

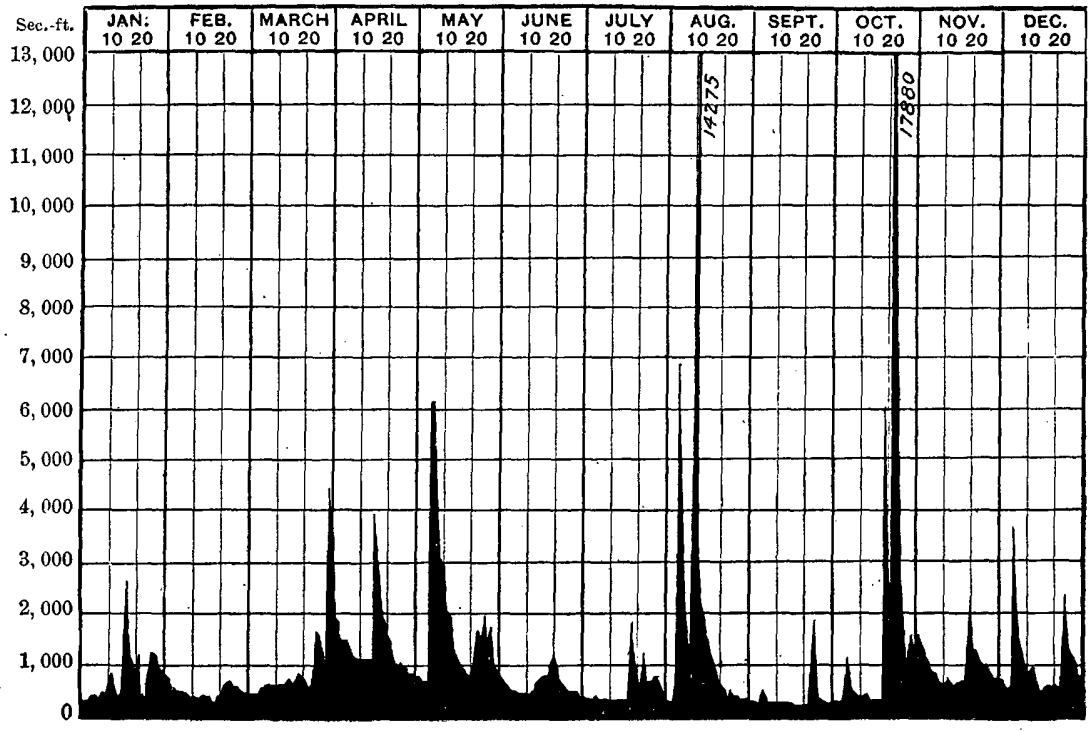

FiG. 35.-Discharge of North (of James) River at Glasgow, Virginia, 1898. 
PROGRESS OF STREAM MEASUREMENTS FOR 1898.

Estimated monthly discharge of James River at Buchanan, Virginia.

[Drainage area, 2,058 square miles.]

\begin{tabular}{|c|c|c|c|c|c|c|}
\hline \multirow[b]{2}{*}{ Month. } & \multicolumn{3}{|c|}{ Discharge, in second.feet. } & \multirow[b]{2}{*}{$\begin{array}{l}\text { Total in acre- } \\
\text { feet. }\end{array}$} & \multicolumn{2}{|c|}{ Run-off. } \\
\hline & $\begin{array}{l}\text { Maxi- } \\
\text { mum. }\end{array}$ & $\begin{array}{l}\text { Mini- } \\
\text { mum. }\end{array}$ & Mean. & & $\begin{array}{l}\text { Depth in } \\
\text { inches. }\end{array}$ & $\begin{array}{c}\text { Second- } \\
\text { feet per } \\
\text { square } \\
\text { mile. }\end{array}$ \\
\hline 1898. & & & & & & \\
\hline January............ & 3,830 & 870 & 1,897 & 116,643 & 1.06 & 0.92 \\
\hline February ............ & 1,700 & 800 & 1,084 & 60,202 & 0.55 & 0.53 \\
\hline March .......... & 11,930 & 940 & 2,305 & 141,730 & 1.29 & 1.12 \\
\hline April... & 8,580 & 1,380 & 3,509 & 208,800 & 1.93 & 1. 73 \\
\hline May ....... & 19,770 & 1,010 & 3,537 & 217,483 & 1.98 & 1. 72 \\
\hline June ...... & 1,380 & 610 & 889 & 52,899 & 0.48 & 0.43 \\
\hline July ... & 1,720 & 510 & 734 & 45,132 & 0.47 & 0.41 \\
\hline August... & 21,345 & 730 & 3,298 & 202,787 & 1.84 & 1. 60 \\
\hline September & 5,050 & 510 & 900 & 53,554 & 0.49 & 0.44 \\
\hline October ...... & 31,280 & 670 & 3,535 & 217,360 & 1. 98 & 1.72 \\
\hline November.. & 6,660 & 1,090 & 1,991 & 118,473 & 1.08 & 0.97 \\
\hline December ... & 5,230 & 1,180 & 2,148 & 132,075 & 1.20 & 1.04 \\
\hline The year ....... & 31,280 & 510 & 2,152 & $1,567,138$ & 14.35 & 1.05 \\
\hline
\end{tabular}

Note.-Gage heights for 1898 are given in Water-Supply and Irrigation Paper No. 27, page 23; measurements, page 24; results for 1897 in Water-Supply and Irrigation Paper No. 15, page 24; and in the Nineteenth A nnual Report, Part IV, page 172.

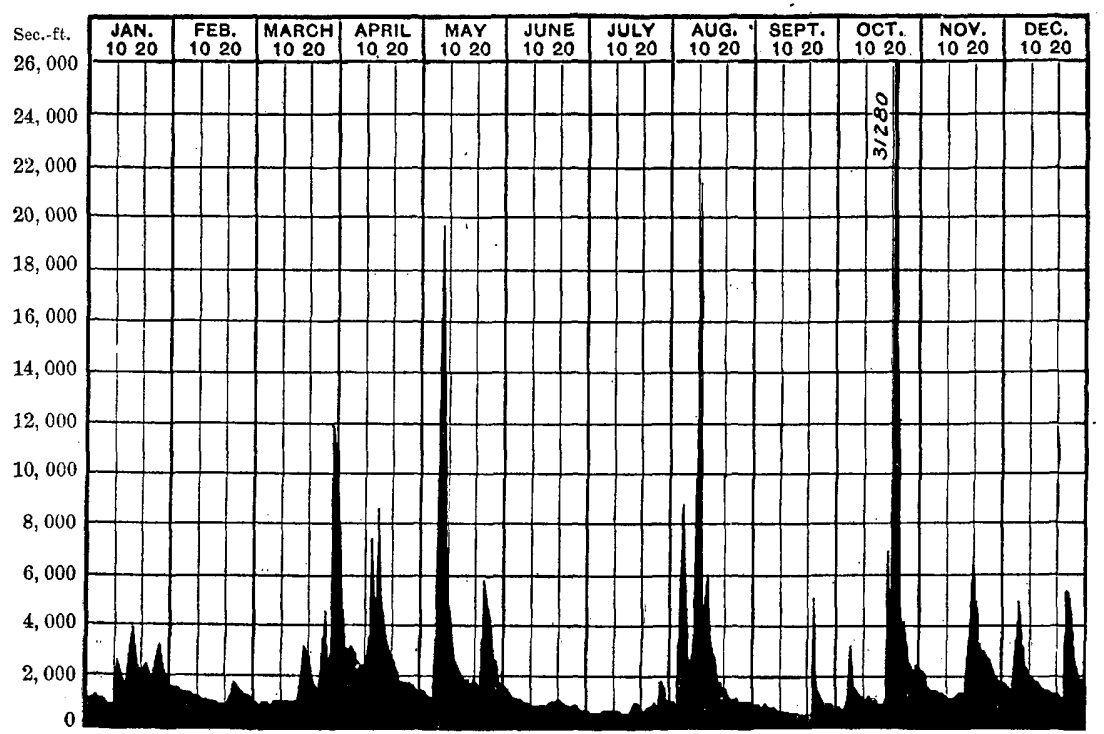

FiG. 36.-Discharge of James River at Bachanain, Virginia, 1898. 


\section{SOUTHERN ATLANTIC COAST DRAINAGE.}

Under this general head are included the streams flowing into the Atlantic from the Roanoke on the north to Altamaha River of southern Georgia.

\section{ROANOKE RIVER.}

Measurements at several points along this river have been carried on, under the direction of Prof. J. A. Holmes, State geologist of North Carolina, by E. W. Myers, the results of which are shown in the following tables.

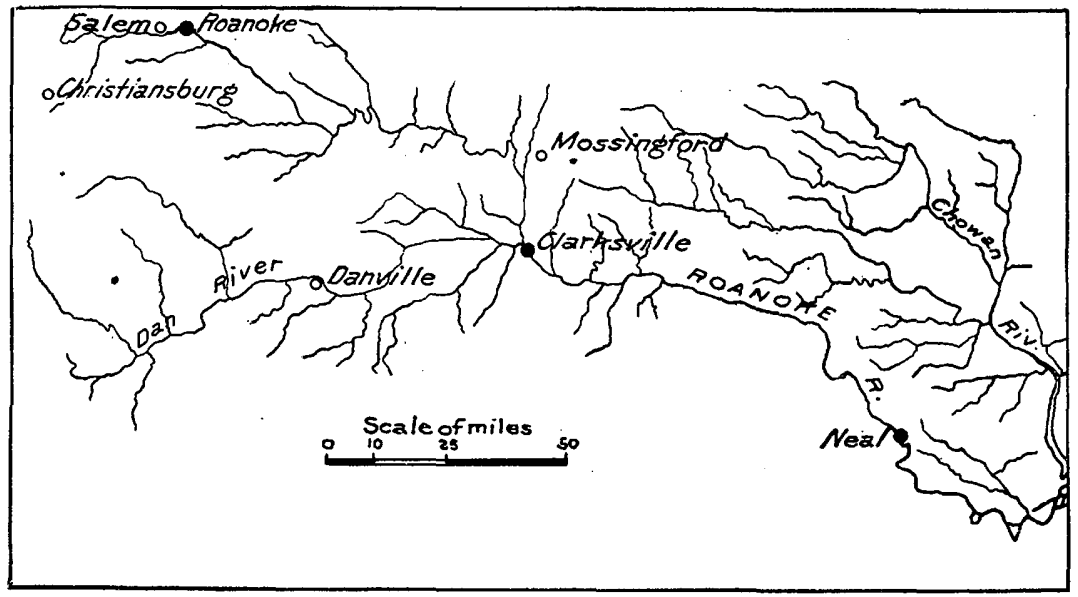

Fig. 37.-Relative location of river and rainfall observations in basin of Roanoke River.

PRECIPITATION IN THE BASIN OF ROANOKE RIVER.

The principal observations of rainfall made within the basin of the Roanoke River are at Christiansburg, Salem, Bedford City, and Clarksville. The relative location of these points is shown in fig. 37, in connection with the points of river measurement, which are at Roanoke, Clarksville, and Neal. The following table gives the names and locations of the stations, the elevations, and the number of years during which the observations have been made, or rather, the number of com. plete monthly observations used in computing the normals:

Location of rainfall stations.

\begin{tabular}{|c|c|c|c|c|c|c|}
\hline Station. & County. & State. & Latitude. & $\begin{array}{l}\text { Longi. } \\
\text { tude. }\end{array}$ & $\begin{array}{l}\text { Eleva- } \\
\text { tion. }\end{array}$ & $\begin{array}{l}\text { Length of } \\
\text { record. }\end{array}$ \\
\hline & Montoromerv & Virginia & $\begin{array}{cc}\circ & 1 \\
37 & 05\end{array}$ & ${ }^{\circ}$, & Feet. & $\begin{array}{r}\text { Years. } \\
9-12\end{array}$ \\
\hline Salem........... & Roanoke...... & .... do .... & $37 \quad 18$ & 8003 & 1,200 & $4-8$ \\
\hline Bedford City... & Bedford ...... & .... do .... & 3720 & 7928 & 900 & $6-9$ \\
\hline Clarksville ..... & Mecklenburg .. & ..... do ..... & 3638 & 7833 & 280 & $3-7$ \\
\hline
\end{tabular}


In the following table are given the figures of normal or average monthly precipitation from the time of the beginning of the record to and including 1897 , together with the total precipitation, by months, for the years 1896, 1897, and 1898, and also the amount by years. In obtaining the normal precipitation the average is taken for all of the months during which observations were made.

Precipitation in the basin of Roanoke River.

CHRISTIANSBURG.

\begin{tabular}{|c|c|c|c|c|c|c|c|c|c|c|c|c|c|}
\hline Year. & Jan. & Feb. & Mar. & Apr. & May. & June. & Tuly. & Aug. & Sept. & Oct. & Nov. & Dec. & Annual. \\
\hline Normal & 2.53 & 3. 12 & 3.05 & 2.31 & 3.24 & 3. 17 & 3. 82 & 3. 72 & 3. 33 & 3.05 & 1. 78 & 2.01 & 36.13 \\
\hline 1896. & 1.07 & 2. 64 & 6.36 & 2. 80 & 3.91 & 3.76 & 6.94 & 1.21 & 5. 20 & 1.15 & 3.72 & 0.60 & 39.36 \\
\hline 1897. & 1.59 & 6.80 & 3.62 & 1.76 & 2.88 & 2.04 & 4.34 & 3. 23 & 2.13 & 3. 88 & 0.81 & 3.66 & 36.74 \\
\hline 1898. & 2. 78 & 0.39 & 3.08 & 1.93 & 5.86 & 2.52 & 4.21 & 3.13 & 4.17 & 5. 11 & 2.28 & 2.54 & 38.00 \\
\hline \multicolumn{14}{|c|}{ SALEM. } \\
\hline Normal & 2.88 & 4.38 & 3.45 & 2. 74 & 3.96 & 3.32 & 4.51 & 2.45 & 4.01 & 2.54 & 2.19 & 2.64 & 39.07 \\
\hline 1896. & 2.82 & 4. 37 & 5.77 & 2.46 & 2.01 & 4.79 & 6.53 & 1.41 & 4.92 & 0.53 & 5.16 & 0.41 & 41. 18 \\
\hline 1897. & 1.69 & 7.56 & 3.73 & 1.56 & 4.03 & 1.31 & 3.64 & 1.76 & 2.56 & 4. 17 & 1.25 & 3.82 & 37.08 \\
\hline $1898 \ldots$. & 2.95 & 0.59 & 3.35 & 1.99 & 6. 74 & 2.82 & 5.06 & 4. 14 & 3.66 & 8.63 & 1.50 & 2.58 & 40.00 \\
\hline \multicolumn{14}{|c|}{ BEDFORD CITY. } \\
\hline Normal & 2.56 & 3.99 & 3.26 & 2.65 & 3.82 & 3.17 & 3.30 & 3.76 & 3.46 & 3.20 & 2.71 & 2.64 & 38.52 \\
\hline $1896 \ldots$ & 2.16 & 4.30 & 5.13 & 1.89 & 1. 82 & $\ldots$. & $\ldots$. & 3.55 & 6.75 & $\ldots \ldots$ & 5.00 & $\ldots \ldots$ & ....... \\
\hline 1897. & $a 2.56$ & $a 3.99$ & 3.10 & 1.50 & 3. 70 & 3.68 & 1.70 & 0.87 & 1.00 & 3.63 & 2.52 & 3.55 & 31.80 \\
\hline 1898. & 2.48 & 1.02 & 4.03 & 3.21 & 7.81 & 2.53 & 4. 26 & 3.67 & 4.08 & 8.66 & 2.05 & 4. 16 & 47.96 \\
\hline \multicolumn{14}{|c|}{ CLARKSVILLE. } \\
\hline Normal . & 3.53 & 5. 16 & 3.81 & 3.81 & 4. 71 & 3. 08 & 5.34 & 4.07 & 2. 32 & 2.14 & 2. 20 & 2.48 & 42.65 \\
\hline 1896. & a..... & ....... & 4.16 & 5.40 & 4.46 & 3.17 & 9.47 & 0.28 & - & ....... & $\ldots$ & $\ldots$ & \\
\hline 1897. & $\ldots$. & $\ldots \ldots$ & 4.58 & 2.85 & 4.59 & 2.68 & $\ldots \ldots$ & 1.16 & 0.25 & 1.15 & 1.03 & 2.45 & $\ldots \ldots$ \\
\hline 1898. & 1.55 & $a 5.16$ & 2. 10 & 1.80 & 5.46 & 4.18 & 4.27 & 3.42 & 4.10 & 3.38 & 1. 80 & 1.65 & 38.87 \\
\hline \multicolumn{14}{|c|}{ AVERAGE. } \\
\hline Normal. & 2.88 & 4.16 & 3. 39 & 2.88 & 4. 18 & 3.19 & 4.24 & 3.50 & 3.28 & 2. 73 & 2.22 & 2.44 & 39.09 \\
\hline 1896. & 2.02 & 3.77 & 5.36 & 3.14 & 3.05 & 3. 91 & 7.65 & j. 61 & 5. 62 & 0.84 & 4.63 & 0.51 & 42.11 \\
\hline $1897 \ldots$ & 1.95 & 6. 12 & 3.76 & 1.92 & 3.80 & 2.43 & 3. 23 & 1.76 & 1.49 & 3. 21 & 1.40 & 3.37 & 34.44 \\
\hline 1898. & 2.44 & 1.79 & 3.14 & 2. 23 & 6.47 & 3.01 & 4.45 & 3.59 & 4.00 & 6.45 & 1.91 & 2.73 & 42. 21 \\
\hline
\end{tabular}

$a$ Record for month missing and normal value substituted. 
Depth of run-off, in inches, from Roanoke drainage basin.

ROANOKE, AT ROANOKE

\begin{tabular}{|c|c|c|c|c|c|c|c|c|c|c|c|c|c|}
\hline Year. & Jan. & Feb. & Mar. & Apr. & May. & June. & July. & Aug. & Sept. & Oct. & Nov. & Dec. & Annual. \\
\hline 1897. & 0.20 & 5.13 & 2.81 & 1.16 & 2.65 & 1.08 & 0.61 & 0.47 & 0.53 & 0.75 & 0.21 & 0.39 & 15.99 \\
\hline i898. . & 1.48 & 0.95 & 1.07 & 1. 41 & 2.64 & $0.7 \mathrm{~s}$ & 0.56 & 1.87 & 1.19 & 3.59 & 1.50 & 2.14 & 19.15 \\
\hline Average & 0.84 & 3.04 & 1.94 & 1. 28 & 2. 65 & 0.92 & 0.59 & 1.17 & 0.86 & 2.17 & 0.86 & 1.27 & 17.57 \\
\hline \multicolumn{14}{|c|}{ DAN, AT CLARKSVILLE. } \\
\hline 1896. & $a 0.78$ & 1.48 & 1.53 & 1. 44 & 0.84 & 0.64 & 1.49 & 0.37 & 0.41 & 0.58 & 0.68 & 0.72 & 10.96 \\
\hline 1897 & 0.78 & 2.53 & 1.83 & 1.02 & 1.52 & 0.39 & 0.43 & 0.30 & 0.22 & 0.48 & 0.50 & 0.68 & 10.68 \\
\hline Average & 0.78 & 2.01 & 1.68 & 1. 23 & 1.18 & 0.52 & 0.96 & 0.34 & 0.32 & 0.53 & 0.59 & 0.70 & 10.84 \\
\hline \multicolumn{14}{|c|}{ STAUNTON, AT CLARKSVILLE. } \\
\hline 1896. & $a 1.88$ & 1.42 & 1.02 & 1. 28 & 0.75 & 0.52 & 1.20 & 0.28 & 0.37 & 0.54 & 0.63 & 0.67 & 10.56 \\
\hline 1897. & 1.88 & 3. 11 & 2.10 & 1. 13 & 1. 74 & 0.72 & 0.45 & 0.32 & 0.22 & 0.49 & 0.52 & 0.78 & 13.46 \\
\hline A verage & 1.88 & 2.27 & 1.56 & 1. 21 & 1.25 & 0.62 & 0.83 & 0.30 & 0.30 & 0.52 & 0.58 & 0.73 & 12.05 \\
\hline \multicolumn{14}{|c|}{ ROANOKE, AT NEAL. } \\
\hline 1896. & & & & & & & ...... & 0.41 & 0.41 & 1. 21 & 0.75 & 0.98 & .. \\
\hline $1897 \ldots$ & 0.60 & 3. 36 & 3.02 & 1.08 & 1.15 & 0.55 & 0.52 & 0.36 & 0.28 & 0.33 & 0.40 & 0.72 & 12.37 \\
\hline $1898 \ldots \ldots \ldots$ & 0.61 & 0.43 & 0.49 & 0.88 & 1.73 & 0.69 & 0.49 & 0.63 & 1.02 & 1.13 & 0.82 & 1.19 & 10.11 \\
\hline Average. & 0.61 & 1.90 & 1.76 & 0.98 & I. 44 & C. 62 & 0.51 & 0.47 & 57 & 0.89 & 0.66 & 0.63 & 11.04 \\
\hline
\end{tabular}

Annual rainfall and $r u n-o f f$

\begin{tabular}{|c|c|c|c|c|}
\hline Station. & Normal. & 1896. & 1897. & 1898. \\
\hline RAINFALL. & Inches. & Inches. & Inches. & Inches. \\
\hline Christiansburg ................ & 36.13 & 39. 36 & 36.74 & 38.00 \\
\hline Salem $\ldots \ldots \ldots \ldots \ldots \ldots \ldots$ & 39.07 & 41.18 & 37.08 & $40.00^{\prime}$ \\
\hline 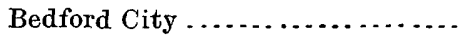 & 38.52 & $\ldots \ldots \ldots$ & 31.80 & 47.96 \\
\hline Clarksville ... & 42.65 & & ... & 38.87 \\
\hline Average........ & 39.09 & 40.27 & 35.21 & 41. 21 \\
\hline RUN-OFF. & & & & \\
\hline Roanoke at Roanoke.............. & 17.57 & ......... & 15.99 & 19.15 \\
\hline Roanoke at Neal... & 11.04 & ......... & 12.37 & 10.11 \\
\hline Dan at Clarksville.............. & 10.84 & 10.96 & 10.68 & $\ldots \ldots \ldots$ \\
\hline Staunton at Clarksville..... & 12.05 & 10.56 & 13.46 & . \\
\hline Average................... & 12.88 & 10.76 & 13.13 & 14. 63 \\
\hline Percentage of rainfal] ....... & 32.95 & 26.72 & 37.29 & 35.50 \\
\hline
\end{tabular}


140 PROGRESS OF STREAM MEASUREMENTS FOR 1898.

Estimated monthly discharge of Roanoke River at Roanoke, Virginia.

[Drainage area, 388 square miles.]

\begin{tabular}{|c|c|c|c|c|c|c|}
\hline \multirow[b]{2}{*}{ Month. } & \multicolumn{3}{|c|}{ Discharge in second-feet. } & \multirow{2}{*}{$\begin{array}{l}\text { Tọtal in acre- } \\
\text { feet. }\end{array}$} & \multicolumn{2}{|c|}{ Run-off. } \\
\hline & $\begin{array}{l}\text { Maxi. } \\
\text { mum. }\end{array}$ & $\begin{array}{l}\text { Mini- } \\
\text { mum. }\end{array}$ & Mean. & & $\begin{array}{l}\text { Depth in } \\
\text { inches. }\end{array}$ & $\begin{array}{c}\text { Second. } \\
\text { feet per } \\
\text { square } \\
\text { mile. }\end{array}$ \\
\hline 1897.* & & & & & & \\
\hline January $\because \ldots \ldots \ldots$ & 92 & 47 & 66 & 4,058 & 0.20 & 0.17 \\
\hline February ......... & 11,550 & 47 & 1,911 & 106,130 & 5.13 & 4.93 \\
\hline March .............. & 3,632 & 120 & 946 & 58,167 & 2.81 & 2.44 \\
\hline April $\ldots \ldots \ldots \ldots$ & 640 & 230 & 402 & 23,921 & 1.16 & 1.04 \\
\hline 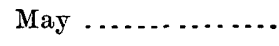 & 3,900 & 310 & $894^{\prime}$ & 54,970 & 2.65 & 2.30 \\
\hline Juue.............. & 565 & 85 & 377 & 22,433 & 1.08 & 0.97 \\
\hline July .............. & 725 & 70 & 204 & 12,544 & 0.61 & 0.53 \\
\hline August. . . . . . . . . . & 565 & 77 & 160 & 9,838 & 0.47 & 0.41 \\
\hline September .... & 640 & 33 & 182 & 10,829 & 0.53 & 0.47 \\
\hline October ............. & 725 & 110 & 252 & 15,494 & 0.75 & 0.65 \\
\hline November......... & 110 & 55 & 75 & 4,463 & 0.21 & 0.19 \\
\hline Decembèr ......... & 280 & 55 & 130 & $\cdot 7,993$ & 0.39 & 0.34 \\
\hline The year..... & 11,550 & 33 & 467 & 330,840 & 15.99 & 1. 20 \\
\hline 1898. & & & & & & \\
\hline January............ & 1,320 & 110 & 498 & 30,621 & 1. 48 & 1. 28 \\
\hline February .......... & 770 & 120 & 355 & 19,716 & 0.95 & 0.91 \\
\hline March ..... & 2,200 & 60 & 359 & 22,074 & i. 07 & 0.93 \\
\hline April $1-16 . . \ldots \ldots$ & 1,035 & 280 & 490 & 29,157 & 1.41 & 1. 26 \\
\hline May ...... & 5,520 & 80 & 888 & 54,601 & 2.64 & 2.29 \\
\hline June .................. & 530 & 120 & 265 & 15,769 & 0.75 & 0.68 \\
\hline July ...... & 565 & 30 & 191 & 11,744 & 0.56 & 0.49 \\
\hline Angust..... & 2,289 & 135 & 629 & 38,676 & 1.87 & 1. 62 \\
\hline September & 3,095 & 135 & 417 & 24,813 & 1.19 & 1.07 \\
\hline October.... & 5,700 & 280 & 1,208 & 74,278 & 3.59 & 3.11 \\
\hline November ...... & 980 & 340 & 521 & 31,002 & 1.50 & 1.34 \\
\hline December ..... & 2,826 & 230 & 720 & 44,271 & 2.14 & 1. 86 \\
\hline The year.... & 5,700 & 30 & 545 & 396,722 & 19.15 & 1.40 \\
\hline
\end{tabular}

NoTe.-Gage heights for 1898 are given in Water-Supply and Irrigation Paper No. 27, page 32 measurements, page 44; results for 1897 in Water-Supply and Irrigation Paper No. 15, page 25, and in the Nineteenth Annual Report, Part IV, page 174. 


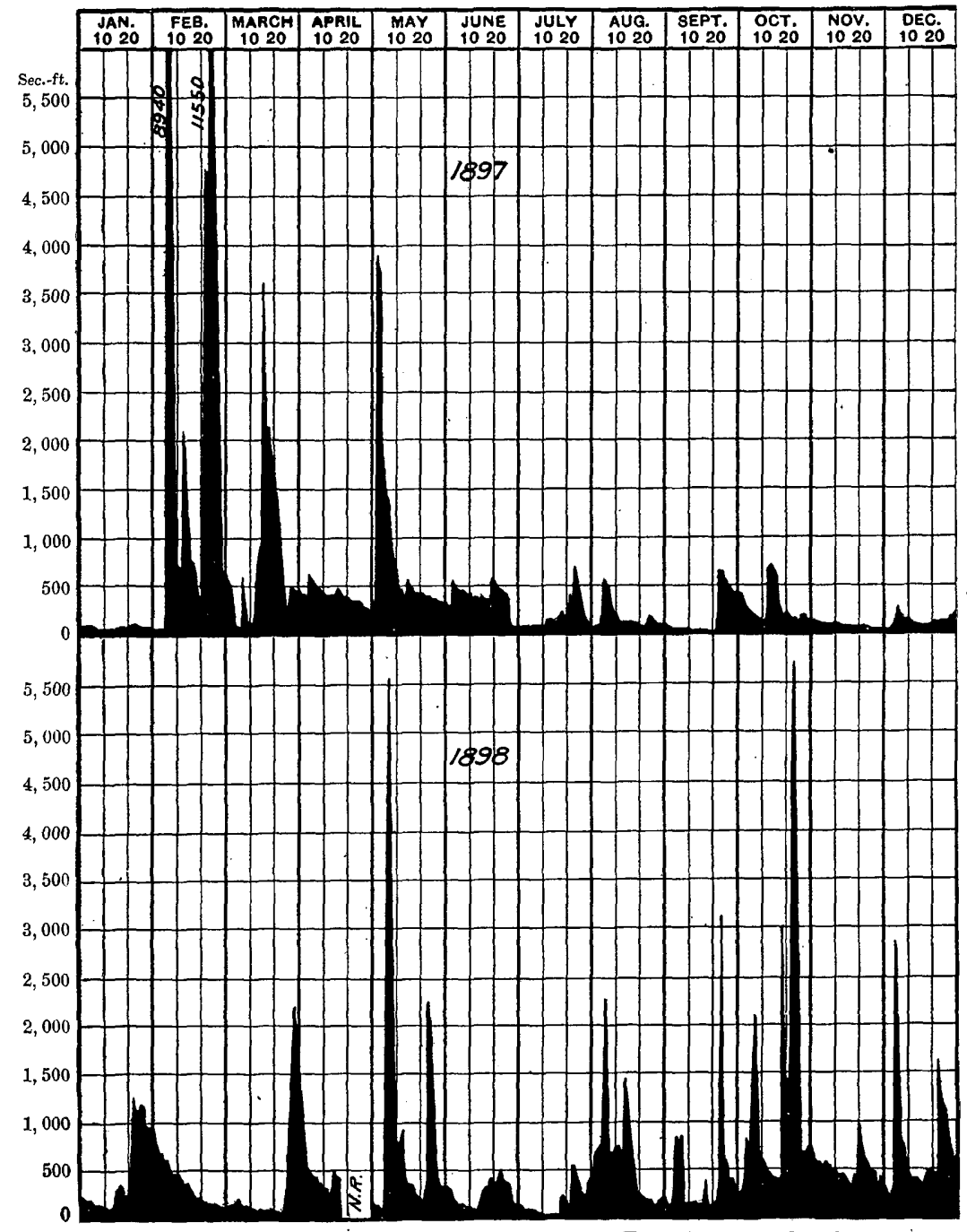

Fre. 38.-Discharge of Roanoke River at Roanoke, Virginia, 1897 and 1898.

The above figure shows the fluctuations of supply near the head waters of Roanoke River, where the drainage area is only 388 square miles. For comparison with this, reference should be made to the diagram on the next page showing the fluctuations of the river in its lower course, where the drainage area is 8,717 square miles. The vertical distance in this latter diagram represents values about ten times as great as those in fig. 38 . 
Estimated monthly discharge of Roanoke River at Neal, North Carolina.

[Drainage area, 8,717 square miles.]

\begin{tabular}{|c|c|c|c|c|c|c|}
\hline \multirow[b]{2}{*}{ Month. } & \multicolumn{3}{|c|}{ Discharge in second-feet. } & \multirow[b]{2}{*}{$\begin{array}{l}\text { Total in acre- } \\
\text { feet. }\end{array}$} & \multicolumn{2}{|c|}{ Run-off. } \\
\hline & $\begin{array}{l}\text { Maxi- } \\
\text { mum. }\end{array}$ & $\begin{array}{l}\text { Mini-' } \\
\text { 'mum. }\end{array}$ & Mean. & & $\begin{array}{l}\text { Depth in } \\
\text { inches. }\end{array}$ & $\begin{array}{l}\text { Second- } \\
\text { feet per } \\
\text { square } \\
\text { mile. }\end{array}$ \\
\hline \multicolumn{7}{|l|}{1898.} \\
\hline January ......... & 11,300 & 3,200 & 4,597 & 282,660 & 0.61 & 0.53 \\
\hline February & 5,910 & 2,935 & 3,544 & 196,824 & 0.43 & 0.41 \\
\hline March .... & 6,900 & 2,935 & 3,736 & 229,719 & 0.49 & 0.43 \\
\hline April ..... & 14,120 & 3,568 & 6,903 & 410,756 & 0.88 & 0.79 \\
\hline May". & 29,859 & 3,200 & 13,100 & 805,493 & 1. 73 & 1.50 \\
\hline June.... & 14,755 & 2,445 & 5,399 & 321,262 & 0.69 & 0.62 \\
\hline July $\ldots$. & 5,910 & 2,347 & 3,766 & 231,564 & 0.49 & 0.43 \\
\hline August.. & 14,595 & 2,895 & 4,815 & 296,065 & 0.63 & 0.55 \\
\hline September & 34,274 & 2,060 & 7,980 & 474,842 & 1.02 & 0.92 \\
\hline October. & 28,762 & 2,855 & 8,582 & 527,690 & 1. 13 & 0.98 \\
\hline November. & 17,204 & 3,810 & 6,437 & 383,027 & 0.82 & 0.74 \\
\hline December. & 24,735 & 3,910 & 8,958 & 550,810 & 1. 19 & 1.03 \\
\hline 'The year. & 34,274 & 2,060 & 6,485 & $4,710,712$ & 10.11 & $0.7 t$ \\
\hline
\end{tabular}

Note.-Gage heights for 1898 are given in Water-Supply and Irrigation Paper No. 27, page 33 ; rating table, page 45; results for 1897 in Water. Supply and Irrigation Paper No. 15, page 28, and in the Nineteenth Annual Report, Part IV, page 181.

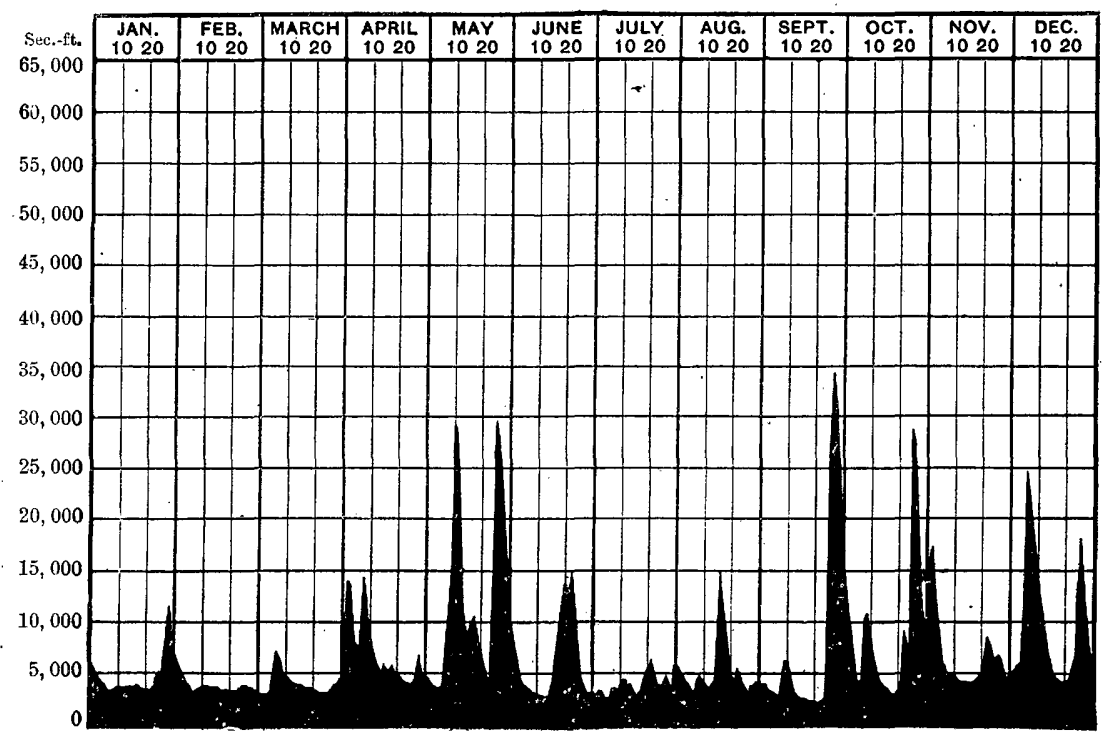

FIx. 39.-Discharge of Roanoke River at Neal, North Carolina, 1898. 
TAR RIVER.

Estimated monthly discharge of Tar River at Tarboro, North Carolina.

[Drainage area, 2,290 square miles.]

\begin{tabular}{|c|c|c|c|c|c|c|}
\hline \multirow[b]{2}{*}{ Month. } & \multicolumn{3}{|c|}{ Discharge in second-feet. } & \multirow{2}{*}{$\begin{array}{l}\text { Total in acre- } \\
\text { feet. }\end{array}$} & \multicolumn{2}{|c|}{ Run-off. } \\
\hline & $\begin{array}{l}\text { Maxi- } \\
\text { mum. }\end{array}$ & $\begin{array}{l}\text { Minj- } \\
\text { mum. }\end{array}$ & Mean. & & $\begin{array}{l}\text { Depth in } \\
\text { inches. }\end{array}$ & $\begin{array}{c}\text { Second } \\
\text { feet per } \\
\text { square } \\
\text { mile. }\end{array}$ \\
\hline 1898. & & & & & & \\
\hline January & 2,957 & 905 & 1,380 & 84,8503 & 0.69 & 0.60 \\
\hline February ... & 1,580 & 730 & 1,051 & 58,370 & 0.48 & 0.46 \\
\hline March ...... & 3,787 & 750 & 1,697 & 104,345 & 0.85 & 0.74 \\
\hline April ............... & 5,510 & 905 & $2, \overline{5} 23$ & 150,129 & 1.23 & 1. 10 \\
\hline May ..... & 8,680 & 1,085 & 3,438 & 211,394 & 1. 73 & 1.50 \\
\hline June.... & 3,420 & 470 & 1,600 & $\because \quad 95,207$ & 0.78 & 0.70 \\
\hline July .... & 6,925 & 385 & 2,419 & 148,738 & 1. 22 & 1.06 \\
\hline August.. & 4,880 & 505 & 1,733 & 106,558 & 0.87 & 0.76 \\
\hline September & 4,460 & 360 & 1,356 & 80,688 & 0.65 & 0.59 \\
\hline October. & 1,430 & 385 & 816 & 50,174 & 0.41 & 0.36 \\
\hline November. & 2,735 & 690 & 1,338 . & 79,617 & 0.64 & 0.58 \\
\hline December . - & 8,050 & 1,480 & 3,110 & 191,227 & 1.57 & 1. 36 \\
\hline The year & 8,680 & 360 & 1,872 & $1,361,300$ & 11. 12 & 0.82 \\
\hline
\end{tabular}

Note. -Gage heights for 1898 are given in Water.Supply and Irrigation Paper No. 27, page 34; measurements, page 44; J'esults for 1897.in Water-Supply and Irrigation Paper No. 15, page 29, and in the Nineteenth Annual Report, Part IV, page 183.

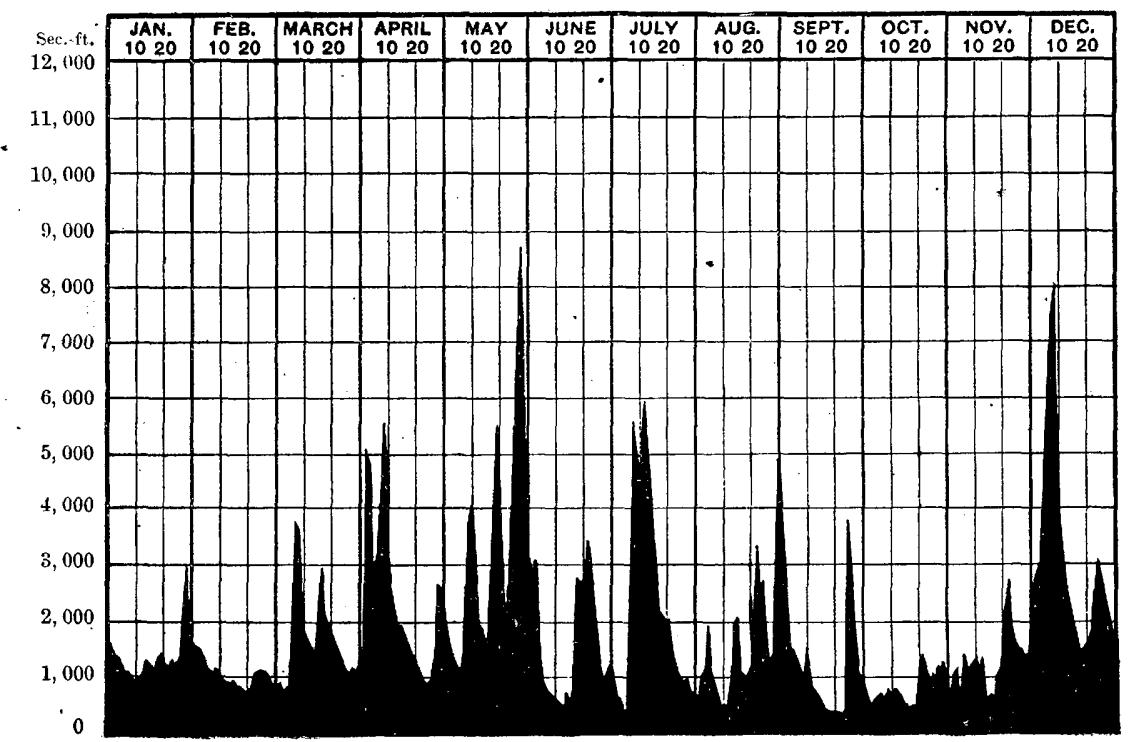

Fra. 40-Discharge of Tar River at Tarboro, North Carolina, 1898. 
NEUSE RIVER.

Estimated monthly discharge of Neuse River at Selma, North Carolina.

[Drainage area, 1,175 square miles.]

\begin{tabular}{|c|c|c|c|c|c|c|}
\hline \multirow[b]{2}{*}{ Month. } & \multicolumn{3}{|c|}{ Discharge in second-feet. } & \multirow[b]{2}{*}{$\begin{array}{c}\text { Total in acre. } \\
\text { feet. }\end{array}$} & \multicolumn{2}{|c|}{ Run.off. } \\
\hline & $\begin{array}{l}\text { Maxi- } \\
\text { mum. }\end{array}$ & $\begin{array}{l}\text { Mini- } \\
\text { mum. }\end{array}$ & Mean. & & $\begin{array}{l}\text { Depth in } \\
\text { inches }\end{array}$ & $\begin{array}{c}\text { Second- } \\
\text { feet per } \\
\text { square } \\
\text { mile. }\end{array}$ \\
\hline 1898. & & & & & & \\
\hline January ........... & 3,050 & 350 & $6 \mathrm{~b} 1$ & 40,644 & 0.64 & 0.56 \\
\hline February ......... & 792 & 325 & 430 & 23,881 & 0.39 & 0.37 \\
\hline March .... & 4,150 & 375 & $1, \mathbf{1 3 2}$ & 69,604 & 1. 10 & 0.96 \\
\hline April ................ & 5,490 & 400 & 1,614 & 96,039 & 1.53 & 1.37 \\
\hline May ..... & 5,250 & 275 & 1,798 & 110,555 & 1. 76 & 1. 53 \\
\hline June..... & 1,960 & 230 & 555 & 33,025 & 0.53 & 0.47 \\
\hline Julg ...... & 3,050 & 252 & 927 & 56,999 & 0. 91 & 0.79 \\
\hline August. . & 4,920 & 252 & 1,310 & 80,549 & 1. 28 & 1. 11 \\
\hline September . . & 6,350 & 325 & 1,379 & 82,056 & 1.31 & 1.17 \\
\hline October . . . . . . . . & 732 & 185 & 424 & 26,071 & 0.41 & 0.36 \\
\hline November.. & 2,390 & $42 \breve{\jmath}$ & 857 & 50,995 & 0.81 & 0.73 \\
\hline December ... & 5,470 & 475 & 1,300 & 79,934 & 1. 28 & 1.11 \\
\hline The year. & 6,350 & 185 & 1,032 & 750,352 & 11.95 & 0.87 \\
\hline
\end{tabular}

NoTE.-Gage heights for 1898 are given in Water-Supply and Irrigation Paper No. 27, page 34; measurements, page 44; results for 1897 in Water-Supply and Irrigation Paper No. 15, page 30, and in the Nineteenth Annual Report, Part IV, page 185.

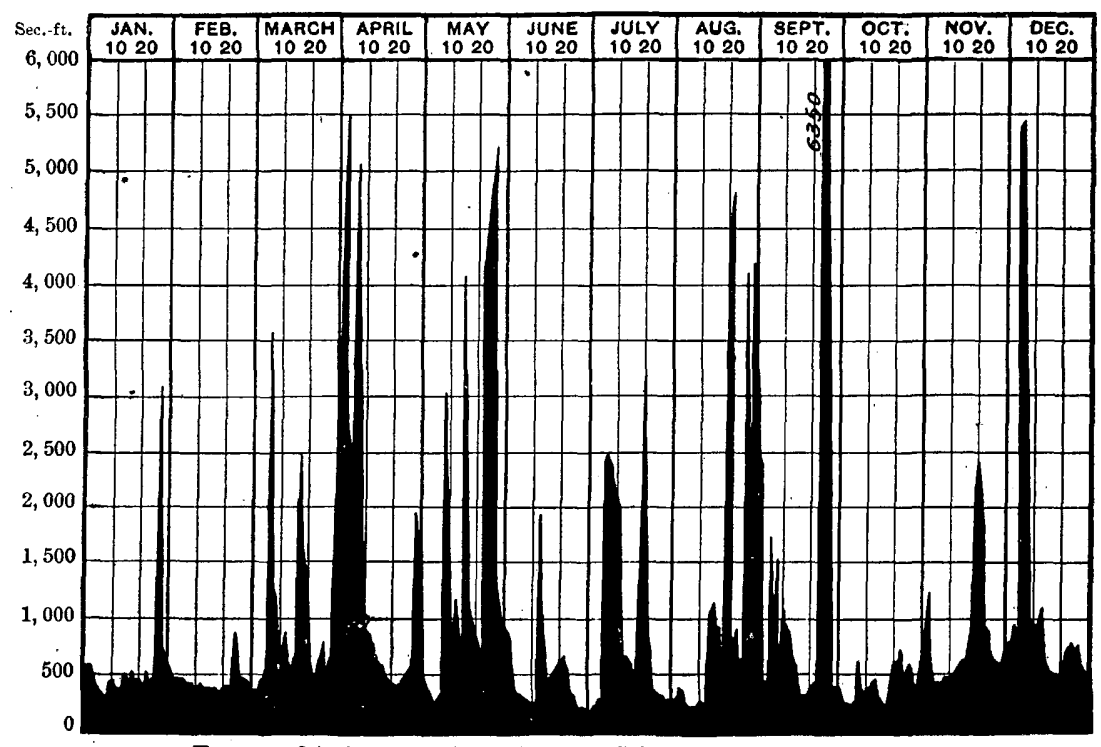

Fig. 41.-Discharge of Neuse River at Selma, North Carolina, 1898. 
CAPE FEAR RIVER.

Estimated monthly discharge of Cape Fear River at Fayetteville, North Carolina.

[Drainage area, 4,493 square miles.]

\begin{tabular}{|c|c|c|c|c|c|c|}
\hline \multirow[b]{2}{*}{ Month. } & \multicolumn{3}{|c|}{ Discharge in second-feet. } & \multirow[b]{2}{*}{$\begin{array}{l}\text { Total in acre- } \\
\text { feet. }\end{array}$} & \multicolumn{2}{|c|}{ Run-off. } \\
\hline & $\begin{array}{l}\text { Maxi- } \\
\operatorname{mum} .\end{array}$ & $\begin{array}{l}\text { Mini- } \\
\text { mum. }\end{array}$ & Mean. & & $\begin{array}{l}\text { Depth in } \\
\text { inches. }\end{array}$ & $\begin{array}{c}\text { Second- } \\
\text { feet per } \\
\text { square } \\
\text { mile. }\end{array}$ \\
\hline 1898. & & & & & & \\
\hline January .... & 7,333 & 1,319 & 2,126 & 130,723 & 0.54 & 0.47 \\
\hline February ........... & 2,740 & 1,145 & 1,735 & 96,357 & 0.41 & 0.39 \\
\hline March ......... & 12,249 & 1,273 & 3,303 & 203,095 & 0.85 & 0.74 \\
\hline April.............. & 13,608 & 1,620 & 4,395 & 261,520 & 1.09 & 0.98 \\
\hline May... & 6,133 & 1,145 & 2,369 & 145,665 & 0.61 & 0.53 \\
\hline June ...... & 3,280 & 519 & 1,181 & 70,274 & 0.29 & 0.26 \\
\hline July & 8,665 & 489 & 2,793 & 171,736 & 0.71 & 0.62 \\
\hline Angust. . & 24,072 & 910 & $5,655^{\circ}$ & 347,715 & 1.45 & 1.26 \\
\hline September & 10,277 & 876 & 3,674 & 218,618 & 0.91 & 0.82 \\
\hline 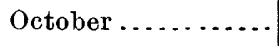 & 4,955 & 612 & 1,739 & 106,928 & 0.45 & 0.39 \\
\hline November ......... & 7,333 & 1,417 & 2,982 & 177,441 & 0.73 & 0.66 \\
\hline December ......... & 9,781 & 1,994 & 3,387 & 208,260 & 0.86 & 0.75 \\
\hline The year.. & 24,072 & 489 & 2,945 & $2,138,332$ & 8.90 & 0.66 \\
\hline
\end{tabular}

NotE-Gage heights for 1898 are given in Water-Supply and Irrigation Paper No. 27, page 36; measurements, page 44; rating table, page 45; results for 1897 in Water-Supply and Irrigation Paper No. 15, page 31, and in the Nineteenth Annual Report, Part IV, page 187.

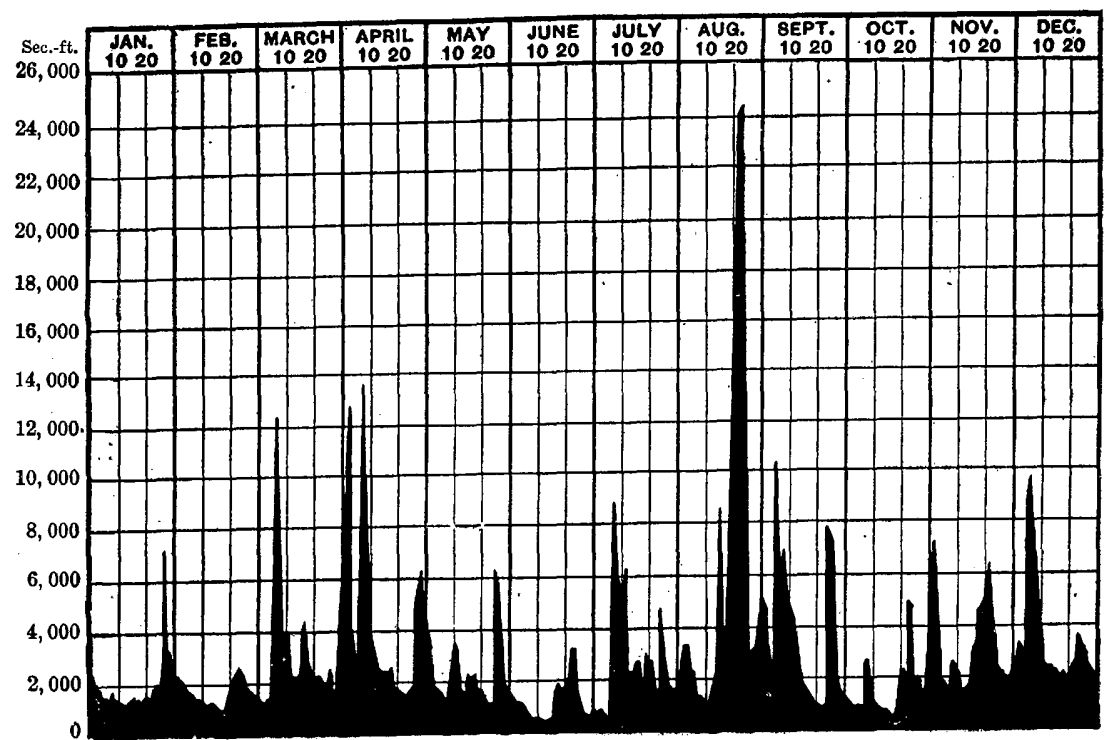

Fig. 42.-Discharge of Cape Fear River at Fayetteville, North Carolina, 1898. 20 GEOL, P'T $4-10$ 


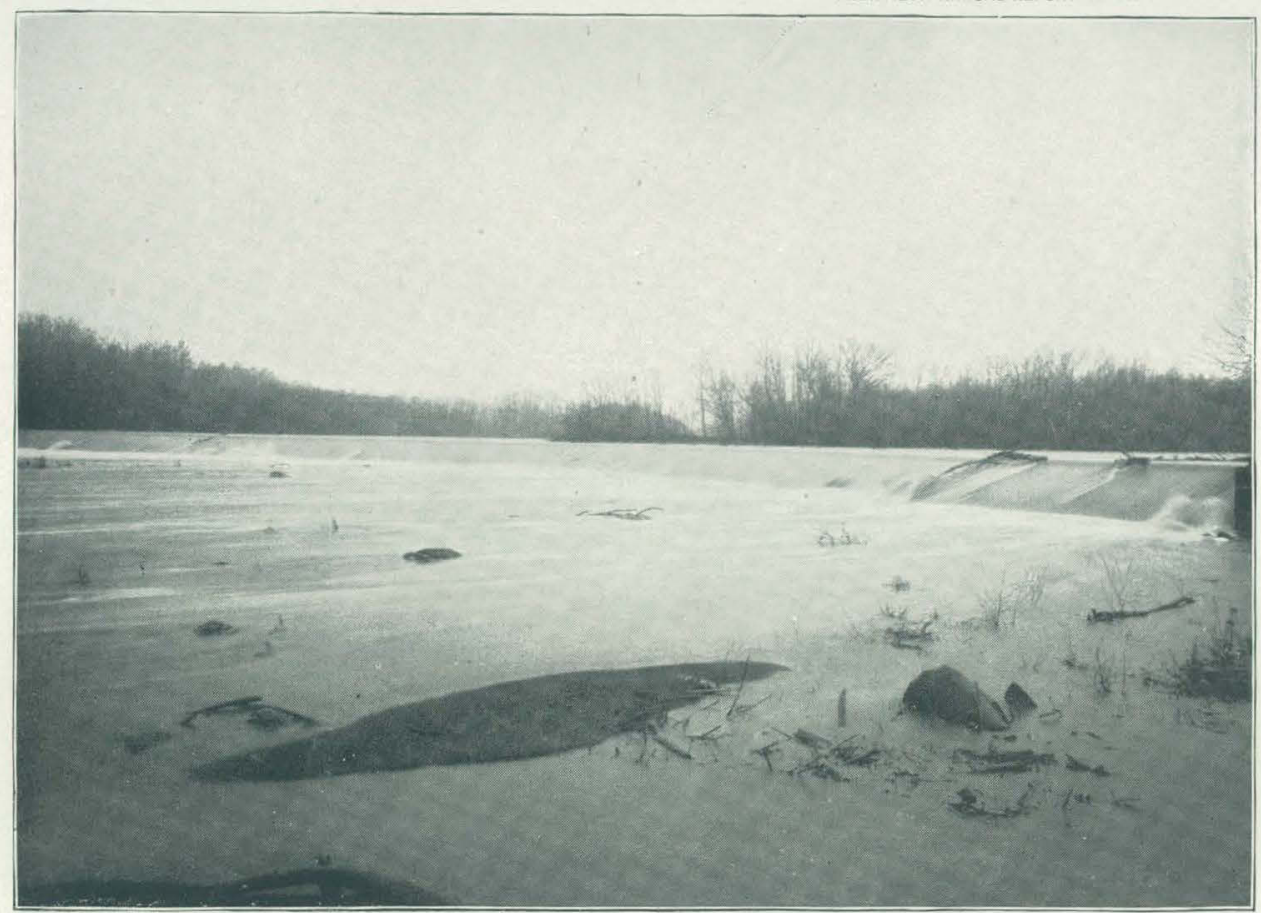

A. DAM ACROSS DEEP RIVER NEAR LOCKVILLE, NORTH CAROLINA.

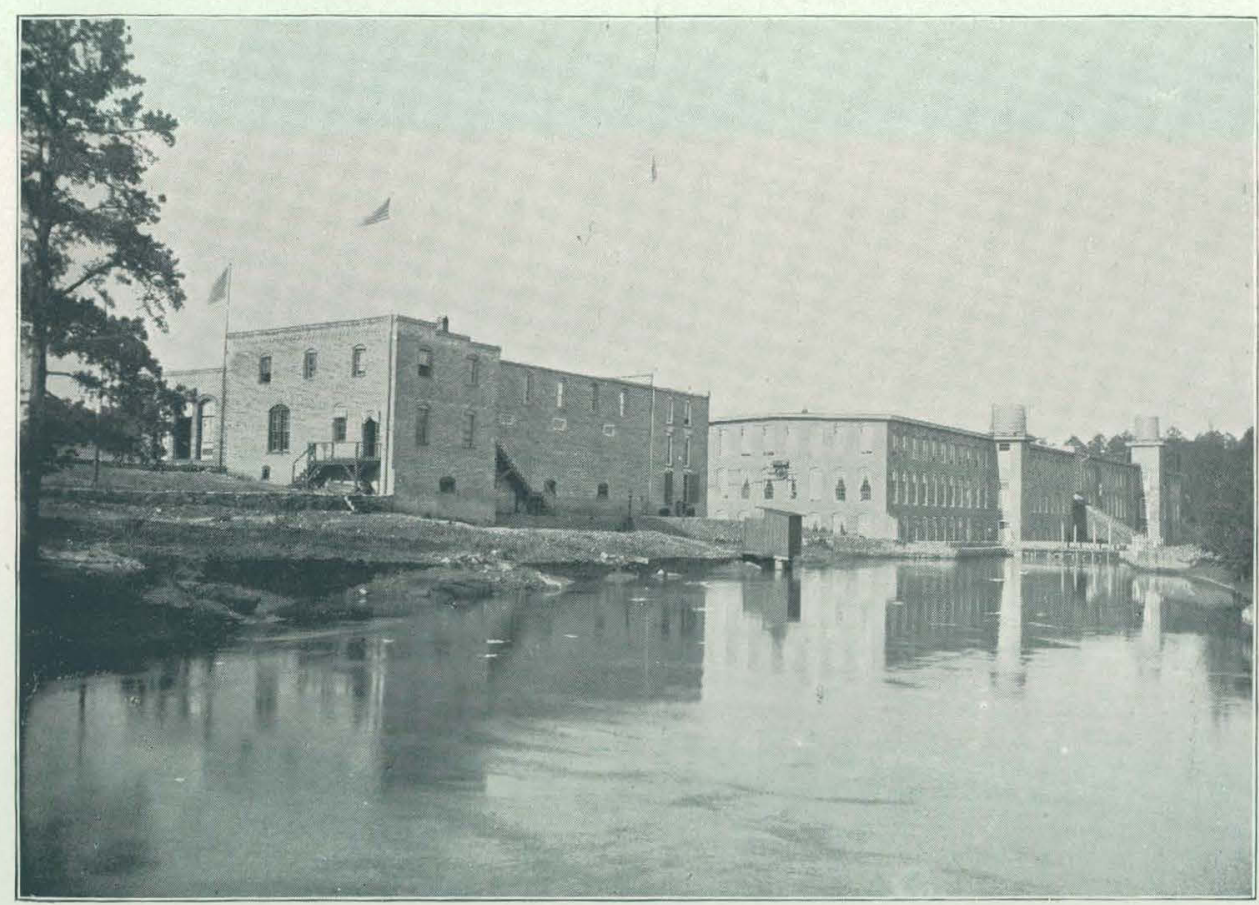

B. CANAL FROM BROAD RIVER TO HENRIETTA COTTON MILL NO. 1, RUTHERFCRD COUNTY, NORTH CAROLINA. 


\section{HAW RIVER. •}

Moncure station on Haw River is described in Water-Supply and Irrigation Paper No. 27, pages 25-26; gage heights for 1898 are given on page 35 , and measurements on page 44 .

\section{DEEP RIVER.}

Moncure station on Deep River is described in Water-Supply and Irrigation Paper No. 27, page 26; gage heights for 1898 are given on page 35 , and measurements on page 44 .

On Pl. VIII, $A$, is shown a view of the dam across Deep River, about 3 miles above its junction with Haw River to form Cape Fear River. This is near Lockville, North Carolina, on the Seaboard Air Line. On Pl. VIII, $B$, is a view of a canal from Broad River in Rutherford County, North Carolina, supplying water power for the Henrietta Cotton Mill No. 1. In the center of the larger buildings is a rope case in which are the ropes transmitting power from the water wheels.

\section{YADKIN RIVER.}

Estimated monthly discharge of Yadkin River at Salisbury, North Ċarolina.

[Drainage area, 3,399 square miles.]

\begin{tabular}{|c|c|c|c|c|c|c|}
\hline \multirow[b]{2}{*}{ Month. } & \multicolumn{3}{|c|}{ Discharge in second-feet. } & \multirow[b]{2}{*}{$\begin{array}{c}\text { Total in acre- } \\
\text { feet. }\end{array}$} & \multicolumn{2}{|c|}{ Run-off. } \\
\hline & $\begin{array}{l}\text { Maxi- } \\
\text { mum. }\end{array}$ & $\begin{array}{l}\text { Mini- } \\
\text { mum. }\end{array}$ & Mean. & & $\begin{array}{c}\text { Depth in } \\
\text { inches. }\end{array}$ & $\begin{array}{c}\text { Second- } \\
\text { feet per } \\
\text { square } \\
\text { mile. }\end{array}$ \\
\hline 1898. & & & & & & $\cdot$ \\
\hline January ........... & 9,290 & 2,100 & 3,460 & 212,747 & 1. 18 & 1. 02 \\
\hline February ..... & 2,850 & 1,400 & 1,957 & 108,686 & 0.60 & 0.58 \\
\hline March ............ & 13,820 & 1,725 & 3,119 & 191,780 & 1.06 & 0.92 \\
\hline April.... & 10,645 & 1,550 & 2,977 & 177,144 & 0.98 & 0.88 \\
\hline May ................... & 12,058 & 1,550 & 2,928 & 180,036 & 0.99 & 0.86 \\
\hline June .............. & 2,567 & 1,400 & 1,855 & 110,380 & 0.61 & 0.55 \\
\hline July . . . . . . . . . & 10,450 & 1,100 & 3,178 & 195,408 & 1.08 & 0.94 \\
\hline August $\ldots \ldots \ldots \ldots$ & 12,880 & 1,725 & 5,185 & 318,813 & 1. 76 & 1.53 \\
\hline September ........ & 79,998 & 1,400 & 8,297 & 493,706 & 2.72 . & 2.44 \\
\hline October ............... & 16,550 & 1,725 & 4,411 & 271,222 & 1.50 & 1.30 \\
\hline November....... & 4,800 & 1,725 & 2,211 & 131,564 & 0.72 & 0.65 \\
\hline December ......... & 12,645 & 1,550 & 3,257 & 200,265 & 1.10 & 0.96 \\
\hline The year..... & 79,998 & 1,100 & 3,569 & $2,591,751$ & 14.30 & 1.05 \\
\hline
\end{tabular}

; Note.-Gage heights for 1898 are given in Water-Supply and Irrigation Paper No. 27, page 36; measurements, page 44 ; results for 1897 in Water-Supply and Irrigation Paper No. 15, page 32, and in the Nineteenth Annual Report, Part IV, page 194. 


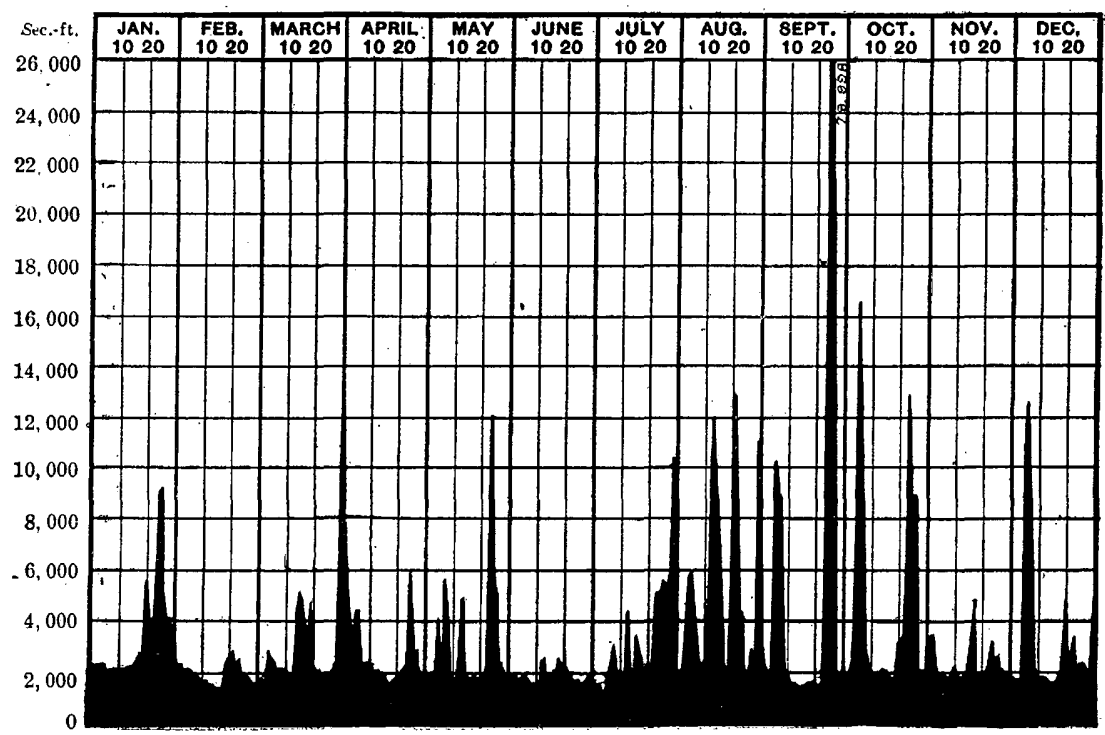

Fra. 43.-Discharge of Yadkin River at Salisbury, North Carolina, 1898.

Estimated nonthly discharge of Yadkin River at Norwood, North Carolina.

[Drainage area, 4,611 square miles.]

\begin{tabular}{|c|c|c|c|c|c|c|}
\hline \multirow[b]{2}{*}{ Month. } & \multicolumn{3}{|c|}{ Discharge in second-feet. } & \multirow[b]{2}{*}{$\begin{array}{l}\text { Total in acre- } \\
\text { feet. }\end{array}$} & \multicolumn{2}{|c|}{ Run-off. } \\
\hline & $\begin{array}{l}\text { Maxi- } \\
\text { zuum. }\end{array}$ & $\begin{array}{l}\text { Mini- } \\
\text { mum. }\end{array}$ & Mean. & & $\begin{array}{l}\text { Depth in } \\
\text { inches. }\end{array}$ & $\begin{array}{l}\text { Second- } \\
\text { feet per } \\
\text { square } \\
\text { mile. }\end{array}$ \\
\hline 1898. & & & & & & \\
\hline January.. & 11,330 & 2,780 & 4,506 & 277,063 & 1.13 & 0.98 \\
\hline February & 4,300 & 2,780 & 3,445 & 191,325 & 0.78 & 0.75 \\
\hline March .... & 27,490 & 2,780 & 5,972 & 367,204 & 1.49 & 1.29 \\
\hline April ...... & 15,820 & 3,540 & 6,128 & 364,641 & 1.48 & 1.33 \\
\hline May & 18,000 & 2,400 & 4,469 & 274,788 & 1.12 & 0.97 \\
\hline June..... & 5,820 & 1,650 & 2,755 & 163,934 & 0.67 & 0.60 \\
\hline July ...... & 8,480 & 1,380 & 3,928 & 241,523 & 0.98 & 0.85 \\
\hline August......... & 12,800 & 2,110 & 5,353 & 329,143 & 1.34 & 1.16 \\
\hline September .. & 63,260 & 1,820 & 8,887 & 528,813 & 2.15 & 1.93 \\
\hline October... & 23,840 & 3,160 & 7,045 & 433,180 & 1.76 & 1.53 \\
\hline November & 9,240 & 3,540 & 5,858 & 348,575 & 1.41 & 1.27 \\
\hline December... & 17,270 & 3,540 & 7,461 & 458,759 & 1.87 & 1. 62 \\
\hline The year & 63,260 & 1,380 & 5,484 & $3,978,948$ & 16.18 & 1.19 \\
\hline
\end{tabular}




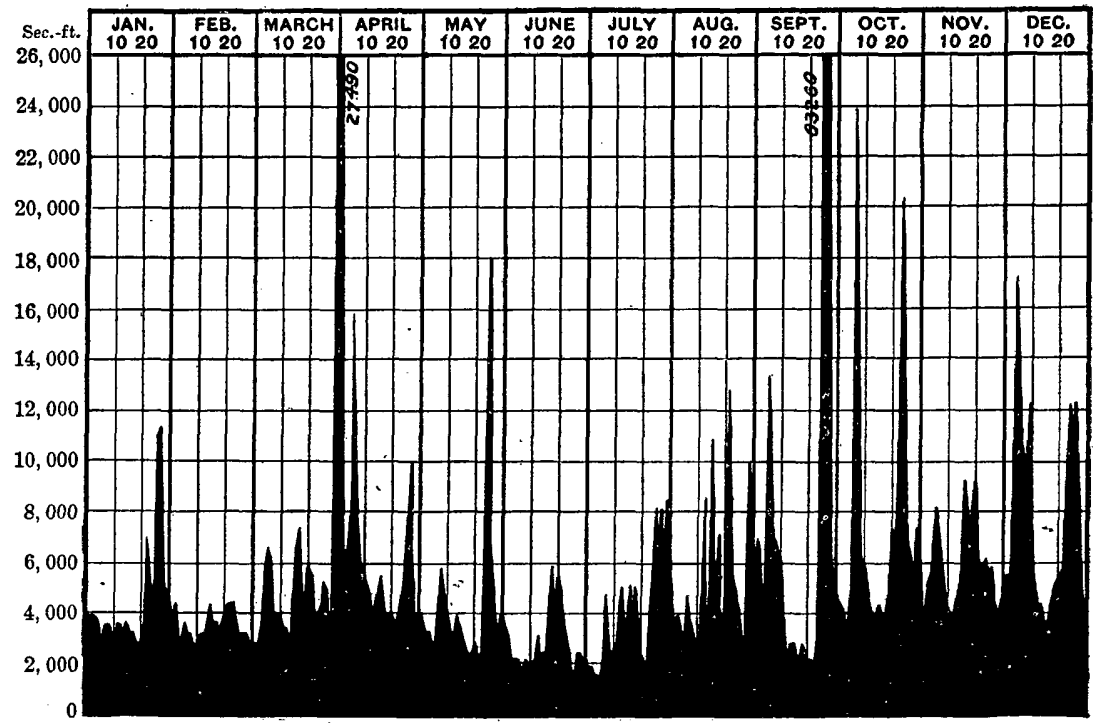

Frg. 44.-Discharge of Yadkin River at Norwood, North Carolina, 1898.

SANTEE RIVER.

Santee River is formed by the junction of Wateree and Congaree rivers in South Carolina. The former stream is known by the name of Catawba River through North Carolina, while the latter is formed at Columbia by the confluence of the Broad and Saluda rivers. The headwaters are in the Blue Ridge in the western part of the State, adjoining the tributaries of the Yadkin on the northeast and of the Tennessee on the west.

Measurements of the flow of a number of tributaries of Santee River have been made at points in North Carolina and South Carolina, as shown on the following pages. On Catawba River two stations have been established, the upper at Catawba, North Carolina, where the drainage area is 1,535 square miles, and the lower about 10 miles below the State line, in South Carolina, where the drainage area is 2,987 square miles. The distance between these stations is approximately 75 miles. On the head waters of Congaree, river stations have been maintained on Broad River at Alston, about 25 miles above Columbia, South Carolina, and on Saluda at Waterloo, about 80 miles above Columbia. The measurements on these streams have been made by Mr. E. W. Myers, under the direction of Prof. J. A. Holmes. 
CATAWBA RIVER.

Estimated monthly discharge of Catawba River at Catawba, North Carolina.

[Drainage area, 1,535 square miles.]

\begin{tabular}{|c|c|c|c|c|c|c|}
\hline \multirow[b]{2}{*}{ Month. } & \multicolumn{3}{|c|}{ Discharge in second feet. } & \multirow[b]{2}{*}{$\begin{array}{c}\text { Total in acre- } \\
\text { feet: }\end{array}$} & \multicolumn{2}{|c|}{ Run·off. } \\
\hline & $\begin{array}{l}\text { Maxi- } \\
\text { mum. }\end{array}$ & $\begin{array}{l}\text { Mini- } \\
\text { mum. }\end{array}$ & Mean. & & $\begin{array}{l}\text { Depth in } \\
\text { inches. }\end{array}$ & $\begin{array}{c}\text { Second. } \\
\text { feet per } \\
\text { square } \\
\text { mile. }\end{array}$ \\
\hline 1898. & & & & & & \\
\hline January ............. & 9,700 & 1,280 & 2,103 & 129,310 & 1.58 & 1.37 \\
\hline February . . . . . . . . & 1,725 & 1,350 & $1,417^{\circ}$ & 78,696 & 0.96 & 0.92 \\
\hline March....... & 15,600 & 1,280 & 2,270 & 139,578 & 1. 71 & 1.48 \\
\hline April...... & 3,675 & 1,575 & 1,949 & 115,973 & 1.42 & 1.27 \\
\hline May......... & 4,135 & 1,210 & 1,600 & 98,381 & 1.20 & 1.04 \\
\hline June.... & 4,135 & 1,000 & 1,322 & 78,664 & 0.95 & 0.86 \\
\hline Julg ........ & $14 ; 125$ & 1,140 & 3,321 & 204,202 & 2.48 & 2.15 \\
\hline August.... & 21,942 & 2,100 & 5,042 & 310,022 & 3.80 & 3.29 \\
\hline September & 52,600 & 1,500 & 6,620 & 393,916 & $4.79^{\circ}$ & 4.30 \\
\hline October.... & 27,400 & 2,675 & 7,250 & 445,788 & 5.45 & 4.72 \\
\hline November... & 3,675 & 1,875 & 2,691 & 160,125 & $1: 95$ & 1.75 \\
\hline December... & 9,995 & 2,175 & 3,162 & 194,425 & 2.38 & 2.06 \\
\hline The year. & 52,600 & 1,000 & 3,229 & $2,349,080$ & 28.67 & 2.10 \\
\hline
\end{tabular}

NoтE.-Gage heights for 1898 are given in Water-Supply and Irrigation Paper No. 27, page 37; measurements, page 44; rating table, page 45; results for 1897 in Water-Supply and Irrigation Paper No. 15, page 34, and in the Nineteenth Annual Report, Part IV, page 204.

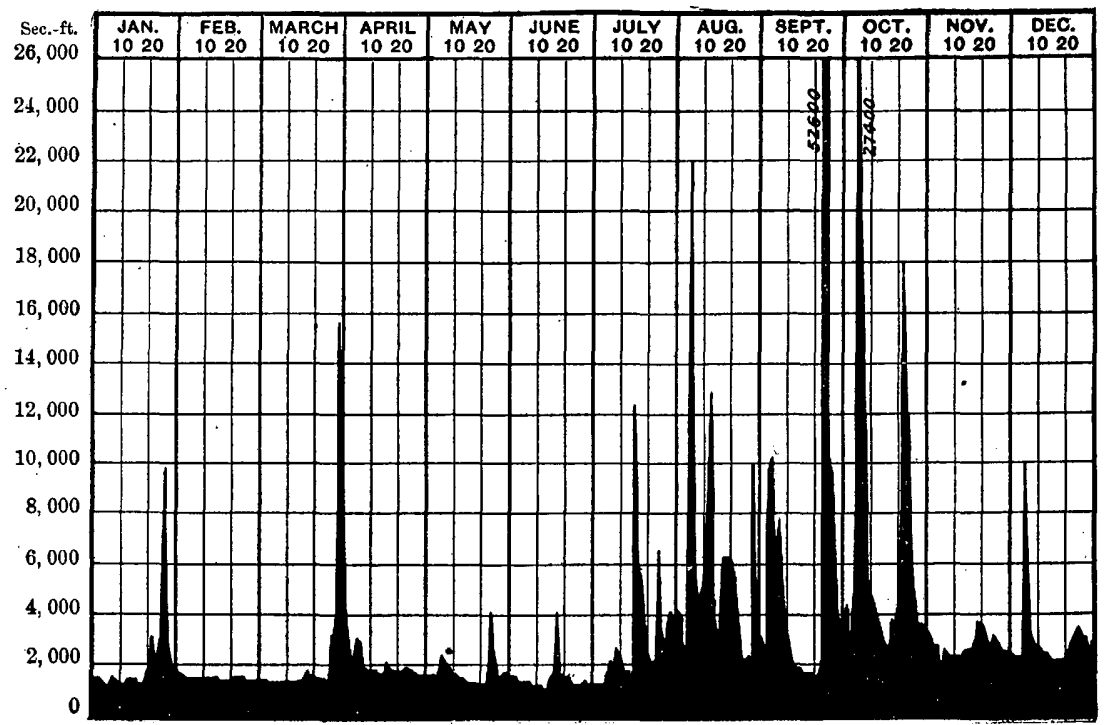

Fig. 45.-Discharge of Catawba River at Catawba, North Carolina, 1898. 
Estimated monthly discharge of Catawba River near Rockhill, South Carolina.

[Drainage area, 2,987 square miles.]

\begin{tabular}{|c|c|c|c|c|c|c|}
\hline \multirow[b]{2}{*}{ Month. } & \multicolumn{3}{|c|}{ Discharge in second-feet. } & \multirow[b]{2}{*}{$\begin{array}{c}\text { Total in acre } \\
\text { feet. }\end{array}$} & \multicolumn{2}{|c|}{ Run-off. } \\
\hline & $\begin{array}{l}\text { Maxi- } \\
\text { mum. }\end{array}$ & $\begin{array}{l}\text { Mini- } \\
\text { mum. }\end{array}$ & Mean. & & $\begin{array}{l}\text { Depth in } \\
\text { inches. }\end{array}$ & $\begin{array}{c}\text { Second } \\
\text { feot per } \\
\text { square } \\
\text { mile. }\end{array}$ \\
\hline 1898. & & & - & & & \\
\hline January ....' & 9,450 & 2,810 & 3,652 & 224,554 & 1.41 & 1. 22 \\
\hline February ... & 3,700 & 2,610 & 2,968 & 164,834 & 1.03 & 0.99 \\
\hline 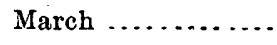 & 18,400 & 2,610 & 3,674 & 225,907 & 1.42 & 1.23 \\
\hline April ............. & 10,500 & 2,610 & 4,090 & 243,371 & 1.53 & 1. 37 \\
\hline 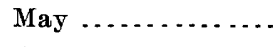 & 4,480 & 2,100 & 2,747 & 168,908 & 1.06 & 0.92 \\
\hline June ............... & 7,220 & 1,800 & 2,650 & 157,686 & 0.99 & 0.89 \\
\hline July ...... & 9,600 & 1,800 & 3,824 & 235,130 & 1.48 & 1. 28 \\
\hline August .. & 22,500 & 3,240 & 6,355 & 390,756 & 2.46 & 2.13 \\
\hline September & $\ldots \ldots$ & $\ldots \ldots$ & $a 6,042$ & $a 359,524$ & $a 2.25$ & $a 2.02$ \\
\hline October .... & $36,5 \mathrm{c} 0$ & 4,480 & 10,489 & 644,947 & 4.05 & 3.51 \\
\hline November... & 6,640 & 5,000 & 5,523 & 328,641 & 2.06 & 1.85 \\
\hline December........... & 12,080 & 4,480 & 6,185 & 380,303 & 2.39 & 2.07 \\
\hline The year..... & 36,500 & 1,800 & 4,850 & $3,524,561$ & 22.13 & 1. 62 \\
\hline
\end{tabular}

a Approximate.

Note.-Gage heights for 1898 are given in Water-Supply and Irrigation Paper No. 27, page 38; measurements, page 44; rating table, page 45; results for 1897 in Water-Supply and Irrigation Paper No. 15, page 35, and in the Nineteenth Annual Report, Part IV, page 204.

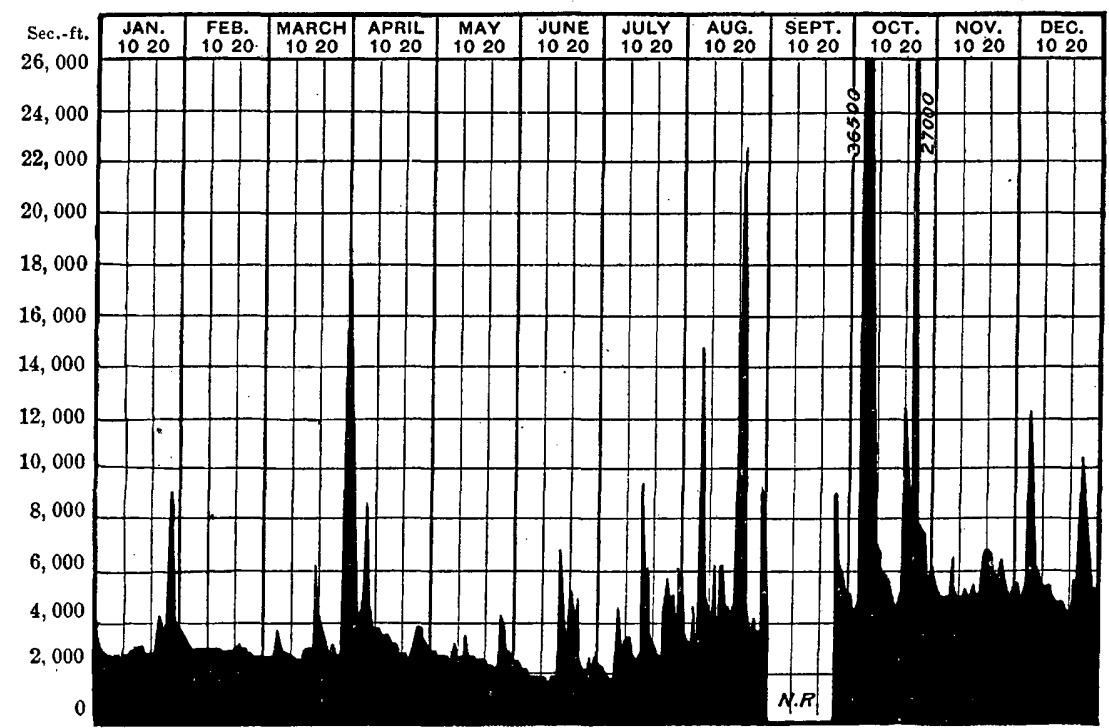

FIG. 46.-Discharge of Catawba River at Rockhill, South Carolina, 1898. 


\section{BROAD RIVER.}

Estimated monthly discharge of Broad River at Alston, South Carolina.

[Drainage area, 4,609 square miles.]

\begin{tabular}{|c|c|c|c|c|c|c|}
\hline \multirow[b]{2}{*}{ Month. } & \multicolumn{3}{|c|}{ Discharge in second-feet. } & \multirow[b]{2}{*}{$\begin{array}{l}\text { Total in acre- } \\
\text { feet. }\end{array}$} & \multicolumn{2}{|c|}{ Run-off. } \\
\hline & $\begin{array}{l}\text { Maxi- } \\
\text { mum. }\end{array}$ & $\begin{array}{l}\text { Mini. } \\
\text { mum. }\end{array}$ & Mean. & & $\begin{array}{l}\text { Deptb in } \\
\text { inches. }\end{array}$ & $\begin{array}{c}\text { Second- } \\
\text { feet per } \\
\text { square } \\
\text { mile. }\end{array}$ \\
\hline 1897. & & & & & & \\
\hline January ... & 16,450 & 2,520 & 4,382 & 269,440 & 1.09 & 0.95 \\
\hline February.. & 47,375 & 3,000 & 13,460 & 747,531 & 3.04 & 2.92 \\
\hline March..... & 28,500 & 4,397 & 11,056 & 679,811 & 2. 77 & 2.40 \\
\hline April... & 39,500 & 4,215 & 9,958 & 592,541 & 2.41 & $2.16^{\circ}$ \\
\hline May ....... & 9,055 & 3,150 & 4,636 & 285,058 & 1.16 & 1.01 \\
\hline June...... & 28,000 & 2,850 & 6,840 & 407,007 & 1.65 & 1.48 \\
\hline July ...... & 11,620 & 2,780 & 4,330 & 266,243 & 1.04 & 0.94 \\
\hline August........ & 13,460 & 2,080 & 3,663 & 225,231 & 0.92 & 0.80 \\
\hline September & 8,005 & 1,900 & 2,739 & 162,981 & 0.65 & 0.59 \\
\hline October ..... & 15,185 & 1,980 & 3,658 & 224,923 & 0.91 & 0.79 \\
\hline November... & 7,590 & 2,205 & 3,210 . & 191,008 & 0.78 & 0.70 \\
\hline December ....... & 5,990 & 2,850 & 3,786 & 232,794 & 0.94 & 0.82 \\
\hline The Jear & 47,375 & 1,900 & 5,976 & $4,284,568$ & 17.36 & 1.30 \\
\hline 1898. & 14.150 & 2850 & 4608 & 283,337 & 1,15 & 1.00 \\
\hline February. & 4,490 & 2,925 & 3,443 & 191,215 & 0.77 & 0.74 \\
\hline March ... & 10,360 & 3,000 & 4,082 & 250,994 & 1.02 & 0.89 \\
\hline April...... & 14,495 & 3,460 & 6,029 & 358,750 & 1.46 & 1. 31 \\
\hline May ....... & 4,397 & 2,010 & 2,958 & 181,882 & 0.74 & 0.64 \\
\hline June..... & 6,090 & 1,835 & 2,928 & 174,228 & 0.71 & 0.64 \\
\hline July ..... & 12,770 & 1,815 & 4,960 & 304,980 . & 1.25 & 1.08 \\
\hline August.... & 15,875 & 3,460 & 7,074 & 434,966 & 1.76 & 1.53 \\
\hline September & 28,500 & 2,010 & 7,444 & 442,948 & 1.81 & 1.62 \\
\hline October ... & 18,800 & 2,850 & 6,459 & 397,151 & 1.61 & 1.40 \\
\hline November... & 6,890 & 3,620 & 4,637 & 275,919 & 1.13 & 1.01 \\
\hline December .......... & 12,310 & 3,227 & 5,666 & 348,391 & 1.42 & 1.23 \\
\hline The year. & 28,500 & 1,815 & 5,024 & $3,644,761$ & 14.83 & 1.09 \\
\hline
\end{tabular}

NOTE.-Gage heights for 1898 are given in Water-Supply and Irrigation Paper No. 27, page 39; measurements, page 44; rating table, page 45; results for 1897 in Water-Supply and Trrigation Paper No. 15, page 34, and in the Nineteenth Annual Report, Part IV, page 204. 


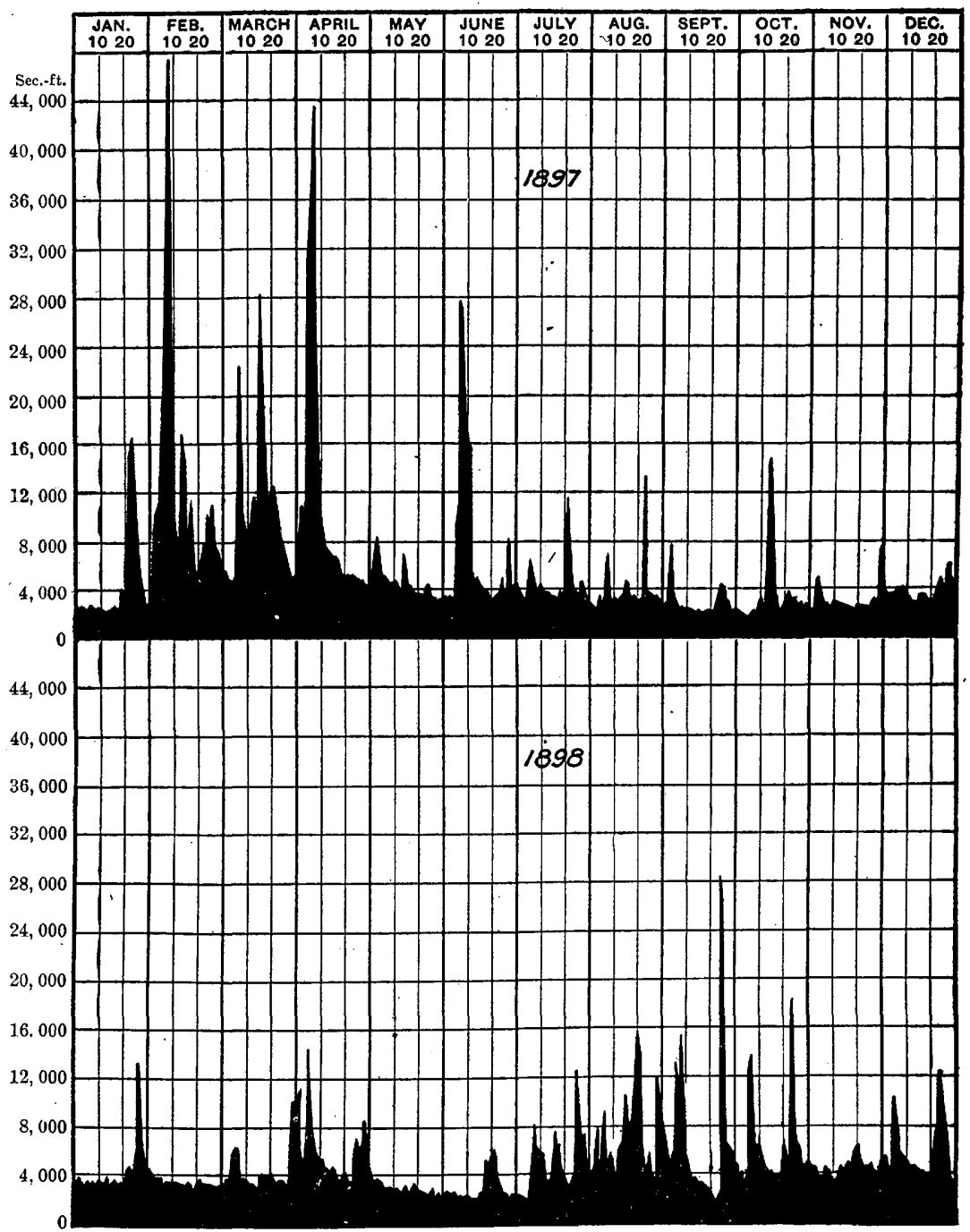

Fig. 47.-Discharge of Broad River at Alston, South Carolina, 1897 and 1898.

The above diagram gives the daily fluctuations of Broad River for two years, bringing out the striking difference that during 1897 the greater part of the water occurred in February, March, and April, while in 1898 the floods during late winter and spring are few and small. This difference is noticeable on a number of diagrams given on the preceding pages. 
SAITTDA RIVER.

Estimated monthly discharge of Saluda River at Waterloo, South Carolina.

[Drainage area, 1,056 square miles.]

\begin{tabular}{|c|c|c|c|c|c|c|}
\hline \multirow{2}{*}{ Month. } & \multicolumn{3}{|c|}{ Discliarge in second-feet. } & \multirow{2}{*}{$\begin{array}{c}\text { Total in acre- } \\
\text { feet. }\end{array}$} & \multicolumn{2}{|c|}{ Run-off. } \\
\hline & $\begin{array}{l}\text { Maxi- } \\
\text { mum. }\end{array}$ & $\begin{array}{l}\text { Mini- } \\
\text { mum. }\end{array}$ & Mean. & & $\begin{array}{c}\text { Depth in } \\
\text { inches. }\end{array}$ & $\begin{array}{c}\text { Second. } \\
\text { feet per } \\
\text { square } \\
\text { mile. }\end{array}$ \\
\hline 1897. & & & & & & \\
\hline January .......... & 6,530 & 782 & 1,550 & 95,306 & 1.69 & 1.47 \\
\hline February .......... & 12,330 & 1,420 & 3,653 & 202,877 & 3.60 & 3.46 \\
\hline 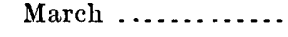 & 8,330 & 1,160 & 3,382 & 207,952 & 3.70 & 3.20 \\
\hline April .... & 12,730 & 1,360 & $.3,125$ & 185,950 & 3.41 & 2.96 \\
\hline May .... & 5,030 & 651 & 1,668 & 102,562 & 1. 82 & $1 . \dot{58}$ \\
\hline June....... & 7,980 & 630 & 1,806 & 107,464 & 1. 91 & 1. 71 \\
\hline July ........ & 2,430 & 672 & 1,140 & . 70,096 & 1.25 & 1.08 \\
\hline August...... & 2,355 & 375 & 912 & 56,077 & 0.99 & 0.86 \\
\hline September . & 1,512 & 350 & 778 & 46,294 & 0.82 & 0.74 \\
\hline October.... & 3,270 & 335 & 1,001 & 61,549 & 1.09 & 0.95 \\
\hline November... & 2,092 & 485 & 1,165 & 69,322 & 1.23 & 1.10 \\
\hline December ... & 1,512 & 715 & 1,166 & 71,695 & 1.27 & 1. 10 \\
\hline The year..... & 12,730 & 335 & 1,779 & $1,277,144$ & 22.78 & 1.68 \\
\hline 1898. & & & & & & \\
\hline January .......... & 4,055 & 570 & 1,369 & 84,177 & 1.50 & 1.30 \\
\hline February ......... & 1,330 & 505 & 1,009 & 56,037 & 1.00 & 0.96 \\
\hline March .............. & 3,710 & 527 & 1,213 & 74,585 & 1.35 & 1.17 \\
\hline April.... & 3,470 & 805 & 1,612 & 95,920 & 1. 71 & 1.53 \\
\hline May ... & 1,420 & 400 & 968 & 59,520 & 1.06 & 0.92 \\
\hline June....... & 2,167 & 350 & 888 & 52,840 & 0.93 & 0.84 \\
\hline July ...... & 4,100 & 290 & 1,453 & 89,342 & 1.59 & 1.38 \\
\hline August... & 6,830 & 1,052 & 2,331 & 143,329 & 2.55 & 2.21 \\
\hline September . & 8,230 & 828 & 2,263 & 134,658 & 2.39 & 2.14 \\
\hline October ......... & 7,080 & 1,160 & 2,314 & 142,283 & 2.53 & 2.19 \\
\hline November. & 2,655 & 693 & 1,469 & 87,411 & 1.55 & 1.39 \\
\hline December . & 3,830 & 900 & 1,992 & 122,484 & 2.18 & 1.89 \\
\hline The year & 8,230 & 290 & 1,573 & $1,142,586$ & 20.34 & 1.49 \\
\hline
\end{tabular}

Note.-Gage heights for 1898 are given in Water-Supply and Irrigation Paper No. 27, page 39; measurements, page 44; rating table, page 46; results for 1897 in Water-Supply and Irrigation Paper No. 15, page 38, and in the Nineteentb Annual Report, Part IV, page 221. 


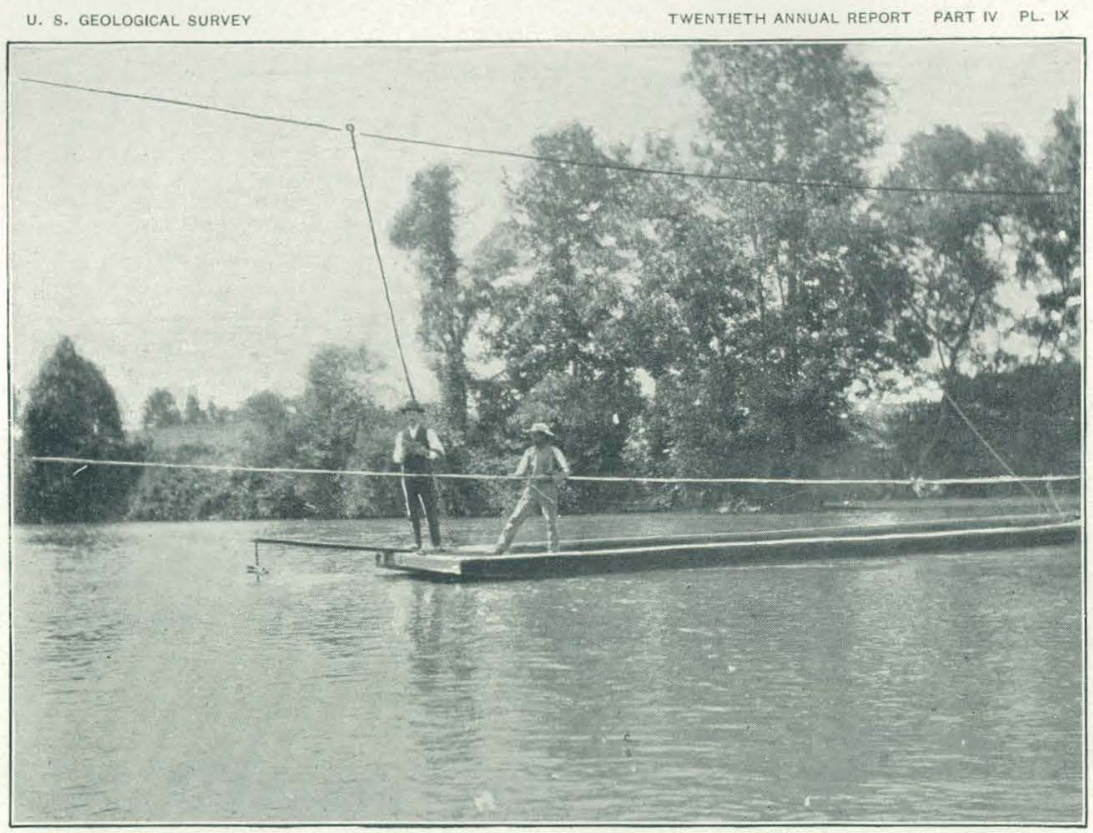

A. MEASUREMENT OF TUGALOO RIVER FROM FERRYBOAT NEAR FORT MADISON, SOUTH CAROLINA.

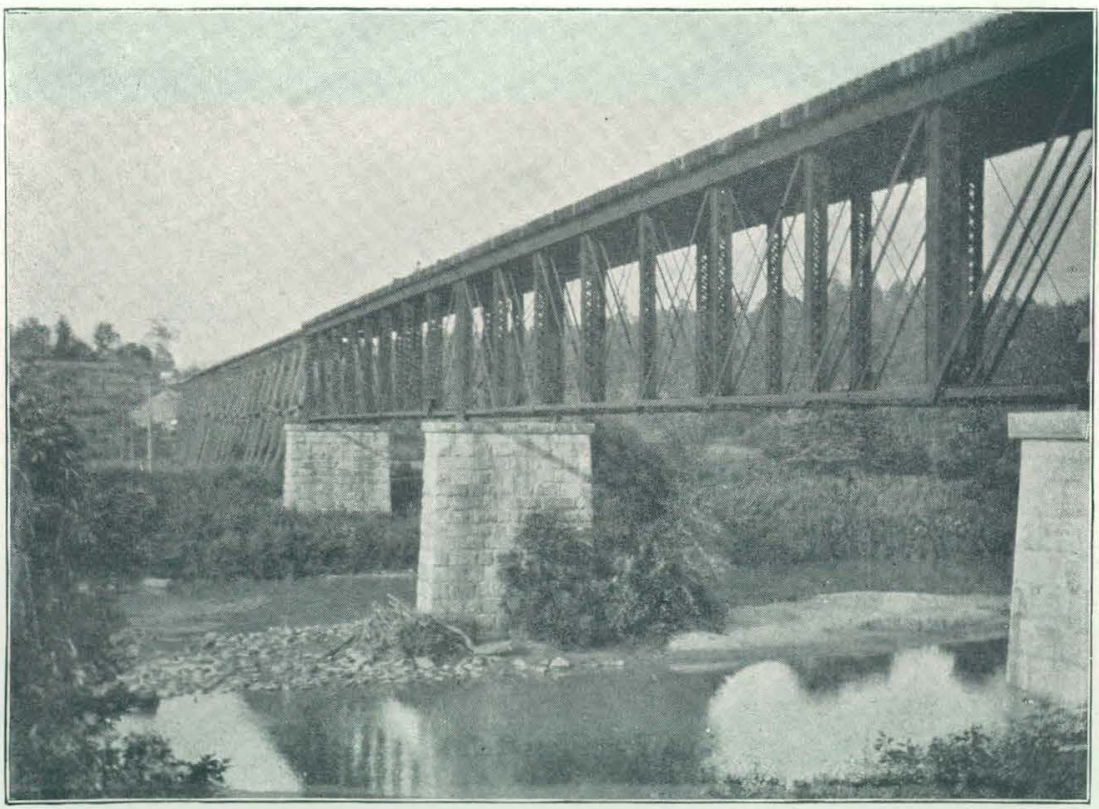

B. BROAD RIVER NEAR CARLTON, GEORGIA. 


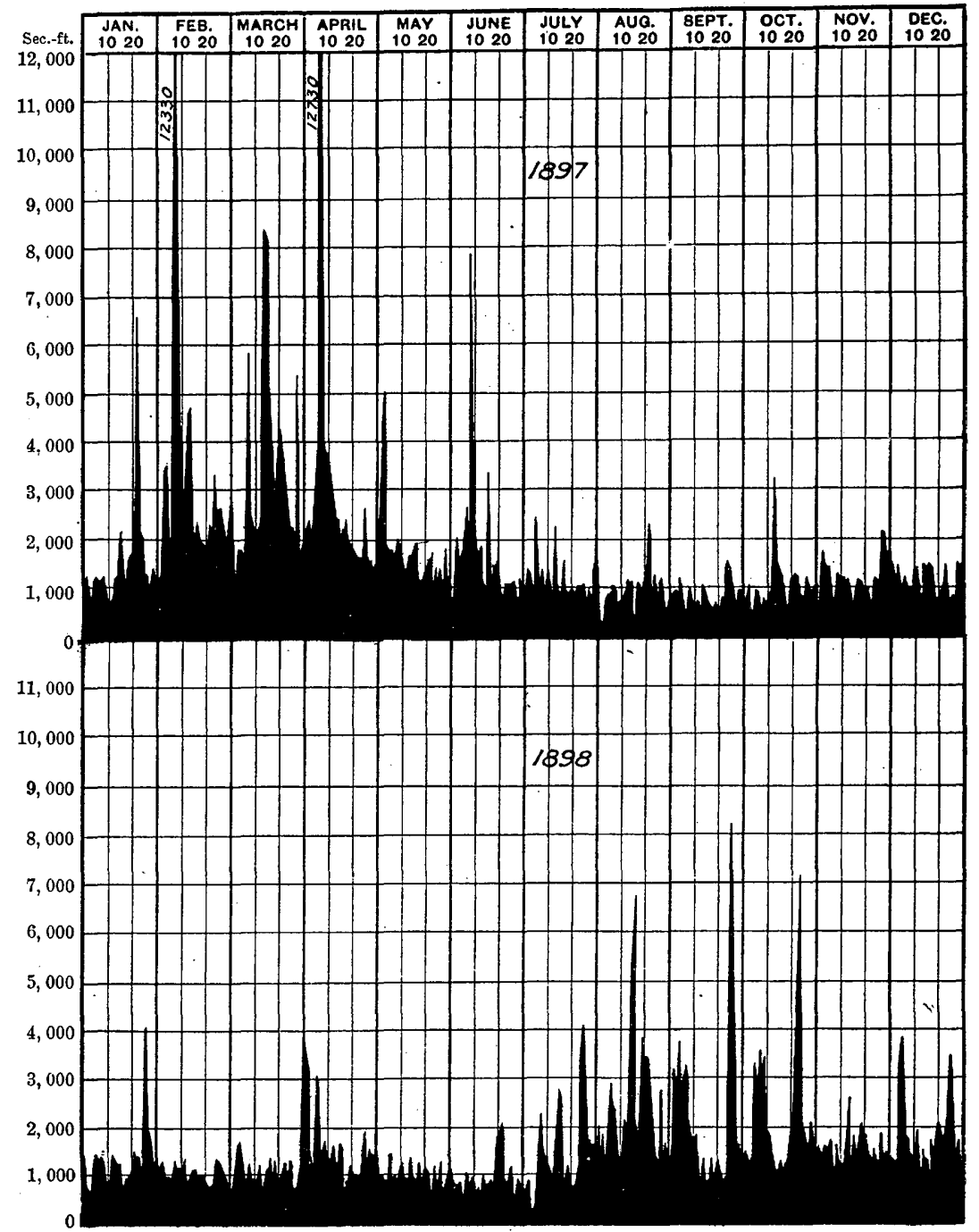

Fig. 48.-Discharge of Saluda River at Waterloo, South Carolina, 1897 and 1898.

\section{SAVANNAH RIVER.}

Savannah River is formed by the junction of the Tugaloo with the Seneca (or Keowee) River about 100 miles above Augusta, Georgia. These rivers have their sources in the Blue Ridge Mountains in North and South Carolina and Georgia. Augusta, Georgia, is the head of navigation on the Savannah River, this being the point at which the stream passes out of the crystalline rocks into the younger geological formation, or crosses what is known as the "fall line." From Augusta to Savannah are over 200 miles of river navigable for steamboats draw- 
ing from 4 to 5 feet at ordinary low water. From Savannab to the sea, a distance of 20 miles, there is navigation for large seagoing vessels.

From the junction of the Tugalon and Seneca rivers to the city of Augusta the Savannah River falls 448 feet, nearly all of this being available for water power, as it occurs at a number of shoals with long stretches of comparatively quiet water between. Practically all of this immense power is running to waste except the 50.foot fall that is developed by the Augusta Canal, which furnishes power for city waterworks and electric plant and for many large manufacturing establishments. All of the tributaries entering above Augusta have good shoals on them, only a few of which are utilized.

A summary of the older utilized powers of this basin is given in the Tenth Census Report. There are new developments at Augusta and on many of the tributaries. Prominent among these are the Elberton electric light plant, on Beaverdam Creek, the Headmont factory on the same stream, and the Anderson, South Carolina, electric plant, on Seneca River.

During the year 1898 river stations were maintained at Madison, South Carolina, on Tugaloo River (Pl. IX, $A$ ); at Carlton, Georgia, on Broad River (Pl. IX, $B$ ); at Calhoun Falls, South Carolina, on Savannah River; and at Augusta, Georgia, on Savannah River. These furnish data for computing the discharge as given in the tables on pages 162 to 165 , while a fair idea of the most important shoals in this basin in Georgia can be obtained from the following tabular statement taken from Bulletin No. 3A of the Georgia geological survey, compiled by B. M. Hall and printed in 1896. It must be remembered that the shoals mentioned in this statement are only the abrupt descents at certain points, and do not cover the fall that can be utilized by dams. For instance, those given for the Savannah proper aggregate only 247 feet, while the total fall of the river from the top of McDaniels Shoal to the foot of Augusta Shoal is 448 feet.

Water powers in Savannah Basin.

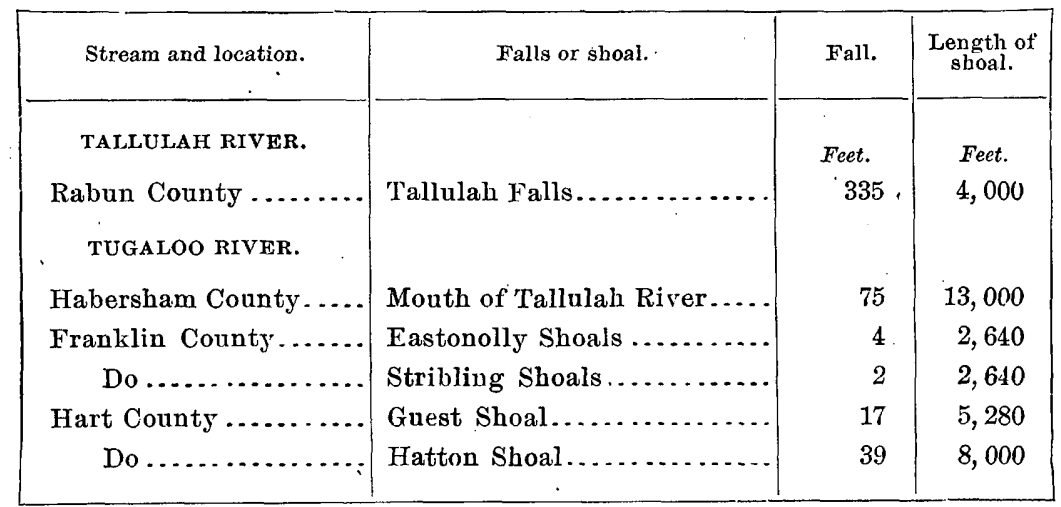


Water powers in Savannah Basin-Continued.

\begin{tabular}{|c|c|c|c|}
\hline Stream and location. & Falls or shoal. & Fall. & $\begin{array}{l}\text { Length of } \\
\text { shoal. }\end{array}$ \\
\hline BROAD RIVER. & . & & \\
\hline Elbert County ...... & Bakers Ferry $\ldots . . . . . . . .$. & 3 & 600 \\
\hline 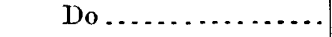 & Anthonys Shoals............ & 70 & 6,600 \\
\hline Do $\ldots \ldots \ldots \ldots$ & Smith Shoals..... & 10 & 2,640 \\
\hline SAVANNAH RIVER. & & & \\
\hline Hart County .......... & McDaniels Shoals ........... & 30 & 26,000 \\
\hline Elbert County..... & Ferrills Ledge............... & 3 & 360 \\
\hline Do $\ldots \ldots \ldots$ & Middletons Shoal.. & 18 & 5,280 \\
\hline Do ........... & Greggs Shoal..... & 14 & 5,280 \\
\hline Do ....... & Bowmans Ledge. & 3 & 120 \\
\hline Do .... & Cherokee Shoal.... & 9 & 2,640 \\
\hline Do............ & Trotters Shoal. & 75 & 37,000 \\
\hline Lincoln County .... & Long Shoal.... & 35 & 26,000 \\
\hline Columbia County... & Blue Jacket Shoal. & 10 & 600 \\
\hline Richmond County...... & Augusta ...... & 50 & 37,000 \\
\hline
\end{tabular}

The Carolina gold belt crosses this basin diagonally, passing through McCormick, South Carolina, and ending at Sparta, Georgia. It is a region of hard quartz fissure veins, and some of the stamp mills in use are run by water power.

A view of Savannah River at the Seaboard Air Line bridge near Calhoun Falls, South Carolina, is given in Pl. $\mathrm{X}, A$. This shows the east channel from the South Carolina bank below the bridge. On Pl. $\mathrm{X}, B$, is a view of Oconee River at the Georgia Railroad bridge near Carey, Georgia, looking from the left bank below the bridge.

A survey of Savannah River was made ${ }^{1}$ between May 16 and August 6, 1889, by Mr. George W. Brown, assistant engineer, United States Army, from whose report the following statements have been taken:

The basin of the Savannah River above Augusta comprises an area of about 7,294 square miles of hilly country, extending to the Blue Ridge Mountains, and having a width of from 40 to 50 miles. This portion of the river is fully described in the report on the survey of the Savannah River above Augusta, dated January 31, 1890. The river basin below Augusta has an area of about 3,211 square miles, with an average width of 30 miles, giving a total drainage area of 10,505 square miles. In this lower portion of the valley the soil is quite sandy and permeable, forming good farming lands, the principal products of which are cotton, grain, potatoes, and garden produce. The timbered lands produce lumber and naval stores. Low $\mathrm{swamp}$ lands border the river for a width of from 3 to 10 miles.

-The river carries considerable sediment, the amount being greatly increased during freshets. The bottom is composed of fine sand and mud. Rock occurs only in a few places, and at considerable depths, offering no obstruction to navigation. The banks vary in height, from about 25 foet above low-water level at Augusta to about 
4 feet at the Cross Tides. The distance in a direct line from Augusta to Savannall is 107 miles. Following the river channel, the distance is $202 \frac{1}{2}$ miles. This distance

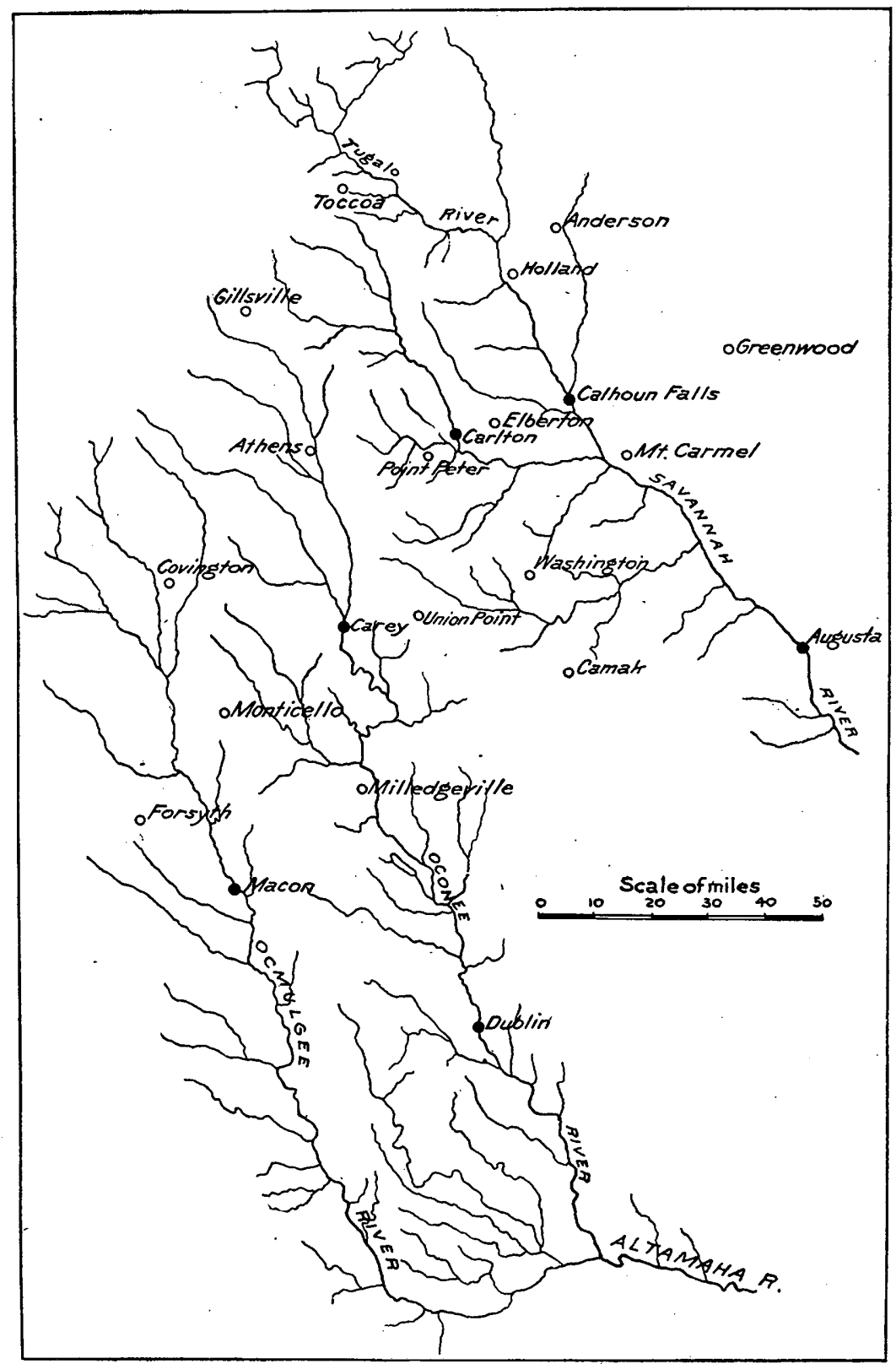

FIG. 49.-Relative location of river and rainfall observations in basins of Savannah and Altamaha rivers.

has formerly been greatly overestimated, never, so far as is known, having been established by an actual survey until that of 1889 was made. For the first 30 miles 


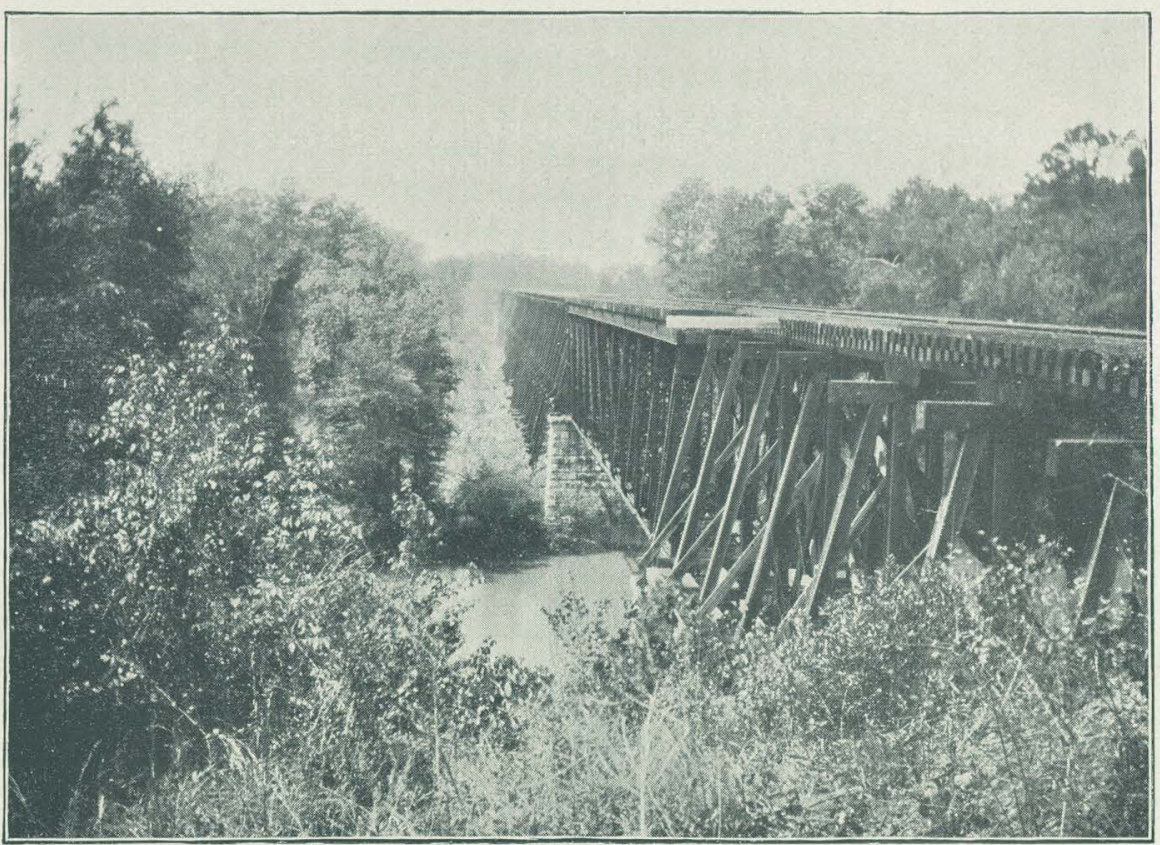

A. SAVANNAH RIVER NEAR CALHOUN FALLS, SOUTH CAROLINA.

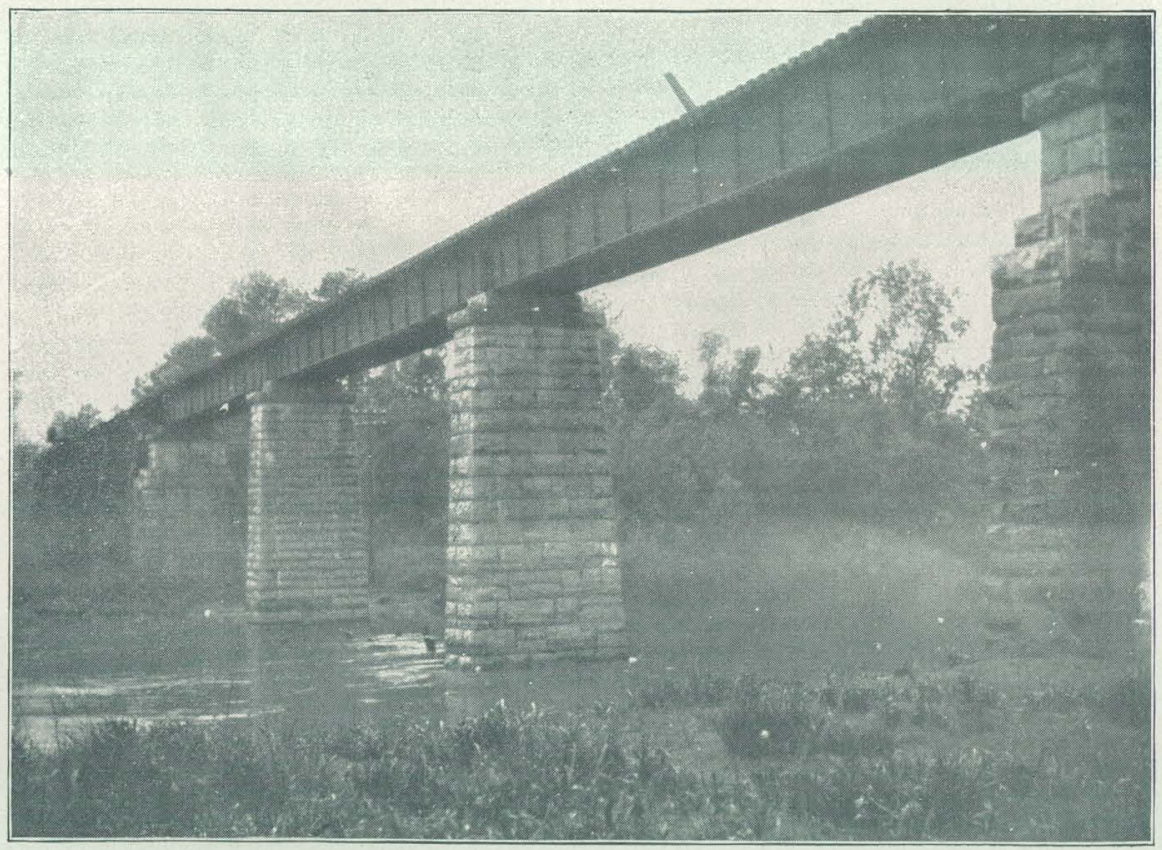

$B$ OCONEE RIVER AT CAREY, GEORGIA 
below Augusta the river widths are excessive, varying between 500 and 900 feet. Seven out of the nine bars on the river occur on this portion of the stream. For the remainder of the river the average low-water width is 300 feet.

The total fall between low water at Augusta and mean low tide at Savannah is 108 feet, giving a mean slope of 0.5333 of a foot per mile. The middle third of the river has the steepest slope, viz, 0.636 of a foot per mile, while from this part to the tidal portion the slope is about 0.5 of a foot per mile.

The river was gaged at four points, viz, Augusta, Hancocks Landing, Cohens Bluff, and Gaffneys Landing.

PRECIPITATION IN BASINS OF SAVANNAH AND ALTAMAHA RIVERS.

The principal rainfall stations in the basins of the Savannah and Altamaha rivers are at Toccoa, Gillsville, Holland, Anderson, Green. wood, Point Peter, Elberton, Mount Carmel, Washington, Athens, Covington, Monticello, Milledgeville. The relative location of these points is shown on fig. 49 , in connection with the points of river measurement, which are located at Carlton, Calhoun Falls, Augusta, Carey, Macon, and Dublin. Measurements have also been made near Fort Madison, South Carolina, on Tugaloo River.

The following table gives the names and locations of the stations, the elevations, and the lengths of the records:

Location of rainfall stations in basins of Savannah and Altamaha rivers.

\begin{tabular}{|c|c|c|c|c|c|c|c|c|}
\hline Station. & County. & State. & & $\begin{array}{l}\text { ati. } \\
\text { dide. }\end{array}$ & & $\begin{array}{l}\text { ngi. } \\
\text { de. }\end{array}$ & $\begin{array}{c}\text { Eleva. } \\
\text { tion. }\end{array}$ & $\begin{array}{l}\text { Length o } \\
\text { record. }\end{array}$ \\
\hline Toccoa & Habersham & Georgia ........... & & & $\begin{array}{l}\circ \\
83\end{array}$ & & $\begin{array}{l}\text { Feet. } \\
66 \overline{0}\end{array}$ & $\begin{array}{r}\text { Years. } \\
7-18\end{array}$ \\
\hline Gillsville ... & Hall .... & .... do ........... & 34 & 13 & 83 & 56 & 1,052 & $7-9$ \\
\hline Holland .... & Anderson ... & South Carolina.. & & 22 & 82 & 50 & 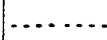 & $4-6$ \\
\hline Anderson ... & ..... do ..... & .... do $\ldots . . . .$. & 34 & 28 & 82 & 41 & 764 & $6-10$ \\
\hline Greenwood & Abbeville... & .... do .......... & 34 & 11 & 82 & 09 & 671 & 5-14 \\
\hline Point Peter. & Oglethorpe. & Georgia & 33 & 55 & 83 & 05 & 1,000 & $8-9$ \\
\hline Elberton ... & Elbert ....... & ....do .......... & 34 & 7 & 82 & 52 & 710 & 7 \\
\hline $\begin{array}{l}\text { Mount Car- } \\
\text { mel. }\end{array}$ & Abbeville ... & South Carolina.. & 34 & & 82 & 30 & . & 6 \\
\hline Washington. & Wilkes.... & Georgia & 38 & 42 & 82 & 44 & $\ldots$ & $5-14$ \\
\hline Athens ..... & Clarke .... & $\ldots \ldots$ do $\ldots .$. & 33 & 58 & 83 & 23 & 850 & $18-23$ \\
\hline Covington.. & Newton... & $\ldots$. do $\ldots$. & & 37 & 83 & & 748 & $4-8$ \\
\hline
\end{tabular}

In the following table are given the figures of normal or average monthly precipitation from the time of the beginning of the record to and including 1897, together with the total precipitation, by months, for the years 1896,1897, and 1898; and also the amount by years. In obtaining the normal precipitation the average is taken for all of the months during which observations were made. 
Precipitation at stations in drainage basins of Savannah and Altamaha vivers.

TOCCOA.

\begin{tabular}{|c|c|c|c|c|c|c|c|c|c|c|c|c|c|}
\hline Year. & Jan. & Feb. & Mar. & Apr. & May. & June. & July. & Ang. & Sept. & Oct. & Nov. & Dec. & Annual. \\
\hline Normal...... & 5.66 & 5.17 & 5.21 & 4.87 & 4.25 & 4.56 & 6.10 & 6.41 & 4.33 & 2.49 & 3.74 & 4.08 & 56.87 \\
\hline 1896. & 4.60 & 4.68 & 2.04 & 2.54 & 4.11 & 3.40 & 13.10 & 1.29 & 2.32 & 1.56 & 8.22 & 1.04 & 48.92 \\
\hline 1897. & 4.71 & 6.77 & 7.46 & 7. 19 & 0.85 & 1.24 & 6.03 & 2.59 & 0.50 & 3.44 & 3.71 & 4.44 & 48.93 \\
\hline 1898. & 4.68 & 0.69 & 5.58 & 5.08 & 1.18 & 0.89 & 9.39 & 9.13 & 11.98 & 7.62 & 3.26 & 2.79 & 62.27 \\
\hline \multicolumn{14}{|c|}{ GILLSVIILE. } \\
\hline Normal....... & 4.82 & 4.68 & 5.04 & 3.30 & 3. 34 & 3.80 & 6.48 & 4.65 & 3.87 & 1. 66 & 2.65 & 2.88 & 47.17 \\
\hline 1896. & 4. 45 & 2.14 & 2.11 & 0.80 & 4.68 & 2.82 & 7.62 & 1.48 & 1.48 & 1.57 & 6.13 & 0.40 & 35.68 \\
\hline 1897. & 4.26 & 5.40 & 6.50 & 6.62 & 0.00 & 2.48 & 10.94 & 2.95 & 0.00 & 5.11 & 1.83 & 3.91 & 50.00 \\
\hline 1898. & 1.26 & 0.36 & 3.54 & 4. 20 & 1.03 & 2.64 & 6.75 & 7.78 & 10.13 & 8.18 & 3.17 & 3.54 & 52.58 \\
\hline \multicolumn{14}{|c|}{ HOLLAND. } \\
\hline Normal.. & 5.30 & 4.48 & 3.74 & 2.85 & 3.04 & 4.24 & 6.01 & 5.81 & 3.62 & 3.10 & 3.42 & 3.77 & 49.38 \\
\hline 1896. & 4.70 & 4.61 & 2.04 & 2.16 & 2.70 & 4.00 & 8.63 & 4.12 & $a 3.62$ & 2.21 & 6.44 & 2.50 & 47.73 \\
\hline $1897 .$. & 4.80 & 6.63 & 6.72 & 4.62 & 1.19 & 4. 80 & 5. 82 & 2.66 & 1.76 & 4.35 & 4.40 & 3.09 & 50.84 \\
\hline $1898 \ldots$ & 3.60 & 1.03 & 4.75 & 6.23 & 0.65 & 1.67 & 7.56 & 7.70 & 5.95 & 6.53 & 3.52 & 3.58 & 52.77 \\
\hline \multicolumn{14}{|c|}{ ANDERSON. } \\
\hline Normal & 4. 52 & 5.14 & 3. 61 & 2. 70 & 3.82 & 5.51 & 4.92 & 4. 79 & 2.97 & 2.65 & 3.80 & 3.21 & 47.64 \\
\hline $1896 \ldots$ & 4.36 & 4.00 & 2.02 & 1.02 & 1.67 & 4. 73 & 7.44 & 1.11 & 2.91 & 1.85 & 7.46 & 2.48 & 41.05 \\
\hline 1897. & 3.85 & 6.81 & 5.39 & 4.20 & 1.73 & 3.12 & 6.06 & 6.32 & 1.98 & 4.17 & 4.28 & 2. 76 & 50.67 \\
\hline $1898 \ldots$ & 3.83 & 0.95 & 4.16 & 4.03 & 1.03 & 3.98 & 9.01 & 9.34 & 5.50 & 4.83 & 3.27 & 3.16 & 53.09 \\
\hline \multicolumn{14}{|c|}{ GREEN WOOD. } \\
\hline Normal & 2.53 & 2.89 & 2.06 & 2.55 & 3.77 & 4.54 & 5.05 & 3.76 & 4.00 & 1.95 & 2.32 & 2.18 & $\$ 7.60$ \\
\hline $1896 .$. & 4.48 & 4.40 & 1.65 & 2.26 & 1.94 & 4.21 & 15.72 & 2.62 & 0.56 & $a 1.95$ & 8.11 & 2.89 & 50.79 \\
\hline $1897 \ldots$ & 4.25 & 7.56 & 4.04 & 4.28 & 2.20 & 3.39 & 5.16 & 3.14 & 3.04 & 2.34 & 2.34 & 1.92 & 43.66 \\
\hline $1898 \ldots \ldots \ldots$ & 2.59 & 0.57 & 3.77 & 4.12 & 1.65 & 4.15 & 4.92 & 7.18 & 4.44 & 5.59 & 3.85 & 2.22 & 45.05 \\
\hline \multicolumn{14}{|c|}{ POINT PETER. } \\
\hline Normal. & 5.81 & 5.12 & 5.54 & 3.40 & 2.81 & 3.52 & 5.21 & 5.11 & 3.56 & 2.31 & 3.21 & 2.94 & 47.64 \\
\hline 1896. & 5.40 & 4. 60 & 3.35 & 2.90 & 2.55 & 1.45 & 8.65 & 1.10 & 1.25 & 2.35 & 6.60 & 3.15 & 43.35 \\
\hline $1897 .$. & $a 5.81$ & 6.50 & 5.68 & 6.51 & 0.96 & 3.91 & 4.37 & 6.74 & 2.05 & 2.21 & 3.00 & 3.05 & 50.79 \\
\hline $1898 . .$. & 3. 10 & 0.70 & 4.25 & 5. 38 & 0.17 & 1.82 & 11.51 & 8.74 & 2.59 & 8.79 & $4: 58$ & 3.62 & 55.25 \\
\hline \multicolumn{14}{|c|}{ ELBERTON. } \\
\hline Norma & 6.16 & 4.68 & 5.57 & 3.21 & 2.25 & 4.32 & 5.82 & 4.55 & 2.41 & 2.18 & 2.87 & 3.53 & 47.55 \\
\hline 1896. & 5.45 & 4.91 & 3.41 & 2.23 & 2.10 & 2.79 & 7.46 & 1.44 & 2.13 & 2.27 & 5.61 & 2.82 & 46.62 \\
\hline 1897 & 4.06 & 6.43 & 7.94 & 5.02 & 1.01 & 5. 66 & 5.33 & 4. 07 & 1.45 & 2.80 & 1.65 & 3.35 & 48.77 \\
\hline 1898. & 2. 90 & 1.14 & 4.50 & 5.35 & 3.66 & 2.37 & 7.72 & 12.15 & 5.63 & 7.10 & 4. 76 & 2.82 & $60 . j 0$ \\
\hline \multicolumn{14}{|c|}{ MOUNT CARMEL. } \\
\hline Normal ....... & 4.46 & 5.03 & 3.71 & 3.30 & 2.80 & 4.06 & 6.15 & 6.41 & 3.50 & 2.31 & 3.37 & 3.33 & 48.08 \\
\hline $1896 \ldots$ & 3. 81 . & 5.78 & 2.40 & 2.46 & 2.55 & 2.09 & 10.27 & 4.26 & 2.53 & 2.37 & 8.17 & 4.63 & 51. 33 \\
\hline $1897 \ldots$ & 3.93 & 7.93 & 4. 39 & 5.50 & 2.97 & 1.82 & 4.86 & 6.38 & 2. 78 & 1.87 & 2.43 & 1.56 & 46.42 \\
\hline $1898 \ldots$ & 2.54 & 0.43 & 4.22 & 5.05 & 0.98 & 2.77 & 8.93 & 8. 30 & 10.64 & 6.13 & 3.78 & 3.41 & 57.18 \\
\hline
\end{tabular}

$a$ Estimated. 
Precipitation at stations in drainage basins of Savannah and Altamaha rivers-Cont'd. WASHINGTON.

\begin{tabular}{|c|c|c|c|c|c|c|c|c|c|c|c|c|c|}
\hline Year. & Jan. & Feb. & Mar. & Apr. & May. & June. & July. & Aug. & Sept. & Oct. & Nov. & Dec. & Annual. \\
\hline Normal ...... & 4.31 & 5.15 & 4.65 & 2.32 & 3.58 & 3.84 & 5.27 & 5. 01 & 3.73 & 2.46 & 2.56 & 2.85 & 45.73 \\
\hline $1896 \ldots \ldots \ldots$ & 3.85 & 4.42 & 2.98 & 1.28 & 2.78 & 4.75 & 11.94 & 1.54 & 3.07 & 2.84 & 6.35 & 3.80 & 49.60 \\
\hline $1897 .$. & 3.10 & 8.72 & 5.38 & 3.28 & 3.73 & 2.54 & 6.16 & 6.95 & 5.94 & 4.08 & 2.80 & 1.55 & 54.23 \\
\hline $1898 \ldots$ & 2.95 & 0.34 & 3.97 & 4.84 & 0.89 & 2.51 & 7.11 & 7.07 & 4.22 & 4.82 & 7.03 & 2.88 & 48.63 \\
\hline \multicolumn{14}{|c|}{ ATHENS. } \\
\hline Normal & 5.99 & 5.16 & 5.31 & 3.47 & 4.01 & 4.53 & 5. 04 & 4.66 & 3.55 & 2.39 & 3.03 & 3.83 & 52.48 \\
\hline 1896. & ...... & ...... & ....... & ..... & 1.78 & 3.93 & 10.31 & 1.00 & 0.66 & 1.82 & & & $\cdots$ \\
\hline 1897. & ....... & .... & $\cdots \cdots$ & ...... & 0.61 & 2.85 & 3.19 & 4.17 & 0.64 & 3.12 & 1.10 & 2.83 & $\ldots$ \\
\hline $1898 \ldots$ & 2.93 & 0.66 & 3.55 & 5.58 & 2.48 & 1.53 & 5.43 & 5.73 & 6. 36 & 7.40 & 3.85 & 3.81 & 49.31 \\
\hline \multicolumn{14}{|c|}{ COVINGTON. } \\
\hline Normal. & 4.34 & 4.07 & 5.60 & 4.83 & 2.41 & 2.96 & 4.90 & 5.34 & 2.10 & 2.37 & 2.91 & 3.10 & 44.93 \\
\hline 1896. & 4.59 & 2.67 & 2.95 & 2.94 & 1.88 & 3.71 & 7.24 & 3. 16 & 0.90 & 2. 62 & 9.78 & 1.11 & 43.55 \\
\hline $1897 \ldots$ & 2.51 & 6.27 & 7.58 & 4.29 & 0.95 & 2.68 & 3.52 & 5.44 & 0.98 & 2.98 & 1.32 & 3.07 & 41.59 \\
\hline $1898 \ldots$ & 3.86 & 1.06 & 3.59 & 5.93 & 1.98 & 1.46 & 10.20 & 10.69 & 5.33 & 9.55 & 4.04 & 4.85 & 62.54 \\
\hline \multicolumn{14}{|c|}{ A VERAGES. } \\
\hline Normals & 4. 90 & 4.69 & 4.56 & 3.35 & 3.28 & 4.17 & 5.54 & 5.14 & 3.42 & 2.35 & 3.08 & 3.25 & 47.73 \\
\hline $1896 \ldots$ & 4.36 & 4.22 & 2.50 & 2.06 & 2.61 & 3.44 & 9.85 & 2.10 & 1.78 & 2.13 & 7.29 & 2.48 & 44.82 \\
\hline $1897 \ldots$ & 4. 13 & 6.90 & 6.11 & 5.15 & 1.47 & 3.14 & 5.59 & 4.67 & 1.92 & 3.32 & 2.62 & 2.87 & 47.89 \\
\hline $1898 \ldots$ & 3.11 & 0.72 & 4.17 & 5.07 & 1.43 & 2.34 & 8.05 & 8.53 & 6.62 & 6.96 & 4. 10 & 3. 33 & 54.43 \\
\hline
\end{tabular}

Depth of run-off in inches from Savannah drainage basin.

\section{SAVANNAH, NEAR CALHOUN FALLS.}

\begin{tabular}{|c|c|c|c|c|c|c|c|c|c|c|c|c|c|}
\hline Year. & Jan. & Feb. & Mar. & Apr. & May. & June. & July. & Ang. & Sept. & Oct. & Nor. & Dec. & Annual. \\
\hline 1896. & & & & $\cdots$ & & . & ... & 0.90 & 0.97 & 0.77 & 2.32 & 2.75 & \\
\hline 1897. & 1.89 & 1.98 & 1.86 & 2.65 & 2.56 & 1.93 & 1. 83 & 1.13 & 0.77 & 0.94 & 1.16 & 1.43 & 20.13 \\
\hline 1898. & 1.91 & 1.24 & I. 54 & 2.22 & 1.01 & 0.72 & 2.69 & 2. 63 & 0.87 & 0.86 & 1.74 & 2.09 & 19.52 \\
\hline Normal.. & 1.90 & 1. 61 & 1.70 & 2.44 & 1.79 & 1. 33 & 2.26 & 1.55 & 0.87 & 0.86 & 1.74 & 2.09 & 20.14 \\
\hline \multicolumn{14}{|c|}{ SAVANNAH AT AUGUSTA. } \\
\hline 1884. & 1.67 & 1. 97 & 5.24 & 2.77 & 1.03 & 2.30 & 1.32 & 0.73 & $0.4 \mathrm{I}$ & 0.39 & 0.44 & 1.57 & 19.84 \\
\hline 1885. & 3.48 & 2.66 & 1.35 & 0.82 & 1.11 & 0.99 & 0.61 & 0.62 & 1.19 & 1.85 & 1.78 & 1.78 & 18.24 \\
\hline $1886 .$. & 3.75 & 1.29 & $2.06^{\circ}$ & 3.29 & 3.09 & 2.53 & 3.04 & 1.15 & 0.83 & 0.51 & 0.80 & 1.07 & 23.41 \\
\hline 1887. & 0.97 & 1.87 & 1.55 & 0.87 & 0.73 & 0.98 & 1.92 & 5. 61 & 0.76 & 0.88 & 0.66 & 1. 34 & 18.14 \\
\hline $1888 \ldots$ & 2.68 & 2.94 & 3.86 & 2.26 & 2. 17 & 1.28 & 0.83 & 0.96 & 7.09 & 2.00 & 2. 99 & 2.01 & 31.07 \\
\hline 1889. & 4.24 & 3.76 & 2.45 & 1.63 & 1.04 & 1.01 & 1. 70 & 2.55 & 1.45 & 0.79 & 1.54 & 0.86 & 23.02 \\
\hline $1890 \ldots$ & 0.80 & 1.34 & 1.95 & 1.27 & 1.53 & 0.84 & 1. 29 & 0.95 & 1.26 & 3.09 & 0.82 & 1.12 & 16.26 \\
\hline $1891 .$. & 2. 31 & 4. 88 & 6.57 & 3.00 & 1.38 & 1.32 & 1.03 & 2.11 & 0.86 & 0.55 & 0.92 & 0.73 & 25.66 \\
\hline $1898 \ldots$ & 1. 16 & 0.68 & 0.99 & 2. 01 & 0.67 & 0.54 & 2.14 & 2. 67 & 3. 88 & 2.67 & 1.90 & 1.97 & 20.28 \\
\hline Normal .. & 2.34 & 2.38 & 2.89 & 1.99 & 1.42 & 1. 31 & 1. 54 & 1.93 & 1.97 & 1.41 & 1. 32 & $1.38^{\circ}$ & 21.88 \\
\hline
\end{tabular}


Depth of run-off in inches from Savannah drainage basin-Continued. OCONEE AT CAREY.

\begin{tabular}{|c|c|c|c|c|c|c|c|c|c|c|c|c|c|}
\hline Year. & Jan. & Feb. & Mar. & Apr. & May. & June. & July. & Aug. & Sept. & Oct. & Nov. & Dec. & A nnual. \\
\hline 1896. & & & & & & & & & & & 0.71 & 1.06 & \\
\hline 1897. & 1.81 & 2.25 & 2.61 & 1.19 & 0.97 & 0.65 & 1.16 & 0.81 & 0.38 & 0.63 & 0.69 & 0.95 & 14.10 \\
\hline $1898 \ldots$ & 1.15 & 0.83 & 1. 12 & . & & & & & & & & & $\cdots$ \\
\hline \multicolumn{14}{|c|}{ OCONEE AT DUBLIN. } \\
\hline 1898. & a1. 48 & 0.33 & 0.71 & 1.34 & 0.49 & 0.32 & 0.85 & 1.57 & 2.84 & 2.05 & 1.90 & 2.02 & 16.10 \\
\hline \multicolumn{14}{|c|}{ OCMULGEE AT MACON. } \\
\hline 1893. & 0.48 & 2.44 & 1.90 & 0.89 & 0.87 & 1.08 & 0.67 & 1.10 & 1.28 & 0.91 & 0.71 & 0.85 & 13. 18 \\
\hline $.7894 \ldots \ldots$ & 1.07 & 1.92 & 1.63 & 1.10 & 0.69 & 0.62 & 1.13 & 1.83 & 1.25 & 1.35 & 0.91 & 1.35 & 14.85 \\
\hline $1895 \ldots$ & 2.24 & 1.13 & 3.90 & 2.32 & 1.54 & 1.07 & 2.08 & 2.16 & 1.15 & 0.49 & 0.47 & 0.61 & 19.16 \\
\hline $1896 \ldots$ & 1.59 & 1.73 & 1.37 & 0.67 & 0.47 & 0.41 & 3.54 & 0.54 & 0.28 & 0.23 & 1.48 & 1.56 & 13.87 \\
\hline $1897 .$. & 0.64 & 1.83 & 4. 22 & 2.51 & 0.81 & 0.79 & 0.91 & 0.84 & 0. 32 & 0.30 & 0.36 & 0.51 & 14.04 \\
\hline $1898 \ldots$ & 0.62 & 0.42 & 0.60 & 1.20 & 0.44 & 0.30 & 0.78 & 2.20 & 2.77 & 2.72 & 1.70 & 1. 69 & 15.44 \\
\hline Normal.. & 1.11 & 1.58 & 2.27 & 1.45 & 0.80 & 0.71 & 1.52 & 1.45 & 1.17 & 1.00 & 0.94 & 1.09 & 15.09 \\
\hline
\end{tabular}

$$
a \text { Estimated. }
$$

Rainfall and run-off, Savannah and Altamaha vivers.

\begin{tabular}{|c|c|c|c|c|c|}
\hline Station. & Normal. & 1895 . & 1896. & 1897. & 1898. \\
\hline RAINFALL. & Inches. & Inches. & Inches. & Inches. & Inches. \\
\hline Toccoa ......... & 56.87 & $\ldots \ldots$ & 48.92 & 48.93 & 62.27 \\
\hline Gillsville $\ldots \ldots \ldots \ldots \ldots \ldots \ldots$ & 47.17 . & $\ldots \ldots$ & 35.68 & 50.00 & 52.58 \\
\hline Holland ................... & 49.38 & $\ldots \ldots$ & 47.73 & 50.84 & 52.77 \\
\hline Anderson............. & 47.64 & $\ldots$ & 41.05 & 50.67 & 53.09 \\
\hline Greenwood .............. & 37.60 & $\ldots$ & 50.79 & 43.66 & 45.05 \\
\hline Point Peter ................... & 47.64 & $\ldots \ldots$ & 43.35 & 50.79 & 55.25 \\
\hline 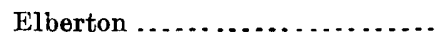 & 47.55 & $\ldots \ldots$ & 46.62 & 48.77 & 60.10 \\
\hline Mt. Carmel. ............. & 48.08 & $\ldots \ldots$ & 51.33 & 46.42 & 57.18 \\
\hline 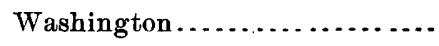 & 45.73 & & 49.60 & 54.23 & 48.63 \\
\hline Athens $\ldots \ldots \ldots \ldots . . . . .$. & 52.48 & $\ldots$ & $\ldots \ldots$ & $\ldots \ldots$ & 49. 31 \\
\hline Covington ........... & 44.93 & $\ldots$ & 43.55 & 41.59 & 62.54 \\
\hline Average.. & 47.73 & $\ldots \ldots$ & 45.86 & 48.59 & 54.43 \\
\hline RUN-OFF. & & & & & \\
\hline Calhoun Falls........... & 20.13 & $\ldots$ & $\ldots \ldots$ & 20.13 & $\ldots . .$. \\
\hline Augusta................... & 21.88 & & & $\ldots . .$. & 20.28 \\
\hline Carey $\ldots . . . . . . . .$. & $a 14.10$ & $\cdots$ & $\ldots \ldots$ & 14.10 & ......... \\
\hline Dublin ........... & a 16.10 & 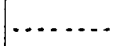 & & $\ldots \ldots$ & 16. 10 \\
\hline Macon.............. & 15.09 & 19.16 & 13.87 & 14.04 & 15. 44 \\
\hline Average.... & 17.46 & 19. 16 & 13.87 & 16.09 & 17.27 \\
\hline Percentage of rainfall & 36.58 & $1-$ & 30.24 & 33.11 & 31. 69 \\
\hline
\end{tabular}

20 GEOL, PT $4-11$ 
TUGALOO RIVER.

Estimated monthly discharge of Tugaloo River at Madison, South Carolina.

[Drainage area, 593 square miles.]

\begin{tabular}{|c|c|c|c|c|c|c|}
\hline \multirow[b]{2}{*}{ Month. } & \multicolumn{3}{|c|}{ Discharge in second-feet. } & \multirow[b]{2}{*}{$\begin{array}{c}\text { Total in acre } \\
\text { feet. }\end{array}$} & \multicolumn{2}{|c|}{ Run.off. } \\
\hline & $\begin{array}{l}\text { Maxi- } \\
\text { mum. }\end{array}$ & $\begin{array}{l}\text { Mini- } \\
\text { mam. }\end{array}$ & Mean. & & $\begin{array}{l}\text { Depth in } \\
\text { inches. }\end{array}$ & $\begin{array}{c}\text { Second- } \\
\text { feet per } \\
\text { square } \\
\text { mile. }\end{array}$ \\
\hline 1898. & & & & & & \\
\hline July $19-31 \ldots \ldots$ & $\ldots \ldots$. & $\ldots \ldots$ & 1,824 & $a 112,154$ & $a 3.55$ & a.3.08 \\
\hline August.... & 6,982 & 1,200 . & 3,354 & 206,231 & 6.52 & 5. 66 \\
\hline September ........ & 13,658 & 1,807 & 3,771 & 224,390 & 7.10 & 6.36 \\
\hline October.... & 13,816 & 1,620 & 4,238 & 260,586 & 8.24 & 7.15 \\
\hline November......... & 4,257 & 1,874 & 2,267 & 134,896 & 4. 26 & 3.82 \\
\hline December .......... & 5,442 & 1,560 & 2,159 & 132,753 & 4.20 & 3.64 \\
\hline
\end{tabular}

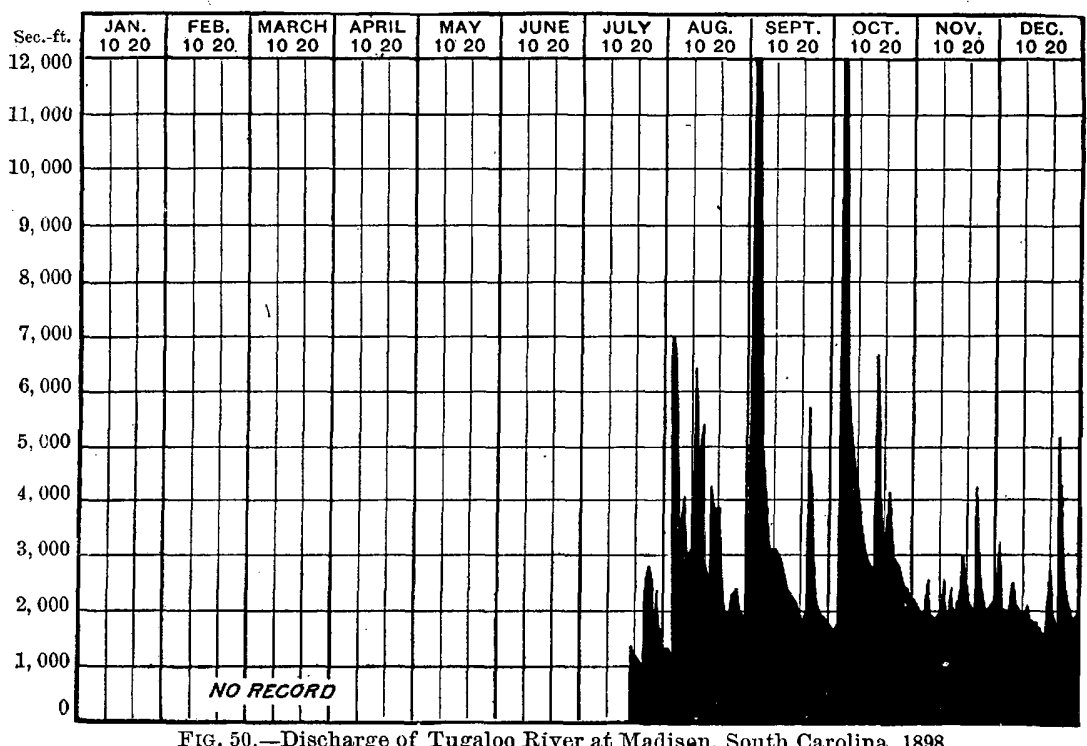

Fig. 50.-Discharge of Tugaloo River at Madisen, South Carolina, 1898. 
BROAD RIVER.

Estimated monthly discharge of Broad River at Carlton, Georgia.

[Drainage area, 762 square miles.]

\begin{tabular}{|c|c|c|c|c|c|c|}
\hline \multirow[b]{2}{*}{ Month. } & \multicolumn{3}{|c|}{ Discharge in second-feet. } & \multirow[b]{2}{*}{$\begin{array}{c}\text { Total in acre. } \\
\text { feet. }\end{array}$} & \multicolumn{2}{|c|}{ Run-off. } \\
\hline & $\begin{array}{l}\text { Maxi. } \\
\text { mum. }\end{array}$ & $\begin{array}{l}\text { Mini } \\
\text { mum. }\end{array}$ & Mean. & & $\begin{array}{l}\text { Depth in } \\
\text { inches. }\end{array}$ & $\begin{array}{c}\text { Second- } \\
\text { feet per } \\
\text { square } \\
\text { mile. }\end{array}$ \\
\hline 1898. & & & & & & \\
\hline January .......... & 3,462 & 505 & 887 & 54,540 & 1.34 & 1. 16 \\
\hline February ........... & 738 & 505 & 575 & 31,934 & 0.78 & 0.75 \\
\hline March ............. & 2,776 & 505 & 730 & 44,886 & 1.15 & 1.00 \\
\hline April $\ldots \ldots \ldots \ldots \ldots$ & 3,609 & 577 & 1,078 & 64,145 & 1.57 & 1. 41 \\
\hline May ..... & 700 & 385 & 524 & 32,220 & 0.79 & 0.69 \\
\hline June ............... & 850 & 300 & 422 & 25,111 & 0.61 & 0.55 \\
\hline 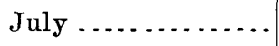 & 7,284 & 300 & 1,455 & 89,465 & 2.20 & 1.91 \\
\hline August. . . . . . . . . & 5,275 & 480 & 1,533 & 94,261 & 2.32 & 2.01 \\
\hline September ........ & 16,937 & 666 & 2,961 & 176,191 & 4.34 & 3.89 \\
\hline Oetober ......... & 9,440 & 632 & 1,786 & 109,818 & 2.70 & 2.34 \\
\hline November . . . . . . . . & 1,943 & 775 & 1,099 & 65,395 & 1.61 & 1.44 \\
\hline December . . . . . . . . & 3,217 & 850 & 1,319 & 81,103 & 1.99 & 1.73 \\
\hline The year. & 16,937 & 300 & 1,197 & 869,069 & 21.40 & 1.57 \\
\hline
\end{tabular}

Nоте._Gage heights for 1898 are given in Water-Supply and Irrigation Paper No. 27, page 42 ; measurements, page 44; rating table, page 46; results for 1897 in Water-Supply and Irrigation Paper No. 15 , page 40 , and in the Nineteenth Annual Report, Part IV, page 225.

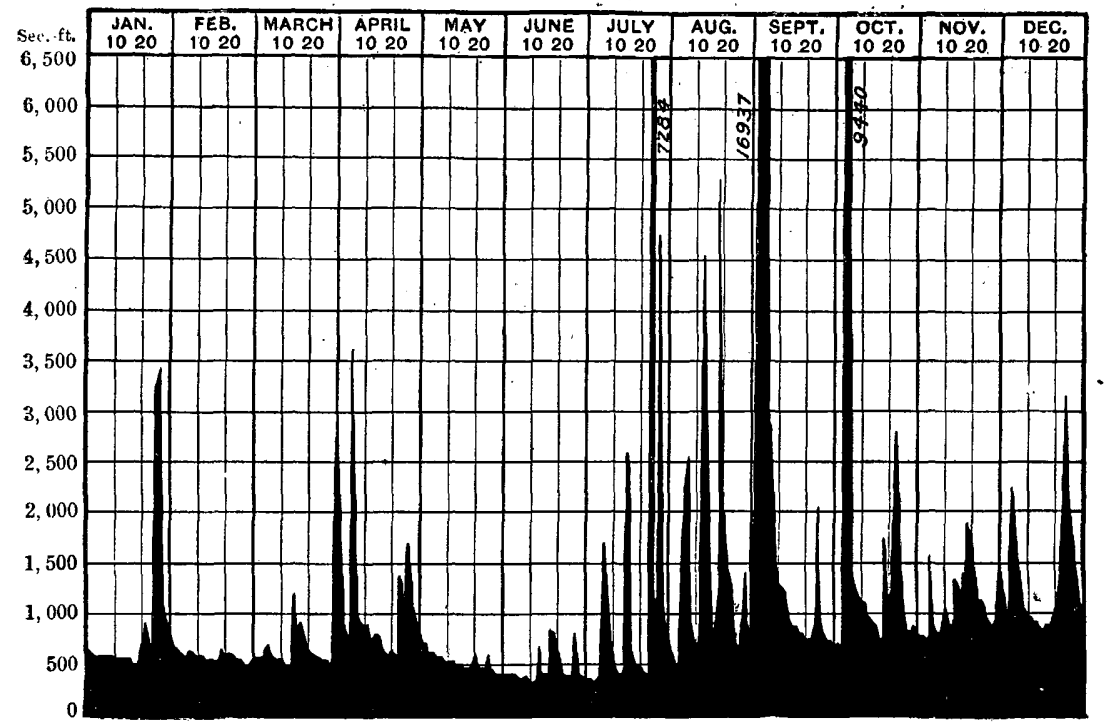

Fig. 51.-Discharge of Broad River at Carlton, Georgia, 1898. 
164 PROGRESS OF STREAM MEASUREMENTS FOR 1898.

Estimated monthly discharge of Savannah River at Calhoun Falls, South Carolina.

[Drainage area, 2,712 square miles.]

\begin{tabular}{|c|c|c|c|c|c|c|}
\hline \multirow[b]{2}{*}{ Month. } & \multicolumn{3}{|c|}{ Discharge in second.feet. } & \multirow[b]{2}{*}{$\begin{array}{c}\text { Total in acre- } \\
\text { feet. }\end{array}$} & \multicolumn{2}{|c|}{ Run-off. } \\
\hline & $\begin{array}{l}\text { Maxi. } \\
\text { mum. }\end{array}$ & $\begin{array}{l}\text { Mini- } \\
\text { mum. }\end{array}$ & Mean. & & $\begin{array}{l}\text { Depth in } \\
\text { inches. }\end{array}$ & $\begin{array}{c}\text { Second. } \\
\text { feet per } \\
\text { square } \\
\text { mile. }\end{array}$ \\
\hline 1898. & & & . & & & \\
\hline January .......... & 17,500 & 2,140 & 4,500 & 276,696 & 1. 91 & 1. 66 \\
\hline February & 6,250 & 2,340 & 3,231 & 177,941 & 1.24 & 1. 19 \\
\hline March .... & 23,750 & 2,235 & 3,638 & 223,693 . & 1.54 & 1.34 \\
\hline April .... & 13,000 & 2,560 & 5,396 & 321,084 & 2.22 & 1.99 \\
\hline 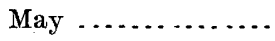 & 4,000 & 1,580 & 2,399 & 147,510 & 1.01 & 0.88 \\
\hline June .... & 2,560 & 1,520 & 1,761 & 104,787 & 0.72 & 0.65 \\
\hline July ............ & 15,250 & 1,350 & 6,314 & 388,235 & 2.69 & 2.33 \\
\hline August $1-9 \ldots \ldots \ldots$ & $\ldots \ldots$ & $\ldots . .$. & 7,137 & 438,840 & 3.03 & 2.63 \\
\hline
\end{tabular}

NoTE.-Gage beights for 1898 are given in Water-Supply and Irrigation Paper No. 27, page 40; measurements, page 44; rating table, page 46; results for 1897 in Water-Supply and Irrigation Paper No. 15, page 39; and in the Nineteenth Annual Report, Part IV, page 223.

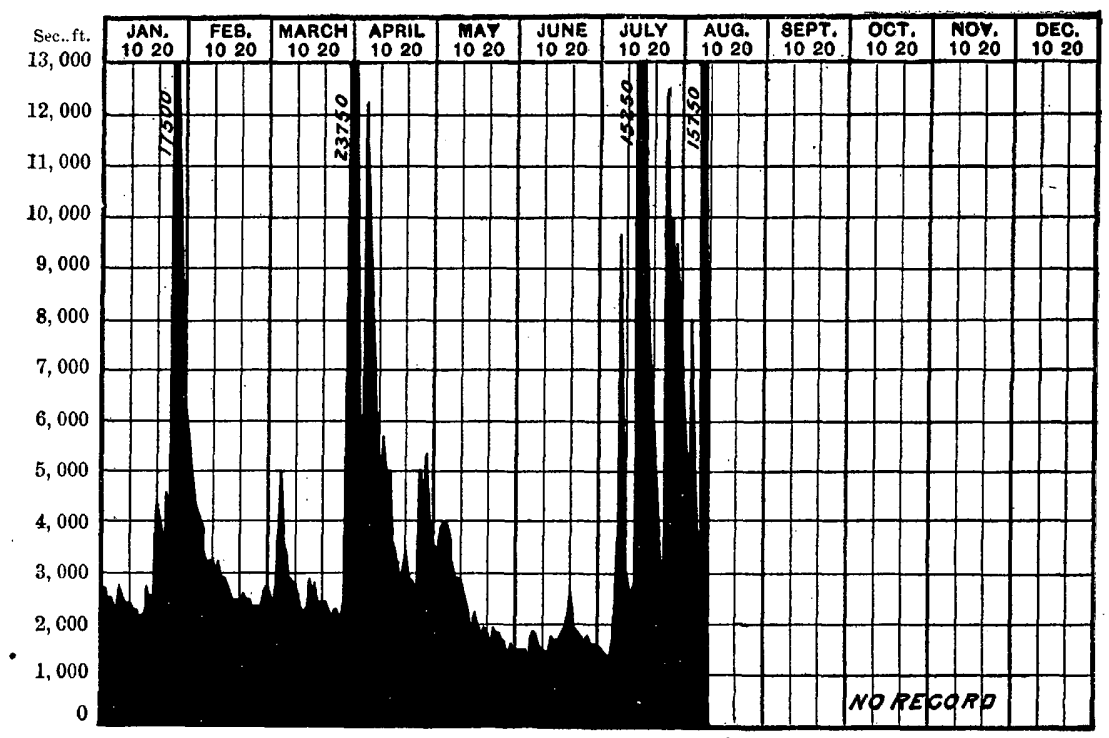

Fig. 52.-Discharge of Savannah River at Calhoun Fatls, South Carolina, 1898. 
Estimated monthly discharge of Savannah River at Augusta, Georgia.

[Drainage area, 7,294 square miles.]

\begin{tabular}{|c|c|c|c|c|c|c|}
\hline$\because \quad \ddots$ & \multicolumn{3}{|c|}{ Discharge in second-feet. } & \multirow{2}{*}{$\begin{array}{l}\text { Total in acre } \\
\text { feet. }\end{array}$} & \multicolumn{2}{|c|}{ Run-off. } \\
\hline Month. & $\begin{array}{l}\text { Maxi- } \\
\text { mura. }\end{array}$ & $\begin{array}{l}\text { Mini. } \\
\text { mum. }\end{array}$ & Mean. & & $\begin{array}{l}\text { Depth in } \\
\text { inches. }\end{array}$ & $\begin{array}{c}\text { Second- } \\
\text { feet per } \\
\text { square } \\
\text { mile. }\end{array}$ \\
\hline 1898. & & . & & & $\cdots$ & \\
\hline January..... & 36,680 & - 3,910 & 7,389 & 454,335 & 1. 16 & 1.01 \\
\hline February ....... & 6,820 & 3,705 & 4,462 & 247,807 & 0.64 & 0.61 \\
\hline March ......... & 23,000 & 3,705 & 6,258 & 384,792 & 0.99 & 0.86 \\
\hline April ..... & 42,400 & 5,244 & 13,117 & 780,514 & 2.01 & 1.80 \\
\hline May .... & 7,800 & 3,016 & 4,200 & 258,250 & 0.67 & 0.58 \\
\hline June .. & 11,000 & 2,475 & 3,481 & 207,133 & 0.54 & 0.48 \\
\hline July & 41,080 & 2,377 & $\mathbf{1 3 , 5 7 8}$ & 834,884 & 2.14 & 1.86 \\
\hline 'August. & 50,706 & 4,660 & 16,821 & $1,034,290$ & 2.66 & 2.31 \\
\hline September & 88,160 & 6,274 & 25,378 & $1,410,093$ & 3.88 & 3.48 \\
\hline October & 68,800 & 5,400 & 16,835 & $1,035,150$ & 2.72 & 2.31 \\
\hline Noviember... & 39,760 & 6,364 & 12,454 & 741,063 & 1.90 & 1.70 \\
\hline December. & 34,480 & 6,914 & 12,503 & 768,784 & 1.97 & 1.71 \\
\hline The year & 88,160 & 2,084 & 11,373 & $8,157,095$ & 21.28 & 1.56 \\
\hline
\end{tabular}

NoтE.-Gage heights for 1898 are given in Water-Supply and Irrigation Paper No. 27, page 41; measurements, page 44; rating table, page 46.

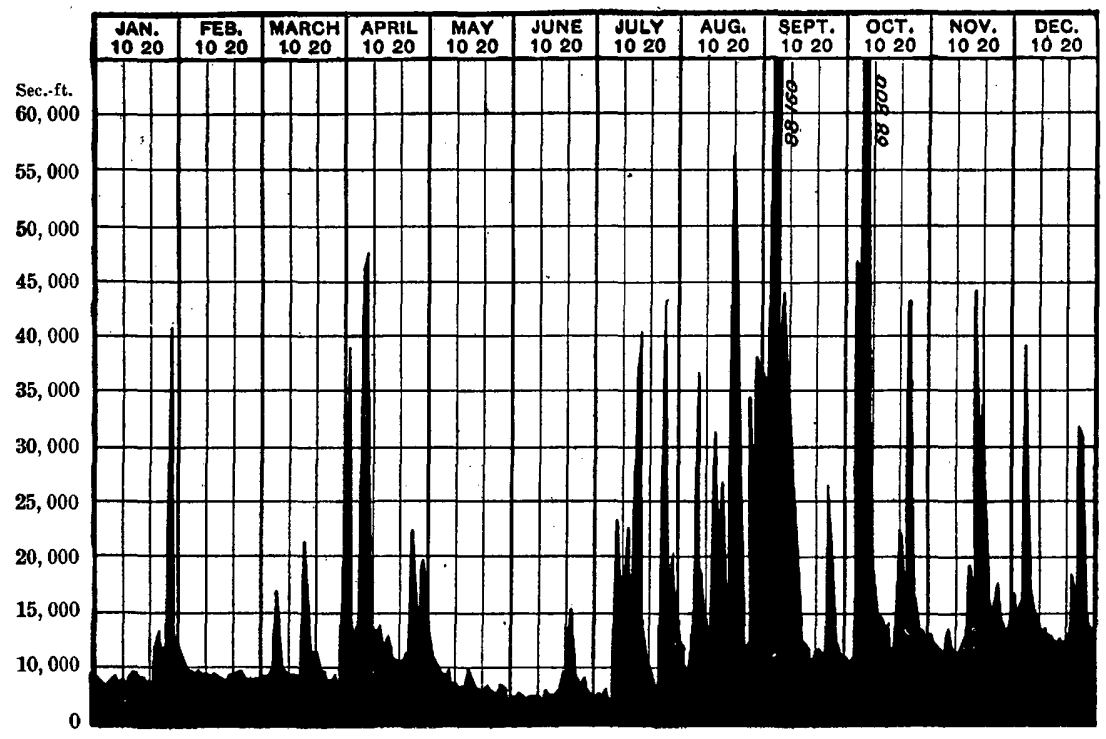

Fig. 53.-Discharge of Savannah River at Augusta, Georgia, 1898. 


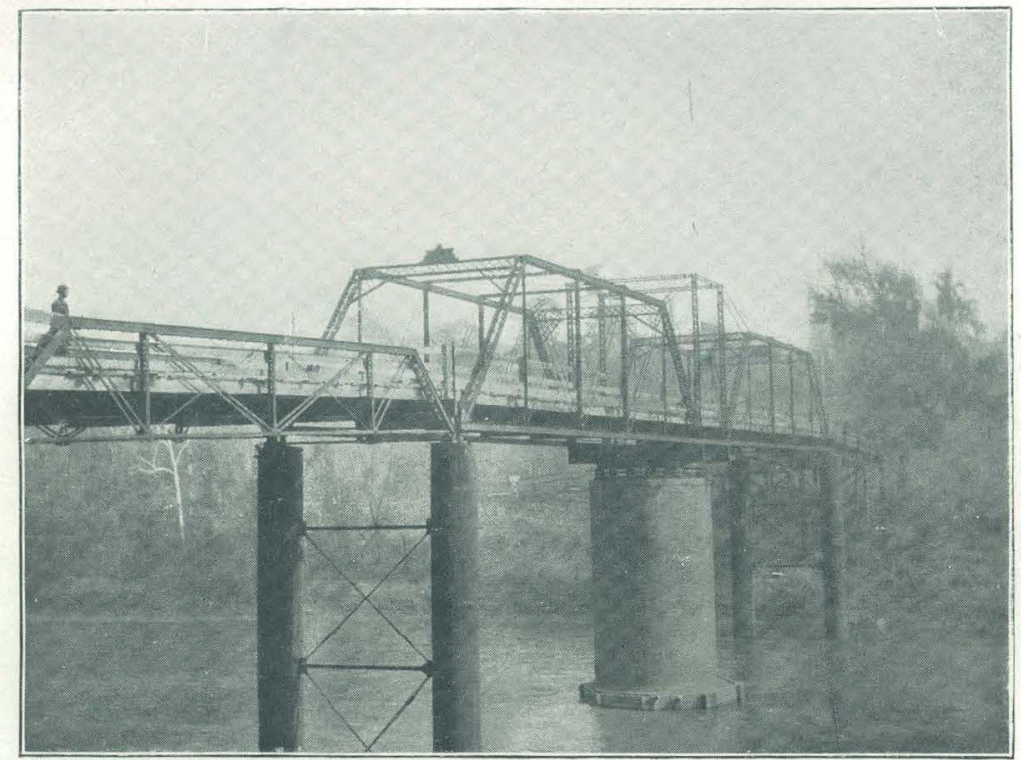

A. OCONEE RIVER NEAR DUBLIN, GEORGIA.

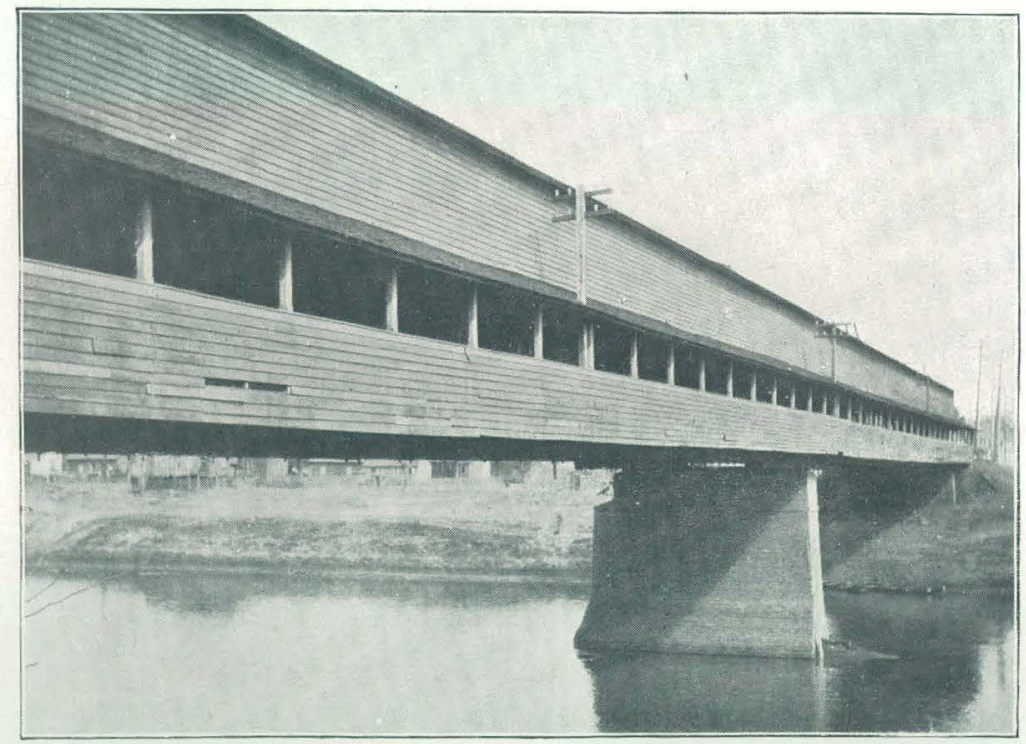

B. OCMULGEE RIVER AT MACON, GEORGIA. 


\section{ALTAMAHA RIVER.}

Altamaha River is formed by the junction of the Oconee and Ocmulgee rivers. The basin heads southeast of the Chattahoochee Ridge, and covers a large area in central Georgia, being bounded on the northeast by the Savannah and Ogeechee basins and on the northwest and south by the Apalachicola, Suwanee, and Satilla basins. The "fall line," or line between the ancient crystalline rocks and the younger geological formations, passes through Milledgeville on the Oconee and through Macon on the Ocmulgee. All the water powers of importance are north of this line.

During 1898 river stations have been maintained at Carey and Dublin, on the Oconee River (Pl. XI, $A$ ), and at Macon on the Ocmulgee River (Pl. XI, $B$ ). Measurements of discharge have been made on some of the tributaries, from which comparative estimates have been prepared. The Ocmulgee River is formed by the junction of the South and Yellow rivers. Alcovy River and Towaliga River are large tributaries.

The Oconee River is formed near Athens, Georgia, by the junction of the North Oconee and Middle Oconee rivers. The Apalachee River and Little River are large tributaries.

The following tabular statement, taken from Bulletin No. 3A, of Georgia geological survey, compiled by B. M. Hall in 1896, shows the most prominent shoals on the large streams of this basin, but there is considerable fall between the shoals, which is not given:

Water powers in Altamaha Basin.

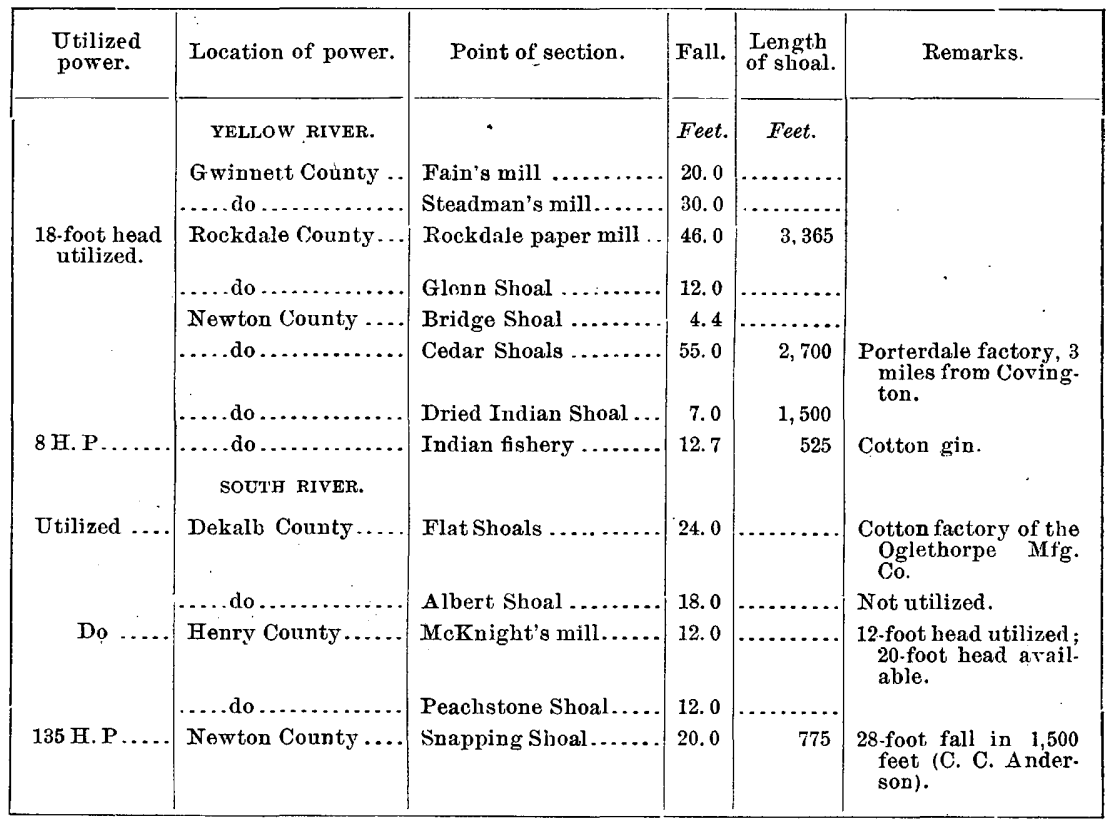


Water powers in Altamaha Basin-Continued.

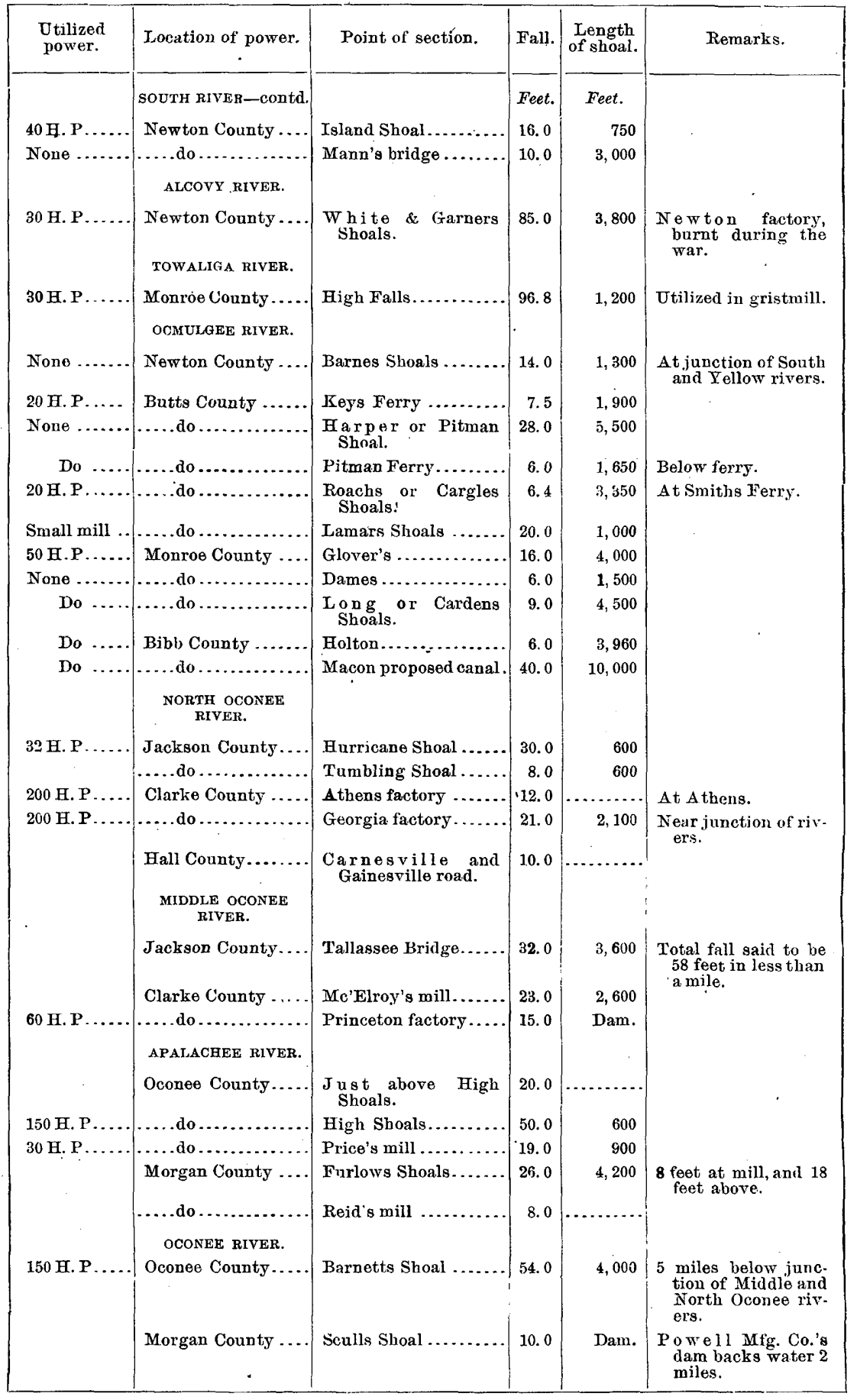


Water powers in Altamaha Basin-Continued.

\begin{tabular}{|c|c|c|c|c|c|}
\hline $\begin{array}{l}\text { Utilized } \\
\text { power. }\end{array}$ & Location of power. & Point of section. & Fall. & $\begin{array}{c}\text { Length } \\
\text { of shoal. }\end{array}$ & Remarks. \\
\hline . & 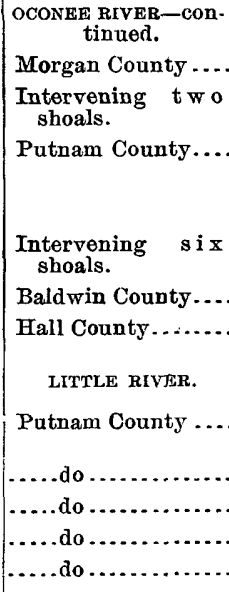 & 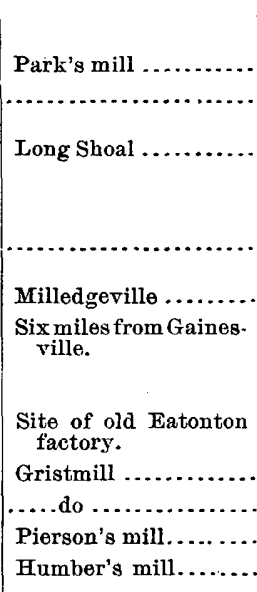 & $\begin{array}{r}\text { Feet. } \\
8.0 \\
7.0 \\
12.0 \\
\\
33.0 \\
34.0 \\
39.0 \\
\\
\\
25.0 \\
8.0 \\
13.5 \\
7.0 \\
9.0\end{array}$ & 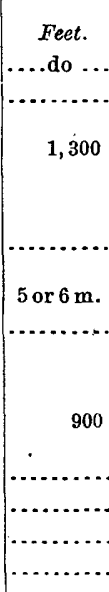 & $\begin{array}{l}\text { Gristmill. } \\
\text { Old factory site, not } \\
\text { in use; head can be } \\
\text { made } 15 \text { or } 20 \text { feet } \\
\text { by dam. } \\
\text { Canal proposed. } \\
\text { Head waters. }\end{array}$ \\
\hline
\end{tabular}

NoTE.-The foregoing is a very imperfect statement concerning the water powers of the Altamaha Basin, but it is the best that can be made with the data at hand.

Some of the new developments on this basin are: Athens, Georgia, electric light and power plant, on Middle Oconee River; New Athens, Georgia, waterworks, by steam pumps, delivering a fine supply of filtered water from North Oconee River; and electric light for Eatonton, Georgia, from a power on Little River. .It is also proposed to furnish water, light, and power to the Georgia convict farm, at Milledgeville, Georgia, from a power on the Oconee River at that point.

The following facts concerning Altamaha River have been taken from a report by the United States Engineer Corps: ${ }^{1}$

The distance in a direct line from the junction of the Ocmulgee and Oconee rivers to the town of Darien, which is situated on the north bank of the river, 19 miles from the coast, is 75 miles. Following the river channel the distance is 131 miles, as determined by the survey of 1888-89.

The valley of the Altamaha, about 3,000 square miles in area, is a low, undulating country, with a sandy, permeable soil. Probably not more than 20 per cent of the rainfall of the region finds its way to the river. Its volume is mostly derived from the drainage of the clayey hills of central and north Georgia, brought down by its tributaries. The total area drained by the Altamaha and its tributaries is about 14,620 square miles.

The total fall of the river between summer low water at the forks and mean low water at Darien is 83 feet, making an average slope of 0.633 feet, or 7.6 inches per mile. With local exceptions, the slope is practically uniform at the rate of 8.44 inches per mile as far down as Fort Barrington, where tidal fluctuations at low water begin to be appreciable. In the tidal reaches the low-water slope is 3.6 inches per mile. Local exceptions to the uniformity of slope occur as follows: At English Eddy the slope is 20.4 inches per mile; at Stooping Gum Cut, 24 inches; at Beards

1 Fifty-first Congress, second session, Ex. Doc. No. 283, page 2. 
Bluff, 26.4 inches; at Alligator Creek, Marrow Bone Bar, and Doctortown, each 12 inches; through the Narrows, a distance of 12 miles, 13.2 inches per mile; at Phinholloway Creek, 33.6 inches per mile.

Gagings of the river were made in October, 1888, and again at a different stage of water, but at the same places, in October, 1889. The results are shown in the following table:

Discharge of Altamaha River, 1888-89.

\begin{tabular}{|c|c|c|c|c|}
\hline Date. & Place. & $\begin{array}{c}\text { Stage of } \\
\text { water. }\end{array}$ & $\begin{array}{l}\text { Mean veloc- } \\
\text { ity per sec- } \\
\text { ond. }\end{array}$ & Discharge. \\
\hline & & Feet. & Feet. & Second-feet. \\
\hline October, 1888......... & Town Bluff.......... & 7.2 & 2.47 & 20,476 \\
\hline October, 1888........ & Oberry Bar......... & 4.5 & 3.51 & 20,310 \\
\hline October, $1889 \ldots \ldots \ldots$ & Town Bluff............ & 0.0 & 1.12 & 4,727 \\
\hline October, $1889 \ldots \ldots$ & Oberry Bar........... & 0.0 & 2.21 & 5,037 \\
\hline
\end{tabular}

These results may be checked by comparison with the joint discharge of the Oconee and Ocmulgee rivers, determined at about the same time, as follows:

In October, 1888, the joint discharge of Ocmulgee and Oconee rivers, 1 mile above the Forks, gaged during falling river and previous to gagings at Town Bluff, was 21,303 cubic feet per second. In October, 1889 , the joint discharge at low water of these rivers (but omitting the discharge of the Little Ocmulgee) was 4,625 cubic feet per second.

In comparing Town Bluff and Oberry Bar low-water discharges, as given in the above table, it must be remembered that the Ohoopee River adds a considerable volume to the flow between those points.

Owing to the limited number of actual discharge measurements it is impossible to arrive at the mean discharge except by deducting it approximately from the rainfall in the river basin. This, as determined by observations covering about twenty years, is 50 inches per year. In the upper part of the river basin the soil is clayey, and probably 60 per cent of the rainfall is carried off by the rivers tributary to the Altamaha. About 20 per cent will be the proper proportion for the permeable soil of the lower valley. Giving to these percentages weights proportional to the areas to which they apply, the average deduced is 37 per cent for the whole area, and this gives for the mean discharge of the Altamaha, at its mouth, about 19,000 cubic feet per second.

The freshets on this river are sometimes of great magnitude. That of August, 1887, was the highest known for many years. The water rose at Town Bluff to a height of 21 feet above summer low water; at Ohoopee White Bluff to 19 feet, and at Fort Barrington to 14 feet. The low swamp lands bordering the river are from 2 to 4 miles wide, and are flooded at stages of from 5 to 10 feet; so the discharge during the above-mentioned freshet must have been enormous. It probably exceeded 100,000 cubic feet per second. Freshets of less magnitude occur during the winter season of nearly every year, the river rising out of its banks and flooding the bottom lands.

The river winds through low bottom lands or swamps, bordered on either side by the line of sandy bluffs, separating them distinctly from the high land beyond. The soil is a light-colored sticky earth, containing sand, clay, and silt. Roads through the swamps soon become worked up into a thick mud, even in comparatively dry weather. The banks are from' 4 to 8 feet high and are easily eroded, except on the surface where protected by the roots of the dense growth of trees, brush, and cypress knees. Where the river winds in close to the bluffs a high bank is found on one side, and such banks are usually selected for steamboat or timber landings, since they are not subject to overflow. Rock occurs only in the upper part of the valley. 


\section{OCONEE RIVER.}

Estimated monthly discharge of Oeonee River at Dublin, Georgia.

[Drainage area, 4,182 square miles. $a$ ]

\begin{tabular}{|c|c|c|c|c|c|c|}
\hline \multirow[b]{2}{*}{ Month. } & \multicolumn{3}{|c|}{ Discharge in second.feet. } & \multirow[b]{2}{*}{$\begin{array}{l}\text { Total in acre- } \\
\text { feet. }\end{array}$} & \multicolumn{2}{|c|}{ Run.off. } \\
\hline & $\begin{array}{l}\text { Maxi- } \\
\text { mum. }\end{array}$ & $\begin{array}{l}\text { Mini- } \\
\text { mum. }\end{array}$ & Mean. & & $\begin{array}{l}\text { Depth in } \\
\text { inches. }\end{array}$ & $\begin{array}{l}\text { Second. } \\
\text { feet per } \\
\text { square } \\
\text { mile. }\end{array}$ \\
\hline 1898. & & & & & & . \\
\hline February 11-28.... & 2,429 & 1,746 & 2,040 & 113,296 & 0.51 & 0.49 \\
\hline March ...... & 4,360 & 1,746 & 2,582 & 158,748 & 0.71 & 0.62 \\
\hline April ..... & 11,260 & 2,080 & 5,011 & 298,175 & 1. 34 & 1.20 \\
\hline May ....... & 4,460 & 1,140 & 1,794 & 110,310 & 0.49 & 0.43 \\
\hline June .......... & 2,012 & 890 & 1,201 & 71,464 & 0.32 & 0.29 \\
\hline July ......... & 7,840 & 865 & 3,104 & 190,859 & 0.85 & 0.74 \\
\hline August...... & 12,514 & 2,500 & 5,697 & 350,297 & 1.57 & 1.36 \\
\hline September .. & 27,904 & 2,012 & 10,648 & 633,599 & 2.84 & '2. 2.55 \\
\hline October ............ & 18,100 & 1,878 & 7,449 & 458,021 & 2.05 & 1.78 \\
\hline November. . . . . . . . & 16,960 & 2,500 & 7,097 & 422,301 & 1.90 & 1.70 \\
\hline December ......... & 14,224 & 4,360 & 7,338 & 451,199 & 2.02 & 1.75 \\
\hline
\end{tabular}

a As measured by Prof. B. M. Hall.

Note.-Gage heights for 1898 are given in Water-Supply and Irrigation Paper No. 27, page 43; rating table, page 44; results for 1897 in Water-Supply and Irrigation Paper No.15, page 42, and in the Nineteenth Annual Report, PartI V, page 227.

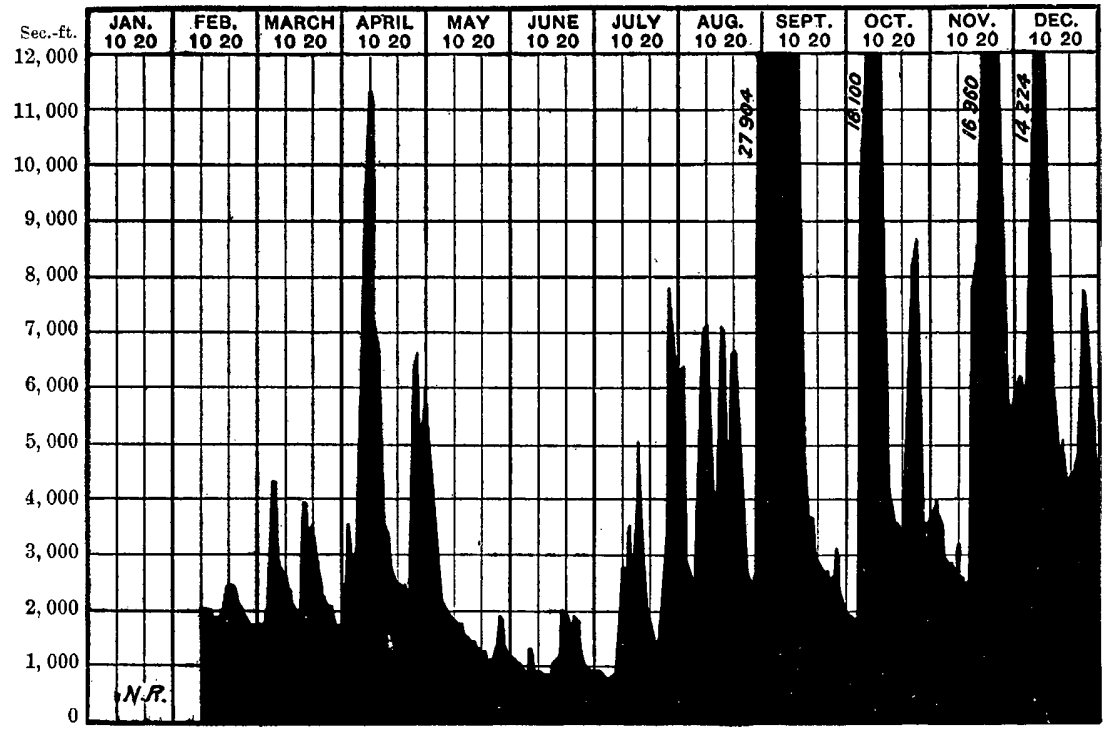

Fig. 54.-Discharge of Oconee River at Dublin, Georgia, 1898. 
Estimated nonthly discharge of Oconee. River at Carey, Georgia.

[Drainage area, 1,346 square miles.]

\begin{tabular}{|c|c|c|c|c|c|c|}
\hline \multirow[b]{2}{*}{ Month. } & \multicolumn{3}{|c|}{ Discharge in second-feet. } & \multirow[b]{2}{*}{$\begin{array}{c}\text { Total in acre- } \\
\text { feet. }\end{array}$} & \multicolumn{2}{|c|}{ Run off. } \\
\hline & $\begin{array}{l}\text { Maxi- } \\
\text { mam. }\end{array}$ & $\begin{array}{l}\text { Mini- } \\
\text { mum. }\end{array}$ & Mean. & & $\begin{array}{l}\text { Depth in } \\
\text { inches. }\end{array}$ & $\begin{array}{c}\text { Second- } \\
\text { feet per } \\
\text { square } \\
\text { mile. }\end{array}$ \\
\hline 1898. & & & & & & \\
\hline 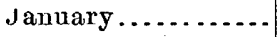 & 5,180 & 815. & 1,340 & 82,395 & 1. 15 & 1.00 \\
\hline February. . & 1,408 & 890 & 1,079 & 59,925 & 0.83 & 0.80 \\
\hline March $a \ldots \ldots \ldots$ & 2,464 & 970 & 1,300 & 79,934 & 1. 12 & 0.97 \\
\hline
\end{tabular}

$a$ Station discontinued

NOTE._Gage heights for 1898 are given in Water-Supply and Irrigation Paper No. 27, page 43; measurements, page 44; rating table, page 46; results for 1897 in Water-Supply and Irrigation Paper No. 15, page 41, and in the Nineteenth Annual Report, Part IV, page 227.

\section{OCMULGEF RIVER.}

Estimated monthly discharge of Ocmulgee River at Macon, Georgia.

- [Drainage area, 2,425 square miles.]

\begin{tabular}{|c|c|c|c|c|c|c|}
\hline \multirow[b]{2}{*}{ Month. } & \multicolumn{3}{|c|}{ Discharge, in second-feet. } & \multirow[b]{2}{*}{$\begin{array}{c}\text { Total in acre- } \\
\text { feet. }\end{array}$} & \multicolumn{2}{|c|}{ Run•off. } \\
\hline & $\begin{array}{l}\text { Maxi. } \\
\text { mum. }\end{array}$ & $\begin{array}{l}\text { Mini. } \\
\text { mum. }\end{array}$ & Mean. & & $\begin{array}{l}\text { Depth in } \\
\text { inches. }\end{array}$ & $\begin{array}{l}\text { Second- } \\
\text { feet per } \\
\text { square } \\
\text { mile. }\end{array}$ \\
\hline 1898. & & & & , & & \\
\hline January ............ & 3,472 & 860 & 1,300 & 79,934 & 0.62 & 0.54 \\
\hline February...... & 1,195 & 820 & 964 & 53,538 & 0.42 & 0.40 \\
\hline March ... & 2,675 & 840 & 1,263 & 77,660 & 0.60 & 0.52 \\
\hline April ............. & 12,120 & 940 & 2,619 & 155,841 & 1.20 & 1.08 \\
\hline May ....... & 1,555 & 600 & 909 & 55,893 & 0.44 & 0.38 \\
\hline June .............. & 1,740 & 388 & 653 & 38,856 & 0.30 & 0.27 \\
\hline July & 5,880 & 405 & 1,645 & 101,148 & 0.78 & 0.68 \\
\hline August................ & 15,000 & 940 & 4,630 & 284,689 & 2.20 & 1.91 \\
\hline September ......... & 31,640 & 1,040 & 6,008 & 357,500 & 2.77 & 2.48 \\
\hline October ..... & 28,760 & 1,020 & 5,734 & 352,572 & 2.72 & 2.36 \\
\hline November ... & 18,520 & 1,555 & 3,698 & 220,046 & 1.70 & 1.52 \\
\hline December ......... & 16,920 & 2,042 & 3,567 & 219,328 & 1.69 & 1. 47 \\
\hline The year... & 31,640 & 388 & 2,749 & $1,997,005$ & 15.44 & 1.13 \\
\hline
\end{tabular}

NoтE.-Gage heights for 1898 are given in Water-Supply and Irrigation Paper No. 27, page 43, measurements, page 44; rating table, page 46; results for 1897 in Water-Supply aud Irrigation Paper No. 27, page 32, and in the Nineteenth Annual Report, Part IV, page 230. 


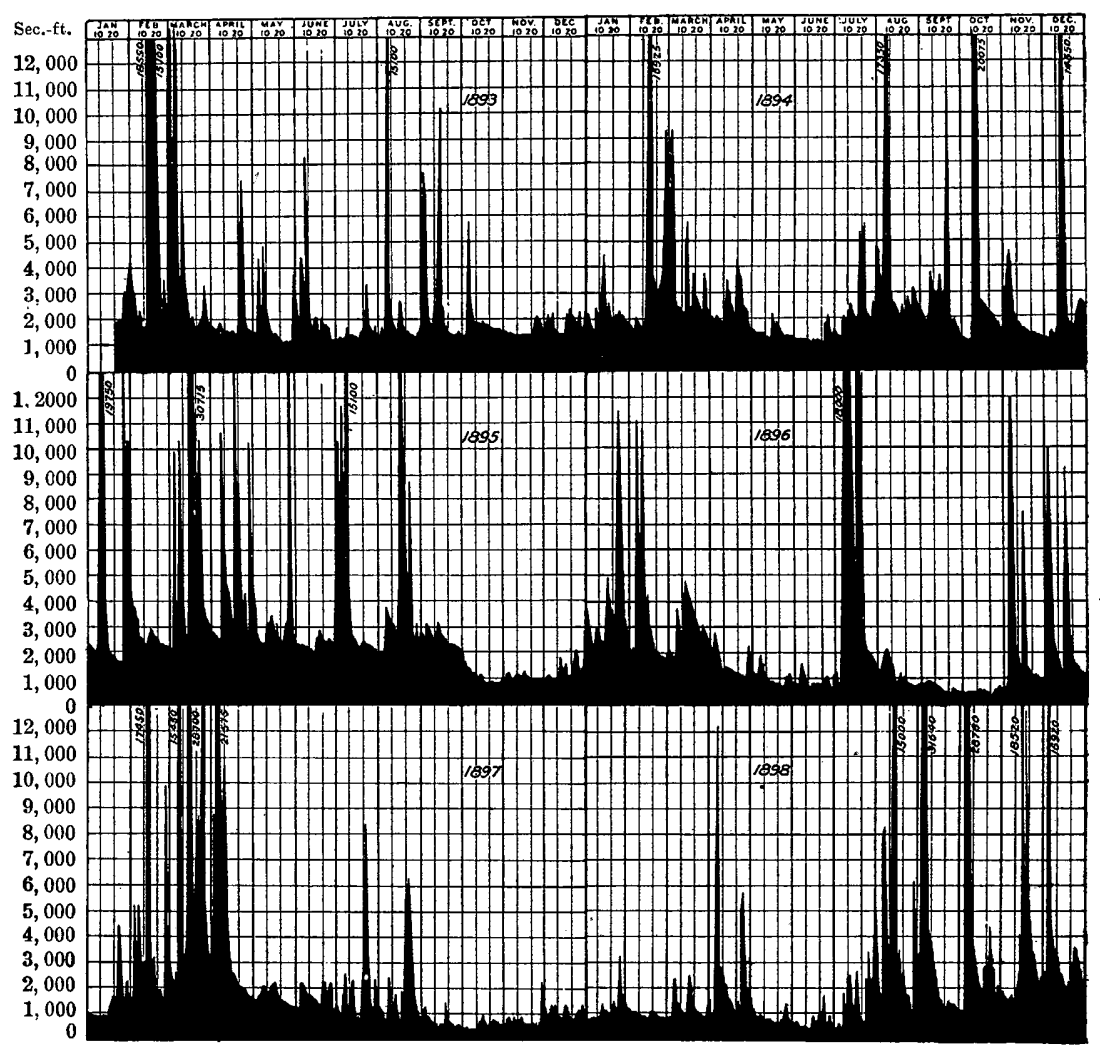

Fig. 55.-Discharge of Ocmulgee River at Macon, Georgia, 1893-1898.

\section{EASTERN GULF DRAINAGE.}

Under this heading are included the rivers flowing into the Gulf of Mexico at points east of the mouth of the Mississippi. The principal measurements have been on the Chattahoochee, Alabama, and Black Warrior rivers, and their tributaries in northern Georgia and Alabama.

\section{CHATTAHOOCHEE RIVER.}

Chattahoochee River rises in the Blue Ridge Mountains of northeastern Georgia and flows in a śoutheasterly course across the State to West Point, Georgia, from which point to the Florida line its west bank at high water forms the line between Georgia and Alabama. It erosses the "fall line" at Columbus, Georgia, above which point it has many fine shoals, which are enumerated on page 175 in tabular form. A more detailed description of this river is given on pages 84 and 85 of Part IV of the Eighteenth Annual Report, and on page 233 of Part IV of the Nineteenth Annual Report of this Survey.

This river drains a large area of the Dahlonega gold belt in the northeastern part of the State, in which hydraulic mining of the sapro- 
lite ores is an important industry. These veins or belts of auriferous decomposed schists vary in thickness from 50 to 150 feet, and are decomposed to the level of the adjacent large streams, giving a breast or heading in the open cut of from 100 to 150 feet in depth above sluice grade. The mining is done by hydraulic giant or nozzle under pressure from reservoirs on the hilltop, in the same manner that the great gravel deposits of the Pacific slope are worked; but as the material is vein matter instead of placer gravel, a stamp mill is located at the lower end of the sluice flume, which is generally from a half mile to a mile in length, and the solid material, which is mainly quartz, is automatically dumped over a "grizzly" into bins on the mill floor, from which it is fed into the stamp mill. The sand and slimes after passing through the grizzly are automatically deprived of their coarser materials by screens or settling bins and pass off through a flume to the stream. The coarser sand is also fed into the stamp mill. About 35 per cent of the gold obtained is liberated on the way to the mill and is caught in the riffles of the sluice flume; the remainder is caught at the mill by free amalgamation in the batteries and on the plates. This is a wasteful process, involving a loss of from 40 to 60 per cent of the gold in the ore, but the success of the process depends upon the cheap handling of large masses of low-grade material. The proportion of the ore that has to be milled varies with the equipment and material from one-fifth to one-tenth of the original bulk. The water supply for these mining operations is taken from the mountain streams, at a high level, and bronght by gravity in deep, narrow, swiftly running ditches or canals, along the hillsides, and finally on the hilltops over the mines, at which point it has an elevation of from 200 to 300 feet above the streams.

Some of the most important mining canals which have been constructed on this watershed are:

Blake Ditch, in White County, Georgia, from headwaters of Town Creek. It is 6 miles long, area of waterway 4 feet by $2 \frac{1}{2}$ feet, grade 5 feet to the mile, supply about 200 miner's inches.

Loud Ditch, in White County, Georgia, is from Town Creek. Its length is 25 miles, area of waterway 3 feet by 5 feet, grade 4 feet to the mile, supply from 300 to 500 miner's inches.

Singleton Ditch, in Lumpkin County, is from Wards Creek. Its length is 12 miles, area of waterway about 2 feet by 3 feet, supply about 100 miner's inches.

Hand Ditch (or Yahoola Canal), in Lumpkin County, Georgia, is from the upper waters of Yahoola Creek. It runs through the town of Dahlonega. The length of main ditch is 22 miles, and the length of additional distributing ditches to different mines about 20 miles. The main ditch has an area of waterway of about 4 by 6 feet, and a grade of 5 feet to the mile. It supplies from 15 to 25 second-feet of water. There are on the main line three-quarters of a mile of 36 -inch wooden pipe, and 3,000 feet of 36-inch wrought-iron pipe across Yahoola Creek, a depression of about 300 feet. The branch ditch running toward Auraria crosses Crane Creek in about 3,500 feet of 24-inch wrought-iron pipe, the lowest point of which is under a pressure of about 300 feet.

Cane Creek Ditch is in Lumpkin County, Georgia, receiving water from Cane Creek. The length is 18 miles, grade 3 feet per mile, and the supply from 100 to 200 miner's inches. 


\section{PROGRESS OF STREAM MEASUREMENTS FOR 1898.}

Etowah Ditch, in Lumpkin County, 7 miles long, brings from 20 to 25 second-feet of water from a tributary of the Etowah River and pours it over the divide into Cane Creek of the Chattahoochee watershed, in order to increase the water power of the Barlow Stamp Mill, which is on Cane Creek, a long distance below. From the divide or top of the ridge to Cane Creek it falls 200 feet or more.

Dukes Creek Ditch is in White County, from Dukes Creek. This, with Glade Ditch, in Hall County, from Flat Creek, is also on the Chattahoochee watershed.

In the Dahlonega region, but on the Etowah River watershed, three important mining ditches have been constructed; the Mill Creek Ditch, about 20 miles long; the Shoal Ureek Ditch, with 20 miles of main canal and 31 miles of distributive ditches, and the Nimblewell or Kin Mori Ditch, 35 miles long. The two last named are partly in Dawson County.

It must not be understood from the above that all of the gold mining in Georgia is of this nature. Underground vein mining is carried on in the Dahlonega belt and other gold belts of the State quite extensively. Most of the gold stamp mills on the Chattahoochee watershed are run by water power. The Dahlonega Consolidated Gold Mining Company is erecting a 120 -stamp mill, each stamp weighing 800 pounds, with ore breakers, self-feeders, concentrators, and chlorination plant to be used for working the large masses of pyritic gold ores that have been exposed by the hydraulic mining above described. This mill is to be run by water power from the Hand ditch under a very high head.

The city of Atlanta draws its water supply from the Chattahoochee River. Pumping Station No. 1, on the river bank, 6 miles from the city, has two ten-million-gallon Holly engines for pumping the water into a large reservoir situated near the city limits. Here it is filtered and pumped into the city mains from Station No. 2, which plant consists of two twelve-million-gallon Holly engines.

The only new water-power developments of importance are at Columbus, Georgia. - There are two dams across the Chattahoochee River at Columbus that were built many years ago and are still doing good service. These are the Eagle and Phœnix dam and the City Mills dam. The former is 25 feet.high and operates the three cotton mills of the Eagle and Phœnix Mills-43,216 spindles and 1,338 looms, and one woolen mill of the Eagle and Phœnix Mills of 3,936 woolen spindles and 156 woolen looms. Also mills Nos. 1 and 2 of the Muscogee Manufacturing Company-12,300 spindles. The latter dam, with 10-foot head, operates the large flour and corn mills of the City Mills Company, and also furnishes power for the combined stations of the Columbus Railroad Company and the Brush Electric Light and Power Company. The power station contains six 68-inch Leffel "Sampson" turbines, capable of developing 232 horsepower, each under a 10-foot head. These operate electric generators for running all the street cars of the Columbus Railroad Company, and other generators for incandescent and arc lights, and the motors for manufacturing establishments in the city.

A short distance above the City Mills the Columbus Power Company, 
recently formed, with a capital of $\$ 200,000$, is developing 8,000 horsepower by building a dam across the river at Lovers Leap, in North Highlands, just outside of the city limits. The dam will develop a head of 35 feet.

The following tabular statement of tributaries in the Apalachicola Basin is taken from Bulletin No. 3A of the Georgia geological survey, compiled by Prof. B. M. Hall. ${ }^{1}$ This bulletin also gives a statement of the important water powers on the large streams of the basin.

Important creeks and rivers in Apalachicola Basin.

\begin{tabular}{|c|c|c|c|c|}
\hline Name. & Tributary to- & County. & $\begin{array}{c}\text { Dis- } \\
\text { charge. }\end{array}$ & Remarks. \\
\hline & & . & $\begin{array}{l}\text { Second- } \\
\text { feet. }\end{array}$ & \\
\hline Stauding Boy .... & Chattahoochee. - & Muscogee... & $\cdots .$. & $\begin{array}{l}\text { Large shoal on creek } 2 \text { miles } \\
\text { from mouth. }\end{array}$ \\
\hline Mulberry .. & $\therefore$ do & Harris . & $\cdots$ & $\begin{array}{l}\text { Large creek; falls } 60 \text { feet in } \\
\text { one-fourth mile. }\end{array}$ \\
\hline Mountain.. & do & .....do . & 60 & $\begin{array}{l}20 \text {-foot fall on shoal at river } \\
\text { road. }\end{array}$ \\
\hline Old House ..... & ...do. & .... .do ... & - & \\
\hline Flat Shoals... & ..do . & ..... do $\ldots$. & 80 & $\begin{array}{l}\text { Troup factory ; 18-foot fall, } \\
\text { low water. }\end{array}$ \\
\hline Muddy. & $\ldots d o$ & Troup . & 7 & $\begin{array}{l}5 \frac{1}{2} \text { miles from Lagrange; } 10- \\
\text { foot fall, low water. }\end{array}$ \\
\hline Tellow Jacket. & ....do & .....to. & 87 & 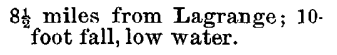 \\
\hline Beach. . & Yellow Jacket.. & .....do. & 35 & $\begin{array}{l}5 \text { miles from Lagrange; } 15 . \\
\text { foot fall, low water. }\end{array}$ \\
\hline Panther ... & Chattahoochee.... & .....do ... & 25 & $\begin{array}{l}3 \text { miles from Lagrange; } 10 . \\
\text { foot fall, low water. }\end{array}$ \\
\hline Flat ......... & .....do. & .....do. & 20 & $\begin{array}{l}\text { Gorham's mill; } 12 \text {-foot fall, } \\
\text { low water. }\end{array}$ \\
\hline New River.. & .....do. & Heard ... & 133 & $\begin{array}{l}\text { One-fourth mile of mouth; } \\
\text { 10-foot fall, low spring } \\
\text { stage. }\end{array}$ \\
\hline Whittaker....... & .....do... & ..... do ... & 91 & Whittaker's mill; 30-foot fall. \\
\hline Hillabuhatchee.. & .....do ....... & ..... do ... & $\cdots$ & \\
\hline Centralhatchee.. & ..... do ........ & .... do .... & 60 & 8 -foot fall; sawmill. \\
\hline Wahoo ....... & . . . do ......... & Coweta....... & 41 & $\begin{array}{l}\text { At Sergeant's; at mean low } \\
\text { water. Fall } 33 \text { feet in } 1,600 \\
\text { feet. Cotton factory and } \\
\text { grist mill. }\end{array}$ \\
\hline Snake ....... & ....do & Carroll $\ldots . .$. & 3 & 14-foot fall. \\
\hline Dog River..... & ....do ... & .....do ......... & 25 & Above Watkin's mill. \\
\hline Bear........ & ...do... & Douglass. & 53 & $\cdot$ \\
\hline Camp .......... & $\ldots$. do $\ldots . . .$. & Campbell . & ... & \\
\hline Sweetwater.... & ..... do .......... & Paulding . & 167 & $\begin{array}{l}\text { Austell Shoals, near mouth, } \\
\text { has } 80 \text { feet of fall. At } \\
\text { Hayes Bridge is } 80 \text { second. } \\
\text { feet at low water. }\end{array}$ \\
\hline Powder Spring .. & Sweetwater.... & Cobb ..... & $34^{\circ}$ & Powder Springs; low water. \\
\hline Noses.... & .....do ... & $\ldots$. do ... & $\cdots$ & \\
\hline Soap ....... & Chattaboochee. & .... do ......... & 62 & $\begin{array}{l}\text { Paper mill ; } 67 \text { feet head, low } \\
\text { spring stage. }\end{array}$ \\
\hline - Utoy $\ldots$ & .... do ..... & Fulton......... & & \\
\hline Nickajack ....... & ..... do .............. & Cobb ..... & & $\begin{array}{l}\text { 29.foot fall at Ruff's mill and } \\
\text { 21-foot at Concord factory. }\end{array}$ \\
\hline
\end{tabular}

1 A Preliminary Report on a part of the Water Powers of Georgia, Compiled from 1 he notes of C. C. Anderson, late assistant geologist, by B. M. Hall, special assistant, Atlanta, 1896.152 pp. 
Important creeks and rivers in Apalachicola Basin-Continued.

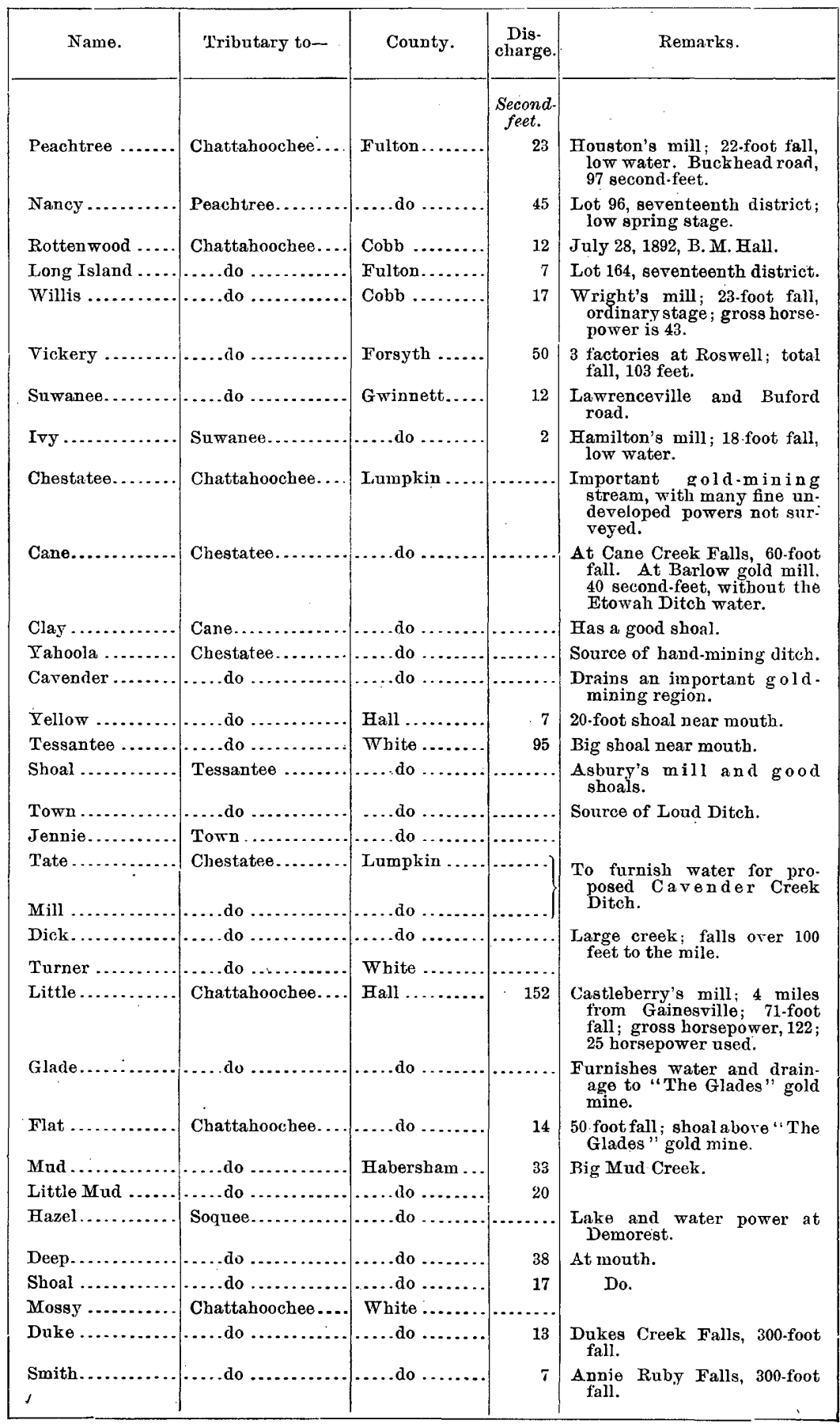


Important creeks and rivers in Apalachicola Basin-Continued.

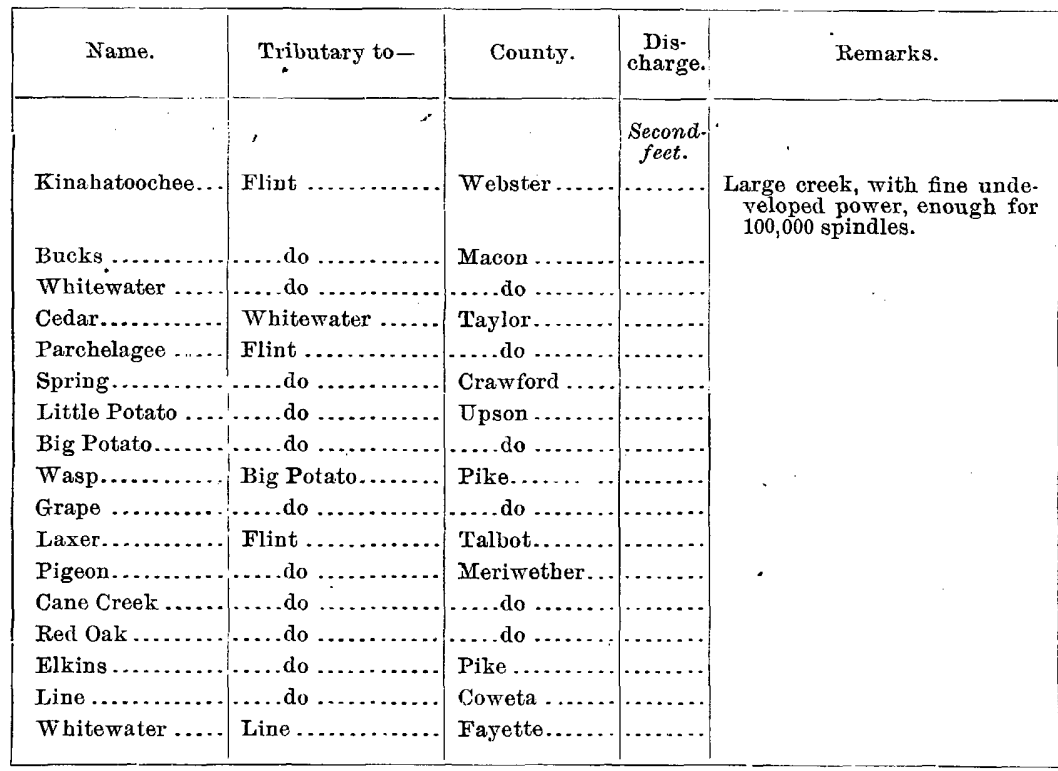

PRECIPITATION IN BASINS OF CHATTAHOOCHEE AND COOSA RIVERS.

The principal observations of rainfall made within the basins of the Chattahoochee and Coosa rivers are at Diamond, Ramsey, Adairsville, Rome, Dahlonega, Gainesville, Marietta, Atlanta, Newnan, and Lagrange. The relative location of these points is shown in fig. 56, in connection with the points of river measurement, which are located at Carters, Canton, Oakdale, and West Point.

The following table gives the names and locations of the stations, the elevations, and the lengths of records, the latter being the number of years during which complete records were had for the different months.

Location of rainfall stations.

\begin{tabular}{|c|c|c|c|c|c|c|}
\hline Station. & County. & State. & Latitude. & $\begin{array}{l}\text { Longi- } \\
\text { tude. }\end{array}$ & $\begin{array}{c}\text { Eleva- } \\
\text { tion. }\end{array}$ & $\begin{array}{l}\text { Length of } \\
\text { record. }\end{array}$ \\
\hline & & & $\circ$, & $\circ \quad 1$ & Feet. & Fears. \\
\hline Diamond & Gilmer .... & Georgia ... & 3440 & 8417 & 2,020 & $7-9$ \\
\hline Ramsey ........ & Murray ... & $\ldots$....do .... & 3442 & $84 \quad 45$ & ........ & $4-5$ \\
\hline Adairsville ..... & Bartow .. & ..... do .... & 3422 & 84. 56 & 772 & $5-6$ \\
\hline Rome. . . . . . . & Floyd ..... & ..... do .... & 3416 & 8508 & 576 & $17-18$ \\
\hline Dahlonega...... & Lumpkin & $\ldots$ do .... & 3432 & 8359 & 2,000 & $6-9$ \\
\hline Gainesville ..... & Hall ...... & .... do .... & 3418 & 8347 & 1,254 & $12-25$ \\
\hline Marietta.. & Cobb... & .... do .... & 3358 & 8430 & 1,133 & $10-13$ \\
\hline Atlanta.......... & Fulton ....... & ..... do .... & 3346 & 8423 & 1,131 & $30-33$ \\
\hline Newnan ........ & Coweta ... & ....do. & 3323 & 8445 & 959 & $2-16$ \\
\hline Lagrange........ & Troup...... & $\ldots$. do .... & 3302 & 8501 & 742 & $14-17$ \\
\hline
\end{tabular}

20 GEOL, PT $4-12$ 
In the following table are given the figures of normal or average monthly precipitation from the beginning of the record to and including 1897, together with the total precipitation, by months, for the years

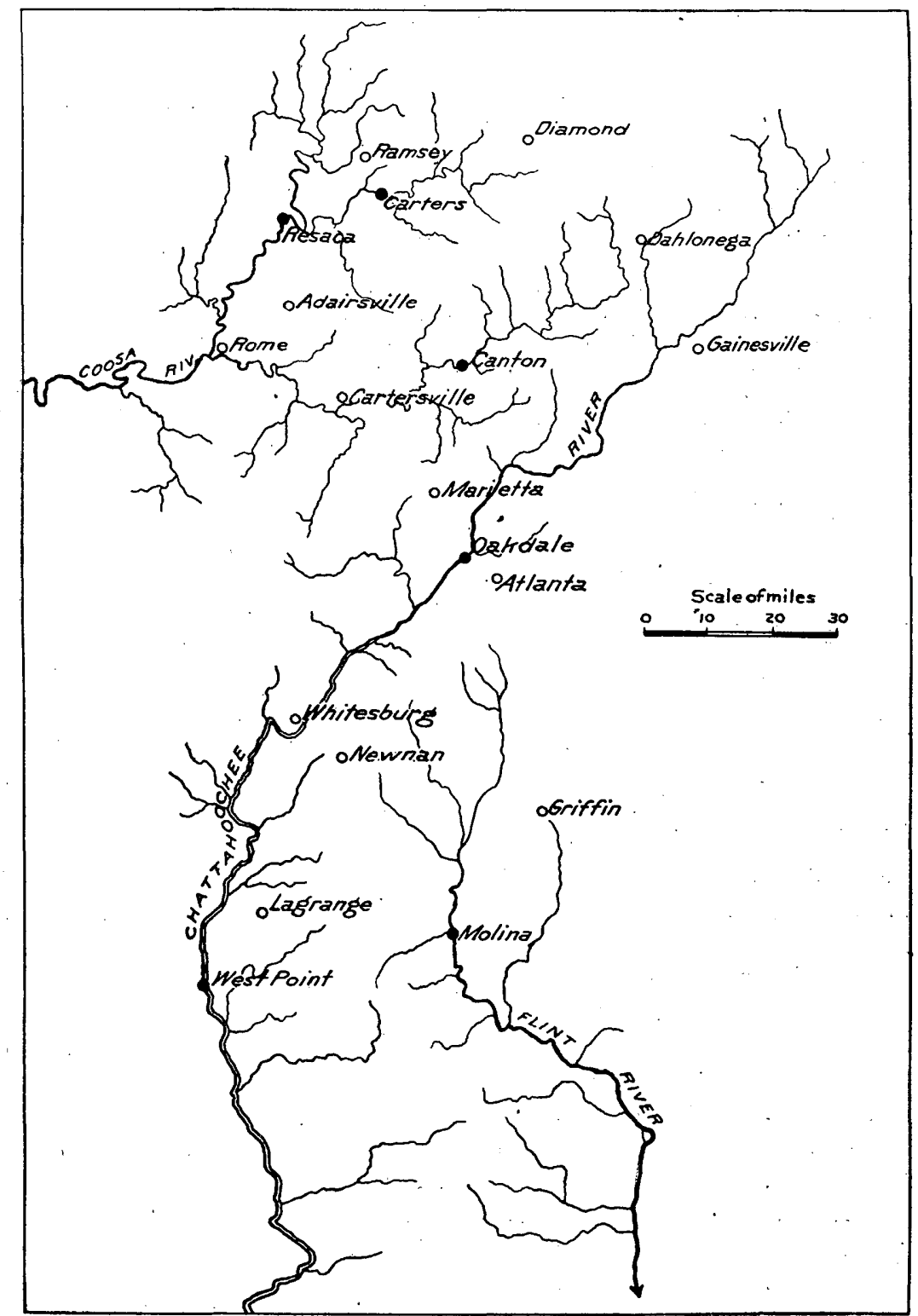

Fia. 56.-Relative location of river and rainfall observations in basins of Chattahoochee and Coosa rivers.

1896,1897 , and 1898, and the amount by years. In obtaining the normal precipitation the average is taken for all of the months during which observations were nade. 
Rainfall at stations in drainage basins of Chattahoochee and Coosa rivers.

DIAMOND.

\begin{tabular}{|c|c|c|c|c|c|c|c|c|c|c|c|c|c|}
\hline Year. & Jan. & Feb. & Mar. & Apr. & May. & June. & Jul. & Aug. & Sept. & Oct. & Nov. & Dec. & Annual. \\
\hline Normal....... & 5.64 & 8.56 & 6.56 & 5.40 & 5.57 & 6.19 & 8.46 & 6.41 & 4.99 & 2.50 & 4.66 & 4.77 & 69.71 \\
\hline 1896. & 3.32 & 3.70 & 3.33 & 2.34 & 2.55 & 4.75 & 11.31 & 2.76 & 3.13 & 2.29 & 9.17 & 1.71 & 50.36 \\
\hline $1897 \ldots \ldots \ldots$ & 4.89 & $a 8.56$ & 9.27 & 5.44 & 1.67 & 5. 48 & 5.92 & 3.93 & 0.09 & 4. 01 & 2.68 . & 7.97 & 59.91 \\
\hline 1898. & $\alpha 5.64$ & 0.78 & 6.28 & 6.27 & 1.22 & 3. 04 & 6.98 & 11.74 & 6.93 & 11.77 & 4.52 & 2.35 & 67.52 \\
\hline \multicolumn{14}{|c|}{ RAMSEY. } \\
\hline Normal. & 4.12 & 3.84 & 5.33 & 4.08 & 3.53 & 2.47 & 5.42 & 3.49 & 1.84 & 1.84 & 2.48 & 3.88 & 42.32 \\
\hline 1896. & 2.77 & 4.11 & 2.50 & 3.27 & 3.94 & 1.27 & 5.14 & 2.09 & 3.58 & 1.65 & 6.88 & 0.33 & 37.53 \\
\hline 1897. & 2.17 & 5.34 & 9.91 & 6.13 & 2.33 & 2. 94 & 8.05 & 4.84 & 0.11 & 2. 32 & 1.81 & 6.50 & 52.45 \\
\hline $1898 \ldots$ & 5.19 & 0.68 & 5.38 & 4.56 & 0.16 & 3.95 & 6.79 & 5.15 & $\begin{array}{r}8.44 \\
1 \\
\end{array}$ & 6.91 & 3.82 & 1.46 & 52.49 \\
\hline \multicolumn{14}{|c|}{ ADAIRSVILLE. } \\
\hline Normal. & 4.82 & 4.44 & 4.70 & 4.38 & 3.08 & 3.46 & 5.12 & 3.69 & 2.36 & 1.01 & 2. 65 & 3.97 & 43.68 \\
\hline 1896. & 3.64 & 3.67 & 2.66 & $1: 58$ & 3.18 & 1.33 & 6.16 & 2.36 & 4.73 & 1.04 & 4. 34 & 1.23 & 35.92 \\
\hline 1897. & 4.39 & 5.10 & 7.60 & 4.27 & 0.73 & 0.91 & 8.62 & 5.11 & 0.18 & 1.92 & 1.68 & 6.21 & 46.72 \\
\hline 1898. & 4.95. & 0.73 & 3.54 & 5.87 & 0.73 & 5.89 & 7.27 & 5.23 & 9.98 & 7.14 & 3.21 & 1.87 & 56.41 \\
\hline \multicolumn{14}{|c|}{ ROME. } \\
\hline Normal ... & 5.83 & 4.56 & 5.96 & 4. 17 & 3. 09 & 4.13 & 4.28 & 4.25 & 2.54 & 2.11 & 3.26 & 4.20 & 48.38 \\
\hline $1896 \ldots$ & 4.06 & 4. 26 & 3.22 & 1.91 & 3.10 & 1.85 & 5.30 & 4.51 & 3.45 & 1.45 & 4.96 & 1.47 & 39.54 \\
\hline 1897 & 5.43 & 5.78 & 9.80 & 3. 16 & 0.91 & 3.34 & 7.68 & 2.65 & 0.00 & 1.15 & 1.35 & 6.83 & 48.08 \\
\hline $1898 \ldots$ & 5.05 & 0.86 & $3: 58$ & 6.62 & 0.98 & 3.00 & 7.54 & 5.10 & 7.49 & 7.15 & 3.31 & 1.80 & 52.48 \\
\hline \multicolumn{14}{|c|}{ DAHLONEGA. } \\
\hline Normal & 6.98 & 5.25 & 6.10 & 4.10 & 4. 81 & 5.76 & 7. 38 & 6.48 & 3.91 & 2.81 & $4.48^{\prime}$ & 5.01 & 63.07 \\
\hline 1896 & 4.57 & 4.81 & 2.91 & 2.07 & 5.05 & 4.62 & 8.03 & 2.95 & 1.82 & 3.36 & 7.86 & 0.97 & 49.02 \\
\hline $1897 .$. & 5.77 & 6.01 & 9.98 & 7.10 & 0.90 & 2.05 & 8.27 & 1.75 & 0.65 & 3.69 & 3.51 & 6.08 & 55.76 \\
\hline $1898 \ldots$ & 5.54 & 1.38 & 4.60 & 5.53 & 1.00 & 3.87 & 10.62 & 10.69 & 12.08 & 8.32 & 4.45 & 3.69 & 71.77 \\
\hline \multicolumn{14}{|c|}{ GAINESVILLE. } \\
\hline Normal & 6.42 & 6.63 & 6. 69 & 4.08 & 3.52 & 4.46 & 4.89 & 5.84 & 4.09 & 2.63 & 3.94 & 5.23 & 59.52 \\
\hline $1896 \ldots$ & ....... & ....... & $\ldots \ldots$ & $\ldots . .$. & 1.53 & 2.08 & 10.61 & 0.77 & 1.62 & $\ldots .$. & 6.77 & 2.02 & $\cdots \cdots \cdots$ \\
\hline 1897. & 4.40 & 4.89 & 6.90 & a4. 08 & 1.15 & 3.03 & 14.43 & 2.48 & 0.05 & 2.67 & 3.46 & 2.78 & 50.32 \\
\hline $1898 \ldots$ & 3.24 & 0.79 & 4.41 & 5.29 & 1.03 & 1.23 & 12.12 & 9.58 & 6. 71 & 7.30 & 3.58 & 3.37 & 58.65 \\
\hline \multicolumn{14}{|c|}{ MARIETTA: } \\
\hline Normal & 5. 25 & 5.08 & 5.68 & 3.19 & 3.29 & 4.10 & 5.54 & 4.33 & $3 . \dot{56}$ & 2.03 & 3.42 & 3.55 & 49.02 \\
\hline 1896. & 4.01 & 3.75 & 3.44 & 1.28 & 2.14 & 2.58 & 9.36 & T. $b$ & 1.40 & 1.82 & 4.94 & 1.45 & 36. 17 \\
\hline $1897 .$. & 4. 02 & 4. 29 & 7.14 & .4 .35 & 0.41 & 2.63 & 8.41 & 3.86 & T. $b$ & 2.33 & 1.84 & 3.91 & 43.19 \\
\hline $1898 \ldots$ & 3.33 & 0.68 & 4.70 & 3.92 & 0.63 & 1.94 & 13.19 & 6.21 & 8.59 & 6.54 & 3.25 & 1.78 & 54.76 \\
\hline \multicolumn{14}{|c|}{ ATLANTA. } \\
\hline Normal. & 5.10 & 5. 10 & 5.70 & 4.20 & 3.50 & 4.00 & 3.90 & 4.50 & 3.60 & 2.20 & 3.70 & 4. 50 & 50.00 \\
\hline $1896 \ldots$ & 3. 12 & 3.04 & 3.29 & 0.58 & 1.95 & 2.66 & 7.55 & 1.97 & 1.36 & 1.28 & 5.90 & 1.42 & 34.12 \\
\hline $1897 \ldots \ldots$ & 3.48 & 4.59 & 5.74 & 5.06 & 0.34 & 2.07 & 4.74 & 6. 01 & 0.14 & 1.80 & 2.29 & 3.00 & 39.26 \\
\hline $1898 \ldots$ & 2.99 & 0.62 & 4. 09 & 5.15 & 1.35 & 0.89 & 10.22 & 6.66 & 6.33 & 5.06 & 3.36 & 3.84 & 50.56 \\
\hline
\end{tabular}

$a$ No record; normal value inserted. 
180 PROGRESS OF STREAM MEASUREMENTS FOR 1898.

Rainfall at stations in drainage basins of Chattahoochee and Coosa vivers-Continued. NEWNAN.

\begin{tabular}{|c|c|c|c|c|c|c|c|c|c|c|c|c|c|}
\hline Year. & Jan. & Feb. & Mch. & Apr. & May. & June. & July. & Aug. & Sept. & Oet. & Nov. & Dec. & Annual. \\
\hline Normal & & & & 4. 38 & 3.34 & 4.99 & 5.35 & 5.01 & 3.61 & 2.21 & 2.81 & 2.16 & \\
\hline $1896 .$. & & & $\cdots$ & $\cdots$ & 1.82 & 3.72 & 10.14 & 2.02 & 1.26 & 1.19 & 7.30 & 0.95 & \\
\hline $1897 \ldots$ & 3.17 & 6.70 & 8.43 & 4.83 & 0.66 & 4.61 & 5. 29 & 4.85 & 0.21 & 1.08 & 2.24 & 3.37 & 45.44 \\
\hline 1898. & 1.88 & $\cdots \cdots$ & 4.74 & 5.22 & 0.83 & 2. 93 & 7.37 & 14.59 & 2.81 & 8.15 & 4.50 & 4.15 & \\
\hline \multicolumn{14}{|c|}{ LAGRANGE. } \\
\hline Normal & 4.60 & 4.95 & 6.44 & 3. 32 & 2.86 & 4.37 & 5.35 & 4. 77 & 2.21 & 2. 33 & 2.93 & 4.77 & 48.90 \\
\hline 1896. & 4.98 & 4. 65 & 4. 12 & 1.65 & 1.53 & 1.66 & 11.05 & 1.28 & 3.58 & 1.07 & 7.15 & 1.69 & 44.41 \\
\hline $1897 \ldots \ldots \ldots \ldots$ & 2.72 & 5.82 & 9.40 & 6.09 & 1.16 & 2.27 & 7.86 & 4.76 & T. $b$ & 1.70 & 1.50 & 1.75 & 45.03 \\
\hline $1898 \ldots \ldots \ldots$ & 2.74 & 0.87 & 3.59 & 4.90 & 0.22 & 3.73 & 4. 76 & 12. 71 & 1.63 & 6.35 & 4.31 & 4.53 & 50.34 \\
\hline \multicolumn{14}{|c|}{ A VERAGE. } \\
\hline Normals & 5.42 & 5.39 & 5. 91 & 4. 13 & 3.66 & 8.05 & 5.57 & 4. 88 & 3.27 & 2.17 & 3.43 & 4.20 & 56.08 \\
\hline 1896. & 3.81 & 4.00 & 3.18 & 1.84 & 2.68 & 2.65 & 8.47 & 2.13 & 2.59 & 1.68 & 6.50 & 1.32 & .40 .85 \\
\hline $1897 \ldots$ & 4.04 & 5.71 & 9.42 & 5.58 & 1.03 & 2.93 & 7. 93 & 4.02 & 0.14 & 2.27 & 2.24 & 4.84 & .50 .15 \\
\hline $1898 \ldots$ & 4.06 & 0.82 & 4.49 & 5.33 & 0.82 & 3.05 & 8.69 & 7.87 & 7.10 & 7.47 & 3.83 & 2.88 & 56.41 \\
\hline
\end{tabular}

Depth of run-off, in inches, from Chattahoochee and Coosa drainage basins.

$i$ CHATTAHOOCHEE AT OAKDALE.

\begin{tabular}{|c|c|c|c|c|c|c|c|c|c|c|c|c|c|}
\hline Tear: & Jan. & Feb. & Mar. & Apr. & May. & June. & July & Aug. & Sept. & Oct. & Nov. & Dec. & Annual. \\
\hline 1895. & & $\ldots$ & & & . & 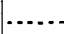 & & $\cdots$ & $\cdots$ & 0.43 & 0.92 & 1.06 & \\
\hline 1896. & 2.09 & 1.90 & 1.33 & 1. 14 & 1.02 & 0.91 & 2.89 & 0.79 & 0.60 & 0.67 & 1.15 & 1.07 & 15.56 \\
\hline 1897. & 1.90 & 2.49 & 4. 19 & 3.68 & 1.58 & 1.02 & 2. 48 & 1.07 & 0.60 & 0.72 & 0.77 & 1.36 & 21.86 \\
\hline 1898. & 1.69 & 0.97 & 1.46 & 2.45 & 1.15 & 0.84 & 2.08 & 3.53 & 5. 31 & 4. 51 & 2.14 & 2.35 & 28.48 \\
\hline Average. & 1. 89 & 1.79 & 2.33 & 2.42 & 1.25 & 0.92 & 2.48 & 1.80 & 2.17 & 1. 58 & 1.25 & 1.46 & 21.34 \\
\hline \multicolumn{14}{|c|}{ CHATTAHOOCHEE AT WEST POINT. } \\
\hline 1896. & & & & & & & & 0.93 & 0.49 & 0.56 & 1. 72 & 1.04 & \\
\hline 1897. & 1.49 & 2.68 & 4.55 & 3.12 & 1.42 & 0.90 & 1.76 & 1.48 & 0.38 & 0.45 & 0.48 & 1.30 & 20.01 \\
\hline $1898 . .$. & 1.16 & 0.73 & 0.97 & 2.34 & 0.78 & 0.50 & 1.49 & 3. 01 & 3. 75 & 3. 32 & 2.00 & 1.84 & 21.89 \\
\hline Average. & 1.34 & 1.71 & 2.76 & 2.73 & 1.10 & 0.70 & 1.63 & 1.81 & 1.54 & 1.44 & 1.40 & $1.39^{\circ}$ & 19.55 \\
\hline \multicolumn{14}{|c|}{ COOSAWATTEE AT CARTERS. } \\
\hline 1896 & & & & & ...... & & $\cdots$ & 0.33 & 0.55 & 0.63 & 1. 25 & 1.49 & \\
\hline $1897 .$. & 1.53 & 2. 14 & 4.27 & 3.22 & 2. 08 & 1.33 & 1. 71 & 1.07 & 0.55 & 0.63 & 0.55 & 0.95 & 20.03 \\
\hline 1898. & 1.95 & 1.18 & 1.49 & 2.83 & 1.22 & 0.95 & 1.06 & 2.19 & 2. 32 & 3.64 & 1.73 & 1.50 & 22.06 \\
\hline Average. & 1.74 & 1.66 & 2.88 & 3.03 & 1.65 & 1,14 & 1.39 & 1. 20 & 1. 14 & 1. 63 & 1.18 & 1.31 & 19. 95 \\
\hline
\end{tabular}


Depth of run-off, in inches, from Chattahoochee and Coosa drainage basins-Continued. OOSTANAULA AT RESACA.

\begin{tabular}{|c|c|c|c|c|c|c|c|c|c|c|c|c|c|}
\hline Year. & Jan. & Feb. & Mch. & Apr. & May. & June. & July. & Aug. & Sept. & Oct. & Nov. & Dec. & Annual. \\
\hline $1896 .$. & & & & & & & & & & & & & \\
\hline 1897. & 1.58 & 1.78 & 2.00 & 1.73 & 1.76 & 0.87 & 1.51 & 0.72 & 0.35 & 0.38 & 0.41 & 1.68 & 14.77 \\
\hline $1898 \ldots \ldots \ldots$ & 3.22 & 1.01 & 1.84 & 3.58 & 0.99 & 0.82 & 0.91 & 1.57 & 3.77 & 4.05 & 1.77 & 1.71 & 25.24 \\
\hline Average. & 2.40 & 1.40 & 1.92 & 2.66 & 1.38 & 0.85 & 1.21 & 1.15 & 2.06 & 2.22 & 1.09 & 1.70 & 20.04 \\
\hline \multicolumn{14}{|c|}{ ETOWAH AT CANTON. } \\
\hline 1895 & 5.08 & 2.14 & 4. 35 & 3.48 & 2.79 & 2.22 & 2.28 & 3.24 & 1. 91 & 1. 31 & 1.35 & 1.64 & 31.79 \\
\hline $1896 \ldots$ & ........ & $\ldots \ldots$ & ... & ....... & & .. & ..... & $\ldots$ & 0.40 & 0.95 & 1. 76 & 1.21 & $\ldots$ \\
\hline $1897 \ldots$ & 2.28 & 2.23 & 4.45 & 4.14 & 1.98 & 1.74 & 2.26 & 1.64 & 0.65 & 1.12 & 1.07 & 1.79 & 25.35 \\
\hline $1898 \ldots$. & 2.14 & 1.02 & 1.94 & 2.14 & 1.12 & 0.91 & 2. 66 & 3.99 & 3.62 & 4.36 & 2.60 & 3.66 & 30.16 \\
\hline Average. & 3.17 & 1. 80 & 3.58 & 3.25 & 1.96 & 1.62 & 2.40 & 2.96 & 165.00 & 1.94 & 1. 70 & 2.08 & 28.11 \\
\hline
\end{tabular}

Annual rainfall and run-off of Chattahoochee and Coosa rivers.

\begin{tabular}{|c|c|c|c|c|}
\hline Station. & Normal. & 1896. & 1897. & 1898. \\
\hline RAINFALL. & Inches. & Inches. & Inches. & Inches. \\
\hline Diamond $\ldots \ldots \ldots \ldots \ldots \ldots \ldots$ & 69.71 & 50.36 & 59.91 & 67.52 \\
\hline Ramsey ......................... & 42.32 & 37.53 & 52.45 & 52.49 \\
\hline Adairsville . . . . . . . . & 43.63 & 35.92 & 46. 72 & 56.41 \\
\hline Rome...... & 48.38 & 39.54 & 48.08 & 52.48 \\
\hline Dahlonega . & 63.07 & 49.02 & 55. 76 & 71.77 \\
\hline Gainesville .... & 59.52 & $\ldots \ldots \ldots$ & 50.32 & 58.65 \\
\hline Marietta ..... & 49.02 & 36.17 & 43.19 & 54.76 \\
\hline Atlanta $\ldots \ldots \ldots \ldots \ldots$ & 50.00 & 34.12 & 39.26 & $50.56^{\circ}$ \\
\hline Newnan . . . . . . . . . . . . . & $\ldots \ldots$ & $\ldots \ldots \ldots$ & 45.44 & $\ldots \ldots \ldots$ \\
\hline 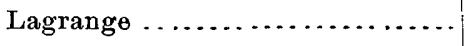 & 48.90 & 44.41 & 45.03 & 50.34 \\
\hline Average & 52.73 & 40.88 & 48.62 & 57.22 \\
\hline RUN-OFF: & & & & \\
\hline Chattahoochee at Oakdale....... & 21.34 & 15.56 & 21. 86 & 28.48 \\
\hline Chattahoochee at West Point... & 19.55 & $\ldots \ldots$ & 20.01 & 21.89 \\
\hline Coosawattee at Carters ..... & 19.95 & $\cdots \cdots$ & 20.03 & 22.06 \\
\hline Oostanaula at Resaca ....... & 20.04 & $-\cdot$ & 14.77 & 25.24 \\
\hline Etowah at Cantion ............ & 28.11 & - & 25.35 & 30.16 \\
\hline Average. & 21.80 & 15.56 & 20.40 & 25.57 \\
\hline Percentage of rainfall. & 41. 34 & 38.06 & 41.87 & 44.69 \\
\hline
\end{tabular}


Estimated nionthly discharge of Chattahoochee River at Oakdale, Georgia.

[Drainage area, 1,560 square miles.]

\begin{tabular}{|c|c|c|c|c|c|c|}
\hline \multirow[b]{2}{*}{ Month. } & \multicolumn{3}{|c|}{ Discharge in second-feet. } & \multirow[b]{2}{*}{$\begin{array}{l}\text { Total in acre- } \\
\text { feet. }\end{array}$} & \multicolumn{2}{|c|}{ Run-off. } \\
\hline & $\begin{array}{l}\text { Maxi. } \\
\text { mum. }\end{array}$ & $\begin{array}{l}\text { Mini- } \\
\text { mum. }\end{array}$ & Mean. & & $\begin{array}{l}\text { Depth in } \\
\text { inches. }\end{array}$ & $\begin{array}{c}\text { Second. } \\
\text { feet per } \\
\text { square } \\
\text { mile. }\end{array}$ \\
\hline 1898. & & & & & & \\
\hline January... & 9,150 & 1,295 & 2,288 & 140,686 & 1.69 & 1.47 \\
\hline February .. & 1,920 & 1,240 & 1,450 & 79,529 & 0.97 & 0.93 \\
\hline March ... & 10,200 & 1,185 & 1,984 & 121,992 & 1.46 & 1. 27 \\
\hline April .... & 14,325 & 1,688 & 3,425 & 203,801 & 2.45 & 2.20 \\
\hline May ....... & 2,165 & 1,158 & 1,566 & 96,290 & 1.15 & 1.00 \\
\hline June....... & 2,095 & 920 & 1,181 & 70,274 & 0.84 & 0.76 \\
\hline July ...... & 14,020 & 730 & 2,806 & 172,535 & 2.08 & 1.80 \\
\hline August..... & 18,700 & 1,490 & 4,774 & 293,544 & 3.53 & 3.06 \\
\hline September . & 33,975 & 1,925 & 7,434 & 442,353 & 5.31 & 4.77 \\
\hline October..... & 28,450 & 1,850 & 6,096 & 374,831 & 4.51 & 3.91 \\
\hline November.... & 4,530 & 2,150 & 2,889 & 171,907 & 2.14 & 1.92 \\
\hline December... & 8,050 & 2,112 & 3,179 & 195,470 & 2.35 & 2.04 \\
\hline The year & 33,975 & 730 & 3,256 & $2,363,212$ & 28.48 & 2.09 \\
\hline
\end{tabular}

Nore.-Gage heights for 1898 are given in Water-Supply and Irrigation Paper No: 27, page 50; measurements, page 57; rating table, page 58; results for 1897 in Water-Supply and Irrigation Paper No. 15, page 46, and in the Nineteenth Annual Report, Part IV, page 235.

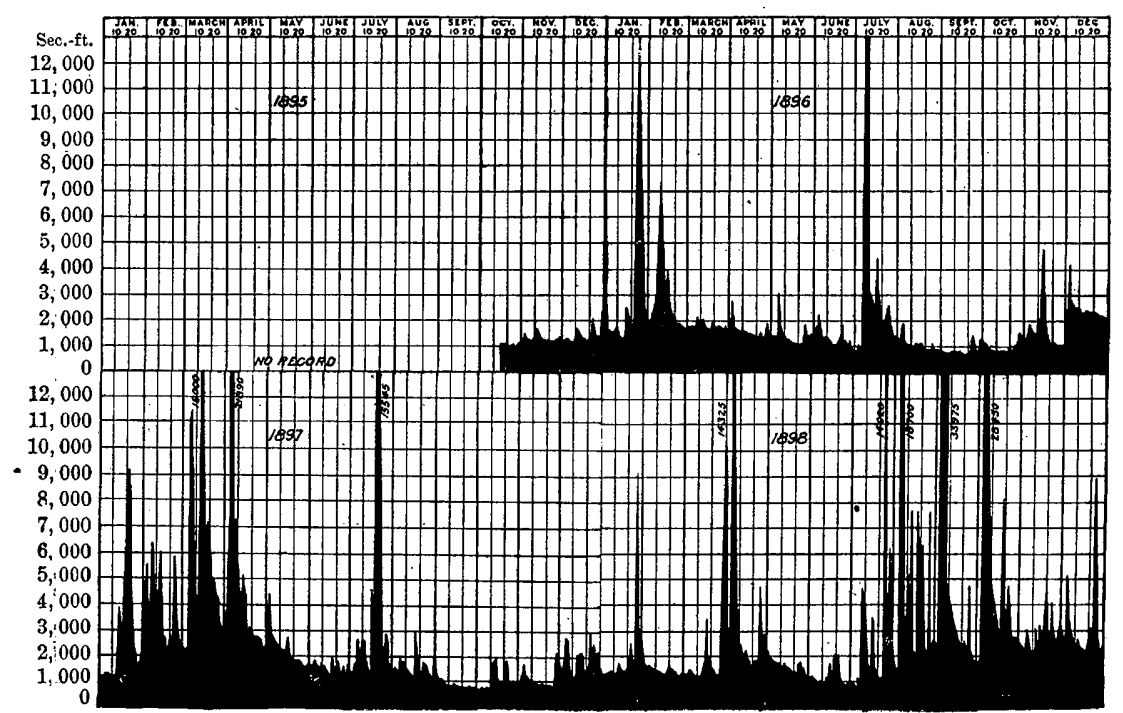

FIG. 57.-Discharge of Chattahoochee River at Oakdale, Georgia, 1895-1898. 
Estimated monthly discharge of Chattahoochee River at West Point, Georgia.

[Drainage area, 3,300 squäre miles.]

\begin{tabular}{|c|c|c|c|c|c|c|}
\hline \multirow[b]{2}{*}{ Month. } & \multicolumn{3}{|c|}{ Discharge in second-feet. } & \multirow[b]{2}{*}{$\begin{array}{c}\text { Total in acre. } \\
\text { feet. }\end{array}$} & \multicolumn{2}{|c|}{ Run-off. } \\
\hline & $\begin{array}{l}\text { Maxi. } \\
\text { mum. }\end{array}$ & $\begin{array}{l}\text { Mini- } \\
\text { mum. }\end{array}$ & Mean. & & $\begin{array}{l}\text { Depth in } \\
\text { inches. }\end{array}$ & $\begin{array}{l}\text { Second. } \\
\text { feet per } \\
\text { square } \\
\text { mile. }\end{array}$ \\
\hline 1898. & & & & & & \\
\hline January ............ & 10,800 & 1,970 & 3,321 & 204,202 & 1. 16 & 1.01 \\
\hline February ........... & 3,430 & 1,840 & 2,319 & 128,791 & 0.73 & $0: 70$ \\
\hline March . . . & 6,140 & 1,970 & 2,785 & 171,244 & 0.97 & 0.84 \\
\hline April...... & 20,750 & 2,310 & 6,931 & 412,422 & 2.34 & 2.10 \\
\hline May & 3,700 & 1,540 & 2,235 & 137,426 & 0.78 & 0.68 \\
\hline June ....... & 2,100 & 1,180 & 1,491 & 88,720 & 0.50 & 0.45 \\
\hline July ....... & 15,240 & 950 & 4,267 & 262,369 & 1.49 & 1. 29 \\
\hline August...... & 23,940 & 3,170 & 8,615 & 529,719 & 3.01 & 2.61 \\
\hline September ... & 57,350 & 1,600 & 11,080 & 659,304 & 3.75 & 3.36 \\
\hline October ..... & 40,330 & 1,600 & 9,511 & 584,812 & 3.32 & 2.88 \\
\hline November ... & 10,110 & 3,890 & 5,904 & ' 351,312 & 2.00 & 1. 79 \\
\hline December.. & 9,834 & 3,795 & 5,272 & 324,165 & 1: 84 & 1. 60 \\
\hline$\therefore$ The year.. & 57,350 & 950 & 5,311 & $3,854,486$ & 21.89 & 1.61 \\
\hline
\end{tabular}

Note.-Gage heights for 1898 are given in Water-Supply and Irrigation Paper No. 27, page 51; measurements, page 57; rating table, page 58; results for 1897 in Water-Supply and Irrigation Paper No. 15, page 47, and in the Nineteenth Annual Report, Part IV, page 237.

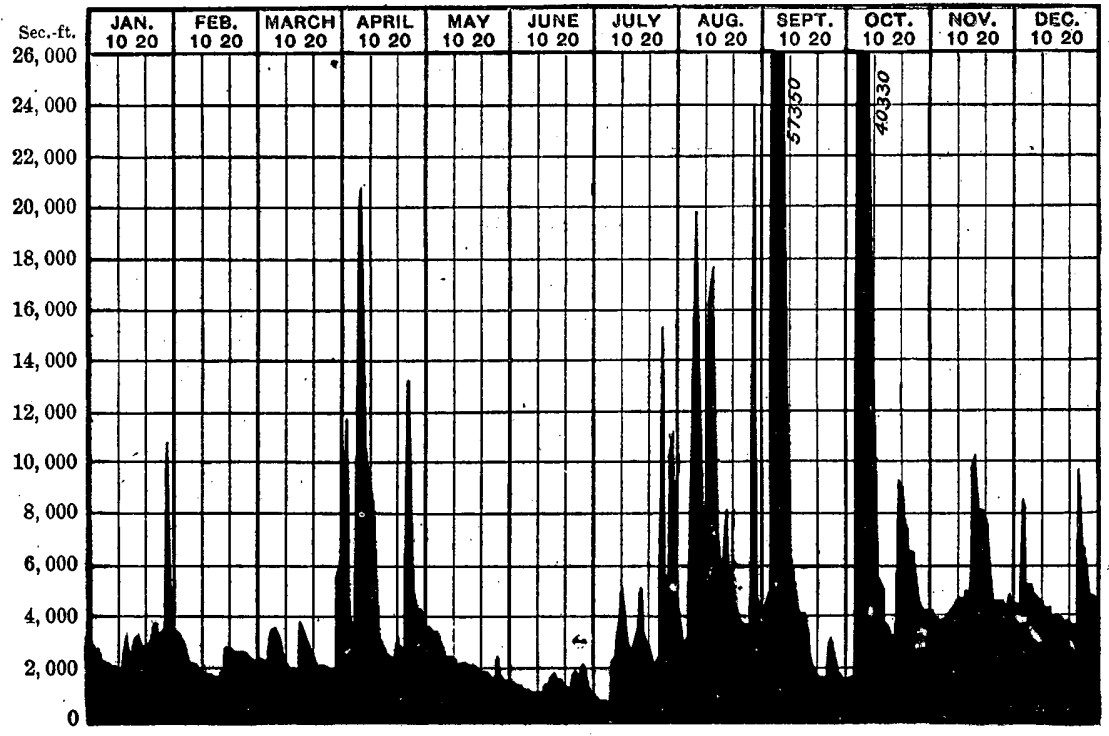

FIG. 58.-Discharge of Chattahoochee River at West Point, Georgia, 1898. 


\section{FLINT RIVER.}

Flint River rises near Atlanta, Georgia, and drains a large area in western and southwestern Georgia, uniting with the Chattahoochee at the southwest corner of the State to form the Apalachicola River. It crosses the "fall line" near Knoxville, Georgia, at a point on a direct line between Macon and Columbus. Above the "fall line" the river and its tributaries are swift and have numerous shoals, shown in the tabular statement on page 177. The river stations on Flint River are at Molina and Albany, Georgia.

Estimated monthly discharge of Flint River at Molina, Georgia

[Drainage area, 892 square miles.]

\begin{tabular}{|c|c|c|c|c|c|c|}
\hline \multirow[b]{2}{*}{ Month. } & \multicolumn{3}{|c|}{ Discharge in second-feet. } & \multirow[b]{2}{*}{$\begin{array}{l}\text { Total in acre. } \\
\text { feet. }\end{array}$} & \multicolumn{2}{|c|}{ Run-off. } \\
\hline & $\begin{array}{l}\text { Maxi- } \\
\text { mum. }\end{array}$ & $\begin{array}{l}\text { Mini- } \\
\text { mum. }\end{array}$ & Mean. & & $\begin{array}{l}\text { Depth in } \\
\text { inches. }\end{array}$ & $\begin{array}{c}\text { Second- } \\
\text { feet per } \\
\text { square } \\
\text { milo. }\end{array}$ \\
\hline 1898. & & & & & & \\
\hline January............. & 1,645 & 531 & 911 & 56,016 & 1. 18 & 1. 02 \\
\hline February ........... & 850 & 566 & 663 & 36,821 & 0.77 & 0.74 \\
\hline March.: & 1,985 & 496 & 936 & $57,5 \overline{5} 3$ & 1.21 & 1. 05 \\
\hline April........ & 6,580 & 496 & 1,634 & 97,232 & 2.05 & 1. 84 \\
\hline 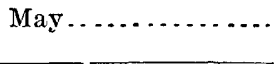 & 606 & 275 & 361 & 22,197 & 0.45 & 0.40 \\
\hline
\end{tabular}

Note.-Gage heights for 1898 are given in Water.Supply and Irrigation Paper No. 27, page 49; measurements, page 57; rating table, page 58; results for 1897 in Water-Supply and Irrigation Paper No. 15, page 45, and in the Nineteenth Annual Report, Part IV, pages 233-234.

\section{ALABAMA RIVER.}

COOSA RIVER.

Elaborate surveys of Coosa River have been made by the Corps of Engineers, United States Army, and a full description of its characteristics can be found in their publications. When the locks which have been planned and partly constructed are all completed it will be navigable from the Gulf to Rome, Georgia; and its tributary, the Oostanaula, will be navigable to Carters, Georgia, on the Coosawattee River. Steamboats have been running on parts of the Coosa and Oostanaula for many years. From Ellijay, Georgia, to Carters, the Coosawattee River is a continuous shoal for about 17 miles. This latter stream is formed by the junction of the Ellijay River and the Cartecay River, near Ellijay, both of these being mountain streams with many shoals. 
Estimated monthly discharge of Coosa River at Rome, Georgix.

[Drainage area, 4,001 square miles.]

\begin{tabular}{|c|c|c|c|c|c|c|}
\hline \multirow[b]{2}{*}{ Month. } & \multicolumn{3}{|c|}{ Discharge, in second-feet. } & \multirow{2}{*}{$\begin{array}{l}\text { Total in acre } \\
\text { feet. }\end{array}$} & \multicolumn{2}{|c|}{ Run-otr. } \\
\hline & $\begin{array}{l}\text { Maxi. } \\
\text { mum. }\end{array}$ & $\begin{array}{l}\text { Mini. } \\
\text { mum. }\end{array}$ & Mean. & & $\begin{array}{l}\text { Depth in } \\
\text { inches. }\end{array}$ & $\begin{array}{l}\text { Second. } \\
\text { feet per } \\
\text { square } \\
\text { mile. }\end{array}$ \\
\hline \multicolumn{7}{|l|}{1897.} \\
\hline January........... & 17,025 & 1,800 & 4,820 & 296,372 & 1.38 & 1.20 \\
\hline February .. & 20,925 & 4,220 & 10,100 & 560,926 & 2.62 & 2.52 \\
\hline 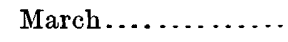 & 44,910 & 4,700 & 22,537 & $1,385,755$ & 6.49 & 5. 63 \\
\hline April............ & 35,150 & 4,860 & 12,304 & 732,137 & 3.43 & 3.07 \\
\hline May........... & 8,250 & 2,930 & 4,421 & 271,838 & 1.27 & 1.10 \\
\hline June . . . . & 4,540 & 1,900 & 2,884 & 171,610 & 0.80 & 0.72 \\
\hline July ........... & 23,460 & 1,800 & 5,184 & $318,7 \bar{\jmath} 4$ & 1.50 & 1.30 \\
\hline August. . . . . . & 4,860 & 1,360 & 2,256 & 138,717 & 0.64 & 0.56 \\
\hline September & 1,900 & 900 & 1,106 & 65,811 & 0.31 & 0.28 \\
\hline . October ........ & 2,570 & 1,010 & 1, 5̆18 & 93,339 & 0.44 & 0.38 \\
\hline November ... & 2,000 & 1,440 & 1,626 & 96,754 & 0.46 & 0.41 \\
\hline December ...: . & 9,810 & 1,900 & 4,086 & 251,240 & 1.18 & 1.02 \\
\hline The yea & 44,910 & 900 & 6,070 & $4,383,253$ & 20.52 & 1.52 \\
\hline \multicolumn{7}{|l|}{1898.} \\
\hline January ...... & 26,970 & 2,220 & 7,272 & 447,138 & 2.10 & 1.82 \\
\hline February ... & 5,520 & 2,110 & $2 ; 705$ & 150,228 & 0.71 & 0.68 \\
\hline March ........ & 20,730 & 2,110 & 4,384 & 269,563 & 1.27 & 1.10 \\
\hline April ......... & 32,040 & 4,540 & 9,430 & 561,123 & 2.63 & 2. 36 \\
\hline May .... & 4,220 & 2,330 & 2,778 & 170,814 & 0.79 & 0.69 \\
\hline June .... & 5,520 & 2,110 & 2,866 & 170,538 & 0.80 & 0.72 \\
\hline July $\ldots . .$. & 6,690 & 1,900 & 3,670 & 225,661 & 10.59 & 9.17 \\
\hline August......... & 17,805 & 2,930 & 6,079 & 373,786 & 1. $7 . \overline{5}$ & 1. 52 \\
\hline September.. & 45,885 & 3,060 & 12,114 & 720,832 & 2.26 & 3.03 \\
\hline October ....... & 44,910 & 3,060 & 11,830 & 727,403 & 3.41 & 2.96 \\
\hline November......... & 12,150 & 3,060 & 5,213 & 310,194 & 1.45 & 1.30 \\
\hline December.... & 8,250 & 3,610 & 4,996 & 307,194 & 1.44 & 1. 25 \\
\hline The year.. & 45,885 & 1,900 & 6,111 & $4,434,474$ & 29.20 & 2.22 \\
\hline
\end{tabular}

NoтE.-Gage heights for 1898 are given in Water-Supply and Irrigation Paper No. 27, page 53; measurements, page 57 ; rating table, page 58. 

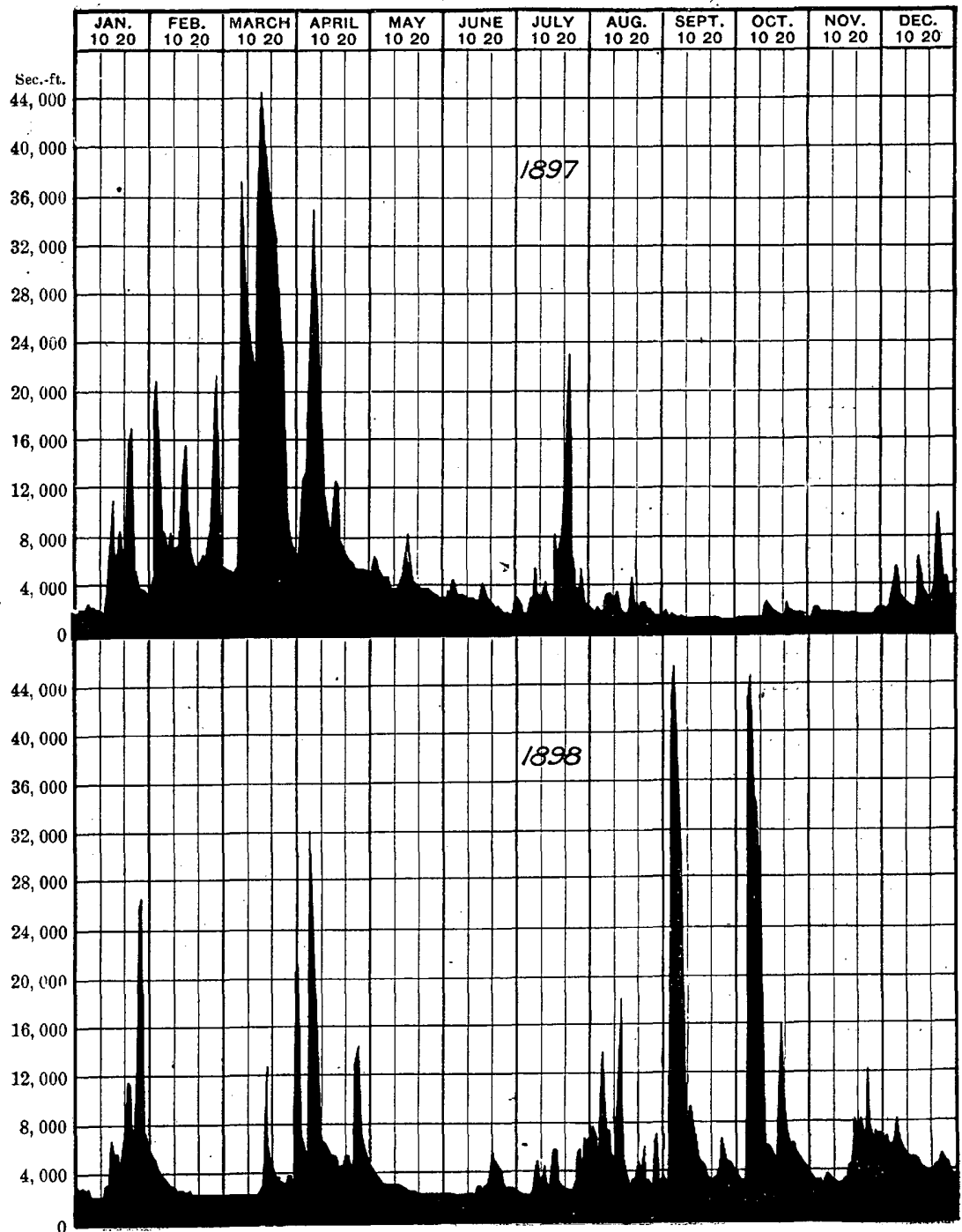

FiG. 59.-Discharge of Coosa River at Rome, Georgia, 1897 and 1898.

The above figure gives the fluctuations for Coosa River at Rome for the years 1897 and 1898 , showing the difference in the character of: flow during these two years. The stream is also measured at Riverside, Alabama, where the drainage area is considerably greater. The results at the latter place are given on the opposite page. 
Estimated monthly discharge of Coosa River at Riverside, Alabama.

[Drainage area, 6,850 square miles.].

\begin{tabular}{|c|c|c|c|c|c|c|}
\hline \multirow[b]{2}{*}{ Month. } & \multicolumn{3}{|c|}{ Discharge in second-feet. } & \multirow{2}{*}{$\begin{array}{c}\text { Total in acre. } \\
\text { feet. }\end{array}$} & \multicolumn{2}{|c|}{ Run.off. } \\
\hline & $\begin{array}{l}\text { Maxi- } \\
\text { mum. }\end{array}$ & $\begin{array}{l}\text { Mini } \\
\text { mum. }\end{array}$ & Mean. & & $\begin{array}{l}\text { Depth in } \\
\text { inches. }\end{array}$ & $\begin{array}{c}\text { Second. } \\
\text { feet per } \\
\text { square } \\
\text { mile. }\end{array}$ \\
\hline 1898. & & & & & . & \\
\hline January ........... & 35,084 & 3,550 & 11,572 & 711,539 & 1.95 & 1. 69 \\
\hline February . . . . . . . & 16,760 & $3,6 \overline{5} 5$ & 5,763 & 320,161 & 0.87 & 0.84 \\
\hline March $\ldots . . . \ldots \ldots$ & 15,045 & 3,550 & 5,852 & 359,828 & 0.68 & 0.59 \\
\hline April...... & 36,160 & 8,260 & 18,133 & $1,078,986$ & 2.95 & 2.65 \\
\hline May....... & 9,560 & 3,028 & 4,684 & 288,010 & 0.78 & 0.68 \\
\hline June . . . . . . . . . & 5,540 & 2,320 & 3,281 & 195,233 & 0.54 & 0.48 \\
\hline July $\ldots \ldots \ldots \ldots . .$. & 9,900 & 2,140 & 4,289 & 263,722 & 0.72 & 0.63 \\
\hline August ..... & 19,161 & 3,970 & 8,758 & 538,512 & 1.48 & 1.28 \\
\hline September & 41,920 & 3,865 & 13,927 & 828,712 & 2.26 & 2.03 \\
\hline October.... & 72,160 & 3,760 & 19,936 & $1,225,825$ & 3.36 & 2.91 \\
\hline November. & 20,190 & 5,300 & 8,375 & 498,345 & 1.36 & 1.22 \\
\hline December .. & 9,900 & 5,070 & 7,376 & 453,535 & 1.25 & 1.08 \\
\hline The year . .... & 72,160 & 2,140 & 9,329 & $6,762,408$ & 18.20 & 1. 34 \\
\hline
\end{tabular}

Note.-Gage heights for 1898 are given in Water-Supply and Irrigation Paper No. 27, page 54; measurements, page 57; rating table, page 58; results for 1897 in Water.Supply and Irrigation Paper No. 15, page 51, and in the Nineteenth Annual Report, Part IV, page 246.

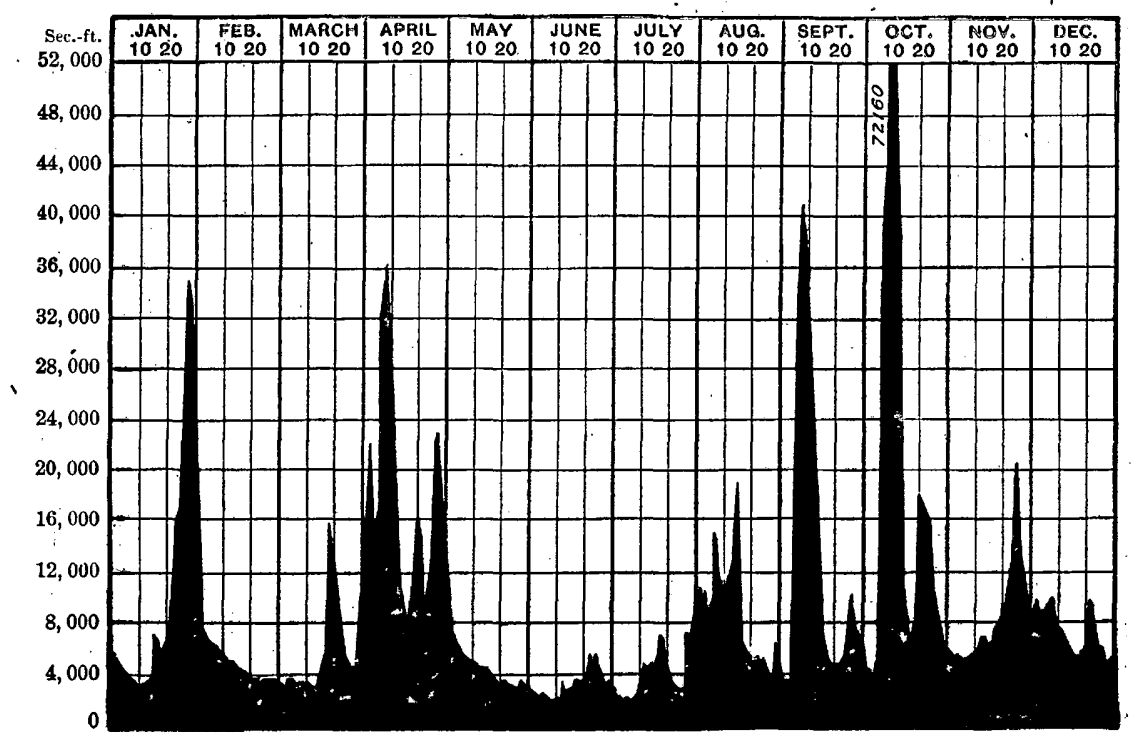

Fig. 60.-Discharge of Coosa River at Riversid9, Alabama, 1898. 


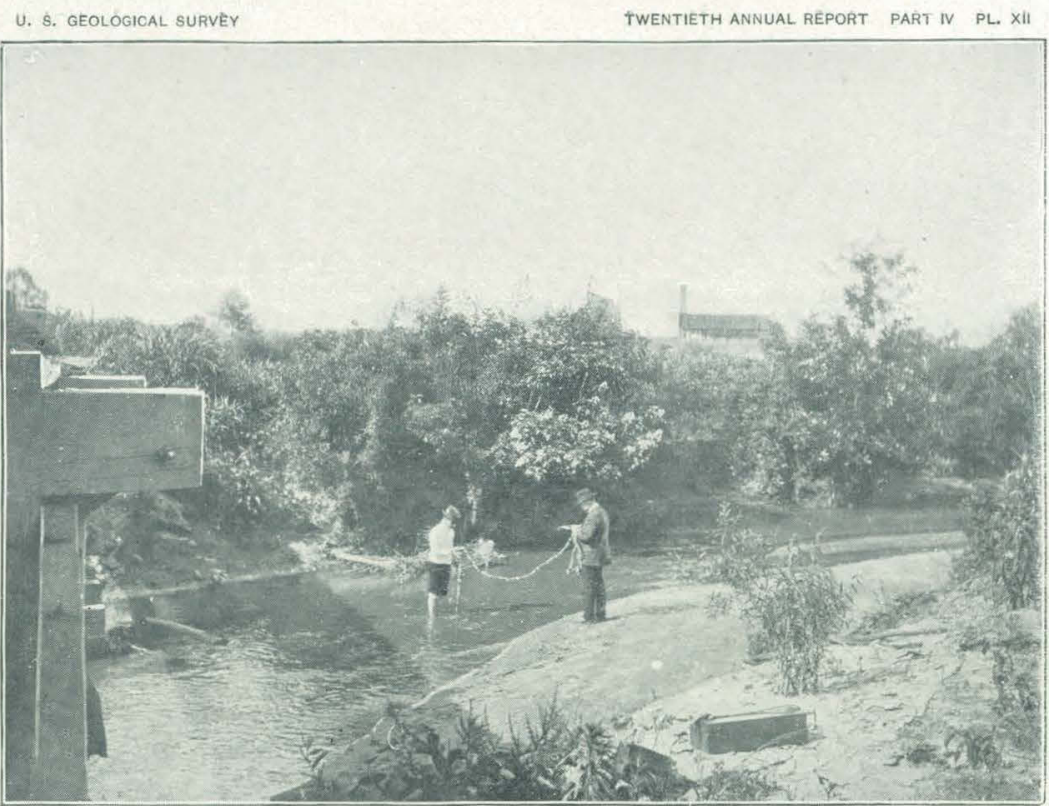

A. PROCTORS CREEK NEAR OAKDALE, GEORGIA.

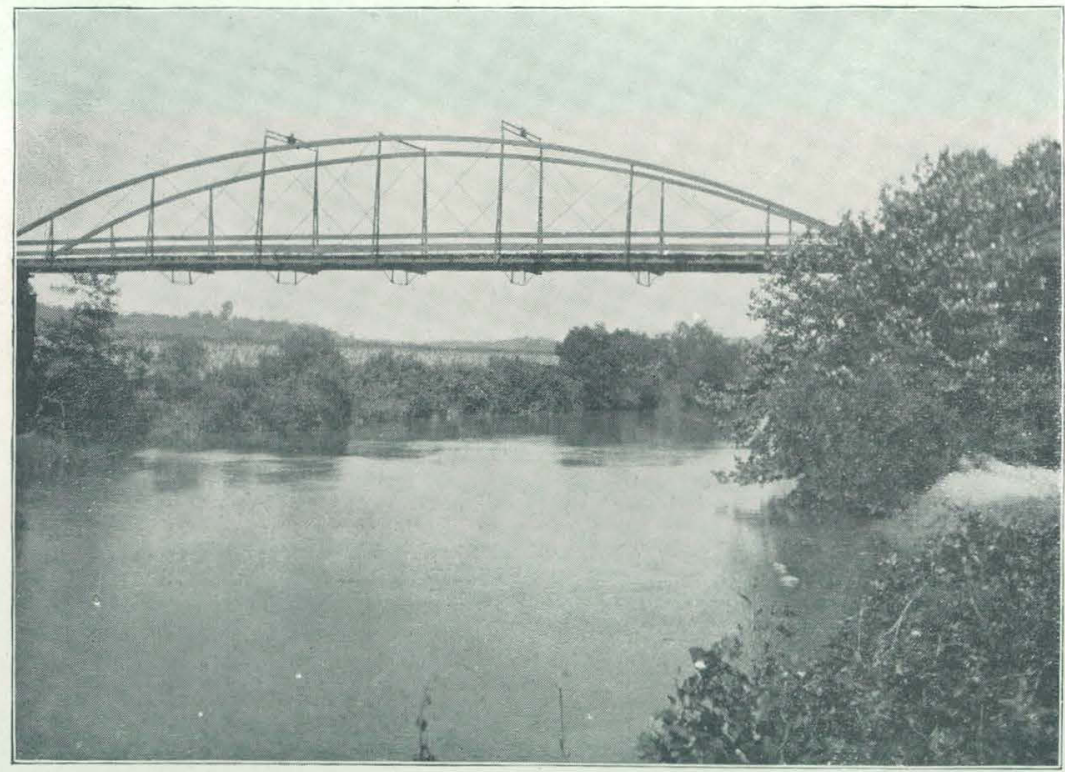

B. ETOWAH RIVER AT CANTON, GEORGIA. 
Observations of the daily changes in the height of Coosa River have also been made at Wetumpka, Alabama, as described on page 54 of Water-Supply and Irrigation Paper No. 15, and on page 241 of Part IV of the Nineteenth Annual Report. Heights for 1898 are given in Water-Supply and Irrigation Paper No. 27, page 55.

NTOWAH RIVER.

Etowah River crosses the "fall line" at Cartersville, Georgia, but in passing over the bed rock of hard blue limestone and Knox dolomite below . Cartersville it falls 145 feet in 45 miles.

In the catchment basin of Long Swamp Oreek, in Pickens County, Georgia, on the headwaters of Etowah River, is a vast bed of crystalline inarble, which, on account of its great strength and beauty, has become one of the most popular of building and ornamental stones. The four large quarrying companies are: The Georgia Marble Company, the Piedmont Marble Company, the Southern Marble Company, and the Amicalola Marble and Power Company. These companies own and operate nine well-equipped quarries, having $47 \mathrm{gangs}$ of saws, with rubbing beds, lathes, and other finishing machinery, the best modern derricks, travelers, etc., and 15 miles of railroad connecting the quarries with Tate and Ballground on the Atlanta, Knoxville and Northern Railroad. The milling and tinishing companies that saw and finish this marble but have no quarries are: George B. Sickles \& Co., Tate, Georgia; Blue Ridge Marble Company, Nelson, Georgia; Georgia Marble Finishing Company, Canton, Georgia; and the Kenesaw Marble Company, Marietta, Georgia. They all have large mills with every modern improvement. The operation of quarrying, milling, and finishing requires a good water supply, which is easily obtained from the high mountain streams of this region.

The only water power used so far for driving machinery is at the mill of the Southern Marble Company, where there is a Pelton wheel, operating under a head of 210 feet, with water obtained from Rocky Creek by a race 1 mile long and through 1,500 feet of pipe. It is estimated that the steam power now being used in the valley amounts to 1,200 horsepower or more, all of which could be supplied electrically from the Heard Shoal on the Amicalola River, 8 miles away, where the fall is 234 feet in a short distance. The discharge measurements made on this stream in 1898 are noted on page 45 of Water-Supply Paper No. 27.

Above Cartersville the Etowah River drains the Dahlonega gold belt for many miles, and there are long stretches of its bed where it is believed that large profits could be made by using dredge boats, as has been successfully done on the Chestatee River of the Chattahoochee watershed. The few powers that are developed on the Etowah and its tributaries are used for running saw and grist mills and gold-stamp mills. The most important of these is at the Creighton gold mines, in Cherokee County, 6 miles east of Ballground, Georgia. Here a dam 
on the river furnishes power for runving 23 stamps of 850 pounds each, also 10 concentrators, an electric plant, and.a Rand duplex air compressor. There is also at the mill a large chlorination plant. The air compressor operates drills in the mine and at the same time gives good ventilation. The mine has been working successfully for years, and is steadily increasing its output, the workings on the large pyritic quartz vein having reached a depth of about 500 feet.

A tabulated statement, given in Bulletin No. 3A, pages 22 to 27 of the Georgia geological survey, ${ }^{1}$ affords an idea of the water powers on the Georgia tributaries of the Coosa and Tallapoosa rivers. The discharges there given are from actual measurements made prior to 1895 , but the stages of water at which they were taken are only approximated.

Estimated monthly discharge of Etowah River at Canton, Georgia.

[Drainage area, 604 square miles.]

\begin{tabular}{|c|c|c|c|c|c|c|}
\hline \multirow[b]{2}{*}{ Month: } & \multicolumn{3}{|c|}{ Discharge in second feet. } & \multirow[b]{2}{*}{$\begin{array}{c}\text { Total in acre- } \\
\text { feet. }\end{array}$} & \multicolumn{2}{|c|}{ Run-off. } \\
\hline & $\begin{array}{l}\text { Maxi. } \\
\text { mum. }\end{array}$ & $\begin{array}{l}\text { Mini- } \\
\text { mum. }\end{array}$ & Mean. & & $\begin{array}{l}\text { Depth in } \\
\text { inches. }\end{array}$ & $\begin{array}{c}\text { Second- } \\
\text { feet per } \\
\text { square } \\
\text { mile. }\end{array}$ \\
\hline 1898. & & & & & & \\
\hline January ........... & 5,138 & 380 & 1,121 & 68,928 & 2.14 & 1.86 \\
\hline February . . . . . . . . . & 924 & 470 & 625 & 34,711 & 1.02 & 0.98 \\
\hline March......... & 4,640 & 310 & 1,014 & 62,349 & 1.94 & 1. 68 \\
\hline April.... & 3,460 & 560 & 1,160 & 69,025 & 2.14 & 1.92 \\
\hline May ........ & 924 & 380 & $\tilde{5} 84$ & 35,909 & 1. 12 & 0.97 \\
\hline fune $\ldots . . . .$. & 833 & 310 & 497 & 29,573 & 0.91 & 0.82 \\
\hline July $\ldots \ldots \ldots \ldots$ & 6,549 & 380 & 1,388 & 85,345 & 2.66 & 2.30 \\
\hline August... & 5,470 & 922 & 2,087 & 128,325 & 3.99 & 3.46 \\
\hline September. & 10,035 & 922 & 1,964 & 116,866 & 3.62 & 3.25 \\
\hline October ..... & 11,695 & 855 & 2,286 & 140,562 & 4.36 & 3.78 \\
\hline November... & 2,150 & 1,059 & 1,409 & 83,841 & 2.60 & 2.33 \\
\hline December .... & 2,483 & 1,498 & 1,913 & 117,627 & 3.66 & 3.17 \\
\hline The year ..... & 11,695 & 310 & 1,337 & 973,061 & 30.16 & 2.21 \\
\hline
\end{tabular}

NoтE.-Gage heights for 1898 are given in Water-Supply and Irrigation Paper No. 27, page 51; measurements, page 57; rating table, page 58. Results for 1897 in Water-Supply and Irrigation Paper No. 15, page 47, and in the Nineteenth Annual Report, Part IV, page 237.

1A Preliminary Report on a part of the Water Powers of Georgia, Compiled from the notes of C.C. Anderson by B. M. Hall, Atlanta, Georgia, 1896, being Bulletin $3 \mathrm{~A}$ of the Geological Survey of Georgia. 


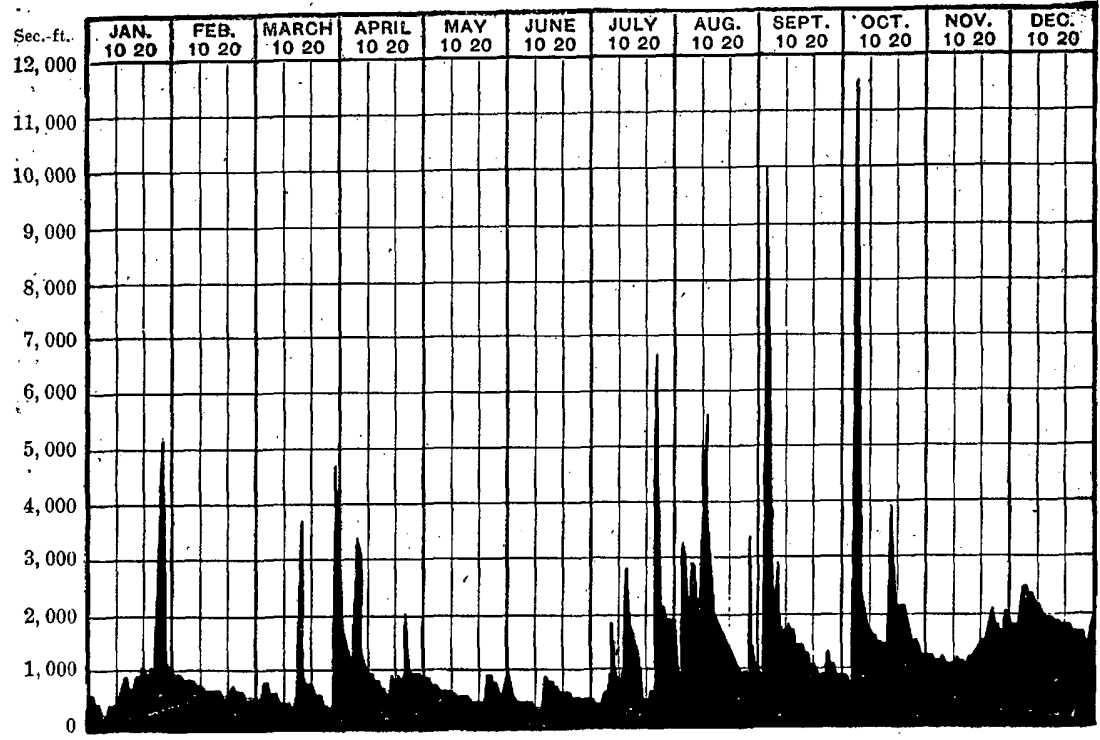

Fra. 61.-Discharge of Etowah River at Canton, Georgia, 1898.

OOSTANAULA RIVER.

Estimated monthly discharge of Oostanaula River at Resaca, Georgia.

[Drainage area, 1,527 square miles.]

\begin{tabular}{|c|c|c|c|c|c|c|}
\hline \multirow[b]{2}{*}{ Month. } & \multicolumn{3}{|c|}{ Discharge in second feet. } & \multirow{2}{*}{$\begin{array}{c}\text { Total in acre- } \\
\text { feet. }\end{array}$} & \multicolumn{2}{|c|}{ Run-off. } \\
\hline & $\begin{array}{l}\text { Maxi. } \\
\text { mum. }\end{array}$ & $\begin{array}{l}\text { Mini- } \\
\text { mum. }\end{array}$ & Mean. & & $\begin{array}{l}\text { Depth in } \\
\text { inches. }\end{array}$ & $\begin{array}{l}\text { Second- } \\
\text { feet per } \\
\text { square } \\
\text { mile. }\end{array}$ \\
\hline 1898. & & & & & . & \\
\hline January .......... & 15,660 & 1,030 & 4,262 & 262,062 & 3.22 & 2.79 \\
\hline February .. & 2,720 & 1,085 & 1,487 & $82,584^{\prime}$ & 1.01 & 0.97 \\
\hline March ...... & 10,600 & 1,030 & 2,449 & 150,584 & 1.84 & 1.60 \\
\hline April $\ldots \ldots \ldots \ldots$ & 16,320 & 2,170 & 4,909 & 292,105 & 3.58 & 3.21 \\
\hline May .............. & 2,205 & 848 & 1,311 & 80,611 & 0.99 & 0.86 \\
\hline June........... & 2,860 & 616 & 1,124 & 66,882 & 0.82 & 0.74 \\
\hline July ............ & 2,860 & 594 & $.1,203$ & 73,970 & 0.91 & 0.79 \\
\hline August..... & 4,715 & 1,030 & 2,084 & 128,142 & 1.57 & 1.36 \\
\hline September .. & 19,950 & 1,058 & 5,169 & 307,576 & 3.77 & 3.38 \\
\hline Öctober ... & 22,150 & 976 & 5,362 & 329,699 & 4.05 & 3.51 \\
\hline November... & 5,430 & 1,485 & 2,435 & 144,892 & 1. 77 & 1.59 \\
\hline December ... & 4,110 & 1,615 & 2,258 & 138,840 & 1.71 & 1. 48 \\
\hline The year. & 22,150 & 594 & 2,838 & $2,057,947$ & 25.24 & 1.86 \\
\hline
\end{tabular}

NoTE.-Gage heights for 1898 are given in Water-Supply and Irrigation Paper No. 27, page 52; measurements, page 57; rating table, page 58. Results for 1897 in Water-Supply and Irrigation Paper No. 15, page 50, and in the Nineteenth Annual Report, Part IV, page 245. 


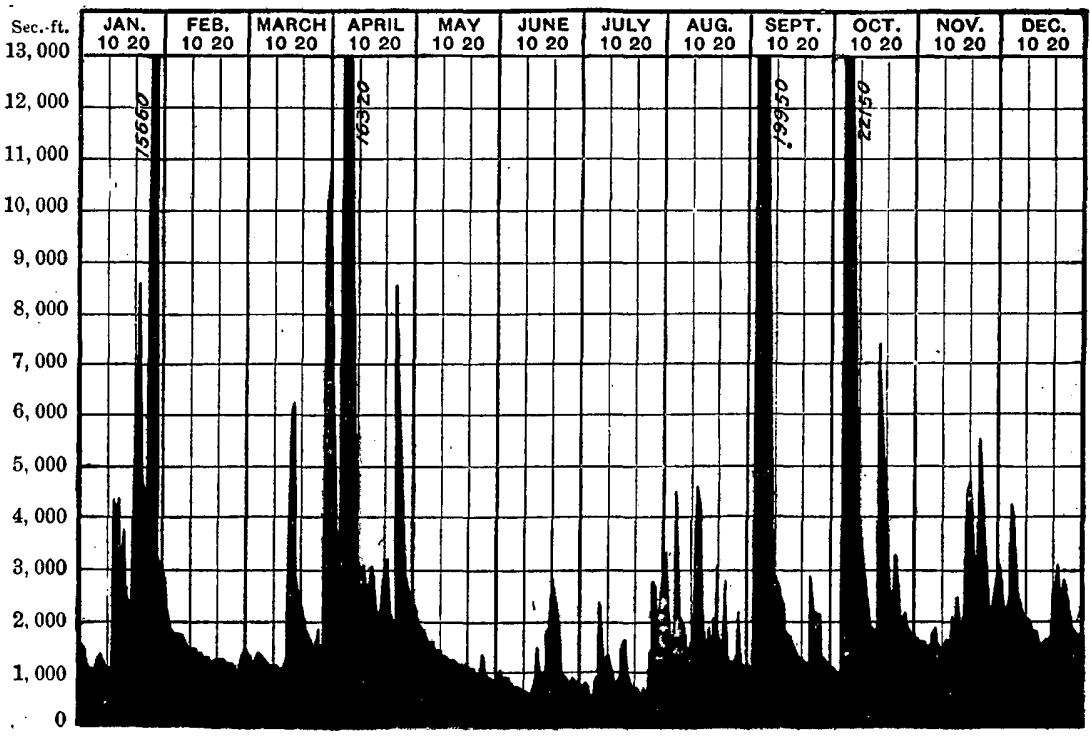

Fig. 62.-Discharge of Oostanaula River at Resaca, Georgia, 1898.

COOSA WATTEE RIVER.

Estimated monthly discharge of Coosavattee River at Carters, Georgia.

[Drainage area, 532 square miles.]

\begin{tabular}{|c|c|c|c|c|c|c|}
\hline \multirow[b]{2}{*}{ Month. } & \multicolumn{3}{|c|}{ Discharge in second-feet. } & \multirow[b]{2}{*}{$\begin{array}{c}\text { Total in acre- } \\
\text { feet. }\end{array}$} & \multicolumn{2}{|c|}{ Run.off. } \\
\hline & $\begin{array}{l}\text { Maxi. } \\
\text { mum. }\end{array}$ & $\begin{array}{l}\text { Mini- } \\
\text { mum. }\end{array}$ & Mean. & & $\begin{array}{l}\text { Depth in } \\
\text { inches. }\end{array}$ & $\begin{array}{l}\text { Second- } \\
\text { feet per } \\
\text { square } \\
\text { mile. }\end{array}$ \\
\hline . $\quad 1898$. & & & & & . & \\
\hline Jauuary ......... & 3,720 & 313 & 898 & 55,216 & 1.95 & 1. 69 \\
\hline February . . . . . . . & 771 & 423 & 601 & 33,378 & 1.18 & 1.13 \\
\hline March ............ & 3,300 & 355 & 687 & 42,242 & 1. 49 & 1. 29 \\
\hline April $\ldots \ldots \ldots \ldots$ & 5,314 & 722 & 1,351 & 80,390 & 2.83 & 2.54 \\
\hline May ......... & 796 & 442 & 566 & 34,802 & 1.22 & 1. 06 \\
\hline June....... & 771 & 313 & 459 & 27,312 & 0.95 & 0.86 \\
\hline July .... & 1,624 & 313 & $491^{\circ}$ & 30,191 & 1. 06 & 0.92 \\
\hline August. .... & 4,154 & 541 & 1,012 & 62,226 & 2. 19 . & 1.90 \\
\hline September. & 5,228 & 423 & 1,109 & 65,990 & 2.32 & 2.08 \\
\hline October..... & 8,070 & 499 & 1,675 & 102,992 & 3.64 & 3.15 \\
\hline November... & 1,200 & 627 & 823 & 48,972 & 1.73 & 1.55 \\
\hline December ...... & 1,031 &.$\breve{5} 41$ & 689 & 42,365 & 1.50 & 1.30 \\
\hline The year. & 8,070 & 313 & 863 & 636,076 & 22.06 & 1. 62 \\
\hline
\end{tabular}

NotE.-Gage heights for 1898 are given in Water-Supply and Irrigation Paper No. 27, page 52; measurements, page 57; rating table, page 58; results for 1897 in Water.Supply and Irrigation Paper No. 15, page 49, and in the Nineteenth Annual Report, Part IV, page 243. 


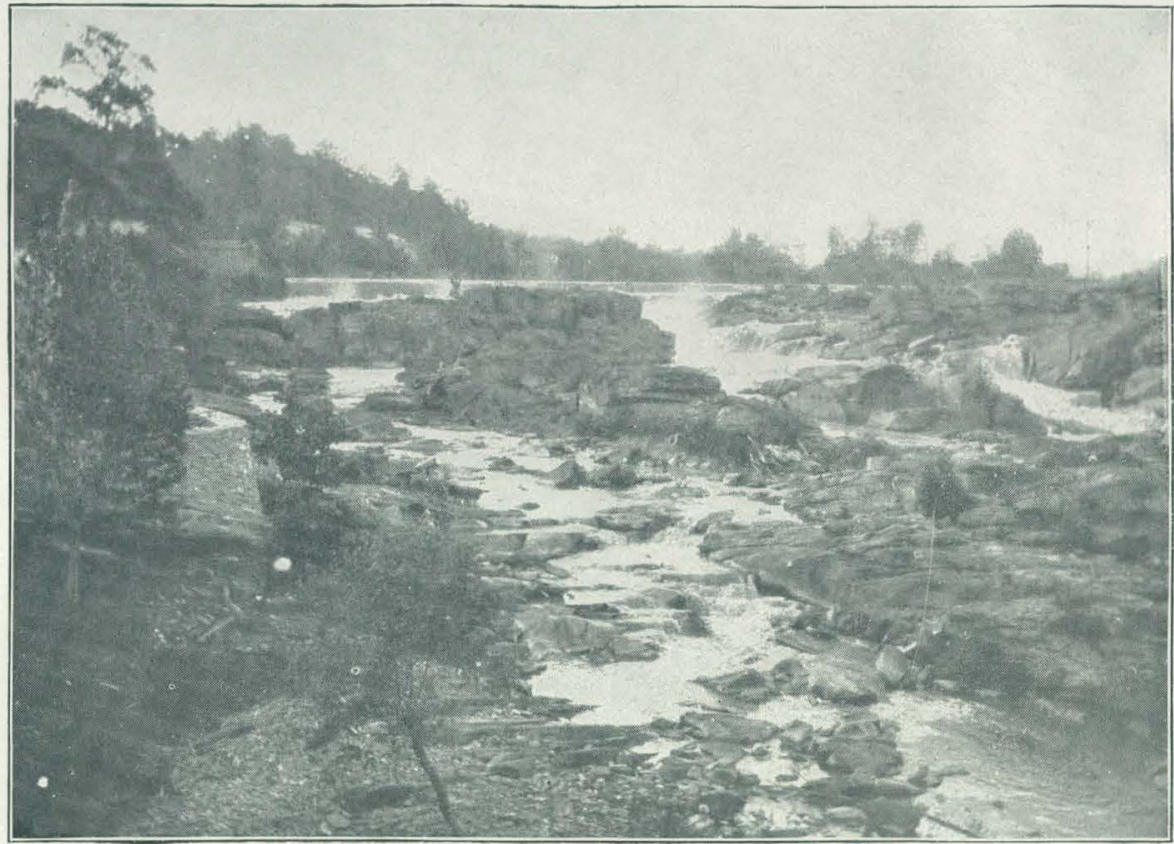

A. TALLASSEE FALLS ON TALLAPOOSA RIVER, aLABAMA.

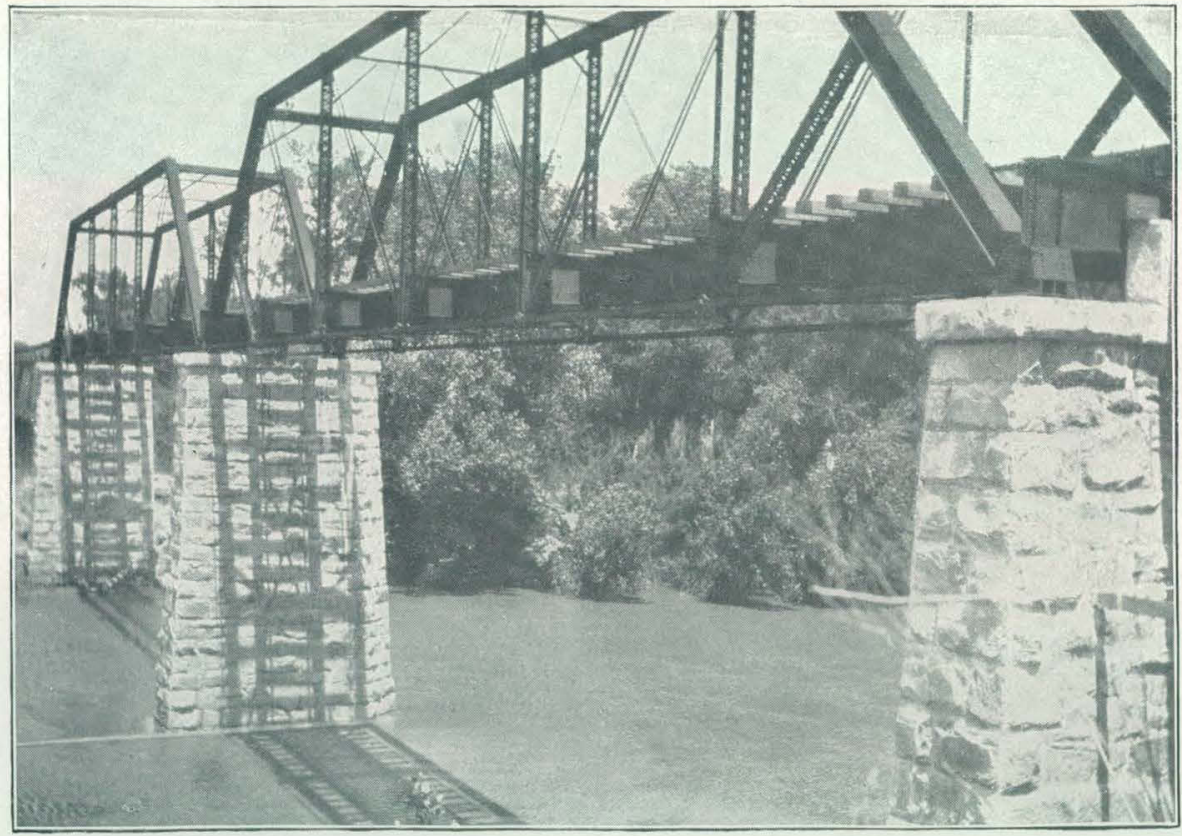

B. TALLAPOOSA RIVER aT MILSTEAD, aLABAma. 


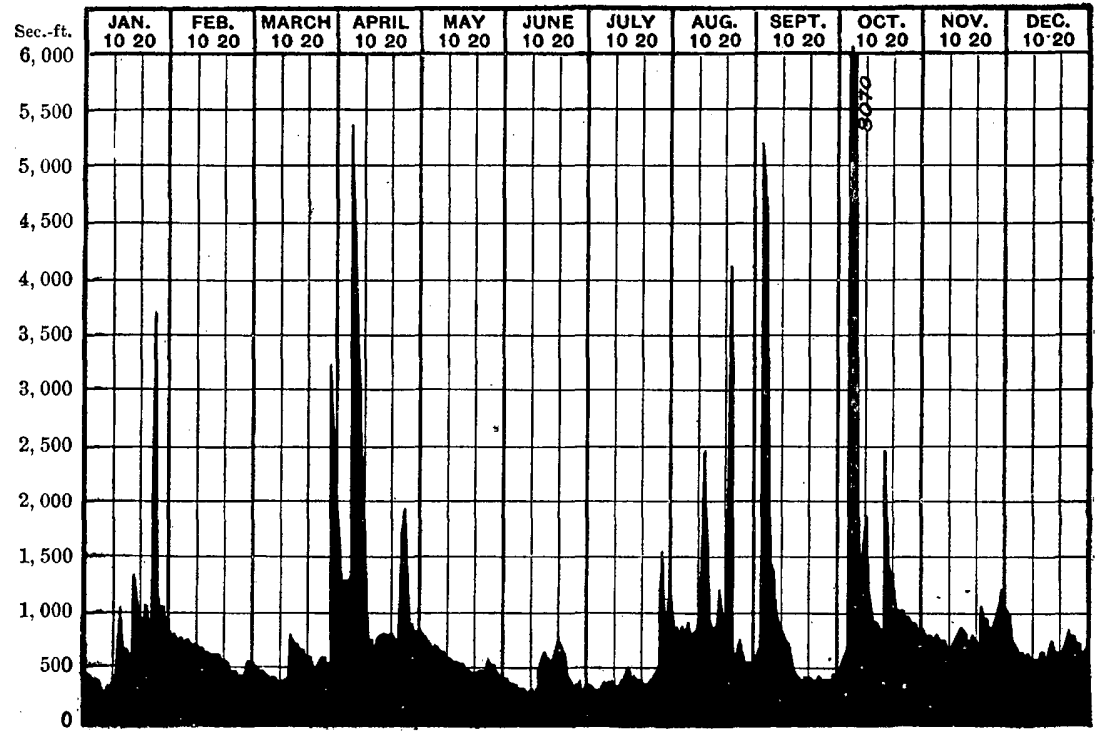

Fig. 63.-Discharge of Coosa wattee River at Carters, Georgia, 1898.

TALLAPOOSA RIVER.

Tallapoosa River rises in western Georgia, near the Alabama line, and flows to the southwest, occupying a basin intermediate between the Chattahoochee River and the Coosa River basins. It crosses the "fall line" at Tallassee, Alabama, above which point there are many shoals, both on the main river and its tributaries. Nearly the entire basin is in the crystalline rocks, this being a gold region of importance. It is a continuation of the Dahlonega gold belt, which runs through Georgia in a southwesterly direction and extends into Alabama to the "fall line" or southwestern border of the crystalline rocks, and has a great width on the Tallapoosa watershed.

There are no developed water powers of any considerable magnitude except that at Tallassee, shown in Pl. XIII, A. Here the river power has been used for extensive manufacturing since 1846. The Tallassee Falls Manufacturing Company, in addition to the large cotton mills already in operation on the west side of the river, were building in 1898-99 a new 50,000-spindle mill on the east side of the river and developing 60 feet of fall by a new dam and race to utilize the entire river. The following is a description of the improvements nearing completion at the end of 1898 :

The Tallassee Falls Manufacturing Company is at work on the development of the entire river power on the east side of the river. The present power is derived from a wing dam built in the river from the west side, which is about 600 feet long; however, only 34 feet of the 52-foot fall have been utilized for these old works. The new works consist of a dam about 20 feet in height, reaching from the head-gates on the east side of the river to a point on the wing dam spoken of 400 feet from its shore end. This will raise the old dam 10 feet higher. The dam has a width of 6 feet on 
top with a batter of 0.3 foot horizontal to 1 foot vertical on downstream side for the upper 10 feet, and 0.7 foot horizontal to 1 foot vertical below the bottom of this 10 -foot section. The head-gates consist of 11 gates 7 feet 6 inches high, 6 feet 6 inches wide, with semicircular arch and piers 3 feet thick between gates.

The canal carrying the water to the power house is 580 feet long, with a waterway 100 feet wide by 6 feet deep. Its boundary on the east side is the natural rock, on the west side a retaining wall, which at some places had to be built 30 feet high. The width of masonry on top is 6 feet, its slope toward the west similar to that of the dam. The conduits between the canal and the wheels are to consist of 6 circular tubes of 10 feet diameter and one of 8 feet in diameter. The distance from the west line of the power house to the inside or east side of the building line of the head gates first spoken of is 93 feet. The tailrace is designed for a waterway of 80 feet by 9 feet. It is excavated from solid rock and is about 400 feet in length. 'The power is conveyed from the power house to the mill in a semicircular tunnel 16 feet 6 inches in diameter and 135 feet long by means of two 10-inch shafts. The rope drive is on the northwest corner of the mill, and 6 drums will convey the power from the two shafts to the shafting of the mill. The main mill building is 128 feet broad and 448 feet long; it has 4 stories of 15 feet. It will contain over 50,000 spindles.

A short distance above Tallassee on Tallapoosa River a dam has been begun for the development of powier for electrical transmission to Montgomery, Alabama.

Big Sandy Creek is a large tributary of the Tallapoosa. It has a shoal of about 50-feet fall near Dadeville, Alabama, which will probably be developed for a cotton factory by a company that is being organized for that purpose.

Estimated monthly discharge of Tallapoosa River at Milstead, Alabama.

[Drainage area, 3,840 square miles.]

\begin{tabular}{|c|c|c|c|c|c|c|}
\hline \multirow[b]{2}{*}{ Month. } & \multicolumn{3}{|c|}{ Discharge in second-feet. } & \multirow[b]{2}{*}{$\begin{array}{c}\text { Total in acre- } \\
\text { feet. } \\
.\end{array}$} & \multicolumn{2}{|c|}{ Run-off. } \\
\hline & $\begin{array}{l}\text { Maxi- } \\
\text { mum. }\end{array}$ & $\begin{array}{l}\text { Mini- } \\
\text { mum. }\end{array}$ & Mean. & & $\begin{array}{l}\text { Depth in } \\
\text { inches. }\end{array}$ & $\begin{array}{l}\text { Second- } \\
\text { feet per } \\
\text { square } \\
\text { mile. }\end{array}$ \\
\hline 1898. & & & & & & \\
\hline January ... & 4,105 & 1,575 & 2,426 & 149,170 & 0.72 & 0.63 \\
\hline February ......... & 2,265 & 1,690 & 1,912 & 106,187 & 0.52 & 0.50 . \\
\hline March ...... & 5,715 & 1,575 & 2,313 & 142,222 & 0.69 & 0.60 \\
\hline April .......... & 21,240 & 2,150 & 5,748 & 342,029 & 1.67 & 1.50 \\
\hline May ....... & 2,610 & 885 & 1,493 & 91,802 & 0.45 & 0.39 \\
\hline June..... & 3,070 & 540 & 1,314 & 78,188 & 0.38 & 0.34 \\
\hline July ....... & 5,485 & 885 & 2,493 & 153,290 & $0.7 \breve{5}$ & 0.65 \\
\hline August............ & 25,610 & 1,920 & 7,418 & 456,118 & 2.22 & 1.93 \\
\hline September ........ & 6,520 & 1,345 & 2,637 & 156,912 & 0.77 & 0.69 \\
\hline October....... & 36,420 & 1,115 & 7,280 & 447,633 & 2.19 & 1.90 \\
\hline November.......... & 16,180 & 2,035 & 6,049 & 359,940 & 1.76 & 1.58 \\
\hline December .......... & 11,120 & 3,530 & 5,741 & 353,003 & 1.73 & 1.50 \\
\hline The year & 36,420 & 540 & 3,902 & $2,836,494$ & 13.85 & 1.02 \\
\hline
\end{tabular}

Note.-Gage heights for 1898 are given in Water-Supply and Irrigation Paper No. 27, page 56; measurements, page 57; rating table, page 58; results for 1897 in Water-Supply and Irrigation Paper No. 15, page 56, and in the Nineteenth Annual Report, Part IV, page 24y.

$$
20 \text { GEOL, PT } 4-13
$$




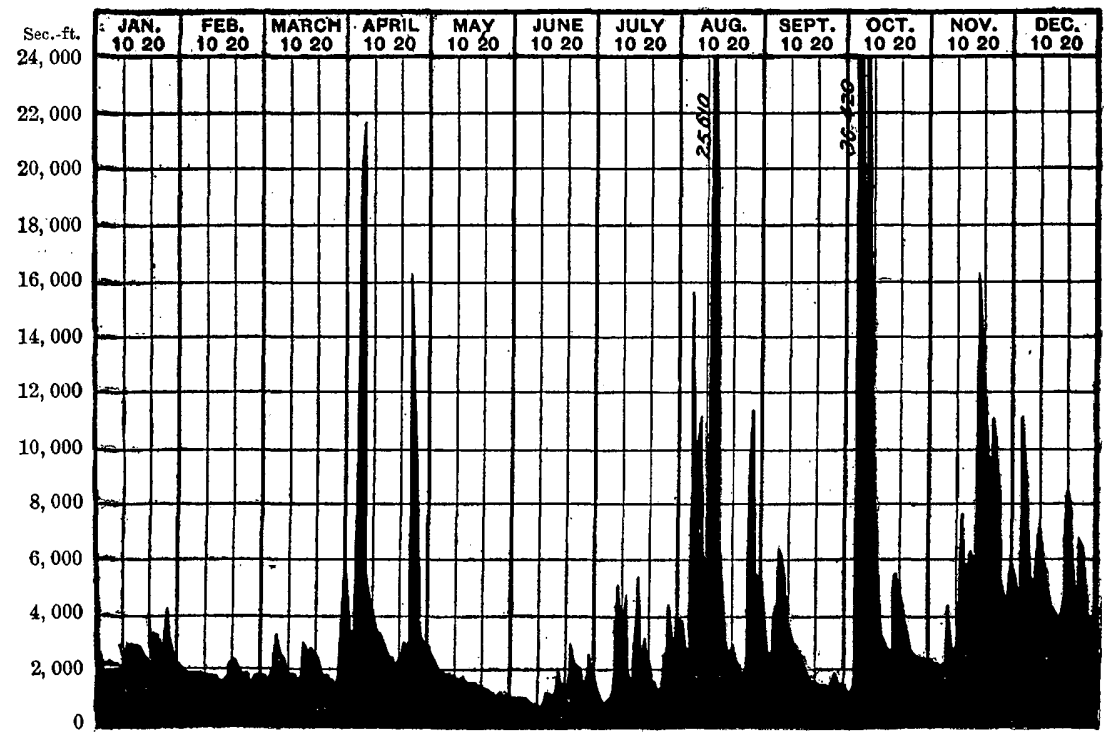

Fig. 64.-Discharge of Tallapoosa River at Milstead, Alabama, 1898.

A view of Tallapoosa River at Tallassee Falls, looking upstream, is given on Pl. XIII, $A$. On Pl. XIII, $B$, is shown a view of the river at Milstead, Alabama, 6 miles below Tallassee Falls. The view is from the left bank below the bridge.

BLACK WARRIOR RIVER.

Estimated monthly discharge of Black Warrior River at Tuscaloosa, Alabama. [Drainage area, 4,900 square miles.]

\begin{tabular}{|c|c|c|c|c|c|c|}
\hline \multirow[b]{2}{*}{ Month. } & \multicolumn{3}{|c|}{ Discharge in second.feet. } & \multirow[b]{2}{*}{$\begin{array}{c}\text { Total in acre- } \\
\text { feet. }\end{array}$} & \multicolumn{2}{|c|}{ Run-off. } \\
\hline & $\begin{array}{l}\text { Maxi- } \\
\text { mum. } \\
\text {. }\end{array}$ & $\begin{array}{l}\text { Mini- } \\
\text { mum. }\end{array}$ & Mean. & & $\begin{array}{l}\text { Depth in } \\
\text { inches. }\end{array}$ & $\begin{array}{c}\text { Second- } \\
\text { feet per } \\
\text { square } \\
\text { mile. }\end{array}$ \\
\hline 1898. & & & & & & \\
\hline January . . . . . . . . & 75,000 & $\mathbf{1}, 972$ & 16,577 & $1,019,287$ & 3.90 & 3.38 \\
\hline February .......... & 12,230 & 1,752 & 3,902 & 216,706 & 0.83 & 0.80 \\
\hline 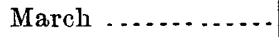 & 17,120 & 1,370 & 3,626 & 222,955 & 0.85 & 0.74 \\
\hline April ............... & 55,800 & 4,295 & 15,620 & 929,452 & 3.56 & 3.19 \\
\hline 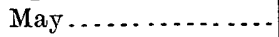 & 6,060 & 370 & 1,766 & 108,589 & 0.41 & 0.36 \\
\hline 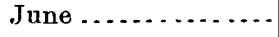 & 710 & 160 & 303 & 18,030 & 0.07 & 0.06 \\
\hline July ................. & 1,395 & 250 & 549 & 33,757 & 0.13 & 0.11 \\
\hline 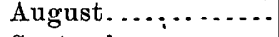 & 7,600 & 430 & 1,785 & 109,756 & 0.41 & 0.36 \\
\hline September. & 670 & 140 & 252 & 14,995 & 0.06 & 0.05 \\
\hline October ............ & 2,444 & 130 & 880 & 54,109 & 0.21 & 0.18 \\
\hline November . . . . . . . . & 6,265 & 280 & 1,626 & 96,754 & 0.37 & 0.33 \\
\hline December ........... & $\mathbf{1 4}, 580$ & 1,045 & 3,763 & 231,379 & 0.89 & 0.77 \\
\hline The year ..... & 75,000 & 130 & 4,221 . & $3,055,769$ & 11.69 & 0.86 \\
\hline
\end{tabular}

Noт:.-Gage heights for 1898 are given in Water-Supply and Irrigation Paper No. 27, page 56 rating table, page 58; results for 1897 in Water-Supply and Irrigation Paper No. 15, page 57, and in the Nineteenth Annual Report, Part IV, page 250. 


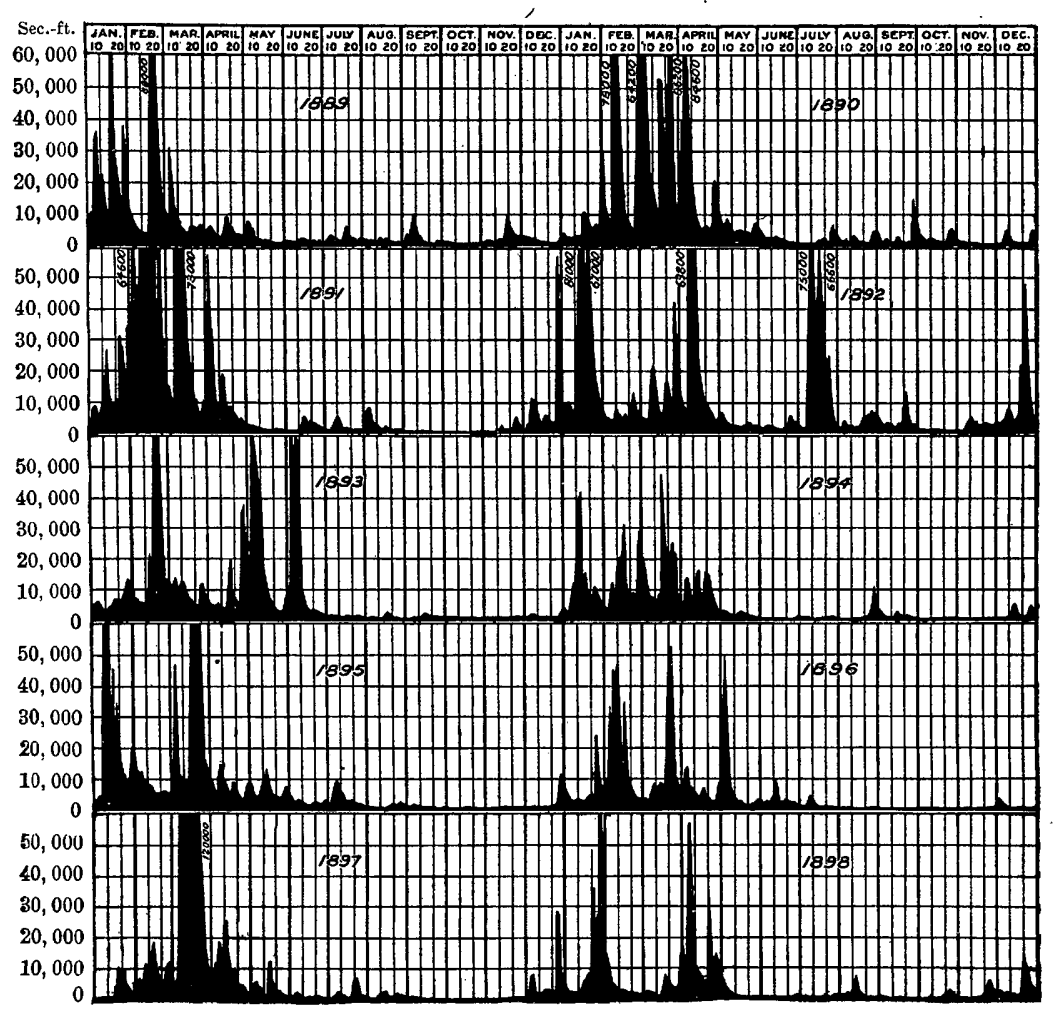

Fig. 65-Discharge of Black Warrior River at Tuscaloosa, Alabama, 1889-1898.

OHIO RIVER DRAINAGE.

Under this heading are included such data as have been obtainable concerning the streams which flow into the Ohio River. Most of the systematic measurements have been made in West Virginia upon headwaters of Kanawha River, and also in North Carolina and Tennessee upon tributaries of Tennessee River, but a few facts have been obtained concerning streams in Ohio and Penvsylvania.

\section{ALLEGHENY RIVER.}

A survey of Allegheny River was made during 1897 by Mr. George M. Lehman, assistant engineer, under the direction of Maj. Charles F. Powell, Corps of Engineers, U. S. A. Two discharge measurements were made by means of surface and deep floats, as noted below, the first at Franklin, showing a flow of 1,000 second-feet, and the second at a point 20 miles below that town, giving a discharge of 1,250 secondfeet. French Creek was measured just above its mouth at about the same time. The Allegheny was at a stage of 0.5 feet above low water, and French Creek was probably at a slightly lower stage. The Allegheny differs from most streams in having a solid bottom of cumpact 


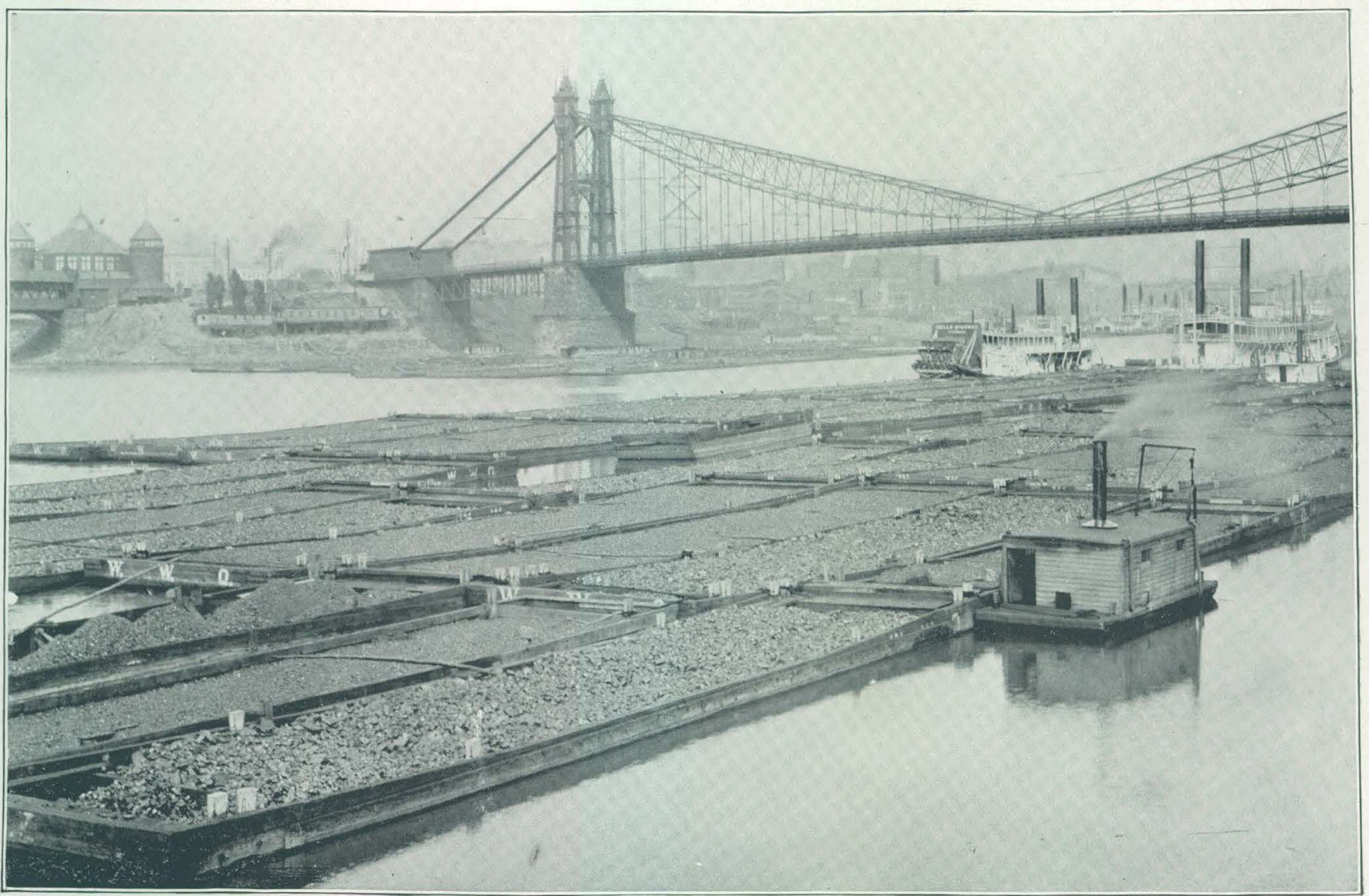

JUNCTION OF ALLEGHENY AND MONONGAHELA RIVERS AT PITTSBURG, PENNSYLVANIA. 
gravel ranging from the size of a cherry to that of a cobblestone, the spaces being filled by sand. The banks are generally of clay, sand, and gravel, with height of about 20 feet above low water, affording excellent opportunities for current meter meàsurements.

A view of the junction of the Allegheny and Monongahela is given on Pl. XIV, showing the bridge across the mouth of the latter and in the foreground a tow of coal barges in the pool just below Pittsburg, waiting for a rise in the river in order to go downstream to lower river points. The long periods of drought and low water seriously impede the commerce on the Ohio, especially in its upper course.

Mr. Thomas P. Roberts states that in October, 1838, Lieutenant Sanders, United States tnpographical engineer, measured the Allegheny River at Pittsburg and reported its discharge to be 1,330 cubic feet per second. This was a season of remarkable drought, and for the valley in general has been equaled only in 1895. A somewhat smaller discharge has been reported in recent years, the authority for which Mr. Roberts can not give, the figures being about 1,260 cubic feet. - There are no reliable records of any gagings of the Allegheny River at Pittsburg made since 1838 .

During the years 1866 to 1870 , when Mr. Roberts was engaged on the improvement of the Ohio River, he several times gaged the discharge of the Ohio River with considerable care. At Brunots Island, about $2 \frac{1}{2}$ miles below the junction of the Allegheny and Monongahela rivers, the least discharge found was about 1,700 cubic feet per second, at which time the channel depth of the Ohio for purposes of navigation was between 12 and 14 inches. In more recent years a somewhat less discharge has been found in the Ohio at Davis Island dam, 5 miles below Pittsburg. In 1895 he estimated the discharge of the Monongahela River at Pittsburg to be $\mathbf{1 7 0}$ cubic feet per second-making approximately one-tenth of the discharge of the Ohio-the difference in discharge at low water per unit of area of basin of the Allegheny River and Monongahela being very striking. The area of the basin of the Monongahela is about 7,200 square miles, and that of the Allegheny 11,400 square miles.

In the report to Colonel Merrill on surveys of the Allegheny River in $1878, \mathrm{Mr}$. Roberts stated his belief that from the fact that so many of the tributaries below French Creek were either dried up or nearly dried up he doubted whether much more water passed Pittsburg than could be found at Franklin below the mouth of French Creek. He found the Clarion discharging 18 cubic feet per second, and the Kiskiminitas approximately 83 cubic feet per second.

In the dry season of $1838, \mathrm{Mr}$. Thomas Stewart, a canal engineer of that period, gaged the Monongahela at Brownsville, 55 miles above Pittsburg, and below a drainage of about 4,800 square miles, and reported a discharge of only 23 cubic feet per second. Mr. W. Miluor Roberts, chief engineer of the Monongahela Navigation Company, then 
engaged on surveys of the river, had a few weeks before also gaged the river at Brownsville and reported the discharge at 25 cubic feet per second. This very small discharge of the Monongahela at Brownsville is believed by Mr. Thomas P. Roberts, from the appearance of the upper tributaries, to have been equaled in the fall of 1895. Fortunately such phenomenally low water is of rare occurrence, otherwise navigation would be interfered with materially. Since the dams have been built in the Monongahela it is impossible to gage the minimum discharge of the river very accurately. The mean velocity of current in the lower pools is not much more than 1 foot per minute, which velocity Mr. Roberts determined by noting the progress from day to day of patches, sometimes acres in extent, of discolored water, the distance traversed, depth, and shape of the river bed furnishing the elements for calculating the discharge. Leakage at the dams and about the lock gates renders measurements at such points very uncertain when dealing with such small discharges. Some of the dams are over 900 feet in length. The Youghiogheny River, basin 1,775 square miles, aided possibly by large springs in the bed of the river in pools Nos. 1 and 2, is the cause of the increase in discharge from 25 cnbic feet at Brownsville to 170 cubic feet per second at Pittsburg. The minor tributaries of the Monongahela and Ohio, those entering from the west on the Monongahela and from the south on the Ohio, as a rule, become dry. This holds for creeks of 200 square miles drainage in seasons of great drought. The conditions reported by Captain Chittenden ${ }^{1}$ in the Muskingum Valley, Ohio, in 1895, prevailed in western Pennsylvania south of the terminal moraine, or glacial drift limits.

\section{MAHONING RIVER AND FRENCH CREEK.}

In a report on the Lake Erie and Ohio River Ship Canal, prepared by the provisional committee of the Chamber of Commerce of Pittsburg, Pennsylvania, and printed in $189 \bar{i}$, are, on pages 101 and 143, references to measurements of Mahoning River and French Creek. Daily gage readings at one station each on these streams were maintained from about March 15 to the end of August, 1895. These stations were on the Upper Mahoning at Newton Falls, Ohio, and on French Creek at Saegerstown, Pennsylvania. It was difficult to obtain an accurate computation of the flow of French Creek, on account of the number of mills along the stream, most of which closed down at night, ponding the water. Nothing was done with the daily reports, but on every occasion that Mr. Thomas P. Roberts or Mr. George M. Lehman visited Freuch Creek at the Bemus dam a gaging was made. Several of these measurements were made after the daily reports were discontinued and at times when the discharge was less than that prior to September 1.

\footnotetext{
' A nnual report of the Chief of Engineers, U. S. Army, 1896, pp. 2973 to 3091. 'Surrey of canal con. necting the waters of Lake Erie with the Ohio River throngh the State of Ohio. Report by Capt. Hiram M. Chittenden.
} 
The least recorded measurement on French Creek, at Meadville, below the Bemus dam, was about 250 cubic feet per second. Mr. Lehman reported to Maj. Charles F. Powell, United States engineer, a measurement made of the discharge of French Creek at its mouth in September, 1897, of 230 cubic feet per second, and of the Allegheny River, just below the mouth of French Creek, on the same date, of 1,250 eubic feet per second. The discharge of the Allegheny at the same place of 1,500 cubic feet per second, referred to in the canal report, was from a measurement made by Mr. Thomas P. Roberts in 1878 or 1879, while he was assistant engineer under Col. William E. Merrill.

Mr. Roberts states that the gagings of French Creek and of the Allegheny River, just below the mouth of French Creek, made in September, 1897, by Mr. Lehman, represent very low water conditions, the lowest known for French Creek, and probably very near the minimum at that point for the Allegheny. Such small discharges are to be witnessed only in the fall of the year after an unusually protracted season of drought. It is interesting to note in the case of the Allegheny that its tributaries below the mouth of French Creek contribute in dry periods only a small amount of water, doing little more than supplying losses due to evaporation. The area of the entire watershed of the Allegheny River, as recently determined from the best maps available, is 11,400 square miles. The area of its principal tributary basins from French Creek to Pittsburg-123 miles-is as follows: French Creek, 1,180; Clarion River, 1,175; Red Bank Creek, 526; Mahoning River, 397; Kiskiminitas River, 1,846 square miles. The watershed of the Allegheny above the mouth of French Creek is 5,950 square miles.

As pointed out by Mr. Roberts there is in this valley a marked difference in the low-water discharges of the streams originating in glacial drift areas, especially where the drift is deep, these being much more equable in flow, and in times of drought more persistent in discharge than those tributaries which drain subglacial areas. French Creek alone in such periods discharges considerably more water than all the other streams below combined.

Later measurements of Mahoning River ${ }^{1}$ have been made by Prof. C. N. Brown, these being at Alliance, Warren, and Youngstown. The measurements at Alliance, where the drainage area is 82 square miles, gave on August 18, 1897, a discharge of 16 second-feet, and on September 26 and October 10 a little over 2 second-feet. Measurements at Warren, where the drainage area is 596 square miles, were considered unsatisfactory because of the many milldams on the river above the town modifying the flow. The discharge at Youngstown, where the drainage area is 967 square miles, was also much affected by the milldams.

\footnotetext{
1 Preliminary Report on an Investigation of Rivers and Deep Ground Waters of Obio as Sources of Public Water Supplies, by the Ohio State Board of Health, 1897-1898.
} 


\section{YOUGHIOGHENY RIVER}

Youghiogheny River rises in the extreme western portion of Maryland and flows northerly across the State line into Pennsylvania, where it meets Laurel Hill Creek and Castleman River at the point known as Confluence. From here it flows northwesterly, entering Monongahela River a short distance above the city of Pittsburg. The flow of the npper portion of the stream has been measured at Friendsville, about 5 miles south of the Pennsylvania line and 18 miles above Confluence. The station at Friendsville, on Youghiogheny River, is described in Water-Supply and Irrigation Paper No. 27, page 59; gage heights are given on page 61 and measurements on page 66 .

\section{KANAWHA RIVER.}

\section{PRECIPITATION IN THE BASIN OF KANAWHA RIVER.}

The principal observations of rainfall made within the basin of the Kanawha River are at Marion, Wytheville, Bluefield, Marlinton, White Sulphur Springs, Hinton, and Nuttallburg. The relative location of these points is shown on fig. 66 , in connection with the points of river measurement which are at Alderson and Fayette.

The following table gives the names and locations of the stations, the elevations, and the number of years during which the observations have been made, or, rather, the number of complete monthly observations used in computing the normals :

Location of rainfall stations.

\begin{tabular}{|c|c|c|c|c|c|c|}
\hline Station. & County. & State. & Latitude. & $\begin{array}{l}\text { Longi- } \\
\text { tude. }\end{array}$ & $\begin{array}{l}\text { Eleva- } \\
\text { tion. }\end{array}$ & $\begin{array}{l}\text { Length of } \\
\text { record. }\end{array}$ \\
\hline Marion .......... & Smyth. & Virginia .... & $\begin{array}{l}\circ \\
3650\end{array}$ & $\begin{array}{cc}\circ & \prime \\
81 & 30\end{array}$ & $\begin{array}{l}\text { Feet. } \\
2,124\end{array}$ & $\begin{array}{l}\text { 'Years. } \\
16-17\end{array}$ \\
\hline Wytheville. & Wythe.. & .... do ....... & 3655 & 8102 & 2,235 & $29-32$ \\
\hline Bluefield ....... & Mercer...... & $\begin{array}{l}\text { West Vir- } \\
\text { ginia. }\end{array}$ & 3716 & 8113 & 2,563 & $3-6$ \\
\hline Marlinton ..... & Pocahontas. & .... do ...... & 3813 & 8006 & $\ldots . .$. & $.2-5$ \\
\hline $\begin{array}{l}\text { White Sulphur } \\
\text { Springs. }\end{array}$ & Greenbrier. & .... do ... & 3750 & 8025 & 2,000 & $10-14$ \\
\hline Hinton . & Summers.... & ....do. . & 3740 & 8052 & 1,372 & $8-10$ \\
\hline Nuttallburg .... & Fayette.... & .... do ...... & $\begin{array}{ll}38 & 03\end{array}$ & 8103 & ........ & $4-5$ \\
\hline
\end{tabular}


In the following table are given the figures of normal or average monthly precipitation from the time of the beginning of the record to and including 1897, together with the total precipitation, by months,

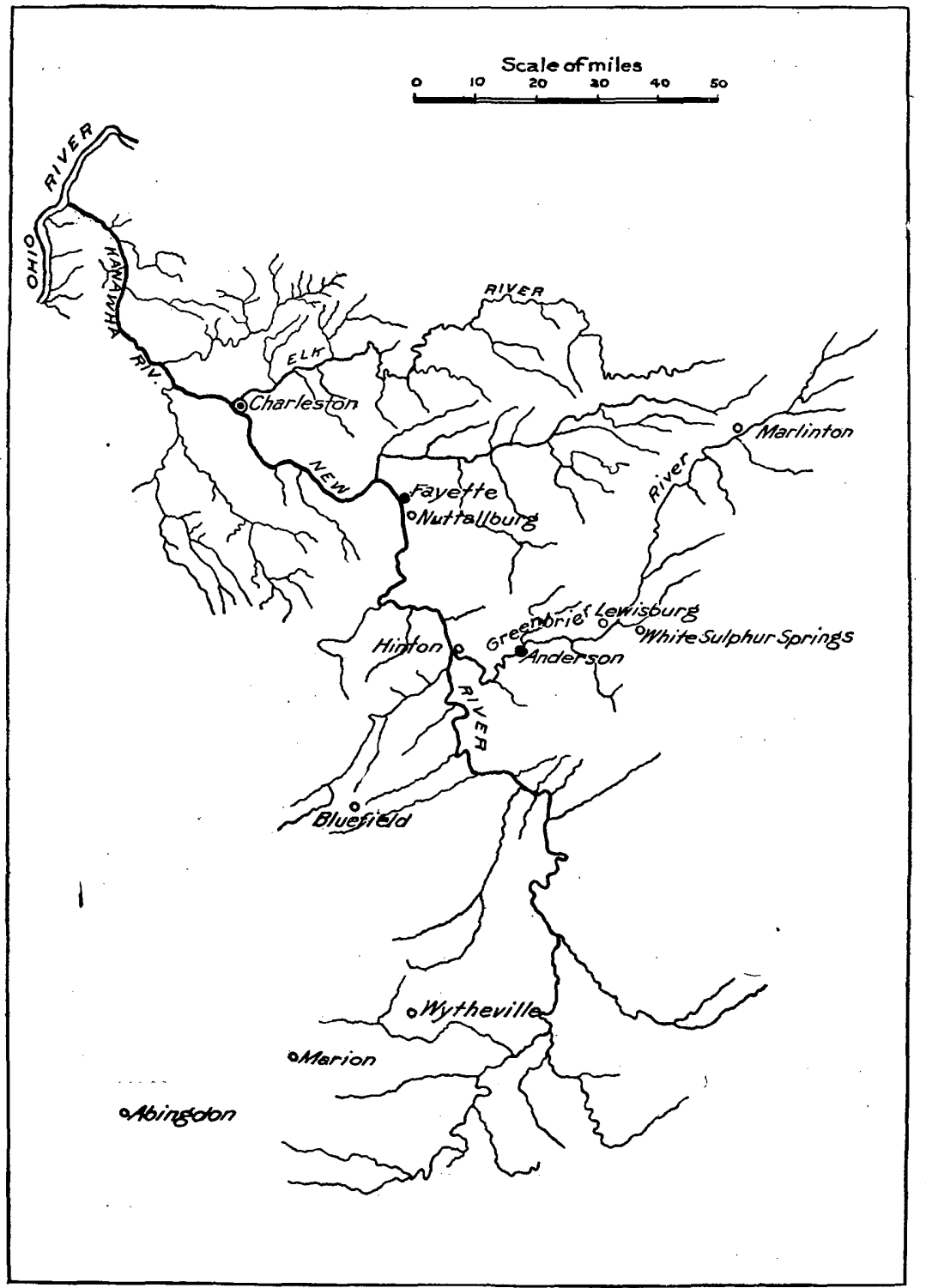

Fig. 66.-Relative location of river and rainfall observations in basin of Kanawha River.

for the years 1896,1897 , and 1898, and also the amount by years. In obtaining the normal precipitation the average is taken for all of the months during which observations were made: 
Rainfall at stations in drainage basin of Kanawha River.

MARION.

\begin{tabular}{|c|c|c|c|c|c|c|c|c|c|c|c|c|c|}
\hline Year. & Jan. & Feb. & Mar. & Apr. & May. & June. & July. & A ug. & Sept. & Oct. & Nov. & Dec. & Annual. \\
\hline Normal & 3.20 & 4.10 & 4. 10 & 3.50 & 4.20 & 5.00 & 4.00 & 3.80 & 2.60 & 2.50 & 2.40 & 2.90 & 42.30 \\
\hline 1896 . & $\alpha 3.20$ & 2.60 & 8.00 & 1.50 & 3.20 & 6.54 & 4.40 & 4.76 & $a 2.60$ & 0.50 & 5.60 & 2.10 & 45.00 \\
\hline 1897. & 2. 40 & 9.71 & 7.46 & 1.57 & 3.56 & 5.83 & 4.97 & 4.63 & 1.35 & 1.50 & 1.55 & 4.08 & 48.61 \\
\hline 1898. & $4.26 \mid$ & 0.95 & a4. 10 & 2.08 & 5.63 & 4.10 & 6.03 & 7.15 & 3.50 & 5.43 & 2.30 & 2.40 & 47.93 \\
\hline \multicolumn{14}{|c|}{ WYTHEVILLE. } \\
\hline Normal & 3.30 & 3.50 & 3.50 & 3.30 & 3.70 & 4.00 & 4.00 & 4.00 & 3. 60 & 3.00 & 2.60 & 2. 80 & 41.80 \\
\hline 1896. & 1.76 & 3.66 & 5.44 & 1.30 & 2.76 & 7.15 & & 4. 22 & ...... & & & & \\
\hline $1897 .$. & 1.43 & 9.37 & 4.69 & 1.72 & 3.26 & 1.98 & 3.72 & 4. 13 & 0.92 & 2.08 & 1.26 & 4.13 & 39.69 \\
\hline 1898. & 3. 30 & 0.65 & 4.15 & 2.19 & 4.41 & 2. 17 & 5.63 & 5.61 & 6.40 & 5. 38 & 1.81 & 2.48 & 44. 18 \\
\hline \multicolumn{14}{|c|}{ BLUEFIELD. } \\
\hline Normal & 2.61 & 4.20 & 3. 92 & 3.28 & 4.75 & 4.52 & 5.51 & 4.91 & 2.75 & 2.35 & 2.66 & 2.37 & 43.83 \\
\hline 1896. & 1. 36 & 2.62 & 6.38 & 2.15 & 2.18 & $a 4.52$ & a5.51 & 5.69 & 5.28 & 1. 39 & 4. 58 & 1.40 & 43.06 \\
\hline 1897. & 1.78 & 6.28 & 4.74 & 1.58 & 4. 43 & 4.39 & 6.78 & 2.34 & 0.62 & 0.65 & 1.42 & 3.50 & 38.51 \\
\hline $1898 \ldots$ & 2.96 & 0.98 & 3.53 & ........ & $\cdots \cdots$ & $\cdots \cdot \cdot$ & 6.42 & 6.15 & 3.15 & 6.36 & 3.02 & 2.25 & ....... \\
\hline \multicolumn{14}{|c|}{ MARLINTON. } \\
\hline Norma & 1.81 & 4.61 & 3. 44 & 2. 81 & 4.42 & 4.45 & 6. 72 & 3. 01 & 2. 64 & 2. 21 & 2. 93 & 2.94 & 41: 99 \\
\hline 1896 & $1.45^{-}$ & 5.26 & 6.99 & 1.82 & 3.74 & 3.71 & 7. 80 . & 3.28 & 4.48 & 1. 22 & 4.93 & 1.08 & 45.76 \\
\hline 1897. & 2.17 & 5.88 & 5.21 & 2. 85 & 7.06 & 5.59 & 5. 65 & 2.74 & 0.80 & 0.95 & 4.08 & $\begin{array}{l}4.64 \\
\end{array}$ & 47.62 \\
\hline 1898 & 5.61 & 1.47 & 5.23 & 4. 32 & 5.27 & 7.50 & 6.76 & 9.15 & 3. 33 & 4.54 & 3.85 & 3.71 & 60.74 \\
\hline \multicolumn{14}{|c|}{ WHITE SULPHUR SPRINGS. } \\
\hline .Normal .... & 2.20 & 3.60 & 3.90 & 3.00 & 4.00 & 3.80 & 4.00 & 290 & 2.40 & 2. 30 & 3. 10 & 3. 00 & 38.20 \\
\hline 1896. & & & & 2. 76 & 2.13 & 5.08 & 5. 30 & 3.80 & 5.15 & 0.90 & 5.07 & & \\
\hline 1897. & 0.90 & \begin{tabular}{|l|}
7.07 \\
\end{tabular} & 4. 91 & 1. 77 & 6. 80 & 6.55 & 6.59 & 5.93 & 0.45 & $\ldots . .$. & & .... & $\cdots$ \\
\hline 1898 & & & 4.03 & 3. 07 & 4.56 & & & & 1.86 & 5.70 & & & \\
\hline \multicolumn{14}{|c|}{ HIN'TON. } \\
\hline Normal & 2.33 & 3.62 & 3.10 & 3. 22 & 4. 22 & 3.99 & 3. 63 & 2.71 & \begin{tabular}{|l|}
2.59 \\
\end{tabular} & 1.74 & 1.99 & 2.41 & 35.55 \\
\hline 1896. & 0.92 & 3.16 & 5.46 & 2. 64 & 3.97 & 5.87 & 4.35 & 2.08 & 3.91 & 1.03 & 3.79 & 1.55 & 38.73 \\
\hline 1897. & 1.55 & 7.08 & 4. 59 & 2.03 & 3.56 & 3.42 & 5.03 & 2.55 & 0.34 & 0.76 & 1.00 & 3.76 & 35.67 \\
\hline 1898. & 3. 31 & 0.91 & 4.15 & 2. 30 & 4. 44 & 2.80 & 5.34 & 8.45 & 2.90 & \begin{tabular}{|l|}
4.58 \\
\end{tabular} & 2.32 & 1.94 & 43.44 \\
\hline \multicolumn{14}{|c|}{ NUTTALLBURG. } \\
\hline Normal. & 2.37 & 4. 25 & 4.57 & 4.15 & 3. 59 & 4.10 & 3.98 & 3.24 & 2.66 & 2. 77 & 2.80 & 2.76 & 41.24 \\
\hline 1896 . & 1.80 & 4.65 & 6.00 & 2. 60 & 2. 30 & 7.40 & 4.30 & 3.40 & $\begin{array}{l}3.75 \\
\end{array}$ & 2.60 & 3.50 & 0.80 & 43.10 \\
\hline 1897. & 1.50 & 6.80 & 4.60 & 2.00 & 4.05 & 4.15 & 8.20 & 1.85 & 0.80 & $a 2.77$ & $\mid a 2.80$ & 4.65 & 44.17 \\
\hline 1898 & & & 4.25 & & & 3.10 & 6.80 & 4.85 & 2.50 & & 2.10 & & \\
\hline \multicolumn{14}{|c|}{ AVERAGES. } \\
\hline Normal . & 2. 55 & 3.98 & 3.79 & 3. 32 & 4. 13 & 4.27 & 4. 55 & 3.51 & 2.75 & 2.41 & 2.64 & 2.74 & 40.64 \\
\hline 1896 & 1.75 & 3.66 & 6.38 & 2.11 & $2.90^{\circ}$ & 5.75 & 5.28 & 3.89 & 4.20 & 1.27 & 4.58 & 1.39 & 43.16 \\
\hline $1897 .$. & 1.68 & 7.46 & 5.17 & 1.93 & 4. 68 & 4.56 & 5.85 & 3.45 & 0.75 & 1.45 & 2.02 & 4.13 & 43. 13 \\
\hline 1898. & 3. 89 & 0.99 & 4. 21 & 2.79 & 4.05 & 3. 93 & 6.16 & 6.89 & 3.38 & 5.33 & 2.57 & 2.56 & 46.75 \\
\hline
\end{tabular}


Depth of run-off, in inches, from Kanawha drainage basin.

GREENBRIER AT ALDERSON.

\begin{tabular}{|c|c|c|c|c|c|c|c|c|c|c|c|c|c|}
\hline Year. & Jan. & Feb. & Mar. & Apr. & May. & June. & July. & Ang. & Sept. & Out. & Nov. & Dec. & Annual. \\
\hline 1895. & & & & . & & .... & $\because \ldots$. & 0.23 & 0.13 & 0.06 & 0.12 & 0.41 & \\
\hline $1896 \ldots$ & 0.90 & 2.38 & 3.05 & 2.26 & 1.31 & 0.74 & 2.03 & 0.92 & 0.39 & 0.91 & 2.01 & 1.21 & 18.11 \\
\hline 1897. & 0.77 & 6.00 & 3.56 & 1.82 & 3.43 & 0.87 & 1.82 & 0.41 & 0.08 & 0.08 & 0.19 & 1.09 & 20.12 \\
\hline $1898 \ldots$. & 3.06 & 1.57 & 3.12 & 3. 30 & 3.00 & 0.59 & 0.56 & 3.62 . & 0.21 & 1.58 & 1.99 & 1.87 & 24.47 \\
\hline Average. & 1.58 & 3. 32 & 3.24 & 2.46 & 2.58 & 0.73 & 1.47 & 1.30 & 0.20 & 0.66 & 1.08 & 1.15 & 19.77 \\
\hline \multicolumn{14}{|c|}{ NEW AT FAYETTE. } \\
\hline 1895. & & & & $\cdots$ & & $\ldots$ & 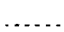 & 0.78 & 0.53 & 0.47 & 0.50 & 0.81 & \\
\hline $1896 \ldots$ & 1.01 & 2.01 & 3.17 & 3.05 & 1.18 & 1.04 & 2.41 & 0.74 & 0.50 & 0.94 & 1.48 & 0.93 & 18.46 \\
\hline 1897. & 0.76 & 4.65 & 4. 10 & 1. 91 & 2. 29 & 1.08 & 1.44 & 0.60 & 0.28 & 0.38 & 0.32 & 0.61 & 18.42 \\
\hline $1898 \ldots \ldots \ldots$ & 1.67 & 0.85 & 1.95 & 2.41 & 2.14 & 0.74 & 0.63 & 2.35 & 0.98 & 2.04 & 1.22 & 1.49 & 18.47 \\
\hline Average. & 1.15 & 2.50 & 3. 07 & 2.46 & 1.87 & 0.95 & 1.49 & 1.12 & 0.57 & 0.96 & 0.88 & 0.96 & 17. 98 \\
\hline
\end{tabular}

Annual rainfall and run-off from Kanawha drainage basin.

\begin{tabular}{|c|c|c|c|c|}
\hline Station. . & Normal. & 1896. & 1897. & 1898. \\
\hline $\begin{array}{l}\text { RAINFALL. } \\
\text { Marion }\end{array}$ & $\begin{array}{l}\text { Inches. } \\
42.30\end{array}$ & $\begin{array}{l}\text { Inches. } \\
45.00\end{array}$ & $\begin{array}{l}\text { Inches. } \\
48.61\end{array}$ & $\begin{array}{l}\text { Inches. } \\
47.93\end{array}$ \\
\hline Wytheville............. & 41.80 & $\ldots \ldots \ldots$ & 39.69 & 44.18 \\
\hline Bluefield .................... & 43.83 & 43.06 & 38.51 & $\ldots \ldots \ldots$ \\
\hline Marlinton $\ldots \ldots \ldots \ldots \ldots \ldots \ldots \ldots$ & 41.99 & 45.76 & 47.62 & 60.74 \\
\hline White Sulphur Springs . . . . . . . . . & 38.20 & $\ldots . .$. & ....... & $\ldots \ldots . . . . .$. \\
\hline Hinton......... & 35.55 & 38.73 & 35.67 & 43.44 \\
\hline Nuttallburg .......... & 41.24 & 43.10 & 44.17 & .......... \\
\hline Average...... & 40.70 & 43.13 & 42.38 & 49.07 \\
\hline RUN-OFF. & & & & \\
\hline Greenbrier .. & 19.77 & 18.11 & 20.12 & 24.47 \\
\hline New .................. & 17.98 & 18.46 & 18.42 & 18.47 \\
\hline Arerage....... & 18.88 & 18.29 & 19.27 & 21.47 \\
\hline Percentage of rainfall. & 46.39 & 42.41 & 45.47 & 43.75 \\
\hline
\end{tabular}

NEW. RIVER.

Radford station on New River is described in Water-Supply and Irrigation Paper No. 27, page 59; gage heights are given on page 61 , and measurements on page 65 . 
Estimated monthly discharge of New River at Fayette, West Virginia.

[Drainage area, 6,200 square miles.]

\begin{tabular}{|c|c|c|c|c|c|c|}
\hline \multirow[b]{2}{*}{ Month. } & \multicolumn{3}{|c|}{ Discharge in second-feet. } & \multirow[b]{2}{*}{$\begin{array}{l}\text { Total in acre. } \\
\text { feet. }\end{array}$} & \multicolumn{2}{|c|}{ Run-off. } \\
\hline & $\begin{array}{l}\text { Maxi- } \\
\text { mum. }\end{array}$ & $\begin{array}{l}\text { Mini. } \\
\text { mum. }\end{array}$ & Mean. & & $\begin{array}{l}\text { Depth in } \\
\text { inches. }\end{array}$ & $\begin{array}{c}\text { Second- } \\
\text { feet per } \\
\text { squaro } \\
\text { mile. }\end{array}$ \\
\hline 1898. & & & & 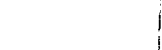 & & \\
\hline January ........... & 20,920 & 2,895 & 9,002 & 553,514 & 1.67 & 1.45 \\
\hline February ....... & 10,362 & 2,180 & 5,061 & 281,074 & 0.85 & 0.82 \\
\hline March.... & 48,944 & 3,500 & 10,494 & 645,251 & 1.95 & 1. 69 \\
\hline April....... & 40,376 & 6,218 & 13,369 & 795,510 & 2.41 & 2.16 \\
\hline May ..... & 38,601 & 4,000 & 11,493 & 706,672 & 2.14 & 1.86 \\
\hline Júne ....... & 15,110 & 1,970 & 4,137 & 246,168 & 0.74 & 0.67 \\
\hline July ...... . & 8,122 & 1,850 & 3,412 & 209,797 & 0.63 & 0.55 \\
\hline August...... & 53,585 & 3,312 & 12,665 & 778,746 & 2.35 & 2,04 \\
\hline September......... & 18,700 & 2,010 & 5,485 & 326,379 & 0.98 & 0.88 \\
\hline October.... & 61,080 & 2,530 & 10,981 & 675,810 & 2.04 & 1. 77 \\
\hline November ......... & 15,110 & 3,375 & 6,741 & 401,116 & 1.22 & 1.09 \\
\hline December .......... & 17,600 & 4,450 & 7,975 & 490,367 & 1.49 & 1.29 \\
\hline The year.... & 61,080 & 1,850 & 8,401 & $6,110,404$ & 18.47 & 1.36 \\
\hline
\end{tabular}

Note.-Gage heights for 1898 are given in Water-Supply and Irrigation Paper No. 27, page 62 measurements, page 65; results for 1897 in Water:Supply and Irrigation Paper No. 15, page 59, and in the Nineteenth. Annual Report, Part IV, pages 255 to 256 .

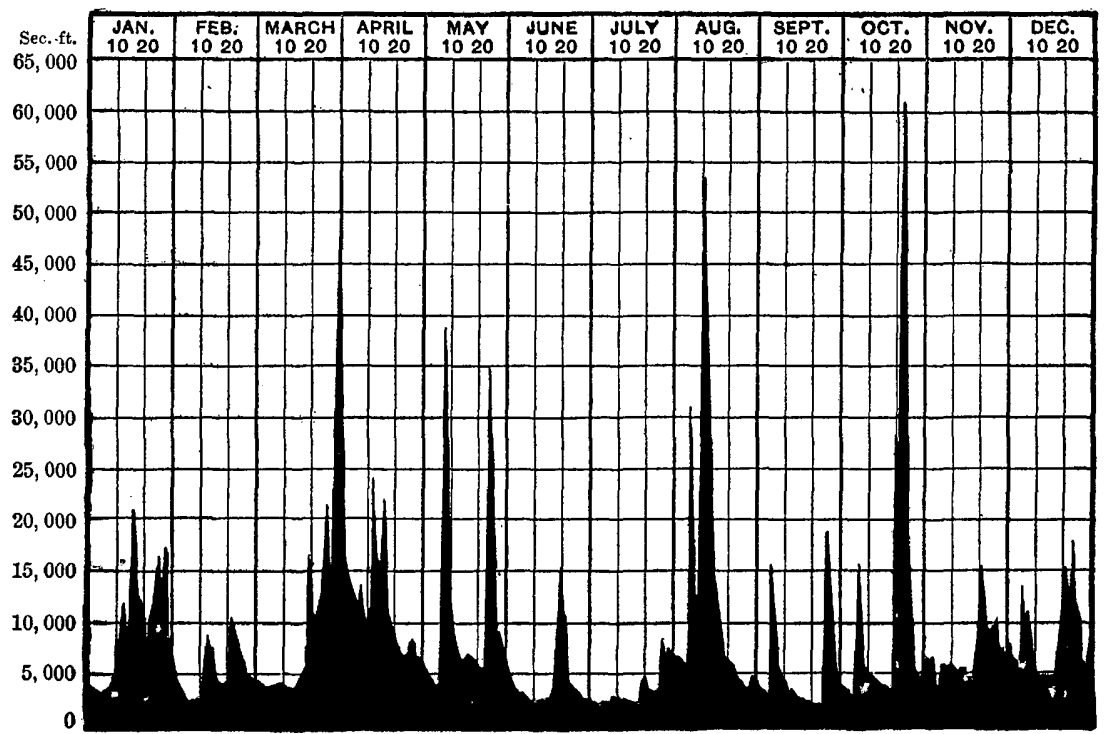

Fig. 67.-Discharge of Now River at Fayette, West Virginia, 1898. 
GREENBRIER RIVER.

Estimated monthly discharge of Greenbrier River at Alderson, West Virginia.

[Drainage area, 1,344 square miles.]

\begin{tabular}{|c|c|c|c|c|c|c|}
\hline \multirow[b]{2}{*}{ Month. } & \multicolumn{3}{|c|}{ Discharge in second.feet. } & \multirow[b]{2}{*}{$\begin{array}{c}\text { Total in acre- } \\
\text { feet. }\end{array}$} & \multicolumn{2}{|c|}{ Run-off. } \\
\hline & $\begin{array}{l}\text { Maxi. } \\
\text { muma. }\end{array}$ & $\begin{array}{l}\text { Mini- } \\
\text { mum. }\end{array}$ & Mean. & & $\begin{array}{c}\text { Depth in } \\
\text { inches. }\end{array}$ & $\begin{array}{c}\text { Second } \\
\text { feet per } \\
\text { square } \\
\text { mile. }\end{array}$ \\
\hline 1898. & & & & & & \\
\hline January .............. & 15,100 & 540 & 3,567 & 219,328 & 3.06 & 2.65 \\
\hline February .......... & 5,790 & 700 & 2,030 & 112,740 & 1.57 & 1. 51 \\
\hline March ................ & 15,430 & $\mathrm{i}, 030$ & 3,633 & 223,376 & 3.12 & 2.70 \\
\hline April............. & 12,800 & 1,530 & 3,979 & 236,767 & 3.30 & 2: 96 \\
\hline May ........ & 15,770 & 1,030 & 3,492 & 214,716 & 3.00 & 2.60 \\
\hline June .......... & 1,275 & 370 & 711 & 42,307 & 0.59 & 0.53 \\
\hline July . ...... & $3,00^{2} 0$ & 210 & 662 & 40,705 & 0.56 & 0.49 \\
\hline August................ & 48,700 & 370 & 4,216 & 259,233 & 3.62 & 3.14 \\
\hline September .... & 450 & 180 & 258 & 15,352 & 0.21 & 0.19 \\
\hline October .... & 21,950 & 155 & 1,846 & 113,506 & 1.58 & 1.37 \\
\hline November......... & 9,950 & 760 & 2,397 & 142,631 & 1.99 & 1.78 \\
\hline December..... & 8,600 & 590 & 2,179 & 133,982 & 1.87 & 1.62 \\
\hline The year . & 48,700 & 155 & 2,414 & $1,754,643$ & 24.47 & 1. 80 \\
\hline
\end{tabular}

Note.-Gage heights for 1898 are given in Water-Supply and Irrigation Paper No. 27, page 61; measurements, page 65; results for 1897 in Water-Supply and Irrigation Paper No. 15, page 58, and in the Nineteenth Annual Report, Part IV, pages 253 to 254.

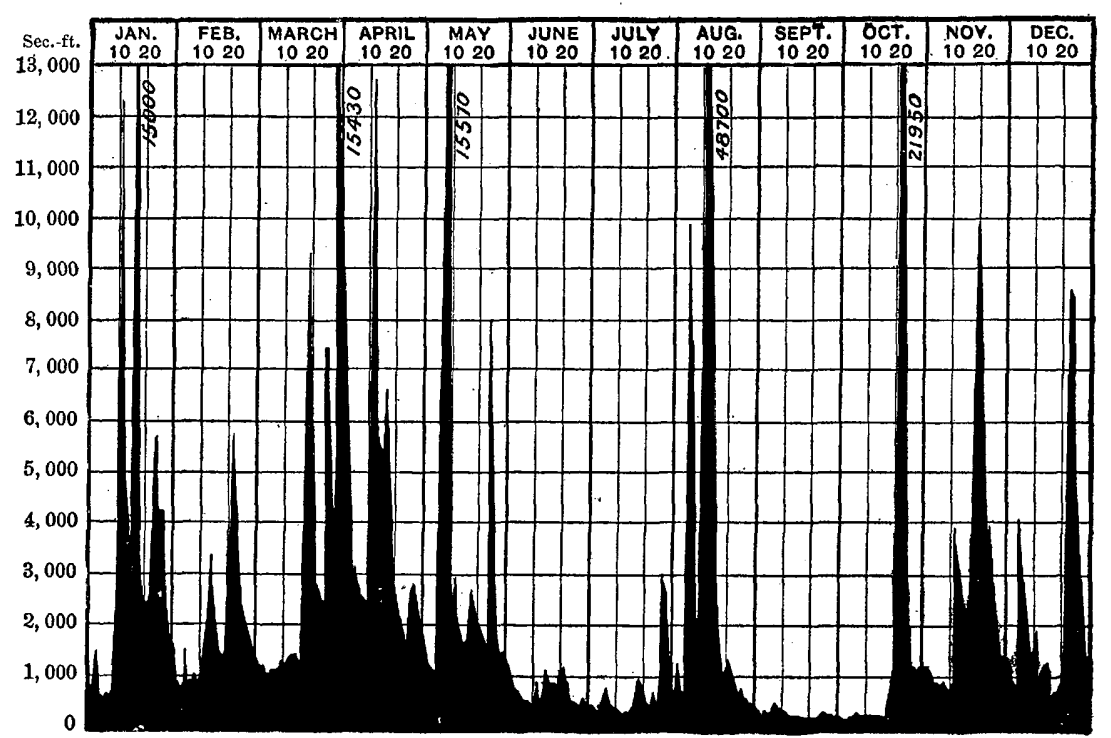

FiG. 68.-Discharge of Greenbrier River at Alderson, West Virginia, 1898. 


\section{TENNESSEE RIVER BASIN.}

\section{FRENCH BROAD RIVER.}

Estimated monthly discharge of French Broad River at Asheville, North Carolina.

[Drainage area, 987 square miles.]

\begin{tabular}{|c|c|c|c|c|c|c|}
\hline \multirow[b]{2}{*}{ Month. } & \multicolumn{3}{|c|}{ Discharge in second-feet. } & \multirow[b]{2}{*}{$\begin{array}{l}\text { Total in acre- } \\
\text { feet. }\end{array}$} & \multicolumn{2}{|c|}{ Run-off. } \\
\hline & $\begin{array}{l}\text { Maxi- } \\
\text { mum. }\end{array}$ & $\begin{array}{l}\text { Mini- } \\
\text { mum. }\end{array}$ & Mean. & & $\begin{array}{c}\text { Depth in } \\
\text { inches. }\end{array}$ & $\begin{array}{l}\text { Second- } \\
\text { feet per } \\
\text { square } \\
\text { mile. }\end{array}$ \\
\hline 1898. & & & & & & . \\
\hline January . :. & 3,230 & 801 & 1,345 & 82,701 & 1.57 & 1.36 \\
\hline February ... & 1,430 & 801 & 968 & 53,760 & 1. 02 & 0.98 \\
\hline March....... & 3,930 & 745 & 1,051 & 64,624 & 1.23 & 1.07 \\
\hline April....... & 2,530 & 903 & 1,575 & 93,719 & 1.79 & 1.60 \\
\hline May ...... & 1,930 & 782 & 1,036 & 63,702 & 1.21 & 1.05 \\
\hline June.... & 2,430 & 715 & 1,020 & 60,694 & 1.15 & 1.03 \\
\hline July ...... & 4,930 & 675 & 2,051 & 126,112 & 2.40 & 2.08 \\
\hline August..... & 5,180 & 1,630 & 2,911 & 178,992 & 3.40 & 2.95 \\
\hline September . & 4,530 & 1,330 & 2,330 & 138,644 & 2.63 & 2.36 \\
\hline October..... & 6,030 & 1,230 & 2,982 & 183,357 & 3.48 & 3.02 \\
\hline November.... & 1,530 & 930 & 1,197 & 71,226 & 1.35 & 1.21 \\
\hline December........... & 3,430 & 875 & 1,693 & 104,099 & 1.98 & 1.72 \\
\hline The year. & 6,030 & 675 . & 1,680 & $1,221,630$ & 23.21 & 1. 70 \\
\hline
\end{tabular}

Note.-Gage heights for 1898 are given in. Water-Supply and Irrigation Paper No. 27, page 62 measurements, page 65; rating table, page 66; results for 1897 in Water-Supply and Irrigation Paper No. 15, page 60, and in the Nineteenth Annual Report, Part IV, pages 257 to 259 .

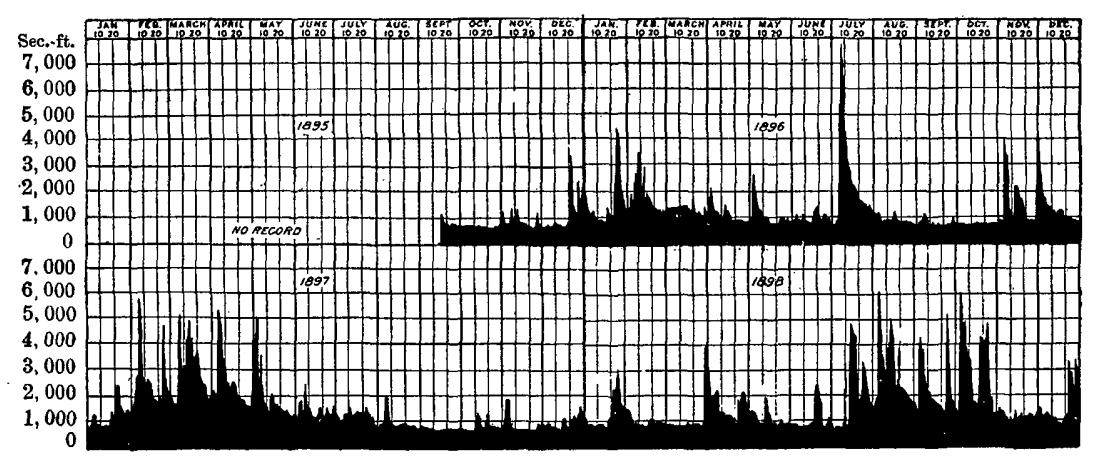

Fig. 69.-Discharge of French Broad River at Asheville, North Carolina, 1895-1898. 
TUCKASEGEE RIVER.

Estimated monthly discharge of Tuckasegee River at Bryson, North'Carolina.

[Drainage area, 662 square miles.]

\begin{tabular}{|c|c|c|c|c|c|c|}
\hline \multirow[b]{2}{*}{ Month. } & \multicolumn{3}{|c|}{ Discharge in second-feet. } & \multirow[b]{2}{*}{$\begin{array}{l}\text { Total in acre- } \\
\text { feet. }\end{array}$} & \multicolumn{2}{|c|}{ Run-off. } \\
\hline & $\begin{array}{l}\text { Maxi- } \\
\text { mum. }\end{array}$ & $\begin{array}{l}\text { Mini- } \\
\text { mum. }\end{array}$ & Mean. & & $\begin{array}{l}\text { Depth in } \\
\text { inches. }\end{array}$ & $\begin{array}{l}\text { Second. } \\
\text { feet per } \\
\text { square } \\
\text { mile. }\end{array}$ \\
\hline 1898. & & & & & & \\
\hline January.... & 8,425 & 400 & 1,910 & 117,442 & 3.32 & 2.88 \\
\hline February. & 1,325 & 602 & 893 & 49,595 & 1.41 & 1.35 \\
\hline $\operatorname{March} . .$. . & 17,775 & 535 & 1,939 & 119,225 & 3.38 & 2.93 \\
\hline April.... & 3,425 & 1,475 & 2,107 & 125,375 & 3.55 & 3.18 \\
\hline May...... & 1,550 & 810 & 1,155 & 71,019 & 2.01 & 1.74 \\
\hline June..... & 1,400 & 467 & 672 & 39,987 & 1.13 & 1.01 \\
\hline July ....... & 2,200 & 535 & 1,149 & 70,650 & 2.01 & 1.74 \\
\hline August. ..... & 22,650 & 1,175 & 3,373 & 207,399 & 5.87 & 5.09 \\
\hline September . & 26,050 & 1,100 & 3,876 & 230,638 & 6.72 & 5.86 \\
\hline October .............. & 21,750 & 1,100 & 3,826 & 235,253 & 6.66 & 5.78 \\
\hline November... & 2,375 & 1,250 & 1,763 & 104,906 & 2.97 & 2.66 \\
\hline December ........... & 3,075 & 950 & 1,838 & 113,015 & 3.21 & 2. 78 \\
\hline The year..... & 26,050 & 400 & 2,042 & $1,484,504$ & 42.24 & 3.08 \\
\hline
\end{tabular}

NoTE.-Gage heights for 1898 are given in Water-Supply and Irrigation Paper No. 27, page 63; measurements, page 65; rating table, page 66; results for 1897 in Water-Supply and Irrigation Paper No. 15 , page 61 .

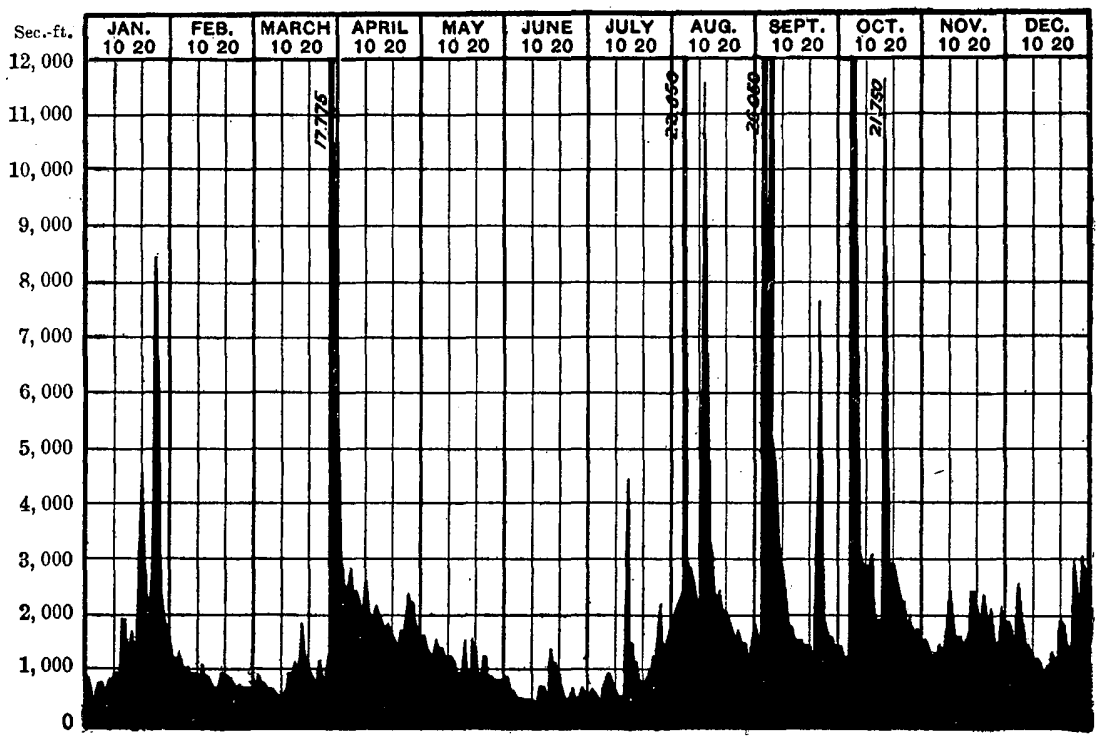

Fia. 70.-Discharge of Tuckasegee River at Bryson, North Carolina, 1898. 
LITTLE TENNESSEE RIVER.

Estimated monthly discharge of Little Tennessee River at Judson, North Carolina.

[Drainage area, 675 square miles.]

\begin{tabular}{|c|c|c|c|c|c|c|}
\hline \multirow[b]{2}{*}{ Month. } & \multicolumn{3}{|c|}{ Discharge in second-feet. } & \multirow{2}{*}{$\begin{array}{c}\text { Total in acre. } \\
\text { feet. }\end{array}$} & \multicolumn{2}{|c|}{ Run-off. } \\
\hline & $\begin{array}{l}\text { Maxi- } \\
\text { mum. }\end{array}$ & $\begin{array}{l}\text { Mini- } \\
\text { mum. }\end{array}$ & Mean. & & $\begin{array}{l}\text { Depth in } \\
\text { inches. }\end{array}$ & $\begin{array}{c}\text { Second- } \\
\text { feet per } \\
\text { square } \\
\text { mile. }\end{array}$ \\
\hline 1897. & 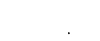 & & & & & \\
\hline January ............ & 4,160 & 1,670 & 2,393 & 147,141 & 4.09 & 3.55 \\
\hline February ......... & 14,475 & 1,825 & 4,631 & 257,193 & 7.14 & 6.86 \\
\hline 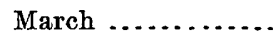 & 16,950 & 1,907 & 7,689 & 472,781 & 13.13 & 11.39 \\
\hline April $\ldots . . . . . .$. & 11,938 & 1,282 & 4,403 & 261,997 & 7.27 & 6.52 \\
\hline 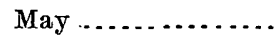 & 4,970 & 1,360 & 2,444 & 150,277 & 4. 17 & 3.62 \\
\hline June .............. & 4,160 & 925 & 2,000 & 119,008 & 3.30 & 2.96 \\
\hline July .............. & 4,970 & 1,515 & 2,379 & 146,280 & 4.06 & 3.52 \\
\hline August. . . . . . . . . . . & 2,650 & 755 & 1,676 & 103,054 & 2.86 & 2.48 \\
\hline September ......... & 925 & 407 & 724 & 43,081 & 1.19 & 1.07 \\
\hline October ............ & 3,770 & 407 & 832 & 51,158 & 1.42 & 1.23 \\
\hline November ........... & 1,515 & 610 & 767 & 45,640 & 1.27 & 1. 14 \\
\hline December .......... & 3,770 & 567 & 1,542 & 94,814 & 2.63 & 2.28 \\
\hline The year ..... & 16,950 & 407 & 2,623 & $1,892,424$ & 52.53 & 3.89 \\
\hline 1898. & . & & & & & \\
\hline January .......... & 5,830 & 705 & 1,570 & 96,536 & 2.69 & 2.33 \\
\hline February ........... & 1,515 & 370 & 799 & 44,374 & 1.53 & 1.18 \\
\hline March ......... & 12,338 & 370 & 1,796 & 110,432 & 2.97 & 2.66 \\
\hline April ..... & 6,290 & 1,060 & 2,416 & 143,762 & 3.99 & 3.58 \\
\hline 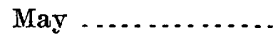 & 3,113 & 335 & 1,885 & 115,905 & 3.22 & 2.79 \\
\hline 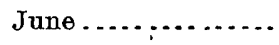 & 805 & 300 & 564 & 33,560 & 0.93 & 0.84 \\
\hline July $\ldots \ldots \ldots \ldots$ & 8,770 & 275 & 1,246 & 76,614 & 2.13 & 1.85 \\
\hline August.............. & 22,600 & 1,592 & 5,836 & 358,844 & 9.97 & 8.65 \\
\hline September ........ & 30,350 & 1,670 & 4,518 & 268,839 & 7.46 & 6.69 \\
\hline October ............. & 38,100 & 1,747 & 5,812 & $3 \check{5} 7,368$ & 9.93 & 8.61 \\
\hline November . . . . . . . . . & 3,770 & 2,405 & 2,847 & 169,408 & 4.70 & 4.21 \\
\hline December ........... & 4,550 & 1,825 & 2,190 & 134,659 & 3.74 & 3.24 \\
\hline The year ..... & 38,100 & 275 & 2,623 & $1,910,301$ & 53.26 & 3.89 \\
\hline
\end{tabular}

NoTk.-Gage heights for 1898 are given in Water-Supply and Irrigation Paper No. 27, page 63; measurements, page 65; rating table, page 66; results for 1897 in Water-Supply and Irrigation Paper No. 15 , page 62 . 


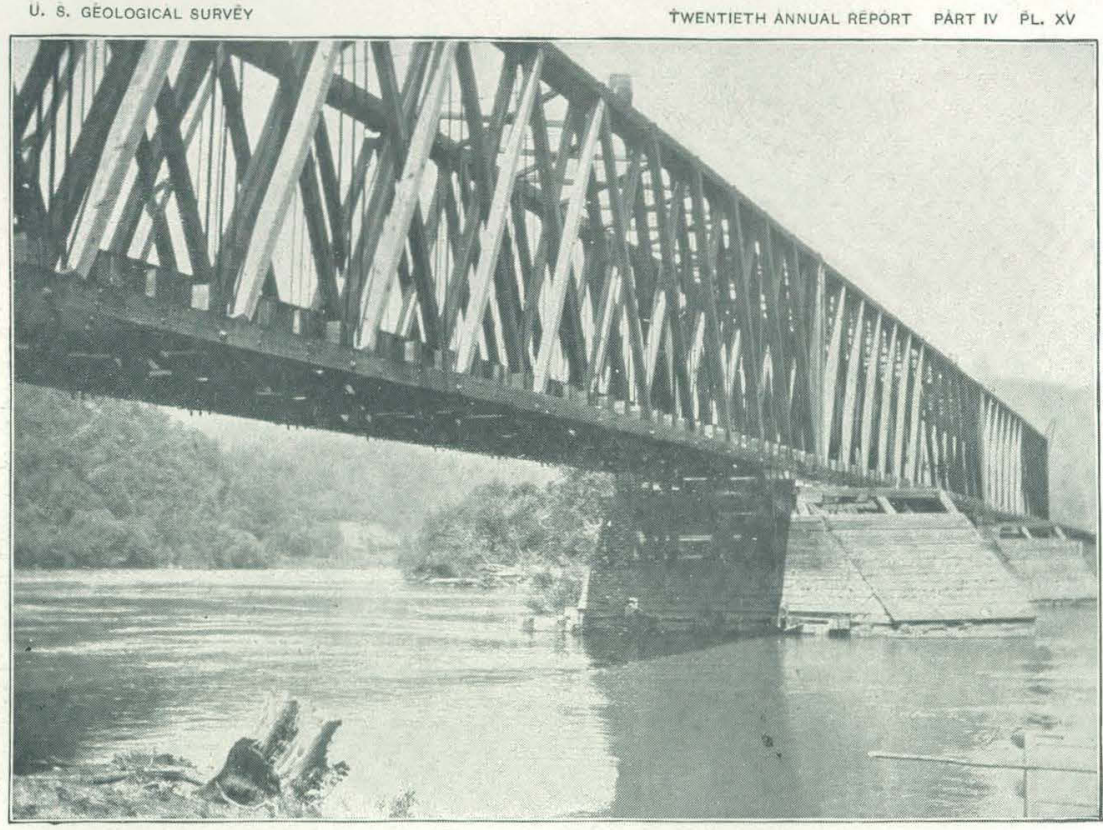

A. HIWASSEE RIVER AT RELIANCE, TENNESSEE.

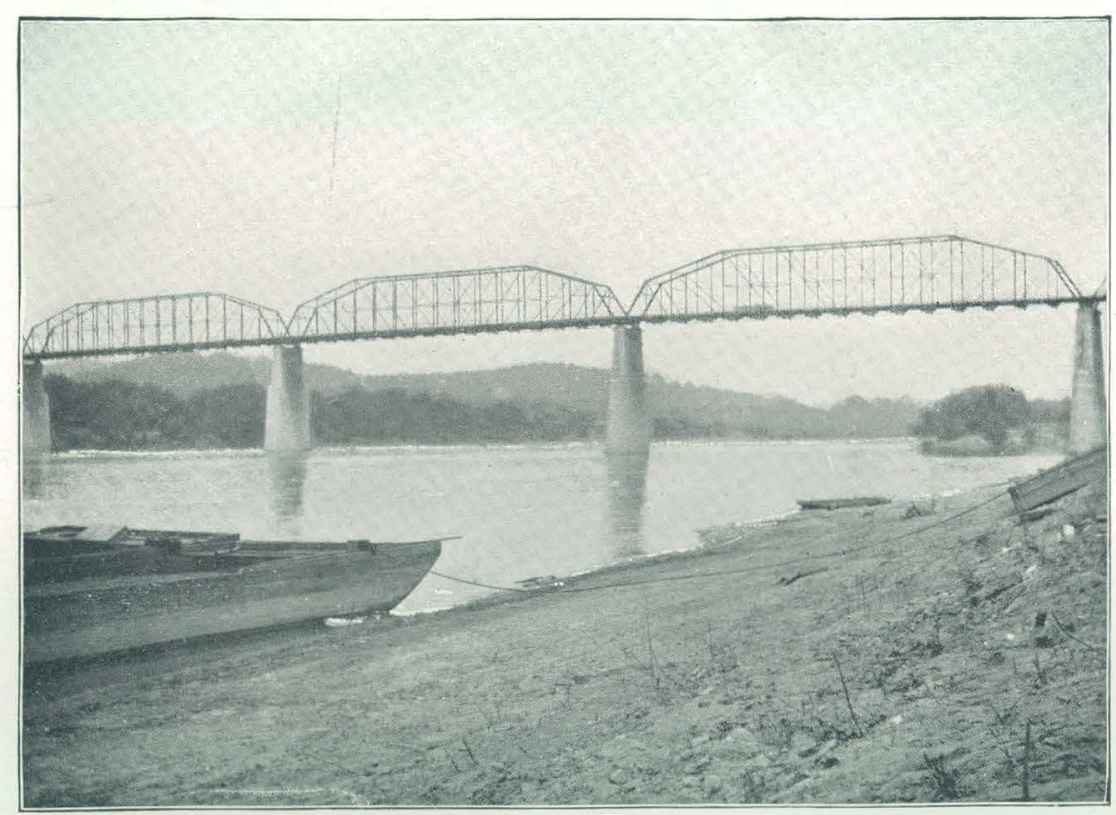

B. TENNESSEE RIVER AT CHATTANOOGA, TENNESSEE. 


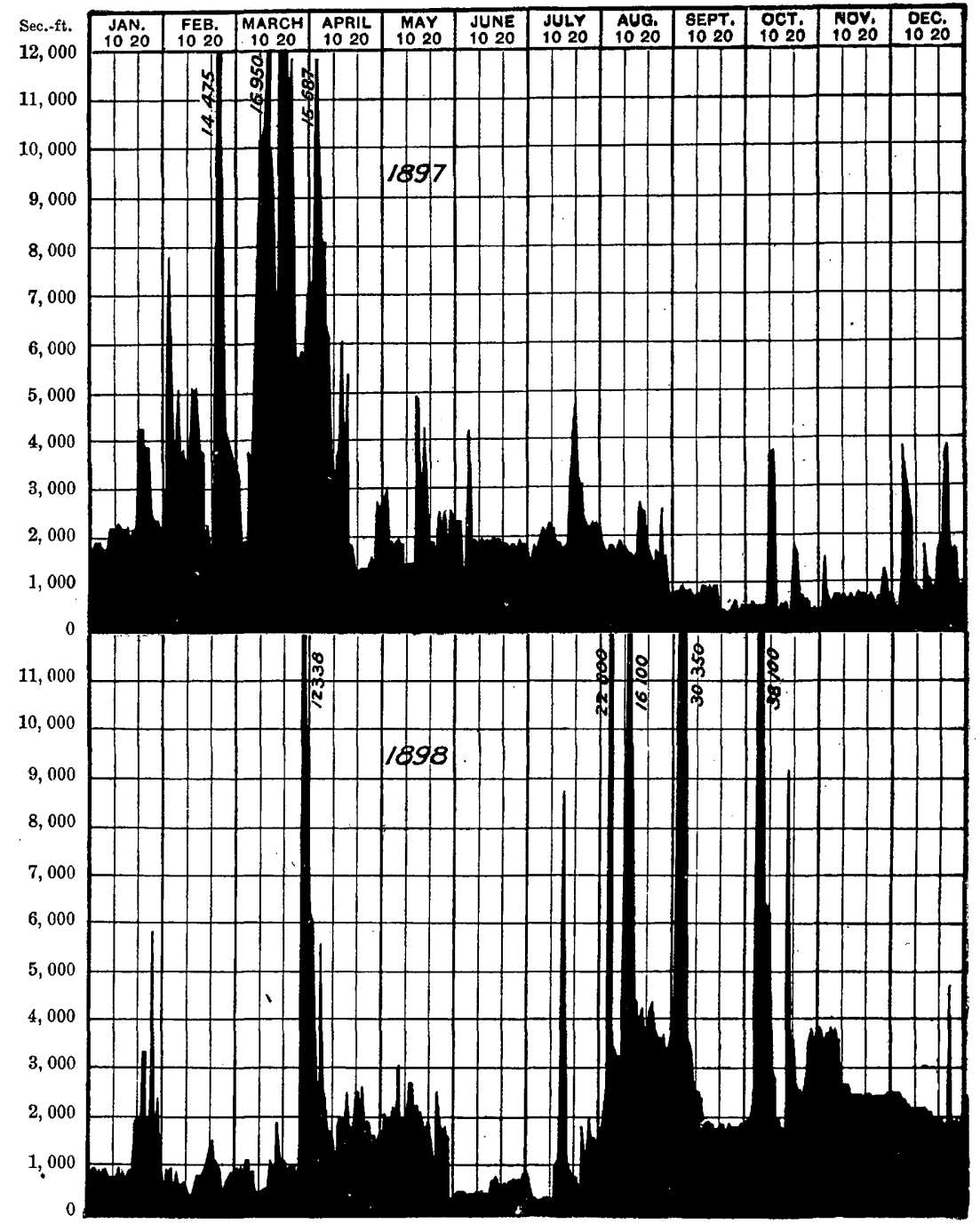

FIG. 71.-Discharge of Little Tennessee River at Judson, North Carolina, 1897-1898.

HIWASSEE RIVER.

Hiwassee River, Nottely River, and Toccoa River (known in Tennessee as the Okoee) are mountain tributaries in Georgia, North Carolina, and Tennessee, having a great number of excellent shoals in close proximity to the Atlanta, Knoxville and Northern Railway that are capable of easy development. It is proposed to establish additional stations on these streams during the year 1899, and discharge measurements will be made at Weather Bureau stations on other branches of Tennessee River.

A view of Hiwassee River at the Atlanta, Knoxville and Northern Railway near Reliance, Tennessee, is shown on Pl. XV, $A$. The view 
is looking from the left bank above the bridge. On Pl. $\mathrm{XV}, B$, is a view of Tennessee River at Chattanooga, Tennessee. The view is taken below the Hamilton County bridge from the left bank.

Estimated monthly discharge of Hiwassee River at Murphy, North Carolina.

[Drainage area, 410 square miles.]

\begin{tabular}{|c|c|c|c|c|c|c|}
\hline \multirow[b]{2}{*}{ Month.' } & \multicolumn{3}{|c|}{ Discharge in second feet. } & \multirow[b]{2}{*}{$\begin{array}{l}\text { Total in acre- } \\
\text { feet. } \\
\end{array}$} & \multicolumn{2}{|c|}{ Run.off: } \\
\hline & $\begin{array}{l}\text { Maxi. } \\
\text { mum. }\end{array}$ & $\begin{array}{l}\text { Mini- } \\
\text { mum. }\end{array}$ & Mean: & & $\begin{array}{l}\text { Depth in } \\
\text { inches. }\end{array}$ & $\begin{array}{c}\text { Second- } \\
\text { feet per } \\
\text { square } \\
\text { mile. }\end{array}$ \\
\hline 1898. & & & & & & \\
\hline January ............ & 2,870 & 400 & 920 & 56,569 & 2.58 & 2.24 \\
\hline February .......... & 720 & 450 & 542 & 30,110 & 1.37 & 1.32 \\
\hline 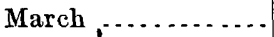 & 6,220 & 450 & 889 & 54,663 & 2.50 & 2.17 \\
\hline 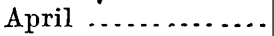 & 3,870 & 770 & 1,287 & 76,582 & 3.50 & 3.14 \\
\hline May ................. & 920 & 400 & 612 & 37,631 & 1.72 & 1.49 \\
\hline June.... & 640 & 332 & 403 & 23,980 & 1. 09 & 0.98 \\
\hline 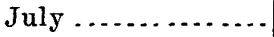 & 1,320 & 315 & 635 & 39,045 & 1. 79 & 1.55 \\
\hline August . . . . . . . . & 5,120 & 720 & 1,691 & 103,976 & 4.75 & 4. 12 \\
\hline September ..... & 9,070 & 570 & 1,878 & 111,749 & 5.11 & 4.58 \\
\hline October ...... & 9,520 & 640 & 1,924 & 118,303 & 5.41 & 4.69 \\
\hline November......... & 1,820 & 820 & 1,117 & 66,466 & 3.02 & 2.71 \\
\hline December .......... & $1,220^{\circ}$ & 820 & 980 & 60,258 & 2.76 & 2.39 \\
\hline The year & 9,520 & 315 & 1,073 & 779,332 & 35.60 & $\begin{array}{l}2.62 \\
,\end{array}$ \\
\hline
\end{tabular}

Note.-Gage heights for 1898 are given in Water-Supply and Irrigation Paper No. 27, page 64; measurements, page 65 ; rating table, page 66 ; results for 1897 in Water-Supply and Irrigation Paper No. 15 , page 63, and in the Nineteenth Annual Report, Part IV, page 259.

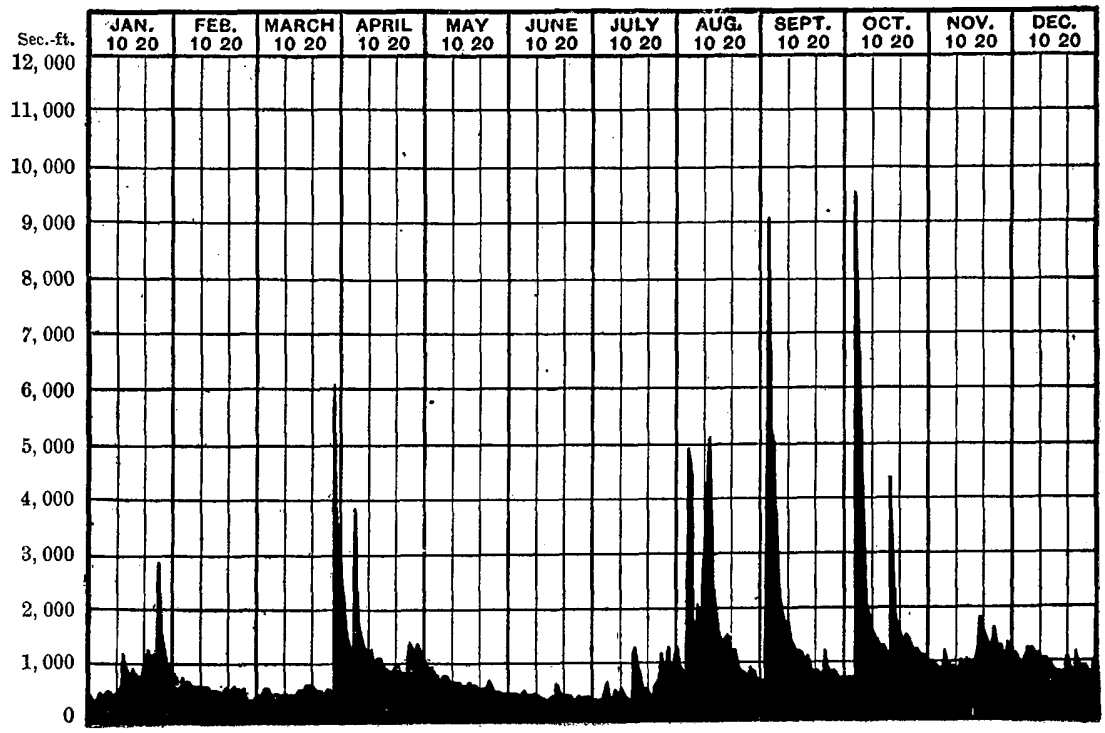

Frg. 72.-Disebarge of Hiwassee River at Murphy, North Carolina, 1898. 20 GEOL, PT $4 \longrightarrow \mathbf{1 4}$ 
TOCCOA RIVER.

Toccoa River rises in northern Georgia and flows northwesterly across the State line into Tennessee, discharging into Tennessee River about 30 miles above Chattanooga. Measurements of the head waters have been made in Georgia at a point about 4 miles east of the town of Blue Ridge, on the Atlanta, Knoxville and Northern Railroad, 103 miles northerly from Atlanta. Blue Ridge station on Toccoa River was established November 25, 1898; no rating table has been constructed. It is described in Water-Supply and Irrigation Paper No. 27, page 60; gage heights are given on page 64 and measurements on page 65 .

\section{TENNESSEE RIVER AT CHATTANOOGA.}

Results of measurements on tributaries of Tennessee River have been given, beginning on page 205 . The main stream has been measured at Chattanooga, Tennessee. The station is located at the foot of Lookout street, just below Chattanooga Island.

Estimated nonthly discharge of Tennessee River at Chattanooga, Tennessee.

[Drainage area, 21,418 square miles.]

\begin{tabular}{|c|c|c|c|c|c|c|}
\hline \multirow[b]{2}{*}{ Month. } & \multicolumn{3}{|c|}{ Discharge in second-feet. } & \multirow[b]{2}{*}{$\begin{array}{l}\text { Total in acre } \\
\text { feet. }\end{array}$} & \multicolumn{2}{|c|}{ Run-off. } \\
\hline & $\begin{array}{l}\text { Maxi. } \\
\text { mum. }\end{array}$ & $\begin{array}{l}\text { Mini. } \\
\text { mum. }\end{array}$ & Mean. & & $\begin{array}{c}\text { Depth in } \\
\text { inches. }\end{array}$ & $\begin{array}{c}\text { Second- } \\
\text { feet per } \\
\text { square } \\
\text { mile. }\end{array}$ \\
\hline 1898. & & & & & & \\
\hline January ......... & 124,860 & 14,344 & 59,509 & $3,778,785$ & 3.20 & 2.77 \\
\hline February .. & 47,115 & 16,900 & 22,994 & $1,277,022$ & 1.11 & 1.07 \\
\hline March ..... & 88,725 & $15,-008$ & 24,774 & $1,523,304$ & 1.28 & 1.11 \\
\hline April ..... & 121,940 & 39,085 & 60,048 & $3,573,096$ & 3.12 & 2.80 \\
\hline May ...... & 38,720 & 17,920 & 23,701 & $1,457,327$ & 1.28 & 1.11 \\
\hline June........ & 32,515 & 10,245 & 16,395 & 975,569 & 0.85 & 0.77 \\
\hline July ....... & 49,670 & 11,853 & 20,063 & $1,233,633$ & 1.08 & 0.94 \\
\hline August .... & 107,705 & 20,410 & 50,638 & $3,113,629$ & 2.72 & 2.36 \\
\hline September.. & 174,500 & 18,190 & 47,349 & $2,817,454$ & 2.46 & 2.21 \\
\hline October..... & 115,370 & 16,900 & 44,215 & $2,718,691$ & 2.38 & 2.06 \\
\hline November... & 42,005 & 20,700 & 28,415 & $1,690,806$ & 1.48 & 1.33 \\
\hline December ....... & 35,800 & 19,000 & 28,909 & $1,777,556$ & 1.56 & 1.35 \\
\hline The year. & 174,500 & 10,245 & 35,584 & $25,936,872$ & 22.52 & 1.66 \\
\hline
\end{tabular}

NoTE.-Gage heights for 1898 are given in Water-Supply and Irrigation Paper No. 27, page 64; measurements, page 65; rating table, page 66; results for 1897 in Water-Supply and Irrigation Paper No. 15, page 64, and in the Nineteenth Annual Report, Part IV, pages 260 to 262. 


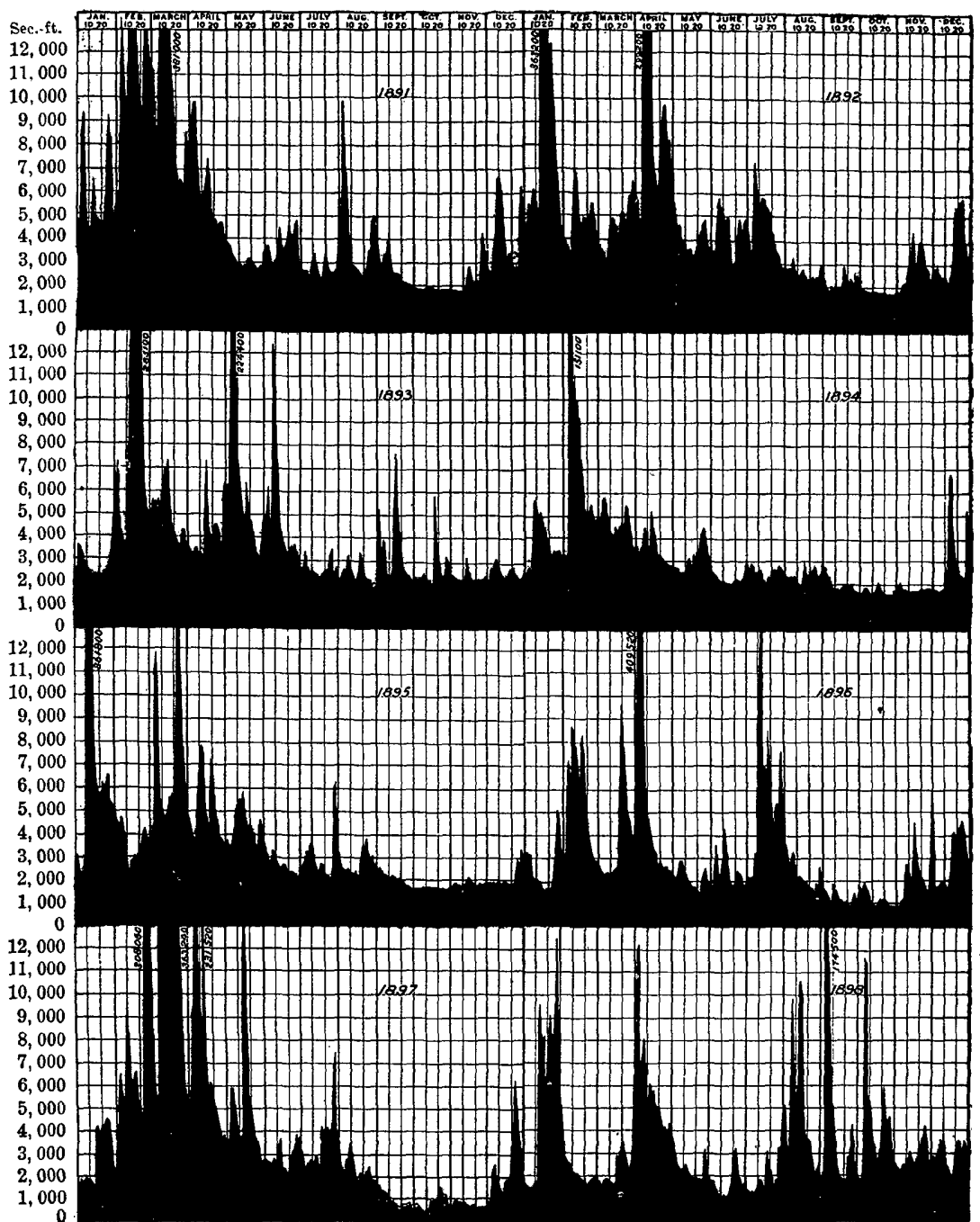

Fig. 73.-Discharge of Tennessee River at Chattanooga, Tennessee, 1891-1898.

The above figure shows graphically the fluctuations of Tennessee River at Chattanooga from 1891 to 1898 , inclusive. The figures of monthly flow are given in the Eighteenth Annual Report, Part IV, page 119, for the years 1890 to 1895 , inclusive. Those for 1896 and 1897 are given in the Nineteenth Annual Report, Part IV, page 261; and those for 1898 are shown on the opposite page. 


\section{SCIOTO RIVER.}

Scioto River drains an area of 6,432 square miles lying in the central and southern part of the State of Ohio. The stream has a general southerly course and empties into Ohio River at a point about 110 miles above the city of Cincinnati. The drainage basin as a whole is relatively long and narrow, the tributaries flowing through what may be classed as a prairie country, from which the run-off is small. The chief interest in connection with this stream is the use of its waters for municipal supplies. The city of Columbus is situated a little above the center of the drainage basin. Above this are a number of important towns, among them Marion, with a population in 1890 of 17,783, and Delaware, with a population of 9,810 , besides numerous smaller towns. The sewage from many of these flows into the creeks and ultimately in diluted form reaches Scioto River, rendering its water of dubious character for domestic use. ${ }^{1}$

The increase of population and consequently of pollution within the district where drainage constitutes the chief source of supply to Scioto River is a growing menace to the health of Columbus and other cities and towns along the river. It is evident that before use the water should be artificially purified. From the low-water flow of the stream it is evident that storage must be had at one or more places. There is now in contemplation a project for building a reservoir on Scioto River near the city of Columbus. According to a report by Mr. James D. Schuyler ${ }^{2}$ the Scioto above the junction with the Olentangy at Columbus has a total watershed of 970 square miles. For 20 miles or more the Scioto flows through a straight, narrow gorge or canyon in the limestone, 75 to 100 feet in depth and with a width of from 500 to 1,500 feet. Through this canyon the average grade of the river is oetween 4 and 5 feet per mile. It is proposed to construct a concrete masonry dam near the lower end of this gorge, at a point known as the Lakin site, about 5 miles above the present city waterworks. The amount of water available at this point has been estimated from measurements made at the State dam at Columbus, beginning in January, 1897. From these measurements it appears that the total discharge of the river during the year 1897 was 33,712 million cubic feet, or 773,921 acre-feet, representing a mean run-off of 23.4 per cent of the precipitation. The Scioto above the proposed dam has a watershed of about two-thirds the total area draining past the State dam, and it has been assumed in making computations of the amount available at the proposed dam that this ratio of the drainage area holds good for the discharge, giving a mean flow of 710 cubic feet per second throughout the year if evenly

1 Preliminary Report of an Investigation of Rivers and Deep Ground Waters of Ohio as Sources of Public Water Supplies, by the Ohio State Board of Health, 1897-1898.

${ }^{2}$ Report on the Construction of the Proposed Concrete Masonry Dam for the Water Supply of the City of Columbus, by James D. Schuyler, consulting engineer, July 26, 1898. 
distributed. The percentage of flow during the different months of the year are given in the following table:

Estimated monthly percentage of flow of Scioto River at Columbus, Ohio.

\begin{tabular}{|c|c|c|c|}
\hline Month. & Per cent. & Montl. & Per cent. \\
\hline January.... & 3.15 & August..... & 1.60 \\
\hline February & 20.75 & September & 0.55 \\
\hline March $\ldots \ldots \ldots \ldots \ldots \ldots$ & 46.15 & October $\ldots \ldots \ldots$ & 0.20 \\
\hline April & 4.90 & November. & 1.90 \\
\hline May .................. & 5.55 & December $\ldots \ldots \ldots \ldots \ldots$ & 8.20 \\
\hline June . . . . . . . . . . . . & 2.85 & Total & 100.00 \\
\hline July $\ldots \ldots \ldots \ldots . . . . . . . .$. & 4.20 & & \\
\hline
\end{tabular}

The great inequality shown in the above figures is probably larger than it would be under natural conditions. It arises not only from variations due to the seasons and the increased evaporation from cultivated soil and vegetation, but also from extensive underdrainage of the farm lands of the upper Scioto by means of tile drains, which rapidly draw down the ground waters in winter, leaving the lands in a condition to absorb the spring and summer rains. An estimate has been given by Mr. Schuyler of the probable discharge in dry and wet years, based on the measurements available and an examination of the rainfall records. The minimum recorded rainfall of the Scioto basin is about 28.5 inches, and the dry-year run-off has been estimated at 4.5 inches, or 16.8 per cent of the precipitation.

Estimated discharge in dry and wet years of Scioto River at proposed Lakin dam site.

\begin{tabular}{|c|c|c|c|c|}
\hline \multirow{2}{*}{ Month. } & \multicolumn{2}{|c|}{ Dry years. } & \multicolumn{2}{|c|}{ Wet years. } \\
\hline & $\begin{array}{l}\text { Second- } \\
\text { feet. }\end{array}$ & $\begin{array}{l}\text { Horse. } \\
\text { power. }\end{array}$ & $\begin{array}{l}\text { Second- } \\
\text { feet. }\end{array}$ & $\begin{array}{l}\text { Horse. } \\
\text { power. }\end{array}$ \\
\hline Janpary $\ldots \ldots \ldots \ldots \ldots \ldots \ldots$ & 782 & 3,550 & 1,032 & 4,500 \\
\hline February $\ldots \ldots \ldots \ldots \ldots \ldots \ldots$ & 865 & 3,800 & 1,620 & 7,100 \\
\hline 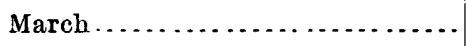 & 665 & 2,930 & 1,470 & 6,450 \\
\hline April . . . . . . . . . . . . & 462 & 2,000 & 1,170 & 5,300 \\
\hline 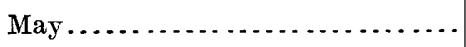 & 253 & 1,110 & 705 & 3,100 \\
\hline June $\ldots \ldots \ldots \ldots \ldots \ldots \ldots$ & 110 & 484 & 392 & 1,720 \\
\hline July $\ldots \ldots \ldots \ldots \ldots \ldots \ldots \ldots$ & 42 & 182 & 136 & 600 \\
\hline August. . . . . . . . . . . . . . & 26 & 114 & 60 & 264 \\
\hline September $\ldots \ldots \ldots \ldots \ldots \ldots \ldots . . . .$. & 16 & 70 & 109 & 480 \\
\hline October $\ldots \ldots \ldots \ldots \ldots \ldots \ldots$ & 23 & 100 & 151 & 660 \\
\hline November $\ldots \ldots \ldots \ldots \ldots \ldots . . . . . . . . .$. & 122 & 537 & 313 & 1,370 \\
\hline Décember $\ldots \ldots \ldots \ldots \ldots \ldots \ldots \ldots$ & 500 & 2,200 & 555 & 2,440 \\
\hline
\end{tabular}


In the above table the estimated discharge in cubic feet per second in dry and wet years has been given, together with the possible horsepower available at the proposed dam on a basis of 75 per cent efficiency, the height being at an elevation of 112 feet above city datum and the spillway at an elevation of 95 feet. The following table gives the capacity of the proposed reservoir:

Capacity of proposed reservoir on Scioto River near Columbus, Ohio.

\begin{tabular}{|r|r|r|}
\hline Elevation. $a$ & Surface area. & Capacity. \\
\cline { 2 - 3 } Feet. & Acres. & Acrefeet. \\
43 & 16 & $\ldots . . . .$. \\
50 & 46 & 264 \\
60 & 200 & 1,553 \\
70 & 329 & 4,114 \\
80 & 449 & 8,102 \\
90 & 676 & 13,795 \\
100 & 873. & 21,565 \\
110 & 1,114 & 31,465 \\
115 & 1,262 & 36,870 \\
\hline
\end{tabular}

a Elevation above city datum, this latter being 43 feet below low. water and 34 feet below the lowest foundations.

The total drainage area of Scioto River below Columbus, including Olentangy River, is 1,667 square miles. The flood flow, as given by $\mathrm{Mr}$. Julian Griggs, ${ }^{1}$ city engineer, often reaches from 30,000 to 40,000 secondfeet. The greatest and most disastrous flood on record was that of March 23, 1898, when it is believed that the discharge reached 75,000 second-feet. At this time the maximum rise was 18.75 feet at the Columbus State Hospital pumping station, or 2.75 feet higher than ever before reached at that point. The average flow for six months of the wet season is about 600 second-feet, during which time it seldom falls as low as 250 second-feet. During the dry weather of summer and autumn the flow is very small. In August, September, and October, 1897 , the average was about 30 second-feet, consisting of little more than the sewage of the city slightly diluted.

The low-water flow of Scioto River has been measured by Prof. C. N. Brown, ${ }^{2}$ at Kenton, where the drainage area is 153 square miles; at Marion, on the Little Scioto, with a drainage area of 109 square miles; at Columbus, with a drainage area of 1,070 square miles, and at Shadeville, where the drainage area is 1,670 square miles. The flow at Ken-

\footnotetext{
IA report to the director of public improvements of the city of Columbus, Ohio, on the proper disposal of the sewage of the city, May 1, 1898; Julian Griggs, chief engineer, department of public improvements.

2 Report on stream gagings and sources of pollution of the Olentangy and Mahoning rivers, by C.N. Brown; pp. 142-179 of the Preliminary Report of an Investigation of Rivers and Deep Ground Waters of Ohio as Sources of Public Water Supplies, by the Ohio State Board of Health, 1897-98.
} 
ton was from about 2 to 5 second-feet; at Marion, from 1 to 2 secondfeet, and at Columbus the minimum flow was estimated to be a little under 5 second-feet. The lowest flow at Shadeville was probably on October 30, when the discharge was about 25 second-feet. On the accompanying figure (fig. 74) is given the relative location of points of observation of rainfall and river flow on the drainage basin above the city of Columbus.

\section{OLENTANGY RIVER.}

This stream, as shown on fig. 74, is one of the principal tributaries of Scioto River, draining a narrow strip of country of an area of about 523

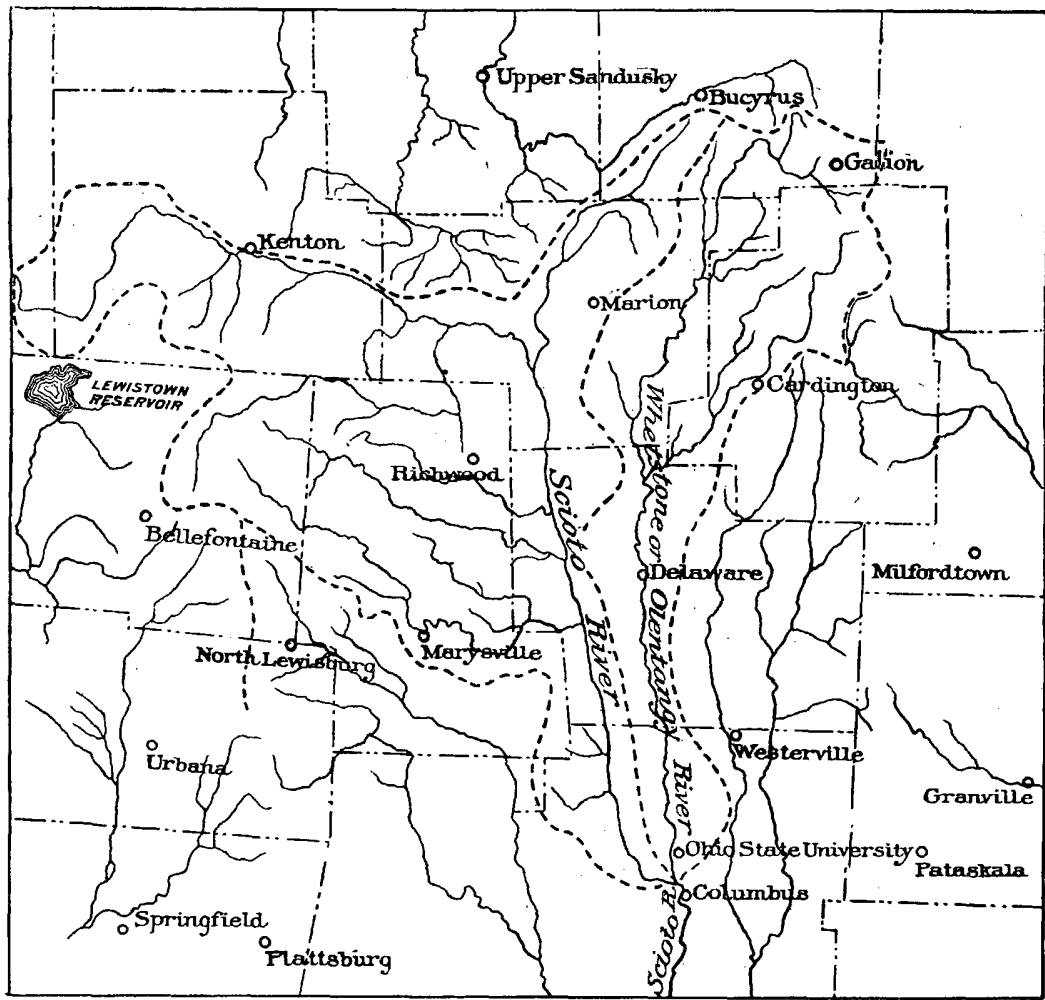

Fig. 74.-Relative location of river and rainfall observations in basin of Scioto River above Columbus, Ohio.

square miles. Measurements of the low-water flow have been made, as notèd above, by Prof. C. N. Brown, in connection with determination of the minimum discharge of Scioto River. These measurements were at Galion, where the drainage area is 29 square miles, and at Columbus, near the mouth of the river. At the former place, during September and ${ }^{\circ}$ October of 1897 , the stream was dry, except for sewage from Galion. At Columbus the flow was from 1 to 5 cubic feet per second. During the winter of 1892-93 measurements were made of Olentangy River by 


\section{PROGRESS OF STREAM, MEASUREMENTS FOR 1898.}

students of engineering of the Ohio State University, under direction of Professor Brown. The results of the computations of daily discharge are shown in the accompanying figure (fig. 75). Comparing the total run-off with the rainfall, it appears that in December, 1892, the run-off was 25 per cent of the rainfall; in January, 1893, it was 34 per cent; in February, 89 per cent; in March, 117 per cent; in April, 50 per cent, and for the four months the average was 63 per cent.

The total discharge of Olentangy River, shown by fig. 75, was as follows:

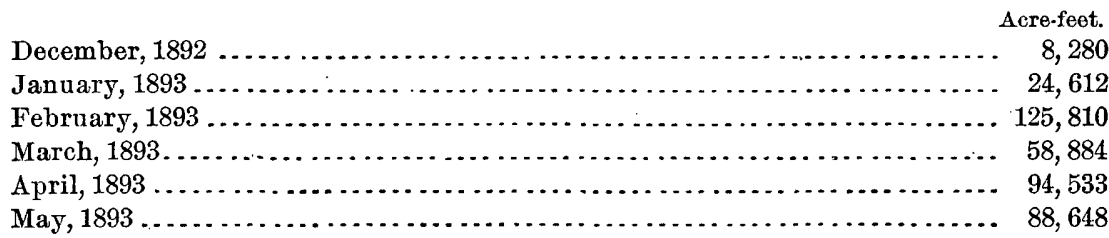

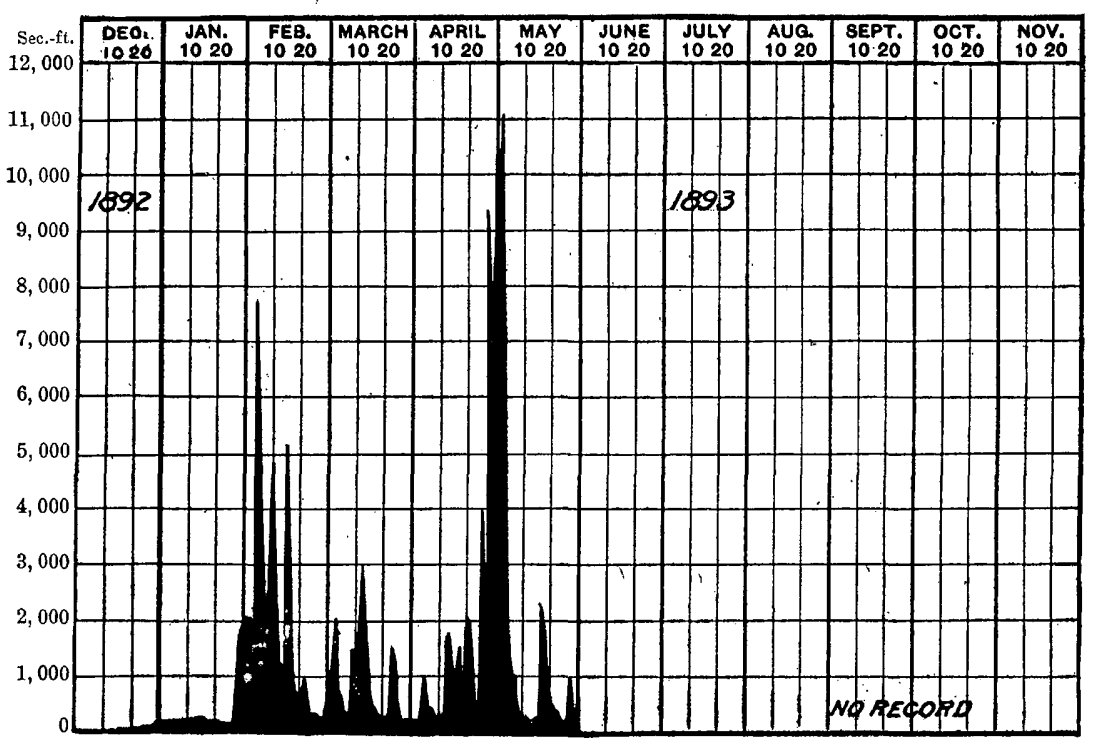

F1G. 75.-Discharge of Olentangy River at Columbus, Ohio, December. 1892, to May, 1893.

\section{GREAT LAKES DRAINAGE.}

A study of the Great Lakes has been made by Mr. G. K. Gilbert, the results being printed in the Eighteenth Annual Report, Part II, pp. 595-647. In this paper are discussed the gage readings and the question whether the land has recently been tilted to an amount appreciable in the records of the height of water. ${ }^{1}$

Other facts concerning the Great Lakes and river system have been presented by Mr. Lyman E. Cooley in the report of the Deep Waterways

\footnotetext{
1 Recent earth movement in the.Great Lakes region, by Grove Karl Gilbert: Eighteenth Ann. Rept., Part II, 1898, pp. 595-647.
} 
Commission. ${ }^{1}$ This report gives profiles and maps of water routes, a discussion of the hydrology and of the principal problems connected with navigation. Following its transmission to Congress, on January 18, 1897, a second commission known as the Board of Engineers on Deep Waterways was created for the purpose of making surveys and examinations, including estimate of cost of deep waterways between the Great Lakes and the Atlantic tide waters. (Stat. L. Vol. 30, pp. $50,336,1109$.)

This later commission has not yet made its report, but it is understood that careful measurements have been made of the discharge of Detroit and Niagara rivers. It is asserted that the measurements at the head of St. Clair River bave shown an extraordinary change within a few years, by which the slope has been decreased over a foot, and the level of Lakes Huron and Michigan have been permanently lowered. At the time of the survey made in 1867, the gorge at the head of the river was 800 feet wide, 48 feet deep, and had an area of cross section of 30,000 square feet. In 1899 the same section was found to be 66 feet deep, with an area of 36,000 square feet. The levels of the lake indicate that the deepenings occurred about 1885 and 1886. By this change the slope of the rapids has been diminished by over 1 foot.

Discharge measurements of the outflow of the Great Lakes were made in 1867,1868 , and 1869 by Mr. D. Farrand Henry, his report being contained in the Annual Reports of the Chief of Engineers for 1868, 1869, and 1870. 'These measurements were made by floats and meters. The results of these and later measurements are being compiled and discussed by the Board of Engineers on Deep Waterways, whose report is not yet available.

\section{MENOMINEE RIVER, MICHIGAN.}

Menominee River forms a portion of the boundary between Wisconsin and the upper peninsula of Michigan. The name is applied to that portion of the stream from the junction of Brule, Paint, and Michigamme rivers, near the town of Florence, Wisconsin, down to the mouth of the river at Green Bay, Lake Michigan. Besides the three rivers named, others add to the flow at intervals, among the larger of which are Pine, Popple, Sturgeon, Bum Wum, Wausaukee, and Cedar rivers. In all of these, as well as in the Menominee itself, the current is rapid and heads of from 6 to 10 feet could be created at many points at present not considered because the larger falls are still unimproved. The smaller feeders, however, are of comparatively small volumes, and these may be neglected. At the mouth of the river are two cities, that on the north, in Michigan, known as Menominee, and on the south, in Wisconsin, known as Marinette. Within the city limits are two dams on

\footnotetext{
1 Report on Technical Work, by L. E. Cooley, Chicago, December, 1896, in Report of the United States Deep Waterways Commission, Fifty-fourth Congress, second session, H. R. Doc, No. 192. See also Water-Supply and Irrigation Paper of the U.S. Geological Survey No. 24, p. 48.
} 
the river, the power from which is apparently utilized by paper and grist mills. Proceeding upstream from this point there are no improvements until Lower Quinnesec Falls is reached. At this point is a nearly vertical descent of 60 feet, giving about 10,000 horsepower, of which 4,000 horsepower are now used by Kimberly, Clark \& Co. Preparations are being made to utilize a larger proportion of this power. A few miles above this point is Upper Quinnesec Falls, with a fall of about 60 feet. At this point is an air-compressor plant, from which air is piped to Iron Mountain and used for power in mining operations. From above Twin Falls, located 5 miles west of Iron Mountain, to the mouth of the river, at Menominee, the fall is over 500 feet.

\section{DESPLAINES RIVER.}

Desplaines River drains an area of 630 square miles lying immediately to the west and northwest of the city of Chicago. Its waters, in the natural condition, were tributary to Illinois River, which heads near the shores of Lake Michigan and flows southwesterly, entering the Mississippi River a short distance above the mouth of the Missouri River. By the construction of regulation works its waters are controlled in order to keep them from interfering with the operation of the Chicago drainage canal. At a point south of Riverside the flood waters are divided, a portion going to Joliet and thence to the Mississippi River, and the excess over 5,000 second-feet into Chicago River. When the canal is completed the regulation works or spillway will be raised so that none of the flood waters will enter Chicago River. The drainage basin is typical of a large extent of country draining to the Mississippi and to the 'Great Lakes, and therefore the data pertaining to the run-off are suggestive of what may be expected from a considerable portion of the Northwest.

Systematic measurements of the flow from this basin have been made by the Chicago drainage and water-supply commission, the city of Chicago, and the sanitary district of Chicago. These corporations have maintained a gage at Riverside almost continuously since May 13, 1886. The stage of the river has been recorded once or twice each day and occasional discharge measurements have been made, and from these estimates of the daily flow have been had. The results for the years 1886 to 1896 , inclusive, have been published by Mr. Thomas T. Johnston. ${ }^{1}$ Later facts for the years 1896-1898, inclusive, have been obtained from Mr. G. M. Wisner, assistant engineer of the sanitary district of Chicago. An examination of the highest authentic water marks along the riverthose for 1889 and 1892-indicate a maximum flow of 13,500 secondfeet. This is the equivalent of 21 second-feet per square mile, or a rainfall of 1.25 inches per day over the area of the whole basin. The following table gives in condensed form the monthly flow taken from the data prepared by Mr. Johnston.

\footnotetext{
1 Journal of the Western Society of Engineers, Vol. I, No. 3, June, 1896, pp. 297-404.
} 
Estimated monthly discharge of Desplaines River at Riverside, Illinois.

[Drainage area, 630 square miles.]

\begin{tabular}{|c|c|c|c|c|c|c|}
\hline \multirow[b]{2}{*}{ Month. } & \multicolumn{3}{|c|}{ Discharge in second-feet. } & \multirow[b]{2}{*}{$\begin{array}{c}\text { Total in acre- } \\
\text { feet. }\end{array}$} & \multicolumn{2}{|c|}{ Run-off. } \\
\hline & $\begin{array}{l}\text { Maxi- } \\
\text { muni. }\end{array}$ & $\begin{array}{l}\text { Mini- } \\
\text { mum. }\end{array}$ & Mean. & & $\begin{array}{l}\text { Depth in } \\
\text { inches. }\end{array}$ & $\begin{array}{c}\text { Second- } \\
\text { feet per } \\
\text { square } \\
\text { mile. }\end{array}$ \\
\hline 1886. & & & & & & \\
\hline May $13-31 . . . . . .$. & 2,118 & 236 & 1,073 & 65,977 & 1.96 & 1.70 \\
\hline June ............... & 268 & 7 & 87 & 5,177 & 0.16 & 0.14 \\
\hline July ............. & 221 & 0 & 77 & 4,735 & 0.14 & 0.12 \\
\hline August. . . . . . . . . & 51 & 0 & 5 & 307 & 0.00 & 0.00 \\
\hline September ......... & 128 & 0 & 16 & 952 & 0.03 & 0.03 \\
\hline October ............ & 70 & 0 & 4 & 246 & 0.00 & 0.00 \\
\hline November.......... & 0 & 0 & 0 & 0 & 0.00 & 0.00 \\
\hline December . . . . . . . . & 0 & 0 & 0 & 0 & 0.00 & 0.00 \\
\hline 1887. & & & & & & \\
\hline January .......... & 2,280 & 0 & 481 & 29,575 & 0.87 & 0.76 \\
\hline February .......... & 9,650 & 650 & 3,380 & 187,715 & 5.59 & 5.37 \\
\hline March ............. & 3,160 & 280 & 1,469 & 90,325 & 2.69 & 2.33 \\
\hline April $\ldots \ldots \ldots \ldots$ & 530 & 120 & 291 & 17,316 & 0.52 & 0.46 \\
\hline 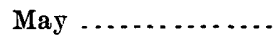 & 200 & 20 & 69 & 4,243 & 0.13 & 0.11 \\
\hline June ............... & 45 & 0 & 9 & 536 & 0.01 & 0.01 \\
\hline July .............. & 490 & 0 & 182 & 11,192 & 0.33 & 0.29 \\
\hline August. ............. & 160 & 60 & 96 & 5,902 & 0.17 & 0.15 \\
\hline September . . . . . . & 215 & 80 & 122 & 7,259 & 0.21 & 0.19 \\
\hline October................ & 450 & 245 & 342 & 21,028 & 0.62 & 0.54 \\
\hline November, 1-26..... & 325 & 215 & 266 & 15,828 & 0.47 & 0.42 \\
\hline December, $4-31 \ldots$. & 1,000 & 415 & 857 & 52,694 & 1.57 & 1.36 \\
\hline The year...... & 9,650 & 0 & 630 & 443,613 & 13.18 & 1. 00 \\
\hline 1888. & & & & & & \\
\hline January ............ & 850 & 600 & 748 & 45,993 & 1.37 & 1.19 \\
\hline February ......... & 4,110 & 600 & 1,507 & 83,694 & 2.58 & 2.39 \\
\hline March $\ldots \ldots \ldots$ & $' 4,035$ & $\cdot 1,280$ & 4,003 & 246,134 & 7.30 & 6.35 \\
\hline September ......... & 110 & 0 & 19 & 1,131 & 0.03 & 0.03 \\
\hline October ..... & 0 & 0 & 0 & 0 & 0.00 & 0.00 \\
\hline November .......... & 0 & 0 & 0 & 0 & 0.00 & 0.00 \\
\hline December . . . . . . . . & 0 & 0 & 0 & 0 & 0.00 & 0.00 \\
\hline 1889. & & & & & & \\
\hline January . . . . . . . . & 470 & 0 & 156 & 9,592 & 0.29 & 0.25 \\
\hline February ......... & 90 & 0 & 8 & 444 & 0.01 & 0.01 \\
\hline March ............ & 625 & 0 & 233 & 14,326 & 0.43 & 0.37 \\
\hline April.............. & 1,350 & 5 & 635 & 37,785 & 1.13 & 1.01 \\
\hline May ............ & 470 & 0 & 214 & 13,158 & 0.39 & 0.34 \\
\hline
\end{tabular}


Estimated monthly discharge of Desplaines River at Riverside, Illinois-Cont'd.

[Drainage area, 630 square miles.]

\begin{tabular}{|c|c|c|c|c|c|c|}
\hline \multirow[b]{2}{*}{ Month. } & \multicolumn{3}{|c|}{ Discharge in second-feet. } & \multirow[b]{2}{*}{$\begin{array}{l}\text { Total in acre. } \\
\text { foet. }\end{array}$} & \multicolumn{2}{|c|}{ Run•off. } \\
\hline & $\begin{array}{l}\text { Maxi. } \\
\text { mum. }\end{array}$ & $\begin{array}{l}\text { Mini. } \\
\text { muw. }\end{array}$ & Mean. & & $\begin{array}{l}\text { Depth in } \\
\text { inches. }\end{array}$ & $\begin{array}{c}\text { Second. } \\
\text { feet per } \\
\text { square } \\
\text { mile. }\end{array}$ \\
\hline 1889. & & & & & & \\
\hline June ........... & 2,235 & 10 & 1,112 & 66,168 & 1.97 & 1. 77 \\
\hline July ............. & 3,620 & 0 & 597 & 36,707 & 1.09 & 0.95 \\
\hline August............. & 1,120 & 0 & 245 & 15,064 & 0.45 & 0.39 \\
\hline September ..... & 0 & 0 & 0 & 0 & 0.00 & 0.00 \\
\hline October ........ & 0 & 0 & 0 & 0 & 0.00 & 0.00 \\
\hline November . . . . . . & 0 & 0 & 0 & 0 & 0.00 & 0.00 \\
\hline December 1-29. . & 470 & 0 & 204 & 12,543 & 0.37 & 0.32 \\
\hline The year.... & 3,620 & 0 & 284 & 205,787 & 6.13 & 0.45 \\
\hline 1890. & & & & & & \\
\hline July .............. & 80 & 5 & 54 & 3,320 & 0.10 & 0.09 \\
\hline August............ & 45 & 0 & 10 & 615 & 0.02 & 0.02 \\
\hline September ........ & 45 & 0 & 7 & 417 & 0.01 & 0.01 \\
\hline October........ & 36 & 0 & 11 & 676 & 0.02 & 0.02 \\
\hline November...... & 90 & 0 & 20 & 1,190 & 0.03 & 0.03 \\
\hline December 1-27... & 54 & 0 & 20 & 1,229 & 0.03 & 0.03 \\
\hline 1892. $a$ & & & & & & \\
\hline May ......... & 10,120 & 550 & 2,481 & 152,550 & 4.58 & 3.94 \\
\hline June.......... & 12,000 & 1,420 & 3,409 & 202,849 & 6.06 & 5.41 \\
\hline July .......... & 2,190 & 45 & 433 & 26,624 & 0.79 & 0.69 \\
\hline August........ & 60 & 0 & 14 & 861 & 0.02 & 0.02 \\
\hline September ..... & 60 & 0 & 9 & 535 & 0.01 & 0.01 \\
\hline October......... & 10 & 0 & 2 & 123 & 0.00 & 0.00 \\
\hline November.......... & 30 & 0 & 12 & 714 & 0.02 & 0.02 \\
\hline December ........ & 70 & 0 & 22 & 1,353 & 0.03 & 0.03 \\
\hline 1893. & & & & & & \\
\hline Tanuary .... & 10 & 0 & 5 & 307 & 0.00 & 0.00 \\
\hline February .... & 1,000 & 7 & 187 & 10,386 & 0.31 & 0.30 \\
\hline March .......... & 7,100 & 610 & 2,818 & 173,272 & 5.14 & 4.47 \\
\hline April ...... & 3,550 & 160 & 1,012 & 60,242 & 1.79 & 1.60 \\
\hline 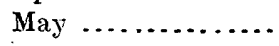 & 2,645 & 120 & 716 & 44,025 & 1. 31 & 1.14 \\
\hline 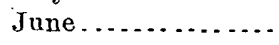 & 2,700 & 120 & 771 & 45,878 & 1.36 & 1.22 \\
\hline July ........ & 180 & 14 & 77 & 4,734 & 0.15 & 0.12 \\
\hline August..... & 10 & 0 & 1 & 61 & 0.00 . & 0.00 \\
\hline September ..... & 0 & 0 & 0 & 0 & 0.00 & 0.00 \\
\hline October.... & 110 & 0 & 10 & 615 & 0.02 & 0.02 \\
\hline November.......... & 10 & 0 & 1 & 60 & 0.00 & 0.00 \\
\hline December ........... & 550 & 0 & 145 & 8,916 & 0.30 & 0.26 \\
\hline The year....... & 7,100 & 0 & 479 & 348,496 & 10.38 & 0.76 \\
\hline
\end{tabular}

$a$ No figures for 1891 . 
Estimated monthly discharge of Desplaines River at Riverside, Illinois-Cont'd.'

[Drainage area, 630 square miles.]

\begin{tabular}{|c|c|c|c|c|c|c|}
\hline \multirow[b]{2}{*}{ Month. } & \multicolumn{3}{|c|}{ Discharge in second.feet. } & \multirow{2}{*}{$\begin{array}{l}\text { Total in acre } \\
\text { feet. }\end{array}$} & \multicolumn{2}{|c|}{ Run-off. } \\
\hline & $\begin{array}{l}\text { Maxi- } \\
\text { mum. }\end{array}$ & $\begin{array}{l}\text { Mini. } \\
\text { mum. }\end{array}$ & Mean. & & $\begin{array}{l}\text { Depth in } \\
\text { inches. }\end{array}$ & $\begin{array}{c}\text { Second- } \\
\text { feet per } \\
\text { square } \\
\text { mile. }\end{array}$ \\
\hline 1894. & & & & & & \\
\hline January .......... & 1,385 & 35 & 274 & 16,848 & 0.51 & 0.44 \\
\hline February ......... & 2,370 & 120 & 642 & 35,654 & 1.06 & 1.02 \\
\hline March ................ & 6,960 & 80 & 1,668 & 102,561 & 3.05 & 2.65 \\
\hline April $\ldots \ldots \ldots$ & 1,460 & 110 & 430 & 25,586 & 0.75 & 0.68 \\
\hline 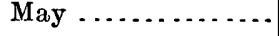 & 3,160 & 160 & 1,040 & 63,947 & 1.90 & 1.65 \\
\hline June.............. & 160 & 9 & 42 & 2,499 & 0.08 & 0.07 \\
\hline July ............. & 22 & 0 & 0 & 0 & 0.00 & 0.00 \\
\hline August............ & 0 & 0 & 0 & 0 & 0.00 & 0.00 \\
\hline September ......... & 203 & 0 & 35 & 2,083 & 0.07 & 0.06 \\
\hline October............. & 0 & 0 & 0 & 0 & 0.00 & 0.00 \\
\hline November . . . . . . . . & 12 & 0 & $\overline{5}$ & 298 & 0.00 & 0.00 \\
\hline December ...... & 44 & 0 & 10 & 615 & 0.02 & 0.02 \\
\hline The year ....... & 6,960 & .0 & 346 & 250,091 & 7.44 & 0.55 \\
\hline 1895. & & & & & & \\
\hline January ........... & 0 & 0 & 0 & 0 & 0.00 & 0.00 \\
\hline February .......... & 2,109 & 0 & 116 & 6,442 & 0.19 & 0.18 \\
\hline 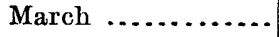 & 1,919 & 77 & 386 & 23,734 & 0.70 & 0.61 \\
\hline April ............ & 706 & 8 & 166 & 9,878 & 0.29 & 0.26 \\
\hline May................ & 233 & 6 & 61. & 3,751 & 0.10 & 0.09 \\
\hline June . .......... & 4 & 0 & 0 & 0 & 0.00 & 0.00 \\
\hline July ............. & 0 & 0 & 0 & 0 & 0.00 & 0.00 \\
\hline August $\ldots . . .$. & 71 & 0 & 4 & 246 & 0.00 & 0.00 \\
\hline September ......... & 184 & 0 & 32 & 1,904 & 0.00 & 0.05 \\
\hline October ......... & 0 & 0 & 0 & 0 & 0.00 & 0.00 \\
\hline November ........... & 6 . & 0 & 1 & 60 & 0.00 & 0.00 \\
\hline December . ......... & 6,268 & 0 & 984 & 60,504 & 1.80 & 1.56 \\
\hline The year ..... & 6,268 & 0 & 146 & 106,519 & 3.08 & 0.23 \\
\hline 1896. & & & & & & \\
\hline January $\ldots \ldots \ldots \ldots$ & 412 & 6 & 140 & 8,608 & 0.25 & 0.22 \\
\hline February .......... & 4,194 & 73 & 619 & 35,604 & 1.06 & 0.98 \\
\hline 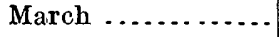 & 1,749 & 233 & 604 & 37,139 & 1. 10 & 0.96 \\
\hline April.................... & 1,006 & 184 & 433 & 25,766 & 0.75 & 0.68 \\
\hline May ...... & 1,392 & 1 & 212 & 13,035 & 0.39 & 0.34 \\
\hline 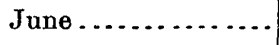 & 418 & 0 & 53 & 3,154 & 0.10 & 0.09 \\
\hline JuJy $\ldots \ldots \ldots \ldots$ & 124 & 0 & 11 & 676 & 0.02 & 0.02 \\
\hline
\end{tabular}


Estimated monthly discharge of Desplaines River at Riverside, Illinois-Cont'd.

1

\begin{tabular}{|c|c|c|c|c|c|c|}
\hline \multirow[b]{2}{*}{ Month. } & \multicolumn{3}{|c|}{ Discharge in second-feet. } & \multirow[b]{2}{*}{$\begin{array}{l}\text { Total in acre. } \\
\text { feet. }\end{array}$} & \multicolumn{2}{|c|}{ Run-off. } \\
\hline & $\begin{array}{l}\text { Maxi. } \\
\text { mum. }\end{array}$ & $\begin{array}{l}\text { Mini- } \\
\text { mum. }\end{array}$ & Mean. & & $\begin{array}{c}\text { Depth in } \\
\text { inches. }\end{array}$ & $\begin{array}{l}\text { Second- } \\
\text { feet per } \\
\text { square } \\
\text { mile. }\end{array}$ \\
\hline 1896. & & & & & & \\
\hline August.... & 176 & 0 & 33 & 2,029 & 0.06 & 0.05 \\
\hline September ..... & 412 & 0 & 182 & 10,830 & 0.32 & 0.29 \\
\hline October.... & 494 & 1 & 180 & 11,070 & 0.33 & 0.29 \\
\hline November ..... & 630 & 1 & 271 & 16,125 & 0.48 & 0.43 \\
\hline December ... & 305 & 6 & 103 & 6,332 & 0.18 & 0.16 \\
\hline The year.. & 4,194 & 0 & 237 & 170,368 & 5.04 & 0.38 \\
\hline 1897. & & & & & & \\
\hline January .... & 8,660 & 100 & 2,882 & 177,044 & 5.26 & 4.57 \\
\hline February..... & 2,136 & 418 & 841 & 46,650 & 1.38 & 1.33 \\
\hline March ....... & 7,382 & 164 & 2,520 & 154,949 & 4.60 & 4.00 \\
\hline April ..... & 3,406 & 284 & 1,061 & 63,134 & 1.87 & 1.68 \\
\hline May & 1,838 & 44 & - 328 & 20,167 & 0.60 & 0.52 \\
\hline June...... & 630 & 6 & 149 & 8,866 & 0.26 & 0.23 \\
\hline July ..... & 89 & 1 & 34 & 2,091 & 0.06 & 0.05 \\
\hline August..... & 6 & 0 & 0 & 0 & 0.00 & 0.00 \\
\hline September .. & 0 & 0 & 0 & 0 & $\cdot 0.00$ & 0.00 \\
\hline October ..... & 0 & 0 & 0 & 0 & 0.00 & .0 .00 \\
\hline November..... & 39 & 0 & 6 & 357 & 0.01 & 0.01 \\
\hline December... & 6 & 0 & 4 & 238 & 0.01 & 0.01 \\
\hline The year.. & 8,660 & 0 & 652 & 473,496 & 14.05 & 1.03 \\
\hline 1898. & & & & & & \\
\hline January .... & 510 & 0 & 102 & 6,271 & 0.18 & 0.16 \\
\hline February & 4,110 & 64 & $1 ; 134$ & 62,757 & 1.87 & 1.80 \\
\hline March ..... & 8,960 & 260 & 3,172 & 195,038 & 5.83 & 5.03 \\
\hline April ..... & 880 & 98 & 276 & 16,423 & 0.49 & 0.44 \\
\hline May ......... & 260 & 69 & 122 & 7,501 & 0.22 & 0.19 \\
\hline June....... & 5,000 & 75 & 747 & 44,449 & 1.33 & 1.19 \\
\hline July ...... & 1,060 & 10 & 161 & $.9,900$ & 0.30 & 0.26 \\
\hline August..... & 75 & 0 & 24 & 1,476 & 0.04 & 0.04 \\
\hline September . & 30 & 0 & 8 & 476 & 0.01 & 0.01 \\
\hline October.......... & 109 & 10 & 26 & 1,599 & 0.04 & 0.04 \\
\hline November...... & 850 & 53 & 238 & 14,162 & 0.43 & 0.38 \\
\hline Decomber ... & 450 & 0 & 99 & 6,087 & 0.18 & 0.16 \\
\hline 'The year..... & 8,960 & 0 & 509 & 366,139 & 10.92 & 0.81 \\
\hline
\end{tabular}


A comparison of the rainfall and run-off of Desplaines River above Riverside has been prepared by Mr. Johnston, ' the recorded rainfall at Chicago being taken to reprepresent that of the whole basin. There are a considerable number of points at which rainfall has been measured within or near the area drained, but the figures obtained for the points mentioned are considered as being fairly representative. The records for Chicago begin in 1871. It is stated that the maximum rainfall in twelve consecutive months since that year occurred between September, 1881, and September, 1882, being 53.43 inches. The minimum rainfall for a similar period occurred between November, 1894, and November, 1895, and was 22.86 inches. The total run-off during this latter period was equivalent to 1.39 inches, or a trifle over 6 per cent of the total rainfall.

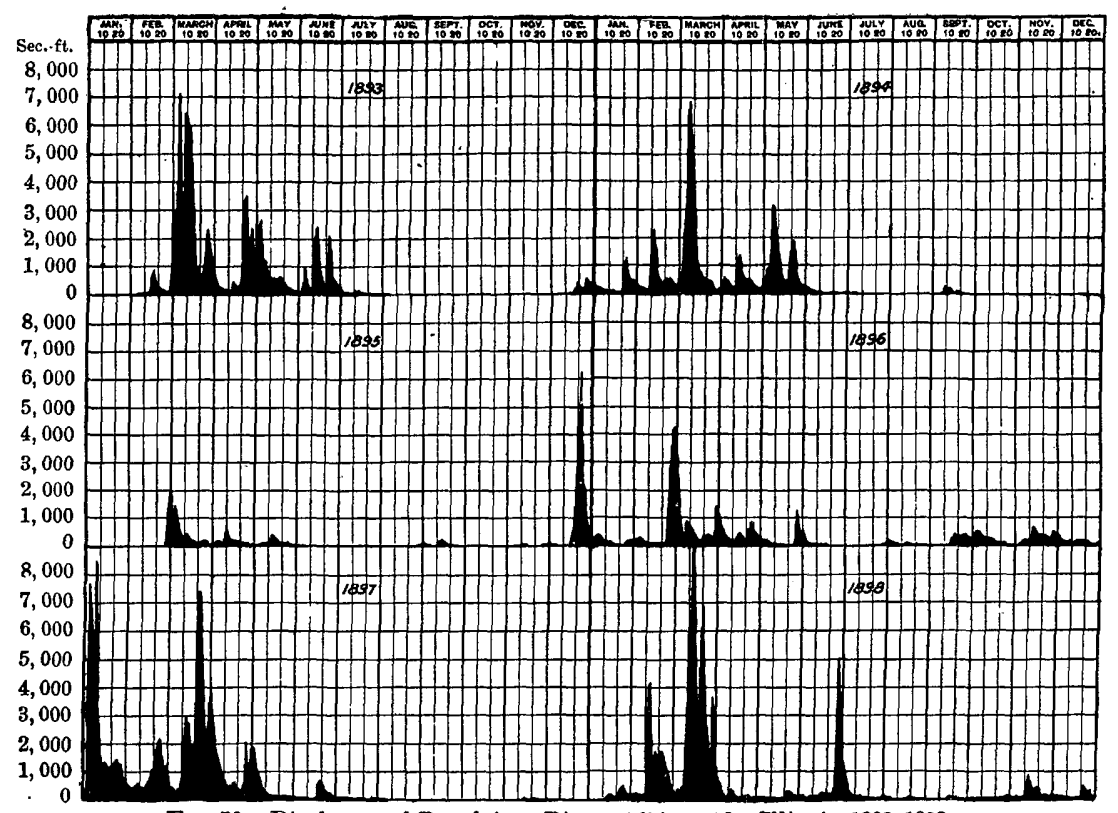

Fig. 76.-Discharge of Desplaines River at Riverside, Illinois, 1893-1898.

MAUMEE RIVER.

Waterville station, on Maumee River, was established November 19, 1898. No rating table has been constructed. It is described in WaterSupply and Irrigation Paper No. 27, page 66. Gage heights are given on page 67 and measurements on page 68 .

\section{SANDUSKY RIVER.}

Mexico and Fremont stations, on Sandusky River, were established in November, 1898. No rating tables have been constructed. These stations are described in Water-Supply and Irrigation Paper No. 27, on pages 66 and 67. Gage heights are given on page 67 and measurements on page 68 . 


\section{NIAGARA RIVER.}

In the summer of 1841 measurements were made of the discharge of Niagara River at Blackrock harbor, this being above the falls. The computed discharge was 374,000 second-feet.' Corrections and recomputations of this data were made by Mr. D. Farrand Henry, reducing the discharge to 269,277 second-feet. This corrected for difference in gage height gave 245,797 second-feet, or about 2,000 second-feet more than the measurements made in $186 \pi .1$

Mr. Henry's computations, based on data then available, made the discharge about one-half of the probable rainfall, allowance being made by him for the probable evaporation.

Gagings of St. Clair and Niagara rivers were continued in 1869, observations being made throughout the season. The results are shown in the Annual Report of the Chief of Engineers for 1870, pages 567 and 568 .

The discharges of St. Clair River were computed for days at intervals from July 16 to September 3, 1869, and those for Niagara River from June 12 to September 25, 1869. The mean discharge of St. Clair River during the time given was ascertainer to be 217,653 second-feet, varying from a minimum of 178,681 second-feet on July 21 to a maximum of 258,085 second-feet on August 23.

The discharges of Niagara River varied from a minimum of 172,669 second-feet on August 26,1869, to a maximum of 257,445 second-feet on June 18, 1869, the average being 212,860 second-feet. By months the average discharge was as follows:

Second.feet.

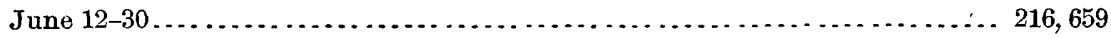

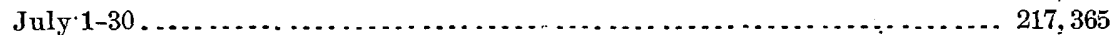

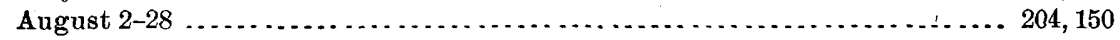

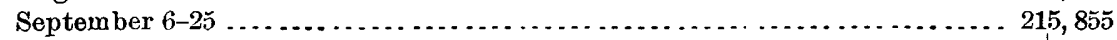

A description of the methods and results of measurements of the discharge of Niagara River, made by Mr. J. C. Quintus in 1891-92, is contained in Engineering News, March 2, 1893, vol. 29, pages 194-196. The measurements were made at a point about 1,000 feet below the international bridge, in front of Blackrock and near the foot of Squaw Island. The discharge measurements were made at intervals from December 11, 1891, to May 28, 1892, the reading on the Buffalo gage ranging from -2.95 to +0.15 . The zero of this gage is at mean level of Lake Erie, or 572.96 feet above mean tide at New York. The discharges ranged from 164,648 second-feet np to 236,762 second-feet.

It has been demonstrated that discharge measurements made when the level of Lake Erie is materially affected by wind are worthless. The work done ${ }^{2}$ in 1891-92 by Mr. J. C. Quintus was carried on for the greater part under unfavorable conditions, and it is probable that the reverse discharge curve platted by him was due to those conditions.

\footnotetext{
1 Report of Chief of Engineers, U. S. Army, 1868, pages 965-966.

2 Measurement of discharge of Niagara River: Report of J. C. Quintus, inspector, in Annual Report of Chief of Engineers, United States Army, 1893, pp. 1364-4371.
} 


\section{GENESEE RIVER.}

Genesee River has been described by Mr. George W. Rafter in his report on the Water Resources of the State of New York. ${ }^{1}$ This river rises in the northern part of Pennsylvania and continues north across the State of New York into Lake Ontario. In the upper or southern part of its course it flows through comparatively broad allavial valleys, but near Portage it enters a deep, narrow canyon, having a fall of 330 feet, the greater part of this being at the Portage Falls. Below this canyon the river again enters a broad valley, from 1 to 2 miles in width, in which it continues to near Rochester, where there is a descent of 263 feet in about 3 miles. Measurements of the flow of the river have been made as described in the Nineteenth Annual Report, Part IV, pages 262-264. The results of the computations of monthly discharge are given in the following table, and the daily fluctuations are shown graphically in fig. 77 .

Estimated monthly discharge of Genesee River at Mount Morris, New York.

[Drainage area, 1,070 square miles.]

\begin{tabular}{|c|c|c|c|c|c|c|}
\hline \multirow[b]{2}{*}{ Month. } & \multicolumn{3}{|c|}{ Discharge in second-feet. } & \multirow[b]{2}{*}{$\begin{array}{c}\text { Total in acre } \\
\text { feet. }\end{array}$} & \multicolumn{2}{|c|}{ Run-off. } \\
\hline & $\begin{array}{l}\text { Maxi- } \\
\text { mum. }\end{array}$ & $\begin{array}{l}\text { Mini- } \\
\text { mum. }\end{array}$ & Mean. & & $\begin{array}{l}\text { Depth in } \\
\text { inches. }\end{array}$ & $\begin{array}{l}\text { Second. } \\
\text { feet per } \\
\text { square } \\
\text { mile. }\end{array}$ \\
\hline 1893. & & & & & & \\
\hline September ......... & 1,316 & 122 & 314 & 18,684 & 0.37 & 0.33 \\
\hline October........ & 2,158 & . 123 & 356 & 21,890 & 0.44 & 0.38 \\
\hline November......... & 2,891 & 186 & 516 & 30,704 & 0.60 & 0.54 \\
\hline December . . . . . . . & 15,380 & 354 & 2,170 & 133,429 & 2.70 & 2.34 \\
\hline 10 & & & & & & \\
\hline January ... & 6,162 & 439 & 1,297 & 79,749 & 1.61 & 1.40 \\
\hline February .......... & 2,615 & 379 & 884 & 49,095 & 0.90 & 0.86 \\
\hline March ....... & 16,142 & 791 & 3,074 & 189,014 & 3.82 & 3.31 \\
\hline April .......... & 15,179 & 482 & 3,245 & 193,090 & 3.78 & 3.39 \\
\hline May ....... & 11,108 & 390 & 4,108 & 252,592 & 5.11 & 4.43 \\
\hline June ............... & 5,214 & 186 & 1,050 & 62,479 & 1.23 & 1. 10 \\
\hline July $\ldots \ldots \ldots \ldots$ & 265 & 100 & 132 & 8,116 & 0.16 & 0.14 \\
\hline August......... & 648 & 100 & 200 & 12,298 & 0.25 & 0.22 \\
\hline September...... & 8,564 & 100 & 888 & 52,840 & 1.03 & 0.93 \\
\hline October $6-31 \ldots$ & 2,485 & 148 & 407 & 25,026 & 0.51 & 0.44 \\
\hline November...... & 1,579 & 461 & 782 & 46,532 & 0.91 & 0.82 \\
\hline December .......... & 1,161 & 156 & 568 & 34,925 & 0.70 & 0.61 \\
\hline The year. & 16,142 & 100 & 1,386 & $1,005,756$ & 20.01 & 1.47 \\
\hline
\end{tabular}

1 Water-Supply and Irrigation Papers of the U. S. Geological Surrey Nos. 24 and 25 . 20 GEOL, PT $4-15$ 
Estimated monthly discharge of Genesee River at Mount Morris, New York-Continued.

[Drainage area, 1,070 square miles.] .

\begin{tabular}{|c|c|c|c|c|c|c|}
\hline \multirow[b]{2}{*}{ Month. } & \multicolumn{3}{|c|}{ Discharge in second-feet. } & \multirow[b]{2}{*}{$\begin{array}{c}\text { Total in acre- } \\
\text { feet. }\end{array}$} & \multicolumn{2}{|c|}{ Run-off. } \\
\hline & $\begin{array}{l}\text { Maxi- } \\
\text { mum. }\end{array}$ & $\begin{array}{l}\text { Mini- } \\
\text { mum. }\end{array}$ & Mean. & & $\begin{array}{c}\text { Depth in } \\
\text { inches. }\end{array}$ & $\begin{array}{c}\text { Second- } \\
\text { feet per } \\
\text { square } \\
\text { mile. }\end{array}$ \\
\hline 1895. & & & & & & \\
\hline January . . . . . . . . . & 1,657 & 218 & 604 & 37,139 & 0.76 & 0.66 \\
\hline February .......... & 440 & 180 & 224 & 12,440 & 0.23 & 0.22 \\
\hline March . . . . . . . . & 8,850 & 600 & 1,803 & 110,863 & 2.24 & 1.94 \\
\hline April................ & 10,230 & 220 & 1,927 & 114,664 & 2.24 & 2.01 \\
\hline May ..... & 390 & 150 & 174 & 10,699 & 0.22 & 0.19 \\
\hline June ................. & 370 & 100 & 128 & 7,617 & 0.14 & 0.13 \\
\hline July .............. & 190 & 100 & 105 & 6,456 & 0.13 & 0.11 \\
\hline August. . . . . . . . . . & 170 & 100 & 115 & 7,071 & 0.14 & 0.12 \\
\hline September ....... & 100 & 100 & 100 & 5,950 & 0.11 & 0.10 \\
\hline October ............ & 170 & 120 & 104 & 6,395 & 0.12 & 0.11 \\
\hline November .......... & 1,860 & 110 & 449 & 26,717 & 0.53 & 0.47 \\
\hline December . . . . . . . & 11,220 & 130 & 1,226 & 75,384 & 1.52 & 1. 32 \\
\hline The year.... & 11,220 & 100 & 580 & 421,395 & 8. 38 & 0.62 \\
\hline 1896. & & & & . & & \\
\hline January ....... & 1,630 & 180 & 436 & 26,809 & 0.54 & 0.47 \\
\hline February ...... & 3,840 & 350 & 907 & 52,171 & 0.98 & 0.91 \\
\hline March ........ & 15,220 & 540 & 2,786 & 171,305 & 3.46 & 3.00 \\
\hline 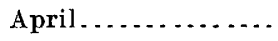 & 14,210 & 270 & 3,245 & 193,090 & 3.77 & 3.38 \\
\hline 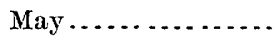 & 360 & 100 & 157 & 9,654 & 0.20 & 0.17 \\
\hline June.... & 1,700 & 180 & 296 & 17,613 & 0.44 & 0.39 \\
\hline July .................. & 600 & 100 & 226 & 13,896 & 0.28 & 0.24 \\
\hline August......... & 580 & 120 & 188 & 11,560 & 0.23 & 0.20 \\
\hline September ..... & 380 & 110 & 148 & 8,807 & 0.18 & 0.16 \\
\hline October ......... & 13,350 & 330 & 1,664 & 102,316 & 2.01 & 1. 74 \\
\hline November ........... & 1,160 & 230 & 782 & 46,532 & 0.91 & 0.82 \\
\hline
\end{tabular}

In the above table the maximum and minimum discharges have been taken from the diagrams showing daily flow of the stream. The mean discharges have been obtained from table No. 1, on page 629, of the report of the State engineer of New York for 1896. These averages, as stated by Mr. Rafter, have been corrected from the values given on the diagrams, as follows: For mean monthly flows of less than 1,000 second-feet, 5 per cent has been deducted; over 1,000 second-feet and less than 3,000 second-feet, 10 per cent has been deducted; over 3,000 second-feet, 5 per cent has been deducted. These corrections have been made in accordance with the results of weir measurements made in the summer and fall of 1896 . The depth in inches on the watershed has been taken from table No. 2, on page 631, of the same report. Measurements have also been made from June 17 to December 2, 1890, the results being given on Plate II, Appendix F, of the annual report of the State engineer of New York for 1890 . 


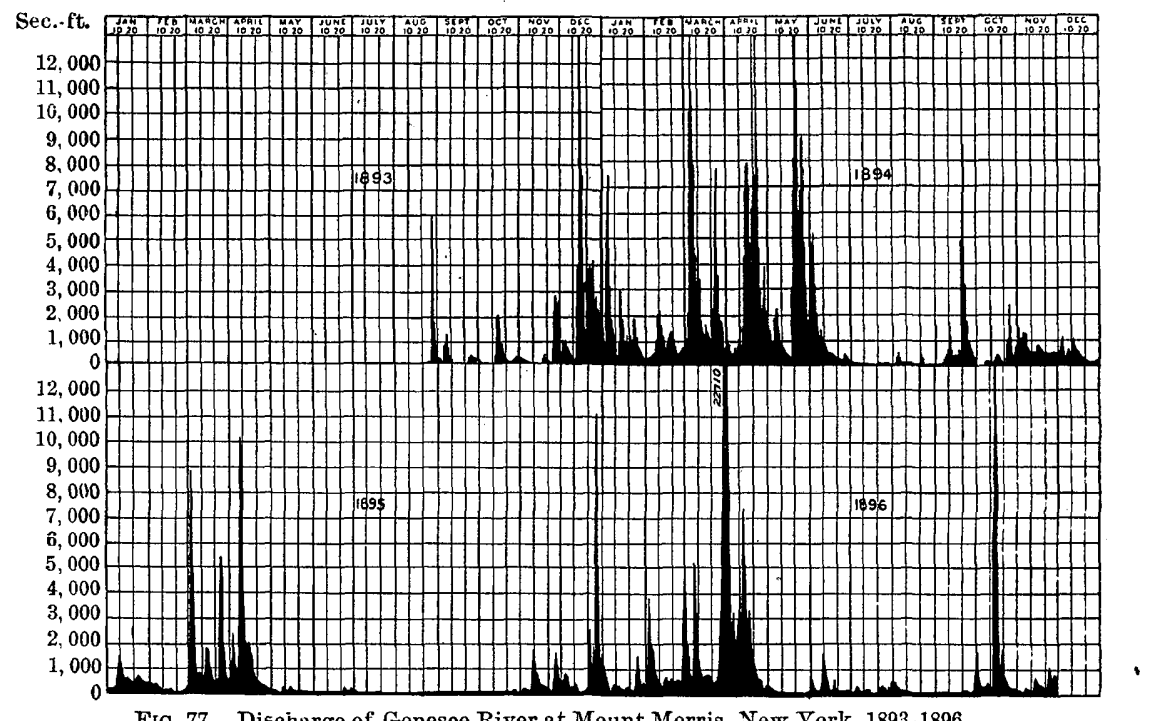

Fra. 77._Discharge of Genesee River at Mount Morris, New Tork, 1893-1896.

OTTAWA RIVER.

One of the principal tributaries of the St. Lawrence from the northern or Canadian side is Ottawa River, on an island at the mouth of which the city of Montreal has been placed. Mr. T. C. Clarke, engineer, from 1858 to 1860 in eharge of the survey for the Ottawa River Canal, measured the discharge of the river at Carillon, just above its entrance into the lake of Two Mountains, from which lake it divides and enters the St. Lawrence on both sides of the Island of Montreal. He gives the discharge as $5,000,000$ cubic feet per minute, or 83,333 second-feet.

\section{UPPER MISSISSIPPI RIVER DRAINAGE.}

The Upper Mississippi River, or that portion of the Mississippi above the mouth of the Missouri, has been surveyed and studied by the officers of the Engineer Corps, United States Army. The principal figures of discharge are printed in the reports of the Chief of Engineers, United States Army, and have been compiled in a pamphlet issued by the Mississippi River Commission entitled "Tabulated Results of Discharge Observations, Mississippi River and its Tributaries and Outlets, 1838-1894."

\section{MISSISSIPPI RIVER IN MINNESOTA.}

The headwaters of the Mississippi River have particular interest to students of water conservation because of the fact that the Government has planned and constructed a number of large reservoirs. The relative location of these is shown by the accompanying illustration, fig. 78. This is taken from the Annual Report of the Chief of Engineers, United States Army, for 1896, page 1844. 


\section{RESERVOIRS.}

The reservoirs at the head of the Mississippi River have been formed by closing the outlets of natural lakes by means of log and stone lams similar to those construeted by lumbermen. The cost of such work in proportion to the amount of water held is extremely small, as the basins

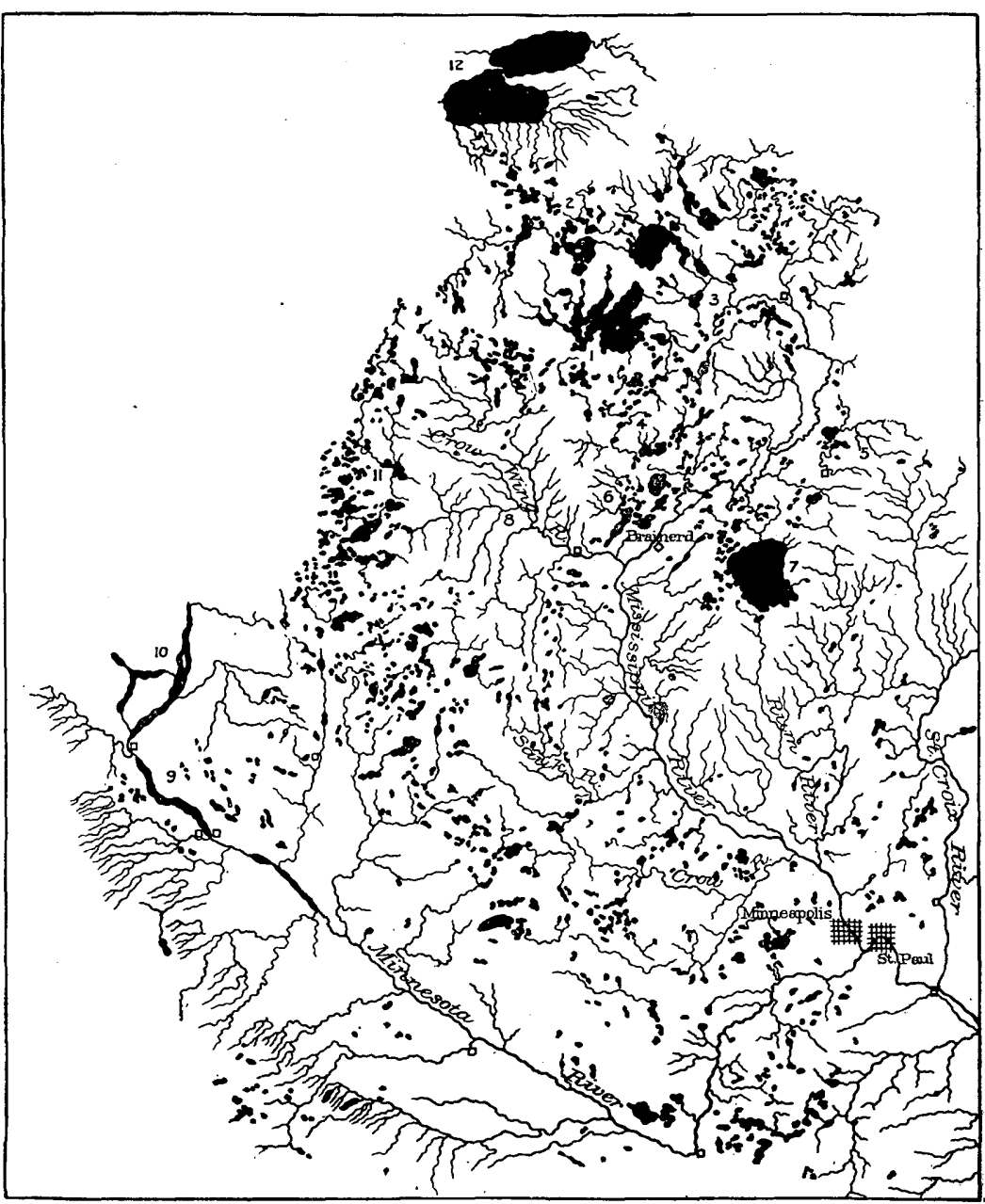

FIG. 78.-Lakes and reservoirs at sourees of the Mississippi River: 1, Leech Lake; 2, Lake Winnibigoshish; 3, Pokegama Falls; 4, Pine River; 5, Sandy Lake; 6. Gull Lake; 7, Millo Lacs; 8, Crow Wing River; 9, Big Stone Lake; 10, Lake Traverse; 11, Otter Tail Lake; 12, Red Lake.

of the lakes are very broad. Estimates of this cost per acre-foot stored have been made by the engineers in charge and are quoted on page 42 of this volume in comparison with cost of other reservoirs.

The purpose of these reservoirs is to collect the surplus water, prin. cipally from the precipitation of winter, spring, and early summer, to 
be systematically released so as to benefit navigation upon the Mississippi River below the dams and as far down as Lake Pepin. A reduction of the height of floods in localities immediately below the dam is expected to be gained to some extent, but control of extended flood's or freshets is not expected. The records indicate that a rise in the river at St. Paul commences in from seven to eight days following the release of water from the distributing reservoir at Pokegama Falls, and in about five days thereafter the full effect is felt. The rise on the signalservice gage at St. Paul, due to the rise of water, in 1893 was 1 foot; in 1894 it was 1.3 feet, and in 1895, 1.2 feet. $^{1}$

There are five completed reservoirs, the principal details for which are given in the following table. The capacity given is that above the original contents before the dams were constructed. In the case of two of the reservoirs-Pokegama Falls and Sandy Lake-the full capacity can be utilized each year, but the three remaining reservoirs have never been filled. Lake Winnibigoshish has been a little more than half filled, and Leech Lake and Pine River reservoirs have been about two-thirds filled. The two upper reservoirs-Winnibigoshish and Leech lakeshave capacities such that the average annual rainfall has not been sufficient to furnish a full supply. It is possible that in 1897 they might have been filled it the dams had been in condition to safely hold all of the water. The timber, sluiceways, however, were in such need of repairs that it would have been unsafe to have retained the full quantity of water. The cost given in round numbers includes extraordinary repairs to Pine River reservoir, $\$ 13,000$, to close a crevasse formed June 17 , 1896. The expenditures for maintenance and repairs have been; in round numbers, from $\$ 20,000$ to $\$ 30,000$ a year:

\begin{tabular}{|c|c|c|c|c|c|c|c|}
\hline Name. & $\begin{array}{l}\text { Year com. } \\
\text { pleted. }\end{array}$ & $\begin{array}{c}\text { Distance } \\
\text { above } \\
\text { St. Paul. }\end{array}$ & $\begin{array}{c}\text { Drainage } \\
\text { area. }\end{array}$ & $\begin{array}{l}\text { Height } \\
\text { of dam. }\end{array}$ & $\begin{array}{c}\text { Maximum } \\
\text { capacity. }\end{array}$ & Cost. & $\begin{array}{l}\text { Cost } \\
\text { per acre- } \\
\text { foot. }\end{array}$ \\
\hline & $=$ & Miles. & Sq. miles. & Feet. & Acre-feet. & & \\
\hline Winvibigoshish .. & 1884 & 411 & 1,442 & 14 & $1,033,600$ & $\$ 216,000$ & $\$ 0.21$ \\
\hline Leech,$\ldots . . . . .$. & 1884 & 411 & 1,163 & 6 & 759,700 & 173,000 & .23 \\
\hline Pokegama... & 1884 & 341 & 660 & 9 & 107,900 & 85,000 & .79 \\
\hline Pine River ....... & 1886 & 194 & 562 & 17 & 172,200 & 103,000 & .60 \\
\hline Sandy Lake...... & 1895 & 261 & 422 & 9 & 72,500 & 114,000 & .16 \\
\hline Total & & & 4,249 & & $2,145,900$ & 691,000 & .32 \\
\hline
\end{tabular}

1 Rept. Chief Engineers U.S. A., 1896, p. 1841.

${ }^{2}$ Report on the Mississippi River Floods by the Committee on Commerce, United States Senate, pursuant to Senate Resolution No.75, Fifty-fifth Congress, first session, printed as Fifty-fifth Congress, third session, Senate Report No. 1433, pp. 16-18. 
At the time the reservoirs were inaugurated they were situated in the wilderness and no method of transporting cement or other building material was available for the construction of the dams. These were built of timber, and at the present time are much decayed, necessitating extensive repairs to the dams at Winnibigoshish and Leech lakes before these reservoirs can be filled. It is urged that the timber por. tions should be replaced with permanent masonry, preferably concrete. ${ }^{1}$ Land values have also greatly increased, and as a general conclusion it is stated that there is no longer a question of building new reservoirs, but of completing and making permanent those already built.

\section{MISSISSIPPI RIVER AT ST. PAUL.}

Measurements of the Mississippi River at St. Paul below the mouth of Minnesota River have been made by the Corps of Engineers, largely for the purpose of determining the results of water storage on the headwaters. In the Nineteenth Annual Report, Part IV, on pages 264-270, is given a description of the methods employed and computations of the monthly flow. The accompanying table gives similar computations for 1898, these being based upon the observations of height made by the Weather Bureau and a rating table obtained as described in the Nineteenth Annual Report.

Estimated monthly discharge of Mississippi River at St. Paul, Minnesota

[Drainage area, 36,085 square miles.]

\begin{tabular}{|c|c|c|c|c|c|}
\hline \multirow{2}{*}{ Month. } & \multicolumn{3}{|c|}{ Discharge in second feet. } & \multicolumn{2}{|c|}{ Run-off. } \\
\hline & Maximum. & Minimum. & Mean. & $\begin{array}{l}\text { Depth in } \\
\text { inches. }\end{array}$ & $\begin{array}{c}\text { Second-feet } \\
\text { per square } \\
\text { mile. }\end{array}$ \\
\hline 1898. & & & & & \\
\hline March 20-31..... & 48,550 & 7,876 & 23,135 & 0.74 & 0.64 \\
\hline April....... & 71,275 & 32,390 & 55,654 & 1. 72 & 1.54 \\
\hline May ............ & 30,875 & 11,652 & 18,010 & 0.58 & 0.50 \\
\hline June ........... & 17,152 & 11,318 & 14,296 & 0.45 & 0.40 \\
\hline July ............ & 49,055 & 16,030 & 32,883 & 1.05 & 0.91 \\
\hline August.......... & 25,574 & 9,150 & 15,306 & 0.48 & 0.42 \\
\hline September ... & 12,320 & 9,150 & 10,503 & 0.32 & 0.29 \\
\hline October...... & 10,350 & 7,682 & 8,573 & 0.28 & 0.24 \\
\hline November 1-27 ... & 7,876 & 5,060 & 7,008 & 0.21 & 0.19 \\
\hline
\end{tabular}

In order to supplement the records at St. Paul, two parties for measuring river flow were placed in the field in September, 1896, for a period of one year, the object being to obtain more precise information as to the effect of the reservoir water upon the river at St. Paul. The

I Rept. Chief Engineers, U.S. A., 1898, p. 1812. 
first party was located at the mouth of Crow Wing River and measured the Mississippi, Crow Wing, and Gull rivers. The second party was located at Anoka and measured the Mississippi, Rum, Crow, and Elk rivers. ${ }^{1}$ A view of the apparatus used on Rum 'River at Anoka is shown in Pl. V of the Nineteenth Annual Report, Part IV.

A list of discharge measurements, made at or near St. Paul during the fiscal year ending June 30, 1897, has been given in the Report of the Chief of Engineers, U. S. A., for 1897, page 2164. Following this, on page 2169 , is a comparison of run-off to rainfall on the watershed above St. Paul for the years 1894, 1895, and 1896, the principal figures of which are given below.

Relation of rainfall and run-off above St. Paul, Minniesota.

[Drainage area, 36,085 square miles.]

\begin{tabular}{|c|c|c|c|}
\hline Year. & Rainfall. & $\begin{array}{l}\text { Mean dis. } \\
\text { charge. }\end{array}$ & $\begin{array}{l}\text { Per cent of } \\
\text { rainfall. }\end{array}$ \\
\hline 1800 & Inches. & Second.feet. & \\
\hline $1894 \ldots \ldots \ldots \ldots \ldots \ldots \ldots \ldots \ldots \ldots \ldots \ldots \ldots \ldots \ldots \ldots \ldots$ & 23.55 & 7,215 & 11.53 \\
\hline $1895 \ldots \ldots \ldots \ldots \ldots \ldots \ldots$ & 22.05 & 3,912 & 6.67 \\
\hline $1896 \ldots$. & 31.65 & 8,492 & 10.12 \\
\hline
\end{tabular}

The depth of rainfall given in the above table is assumed from the mean of records at the reservoir; also at St. Paul and at Morris, Minnesota. The drainage area above St. Paul contains two distinct meteorological basins, drained, respectively, by Minnesota River, 16,350 square miles, and by Mississippi River above the junction of this stream, 19,735 square miles. The depth of rainfall on the drainage basin of the Minnesota is less than that on the Mississippi, and the ratio of run-off to rainfall is correspondingly different. ${ }^{2}$

The measurements of the flow of Mississippi River at St. Paul were discontinued in December, 1897, as it was found that no definite information concerning the value of the reservoir water could be secured without a more complete system of measurement at numerous points below as well as above St. Paul. Measurements were continued at the reservoir dams, giving data for computing the run-off. A discussion of the relation of rainfall and run-off for the three upper dams, Leech Lake, Lake Winnibigoshish, and Pokegama Falls, has been given for the years 1885 to 1895 , inclusive, in the Report of the Chief of Engineers for 1896, on page 1843 . 


\section{. UPPER MISSOURI RIVER DRAINAGE.}

PRECIPITATION IN THE BASIN OF THE UPPER MISSOURI RIVER.

The principal observations of rainfall made within the basin of the Upper Missouri are at Virginia City, Bozeman, Martinsdale, Fort Logan, and Helena. The relative location of these points is shown on fig. 79 , in connection with the points of river measurement, which are at Salesville, Bozeman, Redbluff, Sappington, Iıgan, Threeforks, and Townsend.

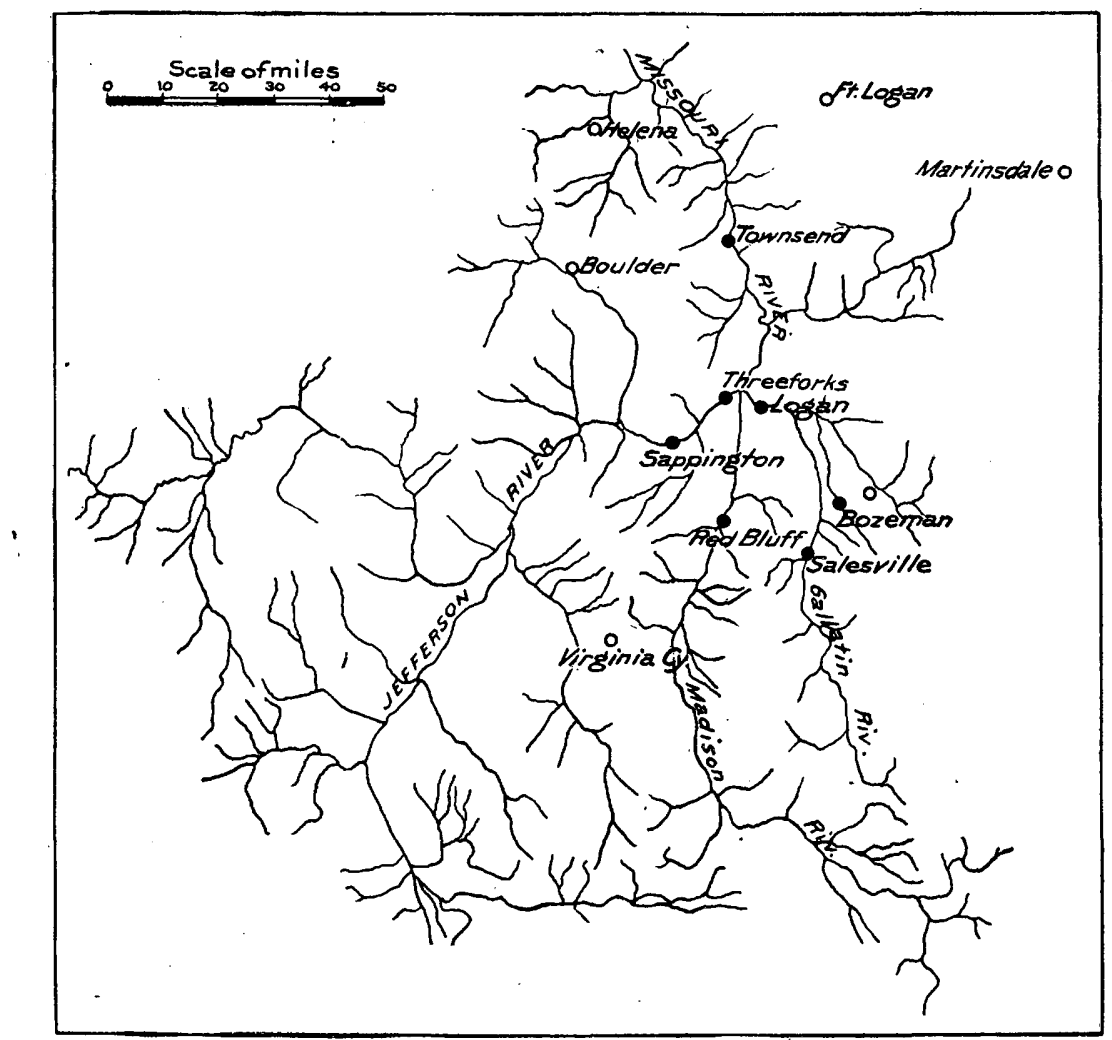

Fif. 79.-Relative location of river and rainfall observations in basin of the Upper Missouri River.

The following table gives the names and location of the stations, the elevations, and the number of years the observations have been made.

Location of rainfall stations.

\begin{tabular}{|c|c|c|c|c|c|c|}
\hline Station. & County. & State. & Latitude. & $\begin{array}{c}\text { Longi- } \\
\text { tude. }\end{array}$ & $\begin{array}{c}\text { Eleva- } \\
\text { tion. }\end{array}$ & $\begin{array}{l}\text { Length of } \\
\text { record. }\end{array}$ \\
\hline Virginia City & Madison ........ & Montana... & $\begin{array}{cc}\circ & \prime \\
45 & 17\end{array}$ & $\begin{array}{c}0 \\
11154\end{array}$ & $\begin{array}{l}\text { Feet. } \\
5,600\end{array}$ & $\begin{array}{l}\text { Years. } \\
17-19\end{array}$ \\
\hline Bozeman .... & Gallatin . . . . . . . & $\ldots .$. do .... & 4540 & 11100 & 4,600 & $20-22$ \\
\hline Martinsdale ... & Meagher ... & $\ldots$... do ... & 4627 & 11023 & 4,707 & 8 \\
\hline Fort Logan ... & $\ldots .$. do .... & $\ldots$...do $\ldots .$. & 4640 & 11109 & $\ldots \ldots$ & $12-15$ \\
\hline Helena ...... & Lewis and Clarke & $\ldots . d o \ldots$. & 4635 & 11203 & 4,108 & $17-18$ \\
\hline
\end{tabular}


In the following table are given the figures of normal or average monthly precipitation from the time of the beginning of the record to and including 1897, together with the total precipitation by months for the years 1896, 1897, and 1898, and also the amount by years. In obtaining the normal precipitation the average is taken for all of the months during which observations were made.

Rainfall at stations in drainage basin of the Upper Missouri River.

VIRGINIA CITY.

\begin{tabular}{|c|c|c|c|c|c|c|c|c|c|c|c|c|c|}
\hline Year. & Jan. & Feb. & Mar. & Apr. & May. & June. & July. & Aug. & Sept. & Oet. & Nov. & Deo. & Annual. \\
\hline Normal & 0.52 & 0.60 & 1.09 & 1.25 & 2.74 & 2.53 & 1.29 & 1.22 & 1.42 & 0.88 & 0.80 & 0.78 & 15.12 \\
\hline 1896. & 0.67 & 0.65 & 0.98 & 2.15 & 4.28 & 1.25 & 1.19 & 0.86 & 1.73 & 0.72 & 1.84 & 0.25 & 16.57 \\
\hline 1897. & 0.21 & 1.28 & 2.35 & 1. 29 & 2.91 & 3.22 & 1.43 & 0.52 & 1.64 & 1.75 . & 1.77 & 1.10 & 19.47 \\
\hline 1898. & 0.74 & 0.33 & 2.08 & 0.74 & . & $\because$ & & & & & . & ….... & $\ldots$ \\
\hline \multicolumn{14}{|c|}{$\mathrm{BOZ}$} \\
\hline Normal & 0.96 & 0.89 & 1.66 & 1.80 & 3.81 & 3.42 & 1.15 & 1.05 & 1.66 & 1.31 & 0.96 & 1.38 & 20.05 \\
\hline $1896 \ldots$ & 0.50 & 0.70 & 1.05 & 1.45 & 5.03 & 2.55 & 1.15 & 0.38 & 3.60 & 0.55 & 1.70 & 0.40 & 19.06 \\
\hline $1897 \ldots$ & 1.10 & 1.00 & 1.10 & 1.58 & 0.35 & 3.90 & 2.59 & 0.27 & 0.95 & 2.92 & $(0.96)$ & $(1.38)$ & 18.10 \\
\hline $1898 \ldots$ & .0 .60 & 0.49 & 1.62 & 1.07 & 4.60 & 3.18 & 0.84 & $0.47^{\circ}$ & 0.93 & $\ldots$. & $\ldots \ldots$ & $\cdots$ & $\ldots$ \\
\hline \multicolumn{14}{|c|}{ MARTINSDALE. } \\
\hline Normal & 1.32 & 0.95 & 1.13 & 1.14 & 1.73 & 2.91 & 1.66 & 0.62 & 1.55 & 0.84 & 1.43 & 0.76 & 16.04 \\
\hline $1896 \ldots$ & 0.65 & 0.10 & 0.65 & 2.80 & 4.00 & 1.71 & 2.53 & 0.49 & .. 49 & 0.01 & 2.10 & 0.10 & 17.63 \\
\hline 1897. & 0.40 & 0.80 & 0.80 & 0.72 & 0.96 & 3.68 & 1.74 & 0.68 & 0.23 & 1.90 & 3.15 & 0.50 & 15.56 \\
\hline $1898 \ldots$ & 0.40 & 0.18 & 1.30 & 0.65 & 4.43 & 4.63 & 1. 76 & 0.24 & 1.26 & 0.72 & 1.00 & 0.07 & 16. 64 \\
\hline \multicolumn{14}{|c|}{ FORT LOGAN. } \\
\hline Normal & 0.79 & 0.54 & 0.95 & 1.11 & 2.58 & 2.11 & 1.43 & 1.15 & 0.87 & 0.72 & 1.20 & 0.38 & 13.83 \\
\hline 1896. & $\ldots \ldots$ & 0.02 & 0.19 & 0.26 & 1.48 & 0.62 & 2.90 & ...... & ...... & 0.44 & 2. 71 & $\ldots \ldots$ & ........ \\
\hline $1897 \ldots$ & 0.62 & 0.62 & 0.74 & 0.82 & 1. 22 & 3. 98 & 2.21 & ...... & 0.48 & 1.96 & 2.59 & $(0.38)$ & 15.62 \\
\hline 1898 & 0.09 & 0.00 & 1.68 & 0.66 & 4.48 & 3.23 & 1.76 & 0.49 & 0.40 & 1.23 & 2.04 & 0.56 & 16.62 \\
\hline \multicolumn{14}{|c|}{ HELENA. } \\
\hline Normal .. & 1.27 & 0.78 & 0.69 & 1.13 & 1.60 & 2.40 & 1.15 & 0.64 & 1.21 & 0.82 & 0.91 & $0.8 \dot{6}$ & 13.46 \\
\hline $1896 \ldots$ & 0.72 & 0.59 & 1. 71 & 1.23 & 2.25 & 0.71 & 0.89 & 0.86 & 2.54 & 0.24 & 3.29 & 0.35 & 15. 38 \\
\hline $1897 \ldots$ & 0.80 & 1.49 & 1.23 & 1.15 & 1.14 & 3.66 & 1.89 & 0.52 & 0.66 & 0.81 & 2.22 & 0.59 & 16.16 \\
\hline $1898 \ldots$ & 0.20 & 0.52 & 2.39 & 0.56 & 4.88 & 3.52 & 1.71 & 0.71 & 0.87 & 1.10 & 0.66 & 0.28 & 17.40 \\
\hline \multicolumn{14}{|c|}{ AVERAGE. } \\
\hline Normal & 0,97 & 0.75 & 1.10 & 1.29 & 2.49 & 2.67 & 1. 34 & 0.94 & 1.34 & 0.91 & 1.06 & 0.83 & 15.69 \\
\hline $1896 \ldots$ & 0.79 & 0.41 & 0.92 & 1.58 & 3.41 & 1.37 & $1.7 \hat{3}$ & 0.65 & 2.49 & 0.39 & 2.33 & 0.28 & 16.35 \\
\hline $1897 \ldots$ & 0.63 & 1.04 & 1.24 & 1.11 & 1.32 & 3.69 & 1.97 & 0.40 & 0.79 & 1.87 & 2. 14 & 0.79 & 16.99 \\
\hline $1898 \ldots$ & 0.41 & 0.30 & 1.81 & 0.74 & 4.60 & 3.64 & 1.52 & 0.48 & 0.87 & 1.02 & 1.23 & 0.30 & 16. 92 \\
\hline
\end{tabular}


Depth of run-off, in inches, from Upper Missouri drainage basin. WEST GaLLATIN AT SALESVILLE.

\begin{tabular}{|c|c|c|c|c|c|c|c|c|c|c|c|c|c|}
\hline Fear. & Jan. & Feb. & Mar. & Apr. & May. & June. & July. & Aug. & Sept. & Oct. & Nov. & Dec. & Annual. \\
\hline $1896 \ldots \ldots \ldots$ & 0.33 & 0.31 & 0.33 & 0.40 & 1.16 & 9.06 & 2.91 & 1.01 & 0.81 & 0.70 & 0.44 & 0.20 & 17.66 \\
\hline $1897 .$. & 0.33 & 0.30 & 0.40 & 0.75 & 5.15 & 3.64 & 1.76 & 0.85 & 0.65 & 0.70 & 0.58 & 0.60 & 15.71 \\
\hline $1898 \ldots$. & 0.81 & 0.97 & 0.75 & 1.09 & 3.44 & 6. 02 & 2.62 & 1.25 & 1.04 & 1.05 & 0.91 & 1.01 & 20.96 \\
\hline Average. & 0.49 & 0.53 & 0.49 & 0.75 & 3.25 & 6.24 & 2.43 & 1.04 & 0.83 & .0 .82 & 0.64 & 0.60 & 18. 02 \\
\hline \multicolumn{14}{|c|}{ MIDDLE CREEK NEAR BOZEMAN. } \\
\hline 1896. & & & & 0.68 & 2.01 & 7.72 & 3.44 & 0.92 & 0.80 & 0.79 & & & \\
\hline 1897. & & $\ldots$ & & $\ldots \ldots$ & $\ldots .$. & $\ldots \ldots$ & & ....... & $\ldots \ldots$ & $\cdots$ & ….. & ..... & \\
\hline 1898. & . & …... & $\ldots . .$. & 4.25 & 10.73 & 11.42 & 9.79 & 8.90 & 8.40 & 6.15 & 0.22 & 0.27 & $\cdots$ \\
\hline Average. & . & ….... & $\cdots \ldots$ & 2.47 & 6.37 & 9.57 & 6.62 & 4.91 & 4.60 & 3.47 & 0.22 & 0.27 & $\cdots$ \\
\hline \multicolumn{14}{|c|}{ GALLATIN AT LOGAN. } \\
\hline 1896 & 0.48 & 0.44 & 0.49 & 0.49 & 0.77 & 3.11 & 0.86 & 0.49 & 0.47 & 0.48 & 0.47 & 0.51 & 9.06 \\
\hline $1897 \ldots$ & 0.49 & 0.42 & 0.46 & 0.68 & 2.69 & 2.00 & 0.49 & 0.32 & 0.36 & 0.44 & 0.47 & 0.46 & 9. 28 \\
\hline $1898 \ldots \ldots$ & 0.09 & 0.06 & 0.46 & 0.71 & 1.69 & 3.15 & 0.71 & 0.26 & 0.45 & 0.56 & 0.37 & $(0.49)$ & 9.00 \\
\hline Average: & 0.35 & 0.34 & 0.47 & 0.63 & 1.72 & 2.75 & 0.69 & 0.36 & 0.43 & 0.49 & 0.44 & 0.49 & 9.16 \\
\hline \multicolumn{14}{|c|}{ MADISON AT REDBLUFF. } \\
\hline 1896. & & & & & & & & & & & & & \\
\hline 1897 & 0.89 & 0.80 & 0.89 & 1.01 & 1.85 & 2. 36 & 1.41 & 0.93 & 0.82 & 0.87 & 0.90 & 0.93 & 13.66 \\
\hline 1898. & $\cdots$ & $\cdots \cdots$ & $\cdots \ldots$ & $\cdots \cdots$ & 2.16 & 3.21 & 2.01 & 1.48 & 1.20 & 1.20 & 0.54 & $\cdots \cdots$ & ......... \\
\hline Average. & 0.89 & 0.80 & 0.89 & 1.01 & 2.02 & 2.79 & 1.71 & 1.21 & 1.01 & 1.04 & 0.72 & 0.93 & 15.02 \\
\hline \multicolumn{14}{|c|}{ MADISON AT THREEFORKS. } \\
\hline 1896. & 0.71 & 0.67 & 0.76 & 0.83 & 1.06 & 2.93 & 1.29 & 0.71 & 0.68 & 0.68 & 0.64 & 0.67 & 11.63 \\
\hline \multicolumn{14}{|c|}{ JEFFERSON AT SAPPINGTON. } \\
\hline 1896. & 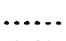 & & $\cdots$ & & & …. & & & 0,17 & 0.17 & 0.19 & 0.21 & \\
\hline 1897. & 0.20 & 0.18 & 0.20 & 0.41 & 1.10 & 0.54 & 0.30 & 0.10 & 0.09 & 0.12 & 0.16 & 0.18 & 3.58 \\
\hline 1898 & ...... & $\cdots$ & 0.17 & 0.44 & 0.77 & 1.01 & 0.44 & 0.14 & 0.14 & 0.17 & 0.19 & ....... & $\ldots \ldots \ldots$ \\
\hline Average. & 0.20 & 0.18 & 0.19 & 0.43 & 0.94 & 0.78 & 0.37 & 0.12 & 0.13 & 0.15 & 0.18 & 0.20 & 3.87 \\
\hline \multicolumn{14}{|c|}{ MISSOURI AT TOW NSEND. } \\
\hline 1896. & 0.29 & 0.27 & 0.29 & 0.33 & 0.60 & 1.99 & 0.72 & 0.31 & 0.32 & 0.31 & 0.29 & 0.30 & 5.71 \\
\hline $1897 \ldots \ldots \ldots$ & 0.22 & 0.20 & 0.24 & 0.55 & 1.26 & 0.87 & 0.43 & 0.21 & 0.20 & 0.26 & 0.27 & 0.29 & 5.00 \\
\hline $1898 \ldots \ldots \ldots$ & 0.24 & 0.22 & 0.36 & 0.46 & 0.81 & 1.41 & 0.49 & 0.18 & 0.20 & 0.24 & 0.15 & $(0.24)$ & 5.00 \\
\hline Average. & 0.25 & 0.23 & 0.30 & 0.45 & 0.89 & 1.42 & 0.55 & 0.23 & 0.24 & 0.27 & 0.20 & 0.28 & 5.31 \\
\hline
\end{tabular}


Rainfall and run-off.

\begin{tabular}{|c|c|c|c|c|}
\hline Station. & Nor'mal. & 1896. & 1897. & 1898. \\
\hline \multicolumn{5}{|l|}{$\cdot$} \\
\hline RAINFALL. & & & & \\
\hline Virginia City $\ldots \ldots \ldots \ldots \ldots$ & 15. 12 & 16.57 & 19.47 & $\ldots \ldots . .$. \\
\hline Bozeman $\ldots \ldots \ldots \ldots \ldots \ldots$ & 20.05 & 19.06 & 18.10 & \\
\hline Martinsdale ............ & 16.04 & 17.63 & 15.56 & 16.64 \\
\hline Fort Logan ................ & 13.83 & $\ldots . . . .$. & 15.62 & 16.62 \\
\hline Helena..................... & 13.46 & 15.38 & 16.16 & 17.40 \\
\hline Average....... & 15.70 & 17.16 & 16.98 & 16.89 \\
\hline KUN-OFF. & & & & \\
\hline West Gallatin . . . . . . . . . . . . . & 18.02 & 17.66 & 15.71 & 20.96 \\
\hline Gallatin . . . . . . . . . . . . . . & 9.16 & 9.06 & 9.28 & 9.00 \\
\hline Madison at Redbluff........... & 15.02 & $\ldots \ldots . .$. & 13. 66 & \\
\hline Madison at Threeforks .......... & 11.63 & 11. 63 & $\therefore \ldots . . .$. & $\cdots$ \\
\hline Jefferson $\ldots \ldots \ldots \ldots$ & 3.87 & .......... & 3.58 & \\
\hline Missouri $\ldots \ldots \ldots \ldots \ldots$ & 5.31 & 5.71 & 5.00 & 5.00 \\
\hline Average................... & 10.50 & 11.02 & 9.45 & 11.65 \\
\hline Percentage of rainfall,.. & 66.87 & 64.22 & 55.65 & 68.92 \\
\hline
\end{tabular}

The above percentage of run-off is notably large, and is probably due to the fact that the measurements of rainfall do not represent the precipitation upon the greater part of the catchment basin. The altitude of the localities at which rainfall has been measured is less than that of the country from which the greater part of the water comes. It is probable that the snowfall of the winter is not only considerably greater than might be inferred from the figures given above, but that, owing to the low temperature, a large part of the snow ultimately contributes to the flow of the stream.

\section{MADISON RIVER. ${ }^{1}$}

This stream has its source in Yellowstone National Park, only a few miles from the Gallatin. The country about the head waters of this stream and for many miles below is too high for profitable husbandry except that of summer stock ranging, for which it is famous. Settlements begin at the mouth of Indian Creek, perhaps 50 miles below its source, and some water is used, principally, however, from side streams tributary to the main river. About 15 miles below the mouth of Indian Creek ranches devoted to diversified farming-grain, hay, and live stock-are opened up, and a very rich and fertile valley extends 10 miles below Ennis, where the river enters the Madison Canyon. In this locality are numerous sheep ranches, the leading crop being alfalfa for winter feed.

I From report by Mr. S. M. Emery, Director of Experiment Station, Bozeman, Montana. 


\section{PROGRESS OF STREAM MEASUREMENTS FOR 1898.}

The canyon of the Madison extends from about 10 miles below Ennis to the iron bridge near the mouth of Cherry Creek, at which place the gaging station is located. At high water this canyon is impassable to rowboats, owing to the numerous falls and rapids. Accurate surveys of the river in this vicinity have been made with a view to locating an extensive mining water power. The possibilities of this power are said to be exceeded only by that of the Missouri at Great Falls, Montana. The location of such a plant will call for a large production of farm commodities and enhance the value of all the farming area tributary thereto.

Below the mouth of the canyon the valley of the Madison widens until it joins the valley of the Gallatin. Upon the foothills of the divides between both the Madison and Gallatin and the Madison and Jefferson are broad plateaus, whose heights are such as to render impossible the diversion of water by individual effort. This must be done, if at all, by cooperation or by corporate capital. In 1890 the Anaconda Copper Company, of Butte, Montana, purchased several thousand acres of land, lying in the three forks of the Gallatin, Madison, and Jefferson, with the intention of establishing there an extensive smelter plant. It was part of the plan to divert the waters of the Madisou to cover the smelter location, which was considerably higher than the natural water level at Threeforks. Of the three streams-the Jefferson, Madison, and Gallatin-the waters of the Madison are of the least immediate value for irrigation and possess the greatest possibilities of future manufacturing value. It is noteworthy that all of the streams in this region are remarkably pure and free from matter objectionable in irrigation or in domestic use. Although there are great quantities of alkaline or earthy salts in the soils of the valleys of Montana, yet these are seldom encountered in solution in the water of the streams.

Estimated monthly discharge of Madison Ricer at Redbluff, Montana.

[Drainage area, 2,085 square miles.]

\begin{tabular}{|c|c|c|c|c|c|c|}
\hline \multirow{2}{*}{ Month. } & \multicolumn{3}{|c|}{ Discharge in second.feet. } & \multirow[b]{2}{*}{$\begin{array}{c}\text { Total in acre. } \\
\text { feet. }\end{array}$} & \multicolumn{2}{|c|}{ Run-off. } \\
\hline & $\begin{array}{l}\text { Maxi- } \\
\text { mum. }\end{array}$ & $\begin{array}{l}\text { Mini. } \\
\text { mum. }\end{array}$ & Mean. & & $\begin{array}{l}\text { Depth in } \\
\text { inches. }\end{array}$ & $\begin{array}{c}\text { Second- } \\
\text { feet per } \\
\text { square } \\
\text { mile. }\end{array}$ \\
\hline 1898. & & & & & & \\
\hline May $7-31 \ldots \ldots \ldots$ & 6,375 & 2,962 & 4,834 & 297,233 & 2.67 & 2.32 \\
\hline June ............. & 8,000 & 3,450 & 6,001 & 357,084 & 3.21 & 2.88 \\
\hline July ...... & 4,425 & 2,800 & 3,623 & 222,771 & 2,01 & 1.74 \\
\hline August... & 3,125 & 2,150 & 2,679 & 164,726 & 1. 48 & 1.28 \\
\hline September . . . . . . & 2,800 & 2,150 & 2,258 & 134,360 & 1.20 & 1.08 \\
\hline October... & 2,312 & 2,150 & 2,160 & 132,814 & 1. 20 & 1.04 \\
\hline November 1-14 . . . . & $\ldots \ldots$ & $\ldots \ldots$ & 2,150 & 127,934 & 1,15 & 1.03 \\
\hline
\end{tabular}

Note.-Gage heights for 1898 are given in Water-Supply and Irrigation Paper No. 27, page 71; measurements, page 74; rating table, page 75 . Results for 1897 in Water-Supply and Irrigation Paper No, 15, page 69, and in the Nineteenth Annual Report, Part IV, pages 279 to 280 . 


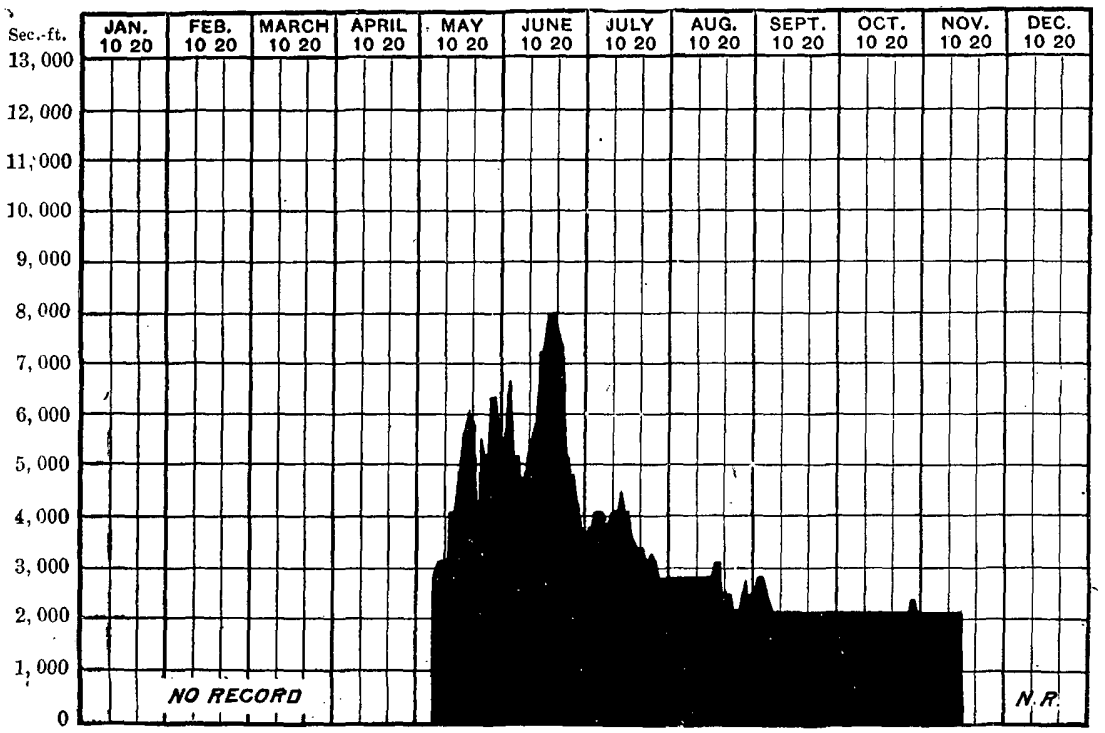

Frg. 80.-Discharge of Madison River at Redbluff, Montana, 1898.

\section{JEFFERSON RIVER.}

Jefferson River, although the principal source of the Missouri, is the shortest of the three streams, from the fact that the name is applied to an extent of less than 100 miles-that is, from the junction of the Ruby, Beaverhead, and Bighorn rivers, near Twin Bridges, Montana, to Threeforks, where Jefferson River, together with Madison and Gallatin rivers, unite to form Missouri River. Beginning at Twin Brilges . there is on the east side of the river a large area of tillable land, extending downstream a distance of perhaps 50 miles to the mouths of North and South Boulder creeks, which are tributary to Jefferson River. At the mouth of the two Boulder creeks the stream enters and traverses a canyon until the vicinity of Willow Creek is reached, a distance of about 25 miles. At Willow Creek the Gallatin Valley is entered, and there is ample opportunity for the use of water from this stream.

Surveys have been made which lead to the belief that water from Jefferson River can be diverted above Whitehall and conducted by a high-line canal across or around Boulder Mountains, so as to irrigate a large area of valuable land now lying idle in what is called the Crow Creek Basin. This creek is a tributary to the Missouri River in the vicinity of Toston, Montana. As yet but a small amount of the water of Jefferson River has been employed in irrigation. The ditches in use are small, usually cooperative in character, and have been easy and cheap of construction. The future canal work, if extensive, must be done by the General Government or by wealthy corporations, and will render valuable large areas both in the Gallatin and Crow Creek valleys, which are now unproductive except as range lands. These lands when. 


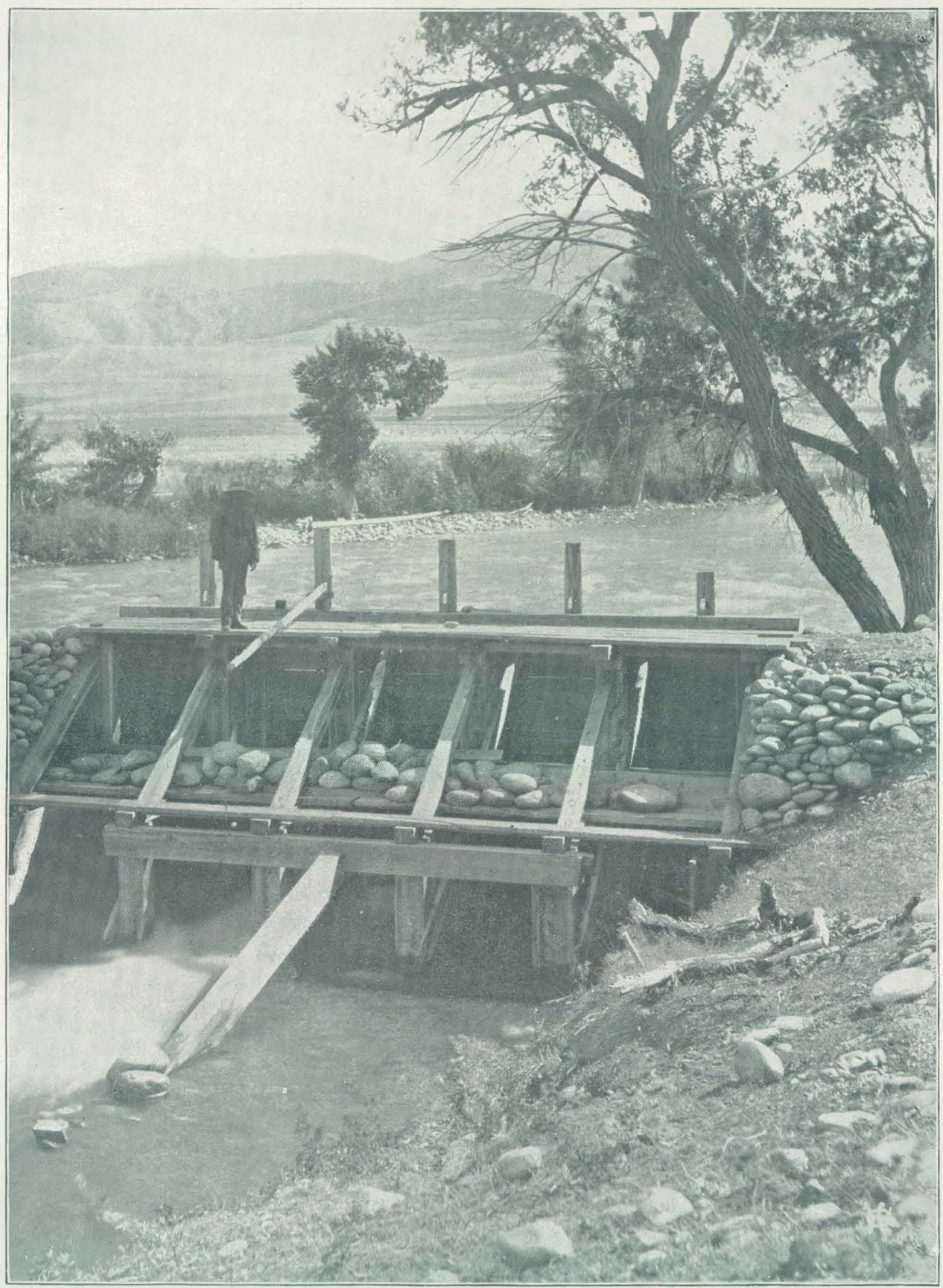

HEAD GATE OF CANAL OF THE WEST GALLATIN IRRIGATION COMPANY, GALLATIN COUNTY, MONTANA. 
reclaimed possess the merit of being easy of access to the Northern Pacific Railway and will be valuable for farming.

Estimated monthly discharge of Jefferson River at Sappington, Montana.

[Drainage area, 8,984 square miles.]

\begin{tabular}{|c|c|c|c|c|c|c|}
\hline \multirow{2}{*}{ Month. } & \multicolumn{3}{|c|}{ Discharge in second.feet. } & \multirow[b]{2}{*}{$\begin{array}{l}\text { Total in acre- } \\
\text { feet. }\end{array}$} & \multicolumn{2}{|c|}{ Run-off. } \\
\hline & $\begin{array}{l}\text { Maxi- } \\
\operatorname{mnm} .\end{array}$ & $\begin{array}{l}\text { Mini- } \\
\text { mum. }\end{array}$ & Mean. & & $\begin{array}{l}\text { Depth in } \\
\text { inches. }\end{array}$ & $\begin{array}{c}\text { Second. } \\
\text { feet per } \\
\text { square } \\
\text { mile. }\end{array}$ \\
\hline 1898. & & & & & & . \\
\hline January .... & $\ldots \ldots$ & $\ldots \ldots$ & $a 1,500$ & $a 92,232$ & $a 0.20$ & $a 0.17$ \\
\hline February ......... & $\ldots \ldots$ & $\ldots . .$. & $a 1,500$ & $a 83,306$ & $a 0.18$ & $a 0.17$ \\
\hline March ............. & 2,100 & 1,150 & 1,368 & 84,116 & 0.17 & 0.15 \\
\hline April $\ldots \ldots \ldots \ldots$ & 6,720 & 1,390 & 3,472 & 206,598 & 0.44 & 0.39 \\
\hline May . . . . . . . . & 10,130 & 3,500 & 5,982 & 367,821 & 0.77 & 0.67 \\
\hline June $\ldots \ldots . \ldots . .$. & 9,730 & 5,100 & 8,143 & $484, \overline{5} 41$ & 1. 01 & 0.91 \\
\hline July $\ldots \ldots \ldots \ldots$ & 6,220 & 1,390 & 3,440 & 211,519 & 0.44 & 0.38 \\
\hline August. . . . & 1,310 & 1,000 & 1,060 & 65,177 & 0.14 & 0.12 \\
\hline September . & 1,620 & 1,000 & 1,182 & 70,334 & 0.14 & 0.13 \\
\hline October.... & $1, \overline{5} 40$ & 1,150 & 1,351 & 83,070 & 0.17 & 0.15 \\
\hline November... & 1,800 & 1,390 & 1,509 & 89,792 & 0.19 & 0.17 \\
\hline December ......... & $\cdots \cdot$ & $\ldots \ldots$ & $a 1,400$ & $a 86,083$ & $a 0.18$ & $a 0.16$ \\
\hline The year... & 10,130 & 1,000 & 2,659 & 160,382 & 0.34 & 0.30 \\
\hline
\end{tabular}

- NoTE.-Gage heights for 1898 are given in Water-Supply and Irrigation Paper No. 27, page 71, measurements, page 74; rating table, page 75; results for 1897 in Water-Supply and Irrigation Paper No. 15, page 70, and in the Nineteenth Annual Report, Part IV, pages 281-283.

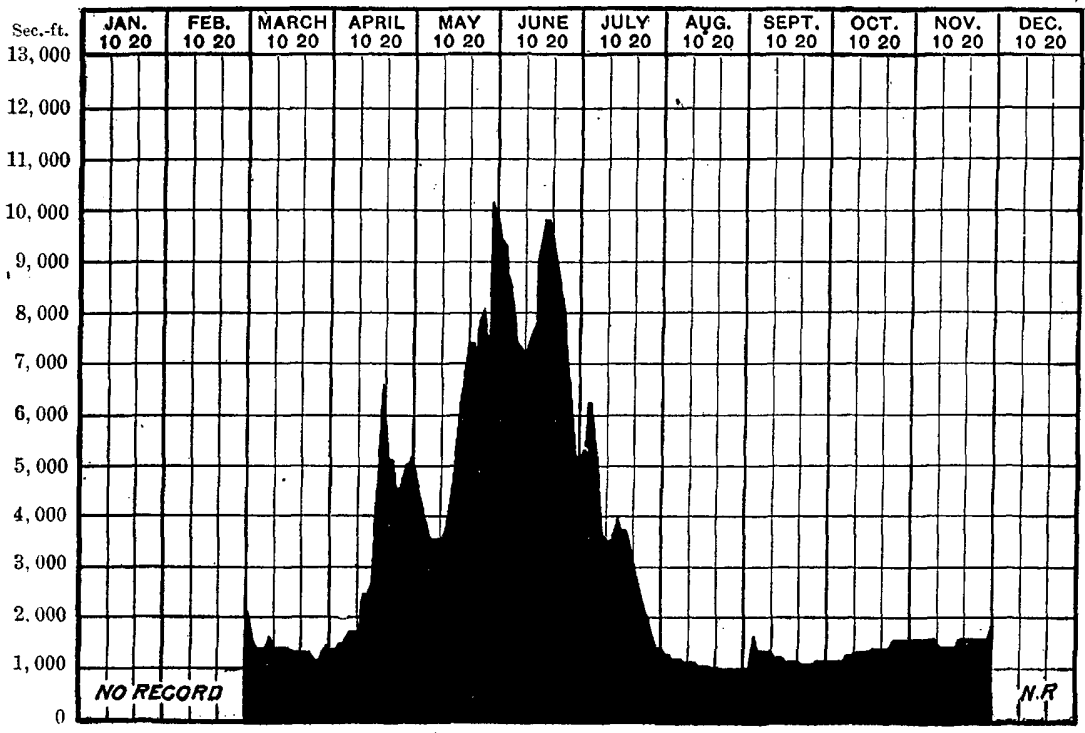

FiG. 81.-Discharge of Jefferson River at Sappington, Montana, 1898. 


\section{GALLATIN RIVER.}

Gallatin River, one of the three principal sources of the Missouri, has its origin in Yellowstone National Park. About 75 miles below its head it debouches from Gallatin Canyon into the fertile Gallatin Valley, a region having an extent in round numbers of 1,200 square miles. In this valley the crops have been uniformly successful for thirty years, the wheat and barley being of particularly fine quality.

For many years those farming this valley have pursued the summerfallow system-that is, they permit from one-third to one-half of the total cultivated farm areas to lie idle each season, to be plowed in June for the succeeding crop. These fallow lands are not irrigated during the idle period, but with the advent of a more enlightened policy this system is giving way to clover and legume culture of the otherwise idle tracts. As a result of this change in custom is due the demand for larger quantities of water than have been in use. Although a large part of the western boundaries of the valley is formed by the Jefferson River, nearly all of the cultivated land is at present irrigated from Gallatin River and its principal tributaries-Bear, Cottonwood, Middle, Bozeman, Rocky, Bridger, Reese, and Dry creeks. The supply has usually been adequate, owing to the diminution of total area resulting from letting lands lie fallow. A view of the headgates of one of the principal canals is given in Pl. XVI.

Large tracts of lands adjacent to the valley proper and extending back into the foothills of the surrounding mountain ranges are farmed, the crops of winter wheat being raised without irrigation. By deep plowing and intensive culture this area of so-called "dry farming" can be extended farther out into the valley than it is now and thus some relief be afforded to the demands for water. On the other hand, there are still extensive areas of this valley bordering Gallatin River and at or near the center of the valley which have been neglected as farm lands, owing to the fact that the soil is somewhat gravelly. It has been recently determined that these lands are well adapted to alfalfa culture, and they are being bought from the Northern Pacific Railway Company to be used for producing this forage plant. This will call for water in addition to that already in use.

A comparatively small amount of water from Gallatin River proper has been taken out for irrigation purposes, though some large ditches, with capacities of 40 to 50 second-feet, are now under process of construction. This river is one of the most regular in its volume of supply in the State, and the rights to water from this source are highly regarded because of their permanency.

${ }^{1}$ From report by Mr. S. M. Emery, Bozeman, Montana. 
Estimated monthly discharge of Gallatin River at Logan, Montana.

\begin{tabular}{|c|c|c|c|c|c|c|}
\hline \multirow[b]{2}{*}{ Month. } & \multicolumn{3}{|c|}{ Discharge in second-feet. } & \multirow[b]{2}{*}{$\begin{array}{l}\text { Total in acre- } \\
\text { feet. }\end{array}$} & \multicolumn{2}{|c|}{ Run off'. } \\
\hline & $\begin{array}{l}\text { Maxi- } \\
\text { mum. }\end{array}$ & $\begin{array}{l}\text { Mini- } \\
\text { mum. }\end{array}$ & Mean. & & $\begin{array}{l}\text { Depth in } \\
\text { incbes. }\end{array}$ & $\begin{array}{c}\text { Second. } \\
\text { feet per } \\
\text { square } \\
\text { mile. }\end{array}$ \\
\hline 1898. & * & & & & & \\
\hline January ............. & $\cdots . .$. & & $a 1,000$ & $a 61,488$ & $a 0.71$ & $a 0.62$ \\
\hline February... & & & $a 700$ & $a 38,876$ & $a 0: 45$ & $a 0.43$ \\
\hline Mareh ....... & 730 & 595 & 653 & 40,152 & 0.46 & 0.40 \\
\hline April........ & 1,720 & 640 & 1,029 & 61,230 & 0.71 & 0.64 \\
\hline 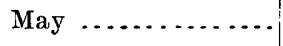 & 4,757 & 1,000 & 2,385 & 146,649 & 1. 69 & 1.47 \\
\hline June ... . . . . . . . . & 6,107 & 2,597 & 4,577 & 272,350 & 3.15 & 2.83 \\
\hline July ......... & 2,462 & 370 & 1,004 & 61,734 & 0.71 & 0.62 \\
\hline August......... & 370 & 370 & 370 & 22,751 & 0.26 & 0.23 \\
\hline September ......... & 730 & 370 & 646 & 38,440 & 0.45 & 0.40 \\
\hline October .............. & 820 & 730 & 790 & 48,576 & 0.56 & 0.49 \\
\hline November $1-21 \ldots$. & 820 & 730 & 762 & 45,342 & 0.53 & 0.47 \\
\hline December ..... & $\ldots . .$. & $\ldots \ldots$ & $a 800$ & $a 49,190$ & $a 0.56$ & $a 0.49$ \\
\hline The year ..... & 6,107 & 370 & 1,226 & 886,778 & 10.24 & 0.76 \\
\hline
\end{tabular}

Noте.-Gage heights for 1898 are given in Water-Supply and Irrigation Paper No. 27, page 70; measurements, page 74; rating table, page 75 . Results for 1897 in Water.Supply and Irrigation Paper No. 15, page 68, and in the Nineteenth Annual Report, Part IV, pages 277 to 278.

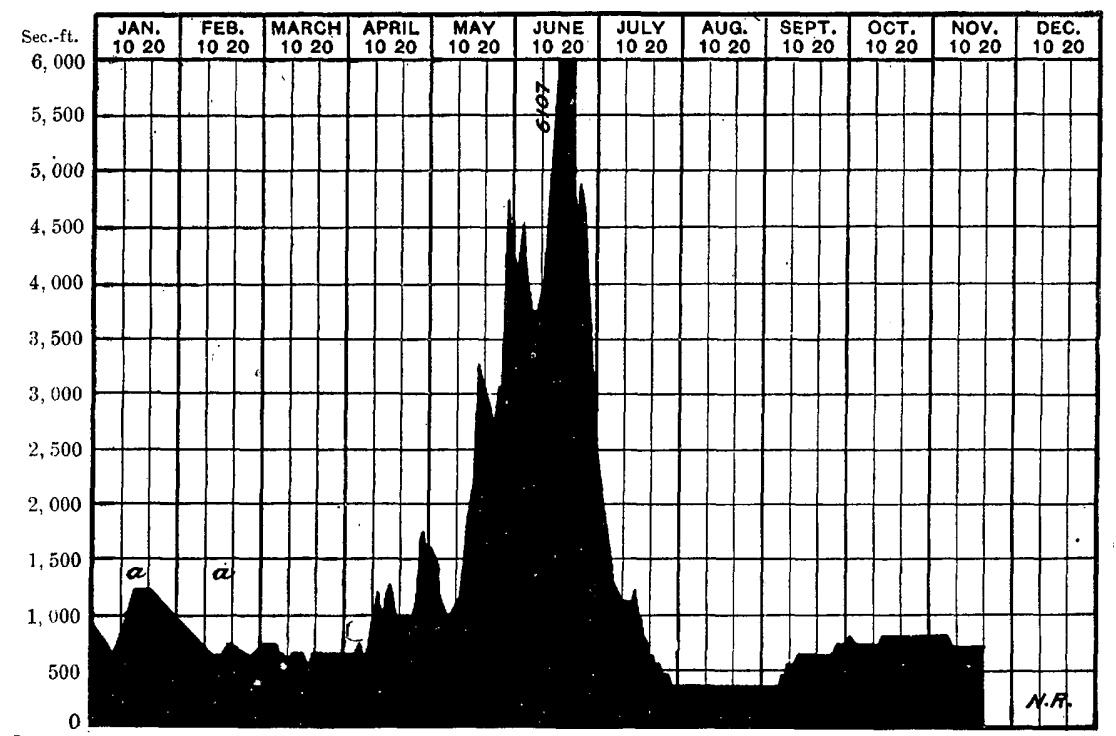

FIG. 82.-Discharge of Gallatin River at Logan, Montana, 1898. 
WEST GALLATIN RIVER.

Estimated monthly discharge of West Gallatin River at Salesville, Montana.

[Drainage area, 860 square miles.]

\begin{tabular}{|c|c|c|c|c|c|c|}
\hline \multirow[b]{2}{*}{ Month. } & \multicolumn{3}{|c|}{ Discharge in second-feet. } & \multirow[b]{2}{*}{$\begin{array}{l}\text { Total in acre- } \\
\text { feet. }\end{array}$} & \multicolumn{2}{|c|}{ Run-off. } \\
\hline & $\begin{array}{l}\text { Maxi- } \\
\text { mum. }\end{array}$ & $\begin{array}{l}\text { Mini. } \\
\text { mum. }\end{array}$ & Mean. & & $\begin{array}{l}\text { Depth in } \\
\text { inches. }\end{array}$ & $\begin{array}{c}\text { Second. } \\
\text { feet per } \\
\text { square } \\
\text { mile. }\end{array}$ \\
\hline 1898. & & & & & & \\
\hline January ........... & $\ldots \ldots$. & $\ldots \ldots$ & $a 600$ & c. 36,893 & $a 0.81$ & $a 0.70$ \\
\hline February ........... & $\ldots \ldots$ & $\ldots \ldots$ & $a 800$ & $a 44,430$ & $a 0.97$ & $a 0.93$ \\
\hline March ............... & 630 & 560 & 556 & 34,187 & 0.75 & $0.65^{\circ}$ \\
\hline April $\ldots . . . .$. & 1,420 & 590 & 841 & 50,043 & 1.09 & 0.98 \\
\hline May .............. & 5,051 & 960 & 2,564 & $157,65 \overline{5}$ & 3.44 & 2.98 \\
\hline June....... & 7,226 & 2,615 & 4,642 & 276,218 & 6.02 & 5.40 \\
\hline July ....... & 2,702 & 1,145 & 1,948 & $119,7.79$ & 2.62 & 2.27 \\
\hline August............. & 1,100 & 840 & 931 & 57,245 & 1.25 & 1.08 \\
\hline September ........ & 900 & 780 & 810 & 48,198 & 1.04 & 0.94 \\
\hline October ......... & 840 & 780 & 784 & 48,207 & 1.05 & 0.91 \\
\hline Norember . . . . . . . & 780 & 670 & 704 & 41,891 & 0.91 & 0.82 \\
\hline Deceinber... & 960 & 630 & 756 & 46,485 & 1.01 & 0.88 \\
\hline The year ..... & 7,226 & 560 & 1,328 & 961,231 & 20.96 & 1.55 \\
\hline
\end{tabular}

a Approximate.

Note.-Gage heights for 1898 are given in Water-Supply and Irrigation Paper No. 27, page 69; measurements, page 74; rating table, page 74 ; results for 1897 in Water-Supply and Irrigation Paper No. 15, page 66, and in the Nineteenth Annual Report, Part IV, pages 275 to 277.

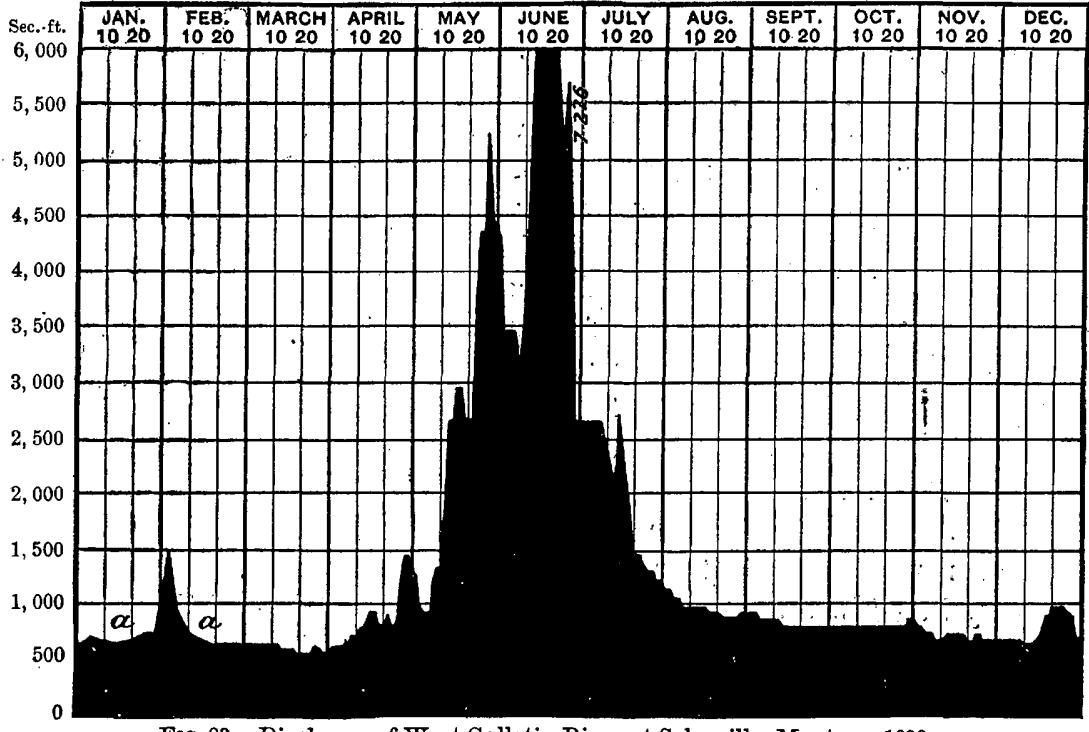

FrG. 83.-Discharge of West Gallatin River at Salesville, Montana, 1898. 20 GEOL, PT $4-16$ 


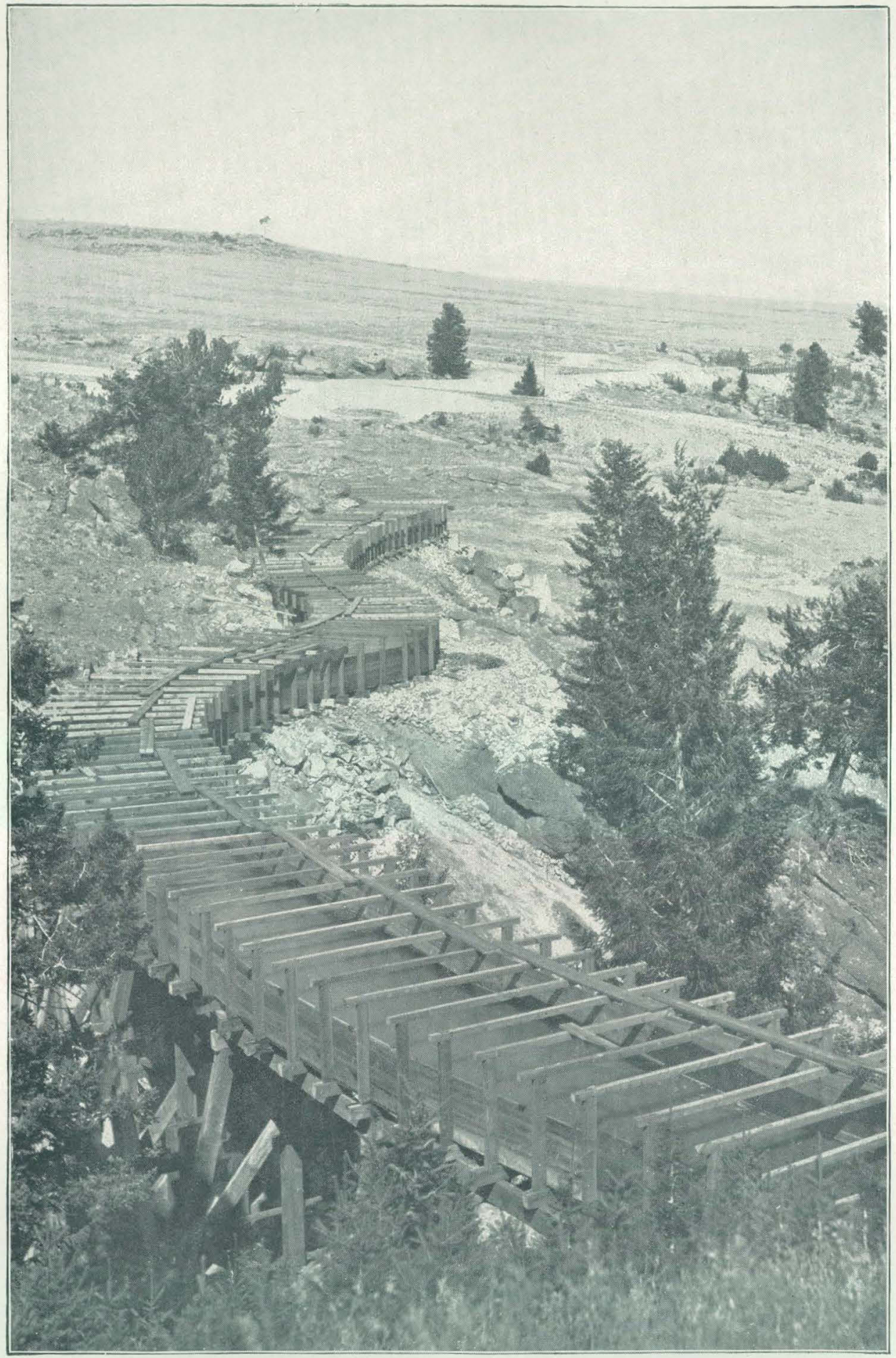

FLUME AND TRESTLE ACROSS ROCKY CANYON, MONTANA. 
A view of West Gallatin River is shown in Pl. XVI. This is at the head gate of the West Gallatin Irrigation Company's canal in Gallatin County, Montana. This head gate is located on the west bank of the river in T. 3 S., R. 4 E., sec. 33 . The torrential character of the stream is shown by the ripples in the bed and the size of the bowlders along the banks. In Pl. XVII is given a view of the flume and trestle across Rocky Canyon, leading from a tunnel of the West Gallatin Irrigation Company's canal.

$$
\text { MIDDLE CRKEK. }
$$

Middle Creek, so called from being the middle stream lying between Cottonwood and Sour Dough or Bozeman creeks, is one of the most important feeders to the West Gallatin River. Rising as it does in the Gallatin Mountains on the north slope, and in the neighborhood of very high mountains, its watershed has a heavy snow and rain fall. The mountain slopes are well timbered, and an area of about 43,000 acres was set aside by Presidential proclamation in 1899 as the Gallatin Forest Reserve. Approximately the same number of acres belonging to and constituting a part of the land grant of the Northern Pacific Railway lies alongside of this reserve. Thus there is a compact and valuable timbered area of advantage in the conservation of the water supply of Middle Creek. This reserve was created in large part upon the advice and request of the Montana Experiment Station and Agricultural College, as it is proposed to make a special study of irrigation by the station and of forestry by the college.

The water of Middle Creek is in large part owned by the Middle Creek Ditch Company, whose rights run back to 1868. There are other interested owners of Middle Creek water, but the statutory amount of water must first be supplied to the Middle Creek Ditch Company before later rights are entitled to any water. This condition of affairs exists only in periods of low water in extremely dry seasons. Their canal or ditch carries about 50 second-feet of water and is for about 5,000 acres of land. The gradual abandonment of the fallow system and the planting of clover on the lands previously idle is rendering it necessary to add to the water supply. This will be accomplished by the reservoir system, there being a number of exceptionally fine reservoir sites on the headwaters of the stream. A low value has always been attached to this water, the highest selling price for a 50 -inch right being $\$ 350$. That it is possible to administer such property cheaply is shown by the assessment for 1898 , which was $\$ 4$ per share, and that of $1899, \$ 2.50$ per share. There are 60 shares of stock in the company, and practically the sole annual expense of administration is the salary of a water tender through the irrigation season.

It may be of interest to note that the irrigation plan of the Montana, Experiment Station contemplates examining the entire farm lands under the Middle Creek Ditch. It is a matter of small interest to farmers already located under streams whose surplus water has long since been 
apportioned that Montana has to-day more available water for irrigation in the aggregate than any other State. These men are not situated where the excess waters can be diverted to them. It is confidently believed, however, that a much less water consumption per acre can be profitably employed than is now used. Intelligent economy of usage results substantially the same as an increased supply. In many parts of the State, so excessive has been the use of water that injurious amounts of alkali have been brought to the surface. This originally existed in crystalline form far below the surface, but, dissolved by the too free use of water, it has been brought up through the soil to again be crystallized by evaporation, with the result of impairing the value of the land. The actual amount of water required under normal conditions to successful crop-production will be the subject of one of the most important investigations undertaken by the Montana Experiment Station. A view of the method of measuring Middle Creek is given on Pl. XVıII, $A$; and on Pl. XVIII, $B$, is shown the gaging station on West Gallatin River.

Estimated monthly discharge of Middle Creek at Bozeman, Montana.

[Drainage area, 55 square miles.]

\begin{tabular}{|c|c|c|c|c|c|c|}
\hline \multirow[b]{2}{*}{ Month. } & \multicolumn{3}{|c|}{ Discharge in second.feet. } & \multirow[b]{2}{*}{$\begin{array}{l}\text { Total in acre- } \\
\text { feet. }\end{array}$} & \multicolumn{2}{|c|}{ Run-off. } \\
\hline & $\begin{array}{l}\text { Maxi. } \\
\text { mum. }\end{array}$ & $\begin{array}{l}\text { Maxi. } \\
\text { mum. }\end{array}$ & Mean. & & $\begin{array}{l}\text { Depth in } \\
\text { inches. }\end{array}$ & $\begin{array}{c}\text { Second- } \\
\text { feet per } \\
\text { square } \\
\text { mile. }\end{array}$ \\
\hline 1898. & & & & & & \\
\hline April 18-30....... & ....... & $\ldots \ldots$ & 484 & 28,000 & 9.82 & 8.80 \\
\hline $\mathrm{Ma}, \ldots \ldots \ldots . . . .$. & 575 & 455 & 511 & 31,420 & 10.73 & 9.29 \\
\hline June............. & 725 & 470 & 563 & 33,501 & 11.42 & 10.24 \\
\hline July ...... & 522 & 440 & 476 & 29,268 & 9.79 & 8.66 \\
\hline August...... & 432 & 417 & 424 & 26,071 & 8.90 & 7.71 \\
\hline Septémber & 417 & 403 & 414 & 24,635 & 8.40 & 7.53 \\
\hline October $1-22$ & 417 & 410 & 413 & 25,395 & 8.66 & 7.51 \\
\hline November ......... & $\ldots \ldots$ & $\ldots \ldots$ & $a 500$ & 29,752 & 10.14 & 9.09 \\
\hline December . . . . . . . & $\ldots \ldots$ & $\ldots \ldots$ & $a 400$ & 24,595 & 8.38 & 7.27 \\
\hline
\end{tabular}

a Approximate.

NoTE.-Gage heights for 1898 are given in Water-Supply and Irrigation Paper No. 27, page 70 measurements, page 74; rating tabie, page 75. Results for 1897 in Water.Supply and Irrigation Paper No. 15, page 67, and in the Nineteenth Annual Report, Part JV, page 271.

\section{MISSOURI RIVER BELOW THREE FORKS.}

A reconnaissance of Missouri River from Threeforks to Fort Benton was made in 1872 by Mr. Thomas P. Roberts, then employed by the Northern Pacific Railroad Company. The results were printed in 1875, under authority of the Secretary of War, for the use of the Engineer Department. Mr. Roberts states that on July 27,1872 , a measurement 


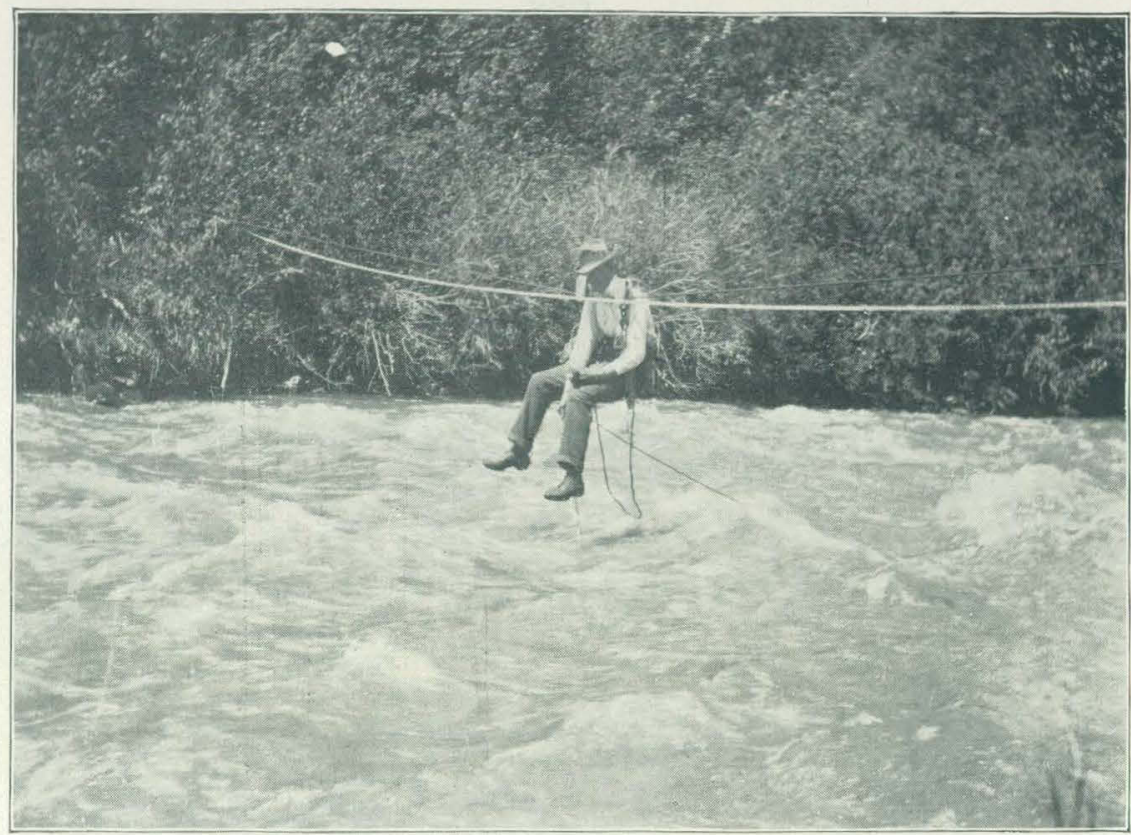

A. MEASURING MIDDLE CREEK ABOVE BOZEMAN. MONTANA

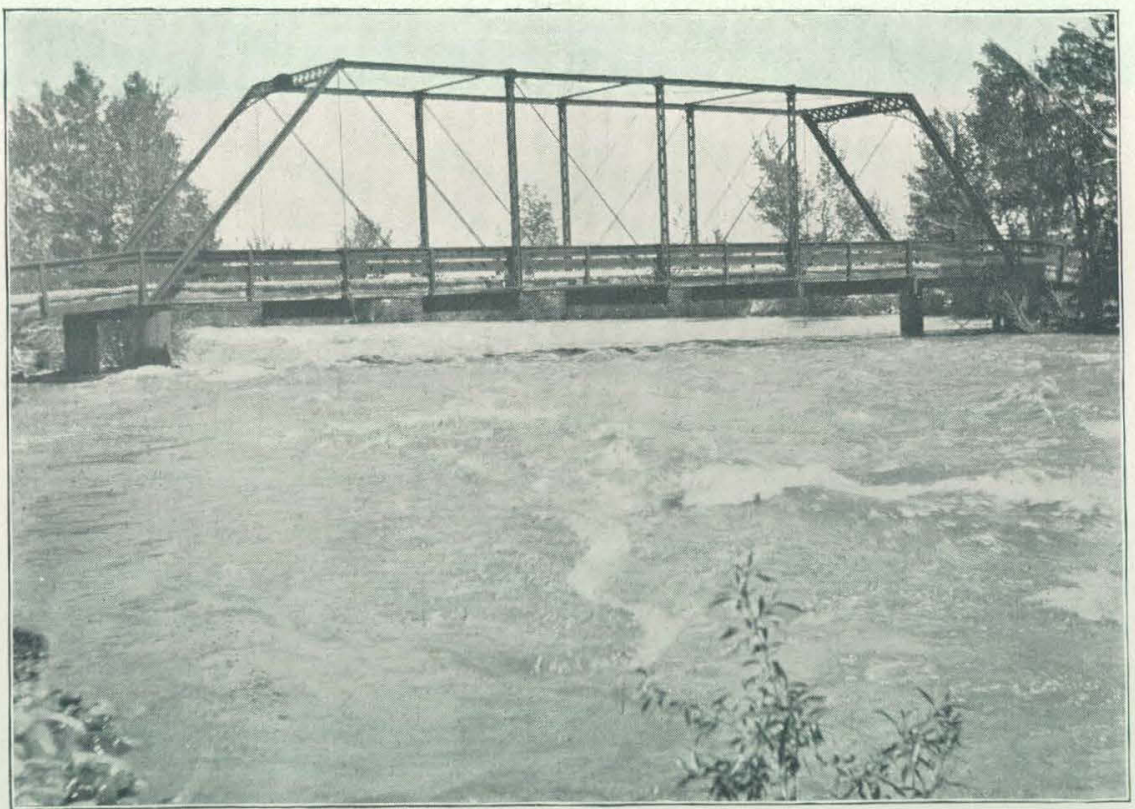

$B$ GAGING STATION ON WEST GALLATIN RIVER, 6 MILES ABOVE SALESVILLE, MONTANA. 
of the tributaries of Missouri River was made at Threeforks, giving the following results: Jefferson River, 3,778 second-feet; Madison River, 2,670 second-feet; Gallatin River, 2,090 second-feet. Total Missouri, 8,538 second-feet. On this date the Missouri River was reported to be 8 inches above low-water mark.

At French Bar, about 71 miles below Threeforks, cross sections were taken at a narrow but favorable place, where the width was 255 feet, - average depth 7.73 feet, average velocity 5.5 feet per second. The estimated discharge was 10,000 second-feet. On August 12, 1872, measurements were made at Fort Benton, the river being 11 inches above low water. The discharge was found to be 11,132 second-feet.

Later measurements have been made at various points along Missouri River, as described in the Twelfth Annual Report, Part II, pages 236 and 237. Temporary river stations were established at Canyon Ferry, Craig, Toston, and finally at Townsend, where the Missouri River Commission has maintained observations of river height since 1891. The discharges given in the following table are based upon the heights thus observed during 1898 and upon occasional measurements of river flow by Mr. Roe Emery.

Estimated monthly discharge of Missouri River at Townsend, Montana.

[Drainage area, 14,500 square miles.]

\begin{tabular}{|c|c|c|c|c|c|c|}
\hline \multirow[b]{2}{*}{ Month. } & \multicolumn{3}{|c|}{ Discharge in second-feet. } & \multirow[b]{2}{*}{$\begin{array}{c}\text { Total in acre- } \\
\text { feet. }\end{array}$} & \multicolumn{2}{|c|}{ Run-off. } \\
\hline & $\begin{array}{l}\text { Maxi } \\
\text { mum. }\end{array}$ & $\begin{array}{l}\text { Mini- } \\
\text { mum. }\end{array}$ & Mean. & & $\begin{array}{l}\text { Depth in } \\
\text { inches. }\end{array}$ & $\begin{array}{c}\text { Second- } \\
\text { feet per } \\
\text { square } \\
\text { mile. }\end{array}$ \\
\hline 1898. & & & & & & \\
\hline January .......... & $\ldots \ldots \ldots$ & $\ldots \ldots$ & $a 3,000$ & 184,464 & 0.24 & 0.21 \\
\hline February .......... & $\ldots \ldots$ & $\ldots \ldots$ & $a 3,000$ & 166,611 & 0.22 & 0.21 \\
\hline 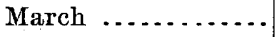 & 15,940 & 2,870 & 4,490 & 276,081 & 0.36 & 0.31 \\
\hline April $\ldots \ldots \ldots \ldots$ & 8,770 & 3,190 & 5,989 & 356,369 & 0.46 & $' 0.41$ \\
\hline Mas ........ & 21,290 & 5,795 & 10,205 & 627,485 & 0.81 & 0.70 \\
\hline June .............. & 25,010 & 9,645 & 18,308 & $1,089,399$ & 1. 41 & 1.26 \\
\hline July ............ & 10,180 & 2,870 & 6,190 & 380,611 & 0.49 & 0.43 \\
\hline August......... & 2,870 & 2,100 & 2,374 & 145,973 & 0.18 & 0.16 \\
\hline September .. & 2,870 & 2,245 & 2,621 & $15 \dot{5}, 960$ & 0.20 & 0.18 \\
\hline October ............ & 3,830 & 2,550 & 3,154 & 193,933 & 0.24 & $0: 22$ \\
\hline November $1-19 \ldots$ & 3,830 & 2,870 & 3,342 & 198,862 & 0.26 & 0.23 \\
\hline December ...... & $\ldots \ldots$ & $\ldots \ldots$ & $a 3,000$ & 184,464 & 0.24 & 0.21 \\
\hline The year ..... & 25,010 & 2,100 & 5,472 & $3,960,212$ & 5.11 & 0.38 \\
\hline
\end{tabular}

a Approximate.

Note.-Gage heights for 1898 are given in Water-Supply and Irrigation Paper No. 27, page 72; measurements, page 75; rating table, page 76. Results for 1897 in Water-Supply and Irrigation Paper No. 15, page 65, and in the Nineteenth Annual Report, Part IV, pages 283 to 285. 


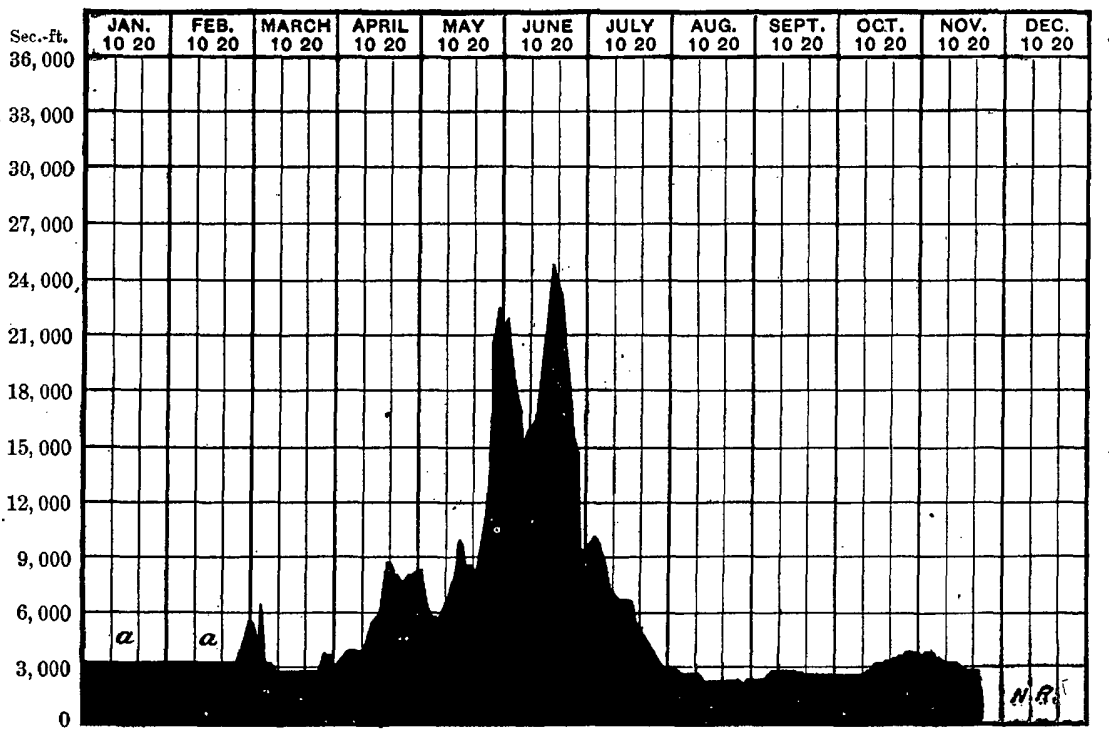

FiG. 84.-Discharge of Missouri River at Townsend, Montana, 1898.

MILK RIVER AT HAVRE,

Measurements of Milk River were begun on May 15, 1898, at a point about a quarter of a mile northwest of Havre, Montana. The floods of the early spring had already subsided, so that the results given in the following table and in fig. 85 do not represent the highest water of the year.

Estimated monthly discharge of Milk River at Havre, Montana.

[Drainage area, 7,300 square miles.]

\begin{tabular}{|c|c|c|c|c|c|c|}
\hline \multirow[b]{2}{*}{ Month. } & \multicolumn{3}{|c|}{ Discharge in second-feet. } & \multirow[b]{2}{*}{$\begin{array}{l}\text { Total in acre- } \\
\text { feet. }\end{array}$} & \multicolumn{2}{|c|}{ Run-off. } \\
\hline & $\begin{array}{l}\text { Maxi- } \\
\text { mum. }\end{array}$ & $\begin{array}{l}\text { Mini- } \\
\text { mum. }\end{array}$ & Mean. & & $\begin{array}{l}\text { Depth in } \\
\text { inches. }\end{array}$ & $\begin{array}{l}\text { Second- } \\
\text { feet per } \\
\text { square } \\
\text { mile. }\end{array}$ \\
\hline 1898. & & & $i$ & & & . \\
\hline May $15-31$. & 2,432 & 836 & 1,396 & 85,837 & 0.22 & 0.19 \\
\hline Juue $\ldots . .$. & 2,546 & 200 & 1,354 & 80,568 & 0.21 & 0.19 \\
\hline July ........ & 950 & 0 & 168 & 10,330 & 0.02 & 0.02 \\
\hline August ......... & 893 & 33 & 113 & 6,948 & 0.02 & 0.02 \\
\hline September ........ & 104 & 11 & 53 & 3,154 & 0.01 & 0.01 \\
\hline October ......... & 125 & 11 & 88 & 5,411 & 0.01 & 0.01 \\
\hline November $1-19 . . .$. & 110 & 93 & 100 & 5,950 & 0.01 & 0.01 \\
\hline December .......... & 125 & 110 & 113 & 6,948 & $0: \dot{02}$ & 0.02 \\
\hline
\end{tabular}

NoTE-Gage heights for 1898 are givẹn in Water-Supply and Irrigation Paper No. 27, page 72; measurements, page 75 , and rating table, page 76 . 


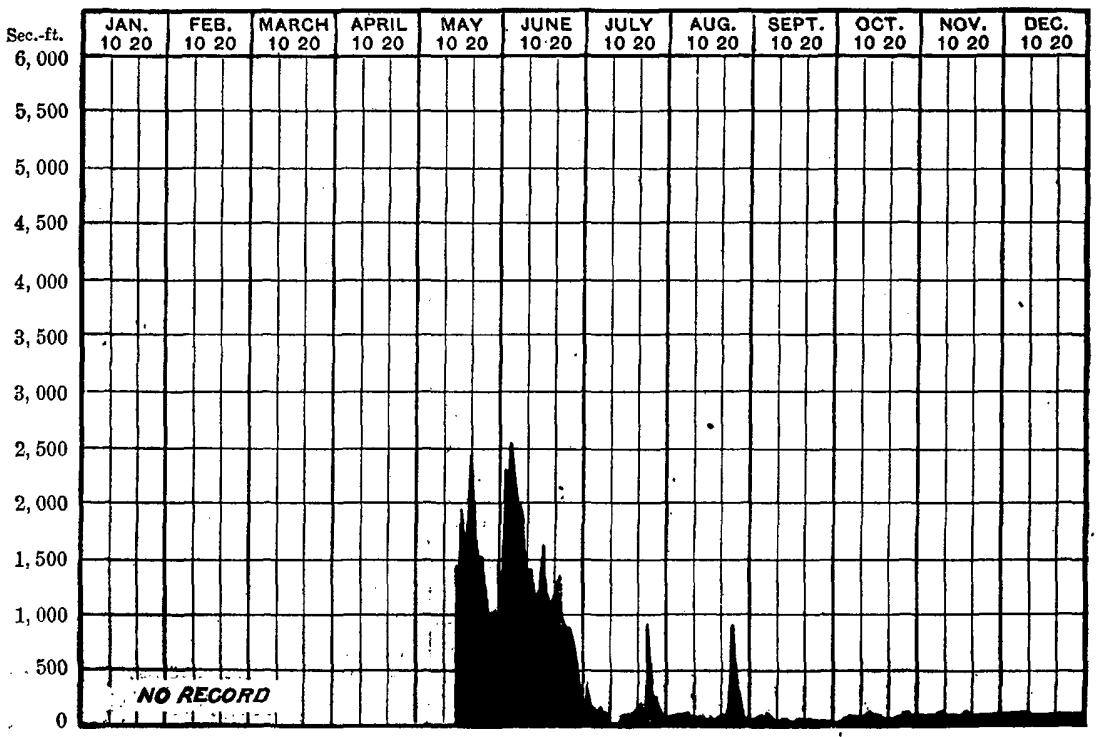

Fig. 85.-Discharge of Milk River at Havre, Montana, 1898.

\section{YELTOWSTONE DRAINAGE BASIN.}

The drainage basin of Yellowstone River includes a portion of southeastern Montana and the northern part of Wyoming. The principal streams besides the Yellowstone are the Bighorn, which receives the water from the slope of the Absoroka Range, and also from the western slope of the Bighorn Mountains. To the east of this is Rosebud River, draining the northern slopes of the Bighorn Mountains, and the Tongue and Powder rivers, obtaining their water from the eastern slopes of these mountains. On the head waters of the latter streams, particularly in the vicinity of Buffalo and Sheridan, Wyoming, irrigation has been largely developed and the water-storage problem has become of great importance. The conditions are more fully described in WaterSupply and Irrigation Paper No. 23, entitled "Water-Right Problems of the Bighorn Mountains."

\section{YELLOWSTONE RIVER. ${ }^{1}$}

Yellowstone River has its source in the lake of the same name, situated in Yellowstone National Park. This river flows in a northerly course into Montana, through which it continues to its junction with the Missouri near the North Dakota line. The Yellowstone Valley contains the largest body of irrigable land in the State. Its altitude is about 2,500 feet. This comparatively low elevation, with favorable climate, especially in the winter season, renders this section remarkably well adapted to live stock. As pointed out by Mr. S. M. Emery, the 
Montana snowfall is not so heavy usually as that of the States to the eastward, and that which falls is driven into the coulées and draws by the force of the winds, thus leaving the land in large part free of snow and the cured grass accessible to live stock. This peculiarity of the winds and the natural adaptability of the soil of this valley to alfalfa production must convert this extensive region, 500 miles in length and from 2 to 10 miles in width, into a vast summer and winter feeding ground for both cattle and sheep.

The oldest alfalfa fields of the Yellowstone have been seeded for fourteen years and are still profitable to the farmer, but it is probable that he can not afford to keep these fertile lands seeded indefinitely. The natural increment to soil from the combined effects of the collections of nitrogen legumes and the consumption of the forage by sheep will soon fit these soils for large crops of wheat, oats, and barley. Breweries and flour mills are rapidly springing up in this territory and the development of the coal fields of Carbon County, situated upon Clarks Fork of the Yellowstone, will create an active demand for farm produce of all kinds.

There are extensive areas of extremely fertile soil upon the vast benches between the Yellowstone and Missouri, much of which is capable of irrigation by water from Yellowstone River, and it is probable that great enterprises for this purpose will be undertaken. Chemical analysis of the waters indicate that they are naturally fairly free from alkali and possess great value for use on the lands.

The point of measurement of the Yellowstone River is at the highway bridge, 5 miles south of Livingston, Montana, at the mouth of Yellowstone Canyon. Observations were begun at this point on May 2, 1897 , and were continued through 1898 , the results being shown on page 73 of Water-Supply Paper No. 27. The following measurements of discharge were made during 1898 :

List of discharge measurements made on Yellowstone River at Livingston, Montana.

\begin{tabular}{|c|c|c|c|}
\hline Date. & Hydrographer. & $\begin{array}{c}\text { Gage } \\
\text { height. }\end{array}$ & Discharge. \\
\hline April $14 \ldots \ldots \ldots$ & Roe Emery $\ldots \ldots \ldots \ldots \ldots \ldots \ldots$ & $\begin{array}{l}\text { Feet. } \\
1.40\end{array}$ & $\begin{array}{c}\text { Second feet. } \\
2,490\end{array}$ \\
\hline May $16 \ldots .$. & $\ldots$ do .... & 4.17 & 8,571 \\
\hline June $21 \ldots$ & .... do .. & 6.80 & 19,782 \\
\hline July $20 \ldots \ldots \ldots$ & $\ldots$. do, ... & - 3.90 & 5,948 \\
\hline August 7 .. & .....do... & 2.80 & 4,501 \\
\hline August $31 \ldots \ldots$. & $\ldots$ do $\ldots . . . . . . .$. & 2.60 & 4,165 \\
\hline September $15 \ldots$ & $\ldots \ldots$ do $\ldots \ldots \ldots \ldots \ldots$ & 1.80 & 3,248 \\
\hline October $6 \ldots \ldots$. & $\ldots$...do .. & 1. 40 & 2,465 \\
\hline October $23 \ldots$ & .....do ... & 1.30 & 2,255 \\
\hline November $2 \ldots .$. & .... do .. & 1.20 & 2,123 \\
\hline
\end{tabular}


Estimated monthly discharge of Yellowstone River at Livingston, Montana.

[Drainage area, 3,580 square miles.]

\begin{tabular}{|c|c|c|c|c|c|c|}
\hline \multirow{2}{*}{ Month. } & \multicolumn{3}{|c|}{ Discharge in second.feet. } & \multirow[b]{2}{*}{$\begin{array}{l}\text { Total in acre- } \\
\text { feet. }\end{array}$} & \multicolumn{2}{|c|}{ Run.off. } \\
\hline & $\begin{array}{l}\text { Maxi- } \\
\text { mum. }\end{array}$ & $\begin{array}{l}\text { Mini- } \\
\text { mum. }\end{array}$ & Mean. & & $\begin{array}{l}\text { Depth in } \\
\text { inches. }\end{array}$ & $\begin{array}{c}\text { Second- } \\
\text { feet per } \\
\text { square } \\
\text { mile. }\end{array}$ \\
\hline 1898. & & & & & & \\
\hline January.... & & $\ldots$. & $a 1,500$ & $a 92,232$ & $a 0.48$ & $a 0.42$ \\
\hline February... & . & $\ldots$ & $a 1,800$ & $a 99,967$ & $a 0.52$ & $a 0.50$ \\
\hline March 1-21. . & 2,119 & 1,608 & 1,900 & 116,827 & 0.61 & 0.53 \\
\hline April.... - & 5,039 & 1,973 & 2,895 & 172,264 & 0.90 & 0.81 \\
\hline May........ & 15,622 & 3,506 & 7,560 & 464,849 & 2.44 & 2.11 \\
\hline June....... & 23,239 & 8,696 & 14,976 & 891,132 & 4.66 & 4. 18 \\
\hline July ...... & 12,621 & 5,039 & 8,560 & 526,337 & 2.76 & 2.39 \\
\hline August ...... & 5,039 & 3,579 & 4,356 & 267,842 & 1.39 & 1.21 \\
\hline September.. & 3,944 & 2,630 & 3,134 & 186,486 & 0.98 & 0.88 \\
\hline October ..... & 2,776 & 2,192 & 2,456 & 151,015 & $0 ! 79$ & 0.69 \\
\hline November... & 2,192 & 1,754 & 1,985 & 118,115 & 0.61 & 0.55 \\
\hline December... & 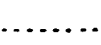 & …..... & $a 1,600$ & 98,381 & $a 0.52$ & $a 0.45$ \\
\hline The year & 23,239 & & 4,394 & $3,185,44 \%$ & 16.66 & 1.23 \\
\hline
\end{tabular}

$$
a \text { Approximate. }
$$

NOTE.-Gage heights for 1398 are given in Water-Supply and Irrigation Paper No. 27, page 73, rating table, page 76; results for 1897 in Water-Supply and Irrigation Paper No. 15, page 74, and in the Nineteenth Anuuál Report, Part IV, pages 287 to 289.

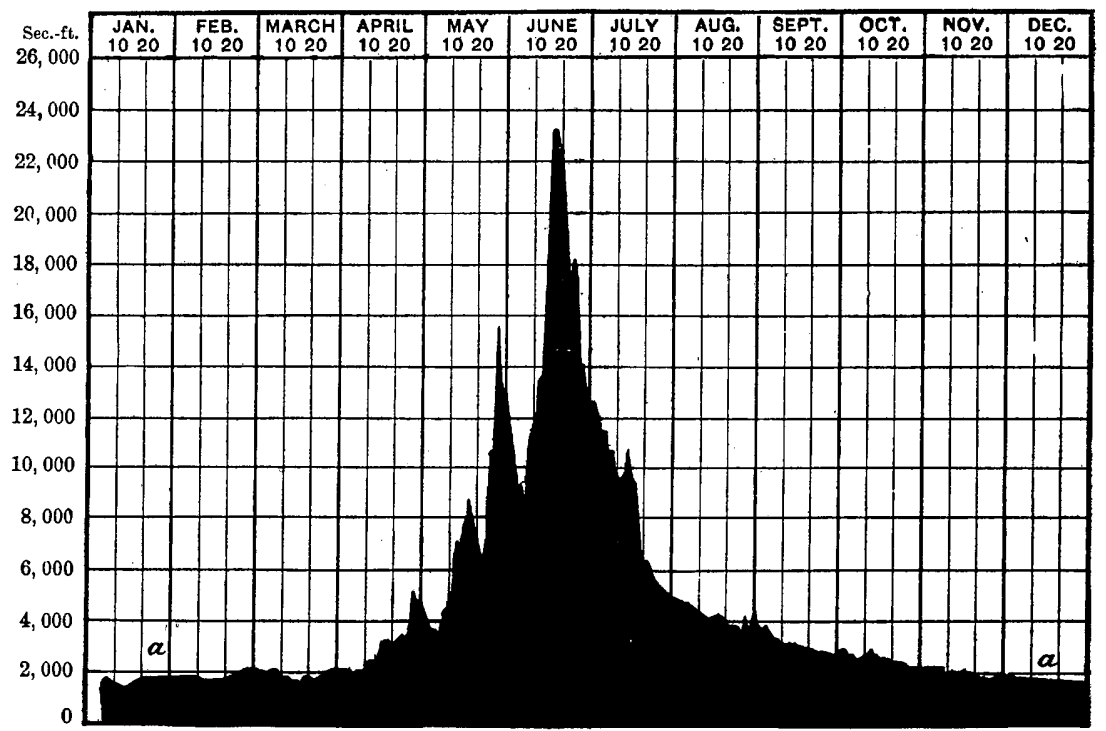

FIG. 86.-Discharge of Yellowstone River at Livingston, Montana, 1898. 


\section{SHOSHONE RIVER.}

Shosbone River is the largest tributary of Bighorn River. It heads in the mountains on the east of the Yellowstone National Park, and flows in a general northeasterly course through the Bighorn Basin. A station for measuring the amount of water was established at Lovell on May 23, 1897. The results of observations of height during 1898 have been printed on page 73 of Water-Supply and Irrigation Paper No. 27. No discharge measurements were made during 1898.

Estimated monthly discharge of Shoshone River at Lovell, Wyoming.

[Drainage area, 2,720 square miles.]

\begin{tabular}{|c|c|c|c|c|c|c|}
\hline \multirow[b]{2}{*}{ Month. } & \multicolumn{3}{|c|}{ Discharge in second-feet. } & \multirow[b]{2}{*}{$\begin{array}{c}\text { Total in acre. } \\
\text { feet }\end{array}$} & \multicolumn{2}{|c|}{ TRun-off. } \\
\hline & $\begin{array}{l}\text { Maxi- } \\
\text { mum. }\end{array}$ & $\begin{array}{l}\text { Mini. } \\
\text { mum. }\end{array}$ & Mean. & & $\begin{array}{l}\text { Depth in } \\
\text { inches. }\end{array}$ & $\begin{array}{c}\text { Second- } \\
\text { feet per } \\
\text { square } \\
\text { yard. }\end{array}$ \\
\hline 1898. & & & & 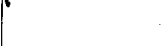 & & \\
\hline 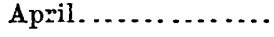 & 3,640 & 270 & 886 & 52,721 & 0.37 & 0.33 \\
\hline 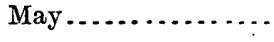 & 12,340 & 600 & 4,367 & 268,518 & 1.86 & 1.61 \\
\hline June ................ & 11,180 & 3,350 & 7,458 & 443,781 & 3.05 & 2.74 \\
\hline July ...... & 8,280 & 1,250 & 4,576 & 281,369 & 1.94 & 1.68 \\
\hline August.... - & 2,770 & 270 & 1,288 & 78,197 & 0.54 & 0.47 \\
\hline September ......... & 2,190 & 150 & 414 & 24,635 & 0.17 & 0.15 \\
\hline
\end{tabular}

NoTe.-Gage heights for 1898 are given in Water-Supply and Irrigation Paper No. 27, page 73, rating table, page 76; resuits for 1897 are given in Water.Supply and Irrigation Paper No. 15, page 76, and in the Nineteenth Annual Report, Part 1V, pages 290 to 293.

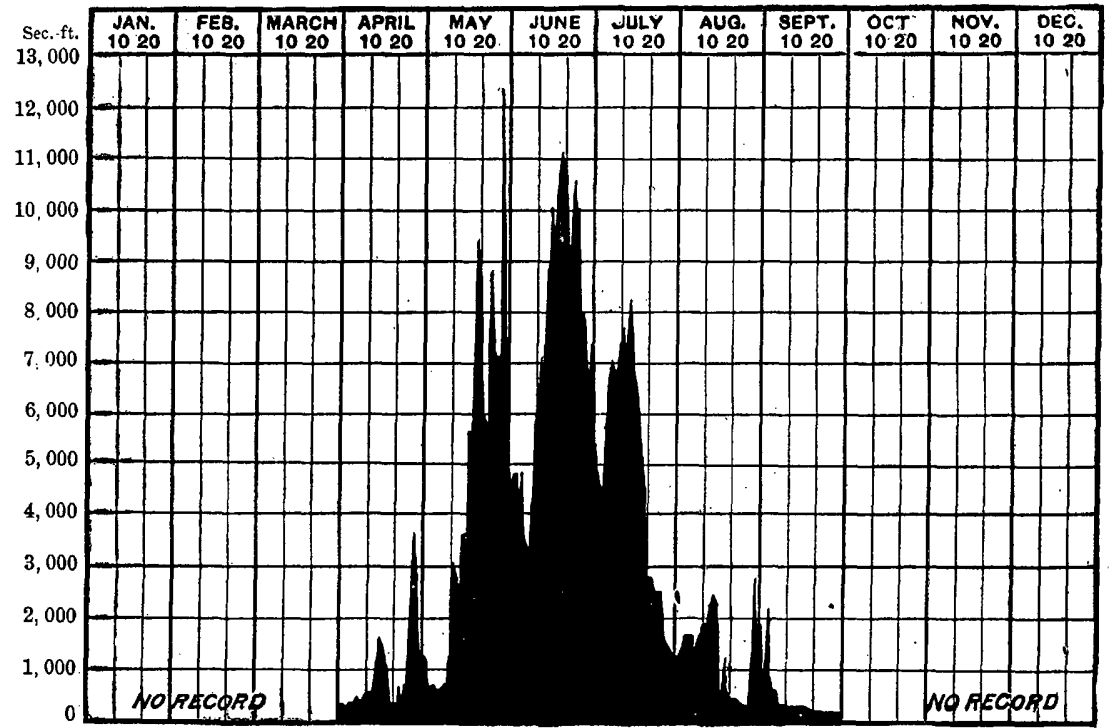

FIa. 87.-Discharge of Shoshone River at Lovell, Wyoming, 1898. 


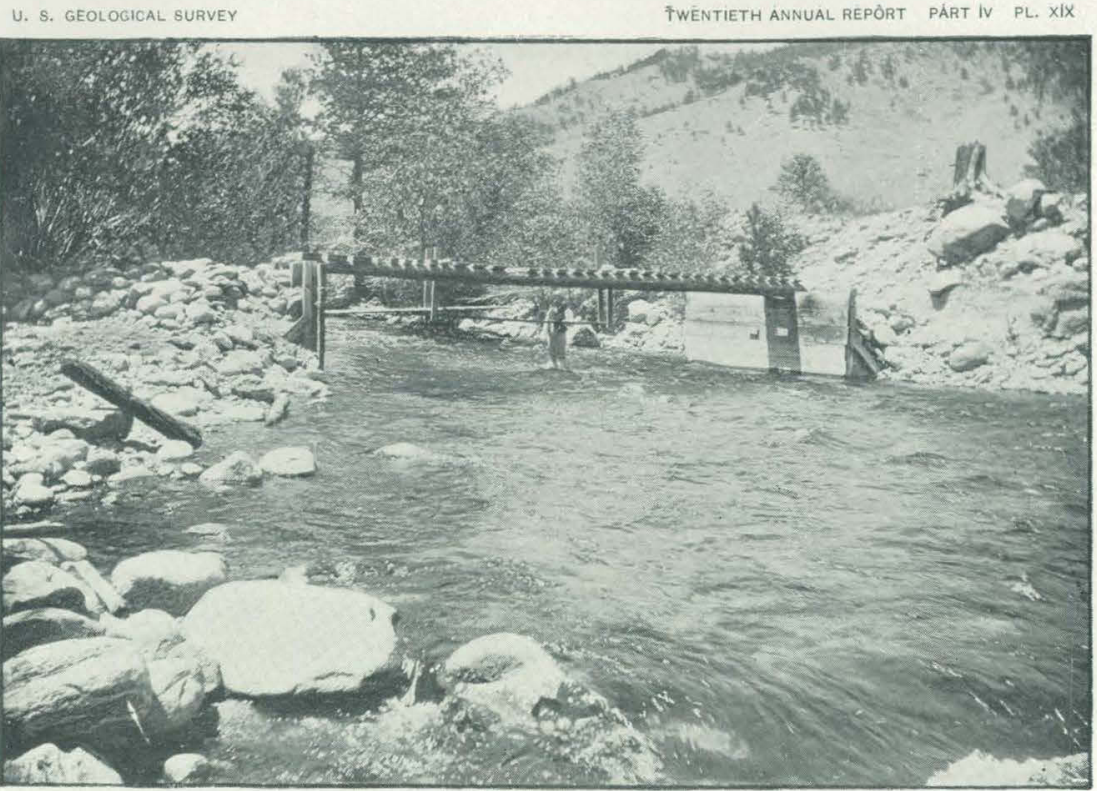

A. GAGING STATION ON CLEAR CREEK, WYOMING.

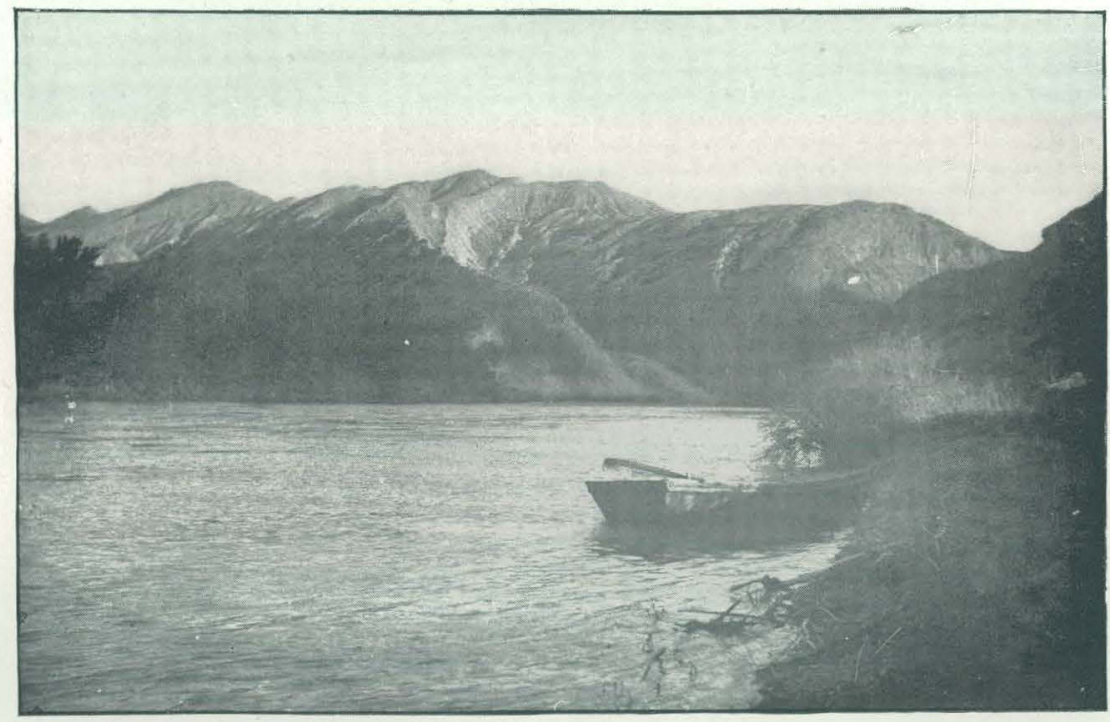

B. BIGHORN RIVER, WYOMING 


\section{CLEAR CREEK.}

Clear Creek is one of the most important tributaries of Powder River, receiving the drainage from Cloud Peak and other portions of the summits of Bighorn Mountains. The location of the stream and its principal tributaries, together with the irrigation systems taking water from these, is shown on fig. 2 of Water-Supply and Irrigation Paper No. 23. The point of measurement is about 4 miles west of Buffalo, Wyoming, at a flume erected for this purpose shown on Pl. XIX, $A$. The results of observations for 1898 are shown on page 73 of WaterSupply Paper No. 27. No discharge measurements were made during 1898. Observations at this point were begun in 1889, but there were not sufficient measurements made to allow the discharge for 1890 to be computed. One measurement was made soon after the rod was put in place, but the meter was damaged before the work was completed and the results are not considered trustworthy, and it was not until 1894 that estimates were available. The figures for a portion of 1894,1896 , and 1897 have been printed on page 30 of Water-Supply and Irrigation Paper No. 23.

Estimated monthly discharge of Clear Creek at Buffalo, Wyoming.

[Drainage area, 118 square miles.]

\begin{tabular}{|c|c|c|c|c|c|c|}
\hline \multirow[b]{2}{*}{ Month. } & \multicolumn{3}{|c|}{ Discharge in second-feet. } & \multirow[b]{2}{*}{$\begin{array}{l}\text { Total in acre- } \\
\text { feet. }\end{array}$} & \multicolumn{2}{|c|}{ Run-off. } \\
\hline & $\begin{array}{l}\text { Maxi- } \\
\text { mum. }\end{array}$ & $\begin{array}{l}\text { Mini- } \\
\text { mum. }\end{array}$ & Mean. & & $\begin{array}{l}\text { Depth in } \\
\text { inches. }\end{array}$ & $\begin{array}{c}\text { Second. } \\
\text { feet per } \\
\text { square } \\
\text { mile. }\end{array}$ \\
\hline 1898. & & & & & & \\
\hline January ........... & $\ldots \ldots$ & $\ldots \ldots \ldots$ & $a 20$ & $a 1,229$ & $a 0.20$ & $a 0.17$ \\
\hline February .......... & $\mid \ldots \ldots$ & $\ldots \ldots \ldots$ & $a 20$ & $a 1,111$ & $a 0.18$ & $a 0.17$ \\
\hline March................ & .. & $\ldots \ldots$ & $a 21$ & $a 1,291$ & $a 0.21$ & $a 0.18$ \\
\hline 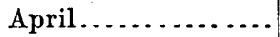 & . & - & $a 150$ & $a 8,926$ & a 1.42 & $a 1.27$ \\
\hline May $15-31 \ldots \ldots \ldots$ & $\ldots \ldots$ & $\ldots \ldots$ & 461 & 33,346 & 4.51 & 3.91 \\
\hline $\operatorname{Jun}{ }^{\prime} \ldots \ldots \ldots$ & 853 & 303 & 576 & 34,274 & 5.44 & 4.88 \\
\hline July $\ldots \ldots \ldots$ & 303 & 82 & 176 & 10,822 & 1.72 & 1. 49 \\
\hline August..... & 92 & 17 & 48 & 2,951 & 0.47 & 0.41 \\
\hline September ... & 39 & 17 & 27 & 1,607 & 0.26 & 0.23 \\
\hline October ................. & 46 & 29 & 38 & 2,337 & 0.37 & 0.32 \\
\hline November .. & $\ldots \ldots$ & ....... & $a 26$ & $a 1,547$ & $a 0.24$ & $a 0.22$ \\
\hline December ... & $\cdots$ & $\mid \ldots \ldots$ & $a 19$ & $a \mathbf{1}, 168$ & $a 0.18$ & $a 0.16$ \\
\hline The sear.... & $\ldots \ldots$ & $\ldots \ldots$ & 132 & 100,609 & 15.20 & 1. 12 \\
\hline
\end{tabular}




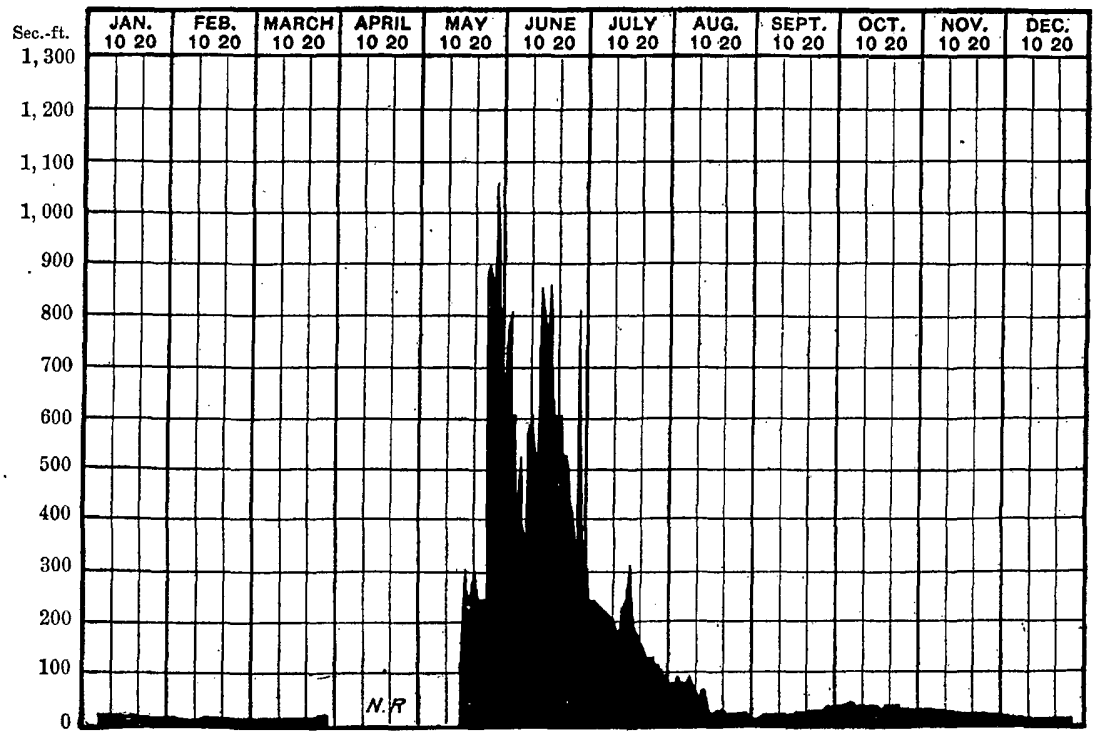

Fig. 88.-Discharge of Clear Creek at Buffalo, Wyoming, 1898.

\section{CHEYENNE RIVER.}

The creeks issuing from the Black Hills in South Dakota and flowing outward in all directions unite, forming either the North or the South Fork of the Cheyenne, these two branches almost encircling the mountain area. From the junction of these forks the river flows in a general course a little north of east, entering the Missouri River at about the center of the State of South Dakota, between the Moreau, or Owl River, on the north, and Bad River, which drains the country on the south. The two forks of the Cheyenne River intercept the drainage from the Black Hills, which otherwise would apparently flow into these streams.

The principal tributaries of the North Fork of the Cheyenne receiving water from the northern part of the Black Hills are the Belle Fourche, Redwater, Spearfish, Whitewood, Bear Butte, and Warren creeks. Those of the South Fork draining the southern part of the Black Hills are, in Wyoming, Antelope, Black Thunder, Beaver, and Sage creeks, and in South Dakota, Hat Creek, entering from the south; also Fall River, Beaver, French, Battle, Spring, Ranch, Boxelder, and Elk creeks. The streams just, enumerated from Fall River to Elk Creek, inclusive, carry considerable volumes of water from the higher portions of the Black Hills, and are thus valuable in the irrigation of the lower lands.

Although the flow of these streams draining the Black Hills is relatively small, yet with the rapid descent it is practicable to develop a considerable amount of water power, especially by providing storage works. A portion of the power is now used, the water wheels being 


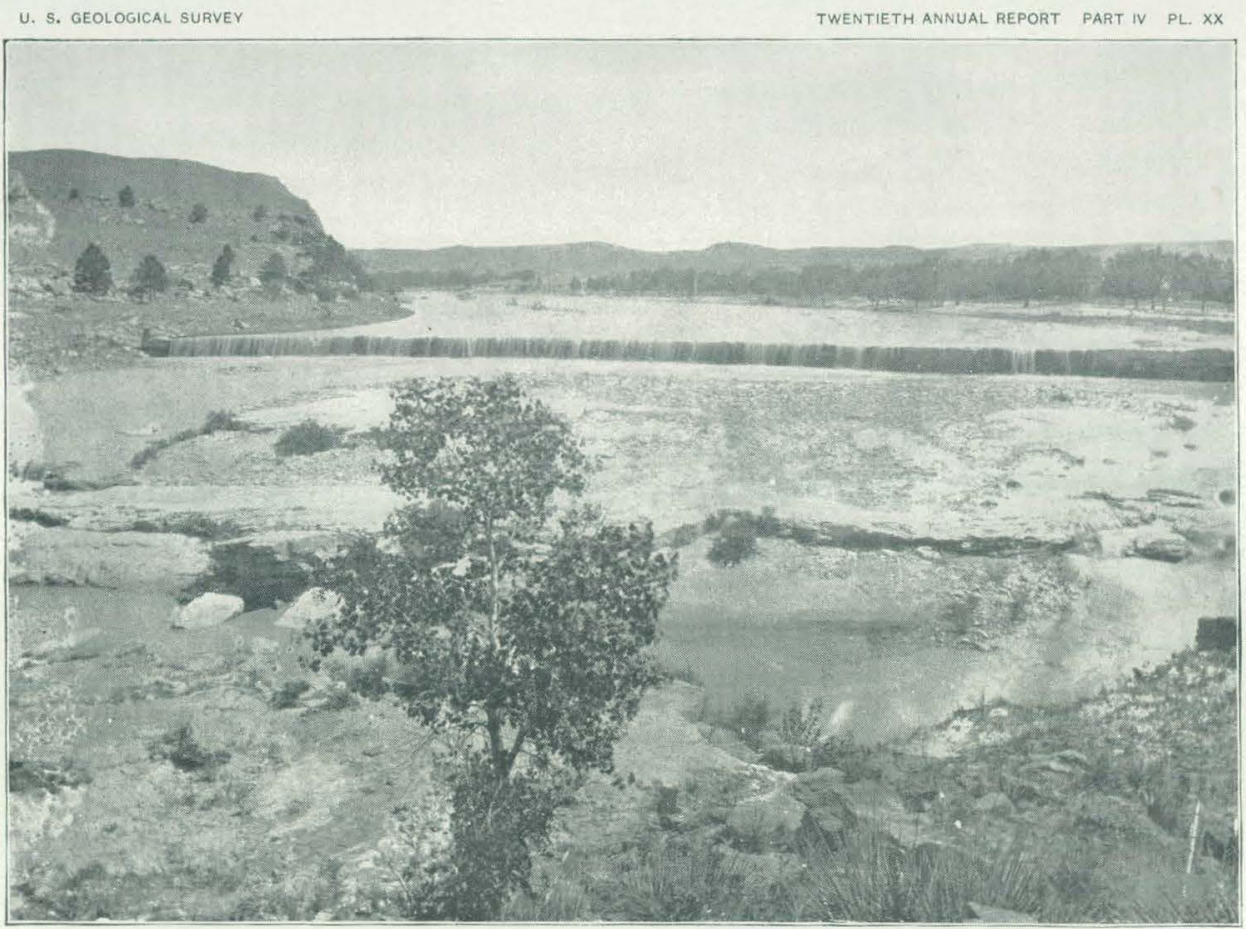

1. FALLS OF CHEYENNE RIVER, FALL RIVER COUNTY, SOUTH DAKOTA.

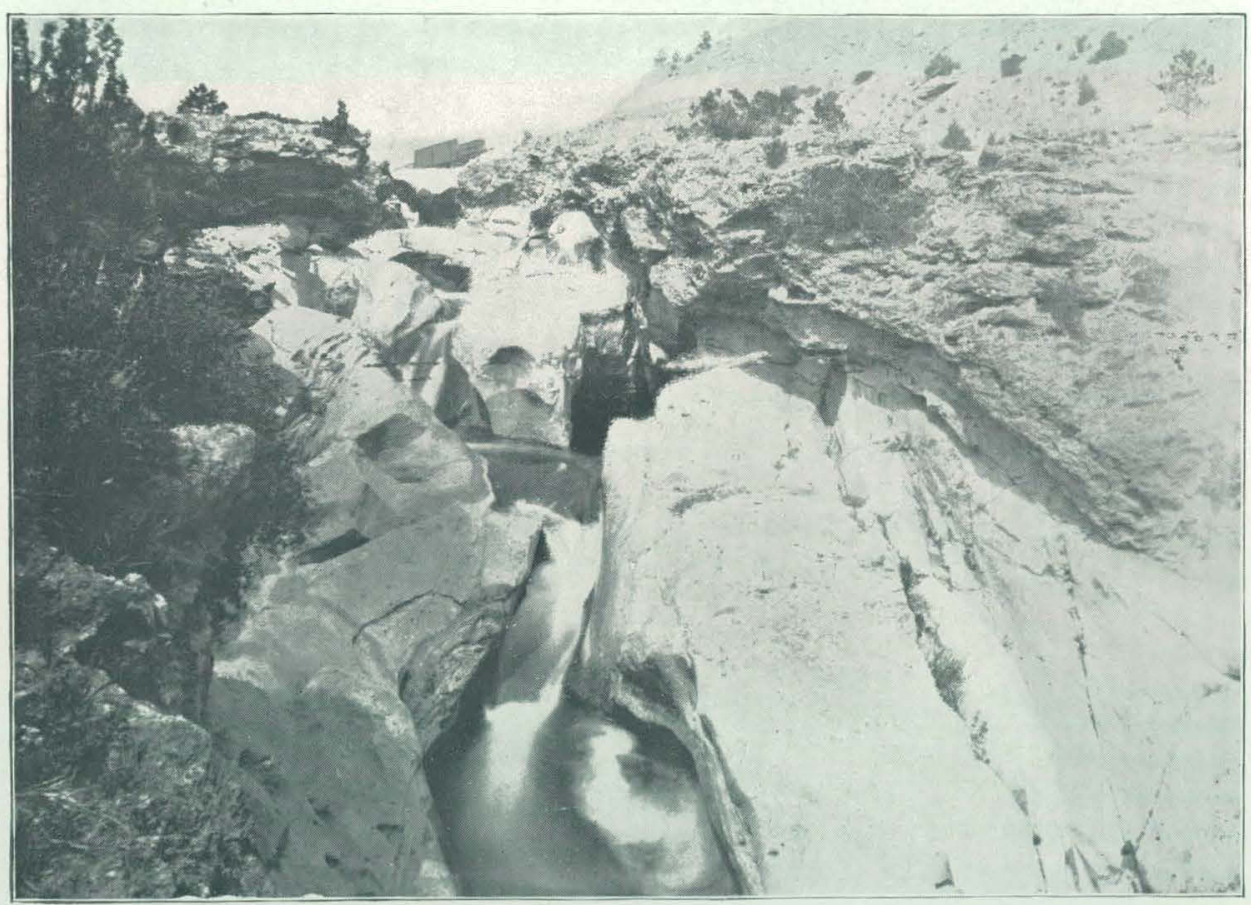

B. DAKOTA SANDSTONE AT CASCADES OF FALL RIVER NEAR EVANS'S QUARRY, BLACK HILLS, SOUTH DAKOTA. 
small, old-fashioned, or homemade. In order to obtain the best results it will be necessary to employ various forms of Pelton or high-pressure wheels, to which water is conducted by various forms of pipes, wooden or steel. The falls of Cheyenne River, in Fall County above the mouth of Fall River, are shown on the accompanyiug Pl. XX; and also the falls of Fall River near Evan's Quarry. Here the water descends rapidly over the outcrop of the Dakota sandstone. Another view, PI. XXI, taken about a quarter of a mile above Evan's Quarry, gives a general conception of the character of the stream.

The use of water for irrigation has been extended until the summer flow is entirely claimed, and there is more land under irrigation than can readily be supplied. The ditches are small, being built generally by a cooperative association of farmers. The construction of these is crude, and the methods of employing water wasteful, so that it is probable that by better practice larger areas of land could be brought under cultivation, especially if storage reservoirs were constructed. There are many favorable localities for holding water, particularly at points where the streams flowing from the central mass of mountains cut through the outer rim of upturned rocks. Behind these socalled hogbacks are broad valleys, where water could be stored by dams placed in the narrow gorges.

During the summer of 1898 a thorough study of the geologic conditions of the area to the east of the Black Hills was made by Mr. N. H. Darton, with a view to ascertaining the distribution of underground waters and of obtaining the facts bearing upon the artesian conditions throughout the country to the east. A general reconnaissance of the Bad Lands was made, and information was had concerning the probability of obtaining artesian flow in the valleys of Cheyenne and White rivers. On September 12,1898, French Creek was examined in its lower portion and found to be nearly dry. Ranches were found at short intervals along the creek, the principal crop being corn, apparently raised mainly for forage. Many small ditches lead from the ravines on each side of the main stream, these being dry at this season of the year. The creek was discharging about 0.5 of a secondfoot, but there were signs indicating a larger volume of water during the fall.

At the point where Battle Oreek joins Cheyenne River are broad alluvial flats covered with cottonwood trees. At this place there were about 100 second-feet of water. in the south fork of Cheyenne River. This water was distinctly alkaline to the taste. Below the mouth of Battle Oreek what is known as the "Old Flour Trail" crosses the Bad Lands, coming from the south. This is an old road upon which freight, consisting principally of flour, was hauled to the military posts. It is on a nearly level plateau, extending between the White and Cheyenne rivers, a remnant of a great plain, now deeply dissected into bad lands. The road itself is nearly level, but at a short distance on either side 
are the heads of precipitous canyons.' In one place, known as "The Pass," these canyons approach from opposite sides within a few hundred feet of each other, and in their encroachment threaten to cut the plateau in two. By following the established roads or trails it is possible to pass through the Bad Lands with ease, but by attempting a different route progress may become impossible. These plateaus are for the most part covered with grass, furnishing excellent pasturage for the cattle of the Indians of the Pine Ridge Reservation and of their white neighbors. Following the Flour Trail south from Cheyenne River the road leads down to a point a few miles above the mouth of Wounded Knee Creek, which flows into White River from the south at this point.

The south fork of Cheyenne River, near the mouth of Rapid Creek, was carrying on September 20,1898, about 100 second-feet. The valley. at this point is broad, but the river meanders back and forth from the cliffs on one side to those on the other, cutting the bottom into tracts of a few thousand acres. Irrigation development by means of canals of considerable size is thus prevented. Pumping water has been tried and found to be successful. For example, Marshall Nye, of Creston, South Dakota, has on the south bank of White River a 15-horse power engine operating two link-belt water elevators, and these are estimated to discharge about 3 second-feet, or more water than can be distributed by one man. There is ample fuel in the cottonwoods along the river and the driftwood brought down by the stream.

\section{WHITE RIVER.}

White River rises in the extreme northwestern corner of Nebraska, in Sioux and Dawes counties, and flows northeasterly along the front of Pine Ridge, from which it receives numerous tributaries. On reaching the State line it crosses in to South Dakota, and flows in a northerly course through the Pine Ridge Indian Reservation. Turning easterly it forms the northern boundary of the reservation, and also of the Rosebùd Indian Reservation adjoining on the east. The principal tribataries come from the south, little water being received from the north, as the tributaries of Bad River head within a few miles of the northern bank of White River. The upper part of the drainage basin, particularly in the Pine Ridge Indian Reservation, consists mainly of bad lands, from which a considerable amount of water is discharged immediately after storms, the floods carrying great quantities of earthy matter in suspension and giving the water a peculiar white color. Even in times of drought the water is not clear, but has a milky appearance. A sample was taken on September 18, 1898, at a point on White River near Pumpkin Creek, aböut 12 miles above Corn Creek. At that time the river was discharging about 20 second-feet. The sample, as examined at the Survey laboratory in Washington, contained the following solids in suspension and solution: 


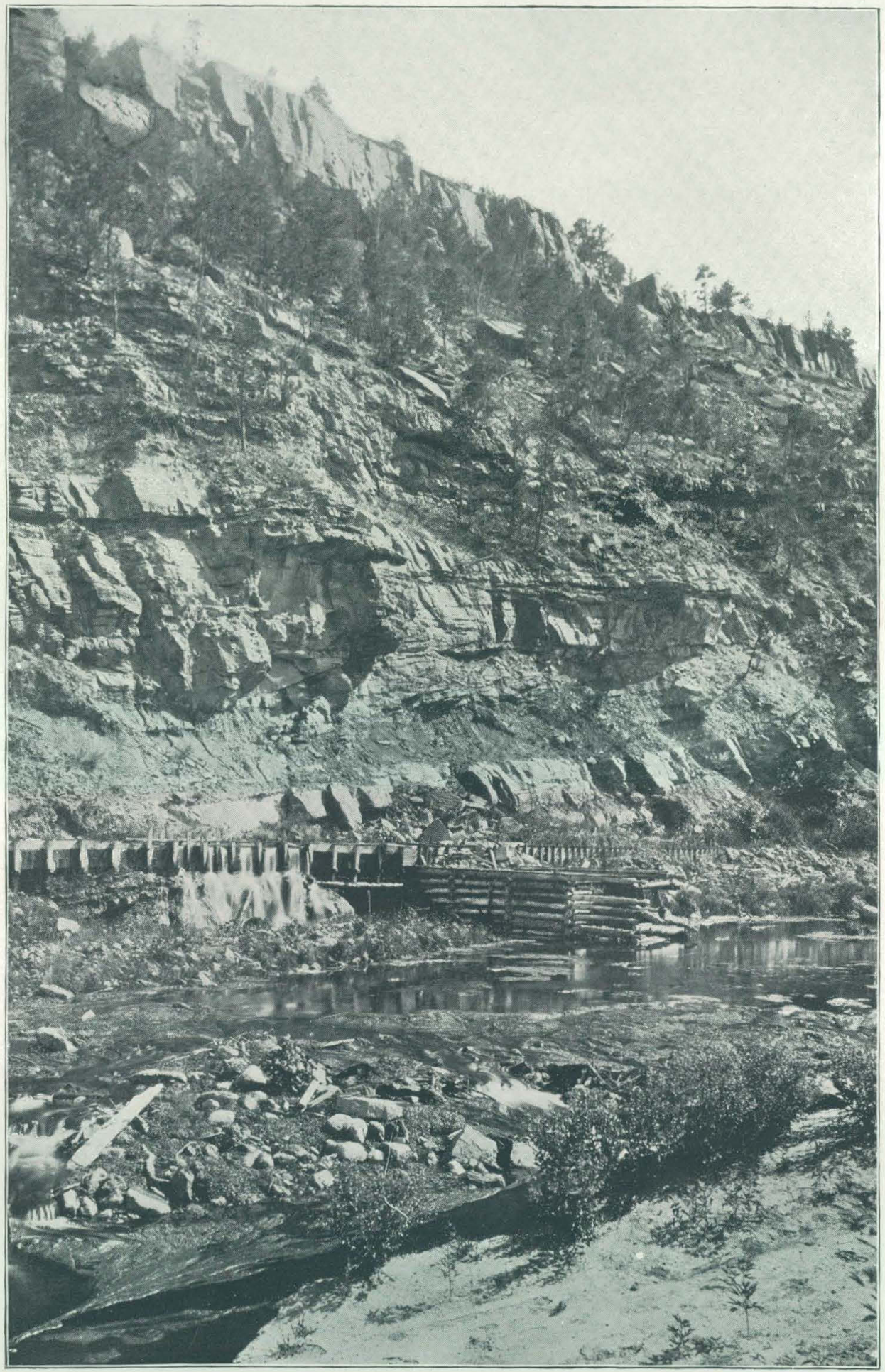

FALL RIVER, ONE-FOURTH OF A MILE ABOVE EVANS'S QUARRY, BLACK HILLS, SOUTH DAKOTA. 
Analysis of water from White River.

. One thousand cubic centimeters held in suspension. $4.7 \mathrm{grams}$, or approximately 0.47 per cent, of clayey matter, roughly combined as follows:

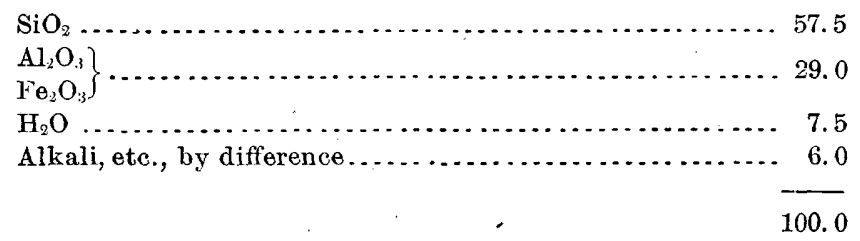

The clay contains more iron than its color in the water would indicate. It burns dark red-brown. In solution the water held approximately 340 parts per million, chiefly sodium carbonate, with some sulphate. Lime and magnesia were absent in more than traces. Reaction faintiy alkaline.

Measurements of White River have been made at points in Nebraska by Prof. O. V. P. Stout and his assistants, the results being given in the table on page 303 . Most of these were made in the vicinity of Crawford, where the drainage area is only about 270 square miles as measured from the Land Office map.

Soldier Creek flows into White River from the north, above Urawford, at Fort Robinson. On June 24, 1896, the discharge at this point. was 3.2 second-feet, and on August 14, 1897, at a point 5 miles above Fort Robinson, was 2.3 second-feet. On April 27, 1898, at Fort Robinson it was 3.6 second-feet.

Measurements have also been made of Big and Little Cottonwood creeks, which enter White River below Crawford. The discharge of Little Cottonwood Creek, in sec. 7, T. 32 N., R. 5 W., was on June 25, 1896, about 0.1 second-foot, and of Big Cottonwood Creek, 6 miles west of Whitney, on the same day, was 0.2 second-foot.

Two of the tributaries of White River are known as White Clay Creek, the first and smaller entering from the south immediately below Crawford, and the second heading near Rushville and flowing north across the State line by the Pine Ridge Agency. Measurements of the first of these have been made near the mouth, the flow on June 24 , 1896, being 4 second-feet, and on September 21, 1898, about 0.8 secondfoot. Other small tributaries, such as Ash, Indian, Dead Horse, and Bordeaux, have been measured, as shown in the table.

White River was visited in September, 1898 , at points near the mouth of Wounded Knee Creek and for 20 miles below. The country in this vicinity is open and the valleys are broad, with fair grazing. Wounded Knee Creek was carrying about 2 second-feet at a point near the schoolhouse, a short distance above the mouth, and White River above the creek was discharging about 12 second-feet. A small amount of irrigation is practiced by the "squaw men" living in the valley of the creek, potatoes and vegetables being successfully raised. There are a number of ranches of Indians and half-breeds along White River, their only occupation being cattle raising. A view of White River in 
this vicinity is shown on Pl. XXII. At $A$ is a photograph taken looking up White River from Tibbitts's Ranch, opposite Pumpkin Creek, South Dakota; and at $B$ is a view taken looking down White River, near the mouth of Medicine Root Creek, South Dakota.

\section{NIOBRARA RIVER.}

Niobrara River rises in eastern Wyoming and flows across the State line into Nebraska, continuing along the northern side of that State near the boundary of South Dakota, and entering Missouri River about 50 miles above the mouth of James or Dakota River. Measurements of the stream have been made at various points, as noted in the list given on page 301 , most of these being near the headwaters and at the middle distance of its course, at Fort Niobrara.

A station for the measurement of Niobrara River was established on July 22, 1897, at a point about 3 miles east of Valentine, Nebraska. Gage heights were not observed during 1898, but measurements were made as shown by the following table:

List of discharge measurements made on Niobrara River at Valentine, Nebraska.

\begin{tabular}{|c|c|c|c|}
\hline Date. & Hydrographer. & $\begin{array}{c}\text { Gage } \\
\text { height. }\end{array}$ & Discharge. \\
\hline & & Feet. & Second-feet. \\
\hline April $25 \ldots \ldots \ldots$ & 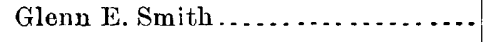 & 0.05 & 987 \\
\hline May $13 \ldots \ldots \ldots \ldots$ & 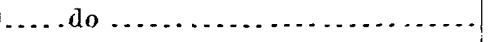 & 0.23 & 1,588 \\
\hline May $24 \ldots . . . . . .$. & 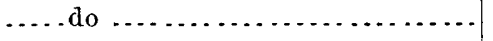 & 0.10 & 1,156 \\
\hline June $12 \ldots \ldots .$. & $\ldots$ do ...... & 0.05 & 876 \\
\hline July $27: \ldots \ldots \ldots$ & $\ldots \ldots$ do $\ldots \ldots \ldots \ldots$ & 0.35 & 690 \\
\hline August $21 \ldots . .$. & ....do do.......... & 0.39 & 677 \\
\hline September $7 \ldots .$. & $\ldots$ do $\ldots \ldots \ldots \ldots \ldots \ldots \ldots$ & 0.32 & 748 \\
\hline September $26 \ldots$. & 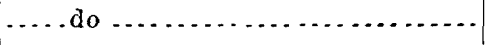 & 0.28 & 840 \\
\hline October $16 \ldots \ldots$ & 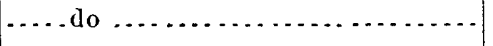 & 0.18 & 867 \\
\hline October $29 \ldots$ & 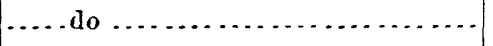 & 0.12 & 960 \\
\hline November $17 \ldots$. & $\ldots$ do $\ldots . . . . . . . . .$. & 0.5 & 960 \\
\hline December $17 . . . .$. & 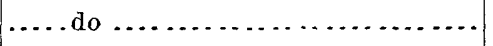 & Ice. & 843 \\
\hline December $28 \ldots .$. & ..... do .. & Ice. & 964 \\
\hline
\end{tabular}

\section{PLATTE RIVER DRAINAGE.}

Under this heading are included the North and South Platte and their numerous tributaries receiving water from eastern Wyoming and northeastern Colorado. The North Platte is the larger stream, flow. ing continuously throughout the year, while the South Platte, owing partly to the diversion of water for irrigation, is dry much of the time near the Colorado State line and from there down to the junction with the North Platte. 


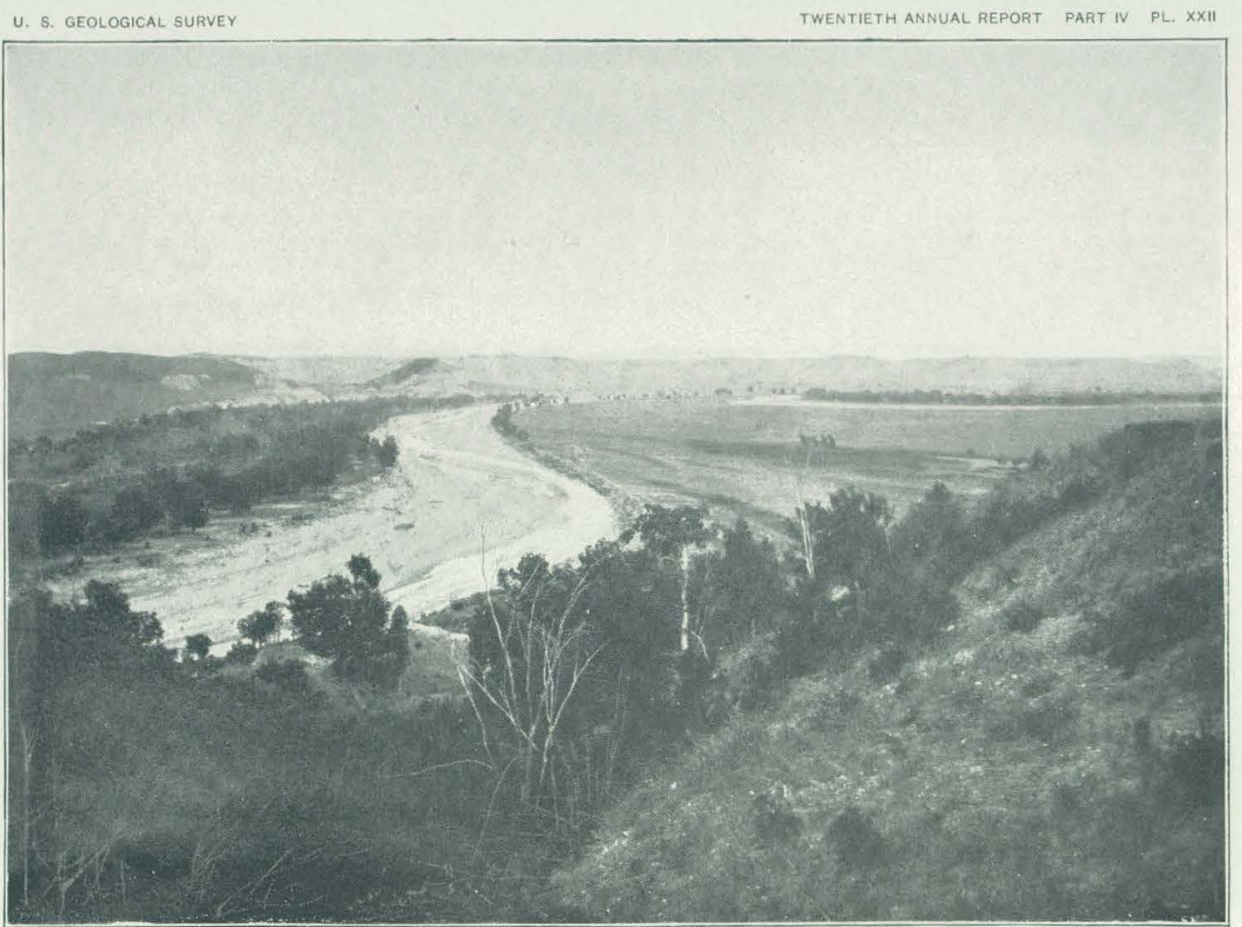

A. LOOKING UP WHITE RIVER FROM TIBBITTS'S RANCH, OPPOSITE PUMPKIN CREEK, SOUTH DAKOTA.

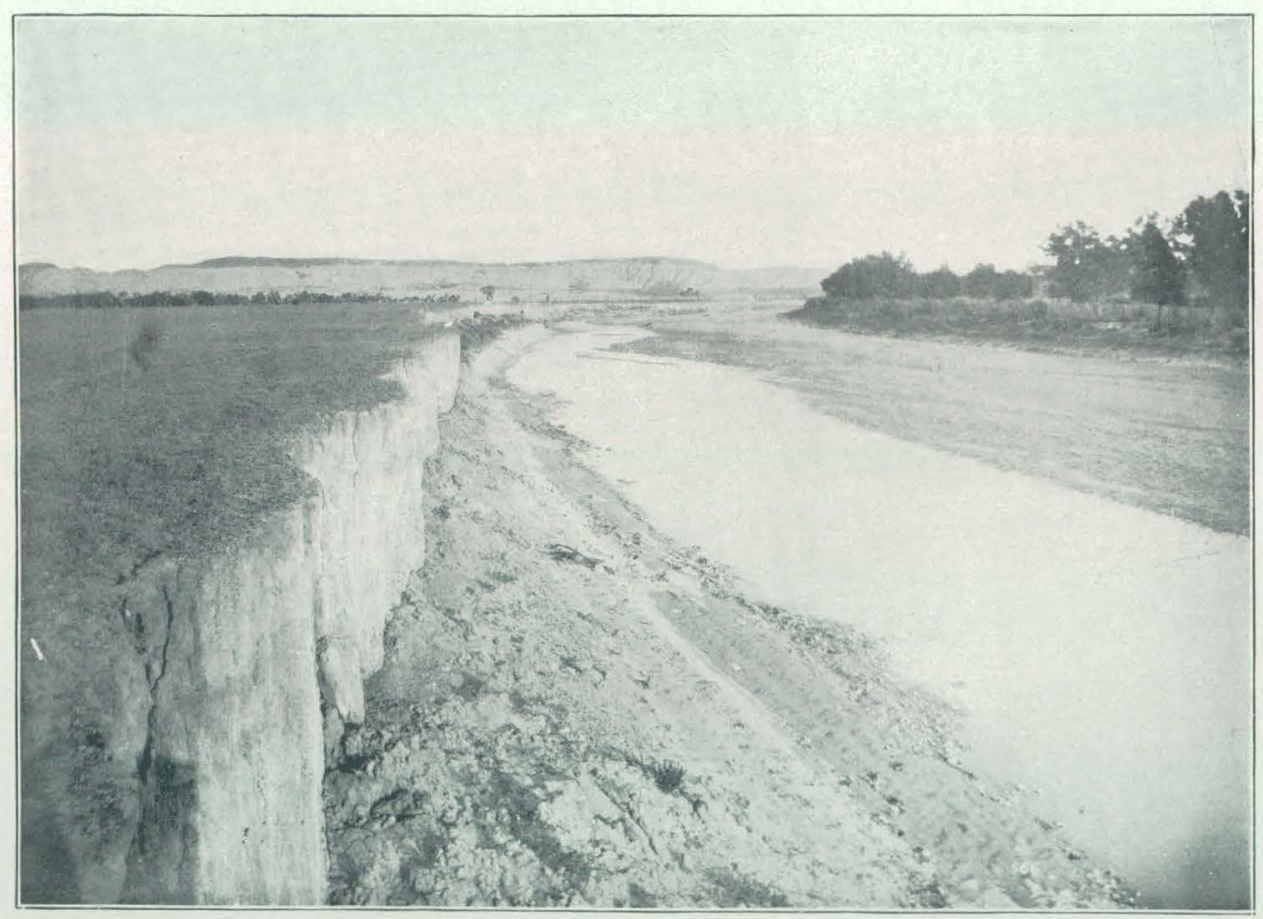

B LOOKING DOWN WHITE RIVER FROM NEAR MOUTH OF MEDICINE ROOT CREEK, SOUTH DAKOTA. 


\section{PLATTE RIVER.}

The main Platte in Nebraska, although receiving water continuously from the North Platte, becomes almost, if not quite, dry during the extreme droughts, owing to the excessive evaporation and seepage in the broad, sandy bed. Few, if any, tributaries enter the Platte River

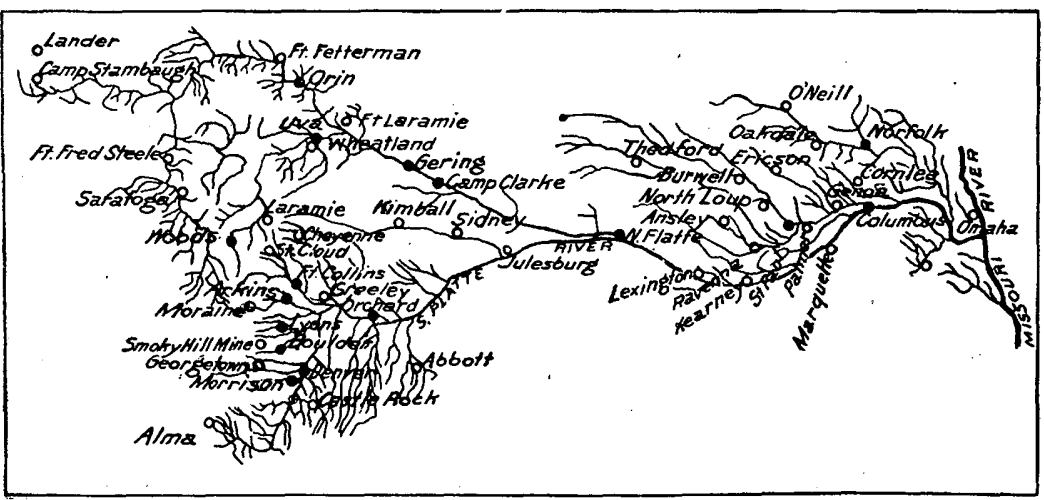

FIQ. 89.-Relative location of river and rainfall observations in basin of Platte River.

from the south, the headwaters of the Republican River approaching within a few miles of the south bank of the Platte. From the north, however, a considerable amount of water is received from rivers draining the sand-hill area of central and western Nebraska.

PRECIPITATION IN THE BASIN OF PLATTE RIVंER.

The principal observations of rainfall made within the basin of the Platte River are at Lander, Camp Stambaugh, Laramie, St. Cloud, Wheatland, Fort Laramie, Cheyenne, Fort Collins, Moraine, Smoky Hill mine, Georgetown, Alma, Castlerock, Denver, Greeley, Kimball, Alliance, Sidney, North Platte, Thedford, Lexington, Kearney, Ravenna, Ansley, Burwell, North Loup, Palmer, Ericson, Oakdale, O'Neill, Norfolk, Cornlea, Genoa, Marquette, Lincoln. The relative location of these points is shown by fig. 89 , in connection with the points of river measurement which are at Orin Junction, Uva, Gering, Camp Clarke, Woods, Arkins, Lyons, Boulder, Denver, Morrison, Orchard, North Platte, St. Paul, Norfolk, and Columbus. The following table gives the names and location of the stations, the elevations, and the number of years during which the observations have been made; or, rather, the number of complete monthly observations used in computing the normals. 
Location of rainfall stations.

\begin{tabular}{|c|c|c|c|c|c|c|}
\hline Station. & County. & State. & Latitude. & $\begin{array}{l}\text { Longi. } \\
\text { tude. }\end{array}$ & $\begin{array}{l}\text { Eleva. } \\
\text { tion. }\end{array}$ & $\begin{array}{l}\text { Length of } \\
\text { record. }\end{array}$ \\
\hline & & & $\circ \quad$, & & & \\
\hline Lander ... & Fremont .... & Wyoming & & & 5,377 & $18-20$ \\
\hline Laramie & Albany... & ..... do. & 4124 & 10535 & 7,161 & $15-19$ \\
\hline St. Cloud.. & Larimer. . & Colorádo & 4033 & 10528 & $\ldots \ldots$. & $5-7$ \\
\hline Wheatland..... & Laramie..... & Wyoming ... & 423 & 10457 & $4,74.7$ & $4-5$ \\
\hline Fort Laramie & .....do & ..... do . & 4212 & 10433 & 4,250 & $27-34$ \\
\hline Gering ... & Scotts Bluff. & Nebraska. & 4151 & 10343 & 3,902 & $7-9$ \\
\hline Cheyenne. & Laramie & Wyoming & 4108 & 10448 & 6,105 & 28 \\
\hline Fort Collins. & Larimer..... & Colorado. & 4035 & 1054 & 4,995 & 15-19 \\
\hline Moraine.... & .... do . ...... & .... do ... & 4021 & 10535 & 7,900 & $8-9$ \\
\hline Smoky Hill mine & Boulder. & .....do. & 4000 & 10514 & 7,800 & $7-8$ \\
\hline Georgetown .... & Clear Creek & .....do. & 3942 & 10541 & 8,500 & 12 \\
\hline Alma ...... & Park. & .....do & 3918 & 10604 & 10,300 & $9-10$ \\
\hline Castlerock & Douglas. & .....do & 3922 & 10452 & 6,220 & $6-9$ \\
\hline Denver.... & Arapahoe & .... do ... & 3946 & 10500 & 5,309 & $26-27$. \\
\hline Greeley ... & Weld .... & .....do .. & 4026 & 10442 & 4,637 & $6-9$ \\
\hline Kimba1l . & Cheyenne & Nebraska & 4113 & 10340 & 4,697 & $6-10$ \\
\hline Alliance.... & Boxbutte. & .....do do & 425 & 10252 & 3,968 & $5-6$ \\
\hline Sidney .... . & Cheyenne & ..... do . & 418 & 10258 & 3,820 & $\ldots$ \\
\hline North Platte ... & Lincoln. & ....do do & 4108 & 10045 & 2,841 & $23-24$ \\
\hline Thedford.. & Thomas. & ..... do. & 4158 & 10032 & 2,842 & ...... \\
\hline Lexington & Dawson .. & ..... do . & 3947 & 9943 & 2,385 & $8-9$ \\
\hline Kearney .. & Buffialo... & ..... do & 4041 & 9905 & 1,997 & $19-22$ \\
\hline Ravenna... & .....do ... & .... do . . & 412 & 9854 & 2,008 & 20 \\
\hline Ansley ..... & Custer ... & .....do. & 4115 & 9922 & 2,307 & $7-9$ \\
\hline Burwell... & Garfield... & .....do. & 4143 & 99,00 & 2,180 & $11-14$ \\
\hline North Loup & Valley ....... & .....do & 4130 & 9841 & 9,961 & $9-10$ \\
\hline Palmer... & Merrick... & .....do & 4114 & 9815 & 1,796 & 11 \\
\hline Ericson ... & Wheeler... & .....do & 4148 & 9842 & 2,029 & $7-8$ \\
\hline Oakdale... & Antelope.... & .....do. & 4204 & 9757 & 1,722 & $9-13$ \\
\hline o'Neill .... & Holt ..... . & .....do. & 4228 & 9837 & 1,975 & $7-8$ \\
\hline Norfolk & Madison .... & ..... do. & $42 \quad 3$ & 9724 & 1,532 & $11-15$ \\
\hline Cornlea : & Platte..... & .... do . & 4141 & 9733 & 1,742 & $12-13$ \\
\hline Genoa.... & ....do... & ....do. & 4127 & 9744 & 1,584 & $22-23$ \\
\hline Marquette & Hamilton ... & .... do .. & 4058 & 9800 & 1,830 & $17-18$ \\
\hline Lincoln. & Lancaster... & .... do & 4048 & 9642 & 1,647 & 19 \\
\hline
\end{tabular}

In the following table are given the figures of normal or average monthly precipitation from the time of the beginning of the record to and including 1897 , together with the total precipitation, by months, for the years 1896, 1897, and 1898, and also the amount by years. In obtaining the normal precipitation the average is taken for all of the months during which observations were made. 
Rainfall at stations in drainage basin of Platte River.

LANDER.

\begin{tabular}{|c|c|c|c|c|c|c|c|c|c|c|c|c|c|}
\hline Year. & Jan. & Feb. & Mar. & Apr. & May. & June. & July. & Aug. & Sept. & Oct. & Nov. & Dec. & Annual. \\
\hline Normal . & 0.64 & 0.41 & 1.50 & 1.86 & 2.06 & 0.80 & 0.77 & 0.65 & 0.56 & 0.87 & 0.55 & 0.42 & 11.09 \\
\hline 1896. & 0.25 & 0.20 & 1.62 & 1.60 & 2.13 & 0.60 & 1.67 & 1. 19 & 0.93 & 0.46 & 0.42 & 0.00 & $11 . .07$ \\
\hline $1897 \ldots$ & 0.23 & 1.11 & 1.38 & 1.14 & 1.25 & 0.85 & 1.21 & 1.04 & 0.15 & 1.12 & 0.44 & 1.29 & 11.21 \\
\hline 1898. & 0.33 & T. & 2.73 & 1.08 & 6.02 & 3.02 & 0.67 & 0.62 & 0.36 & 2.22 & 0.25 & 0.69 & 17.99 \\
\hline \multicolumn{14}{|c|}{ LARAMIE: } \\
\hline Normal & 0.40 & 0.44 & 0.83 & 1.09 & 1.52 & 1.34 & 1.62 & 1.37 & 0.94 & 0.83 & 0.57 & 0.45 & 11.40 \\
\hline 1896. & 0.44 & 0.17 & 0.59 & 3.53 & 2.37 & $2: 72$ & 1.66 & 0.89 & 1.16 & 0.18 & 0.09 & T. & 13.80 \\
\hline 1897. & 0.39 & 0.35 & 4.23 & 0.55 & 1.85 & 0.72 & 1.29 & 1.11 & 0.32 & 0.55 & 0.33 & 0.77 & 12.46 \\
\hline 1898. & 0.05 & 0.01 & 0.40 & 1.26 & 1.88 & 0.90 & 0.65 & 1.16 & T. & 0.48 & 0.61 & 0.23 & 7.63 \\
\hline \multicolumn{14}{|c|}{ FORT LARAMIE. } \\
\hline Normal. & 0.4 & 0.6 & 0.7 & 1.3 & 2.5 & 1.5 & 1.5 & 1.2 & 0.9 & 0.8 & 0.6 & 0.5 & 12.5 \\
\hline 1896. & 1.29 & 0.61 & 1.14 & 0.97 & 2.63 & 2.34 & 1.41 & 1.00 & 1.75 & 0.83 & 0.73 & 0.00 & 14.67 \\
\hline $1897 \ldots$ & 0.29 & 0.38 & 2.17 & 1.03 & 1.23 & 2.03 & 0.99 & 2.06 & 1.14 & 1.02 & 0.63 & 0.78 & 13. 75 \\
\hline 1898. & 1.41 & 0.26 & 0.25 & 0.75 & 4.60 & 1.27 & 1.61 & 1.13 & 0.44 & 0.44 & 0.55 & 0.25 & 12.96 \\
\hline \multicolumn{14}{|c|}{ GERING. } \\
\hline Norm & 0.71 & 0.42 & 0.88 & 1.64 & 2.00 & 2.86 & 1.95 & 1.39 & 0.65 & 0.56 & 0.49 & 0.52 & 14.07 \\
\hline 1896. & 0.40 & 0.36 & 1.50 & 0.66 & 2.42 & 3.44 & 1.90 & 1.31 & 1.89 & 0.33 & 0.48 & ...... & 14.69 \\
\hline 1897. & 0.19 & 0.30 & 1.08 & 1.40 & 1.79 & 0.67 & 2.76 & \begin{tabular}{|l|}
1.96 \\
\end{tabular} & 0.30 & 0.10 & 0.68 & 0.40 & 11.63 \\
\hline 1898. & $\cdots$ & $\cdots \cdots \cdot$ & 0.30 & 1.80 & 4.90 & 1.38 & 1.65 & 0.60 & 0.28 & 0.57 & 1.10 & ...... & \\
\hline \multicolumn{14}{|c|}{ CHEYENNE. } \\
\hline Normal & 0.4 & 0.4 & 0.9 & 1.5 & 2.3 & 1.5 & 2.0 & 1.6 & 1.0 & 0.7 & 0.3 & 0.3 & 12.9 \\
\hline 1896. & 0.68 & 0.31 & 2.06 & 2.08 & 2.85 & 1.41 & 6.35 & 2.52 & 2.08 & 0.28 & 0.14 & 0.03 & 20.79 \\
\hline 1897. & 0.27 & 0.57 & 2.32 & 0.60 & 3.07 & 1. 60 & 3.77 & 1.66 & 0.41 & 1.03 & 0.68 & 1.27 & .17 .25 \\
\hline $1898 \ldots$ & 0.48 & 0.06 & 0.39 & 0.68 & 3.72 & 2.33 & 1.83 & 0.90 & $0.47^{\circ}$ & 0.25 & 1.58 & 0.36 & 13.05 \\
\hline \multicolumn{14}{|c|}{ ST. CLOUD. } \\
\hline Normal & 0.70 & 0.73 & 2.12 & 2.13 & 4.07 & 1.68 & 1.58 & 1.82 & 1.27 & 1.09 & 0.34 & 0.59 & 18.12 \\
\hline $1896 \ldots$ & 0.20 & 0.00 & 1.90 & 1.15 & 1.30 & 2.57 & 2.59 & 3.73 & 2.27 & $(1.09)$ & 0.01 & 0.00 & 16.81 \\
\hline $1897 \ldots$ & 0.10 & 0.85 & 4.10 & 2.12 & 2.47 & 1.51 & 1.31 & $\ldots$ & $\ldots$ & $\ldots$ & $\ldots$ & ....... & $\cdots$. \\
\hline 1898. & ......... & $\cdots$ & $\ldots$ & $\cdots$ & ….... & .. & .. & & & & & & \\
\hline \multicolumn{14}{|c|}{ WHEATLAND. } \\
\hline Normal. & 0.68 & 0.36 & 0.98 & 0.76 & 1.76 & 1.78 & 0.86 & 1.01 & 0.25 & 0.76 & 0.66 & 0.48 & 10.34 \\
\hline $1896 \ldots$ & 1.70 & 0.60 & 1.40 & 0.55 & 2.73 & 1.78 & 0.52 & 2.19 & 0.40 & 0.12 & 0.85 & 0.00 & 12.84 \\
\hline $1897 .$. & 6.30 & 0.15 & 1.10 & 0.62 & 0.87 & 1.63 & 0.93 & 2.60 & T. & 0.30 & 0.70 & 0.50 & 9.70 \\
\hline $1898 .$. & 0.80 & $\mathbf{T}$. & 0.85 & 0.32 & 4,33 & 1.65 & 2.34 & 0.48 & 0.02 & 0.19 & 0.76 & 0.70 & 12.44 \\
\hline \multicolumn{14}{|c|}{ FOR'T COLLINS. } \\
\hline Normal. & 0.67 & 0.56 & 0.89 & 1. 71 & 2.86 & 1.67 & 1. 90 & 1.34 & 0.90 & 0.89 & 0.40 & 0.32 & 14.11 \\
\hline $1896 \ldots$ & 0.43 & 0.03 & 1.73 & 1.26 & 1.68 & 3.05 & 3.05 & 2.20 & 1.55 & 0.49 & 0.05 & 0.24 & 15.76 \\
\hline $1897 \ldots$. & 0.18 & 0.54 & 2.15 & 1.39 & 2.06 & 1.69 & 2.65 & 1.74 & 0.75 & 0.75 & 0.67 & 0.67 & 15. 24 \\
\hline 1898 & 0.14 & 0.08 & 0.50 & 1.08 & 3.65 & 1.37 & 0.50 & 0.98 & 0.50 & 0.82 & 1.24 & 0.17 & 11.03 , \\
\hline
\end{tabular}


Rainfall at stations in drainage basin of Platte River-Continued.

MORATNE.

\begin{tabular}{|c|c|c|c|c|c|c|c|c|c|c|c|c|c|}
\hline Year. & Jan. & Feb. & Mar. & $\Delta \mathrm{pr}$ & May. & June. & July. & Aug. & Sept. & Oct. & Nov. & Dec. & Annual. \\
\hline Normal & 0.79 & 1.48 & 1.83 & 1. 70 & 2.98 & 1.07 & 2.43 & 1.99 & 1.13 & 1.00 & 0.73 & 0.73 & 17.86 \\
\hline 1896. & 0.53 & 0.22 & 2.87 & 1.08 & 1.62 & 0.49 & 3.88 & 2.50 & 2.74 & 0.75 & 0.30 & 0.30 & 17.28 \\
\hline 1897. & 0.61 & 1.68 & 1.86 & 1.29 & 2.30 & 1.79 & 2.52 & 2.43 & 0.78 & 1.16 & 1.25 & 1.20 & 18.87 \\
\hline $1898 \ldots$ & 0.50 & 1.05 & 1.32 & 1.44 & 3,05 & 1.93 & 2.19 & 1.67 & 0.40 & 0.99 & 1.77 & 0.55 & 16.86 \\
\hline \multicolumn{14}{|c|}{ SMOKY HILL MTNE. } \\
\hline Normal. & 1.02 & 1.53 & 3.33 & 2.24 & 4.04 & 2.14 & 3.05 & 2.42 & 1. 27 & 1.76 & 1.33 & 1.02 & 25.15 \\
\hline 1896. & 1.10 & 0.40 & 3. 60 & 1. 60 & 1.15 & 1. 69 & 3.56 & 4.45 & 1.92 & 1.40 & 0.30 & 0.20 & 21. 37 \\
\hline 1897. & 0.40 & 2.10 & 6.30 & 2.81 & 2. 30 & 3.80 & 3.65 & 3.91 & 1.95 & 3.85 & 0.80 & 0.70 & 32.57 \\
\hline $1898 \ldots$ & 0.90 & 0.90 & 0.80 & 3.36 & 3.95 & 3.51 & 2.93 & 2.78 & 1.30 & 1.35 & 2.17 & 1.18 & 25.14 \\
\hline \multicolumn{14}{|c|}{ GEORGETOWN. } \\
\hline Normal & $0.43^{\circ}$ & 0.66 & 1.21 & 1.46 & 2.88 & 1.27 & 2.44 & 2.16 & 1.06 & 1.12 & 0.69 & 0.66 & 16.04 \\
\hline 1896. & 0.25 & 0.45 & 2.48 & 1.22 & 1.15 & 0.58 & 2.18 & 2.81 & 2.04 & 0.75 & 0.50 & 0.60 & 15. 01 \\
\hline 1897. & 0.45 & 0.55 & 2.00 & 1.43 & 3.75 & 1.71 & 2.55 & 2.59 & 1.42 & 3.32 & 0.20 & 0.85 & 20.52 \\
\hline \multicolumn{14}{|c|}{ - ALMA. } \\
\hline Normal & 0.74 & 0.76 & 1.35 & 1.16 & 1.61 & 0.67 & 2.57 & 2.54 & 0.75 & 0.87 & 1.40 & 0.55 & 14.97 \\
\hline $1896 .$. & 0.51 & 0.37 & 3.30 & 0.74 & 0.45 & 0.01 & 2.89 & 1.67 & 2.19 & 1.13 & 0.77 & 0.16 & 14.19 \\
\hline 1897 & 0.81 & 1.20 & 2.32 & 1.14 & 1.79 & 1.39 & 1.22 & 3.35 & 0.81 & ….. & - . n & $\cdots \cdots$ & \\
\hline \multicolumn{14}{|c|}{ CASTLE ROCK. } \\
\hline Normal & 0.63 & 0.94 & 1.36 & 1.83 & 2.44 & 1.99 & 2.85 & 2.77 & 0.86 & 1.38 & 0.57 & 0.78 & 18.40 \\
\hline 1896. & 0.65 & 0.95 & 1.80 & 2.30 & 1.61 & 0.70 & 3.67 & 3.57 & 2.80 & 1.62 & 0.32 & 0.45 & 20.44 \\
\hline $1897 \ldots$ & 0.47 & 1.20 & 2.50 & 1.37 & 2.44 & 3.12 & 3.59 & 8.10 & 0.24 & 2.82 & $(0.57)$ & 1.23 & 27.56 \\
\hline 1898 & $(0.63)$ & $(0.94)$ & 0.40 & 1.76 & 4.48 & 1.82 & 4.20 & 1.49 & 1.35 & 1.17 & 1.00 & 0.99 & 20.23 \\
\hline \multicolumn{14}{|c|}{ DENVER. } \\
\hline Normal & 0.55 & 0.52 & 0.98 & 1.97 & 2.78 & 1.41 & 1.77 & 1.47 & 0.81 & 0.93 & 0.59 & 0.64 & 14.42 \\
\hline 1896. & 0.25 & 0.24 & 1.43 & 0.93 & 1. 27 & 0.89 & 2.80 & 0.97 & 1.81 & 0.84 & 0.10 & 0.31 & 11.84 \\
\hline 1897 & 0.58 & 0.82 & 0.90 & 1.31 & 3.15 & 2.16 & 2.06 & 1.44 & 0.44 & 1.64 & 0.24 & 0.63 & 15. 37 \\
\hline 1898. & 0.20 & 0.68 & 0.28 & 1.20 & 4.88 & 0.94 & 0.67 & 0.96 & 0.28 & 1.05 & 0.85 & 0.99 & 12.98 \\
\hline \multicolumn{14}{|c|}{ GREELEY. } \\
\hline Normal.. & 0.18 & 0.43 & 0.69 & 1.46 & 2.04 & 1.51 & 1.76 & 1.12 & 0.54 & 0.67 & 0.76 & 0.17 & 11.33 \\
\hline $1896 \ldots$ & 0.67 & 0.18 & 0.93 & 1.18 & 1.42 & 0.46 & 4.82 & 2.15 & 0.99 & 0.63 & 0.02 & 0.07 & 13.52 \\
\hline $1897 \ldots$ & 0.06 & 0.61 & 2.02 & 0.81 & 3.20 & 2.47 & 2.98 & 1.75 & 0.29 & 1.11 & 0.40 & 0.38 & 16.09 \\
\hline $1898 \ldots$ & 0.20 & 0.33 & 0.23 & $\mid(1.46)$ & 5.83 & 1.69 & 3.50 & 0.83 & 0.13 & 0.78 & 0.60 & 0.37 & 15.95 \\
\hline \multicolumn{14}{|c|}{ KIMBALL. } \\
\hline Normal.. & 0.65 & 0.66 & 1.02 & 1.64 & 2.33 & 2.12 & 2.52 & 1. 41 & 0.55 & 0.55 & 0.21 & 0.52 & 14.18 \\
\hline $1896 \ldots$ & 0.40 & $(0.66)$ & $(1.02)$ & 1.75 & 2.26 & 1.48 & 2.43 & 2.22 & 1.66 & 0.20 & 0.30 & 0.00 & 14.38 \\
\hline $1897 \ldots \ldots . .$. & 0.20 & 0.75 & 1.70 & 1.10 & 3.86 & 2.16 & 6.42 & 1.66 & 0.44 & 0.88 & 0.60 & 1.15 & 20.92 \\
\hline $1898 \ldots$ & 0.65 & 0.15 & 0.75 & 1.32 & 6.49 & 2.61 & 2.26 & 0.45 & 0.60 & 0.65 & 1.60 & 0.55 & 18. 08 \\
\hline
\end{tabular}


260 PROGRESS OF STREAM MEASUREMENTS FOR 1898.

Rainfall at stations in drainage basin of Platte River-Continued.

ALLIANCE.

\begin{tabular}{|c|c|c|c|c|c|c|c|c|c|c|c|c|c|}
\hline Year. & Jan. & Feb. & Mar. & Apr. & May. & June. & July. & Aug. & Sept. & Oct. & Nov. & Dec. & Annual. \\
\hline Normal & 0.98 & 0.34 & 1.45 & 2.25 & 2.35 & 3.47 & 2.36 & 1.63 & 0.66 & 0.46 & 0.49 & 0.44 & 16. 88 \\
\hline 1896. & $\begin{array}{l}0.60 \\
\end{array}$ & 0.09 & 2.10 & 0.80 & 2.00 & 4.04 & 3.77 & 0.26 & 1.41 & 0.70 & 0.39 & 0.00 & 16.11 \\
\hline 1897. & 0.43 & 0.21 & 1.21 & 2. 13 & 2.52 & 2.01 & 1.73 & 2.15 & 0.06 & 0.36 & 0.64 & 1.10 & 14. 55 \\
\hline 1898. & 1.14 & $\mathbf{T}$ & 0.30 & 0.53 & 4.81 & 1.10 & 4.76 & 0.20 & T. & T. & 0.60 & 0.00 & 13.44 \\
\hline \multicolumn{14}{|c|}{ SIDNEY. } \\
\hline Norn & 0.70 & 0.60 & 0.8 & 1.8 & 2. 50 & 1.40 & 2.2 & 1.8 & 1.0 & 1.0 & 0.3 & 0.3 & 14.4 \\
\hline 1896. & $(0.70)$ & 0.50 & 2. 80 & 1.73 & 2.94 & 3.29 & 3.01 & 0.96 & 1.32 & 0.60 & 0.50 & T. & 18. 35 \\
\hline 1897 & 0.15 & 0.40 & 2.25 & 2.10 & 3.38 & 1.42 & 2.15 & 3.61 & T. & 1.50 & 0.20 & 0.60 & 17.76 \\
\hline \multicolumn{14}{|c|}{ NORTH PLATTE. } \\
\hline Norm & 0.5 & 0.4 & 0.8 & 2.2 & 2.6 & 3.3 & 2.7 & 2.4 & 1.3 & 1.1 & 0.3 & 0.6 & 18.2 \\
\hline 1896 . & 0.27 & 0.06 & 0.87 & 3.44 & 1.47 & 2.76 & 1.86 & 2.07 & 1.84 & 1.51 & 0.16 & 0.21 & 16.72 \\
\hline 1897. & 0.47 & 0.46 & 0.66 & 2.59 & 0.11 & 1.72 & 1.85 & 3.05 & 0.59 & 4. 11 & 0.85 & 0.63 & 17.09 \\
\hline 1898 & 0.77 & 0.19 & 0.64 & 1.42 & 4.12 & 2.54 & 1.29 & 1.40 & 2.56 & 0.07 & 0.51 & 0.03 & 15. 54 \\
\hline \multicolumn{14}{|c|}{ THEDFORD. } \\
\hline Norm & 0.23 & 1.04 & 0.79 & 3.05 & 1.71 & 3.98 & 2.06 & 1.85 & 0.95 & 1.23 & 0.63 & 0.51 & 18.03 \\
\hline 1896 & 0.12 & 0.05 & 1.85 & 6. 43 & 0.98 & 4.18 & 3.03 & 0.00 & 0.72 & 1.30 & 0.76 & 0.24 & 19.66 \\
\hline 1897. & 0.50 & 0.20 & 0.26 & 3.11 & 0.34 & 3.89 & 1.55 & 1.91 & 0.46 & 1.78 & 0.40 & 1.50 & 15.90 \\
\hline \multicolumn{14}{|c|}{ LEXINGTON. } \\
\hline Normal & 0.85 & 0.97 & 1. 32 & 2.64 & 2.83 & 3. 34 & 2.20 & 2.25 & 1.43 & 1.35 & 0.58 & 0.76 & 20.52 \\
\hline 189 & 0.38 & 0.20 & 2. 06 & 4.66 & 3.90 & 97 & .27 & 1.69 & 3.02 & 1.60 & 28 & 0.20 & 2.23 \\
\hline 189 & 0.20 & 0.81 & 1.59 & 4.24 & 0.30 & 4.61 & 0.72 & 1.57 & 1.60 & 4.13 & 0.72 & 1.30 & 21.79 \\
\hline 1898 & 0.30 & 0.30 & 0.10 & 2.23 & 2.62 & 4.36 & 1.29 & 2.51 & 2.92 & 0.73 & 0.80 & 0.35 & 18.51 \\
\hline \multicolumn{14}{|c|}{ KEARNEY. } \\
\hline Norn & 0.56 & 0.52 & 1. 15 & 2. 53 & 4. 52 & 3.51 & 4. 35 & 2.40 & 2.11 & 1.72 & 0.91 & 0.62 & 24.90 \\
\hline 1896. & 0.30 & T. & 2.10 & 4.96 & 6. 90 & 3.26 & 3. 49 & 3.49 & 1.98 & 1.25 & 1.55 & 0.04 & 29.82 \\
\hline 1897 & $(0.56)$ & 0.99 & 1.08 & 6. 52 & 1.18 & 3.36 & 4.01 & 1.60 & 2.51 & 5. 70 & 0.82 & 1.68 & 30.01 \\
\hline 1898. & 0.17 & 0.25 & 0.04 & 3. 60 & 4.11 & 4.18 & 1.76 & 2.53 & 3.40 & 0.65 & 0.45 & 0.10 & 21.24 \\
\hline \multicolumn{14}{|c|}{ RAVENNA. } \\
\hline Norn & 0.7 & 0.8 & 1.4 & 2.9 & 3.5 & 3.8 & 4.1 & 2.8 & 1.9 & 1.60 & 0.60 & 0.7 & 24.8 \\
\hline 1896 & 0.35 & 0.12 & 1. 67 & 5. 72 & 4.58 & 2.66 & 5. 37 & 0.89 & 3. 25 & 1. 45 & 1.30 & 0.14 & 27.50 \\
\hline 1897 & 0.60 & 0.88 & 1.61 & 5.21 & 1.94 & $\begin{array}{l}5.82 \\
\end{array}$ & 1.73 & 6.54 & 1.63 & 4.96 & 0.30 & 1.53 & 32.75 \\
\hline 1898 & 0.33 & 0.68 & 0.23 & 2.23 & 3.15 & 3.25 & 2.19 & 1.72 & 3. 10 & 0.56 & 0.69 & 0.37 & 18.50 \\
\hline \multicolumn{14}{|c|}{ ANSLEY. } \\
\hline Norma] & 0.60 & 0.60 & 1.53 & 3.11 & 2.72 & 3.89 & 2.72 & 2.14 & 1.34 & 1.60 & 0.40 & 0.42 & 21.07 \\
\hline 1896 & 0.63 & 0.03 & 1.95 & 4.66 & 3.52 & 2.92 & 1.85 & 0.64 & 2.55 & 1.75 & $0.80^{\circ}$ & 0.02 & 21.32 \\
\hline .1897 & 0.40 & 0.47 & 1.46 & 5.00 & 1.54 & 4.57 & 0.92 & 4.55 & 1.37 & 4.98 & 0.35 & 1.52 & 27.13 \\
\hline $1898 .$. & 0.35 & 0.45 & 0.10 & 2.69 & 3. 87 & 3.49 & 1. 42 & 2.12 & 1.64 & 1.08 & 0.45 & 0.20 & 17.86 \\
\hline
\end{tabular}


Rainfall at stations in drainage basin of Platte River-Continued.

BURWELL.

\begin{tabular}{|c|c|c|c|c|c|c|c|c|c|c|c|c|c|}
\hline Year. & Jan. & Feb. & Mar. & Apr. & May. & June. & July. & Aug. & Sept. & Oct. & Nov. & Dec. & Annual. \\
\hline Normal .. & 0.39 & 0.48 & 0.97 & 2.18 & 2.65 & 3. 69 & 3.52 & 1.82 & 1.66 & 1.38 & 0.39 & 0.51 & 19.64 \\
\hline $1896 .$. & 0.35 & 0.10 & 1.85 & 3.85 & 1.71 & 4.70 & 3.77 & 1.47 & 0.92 & 1.29 & 0.70 & $\mathbf{T}$ & 20.71 \\
\hline $1897 .$. & 0.50 & 0.40 & 1.60 & 3.24 & 0.60 & 2.44 & 1.87 & 1.41 & T. & 3.89 & $0: 20$ & 1.55 & 17.70 \\
\hline $1898 .$. & 1.00 & 0.30 & T. & 1.68 & 3.14 & 2.68 & 2.33 & 4.68 & 0.86 & 0.56 & 0.30 & 0.65 & 18.18 \\
\hline \multicolumn{12}{|c|}{ NORTH LOUP. } & \multicolumn{2}{|l|}{ 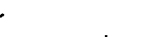 } \\
\hline Normal . & 0.76 & 0.48 & 1.02 & 3.50 & 2.61 & 4.82 & 3.57 & 2.33 & 1.41 & 1.60 & 0.45 & 0.46 & 23.01 \\
\hline $1896 .$. & 0.24 & T. & 0.83 & 7.25 & 3.44 & 8.00 & 4.32 & 0.55 & 2.44 & 2.18 & 1.12 & $\mathrm{~T}$ & 30.37 \\
\hline $1897 .$. & 0.80 & 0.36 & 1.42 & 6.05 & 0.72 & 7.87 & 1.19 & 2. 54 & 1.00 & 4.65 & 0.10 & 1.40 & 28.10 \\
\hline $1898 .$. & 0.55 & 0.40 & 0.20 & 1.00 & 3.65 & 4.43 & 0.99 & 1.97 & 1.78 & 0.53 & 0.70 & 0.30 & 16.50 \\
\hline \multicolumn{14}{|c|}{ PALMER. } \\
\hline Normal & 1.03 & 0.79 & 1.70 & 3.16 & 3.51 & 3.54 & 3.55 & 2.45 & 1.66 & 1.21 & 0.69 & 0.75 & 24.04 \\
\hline 1896. & 0.00 & 0.60 & 0.90 & 7.55 & 6.55 & 4.35 & 2.50 & 0.45 & 2.05 & 2.50 & 1.30 & 0.35 & 29.10 \\
\hline 1897. & 1.10 & 0.50 & 3.17 & 4.44 & 2.30 & 4.84 & 2.06 & 3.49 & 2.69 & 4.68 & 0.08 & 2.00 & 31.35 \\
\hline $1898 \ldots . . . .$. & 0.40 & 0.50 & 0.85 & 1.98 & 3. 38 & 8.12 & 0.97 & 3.65 & 3.18 & 0.66 & 0.35 & $\mathbf{T}$ & 24.04 \\
\hline \multicolumn{14}{|c|}{ ERICSON. } \\
\hline Normal...... & 0.64 & 0.69 & 1.40 & 3.78 & 2.44 & 3.67 & 2.98 & 2.02 & 1.39 & 1.66 & 0.24 & 0.50 & 21.41 \\
\hline 1896. & 0.50 & $\mathbf{T}$ & 1.10 & 6.20 & 2.71 & 4.86 & 4. 36 & 2.07 & 2.63 & 1.90 & 0.60 & 0.25 & 26.73 \\
\hline $1897 .$. & 1.00 & 0.50 & 2.64 & 4.25 & 2.07 & 3.85 & 1.98 & 2.61 & 0.87 & 3.84 & 0.10 & 1.50 & 25.21 \\
\hline 1898. & 0.70 & 0.40 & 0.20 & 1.38 & 3.92 & 2.48 & 1.91 & 2.68 & 0.91 & 0.35 & $\begin{array}{l}0.53 \\
1\end{array}$ & 0.20 & 15.66 \\
\hline \multicolumn{14}{|c|}{ OAKDALE. } \\
\hline Normal . & 0.58 & 0.63 & 1.30 & 3.57 & 3.18 & 3.69 & 3.19 & 2.63 & 1.35 & 1.31 & 0.71 & 0.66 & 22.80 \\
\hline $1896 \ldots$ & 0.13 & 0.05 & 1.14 & 6.94 & 2.51 & 4.50 & 6.17 & 1.12 & 1.76 & 2.39 & 2.66 & 0.07 & 29.44 \\
\hline $1897 \ldots$ & 1.61 & 0.51 & 1.78 & 3. 36 & 1.12 & 4.87 & 2.98 & 3.38 & 1.15 & 2.33 & 0.64 & 1.44 & 25.17 \\
\hline $1898 \ldots \ldots \ldots \ldots$ & 0.55 & 0.78 & 0.69 & 1.88 & 5. 75 & 4.82 & 2.15 & 2.92 & 0.93 & 1.15 & 0.53 & 0.44 & 22.59 \\
\hline \multicolumn{14}{|c|}{ O'NEILL. } \\
\hline Normal.. & 0.51 & 0.52 & 1.59 & 4.56 & 2. 37 & 4.24 & 2.07 & 2.30 & 1.71 & 1.25 & 0.43 & 0.60 & 22.17 \\
\hline 1896. & 0.32 & 0.04 & 1.36 & 6.86 & 1.77 & 5.87 & 3.85 & 1.56 & 3.41 & 1.84 & 1.37 & $0.10^{\circ}$ & 28.35 \\
\hline $1897 \ldots$ & 1.31 & 0.48 & 1.69 & 4.85 & 1. 35 & 3.15 & 1.51 & 2.26 & 3. 70 & 3.84 & 0.13 & 1.86 & 26.13 \\
\hline $1898 \ldots$ & 0.38 & 0.42 & 0.75 & $\cdot 1.39$ & 5.62 & 2.82 & 3.87 & 2.33 & 1.29 & (1.25) & 0.20 & 0.05 & 20.37 \\
\hline \multicolumn{14}{|c|}{ NOR்FOLK. } \\
\hline Normal. & 0.35 & 0.74 & 1.05 & 2.80 & 3.58 & 4.31 & 4.05 & 3.58 & 2.56 & 1.36 & 0.63 & 0.84 & 25.85 \\
\hline $1896 \ldots$ & 0.27 & 0.02 & 0.67 & 5.92 & 3. 30 & 5.26 & 5.65 & 1.08 & 2.25 & 2.50 & 2.54 & 0.15 & 29.61 \\
\hline $1897 \ldots$ & 0.70 & 0.43 & 1.55 & 3.86 & 1.03 & 2.93 & 3. 72 & 2.67 & 1.43 & 2.97 & 0.26 & 2.10 & 23.65 \\
\hline $1898 \ldots$ & 0.69 & 0.70 & 0.72 & 1.49 & 3.53 & 6.04 & 1.60 & 2.01 & 1.46 & 0.86 & 0.31 & 0.42 & 19.83 \\
\hline \multicolumn{14}{|c|}{ CORNLEA. } \\
\hline Normal ....... & 0.65 & 0.62 & 1.08 & 3.19 & 3.17 & 4.08 & 3.20 & 2.86 & 2.43 & 1.54 & 0.67 & 0.61 & 24.10 \\
\hline $1896 \ldots$ & 0.52 & 0.01 & 0.80 & (3.19) & $(3.17)$ & 2.78 & 4.20 & 0.45 & 3.48 & 1.85 & 2.38 & 0.22 & 23.05 \\
\hline $1897 . .$. & 1.47 & 0.45 & (1.08) & 4.64 & 2.69 & 5.62 & 3.50 & 3.46 & 1.62 & 3.85 & 0.27 & 1.16 & 29.81 \\
\hline $1898 . .$. & 0.46 & 0.66 & 0.77 & 1.54 & 6.18 & 5.07 & & & & & & ....... & . \\
\hline
\end{tabular}


PROGRESS OF STREAM MEASUREMENTS FOR 1898.

Rainfall at stations in drainage basin of Platte River-Continued.

GENOA.

\begin{tabular}{|c|c|c|c|c|c|c|c|c|c|c|c|c|c|}
\hline Year. & Jan. & Feb. & Mar. & Apr. & May. & June. & JuIy. & Ang. & Sept. & Oct. & Nov. & Dec. & Annual. \\
\hline Normal & 0.8 & 0.8 & 1.2 & 3.1 & 4. 0 & 4.4 & 3.9 & 2.6 & 2.8 & 1. 6 & 0.8 & 0.9 & 26.9 \\
\hline 1896 . & 0.46 & 0.09 & 0.56 & 7.57 & 4.09 & 5.47 & 3.27 & 1.41 & 2.40 & 2. 03 & 2.41 & 0.27 & 30.01 \\
\hline 1897 & 1.36 & 0.64 & 1.81 & 5.47 & 1.64 & 3.80 & 4. 59 & 2.93 & 2.71 & 4. 12 & 0.34 & 1.44 & 30.85 \\
\hline 1898. & 0.58 & 0.94 & 0.82 & 2.78 & 4. 58 & 3.91 & 1.36 & 3.98 & 2.02 & 1.13 & 0.55 & 0.15 & 22.80 \\
\hline \multicolumn{14}{|c|}{ MARQUETTE. } \\
\hline Normal & 0.7 & 0.8 & 1.10 & 2.8 & 3.8 & 4.1 & 3.8 & 2.7 & 1.9 & 1.8 & 0.6 & 1.0 & 25. i \\
\hline 1896. & 0.20 & 0.22 & 1.06 & 7.30 & 7.15 & 4. 24 & 5.29 & 0.90 & 2.22 & 2.76 & 1.65 & 0.12 & 33.11 \\
\hline 1897 & 1.53 & 0.77 & 1.93 & 4.48 & 2.48 & 3.40 & 1.82 & 1.72 & 1.83 & 4.79 & 0.75 & 1.45 & 26.95 \\
\hline 1898. & 0.47 & 0.50 & 0.50 & 2.12 & 3.85 & 6.46 & 0.62 & 1.74 & 2.44 & 1.10 & 0.90 & 0.32 & 21.02 \\
\hline \multicolumn{14}{|c|}{ - LINCOLN. } \\
\hline Norma & 0.77 & 0.97 & 1.29 & 2.46 & 4.25 & 4.39 & 3.90 & 3.10 & 1.90 & 1.85 & 0.75 & 0.68 & 26.31 \\
\hline 1896. & 0.32 & 0.27 & 1.28 & 4.57 & 10.11 & 3.05 & 5.63 & 3.39 & 4.57 & 3.02 & 1.48 & 0.37 & 38.06 \\
\hline 1897. & 0.65 & 0.90 & 1. 48 & 6.15 & 2.22 & 2.17 & 2.54 & 2. 69 & 1. 71 & 2. 77 & 0.29 & 2.10 & 25.67 \\
\hline 1898 & 0.83 & 0.99 & 1. 40 & 3.88 & 4. 33 & 3.99 & 3.93 & 3.45 & $\cdot 2.32$ & 1.55 & 0.95 & 0.48 & 28.10 \\
\hline \multicolumn{14}{|c|}{ AVERAGES. } \\
\hline Normal & 0.63 & 0.68 & 1.24 & 2.32 & 2.10 & 2.77 & 2.63 & 2.05 & 1. 28 & 1.18 & 0.59 & 4.29 & 21.76 \\
\hline $1896 \ldots$ & 0.47 & 0.23 & 1.61 & 3.49 & 2.92 & 2.92 & 3.40 & 1. 71 & 2. 07 & 1. 30 & 0.84 & 0.16 & 18.20 \\
\hline $.1897 \ldots$ & 0.77 & 0.67 & 1.95 & 2.91 & 1.91 & 2.90 & 2.35 & 2. 69 & 1.07 & 2.69 & 0.47 & 1. 20 & 21.58 \\
\hline 1898 & 0.55 & 0.47 & 1.58 & 1.71 & 4.28 & 3.14 & 1.98 & 1.87 & 1.27 & 0.80 & 0.79 & 0.44 & 17.88 \\
\hline
\end{tabular}

Run-off, in inches, from Platte drainage basin.

LARAMIE RIVER AT WOOIS LANDING.

\begin{tabular}{|c|c|c|c|c|c|c|c|c|c|c|c|c|c|}
\hline Year. & Jan. & Feb. & Mar. & Apr. & May. & June. & July. & Aug. & Sept. & Oct. & Nov. & Dec. & Annual. \\
\hline 1896. & $\mid \ldots \ldots$ & $\therefore \ldots$ & $\ldots$ & 0.36 & 1.64 & 1.19 & 0.33 & 0.24 & 0.29 & 0.15 & & & \\
\hline $1897 \ldots$ & 0.18 & 0.17 & 0.18 & 0.23 & 5.22 & 4.01 & 0.70 & 0.24 & 0.17 & 0.16 & 0.17 & 0.18 & 11.61 \\
\hline $1898 \ldots$ & $\ldots .$. & 10 & ..... & 0.33 & 1.68 & 2.49 & 0.23 & 0.12 & 0.10 & 0.12 & & $\cdots$ & $\cdots$ \\
\hline Average. & 0.18 & 0.17 & 0.18 & 0.31 & 2.85 & 2.56 & 0.42 & 0.20 & 0.19 & 0.14 & 0.17 & 0.18 & 7.55 \\
\hline \multicolumn{14}{|c|}{ NORTH PLATTE AT ORIN JUNC'IION. } \\
\hline 1896. & . & & ... & 0.14 & 0.39 & 0.39 & 0.10 & 0.08 & 0.08 & 0.04 & & & \\
\hline 1897 & 0.07 & 0.09 & 0.12 & 0.36 & 1.08 & 0.68 & 0.14 & 0.08 & 0.04 & 0.03 & 0.04 & 0.04 & 2. 79 \\
\hline $1898 .$. & 0.054 & 0.064 & 0.054 & 0.14 & 0.43 & 0,46 & 0.10 & 0.04 & 0.03 & 0.046 & 0.045 & 0.054 & 4. 37 \\
\hline A rerage. & 0.062 & 77 & 0.087 & 0.21 & 0.63 . & 0.51 & 0.11 & 0.07 & 0.05 & 0.039 & 0.043 & 0.047 & 1.94 \\
\hline \multicolumn{14}{|c|}{ LARAMTE AT UVA. } \\
\hline 1896. & . & & & 0.030 & 0.090 & 0.090 & 0.010 & 0.020 & 0.000 & 0.000 & & ... & \\
\hline $1897 \ldots$ & 0.036 & 0.032 & 0.054 & 0.250 & 0.450 & 0.368 & 0.015 & 0.039 & 0.004 & 0.006 & 0.006 & 0.006 & 1.27 \\
\hline 1898. & 0.005 & 0.005 & 0.011 & 0.027 & 0.150 & 0.230 & 0.009 & 0.001 & 0.001 & 0.001 & 0.003 & 0.007 & 0.45 \\
\hline Average & 0.021 & 0.019 & 0.083 & 0.102 & 0.230 & 0.229 & 0.011 & 0.020 & 0.002 & 0.002 & 0.005 & 0.007 & 0.68 \\
\hline
\end{tabular}


Run-off, in inches, from Platte drainage basin-Continued. NORTH PLATTE AT GERING.

\begin{tabular}{|c|c|c|c|c|c|c|c|c|c|c|c|c|c|}
\hline Year. & Jan. & Feb. & Mar. & Apr. & May. & June. & July. & Aug. & Sept. & Oct. & Nor. & Dec. & Annual. \\
\hline 1896 . & & & & $\cdots$ & $\cdots \cdots$ & & ...... & $\ldots \ldots$ & $\ldots \ldots$ & & & & \\
\hline 1897. & & & & $\ldots \ldots$ & ...... & $\ldots$. & 0.100 & 0.040 & 0.020 & 0.020 & 0.02 & 0.02 & \\
\hline $1898 \ldots$ & $\ldots . .$. & $\ldots \ldots$ & ....... & 0.14 & 0.35 & 0.41 & 0.097 & 0.008 & 0.005 & 0.012 & $\ldots$ & $\ldots . .$. & \\
\hline Average. & &. & .. & 0.14 & 0.35 & 0.41 & 0.099 & 0.024 & 0.013 & 0.016 & 0.02 & 0.02 & \\
\hline \multicolumn{14}{|c|}{ NORTH PLATTE AT CAMP CLARKE. } \\
\hline 1897. & 0.106 & 0.095 & 0.060 & 0.164 & 0.400 & 0.332 & 0.099 & 0.049 & 0.022 & 0.022 & 0.022 & 0.023 & 1. 39 \\
\hline 1898. & ...... & $\ldots \ldots$ & ...... & 0.080 & 0.250 & 0.330 & 0.080 & 0.010 & 0.040 & 0.010 & ...... & $\ldots$. & $\ldots$. \\
\hline Average & 0.106 & 0.095 & 0.060 & 0.122 & 0.325 & 0.331 & 0.090 & 0.030 & 0.031 & 0.016 & 0.022 & 0.023 & 1. 25 \\
\hline \multicolumn{14}{|c|}{ NORTH PLATTE AT NORTH PLATTE. } \\
\hline 1896. & $\ldots \ldots$ & ....... & $\cdots$ & 0.078 & 0.180 & 0.240 & 0.046 & 0.037 & 0.033 & 0.046 & 0.083 & 0.175 & … \\
\hline 1897. & 0.280 & 0.236 & 0.158 & 0.200 & 0.565 & 0.545 & 0.149 & 0.116 & 0.024 & 0.046 & 0.084 & 0.207 & 2.61 \\
\hline 1898. & 0.210 & 0.200 & 0.090 & 0.100 & 0.21 .0 & 0.270 & 0.080 & 0.010 & 0.010 & 0.020 & 0.040 & 0.140 & 1. 38 \\
\hline Average & 0.250 & 0.218 & 0.124 & 0.126 & 0.318 & 0.352 & 0.092 & 0.054 & 0.022 & 0.037 & 0.069 & 0.174 & 1.84 \\
\hline \multicolumn{14}{|c|}{ LOUP AT COLUMBUS. } \\
\hline 1897. & & & & 0.30 & 0.21 & 0.20 & 0.30 & 0.20 & 0.16 & 0.36 & & & \\
\hline $1898 \ldots$ & $\ldots$ & & $\cdots$ & 0.23 & 0.30 & 0.33 & 0.16 & 0.23 & 0.17 & 0.21 & 0.22 & & \\
\hline Average & ... & 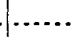 & & 0.27 & 0.26 & 0.27 & 0.23 & 0.22 & 0.17 & 0.29 & 0.22 & & \\
\hline \multicolumn{14}{|c|}{ BEAR CREEK AT MORRISON. } \\
\hline 1896. & & & & 0.28 & 0.35 & 0.21 & 0.17 & 0.30 & 0.32 & 0.22 & ........ & & \\
\hline 1897. & .. & $\ldots$ & $\cdots$ & ...... & 1.02 & 1.15 & 0.78 & 1. 35 & 0.44 & 0.37 & 0.22 & 0.14 & \\
\hline 1898. & $\ldots \ldots$ & & $\cdots$ & ....... & 0.74 & 0.93 & 1.01 & 0.45 & 0.30 & 0.20 & 0.16 & (...... & \\
\hline Average. & & & & (....... & 0.70 & 0.76 & 0.65 & 0.70 & 0.35 & 0.26 & 0.19 & 0.14 & \\
\hline \multicolumn{14}{|c|}{ SOUTH PLATTE AT DENVER. } \\
\hline 1896 & 0.060 & 0.050 & 0.070 & 0.090 & 0.090 & 0.060 & 0.040 & 0.030 & 0.040 & 0.030 & 0.030 & 0.030 & 0.62 \\
\hline 1897. & 0.029 & 0.023 & 0.054 & 0.136 & 0.220 & 0.297 & 0.118 & 0.206 & 0.078 & 0.081 & 0.118 & 0.066 & 1.43 \\
\hline 1898. & 0.040 & 0.040 & 0.030 & 0.110 & 0.440 & 0.450 & 0.660 & 0.100 & 0.060 & 0.040 & 0.030 . & 0.030 & 2.03 \\
\hline Average. & 0.043 & 0.038 & 0.051 & 0.112 & 0.250 & 0.269 & 0.273 & 0.112 & 0.059 & 0.050 & 0.059 & 0.042 & 1.86 \\
\hline \multicolumn{14}{|c|}{ BOULDER CREEK AT BOULDER. } \\
\hline 1895. & & & & A.... & 1.19 & 3.12 & 2.28 & 1.33 & 0.54 & 0.29 & & & \\
\hline 1896. & & 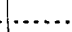 & & 0.50 & 1.54 & 1.65 & 0.97 & 0.64 & 0.46 & 0.21 & $\ldots$ & ...... & \\
\hline $1897 \ldots$ & & . & & ….. & 3. 66 & 5.01 & 3.83 & 2.41 & 0.90 & 0.53 & 0.41 . & 0.68 & \\
\hline $1898 \ldots$ & ...... & ...... & ...... & ….. & 2.63 & 4.89 & 2.41 & 0.70 & 0.32 & 0.09 & 0.44 & ..... & $\ldots .$. \\
\hline Average . & $\ldots . .$. & $\ldots$ & $\because \cdots \cdots$ & 0.50 & 2.26 & 3.67 & 2.37 & 1.27 & 0.56 & 0.26 & 0.43 & 0.68 & \\
\hline
\end{tabular}


Run-off, in inches, from Platte drainage basin-Continued.

ST. VRAIN AT LYONS.

\begin{tabular}{|c|c|c|c|c|c|c|c|c|c|c|c|c|c|}
\hline Year. & Jan. & Feb. & Mar. & Apr. & May. & June. & July. & A.ug. & Sept. & Oct. & Nov. & Dec. & Annual. \\
\hline 1895. & & & & & ........ & 2.34 & 2.26 & 1.27 & 0.49 & 1.04 & $\cdots$ & & \\
\hline $1896 .$. & $\ldots$ & & & 0.39 & 1.27 & 1.71 & 1.16 & 0.87 & 0.68 & 0.30 & -... & & \\
\hline $1897 .$. & - & & & $\ldots \ldots$ & 2.82 & 3.56 & 2.53 & 1.51 & 0.65 & 0.24 & 0.19 & 0.22 & \\
\hline 1898. & & & & ...... & 1.16 & 2.30 & 1.27 & 0.58 & 0.32 & 0.08 & 0.07 & ....... & \\
\hline Average. & & & 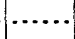 & 0.39 & 1.75 & 2.48 & 1.81 & 1.06 & 0.54 & 0.42 & 0.13 & 0.22 & \\
\hline \multicolumn{14}{|c|}{ BIG THOMPSON CREEK AT ARKINS. } \\
\hline 1896. & & & & & 0.83 & 1.03 & 0.85 & 0.54 & 0.44 & 0.25 & $\cdots$ &.. & \\
\hline 1897. & & & & $\cdots$ & 1.58 & 1.68 & 1.00 & .0 .49 & 0.13 & 0.07 & 0.10 & 0.15 & \\
\hline 1898. & $\cdots$ & & & .. & 0.62 & 1.38 & 0.90 & 0.29 & 0.11 & 0.04 & 0.02 & ...... & $\ldots$ \\
\hline Average. & & .. & $\cdots$ & ... & 1.01 & 1.36 & 0.92 & 0.37 & 0.23 & 0.12 & 0.06 & 0.15 & \\
\hline \multicolumn{14}{|c|}{ SOUTH PLATTE AT ORCHARD. } \\
\hline 1895. & & & & $i^{\prime}$ & & & & $\cdots$ & & & 0.024 & 0.071 & \\
\hline $1896 \ldots$ & 0.072 & 0.026 & 0.054 & ....... & $\ldots$ & ...... & $\ldots$ & .... & $\ldots \ldots$ & ...... & ...... & 0.074 & \\
\hline 1897. & 0.059 & 0.047 & 0.013 & 0.048 & 0.084 & 0.240 & 0.032 & 0.075 & 0.009 & 0.029 & 0.100 & 0.115 & 0.851 \\
\hline $1898 \ldots$ & 0.100 & 0.730 & 0.070 & 0.030 & 0.180 & 0.080 & 0.010 & 0.030 & 0.010 & 0.020 & 0.080 & 0.250 & 1.590 \\
\hline Average & 0.077 & 0.268 & 0.046 & 0.039 & 0.132 & 0.160 & 0.021 & 0.053 & 0.010 & 0.025 & 0.068 & 0.128 & 1.030 \\
\hline \multicolumn{14}{|c|}{ PLATTE AT COLUMBUS. } \\
\hline 1897. & & & & ...... & 0.24 & 0.33 & 0.06 & & & & & & \\
\hline 1898. & ........ & $\ldots$ & ......... & 0.03 & 0.12 & 0.22 & 0.06 & ..... & $\therefore \ldots$ & $\because \cdots \cdots$ & ....... & $\cdots$ & \\
\hline Average. & $\ldots \ldots$ &. & $\cdots$ & 0.03 & 0.18 & 0.28 & 0.06 & .... & & & & & \\
\hline \multicolumn{14}{|c|}{ NORTH LOUP AT ST. PAUL. } \\
\hline 1897. & 0.29 & 0.26 & 0.29 & 0,37 & 0.28 & 0.32 & 0.28 & 0.21 & 0.22 & 0.29 & 0.28 & 0.29 & 3.38 \\
\hline 1898. & ....... & ....... & $\cdots \cdots$ & $\cdots .$. & ....... & ....... & …... & $\mid \cdots \cdots$ & ....... & 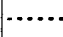 & …... & ...... & $\cdots \cdots$ \\
\hline Average & 0.29 & 0.26 & 0.29 & 0.37 & 0.28 & 0.32 & 0.28 & 0.21 & 0.22 & 0.29 & 0.28 & 0.29 & 3.38 \\
\hline \multicolumn{14}{|c|}{1} \\
\hline 1897. & 0.46 & 0.37 & 0.37 & ....... & 0.25 & 0.14 & 0.12 & 0.09 & 0.07 & 0.09 & 0.09 & 0.09 & 2.14 \\
\hline 1898. & $\ldots$. & ....... & ...... & 0.21 & 0.33 & 0.35 & 0.15 & 0.14 & 0.09 & 0.12 & 0.13 & ....... & ...... \\
\hline Arerage. & 0.46 & 0.37 & 0.37 & 0.21 & 0.29 & 0.25 & 0.14 & 0.12 & 0.08 & 0.11 & 0.11 & 0.09 & 2. 60 \\
\hline
\end{tabular}


Rainfall and run-off.

\begin{tabular}{|c|c|c|c|c|}
\hline Station. & Normal. & 1896. & 1897. & 1898. \\
\hline RAINFALL. & & & . & \\
\hline 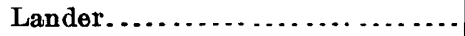 & 11.09 & 11.07 & 11. 21 & 17.99 \\
\hline 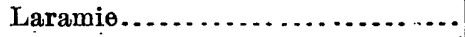 & 11.40 & 13.80 & 12.46 & 7.63 \\
\hline St. Cloud $\ldots \ldots \ldots \ldots \ldots \ldots$ & 18.12 & 16.81 & ............ & $\ldots \ldots \ldots$ \\
\hline 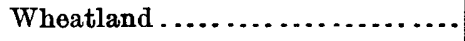 & 10.34 & 12.84 & 9.70 & 12.44 \\
\hline Fort Laramio.................... & 12.50 & 14.67 & 13.75 & 12.96 \\
\hline Gering $\ldots \ldots \ldots \ldots \ldots \ldots \ldots \ldots$ & 14.07 & 14.69 & 11.63 & \\
\hline Cheyenne $\ldots . . . . . . . . . . . .$. & 12.90 & 20.79 & 17.25 & 13.05 \\
\hline Fort Collins...$\ldots \ldots \ldots \ldots \ldots \ldots$ & 14.11 & 15. 76 & 15.24 & 11.03 \\
\hline 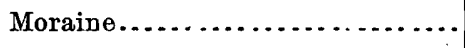 & 17.86 & 17.28 & 18.87 & 16. 86 \\
\hline Smoky Hill mine................ & 25.15 & 21. 37 & 32.57 & 25.14 \\
\hline Georgetown $\ldots \ldots \ldots \ldots \ldots \ldots \ldots$ & 16.04 & 15.01 & 20.82 & \\
\hline Alma $\ldots \ldots \ldots \ldots \ldots \ldots \ldots$ & 14.97 & 14.19 & $\ldots \ldots \ldots$ & $\ldots .$. \\
\hline Castle Rock ................... & 18.40 & 20.44 & 27.65 & 20.23 \\
\hline Denver $\ldots \ldots \ldots \ldots \ldots \ldots \ldots$ & 14.42 & 11.84 & 15.37 & 12.98 \\
\hline Greeley.$\ldots \ldots \ldots \ldots \ldots \ldots \ldots$ & 11.33 & 13.52 & 16. 09 & 15.95 \\
\hline 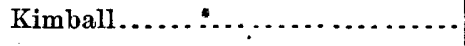 & 14.18 & 14.38 & 20.92 & 18.08 \\
\hline 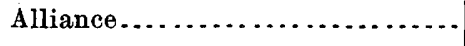 & 16.88 & 16. 11 & 14.55 & 13.44 \\
\hline Sidney . . . . . . . . . . . . . . . . . & 14.40 & 18. 35 & 17.76 & $\ldots \ldots$ \\
\hline North Platte............. & 18.20 & 16.72 & 17.09 & 15.54 \\
\hline Thedford . . . . . . . . . . . . . . . . & 18.03 & 19.66 & 15.90 & ........... \\
\hline 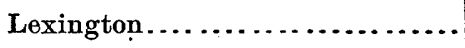 & 20.52 & 22.23 & 21.79 & 18.51 \\
\hline Kearney ........................ & 24.90 & 29.82 & 30.01 & 21.24 \\
\hline 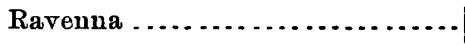 & 24.80 & 27.50 & 32.75 & 18.50 \\
\hline Ansley $\ldots . . . \ldots \ldots \ldots \ldots$ & 21.07 & 21.32 & 27.13 & 17.86 \\
\hline Burwell ....................... & 19.64 & 20.71 & 17.70 & 18. 18 \\
\hline North Loup............... & 23.01 & 30.37 & 28.10 & 16.50 \\
\hline 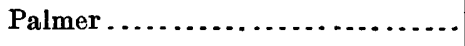 & 24.04 & 29.10 & 31.35 & 24.04 \\
\hline Ericson $\ldots \ldots \ldots \ldots \ldots \ldots$ & 21. 41 & 26. 73 & 25.21 & 15. 66 \\
\hline 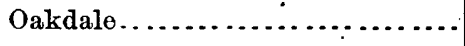 & 22.80 & 29.44 & 25.17 & 22.59 \\
\hline O'Neill. . . . . . . . . . . . . . . . . & $22 . \dot{17}$ & 28.35 & 26.13 & 20.37 \\
\hline Norfolk ........................ & 25.85 & 29.61 & 23.65 & 19.83 \\
\hline Cornelia . . . . . . . . . . . . . . . & 24.10 & 23.05 & 29.81 & $\ldots \ldots \ldots$ \\
\hline Genoa. . . . . . . . . . . . . . & 26.90 & 30.01 & 30.85 & 22.80 \\
\hline Marquette............ & 25.10 & 33.11 & 26.95 & 21.02 \\
\hline Lincoln $\ldots \ldots \ldots \ldots \ldots \ldots$ & 26.31 & 38.06 & 25.67 & 28.10 \\
\hline Average. & 18.77 & 21. 10 & 21.55 & 17.84 \\
\hline RUN-OFE. & ' & & 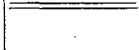 & \\
\hline 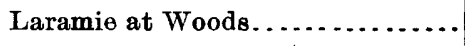 & 7.55 & & 11.61 & \\
\hline North Platte at Orin Junction .... & 1.94 & & 2.79 & 4.37 \\
\hline 'Laramie at Uva $\ldots . . . . . . . . . . .$. & 0.68 & $\cdots$ & 1. 27 & 0.45 \\
\hline North Platte at Gering .. & (.......... & & & \\
\hline
\end{tabular}


Rainfall and run-off-Continued.

\begin{tabular}{|c|c|c|c|c|}
\hline Station. & Normal. & 1896. & 1897. & 1898. \\
\hline RUN-OFF-continued. & & & & \\
\hline North Platte at Camp Clarke & 1.25 & ..... & 1.39 & $\ldots$. \\
\hline North Platte at North Platte...... & 1. 84 & & 2.61 & 1. 38 \\
\hline Platte at Columbus..... & $\therefore \ldots$. & $\cdots$ & $\ldots \ldots$ & $\cdots$ \\
\hline Loup at Columbus . . . . . . . . . . . . & $\ldots$ & . & 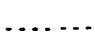 & \\
\hline Bear Creek at Morrison.... & $\ldots$. & $\ldots . . .$. & .. & $\ldots$. \\
\hline South Platte at Denver........... & 1. 36 & 0.62 & 1. 43 . & 2.03 \\
\hline Boulder Creek at Boulder......... & $\ldots .$. & $\ldots \ldots \ldots$ & $\cdots$ & $\cdots$ \\
\hline St. Vrain Creek at Lyons .. & . & $\cdot$ & $\ldots$ & \\
\hline Big Thompson Creek at Arkins ... & $\ldots$. & & & \\
\hline South Platte at Orchard .... & 1. 03 & & 0.85 & 1.59 \\
\hline North Loup at St. Paul ..... & 3.38 & & 3.38 & \\
\hline Elkhorn at Norfolk.... & 2. 60 & & 2.14 & \\
\hline Average run-off ..... & 2.40 & 0.62 & 3.05 & 1.96 \\
\hline Percentage of rainfall & 12.79 & $\ldots$ & $\begin{array}{l}14.15 \\
\text {. }\end{array}$ & 10.99 \\
\hline
\end{tabular}

NORTH PLATTE RIVER.

Estimated monthly discharge of North Platte River at Orin Junction, Wyoming.

[Drainage area, 14,828 square riles.]

\begin{tabular}{|c|c|c|c|c|c|c|}
\hline \multirow[b]{2}{*}{ Month. } & \multicolumn{3}{|c|}{ Discharge in second-feet. } & \multirow[b]{2}{*}{$\begin{array}{l}\text { Total in acre- } \\
\text { feet. }\end{array}$} & \multicolumn{2}{|c|}{ Run-off. } \\
\hline & $\begin{array}{l}\text { Maxi- } \\
\text { mum. }\end{array}$ & $\begin{array}{l}\text { Mini- . } \\
\text { mum. }\end{array}$ & Mean. & & $\begin{array}{l}\text { Depth in } \\
\text { inches. }\end{array}$ & $\begin{array}{c}\text { Second- } \\
\text { feet per } \\
\text { square } \\
\text { mile. }\end{array}$ \\
\hline 1898. & & & & & & \\
\hline January ............ & $\ldots \ldots$ & $\ldots \ldots$ & $a 700$ & $a 43,042$ & $a 0.05$ & $a 0.05$ \\
\hline February . . . . . & $\ldots \ldots \ldots$ & $\ldots \ldots$ & $a 900$ & $a 49,983$ & $a 0.06$ & $a 0.06$ \\
\hline March ............ & $\ldots \ldots$ & $\ldots \ldots$ & $a 700$ & $a 43,042$ & $a 0.05$ & $a 0.05$ \\
\hline April $\ldots \ldots \ldots \ldots$ & 3,895 & 700 & 1,859 & 110,622 & 0.14 & 0.13 \\
\hline May ............ & 15,635 & 2,555 & 5,552 & 341,381 & 0.43 & 0.37 \\
\hline June . . . . . . . . . . & 7,880 & 3,895 & $6,06 \mathrm{~L}$ & 360,654 & 0.46 & 0.41 \\
\hline July ............ & 3,512 & 700 & 1,284 & 78,951 & 0.10 & 0.09 \\
\hline August........... & 825 & 430 & 583 & 35,849 & 0.04 & 0.04 \\
\hline September .......... & 550 & 370 & 399 & 23,742 & 0.03 & 0.03 \\
\hline October............ & $\ldots \ldots$ & $\ldots \ldots$ & $a 600$ & $a 36,893$ & $a 0.05$ & $a 0.04$ \\
\hline November .......... & $\ldots . . .$. & $\ldots$ & $a 600$ & $a 35,702$ & $a 0.05$ & $a \dot{0.04}$ \\
\hline December . . . . . . . . & & $\cdots$ & $a 700$ & $a 43,042$ & $a 0.05$ & $a 0.05$ \\
\hline The year & $\cdots$ & $\ldots$ & 1,662 & $1,202,903$ & 1. 51 & 0.11 \\
\hline
\end{tabular}

a Approximate.

Note.-Gage heights for 1898 are given in Water-Supply and Irrigation Paper No.27, page 79; measurements, page 86; rating table, page 88; results for 1897 in Water-Supply and Irrigation Paper No. 15, page 83, and in the Nineteenth Annual Report, Part IV, pages 304 to 307. 


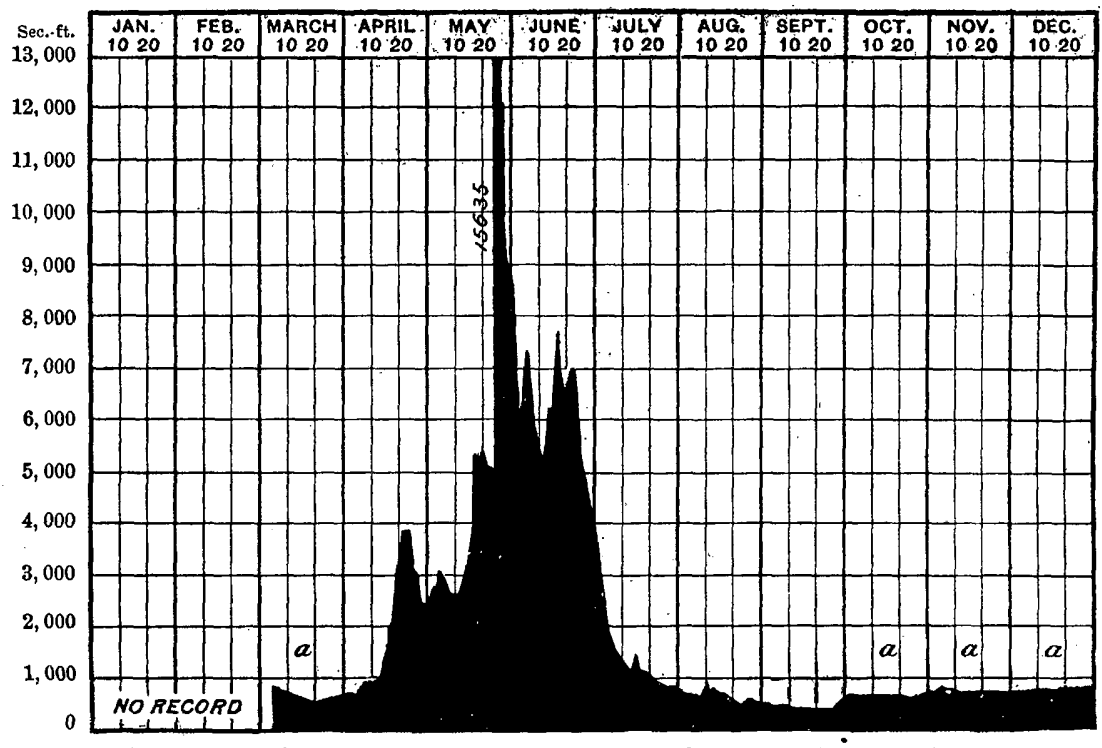

FrG. 90.-Discharge of North Platte River at Orin Junction, Wyoming, 1898.

Estimated monthly discharge of North Platte River at Gering, Nebraska.

[Drainage area, 24,340 square miles.]

\begin{tabular}{|c|c|c|c|c|c|c|}
\hline \multirow{2}{*}{ Month. } & \multicolumn{3}{|c|}{ Discharge in second.feet. } & \multirow[b]{2}{*}{$\begin{array}{l}\text { Total in acre- } \\
\text { feet. }\end{array}$} & \multicolumn{2}{|c|}{ Run-off. } \\
\hline & $\begin{array}{l}\text { Maxi- } \\
\text { mumm. }\end{array}$ & $\begin{array}{l}\text { Mini. } \\
\text { mum. }\end{array}$ & Mean. & & $\begin{array}{l}\text { Depth in } \\
\text { inches. }\end{array}$ & $\begin{array}{c}\text { Second- } \\
\text { feet per } \\
\text { square } \\
\text { mile. }\end{array}$ \\
\hline 1898. & . & & & & & , \\
\hline April ... & 6,500 & 1,000 & 3,108 & ' $\quad 184,938$ & 0.14 & 0.13 \\
\hline May .... & $18, \breve{500}$ & 3,400 & 7,326 & 450,461 & 0.35 & 0.30 \\
\hline June...... & 12,150 & 5,700 & 9,002 & 535,655 & 0.41 & 0.37 \\
\hline July ....... & 5,700 & 500 & 2,048 & 125,927 & 0.10 & 0.08 \\
\hline August.... & 350 & 100 & 177 & 10,883 & 0.01 & 0.01 \\
\hline September ... & 200 & 50 & 100 & 5,950 & 0.005 & 0.004 \\
\hline October ............. & 500 & 100 & 258 & 15,864 & 0.01 & 0.01 \\
\hline
\end{tabular}

Note.-Gage heights for 1898 are given in Water-Supply and Irrigation Paper No. 27, page 80; measurements, page 86; rating table, page 88; results for 1897 , in Water-Supply and Irrigation Paper No. 15, page 84, and in the Nineteenth Annual Report, Part IV, pages 304 to 308. 


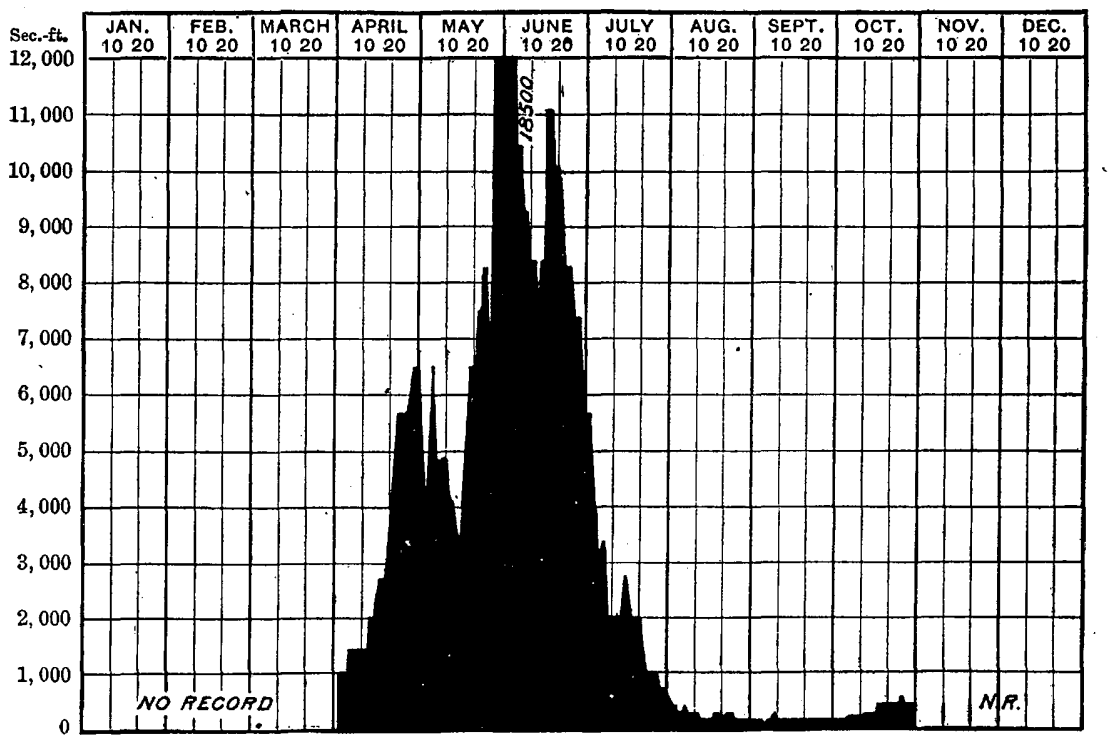

Fie. 91.-Discharge of North Platte River at Gering, Nêbraska, 1898.

Estimated monthly discharge of North Platte River at Camp Clarke, Nebraska.

[Drainage area, 24,830 square miles.]

\begin{tabular}{|c|c|c|c|c|c|c|}
\hline \multirow[b]{2}{*}{ Month. } & \multicolumn{3}{|c|}{ Discharge in second-feet. } & \multirow[b]{2}{*}{$\begin{array}{l}\text { Total in acre. } \\
\text { feet. }\end{array}$} & \multicolumn{2}{|c|}{ Run-off. } \\
\hline & $\begin{array}{l}\text { Maxi. } \\
\text { mum. }\end{array}$ & $\begin{array}{l}\text { Mini- } \\
\text { mum. }\end{array}$ & Mean. & & $\begin{array}{l}\text { Depth in } \\
\text { inches. }\end{array}$ & $\begin{array}{c}\text { Second. } \\
\text { feet per } \\
\text { square } \\
\text { mile. }\end{array}$ \\
\hline 1898. & & & & & & \\
\hline$\Lambda$ pril $\ldots . \ldots \ldots \ldots$ & 3,400 & 675 & 1,630 & 96,992 & 0.08 & 0.07 \\
\hline May ....... & 17,000 & 2,350 & 5,403 & 332,220 & 0.25 & 0.22 \\
\hline June....... & 10,600 & 4,550 & 7,390 & $4.39,735$ & 0.33 & 0.30 \\
\hline July ....... & 4,200 & 780 & 1,617 & 99,426 & 0.08 & 0.07 \\
\hline August............. & 800 & 60 & 266 & 16,356 & 0.01 & 0.01 \\
\hline September ......... & 200 & 60 & 110 & 6,545 & 0.004 & 0.004 \\
\hline October ............. & 425 & 110 & 245 & 15,065 & 0.01 & 0.01 \\
\hline
\end{tabular}

Note.-Gage heights for 1898 are given in Water-Supply and Irrigation Paper No. 27, page 80, measurements, page 86; rating table, page 88; results for 1897, in Water Supply and Irrigation Paper No.15, page 85, and in the Nineteenth Annual Report, Part IV, pages 308 to 310 . 


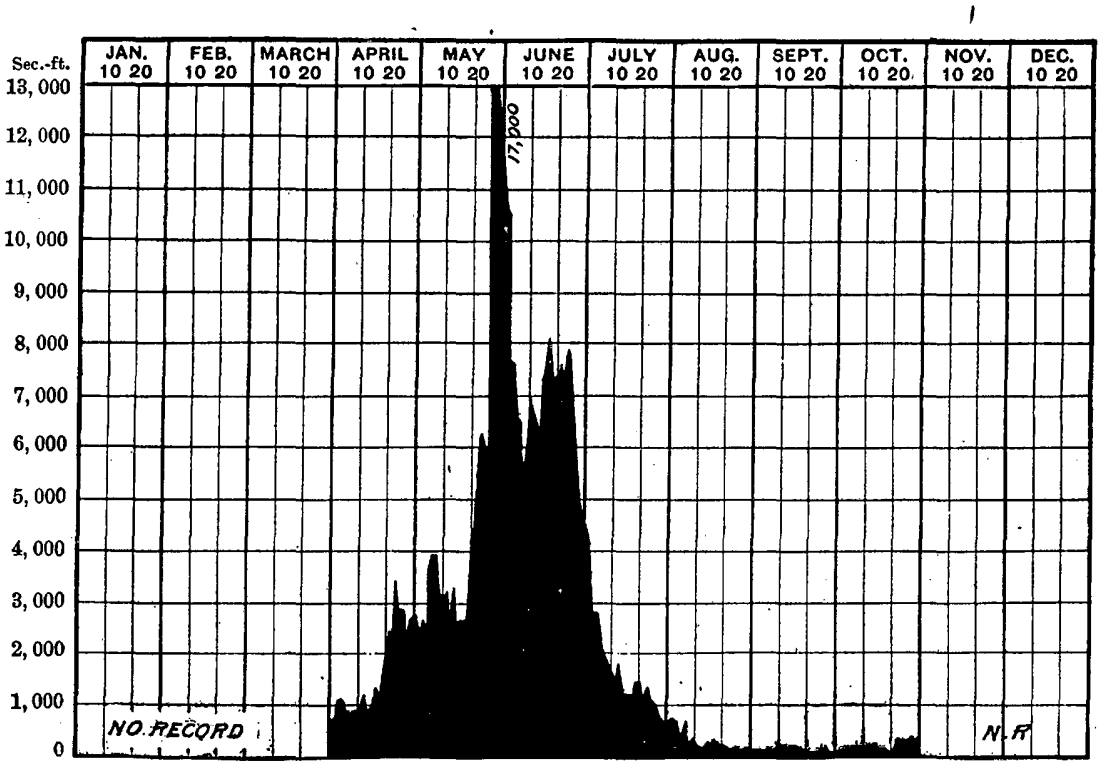

Frg. 92.-Discharge of North Platte River at Camp Clarke, Nebraska, 1898.

Estimated monthly discharge of North Platte River at North Platte, Nebraska.

[Drainage area, 28,517 square miles.]

\begin{tabular}{|c|c|c|c|c|c|c|}
\hline \multirow[b]{2}{*}{ Month. } & \multicolumn{3}{|c|}{ Discharge in second-feet. } & \multirow[b]{2}{*}{$\begin{array}{l}\text { Total in acre- } \\
\text { feet. }\end{array}$} & \multicolumn{2}{|c|}{ Run-off. } \\
\hline & $\begin{array}{l}\text { Maxi- } \\
\text { mum. }\end{array}$ & $\begin{array}{l}\text { Mini- } \\
\text { mum. }\end{array}$ & Mean. & & $\begin{array}{l}\text { Depth in } \\
\text { inches. }\end{array}$ & $\begin{array}{c}\text { Second- } \\
\text { feet per } \\
\text { square } \\
\text { mile. }\end{array}$ \\
\hline 1898. & & & & & & \\
\hline January ............. & 5,848 & 4,864 & 5,178 & 318,383 & 0.21 & 0.18 \\
\hline February............ & 8,270 & 2,922 & 5,342 & 296,679 & 0.20 & 0.19 \\
\hline March..... & 3,354 & 1,270 & 2,226 & 136,871 & 0.09 & 0.08 \\
\hline April....... & 3,785 & 1,557 & 2,540 & 151,140 & 0.10 & 0.09 \\
\hline May ..... & 14,646 & 3,570 & 5,276 & 324,409 & 0.21 & 0.19 \\
\hline June....... & 12,034 & 4,433 & 6,878 & 409,269 & 0.27 & 0.24 \\
\hline July ............. & 4,433 & 324 & 1,846 & 113,506 & 0.08 & 0.07 \\
\hline August...... & 1,413 & 80 & 353 & 21,705 & 0.01 & 0.01 \\
\hline September & •984. & 50 & 352 & 20,945 & 0.01 & 0.01 \\
\hline October ........... & 697 & 254 & 471 & 28,961 & 0.02 & 0.02 \\
\hline November .- & 2,275 & 660 & 1,088 & 64,740 & 0.04 & 0.04 \\
\hline December .. & 4,433 & 2,275 & 3,472 & 213,486 & 0.14 & 0.12 \\
\hline The year.... & 14,646 & 50 & 2,919 & $2,100,094$ & 1.38 & 0.10 \\
\hline
\end{tabular}

Notz.-Gage heights for 1898 are given in Water-Supply and Irrigation Paper No. 27, page 81; measurements, page 86; rating table. page 88; results for 1897 in Water-Supply and Irrigation Paper No. 15, page 86, and in the Nineteenth Annual Report, Part IV, page 310. 
U. S. GEOLOGICAL SURVEY

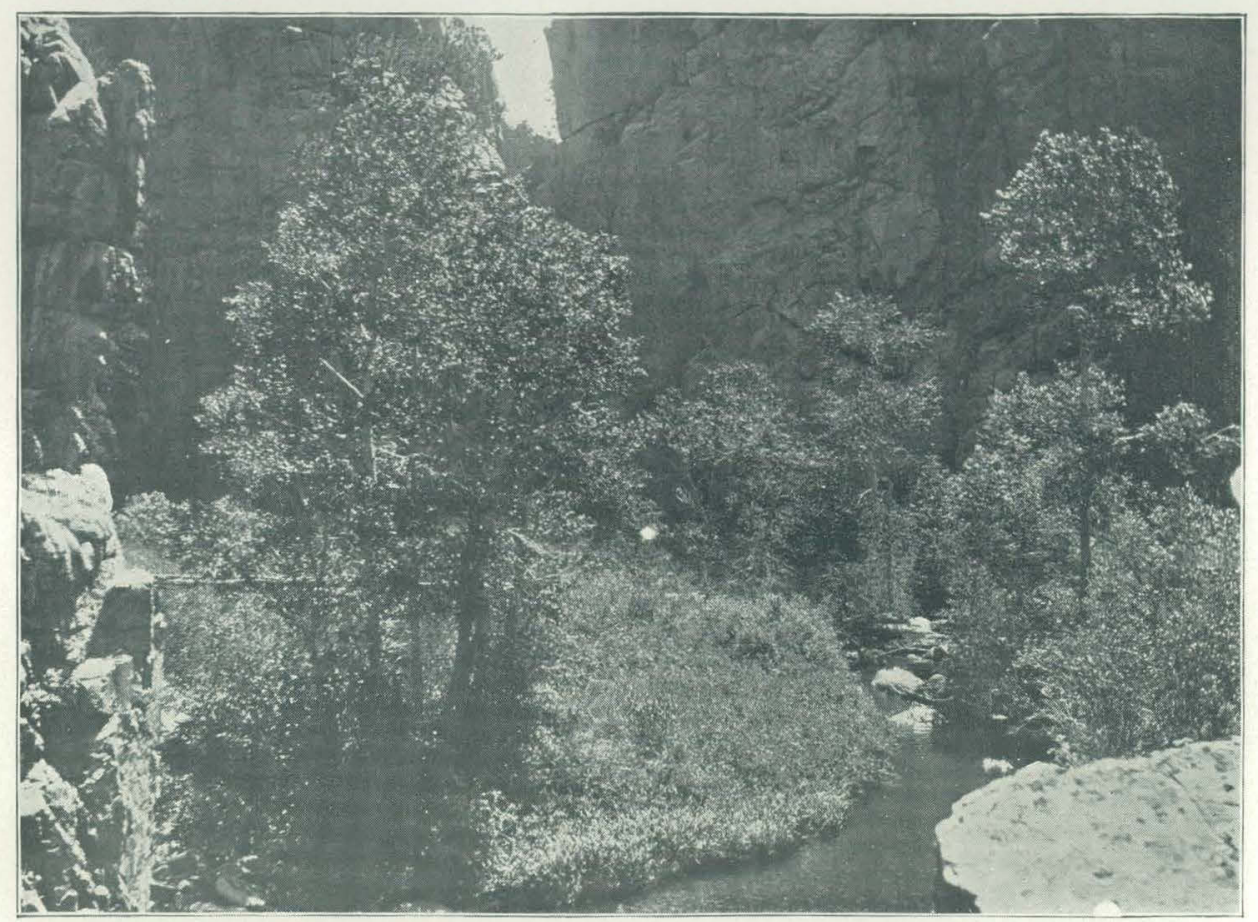

A. GORGE OF HORSESHOE CREEK IN UPPER RESERVOIR SITE, ALBANY COUNTY, WYOMING.

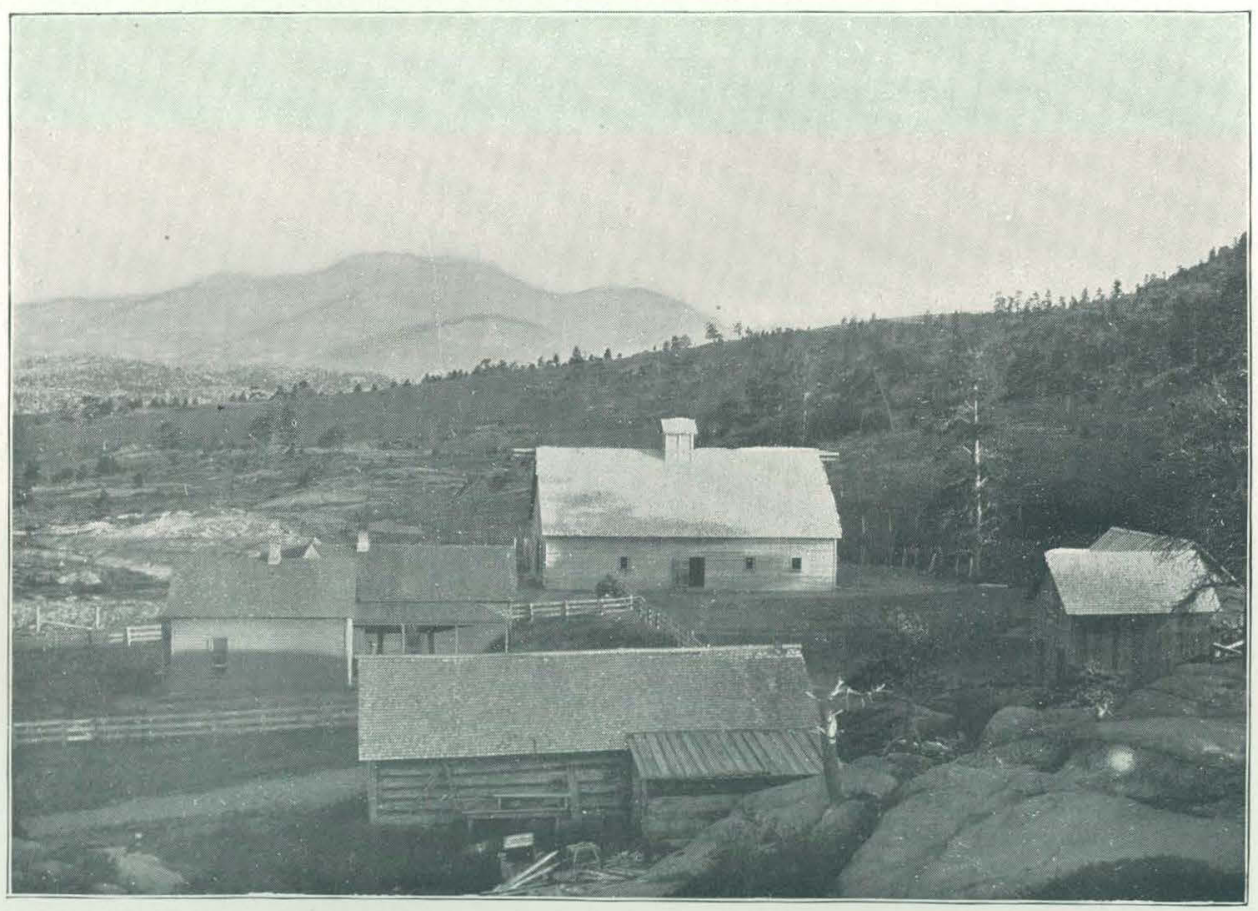

B. RANCH ON HORSESHOE CREEK, WYOMING. 
HORSESHOE CREEK."

Horseshoe Creek drains the northern slope of Laramie Peak and flows from its base in a northwesterly direction for a few miles, when it turns to the northeast. After this it cuts through the ridges which run north from the peak and which form the western limit of the prairie land that stretches to the North Platte River. Through this the creek continues in an easterly and southeasterly course, finally emptying into North Platte River on the same side and about 30 miles above the mouth of Laramie River. Fig. 93 shows the relative location of the irrigation ditches along the lower course of the stream.

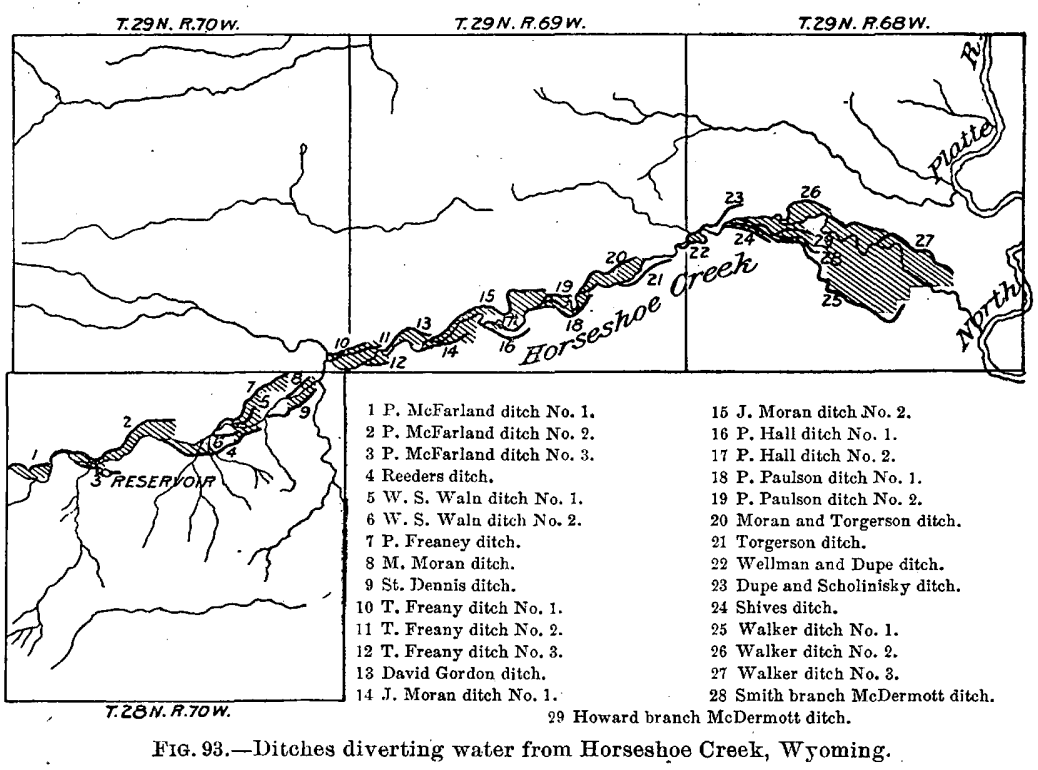

The country lying north of Laramie Peak, which is drained by this stream, is called Horseshoe Basin. It abounds in meadow land, the surface being broken by giant granite bowlders and ridges. These ridges in particular aid the ranchmen of the park in keeping their flocks and herds on a fixed. range, and by fencing between ridges at intervals a stockman can often control a large area. The principal forage growth is buffalo grass, which during June, 1898, attained a height of 5 or 6 inches. The ranch houses and improvements generally are permanent in character. Surveys of two reservoir sites were made by Mr. Clarence T. Johnston during the spring of 1898 .

RESERVOIR SITES ON HORSESHOE CREEK.

The dam site of the largest reservoir (fig. 94) is located 10 miles north of the summit of Laramie Peak, in Albany County, Wyoming, and on Horseshoe Creek, at one of the gorges where the creek cuts through a

1 Report by Clarence T. Johnston. 
ridge on its way to the open country. At this locality, according to the descriptions by Mr. Johnston, the water has worn away a solid granite ridge (shown in fig. 95). At a height of 80 feet above low-water mark the gorge is 58.37 feet wide. This narrows to 15.36 feet at 46 feet above the same line. An unlimited supply of granite can be had at the dam site for a masonry dam, and timber can be secured within a few hundred feet for the construction of a rock-filled crib dam.

One thousand and fifty yards of masonry would build a circular-arch dam 60 feet long on top, 30 feet long on the bottom, 60 feet high, and having a thickness of 15 feet at the bottom and 6 feet at the top. At $\$ 8$ ver yard the masonrv dam would cost $\$ 8.400$. Two 2 -foot cast

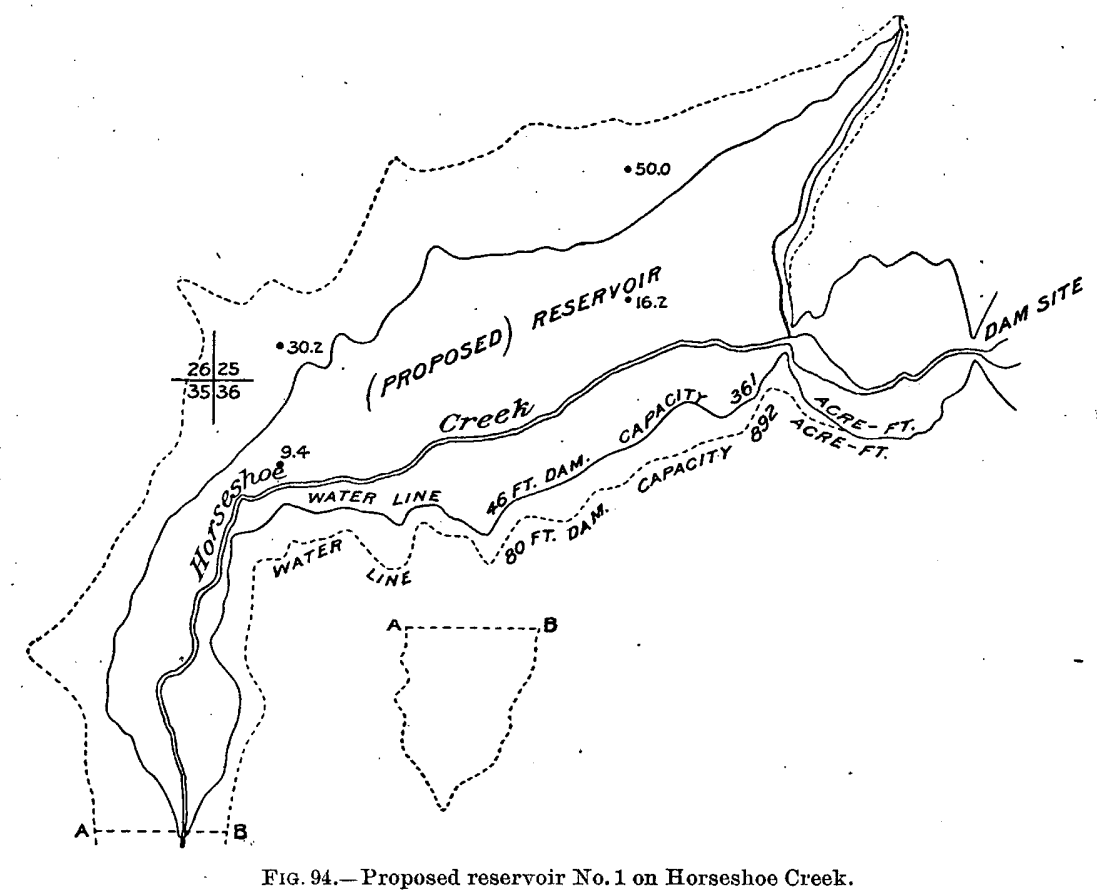

valves and 30 feet of 2 -foot cast pipe in place would add $\$ 500$, making a total outlay of $\$ 8,900$, or $\$ 10$ per acre-foot of water stored.

A rock-filled crib dam would cost less than $\$ 1,000$, if not built above 50 feet in height; adding $\$ 500$ to this for valves and pipe, the entire outlay for a reservoir storing 361 acre-feet would be $\$ 1,500$. This is less than $\$ 5$ per acre-foot.

Three hundred and fifty feet above the dam site a second ridge has been worn away. On the north side of this a cliff extends vertically above the water for 130 feet. That on the south side is high, but it does not rise as abruptly from the water's edge:

The fall of the stream in this vicinity is unfortunately large. The cheapness of the work of damming the stream is, however, so marked 
that the slope of the stream bed toward the dam site is partially com. pensated for by the depth of water.

At this site there would be no loss of water through percolation, as the bedrock underlies the entire area. In average years losses by evaporation would be made up by local precipitation. This reservoir would store sufficient water to enable all the land along the creek to

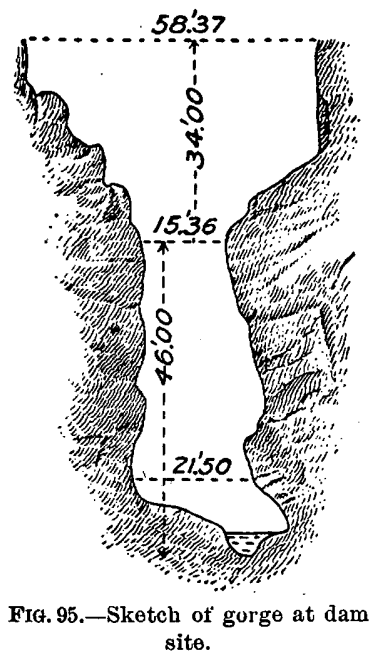

be cultivated. Since the flow of the stream is in excess of the demands upon it until June 15 , no water would be used from the storage works until after June 20 . One irri. gation of cereal crops after that date would suffice to insure a crop.

The conditions on the creek to-day are somewhat as follows: The first, second, and third rights on the stream control sufficient water to irrigate 1,318 acres under the Walker ditches, shown in fig.

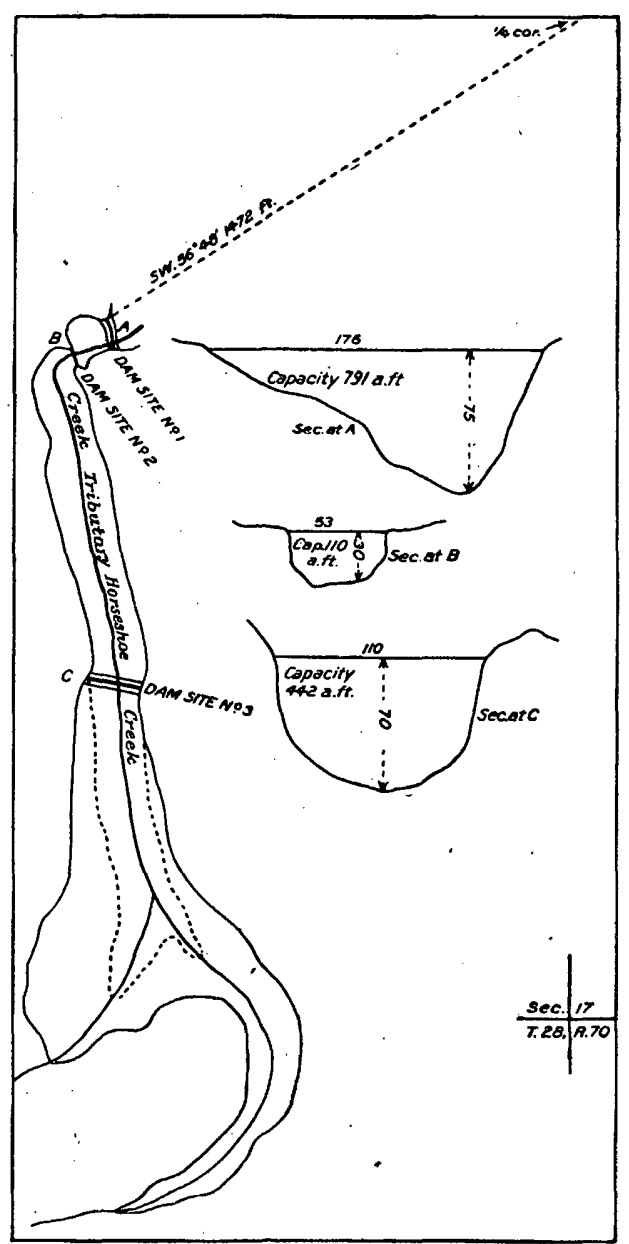

FiG. 96.-Small reservoir on Horseshoe Creek. 93 as ditches Nos. 25,26 , and 27 . This land, under the State law, is entitled to 18.83 feet of water per second. It is located near the mouth of the creek, and its return seepage waters are of no benefit to the other irrigators. On June 24, 1898, the creek contained 22.45 cubic feet per second above all diverting works. This is less than 4 eubic feet per second in excess of what the first three rights possess, and the water commissioner was called upon to close the headgates of the ditches 
having later appropriations, that the Walker ditches might receive their allotment. The total amount of water decreed to the ditches on Horseshoe Creek is 58.46 cubic feet per second.

The minimum discharge of the creek is 20 cubic feet per second. Nearly 40 cubic feet per second is wanting to supply the ditches for 10 days or 2 weeks. The reservoir. would furnish 40 cubic feet per second for 11 days and 30 cubic feet per second for 2 weeks. After the reservoir supply was exhausted sùch surplus water as flows from local rains could be held for the crops requiring late irrigation.

A second site, known as the McFarlane site, is not so promising as that described above. It is located immediately east of the mountains, on a small tributary to Horseshoe Creek on the south. The formation there is sandstone, this material underlying the entire basin, so that no water would be lost through seepage. The creek follows a canyon for 1,800 feet before entering the Horseshoe Creek meadows. In this canyon three dam sites were surveyed and the water line of the reservoir for each was located. Dam site No. 1 promises the cheapest water storage. It will require a dam 70 feet high and 176 feet long. If made of earth it would require 75,000 yards of material and cost $\$ 10$ per acre-foot of water stored. This is estimating the work at 10 cents per yard and adding $\$ 500$ for valves and pipes. An overflow could be made at the northern extremity of the dam, where the bed rock crops out. Fig. 96 gives the outline of this reservoir and the relative sections at the dam sites. The other sites compare as follows with site No. 1:

\begin{tabular}{|r|r|r|r|r|r|r|r|}
\hline $\begin{array}{c}\text { Dam } \\
\text { site. }\end{array}$ & $\begin{array}{c}\text { Height } \\
\text { dam. }\end{array}$ & $\begin{array}{r}\text { Capacity } \\
\text { reservoir. }\end{array}$ & $\begin{array}{l}\text { Material in } \\
\text { dam. }\end{array}$ & $\begin{array}{r}\text { Quantity. } \\
\text { Feet. }\end{array}$ & $\begin{array}{r}\text { Acrefeet. } \\
\text {-Cost per } \\
\text { yard. }\end{array}$ & $\begin{array}{l}\text { Cost }+\$ 500 \\
\text { for outlet. }\end{array}$ & $\begin{array}{c}\text { Cost per } \\
\text { acre-foot. }\end{array}$ \\
\hline No. 1. & 75 & 791 & Earth ... & 75,000 & $\$ 0.10$ & $\$ 8,000$ & $\$ 10.00$ \\
No. 2. & 30 & 110 & Masonry & .400 & 10.00 & 4,500 & 41.00 \\
No. 3. & 70 & 442 & Earth ... & 52,000 &. .10 & 5,700 & 12.80 \\
\hline
\end{tabular}

Characteristic views of the reservoir sites described above are shown on the accompanying Pls. XXIII and XXIV. In Pl. XXIII, $A$, is a picture of the gorge on Horseshoe Creek in the upper reservoir site, the location being shown on the small map, fig. 94. Bis a view of one of the ranch houses on the creek. In Pl. XXIV, $A$, is a picture of the dam site of the small reservoir, the outline of which is shown in fig. 96 .

20 GEOL, PT $4-18$ 


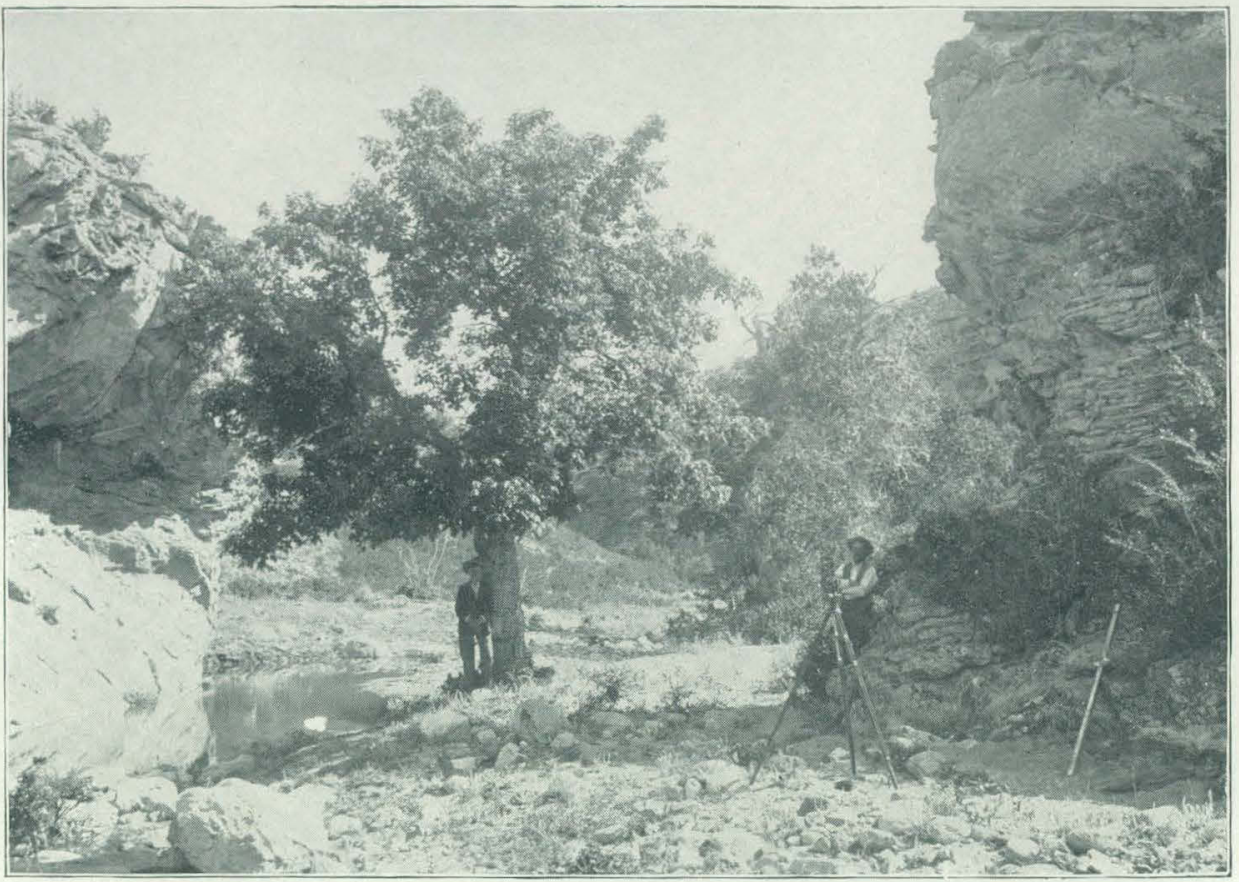

A. DAM SITE OF SMALL RESERVOIR ON HORSESHOE CREEK WYOMING

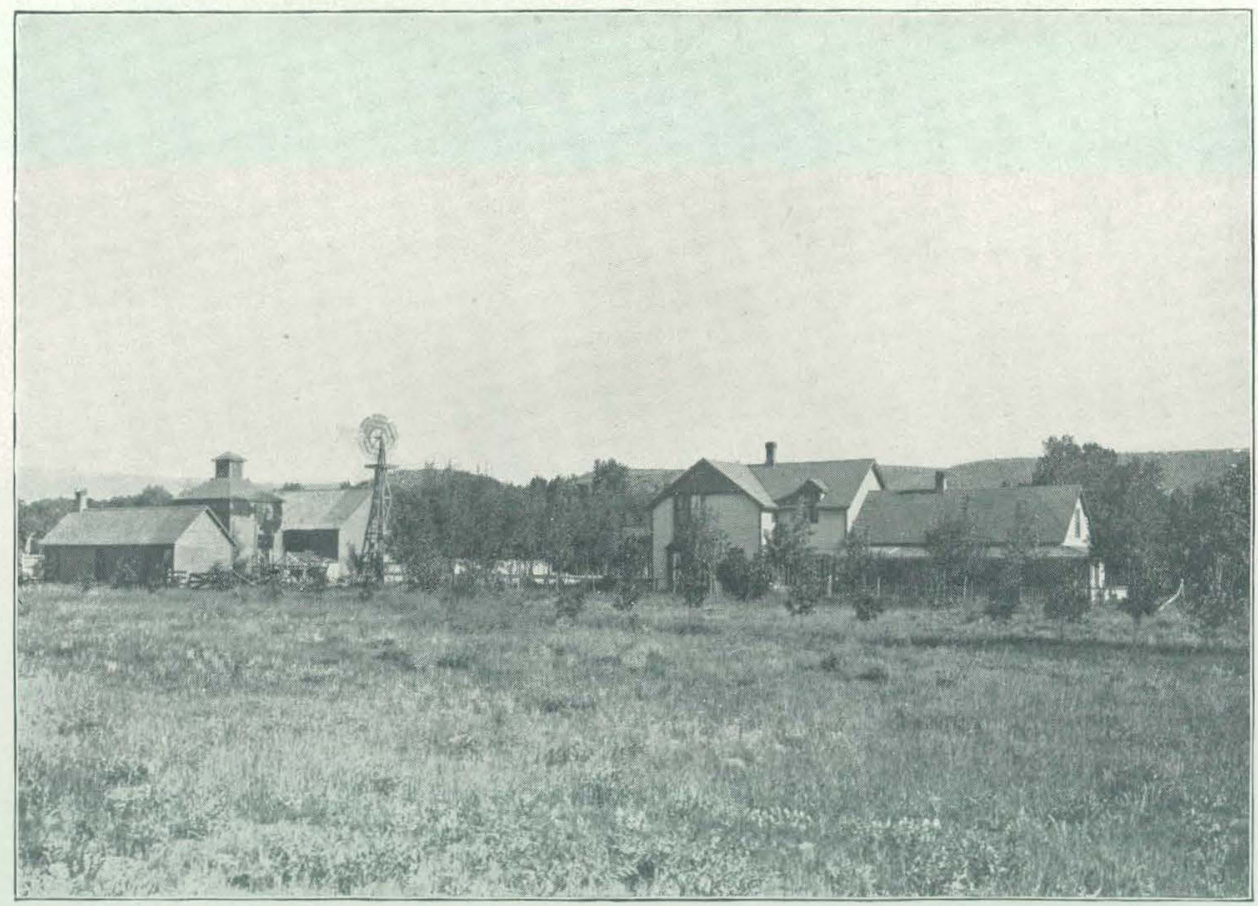

B. MCFARLANE'S RANCH ON HORSESHOE CREEK, WYOMING. 
LARAMIE RIVER.

Estimated monthly discharge of Laramie River at Woods Landing, Wyoming.

[Drainage area, 435 square miles.]

\begin{tabular}{|c|c|c|c|c|c|c|}
\hline \multirow[b]{2}{*}{ Month. } & \multicolumn{3}{|c|}{ Diseharge in second-feet. } & \multirow{2}{*}{$\begin{array}{c}\text { Total in acre- } \\
\text { feet. }\end{array}$} & \multicolumn{2}{|c|}{ Run-off. } \\
\hline & $\begin{array}{l}\text { Maxi- } \\
\text { mum. }\end{array}$ & $\begin{array}{l}\text { Mini- } \\
\text { mum. }\end{array}$ & Mean. & & $\begin{array}{l}\text { Depth in } \\
\text { inches. }\end{array}$ & $\begin{array}{c}\text { Second- } \\
\text { feet per } \\
\text { square } \\
\text { mile. }\end{array}$ \\
\hline 1898. & & & . & & & \\
\hline 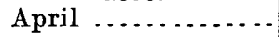 & 350 & 85 & 129 & 7,676 & 0.33 & 0.30 \\
\hline May .................. & 1,572 & 125 & 636 & 39,106 & 1. 68 & 1.46 \\
\hline June .............. & 1,400 & 245 & 969 & 57,659 & 2. 49 & 2.23 \\
\hline July ............. & 200 & 50 & 89 & 5,472 & .23 & .20 \\
\hline August................ & 50 & 40 & 44 & 2,705 & .12 & .10 \\
\hline September . . . . . . . & 40 & 40 & 40 & 2,380 & .10 & .09 \\
\hline October $1-20 \ldots \ldots$ & 45 & 45 & 45 & 2,767 & .12 & .10 \\
\hline
\end{tabular}

NoTE.-Gage heights for 1898 are given in Water-Supply and Irrigation Paper No. 27, page 78, measurements, page 86; rating table, page 88; rates for 1897 in Water-Supply and Irrigation Paper No. 15, page 81; and in the Nineteenth Annual Report, Part IV, pages 300 to 302.

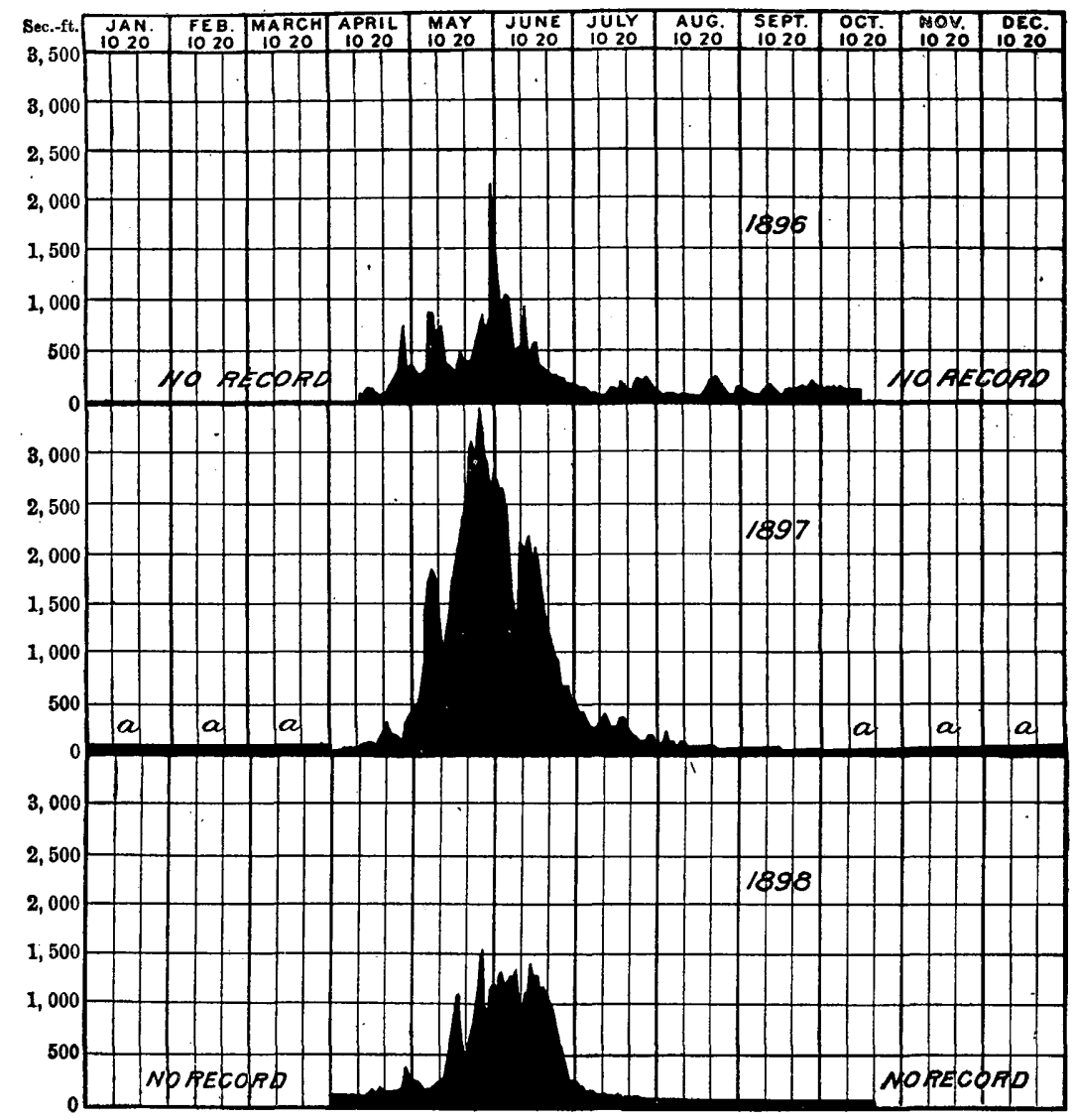

Fig. 97.-Discharge of Laramie River at Woods Landing, Wyoming, 1896-98. 
Estimated monthly discharge of Laramie River at Uva, Wyoming.

[Drainage area, 3,179 square miles.]

\begin{tabular}{|c|c|c|c|c|c|c|}
\hline \multirow[b]{2}{*}{ Month. } & \multicolumn{3}{|c|}{ Discharge in second-feet. } & \multirow[b]{2}{*}{$\begin{array}{c}\text { Total in acre- } \\
\text { feet. }\end{array}$} & \multicolumn{2}{|c|}{ Run-off. } \\
\hline & $\begin{array}{l}\text { Maxi- } \\
\text { mum. }\end{array}$ & $\begin{array}{l}\text { Mini- } \\
\text { mum. }\end{array}$ & Mean. & & $\begin{array}{l}\text { Depth in } \\
\text { inches. }\end{array}$ & $\begin{array}{c}\text { Second. } \\
\text { feet per } \\
\text { square } \\
\text { mile. }\end{array}$ \\
\hline 1898. & . & & & & & \\
\hline January . & $\ldots .$. & $\ldots . .$. & $a 15$ & ' $a 922$ & $a 0.005$ & $a 0.005$ \\
\hline February ... & & $\ldots \ldots$ & $a 15$ & $a 833$ & $a 0.005$ & $a 0.005$ \\
\hline March ..... & $\therefore .$. & $\ldots \ldots$ & $a 30$ & $a 1,844$ & $a 0.011$ & $a 0.009$ \\
\hline April $\ldots \ldots \ldots \ldots \ldots$ & 190 & 451 & 76 & 4,522 & 0.027 & 0.024 \\
\hline May $\ldots \ldots \ldots \ldots$ & 1,220 & 50 & 413 & 25,395 & 0.150 & 0.130 \\
\hline June.............. & 970 & 80 & 654 & 38,916 & 0.230 & 0.206 \\
\hline July $\ldots \ldots \ldots \ldots \ldots$ & 62 & 1 & 27 & 1,660 & 0.009 & 0.008 \\
\hline August $\ldots \ldots \ldots \ldots$ & 5 & 1 & 2 & 135 & 0.001 & 0.001 \\
\hline September ......... & 2 & 2 & 2 & 119 & 0.001 & 0.001 \\
\hline October .......... & 4 & 2 & 3 & 154 & 0.001 & .0 .001 \\
\hline November $6-26 \ldots$ & & $\ldots \ldots$ & 9 & 536 & 0.003 & 0.003 \\
\hline December...... & $\ldots$ & $\cdots$ & $a 18$ & 1,107 & 0.007 & 0.006 \\
\hline The year & & & 105 & 76,143 & 0.450 & 0.033 \\
\hline
\end{tabular}

a Approximate.

NOTE.-Gage heights for 1898 are given in Water-Supply and Irrigation Paper No. 27, page 79; measurements, page 86; rating table, page 88; results fer 1897 in Water-Supply and Irrigation Paper No. 15, page 82, and in the Nineteenth Annual Report, Part IV, pages 302 to 304. 


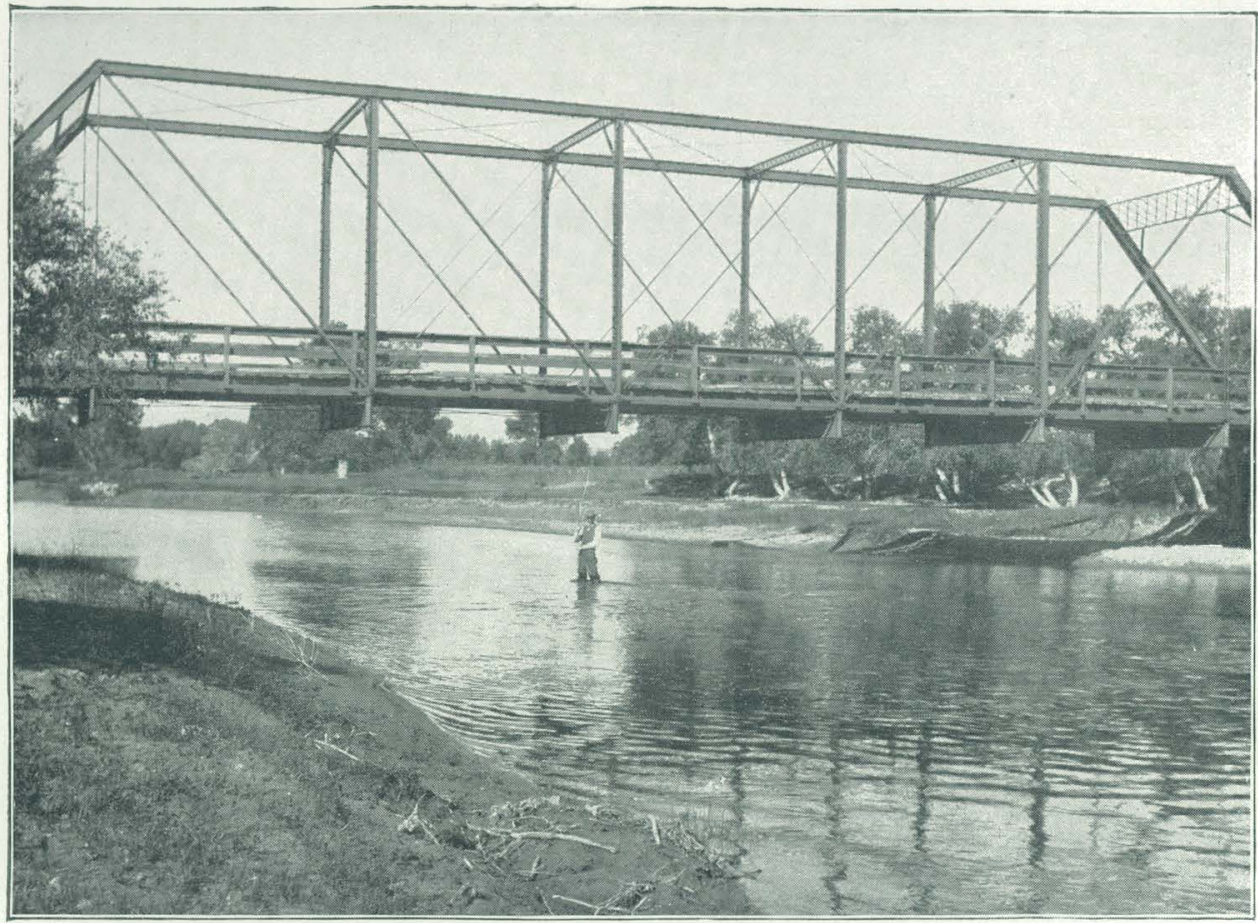

A. MEASURING LARAMIE RIVER AT UVA, WYOMING.

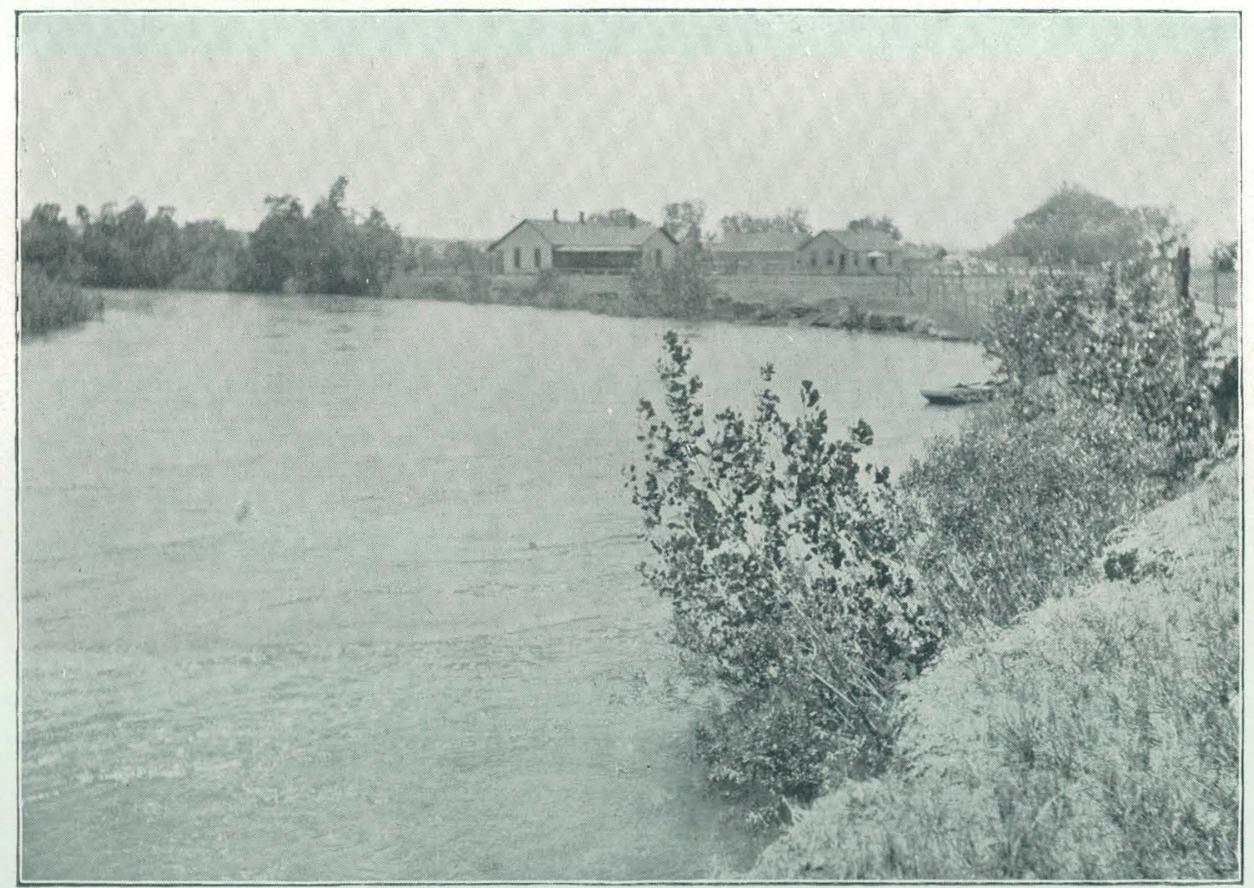

B. LARAMIE RIVER NEAR UVA, WYOMING. 


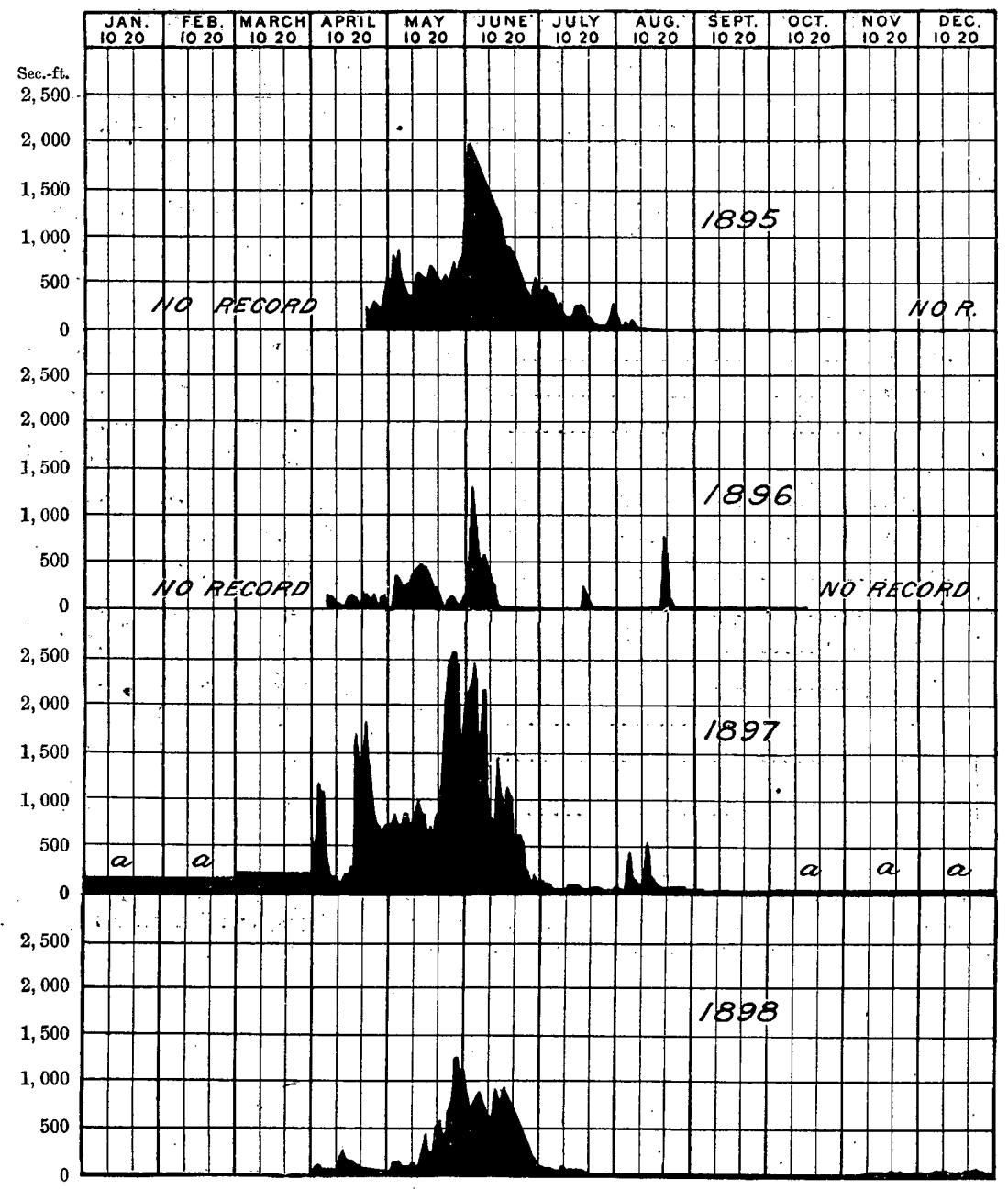

Fig. 98.-Discharge of Laramie River at Uva, Wyoming, 1895-1898.

On Pl. XXV, $A$, is a view of the wagon bridge near Uva, Wyoming, from which, or under which, measurements of Laramie River are made. In the same plate at $B$ is a general view of the stream.

RESERVOIR SITYS ON LARAMIE RIVER.

Laramie River has been described in the Nineteenth Annual Report, Part IV, beginning on page 300 . Measurements of the stream are made, as shown by the above tables, at Woods Landing, where the river leaves the mountains and enters upon Laramie Plains, and again at Uva after most of the water has been diverted for irrigation and before what is left in the stream empties into North Platte River. One of the most important diversions from the river is that of the Wyoming Development Company, whose works are described and illustrated in the 
volume just named. The development of irrigation under this system has been such as to render necessary additional water storage besides that provided by the reservoirs in the vicinity of Wheatland. Fortunately there exists a natural depression or peculiar combination of topographic features such as to render possible storage of waters along the course of Laramie River above the point of diversion of the tunnel of the Wyoming DevelopmentCompany. This reservoir has been surveyed by Mr. Clarence T. Johnston, the principal outlines being given in the accompanying fig. 99. There already exist three small lakes, filling depressions in the ground. By throwing a relatively low dam across the river at the point shown water can be held within the space inclosed by the irregular line, the total area being 5,060 acres.

\section{SOUTH PLATTE RIVER.}

The sources of South Platte River are in what is known as South Park, situated very nearly in the center of Colorado, in the mountainous regions about 75 miles south. west from Denver. South Park forms a large basin, surrounded by mountain peaks, some of which reach an altitude of over 13,000 feet; the average elevation of the park itself is about 8,000 feet. Some hundreds of smali

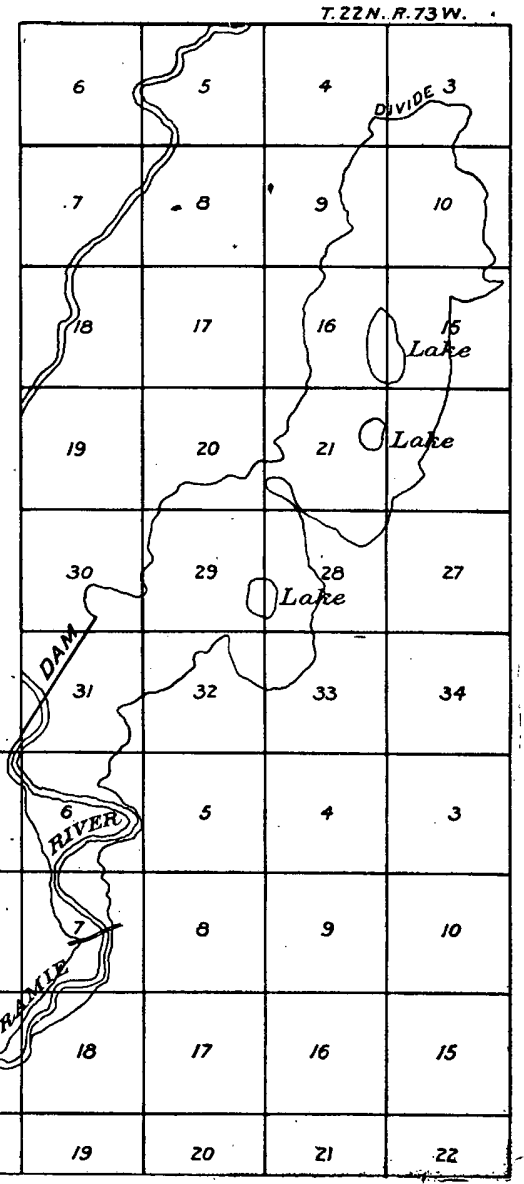

F1G. 99.-Proposed reservoir of Wyoming Development Company on Laramie River.

irrigation ditches, from which irrigation is practiced, are taken out within the limits of the park, but the altitude is too high to raise much excepting the hardiest crops.

Leaving South Park the river flows for a distance of 30 or 40 miles through a deep canyon, known as Platte Canyon. In this canyon and arso in the park above are several large reservoir sites, which have been filed upon under the laws of the State of Colorado by various companies, for the storage of water. Sites particularly worthy of men- 
tion are the Tarryall site, or "Rampart reservoir," on Tarryall Creek, which proposes to store $4,110,678,896$ cubic feet of water; the Denver Power and Irrigation Company's reservoir, with 1,244,951,310 cubic feet, and a still larger one by the Denver Union Water Company, which has already begun work. All of these reservoirs are designed to store water, both for power and irrigation.

Another important project is a proposed reservoir near Fort Morgan, about 75 miles below Denver, which is expected to store water for the irrigation of a large body of land in that vicinity. The expectation of the owners of the enterprise is to save the winter flow, as well as that of the flood season, the records kept by this office at Orchard demonstrating that the winter flow is ample to furnish, water to fill a number of such reservoirs. It seems probabie that this work, which is under the direction of Mr. D. A. Camfield, of Greeley, Colorado, may result in reclaiming upwards of 30,000 acres.

The river begins to enter the plains at a point about 20 miles southwest of Denver, flowing in a nearly northerly direction to a point near the town of Greeley, where it is joined by its main tributary, the Cache la Poudre; thence it turns in a more easterly direction, and leaves the State of Colorado at a point near its northeast corner, joining the North Platte and forming the Platte River some miles below. After entering the plains many large ditches are taken from it, making use of its waters for irrigation to such an, extent that the stream becomes practically dry during the greater part of the irrigating season for 70 or 80 miles above where it joins the North Platte, although water is used during the high stages of the stream for some distance into Nebraska.

Two stations were maintained upon the Sonth Platte itself in the year 1898, no reports having been made for the station located at Deansbury, described in Part IV of the Nineteenth Annual Report of the United States Geological Survey, on page 311, and in'Water-Supply and Irrigation Paper No. 15, page 87. The first station upon the river maintained during the year was the one at Denver. The observer was J. H. Hodgson, water commissioner of district No. 2. The second was at Orchard, as described in Water-Supply and Irrigation Paper No. 15, page 89, excepting that the station was moved about 300 yards downstream to a county bridge, a vertical gage rod being spiked to a pile nearly in the center of the bridge.

The discharge of the South Platte was in general somewhat higher than the normal early in the season, owing to spring and summer rains in the mountains, and rather less than the normal later in the season. The supply was sufficient to mature good crops generally in the cultivated area along its banks, although very early in the year, before the spring rains began, there was some fear that there would be a shortage so great that crops might be generally ruined.

The same is true of the tributaries emptying into the South Platte 
from the west, upon a number of which stations were maintained as follows, the tributaries being given in their order down the South Platte: Morrison station, on Bear Creek; Marshall, on South Boulder Creek; Boulder station, on Boulder Creek; Lyons station, on St. Vrain Creek; Arkins . station, on Big Thompson River; and Fort Collins station, on the Cache la Poudre River-all of these tributaries entering the South Platte from the west, the Cache la Poudre being the last and principal one. They are all similar in their nature, rising in the Rocky Mountains west and northwest of Denver, running for some distance through canyens and a mountainous country, and then, leaving the mountains, for distances varying from 15 to 50 miles through a rich agricultural country, for which the water from the various streams is taken by means of irrigation ditches. The country through which these streams flow is in many places well cultivated, and furnishes an excellent example of the success that may be attained in farming by irrigation. The normal flow of these streams is practically exhausted throughout the greater part of the season, but upon several of them, as well as upon the South Platte itself, there is considerable water going to waste, both during the winter and during the highwater period, from the middle of May to the first of July in ordinary years, which will eventually be stored.

Estimated monthly discharge of South Platte River at Denver, Colorado.

\begin{tabular}{|c|c|c|c|c|c|c|}
\hline & [Drai & area, & $10 \mathrm{squ}$ & miles] & & \\
\hline \multirow[b]{2}{*}{ Month. } & \multicolumn{3}{|c|}{ Discharge in second-feet. } & \multirow[b]{2}{*}{$\begin{array}{l}\text { Total in acre- } \\
\text { feet. }\end{array}$} & \multicolumn{2}{|c|}{ Run-off. } \\
\hline & $\begin{array}{l}\text { Maxi- } \\
\text { mum. }\end{array}$ & $\begin{array}{l}\text { Mini- } \\
\text { mum. }\end{array}$ & Mean. & & $\begin{array}{l}\text { Depth in } \\
\text { inches. }\end{array}$ & $\begin{array}{l}\text { Second- } \\
\text { feet per } \\
\text { square } \\
\text { mile. }\end{array}$ \\
\hline 1898. & & & & & & \\
\hline January ........... & 334 & 69 & 164 & 10,084 & 0.04 & 0.04 \\
\hline February ........... & 239 & 90 & 153 & 8,497 & 0.04 & 0.04 \\
\hline March & 184 & 50 & 121 & 7,440 & 0.03 & 0.03 \\
\hline April ..... & 759 & 50 . & 377 & 22,433 & 0.11 & 0.10 \\
\hline May & 2,308 & 525 & 1,444 & 88,789 & 0.44 & 0.38 \\
\hline June..... & 2,020 & 308 & 1,552 & 92,350 & 0.45 & 0.40 \\
\hline July ....... & 1,732 & 168 & 672 & 41,320 & 0.21 & 0.18 \\
\hline August..... & 844 & 168 & 328 & 20,168 & 0.10 & 0.09 \\
\hline September .. & 308 & 139 & 187 & 11,127 & 0.06 & 0.05 \\
\hline October........ & 239 & 69 & 146 & 8,977 & 0.04 & 0.04 \\
\hline November .......... & 239 & 69 & 131 & 7,795 & 0.03 & 0.03 \\
\hline December ...... & 168 & 50 & 98 & 6,026 & 0.03 & 0.03 \\
\hline The year..... & 2,308 & 50 & 448 & 325,006 & 1.58 & 0.12 \\
\hline
\end{tabular}

NoTE.-Gage heights for 1898 are given in Water-Supply and Irrigation Paper No. 27, page 84; measurements, page 86; rating table, page 89 . Results for 1897 in Water-Supply and Irrigation Paper No. 15, page 88, and in the Nineteenth Annual Report, Part IV, pages 311-315. 


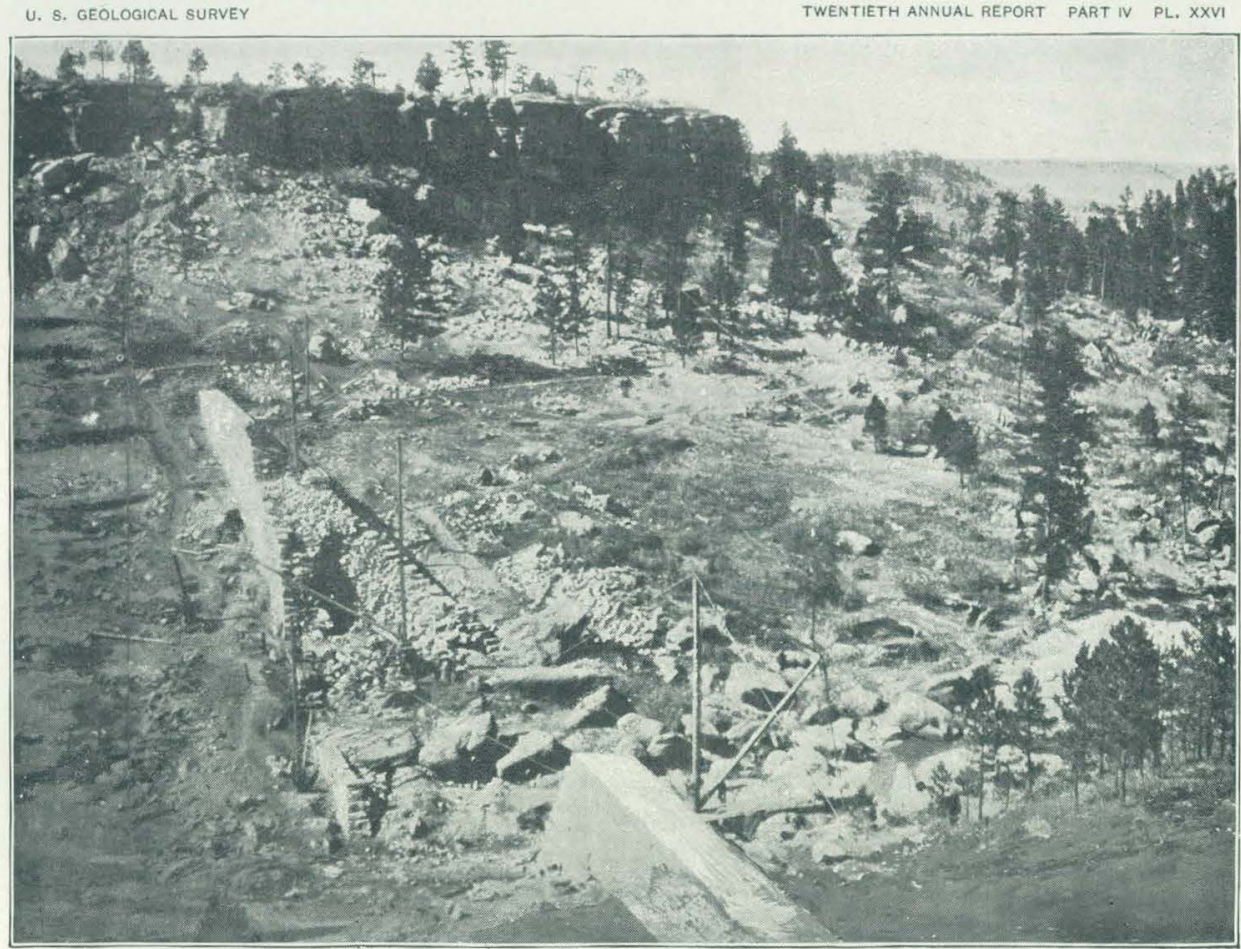

A. CASTLEWOOD DAM DURING CONSTRUCTION.

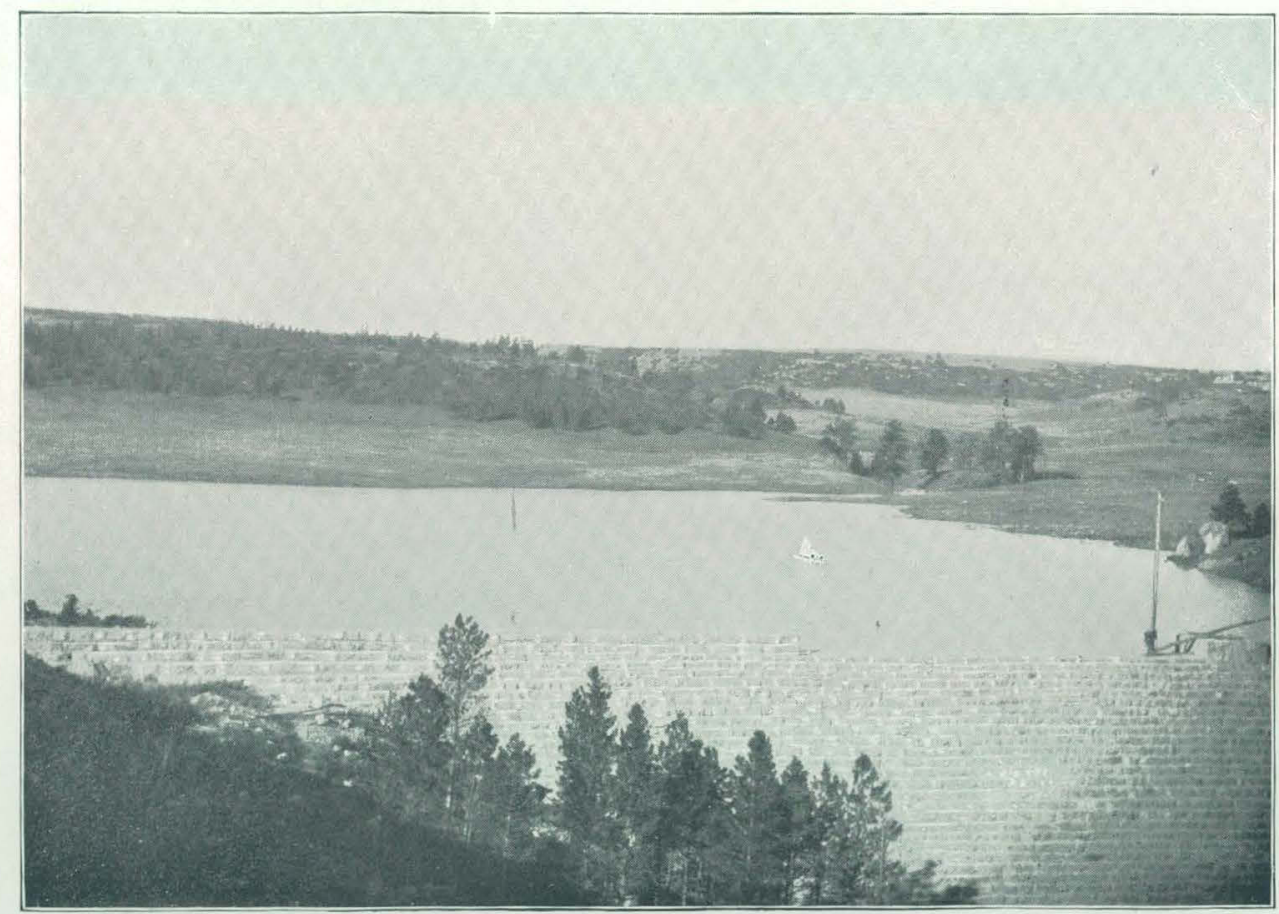

B. CASTLEWOOD LAKE AND DAM, DOUGLAS COUNTY, COLORADO, 


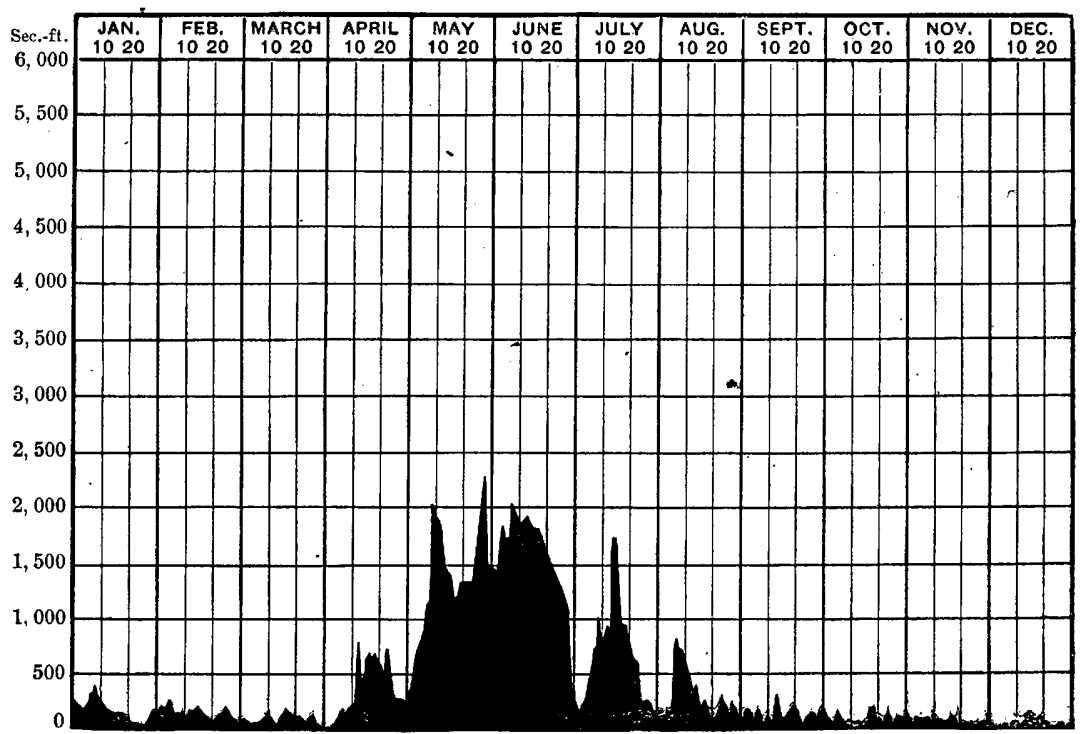

FIG. 100.-Discharge of South Platte River at Denver, Colorado, 1898.

CHERRY CREEK.

Cherry Creek is a tributary of the South Platte, entering from the right-hand or Great Plains side and receiving the drainage of a portion of the high divide between the Arkansas and Platte drainage basins. The city of Denver has been placed at the junction of this creek with the river. In its natural condition the stream was exceedingly erratic, the channel being dry throughout a considerable portion of the year, but receiving at irregular intervals great volumes of flood waters from what are known as cloud-bursts or local storms. In the early history of Denver these floods were particularly destructive. Owing to its erratic character the stream has been of little value in irrigation, since a constant supply could not be depended upon. In order to remedy that defect various storage projects for holding flood waters have been proposed, and one of these, that of the Denver Land and Water Storage Company; has been carried into effect, resulting in the construction of the Castlewood Dam.

CASTLEWOOD DAM.

The reservoir and dam of the Denver Land and Water Storage Company are located in Douglas County, Colorado, about 8 miles southeasterly from Castlerock, the county seat. ${ }^{1}$ The drainage area above the dam site is comprised mainly of somewhat rolling and rocky hills with open valleys. The hills are covered with a scattering growth of pine and cedar. The reservoir itself has an area of 180 acres; the

1 The Castlewood rock-filled dam, and the canal of the Denver Land and Water Company, by W. P. Hardesty, C. E., Progress Building, Salt Lake City. Engineering News, Vol. XLI, No.6, page 82, February $9,1899$. 
average depth is 34 feet, and the capacity $270,000,000$ cubic feet, or 6,198 acre-feet; the basin is about 1 mile long by about three-quarters of a mile in width, the bottom being flat and the sides comparatively steep. The dam is built at a point where the stream has eut through the rocks, forming a canyon in the sandstone. Under this the shales have been converted, to a large extent, into clay, and a solid rock foundation for the dam could not be had. It was not practicable to construct a solid masonry dam, and therefore the engineer for the company, Mr. A. M. Welles, of Denver, decided upon a loose rock dam with a masonry facing and backing. The original outlines of the dam • are described in the Thirteenth Annual Report, Part III., on pages 302 and 303, and a view of the dam partly completed is given on Pl. CXLI, of that volume.

A view of Castlewood Dam during construction is shown in Pl. XXVI, $A$, and in the same plate $B$ is a front view of the dam, showing the lake and the general character of the catchment basin.

The following statements from the report by Mr. W. P. Hardesty give the principal data concerning this structure:

The dam is 600 feet long on top, 70 feet high above the ground on the upper and 80 feet high on the lower side, and 8 feet wide on top. The back or water side is battered 1 to 10 , the face 1 to 1 . The crest of the dam is of masonry, 4 feet high and 8 feet wide. The upper one-, half of this is supported by the masonry retaining wall forming the back. This is, a 4-foot wall that slants or batters 1 to 10 upstream, thus leaning the same amount downstream, and being supported by the loose rock filling. The lower slope wall is of large blocks of stone in single layers laid directly on the loose rock. The upper wall is carried into the ground and rests on a concrete footing, at a depth varying from about 5 feet near the ends to 22 feet at the middle. The natural foundation consists of a hard, sandy clay. This was partly covered by large bowlders, which had to be removed. The masonry is all rubble, laid in Portland cement, and the blocks of stone are quite large. The loose rock filling is also of large pieces of stone dumped in from above and not arranged by hand. The weight of the dam is estimated at 100,000 tons, or $9 \frac{1}{2}$ times the pressure of the water against it when full.

Near the middle of the dam is the spillway for carrying the surplus water. This is $\mathbf{1 0 0}$ feet long and is 4 feet below the crest of the dam. The upper retaining wall is here made vertical on the inside and battering on the outside, reaching a thickness of 11 feet at the ground at the lowest point. At the toe of the lower slope or wall a foot wall is placed for it to rest on, being 4 feet wide and founded on concrete. Adjoining the west end of the dam is an additional spillway or by-pass about 30 feet wide. This is excavated in the earth and rock, is paved, and has masonry sides.

At the west end of the spillway is the valve chamber. This is 6 feet 
by 7 feet inside and its walls are 5 feet thick and vertical. Where the four sets of pipes from the reservoir enter the chamber the upper wall is stepped inward to give room for working the valves of each one, and the lower wall is cut under to retain the size of the chamber, thus requiring arches to support it.

The reservoir is tapped by four sets of two 12-inch pipes. When first built the bottom of the reservoir directly in front of the dam was 10 feet below the lower pair, but it has since silted up to them. Owing to the earth slope for production of foundations, which at this point reaches a short distance above the upper tier of outlets, it was necessary to convey all the outlet pipes to the face of the foundations, that their intake ends might not be obstructed. To this end they are embedded in a solid masonry bench. They pass through the upper wall of the chamber, embedded in concrete. At the bottom of the chamber a 36-inch conduit takes the discharge of the 12-inch pipes and passes it through the dam and returns it to the creek at the lower side.

Many objections were made against this dam while it was being built, by the inhabitants living along Cherry Creek below the dam, as it was not generally considered safe. A stream of water flowed from beneath it, which gave additional uneasiness. In the spring of 1891 a committee declared the dam faulty in construction, but thought it could be made perfectly safe by providing an embankment of earth on the water side, carrying it up to the level of the spillway, paving it, and making other improvements. An embankment had already been built part of the way up, but not as near the ends of the dam as originally intended by Mr. Welles.

This recommendation, however, was not carried out, and soon after this, through neglect, the property began to deteriorate. The reservoir continued in use until May, 1897, when the dam partially failed. This was caused by the continued washing of the waves, finally undermining the foundation of the masonry on the east side. At this place it settled and several cracks 2 to 4 inches deep were formed, extending horizontally. The reservoir was full at the time. The water poured through the cracks and came out on the lower slope of the dam. The reservoir was emptied, but during the following August the greatest flood ever known came down and filled the reservoir in four hours. Water from this passed through the breaks for ten days, with no additional damage, it is said. The water on reaching the toe of the lower slope ran down the angle formed by this and the side hill, undermining the masonry so that it settled badly downward and outward. At the west end of the failure a large crack ran up the slope.

During the eight years that the dam has stood there has been no settlement of the upper wall of the dam, except a comparatively slight one along the part that failed. Beginning 125 feet to 150 feet from the west end, the lower half of the 8-foot crest, which rested on loose rock, settled away so that a large crack was formed between it and the upper half, reaching nearly to the east end. This has been repaired by rais- 
ing the lower edge of the first course of masonry of the lower half until the crack was closed, then filling the open joint formed with cement and spawls. This, however, was only a matter of appearance and did not figure any in the dam's stability. After the break nothing was done with the property until 1898, when energetic steps were taken to put all the system in thorough repair. The dam has been repaired and improved as follows:

Where the break started all the masonry of the upper wall at all disturbed was removed, making an opening about 30 feet long, which with an arched top and the addition of some props supported itself temporarily.

The bottom of this was then widened out by an outside concrete footing and the wall sloped up into the top of the opening made. At the toe of the lower slope or wall where it failed a foot wall was laid to prevent any future undermining, and the slope was then restored. At the foot of the spillway and for 50 feet each way an apron or pavement of stone with paved top was made to catch the shock of falling water. This is about 25 feet wide at the bottom of the gorge.

On the upper side the embankment of earth was very greatly strengthened. A clay puddle wall was put in next to the masonry, beginning 3 feet wide at the west end and increasing to 8 feet at the valve chamber. For 150 feet east of here (covering the lowest part of the ground) no puddle is used, but east of there-including the break-the puddling is 6 feet wide. This clay puddle wall was carried down to the natural surface of the ground for its entire distance, except that along the line of the break it was carried to a level with the bottom of the foundations. The remainder of the old bank is regarded as having been packed enough by seven or eight years' exposure and water. No puddle was used where the dam is highest for the reason that there the foundations are too far below the surface of the water to ever be affected by wave action. Along the sides there is much more danger. The puddle walls were carried 1 to 2 feet into the natural ground at each end. The top of the earth embankment in the middle, at the west end of the spillway, was made 35 feet below the crest of the dam, and it runs in a straight line from there to the high ground near each end. A riprap of heavy stone covers the entire embankment to protect it from the waves.

The cost of a dam of this character is much below that of a solid masonry one, and there is very much less danger to the country below, in case of a complete failure, as the structure would remain in place as a loose rock pile in any event. ${ }^{1}$

CANAL SYSTEM.

The water after passing through the dam and returning to the creek passes on down the canyon. The distance to the mouth is over $1 \frac{1}{2}$

IA full description of this dam, prepared by Mr. A.M. Welles, with illustrations, is given in the Engineering Record, Dec. 24, 1898. 
miles and the fall nearly 300 feet. Here the water is diverted into the Arapahoe Canal. The head gate consists of three gates $3 \frac{3}{4}$ feet wide by $3 \frac{1}{2}$ feet high, of oak, with slides made of angle irons. The canal was designed to be 12 feet wide in the bottom, but it is now in many places much narrower. The depth of water is 4 feet. The fall for $24_{4}^{3}$ miles is 2.64 feet per mile, then it is 5.28 feet. The main canal is 38 to 40 miles long, and there are 30 to 35 miles of laterals. The canal was intended to carry 150 cubic feet of water per second. A bank on the lower side only is needed. There are but few places where the canal is in embankment, by far the greater part of it being through cut. No solid rock is encountered. For crossing the drainage streams along the route there are six pipes lines in the form of inverted siphons, while a number of flumes are used for the smaller openings.

A system of lower reservoirs to afford additional capacity is designed, being located on the plains country and adjacent to the land to be irrigated. One of these, the Clark reservoir, with a capacity of $30,000,000$ cubic feet, was built soon after the canal.

The land to be irrigated begins about 20 miles south by southeast of Denver, and approaches to within $7 \frac{1}{2}$ miles of the center of the city. The company owns about 14,000 acres of fruit lands, and has a farm of its own called the "Colony," on which it has 30,000 to 40,000 fruit trees.

BEAR CREeK.

Morrison station, on Bear Creek, was changed to a point about a quarter of a mile above, on account of the Denver Union Water Company taking water from the stream at this second point. No regular station was established, but the discharge for the year was furnished by the Denver Union Water Company:

Estimated monthly discharge of Bear Creek, Morrison, Colorado.

[Drainage area, 170 square miles.]

\begin{tabular}{|c|c|c|c|c|c|c|}
\hline \multirow[b]{2}{*}{ Month. } & \multicolumn{3}{|c|}{ Diseharge in second-feet. } & \multirow[b]{2}{*}{$\begin{array}{c}\text { Total in acre- } \\
\text { feet. }\end{array}$} & \multicolumn{2}{|c|}{ Run-off. } \\
\hline & $\begin{array}{l}\text { Maxi- } \\
\text { mum. }\end{array}$ & $\begin{array}{l}\text { Mini- } \\
\text { mum. }\end{array}$ & Mean. & & $\begin{array}{l}\text { Depth in } \\
\text {-inches. }\end{array}$ & $\begin{array}{c}\text { Second- } \\
\text { feet per } \\
\text { square } \\
\text { mile. }\end{array}$ \\
\hline \multicolumn{7}{|l|}{1898.} \\
\hline May................ & 143 & 60 & 109 & 6,702 & 0.74 & 0.64 \\
\hline June . . . . . . . . . . . & 182 & 117 & 143 & 8,509 & 0.93 & 0.84 \\
\hline July ............. & 208 & 91 & 150 & 9,223 & 1. 01 & 0.88 \\
\hline August..... & 117 & 47 & 68 & 4,046 & 0.45 & 0.40 \\
\hline September & 78 & 31 & 45 & 2,678 & 0.30 & 0.27 \\
\hline October ........... & 31 & 26 & 29 & 1,783 & 0.20 & 0.17 \\
\hline November .......... & 29 & 20 & 23 & 1,369 & 0.16 & 0.14 \\
\hline
\end{tabular}

Noxe.--Gage beights for 1898 are given in Water-Supply and Irrigation Paper No. 27, page 81, and measurements, page 86; results for 1897 in Water.Supply and Irrigation Paper No. 15, page 91, and in the Nineteenth Annual Report, Part IV, page 317. 


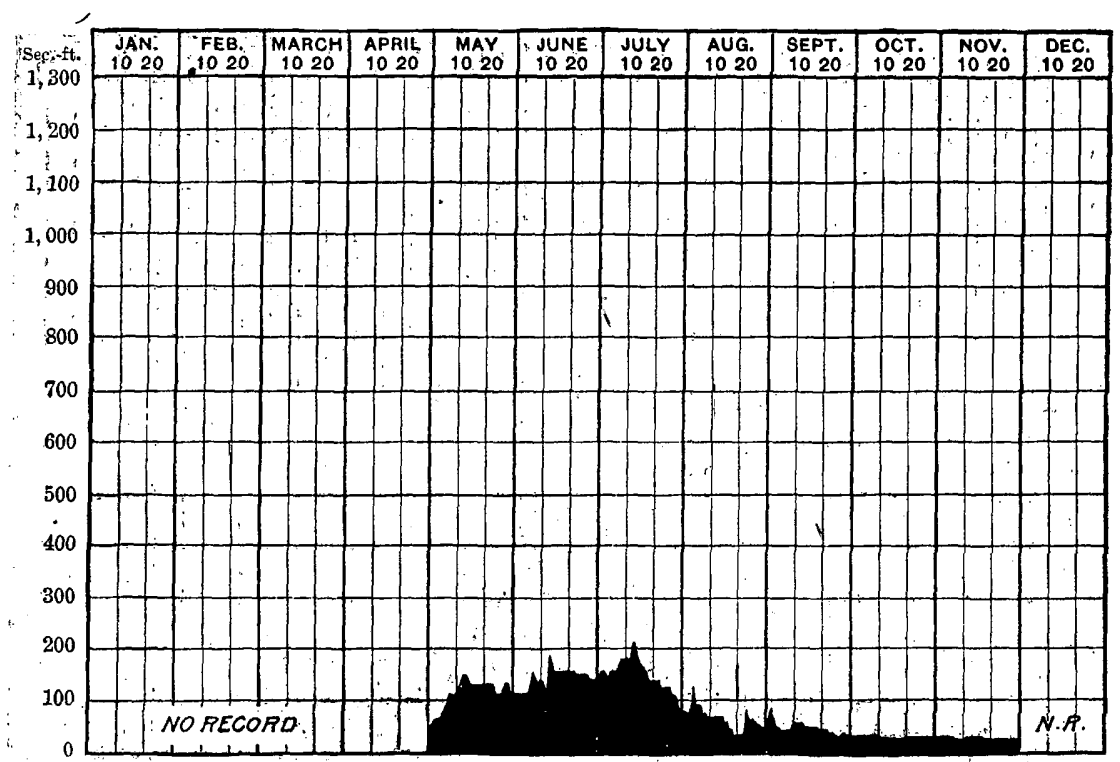

Frg. 101.-Discharge of Bear Creek at Morrison, Colorado, 1898.

ST, VRAIN CREEK.

Estimated monthly discharge of St, Vrain Creek at Lyons, Colorado.

[Drainage area, 209 square miles.]

\begin{tabular}{|c|c|c|c|c|c|c|}
\hline \multirow[b]{2}{*}{$\begin{array}{c}r \\
\cdot . \\
\cdot \\
\cdot\end{array}$} & \multicolumn{3}{|c|}{ Discharge in second-feet. } & \multirow{2}{*}{$\begin{array}{l}\text { Total in acre- } \\
\quad \text { feet. }\end{array}$} & \multicolumn{2}{|c|}{ Run-off. } \\
\hline & $\begin{array}{l}\text { Maxi- } \\
\text { mum. }\end{array}$ & $\begin{array}{l}\text { Mini- } \\
\text { mum. }\end{array}$ & Mean. & & $\begin{array}{l}\text { Depth in } \\
\text { inches. }\end{array}$ & $\begin{array}{l}\text { Second- } \\
\text { feet per } \\
\text { square } \\
\text { mile. }\end{array}$ \\
\hline 1898. & & & & & & \\
\hline May ................... & . 333 & 31 & 211 & 13,974 & 1.16 & 1. 01 \\
\hline June . . . . . . . &. .551 & 256 & 431 & 25,645 & 2.30 & 2.06 \\
\hline . July .............. & 372 & 64 & 229 & 14,081 & 1. 27 & 1.10 \\
\hline : August $\ldots \ldots \ldots$ & 153 & 40 & 104 & 6,395 & 0.58 & 0.50 \\
\hline September & 128 & 11 & 61 & 3,630 & 0,32 & 0.29 \\
\hline October .............. & 22 & 11 & 15 & 922 & 0.08 & $0.07:$ \\
\hline November .......... & 22 & 6. & $\begin{array}{r}12 \\
. \\
\end{array}$ & 714 & 0.07 & 0.06 \\
\hline
\end{tabular}

Noте.-Gage heights for 1898 are given in Water-Supply and Irrigation Paper No. 27, page 83; meas arements, page 86; rating țable, page 89; results for 1897 in Water-Supply and Irrigation Paper No. 15, page 93, and in the Nineteenth Annual Report, Part IV, pages 320 to 321 , 


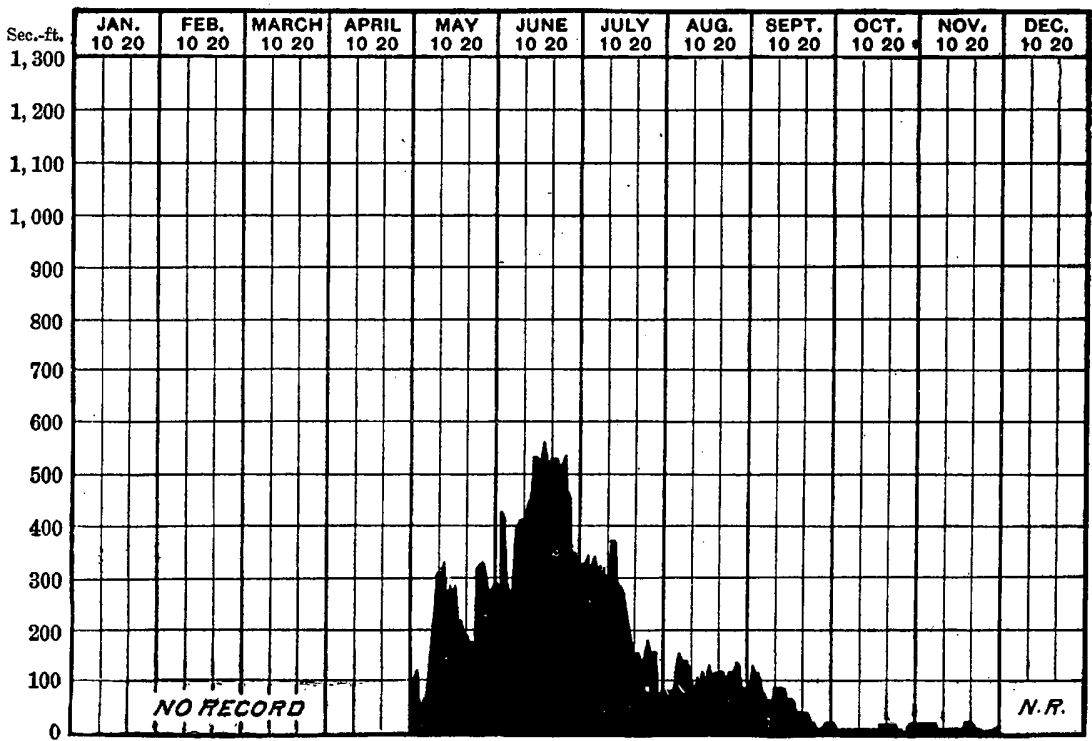

Fra. 102.-Discharge of the St. Vrain River at Lyons, Colorado, 1898.

BOULDER CREKK.

Estimated monthly discharge of Boulder Creek at Boulder, Colorado.

[Drainage area, 102 square miles.]

\begin{tabular}{|c|c|c|c|c|c|c|}
\hline \multirow{2}{*}{ Month. } & \multicolumn{3}{|c|}{ Discharge in second-feet. } & \multirow[b]{2}{*}{$\begin{array}{l}\text { Total in acre- } \\
\text { feet. }\end{array}$} & \multicolumn{2}{|c|}{ Run-off. } \\
\hline & $\begin{array}{l}\text { Maxi- } \\
\text { mum. }\end{array}$ & $\begin{array}{l}\text { Mini- } \\
\text { mum. }\end{array}$ & Mean. & & $\begin{array}{l}\text { Depth in } \\
\text { inches. }\end{array}$ & $\begin{array}{l}\text { Second- } \\
\text { feet per } \\
\text { square } \\
\text { mile. }\end{array}$ \\
\hline 1898. & & & & & & \\
\hline May ...... & 399 & 75 & 233 & 14,327 & 2.63 & 2.28 , \\
\hline June..... & 566 & 316 & 447 & 26,598 & 4.89 & 4.38 \\
\hline July . ..... & 350 & 75 & 213 & 13,097 & 2.41 & $2.09 !$ \\
\hline August..... & 184 & 29 & 62 & 3,812 & 0.70 & 0.61 \\
\hline September. & 98 & 5 & 30 & 1,785 & 0.32 & 0.29 \\
\hline October............... & 20 & 3 & 8 & 482 & 0.09 & $0.08 !$ \\
\hline November ........... & 138 & 3 & 40 & 2,380 & 0.44 & 0.39 \\
\hline
\end{tabular}

Note.-Gage heights for 1898 are given in Water-Supply and Irrigation Paper No. 27, page 82; meas urements, page 86; rating table, page 89; results for 1897 in Water-Supply and Irrigation Paper No. 15, page 92, and in the Nineteenth Annual Report, Part IV, pages 319 to 320. The drainage area, according to the report of the State engineer of Colorado, is 179 square miles. 


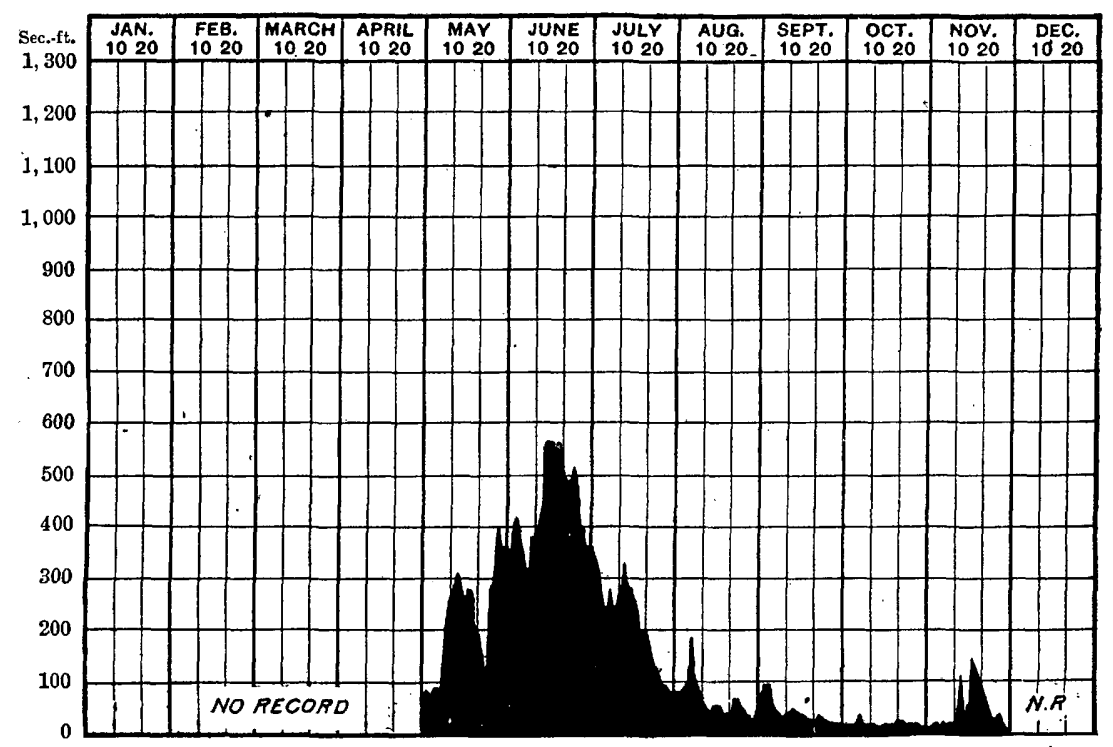

Fiя. 103.-Discharge of Boulder Creek at Boulder, Colorado, 1898.

SOUTH BOULDER CREEK.

Estimated monthly discharge of South Boulder Creek at Marshall, Colorado.

[Drainage area, 125 square miles.]

\begin{tabular}{|c|c|c|c|c|c|c|}
\hline \multirow[b]{2}{*}{ Month. } & \multicolumn{3}{|c|}{ Discharge in second-feet. } & \multirow[b]{2}{*}{$\begin{array}{l}\text { Total in acre- } \\
\text { feet. }\end{array}$} & \multicolumn{2}{|c|}{ Run-off. } \\
\hline & $\begin{array}{l}\text { Maxi- } \\
\text { mum. }\end{array}$ & $\begin{array}{l}\text { Mini- } \\
\text { mum. }\end{array}$ & Mean. & & $\begin{array}{c}\text { Depth in } \\
\text { inches. }\end{array}$ & $\begin{array}{l}\text { Second. } \\
\text { feet per } \\
\text { square } \\
\text { mile. }\end{array}$ \\
\hline - $\quad 1898$ & & & & & & \\
\hline May ......... & 276 & 36 & 194 & 11,929 & 1. 79 & 1.55 \\
\hline June........ & 364 & 226 & 285 & 16,959 & 2.54 & 2.28 \\
\hline July $\ldots . . . . . . . .$. & 238 & 64 & 137 & 8,424 & 1.27 & 1.10 \\
\hline August. ..... & 78 & 18 & 42 & 2,582 & 0.39 & 0.34 \\
\hline September .......... & 52 & 12 & 22 & 1,309 & 0.20 & 0.18 \\
\hline October..... & 31 & 9 & 20 & 1,230 & 0.18 & 0.16 \\
\hline November......... & 26 & 9 & 18 & 1,071 & 0.16 & 0.14 \\
\hline
\end{tabular}

NoTE.-Gage heights for 1898 are given in Water-Supply and Irrigation Paper No. 27, page 82; measurements, page 86 ; rating table, page 89 ; results for 1897 in Water-Supply and Irrigation Paper No. 15, page 91, and in the Nineteenth Annual Report, Part IV, page 318. 


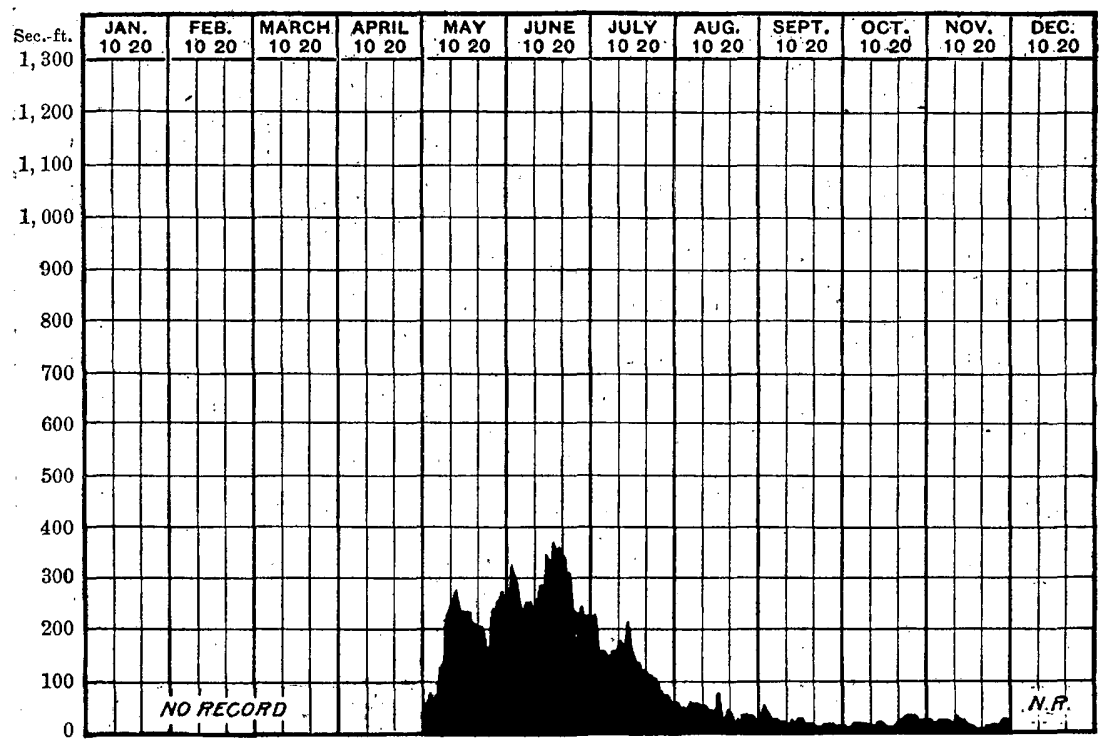

Fig. 104.-Discharge of Sonth Boulder Creek at Marshall, Colorado, 1898.

BIG THOMPSON CREEK.

Estimated monthly discharge of Big Thompson Creek at Arkins, Colorado.

[Drainage area, 305 square miles.]

\begin{tabular}{|c|c|c|c|c|c|c|}
\hline \multirow[b]{2}{*}{ Month. } & \multicolumn{3}{|c|}{ Discharge in second-feet. } & \multirow[b]{2}{*}{$\begin{array}{l}\text { Total in acre- } \\
\text { feet. }\end{array}$} & \multicolumn{2}{|c|}{ Run-off. } \\
\hline & $\begin{array}{l}\text { Maxi- } \\
\text { mum. }\end{array}$ & $\begin{array}{l}\text { Mini- } \\
\text { mum. }\end{array}$ & Mean. & & $\begin{array}{l}\text { Depth in } \\
\text { inches. }\end{array}$ & $\begin{array}{c}\text { Second- } \\
\text { feet per } \\
\text { square } \\
\text { mile. }\end{array}$ \\
\hline 1898. & & & & & & \\
\hline May ................ & 341 & 13 & 164 & 10,084 & 0.62 & 0.54 \\
\hline June ............. & 605 & 85 & 377 & 22,432 & 1. 38 & 1.24 \\
\hline July ...... & 517 & 85 & 237 & 14,573 & 0.90 & 0.78 \\
\hline August............ & 173 & 45 & .79 & 4,858 & 0.29 & 0.26 \\
\hline September ......... & 97 & 8 & 32 & 2,142 & 0.11 & 0.10 \\
\hline October ................ & 24 & 2 & 12 & $738-$ & 0.04 & 0.04 \\
\hline Norember .......... & 24 & 2 & 7 & 417 & 0.02 & 0.02 \\
\hline
\end{tabular}

No'TE.-Gage heights for 1898 are given in Water-Supply and Irrigation Paper No. 27, page 83; measurements, page 86; rating table, page 89 ; results for 1897 in Water-Supply and Irrigation Paper No. 15, page 94, and in the Nineteenth Annual Report, Part IV, pages 321-322. 


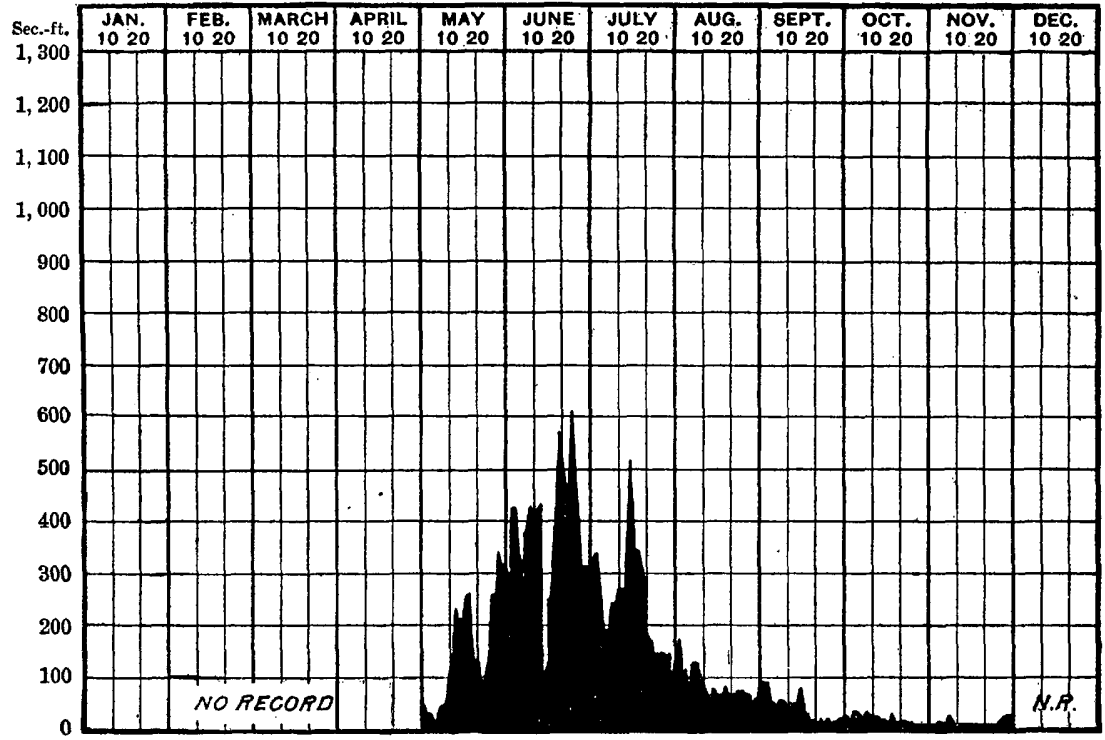

Fita. 105.-Discharge of Big Thompson Creek at Arkins, Colorado.

SEEPAGE MEASUREMENTS.

In addition to the measurements made on Big Thompson Creek, as noted on page 322 of the Nineteenth Annual Report, Part IV, investigations of seepage or return waters were carried on by Prof. L. G. Carpenter, of the Agricultural College at Fort Collins, Colorado, on November 5 to 8,1897 , and on November 2 to 4, 1898. As stated by Professor Carpenter in the report of the Experiment Station for 1898, page 192, it is to be noted that increase of return water in 1898 is less than in 1897, presumably because of the smaller water supply of 1898 .

Results of seepage measurements.

\begin{tabular}{|c|c|c|}
\hline . & 1897. & 1808. \\
\hline BIG THOMPSON CREEK.- & Sec.feet. & Sec.feet. \\
\hline Handy to the Home Supply ditch $\ldots \ldots \ldots \ldots \ldots \ldots \ldots$ & 0. & 0. \\
\hline 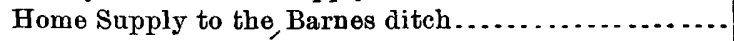 & 15.78 & 8.13 \\
\hline Barnes to the Loveland \& Greeley canal . . . . . . . . . . . . & 4. 62 & 3.52 \\
\hline Loveland \& Greeley to the Big Thompson ditch ...... & 12.38 & 13.31 \\
\hline Big Thompson to the Hill \& Brush ditch . . . . . . . . . & 4.52 & 6. 62 \\
\hline Hill \& Brush to the Big Thompson and Platte canal .. & 12.42 & 9.59 \\
\hline Big Thompson and Platte to the Evanstown ditch..... & 14. 36 & 11.59 \\
\hline Total $\ldots \ldots \ldots \ldots \ldots \ldots \ldots . . . . . . . . . . .$. & 64.08 & 52.74 \\
\hline LITTLE THOMPSON CREEK. & & \\
\hline From Eagle ditch to Dry Creek . . . . . . . . . . . & 1.35 & 3.16 \\
\hline 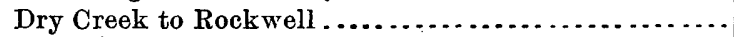 & 2. 77 & 1.52 \\
\hline Rockwell to Miner ditch...... & 2.43 & 1.32 \\
\hline Miner ditch to mouth $\ldots \ldots \ldots \ldots \ldots \ldots \ldots \ldots$ & 4.08 & 2.89 \\
\hline Total for Little Thompson... & 10.63 & 8.89 , \\
\hline Total for both Big and Little Thompson . & 74.71 & 61.63 \\
\hline
\end{tabular}

20 GEOL, PT $4-19$ 
CACHE LA POUdRE RIVER.

Measurements of Cache la Poudre River have been continued by Prof. L. G. Carpenter, of Fort Collins, Colorado. The station is described on page 30 of Bulletin No. 131, and also on page 112 of Bulletin No. 140. The results for the years 1889 to 1894 are discussed in WaterSupply and Irrigation Paper No. 9, on pages 16-27, and the fluctuations are illustrated by diagrams. Professor Carpenter has published general statements concerning the stream, from which the following extracts are made:

Cache la Poudre River is typical of the irrigation streams of the eastern slope of the Rocky Mountains, and its record, which has been maintained longer and more continuously than any other in Colorado or the West, applies, in its general features, to the other streams of the eastern slope, and therefore its record is of more local importance.

The conditions which cause years of high or low, early or late, water are usually widespread, and give common features to the streams of a large area. So much are the conditions of snow fall and of melting alike, that the highest water of the year is often on the same day for a couple of hundred miles along the range.

The year 1898 has been exceptionally low in its water supply. The small amount of snow fall in the mountains during the preceding winter gave indication of this, and the little which fell early in the season gave reason to expect that the late water would be unusually low, unless maintained by storms. Although the rains of May were abundant, the dry ground absorbed a large proportion of the rainfall, and a relatively small amount reached the river. Fortunately; storms helped to some extent on this stream, but not so much as on the Arkansas; nevertheless the year has been abnormally low.

Since the early settlement the areas of forest have become much less from fires and denudation for mining and railroad purposes. The amount used for domestic purposes is of small importance, except, as careless and irresponsible cutting gives conditions favoring the spread of the devastating forest fires. From the standpoint of the water supply on which agriculture depends, the protection of the forests becomes of vital importance. The protecting influence of the forests on the snow cover is of the greatest importance. The letting in of the sun and wind melts and evaporates the snow without sensible formation of water, dries the springs, and lessens the amount of water available for use. It is safe to say that with the former forest cover, even with the small snow fall and little rainfall, the low stage of the river would not have fallen to 34 second-feet, as it did this year, but would have been several times more, for the innumerable small springs would have continued their supply.

If the forest cover continues to be removed, autumns of low water like the present will cease to be exceptional, but become the rule, the river will be lower than it has been this year, and may become as dry as some of the tributaries.

During the year 1898, starting with an average of 184 second-feet for the week ending April 26, the river rapidly rose after the middle of May. The highest of the year was the week of June 21, which averaged 1,543 feet. Then the river rapidly dropped the next week to 1,200 feet, and the week following to 744 feet. By August 1, there were only 220 feet. Early in September there were only 100 feet, and by October 1 it had reached the unprecedented low stage of 34 second-feet. After a couple of weeks the early snows in the mountains had the effect of raising the river.

In comparing with previous years, it is instructive to note the high water and the average for the whole season. Taking the record by years, the closing dates of the weeks of high water and the average for the week have been given as below. The periods of high water are the resultant of the amount of snow, the effect of warm weather, and of rains. No attempt to discriminate is made. 
Average flow of Cache la'Poudre River for the period of twenty-seven weeks, from April 26 to November 1; also of single week of greatest flow, 1884 to 1898.

\begin{tabular}{|c|c|c|c|}
\hline Year. & Aver age. & Maximum. & $\begin{array}{c}\text { Week } \\
\text { ending- }\end{array}$ \\
\hline$*$ & Sec.feet. & Sec. feet. & . \\
\hline 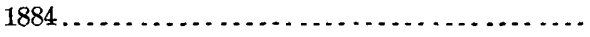 & 1,761 & 5,071 & June 14 \\
\hline 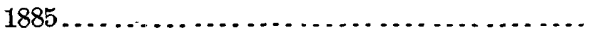 & 1,196 & 3,330 & June 7 \\
\hline 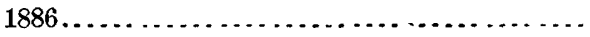 & 747 & $\cdot 2,439$ & May 31 \\
\hline $1887 \ldots \ldots \ldots \ldots \ldots$ & 720 & 2,400 & June 7 \\
\hline 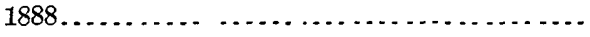 & 400 & 1,240 & June 14 \\
\hline 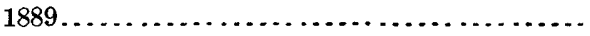 & 482 & 1,545 & June 7 \\
\hline 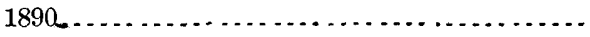 & 567 & 1,592 & May 31 \\
\hline 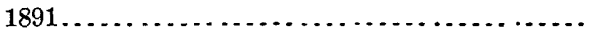 & 671 & 2,692 & June 14 \\
\hline $1892 \ldots \ldots \ldots \ldots$ & a 753 & 2,057 & June 28 \\
\hline 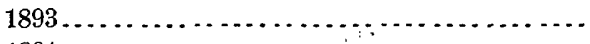 & $b 815$ & 2,445 & June 14 \\
\hline $1894 \ldots \ldots \ldots$ & 804 & 3,196 & June 7 \\
\hline 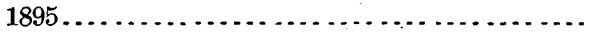 & 914 & 2,914 & June 14 \\
\hline 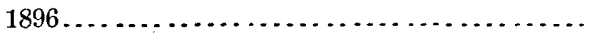 & 520 & 1,736 & May 31 \\
\hline $1897 \ldots \ldots \ldots \ldots . . . .$. & 793 & 2,220 & June 14 \\
\hline 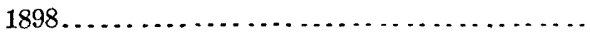 & 451 & 1,543 & June 21 \\
\hline
\end{tabular}

The average for the twenty-seven weeks of 1898, from April 26 to November 1, has been 4.51 cubic feet per second, an amount less than for any other year of which we

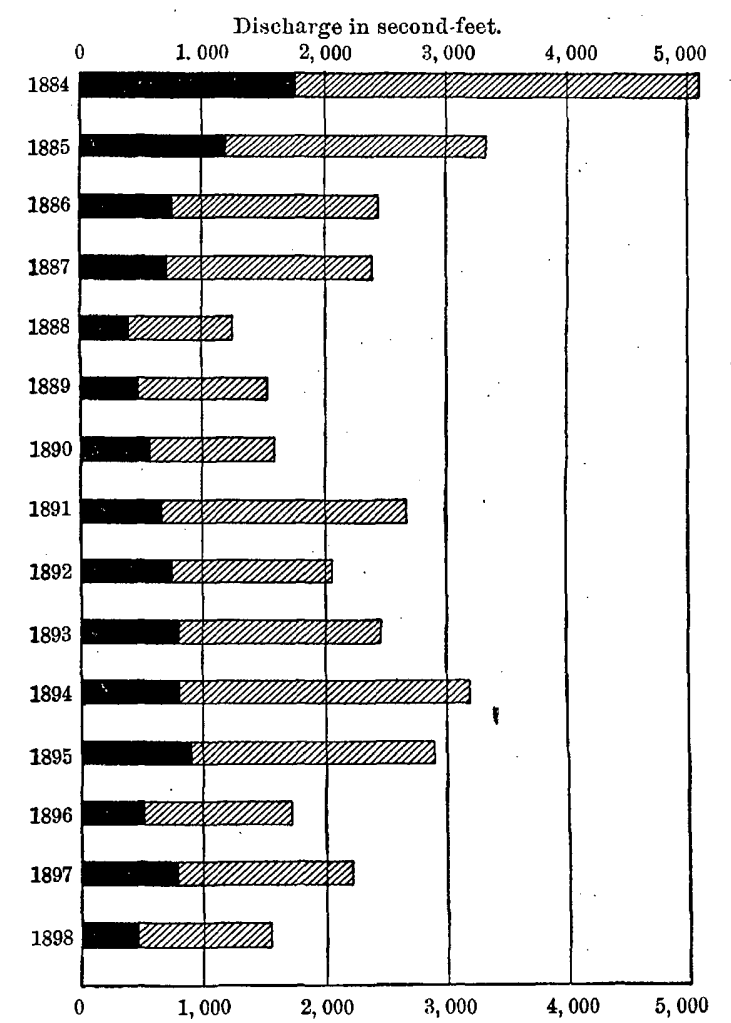

FIG. 106.-Average discharge of Cache la Poudre River, 1884 to 1898. 


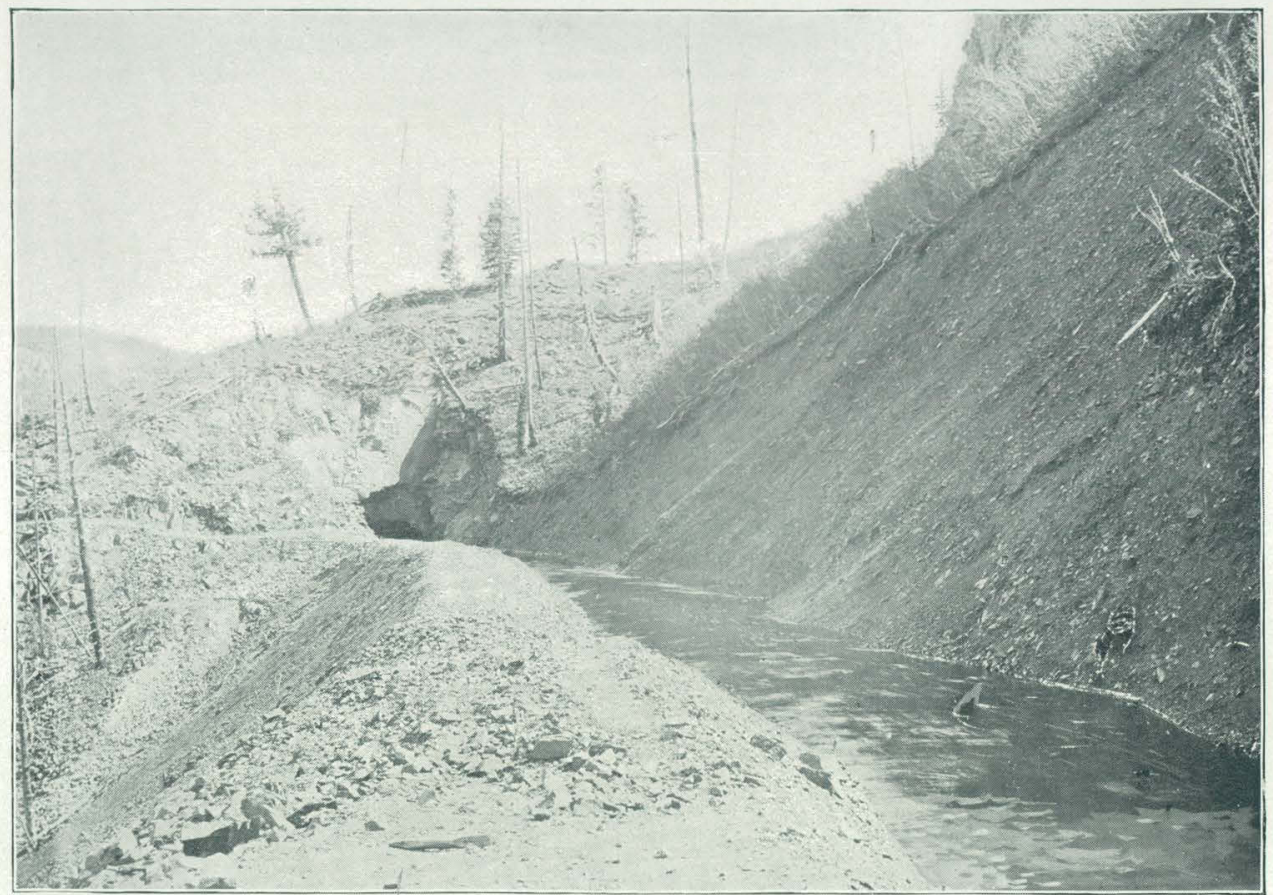

A. SKY-LINE DITCH-DIVERTING WATER FROM LARAMIE RIVER TO CACHE LA POUDRE RIVER.

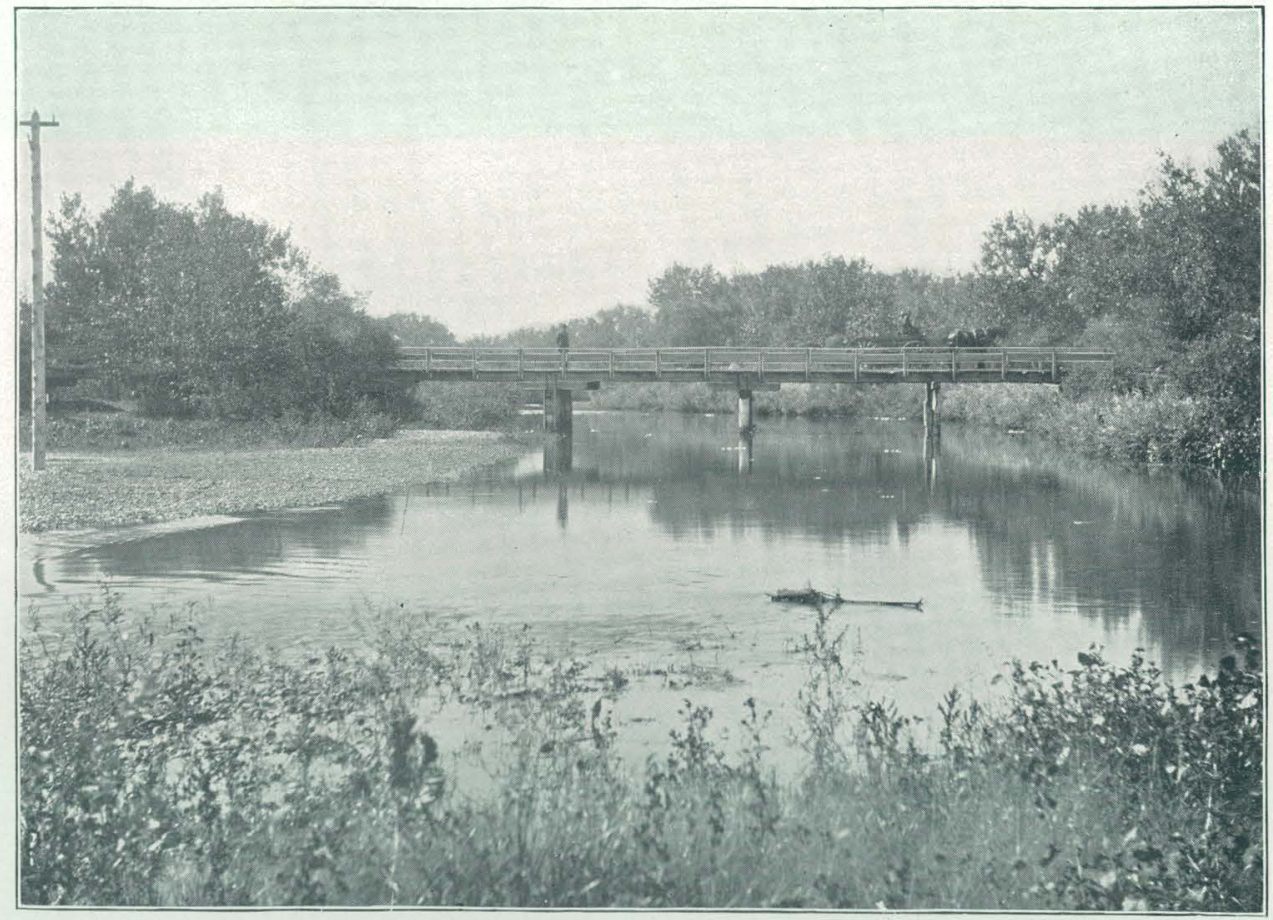

B. CACHE LA POUDRE RIVER, 1 MILE NORTH OF GREELEY, COLORADO, 
have record except 1888, when the average fell to 400 cubic feet per second. In 1898 the river fell lower than in 1888 after the middle of July, when the effect of the early compact snow and of the small springs would influence the stream, the higher average being largely due to the higher water in May and June.

The year 1898 has thus averaged but little over one-fourth of the amount received in $\mathbf{1 8 8 4}$ for the corresponding time, and if deduction be made of the water received from other watersheds it would be less than one-fourth.

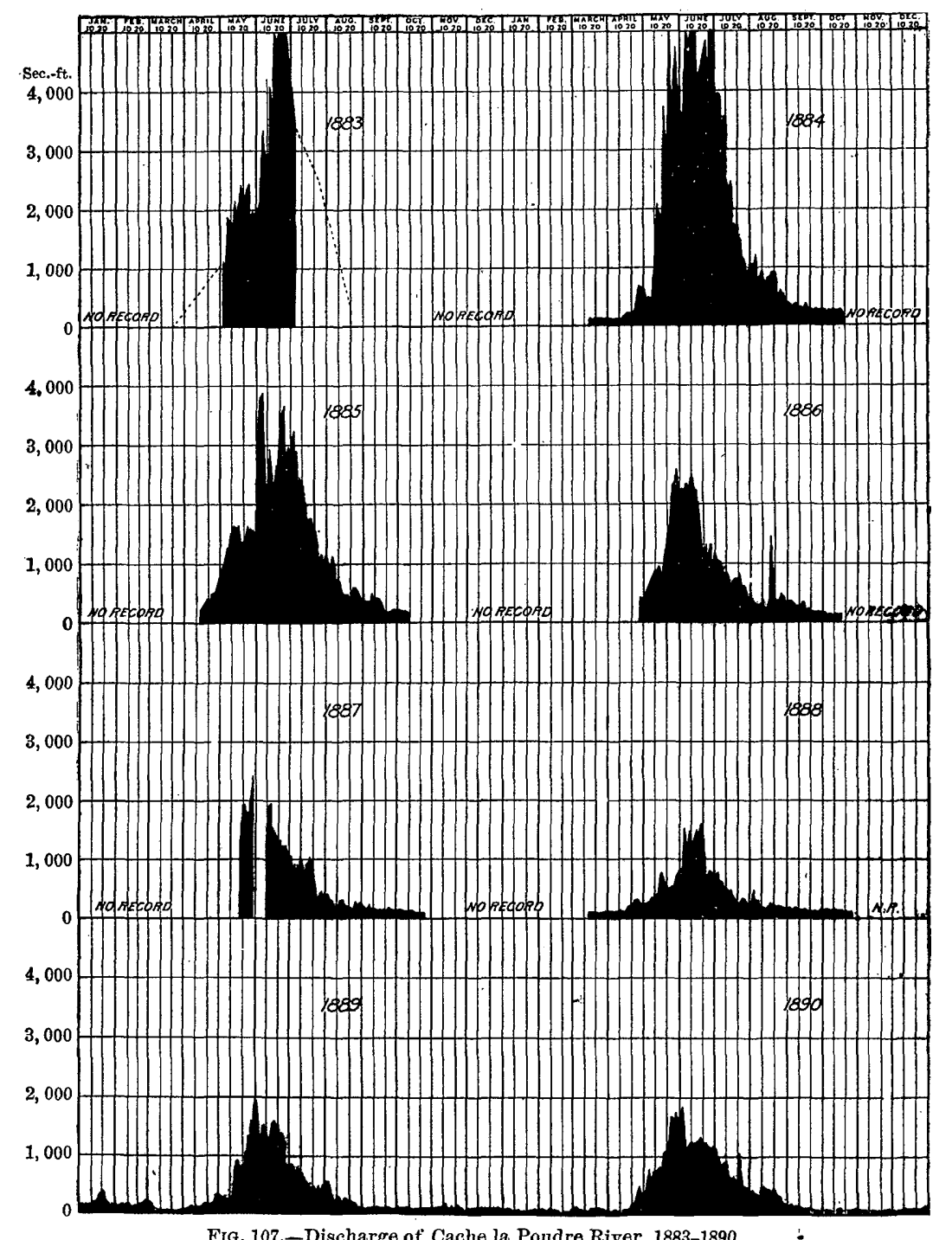

Fig. 107.-Discharge of Cache la Poudre River, 1883-1890.

The river water of 1898 during these twenty-seven weeks, if applied to the whole of the irrigated area of the valley, which may be called 130,000 acres, would cover it to a depth of about 16 inches. The rainfall during the same time has been about 8 inches, or the total moisture has amounted to about 24 inches, which would be increased by the amount stored in the various reservoirs during the winter and spring. 
On Pl. XXVII, $A$, is a view of the ditch taking water from Laramie River into the catchment basin of Cache la Poudre River. It is described in Water-Supply and Irrigation Paper No. 9, on page 42. It is commonly known as the Sky Line ditch, is stated to be 5 miles long, with a capac-

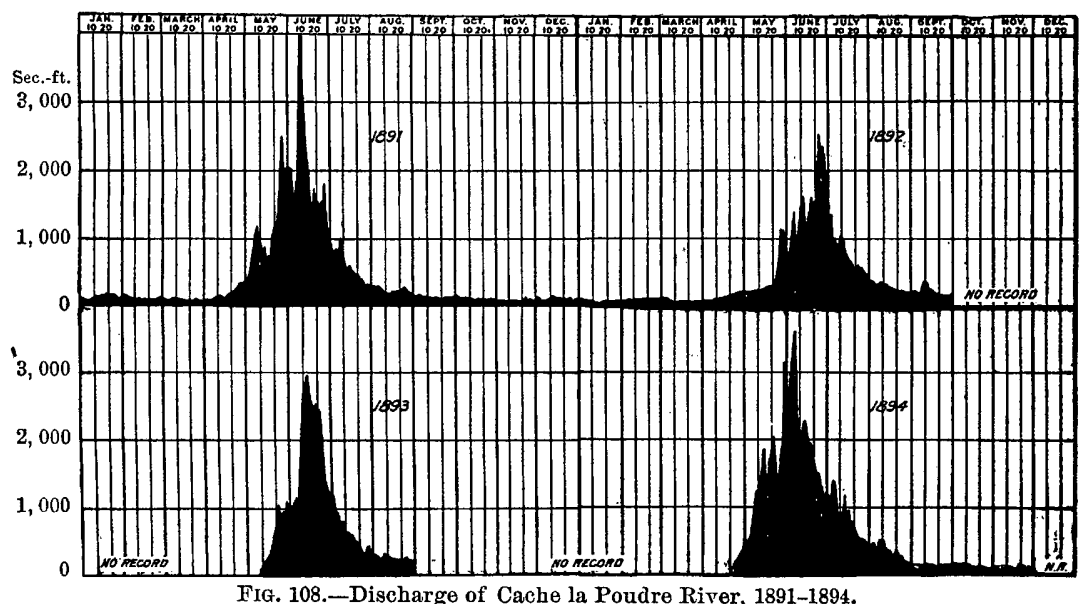

ity of about 100 second-feet. On the same plate, $B$, is a view of Cache la Poudre River about 1 mile north of Greeley, showing the general character of the stream below the point at which the greater part of the water is diverted.

Estimated monthly discharge of South Platte River at Orchard, Colorado.

[Drainage area, 12,260 square miles.]

\begin{tabular}{|c|c|c|c|c|c|c|}
\hline \multirow[b]{2}{*}{ Month. } & \multicolumn{3}{|c|}{ Discharge in second-feet. } & \multirow[b]{2}{*}{$\begin{array}{l}\text { Total in acre. } \\
\text { feet. }\end{array}$} & \multicolumn{2}{|c|}{ Run-off. } \\
\hline & $\begin{array}{l}\text { Maxi- } \\
\text { mum. }\end{array}$ & $\begin{array}{l}\text { Mini- } \\
\text { mum. }\end{array}$ & Mean. & & $\begin{array}{l}\text { Depth in } \\
\text { inches. }\end{array}$ & $\begin{array}{c}\text { Second- } \\
\text { feet per } \\
\text { square } \\
\text { mile. }\end{array}$ \\
\hline 1898. & & & & & & \\
\hline January ............ & ], 392 & 523 & 1,068 & 65,669 & 0.10 & 0.09 \\
\hline February ......... & 1,147 & 475 & 811 & 45,041 & 0.07 & 0.07 \\
\hline March.............. & 715 & 523 & 576 & 35,417 & 0.07 & 0.06 \\
\hline April ............. & 619 & 10 & 363 & 21,600 & 0.03 & 0.03 \\
\hline Мау................. & 3,214 & 10 & 1,946 & 119,656 & 0.18 & 0.16 \\
\hline June ... & 2,090 & 0 & 776 & 46,175 & 0.08 & 0.07 \\
\hline July & 781 & 40 & 173 & 10,637 & 0.01 & 0.01 \\
\hline August. . . . . . . . . . & 40 & 40 & 40 & 2,460 & 0.003 & 0.003 \\
\hline September ......... & 113 & 40 & 69 & 4,106 & 0.01 & 0.01 \\
\hline October ............. & 408 & 113 & 215 & 13,220 & 0.02 & 0.02 \\
\hline November .......... & 3,026 & 288 & 808 & 48,079 & 0.08 & 0.07 \\
\hline Decémber ........... & 3,026 & 2,090 & 2,651 & 163,005 & 0.25 & 0.22 \\
\hline The year ....... & 3,214 & 0 & 791 & 575,065 & 0.90 & 0.07 \\
\hline
\end{tabular}

NoтE.-Gage heights for 1898 are given in Water-Supply and Irrigation Paper No. 27, page 84; measurements, page 86; rating table, page 89 ; the results for 1897 in Water-Supply and Irrigation Paper No. 15, page 89, and in the Nineteenth Annual Report, Part IV, pages 315 to 316. 


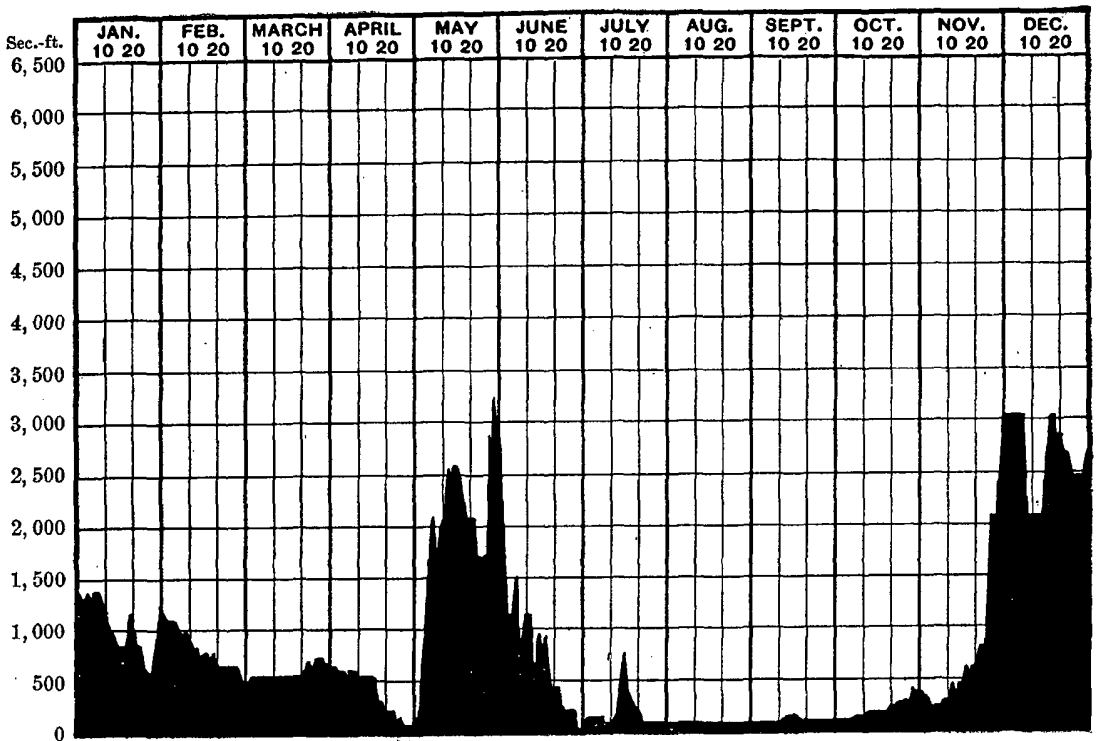

FIG. 109.-Discharge of South Platte River at Orchard, Colorado, 1898.

\section{LOUP RIVER.}

Estimated monthly discharge of Loup River at Columbus, Nebraska.

[Drainage area, 13,542 square miles.]

\begin{tabular}{|c|c|c|c|c|c|c|}
\hline \multirow[b]{2}{*}{ Month. } & \multicolumn{3}{|c|}{ Discharge in second-feet. } & \multirow[b]{2}{*}{$\begin{array}{l}\text { Total in acre- } \\
\text { feet. }\end{array}$} & \multicolumn{2}{|c|}{ Run-off. } \\
\hline & $\begin{array}{l}\text { Maxi- } \\
\text { mum. }\end{array}$ & $\begin{array}{l}\text { Mini- } \\
\text { mum. }\end{array}$ & Mean. & & $\begin{array}{c}\text { Depth in } \\
\text { inches. }\end{array}$ & $\begin{array}{l}\text { Second. } \\
\text { feet per } \\
\text { square } \\
\text { mile. }\end{array}$ \\
\hline 1898. & & & & & & \\
\hline 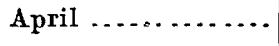 & 3,520 & 2,130 & 2,794 & 166,254 & 0.23 & 0.21 \\
\hline May .............. & 5,100 & 2,425 & 3,509 & 215,761 & 0.30 & 0.26 \\
\hline $\operatorname{Jun}{ } \ldots \ldots \ldots \ldots$ & 6,675 & 2,000 & 4,022 & 239,325 & 0.33 & 0.30 \\
\hline July ........ & 2,530 & 1,620 & 1,946 & 119,656 & 0.16 & 0.14 \\
\hline August.... & 4,725 & 1,650 & 2,655 & 163,251 & 0.23 & 0.20 \\
\hline September & 2,950 & 1,460 & 2,003 & 119,187 & 0.17 & 0.15 \\
\hline October .... & 2,900 & 2,025 & 2,477 & 152,306 & 0.21 & 0.18 \\
\hline November $1-12$. & 2,900 & 2,450 & 2,668 & 158,757 & 0.22 & 0.20 \\
\hline
\end{tabular}

Note._Gage heights for 1898 are given in Water-Supply and Irrigation Paper No. 27, page 85; measurements, page 87; results for 1897 in Water-Supply and Irrigation Paper, No. 15, page 97, and in the Nineteenth Annual Report, Part IV, pages 323-333. 


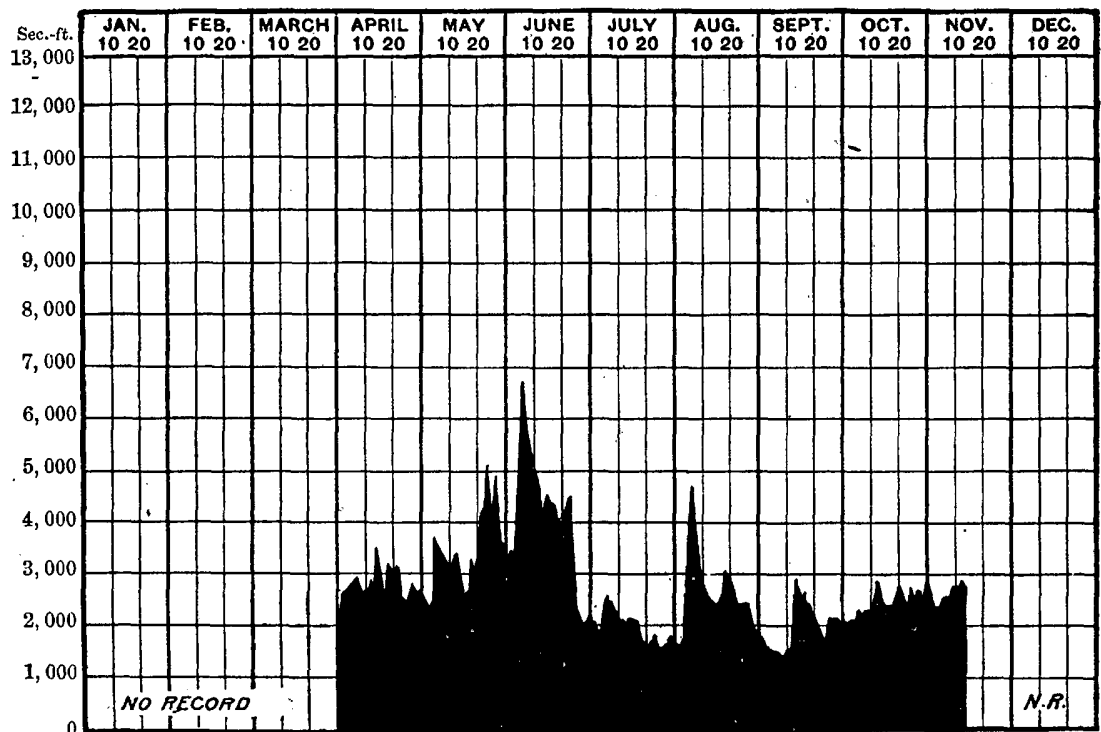

FIG. 110.-Discharge of Loup River at Columbus, Nebraska, 1898.

PLATTE RIVER AT COLUMBUS, NEBRASKA.

Estimated monthly discharge of Platte River at Columbus, Nebraska.

[Drainage area, 56,867 square miles.]

\begin{tabular}{|c|c|c|c|c|c|c|}
\hline \multirow[b]{2}{*}{ Month. } & \multicolumn{3}{|c|}{ Discharge in second-feet. } & \multirow[b]{2}{*}{$\begin{array}{l}\text { Total in acre- } \\
\text { feet. }\end{array}$} & \multicolumn{2}{|c|}{ Run-off. } \\
\hline & $\begin{array}{l}\text { Maxi. } \\
\text { mum. }\end{array}$ & $\begin{array}{l}\text { Mini- } \\
\text { mum. }\end{array}$ & Mean. & & $\begin{array}{l}\text { Depth in } \\
\text { inches. }\end{array}$ & $\begin{array}{c}\text { Second- } \\
\text { feet per } \\
\text { square } \\
\text { mile. }\end{array}$ \\
\hline 1898. & & & & & & \\
\hline April 17-30 ........ & 2,700 & 500 & 1,477 & 87,887 & 0.03 & 0.03 \\
\hline May ....... & 10,700 & 1,500 & 5,851 & 359,766 & 0.12 & 0.10 \\
\hline June ............. & 24,600 & 5,100 & 11,278 & 671,086 & 0.22 & 0.20 \\
\hline July $1-20 \ldots \ldots$. . . & 6,100 & 500 & 3,029 & 186,247 & 0.06 & 0.05 \\
\hline
\end{tabular}

NoTE.-Gage heights for 1898 are given in Water-Supply and Irrigation Paper No. 27, page 85; measurements, page 87; results for 1897 in Water-Supply and Irrigation Paper No. 15, page 98, and in the Nineteenth Annual Report, Part IV, pages 333-334. 


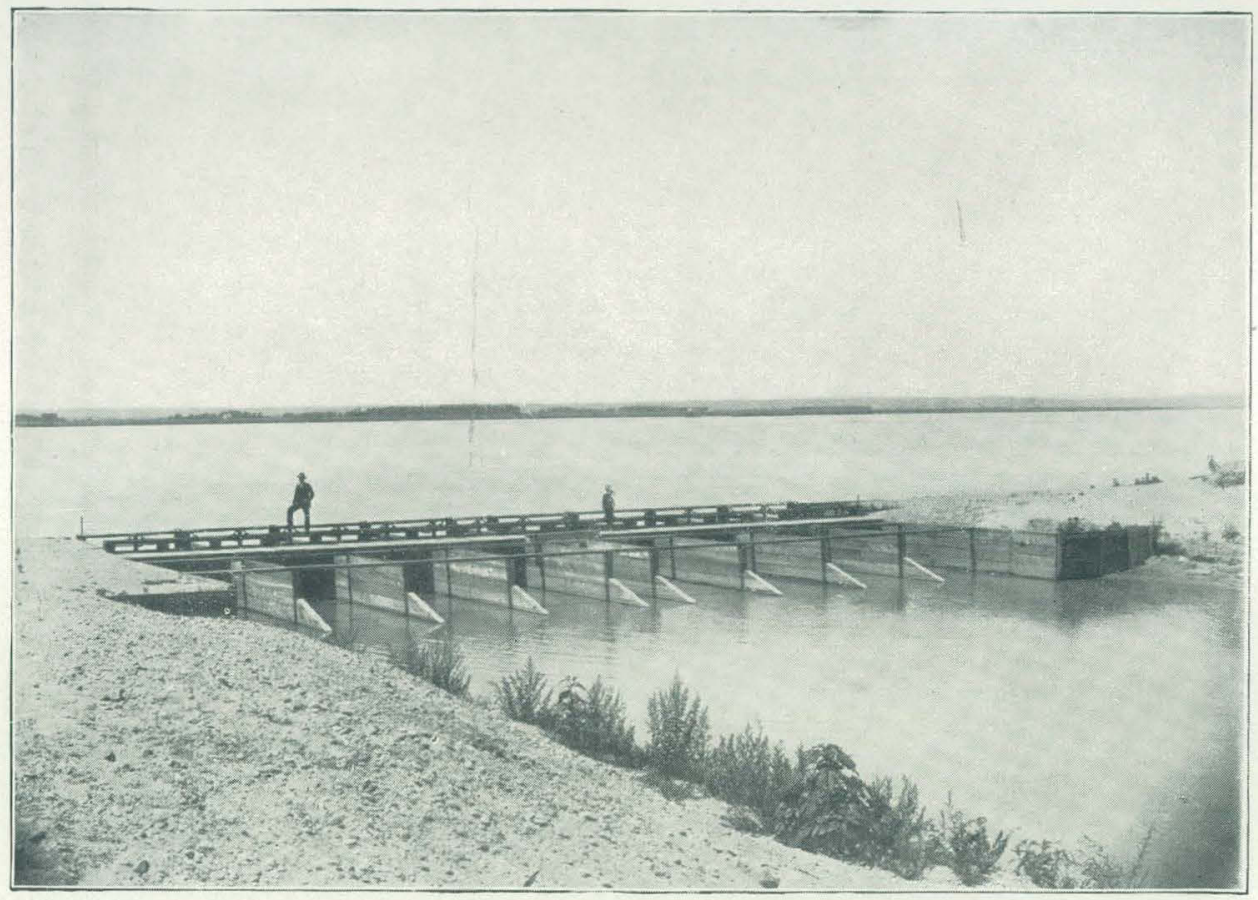

A. HEAD GATES OF CANAL OF FARMERS AND MERCHANTS IRRIGATION COMPANY ON PLATTE RIVER NEAR COZAD, NEBRASKA.

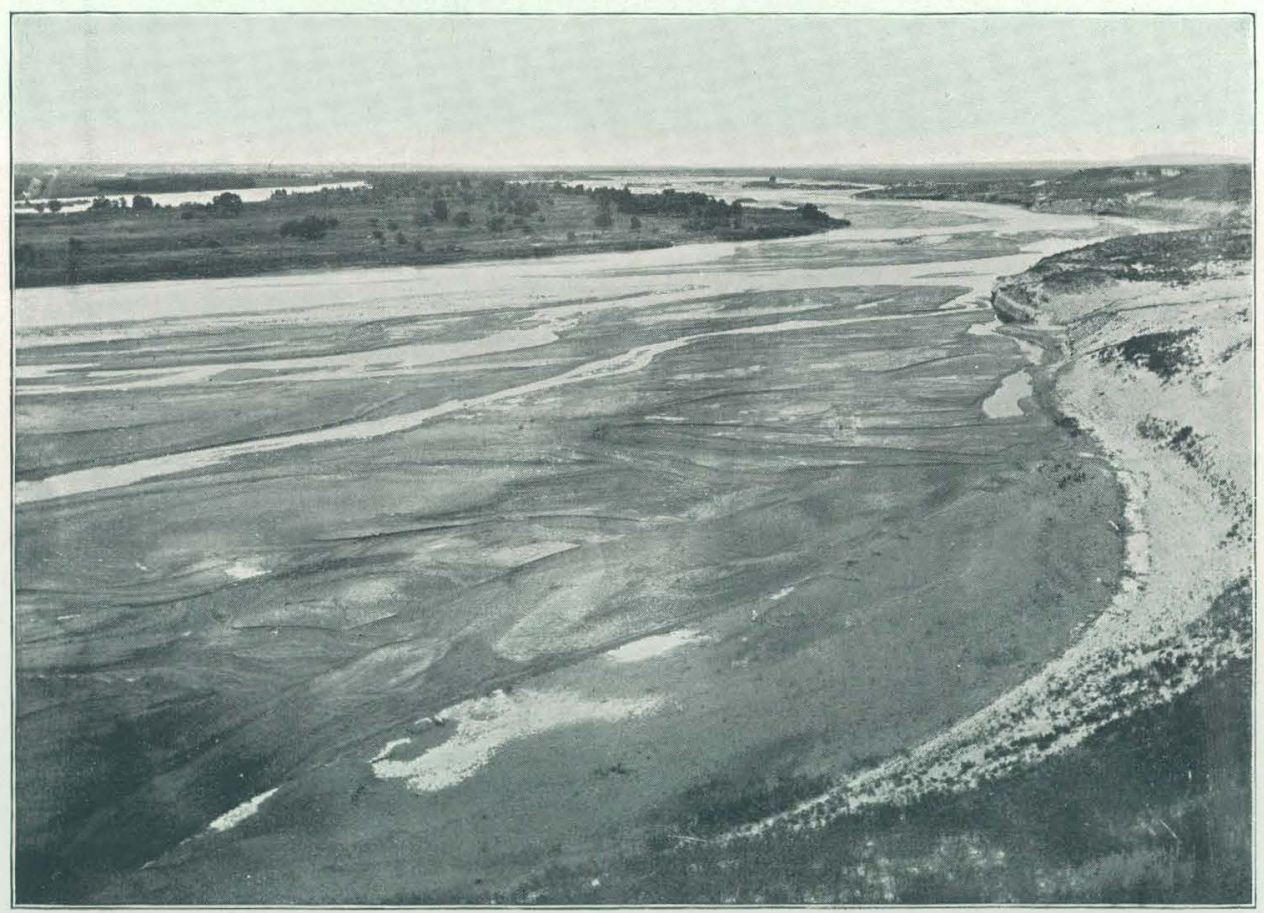

B. LOOKING DOWN NORTH PLATTE RIVER FROM THE NEBRASKA-WYOMING LINE. 
296' PROGRESS OF STREAM MEASUREMENTS FOR 1898.

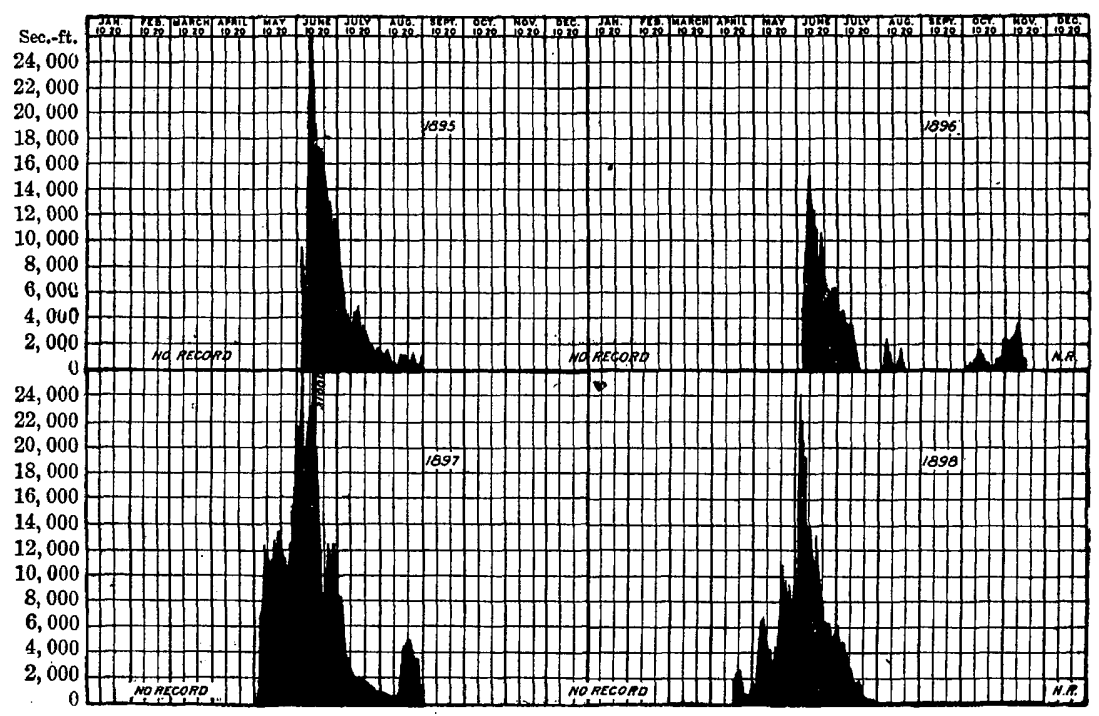

FIG. 111.-Discharge of Platte River at Columbus, Nebraska, 1898.

A view of Platte River above Columbus, near the town of Cozad, is shown on Pl. XXVIII, 4 . This is a view of the head gates of the Farmers and Merchants' Irrigation Company's canal in Dawson County Nebraska. This diverts water from the north side of the river, covering lands to the north of Lexington. On the same plate, $B$, is shown the North Platte near the Nebraska-Wyoming State line.

ELKHORN RIVER.

Estimated monthly discharge of Elkhorn River at Norfolk, Nebraska.

[Drainage area, 2,474 square miles.]

\begin{tabular}{|c|c|c|c|c|c|c|}
\hline \multirow[b]{2}{*}{ Month. } & \multicolumn{3}{|c|}{ Discharge in second-feet. } & \multirow[b]{2}{*}{$\begin{array}{c}\text { Total in acre- } \\
\text { feet. }\end{array}$} & \multicolumn{2}{|c|}{ Run-off. } \\
\hline & $\begin{array}{l}\text { Maxi. } \\
\text { mum. }\end{array}$ & $\begin{array}{l}\text { Mini. } \\
\text { mum. }\end{array}$ & Mean. & & $\begin{array}{l}\text { Depth in } \\
\text { inches. }\end{array}$ & $\begin{array}{l}\text { Second. } \\
\text { feet per } \\
\text { square } \\
\text { mile. }\end{array}$ \\
\hline 1898. & & & & & & \\
\hline April .............. & 500 & 399 & 464 & 27,610 & 0.21 & 0.19 \\
\hline May ................. & 1,470 & 405 & 704 & 43,288 & 0.33 & 0.29 \\
\hline June............... & ........ & 475 & $a 1,000$ & 59,504 & $0.45^{\prime}$ & 0.40 \\
\hline July $\ldots . . . . . .$. & 435 & 200 & 317 & 19,492 & 0.15 & 0.13 \\
\hline August...... & 440 & 210 & 285 & 17,524 & 0.14 & 0.12 \\
\hline September . ........ & 235 & 160 & - 195 & 11,603 & 0.09 & 0.08 \\
\hline October $\ldots . . . . .$. & 280 & 185 & 236 & 14,511 & 0.12 & 0.10 \\
\hline November 1-19 .. & 335 & 285 & 303 & 18,030 & 0.13 & 0.12 \\
\hline
\end{tabular}

a Approximate.

Norr._Gage heights for 1898 are given in Water-Supply and Irrigation Paper No. 27, page 85; measurements, page 87; results for 1897 in Water-Supply and Irrigation Paper No. 15, page 99, and in the Nineteenth Annual Report, Part IV, pages 334-335. 


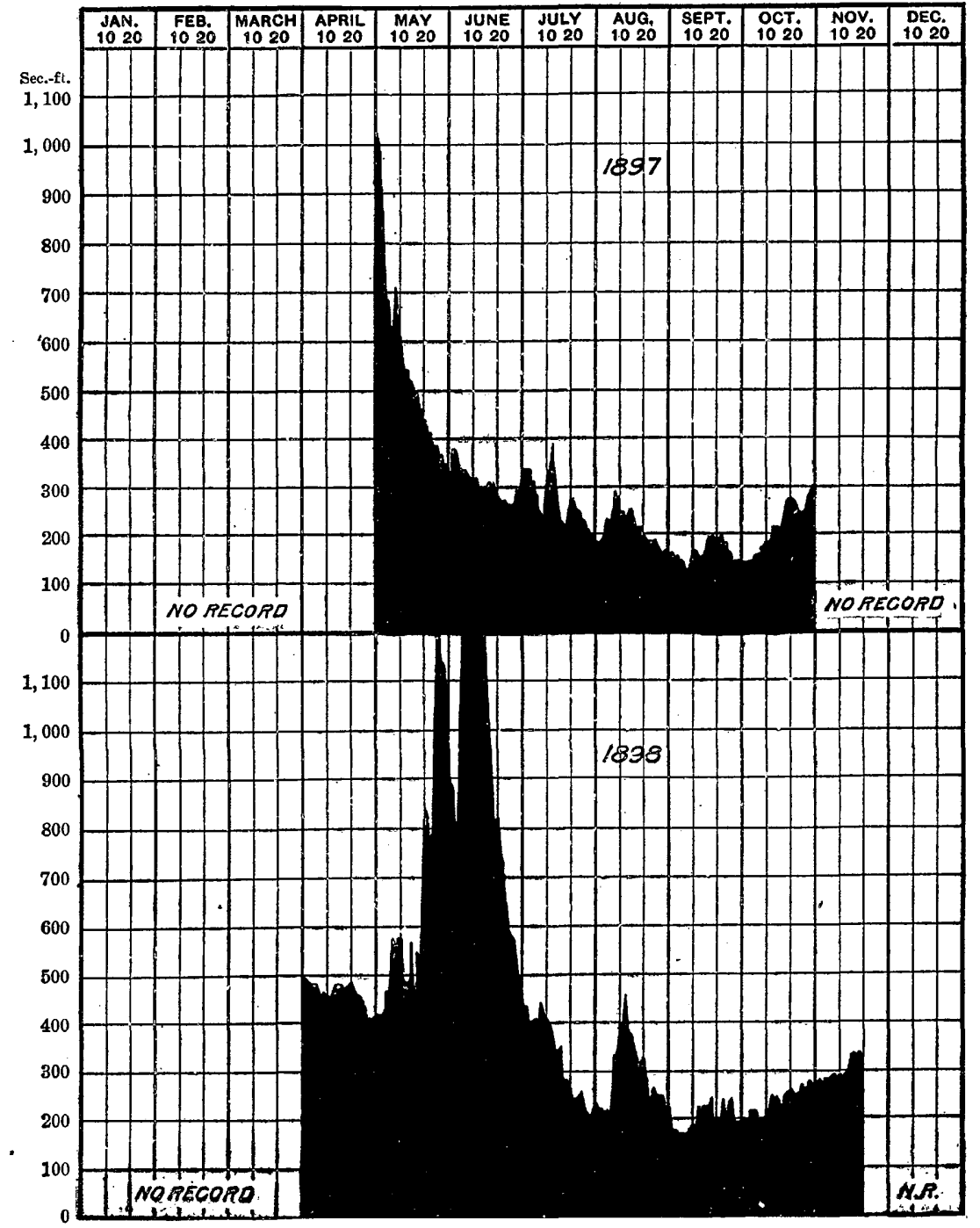

FıG. 112.-Discharge of Elkhorn River at Norfolk, Nebraska, 1897-98.

MISCELLANEOUS MEASUREMENTS IN NEBRASKA.

For convenience of comparison the miscellaneous measurements made in the State of Nebraska have been brought together and arranged in alphabetical order, according to the names of the streams. This table was prepared originally for the State engineer of Nebraska, and printed in slightly different form in the second biennial report of the State engineer, secretary of the State board of irrigation, 1897-98, pages 175 to 189. 
Miscellaneous measurements in Nebraska made at points other than regular gaging stations during the years 1894 to 1898 , inclusive:

\begin{tabular}{|c|c|c|c|}
\hline Name of stream. & Where measured. & Date. & Discharge. \\
\hline & & & Second-feet. \\
\hline \multirow[t]{2}{*}{$\begin{array}{l}\text { Arickaree Fork of Re. } \\
\text { publican. }\end{array}$} & Haigler ................ & June 17,1896 & 6.1 \\
\hline & & July 16,1896 & 3.6 \\
\hline \multicolumn{4}{|l|}{ Ash Creek: } \\
\hline East $a$. & $\frac{1}{2}$ mile above mouth......... & June 25, 1896 & 1.1 \\
\hline West .... & N. line sec. 25, T. 32, R. $51 . \ldots \ldots \ldots$ & .....do ........ & 1.7 \\
\hline \multirow[t]{2}{*}{ 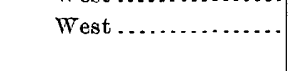 } & Head of Mace ditch........ & Aug. 18,1897 & 0.9 \\
\hline & Sec. 12, T. 32, R. $51 \ldots \ldots \ldots \ldots \ldots \ldots$ & Sept. 21,1898 & $b 0.5$ \\
\hline Ash Creek $c . . . .$. & Abore Spragg's dam, sec. 10, T. 31 , R. 17. & June 20,1898 & 2.2 \\
\hline Antelope Creek $c \ldots . . .$. & Sec. 21, T. 32, R. $40 \ldots \ldots \ldots \ldots \ldots \ldots \ldots$ & June 2,1898 & 3.1 \\
\hline Buffalo Creek......... & 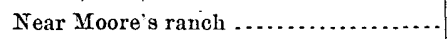 & June 17,1896 & 7.9 \\
\hline \multirow[t]{3}{*}{ Blue Creek .............. } & (n. & $\ldots \ldots \ldots \ldots \ldots$ & 105.0 \\
\hline & Sec. 30, T. 16, R. $42 \ldots \ldots$ & Mar. 28, 1897 & 115.0 \\
\hline & Sec. 33, T. 17, R. $42 \ldots$ & Aug. 31,1898 & 80.6 \\
\hline \multirow[t]{3}{*}{ Birdwood Creek .......... } & 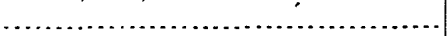 & ............... & $126: 0$ \\
\hline & 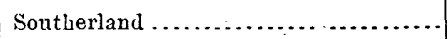 & Sept. 9,1896 & 133.0 \\
\hline & Beauchamp's dam, sec. 15 , T. 15, R. $33 \ldots$ & May 7,1898 & 123.3 \\
\hline \multirow[t]{6}{*}{ Beaver Creek............ } & Genoa $\ldots \ldots \ldots \ldots \ldots \ldots \ldots$ & Sept. 7,1894 & 71.0 \\
\hline & Do.... & July 14,1896 & 110.0 \\
\hline & Do... & Aug. 14, 1896 & 112.2 \\
\hline & Do........... & June 21,1898 & 149.7 \\
\hline & Albion............. & July 21,1896 & 47.4 \\
\hline & Do................... & Apr. 23,1898 & 88,6 \\
\hline \multirow[t]{6}{*}{ Blue River ............... } & Beatrico .............. & Aug. 21,1897 & 203.0 \\
\hline & Do.............. & July 4,1898 & 285.0 \\
\hline & Seward, below dam......... & July 1,1898 & 42.7 \\
\hline & Milford, below mill ......... & .... do ........ & 53.4 \\
\hline & Crete, below mill....... & July 2,1898 & 126. 6 \\
\hline & 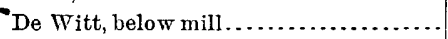 & .... do ........ & 202.0 \\
\hline \multirow[t]{2}{*}{ Boardman Creek .......... } & 2 miles above mouth............. & Jųly 24,1897 & $b 1.0$ \\
\hline & Sec. 6, T. 29, R. $33 \ldots \ldots \ldots \ldots \ldots$ & May 20,1898 & $b 40.0$ \\
\hline \multirow[t]{2}{*}{ Boggy Creek .............. } & Between secs. 17 and 18, T. 32, R. $54 . \ldots$ & May 8,1897 & 0.1 \\
\hline & Sec. 31, T. 33, R. $54 \ldots \ldots \ldots \ldots \ldots \ldots \ldots$ & .....do ........ & 0.3 \\
\hline \multirow[t]{2}{*}{ Bone Creek .............. } & At Ainsworth . . . . . . . . . & June 12,1898 & 3.9 \\
\hline & At Long Pine .............. & Sept. 8,1898 & 13.8 \\
\hline Burton Creek............. & At moutb, T. 35, R. $10 \ldots \ldots \ldots \ldots$ & Sept. 17,1898 & 5.5 \\
\hline Buck Creek. ............. & Sec. 14, T. 31, R. $41 \ldots \ldots \ldots \ldots \ldots \ldots$ & Sept. 1,1898 & $b 4.0$ \\
\hline Bordeanx Creek, Big & Sec. 25, T. 33, R. $48 \ldots \ldots \ldots \ldots \ldots$ & Sept. 22,1898 & $1.9^{\circ}$ \\
\hline Calamus River...... & Burwell $\ldots \ldots \ldots \ldots \ldots \ldots$ & July 10,1896 & 368.0 \\
\hline \multirow[t]{7}{*}{ Cedar River .............. } & Fullertion .................... & Sept. 15,1894 & 210.6 \\
\hline & Do $\ldots \ldots \ldots \ldots$ & July 11,1896 & 338.0 \\
\hline & Do.............. & June 21,1898 & 277.0 \\
\hline & Cedar Rapids ............. & July 21,1896 & 212.0 \\
\hline & Ericson...$\ldots \ldots \ldots$ & Mar. 16,1895 & 152.0 \\
\hline & Do............... & June 1,1895 & 214.0 \\
\hline & Do................ & Aug.,- 1895 & 112.1 \\
\hline \multicolumn{4}{|l|}{ Cottonwood Creek: $a$} \\
\hline Little......... & Sec. 7, T. 32, R. $51, \ldots \ldots \ldots \ldots \ldots$ & June 25,1896 & 0.1 \\
\hline $\operatorname{Big} \ldots \ldots \ldots \ldots$ & Six miles west of Whitney .................. & .... do ........ & 0.2 \\
\hline Clear Creek........ & Sec. 29, T. 16, R.41................. & Nov. 23,1896 & 12.8 \\
\hline Coon Creek . . ............ & Above Winterer's ditch, sec. 34, T. 15, R. 7 & May 19,1898 & 0.8 \\
\hline Coldwater Creek......... & Sec. 26, T. 18, R. $46 \ldots \ldots \ldots \ldots \ldots \ldots \ldots$ & May 25,1898 & 2.9 \\
\hline
\end{tabular}

$a$ Tributary of White River. $\quad b$ Discharge estimated. $\quad c$ Tributary of Niobrara River. 
Miscellaneous measurements in Nebraska made at points other than regular gaging stations during the years 1894 to 1898 , inclusive-Continued.

\begin{tabular}{|c|c|c|c|}
\hline Name of stream. & Where measured. & Date. & Discharge. \\
\hline · & & & Second-feet. \\
\hline Crooked Creek... & $\begin{array}{l}\text { At head of Mutz ditch, SW. } \frac{1}{4} \text { sec. } 20 \text {, } \\
\text { T. } 34, \text { R. } 19 .\end{array}$ & June 18,1898 & 0.7 \\
\hline \multirow{3}{*}{ Chadron Creek ........... } & Above Chadron waterworks... & Sept. 14,1897 & 1.6 \\
\hline & Below Chadron waterworks. & ..... do ........ & 1.0 \\
\hline & Sec. 36, T. 33, R. $19 . \ldots \ldots \ldots$ & Sept. 23,1898 & $a 1.3$ \\
\hline \multirow[t]{4}{*}{ Dismal River ............ } & Dunning.................. & Aug. 23, 1895 & 29.4 \\
\hline & Do................ & Aug. 22,1894 & 435.0 \\
\hline & Do.......... & Apr. 28,1898 & 368.7 \\
\hline & Do...................... & Nov. 1,1898 & 351.0 \\
\hline Deer Creek........ & Sec. 22, T. 30, R. $43 . \ldots$ & June 1,1898 & $a 12.0$ \\
\hline \multirow[t]{2}{*}{ Dead Horse Creek........ } & Sec. 31, T. 33, R. $50 \ldots \ldots \ldots$ & Sept. 21,1898 & $a 0.3$ \\
\hline & Sec. 7, T. 32, R. $49 .$. & Sept. 23, 1898 & $a 0.6$ \\
\hline \multirow[t]{12}{*}{ Elkhorn River........... } & Atkinson ................ & Oct. 2,1896 & 11.1 \\
\hline & Do.... & May 24,1898 & 110.5 \\
\hline & Arlington ..... & $\begin{array}{l}\text { Late Ang., } \\
1894 .\end{array}$ & 214.0 \\
\hline & Do.... & May 26,1898 & $1,808.0$ \\
\hline & Do.... & Dec. 15,1898 & 422.0 \\
\hline & Waterloo ... & Ang. 15, 1896 & 280.0 \\
\hline & Do.......... & July 17,1896 & 495.0 \\
\hline & O'Neill........... & June 23,1897 & 20.6 \\
\hline & Do.... & June 10,1898 & 288.0 \\
\hline & Do........ & Aug. 17, 1898 & 31.3 \\
\hline & Ewing .......... & Sept. 3,1897 & 9.8 \\
\hline & Do.................. & Aug. 18, 1898 & 53.5 \\
\hline \multirow[t]{6}{*}{$\begin{array}{l}\text { Elkhorn River, North } \\
\text { Fork. }\end{array}$} & Norfolk,$\ldots \ldots \ldots \ldots \ldots$ & July 16,1896 & 70.0 \\
\hline & Do... & Mar. 24, 1897 & 701.0 \\
\hline & Do ... & May 6,1897 & 166.0 \\
\hline & Do.... & May 24,1897 & 77.0 \\
\hline & Do......... & July 30,1897 & 69.8 \\
\hline & Do............................. & June 20,1898 & 162.0 \\
\hline $\begin{array}{l}\text { Elkhorn River, South } \\
\text { Fork. }\end{array}$ & Ewing.............................. & Sept. 3,1897 & 18. 2 \\
\hline \multirow[t]{8}{*}{ Frenchman River......... } & Sec. 33, T. 4, R. 32 . & June 19,1896 & 26.3 \\
\hline & Culbertson...$\ldots \ldots \ldots$ & .....do ........ & 13.4 \\
\hline & Do......................... & Nov. 25,1892 & 177.0 \\
\hline & Do $\ldots \ldots \ldots \ldots \ldots \ldots \ldots$ & Mar. 22, 1895 & 120.0 \\
\hline & Wauneta ........................ & Apr. 14,1897 & 127.9 \\
\hline & Palisade ................... & July 2,1897 & 63.2 \\
\hline & Do................. & July 19,1897 & 73.3 \\
\hline & . Do $b \ldots \ldots \ldots \ldots \ldots \ldots \ldots \ldots \ldots \ldots \ldots \ldots \ldots \ldots \ldots$ & July 7,1898 & 92.0 \\
\hline Gordon Creek .... & Sec. 15. T. 32, R. $29 \ldots \ldots \ldots \ldots \ldots \ldots \ldots$ & July 23,1897 & 3.5 \\
\hline \multirow[t]{2}{*}{ Horse Creek .............. } & $\begin{array}{l}\text { Burlington and Missouri River Ry: } \\
\text { crossing. }\end{array}$ & June 16,1896 & 0.2 \\
\hline & At State line above Gering......... & Oct. 15,1897 & 10.5 \\
\hline \multirow{3}{*}{ Hat Creek, east........... } & Sec. 23, T. 32, R. $55 \ldots \ldots \ldots \ldots \ldots \ldots \ldots \ldots$ & July 10,1897 & 0.3 \\
\hline & Above mouth, sec. 14, T. 33, R. $55 \ldots \ldots$. & ..... do ........ & 1.0 \\
\hline & 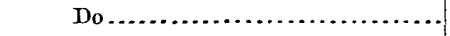 & ..... do ........ & 0.5 \\
\hline \multirow[t]{3}{*}{ Hat Creek ................ } & Just below contluence, sec. 14, T. 33, R. 55 & ..... do ........ & 1.6 \\
\hline & $\begin{array}{l}\text { Head of Brewster or Steele ditch, sec. } \\
\text { 16, T. } 32, \text { R. } 55 \text {. }\end{array}$ & July 16,1897 & 0.7 \\
\hline & Sec. 23, T. 33, R. $55 . \ldots \ldots$ & Sept. 30,1898 & 1.4 \\
\hline
\end{tabular}


Miscellaneous measurements in Nebraska made at points other than regular gaging stations during the years 1894 to 1898, inclusive-Continued.

\begin{tabular}{|c|c|c|c|}
\hline Name of stream. & Where measured. & Date. & Discharge. \\
\hline & & & Second-feet. \\
\hline Harney Creek........... & Sec. 31, I. 33, R. 23,.......... & June 11,1898 & 23.5 \\
\hline Indian Creek ............ & Near mouth $\ldots \ldots \ldots \ldots \ldots \ldots \ldots \ldots \ldots \ldots \ldots \ldots$ & June 25,1896 & 0.1 \\
\hline Jim Creek ...... & $\begin{array}{l}\text { Above Woodruffs dam, SE. } \frac{1}{6} \text {, sec. } 14 \text {, } \\
\text { T. } 33, \text { R. } 57 \text {. }\end{array}$ & July 22,1897 & 0.2 \\
\hline Keya Paha River.. & $\begin{array}{l}\text { Above mouth of Burton Creek, T. } 35 \\
\text { R. } 19 \text {. }\end{array}$ & June 17,1898 & 62.0 \\
\hline \multirow[t]{3}{*}{ Loup River............. } & Fullerton...$\ldots \ldots \ldots \ldots \ldots \ldots$ & Sept. 16, 1894 & $1,704.0$ \\
\hline & Do................ & $J$ aly 11,1896 & $2,900.0$ \\
\hline & Sec. 13, T. 7, R. $2 \ldots$ & Aug. 19, 1894 & $1,335.0$ \\
\hline \multirow[t]{3}{*}{ Loup River, north ........ } & Moulton $\ldots \ldots \ldots \ldots \ldots \ldots$ & Nov. 2,1894 & 460.0 \\
\hline & 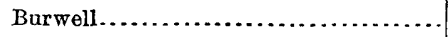 & July 9,1896 & 625.0 \\
\hline & Below mouth Wanaduza Creek.......... & July 24,1897 & 129.8 \\
\hline \multirow[t]{7}{*}{ Loup River, middle...... } & Forks $8 \frac{1}{2}$ miles above Mullen. & Ang. 20,1895 & 41.8 \\
\hline & Mullen $\ldots \ldots \ldots \ldots \ldots$ & ..... do ........ & 120.0 \\
\hline & Seneca.......... & Aug. 21, 1895 & 216.2 \\
\hline & Do............. & Aug. 30,1896 & 212.3 \\
\hline & Do......... & Apr. 28,1898 & 221.6 \\
\hline & Do............ & $\ldots$ do ........ & 198.0 \\
\hline & Thedford .... & Apr. 22,1895 & 284.3 \\
\hline \multirow[t]{7}{*}{, } & Dunning ............... & Apr. 23,1895 & 321.5 \\
\hline & Do......... & Apr. 28,1898 & 410.0 \\
\hline & Do................... & Nov. 1,1898 & 433.0 \\
\hline & Do $\ldots \ldots \ldots \ldots \ldots \ldots$ & A.ug. 30,1896 & 323.0 \\
\hline & Gates, Custer County ......... & Aug. 25,1894 & 850.0 \\
\hline & Loup City ........... & Aug. 29, 1895 & 878.6 \\
\hline & Boelus .......... & May 28,1897 & 837.0 \\
\hline \multirow{7}{*}{ Loup River, sonth ........ } & Callaway....$\ldots \ldots \ldots$ & Aug. 28, 1895 & 48.0 \\
\hline & Do........... & Aug. 3,1898 & 82.9 \\
\hline & Arnold ......... & Aug. 4,1898 & 31.5 \\
\hline & Georgetown ... & Sept. 10,1896 & 68.0 \\
\hline & Ravenna....... & Aug. 31,1895 & 296.0 \\
\hline & Do.............. & Aug. 29, 1896 & 142.0 \\
\hline & St. Michaels .......... & May 28,1898 & 220.0 \\
\hline Looking Glass Creek. & Near mouth......................... & July,- 1896 & 15. 0 \\
\hline Lodgeople Creek..... & Kimball...$\ldots \ldots \ldots$ & May 26, 1896 & 4.5 \\
\hline Lonergan Creek .... & Sec. 17, T. 15, R.39............ & May 22, 1898 & 6.1 \\
\hline \multirow[t]{2}{*}{ Long Pine Creek ......... } & Long Pine ....................... & June 20,1898 & 50.4 \\
\hline & 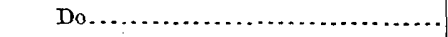 & Aug. 21, 1898 & 44.3 \\
\hline \multirow[t]{6}{*}{ Minichaduza River...... } & Fort Niobrara............. & Oct. $\quad 4,1896$ & 45.2 \\
\hline & Valentine........ & June 24,1897 & 21.2 \\
\hline & Do.......... & May 14,1898 & 23.2 \\
\hline & Do........ & May 18,1898 & 105.8 \\
\hline & Do........... & May 24,1898 & 89.5 \\
\hline & Do.................. & June 6,1898 & 33.9 \\
\hline \multirow[t]{7}{*}{1} & Do.................. & June 12,1898 & 52.5 \\
\hline & Do.......... & July 27, 1898 & 15.3 \\
\hline & Do................. & Aug. 21, 1898 & 18.2 \\
\hline & Do $\ldots \ldots \ldots \ldots$ & Sept. 7,1898 & 18.8 \\
\hline & Do.................... & Sept. 27,1898 & 22.1 \\
\hline & Do............... & Oct. 15,1898 & 22.5 \\
\hline & Do.................................. & Oct. 29,1898 & 27.0 \\
\hline Monroe Creek ...... & $\begin{array}{l}\text { At head of Schilt ditch, SW. } \frac{1}{4} \text { sec. } 27, \\
\text { T. } 33, \text { R. } 56 .\end{array}$ & $J$ uly 20,1897 & 0.2 \\
\hline
\end{tabular}


Miscellaneous measurements in Nebraska made at points other than regular gaging stations during the years 1894 to 1898 , inclusive-Continued.

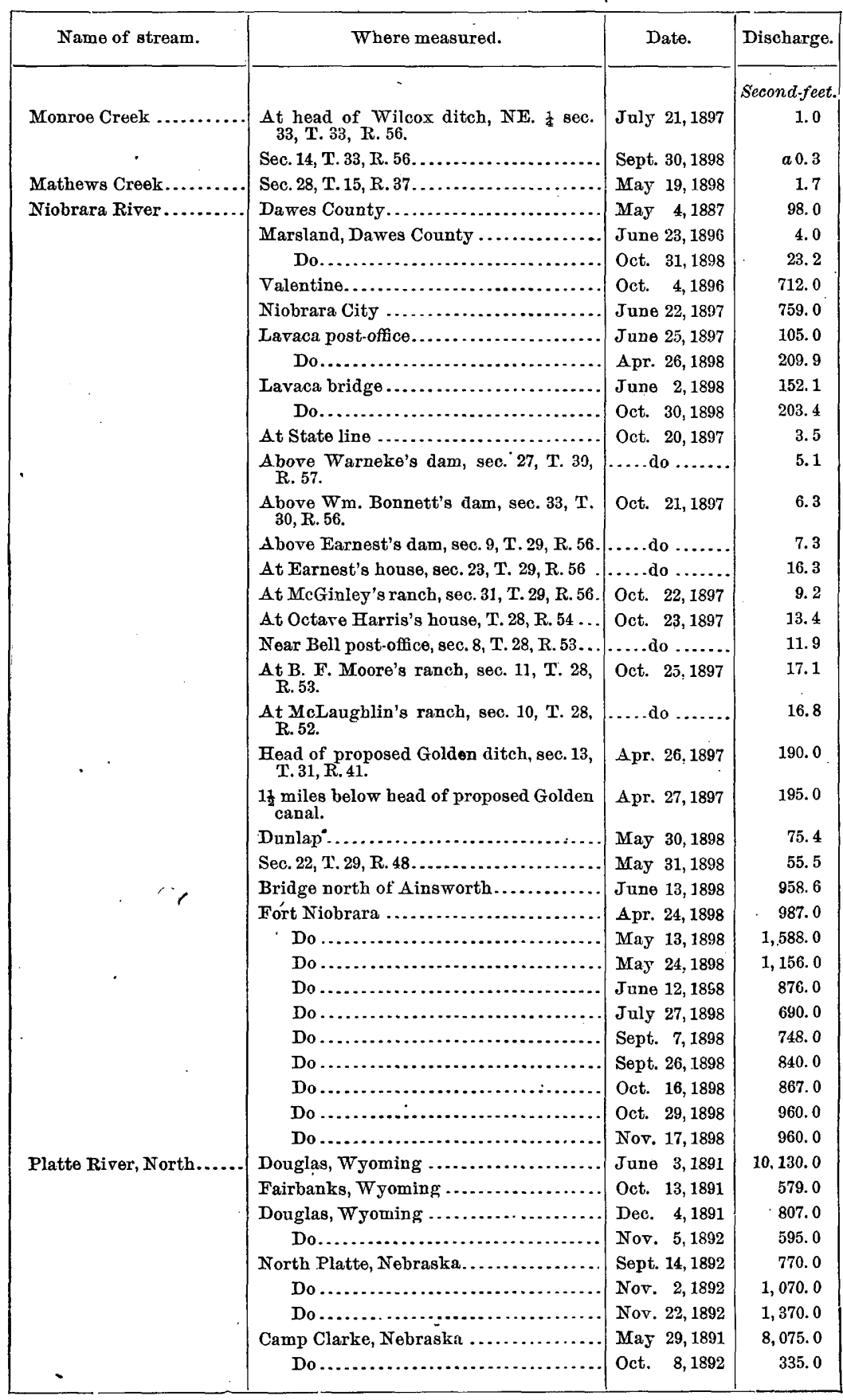

a Above head of Culberson ditch. 
- Miscellaneous measurements in Nebraska made at points other than regular gaging stations during the years 1894 to 1898 , inclusive-Continued.

\begin{tabular}{|c|c|c|c|}
\hline Name of stream. & Where measured. & Date. & Discharge. \\
\hline \multirow{5}{*}{ Platte River, North...... } & & & Second-feet. \\
\hline & Camp Clarke, Nebraska...... & July 26, 1894 & $a 1,900.0$ \\
\hline & Lewellen Bridge............ & Sept. 1,1898 & $b 5.0$ \\
\hline & Railroad bridge, North Platte & Sept. $2,1898^{\circ}$ & $b 12.0$ \\
\hline & Gering Bridge............... & Nov. 7,1898 & 593.4 \\
\hline Platte River.............. & Columbus................. & Sept. 17, 1894 & Dry. \\
\hline \multirow{2}{*}{-} & Do.................... & Oct. 6,1894 & Dry. $c$ \\
\hline & Fremont... & Aug. 14, 1894 & $1,420.0$ \\
\hline \multirow{3}{*}{. } & Do $\ldots . . . . . . . . . . . .$. & $\begin{array}{l}\text { Late Aug., } \\
\quad 1894 .\end{array}$ & $1,209.0$ \\
\hline & Grand Island. & Sept. 7,1898 & Dry. \\
\hline & Do...................... & Sept. 15, 1898 & 12.0 \\
\hline \multirow[t]{4}{*}{ Platte River, South ....... } & Julesburg, Colorado ......... & October...... & 653.0 \\
\hline & North Platte................ & Early Nov... & 450.0 \\
\hline & Do $\ldots \ldots \ldots \ldots \ldots$ & Late Nor.... & 645.0 \\
\hline & Do $\ldots \ldots \ldots$ & June 29,1896 & 0.0 \\
\hline \multirow[t]{2}{*}{ Pawnee Creek ............. } & $\begin{array}{l}\text { Above Plummer ditch, sec. } 19, \text { T. } 13, \mathrm{R} \text {. } \\
27 .\end{array}$ & Apr. 25,1898 & $4.9^{\circ}$ \\
\hline & Above Holcomb's ditch........ & .....do do........ & 4.7 \\
\hline Plum Creek. & At mouth, sec. 13, T. 22, R. $32 \ldots \ldots \ldots$ & June 13,1898 & 101.1 \\
\hline \multirow[t]{2}{*}{ Pine Creek . . .................. } & 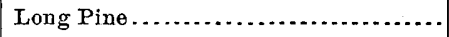 & Oct. $\quad 3,1896$ & 47.1 \\
\hline & Long Pine, sec. 33, T. 30, R. $44 \ldots$ & Oct. 1,1898 & 24.5 \\
\hline Pole Creek ........ & Long Pine, sec. 28, T. 32, R. $40 \ldots$ & Oct. $\quad 2,1898$ & $c 2.0$ \\
\hline \multirow{10}{*}{ Republican River........ } & Haigler $d \ldots \ldots \ldots \ldots \ldots$. & Oct. 17,1896 & 8.2 \\
\hline & Haigler $d \ldots \ldots \ldots \ldots$ & Oct. 16,1896 & 6.1 \\
\hline & Doe................... & Oct. 17,1896 & 14.9 \\
\hline & Do............. & July 16,1896 & 9.8 \\
\hline & Do $\ldots \ldots \ldots$...... & Aug. 25, 1896 & 10.0 \\
\hline & Do........... & Sept. 18,1896 & 24.5 \\
\hline & McCook . . . . . . . . . . & Apr. 13,1897 & 745.0 \\
\hline & Do $\ldots \ldots \ldots \ldots \ldots . . . . .$. & July 19,1897 & 0.0 \\
\hline & 2 miles west of Ives ....... & Aug. 25,1896 & 5.0 \\
\hline & 7 miles west of Benkelman. . & June 16,1896 & 87.5 \\
\hline \multirow[t]{4}{*}{. } & Benkelman .............. & .....do ........ & 29.3 \\
\hline & Do $\ldots \ldots \ldots \ldots$ & Aug. 25, 1896 & 5.0 \\
\hline & Culbertson $f \ldots$. & May 16,1896 & 78.4 \\
\hline & Do $\ldots \ldots \ldots$ & June 19,1896 & 6.5 \\
\hline \multirow{8}{*}{$\cdot$} & Do ......... & Sept 10,1896 & 0.0 \\
\hline & Do..... & Nov. 25,1892 & 209.0 \\
\hline & Do $\ldots . . . . . .$. & June 25,1898 & 91.3 \\
\hline & Oxford.................. & June 3,1895 & $16,000.0$ \\
\hline & Do $\ldots \ldots \ldots$ & Sept. 12,1895 & 55.0 \\
\hline & Do $\ldots \ldots \ldots \ldots \ldots$ & May 17,1896 & 254.5 \\
\hline & Do.................... & June 16,1896 & 109.4 \\
\hline & Do $\ldots \ldots \ldots \ldots \ldots$ & June 24,1898 & 385.0 \\
\hline \multirow{5}{*}{ Rock Creek............. } & Burlington and Missouri Rwy. crossing. & June 16,1896 & 12.1 \\
\hline & 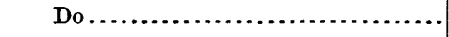 & Aug. 25,1896 & 12.2 \\
\hline & Above Moore ditch, sec. 12, T. 32, R. 22 .. & June 14,1898 & 2.3 \\
\hline & Sec. 4, T. 31, R. 18.................. & June 20,1898 & 2.1 \\
\hline & Sec. 28, T. 32, R. $18 . . . . .$. & .....do ........ & 4.4 \\
\hline
\end{tabular}

$a$ Measurement approximated by floats.

$b$ dbove head of Culberson ditch.

$c$ Water in $e$ Below mouth of Arickaree Creek. $d$ Above mouth of Arickaree Creek.

$f$ Above mouth of Frenchman Creek. 
Miscellaneous measurements in Nebraska made at points other than regular gaging stations during the years 1894 to 1898, inclusive--Continued."

\begin{tabular}{|c|c|c|c|}
\hline Name of stream. & Where measured. & Date. & Discharge. \\
\hline • & & & Second-fee \\
\hline \multirow[t]{3}{*}{ Stinking Water Creek... } & Palisade $a$. & June 19,1896 & 12.2 \\
\hline & Do $b \ldots . .$. & Sept. 17,1896 & 20.0 \\
\hline & Do ........... & July 7,1898 & 23.6 \\
\hline \multirow[t]{2}{*}{ Shell Creek............... } & Platte Center ................. & July 21,1896 & 47.4 \\
\hline & Schuyler...$\ldots \ldots \ldots$ & July 24,1896 & 26.3 \\
\hline \multirow[t]{3}{*}{ Soldier Creek. ............ } & Fort Robinson $\ldots \ldots \ldots \ldots \ldots \ldots \ldots$ & June $24,1 \varepsilon 96$ & 3.2 \\
\hline & $\begin{array}{l}5 \text { miles above Fort Robinson, sec. } 5 \text {, } \\
\text { T. } 31, \text { R. } 53 \text {. }\end{array}$ & Aug. 14, 1897 & 2.3 \\
\hline & Fort Robiuson ............. & Apr. 27,1898 & 3.6 \\
\hline \multirow[t]{2}{*}{ Squaw Creek . . . . . . . . . } & Sec. 1, T. 31, R. 52............. & June 24,1896 & 0.6 \\
\hline & At Patrick Dunns ............ & July 22,1897 & 0.1 \\
\hline \multirow[t]{6}{*}{ Snake River............. } & 4 miles east of sec. 2, 'T. 30, R. $31 \ldots$ & Mar. 16,1897 & 222.0 \\
\hline & Sec.2,T.30, R.31. .......... & Mar. 22, 1897 & 250.0 \\
\hline & 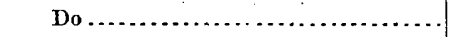 & Apr. 13,1897 & 225.0 \\
\hline & 4 miles east of sec. 2, T. 30, R. $31 \ldots$ & $\ldots .$. do ....... & 240.0 \\
\hline & At mouth $\ldots . . . \ldots \ldots \ldots \ldots \ldots$ & July 23,1897 & 280.0 \\
\hline & At mouth of Boardman Creek ..... & July 24,1897 & 215.0 \\
\hline \multirow[t]{4}{*}{ Sowbelly Creek. } & $\begin{array}{l}\text { Above head of Shaefer ditch, NE. } \frac{1}{4}, \\
\text { sec. } 7, T .32, \text { R. } 55 \text {. }\end{array}$ & July 16,1897 & 1.4 \\
\hline & Bodarc post-offlce ................... & July 14,1897 & 1.54 \\
\hline & Bridge south of Gilchrist... & July 24,1897 & .08 \\
\hline & Sec. 19, T. 33, R. $55 \ldots \ldots \ldots \ldots \ldots \ldots$ & Sept. 30,1898 & $c 1.00$ \\
\hline Skunk Creek . & Above Miller's dam, sec. 12, T. 14, R. 37. . & May 18,1898 & 2. 02 \\
\hline \multirow[t]{4}{*}{ Spring Creek ............. } & $\begin{array}{l}\text { Above Holloway's ditch, sec. } 29, \text { T. } 15 \\
\text { R. } 37 \text {. }\end{array}$ & May 19,1898 & 1.11 \\
\hline & Above William's ditch, sec.28,T. 16, R.41 & May 23,1898 & 4.59 \\
\hline & A bove Barber ditch, sec. 29, T. 16, R. $41 \ldots$ & $\ldots . . . d 0 \ldots . .$. & 6.73 \\
\hline & At Mill, Mills's post.office, T. 34, R. 18 . & June 16,1898 & 7. 30 \\
\hline Union Creek.. & Madison ............................. & July 23,1896 & 38.3 \\
\hline Victoria Creek. . & Sec. 1, 'T. 19, R. $21 \ldots \ldots \ldots \ldots \ldots \ldots \ldots$ & July 28,1896 & 5.2 \\
\hline \multirow[t]{2}{*}{ White Clay Creek ....... } & Sec. 1, 'J.. 31, R. $52 \ldots \ldots \ldots \ldots \ldots$....... & June 24,1886 & 4.0 \\
\hline & Sec. 2, T. 31, R. $52 \ldots \ldots \ldots \ldots \ldots \ldots \ldots \ldots$ & Sept. 21,1898 & $c 0.8$ \\
\hline Warbonnet Sp. $\mathbf{b}_{i}$ & $\begin{array}{l}\text { Athead of Biehle ditch, SW. } \frac{1}{4}, \text { sec. } 32, T \text {. } \\
33, \text { R. } 56 \text {. }\end{array}$ & July 21,1898 & 0.27 \\
\hline $\begin{array}{l}\text { Warbonnet, Midd le } \\
\text { Branch. }\end{array}$ & $\begin{array}{l}\text { At bead of Garton's ditch, SW. } 1, \text { sec.31, } \\
\text { T. } 33, \text { R. } 56 \text {. }\end{array}$ & ...... do ....... & 0.26 \\
\hline \multirow[t]{2}{*}{ Warbonnet Creek........ } & Brewster's, sec. 21, T. 33, R. $56 \ldots \ldots \ldots$... & July 23,1897 & 0.51 \\
\hline & Sec. 21, T. 33, R. $56 . \ldots \ldots \ldots \ldots \ldots \ldots$ & Sept. 29,1898 & 1.23 \\
\hline White Horse Creek. . & $\begin{array}{l}\text { Above Lamplugh's lakes, sec. } 5 \text {, T. } 14, \\
\text { R. } 30 \text {. }\end{array}$ & May 3,1898 & 2.33 \\
\hline \multirow[t]{3}{*}{ White Tail Creek......... } & $\begin{array}{l}\text { Above White Tail Canal, sec. } 22, \text { T. } 15 \\
\text { R. } 38 \text {. }\end{array}$ & May 20,1898 & 24.67 \\
\hline & Abore Reed ditch, sec. 15, T. 15, R. $38 \ldots$ & .....do. & 24.62 \\
\hline & $\begin{array}{l}\text { Above Holloway, Phelps canal, sec. 36, } \\
\text { T. } 15, \text { R. } 30 \text {. }\end{array}$ & .....do do....... & 26.06 \\
\hline \multirow[t]{2}{*}{ West Middle Creek...... } & Above Allen's ditch, sec. 29, T. 33, R. $23 .$. & June 11,1828 & 1.84 \\
\hline & NE. $\frac{1}{4}$ of NW. $\frac{1}{4}$, sec. 29, T. 33, R. $23 \ldots$ & ..... do ....... & 0.87 \\
\hline Wood River ......... & Glenwood.................... & Aug. 8, 1898 & 5.82 \\
\hline \multirow[t]{6}{*}{ White River.............. } & Sec. 23, T. 31, R. $53 . \ldots \ldots \ldots \ldots$ & June 24,1896 & 23.3 \\
\hline & Crawford $\ldots \ldots \ldots \ldots \ldots \ldots$ & Sept. 24, 1896 & 30.7 \\
\hline & Whitney............. & Sept. $25,1.896$ & 27.2 \\
\hline & .....Do ........................... & Sept. 21,1898 & $c 8.0$ \\
\hline & I mile below mouth Kyle Creek.. & Aug. 11, 1897 & 6.6 \\
\hline & Railroad bridge above Glen... & Aug. 13,1897 & 5.7 \\
\hline
\end{tabular}

$a$ Abore mill at Palisade.

$b$ Below mill at Palisade.

$c$ Estimated. 


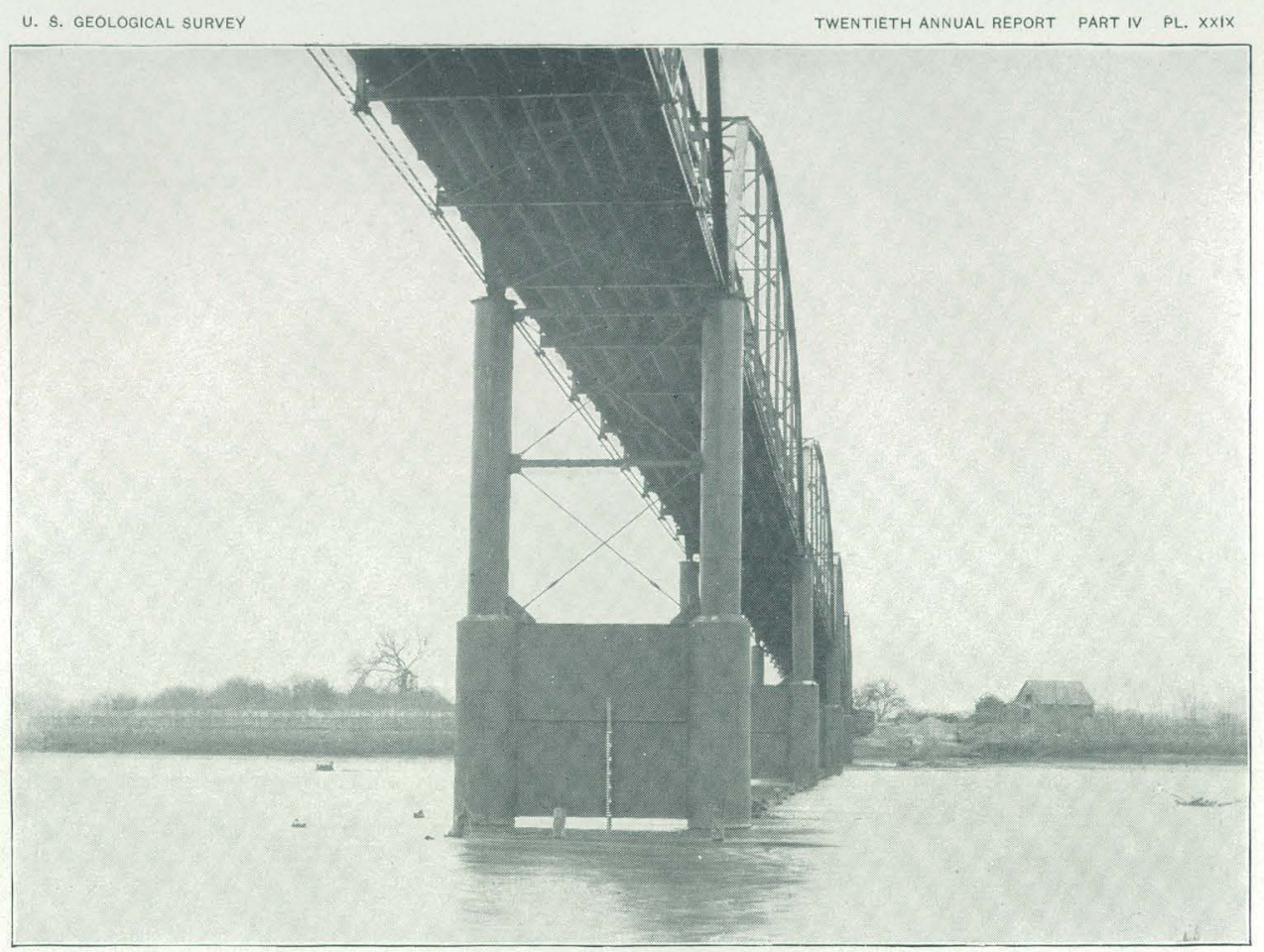

A. GAGE ON KANSAS RIVER AT LECOMPTON KANSAS

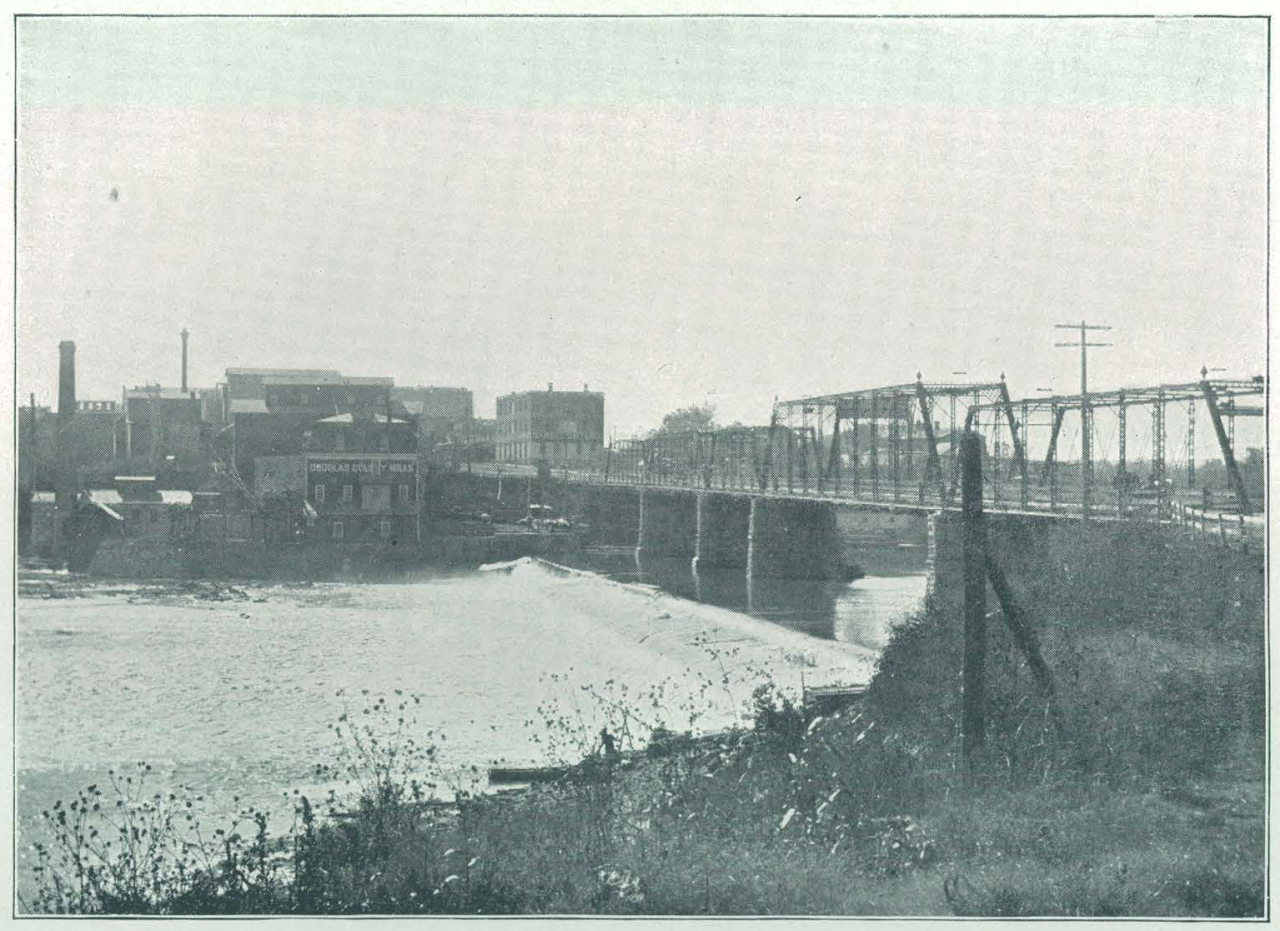

B. DAM ON KANSAS RIVER AT LAWRENCE, KANSAS 
Miscellaneous measurements in Nebraska made at points other than regular gaging stations during the years 1894 to 1898 , inclusive-Continued.

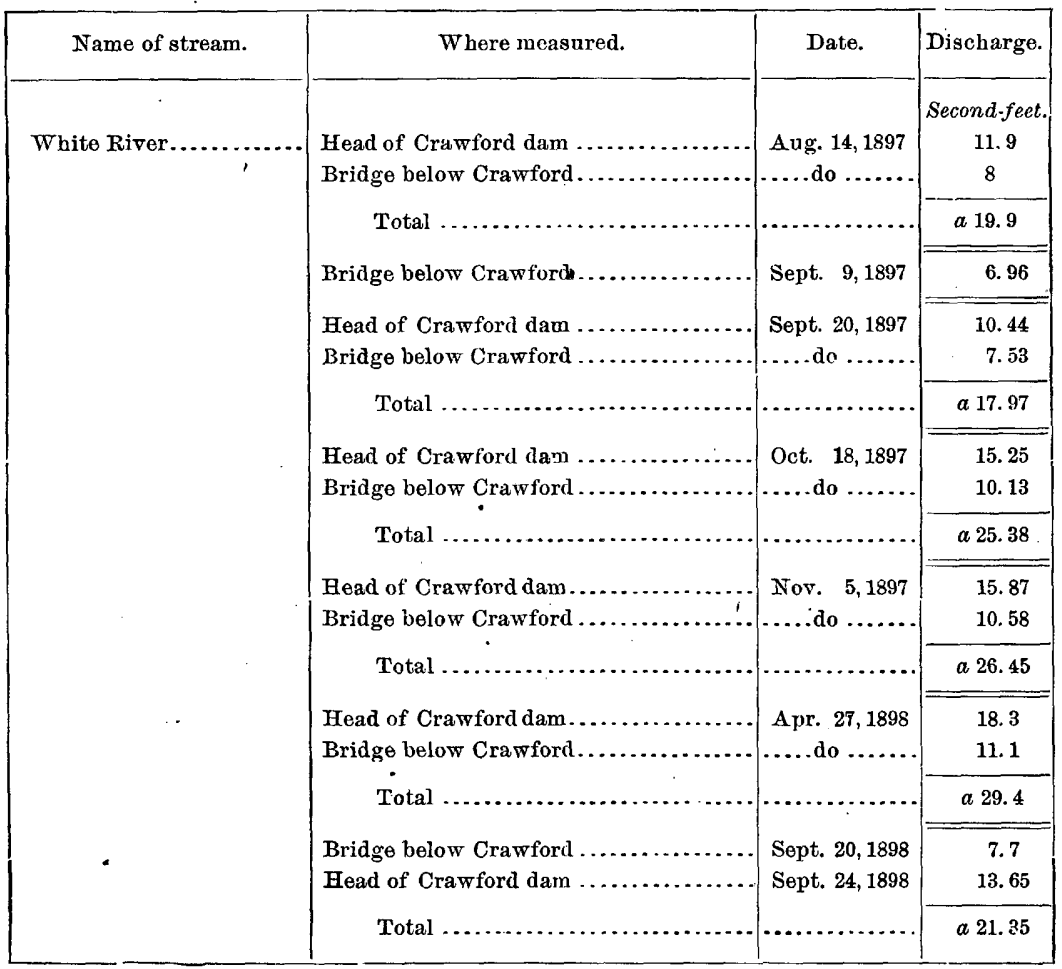

$a$ When these measurements were taken, the water was all diverted into the Crawford ditch. The gagings at the bridge below Crawford show only the water accumulated between the two points, from Soldier Creek, seepage, springs, etc.

The actual discharge of the stream at Crawford with the Crawford ditch closed would be a little less than the sum of the discharges at the two points.

\section{KANSAS RIVER DRAINAGE.}

Kansas River drains an area between the Platte on the north and the Arkansas on the south. 'The headwaters of these two streams encircle the Kansas River basin on the west, and cut it off from the mountains, so that its entire drainage area is well within the Great Plains. Its discharge, therefore, has peculiar interest from the fact that the run-off is not affected by mountain storms or melting snow from the highlands. The greater part of its low-water summer supply is received from seepage from gravels and other pervious deposits, which make up a considerable portion of the plain's area.

\section{KANSAS RIVER.}

Kansas River is formed by the union of the Smoky Hill and Republican rivers in the northern part of Geary County, Kansas, 2 miles east of Junction City. It flows almost directly east a distance of 115 miles 
in a straight line and empties into the Missouri River at Kansas City. The length along the center line of the river is about 170 miles, according to measurements on the topographic atlas sheets. It falls from an elevation of 1,071 feet to 742 feet, or has a mean fall of 1.94 feet to the mile. From Kansas City to Manhattan the width varies from 500 to 1,000 feet. At the Lawrence gaging station, Pl. XXIX, $B$, it is 690 feet wide; at Lecompton gaging station it is about 800 feet wide; from Manhattan to the Junction it is 300 to 600 feet wide. The distance between 50 -foot contours is as follows:

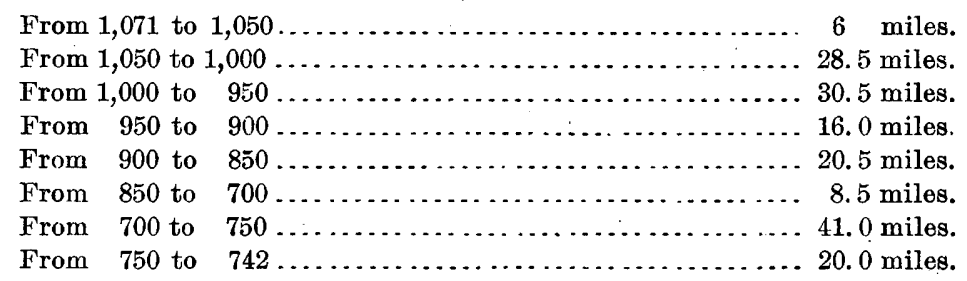

The principal tributaries are the Big Blue River; entering from the north near Mauhattan, and the Delaware, also entering from the north near Lecompton. A view of the latter is given on Pl. XXX, $A$.

\section{PRECIPITATION IN THE BASIN OF KANSAS RIVER.}

The principal observations of rainfall made within the basin of Kansas River are at Imperial, Wallace, Ough, Culbertson, Indianola, Precept, Holdrege, Minden, Redcloud, Harvard, David City, York, Crete, Geneva, Hebron, Fairbury, in Nebraska; and Sharon Springs, Wallace, Colby, Monument, Oberlin, Norton, Grainfield, Gove City, Eureka

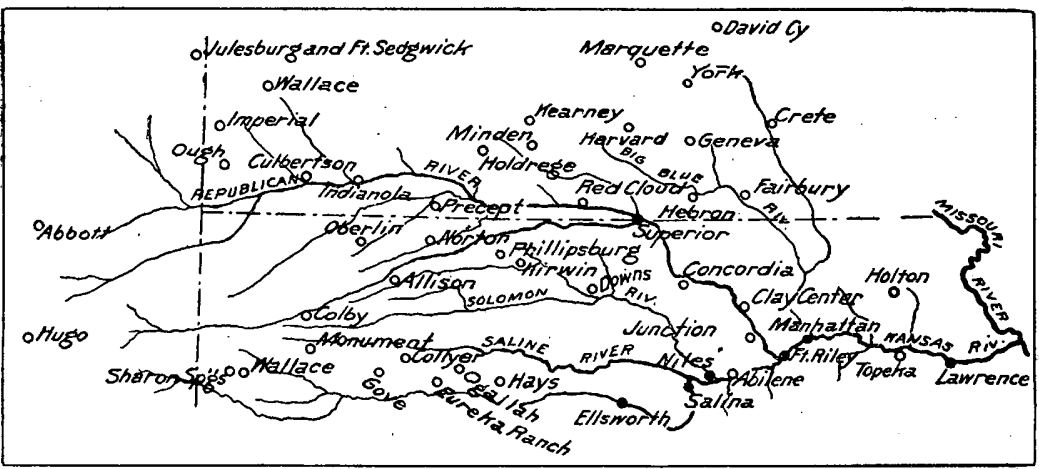

FIG. 113.-Relative location of river and rainfall observations in basin of Kansas River.

Ranch, Hays City, Phillipsburg, Kirwin, Downs, Concordia, Salina, Abilene, Fort Riley, Manhattan, Topeka, and Lawrence, in the State of Kansas. The relative location of these points is shown on fig. 115 in connection with the points of river measurement which are at Superior; Ellsworth, Salina, Niles, Junction City, Manhattan, and Lawrence. The following table gives the name and location of the stations, the 20 GEOL, PT $4-20$ 
elevation, and the number of years during which the observations have been made, or, rather, the number of complete monthly observations used in computing the normals:

\begin{tabular}{|c|c|c|c|c|c|c|}
\hline Station. & County. & State. & Latitude. & $\begin{array}{l}\text { Longi- } \\
\text { tude. }\end{array}$ & $\begin{array}{l}\text { Eleva- } \\
\text { tion. }\end{array}$ & $\begin{array}{l}\text { Length of } \\
\text { recorá. }\end{array}$ \\
\hline Imperial & Chase. & Nebraska. & $\begin{array}{c}\circ \\
40 \quad 30\end{array}$ & $\begin{array}{cc}\circ & \prime \\
101 & 43\end{array}$ & $\begin{array}{l}\text { Feet. } \\
3,278\end{array}$ & $\begin{array}{c}\text { Years. } \\
5-8\end{array}$ \\
\hline Wallace.... & Lincoln . & ....do . . & $40 \quad 49$ & 10114 & 3,116 & $5-7$ \\
\hline Ough ..... & Dundy & ....do & $40 \quad 19$ & 10130 & $\ldots \ldots \ldots$ & $6-7$ \\
\hline Culbertson . & Hitcheock & ....do & 4014 & 10049 & 2,576 & $9-11$ \\
\hline Indianola ..... & Red Willow & ...do & 4014 & 10023 & $2,37 \cdot 2$ & $10-12$ \\
\hline Precept ..... & Furnass. & .... do & 4003 & 9946 & 2,147 & $15-16$ \\
\hline Holdrege .. & Phelps .. & ....do .. & 4027 & 9922 & 2,324 & $5-8$ \\
\hline Minden & Kearney . & .... do. & 4030 & 9856 & 2,190 & 20 \\
\hline Redcloud ... & Webster. & .... do & $40 \quad 05$ & 9831 & 1,650 & $6-10$ \\
\hline Harvard ... & Clay:... & ... do & 4037 & 9802 & 1,812 & $7-9$ \\
\hline David City... & Butler... & $\ldots$... do .. & 4115 & 9706 & 1,619 & $9-10$ \\
\hline York ........ & York .... & ....do .. & 4053 & 9734 & 1,642 & $8-11$ \\
\hline Crete ... & Saline ... & ....do. & 4038 & 9659 & 1,368 & $17-18$ \\
\hline Geneva .... & Fillmore.. & ....do .. & 4032 & 9735 & 1,632 & $5-9$ \\
\hline Hebron & Thayer. & $\ldots$ do & $40 \quad 09$ & 9734 & 1,421 & $10-12$ \\
\hline Fairburg........ & Jefferson & ....do. & 4008 & 9708 & 1,318 & $13-14$ \\
\hline Sharon Springs. & Wallace & Kansas & 3854 & 10143 & 3,440 & $9-10$ \\
\hline Wallace... & .....do... & ....do & 3854 & 10135 & 3,253 & $22-24$ \\
\hline Colby ........... & Thomas ... & ... do . & 3920 & 10133 & 3,552 & $6-8$ \\
\hline Monument ..... & Logan .... & ...do do & 3906 & 10101 & 3,180 & $7-10$ \\
\hline Oberlin .... & Decatur ... & ....do. & 3948 & 10032 & 2,539 & $10-11$ \\
\hline Norton ..... & Norton .. & ...do & 3950 & 9952 & 2,284 & 6 \\
\hline Grainfield .. & Gove.... & ....do & 3906 & 10029 & 2,811 & $10-12$ \\
\hline Gove City... & .... do... & ...do & 3858 & 10030 & $\ldots$ & $8-9$ \\
\hline Eureka Ranch. & Trego .... & ... do & $\ldots$. & $\ldots \ldots$ & $\cdots$ & $\ldots \ldots$ \\
\hline Hays City... & Ellis ..... & ....do & 3850 & 9021 & 2,107 & $20-23$ \\
\hline $\begin{array}{l}\text { Phillipsburg } \\
\text { Kirwin...... }\end{array}$ & Phillips & ....do . & 3940 & 9908 & 1,939 & $9-11$ \\
\hline Downs..... & Osborne. & ....do & 3932 & 9825 & 1,488 & $19-20$ \\
\hline Concordia. & Cloud ... & $\ldots$. do & 3934 & 9740 & 1,410 & $12-13$ \\
\hline Salina .... & Saline ..... & ....do & 3850 & 9736 & 1,225 & $13-15$ \\
\hline Abilene .... & Dickinson & $\ldots$ do & 3855 & 9712 & 1,157 & $7-9$ \\
\hline Ft. Riley.... & Geary. .... & ...do & $\begin{array}{ll}39 & 02\end{array}$ & 9700 & 1,072 & $43-45$ \\
\hline Manhattan ..... & Riley ..... & .... do & $\begin{array}{lll}39 & 12\end{array}$ & 9637 & 1,125 & $36-40$ \\
\hline Topeka ......... & Shawnee & .... do .. & $\begin{array}{ll}39 & 03\end{array}$ & $95 \quad 39$ & 884 & $21-23$ \\
\hline Lawrence...... & Douglas & ....do & 3858 & 9514 & 849 & $32-34$ \\
\hline
\end{tabular}


In the following table are given the figures of normal average monthly precipitation from the time of the beginning of the record to and including 1897, together with the total precipitation by months for the years 1896, 1897, and 1898, and also the amount by years. In obtaining the normal precipitation the average is taken for all of the months during which the observations were made.

Rainfall at stations in drainage basin of Kansas River.

IMPERIAL.

\begin{tabular}{|c|c|c|c|c|c|c|c|c|c|c|c|c|c|}
\hline Year. & Jan. & Feb. & Mar. & Apr. & May. & June. & July. & Aug. & Sept, & Oet. & Nov. & Dec. & Annual. \\
\hline Normal ...... & 0.68 & 0.82 & 1.18 & 2. 36 & 2. 30 & 3.26 & 2.25 & 2.91 & 0.53 & 1.09 & 0.32 & 0.54 & 18.24 \\
\hline $1896 \ldots$ & 0.50 & 0.20 & 1.10 & 4. 30 & 1. 34 & 4.60 & 3.15 & 1.45 & 1.40 & 1.00 & 0.20 & 0.35 & 19.59 \\
\hline $1897 \ldots$ & 0.50 & 0.70 & 2.05 & 2.55 & 1.95 & 2.38 & 1. 23 & 6.03 & 0.51 & 3.87 & 0.52 & 0.70 & 22.99 \\
\hline 1898.. & 0.50 & 0.22 & 0.56 & 1.82 & 7.29 & 3.55 & 3. 37 & 0.88 & 4.02 & 0.30 & 0.86 & 0.92 & 24.29 \\
\hline \multicolumn{14}{|c|}{ W ALLACE, NEBR. } \\
\hline Normal & 0.69 & 0.60 & 1.27 & 2.75 & 1.56 & 3.48 & 2.68 & 1.62 & 0.29 & 0.50 & 0.17 & 0.35 & 15.96 \\
\hline $1896 \ldots$ & $0.5 \dot{0}$ & 0.20 & 2.60 & 4.59 & 0.80 & 3. 38 & 6. 06 & 1.86 & 0.96 & 0.70 & 0.10 & 0.50 & 22.25 \\
\hline 1897. & 0.23 & 0,50 & 1.35 & 2.23 & $\mathrm{~T}$ & 1.46 & 0.86 & 1.62 & 0.12 & 0.60 & 0.50 & 0.70 & 10.17 \\
\hline $1898 \ldots$ & 1.05 & 0.10 & 0.30 & 0.55 & 4. 80 & 2.26 & .... & ...... & 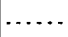 & ...... & ..... & 0.02 & $\ldots .$. \\
\hline \multicolumn{14}{|c|}{ OUGH. } \\
\hline Normal & 0.33 & 0.65 & 0.88 & 1.98 & 2.27 & 3.57 & 2.41 & 2.31 & 0.61 & 1.10 & 0.16 & 0.41 & 16.68 \\
\hline 1896. & 0.71 & 0.10 & 0.90 & 2.58 & 1.74 & 3.68 & 0.73 & 0.85 & 0.99 & 0.60 & T. & 0.25 & 13.13 \\
\hline 1897. & 0.20 & $\mathbf{T}$. & 2.19 & 2.85 & 0.68 & 2.76 & 1.30 & 5.78 & 0.63 & 3. 77 & 0.33 & 0.50 & 20.99 \\
\hline 1898.. & 0.20 & $\mathbf{T}$. & 0.45 & 3.80 & 5.50 & 3.24 & 1. 28 & 1.92 & 3.80 & 0.40 & 0.30 & T. & 20.89 \\
\hline \multicolumn{14}{|c|}{ - CULBERTSON. } \\
\hline Normal & 0.45 & 0.54 & 0.94 & 3.02 & 2.46 & 3.94 & 2.95 & 3.07 & 1.12 & 1.05 & 0.27 & 0.39 & 20.20 \\
\hline 1896. & 0.56 & 0.00 & 0.57 & 4. 38 & 2. 77 & 3.08 & 0.53 & 2.67 & 1.97 & 1.80 & 0.10 & $\mathrm{~T}$. & 18.43 \\
\hline 1897. & 0.71 & 0.77 & 1.90 & 4.73 & 0.75 & 8.67 & 1.29 & 2.95 & 1.13 & 4.84 & 0.38 & 0.85 & 28.97 \\
\hline $1898 \ldots$ & 0.40 & 0.00 & 0.24 & 3.02 & 3.84 & 3.48 & 1.44 & 1.34 & 3.90 & 2.52 & 0.37 & 0.07 & 20.62 \\
\hline \multicolumn{14}{|c|}{ INDIANOLA. } \\
\hline Normal & 0.62 & 0.76 & 0.78 & 2.11 & 2.57 & 3.61 & 2.69 & 2.51 & 1. 42 & 1.43 & 0.21 & 0.74 & 19.45 \\
\hline $1896 \ldots$ & T. & 0.00 & 1.00 & 3. 70 & 2.44 & 3.59 & 1. 37 & 2.95 & 1.54 & 1.87 & 0.15 & $\mathbf{T}$ & 18.61 \\
\hline $1897 .$. & 0.80 & 0.47 & 1.00 & 5. 23 & 0.74 & 6.31 & 0.75 & 0.82 & 1.88 & 4.86 & 0.30 & 1.25 & 24.51 \\
\hline 1898. & 0.60 & 0.00 & 0.25 & 3.18 & 5.22 & & & .. & .. & & & C...... & \\
\hline \multicolumn{14}{|c|}{ PRECEPT. } \\
\hline Normal & 0.55 & 0.75 & 0.86 & 3.00 & 3.85 & 4.42 & 4.04 & 2.81 & 1.68 & 1.53 & 0.51 & 0.79 & 24.79 \\
\hline $1896 \ldots$ & 0.56 & 0.06 & 0.56 & 4.98 & 2.68 & 5.83 & 3.28 & 2.54 & 2.15 & 0.87 & 0.33 & 0.14 & 23.98 \\
\hline $1897 . \ldots$ & 0.28 & 0.38 & 1.30 & 5. 30 & 0.85 & 3.54 & 3.13 & 1.50 & 2.16 & 4.81 & 0.39 & 1.09 & 24.73 \\
\hline 1898 & $\ldots$ & & & & & & & ${ }_{1}$ & & & & $\ldots \ldots$ & $\ldots$ \\
\hline
\end{tabular}




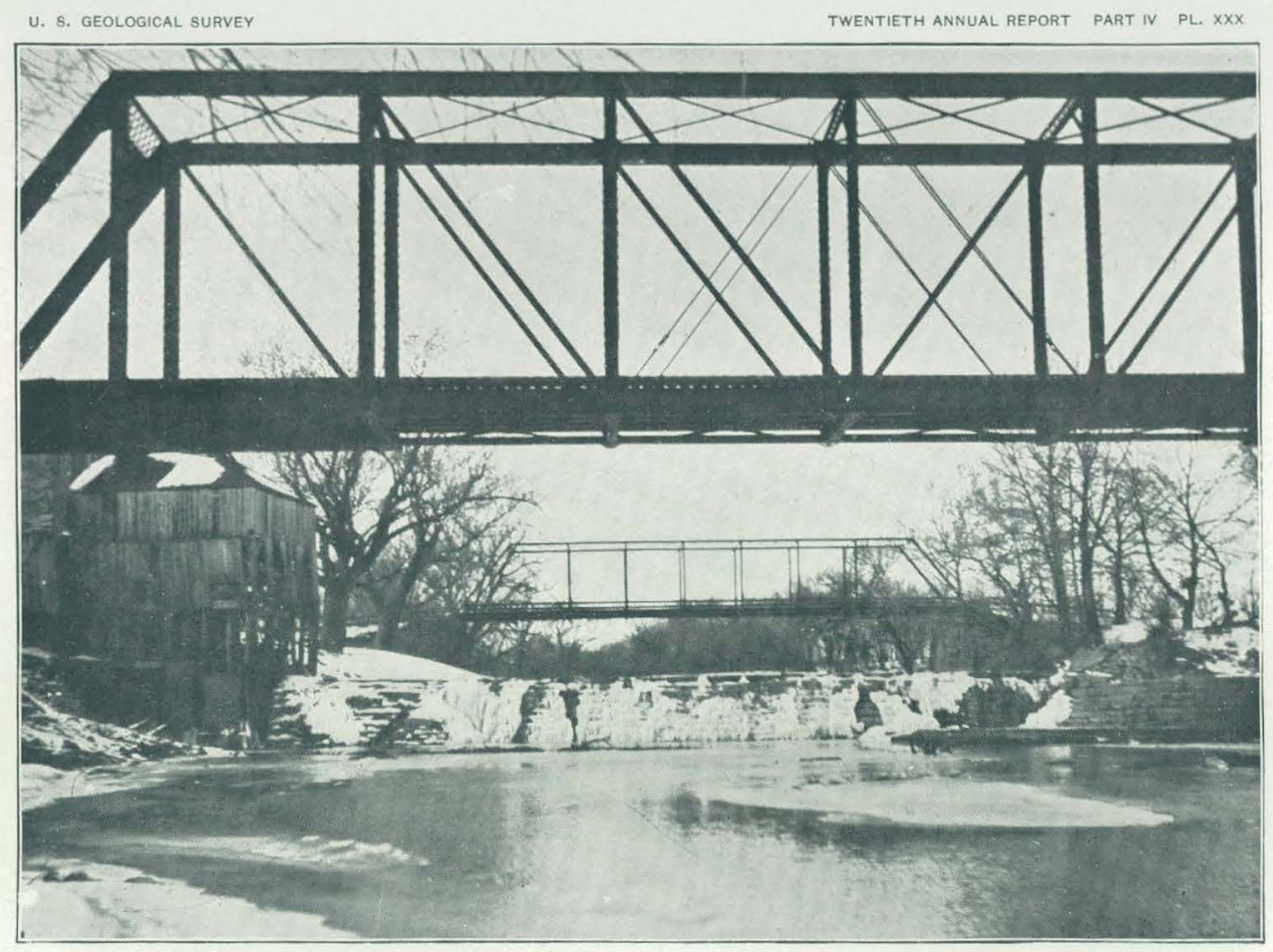

A. DAM ON DELAWARE RIVER NEAR VALLEY FALLS, KANSAS.

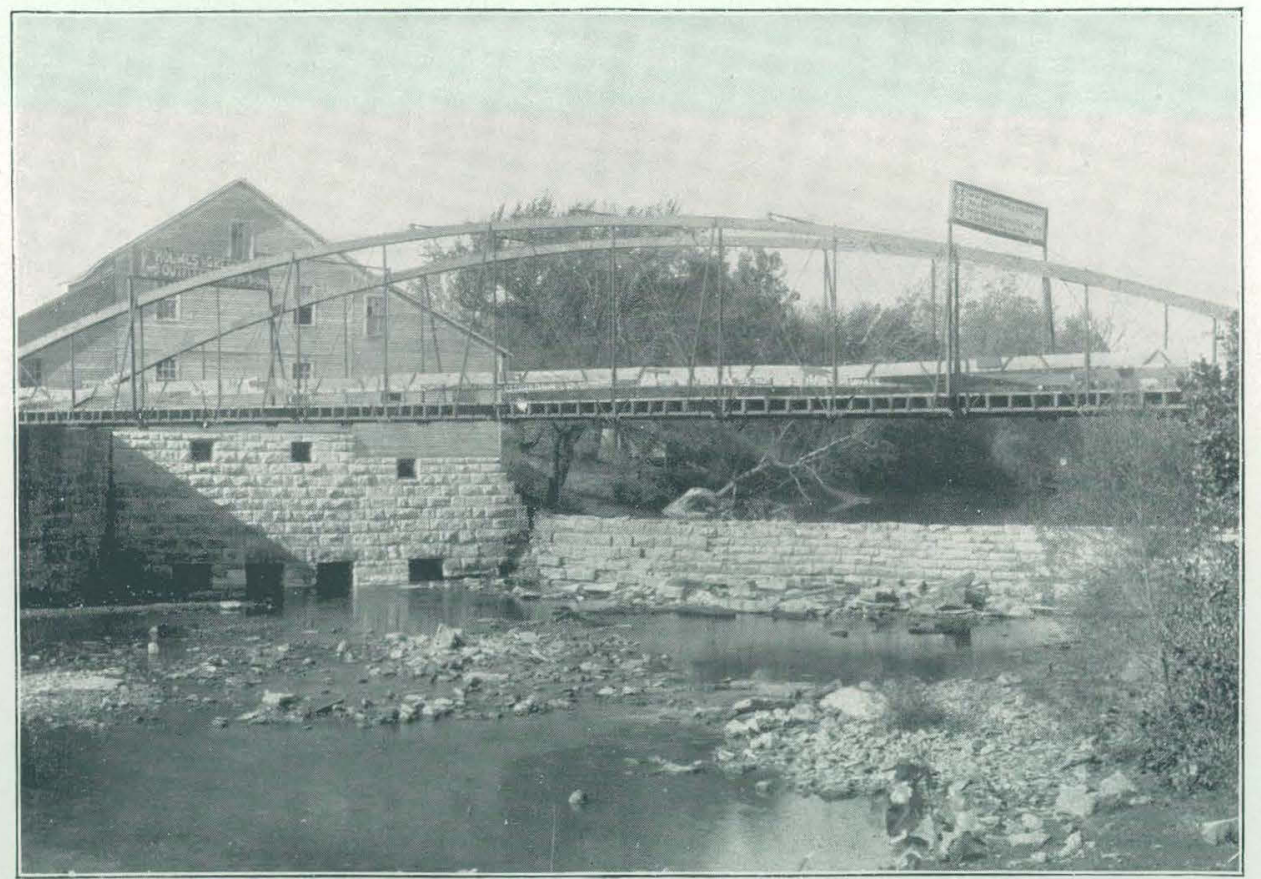

B. COTTONWOOD RIVER AT COTTONWOOD FALLS, KANSAS 


\section{PROGRESS OF STREAM MEASUREMENTS FOR 1898.}

Rainfall at stations in drainage basin of Kansas River-Continued. HOLDREGE.

\begin{tabular}{|c|c|c|c|c|c|c|c|c|c|c|c|c|c|}
\hline Year. & Jan. & Feb. & Mar. & Apr. & May. & June. & July. & Aug. & Sept. & Oct. & Nov. & Dec. & Annual. \\
\hline Normal & 0.61 & 1.02 & 1.06 & 3.05 & 3.96 & 3.74 & 2.44 & 2.27 & 1.87 & 1.23 & 0.49 & 0.58 & 22.32 \\
\hline 1896. & $|\ldots \ldots|$. & ...... & 1.20 & 5.80 & 4.97 & …. & 3.12 & $\ldots .$. & 2.36 & 0.70 & ....... & ....... & | \\
\hline 1897. & 0.70 & 1.01 & 2.30 & 5.80 & 2.80 & 3.45 & 3.85 & 0.95 & 2.30 & 4.35 & 0.27 & 1.00 & 28.78 \\
\hline $1898 \ldots$ & 0.80 & 0.25 & 0.03 & 3.35 & 4.96 & 3.85 & 1.85 & 1.83 & 5.05 & 0.73 & 0.10 & $\mathrm{~T}$. & 22.80 \\
\hline \multicolumn{14}{|c|}{ MINDEN. } \\
\hline Normal & 1.10 & 1.10 & 1.50 & 3.90 & 5.20 & 5.20 & 5. 90 & 3.20 & 2.40 & 2.10 & 1.00 & 0.80 & 32.5 \\
\hline 1896. & 0.75 & 0.15 & 1.72 & 10.82 & 6.28 & 2.61 & 3.54 & 2.61 & 2.63 & 1.87 & 1.77 & 0.09 & 34.84 \\
\hline 1897. & 0.80 & 1.25 & 1.93 & 4.48 & 2.11 & 4.99 & 3.05 & 2.27 . & 1.04 & 7.34 & 0.97 & 1.61 & 31.84 \\
\hline $1898 \ldots \ldots$ & 0.31 & 0.44 & 2.30 & 3.96 & 4.91 & 4.11 & 1.50 & 3.95 & 4.39 & 1.04 & 0.89 & 0.30 & 26.03 \\
\hline \multicolumn{14}{|c|}{ REDCLOUD. } \\
\hline Normal & 0.27 & 0.50 & 0.59 & 3.16 & 3.74 & 5.54 & 3.42 & 2.65 & 2.28 & 1.71 & 0.56 & 0.53 & 24.95 \\
\hline $1896 \ldots$ & 0.49 & 0.05 & 0.94 & 5.31 & 5.48 & 2.85 & 1.68 & 5.69 & 2.39 & 2. 39 & 1.56 & 0.25 & 29.08 \\
\hline 1897. & 0.40 & 0.35 & 0.93 & 4.97 & 1.63 & 10.93 & 4. 32 & 1.06 & 1.44 & 5.21 & 0.60 & 0.84 & 32.69 \\
\hline $1898 \ldots$ & 0.45 & 0.15 & 0.27 & 3.10 & 3.25 & 1.30 & 1.63 & $0: 28$. & 4.75 & 0.84 & 0.93 & 0.73 & 17.68 \\
\hline \multicolumn{14}{|c|}{ HARVARD. } \\
\hline Normal & 1.10 & $0.83^{\circ}$ & 1. 22 & 3.69 & 4.07 & 3.96 & 2. 52 & 2.88 & 1.82 & 2.47 & 0.81 & 0.86 & 26.23 \\
\hline 1896. & 0.30 & 0.25 & 1.45 & 9.27 & 6.55 & 1.85 & 3. 19 & 2. 27 & 3.04 & 2.94 & 1.49 & 0.06 & 32.66 \\
\hline 1897. & 1.25 & 0.60 & 1.86 & 4.19 & 3.06 & 3.74 & 1.79 & 2.56 & 1.34 & 4.27 & 0.57 & $1.62^{\circ}$ & 26.85 \\
\hline 1898. . & 0.30 & 1.00 & 0.40 & 4.38 & 3.05 & 6.02 & 0.77 & 5.11 & 4.37 & 1.62 & 0.67 & 0.38 & 28. 07 \\
\hline \multicolumn{14}{|c|}{ DAVID CITY. } \\
\hline Normal & 0.92 & 0.73 & 1.85 & 3.72 & 3. 31 . & 4.59 & 3.85 & 2.82 & 1.84 & 2.03 & 0.82 & 0.82 & 27.30 \\
\hline 1896 & 0.60 & 0.25 & 2.70 & 10.25 & 7.60 & 2.80 & 6.90 & 1.45 & 4.25 & 3.30 & 2.60 & 0.25 & 42.95 \\
\hline $1897 \ldots$ & 0.95 & 0.50 & 1. 75 & 6. 60 & 2.65 & 2.00 & 1.90 & 3. 30 & 1. 10 & 4.10 . & 0.30 & 1.30 & 26.45 \\
\hline 1898. & 0.75 & 0.50 & 0.75 & 2.75 & 6.80 & 5. 30 & 0.70 & 2. 80 & 2.20 & 1.65 & 0.80 & 0.40 & 25.40 \\
\hline \multicolumn{14}{|c|}{ YORK. } \\
\hline Normal & 0.58 & 0.80 & 1.37 & 3.88 & 3.90 & 4. 44 & 3.54 & 2.58 & 1.72 & 1. 74 & 0.72 & 0.58 & 25.85 \\
\hline 1896. & 0.90 & 0.00 & 1.94 & 11. 22 & 7.19 & 3.32 & 3.71 & 1.25 & 4.12 & 2.46 & 1.40 & 0.21 & 37.72 \\
\hline $1897 \ldots$ & 0.50 & 1.10 & 2.80 & 5.45 & 2.24 & 1.76 & 1.60 & 1.68 & 0.72 & 4.52 & 0.60 & 1.30 & 24.27 \\
\hline $1898 \ldots$ & 0.50 & 0.70 & 0.75 & 4. 73 & 4.63 & 4.76 & 0.28 & 1.39 & 2.16 & 1. 20 & 0.30 & 0.80 & 22.20 \\
\hline \multicolumn{14}{|c|}{ CRETE. } \\
\hline Normal. & 0.8 & 0.9 & 1.8 & 2.7 & 4.5 & 4. 6 & 3.9 & 3.2 & 1.8 & 2.2 & 0.6 & 0.6 & 27.6 \\
\hline 1896. & 0.54 & 0.19 & 2.45 & 4.45 & 7.98. & 3. 71 & 8.21 & 3. 66 & 3.85 & 3.89 & 1.58 & 0.52 & 40.99 \\
\hline $1897 \ldots$ & 1.45 & 0.90 & 3.07 & 4.38 & 1.69 & 2.41 & 3.73 & 3.50 & 1.11 & 4.23 & 0.35 & 1.10 & 27.92 \\
\hline $1898 \ldots$ & 0.29 & 1.23 & 0.40 & 4.25 & 3.30 & 3.92 & 1.84 & 2.76 & 2.25 & 1.44 & 0.50 & 0.60 & 22.78 \\
\hline \multicolumn{14}{|c|}{ GENEVA: } \\
\hline Normal & 0.63 & 1.21 & 1.22 & 3.25 & 4.57 & 4.95 & 2.82 & 3.72 & 2.03 & 2.41 & 0.83 & 0.72 & 28.38 \\
\hline $1896 \ldots$ & 0.47 & 1.25 & 1.56 & 7.11 & 5.38 & 4.25 & 1.98 & 4. 96 & 4. 11 & 3. 32 & 1.98 & 0.19 & 36.56 \\
\hline $1897 . \ldots$ & 0.60 & 0.93 & 1.61 & 4.69 & 2.61 & 4.42 & 2,39 & 3.04 & 2.94 & 5.79 & 0.45 & 1.05 & 30.52 \\
\hline $1898 \ldots$ & 0.86 & 0.87 & 0.25 & 2.78 & 5.35 & 11.62 & 0.35 & 4.97 & 3.35 & 2.14 & 0.82 & 0.75 & 34.11 \\
\hline
\end{tabular}


Rainfall at stations in drainage basin of Kansas River-Continued.

HEBRON.

\begin{tabular}{|c|c|c|c|c|c|c|c|c|c|c|c|c|c|}
\hline Year. & Jan. & Feb. & Mar. & Apr. & May. & June. & July. & Aug. & Sept. & Oct. & Nov. & Dec. & Annual. \\
\hline Normal ....... & 0.88 & 0.60 & 1.70 & 2.39 & 4.35 & 4.33 & 4.15 & 3.37 & 2.28 & 1.64 & 1.13 & 0.56 & 27.38 \\
\hline $1896 .$. & 0.40 & 0.13 & 1.03 & 3.52 & 6.00 & 4.45 & 4.63 & 4.65 & 3.21 & 3.31 & 1.67 & 0.26 & 33.26 \\
\hline $1897 . \ldots \ldots \ldots \ldots$ & 0.65 & 0.42 & 1.33 & 3.12 & 3.27 & 5.52 & 3.56 & 2.63 & 1.22 & 4.70 & 0.45 & 1.00 & 27.87 \\
\hline $1898 \ldots$ & 1.16 & 0.71 & 0.88 & 3.91 & 4.63 & 6.11 & 0.71 & 1.76 & 2.47 & 1.12 & 1.00 & 0.94 & 25.40 \\
\hline \multicolumn{14}{|c|}{ FAIRBंURY. } \\
\hline Normal ....... & 0.7 & 0.7 & 1.8 & 2.4 & 4.4 & 3.8 & 5.0 & $3: 2$ & 2.1 & 2.3 & 0.7 & 0.7 & 27.8 \\
\hline $1896 .$. & 0.18 & 0.18 & $0.4 \overline{5}$ & 2.34 & 8.75 & 5.77 & 2.78 & 5.49 & 3.22 & 2.82 & 1.14 & 0.40 & 33.52 \\
\hline $1897 \ldots$ & 0.44 & 0.20 & 1.15 & 3.35 & 3.65 & 5.82 & 6.26 & 3.37 & 1.37 & 4.97 & 0.36 & 1.40 & 32.34 \\
\hline $1898 \ldots \ldots \ldots$ & 1.02 & 1.09 & 1.30 & 5.66 & 5.14 & 3.07 & 0.80 & 1.46 & 3.72 & 1.89 & 0.92 & 0.90 & 26.97 \\
\hline \multicolumn{14}{|c|}{ SHARON SPRINGS. } \\
\hline Normal.. & 0.52 & 0.59 & 1.01 & 1.88 & 2.03 & 2.95 & 2.99 & 2.57 & 0.76 & 0.93 & 0.19 & 0.52 & 16.94 \\
\hline 1896. & 0.25 & $\mathrm{~T}$. & 0.75 & 3.00 & $\mathbf{T}$ & 2.25 & 2.12 & 2.50 & 1.25 & 1.00 & $\mathrm{~T}$. & 0.75 & 13.87 \\
\hline $1897 \ldots$ & $(0.52)$ & 0.70 & 1.50 & 3.00 & 0.00 & 4.10 & 3.75 & 3.45 & 1.75 & 3.00 & 0.40 & 0.30 & 22.47 \\
\hline 1898. & 0.20 & $\ldots \ldots$ & 0.15 & & & & & & & $\cdots$ & & & - \\
\hline \multicolumn{14}{|c|}{ WALLACE. KANSAS. } \\
\hline Normal & 0.2 & 0.4 & 0.5 & 1.7 & 2.6 & .2 .2 & 3.4 & 1.8 & 1.3 & 0.9 & 0.4 & $0.4^{\prime \prime}$ & 15.8 \\
\hline $1896 \ldots$ & 0.16 & T. & 0.32 & 3. 37 & 0.39 & 1. 10 & 4.48 & 2.00 & 1.06 & 0.93 & 0.07 & 0.38 & 14.26 \\
\hline $1897 .$. & 0.01 & 0.15 & 0.81 & 2.09 & 0.49 & 1.58 & 2.72 & 4.83 & 1. 79 & 4.43 & 0.35 & 0.36 & 19.61 \\
\hline 1898. & 0.30 & 0.00 & 0.19 & 0.75 & 5.17 & 1.43 & 3.47 & 1.20 & 1.33 & 0.62 & T. & 0.70 & 15.16 \\
\hline \multicolumn{14}{|c|}{ COLBY. } \\
\hline Normal & 0.39 & 0.42 & 0.72 & 2.18 & 2.35 & 3.68 & 2.63 & 2.42 & 1.08 & 1.36 & 0.32 & 0.36 & 17.91 \\
\hline $1896 \ldots$ & 0.46 & 0.10 & 0.48 & 5.11 & 2.13 & 5.39 & 2.00 & 2.83 & 1.47 & 1.62 & 0.25 & 0.16 & 22.00 \\
\hline $1897 \ldots$ & 0.22 & 0.65 & 2.13 & 4.06 & 1.73 & 4.74 & 1.83 & 4.84 & 3.19 & 5.50 & 0.18 & 0.47 & 29.54 \\
\hline $1898 .$. & 0.04 & 0.02 & 0.24 & 1.11 & 4.51 & 2.85 & 1.35 & 0.64 & 3.00 & 0.55 & 0.35 & 0.42 & 15.08 \\
\hline \multicolumn{14}{|c|}{ MONUMENT. } \\
\hline Normal. & 0.32 & 0.60 & 0.66 & 2.60 & 2.27 & 3.36 & 2.81 & 1.81 & 1.00 & 0.73 & 0.43 & 0.22 & 16.81 \\
\hline $1896 \ldots$ & 1.00 & T. & 0.35 & 4.70 & 1.25 & 2.58 & 2.50 & 2.50 & 1.75 & 1.10 & $\mathrm{~T}$. & 0.50 & 18.23 \\
\hline $1897 \ldots$ & 0.02 & 0.50 & 1.25 & 3.75 & 0.00 & 1.08 & 4. 50 & 5.25 & 2.75 & 4.50 & $0 . \overline{00}$ & 0.35 & 23.95 \\
\hline 1898. & $\cdots$ & ….... & & $\cdots \cdots$ & $\cdots$ & & & & & & & & \\
\hline \multicolumn{14}{|c|}{ OBERLIN. } \\
\hline Normal & 0.48 & 0.88 & 1.77 & 3.61 & 3.60 & 3.87 & 4.00 & 2.41 & 1.42 & 1.16 & 0.56 & 0.67 & 24.43 \\
\hline $1896 \ldots \ldots$ & 0.40 & 0.20 & 0.90 & 6.01 & 4.47 & 5.36 & 2.82 & 2.88 & 1.60 & 1.75 & 0.50 & 0.10 & 25.49 \\
\hline $1897 \ldots$ & $0: 40$ & 1.10 & 3.30 & 6.70 & 0.28 & 5.00 & 2.65 & 4. 75 & 2.94 & 5.07 & 0.50 & 1.80 & 34.49 \\
\hline $1898 \ldots$ & $(0.48)$ & 0.00 & 0.40 & 2. 18 & 5.03 & 3.43 & 5.30 & 1. 35 & 5.61 & 1.70 & 1.00 & 0.40 & 26.88 \\
\hline \multicolumn{14}{|c|}{ NORTON. } \\
\hline Normal .. & 0.39 & 0.61 & 0.49 & 1. 28 & 2.23 & 3.21 & 4.35 & 1. 74 & 2.68 & 0.90 & 0.29 & 0.85 & 19.02 \\
\hline $1896 \ldots \ldots \ldots$ & 0.45 & $\mathrm{~T}$. & 0.10 & 1.61 & 0.70 & 1.64 & 0.90 & 0.22 & 2.01 & 0.75 & 0.24 & 0.68 & 9.30 \\
\hline $1897 \ldots \ldots \ldots$ & 0.80 & 1.55 & 0.10 & 3. 49 & …... & ...... & ...... & ...... & ........ & & …... & $\cdots$ & 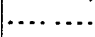 \\
\hline $1898 \ldots$ & 0.19 & 0.01 & 0.16 & 3.62 & 5.60 & ...... & 4.98 & 1.87 & & & 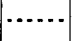 & & \\
\hline
\end{tabular}




\section{PROGRESS OF STREAM MEASUREMENTS FOR 1898.}

Rainfall at stations in drainage basin of Kansas River-Continued. GRAINFIELD.

\begin{tabular}{|c|c|c|c|c|c|c|c|c|c|c|c|c|c|}
\hline Year. & Jan. & Feb. & Mar. & Apr. & May. & June. & July. & Ang. & Sept. & Oct. & Nov. & Dec. & Annual. \\
\hline Normal & 0.4 & 0.6 & 1.3 & 3.3 & 3.8 & 3.2 & 3.5 & 1.8 & 1.7 & 1.1 & 0.3 & 0.2 & 21.2 \\
\hline 1896. & T. & $\mathbf{T}$. & 0.20 & 4. 22 & 2.92 & 6.41 & 4.55 & 4.15 & 3.50 & 2.10 & T. & T. & 28.45 \\
\hline 1897. & T. & 0.50 & 6.00 & 3.80 & 1.50 & 4.02 & 3. 75 & 3.00 & 2.70 & 1.50 & $\mathrm{~T}$. & 0.30 & 27.07 \\
\hline 1898. & 0.45 & 0.00 & 0.02 & $\ldots$ & .. & ..... & $\ldots$ & $\ldots$ & ..... & $\ldots$ & ....... & $\ldots$ & .... \\
\hline \multicolumn{14}{|c|}{ GOVE. } \\
\hline Normal & 0.60 & 0.84 & 0.78 & 2.27 & 2. 60 & 3.68 & 3.94 & 1.54 & 2.06 & 0.92 & 0.48 & 0.42 & 20.13 \\
\hline 1896 & 0.78 & 0.00 & 0.45 & 4.08 & 2.80 & 4. 31 & 3.03 & 1.61 & 4.15 & 2. 00 & 0.20 & 0.12 & 23.53 \\
\hline 1897. & 0.20 & 1.00 & 1.75 & 4.68 & 3.53 & 4.49 & 4. 77 & 1.87 & 3.42 & 2.67 & 0.15 & 0.30 & 28.83 \\
\hline $1898 .$. & 0.40 & 'T. & 0.27 & 1.66 & 6.65 & 5. 41 & 1. 27 & 0.91 & 4.54 & $(0.92)$ & 0.80 & 0.82 & 23.65 \\
\hline \multicolumn{14}{|c|}{ EUREKA RANCH. } \\
\hline Normal & 0.79 & 0.93 & 0.87 & 2.11 & 2.66 & 2.78 & 3. 37 & 1.94 & 1.28 & 1.31 & 0.50 & 0.64 & 19.18 \\
\hline 1896. & 0.68 & 0.02 & 0.55 & 3.69 & 2.41 & 4.42 & 1.81 & 1.17 & 1.37 & 2.05 & 0.35 & 0.15 & 18.67 \\
\hline $1897 .$. & 0.69 & 0.49 & 0.35 & 5.96 & 1.15 & 2.00 & 3.28 & 1.75 & 1.11 & 2.57 & 0.07 & 0.27 & 19.69 \\
\hline 1898. & 1.28 & 0.25 & 0.36 & 1.22 & 5.25 & 2.25 & 0.82 & 0.78 & 6.53 & 0.42 & 1.02 & 0.55 & 20.73 \\
\hline \multicolumn{14}{|c|}{ HAYS. } \\
\hline Normal. & 0.75 & 0.88 & 1.82 & 2.34 & 2.92 & 2.79 & 3.11 & 3.17 & 2.59 & 1.39 & 0.96 & 1.40 & 24.12 \\
\hline 1896. & 0.50 & $\mathbf{T}$. & 0.45 & 4.50 & 3.01 & 6.19 & 1.64 & 1.95 & 4.90 & 3.85 & 0.35 & 0.30 & 27.70 \\
\hline 1897. & 0.20 & 0.50 & 1.60 & 7.92 & 1.65 & 3.10 & 2.83 & $(3.17)$ & 2.66 & 3.75 & T. & 0.30 & 27.68 \\
\hline 1898. & ....... & 0.25 & $\ldots$. & 2.38 & 10.42 & 1.97 & 2.36 & 1.40 & 7.21 & ….... & $\cdots$ & $\cdots \cdots$ & \\
\hline \multicolumn{14}{|c|}{ KIRWIN AND PHILLIPSBURG. } \\
\hline Normal. & 0.60 & 0.70 & 1.18 & 2.32 & 2.71 & 3.75 & 4.15 & 2.30 & 1. 71 & 1.45 & 0.45 & 0.42 & 21.74 \\
\hline $1896 .$. & 1.23 & 0.20 & 1.00 & 4.55 & 3. 99 & 5. 02 & 5.68 & 5.10 & 2.88 & 1.64 & $\mathrm{~T}$. & 0.62 & 31.91 \\
\hline 1897. & 1.58 & $(0.70)$ & 1. 70 & .4 .56 & 0.18 & 4.29 & $(4.15)$ & 1.81 & 2.41 & 5.18 & 0.10 & 0.90 & 27.56 \\
\hline $1898 \ldots$ & 1.20 & 0.15 & 0.20 & 3.26 & 3.39 & 3.57 & 3.44 & 1.57 & 5.20 & 1.06 & 1.30 & 0.53 & 24.87 \\
\hline \multicolumn{14}{|c|}{ DOWNS. } \\
\hline Normal & 0.9 & 1.0 & 1.2 & 2.7 & 2.3 & 4.0 & 4.2 & 2.6 & 2.1 & 1.7 & 1.0 & 0.6 & 25.30 \\
\hline $1896 \ldots$ & 0.91 & 0.25 & 1.14 & 7.10 & 5.08 & 3.10 & 2.65 & 2.65 & 4.24 & 3.11 & 0.56 & 0.20 & 30.99 \\
\hline 1897. & 0.85 & 0.92 & 1.03 & 5.04 & 1.98 & .... & ........ & $\cdots$ & n...... & ........ & ....... & $\cdots$ & n........ \\
\hline 1898. & ...... & ....... & ..... & $\cdots$ & & $\alpha_{1}$ & ..... & $\cdots$ & ... & ....... & & $\cdots$ & 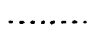 \\
\hline \multicolumn{14}{|c|}{ CONCORDIA. } \\
\hline Normal & 0.78 & 0.85 & 1.67 & 2.29 & 4.27 & 4.43 & 3.77 & 2.83 & 2.35 & 1.93 & 0.82 & 0.48 & 26.47 \\
\hline $1896 .$. & 0.52 & 0.30 & 1.02 & 2.60 & 6.46 & 2.12 & 9.27 & 3.09 & 3.53 & 2.56 & 1.78 & 0.09 & 33.34 \\
\hline $1897 .$. & 0.91 & 0.52 & 1.44 & 4.20 & 2.13 & 6.82 & 5. 31 & 1.88 & 1.20 & 5.80 & 0.39 & 0.85 & 31.45 \\
\hline 1898. & $\ldots$. & & & & & & & & & & & & \\
\hline \multicolumn{14}{|c|}{ SALINA. } \\
\hline Normal & 0.7 & 0.7 & 1.3 & 2.7 & 4.1 & 4.1 & 4,0 & 2.8 & 1.8 & 2.2 & 0.6 & 0.8 & 25.80 \\
\hline $1896 .$. & 0.40 & 0.18 & 0.87 & 5.39 & 5.41 & 9. 97 & 6.16 & 2.08 & 3.07 & 3.01 & 1.13 & 0.27 & 37.94 \\
\hline $1897 \ldots$ & 1.00 & 1.66 & 1.60 & 3.72 & 1.54 & 1.83 & 2.91 & 2.00 & 1.15 & 2.29 & 0.01 & 0.79 & 20.50 \\
\hline $1898 \ldots$ & 1.71 & 0.33 & 0.87 & 3.48 & 5.45 & 2.92 & 2.61 & 0.97 & 3.08 & 1.67 & 0.83 & 1. 67 & 25.59 \\
\hline
\end{tabular}


Rainfall at stations in drainage basin of Kansas River-Continued.

ABILENE.

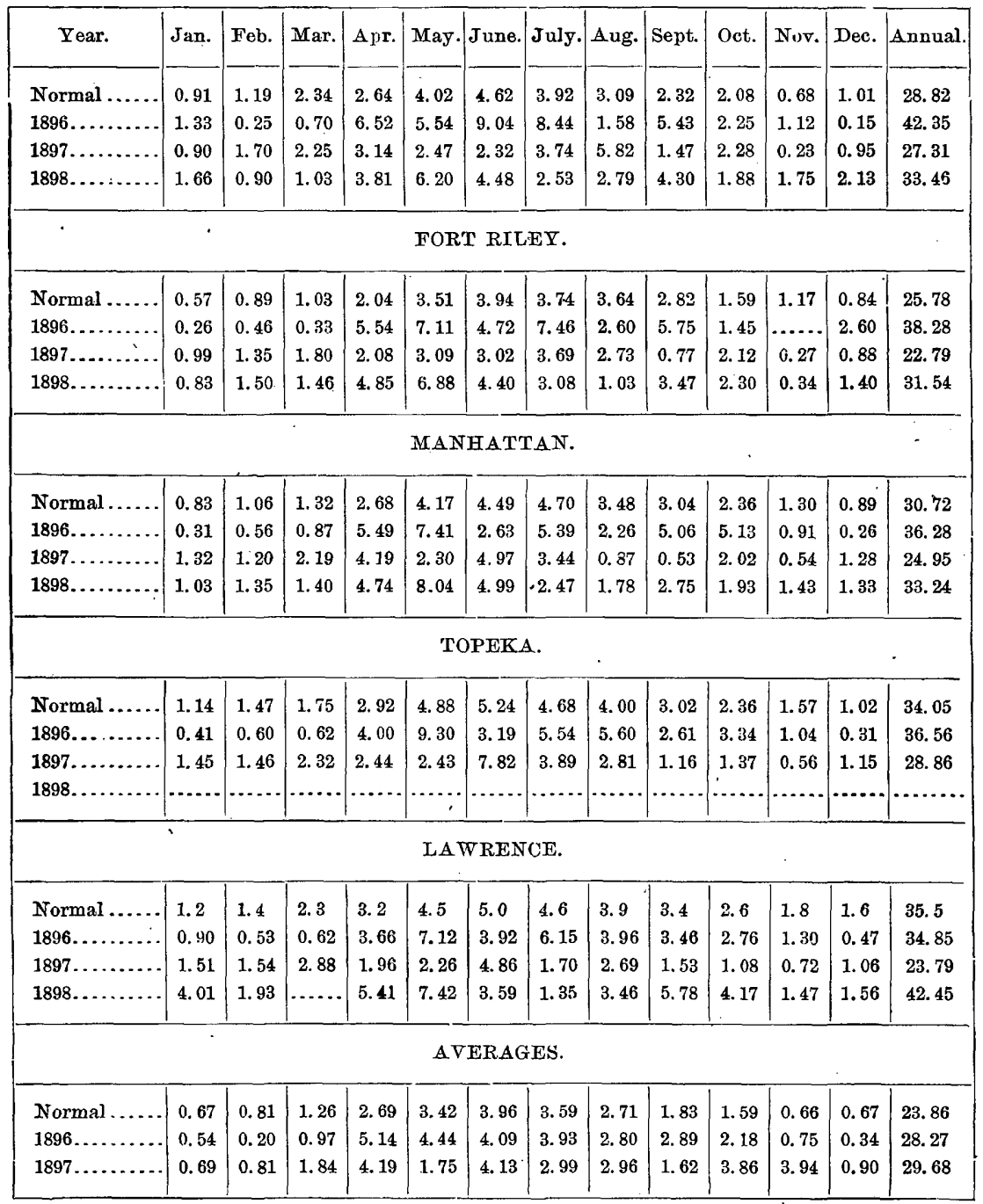

Depth of run-off, in inches, from Kansas drainage basin. REPUBLICAN AT SUPERIOR.

\begin{tabular}{|c|c|c|c|c|c|c|c|c|c|c|c|c|c|}
\hline Xear. & Jan. & Feb. & Mar. & Apr. & May & June & July. & Aug. & Sept. & Oet. & Nov. & Dec. & Anniual. \\
\hline 1897. & 0.04 & 0.04 & 0.03 & 0.06 & 0.02 & 0.02 & 0.05 & 0.01 & 0.003 & & & & \\
\hline $1898 .$. & ...... & ........ & .. & 0.01 & 0.06 & 0.07 & 0.02 & 0.01 & 0.01 & 0.01 & 0.01 & & \\
\hline Average & 0.04 & 0.04 & 0.03 & 0.04 & 0.04 & 0.05 & 0.04 & 0.01 & 0.02 & 0.01 & 0.01 & & \\
\hline
\end{tabular}




\section{2}

PROGRESS OF STREAM MEASUREMENTS FOR 1898.

Depth of run-off, in inches, from Kan'sas drainage basin-Continued. REPUBLICAN AT JUNCTION CITTY.

\begin{tabular}{|c|c|c|c|c|c|c|c|c|c|c|c|c|c|}
\hline Iear. & Jan. & Feb. & Mar. & Apr. & May. & June. & July. & Aug. & Sept. & Oct. & Nov. & Dec. & Annual. \\
\hline 1895. & $\cdots$ & $\cdots$ & $\ldots$. & & 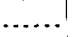 & $\ldots \ldots$ & 0.09 & 0.16 & 0.03 & 0.01 & 0.01 & 0.02 & \\
\hline $1896 \ldots \ldots \ldots$ & 0.02 & 0.03 & 0.02 & 0.06 & 0.09 & 0.06 & 0.16 & 0.04 & 0.03 & 0.02 & 0.03 & 0.04 & 0.60 \\
\hline $1897 .$. & 0.03 & 0.05 & 0.04 & 0.09 & 0.04 & 0.07 & 0.08 & 0.03 & 0.01 & 0.01 & 0.03 & 0.03 & 0.50 \\
\hline $1898 \ldots \ldots \ldots$ & 0.03 & 0.04 & 0.03 & 0.04 & 0.09 & 0.09 & 0.02 & 0.01 & 0.01 & 0.01 & 0.01 & 0.02 & 9.40 \\
\hline Average. & 0.03 & 0.04 & 0.03 & 0.06 & 0.07 & 0.07 & 0.09 & 0.06 & 0.02 & 0.01 & 0.02 & 0.03 & 0.53 \\
\hline \multicolumn{14}{|c|}{ BLUE AT MANHATTAN. } \\
\hline 1895 . & $\cdots$ & $\cdots \cdot$ & ..... & 0.04 & 0.07 & 0.19 & 0.10 & 0.24 & 0.15 & 0.06 & 0.07 & 0.07 & $\ldots$ \\
\hline $1896 \ldots$ & 0.07 & 0.06 & ...... & 0.13 & 0.59 & 0.55 & 0.67 & 0.31 & 0.19 & 0.13 & 0.14 & 0.09 & 3.06 \\
\hline $1897 \ldots$ & 0.12 & 0.14 & 0.17 & 0.93 & 0.28 & 0.35 & 0.31 & 0.21 & 0.07 & 0.07 & 0.08 & 0.09 & 2.82 \\
\hline $1898 \ldots$ & 0.08 & 0.23 & 0.09 & 0.18 & 0.43 & 0.53 & 0.09 & 0.06 & 0.04 & 0.04 & 0.06 & 0.07 & 1.90 \\
\hline Average. & 0.09 & 0.14 & 0.13 & 0.32 & 0.34 & 0.41 & 0.29 & 5.21 & 0.11 & 0.08 & 0.09 & 0.08 & 2.29 \\
\hline \multicolumn{14}{|c|}{ KANSAS AT LAWRENCE. } \\
\hline $1895 \ldots$ & & $\cdots$ & 0.03 & 0.03 & 0.02 & 0.11 & 0.12 & 0.22 & 0.09 & 0.02 & 0.02 & 0.02 & 0.76 \\
\hline $1896 \ldots$ & 0.02 & 0.03 & 0.02 & 0.08 & 0.26 & 0.28 & 0.45 & 0.17 & 0.08 & 0.04 & 0.07 & 0.05 & 1.55 \\
\hline $1897 \ldots$ & 0.04 & 0.08 & 0.07 & 0.25 & 0.11 & 0.14 & 0.20 & 0.06 & 0.02 & 0.02 & 0.04 & 0.02 & 1.04 \\
\hline 1898 & 0.02 & 0.05 & 0.04 & 0.07 & 0.28 & 0.26 & 0.05 & 0.02 & 0.03 & 0.02 & 0.01 & 0.03 & 0.88 \\
\hline - Average. & 0.03 & 0.05 & 0.04 & 0.11 & 0.17 & 0.20 & 0.21 & 0.12 & 0.06 & 0.03 & 0.04 & 0.03 & 1.09 \\
\hline \multicolumn{14}{|c|}{ SMOKY HILL AT ELLSWORTH. } \\
\hline 1895 . & & $\cdots$ & .... & 0.001 & 0.001 & 0.10 & 0.22 & 0.03 & 0.01 & 0.003 & 0.003 & 0.003 & \\
\hline 1896. & 0.004 & 0.004 & 0.002 & 0.02 & 0.01 & 0.04 & 0.03 & 0.02 & 0.01 & 0.01 & 0.01 & 0.01 & 1.61 \\
\hline 1897 . & 0.01 & 0.02 & 0.01 & 0.02 & 0.03 & 0.01 & 0.01 & 0.01 & 0.01 & 0.01 & 0.01 & 0.01 & 0.16 \\
\hline 1898. & 0.01 & 0.01 & 0.003 & 0.003 & 10.02 & 0.04 & 0.01 & 0.003 & 0.18 & 0.004 & 0.003 & 0.01 & 0.44 \\
\hline Average. & 0.01 & 0.01 & 0.01 & 0.01 & 0.02 & 0.05 & 0.07 & 0.02 & 0.05 & 0.01 & 0.01 & 0.01 & 0.28 \\
\hline \multicolumn{14}{|c|}{ SALINE AT BEVJERLY. } \\
\hline 1895 . & & & & & & ....... & 0.20 & 0.04 & 0.01 & 0.01 & 0.01 & 0.01 & \\
\hline 1896. & 0.02 & 0.02 & 0.02 & 0.06 & 0.13 & 0.94 & 0.12 & 0.05 & 0.02 & 0.11 & 0.03 & 0.026 & 1.52 \\
\hline $1897 \ldots$ & 0.02 & 0.03 & 0.02 & 0.08 & 0.06 & 0.19 & $\cdots$ & & & & & $\cdots$ & $\cdots$ \\
\hline $1898 \ldots$ & $\ldots .$. & $\ldots .$. & $\cdots \cdots$ & $\ldots \ldots$ & $\cdots \cdots$ & $\cdots \cdots$ & $\cdots \cdots$ & $\cdots \cdots$ & 1 & $\cdots \cdots \cdots$ & (...... & $\cdots \cdots$ & -....... \\
\hline Average . & $\overline{0.02}$ & 0.03 & 0.02 & 0.07 & 0.10 & 0.57 & 0.16 & 0.05 & 0.02 & $\overline{0.06}$ & $\overline{0.02}$ & $0 . \overline{01}$ & 1.13 \\
\hline \multicolumn{14}{|c|}{ SOLOMON AT NILES. } \\
\hline 1896. & & & & & & & & & & & & $\cdots \ldots$ & \\
\hline 1897. & 2 & & & $\cdots \cdots$ & 0.05 & 0.18 & 0.14 & 0.03 & 0.02 & 0.02 & 0.02 & 0.02 & \\
\hline 1898. & 0.02 & 0.02 & 0.02 & 0.02 & 0.04 & 0.09 & 0.02 & 0.01 & 0.01 & 0.01 & 0.01 & 0.02 & 0.29 \\
\hline Average. & 0.02 & 0.02 & 0.02 & 0.02 & 0.05 & 0.14 & 0.08 & 0.02 & 0.02 & 0.02 & 0.02 & 0.02 & 0.40 \\
\hline \multicolumn{14}{|c|}{ SALINE AT SALINA. } \\
\hline 1897. & $\cdots$ & $\ldots .$. & & $\ldots$ & 0.05 & 0.09 & 0.03 & 0.03 & 0.01 & 0.01 & 0.01 & 0.01 & 0.24 \\
\hline $1898 \ldots$ & 0.02 & 0.02 & 0.01 & 0.01 & 0.04 & 0.09 & 0.03 & 0.01 & 0.04 & 0.01 & 0.01 & 0.05 & 0.34 \\
\hline Average. & 0.02 & 0.02 & 0.01 & 0.01 & 0.05 & 0.09 & 0.03 & 0.02 & 0.03 & 0.01 & 0.01 & 0.03 & 0.33 \\
\hline
\end{tabular}


IRainfall and run-off

\begin{tabular}{|c|c|c|c|c|}
\hline Station. & Normal. & 1896. & 1897. & 1898. \\
\hline RAINFALL. & & & & . \\
\hline Imperial ... & 18.24 & 19.59 & 22.99 & 24.29 \\
\hline 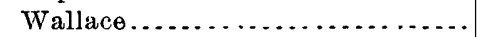 & 15.96 & 22.25 & 10.17 & $\ldots \ldots$ \\
\hline Ough $\ldots \ldots \ldots \ldots \ldots \ldots$ & 16.68 & 13. 13 & 20.99 & 20.89 \\
\hline Culbertson. . . . . . . . . . . . . . & 20.20 & 18.43 & 28.97 & 20.62 \\
\hline Indianola $\ldots . \ldots \ldots \ldots \ldots \ldots \ldots$ & 19.45 & 18.61 & 24.51 & $\ldots . . . . .$. \\
\hline Precept $\ldots \ldots \ldots \ldots \ldots \ldots \ldots \ldots$ & 24.79 & 23. 98 & 24. 73 & $\ldots \ldots . . .$. \\
\hline Holdrege...................... & 22.32 & $\ldots \ldots \ldots$ & 28.78 & 22.80 \\
\hline Minden $\ldots \ldots \ldots \ldots$ & 32.50 & 34.84 & 31.84 & 26.03 \\
\hline 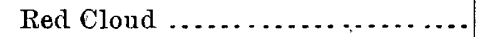 & 24.95 & 29.08 & 32.59 & 17.68 \\
\hline 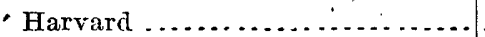 & 26.23 & 32.66 & 26.85 & 28.07 \\
\hline David City $\ldots \ldots \ldots \ldots \ldots \ldots$ & 27.30 & 42.95 & 26.45 & 25.40 \\
\hline York $\ldots \ldots \ldots \ldots \ldots \ldots \ldots \ldots$ & 25.85 & 37.72 & 24.27 & 22.20 \\
\hline Crete $\ldots \ldots \ldots \ldots \ldots \ldots \ldots \ldots$ & 27.60 & 40.99 & 27.92 & 22.78 \\
\hline Geneva............... & 28.38 & 36.56 & 30.52 & 34.11 \\
\hline Hebron $\ldots \ldots \ldots \ldots \ldots \ldots \ldots \ldots$ & 27.38 & 33.26 & 27.87 & 25.40 \\
\hline Fairbury $\ldots \ldots \ldots \ldots \ldots \ldots \ldots \ldots$ & 27.80 & 33.52 & 32.34 & 26.97 \\
\hline 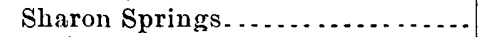 & 16.94 & 13.87 & 22.47 & $\ldots \ldots$ \\
\hline Wallace, Wallace County ......... & 15.80 & 14.26 & 19.61 & 15.16 \\
\hline Colby $\ldots \ldots \ldots \ldots \ldots \ldots \ldots$ & 17.91 & 22.00 & 29.54 & 15.08 \\
\hline Monument $\ldots \ldots \ldots \ldots \ldots \ldots \ldots$ & 16.81 & 18.23 & 23.95 & . . . . . . . \\
\hline Oberlin $\ldots \ldots \ldots \ldots \ldots \ldots$ & 24.43 & 25.49 & 34.49 & 26.88 \\
\hline Norton $\ldots \ldots \ldots \ldots$ & 19.02 & 9.30 & $\ldots \ldots$ & \\
\hline Grainfield ....................... & 21.20 & 28.45 & 27.07 & $\ldots \ldots \ldots$ \\
\hline 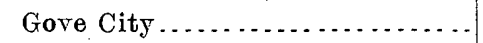 & 20.13 & 23.53 & 28.83 & 23.65 \\
\hline Eureka Ranch . . . . . . . . . . . . . . & 19.18 & 18.67 & 19.69 & 20.73 \\
\hline 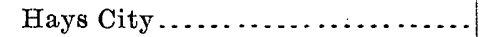 & 24.12 & 27.70 & 27.68 & $\ldots \ldots \ldots$ \\
\hline Kirwin $\ldots \ldots \ldots \ldots \ldots \ldots \ldots$ & 21.74 & 31.91 & 27.56 & 24.87 \\
\hline 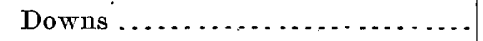 & 25.30 . & 30.99 & $\ldots .$. & $\ldots$ \\
\hline Concordia ........... & 26.47 & 33.34 & 31.45 & $\ldots \ldots$ \\
\hline 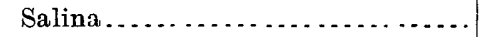 & 25.80 & 37.94 & 20.50 & 25.59 \\
\hline Abilene $\ldots \ldots \ldots \ldots \ldots \ldots \ldots$ & 28.82 & 42.35 & 27.31 & 33.46 \\
\hline Fort Riley...$\ldots \ldots \ldots \ldots \ldots$ & 25.78 & 38.28 & 22.79 & 31.54 \\
\hline Manhattan ........... & 30.72 & 36.28 & 24.85 & 33.24 \\
\hline 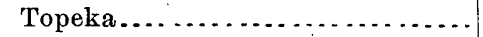 & $3 \dot{4} .05$ & 36.56 & 28.86 & \\
\hline Lawrence $\ldots . . . . . . . . . . . .$. & 35.50 & 34.85 & 23.79 & 42.4 .5 \\
\hline Average............. & 23.87 & 28.28 & 26.13 & 25.41 \\
\hline RUN-OFF. & & & & \\
\hline blican at Superior............ & & & & \\
\hline Republican at Junction City...... & 0.53 & 0.60 & 0.50 & 0.40 \\
\hline Blue at Manhattan . . . . . . . . . . . & 2.29 & 3.06 & 2.82 & 1.90 \\
\hline Kansas at Lawrence............. & 1.09 & 1.55 & 1.04 & 0.88 \\
\hline Smoky Hill at Ellsworth ..... & 0.28 & 1. 61 & 0.16 & 0.44 \\
\hline Saline at Beverly . . . . . . . . . . . . & 1. 13 & 1.52 & 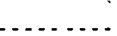 & 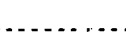 \\
\hline Solomon at Niles .. & 0.45 & $\ldots \ldots \ldots$ & & 0.29 \\
\hline Saline at Saline .................. & 0.33 & $\ldots \ldots \ldots$ & 0.24 & 0.34 \\
\hline Average. & 0.87 & 1.67 & $0 . \dot{95}$ & 0.71 \\
\hline Percentage of rainfall.. & 3.65 & 5.91 & 3.64 & 2.79 \\
\hline
\end{tabular}


314 PROGRESS OF STREAM MEASUREMENTS FOR 1898. SOLOMON RIVER.

Estimated monthly discharge of Solomon River at Niles, Kansas.

[Drainage area, 6,815 square miles.]

\begin{tabular}{|c|c|c|c|c|c|c|}
\hline \multirow[b]{2}{*}{ Month. } & \multicolumn{3}{|c|}{ Discharge in second-feet. } & \multirow[b]{2}{*}{$\begin{array}{l}\text { Total in acre. } \\
\text { feet. }\end{array}$} & \multicolumn{2}{|c|}{ Run-off. } \\
\hline & $\begin{array}{l}\text { Maxi- } \\
\text { mum. }\end{array}$ & $\begin{array}{l}\text { Mini- } \\
\text { mum. }\end{array}$ & Mean. & & $\begin{array}{l}\text { Depth in } \\
\text { inches. }\end{array}$ & $\begin{array}{l}\text { Second. } \\
\text { feet per } \\
\text { square } \\
\text { mile. }\end{array}$ \\
\hline 1898. & & & e & & & \\
\hline January ............ & 172 & 126 & 155 & 9,531 & 0.02 & 0.02 \\
\hline February ........ & 260 & 109 & 164 & 9,108 & 0.02 & 0.02 \\
\hline March ..... & 190 & 98 & 131 & 8,055 & 0.02 & 0.02 \\
\hline 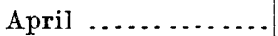 & 353 & 109 & 146 & 8,688 & 0.02 & 0.02 \\
\hline May .............. & 677 & 160 & 243 & 14,942 & 0.04 & 0.04 \\
\hline June .............. & 1,175 & 196 & 534 & 31,775 & 0.09 & 0.08 \\
\hline July ............. & 335 & 79 & 156 & 9,592 & 0.02 & 0.02 \\
\hline August............... & 103 & 35 & 56 & 3,443 & 0.01 & 0.01 \\
\hline September ..... & 190 & 42 & 79 & 4,701 & 0.01 & 0.01 \\
\hline October..... & 79 & 47 & 58 & 3,566 & 0.01 & 0.01 \\
\hline November... & 120 & 47 & 72 & 4,284 & 0.01 & 0.01 \\
\hline December ... & 268 & 87. & 147 & 9,039 & 0.02 & 0.02 \\
\hline The year ..... & 1,175 & 35 & 162 & 116,724 & 0.29 & 0.02 \\
\hline
\end{tabular}

NoTE.-Gage heights for 1898 are given in Water-Supply and Irrigation Paper No. 27, page 92 ; measurements, page 95 ; rating table, page 96 ; results for 1897 in Water-Supply and Irrigation Paper No. 16, page 111, and in the Nineteenth Annual Report, Part IV, page 342.

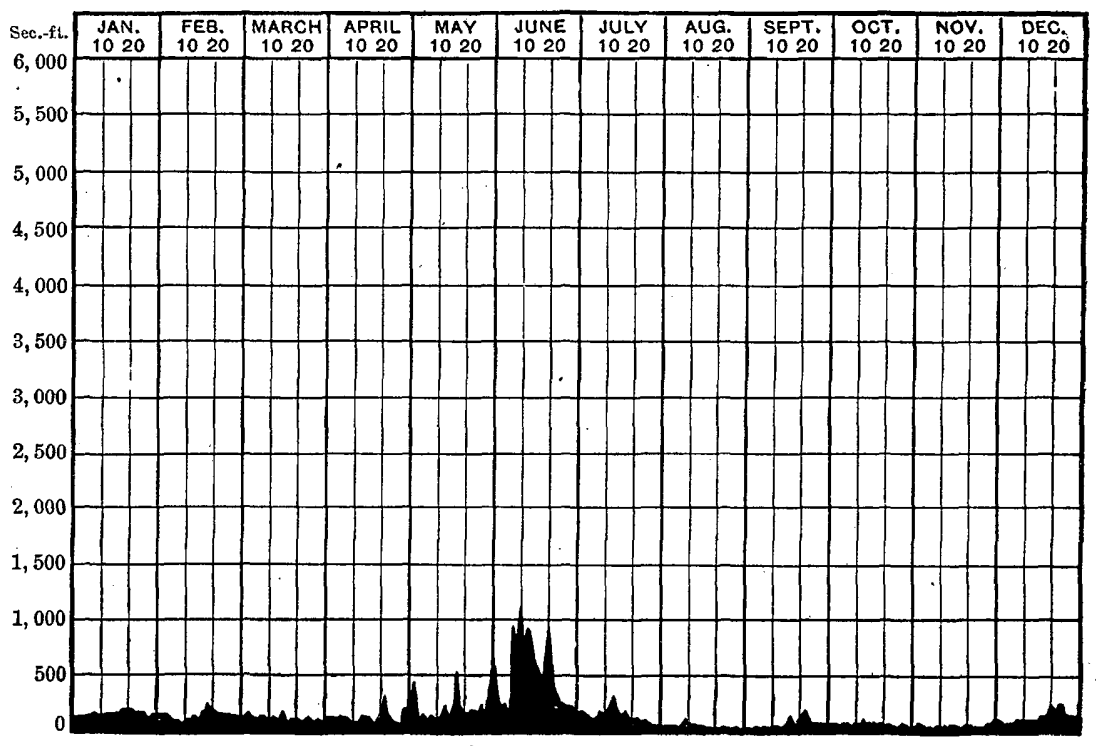

FrG. 114.-Discharge of Solomon River at Niles, Kansas. 
SMOKY HILL RIVER.

Measurements of Smoky Hill River were begun on April 17, 1895, as described in the Eighteenth Annual Report, Part IV, on page 212. The measurements of discharge have been carried on at this and neighboring stations by Mr. W. G. Russell. The following table gives the results of the computatious for 1898, and fig. 115 below shows graphically the fluctuations of the stream for the years during which the station has been maintained.

Estimated monthly discharge of Smoky Hill River at Ellsworth, Kansas.

[Drainage area, 7, 980 square miles.]

\begin{tabular}{|c|c|c|c|c|c|c|}
\hline \multirow[b]{2}{*}{ Month. } & \multicolumn{3}{|c|}{ Discharge in second-feet. } & \multirow[b]{2}{*}{$\begin{array}{l}\text { Total in acre- } \\
\text { feet. }\end{array}$} & \multicolumn{2}{|c|}{ Run-off. } \\
\hline & $\begin{array}{l}\text { Maxi- } \\
\text { mum. }\end{array}$ & $\begin{array}{l}\text { Mini- } \\
\text { mum. }\end{array}$ & Mean. & & $\begin{array}{l}\text { Deptb in } \\
\text { inches. }\end{array}$ & $\begin{array}{c}\text { Second- } \\
\text { feet per } \\
\text { square } \\
\text { mile. }\end{array}$ \\
\hline 1898. & & & & , & & . \\
\hline January . . . . . . . . . & 70 & 18 & 36 & 2,214 & 0.005 & 0.005 \\
\hline February ......... & 95 & 21 & 47 & 2,610 & 0.006 & 0.006 \\
\hline March ............... & 32 & 16 & 24 & 1,476 & 0.003 & 0.003 \\
\hline April $\ldots . . . . .$. & 37 & 15 & 20 & 1,190 & 0.003 & 0.003 \\
\hline 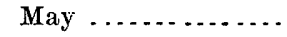 & 1,000 & 32 & 136 & 8,362 & 0.020 & 0.017 \\
\hline June............. & 717 & 78 & 281 & 16,721 & 0.039 & 0.035 \\
\hline July ............ & 78 & 18 & 43 & 2,644 & 0.006 & 0.005 \\
\hline August. . . . . . . . . . & 105 & 15 & 25 & 1,537 & 0.004 & 0.003 \\
\hline September ...... & 763 & 14 & 131 & 7,795 & 0.018 & 0.016 \\
\hline October . . . . . . . . & 55 & 18 & 30 & 1,845 & 0.004 & 0.004 \\
\hline November .......... & 42 & 18 & 19 & 1,131 & 0.003 & 0.002 \\
\hline December ...... & 147 & 24 & 53 & 3,259 & 0.007 & 0.006 \\
\hline The year ...... & 1,000 & 14 & 70 & 50,784 & 0.118 & 0.009 \\
\hline
\end{tabular}

NoтE.-Gage heights for 1898 are given in Water-Supply and Irrigation Paper No. 27, page 93; measurements, page 95; rating table, page 96; results for 1897 in Water-Supply and Irrigation Paper No. 16, page 114, and in the Nineteenth Annual Report, Part IV, page 346.

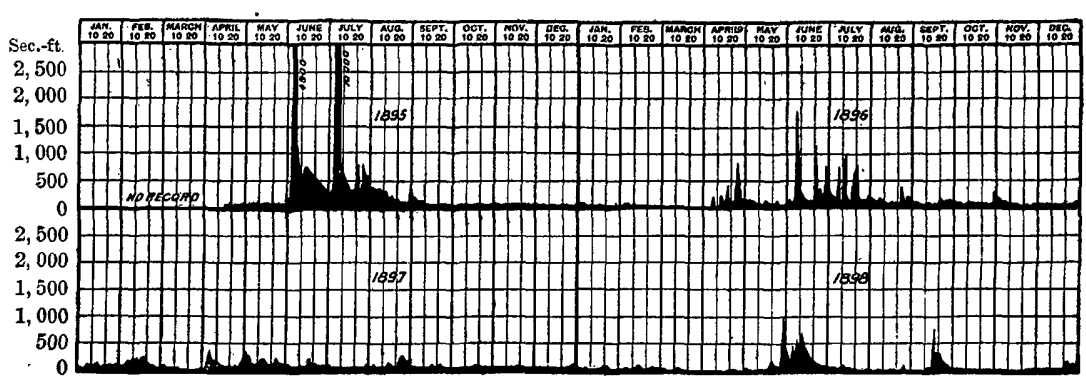

FIG. 115.-Discharge of Smoky Hill River at Ellsworth, Kansas, 1895-1898. 
SALINE RIVER.

Estimated monthly discharge of Saline River at Salina, Kansas.

[Drainage area, 3,311 square miles.]

\begin{tabular}{|c|c|c|c|c|c|c|}
\hline \multirow[b]{2}{*}{ Month. } & \multicolumn{3}{|c|}{ Discharge in second-feet. } & \multirow[b]{2}{*}{$\begin{array}{l}\text { Total in acre- } \\
\text { feet. }\end{array}$} & \multicolumn{2}{|c|}{ Run-off. } \\
\hline & $\begin{array}{l}\text { Maxi- } \\
\text { mum. }\end{array}$ & $\begin{array}{l}\text { Mini- } \\
\text { mum. }\end{array}$ & Mean. & & $\begin{array}{l}\text { Depth in } \\
\text { inches. }\end{array}$ & $\begin{array}{c}\text { Second. } \\
\text { feet per } \\
\text { square } \\
\text { mile. }\end{array}$ \\
\hline 1898. . & & & & & & \\
\hline January .......... & 82 & 40 & - 57 & 3,505 & 0.02 & 0.02 \\
\hline February... & 94 & 34 & 50 & 2,777 & 0.02 & 0.02 \\
\hline March............ & 46 & 24 & 37 & 2,275 & 0.01 & 0.01 \\
\hline April.... & 60 & 24 & 35 & 2,083 & 0.01 & 0.01 \\
\hline May ....... & 1,095 & 34 & 109 & 6,702 & 0.04 & 0.03 \\
\hline June......... & 1,100 & 72 & 271 & 16,126 & 0.09 & 0.08 \\
\hline July ..... & 421 & 22 & 86 & 5,288 & 0.03 & 0.03 \\
\hline August... & 32 & 7 & 20 & 1,230 & 0.01 & 0.01 \\
\hline September & 970 & 6 & 121 & 7,440 & 0.04 & 0.04 \\
\hline October..... & 52 & 22 & 35 & 2,152 & 0.01 & 0.01 \\
\hline November.: & 40 & 15 & 25 & 1,488 & 0.01 & 0.01 \\
\hline December . ... & 690 & 29 & 144 & 8,854 & 0.04 & 0.04 \\
\hline The year ..... & 1,100 & 6 & 83 & 59,920 & 0.33 & 0.03 \\
\hline
\end{tabular}

Note.-Gage heights for 1898 are given in Water-Supply and Irrigation Paper No. 27, page 93; measurements, page 95; rating table, page 96 ; results for 1897 in Water-Supply and Irrigation Paper No. 16, page 113, and in the Nineteenth Annual Report, Part IV, page 343:

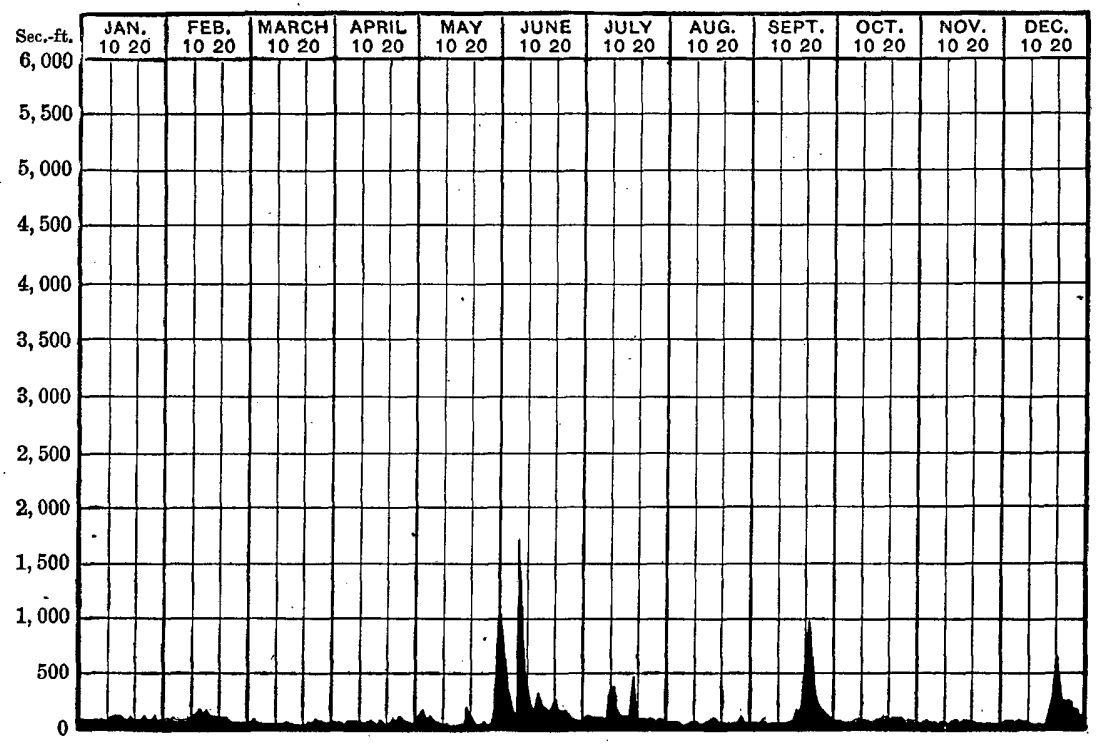

FIG. 116.-Discharge of Saline River at Salina, Kansas, 1898. 
REPUBLICAN RIVER.

Estimated monthly discharge of Republican River at Superior, Nebraska.

[Drainage area, 22,347 square miles.]

\begin{tabular}{|c|c|c|c|c|c|c|}
\hline \multirow[b]{2}{*}{ Month. } & \multicolumn{3}{|c|}{ Discharge in second-feet. } & \multirow{2}{*}{$\begin{array}{l}\text { Total in acre. } \\
\text { feet. }\end{array}$} & \multicolumn{2}{|c|}{ Run-off. } \\
\hline & $\begin{array}{l}\text { Maxi- } \\
\text { mum. }\end{array}$ & $\begin{array}{l}\text { Mini- } \\
\text { mam. }\end{array}$ & Mean. & & $\begin{array}{l}\text { Depth in } \\
\text { inches. }\end{array}$ & $\begin{array}{l}\text { Second- } \\
\text { foot per } \\
\text { square } \\
\text { mile. }\end{array}$ \\
\hline 1898. & $\cdot$ & & & & - & - \\
\hline April $20-30 \ldots \ldots$ & 2,130 & 490 . & 755 & 44,926 & 0.03 & 0.03 \\
\hline May ........ & $1 ; 870$ & 500 & 1,053 & 64,747 & 0.06 & 0.05 \\
\hline June.... & 2,300 & 560 & 1,235 & 73,487 & 0.07 & 0.06 \\
\hline July ....... & 1,345 & 220 & 479 & 29,453 & 0.02 & 0.02 \\
\hline August ..... & 380 & 100 & 195 & 11,990 & 0.01 & 0.01 \\
\hline September . & 470 & 185 & 289 & 17,197 & 0.01 & 0.01 \\
\hline October...... & 365 & 145 & 264 & 16,233 & 0.01 & 0.01 \\
\hline November 1-19 .. & 470 & 320 & 382 & 22,731 & 0.02 & 0.02 \\
\hline
\end{tabular}

NoтE.-Gage heights for 1898 are given in Water-Supply and Irrigation Paper No. 27, page 91; measurements, page 95; results for 1897 in Water Supply and Irrigation Paper No.16, page 107, and in the Nineteenth Annual Report, Part IV, page 338.

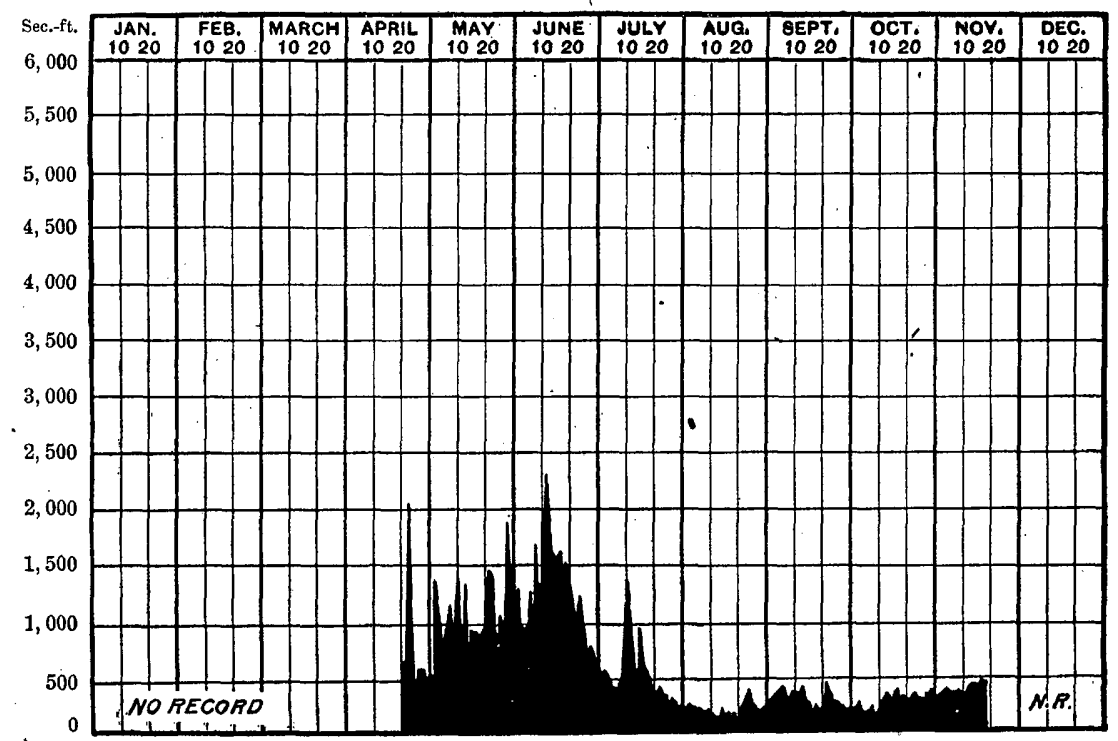

FrG. 117.-Discharge of Republican River at Superior, Nebraska, 1898. 
Estimated monthly discharge of Republican River at Junction City, Kansas.

[Drainage area, 25,837 square miles.]

\begin{tabular}{|c|c|c|c|c|c|c|}
\hline \multirow{2}{*}{ Month. } & \multicolumn{3}{|c|}{ Discharge in second-feet. } & \multirow[b]{2}{*}{$\begin{array}{c}\text { Total in acre- } \\
\text { feet. }\end{array}$} & \multicolumn{2}{|c|}{ Run-off. } \\
\hline & $\begin{array}{l}\text { Maxi- } \\
\text { mum. }\end{array}$ & $\begin{array}{l}\text { Mini- } \\
\text { mum. }\end{array}$ & Mean. & & $\begin{array}{c}\text { Depth in } \\
\text { inches. }\end{array}$ & $\begin{array}{l}\text { Second. } \\
\text { foot per } \\
\text { square } \\
\text { mile. }\end{array}$ \\
\hline 1898. & & & & & & \\
\hline January ..... & 900 & 475 & 732 & 45,009 & 0.03 & 0.03 \\
\hline February & 1,895 & 645 & 1,034 & 57,425 & 0.04 & 0.04 \\
\hline March .... & 825 & 475 & 656 & 40,336 & 0.03 & 0.03 \\
\hline April.... & 1,310 & 590 & 804 & 47,841 & 0.03 & 0.03 \\
\hline May ....... & 7,175 & 862 & 2,126 & 130,723 & 0.09 & 0.08 \\
\hline June ..... & 6,165 & 700 & 2,125 & 126,446 & 0.09 & 0.08 \\
\hline July ........ & 645 & 210 & 429 & 26,378 & 0.02 & 0.02 \\
\hline August...... & 252 & 69 & 142 & 8,732 & 0.01 & 0.01 \\
\hline September & 325 & 69 & 155 & 9,223 & 0.01 & 0.01 \\
\hline October............ & 252 & 124 & 190 & 11,683 & 0.01 & 0.01 \\
\hline November..... & 475 & 210 & 310 & 18,446 & 0.01 & 0.01 \\
\hline December .......... & 645 & 325 & 403 & 24,780 & 0.02 & 0.02 \\
\hline The year & 7,175 & 69 & 759 & 547,022 & 0.39 & 0.03 \\
\hline
\end{tabular}

Note.-Gage heights for 1898 are given in Water-Supply and Irrigation Paper No. 27, page 92; measurements, page 95; rating table, page 96; results for 1897 in Water-Supply and Irrigation Paper No. 16, page 109, and in the Nineteenth Annual Report, Part IV, page 339.

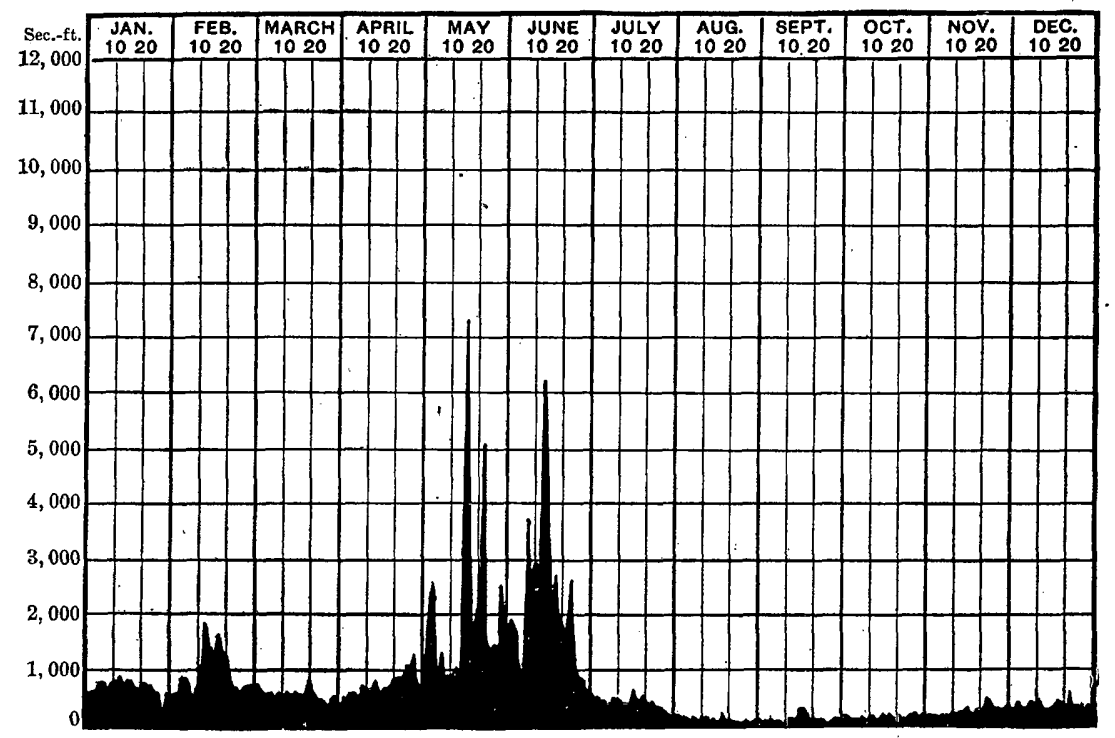

FIG. 118.-Discharge of Republican River at Junction City, Kansas, 1898. 
BLUE RIVER.

Estimated monthly discharge of Blue River at Manhattan, Kansas.

[Drainage area, 9,490 square miles.]

\begin{tabular}{|c|c|c|c|c|c|c|}
\hline \multirow[b]{2}{*}{ Month. } & \multicolumn{3}{|c|}{ Discharge in second-feet. } & \multirow[b]{2}{*}{$\begin{array}{c}\text { Total in acre. } \\
\text { feet. }\end{array}$} & \multicolumn{2}{|c|}{ Run-off. } \\
\hline & $\begin{array}{l}\text { Maxi- } \\
\text { mum. }\end{array}$ & $\begin{array}{l}\text { Mini- } \\
\text { mum. }\end{array}$ & Mean. & & $\begin{array}{l}\text { Depth in } \\
\text { inches. }\end{array}$ & $\begin{array}{c}\text { Second- } \\
\text { foot per } \\
\text { square } \\
\text { mile. }\end{array}$ \\
\hline 1898. & . & & & & & \\
\hline January................ & 830 & 555 & 732 & 45,009 & 0.08 & 0.08 \\
\hline February . . . . . . . . & 5,319 & 500 & 2,078 & 115,406 & 0.23 & 0.22 \\
\hline March....... & 1,050 & 527 & 765 & 47,028 & 0.09 & 0.08 \\
\hline April....... & 3,335 & 610 & 1,485 & 88,363 & 0.18 & 0.16 \\
\hline May.................... & 8,548 & 1,522 & 3,491 & 214,653 & 0.43 & 0.37 \\
\hline June ....... & 10,774 & 1,081 & 4,496 & 267,530 & 0.53 & 0.47 \\
\hline July $\ldots \ldots \ldots \ldots$ & 1,333 & 500 & .740 & 45,501 & 0.09 & 0.08 \\
\hline August..... & 610 & 230 & 454 & 27,916 & 0.06 & 0.05 \\
\hline September & 665 & 230 & 377 & 22,433 & 0.04 & 0.04 \\
\hline October ............. & 637 & 207 & 360 & 22,136 & 0.04 & 0.04 \\
\hline November. & 555 & 342 & 443 & 26,361 & 0.06 & 0.05 \\
\hline December . & 775 & 432 & 615 & 37,815 & 0.07 & 0.06 \\
\hline The year ..... & 10,774 & 207 & 1,336 & 960,151 & 1.90 & 0.14 \\
\hline
\end{tabular}

NoTe.-Gage heights for 1898 are given in Water Supply and Irrigation Paper No. 27, page 94; measurements, page 95, and rating table, page 96; results for 1897 in Water-Supply and Irrigation Paper No. 16, page 115, and in the Nineteenth Annual Report, Part IV, page 347.

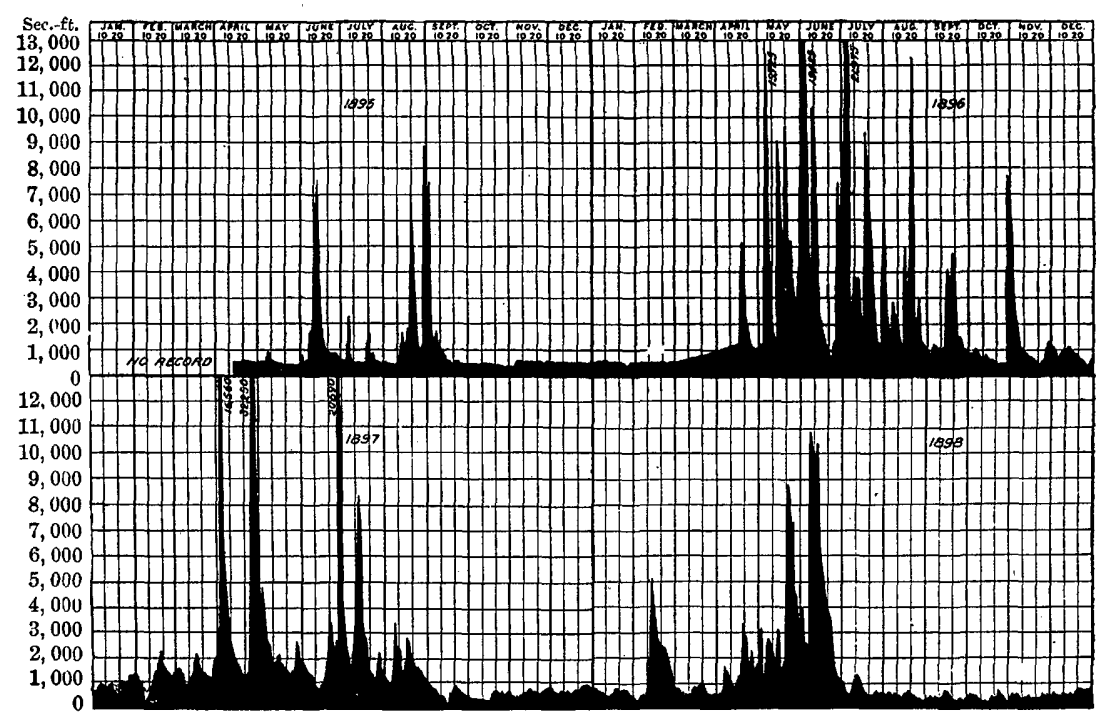

FIG. 119.-Discharge of Blue River at Manhattan, Kansas, 1895-1898. 


\section{KANSAS RIVER AT LAWRENCE.}

The Kansas River above Lawrence meanders through the bottom land, crossing and recrossing it, but as a rule being eloser to the southern border than the northern. This bottom, which includes all lands adjacent to the river and not more than 20 feet above it, is mainly alluvial and varies in width from one-half to 4 miles. The bed of the river is mainly sandy, though in a few places it is rocky. At Lawrence and other places this sand is used for building purposes. The banks are, as a rule, not more than 8 or 10 feet high, except where the river runs in near the bluffs, where they are 30 to 40 feet high. At low stage of river the width is usually not more than one-half or one-fourth that at high water. For example, at the Lecompton gaging station, shown on Pl. XXIX, $A$, on November 19, 1898, the width of the stream was 219 feet, the greatest depth 4.8 feet, and the discharge was 954 second-feet. Although the river has a fall of about 329 feet, only 9 feet of this is utilized for power. The view on Pl. XXIX, $B$, shows the dam at Lawrence, the only one on the river. Reference should be made to the description of this dam in Vol. XVII of the Tenth Census, Part II, p. 58.

The following table is condensed from the results of a chemical analysis made under the direction of Dr. Edward Barton, of the Kansas University. The samples were taken about 12 feet from the south bank of the river and from 12 to 15 inches below the surface at the gaging station at Lawrence, Kansas. In the diagram (fig. 120) are plotted the solids carried in the river at this particular place for different gage readings, the curve A B showing graphically the relation between height of water and solid matter carried by river. The rating curve $\mathrm{CD}$ for this station is also shown for comparison.

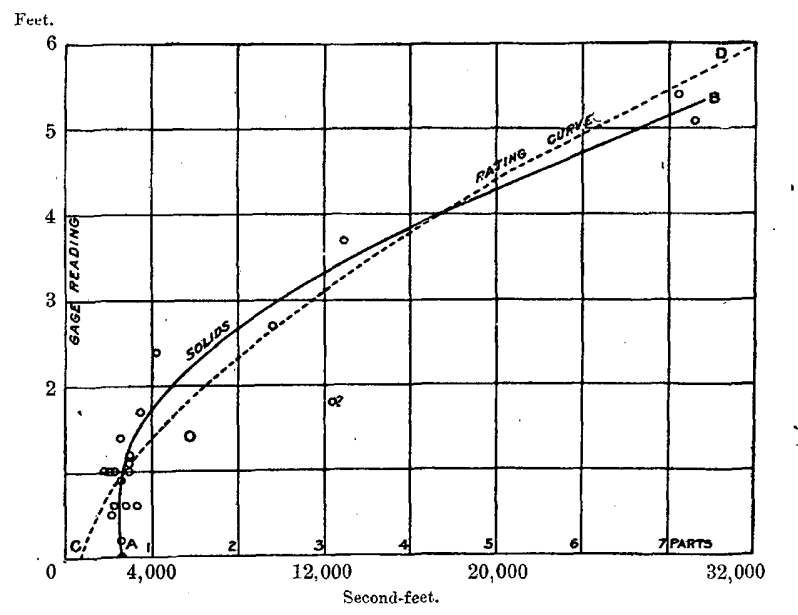

Fig. 120.-Relation of gage height to solids carried in suspension by Kansas River at Lawrence, Kansas. 
Results of analyses of Kansas River water at gaging station, Lawrence, Kansas, expressed in parts per million.

\begin{tabular}{|c|c|c|c|c|c|c|c|c|}
\hline Date collected. & $\begin{array}{l}\text { Gage } \\
\text { read- } \\
\text { ing. }\end{array}$ & $\begin{array}{l}\text { Total } \\
\text { solids. }\end{array}$ & $\begin{array}{c}\text { Free am. } \\
\text { monia. }\end{array}$ & $\begin{array}{l}\text { Albumi- } \\
\text { noid am- } \\
\text { nunia. }\end{array}$ & Nitrates. & Nitrites. & Chlorine. & $\begin{array}{l}\text { Hard- } \\
\text { ness. }\end{array}$ \\
\hline 1898. & & . & 8 & & & & & \\
\hline Feb. $4 \ldots \ldots$ & 0.0 & 644 & 0.0192 & 0.0945 & 0.3345 & 0 & 114.0 & (a) \\
\hline $11 .$. & 1.1 & 736 & 0.1710 & 0.6120 & 0.2086 & Trace. & 86.0 & $\ldots$. \\
\hline $18 \ldots$ & 1.4 & 1,410 & 0.4000 & 2.2900 & 1.0705 & (a) & 41.0 & \\
\hline $25 \ldots$ & .8 & 607 & ก. 2532 & 0.9300 & 0.4503 & $\cdots$ & 69.0 & \\
\hline Mar. $5 \ldots$ & .6 & 844 & 0.0666 & 0.3120 & 0.4393 & ... & 69.0 & . \\
\hline $11 \ldots$ & .6 & 574 & 0.0066 & 0.2990 & 0.3239 & 0 & 77.0 & 215 \\
\hline $18 \ldots$ & 1.0 & 566 & 0.0200 & 0.5100 & 0.2306 & ... & 67.0 & 220 \\
\hline 25 & .9 & 656 & 0.0360 & 0.7000 & 0.6382 & & 58.0 & 230 \\
\hline Apr. $1 \ldots$ & .6 & 706 & 0.0600 & 0.5600 & 0.2865 & $\cdots$ & 67.3 & 240 \\
\hline $8 \ldots$ & 1.0 & 744 & 0.0850 & 0.6450 & 0.2430 & ... & 59.0 & 230 \\
\hline $15 \ldots$ & 1.0 & 446 & 0.0390 & 0.5960 & 0.3790 & 0 & 56.0 & 205 \\
\hline $22 \ldots$ & 1.8 & 3,080 & 0.3100 & 5.9900 & 0.1500 & 0.0002 & 37.0 & 170 \\
\hline $29 \ldots$ & 1.2 & 750 & 0.1250 & 0.8950 & 0.3705 & Trace. & 46.0 & 210 \\
\hline May $6 . .$. & 2.7 & 2,426 & 0.3400 & 4.8100 & $(a)$ & $\ldots$. & 41.0 & \\
\hline $13 \ldots$ & 1.7 & 868 & 0.1100 & 1.1100 & 0.0244 & & 26.0 & 204 \\
\hline $16 \ldots$ & 5.1 & 7,348 & 0.6600 & 10.2900 & $\ldots \ldots$ & ... & 18.7 & \\
\hline June 10. & 5.4 & 7,132 & 0.2000 & 15.0100 & $\ldots \ldots \ldots$ & 0.0250 & 13.2 & \\
\hline $17 \ldots$ & 3.7 & 3,248 & 0.2800 & 4. 7200 & 0.1811 & & 9.6 & $\cdots$ \\
\hline $24 \ldots$ & 2.4 & 1,058 & 0.1500 & 1.2800 & ........ & 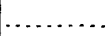 & 19.0 & 166 \\
\hline July $1 \ldots$ & 1.4 & 618 & 0.1700 & 0.9200 & 0.0579 & 0.0080 & 18.0 & 214 \\
\hline $15 \ldots$ & 1.0 & 528 & 0.2450 & 1.0000 & 1.5603 & 0 & 46.0 & 140 \\
\hline Aug. $1 \ldots$ & 0.5 & 536 & 0.0540 & 0.5300 & 0.0584 & 0 & 56.0 & 120 \\
\hline $14 \ldots$ & 0.2 & 642 & 0.0480 & $0.3 \div 20$ & 0.1659 & 0.0004 & 82.0 & 120 \\
\hline June $10 .$. & 5.4 & $b 286$ & 0.1710 & 0.1335 & $(a)$ & 0.0250 & 13.2 & (a) \\
\hline $17 .$. & 3.7 & $b 230$ & 0.1040 & 0.2870 & 0.3261 & $(a)$ & 9.6 & $\ldots$ \\
\hline $24 \ldots$ & 2.4 &.$b 284$ & 0.1260 & 0.2600 & ....... & ......... & 19.0 & 162.6 \\
\hline July $1 \ldots$ & 1.4 & $b 392$ & 0.0990 & 0.2450 & 0.3222 & 0.0080 & 18.0 & 220.0 \\
\hline $15 \ldots$ & 1.0 & $b 456$ & 0.0200 & 0.5000 & 0.3950 & 0.0003 & 45.0 & $125.0^{\circ}$ \\
\hline Aug. $1 \ldots . .$. & 0.5 & $b 490$ & 0.0530 & 0.2400 & 0.0077 & 0.0000 & 56.0 & 120.0 \\
\hline $14 \ldots \ldots$ & 0.2 & $b 508$ & 0.0420 & 0.2390 & 0.0001 & 0.0004 & 82.0 & 120.0 \\
\hline
\end{tabular}

Measurements at Lawrence have been made by Prof. E. C. Murphy, of the State University, who has also carried on work at Liberty on ,Verdigris River and at Iola on Neosho River, as described on later pages. The conditions at the dam at Lawrence have not been found favorwble for accuracy of results, and observations have been trans. ferred to the bridge at Lecompton, 11 miles up the river. The results obtained at Lawrence are shown in the table on the next page, and graphically for the years 1896 to 1898, inclusive, in fig. 121.

20 GEOL, PT $4-21$ 
Estimated monthly discharge of Kansas River at Lawrence, Kansas.

[Drainage area, 59,841 square miles.]

\begin{tabular}{|c|c|c|c|c|c|c|}
\hline \multirow[b]{2}{*}{ Month. } & \multicolumn{3}{|c|}{ Discharge in second-feet. } & \multirow[b]{2}{*}{$\begin{array}{c}\text { Total in acre- } \\
\text { feet. }\end{array}$} & \multicolumn{2}{|c|}{ Run-off. } \\
\hline & $\begin{array}{l}\text { Maxi- } \\
\text { mum. }\end{array}$ & $\begin{array}{l}\text { Mini- } \\
\text { mum. }\end{array}$ & Mean. & & $\begin{array}{l}\text { Depth in } \\
\text { inches. }\end{array}$ & $\begin{array}{c}\text { Second. } \\
\text { feet per } \\
\text { square } \\
\text { mile. }\end{array}$ \\
\hline 1898. & & & & & & \\
\hline January ............ & 1,255 & 863 & $.1,125$ & 69,174 & 0.02 & 0.02 \\
\hline February ........ & 6,490 & 692 & 2,700 & 149,950 & 0.05 & 0.05 \\
\hline March ....... & 6,490 & 1,643 & 2,412 & 148,309 & 0.04 & 0.04 \\
\hline April ...... & 6,490 & 1,643 & 3,497 & $208 ; 085$ & 0.07 & 0.06 \\
\hline May ....... & 26,235 & 5,207 & 14,555 & 894,958 & 0.28 & 0.24 \\
\hline June. . . . . . . . . . . & 28,990 & 4,803 & 13,684 & 814,253 & 0.26 & 0.23 \\
\hline July ...... & 4,803 & 1,255 & 2,570 & 158,024 & 0.05 & 0.04 \\
\hline August .... & 2,395 & 692 & 1,008 & 61,980 & 0.02 & 0.02 \\
\hline September .. & 2,687 & 692 & 1,397 & 83,127 & 0.03 & 0.02 \\
\hline October .... & 1,177 & 592 & 825 & 50,728 & 0.02 & 0.01 \\
\hline November.......... & 1,032 & $\cdot 517$ & 746 & 44,390 & 0.01 & 0.01 \\
\hline December ........... & 4,035 & 507 & 1,448 & 89,035 & 0.02 & 0.02 \\
\hline The year & 28,990 & 507 & 3,831 . & $2,772,013$ & 0.87 & 0.06 \\
\hline
\end{tabular}

Note.-Gage heights for 1898 are given in Water-Supply and Irrigation Paper No. 27, page 94; measurements, page 96; rating table, page 96; results for 1897 in Water-Supply and Irrigation Paper No. 16, page 116, and in the Nineteenth Annual Report, Part IV, page 349.

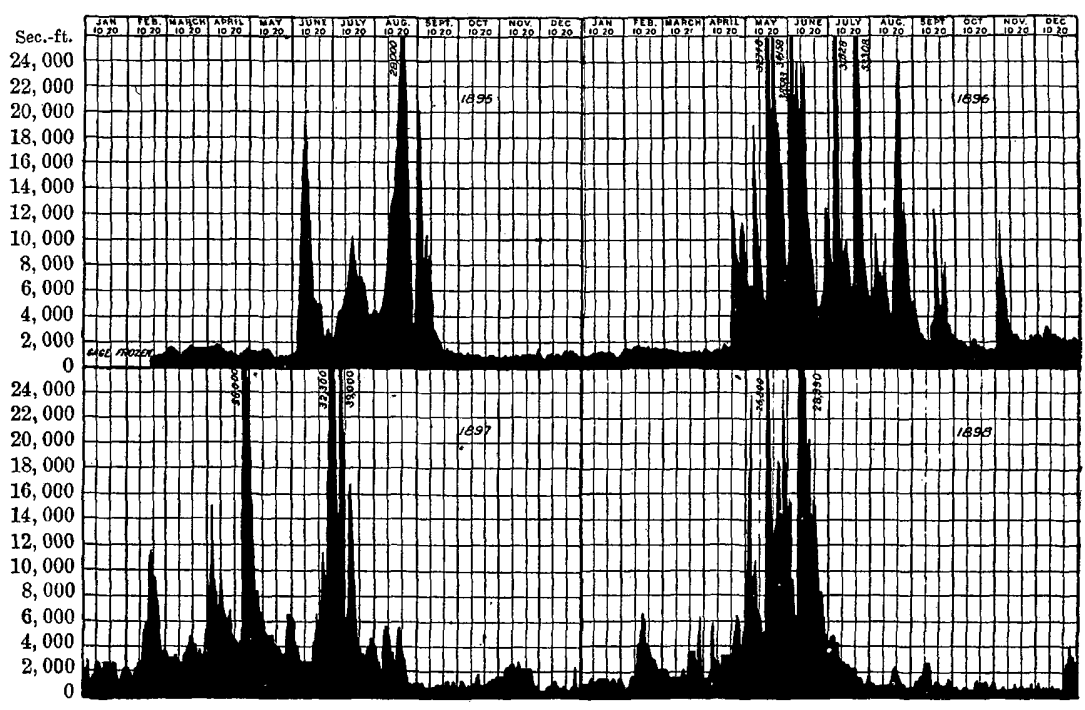

Fia. 121.-Discharge of Kansas River at Lawrence, Kansas, 1895-98. 


\section{ARKANSAS, RIVER DRAINAGE.}

Arkansas River, rising in the vicinity of Leadiville, Colorado, flows southerly and then, turning abruptly eastward, passes out through the Rocky Mountain front and continues across Colorado into Kansas, where, at about the middle of the State, it makes a great bend, swinging to the southward, and passes into Indian Territory and from there flows through the State of Arkansas, entering the Mississippi River about 25 miles, in a straight line, north of Greenville, Mississippi. The

- headwater streams, during summer at least, are fully used in irrigation, and the bed of the stream is often dry from a point above the Kansas line through the State of Kansas. In time of flood some water, relatively insignificant in amount, is contributed to the main stream from the Rocky Mountain area. In its lower reaches in the State of Arkansas the stream is navigable, but there is no considerable transportation by water above Little Rock, although in times of flood small vessels are reported to go up as high as Fort Smith. So far as ascertained no form of river transportation has ever been used from Wichita or other Kansas towns, and at Wichita it is stated that there is very little water in the river during ten months of the year. During most years there is no water visible for miles west of the mouth of the Little Arkansas River, which contributes a small amount at this point.

\section{ARKANSAS RIVER.}

Measurements of the amount of water in this stream have been made at various points in Colorado and in Kansas, the results of which are given in the following pages. Seepage measurements have also been carried on by Prof. L. G. Carpenter and officials connected with the State engineer's office, the results being of great practical value owing to the numerous diversions of water from the stream.

Considerable attention is being paid to the storage of water upon the Arkansas, there being a number of fine sites. The Twin Lakes site was described in the Nineteenth Annual Repòrt, Part IV, page 352. Work is now under way upon the dam for this reservoir, which is expected to store over three billions of cubic feet of water, to be used below Pueblo.

The Great Plains Water Company also is at work upon a system of enormous reservoirs in the vicinity of Lamar, Colorado, the available capacity claimed being over seven billions of cubic feet.

The discharge of the Arkansas and tributaries in 1898 was about the normal, few crops failing for lack of water, although at times a shortage seemed imminent. Very little water crossed the Colorado-Kansas line during the year, however.

Owing to the fact that the entire flow of the stream is exhausted during a great part of the irrigation season, by ditches taking water to the agricultural lands, a number of stations were maintained for the purpose of assisting in studying the problems connected with the water 


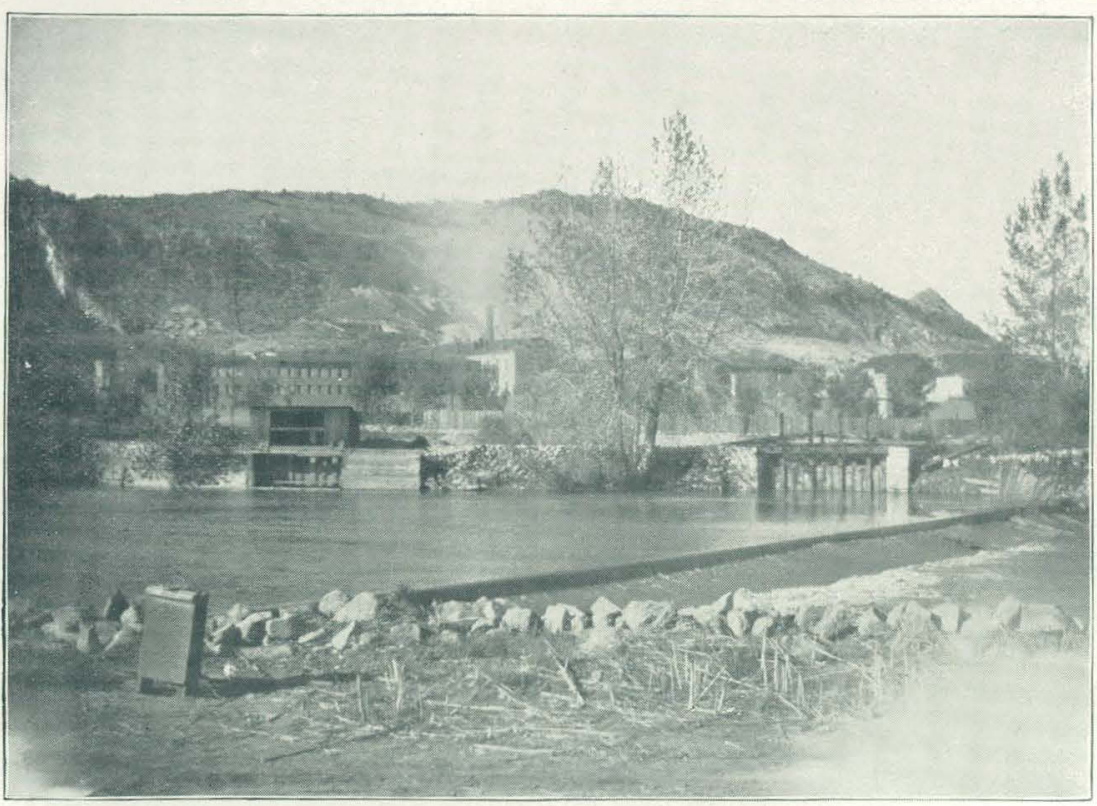

A. NEW DIVERTING DAM AT CANYON, COLORADO.

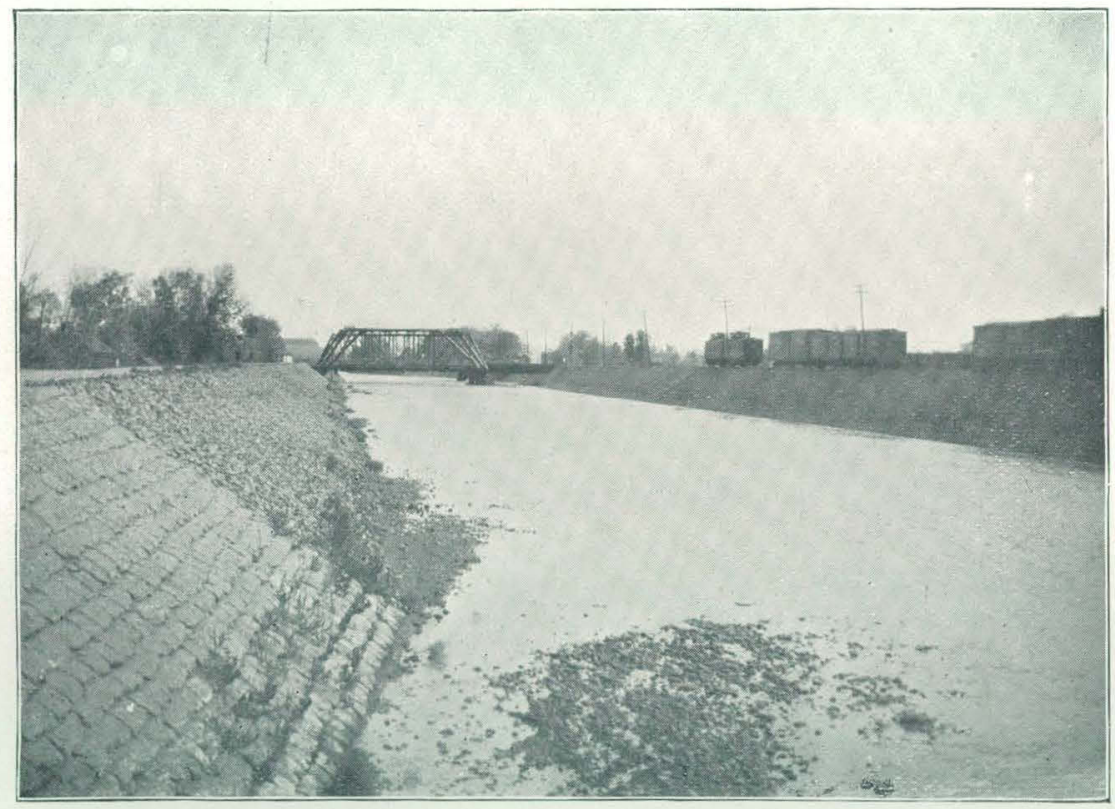

B. ARKANSAS RIVER BELOW MAIN STREET BRIDGE, PUEBLO, COLORADO. 
supply in the Arkansas, and to aid in regulating the distribution of water throughout the various water districts of the State of Colorado lying along this stream.

Pueblo station was maintained, as described in Water-Supply and Irrigation Paper No. 16, page 120, up to July 10, 1898, at which time a new gage rod was placed at the south end of the Main street bridge. The new gage rod is a 2 by 8 inch timber 15 feet long, well painted, and bolted to the masonry wall of the city levee; the intervals between the spaces are 0.104 feet. This change became necessary owing to a change in the channel of the Santa Fe avenue bridge, leaving the old rod high and dry, and the present location being better on account of its greater convenience for the water commissioner, who is provided with a rating table of the river at this point, and this being also the point at which all gagings have been made. The station is a most important one, being to a great extent the key by which the distribution of water in the Lower Arkansas is controlled. In making up the discharge table the gage heights of both rods are used, as they were practically the same. The observer up to September 1, 1898, was $\mathrm{Mr}$. R. L. Holden, of Pueblo. Mr. C. W. Reece, water commissioner of Colorado water district No. 14, made observations after July 10. Ratings are kept up throughout the year. A view of the river at Pueblo is given in Pl. XXXI, $B$.

Nepesta station was maintained, as described in Water-Supply and Irrigation Paper No. 16, page 121, from April 26 until November 30, 1898 , T. F. Hynes and S. M. Butts acting as observers during that time. The bed of the stream is sandy and shifting, and the discharges must be accepted as approximate only.

Manzanola station was established September 29, 1897, by Mr. Porter J. Preston, at a point about half a mile north from Manzanola, at a wagon bridge across the river. The gage rod is a vertical 2 by 6 inch timber 2 feet long, with a 1 by 6 inch scale, securely wired to the downstream side of lower right-hand cylinder of wagon bridge. The river is curved above and below, and the channel is sandy and somewliat shifting, though subject to less change than most places east of Pueblo. In 1898 observations were-taken from May 18 to October 22 by $\mathrm{Mr}$. M. D. Lyle, ditch rider of the Catlin Canal. As only two gagings of the stream were made at this point the data is insufficient for a rating table, and hence none is given.

Rockyford station was maintained as described in Water-Supply and Irrigation Paper No. 16, page 122, the observer being Mr. S. W. Cressy, as heretofore. A rating table was made up of the gagings made in 1897 and 1898, but owing to there being so fow the rating table must be cousidered as merely approximate.

Lamar station is located at the head of the Amity Canal, 7 miles west of Lamar, Colorado. The canal is taken out on the north side of the river at a point where there is a wooden dam extending clear across 
the stream. The dam is 380 feet long, the last 80 feet of the crest on the south side being 14 inches higher than the remaining 300 feet, which latter is 4 feet 4 inches above the floor of the headgate. The river at this point washes against a sandstone bluff on its north side, and the canal is taken out at the foot of the bluff. The dam renders the river channel unvarying, and, taken in connection with the canal, it furnishes an excellent place for obtaining the total discharge of the river at this point, particularly as the headgate keeper lives upon the spot. During the past year, however, reports have been sent in for the canal alone, no record being kept of the amount passing down the river. The observer is Mr. E. R. Bannister, headgate keeper of the Amity Canal.

Granada station is located at the headgate of the Buffalo Creek Canal, 2 miles northeast of Granada. The equipment consists of a bridge upon the headgate of the canal, there being an earth dam across the Arkansas at this point. This dam sometimes breaks during high water, however, and has to be repaired, thus making the gage readings of no great value except as showing the rise and fall of the water.

The channel is straight for about 2,600 feet above and for about 800 feet below, and the water is swift. The banks are high, but the channel is gravelly and liable to change.

The observer is Mr. Ben Riley, ditch rider of the Buffalo Creek ditch, who takes the observations once each day. No gagings have been made at this point, as the bed of the stream is so changeable that gagings would be of but little value. It is hoped that different arrangements, giving more valuable results, can be made during the next year. Readings were taken from the rod from July 24 to November 19, 1898, inclusive, and ranged from 0.2 foot to 1.6 feet, but owing to the changes in the dam at different times, they are of little value and are therefore not given.

PRECIPITATION IN THE BASIN OF ARKANSAS RIVER.

The principal observations of rainfall made within the basin of the Arkansas River are at Twin Lakes, Canyon City, Husted, Pueblo,

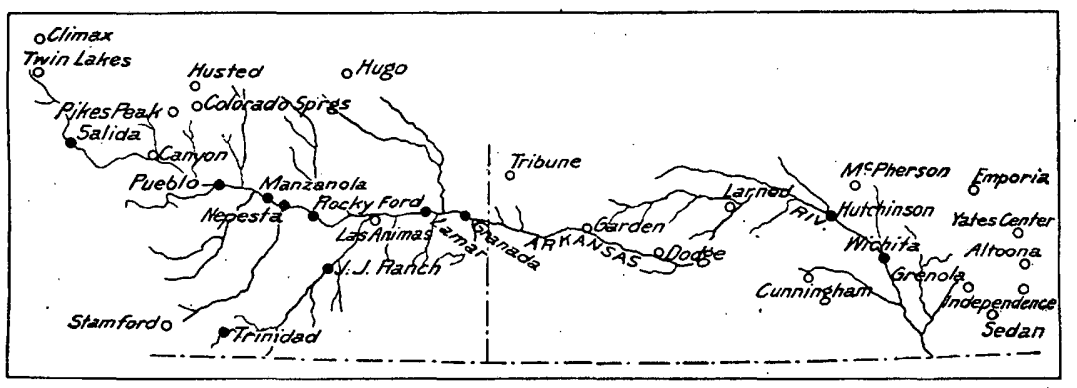

FIa. 122.-Relative location of river and rainfall observations in basin of Arkansas River. 
Stamford, Rockyford, Hugo, Las Animas, Lamar, Dodge City, Hutchinson, Cunningham, McPherson, Grenola, and Sedan. The relative location of these points is shown on fig. 116, in connection with the river measurements, which are at Twin Lakes, Salida, Canyon, Las Animas, Pueblo, Granite, Nepesta, Rockyford, Trinidad, and Hutchinson. The following table gives the namés and locations of the stations, the elevation, and time of beginning of the record:

Location of rainfall stations.

\begin{tabular}{|c|c|c|c|c|c|c|}
\hline Station. & County. & State. & Latitude. & $\begin{array}{l}\text { Longi- } \\
\text { tude. }\end{array}$ & $\begin{array}{l}\text { Elera. } \\
\text { tion. }\end{array}$ & $\begin{array}{l}\text { Length of } \\
\text { record. }\end{array}$ \\
\hline - & 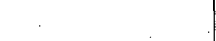 & . & 01 & 01 & & \\
\hline Twin Lakes. . & Lake.......... & Colorado .. & 3904 & 10620 & 9,012 & $4-8$ \\
\hline Canyon City.... & Fremont ..... & $\ldots$... do ... & 3827 & 10513 & 5,363 & $\ldots \ldots$ \\
\hline Husted... & El Paso ... & $\ldots$. . do .... & 3929 & 104.49 & 6,596 & $10-12$ \\
\hline Pueblo ...... & Pueblo .... & ....do. & 3818 & 10437 & 5,734 & $19-23$ \\
\hline Stamford ...... & Las Animas & $\ldots . . d o$ & 3715 & 10500 & 9,500 & 8 \\
\hline Rockyford . & Otero... & $\ldots$ do & 3804 & 10341 & 4,177 & $7-9$ \\
\hline Hugo........... & Lincoln ....... & ....do & 3909 & 10327 & 5,052 & $5-7$ \\
\hline Las Animas. & Bent .......... & $\ldots .$. do & 3804 & 10313 & $.3,892$ & 15 \\
\hline Lamar.... & Prowers...... & ....do & 3806 & 10238 & 3,592 & $6-9$ \\
\hline Dodge City . & Ford ....... & Kansas.... & 3745 & 10000 & 2,512 & 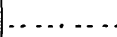 \\
\hline Hutchinson . . & Reno...... & $\ldots$ do & 3803 & 9755 & 1,529 & $6-8$ \\
\hline Cunningluam.... & Kingman.. & .... do & 3739 & 9824 & 1,700 & 14 \\
\hline MePherson & MePherson & $\ldots .$. do & 3822 & 9740 & 1,488 & $10-12$ \\
\hline Grenola .. & Elk ...... & $\ldots .$. do .... & 3726 & 9626 & 1,116 & $14-15$ \\
\hline Sedan .... & Chautauqua... & .... do & $\begin{array}{ll}37 & 08\end{array}$ & 9611 & 836 & $11-13$ \\
\hline
\end{tabular}

In the following table are given the figures of normal or average monthly precipitation from the time of the beginning of the record to and including 1897, together with the total precipitation by months for the years 1896, 1897, and 1898, and also the amount by years.

In obtaining the normal precipitation the average is taken for all of the months during which observations were made. 
Rainfall at stations in drainage basin of Arkansas River.

TWIN LAKES.

\begin{tabular}{|c|c|c|c|c|c|c|c|c|c|c|c|c|c|}
\hline Year. & Jan. & Feb. & Mar. & Apr. & May & June. & July. & Aug. & Sept. & Oct. & Nov. & Dęc. & Annual. \\
\hline Normal ....... & 1.33 & 1.38 & 1.01 & 1.04 & 1.23 & 0.42 & 2.52 & 1.31 & 0.89 & 0.98 & 1.03 & 1.44 & 14.58 \\
\hline $1896 \ldots$ & 4.80 & 0.98 & 1.47 & ....... & 1.25 & ...... & . & 1.05 & 1.50 & 0.48 & 2.43 & 0.42 & $\ldots \ldots$ \\
\hline $1897 \ldots$ & 0.79 & 3.40 & 1.38 & 1.09 & ...... & $0: 97$ & 1.00 & 1.52 & 1.14 & 1.62 & 0.73 & 0.45 & ....... \\
\hline 1898. & & & - & $\cdots$ & 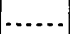 & $\ldots$ & $\ldots$ & $\ldots .$. & $\ldots$ & $\ldots . .$. & 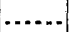 & $\cdots$ & \\
\hline \multicolumn{14}{|c|}{ MCPHERSON. } \\
\hline Normal. & 0.82 & 1.15 & 1.47 & 2.11 & 5.25 & 6.09 & 4.59 & 3.17 & 2.54 & 2.73 & 0.89 & 0.99 & 31.80 \\
\hline 1896. & 0.59 & 0.25 & 0.51 & 2.57 & 2.77 & 8.38 & 8.59 & 2.24 & 3.57 & 3. 99 & 1. 10 & 0.62 & 32.48 \\
\hline 1897 & 1.16 & 1.40 & 1.90 & 4.13 & 2.92 & 3. 22 & 7.13 & 2.57 & 1.58 & 1.99 & 0.08 & 0.19 & 28.27 \\
\hline 1898. & 1.77 & 1.06 & 1.48 & 6.16 & 6.34 & 5.90 & 2.53 & 2.56 & 3.75 & 2.33 & 1.13 & 2.37 & 37.38 \\
\hline \multicolumn{14}{|c|}{ GRENOLA. } \\
\hline Normal & 1.41 & 1.30 & 1.82 & 3. 81 & 3.37 & 4. 31 & 3. 71 & 3. 68 & 3.52 & 2.60 & 1.34 & 1.41 & 32.28 \\
\hline $1896 \ldots$ & 0.35 & $\mathbf{T}$ & 0.90 & 1.65 & 1.75 & 5.30 & 5.50 & 0.10 & 3.10 & 4.45 & 2.25 & 0.35 & 25.70 \\
\hline $1897 .$. & 0.95 & 0.90 & 3.53 & 5.77 & 1.56 & 2.98 & 4.62 & 3.30 & 1.09 & 1.42 & 0.21 & 1.15 & 27.48 \\
\hline $1898 \ldots$ & 3.34 & 2.32 & 2.08 & 2.26 & 6.22 & 5.70 & 6.21 & 3.01 & -3.77 & 2.93 & 1.50 & 1.89 & 41.23 \\
\hline \multicolumn{14}{|c|}{ SEDAN. } \\
\hline Normal & 1.24 & 1.38 & 2.24 & 3.68 & 4.80 & 3.92 & 3.14 & 3.05 & 3.64 & $2,1.8$ & 1.46 & 1.79 & 32.52 \\
\hline 1896 . & 0.54 & 0.25 & 1.55 & 1.98 & 5.51 & 5.84 & 4.54 & 0.72 & 3.48 & 3.67 & 2.12 & 0.68 & 30.88 \\
\hline $1897 .$. & 2.10 & 1.07 & 4.07 & 5.15 & 1.84 & 3.79 & 4.06 & 3.43 & 1.52 & 1.97 & 0.19 & 0.94 & 30.13 \\
\hline $1898 .$. & 4.97 & 2.06 & 2.81 & 1.40 & 5.62 & 5.49 & 5.83 & 3.23 & 5.66 & 2.25 & 0.84 & 2.49 & 42.65 \\
\hline \multicolumn{14}{|c|}{ CANON CrTY. } \\
\hline Normal....... & 0.50 & 0.70 & 0.74 & 1.34 & 1.83 & 0.79 & 2.21 & 1.75 & 0.49 & 0.84 & 0.39 & 0.44 & 12.02 \\
\hline $1896 .$. & 0.14 & 0.26 & 1.14 & 0.63 & 1.06 & 0.23 & 2.95 & 2.91 & 1. 62 & 0.55 & 0.44 & 0.03 & 11.96 \\
\hline $1897 \ldots$ & 0.08 & 0.97 & 0.36 & 0.75 & 1.12 & 1.59 & 1.55 & 2.04 & 0.86 & 1.22 & 0.20 & 0.39 & 11.13 \\
\hline 1898. & 0.56 & 0.39 & 0.71 & 0.91 & 2.89 & 1.07 & 1.83 & 0.80 & 0.27 & 0.82 & 0.15 & 1.05 & 11.45 \\
\hline \multicolumn{14}{|c|}{ HUSTED. } \\
\hline Normal & 0.29 & 0.33 & 1.01 & 1.63 & 2.53 & 1.68 & 3.04 & 2.43 & 0.64 & 1.08 & 0.34 & 0.36 & 15. 36 \\
\hline $1896 \ldots$ & 0.43 & 0.37 & 2.25 & 1.96 & 1. 25 & 0.94 & 3.80 & 3.08 & 2.59 & 0.86 & 0.20 & 0.27 & 18.00 \\
\hline $1897 \ldots$ & 0.43 & 0.96 & 2.06 & 1. Co & 1.23 & 1.70 & 3.00 & 1.81 & 0.70 & 1.45 & 0.33 & 0.26 & 15.53 \\
\hline $1898 \ldots$ & 0.28 & 0.15 & 0.31 & 1.77 & 5.34 & 2.71 & 2.81 & 1.37 & 0.49 & 0.63 & 0.49 & 0.50 & 16.85 \\
\hline \multicolumn{14}{|c|}{ PUEBLO. } \\
\hline Normal. & 0.42 & 0.62 & 0.54 & 1.28 & 1.62 & 1.25 & 2.15 & 1.72 & 1.03 & 0.59 & 0.61 & 0.49 & 12.32 \\
\hline $1896 \ldots$ & 0.41 & 0.31 & 0.89 & 0.57 & 1.13 & 0.35 & 2.08 & 1.98 & 1.41 & 0.71 & 0.34 & 0.63 & 10.81 \\
\hline $1897 \ldots \ldots \ldots$ & 0.55 & 1.47 & 0.32 & 0.24 & 1.93 & 2. 13 & 1.45 & 2.14 & 0.77 & 1.22 & .0 .10 & 0.39 & 12.71 \\
\hline \multicolumn{14}{|c|}{ STAMFORD. } \\
\hline Normal ....... & 1.26 & 2.58 & 2.11 & 2.53 & 2.39 & 1.29 & 3. 14 & 2.86 & 0.97 & 1.61 & 1.28 & 2.68 & 24.70 \\
\hline $1896 \ldots$ & 1.40 & 0.70 & 1.48 & 5.50 & 0.80 & 1.60 & 4.30 & 2.20 & 0.80 & 1.80 & 0.95 & 2.50 & 24.00 \\
\hline $1897 \ldots \ldots \ldots$ & 1.25 & 5.75 & 1.40 & 2.60 & 3.05 & 2.21 & 2.28 & 3.13 & 3.39 & 4. 30 & 0.40 & 2.00 & 31.76 \\
\hline $1898 \ldots$. & 0.91 & 1.83 & 1.40 & 3.99 & 2.52 & 2.61 & 4.71 & 3.03 & 1.45 & 2.28 & 0.99 & 1.59 & 27.31 \\
\hline
\end{tabular}


Rainfall at stations in drainage basin of Arkansas River-Continued. ROCKYFORD.

\begin{tabular}{|c|c|c|c|c|c|c|c|c|c|c|c|c|c|}
\hline Xear. & Jan. & Feb. & Mar. & Apr. & May. & June. & July. & Ang. & Sépt. & Oct. & Nov. & Dec. & Annual. \\
\hline Normal. & 0.46 & 0.32 & 0.56 & 0.97 & 1.92 & 0.81 & 3.31 & 1.25 & 0.72 & 0.86 & 0.24 & 0.57 & 11.99 \\
\hline $1896 .$. & 0.32 & 0.18 & 0.41 & 0.55 & 1.12 & 0.47 & 2.07 & 0.47 & 1.85 & 1.60 & 0.00 & 0.70 & 9.74 \\
\hline $1897 .$. & 0.75 & 0.37 & 0.20 & 0.44 & ...... & $\ldots \ldots$ & ...... & 0.73 & 0.79 & 2.64 & 0.19 & 1.06 & ....... \\
\hline $1898 \ldots$ & 0,40 & 0.00 & 0.16 & 1.06 & 2.71 & 3.16 & 3.52 & 0.92 & 1.55 & 1.36 & 0.37 & 0.83 & 16.04 \\
\hline \multicolumn{14}{|c|}{ HUGO. } \\
\hline Normal. & 0.18 & 0.28 & 0.59 & 0.78 & 2.48 & 1.48 & 2.67 & 2.71 & 0.53 & 0.32 & 0.08 & 0.32 & 12.42 \\
\hline $1896 \ldots$ & 0.52 & 0.30 & 1.25 & 1.22 & 1.05 & 0.70 & 3.42 & 2.80 & 0.65 & 0.57 & 0.02 & 0.28 & 12.78 \\
\hline 1897. & 0.14 & $(0.28)$ & $(0.59)$ & 0.49 & 0.70 & 1.68 & 1.35 & 6.21 & 0.42 & 0.96 & T. & 0.22 & 13.04 \\
\hline $1898 .$. & $\mathrm{T}$. & 0.00 & 0.45 & 1.24 & 4.75 & 1.10 & 2.90 & 2.07 & 1.50 & 0.50 & $\mathrm{~T}$ & 0.35 & 14.86 \\
\hline \multicolumn{14}{|c|}{ LAS ANIMAS. } \\
\hline Normal & 0.29 & 0.37 & 0.78 & 1.09 & 1.81 & 1.37 & 1.60 & 1.60 & 0.61 & 0.61 & 0.17 & 0.61 & 10.91 \\
\hline $1896 \ldots$ & 0.25 & 0.23 & 0.50 & 1.60 & 2.45 & 0.60 & 1. 30 & 0.30 & 2.45 & 1.43 & 0.00 & 0.70 & 11.81 \\
\hline 1897. & 0.45 & 0.46 & 3.60 & 0.85 & 0.80 & 1. 26 & 1.20. & 1.60 & 0.90 & 2.57 & 0.00 & 0.20 & 13.89 \\
\hline 1898. & 0.40 & 0.00 & 0.40 & 1.17 & 2.52 & 2.45 & 2.90 & 2.40 & 1.70 & 1. 30 & $\mathbf{T}$ & 0.39 & 15.63 \\
\hline \multicolumn{14}{|c|}{ LAMAR. } \\
\hline Normal & -0.18 & 0.22 & 1.24 & 1. 19 & 1.79 & 1.92 & 2.95 & 1.78 & 1.08 & 0.92 & 0.16 & 0.53 & 13.96 \\
\hline $1896 .$. & ...... & ..... & ...... & $\ldots$. & 0.55 & 2.57 & 1.69 & 0.48 & 2.53 & 0.87 & 0.00 & 0.65 & ........ \\
\hline $1897 .$. & 0.06 & 0.34 & 0.38 & 0.45 & 1.00 & 2.87 & 1.61 & 4.86 & 0.51 & 2.86 & 0.04 & 0.14 & 15.12 \\
\hline $1898 \ldots$ & 0.92 & 0.00 & 1.06 & 1,38 & 3.47 & 3.67 & 1.52 & 0.91 & 1.60 & 1.55 & 0.46 & 1.30 & 17.84 \\
\hline \multicolumn{14}{|c|}{ DODGE CITY. } \\
\hline Normal & 0.48 & 0.71 & 0.91 & 1.83 & 3.04 & 3.24 & 3.25 & 2.79 & 1.30 & 1.35 & 0.47 & 0.61 & 19.98 \\
\hline $1896 \ldots$ & 0.49 & T. & 0.25 & 5.50 & 1.13 & 1.98 & 5.41 & 0.73 & 1.06 & 2.45 & 0.34 & 0.53 & 19.87 \\
\hline $1897 . .$. & 1.44 & 2.38 & 0.26 & 3.21 & 1.49 & 2.31 & 3.91 & 3.06 & 0.60 & 2.66 & 0.06 & 0.20 & 21.58 \\
\hline \multicolumn{14}{|c|}{ HUTCHINSON. } \\
\hline Normal & 0.71 & 1.31 & 1.41 & 1.76 & 2.42 & 4.78 & 4.62 & 1. 77 & 2.72 & 2.43 & 0.68 & 1.21 & 25.82 \\
\hline $1896 \ldots$ & 0.72 & 0.34 & 1.15 & 2.97 & 2.06 & 6.51 & 6.72 & 0.85 & 6.44 & 4.45 & 1.70 & 0.53 & 34.44 \\
\hline $1897 \ldots$ & 0.95 & 1.20 & 1.08 & 3.19 & 2.98 & 1.18 & 3.43 & 1.12 & ...... & $\ldots . .$. & $\ldots . .$. & 1.17 & ........ \\
\hline 1898. & 1.47 & 0.50 & 1.81 & 6.40 & 3.88 & 5.93 & 3.20 & 5.49 & 3.46 & 1.91 & 1.12 & 2.59 & 37.76 \\
\hline \multicolumn{14}{|c|}{ CUNNINGHAM. } \\
\hline Normal & 0.8 & 0.8 & 1.2 & 2.6 & 2.6 & 4.3 & 3.4 & 2.8 & 1.7 & 1.9 & 0.6 & 0.7 & 23.40 \\
\hline $1896 \ldots$ & 0.71 & 0.12 & 0.33 & 1.68 & 1.27 & 6.11 & 5.11 & 0.08 & 3.17 & 2.12 & 1.61 & $0.38^{\circ}$ & 22.69 \\
\hline $1897 \ldots$ & 0.65 & 0.45 & 1.21 & 4.36 & 2.04 & 1.69 & 2.93 & 3.96 & 2.19 & 1.42 & 0.06 & 0.55 & 21.51 \\
\hline $1898 \ldots$ & 1.08 & 0.84 & 0.54 & 4.52 & 6.85 & 6.55 & 3.45 & 2.27 & 2.11 & 1.40 & 0.48 & 2.00 & 32.09 \\
\hline \multicolumn{14}{|c|}{ AVERAGES. } \\
\hline Normal & 0.69 & 0.90 & 1.18 & 1.84 & 2.61 & 251 & 3.09 & 2.31 & 1.49 & 1.40 & 0.65 & 0.94 & 19.61 \\
\hline $1896 \ldots$ & 0.83 & 0.31 & 1.61 & 2.18 & 1.68 & 2.97 & 4.11 & 1.33 & 2.41 & 2,00 & 0.90 & 0.62 & 20.95 \\
\hline $1897 \ldots$ & 0.78 & 1.51 & 1.55 & 2.29 & 1.74 & 2.11 & 2.82 & 2.77 & 1.18 & 2.02 & 0.19 & 0.62 & 19.58 \\
\hline $1898 \ldots$ & $\cdots$ & & & & & & & & & & $\cdots \cdots$ & & \\
\hline
\end{tabular}


Depth of run-off, in inches, from Arkansas drainage basin. ARKANSAS AT GRANITE.

\begin{tabular}{|c|c|c|c|c|c|c|c|c|c|c|c|c|c|}
\hline Year. & Jan. & Feb. & Mar. & Apr. & May. & June. & July. & Aug. & Sept. & Oct. & Nov. & Dec. & Annual \\
\hline 1897. & & & & & 3.01 & 3.83 & 1.95 & 0.94 & 0.45 & 0.31 & $(0.30)$ & $(0.31)$ & \\
\hline 1898 . & & $\cdots$ & & ...... & ...... & $\ldots . .$. & ....... & 0.31 & 0.12 & ...... & ........ & $\cdots$ & - $\ldots \ldots$ \\
\hline Average. & $\cdots$ & $\therefore$. & & a..... & 3.01 & 3.83 & 1.95 & 0.63 & 0.29 & 0.31 & $(0.30)$ & $(0.31)$ & \\
\hline \multicolumn{11}{|c|}{ ARKANSAS AT SALIDA. } & \multicolumn{3}{|c|}{ 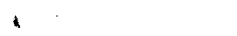 } \\
\hline 1895. & & & & 0.71 & 1.53 & 1.54 & 1.15 & 0.85 & 0.53 & 0.39 & & & \\
\hline 1896 & & & & & & & & & …... & $\cdots$ & $\cdots$ & ...... & \\
\hline 1897. & & & & …. & 1.64 & 1. 77 & 0.98 & 0.52 & 0.38 & 0.29 & 0.29 & 0.30 & \\
\hline 1898. & & $\cdots$ & & ....... & $\ldots .$. & ....... & ...... & 0.28 & 0.19 & 0.22 & 0.26 & ....... & $\cdots$ \\
\hline Average. & & .. & ....... & 0.71 & 1.59 & 1.66 & 1.07 & 0.55 & 0.37 & 0.30 & 0.28 & 0.30 & \\
\hline \multicolumn{14}{|c|}{ ARKANSAS AT CANYON CITY. } \\
\hline 1895. & 0.13 & 0.13 & 0.17 & 0.31 & 0.56 & 0.69 & 0.53 & 0.41 & 0.23 & 0.20 & 0.18 & 0.17 & 3. 71 \\
\hline $1896 \ldots$ & 0.17 & 0.15 & 0.17 & 0.20 & 0.48 & 0.35 & 0.21 & 0.15 & 0.11 & 0.10 & 0.10 & 0.22 & 2.41 \\
\hline $1897 \ldots$ & 0.14 & 0.12 & 0.14 & 0.11 & 0.66 & 0.90 & 0.41 & 0.21 & 0.13 & 0.17 & 0.19 & 0.15 & 3.33 \\
\hline $1898 \ldots$ & $(0.10)$ & $(0.11)$ & $(0.13)$ & $(0.14)$ & 0.35 & 0.88 & 0.60 & 0.13 & 0.07 & 0.08 & 0.11 & 0.13 & 2.83 \\
\hline Average. & 0.14 & 0.13 & 0.15 & 0.19 & 0.49 & 0.71 & 0.44 & 0.23 & 0.14 & 0.14 & 0.15 & 0.17 & 3.08 \\
\hline \multicolumn{14}{|c|}{ ARKANSAS AT PUEBLO. } \\
\hline 1894 & & & & & & & & $\ldots$ & 0.03 & $0 . \dot{10}$ & 0.10 & 0.09 , & \\
\hline 1895. & 0.12 & 0.11 & 0.09 & 0.18 & 0.39 & 0.53. & 0.47 & 0.32 & 0.12 & 0.14 & 0.13 & 0.12 & 2.72 \\
\hline $1896 \ldots$ & 0.13 & 0.11 & 0.10 & 0.11 & 0.28 & 0.21 & 0.16 & 0.13 & 0.08 & 0.07 & 0.08 & 0.08 & 1.54 \\
\hline $1897 \ldots$ & 0.08 & 0.07 & 0.06 & 0.06 & 0.41 & 0.54 & 0.26 & 0.12 & 0.07 & 0.10 & 0.12 & 0.09 . & 1.98 \\
\hline $1898 \ldots$ & 0.07 & 0.08 & 0.07 & 0.08 & 0.18 & 0.48 & 0.35 & 0.07 & 0.03 . & 0.05 & 0.07 & 0.08 & 1.61 \\
\hline A verage. & 0.10 & 0.09 & 0.08 & 0.11 & 0.32 & 0.44 & 0.31 & 0.16 & 0.06 & 0.09 & 0.10 & 0.09 & 1.96 \\
\hline \multicolumn{14}{|c|}{ ROCKXFORD. } \\
\hline 1897. & ....... & ….. & $\cdots$ & . . . . & 0.12 & 0.18 & 0.06 & 0.06 & 0.004 & 0.015 & 0.016 & 0.005 & ..... \\
\hline 1898. & 0.01 & 0.01 & 0.03 & 0.02 & 0.13 & 0.20 & 0.13 & 0.03 & 0.02 & 0.03 & 0.05 & 0.02 & 0.68 \\
\hline Average & 0.01 & 0.01 & 0.03 & 0.02 & 0.13 & 0.19 & 0.10 & 0.05 & 0.03 & 0.09 & 0.11 & 0.04 & 0.81 \\
\hline \multicolumn{14}{|c|}{ ARKANSAS AT HUTCHINSON. } \\
\hline 1895. & $\mid .2 .$. & & & & 0.001 & 0.03 & 0.13 & 0.09 & 0.012 & 0.002 & 0.001 & 0.002 & \\
\hline 1896. & 0.014 & 0.011 & 0.005 & 0.004 & 0.002 & 0.005 & 0.009 & 0.002 & 0.001 & 0.002 & 0.003 & 0.002 & 0.060 \\
\hline $1897 \ldots$ & 0.004 & 0.016 & 0.008 & 0.008 & 0.008 & 0.009 & 0.002 & 0.010 & 0.002 & 0.001 & 0.001 & 0.001 & 0.070 \\
\hline $1898 \ldots$ & 0.011 & 0.014 & 0.004 & 0.004 & 0.013 & 0.051 & 0.019 & 0.003 & 0.002 & 0: 001 & 0.001 & 0.004 & 0.127 \\
\hline Average & 0.010 & 0.014 & 0.006 & 0.005 & 0.006 & 0,017 & 0.013 & 0.006 & 0.004 & 0.002 & 0.002 & 0.002 & 0.087 \\
\hline \multicolumn{14}{|c|}{ PURGATOIRE AT TRINIDAD. } \\
\hline 1896. & ...... & $\cdots$ & & ....... & 0.10 & 0.09 & 0.53 & 0.12 & 0.11 & 0.12 & 0.06 & 0.06 & \\
\hline 1897. & 0.06 & 0.07 & 0.08 & 0.24 & 1.14 & 0.60 & 0.39 & 0.44 & 0.14 & 0.09 & 0.07 & 0.06 & 3.38 \\
\hline 1898. & $\cdots \cdots$ & $\ldots \ldots$ & $\cdots \cdot \cdots$ & $\cdots \cdots$ & 0.41 & 0.57 & 0.40 & 0.28 & 0.26 & 0.06 & 0.06 & $\cdots \cdot \cdots$ & \\
\hline Average. & $\overline{0.06}$ & 0,07 & 0.08 & $0 . \dot{24}$ & 0.55 & 0.42 & 0.44 & $\overline{0.28}$ & 0.17 & $\overline{0.09}$ & 0.06 & 0.06 & 2.52 \\
\hline
\end{tabular}


Rainfall and run-off, Arkansas River basin.

\begin{tabular}{|c|c|c|c|c|c|}
\hline Station. & Normal. & 1896. & 1897. & 1898. & 1895. \\
\hline \multicolumn{6}{|l|}{ RAINFALL. } \\
\hline 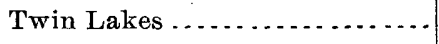 & 14.58 & $\ldots \ldots$. & 15. 32 & $\ldots \ldots$ & $\ldots$ \\
\hline 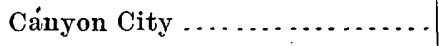 & 12.02 & 11.96 & $11.13^{\prime}$ & 11.45 & \\
\hline 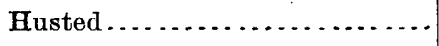 & 15. 36 & 18. 00 & 15.53 & 16.85 & \\
\hline Pueblo $\ldots \ldots \ldots \ldots \ldots \ldots . . . . . . . .$. & 12.32 & 10.81 & 12.71 & $\ldots \ldots . .$. & \\
\hline 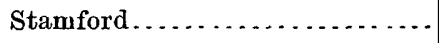 & 24.70 & 24.00 & 31.76 & 27.31 & \\
\hline Rockyford $\ldots \ldots \ldots \ldots \ldots \ldots$ & .11 .99 & 9.74 & 0.00 & 16. 04 & \\
\hline Hugo ..................... & 12.42 & 12.78 & 13.04 & 14.86 & \\
\hline Las Animas $\ldots . . . \ldots \ldots \ldots$ & 10.91 & 11.81 & 13.89 & 15.63 & \\
\hline 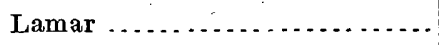 & 13.96 & $\ldots \ldots$ & 15.12 & 17.84 & \\
\hline Dodge City............... & 19.98 & 19.87 & 21.58 & ......... & \\
\hline 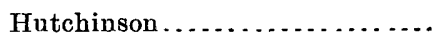 & 25.82 & 34.44 & $\ldots \ldots$ & 37.76 & \\
\hline Cunningham ..... & 23.40 & 22.69 & 21.51 & 32.09 & \\
\hline 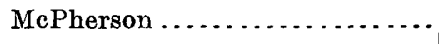 & 31.80 & 32.48 & 28.27 & 37.38 & \\
\hline Grenola . . . . . . . . . . . . . & 32.28 & 25.70 & 27.48 & 41.23 & \\
\hline Sedan $\ldots \ldots \ldots \ldots \ldots \ldots$ & 32.52 & 30.88 & 30.13 & 42.65 & \\
\hline Average $\ldots \ldots \ldots \ldots$ & 19.60 & 20.40 & 18. 39 & 25.10 & \\
\hline RUN-OFF. & & & & & ' \\
\hline Arkansas at Canyon City ....... & 3.08 & 2.41 & 3.33 & 2.83 & 3.71 \\
\hline Arkansas at Pueblo............. & 1. 96 & 1.54 & 1. 98 & 1. 61 & 2.72 \\
\hline Arkansas at Rockyford ......... & 0.81 & ........ & …..... & 0.68 & \\
\hline Arkansas at Hutchinson ........ & 0.087 . & 0.060 & 0.070 & 0.127 & \\
\hline Purgatoire at Trinidad ......... & 2.52 & $\cdots$ & 3.38 & $\cdots$ & $\cdots$ \\
\hline 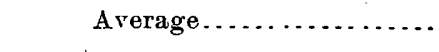 & 1.69 & 1.34 & 2. 19 & 1. 31 & \\
\hline Percentage of rainfall & 8.62 & 6.57 & .11 .91 & 5.22 & \\
\hline
\end{tabular}

Estimated monthly discharge of Arkansas River at Granite, Colorado.

[Drainage area, 425 square miles.]

\begin{tabular}{|c|c|c|c|c|c|c|}
\hline \multirow[b]{2}{*}{ Month. } & \multicolumn{3}{|c|}{ Discharge in second-feet. } & \multirow[b]{2}{*}{$\begin{array}{c}\text { Total in acre- } \\
\text { féet. }\end{array}$} & \multicolumn{2}{|c|}{ Run-off. } \\
\hline & $\begin{array}{l}\text { Maxi- } \\
\text { mum- } \\
\text { - }\end{array}$ & $\begin{array}{l}\text { Mini. } \\
\text { mum. }\end{array}$ & Mean. & & $\begin{array}{l}\text { Depth in } \\
\text { inches. }\end{array}$ & $\begin{array}{c}\text { Second- } \\
\text { feet per } \\
\text { square } \\
\text { mile. }\end{array}$ \\
\hline 1898. & & & & & & \\
\hline Angust............ & 151 & 75 & 113 & 6,948 & 0.31 & 0.27 \\
\hline September ........... & 93 & 8 & , 45 & 2,678 & 0.12 & 0.11 \\
\hline
\end{tabular}

Note.-Gage heights for 1898 are given in Water-Supply and Irrigation Paper No. 28, page 110; measurements, page 116; rating table, page 117; results for 1897 in Water-Supply and Irrigation Paper No. 16, page 117, and in the Nineteenth Annual Report, Part IV, page 353. 
Estimated monthly discharge of Arkansas River at Salida, Colorado.

[Drainage area, 1,160 square miles.]

\begin{tabular}{|c|c|c|c|c|c|c|}
\hline \multirow{2}{*}{ Month. } & \multicolumn{3}{|c|}{ Discharge in second-feet. } & \multirow[b]{2}{*}{$\begin{array}{l}\text { Total in acre- } \\
\text { feet. }\end{array}$} & \multicolumn{2}{|c|}{ Run-off. } \\
\hline & $\begin{array}{l}\text { Maxi. } \\
\text { mum. }\end{array}$ & $\begin{array}{l}\text { Mini. ' } \\
\text { mum. }\end{array}$ & Mean. & & $\begin{array}{l}\text { Depth in } \\
\text { inches. }\end{array}$ & $\begin{array}{c}\text { Second. } \\
\text { feet per } \\
\text { square } \\
\text { mile. }\end{array}$ \\
\hline 1898. & & & & & & \\
\hline August... & 423 & 169 & 280 & 17,217 & 0.28 & 0.24 \\
\hline September & 314 & 169 & 199 & 11,841 & 0.19 & 0.17 \\
\hline October............ & 314 & 100 & 223 & 13,712 & 0.22 & 0.19 \\
\hline November .......... & 314 & 204 & 267 & 15,888 & 0.26 & 0.23 \\
\hline
\end{tabular}

Note.--Gage heights for 1898 are given in Water-Supply and Irrigation Paper No. 28, page 110 measurements, page 116; rating table, page 117; results for 1897 in Water-Supply and Irrigation Paper No. 16, page 118, and in the Nineteenth Annual Report, Part IV, pages 354 and 355.

Estimated monthly discharge of Arkansas River, at Canyon City, Colorado.

[Drainage area, 3,060 square miles.]

\begin{tabular}{|c|c|c|c|c|c|c|}
\hline \multirow[b]{2}{*}{ Month. } & \multicolumn{3}{|c|}{ Discharge in second.feet. } & \multirow[b]{2}{*}{$\begin{array}{l}\text { Total in acre. } \\
\text { feet. }\end{array}$} & \multicolumn{2}{|c|}{ Run-off. } \\
\hline & $\begin{array}{l}\text { Maxi- } \\
\text { mum. }\end{array}$ & $\begin{array}{l}\text { Mini- } \\
\text { mum. }\end{array}$ & Mean. & & $\begin{array}{l}\text { Depth in } \\
\text { inches. }\end{array}$ & $\begin{array}{l}\text { Second- } \\
\text { feet per } \\
\text { square } \\
\text { mile. }\end{array}$ \\
\hline 1888. & & & & & & \\
\hline January . . . . . . . . . & $\ldots \ldots$ & $\ldots \ldots \ldots$ & $a 400$ & $a 24,600$ & $a 0.15$ & $a 0.13$ \\
\hline February........ & $\ldots \ldots$ & ........ & $a 500$ & $a 27,750$ & $a 0.17$ & $a 0.16$ \\
\hline March.................. & ......... & ...... & $a 600$ & $a 36,900$ & $a 0.22$ & $a 0.20$ \\
\hline April.................. & $\ldots \ldots \ldots$ & $\ldots \ldots$ & $a 1,000$ & $a 59,500$ & $a 0.36$ & $a 0.33$ \\
\hline 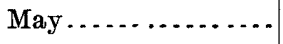 & 1,570 & 1,280 & 1,440 & 88,560 & 0.54 & 0.47 \\
\hline June............... & 2,760 & 1,120 & 2,090 & 124,355 & 0.76 & 0.68 \\
\hline July $\ldots \ldots \ldots \ldots \ldots$ & 1,870 & 850 & 1,350 & 83,025 & 0.51 & 0.44 \\
\hline August................. & 1,100 & 800 & 932 & 57,318 & 0.35 & 0.30 \\
\hline Septomber .......... & 850 & 430 & 605 & 35,997 & 0.22 & 0.20 \\
\hline October ................ & $\ldots \ldots \ldots$ & $\ldots \ldots \ldots$ & $a 500$ & $a 30,750$ & $a 0.19$ & $a 0.16$ \\
\hline November ........... & $\cdots$ & $\cdots$ & $a 500$ & $a 29,750$ & $a 0.18$ & $a 0.16$ \\
\hline December............ & $\ldots \ldots . .$. & $\ldots \ldots$ & $a 400$ & $a 24,600$ & $a 0.15$ & $a 0.13$ \\
\hline The year. & $\cdots$ & $\cdots$ & 860 & 623,105 & 3.80 & 0.28 \\
\hline 1889. & 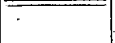 & & $\therefore$ & & & \\
\hline Januars . . . . . . . . . & & & $a 300$ & $a 18,450$ & $a 0.11$ & $a 0.10$ \\
\hline February ........... & $\therefore$ & .. & $a 300$ & $a 16 ; 620$ & $a 0.10$ & $a 0.10$ \\
\hline March..... & $\ldots \ldots$ & $\therefore \ldots$ & $a 300$ & $a 18,450$ & $a 0.11$ & $a 0.10$ \\
\hline April. . . . . . . . . . & 438 & 214 & 300. & 17,850 & 0.11 & 0.10 \\
\hline 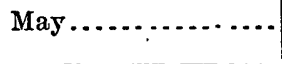 & 1,960 & 324 & 600 & 36,900 & 0.23 & 0.20 \\
\hline
\end{tabular}

a Approximate. 
332 PRÓGRESS OF STREAM MEASUREMENTS FOR 1898.

Estimated monthly discharge of Arkansas River, at Canyon City, Colorado-Cont'd.

\begin{tabular}{|c|c|c|c|c|c|c|}
\hline \multirow[b]{2}{*}{ Month. } & \multicolumn{3}{|c|}{ Discharge in second-feet. } & \multirow[b]{2}{*}{$\begin{array}{l}\text { Total in acre- } \\
\text { feet. }\end{array}$} & \multicolumn{2}{|c|}{ Run-off. } \\
\hline & $\begin{array}{l}\text { Maxi. } \\
\text { mum. }\end{array}$ & $\begin{array}{l}\text { Mini- } \\
\text { mum. }\end{array}$ & Mean. & & $\begin{array}{l}\text { Depth in } \\
\text { inches. }\end{array}$ & $\begin{array}{l}\text { Second- } \\
\text { feet per } \\
\text { square } \\
\text { mile. }\end{array}$ \\
\hline 1889. & & & & & & . \\
\hline June.... & 2,010 & 1,002 & 1,374 & 81,753 & 0.50 & 0.45 \\
\hline July $\ldots . .$. & 1,150 & 290 & 602 & 37,023 & 0.23 & 0.20 \\
\hline August.... & 2,620 & 243 & 340 & 20,910 & 0.13 & 0.11 \\
\hline September. & . 258 & 190 & 220 & 13,090 & 0.08 & 0.07 \\
\hline October........ & 284 & 190 & 223 & 13,715 & 0.08 & 0.07 \\
\hline November... & 335 & 243 & 299 & 17,790 & 0.11 & 0.10 \\
\hline December ...... & 438 & 274 & 335 & 20,602 & 0.13 & 0.11 \\
\hline The year. & 2,620 & 190 & 433 & $313 ; 153$ & 1.92 & 0.14 \\
\hline 1890. & & & & & & \\
\hline January..... & 494 & 180 & 310 & 19,065 & 0.12 & 0.10 \\
\hline February ...... & 446 & 250 & 363 & 20,146 & 0.12 & 0.12 \\
\hline March .... & 391 & 180 & 320 & 19,683 & 0.12 & 0.10 \\
\hline April ...... & 980 & 200 & 477 & 28,381 & 0.17 & 0.16 \\
\hline May ....... & 3,270 & 841 & 2,090 & 128,535 & 0.79 & 0.68 \\
\hline June...... & 3,260 & 2,068 & 2,611 & 155,354 & 0.95 & 0.85 \\
\hline July ....... & 2,132 & 920 & 1,571 & 96,616 & 0.59 & 0.51 \\
\hline August....... & 1,425 & 580 & 670 & 41,205 & 0.25 & 0.22 \\
\hline September .... & 625 & 455 & 519 & 30,880 & 0.19 & 0.17 \\
\hline October......... & 605 & 505 & 531 & 32,656 & 0.20 & 0.17 \\
\hline November...... & 555 & 480 & 522 & 31,059 & 0.19 & '0.17 \\
\hline December... & 580 & 455 & 502 & 30,873 & 0.19 & 0.16 \\
\hline The year: & 3,270 & 180 & 874 & 634,453 & 3. 88 & 0.28 \\
\hline 1891. & & & & & & \\
\hline January.... & 505 & 325 & 431 & 26,506 & 0.16 & 0.14 \\
\hline February .. & 580 & 365 & 474 & 26,307 & 0.16 & 0.15 \\
\hline March ... & 685 & 530 & 586 & 36,039 & 0.22 & 0.19 \\
\hline April ...... & 1,600 & 580 & 857 & 50,992 & 0.31 & 0.28 \\
\hline May .... & 3,700 & 1,340 & 2,012 & 123,738 & 0.76 & 0.66 \\
\hline Iune...... & 4,230 & 1,600 & 3,231 & 195,814 & 1. 20 & 1.07 \\
\hline July ...... & 2,810 & 770 & 1,468 & 90,282 & 0.55 & 0.48 \\
\hline August..... & 1,925 & 530 & $9 \mathfrak{s} 1$ & 58,486 & 0.36 & 0.31 \\
\hline September . & 715 & 345 & 473 & 28,143 & 0.17 & 0.15 \\
\hline October..... & 825 & 530 & 624 & 38,376 & 0.24 & 0.20 \\
\hline November...... & 530 & 430 & 498 & 29,631 & 0.18 & 0.16 \\
\hline December ...... & 605 & 345 & 476 & 29,274 & 0.18 & 0.16 \\
\hline The year..... & 4,230 & 325 & 1,012 & 733,588 & 4.49 & 0.35 \\
\hline
\end{tabular}


Estimated monthly discharge of Arkansas River, at Canyon City, Colorado-Cont'd.

\begin{tabular}{|c|c|c|c|c|c|c|}
\hline \multirow[b]{2}{*}{ Month. } & \multicolumn{3}{|c|}{ Discharge in second-feet. } & \multirow[b]{2}{*}{$\begin{array}{l}\text { Total in acre- } \\
\text { feet. }\end{array}$} & \multicolumn{2}{|c|}{ Ran-off. } \\
\hline & $\begin{array}{l}\text { Maxi- } \\
\text { mum. }\end{array}$ & $\begin{array}{l}\text { Mini- } \\
\text { mum. }\end{array}$ & Mean. & & $\begin{array}{l}\text { Depth in } \\
\text { inches. }\end{array}$ & $\begin{array}{c}\text { Second- } \\
\text { feet per } \\
\text { square } \\
\text { mile. }\end{array}$ \\
\hline 1892. & & & & & & \\
\hline January .......... & 630 & 345 . & 496 & 30,504 & 0.19 & 0.16 \\
\hline February ..... & 555 & 430 & 493 & 28,347 & 0.17 & 0.16 \\
\hline March.......... & 605 & 430 & 524 & 32,226 & 0.20 & 0.17 \\
\hline April...... & 715 & 410 & 522 & 31,059 & 0.19 & 0.17 \\
\hline May ........... & 2,250 & 685 & 1,241 & 76,322 & 0.47 & 0.41 \\
\hline June........... & 4,750 & 1,780 & 2,787 & 165,826 & 1.01 & 0.91 \\
\hline July .......... & 3,050 & $\mathbf{1}, 060$ & 1,798 & 110,577 & 0.68 & 0.59 \\
\hline August. . . . . . . . & 1,425 & 455 & 769 & 47,293 & 0.29 & $0.2 \overline{5}$ \\
\hline September ..... & 530 & 365 & 435 & 25,882 & 0.16 & $0.14^{\circ}$ \\
\hline October ......... & 605 & 410 & 511 & 31,426 & 0.19 & 0.17 \\
\hline November ...... & 605 & 455 & 527 & 31,356 & ). 19 & 0.17 \\
\hline December ...... & 630 & 480 & 561 & 34,502 & 0.21 & 0.18 \\
\hline The year..... & 4,750 & 345 & 889 & 645,320 & 3.95 & 0.29 \\
\hline 1893. & & & & & & \\
\hline January ......... & 580 & 430 & 505 & 31,058 & 0.19 & 0.16 \\
\hline February ...... & 630 & 455 & 533 & 29,582 & 0.18 & 0.17 \\
\hline March ......... & 885 & 480 & 555 & 34,133 & 0.21 & 0.18 \\
\hline April . . . . . . . . & 800 & 480 & 568 & 33,796 & 0.21 & 0.19 \\
\hline 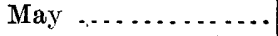 & 3,210 & 480 & $\mathbf{1}, 480$ & 91,020 & 0.56 & 0.48 \\
\hline June .......... & 4,750 & 1,875 & 3,115 & 185,343 & 1. 14 & 1.02 \\
\hline Júly ........... & 2,810 & 290 & 1,069 & 65,731 & $0.4 n$ & 0.35 \\
\hline August................ & 1,715 & 200 & 563 & 34,617 & 0.21 & 0.18 \\
\hline September ......... & 810 & 290 & 477 & - 28,384 & 0.18 & 0.16 \\
\hline October......... & $\cdots$ & $\cdots$ & $a 500$ & 30,744 & 0.18 & 0.16 \\
\hline November...... & - & $\cdots$ & $a 500$ & 29,752 & 0.18 & 0.16 \\
\hline December ...... & 580 & 390 & 428 & 26,317 & 0.16 & 0.14 \\
\hline The year..... & 4,750 & 200 & 857 & 620,477 & 3.80 & 0.27 \\
\hline 1894. & & & & & & \\
\hline January ...... & 580 & 390 & 445 & 27,362 & 0.17 & 0.15 \\
\hline February ...... & 510 & 390 & 420 & 23,326 & 0.15 & 0.14 \\
\hline March ........... & 810 & 340 & 505 & 31,051 & 0.18 & 0.16 \\
\hline April .... & 1,080 & 390 & 627 & 37,310 & 0.23 & 0.21 \\
\hline May $: . . . . . .$. & 4,400 & 990 & $\mathbf{1}, 960$ & 120,515 & 0.74 & 0.64 \\
\hline June....... & 4,400 & 1,290 & 2,704 & 160,899 & 0.98 & 0.88 \\
\hline $\mathrm{Jul} s \ldots .$. & 2,315 & 730 & $1,393^{\circ}$ & 85,652 & 0.52 & 0.45 \\
\hline August.... & 810 & 580 & 710 & 43,656 & 0.26 & 0.23 \\
\hline
\end{tabular}

a Approximate. 
Estimated monthly discharge of Arkansas River, at Canyon City, Colorado-Cont'd.

\begin{tabular}{|c|c|c|c|c|c|c|}
\hline \multirow[b]{2}{*}{ Month. } & \multicolumn{3}{|c|}{ Discharge in second feet. } & \multirow[b]{2}{*}{$\begin{array}{l}\text { Total in } 2 \text { cre }- \\
\text { feet. }\end{array}$} & \multicolumn{2}{|c|}{ Run-off. } \\
\hline & $\begin{array}{l}\text { Maxi- } \\
\text { mum. }\end{array}$ & $\begin{array}{l}\text { Mini- } \\
\text { mum. }\end{array}$ & Mean. & & $\begin{array}{l}\text { Depth in } \\
\text { inches. }\end{array}$ & $\begin{array}{c}\text { Second- } \\
\text { feet per } \\
\text { square } \\
\text { mile. }\end{array}$ \\
\hline 1894. & & & & & & \\
\hline September ........ & 810 & 390 & 551 & 32,786 & 0.20 & 0.18 \\
\hline October ............ & 450 & 245 & 294 & 18,077 & 0.12 & 0.10 \\
\hline November ....... & 290 & 245 & 260 & 15,471 & 0.09 & 0.08 \\
\hline December....... & 340 & 245 & 268 & 16,479 & 0.10 & 0.09 \\
\hline The year. & 4,400 & 245 & 845 & 612,584 & 3.74 & 0.28 \\
\hline 1895. & & & & & & \\
\hline January.... & 398 & 298 & 344 & 21,149 & 0.13 & 0.11 \\
\hline February..... & 458 & 298 & 361 & 20,049 & 0.13 & 0.12 \\
\hline March .... & 584 & 398 & 471 & 28,960 & 0.17 & 0.15 \\
\hline April ...... & 1,774 & 458 & 868 & 51,650 & 0.31 & 0.28 \\
\hline May ........... & 2,404 & 790 & 1,506 & 92,600 & 0.56 & 0.49 \\
\hline June.......... & 2,588 & 1,308 & 1,900 & 113,058 & 0.69 & 0.62 \\
\hline July .......... & 2,224 & 1,024 & 1,413 & 86,882 & 0.53 & 0.46 \\
\hline August...... & 2,143 & 790 & 1,095 & 67,328 & 0.41 & 0.36 \\
\hline September ..... & 942 & 458 & 635 & 37,786 & 0.23 & 0.21 \\
\hline October......... & 827 & 398 & 505 & 31,051 & 0.20 & 0.17 \\
\hline November ...... & 520 & 398 & 499 & 29,693 & 0.18 & 0.16 \\
\hline December... & 520 & 256 & 444 & 27,301 & 0.17 & 0.15 \\
\hline The year. & 2,588 & 256 & 837. & 607,507 & 3.71 & 0.27 \\
\hline 1896. & & & - & & . & \\
\hline January..... & 489 & 428 & 454 & 27,915 & 0.17 & 0.15 \\
\hline February ...... & 520 & 371 & 438 & 25,194 & 0.15 & 0.14 \\
\hline March ........... & 942 & 344 & 472 & 29,022 & 0.17 & 0.15 \\
\hline April ......... & 864 & 398 & 558 & 32,965 & 0.20 & 0.18 \\
\hline May ...... & 2,775 & 650 & 1,276 & 78,458 & 0.48 & 0.42 \\
\hline June .......... & 2,496 & 398 & 959 & 57,065 & 0.35 & 0.31 \\
\hline July ........... & 1,988 & 235 & 538 & 33,080 & 0.21 & 0.18 \\
\hline August............ & 2,876 & 144 & 395 & 24,287 & 0.15 & 0.13 \\
\hline September ......... & 520 & 192 & 313 & 18,625 & 0.11 & 0.10 \\
\hline October............ & 344 & 235 & 285 & 17,524 & 0.10 & 0.09 \\
\hline November .......... & 344 & 124 & 267 & 15,888 & 0.10 . & 0.09 \\
\hline December....... & 1,258 & 218 & 579 & 35,601 & 0.22 & 0.19 \\
\hline The year & 2,876 & 124 & 544 & 395,624 & 2.41 & 0.18 \\
\hline
\end{tabular}


Estimated monthly discharge of Arkansas River, at Canyon City, Colorado-Cont'd.

\begin{tabular}{|c|c|c|c|c|c|c|}
\hline \multirow{2}{*}{ Month. } & \multicolumn{3}{|c|}{ Discharge in second-feet. } & \multirow[b]{2}{*}{$\begin{array}{c}\text { Total in acre- } \\
\text { feet. }\end{array}$} & \multicolumn{2}{|c|}{ Run-off. } \\
\hline & $\begin{array}{l}\text { Maxi- } \\
\text { mum. }\end{array}$ & $\begin{array}{l}\text { Mini. } \\
\text { mum. }\end{array}$ & Mean. & & $\begin{array}{l}\text { Depth in } \\
\text { inches. }\end{array}$ & $\begin{array}{c}\text { Second- } \\
\text { feet per } \\
\text { square } \\
\text { mile. }\end{array}$ \\
\hline 1897. & & & & & & \\
\hline January ... & ....... & $\ldots \ldots \ldots$ & $a 380$ & $a 23,365$ & $a 0.14$ & $a 0.12$ \\
\hline February ... & $\ldots \ldots$. & $\ldots \ldots$. & $a 380$ & $a 21,105$ & $a 0.12$ & $a 0.12$ \\
\hline March ..... & $\ldots \ldots$ & $\ldots . .$. & $a 380$ & $a 23,365$ & $a 0.14$ & $a 0.12$ \\
\hline April $\ldots .$. & 530 & 230 & 320 & 19,041 & 0.11 & 0.10 \\
\hline May $\ldots . . . . . . .$. & 3,281 & 500 & 1,741 & 107,050 & 0.66 & 0.57 \\
\hline June................ & 3,395 & 1,628 & 2,464 & 146,618 & 0.90 & 0.81 \\
\hline July ................ & 1,799 & 500 & 1,115 & 68,560 & 0.41 & 0.36 \\
\hline August............. & 1,180 & 335 & 553 & 34,002 & 0.21 & 0.18 \\
\hline September ..... & 410 & 335 & 366 & 21,778 & 0.13 & $0.12^{\prime}$ \\
\hline October ............. & 620 & 370 & 471 & 28,960 & 0.17 & 0.15 \\
\hline November.......... & 620 & 370 & 519 & 30,883 & 0.19 & 0.17 \\
\hline December ..... & $\ldots \ldots \ldots$ & $\ldots \ldots \ldots$ & $a 400$ & 24,595 & 0.15 & 0.13 \\
\hline The year. & $\cdots$ & $\ldots \ldots \ldots$ & 757 & 549,322 & 3.33 & 0.25 \\
\hline 1898. & & & & & & \\
\hline January .. & & & $a 270$ & $a 16,602$ & $a 0.10$ & $a 0.09$ \\
\hline February ..... & & $\cdots$ & $a 350$ & $a 19,438$ & $a 0.11$ & $a 0.11$ \\
\hline March ..... & $\cdots$ & $\cdots$ & $a 338$ & $a 20,783$ & $a 0.13$ & $a 0.11$ \\
\hline April..... & …..... & $\ldots \ldots$ & $a 393$ & $a 23,386$ & $a 0.14$ & $a 0.13$ \\
\hline May ............. & 1,682 & 4.08 & 909 & 55,892 & 0.35 & 0.30 \\
\hline June ....... & 3,245 & 1,620 & 2,428 & 144,476 & $0.88^{\circ}$ & 0.79 \\
\hline ' July ....... & 2,745 & 476 & 1,613 & 99,180 & 0.61 & 0.53 \\
\hline August......... & 870 & 242 & 326 & 20,045 & 0.13 & 0.11 \\
\hline September .......... & 213 & 160 & 189 & 11,247 & 0.07 & 0.06 \\
\hline October ............ & 316 & 160 & 228 & 14,019 & .0 .08 & 0.07 \\
\hline November.......... & 360 & 242 & 302 & 17,970 & 0.11 & 0.10 \\
\hline December.. & - $\ldots . .$. & $\ldots \ldots \ldots$ & $a 350$ & $a 21,521$ & $a 0.13$ & $a 0.11$ \\
\hline The year.. & $\cdots$ & & 640 & 464,559 & 2.84 & 0.21 \\
\hline
\end{tabular}

a Appproximate.

Note.-Gage heights for 1898 are given in Water-Supply and Irrigation Paper No. 28, page 110; measurements, page 116; rating table, page 117; results for 1897 in Water-Supply and Irrigation Paper No. 16, page 119, and in the Nineteenth Annual Report, Part I $\nabla$, pages 355 to 356. 


\section{PROGRESS OF STREAM MEASUREMENTS FOR 1898.}

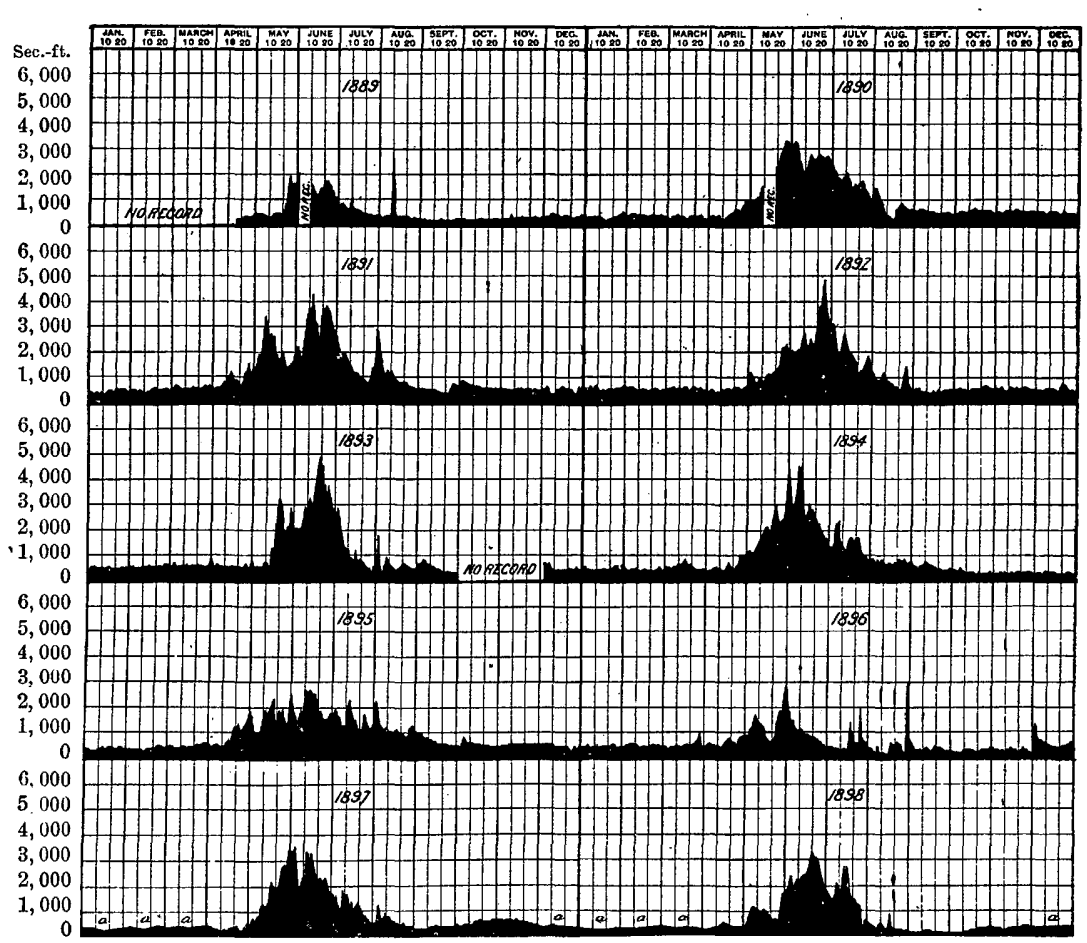

Fig. 123.-Arkansas River, at Canon City, Colorado, 1889-1898.

Estimated monthly discharge of Arkansas River at Pueblo, Colorado.

[Drainage area, 4,600 square miles.]

\begin{tabular}{|c|c|c|c|c|c|c|}
\hline \multirow[b]{2}{*}{ Month. } & \multicolumn{3}{|c|}{ Discharge in second-feet. } & \multirow{2}{*}{$\begin{array}{l}\text { ' } \\
\text { Total in acre- } \\
\text { feet. }\end{array}$} & \multicolumn{2}{|c|}{ Run-off. } \\
\hline & $\begin{array}{l}\text { Maxi. } \\
\text { mum. }\end{array}$ & $\begin{array}{l}\text { Mini. } \\
\text { mum. } \\
\text {. }\end{array}$ & Mean. & & $\begin{array}{l}\text { Depth in } \\
\text { inches. }\end{array}$ & $\begin{array}{l}\text { Second- } \\
\text { feet per } \\
\text { square } \\
\text { mile. }\end{array}$ \\
\hline 1898. & & & & & & \\
\hline January ........... & 425 & 178 & 330 & 20,291 & 0.08 & 0.07 \\
\hline February ......... & 470 & 232 & 385 & 21,382 & 0.09 & 0.08 \\
\hline March ........ & 425 & 232 & 320 & 19,676 & 0.08 & 0.07 \\
\hline April .......... & 620 & 232 & 370 & 22,016 & 0.09 & 0.08 \\
\hline May ....... & 1,258 & 470 & 841 & 51,711 & 0.21 & 0.18 \\
\hline June ...... & 3,290 & 1,258 & 2,202 & 131,028 & 0.54 & 0.48 \\
\hline July ...... & 5,385 & 470 & 1,605 & 98,688 & 0.40 & 0.35 \\
\hline Angust............. & 948 & 123 & 306 & 18,815 & 0.08 & 0.07 \\
\hline Sèptember . .... & 266 & 46 & 125 & 7,438 & 0.03 & 0.03 \\
\hline October ........... & 425 & 31 & 210 & 12,912 & 0.06 & 0.05 \\
\hline November .......... & 402 & 232 & 309 & 18,387 & 0.08 & 0.07 \\
\hline December.. & 470 & 178 & 363 & 22,320 & 0.09 & $\cdot 0.08$ \\
\hline The year & 5,385 & 31 & 614 & 444,664 & 1.82 & 0.13 \\
\hline
\end{tabular}

Note.-Gage heights for 1898 are given in Water-Supply and Irrigation Paper No. 28, page 111; measurements, page 116; rating table, page 117; results for 1897 in Water-Supply and Irrigation Paper No. 16, page 120, and in the Nineteenth Annual Report, Part IV, pages 356 to 357. 


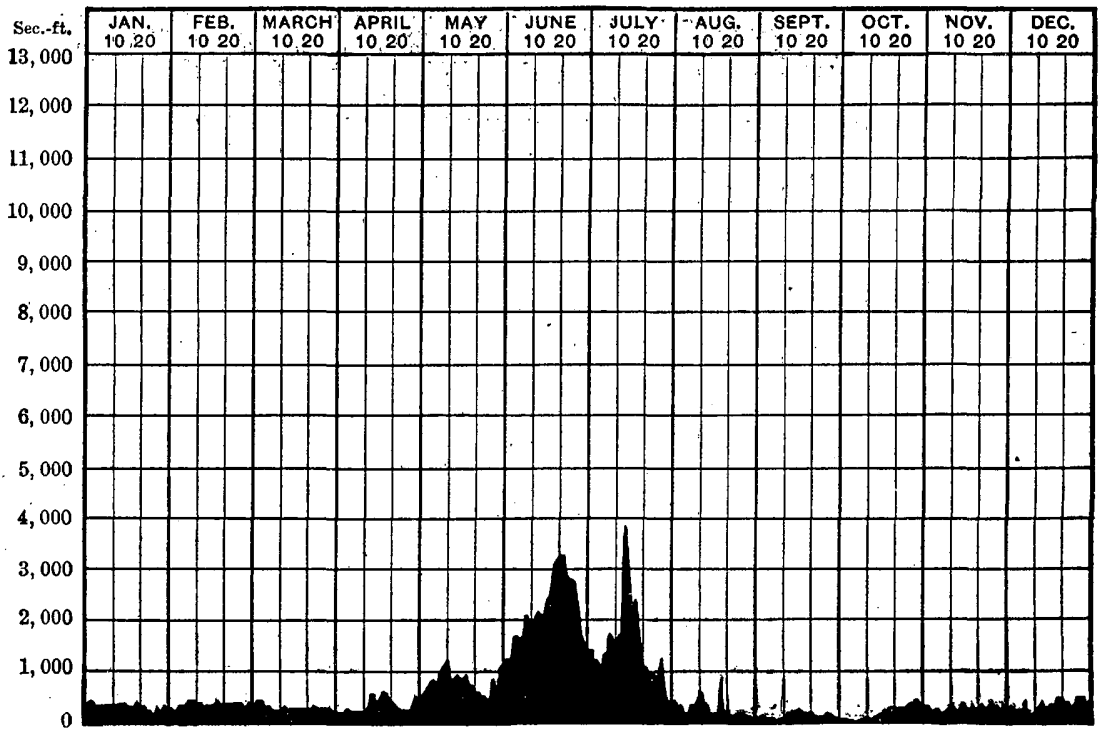

Fra. 124.-Discharge of Arkansas River at Pueblo, Colorado, 1898.

Estimated monthly discharge of Arkansas River at Nepesta, Colorado.

\begin{tabular}{|c|c|c|c|c|c|c|}
\hline \multirow[b]{2}{*}{ Month. } & \multicolumn{3}{|c|}{ Discharge in second-feet. } & \multirow[b]{2}{*}{$\begin{array}{c}\text { Total in acre- } \\
\text { feet. }\end{array}$} & \multicolumn{2}{|c|}{ Run-off. } \\
\hline & $\begin{array}{l}\text { Maxi- } \\
\text { mum. }\end{array}$ & $\begin{array}{l}\text { Mini- } \\
\text { mum. }\end{array}$ & Mean. & & $\begin{array}{l}\text { Depth in } \\
\text { inches. }\end{array}$ & $\begin{array}{c}\text { Second- } \\
\text { feet per } \\
\text { square } \\
\text { mile. }\end{array}$ \\
\hline 1898. & & & & & & \\
\hline 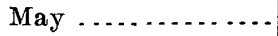 & 2,055 & 350 & 1,116 & 68,621 & & \\
\hline June................... & 3,665 & 918 & 2,103 & 125,137 & & \\
\hline July . . . . . . . . & 4,125 & 136 & 1,310 & 80,549 & & \\
\hline August. & 635 & 127 & 311 & 19,123 & & \\
\hline September . . . . . . . & 294 & 160 & 232 & 13,805 & $\ldots$ & $\ldots \ldots$ \\
\hline October ............ & 511 & 160 & 279 & 17,155 & $\ldots$ & \\
\hline Norember ......... & 511 & 260 & 366 & 21,778 & .. & \\
\hline
\end{tabular}

Note.-Gage heights for 1898 are given in Water-Supply and Irrigation Paper No. 28, page 112; measurements, page 116; rating table, page 117; results for 1897 in Water.Supply and Irrigation Paper No. 16, page 121, and in the Nineteenth Annual Report, Part IV, page 358.

20 GEOL, PT $4-22$ 


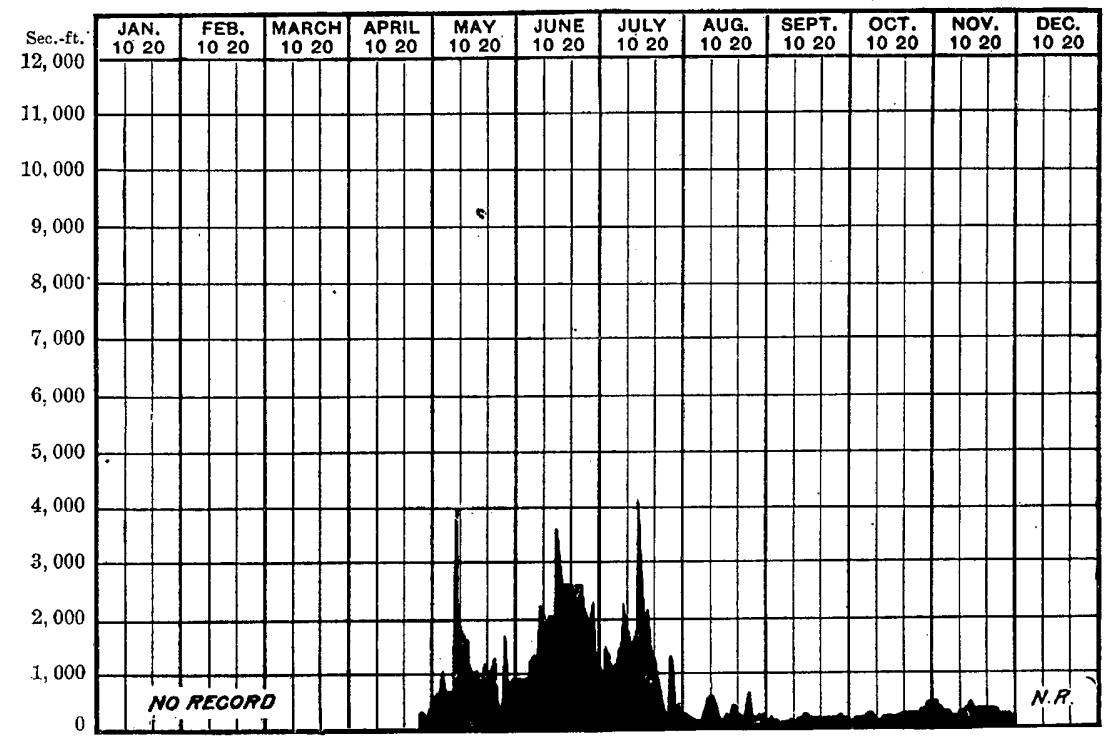

Fig. 125.-Discharge of Arkansas River at Nepesta, Colorado, 1898.

Esiimated monthly discharge of Arkansas River at Rockyford, Colorado.

[Drainage area, 11,440 square miles.]

\begin{tabular}{|c|c|c|c|c|c|c|}
\hline \multirow{2}{*}{ Month. } & \multicolumn{3}{|c|}{ Discharge in second.feet. } & \multirow[b]{2}{*}{$\begin{array}{l}\text { Total in acre- } \\
\text { feet. }\end{array}$} & \multicolumn{2}{|c|}{ Run-off. } \\
\hline & $\begin{array}{l}\text { Maxi- } \\
\text { mum. }\end{array}$ & $\begin{array}{l}\text { Mini- } \\
\text { mum. }\end{array}$ & Mean. & & $\begin{array}{l}\text { Depth in } \\
\text { inches. }\end{array}$ & $\begin{array}{l}\text { Second- } \\
\text { feet per } \\
\text { square } \\
\text { mile. }\end{array}$ \\
\hline 1898. & & & & & & \\
\hline January & & $\ldots$ & $a 75$ & $a 4,612$ & $a 0.008$ & $a 0.007$ \\
\hline February 20-28. & 193 & 34 & 75 & 4,165 & 0.01 & 0.01 \\
\hline March ....... & 393 & 129 & 254 & 15,618 & 0.03 & 0.02 \\
\hline April $\ldots$ & 550 & 64 & 213 & 12,674 & 0.02 & 0.02 \\
\hline May .... & 3,832 & 108 & 1,206 & 74,155 & 0.13 & 0.12 \\
\hline June ...... & 3,284 & 315 & 2,047 & 121,805 & 0.20 & 0.18 \\
\hline July ....... & 3,754 & 193 & 1,249 & 76,799 & 0.13 & 0.11 \\
\hline August....... & 706 & 108 & 269 & 16,540 & 0.03 & 0.02 \\
\hline September .... & 393 & 64 & 157 & 9,342 & 0.02 & 0.01 \\
\hline October .............. & 550 & 84 & 246 & 15,126 & 0.03 & 0.02 \\
\hline November .......... & 862 & 84 & 530 & 31,537 & 0.05 & 0.05 \\
\hline December $1-17$. & 393 & 84 & 228 & 14,020 & 0.02 & 0.02 \\
\hline The year. & 3,832 & 34 & 546 & 396,393 & 0.68 & 0.49 \\
\hline
\end{tabular}

$a$ Approximate.

NoTe.-Gage heights for 1898 are given in Water-Supply and Irrigation Paper No. 28, page 112; measurements, page 116; rating table, page 117; results for 1897 in Water-Supply and Irrigation Paper No. 16, page 122, and in the Nineteenth Annual Report, Part IV, page 353. 


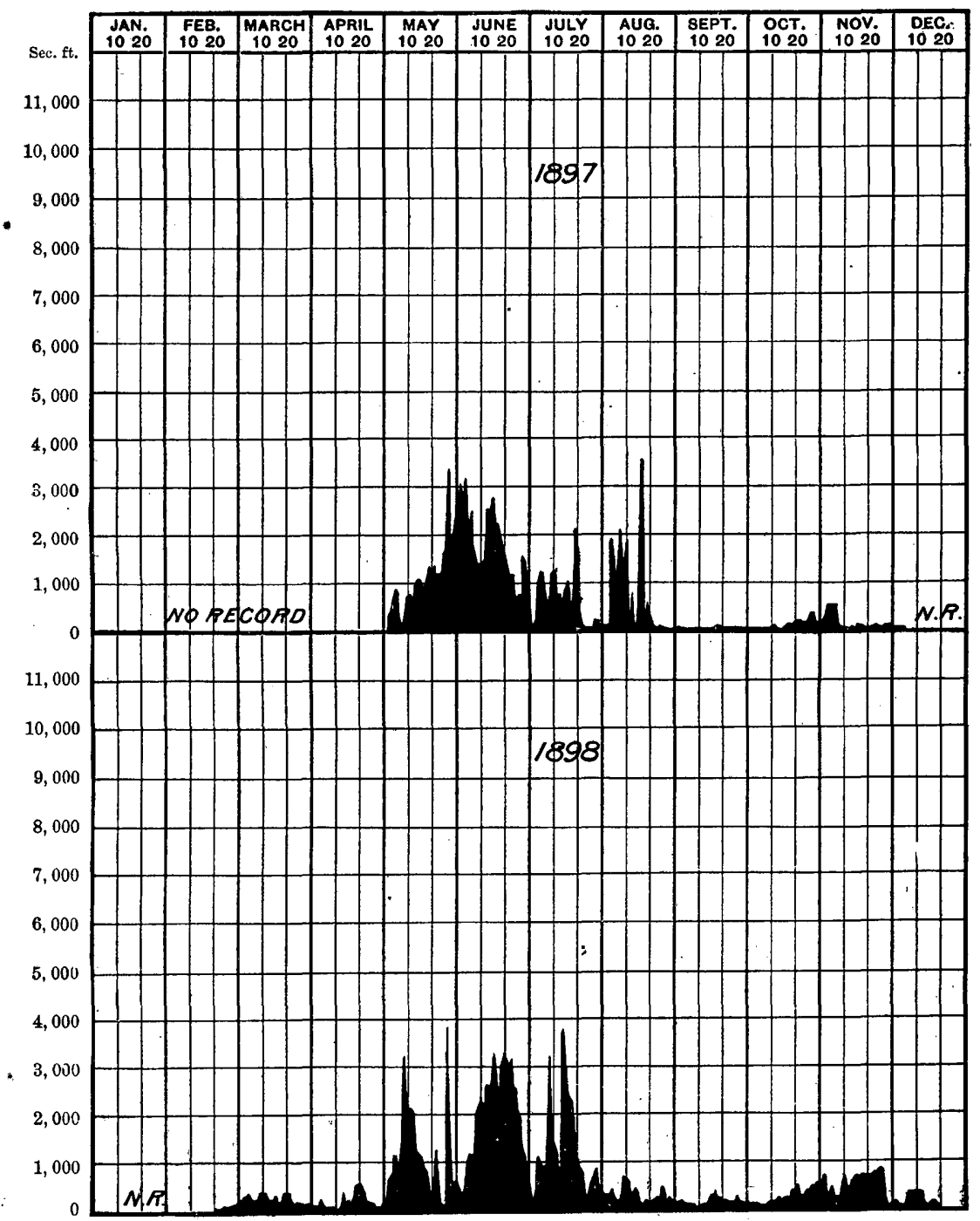

Fig. 126.-Discharge of Arkansas River at Rockyford, Colorado, 1897-98.

LAGUNA CANAL.

Mr. H. R. Holbrook, president of the Laguna Canal Company, writes that the Lake Canal was built in 1892, heading about one-half mile below Manzanola (formerly Catlin), and following along on the north side of the river to the vicinity of Rockyford, where it gradually turned toward the northeast, ending finally at Horse Creek, a distance of 25 miles. It is 20 feet wide on the bottom, and constructed with a grade of 0.026 or 1.37 feet per mile. It has been found that this is a satisfactory grade for a canal of this size, carrying 4 feet of water in depth. It was generally supposed that ditches with as light a grade as this, 


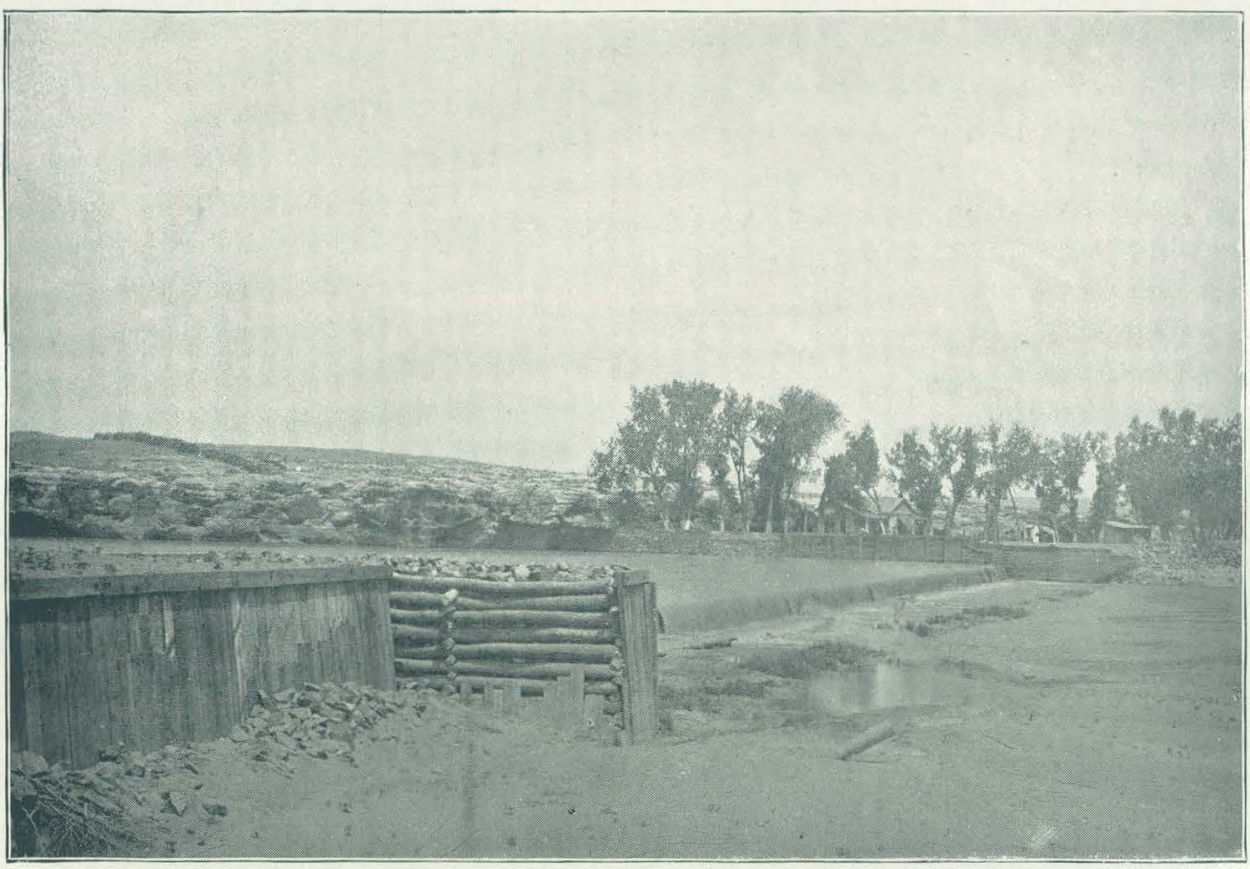

A. DAM OF AMITY CANAL IN ARKANSAS RIVER, COLORADO.

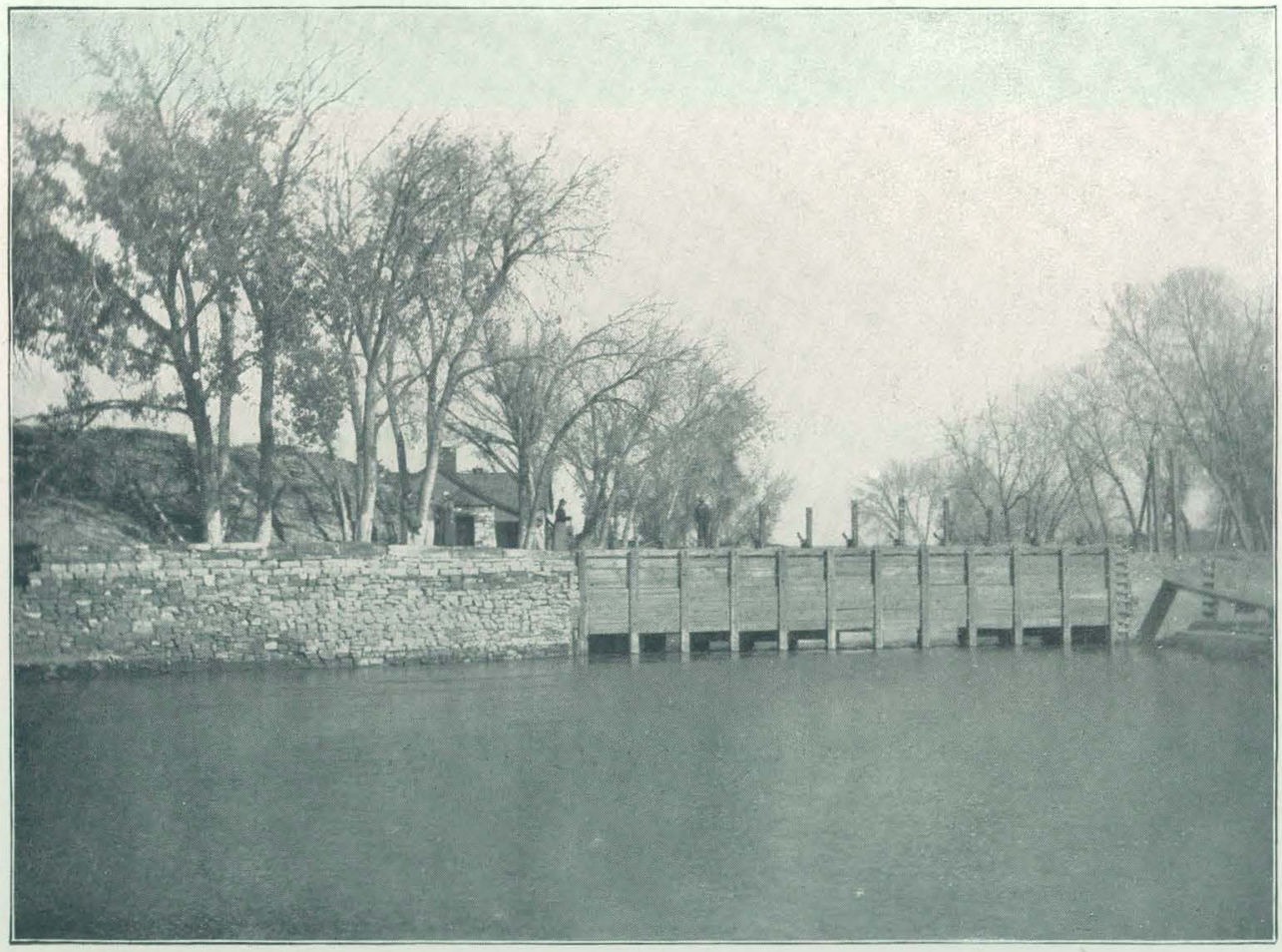

B. HEAD GATE OF AMITY CANAL 
and taking water from the Arkansas River, would fill up rapidly on account of the large amount of matter in suspension in the water. This has been proved not to be the case, for the canal has kept clean and water grass has not grown in the bottom.

Reservoir No. 1, situated about 5 miles east of Rockyford, was completed in 1895, and has been in operation for three years. It is located in a natural basin 45 feet in depth. When filled it has a sur- • face-water area of 600 acres. At a point 20 feet below the grade of the canal an outlet was cut at the rim of the basin, this cut being 15 feet deep at the center and about half a mile long. A canal 8 feet wide on the bottom, carrying 3 feet in depth of water, has been built from the reservoir for a distance of 15 miles, covering 3,000 acres. It has been found, however, that the clear water from the reservoir is not as good for irrigation as the water taken directly from the main canal. It percolates rapidly into the soil so that about one-half of the land under the reservoir canal is water-logged, injuring the production of crops. Water grass grows in the bottom, making the cost of maintenance of the canal from the reservoir much more than that of the main canal, carrying muddy water. The reservoir can be drawn down 15 feet, leaving water 30 feet in depth below the outlet.

An artesian well has been sunk by the same company at the southeast corner of section 27 , T. 22 S., R. 55 W., to a depth of 670 feet. Of this 20 feet was through sand and clay, 155 feet of limestone and associated rocks, 385 feet of black shale, and 110 feet of sandstone, probably belonging to the Dakota group. The flow is reported to be 55 gallons per minute, and the temperature of the water $71^{\circ}$. No analysis has been made, but it is believed that the mineral matter in solution is less than that in the wells at Rockyford, and that it is preferable for domestic use.

The view on Pl. XXXII, $A$, shows the Arkansas River at the head of A mity Canal. This is above the town of Lamar and takes water out upon the opposite or north side of the river covering lands to the north of Granada and carrying water to or across Kansas State line. The view is from the south bank of the river looking north. On the same plate at $B$ is a view of the head gates on the north bank of the river.

\section{PURGATORY RIVER.}

The principal tributaries of Arkansas Kiver, coming from the south, in Colorado are Huerfano, A pishapa, and Purgatory rivers. These rise in the Sangre de Cristo Range and flow' in a general northeasterly direction across the plains. - In their upper courses they carry considerable water, especially in the spring, but during the summer the volume shrinks and practically all of the available supply is taken for irrigation; so that little or no water is contributed to Arkansas River. During the times of storm or local "cloud-bursts" these channels often 
discharge great volumes of water into the main stream, but these floods are of short duration and usually do more harm than good.

Estimated monthly discharge of Purgatory River at Trinidad, Colorado. [Drainage area, 742 square miles.]

\begin{tabular}{|c|c|c|c|c|c|c|}
\hline - & Ḋischa & in secc & nd feét. & & Ro & off. \\
\hline $\begin{array}{l} \\
\\
\text { Month.. } \\
\end{array}$ & $\begin{array}{c}\text { Maxi } \\
\text { mum. } \\
: \vdots\end{array}$ & $\begin{array}{l}\text { Mini } \\
\text { mum. }\end{array}$ & Mean. & $\begin{array}{c}\text { Total in acre- } \\
\text { foet. } \\
\therefore \\
\quad:\end{array}$ & $\begin{array}{l}\begin{array}{l}\text { Depth in } \\
\text { inches. }\end{array} \\
.\end{array}$ & $\begin{array}{c}\text { Second. } \\
\text { feet per } \\
\text { square } \\
\text { mile. }\end{array}$ \\
\hline 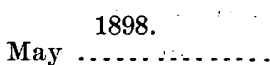 & .882 & $\therefore 109$ & 264 & 16,233 & 0.41 & 0.36 \\
\hline June ............. & 1, 282 & 109 & 377 & 22,433 & 0.57 & 0.51 , \\
\hline July ........ & 1,147 & 81 & 259 & 15,925 & 0.40 & 0.35 \\
\hline August. & .752 & 42 & .181 & 11,129 & 0.28 & 0.24 \\
\hline September & 1, 282 & : $\quad 42$ & 173 & 10,294 & 0.26 & 0.23 \\
\hline October. ... & .58 & . : 31 & 39 & 2,398 & 0.06 & 0.05 \\
\hline November ... & 42 & 36 & 39 & 2,321 & 0.06 & 0.05 \\
\hline
\end{tabular}

No'TE.-Gage heights for 1,898, are given in Water.Supply and Irrigation Paper No. 28,.page 113; measurements, page 116; rating table, page 117. Results for 1897 in Water-Supply and Irrigation Paper No. 16, page 123, and in the Nineteenth Annual Report, Part IV, pages 358 to 360 .

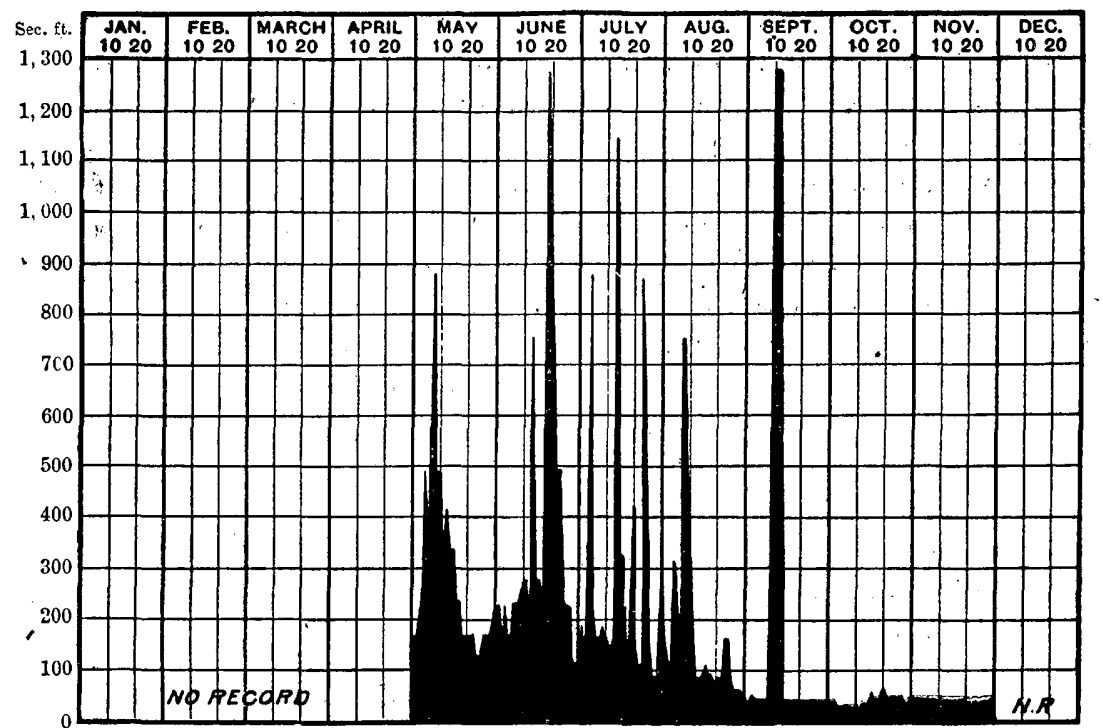

Fit. 127.-Discharge of Purgatory River at Trinidad, Colorado, 1898.

Observatious on Purgatory River have been made at three points, the uppermost being at Trinidad, near the mountains, where the drainage is only 742 square miles. Here the stream is perennial and furnishes a supply of water for the cultivation of a considerable area of farm land. At a point about 100 miles farther down, following the 
course of the stream, observations have been made at what is known as J. J. ranch, this being well out on the plains. A third point of observation is near the town of Las Animas, where the stream empties into Arkansas River.

The station at Trimidad is located at the Las Animas street bridge. The first measurement was made on September 24, 1895. Regular observations were begun on May 1, 1896, and have been maintained during the greater part of 1897 and 1898.

J. J. ranch station on Purgatory River was established June 13, 1898, by C. W. Beach, at the J. J. ranch, 22 miles south of La Junta and about 27 miles above the mouth of the Purgatory River, and half a mile below the mouth of Smith Canyon, a large tributary of the Purgatory. The gage rod is nailed to a pole, which is securely fastened by means of poles driven into the bank. The river channel is straight for a distance of 400 feet above and 200 feet below the rod. The bed is gravelly and shifting. Not enough.measurements were made in 1898 to compute a rating table, so the discharges are not given.

Observations were taken from June 13 to July 2, inclusive, and again from August 7 to November 12, inclusive, the readings of the gage varying from 2.3 to 5.7 , correspouding to discharge of from 30 to several hundred cubic feet per second, both the highest and the lowest stages being in August. This station is of especial value to the Great Plains Water Company; which has maintained it, being connected to the headquarters of the Company at Las Animas and La Junta by telephone. Reference is made to this station in Water-Supply and Irrigation Paper No. 28, page 108; gage heights are given on page 113, and measurements on page 116.

Las Animas station was established May 12, 1898, by C. W. Beach, under the direction of the Great Plains Water Company, but was kept up for only a part of the month of May, 1898, Mr. Beach taking all the observations and making two gagings, from which an approximate rating table was made, giving 700 cubic feet per second as the maximum, 326 as the mean, and 31 for the minimum flow.

\section{ARKANSAS RIVER AT LAS ANIMAS, COLORADO.}

Las Animas station on Arkansas River is described in Water-Supply and Irrigation Paper No. 28, page 109. No measurements were made in 1898 and no rating table constructed. Gage heights are given in Water-Supply Paper referred to on page 113.

\section{ARKANSAS RIVER AT HUTCHINSON, KANSAS.}

Occasional observations and measurements of Arkansas River have been made at points in Colorado below Las Animas, notably at Lamar and Granada, as described on pages 324 and 325 . Passing into Kan: sas, the flow has not been systematically determined until the stream has continued more than halfway across that State. At Butchinson 
observations were begun in 1895 and have been maintained during the succeeding years, the results being shown graphically in fig. 128.

Estimated monthly discharge of Arkansas River at Hutchinson, Kansas.

[Drainage area, 34,000 square miles.]

\begin{tabular}{|c|c|c|c|c|c|c|}
\hline \multirow[b]{2}{*}{ Month. } & \multicolumn{3}{|c|}{ Discharge in second-feet. } & \multirow[b]{2}{*}{$\begin{array}{c}\text { Total in acre- } \\
\text { feet. }\end{array}$} & \multicolumn{2}{|c|}{ Run-off. } \\
\hline & $\begin{array}{l}\text { Maxi- } \\
\text { mumu. }\end{array}$ & $\begin{array}{l}\text { Mini- } \\
\text { mum. }\end{array}$ & Mean. & & $\begin{array}{l}\text { Depth in } \\
\text { inches. }\end{array}$ & $\begin{array}{c}\text { Second. } \\
\text { feet per } \\
\text { square } \\
\text { mile. }\end{array}$ \\
\hline 1898. & & & & & & \\
\hline January .......... & 765 & 44 & 311 & 19,123 & 0.011 & 0.009 \\
\hline February ......... & 1,060 & 188 & 450 & 24,992 & 0.014 & 0.013 \\
\hline 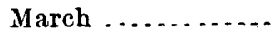 & 164 & 60 & 109 & 6,702 & 0.004 & 0.003 \\
\hline April ................. & 540 & 60 & 106 & 6,307 & 0.004 & 0.003 \\
\hline May .................. & 1,690 & $\cdot 188$ & 377 & 23,181 & 0.013 & 0.011 \\
\hline June $\ldots . . . \ldots \ldots$ & 2,830 & 645 & 1,548 & 92,112 & 0.051 & 0.046 \\
\hline July ....... & 1,525 & 140 & 559 & 34,372 & 0.019 & 0.017 \\
\hline August. . . . . . . . . . & 218 & 18 & 91 & 5,595 & 0.003 & 0.003 \\
\hline September ........ & 420 & 4 & 64 & 3,808 & 0.002 & 0.002 \\
\hline October ............. & 44 & 18 & 33 & 2,029 & 0.001 & 0.001 \\
\hline November... & 82 & 18 & 29 & 1,726 & 0.001 & 0.001 \\
\hline December .......... & 645 & 32 & 120 & 7,379 & 0.004 & 0.003 \\
\hline The year. & 2,830 & 4 & 316 & 227,326 & 0.127 & 0.09 \\
\hline
\end{tabular}

Note.-Gage heights for 1898 are given in Water-Supply and Irrigation Paper No. 28, page 114; measurements, page 116; rating table, page 117. Results for 1897 in Water-Supply and Irrigation Paper No.16, page 124, and in the Nineteenth Annual Report, Part IV, pages 360 to 361 .

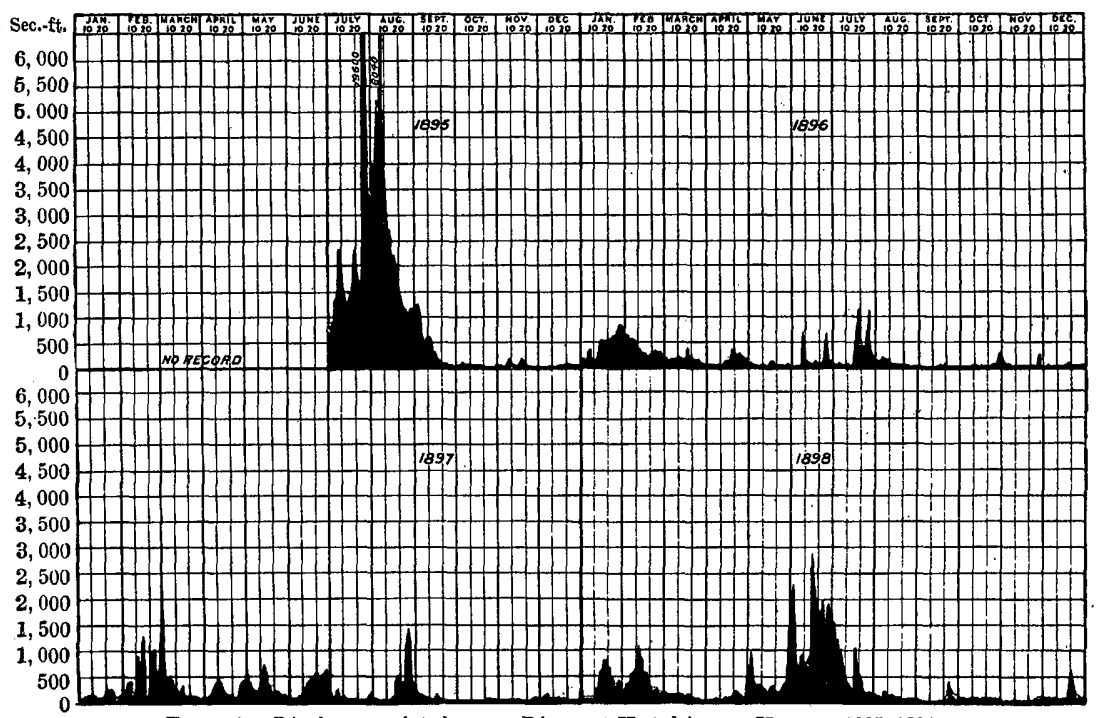

Fig. 128.-Discharge of Arkansas River at Hutchinson, Kansas, 1895-1898. 
VERDIGRIS RYVER.

Estimated monthly discharge of Verdigris River at Liberty, Kansas.

[Drainage area, 3,067 square miles.]

\begin{tabular}{|c|c|c|c|c|c|c|}
\hline \multirow[b]{2}{*}{ Month. } & \multicolumn{3}{|c|}{ Discharge in second-feet. } & \multirow[b]{2}{*}{$\begin{array}{l}\text { Total in acre- } \\
\text { feet. }\end{array}$} & \multicolumn{2}{|c|}{ Run.off. } \\
\hline & $\begin{array}{l}\text { Maxi. } \\
\text { mun. }\end{array}$ & $\begin{array}{l}\text { Mini- } \\
\text { mum. }\end{array}$ & Mean. & & $\begin{array}{c}\text { Depth in } \\
\text { inches. }\end{array}$ & $\begin{array}{l}\text { Second. } \\
\text { feet per } \\
\text { square } \\
\text { mile. }\end{array}$ \\
\hline 1898. & & & & & & \\
\hline January.... & 1,010 & 9 & $106 a$ & $6,518 a$ & $0.04 a$ & $0.03 a$ \\
\hline February....$\ldots \ldots$ & 10,606 & 39 & $1,084 a$ & $60,202 a$ & $0.37 a$ & $0.35 a$ \\
\hline March ...... & 6,383 & 52 & 1,335 & 82,086 & 0.51 & 0.44 \\
\hline April.... & 3,267 & 230 & 859 & 51,114 & 0.31 & 0.28 \\
\hline May ..... & 30,690 & 579 & 6,185 & 380,303 & 2.33 & 2.02 \\
\hline June ..... & 10,073 & 475 & 2,455 & 146,082 & 0.89 & 0.80 \\
\hline July ........ & 5,727 & 39 & 390 & 23,980 & 0.15 & 0.13 \\
\hline Angust.... & 7,285 & 9 & 498 & 30,620 & 0.18 & 0.16 \\
\hline September. & 4,087 & 2 & 515 & 30,645 & 0.19 & 0.17 \\
\hline October.... & 256 & 14 & 61 & 3,751 & 0.02 & 0.02 \\
\hline November.... & 830 & 28 & 121 & 7,200 & 0.04 & 0.04 \\
\hline Decẹmber .. & 10,942 & 87 & 1,457 & 89,588 & 0.54 & 0.48 \\
\hline The year. & 30,690 & 2 & 1,255 & 912,089 & 5.57 & $0.41^{\circ}$ \\
\hline
\end{tabular}

a Approximate.

Notw-Gage heights for 1898 are given in Water-Supply and Irrigation Paper No. 28, page 115 measurements, page 116; rating table, page117. Results for 1897 in Water-Supply and Irrigation Paper No. 16, page 125, and in the Nineteenth Annual Report, Part IV, pages 369 to 372.

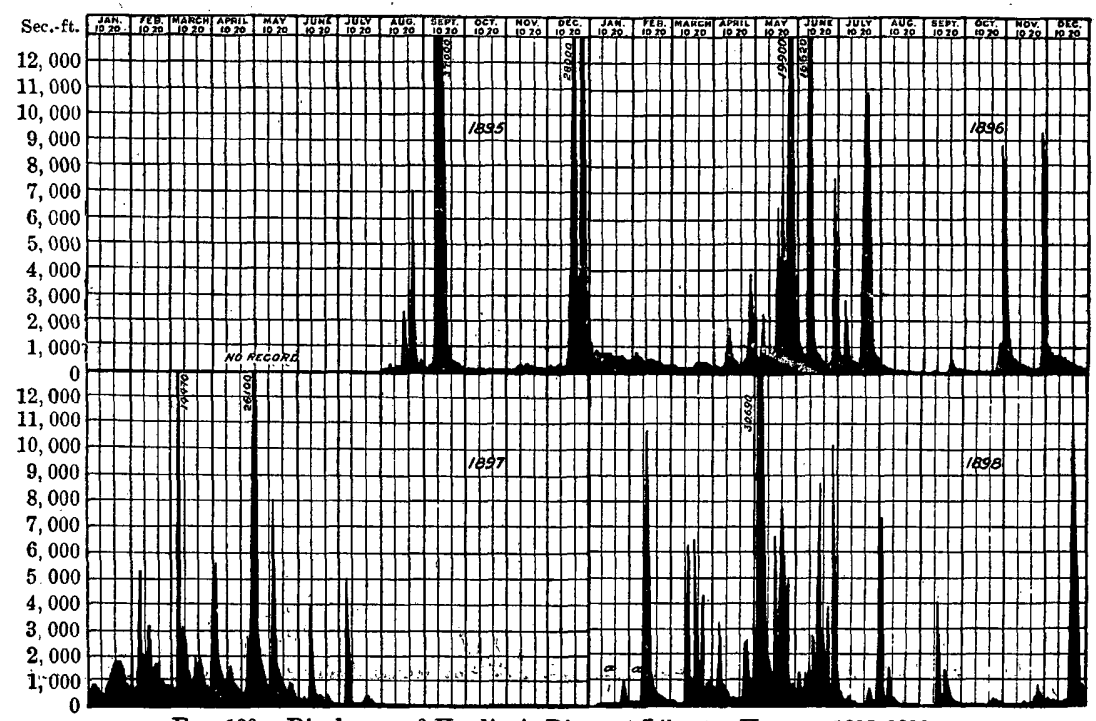

Fig. 129.-Discharge of Verdigris River at Liberty, Kansas, 1895-1898. 


\section{NEOSHO .RIVER.}

Neosho River rises in the northern part of Morris County, Kansas, flows in a southeasterly and southerly direction through part of Kansas and Indian Territory, and empties into Arkansas River near Fort Gibson. In a direct course this river has a length of 260 miles, but the distance along the river is much more than this, as it is very crooked. It falls from an elevation of 1,500 feet to 800 feet, at a point about 27 miles north of the Kansas and Indian Territory line, the dis. tance being 136 miles. From this point to the mouth, a distance of 110 miles in a straight line, it falls about 300 feet. It drains a long, narrow strip of land just east of Verdigris River and west of Osage and White rivers. The distance between 50-foot contours is as follows:

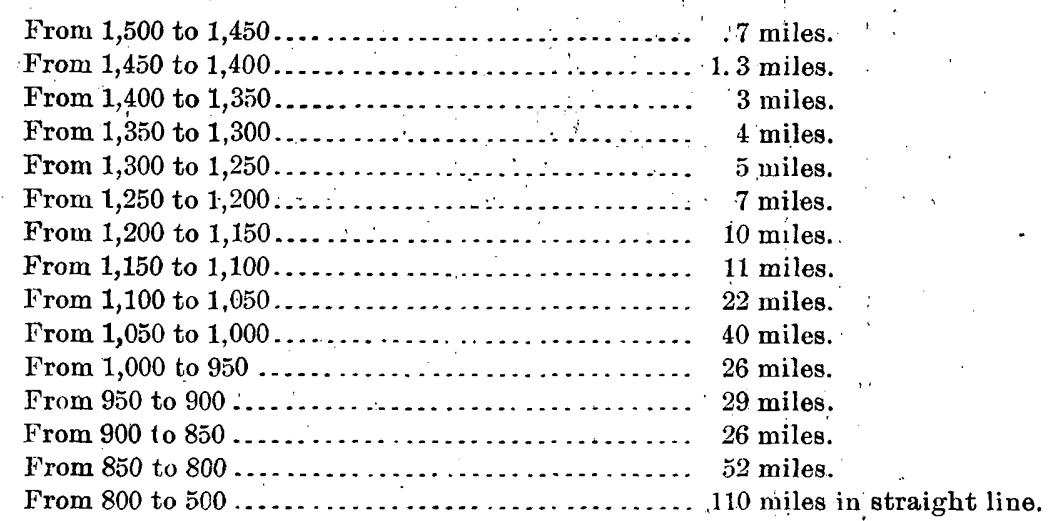

The characteristics of this river can perhajps best be brought out by comparing it with its companion river, the Verdigris. The Neosho River is about 40 miles farther north and at about 100 feet greater elevation than the Verdigris.' They flow nearly parallel and empty into the Arkansas River at nearly the same place. The Verdigris falls more rapidly in its upper course, reaching the State-line at an elevation of about 680 feet, falling from 1,400 feet to 680 feet in about $15 \mathrm{~L}$ miles. The Neosho falls more gradually, reaching the State line at an elevation of about 770 feet, and falling from 1,500 feet to 770 feet in about 267 miles. From the State line to the mouth the Neosho falls about 270 feet; the Verdigris about 180 feet. As a result of these differences in topography the Verdigris flows in a narrow, deep channel, the river bottom being subject to overflow in only a few places, when the water is very high. The Neosho is wider, has lower banks, and is subject to overflow in many places, notably near Chanute, Kansas, where there are embankments aloug the river for several miles.' Near the mouth the differences are very markëd; the Verdigris is deep, 250 feet wide, and sluggish, with scarcely a perceptible current at ordinary stage of water; the Neosho is 600 to 800 feet wide, and shallow, with rapid velocity.

${ }^{1}$ Nineteenth Ann. Rept., Part IV, p. 363. 
346 PROGRESS OF STREAM MEASUREMENTS FOR 1898.

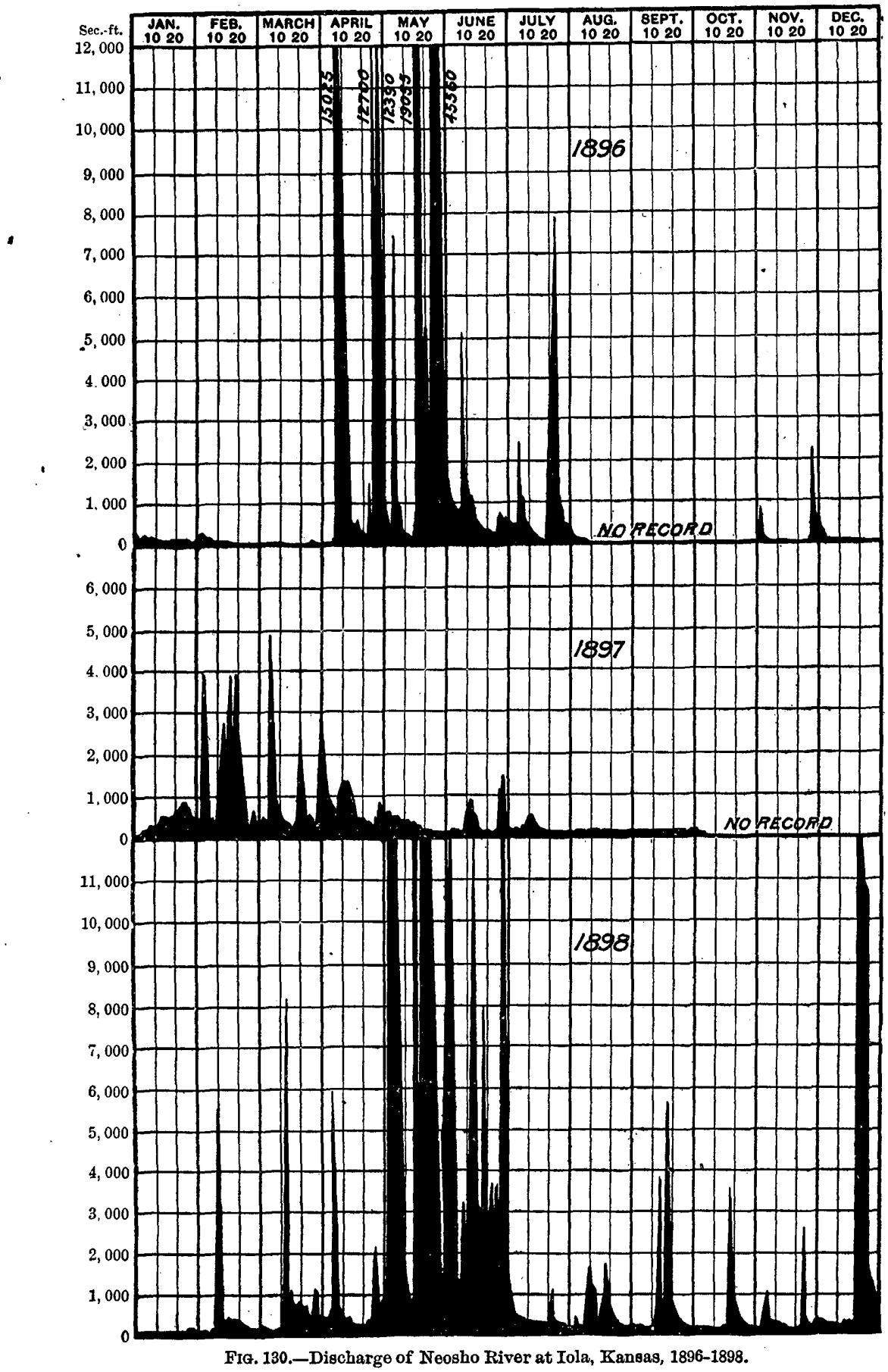


The principal tributaries of the Neosho are the Cottonwood, shown on PI. XXX, $B$; which enters it from the west, near Emporia, Kansas, and Spring River, which enters it from the east, a little south of the Kansas line. The discharge of the Neosho from 1896 to 1898, both inclusive, is shown in fig. 130.

Estimated monthly discharge of Neosho River at Iola, Kansas.

[Drainage area, 3,670 square miles.]

\begin{tabular}{|c|c|c|c|c|c|c|}
\hline \multirow[b]{2}{*}{ Montl. } & \multicolumn{3}{|c|}{ Discharge in second.feet. } & \multirow[b]{2}{*}{$\begin{array}{l}\text { Total in acre- } \\
\text { f'eet. }\end{array}$} & \multicolumn{2}{|c|}{ Run-off. } \\
\hline & $\begin{array}{l}\text { Maxi. } \\
\text { mun. }\end{array}$ & $\begin{array}{l}\text { Mini- } \\
\text { mum. }\end{array}$ & Mean. & & $\begin{array}{c}\text { Depth in } \\
\text { inches. }\end{array}$ & $\begin{array}{l}\text { Second. } \\
\text { feet per } \\
\text { square } \\
\text { mile. }\end{array}$ \\
\hline 1898. & & & & & & \\
\hline January .......... & 50 & 1 & 7 & 430 & .002 & $.00^{\prime} 2$ \\
\hline February .......... & 5,060 & 1 & 466 & 25,881 & .146 & .127 \\
\hline $\operatorname{March} \ldots \ldots \ldots \ldots$ & 7,077 & 80 & 692 & 42,550 & .218 & .188 \\
\hline April $\ldots \ldots \ldots$ & 5,460 & 220 & 753 & 44,807 & .237 & .205 \\
\hline May................... & 26,225 & 1,250 & 8,855 & 544,476 & 2. 785 & 2.413 \\
\hline June . . . . . . . . . . . . & 27,875 & 1,250 & 5,360 & 318,941 & 1.686 & 1. 461 \\
\hline July .............. & 1,050 & 180 & 392 & 24,103 & .123 & .107 \\
\hline August.............. & 1,825 & 110 & 543 & 33,388 & .171 & $\therefore 148$ \\
\hline September ........ & 5,220 & 110 & 678 & 40,344 & .213 & .185 \\
\hline October ............. & 3,620 & 50 & 395 & 24,288 & .124 & .108 \\
\hline November.......... & 3,695 & 145 & 482 & 28,681 & .152 & .131 \\
\hline December . .......... & 16,077 & 305 & 2,311 & 142,099 & .727 & .629 \\
\hline The year.. & 27,875 & 1 & 1,745 & $1,269,988$ & 6.584 & .475 \\
\hline
\end{tabular}

Noте.-Gage heights for 1898 are given in Water-Supply and Irrigation Paper No. 28, page 115 measurements, page 116, and rating table, page 117; results for 1897 in Water-Supply and Yrrigation Paper No. 16, page 126, anıl in the Nineteenth Annual Report, Part IV, pages 361 to 363.

\section{LOWER MISSISSIPPI RIVER.}

Measurements of the flow of various head-water streams tributary to the Lower Mississippi have been made at various points, as shown in the preceding pages. The main river itself is a subject of continual study by the Mississippi River Commission, in whose annual publications are contained data showing its regimen. The matter of particular interest in this connection is the relation which the high waters of the upper tributaries bear to the great flood of the lower river, and of the possible effect of reservoirs in holding back some of the excess supply. If it can be shown that the disastrous floods of the Mississippi and Missouri can be perceptibly modified by storage reservoirs in the arid region, it will be possible to urge the construction of storage works, not only for the conservation of water for irrigation, but also as a means of relief to the rich alluvial lands periodically flooded (PI. XXXIII). 


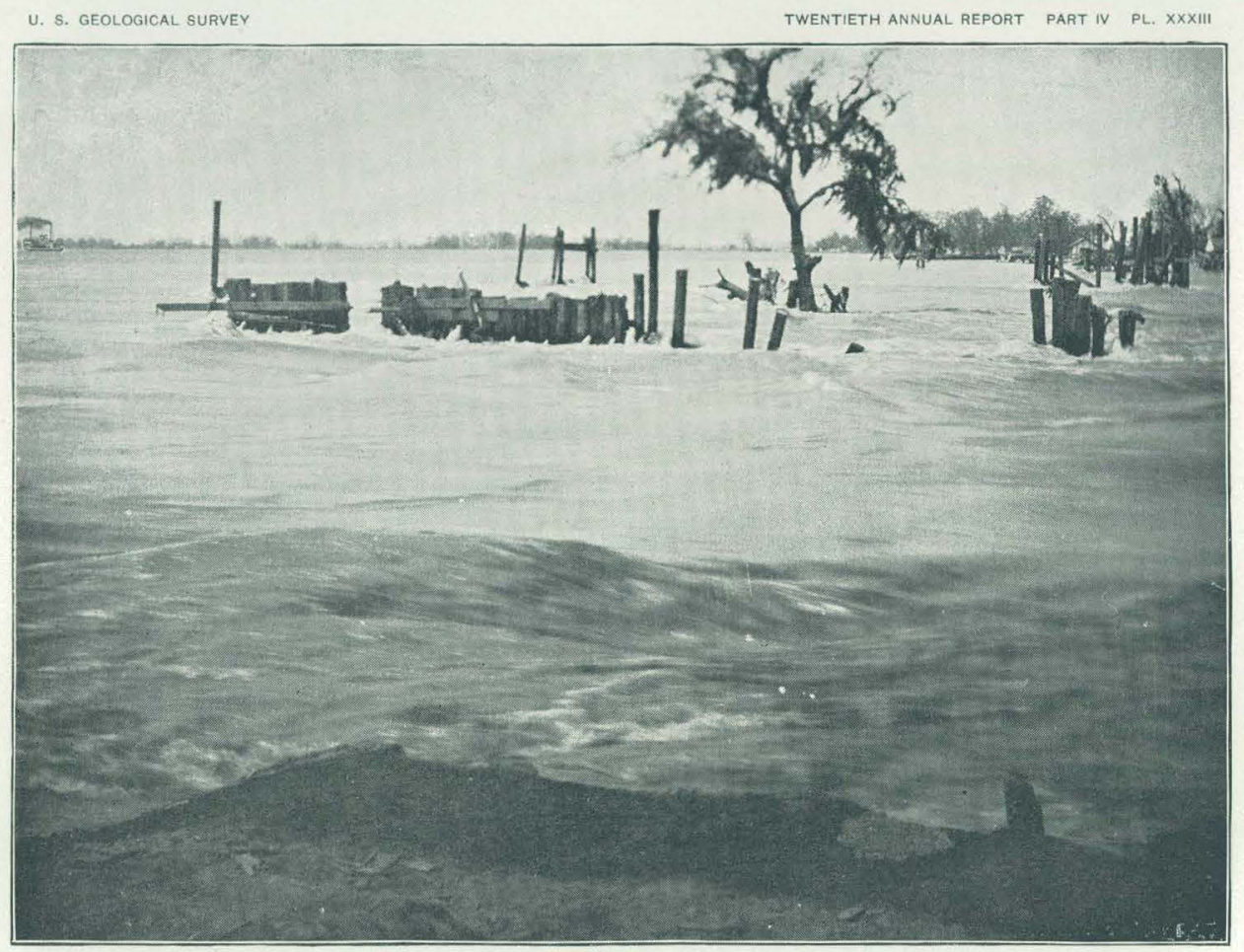

A. NITA CREVASSE, MISSISSIPPI RIVER, LOUISIANA.

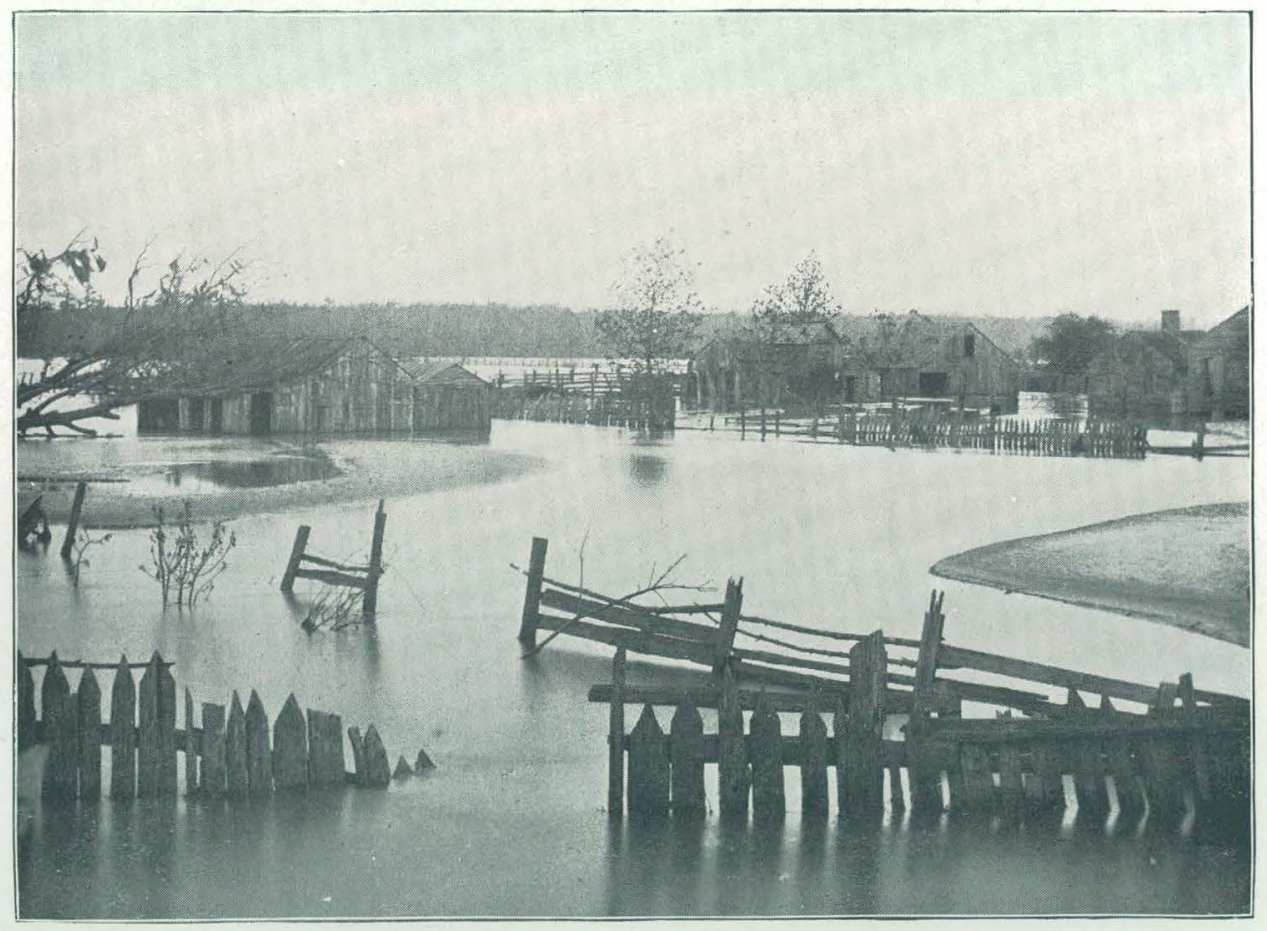

B. BACKWATER FROM NITA CREVASSE. 
In order to arrive at definite conclusions in this matter it is essential to make a thorough study of the hydrographic data-not only of records of heights of rivers, but also of volumes of discharge. Gage readings

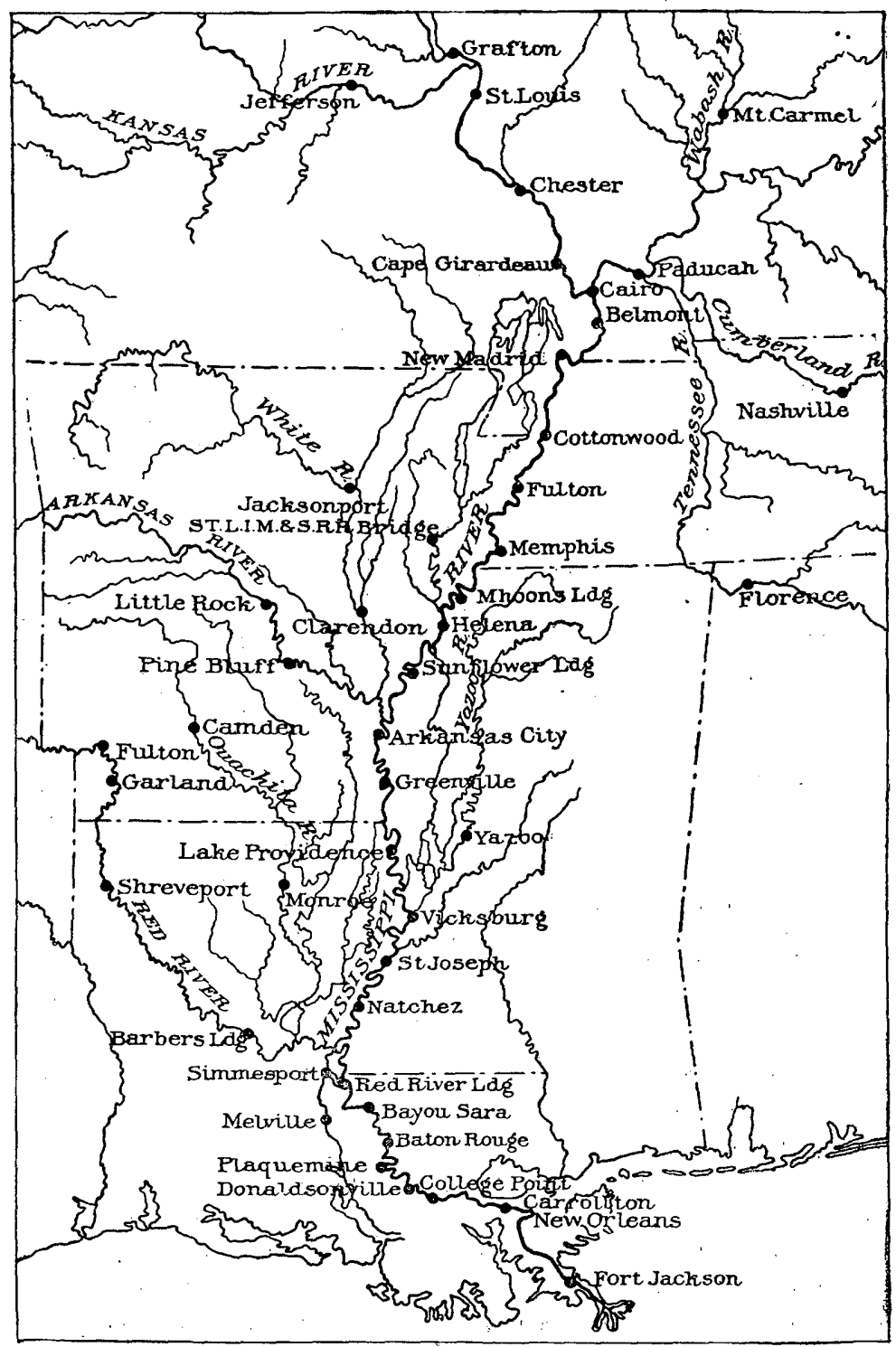

FIG. 131.-Relative location of observation stations along Lower Mississippi River.

are being maintained both by the Weather Bureau and by the Missis. sippi River Commission. The relative positions of the various gages along the river are shown by the accompanying map, fig. 131. Readings made at these points are published annually by the commission. 
The origin of floods in the Mississippi River has been discussed in many publications, notably in reports by Park Morrill ${ }^{~}$ and by William Starling. ${ }^{2}$ A Congressional committee has also taken testimony, and the result has been printed during 1898, giving facts of interest. ${ }^{3}$

The control of the floods in the various tributary streams and in the main rivers has, been for many years one of the most important national problems. Many opinions have been held by different students of the subject, and there is still a wide divergence of view as regards the means to be used to prevent overflow and the destruction of property. The determination of the proper methods has been largely left in the hands of experts, such as members of the Mississippi and of the Missouri River commissions. The collection of the physical facts upon which conclusions must ultimately be founded is, however, dependent in part upon the activities of various scientific bureaus, such as the Weather Bureau in its study of rainfall, the Geological Survey in its topographic mapping and hydrographic examinations, as above noted, and partıcularly upon the researches of the army engineers or boards in their detailed surveys for specific purposes. It is only after a thorough knowledge of the results obtained through these careful investigations, as well as of the facts brought together by various Congressional committees, that a comprehensive knowledge can be had of this great drainage system.

One of the most popular of projects conceived as contributing toward the regulation of floods has been that of building storage reservoirs on the western side of the basin, where the water can be held and used in irrigation. This matter has been discussed in a most thorcugh manner by Capt. Hiram M. Chittenden is his report upon "The Preliminary Examination of Reservoir Sites in Wyoming aud Colorado." 4 In this report Captain Chittenden points out the fact that few people have a correct knowledge of the origin and magnitude of great floods like those on the Mississippi River. He calls attention to the common error in conceiving that these floods come from the melting snows on the mountains to the west, and shows that the floods of the Mississippi nearly all come at seasons when the flow from the mountains is very small. This is graphically illustrated by diagrams prepared by Mr. James A. Seddon, which show at a glance the relative insignificance of the amount of water contributed early in the year by the Missouri in comparison with the great volumes carried by the Ohio (p. 48). The floods of the Mississippi River do not come from the arid or subhumid regions, but from heavy rains in the low regions east of the ninety-

\footnotetext{
1 United States Department of A griculture, Weather Bureau Bulletin E-Floods of the Mississipp River. Prepared under the direction of Willis L. 'Moore, Chief of the Bureau, by Park Morrill, Washington, D. C., 1897.

2 The floods of the Mississippi River, including an account of their principal cause and effects, and a description of the levee system and other means proposed and tried for the contron of the river. with a particular account of the great flood of 1897 , by William Starling.

${ }^{3}$ Report on the Mississippi River Floods by the Committee on Commerce, United States Senate, Fifty-fifth Congress, Third session, Senate Report No. 1433.

4 Fifty-fifth Congress, second session, H. R. Doc. No. 141.
} 
eighth meridian or from streams still farther east, particularly the Ohio. He shows, however, that a system of reservoirs might be built upon the Missouri which would notably diminish the June rise. It is further stated by Captain Chittenden that the benefit to the lower river is not worth the cost, but that the construction might be justifiable by other considerations, such as that of irrigation.

The principal conclusions of Captain Chittenden on this point are of such importance that they may be quoted in full:

While it is perhaps physically practicable to build reservoirs of sufficient aggregate capacity on the watershed of any stream, even so large a stream as the Mississippi, as to exercise some influence in diminishing the height of floods, the great cost of such works, as compared with the results to be expected from them, will always prohibit their construction, unless it is called for by other and more direct causes.

A general system of reservoirs in the arid regions sufficient to contain the flow of the streams over what is possible to draw from them directly in irrigation would, it is believed, cause some reduction in the flood height of the Missouri River during the June rise. The amount of this reduction would, of course, depend upon the distance of the section of river considered from the points of storage, and would diminish rapidly with an increase of this distance.

Reserroir construction in the arid regions of the West is an indispensable condition to the highest development of that section. It can properly be carried out only through public agencies. Private enterprise can never accomplish the work successfully. As between State and Nation, it falls more properly under the domain of the latter.

The linking together, even though by slender ties, of the agricultural interests of the arid region with those of the Mississippi Valley is, in the West especially, one of the most popular propositions, as tending to add strength to the demand for building great storage works under the auspices of the National Government. All facts, therefore, which bear upon the matter have a peculiar interest, and the demonstration that the great cost of such works, as compared with the results to be expected from them, will prohibit their construction as far as prevention of floods is concerned, must be a matter of disappointment to many earnest advocates.

While there may be questions as to the feasibility of controlling the flood waters by means of storage reservoirs, there can be little difference of opinion as to measures for the direct protection of lowlands along the course of the stream. The development of the levee system for confining high water within the main channel has progressed steadily for many years, until the Lower Mississippi is bordered on both sides by lines of dikes throughout the greater part of its length. The relative location of these is shown on fig. 132. The first levee construction was begun in New Orleans, and from this point they have been gradually extended up the stream. Two of the great basins adjoining the river-St. Francis and White River-have been recently closed. In 1896 the last gap was filled and the line of levee was made continuous from the hills at Helena to a point 8 miles above the mouth of White River. 
The great flood of 1897 and the resulting destruction called public attention to the importance of raising and strengthening the levees. It was shown that the height of water from a point about 100 miles below Cairo to the Gulf was greater than previously recorded. As far as volume of water was concerned, however, it is asserted that the flood of 1882 was greater than that of 1897 . It appears probable that

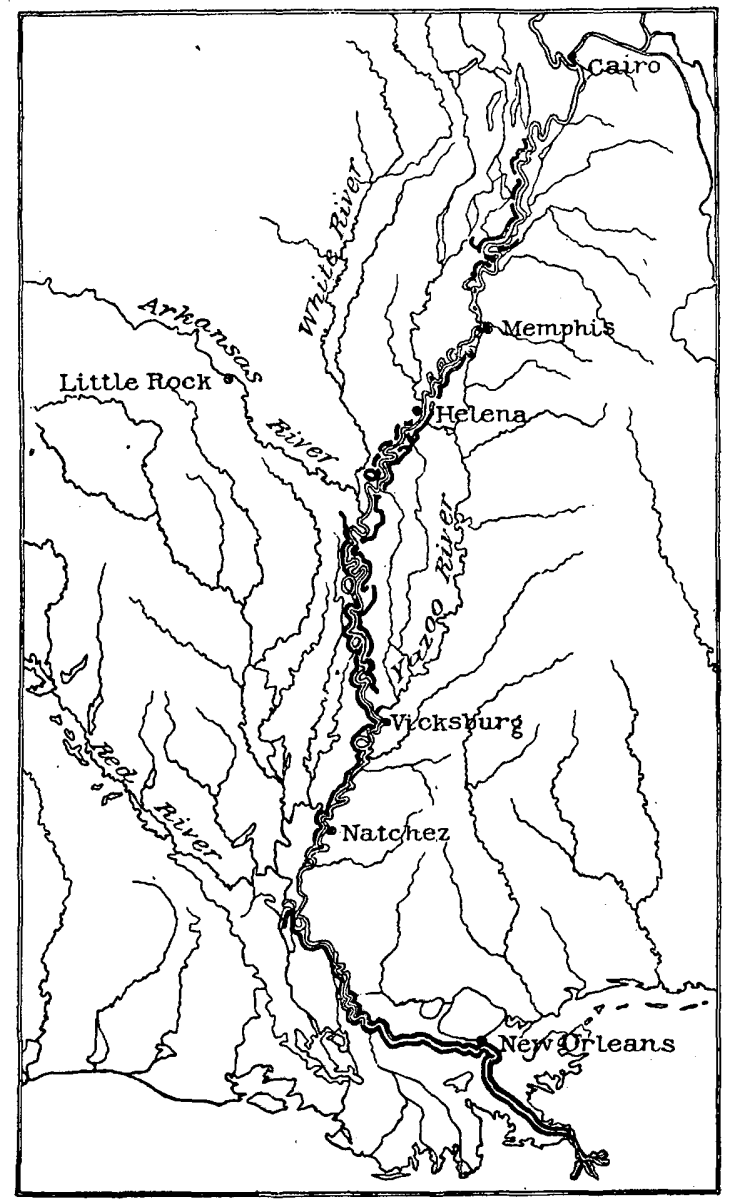

Fig. 132.-Extent of levee system.

the disastrous effects of the flood of 1897 were increased because of the extensive inclosure of basins which in a state of nature had been annually or periodically overflowed. It has been argued that the extension of the levees since 1882 tended to increase the height of the flood of 1897. At the same time it is true that if the levees had not been in existence a larger area would have been submerged by the latter flood. The whole matter has been discussed in the report of a 


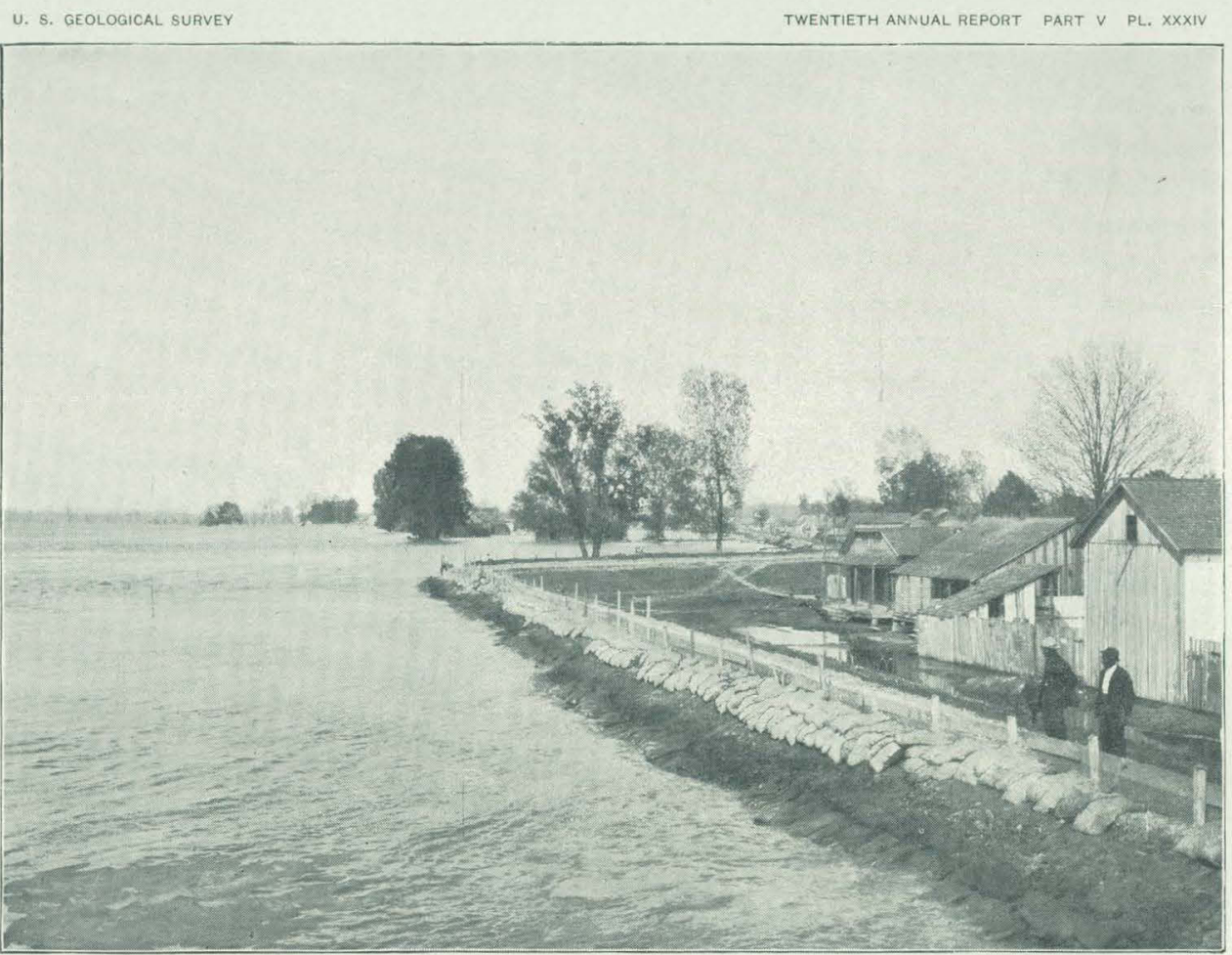

A. TOPPED LEVEE REVETTED AGAINST STORIMS AT GREENVILLE. MISSISSIPPI.

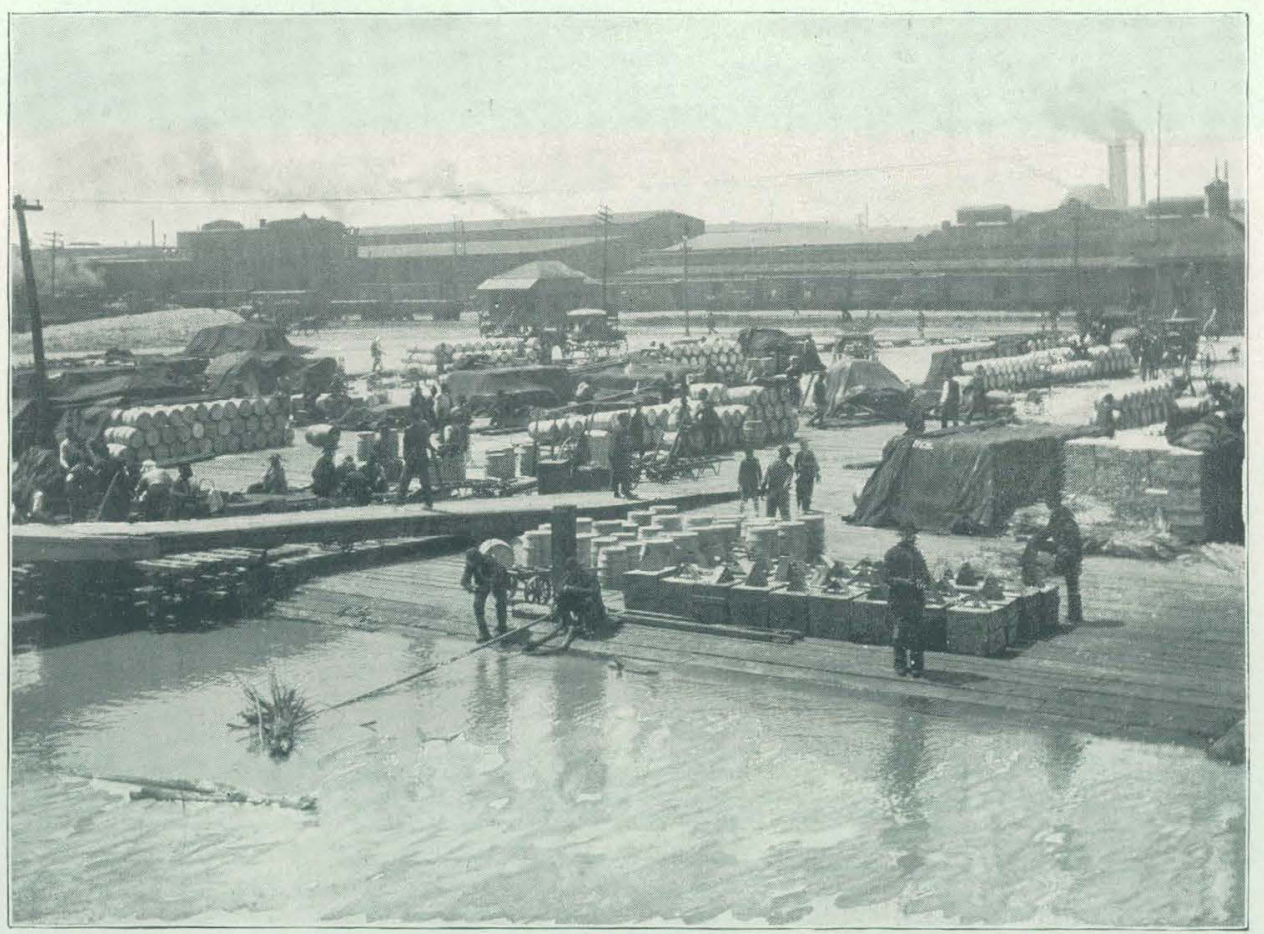

B. WHARVES AT NEW ORLEANS DURING FLOOD. 
committee of the United States Senate, as previously mentioned. ${ }^{1}$ This committee arrived at the conclusion that the basins and bottoms along the Mississippi River, exposed to the floods, can be protected only by a complete system of levees from Cairo to the head of the passes below New Orleans. It is estimated that these levees can be completed and brought to a sufficient height to afford protection against floods at the highest possible stages at a cost of about twenty million dollars. Until this system is complete, breaks in the levees, or crevasses, with resulting inundations, accompanied by loss of life and property, are liable to occur.

\section{GEOLOGIC STRUCTURE.}

As bearing upon the general coudition of ground waters, and to a less extent upon problems of river control, the following paragraphs prepared by Mr. W J McGee are inserted, together with a generalized geologic section across the region. Mr. McGee states that there are three unconformities of much importance in the geologic development of the Lower Mississippi, these being shown in the section, fig. 133.

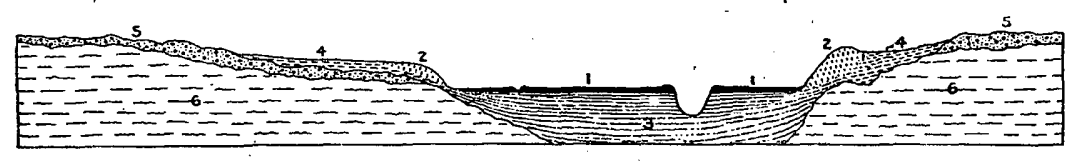

FIG. 133.-Geologic section of the Lower Mississippi Valley, according to McGee.

1. Alluvium, Generally a thin veneer only; ranging from 2 to 10 feet in thickness; occasionally absent, elsewhere thickening downward, filling abandoned channels of river or bayous; alwajs thickening, also along banks of river and bayous, where it rises in natural levees, usually from 1 to 5 feet in height.

2. Loess. Best developed along the bluffs overlooking the river bottom; it grades both horizontally and vertically into brown loam; in some cases, especially along the eastern bluff line, it has accumulated in a ridge skirting the bluff scarp, much as the natural levees of alluvium skirt the river banks.

3. Lower Mississippi blue clay (Port Hudson formation of Hilgard). An estuarine deposit, overlain unconformably by the alluvium; exposed in all cuttings in the river banks at low water, and at all stages of river in the area lifted by the New Madrid earthquake; grades laterally into the brown loam, and is gravelly at depths; where it forms the surface by reason of absence of alluvium it constitutes the "buckshot lands". of the Lower Mississippi.

4. Brown loam (of Hilgard): A deposit of slack and probably brackish waters, mantling the bluffs and adjacent highlands to altitudes of from 200 to 500 feet above the river, the material, like that of the loess and a part of the blue clay, being generally calcareous and evidently formed of glacial mud from the Upper Mississippi region; grades laterally and horizontally into loess, and also into the blue clays.

5. Lafasette formation (Orange Sand of earlier literature). A deposit of brown, red, or orange gravel and sand, often grading down ward in to stratified sands containing beds of silicious clay; unconformable to all the underlying formations, and largely eroded before the later formations were deposited.

1 Report on the Mississippi River Floods, by the Committee on Commerce, United States Senate, Fifty-fifth Congress, Third session, Senate Report No. 1433. 
6. Tertiary deposits (Grand Gulf, White Limestone, Lignitic or Eolignitic according to latitude). Marine and brackish water formations of several thousand feet thickness in the aggregate, or several hundred feet at nearly any point in the Lower Mississippi region; they rest unconformably on Cretaceous and Paleozoic formations toward the borders of the region.

The alluvium is recent; the loess, blue clay, and brown loam are Pleistocene; the Lafayette is nonfossiliferous, but is indicated to be Pliocene by physical relations; the Grand Gulf is Miocene, and the White Limestone and Lignitic are Eocene.

The Pleistocene deposits (loess, blue clay, and brown loam) represent at least two periods of accumulation, corresponding with the principal episodes in glaciation of the Upper Mississippi region, but the deposits.can not be discriminated generally in the field or distinguished in small-scale sections; collectively, they correspond with the Columbia formation of eastern United States in its two divisions

The first of the three unconformities is that separating the Lafayette formation from the older Tertiary deposits. It represents what has been called the Tennesseean erosion period, which was of great duration. During this period the continent was low and quiescent and was extensively base-leveled in such manner as to produce a uniform surface of vast extent, not only in the Lower Mississippi region but throughout eastern and southern United States. Remnants of this plane of uncon. formity are shown on both sides of the valley, the plane being depressed on the west by later deformation.

The second unconformity is that separating the Pleistocene deposits from the Lafayette and older formations. It represents what has been called the Ozarkian erosion period. During this period, which immediately succeeded the time of deposition of the Lafayette formation, the continent was lifted several hundred feet and all the rivers of eastern and southern United States carved canyons, that of the Mississippi being several hundred feet in depth (probably a thousand feet in the latitude of Baton Rouge) and scores of miles in width, while fully half of the Lafayette formation was carried away. This is the greatest unconformity of southeastern United States, at least since the begin. ning of the Cretaceous.

The third unconformity is that separating the Alluvium from the Pleistocene deposits. In general the profile retains the characteristics determined during the subsidence of the Pleistocene; yet the surface of the Port Hudson has undoubtedly been planed smooth by the wandering of river and bayous, while the floodplain has encroached on the bases of the bluffs on both sides, especially on the west.

\section{WESTERN GULF DRAINAGE.}

Under this heading are included the streams flowing into the Gulf of Mexico west of the mouth of the Mississippi, that is to say, those of Texas to the Rio Grande. Measurements have been made on Trinity River near Dallas, on Brazos River, near Waco and Lewis, on Colorado River near Austin, on Guadalupe River near New Braunfels, on Pecos 20 GEOL, P' $4-23$ 


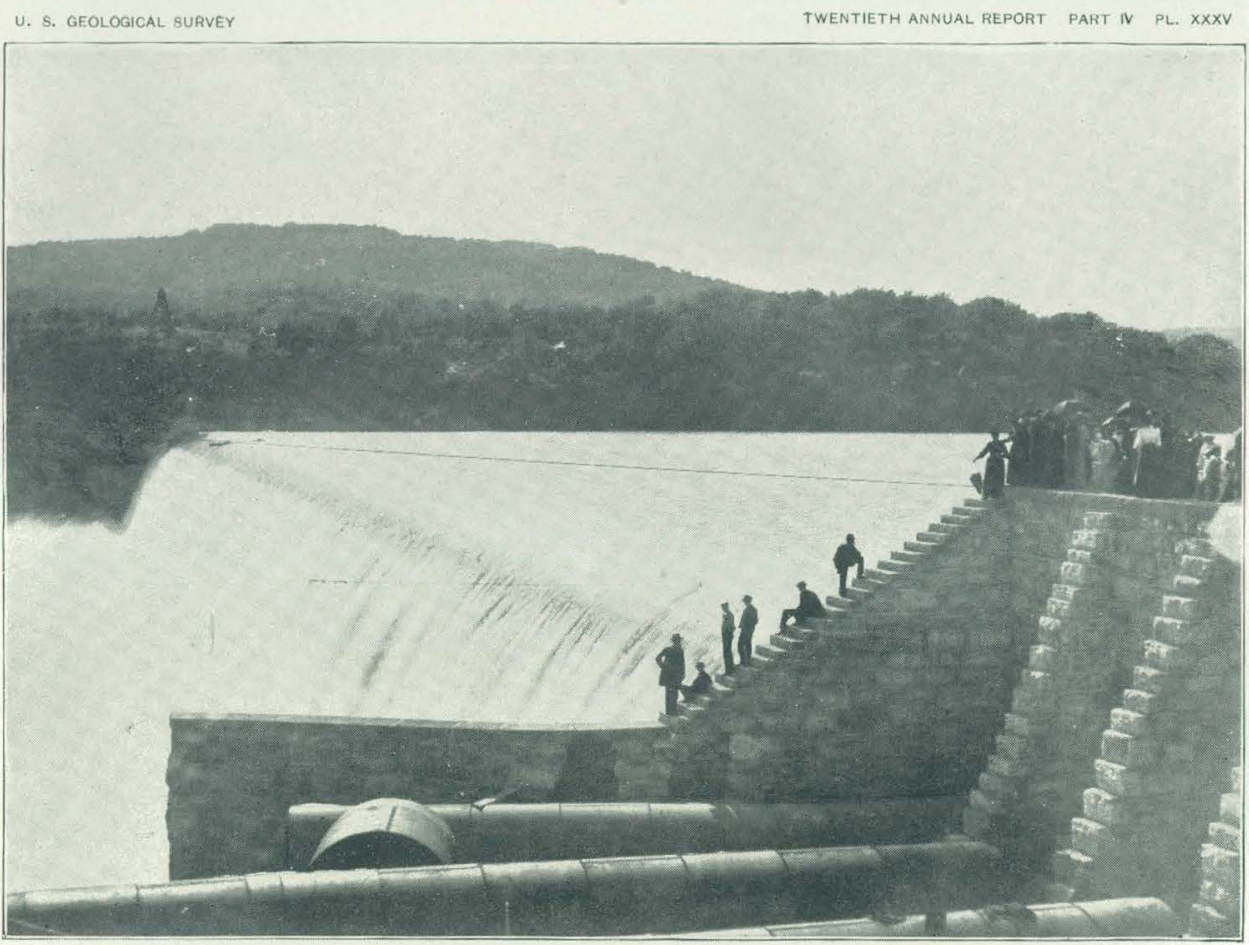

A. DAM AT AUSTIN, TEXAS, DURING FLOOD

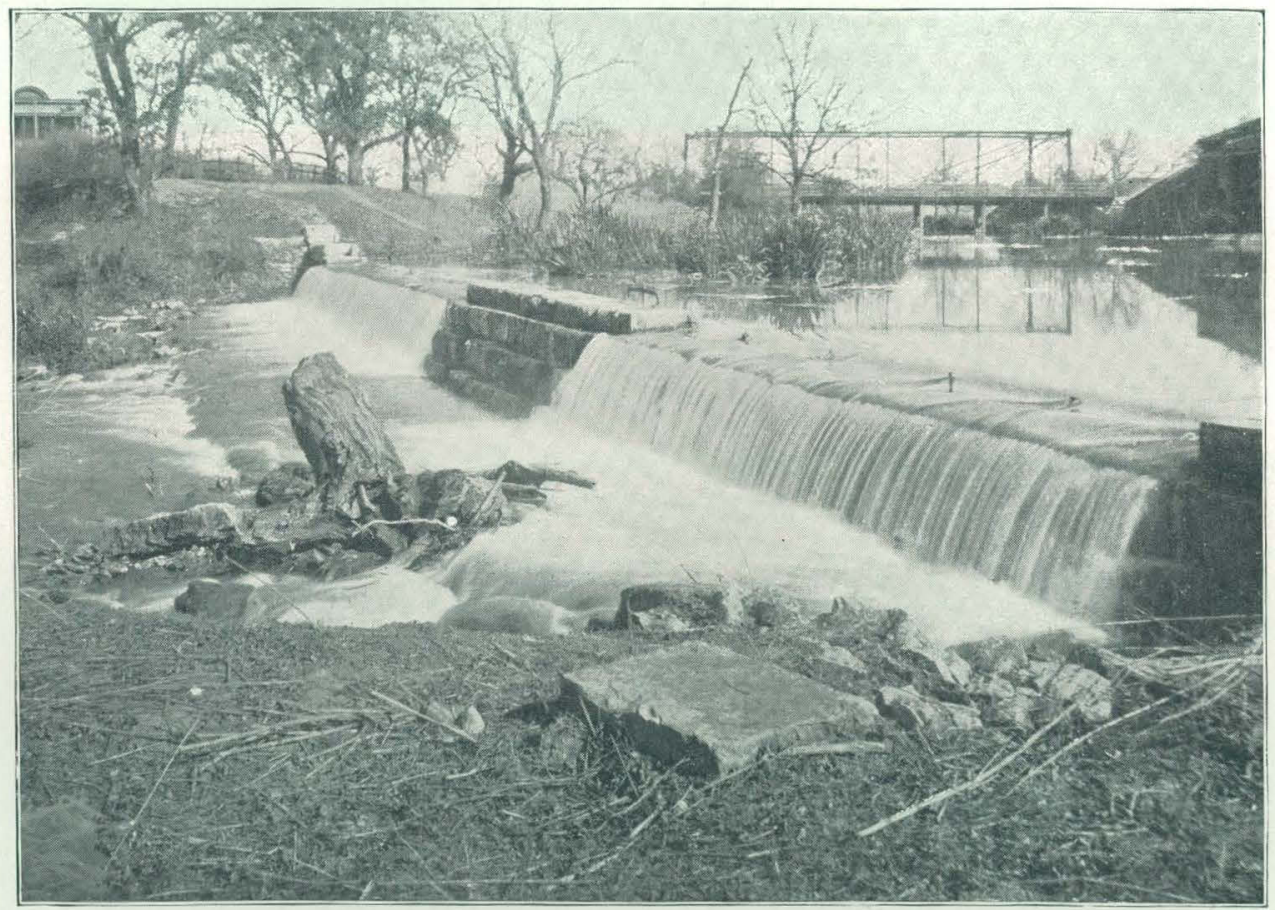

B. SAN ANTONIO RIVER AT SAN ANTONIO, TEXAS. 


\section{PROGRESS OF STREAM MEASUREMENTS FOR 1898.}

River near the town of Pecos, and on the Rio Grande at points in Colorado and New Mexico, as well as at El Paso, Texas. The work in Texas has been under the immediate charge of Prof. Thomas U. Taylor, of Austin; while that in New Mexico has been carried on by Mr. Phillip E. Harroun, of Albuquerque.

\section{TEXAS STREAMS.}

Dallas station on Trinity River was established on October 1, 1898. No rating table has been constructed. This station is described in Water-Supply and Irrigation Paper No. 28, page 118; gage heights are given on page 121, and measurements on page 129 .

Waco and Lewis stations on Brazos River are described in WaterSupply and Irrigation Paper No. 28, page 118; gage heights are given

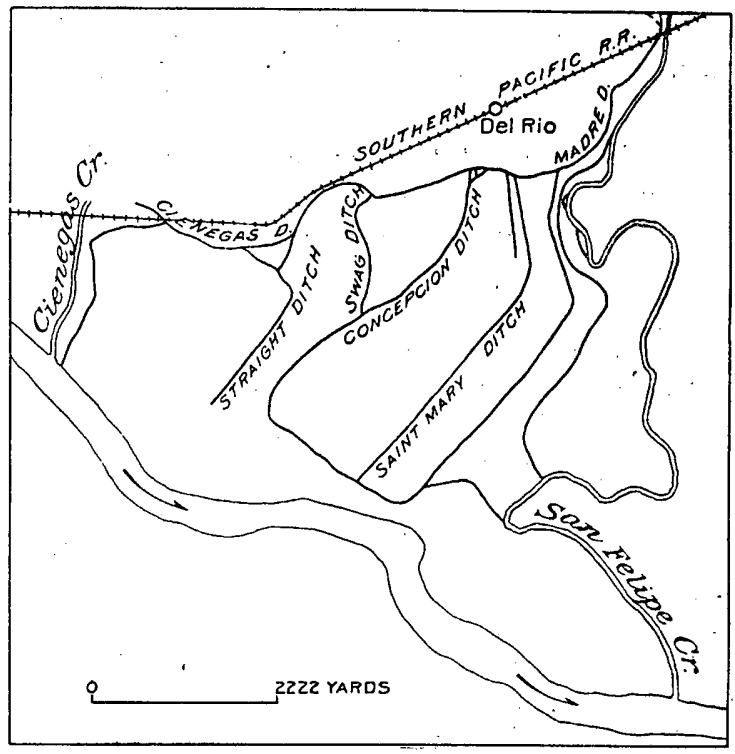

Frø. 134--Irrigation system near Del Rio, Texas.

on page 121, and measurements on page 129. No rating tables have been constructed.

Measurements of Colorado River (of Texas) are made at two points near Austin. These are described in Water-Supply and Irrigation Paper No. 28, on pages 118 and 119; gage heights are given on pages 122 to 124 , and measurements on page 129 . No rating table has been constructed.

A view of the water of Colorado River passing over the Austin dam is shown on $\mathrm{Pl}$. XXXV, $A$. This is taken from the power house, looking across along the crest of the dam. On the same plate at $B$ is a view of San Antonio River in the city of San Antonio. 
New Braunfels station on Guadalupe River is described in WaterSupply and Irrigation Paper No. 28, on page 119; gage heights are given on page 124, and measurements on page 129. No rating table has been constructed.

Passing westward from New Braunfels the first streams of importance are those forming the head waters of San Antonio River, which ultimately unites with Guadalupe Riverin San Antonio Bay. This stream, like others in that part of Texas, receives its principal supply from springs. The line of springs is traceable westerly to the vicinity of Del Rio. Here four large springs issue at a point about a mile east of the town, to form San Felipe Creek. The waters are diverted into ditches, supplying agricultural lands and furnishing water power. Views of the masonry dams diverting water are given on Pl. V.II of Water-Supply Paper No. 13. The relative location of these ditches is shown on the accompanying fig. 134 . The main ditches are about 4 miles in length and 10 feet wide. The area irrigated aggregates about 4,000 acres.

\section{RIO GRANDE.}

This river is described in the Twelfth Annual Report of the United States Geological Survey, Part II, pages 240 to 290 , inclusive, and in the Nineteenth Annual Report, Part IV, page 381 , to which reference may be made.

The water supply of the Rio

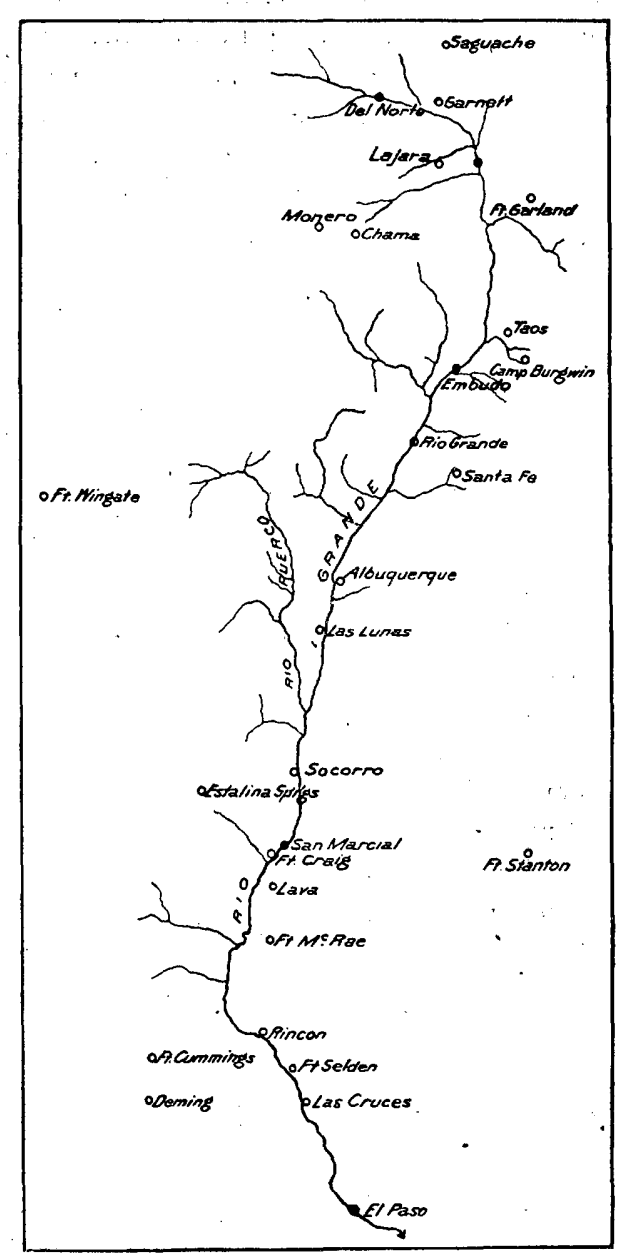

Fig. 135.-Relative location of rirer and rainfall obser. vations in basin of upper Rio Grande.

Grande was rather below the normal in 1898, though erops were generally matured. The season was very dry, as a rule, and, owing to a light fall of snow in the winter, there were at times fears of a shortage. There is no doubt that storage of winter and flood flow must soon be practiced to a considerable extent upon the head waters of the river and its tributaries. 
The only gaging station in Colorado maintained throughout 1898 was the one above Del Norte, described in Water-Supply and Irrigation Paper No. 16, page 127, the observer at this point being J. S. Regan, of Del Norte.

PRECIPITATION IN UPPER BASIN OF RIO GRANDE.

The principal observations of rainfall made within the basin of the upper Rio Grande are at Saguache, Garnett, Fort Garland, Monero, Chama, Santa Fe, Albuquerque, Los Lunas, Socorro, Fort Craig, Fort McRae, Rincon, Deming, and Las Cruces. The relative location of these points is shown on fig. 135, in connection with the points of river measurements, which are at Del Norte, Embudo, Albuquerque, Rio Grande, San Marcial and El Paso. The following table gives the names and location of the stations, the elevation, and time of beginning of the record:

Location of rainfall stations.

\begin{tabular}{|c|c|c|c|c|c|c|}
\hline Stations. & County. & State. & Latitude. & $\begin{array}{l}\text { Longi- } \\
\text { tude. }\end{array}$ & $\begin{array}{c}\text { Eleva- } \\
\text { tion. }\end{array}$ & $\begin{array}{c}\text { Length of } \\
\text { record. }\end{array}$ \\
\hline Saguache..... & Saguache ... & Colorado... & $\begin{array}{cc}\circ & 1 \\
38 & 05\end{array}$ & $\begin{array}{cc}\circ & \prime \\
106 & 06\end{array}$ & 7,740 & $5-8$ \\
\hline Fort Garland & Castilla.. & .....do do & $\begin{array}{ll}37 & 25\end{array}$ & 10523 & 7,937 & $20-24$ \\
\hline Monero... & Rio Arriba & New Mexico. & $36 \quad 56$ & 10659 & 7,356 & $7-9$ \\
\hline Chama ... & ....do ...... & .....do. & $36 \cdot 55$ & 10647 & 7,862 & $6-8$ \\
\hline Santa $\mathrm{Fe} \ldots$. & Santa Fe.... & .... do .. & $\begin{array}{ll}35 & 41\end{array}$ & 10558 & $7,0 \leq 6$ & $40-44$ \\
\hline Albuquerque & Bermalillo ... & .....do do. & $\begin{array}{ll}35 & 04\end{array}$ & 10643 & 5,026 & $20-23$ \\
\hline Los Lunas .... & Valencia. & .....do & $\begin{array}{ll}34 & 48\end{array}$ & 10652 & 5,000 & $7-12$ \\
\hline Socorro ....... & Socorro... & .....do. & $\begin{array}{ll}34 & 06\end{array}$ & 10656 & 4,600 & $7-10$ \\
\hline Fort Craig ... & .....do ... & .....do. & $\begin{array}{ll}33 & 37\end{array}$ & 10702 & 4,448 & $27-32$ \\
\hline Fort McRae... & Sierra....... & ...do. & $33 \quad 30$ & 10702 & 4,395 & $7-12$ \\
\hline Rincon & Donna Ana.. & ....do . . & $32 \quad 41$ & 10702 & 4,500 & $7-9$ \\
\hline Deming. & Grant ........ & ....do. & $\begin{array}{ll}32 & 17\end{array}$ & 10752 & 4,327 & $13-15$ \\
\hline Las Cruces.... & Donna Ana.. & $\ldots$. do ... & $\begin{array}{ll}32 & 19\end{array}$ & 10652 & 3,500 & $19-21$ \\
\hline
\end{tabular}

Precipitation at stations in upper basin of Rio Grande.

FORT GARLAND.

\begin{tabular}{|c|c|c|c|c|c|c|c|c|c|c|c|c|c|}
\hline Year. & Jan. & Feb. & Mar. & Apr. & May. & June. & July. & Aug. & Sept. & Oct. & Nor. & Dec. & Annual. \\
\hline Normal ...... & 0.48 & 0.81 & 0,77 & 1.09 & 1. 16 & 0.98 & 2.24 & 1.85 & 1.21 & 0.67 & 0.87 & 0.89 & 13.02 \\
\hline 1896. & 0.11 & 0.49 & 1.24 & 1.84 & 0.24 & 0.26 & 3.16 & 1.05 & 0.74 & 1.54 & 0.24 & 1.40 & 12.31 \\
\hline 1897. & 0.47 & 0.92 & 1.32 & 0.51 & 2.20 & 0.68 & 1. 71 & 0.77 & 1.95 & 2. 00 & 0.00 & 1.40 & 13.93 \\
\hline $1898 \ldots$ & 1.20 & 0.05 & 0.60 & $(1.09)$ & 1.32 & 1.45 & 3.88 & 1.06 & 0.51 & 0.58 & 1.17 & 0.36 & 13.27 \\
\hline \multicolumn{14}{|c|}{ MONERO. } \\
\hline Normal & 1.30 & 2.24 & 1.57 & 0.70 & 1.46 & 0.39 & 2.47 & 1.89 & 2.07 & 1.34 & 0.67 & 1.70 & 17.80 \\
\hline $1896 \ldots$ & 0.78 & 0.54 & 0.42 & 0.44 & 0.05 & 0.22 & 1.71 & 1.22 & 1.15 & 3.82 & 1.06 & 1.13 & 12.54 \\
\hline $1897 \ldots$ & 1.37 & 2.25 & 2.31 & 0.84 & 2.55 & 0.32 & 2.86 & 2.04 & 3. 66 & 1.99 & $(0.67)$ & 0.70 & 21.56 \\
\hline $1898 \ldots$ & $\ldots$ & ...... & 0.61 & 1.93 & 1.16 & $\ldots \ldots$ & ..... & 0.85 & 0.30 & 0.11 & 0.55 & 0.76 & $\cdots$ \\
\hline
\end{tabular}


Precipitation at'stations in upper basin of Rio Grande-Continued.

CHAMA.

\begin{tabular}{|c|c|c|c|c|c|c|c|c|c|c|c|c|c|}
\hline Year. & Jan. & Feb. & Mar. & Apr. & May. & June. & July. & Aug. & Sept. & Oct. & Nov. & Dec. & Annual. \\
\hline Normal & 2.42 & 3.83 & 3.11 & 1.17 & 1.22 & 0.35 & 2. 39 & 2.22 & 2.24 & 1. 31 & 1.28 & 2.51 & 24.05 \\
\hline 1896. & 1.65 & 2.10 & 2.20 & 2.30 & 0.05 & 0.19 & 2.16 & 0.78 & 1.80 & 1.47 & 2.15 & 1.80 & 18.65 \\
\hline $1897 \ldots$ & 2.58 & 4.90 & 5.53 & 0.79 & $\cdots \cdots$ & $\cdots \cdots$ & ......... & a...... & ....... & a...... & ......... & *n..... & anc. \\
\hline \multicolumn{14}{|c|}{ SANTA FE. } \\
\hline Normal. & 0.65 & 0.88 & 0.71 & 0.74 & 1.01 & 1.10 & 2.73 & 2.72 & 1.58 & 1.11 & 0.79 & 0.82 & 14.84 \\
\hline 1896 & 0.36 & 0.57 & 0.53 & 1.11 & 0.27 & 0.69 & 3.78 & 1.47 & 1.39 & 3.19 & 0.25 & 0.67 & 14.28 \\
\hline $1897 .$. & 1.11 & 1.10 & 2.06 & 0.87 & 4. 35 & 0.57 & 2.85 & 2.33 & 2.49 & 1.95 & 0.08 & 0.64 & 20.40 \\
\hline \multicolumn{14}{|c|}{ ALBUQUERQDE. } \\
\hline Normal. & 0.36 & 0.26 & 0.20 & 0.31 & 0.52 & 1.03 & 1.21 & 1.66 & 0.92 & 0.86 & 0.35 & 0.27 & 7.95 \\
\hline 1896 & 0.06 & 0.07 & 0.01 & $\therefore \mathbf{T}$ & 0.07 & 0.32 & 1.98 & 0.81 & 0.72 & 2.55 & 0.05 & 0.38 & 7.02 \\
\hline $1897 \ldots$ & 0.57 & 0.13 & 0.72 & 0.63 & 2.07 & 0.99 & 0.31 & 1.31 & 1.22 & 1.44 & $\mathbf{T}$ & 0.35 & 9.74 \\
\hline $1898 .$. & 0.58 & 0.54 & 0.34 & 0.33 & 0.12 & 1.00 & 1.25 & 0.60 & 0.28 & 0.15 & 0.50 & 0.70 & 6.39 \\
\hline \multicolumn{14}{|c|}{ LOS LUNAS. } \\
\hline Normal & 0.55 & 0.32 & 0.47 & 0.52 & 1.16 & 0.52 & 1.08 & 0.46 & 0.54 & 1.02 & 0.16 & 0.40 & 7.20 \\
\hline $1896 .$. & $\mathrm{T}$ & $\mathbf{T}$ & 0.00 & 0.00 & 0.00 & 0.10 & 1.65 & 0.95 & 1.55 & 3.00 & $\mathbf{T}$ & 0.40 & 7.65 \\
\hline $1897 .$. & 1.45 & 0.25 & 0.15 & 0.50 & 1.30 & 0.25 & 0.80 & 0.00 & 0.55 & 0.80 & $\mathbf{T}$ & 0.15 & 6.20 \\
\hline $1898 \ldots$ & 1. 30 & 0.85 & 0.30 & 0.75 & $0 .: 5$ & ....... & ....... & $\cdots \cdot$ & $\ldots .$. & 0.00 & 1.00 & 0.87 & $\ldots \ldots$ \\
\hline \multicolumn{14}{|c|}{ SOCORRO. } \\
\hline Normal & 0.36 & 0.22 & 0.34 & 0.27 & 0.47 & 0.42 & 2.01 & 1.23 & 1.47 & 1.68 & 0.39 & 0.68 & 9.54 \\
\hline 1896. & $\ldots .$. & …... & ...... & …... & ...... & 0.43 & 3.00 & 0.88 & 1.35 & .4 .89 & 0.00 & 0.02 & $\ldots \ldots$ \\
\hline $1897 \ldots$ & 0.51 & $\begin{array}{lll}0 & 05\end{array}$ & 0.58 & 1.00 & 1.20 & 0.57 & 2.03 & 1.02 & 2.47 & 1.18 & 0.00 & 0.00 & 10.61 \\
\hline $1898 .$. & 0.78 & 0.44 & 0.92 & $\cdots \cdots$ & ….... & & $\cdots \cdots$ & & ....... & 0.04 & 0.69 & 0.55 & $\cdots \cdots$ \\
\hline \multicolumn{14}{|c|}{ FORT CRAIG. } \\
\hline Normal & 0.30 & 0.35 & 0.29 & 0.18 & 0.34 & 0.68 & 1.93 & 2.27 & 1.77 & 0.93 & 0.54 & 0.34 & 9.92 \\
\hline $1896 .$. & 0.01 & $\mathbf{T}$ & $T$ & 0.00 & $\mathbf{T}$ & 0.18 & 1.29 & 0.59 & 0.95 & 3.53 & $T$ & $\mathbf{T}$ & 6.55 \\
\hline $1897 \ldots$ & 0.59 & $\mathbf{T}$ & 0.34 & 0.37 & 1.63 & 0.85 & 1.18 & 0.38 & 2.92 & 1.88 & $(0.54)$ & $(0.34)$ & 11.02 \\
\hline \multicolumn{14}{|c|}{ FORT MCRAE. } \\
\hline Normal & 0.22 & 0.20 & 0.32 & 0.52 & 0.50 & 1.40 & 2.38 & 3.09 & 1.56 & 0.78 & 0.32 & 0.31 & 11.60 \\
\hline $1896 \ldots$ & 0.00 & 0.00 & 0.00 & 0.00 & 0.02 & 0.27 & 2.84 & 2.10 & 1.10 & 4.10 & 0.15 & 0.26 & 10.84 \\
\hline $1897 .$. & 0.40 & 0.00 & 1.01 & 1.56 & 1.20 & 1.58 & 3.79 & 3.38 & 3.23 & 0.74 & 0.00 & 0.00 & 16.89 \\
\hline \multicolumn{14}{|c|}{ RINCON. } \\
\hline Normal. & 0.52 & 0.64 & 0.25 & 0.09 & 0.30 & 0.21 & 2.77 & 2.94 & 3.82 & 0.53 & 0.47 & 0.37 & 12.91 \\
\hline $1896 \ldots$ & 0.09 & 0.01 & 0.05 & 0.08 & 0.04 & 0.32 & 3.63 & 0.31 & (3. 82) & 1.83 & 0.12 & 0.01 & 10.31 \\
\hline $1897 \ldots$ & 1.32 & 0.00 & 0.00 & 0.18 & 0.88 & 0.20 & 1.95 & 2.61 & 4.23 & 0.46 & 0.00 & $\mathbf{T}$ & 11.83 \\
\hline $1898 \ldots$ & 0.62 & 0.00 & 0.15 & 0.55 & 0.15 & 1.55 & 3.62 & 2.63 & 0.90 & 0.23 & $\mathbf{T}$ & 0.73 & 11.13 \\
\hline \multicolumn{14}{|c|}{ DEMING. } \\
\hline Normal ...... & 0.48 & 0.47 & 0.41 & 0.07 & 0.25 & 0.34 & 1.89 & 1.72 & 1.43 & 0.93 & 0.63 & 0.30 & 8.92 \\
\hline $1896 \ldots$ & 0.60 & $\mathbf{T}$ & 0.00 & 0.20 & 0.00 & 0.15 & 4.30 & 1.95 & 2.00 & 3.25 & 0.25 & 0.00 & 12.70 \\
\hline $1897 \ldots$ & $1.5 \overline{5}$ & $(0.47)$ & 0.42 & 0.00 & 0.00 & 0.50 & 2.89 & 1.41 & 1.87 & 1.57 & 0.00 & T. & 10.68 \\
\hline $1898 \ldots$ & $(1.48)$ & $\mathrm{T}$ & 1.42 & c. 30 & 0.00 & T. & 1.66 & 1.73 & 0.21 & 0.00 & 0.10 & 0.60 & 6.50 \\
\hline
\end{tabular}


Precipitation at stations in upper basin of Rio Grande-Continued, LAS CRUCES.

\begin{tabular}{|c|c|c|c|c|c|c|c|c|c|c|c|c|c|}
\hline Year. & Jan. & Feb. & Mar. & Apr. & May. & June. & July. & Aug. & Sept. & Oct. & Nov. & Dec. & Annual. \\
\hline Normal & 0.22 & 0.37 & 0.19 & 0.09 & 0.26 & 0.32 & 1.46 & 1.19 & 0.96 & 0.51 & 0.52 & 0.33 & 6.42 \\
\hline 1896 & 0.31 & 0.11 & 0.00 & 0.11 & 0.10 & 1.01 & 2.50 & 0.47 & 1.24 & 2. 14 & 0.00 & $\mathrm{~T}$. & 7.99 \\
\hline $1897 \ldots$ & 0.35 & 0.00 & 0.46 & 0.23 & 1.54 & 0.07 & 2.25 & 1.16 & 2.14 & 0.73 & $\mathbf{T}$. & 0.03 & 8.96 \\
\hline 1898. & 0.38 & 0.02 & 0.26 & 0.69 & T. & 1.83 & 2.18 & $\therefore$ & & & $\cdots \cdots$ & & \\
\hline \multicolumn{14}{|c|}{ AVERAGES. } \\
\hline Notmal & 0.63 & 0.84 & 0.67 & 0.48 & 0.73 & 0.66 & 1.99 & 1.89 & 1.55 & 0.96 & 0.55 & 0.70 & 11.64 \\
\hline $1896 \ldots$ & 035 & 0.32 & 0.37 & 0.51 & 0.07 & 0.32 & 2.67 & 0.99 & 1.14 & 2. 72 & 0.33 & 0.49 & 10.28 \\
\hline $1897 .$. & 1.35 & 0.83 & 1.19 & 0.58 & 1.70 & 0.69 & 1.92 & 1.43 & 2.33 & 1.35 & 0.02 & 0.33 & 13.72 \\
\hline $1898 \ldots \ldots \ldots$ & 0.70 & 0.25 & 0.52 & 0.80 & 0.48 & 1.11 & 2.19 & 1.32 & 0.37 & 0.16 & 0.60 & 0.55 & 9.05 \\
\hline
\end{tabular}

Depth of run-off in inches from Rio Grande drainage basin. RIO GRANDE AT DEL NOR'CE.

\begin{tabular}{|c|c|c|c|c|c|c|c|c|c|c|c|c|c|}
\hline Year. & Jan. & Feb. & Mar. & Apr. & May. & June. & July. & Aug. & Sept. & Oct. & Nov. & Dec. & Annual \\
\hline 1895. & 0.66 & 0.73 & 0.53 & 1.50 & 1.74 & 1.76 & .0 .79 & 0.60 & 0.36 & 0.36 & 0.28 & 0.83 & 10.14 \\
\hline $1896 \ldots$ & 1.06 & 0.97 & 0.89 & 1.18 & 1.96 & 0.65 & 0.33 & 0.22 & 0.38 & 0.39 & 0.24 & 0.31 & 8.58 \\
\hline 1897. & 082 & 0.74 & 0.82 & 0.84 & 2.92 & 2.70 & 0.91 & 0.39 & 0.50 & 1.21 & 0.54 & 0.66 & 13.05 \\
\hline $1898 . .$. & $(113)$ & $(1.09)$ & $(1.21)$ & 1.53 & 2.24 & 3.50 & 1.35 & 0.42 & 0.26 & 0.22 & 0.64 & 1.07 & 14.66 \\
\hline A rerage & 0.92 & 0.88 & 0.86 & 1.26 & 2.22 & 2.15 & 0.85 & 0.41 & 0.38 & 0.55 & 0.43 & 0.72 & 11.63 \\
\hline \multicolumn{14}{|c|}{ RIO GRANDE AT EMBUDO. } \\
\hline 1896. & 0.09 & 0.09 & 116 & $0: 29$ & 0.26 & 0.06 & 0.04 & 0.03 & 0.03 & 0.06 & 0.07 & 0.07 & 1.25 \\
\hline $1.897 \ldots$ & 0.07 & 0.06 & 0.09 & 0.27 & 0,90 & 0.73 & 0.21 & 0.06 & 0.06 & 0.25 & 0.18 & 0.09 & 2.97 \\
\hline $1898 \ldots$ & 0.08 & 0.07 & 0.12 & 0.36 & 0.36 & 0.56 & $=0.43$ & 0.08 & 0.06 & 0.04 & 0.06 & 0.06 & 2.28 \\
\hline Average & 0.08 & 0.07 & 0.46 & 0.31 & 0.51 & 0,45 & 0.23 & 0.06 & 0.05 & 0.12 & 0.10 & 0.07 & 2. 51 \\
\hline \multicolumn{14}{|c|}{$4 !$} \\
\hline $1896 \ldots$ & 0.06 & 0.05 & 0.12 & 0.35 & 0.28 & 0.06 & 0.04 & 0.02 & 0.03 & 0.04 & 0.04 & 0.04 & 1.13 \\
\hline 1897. & 0.04 & 0.05 & 0.10 & 0.50 & 1.18 & 0.61 & 0.16 & 0.04 & 0.07 & 0.23 & 0.12 & 0.06 & 3.00 \\
\hline $1898 \ldots$ & 0.03 & 0.04 & 0.06 & 0.45 & 0.33 & 0.38 & 0.26 & 0.07 & 0.03 & 0.37 & 0.06 & 0.07 & 2.15 \\
\hline Average. & 0.04 & 0.05 & 0.09 & 0.43 & 0.60 & 0.35 & 0.15 & 0.04 & 0.04 & $0: 35$ & 0.07 & 0.06 & 2.27 \\
\hline \multicolumn{14}{|c|}{ RIO GRANDE AT SAN MARCIAL. } \\
\hline 1895. & 0.04 & 0.08 & 0.19 & 0.15 & 0.16 & 0.10 & 0.12 & & & & $\cdots$ & & \\
\hline $1896 \ldots$ & $(0.03)$ & 0.02 & 0.02 & 0.12 & 008 & 0.01 & 0.02 & 0.004 & 0.006 & 0.03 & 0.01 & 0.02 & 0.37 \\
\hline $1897 \ldots$ & 0.013 & 0.017 & 0.028 & 0.142 & 0.505 & 0.244 & 0.044 & 0.004 & 0.075 & 0.188 & 0.117 & 0.002 & 1. 48 \\
\hline $1898 \ldots \ldots$ & 0.04 & 0.04 & 0.04 & 0.18 & 0.11 & 0.08 & 0.11 & 0.01 & 0.003 & 0.001 & 0.01 & 0.02 & 0.64 \\
\hline Average. & 0.03 & 0.04 & 0.07 & 0.15 & 0.21 & 0.11 & 0.07 & 0.006 & .028 & .073 & 0.043 & 0.008 & 0.84 \\
\hline \multicolumn{14}{|c|}{ RIO GRANDE AT EL PASO. } \\
\hline $1897 .$. & 0.011 & 0.006 & 0.002 & 0.064 & 0.320 & 0.226 & 0.051 & 0.005 & 0.025 & 0.068 & 0.043 & 0.026 & 0.847 \\
\hline $1898 \ldots \ldots \ldots$ & 0.018 & 0.021 & 0.013 & 0.061 & 0.087 & 0.070 & 0.122 & 0.020 & 0.001 & 0.001 & 0.001 & 0.003 & 0.418 \\
\hline Average. & 0.014 & 0.014 & 0.008 & 0.062 & 0.204 & 0.148 & 0.086 & 0.012 & 0.013 & ก. 034 & 0.022 & 0.014 & 0.631 \\
\hline
\end{tabular}


Rainfall and run-off:

\begin{tabular}{|c|c|c|c|c|}
\hline Station. & Normal. & 1896. & 1897. & 1898. \\
\hline ' & & & & \\
\hline Saguacbe $\ldots \ldots \ldots \ldots \ldots \ldots \ldots \ldots \ldots \ldots$ & 7.19 & $\ldots \ldots$ & 8. $84:$ & 8.06 \\
\hline Fort Gariand....... & 13.02 & 12.31 & 13.93 & 13.27 \\
\hline Monero ............. . & 17.80 & 12.54 & 21.56 & $\ldots . . .$. \\
\hline 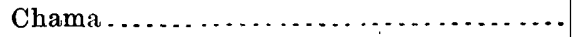 & 24.05 & 19.65 & $\ldots \ldots$ & \\
\hline Sante $\mathbf{F e} \ldots \ldots \ldots \ldots \ldots \ldots \ldots \ldots$ & 14. 48 & 14. 28 & 20.40 & $\ldots$ \\
\hline 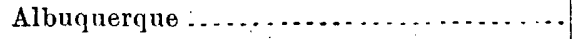 & 7.95 & 7,02 & 9.74 & 6.39 \\
\hline Los Lunas .... & 7.20 & 7.65 & 6. 20 & \\
\hline 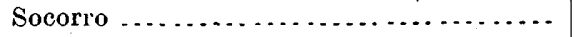 & 9.54 & $\ldots .$. & 10.61 & $\ldots$. \\
\hline Fort Craig . . . . . . . . . . . . . . & 992 & 6.55 & 11. 02 & $\ldots \ldots$. \\
\hline Fort McRae . . . . . . . . . . . . . . . & 11.60 & 10.84 & 16. 89 & $\therefore \ldots \ldots$ \\
\hline 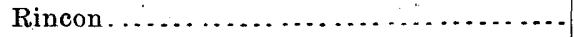 & 12.91 & 10.31 & 11.83 & 11. 13 \\
\hline Deming $\ldots \ldots \ldots \ldots \ldots \ldots \ldots$ & 8.92 & 12.70 & 10.68 & 6.50 \\
\hline Lascruces & 6.42 & 7.99 & 8.96 & $\ldots \ldots$ \\
\hline Average. & 11. 64 & 10.28 & 13.72 & 9.05 \\
\hline RUN-OFF. & & & & \\
\hline Rio Grande at Del Norte................. & 11.63 & 8.58 & 1305 & 14. 66 \\
\hline Rio Grande at Embudo .... & 2.51 & 1.25 & 297 & 2.28 \\
\hline Rio Grande at Rio Grande ................. & 2. 27 & 1.13 & 3.00 & 2.15 \\
\hline 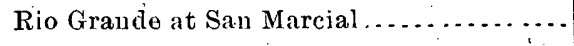 & $0 .-84$ & 0.37 & 1. 48 & 0.64 \\
\hline Average........... & 4.31 & 2.83 & 5.12 & 4.93 \\
\hline Percentage of rainfall $\ldots \ldots \ldots \ldots \ldots$ & 37.03 & 27.53 & 37.32 & 54.48 \\
\hline
\end{tabular}

Systematic measurements of the Rio Grande were begun near Del Norte, Colorado, on October 11, 1889, and have been maintained almost continuously since that time, yielding results showing the fluctuations through nearly ten years. These are given in the following table, and are shown graphically in fig. 136, p. 365 . It is probable that the flow shown during the months of January and February may be considerably in error due to the difficulty of securing accurate results while the river is obstructed in whole or part by ice. The diminution in volume in the years 1893 to 1896 , inclusive, is notable on the diagram. 
Estimated monthly discharge of Rio Grande at Del Norte, Colorado.

[Draiuage area, 1,400 square miles.]

\begin{tabular}{|c|c|c|c|c|c|c|}
\hline \multirow[b]{2}{*}{ Month. } & \multicolumn{3}{|c|}{ Discharge in second.feet. } & \multirow[b]{2}{*}{$\begin{array}{l}\text { Total in acre- } \\
\text { feet. }\end{array}$} & \multicolumn{2}{|c|}{ Run.off: } \\
\hline & $\begin{array}{l}\text { Maxi. } \\
\text { mum. }\end{array}$ & $\begin{array}{l}\text { Mini. } \\
\text { mum. }\end{array}$ & Mean. & & $\begin{array}{l}\text { Depth in } \\
\text { inches. }\end{array}$ & $\begin{array}{l}\text { Second. } \\
\text { feet per } \\
\text { square } \\
\text { mile. }\end{array}$ \\
\hline 1889. & & & & & & \\
\hline October 11-31. & .345 & 214 & 278 & 17,097 & 0.23 & 0.20 \\
\hline November... & 364 & 290 & 319 & 18,980 & .0 .25 & 0.23 \\
\hline December ...... & 364 & 200 & 281 & 17,281 & 0.23 & 0.20 \\
\hline 1890. & & & & & & \\
\hline January ........ & 1,000 & 326 & 552 & 33,948 & 0.45 & 0.39 \\
\hline February ..... & 896 & 745 & 796 & 44,178 & 0.59 & 0.57 \\
\hline March $\ldots . . . . . .$. & 842 & 404 & 487 & 29,950 & 0.40 & 0.35 \\
\hline April........ & 1,380 & 404 & 913 & 54,323 & 0.73 & 0.65 \\
\hline May ....... & 5,930 & 1,990 & $\cdot 4,331$ & 266,356 & 3.57 & 3.09 \\
\hline June.......... & 5,555 & 2,550 & 3,807 & 226,516 & 3.03 & 2. 72 \\
\hline July ...... & 2,260 & 862 & 1,515 & 93,172 & 1.25 & 1.08 \\
\hline Angust....... & 930 & 450 & 612 & 37,638 & 0.50 & 0.44 \\
\hline September .. & 450 & 326 & 383 & 22,788 & 0.31 & 0.27 \\
\hline October........ & 862 & 307 & 470 & 28,905 & 0.39 & 0.34 \\
\hline November..... & 610 & 345 & 478 & 28,441 & 0.38 & 0.34 \\
\hline December .... & 670 & 475 & 565 & 34,747 & 0.46 & 0.40 \\
\hline The year & 5,930 & 307 & 1, 242 & 900,962 & 12.06 & 0.89 \\
\hline 1891. & & & & & & \\
\hline January.... & 1,320 & 670 & 990 & 60,885 & 0.81 & 0.71 \\
\hline February ... & 1,410 & 1,196 & 1,294 & 71,817 & 0.96 & 0.92 \\
\hline March ...... & 1,460 & 930 & 1,280 & 78,720 & 1.05 & 0.91 \\
\hline April..... & 3,160 & 796 & 1,410 & 83,895 & 1.12 & 1.01 \\
\hline May. & $5,650^{-}$ & 1,860 & 3,285 & 202,027 & 2.70 & 2.34 \\
\hline Juné...... & 5,555 & 2,190 & 4,146 & 246,687 & 3.31 & 2.96 \\
\hline July ..... & 3,565 & 862 & 1,693 & 104,119 & 1.39 & 1.21 \\
\hline August..... & 1,460 & 404 & 663 & 40,774 & 0.54 & 0.47 \\
\hline September ........ & 1,234 & 290 & 527 & 31,356 & 0.42 & 0.38 \\
\hline October ............ & 2,475 & 450 & 844 & 51,906 & 0.69 & 0.60 \\
\hline November ......... & 450 & 308 & 374 & 22,253 & 0.30 & 0.27 \\
\hline Decomber... & …..... & $\cdots$ & $a 325$ & $a 19,987$ & $a 0.27$ & $a 0.23$ \\
\hline The year..... & 5,650 & 290 & 1,403 & $1,014,426$ & 13.56 & 1.00 \\
\hline
\end{tabular}

a Approximate. 
Estimated monthly discharge of Rio Grande at Del Norte, Colorado-Continued.

[Drainage area, 1.400 square miles.]

\begin{tabular}{|c|c|c|c|c|c|c|}
\hline \multirow[b]{2}{*}{ Month. } & \multicolumn{3}{|c|}{ Discharge in second feet. } & \multirow{2}{*}{$\begin{array}{c}\text { Total in acre- } \\
\text { feet. }\end{array}$} & \multicolumn{2}{|c|}{ Run-off. } \\
\hline & $\begin{array}{l}\text { Maxi. } \\
\text { mumi. }\end{array}$ & $\begin{array}{l}\text { Mini. } \\
\text { mum. }\end{array}$ & Meau. & & $\begin{array}{l}\text { Depth in } \\
\text { Inches. }\end{array}$ & $\begin{array}{c}\text { Second. } \\
\text { feet per } \\
\text { square } \\
\text { mile. }\end{array}$ \\
\hline 1892. & & & & & & \\
\hline January ........... & $\ldots \ldots$ & $\ldots \ldots$ & $a 300$ & $a 18,450$ & $a 0.25$ & $a 0.21$ \\
\hline February ........... & $\cdots \ldots$ & $\ldots \ldots$. & a 300 & a 17,250 & $a 0.23$ & $a 0.21$ \\
\hline March $22-31 \ldots$. & 345 & 290 & 316 & 19,434 & 0.26 & 0.23 \\
\hline April ..... & 2,400 & 345 & 1,047 & 62,296 & 0.83 & 0.75 \\
\hline May........... & 4,710 & 1,510 & 2,605 & 160,207 & 2.15 & 1.86 \\
\hline June ............. & 3,160 & 1,152 & 2,187 & · 130,126 & 1. 74 & 1.56 \\
\hline July ........... & 1,074 & 554 & 740 & 45,510 & 0.61 & 0.53 \\
\hline August.............. & 610 & 308 & 444 & 27,306 & 0.38 & 0.32 \\
\hline September & 308 & 243 & 262 & 15,589 & 0.21 & 0.19 \\
\hline October ......... & 290 & 243 & 259 & 15,928 & 0.21 & .0 .18 \\
\hline November .......... & 829 & 243 & 360 & 21,420 & 0.29 & 0.26 \\
\hline December ... . . . . . . & 1,074 & 862 & 922 & 56,703 & 0.76 & 0.66 \\
\hline The year.... & 4,710 & 243 & 812 & 590,219 & 7.92 & 0.58 \\
\hline 1893 & & & & & & \\
\hline January ............. & 1,113 & 862 & 966 & 59,409 & 0.80 & 0.69 \\
\hline Feloruary .......... & $\ldots \ldots . .$. & $\ldots$ & $a 700$ & $a 38,850$ & $a 0.52$ & $a 0.50$ \\
\hline March ......... & $\cdots$ & -. & $a 500$ & $a 30,750$ & $a 0.41$ & $a 0.36$ \\
\hline April $\ldots \ldots \ldots \ldots$ & 1,037 & 326 & 533 & 31,714 & 0.42 & 0.38 \\
\hline May ............ & 3,320 & 732 & 1,944 & 119,556 & 1.60 & 1.39 \\
\hline June.......... & 2,850 & 670 & 1,749 & 104,066 & 1.39 & 1.25 \\
\hline July $\ldots$. . & 640 & 290 & 395 & 24,292 & 0.33 & 0.28 \\
\hline August........... & 450 & 258 & 324 & 19,926 & 0.27 & 0.23 \\
\hline September . & 345 & 228 & 270 & 16,065 & 0.22 & 0.19 \\
\hline October ........... & 308 & 243 & 263 & 16,175 & 0.22 & 0.19 \\
\hline November... & - 450 & 214 & 278 & 16,600 & 0.22 & 0.19 \\
\hline December ...... & 862 & 228 & 642 & 39,483 & 0.53 & 0.46 \\
\hline The year..... & 3,320 & 214 & 714 & 516,886 & 6.93 & 0.51 \\
\hline
\end{tabular}

a Approximate. 
362 PROGRESS OF STREAM MEASUREMENTS FOR 1898.

Estimated monthly discharge of Rio Grande at Del Norte, Colorado-Continued.

[Drainage area, 1.400 square miles. ]

\begin{tabular}{|c|c|c|c|c|c|c|}
\hline \multirow[b]{2}{*}{ Month. } & \multicolumn{3}{|c|}{ Discliarge in second-feet. } & \multirow[b]{2}{*}{$\begin{array}{l}\text { Total in acre } \\
\quad \text { feet. } \\
\vdots \\
\vdots\end{array}$} & \multicolumn{2}{|c|}{ Run-off: } \\
\hline & $\begin{array}{l}\text { Maxi } \\
\text { mum. }\end{array}$ & $\begin{array}{l}\text { Mini. } \\
\text { mura. }\end{array}$ & Mean. & & $\begin{array}{c}\text { Depth in } \\
\text { inches. }\end{array}$ & $\begin{array}{l}\text { Secomil. } \\
\text { feet per } \\
\text { square } \\
\text { mile. }\end{array}$ \\
\hline 1894. & & & & & & \\
\hline Januạry ... & 1,113 & 896 & 1,003 & 61,672 & 0.82 & 0.71 \\
\hline February ........ & 1,037 & 930 & 995 & 55,259 & 0.74 & 0.71 \\
\hline March ... & 1,113 & 404 & 831 & 51,096 & 0.69 & 0.60 \\
\hline April .......... & 1,510 & 404 & 699 & 41,611 & 0.56 & 0.50 \\
\hline May ........ & 2,850 & 1,074 & 1,798 & 110,555 & 1.48 & 1.28 \\
\hline June.... & 1,410 & 345 & $\cdots 802$ & 47,722 & 0.63 & 0.57 \\
\hline July .......... & 370 & 245 & 292 & $-\quad 17,954$ & 0.24 & 0.21 \\
\hline August ..... & 430 & 245 & 309 & 18,999 & 0.24 & 0.21 \\
\hline September. ..... & 370 & 230 & 286 & 17,018 & 0.22 & 0.20 \\
\hline Octọer... & 350 & 260 & 289 & 17,770 & 0.24 & 0.21 \\
\hline November... & 260 & 200 & 236 & 14,043 & 0.19 & 0.17 \\
\hline December...... & 490 & 210 & 288 & 17,709 & 0.24 & 0.21 \\
\hline The year. & 2,850 & 200 & 652 & 471,408 & 6.29 & 0.46 \\
\hline 1895. & & & & & & \\
\hline January .... & 894 & 680 & 801 & 49,252 & 0.66 & 0.57 \\
\hline February ... & $.1,061$ & 894 & 953 & 52,927 & 0.73 & 0.68 \\
\hline March ..... & 960 & 403 & 638 & 39,229 & 0.53 & 0.46 \\
\hline April...... & 3,129 & 650 & 1,883 & 112,047 & 1.50 & 1.34 \\
\hline May ....... & 3,129 & 1,382 & 2,116 & 130,108 & 1.74 & 1.51 \\
\hline June ..... & 3,804 & 1,172 & 2,209 & 131,445 & 1.76 & 1.58 \\
\hline July ....... & 1,252 & $\because 770$ & 958 & 58,905 & 0.79 & 0.69 \\
\hline August. .... & 960 & 566 & 720 & 44,271 & 0.60 & 0.52 \\
\hline September : & 566 & 376 & 454 & 27,015 & 0.36 & 0.32 \\
\hline October $\ldots \ldots \ldots$ & 484 & 403 & 435 & 26,747 . & 0.36 & 0.31 \\
\hline November .......... & 403 & 322 & , 353 & 21,005 & 0.28 & 025 \\
\hline December ....... & 1,212 & 403 & 1,008 & 61,980 & 0.83 & 0.72 \\
\hline The year. & 3,804 & * 322 & 1,044 & $\therefore 754,931$ & 10.14 & 0.75 \\
\hline
\end{tabular}


Estimated monthly discharge of Rio Grande at Del Norte, Colorado-Contiuued.

[Drainage area. 1.400 square miles.]

\begin{tabular}{|c|c|c|c|c|c|c|}
\hline \multirow{2}{*}{ Month. } & \multicolumn{3}{|c|}{ Discharge in second feet } & \multirow[b]{2}{*}{ Total in acre- } & \multicolumn{2}{|c|}{ Run off. } \\
\hline & $\begin{array}{l}\text { Maxi } \\
\operatorname{mum}\end{array}$ & $\begin{array}{l}\text { Mini. } \\
\text { mừm. }\end{array}$ & Mean & & $\begin{array}{l}\text { Depth in } \\
\text { inches. }\end{array}$ & $\begin{array}{c}\text { Second. } \\
\text { teet per } \\
\text { square } \\
\text { mile }\end{array}$ \\
\hline 1896. & & & & & & \\
\hline January... & 1,428 & 1,172 & 1,293 & 79,504 & 1.06 & 0.92 \\
\hline February & 2,154 & 960 & 1,258 & 72,361 & 0.97 & 0.90 \\
\hline March ......... & 1,336 & 830 & 1,081 & 66,469 & 0.89 & 0.77 \\
\hline April.... & 3,054 & 594 & 1,484 & 88,304 & 1.18 & 1.06 \\
\hline May ...... & 3,579 & 1,212 & 2,374 & 145,973 & 1.96 & 1. 70 \\
\hline June........ & 1,766 & 430 & 821 & 48,853 & 0.65 & 0.59 \\
\hline July ......... & 650 & 322 & 403 & 24,780 & 0.33 & 0.29 \\
\hline August. ........ & 403 & 214 & 261 & 16,048 & 0.22 & 0.19 \\
\hline September . . & 1,294 & 268 & 477 & 28,838 & 0.38 & 034 \\
\hline October....... & 566 & 403 & 469 & 28,338 & 0.39 & 0.34 \\
\hline November...... & 376 & 268 & 310 & 18,446 & 0.24 & 0,22 \\
\hline December... & 430 & 322 & 375 & 23,058 & $0.31^{\circ}$ & 0.27 \\
\hline The year & 3,579 & 214 & 884 & 641,017 & 858 & 0.63 \\
\hline 1897. & & & & & & \\
\hline January ... & & $\cdots$ & $a 1,000$ & $a 61,488$. & $a 0.82$ & $a 0.71$ \\
\hline February & & $\cdots$ & $a 1,000$ & $a 5 \tilde{5}, 537$ & $a 0.74$ & $a 071$ \\
\hline March .... & - . . . & c....... & $a 1,000$ & $a 61,488$ & $a 0.82$ & $a 0.71$ \\
\hline April .... & 2,111 & 598 & 1,067 & 63,491 & 0.84 & 076 \\
\hline May ..... & 5,234 & 1,660 & 3,537 & 217,483 & 2.92 & 253 \\
\hline June...... & 4,830 & 1,660 & 3,391 & 201,778 & 2.70 & 2.42 \\
\hline $\mathrm{J} n 1 \mathrm{l} \ldots . .$. & 2,261 & 570 & 1,108 & 68,129 & 0.91 & 079 \\
\hline August............ & 598 & 354 & 475 & 29,207 & 0.39 & 0.34 \\
\hline September : ..... & 972 & 354 & 631 & $.37,547$ & 0.50 & 0.45 \\
\hline October ..... & 2,261 & 756 & 1,472 & 90,510 & 1.21 & 1.05 \\
\hline November......... & 860 & 542 & 665 & 39,570 & 0.54 & 0.48 \\
\hline December... & & & $a 800$ & $a 49,190$ & $a 0.66$ & $a 0.57$ \\
\hline The year. & & & 1,346 & 975,418 & 13.05 & 0.96 \\
\hline
\end{tabular}

a Approximate. 


\section{PROGRESS OF STREAM MEASUREMENTS FOR 1898.}

Estimated monthly discharge of Rio Grande at Del Norte, Colorado-Continued.

[Drainage area, 1,400 square miles.]

\begin{tabular}{|c|c|c|c|c|c|c|}
\hline \multirow[b]{2}{*}{ Month. } & \multicolumn{3}{|c|}{ Discharge in second-feet. } & \multirow[b]{2}{*}{$\begin{array}{c}\text { Total in acre- } \\
\text { feot. }\end{array}$} & \multicolumn{2}{|c|}{ IRun·off. } \\
\hline & $\begin{array}{l}\text { Maxi- } \\
\text { mum. }\end{array}$ & $\begin{array}{l}\text { Mini- } \\
\text { mum. }\end{array}$ & Mean. & & $\begin{array}{l}\text { Depth in } \\
\text { inches. }\end{array}$ & $\begin{array}{c}\text { Second- } \\
\text { feet per } \\
\text { square } \\
\text { mile. }\end{array}$ \\
\hline 1898. & & & & & & \\
\hline January ........... & $\ldots \ldots$ & $\ldots \ldots$ & $a 1,377$ & $a 84,669$ & $a 1.13$ & $a 0.98$ \\
\hline February .......... & . & & $a 1,472$ & $a 81,751$ & $a 1.09$ & $a 1.05$ \\
\hline March ............ & $\ldots \ldots$ & $\ldots \ldots$ & $a 1,471$ & $a 90,449$ & $a 1.21$ & $a 1.05$ \\
\hline April ... & 3,406 & 890 & 1,912 & 113,772 & 1.53 & 1.37 \\
\hline May .... & 4,382 & 2,152 & 2,722 & 167,369 & 2.24 & 1. 94 \\
\hline June.............. & 5,266 & $2, \grave{824}$ & 4,390 & 261,223 & 3.50 & 3.14 \\
\hline July .... & 2,664 & 708 & 1,643 & 101,024 & 1.35 & 1.17 \\
\hline 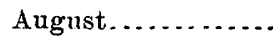 & 614 & 384 & $\check{5} 09$ & $3 l, 297$ & 0.42 & 0.36, \\
\hline September & 398 & 260 & 319 & 18,982 & 0.26 & 0.23 \\
\hline October............. & 328 & 220 & 259 & 15,925 & 0.22 & 0.19 \\
\hline November... & 1,442 & 234 & 816 & 48,555 & 0.64 & 0.58 \\
\hline December ..... & $\ldots \ldots$ & $\ldots \ldots$ & $a 1,3 \subset 0$ & $a 79,934$ & $a 1.07$ & $a 0.93$ \\
\hline The year. & & $\cdots$ & 1,517 & $1,094,850$ & 14.66 & 1. 08 \\
\hline
\end{tabular}

$a$ A pproximate.

NoTE.-Gage heights of 1898 are given in Water-Supply and Irrigation Paper No. 28, page 126 measurements, page 129; rating table. page 130. Results for 1897 in Water-Supply and Irrigation Paper No. 16, page 127, and in the Nineteenth Annual Report, Part IV, page 381.

Estimated monthly discharge of Rio Grande at Embudo, New Mexico.

[Drainage area, 7,000 square miles.]

\begin{tabular}{|c|c|c|c|c|c|c|}
\hline \multirow{2}{*}{ Month. } & \multicolumn{3}{|c|}{ Discharge in second-feet. } & \multirow[b]{2}{*}{$\begin{array}{l}\text { Total in acre } \\
\text { feet. }\end{array}$} & \multicolumn{2}{|c|}{ Rus-off. } \\
\hline & $\frac{\text { Maxi- }}{\operatorname{mum} .}$ & $\begin{array}{l}\text { Mini. } \\
\text { mum. }\end{array}$ & Mean. & & $\begin{array}{l}\text { Depth in } \\
\text { inches. }\end{array}$ & $\begin{array}{c}\text { Second- } \\
\text { feet per } \\
\text { square } \\
\text { mile. }\end{array}$ \\
\hline 1889. & & & & & & \\
\hline January ...... & 495 & 379 & 431 & 26,506 & 0.07 & 0.06 \\
\hline February ........... & $\mathbf{5 7 6}$ & 420 & 473 & 26,251 & 0.07 & 0.07 \\
\hline 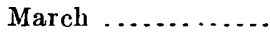 & 1,042 & 537 & 784 & 48,216 & 0.13 & 0.11 \\
\hline April ..... & 4,420 & 970 & 2,261 & 134,530 & 0.36 & 0.32 \\
\hline May ....... & 5,075 & 2,443 & 3,430 & 210,945 & 0.556 & 0.49 \\
\hline June...... & 5,660 & 1,390 & 2,922 & 173,859 & 0.47 & 0.42 \\
\hline July ...... & 1,105 & 236 & 471 & 28,966 & 0.07 & 0.07 \\
\hline August.... & 253 & 181 & 206 & 12,669 & 0.03 & 0.03 \\
\hline September & 264 & 184 & 212 & 12,614 & 0.03 & 0.03 . \\
\hline October ........... & 324 & 243 & 283 & 17,404 & 0.05 & 0.04 \\
\hline November . . . . . . . . . & 507 & 253 & 366 & 21,777 & 0.06 & 0.05 \\
\hline December ......... & 610 & 364 & 542 & 33,333 & 0.09 & 0.08 \\
\hline 'The year. & 5,660 & 181 & 1,032 & $747 ; 070$ & 1.99 & 0.15 \\
\hline
\end{tabular}




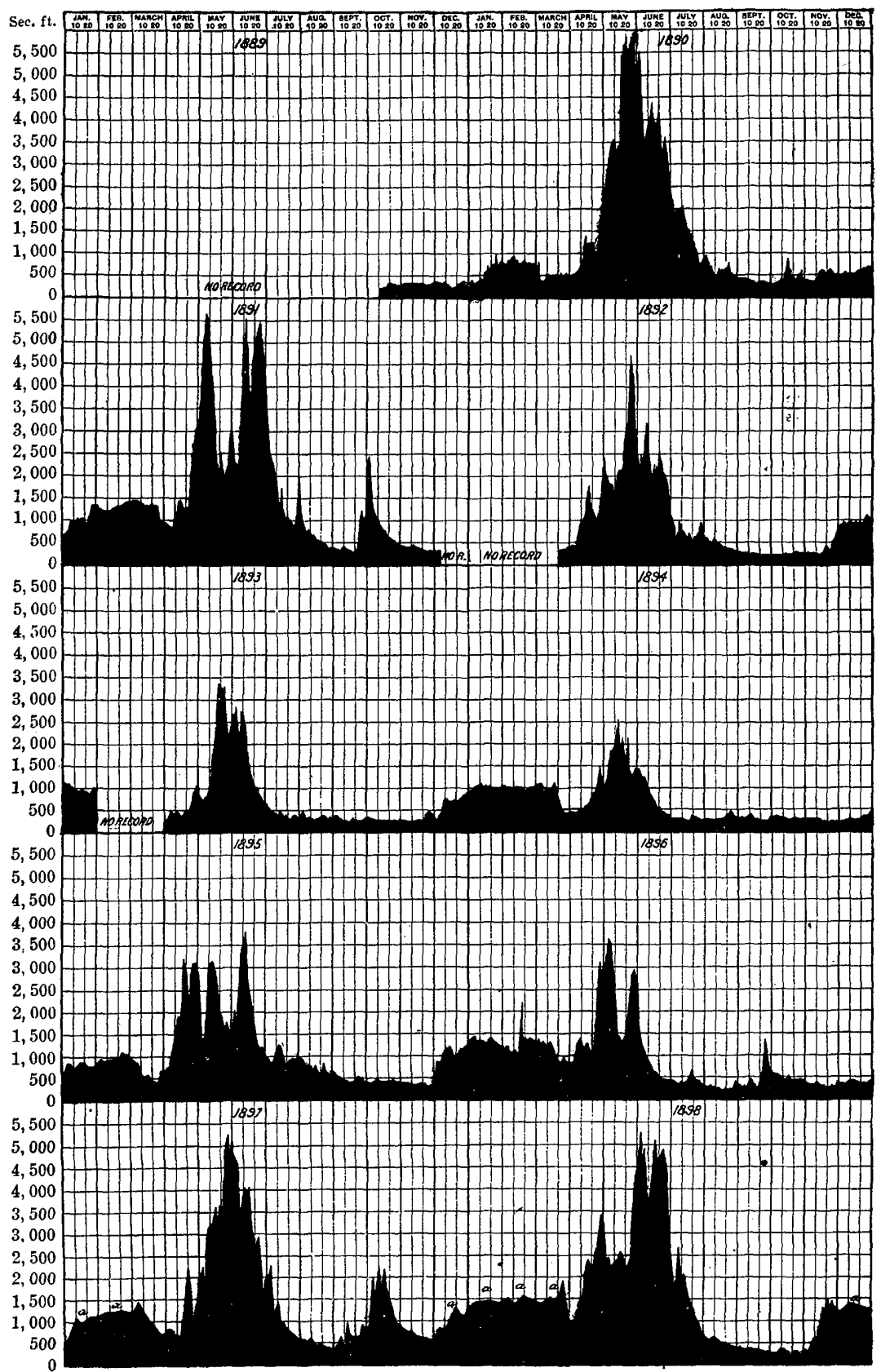

FiG. 136. -Discharge of Rio Grande at Del Norte, Colorado, 1889-1898. 


\section{PROGRESS OF STREAM MEASUREMENTS FOR 1898.}

Estimated monthly discharge of Rio Grande at Embudo, New Mexico-Continued.

[Orainage area, 7,000 square miles.]

\begin{tabular}{|c|c|c|c|c|c|c|}
\hline \multirow[b]{2}{*}{ Month. } & \multicolumn{3}{|c|}{ Discharge in second feet. } & \multirow{2}{*}{$\begin{array}{l}\text { Total in acre- } \\
\text { feet. }\end{array}$} & \multicolumn{2}{|c|}{ Run-off. } \\
\hline & $\begin{array}{l}\text { Maxi. } \\
\text { mum. }\end{array}$ & $\begin{array}{l}\text { Mini. } \\
\text { mum. }\end{array}$ & Mean. & & $\begin{array}{l}\text { Depth in } \\
\text { inches. }\end{array}$ & $\begin{array}{c}\text { Second- } \\
\text { feet per } \\
\text { square } \\
\text { mile. }\end{array}$ \\
\hline 1890. & & & & 1 & & \\
\hline January .......... & 617 & 260 & 437 & 26,875 & 0.07 & 0.07 \\
\hline February ...... & 670 & 344 & 553 & 30,691 & $\cdot 0.08$ & 0.08 \\
\hline March ............ & 1,044 & 330 & 682 & 41,943 & 0.11 & 0.10 \\
\hline April ....... & 3,220 & 842 & 2,083 & 123,938 & 0.33 & 0.30 \\
\hline May ....... & 6,071 & 2,660 & 4,960 & 305,040 & 0.82 & 0.71 \\
\hline June............. & 5,740 & 2,768 & 4,107 & 244,366 & 0.65 & 0.59 \\
\hline July ........ & 2,640 & 920 & 1,593 & 97,969 & 0.26 & 0.23 \\
\hline August $\ldots . .$. & 1,134 & 636 & 814 & 50,061 & 0.13 & 0.12 \\
\hline September .... & 1,044 & 496 & 545 & 32,427 & 0.09 & 0.08 \\
\hline October ........ & 606 & 523 & $\cdot 562$ & 34,563 & 0.09 & 0.08 \\
\hline November. & 699 & 550 & 616 & 36,652 & 0.10 & 0.09 \\
\hline December .......... & 660 & 636 & 648 & 39,852 & 0.11 & 0.09 \\
\hline The year... & 6,071 & 260 & 1,467 & $1,064,377$ & 2.84 & 0.21 \\
\hline 1891. & & & & & & \\
\hline January & 666 & 550 & 586 & 36,039 & 0.10 & 0.08 \\
\hline February - - & 1,000 & 550 & 616 & 34,182 & 0.09 & 0.09 \\
\hline March .... & 1,450 & 735 & 917 & 56,395 & 0.15 & 0.13 \\
\hline April ... & 5,690 & 735 & 2,370 & 141,015 & 0.38 & 0.34 \\
\hline May ....... & 8,550 & 4,520 & 5,965 & 366,847 & 0.98 & 0.85 . \\
\hline June ..... & 6,340 & 4,325 & 5,040 & 299,880 & 0.80 & 0.72 \\
\hline July ...... & 4,130 & 1,250 & 2,356 & 144:, 894 & 0.39 & 0.34 \\
\hline August.... & 1,805 & . 320 & 933 & 57,379 & 0.15 & 0.13 \\
\hline September & 2,025 & 320 & 469 & 27,905 & 0.08 & 0.07 \\
\hline October . & 3,350 & 225 & 1,681 & 103,381 & 0.28 & 0.24 \\
\hline November. . & 970 & 515 & 778 & 46,291 & 0.12 & 0.11 \\
\hline December ..... & 880 & 340 & 553 & 34,009 & 0.09 & 0.08 \\
\hline The year. & 8,550 & 225 & 1,855 & $1,348,217$ & 3.61 & 0.26 \\
\hline
\end{tabular}


Estimated monthly discharge of Rio Grande at Embudo, New Mexico-Continued.

[Drainage area, $\mathbf{7}, 000$ squaré miles:]

\begin{tabular}{|c|c|c|c|c|c|c|}
\hline \multirow{2}{*}{ Month. } & \multicolumn{3}{|c|}{ Discharge in second.feet. } & \multirow{2}{*}{$\begin{array}{l}\text { Total in acre- } \\
\text { feet. }\end{array}$} & \multicolumn{2}{|c|}{ Run off'. } \\
\hline & $\begin{array}{l}\text { Maxi- } \\
\text { mum. }\end{array}$ & $\begin{array}{l}\text { Mini- } \\
\text { mum. }\end{array}$ & Mean. & & $\begin{array}{l}\text { Depth in } \\
\text { inches }\end{array}$ & $\begin{array}{c}\text { Second. } \\
\text { feet per } \\
\text { square } \\
\text { mile. }\end{array}$ \\
\hline 1892. & & & & & & \\
\hline January . . . ........ & 615 & 440 & 497 & 30,565 & 0.08 & 0.07 \\
\hline February ........... & 700 & 490 & 596 & 34,270 & 0.09 & 0.08 \\
\hline March ... & 1,550 & 700 & 1,051 & 64,636 & 0.17 & 0.15 \\
\hline April.......... & 4,910 & 860 & 2,979 & 177,250 & 0.47 & 0.42 \\
\hline May ............... & 6,665 & 4,130 & 4,890 & 300,735 & 0.81 & 0.70 \\
\hline June .............. & 4,715 & 1,550 & 3,146 & 187,187 & 0.50 & 0.45 \\
\hline July .......... & 1,400 & 280 & 538 & 33,087 & 0.09 & 0.08 \\
\hline August . . . . . . . . . & 300 & 152 & 191 & 11,746 & 0.04 & 0.03 \\
\hline September ......... & 165 & 140 & 152 & 9,044 & 0.02 & 0.02 \\
\hline October . . . . . . . & 260 & 165 & 202 & 12,423 & 0.03 & 0.03 \\
\hline November .......... & 400 & 243. & 317 & 18,861 & 0.05 & 0.05 \\
\hline December . . ....... & 490 & 165 & 324 & 19,926 & $\dot{0.05}$ & 0.05 \\
\hline The year. & 6,665 & 140 & 1,240 & 899,730 & $2.4 \mathrm{C}$ & 0.18 \\
\hline 1893. & & & & & & \\
\hline January .. & 360 & 280 & 332 & 20,418 & 0.06 & 0.05 \\
\hline February ..... & 465 & 340 & 415 & 23,033 & 0.06 & 0.06 \\
\hline March .... & - 670 & 360 & 501 & 30,812 & 0.08 & 0.07 \\
\hline April ... & 2,465 & 700 & 1,436 & 85,442 & 0.23 & 0.21 \\
\hline May .. & 5,105 & 1,500 & 3,119 & 191,819 & 0.51 & 0.45 \\
\hline June....... & 3,740 & 540 & 2,533 & 150,714 & 0.41 & 0.36 \\
\hline July ........ & 1,150 & 130 & 226 & 13,899 & 0.04 & 0.03 \\
\hline 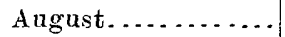 & 565 & 140 & 230 & 14,145 & 0.04 & 0.03 \\
\hline September & 440 & 225 & 287 & 17,077 & 0.05 & 0.04 \\
\hline October . . . . . . . . & 420 & 340 & 363 & 22,325 & 0.06 & 0.05 \\
\hline November ........... & & $\ldots$ & a 330 & 19,636 & 0.06 & 0.05 \\
\hline December ............ & & $\cdots$ & a 320 & 19,676 & 0.06 & 0.05 \\
\hline The sear. & 5,105 & 140 & 841 & 608,996 & 1.66 & 0.12 \\
\hline $1895 . b$ & & & & & & \\
\hline January .... & 552 & 432 & 475 & 29,207 & 0.08 & 0.07 \\
\hline February $\ldots . . .$. & 672 & 420 & 503 & 27,935 & 0.07 & 0.07 \\
\hline March . . . . . . . . & 1,410 & 640 & 759 & 46,546 & 0.13 & 0.11 \\
\hline April ... & 4,290 & 592 & 2,541 & 151,200 & 0.40 & 0.36 \\
\hline May ..... & 4,290 & 1,573 & 2,679 & 164,725 & 0.44 & 0.38 \\
\hline June ...... & 4,985 & 790 & 3,021 & 179,762 & 0.4 .8 & 0.43 \\
\hline July ..... & 2,530 & 612 & 1,335 & 82,086 & 0.22 & 0.19 \\
\hline August............... & 2,016 & 652 & 1,080 & 66,407 & 0.17 & 0.15 \\
\hline Septenuber . . . . . . & 1,146 & 480 & 636 & 37,845 & 0.10 & 0.09 \\
\hline October . . . . . . . & 572 & 460 & 494 & 30,375 & 0.08 & 0.07 \\
\hline November.......... & 700 & 540 & 611 & 36,357 & 0.10 & 0.09 \\
\hline December ........... & 580 & 420 & 534 & 32,834 & 0.09 & 0.08 \\
\hline The year .... & 4,985 & 420 & 1,222 & 885,279 & 2.36 & 0.17 \\
\hline
\end{tabular}




\section{PROGRESS OF STREAM MEASUREMENTS FOR 1898.}

Estimated monthly discharge of Rio Grande at Embudo, New Mexico-Continued.

\begin{tabular}{|c|c|c|c|c|c|c|}
\hline \multirow[b]{2}{*}{ Month. } & \multicolumn{3}{|c|}{ Discharge in second-feet. } & \multirow[b]{2}{*}{$\begin{array}{l}\text { Total in acre } \\
\text { feet. }\end{array}$} & \multicolumn{2}{|c|}{ Run.off. } \\
\hline & $\begin{array}{l}\text { Maxi. } \\
\text { mun. }\end{array}$ & $\begin{array}{l}\text { Mini } \\
\text { mun. }\end{array}$ & Mean. & & $\begin{array}{l}\text { Depth in } \\
\text { inches. }\end{array}$ & $\begin{array}{c}\text { Second } \\
\text { feet per } \\
\text { square } \\
\text { mile. }\end{array}$ \\
\hline 1896 & & & ' & & & \\
\hline January... & 660 & 460 & 532 & 32,712 & 0.09 & 0.08 \\
\hline February & 640 & 480 & 551 & 31,694 & 0.09 & 0.08 \\
\hline March ... & 2,100 & 580 & 957 & 58,844 & 0.16 & 0.14 \\
\hline April ..... & 2,720 & 1,200 & 1,797 & 106,929 & 0.29 & 0.26 \\
\hline May & 2,980 & 850 & 1,598 & 98,259 & 0.26 & 0.23 \\
\hline June....... & 990 & 210 & 367 & 21,838 & 0.06 & 0.05 \\
\hline July .............. & 1,380 & 210 & 299 & 18,385 & 0.04 & 0.04 \\
\hline August.............. & 310 & 210 & 249 & 15,310 & 0.03 & 0.03 \\
\hline September .......... & 580 & 210 & 228 & 13,570 & 0.03 & 0.03 \\
\hline October ................. & 1,090 & 275 & 349 & 21,459 & 0.06 & 0.05 \\
\hline November ........... & 660 & 210 & 395 & 23,504 & 0.07 & 0.06 \\
\hline December ........... & 500 & 380 & 414 & 25,456 & 0.07 & 0.06 \\
\hline The year. & 2,980 & 210 & 645 & 467,960 & 1.25 & 0.09 \\
\hline 1897 & & & & & & \\
\hline January & 435 & 375 & 394 & 24,226 & 0.07 & 0.06 \\
\hline February ........... & 480 & 375 & 408 & 22,659 & 0.06 & 0.06 \\
\hline March $\ldots \ldots \ldots \ldots$ & 865 & 410 & 561 & 34,495 & 0.09 & 0.08 \\
\hline April......... & 3,177 & 700 & 1,698 & 101,038 & 0.27 & ¿. 24 \\
\hline May .................. & 8,745 & 3,177 & 5,443 & 334,679 & 0.90 & 0.78 \\
\hline June............. & 7,600 & 2,270 & 4,621 & 274,968 & 0.73 & 0.66 \\
\hline July $\ldots . . . . . .$. & 2,465 & 375 & 1,274 & 78,336 & 0.21 & 0.18 \\
\hline August............ & 1,015 & 285 & 338 & 20,783 & 0.06 & 0.05 \\
\hline September ..... & 460 & 285 & 344 & 20,469 & 0.06 & 0.05 \\
\hline October................ & 2,150 & 495 & 1,538 & 94,569 & 0.25 & 0.22 \\
\hline November .......... & 1,435 & 745 & 1,138 & 67,716 & 0.18 & 0.16 \\
\hline December .......... & 745 & 460 & 551 & 33,880 & 0.09 & 0.08 \\
\hline The year & 8,745 & 285 & 1,497 & $1,107,818$ & 2.97 & 0.22 \\
\hline 1898. & & & & & & \\
\hline January....... & 605 & 385 & 488 & 30,006 & 0.08 & 0.07 \\
\hline February ..... & 660 & 425 & 471 & 26,159 & 0.07 & 0.07 \\
\hline March ...... & 912 & 537 & 695 & 42,733 & 0.12 & 0.10 \\
\hline April........ & 3,540 & 660 & 2,240 & 133,289 & 0.36 & 0.32 \\
\hline May .......... & 3,467 & 1,515 & 2,149 & 132,137 & 0.36 & 0.31 \\
\hline June.......... & 4,410 & 2,400 & 3,480 & 207,074 & 0.56 & 0.50 \\
\hline July ......... & 4,700 & 800 & 2,566 & 157,777 & 0.43 & 0.37 \\
\hline August........ & 987 & 310 & 478 & 29,391 & 0.08 & 0.07 \\
\hline September ........ & 385 & 310 & 338 & 20,112 & 0.06 & 0.05 \\
\hline October ............ & 345 & 265 & 283 & 17,401 & 0.04 & 0.04 \\
\hline November......... & 425 & 285 & 357 & 21,243 & 0.06 & 0.05 \\
\hline December....... & 385 & 265 & 339 & 20,844 & 0.06 & 0.05 \\
\hline The year & 4,700 & 265 & 1,157 & 838,166 & 2.28 & 0.17 \\
\hline
\end{tabular}

Note.-Gage heights for 1898 are given in Water Supply and Irrigation Paper No. 28, page 127, meas urements. page 129 , rating table. page 130 , results for 1897 in Water.supply and Irrigation Paper No. 16. page 128, and in the Nineteenth Annual Report. Part IV, page 384 . 


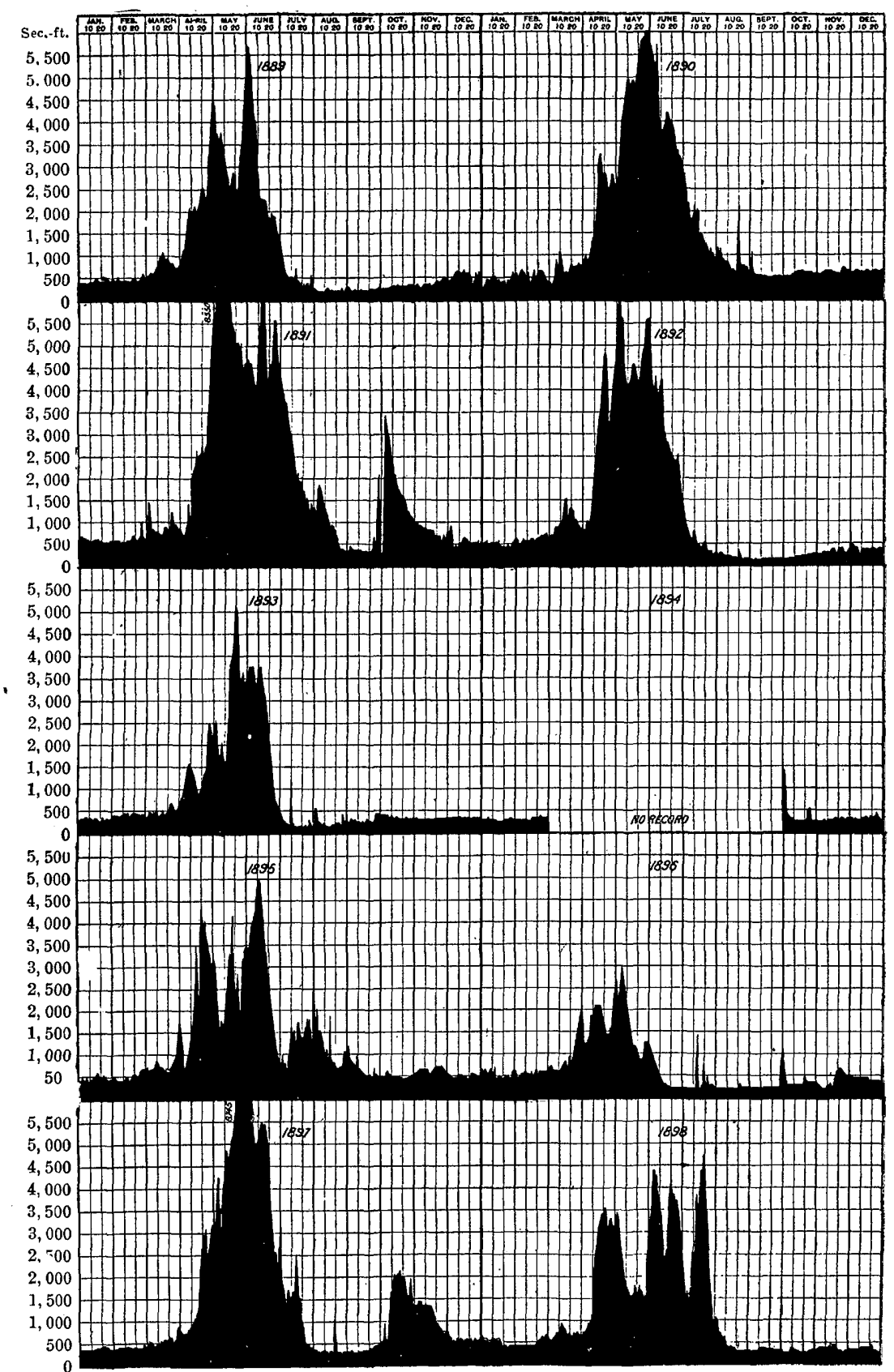

Fir. 137.-Discharge of the Rio Grande at Embudo, New Mexico, 1889-1898. 20 GEOL, PT $4-24$ 
The figures and diagram given on the preceding pages show the flow of the Rio Grande in the northeru or upper part of New Mexico. Below this point of measurement several tributaries enter, notably Chama River from the west; this joins the Rio Grande in Espanoia Valley. Below this valley the stream enters a narrow canyon, in the upper end of which is located the next river station, known as Rio Grande. Measurements were begun here in February; 1895, and have been maintained continuously, giving results for four years. Those for 1895 are contained in Bulletin No. 140, on page 175; those for 1896 are in the Eighteenth Annual Report, on page 252; and those for 1897 are in the Nineteenth Annual Report, on page 386. The following table gives the results for 1898:

Estimated monthly discharge of the Rio Grande at Rio Grande, New Mexico.

[Drainage area 11,250 square miles.]

\begin{tabular}{|c|c|c|c|c|c|c|}
\hline \multirow[b]{2}{*}{ Month. } & \multicolumn{3}{|c|}{ Discharge, in second-feet. } & \multirow[b]{2}{*}{$\begin{array}{c}\text { Total in acre } \\
\text { feet. }\end{array}$} & \multicolumn{2}{|c|}{ Run-off. } \\
\hline & $\begin{array}{l}\text { Maxi- } \\
\text { mum. }\end{array}$ & $\begin{array}{l}\text { Mini- } \\
\text { mum. }\end{array}$ & Mean. & & $\begin{array}{l}\text { Deptih in } \\
\text { inches. }\end{array}$ & $\begin{array}{c}\text { Second- } \\
\text { feet per } \\
\text { square } \\
\text { mile. }\end{array}$ \\
\hline 1898. & & & & & & \\
\hline January ............. & 475 & 290 & 353 & 21,705 & 0.03 & 0.03 \\
\hline February.......... & 630 & 320 & 449 & 24,936 & 0.04 & 0.04 \\
\hline March ......... & 790 & 400 & 544 & 33,449 & 0.06 & 0.05 \\
\hline April............ & 8,020 & 425 & 4,468 & 265,864 & 0.45 & 0.40 \\
\hline May............... & 7,060 & 1,750 & 3,258 & 200,328 & 0.33 & 0.29 \\
\hline June ............. & $\check{5}, 140$ & 1,910 & 3,764 & 223,973 & 0.38 & 0.34 \\
\hline July ........... & 6,580 & 530 & 2,628 & 161,590 & 0.26 & 0.23 \\
\hline August........... & 2,450 & 255 & 、637 & 39,168 & 0.07 & 0.06 \\
\hline Septemlier ........ & 750 & 230 & 324 & 19,279 & 0.03 & 0.03 \\
\hline October ..... & 710 & 250 & 356 & 21,890 & 0.37 & 0.32 \\
\hline November ......... & 1,150 & 360 & 598 & 35,583 & 0.06 & 0.05 \\
\hline December .......... & 1,090 & 450 & 637 & 39,168 & 0.07 & 0.06 \\
\hline The year.. & 8,020 & 230 & 1,501 & $1,086,933$ & 2.15 & 0.16 \\
\hline
\end{tabular}

Noтk.-Gage heights for 1898 are given in Water-Supply and Irrigation Paper No. 28, page 127, measurements, page 129, rating table, page 130; results for 1897 in Water-Supply and Irrigation Paper No. 16, page 130, and in the Nineteenth Annual Report, Part IV, page 386.

Below the station known as Rio Grande the river is not measured until San Marcial is reached, considerably below the center of the Territory of New Mexico. Measurements were begun at this point in January, 1895, the results being given in various reports above named. 
Estimated monthly discharge of Rio Grande at San Marcial, New Mexico.

[Drainage area, 28,067 square miles.]

\begin{tabular}{|c|c|c|c|c|c|c|}
\hline \multirow[b]{2}{*}{ Month. } & \multicolumn{3}{|c|}{ Discharge in second-feet. } & \multirow[b]{2}{*}{$\begin{array}{c}\text { Total in acre } \\
\text { feet. }\end{array}$} & \multicolumn{2}{|c|}{ Run.off. } \\
\hline & $\begin{array}{l}\text { Maxi- } \\
\text { mum. }\end{array}$ & $\begin{array}{l}\text { Mini- } \\
\text { mum. }\end{array}$ & Mean. & & $\begin{array}{l}\text { Depth in } \\
\text { inches. }\end{array}$ & $\begin{array}{l}\text { Second- } \\
\text { feet per } \\
\text { square } \\
\text { mile. }\end{array}$ \\
\hline 1898. & & & & & & \\
\hline January ............ & 1,090 & 462 & 938 & 57,675 & 0.04 & 0.03 \\
\hline February ........... & 1,290 & 915 & 1,070 & 59,425 & 0.04 & 0.04 \\
\hline 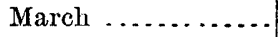 & 1,185 & 775 & 1,011 & 62,164 & 0.04 & 0.04 \\
\hline 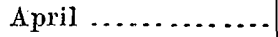 & 11,300 & 775 & 4,562 & 271,458 & 0.18 & 0.16 \\
\hline May .... & 10,205 & 1,000 & 2,697 & 165,832 & 0.11 & ' 0.10 \\
\hline Jume.............. & 3,170 & 1,475 & 2,122 & 126,268 & 0.08 & 0.08 \\
\hline July $\ldots \ldots \ldots$ & 16,775 & 462 & 2,717 & 167,062 & 0.11 & 0.10 \\
\hline 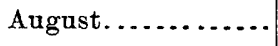 & 1,045 & 50 & 225 & 13,835 & 0.01 & 0.01 \\
\hline September .......... & 878 & 32 & 78 & 4,641 & 0.003 & 0.003 \\
\hline October .............. & $\ldots \ldots$ & $\therefore \ldots \ldots$ & $a 20$ & $a 1,230$ & $a 0.001$ & $a 0.001$ \\
\hline November $5-30 \ldots$. & 372 & 27 & 197 & 11,722 & 0.01 & 0.01 \\
\hline December .......... & 915 & 170 & 380 & 23,365 & 0.02 & 0.01 \\
\hline The year ....... & 16,775 & 27 & 1,335 & $.964,677$ & 0.64 & 0.05 \\
\hline
\end{tabular}

a Approximate.

NoTe.-Gage heights for 1898 are given in Water-Supply and Irrigation Paper No. 28, page 128, measurements, page 129; rating table, page 130; results for 1897 in Water-Supply and Irrigation Paper No. 15, page 131, and in the Nineteenth Annual Report, Part IV, page 387.

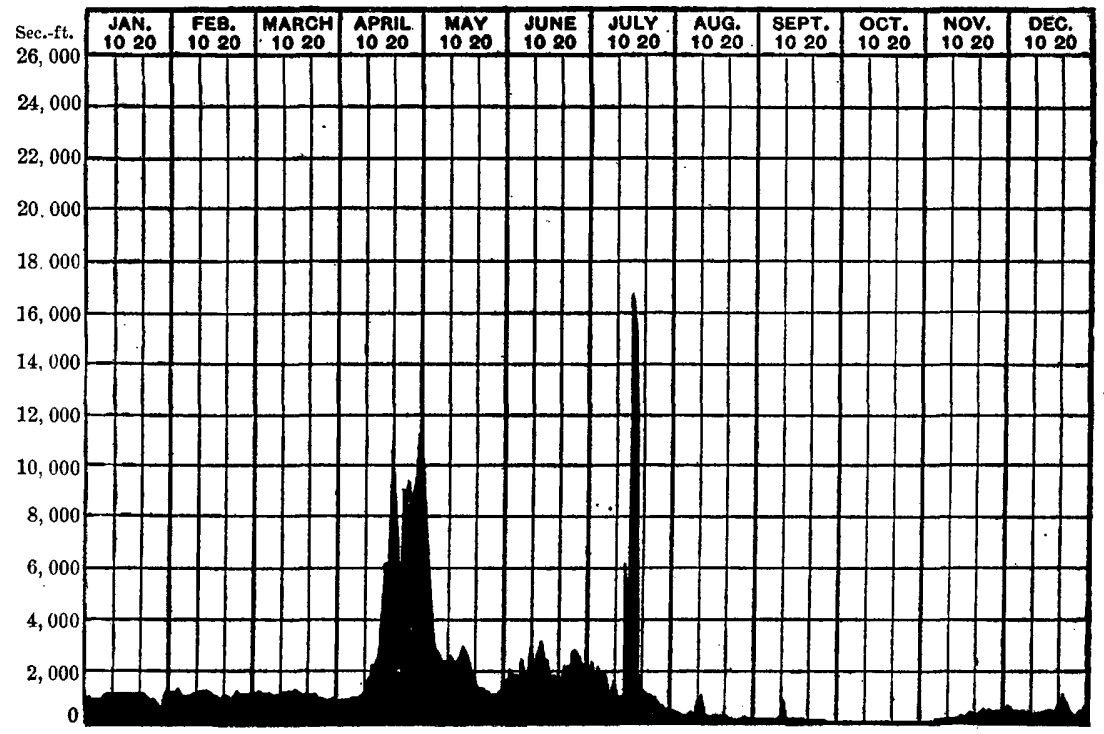

Fre. 138.-Discharge of the Rio Grande at San Marcial, New Mexico, 1898. 


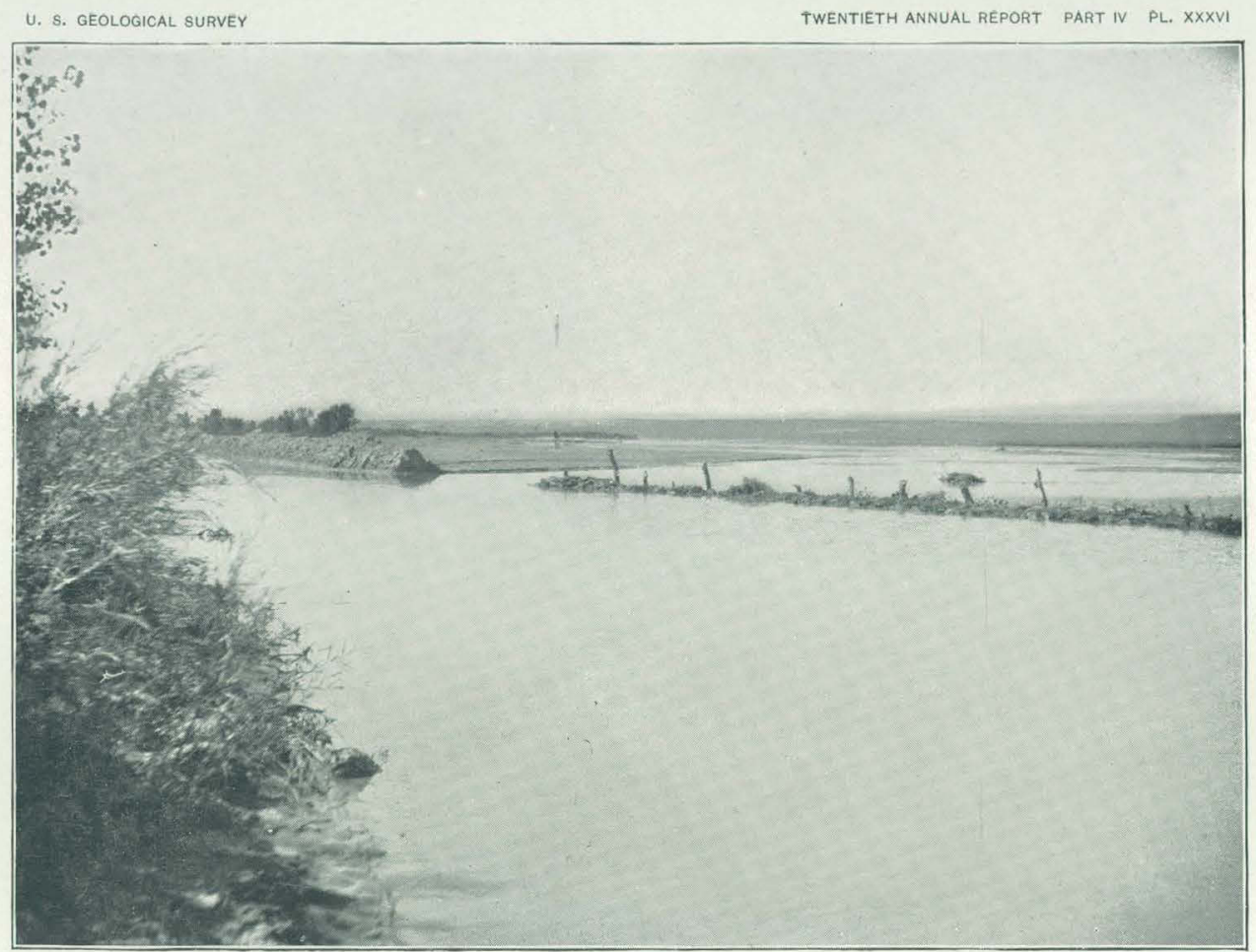

A. BRUSH DAM IN RIO GRANDE, NEW MEXICO.

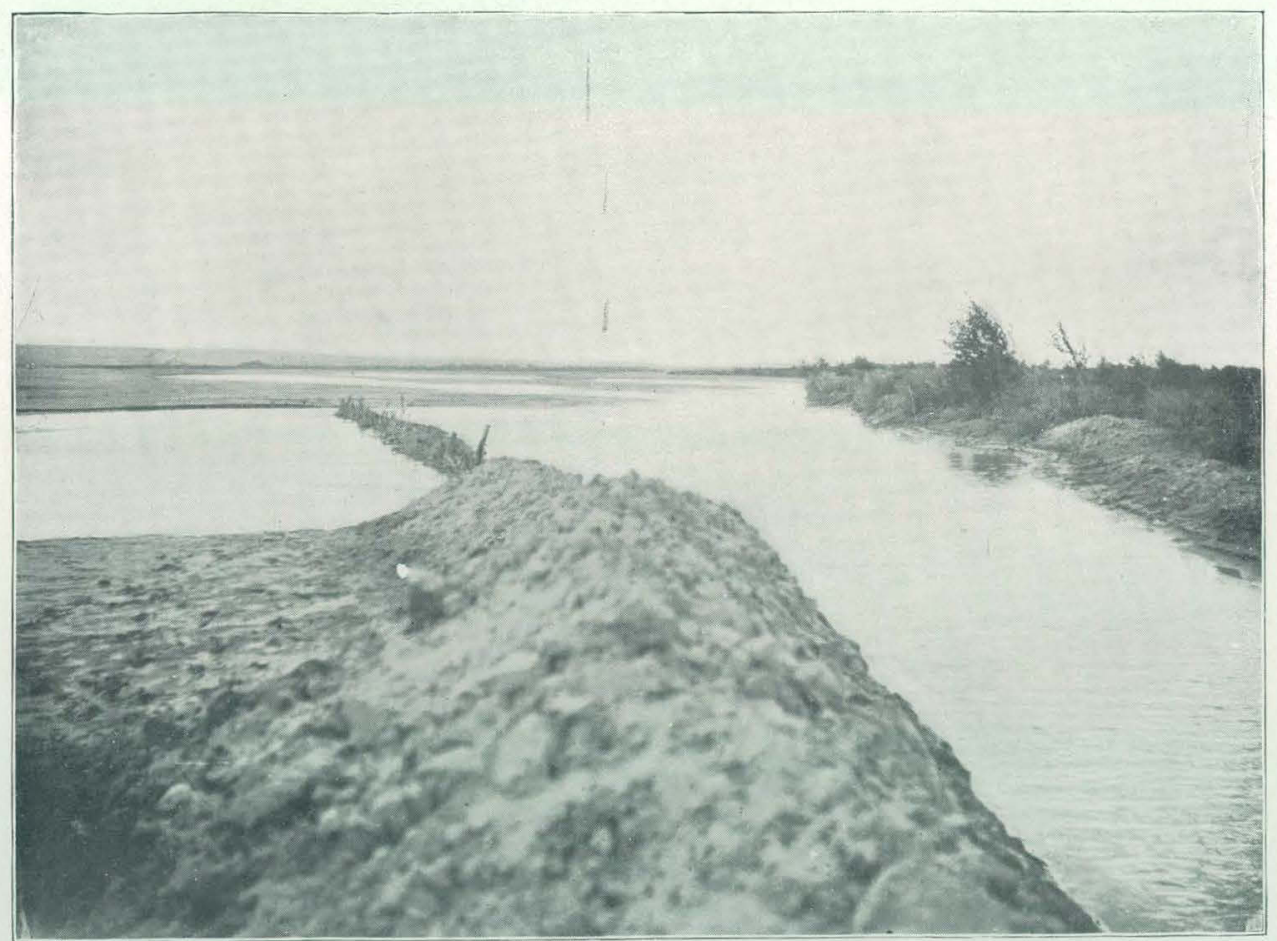

B. HEAD OF DITCH ON RIO GRANDE, NEW MEXICO. 


\section{PROGRESS OF STREAM MEASUREMENTS FOR 1898.}

A general view of the Rio Grande in its lower course in New Mexico is shown on the accompanying plate (PI. XXXVI, $A$ ). In the foreground is a brush and stone dam turning the greater part of the water. into the head of a ditch. On the same plate ait $B$ is a view from the head of one of these ditches looking upstream along the Rio Grande, showing its broad, shallow bed.

The results of measurements of the Rio Grande in New Mexico are given on the preceding pages. Estimates of the discharge have also been prepared at the point where the river leaves New Mexico and forms the international boundary between the Republic of Mexico and the State of Texas. The measurements at this point have been carried on by Mr. T. M. Courchesne, under the direction of Mr. W. W. Follett, consulting engineer of the International (Water) Boundary Commission. A large number of measurements were made during 1898, as shown on page 120 of Water-Supply Paper No. 28. From these and the daily observations of height, given on page 128 of the same paper, an estimate of the monthly flow has been made, as shown in the following table:

Estimated monthly discharge of Rio Grande at El Paso, Texas.

[Drainage area, 30,000 square miles.]

\begin{tabular}{|c|c|c|c|c|c|c|}
\hline \multirow[b]{2}{*}{ Month. } & \multicolumn{3}{|c|}{ Discharge in second-feet. } & \multirow[b]{2}{*}{$\begin{array}{l}\text { Total in acre. } \\
\text { feet. }\end{array}$} & \multicolumn{2}{|c|}{ Run-off. } \\
\hline & $\begin{array}{l}\text { Maxi- } \\
\text { mum. }\end{array}$ & $\begin{array}{l}\text { Mini- } \\
\text { num. }\end{array}$ & Mean. & & $\begin{array}{l}\text { Depth in } \\
\text { inches. }\end{array}$ & $\begin{array}{c}\text { Second. } \\
\text { teet per: } \\
\text { square } \\
\text { mile. }\end{array}$ \\
\hline 1898. & & & & & . & \\
\hline January ... & $\ldots \ldots$ & $\ldots \ldots$ & $a 490$ & 30,129 & 0.018 & 0.016 \\
\hline February .. & 965 & 320 & 606 & 33,655 & 0.021 & 0.020 \\
\hline March ..... & 620 & 99 & 326 & 20,044 & 0.013 & 0.011 \\
\hline April .............. & 4,750 & 15 & 1,646 & 97,944 & 0.061 & 0.055 \\
\hline May ........ & 5,800 & 530 & 2,280 & 140,192 & 0.087 & 0.076 \\
\hline June............... & 3,080 & 522 & 1,875 & 111,570 & 0.070 & 0.063 \\
\hline July ..... & 9,900 & 1,210 & 3,192 & 196,269 & 0.122 & 0.106 \\
\hline August ..... & 1,550 & 100 & 508 & 31,236 & 0.020 & 0.017 \\
\hline September ......... & 170 & 3 & 38 & 2,262 & 0.001 & 0.001 \\
\hline October...... & 3 & 2 & 3 & 160 & 0.001 & 0.001 \\
\hline November.... & 2 & 2 & 2 & 119 & 0.001 & 0.001 \\
\hline December.. & 200 & $\cdot 2$ & 93 & 5,718 & 0.003 & 0.003 \\
\hline The sear .... & 9,900 & 0 & 922 & 669,298 & 0.418 & 0.031 \\
\hline
\end{tabular}




\section{PECOS RIVER.}

Pecos River receives the drainage of the greater part of eastern New Mexico, and, flowing south, crosses the western prolongation of Texas and enters the Rio Grande. The river has been described in some detail in the Twelfth Annual Report, Part II, page 282. A few meas. urements have been made in New Mexico, but systematic observatious have been undertaken only at points in Texas, these being near the town of Pecos, on the Texas and Pacific Railway, and at the viaduct of the Southern Pacific Company, as described in Water-Supply and Irrigation Paper No. 28, pages 119 and 120. Gage heights are given on pages $12 \tilde{s}$ and 126 , and measurements on page 129. No rating tables have been constructed.

\section{COLORADO RIVER DRAINAGE.}

The gieat Colorado River of the West is formed by the junction of the Grand and the Green, these draining portions of Wyoming, Colorado, and Utah. It passes through stupendous canyons, finally emerging into the desert regions of southern Arizona and California, through which it flows into the Gulf of California. Its drainage basin consists for the most part of elevated plateaus, into which the river and its principal tributaries have cut narrow gorges of extraordinary depth. Water can not be diverted or even pumped for irrigation upon these high plateaus, so that, except possibly for water power, the main stream has little economic importance; the upper tributaries, however, before they have reached their canyons, can be taken out to cover adjacent lands, and progress in their utilization has begun to a considerable extent. The principal tributaries below the junction of the Grand and Green are the San Juan, coming from the west, and draining southern Colorado and northern New Mexico, and also the Gila, tlowing through southern Arizona.

\section{COLORADO RIVER.}

Colorado River is navigable for light-draft steamers from Yuma up to The Needles, and even higher at times of flood. Its waters in its lower course have otherwise little economic importance, as above stated, although it is possible that at some future time a portion may be diverted for the irrigation of lands in the Salton Desert, west of Yuma. 


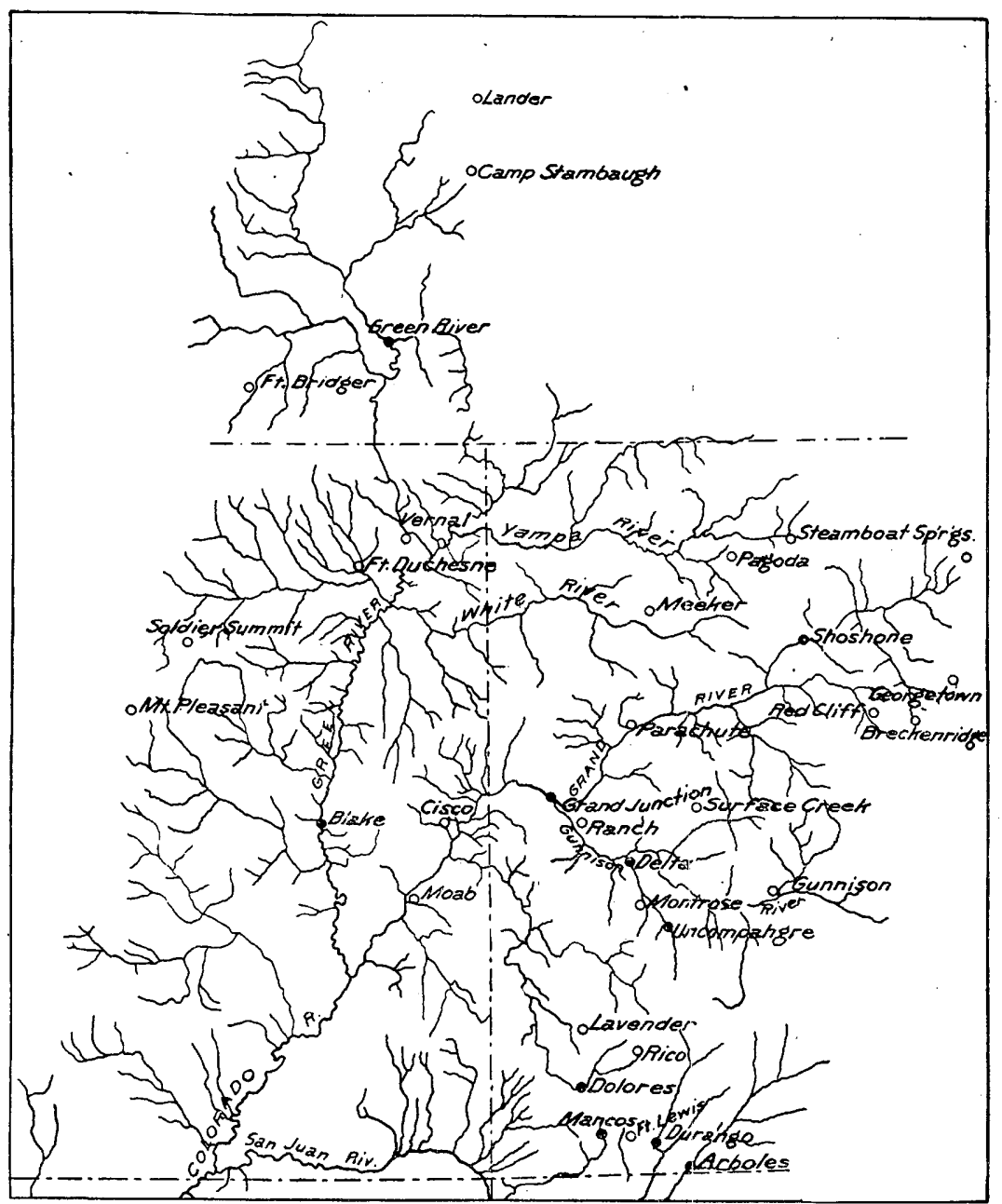

FIG. 139.-Relative location of river and rainfall observations in upper basin of Colorado River.

\section{PRECIPITATION IN THE BASIN OF UPPER GOLORADO RIVER.}

The principal observations of rainfall made within the basin of the Upper Colorado River are at Lander, Camp Stambaugh, Steamboat Springs, Pagoda, Meeker, Breckenridge, Redcliff, Parachute, Surface Creek, Gunnison, Montrose, T. S. Ranch, Delta, Grand Junction, Vernal, Fort Duchesne, Soldier Summit, Cisco, Moab, Fort Lewis, and Rico. The relative location of these points is shown on fig. 134, in connection with Green River, Blake, Shoshone, Uncompahgre, Delta, Grand Junction, Dolores, and Mancos. The following table gives the. 
name and location of the stations, the elevation, and the time of beginning of the record:

Location of rainfall stations.

\begin{tabular}{|c|c|c|c|c|c|c|}
\hline Station. & County. & State. & Latitude. & $\begin{array}{l}\text { Longi. } \\
\text { tude. }\end{array}$ & $\begin{array}{l}\text { Eleva. } \\
\text { tion. }\end{array}$ & $\begin{array}{l}\text { Length } \\
\text { of record. }\end{array}$ \\
\hline SteamboatSprings & Routt...... & Colorado... & 웅 & $\begin{array}{cc}2 & \prime \\
106 & 50\end{array}$ & $\ldots \ldots . . .$. & $4-6$ \\
\hline Pagoda....... & .... do ...... & .... do . & 4020 & 10726 & 6,500 & 7 \\
\hline Meeker....... & Rio Blanco.. & $\ldots$ do $\ldots$. & 3959 & 10747 & 6,182 & $4-7$ \\
\hline Breckenridge..... & Summit ..... & .... do .... & 3928 & 10602 & 9,524 & 9 \\
\hline Redcliff ..... & Eagle....... & .... do . & 3931 & 10621 & 8,656 & $6-9$ \\
\hline Parachute ..... & Garfield ..... & $\ldots . d o$ & 3925 & 10805 & $\check{5}, 10 \breve{5}$ & $7-9$ \\
\hline Surface Creek .. & Delta ...... & ... do .... & ....... & ....... & 6,175 & 6 \\
\hline Gunnison .... & Gunnison & .... do & 3834 & 10652 & 7,558 & $5-8$ \\
\hline Montrose ... & Montrose & $\ldots . d o$ & 3832 & 10756 & 5,811 & 11 \\
\hline 'T. S. Ranch ....... & Mesa ......... & ....do & . & 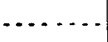 & 5,200 & $9-12$ \\
\hline Delta... & Delta ... & .... do & 3845 & 10802 & 4,980 & 9 \\
\hline Grand Junction. .. & Mesa..... & .... do. & . 3906 & 10833 & 4,594 & 9 \\
\hline Vernal .......... & Uinta....... & Utah. & 4027 & 11025 & 5,050 & $3-4$ \\
\hline Fort Duchesne.... & .... do ...... & .... do & 4035 & 10950 & 4,900 & $10-11$ \\
\hline Soldier Summit... & Wasatch .... & .....do & 3951 & 11108 & 7,477 & $8-10$ \\
\hline Cisco........ & Emery ...... & .... do & 3901 & 10919 & 4,447 & $6-7$ \\
\hline Moab........ & $\ldots$ do $\ldots . .$. & .... do & 3830 & 10929 & 4,000 & $8-9$ \\
\hline Fort Lewis. & La Plata.... & Colorallo.. & 3714 & 10803 & 8,500 & 20 \\
\hline Rico.............. & Dolores ..... & .....do & 3738 & 10803 & 8,737 & $6-8$ \\
\hline
\end{tabular}

In the following table are given the figures of normal or average monthly precipitation, from the time of the beginning of the record to and including 1897 , together with the total precipitation by months for the years 1896, 1897, and 1898; and also the amount by years. In obtaining the normal precipitation the average is taken for all of the months during which observations were made.

Precipitation at stations in drainage basin of Upper Colorado River.

STEAMBOAT SPRINGS.

\begin{tabular}{|c|c|c|c|c|c|c|c|c|c|c|c|c|c|}
\hline Year. & Jan. & Fel. & Mar. & Apr. & May. & June. & July. & Aug. & Sept. & Oct. & Nov. & Dec. & Annual. \\
\hline Normal...... & 2.48 & 2.78 & 1.86 & 2.00 & 1.58 & 0.91 & 1.42 & 0.30 & 1.00 & 0.80 & 1.29 & 2.44 & 18.86 \\
\hline 1896. & ..... & 0.60 & 0.80 & 0.70 & $\ldots$ & …. & …. & ..... & 2.02 & 0.25 & 1.81 & 0.65 & $\cdots$ \\
\hline $1897 \ldots$ & 2.13 & 3. 80 & 2.55 & 2.80 & 1.50 & 0.85 & 0.90 & 0.29 & 0.20 & 0.10 & 1.50 & 2.70 & 19.32 \\
\hline 1898. & 0.36 & 0.47 & 0.83 & 0.63 & $\cdots$ & ...... & 0.00 & - & 0.40 & 1.10 & 1.80 & 1.47 & \\
\hline \multicolumn{14}{|c|}{ PAGODA. } \\
\hline Normal. & 1.62 & 2.29 & 2.74 & 1.81 & 1.69 & 0.92 & 1.42 & 1.57 & 1.65 & 1.23 & 1.24 & 2.02 & 20.20 \\
\hline $1896 \ldots$ & 1.70 & 1.55 & 2.40 & 0.70 & 0.75 & 0.30 & 2.50 & 1.95 & 3.17 & 0.11 & 1.30 & 0.95 & 17.38 \\
\hline $1897 \ldots$ & 1. 70 & 4.35 & 4.92 & 3.50 & 1.85 & 1.55 & 2.51 & 1.87 & 1.00 & 1.75 & 1. 10 & 3.03 & 29.13 \\
\hline $1898 \ldots \ldots . .$. & 1.75 & 0.80 & 1.65 & 0.92 & 2.80 & J. 57 & 1.48 & 1.68 & 0.05 & 2.85 & 2.05 & 1.32 & 18. 92 \\
\hline
\end{tabular}


Precipitation at stations in drainage basin of Upper Colorado River-Continued. MEEKER.

\begin{tabular}{|c|c|c|c|c|c|c|c|c|c|c|c|c|c|}
\hline Year. & Jan. & Feb. & Mar. & Apr: & May. & June. & July. & Aug. & Sept. & Oct. & Nov. & Dec. & Anuual. \\
\hline Normal. & 1.44 & 1.43 & 2.14 & 1.20 & 1.09 & 0.78 & 2.92 & 1.47 & $i .85$ & 1.04 & 1.22 & 1.36 & 17.94 \\
\hline $1896 \ldots$ & 1.24 & 1.37 & 1.83 & 0.39 & 0.54 & 0.16 & 3.56 & 1.35 & 3.66 & 0.28 & 1.43 & 0.17 & 16.28 \\
\hline $1897 .$. & 1.38 & 2. 33 & 3.11 & 2.19 & 1.64 & 1.17 & 3.71 & 2.04 & 2.33 & 1.19 & 1.02 & 2.19 & 24.30 \\
\hline $1898 .$. & 0.67 & $(1.43)$ & 0.73 & 0.79 & 2. 15 & 0.40 & 1.85 & 2.14 & 0.03 & 2. 15 & 1.57 & 0.52 & 14.43 \\
\hline \multicolumn{14}{|c|}{ BRECKENRIDGE. } \\
\hline Normal & 2.13 & 4. 12 & $3.8 \tilde{5}$ & 3. 22 & 2. 59 & 1.54 & 2.11 & 2.02 & 1.45 & 1.47 & 2.86 & 3.29 & 30.65 \\
\hline $1896 .$. & 1.88 & 1.89 & 4.83 & 0.60 & 1.47 & 0.30 & 3.10 & 2.29 & 2.25 & 0.82 & 3.87 & 0.73 & 24.03 \\
\hline 1897 & 2.90 & 1.99 & 3.53 & 4.00 & 1.54 & 1.53 & 1.70 & 2.27 & 1. 16 & 1.02 & 0.60 & 2.25 & 24.49 \\
\hline 1898. & 0.29 & 0.59 & 1.16 & 1.53 & 0.46 & 1.14 & 2.19 & 1.59 & 0.38 & 1.53 & 4.09 & 1.34 & 16.29 \\
\hline \multicolumn{14}{|c|}{ REDCLIFF. } \\
\hline Normal & 2.00 & 2.20 & 2.38 & 1.60 & 1.22 & 0.94 & 1.93 & 1.55 & 1.11 & 1.26 & 1.48 & $2.2 b^{\circ}$ & 19.93 \\
\hline 1896. & 1.30 & 0.66 & 0.56 & 0.40 & 1.17 & 0.60 & 1.06 & 1.63 & 0.63 & 0.55 & 2.32 & 0.08 & 10.96 \\
\hline 1897 & 1.24 & 3. 37 & 2.23 & 0.77 & 0.76 & 1.40 & 1.65 & 0.75 & $(1.11)$ & 0.34 & 1.44 & 1.78 & $\ldots \ldots$ \\
\hline $1898 .$. & 1.13 & 0.63 & 0.87 & 1.07 & 0.73 & 0.09 & 4.00 & 2.80 & 0.70 & 1.94 & 2.78 & $(2.26)$ & 19.00 \\
\hline \multicolumn{14}{|c|}{ PARACHUTE. } \\
\hline Norinal & 0.84 & 0.81 & 1.21 & 0.88 & 0.76 & 0.38 & 0.87 & 0.80 & 1.42 & 0.76 & 0.77 & 0.98 & 10.48 \\
\hline $1896 \ldots .$. & 0.38 & 0.04 & $(1.21)$ & 0.13 . & 0.21 & 0.70 & $(0.87)$ & 1. 27 & 4. 12 & 0.65 & 0.86 & 1.20 & $\ldots \ldots$ \\
\hline 1897. & 1.52 & 1.82 & 0.67 & 3. 98 & 0.66 & 1.05 & 0.80 & 1.52 & 2.55 & 0.57 & 0.20 & $(0.98)$ & $\ldots$ \\
\hline $1898 \ldots$ & 0.26 & 0.00 & 0.85 & $\ldots \ldots$ & ....... & ...... & 0.42 & 1.09 & 0.23 & 0.98 & $0.70^{\circ}$ & 0.70 & $\cdots$ \\
\hline \multicolumn{14}{|c|}{ SURFACE CREEK. } \\
\hline Normal & 1.17 & 1.62 & 1.54 & 0.51 & 0.70 & 0.48 & 0.92 & 1.32 & 1.61 & 0.90 & 0.58 & 1.18 & 12.53 \\
\hline $1896 \ldots$ & 1.12 & 1.00 & 0.68 & 0.05 & 0.70 & 0.16 & 0.80 & 0.93 & 2. 99 & 0.44 & 0.16 & 0.30 & 9.33 \\
\hline $1897 \ldots$ & 0.95 & 1.70 & 2.10 & 1.23 & 1.23 & 1.01 & 0.82 & 0.50 & 2. 25 & 1.79 & 0.45 & 1.02 & 15.05 \\
\hline 1898. & & & $\cdots \cdots$ & & ..... & $\cdots \cdots$ & & & $\ldots$. & & & & $\cdots$ \\
\hline \multicolumn{14}{|c|}{ GUNNISON. } \\
\hline Normal & 1.09 & 0.88 & 0.61 & 0.88 & 0.52 & 0.31 & 1. 28 & 1.03 & 0.52 & 0.55 & 1.25 & 0.48 & 9.40 \\
\hline $1896 \ldots$ & 1.21 & 0.12 & 0.25 & 0.00 & 0.01 & 0.00 & 1.37 & 0.92 & 0.99 & T. & 0.90 & 0.50 & 6.27 \\
\hline $1897 \ldots$ & 0.60 & 1.00 & 1.39 & & .......... & $\cdots$ & 2.01 & 0.90 & 1. 50 & 1.24 & $\ldots \ldots$ & 0.30 & $\cdots$ \\
\hline $1898 \ldots$ & 0.28 & 0.31 & ...... & $\ldots$ & $\mid . . .$. & 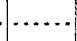 & 1. 93 & 0.68 & 0.06 & 0.13 & 1.06 & 0.30 & $\cdots$ \\
\hline \multicolumn{14}{|c|}{ MONTROSE. } \\
\hline Normal & 0.69 & 0.83 & 0.90 & 1.13 & 0.69 & 0.20 & 0.96 & 1. 21 & 1.06 & 0.80 & 0.63 & 0.74 & 9.84 \\
\hline $1896 \ldots$ & 0.84 & 0.60 & 0.24 & 0.36 & 0.13 & 0.18 & 0.48 & 0.37 & 1.66 & 0.68 & 0.38 & 0.45 & 6.47 \\
\hline $1897 \ldots$ & 0.62 & 2.14 & 3.41 & 0.97 & 1.50 & 0.43 & 1.89 & 0.35 & 2.45 & 1.11 & 0.63 & 0.74 & 16.24 \\
\hline $1898 \ldots$ & ...... & $\ldots$ & & ..... & …... & $\cdots$ & & & ...... & $\ldots$ & & - & $\mid \cdots \ldots$ \\
\hline \multicolumn{14}{|c|}{ T. S. RANCH. } \\
\hline Normal. & 0.83 & 0.75 & 1.22 & 0.64 & 0.81 & 0.23 & 1.07 & 1. 35 & 1.53 & 1.17 & 0.65 & 0.81 & 11. 06 \\
\hline $1896 . .$. & 0.50 & 0.21 & 0.07 & 0.07 & 0.39 & 0.23 & 0.85 & 0.45 & 5.14 & 0.80 & 0.40 & 0.57 & $\ldots \ldots$ \\
\hline $1897 \ldots$ & 1. 32 & 1.45 & 1.88 & 1.15 & 0.55 & 0.28 & 1.73 & 0.94 & 1.87 & 1.88 & 0.86 & 0.54 & 14.45 \\
\hline 1898. & 0.51 & 0.07 & 1.30 & 0.65 & 2.20 & 0.15 & 0.49 & 1.29 & 0.12 & 0.58 & 0.40 & 0.61 & 8.37 \\
\hline
\end{tabular}


Precipitation at stations in drainage basin of Cpper Colorado River-Continued. DELTA.

\begin{tabular}{|c|c|c|c|c|c|c|c|c|c|c|c|c|c|}
\hline Year. & Jan. & Feb. & Mar. & Apr. & May. & June. & July. & Aug. & Sept. & Oct. & Nov. & Dec. & Annual. \\
\hline Normal. & 0.63 & 0.94 & 0.87 & 0.29 & 0.34 & 0.21 & 1.11 & 0.84 & 1.05 & 0.77 & 0.65 & 0.73 & 8.43 \\
\hline 1896. & 0.65 & 0.60 & 0.02 & 0.00 & 0.18 & 0.00 & 1.50 & 0.79 & 2.13 & $(0.77)$ & $(0.65)$ & 0.35 & $\ldots \ldots$ \\
\hline 1897. & 0.49 & 2.19 & 1.50 & 0.05 & 0.65 & 0.76 & 0.90 & 0.46 & 2.47 & 1. 75 & 0.40 & 0.25 & 11.87 \\
\hline $1898 \ldots$ & 0.28 & 0.10 & 0.21 & 0.58 & 0.83 & 0.40 & 0.95 & 0.51 & 0.55 & 0.05 & 0.18 & 0.08 & 4.72 \\
\hline \multicolumn{14}{|c|}{ GRAND JUNCTION. } \\
\hline Normal .. & 0.77 & 0.83 & 1.02 & 0.60 & 0.60 & 0.14 & 0.89 & 1.14 & 1.27 & 0.89 & 0.67 & 0.59 & $9.4 \mathrm{i}$ \\
\hline 1896. & 0.37 & 0.05 & 0.27 & 0.18 & 0.51 & 0.01 & 0.43 & 101 & 3. 78 & 0.79 & 0.49 & 0.33 & 8.22 \\
\hline 1897. & 1.00 & 0.80 & 1.05 & 1.12 & 0.62 & 0.40 & 0.98 & 1.05 & 1.53 & 1.82 & 0. 33 & 0.40 & 11. 10 \\
\hline 1898. & 0.55 & T. & 1.05 & 0.92 & 1.40 & 0.05 & $\mathrm{~T}$. & 0.57 & 0.10 & 0.25 & 0.25 & 0.31 & 5.45 \\
\hline \multicolumn{14}{|c|}{ VERNAL. } \\
\hline Normal & 0.81 & 0.65 & 0.85 & 0.52 & 1.02 & 0.27 & 1.23 & 0.62 & 1.87 & 1.06 & 0.60 & 1.26 & 1076 \\
\hline $1896 \ldots$ & 0.48 & 0.29 & 0.38 & 0.89 & 0.94 & 0.04 & 1.86 & 0.58 & $\cdot 2.48$ & 0.69 & 0.42 & 0.04 & 9.09 \\
\hline 1897. & 0.96 & 1.11 & 0.86 & 0.58 & 0.62 & 0.23 & 1.08 & 0.26 & 2.83 & 2.34 & $\begin{array}{ll}0 & 42\end{array}$ & 1. 20 & 12.49 \\
\hline 1898. & 0.63 & 0.47 & 0.60 & 0.50 & 2.03 & $(0.27)$ & 0.34 & $(0.62) \mid$ & 1.04 & 0.30 & 039 & 0.17 & 736 \\
\hline \multicolumn{14}{|c|}{ FORT DUCBESNE. } \\
\hline Normal & 0.40 & 0.30 & 0.60 & 0.70 & 0.80 & 0.20 & 0.60 & 0.60 & 1. 20 & 0.80 & 0.20 & 0.70 & 7.10 \\
\hline 1896. & 0.06 & 0.09 & 0.14 & 0.21 & 1.40 & 0.03 & 1.45 & 0.64 & 2.23 & 0.54 & 0.20 & 0.00 & 6.99 \\
\hline $1897 .$. & 0.87 & 0.90 & 0.28 & 0.01 & 0.16 & 0.02 & 0.17 & 0.21 & 4.61 & 3.00 & 0.00 & 1.20 & 11.43 \\
\hline $1898 \ldots$ & 0.60 & 0.10 & 0.75 & 0.17 & 0.61 & 0.45 & 0.66 & 0.66 & 0.08 & 005 & 0.13 & 0.10 & 4.36 \\
\hline \multicolumn{14}{|c|}{ SOLDIER SUMMIT. } \\
\hline Norn & 1.36 & 1.14 & 1.58 & 0.44 & 0.59 & 0.14 & 0.91 & 0.55 & 078 & 0.57 & 1. 01 & 1.52 & 10.59 \\
\hline 1896. & 1.16 & 1.15 & 1.47 & 1.02 & 0.38 & 0.14 & 0.86 & 0.49 & 0.48 & 0.60 & 3.25 & 0.90 & 11.90 \\
\hline $1897 .$. & 1.82 & 2.80 & 5.23 & 0.67 & 0.10 & 0.12 & 0.02 & 0.06 & 2.45 & 0.65 & 1.34 & 2.50 & 17.76 \\
\hline 1898. & 1.25 & 0.68 & 2.92 & 1.56 & 3.12 & 0.13 & T. & 0.10 & 0.02 & $(0.57)$ & 1.15 & 1.15 & 12.65 \\
\hline \multicolumn{14}{|c|}{ cIsco. } \\
\hline Normal.. & 0.60 & 0.74 & 0.72 & 0.46 & 0.39 & 0.08 & 0.39 & 0.36 & 1.12 & 0.98 & 0.29 & 0.79 & 6.92 \\
\hline 1896. & 0.23 & T. & $\mathrm{T}$ & $\mathbf{T}$ & $\mathrm{T}$. & 002 & 0.12 & 0.84 & 2.06 & 0.88 & 0.03 & 0.05 & 5. 23 \\
\hline 1897. & 0.60 & 1.85 & 0.58 & 1.46 & 0.20 & T. & 0.65 & 0.15 & 1. 40 & 3.04 & 0.35 & 1.22 & 11.50 \\
\hline $1898 \ldots$ & 0.95 & T. & 0.02 & 0.20 & 1.86 . & 0.22 & T. & 0.44 & 0.00 & 0.00 & $(0.29)$ & $(0.79)$ & 4. 77 \\
\hline \multicolumn{14}{|c|}{ MOAB. } \\
\hline Normal & 0.72 & 0.81 & 0.99 & 0.35 & 0.46 & 0.08 & 0.67 & 0.52 & 1.38 & 0.67 & 0.60 & 0.99 & 8.24 \\
\hline 1896. & 0.45 & $\mathbf{T}$. & 0.18 & 0.11 & 0.17 & 0.03 & 0.66 & 0.51 & 5.97 & 0.83 & 0.30 & 0.32 & 9.53 \\
\hline 1897 & 1.22 & 2.12 & 2.43 & 0.72 & 0.38 & 0.14 & 0.80 & 0.60 & 1.46 & $2.5 \dot{2}$ & 0.48 & 1.65 & 14.52 \\
\hline 1898. & 0.77 & 0.13 & 0.44 & 0.25 & 1.58 & 0.16 & 0.17 & 0.35 & 0.00 & $\mathbf{T}$ & 0.25 & 0.22 & 4.32 \\
\hline \multicolumn{14}{|c|}{$\begin{array}{l}\text { FORT LEWIS. } \\
\text { [Record from } 1875 \text { to } 1882 \text {; and from } 1889 \text { to } 1891 \text {, at Fort Lewis; } 1886 \text { to } 1890 \text {, and } 1894 \text { to } 1897, \\
\text { at Durango.] }\end{array}$} \\
\hline Normal. & 1.80 & 1.80 & 1.30 & 1.50 & 0.80 & 0.80 & 2.00 & 2.10 & 1.20 & 1.50 & 1.40 & 2.20 & 18.40 \\
\hline $1896 \ldots$ & 0.50 & $(1.80)$ & 0.53 & 0.55 & 0.05 & 0.80 & 1.30 & 1.76 & 3.59 & 3.61 & 1.08 & 0.86 & ....... \\
\hline $1897 \ldots$ & 2.61 & 3.70 & 2.72 & 0.45 & 3.22 & 0.40 & 1.38 & 0.93 & 3.55 & 3.89 & 0.09 & 1.99 & 24.93 \\
\hline $1898 \ldots$ & 2.21 & 0.45 & 1.17 & 1.67 & 1.33 & 0.62 & 3.46 & 0.89 & 0.30 & 0.07 & 0.88 & 3.22 & 16.27 \\
\hline
\end{tabular}


378 PROGRESS OF STREAM MEASUREMENTS FOR 1898.

Precipitation at stations in drainage basin of Jpper Colorado River-Continued.

RICO.

\begin{tabular}{|c|c|c|c|c|c|c|c|c|c|c|c|c|c|}
\hline Year. & Jan. & Feb. & Mar. & Apr. & May. & June. & July. & Aug. & Sept. & Oct. & Nov. & Dec. & Annual. \\
\hline Normal. & 2. 78 & 4.25 & 3.34 & 1.01 & 1.84 & 0.55 & 2.51 & 1.96 & 2. 79 & 1.21 & 1. 06 & 2.58 & 25.88 \\
\hline $1896 \ldots$ & 2.40 & 1.40 & 2.10 & 1.20 & 0.35 & 0.59 & 4.13 & 2.32 & 4.46 & 2.20 & 2.40 & 1.70 & 25.25 \\
\hline $1897 \ldots$ & 3. 26 & 5.60 & 6.40 & 1.66 & 4.15 & 0.98 & 2.41 & 1.96 & 5.80 & 2.82 & 1.60 & 2.02 & 38.66 \\
\hline $1898 \ldots \ldots \ldots$ & 3.10 & 1.35 & 3.80 & 2.62 & 3.82 & 1. 60 & 3.10 & 4.13 & 0.88 & 0.15 & 0.85 & $(2.58)$ & 27.98 \\
\hline \multicolumn{14}{|c|}{ AVERAGES. } \\
\hline Normal. & 1.27 & 1.54 & 1.56 & 1.04 & 0.97 & 0.48 & 1.33 & 1.12 & 1.36 & 0.97 & 0.97 & 1.42 & 14.03 \\
\hline $1896 \ldots$ & 0.92 & 0.71 & 0.96 & 0.40 & 0.52 & 0.23 & 1.49 & 1.12 & 2.83 & 0.82 & 1.20 & 0.55 & 11.75 \\
\hline $1897 \ldots \ldots$ & 1.43 & 2.37 & 2.47 & 1.52 & 1.19 & 0.68 & 1.37 & 0.92 & 2.24 & 1.73 & 0.71 & 1.48 & 18.11 \\
\hline 1898. & .... & 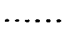 & 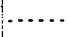 & . & ... & & $\ldots$ & & & & & & \\
\hline
\end{tabular}

Depth of run-off, in inches, from Colorado drainage basin.

GREEN RIVER AT GREEN RIVER.

\begin{tabular}{|c|c|c|c|c|c|c|c|c|c|c|c|c|c|}
\hline Year. & Jan. & Feb. & Mar. & $\Delta$ pr. & May. & June. & July. & Aug. & Sept. & Oct. & Nov. & Dec. & Annual. \\
\hline 1896. & $\cdots$ & $\cdots$ & $\cdots$ & 0.12 & 0.33 & 1.76 & 0.64 & 0.23 & 0.13 & 0.06 & 0.12 & 0.17 & \\
\hline $1897 .$. & 0.28 & 0.27 & 0.30 & 0.29 & 1.51 & 1.13 & 0.43 & 0.25 & 0.07 & 0.16 & 0.11 & 0.09 & 4.89 \\
\hline 1898. & $\ldots$ & 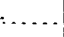 & $\ldots$. & 0.40 & 0.63 & 1.36 & 0.71 & 0.22 & 0.10 & 0.06 & 0.06 & 0.13 & \\
\hline A verage. & 0.28 & 0.27 & 0.30 & 0.27 & 0.82 & 1.42 & 0.59 & 0.23 & 0.10 & 0.09 & 0.10 & 0.13 & 4.60 \\
\hline \multicolumn{14}{|c|}{ GREEN RIVER AT BLAKE. } \\
\hline 1895. & $0.03^{\circ}$ & 0.03 & 0.13 & 0.29 & 0.58 & 0.46 & 0.37 & 0.16 & 0.05 & 0.08 & 0.04 & 0.03 & 2.25 \\
\hline 1896. & 0.03 & 0.04 & 0.10 & 0.22 & 0.48 & 0.69 & 0.35 & 0.18 & 0.16 & 0.12 & 0.08 & 0.04 & 2.49 \\
\hline 1897. & 0.03 & 0.04 & 0.04 & 0.27 & 1.56 & 1.01 & 0.21 & 0.12 & 0.11 & 0.17 & 0.10 & 0.04 & 3.70 \\
\hline 1898. & 0.20 & 0.21 & 0.21 & 0.41 & 0.84 & 1.04 & 0.43 & 0.10 & 0.08 & 0.06 & 0.06 & 0.06 & 3.70 \\
\hline Average. & 0.07 & 0.08 & 0.12 & 0.30 & 0.87 . & 0.80 & 0.34 & 0.14 & 0.10 & 0.11 & 0.07 & 0.04 & 3.04 \\
\hline \multicolumn{14}{|c|}{ GRAND RIVER AT GRAND JUNCTION. } \\
\hline 1897. & 0.14 & 0.12 & 0.15 & 0.48 & 3.93 & 3.27 & 1.18 & 0.40 & 0.23 & 0.24 & 0.21 & 0.21 & 10.56 \\
\hline 1898. & 0.39 & 0.36 & 0.28 & 0.56 & 0.94 & 1.77 & 0.59 & 0.15 & 0.12 & 0.13 & 0.14 & 0.20 & 5.63 \\
\hline Average. & 0.27 & 0.24 & 0.22 & 0.52 & 2.44 & 2.52 & 0.89 & 0.28 & 0.18 & 0.18 & 0.18 & 0.21 & 8.13 \\
\hline \multicolumn{14}{|c|}{ GUNNISON AT GRAND JUNCTION. } \\
\hline $1897 \ldots$ & & & & $\ldots .$. & 2.46 & 1.57 & 0.47 & 0.14 & $0: 09$ & 0.22 & 0.13 & & \\
\hline 1898. & . & $\ldots$ & $\ldots$. & ...... & 0.77 & 1.25 & 0.37 & 0.10 & 0.07 & 0.08 & 0.07 & $\cdots$ & \\
\hline A verage. & $\therefore \ldots$ & & & ....... & 1.62 & 1. 41 & 0.42 & 0.12 & 0.08 & 0.15 & 0.10 & & \\
\hline \multicolumn{14}{|c|}{ UNCOMPAHGRE AT FORT CRAWFORD. } \\
\hline $1896 \ldots$ & $\cdots$ & 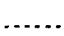 & - . & $\ldots \ldots$ & 2.34 & 1.16 & 0.29 & 0.09 & 0.33 & 0.24 & 0.19 & & \\
\hline $1897 \ldots$ & 0.23 & 0.31 & 0.35 & 0.88 & 1.91 & 2.19 & 1.22 & 0.32 & 0.32 & 0.47 & 0.28 & 0.23 & 8.71 \\
\hline $1898 \ldots$ & $\ldots .$. & $\ldots$. & $\ldots$. & 0.49 & 0.74 & 1.57 & 1.00 & 0.25 & 0.14 & 0.14 & 0.12 & ....... & ....... \\
\hline Average. & 0.23 & 0.31 & 0.35 & 0.69 & 1.66 & 1.64 & 0.84 & 0.22 & 0.26 & 0.28 & 0.20 & 0.23 & 6.91 \\
\hline
\end{tabular}


Depth of run-off, in inches, from Colorado drainage basin-Continued.

ANIMAS AT DURANGO.

\begin{tabular}{|c|c|c|c|c|c|c|c|c|c|c|c|c|c|}
\hline Year. & Jan. & Feb. & Mar. & Apr. & May. & June. & July. & Aug. & Sept. & Oct. & Nov & Dec. & Annual. \\
\hline 1895. & ... & $\ldots$ & & $\cdots \cdots$ & …... & 0.55 & 0.56 & 0.72 & 0.50 & 0.44 & 0.33 & 0.36 & \\
\hline 1896. & $\ldots$ & & $\ldots$ & 1.42 & 3.32 & 1.19 & 0.49 & 0.28 & 1.38 & 0.55 & 0.38 & 0.31 & \\
\hline $1897 .$. & 0.44 & 0.36 & 0.53 & 3. 58 & 6.40 & 4.42 & 1.59 & 0.76 & 1.20 & 1.97 & 0.75 & 0.61 & 22.61 \\
\hline $1898 .$. & 0.54 & 0.34 & 0.44 & 2.08 & 2.50 & 4.72 & 1.94 & 0.52 & 0.36 & 0.23 & 0.22 & 0.36 & 14.25 \\
\hline Average. & 0.49 & 0.35 & 0.48 & 2.36 & 4.07 & 2.72 & 1.15 & 0.57 & 0.86 & 0.80 & 0.42 & 0.41 & $14.6 \varepsilon$ \\
\hline \multicolumn{14}{|c|}{ DOLORES AT DOLORES. } \\
\hline $1896 \ldots$ & & & 0.51 & 1.48 & 1.97 & 0.53 & 0.26 & 0.08 & 0.38 & 0.23 & 0.36 & & \\
\hline $1897 \ldots$ & 0.42 & 0.37 & 0.42 & 2.94 & 5.00 & 2. 91 & 0.75 & 0.30 & 0.78 & 0.81 & 0.35 & 0.24 & 15.29 \\
\hline $1898 \ldots$ & 0.33 & 0.30 & 0.40 & 2.32 & 2.66 & 3.21 & 1. 08 & 0.26 & 0.17 & 0.08 & 0.10 & 0.22 & 11.17 \\
\hline Average. & 0.38 & 0.34 & 0.44 & 2.25 & 3.21 & 2.22 & 0.70 & 0.21 & 0.44 & 0.37 & 0.27 & 0.23 & 10.06 \\
\hline
\end{tabular}

Rainfall and run-off.

\begin{tabular}{|c|c|c|c|c|}
\hline Station. & Normal. & 1896. & 1897. & 1898. \\
\hline RAINFALL. & & & & \\
\hline Steamboat Springs . . . . . . . . . & 18.86 & $\ldots \ldots \ldots$ & 19. 32 & $\ldots \ldots . . . .$. \\
\hline Pagoda $\ldots \ldots \ldots \ldots \ldots \ldots \ldots \ldots$ & 20.20 & 17.38 & 29. 13 & 18.92 \\
\hline Meeker............ & 17.94 & 16.28 & 24.30 & 14.43 \\
\hline Breckenridge ................ & 30.65 & 24.03 & 24.49 & 16. 29 \\
\hline Redeliff ......... & 19.93 & 10.96 & 16.84 & 19.00 \\
\hline Parachnte............... & 10.48 & 11.64 & 16.32 & $\ldots \ldots$ \\
\hline Surface Creek .................. & 12.53 & 9.33 & 15.05 & \\
\hline Gunnison $\ldots \ldots \ldots \ldots \ldots \ldots$ & 9.40 & 6.27 & $\ldots \ldots . . .$. & $\ldots \ldots \ldots$ \\
\hline Montrose.................. & 9.84 & 6.47 & 16. 24 & $\ldots \ldots \ldots$ \\
\hline T. S. Ranch. . . . . . . . . . . . . & 11.06 & 9.68 & 14.45 & 8.37 \\
\hline Delta $\ldots \ldots \ldots \ldots$ & 8.43 & 7.64 & 11.87 & 4. 72 \\
\hline 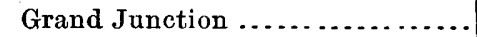 & 9.41 & 8.22 & 11.10 & 5.45 \\
\hline Vernal $\ldots \ldots \ldots \ldots \ldots \ldots$ & 10.76 & 9.09 & 12.49 & 7.36 \\
\hline Fort Ducheswe $\ldots \ldots \ldots \ldots$ & 7. 10 & 6.99 & 11.43 & 4.36 \\
\hline Soldier Summit . . . . . . . . . . . . & 10.59 & 11. 90 & 17. 76 & 12.65 \\
\hline Cisco $\ldots \ldots \ldots \ldots$ & 6.92 & 5.23 & 11.50 & 4. 77 \\
\hline Moab $\ldots \ldots \ldots \ldots \ldots \ldots \ldots \ldots \ldots$ & 8.24 & 9.53 & 14.52 & 4.32 \\
\hline Fort Lewis. . . . . . . . . & 18.40 & 16. 43 & 24.93 & 16.27 \\
\hline Rico.............. & 25.88 & 25.25 & 38.66 & 27.98 \\
\hline Average. & 14.03 & 11.85 & 18.36 & 11. 78 \\
\hline RUN-OFW. & & & & \\
\hline Green River at Green River... & 4.60 & 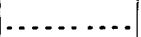 & 4.89 & \\
\hline Green River at Blake. . . . . . . . . . . & 3.04 & 2.49 & 3. 70 & 3. 70 \\
\hline Grand River at Grand Junction... & 8.13 & $\ldots \ldots . .$. & 10.56 & 5.63 \\
\hline Uncompahgre at Fort Craw ford .. & 6.91 & $\ldots \ldots \ldots$ & 8.71 & $\ldots \ldots . .$. \\
\hline Animas River at Durango ......... & 14. 68 & $\ldots \ldots \ldots$ & 22.61 & 14.25 \\
\hline Dolores at Dolores ............... & 10.06 & $\ldots \ldots$ & 15.29 & 11.17 \\
\hline Average............... & 7.90 & $\cdots$ & 10.96 & 8.69 \\
\hline Percentage of rainfall ...... & 56.31 & $\cdots$ & 59.69 & $\ldots \ldots$ \\
\hline
\end{tabular}




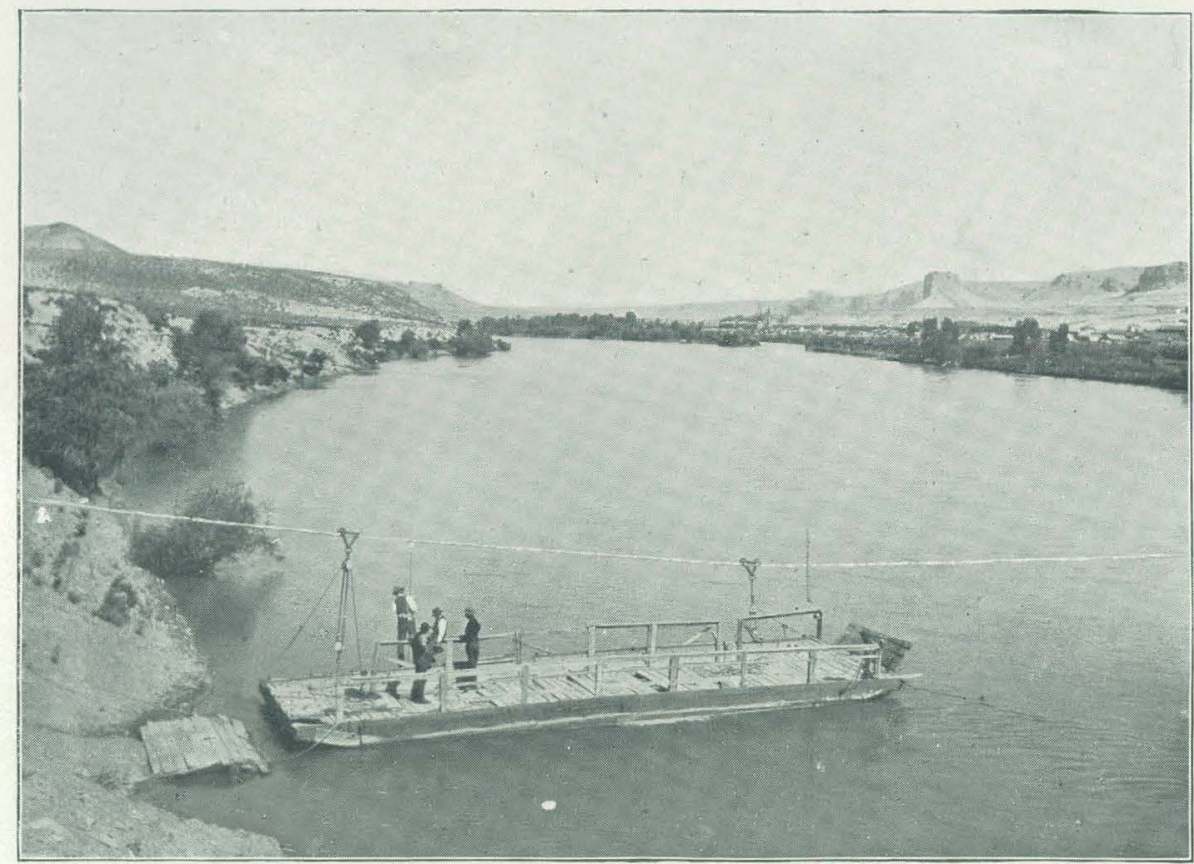

A. MEASURING GREEN RIVER NEAR GREEN RIVER. WYOMING.

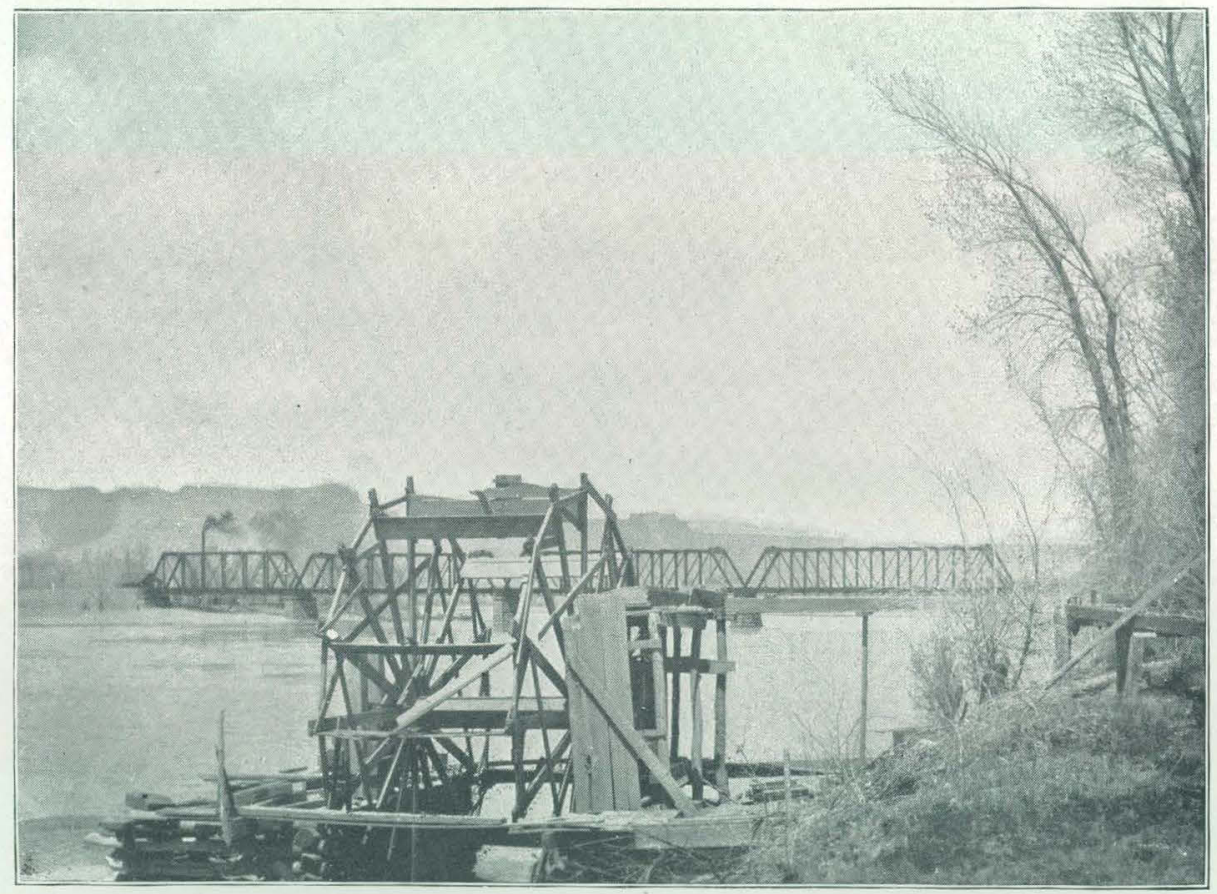

B. GREEN RIVER NEAR BLAKE, UTAH. 
The large percentage of rainfall which appears as run-off in the streams, as shown in the above table, is due mainly to the insertion of the flow of Animas and Dolores rivers, each of these draining relatively small catchment areas of mountainous land. Eliminating these figures it will be seen that the run-off for the large drainage basins is relatively small.

\section{GREEN RIVER.}

Green River, as shown by fig. 139, is the western fork of Colorado River. It has been measured near its head at Green River, Wyoming, and also lower down at Blake, Utab. One of its tributaries (Black Fork) has also been systematically measured and a recommaissance of other important tributaries (Yampa and White rivers) has been made during 1898. The station at Green River, Wyoming, was originally established by the state engineer of Wyoming, results being given in his report for 1894. The present series of measurements was begun in the spring of 1895, figures for that year being given in Bulletin No. 140, on page 200. For 1896 results are given in the Eighteenth Annual Report, Part IV, on page 272, and for 1897 in the Nineteenth Annual Report, Part IV, page 394. The following table and diagram give the results for 1898 :

Estimated monthly discharge of Green River at Green River, Wyoming.

[Drainage area, 7,450 square miles.]

\begin{tabular}{|c|c|c|c|c|c|c|}
\hline \multirow[b]{2}{*}{ Month. } & \multicolumn{3}{|c|}{ Diseharge in second-feet. } & \multirow[b]{2}{*}{$\begin{array}{l}\text { Total in acre. } \\
\text { teet. }\end{array}$} & \multicolumn{2}{|c|}{ Run-off. } \\
\hline & $\begin{array}{l}\text { Maxi- } \\
\text { mum. }\end{array}$ & $\begin{array}{l}\text { Mini- } \\
\text { mum. }\end{array}$ & Mean. & & $\begin{array}{c}\text { Depth in } \\
\text { inches. }\end{array}$ & $\begin{array}{l}\text { Second. } \\
\text { feet per per } \\
\text { square } \\
\text { wuile. }\end{array}$ \\
\hline . $\quad 1898$. & & & . & & & \\
\hline April .... & 5,520 & 800 & 2,664 & 158,519 & 0.40 & 0.36 \\
\hline May .... & 7,680 & 2,320 & 4,063 & 249,826 & 0.63 & 0.55 \\
\hline June.... & 15,120 & 4,200 & 9,064 & 539,344 & 1.36 & 1.22 \\
\hline July .... & 9,120 & 2,160 & 4,620 & 284,075 & 0.71 & 0.62 \\
\hline August ... & 2,080 & 720 & 1,417 & 87,128 & 0.22 & 0.19 \\
\hline September . & 1,200 & 260 & 646 & 38,440 & 0.10 & 0.09 \\
\hline October........... & 400 & 300 & 347 & 21,336 & 0.06 & 0.05 \\
\hline November, $1-26 \ldots$ & 1,280 & 160 & 405 & 24,100 & 0.06 & 0.05 \\
\hline December ... & $\cdots$ & $\cdots$ & $a 849$ & a 52,203 & $a 0.13$ & $a 0.11$ \\
\hline
\end{tabular}

a Approximate.

Note. -Gage heights for 1898 are given in Water-Supply and Irrigation Paper No. 28, page 134 measurements, page 142; rating table, page 144; results for 1897 in Water-Supply and Irrigation Paper No. 16, page 135, and in the Nineteenth Annual Report, Part IV, pages 394 to 496. 


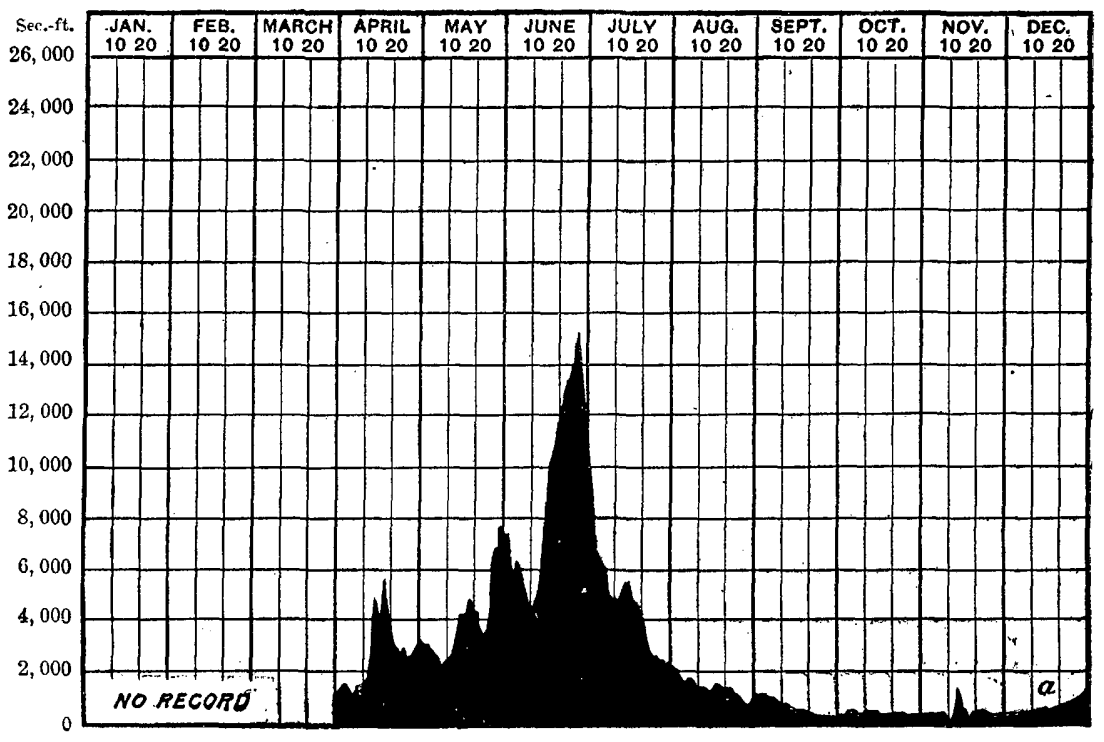

FIG. 140.-Discharge of Green River at Green River, Wyoming, 1898.

The locality at which measurements of Green River are made near Green River, Wyoming, is shown on Pl. XXXVII, $A$. The current meter is held in the water on the upper side of the ferryboat. On the same plate at $B$ is given a view of Green River near Blake, Utah, showing in the foreground one of the water wheels used for raising water for irrigation.

BLACK FORK OF GREEN RIVER.

Black Fork drains a portion of southwestern Wyoming and empties into Green River at a point about 20 miles below the river station just described. Measurements of the stream have been made near Granger, as described in the Nineteenth Annual Report, Part IV, on page 391. The point of measurement is below the principal irrigation ditches, and the results show practically the amount of water which is going to waste. The method of irrigation in this drainage basin is very wasteful. The farmers consider it essential to flood their lands and keep them partially submerged during a great part of the crop season. Hay is the principal crop, the high altitude-6,284 feet at Granger-resulting in short and cold summers. The principal industry is stock raising, hay being produced for winter feed. 
Estimated monthly discharge of Black Fork of Green River at Granger, Wyoming.

[Drainage area, 2,400 square miles.]

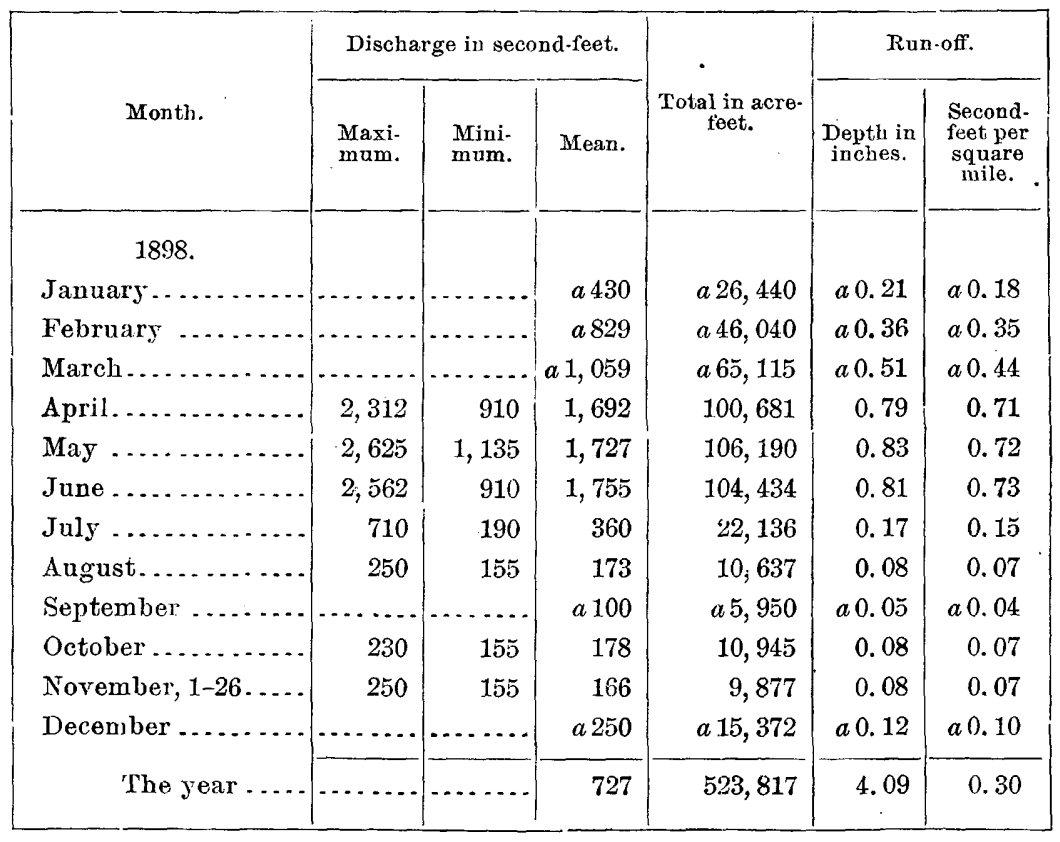

$a$ Approximate.

Note.-Gage heights for 1898 are given in Water-Supply and Irrigation Paper No. 28, page 133 measurements, page 142 ; rating table, page 144 ; results for 1897 in Water-Supply and Irrigation Paper No. 18, page 134, and in the Nineteenth Annual Report, Part IV, pages 391 to 393.

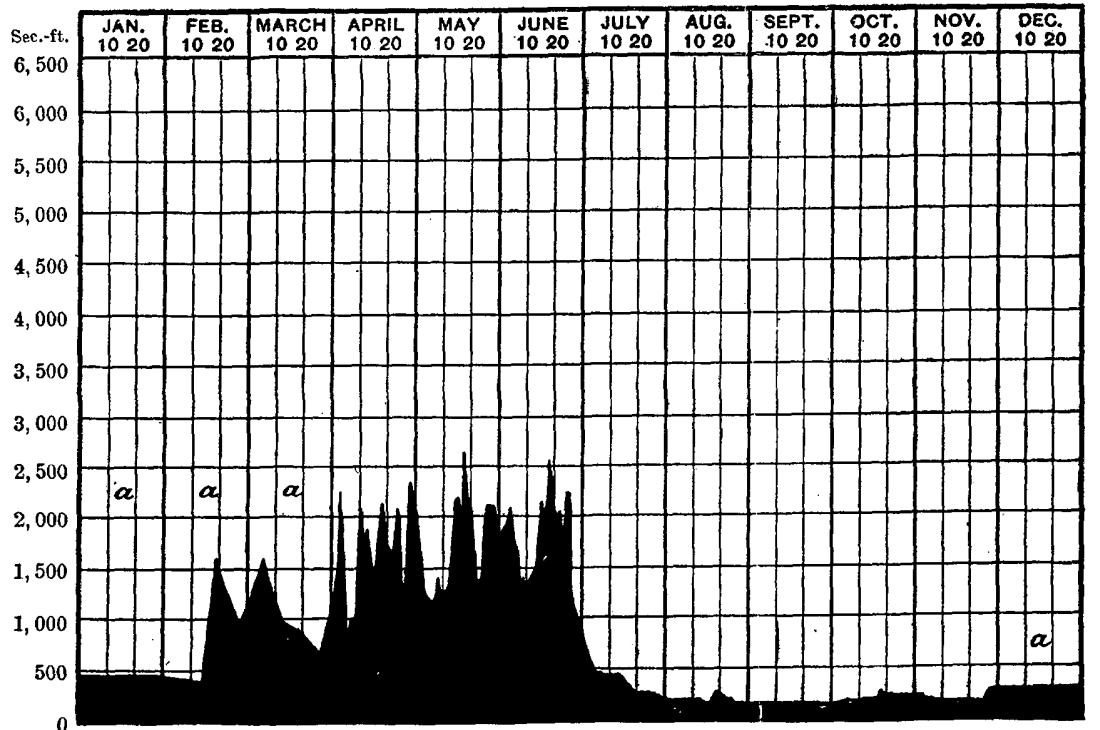

FrG. 141.-Discharge of Black Fork River at Granger, Wyoming, 1898. 
YAMPA AND WHITE RIVERS.

During September, 1898, Mr. A. L. Fellows made a general reconnaissance in northwestern Colorado in order to obtain data concerning the flow of streams useful in irrigation emptying into the Yampa and White rivers, tributaries of Green River. He proceeded from Denver to the station known as Rifle, on the Denver and Rio Grande Railroad, 26 miles west of Glenwood Springs, and from there by stage to the town of Meeker, the county seat of Rio Blanco County, and 45 miles from Rifle. On leaving the latter point the road follows a dry water course to the top of the divide between the Grand and White rivers; then follows another similar dry water course to White River at a point about 4 miles below the town of Meeker. On the way the rocks are seen to be tilted at all possible angles, and for the most part of brilliant color, being almost bare of vegetation. In general the country is rough and of little value except for stock raising and for the coal, which apparently abounds on all sides. The valley of the White River, however, is broad, and with many ranches owned by prosperous settlers whose chief business is raising cattle and hay. Meeker, the only town of Rio Blanco County, is apparently prosperous, being the outfitting point for prospectors, tourists, and sportsmen. The following description of $\mathrm{Mr}$. Fellows' trip is taken from his report: ${ }^{1}$

White River, at Meeker, is a large stream, its discharge being 300 second-feet. In this stream, as well as in all others measured during the trip, the stage of the water was extremely low, being, according to all reports that I could obtain, not more than one-half of the normal low stage. This state of affairs is due, undonbtedly, to the extremely light snowfall of last winter, 1897-98, and to the fact that no rain had fallen in that section for about three months prior to my measurements. I think it safe to say, therefore, that the normal low-water stages would be at least two or three times as great as the stages which I found.

Upon the following day, September 15, Mr. Humphrey Jones, who acted as my guide, and myself took the stage and traveled about 50 miles, from Meeker to Craig, in Routt County. The country passed through on this day was similar to that of the day before, although the last part of it was much less rough, but still quite rolling. On the way we made short stops at the post-offices Axial and Hamilton, each settlement consisting of one family, although the center for several. At the crossing of the streams known as Milk River and Morapos Creek I estimated the flow, the former at 3 second-feet and the latter at 1 second-foot; but judging from the amount of land irrigated from each one they must be of considerable size earlier in the season. I understand, however, that in the case of each creek the supply of water is deficient for the land under it, and that, although there is a great extent of irrigable land along each stream, particularly in what is known as the Axial Basin, these lands can probably never be brought under cultivation unless some means of water storage is found. I was informed that there was an excellent reservoir site at the head of the Morapos Creek, but I did not have time to investigate, although I determined that there was sufficient flow in that stream earlier in the season to fill a large reservoir.

At Hamilton I measured Williams Fork of the Yampa, along which are a number of ranches. The stream is relatively large, although it contained but 25 second-feet

1 Gaging of Streams in Water Division No. 6: Report by A. L. Fellows, in Ninth Biennial Report of the State Engineer of Colorado, for the years 1897 and 1898, Denver, 1899; pp. 409-419. 


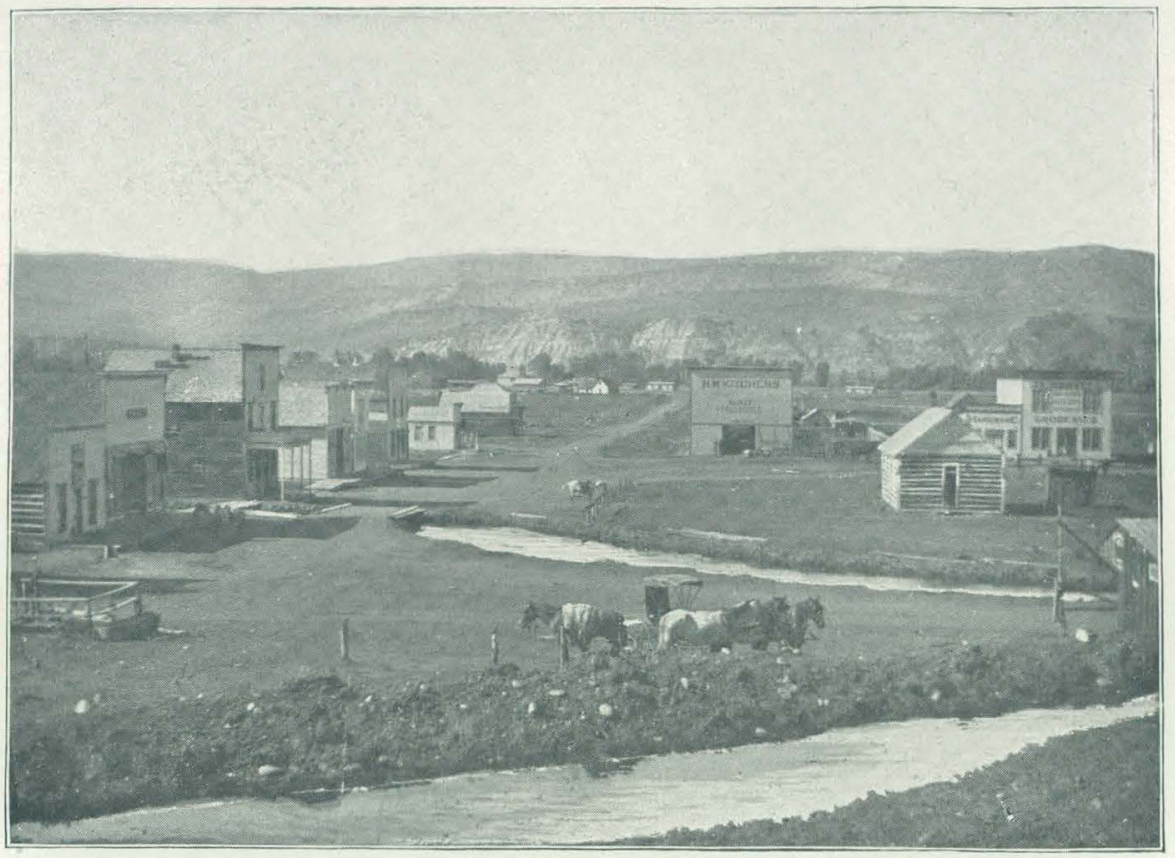

A. HAYDEN, COLORADO.

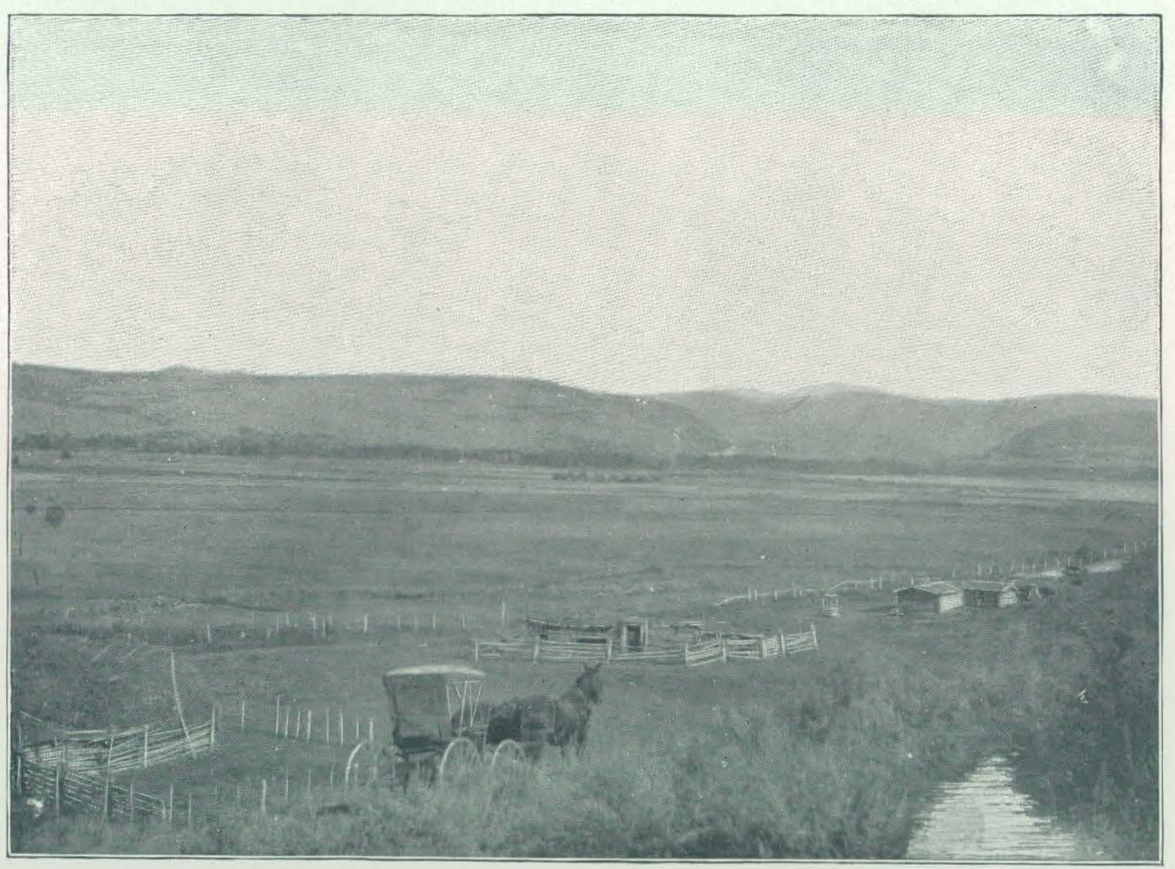

B. VALLEY ABOVE HAYDEN, COLORADO. 


\section{4}

at the time 1 measured it. The country about its head abounds in all kinds of game. The town of Craig, on Yampa River, has a beautiful location. There is a considerable area of agricultural land in the vicinity, but up to the present time the residents have been trying to get along with the water furnished by Fortification Creek, a small stream flowing in from the north. This usually becomes dry some time in June, or in July at the latest. Plans have been made for the construction of a large ditch to be taken from the Yampa River about 20 miles above Craig. This is expected to supply the lands above and below town on the north side of the river. Mr. Frank Cramer, an engineer of experience in irrigation work, has since been appointed engineer in charge, and there is every reason to believe that the diteb, upon which work is in progress, will be a success. The developed lands above the river bottom, however, are rolling, and only a small portion of these can be brought into cultivation. Nearly all the people in the vicinity of Craig, as well as those of Routt Connty in general, are stock growers and apparently prosperous. The country is adapted to stock raising rather than to general agriculture, owing largely to the fact that the amount of tillable land bears a small proportion to the grazing area. The cattle business will probably always be the chief industry of this section, although at some future time the coal supply and the placer beds will attract attention.

On the morning of September 17 we left for Steamboat Springs, situated on the Yampa River about. 45 miles above or east of Craig. The road winds along the river side, sometimes upon the edge of the mesas and sometimes upon the river bottom, through beautiful, well-cultivated rasches. The principal products of the irrigated lands are hay and grain for the winter feed for the stock. Improved ranches with water rights are held at high figures. About noon we passed through the little town of Hayden, shown on Pl. XXXVIII, $A$, which is nearly in the center of the best cnltivated part of the Yampa Valley. A number of ditches are taken out above the town, and the results of irrigation in the neigborhood are very alluring to the promoters of the Craig ditch. The river was measured at a point about 3 miles below Hayden, and there showed a discharge of 111 second-feet. It is at this point that the Craig ditch is to take out its water supply. From the fact that no ditches of importance are taken out below this point, and that this season is the dryest of which there is record, no doubts are entertained but that the Craig ditch, as well as other ditches which may hereafter be constructed along the river, will have an abundant water supply.

Steamboat Springs, Pl. XXXIX, $A$, takes its name from two sulphur springs, which, in spouting from holes in the solid rock, make a noise resembling the sound from the exhaust pipes of a steamer. The town is beautifully located in the mountains, and is a resort not only for sportsmen, but also for tourists and health seekers who come to try the springs which abound in the vicinity. There are said to be over 200 mineral springs in the immediate neighborhood, of which several are hot springs with temperature ranging from 103 to $150^{\circ} \mathrm{F}$. At one of the hot springs comfortable bath houses have been erected. Near the town is an onyx mine, from which blocks of any desired size and of a fine quality may be obtained in apparently inexhaustible quantity.

On the road from Craig we crossed Elk Head River, which we found nearly dry, although it is a good-sized stream up to the first of September, and much land is irrigated from it. Elk River was also crossed about a mile above where it discharges into the Yampa, near Trull post-office, there being at that point 63 second-feet. Yampa River was measured at Steamboat Springs, giving a discharge of 65 secondfeet, and Fish Creek, below Fish Creek Falls, was estimated at 10 second-feet.

On the following day, September 19, we left the valley of Yampa River and turned to the north for Honnold post-office, on Snake River, going by the way of Hahns Peak and Columbine. During the morning we crossed Mad Creek, estimated at 6 second-feet; Big Creek at 4, Willow Creek at 4, and Beaver Creek at 2 second-feetall tributaries of the Elk River. This latter we crossed at a point about 15 miles 
from Steamboat Springs, not far from where it has been suggested that a large ditch might at some future time be taken out to irrigate the lands along the divide for a hundred miles or nore between the Snake and Yampa rivers. This project I had no time to investigate, although later I saw a great area of fine land which could probably be irrigated from such a ditch. On this day the entire country was covered with smoke from forest fires, of which we could distinguish six at one point of our road. At one place we passed along the edge of a fire which afterwards consumed a large part of the town of Columbine. The town of Hahns Peak is at present the county seat of Routt County, but as it is in the extreme northeastern part of the county it is extremely difficult for residents of the western part of the county to reach it, requiring in many cases a three-day trip in wagons or on horseback. An effort is being made to change the location of the county seat from Hahns Peak to some more central point. The present county of Routt is a little larger than the State of Massachusetts. The mountain known as Hahns Peak, and from which the town takes its name, is an imposing mass, and is the center of a large mining terri.tory. This will be of considerable importance if the country is ever reached by railroad. At present, however, most of the ores are of too low a grade for shipment by wagons and only a few mines can afford to freight out their ore.

Honnold post-offee is upon the Gardner Ranch, within the boundaries of which the three forks of the Snake River unite; they are designated as the North, Middle, and South Forks. The discharge of the. Snake River at a point below the union of the forks was only 17 second-feet. Of this amount about. 5 second-feet came from the North Fork, 8 second-feet from the Middle Fork; and 4 second-feet from the South Fork. At this time the stream, although not a large one, probably carries more water than is necessary for all the irrigation that can be done from it during the average season.

On the following morning we started down the valley of Snake River, which runs westerly along the boundary line between Colorado and Wyoming, sometimes in one State and sometimes in the other, crossed Battle Creek, which we estimated at 4 second-feet, and Savory Creek, which we found dry at the point of crossing, although water was running in two or three ditches taken from it. A considerable area of land is irrigated from each of these creeks. We stopped at Slater to measure Slater Fork, which contained 9 second-feet. About 5 miles above the mouth of the Fork is a herd of over 100 fine elk kept under fence.

From Slater post-office we drove in the afternoon to Dixon, a little town in Wyoming, about 2 miles from the Colorado line. This is the vicinity of the so-called "sheep wars." The sheep men of Wyoming sometimes endeavor to bring their sheep over the line into Colorado, the Colorado men driving them back. Probably nothing of this kind will occur again, as it is well understood that the stock men of northwestern Colorado have combined to keep all sheep out of that section.

On the morning of September 21 we measured Snake River at Dixon, finding its discharge to be 19 second-feet, that being not far from the point where it finally leaves the Colorado line. Starting for the Yampa River again, we made two or three stops when just across the Colorado line to look at a large tract of land which may, perhaps, be brought under cultivation. The roads traveled over on that day were within the "Four Mile" country, this being between the Snake and Yampa rivers; and the area which it has been suggested might be covered with a ditch from Elk River. There is much fine land there, but most of it is scattered in small tracts. A ditch is at present being constructed from Slater Fork and other tributaries of Snake River to cover a portion of the Four Mile district with water, principally for placer mining.

On September 23 we drove from Emerson Ranch, by way of Lay post-office, to Maybell, upon Yampa River. The road follows Lay Creek and is surrounded by high mesas or plateaus covered with sagebrush and cedar trees. There are some attractive ranches upon this creek, but the supply of water is so limited that not 20 GEOL; PT $4-25$ 


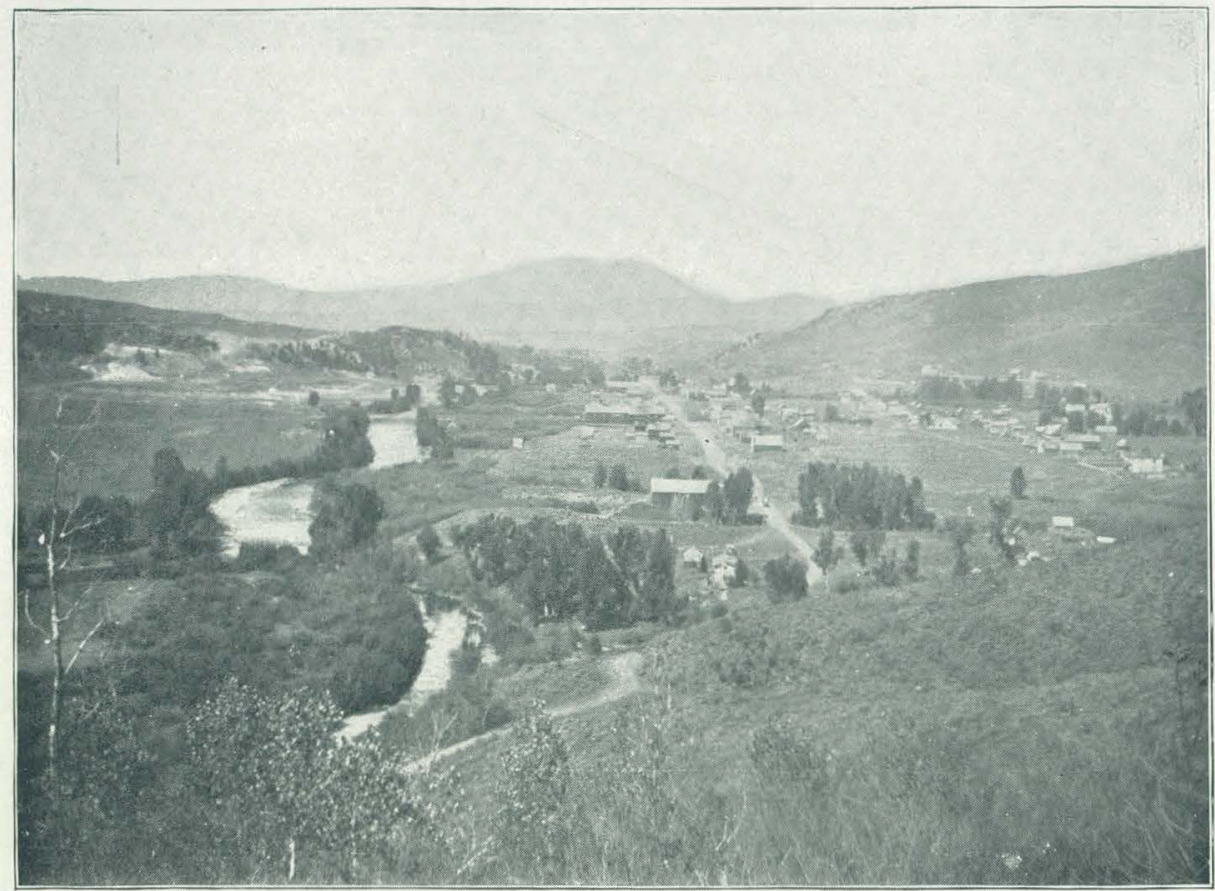

A. STEAMBOAT SPRINGS, COLORADO.

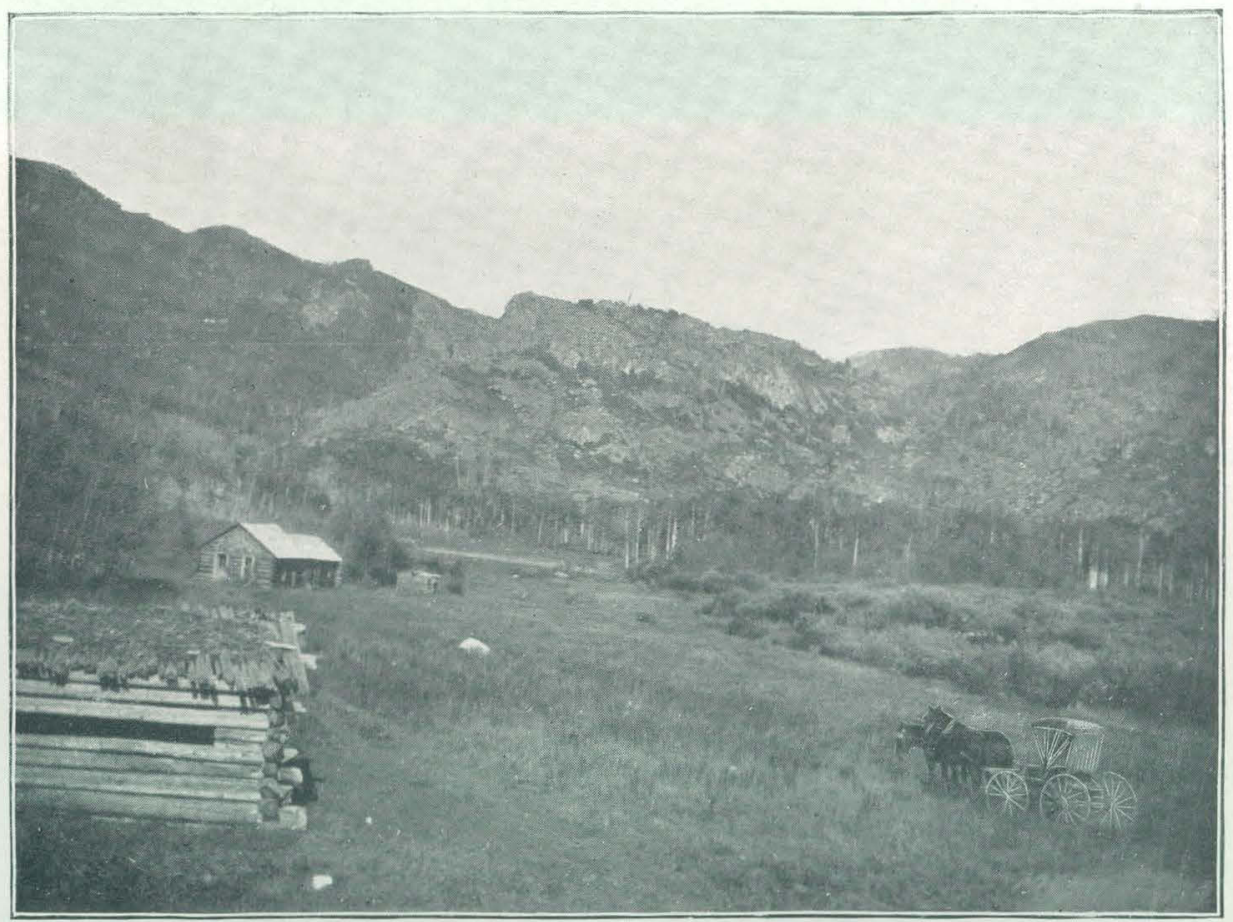

B. ROAD TO FISH CREEK FALLS. 
very much can be done in the way of irrigation. Those who have water, however, are very fortunate in being located where they are surrounded by an immense grazing country. Most of them can raise enough hay to keep their stock during the winter. We forded the Yampa River some distance below Maybell, 2 or 3 miles below the point where the Maybell Colonization Company expects to take out a ditch to cover about 8,000 acres of land, which borders the river upon both sides. This land, when irrigated, will prove very productive. The cost of the ditch will undoubtedly be large, but, in my opinon, it will not be excessive as compared with the body of land to be irrigated.

After leaving Maybell we continued along the south side of Yampa River, crossing at the Thornburg bridge, near the place where the Thornburg massacre occurred several years ago. At this point $I$ measured the river, finding its discharge to be 99 second-feet. This is about the center of the lands eventually to be taken by the Maybell colony. Crossing the river at the bridge we drove several miles farther, to the house of Henry Templeton.

During the morning of September 24 we drove first about 9 miles to the Thompson Crossing of the Snake River, a large part of the way being across a beautiful mesa which lies well for irrigation, but which can probably never be irrigated, owing to its sloping in the wrong direction or against the general trend of the geologic strata. At the Thompson Crossing we found, to our surprise, that Snake River was practically dry, nearly all the flow that we found at Dixon having been lost in the sands between these two points. The crossing is upon the Thompson ranch, the buildings of which were burned by the Indians in the fall of 1897. After leaving this point we drove northwesterly about 35 miles without water until we reached Vermilion Creek, a small stream winding along between high sandstone walls, some of which are of a vermilion color, giving the creek its name. There was a small stream running here, which we estimated at 4 second-feet, and our horses as well as ourselves were glad of an opportunity to drink. Driving several miles farther we arrived, a little after dark, at Ladore post-office, where we found the Thompsons, owuers of the above-mentioned Thompson ranch, and other old-timers, from whom I gained a great deal of information concerning a possible reservoir site and irrigable lands of the vicinity. I was informed that there was a fine reservoir site upon Beaver Creek, about 30 miles distant from Ladore. There is a fine body of land consisting of several thousand acres, which may, perhaps, be irrigated from this proposed site, but I think that the same land could be covered by a ditch taken from Green River, which has an abundant water supply. I measured the Green River on September 24 at Hoys Crossing, 6 miles below Ladore, finding the discharge to be 552 second-feet.

Mr. 'Templeton has a dam and water wheel for raising water from Yampa River, by means of which he can irrigate about 60 acres of land; he expects, however, to take water eventually from Maybell ditch. He showed us a fine garden, in which he raises vegetables for his family and his few neighbors. After leaving his ranch we drove again to Maybell and to the head of the proposed Maybell ditch, which runs for about a mile along a rocky canyon. I suggested that a dam might be put across the river at a very favorable point, as being less expensive than the first mile of the ditch, and it is possible that the suggestion may be acted upon.

The Yampa River is different from any other stream of the West that I have seen; for long stretches of perhaps miles there will be practically no fall whatever, the water standing at this time of the year in pools or lakes. The only perceptible fall is for short distances across bars or riffles and for long distances through rocky canyons. It is in such a canyon that it will be necessary to find the location required for the headwaters of a canal irrigating such lands as it is desired to cover. Especially is this the case in the lower half of the Yampa Valley.

On our return to Craig we drove for about 35 miles across what are known as the Sand Hills, a desolate country, most of which is nearly devoid of vegetation, except, ing sagebrush. A gaging of the Yampa near Craig gave a discharge of 79 second- 
feet. The route from Craig back to Rifle was over practically the same country as that covered twelve days beforè.

In addition to possible irrigation enterprises that have been suggested, there are others of some importance, particularly one at Lily Park, near the junction of the Snake and Yampa rivers. The possibilities for development in this section of the country are very great, and I would recommend that an effort be made to have regular stations for measuring discharges at Meeker upon White River, Craig and Steamboat Springs upon Yampa River, Trull upon the Elk River, and Honnold and Slater upon Snake River, and possibly Hoys' upon Green River. The streams mentioned in general have good cross sections and are not particularly liable to change at the points designated; it would not be necessary, therefore, for discharge measurements to be taken so often as upon the streams nore liable to change. Observations upon the Yampa would be of special value, as upon that stream the proportion of irrigable land to the water supply is greater than upon the others, and Slater is an especially important point, on account of the relations of the two neighboring States in having for some distance a common water süpply:

Estimated monthly discharge of Green River at Blake, Utah.

[Drainage area, 38,200 square miles.]

\begin{tabular}{|c|c|c|c|c|c|c|}
\hline \multirow{2}{*}{ Month. } & \multicolumn{3}{|c|}{ Discharge in second-feet. } & \multirow[b]{2}{*}{$\begin{array}{c}\text { Total in acre. } \\
\text { feet. }\end{array}$} & \multicolumn{2}{|c|}{ Run-off. } \\
\hline & $\begin{array}{l}\text { Maxi. } \\
\text { muim. }\end{array}$ & $\begin{array}{l}\text { Mini. } \\
\text { mum. }\end{array}$ & Mean. & & $\begin{array}{l}\text { Depth.in } \\
\text { inches. }\end{array}$ & $\begin{array}{l}\text { Second- } \\
\text { feet per } \\
\text { square } \\
\text { mile. }\end{array}$ \\
\hline 1898. & & & & & & \\
\hline January'.... & 6,010 & 1,140 & 4,685 & 288,071 & 0.20 & 0.17 \\
\hline February ......... & 6,010 & 4,855 & 5,500 & 305,454 & 0.21 & 0.20 \\
\hline March ..... & 6,430 & 2,910 & 4,657 & 286,350 & 0.20 & 0.17 \\
\hline April..... & 20,350 & 3,490 & 10,479 & 623,423 & 0.41 & 0.37 \\
\hline May ....... & 23,200 & 18,450 & 20,687 & $1,272,002$ & 0.84 & 0.73 \\
\hline June .... & 35,550 & 20,350 & 26,557 & $1,580,248$ & 1.04 & 0.94 \\
\hline July & 27,475 & 3,805 & 10,331 & 635,233 & 0.43 & 0.37 \\
\hline August..... & 3,505 & 2,020 & 2,566 & 157,778 & 0.10 & 0.09 \\
\hline September . & 3,070 & 1,160 & 1,841 & 109,547 & 0.08 & 0.07 \\
\hline October. & 1,600 & 1,200 & 1,460 & 89,772 & 0.06 & 0.05 \\
\hline November.. & 2,020 & 1,080 & 1,413 & 184,079 & 0.06 & 0.05 \\
\hline December ......... & 1,400 & 1,120 & 1,271 & 78,151 & $0.06^{\circ}$ & 0.05 \\
\hline The year. & 35,550 & 1,080 & 7,621 & $5,510,108$ & 3.69 & 0.27 \\
\hline
\end{tabular}

Note.-Gage heights for 1898 are given in Water-Supply and Irrigation Paper No. 28, page 134; rating table, page 144; results for 1897 in Water-Supply and Irrigation Paper No. 16, page 136, and in the Nineteenth Annual Report, Part IV, pages 396 to 398. 


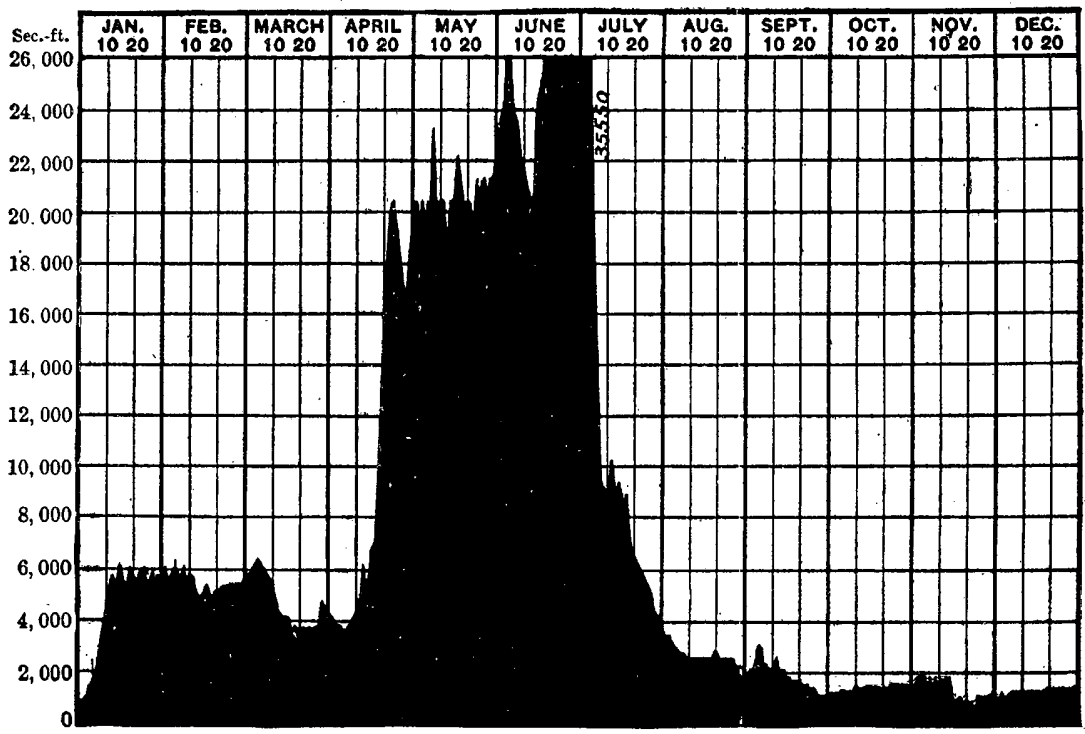

FIG, 142.-Discharge of Green River at Blake, Dtah, 1898.

\section{GRAND RIVER.}

This tributary of Colorado River is described in the Nineteenth Annual Report of the Survey, Part IV, page 399.

A number of large irrigating ditches are taken from this stream and its tributaries, furnishing water for agricultural lands lying along the streams, and nearly all farm crops that may be raised in Colorado are found here. Fruit is raised in considerable quantities, including apples, peaches, apricots; etc., and all small fruits. Alfalfa is a staple product, as are also the small grains. The establishment of a large beet-sugar factory at Grand Junction, upon which work has been begun, has given an impetus to agriculture in this section.

Grand River has in general an abundance of water for all purposes, but upon many of the smaller tributaries there is often a shortage, for irrigation and storage is being extensively practiced, the same being true of the Gunnison River and tributaries also.

The only station maintained upon Grand River in 1898 was that at Grand Junction, a description of which is given in the passage just referred to, and also in Water-Supply and Irrigation Paper No. 16, page 137 .

The figures given in the following table represent the total flow of the stream, the amount in each channel at Grand Junction being ascertained separately and added to give the total discharge. 
Estimated monthly discharge of Grand River at Grand Junction, Colorado.

[Drainage area, 8,644 square miles.]

\begin{tabular}{|c|c|c|c|c|c|c|}
\hline \multirow[b]{2}{*}{ Month. } & \multicolumn{3}{|c|}{ Discharge in second-foet. } & \multirow[b]{2}{*}{$\begin{array}{l}\text { Total in acre- } \\
\text { feet. }\end{array}$} & \multicolumn{2}{|c|}{ Run-off. } \\
\hline & $\begin{array}{l}\qquad \\
\text { Maxi. } \\
\text { mum. }\end{array}$ & $\begin{array}{l}\text { Mini- } \\
\text { mum. }\end{array}$ & Mean. & & $\begin{array}{c}\text { Depth in } \\
\text { inches. }\end{array}$ & $\begin{array}{c}\text { Second. } \\
\text { feet per } \\
\text { square } \\
\text { mile. }\end{array}$ \\
\hline 1898 & & & $\cdot$ & & & \\
\hline January ..... & $\cdots$ & $\ldots \ldots$ & a 2,944 & $a 181,020$ & $a 0.39$ & $a 0.34$ \\
\hline February & & $\therefore$ & $a 2,985$ & $a 165,777$ & $a 0.36$ & $a 0.35$ \\
\hline March .... & & & $a 2,113$ & a 129,924 & $a 0.28$ & $a 0.24$ \\
\hline April ... & & $-\ldots \ldots$ & $a \cdot 4,305$ & $a 256,165$ & $a 0.56$ & $a 0.50$ \\
\hline May ..... & 12,642 & 4,633 & 7,130 & 438,406 & 0.94 & 0.83 \\
\hline June ..... & 17,262 & $8,27 \dot{9}$ & 13,702 & 815,326 & 1.77 & 1.59 \\
\hline July ..... & 7,611 & 1,725 & 4,445 & 273,312 & 0.59 & 0.51 \\
\hline Aúgust..... & 1,725 & 949 & 1,127 & 69,297 & 0.15 & 0.13 \\
\hline September ... & 1,143 & 561 & 907 & 53,970 & 0.12 & 0.11 \\
\hline October $\ldots \ldots \ldots$ & 1,143 & 561 & 915 & 56,261 & 0.13 & 0.11 \\
\hline November.......... & 1,337 & 755 & 1,072 & 63,788 & 0.14 & 0.12 \\
\hline December .. & $\ldots \ldots$ & $\ldots \ldots$ & 1,011 & 62,164 & 0.20 & 0.17 \\
\hline The year... & 17,262 & $\cdots$ & $3,5 \overline{5}$ & $2,565,410$ & 5.63 & 0.42 \\
\hline
\end{tabular}

a Approsimato.

NotE.-Gage heights for 1898 are given in Water.Supply and Irrigation Paper No. 28, page 135; measurements, page 142; rating table, page 144; results for 1897 in Water-Supply and Irrigation Paper No. 16, page 137, and in the Nineteenth Annual Report, Part IV, pages 399 to 401.

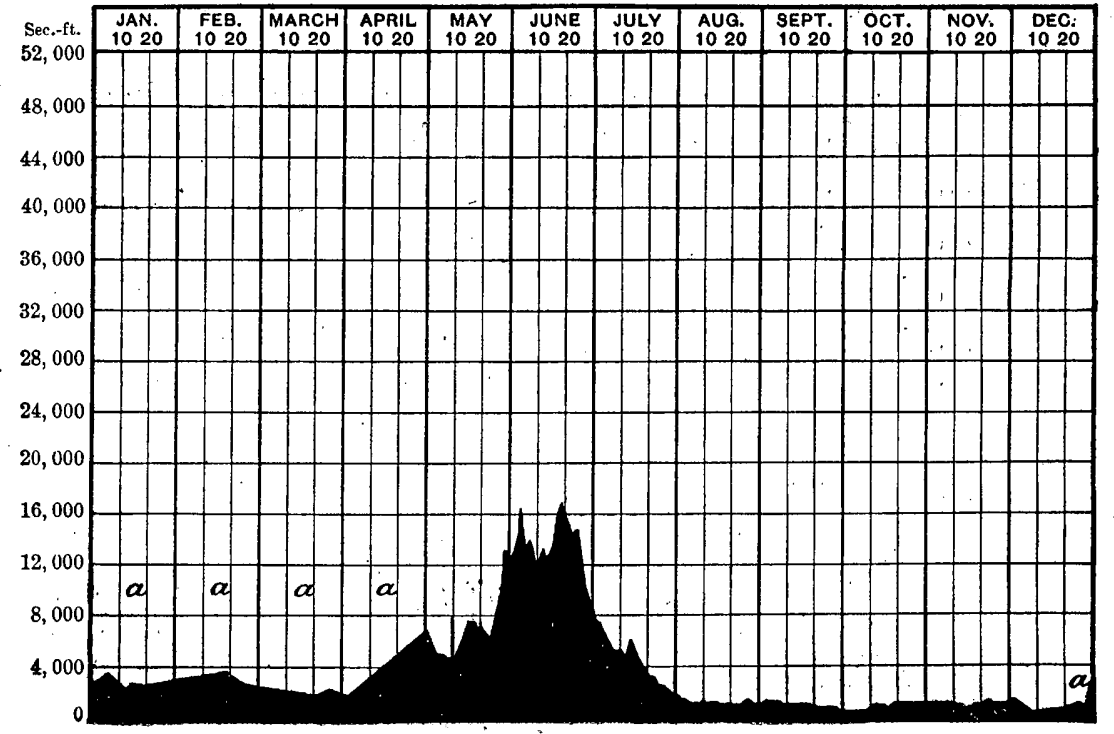

FIG. 143.-Discharge of Grand River at Grand Junction, Colorado, 1898. 
GUNNISON RIVER.

Gunnison River is the largest tributary of the Grand, and drains a section of country adjoining it on the south, and is of a similar nature to the Grand, previously described. Agriculture upon this stream and its tributaries is generally confined to the valleys along the streams and the adjacent mesas.

The only station maintained upon this stream in 1898 was that at Grand Junction, described in Water-Supply and Irrigation Paper No. 16, page 141.

Estimated monthly discharge of Gunnison River at Grand Junction, Colorado.

[Drainage area. 7,935 square miles.]

\begin{tabular}{|c|c|c|c|c|c|c|}
\hline \multirow[b]{2}{*}{ Month. } & \multicolumn{3}{|c|}{ Discharge in second feet. } & \multirow[b]{2}{*}{$\begin{array}{l}\text { Total in acre. } \\
\text { feet. }\end{array}$} & \multicolumn{2}{|c|}{ Run-off. } \\
\hline & $\begin{array}{l}\text { Maxi- } \\
\text { muni. }\end{array}$ & $\begin{array}{l}\text { Mini. } \\
\text { mum. }\end{array}$ & Mean. & & $\begin{array}{c}\text { Depth in } \\
\text { inches. }\end{array}$ & $\begin{array}{l}\text { Second- } \\
\text { feet per } \\
\text { square } \\
\text { mile. }\end{array}$ \\
\hline 1898. & & & & & & \\
\hline May........ & 8,996 & 3,965 & 5,318 & 326,993 & 0.77 & 0.67 \\
\hline June........... & 11,361 & 4,158 & 8,850 & 526,610 & 1.25 & 1.12 \\
\hline July .......... & 3,965 & 1,076 & 2,543 & 156,364 & 0.37 & 0.32 \\
\hline August...... & 968 & 578 & 689 & 42,365 & 0.10 & 0.09 \\
\hline September . & 578 & 399 & 479 & 28,502 & 0.07 & 0.06 \\
\hline October.............. & 672 & 399 & 533 & 32,773 & 0.08 & 0.07 \\
\hline November ........... & 672 & 314 & 497 & 29,573 & 0.07 & 0.06 \\
\hline
\end{tabular}

Nore.-Gage heights for 1898 are given in Water-Supply and Irrigation Paper No. 28, page 136; measurements, page 142; rating table, 144; results for 1897 in Water-Supply and Irrigation Paper No. 16, page 141, and in the Nineteenth Annual Report, Part IV, pages 404 to 406.

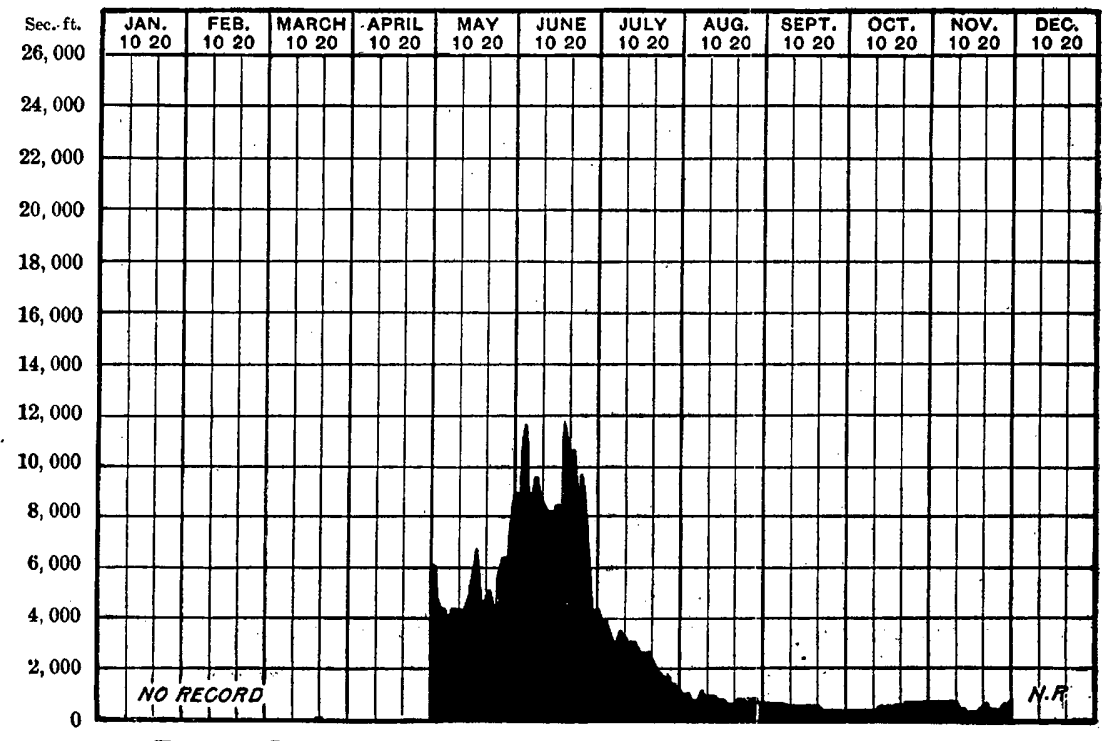

FIG. 144. -Discharge of Gunnison River at Grand Junction, Colorado, 1898. 
UNCOMPAHGRE RIVER.

The Uncompahgre is a tributary of the Gunnison, flowing into it from the south; it rises among some of the highest mountains of southwestern Colorado, and flows in a generally northerly direction, at first through a mountainous region, later emerging into more open valleys, along which are irrigable mesas, easy of access by irrigating canals.

The waters of this stream and its tributaries are exhausted during the normal flow of the irrigating season, and any considerable increase in the amount of irrigated land will be obliged to depend generally upon storage for its supply.

The Survey station upon this stream is located at Fort Orawford, and is described in Water Supply and Irrigation. Paper No. 16, page 139, the observer being Mrs. F. Humphrey; postoffice, Uncompahgre, Colorado. The channel of this stream is in gravel, and seems to be especially liable to change, two rating tables being necessary for calculations of the discharge for 1898 .

Estimated monthly discharge of Uncompahgre River at Fort Crawford, Colorado.

[Drainage area, 497 square miles.]

\begin{tabular}{|c|c|c|c|c|c|c|}
\hline \multirow[b]{2}{*}{ Month. } & \multicolumn{3}{|c|}{ Discharge in second-feet. } & \multirow[b]{2}{*}{$\begin{array}{l}\text { Total in acre- } \\
\text { feet. }\end{array}$} & \multicolumn{2}{|c|}{ Run-off: } \\
\hline & $\begin{array}{l}\text { Maxi- } \\
\text { mum. }\end{array}$ & $\begin{array}{l}\text { Mini- } \\
\text { mum. }\end{array}$ & Mean. & & $\begin{array}{l}\text { Depth in } \\
\text { inches. }\end{array}$ & $\begin{array}{c}\text { Second } \\
\text { feet per } \\
\text { square } \\
\text { mile. }\end{array}$ \\
\hline 1898. & & & & & & \\
\hline April 10-30........ & 478 & $5 \overline{5}$ & 337 & 19,458 & 0.73 & 0.66 \\
\hline May ............. & 521 & 195 & 306 & 18,815 & 0.71 & 0.62 \\
\hline June....... & 985 & 436 & 703 & 41,831 & 1.57 & 1.41 \\
\hline July ....... & 891 & 37 & 430 & 26,440 & 1.00 & 0.87 \\
\hline Angust.............. & 274 & 15 & 111 & 6,825 & 0.25 & 0.22 \\
\hline September ......... & 110 & 37 & 67 & 3,987 & 0.14 & 0.13 \\
\hline October ..... & 92 & 46 & 58 & 3,566 & 0.14 & 0.12 \\
\hline November .......... & 110 & 28 & 54 & 3,213 & 0.12 & 0.11 \\
\hline
\end{tabular}

Note.-Gage heights for 1898 are given in Water-Supply and Irrigation Paper No. 28, page 136; measurements, page 142; rating table, page 144; results for 1897 in Water-Supply and Irrigation Paper No. 16, page 139, and in the Nineteenth Annual Report, Part IV, pages 402 to 404. 


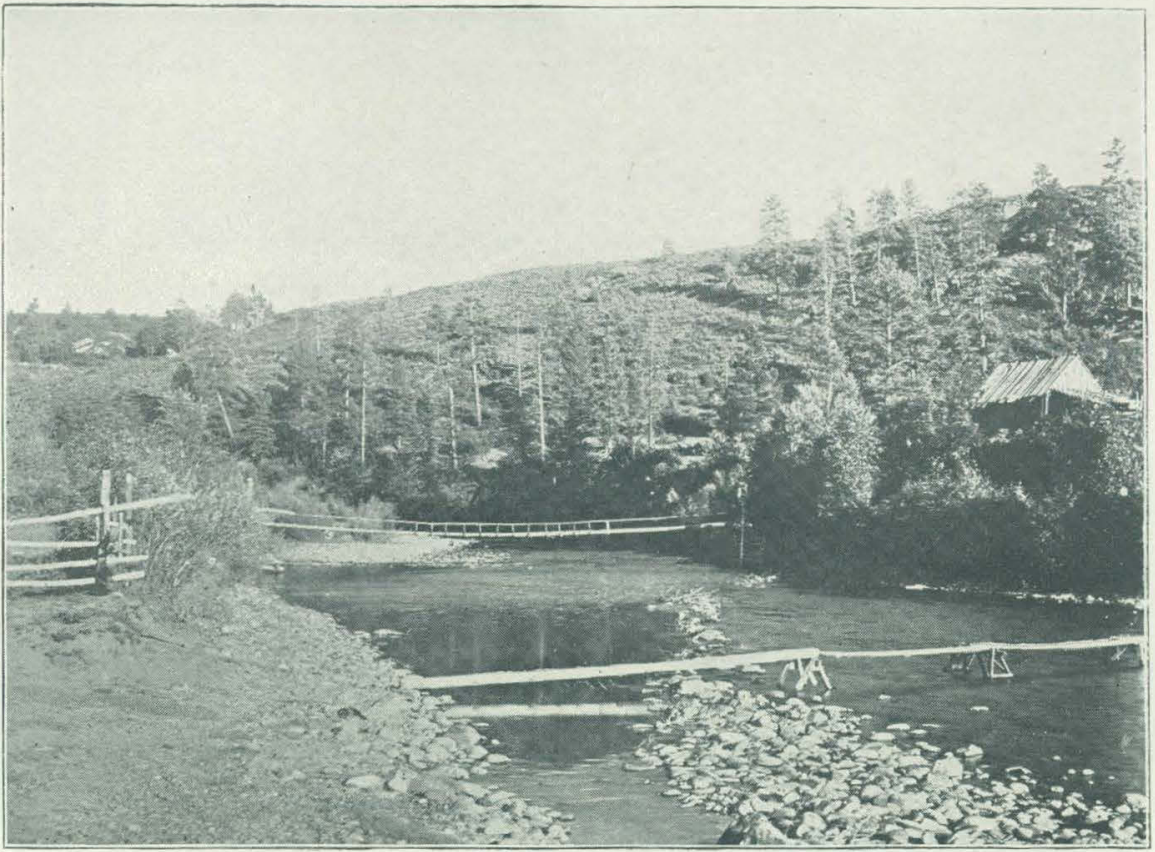

A. GAGING STATION ON DOLORES RIVER NEAR DOLORES, COLORADO

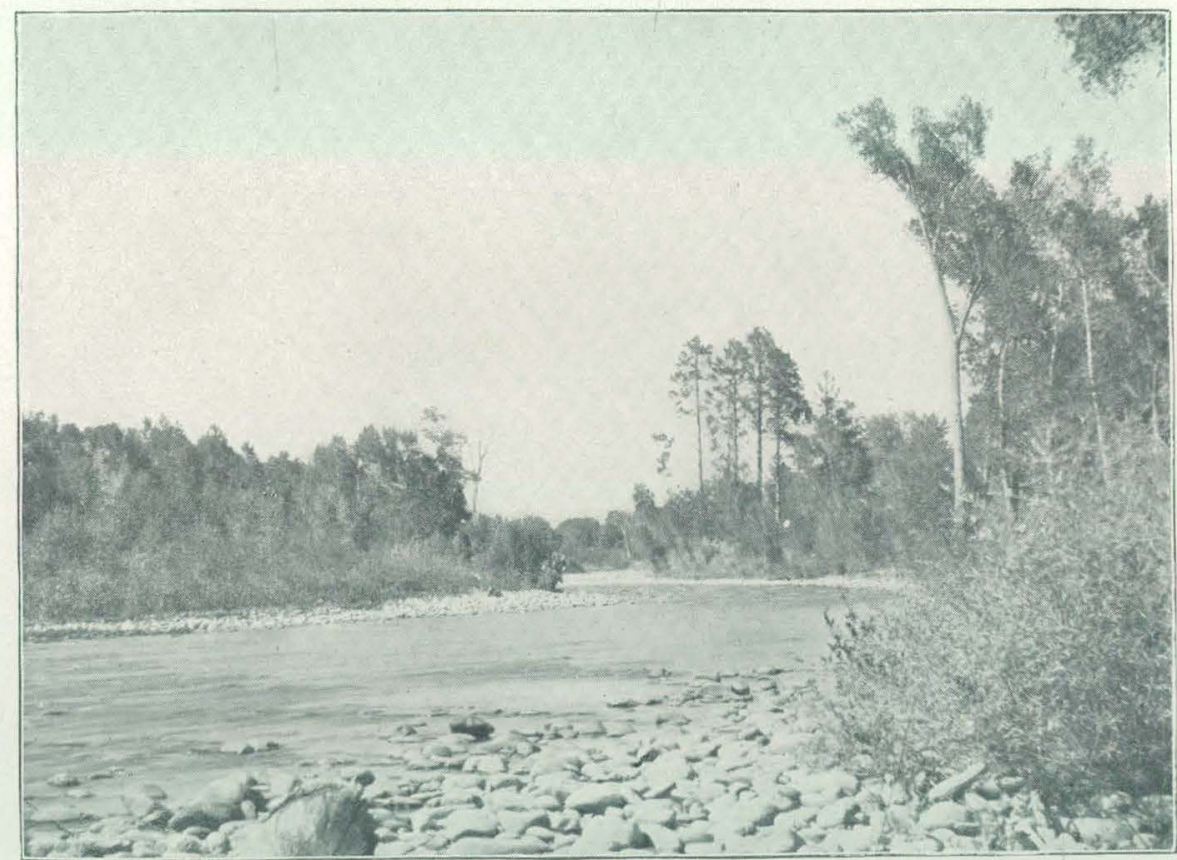

B. LOOKING UP LOS PINOS RIVER FROM NEAR HEAD GATE OF SPRING CREEK DITCH, 6 MILES ABOVE IGNACIO, COLORADO. 


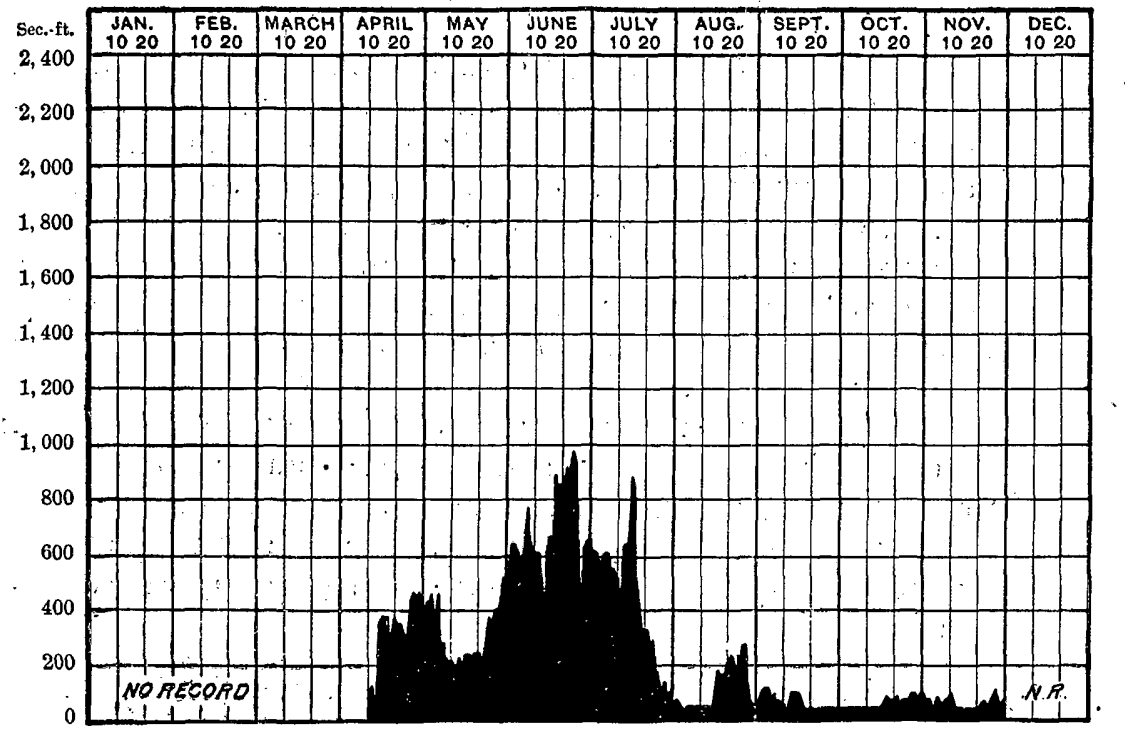

Fig. 145.-Discharge of Uncompahgre River at Fort Crawford, Colorado, 1898.

DOLORES RIVER.

The drainage basin of Dolores River, above Dolores, Colorado, covers 524 square miles of mountainous country, characterized by a rugged topography, the highest point in the basin being Mount Wilson, with an elevation of 14,250 feet. The elevation of the river at Dolores is in the neighborhood of 6,900 feet. The river is formed by the confluence of the West Fork and the East Fork, which drain 1.60 and 281 square miles; respectively, and the latter of which contributes nearly two-thirds of the discharge of the main river. The suowfall in this region is considerable, so that the discharge of the river in spring is very high. After the melting of the snow the river falls rapidly, reaching its low stage usually about the 1st of August, and remaining low during the remainder of the year, except for occasional-rises caused by severe showers. The record, though extending only over a period of four years, is sufficient for a consideration of the flow for storage and irrigation purposes. The rainfall records of this period, as given on page 399 , indicate that the four years in question offer no unusual features.

DOLORES RIVER AT. DOLORES, COLORADO.

The gaging station on Dolores River, shown in Pl. XL, $A$, is located about one-half mile above the railroad depot at Dolores, Colorado. The gage consists of a vertical 2 by 6 inch plank bolted to the abutment of a footbridge on the left side of the river, the observer being Mrs. Mary D. Smith. The records obtained at this point have been published in the annual reports, in Bulletin No. 140, and in WaterSupply and Irrigation Papers Nos. 11 and 16. In the accompanying 
tables are given the daily mean discharges in cubic feet per second throughout the entire period of observation, and the same are represented in graphic form in fig. 146.

Estimated monthly discharge of Dolores River at Dolores, Colorado.

[Drainage area, 524 square miles.]

\begin{tabular}{|c|c|c|c|c|c|c|}
\hline \multirow[b]{2}{*}{ Month. } & \multicolumn{3}{|c|}{ Discharge in second-feet. } & \multirow[b]{2}{*}{$\begin{array}{c}\text { Total in acre- } \\
\text { feet. }\end{array}$} & \multicolumn{2}{|c|}{ Run off. } \\
\hline & $\begin{array}{l}\text { Maxi- } \\
\text { mam. }\end{array}$ & $\begin{array}{l}\text { Mini- } \\
\text { mum. }\end{array}$ & Mean. & & $\begin{array}{c}\text { Depth in } \\
\text { inches. }\end{array}$ & $\begin{array}{c}\text { Second. } \\
\text { feet per } \\
\text { square } \\
\text { mile. }\end{array}$ \\
\hline 1895. & - & & & . & & \\
\hline June $23-30 \ldots \ldots . .$. & $\ldots \ldots \ldots$ & $\ldots \ldots \ldots$ & 702 & 11,139 & 0.40 & 1. 34 \\
\hline July .......... & 490 & 127 & 270 & 16,602 & 0.60 & 0.52 \\
\hline August........... & 548 & 97 & 248 & 15,249 & 0.54 & 0.47 \\
\hline September ......... & 177 & 68 & 99 & 5,891 & 0.21 & 0.19 \\
\hline October ............ & 97 & 68 & 79 & 4,858 & 0.17 & 0.15 \\
\hline November ......... & 405 & 42 & 134 & 7,974 & 0.29 & 0.26 \\
\hline December .......... & 605 & 281 & 419 & 26,378 & $\dot{0} . \overline{9} 2$ & 0.80 \\
\hline 1896. & & & & & & \\
\hline January ..... & $\ldots \ldots$ & $\ldots$ & $a 300$ & 18,446 & 0.66 & 0.57 \\
\hline Fobruary .......... & $\ldots \ldots$ & $\ldots \ldots$ & $a 300$ & 16,661 & 0.59 & 0.57 \\
\hline 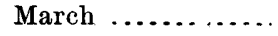 & 557 & 96 & 244 & 15,003 & 0.54 & 0.47 \\
\hline April . . . . . . . . . . & 1,578 & 144 & 747 & 44,450 & 1.60 & 1.43 \\
\hline 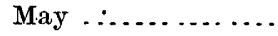 & 1,452 & 373 & 952 & 58,905 & 2.10 & 1.82 \\
\hline June ............. & 781 & 44 & 263 & 15,650 & 0.56 & 0.50 \\
\hline 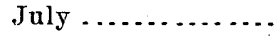 & 480 & 44 & 130 & 7,994 & 0.29 & 0.25 \\
\hline Angust $\ldots \ldots \ldots \ldots$ & 180 & 8 . & 38 & 2,337 & 0.08 & 0.07 \\
\hline Septenber ......... & 1,176 & 28 & 195 & 11,604 & 0.41 & 0.37 \\
\hline October . . . . . . . . & 180 & 96 & 113 & 6,948 & 0.25 & 0.22 \\
\hline Novernber ......... & 618 & 36 & 179 & 10,651 & 0.38 & 0.34 \\
\hline December ......... & $\cdots$ & $\cdots$ & $a 200$ & 12,298 & 0.44 & 0.38 \\
\hline The year.. & -- & $\ldots \ldots \ldots$ & 306 & 220,947 & 7.90 & 0.58 \\
\hline 1897. & & & & & & \\
\hline January .... & $\cdots$ & ........ & $a 200$ & 12,298 & 0.44 & 0.38 \\
\hline February ... & -. & $\cdots$ & $a 200$ & 11,107 & 0.40 & 0.38 \\
\hline March .... & $\ldots \ldots$ & $\ldots \ldots$ & $a 200$ & 12,298 & 0.44 & 0.38 \\
\hline April.... & 2,944 & 235 & 1,483 & 88,244 & 3.15 & 2.83 \\
\hline May .......... & 2,838 & 1,991 & 2,436 & 149,785 & 537 & 4.65 \\
\hline 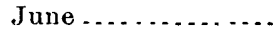 & 2,521 & 570 & 1,465 & 87,173 & 3.12 & 2.80 \\
\hline July ............. & 608 & 186 & 368 & 22,628 & 0.81 & 0.70 \\
\hline August...... & 235 & 76 & 148 & 9,100 & 0.32 & 0.28 \\
\hline September .. & 852 & 76 & 394 & 23,445 & 0.83 & 0.75 \\
\hline October . . . . . . & 570 & 235 & 391 & 24,042 & 0.86 & 0.75 \\
\hline November... & 235 & 108 & 172 & 10,235 & 0.37 & 0.33 \\
\hline December ...: & $\cdots$ & $\ldots \ldots$ & $a 120$ & $\therefore \quad 7,379$ & 0.26 & 0.23 \\
\hline The year ...... & $\because \cdots$ & $\cdots$ & 631 & $4 \quad 457,734$ & $16.37^{\circ}$ & 1.20 \\
\hline
\end{tabular}

a Approximate. 
Estimated monthly discharge of Dolores River at Dolores, Colorado-Continued.

[Drainage area, 524 square miles.]

\begin{tabular}{|c|c|c|c|c|c|c|}
\hline \multirow{2}{*}{ Month. } & \multicolumn{3}{|c|}{ Discharge in second-feet. } & \multirow[b]{2}{*}{$\begin{array}{l}\text { Total in acre. } \\
\text { feet. }\end{array}$} & \multicolumn{2}{|c|}{ Run-off. } \\
\hline & $\begin{array}{l}\text { Maxi- } \\
\text { mum. }\end{array}$ & $\begin{array}{l}\text { Mini- } \\
\text { mum. }\end{array}$ & Mean. & & $\begin{array}{l}\text { Depth in } \\
\text { inches. }\end{array}$ & $\begin{array}{l}\text { Second- } \\
\text { feet per } \\
\text { square } \\
\text { mile. }\end{array}$ \\
\hline 1898. & & & & & & \\
\hline January.... & $\ldots \ldots$ & $\ldots$ & $a 150$ & 9,223 & 0.33 & 0.29 \\
\hline February.... & $\ldots \ldots$ & ... & $a 150$ & 8,331 & 0.30 & 0.29 \\
\hline March...... & ........ & $\ldots$ & $\alpha 200$ & 12,298 & 0.44 & 0.38 \\
\hline April....... & 1,978 & 198 & 1,092 & 64,978 & 2.32 & 2.08 \\
\hline May ........ & 1,874 & 912 & 1,207 & 74,215 & 2.66 & 2.30 \\
\hline June ....... & 2,030 & 784 & 1,510 & 89,851 & 3.21 & 2.88 \\
\hline July .............. & 1,229 & 144 & 490 & 30,129 & 1.08 & 0.94 \\
\hline August....... & 228 & 102 & , 120 & 7,379 & 0.26 & 0.23 \\
\hline September ......... & 293 & 34 & 78 & 4,641 & 0.17 & 0.15 \\
\hline October ................ & 50 & 34 & 37 & 2,275 & 0.08 & 0.07 \\
\hline November.......... & 72 & 34 & 48 & 2,856 & 0.10 & 0.09 \\
\hline December .......... & -..... & 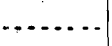 & $a 100$ & 6,149 & 0.22 & 0.19 \\
\hline The year & & & 432 & 312,325 & 11.17 & 0.82 \\
\hline
\end{tabular}

\footnotetext{
$a$ Approximate.
}

Note.-Gage heights for 1898 are given in Water-Supply and Irrigation Paper No. 28, page 138; measurements, page 142; rating table, page 144; results for 1897 in Water-Supply and Irrigation Paper No. 16, page 143, and in the Nineteenth Annual Report, Part IV, pages 407 to 409.

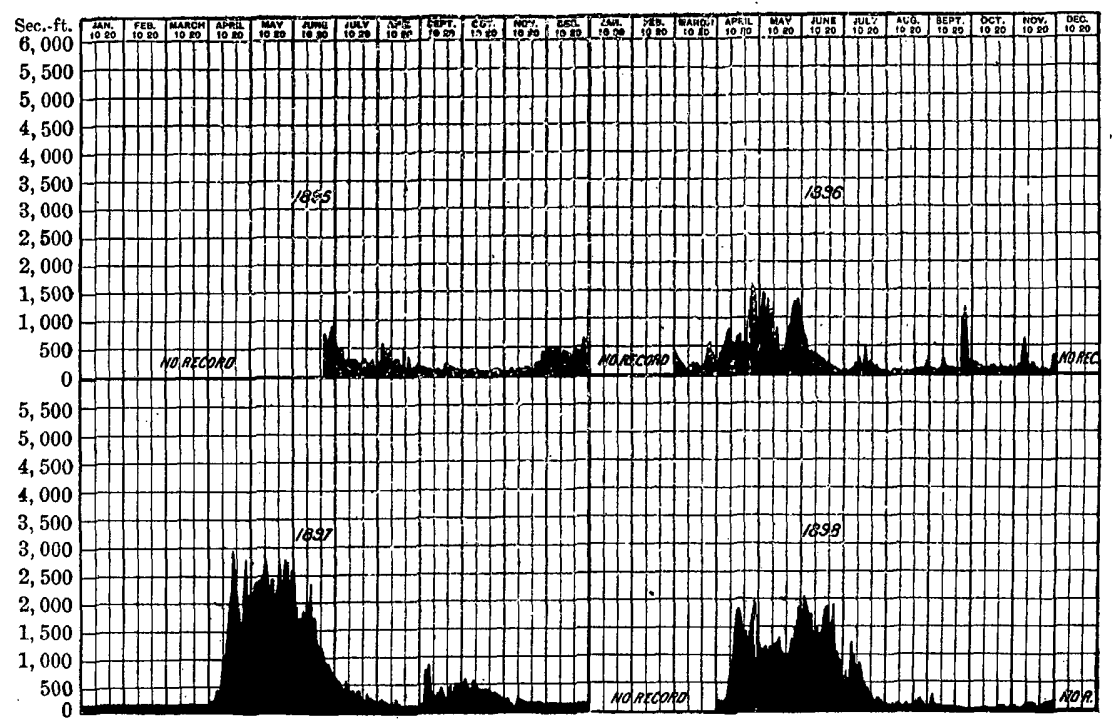

Fig. 146.-Discharge of Dolores River at Dolores, Colorado, 1895-98. 
SAN MIGUEL RIVER:

San Miguel River rises in the San Miguel Mountains and flows in a general northwesterly direction, emptying into the Dolores, of which it is the largest tributary. The river runs through an exceedingly mountainous country, and very little irrigation is practiced upon the stream, but the water is used very extensively for generating power for the various mining camps of that section.

The gaging station upon this stream has been maintained at Fall. creek, near Sawpit, shown in Pl. XLI, $B$ and is described in WaterSupply and Irrigation Paper No. 16, page 142, the observer being Mrs. H. H. Hart, whose post-office address is Sawpit, Colorado.

Estimated monthly discharge of San Miguel River at Fallcreek, Colorado.

[Drainage area, 327.square miles.]

\begin{tabular}{|c|c|c|c|c|c|c|}
\hline \multirow[b]{2}{*}{ Month. } & \multicolumn{3}{|c|}{ Discharge in second-feet. } & \multirow{2}{*}{$\begin{array}{c}\text { Total in acre- } \\
\text { feet. }\end{array}$} & \multicolumn{2}{|c|}{ Run-off: } \\
\hline & $\begin{array}{l}\text { Maxi- } \\
\text { mum. }\end{array}$ & $\begin{array}{l}\text { Mini. } \\
\text { mum. }\end{array}$ & Mean. & & $\begin{array}{l}\text { Depth in } \\
\text { inches. }\end{array}$ & $\begin{array}{l}\text { Second. } \\
\text { feet per } \\
\text { square } \\
\text { mile. }\end{array}$ \\
\hline 1898. & & & . & & & \\
\hline April 11-30......... & (....... & $|\ldots \ldots|$ & 272 & 16,185 & 0.92 & 0.83 \\
\hline 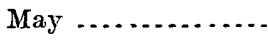 & 545 & 196 & . 296 & 18,200 & 1. 04 & 0.90 \\
\hline June.......... & 1,335 & 571 & 813 & 48,377 & 2.79 & 2.49 \\
\hline July $\ldots \ldots \ldots \ldots \ldots$ & 760 & 109 & 380 & 23,365 & 1.34 & 1.16 \\
\hline August..... & 183 & 109 & 133 & 8,178 & 0.47 & 0.41 \\
\hline September...... & 121 & 66 & 89 & 5,296 & 0.30 & 0.27 \\
\hline October...... & 66 & 30 & 50 & 3,074 & 0.17 & 0.15 \\
\hline November.......... & 66 & 22 & 40 & 2,380 & 0.13 & 0.12 \\
\hline
\end{tabular}

NoTe.-Gage heights for 1898 are given in Water-Supply and Irrigation Paper No. 28, page 137; measurements, page 142; rating table, page 144. Results for 1897 in Water-Supply and Irrigation Paper No.16, page 142, and in the Nineteenth Annual Report, Part IV, pages 406 to 407.

Observations at this point were begun in June, 1895, the results for that year being given in Bulletin No. 140, on page 193. The station has been maintained, figures for 1896 being given in the Eighteenth Annual Report, Part IV, on page 264, and for 1897 in the Nineteenth Annual Report, Part IV, on page 406. The above table and the following diagram (fig. 147) give similar results for 1898. 


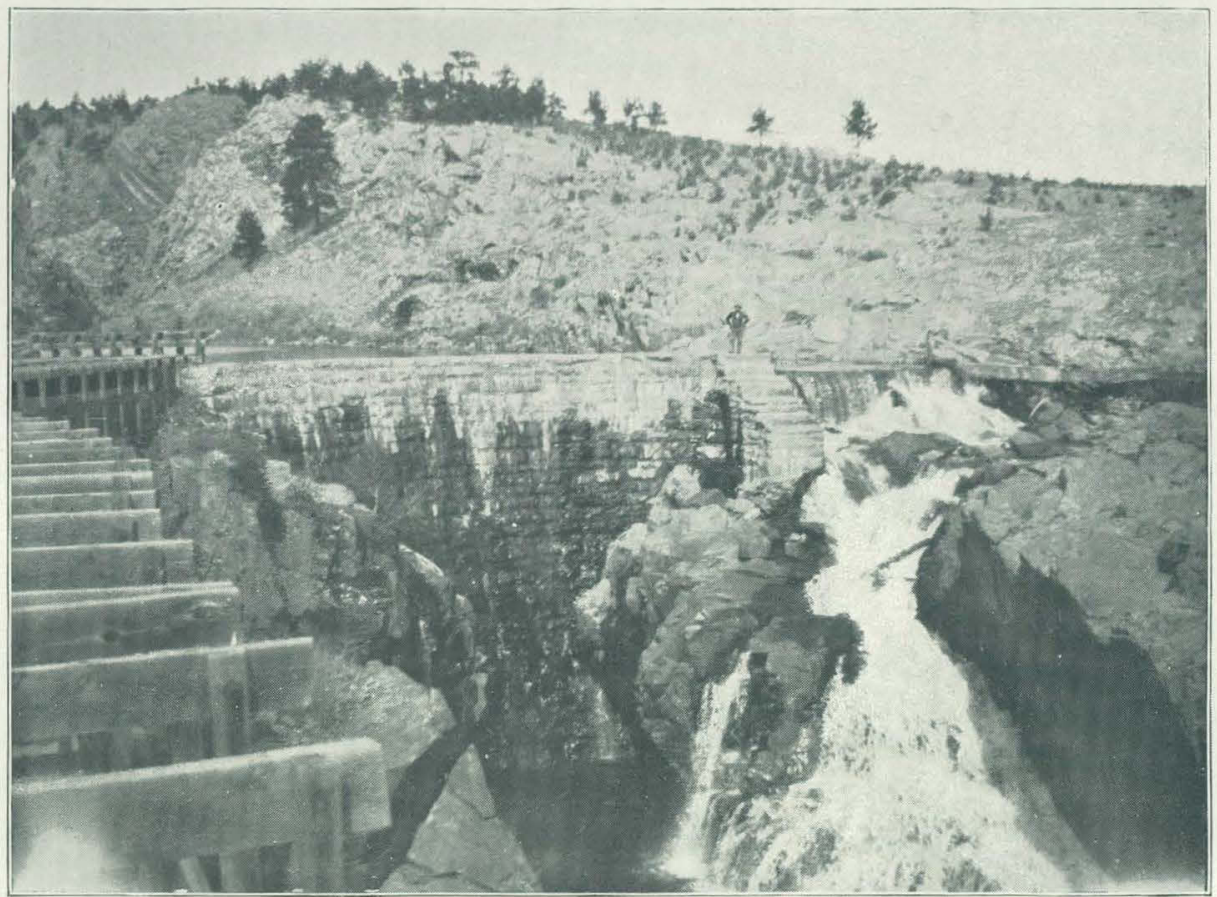

A. HOME SUPPLY DAM, NEAR ARKINS, COLORADO

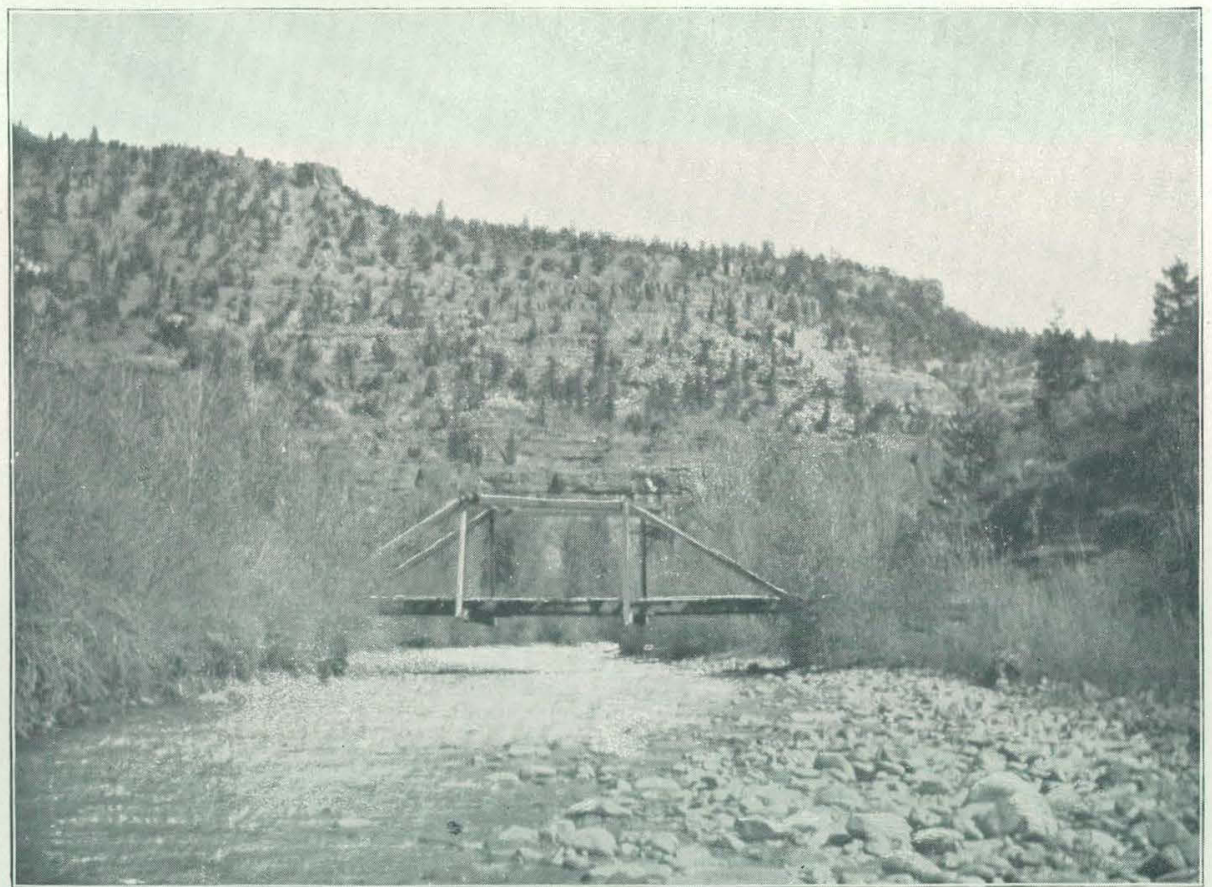

B. GAGING STATION ON SAN MIGUEL RIVER, FALLCREEK, COLORADO 


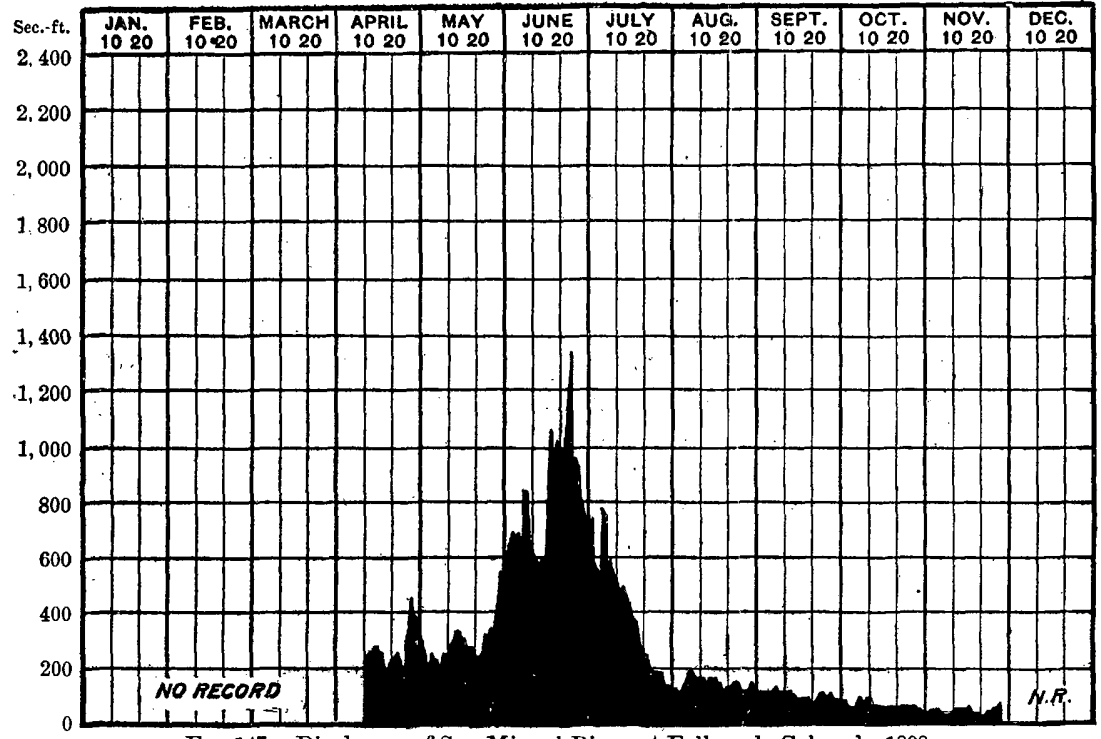

Fia.147.-Discharge of San Miguel River at Fallereek, Colorado, 1898

VARIATIONS IN PRECIPITATION IN SOUTHWESTERN COLORADO.

In order to discuss the fluctuations of discharge of various rivers in southwestern Colorado, particularly Dolores, Mr. Gerard H. Matthes has brought together the precipitation data for ten stations where the rainfall records are most complete. By an examination of these it appears that for the years 1895 to 1898 , inclusive, there are apparently no abnormal conditions. The following tables give for each locality the normal or average by months for the entire period during which observations have been made, and also the monthly and annual rainfall since 1895:

Normal and monthly precipitation at points in southwestern Colorado.

BRECKENRIDGE, SUMMIT COUNTY, COLORADO, ELEVATION 9,524 FEET.

\begin{tabular}{|c|c|c|c|c|c|c|c|c|c|c|c|c|c|}
\hline Year. - & Jan. & Feb. & Mar. & Apr. & May. & June. & J aly. & Aug. & Sept. & Oct. & Nov. & Dec. & Annual. \\
\hline Normal ...... & 192 & 3.88 & 3.60 & 3. 33 & 2.61 & 0.94 & 2.79 & 2.02 & J.. 20 & 1.47 & 3.00 & 3.10 & 29.86 \\
\hline 1895. & 3. 29 & 2. 31 & 237 & 1.88 & 4.39 & 1.81 & 2.43 & 3. 62 & 1.. 11 & 1.95 & 1.76 & 2.67 & 25.59 \\
\hline 1896. & 1.88 & 1.89 & 4.83 & 0.60 & 1.47 & 0.30 & 3.10 & 2.29 & 2.25 & 0.82 & 3.87 & 0.73 & 24.03 \\
\hline 1897. & 2.90 & 1.99 & 3. 53 & 4.00 & 1.54 & 1.53 & 1.70 & 2.27 & 1.16 & 1.02 & 0.60 & .2 .25 & 24.49 \\
\hline $1898 .$. & 0.29 & 0.59 & 1.16 & 1.53 & 0.46 & 1. 14 & 2.19 & 1.59 & 0.38 & 1.53 & 4. 09 & 1.34 & 16. 29 \\
\hline \multicolumn{14}{|c|}{ GUNNISON, GUNNISON } \\
\hline Normal & 0.95 & 0.80 & 0.61 & 0.88 & 0.52 & 0.31 & 1.36 & 0.99 & 0.47 & 0.49 & 1.22 & 0.46 & 9.06 \\
\hline $1895 \ldots$ & 2. 79 & 0.32 & 0.22 & 0.10 & 1.80 & 0.58 & 1.86 & 1,14 & 0.28 & 1.33 & 1.00 & 0.90 & 12.32 \\
\hline 1896. & 1.21 & 0.12 & 0.25 & 0.00 & 0.01 & 0.00 & 1.37 & 0.92 & 0.99 & $\mathrm{~T}$. & 0.90 & 0.50 & 6.27 \\
\hline $1897 \ldots .$. & 0.60 & 1.00 & 1.39 & & & & 2. 01 & 0.90 & 150 & 1.24 & $\ldots . . .$. & 0.30 & \\
\hline $1898 \ldots$ & 0.28 & 0.33 & & & & & 1.93 & 0.68 & 0.06 & 0.13 & 1.06 & 0.30 & \\
\hline
\end{tabular}


Normal and monthly precipitation at points in southwestern Colorado-Continued. RICO, DOLORES COUNTY, COLORADO; ELEVATION 8,737 FEET.

\begin{tabular}{|c|c|c|c|c|c|c|c|c|c|c|c|c|c|}
\hline Year. & Jan. & Feb. & Mar. & Apr. & May. & June. & July. & Aug. & Sept. & Oct. & Nov. & Dec. & Annua \\
\hline Nor & 2.78 & $4.25^{\circ}$ & 3,34 & 1. 21 & 2.09 & 0.68 & 2.58 & 2.27 & 2.55 & 1.08 & 1.03 & 2.58 & 26.44 \\
\hline 1895 & 7.20 & 3.63 & 1.81 & 0.33 & 1.76 & 1.58 & 2.97 & 3.60 & 1.33 & 0.20 & $\ldots$ & 2.75 & \\
\hline 1896 & 2.40 & 1.40 & 2.10 & 1.20 & 0.35 & 0.59 & 4.13 & 2.32 & 4.46 & 2.20 & 2.40 & 1.70 & 25.25 \\
\hline 1897. & 3.26 & 5.60 & 6.40 & 1.66 & 4.15 & 0.98 & 2.41 & $\ldots$. & 5.80 & 2.82 & $1.60^{\circ}$ & 2.02 & \\
\hline 1898. & 3.10 & 1.35 & 3.80 & 2.62 & 3.82 & 1.60 & 3.10 & 4.13 & 0.88 & 0.15 & 0.85 & & \\
\hline \multicolumn{14}{|c|}{ DURANGO, IA PLATA COUNTY, COLORADO, ELEVATION 6,534 FEET. } \\
\hline Nor & 1.67 & 1.95 & 1.33 & 1.44 & 1.12 & 0.54 & 2. 00 & 1.60 & 2.05 & 2.29 & 1. 19 & 2. 21 & 19.39 \\
\hline 1895. & 2.10 & 1. 38 & T. & $\mathrm{T}$ & 0.99 & 0.37 & 1.78 & 2.81 & 0.92 & 1.80 & 2.22 & 1.20 & \\
\hline 1896. & 0.50 & $\ldots$. & 0.53 & 0.55 & 0.05 & ;...... & 1.30 & 1.76 & 3.59 & $3.6 \hat{1}$ & 1.08 & 0.86 & \\
\hline $1897 .$. & 2.61 & 3.70 & 2. 72 & $0.45^{\circ}$ & 3. 22 & 0.40 & 1.38 & 0.93 & 3.55 & 3.89 & 0.09 & 1.99 & 24.93 \\
\hline 1898. & 2. 21 & 0.45 & 1.17 & 1.67 & 1.33 & 0.62 & 3.46 & 0.89 & 0.30 & 0.07 & 0.88 & 3.22 & 16. 27 \\
\hline \multicolumn{14}{|c|}{ DELTA, DELTA COUNTY, COLORADO. ELEVATION 4.980 FEET. } \\
\hline Norr & 0.60 & 0.86 & 0.81 & 0.32 & 0.39 & 0.23 & 1.10 & 0.81 & 1.01 & 0.70 & 0.60 & 0.67 & 8. 10 \\
\hline $1895 \ldots$ & 1.15 & 0.04 & 0.23 & 0.20 & 0.03 & 0.66 & 1.16 & 0.97 & 0.65 & 0.43 & 1.55 & 0.00 & 7.07 \\
\hline $1896 \ldots$ & 0.65 & 0.60 & 0.02 & 0.00 & 0.18 & 0.00 & 1.50 & 0.79 & 2.13 & - $\ldots . .$. & - & 0.35 & $\ldots$. \\
\hline $1897 \ldots$ & 0.49 & 2.19 & 1.50 & 0.05 & 0.65 & 0.76 & 0.90 & 0.46 & 2.47 & 1.75 & 0.40 & 0.25 & 11.87 \\
\hline $1898 \ldots$ & 0.28 & 0.10 & 0.21 & 0.58 & 0.83 & 0.40 & 0.95 & 0.51 & 0.55 & 0.05 & 0.18 & 0.08 & 4.72 \\
\hline
\end{tabular}

GRAND JUNCTION, MESA COUNTY, COLORADO, ELEVATION 4,594 FEET.

\begin{tabular}{|c|c|c|c|c|c|c|c|c|c|c|c|c|c|}
\hline \multirow[b]{2}{*}{ Normal ...... } & & & & & & & & & \multirow[b]{2}{*}{0.97} & & \multirow{2}{*}{8.63} \\
\hline & 0.63 & 0.61 & 0.86 & 0.72 & 0.65 & 0.16 & 0.80 & 1.10 & 1.03 & & 0.67 & 0.43 & \\
\hline $1895 \ldots$ & 1.24 & 0.80 & 0.62 & 0.14 & 0.35 & 0.37 & 1.43 & 2.24 & 0.25 & 0.92 & 2. 39 & 0.10 & 10.85 \\
\hline 1896. & 0.37 & 0.05 & 0.27 & 0.18 & 0.51 & 0.01 & 0.43 & 1.01 & 3.78 & 0.79 & 0.49 & 0.33 & 8.22 \\
\hline $1897 .$. & 1.00 & 0.80 & 1.05 & 1.12 & 0.62 & 0.40 & 0.98 & 1.05 & 1.53 & 1.82 & 0.33 & 0.40 & 11.10 \\
\hline 1898. & 0.55 & $\mathrm{~T}$. & 1.05 & 0.92 & 1.40 & 0.05 & $\mathbf{T}$ & 0.57 & 0.10 & 0.25 & 0.25 & 0.31 & 5.45 \\
\hline
\end{tabular}

MONTROSE, MONTROSE COUNTY, COLORADO, ELEVATION 5,811 FEET.

\begin{tabular}{|c|c|c|c|c|c|c|c|c|c|c|c|c|c|}
\hline Normal & 0.69 & 0.83 & 0.90 & 1.13 & 0.69 & 0.20 & 0.96 & 1. 21 & 1.06 & 0.80 & 0.63 & 0.74 & \\
\hline 1896. & 0.84 & 0.60 & 0.34 & 0.36 & 0.13 & 0.18 & 0.48 & 0.37 & 1.66 & 0.68 & 0.38 & 0.45 & \\
\hline 1897. & 0.62 & 2.14 & 3.41 & 0.97 & 1.50 & 0.43 & 1.89 & 0.35 & 2.45 & 1. 11 & & & \\
\hline
\end{tabular}

PARACHUTE, GARFIELD COUNTY, COLORADO, ELEVATION 5,105 FEET.

\begin{tabular}{|c|c|c|c|c|c|c|c|c|c|c|c|c|c|}
\hline Normal ....... & 0.78 & 0.72 & 1.21 & 0.88 & 0.76 & 0.38 & 0.81 & 0.83 & 1.30 & 0.78 & 0.76 & 0.95 & 10.16 \\
\hline 1895 . & 1.65 & 0.20 & 1.40 & 0.75 & 0.31 & 0.57 & 1.58 & 0.45 & 0.89 & 0.71 & 2.28 & 0.55 & 11.34 \\
\hline 1896. & 0.38 & 0.04 & $\ldots$ & 0.13 & 0.21 & 0.70 & $\cdots$ & 1. 27 & 4. 12 & 0.65 & 0.86 & 1.20 & \\
\hline 1897. & 1.52 & 1. 82 & 0.67 & 3.98 & 0.66 & 1.05 & 0.80 & 1.52 & 2.55 & 0.57 & 0.20 & $\cdots$ & \\
\hline 1898. & 0.26 & 0.00 & 0.85 & & & & 0.42 & 1.09 & 0.23 & 0.98 & 0.70 & 0.70 & $\therefore$ \\
\hline
\end{tabular}

SURFACE CREEK, DELTA COUNTY, COLORADO, ELEVATION 6,175 FEET.

\begin{tabular}{|c|c|c|c|c|c|c|c|c|c|c|c|c|c|}
\hline Normal ....... & 1.09 & 1.46 & 1.47 & 0.60 & 0.99 & 0.46 & 0.97 & 1.22 & 1.46 & 0.81 & 0.56 & 1. 06 & 12.15 \\
\hline 1895. & 2.90 & 1.10 & 0.80 & $\mathrm{~T}$. & 0.45 & 1.33 & 1. 28 & 2. 12 & 1.27 & 1.45 & 1.93 & 0.55 & 15.18 \\
\hline $1896 \ldots$ & 1. 12 & 1.00 & 0.68 & 0.05 & 0.70 & 0.16 & 0.80 & 0.93 & 2.99 & 0.44 & 0.16 & 0.30 & 9. 33 \\
\hline 1897. & 0.95 & 1.70 & 2.10 & 1.23 & 1.23 & 1.01 & 0.82 & 0.50 & 2.25 & 1.79 & 0.45 & 1.02 & 15.05 \\
\hline $1898 \ldots$ & 0.57 & 0.50 & 1. 06 & 1.10 & 2.79 & 0.33 & 1.27 & 0.62 & 0.37 & 0.20 & 0.43 & 0.24 & 9,48 \\
\hline
\end{tabular}


Normal and monthly precipitation at points in southwestern Colorado-Continued.

T. S. RANCH, (a) MESA COUNTY, COLORADO, ELEVATION 5,200 FEET.

\begin{tabular}{|c|c|c|c|c|c|c|c|c|c|c|c|c|c|}
\hline Year. & Jan. & Feb. & Mar. & Apr. & May. & June & July. & Aug. & Sept. & Oct. & Nov. & Dec. & Annual. \\
\hline Normal & 0.83 & 0.75 & 1. 22 & 0.64 & 0.92 & 0.23 & 1.02 & 1. 34 & 1. 41 & 1.12 & 0.63 & 0.79 & 10.90 \\
\hline $1895 \ldots$ & 1.50 & 0.83 & 0.60 & 0.20 & 0.51 & 0.81 & 1.73 & 1.40 & 1.00 & 1.20 & 1.35 & 0.45 & 11.38 \\
\hline 1896. & 0.50 & 0.21 & 0.07 & 0.07 & 0.39 & 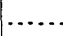 & 0.85 & 0.45 & 5.14 & 0.80 & 0.40 & 0.57 & * \\
\hline $1897 \ldots$ & 1. 32 & 1.45 & 1.88 & 1.15 & 0.55 & 0.28 & 1. 73 & 0.94 & 1.87 & 1.88 & 0.86 & 0.54 & 14.45 \\
\hline 1898. & 0.51 & 0.07 & 1.30 & 0.65 & 2.20 & 0.15 & 0.49 & 1.29 & 0.12 & 0.58 & 0.40 & 0.61 & 8. 37 \\
\hline
\end{tabular}

a Nine miles from Whitewater post-office.

From the above tables there have been computed departures from the normal rainfall at these ten stations. by months. These are given in the following tables, the excess or deficiency for each month being indicated by a plus or minus sign. The mean values for each year indicate whether the precipitation during any one month or year was, as a whole, greater or less than the average. For example, February, March, April, September, and December, of 1895, were months of deficient rainfall, according to the averages for the ten stations, but the year as a whole had a precipitation slightly above the average. For the year. 1896 the precipitation was below the average up to September, excepting for the month of July, and the year as a whole showed a deficiency of over 2 inches. On the other hand, during 1897 there was nearly 4 inches more than during ordinary years, and for 1898 a deficiency of about the same amount:

Departures from normal rainfall at ten stations in southuestern Colorado for the years 1895, 1896, 1897, and 1898.

\begin{tabular}{|c|c|c|c|c|c|c|c|c|c|c|c|c|c|}
\hline Station & Jan. & Feb. & Mar. & Apr. & May. & June. & July. & Aug. & Sept. & Oct. & Nov. & Dec. & Year. \\
\hline 1895 & & & & & & & & & & & & & \\
\hline Breckenridge & +1.37 & -1.57 & -1.23 & -1.45 & +1.78 & +0.87 & -0.36 & +1.60 & -0.09 & +0.48 & -1.24 & -0.43 & -4.27 \\
\hline Gunnison ..... & +1.84 & -0.48 & -0.39 & -0.78 & +1.28 & +0.27 & +0.50 & +0.15 & -0.19 & +0.84 & -0.22 & +0.44 & +3.26 \\
\hline Durango ....... & +0.43 & -0.57 & -1.33 & -1.44 & -0.13 & $\mid-0.17$ & -0.22 & +1.21 & -1.13 & -0.49 & +1.03 & -1.01 & $\ldots \ldots$ \\
\hline Rico........... & +4.42 & -0.62 & -1.53 & -0.88 & -0.33 & +0.90 & +0.39 & +1.33 & -1.22 & -0.88 & $\ldots$ & +0.17 & $\ldots$ \\
\hline Delta... & +0.55 & -0.82 & -0.58 & -0.12 & -0.36 & +0.43 & +0.06 & +0.16 & -0.36 & -0.27 & +0.95 & -0.67 & -1.03 \\
\hline Grand Junction & +0.61 & +0.19 & -0.24 & -0.58 & -0.30 & +0.19 & +0.63 & +1.3 .4 & -0.78 & -0.05 & +1.72 & -0.33 & +2.22 \\
\hline Montrose a... & $\cdots$ & & ….... & & & …... & & & 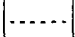 & & & & \\
\hline Parachute..... & +087 & -0.52 & +0.19 & -0.13 & -0.45 & +0.19 & +0.77 & -0.38 & -0.41 & -0.07 & +1.42 & -0.40 & +1.18 \\
\hline Surface Creek & +1.81 & $\begin{array}{ll}-0 & 36\end{array}$ & $6-0.67$ & -0.60 & $-\begin{array}{lll}-0 & 54\end{array}$ & +0.87 & +0.31 & +0.90 & -0.19 & +0.64 & +1.37 & -0.51 & +3.03 \\
\hline T.S. Ranch.. & +0.67 & +0.08 & -0.62 & $2-0.44$ & -0.41 & +0.58 & +0.71 & +0.06 & -0.41 & +0.08 & +0.72 & -0.34 & +0.48 \\
\hline Mean & +1.40 & -0.52 & -0.71 & $1-0.71$ & +0.06 & +0.46 & +0.31 & +0.69 & -0.53 & +0.03 & +0.72 & -0.34 & +0.86 \\
\hline 1896 & & & & & & & & & & & & & \\
\hline Breckenridge & -0.04 & -1.99 & +1.23 & -2.73 & -1.14 & -0.64 & +0.31 & +0.27 & +1.05 & -0.65 & +0.87 & -2.37 & -5.83 \\
\hline Gunnison & +0.26 & -0.68 & -0.36 & -0.88 & -0.51 & -0.31 & +0.01 & -0.07 & +0.52 & -0.49 & -0.32 & +0.04 & -2.79 \\
\hline Durango. & -1.17 & $\cdots$ & -0.80 & -0.89 & -1.07 & $\ldots \ldots$ & -0.70 & +0.16 & +1.54 & +1.32 & -0.11 & -1.35 & \\
\hline Rico .... & -0.38 & -2.85 & -1.24 & -0.01 & -1.74 & -0.09 & +1.55 & +0.05 & +1.91 & +1.12 & +1.37 & -0.88 & -1.19 \\
\hline Delta.. & +0.05 & -0.26 & -0.79 & -0.32 & -0.21 & -0.23 & +0.40 & -0.02 & +1.12 & ....... & $\cdots$ & -0.32 & \\
\hline Grand Ju & -0.26 & -0.56 & -0.59 & -0.54 & -0.14 & -0.15 & -0.37 & -0.09 & +2.75 & -0.18 & -0.18 & -0.10 & -0.41 \\
\hline
\end{tabular}


Departures from normal rainfall at ten stations in southwestern Colorado for the years $1895,1896,189 \%$, and 1898-Continued.

\begin{tabular}{|c|c|c|c|c|c|c|c|c|c|c|c|c|c|}
\hline Station. & Jan. & Feb. & Mar. & Apr. & May. & June. & July. & Aug. & pt. & Oct. & Nov. & Dec. & Year. \\
\hline 1896. & & & & & & 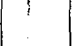 & & & & & & & \\
\hline Montrose & +0.15 & $-0: 23$ & -0.56 & -0.77 & -0.56 & -0.02 & -0.48 & -0.84 & +0.60 & -0.12 & -0.25 & -0.29 & -3.37 \\
\hline Parachute & -0.40 & -0.68 & $\ldots$ & -0.75 & -0.55 & +0.32 & & +0.44 & +2.82 & -0.13 & +0.10 & +0.25 & \\
\hline Surface Creek & +0.03 & -0.46 & -0.79 & -0.55 & -0.29 & -0.30 & -0.17 & -0.29 & +1.53 & $-0,37$ & -0.40 & -0.76 & -2.82 \\
\hline T.S. Rancl & -0.33 & -0.54 & -1.15 & -0.57 & -0.53 & $\ldots . .$. & -0.17 & -0.89 & +3.73 & -0.32 & -0.23 & -0.22 & $\ldots$ \\
\hline Mean & -0.21 & -0.92 & -0.56 & -0.80 & -0.67 & -0.18 & +0.04 & -0.13 & +1.76 & +0.02 & +0.09 & -0.60 & -2.16 \\
\hline 1897 & & & & & & & & & & & & & \\
\hline Breckenridge & +0.98 & -1.89 & -0.07 & +0.67 & -1.07 & -0.59 & -1.09 & +0.25 & -0.04 & -0.45 & -2.40 & -0.85 & -5.37 \\
\hline Gunnison & -0.35 & +0.20 & +0.78 & & & & +0.65 & -0.09 & +1.03 & +0.75 & & -0.16 & . \\
\hline Durango & +0.94 & +1.75 & +1.39 & -0.99 & +2.10 & -0.14 & -0.62 & -0.67 & +1.50 & +1.60 & -1.10 & -0.22 & +5.54 \\
\hline Rico...... & +0.48 & +1.35 & +3.06 & +0.45 & +2.06 & +0.30 & -0.17 & & +3.25 & +1.74 & +0.57 & -0.56 & $\ldots$ \\
\hline Delta. & -0.11 & +1.33 & +0.69 & -0.27 & +0.26 & +0.53 & -0.20 & -0.35 & +1.46 & +1.05 & --0.20 & -0.42 & +3.77 \\
\hline Grand Junction & -0.37 & +0.19 & +0.19 & +0.40 & -0.03 & +0.24 & +0.18 & -0.05 & +0.50 & +0.85 & -0.34 & -0.03 & +2.47 \\
\hline Montrose. & -0.07 & +1.31 & +2.51 & -0.16 & +0.81 & +0.23 & +0.93 & -0.86 & +1.39 & +0.31 & $\ldots \ldots$ & & \\
\hline Parachute. & +0.74 & +1.10 & -0.54 & +3.10 & -0.10 & +0.67 & -0.01 & +0.69 & +1.25 & -0.21 & -0.56 & $\ldots$ & \\
\hline Surface $\mathrm{Cr}$ & -0.14 & +0.24 & +0.63 & +0.63 & +0.24 & +0.55 & -0.15 & -0.72 & +0.79 & +0.98 & -0.11 & -0.04 & +2.90 \\
\hline T. S. Ranc & +0.49 & +0.70 & +0.66 & +0.51 & -0.37 & +0.05 & +0.71 & -0.40 & +0.46 & +0.76 & +0.23 & -0.25 & +3.55 \\
\hline Mear & +0.26 & +0.63 & +0.93 & +0.48 & $+0,43$ & +0.20 & +0.02 & -0.24 & +1.16 & +0.74 & -0.49 & -0.32 & +3.80 \\
\hline 1898. & & & & & & & & & & & & & \\
\hline Breckenrid & -1.63 & -3.29 & -2.44 & -1.80 & -2.15 & +0.20 & -0.60 & -0.43 & -0.82 & +0.06 & +1.09 & -1.76 & -13.57 \\
\hline Gunnison & -0.67 & -0.47 & $\ldots$ & & & & +0.57 & -0.31 & -0.41 & -0.36 & -0.16 & -0.16 & $\ldots \ldots$ \\
\hline Durango & +0.54 & -1.50 & -0.16 & +0.23 & +0.21 & +0.08 & +1.46 & -0.71 & -1.75 & -2.22 & -0.31 & +1.01 & -3.12 \\
\hline Rico. & +0.32 & -2.90 & +0.46 & +1.41 & +1.73 & +0.92 & +0.52 & +1.86 & -1.67 & -0.93 & -0.18 & $\ldots . . .$. & ... \\
\hline Delta & -0.32 & -0.76 & -0.60 & +0.26 & +0.44 & +0.17 & -0.15 & -0.30 & -0.46 & -0.65 & -0.42 & -0.59 & -3.38 \\
\hline Grand Junction & -0.08 & -0.61 & +0.19 & +0.20 & +0.75 & -0.11 & -0.80 & -0.53 & -0.93 & -0.72 & -0.42 & -0.12 & -3.18 \\
\hline Montros & & & & & & & & 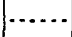 & & & & & \\
\hline Parachute & -0.52 & -0.72 & -0.36 & 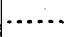 & $\cdots$ & $\cdots$ & -0.39 & +0.26 & -1.07 & +0.20 & -0.06 & -0.25 & $\cdots$ \\
\hline Surface Cre & -0.52 & -0.96 & -0.41 & +0.50 & +1.80 & -0.13 & +0.30 & -0.60 & -1.09 & -0.61 & -0.13 & -0.82 & -2.67 \\
\hline T. S. Ranch. & -0.32 & -0.68 & +0.08 & +0.01 & +1.28 & -0.08 & -0.53 & -0.05 & -1.29 & -0.54 & -0.23 & -0.18 & -2.53 \\
\hline Mes & $\mid-0.46$ & -1.32 & -0.40 & +0 & +0.58 & +0.15 & +0.04 & -0.09 & -1.05 & -0.64 & -0.09 & -0.36 & -3.52 \\
\hline
\end{tabular}

The above tables indicate that none of the four years were abnor. mally dry nor wet, so far as the rainfall data were concerned. These facts are corroborated by the following diagram, fig. 148, showing graphically the rainfall during the period from 1880 to 1898 , as observed at Santa Fe, New Mexico, Fort Wingate, New Mexico, and Salt Lake City, Utah. These stations have been selected because of the fact that they are the nearest stations giving a long record. An inspection of the records of the flow of various rivers, such as the Arkansas at Canyon City, Colorado; the Rio Grande at Embudo, New Mexico, and at Del Norte, Colorado, bear out the same conclusions, namely: That the years 1895 to 1898 , inclusive, were not notably different from those of the preceding decade. These facts are of importance in consideration of the available water supply of Dolores River in the development of storage projects. 


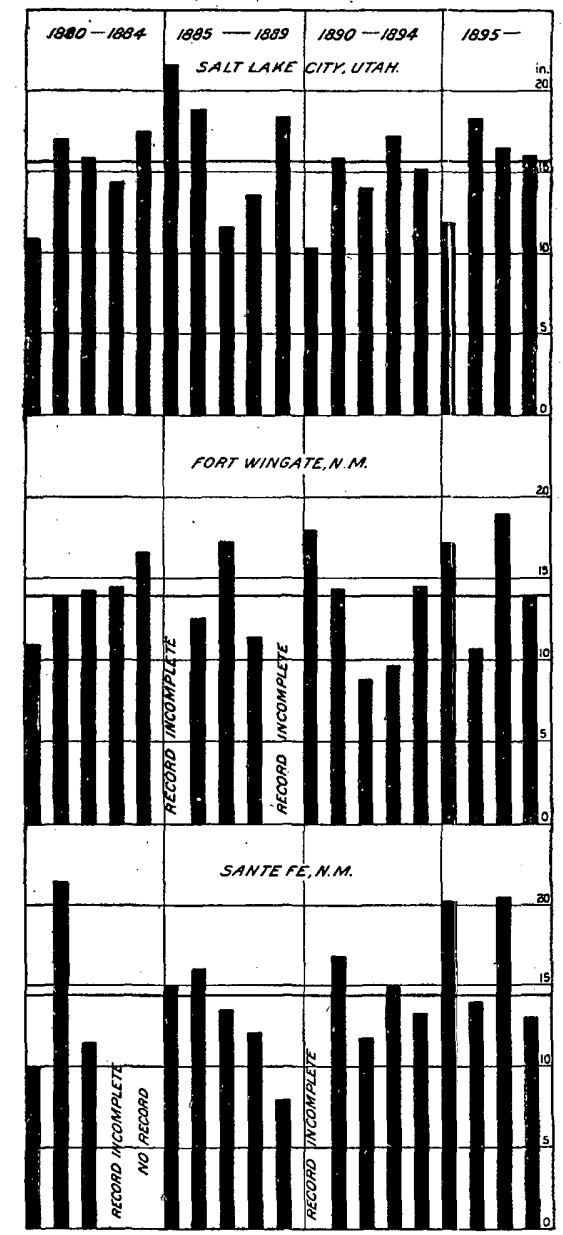

Fir. 148.-Comparison of annual rainfall at Santa Fe, New Mexico, Fort Wingate, New Mexico, and Salt Lake City, Utah.

\section{SAN JUAN RIVER.}

The San Juan River with its tributaries forms another very important branch of the Colorado. The main stream and its tributaries have their rise in the mountains of southwestern Colorado, northwestern New Mexico, northeastern Arizona, and southeastern Utah, the main stream flowing within a very short distance of the corner common to these four States and Territories. The principal tributaries of the San Juan before it' reaches the southwestern corner of Colorado are the Navajo, the Piedra, the Los Pinos, the Florida, the Animas, the La Plata, and the Mancos. All of these tributaries, as well as the main stream, drain parts of the Ute Indian Reservation in southwestern Colorado. They flow generally through comparatively narrow valleys, with irrigable mesas lying adjacent after they leave the mountains. 
Gaging stations were maintained in 1898 upon the San Juan and Piedra at Arboles, as shown in Pl. XLII, $A$ and $B$. the Animas at Durango, and the Mancos at Mancos.

Estimated monthly discharge of San Juan Rirer at Arboles, Colorado.

[Drainage area, 1320 squate miles.]

\begin{tabular}{|c|c|c|c|c|c|c|}
\hline \multirow[b]{2}{*}{ Month. } & \multicolumn{3}{|c|}{ Discharge in second feet. } & \multirow[b]{2}{*}{$\begin{array}{l}\text { Total in acre- } \\
\text { feet. }\end{array}$} & \multicolumn{2}{|c|}{ Run off. } \\
\hline & $\begin{array}{l}\text { Maxi. } \\
\text { mum }\end{array}$ & $\begin{array}{l}\text { Mini. } \\
\text { minu. }\end{array}$ & Mean. & & $\begin{array}{l}\text { Depth in } \\
\text { inches. }\end{array}$ & $\begin{array}{c}\text { Second. } \\
\text { feet per } \\
\text { square } \\
\text { mile. }\end{array}$ \\
\hline 1898. & & & & & & \\
\hline April...... & 2,954 & 241 & 1,488 & $88,5+2$ & 1.26 & 1. 13 \\
\hline May & 3,104 & 1,157 & $1,88 t$ & 115,843 & 1.65 & 1.43 \\
\hline June...... & 3,255 & 1,082 & 2,390 & 142,214 & 2.02 & 1.81 \\
\hline July ...... & 2,579 & 319 & 1,022 & 62,841 & 0.89 & 0.77 \\
\hline August... & 408 & 124 & $25 \overline{5}$ & 15,679 & 0.22 & 0.19 \\
\hline September & 216 & 83 & 123 & 7,319 & 0.10 & 0.09 \\
\hline October .............. & 216 & 83 & 99 & 6,087 & 0.08 & 0.07 \\
\hline November.......... & 83 & 83 & 83 & 4,939 & 0.07 & 0.06 \\
\hline
\end{tabular}

NOTE.-Gage heights for 2898 are given in Water-Supply and Irrigation Paper No. 28, page 138; measurements, page 142; rating table, page 145; results for 1897 in Water-Supply and Irrigation Paper No. 16, page 144, and in the Niveteenth Annual Report, Part IV, pages 409 to 410.

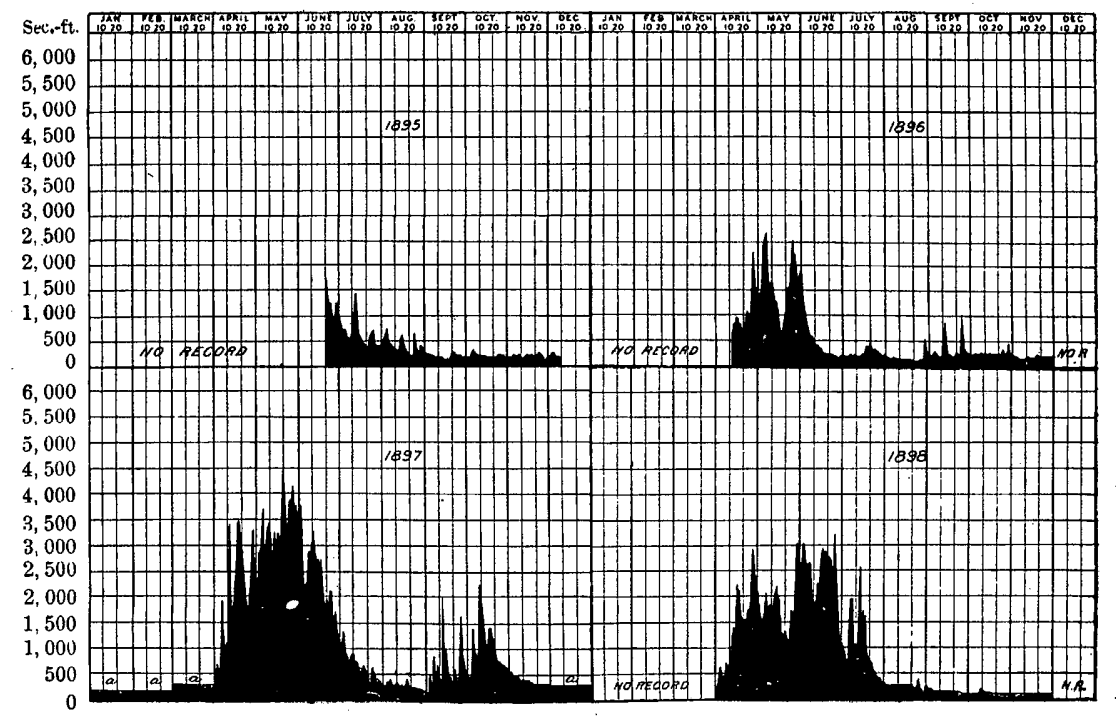

Fig. 149.-Discharge of San Juan River at Arboles, Colorado, 1895-98.

20 GEOL, PT $4-26$ 


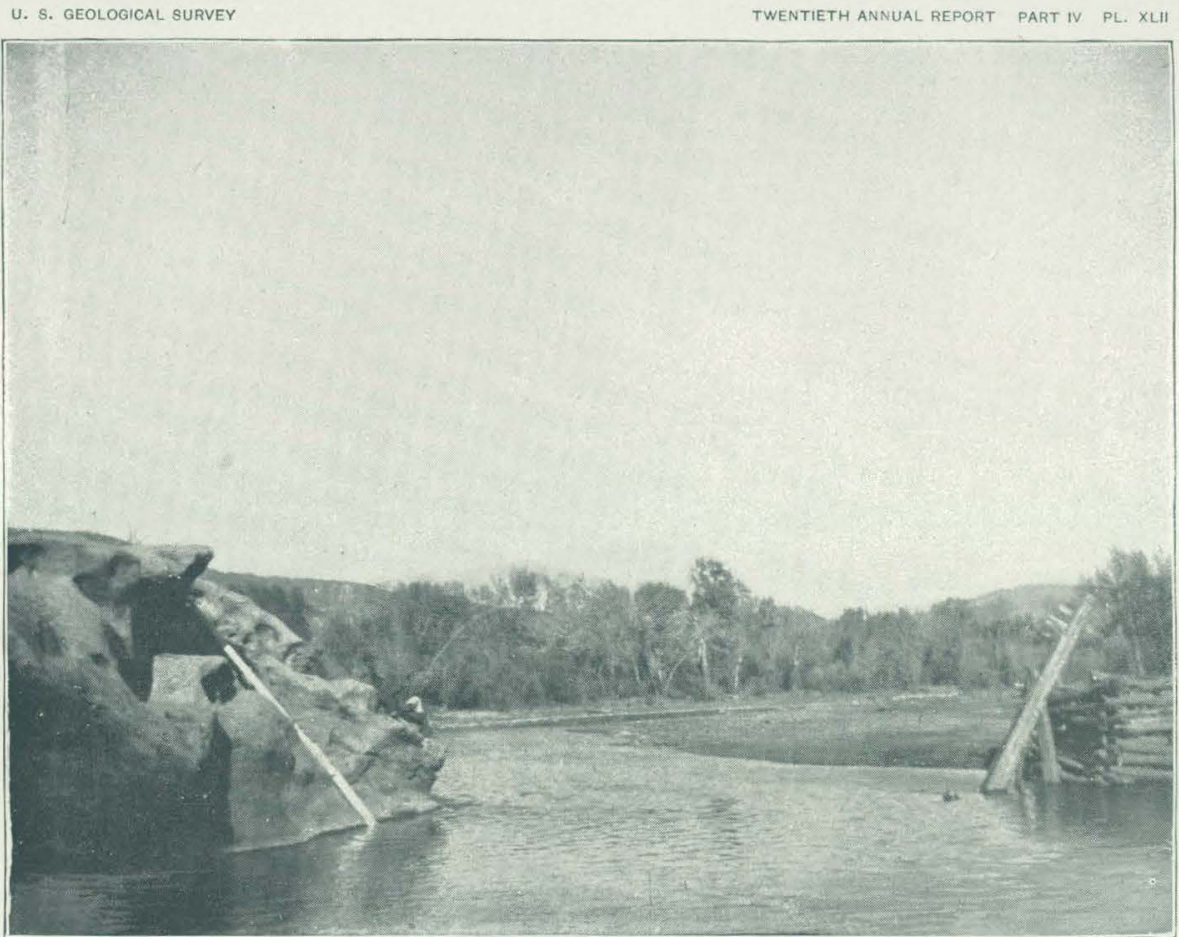

A. GAGING STATION ON SAN JUAN RIVER AT ARBOLES, COLORADO.

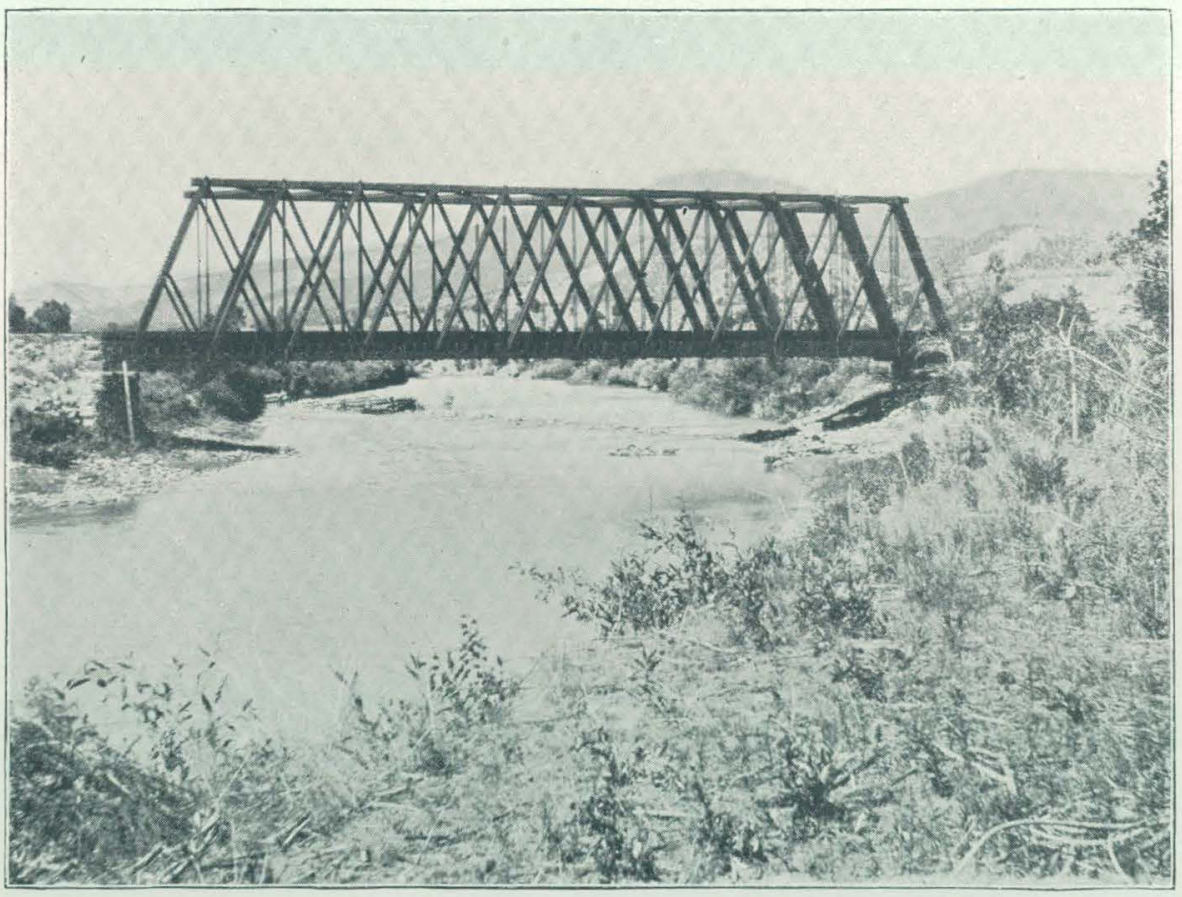

B. GAGING STATION ON PIEDRA RIVER AT ARBOLES, COLORADO. 
PIEDRA RIVER.

Estimated monthly discharge of Piedra River at Arboles, Colorado.

[Drainage area, 670 square miles.]

\begin{tabular}{|c|c|c|c|c|c|c|}
\hline \multirow[b]{2}{*}{ Month. } & \multicolumn{3}{|c|}{ Discharge in second-feet. } & \multirow[b]{2}{*}{$\begin{array}{l}\text { Total in acro- } \\
\text { feet. }\end{array}$} & \multicolumn{2}{|c|}{ Run-off. } \\
\hline & $\begin{array}{l}\text { Maxi- } \\
\text { mum. }\end{array}$ & $\begin{array}{l}\text { Mini- } \\
\text { mum. }\end{array}$ & Mean. & & $\begin{array}{l}\text { Depth in } \\
\text { inches. }\end{array}$ & $\begin{array}{c}\text { Second- } \\
\text { feet per } \\
\text { square } \\
\text { mile. }\end{array}$ \\
\hline 1898. & & & & & & \\
\hline 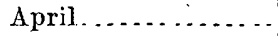 & 1,599 & 361 & 978 & 58,195 & 1. 63 & 1.46 \\
\hline May ..... & 1,564 & 614 & 966 & 59,397 & 1. 66 & 1. 44 \\
\hline June ............. & 1,564 & 614 & 1,211 & 72,059 & 2.02 & 1.81 \\
\hline July ..... & 1,390 & 229 & 585 & 35,970 & 1.00 & 0.87 \\
\hline August............... & 246 & 106 & 149 & 9,162 & 0.25 & 0.22 \\
\hline September ......... & 165 & 52 & 89 & 5,296 & 0.14 & 0.13 \\
\hline October . . . . . . . . & 165 & 52 & 70 & 4,304 & 0.12 & 0.10 \\
\hline November.......... & 52 & 27 . & 37 & 2,202 & 0.07 & 0.06 \\
\hline
\end{tabular}

NoтE.-Gage heights for 1898 are given in Water-Supply and Irrigation Paper No. 28, page 139; measurements, page 142; rating table, page 145; results for 1897 in Water-Supply and Irrigation Paper No. 16, page 145, and in the Nineteentb Annual Report, Part IV, pages 411 to 413.

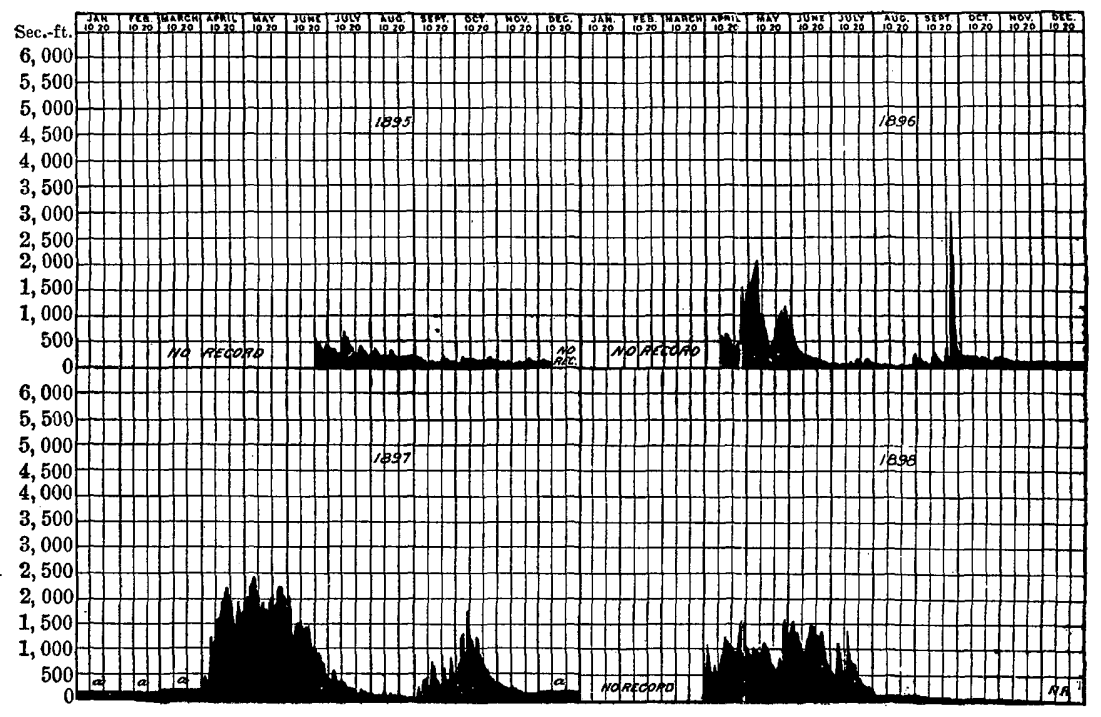

FIG. 150.-Discharge of Piedra River at Arboles, Colorado, 1895-98. 
ANIMAS RIVER.

Estimated monthly discharge of Animas River at Durango, Colorado.

[Drainage area, 812 square miles.]

\begin{tabular}{|c|c|c|c|c|c|c|}
\hline \multirow[b]{2}{*}{ Month. } & \multicolumn{3}{|c|}{ Discbarge in second-feet. } & \multirow[b]{2}{*}{$\begin{array}{c}\text { Total in acre- } \\
\text { feet. }\end{array}$} & \multicolumn{2}{|c|}{ Run-off. } \\
\hline & $\begin{array}{l}\text { Maxi. } \\
\text { mum. }\end{array}$ & $\begin{array}{l}\text { Mini- } \\
\text { mum. }\end{array}$ & Mean. & & $\begin{array}{l}\text { Depth in } \\
\text { inches. }\end{array}$ & $\begin{array}{l}\text { Second- } \\
\text { feet per } \\
\text { square } \\
\text { mile. }\end{array}$ \\
\hline 1898. & & & & & & \\
\hline January........... & $\ldots \ldots$ & $\ldots \ldots$ & $a 378$ & $a 23,242$ & $a 0.54$ & $a 0.47$ \\
\hline February .......... & $\ldots . .$. & $\ldots \ldots$ & $a 267$ & a 14,828 & $a 0.34$ & $a 0.33$ \\
\hline March........ & $\ldots \ldots$ & ....... & $a 306$ & $a 18,816$ & $a 0.44$ & $a 0.38$ \\
\hline April ............ & 2,910 & 412 & 1,510 & 89,851 & 2.08 & 1.86 \\
\hline May ........... & 3,664 & 1,255 & 1,765 & 108,526 & 2.50 & 2.17 \\
\hline June .......... & 4,677 & 2,125 & 3,431 & 204,158 & 4.72 & 4.23 \\
\hline July ....... & 3,220 & 502. & 1,364 & 83,870 & 1.94 & 1.68 \\
\hline August........... & . 502 & 303 & 364 & 22,382 & 0.52 & 0.45 \\
\hline September .... & 442 & 160 & 263 & 15,650 & 0.36 & 0.32 \\
\hline October..... & 177 & 160 & 161 & 9,900 & 0.23 & 0.20 \\
\hline November ...... & 214 & 125 & 158 & $9,4.02$ & 0.22 & 0.20 \\
\hline December .... & $\ldots \ldots$ & $\ldots \ldots$ & a 250 & $a 15,372$ & $a 0.36$ & $a 0.31$ \\
\hline The year ..... & $\ldots \ldots$ & $\ldots \ldots$ & 851 & 615,997 & 14.25 & 1.05 \\
\hline
\end{tabular}

\section{a Approximate.}

Nore.-Gage heights for 1898 are given in Water-Supply and Irrigation Paper No. 28, page 139; measúrements, page 142; rating table, page 145; results for 1897 in Water-Supply and Irrigation Paper No. 16, page 146, and in the Nineteenth Annual Report, Part IV, pages 414 to 415

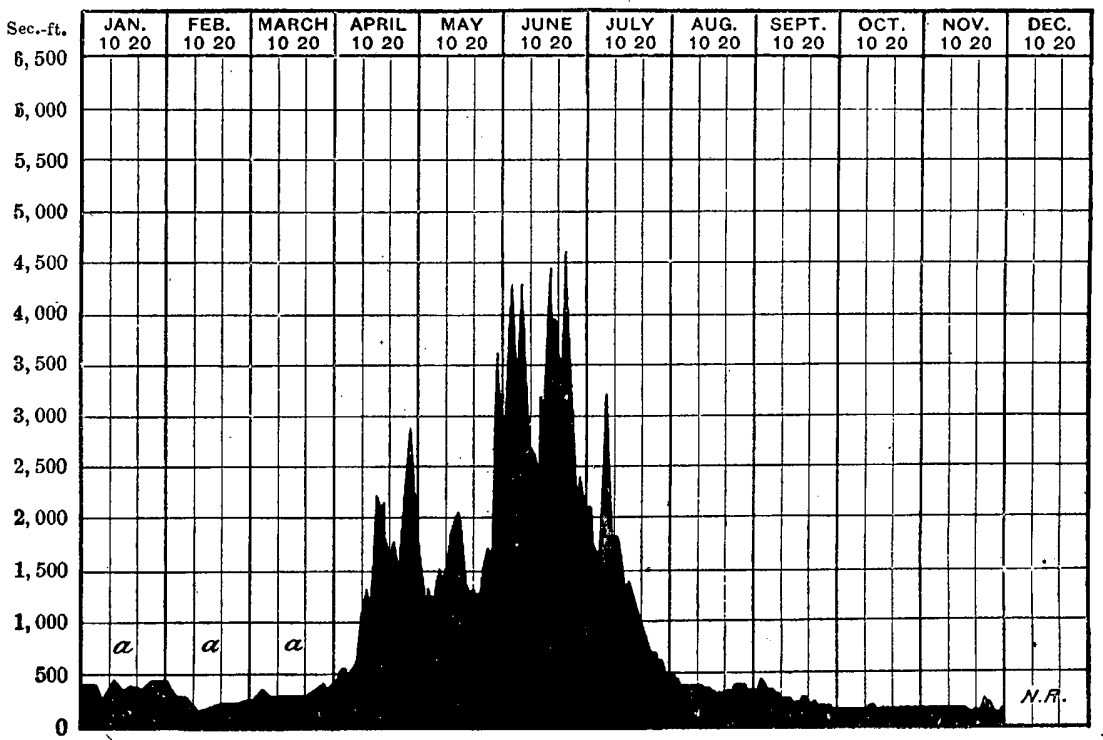

Fra. 151.-Discharge of Animas River at Darango, Colorado, 1898. 
MANCOS NIVER.

Mancos station, on Mancos River, was established April 9, 1898, by Mr. A. L. Fellows, at a point about 100 feet below a wagon bridge near the center of the town of Mancos. The wagon bridge can be used for gaging when the water is high, but ordinarily gagings are made by wading. The location of the station gives about the amount of water not used or stored, and the principal reason for its establishment was to ascertain the amount of water lost that might be stored for beneficial uses, the water supply running short usually by the 1st of July.

Estimated monthly discharge of Mancos River at Mancos, Colorado.

\begin{tabular}{|c|c|c|c|c|c|c|}
\hline \multirow[b]{2}{*}{ Month. } & \multicolumn{3}{|c|}{ Discharge in second-feet. } & \multirow[b]{2}{*}{$\begin{array}{l}\text { Total in acre- } \\
\text { feet. }\end{array}$} & \multicolumn{2}{|c|}{.Run•off. } \\
\hline & $\begin{array}{l}\text { Maxi. } \\
\text { mum. }\end{array}$ & $\begin{array}{l}\text { Mini- } \\
\text { mum. }\end{array}$ & Mean. & & $\begin{array}{l}\text { Deptl in } \\
\text { inches. }\end{array}$ & $\begin{array}{l}\text { Second. } \\
\text { feet jer } \\
\text { square } \\
\text { mile. }\end{array}$ \\
\hline 1898. & & & & & & \\
\hline April $10-30$ & $\ldots$ & ...... & 261 & 15,531 & 2.49 & 2.23 \\
\hline May .... & 270 & 144 & 206 & 12,667 & 2.03 & 1.76 \\
\hline June. & 291 & 144 & 213 & 12,674 & 2. 03 . & 1.82 \\
\hline July .... & 333 & 2 & 104 & 6,395 & 1.02 & 0.89 \\
\hline August.... & 12 & 8 & 9 & 553 & 0.09 & 0.08 \\
\hline September . & 12 & 3 & 6.7 & 399 & 0.07 & 0.06 \\
\hline
\end{tabular}

Note.-Grage heights for 1898 are given in Water-Supply and Irrigation Paper No. 28, page'137; measurements, page 142 , and rating table, page 144 .

The chief interest in connection with the results obtained at this river station is that which has to do with the question of water supply for the diminished reservation of the Southern Utes. The details of the investigation made in 1898 are given, beginning on page 408 of this volume. The results of the examination show that in case water can not be had from Dolores River it may jossibly be practicable to store some of the surplus or flood waters of Mancos River at points below the town of Mancos, if suitable reservoir sites can be found. The figures given in the above table show that a considerable volume of water is available for storage in reservoirs of small size. The question of water conservation on adjacent streams is discussed on page 432, following. 


\section{GILA RIVER.}

Gila River is the most southerly of the large tributaries of Colorado River. It rises in New Mexico and flows westerly across Arizona. It passes alternately through narrow canyons and out upon valleys, wliere its waters are diverted for irrigation. The development of agriculture by this means has been so extensive that all of the available summer How is used, and there is need of additional water to bring extensive tracts of fertile land under cultivation. The floods of this river, as shown by the diagrams of discharge, are very irregular, and although considerable volumes are discharged at such times, these come so suddenly that they can not be of much use to the farmer. The regulation of the flow of the main stream and its tributaries by water storage is urgently needed in order to utilize the lands now vacant. The topographic conditions are peculiarly favorable to water conservation, as there are many localities where clams of moderate size can be consiructed, impounding large quantities of water. Surveys of reservoirs along this stream have been authorized by the act of July 1, 1898 (Stat. L., Vol. 30, page 594). On Pl. XLIII are shown two of the localities where the river enters a narrow gorge. Above both of these gorges the river valley widens, being comparatively flat, so that, except for the depth to bed rock at the dam sites, the conditions are highly favorable for the construction of storage reservoirs. The results of the surveys have been prepared for publication in Water-Supply and Irrigation Paper No. 33, where is given also results of measurements at Buttes and Queen Oreek.

Buttes station, on Gila River, is described on page 147 of WaterSupply and Irrigation Paper No. 16; results are given on pages 415 to 417 of the Nineteenth Annual Report, Part IV. Gage heights are given in Water-Supply and Irrigation Paper No. 28, page 140, and measurements on page 142 .

SALT RIVER.

The principal tributary of Gila River is Salt River. This has been measured for a number of years near its junction with the Verde River, at a point about 30 miles above Phœnix. The measurements at this point and those of Verde River have been made by Mr. W. A. Farish. The results are given in the following table (p. 406). 


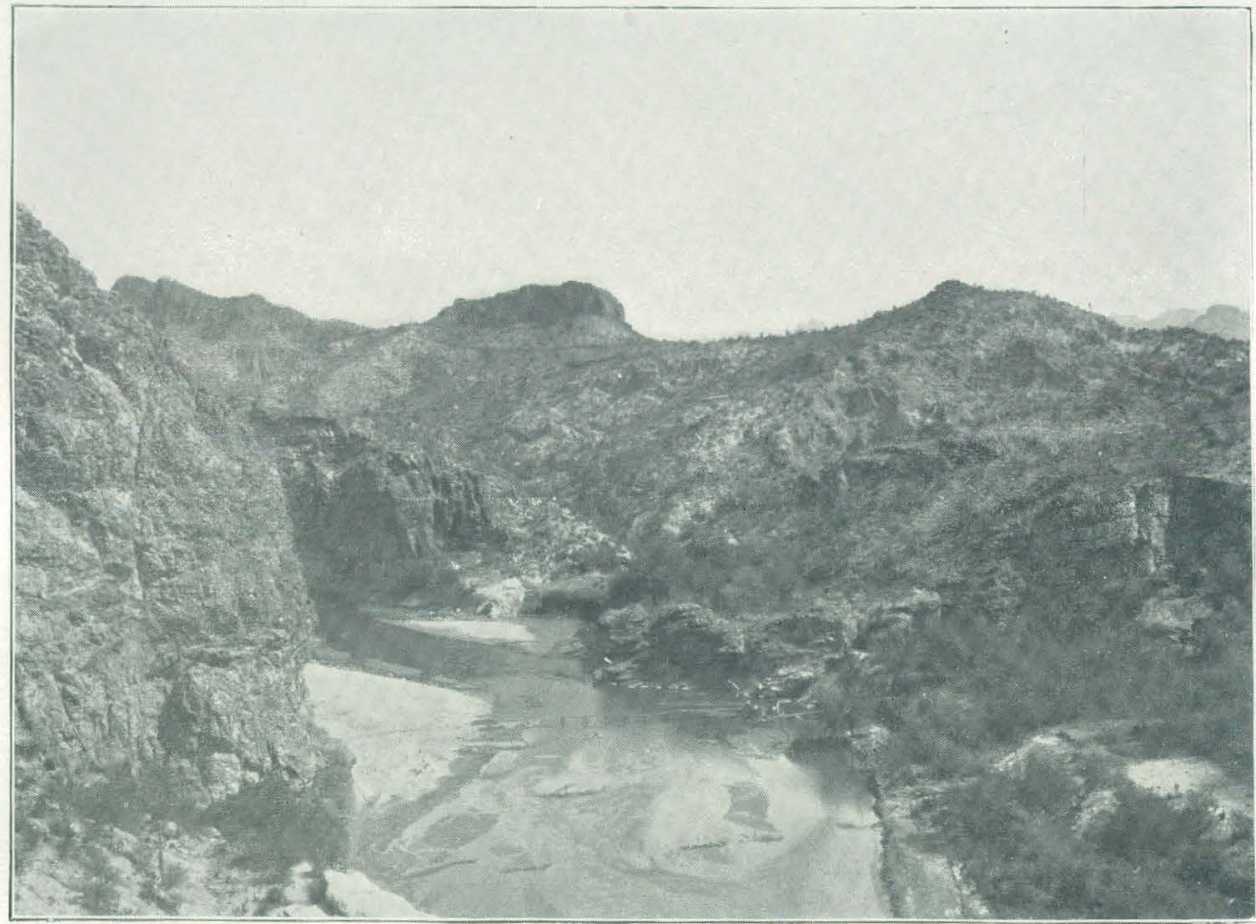

A. DAM SITE AT BUTTES, ARIZONA, LOOKING DOWNSTREAM.

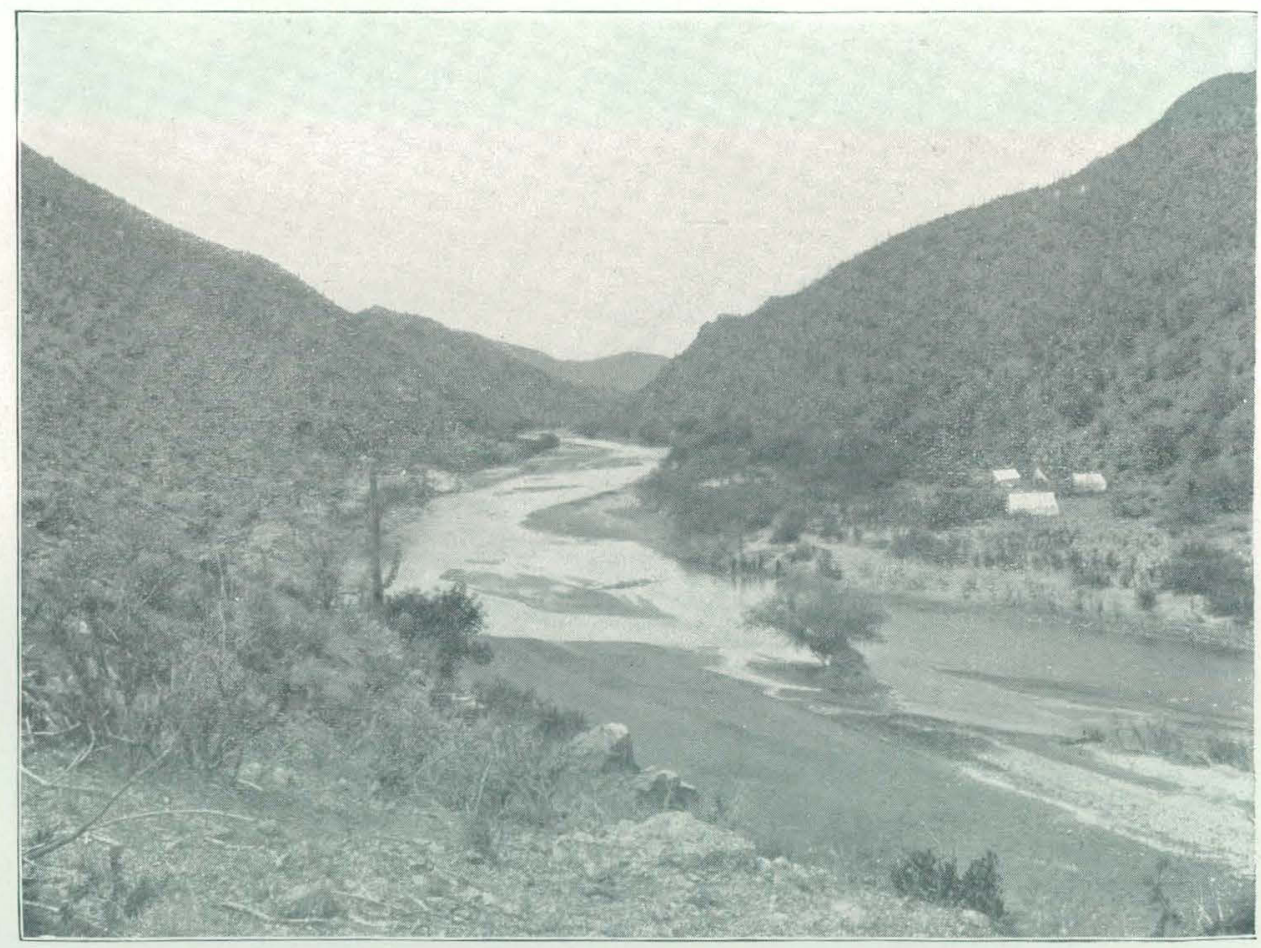

B. DAM SITE BELOW RIVERSIDE, ARIZONA, LOOKING DOWNSTREAM. 
Estimated monthly discharge of Salt River at McDouell, Arizona.

[Drainage area, 6,260 square miles.]

\begin{tabular}{|c|c|c|c|c|c|c|}
\hline \multirow[b]{2}{*}{ Month. } & \multicolumn{3}{|c|}{ Discliarge in second-feet. } & \multirow[b]{2}{*}{$\begin{array}{l}\text { Total in acre- } \\
\text { f'eet. }\end{array}$} & \multicolumn{2}{|c|}{ Run-off. } \\
\hline & $\begin{array}{l}\text { Maxi- } \\
\text { mum. }\end{array}$ & $\begin{array}{l}\text { Mini- } \\
\text { mumi. }\end{array}$ & Mean. & & $\begin{array}{l}\text { Depth in } \\
\text { inches. }\end{array}$ & $\begin{array}{l}\text { Second- } \\
\text { feet per } \\
\text { square } \\
\text { mile. }\end{array}$ \\
\hline 1898. & & & & & & \\
\hline January $\ldots . . . .$. & 1,146 & 255 & 360 & 22,136 & 0.07 & 0.06 \\
\hline February & 782 & 498 & 618 & 34,322 & 0.10 & 0.10 \\
\hline March ..... & 903 & 539 & 724 & $44 ; 517$ & 0.14 & 0.12 \\
\hline April ...... & 1,126 & 539 & 822 & 48,912 & 0.14 & 0.13 \\
\hline May ..... & 741 & 275 & 471 & 28,961 & 0.09 & 0.08 \\
\hline June.... . . & 377 & 195 & 255 & 15,174 & 0.04 & 0.04 \\
\hline July ........ & 851 & 155 & 434 & 26,686 & 0.08 & 0.07 \\
\hline August.... & 1,275 & 137 & 405 & 24,903 & 0.07 & 0.06 \\
\hline September .. & 923 & 155 & 360 & $21,4.21$ & 0.07 & 0.06 \\
\hline October..... & 191 & 155 & 165 & 10,146 & 0.03 & 0.03 \\
\hline November..... & 244 & 191 & 213 & 12,674 & 0.03 & 0.03 \\
\hline December . . . . . . . . . & 423 & 244 & 315 & 19,369 & 0.06 & 0.05 \\
\hline The year & 1,275 & 137 & 429 & 309,221 & 0.92 & 0.07 \\
\hline
\end{tabular}

Note.-Gage heights for 1898 are given in Water-Supply and Irrigation Paper No. 28, page 140 . measurements, page 143; rating table, 145; results for 1897 in Water-Supply and Irrigation Paper No. 16, page 148, and in the Nineteenth Annual Report, Part IV, pages 418 to 420.

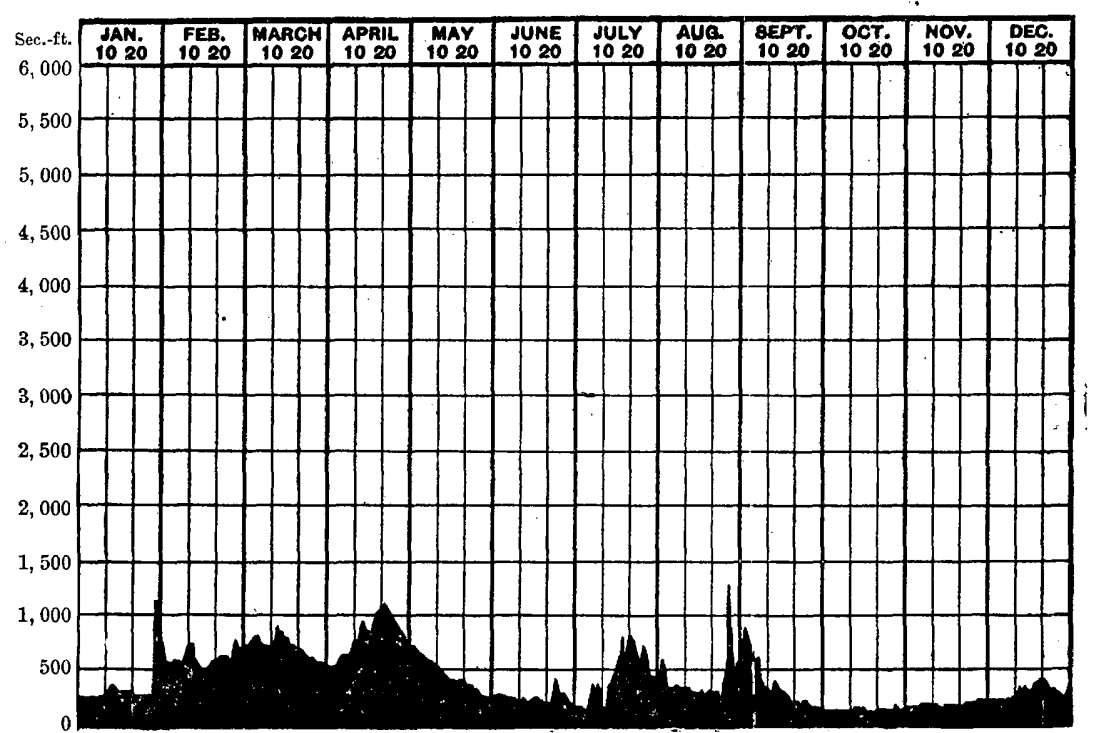

Fig. 152.-Discharge of Salt River at McDowell, Arizona, 1898. 
VERDE RIVER.

Estimated monthly discharge of Verde River at McDowell, Arizona.

[Drainage area, 6,000 square miles.]

\begin{tabular}{|c|c|c|c|c|c|c|}
\hline \multirow[b]{2}{*}{ Momth. } & \multicolumn{3}{|c|}{ Discharge in second-feet. } & \multirow[b]{2}{*}{$\begin{array}{l}\text { Total in acre. } \\
\text { feet. }\end{array}$} & \multicolumn{2}{|c|}{ Run-off. } \\
\hline & $\begin{array}{l}\text { Maxi. } \\
\text { mum. }\end{array}$ & $\begin{array}{l}\text { Mini- } \\
\text { mum. }\end{array}$ & Mean. & & $\begin{array}{l}\text { Depth in } \\
\text { iuches. }\end{array}$ & $\begin{array}{c}\text { Second- } \\
\text { feet per } \\
\text { square } \\
\text { mile. }\end{array}$ \\
\hline 1898. & & & & & & \\
\hline January ......... & 1,680 & 120 & 253 & 15,556 & 0.04 & 0.04 \\
\hline February ...... & 800 & 290 & 496 & 27,546 & 0.09 & 0.08 \\
\hline March $\ldots . . . . .$. & 1,535 & 210 & 639 & 39,291 & 0.13 & 0.11 \\
\hline April ............. & 710 & 180 & 319 & 18,982 & 0.06 & 0.05 \\
\hline May & 280 & 130 & 184 & 11,314 & 0.03 & 0.03 \\
\hline June........... & 160 & 130 & 139 & $8,27 \mathrm{i}$ & 0.02 & 0.02 \\
\hline July ..... & 1,890 & 115 & 323 & 19,861 & 0.06 & 0.05 \\
\hline Augrist.... & 1,730 & 165 & 4.00 & 24,595 & 0.08 & 0.07 \\
\hline September & 1,380 & 165 & 338 & 20,112 & 0.07 & 0.06 \\
\hline October ....... & 180 & 160 & 169 & 10,391 & 0.03 & 0.03 \\
\hline November ... & 230 & 165 & 195 & 11,603 & 0.03 & 0.03 \\
\hline December .......... & 440 & 220 & 303 & 18,631 & 0.06 & 0.05 \\
\hline The year ..... & 1,890 & 115 & 313 & 226,153 & 0.70 & 0.05 \\
\hline
\end{tabular}

NoTE.-Gage heights for 1898 are given in Water-Supply and Irrigation Paper No. 28, page 141, measurements, page 143, and rating table, page 145 ; results for 1897 in Water-Supply and Irrigation Paper No. 16, page 150, and in the Nineteenth Annual Report, Part IV, pages 420 to 423.

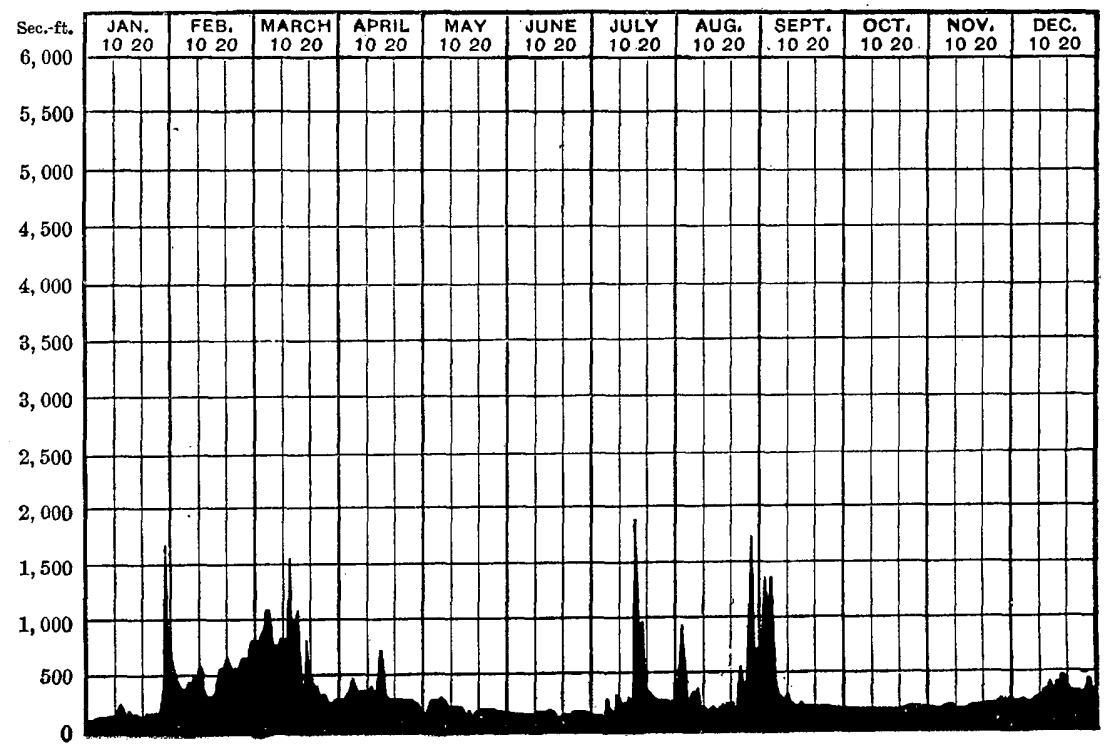

FIG. 153.-Discharge of Verde River at MoDowell, Arizona, 1898. 


\section{INVESTIGATION OF WATER SUPPLY FOR THE SOUTHERN UTE INDIAN RESERVATION.}

An investigation of the practicability of providing a water supply for irrigation purposes on a portion of the reservation of the Southern Utes in Colorado was authorized by the act approved July 1, 1898, and on Jnly 15 instructions were issued to make an examination. Field work was at once entered upon and a preliminary report was forwarded to the Secretary of the Interior on December 19, 1898, the more detailed information being transmitted on March 10, 1899. The field work was carried on by Mr. Gerard H. Matthes, from whose report the statements given in the following pages have been taken. Under instructions of July 19, 1895, Mr. Matthes left Washington and proceeded to southwestern Colorado, making measurements of discharge of the San Juan, Piedra, Los Pinos, Animas, La Plata, and Mancos rivers, all of which streams traverse the Southern Ute Indian Reservation. Repeated measurements were also made of Dolores River at Dolores, Colorado, the flow of this stream being of first importance in a consideration of the practicability of irrigating lands on the western end of the reservation. A reconnaissance of these lands was also made with a view to obtaining irrigation water from various sources.

The lands north of the reservation of the Southern Utes are watered by the irrigating canals and ditches of the Montezuma Valley Canal Company, and it was anticipated that arrangements could be made for the purchase of water rights from this company provided that ample water could be had. ${ }^{1}$ This canal system was therefore inspected from its head gates on Dolores River to the terminus of the present main ditch. Plane-table surveys were made of the two proposed reservoir sites considered by the company as available for purposes of storing flood waters. Later a rapid reconnaissance of the mountain region tributary to Dolores River above Dolores was made, in search of additional reservoir sites, and all possible data were brought together bearing upon the problem of water supply. The result of these examinations showed that while a considerable volume of water might be beld by storage, yet the construction of these works necessitated a lárge outlay of capital before conditions essential to the perpetuity of its availability upon the lands could be assured. The difficulties of making a satisfactory arrangement with the company were such that the conclusion was reached that if possible it would be better to attempt to secure water by storage upon the reservation itself than upon the lands or by the works controlled by individuals or a corporation.

The reservation of the Southern Utes is in the extreme southwestern corner of Colorado, adjacent on the west to Utah and on the south to New Mexico. A projection from the main body of the reservation

\footnotetext{
'For details of this proposed agreement reference should be made to Senate Doc. No. 124, Fifty-fifth
} Congress, second sessiou. 
extends over into the latter State. The main portion of the reservation consists, however, of a narrow strip about 15 miles wide, extending along the sonthern line to Colorado. Originally it continued to a point east of the city of Durango, but in this portion the best lands have been allotted to the Indians and the remainder thrown open to settlement. The existing, or diminished reservation, extends frou a point approximately south of the town of Mancos westerly about 40 miles to the Utah line. The investigation here described was made for the purpose of ascertaining the water supply for this diminished reserve. ${ }^{1}$

\section{TOPOGRAPHY AND HYDROGRAPHY.}

The greater part of the area of the Southern Ute Indian Reservation consists of desert land, sagebrush and grease wood heing the principal vegetation in the valleys and on the lower mesas. At higher altitudes piñon and juniper grow' in abundance, while at rare intervals groves of quaking aspen are to be found. The small amount of rainfall and the scarcity of springs and perennial streams are in a great measure responsible for the aridity of the soil. These factors, together with the high winds which prevail during a large part of the year, and the low rela. tive humidity of the atmosphere, render agriculture possible only where those arid conditions can be off'set by the artificial application of water.

The land slopes in a general southerly direction, draining toward San Juan River, the elevation above sea level in the eastern part areraging 7,000 feet, while in the extreme south western corner it falls below $5,(100$ feet. The seasou for growing crops is consequently short, and with the coll nights that prevail the agriculturist, while studying the irrigation problem, can not afford to lose sight of the climatic conditions caused by the high elevation. It is generally conceded, however, that below the 6,000-foot line it is possible to grow anything produced in the th $\mathrm{m}$. perate region. Experience has proved that the productive qualities of the region under consideration are of a very high standard.

Although the reservation is traversed by several perennial streams, - carrying a fair amount of water, the practical "pplication of these waters to irrigation is very limited. The lands Jying along tuese rivers susceptible of irrigation are of small extent, lne mainly to the narrowness of the valley and also to the moderate fall of the streams, which tends to render ditches long and expensive. Under the allotment act of February 20, 1s95, all the bottom lands along Los Pinos, Piedra, La Plata, and Florida rivers and small areas along San Juan and Navajo rivers and on Cat Creek, together with large areas of mesa land, were allotted to Indians who were willing to attempt farming, and a number of small Iudian farms are now found along these rivers,

${ }^{1}$ For valuable suggestions and assistance received from various persons, Mr Gerard H. Matthes desires to make acknowledgment particularly to Col. David F. Day, former Indian agent of the Southern Ute Reservation, also to Mr. d. L. Fellows, deputy State engineer of Colorado, Mr. S. J. Smith, agent, and Mr. W. H. Blake, foreman, for the Montezuma Valley Canal Company, Mr. L. A. Knackstedt, chief clerk at Ignacio Agency, and Mr. Joe Smith, in charge of Navajo Springs Agency. 


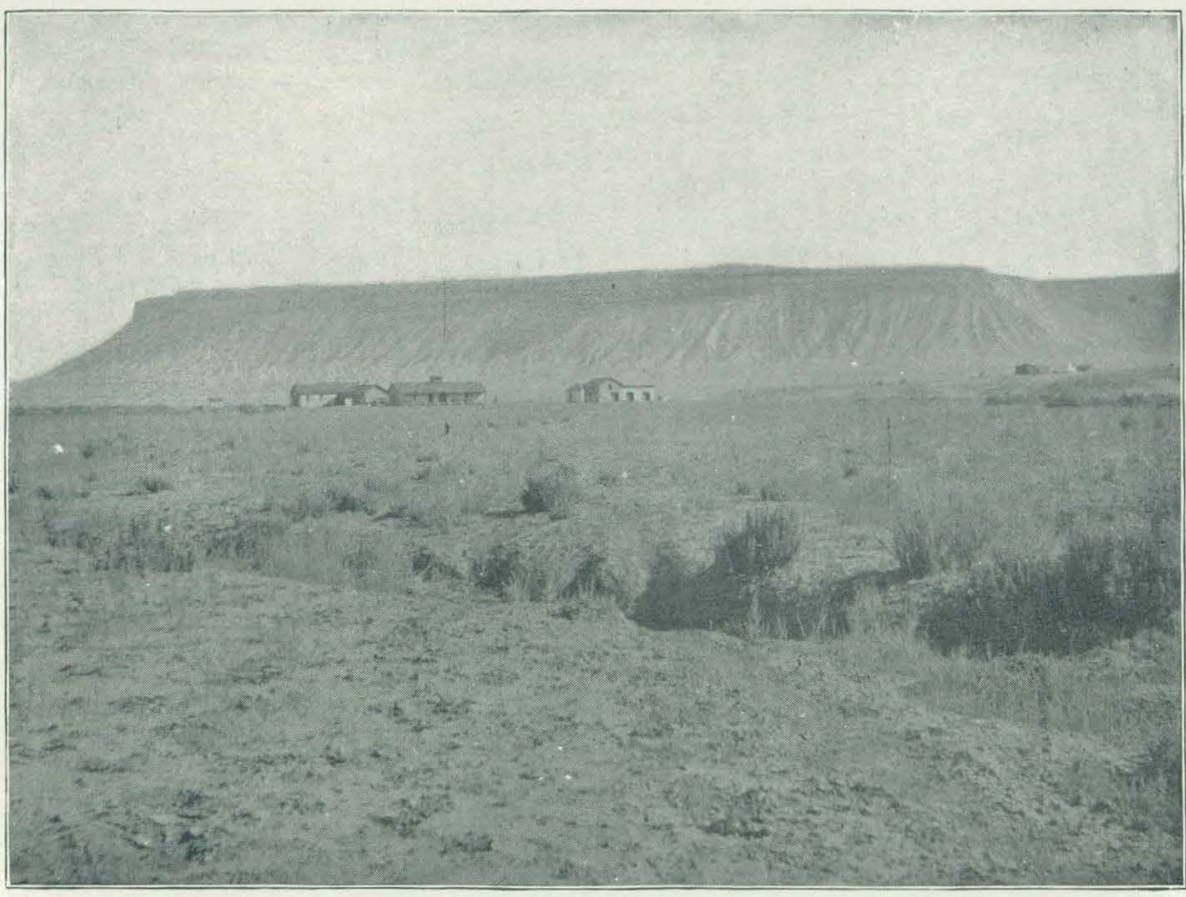

A SUBAGENCY OF SOUTHERN UTES AT NAVAJO SPRINGS, WITH MESA VERDE IN BACKGROUND.

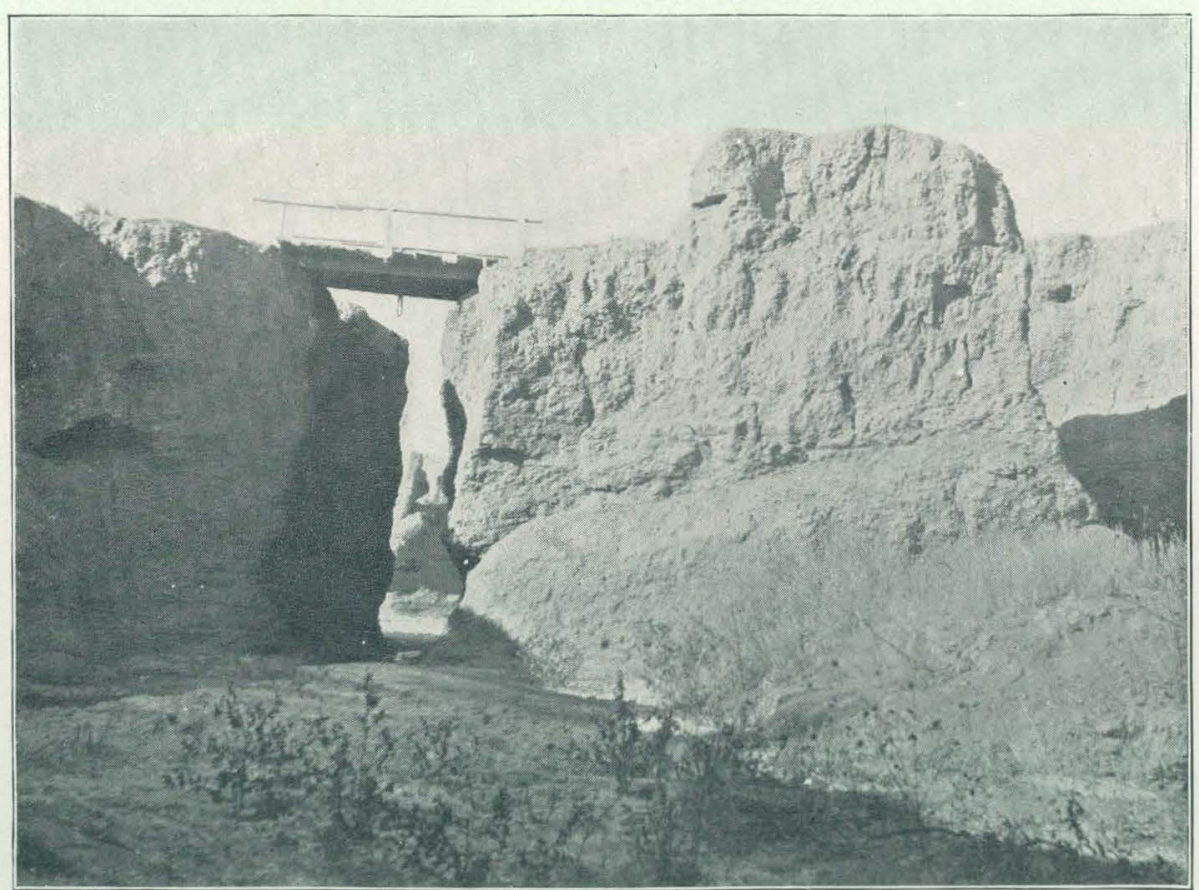

B. CANYON OF RECENT FORMATION BELOW SUBAGENCY. 
utilizing their waters for irrigation. A measurement of Los Pinos River, shown on Pl. XL, $B$, was made August 6,1898, above the head gates of the two main ditches, and the discharge was found to be 246 second-feet. Another measurement made August 7 , at a point about 4 miles below Ignacio Agency, gave a discharge of 196 second-feet. Los Pinos River is a perennial stream with a drainage area above the north line of the reservation of 320 square miles. The Piedra and San Juan rivers were measured near their junction at Arboles, Colorado, on August 8, their discharges being 195 and 294 second.feet, respectively. Regular gaging stations have been maintained on both rivers at this point since June 19,1895 , and the records of flow have been published in this and preceding anuual reports. Similar records of the Animas River, at Duraugo, have been kept, covering the same period, as shown on page 404. A measurement made August 5 gave a discharge of.414 second feet.

La Plata River was measured at Hesperus, Colorado, above the head gates of La Plata ditch, and its discharge found to be 11 second-feet. The flow of the ditch was 2.7 second-feet; the water carried is used in irrigating lands in New Mexico. La Plata River has its head waters in the mountain range of the same name and receives only one tributary of importance-Cherry Creek. Owing to the use of its water for irrigation purposes, the river in its course through the reservation frequently becomes dry during the summer season. A similar condition prevails on the Mancos River, nearly the entire flow of which, during the irrigation season, is diverted into the ditches of the ranchmen located near Mancos, Colorado. The bed of the stream is dry during the period of low water from the point where it enters its canyon through the Mesa Verde down to its mouth, except for occasional stagnant pools of alkaline water, flow taking place only after heavy showers. A regular gaging station was established on the Mancos River, at Mancos, April 9, 1898, by Mr. A. L. Fellows, as described on page 402. In view of the fact that this river has been mentioned in previous reports as a possible source of irrigation water for the lands of the southwestern section of the reserve, a consideration of its flow becomes of importance. As most of the irrigation ditches are taken out of the river above the town, the record may be regarded as representing water not needed for irrigation by the whites.

It will be readily seen from the figures on page 402 that the flow of Mancos River can not be depended on to furnish irrigation water on the reservation lands unless storage facilities are provided. From a rapid reconnaissance of the Mancos Canyon in the Mesa Verde; it appears that the possibilities of storing flood waters by damming the canyon at some suitable point are limited, owing to the rapid slope of the bottom of the canyon, and that the cost of such an undertaking would no doubt be considerable. Time did not permit a thorough survey of the canyon, and no estimates can here be given. A few Ute families located at the 
mouth of Mancos Canyon during the summer of 1898 experienced great difficulty in raising some patches of corn and watermelons, depending for irrigation on such storm waters as happened to come down the canyon.

The San Juan River, after leaving the reservation, flows through the northern portion of New Mexico and enters the reservation once more near its southwestern corner. The river along this portion of its course has but little fall, and its deep canyons render impracticable diversion of its waters upon the neighboring mesa land except at great cost. Discharge measurements on this part of the San Juan River were made at Nolands, near where the river crosses the Utalı State line, on August 18, and again on September 21, the flow on those days being 610 and 380 second-feet, respectively. It is of interest in this connection to compare these quantities with the joint discharges of the principal tributaries. During the periods August 14 to 16 and September 17 to 19 these averaged as follows:

Discharge of principal tributaries of San Juan River.

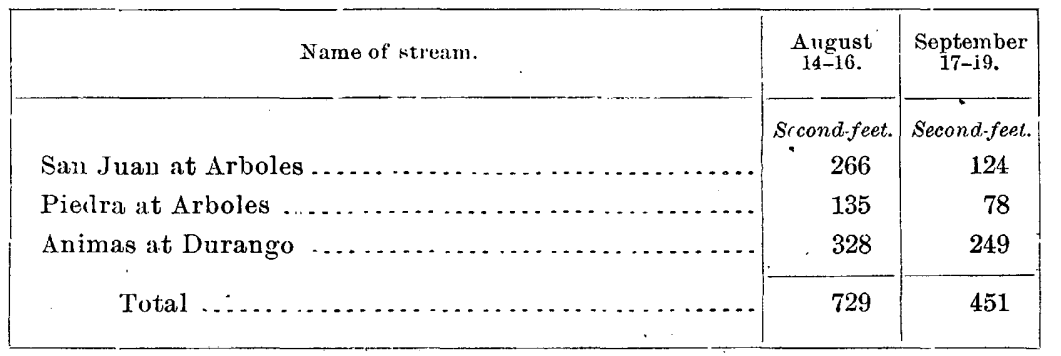

The Mancos River and the canyons entering from the south being dry, and the flow of the La Plata and the Florida rivers probably trifling or zero, the only other tributary, the discharge of which is important in this connection, is the Los Pinos River, no data for which are available. The flow during the above periods may be assumed to lave been 90 and 60 second-feet, respectively-a very low estimate. This makes the combined discharge of the tributaries on Angust 18 about 820 second-feet, against 610 second-feet at Nolands, and on September 20 about 410 second-feet, against 380 second-feet at Nolands. The difference must be accounted for as constituting water used in irrigation and loss by evaporation.

That portion of the diminished reservation which has been regarded as being most favorably situated for becoming agricultural land consists of an extensive area of open country lying directly south of the Sierra El Late, and known as the Aztec and Ruin flats. This site bas the double advantage of presenting long uniform slopes especially well adapted to irrigation, and of isolating, by natural barriers, the Ute Indians from contact with the white settlers. 
GEOLOGY AND UNDERGROUND WATERS.

In regard to the possibilities of obtaining water from underground sources, the following statements represent, in condensed form, the information set forth in the report of Arthur $O$. Spencer, assistant geologist, who made a study of the geology of the region in December, 1898. The formations in the region under consideration consist mainly of sandstones and shales, ranging from the Triassic to the Upper Cretaceous. Of these the sandstones of the La Plata and Gumnison formations (Jurassic) are well adapted to carry water. They are overlain by the Dakota formation, which forms the surface rock of Montezuma Valley. That portion of the latter which drains into McElmo Creek is a shallow synclinal valley, the axis of which lies in a northwesterly direction. The mountain groups which constitute the collecting areas from which these strata derive their water supply lie to the east and northeasst of the Montezuma Valley. They are the La Plata Mountains, the Rico Mountains, and the Wilson group, in all of which there is considerable precipitation in the form of -snow. Structural conditions would therefore be favorable for obtaining artesian waters in the lowest portion of the valley, were it not for the deep canyons surrounding the basin on the north and northeast which cut through the water bearing strata, intercepting their flow. The largest of these are House Canyon, Bear Ureek, and Dolores River canyons, Lost Canyon and Mud Creek Canyon. South of Aztec divide the valley consists of shales overlying the Dakota sandstone, sloping down from the eastern sile of Sierra EI Late. Any springs and ground waters found in these formations must, therefore, be derived from that mountain group.

In brief, the conditions are such as to indicate that undergrome waters, if present, are not likely to occur in such abundance as to warrant the sinking of wells for irrigation purposes.

\section{THE SOUTHERN UTES}

In this connection it is desirable to glance briefly at the history of the Southern Ute Indians, for whose benefit this investigation has been made, and consider the extent to which at the present time they have been rendered self supporting by devoting themselves to agriculture by irrigation.

When the first treaty with the Tabeguache band of Ute Indians was concluded at Conejos, Colorado, on October 7, 1863 (proclaimed by President Lincoln, December 14, 1864), the territory claimed by the Indians as their hunting grounds consisted of that portion of the present State of Colorado comprised between the Grand, Uncompahgre, and Gunnison rivers on the west and the eastern base of the Rocky Mountains on the east, extending as far north as the forty-first parallel of latitude, and bounded on the sonth by the thirty-seventh parallel. By this treaty the lands were reduced to include the territory between 
Uncompahgre, Gunnison, and Bunkara rivers and the Saguache Mountains, extending south to the Rio Grande and east to the one hundred and sixth meridian, and including a large part of the San Luis Valley. At the same time the Muache band of Utes were allowed to occupy these hunting grounds, while provisions were made to aid the Indians in raising cattle and horses.

On March 2, 1868, a treaty was concluded, proclaimed by President Johnson, November 6, 1868, with the Tabeguache, Muache, Kapoti, Wiminuche, Yampa, Grand River, and Uinta bands of Utes, defining the boundary lines of a reservation to include all lands between the thirty-seventh parallel and a line $1 \tilde{s}$ miles north of and running parallel with the fortieth parallel of latitude, and between the one hundred and seventh meridian and the western boundary line of Colorado Territory. This treaty provided for an agency on White River for the Grand River, Yampa, and Uinta bands, and an agency on Los Pinos River for the Tabeguache, Muache, Wiminuche, and Kapoti bands. Provisions were also made to induce Indians to cultivate the soil and to insure the civilization of the tribes by providing for schools, mills, and supplies of clothing, blankets, and food.

By act of Congress approved April 29, 1874, a treaty signed by the tribes September 13, 1873, was ratified. The reservation was dimin ished by the following area, included between the one hundred and seventh meridian and a line 20 miles east of and running parallel with the western boundary of Colorado, and between a line 10 miles north of and running parallel with the thirty eighth parallel and a line 15 miles north of and running parailel with the southern boundary of Colorado. In return the Indians were promised an annuity of $\$ 2.5,000$ and were given the right to hunt in the domain thus relinquished as long as there was any game. Executive orders of November 22, 1875, and February 7,1879 , added considerable land to the territory of the Utes, but these additions were restored again to the public domain by Executive order of August 4, 1882.

After the murker of Indian Agent Meeker and his employees at White River Agency, on September 29, 1879, and the investigation consequent thereto, the principal Ute chiefs were called to Washington and the treaty and act of June 15,1880 , resulted, by which a comprehensive removal and settlement of the various bands was contemplated. The Muache, Kapoti, and Wiminuche bands, known as the Southern Utes, agreed to remove and settle on the unoccupied agricultural lands along the La Plata River, in Colorado, and, if necessary, in New Mexico; and the Uncompahgre Utes, or 'Tabeguache band, agreed to remove and settle on the agricultural lands on Grand River, near the mouth of the Gunnison, and, if necessary, in Utah. The White River Utes, including ail remaining bands, agreed to remove and settle on the Uinta Reservation in Utah. The act, among other things, provided for allotments of land to Indians who were agriculturally inclined, for taking 


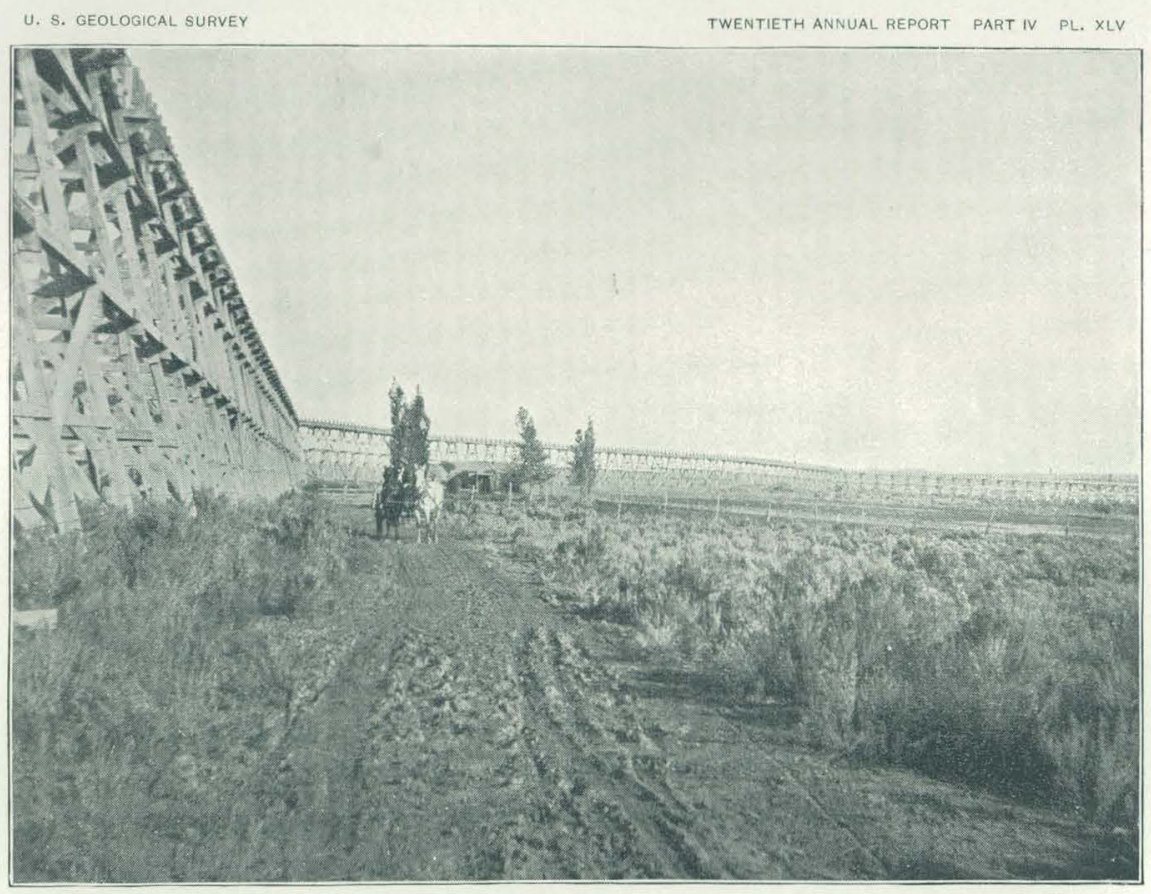

A. FLUME CARRYING WATER TO TOWN OF CORTEZ IN MONTEZUMA VALLEY, COLORADO

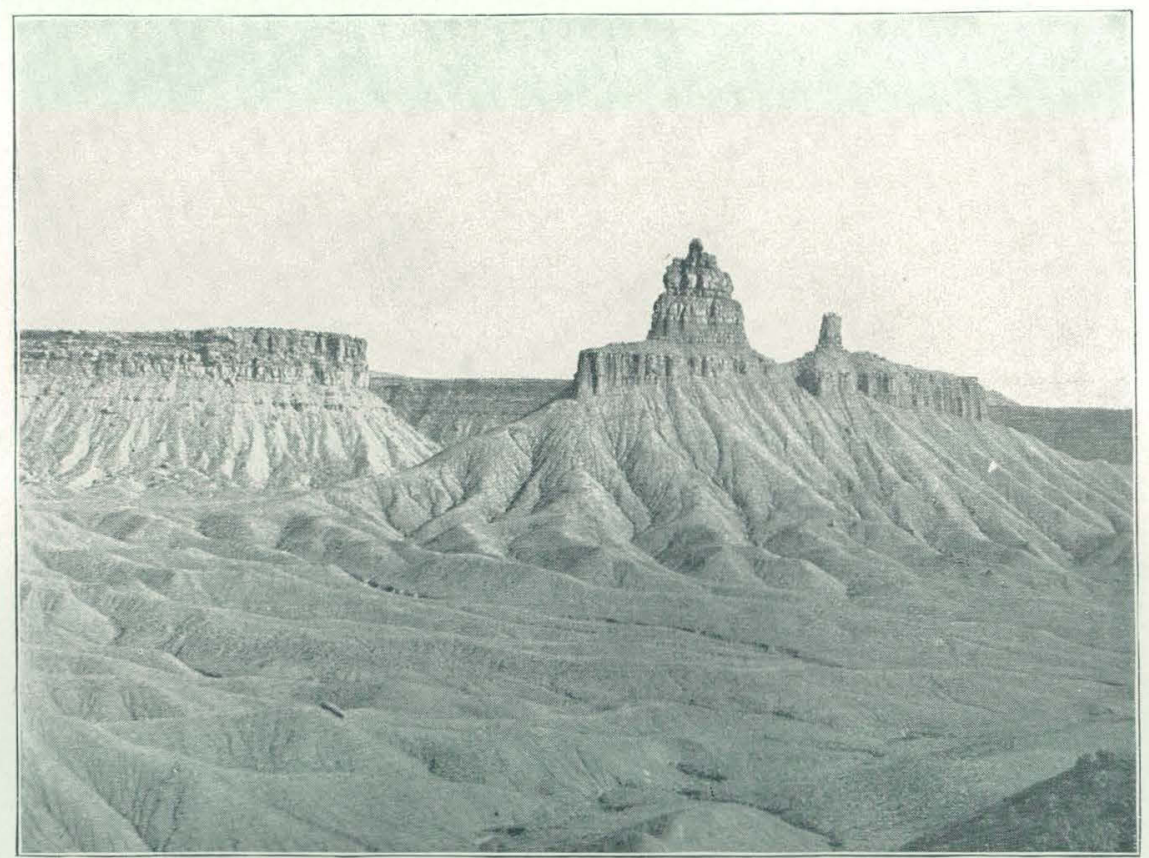

B. PORTION OF WESTERN ESCARPMENT OF MESA VERDE 
a census, for surveys, and for maps. A trust fund was also to be created for the benefit of the Indians, consisting of the proceeds of the sale of unallotted lands. In consideration of the cessions of territory made by them these Indians were to receive an annuity of $\$ 50,000$ besides the annuity of $\$ 25,000$ decreed by act of April 29, 1874 .

The White River and the Uncompahgre Utes were removed to Utah and the lands formerly occupied by them in Colorado declared public lands by act of July 28, 1882. The Muache, Kapoti, and Wiminuche bands, numbering in all about 1.000 , continued to occupy lands in Colorado, known as the Southern Ute Reservation, which consisted of a strip 15 miles wide, beginning at the Utah-Colorado line and extending east for about 106 miles, its southern boundary line coinciding with that of Colorado. The awkward shape of this territory did not fail to develop difficulties, the agency being located in the eastern portion, and in 1885 the $U$ tes expressed their desire to be removed to another reservation, as their present location required them to make long, diffcult, and, in winter, frequently perilous journeys to reach the agency from the western part of the reservation, where the majority had their abodes; and for the further reason that it was almost impossible to prevent their cattle and horses from crossing over into the lands of neighboring white settlers, and to prevent stock belonging to the latter from trespassing on reservation lands. These questions continually gave rise to quarrels and difficulties with whites, who were not willing to respect the rights and properties of the Indians. The serious aspect of the question becomes apparent when it is considered that the Ute Reservation lands are barren, grazing lauds are few, and game is rapidly disappearing. A treaty was finally signed by the Utes November 13,1888 , by which they agreed to remove to a reservation in the southeastern corner of Utah, bounded on the south and west by the San Juan and Colorado rivers, and extending north as far as a line running due west from a point on the Colorado-Utah line; 75 miles north of the point where the San Juan River crosses the latter. The treaty, however, failed to receive the approval of Congress, and the Utes were left for several years in a discouraged and unsettled condition which was anything but stimulating to their farming proclivities.

Congress, on February 20, 1895, passed an act by which the treaty of 1888 was annulled, and the act of June 15, 1880, concerning allotments, reaffirmed. The Muache and Kapoti bands, to the number of 430 , who had been residing on the rivers along the eastern portion of the reservation, took advantage of this act, while the Wiminuches, number. ing about 700, preferred to continue their nomadic life on the western portion of the reservation. For the latter, known as the "unallotted Utes," there was set aside by the act of 1895 that portion of the reservation lying west of the line between Rs. 13 and 14 W. of the New Mexico principal meridian, also Ts. 31 and 32 of Rs. 14, 15, and $16 \mathrm{~W}$. of this meridian, lying partly in Colorado and partly in New Mexico. 
The act further provided that the lands remaining after allotment were to be thrown open to white settlers at the expiration of six mouths after passage of the act, at the discretion of the Secretary of the Interior.

The act of 1880 provides that allotments in severalty are to be made as follows: ${ }^{1}$

'To.each head of a family, one-quarter of a section, with an additional quantity of grazing land, not exceeding one-quarter of a section.

To each single person over 18 years of age, one-eighth of a section, with an additional quantity of grazing land, not exceeding one-eighth of a section.

To each orphan child under 18 years of age, one-eighth of a section, with an additional quantity of grazing land, not exceeding one-eighth of a section; and to each other person under 18 years now living, or who may be born prior to said allotments, one-eighth of a section, with a like quantity of grazing land.

The amount of land so alloted per capita is unquestionably far in excess of what is needed to render Indians self-supporting. It is not only improbable that they will ever feel disposed to cultivate the entire amount, but it is also improbable that irrigation water sufficient to do so will ever be found available.

Irrigation at present is being resorted to on the bottom lands of Los Pinos, Piedra, La Plata, and Sau Juan rivers, the necessary water rights for this purpose having been appropriated by the Govern. ment in accordance with the laws of the State of Colorado. The principal ditches were constructed under Government supervision, the labor being mostly done by Utes. Among the more important works of this class are the West Side and Spring Creek ditches, taken out of Los Pinos River some $5 \frac{1}{2}$ miles above Ignacio A gency, their capacities being 81 and 192 second-feet, respectively. With seeds furnished them, competent farmers to instruct them, and with harvesting machines and implements at their disposal, the Utes have advanced in the art of tilling the soil, are raising crops with gratifying results, and, being fed and clothed in addition by the Government, are living peacefully and contentedly. It is significant, in this respect, to note in the following table the amounts of food supplies issued to the allotted and unallotted Utes respectively, as taken from the records of the Office of Indian Affairs.

1 Rev. Stat., vol. 21, p. 200. 
Food supplies purchased for distribution anong the Southern Utes for the fiscal year ending June 30, 1899.

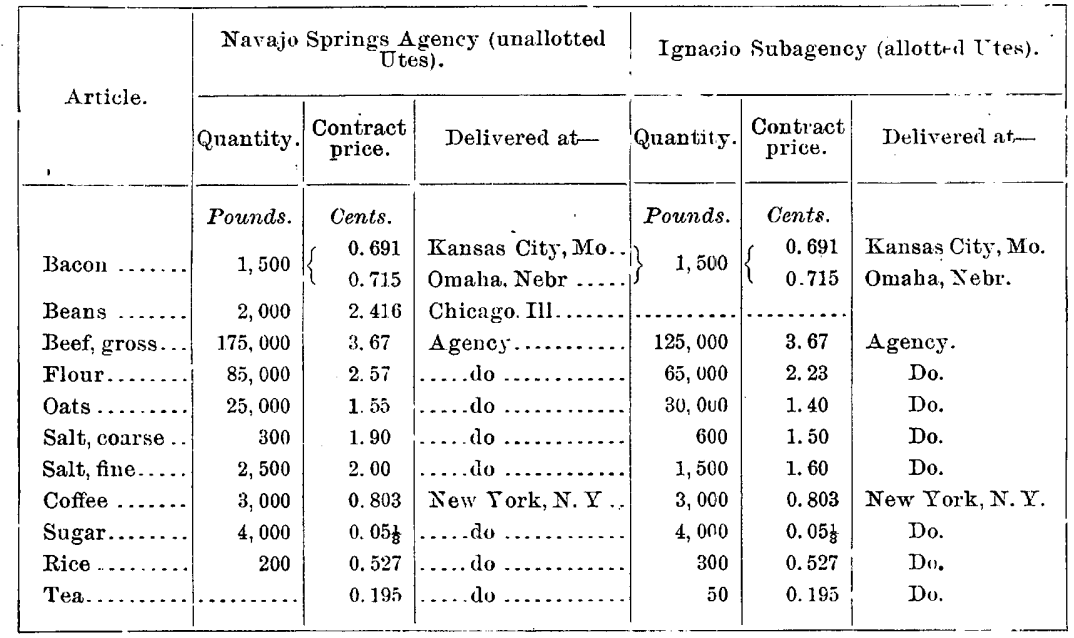

The following table shows the number of individuals in the Winit. nuche tribe (unallotted) receiving supplies at the Navajo Springs Agency, and in the Kapoti and Muache tribes (allotted) receiving supplies at the Ignacio subagency:

Indians unallotted and allotted receiving food suppties at Narajo Springs Agency and Ignacio subagency, respectively.

\begin{tabular}{|c|c|c|}
\hline Sex and age. & $\begin{array}{c}\text { Wiminuche } \\
\text { tribs } \\
\text { (unallotted). }\end{array}$ & $\begin{array}{l}\text { Kapoti and } \\
\text { Muache tribes } \\
\text { (allotted). }\end{array}$ \\
\hline Males over 14 jears of agef............... & 236 & 111 \\
\hline 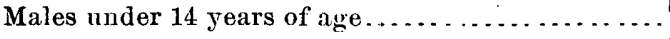 & 108 & 83 \\
\hline Females over 14 years of age...... & 256 & 144 \\
\hline Females under 14 years of age............ & 71 & 77 \\
\hline Total & 671 & 415 \\
\hline
\end{tabular}

Similar figures concerning supplies of clothing, blankets, agricultural implements, hardware, etc., are not given, because the data are not readily accessible. So far as food is concerned, it is apparent that the allotted Utes are at present as much in need of rations as the unallotted. Agricultural pursuits among these Indians must, therefore, be regarded chiefly as a means to induce them to become permanently settled, to adopt quiet modes of life, to adapt themselves gradually to civilized habits, and in the eud to become capable of selfsupport. Obviously their evolution in this direction is dependent entirely on the encouragement, aid, and guidance which they receive from the National Government. 
The object of the investigation has been to ascertain means for providing irrigation water sufficient to turn 10,000 acres of the diminished reserve, on which the unallotted Utes are now located, into agricultural land, to enable them to follow the example of the allotted tribes.

\section{MONTEZUMA VALLEY CANAL.}

It appears that the best means of bringing water upon the diminished reserve is through an extension of the ditch system now in existence in the Montezuma Valley adjoining the reservation on the north. The supply of this system is derived from Dolores River, its head gates being located below the town of Dolores, Colorado. A consideration of the flow of Dolores River becomes, therefore, of importance in this connection. Figures relating to its discharge are readily obtainable, a gaging station having been maintained by the United States Geological Survey at Dolores, since June 23, 1895, as noted on page 392 .

The area of lowlands known as the Montezuma Valley is comprised between the western escarpment of the Mesa Verde on the east, the Sierra El Late and high mesas on the west, and by the divide south of the Dolores River and Lost Canyon Creek on the nortl. It is separated into two portions by Aztec divide, the northern part draining into MeElmo Creek, a tributary of the San Juan River, while the southern portion is drained by Aztec Springs Creek, which empties into Mancos River. The northern portion has a gently undulating topog. raphy, bare of all vegetation except sagebrush, and is particularly well adapted to irrigation.

An extensive system of main ditches and laterals formed by the consoliJation of the works of two companies covers the northern portion of the valley and controls practically the entire extent of arable laud. On the accompanying map, Pl. XLVI, are indicated the principal ditches, and, by means of shading, (1) that portion of the basin which is susceptible of being irrigated, on the hypothesis of carrying the water on the most economical grades, $(2)$ that portion irrigable by the present ditches, and (3) those areas which were actually under irrigation in 1898, aggregating about 8,000 acres.

The head gates of this canal system are on the Dolores River about a mile east of the point where the river changes its course to the northward. The water from the river is diverted into the head gates by means of a low diversion dam of a temporary character; the larger quantity of water is then taken by what is known as main No. 1, through a 7 by 9 foot tunnel, shown on Pl. XLVII, B, 5,400 feet long, through the divide. The water is then turned into the main ditches by means of a diversion dam and gates, and from this point the main ditch, known as East lateral, and farther down as. Rocky Ford lateral, has a bottom width of 10 feet over a distance of $2 \frac{1}{2}$ miles, when it drops into a natural water course. The. ditch passes through natural channels, 20 GEOL, PT $4-27$ 


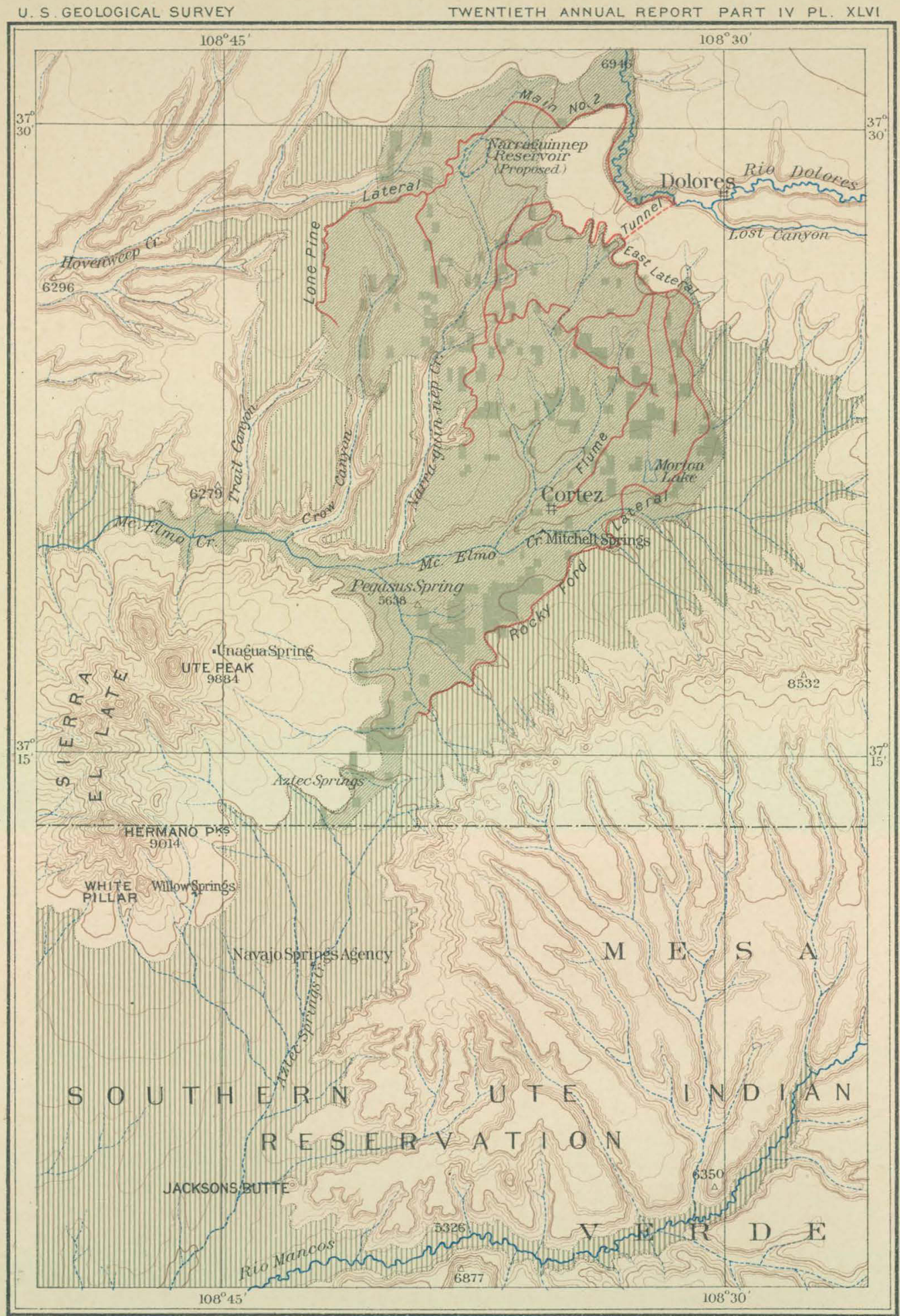

MAP OF CANALS AND IRRIGATED LANDS IN MONTEZUMA VALLEY \begin{tabular}{l|l|l|l|l|l|l} 
Areas irrigated & Areas available for irrigation \\
in 1898 & from the present canals
\end{tabular} 
alternating with constructed ditches during the remainder of its course through the valley, its present terminus being some 4 miles from the northern line of the reservation. Main No. 2 is supplied from the same head gate as No. 1, and has along the first part of its course a bottom width of 20 feet. It passes across the divide into the valley through a deep cut 4,000 feet long and approximately 40 feet deep, shown in Pl. XLVIII, $B$, the main ditch which it supplies being known as Lone Pine lateral.

The owners of this system contemplate building two storage reservoirs, to be knowu as the Narraguinnep and Morton Lake reservoirs, the sites of which are indicated on the map. The former lies near Lone Pine lateral, the water of which will be utilized in feeding it, while in the case of Morton Lake the Rocky Ford lateral is to furnish the water. The company have submitted propositions to furnish water sufficient for irrigation and domestic purposes on the Southern Jte Reservation, the main terms of which are:

* * * To store, convey, and deliver water not to exceed the volume hereinafter described, during the irrigation season, at the north line of the Ute Reservation at a convenient point to be hereafter decided upon, at the rate of $\$ 900$ for each perpetual water right, under the following details :

First. The irrigation season shall be from April 1 to November 1 of each year.

Second. A cubic foot of water per second of time shall constitute one water right.

Third. There shall be one perpetual water right for each 60 acres of land, that being the estimated duty of water.

Fourth. Not less than 166 gerpetual water rights shall be taken under this agreement, being water sufficient for 10,000 acres, the Government to become the absolute owner of the water rights so paid for and to be nnder no expense whatever thereafter, except to pay the pro rata for each water right so owned, its proportion of the annual assessment for maintenance of the company's ditches, but which annual assessment is stipulated and guaranteed at not over the nominal charge of $\$ 1$ per acre; or, if considered more satisfactory and desirable, we offer the following alternate proposition as to the annual assessment or maintenance charge: For the first three years *** $* 1$ per acre per annum, and thereafter a fixed rate of 60 cents per acre per annum. Water sufficient for domestic purposes to be furnished at such other times as in the opinion of the company's general manager it may be reasonably practicable to do so, and when the same will not interfere with necessary work on water ways and structures, the whole year without charge, it being distinctly understood that all liabilities of our company for delivery of water; condition of laterals, etc., ends at said point of delivery on the north line of said Ute Reservation. The distribution of the water thereafter and its disposition upon the said Indian lands to be entirely under the control of and at the expense and risk of the Government.

As has been mentioned in the report submitted by Indiàn Inspector J. G. Wright, dated November 4, 1897, the company, in order to be able to fulfill the obligations imposed upon it by the above contract, proposes to enlarge its system by widening the principal ditches involved and by the construction of one or both of the reservoirs mentioned. Estimates made by the engineer, Thomas H. Wigglesworth, employed by Mr. Wright, place the cost of constructing Morton Lake reservoir, the widening of Rockyford lateral, and new work at $\$ 138,000$, or in the alternative case of constructing Narraguinnep reservoir and the necessary ditches at $\$ 110,000$. 
An inspection was made of those parts of the ditch system most important in the consideration of the fulfillment of the contract and the following facts are of importance.

The head gates of the Dolores River appear to be in excellent condition, and the entire system bears evidence of frequent inspection by the ditch riders. It is reported that large sections of the roof of the tunnel on main No. 1 have collapsed, owing to the undermining action of the water on the rock, which is in places of a very shaly texture. Owing to the length of this tunnel repairs have at all times been diffi. cult and few have been made. Fortunately, the grade being considerable, the flow of the water has not been impeded materially by the obstructions so caused. It is difficult to predict, however, how much longer this tunnel can remain without repairs, as its usefulness will be reduced if further caving in is not prevented. The diversion dam on main No. 1 will also require repairs in order that the stability of its superstructure may be maintained. A section of main No. 2 is badly filled by a rank growth of aquatic plants, which have a tendency to materially impede the flow.

Special emphasis is laid on the fact that although this system furnishes water to nearly 8,000 acres, no rating flumes, weirs, or other devices for measuring the flow are to be found along any of the main ditches. No telephone, nor any other direct means of communication, exists between any part of the system and the head gates, although the system is said to comprise over 100 miles of ditching, and a large share of the work is in adobe soil, which is exceedingly susceptible to washing, causing frequently large breaks in the ditches, which need immediate repairs.

\section{SURVEYS OF RESERVOIR STTES.}

Surveys of both the reservoir sites were made by means of the planetable and stadia, controlled by triangulation, and bench marks were established by lines of levels run throughout the basins. The reference mark in each case was entirely arbitrary. The surveying of the Narraguinnep site was begun on August 29, 1898, the scale adopted being 1:5,000. The site occupies portions of sec. 4 ; of NE. $\frac{1}{4}$ and SE. $\frac{1}{4}$ sec. 5 ; of NE. $\frac{1}{4}$ sec. 8 , and of NW. $\frac{1}{4}$ sec. 9 ; all in T. 37 N., R. 16 W. of the New Mexico principal meridian. All of this land is the property of the State of Colorado.

The locality is peculiarly well adapted for the impounding of water. The basin is small, however, covering not more than 308 acres. From the map of the site herewith published in fig. 154, it will be seen that the outlet of the basin consists of a narrow canyon about 200 feet wide and 60 feet deep, which can be easily dammed. (See also Pl. XLIX.) 
U. S. GEOLOGICAL SURVEY

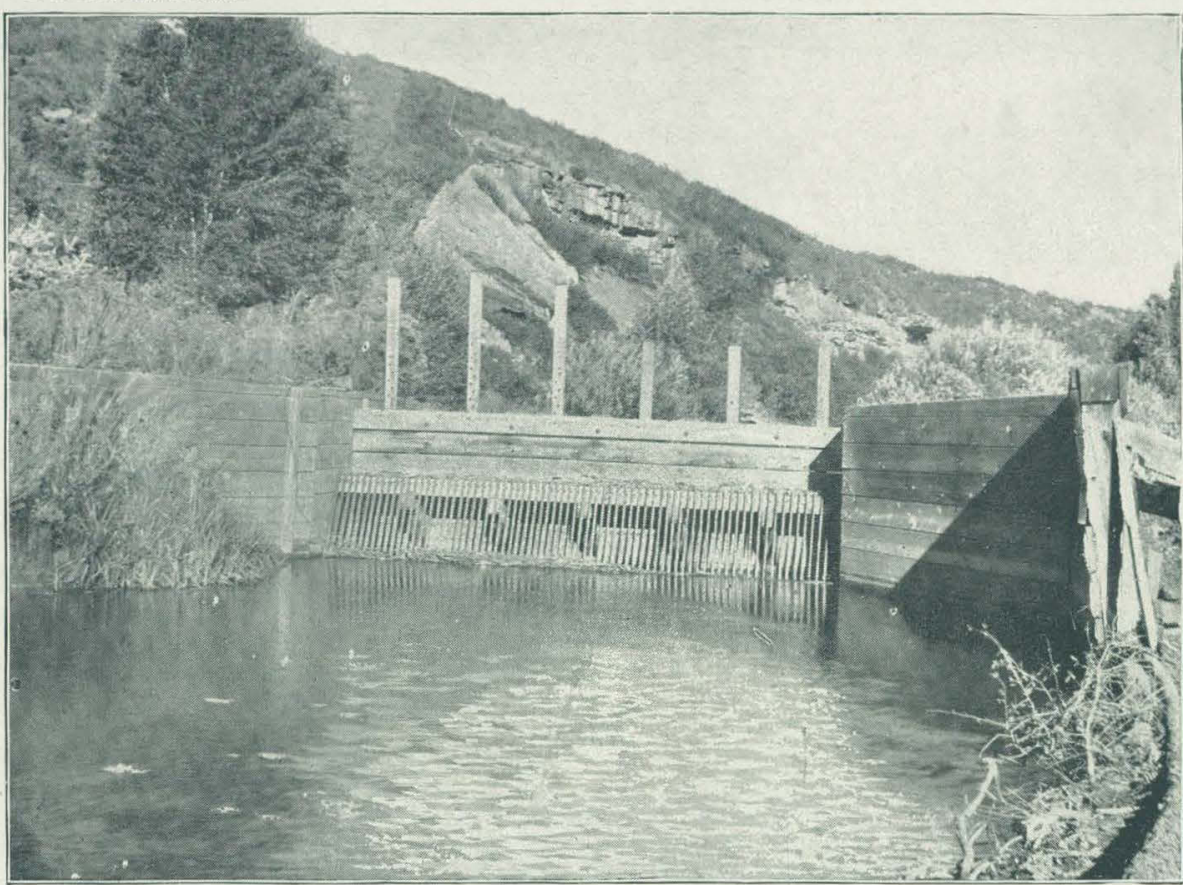

A. HEAD GATE OF MONTEZUMA CANAL ON DOLORES RIVER, COLORADO.

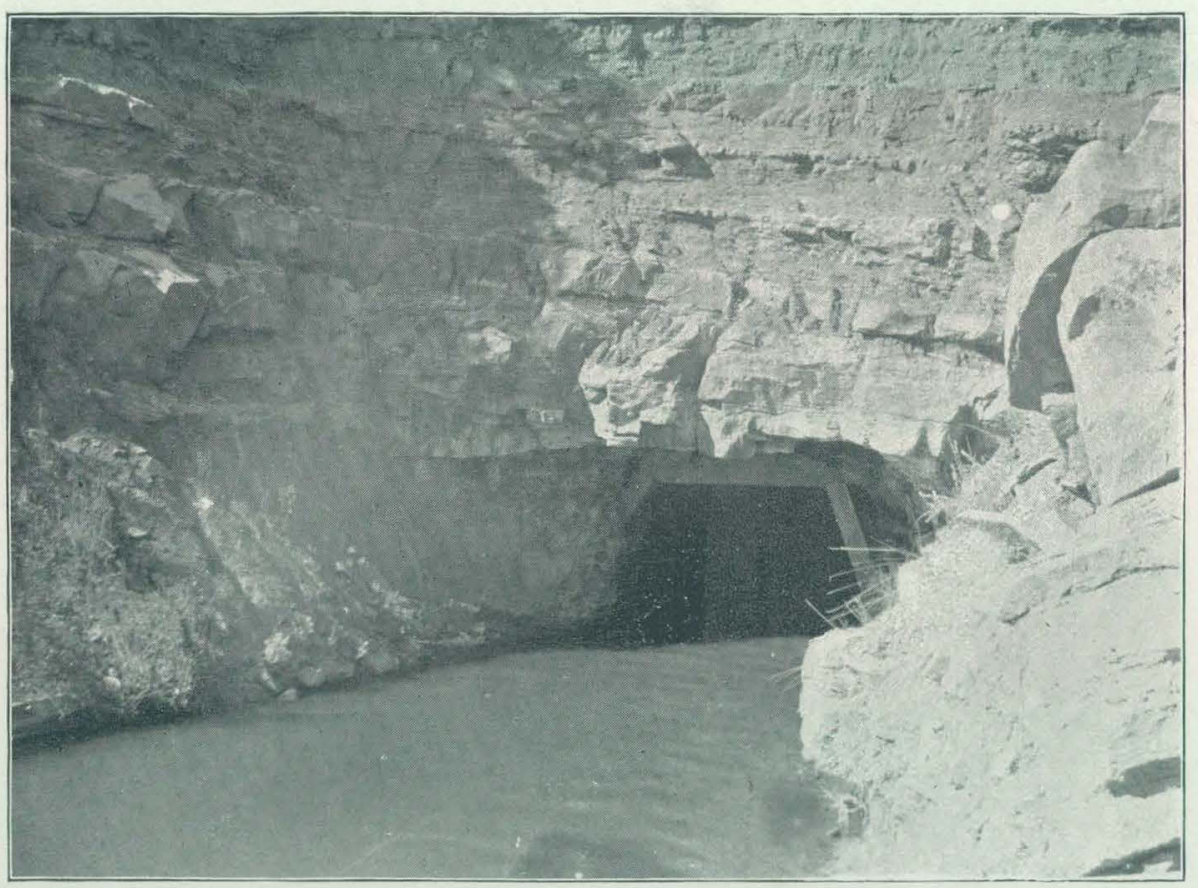

B ENTRANCE TO TUNNEL AT HEAD OF MONTEZUMA CANAL, COLORADO. 


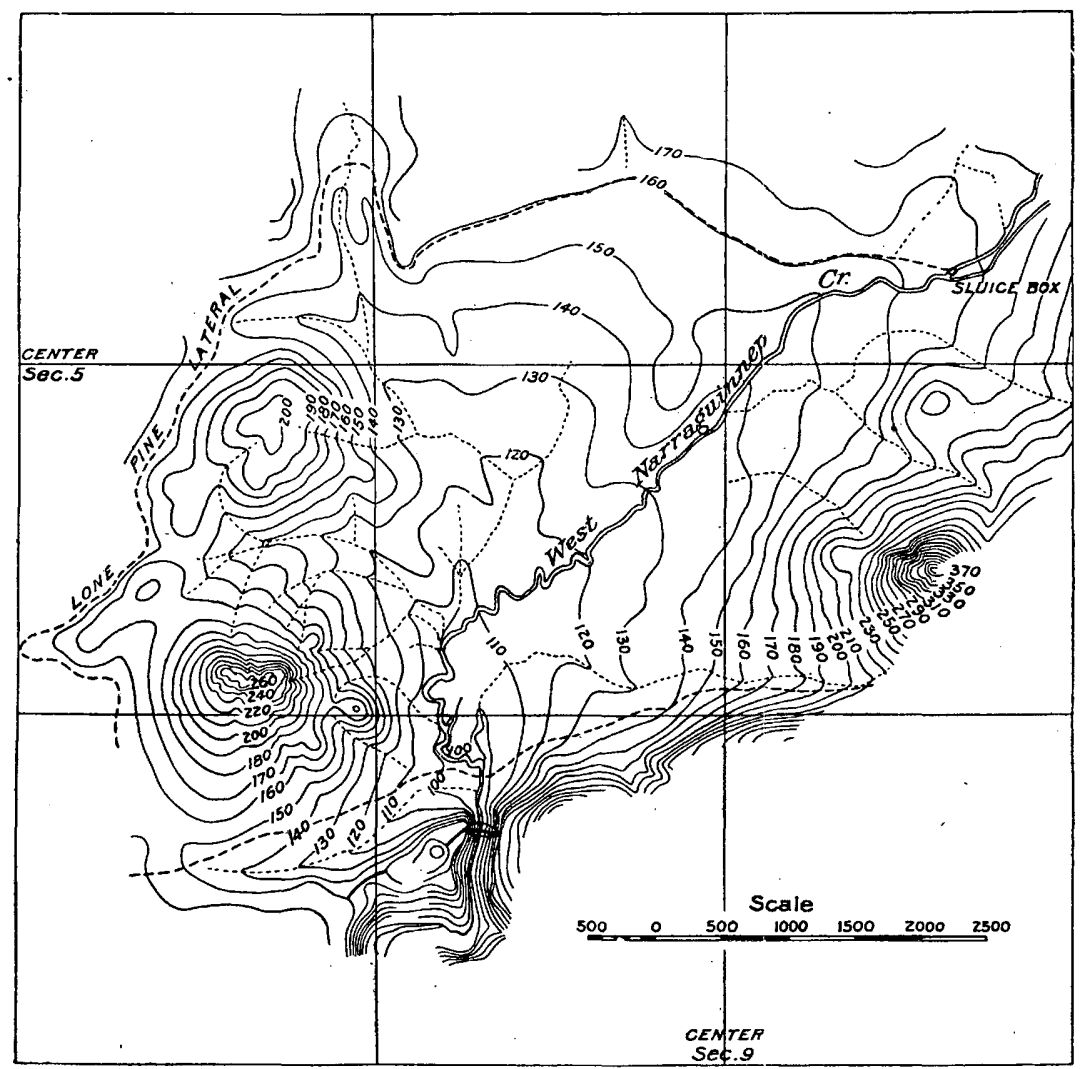

FJG. 154.-M ap of Narraguinnep reservoir site.

Area and capacity of Narraguinnep reservoir.

\begin{tabular}{|r|r|r|r|}
\hline Contour. & Area. & $\begin{array}{r}\text { Capacity of } \\
\text { section. }\end{array}$ & Total capacity. \\
\cline { 1 - 4 } Feet. & Acres. & Acreffeet. & Acrefect. \\
90 & 0.0 & 0.0 & 0.0 \\
100 & 4.9 & 24.5 & 24.5 \\
110 & 26.7 & 158.0 & 182.5 \\
120 & 71.6 & 491.5 & 674.0 \\
130 & 136.1 & $1,038.5$ & $1,712.5$ \\
140 & 217.9 & $1,770.0$ & $3,482.5$ \\
150 & 307.5 & $2,627.0$ & $6,109.5$ \\
& & $6,109.5$ & \\
\hline
\end{tabular}

Lone Pine lateral, which skirts the northern and western edges of the site, is to feed the reservoir, the outlet to be at the dam or at some other convenient point. The bottom of the reservoir consists of a clay 
soil, much resembling adobe, overlying a bed of shale. Except in a few places the basin is devoid of trees.

The type of dam which seems best adapted for this locality is what is known as the rock-filled dam, ample material for such a structure being at hand on or near the site. This has been found preferable to a masonry dam, as the cost of hauling cement would render a construction of the latter type very costly, the nearest railroad station being at Dolores, a distance of 8 miles by wagon road, and the freight rates on the Rio Grande Southern Railroad being extremely high. In design-

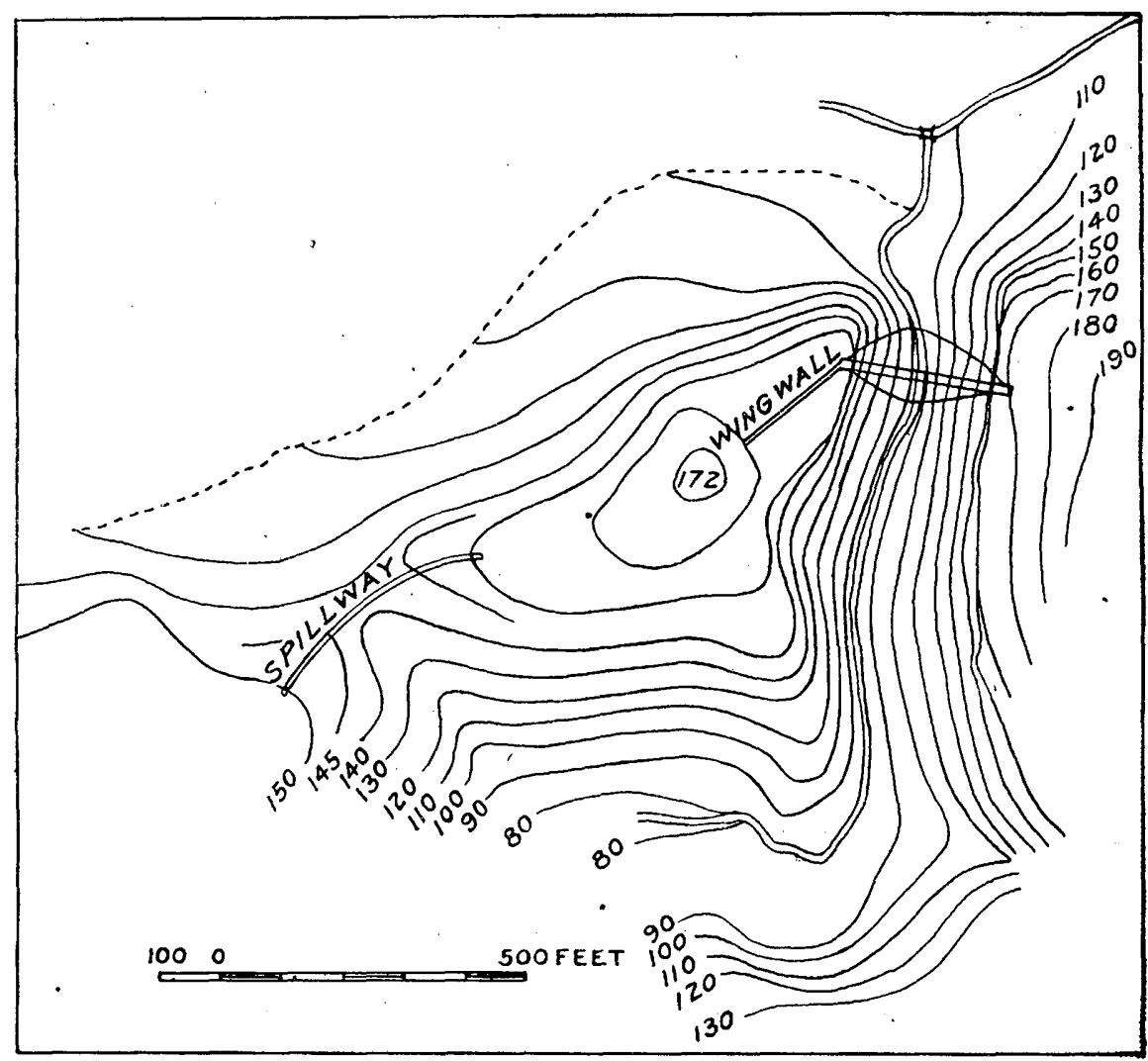

Fig. 155.-Map of Narraguinnep dam site.

ing the dam a top width of 15 feet has been adopted, it being desirable to provide for a road crossing at this point, as the road now existing in the bottom of the basin will have to be abandoned. The interior of the dam is to consist of large loose rock, the iuterstices being filled by ramming smaller rocks and gravel into them. The batter of the water slope is to be 1 to 1 , that of the downstream slope $\frac{1}{2}$ to 1 . Both slopes are to be built with care, and the stones laid by hand to a depth of 3 feet from the surface. In order to render the dam water-tight and prevent seepage at the toe, it is proposed to face the water slope with a 
layer of asphalt concrete, mixed in the proportion of 1 of asphalt, 3 of sand, and 5 of small broken stone, and to build a masonry curtain wall at the upper toe of the dam, extending down to bed rock. This wall is to be no less than 3 feet wide, of good rubble masonry, laid in cement, with batter of 1 to 4 .

In clearing the site for construction special care should be taken to remove, by blasting or otherwise, the loose rock masses composing the walls of the canyon at the abutments, the rock there having wide and extensive fissures, which it would be impossible to calk properly, and which if allowed to remain would become a serious menace to the imperviousness and life of the structure. The locality is favorable for the construction of a cable way, by means of which a great saving of labor can be effected in the handling of the building materials. The use of asphalt concrete facing is advocated as preferable to cement concrete or wooden facing, on account of its plasticity, which allows of its adjusting itself to any settling that may take place, while at the same time it is absolutely impervious to water. No borings have been made at the dam site in order to determine the depth to bed rock, but, judging from the outcrops of rock in the bed of the channel farther down, it is probable that this depth will not exceed 10 feet.

It is assumed that the reservoir, when full, will have its level at the 150-foot contour line indicated on the plan. The crest of the dam has been assumed to be at an elevation of 158 feet. This necessitates the construction of a masonry wing wall 200 feet long and about 5 feet high on top of the western bank, which consists of level ledge, with an approximate elevation of 153 feet. About 500 feet west of the dam site is a low place in the ridge which bounds the reservoir on the south, offering a good location for a spillway. A masoury wall about 400 feet long, with a minimum width of 3 feet, an average height of 6 feet, and the crest at the 150 -foot level, will insure ample safety against overflow from storm water when the reservoir is full. As is apparent from the plan, any such water passing over the spillway will find its way back into the canyon.

Following is an approximate estimate of the cost of construction of the dam and waste way:

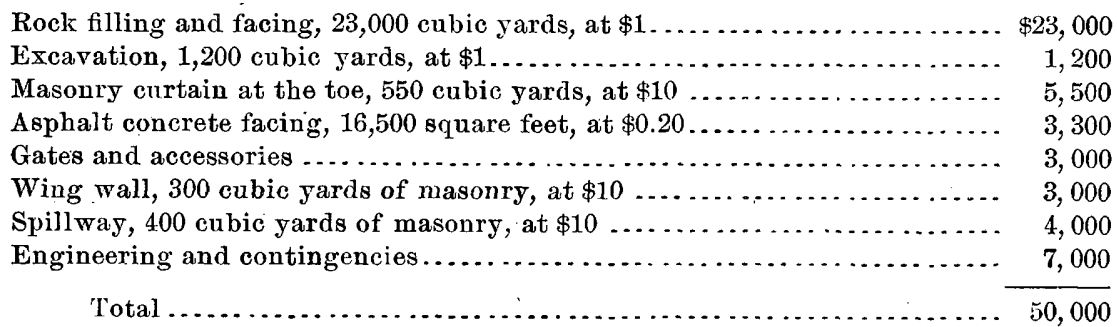

Morton Lake reservoir site is situated in the Montezuma Valley, and embraces 832 acres of farm land, a small portion of which is at present under cultivation. The site derives its yame from a small artificial 
lake, which covers some 123 acres, and which is fed in summer mainly by waste water from irrigated lands to the north of it. As is shown by the topography on the accompanying plan of the reservoir (fig. 156), the scale of survey of which was $1: 7,500$, the area which it is proposed to impound is a shallow basin with irregular outlines, draining into McElmo Creek, and occupying portions of secs. 19 and 20, of the N. $\frac{1}{2}$ of sec. 30 , and of the N. $\frac{1}{2}$ of sec. 29 , all in T. 36 N., R. 15 W. of the New Mexico principal meridian. Rocky Ford lateral finds its way across the basin at present, following a natural channel, once a tributary to McElmo Creek. It is proposed to dam the lower portion of this basin by means of an earthen dam about 8,000 feet long, as indicated on the plan, the water level being assumed to be at contour line 75 .

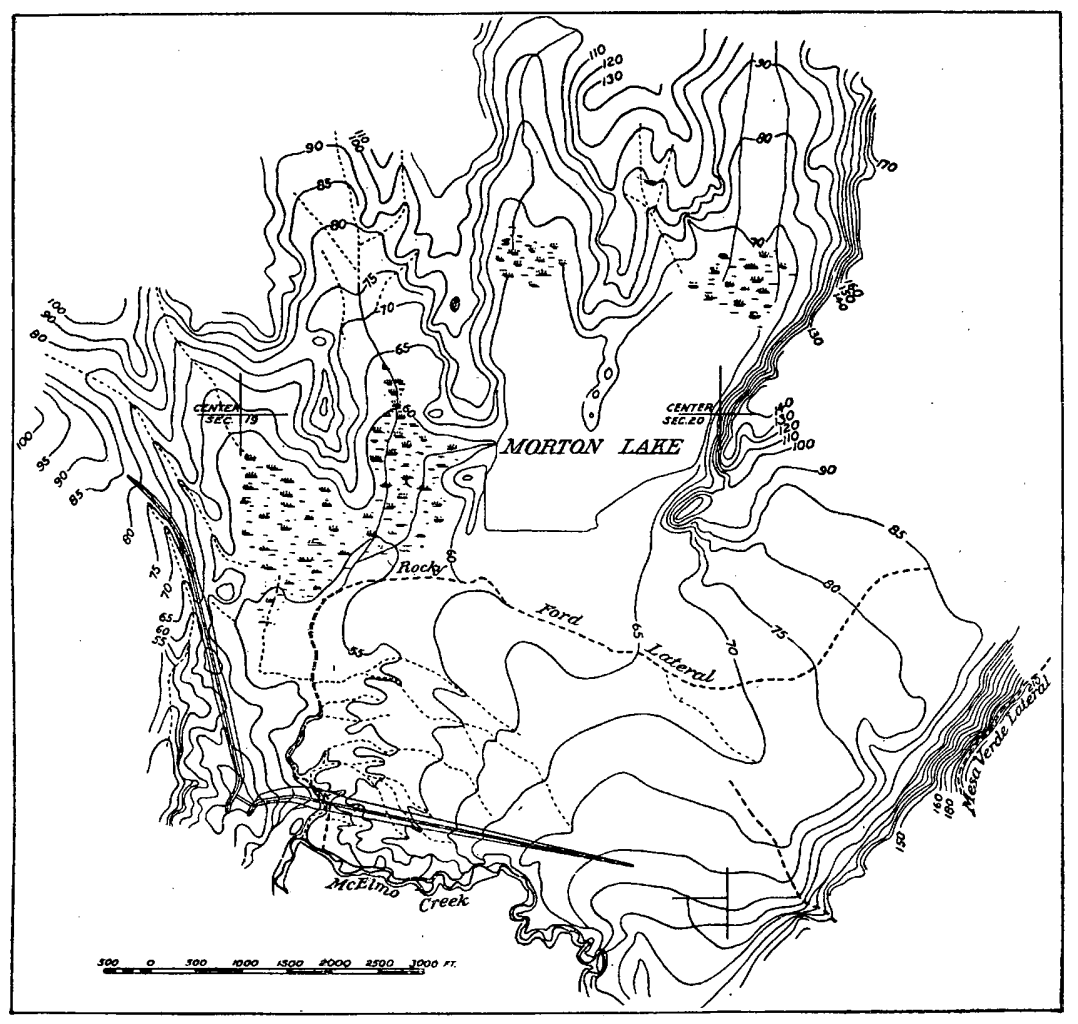

FIG. 156.-Map of Morton Lake reservoir site.

The above map gives ou reduced scale the general outlines of the proposed Morton Lake reservoir. Its area and eapacity at vertical intervals of 5 feet are also shown in the following table. 


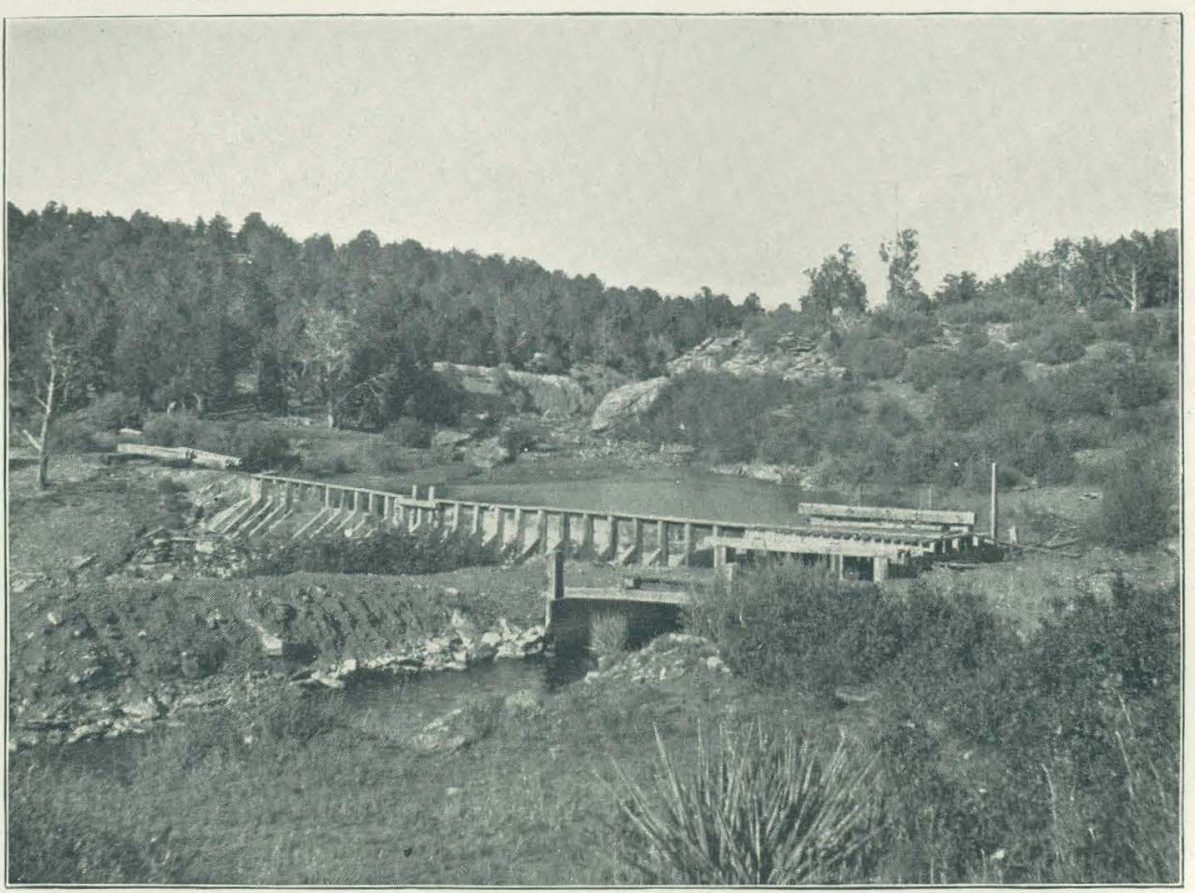

A. DIVERSION WORKS BELOW TUNNEL, MONTEZUMA CANAL, COLORADO.

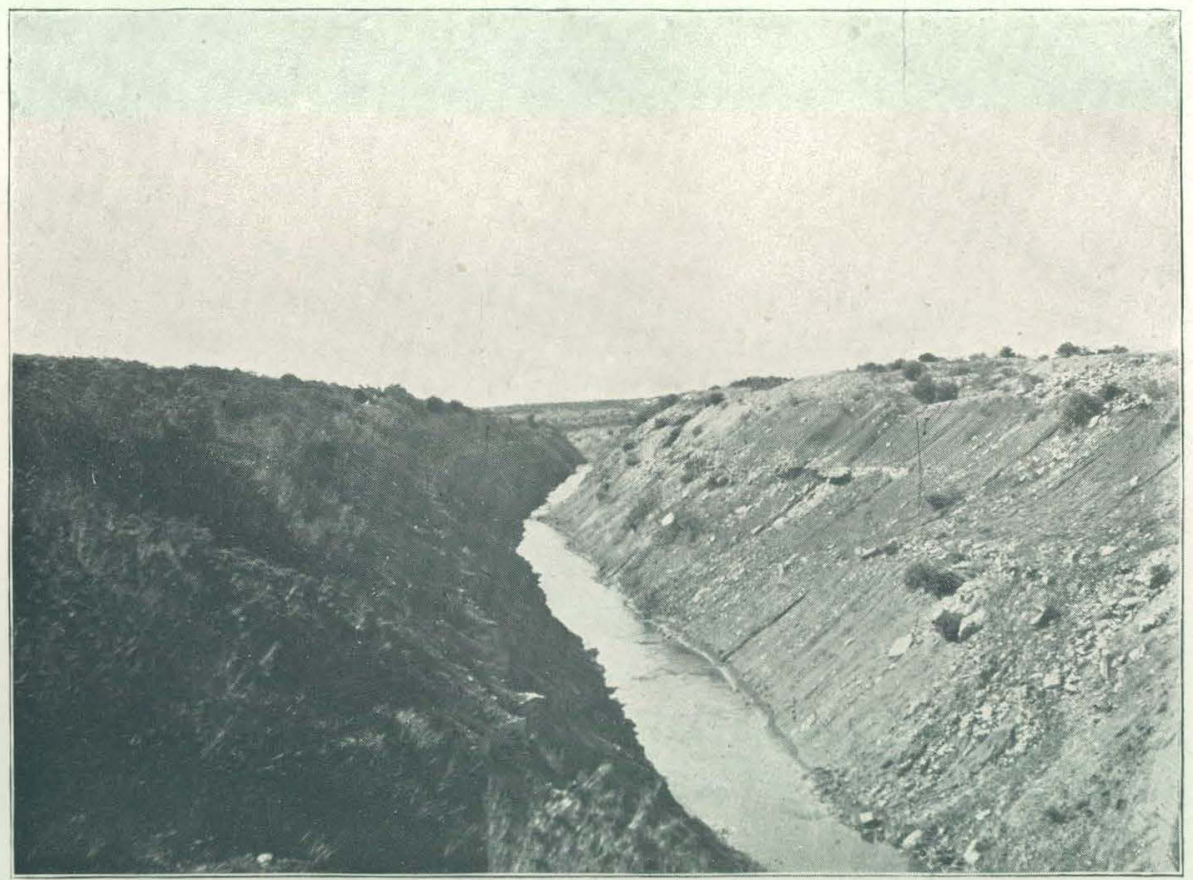

$B$. DEEP CUT OF MAIN CANAL NO. 2 
Area and capacity of Morton Lake reservoir.

\begin{tabular}{|c|r|r|r|}
\hline Contour. & Area. & $\begin{array}{r}\text { Capacity of } \\
\text { section. }\end{array}$ & Total capacity. \\
\hline Feet. & Acres. & Acrefeet. & Acre.feet. \\
50 & 3.2 & 1.6 & 1.6 \\
55 & 60.6 & 159.5 & 161.1 \\
60 & 207.9 & 671.2 & 832.3 \\
65 & 507.2 & $1,787.7$ & $2,620.0$ \\
70 & 674.1 & $2,953.2$ & 5.573 .2 \\
75 & 831.6 & $3,764.2$ & $9,337.4$ \\
& & $9,337.4$ & \\
\hline
\end{tabular}

In designing the dam it has been found desirable, as in the case of Narraguinnep dam, to provide for a roadway on top, since with the tlooding of this land several main roads are destroyed, among them a section of the road from Cortez to Mancos; and tor the further reason that traffic over this dam will tend to prevent prairie dogs from burrowing in its interior-a matter of no little importance, in view of the fact that the only soil available for the construction is of an adobelike consistency, any washing of which would be attended with the gravest consequences. Except for a section about 60 feet long, where the dam crosses an arroyo, its height will not exceed 38 feet in the deepest place, the crest being at the 83-foot level. In computing the contents of the dam a water slope of 3 to 1 and a downstream slope of 2 to 1 were adopted.

In the construction of this dam the greatest care should be exercised in compacting the earthwork by a systematic puddling of the materials as they are being laid in place. Much judgment should be used as to the amount of water needed, as a superabundance of the latter would render a collapse inevitable, owing to the poor quality of the materials available. As a protection against wave action and against the trampling of cattle watering, the water slope should be covered with a loose layer of rock or light riprap.

A site for a spillway was selected on the top of the hill near the cemetery, as is showr on the plan. The hill at this point has an elevation of about 73 feet. As the sandstone rock does not seem to extend much above the 60 -foot contour, the spillway would be best constructed here of timber, the sides consisting of sheet piling and the floor of two aprons made of 4 -inch planking, the crest being at the 75 -foot level. These aprons could be secured by a pile foundation with rock filling up to the required level, the upstream apron to be 30 feet long and the downstream apron 50 feet long. The width of the spillway has been estimated at 200 feet, on a basis of providing for the safe overflow of storm water from about 20 square miles, being approximately the drain. 
age area of Mortou Lake and Rocky Ford lateral. The latter is to feed the reservoir, while the gates would probably be best located so as to discharge into the present ditch.

The following is an approximate estimate of the cost of constructing the dain and spillway, and the probable land damages:

Earth embankment, 430,000 cubic yards, at 10 cents . . . . . . . . . . . . $\$ 43,000$

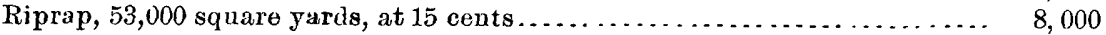

Gates and accessories ....................................... 3,000

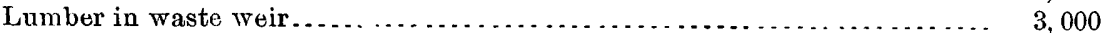

Engineering and contingencies................................. 8,000

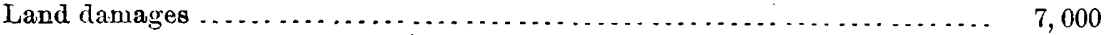

Total

72,000

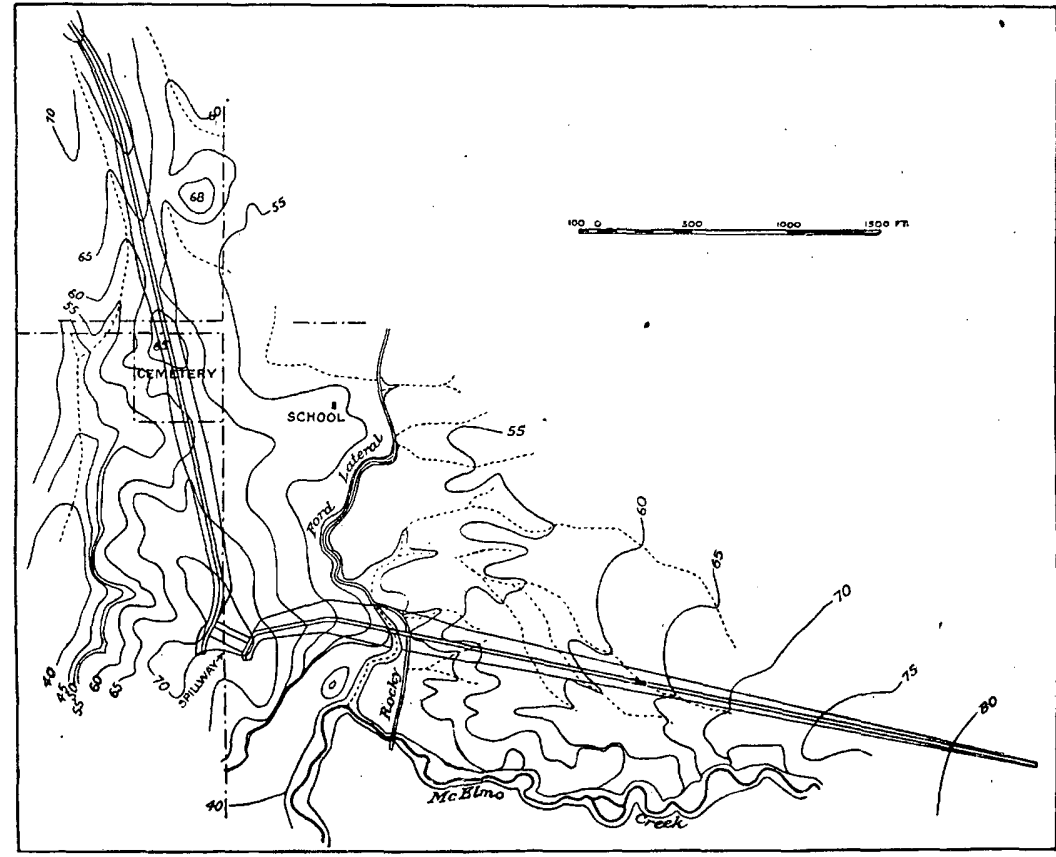

Fic. 157.-Map of Morton Lake dam site.

It was noticed that during the greater part of October the level of Morton Lake remained practically the same, no material fluctuations being apparent. An inspection proved that during that period the depth of the lake probably did not exceed 2 feet in the deepest place, the loss from leakage at the outlet being trifling, while the entire inflow was estimated at nearly 1 cubic foot per second. From this it appears that the evaporation from the surface of the lake would exceed a depth of $\check{5}$ inches a month, a rate which does not seem excessive for this locality as compared with that obtained from actual experiments made elsewhere in the arid regions of the United States. In the discussion which fol- 
lows of the storage capacities of the two reservoirs, evaporation from their surfaces has been allowed for at the following rates:

Estimated evaporation from Narraguinnep and Morton Lake reservoirs.

\begin{tabular}{|c|c|c|c|}
\hline Month. & $\begin{array}{c}\text { Evapora- } \\
\text { tion. }\end{array}$ & Month. & $\underset{\text { Evapora- }}{\text { tion. }}$ \\
\hline & Inches. & & Inches. \\
\hline January ................ & 2 & Angust................. & 9 \\
\hline February .................... & 2 & September ................... & $T$ \\
\hline March $\ldots \ldots \ldots \ldots \ldots$ & 3 & October $\ldots . . . \ldots \ldots \ldots$ & 5 \\
\hline April $\ldots \ldots \ldots \ldots$ & 5.5 & November $\ldots . . . . . . .$. & 3 \\
\hline May ........... & 6.5 & December ............ & 2 \\
\hline June ................... & 7 & & \\
\hline 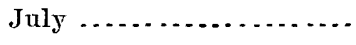 & 8 & The year. & 60 \\
\hline
\end{tabular}

STORAGE CAPACITY OF PROPOSED SYSTEM.

For the sake of simplicity and for convenience of computation the unit adopted in the following discussion is the acre-foot, a quantity representing 1 acre covered by water to the depth of 1 foot. It wili appear, then, that a continuous flow of 1662 cubic feet per second during twenty-four hours is equivalent to 330 acre-feet.

The maximum capacity of the proposed reservoirs, as seen from the preceding tables, is 6,109 acre feet in the Narraguinnep Reservoir and 9,337 acre-feet in the Morton Lake Reservoir or, in other words, the storage from the former, neglecting losses from seepage and evaporation, would furnish a continuous flow of 1662 second-feet during $18 \frac{1}{2}$ days, and the storage from the latter would in a similar way last $28 \frac{1}{5}$ days, while the two reservoirs together would be able to furnish the desired quantity during 46.7 days. An inspection of the discharge of the Dolores River for the past four years will reveal that the periods when little or no water is available to feed the reservoirs extend usually over more than two consecutive months during an irrigation season, the latter being reckoned from April 1 to November 1, and it becomes, therefore, apparent at the first glance that the storage capacity falls short of the requirements. Elaborate computatious have been made in order to ascertain what the probable record for each reservoir would have been throughout the entire period under the following assumptions:

The company having under irrigation about 8,000 acres, the quantity required for its use has been assumed at 100 second-feet, and this has been allowed the company at all times during the irrigation season, when the flow of the river could be made to furnish this amount. Where the flow of the river falls below 100 second-feet the entire amount has been credited to the company, but no storage water has been allowed for its use, this being reserved entirely for supplying the reser- 
vation lands. It has further been assumed that the ditches feeding each reservoir would be enlarged to a maximum capacity of 200 second. feet. All losses by evaporation from the surface of the reservoirs have been duly allowed for, based on the preceding table. The results of these computations, as made for Morton Lake Reservoir, are graphically represented in the diagrams on the following pages, in which the broken line represents the daily discharges in acre-feet of Dolores River. The dotted line running across the lower part of the diagrams indicates the amount of $166 \frac{2}{3}$ second-feet increased by 100 second-feet, being the total amount required throughout the irrigation season by the company for supplying all its customers, including the reservation lands. No allowance has been made here for losses by seepage and evaporation along the ditches between the head gates and the points of delivery. Assuming now an inflow into the reservoir not exceeding a maximum of 200 second-feet, and a constant outflow of $166 \frac{2}{3}$ second-feet, the contents of the reservoir may be indicated by the dotted line in the upper half of the diagram, the ordinates of which represent the contents in acre-feet at any date throughout the period. On this assumption the reservoir would have run dry in 1895 on September 12, in 1896 on July 23, and in 1898 on August 26, while in 1897 there would have been no shortage at any time during the irrigation season. It will be seen from the diagrams that a freshet during the latter part of September, 1896, would have furnished a flow for nearly a week, after which the supply would again have been exhausted. Obviously it is impossible to fill the reservoir or obtain the desired flow when the reservoir has once been allowed to become empty during the latter part of the season, there not being water enough in the river then to supply even the amount required by the present users, not to mention other parties who have prior water rights on the river.

Similar computations based on the same inflow and a continuous outflow of 100 second-feet give results as indicated in the diagrams by a - - - line, from which it appears that on this assumption the reservoir would have run dry in 1895 on October 10 ; it would have run dry in 1896 on August 13, full flow taking place again from September 23 to October 9 ; and in 1898 the flow would have ceased September 21.

It has been ascertained next by a tentative method the amount of water which, on the above assumptions, could have been delivered without interruption during the irrigation seasons of these four years. Taking each year separately, it was found that 70 second-feet would have been the maximum for 1895 , and 50 second-feet would have been the maximum for both 1896 and 1898; or that 50 second-feet would have been a safe maximum for the period. The behavioir of the reservoir under these conditions is represented by a $\cdot \ldots \ldots$... line in the diagrams. It will be noticed that the reservoir has been assumed as full throughout the first part of 1895, although no data of the flow of Dolores River are available before June 23. 


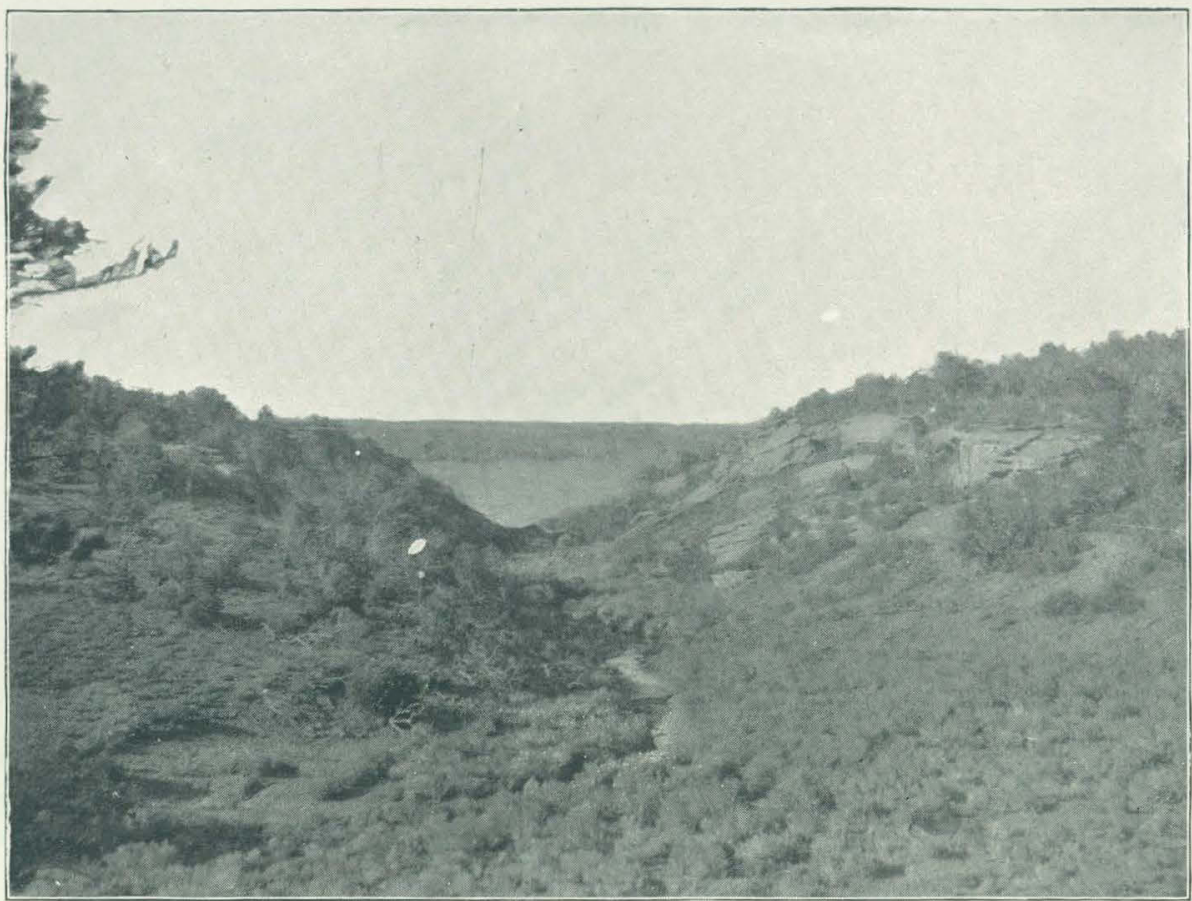

A. LOOKING THROUGH CANYON INTO NARRAGUINNEP RESERVOIR SITE.

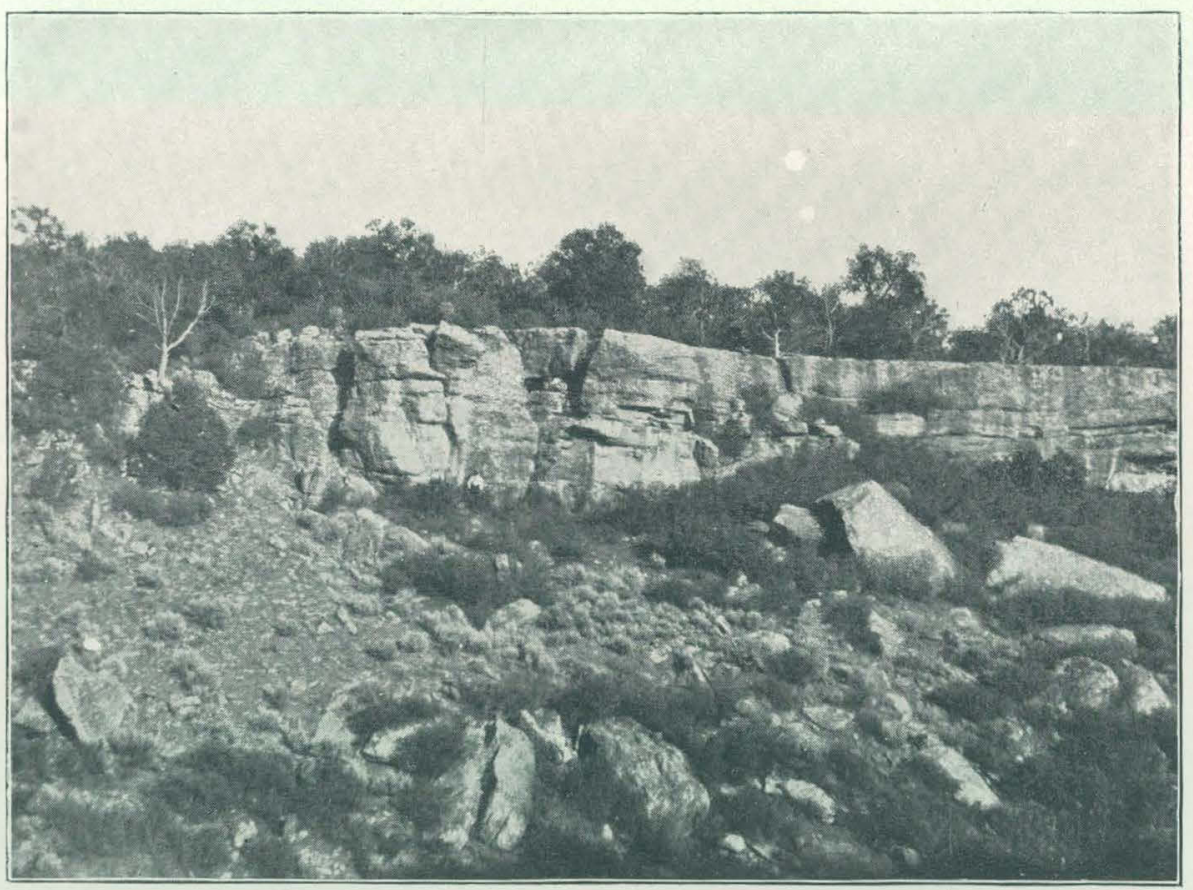

B. WALL OF CANYON, NARRAGUINNEP RESERVOIR SITE. 
These dotted lines just described appear also, in the lower portion of the diagram, indicating the extent to which the flow of the river is
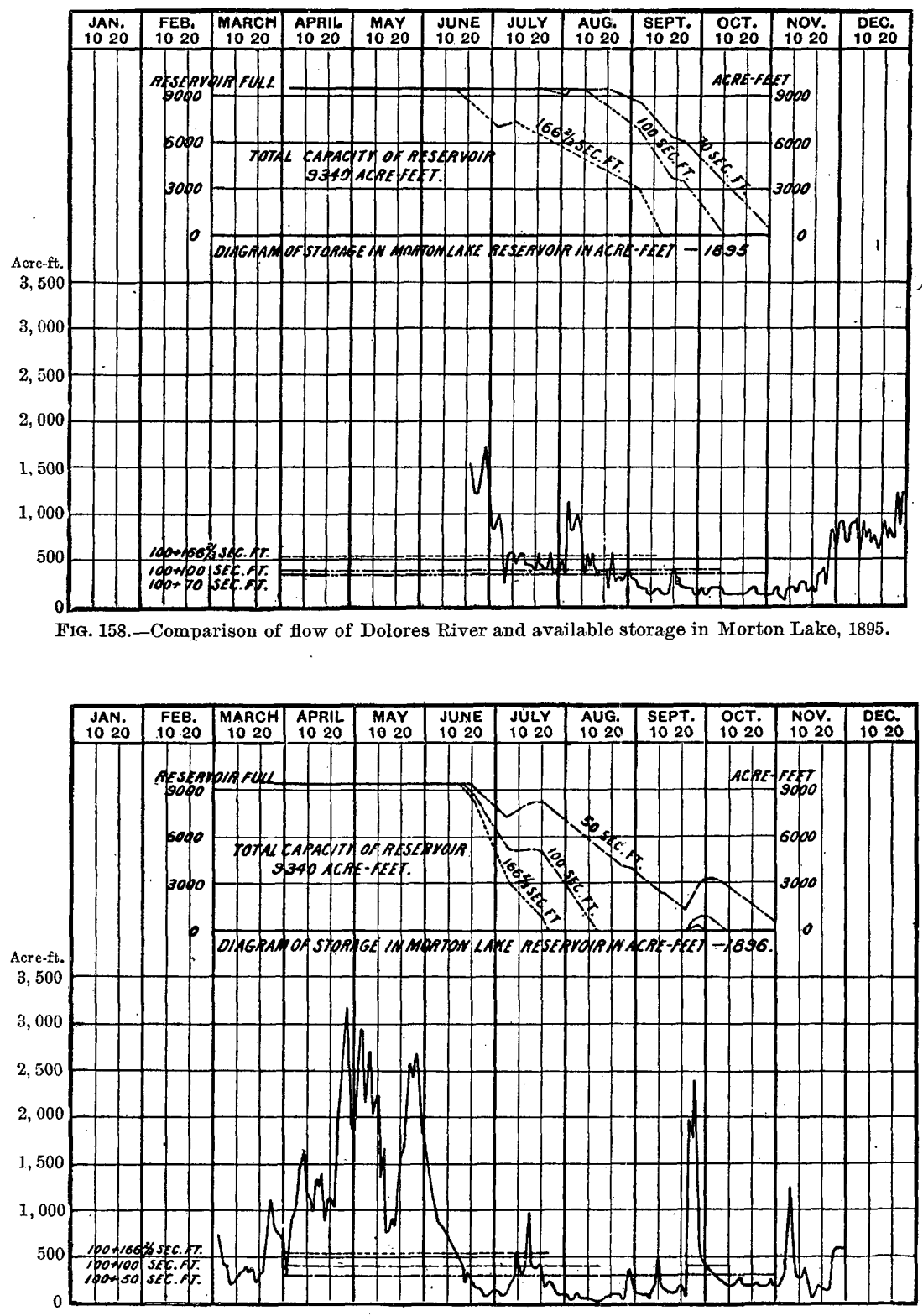

FIG. 159.-Comparison of flow of Dolores River and available storage in Morton Lake, 1896.

utilized in each case, such portions of the discharge curve as project above these lines representing water going to waste. In the case of 1897 the dotted line corresponding to a flow of $166 \frac{2}{3}$ second-feet is the 
only one represented, no shortage occurring in delivering this amount during the contract season of 1897 . The amount of water going to
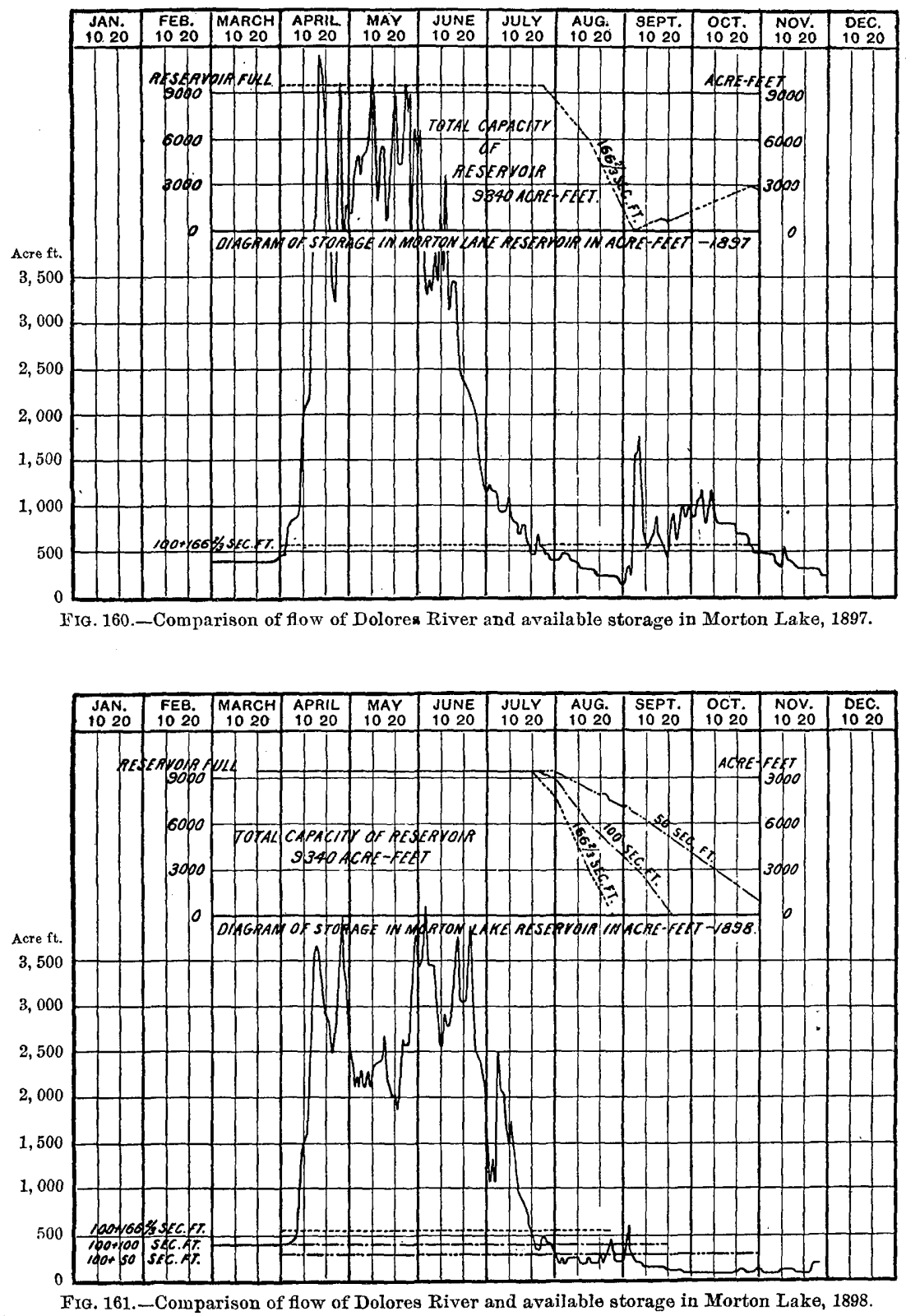

waste during this somewhat wet year will be seeu to be very considerable. 
A comparison of the records of the years succeeding 1895 shows that the assumption before noted is safe, the discharge of the river being usually very high during the irrigating season. The maximum capacity of the feeding ditch, as stated above, has been assumed as 200 secondfeet. Although at first thought it may seem that this capacity is small and allows a considerable quantity of available water to go to waste during the high-water season, it will be observed that the amount is ample not only to fill the reservoir before the beginning of the lowwater season, but even before the beginning of the irrigation season, by taking advantage of the month of March, when no water is needed for irrigation. A larger capacity of the feeding ditch would mean an increase of expenditure, which would not be offiset by the small advan. tage gained in filling the reservoir in less time; nor would the additional storage so gained during the late summer freshets be considerable, since such freshets are usually too sudcien and too short to permit storage with any degree of economy.

Similar computations have been made for the Narraguinnep reservoir, but owing to its inferiority in size to the Morton Lake reservoir, a lengthy discussion here of its probable record during these four years seems unnecessary. An inspection of the diagrams shows that on the supposition of both reservoirs being used in conjunction, not only would it have been impossible to furnish the $166_{3}^{2}$ second-feet required by the proposed contract, but that even a flow of 100 second-feet would have caused a shortage in September, 1896, and in the latter part of October, 1898. Attention is called to the fact that the length of ditches necessary to carry water from the reservoir to the reservation line would exceed 20 miles in open arid country, and that the loss by seepage and evaporation along this route would be considerable, probably amounting to from 10 to 25 per cent of the initial flow. Therefore a larger quantity than the one to be furnished at the reservation line should be allowed for at the outlet of the reservoir, thus materially increasing the duty of the reservoir over the amount assumed above.

Throughout the above discussion no account has been taken of priorities of water rights along the Dolores River and tributaries. As appears from the Sixth Biennial Report of the State Engineer of Colorado (pp. 320-323), the cornpany then known as the Colorado Consolidated Land and Water Company appropriated on November $25,1885,64.60$ secondfeet; its order of priority being No. 35, and the amount previously appropriated by other parties being 35.48 second-feet. Again on February 1,1892 , under order of priority No. 74, the company appropriated $1,235.40$ second-feet, by "constructive priority," its total water rights thus aggregating 1,300 second-feet, previous priorities appropriated by other parties amounting to 105.37 second-feet. To neglect these previous priorities, however, causes no considerable error in the computations made, as the figures of flow of Dolores River used in this discussion refer to the gaging station, located about 2 miles above the 
head gates, there being but a few comparatively small ditches taken out along this distance. Besides, the valley is narrow, and much of the water that is diverted from the river onto adjacent lands sooner or later finds its way back into the main stream through the gravelly subsoil. It is not to be overlooked, nevertheless, that the last-mentioned factors have a tendency to diminish the quantity available for irrigating the reservation lands, and that the above computations leave no margin of safety for such losses.

In view of the insufficient storage capacity of the reservoirs in the Montezuma Valley, efforts were made to ascertain whether other reservoir sites could be found, in order to supplement the deficiency in the first named. Many sites were visited, but few if any appeared to be practicable, the usual objection being too great cost and too small capacity. The valleys as a rule are too narrow and their fall too great, as shown in $\mathrm{Pl} . \mathrm{L}, A$, and $B$, for the construction of reservoirs.

A reconnaissance was made of the country tributary to Dolores River above Dolores and of areas tributary to Montezuma Valley. The work was carried on mostly on horseback, and was of the character of a hasty. inspection, the only instrument used being a hand level, distances being measured by pacing.

A trip was made over the mesa lying between Dolores River and Lost Canyon Creek, where there were reported to be several small sites. Mud Spring Park, on the head waters of Italian Canyon, which drains into the Dolores River, is a small depression in the mesa, in which, at certain times of the year, more or less water gathers, derived from the spring after which this park is named. A low dam, 250 to 300 feet long and 12 feet high in the deepest place, would impound an area of approximately 12 acres, furnishing a probable capacity of 60 acre feet. The drainage area tributary to this site is very limited, and only such waters as result from the melting of the snowfall, which is very considerable in this region, can be depended on to feed the reservoir. It is doubtful whether this site, owing to its small capacity, is of any importance in the consideration of the problem at hand. A small reservoir at , this point might, however, be of benefit for a single ranch, the cost of construction and maintenance of a dam of the above size not being very considerable. There are a number of small basins in this mesa, the majority of which fail to meet the requirements by having too much slope and consequently too little capacity, while the dams necessary would in all cases be of too costly a nature.

Another reservoir site, known as the "Old Fields" reservoir, was visited. It is situated at the head waters of McElmo Creek, about a mile south of the divide between Lost Canyon Creek and the Mancos River. The remnants of a dam at this point indicate that the site was once before utilized for storage purposes. Inspection proved, however, that it is not in the most favorable place, but that by constructing a dam approximately 900 feet long and 30 feet high some distance above 


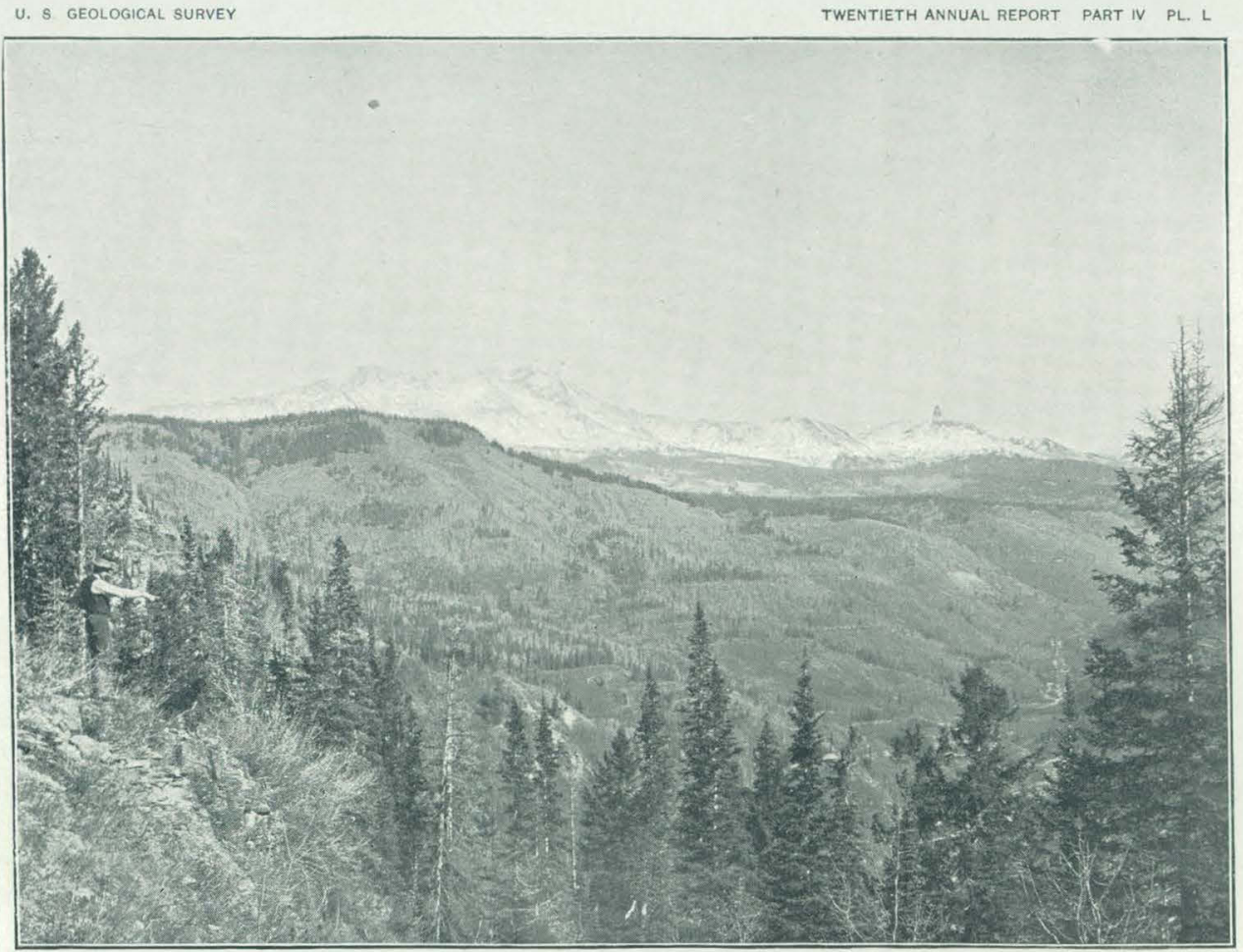

A. HEAD WATERS OF DOLORES RIVER, SHOWING UPPER DRAINAGE BASINS NEAR MOUNT WILSON AND THE LIZARD HEAD.

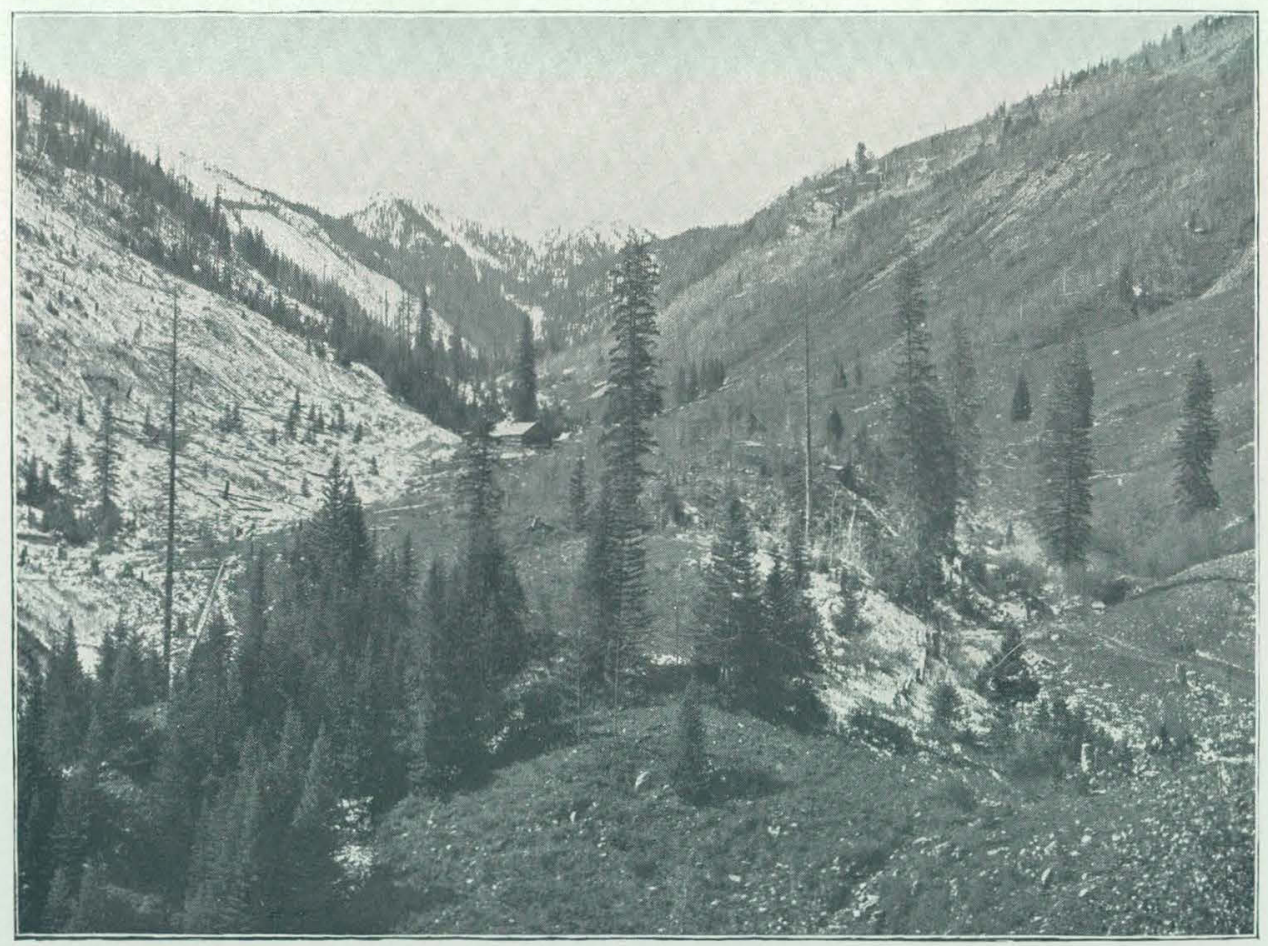

B. HORSE CREEK, ONE OF THE TRIBUTARIES OF DOLORES RIVER. 
the site of the present dam an area of about 25 to 30 acres could be impounded and a probable capacity of 400 acre-feet obtained. This site also depends for the necessary storage water on the water resulting from snowfall, which amounts to 4 or 5 feet. It is possible, however, to feed the reservoir by constructing a ditch diverting the water from Lost Canyon Creek over the divide. Such a ditch is builu at the present time for a large part of the way, and supplies two ranches on the top of the divide. There would be no difficulty in carrying the storage waters into the Montezuma Valley, as natural water channels can be taken advantage of to a great extent.

The mountainous country draining into the West Fork of Dolores River contains a number of small basins which can be filled with water from the tributaries of the West Fork, most of which are perennial streams. In visiting this region the canyon of the West Fork was inspected throughout its entire length, but no dam sites were encountered below the settlement of Dunton. Here the stream cuts through a narrow canyon about 100 feet wide, above which is a shallow basin which has comparatively little fall. A dam 55 feet high and 125 feet long would form a reservoir covering about 80 acres, with an approximate capacity of 1,400 acre-feet. In this basin at present is situated the mining camp of Hot Springs, or Dunton post-office, besides a number of mining claims, some 30 acres of agricultural farm lands, and the hot springs from which the settlement has derived its name. At the time of visit, November $4,189 \mathrm{~s}$, the flow of the West Fork was estimated at 4 second-feet, which is significant, inasmuch as the season immediately preceding bad been very dry. There is, therefore, no doubt as to an abundance of water for supplying a reservoir at this point. This site is located in sec. 32 , T. 41 N., R. 11 W., New Mexico meridian.

On the tributaries of the Fish Fork, which enters the West Fork from the west, the following reservoir sites were visited:

On Groundhog Creek a dam 55 feet high and about 300 feet long would impound an area of 150 acres, consisting of nearly level grazing land which has been used as a cattle camp, and in which there was at the time of visit running water, the total flow amounting to 1 secondfoot. The capacity of the reservoir was estimated at 3,000 acre-feet. It was not possible to ascertain the exact location of this site, the country not having as yet been accurately mapped. It can therefore only be stated here that the Groundhog site lies approximately in sec. 15, T. 41 N., R. 13 W., New Mexico meridian.

At the very head waters of Cottonwood Creek, another tributary of the Fish Fork, a dam could be constructed with an average height of 30 feet, damming the canyon and impounding about 20 acres, with a capacity of about 300 acre-feet. The length of this dam would be 130 feet. Only snow water can be depended on to feed the site.

Another branch of Cottonwood Creek, northeast of the preceding, which has its outlet through a narrow canyon, can be impounded with 
a dam 75 feet high and 600 feet long. A reservoir could thus be formed here covering 200 acres, and having a probable capacity of 3,000 acrefeet. Here again the water resulting from snowfall would mainly be depended on to fill the reservoir.

Another reservoir site was visited on Willow Creek, a tributary of Fish Fork. It is situated about $1 \frac{1}{2}$ miles above the point of discharge of Willow Creek into Fish Fork. A dam 35 feet high and about 400 feet long would back water about 1,800 feet, forming a small reservoir, covering about 20 acres, with a capacity of about 300 acre-feet. This site is within 4 miles of Dunton post-office, and would be fed by Willow Creek and several springs.

In all the above cases ample material is to be found close at hand for the construction of substantial earth or rock filled dams, and there is little doubt that some of the dams described can be built at very moderate cost.

It has been suggested that by thus storing water that would otherwise run to waste during times of high water the company would be enabled to keep on hand a supply which would be available in the latter part of the irrigation season for refilling the reservoirs in the Montezuma Valley and for supplying such deficiencies as would" otherwise occur in the irrigation water contracted for, as shown above. Whether such schemes can be effected without interfering with the water rights of other parties along the river is questionable. Water so stored represents a portion of the natural flow of the river, and when turned into the river again for use at some point below, as in the case at hand, will no doubt be considered by many irrigators as a quantity upon which they are entitled to draw to the full extent of their respective water rights. It may also be asserted that the construction of dams on tributaries for the purpose of storing flood waters will tend to interfere with the flow of such tributaries during the low-water season, thereby injuring parties by depriving them of waters from which they would otherwise derive benefit. Without entering into a discussion of the legal aspects of the question, it may be pointed out here that the litigations likely to arise consequent to such an undertaking should receive due consideration before any steps are taken toward the construction of auxiliary reservoirs.

\section{SUMMARY.}

The results of the investigation may now be summarized as follows:

1. Dolores River furnishes a supply available for irrigating the lands of the diminished Ute reserve.

2. Its flood flow during the months March to June, inclusive, 1896, the driest year of the period considered, exceeded 130,000 acre-feet, or was more than ample, if properly stored, to furnish a continuous flow of - $166 \frac{2}{3}$ second-feet from April 1 to November 1, without interfering with the rights of other irrigators along the river.

$$
20 \text { GEOL, PT } 4-28
$$


3 . The only practical means of bringing water to the reservation is through the ditch system now existing in the Moutezuma Valley, properly enlarged aud equipped with the necessary storage facilities.

4. The capacity of the proposed Morton Lake storage reservoir would have been insufficient to meet the demands of the above contract during the irrigation seasons of 1895,1896 , and 1898 , but would have been sufficient in $189 i$.

5. The joint storage in the two proposed reservoirs would have been insufficient to provide for a constant delivery of 1662 second-feet during the irrigation seasons of 1895,1896 , and 1898.

6 . The joint storage in the proposed reservoirs would have been insufficient to provide for a constant delivery of 100 second feet during the irrigation seasons of 1896 and 1898.

7. The storage in the proposed Morton Lake reservoir could during the irrigation season of 1895 have provided for a continuous flow of 70 second-feet; similarly in 1896 and 1898 it could have provided for a continuous flow of 50 second-feet.

8. It seems improbable, in view of the great cost of construction, that the compauy would find it to its advantage to build both dams when the flow contracted for is to be less than 100 second-feet. Therefore all that the company could have furnished during the period 1895 to 1898 , on the supposition that it had built Morton Lake reservoir, would have been a continuous flow not exceeding 50 second-leet, or water sufficient to irrigate 3,000 acres, not taking account of waste by seepage and evaporation in bringing it to the reservation line.

9. As has been pointed out (pp. 396-400) in a comparison of rainfall and of the flow of streams having head waters in the same mountains as the Dolores, the fluctuations in the precipitation and run-off during the period 1895 to 1898 are of a normal character, and the above conclusions, based on them, may be considered to hold good for average years.

\section{INTERIOR BASIN DRAINAGE.}

Under this heading has been included that portion of the great Interior Basin receiving water from the Sierra Nevada Mountains on the west and Humboldt River on the east. Measurements of the latter stream have been made since 1894 under the immediate direction of Mr. L. H. Taylor.

HUMBOLDT RIVER.

Humboldt River is one of the most important streams in Nevarla, both on account of the volume of its water and of the area of agricultural lands along its course.' It rises in the northeastern part of the State and, as shown on fig. 162, flows in a general westerly and southwesterly direction nearly across Nevada, finally emptying into Humboldt Lake. The overflow from this lake continues southward about 20 miles, emptying into Carson Sink. Thronghont the greater part of its length the Humboldt River flows in a tortuous course through a 
series of rich alluvial valleys, the sites of ancient. lakes: The entire area of the basin drained is about 14,500 square miles, or one-eighth of the entire area of all Nevada. This is included within portions of five different counties, Elko, Eureka, Lander, Nye, and Humboldt. It has been estimated that of this total area one-third is agricultural land, ranging in elevation from 4,000 to 6,500 feet. About one-fourth of the remainder is rolling foothill lands, and the rest cousists of mountain ranges, some of these rising to altitudes of 13,000 feet. These mountains have a general north and south trend, the course of the river

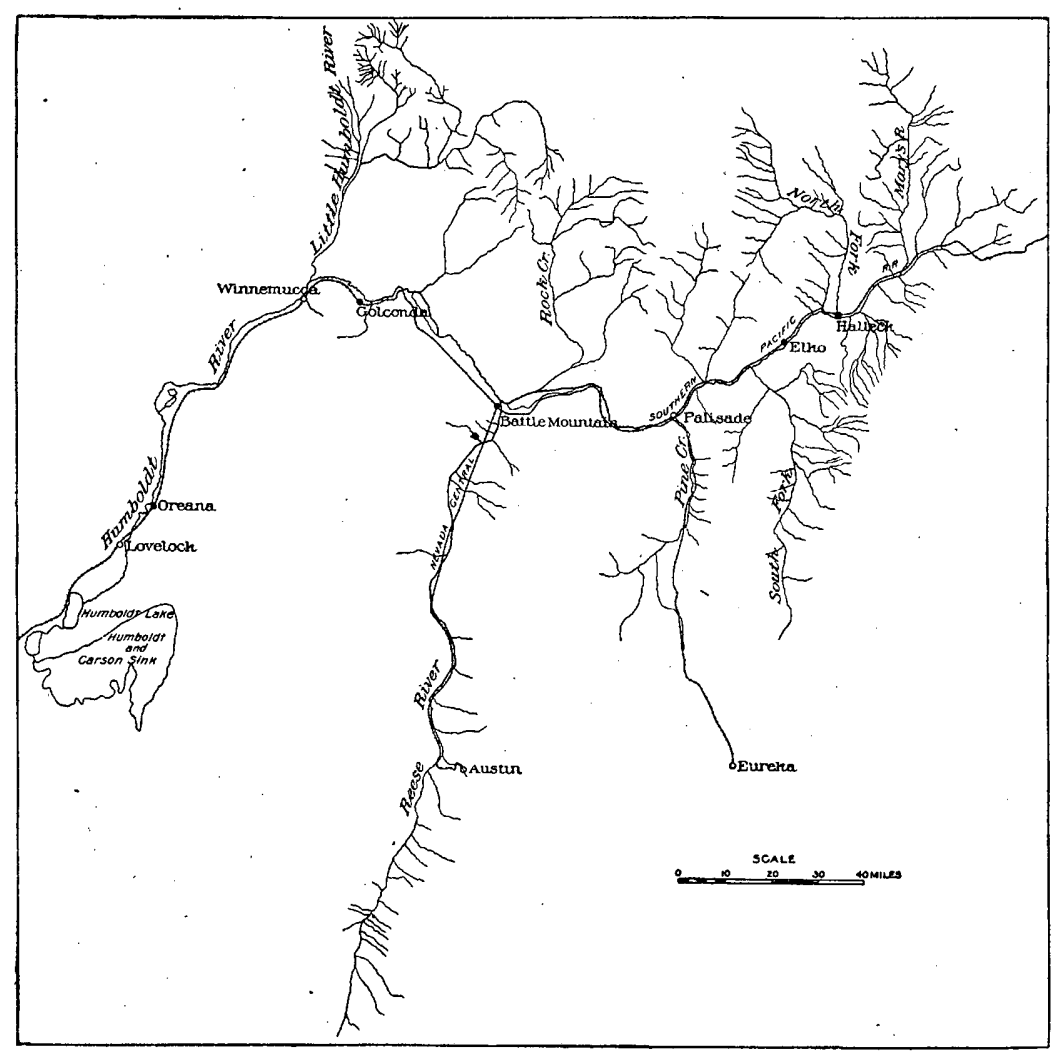

FIG. 162. - Relative location of river and rainfall observations in basin of Humboldt River.

being at right angles to these. Thus the Humboldt Basin is divided into several distinct divisions or districts.

The eastern division of the Humboldt Basin lies within the counties of Elko and Eureka. It consists of a number of smaller basins, the drainage from which has eut what is known as Palisade Canyon through the high ground forming the divide between the eastern basin and the central division. Within this latter division is Battle Mountain Val. ley. To the west of this is Emigrant Canyon, and beyond this the irestern division containing Humboldt Lake. The origin of the existing 
features are discussed by Prof. Israel (). Russell in his monograph on Lake Lahontan. ${ }^{1}$

The agricultural lands are found not only along the main river, but also in the valleys of the numerous tributary streams entering from the north and south. A considerable area has been brought under irrigation in most of these valleys and the soil has been found to be exceedingly fertile wherever there is sufficient supply of water. A number of ditches and canals have been built, sufficient to take the greater part of the water flowing in the streams in ordinary seasons, but a great quantity goes to waste during the spring floods. It has long been obvious that in order to fully utilize the resources of this part of Nevada, storage reservoirs must be built. A general study of the amount of water available for these has been made, river stations having been established at a number of places within the basin of the Humboldt, as described in previous publications. ${ }^{2}$

The following tables give the results of measurements made during 1898, and figs. 163 to 167 show graphically the quantity of water throughout several years.

Estimated monthly discharge of North Fork of Humboldt River at Peko, Nevada.

[Drainage area, 1,020 square miles.]

\begin{tabular}{|c|c|c|c|c|c|c|}
\hline \multirow[b]{2}{*}{ Month. } & \multicolumn{3}{|c|}{ Discharge in second-feet. } & \multirow[b]{2}{*}{$\begin{array}{l}\text { Total in acre- } \\
\text { feet. }\end{array}$} & \multicolumn{2}{|c|}{ Run-off. } \\
\hline & $\begin{array}{l}\text { Maxi- } \\
\text { mum. }\end{array}$ & $\begin{array}{l}\text { Mini- } \\
\text { muns. }\end{array}$ & Mean.' & & $\begin{array}{l}\text { Depth in } \\
\text { inches. }\end{array}$ & $\begin{array}{c}\text { Second. } \\
\text { feet per } \\
\text { square } \\
\text { mile. }\end{array}$ \\
\hline 1898. & & & & & & \\
\hline March 26-31 . . . . . & 55 & 45 & 50 & 3,074 & 0.055 & 0.048 \\
\hline 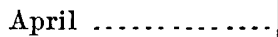 & 229 & 50 & 101 & 6,010 & 0.110 & 0.099 \\
\hline May & 257 & 72 & 147 & 9,039 & 0.166 & 0.144 \\
\hline June ..... & 120 & 11 & 65 & 3,868 & 0.072 & 0.064 \\
\hline July ... & 23 & 6 & 13 & 799 & 0.014 & 0.013 \\
\hline August..... & 7 & 0.3 & 4 & 266 & 0.005 & 0.004 \\
\hline September ... & 1 & 0.3 & 0.6 & 33 & 0.001 & 0.001 \\
\hline October ...... & 8 & 1 & 6 & 379 & 0.007 & 0.006 \\
\hline November .......... & 28 & 8 & 17 & 1,012 & 0.018 & 0.016 \\
\hline December ...... & 28 & 18 & 24. & 1,476 & 0.028 & 0.024 \\
\hline
\end{tabular}

Note.-A description of this station is given in Water-Supply and Irrigation Paper No. 28, page 145. Gage heights for 1898 are given on page 148; measurements, page 153; and rating table, page 154.

${ }^{1}$ Geological History of Lake Lahontan, a Quarternary Lake of Northwestern Nevada, by Israel Cook Russel, Monograph $\dot{X} \mathbf{I}$ of the United States Geological Survey, 1885.

${ }^{2}$ Report of Progress of the Division of Hydrography for the Calendar Years 1893-1894. Bull. No. 131, p.52. Description of Golconda Station on Humboldt River.

Progress Report of the Division of Hydrography for the Calendar Year 1895. Bull. No. 140, p. 215. Description of Humboldt River, Elko, Golconda, and Oreana Stations.

Eighteenth Annual Report, Part IV, Hydrography, p. 299. Description of Elko, Battle Mountain, Golconda, and Oreana Stations on Humboldt River; also Battle Mountain Station on Rock Creek and Mason's Ranch Station at South Fork of Humboldt River.

Nineteenth Annual Report, Part IV, p.424. Results obtained at Elko, Battle Mountain, Humboldt, and Oreana Stations on Humboldt River; also at Mason's Ranch on South Fork of Humboldt River. 


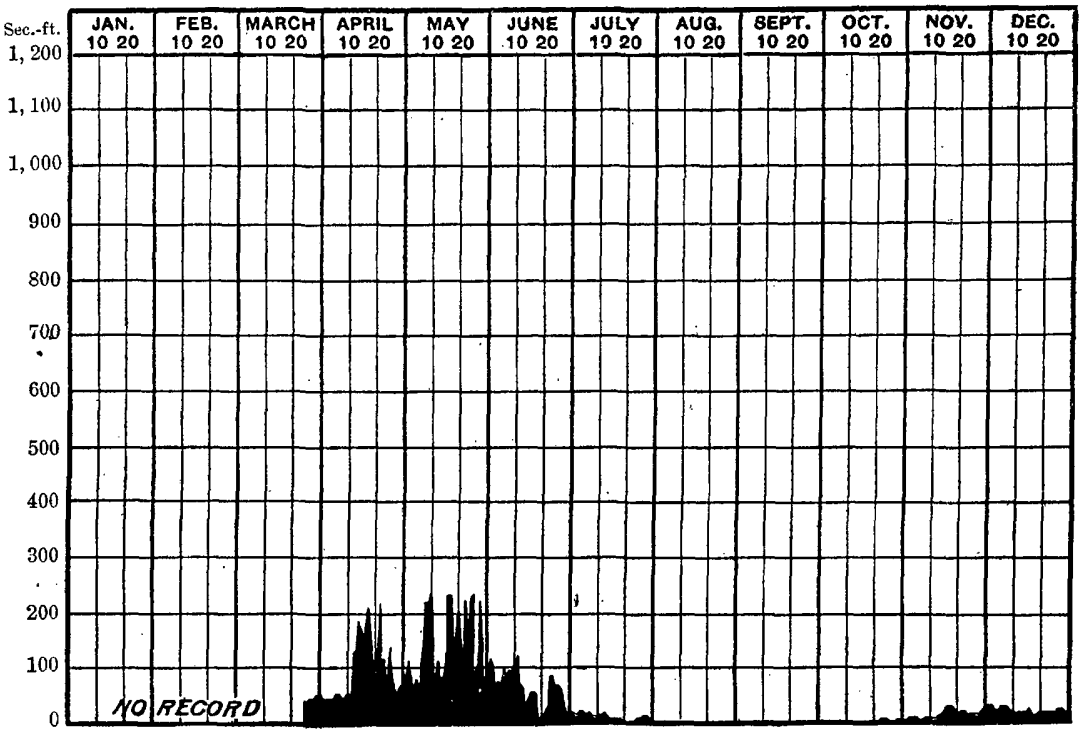

Fig. 163.-Discharge of North Fork of Humboldt River at Peko, Nevada, 1898

Estimated monthly discharge of Humboldt River at Elko, Nevada.

- [Drainage area, 2,840 square miles.]

\begin{tabular}{|c|c|c|c|c|c|c|}
\hline \multirow[b]{2}{*}{ Month. } & \multicolumn{3}{|c|}{ Discharge in second-feet. } & \multirow[b]{2}{*}{$\begin{array}{l}\text { Total in acre- } \\
\text { feet. }\end{array}$} & \multicolumn{2}{|c|}{ Run-off. } \\
\hline & $\begin{array}{l}\text { Maxi. } \\
\text { mum. }\end{array}$ & $\begin{array}{l}\text { Mini. } \\
\text { mum. }\end{array}$ & Mean. & & $\begin{array}{l}\text { Deptb in } \\
\text { inches. }\end{array}$ & $\begin{array}{c}\text { Second- } \\
\text { feet per } \\
\text { square } \\
\text { mile. }\end{array}$ \\
\hline 1898. & & & $\checkmark$ & & & \\
\hline January & 78 & 51 & 65 & 3,997 & 0.027 & 0.023 \\
\hline February ........... & 565 & 57 & 206 & 11,441 & 0.076 & 0.073 \\
\hline 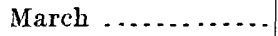 & 565 & 137 & 271 & 16,663 & 0.110 & 0.095 \\
\hline April & 269 & 137 & 209 & 12,436 & 0.081 & 0.073 \\
\hline May ..... & 478 & 199 & 348 & 21,398 & 0.142 & 0.123 \\
\hline June ............... & 450 & 177 & 359 & 21,362 & 0.141 & 0.127 \\
\hline July .. & 177 & 3 & 58 & 3,566 & 0.024 & 0.021 \\
\hline August..... & 3 & 1 & 1 & 81 & 0.001 & 0.001 \\
\hline September ... & 6 & 1 & 2 & 89 & 0.001 & 0.001 \\
\hline October... & 10 & 4 & 6 & 394 & 0.003 & 0.002 \\
\hline November... & 24 & 6 & 15 & 882 & 0.006 & 0.005 \\
\hline December ... & 39 & 19 & 24 & 1,497 & 0.010 & 0.009 \\
\hline 'I'he year..... & อ65 & 1 & 130 & 93,806 & 0.62 & 0.05 \\
\hline
\end{tabular}

Note.-Gage heights for 1898 are giren in Water-Supply and Irrigation Paper No. 28, page 147, measurements, page 153; rating table, page 154; Results for 1897 axe given in Water.Supply and Irrigation Paper No. 16, page 152, and in the Nineteenth Annual Report, Part I.V, pages 424 to 426. 


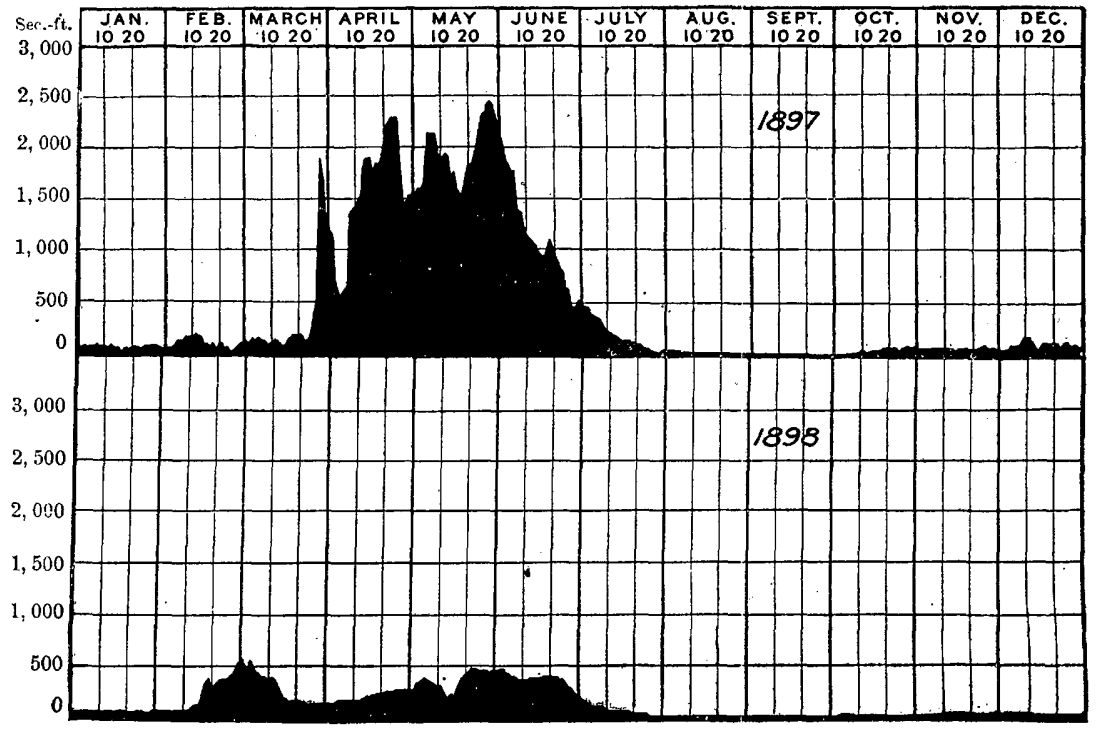

Fia. 164.-Discharge of Humboldt River at Elko, Nerada, 1897-98.

Estimated monthly discharge of Humboldt River at Golconda, Nevada.

[Drainage area, 10,780 square miles.]

\begin{tabular}{|c|c|c|c|c|c|c|}
\hline \multirow{2}{*}{ Month. } & \multicolumn{3}{|c|}{ Discharge in second-feet. } & \multirow[b]{2}{*}{$\begin{array}{l}\text { Total in acre- } \\
\text { feet. }\end{array}$} & \multicolumn{2}{|c|}{ Run-off. } \\
\hline & $\begin{array}{l}\text { Maxi- } \\
\text { mum. }\end{array}$ & $\begin{array}{l}\text { Mini- } \\
\text { mum. }\end{array}$ & Mean. & & $\begin{array}{l}\text { Depth in } \\
\text { inches. }\end{array}$ & $\begin{array}{l}\text { Second. } \\
\text { feet per } \\
\text { square } \\
\text { mile. }\end{array}$ \\
\hline 1898. & & , & & . & & \\
\hline January $\ldots \ldots \ldots$ & 225 & 190 & 205 & 12,605 & 0.022 & 0.019 \\
\hline February ......... & 451 & 190 & $2 b 6$ & 14,773 & 0.026 & 0.025 \\
\hline 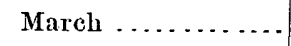 & 485 & 336 & 418 & 25,702 & 0.045 & 0.039 \\
\hline April ..... & 321 & 64. & 190 & 11,306 & 0.020 & 0.018 \\
\hline May ....... & 321 & 22 & 94 & 5,780 & 0.010 & 0.009 \\
\hline June .............. & 351 . & 176 & 249 & 14,816 & 0.026 & 0.023 \\
\hline July ............ & 204 & $\dot{27}$ & 119 & 7,317 & 0.013 & 0.011 \\
\hline August...... & 27 & 2 & 8 & 492 & 0.001 & 0.001 \\
\hline September .... & 2 & 1 & 1 & 60 & 0.000 & 0.000 \\
\hline October ........... & 1 & 1 & 1 & 61 & 0.000 & 0.000 \\
\hline November......... & 1. & 1 & 1 & 60 & 0.000 & 0.000 \\
\hline December ......... & 17 & 1 & 7 & 430 & 0.001 & 0.001 \\
\hline The year.... & 485 & 1 & 130 & 93,402 & 0.164 & 0.012 \\
\hline
\end{tabular}

Nore.-Gage heights for 1898 are given in Water-Supply and Irrigation Paper No. 28, page 148, measurements, page 153; rating table, page 154. Results for 1897 are given in Water-Supply and Irrigation Paper No. 16, page 154, and in the Nineteenth Annual Report, Part IV, page 427. 


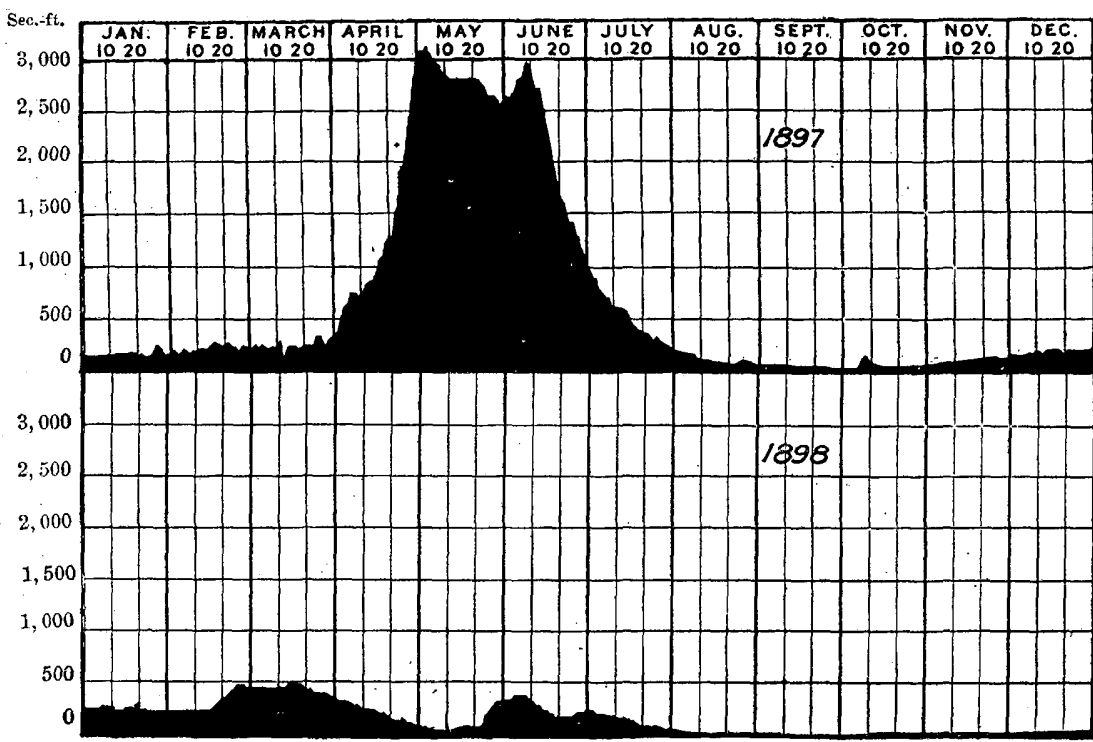

Fig. 165.-Discharge of Humboldt River at Golconda, Nevada, 1897-98.

Estimated monthly discharge of Humboldt River at Oreana, Fevada.

[Drainage area, 13,800 square miles.]

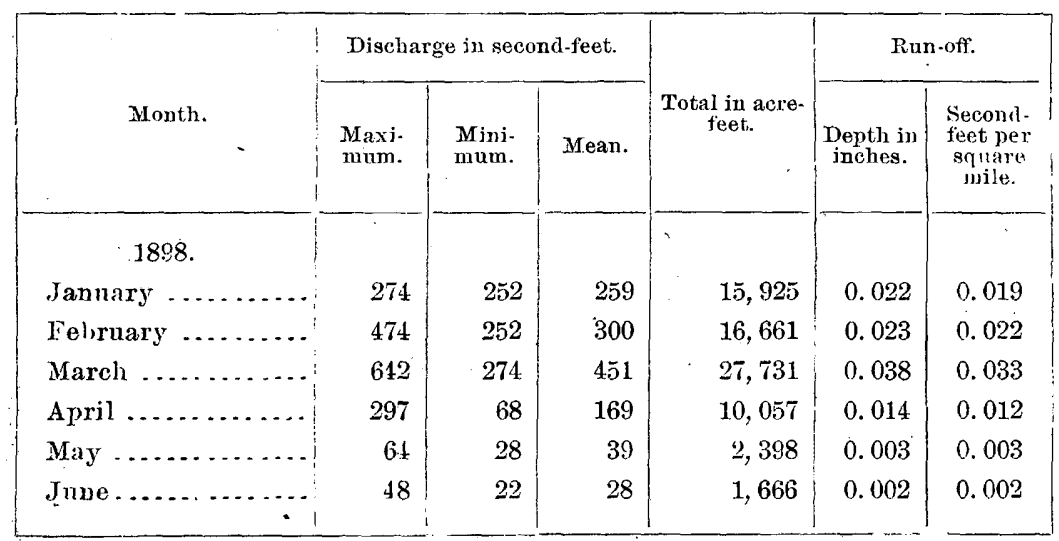

NoxE.-Gage heights for 1898 áre given in Water-Supply and Irrigation Paper No. 28, page 148; measurements, page 153; rating table, page 154. Results for 1897 are given in Water-Supply and Irrigation Paper No. 16, page 155, and in the Nineteenth Anuual Report, Part IV, pages 428 aud 429. 


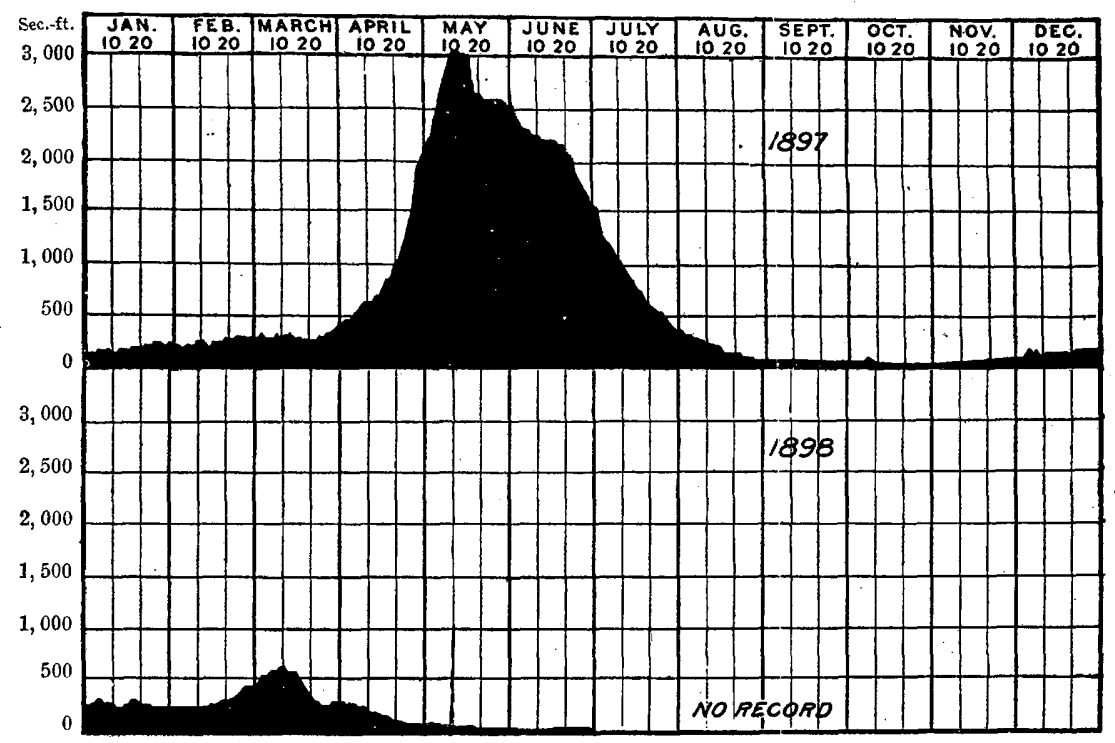

Frg. 166.-Discharge of Humboldt River at Oreana, Nevada, 1897-98.

Estimated monthly discharge of South Fork of Humboldt River at Mason's Ranch, Nevada.

[Drainage area, 1,150 square miles.]

\begin{tabular}{|c|c|c|c|c|c|c|}
\hline \multirow[b]{2}{*}{ Month. } & \multicolumn{3}{|c|}{ Discharge in second-feet. } & \multirow[b]{2}{*}{$\begin{array}{l}\text { Total in acre- } \\
\text { feet. }\end{array}$} & \multicolumn{2}{|c|}{ Run.off. } \\
\hline & $\begin{array}{l}\text { Maxi- } \\
\text { mum. }\end{array}$ & $\begin{array}{l}\text { Mini- } \\
\text { mum. }\end{array}$ & Mean. & & $\begin{array}{l}\text { Depth in } \\
\text { inches. }\end{array}$ & $\begin{array}{c}\text { Second- } \\
\text { feet per } \\
\text { square } \\
\text { mile. }\end{array}$ \\
\hline 1898. & & & & & & \\
\hline January ........ & 132 & 51 & 78 & 4,796 & .0 .078 & 0.068 \\
\hline February ... & 434 & 64 & 191 & 10,608 & 0.173 & 0.166 \\
\hline March ........ & 150 & 70 & 116 & $7,1.33$ & 0.116 & 0.101 \\
\hline April ....... & 276 & 99 & 165 & 9,818 & 0.160 & 0.143 \\
\hline May ....... & 460 & 179 & 290 & 17,856 & 0.288 & 0.252 \\
\hline June............. & 473 & 221 & 355 & 21,124 & 0.345 & 0.309 \\
\hline July .............. & 210 & 14 & 86 & $5,288^{\circ}$ & 0.087 & 0.075 \\
\hline August. ......... & 10 & 0.1 & 4 & 246 & 0.004 & 0.003 \\
\hline September ..... & 6 & 0.1 & 2 & 119 & 0.002 & 0.002 \\
\hline October................ & 29 & 6 & 18 & 1,107 & 0.018 & 0.015 \\
\hline November .......... & 57 & 24 & 29 & 1,726 & 0.028 & 0.025 \\
\hline December .......... & 70 & 29 & 39 & 2,367 & 0.039 & 0.034 \\
\hline The year ..... & 473 & 0.1 & 114 & 82,188 & 1.34 & 0.099 \\
\hline
\end{tabular}

Note.-Gage heights for 1898 are given in Water-Supply and Irrigation Paper No. 28, page 148, measurements, page 153; rating table, page 154. Results for 1897 are given in Water-Supply and Irrigation Paper No. 16, page 156, and in the Nineteenth Annual Report, Part IV, pages 429 to 430. 


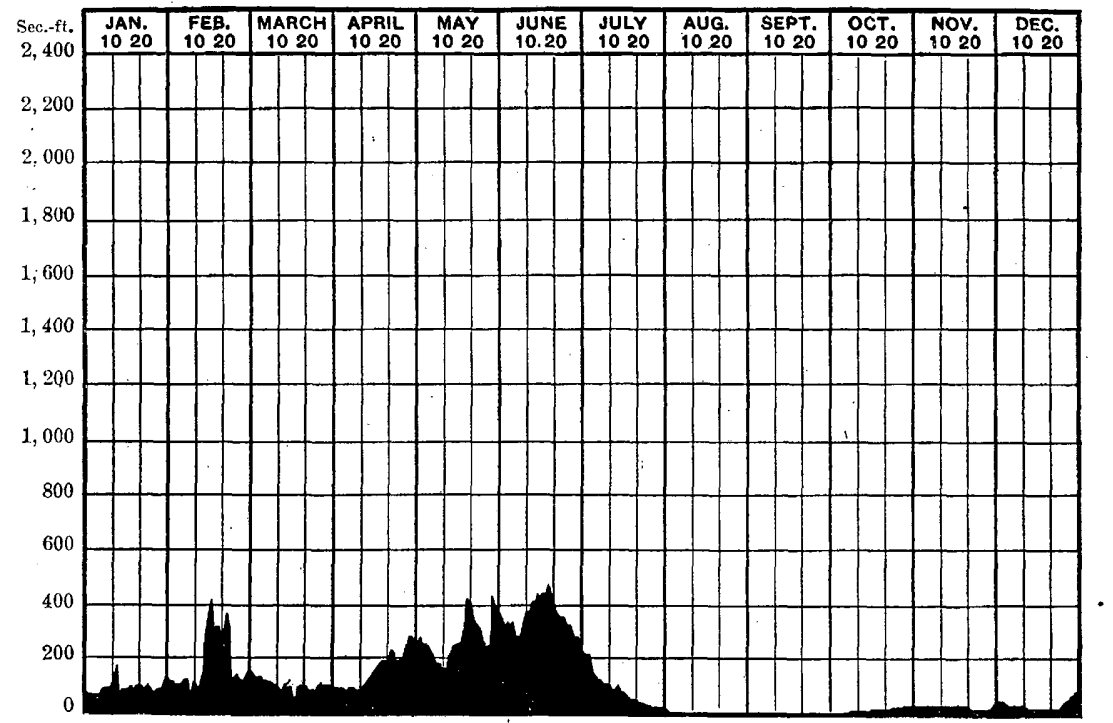

FIG. 167.-Discharge of South Fork of Humboldt River at Mason's Ranch, Nevada, 1898.

Surveys of various reservoir sites along Humboldt River have been made by Mr. L. H. Taylor at the instance of individuals or corporations and a considerable body of valuable information has thus been brought together. The principal sites examined are those on Rock Creek, near Battle Mountain, and in the Lower Humboldt Valley above Oreana. The following facts concerning these localities are taken from the reports by Mr. Taylor.

\section{ROCK CREEK STORAGE SYSTEM.}

Rock Creek reservoir site is located on Rock Creek on the northern boundary of Lander County, the northern part being in Elko County. It is in portions of townships 35 and 36 N., R. $47 \mathrm{E}$. The general shape of the reservoir is shown in fig. 168. The project for utilizing this reservoir site involves the turning back of the stored water into Rock Creek, down which the water will flow to Humboldt River, being diverted by a dam placed about 6 miles above the town of Battle Mountain. Excess water will be allowed to flow in the river down to a point near Golconda, where it can be taken out on the opposite or south side of the stream by means of a second canal. The first canalthat near Battle Mountain-will cover about 60,000 acres of land on the north side of the river extending down the valley a distance of about 30 miles from the diverting dam. The second canal, heading about 4 miles above the town of Golconda, will cover about 40,000 acres on the south side of the river between Golconda and Winnemucca. The water supply for the reservoir and for these canals is shown by the 
tables and diagrams on the preceding pages. The following statement has been preparell by Mr. Taylor:

Rock Creek reservoir site.-The area of watershed tributary to the reservoir at Rock Creek is over 750 square miles, the greater portion of which is high, mountainous territory, where the annual precipitation in the form of snow is very heavy, lingering late in the spring and early summer before it melts. The altitude at the dam is about 5,000 feet and the watershed is mostly over 6,000 feet, aul from that to 10,000 or 11,000 feet.

The mean precipitation at Battle Mountain, elevation 4,511 feet, is abont 7 inches; at Tuscarora, elevation 6,400 feet, about 21 inches, and these are the only two Weather Burean stations near the watershed in question. On the monntains the precipitation increases with the altitude at much greater ratio than in the valleys, and the record kept at the stations on the Central Pacific Railroad shows that this ratio of increase ascending the Sierra Nevada from Sacramento is as great as 3 per cent per hundred feet. On this basis the precipitation and run-off may be roughly estimated as follows:

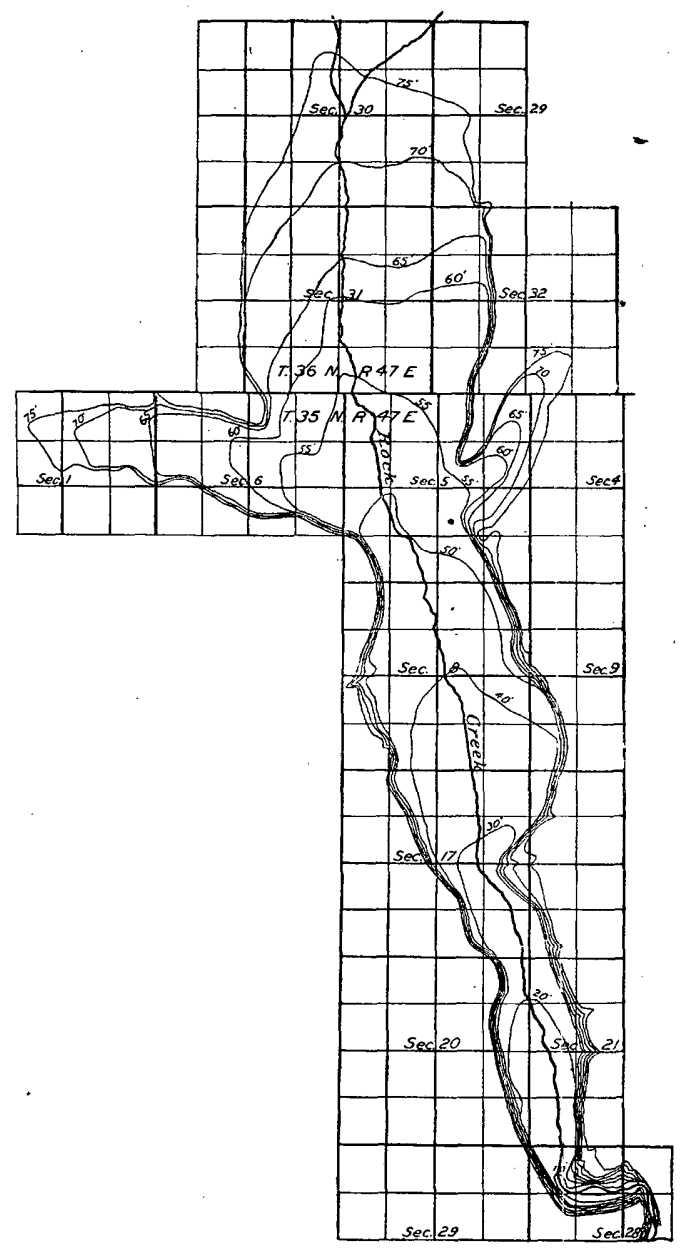

Fir. 168.-Map of Rock Creek reservoir, Lander County, Nevada. 


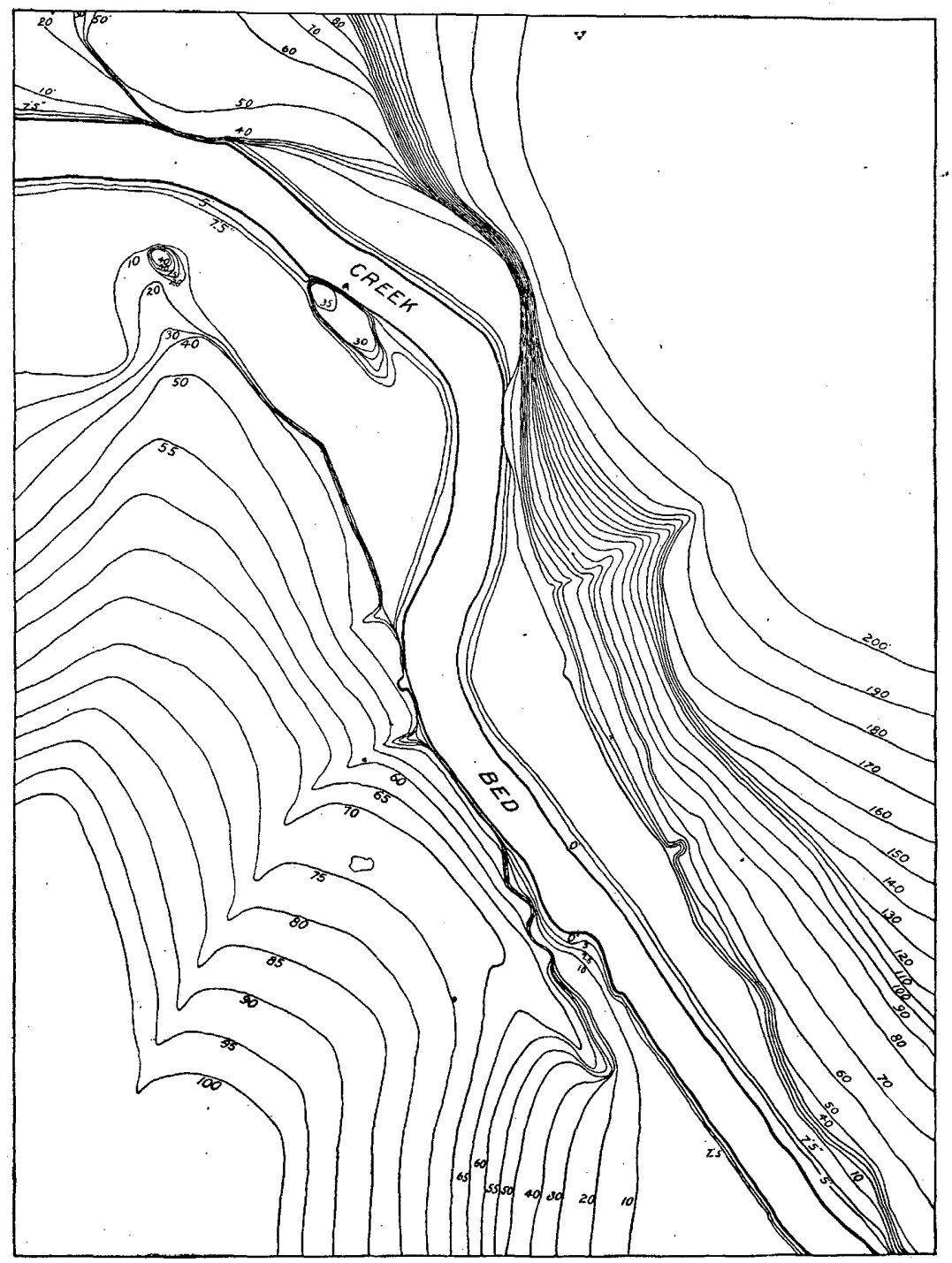

Fra. 169.-Plan of dam site of Rock Creek reservoir, Lander County, Nevada.

Precipitation and run-off from watershed tributary to Rock Creek reservoir.

\begin{tabular}{|c|c|c|c|}
\hline Area. & $\begin{array}{c}\text { Elevation } \\
\text { greater } \\
\text { than- }\end{array}$ & $\begin{array}{c}\text { Precipita. } \\
\text { tiou. }\end{array}$ & Run-off. \\
\hline Sq. miles. & Feet. & Inches. & Inches. \\
188 & 8,000 & 30 & 17.0 \\
376 & 6,500 & 21 & 8.0 \\
188 & 5,000 & 7 & 0.0 \\
\hline & & Mean ...... & 6.25 \\
\hline
\end{tabular}




\section{PROGRESS OF STREAM MEASUREMENTS FOR 1898.}

The percentage of run-off is taken from the "Newell Curve," ${ }^{1}$ and is for the larger volume given for mountainous areas. This estimate gives a run-off of 6.25 inches from the whole watershed, which wonld thus yield about 250,000 acre-feet, or wore than three times the quantity needed to fill the reservoir. The estimate does not seem excessive, but it may neverthe!ess be too high for this arid region. It may therefore be divided by three and still have an ample supply to fill the reservoir and leave a reserve to help maintain evaporation. Confidence is felt in the filling capacity of the reservoir with so large a watershed to keep it supplied. The stream is a living one in the dryest season, and is well stocked with trout in all its tributaries, as well as in the main canyon below the dam site. During the fall of 1895 the lowest, stage reached was about 6 cubic feet per second. It is proposed to build a reservoir having a capacity of 80,000 acre-feet $(26,100,000,000$ gallons), which will furnish all the water that will be required to suppiement the flow of the river during the dryest years and allow ample for evaporation. The survey of the reservoir basin shows that with a dam whose high-water line is 75 feet above the present creek bed the reservoir will cover 3,670 acres and have a.capacity of 80,000 acre-feet, and that if the dam be raised 15 feet higher, making the high-water line at 90 feet, the area will be increased to about 5,700 acres and the capacity to 150,000 acre-feet. However, since it is not certain that the watershed is capable of filling the greater reservoir, estimates have been made for the dam whose high-water line shall be at 75 feet, and height above base 85 feet. Besides this water supply, experience has shown that a considerable portion of the water applied to lands bordering a stream will naturally return in time by percolation to the stream, and may be used again at points farther down. Thus, of the water diverted for the irrigation of lauds near Battle Mountain some will return to the river and be available for use at Golconcla. 'This result is rendered' more certain from the fact that the entire drainage of the Battle Mountain district must pass throngh a narrow canyon before it reaches the lower or Golconda Canal. While the volume of this return water can not be determined beforehand, from a close study of the matter by engineers in Colorado and elsewhere under conditions similar to those existing here, where the return is from 30 to 50 per cent of the amount applied to the land, it is estimated that in time not less than 25 per cent of the volume of water applied to the Battle Monntain tract will return and be available for use at Golconda, tbus increasing the supply at that point during the irrigating season by from 35 to 50 cubic feet per second.

Proposed dam.-The dam site is as remarkable for its general excellence as the reservoir just described, and the combination of the two form one of the most notable localities for a storage reservoir. The gorge where the dam is to be located is walled on both sides by rhyolite, of a reddish-brown color, hard and flinty in its nature, and so crystalline and compact as to have resisted the disintegrating action of the weather. Little stripping of the surface is required to prepare it to receive the foundation of a dam. The bed of the canyon is unfortunately covered with sand, and the depth of the bed rock over the entire foundation has not yet been determined, but from the soundings made it appears that the mean depth will not exceed 6 feet, ranging from 3 feet to perhaps as great a depth as 12 feet. The rock rises almost vertically from the stream bed to a height of 60 feet on the right bank, and about 200 feet on the left bank, the width at bottom being 113 feet; at 56 feet high the width is 155 feet; at 66 feet, 170 feet; at 75 feet high, 250 feet; at 85 feet, 340 feet; and at 100 feet, 480 feet.

The dam recommended for this situation would cost about $\$ 60,000$, and have a height of 85 feet, or 10 feet above high-water line in the reservoir. It would consist of a rock fill or loose-rock embankment with a base of 275 feet up and down stream, a width of 20 feet on top, and side slopes of $1 \frac{1}{2}$ to 1 . This fill can be thrown into place from the adjacent cliff, and almost entirely made at one huge blast, and at a low

'Fonrteenth Annual Keport, Part II, page 151; also Eighteenth Annual Report, Part IV, Pl. LXXXII, page 694 . 
cost. It would contain about 70,000 cubic yards and be faced on the water side by an embankment of earth having a slope of 3 to 1 and covered with a revetment of rock 2 fect thick to prevent erosion. The earth is to be put in by scrapers, well puddled and sluiced into the interstices of the rock embankment as it is built. An abundance of fine loam suitable for the purpose is at hand in the ralley above the dam, within 1,000 feet at the outside.

The outlet to the reservoir is to be by means of a tunnel 6 by 7 feet, excavated in the solid rock to one side of the dam, and to be fitted with suitable pipes and gates. In the Pecos Valley, New Mexico, are two notable structures of this type, but lighter in cross section, which are 1,300 and 1,600 feet in length, one of them forming one of the largest reservoirs in the United States.

The possibility of handling large masses of rock at one blast has been repeatedly demonstrated. Several notable blasts of this character bave been made in railroad construction on the Columbia River and on Vancouver Island, the shots ranging from 40,000 to 100,000 cubic yards and the cost from 3 to $b$ cents per cubie yard. At the Otay dam, near San Diego, a recent blast loosened over 30,000 cubic sards, which was afterwards picked up and convesed by a Lidgerwood wire cableway 100 to 500 feet, at a total cost of about 50 cents per yard. A later blast at the same place loosened and threw out about 80,000 cubic yards. In this location the canyon is so narrow and the rock so hard there will be little difficulty in adjusting the tunnels so as to throw the rock to the right place and almost completely fill the canyon at one blast.

A cableway 600 feet from tower to tower should be used in conveying rock for completing and dressing down the embankment after the first shot, and for the riprapping of the earth slope, as well as in excavating the waste way channel. The fuel to be used for making steam can be cheaply furnished from the sagebrush to be gathered near by in the reservoir lasin. Sand for concrete work is abundant in the creek channel on the spot.

\section{Estimated cost of dam.}

70,000 cubic yards of rock, 75 per cent of which is thrown into place by powder $-52,500$ yards, at

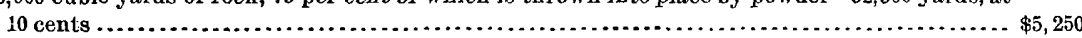

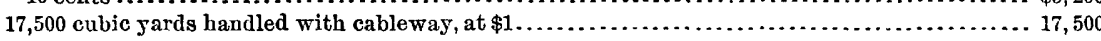

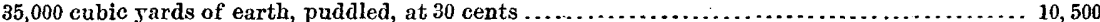

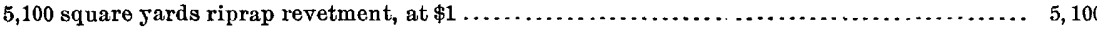

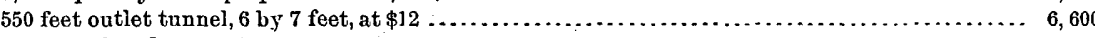

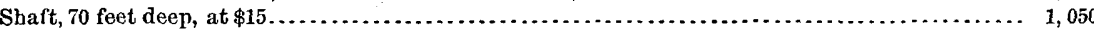
Lining shaft and cross wall in tunnel, etc., 50 cubic yards of concrete, at $\$ 12 \ldots \ldots \ldots \ldots \ldots . .600$ Foot wall of concrete at foot of rock embankment, inside 150 cubic yards, at $\$ 8 \ldots \ldots \ldots \ldots \ldots \ldots 1,200$

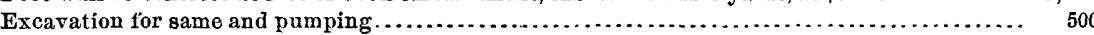

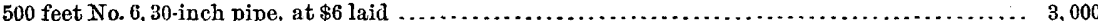

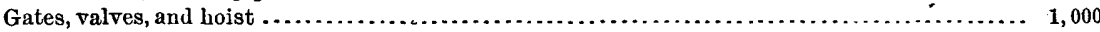

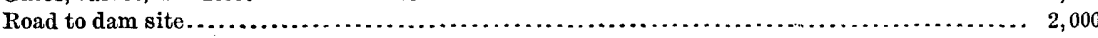
Telephone line .................................................................... 1,000

Engineering and superintendence $\ldots \ldots \ldots \ldots \ldots \ldots \ldots \ldots \ldots \ldots \ldots \ldots \ldots \ldots \ldots \ldots \ldots \ldots \ldots \ldots, 7,000$ Total. ...................

Canals.-The Battle Mountain Canal will have a capacity of about 300 cubic feet per second and will extend about 24 miles in length, with 20 lateral canals, having a total length of about 114 miles and a capacity of about 25 to 50 cubic feet per second each, with outlet gates to each 160 acres of land in the entire tract.

The Golconda Canal will have a capacity of 250 cubic feet per second and a length of about $45 \frac{1}{2}$ miles, with lateral canals having; a total length of 50 miles, and capacity of 20 to 60 feet per second, and with outlet gates to each 160 acres of land to be supplied, as in the case of the Battle Mountain system.

The ordinary flow of the river will be the main reliance for water supply, supplemented, however, by the enormous storage reservoir above described, to be constructed on Rock Creek. This reservoir forms the keystone of the entire project, for without it the water supply of the river would fall short almost every year before the close of the irrigating season. 
As the irrigating season begins about the middle of April and closes from September 1 to 15, it will be seen that even during the very dry season of 1895 (there have been but two others like it for thirty years) two canals of 350 cubic feet per second capacity, such as are projected, would have been supplied. by the stream (even diminislued by the storage of Rock Creek waters) up to about June 10. Thereafter, if the draft on the reservoir had been as great as 400 cubic feet per second (an excessive amount for the latter part of the season) until September 10 (ninety days), it would have drawu 3,110,400,000 cubic feet, or 71,400 acre-feet, of water from the reservoir.

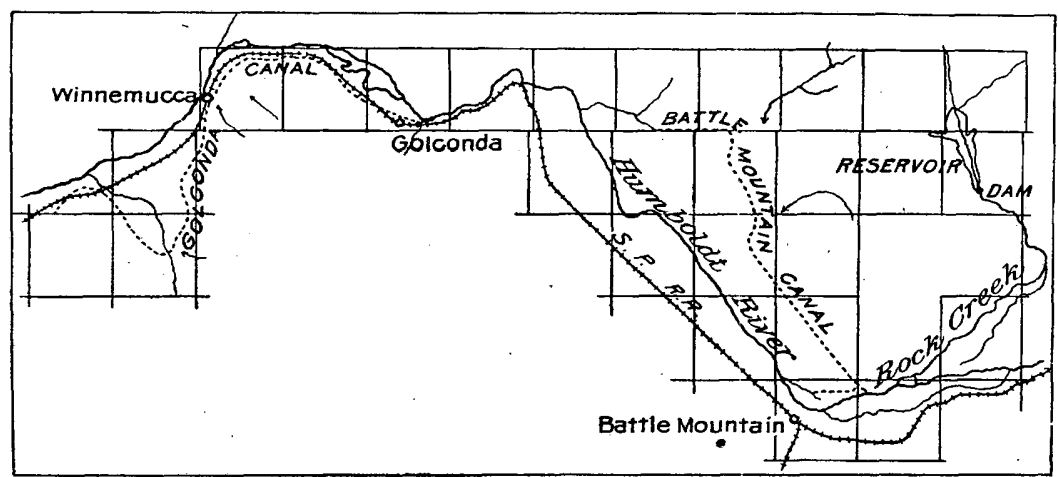

FIG. 170.-Map of proposed reservoir, canals, and irrigable land in Humboldt Valley, between Battle Mountain and Winnemucea, Nevada.

Main canal:

Estimated cost of Battle Mountain Canal.

Regulating weir head gates and dirersion dam and weir........................ $\$ 5,000$

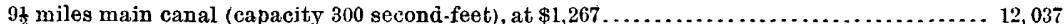

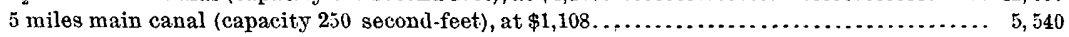

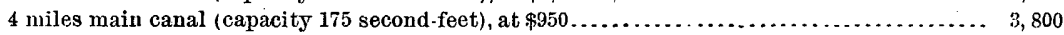

$2 \frac{1}{2}$ miles main canal (capacity 125 second.feet), at $\$ 633 \ldots \ldots \ldots \ldots \ldots \ldots \ldots \ldots \ldots \ldots \ldots \ldots$

3 miles main canal (capacity 100 second-feet), at $\$ 500 \ldots \ldots \ldots \ldots \ldots \ldots \ldots \ldots \ldots \ldots \ldots \ldots, 500$

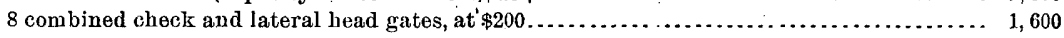

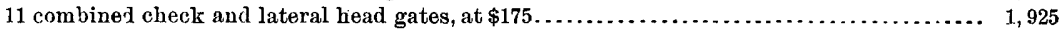
Laterals :

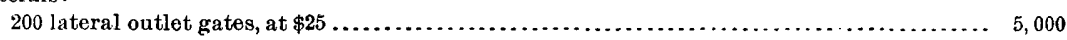

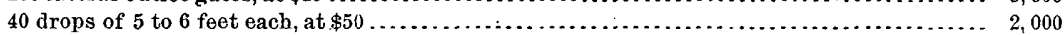

Flumes on laterals across sloughs, about 5,000 lineal feet, at 80 cents................. 4,000

43 miles lateral canals, requiring 1,760 cubic yards per mile, say 2,000 yards at 5 cents per

yard, or $\$ 100$ per mile.............................................. 4,300

71 miles laterals, 5,000 cubic yards per mile, at 5 cents per cubic jard, or $\$ 250$ per mile ...... 17, 750

Improvement of Rock Creek channel...................................... 5,000

Engineering, superintendence, and contingencies, 15 per cent...................... 10,655

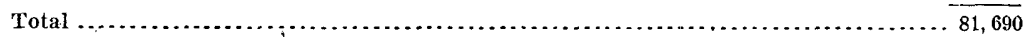

Main canal:

Estimated cost of Golconda Canal.

Diversion dam and head gates......................................... $\$ 6.000$

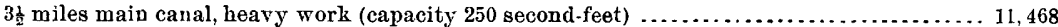

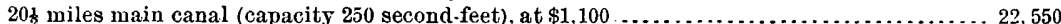

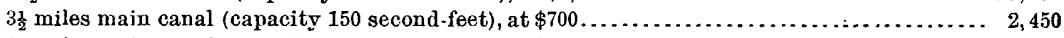

$8 \frac{1}{2}$ miles main canal (capacity 100 second.feet), at $\$ 500 \ldots \ldots \ldots \ldots \ldots \ldots \ldots \ldots \ldots \ldots \ldots \ldots, 250$

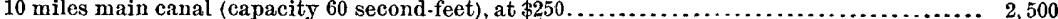

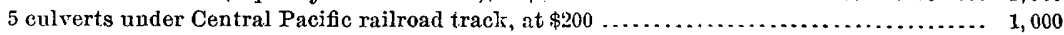

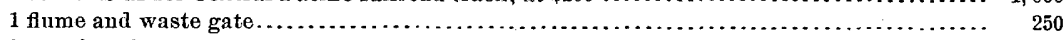

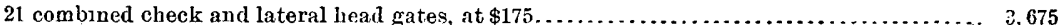

12 combined check and lateral heal gates, at $\$ 150 \ldots \ldots \ldots \ldots \ldots \ldots \ldots \ldots \ldots \ldots \ldots \ldots \ldots, 1,800$ 
Laterals :

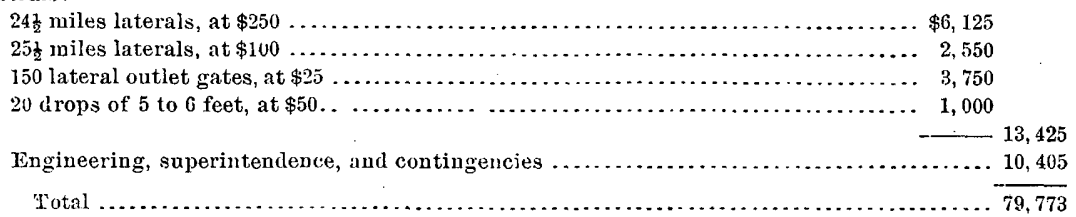

Estimated tolal cost.

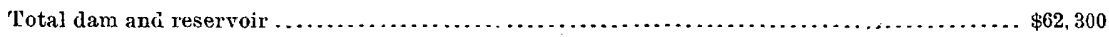
Total Battle Mountain Canal ....................................................... 81,690

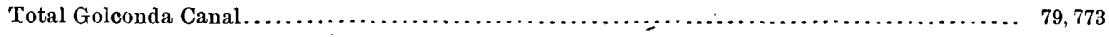

Total cost of works for irrigating 100,000 acres, delivering water to each quarter section

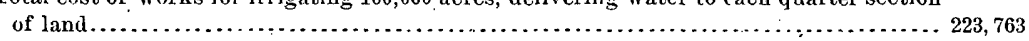

To supply the first 15,000 or 16,000 acres at Battle Mountain, and 10,000 acres at Golconda, which would probably be the only outlay for the first two or three years, the cost would be about as follows:

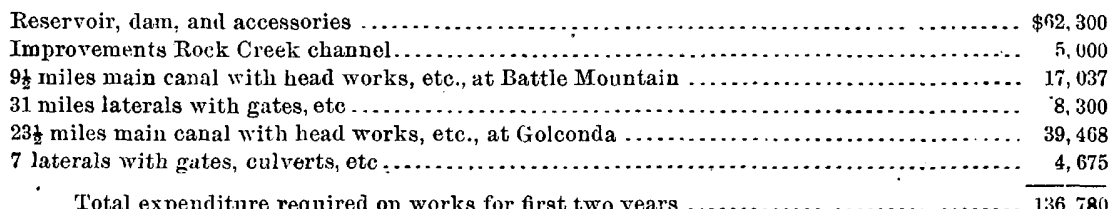

Total expenditure required on works for first two years $\ldots \ldots \ldots \ldots \ldots \ldots \ldots \ldots \ldots \ldots$

The cauals and distributing systems are simple, easy, and cheap in the extreme. On the Battle Mountain system not a single flume or culvert of any sort will be needer on the main canal, while the material to be excavated throughont its course is a fine, loamy soil of the very best and easiest grade for economical work. It can all be contracted for at 5 cents per cubic $y$ ard, and the laterals at 4 cents or less. With the exception of about $3 \frac{1}{2}$ miles of its course, which is along the side of a bench or mesa in gravelly soil, and the fact that it will cross the Central Pacific railroad three times, the main canal of the Golconda system is alike sinple and easy, while the laterals are all through easy ground of the very cheapest character to work.

Head gates and diverting dams.-The site selected for the dam and canal head gate near Battle Mountain is at the point of diversion of the old McIntyre and Blossom ditch, one of the oldest water rights on the Humboldt River, which it is proposed to incorporate into this scheme, and which will furnish it with the basis for the indisputable right to appropriate all the low-water flow of the river passing this point. Here the river is about 100 feet wide and hugs closely to the rocky bills on the north side of the valley, where it is not likely to change its conrse. A loose rock dam has been formed here by annual additions of rock of all sizes, easily handled, for the past 25 or 30 years, until a broal base has been made that is not liable to further settlement, and on which a timber weir can be safely erected and so devised that all the low-water flow can be secured, while extreme flood waters can lie permitted to pass down the stream.

The site of the head works of the Golconda Canal is in the mouth of what is known as Emigrant Canyon, at the point of diversion of the old Humboldt Canai or French ditch. At this point the river channel, with the low or bottom ground bordering it and subject to overflow, has a width of abont 500 feet, and a weir of the same type as that recommended for the head of the Battle Mountain Canal, flanked by low earth embankments across the low ground bordering the channel, will control the stream and regulate the flow into the canal very efficiently. 


\section{LOWER HUMBOLDT STORAGE SYSTEM.}

An examination of a water-storage project in the valley near Humboldt station, Nevada, was made by Mr. L. H. Taylor for the Humboldt Land and Irrigation Company, of Lovelock, Nevada. The enterprise contemplated the utilization of four natural basins or depressions immediately north of Humboldt station on the Central Pacific Railroad and on the left bank of Humboldt River, 33 miles above Lovelock, for the storage of about 55,000 acre-feet of flood waters of Humboldt River. The amount of water has been ascertained by records kept at Oreana, about 20 miles below the reservoir site, these being given from January 27,1896 , as shown by the preceding tables and diagrams. The irrigation season in the Lower Humboldt Valley begins about the 1st of April and lasts until about the middle of August, the greatest quantity of water being used during the months of April, May, and June, when all crops, including grain, are being irrigated.

The amount of water diverted from the river by the six ditch systems now in operation below Oreana at any time during these three months will probably not exceed 320 second-feet. It is probable that by having one consolidated system of ditches this volume could be reduced by about one-half, since after examination 16,000 acres of land are reported to be under cultivation. It is apparent from the figures of river discharge that the flow during the non-irrigating season, added to the surplus water of a part of the irrigating season, is ample, even in dry years like 1898, to fill the reservoirs without interfering with vested rights. The regular flow of the Humboldt frequently falls below the requirements even of present irrigation in the vicinity of Lovelock during the irrigating season, and it has become imperative that some means should be devised to increase the water supply. Storage of the surplus or flood waters which now run to waste is the only apparent means of accomplishing this result. The following details have been taken from a report by Mr. Taylor:

Reservoirs.--Immediately north of Humboldt station on the Central Pacific Railroad are two large and two smailer natural basins which can be utilized as sites for stcrage reservoirs, as shown in the accompanying maps, figs. 171 and 172 . Reservoirs No. 1 and 2, and $A$ and $B$. The small basins (A and $B$ ) are completely inclosed, each having an approximate area of 100 acres, and a maximum depth below the lowest part of the rim in A of 10 feet and in B of 21 feet. Reservoir No. 1 is a similar basin, but instead of being entirely inclosed by high ground or ridges rising miore or less abruptly from its bed, is partly open on the sou th west side at the places marked embankments No. 1 and No. 3, as shown on the map, fig. 172. The ground at these points rises gradually from the bed of the basin to a height of from 2 to 5 feet. At other points where embankments are indicated on the map the natural rim is comparatively low, and must be raised in order to hold a depth of 16 feet of water above the 92-foot contour, as is contemplated.

The following table shows the approximate area and capacity of this reservoir when filled with water to various levels above the 92 foot contour, at which elevation it is proposed to place the outlet gates. The greatest depth below the 92 -foot contour will not exceed 8 inches: 


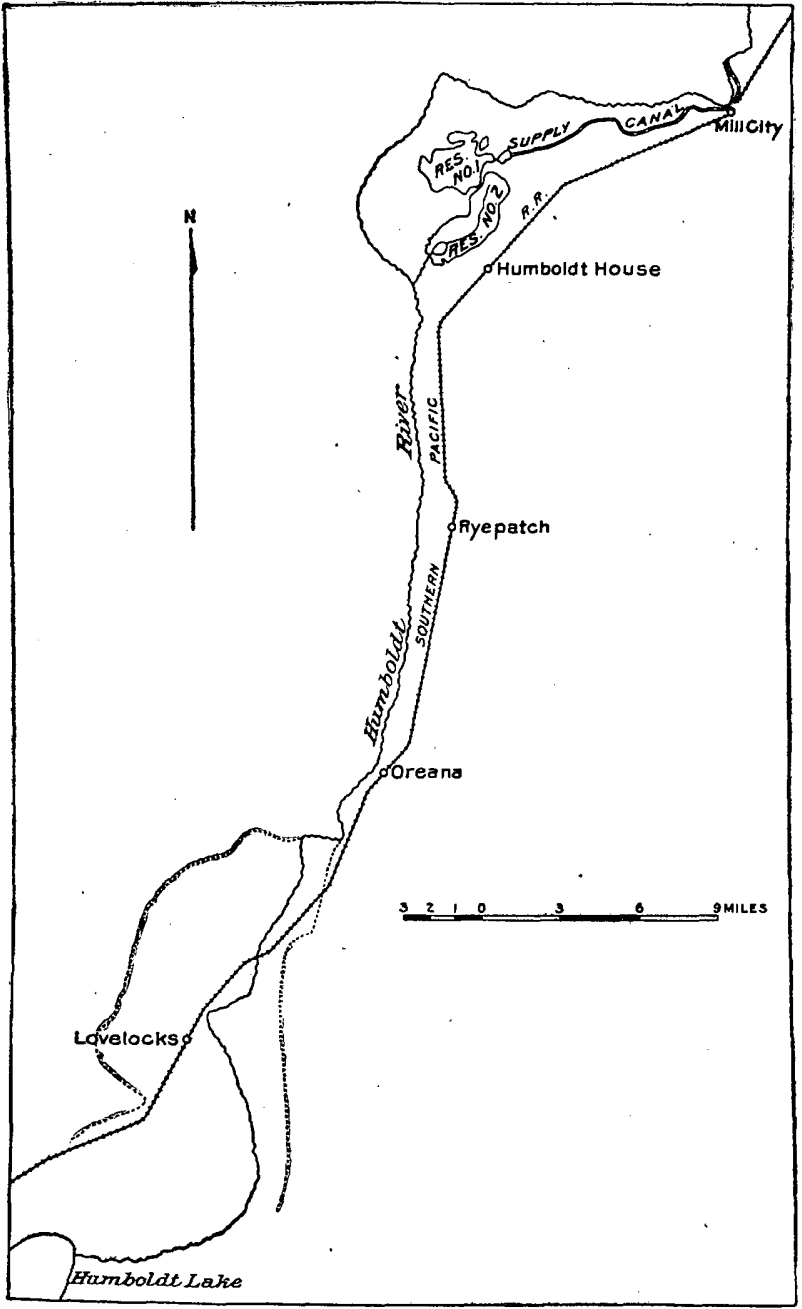

Fig. 171.-Map of Lower Humboldt Valley above Humboldt Lake. Approximate area and capacity of reservoir No. 1.

\begin{tabular}{|r|c|c|}
\hline Contcur. & Area. & Capacity. \\
\cline { 1 - 2 } Feet. & Acres. & Acreffeet. \\
92 & 660 & 160 \\
93 & 1,270 & 965 \\
97 & 1,630 & 6,765 \\
$a 97$ & 1,710 & $\ldots \ldots \ldots \ldots$. \\
99 & 1,930 & 10,405 \\
193 & 2,190 & 18,645 \\
108 & 2,330 & 29,945 \\
& & \\
\hline
\end{tabular}

$a$ Eighty acres embraced in 97-foot contour in sections 4 and 5; see map. 20 GEOL, PT $4-29$ 
Reservoir No. 2 is a basin lying a little lower than No. 1, but differing from it in that it has a direct outlet which completely drains it to the Humboldt River. Across this outlet it is proposed to construct a dam (shown in fig. 172 as dam No. 1) of sufficient height to create a lake having a maximum depth immediately at the dam of 28 feet. About a quarter of a mile to the southeastward from dam No. 1 is a gap in the ridge which forms part of the southwest rim of the basin, which will be closed by dam No. 2. The area of reservoir No. 2, embraced within the 100 -foot contour, will be approximately 2,450 acres, and the capacity about 25,000 acre-feet.

Basin A will have a capacity of about 600 acre-feet, being filled by the canal to a depth of from 6 to 7 feet. Its main value will be as a settling basin in which a great part of the silt which the waters of the Humboldt River carry in considerable quantity at some seasons will be precipitated, as the supply canal for all the reservoirs passes through this basin.

Basin. B can be filled by a small ditch leading from the north side of Basin A, a distance of about 1 mile. Thirteen feet of water can be placed in this basin, giving it a capacity of approximately 800 acre-feet. This water would be drawn off from the north west side into reservoir No. 1 . As the expense of the ditch and outlet would be very great in comparison with the quantity of water stored it has been omitted from the estimates, not being deemed worth the cost at present.

The beds and sides of all these basins are composed of a fine earth or silt deposited by wind and water, and with a texture such as to be practically water-tight. In fact, water accumulating in the inclosed basins from rains and melting snows to a depth of a few inches remains there until evaporated.

Two sets of estimates have been prepared for the embankments for reservoir No.1. The first estimate contemplates filling the reservoir to the 103-foot contour only, giving a capacity of approximately 19,000 acre-feet, the idea being that this quantity of water may be impounded at the outset, and the storage capacity increased in the future, as the cultivated area is extended and the demand for water increases.

The second estimate is for the completion of the reservoir to be filled to the 108foot contour and a capacity of about 30,000 acre-feet, this, it is believed, being about the limit of economical storage in the basin.

The embankments estimated for in each case will have an inner or water slope of 5 horizontal to 1 vertical, and an outside slope of 2 to 1 . The top width will be 20 feet, and the height above high-water flow line 7 feet. The reason for such flat inner slopes is that the cost of riprapping so extensive a surface would greatly exceed that of the additional material for the flatter slopes, and it would be unsafe to leave a steeper embankment exposed to the wave action.

$$
\text { First estimate for reservoir No. 1, filled to 103-foot contour. }
$$

Embankment No. 1, length 3,900 feet, maximum height 16.5 feet, 163,000 cubic yards, at average

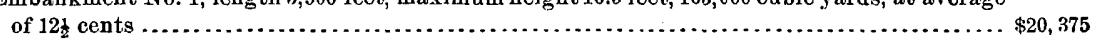
Embankment No. 2, length 1,320 feet, 7,000 cubic yurds, at average of 8 cents................ 560 Embankment No. 3, length 720 feet, 20,000 cubic jards, at average of $12 \frac{1}{2}$ cents ............ 2,500 Enbankment No. 6, length 2,000 feet, 5,000 cubic yards, at average of 8 cents.............. 400

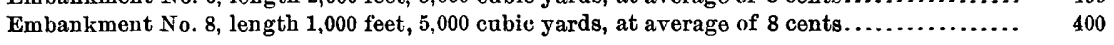

Total cost of embankments..............................................

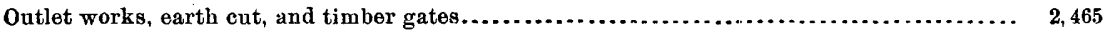

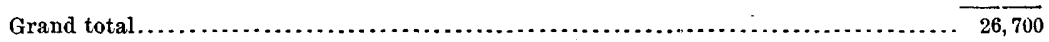

Second estimate for reservoir No. 1, filled to 108-foot contour.

Embankment No. 1, length 4,000 feet, maximum height 23.5 feet, 250,000 cubic yards, at average

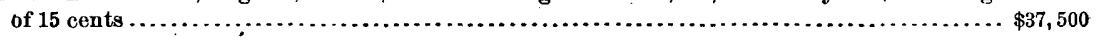
Embankment No. 2, length 1,600 feet, 24,000 cubic yards, at average of 10 cents.............. 2,400 Embankment No. 3, length 750 feet, 40,000 cubic yards, at average of 15 cents ........... 6, 000 Embankment No. 4, length 1,300 feet, 15,000 cubic gards, at average of 10 cents .............. 1,500 Embankment No. 5, length 350 feet, 3,000 cubic yards, at average of 8 cents ................ 210 Embankment No. 6, length 2,600 feet, 40,000 cubic yards, at average of 10 cents ............ 4,000 
Embankment No. 7, length 400 feet, 4,000 cubic 5 ards, at average of 8 cents................. 320 Embankment No. 8, length 2,000 feet, 30,000 cubic yards, at average of 10 cents............. 3,000

Total cost of embankments.

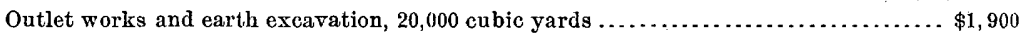

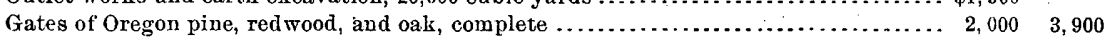
- Grand total........................................................ 58,860

In the second estimate for the outlet works provision is made for five gates of 4 feet clear width each, the shutters to be of oak with bronze bearings, and of ample strength to sustain more than the 16 feet of water which will be against them. They will be operated by means of serew stems working in capstan-head female screws. These gates will be located at the point marked " 0 " on the map, and the water from reservoir No. 1 will flow through reservoir No. 2 into Humboldt River.

To form reservoir No. 2 , two dams or embankments of earth will be required. Thiese will have the same slopes, height above water line, and width of crest as the embankments for reservoir No. 1 .

\section{Estimates of cost of reservoir No. 2.}

Dam No. 1, maximum height 35 feet, 196,000 cubic yards, at average of 19 cents . . Dam No. 2, maximum height 12 feet, 32,000 cubic yards, at average of $12 \frac{1}{2}$ cents............. 4,000

$$
\text { Total cost of dams . . . . . . . . . . . }
$$

\section{Outlet works}

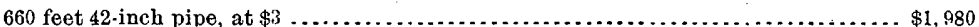

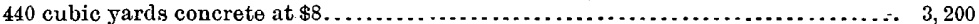

Two 42 -inch low pressure gates................................................ 500

Excavation aud placing gates............................................. 320

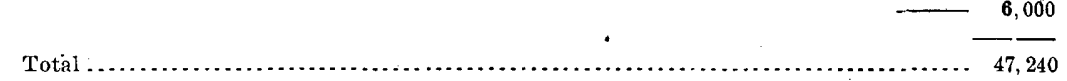

The ontlet works here estimated for will consist of two 42 -inch riveted steel pipes incased in a solid mass of Portlaud cement concrete for tlfeir entire length. They

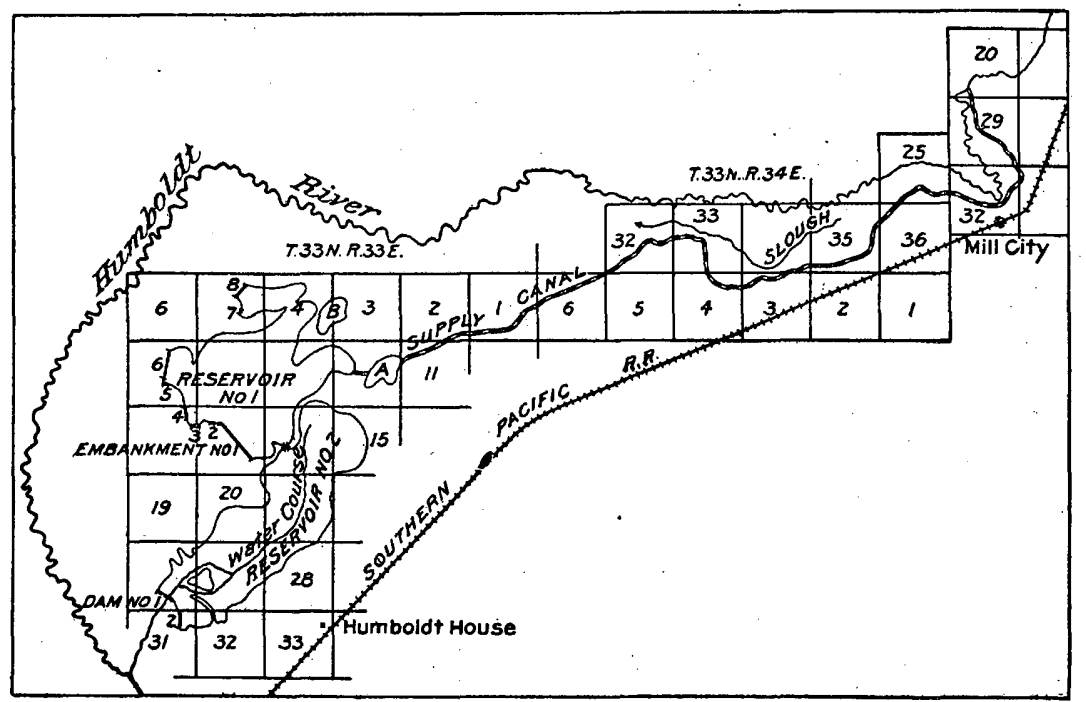

Frg. 172.-Map of proposed reservoir and supply canal in Humboldt County, Nevada.

will be placed at the 77 -foot contour in a trench excavated in the solid earth under the dam. So long as there is more than 7 feet of water above these pipes they will discharge all the water that will be required, and when the head becomes less the 
volume of water in the reservoir is very small. Timber gates could be used here instead of those above estimated for at a cost of about $\$ 4,500$, but it would not be wise nor economical, as in this dry climate the timbers, being alternately wet and dry, would require to be renewed every few years, and the additional cost is but small for permanent construction.

Supply canal. - The canal to conduct the water from the Humboldt River will head in the left bank of the river in township 33 north, range 35 east, Mount Diablo meridian, about 2 miles northwesterly from Mill City station, on the Central Pacific Railroad. At this point the river bottom is abont 400 yards wide and the stream flows near the east side of it in a channel some 8 feet deep and 120 feet wide. Its bed here is a tough, laminated clay-approaching a soft shale-sometimes called, locally, "pipeclay." From this point the canal line takes a general southeasterly course, nearly all the way in light cutting and mostly through level ground, for about 10,000 feet to a high bluff opposite Mill City. Here it will be necessary to change the cbannel of the river, which washes the face of the bluff, by throwing earthern enbankments across both above and below, and making a slight cut across the narrow neck of land a few hnndred feet to the north, in order to start the flow of water that way, when it will cut itself a new channel. This dove, the canal will be excavated in the side of the bluff for a distance of about 600 feet.

.This will be more lasting, safer, and less expensive than fluming, notwithstanding the bluff has a height of from 30 to 50 feet above' water surface in the canal.

After passing this bluff the canal will be formed for some distance by an embankment on the right side at the base of a slope varying from 1 on 1 to $1 \frac{1}{2}$ on 1 . It then enters and runs through comparatively level ground, with the exception of about 600 feet of side hill, to about the east line of section 35 in township 33 north, range 34 east, where it enters the hillside to the south of the river bottom. From here it runs in a general westerly course, following the edge of the river bottom, nearly all the way on side hill, with slopes varying from 2 on 1 to 8 on 1 , for about 4 miles to near the center of section 32 , where it turns to the southwestward, leaving the river bottom and entering the mesa, which for some 3 miles is quite nneven and partly covered with low sand hills and ridges. Through this portion and in the last mile before reaching Basin $A$, which is very level ground, there will be but little extra cutting. From Basin A to reservoir No. 1 will require a cut 900 feet long, with a maximum depth of 12 feet.

Throughout its entire length the canal is in earth of the very cheapest character to handle. No fluming will be required and, aside from the head works, the only structures will be two bridges at road crossings-one opposite Mill City and the other near Basin A; three waste gates for turning the water from the canal back to the river in sections 25 and 32, township 33 north, range 34 east, and in section 3 , township 32 north, range 34 east, the gates to control the flow from Basin A to reservoir No. 1; and three 5-foot timber falls from these gates to the bed of reservoir No. 1, to prevent washing.

The total length of the canal will be 12.7 miles. It will have a uniform grade of 1 in 10,000 , and its dimensions will be, bed width, 25 feet; depth of water, 7 feet; width at flow line, 39 feet, the side slopes being 1 on 1 . The carrying capacity will be about 450 cubic feet per second, or suffeient water to fill the reservoirs in about 62 days. The mean velocity in the canal will be 2 feet per second, and that at the bed about 1.4 feet, which is about as high a velocity as the light material through which the canal runs will stand without erosion.

The diversion dam in the river will be an open-frame structure, consisting of a series of rafters or trusses 4 feet 6 inches apart, center to center, extending across the stream, which is here 120 feet wide, and resting on a double floor or box, the upper surface of which is level with the stream bed, and the bottom 2 feet below. This box will be filled with gravel and will extend about 40 feet up and down stream. It will be supported by 4 rows of 8 by 8 -inch anchor piles driven 12 feet in to the stream bed, and 2 rows of 3 by 12-inch sheet piling driven 8 feet below the lower floor, and extend- 
ing across the stream at right angles to its course. A footbridge of 2-inch planking will extend across the river on top of the trusses before mentioned, at a height of 9 feet above stream bed, and 1.5 feet above high water.

The openings between the trusses will be elosed by means of flashboards 2 inches thick-which will be laid on the inclined front of the trusses to such height as may be required to raise the water to sufficiently fill the canal, which height will not exceed 7.5 feet. During high water in the river all these boards will be removed, thus ailowing the water to flow through unobstructed. They may be removed or inserted at any time from the footbridge. Sheet piling will extend for some distance into the banks on either side of the river, to prevent the possibility of water finding its way through the earth around the end of the dam. The river banks will be protected by timber wings extending a few feet above and below the floor of the dam, and a few feet below the bed of the stream.

The regulating gates, to control the flow of water into the canal, will be immediately adjacent to the dam. They will consist of 5 vertical timber gates, each 4 feet clear width, operated by screws and hand wheels.

As in the case of reservoir No. 1, and for the same reasons, two sets of estimates have been prepared for the supply canal and diversion dam. Estimate. No. 1 is for a canal having a bed width of 14 feet, depth of water 6 feet, and'width at flow line 26 feet. Its carrying capacity will be 200 cubic feet of water per second, or sufficient to fill reservoir No. 1 to the 103 -foot contour in fifty days. Estimate No. 2 is for the canal with a capacity of 450 second-feet, as above described.

\section{First estimate of supply canal and diversion dam.}

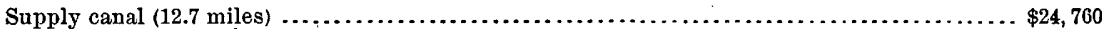

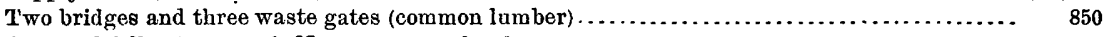

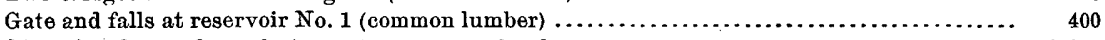

Diversion dam and regulating gates (common lumber) $\ldots \ldots \ldots \ldots \ldots \ldots \ldots \ldots \ldots \ldots \ldots \ldots \ldots, 2,240$

Total

Second estimate of supply canal and diversion dam.

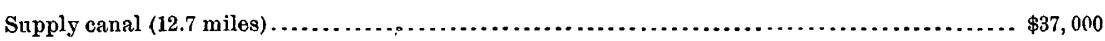

Two bridges and three waste gates (redwood and Oregon pine) $\ldots \ldots \ldots \ldots \ldots \ldots \ldots \ldots \ldots \ldots \ldots \ldots, \quad 1,500$

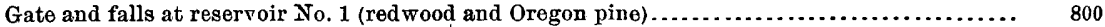

Diversion dam and regulating gates (red wood and Oregon pine) $\ldots \ldots \ldots \ldots \ldots \ldots \ldots \ldots \ldots \ldots, 2,900$

Total

42,200

Estimate No. 1:

SUMMARY OF ESTIMATES.1

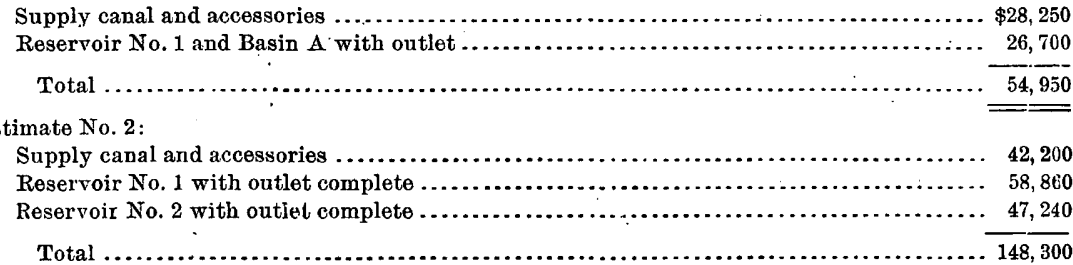

It is believed that the foregoing estimates will be found amply liberal when the easy and simple character of the work is considered. In fact, a considerable amount of earthwork of a similar character has been done in this vicinity at prices ranging from 15 to 30 per cent cheaper than is here estimated for.

Lands to be irrigated. - In the vicinity of Lovelock, on the lower-lying lands, the soil is of such a character and its capacity for retaining moisture such that with only moderate economy and system in the use of water a duty of 150 acres to the cubic

${ }^{1}$ Engineering, superintendence, and contingencies are included in the above estimates. 
foot per second, or one-third of 1 miner's inch per acse, may be easily attained. However, under the existing methods the duty is much less. On the higher or mesa lands, under the same conditions of use, the duty would not be so great. If the regular flow of the river be the main reliance for an irrigation water supply, and the water impounded in these storage reservoirs be used to supplement this at times of scarcity, it is safe to count upon being able to properly irrigate 60,000 acres of land, but it would be hazardous to undertake more.

While it would be possible to conduct water from these reservoirs to and upon a considerable area of the mesa or bench lands burdering Humboldt River, yet it would probably be better to supply water to the low-lying or valley lands in the Lovelock Valley. The cost of conveying water to the mesa lands would be vastly greater-in fact, so great that in the absence of exact data it is doubtful if present land values would warrant it. From the reservoirs the water would flow in a natural water course to the Humboldt River, and thence down the river to the upper end of the Lovelock Valley, a distance, as measured along the railroad, from the outlet of reservoir No. 2, of abont 20 miles, where it can be easily and cheaply diverted by one general system for the irrigation of the entire valley, or it can be supplied to and distributed by existing ditch systems.

\section{' PRECIPITATION IN THE BASIN OF GREAT SALT LAKE.}

The principal observations of rainfall made within the basin of Great Salt Lake are at Paris, Logan, Snowville, Kelton, Promontory, Ogden, Coalville, Salt Lake City, Heber, Tooele, Geneva, Provo, Nephi, and Mount Pleasant. The relative location of these points is shown on fig. 173, in connection with the points of river measurement which are at Collinston, Logan, Ogden, Uinta, Provo, and Geneva.

The following table gives the name and location of the stations, the elevations, and the number of years during which the observations have been made, or, rather, the number of complete monthly observations used in computing the normals:

Location of rainfall stations.

\begin{tabular}{|c|c|c|c|c|c|c|}
\hline Station. & County. & State. & Latitude. & $\begin{array}{l}\text { Longi- } \\
\text { tude. }\end{array}$ & $\begin{array}{l}\text { Elera- } \\
\text { tion. }\end{array}$ & $\begin{array}{l}\text { Length of } \\
\text { record. }\end{array}$ \\
\hline Paris & Bear Lake & Idaho. & \begin{tabular}{cc|}
0 &. \\
42 & 13
\end{tabular} & $\begin{array}{rc}\circ \\
111 . & 13\end{array}$ & $\begin{array}{l}\text { Feet. } \\
5,946\end{array}$ & $3-5$ \\
\hline Logan ..... & Cache.... & Utah.... & 4145 & 11151 & 4,507 & $6-9$ \\
\hline Terrace.... & Boxelder. & ..... do ... & 4132 & 11333 & 4,548 & $25-27$ \\
\hline Snowville .... & .... do .. & $\therefore$... do & 4158 & 11247 & 4,360 & $7-8$ \\
\hline Kelton & .....do & ....do do & 4146 & 1138 & 4,222 & $18-20$ \\
\hline Promontory .... & ....do do & .....do do & 4137 & 11236 & 4,905 & $26-28$ \\
\hline Ogden ... & Weber... & .....do & 4113 & 11200 & 4,340 & $27-28$ \\
\hline Coalville ... & Summit & .... do & 4055 & 11123 & $6,8.52$ & $10-13$ \\
\hline Salt Lake City. & Salt Lake. & ....do. & 4046 & 11154 & 4,354 & $31-34$ \\
\hline Heber .... & Wasatch. & .... do & 4030 & 11125 & 5,440 & $3-5$ \\
\hline Tooele. & Tooele ... & .... do & 4032 & 11218 & 4,900 & $4-8$ \\
\hline Provo & Utah. & ... do. & 4014 & 11140 & 5,050 & $5-8$ \\
\hline Nephi ...... & Juab.... & .....do . . & 3928 & 11150 & & $5-6$ \\
\hline Monnt Pleasant. & Sanpete. & ....do do & 3933 & 11129 & 6,300 & $5-7$ \\
\hline
\end{tabular}


In the following table are given the figures of normal or average monthly precipitation from the time of the beginning of the record to

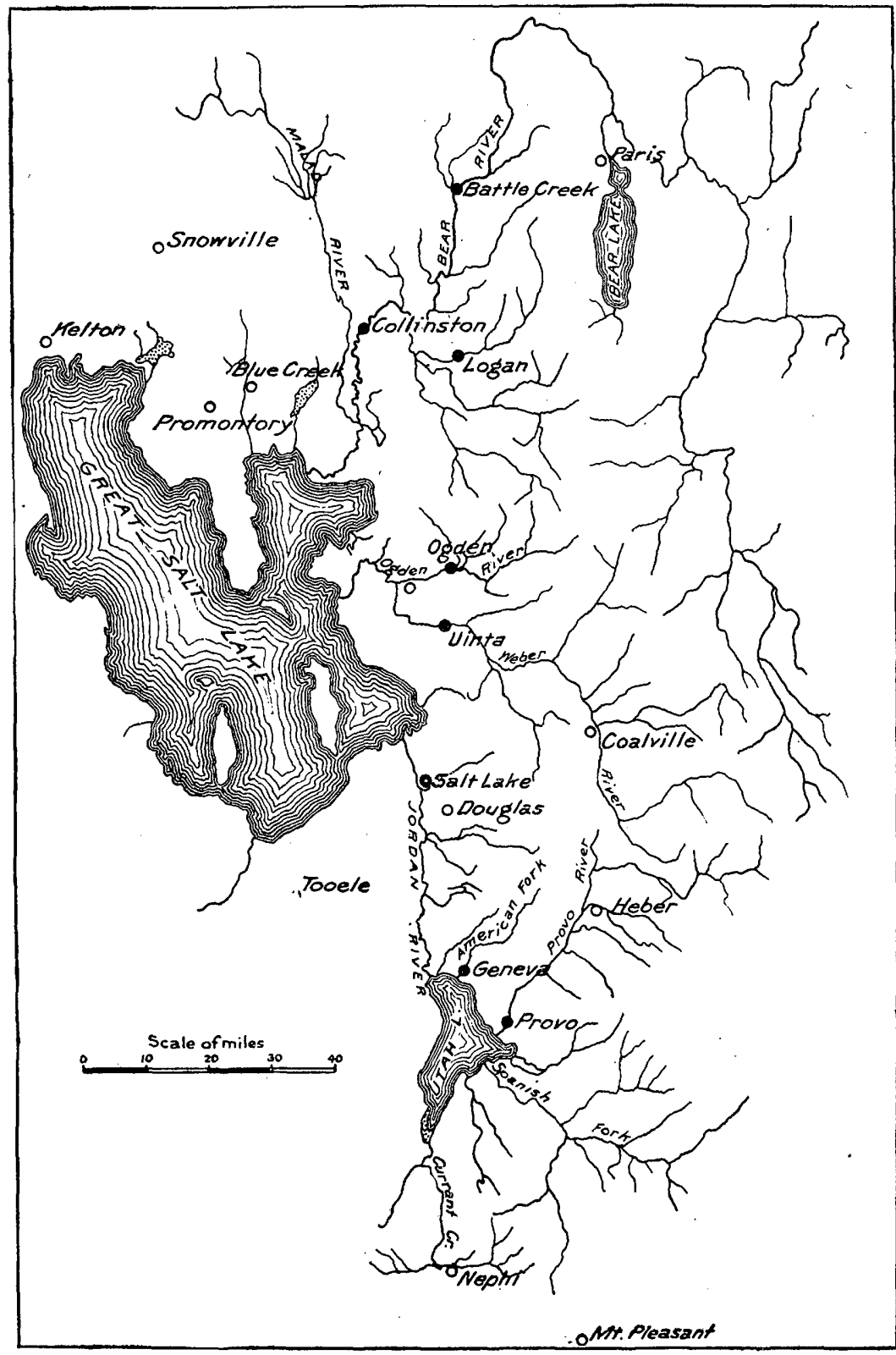

FIG. 173.-Relative location of river and rainfall observations in basin of Great Salt Lake.

and including 1897, together with the total precipitation by months for the years 1896, 1897, and 1898, and also the amount by years. In 
obtaining the normal precipitation the average is taken.for all of the months during which observations were made:

Rainfall at stations in drainage basin of Great Salt Lake.

PARIS.

\begin{tabular}{|c|c|c|c|c|c|c|c|c|c|c|c|c|c|}
\hline Year. & Jan. & Feb. & Mar. & Apr. & May. & June. & July. & Aug. & Sept. & Oct. & Nov. & Dec. & Annual. \\
\hline Normal. & 1.14 & 0.73 & 2.02 & 1.22 & 1.47 & 0.52 & 0.97 & 0.54 & 1.19 & 0.76 & 1.47 & 1. 18 & 13.21 \\
\hline 1896. & 1.71 & 0.72 & 1.62 & 1.91 & 2.27 & 0.07 & 1.27 & 0.65 & 0.94 & 0.05 & 2.17 & 0.71 & 14.09 \\
\hline $1897 \ldots$ & 0.36 & $(0.73)$ & 2.15 & 0.79 & 0.47 & 0.65 & 0.62 & 0.66 & 0.75 & 1.43 & $(1.47)$ & 0.76 & 10.84 \\
\hline $1898 \ldots$ & 0.74 & 0.34 & 1.49 & 0.76 & 3.37 & 0.82 & 0.25 & 0.78 & 0.20 & 0.85 & 1. 32 & 0.81 & 11. 73 \\
\hline \multicolumn{14}{|c|}{ SNOWVILLE. } \\
\hline Normal & 0.37 & 0.84 & 1.57 & 1.05 & 1.51 & 0.69 & 0.63 & 0.19 & 0.77 & 0.88 & 0.75 & 1.16 & 10.41 \\
\hline 1896. & 1.29 & 0.36 & 1.59 & 1.07 & 2.35 & 0.68 & 2.30 & 0.63 & 0.21 & 0.93 & 1.97 & 0.90 & 14.28 \\
\hline 1897. & 1.00 & 0.95 & 0.84 & 0.90 & 0.33 & 0.26 & 0.27 & 0.00 & 0.60 & 3.30 & 0.90 & 0.70 & 10.05 \\
\hline 1898. & 0.80 & 0.30 & 0.76 & 0.76 & $(1.51)$ & $(0.69)$ & 0.06 & 0.06 & 0.14 & 0.51 & 1.61 & 0.60 & 7.80 \\
\hline \multicolumn{14}{|c|}{ TERRACE. } \\
\hline Normal & 0.6 & 0.4 & 0.5 & 0.4 & 0.6 & 0.2 & 0.10 & 0.1 & 0.3 & 0.1 & 0.3 & 0.7 & 4.3 \\
\hline 1896. & 0.15 & 0.40 & 0.95 & 0.63 & 2.28 & 0.00 & $(0.10)$ & 0.30 & 0.00 & 0.00 & 0.32 & 0.00 & 5.13 \\
\hline 1897. & ....... & 0.65 & $\ldots$. & 0.50 & 0.01 & 0.00 & 0.02 & 0.00 & 1.50 & ........ & 0.10 & 0.15 & ......... \\
\hline $1898 \ldots$ & $(0.60)$ & 0.30 & 0.32 & 1.00 & 3.27 & 2.25 & $\mathrm{~T}$. & $\mathrm{T}$ & $\mathbf{T}$ & 0.12 & 1.46 & 0.65 & 9.97 \\
\hline \multicolumn{14}{|c|}{ KELTON. } \\
\hline Normal & 0.7 & 0.6 & 0.6 & 0.80 & 0.5 & 0.4 & 0.4 & 0.2 & 0.5 & 0.4 & 0.3 & 0.90 & 6.30 \\
\hline $1896 \ldots$ & 0.50 & 0.70 & 0.75 & $(0.80)$ & 0.99 & 0.00 & 0.00 & 0.15 & 0.00 & 0.00 & 0.90 & $(0.90) \mid$ & 5.69 \\
\hline 1897. & & & & & & 0.00 & 0.00 & $\ldots .$. & 0.00 & 0.10 & ...... & $\ldots .$. & $\ldots \ldots$ \\
\hline $1898 \ldots \ldots \ldots$ & 0.10 & 0.00 & 0.00 & 1.25 & 2.35 & 0.00 & 0.00 & 0.00 & 'T. & 0.00 & 0.75 & 0.20 & 4.65 \\
\hline \multicolumn{14}{|c|}{ PROMONTORY. } \\
\hline Normal. & 1.10 & 0.9 & 0.9 & 0.8 & 0.8 & 0.5 & 0.2 & 0.4 & 0.7 & 0.6 & 0.5 & 1.0 & 8.4 \\
\hline $1896 . .$. & $\ldots .$. & 3.10 & ...... & 0.10 & $\ldots \ldots$ & 0.00 & 0.75 & 0.00 & T. & 0.15 & 1.10 & 0.32 & ......... \\
\hline $1897 \ldots$ & $(1.10)$ & 1.30 & 0.50 & 0.70 & 1.33 & 0.00 & 0.25 & 0.10 & 0.34 & 2.36 & 0.90 & 0.55 & 9.43 \\
\hline $1898 \ldots$. & 0.60 & 0.05 & 0.60 & 0.02 & ....... & 1.50 & $\mathrm{~T}$ & T. & ........ & 0.00 & ....... & 0.10 & $\ldots$. \\
\hline \multicolumn{14}{|c|}{ OGDEN. } \\
\hline Normal & 1.7 & 1.5 & 1.8 & 1.5 & 1.5 & 0.6 & 0.2 & 0.4 & 0.7 & 1.3 & 1.1 & 1.8 & 14.1 \\
\hline 1896.: & 1.62 & 0.30 & 2.87 & 1.25 & 3.57 & 0.10 & 0.20 & 0.28 & 0.58 & 0.70 & 1.93 & 0.95 & 13.95 \\
\hline $1897 \ldots$ & 1.80 & 2.85 & 2.37 & 1.70 & 0.30 & 0.98 & $\mathrm{~T}$ & 0.00 & 0.55 & 1.93 & 1.51 & 2.25 & 16.24 \\
\hline $1898 \ldots$ & 1.47 & 0.19 & 1.82 & 0.37 & 5.23 & 0.81 & 0.00 & 0.30 & 0.30 & 1.47 & 1.12 & 0.60 & 13.68 \\
\hline \multicolumn{14}{|c|}{ COALVILLE. $a$} \\
\hline Normal ....... & 1.56 & 2.17 & 1.96 & 1. 37 & 1.16 & 0.55 & 0.38 & 0.48 & 0.53 & 1.12 & 1.18 & 1.84 & 14.30 \\
\hline $1896 \ldots$ & $(1.56)$ & $(2.17)$ & 1.01 & 3.83 & 4.22 & 0.00 & 0.71 & 0.05 & 0.13 & 0.72 & 2.25 & 0.90 & 17.55 \\
\hline $1897 . \ldots$ & 1.70 & 5.39 & 8.00 & 1.50 & 0.08 & 0.39 & 0.15 & 0.15 & 0.78 & 0.28 & $(1.18)$ & $(1.84)$ & 21.44 \\
\hline 1898. & & & & & & & & & & & & & $\because$ \\
\hline
\end{tabular}

a 1874 to 1883 at Coalville. 1889 to 1892 at Park City. 
Rainfall at stations in drainage basin of Great Salt Lake-Continued.

SALT LAKE CITY.

\begin{tabular}{|c|c|c|c|c|c|c|c|c|c|c|c|c|c|}
\hline Normal ....... & 1.57 & 1.68 & 2.11 & 2.02 & 1.99 & 1.08 & 0.91 & 1.27 & 1.00 & 1.64 & 1.46 & 1.99 & 18.72 \\
\hline 1896. & 1.26 & 0.69 & 1.99 & 2.53 & 3.67 & 0.25 & $1.35^{\circ}$ & 1.47 & 0.52 & 0.70 & 3.15 & 0.84 & 18.42 \\
\hline 1897. & 1.16 & 3.81 & 2.20 & 2.00 & 0.98 & 0.52 & 0.69 & 0.33 & 0.48 & 1.91 & 1.19 & 1.47 & 16.74 \\
\hline $1898 .$. & 0.58 & 0.38 & 1.71 & 1.30 & 4.19 & 1.45 & 0.18 & 1.35 & 1.15 & 1.57 & 1.95 & 1.28 & 16.09 \\
\hline \multicolumn{11}{|c|}{ HEBER. } & \multicolumn{3}{|c|}{. } \\
\hline Normal. & 2.25 & 2.31 & 2. 36 & 1.27 & 1. 08 & 0.31 & 1.23 & 0.58 & 1.57 & 1.08 & 0.80 & 2.43 & 17.27 \\
\hline 1896. & 2.10 & 0.95 & 2.46 & 2.40 & 1.85 & 0.09 & 3.35 & 0.55 & 1.44 & 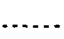 & $\ldots \ldots$ & 0.75 & 17.82 \\
\hline 1897. & 1.30 & 4.10 & 2.90 & 0.90 & 0.70 & 0.38 & 0.56 & 0.49 & 3.14 & 1.50 & 1.00 & $(2.43)$ & 19. 40 \\
\hline 1898. & 1.40 & 0.50 & 3.30 & 1.25 & $(1,08)$ & 0.83 & 0.25 & 0.64 & $(1.57)$ & 1.44 & 1.60 & 1.10 & 14.96 \\
\hline \multicolumn{14}{|c|}{ TOOELE. $a$} \\
\hline Normal & 0.48 & 1.21 & 0.49 & 0.60 & 0.38 & 0.29 & 0.68 & 0.39 & 0.24 & 1.01 & 0.61 & 0.69 & 7.07 \\
\hline $1896 \ldots$ & ..... & ...... & 1.09 & ...... & $\ldots . .$. & 0.02 & 0.88 & 0.93 & 0.30 & 0.92 & 2.07 & 0.29 & - . . . \\
\hline $1897 \ldots$ & 1.15 & 1.95 & 1.68 & $0.9 \mathrm{i}$ & 0.36 & 0.16 & 0.91 & 0.51 & 0.18 & 2.92 & 1.83 & 1.93 & 14.49 \\
\hline 1898.. & 0.75 & 0.34 & 2.38 & 1.21 & 6.35 & 1.58 & 0.14 & 0.38 & 0.13 & 2.40 & 1.79 & 0.80 & 18.25 \\
\hline \multicolumn{14}{|c|}{ Provo. } \\
\hline Normal & 1.21 & 1.28 & 1. 36 & 0.93 & 1. 35 & 0.78 & 0.68 & 0.48 & 0.66 & 0.56 & 0.62 & 1.74 & 11.65 \\
\hline 1896. & 1.45 & 1.55 & 1.58 & 1.32 & 3.04 & 0.00 & 2.59 & 0.81 & 0.91 & 0.31 & 0.40 & 0.33 & 15.34 \\
\hline 1897. & 1.38 & 3.50 & 1.80 & 1.58 & 1. 31 & 0.47 & 0.54 & 0.08 & 0.77 & 1.86 & 0.99 & 1.27 & 15.80 \\
\hline $1898 .$. & 0.91 & 0.45 & 1.05 & 1.24 & 4.59 & 1.43 & 0.19 & 0.94 & 0.05 & 0.92 & 1.18 & 0.63 & 13.58 \\
\hline \multicolumn{14}{|c|}{ NEPHX. } \\
\hline Normal & 1.04 & 1.49 & 1.40 & 3.09 & 1.37 & 0.63 & 0.60 & 1.25 & 1.10 & 1.45 & 0.45 & 2.47 & 16.34 \\
\hline 1896. & 1.16 & 0.60 & 1.49 & 1.23 & 1.58 & 0.36 & 2.26 & 0.71 & 0.54 & 0.50 & 1. 58 & 0.36 & 12.37 \\
\hline $1897 .$. & 1.95 & 1.88 & 2.22 & 1.05 & 0.85 & 0.41 & 0.28 & 0.14 & 1.84 & 3.29 & 1.23 & 1.65 & 16.79 \\
\hline \multicolumn{14}{|c|}{ MOUNT PLEASAN'T. } \\
\hline Normal & 1.32 & 2.29 & 1.71 & 0.46 & 1.01 & 0.51 & 1.21 & 0.44 & 1.13 & 0.94 & 0.93 & 1.68 & 13.63 \\
\hline 1896. & 0.31 & 0.40 & 0.93 & 1.36 & 1.09 & $(0.51)$ & 2.69 & 0.87 & 0.75 & 0.46 & 1.75 & 0.20 & 11.32 \\
\hline $1897 \ldots$ & 1.30 & 3.10 & 2.82 & 0.10 & 0.58 & 0.39 & 0.59 & 0.05 & 2.66 & 2.30 & 0.75 & 1.90 & 16.54 \\
\hline \multicolumn{14}{|c|}{ AVERAGES. } \\
\hline Normal. & 1.14 & 1.34 & 1.45 & 1.19 & 1.13 & 0.54 & 0.63 & 0.53 & 0.80 & 0.91 & 0.81 & 1.51 & 11.98 \\
\hline $1896 \ldots$ & 1.19 & 1.00 & 1.53 & 1.54 & 2.45 & 0.16 & 1.42 & 0.57 & 0.52 & 0.50 & 1.51 & 0.57 & 12.96 \\
\hline $1897 \ldots$ & 1.29 & 2.52 & 2.43 & 1.05 & 0.61 & 0.39 & 0.57 & 0.63 & 1.58 & 1. 97 & 1. 18 & 1.41 & 15.63 \\
\hline $1898 .$. & 0.80 & 0.29 & 1.34 & 0.92 & 3.55 & 1.09 & 0.11 & 0.45 & 0.39 & 0.97 & 1.42 & 0.68 & 12.01 \\
\hline
\end{tabular}

$a 1877$ to 1880 at Deep Creek; 1889 to 1891 at Stockton; 1896 to 1897 at Tooele. 


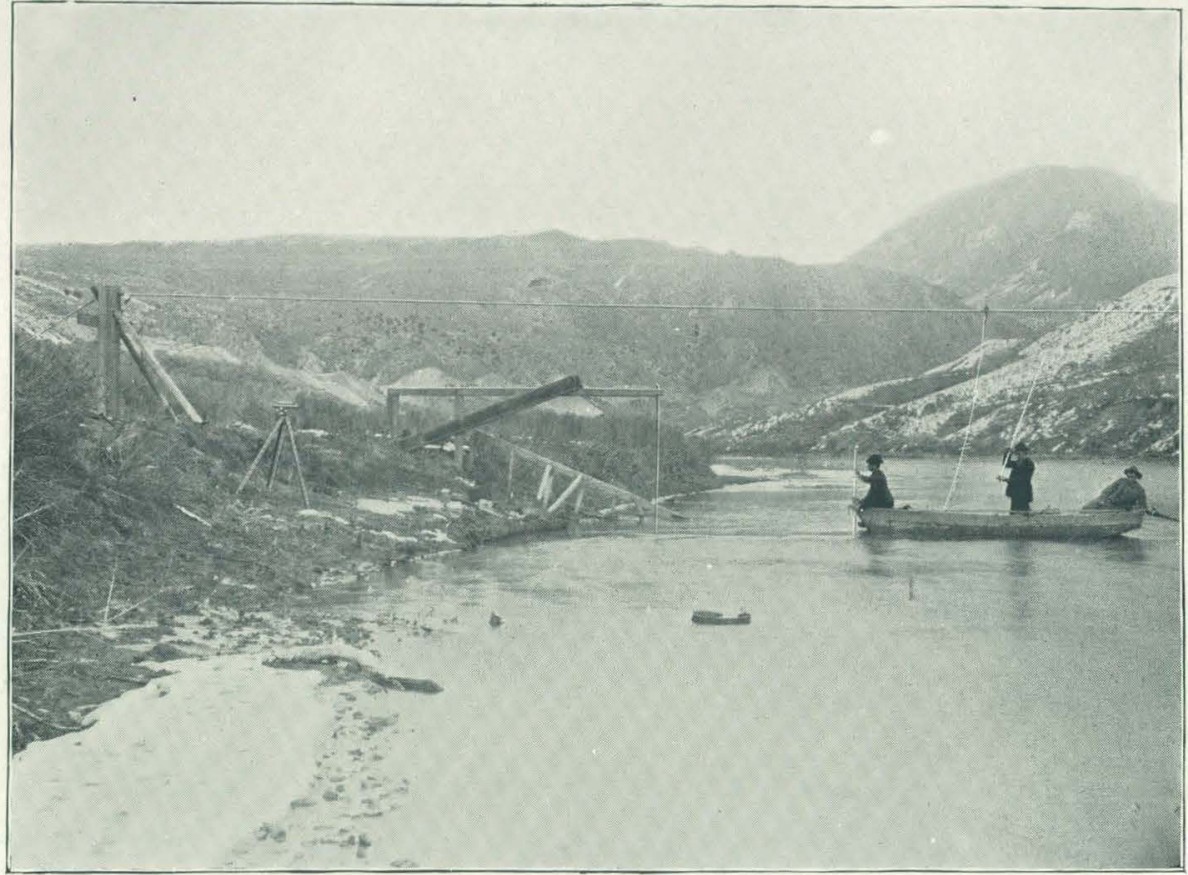

A. MEASURING BEAR RIVER AT COLLINSTON, UTAH.

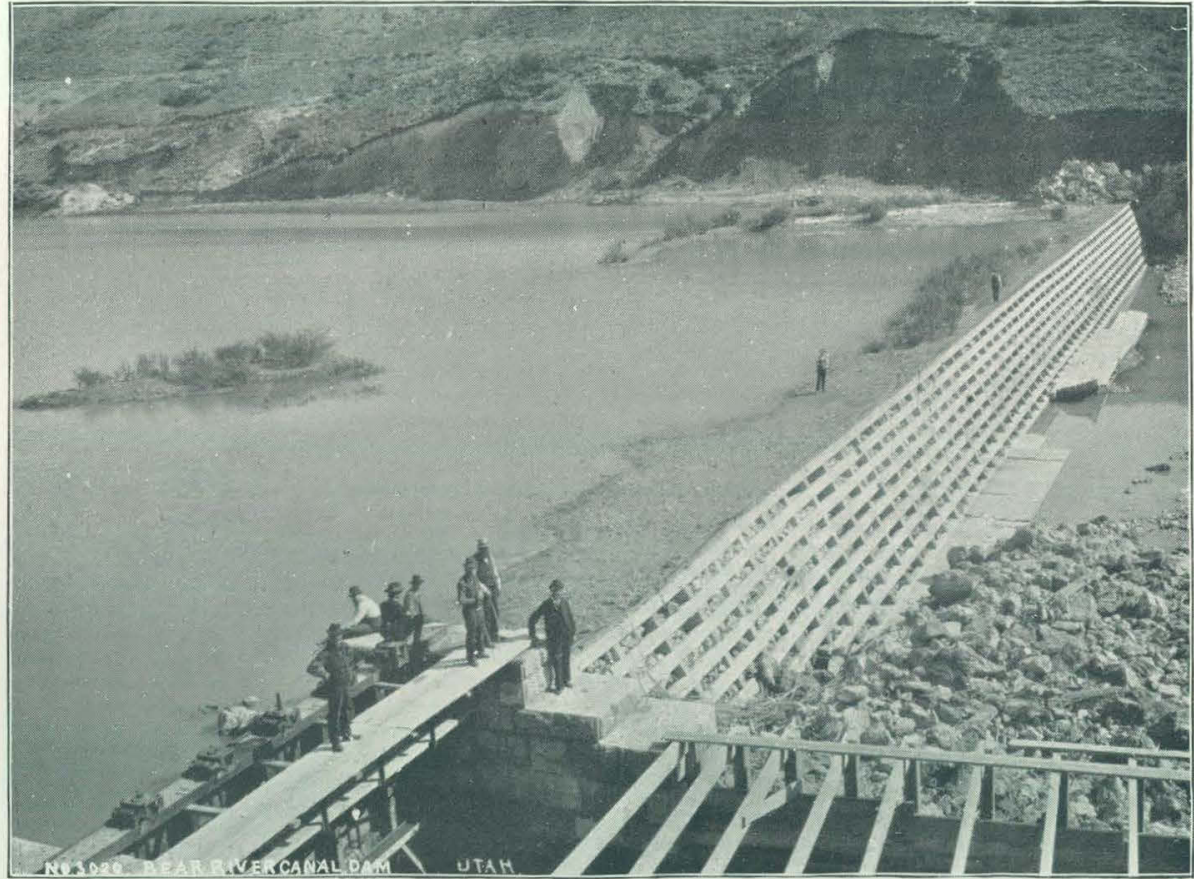

B. DAM OF BEAR RIVER CANAL, UTAH. 
Run-off in inches, from Great Salt Lake drainage basin.

PROVO AT PROVO.

\begin{tabular}{|c|c|c|c|c|c|c|c|c|c|c|c|c|c|}
\hline Year. & Jan. & Feb. & Mar. & Apr. & May. & June. & July. & Aug. & Sept. & Oct. & Nor. & Dec. & Annual. \\
\hline 1896. & 0.58 & 0.50 & 0.71 & 1.09 & 2.10 & 2.72 & 0.69 & 0.56 & 0.54 & 0.61 & 0.73 & 0.70 & 11.53 \\
\hline 1897. & 0.71 & 0.81 & 0.75 & 1. 50 & 3.35 & 1.38 & 0.53 & 0.40 & 0.46 & 0.81 & 0.75 & 0.67 & 12.12 \\
\hline 1898. & 0.51 & 0.50 & 0.70 & 0.98 & 1. 73 & 1.44 & 0.37 & 0.29 & 0.29 & 0.38 & 0.49 & 0.51 & 8.19 \\
\hline Average. & 0.60 . & 0.50 & 0.72 & 1.19 & 2,39 & 1.85 & 0.53 & 0.42 & 0.43 & 0.60 & 0.66 & 0.63 & 10.62 \\
\hline \multicolumn{14}{|c|}{ WEBER AT UINTA. } \\
\hline 1896. & 0.35 & 0.32 & 0.68 & 1.40 & 2.28 & 2.33 & 0.39 & 0.21 & 0.19 & 0.25 & 0.38 & 0.30 & 9.08 \\
\hline $1897 .$. & 0.21 & 0.19 & 0.33 & 1.57 & 2. 90 & 0.84 & 013 & 0.12 & 0.14 & 0.33 & 0.28 & 0.24 & 7. 28 \\
\hline 1898. & 0.20 & 0.21 & 0.29 & 0.92 & 1.15 & 0.53 & 0.21 & 0.07 & 0.12 & 0.22 & 0.30 & 0.30 & 4.52 \\
\hline A verage. & 0.25 & 0.24 & 0.43 & 1.30 & 2.11 & 1.23 & 0.24 & 0.13 & 0.15 & 0.27 & 0.32 & 0.28 & 6.95 \\
\hline \multicolumn{14}{|c|}{ OGDEN AT OGDEN. } \\
\hline 1897. & & $\ldots$ & & $\cdots$ & 4.02 & 1.17 & 0.29 & 0.18 & 0.18 & 0.23 & 0.21 & 0.16 & \\
\hline 1898. & 0.21 & 0.23 & 0.29 & 0.82 & 0.95 & $0,31$. & 0.12 & 0.10 & 0.10 & 0.10 & 0.10 & 0.10 & 3.43 \\
\hline Average. & 0.21 & 0.23 & 0.29 & 0.82 & 2.49 & 0.74 & 0.21 & 0.14 & 0.14 & 0.17 & 0.16 & 0.13 & 5.73 \\
\hline \multicolumn{14}{|c|}{ BEAR AT COLLINSTON. } \\
\hline $1896 . . . \ldots \ldots$. & 0.25 & 0.19 & 0.25 & 0.54 & 0.75 & 1.19 & 0.43 & 0.26 & 0.23 & 0.25 & 0.28 & 0.30 & 4. 92 \\
\hline 1897. & 0.28 & 0.25 & 0.30 & 1.08 & 1.83 & 1.04 & 0.35 & 0.21 & 0.22 & 0.33 & 0.26 & 0.31 & 6.46 \\
\hline $1898 \ldots$ & 0.33 & 0.27 & 0.38 & 0.70 & 0.89 & 0.72 & 0.25 & 0.14 & 0.14 & 0.22 & 0.22 & 0.18 & 4.44 \\
\hline Average. & 0.29 & 0.24 & 0.31 & 0.77 & 1.16 & 0.98 & 0.34 & 0.20 & 0.20 & 0.27 & 0.25 & 0.36 & 5.37 \\
\hline
\end{tabular}

Rainfall and run-off.

\begin{tabular}{|c|c|c|c|c|}
\hline Station. & Normal. & 1896. & 1897. & 1898. \\
\hline \multicolumn{5}{|l|}{ RAINFALL. } \\
\hline 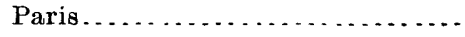 & 13. 21 & 14.09 & 10.84 & 11. 73 \\
\hline Snowville ......... & 10.40 & 14.28 & 10.05 & 7.80 \\
\hline Kelton .... & 6.30 & 5.69 & $\ldots \ldots \ldots$ & 4.65 \\
\hline Terrace $\ldots . . . . . .$. & 4.30 & 5.13 & (......... & 9.97 \\
\hline Promontory $\ldots \ldots \ldots \ldots \ldots \ldots$ & 8.40 & $\ldots \ldots$. & 9.43 & (........... \\
\hline Ogden $\ldots \ldots \ldots \ldots \ldots \ldots \ldots$ & 14.10 & 13.95 & 16.24 & 13.68 \\
\hline Coalville...... & 14.30 & 17.55 & 21.44 & ...... \\
\hline Salt Lake City ............. & 18.72 & 18.42 & 16.74 & 16.09 \\
\hline Heber............ & 17.27 & 17.82 & 19.40 & 14.96 \\
\hline Tooele ... & 7.07 & $\ldots . .$. & 14.49 & 18.25 . \\
\hline Provo ............ & 11.65 & 13.03 & $\ldots \ldots \ldots$ & $\ldots \ldots \ldots$ \\
\hline Nephi.............. & 16.34 & 12.37 & 16. 79 & $\ldots \ldots$ \\
\hline Mount Pleasant ............ & 13.63 & 11. 32 & 16.54 & $\ldots \ldots \ldots$ \\
\hline Average. & 11.98 & 13.06 & 15.20 & 12.14 \\
\hline
\end{tabular}


Rainfall and run-off-Continned.

\begin{tabular}{|c|c|c|c|c|}
\hline Station. & Normal. & 1896. & 1897. & 1898. \\
\hline \multicolumn{5}{|l|}{ RUN-OFF. } \\
\hline Provo $\ldots \ldots$ & 10.62 & 11.53 & 12.12 & 8. 19 \\
\hline Uinta $\ldots \ldots \ldots \ldots \ldots$ & 6.95 & 9.08 & 7.28 & 4.52 \\
\hline Ogden ... & 5.73 & $\ldots \ldots$ & .......... & 3.43 \\
\hline Collinston ................... & 5.37 & 4.92 & 6. 46 & 4.44 \\
\hline Average................. & 7.17 & 8.51 & 8.62 & 5.15 \\
\hline Percentage of rainfall ..... & 59.85 & 65.16 & 56.71 & 42.42 \\
\hline
\end{tabular}

BEAR RIVER.

Estimated monthly discharge of Beav River at Battle Creek, Idaho.

[Drainage area, 4,500 square miles.]

\begin{tabular}{|c|c|c|c|c|c|c|}
\hline \multirow[b]{2}{*}{ Month. } & \multicolumn{3}{|c|}{ Discharge in second-feet. } & \multirow[b]{2}{*}{$\begin{array}{l}\text { Total in acre- } \\
\text { feet. }\end{array}$} & \multicolumn{2}{|c|}{ Run-off. } \\
\hline & $\begin{array}{l}\text { Maxi- } \\
\text { mum. }\end{array}$ & $\begin{array}{l}\text { Mini. } \\
\text { mum. }\end{array}$ & Mean. & & $\begin{array}{l}\text { Depth in } \\
\text { inches. }\end{array}$ & $\begin{array}{c}\text { Second- } \\
\text { feet per } \\
\text { square } \\
\text { mile. }\end{array}$ \\
\hline 1898. & & & & & & \\
\hline January........... & 1,038 & 870 & 950 & 58,414 & 0.24 & 0.21 \\
\hline February .. & 950 & 660 & 783 & 43,486 & 0.18 & 0.17 \\
\hline March $\ldots \ldots \ldots \ldots$ & 950 & 725 & 845 & 51,957 & 0.22 & 0.19 \\
\hline April.... & 3,483 & 870 & 2,377 & 141,441 & 0.59 & 0.53 . \\
\hline May - & 3,125 & 2,469 & 2,788 & 171,429 & 0.71 & 0.62 \\
\hline June... & 3,125 & 1,635 & 2,342 & 139,358 & 0.58 & 0.52 \\
\hline July ....... & 1,635 & 598 & 1,017 & 62,533 & 0.26 & 0.23 \\
\hline August. .......... & 598 & 535 & $\check{5} 43$ & 33,388 & 0.14 & 0.12 \\
\hline September & 535 & 535 & 535 & 31,835 & 0.13 & 0.12 \\
\hline October .... & 660 & 535 & 582 & 35,786 & 0.15 & 0.13 \\
\hline November .......... & 660 & 660 & 660 & 39,273 & 0.17 & 0.15 \\
\hline December... & 660 & 660 & 660 & 40,582 & 0.17 & 0.15 \\
\hline The year. . & 3,483 & 535 & 1,174 & 849,482 & 3.54 & 0.26 \\
\hline
\end{tabular}

Note.-Gage heights for 1898 are given in Water-Supply and Irrigation Paper No. 28, page 149; measurements, page 153; rating table, page 154; results for 1897 in Water-Supply and Irrigation Paper No. 16, page 157, and in the Nineteenth Annual Report, Part IV, pages 431 to 433.

Soda Springs station on Bear River was established May 26, 1896. It is described in Water-Supply and Irrigation Paper No. 28, page 146. Gage heights for 1898 are given on page 149, and rating table on page 153. This station was discontinued July $1,1898$. 


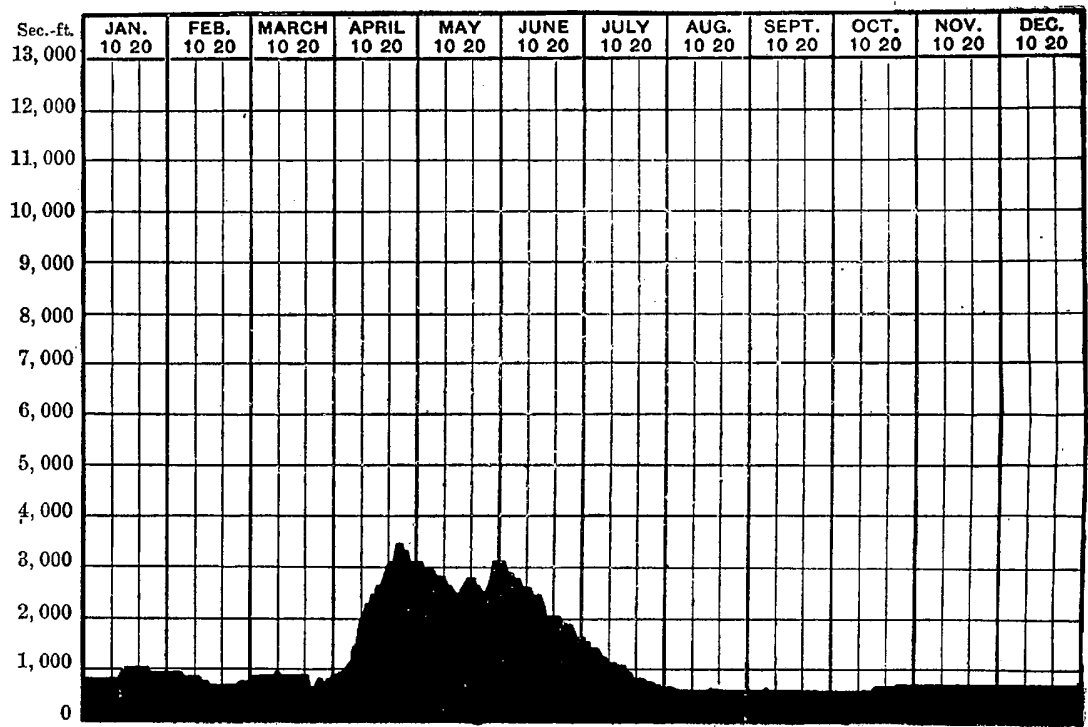

FIG. 174.-Discharge of Bear River at Battle Creek, Idaho, 1898.

Estimated monthly discharge of Bear River at Collinston, Utah.

[Drainage area, 6,000 square miles.]

\begin{tabular}{|c|c|c|c|c|c|c|}
\hline \multirow[b]{2}{*}{ Month. } & \multicolumn{3}{|c|}{ Discharge in second-feet. } & \multirow[b]{2}{*}{$\begin{array}{c}\text { Total in acre* } \\
\text { feet. }\end{array}$} & \multicolumn{2}{|c|}{ Run-off. } \\
\hline & $\begin{array}{l}\text { Maxi- } \\
\text { mum. }\end{array}$ & $\begin{array}{l}\text { Mini- } \\
\text { mum. }\end{array}$ & Mean. & & $\begin{array}{c}\text { Depth in } \\
\text { inches. }\end{array}$ & $\begin{array}{l}\text { Second- } \\
\text { feet per } \\
\text { square } \\
\text { mile. }\end{array}$ \\
\hline 1898. & & & & & & \\
\hline January ........... & 2,078 & 1,382 & 1,716 & 105,513 & 0.33 & 0.29 \\
\hline February........... & 1,875 & 1,382 & 1,573 & 87,360 & 0.27 & 0.26 \\
\hline March .............. & 2,555 & 1,615 & $\mathbf{1}, 989$ & 122,300 & 0.38 & 0.33 \\
\hline April....... & 5,025 & 1,942 & 3,802 & 226,234 & 0.70 & 0.63 \\
\hline May ......... & 5,170 & 4,068 & 4,609 & 283,398 & 0.89 & 0.77 \\
\hline June....... & 5,315 & 2,418 & 3,889 & 231,411 & 0.72 & 0.65 \\
\hline July ............. & 2,218 & 848 & 1,322 & 81,287 & 0.25 & 0.22 \\
\hline August. . . . . . . . . . & 848 & 718 & 734 & 45,132 & 0.14 & 0.12 \\
\hline September ........ & 848 & 718 & 771 & 45,878 & 0.14 & 0.13 \\
\hline October ............. & 1,180 & 848 & 1,104 & 67,883 & 0.22 & 0.19 \\
\hline November ............ & 1,383 & 1,003 & 1,202 & 71,524 & 0.22 & 0.20 \\
\hline December ... & 1,383 & 848 & 967 & 59,459 & 0.18 & 0.16 \\
\hline The year ..... & 5,315 & 718 & 1,973 & $1,427,379$ & 4.44 & 0.33 \\
\hline
\end{tabular}

Nоте.-Gage heights for 1898 are given in Water-Supply and Irrigation Paper No. 28, page 152; measurements, page 153; rating table, page 154; results for 1897 in Water-Supply and Irrigation Paper No. 16, page 159, and in the Nineteenth Annual Report, Part IV, pages 434 to 435. 


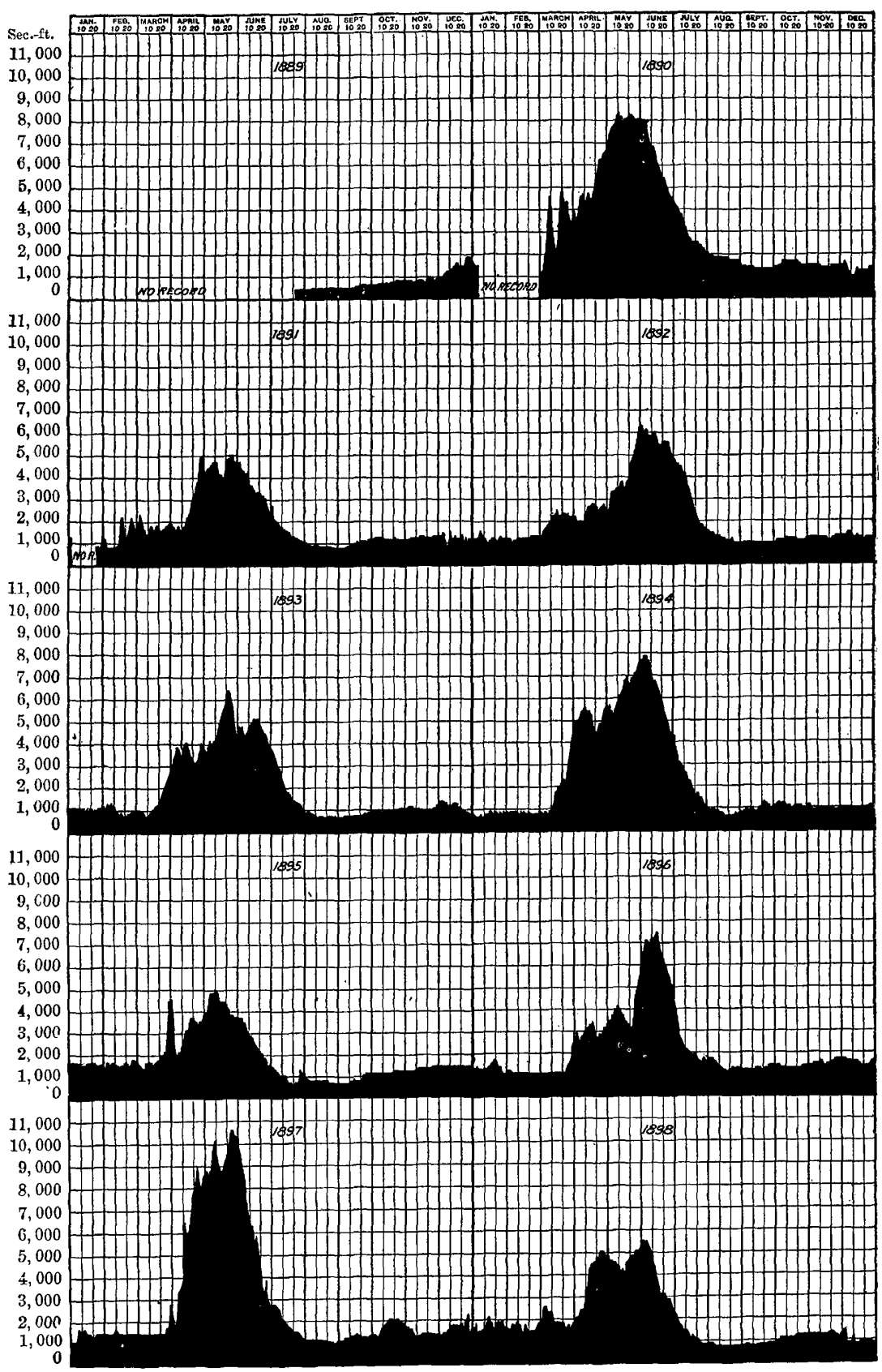

FrG. 175.-Discharge of Bear River at Collinston, Utah, 1889-1898.

On Pl. LI, $A$, is given a view of the river station at Collinston, showing the method of measurement. In the center of the picture is the old inclined gage and near this the overhanging gage, built for the pur- 


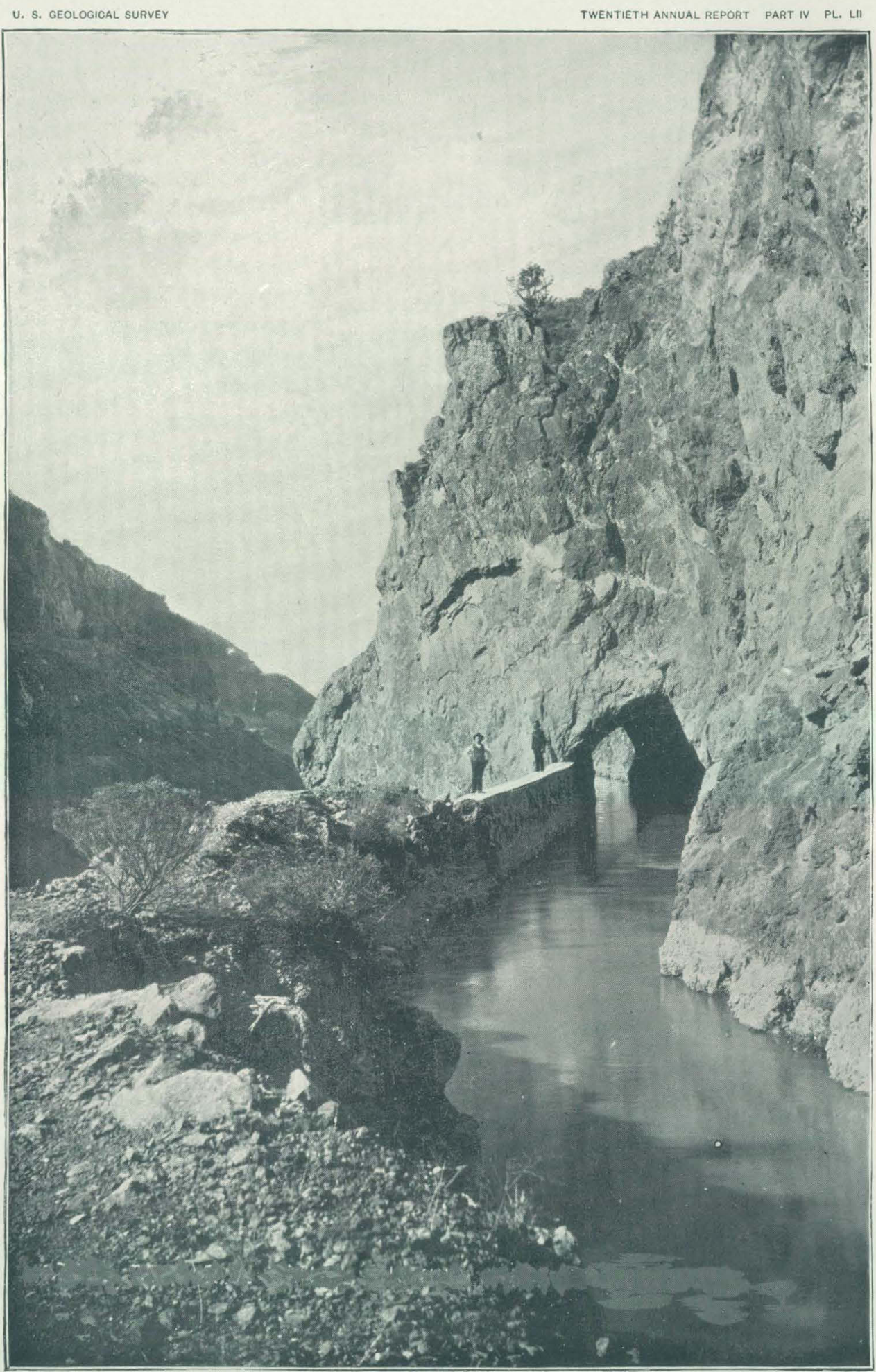

TUNNEL FOR BEAR RIVER CANAL IN CANYON, UTAH. 
pose of making direct ineasurements from a horizontal beam. On the same fgure at $B$ is shown a view of the dam of the Bear River Canal above the river station. This is taken from the head of the canal on the right.hand bank of the canyon.

In Pl. LII is given a view of the canal below the dam, showing its construction in the nearly vertical walls. The water passes alternately through tunnels and out in open cuts supported by substantial masonry.

\section{LOGAN RIVER.}

Logan River is one of the tributaries of Bear River, rising in the mountains west of Bear Lake and flowing in a general southerly and westerly course across the southern end of Cache Valley, then northerly into Bear River above the point where it cuts through the northerly prolongation of the Wasatch Mountains. Measurements of the stream are made at the mouth of the canyon, about 3 miles east of the city of Logan and above the head of all but one of the canals taking water from it. This point is convenient of access from the Agricultural Experiment Station located on the highlands northeast of Logan.

Estimated monthly discharge of Logan River at Logan, Vtah.

[Drainage area, 218 square miles.]

\begin{tabular}{|c|c|c|c|c|c|c|}
\hline \multirow[b]{2}{*}{ Month. } & \multicolumn{3}{|c|}{ Discharge in second-feet. } & \multirow[b]{2}{*}{$\begin{array}{c}\text { Total in acre- } \\
\text { feet. }\end{array}$} & \multicolumn{2}{|c|}{ Run-off. } \\
\hline & $\begin{array}{l}\text { Maxi. } \\
\text { mum. }\end{array}$ & $\begin{array}{l}\text { Mini- } \\
\text { mum. }\end{array}$ & Mean. & & $\begin{array}{l}\text { Depth in } \\
\text { inches. }\end{array}$ & $\begin{array}{c}\text { Second. } \\
\text { feet per } \\
\text { square } \\
\text { mile. }\end{array}$ \\
\hline 1898. & & & & & & \\
\hline January ............. & 167 & 142 & 152 & 9,346 & 0.81 & 0.70 \\
\hline February .......... & 155 & 134 & 147 & 8,164 & 0.70 & 0.67 \\
\hline March ..... & 167 & 125 & 140 & 8,608 & 0.74 & 0.64 \\
\hline 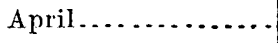 & 582 & 134 & $\cdot 323$ & 19,220 & 1.65 & 1.48 \\
\hline May .. & 778 & 419 & 587 & 36,093 & 3.10 & 2.69 \\
\hline June ...... & 740 & 500 & 663 & 39,451 & 3.39 & 3.04 \\
\hline$\dot{J} u l y \ldots .$. & 472 & 229 & 322 & 19,799 & 1.71 & 1.48 \\
\hline August..... & 264 & 213 & 231 & 14,204 & 1.22 & 1.06 \\
\hline September..... & 213 & 167 & 183 & 10,889 & 0.93 & 0.84 \\
\hline October ..... & 182 & 167 & 172 & 10,576 & 0.91 & 0.79 \\
\hline Noveuber... & 167 & 142 & 160 & 9,521 & 0.81 & 0.73 \\
\hline December.......... & 182 & 108 & 136 & 8,362 & 0.71 & 0.62 \\
\hline The year. & 778 & 108 & 268 & 194,233 & 16.68 & 1. 23 \\
\hline
\end{tabular}

Note.-Gage heights for 1898 are given in Water-Supply and Irrigation Paper No. 28, page 150; measurements, page 153, rating table, page 154; results for 1897 in Water-Supply and Irrigation Paper No. 16, page 158, and in the Nineteenth Annual Report, Part IV, pages 431 to 434. 


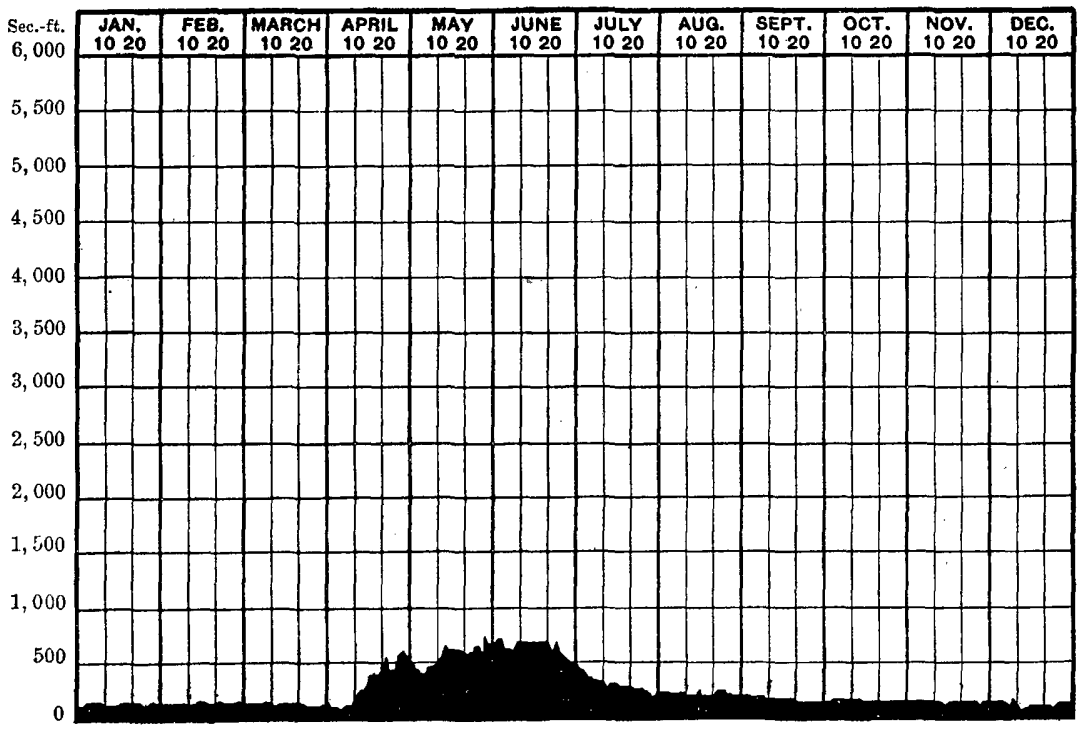

FIG. 176.-Discharge of Logan River at Logan, Utah, 1898.

BEAR LAKE RESERVOIR.

Bear Lake lies across the State line between Idaho and Utah, the southern end being in Utah and the northern end in Idaho. The conditions are described on pages 66 to 70 of the Eleventh Annual Report, Part II, also on pages 327 to 329 of the Twelfth Annual Report, Part II. The reservoir site is shown on Pl. CLXXXIII, opposite page 451 of the Thirteenth Annual Report, Part III, where is given also a detailed description in Land Office terms of the area reserved, this being made under the act of October 2,1888 .

Apparently no action has been taken to utilize this reservoir site, and the reservation of some of the lands has tended to work hardship, as in a case recently brought to the attention of the General Land Office and discussed in the following letter, dated March 9, 1899, addressed by Hon. E. A. Hitchcock, Secretary of the Interior, to the Commissioner of the General Land Office:

The Department is in receipt of your letter of December 23, 1898, with accompanying papers relative to the petition of Carls Hildt to have lots 1, 2, 3, and 4, sec. 8, T. 14 N., R. 5 E., Salt Lake meridian, withdrawn from reservation, and that he be allowed to make homestead entry of said tract.

These lots were reserved for reservoir purposes as the Bear Lake reservoir site No. 1, Utah-Idaho, under the act of October 2, 1888 (25 Stat., 505, 526), making an appropriation for the selection and survey of sites for reservoir purposes, which contained the following provision:

And all the lands which may hereafter be designated or selected by such United States surveys for sites for reservoirs, ditches, or canals for irrigation purposes, and all the lands made susceptible of irrigation by such reservoirs, ditches, or canals are from this time henceforth hereby reserved from sale as the property of the United States, and shall not be subject after the passage of this act to entry, settlement, or occupation until further provided by law. 
The act of August 30, 1890 (26 Stat., 371, 391), repealed so much of said act of October 2, 1888, as provided for the withdrawal of the public lands from entry, occupation, and settlement, and provided that-

* * all entries made or claims initiated in good faith and valid but for said act shall be recognized and may be perfected in the same manner as if said law had not been enacted. Except that reservoir sites heretofore located or selected shall remain segregated and reserved from eutry or settlement as provided by said act, until otherwise provided by law, and reservoir sites hereafter locaterl or selected on public lands shall in like manner be reserved from the date of the locaticu or selection thereof.

By the serenteenth section of the act of March 3, 1891 (26 Stat., 1095), it was provided that the reservoir sites located and selected, and to be located and selected, under said acts-

* * shall be restricted to and shall contain only so much land as is actually necessary for the construction and maintenance of reservoirs, excluding as far as practicable lands occupied by actual settlers at the date of the location of said reservoirs.

The petitioner shows by his corroborated affdavit that he settled upon this land during the month of April, 1889, and that his settlement and residence upon said tract has been continuous from that time to the present.

While the reservoir site embracing the land settled upon by Hildt was not designated or selected for reservoir purposes until $\mathrm{July}, 1889$, it took effect from the date of the act of October 2, 1888, under which the selection was made, and no relief is afforded to Hildt under the act of August 30, 1890. But there is ample authority, under the act of March 3, 1891, in the Secretary of the Interior, to release from reservation any portion of the lands selected for reservoir purposes under the several acts if it shall be made to appear that any lands so selected are not actually necessary for the purposes for which said reservation was made.

This petition was referred to the Director of the Geological Survey, who by letter of January 19, 1899, reported thereon as follows:

The tract of land involved is so small, as compared with the area of land which may be flooded by the construction of a reservoir, that it does not seem desirable to withbold from Hildt the privilege shared by others. It does not seem to me necessary to retain this particular land, and $I$ beg $t$ os suggest that it be released from reser. vation, retaining, if permitted by law, the flowage right to the height of approximately 10 feet abòve the present ordinary lake level. From general knowleidge of the conditions it does not seem desirable to incur the expense of a special survey.

In view of the recommendation of the Director of the Geological Survey, and it appearing that the petitioner has settled upon and improved said tract in ignorance of the reservation for reservoir purposes, and has continued to reside upon and improve said land since the date of his settlement, it is hereby ordered that said lots 1, 2, 3, and 4, of sec. 8, T. 14 N., R. 5 E., Salt Lake meridian, be released from said reservation, and that the Director of the Geological Survey be notified of this action.

\section{OGDEN AND WEBER RIVERS.}

Ogden and Weber rivers receive their water supply from the elevated catchment area immediately east of the Wasatch Mountains. They flow in a general westerly course, cutting through the mountains in deep, narrow canyons, emerging from which they unite and finally flow into Salt Lake. The streams are measured in these canyons, the station on Ogden River being about 5 miles northeast of Ogden, and that of Weber River being at the Union Pacitic Railiroad Bridge, about 12 miles from Ogden. 
Estimated monthly discharge of Ogden River at Ogden, Utah.

[Drainage area, 360 square miles.]

\begin{tabular}{|c|c|c|c|c|c|c|}
\hline \multirow[b]{2}{*}{ Month. } & \multicolumn{3}{|c|}{ Discharge in second-feet. } & \multirow[b]{2}{*}{$\begin{array}{l}\text { Total in acre- } \\
\text { feet. }\end{array}$} & \multicolumn{2}{|c|}{ Run-off. } \\
\hline & $\begin{array}{l}\text { Maxi- } \\
\text { mum. }\end{array}$ & $\begin{array}{l}\text { Mini- } \\
\text { mum. }\end{array}$ & Mean. & & $\begin{array}{l}\text { Depth in } \\
\text { inches. }\end{array}$ & $\begin{array}{l}\text { Second- } \\
\text { feet } \\
\text { per square } \\
\text { mile. }\end{array}$ \\
\hline 1898. & & & & & & \\
\hline Jannuary ............. & 102 & 56 & 65 & 3,997 & 0.21 & 0.18 \\
\hline February ........... & 90 & 67 & 79 & 4,387 & 0.23 & 0.22 \\
\hline 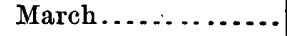 & 116 & 67 & 90 & 5,534 & 0.29 & 0.25 \\
\hline April.............. & 517 & 102 & 267 & 15,888 & 0.82 & 0.74 \\
\hline May................ & 451 & 187 & 297 & 18,262 & 0.95 & 0.83 \\
\hline June ................ & 319 & 36 & 102 & 6,069 & 0.31 & 0.28 \\
\hline July ............. & 39 & 32. & 35 & 2,152 & 0.12 & 0.10 \\
\hline August................. & 44 & 30 & 33 & $2 ; 029$ & 0.10 & 0.09 \\
\hline September. & 32 & 30 & 31 & 1,845 & 0.10 & 0.09 \\
\hline October ............ & 34. & 30 & 32 & 1,968 & 0.10 & 0.09 \\
\hline November ...... & 36 & 32 & 32 & 1,904 & 0.10 & 0.09 \\
\hline December ............ & 34 & 30 & 32 & 1,968 & 0.10 & 0.09 \\
\hline The year ..... & 517 & 30 & 91 & 66,003 & 3. 43 & 0.25 \\
\hline
\end{tabular}

Noте.-Gage heights for 1898 are given in Water.Supply and Irrigation Paper No. 28, page 151, measurement, page 153, rating table, page 154; results for 1897 in Water-Supply and Irrigation Paper No. 16, page 160, and in the Nineteenth Annual Report, Part IV, pages 436 to 439.

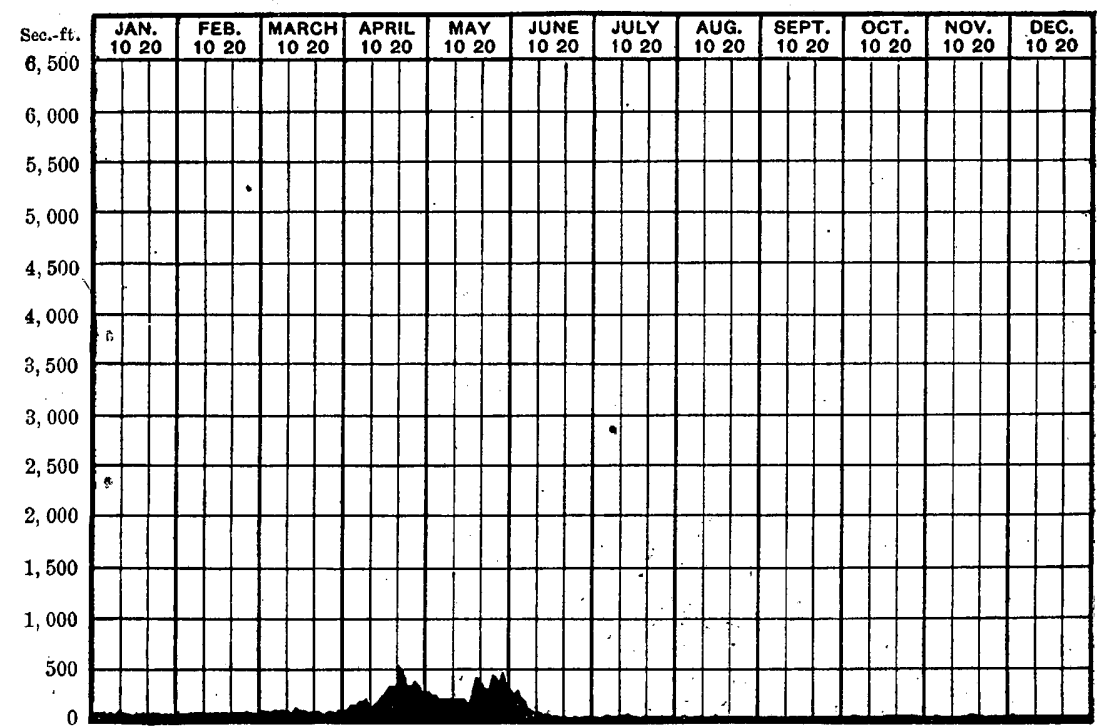

FIG. 177.-Discharge of Ogden River at Ogden, Utah, 1898.

20 GEOL, PT $4-30$ 
Estimated monthly discharge of Weber River at Uinta, Ltah.

[Drainage area, 1,600 square miles.]

\begin{tabular}{|c|c|c|c|c|c|c|}
\hline \multirow[b]{2}{*}{ Month. } & \multicolumn{3}{|c|}{ Discharge in second-feet. } & \multirow{2}{*}{$\begin{array}{l}\text { Total in acre- } \\
\text { feet. }\end{array}$} & \multicolumn{2}{|c|}{ Run-off. } \\
\hline & $\begin{array}{l}\text { Maxi- } \\
\text { mum- }\end{array}$ & $\begin{array}{l}\text { Mini- } \\
\text { mum. }\end{array}$ & Mean. & & $\begin{array}{l}\text { Depth in } \\
\text { inches. }\end{array}$ & $\begin{array}{c}\text { Second- } \\
\text { feet } \\
\text { persquare } \\
\text { mile. }\end{array}$ \\
\hline 1898. & & & & & . & \\
\hline Jaunary ............. & : 310 & 260 & 271 & $\mathbf{1 6}, 663$ & 0.20 & $0: 17$ \\
\hline February ..... & 475 & 260 & $320^{\prime}$ & 17,772 & 0.21 & 0.20 \\
\hline March ............... & 510 & 335 & 392 & 24,103 & 0.29 & 0.25 \\
\hline April........... & 2,118 & 415 & 1,329 & 79,081 & 0.92 & 0.83 \\
\hline May................ & 2,066 & 1,040 & 1,606 & 98,750 & 1.15. & 1.00 \\
\hline June...$: \cdots$ & 1,240 & 310 & 752 & 44,747 & 0.53 & 0.47 \\
\hline July $\ldots \ldots$ & 620 & 165 & 291 & 17,892 & 0.21 & .0 .18 \\
\hline August . - & 115 & 65 & 92 & 5,657 & 0.07 & 0.06 \\
\hline September ..... & 210 & 125 & 171 & 10,175 & 0.12 & 0.11 \\
\hline October ..... & .415 & 210 & 302 & 18,569 & 0.22 & 0.19 \\
\hline November .... & 695 & 415 & 439 & 26,122 & 0.30 & 0.27 \\
\hline December ... & 445 & 415 & 416 & 25,579 & 0.30 & 0.26 \\
\hline The year ..... & 2,118 & 65. & 532 & 385,110 & 4.52 & 0.33 \\
\hline
\end{tabular}

NoTE.-Gage heights for 1898 are given in Water-Supply and Irrigation Paper No. 28, page 151, measurements, page 153, rating table, page 154; results for 1897 in Water-Supply and Irrigation Paper No. 16, page 161, and in the Nineteenth Annual Report, Part IV, pages 440 to 441.

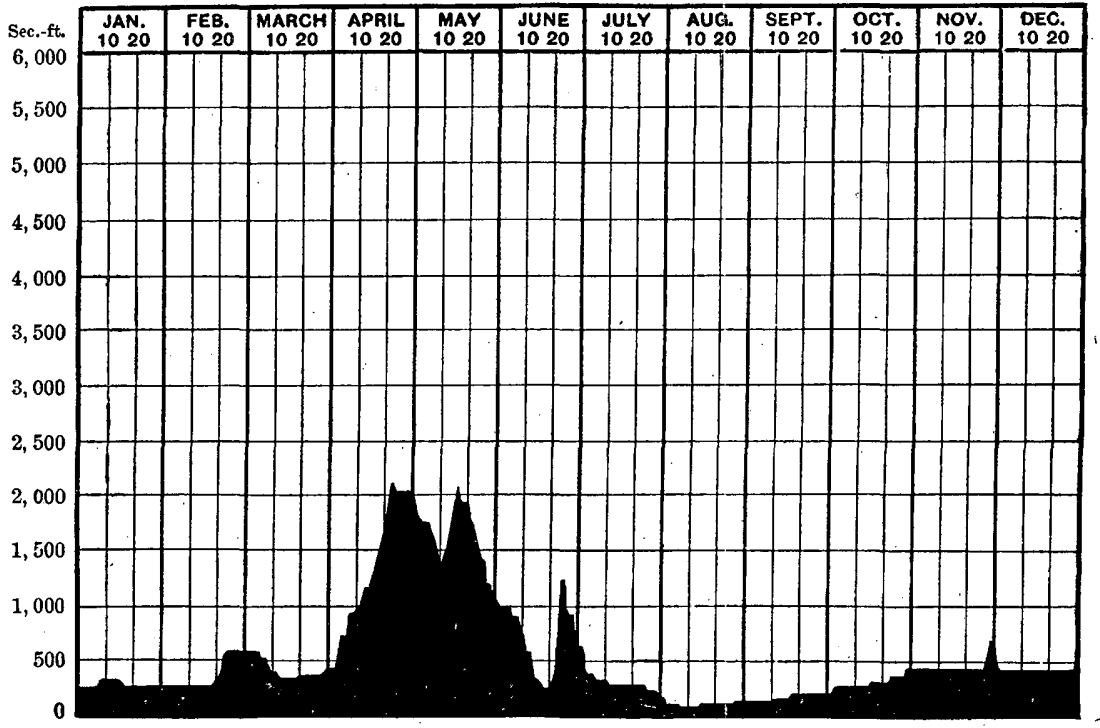

Fig. 178,-Discharge of Weber River at Uinta, Utah, 1898. 
UTAH LAKE.

Geneva station on Utah Lake is described on page 163 of WaterSupply and Irrigation Paper No. 16; results for 1897 are given on page 443 of the Nineteenth Annual Report, Part IV. Gage heights for 1898 are given on page 152 of Water-Supply and Irrigation Paper No. 28.

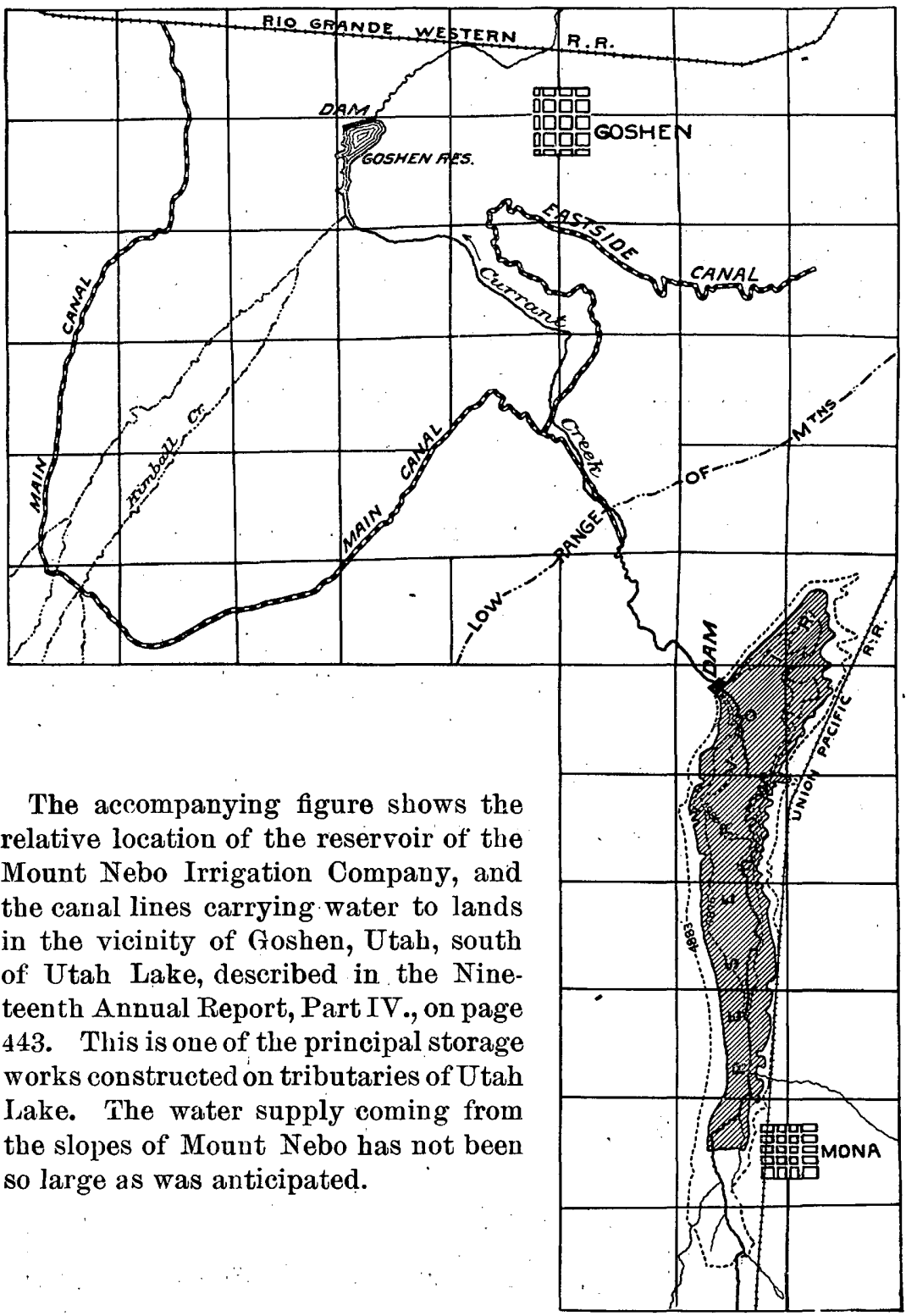

Frg. 179.--Relative location of Mount Nebo reservoir and canal. 
PROVO RIVER.

Estimated monthly discharge of Provo River at Provo, Utah. [Drainage area, 640 square miles.]

\begin{tabular}{|c|c|c|c|c|c|c|}
\hline \multirow[b]{2}{*}{ Month. } & \multicolumn{3}{|c|}{ Discharge in second-feet. } & \multirow[b]{2}{*}{$\begin{array}{l}\text { 'lotal in acre- } \\
\text { feet. }\end{array}$} & \multicolumn{2}{|c|}{ Run-off. } \\
\hline & $\begin{array}{l}\text { Maxi- } \\
\text { mum. }\end{array}$ & $\begin{array}{l}\text { Mini- } \\
\text { mum. }\end{array}$ & Mean. & & $\begin{array}{l}\text { Depth in } \\
\text { inches. }\end{array}$ & $\begin{array}{c}\text { Second } \\
\text { feet per } \\
\text { square } \\
\text { mile. }\end{array}$ \\
\hline 1898. & & & & & & \\
\hline January ............. & 336 & 250 & 283 & 17,401 & 0.51 & 0.44 \\
\hline February .. & 390 & 287 & 307 & 17,050 & 0.50 & 0.48 \\
\hline March ............... & 390 & 390 & 390 & 23,980 & 0.70 & 0.61 \\
\hline April ....... & 972 & 390 & 566 & 33,679 & 0.98 & 0.88 \\
\hline May ...... & 1,132 & 812 & 957 & 58,844 & 1.73 & 1.50 \\
\hline June...... & 1,212 & 287 & 823 & 48,972 & 1.44 & 1.29 \\
\hline July .... & 287 & 167 & 202 & 12,421 & 0.37 & 0.32 \\
\hline August...... & 167 & 146 & 162 & 9,961 & 0.29 & 0.25 \\
\hline September . ......... & 167 & 167 & 167 & 9,937 & 0.29 & 0.26 \\
\hline October .... & 250 & 167 & 210 & 12,912 & 0.38 & 0.33 \\
\hline November.......... & 287 & 250 & 281 & 16,721 & 0.49 & 0.44 \\
\hline December ........... & 287 & 250 & 279 & 17,155 & 0.51 & 0.44 \\
\hline The year.... & 1,212 & 146 & 386 & 279,033 & 8.19 & 0.60 \\
\hline
\end{tabular}

Nore.-Gage heights for 1898 are given in Water-Supply and Irrigation Paper No. 28, page 152; measurements, page 153; rating table, page 154; results tor 1897 in Water-Supply and Irrigation Paper No. 16, page 162, and in the Nineteenth Annual Report, Part IV, pages 441 to 442.

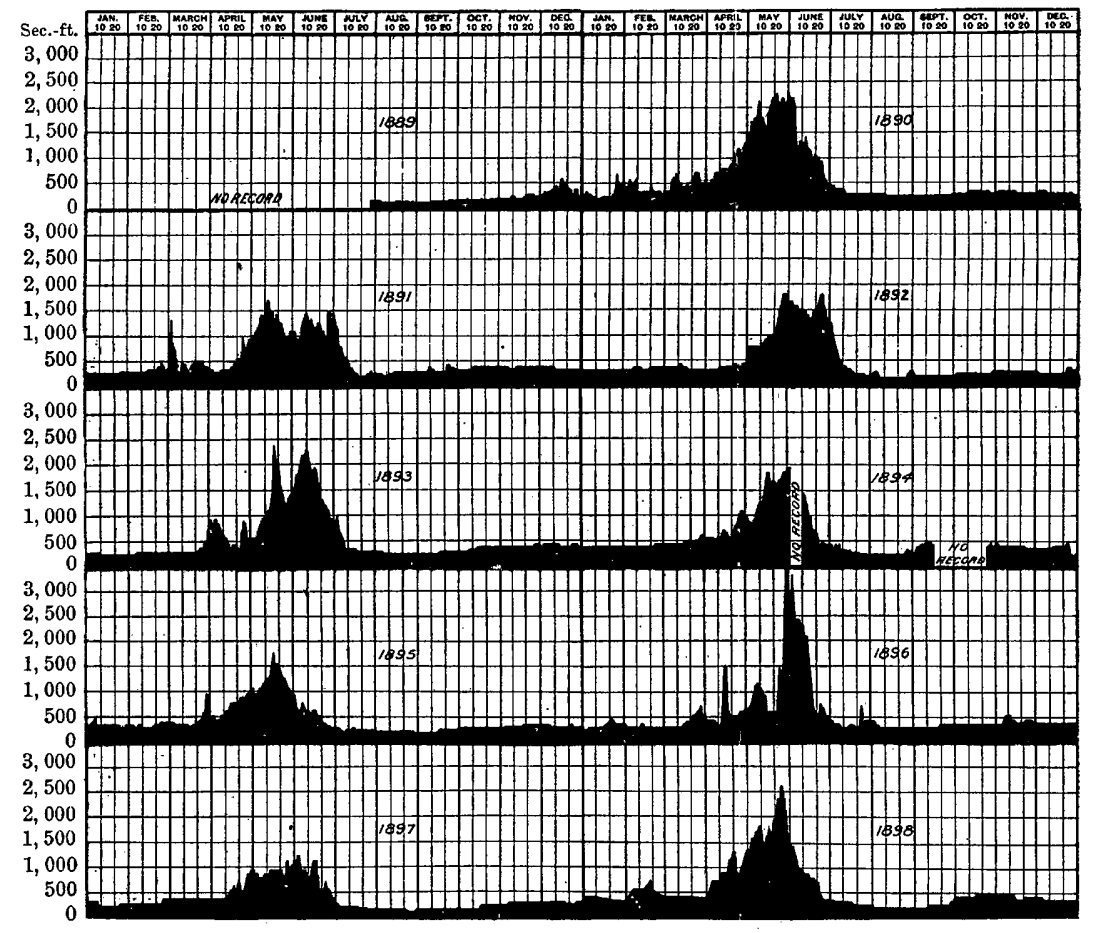

Fig. 180.-Discharge of Provo River at Provo, Utah, 1889-1898. The diagrams for 1897 and 1898 (except the dates) should be transposed. 


\section{AMERICAN FORK RIVER.}

Measurements of American Fork River, Utah, during January, February, and March, 1897, have been given by Mr. R. O. Gemmell, State engineer of Utah. These measurements were made at the mouth of the canyon, over weirs built for dividing the waters of the stream between the towns of American Fork, Lehi, and Pleasant Grove. A gage was set up by Mr. Gemmell and read four times a day by an assistant, but the weirs were poorly constructed. It is believed that the figures are correct within 3 per cent. The maximum and minimum flows of February,.which occurred on the 19th, were caused by snow slides in the canyon, the immediate effect lasting only about one hour.

Maximum, minimum, and mean discharge of American Fork River for three months in 1897.

\begin{tabular}{|c|c|c|c|}
\hline Month. & Maximum. & Minimum. & Mean. \\
\hline 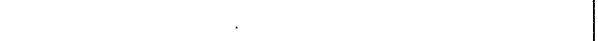 & Second-feet. & Second.feet. & Second-feet. \\
\hline 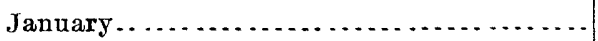 & 25.5 & 23.5 & 24.5 \\
\hline February $\ldots \ldots \ldots \ldots \ldots \ldots \ldots \ldots \ldots \ldots \ldots$ & 48.7 & 2.0 & 25.5 \\
\hline 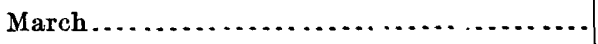 & 30.3 & 23.5 & 26.5 \\
\hline
\end{tabular}

\section{COLUMBIA RIVER DRAINAGE.}

Under this heading are included data concerning the streams of Idaho, Oregon, and Washington, tributary to the Columbia, these being the Snake, Clarks Fork or Missoula, and Yakima rivers.

\section{SNAKE RIVER.}

Snake River rises in western Wyoming and eastern Idaho, in the vicinity of Yellowstone Park, and flows in a general westerly course through the lava-covered plains of southern Idaho, where its waters are used to a small extent for irrigation. Turning northward, it receives the Boise, Payette, Weiser, Owyhee, Malheur, and other streams of less importance in irrigation; and, passing around to the east and north of the Blue Mountains of 'Oregon, enters Columbia River.

\section{PRECIPITATION IN THE BASIN OF SNAKE RIVER.}

The principal observations of rainfall made within the basin of the Snake River are at Lake, Idaho Falls, Fort Hall, Placerville, Lost River, American Falls, Oakley, Hailey, Nampa, Boise City, Payette, and Ruthburg. The relative location of these points is shown on fig. 160 in connection with the points of river measurement, which are at Pocatello, Montgomery, Toponis, Grand View, Boise, Payette, and Weiser. 
The following table gives the names and location of the stations, the elevations, and the number of years during which the observations

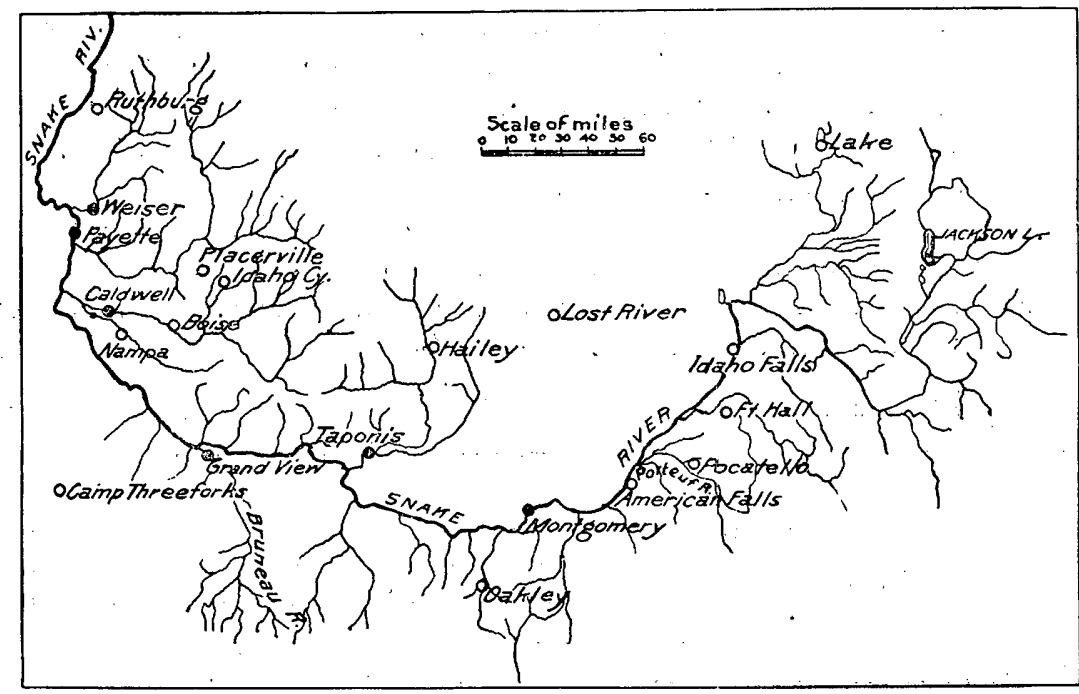

FIG. 181. -Relative location of river and rainfall observations in basin of Snake River.

have been made, or, rather, the number of complete monthly observations used in computing the normals:

Location of rainfall stations.

\begin{tabular}{|c|c|c|c|c|c|c|}
\hline Station. & County. & State. & Latitude. & $\begin{array}{c}\text { Longi- } \\
\text { tude. }\end{array}$ & $\begin{array}{l}\text { Eleva- } \\
\text { tion. }\end{array}$ & $\begin{array}{l}\text { Length of } \\
\text { record. }\end{array}$ \\
\hline Lake. & Fremont & Idaho. & $\begin{array}{cc}\circ & 1 \\
44 & 42\end{array}$ & $\begin{array}{cc}\circ & , \\
111 & 20\end{array}$ & $\begin{array}{l}\text { Feet. } \\
6,000\end{array}$ & $6-8$ \\
\hline Idaho Falls .... & Bingham & . do & 4328 & 11200 & 4,742 & $8-9$ \\
\hline Fort Hall ...... & Oneida. & $\ldots$. do & 4315 & 11200 & 4,870 & $3-7$ \\
\hline Placerville ..... & Boise .... & .... do .... & 4356 & 11557 & 4,000 & $4-8$ \\
\hline Lost River & Blaine .. & .... do & $43 \quad 39$ & 11323 & 6,000 & $7-9$ \\
\hline American Falls & Oneida..., & ..... do .... & 4247 & 11257 & 4,343 & $5-8$ \\
\hline Oakley..... & Cassia ......... & ..... do .... & 4214 & 11355 & 4,191 & $4-5$ \\
\hline Hailey . . & Blaine & .... do & 4332 & 11420 & 5,503 & $2-4$ \\
\hline Nampa.... & Canyon... & ..... do .... & 4335 & 11633 & 2,400 & $4-5$ \\
\hline Boise ..... & Ada ...... & ..... do . & 4338 & 11613 & 2,880 & 27 \\
\hline Payette.... & Canyon ....... & ..... do . & 444 & 11656 & 2,195 & $6-8$ \\
\hline Ruthburg & Washington.. & ..... do & 4447 & 11652 & & $5-7$ \\
\hline
\end{tabular}

In the following table are given the figures of normal or average monthly precipitation from the time of the beginning of the record to and including 1897 , together with total precipitation by months for the years 1896, 1897, and 1898; and also the amount by years. In obtain- 
ing the normal precipitation, the average is taken for all of the months during which observations were made:

Precipitation at stations in drainage basin of Snake River.

- LAKE.

\begin{tabular}{|c|c|c|c|c|c|c|c|c|c|c|c|c|c|}
\hline Year. & Jan. & Feb. & Mar. & Apr. & May. & June. & July. & Aug. & Sept. & Oct. & Nov: & Dec. & Annual \\
\hline Normal. & 2.27 & 2. 13 & 1.69 & 0.57 & 1.23 & 2.07 & 0.60 & 0.64 & 0.96 & 0.88 & $1.74^{\circ}$ & 2.91 & 17.69 \\
\hline 1896. & 3.00 & 1.40 & 2.00 & 1.30 & 2.50 & 0.50 & ...... & $\ldots \ldots$ & $\ldots . . .$. & 1. 36 & 3.40 & 1.40 & $\ldots \ldots$ \\
\hline 1897. & 0.30 & 2.00 & 1.50 & 0.00 & 0.26 & 1.35 & $(0.60)$ & 0.00 & $(0.96)$ & 1.15 & 1.40. & 5.34 & 14.86 \\
\hline 1898. & 2.00 & 1. 30 & 2.00 & 0.35 & 1.07 & 1.21 & 0.35 & 0.60 & 0.00 & $(0.88)$ & 0.80 & 1.50 & 12.06 \\
\hline \multicolumn{12}{|c|}{ IDAHO FALLS. } & \multicolumn{2}{|l|}{$\cdots$} \\
\hline Normal & 2:04 & 1.85 & $2: 20$ & 1.51 & 1.17 & 1.09 & 0.45 & 0.42 & 0.66 & 1.06 & 1.29 & 1.53 & 15.27 \\
\hline $1895 \ldots$ & 1.56 & 0.46 & 3.41 & 1.13 & 2.78 & 0.65 & 1.16 & $1: 08$ & 0.30 & 0.58 & 3.25 & 0.82 & $17: 18$ \\
\hline $1897 .$. & 0.67 & 2.59 & 3.84 & 1.35 & 0.84 & 0.77 & 0.20 & $\mathrm{~T}$ & 0.55 & 1.48 & 1.90 & 1.59 & 15. 77 \\
\hline 1898. & 1.76 & 0.34 & 1.33 & 0.19 & i. 74 & 1.33 & 0.93 & 0.34 & 0.03 & 0.49 & 1.34 & 0.76 & 10.58 \\
\hline \multicolumn{14}{|c|}{ FORT HALL. } \\
\hline$\because$ Normal & 0.62 & 0.77 & 0.64 & 0.30 & 1.77 & 0.58 & $-1: 05$ & $0.64^{\circ}$ & $0: 28$ & 0.85 & 1.24 & 1. 23 & 9.97 \\
\hline $1896 .$. & 1.35 & $(0.77)$ & 1.95 & 1.50 & 2.63 & 0.27 & 0.75 & 1.74 & 0.23 & 0.92 & 2.17 & 0.46 & 14. 74 \\
\hline 1897. & 0.17 & 1.08 & 0.10 & 1.40 & 0.23 & 0.62 & 1.84 & 0.50 & 0.66 & 1.79 & 0.88 & 0.96 & 10.23 \\
\hline 1898. & & 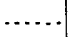 & & $\cdots$ & & & $\cdots$ & $\cdots$ & & & & $\ldots$ & \\
\hline \multicolumn{14}{|c|}{ PLACERVILLE. } \\
\hline Norinal & 2.90 & 3.14 & 3.83 & 2.03 & 2.30 & 0.59 & 0.75 & 0.46 & - 1.32 & 2.34 & 3.09 & 3.30 & 26.05 \\
\hline 1896. . & $\ldots . .$. & $1: 46$ & 4.11 & ...... & 6.26 & 1.70 & 1.86 & 0.91 & 0.45 & $\therefore \ldots$ & 5.96 & 3.62 & ....... \\
\hline $1897 \ldots$ & 1.98 & 4. 94 & 6.74 & 1.41 & 1.43 & 0.39 & 1.26 & $\mathbf{T}$. & 1.27 & 0.71 & (3.09) & 4.10 & 27.32 \\
\hline $1898 \ldots$ & $\ldots .$. & $\cdots$ & & $\ldots$ & $\ldots$. & $\therefore$. & & $\ldots \ldots$ & 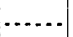 & & & $\therefore \ldots$ & . . . . \\
\hline \multicolumn{14}{|c|}{ ERA, MARTUS, AND LOST RIVER. } \\
\hline Normal & 2. 22 & 1.67 & 2.20 & 0.77 & 1.63 & 0.74 & 0.33 & 0.14 & 051 & 0.75 & 1.14 & 1.80 & 13.90 \\
\hline 1896. & 3.35 & 0.15 & 2.30 & 0.55 & 3.45 & 0.20 & 0.40 & 0.10 & 0.24 & 0.55 & 4.10 & 0.20 & 15.59 \\
\hline 1897. & 0.05 & 0.53 & 1.88 & 0.13 & 0.42. & 1.07 & 0.51 & 0.27 & 0.66 & 1.86 & 0.46 & 0.73 & 8.57 \\
\hline 1898. & 0.38 & 0.02 & 0.20 & 0.08 & 2.06 & 1.26 & 1.82 & 0.80 & 0.25 & 0.45 & 0.33 & 0.03 & 7. 73 \\
\hline \multicolumn{14}{|c|}{ AMERICAN FALLS. } \\
\hline Normal : & 1.37 & 1.23 & 1.65 & j. 34 & 1.36 & 0.92 & $0.56^{\circ}$ & 0.48 & 0.65 & 1.00 & 1.16 & 1. 41 & 13.13 \\
\hline 1896. & 2.32 & 0.26 & 2.39 & 2.23 & 3.60 & 0.83 & 0.79 & 0.74 & $(0.65)$ & (1.00) & 3.88 & 1.00 & $19: 69$ \\
\hline $1897 \ldots$ & 0.53 & 1.85 & 1.82 & ...... & 0.60 & ....... & 0.43 & 0.68 & -..... & 3.09 & 1.86 & 1.57 & ….... \\
\hline 1898. & 0.75 & 0.25 & 0.25 & 0.15 & ...... & 0.28 & 2.00 & 0.40 & 0.00 & $\ldots$ & ...... & 0.00 & $\ldots$. \\
\hline \multicolumn{14}{|c|}{ OAKLEY. } \\
\hline Normal . & 0.78 & 0.42 & 0.92 & 0.76 & 0.75 & 0.54 & 0.34 & 0.70 & 1. 24 & 0.88 & 0.69 & 0.51 & 8.53 \\
\hline $1896 \ldots$ & 1.19 & 0.20 & 1.87 & 0.80 & 1.20 & 0.50 & 0.60 & 0.62 & 0.55 & $(0.88)$ & 1.54 & $(0.51)$ & 10.46 \\
\hline $1897 \ldots \ldots \ldots$ & 0.50 & 0.20 & 0.10 & 0.92 & 0.90 & 0.50 & 0.85 & 0.40 & 1.20 & 2.70 & 1.12 & 1.00 & 10.39 \\
\hline $1898 \ldots$ & 0,70 & 0.30 & 0.30 & 0.20 & 1.10 & 0.58 & 0.85 & 0.25 & 0.00 & 0.30 & 1.40 & 0.20 & 6.18 \\
\hline
\end{tabular}


Precipitation at stations in drainage basin of Snake River-Continued.

HAILEY.

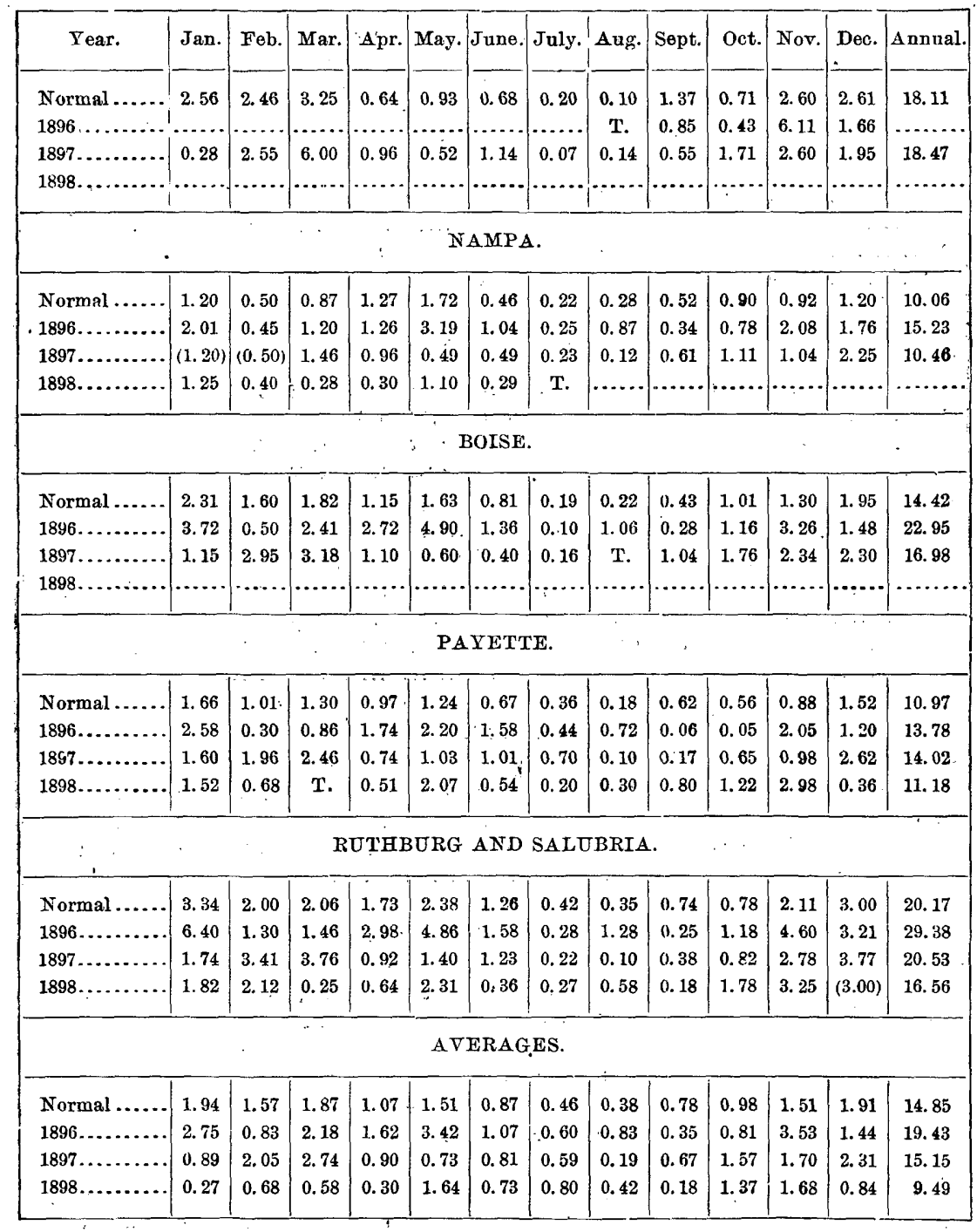


Run-off, in inches, from Snake drainage basin.

SNAKE, AT MONTGOMERY.

\begin{tabular}{|c|c|c|c|c|c|c|c|c|c|c|c|c|c|}
\hline Tear. & Jan: & Feb. & Mar. & Apr. & May. & June. & July. & Aug. & Sept. & Oct. & Nov. & Dec. & Annual. \\
\hline 1895. & & $\cdots$ & & & & & $\cdots$ & 0.20 & 0.22 & 0.23 & 0.23 & 0.24 & \\
\hline 1896. & 0.24 & 0.23 & 0.25 & 0.26 & 0.47 & 1.95 & 0.68 & 0.28 & 0.25 & 0.19 & . $\ldots . .$. & . . . . & 5.33 \\
\hline $1897 \ldots$ & 0.25 & 0.23 & 0.25 & 0.33 & 1.68 & 1.50 & 0.54 & 0.26 & 0.24 & 0.25 & 0.24 & 0.25 & 6.02 \\
\hline $1898 \ldots$ & $\ldots .$. & ...... & 0.28 & 0.43 & 0.90 & 1.03 & 0.47 & 0.23 & 0.21 & 0.24 & 0.26 & 0.30 & 4.83 \\
\hline Average. & 0.25 & 0.23 & 0.23 & 0.34 & 1.02 & 1.49 & 0.56 & 0.24 & 0.23 & 0.23 & 0.25 & 0.28 & 5. 35 \\
\hline \multicolumn{14}{|c|}{ MALADE, AT TOPONIS. } \\
\hline 1896. & & & & & * & 1.93 & 0.61 & 0.08 & 0.07 & & & & \\
\hline 1897. & & & & $\cdots$ & ..... & 0.35 & 0.19 & 0.02 & 0.04 & & & ....... & - \\
\hline 1898 & $\cdots$ & ...... & 0.35 & 0.27 & 0.28 & 0.54 & 0.15 & ...... & ….. & & . & .......... & .... \\
\hline Average. & & & 0.35 & 0.27 & 0.28 & 0.94 & 0.32 & 0.05 & 0.04 & & & & \\
\hline \multicolumn{14}{|c|}{ LITTLE WOOD, AT TOPONIS. } \\
\hline 1896. & & & & & $\ldots . .$. & 0.49 & 0.12 & 0.00 & 0.04 & & & & \\
\hline 1897. & & & & & & 0.18 & 0.32 & 0.02 & 0.08 & & & & \\
\hline 1898. & & & & . &. & $\cdots \cdots$ & $\cdots$ & an..... & $\cdots \cdots$ & $\cdots$ & & & \\
\hline Average. & & & .. & & $\cdots \cdots$ & 0.34 & 0.07 & 0.01 & 0.06 & & & & \\
\hline \multicolumn{14}{|c|}{ BRUNEAU, AT GRANDVIEW. } \\
\hline 1896. & 0.07 & 0.07 & 0.21 & 0.39 & 0.60 & 1.23 & 0.21 & 0.04 & 0.03 & 0.04 & 0.08 & 0.08 & 3. 05 \\
\hline 1897. & 0.06 & 0.08 & 0.30 & 1.01 & 0.45 & 0.57 & 0.13 & 0.03 & 0.03 & 0.06 & 0.08 & 0.08 & 2.88 \\
\hline $1898 \ldots \ldots \ldots$ & 0.07 & 0.13 & 0.14 & 0.44 & 0.44 & 0.28 & 0.07 & 0.02 & 0.01 & 0.04 & 0.05 & 0.05 & 1.30 \\
\hline Average. & 0.07 & 0.09 & 0.22 & 0.61 & 0.50 & 0.69 & 0.14 & 0.03 & 0.02 & 0.05 & 0.07 & 0.07 & 2.56 \\
\hline \multicolumn{14}{|c|}{ BOISE, AT BOISE. } \\
\hline 1895. & 0.58 & 0.54 & 0.70 & 1.89 & 2.85 & 1.72 & 1.15 & 0.46 & 0.45 & 0.43 & 0.41 & 0.38 & 11.56 \\
\hline $1896 \ldots$ & 0.55 & 0.50 & 1.16 & 2.16 & 3.81 & 11.10 & 2.62 & 0.60 & 0.44 & 0.41 & 0.41 & 0.40 & 24.16 \\
\hline 1897. & 0.38 & 0.41 & 0.67 & 2.34 & 6.40 & 3.45 & 1.08 & 0.51 & 0.48 & 0.48 & 0.49 & 0.47 & 17.17 \\
\hline $1898 \ldots$ & 0.25 & 0.52 & 0.91 & 1.91 & 2.46 & 2.28 & 0.89 & 0.35 & 0.30 & 0.40 & 0.43 & 1.15 & 11.85 \\
\hline A verage. & 0.44 & 0.49 & $0.8 \dot{6}$ & 2.08 & 3.88 & 4.64 & 1.44 & 0.48 & 0.42 & 0.43 & 0.44 & 0.60 & 16. 20 \\
\hline \multicolumn{14}{|c|}{ PAYETTE, AT PAYETTE. } \\
\hline 1895. & 0.54 & 0.60 & 0.68 & 0.58 & 0.91 & 2.23 & 0.93 & 0.36 & 0.33 & 0.31 & 0.31 & 0.32 & 8.10 \\
\hline $1896 \ldots$ & …. & 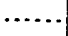 & $\cdots$ & $\cdots$ & 2.10 & 7.69 & 3.46 & 0.69 & 0.48 & …... & & ... & ....... \\
\hline $1897 .$. & & & & $\cdots$ & 4.35 & 3.48 & 1.37 & & & ... & $\ldots$ & $\cdots$ & $\ldots \ldots$ \\
\hline $1898 .$. & $\ldots . .$. & ....... & $\cdots$ & $\ldots \ldots$ & $\ldots \ldots$ & $\ldots .$. & $\cdots \cdots$ & ....... & ....... & $\cdots$ & $\cdots \cdots$ & $\cdots \cdots \cdot$ & $\ldots \ldots$ \\
\hline Average. & ........ & & & $\cdots$ & 2.45 & 4.43 & 1.92 & 0.53 & 0.41 & 0.31 & 0.31 & 0.32 & \\
\hline \multicolumn{14}{|c|}{ WEISER, AT WEISER. } \\
\hline $1895 \ldots \ldots \ldots$ & 0.35 & 0.19 & 1.23 & 1.51 & 1.84 & 0.56 & 0.17 & 0.04 & 0.08 & 0.09 & 0.09 & 0.20 & 6.35 \\
\hline $1896 \ldots$ & 1.83 & 0.55 & 1.52 & 1.38 & 4.04 & 4.56 & 0.68 & 0.16 & 0.16 & 0.14 & 0.10 & 0.17 & 15.29 \\
\hline $1897 \ldots$. & $\ldots . .$. & $\ldots \ldots$ & $\ldots . .$. & 7.26 & 4.84 & 0.83 & 0.26 & 0.06 & 0.08 & 0.10 & 0.10 & 0.10 & ......... \\
\hline $1898 \ldots$ & $(0.10)$ & $(0.21)$ & 0.46 & 1.51 & 1.30 & 0.91 & 0.24 & 0.02 & 0.03 & 0.08 & 0.10 & 0.53 & 5.49 \\
\hline A verage. & $(0.76)$ & $(0.32)$ & 1.07 & 2. 92 & 3.01 & 1. 72 & 0.34 & 0.07 & 0.09 & 0.10 & 0.10 & 0.25 & 10.75 \\
\hline
\end{tabular}




\section{PROGRESS OF STREAM MEASUREMENTS FOR 1898.}

Rainfall and run-off.

\begin{tabular}{|c|c|c|c|c|}
\hline Station. & Normal. & 1896. & 1897. & 1898. \\
\hline RAINFALL. & & & & \\
\hline Lake $\ldots \ldots \ldots \ldots \ldots$ & 17.69 & $\ldots \ldots \ldots$ & 14.86 & 12.06 \\
\hline Idabo Falls.................... & 15.27 & 17.18 & 15.77 & 10.58 \\
\hline Fort Hall $\ldots \ldots \ldots \ldots \ldots \ldots \ldots$ & 9.97 & 14. 74 & 10.23 & $\ldots \ldots . . .$. \\
\hline Placerville $\ldots . \ldots \ldots \ldots \ldots \ldots \ldots$ & 26.05 & $\ldots \ldots \ldots$ & 27. 32 & \\
\hline 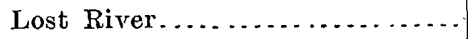 & 13.90 & 15.59 & 8.57 & 7.73 \\
\hline 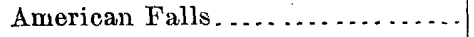 & 13. 13 & 19.69 & .......... & $\ldots .$. \\
\hline 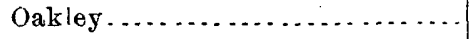 & 8.53 & 10.46 & 10. 39 . & 6.18 \\
\hline Hailey $\ldots \ldots \ldots \ldots \ldots \ldots \ldots \ldots$ & 18.11 & $\ldots \ldots \ldots$ & 18.47 & $\ldots$ \\
\hline Nampa $\ldots \ldots \ldots \ldots \ldots \ldots \ldots \ldots$ & 10.06 & 15. 23 & 10. 46 & \\
\hline Boise $\ldots \ldots \ldots \ldots \ldots \ldots \ldots$ & 14.42 & 22.95 & 16.98 & $\cdots$ \\
\hline Payette $\ldots \ldots \ldots \ldots \ldots \ldots \ldots$ & 10.97 & 13. 78 & 14.02 & 11. 18 \\
\hline Ruthburg $\ldots \ldots \ldots \ldots \ldots \ldots \ldots$ & 20.17 & 29.38 & 20.53 & 16.56 \\
\hline Average. & 14.86 & 17.67 & 15.24 & 10.72 \\
\hline RUN-OFF. & & & & \\
\hline Snake, at Montgomery Ferry ...... & $5: 35$ & 5.33 & 6.02 & 4.83 \\
\hline Bruneau, at Grand View ......... & 2.56 & 3: 05 & 2.88 & 1: 30 \\
\hline Boise, at Boise $\ldots \ldots \ldots \ldots \ldots \ldots$ & 16.20 & 24.16 & 17.17 & $11.8 \breve{5}$ \\
\hline Payette, at Payette............. & 6.35 & $\ldots \ldots \ldots$ & $\therefore \ldots \ldots$ & -...... \\
\hline Weiser, at Weiser................ & 10.75 & 15.29 & $\ldots \ldots \ldots$ & 5.49 \\
\hline Average..... & 8.24 & 11.96 & 8.69 & 5.87 \\
\hline Percentage of rainfall ... & 55.45 & 67.68 & 57.02 & 54.76 \\
\hline
\end{tabular}

Estimated monthly discharge of Snake River at Montgomery Ferry, Idaho.

\begin{tabular}{|c|c|c|c|c|c|c|}
\hline \multirow[b]{2}{*}{ Month. } & \multicolumn{3}{|c|}{ Discharge in second-feet. } & \multirow[b]{2}{*}{$\begin{array}{l}\text { Total in acre- } \\
\text { feet. }\end{array}$} & \multicolumn{2}{|c|}{ Ruw-off. } \\
\hline & $\begin{array}{l}\text { Maxi. } \\
\text { mum. }\end{array}$ & $\begin{array}{l}\text { Mini. } \\
\text { mum. }\end{array}$ & Mean. & & $\begin{array}{c}\text { Depth in } \\
\text { inches. }\end{array}$ & $\begin{array}{c}\text { Second. } \\
\text { foet per } \\
\text { square } \\
\text { mile. }\end{array}$ \\
\hline 1898. & & & & & & \\
\hline March $13-31 \ldots$ & $\ldots \ldots$ & $\ldots \ldots$ & 5,374 & 330,436 & 0.28 & 0.24 \\
\hline April...... & 19,880 & 5,250 & 8,629 & 513,460 & 0.43 & 0.38 \\
\hline May ..... & 25,400 & 12,920 & 17,658 & $1,085,755$ & 0.90 & 0.78 \\
\hline June . . . . . & 26,360 & 15,080 & 20,936 & $1,245,776$ & 1.03 & 0.93 \\
\hline July ...... & 17,240 & 5,250 & 9,142 & 562,123 & 0.47 & 0.41 \\
\hline August... & 5,100 & 4,350 & 4,498 & 276,573 & 0.23 & 0.20 \\
\hline September ......... & 4,600 & 4,350 & 4,383 & 260,806 & 0.21 & 0.19 \\
\hline October ........... & 5,100 & 4,525 & 4,818 & 296,249 & 0.24 & 0.21 \\
\hline Norember...... & 5,400 & 5,100 & 5,173 & $307,814^{\circ}$ & 0.26 & 0.23 \\
\hline December ............ & 9,650 & 4,900 & 5,874 & 361,181 & 0.30 & 0.26 \\
\hline
\end{tabular}

NoTE.-Gage heights for 1898 are given in Water-Supply and Irrigation Paper No. 28, page 160, measurements, page 168; rating table, page 169; results for 1897 , in Water. Supply and Irrigation Paper No. 16; page 165, and in the Nineteenth Annual Report, Part IV, pages 144 to 448. 


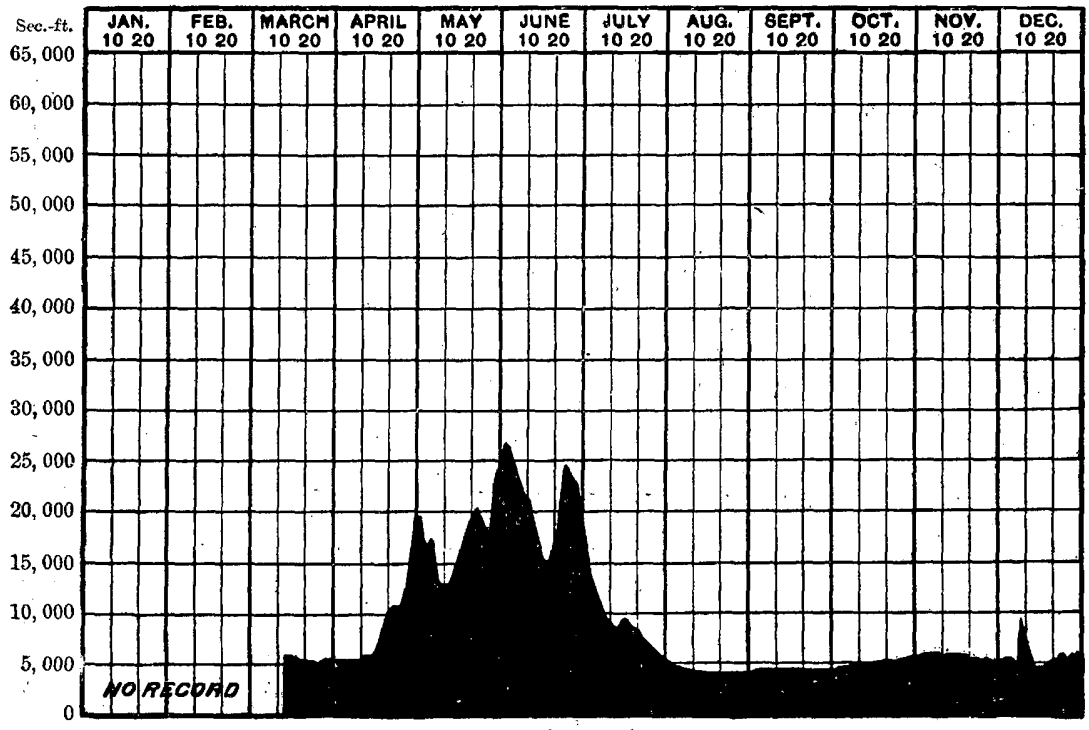

FIa. 182.-Discharge of Snake River at Montgomery Ferry, Idaho, 1898.

PORTNEUTF RIVER.

Estimated monthly discharge of Portneuf River at Pocatello, Idaho.

\begin{tabular}{|c|c|c|c|c|c|c|}
\hline \multirow[b]{2}{*}{ Month. } & \multicolumn{3}{|c|}{ Discharge in second feet. } & \multirow[b]{2}{*}{$\begin{array}{l}\text { Total in acre- } \\
\text { feet: }\end{array}$} & \multicolumn{2}{|c|}{ Run-off. } \\
\hline & $\begin{array}{l}\text { Maxi- } \\
\text { mum. }\end{array}$ & $\begin{array}{l}\text { Mini- } \\
\text { mum. }\end{array}$ & Méan. & & $\begin{array}{l}\text { Depth in } \\
\text { inches. }\end{array}$ & $\begin{array}{l}\text { Second- } \\
\text { feet per per } \\
\text { square } \\
\text { mile. }\end{array}$ \\
\hline 1897. & & & & & & \\
\hline May $18-31 \ldots \ldots$ & 1,881 & 1,229 & 1,665 & 102,377 & & \\
\hline June .............. & 1,160 & 316 & 569 & 33,858 & & \\
\hline July ........... & 316 & 130 & 215 & 13,220 & & \\
\hline August..... & 165 & 80 & 126 & 7,747 & & \\
\hline September ..... & 183 & 113 & 147 & 8,688 & & .. \\
\hline 1898. & & & & & & \\
\hline April $\ldots . .$. & 336 & 165 & 247 & 14,697 & $\ldots$ & $\cdots$ \\
\hline May ............... & 219 & 183 & 203 & 12,482 & & .... \\
\hline June....... & 336 & 147 & 222 & 13,210 & $\ldots$ & \\
\hline July ....... & 165 & 14 & 50 & 3,074 & .. & \\
\hline August...... & 121 & 80 & 89 & 5,472 & & \\
\hline September . & 113 & 80 & 99 & 5,891 & & \\
\hline October.... & $\therefore 183$ & 113 & 140 & 8,608 & & \\
\hline November........ & 201 & 165 & 178 & 10,592 & & \\
\hline December.......... & 257 & 165 & 206 & 12,667 & & \\
\hline
\end{tabular}

NoTE. - Gage heights for 1898 are given in Water-Supply and Irrigation Paper No. 28, page 153; measurements, page 159; rating table, page 168; results for 1897, in Water-Supply and Irrigation Paper No. 16, page 164. 


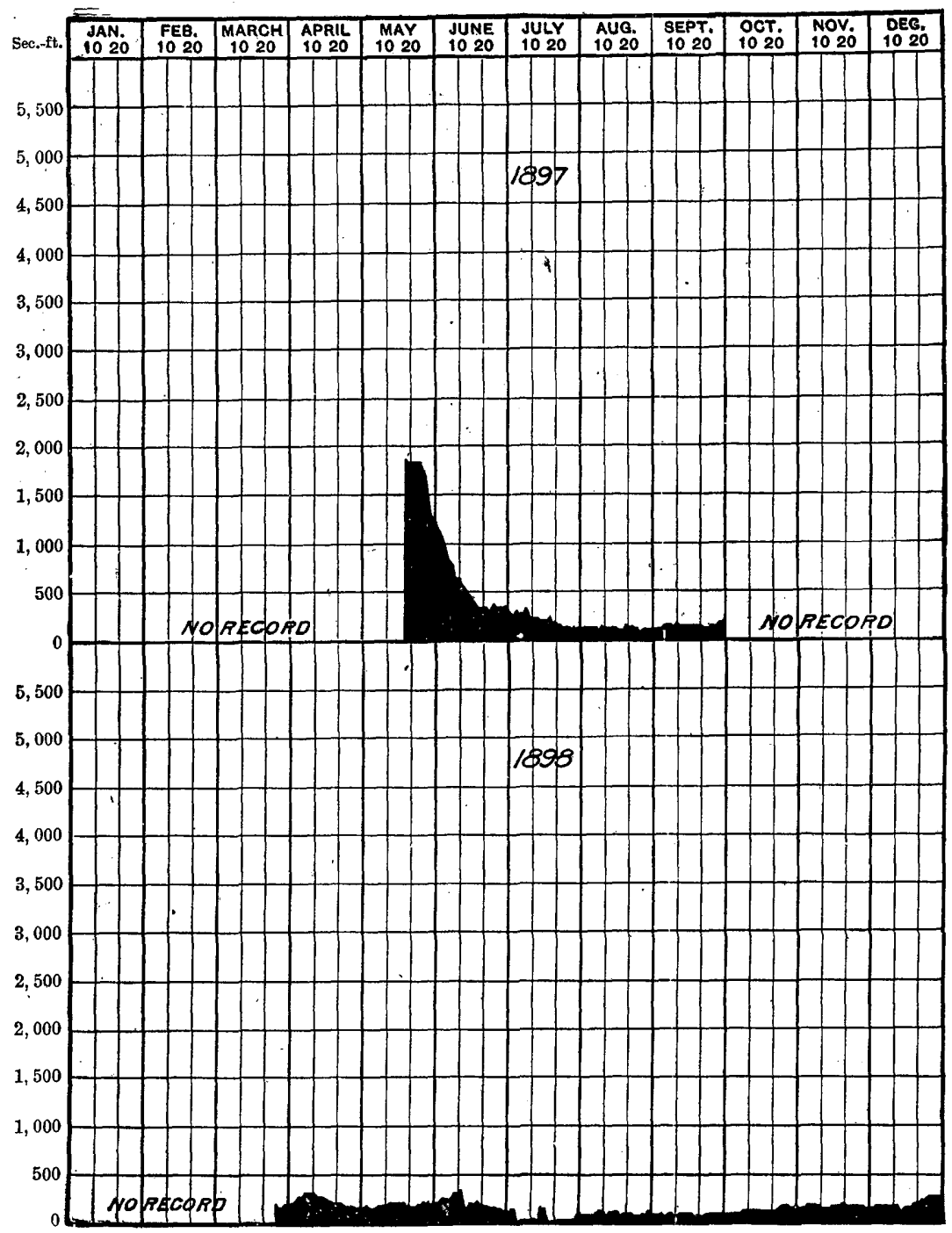

Fia. 183.-Discharge of Portneuf River at Pocatello, Idaho, 1897-98.

Portneuf River receives waters from the mountain range of the same name lying in southeastern Idaho, northwest of Bear Lake. The river flows in a general westerly course across the Fort Hall Indian Reservation into Snake River above American Falls. Measurements have been made at the town of Pocatello, Idaho, giving the flow during a portion of 1897 and the greater part of 1898, as indicated by the accompanying tables and diagrams. 
MALADE AND LITTLE WOOD RIVERS.

Estimated monthly discharge of Malade River at Toponis, Idaho.

[Drainage area, 2,190 square miles.]

\begin{tabular}{|c|c|c|c|c|c|c|}
\hline \multirow[b]{2}{*}{ Month. } & \multicolumn{3}{|c|}{ Discharge in second-feet. } & \multirow[b]{2}{*}{$\begin{array}{l}\text { Total in acre. } \\
\text { feet. }\end{array}$} & \multicolumn{2}{|c|}{ Run·off. } \\
\hline & $\begin{array}{l}\text { Maxi- } \\
\text { mum. }\end{array}$ & $\begin{array}{l}\text { Mini- } \\
\text { muin. }\end{array}$ & Mean. & & $\begin{array}{l}\text { Depth in } \\
\text { inches. }\end{array}$ & $\begin{array}{l}\text { Second. } \\
\text { feet per } \\
\text { square } \\
\text { mile. }\end{array}$ \\
\hline 1898. & & & & & & \\
\hline March 13-31 ........ & $\ldots \ldots$ & $\ldots \ldots$ & 66 & 4,058 & 0.04 & 0.03 \\
\hline April... & 1,290 & 45 & 522 & 31,061 & 0.27 & 0.24 \\
\hline May .. & 740 & 210 & 518 & 31,851 & 0.28 & 0.24 \\
\hline June . . . . . . . . . . & 1,590 & 670 & 1,057 & 62,896 & 0.54 & 0.48 \\
\hline July . . . . . . . . . & 1,490 & 2 & 280 & 17,217 & 0.15 & 0.13 \\
\hline
\end{tabular}

Note.-Gage heights for 1898 of Malade and Little Wood Rivers at Toponis are given in Water-Supply and Irrigation Paper No. 28, page 160; measurements, page 168; rating table, page 169; results for 1897, in Water-Supply and Irrigation Paper No. 16, page 165, and in the Nineteenth Annual Report, Part IV, pages 448 to 449.

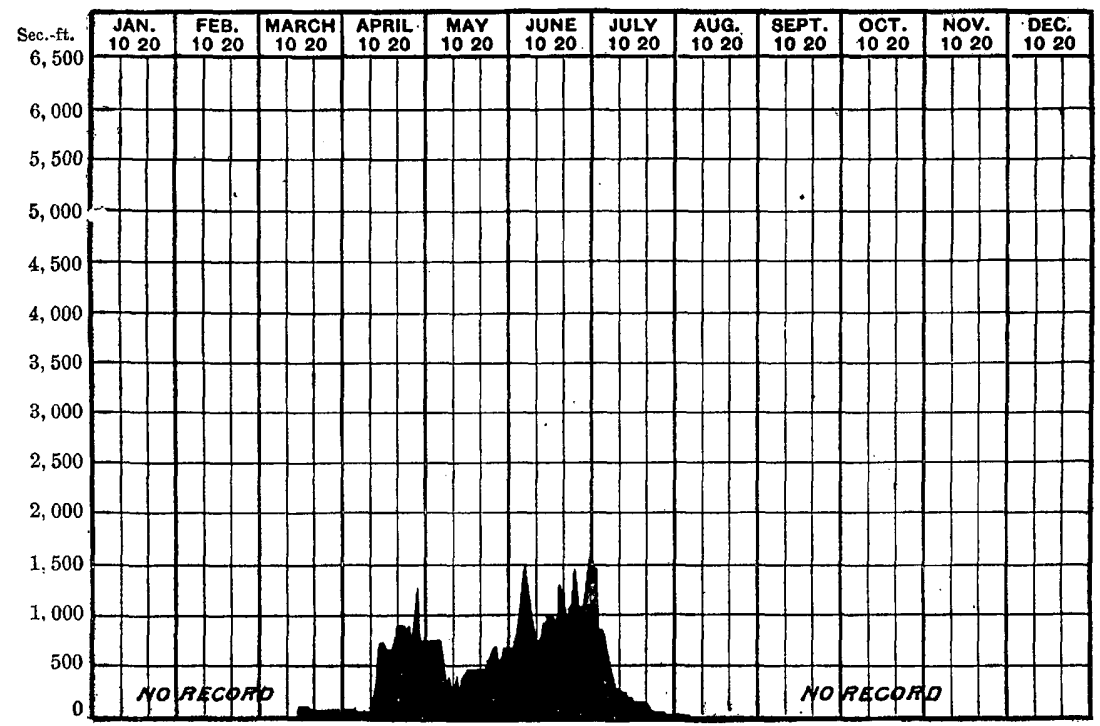

FIG. 184.-Discharge of Malade River at Toponis, Idaho, 1898.

LONGTOM RESERVOIR SITES.

Three miles north of Mountain Home, Elmore County, Idaho, is located a reservoir supplying the vicinity with water for irrigation purposes. This reservoir is filled by means of a feed canal about 8 miles long; taking water from Canyon Creek. During seasons of plentiful snowfall there is sufficient water in this creek to fill the reservoir in the spring, 
but during years of low discharge, as that of 1898 , the supply is not sufficient, and as a consequence the land suffers for want of water. In order to increase the supply a number of propositions have been advanced to utilize what was said to be an excellent reservoir site at the headwaters of Longtom Creek, a tributary of Canyon Creek. The area draining into this site is comprised largely in the reservoir itself, and therefore, owing to its smallness, this reservoir manst of necessity be filled by means of a feed canal from some other source of supply. One or two surveys of sites have been reported, and maps are on file in the office of the State engineer of Idaho showing the location of these and of canal lines for conducting water to lauds below, but no accurate survey of the reservoir itself had been made.

During the summer of 1898 an examination of the locality was made by Mr. Cyrus C. Babb. There were found to be two good sites, separated by a canyon about 2 miles long. On casual inspection one would think the, upper site preferable, and private projects contemplating using these sites have always considered the upper one. They were both surveyed, however, and after measurement, the lower was found to be preferable for two reasons, the length of dam was shorter and the contents greater. One ranch, the property of $\mathrm{H}$. Hubbel, comprising 160 acres, is located in the bottom of the lower site.

The following table brings out various facts concerning the two sites. The first column shows heights of contours for: every 10 feet. Then follows two sets of three columns each, giving data for the lower and upper site respectively. The first column shows the area in acres. The next column exhibits the capacity in acre-feet between each contour. For instance, in the second column, under the lower site, opposite 50 feet, occur the figures 1,134 acre-feet. This means that the coutents between the two contours 40 and 50 feet is 1,134 acre-feet. The last column in each set gives the total capacity in acre-feet of the reservoir up to the elevation which is opposite. For instance, opposite 100 feet in the contour column occur the figures 13,092 acre-feet in the total capacity column for the lower site. This means the contents of the reservoir for that height of dam is the figure quoted. For the lower site, with a height of dam 150 feet, the length of dam would be 450 feet, and the eapacity of the reservoir 37,854 acre-feet. At the upper site, with a height of 140 feet, the length of dam would be 870 feet and the capacity of the reservoir 28,664 acre-feet; while with a height of 150 feet, the length of dam would be 1,050 feet and the capacity 36,213 acre-feet. The relative shape and size of each of these sites is given in Figs. 185 and 186. 
Capacity of Longtom reservoir sites.

\begin{tabular}{|c|c|c|c|c|c|c|}
\hline \multirow{2}{*}{ Contour. } & \multicolumn{3}{|c|}{ Lower site. } & \multicolumn{3}{|c|}{ Upper site. } \\
\hline & Area. & Capacity. & $\begin{array}{c}\text { Total } \\
\text { capacity. }\end{array}$ & Area. & Capacity. & $\begin{array}{c}\text { Total } \\
\text { capacity. }\end{array}$ \\
\hline Feet. & Acres. & Acre-feet. & Acre-feet. & Acres. & Acreffeet. & Acre-feet. \\
\hline 10 & 1.8 & 1 & 1 & 2.8 & 1 & 1 \\
\hline 20 & 41.4 & 216 & 217 & 10.6 & 67 & 68 \\
\hline 30 & 62.7 & 520 & 737 & 20.7 & 157 & 225 \\
\hline 40 & 98.0 & 804 & 1,541 & 36.8 & 288 & 513 \\
\hline 50 & 128.8 & 1,134 & 2,675 & 63.5 & 502 & 1,015 \\
\hline 60 & 153.2 & 1,410 & 4,085 & 92.5 & 780 & 1,795 \\
\hline 70 & 182.2 & 1,677 & 5,762 & 135.7 & 1,141 & 2,936 \\
\hline 80 & 219.4 & 2,008 & 7,770 & 183.5 & 1,646 & 4,582 \\
\hline 90 & 263.1 & 2,412 & 10,182 & 240.6 & 2,121 & 6,703 \\
\hline 100 & 318.8 & 2,910 & 13,092 & 312.8 & 2,767 & 9,470 \\
\hline 110 & 378.1 & 3,484 & 16,576 & 387.3 & 3,500 & 12,970 \\
\hline 120 & 449.0 & 4,136 & 20,712 & 467.4 & 4,273 & 17,243 \\
\hline 130 & 519.3 & 4,842 & 25,554 & 563.0 & 5,152 & 22,395 \\
\hline 140 & 610.0 & 5,646 & 31,200 & 690.9 & 6,269 & 28,664 \\
\hline 150 & 720.8 & 6,654 & 37,854 & 818.8 & 7,549 & 36,213 \\
\hline & & 37,854 & & & 36,213 & \\
\hline
\end{tabular}

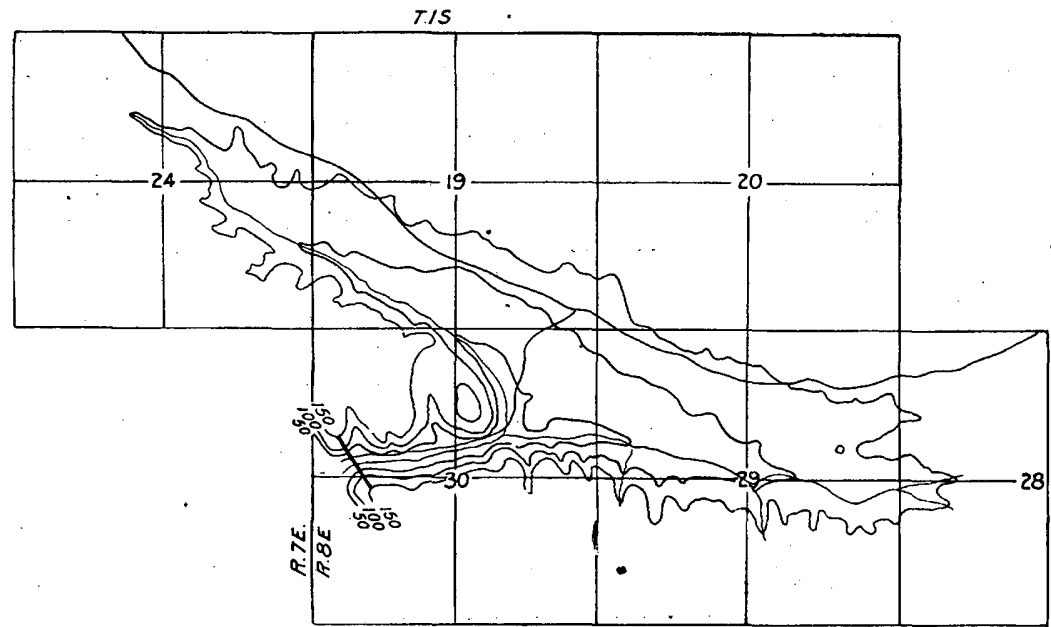

FIG. 185.- - Opper Longtom reservoir site, Elmore County, Idaho. Surveyed August, 1898, by Cyrus C. Babb. 


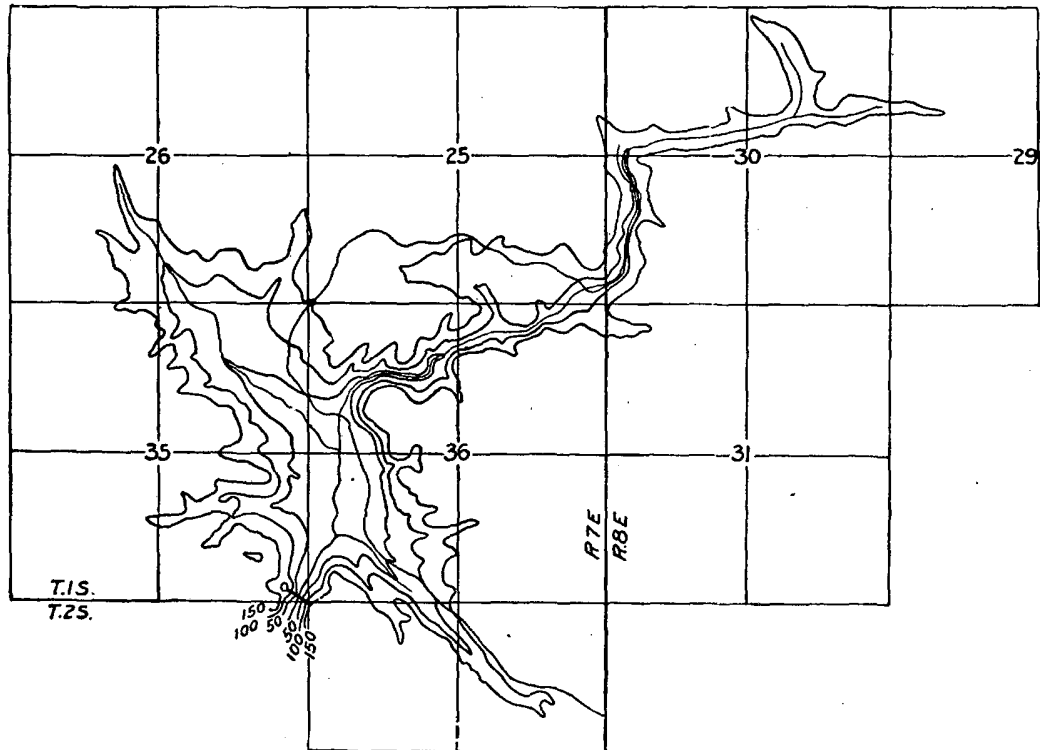

Fig. 186.-Lower Longtom reservoir site, Elmore County, Idaho. Surveyed-August, 1898, by Cyrug C. Babb.

As the result of the surveys and recommendations made by Mr. Cyrus C. Babb, above noted, the Director of the United States Geological Survey, on November 1, 1898, requested that the lands described below be reserved for reservoir purposes under the act of October 2, 1888 (25 Stat. L., p. 526), and the act of October 30, 1890 (26 Stat. L., p. 391).

Lands segregated for Longtom reservoir site, Boise meridian, Elmore County, Idaho.

T. 2 S., R. 7 E.:

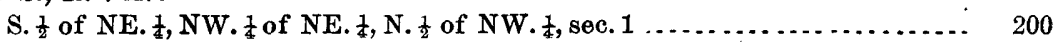

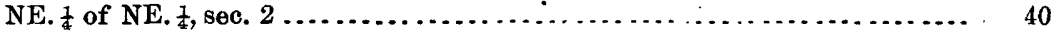

T. 1 S., R. 7 E.:

S. $\frac{1}{2}$ of NE. $\frac{1}{1}$, SE. $\frac{1}{4}$ of N. W. $\frac{1}{4}$, N. $\frac{1}{2}$ of SE. $\frac{1}{4}$, SE. $\frac{1}{4}$ of SE. $\frac{1}{4}$, sec. $24 \ldots \ldots \ldots 240$

SE. $\frac{1}{4}$ of NE. $\frac{1}{4}$, E. $\frac{1}{2}$ of SE. $\frac{1}{4}$, SW. $\frac{1}{4}$ of SE. $\frac{1}{4}, \mathrm{~S} \frac{1}{2}$ of SW. $\frac{1}{4}$, NW. $\frac{1}{4}$ of SW.

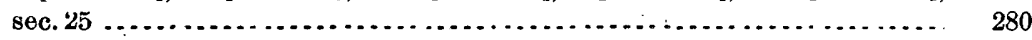

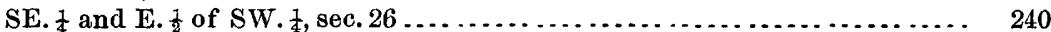

W. $\frac{1}{2}$ of NE. $\frac{1}{4}$, NE. $\frac{1}{4}$ of NW. $\frac{1}{4}$, SE. $\frac{1}{4}$, E. $\frac{1}{2}$ of SW. $\frac{1}{4}$, sec. $35 \ldots \ldots \ldots \ldots \ldots . . . \ldots$

N. $\frac{1}{2}$ of NE. $\frac{1}{4}$, SW. $\frac{1}{4}$ of NE. $\frac{1}{4}, N \cdot \frac{1}{2}$ of NW. $\frac{1}{4}$, SE. $\frac{1}{4}$ of NW. $\frac{1}{4}, E \cdot \frac{1}{2}$ of SW. $\frac{1}{4}$,

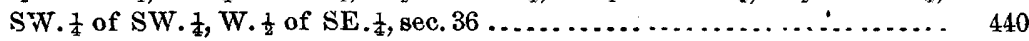

T. 1 S., R. 8 E.:

SW. $\frac{1}{1}$ of NW. $\frac{1}{4}, \mathrm{SW} \cdot \frac{1}{4}, \mathrm{~W} \cdot \frac{1}{2}$ of SE. $\frac{1}{4}, \mathrm{SE} . \frac{1}{4}$ of SE. $\frac{1}{4}$, sec. $19 \ldots \ldots \ldots \ldots \ldots$

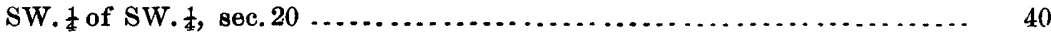

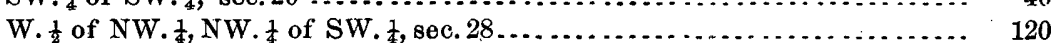

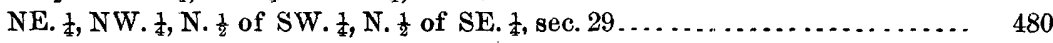

NE. $\frac{1}{4}$, E. $\frac{1}{2}$ of NW. $\frac{1}{4}$, SW. $\frac{1}{4}$ of NW. $\frac{1}{4}, N \cdot \frac{1}{2}$ of SW. $\frac{1}{4}$, SW. $\frac{1}{4}$ of SW. $\frac{1}{4}, N \cdot \frac{1}{2}$ of

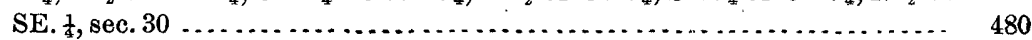

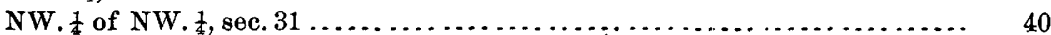

Total 
By letter dated November 9, 1898, Hon. Binger Hermann, Commissioner of the General Land Office, states-

That the tracts above described are, as shown by the tract books of this office, all vacant and unappropriated public lands of the United States, except the tracts in section 36, T. 1 S., R. 7 E., which are not, in my opinion, subject to reservation for reservoir purposes under the acts above mentioned.

Sec. 14, act of March 3, 1863 (12 Stat. L., 814), entitled "An act to provide a temporary Government for the Territory of Idaho," provides :

That when the lands in the said Territory shall be surveyed, under the direction of the Government of the United States, preparatory to bringing the same into market, sections numbered sixteen and thirty-six in each township in said Territory shall be, and the same are hereby, reserved for the purpose of being applied to schools in said Territory, and in the States and Territories hereafter to be erected out of the same.

Section 4 of the act of July 3, 1890 (26 Stat. L., 215), entitled "An act to provide for the admission of the State of Idaho into the Union," provides: "That sections numbered sixteen and thirty-six in every township of said State, and where such sections, or any part thereof, have been sold or otherwise disposed of by or under the authority of any act of Congress, other lands equivalent thereto, in legal subdivisions of not less than one quarter section, and as contiguous as may be to the section in lieu of which the same is taken, are hereby granted to said state for the support of common schools, such indemnity lands to be selected within said State in such manner as the legislature may provide, with the approval of the Secretary of the Interior."

The lands in said section 36 were surveyed June 25, 1893, the plat having been filed in the local office November 19, 1894.

The act of Congress of October 2, 1888 (25 Stat. L., 526), reserving lands for reservoirs, canals, ditches, etc., for irrigating purposes, provided that "all lands which may hereafter be designated or selected" for such purposes, "are from this time henceforth hereby reserved from sale as the property of the United States, and shall not be subject, after the passage of this act, to entry, settlement, or occupation until further provided by law."

The act of Congress of August 30, 1890 (26 Stat. L., 391), repealed so much of the act of 1888 , supra, as provided for the withdrawal of the public lands from entry, occupation, and settlement-

except that reservoir sites heretofore located or selected shall remain segregated and reserved from entry or settlement, as provided by said act, until otherwise provided by law, and reservoir sites hereafter located or selected on public lands shall in like manner be reserved from the date of location or selection thereof.

The grant to the State of Idaho having attached prior to the date of the selection for reservoir purposes, said lands in' section 36 are not subject to reservation for reservoir purposes.

\section{BRUNEAU RIVER.}

Bruneau River rises in northern Nevada and flows in a general northerly course through southern Idaho, emptying into Snake River at a point about south of Boise. Systematic measurements on this river have been made by Mr. Andrew J. Wiley, below the headworks of the Owyhee Land and Irrigation Company, near Grand View, Idaho. The amount of water shown at this point is practically that running to waste into Snake River.

$$
20 \text { GEOL, P'P } 4-31
$$


Estimated monthly discharge of Bruneau River at Grand View, Idaho.

[Drainage area, 1,800 square miles.]

\begin{tabular}{|c|c|c|c|c|c|c|}
\hline \multirow[b]{2}{*}{ Month. } & \multicolumn{3}{|c|}{ Discharge in second.feet. } & \multirow[b]{2}{*}{$\begin{array}{l}\text { Total in acre- } \\
\text { feet. }\end{array}$} & \multicolumn{2}{|c|}{ Run.off. } \\
\hline & $\begin{array}{l}\text { Maxi- } \\
\text { mum. }\end{array}$ & $\begin{array}{l}\text { Mini- } \\
\text { mum. }\end{array}$ & Mean. & & $\begin{array}{c}\text { Depth in } \\
\text { inches. }\end{array}$ & $\begin{array}{l}\text { Second- } \\
\text { feet per } \\
\text { square } \\
\text { mile. }\end{array}$ \\
\hline 1898. & & & & & & \\
\hline January .... & 140 & 70 & 105 & 6,456 & 0.07 & 0.06 \\
\hline February ........... & 920 & 90 & 218 & 12,107 & 0.13 & 0.12 \\
\hline March ....... & 410 & 140 & 214 & 13,158 & 0.14 & 0.12 \\
\hline April ...... & 1,040 & 150 & 698 & $4: 1,534$ & 0.44 & 0.39 \\
\hline May ....... & 850 & 500 & 683 & 41,996 & 0.44 & 0.38 \\
\hline June........ & 620 & 200 & 455 & 27,074 & 0.28 & 0.25 \\
\hline July ....... & 190 & 45 & 102 & 6,272 & 0.07 & 0.06 \\
\hline August ..... & 40 & 25 & 29 & 1,783 & 0.02 & 0.02 \\
\hline September ... & 25 & 15 & 21 & 1,250 & 0.01 & 0.01 \\
\hline October........ & 80 & 45 & 60 & 3,689 & 0.04 & 0.03 \\
\hline November..... & 120 & 65 & 78 & 4,641 & 0.05 & 0.04 \\
\hline December ..... & 130 & .55 & 79 & 4,858 & 0.05 & 0.04 \\
\hline The year. & 1,040 & 15 & 229 & 164,818 & 1.74 & 0.13 \\
\hline
\end{tabular}

Note.-Gage heights for 1898 are given in Water-Supply and Irrigation Paper No. 28, page 161; rating table, page 169; results for 1897, in Water-Supply and Irrigation Paper No. 16, page 167, and in the Nineteenth Annual Report, Part IV, pages 450 to 451.

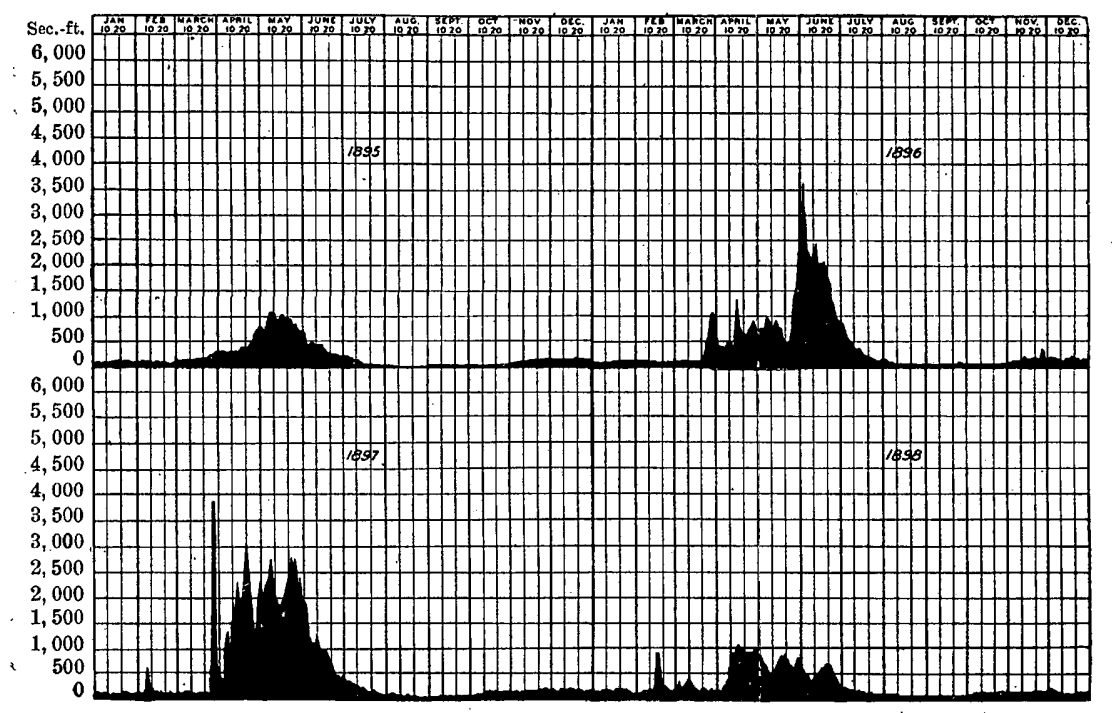

Fia. 187.-Discharge of Bruneau River at Grand View, Idaho, 1895-1898. 
BOISE RIVER.

Estimated monthly discharge of Boise River at Boise, Idaho.

[Draiuage area, 2,450 square miles.]

\begin{tabular}{|c|c|c|c|c|c|c|}
\hline \multirow[b]{2}{*}{ Month. } & \multicolumn{3}{|c|}{ Discharge in second-feet. } & \multirow[b]{2}{*}{$\begin{array}{l}\text { Total in acre- } \\
\text { feet. }\end{array}$} & \multicolumn{2}{|c|}{ Run-off. } \\
\hline & $\begin{array}{l}\text { Maxi. } \\
\text { mum. }\end{array}$ & $\begin{array}{l}\text { Mini- } \\
\text { mum. }\end{array}$ & Mean. & & $\begin{array}{l}\text { Depth in } \\
\text { inches. }\end{array}$ & $\begin{array}{c}\text { Second- } \\
\text { feet per } \\
\text { square } \\
\text { mile. }\end{array}$ \\
\hline 1898. & & & & & & \\
\hline January .... & $\ldots \ldots$ & $\ldots \ldots$ & 550 & 33,818 & 0.25 & 0.22 \\
\hline February ........ & $\ldots \ldots$ & $\ldots \ldots$ & 1,213 & 67,315 & 0.52 & 0.50 \\
\hline 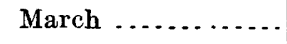 & 2,773 & 1,405 & 1,924 & 118,303 & 0.91 & 0.79 \\
\hline April ..... & 6,535 & 1,234 & 4,198 & 249,798 & 1.91 & 1.71 \\
\hline May ........... & 8,245 & 4,312 & 5,225 & 321,275 & 2. 46 & 2.13 \\
\hline June ....... & 6,022 & 3,457 & 4,990 & 296,925 & 2.28 & 2.04 \\
\hline July ....... & 3,286 & 892 & 1,885 & 115,905 & 0.89 & 0.77 \\
\hline August....... & 1.063 & 550 & 737 & 45,316 & 0.35 & 0.30 \\
\hline September ... & 721 & 550 & 652 & 38,797 & 0.30 & 0.27 \\
\hline${ }^{\prime}$ October ........... & 977 & 859 & 859 & 52,817 & 0.40 & 0.35 \\
\hline November.... & 1,148 & 721 & 935 & 55,636 & 0.43 & 0.38 \\
\hline December ......... & 3,286 & 1,063 & 2,448 & 150,523 & 1.15 & 1.00 \\
\hline The year. & $\ldots . .$. & $\ldots$ & 2,134 & $1,546,428$ & 11.85 & 0.87 \\
\hline
\end{tabular}

NoTE. - Gage heights for 1898 are given in Water-Supply and Irrigation Paper No. 28, page 161; measurements, page 168; rating table, page 169; results for 1897, in Water-Supply and Irrigation Paper No. 16, page 168; and in the Nineteenth Annual Report, Part IV, pages 451 to 454.

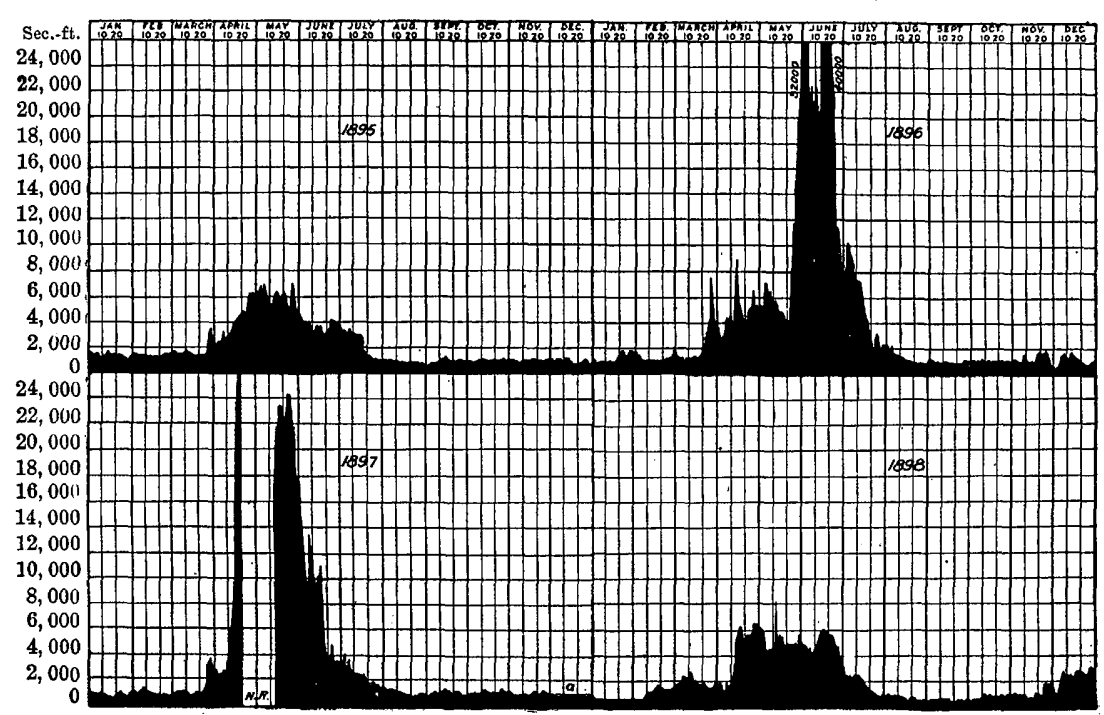

FrG. 188.-Discharge of Boise River at Boise, Idaho, 1895-1898. 
SEEPAGE MEASUREMENTS IN BOISE VALLEY.

A series of measurements of the discharge of the canals taking water from Boise River, between Boise, Idaho, and Caldwell, was made from August 24 to September 2, 1898, to determine the amount of seepage water returning to the river. During the preceding winter the snowfall had been very light in the mountains of Idaho, consequently the discharge of the rivers was correspondingly low, especially during the summer. During the season of 1898 the river was lower than it had been known to be for years. On August 24, 1898, a measurement of the main Boise River was made at the Survey gaging station, 10 miles above Boise, and on August 29 the measurement of the canals and the waste water returning to the river was begun. The field operations were completed on September 2, forty-six measurements having been made.

During the course of the measurements on the first day, August 29, a severe thunderstorm occurred in the lower basin, and it was thought that the rainfall would affect the value of the results, but the report of the observer at the gaging station showed that the river rose only 0.05 of a foot, which could be accurately allowed for in the computations. All of the main canals were measured and many of the smaller ones. It is thought that one or two small ditches and waste sloughs may have been overlooked. The general route traveled, commencing above Boise, Idaho, was down the north bank to Caldwell, and thence returning along the south bank. The first of the following tables gives the results of the measurements in the order made. The second table gives the results of the measurements arranged in four columns. In the first column is the name of the stream; in the second column is the quantity of water, expressed in second-feet, if the measurement was of the river; in the third column is the discharge of the canals withdraw. ing water from the river, and in the last column is the amount of waste returning to the river.

Four measurements of the main river were made, the first being at the gaging station, the second at the head of Eagle Island, the third at the Star Bridge, and the fourth at Caldwell. Considering the first section from the gaging station to Eagle Island, the amount in the river above, due to the rise occasioned by the thunderstorm, as corrected by the observer's report, was 734 second-feet; the amount in the river at Eagle Island was 247 second-feet; the difference is 487 second-feet. To this should be added 135.4 second-feet, the amount of water returning to the river, making 622.4 second-feet. These latter figures subtracted from 744.8 second-feet, the amount taken out by canals in this division, gives as a gain in a distance of 12 miles of 122.4 second-feet.

Considering now the section between Eagle Island and the Star Bridge, the discharge at the latter point of 180 second-feet subtracted from that above of 247 second-feet leaves 67 second-feet. Adding to this 8.3 second-feet wasting into the river we have 75.3 second-feet, 
which, subtracted from 217.1 second-feet, shows a gain in a distance of 11 miles of 141.8 second-feet. Finally, in the third section, between the Star Bridge and Caldwell, the difference in the discharge of the river between the two points is 149 second-feet. Adding to this the waste

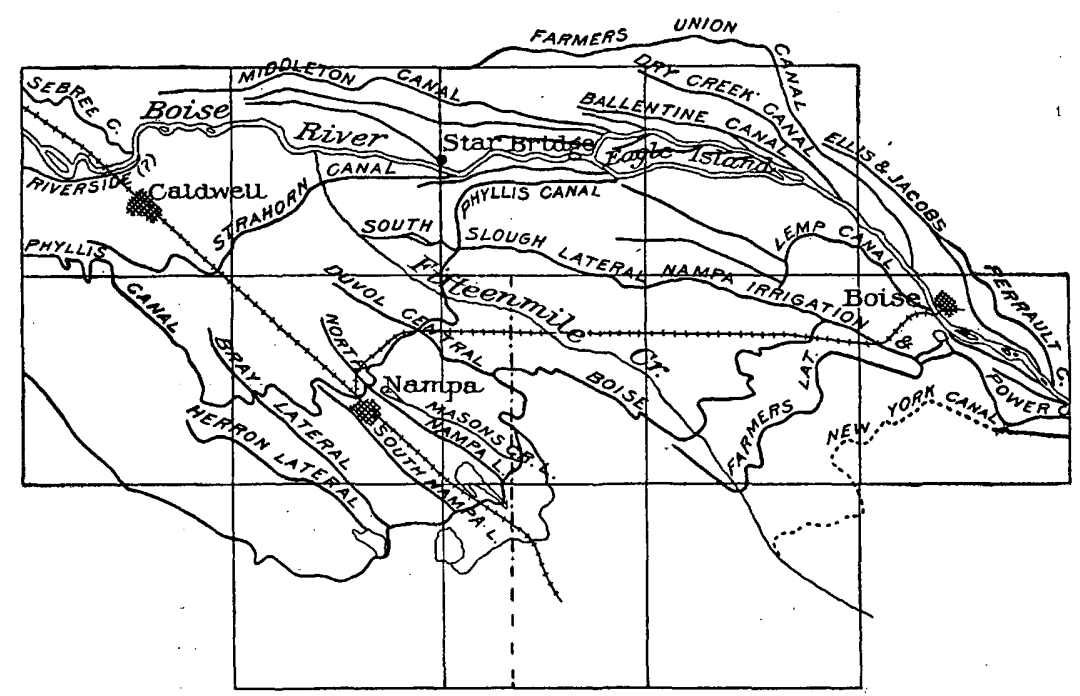

Fra. 189.-Relative location of principal irrigation canals between Boise and Caldwell, Idaho.

into the river of 53.3 second-feet we have 202.3 second-feet. The amount taken out by canals is 198.1 second-feet, showing a loss in a distance of 11 miles of 4.2 second-feet. The accompanying map (fig. 189) shows the location of the various ditches measured.

Measurements of the discharge of canals in Boise Valley. ${ }^{t}$

\begin{tabular}{|c|c|c|c|}
\hline Date. & Name of stream. & Locality of measurement. & Discharge. \\
\hline 1898. & & & Sec.feet. \\
\hline Aug. 24 & Boise River ....... & U. S. G. S. gaging station. & 698.0 \\
\hline \multirow[t]{9}{*}{ Aug. 29} & Perault Canal ............ & Waste gate............. & 81.6 \\
\hline & $\begin{array}{l}\text { Feed to Ellis or Grove Street } \\
\text { ditch. }\end{array}$ & Head Buckley's ranch . & 6.8 \\
\hline & Perault Canal ...................... & $\begin{array}{l}\text { Highway Bridge below Good- } \\
\text { win's-mill. }\end{array}$ & 19.5 \\
\hline & Cottonwood Creek (waste).. & Road Bridge........... & 1.6 \\
\hline & Front Street Canal... & Flume, 100 feet west Broad way & 39.0 \\
\hline & Rossi Canal ......... & Waste gate.................. & 61.3 \\
\hline & Payne Canal ......... & Flume, 1 mile below head.... & 8.7 \\
\hline & Ridenbaugh Canal .. & 200 feet below head.. . & 309.0 \\
\hline & Ryan flume............ & Lift by wheel .......... & 1.3 \\
\hline \multirow[t]{2}{*}{ Aug. 30} & Farmers Union Canal....... & Head gate......................... & 63.0 \\
\hline & Farmers Union Canal.. & Below waste gate.... & 38.8 \\
\hline
\end{tabular}

I Measurements not needed and not used in computations. 
Measurements of the discharge of canals in Boise Valley-Continued.

\begin{tabular}{|c|c|c|c|}
\hline Date. & Name of stream. & Locality of measurement. & Discharge. \\
\hline \multirow{11}{*}{$\begin{array}{c}1898 . \\
\text { Aug. } 30\end{array}$} & & & Second-feet. \\
\hline & Waste slough & 2 miles below soldiers' Home. & 22.2 \\
\hline & Dry Creek Canal. & $\begin{array}{l}\text { Rhodes's ranch, } 150 \text { feet below } \\
\text { head. }\end{array}$ & 61.9 \\
\hline & Farmers Union Canal. & Saxon's ranch. & 3.0 \\
\hline & W'aste, Boise Valley.... & $\begin{array}{l}\text { Flume, Saxon's ranch (Farm- } \\
\text { ers Union). }\end{array}$ & 3.5 \\
\hline & Boise River . & Head Eagle Island............ & 247.0 \\
\hline & Small flume ... & Upper Eagle Island.... & 1.1 \\
\hline & Ballentine Canal. & Patterson's ranch...... & 0.5 \\
\hline & Dry Creek waste... & At bridge $\ldots \ldots \ldots \ldots \ldots \ldots$ & 1.8 \\
\hline & Cassidy Canal....... & $\begin{array}{l}\text { Kendall's ranch, one.fourth } \\
\text { mile below head. }\end{array}$ & 2.1 \\
\hline & Middleton Canal .... & 200 feet below road..... & 88.0 \\
\hline \multirow[t]{12}{*}{ Aug. 31} & Swalley \& McDowell... & Near head................... & 32.8 \\
\hline & Middleton Mill slough. & Head gate............... & 47.3 \\
\hline & Davis \& Hart ditch ... & On Eagle Island........... & 11.0 \\
\hline & Catlin \& Macey ditch & On Eagle island, at head .... & 7.7 \\
\hline & Aitken \& Conway ditches & On Eagle Island, 2 ditches... & 11.0 \\
\hline & Boise River ......... & Star Bridge $\ldots \ldots \ldots$ & 180.0 \\
\hline & Middleton Water Co. & Slough, Blessenger's ranch... & 45.8 \\
\hline & Slough ............. & 1 mile east of Middleton...... & 22.6 \\
\hline & Willow Creek waste... & 1 mile west of Middletou .... & 10.3 \\
\hline & Sebree Canal..... & 100 feet below head.......... & 93.7 \\
\hline & Boise River.... & $\begin{array}{l}300 \text { feet below Cald well High- } \\
\text { way Bridge. }\end{array}$ & 31.0 \\
\hline & Riverside Canal ............ & Caldwell Highway Bridge... & 30.4 \\
\hline \multirow[t]{3}{*}{ Sept. 1} & Tenmile Creek waste.. & Lower Road Bridge.......... & 20.4 \\
\hline & Strahorn Canal... & $\begin{array}{l}\text { Head of slough, Schindler } \\
\text { ranch. }\end{array}$ & 28.2 \\
\hline & Waste slough-Strahorn & Schindler ranch ............. & 25.0 \\
\hline & Eureka Canal .... & $\begin{array}{l}\text { Head gate near head of Phyl- } \\
\text { lis Canal. }\end{array}$ & 26.7 \\
\hline & Phyllis Caual. & Head................. & 0.0 \\
\hline & Waste into Phyllis Canal & 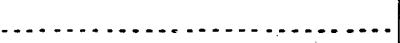 & 3.0 \\
\hline & McCarty Canal ..... & $\begin{array}{l}\text { Headgate, one-fourth mile } \\
\text { below R. R. bridge. }\end{array}$ & 58.5 \\
\hline & Davis ditch .... & $\begin{array}{l}\text { One-fourth mile below R. R. } \\
\text { bridge. }\end{array}$ & 14.5 \\
\hline & Lemp Canal........ & $\ldots .$. do... ........... & 59.3 \\
\hline & Electric-light waste .. & 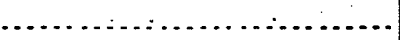 & 18.0 \\
\hline & Rossi waste $\ldots \ldots \ldots$ & Ninth Street Bridge............ & 63.3 \\
\hline Sept. 2 & Electric-car-line waste....... & Main Street Bridge ...... & 30.2 \\
\hline
\end{tabular}


Results of seepage measurements in Boise Valley.

\begin{tabular}{|c|c|c|c|}
\hline Name of stream. & $\begin{array}{l}\text { Water in } \\
\text { river. }\end{array}$ & $\begin{array}{l}\text { Discharge } \\
\text { of canals. }\end{array}$ & $\begin{array}{l}\text { Waste re- } \\
\text { turning to } \\
\text { river. }\end{array}$ \\
\hline U. S. G. S. gaging station $\ldots \ldots \ldots \ldots$. & $\begin{array}{c}\text { Second-feet. } \\
734\end{array}$ & Second-feet. & Second-feet. \\
\hline Ridenbaugh Canal...$\ldots \ldots \ldots \ldots \ldots \ldots$ & $\ldots \ldots \ldots$ & 309.0 & \\
\hline Ryan flume ......... & $\therefore \ldots \ldots$ & 1. 3 & $\ldots$ \\
\hline 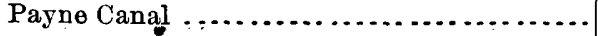 & $\because \ldots \ldots \ldots$ & 8.7 & $\ldots \ldots . . . .$. \\
\hline Perault Canal $\ldots \ldots \ldots \ldots \ldots \ldots \ldots \ldots \ldots$ & $\ldots \ldots \ldots$ & 81.6 & $\ldots \ldots$ \\
\hline 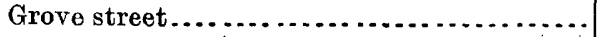 & .......... & 6.8 & ........ \\
\hline Rossi Canal $\ldots \ldots \ldots \ldots \ldots \ldots \ldots \ldots \ldots \ldots$ & ........ & 61.3 & $\cdots$ \\
\hline Front street $\ldots \ldots \ldots \ldots \ldots \ldots \ldots \ldots \ldots$ & $\ldots \ldots \ldots$ & 39.0 & $\ldots \ldots$ \\
\hline Cottonwood Creek.. & - & $\ldots \ldots \ldots$ & 1. 6 \\
\hline Rossi waste ......... & & $\ldots \ldots \ldots$ & 63.3 \\
\hline Electric Light Co ... & - & $\ldots .$. & 18.0 \\
\hline 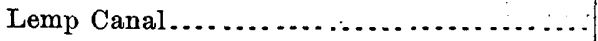 & $\ldots . . .$. & 59.3 & $\ldots \ldots \ldots$ \\
\hline Davis ditch ............ & - & 14.5 & $\ldots$. \\
\hline 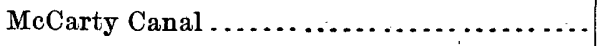 & $\ldots \ldots \ldots$ & 58.5 & $\ldots \ldots .$. \\
\hline 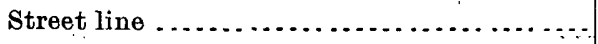 & - & $\ldots \ldots \ldots$ & 30.2 \\
\hline Farmers Union Canal. ................. & ........ & 38.8 & $\ldots \ldots$ \\
\hline 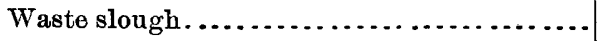 & $\ldots \ldots$ & $\ldots \ldots \ldots$ & 22.3 \\
\hline Dry Creek Canal. . . . . . . . . . . . . . . . . & $\cdots$ & 61.9 & $\cdots$ \\
\hline Farmers Union Canal. ................. & ...... & 3.0 & \\
\hline Small flume, Eagle Island. . . . . . . . . . . . & $\therefore \ldots$ & 1.1 & \\
\hline \multirow[t]{2}{*}{ Boise River, head Eagle Island.............. . } & 247 & $\ldots \ldots \ldots$ & \\
\hline & 487 & 744.8 & 135.4 \\
\hline Boise River at head of Eagle Island. . . . . . . . . & $\therefore 247$ & $\ldots \ldots \ldots$ & $\cdots$ \\
\hline Waste from Boise Valley Canal ............. & ........... & .......... & 3.5 \\
\hline Ballentine Canal ........... & $\ldots \ldots . .$. & 0.5 & $\ldots \ldots$ \\
\hline Dry Creek waste $\ldots \ldots \ldots \ldots \ldots \ldots \ldots$ & .......... & $\therefore \ldots \ldots \ldots$ & 1.8 \\
\hline Eagle Island ditches....... . & $\ldots$ & 29.7 & $\ldots \ldots$ \\
\hline Cassidy Canal ........... & (.......... & 2.1 & . . . . . . \\
\hline Middleton Canal ......... & & 88.0 & \\
\hline Middleton Mill slough ... & & . . 47,3 & - \\
\hline Swalley \& McDowell .... & & $\cdots 22.8$ & \\
\hline Waste into Phyllis ....... & $\ldots$ & 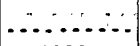 & 3.0 \\
\hline Phyllis................. & ....... & 0.0 & . \\
\hline Eureka.................... & $\therefore \ldots \ldots$. & 26.7 & $\ldots . . .$. \\
\hline 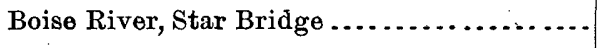 & 180 & $\cdots \ldots \ldots$ & $\cdots$ \\
\hline · & 67 & 217.1 & 8.3 \\
\hline Boise River at Star Bridge.............. & 180 & $\ldots \ldots \ldots$ & 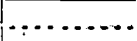 \\
\hline 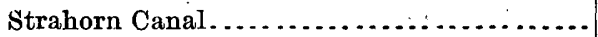 & $\ldots \ldots . . . .$. & 28.2 & $\ldots$ \\
\hline Middleton Water Co........ & & 45.8 & \\
\hline Tenmile Creek waste .... & $\therefore$ & $\ldots \ldots \ldots$ & 20.4 \\
\hline
\end{tabular}




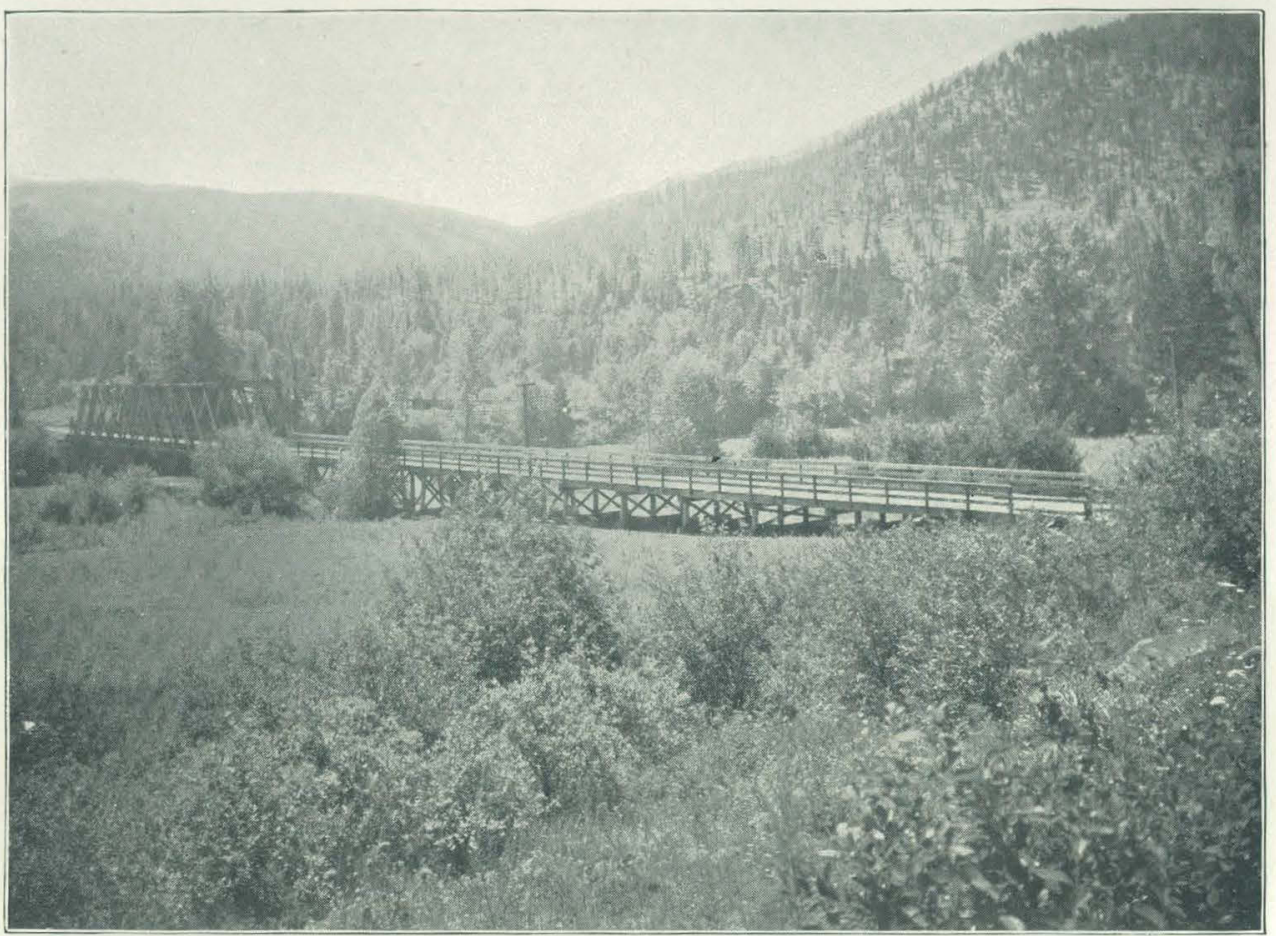

A. GAGING STATION ON BLACKFOOT RIVER, MONTANA.

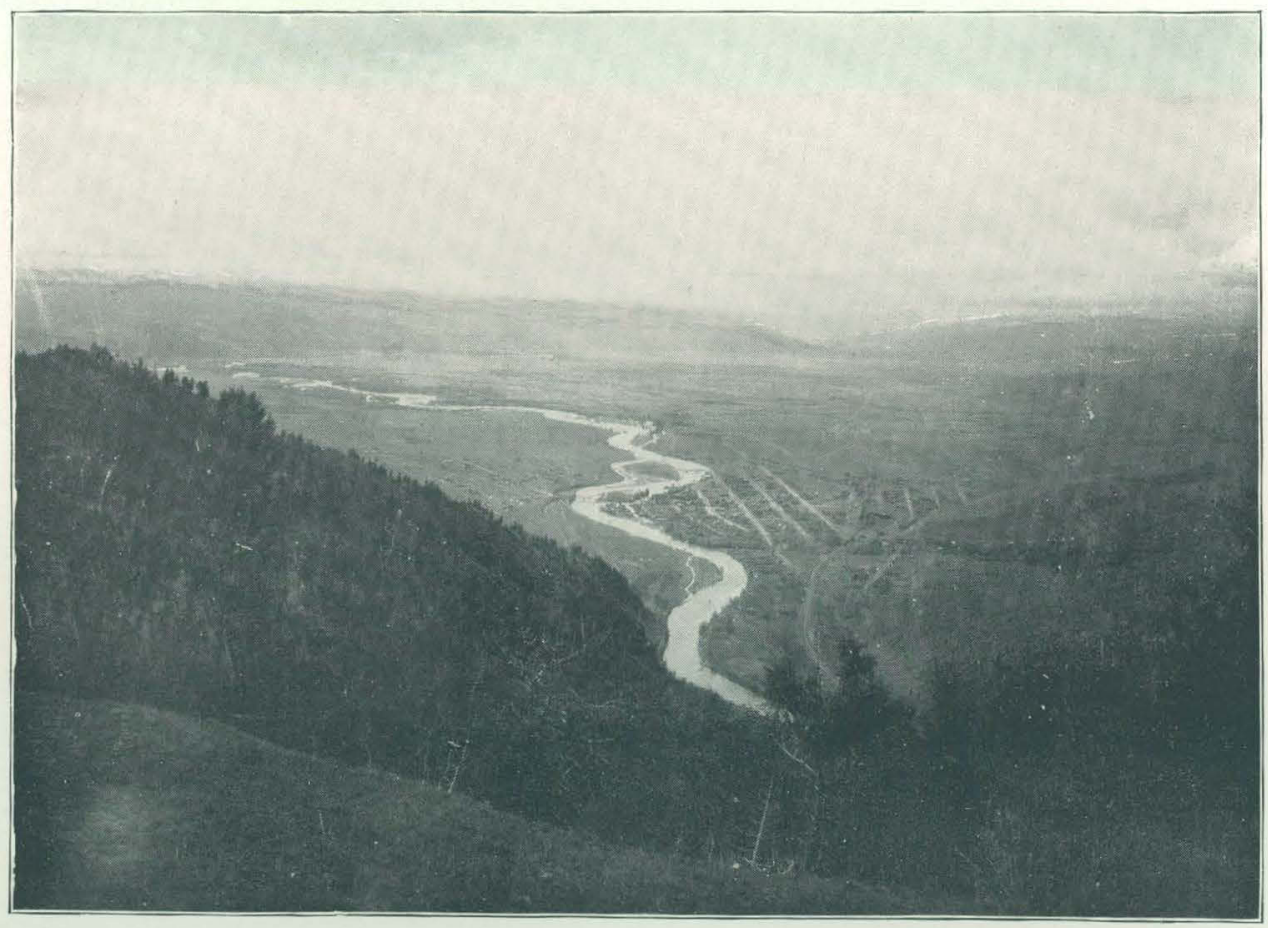

B. MISSOULA RIVER, MONTANA. 
Results of seepage measurements in Boise Valley-Continued.

\begin{tabular}{|c|c|c|c|}
\hline Name of stream. & $\begin{array}{l}\text { Water in } \\
\text { river. }\end{array}$ & $\begin{array}{l}\text { Discharge } \\
\text { of canals. }\end{array}$ & $\begin{array}{l}\text { Waste re- } \\
\text { turning to } \\
\text { river. }\end{array}$ \\
\hline $\begin{array}{l}\text { Slough east of Middleton } \ldots \ldots \ldots \ldots \ldots \\
\text { Willow Creek, west of Middleton } \ldots \ldots \ldots \ldots \\
\text { Riverside Canal } \ldots \ldots \ldots \ldots \ldots \\
\text { Sebree Canal } \ldots \ldots \ldots \ldots \ldots \\
\text { Boise River at Caldwell } \ldots \ldots \ldots \ldots\end{array}$ & 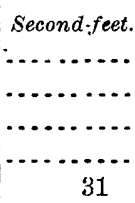 & $\mid \begin{array}{c}\text { Second.feet. } \\
30.4 \\
93.7 \\
\cdots\end{array}$ & $\begin{array}{r}\text { Second-feet. } \\
22.6 \\
10.3 \\
\ldots . . . . . .\end{array}$ \\
\hline . & 149 & 198.1 & 53.3 \\
\hline
\end{tabular}

SUMMARY.

Amount taken out by canals.

Amount in river above cands .............................. 734

Amount of measured return waters . . . . . . . . . . . . . . . . . . . . . . . 197

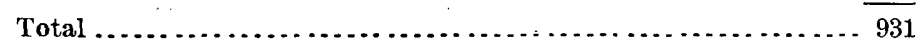

Amount in river at Caldwell station .......................... 31

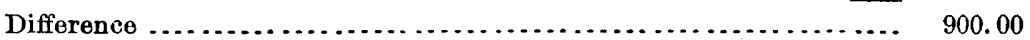

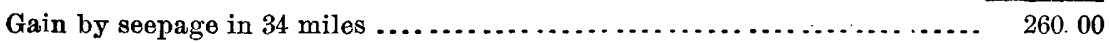

Gain by seepage per mile..................................... 7.65

WEISER RIVER.

Estimated monthly discharge of Weiser River at Weiser, Idaho.

[Drainage area, 1,670 square miles.]

\begin{tabular}{|c|c|c|c|c|c|c|}
\hline \multirow[b]{2}{*}{ Month. } & \multicolumn{3}{|c|}{ Discharge in second-feet. } & \multirow[b]{2}{*}{$\begin{array}{c}\text { Total in acre- } \\
\text { feet. }\end{array}$} & \multicolumn{2}{|c|}{ Run-off. } \\
\hline & $\begin{array}{l}\text { Maxi- } \\
\text { mum. }\end{array}$ & $\begin{array}{l}\text { Mini. } \\
\text { mum. }\end{array}$ & Mean. & & $\begin{array}{l}\text { Depth in } \\
\text { inches. }\end{array}$ & $\begin{array}{c}\text { Second- } \\
\text { feet per } \\
\text { square } \\
\text { mile. }\end{array}$ \\
\hline 1898. & & & & & & \\
\hline January ..... & $\ldots \ldots$ & $\ldots \ldots$ & $a 150$ & $a 9,223$ & $a 0.10$ & $a 0.09$ \\
\hline February .. & $\ldots \ldots$ & $\ldots \ldots$ & $a 300$ & $a 16,661$ & $a 0.21$ & $a 0.18$ \\
\hline March $13-31 \ldots \ldots$ & 1,340 & 120 & 665 & 40,890 & 0.46 & 0.40 \\
\hline April ...... & 3,875 & 120 & 2,250 & 133,884 & 1.51 & 1.35 \\
\hline May ........... & 2,670 & 1,440 & 1,888 & 116,089 & 1.30 & 1. 13 \\
\hline June.............. & 2,120 & 800 & 1,366 & 81,281 & 0.91 & 0.82 \\
\hline July .... & 720 & 100 & 344 & 21,152 & 0.24 & 0.21 \\
\hline August. . . . . . & 100 & 10 & 35 & 2,152 & 0.02 & 0.02 \\
\hline September .... & 90 & 25 & 42 & 2,499 & 0.03 & 0.03 \\
\hline October.... & 135 & 80 & 121 & 7,440 & 0.08 & 0.07 \\
\hline Novembor... & 230 & 135 & 156 & 9,283 & 0.10 & 0.09 \\
\hline December ........... & 1,060 & 170 & 761 & 46,792 & 0.53 & 0.46 \\
\hline The year: & $\cdots$ & $\cdots$ & 673 & 487,346 & ว. 49 & 0.40 \\
\hline
\end{tabular}

a Approximate.

NoTe.-Gage heights for 1898 are given in Water-Supply and Irrigation Paper No. 28, page 155; measirements, page 162; rating table, page 168; results for 1897, in Water-Supply and Irrigation Paper No. 16, page 171, and in the Nineteenth Annual Report, Part IV, pages 456, 457. 


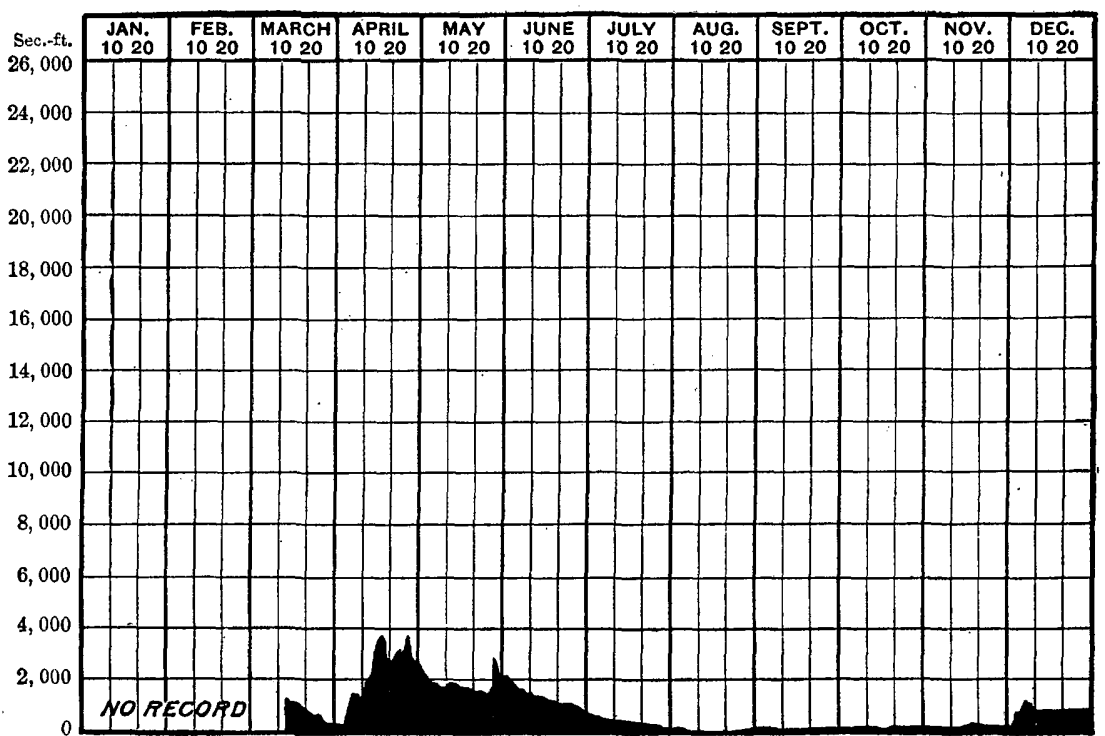

Fra. 190.-Discharge of Weiser River at Weiser, Idaho, 1898.

PALOUSE RIVER.

Estimated monthly discharge of Palouse River at Hooper, Washington.

[Drainage area, 2,210 square miles.]

\begin{tabular}{|c|c|c|c|c|c|c|}
\hline \multirow{2}{*}{ Month. } & \multicolumn{3}{|c|}{ Discharge in second-feet. } & \multirow[b]{2}{*}{$\begin{array}{l}\text { Total in acre- } \\
\text { feet. }\end{array}$} & \multicolumn{2}{|c|}{ Run-off. } \\
\hline & $\begin{array}{l}\text { Maxi- } \\
\text { mum. }\end{array}$ & $\begin{array}{l}\text { Mini- } \\
\text { mum. }\end{array}$ & Mean. & & $\begin{array}{l}\text { Depth in } \\
\text { inches. }\end{array}$ & $\begin{array}{c}\text { Second- } \\
\text { feet per } \\
\text { square } \\
\text { mile. }\end{array}$ \\
\hline 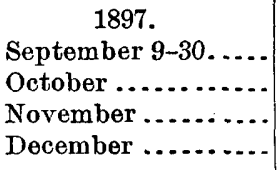 & $\begin{array}{r}86 \\
67 \\
998 \\
2,813 \\
\end{array}$ & $\begin{array}{r}50 \\
50 \\
61 \\
271 \\
\end{array}$ & $\begin{array}{r}64 \\
57 \\
357 \\
1,417 \\
\end{array}$ & $\begin{array}{r}3,808 \\
3,505 \\
21,243 \\
87,128\end{array}$ & $\begin{array}{l}0.03 \\
0.03 \\
0.18 \\
0.74\end{array}$ & $\begin{array}{l}0.03 \\
0.03 \\
0.16 \\
0.64\end{array}$ \\
\hline $\begin{aligned} 1898 . & \end{aligned}$ & 2.450 & 525 & 1,038 & 63.825 & 0.54 & 0.47 \\
\hline February....... & 7,070 & 620 & 3,187 & 176,997 & 1. 50 & 1. 44 \\
\hline 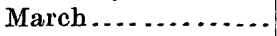 & 3,275 & 1,328 & 2,138 & 131,461 & 1.12 & 0.97 \\
\hline April.............. & 3,011 & 1,856 & 2,408 & 143,286 & 1.22 & 1.09 \\
\hline May $\ldots . . . . . . . . .$. & 1,559 & 393 & 733 & 45,071 & 0.38 & 0.33 \\
\hline $\operatorname{Jun} \theta \ldots . .$. & 735 & 148 & 305 & 18,149 & 0.16 & 0.14 \\
\hline July ...... & 148 & 55 & 100 & 6,149 & 0.05 & 0.05 \\
\hline August. ...... & 55 & 20 & 33 & 2,029 & 0.02 & 0.02 \\
\hline September ... & 30 & 25 & 30 & 1,785 & 0.02 & 0.01 \\
\hline October..... & 73 & 30 & 46 & 2,828 & 0.02 & 0.02 \\
\hline November.... & 131 & 67 & 83 & 4,939 & 0.04 & 0.04 \\
\hline December ............ & 205 & 55 & 99 & 6,087 & $\cdot 0.05$ & 0.05 \\
\hline The year ..... & 7,070 & 20 & 850 & 602,606 & 5.12 & 0.39 \\
\hline
\end{tabular}

NoTE.-Gage heights for 1898 are given in Water-Supply and Irrigation Paper No. 28, page 162; measurements, page 168; rating table, page 170; results for 1897, in Water.Supply and Irrigation Paper No. 16, page 172, and in the Nineteenth Annual Report, Part IV, pages 458, 459. 


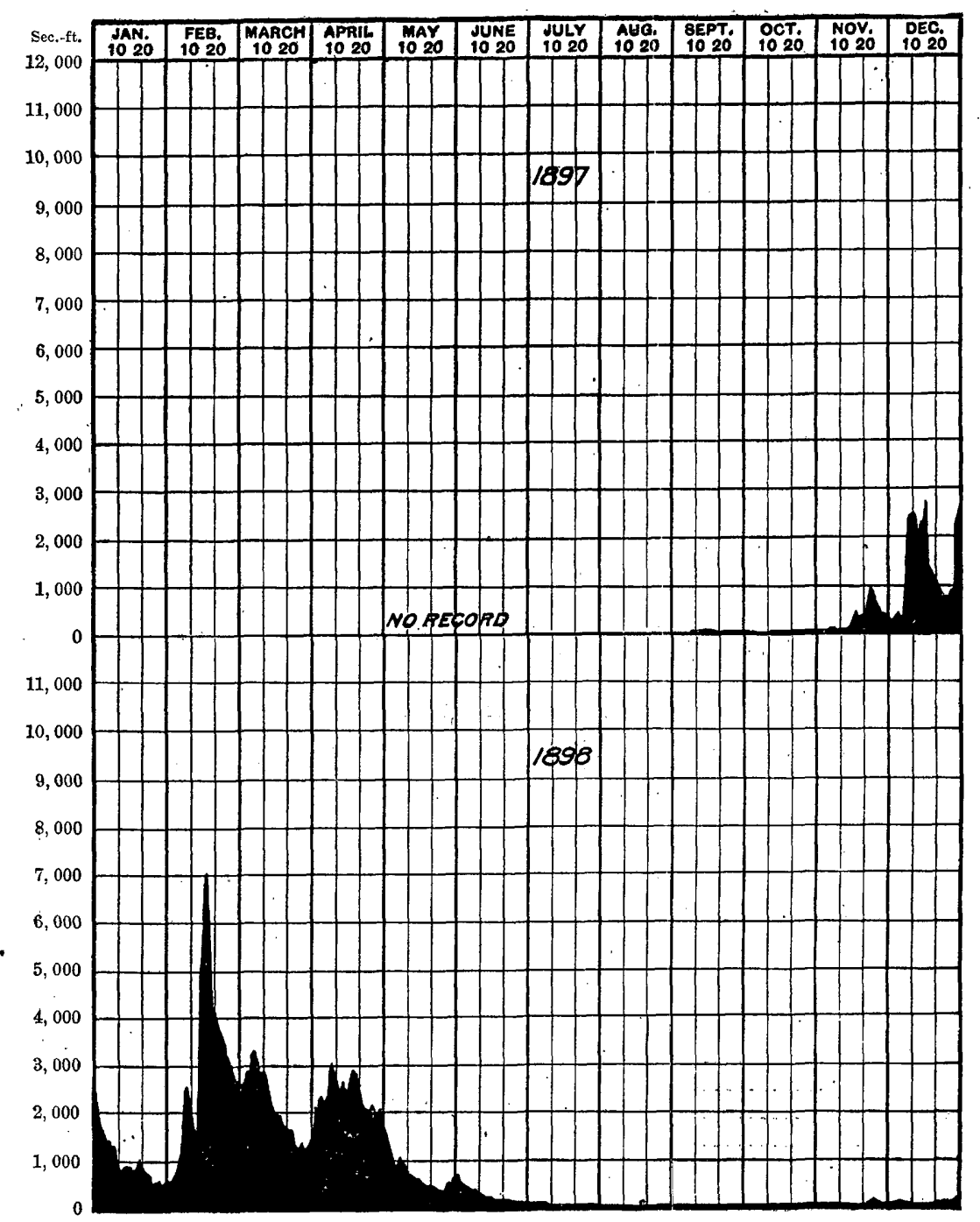

FiG. 191.-Discharge of Palouse River at Hooper, Washington, 1897-98.

MISSOULA RIVER.

Missoula River, one of the most important streams of western Montana, is usually considered as being formed by the Blackfoot and Hellgate rivers. The town of Bonner is at their junction. From this point the river flows in a general westerly course through Missoula Valley and receives from the south Bitterroot River, a view.of. which is given on Pl. LIV, $B . \cdot^{*}$ Missoula Valley itself is shown on Pl. LIII, $B$, with the river winding through it. In the center is the city of Missoula and the Higgins avenue bridge, crossing an island. Measurements are made from the Northern Pacific railroad bridge, one quarter of a mile 
below this highway bridge. Bitterroot River comes in from the left, joining Missoula River beyond the point of the mountain in the foreground. The river beyond the junction is visible in the far distance. This view, taken by Prof. M. J. Elrod, is from an altitude of 4,500 feet, or 1,500 feet above the level of the river.

Estimated monthly discharge of Missoula River at Missoula, Mor :ana.

[Drainage area, 5,960 square miles.]

\begin{tabular}{|c|c|c|c|c|c|c|}
\hline \multirow{2}{*}{ Month. } & \multicolumn{3}{|c|}{ Discharge in second-feet. } & \multirow[b]{2}{*}{$\begin{array}{l}\text { Total in acre } \\
\text { feet. }\end{array}$} & \multicolumn{2}{|c|}{ Run.off. } \\
\hline & $\begin{array}{l}\text { Maxi- } \\
\text { mum. }\end{array}$ & $\begin{array}{l}\text { Mini- } \\
\text { mum. }\end{array}$ & Mean. & & $\begin{array}{c}\text { Depth in } \\
\text { inches. }\end{array}$ & $\begin{array}{c}\text { Second- } \\
\text { feet per } \\
\text { square } \\
\text { mile. }\end{array}$ \\
\hline 1898. & & & & & & \\
\hline July $10-31 \ldots$ & 7,300 & 3,070 & 4,668 & 287,026 & 0.90 & 0.78 \\
\hline August..... & 2,970 & 1,740 & 2,120 & 130,355 & 0.41 & 0.36 \\
\hline September ..... & 1,935 & 1,680 & 1,808 & 107,583 & 0.33 & 0.30 \\
\hline October .... & 2,000 & 1,805 & 1,841 & 113,199 & 0.36 & 0.31 \\
\hline November.......... & 1,870 & 1,620 & 1,762 & 104,846 & 0.33 & 0.30 \\
\hline December $1-4 \ldots \ldots$ & 1,680 & 1,680 & 1,680 & 103,300 & 0.32 & 0.28 \\
\hline
\end{tabular}

NoTE-Gage heights for 1898 are given in Water-Supply and Irrigation Paper No. 28, page 163; measurements, page 169; and rating tabie, page 170 .

\section{BLACKFOOT RIVER.}

Blackfoot River has been described briefly in Water-Supply and Irrigation Paper No. 28, on page 155. Measurements of the stream have been made at the bridge at Bonner, about 6 miles east of Missoula. The view of this bridge is shown on Pl. LIII, $A$.

Estimated monthly discharge of Big Blackfoot River at Bonner, Montana.

\begin{tabular}{|c|c|c|c|c|c|c|}
\hline \multirow[b]{2}{*}{ Month. } & \multicolumn{3}{|c|}{ Discharge in second-feet. } & \multirow[b]{2}{*}{$\begin{array}{c}\text { Total in acre } \\
\text { feet. }\end{array}$} & \multicolumn{2}{|c|}{ Run-off. } \\
\hline & $\begin{array}{l}\text { Maxi- } \\
\text { mum. }\end{array}$ & $\begin{array}{l}\text { Mini-. } \\
\text { mum. }\end{array}$ & Mean. & & $\begin{array}{c}\text { Depth in } \\
\text { inches. }\end{array}$ & $\begin{array}{l}\text { Second- } \\
\text { feet per } \\
\text { 日quare } \\
\text { mile. }\end{array}$ \\
\hline 1898. & & & & & & \\
\hline July 7-31... & 5,520 & 1,550 & 2,797 & 171,982 & 1.30 & 1.13 \\
\hline August......... & 1,613 & 975 & 1,190 & $73,17 \mathrm{i}$ & 0.55 & 0.48 \\
\hline September & 1,030 & 887 & 962 & 57,243 & 0.44 & 0.39 \\
\hline October......... & 1,185 & 837 & 968 & $59, \bar{\jmath} 20$ & 0.45 & 0.39 \\
\hline November .......... & 1,090 & 850 & 897 & 53,375 & 0.40 & 0.36 \\
\hline December $1-10 \ldots .$. & 1,185 & 850 & 939 & 57,737 & 0.44 & 0.38 \\
\hline
\end{tabular}

NoTE.-Gage heights for 1898 are given in Water-Supply and Irrigation Paper No. 28, page 163; measuremențs, page 168 ; and rating table, page 170. 


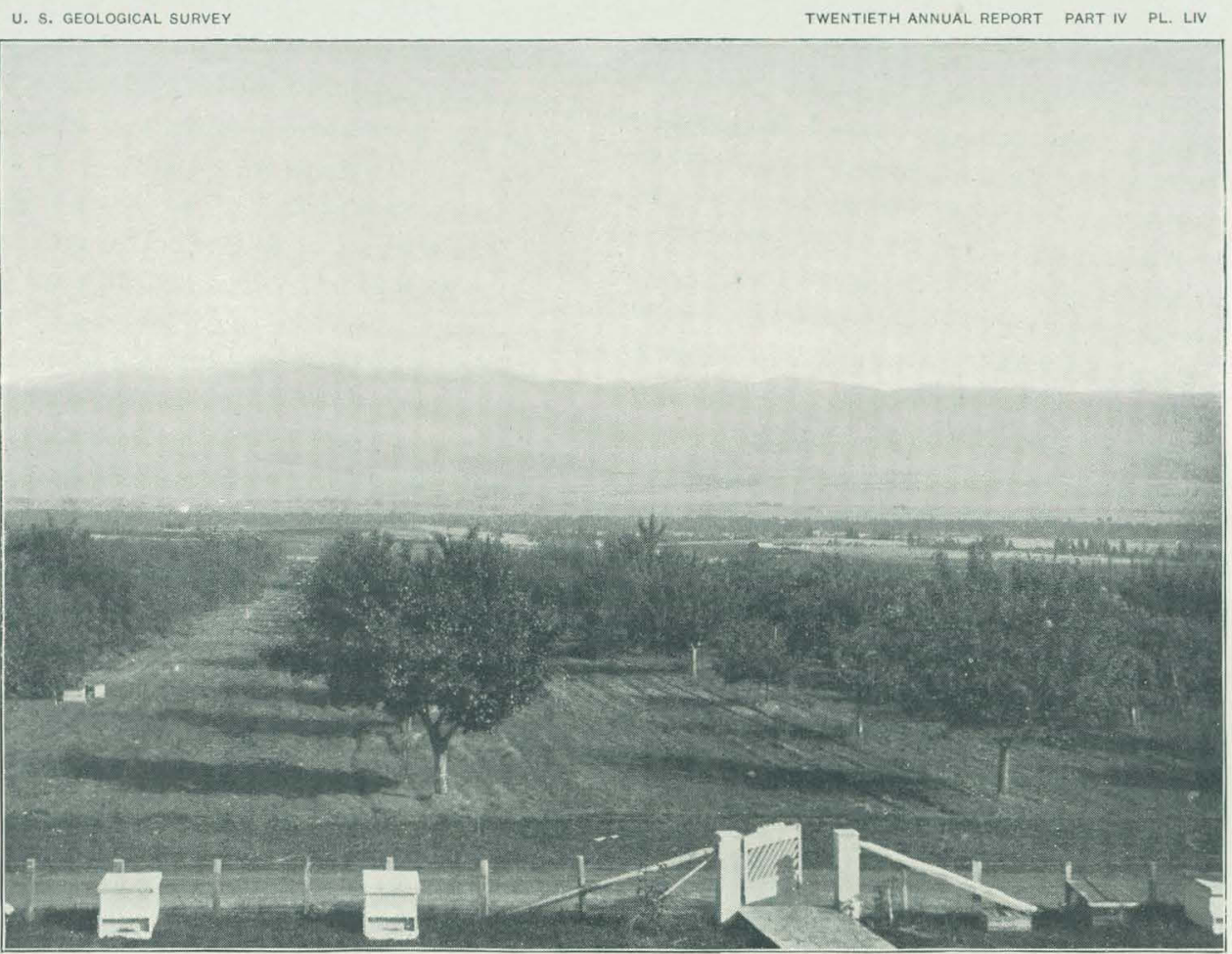

A. LOOKING EAST ACROSS BITTERROOT VALLEY, MONTANA.

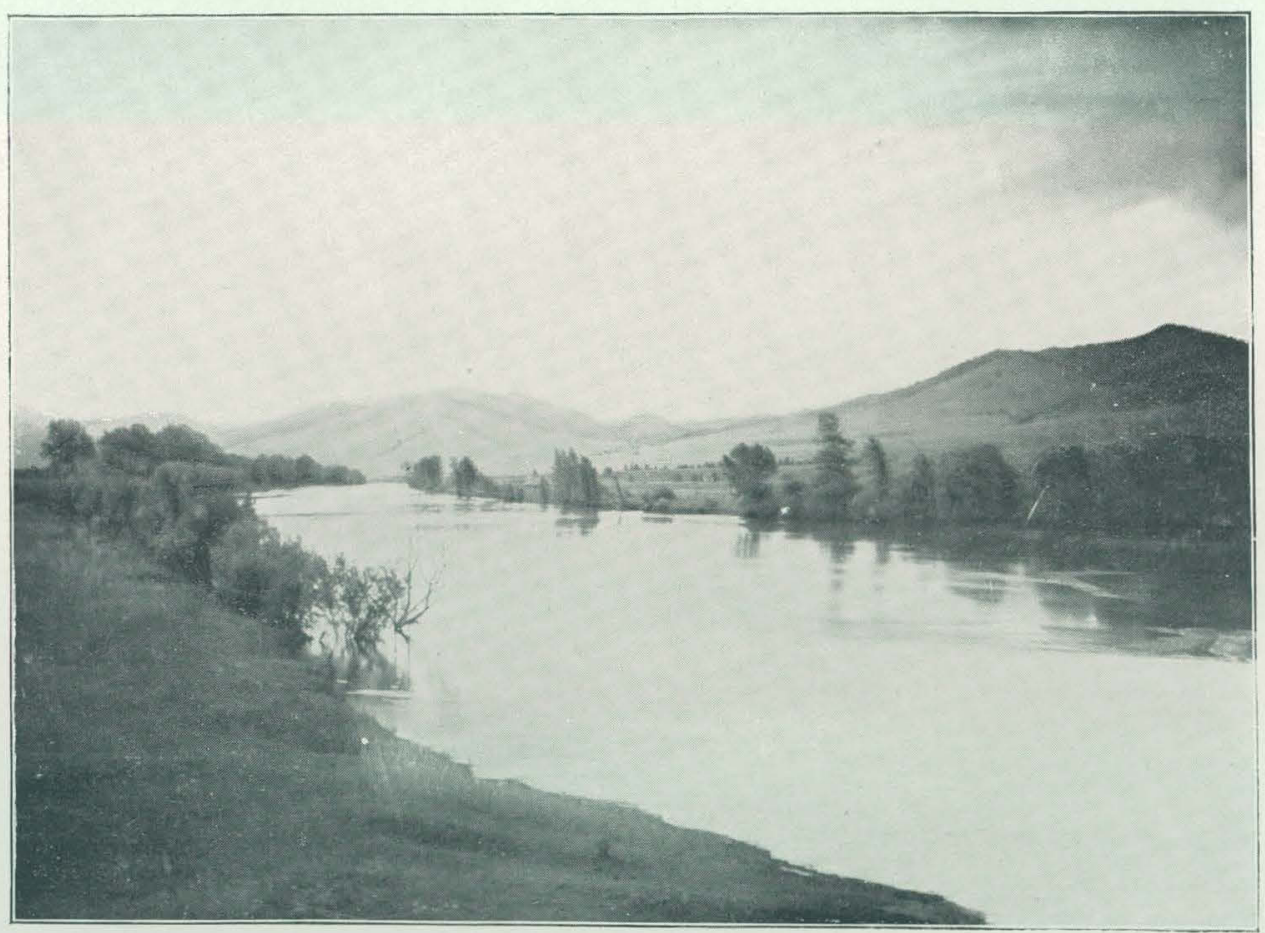

B. BITTERROOT RIVER NEAR MISSOULA, MONTANA. 
BITTERROOT RIVER.

Bitterroot River flows in a general northerly course and enters Missoula River a short distance below its head, at the junction of Blackfoot and Hellgate rivers. A characteristic view of the valley is given on

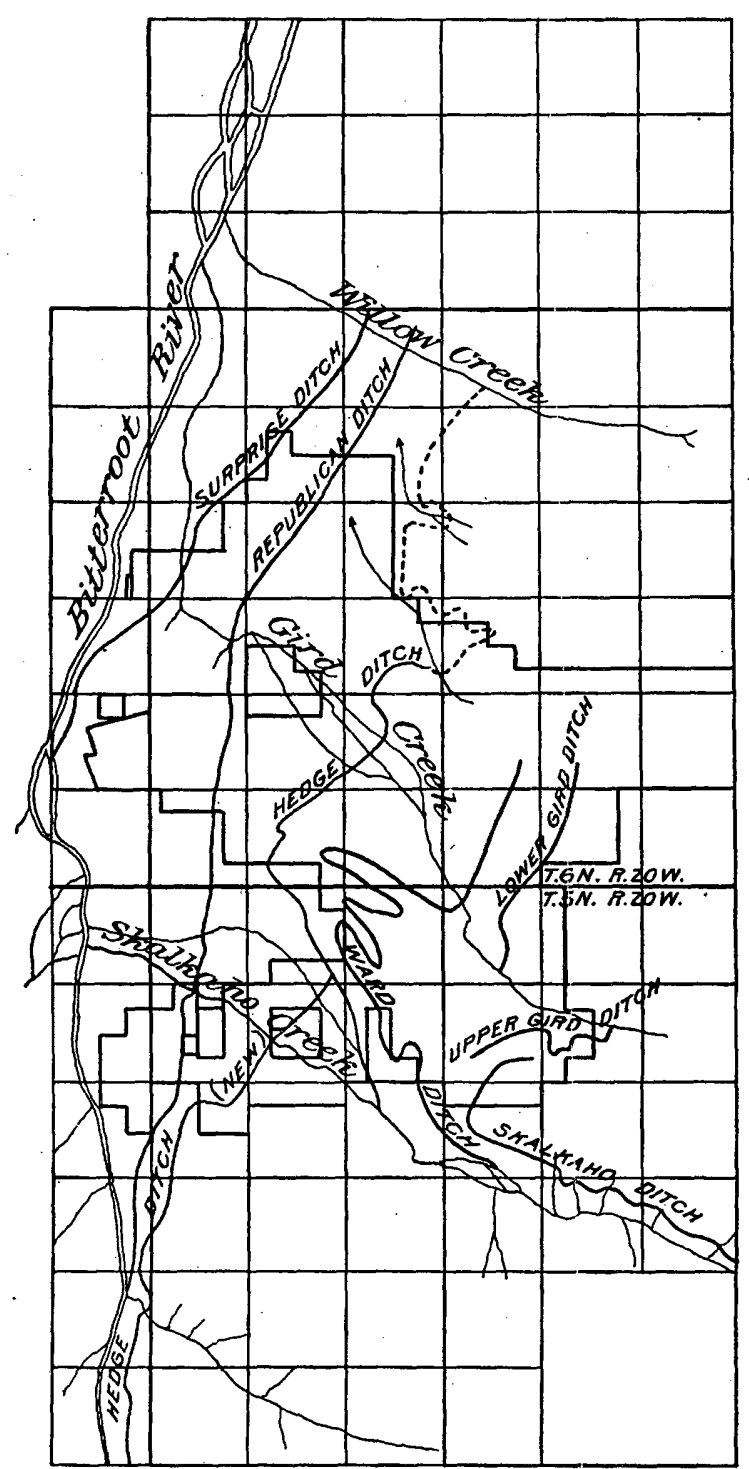

Fia. 192.-Principal streams and ditches in Bitterroot Valley.

Pl. LIV, $A$, looking easterly from Sear's ranch. In the foreground is a prune orchard and in the middle distance the town of Corvallis. A view of the river itself, below the bridge at Missoula where measure- 
ments were made, is given in Pl. LIV, $B$. The following facts have been taken from a report prepared by Mr. H. S. Lord, civil engineer:

This river receives the drainage from about 3,250 square miles. Of this area about one-fourth is tillable, and much of this, comprising Bitterroot Valley, is already cultivated. Irrigation is carried on mainly by use of the water of the tributaries rather than that obtained from the main river. The most notable of the large ditches is that built by Mr. Marcus Daly to carry water to the Bitterroot Stock Farm, at Hamilton. The accompanying map, fig. 192, shows the location of the principal ditches taking water from the east side of Bitterroot River in the vicinity of Hamilton, Montana. The capacity of these is as follows:

Capacity of ditches near Hamilton, Montana.

\begin{tabular}{|c|c|c|}
\hline Name of ditch. & Name of stream. & Capacity. \\
\hline & & Second-feet \\
\hline Skalkaho......... & Skalkaho Creek ................... & 55 \\
\hline Upper Gird....... & Gird Creek $\ldots . . \ldots \ldots \ldots \ldots \ldots$ & 15 \\
\hline Lower Gird ...... & ....do $\ldots$ do $\ldots \ldots \ldots \ldots \ldots \ldots \ldots \ldots \ldots \ldots$ & 10 \\
\hline Ward ........ & 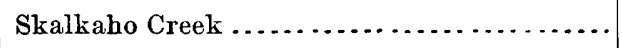 & 80 \\
\hline Hedge ........... & Skalkaho Creek and Bitterroot River ........ & 140 \\
\hline Republican... & 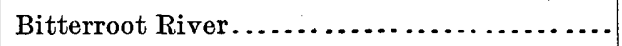 & 130 \\
\hline Surprise....... & 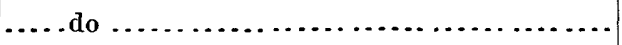 & 50 \\
\hline
\end{tabular}

Ward ditch is used only in high water, as the water carried by it is to be taken by the Skalkaho ditch. In addition to the above-named ditches the Hamilton Flour Mill Company has a flume for supplying power, taking 90 second-feet of water. The Surprise ditch now receives its supply of 50 second-feet from this source. It is proposed to catch all waste waters in the ditches, especially. Hedge ditch, and extend these north until sufficient land is covered to require all the supply available during low water, this quantity being about as follows: Skalkaho ditch, 55 second-feet; Lower Gird, 5 second-feet; Ward, unknown; Hedge ditch, 140 second-feet; Republican ditch, 125 second-feet; Surprise ditch, 5 second-feet. The duty of water in this district is low on account of the fact that the bench lands are underlain with gravel. On the accompanying map the heavy line indicates the boundary of the Bitterroot Stock Farm. The greater part of the lands under these various ditches is cultivated, the principal crops being hay and small grains. There are also extensive apple orchards.

A portion of Bitterroot Valley and of the mountains to the west embraced in the Bitterroot Forest Reserve has been mapped, the area being shown on the Hamilton, Montana, atlas sheet. The field work was carried on by E. C. Barnard, topographer, from whom the following facts have been obtained:

Irrigation is necessary in the part of Bitterroot Valley shown on the 
Hamilton sheet, the supply of water coming from Bitterroot River and more largely from streams heading in the high Bitterroot range west of the valley. The streams coming into the valley from the east carry little water, as they head in a comparatively low country and have but a small discharge during the summer months. Such is not the case, however, with the streams coming in from the west; while they are of no considerable length, they all head in high mountains, receiving water from numerous lakes fed by the melting snow. The snow banks remain throughout the year, being in many places at altitudes of over 7,000 feet above sea level, and in some cases as high as 10,000 feet.

The large irrigation ditch above noted, taken out of the Bitterroot River on the east side, just above the mouth of Lost Horse Creek, and having Skalkaho Creek as a feeder, covers a considerable area on the east side of the valley in the vicinity of Hamilton. On the west side of the river numerous farms are irrigated by ditches leading directly from the most accessible of the small creeks coming from the high mountains, the character of which is shown on Pl. LV, A. This is a view of Mill Creek Canyon looking west, showing a remarkably straight and narrow valley, similar to a number of others in this range. The timber on the south slope is heavy. The elevation of the peak in the distance is 8,958 feet above sea level. The drainage from these slopes is relatively large, but as the area under cultivation has increased, the farmers have found the water from some of the more used streams bas been insufficient during the months of July and August. Accordingly they have cut down the outlets of some of the lakes at the head of these streams. By providing simple devices for regulating the flow they are enabled to store water for the time of year when most needed. This lias been done in a small way with lakes at the heads of Canyon, Bear, and Big creeks.

An additional supply of water during the dry season could be had by utilizing Lake Como (shown on Pl. LV, B). This is about 1 mile long and one-half mile wide, and is near the mouth of Rock Creek. A dam 10 or 15 feet high would almost double the holding capacity of this lake, making a reservoir 2 miles long and one-half mile wide, with an average depth of possibly 20 feet. Rock Creek has a relatively large drainage basin with nearly equal forks, in the heads of which are numerous lakes fed from melting ice. Other lakes in the mountains are noteworthy in any discussion of the resources of the country. On North Fork is Elk Lake, one-half mile long and one-fourth of a mile in width, the capacity of which could be considerably increased by the construction of a dam at its mouth. On South Fork of Lost Horse Creek is Fish Lake, threefourths of a mile long by one-fourth of a mile in width, which could be utilized as a storage reservoir, but it is doubtful whether its capacity can be materially increased. As yet nothing has been done in the way of attempting to utilize water from this stream except by a small ditch. Crude dams have been built at the outlet of the small lakes at the heads 
of: Canyon, Bear, and Blodgett creeks, enabling the farmers who depend upon irrigation from these streams to conserve a sufficient supply of water until the time of most need. The natural channel of the stream is used, the ditches being taken out at a point near the valley. At the head of Bear Creek is Big Lake, 2 miles long by one-fourth of a mile wide. A low, crude dam has already been built, but the storage capacity might be very much increased if necessity for water should arise. Some of the small lakes near the head of Camas Creek could also be used for additional storage.

Estimated monthly discharge of Bitterroot River at Missoula, Montana.

[Drainage area, 3,260 square miles.]

\begin{tabular}{|c|c|c|c|c|c|c|}
\hline & \multicolumn{3}{|c|}{ Discharge in second-feet. } & \multirow[b]{2}{*}{$\begin{array}{c}\text { Total in acre. } \\
\text { feet. }\end{array}$} & \multicolumn{2}{|c|}{ Run-off. } \\
\hline Month. & $\begin{array}{l}\text { Maxi- } \\
\text { mum. }\end{array}$ & $\begin{array}{l}\text { Mini- } \\
\text { mum. }\end{array}$ & Mean. & & $\begin{array}{l}\text { Depth in } \\
\text { inches. }\end{array}$ & $\begin{array}{c}\text { Second. } \\
\text { feet per } \\
\text { square } \\
\text { mile. }\end{array}$ \\
\hline 1898. & & & & & & \\
\hline July 6-31 & 7,930 & 2,000 & 4,148 & 255,052 & 1. 46 & 1.27 \\
\hline August ............. & 1,930 & 950 & 1,201 & 73,847 & 0.43 & 0.37 \\
\hline September & 1,190 & 875 & 1,021 & 60,754 & 0.35 & 0.31 \\
\hline October........ & 1,325 & 1,025 & 1,149 & 70,650 & 0.40 & 0.35 \\
\hline November.... & 1,278 & 1,075 & 1,154 & 68,668 & 0.39 & 0.35 \\
\hline December $1-10 \ldots$. & 1,730 & 1,000 & 1,137 & 69,912 & 0.40 & 0.35 \\
\hline
\end{tabular}

Note,-Gage heights for 1898 are given in Water-Supply and Irrigation Paper No. 28, page 163; measurements, page 168; and rating table, page 170.

\section{LAKE CHELAN.}

Lake Chelan, shown in fig. 193, is in western Washington, on the east side of the Cascade Mountains, from which it receives a large water supply. The lake is notable for its great depth, probably over 1,400 feet, and for the clearness of its waters, as well as for the beauty of the scenery. High mountains seem to rise directly from the lake with almost vertical walls. Near the foot or south end of the lake are low foothills, and good soil, where agriculture to a small extent.is already practiced. Fruit is successfully raised, as well as the ordinary farm products. The country around the lake has been surveyed in part, the results being shown on the Waterville and Methow topographic atlas sheets. The lake is open for navigation throughout the year; 4 small steamers are now plying its waters. The fluctuations of height are observed by Capt. Charles Johnson at a point near the outlet. Lakeside station on Lake Chelan is described in Water-Supply and Irrigation Paper No. 28, page 157, and gage heights for 1898 are given on page 164 . 


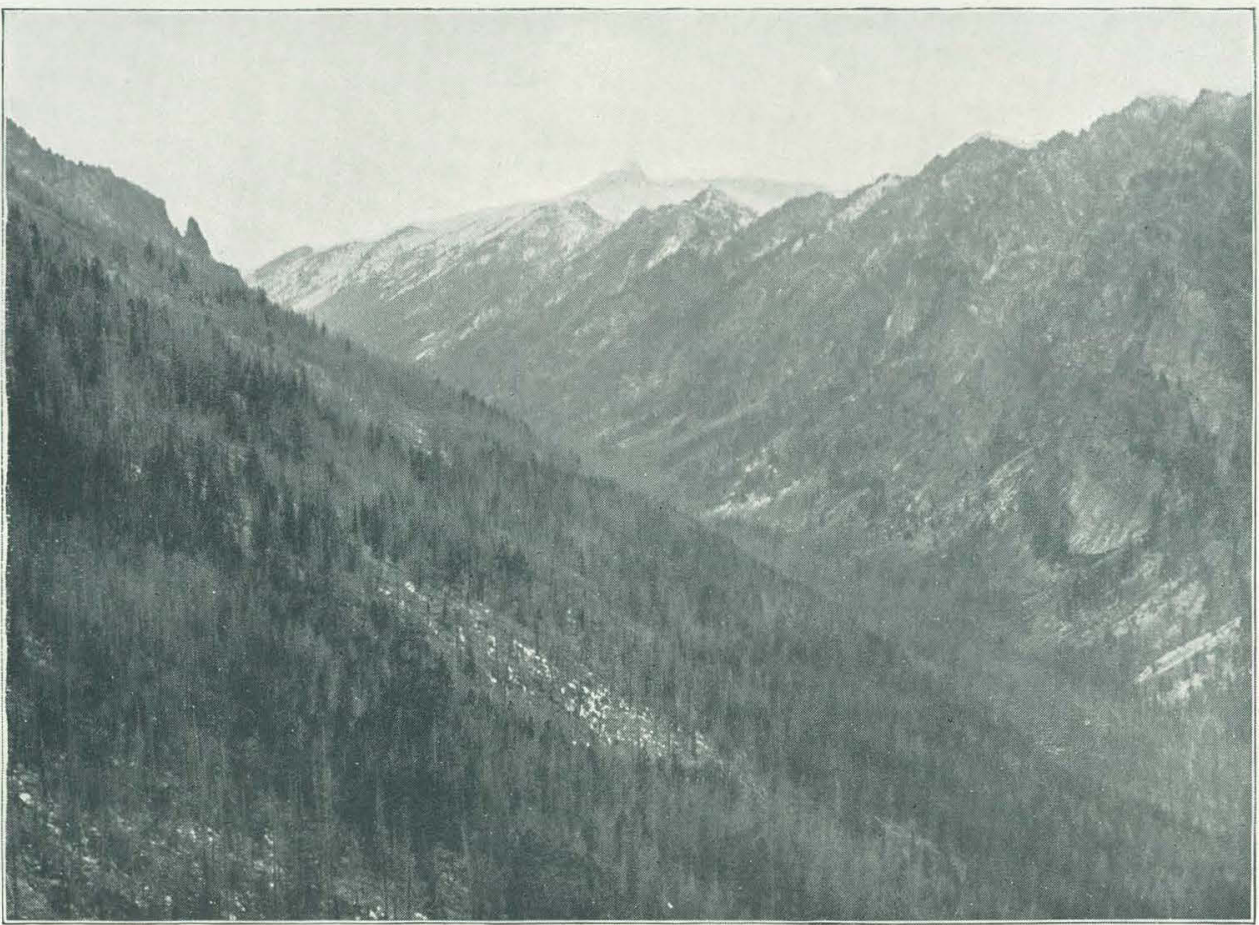

A. MILL CREEK CANYON ON WEST SIDE OF BITTERROOT VALLEY, MONTANA.

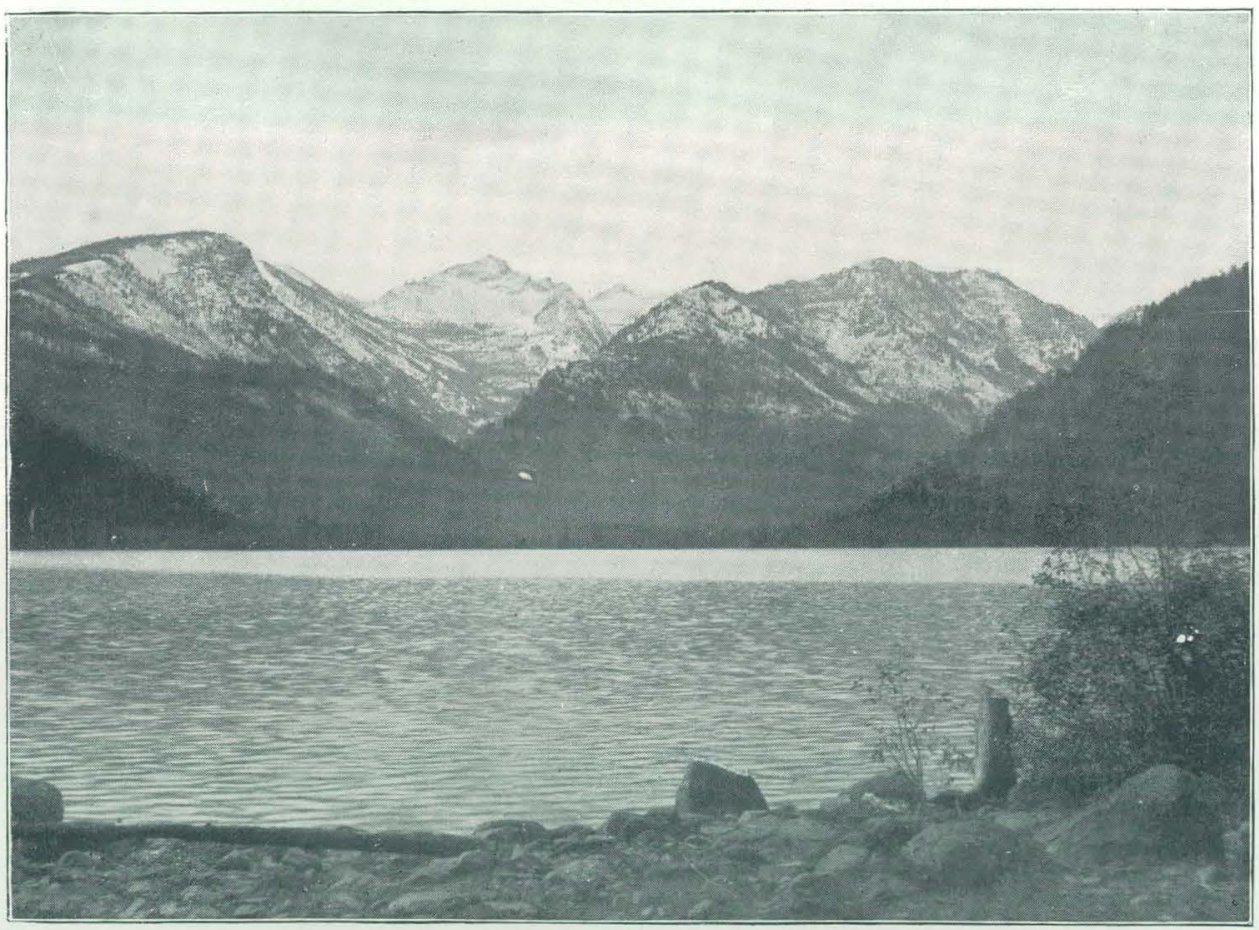

B. LAKE COMO, MONTANA. 


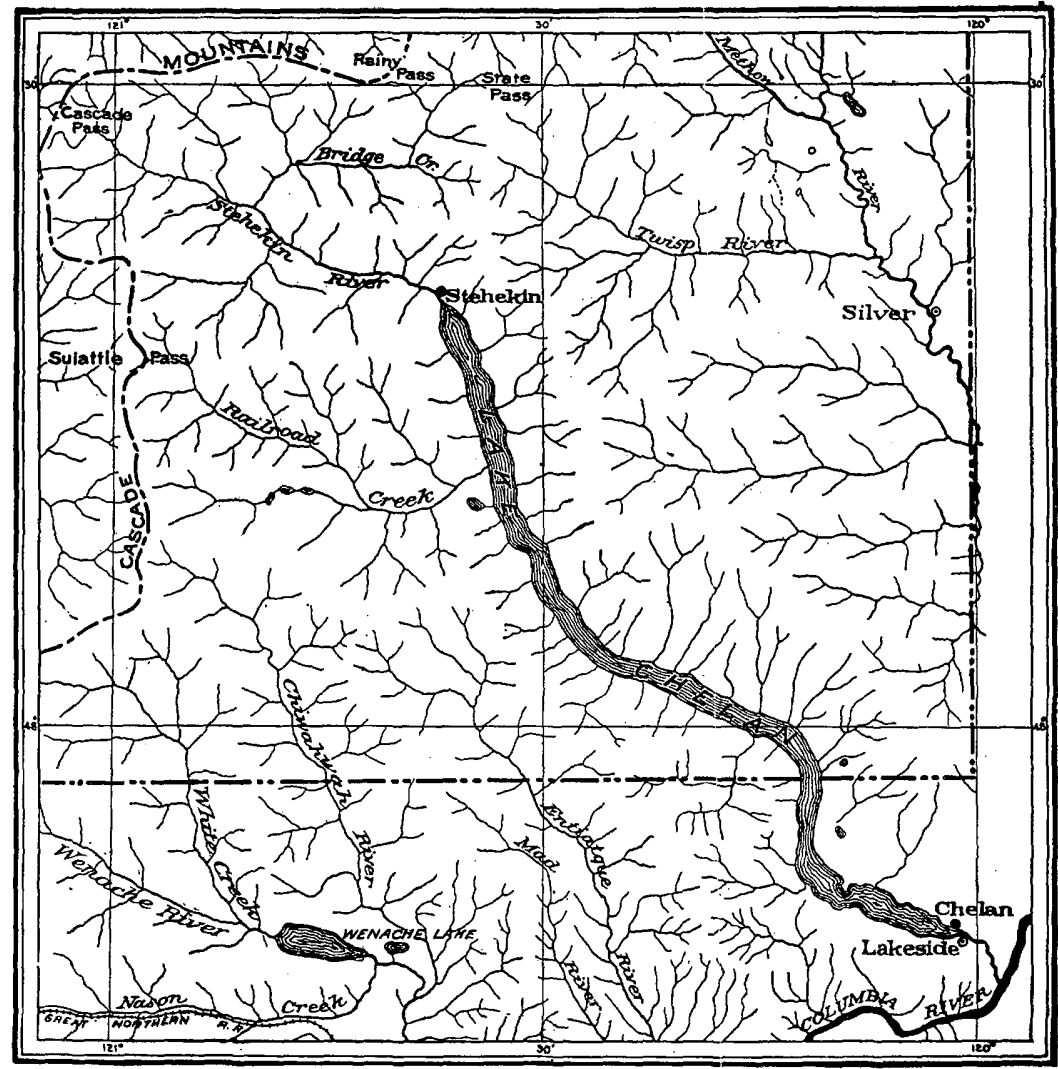

FIG. 193.-Drainage basin of Lake Chelan, Wash.

YAKIMA RIVER.

PRECIPITATION IN THE BASIN OF YAKIMA RIVER.

The principal observations of rainfall made within the basin of the Yakima River are at Lakeside, Waterville, Ellensburg, North Yakima, Fort Simcoe, Kennewick, and Lyle. The relative location of these points is shown on fig. 194, in connection with the points of river measurements which are at North Yakima, Union Gap, and Kiona.

The following table gives the names and locations of the stations, the elevations, and the number of years during which observations have been made; or rather, the number of complete monthly observa tions used in computing the normals. 


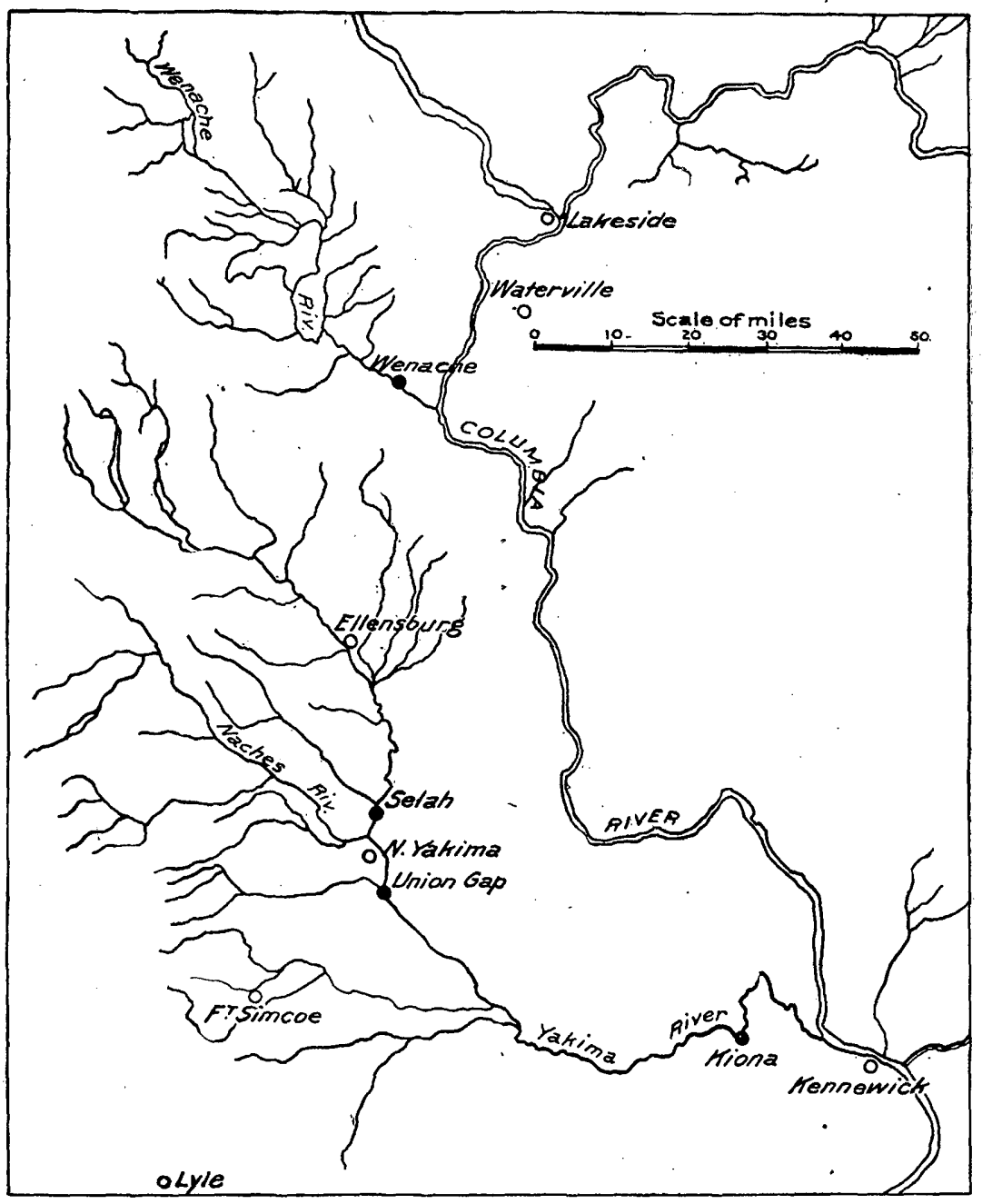

FIG. 194.-Relative location of river and rainfall observations in basin of Yakima River. Location of rainfall stations.

\begin{tabular}{|c|c|c|c|c|c|c|}
\hline Station. & County. & State. & Latitude. & $\begin{array}{c}\text { Longi. } \\
\text { tude. }\end{array}$ & $\begin{array}{l}\text { Eleva. } \\
\text { tion. }\end{array}$ & $\begin{array}{l}\text { Length of } \\
\text { record. }\end{array}$ \\
\hline Lakeside ... & Okanogan... & Washington. & $\begin{array}{c}\circ \\
47 \\
48\end{array}$ & $\begin{array}{c}\circ \\
120 \\
120\end{array}$ & 985 & $4-7$ \\
\hline Waterville...... & Douglas. . & .... do ....... & 4738 & 1207 & 2,500 & $7-8$ \\
\hline Ellensburg ..... & Kittitas. . & .... do .. & 47 & 11732 & 1,500 & $7-9$ \\
\hline North Yakima .. & Yakima..... & $\ldots$ do $\ldots .$. & 4640 & 12030 & 1,000 & $5-7$ \\
\hline Fort Simcoe .... & .... do ... & .... do & 4630 & 12040 & - & $9-11$ \\
\hline Kennewick ..... & $\ldots$......... & .... do ...... & 4612 & 1198 & 350 & $3-4$ \\
\hline Lyle....... & Klickitat.... & ....do ...... & $45 \cdot 43$ & 12119 & 600 & $5-6$ \\
\hline
\end{tabular}

20 GEOL, PT $4-32$ 
In the following table are given the figures of normal or average monthly precipitation, from the time of the beginning of the record to and iucluding 1897 , together with the total precipitation by months for the years 1896, 1897, and 1898, and also the amount by years. In obtaining the normal precipitation the average is taken for all of the mouths during which observations were made.

Rainfall at stations in drainage basin of Yakima River.

LAKESIDE.

\begin{tabular}{|c|c|c|c|c|c|c|c|c|c|c|c|c|c|}
\hline Year. & Jan. & Feb. & Mar. & Apr. & May. & June. & July. & Aug. & Sept. & Oct. & Nov. & Dec. & Annual. \\
\hline Normal. & 1.99 & 0.90 & 0.84 & 0.85 & 1.65 & 0.71 & 0.26 & 0.16 & 0.80 & 0.67 & 2.88 & 2.54 & 14.25 \\
\hline 1896. & 2.50 & 0.18 & 0.70 & 1.33 & 1.80 & 0.09 & 0.01 & 0.67 & 0.64 & 1.00 & 3.00 & 1.78 & 13. 70 \\
\hline $1897 .$. & 1.98 & 2.80 & 0.81 & 0.54 & 1.30 & 1.25 & 0.88 & 0.15 & 0.11 & 0.74 & 2.93 & 3. 37 & 16.86 \\
\hline $1898 \ldots$ & 0.30 & 1.59 & 0.08 & $\mathbf{T}$. & 0.91 & 1.54 & T. & 1.03 & 0.22 & 0.03 & 0.92 & 1.35 & 7.97 \\
\hline \multicolumn{14}{|c|}{ WATERVILLE. } \\
\hline Normal & 1.84 & 1.22 & 1.06 & 1.31 & 1.96 & 0.91 & 0.24 & 0.33 & 0.45 & 0.64 & 1.54 & 2.33 & 13.83 \\
\hline $1896 \ldots$ & 2.75 & 0.00 & 0.70 & 2.61 & 2.16 & 0.39 & 0.00 & 0.85 & 0.89 & 0.81 & 3.10 & 2.82 & 17.08 \\
\hline 1897 & 2.94 & 2.70 & 1.60 & 0.50 & 1.11 & 0.58 & 0.85 & 0.04 & 0.44 & 0.96 & 2.85 & 4.08 & 18.65 \\
\hline $1898 \ldots$. & 0.10 & 1.42 & 0.10 & 0.06 & 0.68 & 1.50 & 0.06 & 0.91 & 0.83 & $\mathrm{~T}$ & 1.55 & 1.00 & 8.21 \\
\hline \multicolumn{14}{|c|}{ ELLENSBUंRG. } \\
\hline Normal & 1.36 & 0.86 & 0.46 & 0.77 & 0.84 & 0.35 & 0.25 & 0.02 & 0.47 & 0.45 & 1.67 & 1. 78 & 9.08 \\
\hline 1896. & 1.89 & 0.58 & 0.71 & 0.94 & 1.26 & 0.17 & 0.00 & $(0.02)$ & 0.63 & 0.22 & 3.45 & 1.36 & 11.23 \\
\hline . 1897. . . & 1.62 & 1.93 & 0.15 & 0.08 & 0.42 & 0.80 & 0.17 & $\mathrm{~T}$. & 0.19 & 0.47 & 3.92 & 2.93 & 12. 68 \\
\hline $1898 \ldots \ldots \ldots$ & 0.36 & 0.47 & 0.12 & 0.03 & 0.12 & 0.73 & 0.05 & 0.29 & 0.22 & 0.22 & 0.56 & 0.54 & 3.71 \\
\hline \multicolumn{14}{|c|}{ NORTH YAKIMA. } \\
\hline Normal.. & 1.61 & 0.85 & 0.63 & 0.60 & 0.90 & 0.36 & 0.09 & 0.07 & 0.25 & 0.41 & 1.25 & 1.36 & 8.38 \\
\hline $1896 \ldots$ & 0.46 & 0.27 & 0.11 & 0.29 & 1.09 & 0.07 & $\mathrm{~T}$. & 0.40 & 0.26 & 0.10 & 1.61 & 1.14 & 5.80 \\
\hline $1897 \ldots$ & 0.89 & 0.85 & 0.25 & 0.03 & 0.26 & 0.68 & 0.13 & 0.05 & $0 . \dot{43}$ & 0.47 & 3.11 & 2.07 & 9.22 \\
\hline $1898 \ldots$ & $\mid \cdots \ldots$. & & & & & & & & & & & & \\
\hline \multicolumn{14}{|c|}{ FORT SIMCOE. } \\
\hline Normal. & 2.54 & 1.86 & 1.11 & 0.45 & 0.69 & 0.30 & 0.11 & 0.17 & 0.39 & 0.68 & 2.15 & 2.62 & 13.07 \\
\hline $1896 \ldots$ & 3.12 & 1.43 & 1.24 & 0.80 & 1.14 & 0.17 & 0.00 & 0.54 & 0.12 & 0.03 & 6.89 & 2.30 & 17.78 \\
\hline $1897 .$. & 0.78 & 1.46 & 0.69 & 0.09 & 0.32 & 1.15 & $\mathbf{T}$. & 0.00 & 0.48 & 1. 39 & 5.47 & 4. 75 & 16.88 \\
\hline $1898 \ldots$ & 0.40 & 1.54 & $\mathbf{T}$. & 0.02 & 0.18 & 0.35 & 0.00 & 0.26 & 0.48 & $\mathbf{T}$ & 1.49 & 1.50 & 6.22 \\
\hline \multicolumn{14}{|c|}{ K. } \\
\hline Normal. & 1.00 & 0.39 & 0.32 & 0.41 & 0.46 & 0.30 & 0.16 & 0.05 & 0.54 & 0.22 & 1.68 & 1.09 & 6.62 \\
\hline $1896 \ldots$ & 0.35 & 0.05 & 0.41 & 0.49 & 0.53 & 0.05 & 0.00 & 0.05 & 0.70 & 0.24 & 1.50 & 1.50 & 5.87 \\
\hline $1897 \ldots$ & 1.30 & 1.00 & 0.30 & 0.11 & 0.55 & 0.50 & 0.63 & 0.07 & 0.54 & 0.12 & 3.38 & 1.21 & 9.71 \\
\hline 1898... & 0.73 & 0.52 & 0.14 & 0.21 & 0.37 & 0.34 & 0.00 & 0.15 & 0.05 & 0.10 & 0.74 & 0.23 & 3.58 \\
\hline
\end{tabular}


Rainfall at stations in drainage basin of Yakima River-Continued.

LYLE.

\begin{tabular}{|c|c|c|c|c|c|c|c|c|c|c|c|c|c|}
\hline Year. & Jan. & Feb. & Mar. & A pr. & May. & June. & Jaly. & Aug. & Sept. & Oct. & Nov. & Dec. & Annual. \\
\hline Normal & 4. 35 & 3.12 & 3.73 & 1.41 & 1.34 & 0.79 & 0.24 & 0.17 & 1.25 & 2.11 & 4.68 & 5.87 & 29. 06 \\
\hline $1896 \ldots$ & 4.42 & 2.23 & 2.65 & 2.09 & 1.90 & 0.23 & T. & 0.62 & $|0.64|$ & 1.12 & 9.95 & 4.59 & 30.44 \\
\hline 1897. & 2.16 & 4.97 & 3.61 & 0.50 & 0.52 & 0.89 & 0.28 & 0.10 & 0.92 & 0.57 & 6.34 & 7. 82 & 28.68 \\
\hline $1898 \ldots \ldots \ldots$ & 1.89 & 2.69 & \begin{tabular}{|l|l|} 
& 0.78
\end{tabular} & 0.33 & 0.26 & 1.03 & 0.25 & 0.01 & 1.95 & 0.54 & 4.34 & 2.16 & 16.23 \\
\hline \multicolumn{14}{|c|}{ AVERAGES. } \\
\hline Normal. & 2.10 & 1.31 & 1.16 & 0.83 & 1.12 & 0.53 & 0.19 & 0.14 & 0.59 & 0.74 & 2.26 & 2.51 & 13.48 \\
\hline 1896. & 2.21 & \begin{tabular}{|l|} 
\\
\end{tabular} & 0.93 & 1.22 & 1.41 & 0.17 & 0.00 & 0.45 & 0.55 & 0.50 & 4. 21 & 2.21 & 14.54 \\
\hline 1897. & 1.67 & 2.24 & 1.06 & 0.26 & 0.64 & 0.84 & 1.42 & 0.06 & 0.44 & 0.67 & 4.00 & 3.75 & 16.05 \\
\hline 1898. & 0.44 & 1.01 & 0.10 & 0.09 & 0.44 & 0.80 & 0.02 & 0.47 & 0.31 & 0.08 & 1.00 & 0.81 & 5.57 \\
\hline
\end{tabular}

Run-off, in inches, from Yakima drainage basin.

XAKIMA, AT SELAH.

\begin{tabular}{|c|c|c|c|c|c|c|c|c|c|c|c|c|c|}
\hline Year. & Jan. & Feb. & Mar. & Apr. & May. & June. & July. & Aug. & Sept. & Oct. & Nov. & Dec. & Annual. \\
\hline 1896. & & & & & & & & & & & & & \\
\hline 1897. & ....... & ...... & ...... & $\ldots . .$. & 1.97 & 2.29 & 1. 21 & 0.32 & 0.40 & 0.17 & 2.26 & 1.59 & \\
\hline 1898. & & & - & & - & ...... & $\cdots$ & .... & - & ..... & ….. & $\ldots$. & \\
\hline \multicolumn{14}{|c|}{ NACHES, AT NORTH YAKIMA. } \\
\hline 1896. & . & 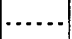 & . & & $\ldots \ldots$ & $\therefore .$. . & $\ldots .$. & 0.98 & 0.47 & 0.41 & 1.91 & 2.24 & \\
\hline 1897 & $\ldots$ & 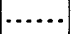 & $\cdots$ & ...... & 1.97 & 2.29 & 1. 21 & 0.32 & 0.40 & 0.17 & 2.26 & 1.59 & \\
\hline 1898. & $(0.58)$ & $(3.12)$ & 1.74 & 3.53 & 5. 98 & 5.02 & 2.08 & 0.68 & 0.40 & 0.52 & 0.57 & 0.67 & 24.89 \\
\hline Average. & $(0.58)$ & $(3.12)$ & 1.74 & 3.53 & 3.98 & 3.66 & 1.65 & 0.66 & 0.42 & 0.37 & 1.58 & 1.50 & 22.79 \\
\hline \multicolumn{14}{|c|}{ ?. } \\
\hline 1896. & $\cdots$ & & & & $\cdots$ & ... & $\ldots \ldots$ & 0.58 & 0.36 & 0.30 & 2.58 & 1.80 & \\
\hline 1897. & 0.74 & 0.95 & 0.86 & 5.07 & 5.47 & 2.40 & 1.15 & 0.40 & 0.27 & 0.28 & 1.79 & 1.38 & 20.76 \\
\hline 1898 & 1.18 & 2.14 & 1.59 & 2.33 & 4.33 & 3.21 & 1.21 & 0.47 & 0.29 & 0.45 & 0.57 & 0.69 & 18.56 \\
\hline Average. & 0.96 & 1.85 & 1.23 & 3.70 & 4. 90 & 2.81 & 1.18 & 0.48 & 0.31 & 0.34 & 1.68 & 1.29 & 20.73 \\
\hline \multicolumn{14}{|c|}{ YAKIMA, AT KIONA. } \\
\hline 1896 & 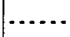 & ....... & .. & $\ldots$ & $\cdots \cdot$ & $\ldots .$. & $\ldots .$. & 0.33 & 0.20 & 0.17 & 1.39 & 2.01 & - \\
\hline $1897 \ldots$ & 1.01 & 0.79 & 0.72 & 2.78 & 3.46 & 1.58 & 0.75 & 0.23 & 0.17 & 0.16 & 1.11 & 1.14 & 13.90 \\
\hline $1898 \ldots \ldots$ & 0.95 & 1.61 & 1.15 & 1.60 & 2.85 & 2.12 & 0.71 & 0.28 & 0.14 & 0.26 & 0.39 & 0.39 & 12.45 \\
\hline Average. & 0.98 & 1.20 & 0.94 & 2.19 & 3.16 & 1.85 & 0.73 & 0.28 & 0.17 & 0.20 & 0.96 & 1.18 & 13. 84 . \\
\hline
\end{tabular}


Rainfall and run-off, basin of Yakima River.

\begin{tabular}{|c|c|c|c|c|}
\hline Station. & Normal. & 1896. & 1897: & 1898. \\
\hline RAINFALL. & & & & \\
\hline 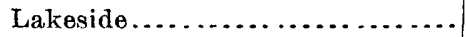 & 14. 25 & 13. 70 & 16.86 & 7.97 \\
\hline 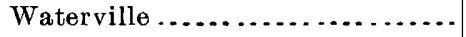 & 13.83 & 17.08 & 18.65 & 8.21 \\
\hline 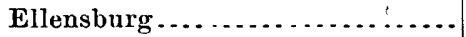 & 9.28 & 11.23 & 12.68 & 3.71 \\
\hline North Yakima $\ldots \ldots \ldots \ldots \ldots \ldots$ & 8.38 & 5.80 & 9.22 & $\ldots \ldots$ \\
\hline Fort Simcoe.................. & 13.07 & 17.78 & 16. 88 & 6.22 \\
\hline Kennewick .................... & 6. 62 & 5.87 & 9.71 & 3.58 \\
\hline 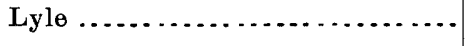 & 29.06 & 30.44 & 28.68 & 16.23 \\
\hline Average. & 13.50 & 14.56 & 16.10 & 7.65 \\
\hline RUN-OFF. & & & & \\
\hline North Yakima....... & 22. 79 & -. & $\ldots \ldots$ & 24.89 \\
\hline Union Gap . . . . . . . . . . . . & 20.73 & $\ldots \ldots \ldots$ & 20.76 & 18.56 \\
\hline Kiona....................... & 13.84 & ........... & 13.90 & 12.45 \\
\hline Average.... & 19.12 & $\ldots \ldots \ldots$ & 17.33 & 18.63 \\
\hline
\end{tabular}

In the above table it will be noted that the average run-off exceeds the average measured rainfall. This arises from the fact that the amount of precipitation has been measured at points relatively low, and in sheltered valleys, while the run-off has come from the higher slopes, where there is probably a heavy fall of snow during the winter. The following tables give the details of the discharge measurements for the year 1898:

Estimated monthly discharge of Yakima River at Union Gap, Washington.

[Drainage area, 3,300 square miles.]

\begin{tabular}{|c|c|c|c|c|c|c|}
\hline \multirow[b]{2}{*}{ Month. } & \multicolumn{3}{|c|}{ Discharge in second-feet. } & \multirow[b]{2}{*}{$\begin{array}{c}\text { Total in acre. } \\
\text { feet. }\end{array}$} & \multicolumn{2}{|c|}{ Run-off. } \\
\hline & $\begin{array}{l}\text { Maxi- } \\
\text { mnm. }\end{array}$ & $\begin{array}{l}\text { Mini- } \\
\text { mum. }\end{array}$ & Mean. & & $\begin{array}{l}\text { Depth in } \\
\text { inches. }\end{array}$ & $\begin{array}{c}\text { Second- } \\
\text { feet per } \\
\text { square } \\
\text { mile. }\end{array}$ \\
\hline 1898. & & & & & & \\
\hline January ............ & 8,270 & 1,894 & 3,350 & 205,985 & 1.18 & 1.02 \\
\hline February .......... & 22,246 & 1,775 & 6,804 & 377,875 & 2.14 & 2.06 \\
\hline 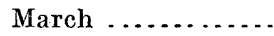 & 6,969 & 2,818 & 4,538 & 279,033 & 1.59 & 1.38 \\
\hline 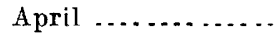 & 12,446 & 3,000 & 6,901 & 410,637 & 2.33 & 2. 09 \\
\hline May ..... & 18,500 & 8,270 & 12,388 & 761,713 & 4.33 & 3.75 \\
\hline June............. & 15,091 & 5,250 & 9,514 & 566,121 & 3.21 & 2.88 \\
\hline July $\ldots \ldots \ldots \ldots$ & 5,250 & 2,170 & 3,480 & 213,978 & 1. 21 . & 1.05 \\
\hline August. . . . . . . . . & 2,170 & 885 & 1,364 & 83,870 & 0.47 & 0.41 \\
\hline September ......... & 985 & 685 & 855 & 50,876 & 0.29 & 0.26 \\
\hline October .............. & 1,775 & 685 & 1,300 & 79,934 & 0.45 & 0.39 \\
\hline November.......... & 2,644 & 1,315 & 1,971 & 117,282 & $\dot{0} .57$ & 0.60 \\
\hline December . . . . . . . & 10,059 & 985 & 1,988 & 122,238 & 0.69 & 0.60 \\
\hline The year . & 22,246 & 685 & 4,538 & $3,269,542$ & 18.56 & 1.37 \\
\hline
\end{tabular}

NoTE.--Gage heights for 1898 are given in Water-Supply and Irrigation Paper No. 28, page 165 measurements, page 169; rating table, page 170; results for 1897, in Water-Supply and Irrigation Paper No. 16, page 175, and in the Nineteenth Annual Report, Part IV, page, 479 to 481 . 


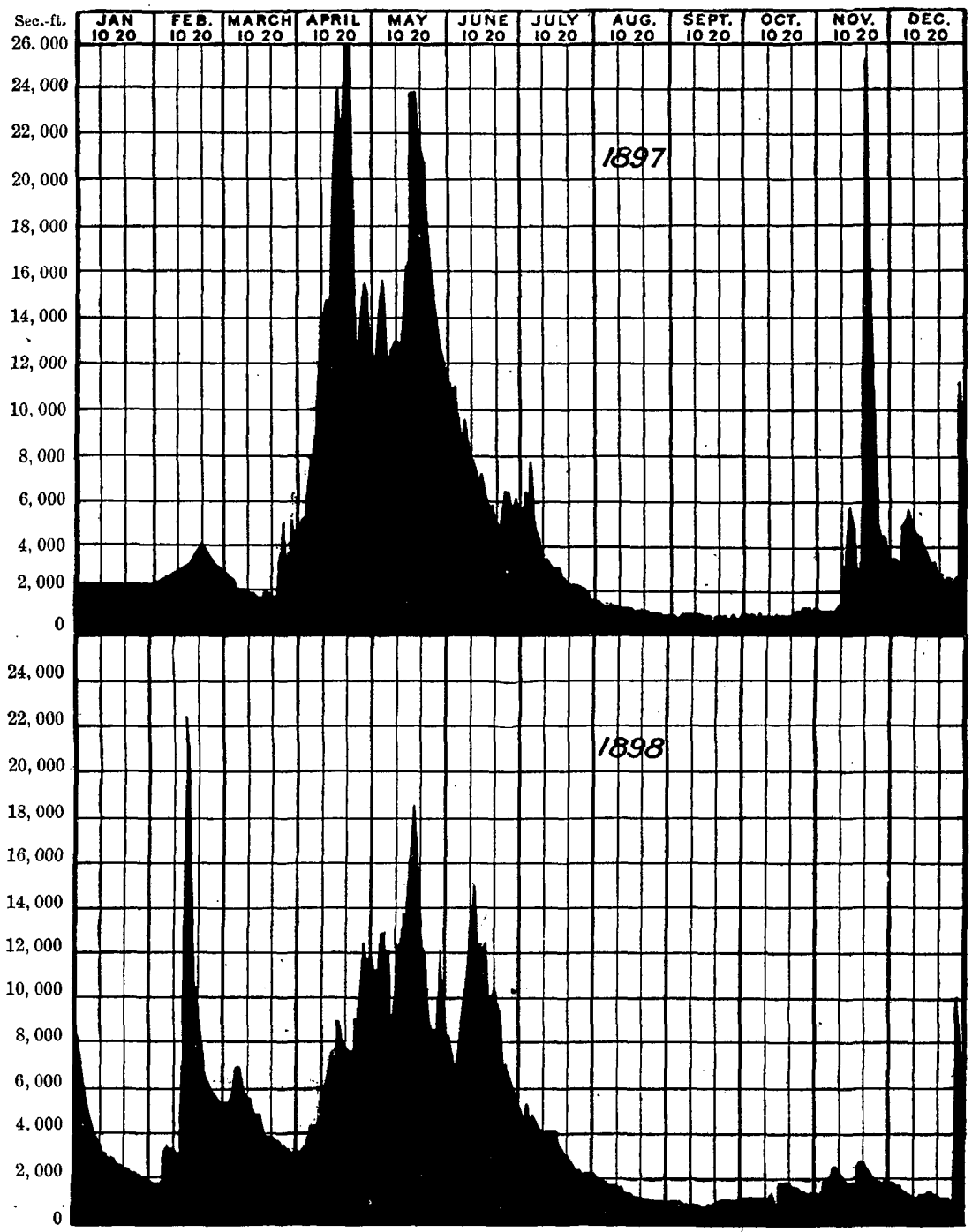

FIG. 195.-Discharge of Yakima River at Union Gap, Washington, 1897-98.

Yakima River has been measured at two points, namely, at Union Gap, below the town of Yakima, and at a place below this, in its lower course at Kiona. These measurements, as well as others in this part of Washington, have been made by Mr. Sydney Arnold. The flow of the principal tributary of Yakimá River, the Naches, has also been ascertained at a point near its mouth, above North Yakima, as shown by the figures on page 503 . 
Estimated monthly discharge of Yakima River at Kiona, Washington.

[Drainage area, 5,230 square miles.]

\begin{tabular}{|c|c|c|c|c|c|c|}
\hline \multirow[b]{2}{*}{ Month. } & \multicolumn{3}{|c|}{ Discharge in second-feet. } & \multirow[b]{2}{*}{$\begin{array}{l}\text { Total in acre. } \\
\text { feet. }\end{array}$} & \multicolumn{2}{|c|}{ Run-off. } \\
\hline & $\begin{array}{l}\text { Maxi- } \\
\text { mum. }\end{array}$ & $\begin{array}{l}\text { Mini- } \\
\text { mum. }\end{array}$ & Mean. & & $\begin{array}{c}\text { Depth in } \\
\text { inches. }\end{array}$ & $\begin{array}{c}\text { Second- } \\
\text { feet per } \\
\text { square } \\
\text { mile. }\end{array}$ \\
\hline \multicolumn{7}{|l|}{1898.} \\
\hline January .......... & 12,487 & 1,762 & 4,323 & 265,813 & 0.95 & 0.83 \\
\hline February ......... & 21,786 & 1,998 & 8,099 & 449,796 & 1. 61 & 1.55 \\
\hline March ............. & 7,275 & 3,120 & 5,202 & 319,861 & 1. 15 & 1.00 \\
\hline 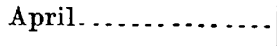 & 12,936 & 3,120 & 7,457 & 443,724 & 1.60 & 1: 43 \\
\hline 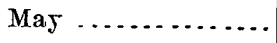 & 18,336 & 9,402 & 12,898 & 793,072 & 2.85 & 2.47 \\
\hline June $\ldots \ldots \ldots . . . . .$. & 14,736 & 5,498 & 9,970 & 593,255 & 2.12 & 1.91 \\
\hline July ........... & 5,190 & 1,938 & 3,236 & 198,975 & 0.71 & 0.62 \\
\hline 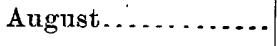 & 1,878 & 780 & 1,242 & 76,368 & 0.28 & 0.24 \\
\hline September .......... & 846 & 612 & 695 & 41,355 & 0.14 & 0.13 \\
\hline October .............. & 1,650 & 916 & 1,191 & 73,232 & 0.26 & 0.23 \\
\hline November... & 2,383 & 1,156 & 1,841 & 109,547 & 0.39 & 0.35 \\
\hline December .......... & 7,998 & 813 & 1, 786 & 109,818 & 0.39 & 0.34 \\
\hline The year.. & 21,786 & 612 & 4,828 & $3,474,816$ & 12.45 & 0.93 \\
\hline
\end{tabular}

NoTE.-Gage heights for 1898 are given in Water-Supply and Irrigation Paper No. 28, page 165; measurements, page 169; rating table, page 170; results for 1897, in Water-Supply and Irrigation Paper No. 16, page 176, and in tho Nineteenth Annual Report, Part IV, pages 482 to 486.

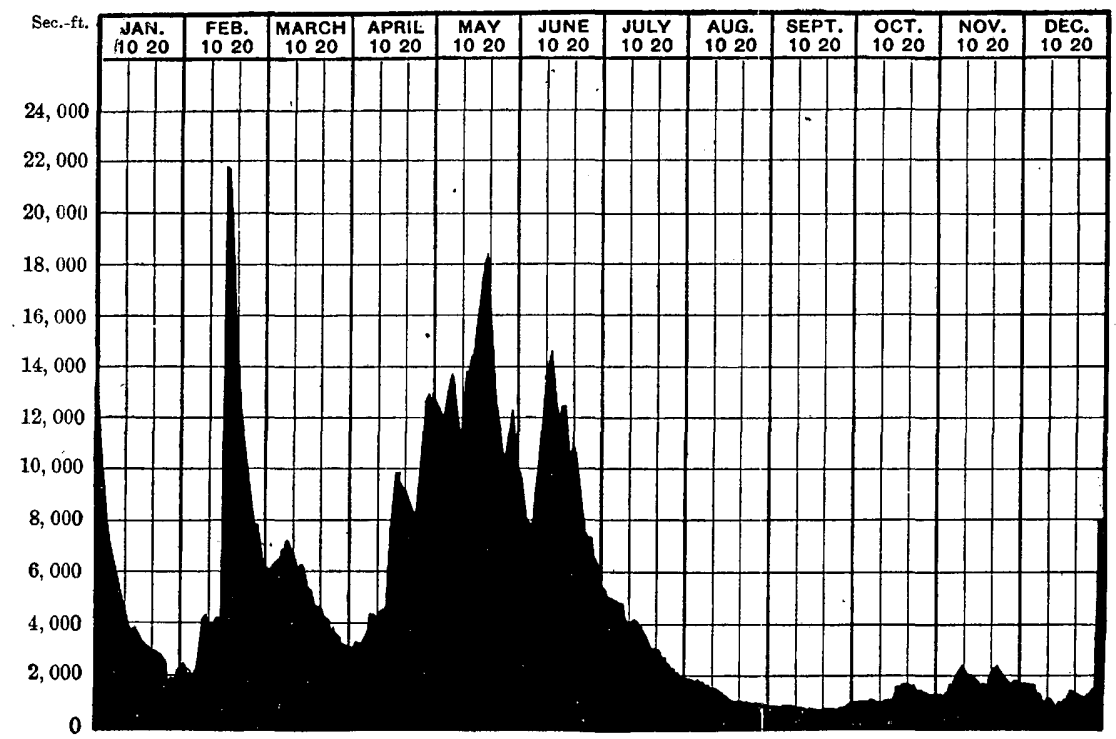

FIG. 196.-Discharge of Yakima River at Kiona, Washington, 1898. 
NACHES RIVER.

Estimated monthly discharge of Naches River at North Yakima, Washington.

- [Drainage area, 1,000 square miles.]

\begin{tabular}{|c|c|c|c|c|c|c|}
\hline \multirow[b]{2}{*}{ Month. } & \multicolumn{3}{|c|}{ Discharge in second-feet. } & \multirow[b]{2}{*}{$\begin{array}{c}\text { Total in acre } \\
\text { feet. }\end{array}$} & \multicolumn{2}{|c|}{ Run-off. } \\
\hline & $\begin{array}{l}\text { Maxi- } \\
\text { mum. }\end{array}$ & $\begin{array}{l}\text { Mini- } \\
\text { mum. }\end{array}$ & Mean. & & $\begin{array}{l}\text { Depth in } \\
\text { inches. }\end{array}$ & $\begin{array}{c}\text { Second. } \\
\text { feet per } \\
\text { square } \\
\text { mile. }\end{array}$ \\
\hline 1898. & & & & & & \\
\hline January .... & $\ldots \ldots$ & $\ldots \ldots$. & $a 500$ & $a 30,744$ & $a 0.58$ & $a 0.50$ \\
\hline February ......... & $\ldots$ & $\ldots \ldots$ & $a 3,000$ & $a 166,612$ & a3. 12 & $a 3.00$ \\
\hline 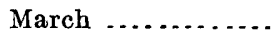 & 2,131 & 913 & 1,507 & 92,662 & 1. 74 & 1. 51 \\
\hline April.............. & 5,800 & 1,019 & 3,159 & 187,973 & 3.53 & 3.16 \\
\hline May ............... & 7,480 & 4,120 & 5,186 & 318,877 & 5. 98 & 5. 19 \\
\hline June $\ldots \ldots \ldots$ & 6,640 & 2,484 & 4,500 & 267,768 & 5.02 & 4.50 \\
\hline July $\ldots \ldots \ldots \ldots$ & 2,867 & 1,019 & 1,798 & 110,555 & 2.08 & 1.80 \\
\hline August. . . . . . . . . & 1,019 & 385 & 594 & 36,524 & 0.68 & 0.59 \\
\hline Soptember ..... & 607 & 325 & 362 & 21,540 & 0.40 & 0.36 \\
\hline October ............. & 811 & 325 & 445 & 27,362 & 0.52 & 0.45 \\
\hline November ........... & 709 & 385 & 510 & 30,347 & 0.57 & 0.51 \\
\hline December.............. & 2,867 & 225 & 580 & 35,663 & 0.67 & 0.58 \\
\hline The year ..... & 7,180 & 225 & 1,845 & $1,326,627$ & 24.89 & 1.85 \\
\hline
\end{tabular}

a Approximate.

NoTE._Gage heights for 1898 are given in Water-Supply and Irrigation Paper No. 28, page 164, and rating table on page 170 .

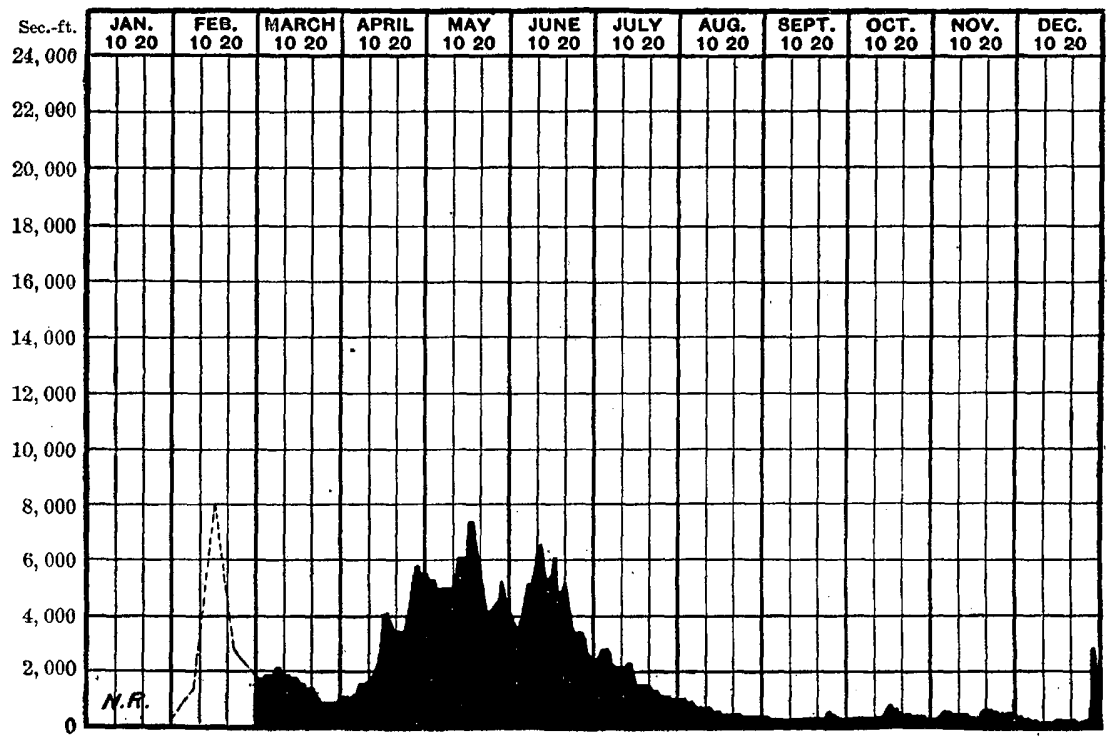

FIt. 197.-Discharge of Naches River at Nortb Yakima, Washington, 1898. 


\section{WENAS CREEK.}

Wenas Creek receives the drainage from an area south of the head waters of Yakima River and east of those of Naches River, being cut off from the high mountains by the smaller tributaries of these streams. It flows in a general southeasterly course and enters Yakima River about 10 miles above the town of North Yakima. Irrigation has been developed to a considerable extent along the stream and a number of ditches have been built, effecting a complete diversion of water during dry seasons, so that, as a result, at the end of 1898 lawsuits were pending in regard to the distribution of water. In the summer season this ereek becomes dry at points below section 13, T. 15 N., R. 17 E. The following list gives the names of the ditches taken out above this point, together with the amount of water found to be flowing on July 26,1898 , and an approximate estimate of the capacity of the ditches, these measurements having been made by Mr. Sydney Arnold:

Flow and estimated capacity of ditches receiving water from Wenas Creek, July 26, 1898.

\begin{tabular}{|c|c|c|c|}
\hline $\begin{array}{l}\text { No. of } \\
\text { measure- } \\
\text { ment. }\end{array}$ & Locality. & $\begin{array}{l}\text { Cubic } \\
\text { feet per } \\
\text { secona. }\end{array}$ & $\begin{array}{l}\text { Estimated } \\
\text { capacity of } \\
\text { ditch. }\end{array}$ \\
\hline \multirow[t]{3}{*}{$1 \ldots .}$. & 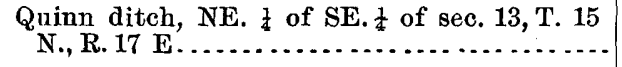 & 0.83 & 2.5 \\
\hline & $\begin{array}{l}\text { Wenas Creek at crossing of county road, SE. } \\
\text { corner of sec. } 13 . . . .\end{array}$ & Dry. & \\
\hline & $\begin{array}{l}\text { Wenas Creek at forks, NE. } \frac{1}{4} \text { sec. } 13, \text { T. } 15 \\
\text { N., R. } 17 \text { E., on Mrs. Chambers's ranch...... }\end{array}$ & 0.81 & \\
\hline 2. & $\begin{array}{c}\text { Mrs. Chambers's ditch (Wenas west fork } \\
\text { stopped by dam) } \ldots \ldots \ldots \ldots \ldots \ldots \ldots \ldots\end{array}$ & Dry. & 5.0 to 7.0 \\
\hline & $\begin{array}{l}\text { Mrs. Chambers's ditch (Wenas west fork } \\
\text { stopped by dam) } . . \ldots \ldots \ldots \ldots \ldots \ldots \ldots \ldots \ldots\end{array}$ & Dry. & 6.0 \\
\hline 4. & “Tom Taylor's" ditch, stopped by dam ...... & Dry. & 2.5 \\
\hline $5 .$. & New “R. Smith," SW. $\frac{1}{4}$ sec. 12 , T. 15 N, R. 17 E. & 0.826 & 2.5 \\
\hline $5 a$ & Old "R. Smith," NE. 责 sec. 24, T. 15 N, R. 17 E. & Dry. & 2.5 \\
\hline $6 \ldots$ & Mrs. Chambers, SW. $\frac{1}{4}$ sec. 12 , T. 15 N, R. 17 E. & 0.110 & \\
\hline 7. & D. N. Pollard, sec. 12 , T. $15 \mathrm{~N}$, R. $17 \mathrm{E} . .$. ... & 0.35 & \\
\hline 8. & S. Longmire, sec. 12, T. 15 N, R. 17 E......... & 1. 28 & 4.0 \\
\hline 9. & 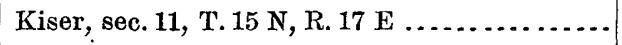 & 0.837 & 2.0 \\
\hline $10 \ldots$ & Kiser, sec. 2. T. $15 \mathrm{~N}$, R. $17 \mathrm{E} \ldots \ldots \ldots \ldots$ & 0.623 & 2.0 \\
\hline $11 \ldots$ & Sherman, sec. 3, T. 15 N, R. 17 E............. & 0.38 & 2.0 \\
\hline $12 \ldots$ & Sherman, sec. 3 , T. 15 N, R. 17 E ............ & 0.188 & 0.5 \\
\hline \multirow[t]{2}{*}{$13 \ldots \ldots$} & Justus (right bank), sec. 33 , T. 16 N, R. 17 E .. & 3.62 & 7.0 \\
\hline & Wenas Creek, middle of sec. 33, T. 16 N., R. $17 \mathrm{E}$ & 3.80 & \\
\hline $14 \ldots$ & Justus (left bank), sec. 33, T. 16 N, R. 17 E... & 0.45 & 2.0 \\
\hline $15 \ldots$ & Milton Burge, sec. 29 , T. 16 N, R. 17 E ........ & 0.465 & $\cdot 1.25$ \\
\hline $16 \ldots$ & Milton Burge, sec. 29, T. 16 N, R. $17 \mathrm{E} . \ldots \ldots$ & 0.78 & 2.0 \\
\hline $17 \ldots$ & Goodwin, sec. 29, T. 16 N, R. 17 E........ & Dry. & 0.40 \\
\hline
\end{tabular}


Flow and estimated capacity of ditches receiving water from Wenas Creek, July 26, • 1898-Continued.

\begin{tabular}{|c|c|c|c|}
\hline $\begin{array}{l}\text { No. of } \\
\text { measure- } \\
\text { ment. }\end{array}$ & Locality. & $\begin{array}{l}\text { Cubic } \\
\text { feet per } \\
\text { second. }\end{array}$ & $\begin{array}{l}\text { Estimated } \\
\text { capacity of } \\
\text { ditch. }\end{array}$ \\
\hline $18 \ldots \ldots$ & Goodwin, sec. 30, T. 16 N., R. 17 E............. & Dry. & 0.40 \\
\hline 19. & Burge \& Pressey, sec. 30, T. 16 N., R. 17 E.... & Dry. & 0.70 \\
\hline 20 & F. Cạdle, sec. 24, T. 16 N., R. 16 E........... & Dry. & 1.00 \\
\hline $21 \ldots$ & $\begin{array}{c}\text { Longmire \& Moore, secs. } 13 \text { and } 24, \text { T. } 16 \text { N., } \\
\quad \text { R. } 16 \mathrm{E} \ldots \ldots \ldots \ldots \ldots \ldots\end{array}$ & 0.872 & 4.0 \\
\hline $22 \therefore$ & W. W. Dickinson, sec. 14, T. 16 N., R. 16 E..... & 0.36 & 1.5 to 2.0 \\
\hline 23. & Jack, secs. 11 and 14, T. 16 N., R. 16 E........ & 0.42 & 0.75 \\
\hline $24 \ldots$ & Jack, secs. 11 and 14, T. 16 N., R. 16 E........ & 1.2 & $? .5$ \\
\hline 25 & Rd. Sisk, secs. 11 and 14, T. 16 N., R. 16 E..... & 0.27 & 0.75 \\
\hline 26 & Purdin Company ditch, sec. 24, T. 15 N., R. 17 E. & Dry. & 4.0 \\
\hline $28 \ldots \ldots$ & R. Smith, sec. 24, T. 15 N., R. 17 E .. & Dry. & $0.4 \check{5}$ \\
\hline $29 \ldots \ldots$ & R. Smith, sec. 24 , T. 15 N., R. 17 E . . . . . . & Dry. & 0.50 \\
\hline
\end{tabular}

RESERVOIR SITES IN YAKIMA COUNTY.

In the Nineteenth Annual Report, Part IV, on page 463, is given a description of the irrigation enterprises in the vicinity of North Yakima, Washington. The largest sources of water supply are the Naches and Yakima rivers. In three other basins, those of the Atanum, Cowiche, and Wenas creeks, irrigation is extensively practiced. These creeks do not drain the main Cascade Range, being cut off by the headwaters of the Klickitat and Naches rivers, as shown in fig. 165 of the Nineteenth Annual Report, Part IV. The snowfall in these lower ridges is comparatively light, and as a result the flow of the streams, especially in the summer season, is low. In none of the three basins above mentioned is there sufficient water to serve the ranchers below, especially in the Atanum, and as a consequence a number of lawsuits have arisen. It would be a great benefit if suitable reservoir sites could be discovered in any of the three basins. In September, 1898, Mr. Cyrus C. Babb; assisted by Mr. Sydney Arnold, made an investigation for the purpose, but with disappointing results. Mr. Babb made a thorough reconnaissance of the Atanum Basin, following up the various forks of the creek, and traveling around the divide. Two so-called sites, as reported by settlers in the basin, were examined, but found to be small and not available. The grades in both were from 300 to 400 feet to the mile.

The next basin examined by Mr. Babb was that of the Wenas, the field work being begun early in October, 1898. A site about 20 miles from North Yakima was discovered and a plane-table survey made of it. The result was also disappointing, as the entire area is comprised within a ranch-that of Mr. A. L. Sherman-no part being on Goveru- 
- ment land. The survey was made for a height of dam of 80 feet, the length at this elevation being 320 feet. The capacity is shown in the following table as 4,450 acre-feet:

Capacity of Wenas Creek reservoir site on A. L. Sherman's ranch.

\begin{tabular}{|r|r|r|r|}
\hline Contour. & Area. & Capacity. & $\begin{array}{r}\text { Total } \\
\text { capacity. }\end{array}$ \\
\hline Feet. & Acres. & Acre-feet. & A.crefeet. \\
0 & .1 & 1 & 1 \\
10 & 3.9 & 20 & 21 \\
20 & 16.0 & 100 & 121 \\
30 & 38.3 & 271 & 392 \\
40 & 56.1 & 472 & 864 \\
50 & 74.2 & 653 & 1,517 \\
60 & 88.4 & 812 & 2,329 \\
70 & 106.0 & 972 & 3,301 \\
80 & 123.6 & 1,149 & 4,450 \\
\hline
\end{tabular}

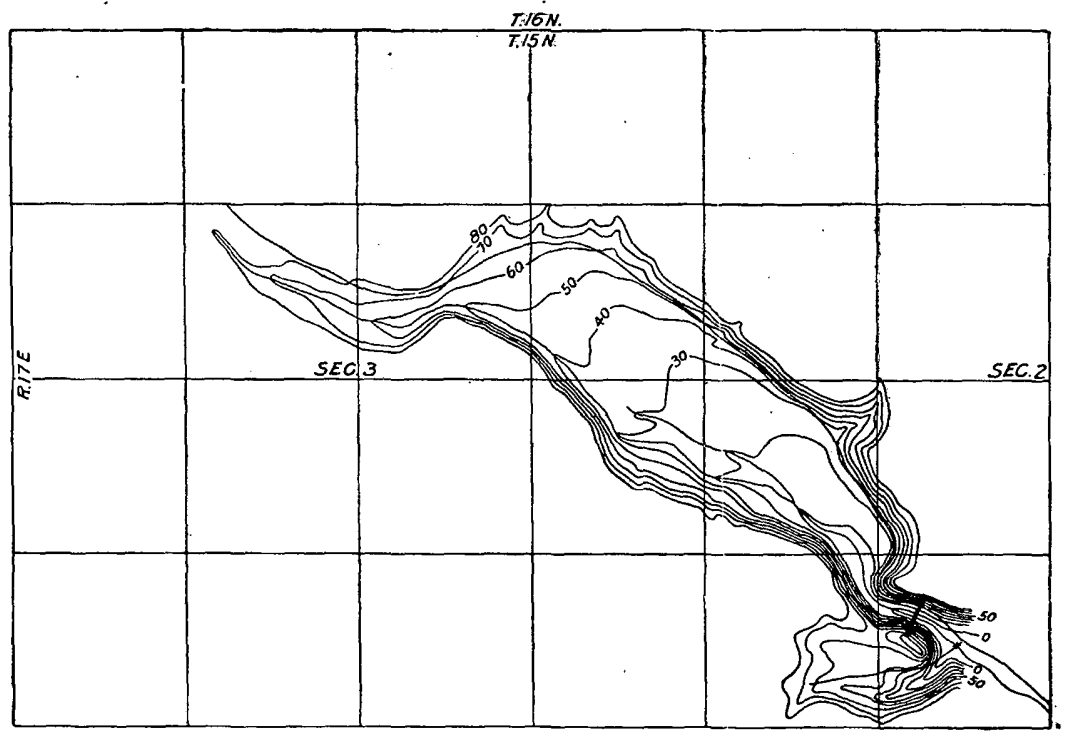

FIG. 198,-Reservoir site, Wenas Creek, Yakima County, Washington. Surveyed October, 1898, by Cyrus C. Babb and Sydney Arnold.

A natural spillway occurs for this elevation, as shown on the map, fig. 198. The elevation of the lowest point is 67 feet. If the reservoir is to be constructed, this saddle should be paved to an elevation of 70 feet, and then the main dam should be carried 10 feet higher, or to a total height of 80 feet. The capacity at the water line of 70 feet is 3,301 acre-feet.

A trip was also made in October, 1898, up the Cowiche, but no avail- 
able sites were discovered, although many of the ranchers along the creek were questioned in regard to sites. One possible site was ex. amined about 10 miles above the junction of the North and South forks. It is on Mr. Grant's ranch, at the union of the two main forks of the South Fork of Cowiche Creek. A few levels were taken and it was learned that a survey of this site was made about the year 1891 . This was for a proposed height of dam of 92 feet, but a level line at this elevation struck the ground at a distance of about three-fourths of a

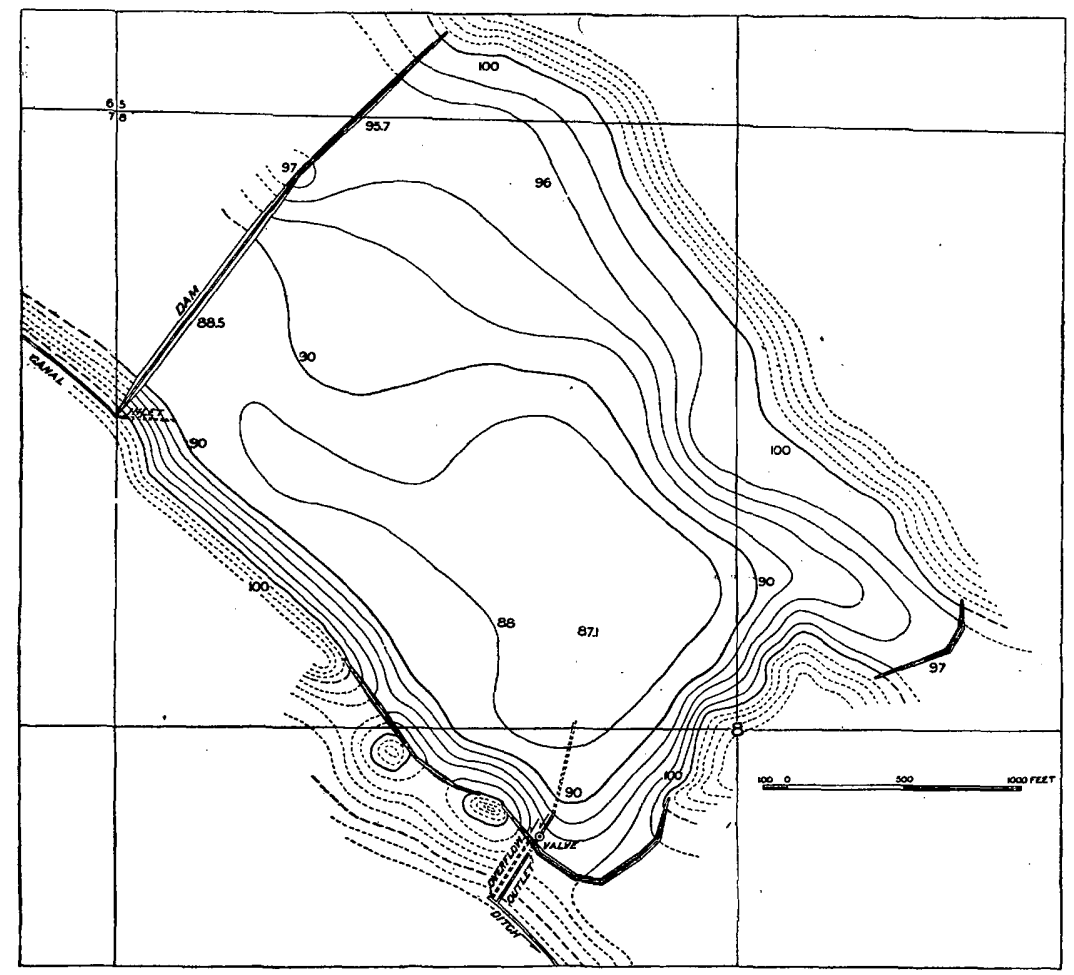

Fig. 199.-_Map of Cowiche reservoir. Surveyed by Sydney Arnold.

mile from the dam site. The capacity of the reservoir, though not surveyed, was estimated not to exceed 1,500 acre-feet.

Probably the only site within this basin is that described in the Nineteenth Annual Report, Part IV, page 466, under the head of Cowiche reservoir, and shown in fig. 199, in a natural depression in the divide between the North Fork of this creek and the Naches River. This reservoir, as built, occupies a little less than one-half of the depression, the other half being controlled by a man owning a dry ranch within the area, which he is holding at a price that is considered too great for profitable purchase for use as a reservoir.

There has been discussion of taking water from the Tieton River and 
bringing it over through a low divide into the headwaters of Cowiche Creek. A similar proposition has been made for the Atanum Basin, by taking water from the Klickitat River. For a preliminary examination of such projects a topographic map of the area under discussion would be of benefit.

\section{ARTESIAN WELLS.}

A number of artesian wells have been drilled in the upper part of Moxee Valley, southeast of North Yakima, as described in the Nineteenth Annual Report, Part IV, on page 467. Additional facts have been obtained concerning later developments, these being furnished by Mr. Sydney Arnold. The following list repeats and continues that printed on page 468 of the volume mentioned:

Artesian wells, Moxee Valley, North Yakima, Washington.

\begin{tabular}{|c|c|c|c|c|c|c|c|c|c|c|c|}
\hline \multirow{2}{*}{ No. } & \multirow{2}{*}{ Well. } & \multicolumn{3}{|c|}{ Location. } & \multirow{2}{*}{ Completed. } & \multirow{2}{*}{$\begin{array}{l}\text { Cost, of } \\
\text { well. }\end{array}$} & \multirow{2}{*}{$\begin{array}{l}\text { Diam. } \\
\text { eter. }\end{array}$} & \multirow{2}{*}{$\begin{array}{l}\text { Eleva- } \\
\text { tion. }\end{array}$} & \multirow{2}{*}{ Depth. } & \multirow{2}{*}{$\begin{array}{l}\text { Depth } \\
\text { to } \\
\text { water }\end{array}$} & \multirow{2}{*}{$\begin{array}{c}\text { Yield } \\
\text { per } \\
\text { minute }\end{array}$} \\
\hline & & Sec. & T. & R. & & & & & & & \\
\hline 1 & Clarke's No. 1 ............ & 6 & 12 & 20 & $1893 \ldots$ & $\$ 2,000$ & $\begin{array}{c}\text { Inches. } \\
6-\dot{4} .5\end{array}$ & Feet. & $\begin{array}{r}\text { Feet. } \\
940\end{array}$ & $\begin{array}{r}\text { Feet. } \\
700\end{array}$ & $\begin{array}{r}\text { Cu.ft. } \\
144\end{array}$ \\
\hline 2 & Clarke's Nos. 2 and 3.... & 31 & 13 & 20 & $1892 \ldots . .$. & 2,500 & $5-3.5$ & 1,060 & 1,050 & 800 & 84 \\
\hline 3 & Meigs's .............. & 32 & 13 & 20 & $\ldots$ & & 6 & 1,140 & 623 & 120 & 18 \\
\hline 4 & Yakima Land Co. No.4.. & 4 & 12 & 20 & $1892 \ldots \ldots$ & & $\cdots$ & 1,258 & 500 & & $\mathbf{0}$ \\
\hline 5 & Yakima Land Co. No. 1.. & 3 & 12 & 20 & $1892 \ldots \ldots$ & & $\ldots .2$ & $b 1,151$ & 314 & & .... \\
\hline 6 & Yakima Land Co. No. 3.. & 3 & 12 & 20 & $\begin{array}{c}\text { Feb. } 25 \\
1892 .\end{array}$ & & 6 & 1,141 & 340 & & 30 \\
\hline 7 & Bradford ................... & 9 & 12 & 20 & $\underset{1897 .}{\text { Mar. 25, }}$ & 600 & 4.5 & 1,090 & 386 & & 36 \\
\hline 8 & Dickson...$\ldots \ldots \ldots \ldots$ & 8 & 12 & 20 & $1898 \ldots \ldots$ & 200 & 4.25 & ....... & 294 & & $\cdots$ \\
\hline 9 & 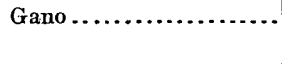 & 8 & 12 & 20 & $\begin{array}{c}\text { Apr. } \\
1897 .\end{array}$ & 400 & 3 & 1,005 & 649 & & 30 \\
\hline 10 & Ellens.................... & 7 & 12 & 20 & $(a)$ & $\ldots \ldots$ & 6 & 1,000 & 550 & & $\cdots$ \\
\hline 11 & 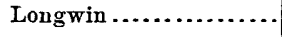 & 8 & 12 & 20 & Sept., 1893 & $\therefore \ldots$. & 3 & 1,005 & 637 & & 28 \\
\hline 12 & 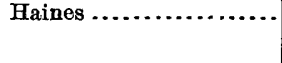 & 8 & 12 & 20 & $\begin{array}{c}\text { Mar. 24, } \\
1896 .\end{array}$ & ... & 6 & 1,080 & 702 & ....... & 22 \\
\hline 13 & Spratt............. & 8 & 12 & 20 & Feb., 1897 & 800 & $6-3$ & $\ldots \ldots$ & 835 & & 30 \\
\hline 14 & Steinweg No. 1............... & 10 & 12 & 20 & $\begin{array}{c}\text { May } 29, \\
1894 .\end{array}$ & $\cdots$ & 6 & 1,120 & 280 & $\therefore$ & 45 \\
\hline 15 & Steinweg No. 2 ... & 10 & 12 & 20 & $\begin{array}{c}\text { Sept. } 15 \\
1894 .\end{array}$ & & 6 & 1,124 & 404 & & $30^{\circ}$ \\
\hline 16 & Steinweg No. 3..... & 10 & 12 & 20 & $\begin{array}{c}\text { June } 12, \\
1895 .\end{array}$ & & 6 & 1,124 & 534 & & 70 \\
\hline 17 & Yàkima Land Co. No.3.. & 14 & 12 & 20 & Jan., 1892 & ... & 8 & 1,195 & 617 & 60 & 0 \\
\hline 18 & 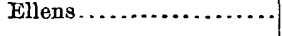 & 5 & 12 & 20 & $1898 \ldots \ldots$ & $\ldots$ & .. & a....... & 728 & & $b 114$ \\
\hline 19 & 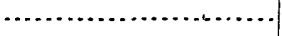 & 5 & 12 & 20 & $1898 \ldots \ldots$ & $\cdots \cdots \cdot$ & ........ & (........ & 689 & $\cdots$ & $\cdots$ \\
\hline 20 & Buwalda ................... & 32 & 13 & 20 & $1899 \ldots \ldots$ & $\cdots$ & $6-5$ & $-\cdots \ldots$. & 653 & $\cdots \cdots \cdot$ & 48 \\
\hline 21 & Clarke............. & 31 & 13 & 20 & $(a)$ & & 5.75 & $b 1,060$ & 400 & & \\
\hline
\end{tabular}

$a$ Not fillished.

$b$ Approximate. .

On March $3 \mathrm{Mr}$. Arnold measured the discharge of wells No. 2 (Clarke's Nos. 2 and 3) and No. 20 (Buwalda's), and on April 20, 1899, he measured No. 1. Well No. 20 is new, being commenced on Novem- 
ber 4, 1898, and completed on March 2, 1899, at a depth of 653 feet. The first 60 feet of this well is 6 inches in diameter, and the remainder 5 inches in diameter. Measurements of the flow were made by conducting the water through a portable weir box placed in the main ditch near the outlet of a large circular pool at the base of the discharge pipe. The dimensions of this box are 3.5 feet wide, 6 feet long, and 1.66 feet deep, the rear end being left open. The sill of the weir is 2.5 feet long and 1 foot above the bottom. The ends of the weir are 0.5 feet from the sides of the box and are vertical.

To facilitate the placing of the weir box in position and tamping to provide against leakage around or under the box the water was temporarily diverted from the main ditch. The weir was then set level with the $Y$-level and rod and an iron pin was driven into the side of the box about 4 feet from the opening and on a level with the sill. The depth of water over this mark was afterwards gaged with a steel rule, graduated to thirty-seconds of an inch. It was found that in calm weather the depth could be read to a single division with ease and certainty. Readings were taken at intervals during half an hour, but no variation in the flow could be detected. The weir opening was beveled outward, the edges being protected with sheet-iron strips nailed on the inside.

For computing the discharge, there was employed the Francis formula for weirs in thin plate, with contraction at ends and no velocity of approach :

$$
\mathrm{D}=3.33\left(\mathrm{~L}-\frac{\mathrm{h}}{5}\right) \mathrm{h}^{\frac{3}{2}}
$$

(Coeff. 3.41 for heads from 0.03 feet to 0.3 feet.)

Results of measurements of flow of artesian wells.

\begin{tabular}{|c|c|c|c|}
\hline Date. & Well. & $\begin{array}{l}\text { Discharge } \\
\text { in second. } \\
\text { feet. }\end{array}$ & $\begin{array}{l}\text { Discharge } \\
\text { in cubic } \\
\text { feet per. } \\
\text { minute. }\end{array}$ \\
\hline 1899. & & & \\
\hline Mar. 2. & No. 2 (Clarke's ö-inch) . ............ & 1.046 & 63 \\
\hline Do......... & No. 2 a (Clarke's $\left.4-3 \frac{1}{2}-i n c h\right) \ldots$ & 0.469 & 28 \\
\hline Do..... & No. 20 (Buwalda's 6-inch) ......... & 0.800 & 48 \\
\hline Apr. $20 \ldots$. & No. 1 (Clarke's 6-inch) ............ & 1.435 & 86 \\
\hline
\end{tabular}

NoTg.-Well No. 1 was measured over a weir 2.5 feet long without end contraction, using the formula $\mathrm{D}=3.33 \mathrm{~L}, \mathrm{~h}^{\frac{3}{2}}$.

The trial boring at Mabton is located on a homestead claim in the SE. $\frac{1}{4}$ of sec. 7, T. 8 N., R. 23 E., W. M., and owned by Messrs. Terrill and Hoover. The bore was down 125 feet on March 25, 1899, and progressing satisfactorily. 


\section{SPOKANE RIVER.}

Spokane River rises in northern Idaho and flows in a general westerly course into the State of Washington, emptying into Columbia River above the Columbia Plains. A general description is given in the Nineteenth Annual Report, Part IV, on page 487. $\Delta$ t about its middle course the river has an abrupt fall, and at this point the eity of Spokane has been placed, on account of the water power. The accompanying diagram (fig. 200) shows the relative position of the point at which river measurements are made. This is indicated by the heavy black dot in the course of the river, and is at the bridge of the Oregon Railway and Navigation Company. Below this point the falls occur, being at about the center of the city. Fig. 201 gives a generalized profile of the slope of Spokane River at this point, showing the abrupt fall and the relative location of the various bridges crossing the river. Computations of daily diseharge have been made since October 25, 1896. The results for 1898 are given in the following table and shown diagrammatically in fig. 202.

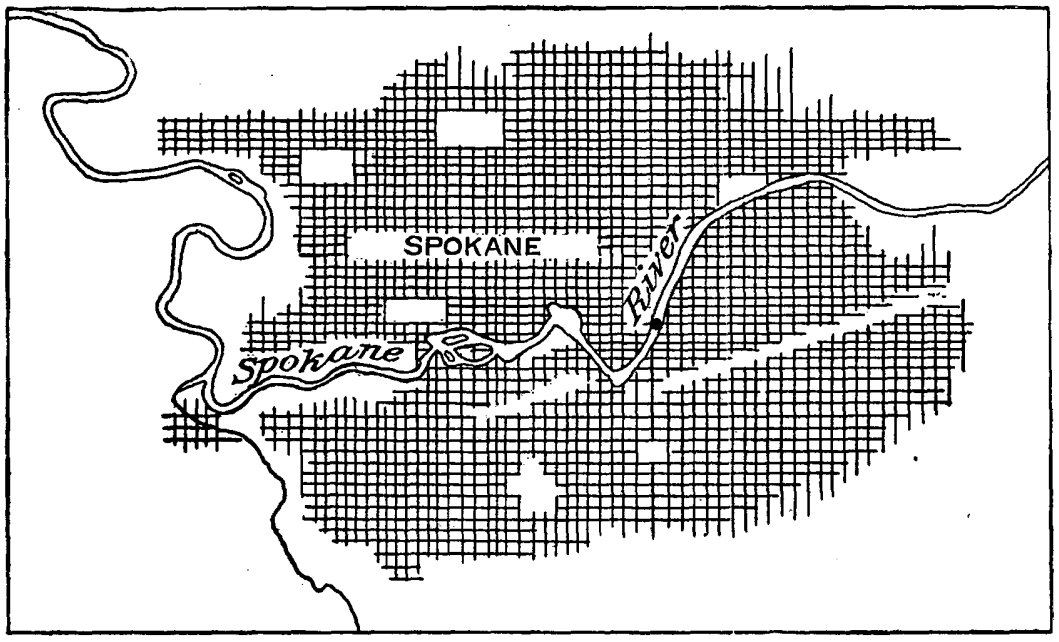

FIG. 200.-Relative location of point of discharge measurements and of fall of Spokane River.

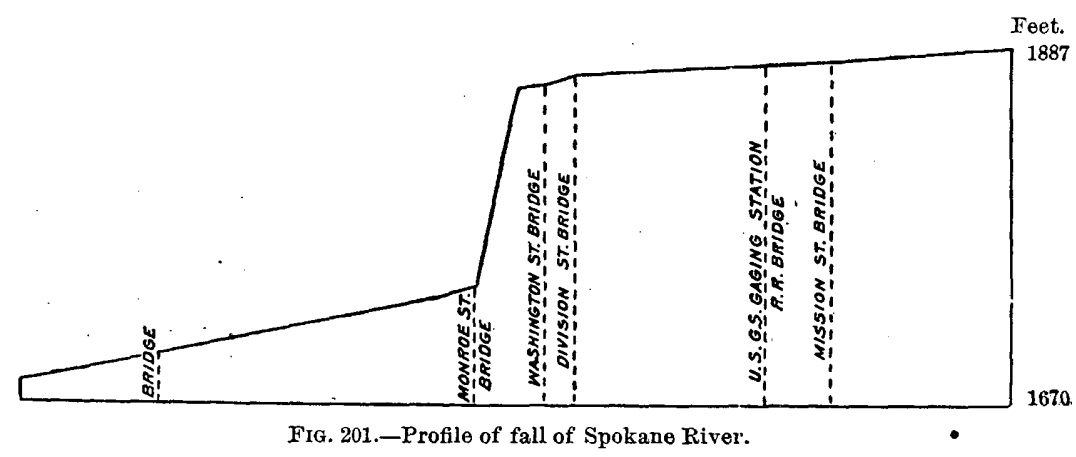


Estimated monthly discharge of Spokane River at Spokane, Washington.

[Drainage area, 4,005 square miles.]

\begin{tabular}{|c|c|c|c|c|c|c|}
\hline \multirow[b]{2}{*}{ Month. } & \multicolumn{3}{|c|}{ Discharge in second-feet. } & \multirow[b]{2}{*}{$\begin{array}{l}\text { Total in acre- } \\
\text { feet. }\end{array}$} & \multicolumn{2}{|c|}{ Run-off. } \\
\hline & $\begin{array}{l}\text { Maxi- } \\
\text { mum. }\end{array}$ & $\begin{array}{l}\text { Mini- } \\
\text { mum. }\end{array}$ & Mean. & & $\begin{array}{l}\text { Depth in } \\
\text { inches. }\end{array}$ & $\begin{array}{c}\text { Second- } \\
\text { feet per } \\
\text { square } \\
\text { mile. }\end{array}$ \\
\hline 1898. & & & & & & \\
\hline January .. & 11,532 & 4,854 & 8,104 & 498,299 & 2.33 & 2.02 \\
\hline February .. & 19,533 & 4,543 & 11,359 & 630,847 & 2.96 & 2.84 \\
\hline March .... & 14,568 & 7,990 & 12,277 & 754,888 & 3.54 & 3.07 \\
\hline April ........ & 27,134 & 7,489 & 14,789 & 880,005 & 4.12 & 3.69 \\
\hline May ......... & 27,510 & 22,892 & 25,182 & $1,548,391$ & 7.26 & 6.29 \\
\hline June....... & 25,640 & 12,267 & 19,535 & $1,162,411$ & 5.44 & 4.88 \\
\hline July ....... & 11,971 & 4,749 & 7,480 & 459,930 & 2.16 & 1.87 \\
\hline August ...... & 4,644 & 2,851 & 3,572 & 219,635 & 1.02 & 0.89 \\
\hline September . . & 2,851 & 2,436 & 2,540 & 151,140 & 0.70 & 0.63 \\
\hline October.... & 2,766 & 2,436 & 2,558 & 157,286 & 0.74 & 0.64 \\
\hline November.. & 3,291 & 2,766 & 3,176 & 188,985 & 0.88 & 0.79 \\
\hline December ...... & 3,474 & 3,682 & 2,887 & 177,516 & 0.83 & 0.72 \\
\hline - The year. & 27,510 & 2,436 & 9,455 & $6,829,333$ & 31.98 & 2.36 \\
\hline
\end{tabular}

Note.-Gage heights for 1898 are given in Water-Supply and Irrigation Paper No. 28, page 166; measurements, page 169; rating table, page 170; results for 1897, in Water-Supply and Irrigation Paper No. 16, page 177, and in the Nineteenth Annual Report, Part IV, pages 487 to 489.

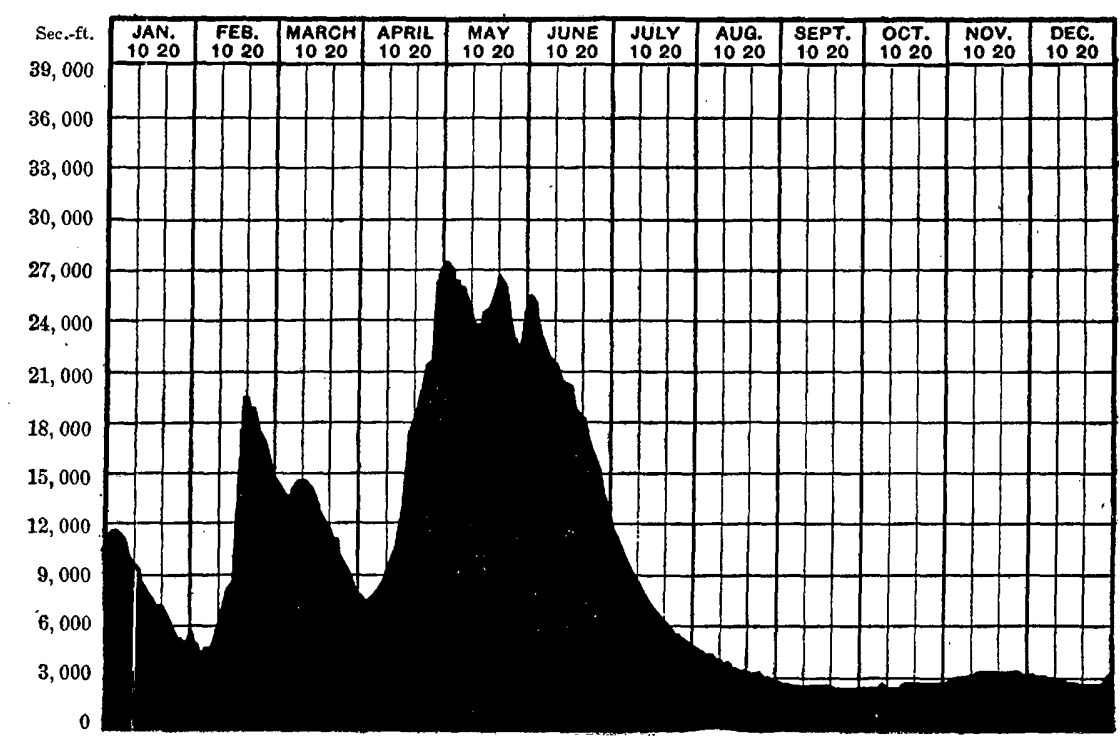

FIG. 202.-Discharge of Spokane River, at Spokane, Washington, 1898. 
WALLAWALLA RIVER.

Whitman station on Walla walla. River is described on page 179 of Water-Supply and Irrigation Paper No. 16; results for 1897 are given on pages 493 to 494 of the Nineteenth Annual Report, Part IV; gage heights for 1898 are given in Water-Supply and Irrigation Paper No. 28 , page 166 . No rating table bas been made.

\section{PRECipitation in The Basin of Palouse aNd WALlawalla RIVERS.}

The principal observations of rainfall made within the basius of the Palouse and Wallawalla rivers are at Rosalia, Dayton, and Wallawalla. The relative location of these points is shown on fig. 203, in connection with the points of river measurements, which are at Hooper and Whitman. The following table gives the name and location of the stations, the elevation and the number of years during which the observations have been made, or, rather, the number of complete monthly observations used in computing the normals:

Location of rainfall stations.

\begin{tabular}{|c|c|c|c|c|c|c|}
\hline Station. & County. " & State. & $\begin{array}{l}\text { Lati- } \\
\text { tude. }\end{array}$ & $\begin{array}{l}\text { Longi- } \\
\text { tude. }\end{array}$ & $\begin{array}{l}\text { Eleva- } \\
\text { tion. }\end{array}$ & $\begin{array}{l}\text { Length of } \\
\text { record. }\end{array}$ \\
\hline Rosalia & Whitman & Washington. & $\begin{array}{cc}\circ & 1 \\
47 & 14\end{array}$ & $\begin{array}{cc}\circ & 1 \\
117 & 24\end{array}$ & $\begin{array}{l}\text { Feet. } \\
2,300\end{array}$ & $\begin{array}{c}\text { Tears. } \\
5-6\end{array}$ \\
\hline Dayton ...... & Columbia & .... do & $46 \quad 19$ & 11756 & 1,683 & $10-13$ \\
\hline Wallawalla.. & Wallawalla. & $\ldots$ do $\ldots . .$. & 464 & 11821 & 1,018 & $28-30$ \\
\hline
\end{tabular}

In the following table are given the figures of normal or average monthly precipitation, from the time of the beginning of the record to and including 1897, together with the total precipitation by months for the years 1896, 1897, and 1898, and also the amount by years. In obtaining the normal precipitation the average is taken for all of the months during which observations were made:

Rainfall at stations in drainage basin of Palouse and Wallawalla rivers.

ROSALIA.

\begin{tabular}{|c|c|c|c|c|c|c|c|c|c|c|c|c|c|}
\hline Year. & Jan. & Feb. & Mar. & Apr. & May. & June. & July. & Aug. & Sept. & Oct. & Nov. & Dec. & Annual \\
\hline Normal. & 2.24 & 1.46 & 1.56 & 1.77 & 2.36 & 0.91 & 0.54 & 0.53 & 1.44 & 1.39 & 3.70 & 2.68 & 20.58 \\
\hline $1896 .$. & 2.75 & 1. 29 & 0.72 & 1.78 & 2.31 & 0.71 & 0.60 & 1.60 & 0.27 & 1.37 & 6.46 & 4.15 & 24.01 \\
\hline 1897. & 1.34 & 2.32 & 2.19 & 1.24 & 1.43 & 3.16 & 1. 18 & 0.21 & 2.08 & 0.24 & 6.52 & 3.90 & 25.91 \\
\hline 1898. & 1. 60 & 1.96 & 1. 50 & 0.68 & 2.53 & 0.40 & 0.48 & 1.10 & 0.84 & 0.95 & 2.52 & 0.80 & 15.36 \\
\hline \multicolumn{14}{|c|}{ DAYTON. } \\
\hline Normal.. & 3.64 & 2. 95 & 2.04 & 2.31 & 1.68 & 1.11 & 0.47 & 0.33 & 1.02 & 1.83 & 2.61 & 3. 70 & 23. 69 \\
\hline $1896 \ldots$ & 3.38 & 0.44 & 1. 31 & 1.14 & 0.76 & 0.43 & 0.23 & 1. 39 & 0.24 & 0.70 & 3.65 & 2.39 & 16.06 \\
\hline $1897 .$. & 1.70 & 2.32 & 1.92 & 1.60 & 0.48 & 2.94 & 0.47 & 0.49 & 1.55 & 0.07 & 3.90 & 2.76 & 20.20 \\
\hline 1898. & 3.40 & 1.69 & $2.02^{\prime}$ & 0.86 & 1.80 & 1.80 & $(0.47)$ & $(0.33)$ & 1.20 & 0.98 & 4.18 & 0.85 & 19.58 \\
\hline
\end{tabular}


Rainfall at stations in drainage basin of Palouse and Wallawalla rivers-Continued.

WALLAW ALLA.

\begin{tabular}{|c|c|c|c|c|c|c|c|c|c|c|c|c|c|}
\hline Year. & Jan. & Feb. & Mar. & Apr. & May. & June. & July. & Aug. & Sept. & Oct. & Nov. & Dec. & Annual. \\
\hline Normal. & 1.60 & 1.40 & 1.50 & 1.40 & 1.70 & 1. 20 & 0.50 & 0.30 & 0.80 & 1.40 & 1.90 & 1.90 & 15.60 \\
\hline $1896 \ldots$ & 1.88 & 1.20 & 1.15 & 3.85 & 1.68 & 0.88 & 0.15 & 1.24 & 0.17 & 1.57 & 3.09 & 2.55 & 19.41 \\
\hline $1897 \ldots$ & 1.85 & 2.61 & 2.38 & 1.75 & 1.05 & 1.51 & 0.84 & 0.42 & 1.44 & 0.23 & 5.15 & 2.44 & 21.67 \\
\hline $1898 \ldots \ldots \ldots$ & 1.88 & 1.33 & 1.52 & 1.83 & 2.26 & 0.84 & 0.22 & 0.22 & 0.56 & 1.09 & 3.74 & 0.85 & 16. 34 \\
\hline \multicolumn{14}{|c|}{ AVERAGES. } \\
\hline Normal... & 2.49 & 1.94 & 1.70 & 1.83 & 1.91 & 1.07 & 0.50 & $0: 39$ & 1.09 & 1.54 & 2.74 & 2.76 & 19.96 \\
\hline $1896 \ldots$ & 2.67 & 0.98 & 1.06 & 2.26 & 1.58 & 0.67 & 0.33 & 1.41 & 0.23 & 1. 21 & 4.40 & 3.03 & 19.83 \\
\hline $1897 \ldots \ldots \ldots$ & $1.63 \mid$ & 2.42 & 2.16 & 1.53 & 0.99 & 2.54 & 0.83 & 0.41 & 1.69 & 0.18 & 5.19 & 3.03 & 22.60 \\
\hline $1898 \ldots \ldots$ & 2.29 & 1.66 & 1.68 & 1.12 & 2.20 & 1.01 & 0.39 & 0.55 & 0.87 & 1.01 & 3.48 & 0.83 & 17.09 \\
\hline
\end{tabular}

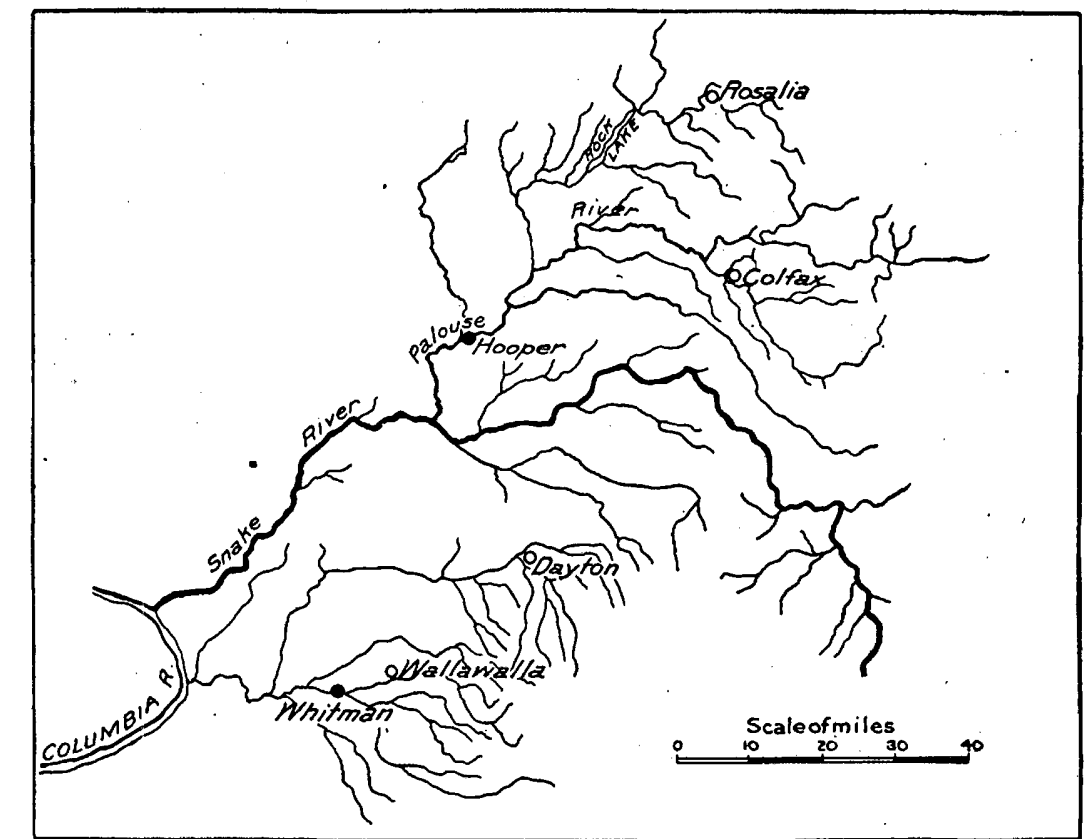

FIG. 203.-Relative location of river and rainfall observations in basins of Palouse and Wallawalla rivers.

Facts concerning the run-off are obtainable at present only from estimates at Hooper, on. Palouse River, the figures for which have been printed on page 489 of this volume. The data of run-off for Wallawalla River have not yet been computed. The table on $\mathrm{p}$. 514 gives the depth of run-off in inches from the Palouse drainage basin at Hooper, and, below this, a comparison of this run-off with the observed rainfall.

20 GEOL, PT $4-33$ 
Depth of run-off, in inches, from Palouse drainage basin at Hooper.

\begin{tabular}{|c|c|c|c|c|c|c|c|c|c|c|c|c|c|}
\hline Year. & $J \operatorname{an}$. & Feb. & Mar. & Apr. & May. & June. & July & Aug. & Sept. & Oct. & Nor. & Dec. & Annual. \\
\hline 1897. & & & & & $\cdots$ & & & . . . & 0.03 & 0.03 & 0.18 & 0.74 & \\
\hline $1898 . \ldots \ldots \ldots$ & 0.54 & 1.50 & 1.12 & 1.22 & 0.38 & 0.16 & 0.05 & 0.02 & 0.02 & 0.02 & 0.04 & 0.05 & 5.12 \\
\hline Average - & 0.54 & 1.50 & 1.12 & 1.22 & 0.38 & 0.16 & 0.05 & 0.02 & 0.03 & 0.03 & 0.11 & 0.40 & 5.56 \\
\hline
\end{tabular}

Rainfall and run-off.

\begin{tabular}{|c|c|c|c|c|}
\hline Station. & Normal. & 1896. & 1897. & 1898. \\
\hline RAINFALL. & & & & \\
\hline Rosalia ................ & 20.58 & 34.01 & 25.91 & 15.36 \\
\hline Dayton...$\ldots \ldots \ldots$ & 23.69 & 16.06 & 20.20 & 19.58 \\
\hline Wallawalla .................. & 15.60 & 19.41 & 21.67 & 16.34 \\
\hline Average... & 19.96 & 19.83 & 22.59 & 17.09 \\
\hline RUN-OFF. & & & & \\
\hline Palouse, at Hooper ............ & 5.56 & $\ldots$ & $\ldots \ldots \ldots$ & - 5. 12 \\
\hline Percentage of rainfall ...... & 27.86 & $\cdots$ & $\cdots$ & 29.96 \\
\hline
\end{tabular}

UMATILLA RIVER.

Umatilla River receives the drainage from a portion of the Blue Mountains in the northeastern part of Oregon and flows in a westerly direction into Columbia River. The mountains in the upper part of the catchment basin are from 4,000 to 7,000 feet in height and are covered with a heavy growth of timber that furnishes valuable supplies of lumber. The stream and the diversions of water from it are described in Bulletin No. 131, pages 68 to 73 . Measurements are made at Gibbon, Oregon, immediately below the mouth of Meacham Creek. A cable is suspended across the stream at a point about one-half mile west of the railroad station of the Oregon Railroad and Navigation Company, known as Bingham Springs. This is on the eastern end of the Umatilla Indian Reservation and is 21 miles east of Pendleton. 
Estimated monthly discharge of Umatilla River at Gibbon, Oregon.

[Drainage area, 353 square miles.]

\begin{tabular}{|c|c|c|c|c|c|c|}
\hline \multirow[b]{2}{*}{ Month: } & \multicolumn{3}{|c|}{ Discharge in second-feet. } & \multirow{2}{*}{$\begin{array}{c}\text { Total in acre. } \\
\text { feet. }\end{array}$} & \multicolumn{2}{|c|}{ Run-off. } \\
\hline & $\begin{array}{l}\text { Maxi- } \\
\text { mum. }\end{array}$ & $\begin{array}{l}\text { Mini- } \\
\text { mam. }\end{array}$ & Mean. & & $\begin{array}{l}\text { Depth in } \\
\text { inches. }\end{array}$ & $\begin{array}{c}\text { Second. } \\
\text { feet per } \\
\text { square } \\
\text { mile. }\end{array}$ \\
\hline 1898. & . & & & & & \\
\hline January ............ & 1,048 & 264 & 482 & 29,637 & 1. 58 & 1.37 \\
\hline February .......... & 3,730 & 264 & 1,000 & 55,537 & 2.95 & 2.83 \\
\hline 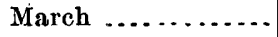 & 1,324 & 412 & 687 & 42,242 & 2.25 & 1.95 \\
\hline April $\ldots \ldots \ldots \ldots$ & 2,339 & 544 & 1,486 & 88,423 & 4.70 & 4.21 \\
\hline May ........... & 1,148 & 334 & 635 & 39,045 & 2.08 & 1. 80 \\
\hline June........ & 568 & 115 & 250 & 14,876 & 0.79 & 0.71 \\
\hline July $\ldots \ldots \ldots \ldots \ldots$ & 115 & 83 & 97 . & 5,964 & 0.32 & 0.28 \\
\hline August . . . . . . . . . . & 83 & 74 & 76 & 4,673 & 0.25 & 0.22 \\
\hline September .......... & 83 & 74 & 76 & 4,522 & 0.24 & 0.22 \\
\hline October $\ldots \ldots \ldots$ & 99 & 83 & 87 & 5,349 & 0.29 & 0.25 \\
\hline November . . . . . . . . & 202 & 99 & . 135 & 8,033 & 0.43 & 0.38 \\
\hline December ............ & 1,252 & 99 & 263 & 16,171 & 0.86 & 0.75 \\
\hline The year ..... & 3,730 & -74 & 440 & 314,472 & 16.74 & 1.25 \\
\hline
\end{tabular}

Note.-Gage heights for 1898 are given in Water-Supply and Irrigation Paper No. 28, page 167, measurements, page 169, rating table, page 170; results for 1897 in Water-Supply and Irrigation Paper No. 16, page 180, and the Nineteenth Annual Report, Part IV, pages 493-494.

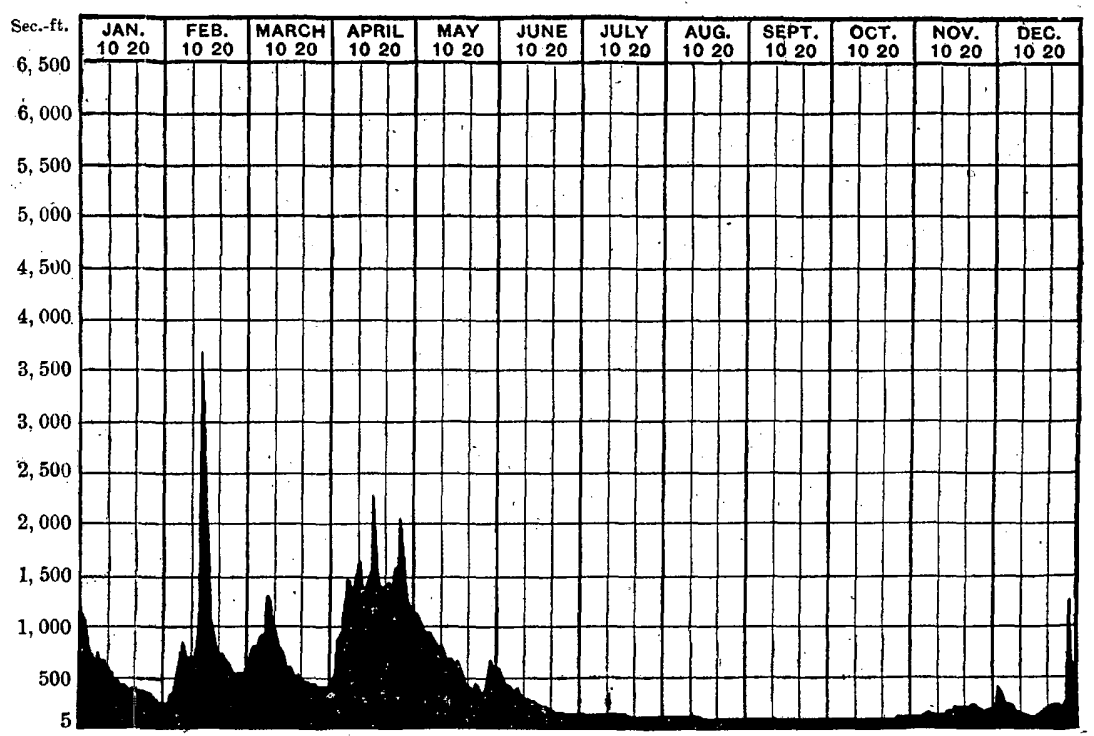

Fig. 204.-Discharge of Umatilla River at Gibbon, Oregon, 1898. 


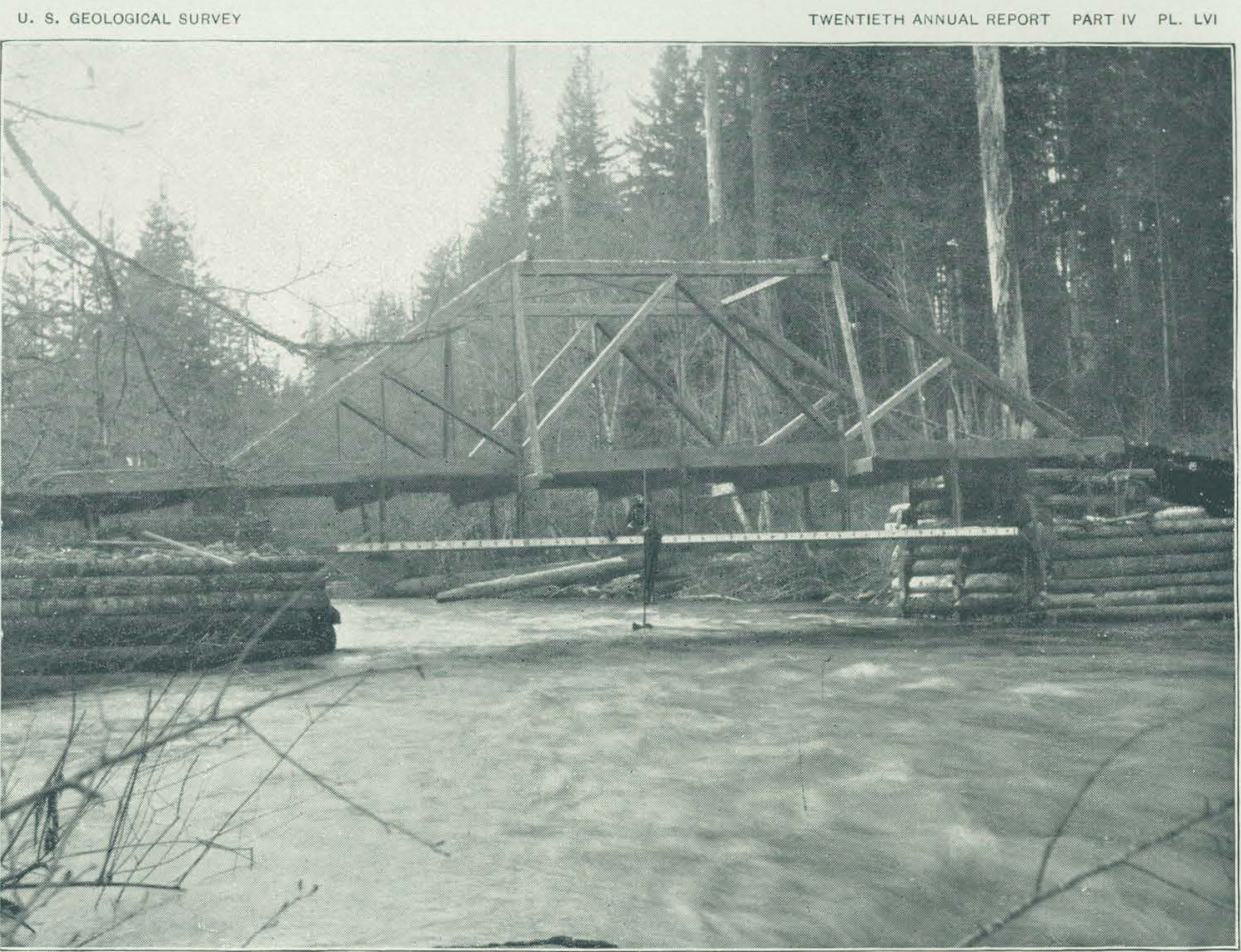

A. GAGING STATION ON CEDAR RIVER, WASHINGTON.

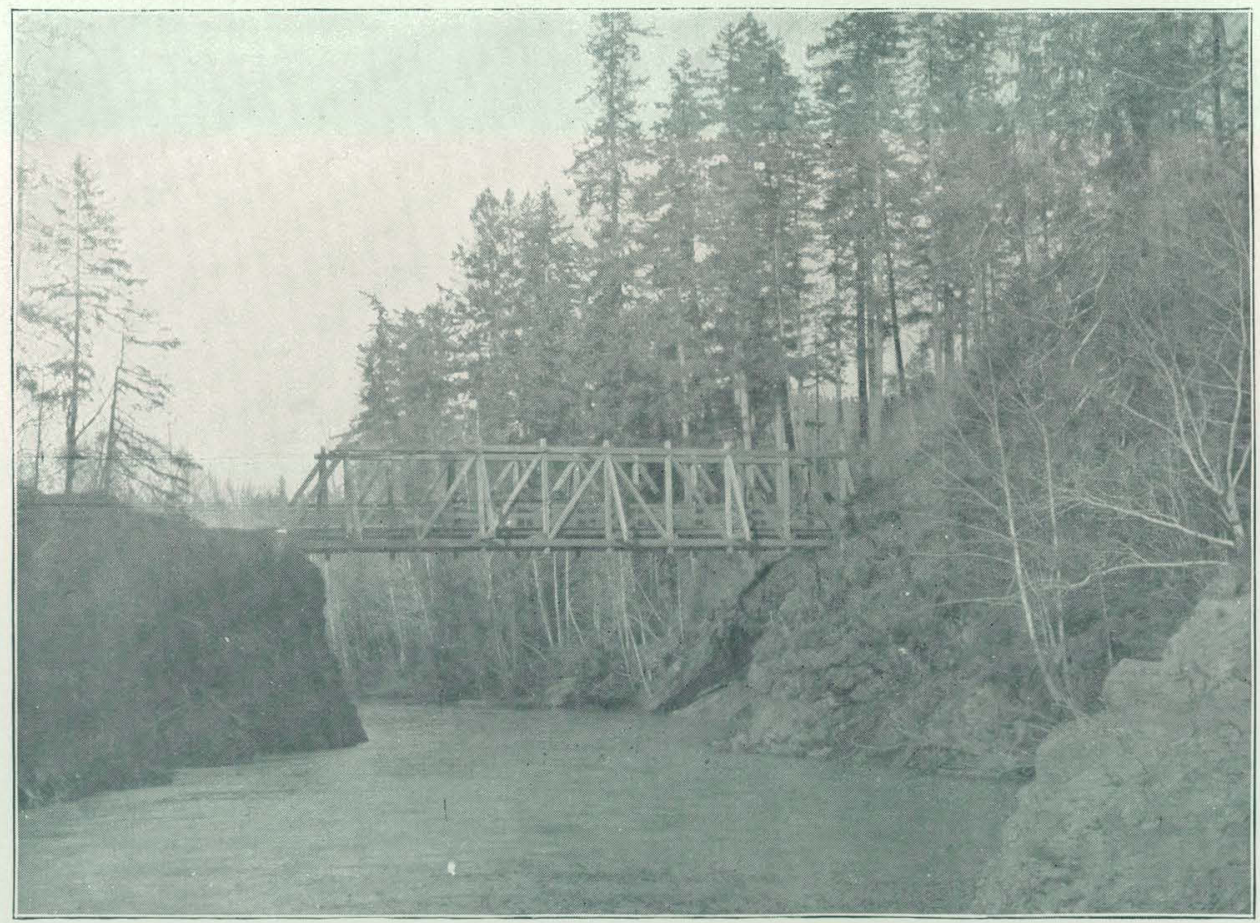

B BRIDGE ACROSS EL'WHA RIVER AT MCDONALD, WASHINGTON 
DESCHUTES RIVER.

Moro station on Deschutes River is described on page 181 of $\dot{\mathrm{W}}$ aterSupply and Irrigation Paper No. 16. A measurement was made in 1898 by Mr. Sydney Arnold. No rating table was constructed, for lack of sufficient data. Gage heights for 1898 are given in Water-Supply and Irrigation Paper No. 28, page 167.

\section{HOOD RIVER:}

Tucker station on Hood River is described on page 181 of WaterSupply and Irrigation Paper No. 16; results for 1897 are given on pages 498 to 500 of the Nineteenth Annual Report, Part IV. Gage heights for 1898 are given in Water-Supply and Irrigation Paper No. 28, page 168. A measurement was made on May 5, the discharge being 1,502 second-feet. No rating table has been constructed.

\section{NORTHERN PACIFIC COAST DRAINAGE.}

Under the heading "Northern Pacific coast drainage" are included facts obtained concerning the streams which flow into Puget Sound from the western slope of the Cascade Range, and also concerning the streams draining the Olympic Mountains and flowing northerly into the Strait of Juan de Fuca or into the Pacific Ocean.

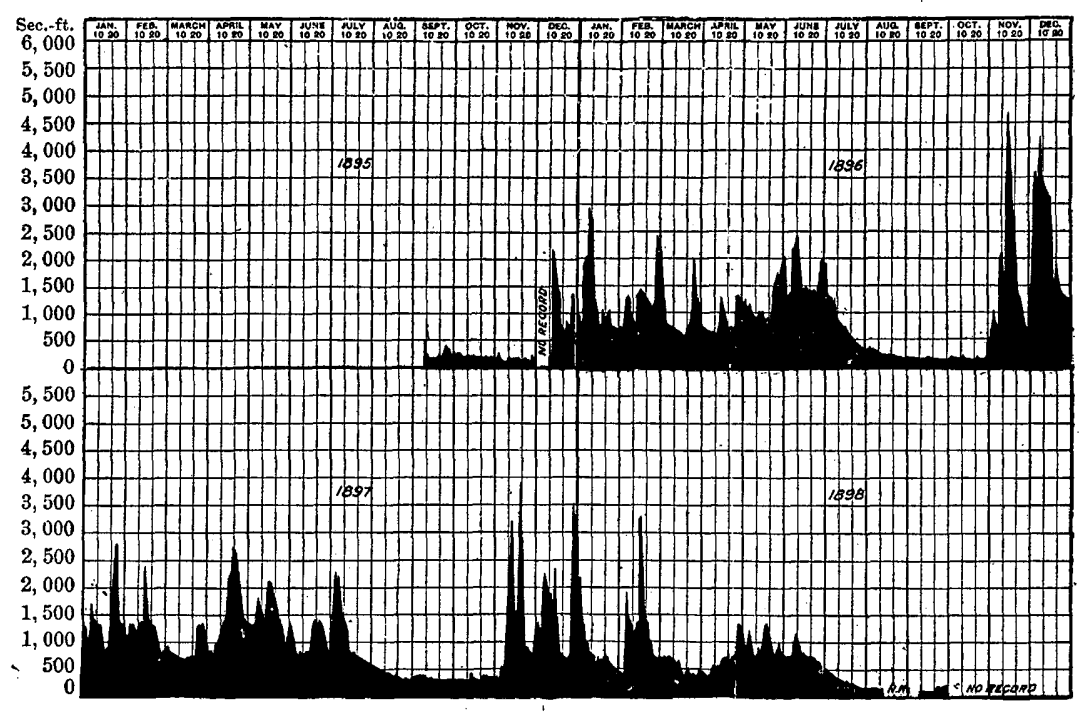

FIG. 205.-Discharge of Cedar River at Clifford's bridge, Washington, 1895-98.

\section{CEDAR RIVER.}

The measurements of Cedar River, Washington, were described in the Nineteenth Annual Report, Part IV, on page 501. Since the time of publication of this report $\mathrm{Mr}$. Theron $\mathrm{A}$. Noble has supplied addi. 
tional data, giving the discharges to August 12, 1898, and occasionally during September, after which time the station at Clifford's bridge was discontinued. These figures of daily flow are given in Water-Supply and Irrigation Paper No. 28, on pages 172 and 173 . Four discharge measurements during $189 \mathrm{~S}$ were taken at Vaughn's bridge, about 3,000 feet below the outlet of Cedar Lake and about 15 miles upstream from Clifford's bridge. The measurements were made by means of current meter. The first was on July 1, 1898, when the gage height was 992.26 and the discharge 366 second-feet. The second was on July 24, with gage height 991.69 feet and discharge 109 second-feet. The third was on September 13, with gage height 991.25 feet and discharge 46 secondfeet. This latter was the lowest made during the summer season. It was checked by means of a submerged float measurement, which gave a discharge of 50 second feet. The last measurement was on October 1 , when the height was 992.01 feet and the discharge 243 secondfeet.

The accompanying PI. LVI, $A$ shows the location of the station at : Clifford's bridge, at which the greater part of the measurements have been made. Observations of water height have also been made at the outlet of Cedar Lake for the months of July to December, 1898. The following table gives the estimated monthly discharge for 1898 up to - the time the station at Clifford's bridge was discontinued, and fig. 205 shows graphically the fluctuations from the time of beginning the observations in 1895 :

Estimated monthly discharge of Cedar River near Seattle, Washington.

\begin{tabular}{|c|c|c|c|c|c|c|}
\hline \multirow[b]{2}{*}{ Month. } & \multicolumn{3}{|c|}{ Discharge in second-feet. } & \multirow{2}{*}{$\begin{array}{l}\text { Total } \\
\text { for month in } \\
\text { acre-feet. }\end{array}$} & \multicolumn{2}{|c|}{ Run.off. } \\
\hline & $\begin{array}{l}\text { Maxi- } \\
\text { mum. }\end{array}$ & $\begin{array}{l}\text { Mini. } \\
\text { mum. }\end{array}$ & Mean. & & $\begin{array}{l}\text { Depth in } \\
\text { inches. }\end{array}$ & $\begin{array}{c}\text { Second- } \\
\text { feet perr } \\
\text { square } \\
\text { mile. }\end{array}$ \\
\hline 1898. & & & & & & t \\
\hline January ... & 2,214 & 423 & 850 & 52,265 & 6.86 & 5.94 \\
\hline February .. & 3,318 & 397 & 1,377 & 76,475 & 10.03 . & 9.63 \\
\hline March ........ & 760 & 408 & 587 & 36,093 & 4.74 & 4.10 \\
\hline April........ & 1,350 & 397 & 716 & 42,605 & 5.59 & 5.01 \\
\hline 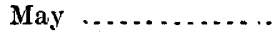 & 1,363 & 790 & 998 & 61,365 & $8.0 \vec{b}$ & 6.98 \\
\hline June......... & 1,191 & 485 & 802 & 47,722 & 6.26 & 5.61 \\
\hline Juls $\ldots \ldots \ldots \ldots$ & 510 & $16 E$ & 289 & 17,770 & 2.33 & 2.02 \\
\hline August 1-12....... & 168 & 136 & 151 & 9,285 & 1.22 & 1.06 \\
\hline September $a . \ldots . .$. & 219 & 71 & 130 & 7,736 & 1.01 & 0.91 \\
\hline
\end{tabular}

$a$ Observations made during eleven days in September, between September 9 and 29. Figures given in Water-Supply Paper No. 28, page 173. 


\section{DUNGENESS RIVER.}

This river receives its supply of water from the eastern slope of the Olympic Mountains of northwestern. Washington. It flows in a northerly direction, entering the Strait of Juan de Fuca about 20 miles east of Port Angeles. A sketch map showing the position of this river is given on fig. 179 of the Nineteenth Anuual Report, Part IV. Meas: urements of river flow are made at a bridge about 9 miles above the mouth of the river and 18 miles southeast of Port Angeles. This and the river stations on Elwha, Calowa, and Solduck rivers are in charge of William J. Ware, resident bydrographer, Port Angeles, Washington.

Estimated monthily discharge of Dungeness River at Seguin, Washington.

[Drainage area, 145 square miles.]

\begin{tabular}{|c|c|c|c|c|c|c|}
\hline \multirow[b]{2}{*}{ Month. } & \multicolumn{3}{|c|}{ Discharge in second-feet. } & \multirow[b]{2}{*}{$\begin{array}{c}\text { Total in acre } \\
\text { feet. }\end{array}$} & \multicolumn{2}{|c|}{ Run-off. } \\
\hline & $\begin{array}{l}\text { Maxi- } \\
\text { mum. }\end{array}$ & $\begin{array}{l}\text { Mini- } \\
\text { num. }\end{array}$ & Mean. & & $\begin{array}{l}\text { Depth in } \\
\text { inches. }\end{array}$ & $\begin{array}{c}\text { Second. } \\
\text { feet per } \\
\text { square } \\
\text { mile. }\end{array}$ \\
\hline 1897. & & & & & · & \\
\hline July $5-31 \ldots \ldots \ldots$ & 669 & 323 & 474 & 29,145 & 3.77 & 3.27 \\
\hline August.... & 438 & 218 & 321 & 19,738 & 2.55 & 2.21 \\
\hline September ......... & 234 & 167 & 181 & 10,770 & 1.39 & 1.25 \\
\hline October.......... & 553 & 138 & 182 & 11,191 & 1.45 & ' 1.26 \\
\hline November.. & 2,954 & 157 & 636 & 37,845 & 4.90 & 4. 39 \\
\hline December .. & 2,875 & 85 & 702 & 43,165 & 5.58 & 4.84 \\
\hline 1898 & & & & & & 1 \\
\hline January $\therefore$ & 273 & 234 & 248 & 15,249 & 1.97 & 1.71 \\
\hline February $\ldots . .$. & 652 & 234 & 342 & 18,994 & 2.46 & 2. 36 \\
\hline -March.... & 288 & 227 & 248 & 15,249 & 1.97 & 1.71 \\
\hline April..... . & $\$ 06$ & 234 & 264 & 15,709 & 2.03 & ${ }^{\star 1} .82$ \\
\hline 'May ....... & 757 & 299 & 443 & 27,239 & 3.53 & 3.06 \\
\hline June $: . .$. & 1,177 & 310 & 550 & 32,727 & 4.23 & 3.79 \\
\hline July $\ldots \ldots \ldots \ldots$ & 546 & 310 & 378 & 23,242 & 3.01 & 2.61 \\
\hline August ............. & 365 & 170 & 239 & 14,696 & 1.90 & 1. 65 \\
\hline September ......... & 383 & 156 & 170 & 10,116 & 1. 31 & 1.17 \\
\hline October .... & 610 & 152 & 185 & 11,375 & 1. 48 & 1.28 \\
\hline November... & 159 & 153 & 155 & 9,223 & 1. 19 & 1.07 \\
\hline December .... & 785 & 150 & 208 & 12,790 & 1.65 & 1. 43. \\
\hline The year. & 1,177 & 150 & 286 & 206,609 & 26. 73 & 1.97 \\
\hline
\end{tabular}

Note.-Gage heights for 1898 are given in Water-Supply and Irrigation Paper No. 28, page 174, measurements, page 176, rating table, page 176; results for 1897 in Water-Supply and Irrigation Paper No. 16, page 182, and in the Nineteenth Annual Report, Part IV, page 503. 


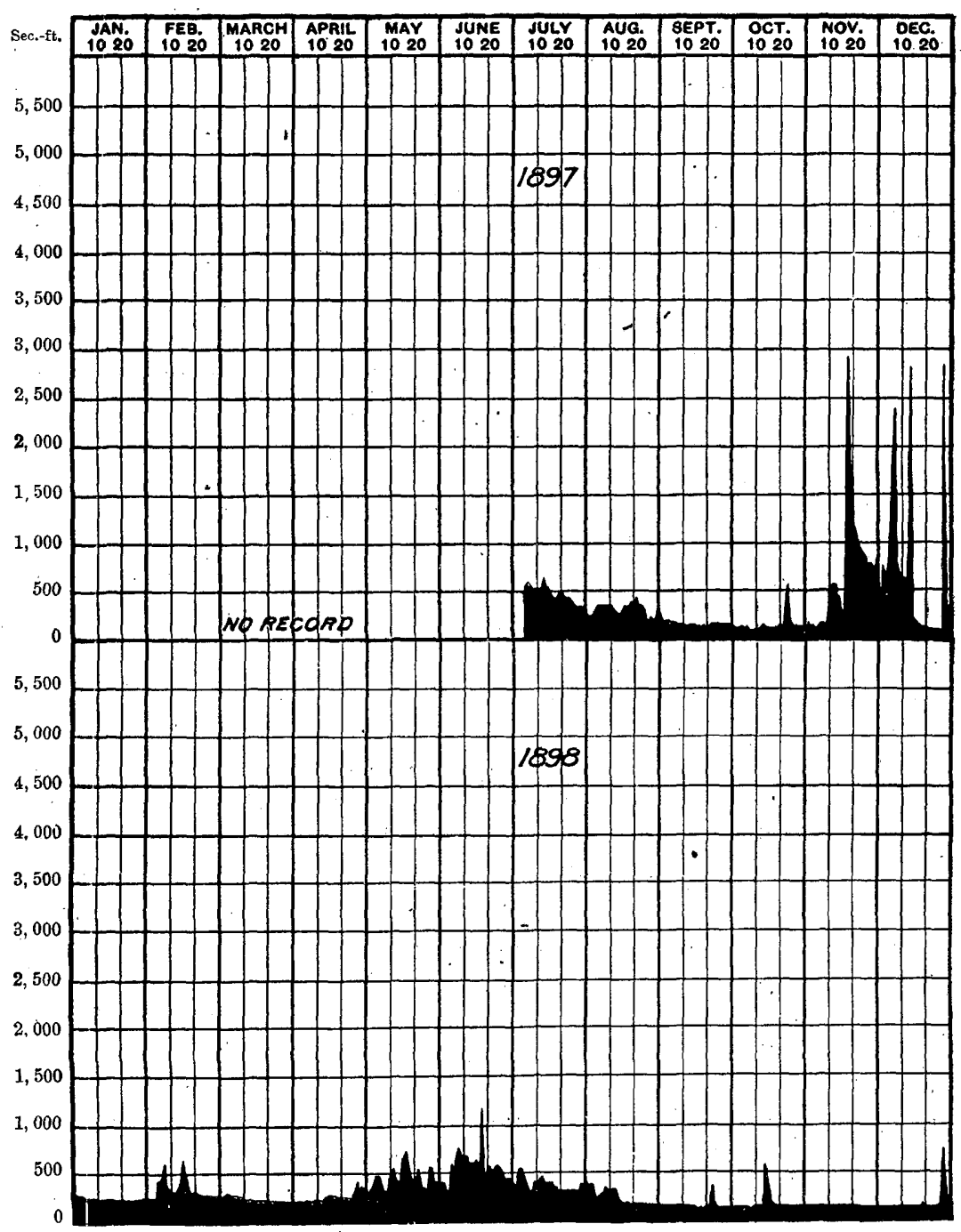

Fra. 206.-Discharge of Dungeness River at Seguin, W ashington, 1897-98.

ELWHA RIVER.

Elwha River rises in the Olympic Mountains and flows northerly, emptying into the Strait of Juan de Fuca about 5 miles westerly of the city of Port Angeles. A general description of the stream is given in the Nineteenth Annual Report, Part IV, on page 505. As there stated, there appears to be an excellent opportunity for the development of water power, particularly by the construction of a dam at a narrow point of the river known as Aldwells Canyon. An examination has been made of the dam site, but a detailed survey has not been had of the area which may be flooded. An estimate of the cost of installing a power 
plant at this point, in sec. 15 , T. 30 N., R. 7 W., of the Willamette meridian, has been made by Mr. Theron A. Noble, in which he shows that with a dam 30 feet high 1,000 horsepower can be made available at a cost of $\$ 47,000$, and with a dam 130 feet high 10,000 horsepower at a cost of about $\$ 250,000$. He estimates that with a dam of the latter height a reservoir can be created of sufficient capacity to increase the flow of the river to about 950 second-feet, this being the most economical height for a masonry structure. It would be possible to build a masonry dam 200 feet high across the canyon, giving a much greater supply of water from storage and about double the head. It is believed that at least 25,000 horsepower can be obtained by building this high dam at the canyon and controlling works at the outlet of Lake Sutherland, which discharges through Indian Creek into Elwha River below the point of measurement and above Aldwells Canyon.

The point where it is proposed to build the masonry dam is about 30 feet wide on the bottom and from 40 to 50 feet wide at the water level, being not more than 70 feet wide at the top. A view showing the eharacter of the canyon is given on Pl. XLVIIT of the Nineteenth Annual Report, Part IV. Above the canyon the hill slopes are very steep, being at an angle of from $30^{\circ}$ to $45^{\circ}$. The rock is compact and is considered as furnishing a satisfactory foundation for a masonry dam. As the natural walls are nearly perpendicular it is proposed to build the masonry dam in the form of an arch, with the convex side upstream. A measurement of the river at this point, made October 25, 1898, and including the flow of Little River and Indian Creek, showed a discharge of 586 second-feet. This has been taken as representing about the lowest stage of the river. A supplemental dam at Lake Sutherland could be easily constructed, as its outlet is through a narrow gorge with precipitous sides. A dam which would raise the waters of the lake 30 feet could be built at a probable cost of not more than $\$ 25,000$.

The point of measurement of Elwha River is at the bridge at McDonald, as shown in Pl. LVI, $B$, this being selected as the most suitable locality. It is, as before stated, above the outlet of Lake Sutherland, and also above Little River, so that, to obtain the total flow, allowance should be made for the discharge of these streams. Gagings at this point were begun on October 8, 1897, by Mr. A. Judson Adams, civil engineer, Port Angeles, and have been coutinued by Mr. William J. Ware, his successor as resideut hydrographer. 
Estimated monthly discharge of Elwha River at McDonald, Washington.

[Drainage area, 188 square miles.]

\begin{tabular}{|c|c|c|c|c|c|c|}
\hline \multirow[b]{2}{*}{ Month. } & \multicolumn{3}{|c|}{ Discharge in second-feet. } & \multirow[b]{2}{*}{$\begin{array}{c}\text { Total in acre- } \\
\text { fęet. }\end{array}$} & \multicolumn{2}{|c|}{ Run.off. } \\
\hline & $\begin{array}{l}\text { Maxi- } \\
\text { mum. }\end{array}$ & $\begin{array}{l}\text { Mini- } \\
\text { mum. }\end{array}$ & Mean. & & $\begin{array}{l}\text { Depth in } \\
\text {-inches. }\end{array}$ & $\begin{array}{c}\text { Second- } \\
\text { feet per } \\
\text { square } \\
\text { mile. }\end{array}$ \\
\hline 1897. & & & & & & \\
\hline October $8-31 \ldots \ldots$ & 1,712 & 170 & 495 & 30,436 & 3.03 & $2: 63$ \\
\hline November ........... & 7,075 & 310 & 1,513 & 90,030 & 8.98 & 8.05 \\
\hline December .......... & 4,807 & $5 ? 0$ & 2,288 & 140,684 & 13.58 & 12.17 \\
\hline 1898. & & & & & & \\
\hline January ....... & 3,087 & 855 & 1,570 & $96, \overline{5} 36$ & 9.63 & 8.35 \\
\hline February ..... & 3,255 & 967 & 2,157 & 119,794 & 11.95 & 11.48 \\
\hline March & 1,862 & 687 & 1,249 & 76,799 & 7.65 & 6.64 \\
\hline April .... & 2,147 & 687 & 1,227 & 73,011 & 7.29 & 6.53 \\
\hline May .... & 2,535 & 1,243 & 2,007 & 123,406 & 12.30 & 10.68 \\
\hline June .............. & 3,282 & 1,637 & 2,232 & 132,813 & 13.24 & 11.87 \\
\hline July ........ & 2,383 & 1,431 & 1,813 & 111,478 & 11.11 & 9.64 \\
\hline August ..... & 1,600 & 631 & 1,200 & 73,786 & $7.35^{\circ}$ & 6.38 \\
\hline September ......... & 2,113 & 470 & 695 & 41,355 & 4. 13 & 3.70 \\
\hline October ............ & 2,917 & 330 & 889 & 54,663 & 5.45 & 4.73 \\
\hline November... & 1,562 & 687 & 1,066 & 63,431 & 6.32 & 5.67 \\
\hline December... & 3,310 & 520 & 1,218 & 74,892 & 7.47 & 6.48 \\
\hline The year ..... & 3,310 & 330 & 1,444 & $1,041,964$ & 103.89 & 7.68 \\
\hline
\end{tabular}

Note.-Gage heights for 1898 are given in Water-Supply and Irrigation Paper No. 28, page 174; measurements, page 176; rating table, page 176; results for 1897 in Water-Supply and Irrigation Paper No. 16, page 183, and in the Nineteenth Annual Report, Part IV, page 505.

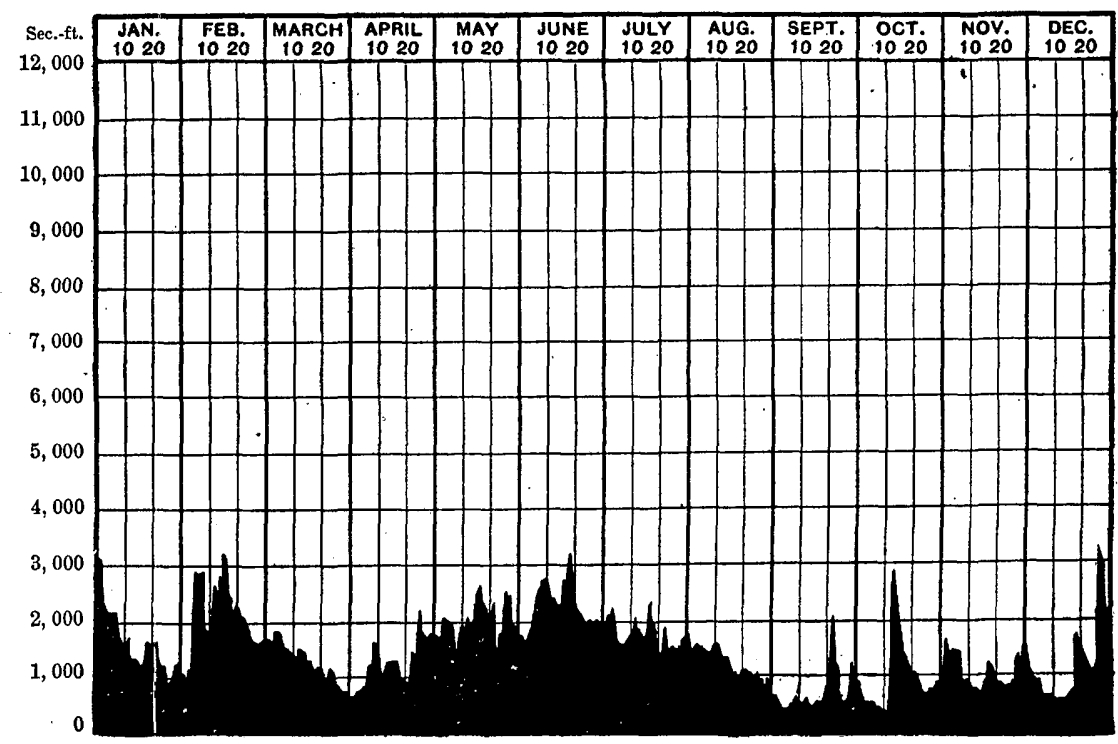

FIG. 207.-Discharge of Elwha River at McDonald, Washington, 1898. 
CALOWA RIVER.

Estimated monthly discharge of Calowa River at Forks, Washington.

[Drainage area, 213 square miles.]

\begin{tabular}{|c|c|c|c|c|c|c|}
\hline \multirow[b]{2}{*}{ Month. } & \multicolumn{3}{|c|}{ Dicharge in second-feet. } & \multirow[b]{2}{*}{$\begin{array}{c}\text { Total in acre- } \\
\text { feet. }\end{array}$} & \multicolumn{2}{|c|}{ Run-off. } \\
\hline & $\begin{array}{l}\text { Maxi- } \\
\text { mum. }\end{array}$ & $\begin{array}{l}\text { Mini- } \\
\text { mum. }\end{array}$ & Mean. & & $\begin{array}{l}\text { Depth in } \\
\text { inches. }\end{array}$ & $\begin{array}{c}\text { Second- } \\
\text { feet per } \\
\text { square } \\
\text { mile. }\end{array}$ \\
\hline - $\quad 1897$. & & & & & & \\
\hline November $12-30$ & $19,04.0$ & 797 & 2,428 & 144,476 & 12.27 & 11. 4 \\
\hline December ....... & 10,200 & 873 & 3,686 & 226,643 & 19.95 & 17.3 \\
\hline 1898. & & & & & & \\
\hline January.... & 3,400 & 689 & 1,227 & 75,446 & 6.65 & 5.77 \\
\hline February . . . . . . . & 8,976 & 797 & 2,940 & 163,278 & 14.37 & 13.80 \\
\hline 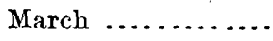 & 1,627 & 474 & 765 & 47,038 & 4.14 & 3.59 \\
\hline April .................. & 3,053 & 301 & 824 & 49,031 & 4. 32 & 3.87 \\
\hline 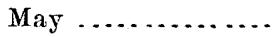 & 621 & 270 & 449 & 27,608 & 2.43 & 2.11 \\
\hline June............. & ], 441 & 270 & 524 & 31,180 & 2.74 & 2.46 \\
\hline July ............ & 892 & 155 & 323 & 19,861 & 1. 75 & 1.52 \\
\hline August $1-13,26-31 \ldots$ & 706 & 105 & 239 & 14,696 & 1. 29 & 1. 12 \\
\hline September ......... & 1,254 & 40 & 329 & 19,577 & 1. 72 & 1.54 \\
\hline Oetober ...... & 3,808 & 379 & 807 & 49,621 & 4.37 & 3.79 \\
\hline November . . . . . . . . & 3,808 & 604 & 1,464 & 87,114 & 7.66 & 6.87 \\
\hline December ......... & 8,432 & 604 & 2,181 & 134,105 & 11.81 & 10.24 \\
\hline The sear.... & 8,976 & 40 & $\begin{array}{c}1,006 \\
.\end{array}$ & 718,555 & 63.25 & 4.72 \\
\hline
\end{tabular}

Note.-Gage heights for 1898 are given in Water-Supply and Irrigation Paper No. 28, page 175; measurements, page 176; rating table, page 176 ; results for 1897 in Water-Supply and Irrigation Paper ৯̀o. 16, page 184.

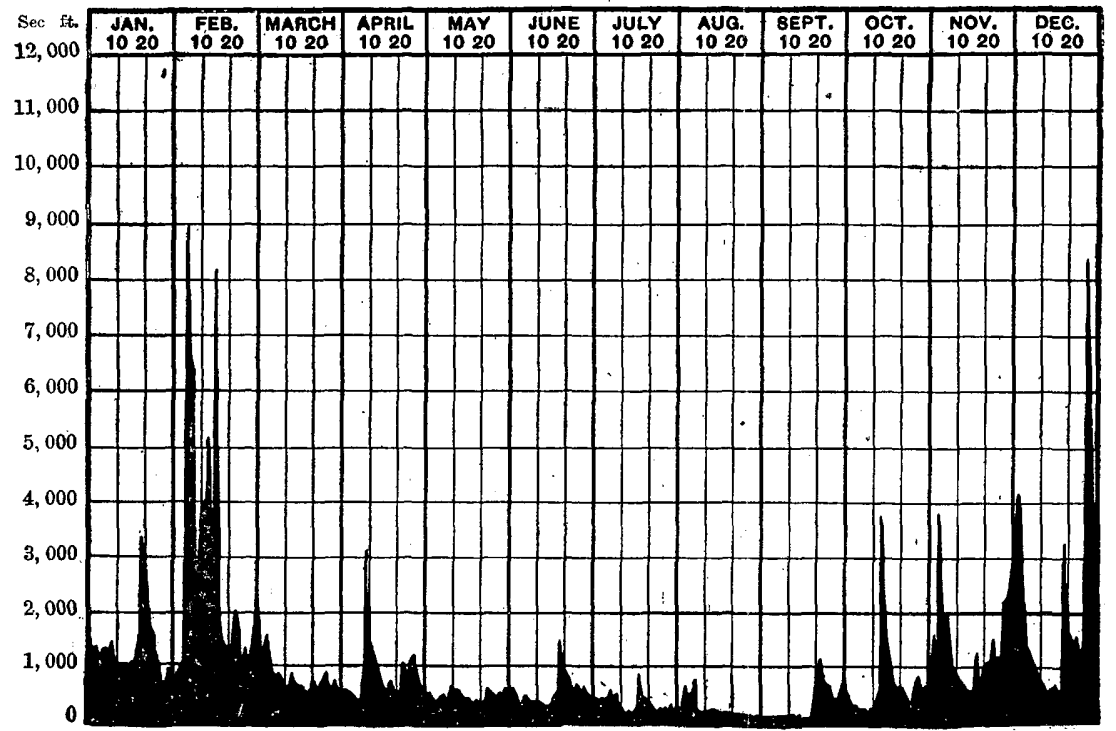

FIG. 208.-Discharge of Calowa River at Forks, Washington, 1898. 


\section{SOLDUCK RIVER.}

Estimated monthly discharge of Solduck River at Quillayute, Washington.

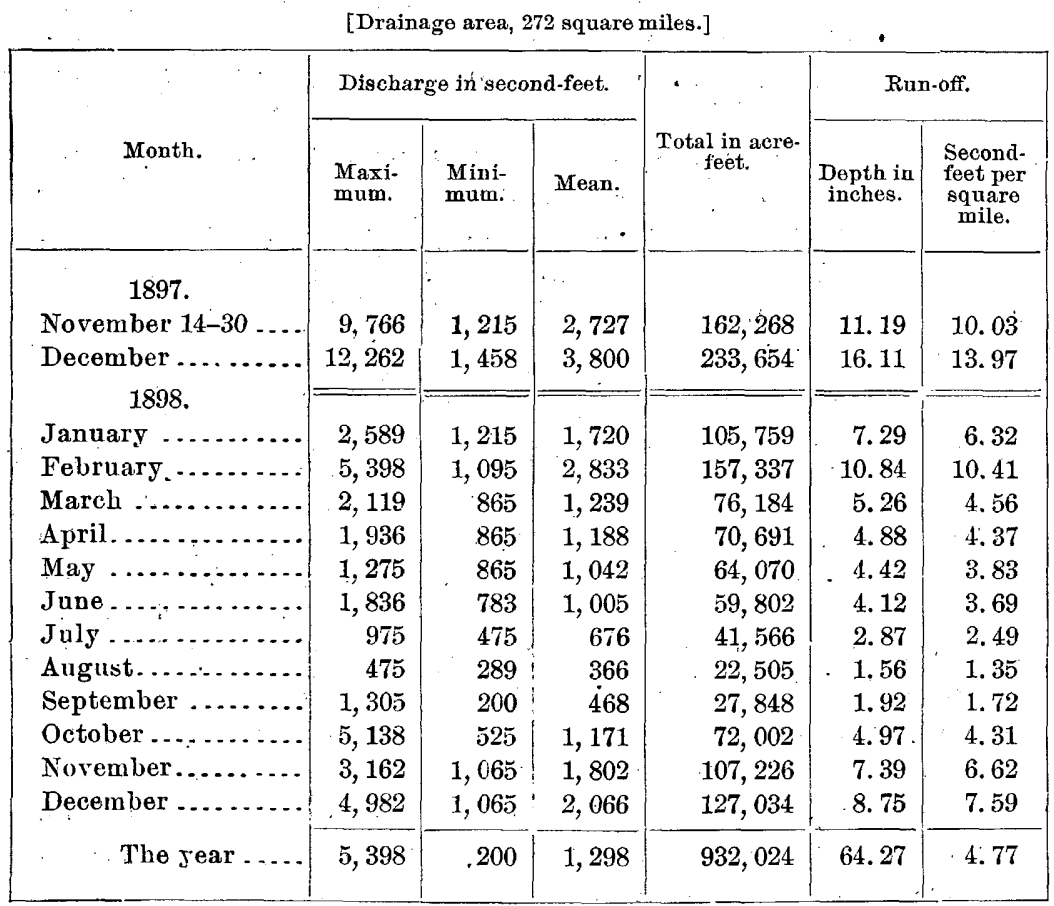

Note.-Gage heights for 1898 are given in, Water-Supply and Irrigation Paper No. 28, page 175 measurements, page 176; rating table, page 176; results for 1897 in Water-Supply and Irrigation Paper No. 16, page 184.

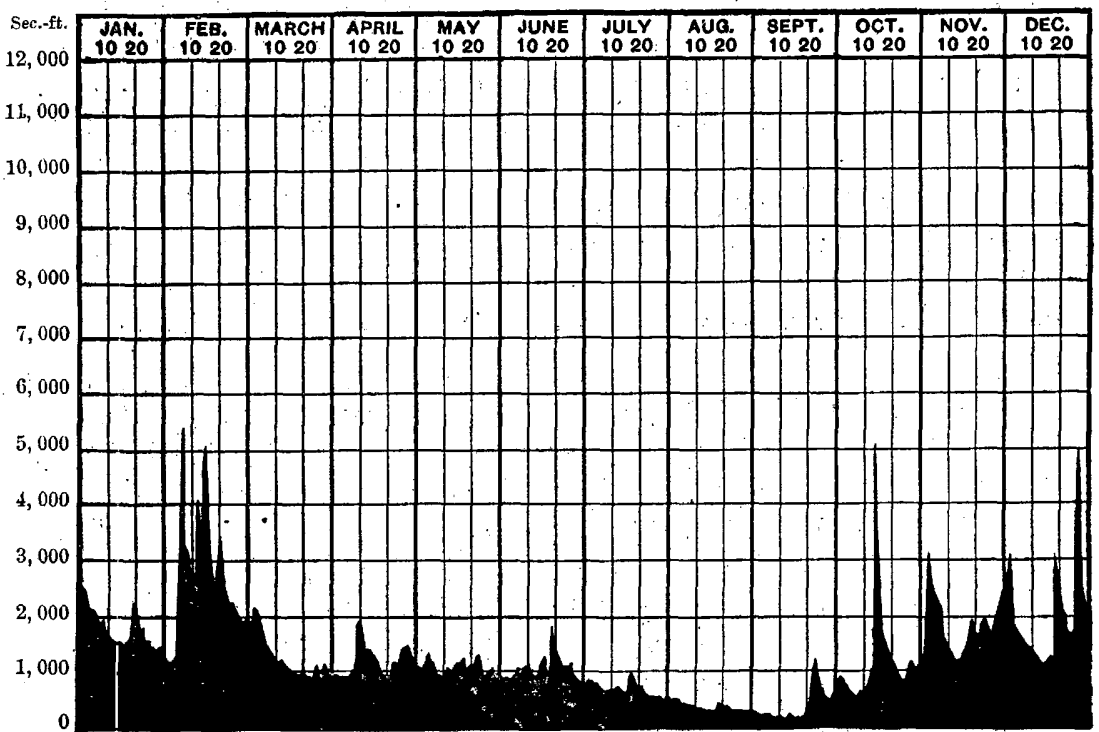

FIG. 209.--Jischarge of Solduck River at Quillayute, Washington, 1898. 


\section{SAN FRANCISCO BAY DRAINAGE،}

Statements concerning the water supply of the central valley of California are included under this heading from the fact that the Sacramento, flowing from the north and San Joaquin from the south, unite in their discharge into San Francisco Bay. All of the work in this area, as well as that in southern California, has been done under the direction of Mr. J. B. Lippincott, of Los Angeles. From his reports the following information has been obtained. All of the river stations described in previous publications have been maintained during the year 1898, but the station at Kingsburg, on Kings River, was abandoned at the end of the year.

$$
\text { LOW WATER OF } 1898 .
$$

During the year 1898 the available water supply diminished to a degree wholly unprecedented in the history of the State. On the Pacific coast there is a distinct wet and dry season, varying in duration with the latitude, the wet season being longest in the northwestern part of the State aud shortest at San Diego, near the Mexican line. The rains usually begin about the 1 st of October and extend to the month of April. In the valley portions of the State there is practically no precipitation during the summer months, but in the high Sierras, in the north and central section, there are frequent thunderstorms in the afternoon. In the coast range of southern California these storms are less frequent and of such violence when occurring that their effect upon the streams is usually of a very transitory nature. The high-water period of the main streams of. the Sacramento and San Joaquin valleys, whose drainage basins extend to the crest of the Sierras, occurs between the middle of April and the 1st of July. This is the period of melting snow in the higher catchment basius of the rivers which have their source at altitudes of from 10,000 to 15,000 feet, where the precipitation is the heaviest. In the months of February and March, when the snow line has encroached on the lower levels of the foothills, warm rains occasionally occur, melting the snow and causing the maximum floods on the streams receiving water from these lower altitudes. The period of low water extends from July, culminating in September, and reaching its limit in the months of October and November.

In the southern end of the State, where warmer: temperatures are the consequence of lower latitude, the mountain winter storms bring less snow and more rain. The snow which is deposited is usually melted early. The high waters in this group of streams prevail in the winter season, the greatest flow probably occurring in the months of January and February. The sudden floods in the streams which issue from the mountain canyons are of a torrential nature, and the high stage is apt to last from three to four days, after which the stream again recedes and a much lower condition of flood takes place. These floods are very 
difficult to measure or record. Driftwood is swept down in great quantities, and the high velocity, often exceeding 10 feet per second, quickly alters the chanuel of the stream. Earth and bowlders are brought down in a most surprising manner and deltas are built rapidly at the mouths of the canyons.

From the above description it will be seen that the seasonal rainfall extends from the latter part of one calendar year to the beginning of the next. The rainfall records covering this period are of the greatest importance in connection with the study of stream flow, since the waters discharged in the spring, summer, and fall are the result of the precipitation which occurs during winter months. It has been determined that the rainfall increases on the coast side of the mountain ranges of California in proportion to the increase in elevation. Observations made near the foot of the mountains may be considered as furnishing a basis to which additions should be made for higher elevations.

On examining the tables of precipitation prepared by seasons, it will be noted that, as above stated, there has been an unusual period of drought duriug the past nine years, this condition being accentuated in the southern end of the State since the season of 1890-91. In Sacramento there have been during this period three seasons when the rainfall exceeded the mean and six when it fell below the mean. At Fresno there have been two seasons of excessive rainfall, two of deficient, and one of mean. At Los Angeles there have been one season of excessive rainfall, one of average rainfall, and seven of deficient. This is the minimum record for the above section, and the season of 1897-98 is preceded by three years of lower record. It will be seen from this that the State of California, particularly its southern section, has been passing through a cycle of the driest years ever reported by rainfall observers in this State, possible exceptions being between 1854-55, also 1858-59, recorded for Sacramento alone. The scarcity of water has been such that only about one-half to one-fourth the usual quantity has been delivered, although full charges have usually been made. It is stated that the situation developed lawlessness and armed interference on Kings River, head gates being blown out by rival canal companies claiming the small amount of water available, and gates opened or closed without regard to acquired rights.

The diminution of river flow resulting from the deficient precipitation can be noted in the records of the following river stations for the six streams measured in the Sacramento and San Joaquin valleys. A number of additional óbservations were made throughout the State during several months, particularly in August and September, when the streams were practically at their lowest stages. The results of these low-water measurements are given in the following table (p. 526), the streams being arranged in geueral geographic order from north to south. 


\section{PROGRESS OF STREAM MEASUREMENTS FOR 1898.}

Low-water measurements in Sacramento and San Joaquin valleys.

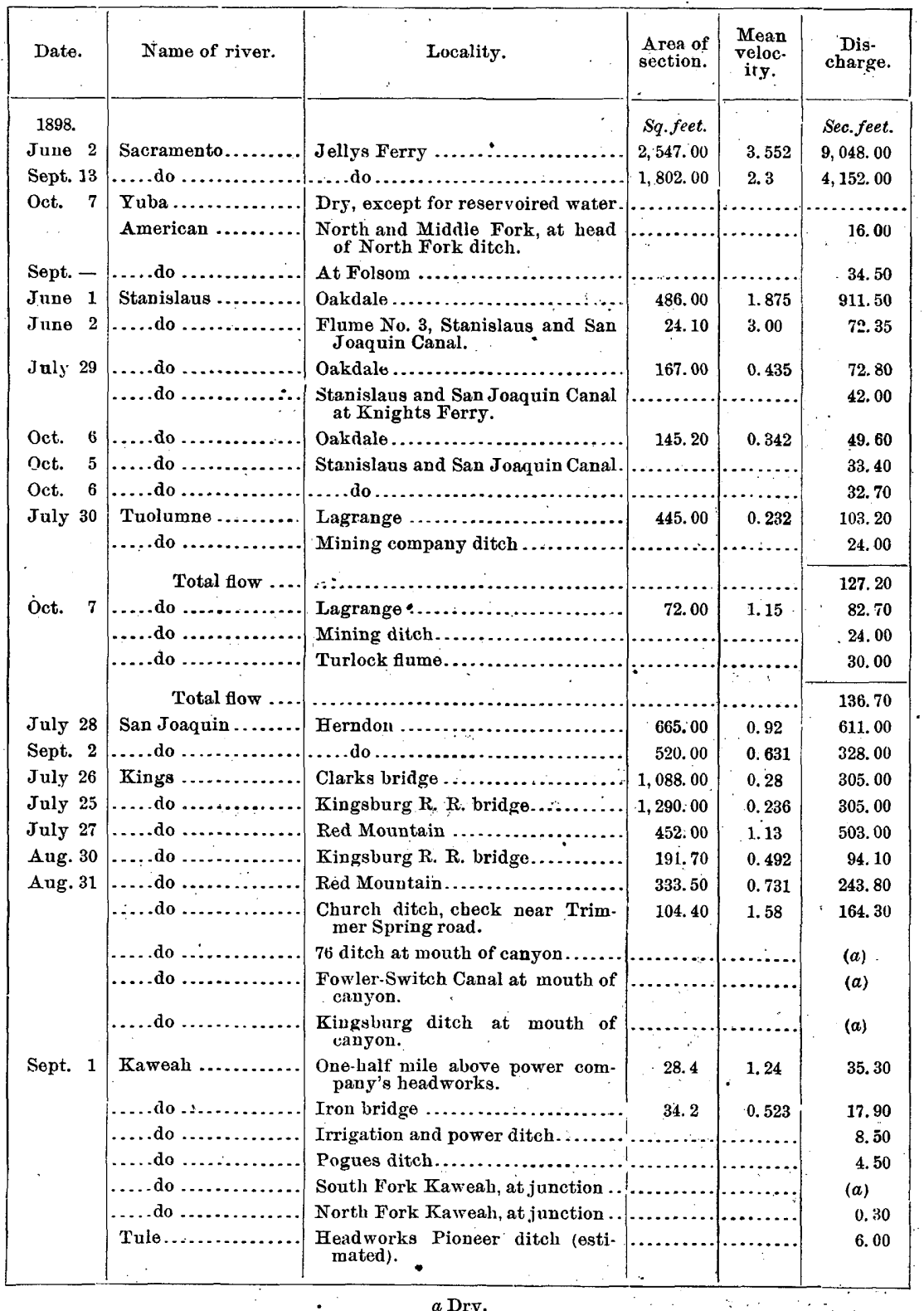

$a$ Dry. 
SACRAMENTO RIVER.

Estimated monthly discharge of Sacramento River at Jellys Ferry, California.

[Drainage are $4,9,134$ square miles.]

\begin{tabular}{|c|c|c|c|c|c|c|}
\hline \multirow[b]{2}{*}{ Month. } & \multicolumn{3}{|c|}{ Discharge in second-feet. } & \multirow[b]{2}{*}{$\begin{array}{l}\text { Total in acre- } \\
\text { feet. }\end{array}$} & \multicolumn{2}{|c|}{ Run-off. } \\
\hline & $\begin{array}{l}\text { Maxi- } \\
\text { mum. }\end{array}$ & $\begin{array}{l}\text { Mini- } \\
\text { mum. }\end{array}$ & Mean. & & $\begin{array}{l}\text { Depth in } \\
\text { inches. }\end{array}$ & $\begin{array}{c}\text { Second- } \\
\text { feet per } \\
\text { square } \\
\text { mile. }\end{array}$ \\
\hline 1898. & & & - & & & \\
\hline January $\ldots \ldots \ldots$ & 6,525 & 5,835 & 6,120 & 376,307 & 0.77 & 0.67 \\
\hline February $\ldots . .$. & 33,600 & 5,835 & 12,479 & 693,049 & 1.43 & 1.37 \\
\hline March .............. & 22,500 & 6,525 & 9,745 & 599,201 & 1.23 & 1.07 \\
\hline April ...... & 7,260 & 6,525 & 6,872 & 408,911 & 0.83 & 0.75 \\
\hline May .... & 10,800 & 5,375 & 6,632 & 407,789 & 0.84 & 0.73 \\
\hline June............... & 10,500 & 5,150 & 6,674 & 397,130 & 0.81 & 0.73 \\
\hline July ...... & 5,150 & 4,475 & 4,700 & 288,994 & 0.60 & 0.52 \\
\hline August.... & 4,475 & 4,250 & 4,276 & 262,923 & 0.54 & 0.47 \\
\hline September ......... & 4,475 & 4,250 & 4,280 & 254,677 & 0.53 & 0.47 \\
\hline October.. & 4,925 & 4,475 & 4,631 & 284,751 & 0.59 & 0.51 \\
\hline Novernber ...... & 6,892 & 4,475 & 4,785 & 284,727 & 0.58 & 0.52 \\
\hline December .......... & 5,950 & 4,700 & 4,991 & 306,887 & 0.63 & 0.55 \\
\hline The year . & 33,600 & 4,250 & 6,349 & $4,565,346$ & 9.38 & 0.70 \\
\hline
\end{tabular}

NoTE.-Gage heights for 1898 are given in Water-Supply and Irrigation Paper No. 28, page 182, measurements, page 185; rating table, 186; results for 1897 in Water-Supply and Irrigation Paper No. 16. page 185, and in the Nineteenth Annual Report, Part IV, page 509.

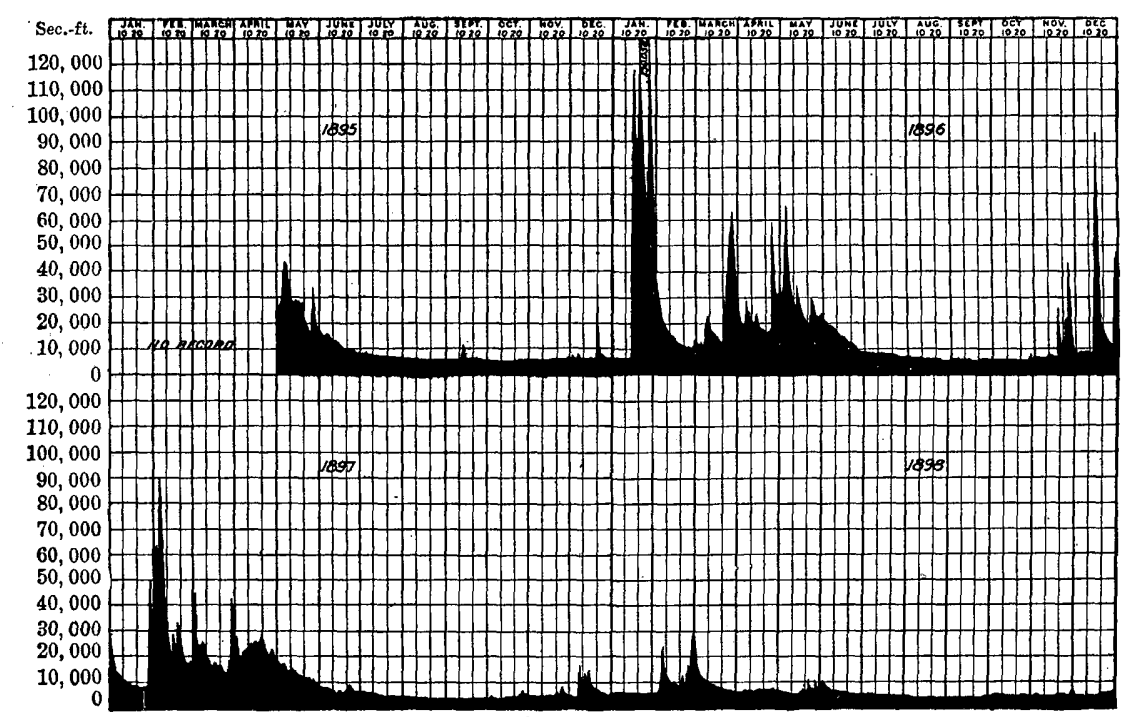

Fig. 210.-Discharge of Sacramento River at Jellys Ferry, California, 1895-1898. 


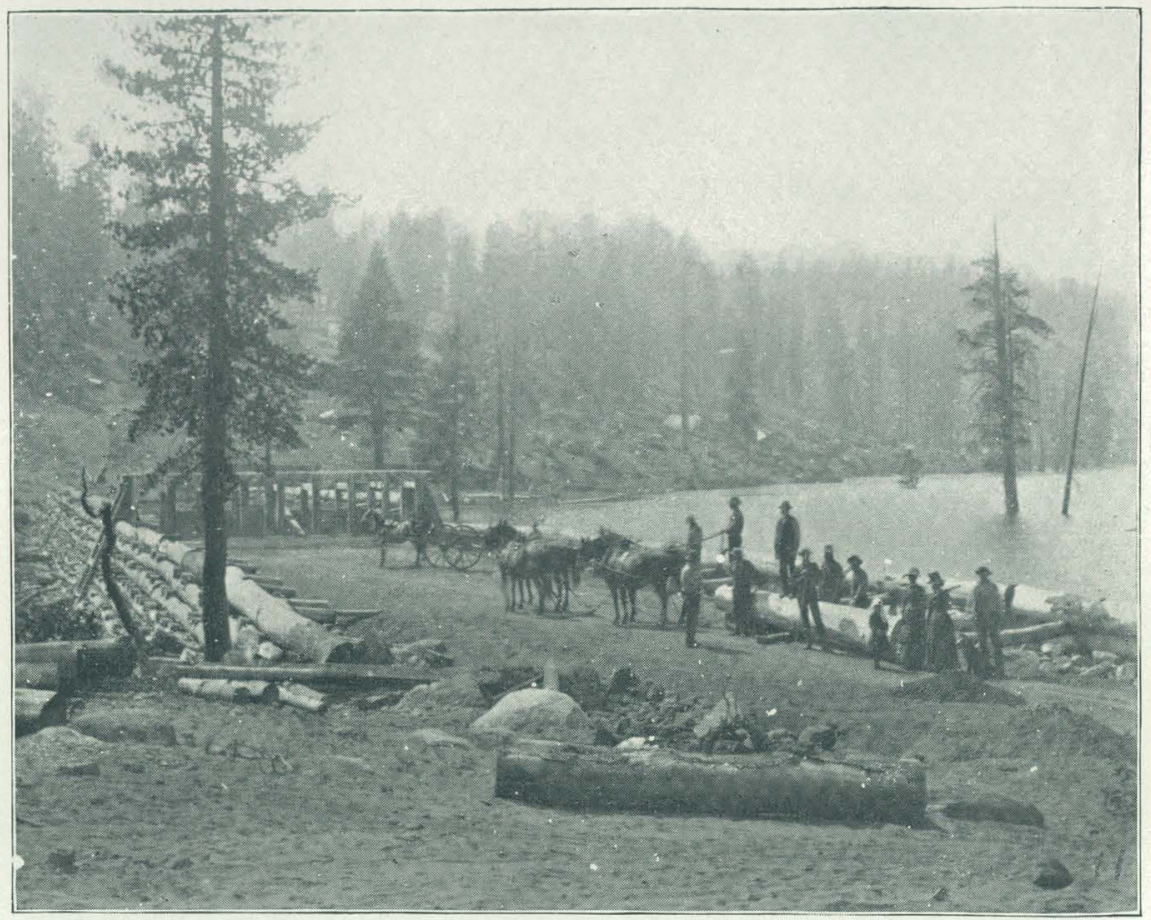

A. BLUE LAKE DAM.

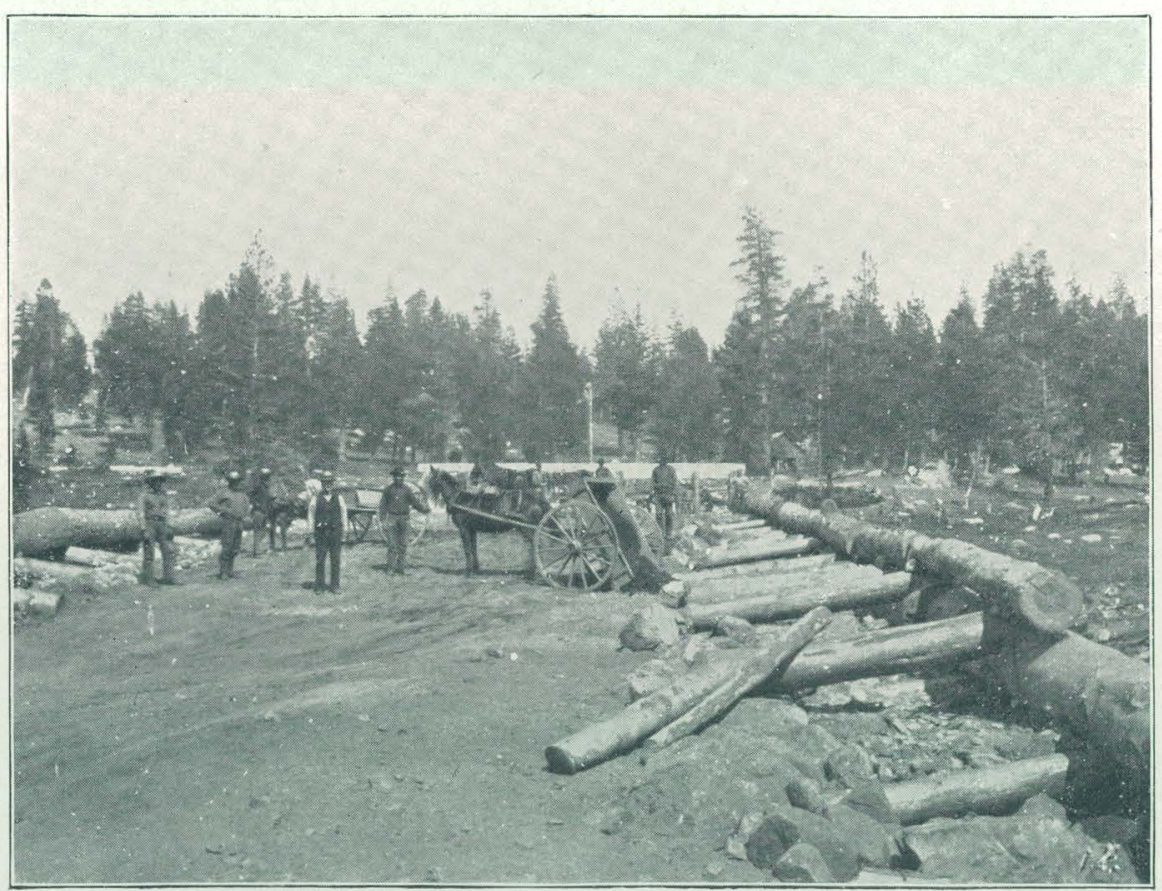

B. METHOD OF CONSTRUCTION OF BLUE LAKE DAM. 
A considerable number of storage works have been built on various tributaries of Sacramento liiver, these being constructed primarily for hydraulic mining and to a less extent for supplying water for irrigation. A typical dam of this character is shown in Pl. LVII. This is at the mouth of South Blue Lake, Alpine County, California, the location being shown on the Markleeville topographic atlas sheet. On the same plate at $B$ is shown the method of construction of this dam, it being one of the reservoirs of the Amador Canal Company. These early $\log$ and crib dams have been to a considerable extent replaced by better structures, but the illustrations are given to exhibit the character of the preliminary work.

\section{CLEAR LAKE.}

A description of Clear Lake, California, is given in the Thirteenth Annual Report, Part III, on pages 405 to 409 , together with a detailed map of the shores and of the depth of water. It is stated that a copy was secured of the record of the rise and fall of the waters of Clear Lake kept from 1873 to 1890 , inclusive, under the direction of Capt. R. S. Floyd, of Kono Tayee Point, and that the levels of the Survey were connected with the zero plane of this gage. Records given below have been printed by Mr. Charles Mifflin Hammond, United States voluntary observer at Ma Tel Vineyard, Upper Lake. In order to bring these figures into accord with those of Captain Floyd, it is necessary to make a correction for difference of datum.

High and low water of Clear Lale.

\begin{tabular}{|r|r|r|r|r|r|r|r|}
\hline \multicolumn{1}{|c|}{ Vear. } & \multicolumn{3}{|c|}{ High water. } \\
\hline
\end{tabular}




\section{SAN JOAQUIN RIVER.}

The head waters of San Joaquin River receive the drainage from the crest of the Sierra Nevada in the vicinity of Mount Whitney and north of this. The fall of the stream is rapid, making possible the development of power, and numerous basins suitable for water storage are reported to exist. A power plant has already been constructed on the North Fork of this river, from which the cities of Fresno and Hanford are lighted and by which power is supplied for general commercial purposes. At one time water was diverted from this stream to irrigate land north of Fresno, the dam being located near Pollasky. This washed out, and since that time no water has been used for irrigation except on the lower portion of the stream. It is believed that the deficiency of water in the district surrounding Fresno can be supplied from San Joaquin River with its ample storage facilities, which are in contrast to the relatively limited opportunities of development on Kings River.

Estimated monthly discharge of San Joaquin River at Herndon, California.

[Drainage area, 1,637 square miles.]

\begin{tabular}{|c|c|c|c|c|c|c|}
\hline \multirow[b]{2}{*}{ Month. } & \multicolumn{3}{|c|}{ Discharge in second-feet. } & \multirow[b]{2}{*}{$\begin{array}{c}\text { Total in acre- } \\
\text { feet. }\end{array}$} & \multicolumn{2}{|c|}{ Run-off. } \\
\hline & $\begin{array}{l}\text { Maxi. } \\
\text { mum. }\end{array}$ & $\begin{array}{l}\text { Mini. } \\
\text { mum. }\end{array}$ & Mean. & & $\begin{array}{l}\text { Depth in } \\
\text { inches. }\end{array}$ & $\begin{array}{c}\text { Second- } \\
\text { feet per } \\
\text { square } \\
\text { mile. }\end{array}$ \\
\hline 1898. & & & & & & \\
\hline January .............. & 763 & 530 & 658 & 40,459 & 0.46 & 0.40 \\
\hline February ......... & 1,425 & 530 & 842 & 46,762 & 0.54 & 0.51 \\
\hline 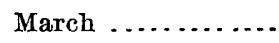 & 1,242 & 763 & 908 & 55,831 & 0.64 & 0.56 \\
\hline April ..... & 5,846 & 1,018 & 2,944 & 175,180 & 2.01 & 1.80 \\
\hline May ..... & 5,141 & 2,262 & 3,206 & 197,131 & 2.26 & 1.96 \\
\hline June...... & 3,744 & 1,730 & 2,718 & 161,732 & 1.85 & 1. 66 \\
\hline July . . . . . . & 1,730 & 530 & 959 & 58,967 & 0.68 & 0.59 \\
\hline August. . & 610 & 350 & 480 & 29,514 & 0.33 & 0.29 \\
\hline September .... & 1,882 & 220 & 363 & 21,600 & 0.24 & 0.22 \\
\hline October... & 763 & 350 & 509 & 31,297 & 0.36 & 0.31 \\
\hline November.. & 350 & 290 & 308 & 18,327 & 0.21 & 0.19 \\
\hline December .. & 1,181 & 240 & 384 & 23,611 & 9.26 & 0.24 \\
\hline The year ....... & 5,846 & 220 & 1,190 & 860,411 & 9.84 & 0.73 \\
\hline
\end{tabular}

Note.-Gage heights for 1898 are given in Water-Supply and Irrigation Paper No.28, page 183; measurements, page 185; rating table, page 186; results for 1897 in Water-Supply and Irrigation Paper No. 16, page 190, and in the Nineteenth Annual Report, Part IV, page 514.

20 GEOL, PT $4-34$ 


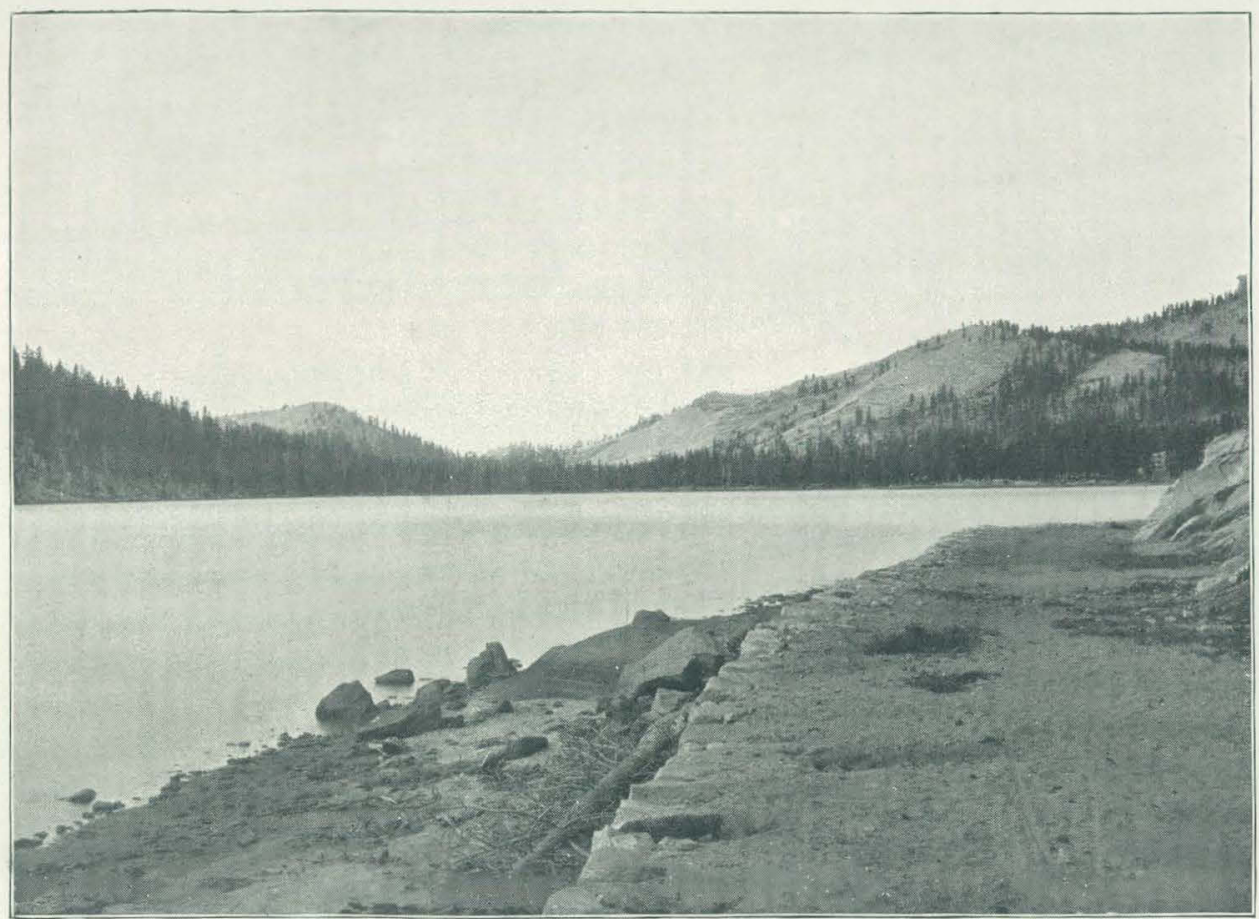

A. LAKE TENAYA, LOOKING SOUTH.

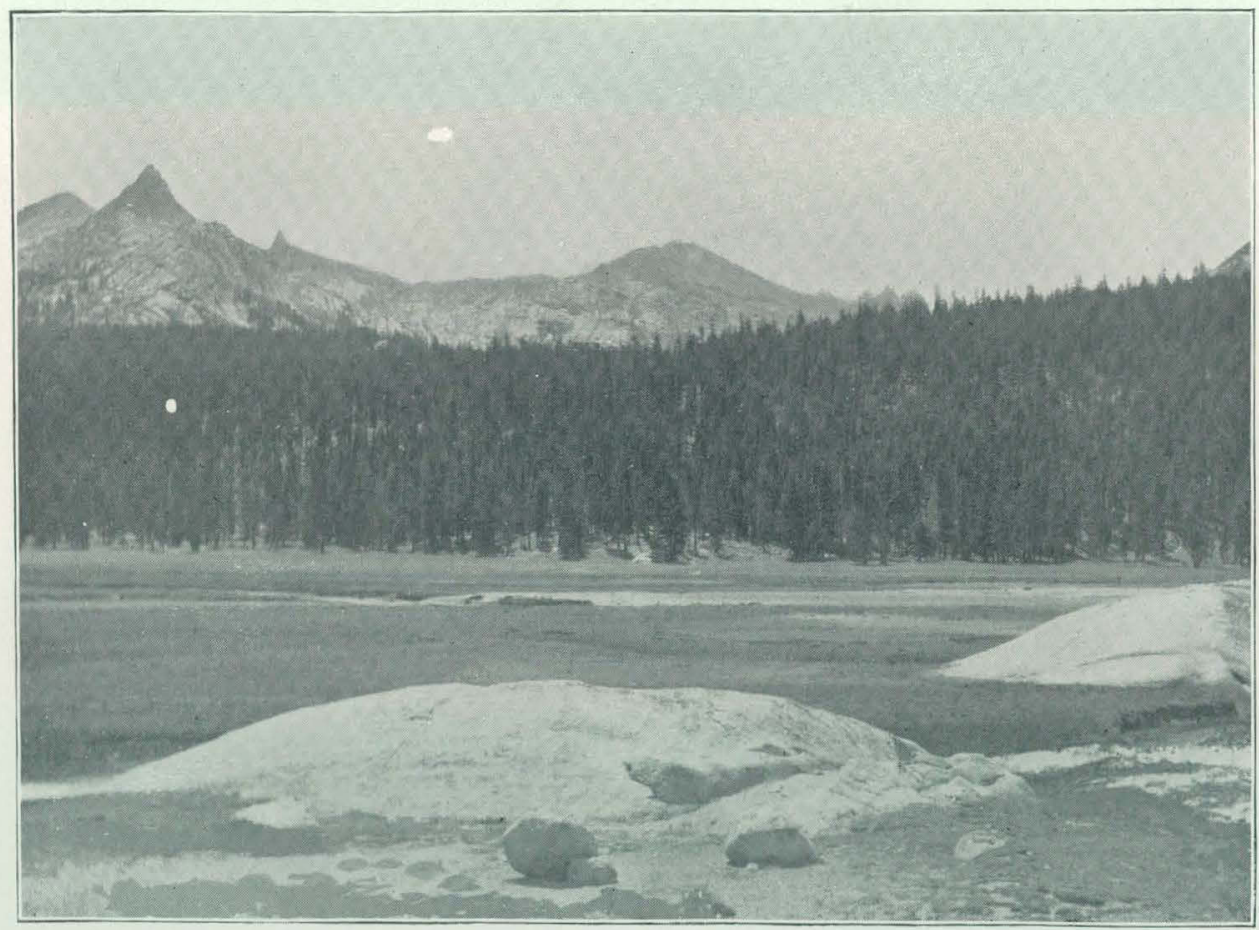

B. TUOLUMNE MEADOWS, LOOKING SOUTH. 


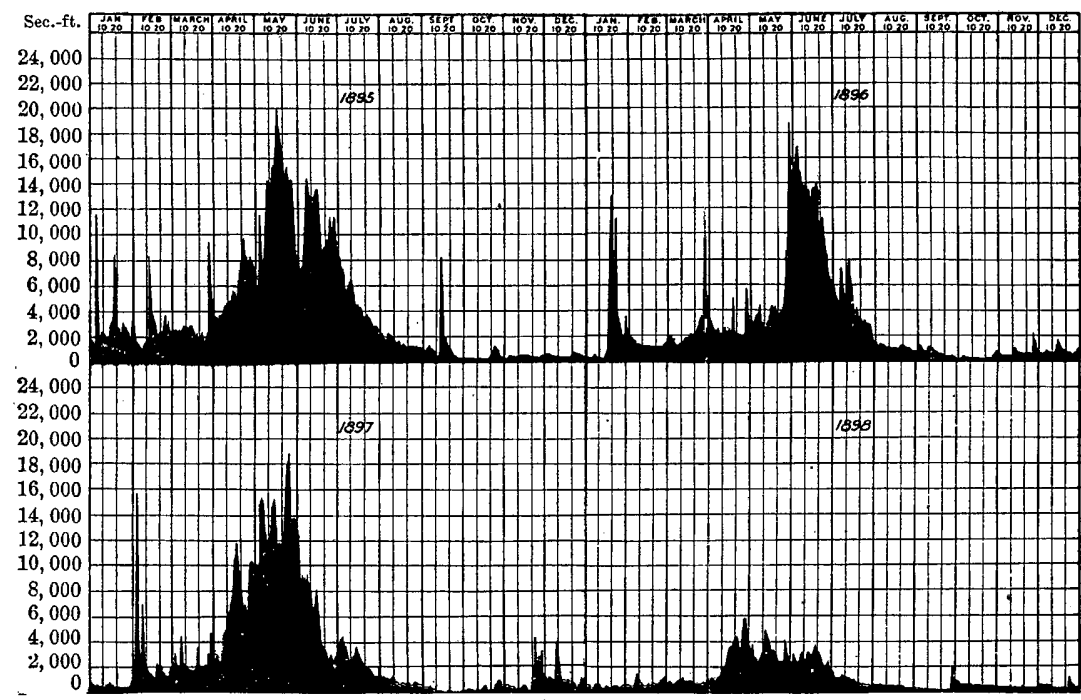

FIG. 211.-Discharge of San Joaquin River at Herndon, California, 1895-1898.

STANISLAUS RIVER.

Estimated monthly discharge of Stanislaus River at Oakdalé, California.

[Drainage area, 1,051 square miles.]

\begin{tabular}{|c|c|c|c|c|c|c|}
\hline \multirow[b]{2}{*}{ Month. } & \multicolumn{3}{|c|}{ Discharge in second-feet. } & \multirow{2}{*}{$\begin{array}{l}\text { Total in acre- } \\
\text { feet. }\end{array}$} & \multicolumn{2}{|c|}{ Run-off. } \\
\hline & $\begin{array}{l}\text { Maxi- } \\
\text { mum. }\end{array}$ & $\begin{array}{l}\text { Mini. } \\
\text { mum. }\end{array}$ & Mean. & & $\begin{array}{l}\text { Depth in } \\
\text { inches. }\end{array}$ & $\begin{array}{l}\text { Second- } \\
\text { feet per } \\
\text { square } \\
\text { mile. }\end{array}$ \\
\hline 1898. & & & & & & \\
\hline January .............. & 336 & 74 & 207 & 12,728 & 0.23 & 0.20 \\
\hline February .. & 1,372 & 156 & 389 & 21,604 & 0.39 & 0.37 \\
\hline March ................ & 1,000 & 336 & 572 & 35,171 & 0.62 & 0.54 \\
\hline April .................... & 3,920 & ' 536 & 1,813 & 107,881 & 1.93 & 1. 73 \\
\hline May ................... & 2,540 & 536 & 1,378 & 84,730 & 1.51 & 1. 31 \\
\hline June.............. . & 880 & 480 & 647 & 38,499 & 0.69 & 0.62 \\
\hline July .............. & 384 & 74 & 167 & 10,268 & 0.18 & 0.16 \\
\hline August................ & 100 & 27 & 66 & 4,058 & 0.07 & 0.06 \\
\hline September ........ & 100 & 50 & 61 & 3,630 & 0.07 & 0.06 \\
\hline October ............... & 100 & 74 & 77 & 4,735 & 0.08 & 0.07 \\
\hline November...... & 100 & 50 & 71 & 4,225 & 0.08 & 0.07 \\
\hline December .......... & 315 & 74 & 139 & 8,547 & 0.15 & 0.13 \\
\hline The year... & 3,920 & 27 & 466 & 336,076 & 6.00 & 0.44 \\
\hline
\end{tabular}

NoTE.-Gage heights for 1898 are given in Water-Supply and Irrigation Paper No, 28, page 182 measurements, page 185; rating table, page 186; results for 1897 in Water-Supply and Irrigation Paper No. 16, page 187, and in the Nineteenth Annual report, Part IV, page 510. 


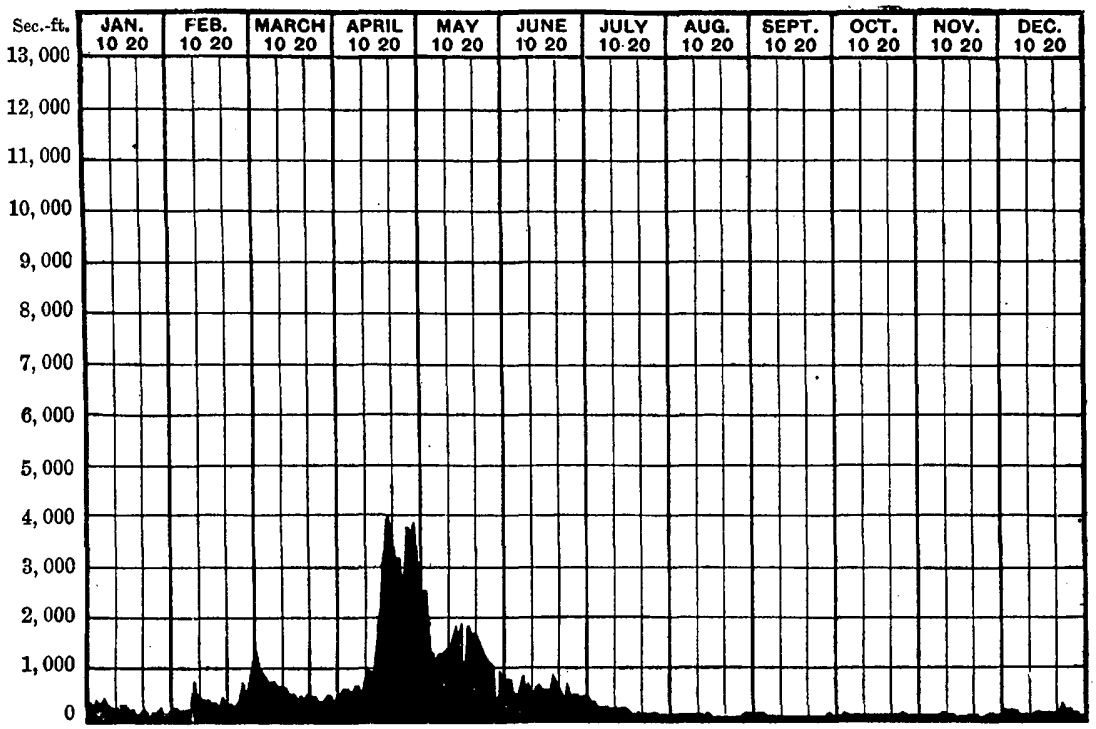

FIG. 212.-Discharge of Stanislans River at Oakdale, California, 1898.

TUOLUMNE RIVER.

Tuolumne River rises on the western or coast slope of the Sierra Nevada, its head waters reaching up to the crest of the mountains in Tuolumne County. The river is fed largely from small mountain lakes occurring high in the drainage basin, where snow remains upon the slopes throughout the year; the opportunities for water storage are thus exceptionally good. The stream has a heavy fall and the opportunities for power development are excellent. The distances from centers of population are also such that electrical power thus obtained will probably have a ready market. During spring high water, which occurs from the first of April to the first of July, the lower course of the river is navigable to the town of Modesto, and boats have occasionally come up to this point, river improvements having been made for this purpose.

Throughout a considerable part of the drainage basiu are a number of mines. The stream crosses the Mother Liode, and numerous quartz mills have been built. The auriferous gravels near Lagrange have been extensively worked and are still operated to a limited extent, a mining ditch diverting 24 second-feet of water being in use near Lagrange. The volume of the river at this point is given in the following table and is shown diagrammatically in fig. 213. This table does not include the quantity of water flowing in the mining ditch, as this is taken out above the point of measurement. 


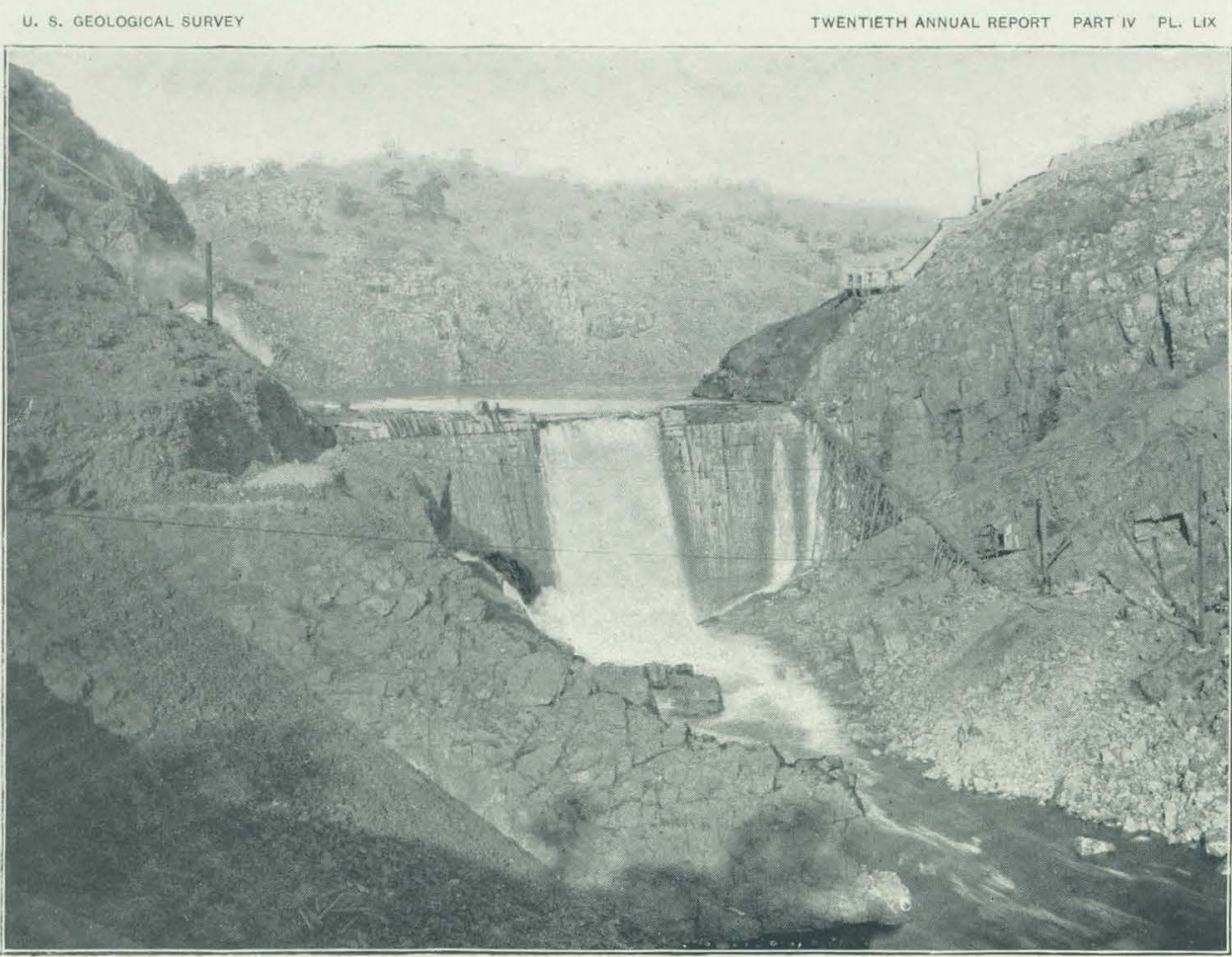

A. LAGRANGE DAM, NEARING COMPLETION.

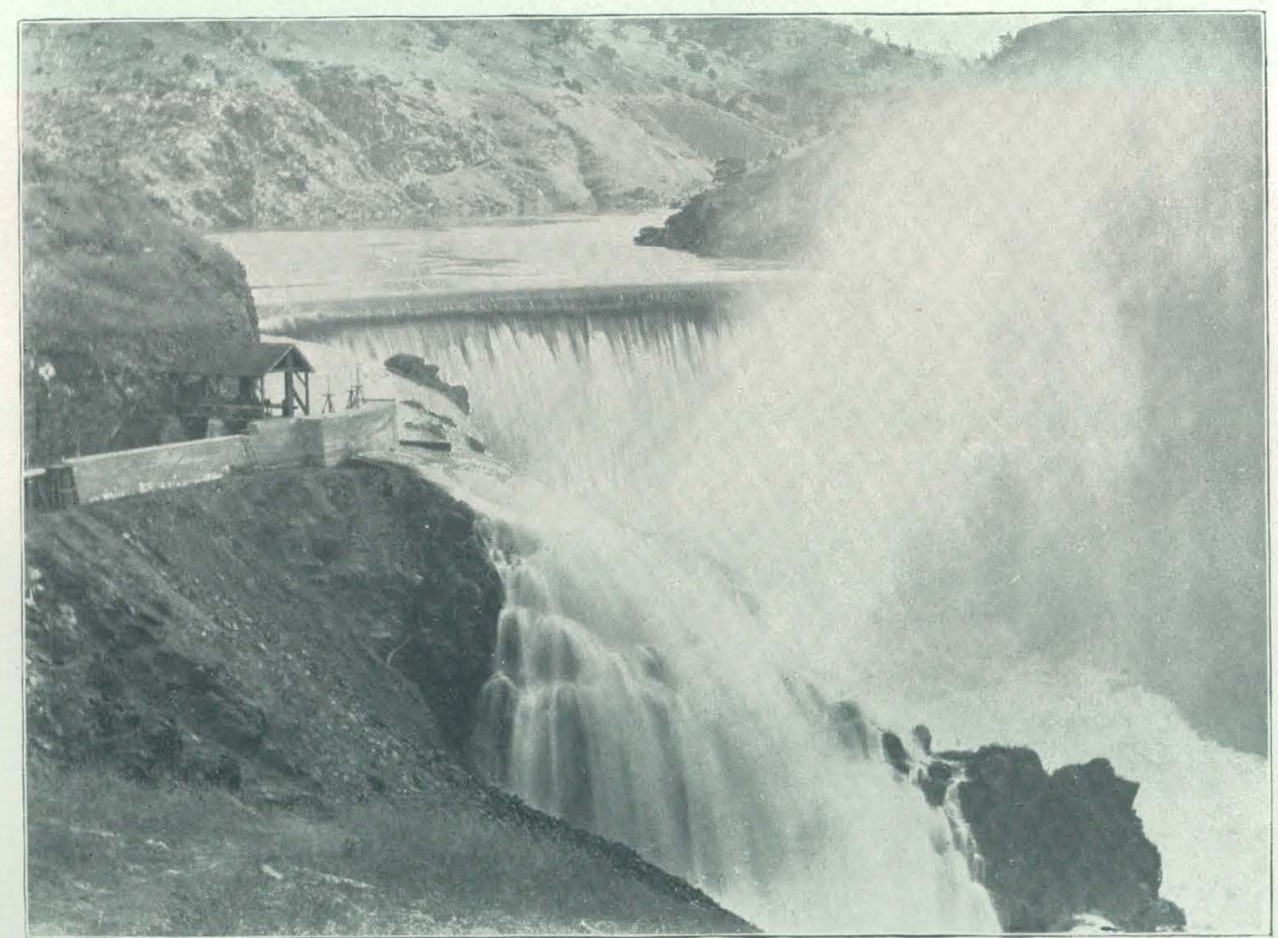

B. LAGRANGE DAM AT TIME OF HIGH WATER. 
Estimated monthly discharge of Tuolumne River at Lagrange, California.

[Drainage area, 1,501 square miles.]

\begin{tabular}{|c|c|c|c|c|c|c|}
\hline \multirow[b]{2}{*}{ Month. } & \multicolumn{3}{|c|}{ Discharge in second-feet. } & \multirow[b]{2}{*}{$\begin{array}{l}\text { Total in acre- } \\
\text { feet. }\end{array}$} & \multicolumn{2}{|c|}{ Run-offe. } \\
\hline & $\begin{array}{l}\text { Maxi- } \\
\text { mum. }\end{array}$ & $\begin{array}{l}\text { Mini. } \\
\text { mum. }\end{array}$ & Mean. & & $\begin{array}{l}\text { Depth in } \\
\text { inches. }\end{array}$ & $\begin{array}{c}\text { Second- } \\
\text { feet per } \\
\text { square } \\
\text { mile. }\end{array}$ \\
\hline 1898. & ' & & & & & \\
\hline January ........... & 750 & 300 & 454 & 27,916 & 0.35 & 0.30 \\
\hline February ... & 2,500 & 300 & 900 & 49,983 & 0.63 & 0.60 \\
\hline 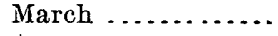 & 2,060 & 750 & 1,224 & 75,261 & 0.94 & 0.82 \\
\hline April .... & 7,800 & 1,270 & 4,014 & 238,849 & 2.78 & 2.67 \\
\hline May ...... & 6,960 & 2,280 & 4,620 & 284,075 & 3.55 & 3.08 \\
\hline June....... & 3,280 & 750 & 2,247 & 133,705 & 1.73 & 1.50 \\
\hline July ....... & 750 & 88 & 277 & 17,032 & 0.21 & 0.19 \\
\hline August.... - & 100 & 76 & 85 & 5,226 & 0.07 & 0.06 \\
\hline September ........... & - $\quad 88$ & 0 & 20 & 1,190 & 0.01 & 0.01 \\
\hline October ....... & $\therefore 88$ & 32 & 52 & $3,197^{\prime}$ & 0.04 . & 0.03 \\
\hline November.......... & 82 & .16 & 39 & 2,321 & 0.03 & 0.03 \\
\hline December ........... & 2,060 & 32 & 256 & 15,741 & 0.20 & 0.17 \\
\hline The year. & 7,800 & 0 & 1,182 & 854,496 & 10.54 & 0.79 \\
\hline
\end{tabular}

Nore._Gage heights for 1898 are given in Water-Supply aud Irrigation Paper No. 28, page 183; measurements, page 185; rating table, page 186; results for 1897 in Water-Supply and Irrigation Paper No. 16, page 188, and in tbo Nineteenth Annual Report, Part IV, page 512.

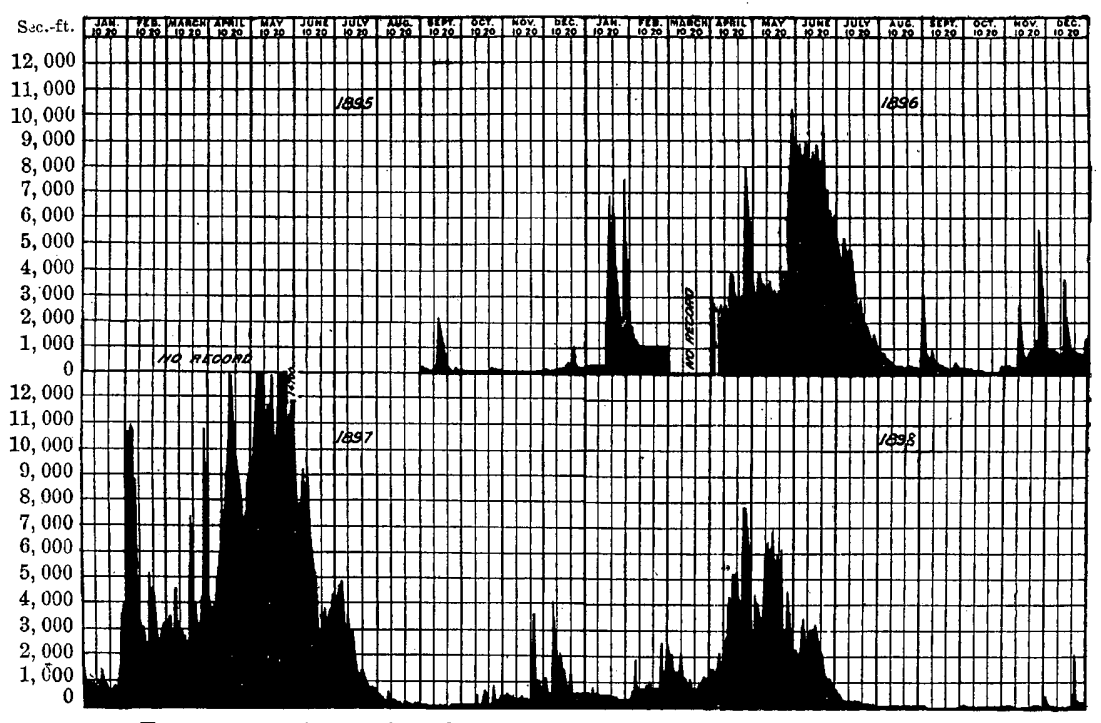

FIG, 213,-Discharge of Tuolumne River at Lagrange, California, 1895-1898. 
On the head waters of Tuolumne River are a number of reservoir sites, some of which may be made of importance in the development of the lands in San Joaquin Valley. On Pl. LVIII, $A$, is shown a view of one of the small bodies of water, Lake Tenaya, tributary to Merced River, and at $B$ is a view looking south across Tuolumne meadows, where it has been proposed to construct a storage reservoir. A preliminary survey of these and other reservoir sites has been made, the results being shown in the Thirteenth Annual, Report, Part III, beginning on page 398. A map of Lake Tenaya, with plan and profile of dam site, is given on Pl. CLXXVIII, page 404, of that volume. This lake is situated on the Tioga road, its location being shown on the Mount Lyell atlas sheet. The preliminary estimates indicate that 23,000 acre-feet can be stored in this basin at a cost of from $\$ 55,000$ to $\$ 90,000$, according to the type of dam constructed. The view given on the accompanying plate (PI. LVIII, $A$ ) is looking southwesterly, across the lake, toward the outlet. This discharges into Tenaya Creek, which flows southwesterly and enters Merced River at the head of the Yosemite Valley; it is, however, typical of small lakes on Tuolumne River.

Tuolumne Meadows, a view of a portion of which is given on $\mathrm{Pl}$. LVIII, $B$, are near Lake Eleanor, but are on the upper head waters of Tuolumne River. The location of these meadows is shown on the Mount Lyell atlas sheet, and a more detailed map is given in the Thirteenth Annual Report, Part III, on Pl. CLXXVII, accompanied by a plan and profile of the dam site. The main dam proposed is 870 feet long and 75 feet high, there being also three lateral dams-250 feet long and 18 feet high, 515 feet long and 65 feet high, and 710 feet long and 45 feet high, respectively. The capacity of the reservoir is placed at 43,185 acre-feet.

The most notable uses of the waters of Tuolumne River are those proposed by the Turlock and Modesto irrigatiou districts, the dam and headworks being placed about 3 miles above the town of Lagrange. A general view of this dam is given in fig. 63 of the Eighteenth Annual Report, Part IV, page 378, the structure being described by Mr. James D. Schuyler and illustrated on page 686 of the same volume. Heading at this diversion dam are canals, one on each side of the river, that for the Turlocis district being on the south or left-hand side of the stream, the location being shown on the Sonora atlas sheet. This canal has a capacity of approximately 1,200 cubic feet. per second. It heads in a tunnel opening above the dam and from this discharges through a sidehill structure exceedingly difficult to maintain. Views of the Lagrange dam with water pouring over its crest are shown on the accompanying Pl. LIX, $A$ and $B$; the first of these $(A)$ being taken before the structure was complete. The canal on the north or right-hand side of the river for the Modesto irrigation district has not been finished, the district having been in litigation since its organization. 


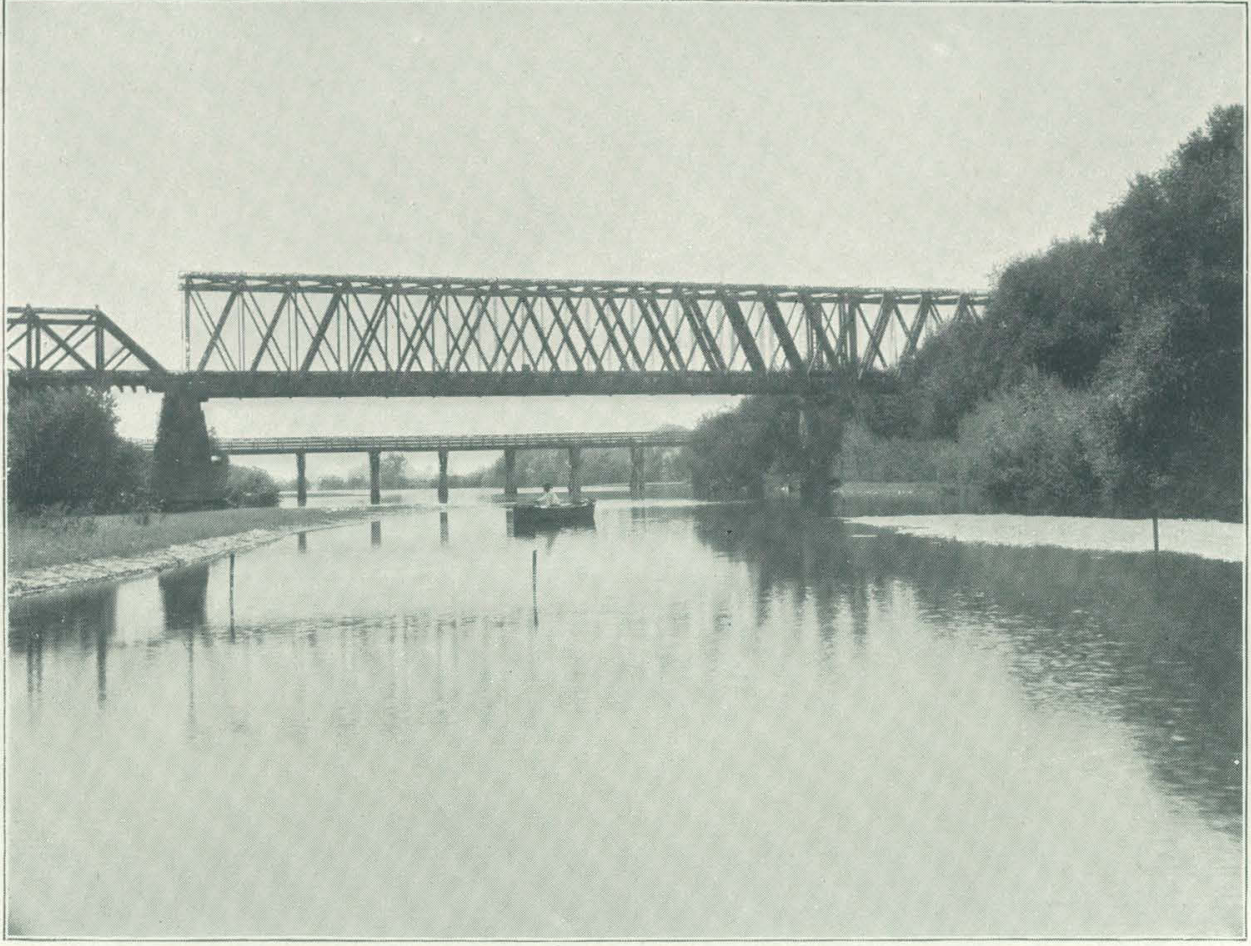

A. KINGSBURG GAGING STATION ON KINGS RIVER, CALIFORNIA.

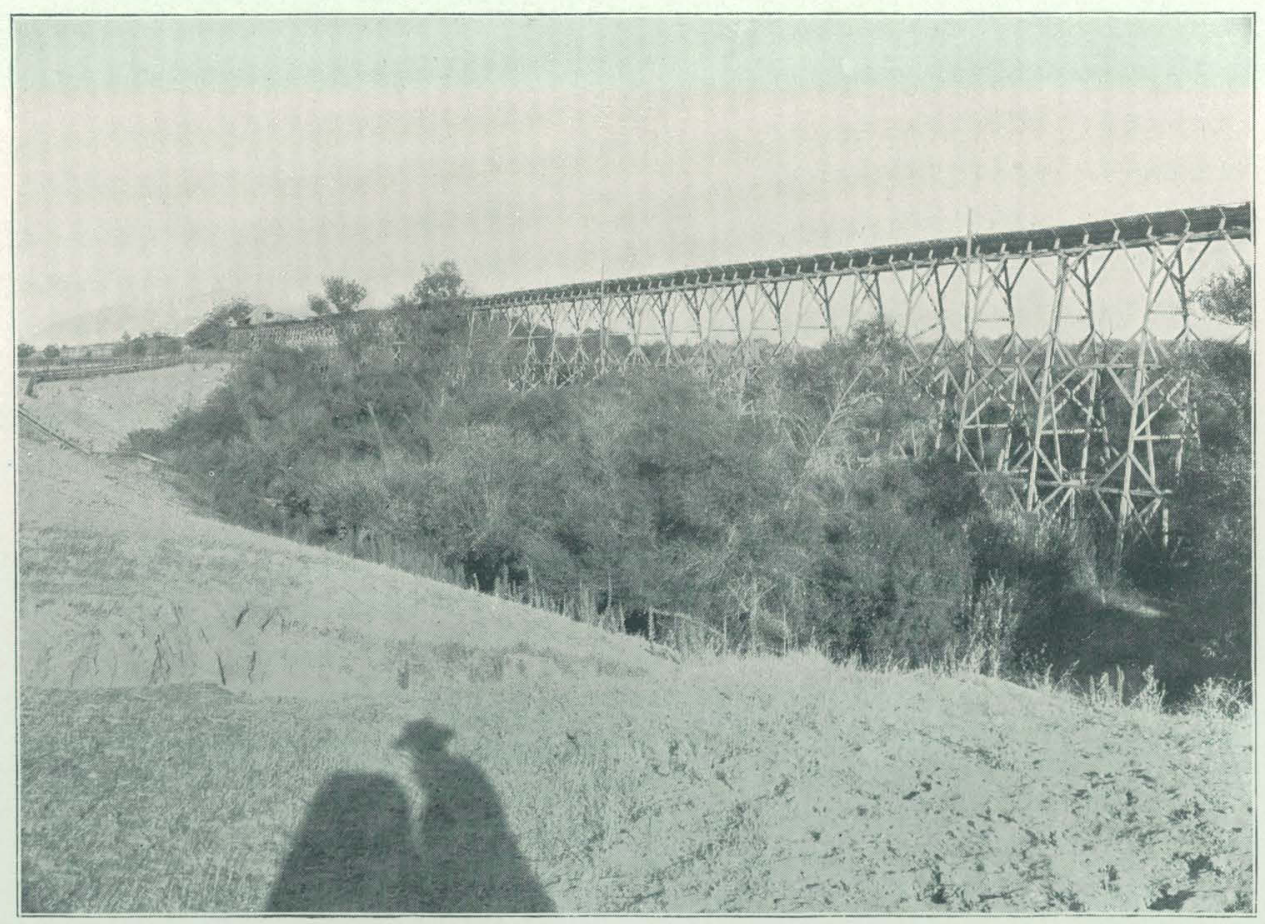

B. LUMBER FLUME AT SANGER, CALIFORNIA. 
KINGS RIVER.

Kings River rises on the western slope of the Sierra Nevada Range, in Fresno County. The water coming from this bigh catchment basin is probably of greater value for irrigation purposes than that of any other stream in central California, being used extensively for the raising of grapes and deciduous fruits in the neighborhood of Fresno, Selma, and Hanford. Outside of southern California this area is more highly developed by irrigation than any other portion of the State. The river has a relatively gentle grade, affording little opportunity for power development. Mining is carried on only to a small extent. A considerable number of irrigation canals divert water from the river below the point where it issues from the mountains, these being described in Water-Supply Paper No. 18, beginning on page 39. Measurements of the volume of Kings River have been made at two points-Kingsburg and Red Mountain.

Kingsburg station on Kings River is described on page 192 of WaterSupply and Irrigation Paper No. 16, also on page 181 of Water-Supply and Irrigation Paper No. 28. Results for 1897 are given on page 520 of the Nineteenth Annual Report, Part IV. Gage heights for 1898 are given on page 184, and measurements on page 185, of Paper No. 28. No rating table for 1898 has been constructed owing to the fact that repeated efforts to establish some relation between heights of water on the gage and volumes discharged or areas of cross section to volumes discharged have failed by reason of the manipulation of the head gates below.

On the accompanying plate ( $\mathrm{Pl}$. LX, $A$ ) is a view of Kings River at the Southern Pacific Railway crossing near Kingsburg, showing the locality at which measurements of the river are made. On the same plate at $B$ is a view of the Sanger Lumber Company's flume at Sanger, California. This takes water from a branch of Kings River near the General Grant National Park, the flume being over 50 miles in length. On the next plate (Pl. LXI, B) is a view of the Fowler Switch Canal near Sanger, California, showing the effect of velocities too great for the bed of the canal.

Red Mountain station is located 15 miles east of Sanger, California, and southwest of Red Mountain. It is at what is called Lower Section No. 9 of the lumber flume, and is above all canal diversions. The following table, on page 535, gives the results obtained by Mr. J. B. Lippincott during 1898, and fig. 214 shows graphically the fluctuations of the stream. 
Estimated monthly discharge of Kings River at Red Mountain, California.

Drainage area, 1,775 square miles.

\begin{tabular}{|c|c|c|c|c|c|c|}
\hline \multirow[b]{2}{*}{ Month. } & \multicolumn{3}{|c|}{ Discharge in second-feet. } & \multirow[b]{2}{*}{$\begin{array}{c}\text { Total in acre- } \\
\text { feet. }\end{array}$} & \multicolumn{2}{|c|}{ Run-off. } \\
\hline & $\begin{array}{l}\text { Maxi. } \\
\text { mum. }\end{array}$ & $\begin{array}{l}\text { Mini. } \\
\text { mum. }\end{array}$ & Mean. & & $\begin{array}{l}\text { Depth in } \\
\text { inches. }\end{array}$ & $\begin{array}{l}\text { Second- } \\
\text { feet per } \\
\text { square } \\
\text { mile. }\end{array}$ \\
\hline 1898. & & & & & & \\
\hline January ............... & 624 & 440 & 506 & 31,113 & 0.33 & 0.29 \\
\hline February.......... & 1,170 & 480 & 705 & 39,154 & 0.41 & 0.40 \\
\hline March ............ & 1,170 & 520 & 895 & 55,032 & 0.58 & 0.50 \\
\hline April.............. & 7,820 & 1,036 & 3,547 & 211,061 & 2,23 & 2.00 \\
\hline May ...... & $6,520^{\circ}$ & 2,450 & 3,536 & 217,422 & 2.29 & 1.99 \\
\hline June $\ldots . . . . .$. & 3,280 & 1,310 & 2,122 & 126,267 & 1.34 & 1.20 \\
\hline July ....... & 1,310 & 440 & 696 & 42,796 & 0.45 & 0.39 \\
\hline August.............. & 400 & 215 & 320 & 19,676 & 0.21 & 0.18 \\
\hline September .. & 780 & 145 & 204 & 12,139 & 0.13 & 0.12 \\
\hline October..... & 728 & 215 & 320 & 19,676 & 0.21 & 0.18 \\
\hline November.......... & 285 & 215 & 231 & 13,745 & 0.14 & 0.13 \\
\hline December .......... & 1,450 & 180 & 315 & 19,369 & 0.21 & 0.18 \\
\hline The year....... & 7,820 & 145 & 1,116 & 807,450 & 8.53 & 0.63 \\
\hline
\end{tabular}

NотE.-Gage heights for 1898 are given in Water-Supply and Irrigation Paper No. 28, page 184, measurements, 185, and rating table, page 186; results for 1897 in Water-Supply and Irrigation Paper No. 16, page 191, and in the Nineteenth Annual Report, Part IV, page 518.

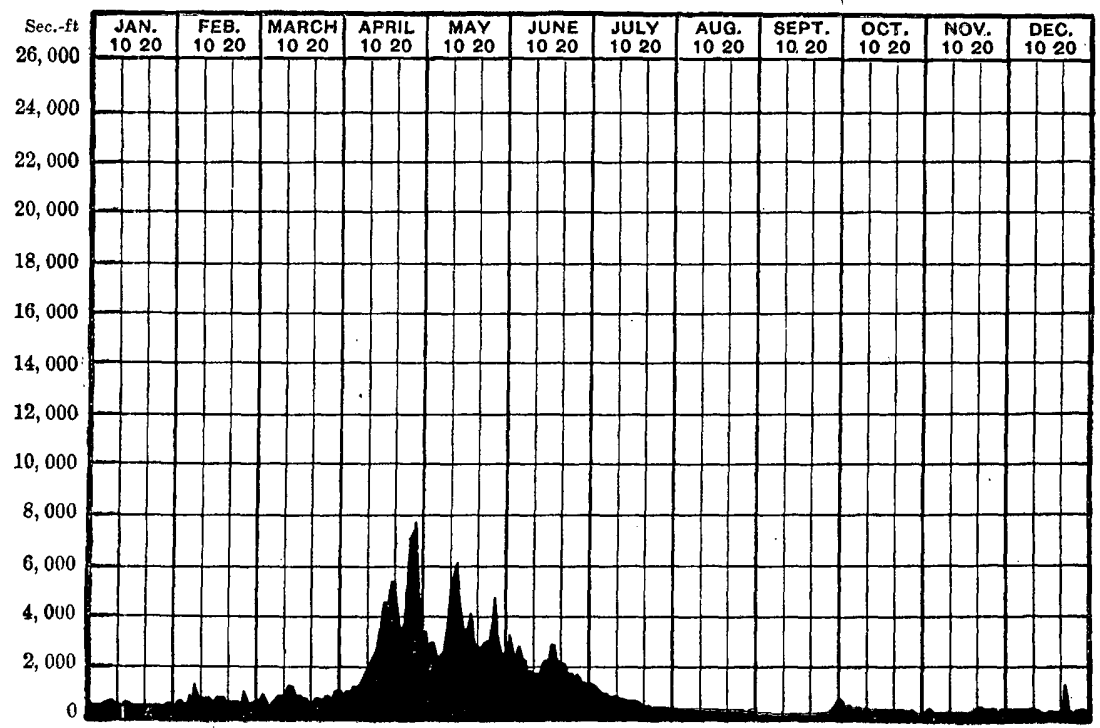

FIG. 214.-Discharge of Kings River at Red Mountain, California, 1898. 


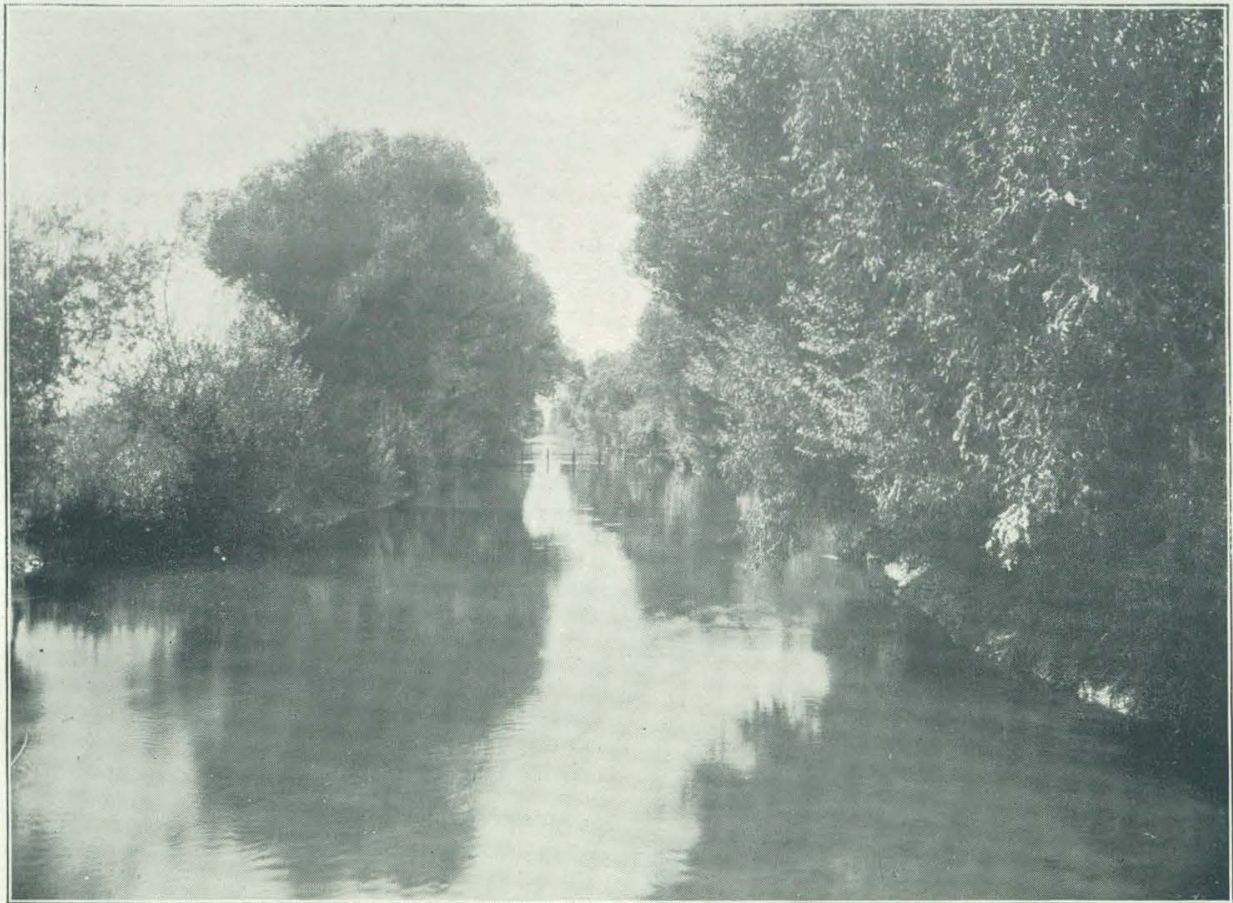

A. CHURCH DITCH, NEAR CENTERVILLE, CALIFORNIA.

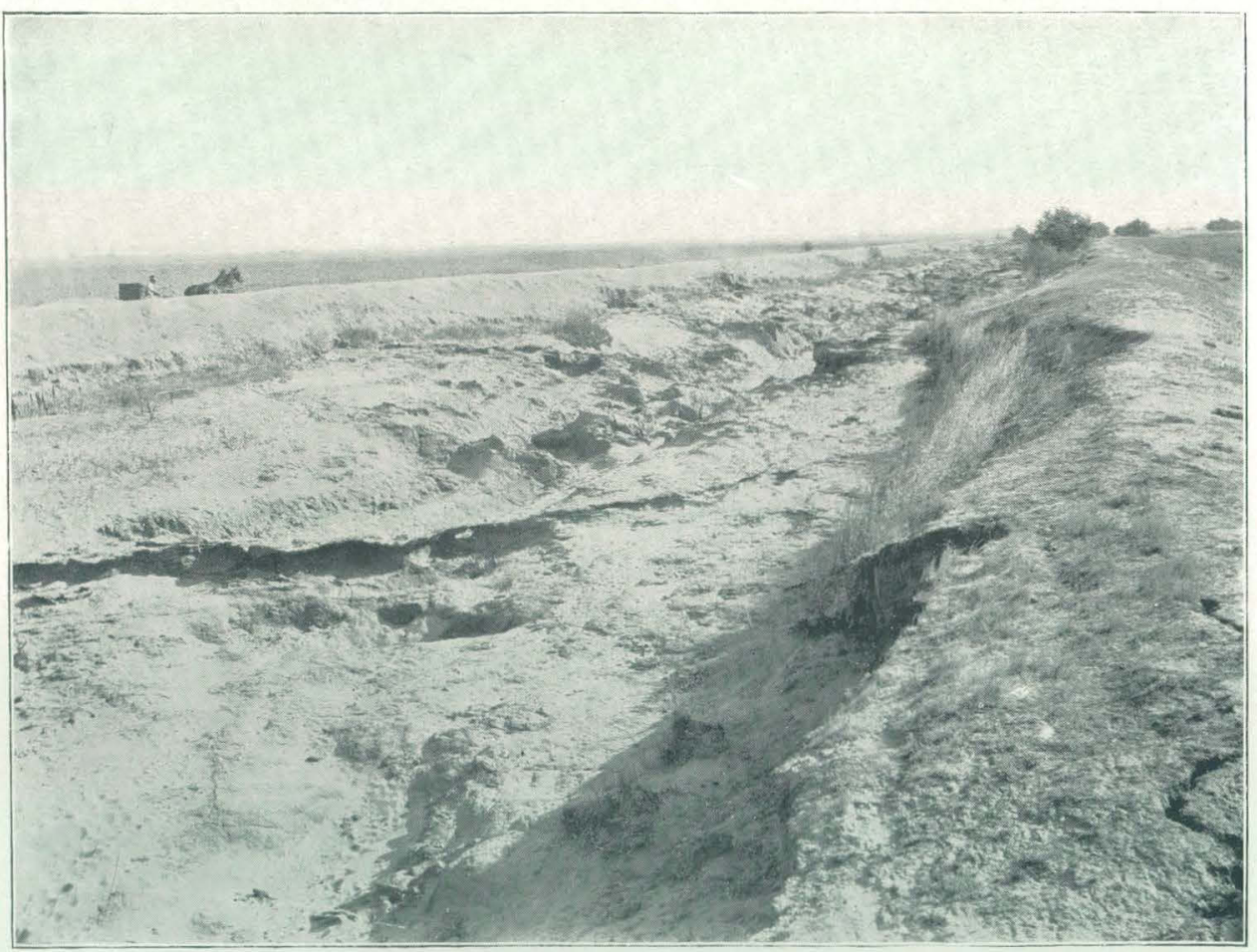

B. EFFECT OF HIGH VELOCITIES ON FOWLER SWITCH CANAL, CALIFORNIA. 
The accompanying Pl. LXI, $A$, gives a view on what is known as the Church ditch, near Centerville, California. This is the local name given the Fresno Canal and Irrigation Company's works, one of the principal irrigating systems from Kings River. Its location is shown on Pl. IV of Water-Supply Paper No. 18, and a general description is given on pages 43 to 47 of the same publication. The Fowler Switeh Canal, a portion of whose eroded channel is shown on Pl. LVI, $B$, is also described in Water-Supply Paper No. 18, beginning on page 48. The excessive gradient given these ditches, particularly in their upper section, results often in disastrous consequences and in large cost for repairs.

KERN RIVER.

Kern River flows from the southern end of the Sierra Nevada, being formed by two large tributaries, known as the North and South forks. These have a general southerly and parallel course, and unite a short distance below the town of Kernville. The run-off from the drainage basin as a whole is notably less than that from the catchment areas to the north. This is probably due to the fact that a portion of the basin is to the east of the high crest, and is sheltered by the mountain mass from the rain-bearing winds. The waters of Kern River are almost completely used for irrigation by the large canals in the southern end of the San Joaquin Valley. The greater part of the land is included in large holdings owned by the Kern County Land Company or by the Miller and Lux estate. The summer flow of the river during the last two or three years has been the lowest known, and has been below the demands of the irrigators. The winter waters are in part stored by the Miller and Lux estate in Buena Vista Lake, into which the river naturally discharges. The waters of this lake are controlled by a system of levees, so that they can be used during the following summer to irrigate lands lying to the northwest. This lake is very broad and shallow and there is great loss by evaporation, so that as a matter of economy it would be desirable to hold this water in the upper mountain valleys; this would afford also a large supply for water power.

The fall of Kern River is sufficiently large for the development of a considerable amount of water power. One plant for this purpose has already been constructed at the mouth of the canyon, furnishing light and power for the town of Bakersfield. A description and view of the works are given in the Nineteenth Annual Report, Part IV, beginning on page 524. Other projects are in an advanced stage for furnishing power to the city of Los Angeles by a transmission line 108 miles in length in one case and about 120 miles in the other. As ordinary bituminous coal costs $\$ 8$ a ton in Los Angeles, the introduction of cheap electric power for manufacturing and other purposes is of the highest importance in connection with the commercial development of that city. The opportunities for storage on Kern River are excellent, 
large meadows being found in the higher portion of the stream, with narrow outlets offering opportunities for the economical construction of dams, notably at Monache Meadow.

Measurements of the South Fork of Kern River were made on July 10 to 17,1898 , at points shown by the accompanying fig. 215. The first of these, marked No. 1, was at a point 700 feet above the junction, giving a flow of a trifle less than 13 second-feet; at the point marked No. 2 the North Fork was measured, showing a discharge of 330 second-feet; at the point indicated as No. 3; near the old engineer camp, the flow was a little less than 18 second-feet; at No. 4, in sec. 6, T. 22 S., R. 36 E., the flow was 10 second-feet; at No. 5, the outlet of Monache Lake, the discharge was 5.3 second-feet. On August 29, at what is known as "the first point of measurement," near Bakersfield, the discharge was estimated to be 115.6 second-feet.

Kern River during 1898 has been measured at a point 7 miles northeast of the town of Bakersfield, California, and 12 miles below the mouth of the canyon, the drainage area being 2,345 square miles. This station was originally established in 1893 by the Kern County Land and Water Company, Walter James being chief engineer and A.K. Warren engineer in charge. The results are given by the

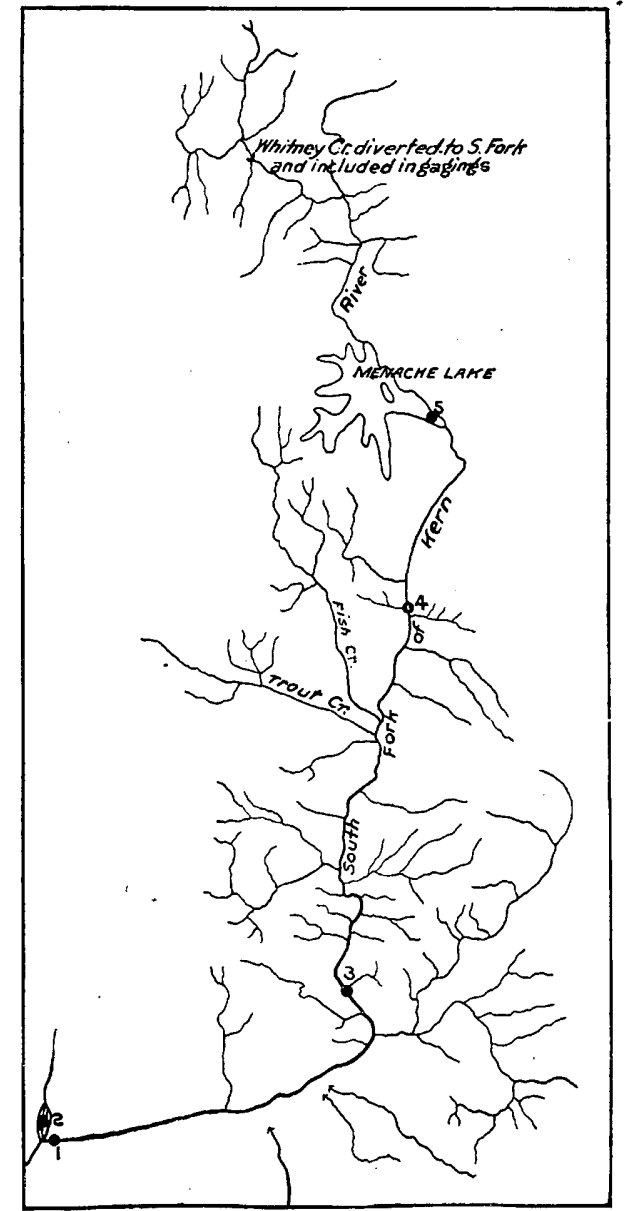

FIG. 215.-Location of measurements on South Fork of Kern River.

land company for publication. The method of procedure is described in the Eighteenth Annual Report, Part IV, page 395. The measurements during 1898 have been carefully made and the table of monthly discharge is given below. The record for 1896 and 1897 and a description of the power plants on Kern River are given in the Nineteenth Annual Report, Part IV, page 524. 


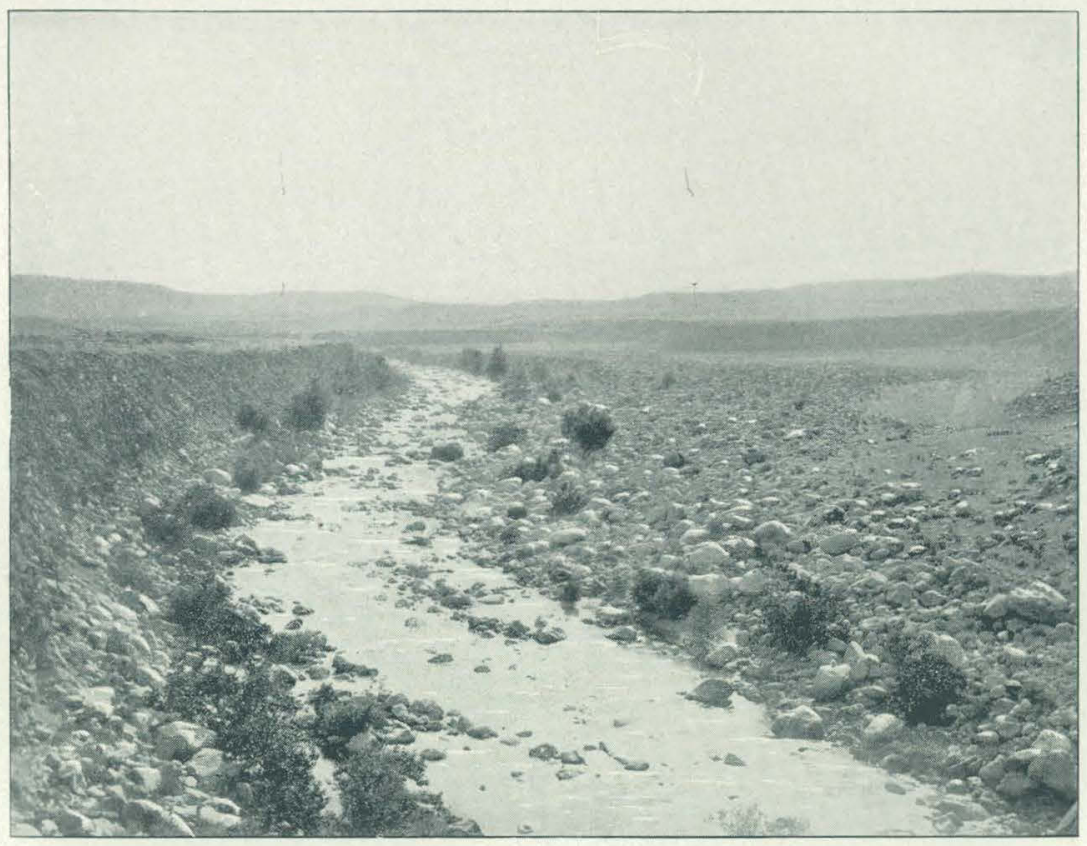

A. KERN RIVER, CALIFORNIA, LOOKING DOWNSTREAM FROM CANYON.

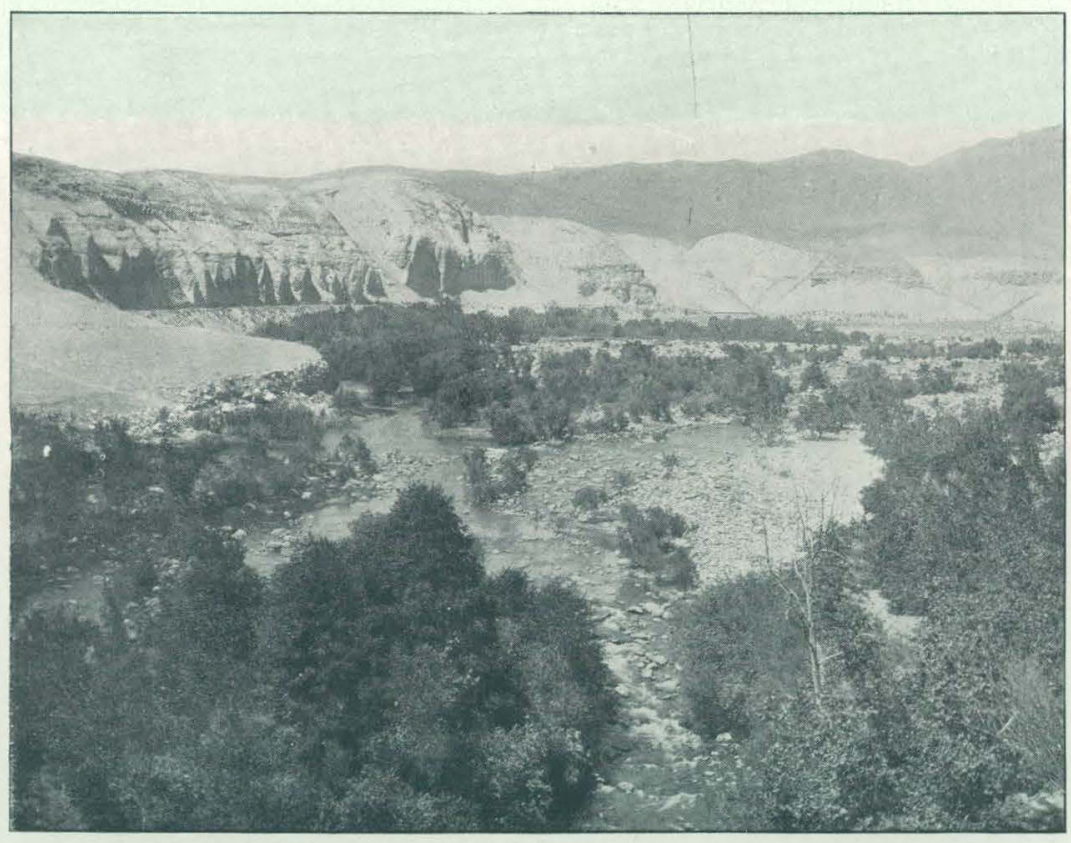

$B$ KERN RIVER, 2 MILES BELOW CANYON, LOOKING UPSTREAM 
Estimated monthly discharge of Kern River at Bakersfield, California.

[Drainage area, 2,345 square miles.]

\begin{tabular}{|c|c|c|c|c|c|c|}
\hline \multirow[b]{2}{*}{ Month. } & \multicolumn{3}{|c|}{ Discharge in second-feet. } & \multirow[b]{2}{*}{$\begin{array}{l}\text { Total in acre- } \\
\text { feet. }\end{array}$} & \multicolumn{2}{|c|}{ Run-off. } \\
\hline & $\begin{array}{l}\text { Maxi- } \\
\text { mum. }\end{array}$ & $\begin{array}{l}\text { Mini- } \\
\text { mum. }\end{array}$ & Mean. & & $\begin{array}{c}\text { Depth in } \\
\text { inches. }\end{array}$ & $\begin{array}{c}\text { Second- } \\
\text { feet per } \\
\text { square } \\
\text { mile. }\end{array}$ \\
\hline 1898. & & & & & & \\
\hline January.... & 400 & 311 & 363 & 22,320 & 0.17 & 0.15 \\
\hline February........... & 923 & 316 & 434 & 24,103 & 0.20 & 0.19 \\
\hline March..... & 485 & 304 & 388 & 23,857 & 0.20 & $\cdot 0.17$ \\
\hline April.......... & 1,342 & 371 & 710 & 42,247 & 0.33 & 0.30 \\
\hline May........ & 980 & 560 & 735 & 45,193 & 0.36 & 0.31 \\
\hline June ....... & 686 & 394 & 551 & 32,786 & 0.26 & 0.23 \\
\hline July ......... & 416 & 127 & 244 & 15,003 & 0.12 & 0.10 \\
\hline August..... & 142 & 86 & 120 & 7,378 & 0.06 & 0.05 \\
\hline September ..... & 294 & 80 & 116 & 6,902 & 0.06 & 0.05 \\
\hline October...... & 232 & 127 & 160 & 9,838 & 0.08 & 0.07 \\
\hline November...... & 188 & 136 & 166 & 9,877 & 0.08 & 0.07 \\
\hline December .......... & 314 & 147 & 199 & 12,236 & 0.09 & 0.08 \\
\hline The year. & 1,342 & 80 & 348 & 251,743 & $\cdot 2.01$ & 0.15 \\
\hline
\end{tabular}

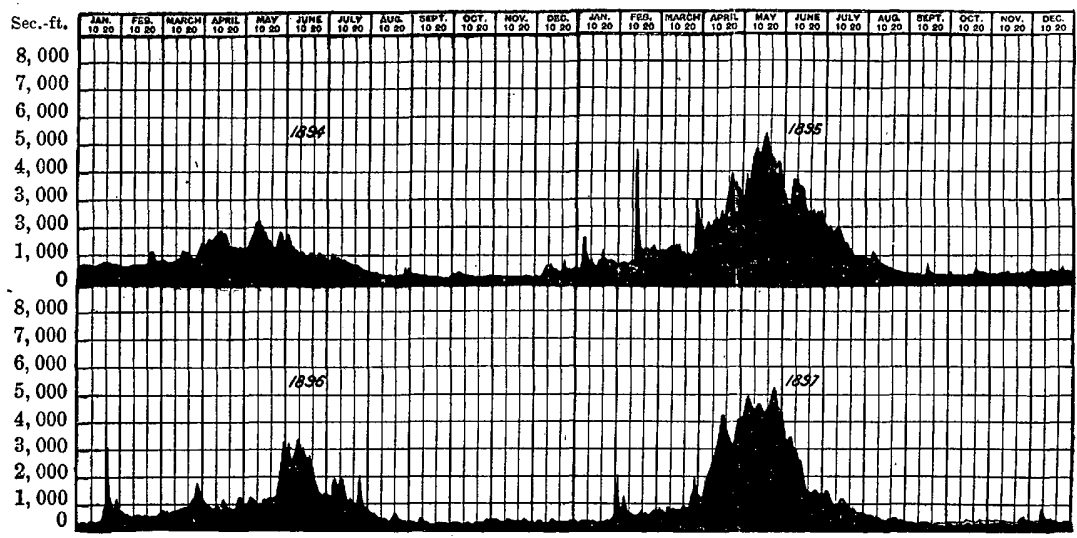

FIG. 216.-Discharge of Kern River at Bakersfeld, California, 1894-1897.

SOUTHERN CALIFORNIA DRAINAGE.

Under the head of Southern California drainage have been included facts obtainable concerning the streams of this part of the State south of the San Joaquin Basin. There are thus included the streams which flow from the mountains north of Los Angeles and San Bernardino into the Mohave Desert, a portion of the Great Interior Basin, as well as those flowing toward the south or southwest, whose waters, in times of flood at least, reach the Pacific Ocean. 
The principal streams flowing into or toward the Mohave Desert are Littlerock Creek, Bigrock Creek, and Mohave River. Each of these, though small in size, is of considerable importance in the atilization of the rich arid lands of this area. Storage systems have been planned upon each of these, that upon Littlerock Creek having already been completed, as described by Mr. J. D. Schuyler in the Eighteenth Annual Report, Part IV, pages 711 to 715 . In the same report reference is made to a proposed storage reservoir at Victor, on Mohave River. The following statements have been taken from a report by Mr. J. B. Lippincott:

The drought condition described on a preceding page in connection with the Sacramento and San Joaquin rivers was felt even to a greater degree in southern California. The record of precipitation for Los Angeles for twenty-seven years does not show a group of conditions similar to those prevailing during the last decade. Certainly the scarcity of water for the last three or four years has no equal in its recorded annals, and no such condition is known to have existed among the Spanish settlers, save by tradition. This unfavorable situation, while it has diminished the amount of water which was available, has by the law of supply and demand enhanced the value of that which did exist. With but one exception (the Riverside Water Company) an instance is not called to mind in the State where the water corporations, irrigation districts, or cooperative water-supply companies have furnished the customary amount of water or that which was contracted for. For instance, according to local papers, the Bear Valley Irrigation Company, in the San Bernardino Valley, during the past season has furnished from one-third to one-fourth of the contracted amount of water, and, neglecting existing contracts, charged 25 cents per miner's inch for a run of twenty-four hours delivering these deficient amounts. This would amount to about $\$ 5$ per acre per season if the full amount was given on a basis of 1 miner's inch to supply 10 acres. From $\$ 100$ to $\$ 200$ has been paid for water on a number of occasions for a run, or irrigation head, of 100 miner's inches flowing twenty-four hours.

The records of a period of this character are of course of the greatest interest to the users of water whose crops and orchards are dependent upon this supply, as well as to investors in large works. On the other hand, it may readily be seen that the water companies themselves may not desire to have records of this character made public. The data acquired for the period of this severe drought are therefore of particular value. While assistance has been kindly rendered in the past by various corporations by compiling the records of stream flow; some of them do not feel inclined in this instance to give records, and in a few cases individuals go so far as to intimate that they will dispute the records as inaccurate in case they are published. 


\section{LITTLEROCK CREEK.}

The point of measurement of Littlerock Creek has been described in the Eighteenth Annual Report, Part IV, page 402, computations of dis charge being made in the flume taking the entire flow of the stream. The results of the measurements during 1898 are given by Mr. Burt Cole. The small amount flowing from June to September, inclusive, is not taken into consideration, as at no time did it exceed 2 second-feet except for a few hours on August 11, when a cloud-burst gave a discharge of probably 100 second-feet for two lours. The water rose at 4 p. m., but before 6 p. m. it had visibly decreased, and at 7 p. m. on August 12 the creek was at its normal condition.

Estimated monthly discharge of Littlerock Creek at Palmdale, California.

[Drainage area, 78 square miles.]

\begin{tabular}{|c|c|c|c|c|c|c|}
\hline \multirow[b]{2}{*}{ Month. } & \multicolumn{3}{|c|}{ Discharge in second.feet. } & \multirow[b]{2}{*}{$\begin{array}{c}\text { Total in acre- } \\
\text { feet. }\end{array}$} & \multicolumn{2}{|c|}{ Run-off. } \\
\hline & $\begin{array}{l}\text { Maxi- } \\
\text { mum. }\end{array}$ & $\begin{array}{l}\text { Mini- } \\
\text { mum. }\end{array}$ & Mean. & & $\begin{array}{l}\text { Depth in } \\
\text { inches. }\end{array}$ & $\begin{array}{l}\text { Second.feet } \\
\text { per square } \\
\text { mile. }\end{array}$ \\
\hline 1898. & & & & & & \\
\hline January ......... & 12.1 & 5.5 & 6.06 & 373 & 0.09 & 0.08 \\
\hline February .......... & 20.0 & 5.0 & 7.00 & 389 & 0.09 & 0.09 \\
\hline March ............ & 6.4 & 5.8 & 6.04 & 371 & 0.09 & 0.08 \\
\hline April..... & 7.4 & 3.7 & 6.10 & 364 & 0.09 & 0.08 \\
\hline May $a \ldots \ldots \ldots \ldots$ & 19.2 & 1.9 & 5.20 & 319 & 0.08 & 0.07 \\
\hline
\end{tabular}

a Dry from June to December, inclusive, except on Aug. 11, when a cloud.burst occurred, which probably amounted to 100 second-feet for two hours.

Note.-Gage heights for 1898 are given in Water-Supply and Irrigation Paper No. 28, page 186; measurements, page 189 ; rating table, page 190. Results for 1897 in Water-Supply and Irrigation Paper No. 16, page 193, and in the Nineteenth Annual Report, Part IV, page 526.

\section{SANTA CLARA RIVER.}

Santa Clara River receives the drainage of the western portion of the San Gabriel Range and the southern slopes of the Ventura high. lands. The main stream flows in a general westerly course and empties in to the Pacific Ocean near San Buenaventura. The head-water streams are adjacent to the Mohave Desert, and the topography is such that one or more of them may be developed toward the western slope to irrigate lands in Antelope Valley, as described by Mr. James D. Schuyler in the Eighteenth Annual Report, Part IV, on page 711. He states that the waters of Piru Creek, a tributary of this river, can be held in reservoirs at favorable localities and when discharged into the channel can be taken out at a lower point by means of a canal leading over the divide either into Antelope Valley or San Joaquin Valley. Several measurements of the waters of this stream were made during 1898 by Mr. F. H. Olmsted, as shown in the following table. 
Measurements of Santa Clara River and tributaries.

\begin{tabular}{|c|c|c|c|c|c|}
\hline Date. & Name of river. & Locality. & $\begin{array}{l}\text { Area of } \\
\text { section. }\end{array}$ & Mean & Discharge. \\
\hline 1898. & & & sq.feet. & Ft.pr.sec. & Sec. feet. \\
\hline June 18 & Santa Clara.. & Camulos ranch.......... & 9.57 & 2.15 & 25.74 \\
\hline Aug. 11 & ..... do ....... & 2 miles east Camulos .......... & 9.23 & 1.88 & 17. 36 \\
\hline Aug. 9 & ..... do ........... & $\begin{array}{l}\text { Flume one-half mile above } \\
\text { San Francisquito Creek. }\end{array}$ & 9.00 & 1.20 & 10.83 \\
\hline \multirow[t]{3}{*}{ Ang. 11} & Sespe.... & Division Point ....................... & 2.66 & 0.92 & 2.46 \\
\hline & Piru ................. & 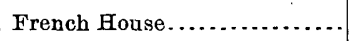 & 1.46 & 0.53 & 0.92 \\
\hline & San Francisquito ... & $\ldots \ldots \ldots \ldots \ldots \ldots \ldots \ldots \ldots, \ldots$ & 1.84 & 1.12 & 2.07 \\
\hline
\end{tabular}

LOS ANGELES RIVER.

Los Angeles River heads immediately south of the drainage basin of Santa Clara River, various tributaries receiving waters from the hills surrounding the San Fernando Plains. At the lower end of these plains the river cuts through a canyon, near the lower mouth of which the city of Los Angeles has been placed. This valley above the city is one of several localities in southern California where the conditions are extraordinarily favorable to the conservation of a small water supply. In these localities mountain streams issuing from canyons have filled the valleys with bowlders and débris. Similar conditions are found in the Santa Ana Valley above Colton and again above Rincon, and in the San Gabriel Valley above Monte. In each instance these gravel-filled valleys have been contracted at their lower end by intercepting ranges of low hills or by beds of impervious materials. The rivers entering the upper portion of these valleys discharge winter floods upon the porous gravel beds, into wbich the waters rapidly sink, forming great gravel-filled reservoirs. The water, of course, can not behave as in an open basin, but, being retarded by the friction of the bowlders or by adhesion to the surface of the rock particles, moves slowly toward the lower outlet, assuming a slope which varies under different conditions. The discharge at the lower outlet, owing to this retarding of the flow, is of remarkable uniformity. For example, Los Angeles River, in spite of the extraordinary drought, was discharging during the spring of 1899 within 10 or 20 per cent of the quantity carried ten years previously, when the available water supply in all the streams was far greater. The district of Riverside, which obtains its water supply from a source of similar character, had even more water than during the preceding years, owing to the excessive irrigation practice upon the bench lands of the upper rim of the valley. There is great regularity in the daily flow of these streams, and thus little necessity for frequent meas. urements; in fact, three or four gagings a year will give a fair conception of the amount delivered. Measurements, therefore, for Los Angeles River at Bridge No. 2, a short distance above the city, also of the San 
Gabriel at Monte and of the Santa Ana rivers near Colton and Rincon, are of interest as showing this flow from underground sources.

Measurements of the Los Angeles River have been made under the direction of the city engineer of Los Angeles, as noted in the Eighteenth Annual Report, Part IV, on pages 413 to 415 . The results obtained at Weir No. 5, which is 4.87 miles above the north boundary of the city, immediately above the Crystal Springs, and at Bridge No. 2, which is about 1,200 feet below Weir No. 5, and which shows the same volume, when corrected for the diversion at a higher point of the main supply or woolen mill ditch and for the Glassell tributary, which enters 1,000 feet below Bridge No. 2, are considered to be fairly representative of the flow of the stream.

This volume varies but slightly from time to time, as shown by the following figures:

Discharge of Los Angeles River at a point about 4 miles above the city limits of Lo8 Angeles, California.

\begin{tabular}{|c|c|c|c|}
\hline & & Sec.- & feet. \\
\hline 1890. & & March 15 . & 65 \\
\hline ist & 69 & March 19 & 66 \\
\hline September ..... & 72 & March 21... & 67 \\
\hline October..... & 67 & June $28 \ldots \ldots \ldots \ldots \ldots \ldots$ & 60 \\
\hline November . . . . . & 69 & mber 14 & 61 \\
\hline December...$\ldots \ldots \ldots \ldots$ & 70 & October $26 \ldots \ldots \ldots \ldots$ & 64 \\
\hline $1 \times 97$. & & November 4 . . . . . . . . . . . & 59 \\
\hline January ...................... & 73 & November $29 \ldots \ldots \ldots \ldots$ & 62 \\
\hline 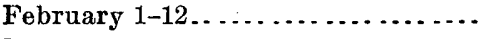 & 85 & December $7 \ldots$. & 61 \\
\hline 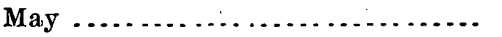 & 64 & December $11 \ldots \ldots \ldots \ldots . . . . .$. & 61 \\
\hline June....................... & 60 & December $19 \ldots \ldots \ldots \ldots . . . . . .$. & 65 \\
\hline July ...................... & 63 & December $21 \ldots \ldots \ldots \ldots \ldots$ & 61 \\
\hline August............... & 60 & 899. & \\
\hline September........... & 56 & January 5 .. & 67 \\
\hline October .......... & 63 & February $14 \ldots$. & 61 \\
\hline fovember...... & 53 & February $25 \ldots$. & 67 \\
\hline 1898. & & March $11 \ldots \ldots \ldots \ldots \ldots \ldots \ldots \ldots \ldots$ & \\
\hline$\ldots . . .$. & 68 & 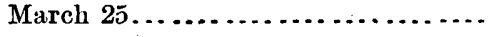 & \\
\hline February $\ldots . . . . . . . . . . . . . .$. & 69 & April $29 \ldots$ & $\tilde{\mathbf{5} 2}$ \\
\hline
\end{tabular}

The above figures of flow of Los Angeles River were obtained by computation made originally on weirs placed in the river, and later from meter measurements at flumes with bridges placed across the channel. A number of corrections have been applied on account of diversions of the water and return by seepage, as well as inflow from various places. Comparatively few floods reach the river channel, the San Fernando Valley above the city acting as a regulator to the flow of the river, the stream on the surface remaining constant, and the water plaue or plane of saturation rising and falling according as the mountain rains, are large or small in the valley. The figures in the 
table are given in whole numbers from the detailed estimate prepared by Messrs. J. B. Lippincott, A. Q. Campbell, and H. P. Vincent for the city engineer.

In the following list is given results of low-water measurements made at various points on Los Angeles River and its tributaries:

Results of low-water measurements on Los Angeles River and its tributaries.

\begin{tabular}{|c|c|c|c|c|c|}
\hline Date. & Name of river. & Locality. & $\begin{array}{l}\text { Area of } \\
\text { sections. }\end{array}$ & Mean & Discharge. \\
\hline 1898. & & & Sq. feet. & $\begin{array}{l}\text { Feet per } \\
\text { second. }\end{array}$ & Second-feet. \\
\hline June 24 & Los Angeles.. & In creek below Macy street... & ............ & ........ & $a 0.50$ \\
\hline 24 & ..... do $\ldots$ & Diversion below Zanja No. $7 \ldots$ & 4.96 & 0.013 & 0.64 \\
\hline 24 & .....do... & Zanja No. $7 \ldots \ldots \ldots \ldots \ldots \ldots$ & 4.05 & 1. $38^{\circ}$ & 5.59 \\
\hline Aug. 10 & . . . do . . . . . & New bridge, Weir B......... & (b) & (.......... & 1.32 \\
\hline 10 & ..... do .............. & San Fernando road crossing... & (b) & ......... & 4.84 \\
\hline 10 & ..... do .............. & North Cahuenga road .......... & (b) & ......... & 9.74 \\
\hline 10 & .....do .......... & Old bridge No. $4 \ldots \ldots \ldots \ldots$. & (b) & $\ldots \ldots$ & 14.45 \\
\hline 10 & .....do .... & Tujunga Creek junction ..... & (b) & .......... & 0.87 \\
\hline 15 & $\ldots$. do .... & Bridge No. 2 at narrows ........ & 20.90 & 1.85 & 38.74 \\
\hline 15 & ..... do............. & Main supply ditch ........... & 11.08 & 1.48 & 16.40 \\
\hline 15 & ....do . . . . . . . & Total river at Crystal Springs. & $\ldots \ldots \ldots$ & ..... & 55.14 \\
\hline 11 & Little Tujunga.... & $\ldots \ldots \ldots \ldots \ldots \ldots \ldots \ldots \ldots \ldots$ & . . ......... & $\ldots \ldots$ & 0.05 \\
\hline Sept. 16 & Arrojo Seco. & $\begin{array}{l}\text { Total flow into Orange Grove } \\
\text { avenue reservoir. }\end{array}$ & 0.318 & J. 88 & 0.598 \\
\hline 16 & .....do. & $\begin{array}{l}\text { Flume pumped from Sheep } \\
\text { Corral Springs. }\end{array}$ & 2.32 & 0.73 & 1. 69 \\
\hline 16 & ..... do & $\begin{array}{l}\text { Marengo Improvement Co. } \\
\text { reservoir. }\end{array}$ & 0.155 & 9.50 & 1.47 \\
\hline 16 & .....do. & $\begin{array}{l}\text { Reservoir No. } 1 \text { P. and L. V. } \\
\text { L. and W. Co. }\end{array}$ & 2.64 & 1. 36 & 3.605 \\
\hline 16 & ....do. & $\begin{array}{l}\text { Tunuel junction Devils Gate, } \\
\text { main supply. }\end{array}$ & 2. 70 & 1.02 & 2.75 \\
\hline Oct. 14 & ...do & Reservoir No. $1 . . . \ldots$. & & & (c) \\
\hline
\end{tabular}

\section{UNDERGROUND WATER OBTAINED FROM THE BED OF THE ARROYO SECO AND THE PASADENA MESA.}

An examination of the underground water supply of the vicinity of Pasadena was made by Mr. J. B. Lippincott in October, 1898, the results of which are given in the following paragraphs.

Pasadena Mesa, lying south of the Sierra Madre, is bounded on the west, along the eastern bank of the Arroyo Seco, by a low range of granite and clay hills, on the south by Raymond Hill, which is of sandstone, and by a dike, the capping of which apparently consists of adobe and clay. This dike extends from Raymond Hill, on the south side of the city of Pasadena, in a direction a little north of east, through Sunny Slope and Baldwin ranches to the base of the Sierra Madre near the mouth of Santa Anita Canyon. It has a southern slope ranging from 100 to 200 feet in height, while toward the north there is no apparent elevation. The mesa proper consists of deposits of sand, gravel, and bowlders, the larger bowlders lying near 
the mountains and the finer material near the southern slope. The voids in this absorbent material act as a storage reservoir, being filled by the flood waters issuing from the steep slopes on the southern face of the Sierra Madre. The underground waters are reenforced by the return water from irrigation on the mesa. From 1893 to 1898 , inclu. sive, was a period of unusual drought, but most of the developments were new.

The Arroyo Seco, draining 21 square miles of the Sierra Madre, issues from these mountains on the west side of Pasadena Mesa, passes through an opening in a granite spur known as Devils Gate, and joins Los Angeles River at Los Angeles. Between the point where the water from this basin issues from the mountains and Devils Gate lies a broad river bottom 2 miles in length, composed of coarse material. In passing over this the water sinks rapidly, diminishing in volume from the mouth of the canyon to Devils Gate.

Pasadena water companies have built extensive development tunnels above Devils Gate, cross cutting beneath the eastern bank and under the mesa land. A submerged dam at Devils Gate assists the tunnel developments by intercepting the underflow. An examination of these tunnels shows there is no impervious strata encountered after the granite ledge at Devils Gate is passed. Of the water obtained from these development works 69 per cent is gained from the portion of the tunnel which is beneath the mesa. A well 4,000 feet above the tunnel and 200 feet deep, in the bed of the wash near the mouth of the mountain canyon of the Arroyo Seco, and which previously contained water, was drained by the extension of this line of tunnels under the Pasadena Mesa.

From the investigations the conclusion is reached that the water from the Arroyo Seco, which sinks between the mouth of the canyon proper and Devils Gate, passes under the eastern bank of the Arroyo Seco between these points and angments the underground water of the Pasadena Mesa. Otherwise it would be difficult to explain the large amount of water which is obtained from the lower development works at the southern dike of the Pasadena Mesa. This mesa is underlain throughout with a sheet of water, sloping from the foot of the moull. tains, where its depth below the surface is from 150 to 200 feet, to the dike at its southern exposure, where the water is practically at the surface, making itself manifest in numerous small springs which rise in drainage lines on the southern face of the dike. With the exception of the Arroyo Seco developments, which in the tabulations are classified by themselves, the principal water product of this mesa is obtained along these drainage lines from the springs. Numerous wells from which water is pumped have been sunk and tunnels run through the dike into the water-bearing gravel.

An interesting feature of these development works is the constant strife existing between the various tunnel and well owners along the 
dike. For instance, the owner of a certain piece of property discovered by a tunnel the presence of a considerable body of water on his land; his neighbor to the south, whose land is at a lower elevation, drained the first tunnel by digging another on a lower grade and extending to his northern property line. This has been done repeatedly, in some cases the water having been so diverted by two or three owners in succession.

The wells are usually bored and lined with 7-inch casing. South of the Santa Fe railroad a charge of 50 cents a foot is made for completing

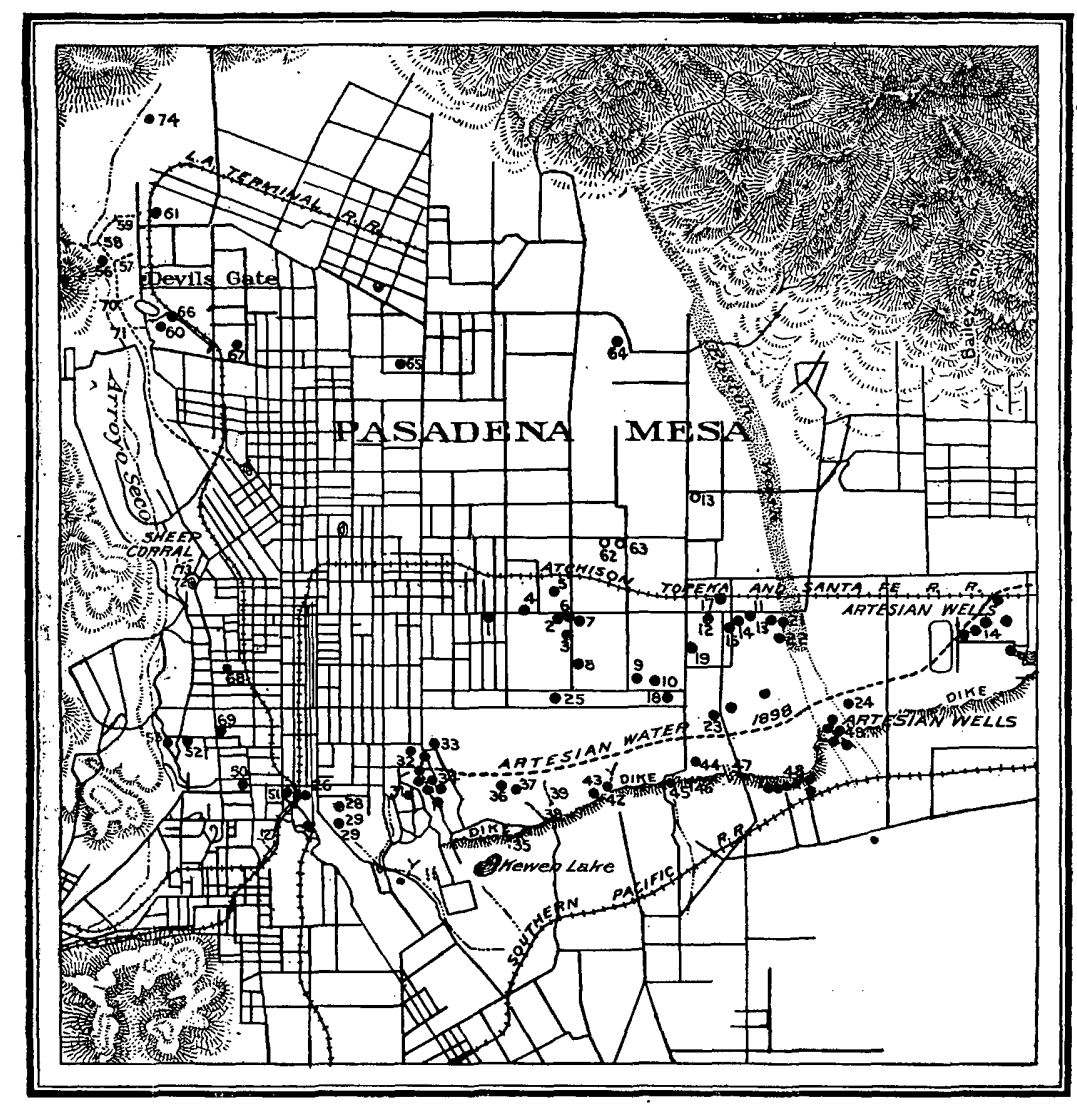

Fra. 217.-Map showing location of artesian wells in the vicinity of Pasadena, California.

the first 50 feet in depth of the well, with an increase of 50 cents per foot for each additional 50 feet in depth. North of the railroad, where the bowlders are larger, a charge of from 10 to 20 per cent more is made for boring. These prices do not include the cost of casing. The data given below concerning depth of wells and depth of water was in nearly all cases obtained from statements made by the owner.

In the following pages are given a compilation of facts with reference to the depth of water in wells through the district and a summary 20 GEOL, PT $4-35$ 
of the water crop from the principal development works. It has been impossible to form an exact conception of the amount of water taken for domestic use and for minor irrigation purposes from the large number of small wells through the mesa, but the water from the larger developments has beeu accurately measured and included in this summary. The accompanying map (fig. 217) shows the position of the wells and development works. The figures refer to the number of the well.

DESCRIPTION OF WRLLS IN THE PASADENA NESA.'

1. Gidding; on Colorado street between Hollister and Chester streets; elevation, 815 feet; depth to water, 103 feet; dug mostly through gravel with no hardpan; digging cost $\$ 1$ per foot and 25 cents extra for every 25 feet additional; 109 feet deep with 6 feet of water; elevation of water, 712 feet.

2. McCallum; Colorado street, in McCallum wash; elevation, 785 feet; 151 feet deep; was dug originally 83 feet; at 90 feet sandstone for 10 feet; 101 feet from surface to water; 50 feet of water; elevation of water, 684 feet; water raised by windmill.

3: Hoover; a bored well with windmill; 11.5 feet deep with 17 feet of water; elevation, 775 feet; water elevation, 677 feet.

4. Moses; bored well; 200 feet deep; elevation, 790 feet; water elevation, 684 feet; originally 100 feet of water, now 94 feet, commencing 106 feet from the surface; $1 \frac{1}{2}$ horsepower gasoline engine with 8-inch stroke, 3-inch cylinder, pumping 1,000 gallons an hour.

5. King; 227 feet deep; elevation, 800 feet; water elevation, 678 feet; originally 117 feet of water, now about 105 feet; water raised by an engine with 12 -inch stroke and 4-inch cylinder, pumping 2,500 gallons per hour.

6. Sterens; 121 feet deep; 31 feet of water; 90 feet to water surface; elevation, 781 feet; water elevation, 618 feet; was dug thirteen years ago.

7. McAdam; 150 feet deep; 57 feet from surface to water; elevation, 740 feet; water elevation, 683 feet.

8. Merwin; 95 feet deep; 55 feet to water; elevation, 735 feet; water elevation, 680 feet; pump capacity, 20 gallons per minute; costs $3 \frac{7}{2}$ to 4 cents an hour to run engine with gasoline at 75 cents per gallon.

9. Butler; bored well; 93 feet deep; 48 feet from surface to water, originally 40 feet; elevation, 718 feet; water elevation, 670 feet.

10. Hutchinson; bored well; 230 feet deep; 36 feet from surface to water; elevation, 713 feet; water elevation, 677 feet; well bored through clay; pressure comes from below.

11. Daniels; 107 feet deep; 40 feet from surface to water; water, 67 feet deep; elevation, 715 feet; water elevation, 675 feet; strata of clay and bowlders with coarse gravel at bottom was encountered.

12. Hodge; 169 feet deep; 87 feet to water; elevation, 725 feet; water elevation, 692 feet.

13. Miles; bored well; 225 feet deep; 143 feet to water; elevation, 835 feet; water elevation, 692 feet.

14. Wilkeson; 177 feet deep; 30 feet from surface to water; elevation, 720 feet; water elevation, 690 feet. Jack Butler, well borer, says that wells during 1898 were 15 feet lower than in previous years.

15. Ackerman; bored well; 149 feet deep; 75 feet from surface to water; elevation, 755 feet; water elevation, 680 feet.

16. Thorndyke; 275 feet deep; 30 feet from surface to water; elevation, 705 feet; water elevation, 675 feet; fine clay encountered at 69 feet and 73 feet from surface, the remainder being gravel strata.

I The unit of measurement is the California miner's inch, which is 0.02 of 1 cubic foot per second. 
17. Lamanda Park; 180 feet deep; originally 80 feet from surface to water; elevation, 740 feet; present water elevation, 680 feet.

18. Titus; 558 feet deep; from surface to water 4 feet, originally 12 feet; elevation, 690 feet; water elevation, 678 ; several strata of cement 1 inch thick were encountered.

19. Butler; 175 feet deep; 75 feet from surface to water; elevation, 720 feet; water elevation, 645 feet.

20. Graves; 88 feet deep; 40 feet from surface to water; elevation, 720 feet; water elevation, 680 feet.

21. Krouser; 113 feet deep; 15 feet from surface to water; elevation, 700 feet; water elevation, 685 feet.

22. Wakefield; 60 feet deep; originally 20 feet to water, now 30 feet; elevation, 703 feet; water elevation, 673 feet.

23. Pavey; 360 feet deep; water elevation, 670 feet; originally flowed 16 miner's inches of water; still flowing but in less volume.

24. Chapman; flowing well; 175 feet deep. There are about 12 flowing wells on this ranch.

25. Hassleys; 500 feet deep; elevation, 600 feet; originally artesian, but now cut by a tunnel at a lower elevation.

26. Raymond; 40 feet to water, which is 4 feet deep; water fell 2 feet during season of 1898; 91 miner's inches of water were pumped from this well during October, 1898; well is brick lined and 12 feet in diameter.

27. Marengo tunnel; run into Raymond Hill at Terminal Railway, Fair Oaks station; it is discharging 18 miner's inches. This tunnel drained a small tunnel on the west side of Fair Oaks avenue.

28. Fluer; dug well, Ipswich street; depth 48 feet, water 12 feet; dug in October, 1897; at first there was a supply of 50 miner's inches, but the supply has diminished to 30 miner's inches; a 6 -inch centrifugal pump with 20 -horsepower engine pumps out the well in 1.5 hours.

29. Stoneman tunnel; was first run in $1892 ; 178$ feet, and in summer of 1898 was extended 164 feet; flows 14.4 miner's inches.

30. Graves tunnel; 530 feet of tunnel and about 100 feet of ditch; water 26 feet below the surface of the ground at the upper end; 20 miner's inches of water obtained.

31. Oak Knoll; about the same class as Khodes well and discharging the same amount of water, 4 miner's inches.

32. Brickyard well; near Lake avenue, northeast from (ak Knoll; 40 feet of well are through clay, 7 feet throngh sand and gravel; 7 miner's inches of water are obtained; this is a brick-lined dug well.

33. Rhodes well; near corner of Lake avenue and Hawkeyestreet; 49 feet deep and water approximately 8 feet in depth; steam plant, 15-horsepower boiler with Smith valve pump; a perpetual flow of 4 niner's inches is obtained.

34. Alhambra water in Mayberry Canyon; 94 miner's inches are obtained, which is not the full capacity of the plant. There are six wells from 350 feet to 750 feet deep, of which five are being pumped and one flows.

35. Potter tunnel; near Kewen Lake; produces 7 miner's inches.

36. Surface water; Patton water in West Canyon, 2 miner's inches.

37. Patton water, East Canyon; 23 miner's inches. '(San Gabriel water not included in this.)

38. San Gabriel Mission; 24.9 miser's inches; comes from the same canyon as Patton water in East Canyon; it is surface water and has been reduced by development works.

39. Shorb water; from tunnel under orange grove on Shorb place; approximately 2 miner's inches is obtained. In small canyon northwest of house there is a stream approximately 5 miner's inches; there are three artesian wells (No. 42 ) southeast of the ranch house, from which 17 miner's inches are obtained. 
60. Lower Painter well; dug in 1894; 96 feet deep; water, 79 feet from surface; elevation, 1,040 feet; water elevation, 961 feet; this is a 4-foot by 7-foot dug well, the material passed through being large bowlders.

61. Upper Painter well; dug well much resembling No: 60; 162 feet deep; 132 feet to water; elevation, 1,130 feet; water elevation, 997 feet.

62. Becker; 200 feet deep; depth to water, as measured in May, 1898, 173 feet; a 6-horsepower gasoline engine is used, which has pumped 5 miner's inches; it is a bored well, cost $\$ 250$, including casing ( $\$ 1$ per foot plus 25 cents additional for each 50 feet additional depth); elevation, 825 feet; water-eleration, 652 feet.

63. Stafford; bored well; 241 feet deep; depth to water, 173 feet; elevation, 825 feet; water elevation, 552 feet.

64. Krank; 300 feet deep; 290 feet to water; elevation, 1,070 feet; water elevation, 780 feet.

65. Meers; on E street; 300 feet deep; 75 feet of water in August, 1897; elevation, 1,060 feet; water elevation, 735 feet.

66. Stone; 100 feet deep; 85 feet to water; elevation, 1,040 feet; water elevation, 955 feet; approximately 15 miner's inches is obtained when pump is run. This is a dug and timbered well and cost for excavation $\$ 1.75$ per vertical foot until water was struck; passed through, say, 65 feet of gravel, 15 feet of sand, and 12 feet of clay.

67. Called Painter well; 170 feet to water; 14 feet lower ground than No. 41; water eleration, 830 feet.

50. Hurlbut; bored well, about 1,300 feet deep; 94 feet through clay; but little water; elevation, 780 feet; water elevation, 520 feet.

(26.) Olmstead; 39 feet deep; elevation, 750 feet; water elevation, 740 feet; the usual depth of water from the surface is 8 feet, but in October, 1898, was 10.5 feet.

51. Pasadena and Pacific power-house well; elevation, 750 feet; water stands 11 feet from original surface of ground; water elevation, 739 feet.

52. Baker; 35 feet deep; elevation, 740 feet; water elevation, 734 feet; supply is said to come from northeast.

53. Pasadena West Side Water Company; about 70 feet deep and 3 feet to water; elevation, 718 feet; water elevation, 715 feet; water comes from northeast.

68. Morehouse; cesspool at this point of 70 feet and no water is encountered; surface elevation, 790 feet.

69. On top of a hill 500 feet east of No. 53 ; 60 feet deep and no water found; surface elevation, 825 feet.

74. In Arroyo Seco at mouth of cauyon; 250 feet deep and dry.

Amount of water developed in the Pasadena Mesa.

No.

[ 1 miner's inch is 0.02 of 1 cubic foot per second.]

27. Raymond Improvement Company's tunnel at Fair Oaks avenue............ 18

26. Marengo well, near Atchison, Topeka and Santa Fe station, Raymond....... 91

26. Snrface water in Marengo canyon, near railroad crossing (S. P.).......... 20

28. Fluer well on Ipswich street, near S. F. Raymond station; intermittent pumping............................................. 30

29. Las Poebles Water Company, near new Graves's tunnel ................. 14

29. Stoneman canyon heads, mear Fluer well ............................. 3

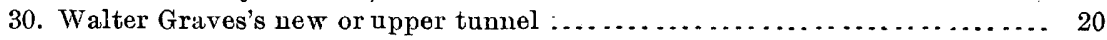

31. Oak Knoll well ................................................ 4

32. Brickkiln well. ................................................ 7

33. C. H. Rhodes's well, near Lake avenue and Hawkeye street ............. 4

34. Alhambra water, artesian wells and air-compressing plant ............ 64

35. Patton tunnel, near Kewin Lake................................ 7

36. Patton water in west canyon.................................... 2

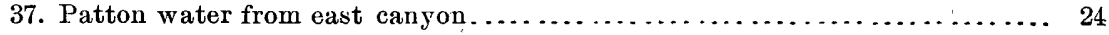


38. San Gabriel Mission water .................................... 25

39. Shorb water northwest from ranch house. . . . . . . . . . . . . . . . . 5

39a. Shorb water in tunnel southwest of ravch house ................. 2

40. Graves's lower tunnel; dry . . . . . . . . . . . . . . . . . . . . . . . . . .

41. Richardson's two tunnels, near Kewin Lake......................... 18

42. Shorb's three artesian wells southeast of honse . . . . . . . . . . . . . . . 17

43. Pump, 13 inches; artesian, 3 inches; tunnel, 22 inches; all belong to Shorb. 38

44. Rose well, east side Santa Anita avenue....................... 20

45. Winston wells, Santa Anita avenue ............................. 12

46. Alexander water, east of Santa Anita avenue . . . . . . . . . . . . . . . . 25

47. Titus ranch............................................. 19

48. Sunny Slope developments................................. 66

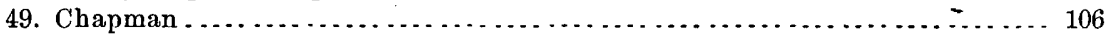

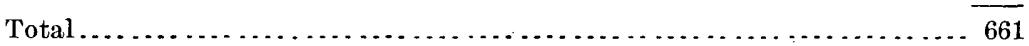

Development near Devils Gate by the United Water Companies.

56. Pumped from well below Devils Gate, but entering tnnnel above sand box.: 7

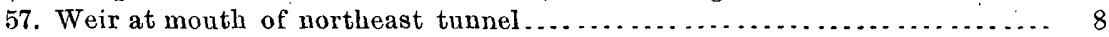

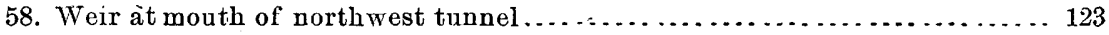

Total from Devils Gate. .............................. 138

59. Total from North Branch. . . . . . . . . . . . . . . . . . . . . . . . . . . . . 118

Total from submerged dam and from under arroyo above dam .......... 5

Flow from the 900 feet of tunnel, east bank of arroyo, or six-tenths of all of Devils Gaté flow from tunnels.

70. Richardson tunnel below Devils Gate..........................

71. Wilson tunnel below Devils Gate............................. 10

Developed at Devils Gate................................ 138

Total upper arroyo development $\ldots \ldots \ldots \ldots \ldots \ldots \ldots \ldots \ldots \ldots \ldots \ldots \ldots \ldots$

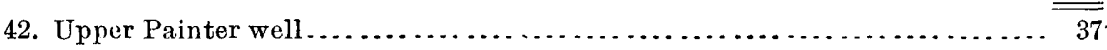

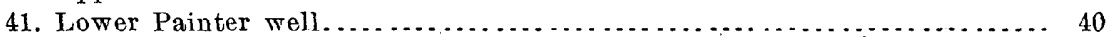

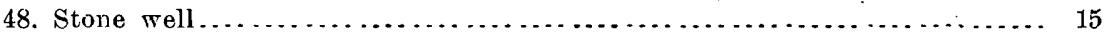

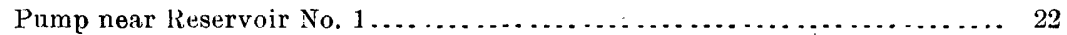

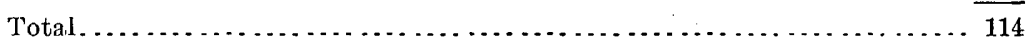

72. Sheep Corral springs, in development cut ..................... 74

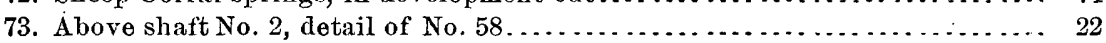

Summary of water dexelopment from Pasadena Mesa.

Devils Gate development. . . . . . . . . . . . . . . . . . . . . . . . . . . 172

Sheep Corral . . . . . . . . . . . . . . . . . . . .

Lower dike in $4 \frac{1}{2}$ miles... . . . . . . . . . . . . . . . . . . . . . . . . . 661

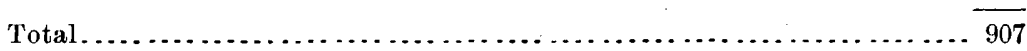

SAN GABRIEL RIVER,

San Gabriel River receives water from the southern slope of the Sierra, the entire drainage basin being included in Los Angeles County, California. The stream has been described in the Eighteenth Annual Report, Part IV, beginning on page 405. Throughout a considerable part of the year the entire flow of the stream is diverted into canals, 
the quantity being measured by various weirs. The excess water in the stream is measured in the bed of the river at a point near the first diversion box. In order to obtain the entire run-off for the 222 square miles drained, it is necessary to add this amount to the total taken by the canals. These data are obtained from Mr. H. F. Parkinson, superintendent for the various irrigation canal companies. Besides these systematic measurements a number of low-water measurements of San Gabriel River were made at various points during the drought of 1898 , as given in the following table.

Results of low-water measurement of waters on San Gabriel River.

\begin{tabular}{|c|c|c|c|c|c|}
\hline Date. & River. & Locality. & $\begin{array}{l}\text { Area of } \\
\text { section. }\end{array}$ & $\begin{array}{c}\text { Mean } \\
\text { velocity. }\end{array}$ & Discharge. \\
\hline $\begin{array}{l}1898 . \\
\text { July } 1\end{array}$ & San Gabriel. & Duarte water & sq. feet. & $\begin{array}{l}\text { Feet per } \\
\text { second. }\end{array}$ & Sec. feet. \\
\hline & ..... do ...... & Azusa water...... & ........ & $\cdots$ & 11. 78 \\
\hline June 21 & .....do ...... & Headworks in canyon........ & $(b)$ & & 13.21 \\
\hline July 3 & .....do ... & Temple ditch $. . . \ldots \ldots \ldots . . .$. & 3. 19 & $\dot{2} .84$ & 9.06 \\
\hline & ..... do $\ldots$... & $\begin{array}{l}\text { Baldwin's ranci house road. } \\
\text { tirst channel. }\end{array}$ & 6.30 & 1.39 & 8. 79 \\
\hline & ..... do .. & Original channel of river...... & 6.61 & 0.93 & 6. 18 \\
\hline & .....do & Camper's station No.11 ....... & 4.01 & 0.83 & 3. 36 \\
\hline & .... do ... & Puenteditch ...................... & ......... & $\therefore \ldots$ & 2.44 \\
\hline . & .....do . & Old Mission Bridge........... & 13.94 & 2.14 & 29.79 \\
\hline & .... do ... & Whittier ditch...$\ldots \ldots \ldots \ldots$ & 0.88 & 2.86 & 2.52 \\
\hline & .....do ... & Total flow at Puente Narrows. & & & 62.14 \\
\hline Aug. 16 & ..... do .... & Headworks in canyon........ & (b) & . & 5. 16 \\
\hline Aug. 31 & ....do. & Flume Whittier ditch....... & 3. 62 & 0.50 & 1.80 \\
\hline & ......do. & Temple ditch $\ldots \ldots \ldots \ldots \ldots$ & 2.67 & 2.57 & 6.88 \\
\hline & ..... do ... & Old channel .................. & 5.39 & 1.45 & 7.81 \\
\hline & ..... do ... & No. 10, No. $11 \ldots \ldots \ldots \ldots$ & 9.16 & 0.67 & 6.17 \\
\hline & ......do ... & Old Mission Bridge . . ......... & 13.61 & 2.05 & 27.91 \\
\hline & ......do ... & Total flow at Puente Narrows. & $\cdots \cdot$ & $\cdots \cdots \cdots$ & 50.57 \\
\hline Aug. 23 & .....do . . & Headwork weir in canyon..... & -...... & $\ldots \ldots \ldots$ & 8.42 \\
\hline & . . . do do. & Mouth East Fork ............... & 4.50 & 1.58 & 7.11 \\
\hline & .....do ... & Mouth West Fork ........... & 3.47 & 0.77 & 2.67 \\
\hline & ..... do ... & $\begin{array}{l}\text { Azusa flume, lower tunnel } \\
\text { developed water. }\end{array}$ & 0.356 & 0.146 & 0.52 \\
\hline July 1 & .....do. & Monrovia Canjon................. & 1.36 & 0.98 & 1.33 \\
\hline
\end{tabular}

There are two tributaries of San Gabriel River, called the East and West forks. As described by Mr. J. B. Lippincott, these approach from opposite directions and unite at a point approximately 8 miles above the mouth of the mountain canyon, through which they descend on an average grade of $\mathbf{1 0 0}$ feet to the mile. The portion of the basin above the 5,000-foot contour, particularly on the northern slopes, is timbered with large pine trees, and its remaining portion is covered with a dense growth of shrubs locally known as white thorn and greasewood. The slopes, as a rule, are exceedingly precipitous, giving the river a lower run-off during summer months and higher flood stages during winter months than the Santa Ana River, described on page 552. The steep grades prevent extensive storage, the possible sites for reservoirs 
being small and the percentage of silt carried during flood being large. The great alluvial cone built at the mouth of the canyon is an evidence of the erosive and transporting action of the stream.

As in the case of other streams of southern California, the water of San Gabriel River is of great value for irrigation purposes and the surface flow is completely diverted during at least nine months of the year at the mouth of the canyon, 2 miles north of Azusa. Besides the surface flow, attempts have been made to obtain the waters percolating beneath the surface, about 2 miles of tumnels having been constructed near the mouth of the canyon. In addition to this a submerged dam is being built in the canyou at the head of the San Gabriel Electric Company's diversion works, in order to completely intercept this seepage water and convey it by tunnels to the power house.

Estimated monthly discharge of San Gabriel River and canals at Azusa, California.

[Drainage area, 222 square miles.]

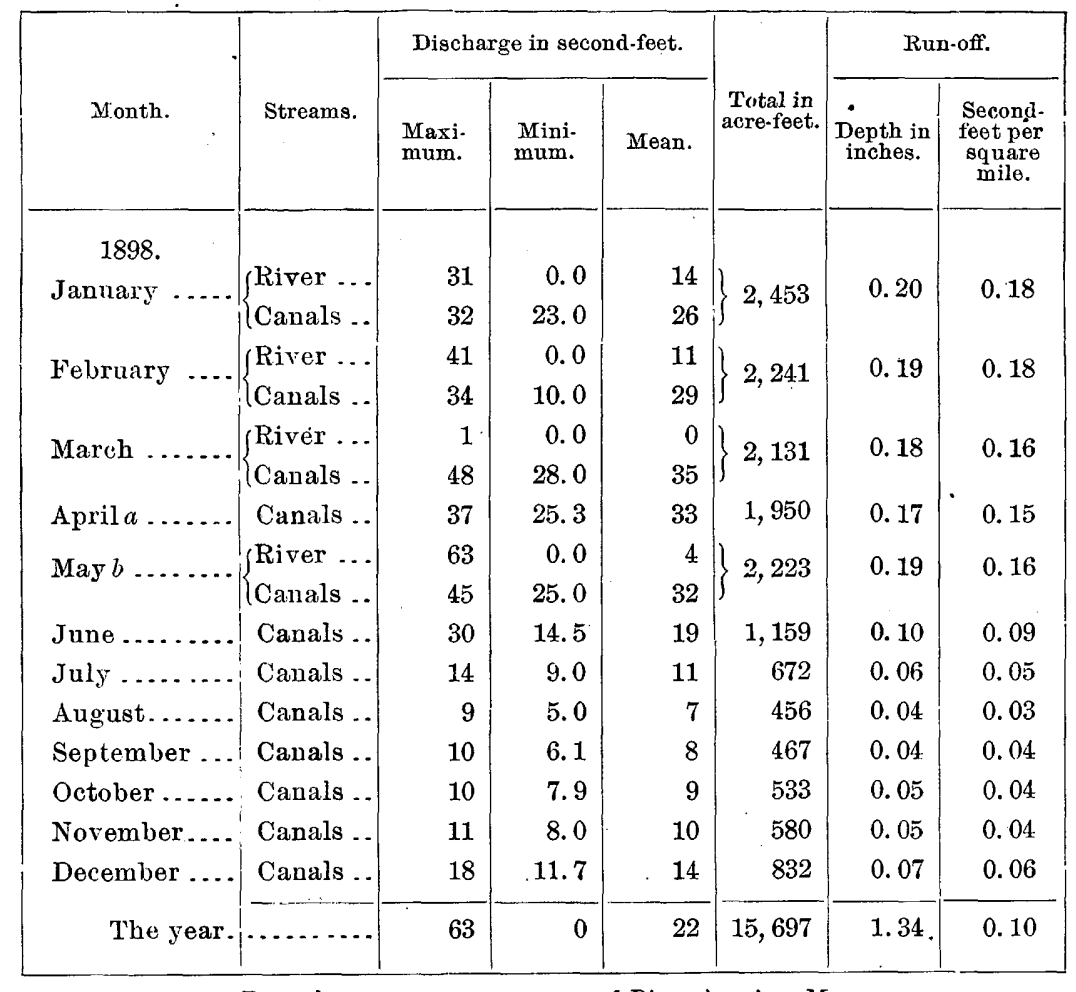

$a$ Rirer dry.

$b$ River dry since May.

Note.-Gage heights for 1898 for the river during the time water was flowing in the channel are given in Water-Supply and Irrigation Paper No. 28, page 189; list of measurements and rating table, page 191. Daily discharge in cubic feet per second of the San Gabriel canals, from September to December, 1898, inclusive, are given in Water-Supply and Irrigation Paper No. 28, page 190, figures for January to August, inclusive, being omitted; results for 1897 are given in Water-Supply and Irrigation Paper No. 16, page 94, and in the Nineteenth Annual Report,' Part IV, page 528. 


\section{SAN ANTONIO AND CUCAMONGA CREEKS.}

The drainage basin of San Antonio Creek is immediately east of that of San Gabriel River. It comprises a little over 24 square miles as measured at the mouth of the canyon. Cucamonga Creek has a drainage area of nearly 7 square miles immediately east of that of San Antonio Creek and south of the Lytle Creek drainage basin. Several measurements were made during the low.water period of 1898 , as shown by the following table:

Measurements of San Antonio and Cucamonga Creeks.

\begin{tabular}{|c|c|c|c|c|c|}
\hline Date. & Creek. & Locality. . & $\begin{array}{l}\text { Area of } \\
\text { section. }\end{array}$ & $\begin{array}{c}\text { Mean } \\
\text { velocity. }\end{array}$ & Discharge. \\
\hline $\begin{array}{l}\text { July } 2 \\
\text { July } \\
\text { A ug. } 26\end{array}$ & 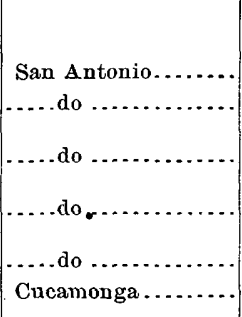 & $\begin{array}{l}\text { In canyon. } \\
\text { Ontario water, near division } \\
\text { box. } \\
\text { Ontario water, below division } \\
\text { box. } \\
\begin{array}{l}\text { Pomona water at Pierces } \\
\text { Camp. } \\
\text { In canyon........ }\end{array}\end{array}$ & $\begin{array}{c}\text { Sq. feet. } \\
\ldots .347 \\
0.24 \\
1.97 \\
(b) \\
.78\end{array}$ & 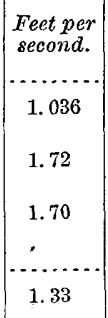 & \begin{tabular}{|r} 
Sec. feet. \\
7.59 \\
0.36 \\
\\
3.87 \\
3.36 \\
10.01 \\
1.04
\end{tabular} \\
\hline
\end{tabular}

SANTA ANA RIVER.

Santa Ana River in its upper portion heads in the western slopes of the San Bernardino Mountains and discharges at a point 4 miles east of Redlands, its waters being completely used in San Bernardino Valley. At the lowest part of this valley the waters again appear in the channel near the point known as Rincon, and, passing through a low range, flow in a general southwesterly course into the Pacific Ocean. This river has been described by Mr. J. B. Lippincott in the Nineteenth Annual Report, in an article on Water Supply of San Bernardino Valley. To the south of the upper catchment basin of Santa Ana River is Mill Creek and next this San Timoteo Creek. Mill Creek has a high drainage basin and a large run-off, while San Timoteo Creek passes over flat valley lands, which absorb the water coming from the high portions of the basin and deliver it through a series of cienegas located at lower levels. To the west of the Santa Ana drainage basin are Plunge, City, and Twin creeks, the catchment area of these streams being shown on the Redlands topographic sheet.

All of these streams entering San Bernardino Valley from the north and east are diverted for irrigation during the greater portion of the year, their waters being carried to the bench lands and much of it returning by seepage and contributing to the supply of underground water. These bench lands have for the most part been constructed by streams which carry gravel and bowlders from the high mountains, 
and deposit these in their lower channels and on the surrounding valley lands. The gravels at the mouth of the canyon and under the adjacent bench lands are saturated with water, which tends to seep gradually toward the lowest point of San Bernardino Valley, where Santa Ana River escapes to the sea. This underground water is, however, interrupted by what is locally known as the "clay dike," which passes across the drainage lines at a point approximately 2 miles east of Colton. As described by Mr. J. B. Lippincott, a cap of adobe overlies the lower portion of the valley south of the city of San Bernardino and east of Colton. The valley itself has a slope of approximately 100 feet to the mile in all directions toward Colton. When this cap is punctured in the area south of San Bernardino and east of Colton artesian water is obtained, the wells as a rule being shallow, ranging in depth from 100 to 500 feet. In addition to this artesian' water a notable amount is obtained from seepage along the drainage lines of the streams entering the valley from the north. Warm Creek is one of the valley streams which rises from springs in these drainage lines east and south of San Bernardino. This surface and underground water is the source of supply for irrigation at Riverside, Colton, and Bloomington. Measurements of these waters are given on later pages.

In the eastern end of San Bernardino Valley fruit culture by irrigation has been more highly developed than in any other portion of the United States, the orange groves of Redlands, Riverside, and Highlands being among the best in California. Land suitable for citrus culture is worth, with good water rights, $\$ 500$ an acre, while water alone is valued as high as $\$ 1,000$ a miner's inch, or $\$ 50,000$ a cubic foot, per second. During 1898 and 1899 the severe drought forced the irrigators to use far less water than was believed to be necessary to sustain the orchards, and a cubic foot per second was made to serve as much as 600 or 700 acres.

An electric power plant has been constructed bv the Southern California Power Company in the canyon of Santa Ana River, the diversion occurring at the mouth of Bear Creek. The total length of the conduit is 14,750 feet, of which 11,640 feet is tunnel and 375 feet flume. The grade of the conduit, is 18 feet in 10,000 . The tunnels are 5 feet 6 inches wide and 4 feet 6 inches high to springing line. The flumes are 5 feet 6 inches wide and 5 feet high. The capacity is 120 cubic feet per second. The power pipe is 30 inches in diameter and is made of riveted steel, it being 2,200 feet in length, with a total fall of 728 feet and an effective bead of 700 feet. Three power pipes are required for the full capacity of the conduit, only one of which is now in place. The theoretical horsepower is 6,363 . The water is discharged through nozzles against Pelton impulse water wheels, which are directly connected with the shaft of the triphased electric generators. The current is conducted to Los Angeles, a distance of 90 miles, under 33,000 volts pressure, and is there used for power and lighting purposes. This is the longest trans- 


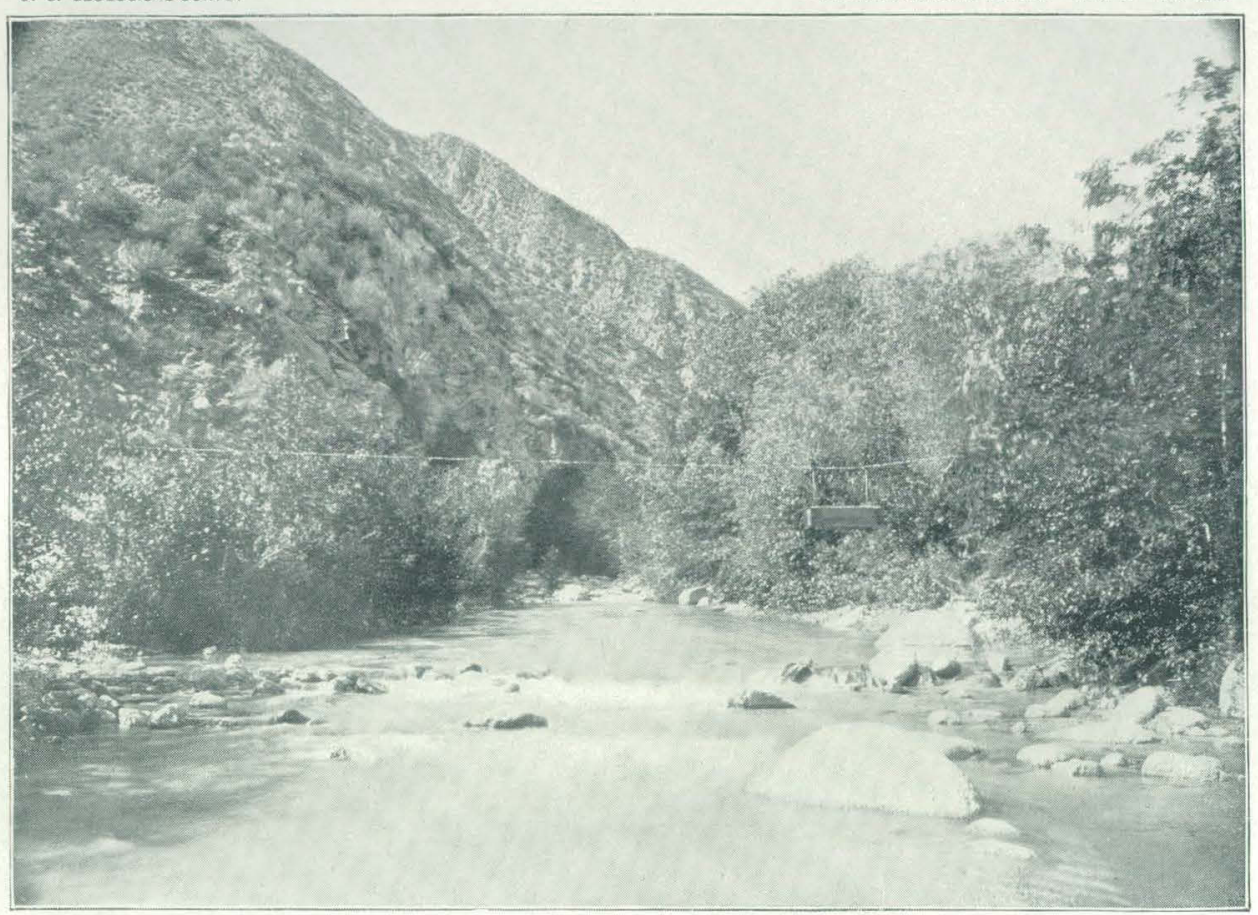

A GAGING STATION ON SANTA ANA RIVER AT WARMSPRINGS, CALIFORNIA.

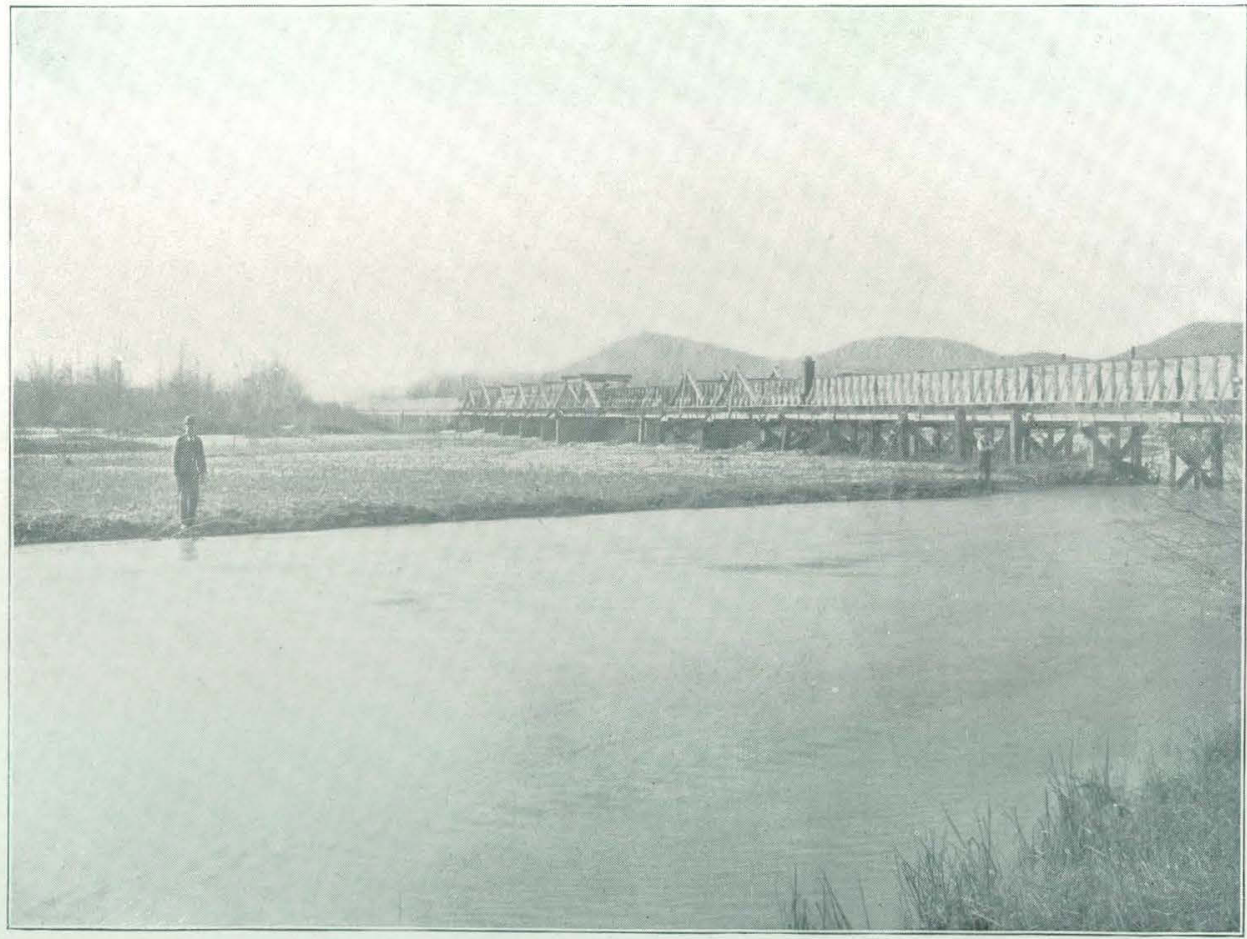

3. FLUME ACROSS SANTA ANA RIVER 


\section{PROGRESS OF STREAM MEASUREMENTS FOR 1898.}

mission plant operated commercially in the world. The transmission has been most satisfactory, the line loss being less than 10 per cent.

Measurements of Santa Ana River have been made, as described in previous reports, near Warmsprings, below the point of diversion of the Santa Ana Canal, so that to obtain the total flow the amount in the canal has been added as given in the following table. On Pl. LXIII, $A$, is given a view of the gaging station. The character of the river in the valley is indicated by the view $B$ of the same plate.

Estimated monthly discharge of Santa Ana River and Canal at Warmsprings, California.

[Drainage area, 188 square miles.]

\begin{tabular}{|c|c|c|c|c|c|c|c|}
\hline \multirow[b]{2}{*}{ Month. } & \multirow[b]{2}{*}{ Streams. } & \multicolumn{3}{|c|}{ Discharge in second-feet. } & \multirow{2}{*}{$\begin{array}{l}\text { Total in } \\
\text { acre-feet. }\end{array}$} & \multicolumn{2}{|c|}{ Run-off. } \\
\hline & & $\begin{array}{l}\text { Maxi. } \\
\text { mum. }\end{array}$ & $\begin{array}{l}\text { Mini- } \\
\text { mum. }\end{array}$ & Mean. & & $\begin{array}{l}\text { Depth in } \\
\text { inches. }\end{array}$ & $\begin{array}{l}\text { Second- } \\
\text { feet per } \\
\text { square } \\
\text { mile. }\end{array}$ \\
\hline $\begin{array}{r}1898 . \\
\text { January - }\end{array}$ & $\left\{\begin{array}{l}\text { River ... } \\
\text { Canal ... }\end{array}\right.$ & $\begin{array}{r}58 \\
\ldots \ldots \ldots\end{array}$ & $\begin{array}{r}33 \\
\ldots . . .6\end{array}$ & $\begin{array}{r}40 \\
9\end{array}$ & 2,987 & 0.30 & 0.26 \\
\hline February & $\left\{\begin{array}{l}\text { River ... } \\
\text { Canal ... }\end{array}\right.$ & $\begin{array}{r}76 \\
\ldots \ldots\end{array}$ & $\begin{array}{r} \\
\\
\ldots 3 \\
\ldots . . .\end{array}$ & $\begin{array}{r}40 \\
8\end{array}$ & 2,688 & 0.27 & 0.26 \\
\hline March ... & $\left\{\begin{array}{l}\text { River ... } \\
\text { Canal ... }\end{array}\right.$ & $\begin{array}{r}40 \\
\ldots \ldots\end{array}$ & $\begin{array}{r}25 \\
\ldots \ldots \ldots\end{array}$ & $\begin{array}{r}32 \\
8\end{array}$ & 2,448 & 0.24 & 0.21 \\
\hline April & $\left\{\begin{array}{l}\text { River ... } \\
\text { Canal ... }\end{array}\right.$ & $\begin{array}{r}34 \\
\ldots \ldots\end{array}$ & $\begin{array}{r}28 \\
\ldots . . .6\end{array}$ & $\begin{array}{r}31 \\
8\end{array}$ & 2,333 & 0.23 & 0.21 \\
\hline May .. & $\left\{\begin{array}{l}\text { River ... } \\
\text { Canal ... }\end{array}\right.$ & $\begin{array}{r}149 \\
\ldots \ldots\end{array}$ & $\begin{array}{r}26 \\
\ldots \ldots\end{array}$ & $\begin{array}{r}55 \\
6\end{array}$ & 3,727 & 0.37 & 0.32 \\
\hline June - & $\left\{\begin{array}{l}\text { River ... } \\
\text { Canal ... }\end{array}\right.$ & $\begin{array}{c}58 \\
\ldots . . .\end{array}$ & $\begin{array}{l}36 \\
\ldots . .\end{array}$ & $\begin{array}{r}44 \\
4\end{array}$ & 2,840 & 0.28 & 0.25 \\
\hline July . & $\left\{\begin{array}{l}\text { River ... } \\
\text { Canal ... }\end{array}\right.$ & $\begin{array}{r}53 \\
\ldots . . .\end{array}$ & $\begin{array}{c}33 \\
\ldots .\end{array}$ & $\begin{array}{r}41 \\
2\end{array}$ & 2,625 & $0 .{ }^{-} 5$ & 0.23 \\
\hline August . & $\left\{\begin{array}{l}\text { River ... } \\
\text { Canal ... }\end{array}\right.$ & $\begin{array}{r}58 \\
\ldots \ldots .\end{array}$ & $\begin{array}{r} \\
\quad 33 \\
\ldots . . .\end{array}$ & $\begin{array}{r}41 \\
2\end{array}$ & 2,653 & 0.26 & 0.23 \\
\hline September ... & $\left\{\begin{array}{l}\text { River ... } \\
\text { Canal ... }\end{array}\right.$ & $\begin{array}{r}45 \\
\ldots . . .\end{array}$ & $\begin{array}{r}28 \\
\ldots . . .6\end{array}$ & $\begin{array}{r}36 \\
2\end{array}$ & 2,223 & 0.22 & 0.20 \\
\hline October ...... & River... & 36 & 19 & 26 & 1,581 & 0.16 & 0.14 \\
\hline November.... & River... & 34 & 18 & 22 & 1,285 & 0.13 & 0.12 \\
\hline December .... & River ... & 28 & 22 & 22 & 1,364 & 0.14 & 0.12 \\
\hline The year. & $\ldots$ & 149 & 18 & 40 & 28,754 & 2.86 & 0.21 \\
\hline
\end{tabular}

Note.-Gage heights for 1898 are given in Water-Supply and Irrigation Paper No. 28, page 190; measurements, page 191; rating table, page 191; results for 1897, in Water-Supply and Irrigation Paper No. 16, page 195, and in the Nineteenth Annual Report, Part IV, page 567. 


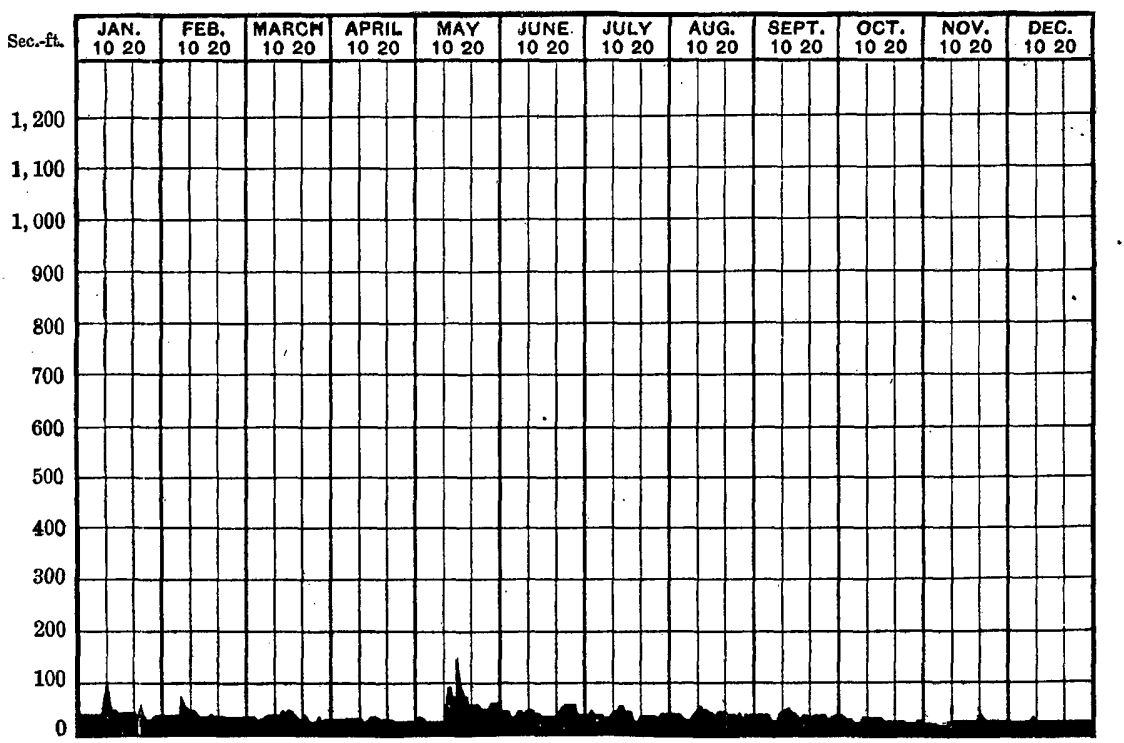

FIG. 218.-Discharge of Santa Ana River at Warmsprings, California, 1898.

\section{LYTLE CREEK.}

Lytle Creek rises on the eastern end of the Sierra Madre Mountains, draining the northern and eastern slopes of the San Antonio Peak and its neighboring spurs. There are three principal forks of the stream, which unite near the hot spring at a point about 4 miles above the opening of the canyon. All of the ordinary summer flow of the stream is diverted at the mouth of its canyon into a masonry canal and passes over a weir, which canal and weir are used in common by all the water companies interested in this supply. It is at this weir that the measurements given below were taken. From July 1 to October 26, 1898, this weir was 6.57 feet in length; after October 26 the length was changed to 6.50 feet. The head on this weir is measured by a ditch tender who resides at the headworks, the readings being taken by a hook gage. The weir bay is not entirely satisfactory, in that considerable sand collects therein and some swirls occur. The following record was furnished by $\mathrm{Mr}$. John $\mathrm{H}$. Caruthers, manager of the Anglo-American Canaigre Company. It is valuable, in that it gives measurements on one of the principal streams tributary to the San Bernardino Valley. On June 10, 1898, this weir was measured by J. B. Lippincott at $4.05 \mathrm{p}$. $\mathrm{m}$. and its discharge computed at 9.46 secondfeet; at $4.30 \mathrm{p} . \mathrm{m}$. on the same date a measurement was made by J. B. Lippincott in the Rialto Canal, below the weir, by means of a meter, and the volume determined at 10.73 second-feet. It can not be assumed that the same error always existed in the weir when measurements were taken, because the changing volume of sand in the bay would necessarily affect the accuracy of the weir. The Grapeland Irrigation district during certain times of the day diverts its water from a point 


\section{PROGRESS OF STREAM MEASUREMENTS FOR 1898.}

above this weir, but at the time of the measurement above referred to this diversion was not occurring. The Anglo-American Canaigre Company diverts its water from the Rialto Canal about 2 miles below the mouth of the canyon, being entitled to the excess water above 11.10 second-feet. The city of San Bernardino obtains 3.0 second-feet from the Rialto Canal. The irrigation water is used largely in the neighborhood of Rialto on the Citrus Belt Irrigation District, on the Grapeland Irrigation District, and for domestic purposes in San Bernardino.

Discharge of Lytle Creek from July 1 to December 31, 1898. a

[Area of watersbed, 54 square miles, as given in report of State engineering department.]

\begin{tabular}{|c|c|c|c|c|c|c|}
\hline Date. & July. & August. & September. & October. & November. & December. \\
\hline 1898. & See.feet. & Sec.-feet. & Sec.-feet. & Sec.feet. & Sec.feet. & Sec.feet. \\
\hline $1 \ldots$ & 9.85 & 8.90 & 8.89 & 9.52 & 10.10 & 10.72 \\
\hline $2 \ldots \ldots \ldots$ & 10.45 & 8.72 & 8.98 & 9.35 & 10.06 & 10.54 \\
\hline $3 \ldots \ldots \ldots$ & 10.63 & 8.69 & 8.85 & 9.13 & 10.15 & 10.45 \\
\hline $4 \ldots \ldots .$. & 10.78 & 7.28 & 8.85 & 9.09 & 10.11 & 10.58 \\
\hline $5 \ldots \ldots$ & 10.41 & 8.21 & 8.92 & 9.10 & 9.93 & 10.72 \\
\hline $6 \ldots$ & 10.27 & 8.43 & 8.76 & $9.80^{\circ}$ & 9.80 & 10.60 \\
\hline $7 .$. & 10.48 & 9.55 & 8.55 & 8.83 & 9.72 & 10.58 \\
\hline $8 \ldots \ldots$ & 10.22 & 8.93 & 8.43 & 9.05 & 10.02 & 10.72 \\
\hline $9 .$. & 10.18 & 8.05 & 8.51 & 9.13 & 10.02 & 10.72 \\
\hline $10 \ldots \ldots$ & 10.14 & 7.62 & 8.47 & 8.89 & 9.93 & 10.72 \\
\hline $11 \ldots$ & 10.40 & 7.31 & 8.35 & 8.64 & 9.93 & 10.89 \\
\hline$\overline{12 . . . . .}$ & 9.92 & 7.08 & 8.39 & 8.52 & - 9.98 & 10.85 \\
\hline $13 .$. & 9.58 & 7.89 & 8.60 & 8.30 & 10.06 & 10.98 \\
\hline $14 \ldots \ldots$ & 9.15 & 7.98 & 9.02 & 8.17 & 10.06 & 10.98 \\
\hline 15. & 9.15 & 8.03 & 8.72 & 8.61 & 10.11 & 11.63 \\
\hline 16. & 9.02 & 8.03 . & 8.56 & 9.05 & 10.21 & 11.26 \\
\hline $17 .$. & 9.52 & 8.12 & 8.28 & 8.62 & 10.17 & 11.26 \\
\hline $18 \ldots .$. & 9.19 & 7.94 & 8.47 & 8.97 & 10.15 & 11.82 \\
\hline $19 \ldots \ldots$ & 7.83 & 8.03 & 8.88 & 8.84 & 10.02 & 11.82 \\
\hline 20. & 6.59 & 8.20 & 8.71 & 8.83 & 10.06 & 11. 66 \\
\hline $21 \ldots$ & 9.30 & 8.47 & 9.18 & 8.88 & 10.06 & 11. 36 \\
\hline 22. & 10.09 & 8.51 & 9.14 & 9.31 & 10.37 & 11.26 \\
\hline 23. & 9.79 & 8.56 & 9.13 & 9.87 & 10.41 & 11.54 \\
\hline 24 & 9.88 & 8. 19 & 9.09 & 9.39 & 10.41 & 11.54 \\
\hline 25 & 9.36 & 8.52 & 8.41 & 9.39 & 10.32 & 11.54 \\
\hline 26. & 9.19 & 8.77 & 9.09 & 9.59 & 10.50 & 11. 54 \\
\hline 27. & 8.34 & 8.97 & 9.31 & 9.50 & 10.72 & 11.17 \\
\hline 28 & 8.65 & 9.13 & 9.48 & 9.21 & 10.76 & 11.36 \\
\hline 29. & 8.72 & 8.56 & 6.90 & 8.95 & 10.80 & 11.54 \\
\hline $30 \ldots$ & 8.93 & 8.68 & 6.78 & 9.42 & 10.72 & 11.54 \\
\hline $31 \ldots \ldots \ldots$ & 8.72 & 8.76 & ....... & 10.27 & $\ldots \ldots$ & 11.40 \\
\hline Mean... & 9.53 & 8.32 & 8.66 & 9.10 & $10 . \overline{19}$ & 11.07 \\
\hline
\end{tabular}

a Furnisbed by Mr. John H. Carruthers, Rialto, California. 
Occasional measurements of Lytle Creek were made during low water of 1898, as shown in the following table:

Measurements of 'Lytle Creek.

\begin{tabular}{|c|c|c|c|c|}
\hline Date. & Locality. & $\begin{array}{l}\text { Area of } \\
\text { section. }\end{array}$ & $\begin{array}{c}\text { Mean } \\
\text { velocity. }\end{array}$ & Discharge. \\
\hline \multirow{4}{*}{$\begin{array}{l}1898 . \\
\text { June } 10\end{array}$} & - & \multirow{5}{*}{$\begin{array}{r}S_{q \cdot} \text { feet. } \\
5.292\end{array}$} & \multirow{2}{*}{$\begin{array}{l}\text { Feet per } \\
\text { second. } \\
2.027\end{array}$} & \multirow{3}{*}{$\begin{array}{r}\text { Sec.-feet. } \\
10.73 \\
0.28\end{array}$} \\
\hline & $\begin{array}{l}\text { Rialto Canal, Anglo-American } \\
\text { Canaigre Company division .. }\end{array}$ & & & \\
\hline & McIntyre ditch $\ldots . . . . . . . .$. & & & \\
\hline & $\begin{array}{l}\text { San Bernardino Domestic res- } \\
\text { ervoir } \ldots . . . . . . . . . . . .\end{array}$ & & & 1.95 \\
\hline June 29 & Whitings ditch ... & & & 0.30 \\
\hline June 27 & $\begin{array}{l}800 \text { feet below Mount Vernon } \\
\text { bridge } \ldots \ldots \ldots \ldots . . . . . . . . .\end{array}$ & (a) & & 0.28 \\
\hline Aug. 27 & Gatehouse, Canaigre Co ........ & (a) & & 10.01 \\
\hline \multirow[t]{3}{*}{ sept. 22} & Whitings ditch. & & & 0.10 \\
\hline & McIntyre ditch ... & & & 0.04 \\
\hline & Carter ditch ............... & & & 0.003 \\
\hline
\end{tabular}

TWIN, CITY, AND PLUNGE CREEKS.

The drainage of the mountain slopes immediately northeast of the city of San Bernardino is received by a succession of small creeks. The drainage area of Twin Creek is 18 square miles; next to the east of this is City Creek, with a drainage area of 24 square miles; and east of this in turn is Plunge Creek, with a drainage area of 18 square miles. Measurements of the outflow were made during the low water of 1898, as shown by the following table:

Measurements of Twin, City, and Plunge creeks.

\begin{tabular}{|c|c|c|c|c|c|}
\hline Date. & Creek. & Locality. & $\begin{array}{l}\text { Area of } \\
\text { section. }\end{array}$ & $\underset{\text { Melocity. }}{\text { Mean }}$ & Discharge. \\
\hline $\begin{array}{l}1898 . \\
\text { June } 11 \\
\text { Sept. } 9\end{array}$ & 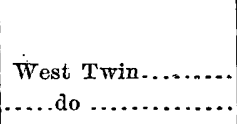 & 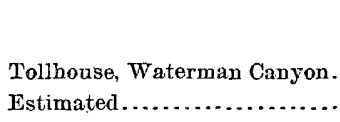 & $\begin{array}{l}\text { Sq. feet. } \\
\quad 0.92\end{array}$ & $\begin{array}{c}\text { Feet per } \\
\text { second. } \\
2.31 \\
\ldots . .\end{array}$ & $\begin{array}{c}\text { Sec.feet. } \\
2.12 \\
0.38\end{array}$ \\
\hline June 11 & $\begin{array}{l}\text { East Twin ........... } \\
\ldots \text {. do } \ldots . . . . . . . . .\end{array}$ & $\begin{array}{l}\text { K. C. Syndicate, flume ........... } \\
\text { K. C. Syndicate, developed..... }\end{array}$ & 2.33 & $\begin{array}{l}0.83 \\
\ldots .\end{array}$ & $\begin{array}{l}1.95 \\
0.11\end{array}$ \\
\hline & Total & & & & 2.06 \\
\hline Sept. 7 & East Twin.. & K. C. Syndicate............... & ........ & ........ & 0.73 \\
\hline June 11 & City ...... & Headworks in canyon......... & 2.295 & 1. 32 & 3.03 \\
\hline June 29 & ....do ... & Longsden \& Farrel ditch...... & 0.878 & 0.82 & 0.723 \\
\hline & ..... do ... & Whitlock ditch ............. & 0.209 & 1. 16 & 0.244 \\
\hline & ..... do .... & Daley ditch across City Creek & 0.396 & 1.56 & 0.62 \\
\hline Sept. 9 & .....do ........ & Headworks in canyon......... & 0.36 & 0.20 & 0.07 \\
\hline Sept. 29 & City .............. & Longsden \& Farrel........... & ...... & ....... & 0.63 \\
\hline June 12 & Plunge.... & 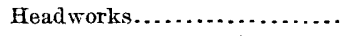 & 1.565 & 1.446 & 2.26 \\
\hline Sept. $" 9$ & .....do ... & Estimated..... & & & 0.20 \\
\hline
\end{tabular}


MILL CREEK.

Mill Creek is one of the most important tributaries of Santa Ana River, although usually considered as a separate stream. It is described by Mr. J. B. Lippincott in the Nineteenth Annual Report, Part IV, beginning on page 551. Its location is shown in part on the Redlands topographic atlas sheet. The stream receives water from the slopes of Grayback Mountain, which rises to a height of 12,000 feet. The greater part of the drainage basin has an elevation of 5,000 feet or more and is favorably exposed to the rainfall, giving a relatively large run-off. Besides the use for irrigation its waters are employed for the development of electric power.

Various measurements of Mill Creek were made during the low-water season of 1898, as shown below:

Measurements of Mill Creek.

\begin{tabular}{|c|c|c|c|c|}
\hline Oate. & Locality. & $\begin{array}{l}\text { Area of } \\
\text { section. }\end{array}$ & $\begin{array}{c}\text { Mean } \\
\text { velocity. }\end{array}$ & Discharge. \\
\hline 1898. & & Sq. feet. & $\begin{array}{l}\text { Feet per } \\
\text { second. }\end{array}$ & Sec.feet. \\
\hline June 12 & McIntosh water at road crossing. & 0.14 & 2.00 & 0.28 \\
\hline & Crafton canal, total flow of ereek. & 1.92 & 9.42 & 18. 10 \\
\hline July 23 & 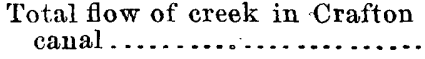 & & & 11.82 \\
\hline \multirow[t]{2}{*}{ Sept. 8} & Crafton canal, total flow of creek. & 1. 23 & 10.62 & 13.07 \\
\hline & McIntosh water at road crossing. & 0.14 & 2.00 & 0.28 \\
\hline
\end{tabular}

WARM CREEK.

Unlike the streams above mentioned, Warm Creek has no mountain watershed of its own. It rises in the northeastern part of the valley about 2 miles north of Santa Ana River, 2 miles west of the opening of City Creek Canyon, and 2 miles south of the edge of the mountain. In its course southwesterly, a distance of about 7 or 8 miles, to the Santa Ana River, near the lower portion of the San Bernardino Basin, it continually receives accessions in volume from springs in its bed and from arroyos or cienegas which join it. Warm Creek is the reappearance of some of the lost waters of the canyon streams from City Creek west to Cajon Pass. Lytle Creek joins it just below the town of San Bernardino, and they thence occupy one channel to the river, half a mile east of Colton. Owing to the fact that Warm Creek waters, although rising in the bottom of a basin, command plains still beyond, this stream, from the constancy of its flow, is one of the most important irrigation feeders in San Bernardino County. ${ }^{1}$

\footnotetext{
1 Irrigation in Southern California, by William Ham. Hall, C. E., State engineer, Sacramento, 1888.
} 
List of vow-woter measurements of Warm Creek, California.

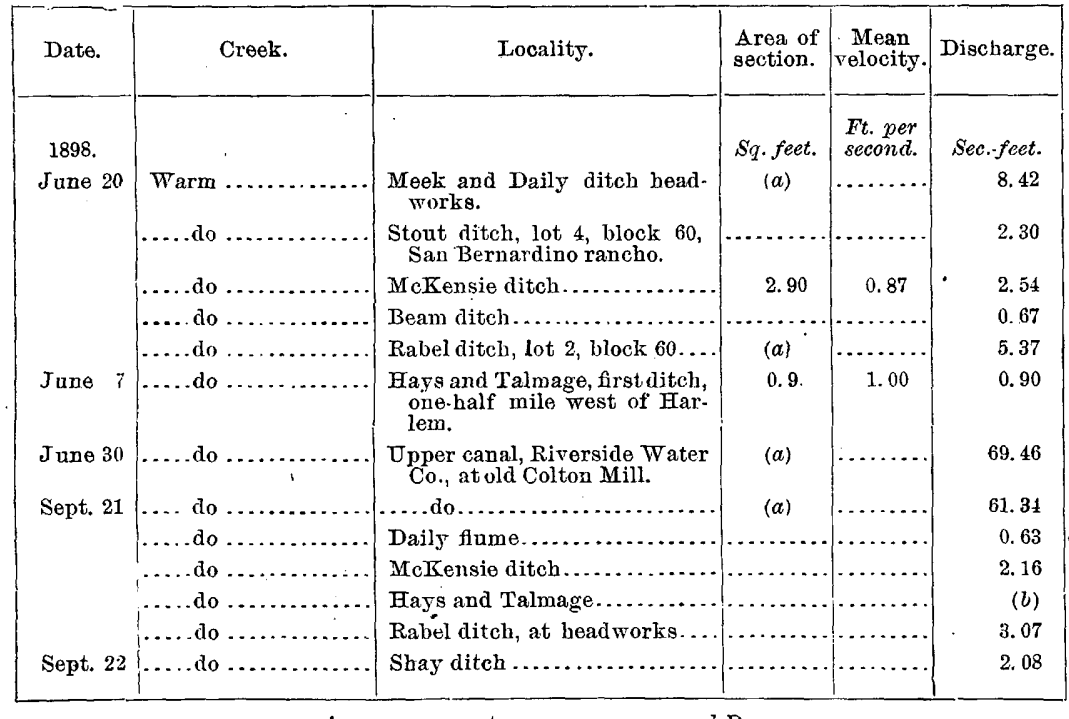

eir measurements.

$b$ Dry.

WELLS IN SAN BERNARDINO VALLEY.

Production from wells in the San Bernardino Valley east of Slover Mountain.

[All electric plants run for twenty-hour days.]

\begin{tabular}{|c|c|c|c|c|}
\hline System. & Class. & Basin. & $\begin{array}{c}\text { June } 30 \\
1898 .\end{array}$ & $\begin{array}{c}\text { Sept. 21, } \\
1898 .\end{array}$ \\
\hline & & & Sec.feet. & Sec.feet. \\
\hline 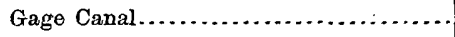 & Artesian... & Santa Ana.... & 26. 26 & 25.66 \\
\hline Riverside Water Co ......... & .....do.... & ..... do ......... & 7.84 & $a 7.84$ \\
\hline 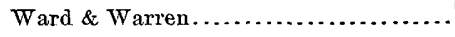 & ..... do ........ & ..... do ......... & 3.25 & $a 3.25$ \\
\hline Martin's pump............... & Pump …..... & ..... do ......... & 0.30 & $a 0.30$ \\
\hline Hunt \& Cooley ............. & Artesian...... & .....do...... & 0.61 & $a 0.61$ \\
\hline Total Santa Ana above Colton.. & & & 38.26 & 37.66 \\
\hline Riverside Water Co... & Artesian.. & City Creek & 6.80 & 6.80 \\
\hline Ranor ranch ........ & .....do. & Lytle Creek .. & 3.00 & 1.64 \\
\hline Bloomington $\ldots \ldots \ldots \ldots \ldots \ldots$ & Pump ........ & ..... do ......... & 5. 20 & 4.51 \\
\hline 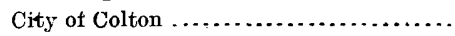 & .... do ..... & .... do ......... & 6.82 & 5.22 \\
\hline Colton terrace $\ldots \ldots \ldots \ldots \ldots$ & Air pump.... & .....do .... & 1.97 & 1.60 \\
\hline Pomeroy \& Marlborough ....... & Gas pump ... & .....do .... & 0.80 & $a 0.80$ \\
\hline 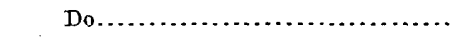 & Artesian.... & $\ldots \ldots$ do $\ldots \ldots . .$. & $a 0.80$ & 0.80 \\
\hline John $\mathrm{Hubb} \ldots \ldots \ldots \ldots \ldots \ldots \ldots \ldots \ldots \ldots \ldots \ldots$ & Pump ....... & .....do ......... & 2.40 & 0.60 \\
\hline Total Lytle Creek Basin.. & & & 20.99 & 15.18 \\
\hline J. E. Garner... & Pụmp :- & Twin Creek .. & $\ldots \ldots \ldots$ & 0.50 \\
\hline Total for entire basin above Colton: & & & 66.05 & 60.14 \\
\hline
\end{tabular}

a Approximate. 


\section{PRECIPITATION ON CALIFORNIA MOUNTAINS.}

In order to obtain precipitation data bearing upon river discharge, a number of rain gages lave been placed by Mr. J. B. Lippincott at various important points. The results obtained at these localities, together with a few figures from other sources, are shown in the following tables. The first table gives the location of the river station and the name of the observer, and the second gives the figures obtained during 1898 . The figures for 1897 are given on page 539 of the Nineteenth Annual Report, Part IV, and for 1896 on page 418 of the Eighteenth Annual Report, Part IV:

Location of rainfall stations.

\begin{tabular}{|c|c|c|c|c|c|c|}
\hline Station. & Observer. & County. & Post-office. & $\begin{array}{l}\text { Lati- } \\
\text { tude. }\end{array}$ & $\begin{array}{l}\text { Longi. } \\
\text { tude. }\end{array}$ & $\begin{array}{l}\text { Eleva- } \\
\text { tion. }\end{array}$ \\
\hline & & & & o " & $0 n$ & Feet. \\
\hline Sisson .............. & S.P.R. R....... & Siskiyou...... & Sisson ........ & 4127 & 12225 & 3,555 \\
\hline Redbluff. . & U. S. W. B........ & Telıama ... & RedbIuff.... & 4012 & 12220 & 324 \\
\hline Sonora......... & Dr. John Shaw.... & Tuolumne.. & Sonora......... & 3800 & 12016 & 1,824 \\
\hline Second Garotte. & J.P. Chamberlain. & ..... do ... & Groveland... & 3749 & 12012 & 2,900 \\
\hline Crockers....... & H. R. Crocker ... & .... do ... & Sequoia........ & 3748 & 11953 & 4,453 \\
\hline Tosemite ...... & $\ldots \ldots \ldots \ldots \ldots \ldots$ & Mariposa . & Yosemite..... & 3745 & 11935 & 4,063 \\
\hline Mountainhome mill & Fred Noller....... & Tuiare....... & Daunt ........ & 3610 & 11843 & 6,680 \\
\hline Kernville ......... & Steven Barton.... & Kern & Isabella .... & 3545 & 11825 & 2,600 \\
\hline Mt. Breckinridge. & Chas. Drubar..... & ....do ..... & Bakersfield ... & 3525 & 11835 & 6,750 \\
\hline Tejon ranch.. & R. M. Pogson..... & ..... do .. & ..... do ... & 3501 & 11845 & 1,450 \\
\hline Fort Tejon.... & J.G.Stitt......... & ..... do ......... & Lebec.......... & 3453 & 11853 & 3,245 \\
\hline Frazier mine.. & H. Porter.......... & Ventura. & Gorman Sta .. & 3449 & 11858 & 8,000 \\
\hline Manzana ....... & E. A. Silves........ & Los Angeles.. & Manzana ..... & 3447 & 11832 & 2,850 \\
\hline La Iiebre.... & J. W. Forbes...... & ......do ........ & Neenach...... & 3446 & 11840 & 3,170 \\
\hline Snedder's... & Burt Snedden...... & Ventura.. & Gorman Sta .. & 3441 & 11903 & 4,900 \\
\hline Mutah flat.. & $\ldots . . d v \ldots . .$. & ......do ... & ...... do ......... & 3438 & 11903 & 4,850 \\
\hline Palmdale... & Burt Cole... & Los Angeles.. & $\begin{array}{l}\text { Wost Palm. } \\
\text { dale. }\end{array}$ & 3425 & 11803 & 3,299 \\
\hline Mount Lowe. & Prof. Lewis Swift. & ..... do... & $\begin{array}{l}\text { Echo Moun- } \\
\text { tain. }\end{array}$ & 3415 & 11807 & 3,200 \\
\hline Hollows camp. & B. M. Follows .... & .....do ... & Azusa ........ & 3414 & 11749 & 1,800 \\
\hline Descanso ............. & E. W. Hulbard.... & San Diego... & Nationai City. & 3250 & 11640 & 3,500 \\
\hline Sweetwater dam... & G. N. Sarage...... & .....do ..... & . . . do . ........ & 3243 & 11700 & 250 \\
\hline Cuyamaca .......... & $\begin{array}{l}\text { San Diego Flume } \\
\text { Co. }\end{array}$ & ..... do .. & San Diego.... & . & $\cdots \cdots$ & 4,800 \\
\hline Upper Holcomb. & $\begin{array}{l}\text { Arrowhead Reser- } \\
\text { voir Co. }\end{array}$ & $\begin{array}{l}\text { San Bernar- } \\
\text { dino. }\end{array}$ & $\begin{array}{l}\text { San Bernar- } \\
\text { dino. }\end{array}$ & 3418 & 11650 & 7,200 \\
\hline Little Bear Valley & $\begin{array}{l}\text { Arrowhead Reser- } \\
\text { voir Co. }\end{array}$ & $\begin{array}{l}\text { San Bernar- } \\
\text { dino. }\end{array}$ & $\begin{array}{l}\text { San Bernar- } \\
\text { dino. }\end{array}$ & & & 5,150 \\
\hline Morse's house & ... do ............. & ....do... & $\ldots$ do ..... & & & 5,350 \\
\hline Deep Creek.. & ....do ... & ....do. & ....do & & & 5,200 \\
\hline Holcomb Creek.. & ..... do ....... & ..... do ... & ..... do. & & & 5,220 \\
\hline Squirrel Inn. & .... do ... & $\ldots$ do $\ldots$ & ..... do ....... & & & 5,300 \\
\hline Gate Houre.. & ..... do ... & .....do... & $\therefore \quad \therefore$ do & & & \\
\hline
\end{tabular}


Results of observation of rainfall for 1898 .

\begin{tabular}{|c|c|c|c|c|c|c|c|c|c|c|c|c|c|}
\hline Station. & Jan. & Feb. & Mar. & Apr. & May. & une. & July. & Aug. & Sept. & Oct. & Nov. & Dec. & Total. \\
\hline Sisson. & (?) & 10.45 & 0.00 & 1. 05 & 6.13 & 1.03 & 0.00 & 0.00 & 0.00 & 0.00 & 1.70 & 2.10 & \\
\hline Redbluff & 0.59 & 5.45 & 0.01 & 0.63 & 2. 28 & 0.14 & 0.00 & T. & 0.45 & 0.46 & 1.21 & 1.69 & 12.91 \\
\hline Sonora ........ & 1.71 & 5.79 & 1.96 & 0.60 & 2.70 & 0.15 & 0.00 & 0.00 & 0.87 & 0.84 & 1.51 & 2.64 & 18.14 \\
\hline $\begin{array}{l}\text { Second } \mathrm{Gar} \text { - } \\
\text { rotte } \ldots \ldots \ldots\end{array}$ & 2.75 & 6.00 & 2.50 & 0.25 & 2.50 & 0.00 & 0.00 & 0.00 & 2.00 & 1.50 & 1.50 & 1.00 & 20.00 \\
\hline Crockers.... & 2.60 & 7.15 & 3.74 & 1.50 & 3.74 & 0.00 & 0.00 & 0.00 & 1.58 & 1.87 & 1.85 & 2.12 & 25.75 \\
\hline Kernville ... & 0.58 & 0.99 & 0.58 & $\mathbf{T}$ & 0.54 & 0.00 & 0.00 & 0.00 & 0.04 & 0.00 & 0.00 & 0.33 & 3.06 \\
\hline Tejon ranch. & 2.32 & 1.68 & 0.94 & 0.17 & 0.84 & 0.00 & 0.00 & 0.00 & 0.34 & 0.42 & 0.57 & 0.87 & 8.15 \\
\hline Fort Tejon... & 1.89 & 1.55 & 1.36 & 0.40 & 0.30 & 0.00 & 0.00 & 0.00 & 0.06 & 0.00 & 0.65 & 0.73 & 7.48 \\
\hline Manzana.... & 0.63 & 0.02 & 0.47 & 0.00 & 0.24 & 0.00 & 0.00 & 0.00 & $\mathbf{T}$ & 0.00 & 0.00 & 0.50 & 1.86 \\
\hline La Liebre.... & 0.53 & 0.38 & 0.81 & 0.00 & 0.45 & 0.00 & 0.00 & 0.00 & 0.20 & 0.00 & 0.00 & 0.66 & 3.03 \\
\hline $\begin{array}{c}\text { Snedden's } \\
\text { ranch ........ }\end{array}$ & 0.60 & 0.41 & 0.65 & 0.00 & 0.54 & 0.35 & 0.00 & 0.00 & 1.75 & 0.00 & 0.00 & 0.30 & 4.00 \\
\hline Mutah Flat... & 0.60 & 0.50 & 0.65 & 0.00 & 0.60 & 0.40 & 0.00 & 0.00 & 1.80 & 0.00 & 0.00 & 0.30 & 4.85 \\
\hline Palmdale.... & 2. 38 & 0.07 & 0.90 & 0.00 & 0.21 & 0.00 & 0.02 & 0.05 & 0.00 & 0.00 & $\mathbf{T}$ & 0.87 & 4.50 \\
\hline Mount Lowe & 1.55 & 2.22 & 1.65 & 2.70 & 2.17 & 0.00 & 0.00 & 0.00 & 0.25 & 0.30 & 0.00 & 0.98 & 11.82 \\
\hline $\begin{array}{c}\text { Fol low's } \\
\text { camp........ }\end{array}$ & 0.00 & 9.80 & 0.00 & 0.85 & 6.16 & 1.03 & 0.00 & 0.53 & 0.00 & 0.00 & 1.70 & 0.70 & 20.77 \\
\hline Descanso..... & 5.28 & 0.89 & 4.11 & 0.90 & 2.35 & 0.00 & 0.15 & 0.83 & 0.00 & 0.00 & 0.35 & 1.00 & 15.86 \\
\hline Cuyamaca ... & 5.47 & 1.97 & 4.06 & 1.24 & 5.97 & 0.00 & 0.00 & 1.32 & 0.00 & 0.00 & 0.88 & 0.96 & 21.87 \\
\hline $\begin{array}{c}\text { Upper } \\
\text { Hombl } \\
\text { comb }\end{array}$ & 2.60 & 0.40 & 1.50 & 0.50 & 0.90 & 0.00 & 0.10 & 0.70 & 0.00 & 0.00 & 0.20 & 1.00 & 7.90 \\
\hline $\begin{array}{c}\text { Little Bear } \\
\quad \text { valley } . . . .\end{array}$ & 3.80 & 1.38 & 2.49 & 0.25 & 4.56 & & 0.00 & $\cdots$ & $\ldots$ & T. & 0.62 & 0.74 & …. \\
\hline Morse's ...... & 6. 37 & 2.96 & 4.22 & 0.70 & 8.27 & $\cdots$ & 0.08 & 0.13 & $\cdots \cdots$ & 0.34 & 0.74 & 1.28 & 25.09 \\
\hline Deep Creek.. & 4.20 & 1.10 & 1.89 & 0.17 & 2.93 & $\ldots \ldots$ & 0.11 & 0.55 & 0.00 & 0.00 & 0.53 & 0.49 & 11.97 \\
\hline $\begin{array}{r}\mathrm{H} \text { o l co } \mathrm{cob} \text { b } \\
\text { Creek ........ }\end{array}$ & 3.05 & 0.52 & 1.27 & 0.10 & 1.46 & 0.00 & 0.00 & 0.66 & 0.00 & 0.00 & 0.57 & 0.48 & 8.11 \\
\hline Squirrel Inn.. & 4.98 & 1.95 & 2.98 & 0.68 & 6.50 & $\cdots$ & 0.00 & …... & 0.05 & 0.37 & 0.70 & 1.35 & 19.56 \\
\hline Gate House .. & 3.80 & 1.38 & 2.49 & 0.25 & 4.56 & 0.00 & 0.00 & 9.00 & 0.00 & T. & 0.62 & 0.74 & 13.84 \\
\hline
\end{tabular}

\section{WHITEWATER RIVER.}

Whitewater River receives drainage from an area immediately south of the catchment basin of Santa Ana River, but, unlike the latter, does not flow toward the Pacific Ocean. Its general course is easterly, the water disappearing into the Salton Desert. A single measurement of the stream was made September 7, 1898, above the head waters of the Palm Valley Water Company. At that time the area of section was 4.14 square feet and the discharge 9.35 second-feet. This stream receives water from the slopes of San Gorgonio Peak, which is approximately 11,750 feet in height. In ordinary years snow remains throughout the summer on this peak, the melting of which maintains the flow of the stream. The upper or western portions of the basin thus yield a high percentage of run-off, while that of the eastern part is deficient. The area above the mouth of Whitewater Canyon is approximately 70 square miles. There are frequent tbunderstorms on this area, similar to those which occur in the high plateaus and mountains of Arizona, sending down sudden floods. The water of the stream is at present used in the vicinity of Palm Spring. A considerable portion, however, 20 GEOL, PT $4-36$ 
could be diverted through the San Gorgonio Pass down the drainage line of San Timoteo Canyon to a point on Redlands Heights above both Riverside and Redlands. There are two intermediate reservoir sites, both of notable capacity, which could be used for storing winter floods. It is probable that the water supply of San Bernardino Valley will be ultimately augmented from this stream. 


\section{HYDROGRAPHY OF NICARAGUA \\ BY}

ARTHUR POWELL DAVIS 



\section{CONTENTS.}

\begin{tabular}{|c|c|}
\hline \\
\hline & \\
\hline \multirow{2}{*}{ 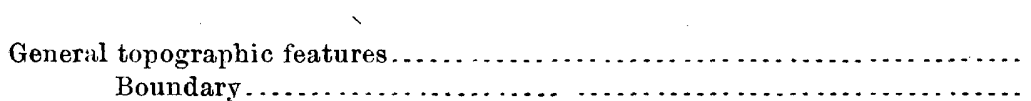 } & 569 \\
\hline & 570 \\
\hline 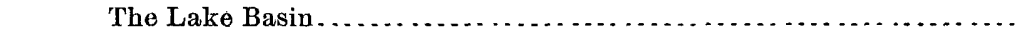 & 570 \\
\hline 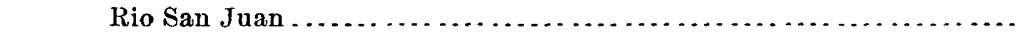 & 571 \\
\hline 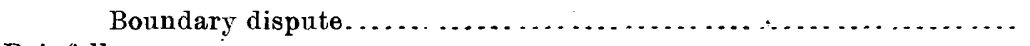 & 573 \\
\hline 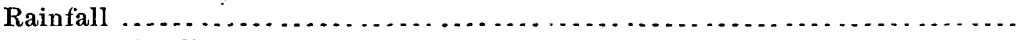 & 574 \\
\hline 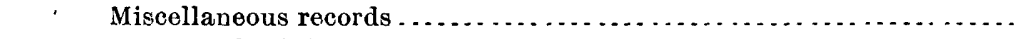 & 574 \\
\hline 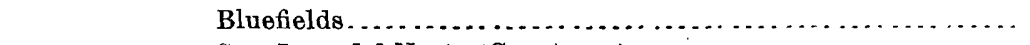 & 576 \\
\hline Norte (Greytown) $\ldots \ldots \ldots \ldots \ldots \ldots \ldots \ldots \ldots$ & 576 \\
\hline - & 576 \\
\hline nada................................... & 577 \\
\hline can & 577 \\
\hline al Commission $\ldots \ldots \ldots \ldots \ldots \ldots \ldots$ & 578 \\
\hline midity $(\ldots \ldots \ldots \ldots \ldots \ldots \ldots \ldots \ldots \ldots$ & 579 \\
\hline 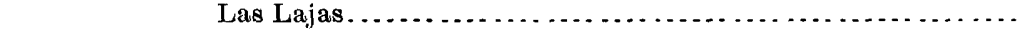 & 579 \\
\hline ation.$\ldots \ldots \ldots \ldots \ldots \ldots \ldots \ldots \ldots$ & 579 \\
\hline 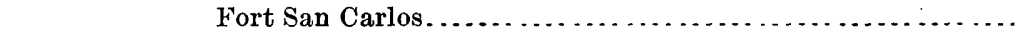 & 580 \\
\hline 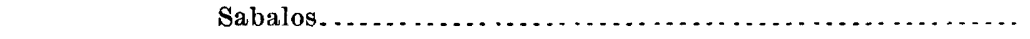 & 580 \\
\hline los station $\ldots \ldots \ldots \ldots \ldots \ldots \ldots$ & 580 \\
\hline (1, & 581 \\
\hline 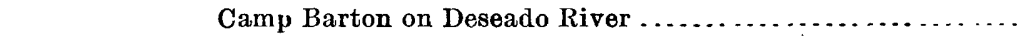 & 581 \\
\hline 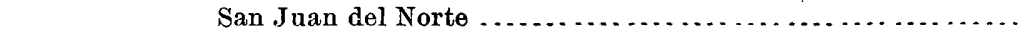 & 581 \\
\hline , n & 582 \\
\hline 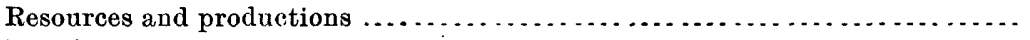 & 582 \\
\hline 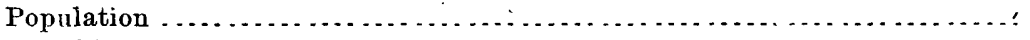 & 584 \\
\hline 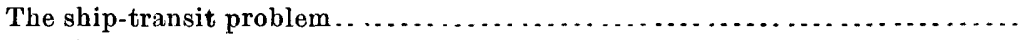 & 585 \\
\hline s........... & 586 \\
\hline (., & 587 \\
\hline 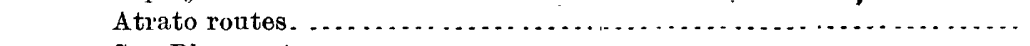 & 587 \\
\hline 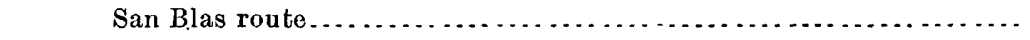 & 588 \\
\hline 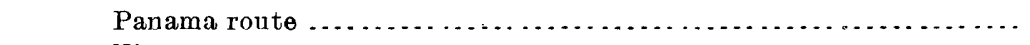 & 588 \\
\hline ............. & 589 \\
\hline өу & 589 \\
\hline 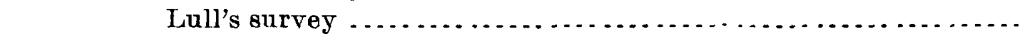 & 590 \\
\hline$\ldots \ldots \ldots \ldots \ldots \ldots \ldots$ & 591 \\
\hline$\ldots \ldots \ldots \ldots \ldots \ldots$ & 591 \\
\hline . & 592 \\
\hline ua Canal Commission, 1898. & 592 \\
\hline 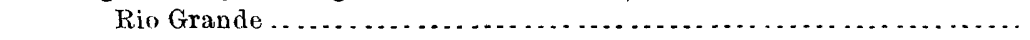 & 594 \\
\hline Grande. . . . . & 594 \\
\hline la River $\ldots \ldots \ldots \ldots \ldots \ldots \ldots \ldots \ldots \ldots \ldots \ldots \ldots \ldots \ldots$ & 594 \\
\hline 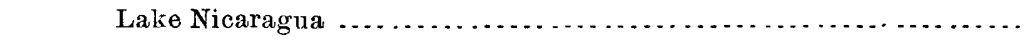 & 596 \\
\hline 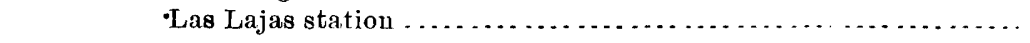 & 596 \\
\hline & 597 \\
\hline
\end{tabular}


Investigations by Nicaragua Canal Commission, 1898-Continued.

Lake Nicaragua-Continued. Page.

Nuevo River ...................................... $\quad 599$

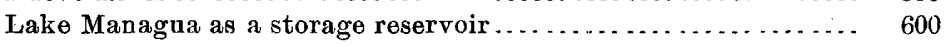

Tipitapa station ........................................... 601

San Ubaldo and Morrito ............................. 603

Fort San Carlos.................................... 604

Frio River ....................................... 604

Dry season inflow to Lake Nicaragua ..................... 606

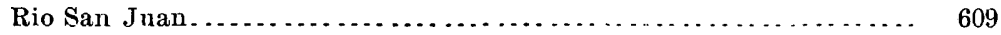

Sabalos station on Rio San Juan ...................... 609

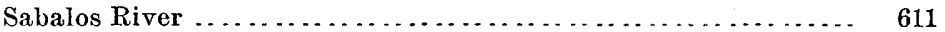

Rio San Carlos ................................... 613

Ochoa station on Rio San Juan........................ 616

Machado River ..................................... $\quad 620$

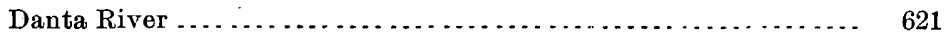

Rio Sàn Francisco .................................... 622

Limpio River .................................... 625

Upper station on the Chancos River..................... 626

Lower station on the Chancos River.................... 628

Nicholson Creek ...................................... 630

Sarapiqui River....................................... 630

Taura River ...................................... 632

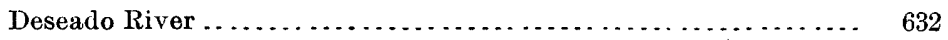

Sediment oloservations ..................................... 635 


\section{L L U S T R A T I O N S.}

Plate LXIV. Map of Nicaragua ............................... 569

LXV. Ometepe in clouds................................ 570

LXVI. Scene on Rio San Juan .......................... 572

LXVII. $A$, Rio San Juan, floating bodega at Machuca; $B$, Tipitapa River, outlet of Lake Managua................... 574

LXVIII. Rainfall diagram, Brito-Deseado ...................... 576

LXIX. Rainfall diagram, Rio San Juan .................... 578

LXX. $A$, Church in Rivas; $B$, Surveyor's camp on Lake Managua.... 584

LXXI. Map of Central America, showing the routes which have been surveyed for interoceanic communication.............. 586

LXXIr. Upper Chagres River.............................. 588

LXXIIT. Dredges on Panama Canal ........................... 590

LXXIV. Map of portions of Nicaragua and Costa Rica, showing route of proposed canal............................... 592

LXXV. A, Tipitapa River below the falls; $B$, Head of Balas Rapids, Rio San Juan ................................... 602

FIG. 219. Comparative rainfall at Rivas and Masaya ................ 575

220. Comparative monthly rainfall at San Juan del Norte (Greytown), Ochoa, Fort San Carlos, and Tola ....................... 578

221. Diagram of daily discharge of Rio San Juan at Sabalos and at Ochoa, and of Rio San Carlos 3 miles above its mouth ............. 617

222. Sediment trap ready for use ............................. 635 



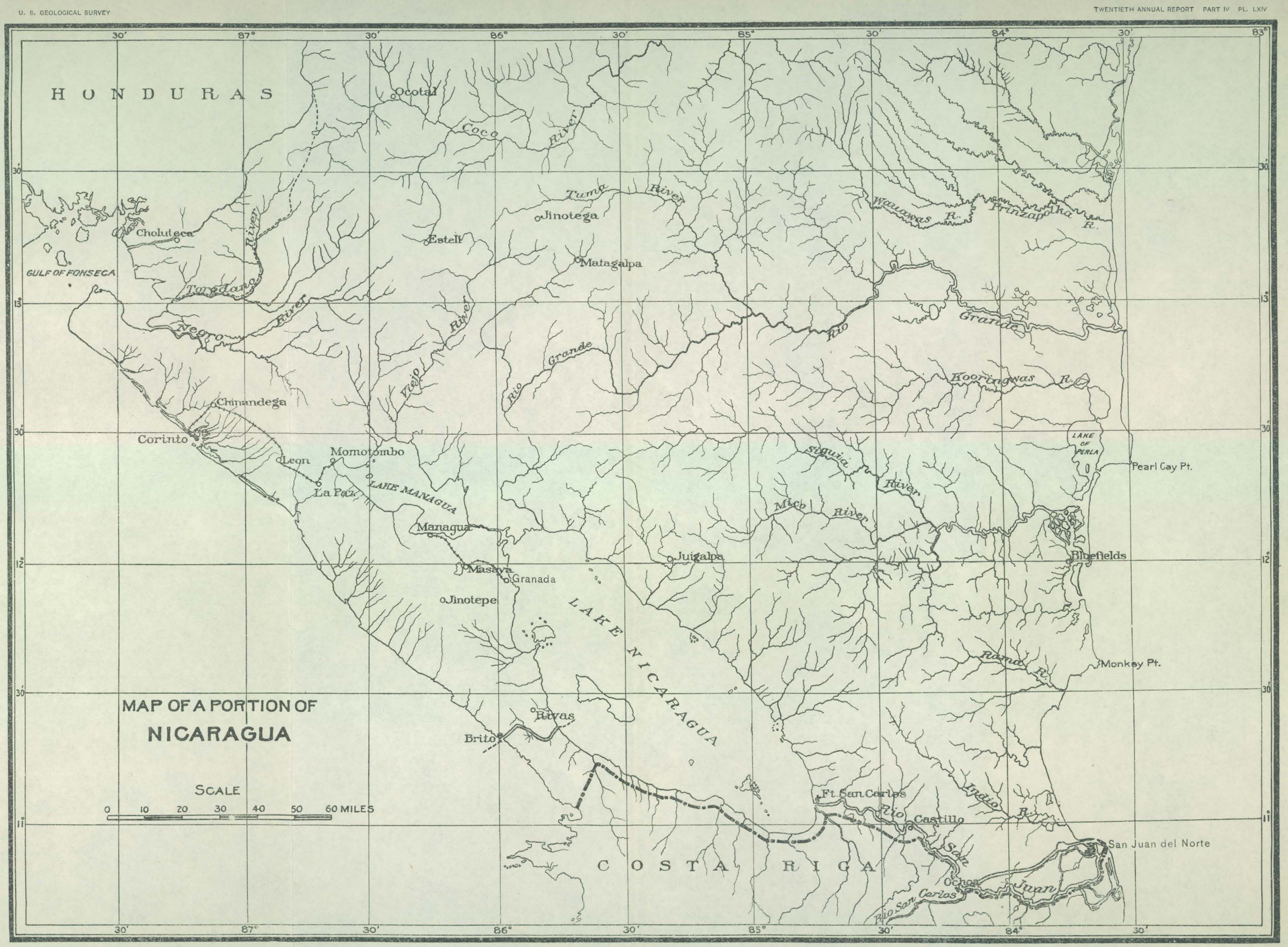




\title{
HYDROGRAPHY OF NICARAGUA.
}

\author{
By Arthur P. Davis.
}

\section{GENERAL TOPOGRAPHIC FEATURES.}

The State of Nicaragua is the largest of the Central American repub. lics. It is comprised between the parallels of $10^{\circ} 41^{\prime}$ and $15^{\circ}$ north latitude, and the meridians of $83^{\circ} 15^{\prime}$ and $87^{\circ} 40^{\prime}$ west longitude. Its area is about 40,000 square miles, or nearly the same as that of the State of Ohio. It is bounded on the east by the Caribbean Sea and on the west by the Pacific Ocean, and lies between the Republics of Honduras and Costa Rica to the north and sonth. In topographic configuration the country is peculiar. The northern part is largely occupied by rugged mountains belonging to the main axis of the Cordilleras, with some peaks exceeding 6,000 feet in altitude. A little farther south this range divides into two main spurs, one following a southeasterly course nearly parallel to the Caribbean coast almost to the southern boundary of Nicaragua, where it is eut through by the Rio San Juan, while the western branch closely follows the Pacific Ocean and is peculiar in its low altitude and the narrow strip of land it occupies. The depression between is occupied by Lakes Managua and Nicaragua, connected by Tipitapa River, and draining to the Atlantic through the San Juan.

There are a number of large rivers in Nicaragua, the most northern being the Coco or Wanks River, which rises in the extreme northwestern portion of the Republic, runs nearly parallel to its northern boundary for 300 miles, and empties into the Atlantic Ocean near Cape Gracias a Dios. The next principal river is the Rio Grande, which, rising in the mountains of Matagalpa and Jinotega, follows a generally eastward course and empties into the Caribbean Sea. It is navigable for 100 miles. Still south of this, and nearly parallel with it, flows the Escondido or Bluefields River, formed by the junction of the Siguia, Mico, and Rama and emptying into Bluefields Bay, on the Caribbean coast, near the town of the same name. It is navigable for seagoing vessels from its mouth to the fork. Still farther south is the San Juan, in many respects the most important river of Central America. This river drains a large area of country, extending from the vicinity of Jinotega, in northern Nicaragua, to the central portion of Costa Rica, and includes within its tributary basin the great lakes Nicaragua and Managua. 


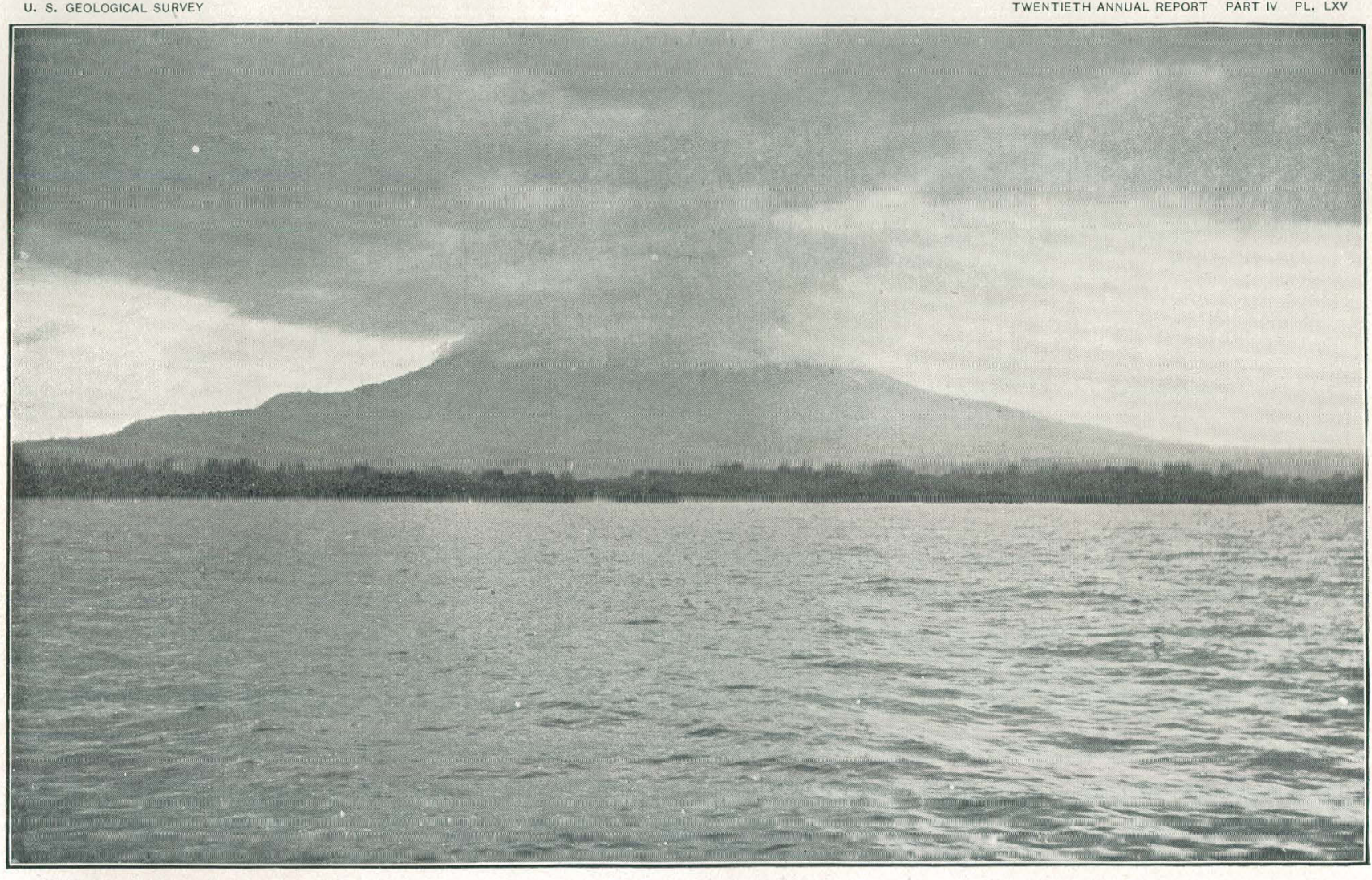

OMETEPE IN CLOUDS. 


\section{BOUNDARY.}

The line which bounds Nicaragua on the north and Honduras on the south follows throughout most of its course the northern boundary of the watershed of Coco River, but at a point near the continental divide it turns southward until it strikes the headwaters of the Guasule River, which stream it follows to its mouth, in the Gulf of Fonseca. The western coast of Nicaragua is well supplied with good harbors, the best being the Gulf of Fonseca, at the western extremity of the Republic, which is one of the really fine harbors of the world. Salinas Bay, at the southern extremity of Nicaragua, is next in importance, while San Juan del Sur and Corinto are harbors suitable for smaller vessels, and from their location are much more convenient and consequently more used.

The eastern coast of Nicaragua for a distance of 20 to 30 miles inland is mostly of a swampy nature. High, rolling country approaches the coast at Monkey Point and near San Juan del Norte (Greytown), but with these exceptions the coastal region is low and flat and during the rainy season is largely covered with water. The only good harbor is at Bluefields, which is much visited by banana steamers. The Rio Grande has a depth of only 8 feet over the bar at its mouth, but it could be cheaply improved. Formerly there was a good harbor at San Juan del Norte, but within the last half century it has been almost completely filled with sand; at the present time a bar closes its entrance, which has a depth of only 4 feet of water.

THE LAKE BASIN.

The peculiar interest attaching to Nicaragua from the American point of view is the promise held out by the remarkable hydrographic and topographic conditions of a practicable route for a large ship canal. These conditions consist of a large, deep lake 100 feet above sea level, separated from the Pacific Ocean by a narrow strip of land containing the lowest depression in the continental divide between the Aretic Ocean and the Straits of Magellan, and a large navigable stream carrying the surplus waters from the lake to the Caribbean Sea. This project is especially fortunate in having at its summit level a magnificent natural reservoir, Lake Nicaragua, fed by an ample drainage basin. This reservoir is useful not only for storing water for operating the locks of the canal but also as a regulator for the control of great floods that could bardly be provided for at practicable cost without its aid. No other proposed route enjoys advantages of this kind.

A recent study of the geology of this region by Dr. C. W. Hayes, of the Geological Survey, has brought to light many interesting facts which serve to explain the origin of these peculiar conditions.

Lake Nicaragui has an area of 2,975 square miles. Its greatest length is from north-northwest to south-southeast, and is about 100 
miles. Its extreme width is about 45 miles. West of the center is an island occupied by the volcanoes Ometepe and Madera, which stands about 5,000 feet above the lake level, adding greatly to the scenic beauty. Madera is the most southern of a line of volcanoes of comparatively recent origin which extends in a northwesterly direction nearly to the Gulf of Fonseca, including Ometepe, Zapatero, Mombacho, Chiltepe, Mornotombo, aud many others.

The prevailing easterly trade winds cause a moderately heavy surf to beat almost constantly on the western shore, resulting in the formation of a decided beach on that side, while the eastern shore is flat and muddy, with no well-marked beach, and aquatic vegetation there grows far out into the water.

Except in the southeastern portion the lake is deep, reaching in one point, near the southern foot of Madera, a depth of 200 feet.

Lake Managua lies to the northwest of Lake Nicaragua and drains in to the latter through the Tipitapa River. Its area is about 500 square miles.

\section{RIO SAN JUAN.}

The San Juan is the sole outlet of Lake Nicaragua and its tributary drainage basin. Its total length from the lake to the sea is $\mathbf{1 2 4}$ miles, and it is usually navigable for light.draft river steamers. It leaves the lake at Fort San Carlos at an altitude varying from about 97 feet to about 110 . Its course for a distance of 26 miles is through a low, swampy country relieved by occasional hills. Through this course the river is sluggish and receives several tributaries of small discharge which, in the dry season, are practically still water. The principal of these are the Melchora, Medio Queso, Palo de Arco, and Negro. The first tributary of importance to the San Juan is the Sabalos River, which enters from the north and empties 26 miles east of Fort San Carlos. About half a mile below the mouth of the Sabalos are the first rapids, called Toro Rapids. These rapids are caused by bowlders and gravel, probably brought into the river by the Sabalos River in former times, but they do not seriously obstruct navigation except in times of extremely low water. Below this point the San Juan receives the waters of a few streams, the principal of which are the Poco Sol and the Santa Cruz. Ten miles below Toro Rapids occur the largest rapids of the river, at Castillo Viejo. At this point the river falls about 5 feet in a few hundred feet, and steamers are seldom taken over the rapids except in high water. A railroad about 2,000 feet long is provided for the portage of freight and passengers on the right bank of the river.

Below Castillo are the Diamond, Balas, and Machuca rapids, the latter being 13 miles from Castillo. All of these rapids admit the passage of river steamers, except at extreme low water. Below Machuca there are no more rapids. The river is deep and sluggish for a distance of about 17 miles, to the point where it receives the waters and sediment of the San Carlos. This river is the largest tributary of the San 


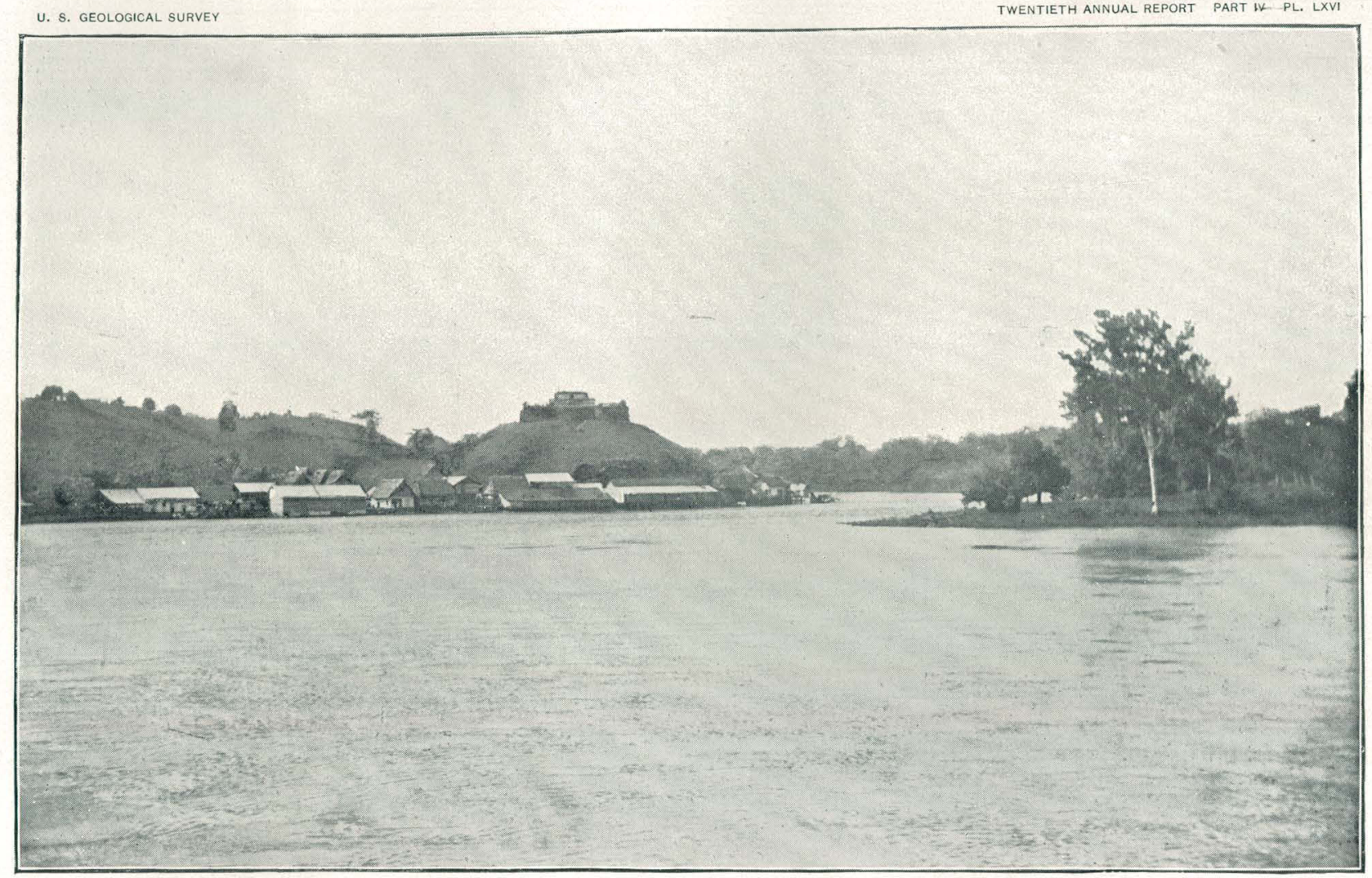

SCENE ON RIO SAN JUAN. 
Juan, rising far to the southward in the mountains of Costa Rica and bearing such a volume of sediment that a delta has been built up at its mouth, and from this point to the sea the San Juan is a shallow stream, with sandy, shifting bed. Twenty-five miles farther down the Sarapiqui empties into the San Juan from Costa Rica, being the second tributary in size to the San Carlos, and, like the latter, bearing large quantities of sediment in times of flood. Eight miles below the mouth of the Sarapiqui the San Juan assumes decidedly the character of a deltaic stream and sends out a small distributary known as the San Juanillo, which meanders through the swamps to the northward and, after receiving the drainage of the Deseado, reenters the San Juan 4 miless above its mouth. Six miles below the exit of the San Juanillo, or 105 miles from Lake Nicaragua, the main stream of the San Juan separates into two large distributaries, the larger, called the Colorado River, flowing eastward directly to the Caribbean, and the smaller or lower San Juan meandering to the northeast and finding its exit into the ocean at San Juan del Norte. Bétween the mouth of the Colorado and the Lower San Juan another distributary, called the Taura River, finds its way from the Lower San Juan to the sea.

The principal obstructions to free navigation of light-draft river craft from San Juan del Norte to Fort San Carlos consist of the shoal character of the Lower San Juan, especially in times of low water, and of the rapids lying between Machuca and the mouth of the Sabalos. For purposes of a ship canal the river also requires deepening below the mouth of the San Carlos and between the Sabalos and Fort San Carlos. - In Tertiary time the range of mountains on the east side of the Isthmus constituted the continental divide, with its lowest depression near Castillo, the point where the Rio San Juan now cuts through it. At that time the San Juan was two rivers, occupying substantially its present position, one flowing to the east and the other to the west. Lakes Nicaragua and Managua did not exist. The spot now occupied by Ometepe and Madera was the head of a bay having its outlet to the Pacific Ocean north of the department of Rivas. The strip of land west of Lake Nicaragua formed the peninsula lying between this bay and the Pacific Ocean.

The post-Tertiary eruption of Madera and Ometepe and the line of volcanoes running from them to the northwest filled the bay and cut off the drainage of all the area lying in this vicinity from exit into the Pacific Ocean. The mean rainfall of the region being greater than the evaporation, water collected in the lowest part of the basin, forming a lake. The surface of this lake continued to rise until it reached the lowest gap in its divide, which happened to be at the head of the San Juan of the west at some point east of the present site of the town of Castillo. At this point it ran over, and the eastern portion of the San Juan was changed from a diminutive creek with an insignificant drainage area to to a roaring torrent, discharging all the surplus waters of the lake and 
its tributaries, draining more than 15,000 square miles. It cut its channel rapidly until it had cut through the softer material and more slowly when it reached the rock. The western San Juan being then merely an arm of the lake, the cutting of the channel could proceed only on the eastern side, and as the controlling summit was lowered it also receded to the westward and is now at Castillo.

This is the history of the formation of Lake Nicaragua and of the transference of the continental divide from the main range on the eastern side of the Isthmus to what was a low spur on the western side.

The lowest gap in the western divide is 152 feet above sea level, or about 50 feet above mean lake level. The summit of the divide on the line of the canal is sensibly flat for a considerable distance-so flat that it requires careful instrumental examination to determine just where the divide is. This was not always the case. In fact, the physical evidence is conclusive that the divide was once much nearer the Pacific coast, probably at the gorge of the Rio Grande below the mouth of the Tola, and much higher than the present divide. The western slope was then very steep, falling perhaps a hundred feet in a mile. The eastern slope, draining toward the lake, had a much gentler slope, due to the distance and elevation of the lake. At that time the Tola River and the Upper Rio Grande drained to the east into the lake. By a familiar law of erosion the waters of the western slope, having a high velocity, cut their channels much more rapidly than those on the east, and caused the divide to move eastward until the Tola River was cut off from its drainage system and its waters turned to the Pacific. This moved the divide with a leap to the eastern side of the Tola Basin. The process did not stop here, however, and the stream continued its encroachments until auother considerable stream was captured, aud now forms the head of what we call the Rio Grande. This located the divide about.where it now exists, and accounts for its unusual physical characteristics and its low altitude. The process stiil goes on, more slowly than before, and if the country is not disturbed by igneous agencies or canal builders the divide will continue its eastward movement, and unless the San Juan succeeds sooner in cutting down the rocky barrier to the east Lake Nicaragua will eventually flow to the Pacific, and the continental divide will be shifted back to the east of the lake.

The details of this history and the evidence on which it is based are discussed at length by Dr. Hayes in a report on the geology and physiography of the Nicaragua Canal route: Report of the Nicaragua Canal Commission, 1897-99, Baltimore, 1899, pp. 87-192, Pls. I-XVIII.

\section{BOUNDARY DISPUTE.}

The promise which the construction of a waterway gives of increased development and commercial importance has long been realized by the Central American republics, and has been a source of considerable jealousy between Nicaragua and Costa Rica, and until recently there 


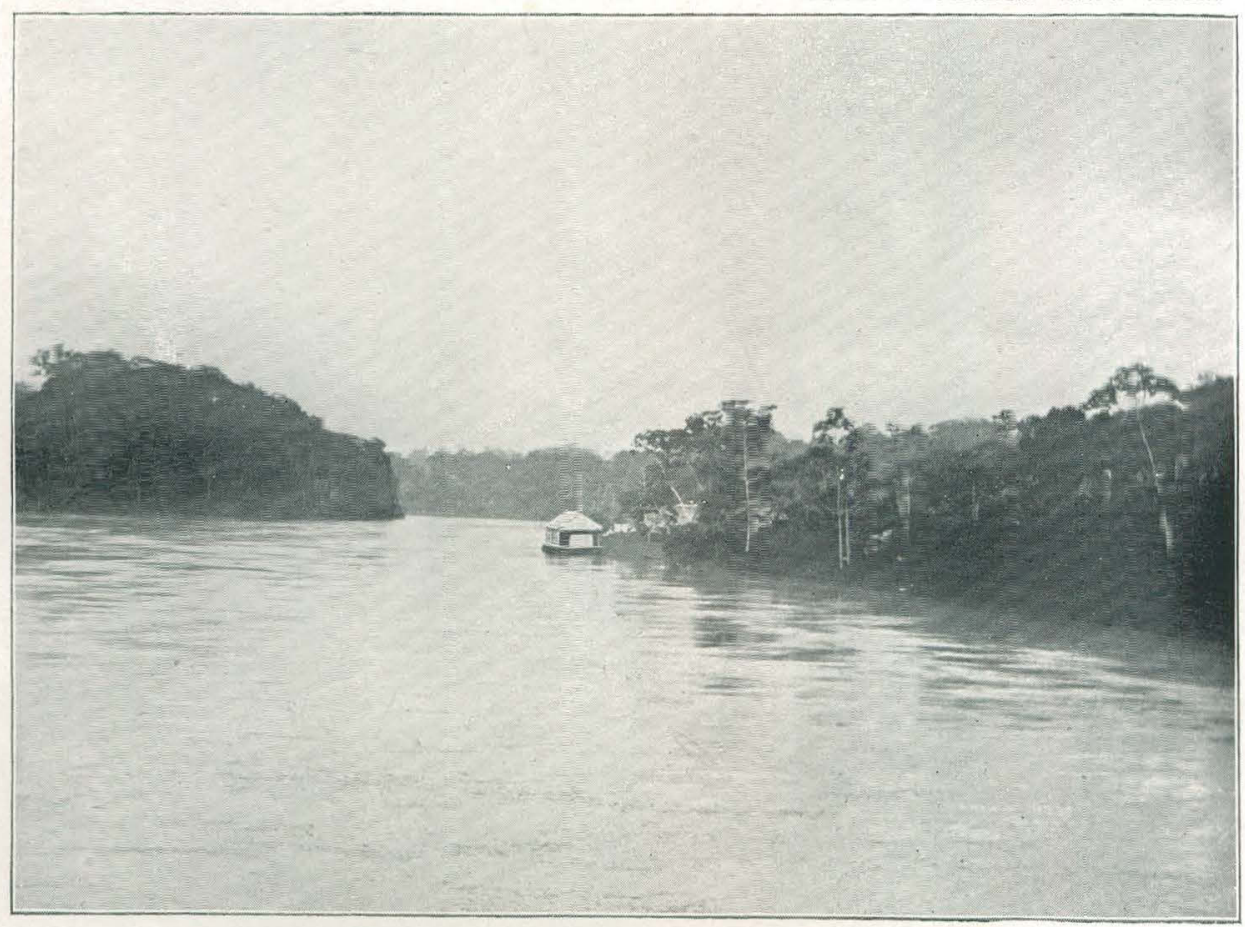

A. RIC SAN . UAN; FL JATING BODEGa AT MACHUD.

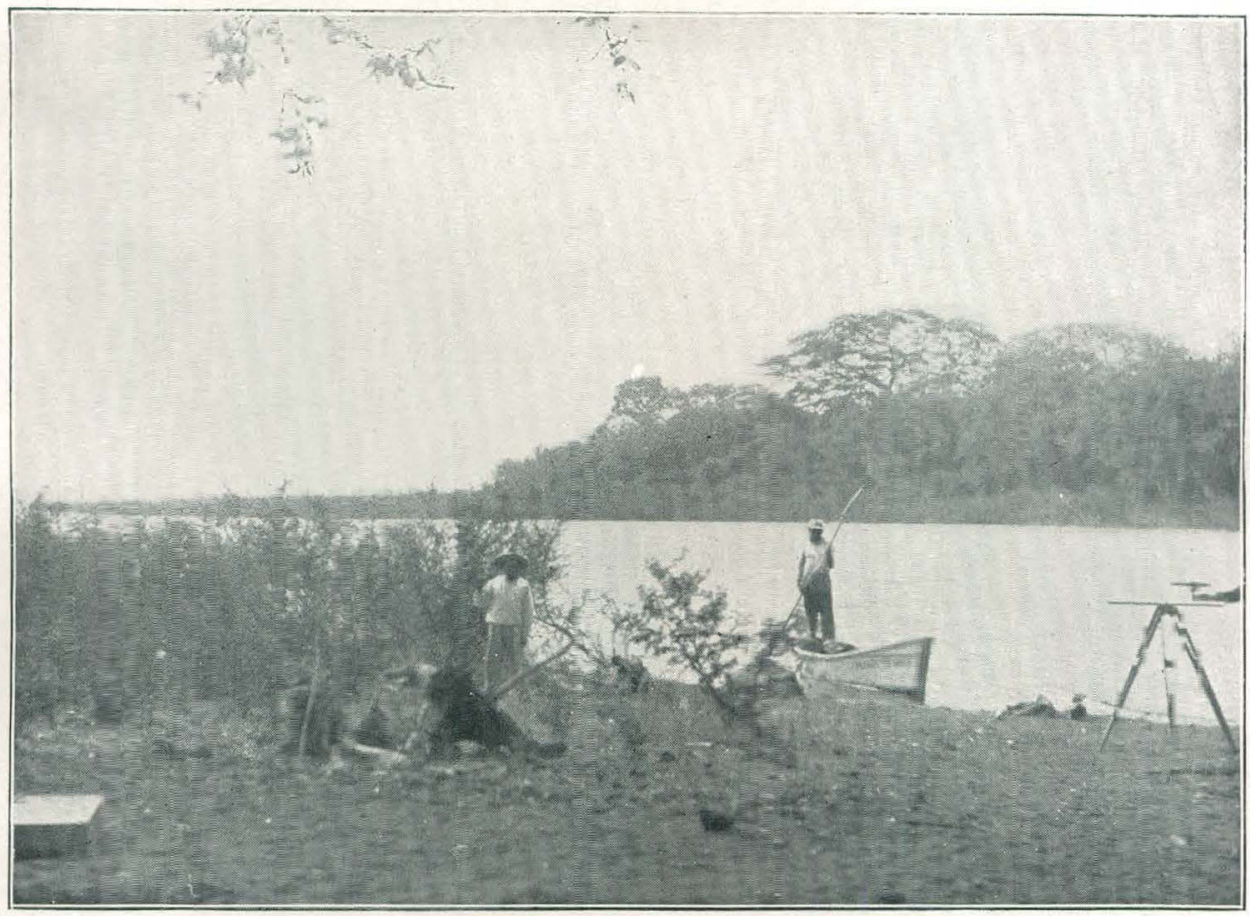

3. IIPITAPA RIVER, DJTLET OF LAKE MANAG JA 
was continual dispute over the boundary line between the republics, each being anxious to preserve and increase its territorial interests in proximity to the proposed canal route. A definite treaty was finally made between the two republies in April, 1858, article 2 of which runs as follows:

The dividing line of the two republics, starting from the northern sea, shall com . mence at the extremity of Castilla Point, at the mouth of the Rio San Juan of Nicaragua, and shall continue its course along the right margin of said river to a point 3 English miles distant from the Castillo Viejo, measured from the exterior fortifications of said castle to the point indicated. From there a curve will start, the center of which shall be said works, and shall preserve a distance of 3 English miles from it throughout its development, terminating at a point which shall be 2 miles distant from the bank of the river, upstream from the castle. From there the line shall continuein the direction of the Sapoa River, which empties into Lake Nicaragua, following a course almost 2 miles distant from the right margin of the Rio San Juan, with its circumvolutions, to its origin at the lake, and of the right margin of the lake itself to the said Sapoa River, where this line, parallel to said margins, will terminate. From the point of intersection with the Sapoa River, which, from what has been said, should be 2 miles distant from the lake, a right astronomical line shall be drawn to the central point of Salinas Bay, in the southern sea, where the demarcation of the territory of the two republics shall terminate. ,

This boundary was for many years unsurveyed, and after the treaty of 1858 a change occurred in the regimen of the San Juan, by which the main portion of its waters, instead of flowing to the sea at San Juan del Norte, as formerly, followed another course to the ocean, known as the Colorado River, while the Lower San Juan, which was formerly the main stream, became a subordinate distributary. This led to a new dispute, Nicaragua claiming that the main stream, or Colorado River, was the true boundary, and calling in question in general the validity of the provisions of the treaty of 1858 . This dispute was submitted to the arbitration of President Cleveland, who made an award on March 22, 1888 , declaring the treaty to be valid. This decision was accepted by both republics, and at their request an umpire was appointed by President Cleveland to decide doubtful points during the survey of the boundary line. Gen. E. P. Alexander, of North Carolina, was appointed to fill this position, and the boundary line is in process of survey at the present time.

\section{RAINFALL.}

\section{MISCELLANEOUS RECORDS.}

Reliable information regarding rainfall in Nicaragua is meager. There is a record of nineteen years at Rivas, which began in January, 1880 , and is still continued. This record has been voluntarily kept by Dr. Earl Flint, an American resident of Rivas. A rainfall record was kept at Masaya from July, 1886, to December, 1896, by Mr. William Climie. The observations were then transferred to Grauada, and have been continued ever since, although results are at hand only to the end of 1897. Observations of rainfall were also made in Granada in 1876 by Ramon Espiuola, and in 1877 by Dr. Flint; also in 1883 and 1884 by 
the National Institute at Granada. At Bluefields observations were made by Hon. W. H. Jackson and others from September, 1883, throughout 1884 and 1885 and a portion of 1886 . The Nicaragua Canal Company kept a record of rainfall at San Juan del Norte for the years 1890, 1891, 1892, and a portion of 1893 . These records have been furnished to this office by the United States Weather Bureau, and are printed below. The Nicaragua Canal Commission took observations at a number of points during the year 1898, in connection with other meteorologic and hydrographic measurements, and the results are given below. Pl. LXVIII shows in diagrammatic form the contrast between the distribution of rainfall on the Atlantic and that on the Pacific coast, and PI. LXIX shows the comparative rainfall at different points on the

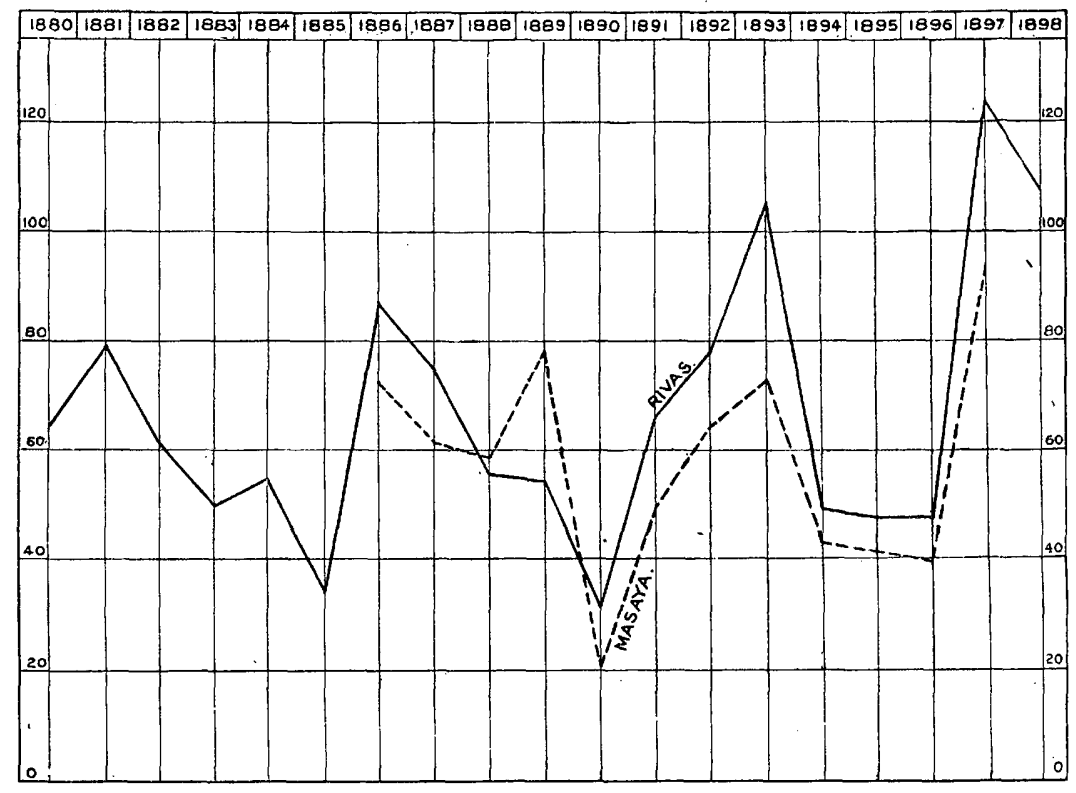

Fig. 219.-Comparative rainfall at Rivas and Masaya.

San Juan. An examination of the records and diagrams shows that along the eastern coast there is no definite dry season. The maximum rainfall yet measured was for the year 1890 , when nearly 300 inches of rain fell at San Juan del Norte, and the year 1892 showed nearly as much. In the region of Lake Nicaragua and on the west coast there is a distinct dry season from about the 1st of December to the middle of May, during which rain seldom falls, and never in large quantities. The total rainfall on the eastern coast is much greater than on the western, both from the absence of any dry season and from heavier monthly rainfall, the mean so far observed at Rivas being under 70 inches, while that at San Juan del Norte is about 250. This fact is easily explained by the direction of the trade winds, which blow with remarkable persistency and uniformity from the Caribbean Sea and 


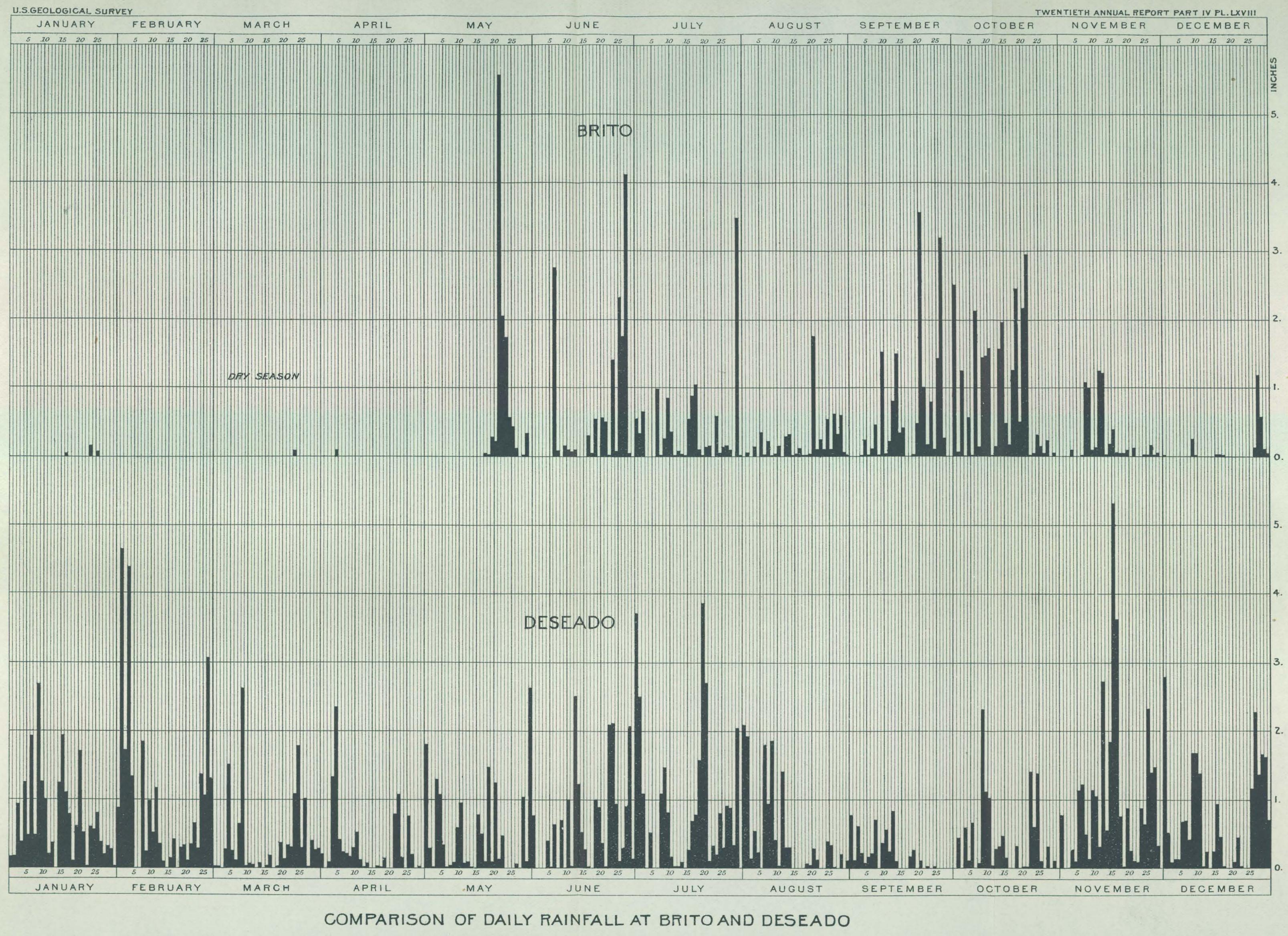


are robbed of the greater part of their moisture in passing over the mountains east of Lake Nicaragua. The gap formed in these mountains by the San Juan, however, allows a portion of the moisture to be carried past even during the dry season, so that at Fort San Carlos, where the San Juan leaves Lake Nicaragua, rain is liable to fall during any month in the year, though in quantities far less than on the Atlantic coast, while on the eastern and southern shores of Lake Nicaragua, a few miles north or south of Fort San Carlos, no rain falls in the dry season.

Rainfall at Bluefields, Nicaragua.

\begin{tabular}{|c|c|c|c|c|c|c|c|c|c|c|c|c|c|}
\hline Year. & Jan. & Feb. & Mar. & Apr. & May. & June. & July. & Aug. & Sept. & Oct. & Nov. & Dec. & Total. \\
\hline 1883. & & & & & & & & .. & 3.42 & 8.13 & 12.13 & 17.00 & \\
\hline $1884 \ldots \ldots$ & 10.25 & 6.39 & 3. 21 & 2.06 & 2.67 & 8.01 & 17.06 & 16.40 & 5.82 & 4.99 & 9.71 & 11.15 & 97.72 \\
\hline 1885. & 1.96 & 1.60 & 2.66 & 2.87 & 5.89 & 13.37 & 19.82 & 11.75 & 8.07 & 2.69 & 7.70 & 3.15 & 81.53 \\
\hline $1886 \ldots$. & 7.28 & 3.94 & 1.63 & & & & & 8.55 & & & ….. & & \\
\hline
\end{tabular}

Rainfall at San Juan del Norte, Nicaragua.

\begin{tabular}{|c|c|c|c|c|c|c|c|c|c|c|c|c|c|}
\hline Year. & Jan. & Feb. & Mar. & Apr. & May. & June. & July. & Aug. & Sept. & Oct. & Nov. & Dee. & Total. \\
\hline 1890 & 26.80 & 6.36 & 5.93 & 18.11 & 4. 93 & 46.84 & 52.55 & 35.72 & 8.14 & 24.36 & 25.55 & 41.65 & 296.94 \\
\hline 1891 & 20.30 & 2.57 & 1.95 & 10.40 & 13.78 & 26.95 & 23.57 & i9. 49 & 14.16 & 20.21 & 28.15 & 32.74 & 214.27 \\
\hline 1892 & 28.57 & 11.38 & 4. 98 & 18.38 & 50.88 & 13.42 & 38.96 & 23.63 & 11.47 & 27.95 & 36.93 & 24.65 & 291.20 \\
\hline 1893 & 17.70 & 7.53 & 3. 93 & 9.99 & 2.77 & & & & 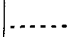 & & 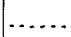 & $\ldots$ & . \\
\hline 1898. & 19.44 & 25.17 & 10.16 & 6. 90 & 9.37 & 19.52 & 24.63 & 16.38 & 7.24 & 12.50 & 32.35 & 17.06 & 200.72 \\
\hline
\end{tabular}

1) Monthly rainfall at Rivas, Nicaragua.

[Latitude, $10^{\circ} 26^{\prime} \mathrm{N}$.; longitude, $85^{\circ} 47^{\prime} \mathrm{W}$.; elevation, 210 feet.] $^{\circ}$

\begin{tabular}{|c|c|c|c|c|c|c|c|c|c|c|c|c|c|}
\hline Year. & Jan. & Feb. & Mar. & Apr. & May. & June. & July. & Aug. & Sept. & Oet. & Nov. & Dec. & Annnal. \\
\hline 1880. & 0.00 & 0.00 & 0.00 & 0.00 & 10.23 & 12.58 & 3.62 & 10.48 & 7.95 & 13.83 & 5.02 & 0.67 & 64.38 \\
\hline 1881. & 0.00 & 0.00 & 0.00 & 0.12 & 5.20 & 13.17 & 8.88 & 6.96 & 7.42 & 24.67 & 10.88 & 1.91 & 79.21 \\
\hline 1882. & 0.00 & 0.13 & 0.00 & 0.00 & 4.26 & 9.80 & 4.04 & 6.25 & 7.65 & 23.38 & 4.20 & 1.61 & 61.32 \\
\hline 1883 & 0.28 & 0.00 & 0.00 & 0.14 & 1.00 & 8.07 & 4.87 & 4.34 & 5.78 & 18.25 & 5.70 & 1.34 & 49.77 \\
\hline 1884. & 0.59 & 0.09 & 0.00 & 2. 03 & 2.80 & 10.43 & 4.98 & 3.84 & 4.48 & 15.83 & 7.43 & 2. 24 & 54.74 \\
\hline $1885 \ldots$ & 0.04 & 0.00 & 0.00 & 0.00 & 1. 78 & 7.27 & 4.81 & 2.76 & 5.40 & 7. 88 & 4. 36 & 0.29 & 34.59 \\
\hline 1886. & 0.23 & 0.20 & 0.00 & 0.17 & 13.00 & 7.87 & 15.00 & 20.80 & 15.30 & 10.40 & 3.75 & 0.49 & 87.21 \\
\hline 1887. & 0.90 & 0.81 & 0.00 & 0.00 & 9.17 & 8.18 & 4. 10 & 5.03 & 19.42 & 22.47 & 2.50 & 2.31 & 74.89 \\
\hline 1888. & 1.83 & 0.04 & 0.00 & 0.00 & 7.12 & 8.50 & 4.18 & 5.00 & 9.80 & 16.80 & 1.11 & 1.13 & 55.51 \\
\hline $1889 \ldots$ & 0.00 & 0.19 & 0.07 & 1.71 & 11. 34 & 11.64 & 7.48 & 12.95 & 9.80 & 24.13 & 3.38 & 1.67 & 84.38 \\
\hline $1890 \ldots$ & 0.49 & 0.11 & 0.94 & 0.00 & 2.63 & 4. 56 & 4.73 & 3.78 & 2. 77 & 9.68 & i. 30 & 0.82 & 31.81 \\
\hline $1891 .$. & 0.00 & 0.00 & 0.00 & 0.78 & 0.75 & 24.58 & 4.38 & 4.21 & 12.42 & 14.90 & 2.34 & 1. 67 & 66.03 \\
\hline $1892 \ldots$ & 0.19 & 0.00 & 0.00 & 0.00 & 13.30 & 9.80 & 9.19 & 7.48 & 12. 22 & 21.26 & 4.40 & 0.43 & 78.27 \\
\hline $1893 \ldots$ & 0.06 & 0.39 & 0.00 & 0.11 & 20.03 & 21.14 & 13.22 & 18.70 & 14.00 & 13.56 & 1. 44 & 2.48 & 105.13 \\
\hline $1894 \ldots$ & 2.12 & 2. 36 & 0.08 & 0.00 & 7.76 & 6.32 & 3.64 & 4.57 & 4.33 & 14.62 & 3.21 & 0.43 & 49.44 \\
\hline $1895 \ldots$ & 0.00 & 0.00 & 0.19 & 0.00 & 8.11 & 11.00 & 5.25 & 3.42 & 8.01 & 8.97 & 2.04 & 0.20 & 47.66 \\
\hline $1896 \ldots$ & 0.40 & 0.08 & 0.00 & T. & 3.26 & 6.23 & 7.43 & 6.57 & 7.40 & 7.42 & 8.62 & 0.39 & 47.80 \\
\hline $1897 \ldots$ & 0.33 & T. & 1.04 & 0.00 & 21.30 & 24.34 & 6.41 & 12.10 & 17.63 & 33.85 & 5.15 & 1.28 & 123.43 \\
\hline 1898. & 1. 07 & 0.12 & 0.10 & 0.00 & 16.17 & 18.95 & 13.65 & 11.85 & 13.99 & 20.83 & 8.19 & 3.14 & 108.06 \\
\hline $\mathrm{M}$ & 0.45 & 0.24 & 0.13 & 0.27 & 8.38 & 11.81 & 6.83 & 7.95 & 9.78 & 16.99 & 4.47 & 1. 29 & 68.61 \\
\hline
\end{tabular}


Monthly rainfall at Masaya, 1886-1896, and Granada, 1897, Nicaragua.

\begin{tabular}{|c|c|c|c|c|c|c|c|c|c|c|c|c|c|}
\hline Year. & Jan. & Feb. & Mar. & Apr. & May. & June. & July. & Aug. & Sept. & Oet. & Nov. & Dec. & Annual. \\
\hline 1886. & & & & & & & 8.23 & 15.26 & 15.34 & 11.19 & 0.69 & 0.02 & 72.70 \\
\hline 1887. & 0.30 & 0.00 & 0.00 & 0.00 & 2.42 & 10.73 & 7.39 & 5.74 & 9.15 & 23.56 & 0.94 & 0.99 & 61.22 \\
\hline 1888. & 0.05 & 0.14 & 0.00 & 0.00 & 7. 99 & 12.09 & 4.95 & 9.50 & 17.21 & 7.67 & 0.00 & 0.00 & 53.70 \\
\hline 1889. & 0.00 & 0.00 & 2. 39 & 1.18 & 6.43 & 17.00 & 7.87 & 13.43 & 14.53 & 13. 36 & 2.34 & 0.25 & 78.78 \\
\hline $1890 \ldots$ & 0.14 & 0.00 & 0.00 & 0.60 & 1.82 & 3.00 & 2.86 & 2. 66 & 2.95 & 5.89 & 0.42 & 0.18 & 20.52 \\
\hline $1891 .$. & 0.19 & 0.00 & 0.00 & 1.02 & 0.48 & 20.94 & 4.52 & 4. 20 & 10.40 & 5.45 & 2.78 & 0.00 & 43.98 \\
\hline 189 & 0.00 & 0.00 & 0.00 & 0.00 & 7. 36 & 14.42 & 8. 70 & 6.75 & 9.64 & 15.71 & 1.66 & 0.30 & 64.54 \\
\hline 1893. & 0.00 & 1.15 & 0.00 & 0.00 & 9.26 & 11.78 & 11.47 & 15.82 & 12.67 & 6.51 & 2.70 & 1.50 & 72.86 \\
\hline 1894. & 0.32 & 0.50 & 0.00 & 0.00 & 7.87 & 4.77 & 3. 32 & 4.00 & 7.49 & 13.42 & 1.08 & 0.11 & 42.88 \\
\hline 1895 & 0.00 & 0.00 & 0.00 & 0.41 & 4.57 & 4.71 & 5. 22 & 2. 90 & 8. 36 & 14.46 & 0.57 & 0.06 & 41.26 \\
\hline 1896. & 0.23 & 0.00 & 0.00 & 0.09 & 5.62 & 7.90 & 7.13 & 2.98 & 6.62 & 4.22 & 4.85 & 0.00 & 39.64 \\
\hline 1897. & 0.00 & 0.00 & 0.97 & 1.77 & 16.63 & 30.79 & 8.88 & 10.87 & 10.21 & 11.97 & 1.25 & 0.28 & 93.62 \\
\hline I & 0.11 & 0.16 & 0.31 & 0.46 & 6.32 & 12.56 & 6. 71 & 7.84 & 10.38 & 11.12 & 1.61 & 0.31 & 57.89 \\
\hline
\end{tabular}

Precipitation at San Jose, Costa Rica.

[Latitude, $9^{\circ} 56^{\prime} \mathrm{N}$.; longitude, $84^{\circ} 8^{\prime} \mathrm{W}$.; elevation, 3,750 feet.]

\begin{tabular}{|c|c|c|c|c|c|c|c|c|c|c|c|c|c|}
\hline Year. & Jan. & Feb. & Mar. & Apr. & May. & June. & July. & Aug. & Sept. & Oct. & Nov. & Dec. & Annual. \\
\hline 1866. & 1.30 & 0.28 & 0.00 & 1. 14 & 5.47 & 4.84 & 12.60 & 6.14 & 10.79 & 9.84 & 6.73 & 4.80 & 63.93 \\
\hline $1867 .$. & 3.86 & 2. 21 & 0.38 & 3.86 & 8.23 & 8.11 & 8.43 & 7.48 & 12.36 & 8.39 & 9.61 & 0.55 & 73.47 \\
\hline 1868. & 0.00 & 0.00 & 7.13 & 0.01 & 3.27 & 5.91 & 4.02 & 5.12 & 8.82 & 15.47 & 5.67 & 0.67 & 56.09 \\
\hline 1869. & 0.28 & 0.00 & 0.28 & 1.10 & 7.95 & 8.58 & 5.91 & 5.20 & 15.47 & 11.06 & 3.07 & 4.02 & 62.92 \\
\hline $1870 .$. & C. 04 & 0.24 & 1.22 & 0.67 & 13. 11 & 10.87 . & 9.45 & 11.18 & 9.45 & 10.32 & 7.24 & 1.30 & 75.09 \\
\hline 1871. & 1.10 & 0.12 & 0.32 & 0.51 & 11.42 & 7. 99 & 14.33 & 12.09 & 9.65 & 13.11 & 4.49 & 0.43 & 5.56 \\
\hline $1872 \ldots$ & 0.12 & 0.12 & 0.59 & 1.97 & 9.61 & 10.04 & 7.56 & 14.88 & 15.63 & 19.84 & 5.59 & 0.83 & 86.78 \\
\hline 1873. & 2. 52 & 0.00 & 0.12 & 2.80 & 2.52 & 8.07 & 5.71 & 3.35 & 15.24 & 10.32 & 4.76 & 0.43 & 55.84 \\
\hline $1874 .$. & 1.81 & 0.04 & 0.79 & 2.36 & 13.23 & 6.57 & 6.38 & 7.13 & 12.56 & 7.52 & 1.65 & 0.79 & 60.83 \\
\hline 1875 & 0.00 & 0.00 & 0.00 & 1. 10 & 9.92 & 7.09 & 3.66 & 11.57 & 10.98 & 13.35 & 0.83 & 1.26 & 59.76 \\
\hline 1876 & 0.55 & 0.00 & 0.43 & 0.24 & 9.72 & 9.33 & 6.02 & 7.56 & 8.11 & 4.61 & 2.76 & 1.10 & .43 \\
\hline 1877 & 0.55 & 0.00 & 0.00 & 0.00 & 9.45 & 6.57 & 8.78 & 6.26 & 10. 20 & 3. 74 & 4. 76 & 3.11 & 53.42 \\
\hline 1878. & 0.00 & 0.00 & 1.50 & 1. 97 . & 3. 59 & 7.36 & 8.07 & 5. 87 & 12.99 & 9.37 & 8.78 & 0.79 & 60.29 \\
\hline 1879. & 0.51 & 0.00 & 1.77 & 7.56 & 8.66 & 12.99 & 18.11 & 11.14 & 13.82 & 9.09 & 2.40 & 0.32 & 86.37 \\
\hline 1880. & 0.32 & 0.00 & 0.00 & 0.59 & 10.00 & 8.27 & 4.09 & 17.17 & 6. 50 & 10.94 & 3.62 & 0.00 & 61.50 \\
\hline 1884. & 0.00 & 0.00 & 0.08 & 0.32 & 0.43 & 2.44 & 0.59 & 0.67 & 4.41 & 1.89 & 7.44 & 1.22 & 19.49 \\
\hline 1885. & 0.00 & 0.00 & 0.00 & 1.85 & 5.98 & 3.07 & 7.84 & 3.86 & 15.59 & 1.2. 87 & 16.22 & 2.32 & 69.60 \\
\hline $1886 \ldots$ & 0.00 & 0.00 & 2.05 & 8.98 & 15.55 & 16.85 & 20.59 & 19.61 & 22.91 & 28.67 & 16.81 & 2.28 & 154.30 \\
\hline $1887 .$. & 0.00 & 0.00 & 0.67 & 0.28 & 9.96 & 14.16 & 5.61 & 9.40 & 11.24 & 13. 16 & 4.93 & 2.07 & 71.48 \\
\hline 1888. & 0.63 & 0.71 & 0.00 & 0.55 & 7.07 & 10.24 & 5.49 & 5.51 & 15.71 & 10.39 & 2.01 & 0.87 & 59.21 \\
\hline $1889 \ldots$ & 0.01 & 0.08 & 2.91 & 2.41 & 14.57 & 8.08 & 6.06 & 10.76 & 16.89 & 20.48 & 2.45 & 0.48 & 85.18 \\
\hline $1890 \ldots$ & 0.87 & 0.08 & 0.75 & 2.52 & 10.08 & 11.65 & 15.67 & 10.55 & 8.35 & 7.99 & 2.56 & 0.71 & 71. 78 \\
\hline 1891. & 0.03 & 0.01 & 0.05 & 0.74 & 4.26 & 7.74 & 8.00 & 9.84 & 12.30 & 15.48 & 5.57 & 1.16 & 65.18 \\
\hline $1892 \ldots$ & 0.00 & 0.00 & 0.13 & 0.07 & 12.17 & 15.06 & 8.70 & 13.75 & 14.84 & 21.36 & 5.03 & 0.44 & 91.55 \\
\hline $1893 \ldots$ & 0.04 & 0.00 & 0.02 & 0.47 & 8. 73 & 15.28 & 13.90 & 13.76 & 20.75 & 14.93 & 7.08 & 2.94 & 97.90 \\
\hline
\end{tabular}

20 GEOL, P'T $4-37$, 


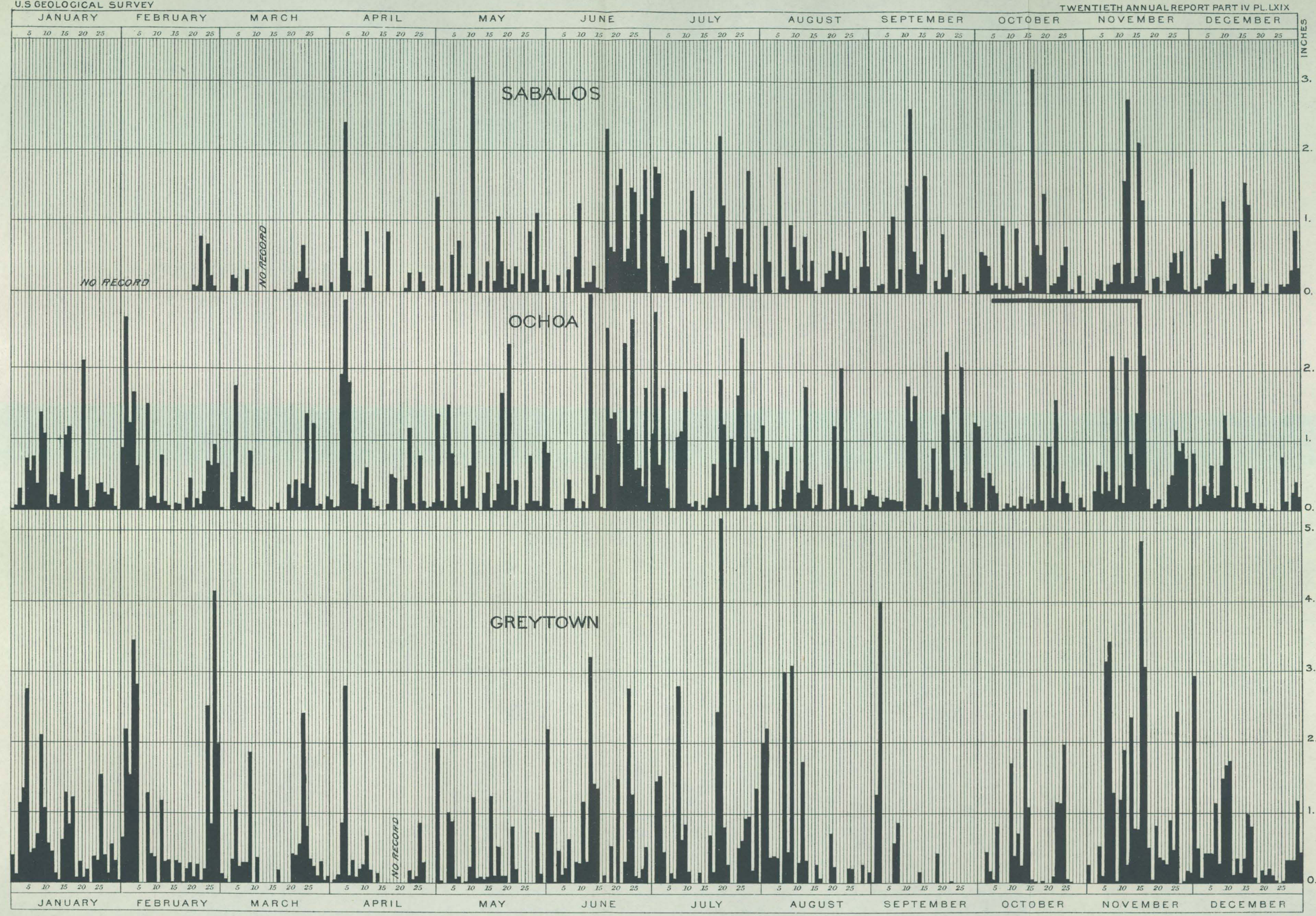

COMPARISON OF DAILY RAINFALL AT THREE STATIONS ON THE RIO SAN JUAN 
RECORDS OF NICARAGUA CANAL COMMISSION.

Monthly rainfall, Nicaragua, 1898.

\begin{tabular}{|c|c|c|c|c|c|c|c|c|c|c|c|c|c|}
\hline Station. & Jan. & Feb. & Mar. & Apr. & May. & June. & July. & Aug. & Sept. & Oct. & Nor. & Dec. & Total. \\
\hline $\begin{array}{c}\text { Brito and } \\
\text { rola } \ldots . . . . .\end{array}$ & 0.25 & 0.00 & 0.08 & 0.08 & 11.30 & 14.86 & 11.42 & 6.17 & 16.60 & 25.70 & 6.01 & 2.41 & 94.88 \\
\hline Rivas..... & 1.07 & 0.12 & 0.10 & 0.00 & 16.17 & 18.95 & 13.65 & 11.85 & 13.99 & 20.83 & 8.19 & $\ldots .$. & 104.92 \\
\hline Las Lajas.... & 0.25 & 0.05 & 1.34 & 0.28 & 10.60 & 13.50 & 10.64 & 8.44 & 6. 79 & $\ldots$ & 4. 41 & 2. 26 & 58.56 \\
\hline Viejo River.. & . & 0.01 & 0.66 & 0.00 & 13.78 & 13.45 & 4.01 & 1.1. 66 & 7.22 & 8.99 & 0.61 & 0.17 & 60.56 \\
\hline Tipitapa. & & 0.00 & 0.26 & 0.00 & 8.56 & 16.88 & 6.24 & 7.82 & 11.25 & 7.12 & 0.93 & 0.17 & 59.23 \\
\hline Morrito...... & 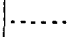 & ..... & ...... & 0.07 & 8.92 & 14.05 & 13.84 & 10.20 & & & & & \\
\hline $\begin{array}{r}\text { FortSan Car- } \\
\text { los......... }\end{array}$ & & & 1.41 & 3.00 & 8.22 & 15.56 & 13.35 & 8.00 & 10.56 & 8.93 & 9.86 & 5.62 & 84.51 \\
\hline Sabalos... & & & 2.10 & 6.00 & 11.69 & 17.13 & 20.69 & 11.33 & 11.42 & 11.50 & 12.17 & 10.20 & 114.23 \\
\hline Castillo...... & $\cdots$ & … & -..... & $\ldots$ & $\ldots$ & & 18.92 & 11.46 & 16.22 & 4.64 & 14.04 & 9.08 & $\ldots \ldots$ \\
\hline Machuca .... & & & & & & & & 8.51 & 12.86 & 9.83 & 15.65 & 6.75 & \\
\hline $\begin{array}{r}\text { Rio San Car- } \\
\text { Jos ............. }\end{array}$ & & & 7.52 & 11.66 & 20.12 & 20.79 & 18.26 & 11.68 & $\cdots$ & & & & \\
\hline Ochoa ..... & 13.07 & 14.08 & 8.04 & 12.23 & 15.2 .3 & 21.47 & 21.60 & 12.08 & 15.12 & 8.02 & 21.50 & 8.38 & 170.84 \\
\hline $\begin{array}{r}\text { San Fran. } \\
\text { cisco.......... }\end{array}$ & 15.33 & 18.43 & 8.72 & 11.25 & 13.87 & 18.87 & 19.22 & 13.45 & 10.95 & 9.00 & 22.38 & 10.61 & 172.08 \\
\hline Sarapiqui... & & & & & ..... & & & $\cdots$ & 11.19 & 11.35 & 18.63 & 6.75 & \\
\hline Deseado $a . .$. & 21.92 & 26.98 & 11.76 & 8.83 & 14.84 & 18.66 & 26.86 & 13.31 & 5.23 & 11.92 & 29.25 & 21.07 & 210.63 \\
\hline $\begin{array}{l}\text { San Juan del } \\
\text { Norte....... }\end{array}$ & 19.44 & 25.17 & 10.16 & 7.82 & 9.37 & 19.52 & 24.63 & 16.38 & 7.24 & 12.50 & 32.35 & 17.06 & 201.64 \\
\hline
\end{tabular}

$a$ Rainfall not observed from December $2 \overline{5}$ to 31,1898 ; the record was completed by including the corresponding days of 1897.

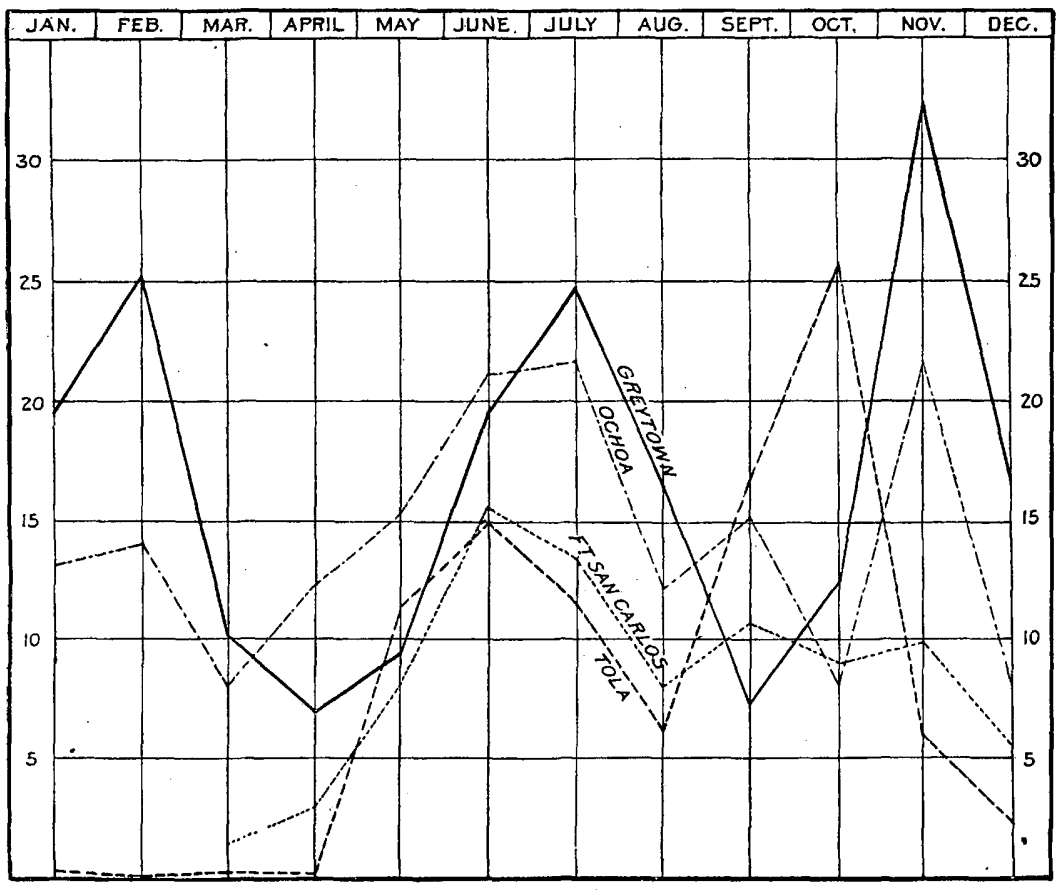

FIG. 220.-Comparative monthly rainfall at San Juan del Norte (Greytown), Ochoa, Fort San Carlos and Tola. 
TEMPERATURE AND RELATIVE HUMIDITY.

The climate of Nicaragua may be regarded as insular, as it is remarkably uniform. It is never very hot, and hardly ever cool. In no part of the country is there the slightest danger of frost. The climate is somewhat cooler and more uniform on the east than on the west coast, but in general it may be said that the temperature seldom exceeds $90^{\circ}$ F., nor falls below $70^{\circ}$. The following synopsis of monthly temperature and relative humidity is made from the observations of the Nicaragua Canal Commission:

Temperature and relative humidity.

LAS LAJAS.

\begin{tabular}{|c|c|c|c|c|}
\hline \multirow{2}{*}{ Month. } & \multicolumn{3}{|c|}{ Temperature. } & \multirow{2}{*}{$\begin{array}{l}\text { Relative } \\
\text { humidity. }\end{array}$} \\
\hline & $\begin{array}{l}\text { Maxi- } \\
\text { mum. }\end{array}$ & $\begin{array}{l}\text { Mini- } \\
\text { mum. }\end{array}$ & Mean. & \\
\hline \multicolumn{5}{|l|}{1898.} \\
\hline February $\ldots \ldots \ldots \ldots \ldots \ldots \ldots$ & 80 & 75 & 77.7 & 81.1 \\
\hline 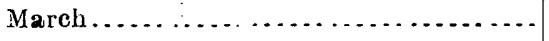 & 84 & 75 & 79.5 & 79.3 \\
\hline$\ldots \ldots \ldots \ldots \ldots \ldots \ldots$ & 86 & 77 & 80.8 & 79.1 \\
\hline 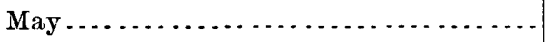 & 91 & 73 & 82.1 & 83.0 \\
\hline 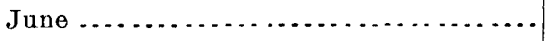 & 91 & 73 & 81.4 & 84.8 \\
\hline$\ldots \ldots \ldots \ldots \ldots \ldots \ldots$ & 85 & 74 & 79.7 & 86.6 \\
\hline 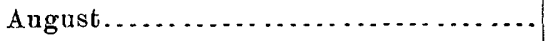 & 85 & 74 & 80.7 & 87.0 \\
\hline$\ldots \ldots \ldots \ldots \ldots \ldots$ & 85 & 73 & $\cdot 79.4$ & 90.4 \\
\hline October ........ & $\ldots . .$. & ... & ....... & - . . . \\
\hline 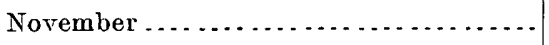 & 86 & 73 & 79.3 & 89.7 \\
\hline December.$\ldots \ldots \ldots \ldots \ldots \ldots \ldots \ldots \ldots$ & 83 & 73 & 78.3 & 91.1 \\
\hline \multicolumn{5}{|c|}{ VIEJO RIVER STALION. } \\
\hline \multicolumn{5}{|l|}{1898.} \\
\hline February $\ldots \ldots \ldots \ldots \ldots \ldots \ldots \ldots \ldots \ldots \ldots$ & 89 & 63 & 78.1 & 58.9 \\
\hline 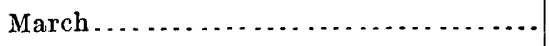 & 97 & 62 & 78.8 & 59.1 \\
\hline April......... & 94 & 69 & 82.8 & 59.4 \\
\hline May ............ & 96 & 71 & 82.3 & 71.0 \\
\hline June......... & 94 & 70 & 80.6 & 81.4 \\
\hline July $\ldots \ldots \ldots \ldots \ldots \ldots \ldots \ldots \ldots \ldots$ & 89 & 70 & 78.8 & 79.6 \\
\hline 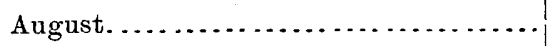 & 90 & 71 & 78.4 & 83.1 \\
\hline September $\ldots \ldots \ldots \ldots \ldots \ldots \ldots$ & 89 & 70 & ...... & $\ldots \ldots \ldots$ \\
\hline
\end{tabular}


Temperature and relative humidity. FORT SAN CARLOS.

\begin{tabular}{|c|c|c|c|c|}
\hline \multirow{2}{*}{ Month. } & \multicolumn{3}{|c|}{ Temperature. } & \multirow{2}{*}{$\begin{array}{l}\text { Relative } \\
\text { humidity. }\end{array}$} \\
\hline & $\begin{array}{l}\text { Maxi. } \\
\text { mum. }\end{array}$ & $\begin{array}{l}\text { Mini- } \\
\text { mum. }\end{array}$ & Mean. & \\
\hline \multicolumn{5}{|l|}{1898.} \\
\hline 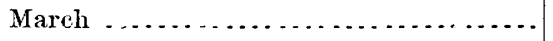 & 88.0 & 70.0 & 78.1 & 58.0 \\
\hline April $\ldots \ldots \ldots \ldots \ldots \ldots \ldots \ldots \ldots \ldots \ldots$ & 88.5 & 70.5 & 78.5 & 79.1 \\
\hline 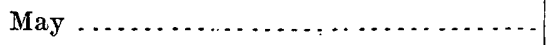 & 91.0 & 73.0 & 80.0 & 85.9 \\
\hline 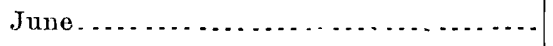 & 90.0 & 73.0 & 79.5 & 88.9 \\
\hline July $\ldots \ldots \ldots \ldots \ldots \ldots \ldots \ldots \ldots \ldots$ & 89.5 & 72.0 & 78.2 & 88.9 \\
\hline August ....... & 89.0 & 73.5 & 79.1 & 89.5 \\
\hline September $\ldots \ldots \ldots \ldots \ldots \ldots \ldots \ldots \ldots$ & 90.0 & 72.5 & 79.6 & 87.3 \\
\hline October $\ldots \ldots \ldots \ldots \ldots \ldots \ldots$ & 90.0 & 74.0 & 79.8 & 88.8 \\
\hline 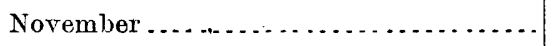 & 88.5 & 72.0 & 77.9 & 90.1 \\
\hline \multicolumn{5}{|c|}{ SABALOS. } \\
\hline 189.3. & & & & \\
\hline February $\ldots \ldots \ldots \ldots \ldots \ldots \ldots \ldots \ldots$ & 90 & 67 & 75.5 & 87.2 \\
\hline 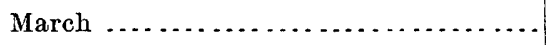 & 90 & 69 & 76.7 & 84.8 \\
\hline April .......... & 89 & 66 & 76.8 & 85.3 \\
\hline May .......... & 89 & 71 & 77.8 & 87.8 \\
\hline June........... & 89 & 71 & 77.7 & 90.0 \\
\hline July $\ldots \ldots \ldots \ldots \ldots \ldots \ldots \ldots \ldots$ & 89 & 71 & 77.1 & 92.0 \\
\hline August $\ldots \ldots \ldots \ldots \ldots \ldots \ldots \ldots \ldots$ & 87 & 70 & 77.5 & 91.0 \\
\hline September $\ldots \ldots \ldots \ldots \ldots \ldots \ldots$ & 90 & 71 & 78.0 & 87.4 \\
\hline October $\ldots \ldots \ldots \ldots \ldots \ldots \ldots \ldots \ldots$ & 90 & 71 & 78.2 & 87.4 \\
\hline November $\ldots \ldots \ldots \ldots \ldots \ldots \ldots \ldots \ldots \ldots$ & 88 & 68 & 77.0 & 90.4 \\
\hline \multicolumn{5}{|c|}{ RIO SAN CARLOS STATION. } \\
\hline 1898. & & & & \\
\hline January $\ldots \ldots \ldots \ldots \ldots \ldots \ldots \ldots \ldots$ & 86 & 69 & 75.8 & 92.0 \\
\hline February $\ldots \ldots \ldots \ldots \ldots \ldots \ldots \ldots \ldots$ & 89 & 66 & 74.5 & 88.1 \\
\hline $\operatorname{March} \ldots \ldots \ldots \ldots \ldots \ldots \ldots \ldots \ldots \ldots$ & 88 & 68 & 77.0 & 86.8 \\
\hline 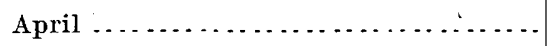 & 91 & 70 & 77.6 & 86.5 \\
\hline 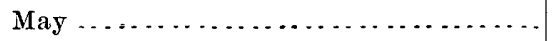 & 95 & 72 & 80.7 & 88.5 \\
\hline June.............................. & 93 & 73 & 79.9 & 87.2 \\
\hline July $\ldots \ldots \ldots \ldots \ldots \ldots \ldots \ldots \ldots \ldots \ldots \ldots$ & 88 & 71 & 77.6 & 89.3 \\
\hline August $\ldots \ldots \ldots \ldots \ldots \ldots \ldots \ldots \ldots$ & 88 & 72 & 78.0 & 89.2 \\
\hline
\end{tabular}


Temperature and relative humidity.

OCHOA.

\begin{tabular}{|c|c|c|c|c|}
\hline \multirow{2}{*}{ Month. } & \multicolumn{3}{|c|}{ Temperature. } & \multirow{2}{*}{$\begin{array}{l}\text { Relative } \\
\text { humidity. }\end{array}$} \\
\hline & $\begin{array}{l}\text { Maxi- } \\
\text { mum. }\end{array}$ & $\begin{array}{l}\text { Mini- } \\
\text { mum. }\end{array}$ & Mean. & \\
\hline 1898. & 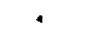 & & & \\
\hline January ....................... & 83 & 66 & 73.9 & 91.6 \\
\hline February $\ldots \ldots \ldots \ldots \ldots \ldots$ & 85 & 66 & 73.3 & 90.4 \\
\hline 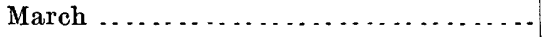 & 87 & 67 & 75.1 & 87.6 \\
\hline 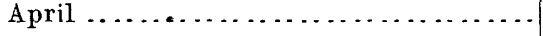 & 88 & 66 & 75.8 & 88.8 \\
\hline 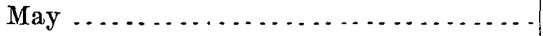 & 94 & 72 & 78.3 & 90.0 \\
\hline 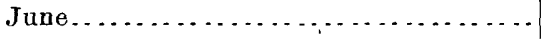 & 90 & 71 & 77.5 & 90.7 \\
\hline July ............................. & 89 & 70 & 76.6 & 91.5 \\
\hline August. . . . . . . . . . . . . . . . . . . & 87 & 71 & 77.0 & $91: 4$ \\
\hline 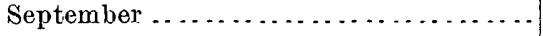 & 91 & 70 & 77.5 & 89.6 \\
\hline 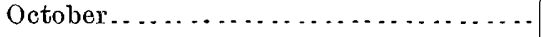 & 95 & 71 & 78.2 & 89.4 \\
\hline 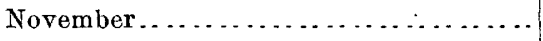 & 89 & 70 & 76.1 & 92.0 \\
\hline 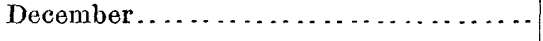 & 58 & 67 & 75.1 & 91.0 \\
\hline \multicolumn{5}{|c|}{ CAMP BARTON ON DESEADO RIVER. } \\
\hline \multicolumn{5}{|l|}{1898.} \\
\hline January ............. & 86 & 65 & 74.1 & 94.7 \\
\hline 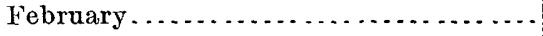 & 84 & 66 & 74.1 & 90.2 \\
\hline 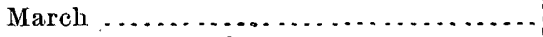 & 87 & 68 & 77.2 & 84.7 \\
\hline April............... & 87 & 67 & 78.8 & 85.2 \\
\hline 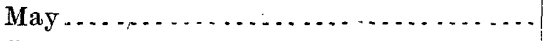 & 91 & 72 & 79.5 & 89.4 \\
\hline 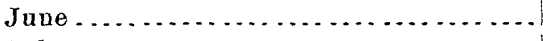 & 86 & 73 & 78.9 & 91.0 \\
\hline July . . . . . . . . . . . . . . . . . . . & 85 & 73 & 78.1 & 92.2 \\
\hline August........ & 87 & 73 & 78.3 & + 91.8 \\
\hline September...... & 91 & 73 & 79.8 & 86.8 \\
\hline October ......... & 89 & 72 & 79.5 & 88.8 \\
\hline 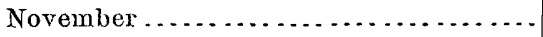 & 88 & 71 & 76.8 & 94.3 \\
\hline December $\ldots \ldots \ldots \ldots \ldots \ldots . . . . . .$. & 84 & 66 & 76.1 & 94.0 \\
\hline \multicolumn{5}{|c|}{ SAN JUAN DEL NORTE, NICARAGUA. } \\
\hline \multicolumn{5}{|l|}{1898.} \\
\hline 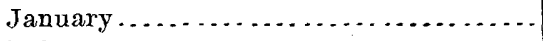 & 86 & 67 & 77.5 & 82.5 \\
\hline 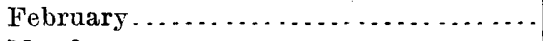 & 84 & 71 & 77.1 & 81.7 \\
\hline 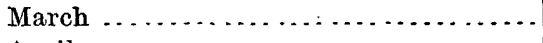 & 90 & 69 & 78.4 & 80.2 \\
\hline April $\ldots \ldots \ldots \ldots \ldots \ldots \ldots \ldots$ & 89 & 69 & 79.9 & 79.0 \\
\hline 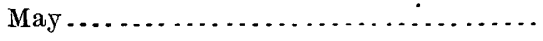 & 94 & 73 & 80.4 & 82.1 \\
\hline 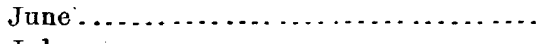 & 90 & 72 & $79 . \hat{\jmath}$ & . 91.4 \\
\hline July $\ldots \ldots \ldots \ldots \ldots \ldots \ldots \ldots \ldots \ldots$ & 90 & · 74 & 80.0 & 91.3 \\
\hline August $\ldots \ldots \ldots \ldots \ldots \ldots \ldots \ldots$ & $9 \overline{5}$ & 73 & 80.0 & 84.9 \\
\hline September . . . . . . . . . . . . . . . . . & 96 & 72 & 81.2 & 85.0 \\
\hline 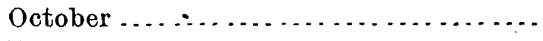 & .96 & 72 & 81.4 & 84.8 \\
\hline November $\ldots \ldots \ldots \ldots \ldots \ldots \ldots \ldots$ & 92 & 72 & 79.7 & 87.7 \\
\hline December $\ldots \ldots \ldots \ldots \ldots \ldots$ & 91 & 72 & 78.3 & 88.0 \\
\hline
\end{tabular}




\section{EVAPORATION.}

Observations were taken at various points during 1898 by the Nicaragua Canal Commission, the principal object being to determine the rate of evaporation from Lake Nicaragua. The obstacles to observations were very great and those made were necessarily somewhat inaccurate, owing chiefly to the frequent and heavy falls of rain. 'The general result seemed to indicate a daily evaporation in the region of Lake Nicaragua of about 0.2 inch per day during the dry season. The observations taken furnished another and probably more reliable method of computing the evaporation from the lake.

Records showing the height of the surface of the lake were kept at San Carlos, San Ubaldo, and Las Lajas. Observations of rainfall were taken at all these places and at Tipitapa, about 10 miles northwest of the lake. A circuit of the lake was made in April and May for the purpose of measuring the inflowing streams, the influx at this season being very small. A record of the discharge of the Rio San Juan was kept at Sabalos above Toro Rapids. From April 10 to May 10 the lake fell 8.64 inches. During the same time rain fell as follows:

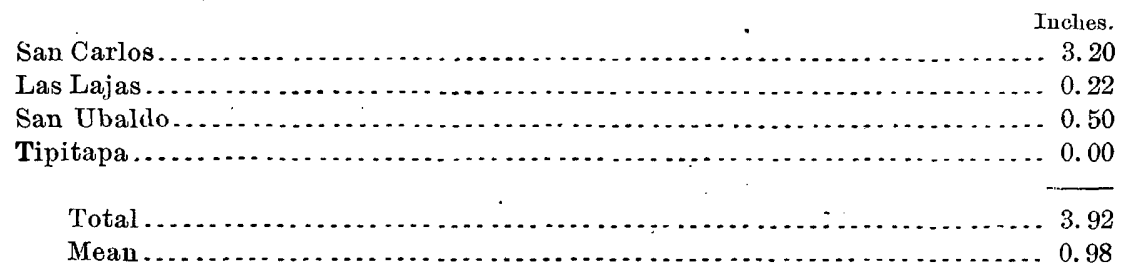

The measured outflow was 714,000 acre-feet, and the inflow is estimated to have been 120,000 acre-feet, making a net decrease of 3.50 inches in lake elevation, due to flowage.

Assembling these facts, we have-

$$
\text { Evaporation for one month }=8.64+0.98-3.50=6.12 \text {. }
$$

This result is about the same as that given by the observations and may be taken as reasonably accurate for the region of Lake Nicaragua during the dry season. In the rainy season of course it is less, and the region lying eastward of Lake Nicaragua having a progressively greater relative humidity also affords a smaller evaporation.

\section{RESOURCES AND PRODUCTIONS.}

Although Nicaragua is almost entirely covered with dense forest growth, really useful timber is not abundant. A district on the Atlantic slope near Bluefields affords large quantities of yellow pine of inferior quality, which, however, is not yet easily accessible.

The only timber yet used to any extent for lumber is cedar, which is soft, straight grained, easily worked, and durable. The trees are scattered and not plentiful. The lumber is mostly sawed by hand, 
All the lumber used by the Maritime Canal Company was imported from the United States.

The timber of greatest value is mahogany, which is cut for export, to be used as an ornamental wood and in cabinet making. The monopoly of its export is conceded to an American firm.

A wild-cotton tree is sometimes used in making canoes.

A number of the forest woods found in Nicaragua are heavy and so hard that it is not possible to drive nails or spikes into them, but are exceedingly durable. Of this class are rosewood, cortes, granadillo, : rouron, lignum-vitæ, nispero, madera negra, guachipilin, guiliguiste, palo de carbon, coyote, and chiquirin." Numerous dyewoods are also found.

A large number of edible tropical fruits are found in Nicaragua, some of them wild and some cultivated. The orange, lemon, cocoanut, pineapple, and banana are all too familiar to need description. The nispero, mango, and zapote are very sweet and juicy, and are eaten in large quautities. The jocote, mamon, guava, guiscoyal, and many others are gathered, sold, and used for food. The breadfruit is one of the most useful of the products of Nicaragua, but is little appreciated and seldom obtainable. It grows upon beautiful trees, which begin to bear at the age of 4 or 5 years, and when properly cared for the yield is enormous. It can be cooked in a great variety of ways and is very palatable and nutritious.

The chief articles of diet among the natives are plantains, beans, and rice. The plantain closely resembles the banana, but is larger, firmer, and not so sweet. It is eaten chiefly while green, being then prepared by boiling. When ripe it is baked or fried, and is very sweet. It is somewhat remarkable that the plantain has not been introduced as an article of food in northern countries.

Beans and rice are raised in Nicaragua, and produce abundantly, but the consumption exceeds the supply, and large quantities are imported.

Coffee of good quality is produced in northern Nicaragua in the neighborhood of Jinotega and Matagalpa, and also in the vicinity of Jinotepe and Managua, being most successfully grown in mountainous regions. It furnishes the principal table beverage, and is largely exported. Another popular table drink is made from "cacao," or chocolate, boiled and served hot. Mixed with parched corn meal, this is sweetened and drunk in cold water, making a refreshing and nutritious beverage. The cultivation of cacao is at present very profitable, the local price being high, and the home demand greater than the supply.

Sugar cane grows abundantly, and nearly all the demand for sugar is supplied by home manufactories, the largest being at San Antonio, operated by an English corporation. The poorer classes use large quantities of a low grade, dark-brown sugar in cakes called "dulce," while a higher grade is used in the cities and some is exported. Large quantities of sugar cane are used in the manufacture of a kind of rum called "aguardiente." 


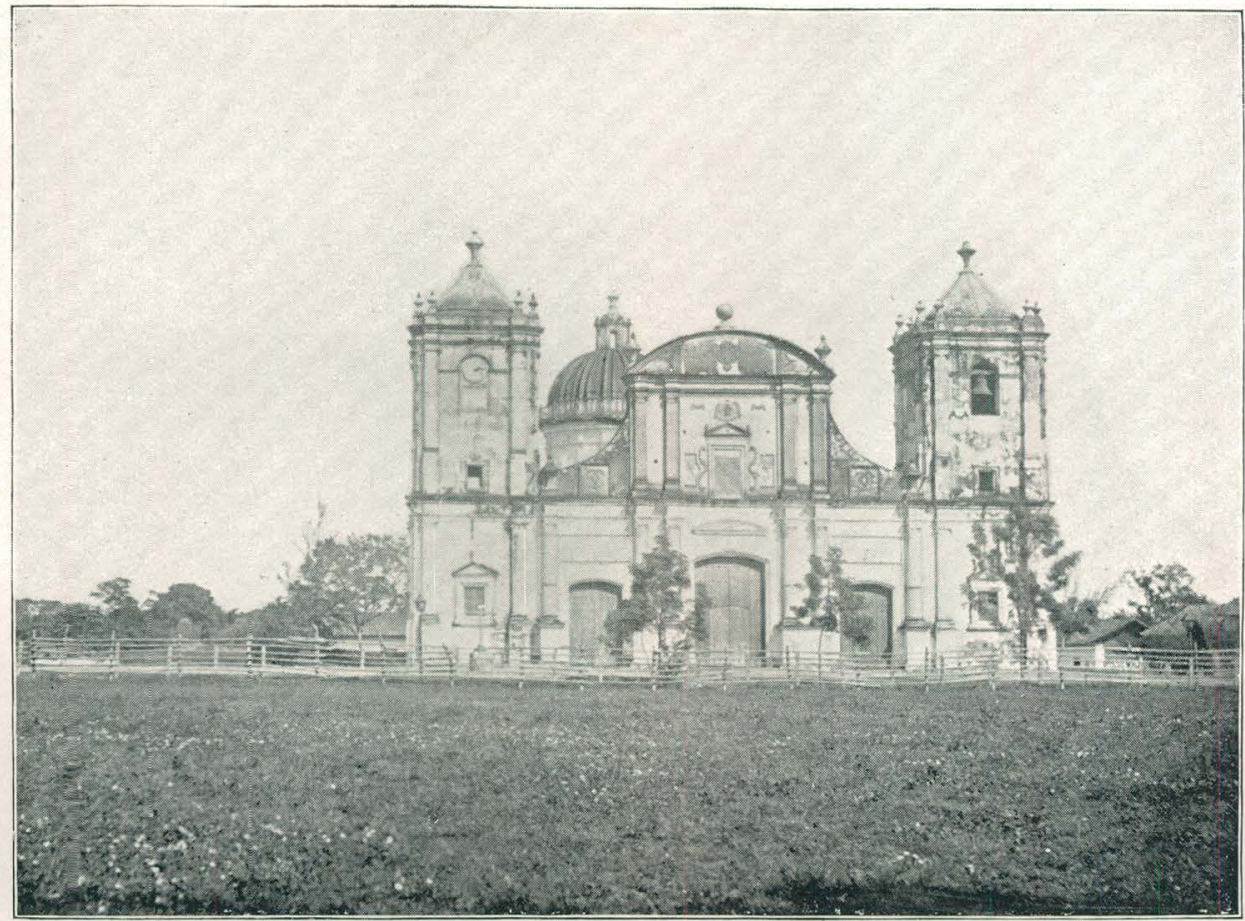

A. CHURCH IN RIVAS.

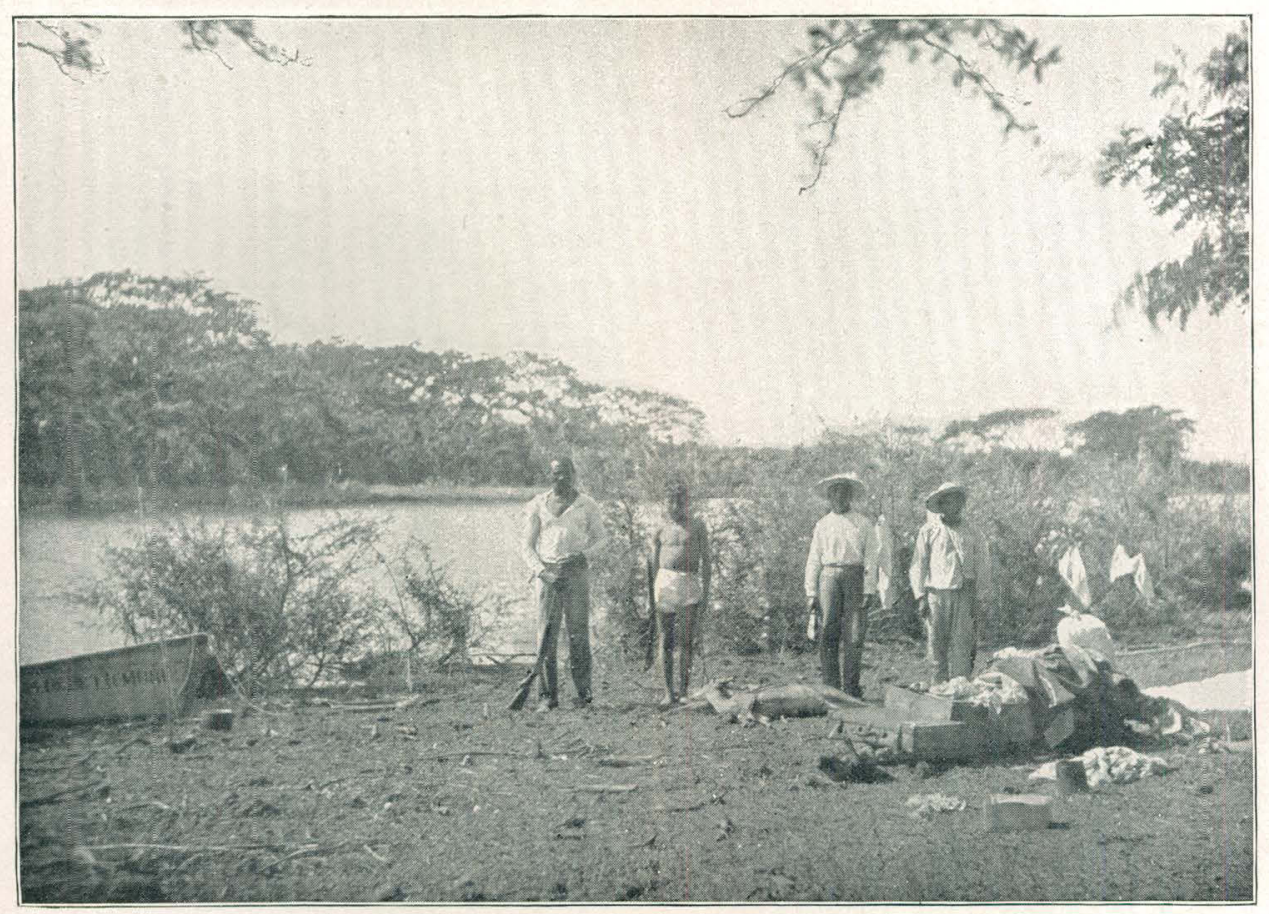

B. SURVEYOR'S CAMP ON LAKE MANAGUA. 
Tobacco of fair quality is grown in sufficient quantity to supply the home demand, which is heavy, as both men and women smoke.

One of the principal exports of Nicaragua is india rubber, or "hule." It is little cultivated, but grows wild. To gather this product, the "huleros" cut two or more vertical channels through the bark of the tree from top to base; then numerous oblique channels are cut leading into the vertical ones. The sap or milk from these wounds coagulates, and is gathered in long strips from the grooves, and is ready for market. Many of the huleros are very destructive, often felling the trees to facili: tate the process of gathering.

The fauna of Nicaragua is characteristic of the Tropics. Monkeys are abundant, and are sometimes killed for food. The tapir, peccary, and deer are the principal game. Fish are caught in most of the streams, and alligators swarm in many of them.

Horses, cattle, sheep, and hogs are raised, and some are exported. Their size, however, is small, and their quality is poor.

Carriages are used in the cities, but in the country the only vehicle in general use is the caretta, a rude, narrow, two-wheeled cart drawn by oxen. The roads are very poor, and in the rainy season usually impassable. The favorite methods of private transportation are by dugout canoe on the lakes and rivers, and by horseback or pack mule on lánd.

There are two railways, one from Corinto to Momotombo, and one from Managua to Granada. They operate in connection with the steamer lines on the lakes and the Rio San Juan, and complete the line of transit from ocean to ocean.

The mineral resources of Nicaragua are considerable, but have been but little exploited. The principal obstacle to their development is the wretched means of transportation. The most common method of access to the mining districts is by means of pack mules, and even this method is difficult in the rainy season. The total production of gold in Nicaragua is estimated at 22,700 ounces per annum. Silver occurs in considerable quantities, and copper, tin, zinc, and antimony are also found. The code of mining laws is a very voluminous document. Mining machinery is admitted free of duty, and no taxes are levied on mines. The rights of foreigners and natives are the same in relation to the ownership and operation of mining property.

\section{POPUlation.}

The present population of Nicaragua is between 300,000 and $400,000-$ only about 8 to the square mile. To each hundred inhabitants there are 50 Indians, 1 negro, 45 of mixed blood, and 4 whites. They are sharply divided into classes, the caballeros, or "gentlemen," and the peons, or laborers, who can be distinguished by their costume as far as they can be seen.

This classification is punctiliously observed on all occasions, and is 
particularly noticeable on railroad trains and steamboats. The upper classes dress very much as we do in summer, that season being perpetual in Nicaragua. Among the lower classes the men's costume usually consists of a straw hat and a short cotton shirt and trousers of darker material. No shoes are worn, but sometimes a pair of light sandals are used as a protection against thorny or hot ground. The dress of the women is even more scant, being minus the hat and sandals, a skirt being substituted for the trousers, and the arms and upper part of the bust being entirely bare.

Article 6 of the constitution of Nicaragua declares that " the religion of the Republic is the Roman Catholic Apostolic." Practically all the inhabitants of the country profess that faith, and this has been the case for nearly four centuries. Marriage. is the exception rather than the rule, and a majority of the children are illegitimate.

The country people and the poor of the cities live in thatched huts, with walls rudely constructed of upright poles, or no walls at all. The better buildings in the cities are of stone, brick, or adobe, stuccoed with cement, and covered with tiles. They are cool and comfortable and almost fireproof, but sadly lacking in light. The President's palace in Managua has glass windows, and a few Americaus in San Juan del Norte enjoy the same luxury. But in Leon, Granada, Rivas, or any other city of Nicaragua, there is hardly a pane of glass. By far the finest buildings are the churches and cathedrals. The sidewalks are often only 3 or 4 feet wide and change their grade with nearly every house they pass, so it is necessary to climb up or down several steps every 50 feet or so. . The streets are narrow and usually unpaved. But most of the towns are built on sandy or rocky ground, so that mud is not much encountered.

The Government of Nicaragua is nominally a Republic, patterned after that of the United States, but in reality it is a military despotism ruled arbitrarily by the President and the army under his command. Insurrections are frequent and greatly disturb the business interests and prosperity of the State, which is being steadily impoverished under these influences.

\section{. THE SHIP-TRANSIT PROBLEM.}

When the three little caravels of Christopher Columbus sailed from Palos, Spain, in 1492, it was with the object of reaching the southern and eastern shores of Asia by a shorter and easier route than any yet known. This was the first systematic effort with this object ever organized, but it marked the beginning of a series of attempts pursuing a similar object, which have increased in magnitude and frequency irregularly to the present day.

For nearly half a century these efforts took the form of a search for a supposed strait through the American isthmus. When at last the many fruitless efforts of this character convinced the world that such 
U. S. GEOLOGICAL SURVEY

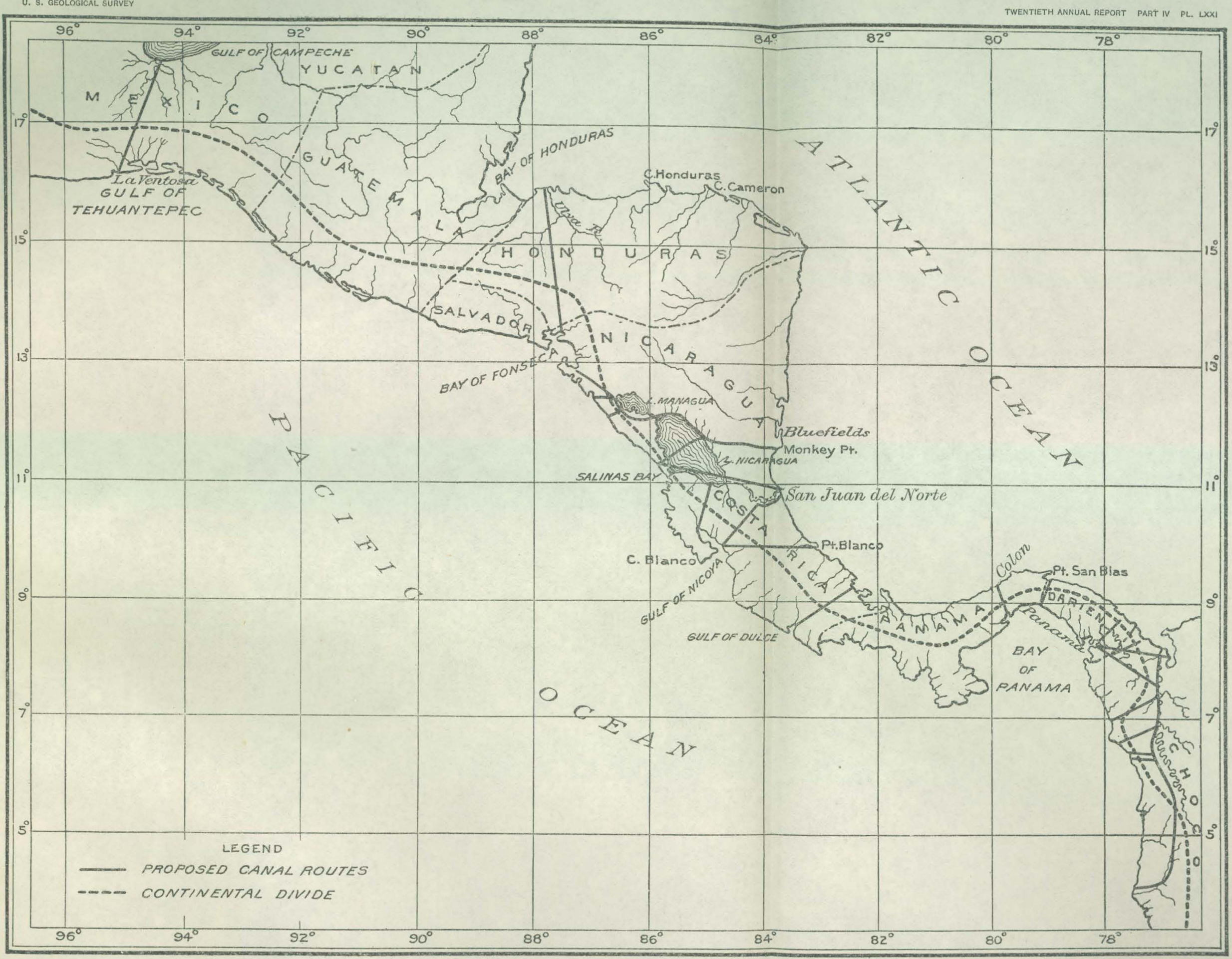

MAP OF CENTRAL AMERICA, SHOWING ROUTES WHICH HAVE BEEN SURVEYED FOR INTEROCEANIC COMMUNICATION. 
a strait did not exist, the dream was changed to one of a canal to be cut across the isthmus, and later it was proposed to construct a railway capable of transferring loaded vessels across the isthmus.

\section{SHIP-RAILWAY PROJECTS.}

The project of a ship railway was promoted by the State of Honduras, with reference to a line across its own territory, connecting the harbors of Puerto Caballos on the Atlantic and La Union on the Pacific. This route was examined by the British-Honduras Interoceanic Railway Company, and is said to offer many attractions as a route for railway transit.

The ship-railway route that has received the most attention, however, is that across the Isthmus of Tehuantepec in Mexico. This route was first explored about 1520, and its advantages were utilized by the Spaniards in the transportation of shipbuilding materials. It was later abandoned and almost forgotten, until in 1771 an expedition was fitted out to examine and report upon the topography of the isthmus and the practicability of a canal by that route. This examination was very superficial, and it was reported that a tide-level canal was feasible. Another examination was made thirty years later, but without result.

After the independence of Mexico was established, an examination was made by Gen. Juan Orbegozo, who reported the canal project as "problematical and gigantic."

In 1842 Don Jose de Garay obtained from the Mexican Goverument a charter for a canal or railway across the isthmus of Tehuantepec and appointed a commission to make a survey of the route. They reported the summit of the route to be 684 feet, and recommended the employment of the Chicapa and the Ostuta rivers as parts of a canal line. The length of the canal in excavation was to be about 50 miles, and 161 locks were to be constructed. A further examination and partial resurvey was made under the same concession in 1851-52, and more detailed information was obtained.

Many years after this Capt. James B. Fads turned his attention to this route. After some investigation and discussion the project for a canal was abandoned on account of the large number of locks and great cost. Uaptain Eads adopted the idea of a ship railway over this route, and worked out elaborate plans which have since been perfected and advocated by Elmer L. Corthell, C. E.

By this project it is proposed to have twelve parallel rails upon which is to run a huge carriage supporting the entire ship and cargo as in a dry dock. Beuds will be provided for when necessary by means of turntables. The motive power is to be two huge locomotives, which rest upon six rails. To provide for the passage of ships going in opposite directions and for repairs, turnouts are to be conveniently placed, the change of direction from the main track to be accomplished by means of a turntable. 
It is maintained on behalf of the Tehuantepec ship railway that it affords transit across the isthmus at a point nearer to the United States than any other proposed route and would shorten more than any other the distance between the Atlantic and the Gulf ports of the United States and the Pacific ports; also that the prevailing winds are much more favorable to commerce than they are by way of any other route, and that this route is more healthful than any of the others. It is also claimed that it could be much more cheaply and quickly constructed than the proposed canals. That it is shorter than any of the routes proposed farther south is unquestionable, but the other advantages claimed are at least doubtful aud are not admitted by the competing routes.

The ship-railway project, however, has never succeeded in attaining the degree of popular approval that has been bestowed upon canal propositions. The general sentiment appears to be summed up in the epigrammatic expression, "A ship is never so well borne as when waterborne." The canal routes which have attained the greatest degree of public favor are the Atrato, San Blas, Panama, and Nicaragua.

\section{CANAL PROJECTS.}

\section{ATRATO ROUTES.}

The Gulf of Darien, an arm of the Caribbean Sea at the point where the isthmus joins the main continent of Sonth America, receives the waters of the Atrato River, a navigable stream which rises and flows due north about 200 miles into the gulf. Its watershed is bounded on the west by the continental divide, which here hugs the Pacific coast very closely, and has several passes of moderate altitude.

Various projects have been proposed to utilize this river and its tributaries to approach the Pacific coast as nearly as possible, and then cut through the range to the sea. Of these projects the two that have received the most favor and attention are the two which utilize the Napipi and Truando rivers, tributaries of the Atrato. Neither of these has been regarded with as much favor as the more northerly routes.

The Napipi-A trato route provides for making use of the Atrato River for a distance of about 140 miles and the construction of about 30 miles of canal, of which $3 \frac{1}{2}$ miles would be in tunnel. The estimated cost of this canal is about $\$ 98,000,000$. The chief objections to this route are the long streteh of river navigation before the canal proper is reached, and the uncertainty of tunnel construction and maintenance, the aggregation of a number of locks close together near the Pacific coast, and the uncertainty of a sufficient water supply for the summit level.

The Truando-Atrato route is a modification of the Napipi-Atrato route, the project being to leave the Atrato River about 80 miles from its mouth and then to cut a sea-level canal through a tunnel under the continental divide into the Pacific, the flow of the Atrato River being diverted into the Pacific Ocean. The length of the cut from the 


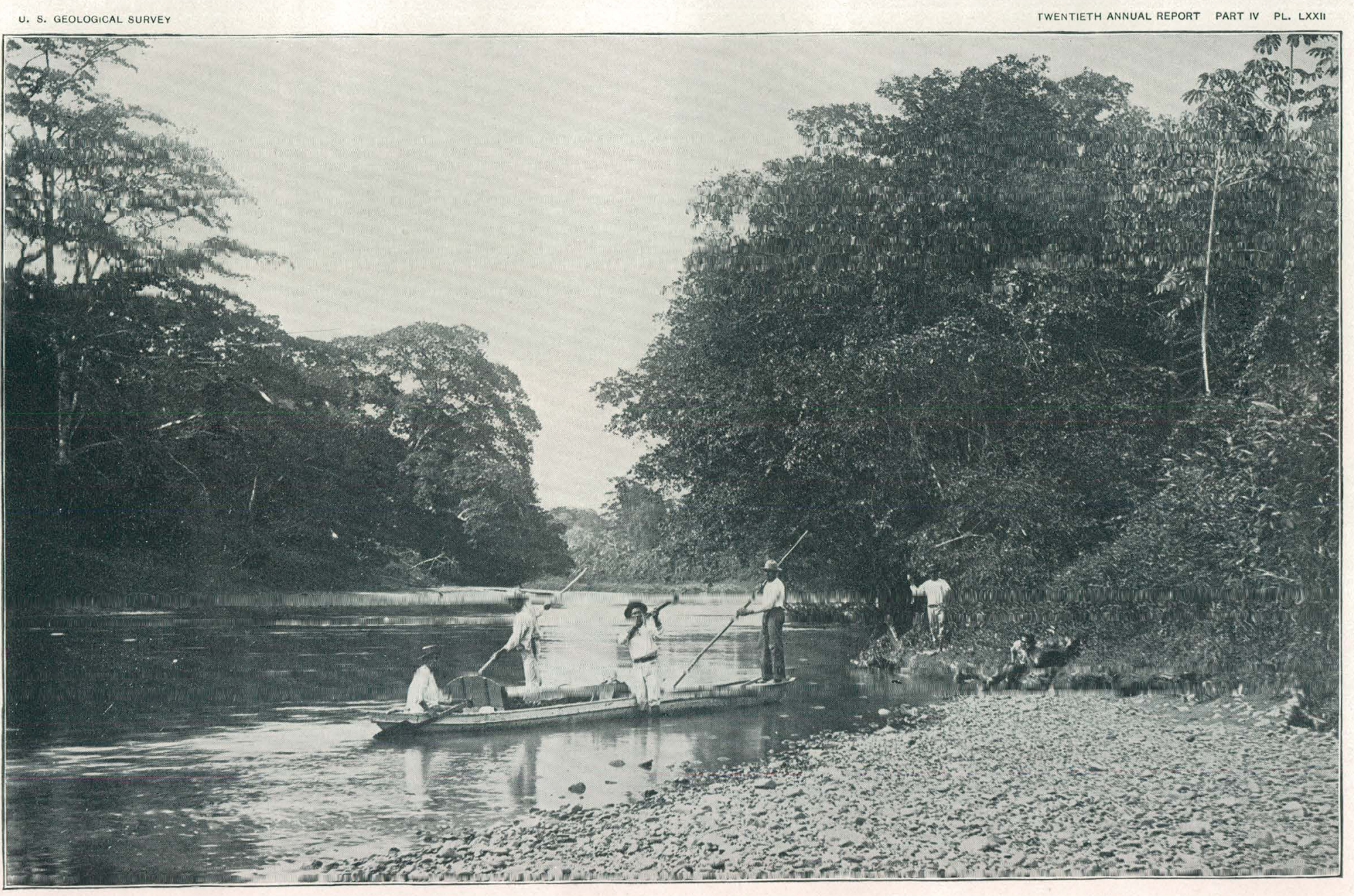


A trato to the Pacific would be 43.2 miles. The cost of the work has been variously estimated from $\$ 135,000,000$ to $\$ 156,000,000$. The chief difficulties of this route are the considerable tnnnel excavation and the control of the flood waters of the Atrato River.

SAN BLAS ROUTE.

This route lies between the Gulf of San Blas in the Caribbean Sea and the mouth of the Bayano River on the Pacific. It is the narrowest part of the entire Isthmus, being only 30 miles from ocean to ocean. It is proposed that the level of the water in this canal be that of ordinary high tide in the Pacific Ocean. The tides in the Caribbean Sea being inconsiderable, no provision need be made to accommodate them, but on the Pacific coast the tides are from 16 to 20 feet, and a lock would have to be provided for maintaining the canal at any desired level. At times of high tide the lock can be left open, while at low tide there would be a considerable descent by means of the lock. This route requires the construction of a tunnel 7 miles long, which it is proposed shall be 80 feet wide at the surface of the water and 140 feet high from the canal bottom. Much disagreement has been developed regarding the practicability and cost of the proposed tunnel. No work of any such magnitude or under such conditions has yet been attempted, and it is claimed that the gloom of a tunnel, the constant shower of chilled water from its roofs and sides, and its deoxygenated condition would rapidly undermine the health of the workmen, who would be unable to combat successfully the malaria and other enemies to health which abound on the Isthmus. The long tunnel required, with the accompany. ing uncertainty of cost and practicability, is the chief objection to the San Blas route, though unquestionably this route has obtained a higher degree of public favor than any other excepting the Panama and Nicaragua routes.

PANAMA ROUTE.

This route lies between Colon (or Aspinwall) on the coast of the Caribbean and Panama on the Bay of Panama. The existence of fairly good harbors at each end is one of the reasons for the advocacy of this route, and in 1851. a railroad was built between these points to accommodate the sudden growth of travel between the Eastern States and California, due to the gold excitement. The total length of this canal from ocean to ocean is 42 miles. Two distinct propositions have been advocated regarding this canal; the first, for a sea level canal, was M. De Lesseps's scheme. The canal proposed by this project has a length of 45.4 miles, a depth of 28 feet, and a bottom width of 72 feet. It was estimated that $75,000,000$ cubic meters of material would have to be moved, at an estimated cost of about $\$ 170,000,000$. The only object in excavating a sea-level canal in preference to one with locks is to avoid the use of locks, but these can not be avoided on' the Ameri- 
can Isthmus, owing to the great range of tides in the Pacifie, and a sen. level canal, if constructed, would require the use of a lock on the Pacific side to control the tides, so that the advantage of such a canal is small when compared to the increased cost of construction which it involves. For many years this project was actively promoted in France, and vast sums of money were subscribed for its construction. A large amount of work was actually done, the canal being practically completed for 7 miles on its northern end, and large quantities of heavy excavation made in the upper and southern portions of the route. The work accomplished, however, represented only a small fraction of the funds subscribed, the remainder being squandered in corruption and reckless extravagance, and the scandals occasioned thereby led to the bankrupticy of the company and the suspension of the work. The sums actually subscribed and put into this work are variously stated as more or less than $\$ 260,000,000$, not more than one-fifth of which is repre. sented by actual construction.

On the reorganization of the company a balance of about $\$ 20,000,000$ remained available for surveys and construction. The sea-level plan was abandoned, more complete surveys were made, and plans were drawn up for a lock canal which is to be supplied with water from reservoirs to be constructed on the Chagres River. A small force is, and has been for several years, at work on construction, and the project is not by any means abandoned, though it is admitted that it will cost over $\$ 100,000,000$ to complete the canal, under any possible plan.

\section{NICARAGUA ROUTE.}

The advantages offered by Nicaragua for interoceanic communication were recognized at a very early period, and surveys were ordered by the Crown of Spain as early as 1524, but were not executed. In later years several superficial examinations were made and many conflicting statements were rendered, but all the really useful knowledge of this Isthmus is of recent date.

CHILDS'S SURVEY.

Nothing reliable and definite as to distances, elevations, etc., was obtained until 1850, when Col. $O$. W. Childs was sent there by the Atlantic and Pacific Ship-Canal Company. He made a reconnaissance of the entire strip of land between the Pacific and Lake Nicaragna and made surveys of several routes to connect them. That from Salinas Bay to Sapoa River he examined and condemned on account of the great elevation to be overcome. The favorite route of Louis Napoleon, by way of Lake Managua, he also condemned on account of its elevation and its great length.

His examination"led him to the conclusion "that the line leading from the mouth of Las Lajas to the Pacific at Brito presented more favorable conditions for the construction of a canal than any other." The correctness of this conclusion is now universally acknowledged. 


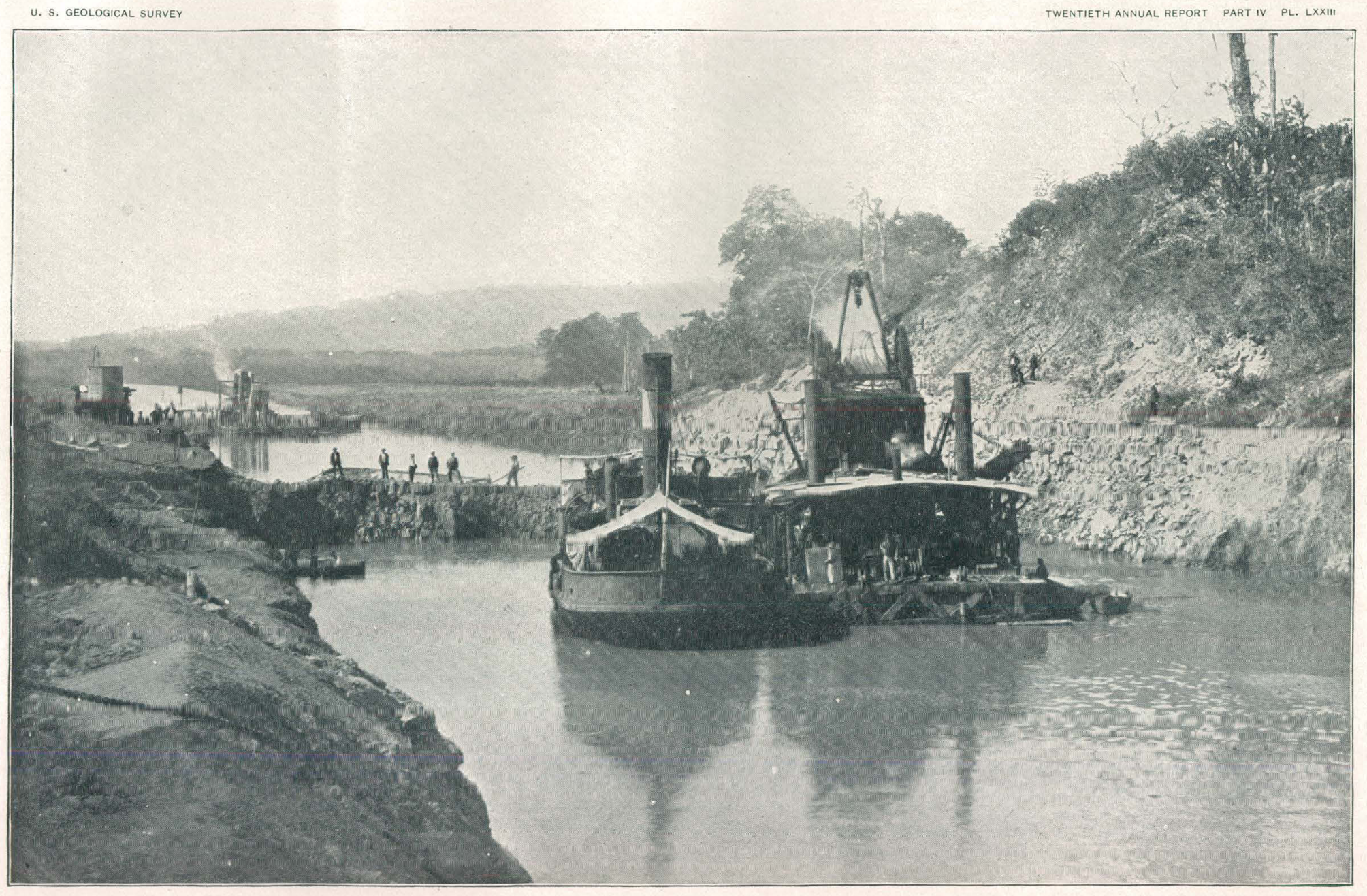


Colonel Childs estimated for the construction of a canal with a continuous depth of 17 feet. He proposed to hold the lake permanently at 108 feet above sea level, and to overcome this elevation by 14 locks on each side, with a maximum lift of 8 feet. The summit was to be controlled by dams at Castillo on the east and Buen Retiro on the west. The total length of his proposed line was 194.4 miles, and the cost was estimated at $\$ 31,538,000$. This included the cost of an artificial harbor at Brito, but at that time there was a good harbor at San Juan del Norte.

The object of this survey was primarily to establish a means of communication with California to accomodate the heavy traffic induced by the discovery of gold.

President Grant took a deep interest in the canal problem, and in 1872 appointed a commission, consisting of Gen. A. A. Humphreys, Chief of Engineers; C. P. Patterson, Superintendent of the Coast Survey, and Commodore Daniel Ammen, of the United States Navy, to examine the information at hand and determine the most feasable route for an interoceanic canal. The routes considered were the Tehuantepec, Nicaragua, Panama, and Atrato-Napipi. The commission unanimously reported in favor of Nicaragua, and this has ever since been regarded as the favorite canal route from the American point of view.

LULL'S SURVEY.

In 1873 an expedition was fitted out by the United States Government for the confirmation and continuation of the Childs survey, which was placed under the charge of Commander E. P. Lull, United States Navy, who surveyed the route with reference to the construction of a canal 26 feet deep. Heconfirmed the surveys of Colonel Childs, but fearing difficulty with the waters of the Upper Rio Grande, he recommended that the canal leave Lake Nicaragua by way of the Medio, instead of Las Lajas. This was shorter by a mile and a half and avoided the Rio Grande, but involved 90 feet deeper cut through the divide. The western half of the routes coincide, and reach the Pacific at Brito. Commander Lull also caused a reconnaissance to be made of a portion of Lake Nicaragua and of the Rio San Juan. It was thought that the river could be improved at the rapids by means of locks, and that by this means and by dredging the river could be converted into a canal to a point near the mouth of the Rio San Carlos. Here it was proposed to construct a dam, and the canal was to leave the river and follow near it until the swamp region was reached below the Sarapiqui, and then to cut across to San Juan del Norte. Eleven locks were proposed west of Lake Nicaragua, and 10 on the east side. The estimate included $\$ 2,500,000$ for the restoration of San Juan del Norte harbor, and was in all $\$ 65,700,000$. 
MARITIME CANAL COMPANY.

Associated with Commander Lull in this survey was Mr. A. G. Menocal, a civil engineer of the Navy, who has since become famous as the chief engineer of the Maritime Canal Company, and to whom is largely due the public interest in the Nicaragua Canal. In $1885 \mathrm{Mr}$. Menocal was sent by the Government to continue the examination, and the plans adopted by Lull were set aside. On the west side he adopted the Childs route, by way of Las Lajas, the Rio Grande to be diverted from its course and turned eastward into Lake Nicaragua. The summit level of Lake Nicaragua was to be maintained at 110 feet by a dam across the San Juan at Ochoa, 3 miles below the mouth of Rio San Carlos, where the sailing line was to leave the river and follow nearly a straight line to San Juan del Norte, the summit level being maintained until the eastern divide had been passed, the descent to the Caribbean being made by 3 locks with a maximum lift of 40 feet.

This necessitated the construction of a series of bigh embankments between Ochoa and the eastern divide, a distance of $12 \frac{1}{2}$ miles, about half of this distance being occupied by steep clay hills, which were to be connected by the embankments, 67 in all, ranging from 6,000 feet long downward. The cut through the eastern divide was to be over 3 miles long and to have a maximum depth of 324 feet.

This project was broadly the one adopted with some modifications by the Maritime Canal Company. Two short basins were added by the construction of dams on the Deseado and the Rio Grande, up to the summit level. All these plans were elaborated in great detail by the company, and the total cost was estimated at $\$ 65,084,176$.

CANAL BOARD OF 1895.

In 1895 Congress provided for a board of engineers to ascertain the feasibility, permanence, and cost of the canal, and appropriated the sum of $\$ 20,000$ for the purpose. Col. Willian Ludlow, of the Army; Uivil Engineer M. T. Endicott, of the Navy, and Mr. Alfred Noble were appointed by Mr. Cleveland to constitute the board. Considering the time and funds available, this board made a very thorough examination of the route, the data, and the estimates, all of which were freely discussed and criticised. They reported that while the canal was undoubtedly feasible the information collected was entirely inadequate for a basis on which to make final estimates of cost, or even to determine the practicability of certain peculiar features involved in the company's plan. They recommended, therefore, that an appropriation of $\$ 350,000$ be made for further surveys and investigation. A provisional estimate made the cost just about double that estimated by the company. 


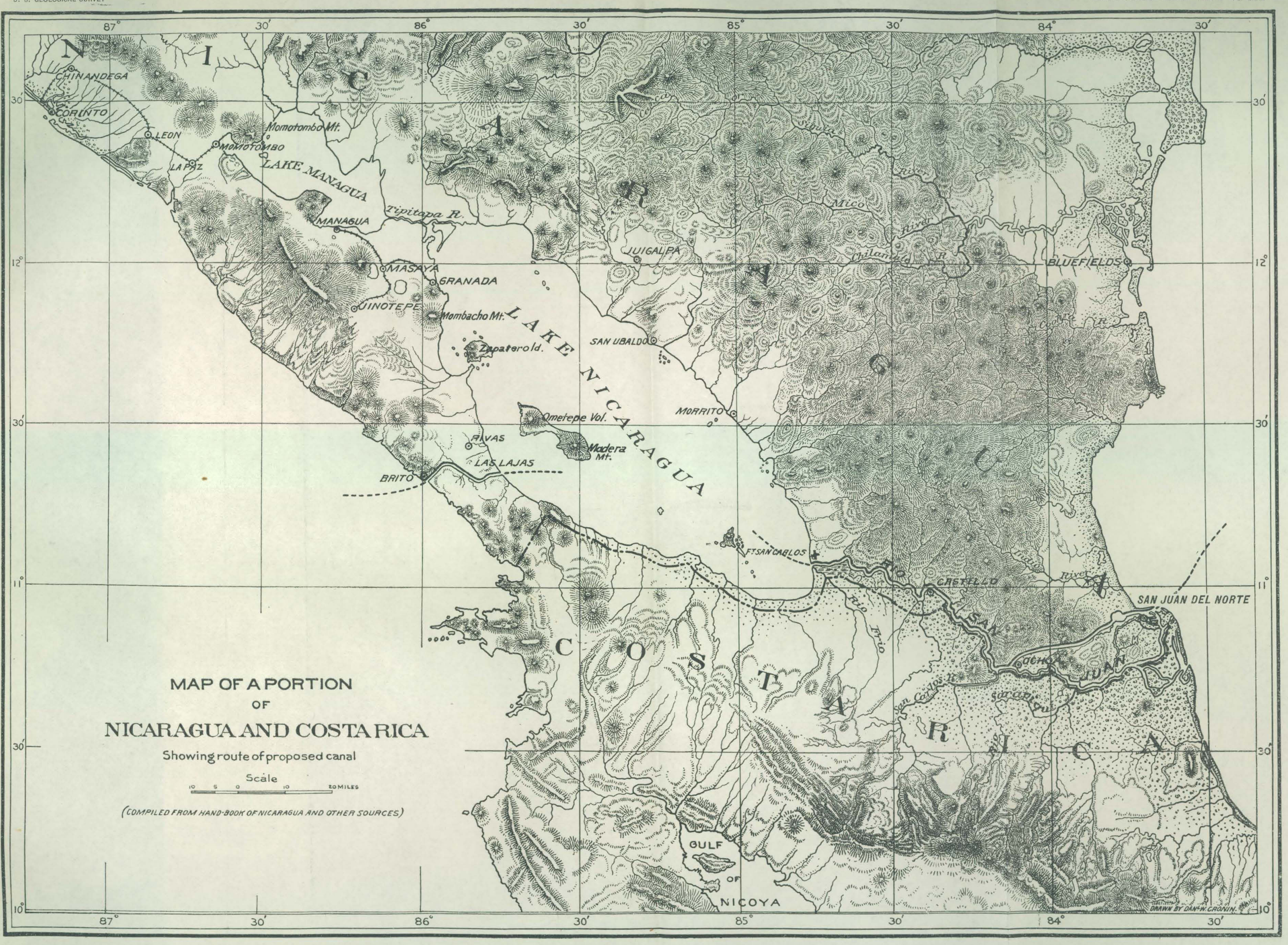


COMMISSION OF 1897.

Accordingly, a commission was appointed by President McKinley, consisting of Rear-Admiral J. G. Walker, Col. Peter C. Hains, and Lewis M. Haupt, for the further survey and examination of the canal route.

This survey continued nearly two years under the supervision of Mr. E. S. Wheeler, chief engineer.

The points of 'weakness in the company's data were numerous and some of them serious. The borings on some parts of the line were meager, and in many cases the results had been confused and the cores taken had been lost. The Ochoa dam was to be constructed of large rocks loosely dumped into the stream and left to find their own foundation. This style of dam involved the use of rocks of very large size and of hard and permanent structure. The intention was to obtain this material from the deep cut through the eastern divide. Investigation, however, created serious doubt as to the existence of a sufficient quantity of hard, permanent rock in the divide for this purpose. No satisfactory information existed as to the foundations for the Ochoa dam and the San Francisco embankments. The large amount of material to be dredged in the Rio San Juan had not been investigated at all. But little was known regarding the foundations of the proposed dam at La Flor and the material to be dredged at Brito.

The greatest lack of information; however, was with reference to the hydrography. Though it was proposed to deal with the floods of the San Juan, San Carlos, San Francisco, and other streams, no attempt had ever been made to measure their flood discharge or even to make an approximate estimate on this point.

It was designed to hold the lake at an elevation of 110 feet above sea level, any rise above that mark-being injurious to property and any fall below reducing the navigable depth of the canal throughout the summit level, yet no attempt whatever had been made to determine the maximum or minimum inflow or the rate of outflow or evaporation from the lake. There was also some discrepancy in the levels and in distances on the Rio San Juan and Lake Nicaragua.

\section{INVESTIGATIONS BY NICARAGUA CANAL COMMISSION.}

The hydrographic and meteorologic information required. related to three principal objects:

1. The water supply for the use and leakage of the canal.

2. The quantity of rainfall and volume of streams considered as obsta. cles to construction.

3. The volume and habit of excessive floods, with reference to their permanent control and discharge without injury to the canal or other property. 
The desired information therefore required an investigation of the discharge of all streams of importance which it was proposed to control during construction, or for which it was necessary to provide diversion channels or spillways, and measurements of rainfall at points as widely distributed as possible throughout the basin of Lake Nicaragua.

It also required an approximate determination of the rate of evap. oration on Lake Nicaragua, and some investigation of the sediment carried by the larger rivers.

The results of rainfall observations will be found on pages $574-578$.

The general method used in observing the regimen and discharge of streams was substantially as follows:

A point was selected as near as practicable to the location concerning which knowledge was desired, having reference to the conditions of the stream itself, the aim being to secure high, permanent banks on both sides of the river and a straight channel of nearly uniform depth and velocity, and to avoid a location a short distance above an:important tributary, because the conditions at such a point might be affected by backwater from floods in that tributary. A gage was placed in the stream near one bank, graduated to feet and tenths, and so situated, if possible, as to be read conveniently from the shore. It was usually possible to fasten such a gage in deep water to the trunk of an overhanging tree and in a vertical position. The height of water indicated by this gage was read and recorded, usually twice every day, and the mean of the two readings was t:lken as the mean gage height for that date. At various intervals, depending upon the facilities available and the change of gage height, measurements of discharge were made with a current meter. Soundings were taken at known distances from an assumed initial point, and the velocity was measured by submerging an electric current meter at six-tenths of the measured depth, and holding it in that position for a length of time sufficient to make a good determination of the velocity at that point, usually one hundred seconds or more. This operation was repeated at short intervals for the entire width of the stream, and from these observations the discharge in cubic feet per second was computed for each section by multiplying the depth, width, and measured velocity together. The discharge of the several sections being added together formed a result for the discharge of the entire stream. At the beginning and end of the gaging a careful note was made of the stage of the water indicated on the river gage, and the mean of those two observations was taken as the mean gage height of the time of observation. The effort was made to have such observations well distributed with reference to the height of water in the river, in order to show the relation of the indications of the gage rod to the actual discharge of the stream. This relation was found to be reasonably definite and uniform for most of the streams, and by plotting the gage heights as ordinates and the discharge results as abscissas, their general relation was established and a curve was drawn which satisfied as nearly as possible all the observations made.

20 GEOL, PT $4-38$ 
RIO GRANDE.

BRITO STATION ON THE RIO GRANDE.

This station was established by D. H. Baldwin on January 8 , about 1 mile below La Flor dam site on the Rio Grande, just below where the stream bends to the north.

A cable and gaging car were put in place for taking measurements. The gage was driven in the bed of the river near the left bank, and the top fastened to the tagged wire. As this was deemed insecure, a new gage was put in place on January 22 about 200 feet farther upstream, which was driven into the clay bottom and spiked to a tree growing on the bank. When the old gage read 1.85 the new gage read 3.38. The readings are here reduced to the datum of new gage.

The channel begins to curve a short distance above the station. The left bank is high and steep; the right may sometimes overflow at high water.

$$
\text { TOLA STATION ON TOLA RIVER. }
$$

Later operations by the surveying parties having shown the desirability of measurements of the Tola River, the Rio Grande station was removed June 13 to a point below the mouth of the Tola River and a station was established on the Tola three-fourths of a mile above its mouth, in order that both streams could be observed from one camp. The station on the Rio Grande is about 300 yards below the junction of the Tola and Rio Grande. The gage is a vertical rod divided to feet and tenths, and fastened to an overhanging tree on the left bank of the river. Near this point the cable is stretched across the river, upon which runs a gaging car, from which measurements are made, a tagged wire being stretched alongside.

List of discharge measurements made on Rio Grande, below mouth of the Tola.

\begin{tabular}{|c|c|c|c|c|c|c|c|}
\hline Date. & Hydrographer. & $\begin{array}{l}\text { Meter } \\
\text { num- } \\
\text { ber. }\end{array}$ & $\begin{array}{c}\text { Gage } \\
\text { height. }\end{array}$ & $\begin{array}{c}\text { Area } \\
\text { of sec. } \\
\text { tion. }\end{array}$ & $\begin{array}{c}\text { Mean } \\
\text { veloc- } \\
\text { ity. }\end{array}$ & $\begin{array}{c}\text { Dis- } \\
\text { charge. }\end{array}$ & Remarks. \\
\hline 1898. & & & Feet. & Sq. feet. & $\begin{array}{l}\text { Feet per } \\
\text { second. }\end{array}$ & $\begin{array}{l}\text { Second. } \\
\text { feet. }\end{array}$ & \multirow{15}{*}{$\begin{array}{l}\text { New gage rod } \\
\text { reads } 35^{\prime} \text { less. }\end{array}$} \\
\hline Jan. 9 & D. H. Baldwin .... & .... & 3.48 & 59 & 1.36 & 80 & \\
\hline Jan. 22 & A.P. Davis ............ & 94 & 3.44 & 56 & 1.11 & 62 & \\
\hline June 4 & .....do ............. & 94 & 2.95 & 26 & .68 & 18 & \\
\hline July 2 & D. H. Baldwin ......... & 1984 & 3.18 & 68 & 2.35 & 161 & \\
\hline July 30 & ..... do .... & 1984 & 6.80 & 315 & 4.15 & 1,306 & \\
\hline Aug. 10 & .....do ......... & 1984 & 2.40 & 70 & .92 & 65 & \\
\hline Aug. 21 & .....do ............ & 1984 & 4. 30 & 164 & 2.93 & 481 & \\
\hline Sept. 14 & ....do do ........... & 1984 & 3.78 & 124 & 2.73 & 339 & \\
\hline Sept. 21 & .....do ................ & Float. & 11.10 & 606 & 4.55 & 2,758 & \\
\hline Sept. 29 & .... do ........... & 1984 & 4.00 & 144 & 2.94 & 423 & \\
\hline Oet. 8 & H. C. Hurd............. & Float. & 3.60 & 122 & 2.33 & 285 & \\
\hline Oct. 9 & . . . do $\ldots \ldots \ldots \ldots$ & Iloat. & 5.92 & 275 & 3.98 & 1,092 & \\
\hline Oct. 10 & $\ldots \ldots$ do $\ldots . . . . . . . .$. & Float. & 5.00 & 213 & 3.38 & 718 & \\
\hline Oct. 15 & . . . do ................. & Float. & 8.80 & 474 & 4.28 & 2,026 & \\
\hline Oct. 27 & ......do do ................... & $\begin{array}{l}\text { Meter } \\
\text { B + B } \\
\text { No. } 1 .\end{array}$ & 4.25 & 163 & 4. 12 & 675 & $\begin{array}{l}\text { Velocity taken } \\
\text { at } 0.5 \text { depth. }\end{array}$ \\
\hline Nov. 28 & $\ldots .$. do $\ldots$. & $\begin{array}{l}\text { Meter } \\
B+B \\
\text { No. } 1 .\end{array}$ & 3.32 & 88 & 2.83 & 249 & Do. \\
\hline
\end{tabular}


Estimated monthly discharge of Rio Grande below mouth of the Tola.

\begin{tabular}{|c|c|c|c|c|}
\hline \multirow{2}{*}{ Month. } & \multicolumn{3}{|c|}{ Discharge in second-feet. } & \multirow{2}{*}{$\begin{array}{l}\text { Total in } \\
\text { acre-feet. }\end{array}$} \\
\hline & $\begin{array}{l}\text { Maxi- } \\
\text { mum. }\end{array}$ & $\begin{array}{l}\text { Mini } \\
\text { mum. }\end{array}$ & Mean. & \\
\hline 1898. & & & & \\
\hline January $6-31 \ldots \ldots \ldots \ldots \ldots$ & 75 & 60 & 69 & 3,340 \\
\hline February $\ldots \ldots \ldots \ldots \ldots$ & 55 & 41 & 49 & 2,720 \\
\hline March....... & 40 & 25 & 35 & 2,150 \\
\hline April $\ldots \ldots \ldots \ldots \ldots \ldots \ldots \ldots \ldots \ldots$ & 35 & 17 & 25 & 1,490 \\
\hline 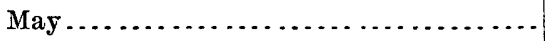 & 85 & 17 & 28 & 1,720 \\
\hline June $\ldots \ldots \ldots \ldots \ldots \ldots \ldots \ldots \ldots \ldots$ & 1,990 & 17 & 110 & 6,550 \\
\hline - . . . & 2,030 & 55 & 121 & 7,440 \\
\hline August $\ldots \ldots \ldots \ldots \ldots \ldots$ & 145 & 45 & 67 & 4,120 \\
\hline September. $\ldots \ldots \ldots \ldots \ldots \ldots$ & 2,975 & 55 & 253 & 15,050 \\
\hline October ....... & 2,065 & 260 & 596 & 36,650 \\
\hline November $\ldots \ldots \ldots \ldots \ldots \ldots \ldots \ldots \ldots$ & 1,028 & 190 & 282 & 16,780 \\
\hline
\end{tabular}

Estimated monthly discharge of Tola River three-fourths of a mile above its mouth.

\begin{tabular}{|c|c|c|c|c|}
\hline \multirow{2}{*}{ Month. } & \multicolumn{3}{|c|}{ Discharge in second.feet. } & \multirow{2}{*}{$\begin{array}{l}\text { Total in } \\
\text { acre-feet. }\end{array}$} \\
\hline & $\begin{array}{l}\text { Maxi- } \\
\text { mum. }\end{array}$ & $\begin{array}{l}\text { Mini- } \\
\text { mum. }\end{array}$ & Mean. & \\
\hline 1898. & & & & \\
\hline 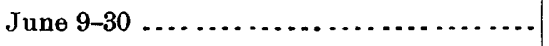 & 355 & 12 & 53 & 2,310 \\
\hline July $\ldots \ldots \ldots \ldots \ldots \ldots \ldots$ & 163 & 21 & 46 & 2,830 \\
\hline August $\ldots \ldots \ldots \ldots \ldots \ldots \ldots \ldots \ldots \ldots \ldots$ & 57 & 20 . & 30 & 1,840 \\
\hline September ............................. & 364 & 39 & 112 & 6,660 \\
\hline October......... & 452 & 130 & 246 & 15,125 \\
\hline November . . . . . . . . . . . . . & 230 & 75 & 126 & 7,500 \\
\hline
\end{tabular}


List of discharge measurements made on Tola River three-fourths of a mile above its mouth.

\begin{tabular}{|c|c|c|c|c|c|c|c|}
\hline No. & Date. & Hydrographer. & $\begin{array}{c}\text { Meter } \\
\text { number. }\end{array}$ & $\begin{array}{c}\text { Gage } \\
\text { height. }\end{array}$ & $\begin{array}{l}\text { Area of } \\
\text { section. }\end{array}$ & $\frac{\text { Mean }}{\text { velocity. }}$ & $\begin{array}{c}\text { Dis- } \\
\text { charge. }\end{array}$ \\
\hline & 1898. & & & Feet. & Sq.feet. & $\begin{array}{l}\text { Feet per } \\
\text { second. }\end{array}$ & Sec.feet. \\
\hline 1 & July 2 & D. H. Baldwin..... & 1984 & 2.21 & 48.1 & 1.41 & 68 \\
\hline 2 & Ang. 10 & $\ldots \ldots$ do $\ldots \ldots \ldots \ldots$ & 1984 & 1. 60 & 29.4 & 0.95 & 28 \\
\hline 3 & Aug. 21 & $\ldots .$. do ..... & 1984 & 2.80 & 28.1 & 2.16 & 61 \\
\hline 4 & Aug. 29 & $\ldots$ do . & 1984 & 4.25 & 98.9 & 2.82 & 279 \\
\hline 5 & Sept. 14 & .....do. & 1984 & 3.02 & 36.6 & 2.80 & $a 102$ \\
\hline 6 & Sept. 21 & .....do . & Floats & 7. 30 & 260.8 & 2.97 & 774 \\
\hline 7 & Oct. 8 & H. C. Hurd .... & Floats. & 3.35 & 53.7 & 2.25 & 122 \\
\hline 8 & Oct. 9 & $\ldots$ do & Floats. & 3.65 & 69.0 & 2.71 & 187 \\
\hline 9 & Oct. 14. & ....do. & Floats. & 4.85 & 132.7 & 3.07 & 408 \\
\hline \multirow[t]{3}{*}{10} & Oct. 17 & .... do . & Floats. & 4.25 & 105.1 & 2.86 & 300 \\
\hline & Nov. 23 & .... do & $\left\{\begin{array}{c}B+B \\
\text { No. 1. }\end{array}\right\}$ & 3.14 & 39.0 & 4.21 & 162 \\
\hline & Nov. 27 & $\ldots$ do & $\left\{\begin{array}{c}B+B \\
\text { No. } 1 .\end{array}\right\}$ & 3.03 & 36.5 & 3.72 & 136 \\
\hline
\end{tabular}

$a \mathrm{New}$ rod.

LAKE NICARAGUA.

IJAS LAJAS STATION.

A station was established on the margin of Lake Nicaragua, about 7 miles southeast of Rivas and about 3,500 feet north of the mouth of Las Lajas, on January 10 . The gage was placed in a long box with open ends and seams, which was rastened to the sunken wreck of a large boiler of one of the old Vanderbilt steamers. The box and the boiler served to protect the gage from the violence of the breakers. prevalent on this coast, but afforded entirely free access to the water. The gage as first placed was insecurely fastened, and during a storm the waves beat it down. It was replaced on February 7 by Mr. J. A. Bull in the position it now occupies. The gage is inclined to the vertical to such an extent that 1 foot vertical corresponds to 1.014 foot on the ror. The 10-foot mark is 0.65 foot below bench mark No. 1, which is the highest point of a large cylinder nearly buried in the sand on shore. The 10-foot mark is 108.13 feet above sea level by the levels of the Nicaragua Canal Commission.

The ebb and flow of the waves kept the water level constantly chang. ing on the rod, and readings were taken by averaging high and low readings occurring within a few seconds. Most of the time the eastern trade winds blew constantly, with considerable force, but during May there were many calm days and some adverse winds.

During April the declining lake surface threatened to leave the gage on dry land, and another gage was placed in deeper water, about 200 . 
feet north of the first one. This was placed vertical and fastened to another portion of the wreck. On this gage the 9 -foot mark is 103.29 feet above sea level. It was observed from May 1 to July 16, when the surf became too deep for the observer to safely read it, and observations were transferred to gage No. 1.

Temperature, humidity, and wind observations were taken at this station, and at the mouth of Las Lajas an evaporation pan and rain gage were maintained and observed.

The ełevation of Lake Nicaragua is given on page 606 .

VIEJO RIVER.

This station is about 500 yards above the ford known as Paso Real on the Viejo River, where the Matagalpa-Leon road crosses the Viejo River. A gage was placed at this point on February 1, which consisted of a vertical unpainted cedar stick, marked with nails and notches to feet and tenths, nailed to a tree on the right bank. A bench mark was established on the right bank, consisting of a wire nail driven in the highest point of a stump 66 feet west of the gage. It is 46.2 feet above zero of gage. A cable was stretched across the river a short distance above the gage, from which measurements of floods were made by means of a gaging car of the usual pattern. Measurements at low water were made by wading.

List of discharge measurements made on Viejo River at Paso Real.

\begin{tabular}{|c|c|c|c|c|c|c|}
\hline 1)ate. & Hydrographer. & $\begin{array}{l}\text { Meter } \\
\text { num. } \\
\text { ber. }\end{array}$ & $\begin{array}{c}\text { Gage } \\
\text { height. }\end{array}$ & $\begin{array}{c}\text { Area of } \\
\text { section. }\end{array}$ & $\begin{array}{c}\text { Mean } \\
\text { velocity. }\end{array}$ & $\begin{array}{c}\text { Dis- } \\
\text { charge. }\end{array}$ \\
\hline 1898. & & & Feet. & Sq.feet. & $\begin{array}{l}\text { Feet per } \\
\text { second. }\end{array}$ & Sec.feet. \\
\hline Feb. 8 & F. C. Green .. & 7 & 2.20 & 17.7 & 1. 60 & 28.3 \\
\hline Feb. 18 & $\ldots \ldots$ do $\ldots . . . .$. & 7 & 2.08 & 14.1 & 1.40 & 20.7 \\
\hline Feb. 28 & .....do ... & 7 & 1.99 & 12.8 & 1. 20 & 15.3 \\
\hline Mar. 8 & $\ldots$ do $\ldots \ldots \ldots$ & 7 & 2. 12 & 14.0 & 1.57 & 22.0 \\
\hline Mar. 18 & .... do .. & 7 & 1.94 & 11.4 & 1.23 & 14.0 \\
\hline Mar. 28 & ..... do ...... & 7 & 1.85 & 10.8 & 0.55 & 6.0 \\
\hline Apr. 8 & ..... do ........... & 7 & 1. 79 & 9.6 & 0.44 & 4.3 \\
\hline Apr. 20 & G.P. Philip & 7 & 1. 72 & 6.2 & 0.61 & 3.8 \\
\hline Apr. 28 & $\ldots$.... do $\ldots \ldots . .$. & 7 & 1. 71 & 5.4 & 0.58 & 3.2 \\
\hline May 6 & ..... do ......... & 7 & 1.71 & 7.2 & 0.37 & 3.5 \\
\hline May 14 & $\ldots$. do .......... & 7 & 1. 70 & 6.8 & 0.32 & 2.2 \\
\hline May 22 & $\ldots$ do & 7 & 3.12 & 62.4 & $3.30^{\circ}$ & 206.0 \\
\hline$\dot{M} a \dot{y} y \quad 25$ & .... do . . . ......... & 7 & 12.52 & 964.0 & 5.06 & $4,874.0$ \\
\hline June 1 & .... do ............. & 7 & 3.65 & 74.0 & 4.29 & 317.0 \\
\hline June 8 & $\ldots \ldots$ do $\ldots . . .$. & 7 & 3.63 & 68.0 & 4.04 & 274.0 \\
\hline June 15 & ..... do ......... & 7 & 2.78 & 32.0 & 3.54 & 114.0 \\
\hline June 22 & $\ldots$ do $\ldots$. & 7 & 11.62 & 895.0 & 4.85 & $4,344.0$ \\
\hline June 29 & ..... do ............ & 7 & 12.34 & 976.0 & 4.65 & $4,539.0$ \\
\hline
\end{tabular}


List of discharge measurements made on Viejo River at Paso Real-Continued.

\begin{tabular}{|c|c|c|c|c|c|c|}
\hline Date. & Hydrographer. & $\begin{array}{c}\text { Meter } \\
\text { num- } \\
\text { ber. }\end{array}$ & $\begin{array}{c}\text { Gage } \\
\text { height. }\end{array}$ & $\begin{array}{l}\text { Area of } \\
\text { section. }\end{array}$ & $\begin{array}{l}\text { Mean } \\
\text { velocity. }\end{array}$ & $\begin{array}{c}\text { Dis- } \\
\text { charge. }\end{array}$ \\
\hline 1898. & & & Feet. & Sq. feet. & $\begin{array}{l}\text { Feet per } \\
\text { second. }\end{array}$ & Sec.feet. \\
\hline July 6 & G.P. Philip ... & 7 & 4.95 & 157.0 & 2.91 & 456.0 \\
\hline July 13 & $\ldots .$. do $\ldots . . . .$. & 7 & 6.50 & 315.0 & 3.08 & $1,072.0$ \\
\hline July 20 & .... do .... & 7 & 3.97 & 93.0 & 3.21 & 266.0 \\
\hline July 27 & ..... do ... & 7 & 3.38 & 55.0 & 2.78 & 152.0 \\
\hline Aug. 3 & $\ldots$. do $\ldots \ldots \ldots \ldots$ & 7 & 3.59 & 66.0 & 2.92 & 192.0 \\
\hline Sept. 19 & .....do .... & 7 & 5. 72 & 188.0 & 4.40 & 828.0 \\
\hline Sept. 27 & ..... do .... & 7 & 8.23 & 460.0 & 4.52 & $2,074.0$ \\
\hline Oct. 3 & Fred. Davis.... & 7 & 5.02 & 144.0 & 3.26 & 469.0 \\
\hline Oct. 10 & .....do... & 7 & 5.00 & 184.0 & 4.41 & 813.0 \\
\hline Oct. 18 & $\ldots \ldots$ do $\ldots \ldots \ldots$ & 7 & 9.90 & 674.0 & 4.89 & $3,300.0$ \\
\hline Oct. 25 & .....do & 7 & 5.41 & 216.0 & 4.11 & 886.0 \\
\hline Nov. 1 & ..... do .... & 7 & 4.00 & 81.0 & 3.48 & 282.0 \\
\hline Nov. 7 & .....do ..... & 7 & 3.42 & 54.0 & 3.42 & 182.0 \\
\hline Nov. 14 & .....do ... & 7 & 3.52 & 72.0 & 3.16 & 228.0 \\
\hline Nov. 21 & ....do .... & 7 & 2.95 & 34.0 & 2.73 & 94.0 \\
\hline Nov. 28 & ..... do ..... & 7 & 2.82 & 35.0 & 2.36 & 82.0 \\
\hline Dec. 5 & ......do ..... & 7 & 2.70 & 27.5 & 2.74 & 75.0 \\
\hline Dec. 10 & .... do ... & 7 & 2.94 & 45.0 & 1.95 & 88.0 \\
\hline Dec. 15 & $\ldots$ do $\ldots . .$. & 7 & 2.68 & 33.5 & 1. 76 & 59.0 \\
\hline Dec. 22 & $\ldots \ldots$ do $\ldots \ldots \ldots \ldots$ & 7 & 2.56 & 28.5 & 1. 71 & 49.0 \\
\hline Dec. 29 & ..... do ... & 7 & 2.45 & 25.0 & 1.59 & 39.0 \\
\hline
\end{tabular}

Estimated monthly discharge of Viejo River at crossing of Matagalpa-Leon road.

\begin{tabular}{|c|c|c|c|c|}
\hline \multirow{2}{*}{ Month. } & \multicolumn{3}{|c|}{ Discharge in second-feet. } & \multirow{2}{*}{$\begin{array}{l}\text { Total for } \\
\text { month in } \\
\text { acre-feet. }\end{array}$} \\
\hline & $\begin{array}{l}\text { Maxi- } \\
\text { mum. }\end{array}$ & $\begin{array}{l}\text { Mini. } \\
\text { mum. }\end{array}$ & Mean. & \\
\hline 1898. & & & & \\
\hline February ............. & 35 & 15 & 24.0 & 1,332 \\
\hline March.$\ldots \ldots \ldots \ldots \ldots \ldots$ & 25 & $\mathbf{5}$ & 13.0 & 800 \\
\hline April........ & 5 & 3 & 3.6 & 214 \\
\hline May ......... & 5,520 & 2 & 324.0 & 19,920 \\
\hline June......... & 15,600 & 50 & $2,170.0$ & 129,120 \\
\hline July . .............. & 2,400 & 155 & 613.0 & 37,680 \\
\hline August. . . . . . . . . . . & 2,750 & 125 & 330.0 & 20,290 \\
\hline September ......................... & 9,745 & 220 & $1,840.0$ & 109,500 \\
\hline October........ & 3,830 & 230 & 965.0 & 59,340 \\
\hline 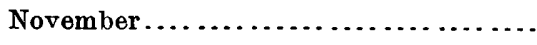 & 253 & 74 & 130.0 & 7,735 \\
\hline December...$\ldots \ldots \ldots \ldots \ldots \ldots \ldots \ldots \ldots \ldots \ldots$ & 92 & 39 & 59.0 & 3,630 \\
\hline
\end{tabular}


NUEVO RIVER.

This station was established February 1 at the bend of the Nueva River, where it approaches nearest the Viejo River, in the neighborhood of Paso Real, and was intended to throw light on the quantity of water that might be added to the supply for Lake Managua by diverting this river into it.

Measurements were made by wading at low water and by means of floats at high water. The stage of the river was ascertained by measuring downward with a tape line from a nail driven into an overhanging trunk of a tree. These measurements were carried on by the same observer who had charge of the station at the Viejo River.

List of discharge measurements made on Nuevo River near the Viejo River.

\begin{tabular}{|c|c|c|c|c|c|c|}
\hline Date. & Hydrographer. & $\begin{array}{c}\text { Meter } \\
\text { number. }\end{array}$ & $\begin{array}{c}\text { Gage } \\
\text { height. }\end{array}$ & $\begin{array}{l}\text { Area of } \\
\text { section. }\end{array}$ & $\begin{array}{c}\text { Mean } \\
\text { velocity. }\end{array}$ & $\begin{array}{c}\text { Dis- } \\
\text { charge. }\end{array}$ \\
\hline 1898. & & & Feet. & Sq.feet. & $\begin{array}{l}\text { Feet per } \\
\text { second. }\end{array}$ & SSc-feet. \\
\hline May 23 & G. P. Philip... & Fleats. & 5.00 & 178.0 & 2.54 & 451.0 \\
\hline May 27 & .... do ... & Floats. & 4.30 & $126.0^{\circ}$ & 2.18 & 275.0 \\
\hline June 3 & .... do ... & 7 & 3.00 & 50.0 & 0.70 & 354.0 \\
\hline June 10 & .....do ... & Floats. & 3.42 & 71.0 & 1.32 & 936.0 \\
\hline June 17 & ..... do ... & 7 & 3.02 & 57.0 & 0.69 & 395.0 \\
\hline June 24 & $\ldots \ldots$ do $\ldots$. & Floats. & 18.19 & 490.0 & 4.81 & $a 2,361.0$ \\
\hline July 1 & .... do ... & Floats. & 14.80 & 230.0 & 3. 01 & 693.0 \\
\hline July 8 & .... do .... & Floats. & 14.70 & 223.0 & 2.79 & 622.0 \\
\hline July 15 & ....do .. & Floats. & 14.30 & 193.0 & 2.29 & 441.0 \\
\hline July 22 & ..... do ... & Floats. & 13.00 & 105.0 & 1.37 & 143.0 \\
\hline July 29 & .... do ..... & Floats. & 13.40 & 132.0 & 2.14 & 282.0 \\
\hline July 29 & .... do $\ldots$ & 7 & 13.40 & 133.0 & 2.03 & 269.0 \\
\hline Aug. 26 & ..... do ... & Floats. & 12.50 & 74.0 & 1.80 & 138.0 \\
\hline Sept. 17 & .... do .... & Floats. & 15.00 & 248.0 & 2.84 & b 704.0 \\
\hline Sept. 28 & ..... do ..... & Floats. & 15.80 & 303.0 & 2.71 & 821.0 \\
\hline Oct. 3 & Fred. Davis & Floats. & 14.10 & 181.0 & 2.35 & 425.0 \\
\hline Oct. 14 & .....do ... & Floats. & 15.20 & 265.0 & 2.83 & 750.0 \\
\hline Oct. 22 & .... do ... & Floats. & 16.40 & 350.0 & 3.93 & $1,376.0$ \\
\hline Oct. 31 & ..... do. & Floats. & 14.10 & 181.0 & 2.84 & 514.0 \\
\hline Nov. 6 & .... do ... & Floats. & 13.30 & 124.0 & 2.76 & 343.0 \\
\hline Nov. 12 & ...... do .. & Floats. & 13.50 & 76.0 & 2.47 & 187.0 \\
\hline Nov. 19 & .... do .... & Floats. & 12.80 & 31.0 & 2.22 & 65.5 \\
\hline Nor. 24 & .....do ... & Floats. & 12.70 & 30.0 & 1.97 & 60.0 \\
\hline Nov. 28 & ..... do & Floats. & 12.70 & 30.0 & 2.17 & 66.0 \\
\hline Dec. 4 & ..... do ... & 7 & 12.60 & 48.0 & 1.06 & 51.0 \\
\hline Dec. 8 & .... . do .... & 7 & 12.50 & 45.0 & 0.99 & 45.0 \\
\hline Dec. 15 & .....do .... & 7 & 12.30 & 42.5 & 1.16 & 49.0 \\
\hline Dec. 21 & .... do ....... & -7 & 12.21 & 36.0 & 0.77 & 28.0 \\
\hline Dec. 30 & .... do .... & 7 & 12.15 & 34.6 & 0.60 & 20.7 \\
\hline
\end{tabular}


LAKE MANAGUA AS A STORAGE RESERVOIR.

Lake Managua has been suggested as a storage reservoir for supply. ing water to Lake Nicaragua during the dry season. This lake lies to the northwest of Lake Nicaragua, has a surface of about 500 square miles and a tributary drainage area of about 2,500 square miles. Its surplus waters are discharged into Lake Nicaragua by way of Tipitapa River. One mile below the point where this river leaves Lake Managua it falls over a cataract, descending about 13 feet in a horizontal distance of 500 feet. It is suggested that a dam might be constructed at this point and the waters of Lake Managua raised about 8 feet above the surface of the rock at the falls without serious damage to property around the margin of the lake. An outlet tunnel or cut might be provided to draw off the water to the level of the river below the falls. These works would be inexpensive, and a storage capacity would thus be secured for a depth of 20 feet over the entire surface of Lake Managua, which, if drawn off, would raise Lake Nicaragua about 3 feet. The water supply, however, is doubtful. It is known that entire years sometimes occur in which there is no outflow from the lake; but, on the other hand, the fact that water does often run out proves beyond question that in the long run the inflow exceeds the evaporation and seepage from the lake.

To reenforce the water supply for this reservoir it has been suggested to divert the Nuevo River into the Viejo River at a point near Paso Real in the Sebaco Plain so that it will flow into Lake Managua, instead of the Atlantic Ocean, as at present. At the point above mentioned the two rivers approach within about a mile of each other, and the intervening country is low and practically tlat. The river channels are 30 or 40 feet deep, and a cut of this depth connecting the two could be made to conduct the waters of the Nuevo River into the Viejo River if a dam were built in the Nuevo River below the point of connection. There is rock on the bottom of the Nuevo River, showing fairly good foundation for such a structure, but the excavation of the canal would be almost entirely in alluvial earth.

The cost of utilizing Lake Managua as a storage reservoir for the summit level would be about as follows:

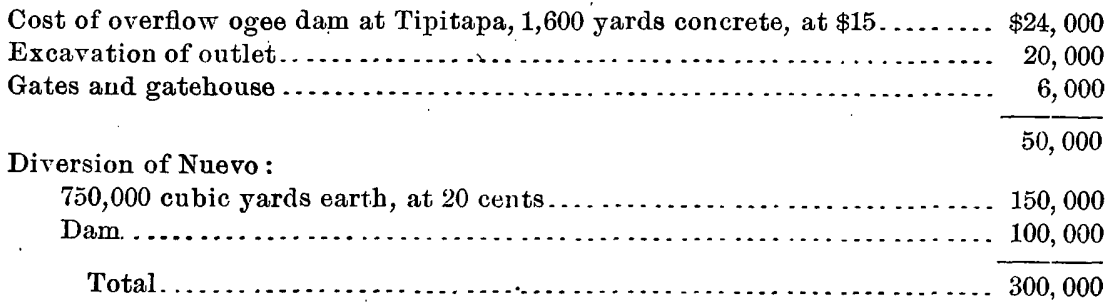

The discharge from Lake Managua 'has been measured for the year 1898, excepting for the months of January and December. Estimating 
the discharge for these two months, we have a total outflow for the year of something over 1,100,000 acre-feet, or enough to raise Lake Nicaragua 0.55 foot, or to raise Lake Managua 3.8 feet. if all had been held.

Had the Nuevo River been diverted into Lake Managua during this year, it would have contributed about 200,000 acre-feet more, sufficient in all to raise Lake Managua about $4 \frac{1}{2}$ feet in excess of evaporation, or enough to raise Lake Nicaragua 8 inches. Though the precipitation and run-off of 1898 were probably above the average, still it would be fair to expect one or more such years in each interval between the years of drought, and to assume that the inflow to Lake Managua during the other years would on an average be equal to the evaporation. If this assumption be correct, we have for $\$ 300,000$ a storage that would cost over $\$ 1,000,000$ to provide in Lake Niearagua. The intormation at hand is not sufficient to admit any conclusion as to the actual quantity of practicable storage, but if in each year of extreme drought Lake Managua could furnish an amount of water equal to-18 inches over its own surface, its storage would be cheaper than the same storage capacity provided by excavation along the canal line. It seems entirely safe to conclude that this could be done. The storage of water in Lake Manag ua would also assist in the control of the surplus waters by reducing the area of the watershed to be provided for.

TIPITAPA STATION.

A gage was placed in this river about 100 yards above Tipitapa Falls, which serves both to register the stage of the river and the beight of Lake Managua, upon which the stage of the river depends. During low water the river was too sluggish above the falls for accurate measurements with current meter, and gagings were made from the bridge below the falls. As the river rose it became very turbulent and swift at the bridge, but at the same time the velocity in the upper river increased and good measurements were made above the falls. Observations of rainfall and evaporation were also made at this point.

Daily gage height, in feet, of Tipitapa River at Tipitapa above falls for 1.898

[This shows the fluctuations of Lake Managua.]

\begin{tabular}{|c|c|c|c|c|c|c|c|c|c|c|c|c|}
\hline Day. & Jan. & Feb. & Mar. & Apr. & May. & June. & July. & Aug. & Sept. & Oct. & Nov. & Dec. \\
\hline 1. & & 4.44 & 3.92 & 3.19 & 2.65 & 3. 61 & 5.41 & 5.19 & 5.72 & 7.34 & 8.05 & 7.05 \\
\hline $2 .$. & & 4.39 & 3.92 & 3.13 & 2.56 & 3.61 & 5.50 & 5.27 & 5.70 & 7.34 & 7.95 & 7. 10 \\
\hline $3 \ldots$ & & 4.42 & 3.92 & ...... & 2.59 & 3.59 & 4.90 & 5.27 & 5.66 & 7.30 & 7.90 & 7.00 \\
\hline $4 .$. & & 4.33 & 3.89 & 2.91 & 2.55 & 3.53 & 5.39 & 5.33 & 5.76 & ...... & 7.80 & 6.95 \\
\hline $5 \ldots$ & & 4. 35 & 3.81 & 3.10 & 2.54 & 3.62 & 5. 36 & 5,24 & 5. 90 & 7.25 & 7.80 & 6.90 \\
\hline $6 .$. & & 4.38 & 3.78 & 3.12 & 2.54 & 3.68 & 5.53 & 5.27 & 5.90 & 7. 25 & 7.75 & 6.85 \\
\hline $7 .$. & & 4. 36 & 3.78 & 3.08 & 2.52 & 3.65 & 5.68 & 5.38 & 5.90 & $7: 30$ & 7.75 & 6.85 \\
\hline 8.. & & 4.32 & 3.86 & 2.99 & 2.49 & 3.62 & 5.44 & 5.37 & 5.70 & 7.40 & 7.70 & 6.80 \\
\hline $9 \ldots$ & & 4.32 & ...... & 2.97 & 2.47 & 3.62 & 5.36 & 5.26 & 5.94 & 7.35 & 7.65 & 6.75 \\
\hline 10. & & 4.28 & 3.81 & 2. 93 & 2.48 & 3.69 & 5.60 & 5.20 & 5.96 & 7.40 & 7.70 & 6.75 \\
\hline 11.. & & 4.25 & 3.78 & 2.95 & 2.49 & 3.71 & 5.42 & 5.23 & 6.14 & 7.35 & 7.65 & 6.72 \\
\hline
\end{tabular}




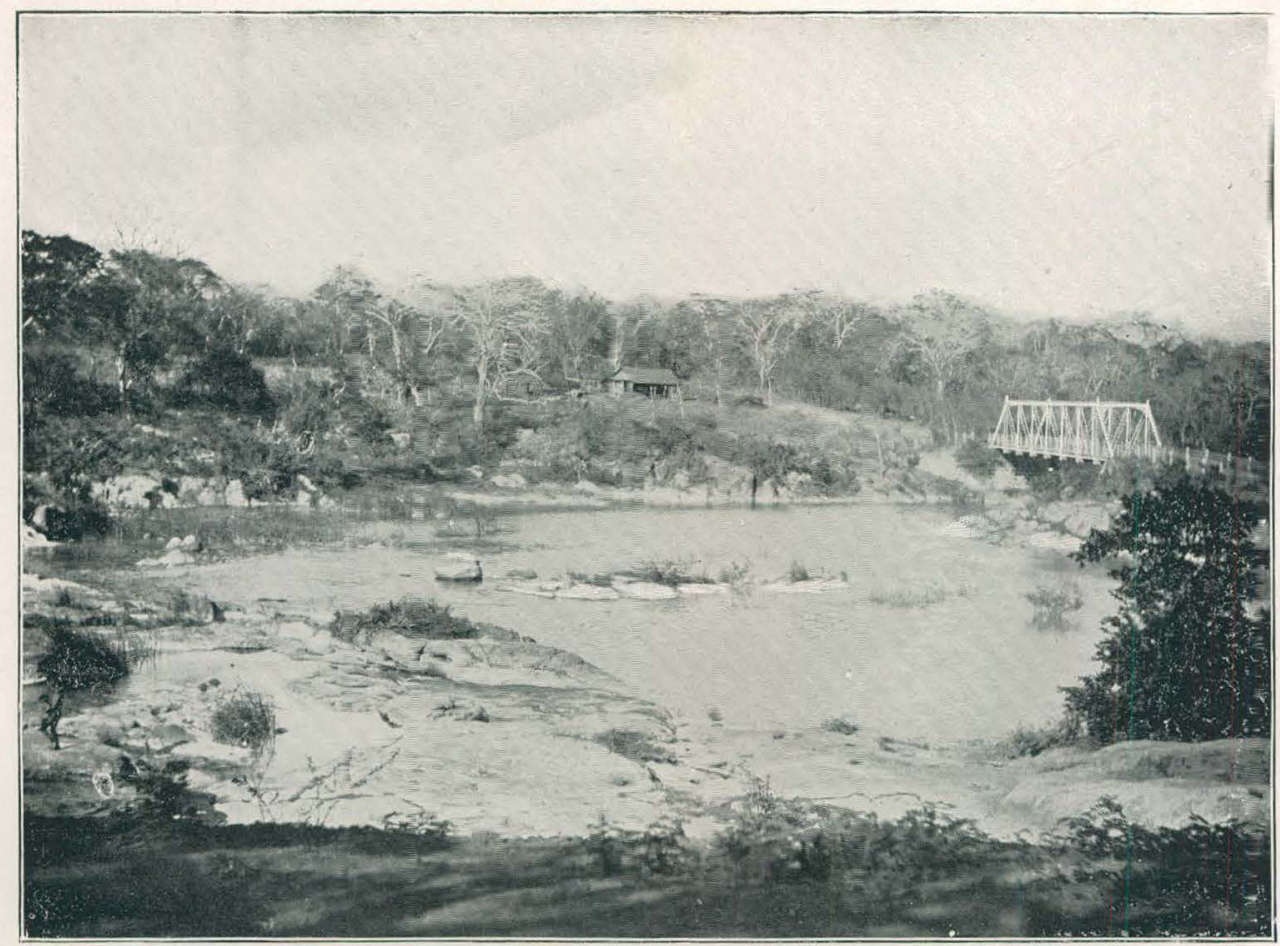

A. TIP TAPA $R$ VER BELOW THE FALLS.

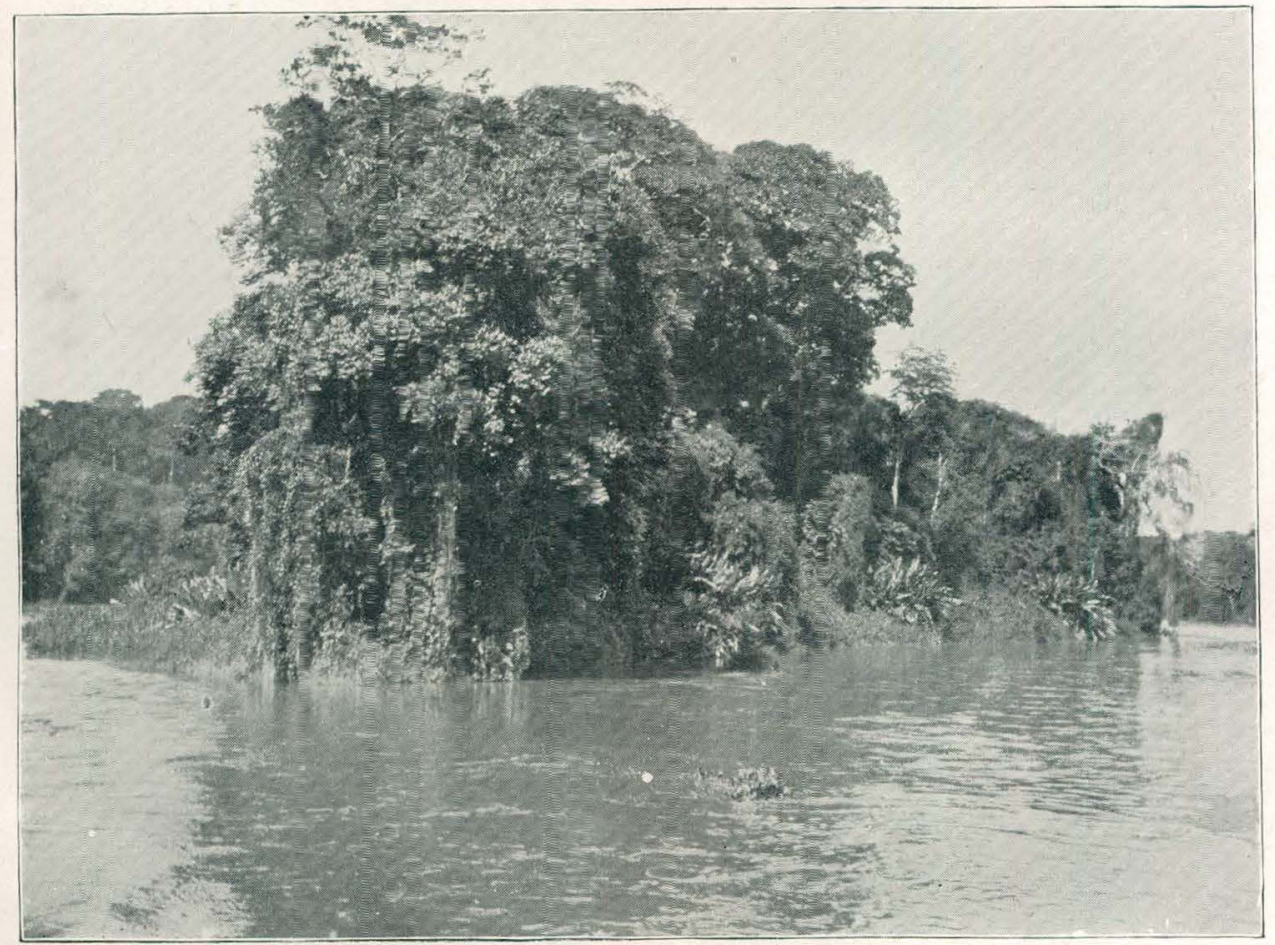

3. HEAD OF BA _AS RAP DS, RIO SAM JUAN. 
Daily gage height of Tipitapa River at Tipitapa above falls for 1898-Continued.

\begin{tabular}{|c|c|c|c|c|c|c|c|c|c|c|c|c|}
\hline Day. & an. & Feb. & Mar. & Apr. & May. & June. & July. & Aug. & Sept. & Oet. & Nov. & Dec. \\
\hline 12. & & 4. 23 & 3.75 & 2.86 & 2.45 & 3.91 & 5. 47 & 5.33 & 6. 28 & 7.35 & 7.65 & 6.70 \\
\hline 13. & & 4.12 & 3.78 & 2.97 & 2.45 & 3. 71 & 5.49 & 5.24 & 6.48 & 7. 32 & 7. 70 & 6.70 \\
\hline 14 & & 4. 17 & 3.74 & 2.98 & 2. 39 & 3.66 & 5.50 & 5.31 & 6.62 & 7.40 & 7.60 & 6.65 \\
\hline 15. & & 4.20 & 3.68 & 2.95 & 2.42 & 3.65 & 5. 42 & 5.37 & 6.76 & 7.37 & 7.55 & 6.60 \\
\hline 16. & & 4. 18 & 3.57 & 2.96 & 2.47 & 3.67 & 5.34 & 5.29 & 6.95 & 7. 50 & 7.50 & 6.55 \\
\hline 17. & & 4.11 & 3.52 & 2.84 & 2.52 & 3.77 & 5.48 & 5.31 & 6.94 & 7. 62 & 7. 40 & 6.55 \\
\hline 18 & & 4.18 & 3.51 & 2.91 & 2.67 & 3.88 & 5. 32 & 5.28 & 6.94 & 7.72 & 7.45 & $6: 50$ \\
\hline 19. & & 4.11 & 3.48 & 2.86 & 2.82 & 3.89 & 5.38 & 5.27 & 6.95 & 7.72 & 7.35 & 6.55 \\
\hline 20. & & 4.16 & 3.41 & 2.78 & 2.80 & 4.03 & 5.32 & 5.27 & 6.96 & 7.87 & 7.30 & 6.50 \\
\hline 21. & & 4.08 & 3.41 & 2.78 & 2.92 & 4.12 & 5. 36 & 5.31 & 7.18 & 7.95 & 7. 30 & 6.52 \\
\hline $22:$ & & 4.05 & 3.40 & 2.77 & 3.03 & 4.51 & 5.48 & 5. 31 & 7.18 & 7.95 & 7.30 & 6,50 \\
\hline 23 & & 4.05 & 3.50 & 2.79 & 3. 18 & 4. 62 & 5.40 & 5.41 & 7.18 & 8.00 & 7.25 & 6.45 \\
\hline 24. & & 4.01 & 3.43 & 2.80 & 3.33 & 4. 76 & 5.33 & 5.36 & 7.24 & 7.92 & 7.25 & 6.40 \\
\hline 25. & & 3.94 & 3. 34 & 2. 79 & 3.57 & 4. 86 & 5. 31 & 5.35 & 7. 26 & 7.95 & 7.20 & 6.40 \\
\hline 26. & & 3.93 & 3.21 & 2.68 & 3. 67 & 4.95 & 5.40 & 5. 38 & 7.20 & 7.95 & 7.20 & 6.35 \\
\hline 27. & & 3. 96 & 3.26 & 2.62 & 3. 70 & 4.87 & 5.26 & 5.42 & 7.31 & 8.00 & 7.15 & 6.30 \\
\hline 28. & & 3.95 & 3.30 & 2.65 & 3.67 & 5.16 & 5.25 & 5.64 & 7.38 & 8.02 & 7.15 & 6.30 \\
\hline 29. & & & 3.28 & 2.67 & 3. 68 & 5.38 & 5.26 & 5.60 & 7.40 & 8.00 & 7.10 & 6.25 \\
\hline 30. & & & 3.16 & 2.60 & 3.58 & 5.43 & 5.30 & 5.68 & 7. 34 & 8.00 & 7.05 & 6.20 \\
\hline 31. & & & 3.13 & ..... & 3.65 & $\ldots$. & 5.39 & 5.69 & $\cdots$ & 8. 00 & $\ldots \ldots$ & 6.20 \\
\hline
\end{tabular}

List of discharge measurements made on Tipitapa River at Tipitapa.

\begin{tabular}{|c|c|c|c|c|c|c|}
\hline Date. & Hydrographer. & Meter. & $\begin{array}{c}\text { Gage } \\
\text { height. }\end{array}$ & $\begin{array}{l}\text { Area of } \\
\text { section. }\end{array}$ & $\underset{\text { velocity. }}{\text { Mean }}$ & Discharge. \\
\hline 1898. & & . & Feet. & Sq. feet. & $\begin{array}{l}\text { Feet per } \\
\text { second. }\end{array}$ & Sec.-feet. \\
\hline Apr. 2 & G. P. Philip........ & Ellis .... & 3.13 & 3.2 & 0.79 & 2.6 \\
\hline May 26 & G. N. Challice.... & $\ldots$ do ... & 3.67 & 45 & 0.47 & 21 \\
\hline June 1 & $\ldots$. . do .... & $\ldots$..... & 3.58 & 46 & 0.27 & 12 \\
\hline June 16 & ..... do & ....do ... & 3.67 & 45 & 0.32 & 15 \\
\hline June 20 & .....do .... & $\ldots$ do ... & 4.04 & 60 & 0.82 & 49 \\
\hline June 22 & $\ldots$ do & ....do ... & 4.50 & 99 & 1.51 & $149^{\circ}$ \\
\hline June 27 & ....do do .... & $\ldots d o \ldots$ & 4.81 & 119 & 1.98 & 236 \\
\hline July 1 & $\ldots$ do $\ldots . . . . .$. & .... do ... & 5.40 & 195 & 3.43 & 669 \\
\hline Aug. 18 & G. R. Wadleigh & .... do & 5.27 & 177 & 3.38 & 597 \\
\hline Aug. 29 & $\ldots$ do .... & $\ldots$ do ... & 5. 60 & 178 & 4. 75 & -1845 \\
\hline Sept. 5 & $\ldots$.... do .... & $\ldots$ do ... & 5.85 & 196 & 6.61 & 1,296 \\
\hline Sept. 10 & $\ldots d o$ & $\ldots$ do .... & 5. 98 & 1,346 & 0.84 & 1,137 \\
\hline Sept. 12 & ..... do & $\ldots$ do & 6. 23 & 1,495 & 0.93 & 1,394 \\
\hline Sept. 13 & ....do do & ....do & 6.44 & 1,602 & 1.11 & 1,771 \\
\hline Sept. 14 & $\ldots$ do ... & $\ldots$ do & 6.58 & 1,601 & 1. 19 & 1,907 \\
\hline Sept. 15 & ....do .... & $\ldots$ do .... & 6. $7 \dot{4}$ & 1,659 & 1. 27 & 2,106 \\
\hline Sept. 16 & ....do .. & ....do & 6. 94 & 1,738 & 1.38 & 2,392 \\
\hline Sept. 21 & $\ldots$ do .... & .... do & 7.18 & 1,834 & 1.55 & 2,851 \\
\hline Sept. 26 & .....do. & $\ldots$ do... & 7.18 & 1,835 & 1. 62 & 2,966 \\
\hline Sept. 28 & ..... do & ....do & 7.36 & 1,909 & 1.71 & 3,186 \\
\hline
\end{tabular}


List of discharge measurements made on Tipitapa Rirer at Tipitapa-Continued.

\begin{tabular}{|c|c|c|c|c|c|c|}
\hline Date. & Hydrographer. & $\begin{array}{c}\text { Meter } \\
\text { number. }\end{array}$ & $\begin{array}{c}\text { Gage } \\
\text { height. }\end{array}$ & $\begin{array}{l}\text { Area of } \\
\text { section. }\end{array}$ & $\underset{\text { velocity. }}{\text { Mean }}$ & Discharge. \\
\hline 1898. & & & Feet. & Sq. feet. & $\begin{array}{l}\text { Feet per } \\
\text { second. }\end{array}$ & Sec.-feet. \\
\hline Oct. 10 & G. P. Philip ...... & Ellis .... & 7.40 & 1,894 & 1.71 & 3,234 \\
\hline Oct. 22 & . . do ........... & $\ldots$ do ... & 7.94 & 2,158 & 2.40 & 5,177 \\
\hline Nor. 2 & $\ldots \ldots$ do $\ldots . . . .$. & $\ldots$ do ... & 7.92 & 2,140 & 2.29 & 4,891 \\
\hline Nov. 4 . & $\ldots$ do $\ldots \ldots \ldots \ldots$ & $\ldots$.... do ... & 7.82 & 2,103 & 2.25 & 4,735 \\
\hline Nov. 9 & $\ldots$. do ....... & ....do ... & 7.69 & 2,038 & 2.12 & 4,325 \\
\hline Nov. 12 & $\ldots$. do ....... & $\ldots$. . do ... & 7.53 & 1,937 & 1.85 & 3,585 \\
\hline Nov. 19 & .... do ........ & $\ldots$.... do ... & 7.42 & 1,925 & 1. 79 & 3,445 \\
\hline Nov. 23 & $\ldots$. . do ....... & ....do ... & 7.25 & 1,862 & 1. 66 & 3,095 \\
\hline Dec. 2 & .... do ....... & ... do ... & 7.08 & 1,785 & 1.57 & 2,810 \\
\hline Dec. 6 & $\ldots$ do ........ & $\ldots$ do ... & 6.85 & 1,684 & 1. 46 & 2,465 \\
\hline Dec. 13 & .....do . . & ... do & 6.70 & 1,608 & 1. 36 & 2,190 \\
\hline Dec. 20 & .... do ... & $\ldots$. do & 6.52 & 1,571 & 1. 24 & $\mathbf{1}, 935$ \\
\hline Dec. 26 & .... do ........ & $\ldots$. do ... & 6.38 & 1,454 & 1. 17 & 1,704 \\
\hline Jan. 1 & .... do & $\ldots$...do ... & 6.22 & 1,401 & 1. 07 & 1,501 \\
\hline
\end{tabular}

Estimated monthly discharge of Tipitapa River at Tipitapa.

\begin{tabular}{|c|c|c|c|c|}
\hline \multirow{2}{*}{ Month. } & \multicolumn{3}{|c|}{ Discharge in second-feet. } & \multirow{2}{*}{$\begin{array}{l}\text { Total for } \\
\text { month in } \\
\text { acre-feet. }\end{array}$} \\
\hline & $\begin{array}{l}\text { Maxi- } \\
\text { mum. }\end{array}$ & $\begin{array}{l}\text { Mini- } \\
\text { mum. }\end{array}$ & Mean. & \\
\hline 1898. & & & & \\
\hline February $\ldots \ldots \ldots \ldots \ldots \ldots \ldots$ & 125 & 37 & 77 & 4,275 \\
\hline March $\ldots \ldots \ldots \ldots \ldots \ldots \ldots \ldots \ldots$ & 36 & 3 & 16.6 & 1,020 \\
\hline April $\ldots \ldots \ldots \ldots \ldots \ldots \ldots \ldots$ & 4 & 0 & 0.5 & 29 \\
\hline May..$\ldots \ldots \ldots \ldots \ldots \ldots \ldots \ldots \ldots \ldots$ & 18 & 0 & 3.8 & 234 \\
\hline June ........................ & 700 & 13 & 121 & 7,200 \\
\hline July $\ldots \ldots \ldots \ldots \ldots \ldots \ldots \ldots \ldots$ & 922 & 280 & 662 & 40,700 \\
\hline August. . . . . . . . . . . . . . . . & 930 & 487 & 626 & 38,490 \\
\hline September ........ & 3,230 & 910 & 2,045 & 121,690 \\
\hline October $\ldots \ldots \ldots \ldots \ldots \ldots$ & 5,380 & 2,910 & 4,040 & 248,410 \\
\hline November $\ldots \ldots \ldots \ldots \ldots \ldots \ldots \ldots$ & 5,500 & 2,150 & 3,640 & 216,600 \\
\hline 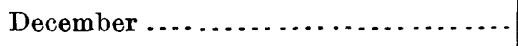 & 2,630 & 1,470 & 1,950 & 119,900 \\
\hline Total .. & & $\cdots$ & $\ldots \ldots$ & 798,548 \\
\hline
\end{tabular}

SAN UBALDO AND MORRITO.

For the purpose of measuring evaporation and rainfall on the northeastern shore of Lake Nicaragua, as well as recording its fluctuations, a station was established at San Ubaldo on April 6, 1898. This point 
was selected on account of the convenience of communication, it being a regular 'stopping place for the Victoria, a steamer plying between Granada and San Carlos. During the month of May, when adverse winds were frequent, the evaporation pan was frequently driven ashore, there being no means of protecting it at this point. This fact, together with the difficulty of obtaining suitable quarters for the observer at this point, decided the removal of this station to Morrito, a native village about 10 miles to the isoutheast. This removal was accomplished on May 24. The lake gage at San Ubaldo was connected by spirit level with two bench marks and with a point indicated by the inhabitants as being the high-water mark of 1893 , the highest stage known since the settlement at this point.

Bench mark No. 1 is the highest point of a large bowlder 10 feet north of the north door of the bodega. It is 5.44 feet above the 9-foot mark of the lake gage.

Bench mark No. 2 is on the top of the middle masonry support of the bodega building. It is 5.3 feet above the 9 -foot mark of the lake gage.

The high-water mark of 1893 is 3.9 feet above the 9-foot mark of the lake gage. Rainfall and evaporation observations were also taken at this station.

At Morrito the gage was fastened to some stakes that had been standing in the margin of the lake for several years and were reasonably solid. Both it and the evaporation pan were partially protected from breakers by a line of swamp grass growing in the lake outside of the water in which they stood. This station was discontinued on September 21 .

$$
\text { FORT SAN CARLOS. }
$$

A gage was established at this point by Lieut. G. C. Hanus, U. S. N., January 4, 1898. It was simply a graduated stick driven in the sand in shallow water and supported by two stakes in the form of braces. On March 13 a more substantial gage was placed in deeper water and firmly fastened to the iron remains of an old wreck of a Vanderbilt steamer about a quarter of a mile north of the town of San Carlos. It was driven as far as possible into the mud and fastened with bolts and cable to the iron wreck. Its zero is at elevation 96.436.

Bench mark No. 1 is on the highest point of the shore end of the stranded boiler and is 12.933 feet above the zero water gage lastdescribed and 9.78 feet above the zero of gage established by Lieutenant Hanis. From the 8th of March, when a special observer was stationed at San Carlos, rainfall, evaporation, temperature, and humidity observations were taken.

$$
\text { FRIO RIVER. }
$$

On May 9 a gage was placed in the Frio River about 1 mile above its mouth, upon which readings were taken every other day, and occasional measurements were made. 
List of discharge measurements made on Frio River, 1 mile above mouth.

\begin{tabular}{|c|c|c|c|c|c|c|}
\hline Date. & Hydrographer. . & $\begin{array}{c}\text { Meter } \\
\text { number. }\end{array}$ & $\begin{array}{c}\text { Gage } \\
\text { height. }\end{array}$ & $\begin{array}{l}\text { Area of } \\
\text { section. }\end{array}$ & $\begin{array}{c}\text { Mean } \\
\text { velocity. }\end{array}$ & Discharge. \\
\hline 1898. & & & Feet. & Sq. feet. & $\begin{array}{l}\text { Feet per } \\
\text { second. }\end{array}$ & Sec.feet. \\
\hline May 13 & H. S. Reed & St. 1 . & 2.63 & 2,375 & 0.51 & 1,198 \\
\hline May 9 & .....do ... & St. 1. & 2.50 & 2,414 & 0.54 & 1,302 \\
\hline May 15 & .... do .... & St. 1. & 2.62 & 2,414 & 0.305 & 737 \\
\hline May 21 & $\ldots .$. do ... & St. 1. & 2.93 & 2,519 & 0.74 & 1,871 \\
\hline June 22 & W. W. Schlecht.... & St. 1. & 3.85 & 2,660 & 2.49 & 6,626 \\
\hline June 30 & ..... do .. & St. 1. & 4.67 & 2,928 & 3.96 & 11,600 \\
\hline July 9 & ..... do ... & St. 1. & 4.90 & 2,947 & 3.74 & 11,032 \\
\hline July 23 & .... do .. & St. 1. & 5.10 & 3,068 & 3.84 & 11,780 \\
\hline Do... & .... do .. & Floats. & 5.05 & 3,060 & 3.56 & 10,885 \\
\hline July 29 & .... do ... & St. 1. & 5.20 & 3,088 & 2.40 & 7,400 \\
\hline Aug. 6 & ..... do .. & St. 1. & 5.25 & 3,096 & 2.48 & 7,684 \\
\hline Aug. 19 & .... . do .... & St. 1. & 5.28 & 3,096 & 2.40 & 7,445 \\
\hline Aug. 31 & E. P. Humphrey ... & 94 & 5.44 & 3,095 & 1.36 & $.4,187$ \\
\hline Sept. 13 & .... do ........ & 94 & 5.80 & 3,438 & 1.45 & $.5,003$ \\
\hline
\end{tabular}

Estimated monthly inflow into Lake Nicaragua in excess of evaporation.

\begin{tabular}{|c|c|c|c|c|}
\hline Month. & Stored in lake. & Outflow. & Total. & Inflow. \\
\hline 1898. & Acre-feet. & Acre-feet. & Acre-feet. & Sec.feet. \\
\hline January $4-31 . . . .$. & $-666,400$ & $+1,032,400$ & $+366,000$ & $+6,590$ \\
\hline February .... & $-1,218,600$ & $+923,800$ & $-294,800$ & $-5,310$ \\
\hline March ......... & $-1,827,800$ & $+863,600$ & $-964,200$ & $-15,680$ \\
\hline April...... & $-1,237,600$ & $+724,100$ & $-513,500$ & $-8,630$ \\
\hline May ....... & $+342,700$ & $+723,300$ & $+1,066,000$ & $+17,340$ \\
\hline June... & $+1,846,900$ & $+841,600$ & $+2,688,500$ & $+45,200$ \\
\hline July ..... . & $+1,980,200$ & $+1,190,900$ & $+3,171,100$ & $+51,570$ \\
\hline August ... & $+856,800$ & $+1,202,200$ & $+2,059,000$ & $+33,490$ \\
\hline September & $+1,504,200$ & $+1,313,600$ & $+2,817,800$ & $+47,350$ \\
\hline October....... & $+1,199,500$ & $+1,440,600$ & $+2,640,100$ & $+42,960$ \\
\hline November & $+609,300$ & $+1,512,000$ & $+2,121,300$ & $+35,650$ \\
\hline December.... & $-437,900$ & $+1,540,000$ & $+1,102,100$ & $+17,920$ \\
\hline & & & 400 & \\
\hline
\end{tabular}


Daily elevation, computed from gage rods, of Lake Nicaragua at Las Lajas, Morrito, and San Carlos for 1898.

[Las Lajas, February 8; San Carlos, January 4; Morrito, April 9 to September 21.]

\begin{tabular}{|c|c|c|c|c|c|c|c|c|c|c|c|c|}
\hline Day. & Jan. & Feb. & Mar. & Apr. & May. & June. & July. & Aug. & Sept. & Oct. & Nov. & Dec. \\
\hline 1. & & 104.87 & 104.24 & 103.40 & 102.67 & $\mid 102.86$ & 103.88 & 104. 94 & 105.34 & 106.04 & 106.79 & 107.05 \\
\hline 2 & & 104.80 & 104.27 & 103.40 & 102.62 & 102.87 & 103.85 & 104.89 & 105.35 & 106.12 & 106.75 & 107.04 \\
\hline 3. & . & 104.90 & 104.20 & 103.36 & 102.61 & 102.82 & 103.93 & 104.89 & 105.33 & 106.14 & 106.69 & 107.00 \\
\hline 4. & 105.30 & 104.86 & 104.24 & 103.34 & 102.59 & 102.77 & 104.08 & 104.96 & 105.32 & 106.12 & 106. 64 & 107.06 \\
\hline 5. & 105.34 & 104.89 & 104.16 & 103.30 & 102.58 & 102.80 & 104.00 & 104.99 & 105.35 & 106.13 & 106.60 & 107.08 \\
\hline 6. & 105.40 & 104.81 & 104.13 & 103.34 & 102.58 & 102.83 & 104.16 & 104.95 & 105.43 & 106.11 & 106.64 & 107.03 \\
\hline 7. & 105.31 & 104.81 & 104.14 & 103.30 & 102.52 & 102.90 & 104.17 & 104.98 & 105.40 & 106.13 & 106.60 & 107.05 \\
\hline 8. & 105.32 & 104.81 & 104.11 & 103.24 & 102.50 & 102.87 & 104.20 & 105.08 & 105.43 & 106.17 & 106.57 & 106. 97 \\
\hline 9. & 105.26 & 104.80 & 104.10 & 103.21 & 102.49 & 102.86 & 104.28 & 105.05 & 100.43 & 106.11 & 106.60 & 106.96 \\
\hline 10. & 105.17 & 104.70 & 104.00 & 103.15 & 102.47 & 102.86 & 104.27 & 105.03 & 105.49 & 106.11 & 106.59 & 106.99 \\
\hline 11. & 105.23 & 104.68 & 104.02 & 103.19 & 102.46 & 102.86 & 104.34 & 105.03 & 105.57 & 106.09 & 106.64 & 106.98 \\
\hline 12. & 105.25 & 104.69 & 104.00 & $103.19^{1}$ & 102.42 & 102.92 & 104.37 & 104.97 & 105.67 & 106.13 & 106.72 & 106.96 \\
\hline 13. & 105.18 & 104.79 & 103.99? & 103.14 & 102.34 & 102.89 & 104.36 & 105.12 & 105.82 & 106.13 & 106. 84 & 106.90 \\
\hline 14 & 105.14 & 104.70 & 103.90 & 103.1.2 & 102.41 & 102.85 & 104.36 & 105.11 & 105.83 & 106.22 & 106.80 & 106.90 \\
\hline 15. & 105.13 & 104.67 & 103.95 & 103.07 & 102. 35 & 102.86 & 104.41 & 105.16 & 105.86 & 106.26 & 106.85 & 106.88 \\
\hline 16. & 105.17 & 104.61 & & 103.06 & 102.43 & 102.82 & 104.45 & 105.18 & 105.91 & 106.24 & 106.88 & 106.91 \\
\hline 17. & $105.16^{\prime}$ & 104. 59 & & 103.06 & 102.39 & 102.85 & 104.42 & 105.21 & 105.96 & 106. 30 & 106.88 & 106.85 \\
\hline 18. & $105.21_{i}$ & 104.59 & & 103.03 & 102.51 & 102.85 & 104.45 & 105.16 & 105.95 & 106.46 & 106.95 & 106.85 \\
\hline 19. & 105.22 & 104.54 & 103.64 & 102.99 & 102.48 & 102.97 & 104.48 & 105.16 & 105.95 & 106.52 & 106.89 & 106.80 \\
\hline 20. & 105.35 & 104.52 & 103.68 & 102.93 & 102.49 & 103.03 & 104.63 & 105.16 & 105.96 & 106.53 & 106.82 & 106.82 \\
\hline 21. & 105.28 & 104.46 & 103.71 & 102.97 & 102.53 & 103.08 & 104.55 & 105.20 & 105.03 & 106.51 & 107.00 & 106. 78 \\
\hline 22. & $105.20^{\prime}$ & 104.42 & 103.52 & 102.94 & 102.81 & 103.29 & 104.63 & 105.21 & 106.09 & 106. 62 & 106.94 & 106.73 \\
\hline 23. & 105.11 & 104.38 & 103.65 & 102.91 & 102.78 & 103.35 & 104.61 & 105.15 & 106.04 & 106.66 & & 106.78 \\
\hline 24. & 105.02 & 104.46 & 103.67 & 102.83 & 102.89 & 103.39 & 104.70 & 105. 18 & 106.12 & 106.74 & & 106.80 \\
\hline $25 .$. & 105.09 & 104.42 & 103.68 & 102.81 & 102.95 & 103.47 & 104.71 & 105.19 & 106. 10 & 106. 73 & & 106.76 \\
\hline $26 \ldots$ & 105.08 & 104.44 & 103.37 & 102.82 & 102.93 & 103.42 & 104.73 & 105.16 & 106.06 & 106.74 & 106.92 & 106. 74 \\
\hline 27. & 105.07 & 104.32 & 103.57 & 102.80 & 102.97 & 103.54 & 104.77 & 105.21 & 106.01 & 106.76 & 106.97 & 106. 70 \\
\hline 28. & 105.05 & 104.31 & 103.50 & 102.75 & 102.94 & 103.68 & 104.84 & 105.20 & 106.12 & 106.72 & 107.00 & 106.68 \\
\hline 29. & 104.90 & & 103.47 & 102.71 & 102.84 & 103.80 & 104.76 & 105.32 & 106.14 & 106.82 & 107.01 & 106. 79 \\
\hline $30 .$. & 105.02 & & 103.48 & 102.70 & 102.93 & 103.85 & 104.92 & 105.33 & 106. 13 & 106. 79 & 107.08 & 106.78 \\
\hline 31. & & & & & & & 104.89 & 105.34 & & 106.76 & & 106.85 \\
\hline
\end{tabular}

DRY SEASON INFLOW TO LAKE NICARAGUA.

For the purpose of determining the amount of storage necessary for maintaining the summit level of Lake Nicaragua at any desired point through the dry season an attempt was made to measure the inflow to Lake Nicaragua during the months of April and May, 1898. This work was begun on April 19, and the following notes and measurements were made of its tributaries:

Negro(?).-First river south of Frio River. Water black and foul. No current. Open water only about 300 yards above mouth. Above this entirely closed by grass. Width, 40 to 200 feet; depth, 8 to 12 feet; discharge, zero, or nearly so.

Another estuary exactly similar in all respects oecurs one-fourth of a mile south, which may be another mouth of the same drainage. Both are almost due south of San Carlos.

A third estuary, wider and longer, but otherwise similar, is one-half 
mile still farther south, and has two branches, the southern and longer being 2 miles long. Water foul. Discharge, zero, or nearly so.

Two other small estuaries farther south were inspected.

Cucaracho (?).-A wide-mouthed, deep estuary, about a mile southwest of the most southerly described above. It has about a mile of open water. No indication of current. Water very black. Discharge, zero.

One-half mile southwest of above is an estuary which is choked with vegetation one-fourth mile above its mouth. Discharge, zero.

One-half mile southwest of above is a deep estuary closed with vegetation one-half mile above its mouth. Discharge, zero.

Araña River.-Water deep and still. Water lettuce and other plants standing on surface, not fastened, do not float out. Water stagnant and foul. All signs indicate absolutely still water. One mile above mouth the channel is choked with vegetation and becomes a swamp.

West of this point occurred several streams with measurable discharge. Their character and volume are indicated in the following table:

\begin{tabular}{|c|c|c|c|c|}
\hline Date. & Stream. & $\begin{array}{l}\text { A rea of } \\
\text { section. }\end{array}$ & Velocity. & Discharge. \\
\hline 1898. & & Square-feet. & $\begin{array}{l}\text { Feet per } \\
\text { second. }\end{array}$ & Second-feet. \\
\hline \multirow[t]{3}{*}{ Apr. 19} & Pisote, East Fork . ......... & 550.0 & 0.82 & 452.0 \\
\hline & Pisote, West Fork ............... & 427.0 & 0.78 & 332.0 \\
\hline & Toro $\ldots \ldots \ldots \ldots \ldots \ldots$ & $\cdots$ & $\ldots \ldots \ldots$ & (a) \\
\hline \multirow[t]{3}{*}{ Apr. 20} & Las Haciendas, 1 mile up. ........ & 78.0 & 1.22 & 95.0 \\
\hline & Oroci, near mouth $\ldots \ldots \ldots \ldots \ldots$ & 57.0 & 0.55 & 33.0 \\
\hline & Mena, three-fourths mile up ...... & 47.0 & 0.91 & 43.0 \\
\hline \multirow[t]{4}{*}{ Apr. 21} & 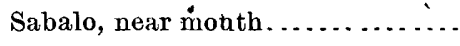 & 20.0 & 1. 70 & 34.0 \\
\hline & Pueblo, one-half mile up......... & 2.3 & 1. 17 & 2.7 \\
\hline & Tiroli, one half mile up......... & 3.1 & 0.32 & 1.3 \\
\hline & Sapoa, 2 miles up . . . . . . . . . . . & 102.0 & 0.29 & 30.0 \\
\hline \multirow[t]{2}{*}{ May 15} & Frio, 2 miles up.. & $2,414.0$ & 0.31 & 737.0 \\
\hline & $\begin{array}{l}\text { Total dry-season inflow to } \\
\text { Lake Nicaragua, southern } \\
\text { end } \ldots \ldots \ldots \ldots \ldots \ldots\end{array}$ & $\ldots$ & $\ldots$ & $1,760.0$ \\
\hline
\end{tabular}

Alligator.-Five miles north of San Carlos, an estuary of stagnant water, 10 feet deep, 40 feet wide. One-half mile above mouth it is choked by vegetation. Discharge, zero.

Consuelo.-Large estuary with large delta and two mouths. Has about half a mile of open water; above this point closed by vegetation. Water stagnant. Discharge, zero.

Murillo.- North of Point Murillo is an estuary which forks about onefourth mile above mouth. Both forks are closed by vegetation a short distance above their junction. Depth, 3 to 7 feet. No measurable velocity. 'Total discharge estimated at 10 second-feet. 
Maria.-About 2 miles north of above is a short estuary of stagnant water. Discharge, zero.

Tule.-Large estuary, wide and deep. Much floating vegetation. No perceptible current. Discharge insignificant.

San Miguelito.-An estuary about a mile long occurs 2 miles north of the town of San Miguelito, emptying into a sort of bay. It is shallow and has no measurable current. Discharge, zero.

Piedras.-A large, deep estuary just north of above. It has two tributaries, one from the right and one from the left, all deep and stag. nant. Floating islands and plants indicate, no current. Discharge, zero.

Tepenaguasape.-Large estuary with large delta. Depth, 18 feet; width, 50 feet. At time of inspection floating islands and other vegetation were moving upstream under the influence of wind. All indications point to stagnancy, as in other streams. Discharge negligible.

Ollate.-This river has a large deltaic formation covered with aquatic vegetation, much of which is floating. At time of inspection it was. choked with vegetation, there being no visible current. Discharge negligible. About one month later, on the 21st of June, a measurement was made about 2 miles above the mouth of the river. At this time the area of cross section at the point of measurement was 1,079 square feet; mean velocity, 3.94 feet per second; discharge, 4,258 cubic feet per second.

Catarina.-A large stream course explored to a distance of about 2 miles. Depth, 10 to 15 feet; width, about 100 feet. No current. Information from natives and all indications denote no discharge.

Ajocuapa.-This river opens directly against the island of the Jobo. group that lies nearest the shore. It has a large delta and is very shallow. Much choked with floating vegetation. Discharge, zero.

Mollales.-When ascended, May 23, this river was stagnant from the mouth nearly to the point of measurement, what slight motion was shown being upstream. Descending it showed current nearly all the way down. This fact and the rise of one-tenth foot which occurred at the point of measurement during inspection indicate that most of the discharge is due to very recent heavy rains, and that the dry-season discharge is negligible. Measurement made 4 miles above mouth. Total area, 66 square feet; mean velocity, 0.73; discharge, 49.

Roblado.-This stream enters the lake at Guapinolapa. On May 24, the date of inspection, it was choked with vegetation about 200 feet above the point of measurement and gave other proofs of normal stagnancy. The discharge found is doubtless due to recent heavy rains. Total area of cross section, 25 square feet; mean velocity, 0.77 feet per second; discharge, 19 second-feet; dry season discharge, zero.

Other streams. - No other stream of measurable discharge was found flowing into the northern end of Lake Nicaragua. The coast between Granada and Rivas was not explored. From the best information. 
obtainable by inquiry it is concluded that the tributaries between these points contribute only an inconsiderable quantity of water at the close of the dry season.

South of Rivas the Medio River was discharging early in May about 1 cubic foot per second.

The mouth of the Lajas was closed in February and remained so until late in May. No other streams of consequence occur between Rivas and Sapoa.

Other discharge measurements of lake tributaries made by A. P. Davis, 1898.

\begin{tabular}{|c|c|c|c|c|c|c|c|}
\hline Date. & Stream. & Locality. & $\begin{array}{c}\text { Meter } \\
\text { num- } \\
\text { ber. }\end{array}$ & $\begin{array}{c}\text { Gage } \\
\text { height. }\end{array}$ & $\begin{array}{c}\text { Area } \\
\text { of sec. } \\
\text { tion. }\end{array}$ & $\begin{array}{l}\text { Mean } \\
\text { veloc- } \\
\text { ity. }\end{array}$ & $\begin{array}{c}\text { Dis- } \\
\text { charge. }\end{array}$ \\
\hline $\begin{array}{r}1898 . \\
\text { Jan. } 18 .\end{array}$ & Las Lajas. & At mouth.......... & 94 & $\begin{array}{l}\text { Feet. } \\
7.88\end{array}$ & $\begin{array}{c}\text { Sq. feet } \\
2.8\end{array}$ & $\mid \begin{array}{r}\text { Feet per } \\
\text { second. } \\
1.46\end{array}$ & $\begin{array}{c}\text { Sec. feet } \\
4.1\end{array}$ \\
\hline Do........ & Guiscoyal ....... & 2 miles up.......... & 94 & $\ldots \ldots$ & 6.1 & 0.32 & 2.0 \\
\hline Jan. $30 \ldots .$. & Jicoral .......... & Jicoral............ & 94 & $\ldots \ldots$ & 20.0 & 0.47 & 9.4 \\
\hline May $12 \ldots . .$. & Machnea ....... & $\frac{1}{2}$ mile up.......... & 94 & ….... & 68.0 & 1.10 & 75.0 \\
\hline Jure $21 \ldots$. & Ollate........... & 3 miles up.......... & 94 & 2.60 & $1,079.0$ & 3.94 & $4,258.0$ \\
\hline July $9 \ldots \ldots$ & Machuca...... & 2 miles up.......... & 94 & $\ldots \ldots$ & 156.0 & 1. 70 & 266.0 \\
\hline
\end{tabular}

RIO SAN JUAN.

SABALOS STATION, ON RIO SAN JUAN.

The Rio San Juan in the vicinity of Fort San Carlos is not well adapted to measurement at all stages, the banks being low and swampy and subject to overflow at medium high stages. The first important tributary entering the river is the Sabalos, which empties at the steamboat station bearing the same name. This is about a quarter of a mile above Toro Rapids, which is the highest point at which it has ever been proposed to dam the river to hold the lake at a high level. A gage was placed about half a mile above the mouth of the Sabalos on December 31, 1897. It consists of a vertical pine board driven into the river bed and spiked to a tree growing on the bank. The elevation of the zero of the gage rod is $\mathbf{9 0 . 8 5}$ feet above sea level. Measurements were made a short distance above the gage by means of a boat anchored in the stream, distances being measured by stretching a tagged rope across the river. The discharge at this point is taken as being essentially the outflow from Lake Nicaragua.

20 GEOL, P'T $4-39$ 
List of discharge measurements made on Rio San Juan above mouth of the Sabalos.

\begin{tabular}{|c|c|c|c|c|c|c|c|}
\hline Date. & Hydrographer. & $\begin{array}{l}\text { Meter } \\
\text { number. }\end{array}$ & $\begin{array}{c}\text { Gage } \\
\text { beight. }\end{array}$ & $\begin{array}{l}\text { Area of } \\
\text { section. }\end{array}$ & $\begin{array}{c}\text { Mean } \\
\text { velocity. }\end{array}$ & $\begin{array}{l}\text { Dis. } \\
\text { charge. }\end{array}$ & Remarks. \\
\hline 1898. & & & Feet. & $S_{q .}$ feet. & $\begin{array}{l}\text { Feet per } \\
\text { second. }\end{array}$ & Sec.-feet. & \\
\hline Jan. 21 & R. C. Wheeler... & B. \& B. 1 & 9.75 & 8,819 & 2.16 & 19,000 & Above Toro Rapids. \\
\hline Fob. 2 & .....do ......... & B. \& B. 1 & 6.30 & 9,417 & 1.85 & 17,360 & Below Toro Rapids. \\
\hline Feb. 21 & .....do. & 1 & 9.27 & 8,576 & 1.92 & 16,530 & Above Toro Rapids. \\
\hline Feb. 25 & ....do do......... & 1 & 9.20 & 9,726 & 1.64 & 16,000 & $\begin{array}{c}\text { Above previous } \\
\text { measurements. }\end{array}$ \\
\hline Mar. 3 & ..... do. & 1 & 9.10 & 9,769 & 1.58 & 15,466 & Upper station. \\
\hline Mar. 8 & ..... do .... & 1 & 9.00 & 9,784 & 1.51 & 14,720 & Do. \\
\hline Mar. 16 & ....do do.... & 1 & 8.90 & 9,713 & 1.48 & 14,406 & Do. \\
\hline Mar. 24 & W. M. Barton ..... & 1 & 8.70 & 9,880 & 1.43 & 14,088 & Do. \\
\hline Mar. 31 & $\ldots \ldots$ do $\ldots \ldots \ldots \ldots$ & 1 & 8.60 & 9,823 & 1.35 & 13,271 & Do. \\
\hline Apr. 8 & ..... do .............. & 1 & 8.60 & 9,823 & 1.30 & 12,760 & Do. \\
\hline Apr. 11 & ..... do .............. & 1 & 8.50 & 9,768 & 1.30 & 12,706 & Do. \\
\hline Apr. 19 & ..... do .............. & 1 & 8.40 & 9,776 & 1.27 & 12,466 & Do. \\
\hline Apr. 25 & .....do ........... & 1 & 8.30 & 9,722 & 1.22 & $1 \mathrm{l}, 897$ & Do. \\
\hline Apr. 29 & .....do ..... & 1 & 8. 20 & 9,667 & 1. 22 & 11,766 & Do. \\
\hline May 10 & ..... do . . . . . . . & 1 & 8. 10 & 9,614 & 1.20 & 11,318 & Do. \\
\hline June 6 & . . . do ...... & 1 & 8.40 & 9,776 & 1.20 & 11,706 & Do. \\
\hline June 16 & .....do ......... & 1 & 8.40 & 9,247 & 1.23 & 11,403 & Do. \\
\hline June 20 & .....do ....... & 1 & 9. 30 & 9,733 & 1.40 & 13,660 & Do. \\
\hline June 26 & .....do & 1 & 9.50 & 9,829 & 1.53 & 15,025 & Do. \\
\hline July 13 & .....do ...... & 1 & 9.60 & 9,876 & 1.72 & 17,020 & Do. \\
\hline Sept. $\overline{5}$ & W. W. Schlecht... & St. 1 & 9.92 & 10,674 & 1.94 & 20,666 & \\
\hline Sept. 11 & .....do do............ & 1 & 11.29 & 11,273 & 1.95 & 21,995 & $\begin{array}{l}\text { Probably back wa- } \\
\text { ter by Sabalos. }\end{array}$ \\
\hline Sept. 14 & ..... do ..... & 1 & 10.49 & 10,684 & 2.12 & 22,673 & River falling. \\
\hline Sept. 21 & R. H. Morrin ...... & 1 & 10.48 & 10,720 & 2.09 & 22,431 & River rising. \\
\hline Oct. 19 & .....do do ............. & 1 & 10.79 & 11,190 & 2.19 & 24,520 & - \\
\hline Oct. 26 & $\ldots$ do .......... & 1 & 10.90 & 10,975 & 2.18 & 23,914 & \\
\hline Nov. 9 & .....do do ............ & 1 & 10.66 & 10,864 & 2.20 & 23,965 & \\
\hline Nov. 17 & .....do ............. & 1 & 12. 21 & 11,816 & 2.16 & 25,550 & \\
\hline Nov. 23 & . . . do ............. & 1 & 10.99 & 11,148 & 2.25 & 25,110 & \\
\hline Dec. 3 & ..... do ......... & 1 & 11.23 & 11,273 & 2.39 & 26,700 & \\
\hline Dec. 13 & ..... do ......... & 1 & 10.99 & 10,972 & 2.32 & 25,500 & \\
\hline Dec. 23 & $\ldots \ldots$ do $\ldots . . . . . . .$. & 1 & 10.78 & 10,862 & 2.28 & 24,775 & \\
\hline
\end{tabular}

Estimated monthly discharge of Rio San Juan above mouth of the Sabalos, or three-fourths mile above Toro Rapids.

\begin{tabular}{|c|c|c|c|c|}
\hline \multirow{2}{*}{ Month. } & \multicolumn{3}{|c|}{ Discharge in second-feet. } & \multirow{2}{*}{$\begin{array}{l}\text { Total for month } \\
\text { in acre-feet. }\end{array}$} \\
\hline & $\begin{array}{l}\text { Maxi- } \\
\text { mum. }\end{array}$ & $\begin{array}{l}\text { Mini- } \\
\text { mum. }\end{array}$ & Mean. & \\
\hline 1898. & & & & \\
\hline January $\ldots \ldots \ldots \ldots \ldots$ & 19,900 & 17,890 & $\mathbf{1 8 , 5 9 0}$ & $1,143,055$ \\
\hline 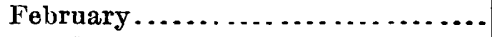 & 17,780 & 15,430 & 16,633 & 923,750 \\
\hline 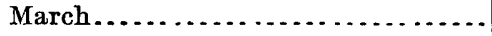 & 15,400 & 12,570 & 14,045 & 863,595 \\
\hline April.............. & 13,070 & 11,580 & 12,169 & 724,105 \\
\hline May ........... & 12,680 & 11,206 & 11,763 & 723,275 \\
\hline June ........ & 18,420 & 11,760 & 14,144 & 841,625 \\
\hline July $\ldots \ldots \ldots \ldots \ldots \ldots \ldots \ldots \ldots$ & 23,510 & 17,360 & 19,369 & $1,190,935$ \\
\hline August....... & 22,290 & 19,110 & 19,552 & $1,202,200$ \\
\hline September ... & 26,210 & $19, \overline{5} 33$ & 22,075 & $1,313,550$ \\
\hline October ...... & 26,630 & 22,130 & 23,430 & $1,440,650$ \\
\hline November ... & 28,490 & 23,450 & 25,410 & $1,5 \mathrm{I} 2,000$ \\
\hline December $\ldots \ldots \ldots \ldots \ldots \ldots \ldots$ & 27,320 & 24,000 & 25,050 & $1,540,260$ \\
\hline
\end{tabular}


SABALOS RIVER.

Occasional measurements of the Sabalos River were made by the observer employed upon the San 'Juan at Sabalos. A gage was placed in this river about 3 miles above its mouth, but at certain times the stream became so sluggish at this point as to be difficult to measure. On April 23 the rod was moved 1 mile farther up the stream. The following measurements were made:

List of discharge measurements made on Sabalos River, $1 \frac{1}{2}$ miles above its mouth.

\begin{tabular}{|c|c|c|c|c|c|c|c|}
\hline Date. & Hydrographer. & $\begin{array}{c}\text { Meter } \\
\text { num- } \\
\text { ber. }\end{array}$ & $\begin{array}{l}\text { Gage } \\
\text { height. }\end{array}$ & $\begin{array}{l}\text { Area of } \\
\text { section. }\end{array}$ & $\begin{array}{l}\text { Mean } \\
\text { veloc- } \\
\text { ity. }\end{array}$ & $\begin{array}{c}\text { Dis. } \\
\text { charge. }\end{array}$ & Remarks. \\
\hline $\begin{array}{l}1898 . \\
\text { Jan. } 24\end{array}$ & R. C. Wheeler. & 2 & $\begin{array}{l}\text { Feet. } \\
6.00\end{array}$ & $\begin{array}{r}\text { Sq. feet. } \\
1004\end{array}$ & $\begin{array}{r}\text { Ft.per } \\
\text { second. } \\
0.29\end{array}$ & $\begin{array}{r}\text { Sec.ft. } \\
291\end{array}$ & \\
\hline Feb. 22 & ......do .... & 2 & 5.60 & 960 & 0.16 & 152 & $\begin{array}{l}\text { Velocity too low for accu- } \\
\text { racy. }\end{array}$ \\
\hline Feb. 22 & ...... do. & 2 & 5.60 & 142 & 0.96 & 136 & Taken 1 mile above gage. \\
\hline Mar. 4 & .....do ......... & 2 & 5.41 & 133 & 0.99 & 131 & \\
\hline Mar. 17 & ..... do .......... & 2 & 5. 20 & 105 & 0.82 & 86 & • \\
\hline Mar. 25 & W. M. Barton..... & 2 & 5.12 & 108 & 1.34 & 145 & \\
\hline Apr. 1 & ....do ..... & 2 & 4.98 & 81 & 0.91 & 74 & \\
\hline Apr. 9 & ..... do .......... & 2 & 4.85 & 88 & 1.42 & 125 & • \\
\hline Apr. 36 & ..... do ....... & 2 & 4.80 & 77 & 1.09 & 84 & \\
\hline Apr. 23 & .....do ......... & 2 & 3.20 & 71 & 1.00 & 71 & New rod $3.20=4.70$ old \\
\hline Apr. 30 & ..... do ..... & 2 & 3.10 & 66 & 1.11 & 73 & \\
\hline May 6 & ...... do ......... & 2 & 3.07 & 62 & 1.05 & 65 & \\
\hline May 22 & ......do....... & 2 & 5.15 & 444 & 1.83 & 812 & Not the regular section. \\
\hline May 27 & $\ldots$... do $\ldots . . . .$. & 2 & 3. 50 & 82 & 1.38 & 113 & \\
\hline June 4 & ......do .... & 2 & 3.31 & 67 & 1.24 & 83 & \\
\hline June 11 & .....do . ....... & 2 & 3. 70 & 99 & 2.56 & 254 & \\
\hline June 18 & $\ldots . . . \mathrm{d} \sigma^{*} \ldots . . . .$. & 2 & 3.47 & 69 & 1.40 & 97 & ' \\
\hline June 27 & ..... do ............ & 2 & 6.19 & 595 & 2.09 & 1,246 & \\
\hline July 2 & .....do ........... & 2 & 6.10 & 613 & 1.89 & 1,158 & \\
\hline July 14 & ......do ............... & 2 & 5. 15 & 443 & 1.50 & 669 & \\
\hline Sept. 7 & W. W. Schlecht... & 1 & 5.13 & 426 & 0.79 & 338 & \\
\hline Sept. 15 & .....do .......... & 1 & 6.03 & 596 & 1.56 & 928 & River falling. \\
\hline Sept. 23 & R. H. Morrin... & 1 & 5.71 & 568 & 1.26 & 717 & River rising. \\
\hline Oct. 11 & $\ldots$.... do $\ldots . . . .$. & 1 & 5.18 & 476 & 0.44 & 213 & . \\
\hline Oct. 27 & .... do ........... & 1 & 5.93 & 581 & 1.15 & 669 & \\
\hline Nov. 11 & ......do do .......... & 1 & 5.81 & 528 & 1.09 & 579 & \\
\hline Nov. 15 & .....do do & 1 & 6.49 & 622 & 1.62 & 1,007 & \\
\hline Nov. 22 & ..... do ................ & 1 & 5.92 & 586 & 0.95 & .509 & \\
\hline Nov, 29 & 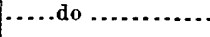 & 1 & 7.70 & 731 & 2.49 & 1,818 & \\
\hline
\end{tabular}


Estimated monthly discharge of Rio San Juan above the mouth of the San Carlos.

[Obtained by subtracting the discharge of the Rio San Carlos from that of the San Juan at Ocboa.]

\begin{tabular}{|c|c|c|c|c|}
\hline \multirow{2}{*}{ Month. } & \multicolumn{3}{|c|}{ Discharge in second-feet. } & \multirow{2}{*}{$\begin{array}{c}\text { Total for month } \\
\text { in } \\
\text { acre. feet. }\end{array}$} \\
\hline & $\begin{array}{l}\text { Maxi- } \\
\text { mum. }\end{array}$ & $\begin{array}{l}\text { Mini- } \\
\text { mum. }\end{array}$ & Mean. & \\
\hline 1898. & & & & \\
\hline Jannary $10-31 \ldots .$. & 23,270 & 19,500 & 21,030 & 917,650 \\
\hline Febrnary $\ldots \ldots \ldots \ldots \ldots \ldots \ldots$ & 34,900 & 18,500 & 22,080 & $1,226,260$ \\
\hline March $\ldots \ldots \ldots \ldots \ldots \ldots \ldots \ldots \ldots$ & 22,000 & 14,600 & 16,850 & $1,036,070$ \\
\hline April $\ldots \ldots \ldots \ldots \ldots \ldots$ & 25,800 & 12,900 & 15,120 & 899,700 \\
\hline May $\ldots \ldots \ldots \ldots \ldots \ldots \ldots \ldots \ldots$ & 19,200 & 11,700 & 14,130 & 868,820 \\
\hline June $\ldots \ldots \ldots \ldots \ldots \ldots \ldots \ldots$ & 39,200 & 13,000 & 22,410 & $1,333,500$ \\
\hline July $\ldots \ldots \ldots \ldots \ldots \ldots \ldots \ldots \ldots \ldots \ldots$ & 43,100 & 26,200 & 32,720 & $2,011,870$ \\
\hline August........................ & 38,400 & 23,000 & 26,170 & $1,609,130$ \\
\hline September $\ldots \ldots \ldots \ldots \ldots \ldots \ldots$ & 41,300 & 22,800 & 29,210 & $1,738,120$ \\
\hline October $\ldots \ldots \ldots \ldots \ldots \ldots \ldots \ldots \ldots$ & 37,600 & 24,700 & 29,320 & $1,802,820$ \\
\hline November $\ldots \ldots \ldots \ldots \ldots \ldots$ & 70,500 & 26,800 & 36,460 & $2,169,520$ \\
\hline December...$\ldots \ldots \ldots \ldots \ldots \ldots$ & 41,800 & 26,300 & 31,570 & $1,941,160$ \\
\hline
\end{tabular}

Elevation of Lake Nicaragua if all water had been held by a dam at Sabalos, 1898.

\begin{tabular}{|c|c|c|c|c|c|c|c|c|c|c|c|c|}
\hline $\mathrm{Da}$ & Jan. & Feb. & Mar. & Apr. & May. & June. & July. & Aug. & Sept. & Oet. & Nov. & Dec. \\
\hline & 105. 32 & \begin{tabular}{|l|}
105.49 \\
\end{tabular} & 105.34 & 104.95 & 104.61 & 105.17 & 106.64 & 108.32 & 109.35 & 110.75 & 112.26 & 113. 31 \\
\hline & 105. 34 & 105.44 & 105. 39 & 104.97 & .104 .57 & 105.19 & 106.63 & 108.29 & 109.38 & 110.85 & 112. 24 & 113. 33 \\
\hline & $\mid 105.36$ & 105.56 & 105.33 & 104.95 & 104.57 & 105.15 & 106.73 & 108.31 & 109.38 & $\mid 110.90$ & 112.21 & 113.32 \\
\hline 4. & 105.38 & 105.53 & 105.39 & 104.94 & 104.56 & 105.11 & 106.90 & 108.40 & 109. 39 & 110.90 & 112.18 & 113.41 \\
\hline & 105.44 & 105.58 & 105.32 & 104.91 & 104.57 & 105.16 & 106.84 & 108.45 & 109.44 & 110.93 & 112.16 & 113.45 \\
\hline 6. & $\mid 105.52$ & 105.52 & 105. 31 & 104.97 & 104.58 & 105.20 & 107.02 & 108.43 & 109.54 & 110.94 & 112.23 & 113.43 \\
\hline & $|105.45|$ & 105.54 & 105.33 & 104.94 & 104.53 & 105.28 & 107.05 & 108.48 & 109.53 & 110.98 & 112.21 & 113.48 \\
\hline & 105.48 & 105.56 & 105.32 & 104.89 & 104.52 & 105.26 & 107.10 & 108.60 & 109.58 & 111.04 & 112.20 & 113.42 \\
\hline 9. & 105.54 & 105.57 & 105.32 & 104.87 & 104.52 & 105.27 & 107.20 & 108.59 & 109.60 & 111.01 & 112.26 & 113.44 \\
\hline 10. & 105.38 & 105.48 & 105.24 & 104.82 & 104.51 & 105.29 & 107.21 & 108.59 & 109.68 & 111. 04 & 112.28 & 113.50 \\
\hline 11. & $\mid 105.45$ & 105.48 & 105.27 & 10488 & 104.52 & 105.30 & 107.30 & 108.61 & 109.79 & 111.64 & 112. 35 & 113.52 \\
\hline 12 & 105.49 & 105.51 & 105.28 & 104.89 & 104.49 & 105.37 & 107.35 & 108.58 & 109.92 & 111.11 & 112.45 & 113.52 \\
\hline 13 & 105.44 & 105.62 & 105.28 & 104.86 & 104.42 & 105.35 & $\mid 107.36$ & 108.75 & 110.10 & 111.13 & 112.60 & 113.49 \\
\hline 14 & 105.42 & 105.55 & 105.21 & 104.85 & 104.50 & 105.32 & 107.38 & 108.76 & 110.13 & 111.24 & 112.59 & 113.52 \\
\hline 15 & 105.43 & 105.54 & \begin{tabular}{|l|}
105.27 \\
\end{tabular} & 104.81 & 164.45 & 105.35 & 107.45 & 108.85 & 110.18 & 111.30 & 112.67 & $113: 52$ \\
\hline 16. & 105.49 & 105.49 & 105.20 & 104.82 & 104.54 & 105.32 & 107.51 & 108.87 & 110.26 & 111.30 & 112.73 & 113.58 \\
\hline 17. & $\mid 105.51$ & 105.49 & 105.15 & 104.83 & 104.51 & 105.36 & 107.50 & 108.92 & 110.34 & 111.39 & 112.76 & 113. 55 \\
\hline 18. & \begin{tabular}{|l|}
105.57 \\
\end{tabular} & 105.51 & 105.09 & 104.81 & 104.64 & 105.37 & 107.55 & 108.89 & 110.35 & 111.58 & 112.86 & 113.58 \\
\hline 19. & $105.60 \mid$ & 105.48 & 105.02 & 104.78 & 104.62 & 105.51 & 107.60 & 108.91 & 110.37 & 111.66 & 112.82 & 113.55 \\
\hline 20 . & $|105.75|$ & 105.48 & 105.07 & 104.73 & 104.65 & 105.58 & 107.77 & 108.93 & 110.40 & 111.70 & 112.78 & 113.60 \\
\hline 21. & 105.70 & 105.43 & 105.12 & 104.79 & 104.70 & 105.65 & 107.71 & 108.99 & 110.49 & 111. 71 & 112.98 & 113.58 \\
\hline 22 . & $|105.63|$ & 105.41 & 104.94 & 104.77 & 105.00 & 105.88 & 107.81 & 109.02 & 110.58 & 111.84 & 112.96 & 113.55 \\
\hline 23. & 105.56 & 105.38 & 105.08 & 104.75 & 104.98 & 105.96 & 107.81 & 108.98 & 110.55 & 111.90 & 112.98 & 113.63 \\
\hline 24. & \begin{tabular}{|c|}
105.49 \\
\end{tabular} & 105.48 & 105.12 & 104.68 & 105.10 & 106.02 & 107.92 & 109.03 & 110.66 & 112.01 & 113.00 & 113.67 \\
\hline 25. & 105.58 & 105.45 & 105.14 & 104.67 & 105.18 & 106.12 & 107.95 & 109.06 & 110.66 & 112.03 & 113.02 & 113.65 \\
\hline 26 & 105.59 & 105.49 & 104.84 & 104.70 & 105.17 & 106.09 & 107.99 & 109.05 & 110,64 & 112.06 & 113.04 & 113.66 \\
\hline & 105.60 & 105.39 & 105.06 & 104.69 & 105.23 & 106. 23 & 108.05 & 109.12 & 110.62 & 112.10 & 113.12 & 113.64 \\
\hline 28 & 105.60 & 105.39 & 105.00 & 104.65 & 105.21 & 106.39 & 108.14 & 109.13 & 110.17 & 112.09 & 113.18 & 113.64 \\
\hline 29 . & 105.47 & & 104.98 & 104.62 & $10 \overline{5} .12$ & 106.53 & 108.08 & 109.27 & 110.80 & 112.21 & 113.22 & 133.78 \\
\hline 30 & 105.60 & & 105.01 & 104.62 & 105.22 & 106.59 & 108.26 & 109.30 & 110.81 & 112.20 & 113.31 & 113.79 \\
\hline 31 & 105.55 & & 104 & & 105.18 & & 108.25 & 109.33 & $\cdots$ & 112.20 & & 313.89 \\
\hline
\end{tabular}


Estimated monthly discharge of tributaries to the Rio San Juan between Sabalos and the Rio San Carlos, being the difference between the discharge of Rio San Juan above Boca San Carlos and at Sabalos.

[Drainage area, 750 square miles, approximately.]

\begin{tabular}{|c|c|c|c|c|c|c|}
\hline \multirow[b]{2}{*}{ Month. } & \multicolumn{3}{|c|}{ Discharge in second-feet. } & \multirow[b]{2}{*}{$\begin{array}{c}\text { Total in acre. } \\
\text { feet. }\end{array}$} & \multicolumn{2}{|c|}{ Run-off. } \\
\hline & $\begin{array}{l}\text { Maxi- } \\
\text { mum. }\end{array}$ & $\begin{array}{l}\text { Mini- } \\
\text { mum. }\end{array}$ & Mean. & & $\begin{array}{l}\text { Depth in } \\
\text { inches. }\end{array}$ & $\begin{array}{c}\text { Second. } \\
\text { feet per } \\
\text { square } \\
\text { mile. }\end{array}$ \\
\hline 1898. & & & & & & \\
\hline January 10-31 ...... & 5,100 & 900 & 2,630 & 114,770 & 2.28 & 3.51 \\
\hline February....... & 17,600 & 2,700 & 5,450 & 302,680 & 7.57 & 7.27 \\
\hline 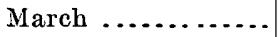 & 6,600 & 1,300 & 2,820 & 173,400 & 4.34 & 3. 76 \\
\hline April....... & 12,700 & 1,100 & 2,960 & 176,130 & 4.40 & 3. 95 \\
\hline May ..... & 7,000 & 500 & 2,380 & 146,340 & 3.31 & 2.87 \\
\hline June....... & 21,000 & 1,000 & 8,270 & 492,100 & 12.31 & 11.03 \\
\hline July ......... & $21,600^{\circ}$ & 7,800 & 13,350 & 820,860 & 20.52 & 17.80 \\
\hline Angust...... & 16,100 & 3,400 & 6,580 & 404,590 & 10.11 & 8.77 \\
\hline September ......... & 15,900 & 2,600 & 7,140 & 424,860 & 10.62 & 9.52 \\
\hline October.... & 11,900 & 2,000 & 6,050 & 373,000 & 9.30 & 8.07 \\
\hline November .......... & 45,000 & 2,800 & 11,080 & 659,360 & 16.47 & 14. 76 \\
\hline December ...... & $\ldots \ldots$ & $\ldots$ & $\ldots$ & $\ldots \ldots \ldots$ & $\ldots \ldots$ & 91.31. \\
\hline
\end{tabular}

RIO SAN CARLOS.

The Rio San Carlos is a wide, swift stream, heading in the high mountains of Costa Rica. From these mountains it obtains large amounts of voleanic sand, portions of which become ground fine enough to be held in suspension, and great quantities are carried both in this way and rolled on the bottom of the stream, especially in times of great floods, to which this river is subject. Its drainage area, as meas. ured from the best maps obtainable, is 1,450 square miles; but this must be regarded as merely a rough approximation, as the country has never been even thoroughly explored, much less accurately mapped. Above the mouth of the San Carlos the San Juan is a stream of comparatively uniform discharge, the greater portion of its water coming from Lake Nicaragua, which acts as a very effective regulator of the floods in the basin. From the mouth of the San Carlos to the foot of Machuca Rapids the San Juan is very deep, and the current is consequently sluggish. This portion is called the Aguas Muertas, or dead waters. It frequently happens that the San Carlos is in flood, and the large volume of water affects the water level of the Aguas Muertas, in proof of which a rise in the San Juan below Machuca Rapids has been observed amounting to nearly 4 feet at a time when the San Carlos was in flood, while no rise whatever occurred above the rapids. The large quantity of material carried by the San Carlos has built a delta at its mouth, so that it flows to the San Juan through two channels around a deltaic island, aud from its mouth to the sea the bottom 
of the San Juan is covered with moving sands brought in by the San Carlos.

A station was established on the San Carlos about 3 miles above its mouth on January 10, 1898. The gage consists of a pine board painted white and graduated to feet and tenths from zero to 15 feet, the reading being continued on another board fastened to another tree a short distance downstream and higher up on the bank. A fiveeighths-inch steel cable was placed across the river at this point, upon which traveled a gaging car from which measurements were made.

In times of high water the stream is so swift that it is difficult to make the meter sink to the desired point in the stream, the tendency of the meter, in spite of heavy lead weights, being to drift downstream and rise to the surface, under the joint influence of the current and the suspending wire. To overcome this difficulty another and smaller cable was thrown across the river, about 200 feet above the main cable, which carried a small pulley block. To this pulley a cord was fastened, and the other end was attached to the meter cord just above the meter. This prevented the instrument from drifting downstream, and a heavy lead sinker would carry it to any desired depth, where it could be held without difficulty. A sediment trap was also employed at this station, suspended from the cable when in operation.

A bench mark was made by driving a spike into a large root of the tree used as a cable support, which stood out from the tree like an abutment. The bench mark is 30.74 feet above zero of the gage. The high water occurring from the second to the eighth of January scoured out the channel of the river somewhat, so that a separate rating table has been made for January and another for the months of February, March, April, and May; still another, somewhat different, is used from the first of June for the balance of the season.

List of discharge measurements made on Rio San Carlos 3 miles above its mouth.

\begin{tabular}{|c|c|c|c|c|c|c|}
\hline Date. & Hydrographer. & $\begin{array}{c}\text { Meter } \\
\text { num- } \\
\text { ber. }\end{array}$ & $\begin{array}{c}\text { Gage } \\
\text { height. }\end{array}$ & $\begin{array}{c}\text { Area of } \\
\text { section. }\end{array}$ & $\begin{array}{l}\text { Mean } \\
\text { velocity. }\end{array}$ & Discharge. \\
\hline 1898. & & & Feet. & sq.feet. & $\begin{array}{l}\text { Feet per } \\
\text { second. }\end{array}$ & Sec.feet. \\
\hline Jan. 27 & R. Breese.......... & 65 & 12.63 & 2,897 & 3.26 & 9,445 \\
\hline Jan. 29 & $\ldots \ldots$ do $\ldots \ldots \ldots$. & 65 & 13.17 & 3,529 & 3.57 & 12,602 \\
\hline Jan. 31 & ..... do ............ & 65 & 12.75 & 3,076 & 3.37 & 10,352 \\
\hline Feb. 2 & $\ldots \ldots$ do $\ldots \ldots \ldots$ & 65 & 16.37 & 5,509 & 4.00 & $a 22,208$ \\
\hline Feb. 4 & $\ldots \ldots$ do $\ldots \ldots \ldots$ & 65 & 17.87 & 6,503 & 4.27 & $b 27,782$ \\
\hline Feb. 5 & .... do ......... & 65 & 19.00 & (c) & (c) & (c) \\
\hline Feb. 10 & $\ldots \ldots$ do ...... & 65 & 14.59 & 4,380 & 4.59 & 14,890 \\
\hline Feb. 11 & $\ldots \ldots$ do $\ldots . . . .$. & 65 & 14.19 & 3,642 & 3. 34 & 12,201 \\
\hline Mar. 12 & $\ldots \ldots$ do $\ldots \ldots \ldots \ldots$ & 65 & 12.22 & 2,372 & 2.88 & 6,834 \\
\hline Apr. 6 & . $\ldots$ do & 65 & 13.10 & 3,092 & 3.01 & 9,331 \\
\hline
\end{tabular}


List of discharge measurements made on Rio San Carlos 3 miles above its mouth-Cont'd.

\begin{tabular}{|c|c|c|c|c|c|c|}
\hline Date. & Hydrographer. & $\begin{array}{c}\text { Meter } \\
\text { num. } \\
\text { ber. }\end{array}$ & $\begin{array}{c}\text { Gage } \\
\text { height. }\end{array}$ & $\begin{array}{l}\text { Area of } \\
\text { section. }\end{array}$ & $\begin{array}{c}\text { Mean } \\
\text { velocity. }\end{array}$ & Discharge. \\
\hline 1898. & & & Feet. & Sq. feet. & $\begin{array}{l}\text { Feet per } \\
\text { second. }\end{array}$ & Sec.-feet. \\
\hline Apr. 21 & R. Breese... & 65 & 11.40 & 1,800 & 2.85 & 5,130 \\
\hline May 13 & R. C. Wh & 65 & 11.03 & 1,615 & 2.56 & 4,139 \\
\hline May 14 & ..... do & 65 & 11.18 & 1,736 & 2.61 & 4,526 \\
\hline May 17 & ...do & 65 & 11.58 & 1,990 & 2.61 & 5,187 \\
\hline May 20 & .... do & 65 & 13.69 & 3,557 & 3.12 & 11,096 \\
\hline June 20 & H. S. Reed. & 65 & .14 .39 & 3,846 & 3.42 & 13,156 \\
\hline June 22 & .....do & 65 & 13.72 & 3,360 & 3.18 & 10,672 \\
\hline June 24 & ..... do & 65 & 16.73 & 5,503 & 3.71 & 20,414 \\
\hline June 27 & ..... do & 65 & 18.55 & 7,227 & 4.08 & 29,480 \\
\hline June 29 & ..... do & 65 & 17.26 & 6,001 & 3.67 & 22,009 \\
\hline June 30 & ..... do & 65 & 15.57 & 4,787 & 3.50 & 16,762 \\
\hline July 4 & .....do & 65 & 14.85 & 4,303 & 2.97 & 12,800 \\
\hline July $\cdot 6$ & .....do & 65 & 15.05 & 4,469 & 3.24 & 14,464 \\
\hline July 10 & ...do & 65 & 20.33 & 8,929 & 4.31 & 38,506 \\
\hline July 13 & ..... do & 65 & 15.43 & 4,761 & 3.31 & 15,763 \\
\hline July 22 & .....do & 65 & 13.88 & 3,520 & 3.04 & 10,700 \\
\hline July 26 & $\ldots . . . d o$ & 65 & 13.20 & 3,036 & 2.88 & 746 \\
\hline July 30 & ..... do & 65 & 13.53 & 3,310 & 2.94 & 9,844 \\
\hline Aug. $\quad 2$ & .....do & 65 & 12.94 & 2,820 & 2.94 & 8,296 \\
\hline Aug. 3 & .....do & 65 & 15. 70 & 4,873 & 3.50 & 17,074 \\
\hline Aug. 5 & .... do & 65 & 15. 20 & 4,499 & 3. 30 & 14,824 \\
\hline Aug. 5 & .....do do & 65 & 15.27 & 41,544 & 3.33 & 15,112 \\
\hline Aug. 14 & $\ldots . d_{0}$ & 65 & 15.93 & 5,114 & 3.27 & 16,730 \\
\hline Aug. 22 & ..... do & 65 & 14.56 & 3,952 & 3.17 & 12,434 \\
\hline Aug. 28 & ..... do & 65 & 13.89 & 3,579 & 3.01 & 10,781 \\
\hline Sept. 8 & .... do & 65 & 12.60 & 2,781 & 2.83 & 7,851 \\
\hline Sept. 10 & ..... do . & 65 & 12.48 & 2,830 & 2.75 & 7,791 \\
\hline Sept. 14 & ..... do ... & 65 & 14.47 & 4,039 & 3.08 & 12,436 \\
\hline Sept. 22 & ..... do & 65 & 14.32 & 3,940 & 3.21 & 12,652 \\
\hline Oct. 4 & ..... do . & 65 & 12.17 & 2,600 & 3.11 & 8,185 \\
\hline Oct. 18 & .... do ... & 65 & 16.69 & 5,472 & 3.79 & 20,714 \\
\hline Oct. 20 & .... do . . & 65 & 16.07 & 5,190 & 3.52 & 18,275 \\
\hline Nov. 14 & ..... do .. & 65 & 18.10 & 5,880 & 3.78 & 23,030 \\
\hline Nov. 17 & .....do . . & $6 \check{5}$ & 20.11 & 8,579 & 3. 76 & 32,265 \\
\hline Nov. 19 & .... do ... & 65 & 16.42 & 5,766 & 3. 32 & 19,120 \\
\hline Nov. 28 & ..... do .. & 65 . & 13.90 & 3,576 & 2.96 & 10,570 \\
\hline Dec. 15 & $\ldots$. do .... & 65 & 13.55 & 3,428 & 3.03 & 10,385 \\
\hline Dec. 19 & $\ldots$ do .......... & 65 & 12.90 & 2,875 & 2.92 & 8,504 \\
\hline Dec. 21 & ..... do .... & 65 & 12.60 & 2,592 & 2.91 & 7,543 \\
\hline Dec. 27 & ..... do .. & 65 & 12.20 & 2,260 & 2.85 & 6,431 \\
\hline Dec. 31 & ..... do. & 65 & 11,94 & 2,195 & 2.51 & 5,505 \\
\hline
\end{tabular}


Estimated monthly discharge of Rio San Carlos 3 miles above its mouth.

[Drajnage alea, approximately, 1,450 square miles. ]

\begin{tabular}{|c|c|c|c|c|c|c|}
\hline \multirow[b]{2}{*}{ Month. } & \multicolumn{3}{|c|}{ Discharge in second-feet. } & \multirow[b]{2}{*}{$\begin{array}{l}\text { Total in acre- } \\
\text { feet. }\end{array}$} & \multicolumn{2}{|c|}{ Run-off. } \\
\hline & $\begin{array}{l}\text { Maxi- } \\
\text { mum. }\end{array}$ & $\begin{array}{l}\text { Mini- } \\
\text { mum. }\end{array}$ & Mean. & & $\underset{\text { in inches. }}{\text { Depth }}$ & $\begin{array}{c}\text { Second } \\
\text { feet per } \\
\text { square } \\
\text { mile. }\end{array}$ \\
\hline 1898. & & & & & & \\
\hline January 10-31. & 28,000 & 10,560 & 16,055 & 700,582 & 9.09 & 11.1 \\
\hline February ..... & 34,300 & 7,400 & 13,530 & 751,380 & 9.68 & 9.3 \\
\hline March ... & 11,340 & 5,140 & 7,030 & 432,260 & 5.53 & 4.8 \\
\hline April ..... & 10,080 & 4,220 & 6,038 & 359,285 & 4.69 & 4.2 \\
\hline May ........ & 11,880 & 4,100 & 5,560 & 341,870 & 4.38 & 3.8 \\
\hline June....... & 32,250 & 5,200 & 10,720 & 637,880 & 8.26 & 7.4 \\
\hline July ............ & 41,600 & 8,400 & 14,094 & 866,600 & 11.18 & 9.7 \\
\hline August............ & 17,100 & 8,800 & 10,990 & 675,750 & 8.76 & 7.6 \\
\hline September ........ & 14.200 & 7,420 & 10,320 & 614,023 & 7.92 & 7.1 \\
\hline October ........... & 32,500 & 8,180 & 12,880 & 791,960 & 10.26 & 8.9 \\
\hline November ........ & 32,260 & 9,680 & 15,440 & 918,750 & 11.88 & 10.6 \\
\hline December .......... & 19,920 & 5,850 & 9,290 & 571,220 & 7.38 & 6.4 \\
\hline
\end{tabular}

OCHOA STATION ON RIO SAN JUAN.

One of the most important as well as most disputed points regarding hydrographic knowledge in Nicaragua is the discharge of the Rio San Juau at Ochoa, where it is proposed to build a high dam. A station was established here on December 30,1897 . A vertical pine gage was fastened to an overhanging pine tree ou the right bank and was graduated to feet and tenths to 15 feet, and continued upward on another plank fastened on the same tree.

A standard copper bench mark of the United States Geological Sur. vey was established on the right bank near the tree which bears the gage. It is a copper plate placed horizontally on top of a stump, with its stem driven into an auger hole in the stump. It is 28.10 feet above the zero of the gage. The channel at this point is straight and the bottom is reasonably permanent.

For purposes of current-meter measurements it was not permissible to extend a cable above the river at this point, on account of navigation. It was first intendèd to make measurements by means of a boat anchored to a small cable stretched across the river, which should carry tags indi. cating distances from the initial point, which, when not in use, was to be held against the bottom of the river by means of sinkers. Experience on this line, however, soon demonstrated that it would be difficult, if not impracticable, to maintain a small cable in the position proposed on account of the large quantities of driftwood, leaves, and brush passing down the river-especially in times of flood, when the gaging appara- 
tus would be most in demand. Another project was therefore inaugurated, which was the anchorage of a number of buoys at short distances from the initial point, said buoys to be constructed of "balsa," a very light, bulky, endogenous wood much used in the construction of rafts, etc. This method of marking distances from the initial point was successfully employed for several months during the season of low water, but as the rains increased and freshets began to come down the river the great quantity of leaves and brush carried by the water attached themselves to the buoys and their anchorages until they were either carried beneath the surface of the river or washed away entirely. The final method permanently adopted required the employment of an addi-

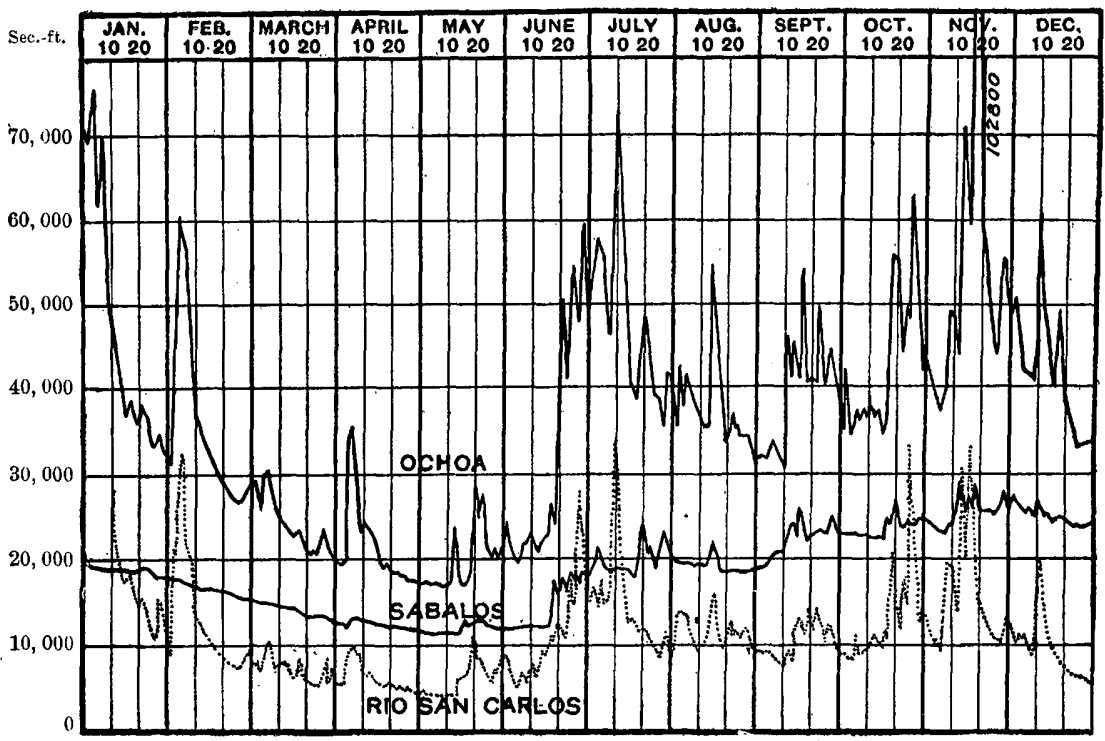

Fig. 221.-Diagram of daily discharge of Rio San J uan at Sabalos and at Ochoa, aud of Rio San Carlos 3 miles above its mouth.

tional instrument man to manipulate a telescope on shore and measure the distance of the boat by means of a stadia rod during the process of gaging.

The highest measurement of discharge yet made at this point was on November 17 , at a gage height of 17.43 feet, when the river was dis. charging 104,930 cubic feet per second. At this stage the river was about 8.5 feet below the flood plain at Ochoa, the formation of which indicates that it is sometimes overflowed.

Dr. C. W. Hayes, geologist of the Nicaragua Canal Commission, expresses the opinion that this flood plain is at intervals of ten to thirty years covered by the floods of the Rio San Juan to a depth of more than 6 inches, but less than 3 feet. In other words, maximum gauge readings of 26.5 to 29 may be expected with moderate frequency at Ochoa station.

Plotting all observations of discharge so far taken as abscissas, with 
corresponding gage heights as ordinates, we obtain a curve indicating the relation of gage height to discharge, showing that the ratio of increase of discharge to increase of gage height is not constant. The curve is concave downward, tending toward a horizontal position, showing that the increase of discharge for increase of gage height is greater at high stages than at low stages; but above a medium stage of the river the line curves but slightly and tbough the concavity is still downward, the curve approaches a straight line; or, in other words, the ratio between gage height and discharge approaches constancy. If we assume as constant the direction given to the line by the higher meas. urements, and continue it upward as a straight line, we obtain as the discharge corresponding to a gage height of 28 feet about 200,000 cubic feet per second. If any curvature be given the extrapolated portion of the curve it will increase this amount.

If the same course of reasoning be applied to the flood plain on the Rio San Carlos, we find that its maximum discharge must be about 100,000 cubic feet per second. Similarly it may be shown by extrapolating the curve discharge of the Rio San Juan at Fort San Carlos that at the stage of 110 feet above sea level the lake must have discharged nearly 40,000 cubic feet per second.

When the measurement of November 17 was made, giving a discharge at Ochoa of 104,298 second-feet, the Rio San Carlos was dis. charging only 32,265 , leaving 72,663 as the amount coming down the San Juan proper, of which probably not more than 28,663 were flowing from the lake, leaving 44,000 to be supplied by the small tributaries between the lake and Boca San Carlos. With such an indicated discharge it would not be excessive to assume a maximum for these tributaries of 60,060 cubic feet per second, and we have the maximum flood at Ochoa made up as follows:

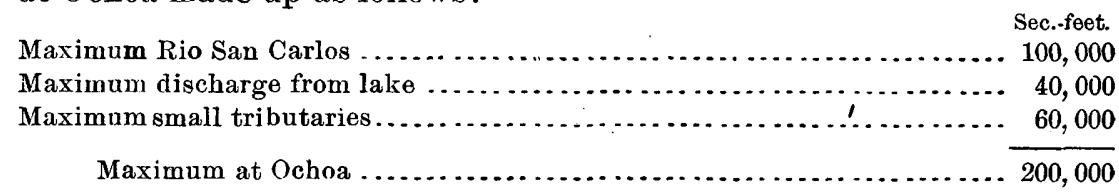

The highest observed discharge of the Sarapiqui River is 30,000 cubic feet per second. It is probable that the extreme maximum is not much less than 70,000 cubic feet per second. The Machado, San Francisco, Tamborcito, and San Juanillo, and a large number of lesser creeks contribute a large aggregate in time of flood, so that it is probable that at rare intervals the increment to the waters of the San Juan below Ochoa may amount to 100,000 cubic feet per second. Such an occurrence coincident with extreme flood conditions above Ochoa, would make a total of 300,000 cubic feet per second discharging into the Caribbean through the various mouths of the San Juan. 
List of discharge measurements made on Rio San Juan at Ochoa.

\begin{tabular}{|c|c|c|c|c|c|c|}
\hline Date. & Hydrographer. & $\begin{array}{l}\text { Meter } \\
\text { num. } \\
\text { ber. }\end{array}$ & $\begin{array}{c}\text { Gage } \\
\text { height. }\end{array}$ & $\begin{array}{l}\text { Area of } \\
\text { section. }\end{array}$ & $\begin{array}{c}\text { Mean } \\
\text { velocity. }\end{array}$ & Discrarge. \\
\hline 1898. & 、 & & Feet. & Sq. feet. & $\begin{array}{l}\text { Feet per } \\
\text { second. }\end{array}$ & Sec.-feet. \\
\hline Jan. 8 & G. R. Wadleigh .. & 1985 & 11. 94 & 13,100 & 4.06 & 52,400 \\
\hline Jan. 12 & $\ldots$ do .............. & 1985 & 9.87 & 11,940 & 3. 67 & 43,830 \\
\hline Jan. 27 & $\ldots$ do $\ldots . . . .$. & 1985 & 8.30 & 9,906 & 3.33 & 33,050 \\
\hline Feb. 8 & 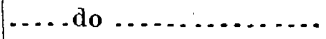 & 1985 & 9.78 & 10,916 & 3.75 & 40,913 \\
\hline Fèb. 16 & $\ldots$ do $\ldots \ldots \ldots \ldots$ & 1985 & 7.65 & 8,966 & 3.29 & 29,458 \\
\hline Feb. 28 & $\ldots . . . . . . . . .$. & 1985 & 7.40 & 8,602 & 3.21 & 27,600 \\
\hline Mar. 10 & .... do .......... & 1985 & 6.73 & 8,132 & 3.07 & 24,974 \\
\hline Mar. 19 & $\ldots .$. do $\ldots . . . . .$. & 1985 & 5.95 & 7,703 & 2.89 & 22,270 \\
\hline Apr. 1 & $\ldots$ do . . . . . . . . . . & 1985 & 5.35 & 7,225 & 2.91 & 21,017 \\
\hline Apr. 14 & 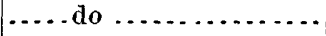 & 1985 & 5. 73 & 7,359 & 3.03 & $22,32 \pi$ \\
\hline Apr. 27 & $\ldots$ do $\ldots \ldots . . .$. & 1985 & 4.99 & 6,728 & 2. 72 & 18,290 \\
\hline May 10 & $\ldots$....... & 1985 & 4.30 & 5,654 & 2.86 & 16,145 \\
\hline June 4 & $\ldots$.... do ... & 1985 & 5.41 & 6,637 & 3.08 & 20,461 \\
\hline June 17 & $\ldots \ldots$ do $\ldots \ldots \ldots \ldots$ & 1985 & 6.64 & 7,794 & 3. 34 & 26,066 \\
\hline June 23 & ....do. do. & 1985 & 9. 68 & 10,922 & 3. 88 & 42,350 \\
\hline June 26 & A.P. Davis ............... & 1894 & 11.13 & 11,994 & 3.88 & $a 46,529$ \\
\hline June 28 & G. R. Wadleigh........ & 1985 & 12.91 & 14,462 & 4.25 & $a 61,410$ \\
\hline July 8 & $\ldots \ldots$ do $\ldots . . . . . .$. & 1985 & 11.52 & 13,418 & 3.86 & 651,821 \\
\hline July 11 & ....do . . . . . . . . . & 1985 & 12. 42 & 14,438 & 3.80 & 55,089 \\
\hline July 16 & $\ldots . .$. do $\ldots . . . .$. & 1985 & 9.12 & 11,211 & 3.32 & 37,213 \\
\hline July 19 & $\ldots . .$. do ...... & 1985 & $10 . \overline{5} 3$ & 12,586 & 3.66 & 46,098 \\
\hline July 25 & $\ldots$. do .............. & 1985 & 8.96 & 9,782 & 3.78 & 36,940 \\
\hline July 28 & $\ldots \ldots$ do $\ldots \ldots . . . .$. & 1985 & 9.56 & 10,506 & 3.97 & 39,832 \\
\hline Aug. 1 & $\ldots$. do $\ldots \ldots \ldots \ldots \ldots$ & 1985 & 8.68 & 9,826 & 3.56 & 35,980 \\
\hline Aug. 3 & $\ldots .$. do $\ldots \ldots \ldots . . . .$. & 1985 & 10.21 & 11,094 & 3.84 & 42,640 \\
\hline Aug. 7 & $\ldots$.... do ... & $198 \overline{0}$ & 9.42 & 10,359 & 3.63 & 37,647 \\
\hline Sept. 3 & H. S. Reed . . . . . . . . & 65 & 7.85 & 8,938 & 3.68 & 32,984 \\
\hline Sept. 12 & $\ldots$. do $\ldots . . . . .$. & 65 & 9.38 & 10,336 & 4.00 & 41,199 \\
\hline Sept. 16 & .....do. & $6 \check{5}$ & 12.02 & 12,761 & 4.47 & 57,047 \\
\hline Sept. 26 & .....do .. & 65 & 9.43 & 9,895 & 4.24 & 41,975 \\
\hline Oct. & .... do .. & 65 & 8.52 & 8,815 & 3. 97 & 34,971 \\
\hline Oct. 17 & $\ldots$ do ... & 65 & 8.88 & 9,026 & 4.44 & 40,087 \\
\hline Oct. 18 & .... do . . & 65 & 11.79 & 12,076 & 4.85 & 58,620 \\
\hline Nov. 8 & .... do .. & 65 & 9.77 & 10,800 & 4. 40 & 47,472 \\
\hline Nov. 13 & ....do .. & 65 & 14.05 & 14,171 & 5.59 & 79,210 \\
\hline Nov. 17 & $\ldots .$. do $\ldots . .$. & 65 & 17.43 & 19,717 & 5.32 & 104,930 \\
\hline Nov. 19 & $\ldots$.... do ... & 65 & 13.00 & 14,734 & 4.53 & 66,800 \\
\hline Nov. 30 & ....do .. & 65 & 10.89 & 12,057 & 4.39 & 52,850 \\
\hline Dec. 12 & $\ldots . . . d o \quad \ldots . . . . .$. & 65 & 11.02 & 12,069 & 4.23 & 51,042 \\
\hline Dec. 19 & $\ldots \ldots d o \ldots \ldots \ldots$ & 65 & 9.28 & 10,872 & 3.89 & 41,904 \\
\hline Dec. 22 & ....do . . . & 65 & 8.60 & 10,286 & 3.88 & 39,859 \\
\hline Dec. 28 & $\ldots$. do ... & 65 & 8.10 & 9,565 & 3.71 & 35,452 \\
\hline Dec. 30 & $\ldots \ldots$ do ................. & 65 & 8.25 & 9,767 & 3.80 & 37,089 \\
\hline
\end{tabular}


Estimated monthly discharge of Rio San Juan at Ochoa.

\begin{tabular}{|c|c|c|c|c|}
\hline \multirow{2}{*}{ Month. } & \multicolumn{3}{|c|}{ Discharge in second.feet. } & \multirow{2}{*}{$\begin{array}{l}\text { Total for month } \\
\text { in acre-feet. }\end{array}$} \\
\hline & $\begin{array}{l}\text { Maxi. } \\
\text { mum. }\end{array}$ & $\begin{array}{l}\text { Mini- } \\
\text { mum. }\end{array}$ & Mean. & \\
\hline 1898. & & & & \\
\hline Jaunary ..... & 75,200 & 32,240 & 45,250 & $2,782,300$ \\
\hline February & 58,530 & 26,080 & 35,400 & $1,966,000$ \\
\hline March .... & 30,650 & 20,140 & 23,800 & $1,463,400$ \\
\hline April ..... & 40,380 & 17,290 & 21,150 & $1,258,510$ \\
\hline May ........ & 34,880 & 16,300 & 19,640 & $1,207,600$ \\
\hline June...... & 60,180 & 18,890 & 33,140 & $1,971,970$ \\
\hline July ...... & 78,050 & 35,540 & 46,810 & $2,878,200$ \\
\hline August..... & 54,100 & 32,020 & 37,230 & $2,289,200$ \\
\hline September & 54,100 & 30,920 & 39,530 & $2,352,200$ \\
\hline October.... & 67,625 & 34,600 & 42,200 & $2,544,800$ \\
\hline November... & 107,000 & 37,080 & 51,890 & $3,087,670$ \\
\hline December $\ldots . \ldots \ldots \ldots \ldots \ldots$ & 65,000 & 32,790 & 40,850 & $2,511,770$ \\
\hline
\end{tabular}

MACHADO RIVER.

The observer of Ochoa also made occasional measurements of discharge of the Machado River, which are given below:

List of discharge measurements made on Machado River, 2 miles above its mouth.

\begin{tabular}{|c|c|c|c|c|c|c|}
\hline Date. & Hydrographer. & $\begin{array}{l}\text { Meter } \\
\text { num- } \\
\text { ber. }\end{array}$ & $\begin{array}{c}\text { Gage } \\
\text { height. }\end{array}$ & $\begin{array}{l}\text { Area of } \\
\text { section. }\end{array}$ & $\begin{array}{c}\text { Mean } \\
\text { velocity. }\end{array}$ & Discharge. \\
\hline 1898. & & & Feet. & Sq. feet. & $\begin{array}{l}\text { Feet per } \\
\text { second. }\end{array}$ & Sec.feet. \\
\hline Mar. 2 & G. A. Wadleigh . & 1985 & 5. 34 & 244 & 0.59 & 144 \\
\hline Mar. 16 & $\ldots$. do .. & 1985 & 5.10 & 212 & 0.57 & 121 \\
\hline Apr. 2 & .... do .... & 1985 & 4.90 & 221 & 0.46 & 102 \\
\hline Apr. 6 & .... do .. & 1985 & 7.87 & 400 & 1.28 & 514 \\
\hline Mar. 27 & .... do ... & 1985 & 5.20 & 229 & 0.60 & 137 \\
\hline June 3 & .... do ... & 1985 & 6.32 & 293 & 0.94 & 276 \\
\hline June 20 & .....do .. & 1985 & 7.56 & 363 & 0.76 & 277 \\
\hline June 30 & ... do do .... & 1985 & 7.72 & 253 & 1.12 & a 284 \\
\hline July 9 & ..... do ... & 1985 & 9.22 & 344 & 1.34 & $a 462$ \\
\hline July 14 & .....do .. & 1985 & 7.11 & 230 & 1.06 & a 244 \\
\hline July 21 & ..... do do & 1985 & 8. 86 & 312 & 1.37 & $a 428$ \\
\hline Aug. 3 & ....do & 1985 & 7.41 & 233 & 1.15 & 267 \\
\hline Aug. $\quad 5$ & $\ldots$. do $\ldots \ldots$. & 1985 & 6.88 & 203 & 1.02 & 208 \\
\hline Aug. 13 & G. H. Williams. & 1985 & 7.06 & 212 & 1.09 & 233 \\
\hline Aug. 17 & ..... do ..... & 1985 & 6.74 & 201 & 1.02 & 206 \\
\hline Aug. 19 & ... do do....... & 1985 & 6.44 & $18 \overline{5}$ & 0.92 & 170 \\
\hline
\end{tabular}

$a$ New station, 1 mile above. 
List of discharge measurements made on Machado River, 2 miles above its mouth-Cont'd.

\begin{tabular}{|c|c|c|c|c|c|c|}
\hline Date. & Hydrographer. & $\begin{array}{c}\text { Meter } \\
\text { num- } \\
\text { ber. }\end{array}$ & $\begin{array}{c}\text { Gage } \\
\text { height. }\end{array}$ & $\begin{array}{l}\text { Area of } \\
\text { section. }\end{array}$ & $\begin{array}{l}\text { Mean } \\
\text { velocity. }\end{array}$ & Discharge. \\
\hline 1898. & & & Feet. & Sq. feet. & $\begin{array}{l}\text { Feet per } \\
\text { second. }\end{array}$ & Sec.feet. \\
\hline Sept. 5 & G. H. Williams . . . . . . & 65 & 5.30 & 226 & 0.65 & $a 148$ \\
\hline Sept. 24 & .... do $\ldots . . .$. & 65 & 6.30 & 167 & 1.02 & $b 170$ \\
\hline Oct. .6 & $\ldots .$. do $\ldots . . . . . .$. & 65 & 6.34 & 163 & 1.06 & 172 \\
\hline Oct. 11 & ....do. & 65 & 5.83 & 145 & 0.89 & 128 \\
\hline Oct. 19 & $\ldots$... do .. & 65 & 6.08 & 153 & 0.87 & 133 \\
\hline Nov. 7 & C. Hayman .... & 65 & 5.48 & 132 & 0.79 & $b 104$ \\
\hline Nov. 15 & $\ldots \ldots$ do ............. & 65 & 6.18 & 160 & 0.87 & $b 139$ \\
\hline Nov. 21 & ..... do. & 65 & 6.80 & 196 & 1.11 & b 218 \\
\hline Nor. 29 & $\ldots$. do . . . . . & 65 & 7.67 & 250 & 1. 37 & $b 343$ \\
\hline Dec. 7 & ..... do. & 65 & 7.05 & 213 & 1.31 & $b 279$ \\
\hline Dec. 17 & $\ldots .$. do $\ldots . .$. & 65 & 6. 74 & 190 & 1.09 & $b 208$ \\
\hline Dec. 27 & ....do & 65 & 5.60 & 143 & 0.79 & b 113 \\
\hline Dec. 31 & $\ldots$. . do .... & 65 & 5.73 & 146 & 0.87 & b 127 \\
\hline
\end{tabular}

a Lower, or old station.

$b$ Upper station.

DANTA RIVER.

This stream is the outlet of the Florida Lagoon, and flows into Rio San Juan about a mile above the mouth of the San Francisco. Its channel is narrow and deep, and contains considerable fallen timber, but is not subject to sudden changes of cross section. The current is usually sluggish, and is sometimes affected by the stage of water in the San Juan.

A gage was established on February 28 , about $1 \frac{1}{2}$ miles above its mouth, and the following measurements of discharge have been made.

List of discharge measurements made on Danta River, $1 \frac{1}{2}$ miles above mouth.

\begin{tabular}{|c|c|c|c|c|c|c|}
\hline Date. & Hydrographer. & $\begin{array}{c}\text { Meter } \\
\text { num- } \\
\text { ber. }\end{array}$ & $\begin{array}{c}\text { Gage } \\
\text { height. }\end{array}$ & $\begin{array}{l}\text { Area of } \\
\text { section. }\end{array}$ & $\begin{array}{c}\text { Mean } \\
\text { velocity }\end{array}$ & Discharge. \\
\hline 1898. & & & Feet. & Sq.feet. & $\begin{array}{l}\text { Feet per } \\
\text { second. }\end{array}$ & Sec.feet. \\
\hline Feb. 28 & W. W. Schlecht........ & 93 & 3.98 & 134.0 & 1.03 & 138.0 \\
\hline Mar. 8 & .... do . . . .............. & 93 & 3.22 & 110.5 & 0.82 & 91.0 \\
\hline Mar. 18 & ......do . & 93 & 2.12 & 82.3 & 0.58 & 47.0 \\
\hline Mar. 28 & $\ldots$ do ...... & 93 & 2.97 & 102.1 & 0.86 & 87.8 \\
\hline Apr. 9 & .... do .. & 93 & 4.23 & 148.0 & 1.07 & 158.7 \\
\hline Apr. 28 & ....do . . & 93 & 2.24 & 76.0 & 0.70 & 53.0 \\
\hline June 15 & C. Hayman . & 93 & 3.65 & 80.4 & 1.31 & 106.0 \\
\hline June 27 & $\ldots .$. do & 93 & 7.45 & 303.0 & 1.08 & 32.8 \\
\hline July 8 & ..... do . . & 93 & 6.17 & 195.0 & 0.82 & 161.0 \\
\hline
\end{tabular}


List of discharge measurements made on Dante River, $1 \frac{1}{2}$ miles above mouth-Continued.

\begin{tabular}{|c|c|c|c|c|c|c|}
\hline Date. & Hydrographer. & $\begin{array}{c}\text { Meter } \\
\text { num- } \\
\text { ber. }\end{array}$ & $\begin{array}{c}\text { Gage } \\
\text { height. }\end{array}$ & $\begin{array}{l}\text { Area of } \\
\text { section. }\end{array}$ & $\begin{array}{c}\text { Mean } \\
\text { velocity. }\end{array}$ & Discharge. \\
\hline 1898. & & & Feet. & Sq. feet. & $\begin{array}{l}\text { Feet per } \\
\text { second. }\end{array}$ & Sec.-feet. \\
\hline July 19 & C. Hayman.... & 93 & 5. 11 & 151.0 & 0.59 & 94.0 \\
\hline July 28 & .... do ..... & 93 & 5. 28 & 165.0 & 0.90 & 149.0 \\
\hline Ang. 8 & .... do .. & 93 & 4.63 & 147.0 & 0.80 & 118.0 \\
\hline Ang. 18 & .... do .......... & 93 & 4. 48 & 135.0 & 0.90 & 121.0 \\
\hline Aug. 28 & .... do .. & 93 & 4.21 & 125.0 & 0.84 & 104.0 \\
\hline Sept. 8 & $\ldots$. . do ...... & 93 & 3.55 & 94.0 & 0.64 & 60.0 \\
\hline Sept. 27 & .... do .. & 93 & 5.08 & 162.0 & 0.60 & 98.0 \\
\hline Oct. 8 & A. Ahrling & 93 & 3.73 & 108.0 & 0.53 & 57. 0 \\
\hline Oct. 18 & .... do . & 93 & 5.65 & 188.0 & 0.12 & $a 23.0$ \\
\hline Oct. 29 & .... do ....... & 93 & 5. 19 & 156.0 & 0.33 & 52.0 \\
\hline Nov. 7 & .... do & 93 & 4.01 & 115.0 & 0.36 & 42.0 \\
\hline Nov. 18 & .... do & 93 & 11. 60 & 432.0 & 1.27 & 549.0 \\
\hline Nov. 28 & ... . do & 93 & 7.18 & 231.0 & 0.82 & 190.0 \\
\hline Dec. 8 & .... do & 93 & 4.75 & 142.0 & 0.58 & 82.0 \\
\hline Dec. 17 & .... do . & 93 & , 5.99 & 193.0 & , 0.37 & 71.0 \\
\hline
\end{tabular}

$a$ Backwater from San Juan.

RIO SAN FRANCISCO.

The canal company's project provides for the construction of large embankments across the valleys of the Limpio, Chanchos, Nicholson, San Francisco, and Danta, and iuvolves the control of these streams during construction, and the receiving of their discharge into the canal after completion. A knowledge of their volume and fluctuations, as well as of the rainfall of the region, is therefore necessary.

The Rio San Francisco has its source on the southwestern slope of the range of hills known as the eastern divide, north of the Rio San Juan. Its priucipal tributary is the Chanchos River, which in turn receives the waters of the Limpio River. The valley of the San Francisco is crossed by the proposed upper line of the canal, which follows for a considerable distance the valleys of the Chanchos and Limpio. The drainage area has never been definitely outined, and only meager information exists as to its extent. It is estimated, however, at about 65 square miles. The maximum discharge yet observed for the San Francisco above the confluence of Nicholson Creek and the Chanchos River is 866 cubic feet per second. A discharge of 888 cubic feet per second has been observed for the Chanchos and 100 for Nicholson Creek. This would indicate a maximum during the time of observation of something less than 2,000 for the San Francisco at its mouth. A rough tentative estimate based upon these figures and upon the greatest rainfall probable in this country would place the extreme maximum 
discharge which can occur at the mouth of the San Francisco as considerably less than 4,000 cubic feet per second. The certainty that this figure is ample is greatly strengthened by the nature of the lower portion of the San Francisco drainage basin, which includes a large area of perfectly flat land that would be flooded in case of a discharge of 3,000 cubic feet per second in the San Francisco and that would act as a storage basin for floods exceeding that amount until they could be discharged through the channel of the river.

On January 2 a station was established near the line of the proposed canal on the Rio San Francisco, about 2 miles by the river above the crossing of the embankment line, and above the mouth of Canyon Surprise.

On February 27 a gagé rod was placed in the river at the crossing of the embankment line, and thereafter observations were taken at this point, which is below the mouth of Canyon Surprise. The channel is narrow and deep, is composed of hard clay and is not subject to rapid change, but it contains large quantities of fallen timber.

Measurements are given below for both stations; rating tables have been constructed, and daily discharges estimated for both, which are given below. Rainfall and hygrometer observations have also been taken.

List of discharge measurements made on Rio San Francisco.

CENTER LINE OF CANAL.

\begin{tabular}{|c|c|c|c|c|c|c|c|}
\hline Date. & Hyolrographer. & $\begin{array}{l}\text { Meter } \\
\text { num. } \\
\text { ber. }\end{array}$ & $\begin{array}{c}\text { Gage } \\
\text { height. }\end{array}$ & $\begin{array}{c}\text { Arrea } \\
\text { of sec. } \\
\text { tion. }\end{array}$ & $\begin{array}{l}\text { Mean } \\
\text { veloc- } \\
\text { ity. }\end{array}$ & $\begin{array}{c}\text { Dis- } \\
\text { eharge. }\end{array}$ & Remarks. \\
\hline 1898. & & & Feet. & $\mid S q \cdot$ feet. & $\begin{array}{l}\text { Feet per } \\
\text { second. }\end{array}$ & $\begin{array}{l}\text { Sec. } \\
\text { feet. }\end{array}$ & \\
\hline Jan. 19 & W. W. Schlecht........ & 93 & 13.52 & 310 & 1.02 & 319 & Upper station. \\
\hline Jan. 25 & ..... do ..................... & 93 & 11.97 & 228 & 0.91 & 208 & Do. \\
\hline Jan. 22 & . . . do do ................... & 93 & 15.12 & 373 & 1. 19 & 445 & Do. \\
\hline Feb. 3 & W.P. Leary ........... & 93 & 15.83 & 407 & 1.16 & 471 & Do. \\
\hline Feb. 10 & ......do ................. & 93 & 12.75 & 264 & 0.83 & 220 & Do. \\
\hline Feb. 20 & .....do .................... & 93 & 10.60 & 168 & 0.74 & 124 & Do. \\
\hline Mar. 2 & W. W. Schlecht... & 93 & 10.86 & 174 & 0.74 & 128 & Do. \\
\hline Mar. 10 & .....do $-\ldots . . . .$. & 93 & 11. 78 & 217 & 0.85 & 184 & Do. \\
\hline Mar. 19 & 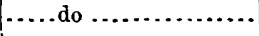 & 93 & 9.77 & 130 & 0.61 & 80 & Do. \\
\hline Mar. 29 & . $\ldots$. do & 93 & 10.26 & 149 & 0.68 & 101 & Do. \\
\hline Apr. 5 & ..... do ............. & 93 & 15.90 & 397 & 1.54 & 610 & Do. \\
\hline Apr. 6 & ..... do .......... & 93 & 16.48 & 429 & 1.32 & 569 & Do. \\
\hline Apr. 20 & .... do .............. & 93 & 9.82 & 134 & 0.60 & 81 & Do. \\
\hline Apr. 30 & . .... do . . . . . . & 93 & 9.36 & 113 & 0.59 & 67 & Do. \\
\hline
\end{tabular}


List of discharge measurements made on Rio San Francisco-Continuerl. LINE OF EMBANKMENTS.

\begin{tabular}{|c|c|c|c|c|c|c|c|}
\hline Date. & Hydrographer. & $\begin{array}{c}\text { Meter } \\
\text { num. } \\
\text { ber. }\end{array}$ & $\begin{array}{c}\text { Gage } \\
\text { height. }\end{array}$ & $\begin{array}{c}\text { Area } \\
\text { of sec- } \\
\text { tion. }\end{array}$ & $\begin{array}{c}\text { Mean } \\
\text { veloc- } \\
\text { ity. }\end{array}$ & $\begin{array}{c}\text { Dis- } \\
\text { charge. }\end{array}$ & Remarks. \\
\hline 1898. & . & & Feet. & Sq. feet. & $\begin{array}{l}\text { Feet per } \\
\text { second. }\end{array}$ & $\begin{array}{l}\text { Sec.- } \\
\text { feet. }\end{array}$ & . \\
\hline Mar. 2 & W. W. Schlecht. & 93 & 5.99 & 171 & 0.87 & 148 & Lower station. \\
\hline Mar. 10 & .... do ........... & 93 & 6. 80 & 213 & 0.97 & 206 & Do. \\
\hline Mar. 19 & ..... do ....... & 93 & 4.52 & 114 & 0.72 & 83 & Do. \\
\hline Mar. 29 & ..... do ...... & 93 & 5.21 & 141 & 0.76 & 108 & Do. \\
\hline Apr. 6 & $\ldots \ldots$ do $\ldots .$. & 93 & 11.01 & 431 & 1.28 & 550 & Do. \\
\hline Apr. 20 & ..... do ...... & 93 & 4. 61 & 116 & 0.71 & 83 & Do. \\
\hline Apr. 30 & ..... do ....... & 93 & 4.09 & 96 & 0.69 & 66 & Do. \\
\hline May 5 & Chas. Hayman ........ & 93 & 6.81 & 213 & 0.99 & 212 & Do. \\
\hline May 9 & $\ldots$. . do ...... & 93 & 4.72 & 115 & 0.80 & 92 & Do. \\
\hline May 12 & ..... do ............. & 93 & 8.17 & 250 & 0.92 & 246 & Do. \\
\hline May 16 & ..... do ........ & 93 & 5.89 & 144 & 0.84 & 124 & Do. \\
\hline May 21 & $\ldots$. do $\ldots . . . . . . . .$. & 93 & 9.53 & 346 & 1,39 & 482 & Do. \\
\hline May 25 & .....do do $\ldots . . . . .$. & 93 & 5.79 & 148 & 0.88 & 131 & Do. \\
\hline May 31 & $\ldots \ldots$ do $\ldots . . . .$. & 93 & 5.67 & 147 & 0.83 & 120 & Do. \\
\hline June 8 & ..... do ...... & 93 & 4.76 & 108 & 0.67 & 74 & Do. \\
\hline June 11 & $\ldots$ do $\ldots . .$. & 93 & 4.60 & .... & $\ldots \ldots$ & $\cdots$ & Do. \\
\hline June 17 & ..... do .... & 93 & 5.27 & 125 & 0.82 & 103 & Do. \\
\hline June 21 & $\ldots .$. do ...... & 93 & 9.68 & 328 & 1.06 & 349 & Do. \\
\hline June 25 & ..... do ....... & 93 & 11.70 & 427 & 1.07 & 459 & Do. \\
\hline July 6 & $\ldots$. do $\ldots .$. & 93 & 11.17 & 364 & 1.01 & 419 & Do. \\
\hline July 21 & .....do ..... & 93 & 11.23 & 374 & 1. 27 & 475 & Do. \\
\hline July 30 & .... do ....... & 93 & 7.66 & 210 & 1.02 & 215 & Do. \\
\hline dug. 10 & $\ldots .$. do ....... & 93 & 8.98 & 280 & 1.13 & 326 & Do. \\
\hline Aug. 22 & $\ldots$. do $\ldots . . .$. & 93 & 6.35 & 164 & 0.87 & 143 & Do. \\
\hline Aug. 31 & .....do .............. & 93 & 5.61 & 147 & 0.75 & 111 & Do. \\
\hline Sept. 10 & ....do do ................... & 93 & 5.26 & 124 & 0.84 & 104 & Do. \\
\hline Sept. 20 & ..... do .............. & 93 & 6.39 & 159 & 0.70 & 111 & Do. \\
\hline Sept. 26 & ..... do ...................... & 93 & 9.47 & 293 & 1.51 & 442 & Do. \\
\hline Oct. 10 & A. Abrling ... & 93 & 6.18 & 161 & 0.78 & 125 & Do. \\
\hline Oct. 14 & ..... do ........... & 93 & 6.80 & 186 & 0.88 & 166 & Do. \\
\hline Oct. 20 & ..... do ....... & 93 & 8. 10 & 231 & 0.59 & 137 & Do. \\
\hline Oct. 24 & ..... do ............. & 93 & 8.29 & 248 & 0.82 & 204 & Do. \\
\hline Oct. 28 & ..... do ......... & 93 & 7.35 & 198 & 0.59 & 116 & Do. \\
\hline Nov. 1 & $\ldots$. do $\ldots . .$. & 93 & 5.95 & 131 & 0.61 & 67 & Do. \\
\hline Nov. 6 & .... do ......... & 93 & 5.43 & 120 & 0.65 & 78 & Do. \\
\hline Nov. 12 & ..... do .......... & 93 & 6.98 & 180 & 0.67 & 121 & Do. \\
\hline Nov. 14 & ..... do ......... & 93 & 10.87 & 385 & 0.82 & 317 & Do. \\
\hline Nov. 16 & . .... do ..................... & 93 & 12.53 & 456 & 1.13 & 515 & Do. \\
\hline Nov. 22 & .....do ................... & 93 & 8.89 & 261 & 1.00 & 263 & Do. \\
\hline Nov. 27 & .....do do .................. & 93 & 9.22 & $282^{\circ}$ & 1.10 & 310 & Do. \\
\hline
\end{tabular}


Estimated monthly discharge of Rio San Francisco at line of embankments.

\begin{tabular}{|c|c|c|c|c|}
\hline \multirow{2}{*}{ Month. } & \multicolumn{3}{|c|}{ D̈ischarge in second-feet. } & \multirow{2}{*}{$\begin{array}{l}\text { Total for } \\
\text { month in } \\
\text { acre-feet. }\end{array}$} \\
\hline & $\begin{array}{l}\text { Maxi- } \\
\text { mum. }\end{array}$ & $\begin{array}{l}\text { Mini- } \\
\text { mum. }\end{array}$ & Mean. & \\
\hline 1898. & & & & \\
\hline January $\ldots \ldots \ldots \ldots \ldots \ldots \ldots$ & 514 & 150 & 314 & 19,310 \\
\hline February $\ldots \ldots \ldots \ldots \ldots \ldots \ldots . . . . . . . .$. & 628 & 108 & 251 & 13,941 \\
\hline March $\ldots \ldots \ldots \ldots \ldots \ldots \ldots \ldots \ldots . . . \ldots \ldots$ & 272 & 76 & 127 & 7,810 \\
\hline April $\ldots \ldots \ldots \ldots \ldots \ldots \ldots \ldots \ldots \ldots$ & 590 & 70 & 128 & 7,620 \\
\hline 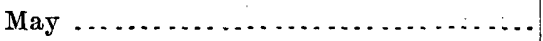 & 417 & 76 & 148 & 9,100 \\
\hline June $\ldots \ldots \ldots \ldots \ldots \ldots \ldots \ldots \ldots \ldots \ldots$ & 626 & 今 76 & 239 & 14,220 \\
\hline July .......... & 866 & 176 & 407 & 25,025 \\
\hline August $\ldots \ldots \ldots \ldots \ldots \ldots \ldots \ldots$ & 545 & $120^{\prime}$ & 236 & 14,510 \\
\hline September $\ldots \ldots \ldots \ldots \ldots \ldots$ & 595 & 102 & 220 & 13,090 \\
\hline October....... & 313 & 75 & 162 & 9,960 \\
\hline November $\ldots . \ldots \ldots \ldots \ldots, \ldots \ldots \ldots \ldots$ & 745 & 57 & 279 & 16,600 \\
\hline December $1-28 \ldots \ldots \ldots \ldots \ldots \ldots \ldots \ldots$ & 605 & 105 & 233 & 12,940 \\
\hline
\end{tabular}

LIMPIO RIVER,

On January 6 a gage was placed on the left bank of the Limpio about 200 yards above its mouth. It consists of a vertical plank driven in the bed of the stream and spiked to a tree growing in the bank.

Three 60-penny nails driven into the tree to which the gage is fastened, and projecting about 1 inch, mark the elevation of 11 feet above datum.

Current meter measurements were made from the trunk of a tree felled across the river.

From January 17 daily observations were taken at this point until February 20, after which observations were taken two or three times a month.

20 GEOL, PT $4-40$ 
List of discharge measurements made on Limpio River near its mouth.

\begin{tabular}{|c|c|c|c|c|c|c|}
\hline Date. & Hydrographer. & $\begin{array}{c}\text { Meter } \\
\text { number. }\end{array}$ & $\begin{array}{c}\text { Gage } \\
\text { height. }\end{array}$ & $\begin{array}{l}\text { Area of } \\
\text { section. }\end{array}$ & $\begin{array}{c}\text { Mean } \\
\text { velocity. }\end{array}$ & Discharge. \\
\hline 1898. & & & Feet. & Sq. feet. & $\begin{array}{l}\text { Feet per } \\
\text { second. }\end{array}$ & Sec.feet. \\
\hline Jan. 21 & H. S. Reed... & 2 & 6.20 & 76 & 1. 31 & 100 \\
\hline Jan. 28 & .....do & 2 & 4.27 & 34 & 0.93 & 32 \\
\hline Feb. 3 & W. W. Schlecht....... & 2 & 9.80 & 200 & 0.39 & $a 78$ \\
\hline Feb. 11 & $\ldots \ldots$ do $\ldots . .$. & 2 & 4.76 & 42 & 0.94 & 40 \\
\hline Feb. 19 & $\ldots$ do ........ & 2 & 3.88 & 22 & 1. 15 & 25 \\
\hline Mar. 12 & ..... do ......... & 93 & 4.08 & 30 & 0.99 & 30 \\
\hline Mar. 23 & $\ldots .$. do ....... & 93 & 3.35 & 15 & 1.14 & 17 \\
\hline Apr. 12 & $\ldots$. do ...... & 93 & 4.05 & 30 & 1.08 & 32 \\
\hline Apr. 23 & $\mid \ldots \ldots$ do $\ldots . . . . . . .$. & 93 & 3.94 & 21 & 1.05 & 22 \\
\hline May 14 & C. Hayman ....... & 93 & 3.80 & 25 & 0.92 & 23 \\
\hline May 24 & $\ldots$. do $\ldots . . .$. & 93 & 3.83 & 24 & 1.10 & 25 \\
\hline June 4 & ..... do $\because . . .$. & 93 & 3.66 & 22 & 0.95 & 22 \\
\hline June 14 & ..... do .......... & 93 & 3.72 & 21 & 0.89 & 19 \\
\hline June 24 & .... do ........ & 93 & 3.45 & 16 & 0.69 & 11 \\
\hline July 2 & $\ldots$. do $\ldots . . .$. & 93 & 7.96 & 116 & 0.52 & 60 \\
\hline July 13 & .... do . . . . . . & 93 & 4.11 & 20 & 1.08 & 22 \\
\hline July 23 & ..... do .... & 93 & 5.29 & 42 & 1.05 & 44 \\
\hline Aug. 3 & .... do ........ & 93 & 5.42 & 53 & 0.76 & 41 \\
\hline Aug. 13 & .... do .... & 93 & 5.04 & 43 & 1.10 & 48 \\
\hline Aug. 23 & .... do ......... & 93 & 4.20 & 34 & 1. 44 & 51 \\
\hline Sept. 3 & .....do .......... & 93 & 3.49 & 19 & 1.28 & 24 \\
\hline Sept. 14 & $\ldots .$. do $\ldots . .$. & 93 & 5.02 & 46 & 0.77 & 35 \\
\hline Sept. 23 & ..... do ......... & 93 & 7.19 & 118 & 0.32 & a 38 \\
\hline Oct. 4 & A. Abrling . & 93 & 4.38 & 34 & 0.51 & 20 \\
\hline Oct. 13 & .... do ........ & 93 & 4.17 & 33 & 0.56 & 18 \\
\hline Oct. 22 & .... do .... & 93 & 4.. 60 & 41 & 0.66 & 29 \\
\hline Nov. 2 & $\ldots$... do .... & 93 & 3.51 & 18 & 0.88 & 16 \\
\hline Nov. 12 & .... do ..... & 93 & 3.93 & 30 & 0.73 & 22 \\
\hline Nov. 14 & $\ldots$.... do .... & 93 & 5.24 & 48 & 0.79 & 38 \\
\hline Nov. 22 & $\ldots \ldots$ do .......... & 93 & 4.48 & 37 & 0.78 & 29 \\
\hline Dec. 3 & $\ldots .$. do ........... & 93 & 4.60 & 36 & 1.08 & 39 \\
\hline Dec. 13 & .... do . . . . . . & 93 & 5.22 & 46 & 1.02 & 47 \\
\hline Dec. 27 & ..... do ............ & 93 & 3.51 & 18 & 0.88 & 16 \\
\hline
\end{tabular}

$a$ Backwater.

UPPER STATION ON THE CHANCHOS RIVER.

On January 17 a gage was placed on the right bank of the Chanchos, about 200 yards above the mouth of the Limpio River. It consists of a vertical pine board, marked in feet and tenths, driven into the bed of the stream and spiked to a tree growing in the bank. Bench mark 
consists of three 60-penny nails driven in the tree, to which gage was fastened, at 13-foot mark, projecting about 3 inches. Gagings were made by current meter from the trunk of a tree felled across the stream.

Daily observations were taken from this point until February 20, after which observations were taken two or three times a month.

List of discharge measurements made on Chanchos River at upper station.

\begin{tabular}{|c|c|c|c|c|c|c|}
\hline Date. & Hydrographer. & $\begin{array}{c}\text { Meter } \\
\text { number. }\end{array}$ & $\begin{array}{c}\text { Gage } \\
\text { height. }\end{array}$ & $\begin{array}{l}\text { Area of } \\
\text { section. }\end{array}$ & $\begin{array}{c}\text { Mean } \\
\text { velocity. }\end{array}$ & Discharge. \\
\hline 1898. & & & Feet. & Sq.feet. & $\begin{array}{l}\text { Feet per } \\
\text { second. }\end{array}$ & Sec.feet. \\
\hline Jan. 21 & H. S. Reed... & 2 & 6.07 & 243 & 0.92 & 226 \\
\hline Jan. 28 & .... do .......... & 2 & 2.65 & 90 & 0.48 & 43 \\
\hline Feb. 5 & W. W. Schlecht. & 2 & 8.00 & 334 & 0.96 & 321 \\
\hline Feb. 11 & $\ldots$... do ........ & 2 & 3.30 & 115 & 0.64 & 74 \\
\hline Feb. 19 & .... do .... & 2 & 2.26 & 70 & $0 . \tilde{53}$ & 37 \\
\hline Mar. 12 & .... do .... & 2 & 2.54 & 80 & 0.62 & 49 \\
\hline Mar. 23 & ..... do ......... & 2 & 1.67 & 50 & 0.46 & 23 \\
\hline Apr. 12 & .... do ...... & 2 & 2.48 & 78 & 0.60 & 47 \\
\hline Apr. 23 & .... do ........... & 2 & 2.50 & 78 & 0.60 & 47 \\
\hline May 14 & C. Hayman ..... & 2 & 2.21 & 66 & 0.38 & 38 \\
\hline May 24 & . . . do ........ & 2 & 2.34 & 76 & 0.64 & 48 \\
\hline Jnne 4 & ..... do ... & 2 & 1.78 & 46 & 0.46 & 22 \\
\hline June 14 & $\ldots$ do $\ldots .$. & 2 & 2.05 & 52 & 0.63 & 33 \\
\hline June 24 & .... do ....... & 2 & 1.92 & 53 & 0.55 & 29 \\
\hline July 2 & ..... do ... & 2 & 6.68 & 243 & 1.22 & 297 \\
\hline July 13 & .... do ... & 2 & 2.60 & 73 & 0.63 & 46 \\
\hline July 23 & .... do ... & 2 & 3.87 & 121 & 0.75 & 91 \\
\hline Aug. 3 & .... do ...... & 2 & 4.10 & 136 & 0.89 & 121 \\
\hline Aug. 13 & .... do .... & 2 & $3 .: 6$ & 112 & 0.69 & 77 \\
\hline Ang. 23 & $\ldots$... do .... & 2 & 2.21 & 64 & 0.65 & 42 \\
\hline Sept. 3 & .... do ........ & 2 & 1.78 & 46 & $\cdot 0.47$ & 23 \\
\hline Sept. 14 & $\ldots$. do $\ldots . . . . .$. & 93 & 3.67 & 113 & 0.83 & 93 \\
\hline Sept. 23 & $\ldots$. do ....... & 93 & 6.05 & 230 & 1.13 & 260 \\
\hline Oct. 4 & $\ldots$. do ...... & 93 & 3.13 & 100 & 0.76 & 76 \\
\hline Oct. 13 & .... do .... & 93 & 2.88 & 91 & 0.80 & 73 \\
\hline Oct. 22 & $\ldots$. . do ...... & 93 & 3.40 & 105 & 0.94 & 98 \\
\hline Nov. 2 & ..... do ......... & 93 & 2.00 & 55 & 0.50 & 28 \\
\hline Nov. 12 & .... do ......... & 93 & 2.52 & 76 & 0.74 & 57 \\
\hline Nov. 14 & .... do .......... & 93 & 3.91 & 115 & 0.95 & 109 \\
\hline Nov. 22 & .... do ........... & 93 & 2.94 & 84 & 0.74 & 62 \\
\hline Dec. 3 & .... do ................... & 93 & 3.12 & 92 & 0.86 & 79 \\
\hline Dec. 13 & $\ldots$. do $\ldots . . . . . .$. & 93 & 3. 73 & 109 & 0.92 & 100 \\
\hline Dec. 27 & $\ldots .$. do $\ldots . . . . . .$. & 93 & 1.89 & 54 & 0.50 & 27 \\
\hline
\end{tabular}


Estimated monthly discharge of Chanchos River above the Limpio.

\begin{tabular}{|c|c|c|c|c|c|}
\hline \multirow{2}{*}{ Month. } & \multirow{2}{*}{$\begin{array}{l}. \\
\therefore \quad \\
\therefore\end{array}$} & \multicolumn{3}{|c|}{ Discharge in second-feet. } & \multirow{2}{*}{$\begin{array}{l}\text { Total in } \\
\text { acre-feet. }\end{array}$} \\
\hline & & $\begin{array}{l}\text { Maxi. } \\
\text { mum. }\end{array}$ & $\begin{array}{l}\text { Mini- } \\
\text { mum. }\end{array}$ & Mean. & \\
\hline \multirow{3}{*}{\multicolumn{2}{|c|}{$\begin{array}{l}\text { January } 17-31 \ldots \ldots \ldots \\
\text { February } 1-20 \ldots \ldots \ldots\end{array}$}} & & & & \\
\hline & & 252 & 36 & 96 & 2,850 \\
\hline & & 395 & 34 & 139 & 5,520 \\
\hline
\end{tabular}

LOWER STATION ON THE CHANCHOS RIVER.

A gage was placed on the left bank of the Chanchos, about one-half mile above the point where the telegraph line intersects the river. It consists of a vertical pine board driven into the bed of the stream, and spiked to a tree growing on the bank. Bench mark consists of two 8-penny nails driven into a notch in a tree 25 feet from the river bank, at nearest point, and 30 feet from gage rod. Tree has one smaller leaning against it.

Measurements of discharge were made from a huge tree trunk lying across the river one-half mile upstream from the gage.

List of discharge measurements made on Chanchos River at lower station.

\begin{tabular}{|c|c|c|c|c|c|c|}
\hline Date. & Hydrographer. & $\begin{array}{c}\text { Meter } \\
\text { number. }\end{array}$ & $\begin{array}{c}\text { Gage } \\
\text { height. }\end{array}$ & $\begin{array}{l}\text { Area os } \\
\text { sectiov. }\end{array}$ & $\underset{\text { velocity. }}{\text { Mean }}$ & Discharge. \\
\hline 1898. & 1 & & Feet. & Sq. feet. & $\begin{array}{l}\text { Feet per } \\
\text { second. }\end{array}$ & Sec.feet. \\
\hline Jan. 10 & N. P. Leary .......... & 93 & 5.98 & 321 & 1.26 & 404 \\
\hline Jan. 20 & W. W. Schlecht. & St. 2 & 2.55 & 199 & 9. 67 & 134 \\
\hline Jan. 27 & .... do .. & St. 2 & 1.82 & 167 & 0.54 & 90 \\
\hline Feb. $\quad 2$ & ..... do ....... & St. 2 & 7.23 & 455 & 1. 48 & 674 \\
\hline Feb. 10 & $\ldots$. do ... & St. 2 & 3.19 & 204 & 0.80 & 162 \\
\hline Feb. 18 & .... do $\quad . . . .$. & St. 2 & 0.92 & 144 & 0.33 & 48 \\
\hline Mar. 7 & ..... do .......... & 93 & 1. 16 & 143 & 0.56 & 80 \\
\hline Mar. 17 & ..... do ......... & 93 & 0.35 & 125 & 0.47 & 58 \\
\hline Mar. 26 & ..... do ........... & 93 & 0.73 & 139 & 0.48 & 67 \\
\hline Apr. 7 & .... do ....... & 93 & 2.15 & 169 & 0.65 & 109 \\
\hline Apr. 16 & $\ldots$. do ........... & 93 & 0.16 & 123 & 0.37 & 46 \\
\hline May 7 & C. Hayman ....... & 93 & 1.17 & 124 & 0.57 & 71 \\
\hline May 30 & $\ldots .$. do $\ldots . . . .$. & 93 & 0.22 & 115 & 0.39 & 45 \\
\hline June 8 & .....do do.......... & 93 & 0.05 & 94 & 0.33 & 32 \\
\hline June 17 & $\ldots$.... do ........ & 93 & 0.18 & 107 & 0.31 & 33 \\
\hline June 29 & .... do ......... & 93 & 5.78 & 264 & 0.84 & 228 \\
\hline July 7 & ..... do .......... & 93 & 3.70 & 201 & 0.68 & 138 \\
\hline July 16 & .... do ................ & 93 & 1.51 & 127 & 0.40 & 51 \\
\hline July 27 & $\ldots$. do $\ldots . . .$. & 93 & 3.01 & 184 & .0 .70 & 130 \\
\hline
\end{tabular}


List of discharge measurements made on Chanchos River at lower station-Continued.

\begin{tabular}{|c|c|c|c|c|c|c|}
\hline Date. & Hydrographer. & $\begin{array}{c}\text { Meter } \\
\text { number. }\end{array}$ & $\begin{array}{c}\text { Gage } \\
\text { height. }\end{array}$ & $\begin{array}{l}\text { Area of } \\
\text { gection. }\end{array}$ & $\begin{array}{l}\text { Mean } \\
\text { velocity. }\end{array}$ & Discbarge. \\
\hline 1898. & & & Feet. & Sq. feet. & $\begin{array}{l}\text { Feet per } \\
\text { second. }\end{array}$ & Sec.feet. \\
\hline Aug. 6 & C. Hayman ..... & 93 & 2.46 & 154 & 0.62 & 97 \\
\hline Aug. 17 & .....do . & 93 & 2.00 & 146 & 0.46 & 67 \\
\hline Aug. 27 & $\ldots$. do .......... & 93 & 1.06 & 102 & 0.57 & 58 \\
\hline Sept. 7 & ..... do .. & 93 & 0.55 & 89 & 0.51 & 45 \\
\hline Sept. 17 & .... do ....... & 93 & 2.89 & 137 & 0.47 & 63 \\
\hline Sept. 26 & .... do ....... & 93 & 2.53 & 123 & 0.47 & 58 \\
\hline Oct. 7 & A. Abrling ......... & 93 & 1.03 & 103 & 0,50 & 51 \\
\hline Oct. 10 & .... do ................. & 93 & 1.15 & 99 & 0.53 & 53 \\
\hline Oct. 18 & .....do ........... & 93 & 1.78 & 111 & 0.41 & 46 \\
\hline Oct. 26 & .... do .............. & 93 & 3.74 & 169 & 0.61 & 103 \\
\hline Nov. 6 & .....do .............. & 93 & 0.79 & 95 & 0.36 & 34 \\
\hline Nov. 14 & ..... do .... & 93 & 5.88 & 255 & 0.62 & 159 \\
\hline Nov. 16 & .... do ......... & 93 & 7.43 & 354 & 1.41 & 498 \\
\hline Nov. 26 & .... do ............ & 93 & 2.80 & 155 & 0.72 & 111 \\
\hline Dec. 7 & .... do .......... & 93 & 3.07 & 168 & 0.78 & 131 \\
\hline Dec. 17 & $\ldots .$. do $\ldots . . . .$. & 93 & 2.90 & 148 & 0.62 & 92 \\
\hline Dec. 23 & $\ldots$. do ........... & 93 & 0.83 & 99 & 0.47 & 47 \\
\hline
\end{tabular}

Estimated monthly discharge of Chanchos River at line of embankments.

\begin{tabular}{|c|c|c|c|c|}
\hline \multirow{2}{*}{ Month. } & \multicolumn{3}{|c|}{ Discharge in second-feet. } & \multirow{2}{*}{$\begin{array}{l}\text { Total for } \\
\text { month in } \\
\text { acre-feet. }\end{array}$} \\
\hline & $\begin{array}{l}\text { Maxi- } \\
\text { mum. }\end{array}$ & $\begin{array}{l}\text { Mini. } \\
\text { mum. }\end{array}$ & Mean. & \\
\hline 1898. & & & & \\
\hline January $\ldots \ldots \ldots \ldots \ldots \ldots \ldots \ldots \ldots$ & 670 & 57 & 181 & 11,130 \\
\hline February $\ldots \ldots \ldots \ldots \ldots \ldots \ldots \ldots \ldots$ & 624 & 43 & 188 & 10,440 \\
\hline March $\ldots \ldots \ldots \ldots \ldots \ldots \ldots \ldots \ldots$ & 72 & 32 & 53 & 3,260 \\
\hline 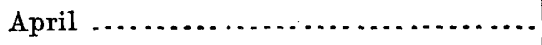 & 582 & 26 & 102 & 6,070 \\
\hline May $\ldots \ldots \ldots \ldots \ldots \ldots \ldots \ldots \ldots \ldots$ & 80 & 38 & 59 & 3,630 \\
\hline June ................ & 370 & 28 & 101 & 6,010 \\
\hline July $\ldots \ldots \ldots \ldots \ldots \ldots$ & 888 & 71 & 228 & 14,020 \\
\hline August............. & 168 & 46 & 95 & 5,840 \\
\hline September .............. & 585 & 35 & 138 & 8,210 \\
\hline October $\ldots \ldots \ldots \ldots \ldots \ldots \ldots \ldots \ldots \ldots \ldots$ & 145 & 46 & 88 & 5,410 \\
\hline November...$\ldots \ldots \ldots \ldots \ldots \ldots \ldots \ldots \ldots$ & 775 & 34 & 182 & 10,830 \\
\hline December...........$\ldots \ldots \ldots \ldots$ & 390 & 40 & 130 & 7,990 \\
\hline
\end{tabular}


NICHOLSON CREEK.

On January 17 a gage rod was placed in Nicholson Creek a short distance below the telegraph line, and the following measurements of discharge were made, which give a fair idea of the size of the stream and its fluctuations. It will be noted that the relation between gage height and its discharge is disturbed by backwater in the San Francisco, but this does not affect the accuracy of the measurements given.

List of discharge measurements made on Nicholson Creek below telegraph line.

\begin{tabular}{|c|c|c|c|c|c|c|}
\hline Date. & Hydrographer. & $\begin{array}{c}\text { Meter } \\
\text { number. }\end{array}$ & $\begin{array}{c}\text { Gage } \\
\text { height. }\end{array}$ & $\begin{array}{l}\text { Area of } \\
\text { section. }\end{array}$ & $\underset{\text { velocity. }}{\text { Mean }}$ & Discharge. \\
\hline 1898. & & - & Feet. & Sq. feet. & $\begin{array}{l}\text { Feet per } \\
\text { second. }\end{array}$ & Sec.-feet. \\
\hline Jan. 21 & N. P. Leary . . . . . . . & 93 & 8.67 & 149.0 & 0.67 & 100.0 \\
\hline Jan. 28 & .... do . & 93 & 5.80 & 57.0 & 0.36 & 32.0 \\
\hline Feb. 15 & $\ldots$. . do .... & 93 & 5.64 & 53.0 & 0.56 & 30.0 \\
\hline Feb. 21 & W. W. Schlecht...... & 93 & 5.02 & 33.9 & 0.69 & 23.5 \\
\hline Mar. 6 & $\ldots .$. do $\ldots$. & 93 & 6.25 & 66.8 & 0.54 & 36.0 \\
\hline Mar. 15 & ..... do & 93 & 4.60 & 169.0 & 0.81 & 13. 7 \\
\hline Mar. 25 & $\ldots .$. do .... & 93 & 4. 70 & 24.5 & 0.85 & 20.8 \\
\hline Apr. 15 & $\ldots$.... do ... & 93 & 4. 46 & 21.0 & 0.82 & 17.0 \\
\hline Apr. 25 & ..... do ... & 93 & 4.30 & 18.0 & 0.74 & 13.4 \\
\hline May 7 & C. Hayman . & 93 & 5.80 & 35.0 & 0.66 & 24.0 \\
\hline May 18 & ..... do & 93 & 4.64 & 21.0 & 0.72 & 16.0 \\
\hline May 30 & ..... do . & 93 & 4.82 & 31.0 & 0.65 & 20.0 \\
\hline June 8 & .... do. & 93 & 4.38 & 15.0 & 0.64 & 10.0 \\
\hline June 17 & .... do .... & 93 & 4.72 & 22.0 & 0.62 & 13.0 \\
\hline June 29 & .....do. . & 93 & 9.52 & 175.0 & 0.48 & 84.0 \\
\hline July 6 & .....do .. & 93 & 9.52 & 158.0 & 0.45 & 71.0 \\
\hline July 14 & ....do do & 93 & 6.85 & 70.0 & 0.36 & 25.0 \\
\hline July 26 & .... do . & 93 & 7.50 & 87.0 & 0.49 & 43.0 \\
\hline Aug. $\quad 6$ & .....do: & 93 & 6.73 & 68.0 & 0.61 & 41.0 \\
\hline Aug. 15 & .....do . & 93 & 8.22 & 104.0 & 0.42 & 43.0 \\
\hline Ang. 25 & .... do. & 93 & 5. 72 & 41.0 & 0.52 & 22.0 \\
\hline Sept. $\overline{5}$ & ..... do. & 93 & 4.91 & 21.0 & 0.54 & 11.0 \\
\hline Sept. 15 & .....do . & 93 & 7.20 & 78.0 & 0.32 & 25.0 \\
\hline Sept. 24 & .....do . & 93 & 8.00 & 100.0 & 0.38 & 38.0 \\
\hline
\end{tabular}

SARAPIQUI RIVER.

The plan of canalizing the Rio San Juan, as sometimes proposed, involves the control of the water of the Sarapiqui River and of the sediment which it brings down from the mountains of Costa Rica.

On July 23 a gage was placed on the left bank of this river about 5 miles above its mouth. It is a vertical rod, graduated to feet and tenths, from zero to 13 feet, and spiked to a tree which hangs over the 
river. Another rod, graduated from 10 to 23 feet, is fastened to a tree about 300 yards upstream, on the same side of the river. At this latter place a galvanized steel cable is placed across the river, from which measurements of discharge are made with the use of a boat, and observations of sediment carried are also made.

List of discharge measurements made on Sarapiqui River 5 miles above mouth.

\begin{tabular}{|c|c|c|c|c|c|c|}
\hline Date. & Hydrographer. & $\begin{array}{c}\text { Meter } \\
\text { number. }\end{array}$ & $\begin{array}{c}\text { Gage } \\
\text { height. }\end{array}$ & $\begin{array}{l}\text { Area of } \\
\text { section. }\end{array}$ & $\begin{array}{c}\text { Mean } \\
\text { velocity. }\end{array}$ & Discbarge \\
\hline 1898. & & & Feet. & Sq.feet. & $\begin{array}{l}\text { Feet per } \\
\text { second. }\end{array}$ & Sec. feet. \\
\hline May 10 & A. P. Davis .... & 94 & $\ldots \ldots$ & 1,046 & 2.92 & 3,050 \\
\hline $\begin{array}{ll}\text { July } 12\end{array}$ & ..... do ... & 94 & $\ldots .$. & 3,686 & 2.65 & 10,762 \\
\hline July 27 & G. R. Wadleigh ....... & 1.985 & 8.84 & 2,238 & 2.35 & 5,252 \\
\hline Aug. 27 & W. H. Smith. & 1985 & 8.51 & 1,922 & 2.43 & 4,677 \\
\hline Aug. 31 & ..... do ....... & 1985 & 8.11 & 1,765 & 2.28 & 4,014 \\
\hline Sept. 3 & .... do ....... & 1985 & 8.25 & 1,823 & 2.34 & 4,264 \\
\hline Sept. 9 & H. W. Durham. & 1985 & -7.52 & 1,617 & 2.10 & 3,399 \\
\hline Sept. 12 & .... do ......... & 1985 & 8.98 & 2,088 & 2.38 & 4,974 \\
\hline Sept. 13 & .... do .. & 1985 & 12.99 & 4,294 & 3.47 & 14,914 \\
\hline Sept. 14 & $\ldots$. do $\ldots$. & 1985 & 13.06 & 4,054 & 3.43 & 13,898 \\
\hline Sept. 21 & ..... do ......... & 1985 & 8.57 & 1,925 & 2.37 & 4,560 \\
\hline Sept. 24 & .... do ..... & 1985 & 8.72 & 1,972 & 2.40 & 4,730 \\
\hline Sept. 27 & $\ldots$...do .... & 1985 & 13.02 & 4,131 & 3.69 & 15,241 \\
\hline Oet. 11 & ..... do .. & 1985 & 11.95 & 3,388 & 3.42 & $\cdot 11,598$ \\
\hline Dec. 21 & ..... do ........ & 1985 & 8.13 & 1,735 & 2.34 & 4,053 \\
\hline
\end{tabular}

Estimated monthly discharge of Sarapiqui River 5 miles above its mouth.

\begin{tabular}{|c|c|c|c|c|c|c|}
\hline \multirow[b]{2}{*}{ Wonth. } & \multicolumn{3}{|c|}{ Discharge in second-feet. } & \multirow[b]{2}{*}{$\begin{array}{l}\text { Total in acre- } \\
\text { teet. }\end{array}$} & \multicolumn{2}{|c|}{ Run-off. } \\
\hline & $\begin{array}{l}\text { Maxi- } \\
\operatorname{mum} .\end{array}$ & $\begin{array}{l}\text { Mini- } \\
\text { mum. }\end{array}$ & Mean. & & $\begin{array}{l}\text { Depth } \\
\text { in inches }\end{array}$ & $\begin{array}{c}\text { Second. } \\
\text { feet per } \\
\text { square } \\
\text { mile. }\end{array}$ \\
\hline $\begin{array}{c}1898 . \\
\text { July } 23-31 \ldots\end{array}$ & & & 5,890 & & & \\
\hline $\begin{array}{c}\text { A ugust } 1-5 \text { and } 18-31 \\
\text { inclusive......... }\end{array}$ & & & $5,5 \overline{0} 0$ & 341,250 & 5.82 & 5.05 \\
\hline September... & 13,140 & 3,360 & 5,890 & 350,780 & 5.97 & 5.35 \\
\hline October $\ldots \ldots \ldots$ & 14,570 & 4,100 & 8,240 & 507,550 & 8.65 & 7.50 \\
\hline November ........... & 30,000 & 4,640 & 11,700 & 696,200 & 11.87 & 10.64 \\
\hline
\end{tabular}


TAURA RIVER.

The waters of the Rio San Juan have two principal outlets, the southern called the Colorado River and the northern called the Lower San Juan. The latter stream sends out another distributary which empties into the ocean between the two larger, and is called the Taura. It seems, however, that a portion of the course of the Taura is, during the season of low water, higher than the water in the San Juan, and becomes a tributary of the latter.

It was visited in May 6, 1898, and was at that time discharging 25 cubic feet per second into the San Juan. On the same day the discharge of the San Juan below the Taura was 1,112 cubic feet per second. The discharge at Ochoa on the same date was 16,950 second feet.

On July 13 the Taura was flowing away from the San Juan, and its volume 200 yards below its exit was 2,234 cubic feet per second. On this day the discharge of the San Juan at Ochoa was 46,000 cubic feetper second.

DESEADO RIVER.

This is a small stream rising in the ridge of hills known in canal literature as the "eastern divide."

According to the company's location, the canal is to follow the valley of the Deseado for a considerable distance, and the plan involves the control and diversion of the waters of this stream. Three locks and several high embankments are to be constructed in this valley, and the volume of the river and the amount of rainfall in this vicinity therefore become important facts, an approximate knowledge of which is necessary to an intelligent discussion of plans and estimate of cost.

On the 25th of December, 1897, a gage was placed in the Deseado at a point about 5 miles above its moutb, measured along the course of the stream; the rain gage was also established at this point, and observations of river height, rainfall, temperature, and humidity were begun by Mr. W. M. Barton.

Subsequent measurements of discharge showed that no definite rela. tion could be established between gage height and discharge of the stream, although the channel consists of hard clay and is not cliangeable. The erratic changes in velocity which the stream exhibited at this point are doubtless due to the fact that it runs through swampy country on a very slight slope. Though there are no definite tributaries anywhere near the gaging station, yet heavy rains in the swamps serve to back the water in the Deseado if occurring below the station, and to accelerate its velocity if occurring above.

On March 4 observations of gage height were begun some distance above, at "Camp Number 7," near the site of the proposed Lock No.1, and the following discharge measurements were made at that point, and from these a rating table was constructed and the table of discharges estimated. 
${ }^{\top}$ ist of discharge measurements made on Deseado River at Camp No. $\%$

\begin{tabular}{|c|c|c|c|c|c|c|c|}
\hline Date. & & Hydrographer. & $\begin{array}{c}\text { Meter } \\
\text { number. }\end{array}$ & $\begin{array}{c}\text { Gage } \\
\text { height. }\end{array}$ & $\begin{array}{l}\text { Area of } \\
\text { section. }\end{array}$ & $\underset{\text { velocity. }}{\text { Mean }}$ & Discharge. \\
\hline 1898. & & & & Feet. & Sq.feet. & $\begin{array}{l}\text { Feet per } \\
\text { second. }\end{array}$ & Sec.feet. \\
\hline Mar. & 8 & W. M. Barton ..... & 2 & 5.60 & 220 & 0.84 & 185 \\
\hline Mar. 1 & 12 & L. E. Lannan ...... & 2 & 5.65 & 224 & 0.78 & 175 \\
\hline Mar. 1 & 18 & $\ldots$ do $\ldots \ldots \ldots$ & 2 & 4.85 & 172 & 0.41 & 70 \\
\hline Mar. & 25 & $\ldots$ do $\ldots \ldots \ldots . .$. & 2 & 5.56 & 223 & 0.54 & 121 \\
\hline Apr. & 1 & $\ldots$ do $\ldots \ldots . . . .$. & 2 & 4. 68 & 171 & 0.38 & 64 \\
\hline Apr. & 6 & $\ldots$ do $\ldots . . . . . .$. & 2 & 7.05 & 298 & $0.80^{\circ}$ & 238 \\
\hline Apr. 1 & 11 & $\ldots$ do $\ldots . . . . . . .$. & 2 & 5.06 & 195 & 0.38 & 74 \\
\hline Apr. 1 & 18 & .... do ................. & 2 & 4.44 & 157 & 0.21 & 33 \\
\hline Apr. 2 & $2 \overline{5}$ & $\ldots$ do ......... & 2 & 4.47 & 167 & 0.30 & 50 \\
\hline May & 2 & $\ldots$ do $\ldots . . . . . . .$. & 2 & 4.88 & 184 & 0.41 & 75 \\
\hline May & 9 & .... do ............ & 2 & 4.65 & 173 & 0.53 & 91 \\
\hline May 1 & 16 & $\ldots$ do $\ldots . . . . . .$. & 2 & 5.08 & 195 & 0.51 & 100 \\
\hline May 2 & 23 & .... do ........... & 2 & 4.83 & 179 & 0.38 & 68 \\
\hline May 3 & 30 & J. C. EIson ......... & 2 & 4.10 & 143 & 0.59 & 56 \\
\hline Júne & 6 & .... do ........... & 2 & 3.95 & 110 & 0.45 & 50 \\
\hline June 1 & 13 & ....do ............ & 2 & 5.08 & 194 & 0.86 & 168 \\
\hline June 2 & 21 & .... do . . . . . . & 2 & 4.88 & 186 & 0.45 & 85 \\
\hline July & 1 & $\ldots d_{0} \ldots . . .$. & 2 & 12.64 & 613 & 1. 30 & 798 \\
\hline July & 9 & $\ldots$ do $\ldots . . . .$. & 2 & 6.78 & 293 & 0.79 & 232 \\
\hline July 1 & 15 & $\ldots$ do $\ldots . . . .$. & 2 & 5.48 & 205. & 0.55 & 113 \\
\hline Aug. & 5 & $\ldots$ do ........... & 2 & 6.72 & 279 & 0.78 & 219 \\
\hline Aug. 1 & 12 & $\ldots .$. do $\ldots . . .$. & 2 & 6.85 & 284 & 0.79 & 227 \\
\hline Aug. 1 & 17 & $\ldots$ do $\ldots . . . . .$. & 2 & 3.76 & 225 & 0.59 & 135 \\
\hline Aug. 2 & 23 & $\ldots$ do ........... & 2 & 5.00 & 178 & 0.58 & 103 \\
\hline Aug. 3 & 30 & $\ldots$ do .......... & 2 & 4.58 & 155 & 0.61 & 95 \\
\hline Sept. & 9 & 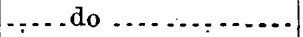 & 2 & 4.52 & 161 & 0.57 & 92 \\
\hline Sept. 1 & 13 & .... do . ........... & 2 & 4.85 & 170 & 0.76 & 132 \\
\hline Sept. 1 & 19 & $\ldots .$. do $\ldots . . .$. & 2 & 4.09 & 137 & 0.39 & 59 \\
\hline Sept. 2 & 23 & $\ldots$ do ............ & 2 & 5.56 & 214 & 0.61 & 132 \\
\hline Sept. 2 & 26 & $\ldots$ do ........... & 2 & 4.01 & 132 & 0.37 & 49 \\
\hline Sept. : & 30 & $\ldots$ do $\ldots . . . . . .$. & 2 & 3. 64 & .115 & 0.37 & 42 \\
\hline Oct. & 7 & $\ldots .$. do $\ldots . .$. & 2 & 4.17 & 140 & 0.46 & 65 \\
\hline Oct. 1 & 10 & $\ldots .$. do $\ldots \ldots \ldots$ & 2 & 4.49 & 155 & 0.51 & 80 \\
\hline Oct. 1 & 17 & $\ldots . .$. do $\ldots . . .$. & 2 & 4.05 & 134 & 0.28 & 38 \\
\hline Oct. 2 & 21 & $\ldots$ do $\ldots . . . .$. & 2 & 3.75 & 119 & 0.46 & 56 \\
\hline Oct. 2 & 24 & 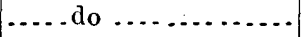 & 2 & 5.95 & 242 & 0.66 & 160 \\
\hline Oct. 2 & 29 & $\ldots$ do $\ldots . . . .$. & 2 & 4.32 & 148 & 0.46 & 68 \\
\hline Nov. & 7 & $\ldots$ do $\ldots . . . . . .$. & 2 & 4.20 & 142 & 0.54 & 77 \\
\hline Nov. 1 & 11 & $\ldots$ do ........... & 2 & 5.09 & 186 & 0.61 & 114 \\
\hline Nov. I & 15 & $\ldots$ do .......... & 2 & 6.08 & 248 & 0.76 & 188 \\
\hline Nov. 1 & 19 & .... do $\ldots . . . . .$. & 2 & 8.42 & 360 & 0.85 & 305 \\
\hline Nov. 2 & 21 & $\mid \ldots$ do $\ldots . . . . . . .$. & 2 & 6.81 & 280 & 0.78 & 220 \\
\hline Nov. 2 & 28 & $\ldots$ do $\ldots . . .$. & 2 & 11.98 & 544 & 1. 13 & 615 \\
\hline Dec. & 2 & $\ldots$ do ....... & 2 & 7.84 & 323 & 0.89 & 287 \\
\hline Dec. & 9 & .... do .................... & 2 & 7.22 & 294 & 0.84 & 247 \\
\hline Dec. 1 & 12 & $\ldots$ do $\ldots . . . . . .$. & 2 & 8.22 & 350 & 0.93 & 324 \\
\hline Dec. 1 & 16 & $\ldots$ do $\ldots . . .$. & 2 & 6.08 & 227 & 0.69 & 156 \\
\hline Dec. 1 & 19 & $\ldots$.... do $\ldots . . . . . . . .$. & 2 & 5.50 & 191 & 0.69 & 134 \\
\hline
\end{tabular}


Estimated monthly discharge of Deseado River at Camp No. \%.

\begin{tabular}{|c|c|c|c|c|}
\hline \multirow{2}{*}{ Month. } & \multicolumn{3}{|c|}{ Discharge in second-feet. } & \multirow{2}{*}{$\begin{array}{l}\text { Total for } \\
\text { month in } \\
\text { acre-feet. }\end{array}$} \\
\hline & $\begin{array}{l}\text { Maxi. } \\
\text { mum. }\end{array}$ & $\begin{array}{l}\text { Mini- } \\
\text { mum. }\end{array}$ & Mean. & \\
\hline 1898. & & & & \\
\hline March $\ldots \ldots \ldots \ldots \ldots \ldots \ldots \ldots \ldots \ldots \ldots$ & 135 & 68 & 107 & 6,579 \\
\hline April $\ldots \ldots \ldots \ldots \ldots \ldots \ldots \ldots \ldots \ldots$ & 462 & 34 & 111 & 6,605 \\
\hline 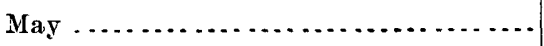 & 223 & 31 & 97 & 5,964 \\
\hline 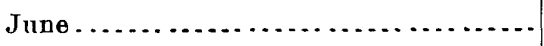 & 267 & 30 & 137 & 8,150 \\
\hline Juls $\ldots \ldots \ldots \ldots \ldots \ldots \ldots \ldots \ldots \ldots \ldots \ldots$ & 794 & 122 & 343 & 21,090 \\
\hline Augnst $\ldots \ldots \ldots \ldots \ldots \ldots \ldots \ldots \ldots \ldots \ldots$ & 482 & 70 & 200 & 12,300 \\
\hline September .... & 243 & 27 & 78 & 4,640 \\
\hline 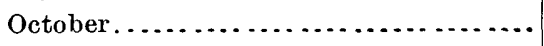 & 278 & 42 & 99 & 6,090 \\
\hline November $\ldots \ldots \ldots \ldots \ldots \ldots \ldots \ldots \ldots \ldots$ & 354 & 77 & 329 & 19,160 \\
\hline December $\ldots \ldots \ldots \ldots \ldots \ldots \ldots \ldots \ldots$ & 324 & 90 & 221 & $\mathbf{1 3}, \mathbf{5 9 0}$ \\
\hline
\end{tabular}

SEDIMENT OBSERYATIONS.

Any proposition for a ship canal which involves the use of the Rio San Juan below the mouth of the Rio San Carlos requires for its intelligent consideration some idea of the quantity of sediment carried by that stream, and if the San Juan is to be used below the mouth of the Sarapiqui the sediment carried by that stream becomes also an important factor. To determine these quantities samples of water were taken daily and' allowed to settle, and the sediment was measured. The samples were obtained at not less than a dozen places in the river, the water aggregating several gallons, and representing approximately the average of the various parts of the current. The samples were thoroughly mixed, and one sample of 100 cubic centimeters was taken and the rest rejected. This sample was allowed to settle for twentyfour bours, and the clear water was poured off and another sample added to the remainder; the clear water was decanted the next day and another sample added, and so on, accumulating any sediment that remained, until it became a measurable quantity, when its depth was read on the graduated glass in which the settlement was made. This reading gives, of course, only the bulk of the loose mud, and not the dry solid matter. The relation between the mud and dry matter as deterwined by a series of experiments for a similar purpose made on sediment from the Gila River, Arizona, was five parts of mud to one of dry material. This factor has therefore been used in reducing the results.

The taking of water samples and measurement of sediment therein would not furnish all the required data, as these streams roll large quantities of sand and gravel along their beds which could not be taken in water samples. So far as could be learned, no attempt at such 
measurement had ever been made, and it was recognized as a difficult task. The method devised was as follows:

A galvanized sheet-iron pan was provided (see fig. 292), 1 meter square and 8 inches deep, with one side $(\dot{L})$ hinged so that it could be opened to lie in the same plane as the bottom of the pan, and a weight and stavs were provided to hold it in this horizontal position. Four chains (S), attached one to each corner of the top of the pan, met about 4 feet above the pan, and united in a ring, and the whole was suspended from a cable stretched across the river with the door open and upstream.

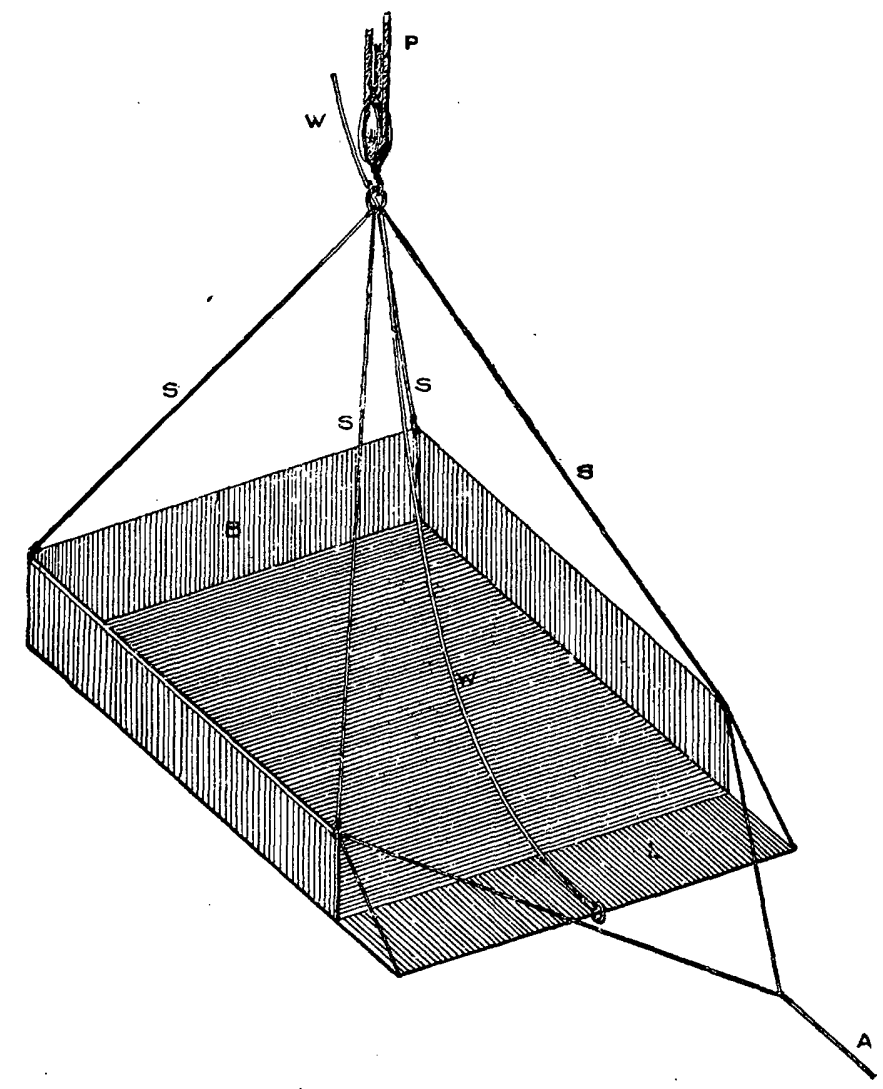

FIG. 222.-Sediment trap ready for use.

An anchor was thrown about 100 feet upstream to hold the pan firmly in position, while it was gently lowered from the cable by means of a rope from shore, working in tackle blocks. The pan was allowed to settle firmly on the bottom and to remain for a limited time, usually one hour. The attempt is to cause the minimum disturbance of natural conditions in the stream, and to.intercept and hold in the pan the sediment traveling along the bottom in the section it occupies. When it is desired to close the observation, a small copper wire (W) which has been fastened to the open door and passed through the ring above the 
pan is stoutly pulled until it raises the lid from the bottom of the stream, whereupon the current catches the lid and slams it shut, when it is automatically fastened by a lateh on each side. Then by means of a windlass on shore the pan is hoisted and brought to land, and the entrapped sediment measured.

There is nothing about this operation to increase the motion of sediment along the bottom into the pan, so it is thought that results can never be too large. On the other hand, some sand may pass under the edge of the lid when the bottom of the river at this point is marred with local inequalities. This is supposed to be one cause of the small results on certain days, when other observations immediately before or after gave large results. Another persistent source of error of unknown magnitude is the washing out of the sediment by the current over the weir (B) formed by the back of the pan. To test the importance of this theoretical possibility, a temporary partition was placed in the pan, perpendicular to the current, and nearly as high as the sides of the pan, the theory being that if all sediment were stopped by the partition and deposited in front of it, that would be good evidence that in the absence of the partition all would be stopped by the back of the pan, and none lost. In the first experiment more sediment was deposited behind than in front of the partition, and the quantity that passed out of the pan is unknown. This result was essentially repeated for most of the experiments, showing conclusively that more or less sediment is carried out over the back of the pan by the scour which it occasions. It is important to bear this fact in mind when studying the results, for it is certain that the results are quantitatively too small, and should be regarded only as showing that large quantities of sediment are traveling on the bed of the stream, and as roughly indicating the relative amount.

Sediment, by water samples, from Rio San Carlos, 1898.

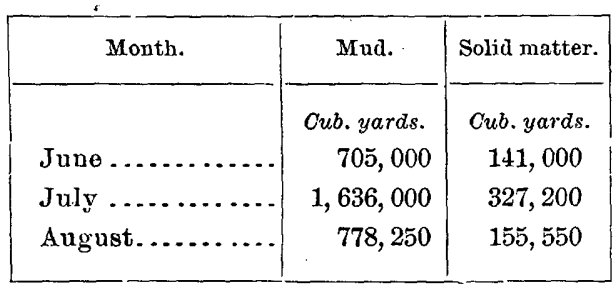

Note:-Five cubic yards of mud are assumed equal to 1 cubic yard solid matter. 
Sediment carried on bottom by Rio San Carlos, Costa Rica, 1898.

\begin{tabular}{|c|c|c|c|c|c|}
\hline Month. & $\begin{array}{l}\text { Mean } \\
\text { per hour. }\end{array}$ & $\begin{array}{c}\text { Total } \\
\text { per month. }\end{array}$ & Month. & $\begin{array}{l}\text { Mean } \\
\text { per hour. }\end{array}$ & $\begin{array}{c}\text { Total } \\
\text { permonth. }\end{array}$ \\
\hline January ....... & $\begin{array}{l}\text { Cub.yards. } \\
\ldots\end{array}$ & Cub.yards. & July .......... & $\begin{array}{c}\text { Cub. yards. } \\
\text { 7. } 68\end{array}$ & $\begin{array}{c}\text { Cub.yards } \\
5,714\end{array}$ \\
\hline February ..... & $\ldots \ldots$ & . & August... & 16.03 & 11,926 \\
\hline March ........ & 5. 61 & 4,174 & September .... & 17.22 & 12,398 \\
\hline April. & 12.91 & 9,295 & October ...... & 18. 42 & 13,704 \\
\hline May .... & 5.59 & 4,159 & November.... & 18.30 & 13,180 \\
\hline June .......... & 10.80 & 7,776 & December ..... & 15. 10 & 11,230 \\
\hline
\end{tabular}

Sediment rolled along the bottom of the Sarapiqui River, 1898.

\begin{tabular}{|c|c|c||c|c|c|}
\hline Montb. & $\begin{array}{c}\text { Mean } \\
\text { per hour. }\end{array}$ & $\begin{array}{c}\text { Total } \\
\text { per month. }\end{array}$ & Month. & $\begin{array}{c}\text { Mean } \\
\text { per hour. }\end{array}$ & $\begin{array}{c}\text { Total } \\
\text { per month. }\end{array}$ \\
\hline September .... & $\begin{array}{c}\text { Cub.yards. } \\
1.76\end{array}$ & Cub.yards. \\
October ....... & 4.00 & 2,970 & November . . . & 6.06 & 4,360 \\
& December . . ... & 12.20 & 9,080 \\
\hline
\end{tabular}





\section{N D EX.}

A.

Abilene, Kans., location and elevation of.. 306 rainfall at........................ 311,313

Adairsville, Ga., location and elevation of.. 177 rainfall at........................ 179, 181 Adams, A. J., work of................. 520 Ainsworth, Nebr., stream measurements at 298 Ajocuapa River, Nicaragua, character of.. 608 Alabama, strean measurements in $51,187,192-195$ Albion, Nebr., stream measurements at.... 298 Albuquerque, N. Mex., location and eleva. tion of....................... 356 rainfall at.

Alcovy River, Ga., water power on....... 167 Alderson, W. Va., rainfall at............ 51 stream measurements at......... 51, 202, 204

Alexander, E. P., arbitration by........... 574

Allegheny River, Pa., measurements of.. 195-197 plate showing view of junction of Monongahela River and ............. 196 drainage area of.................... 198 Alliance, Nebr., location and elevation of.. 257 rainfall at....................... 260,265 Alliance, Pa., stream measurements at.... 198 Alligator River, Nicaragua, character of.. 607 Alluvium in the Lower Mississippi Valley. $\quad 352$ Alma, Colo., location and elevation of...... 257 rainfiall at. ...................... 259, 265 Almon, Ga., stream measurements at..... 51 Alston, S. C., stream measurements at. 50, 151-152 Altamaha River, map showing location of stations in basin of.............. 157

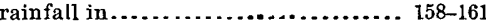
water powers in basin of............ 166-168 hydrography of.................. 168-169 measurements of tributaries of. 51,161,170-172

American Falls, Idaho, location and elevation of.. 470

rainfall at..... 471,474

American Fork River, Utah, measurements of............................ 61,469 American River, Cal., measurements of... 526 A mity Canal, Colo., plate showing views of. 340 Amity Land and Canal Company, acknowledgments to.

Ammen, D., reference to .

Analyses of water from Analysis of water from White River, Nebr. $\quad 254$ Anderson, S. C., location and elevation of.. 158 rainfall at. ...................... 159, 161 Androscoggin River, Me., measurements of ......................... 46,66-72 plate showing views of .............. 66 diagram showing discharge of.........
A Page. $379,403,411$ diagram showing discharge of......... 403 Annapolis, Md., location and elevation of.. 112 rainfall at...................... 113, 114 Ansley, Nebr,, location and elevation of... 257 rainfall at.................... 260, 265 Antelope Creek, Nebr., measurements of.. 298 Antietam Creek, Md., measurements of.... 49, $120,121,122$ diagram showing discharge of........ 122 Apalachee River, Ga., water powers on.... 167 Apalachicola Basin, Ga., important creeks

and rivers in................. 175-177 Arana River, Nicaragua, character of...... 607 Arboles, Colo., stream measurements at.. 58, rainfall at.................... $59,401,402,410$ plate showing views of gaging station at 402 Arizona, reservoir surveys in............. 29 stream measurements in ......... 59,406-407 Arkansas River, measurements of ........ 56 57 , $323-324,329,330-339,342-343$ diagrams showing discharge of...... 336, $337,338,339,343$ plates showing views of ............ 324,340 map showing location of stations in basin of...................... 325 rainfall in basin of ................... $325-330$ Arkins, Colo., stream measurements at. 55, 288-289 plate showing views of Home Supply dam near. Arlington, Nebr., stream measurements at. $\quad 299$ Arnold, Nebr., stream measurements at.... 300 Arnold, S., work of............ 22, 504, 505, 508 Arrowhead Reservoir Company, aid by.... 561 Arroyo Seco, Cal., underground water from Pasadena Mesa and the bed of the... 543-549 Artesian wells, investigations of.......... 44 Artesian wells in Moxee Valley, Wash .... 508 Ash Creek, Nebr., measurements of ...... 298 Asherille, N. C., stream measurements at. 52, 205 Ashland, Va., geographic position of...... 132 rainfall at....................... 133, 134 Athens, Ga., location and elevation of ...... 158 rainfall at......................... 160,161 Atkinson, Nebr., stream measurements at.. 299 Atlanta, Ga., location and elevation of..... 177 rainfall at.......................... 179, 181 Atrato Canal routes, discussion of ....... 587-588 A.ugusta, Ga., stream measurements at... 50-51,

Augusta, Mont., stream measurements at .. 53 
Austin, Tex., references to stream measurements at. Azuza, Cal., stream measurements at ..... 64,551 location and elevation of ............. 560 rainfall at

Babb, C. C., work of ............... 25, 478, 505 Bachmans Valley, Md., location and eleva. tion of $\ldots \ldots \ldots \ldots \ldots \ldots \ldots \ldots \ldots, 112$

rainfall at....................... 112,114

Bakersfield, Cal., stream measurements at 64 ,

536-538

rainfall at....................... 561

Bald win, D. H., work of ................ 594

Ballentine Canal, Idaho, measurements of. 486,487 Baltimore, Md., location and elevation of... 112 rainfall at...................... 113, 114

Bannister, E. R., aid by .................. 325

Barbour, E. H., work of ................ 45

Barnard, E. C., work of .................. 493-495

Barton, E., analyses of water by........... 321

Barton, S., aid by ........................ $\quad 560$

Barton, W.M., work of................. 632

Battle Creek, Idaho, rainfall at............. 60

stream measerements at......... 60,459-460

Battle Mountain, Nev., stream measure. ments at ....................... 59,60

Battle Mountain Canal, Nev., estimated cost

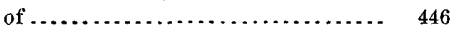

Beach, C. W., acknowledgments to ....... 23

Bear Creek, Colo., measurements of....... 54 ,

$263,284-285$

diagram showing discharge of........ 285

Bear Lake reservoir site, Utah, settlement

on ............................. 463-464

Bear River, Utab, measurements of........ 60 , $458,159,462$

plate showing views of .............. 458 diagrams showing discharge of...... 460,461 Bear River Canal, Utab, plates showing views of..................... 462,468

Beatrice, Nebr., stream measurements at.. 298 Beaver Creek, Nebr., measurements of..... 298 Bedford City, Va., location and elevation of. $\quad 137$

rainfall at...................... 138, 139

Bell, Nebr., stream measurements at...... 301 Beloit, Kans., stream measurements at.... 55 Benkelman Nebr., stream measurements at. $\quad 302$ Bethlehem, Pa., stream measurements at.. 86-88 Beverly, Kans., stream measurements at.... 56,

Big Bordeaux Creek, Nebr., measurements 312,313

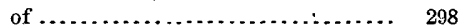

Big Cottonwood Creek, Nehr., measure ments of ................... 254, 298

Big Goose Creek, Wyo., measurements of.. 53 Bighorn River, Wyo., stream measurements in basin of............... 53,249 plate showing view of............... 250 Big Thompson Creek, Colo., measurements of $\ldots \ldots \ldots \ldots \ldots \ldots \ldots \ldots \ldots \ldots, 55,288-289$ diagram showing discharge of........ 289 seepage measurements on............. 289
Birdwood Creek, Nebr. Page.

measurements of.. 298 itterroot River, Mont., measurements of. 62,495 plate showing view of............... 492 map showing principal streams and ditches in valley of ................ 492 plate showing view of valley of......... 492 irrigation in valley of.............. 492-495 Blackfoot River, Mont., plate sbowing view of gaging station on............. 488 measurements of ................... 491 Black Fork of Green River, Wyo., measurements of . ................ 58, 381-382 diagram showing discharge of........ 382 Black Hills, S. Dak., plate showing Dakota sandstone in .................... 252 Blackrock Harbor, N. X., stream measurements at ........................ 224

Blacksburg, Va., geographic position of.... 132 rainfall at ........................ 133, 134 Black Warrior River, Ala., measurements of ....................... 51,194-195 diagram showing discharge of......... 195 Blake, Utah, rainfall at .................. 58 stream measurements at .. $58,378,379,387-388$ plate showing view of G reen River near. $\quad 380$ Blake, W.H., acknowledgments to........ 409 Blue Creek, Nebr., measurements of ....... 298 Bluefield, W. Va., location and elevation of. 199 rain 1 all at ..................... 201, 202 Bluefields, Nicaragua, rainfall at ........ 576 Blue Lake dam, Cal., plate sbowing views of ............................ 528 Blue Ridge, Ga., reference to stream measurements at ..................... 210 Blue River. Kans., measurements of ....... 56 $312,313,31_{6}$ diagram showing discharge of ........ 319 Blue River, Nebr.. measurements of ...... 298 Boardman Creek, Nebr., measurements of.. 298 Boca, Cal., stream measurements at....... 59 Bodare, Nebr., stream measurements at... 303 Boelus, Nebr., stream measurements at ... 300 Boggy Creek, Nebr., measurements of. .... 298 Boise, Idaho, st ream measurements at ..... 62 , $473,474,483$ . map showing location of principal irri. gation canals between Caldwell and. 485 Boise River, Idaho, measurements of ...... 62 $473,474,483,485,486$ diagram showing discharge of ........ 483 seepage measurements in valley of... 484-488 Bone Creek, Nebr., measurements of ..... 298 Bonner, Mont., stream measurements at... 49 ! Bonlder, Colo., stream measurements at ... 54 , $263,286-287$ Boulder Creek, Colo., measurements of .... 54 , $263,286-287$

diagram showing discharge of......... 287 Boundary dispute between Nicaragua and Costa Rica .................... 573-574 Boyd, J. U., mentioned ................. 86 Boyds Corners, $N$. $Y$., rainfall at.......... 82-83 Bozeman, Mont., location and elevation of. 232 rainfall at....................... 233,235 
Bozeman, Mont., plate showing method of measuring Middle Creek above .... 24 24

Bradford, W., mentioned .................. 86 Brazos River, T'ex., references to measurements of .......................... Breckenridge, Colo., location and eleva tion of. .......................... rainfall at. $\ldots .376,379,396,398,399$

Brito, Nicaragıa, rainfall at............ 578 stream measurements at............ 594 diagram showing rainfall at...... 576

Broad River, Ga., measurements of ....... 51,163 plate showing view of.............. 154 water powers on $. . . \ldots \ldots \ldots \ldots \ldots \ldots \ldots . .156$ diagram showing discharge of......... 163

Broad River, N.C., plate showing view of canal from...................... 146

Broad River, S. C., measurements of.. . 50, 151-152 diagram showing discharge of........ 152 Brown, C. N., work of .......... 198, 214-215, 216 Brown, G. W., work of................. 156

Brownsville, Pa., stream measurements at 196-197 Bruneau River, Idaho, measurements of $473,474,481-482$

diagram showing discharge of 482

Bryson, N. C., stream measurements at... 52, 206 Buchanan, Va, rainfall at...

stream measurements at . ........ 49,134;136

Buck Creek, Nebr., measurements of ...... 298

Buckingham, Va., geographic position of.. $\quad 132$ rainfall at....................... 133, 134

Buel, E. D., mentioned................... 86

Buffalo, Wyo., stream measurements at.

Buffalo Canal Company, acknowledgments to .............................

Buffalo Creek, Nebr., measurements of.....

Bull, J. A., work of.

Burlington and Missouri River Railroad, acknowledgments to ..............

Burton Creek, Nebr., measiurements of...

Burwell, Nebr., location and elevation of rainfall at....................... 261,265 stream measurements at .............. 298

Buttes, Ariz., plate showing view of dam site at.

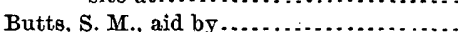

C.

Cache la Poudre River, Colo., méasurements of ......... 55,291-292 general statements concerning........ 290 diagrams showing discharge of .. 291, 292, 293 plate showing view of.

plate showing riew of sky-line ditch diverting water from Laramie River to ..............................

Calamps River, Nebr., measurements of ... Caldwell, H. W., aid by.

Caldwell, Idabo, map showing location of principal irrigation canals between

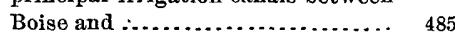

Calhoun Falls, S. C., rainfall at ............. $\quad 50$ stream measurements at ......... 50, 160, 164 plate showing view of Savannah River at. .

20 GEOL, PT $4-41$
California, reservoir surveys in stream measurements in .......63-64, 524-560 variation in rainfall and water supply

in ....................... 524-525,539 rainfall in ........................... 560-561 Callaway, Nebr., stream measurements at . $\quad 300$ Calowa River, Wash., measurements of... 63, 522 diagram showing discharge of ......... 522

Camfield, D. A., work of ............... 278

Campbell, A. Q., reference to .............. 543

Camp Clarke, Nebr., stream measurements

at......... 54, 263, 266, 268-269, 301-302

Cauton, Ga., rainfall at ............... 51 stream measurements at .......... 51, 189-190 plate showing view of Etowah River at 188 Canyon, Colo., stream measurements at .... 56, $329,330,331-336$ plate showing view of new diverting tam at ...................... 324 location and elevation of ............... 326 rainfall at .......................... 327,330 Cape Fear River, N. C., measurements of.. 50, 145 diagram showing discharge of........ 145 Carey, Ga., stream measurements at... 51, 161, 171 plate showing views of Oconee liver at , 158 Carillon, Quebec, stream measurements at.. $\quad 227$ Carlton, Ga., rainfall at.................... stream measurements at............. 51,163 plate showing view of Broad River near 154 Carpenter, L. G., work of............ 289, 290, 323 Caruthers, J.H., aid by ............... 23, 555 Carters, Ga., rainfall at................... stream measurements at...... 51, 180, 191-192 Cassidy Canal, Idaho, measurements of .. 486, 487 Castillo, Nicaragua, rainfall at ............ 578 Castlerock, Colo., location and elevation of. $\quad 257$ rainfall at........................ 259, 265

Càstlewood dam, Colo., description of.... 280-283 Castlewood Lake and dam, Colo., plate showing views of ................. 280

Catarina River, Nicaragua, character of.... 608 Catawba, N. C., stream measurements at .. 50, 149 Catawba River, measurements of...... 50, 149-150 diagrams showing discharge of ...... 149, 150

Catlin \& Macev ditch, Idaho, measurement

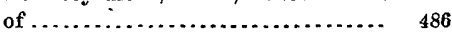

Cedar Rapids, Nebr., stream measurements

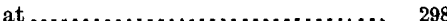

Cedar River, Nebr., measurements of...... 298 Cellar River, Wash., measurements of. $63,516-517$ diagram showing discharge of ........ 516 plate showing gaging station on ...... 516 Centerville, Cal., plate showing riew of Church ditch near

Central America, map of..... Chadron Creek, Nebr., measurements of.... 299 Chaffee, F. P., acknowledgments to......... 23 Chagres River, Nicaragua, plate showing view on ........................ 588 Chama, N. Mex., location and elevation of.. 356 rainfall at........................ 357,359 Chamberlain, J. P., aid by.............. $\quad 560$ Chanchos River, Nicaragua, measurements of ............................ 626-629 Chattahooche River, Ga., measurements of 51, $180,181,182-183$ 
Chattahooche Piver, along ............................ 172-174 water powers on ................... 174 tributaries of . . . . . . . . rainfall in basin of ............... 177-181 map showing location of stations in basin of . diagrams showing discharge of...... 182, 183 Chattanooga, Tenn., stream measurements at........................ 52,210-211 plate showing view of Tennessee River

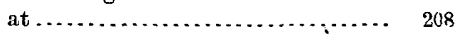

Chelan, Lake, Wash., description of........ 495 map of drainage basin of ............ 496

Cherry Creek, Colo., irrigation from ...... 280-284 Chesapeake and Ohjo Railway, acknowledg.

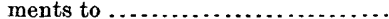

Chestatee River, Ga., tributaries of....... 176

Cheyenne, Wyo., location and elevation of. 257 258,265

Cheyenne River, S. Dak., course and tributaries of... irrigation from.................... plate showing riew of falls of ......... 252 topography near................ 252-253

Childs, $O$. W., surrey of canal route by .. 589-590

Chittenden, H. M., mentioned ............ 197 cited on floods in the Mississippi River ....................... 349, 350

Christiansburg, Va., location and elevation of .......................... 137 rainfall at....................... 138, 139

Church ditch, Cal., platu showing view of.. 536

Cisco, Utah, location and elevation of...... 375 rainfall at..................... 377,379

City Creek, Cal., measurements of........ $\quad 557$

Clapp, W. B., acknowledgments to....... 23

Clark, W. B., work of................... 22

Clarke, T. C., aid by .................. $\quad 227$

Clarksville, $\nabla a$., rainfall at............... 50 stream measurements at ........... 50, 139 location and elevation of ............. 137 rainfall at....................... 139

Clear Creek, Nebr., measurements of..... 298

Clear Creek, Wyo., measurements of.. 53, 250-251 plate showing gaging station on........ 250 diagram showing discharge of.......... 251

Clear Lake, Cal., measurements of......... 528

Cleveland, G., arbitration by............. 574 mentioned.................. 591

Clifford's bridge, Wash., stream measurements at .........................

Climie, W. records kept by......................

Coalville, Utah, location and elevation of.. 454 rainfall at..................... 456,458

Cobb, P. L., mentioned ....................

Cobbosseecontee River, Me., measurements of ............................

Coco River, Nicaragua, course of......... 569

Codman, J.E., work of................ 88,94 aid by........................ 108

Cole, B., acknowledgments to............ 23 aid by ........................... 560

Colby, Kans., location and eleration of.... 306 rainfall at. ..................... 309, 313

Collinston, Utah, rainfall at
Page. $458,459,460-462$

plate showing view of Bear River at... 458

Colorado, reserroir sites in ............ 31-32 stream measurements in .......... 54-55, 57 , $279-280,284-294,329,330,331-342,358$, $359-364,365,378,379,388-396,401-404$ rainfall in ............ 258, 259, 265, 327-328 $330,357,359,376-377,378,379,396-399$

Colorado Midland Railway, acknowledg.

ments to ....................... 23

Colorado River, Tex., references to meas. urements of ......................

Colorado River, Upper, map showing loca tion of stations in basin of.......... 374 rainfall in basin of . ................ 374-379

Colton, A. T., work of .................. 22 Columbus, Nebr., rainfall at ............. stream measurements at.. 55, 263, 294-296, 302 Columbus, Ohio, stream measur̃ements at.... 212215, 216 Coldwater Creek, Nebr., measurements of.. 298 Concordia, Kans., location and elevation of. 306 rainfall at....................... 310,313 Connecticut, rainfall at Hartford......... 47 stream measurements in ............. 47 Connecticut River, measurements of.... 47,76-78 diagram showing discharge of......... 77 Como, Lake, Mont., plate showing riew of'.. 496 Consuelo River, Nicaragua, character of.... $\quad 607$ Cooley, L. E., reference to ............... 216 Coon Creek., Nebr., measurements of ...... 298 Cooper, T., acknowledgments to........... 24 Cortez, Colo., plate showing view of flume carrying water to ................ 414

Coosa River, Ala., measurements of... 51, 184-188 rainfall in basin of .................. 177-181 map showing location of stations in basin of ...................... 178 diagrams showing discharge of ...... 186, 187 Coosawattee River, Ga., measurements of. 51 , 180, 191-192

diagram showing discharge of......... 192 Cornlea, Nebr., location and eleration of ... 257 rainfall at....................... 261, 265 Corthell, E. L., work of .................. 586 Costa Rica, boundary dispute between Nicaragua and $\ldots \ldots \ldots \ldots \ldots \ldots \ldots .573-574$ map of portions of Nicaragua and, show. ing route of proposed canal ....... 574 Cottonwood Creek, Idaho, measurements of ........................ 485, 487 Cotton wood Creek, Nebr., measurements of. 298 Cottonwood River, Kans., plate showing view of ...................... 308

Covington, Ga., location and eleration of... 158 rainfall at ..................... 160,161 Cow iche Creek, reser voir site on ......... 506-507 map of reservoir on ................. 507

Cozad, Nebr., plate showing view of head gate of canal of Farmers and Mer. chants' Irrigation Company on Platte River at .................. 296 Craig, Colo., irrigation and agriculture near. $\quad 384$ Craig, Mont., stream measurements at..... 53 Cramer, F., reference to................. 384 
Page.

Crawford, Nebr., stream measurements at. 54,303 Cressy, S. W., acknowledgments to........ 23

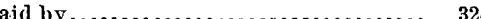

Crete, Nebr., stream measurements at .... 298 location and elevation of ........... 306 rain fall at . ........................ 308,313

Crocker, H. R., aid by .................. 560

Crockers; Cal., location and elevation of ... 560 rainfall at.

Crooked Creek, Nebr., measurements of .

Croton dam, N.Y., fgure showing section of. 84

Croton River, N. Y., measurements of... 47, 81-84 plate showing view of ............... 74

Cucamonga Creek, Cal., measurements of.. 552

Cucaracho River, Nicaragua, character of.. $\quad 607$

Culbertson, Nebr., stream measurements

at ......................... 299, 302

location and elevation of $\ldots \ldots \ldots \ldots \ldots . \quad 306$ rainfall at....................... 307,313

Cumberland, $M d$., rainfall at ........ 49, 118, 121 stream measurements near ....... 49, 120,121 location and elevation of.

Cunningham, Kans., location and elevation of . rainfall at. location and elevation of.. 560 rainfall at....................... 561

D.

Dahlonega, Ga., location and elevation of... 177 rainfall at. ....................... 179, 181 Dakota sandstone at cascades of Fall River, S. Dak., plate showing............. 252

Dale Enterprise, Va., location and elevation of ............................. 11

rainfall at -

Dallas, Tex., references to stream measurements at ...

Daly, $M$., mentioned. .'

Dan River, Va., measurements of......... 50, 139

Dante River, Nicaragua, nieasurèments of ..........................621-622

Darton, N. H., work of................ 44, 252

Daunt, Cal., location and elevation of....... 560

Dávid City, Nebr., location and elevation of 306 rainfall at 308,313

Davis, A.P., hydrography of Nicaragua. 563-637 work of .......................... 609

Davis ditch, Idaho, measurements of .... 486, 487

Davis \& Hart ditch, Idaho, measurements of .

Day, D. F, acknowledgments to ........... 486

Dayton, Wash., location and elevation of... 512 rainfall at ..................... 512,514

Dead Horse Creek, Nebr., measurements of 299

Dean, J. L., aid by ....................... 64

Deansbury, Colo., stream measurements at. $\quad 54$

Deep Creek, Cal., elevation of ........... 560 rainfall at........................ 561

Deep River, N. C., plate showing view of dam across ..................... 146 references to measurements of......... 146

Deer Creck, Nebr., measurements of....... 299

Delaware River, measurements of....... 48, 84-86 diagram showing discharge of
Delaware River, Kans., plate showing view Page

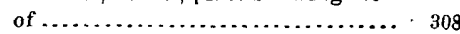

Del Norte, Colo., stream measurements at ................... 57, 358, 359-364

Del Rio, 'T'ex., map showing irrigation system near ...................... 354

Delta, Colo., location and elevation of..... $\quad 375$ rainfall at ............. $377,379,397,398,399$ Deming, N. Mex., location and elevation of. $\quad 356$

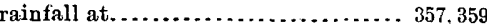

Denver, Colo., stream measurements at. . 54, 263 location and elevation of ............ $\quad 257$ raiufall at........................ 259, 265 Denver Land and Water Storage Com. pany, irrigation system of...... 280-284

Denver Union Water Company, aid by..... 284

Denver and Gulf Railroad, acknowledg. ments to........................

Denver and Rio Grande Railroad, acknowl. edgments to..................... 23

Descanso, Cal., location and elevation of... 560 rainfall at........................... 561

Deschutes River, Oreg., references to meas. urements of.................... 63,516

Deseado, Nicaragua, rainfall at........... 578 diagram showing rainfall at............ 576

Deseado River, Nicaragua, temperature and relative humidity on............. 581 measurements of .................. 632-634 Desplaines River, Ill., measurements of... $5 \dot{z}$, 218-223 drainage basin of ................ 218 diagram showing discharge of........ 223 Dewitt, Nebr., stream measuremenis at... 298 Diamond, Ga., location and elevation of.... 177 rainfall at......................... 179, 181

Dickson, L. H., acknowledgments to....... 23 Discharge data, résumé of................ 46-64 Dismal River, Nebr., measurements of..... 299 District of Columbia, rainfall in . ........ 119, 121 Dobson, A., work of ................... 22 Dodge, Kans., location and elevation of.... $3 \div 6$ rainfall at........................ 328, 330 Dolores, Colo., stream measurements at... 58 , plate showing view of gaging station near ........................... 392 Dolores River, Colo., measurements of.... 58 , $379,392-394$ plate showing view of gaging station on. 392 diagram showing discharge of ........ 394 diagrams showing comparison of stor. age in Morton Lake and flow of .. 428, 429 plate showing view of head waters of... 432 Douglas, Nebr., stream measurements at... 301 Downs, Kans, location and elevation of ... 306 rainfall at....................... 310,313 Dry Creek Canal, Idaho, measurements of. $\quad 487$ Drubar, C., aid by ..................... 560 Dublin, Ga., rainfall at................... 51 stream measurements at ......... 51, 161, 170 plate showing view of Oconee River near ......................... 166 Dungeness River, Wash., measurements of. 63 , 
Dungeness River, Wash., diagram showing discharge of ...................... Dunham, B., acknowledgments to.......... Dunlap, Nebr., stream measurements at Dunning, Nebr., stream measurements at. 299, 300 Durango, Colo., stream measurements at... 59,

rainfall at $397,398,399$

E.

Eads, J. B., work of. .

Eagle Island, Idabo, stream measurements

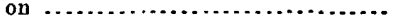

East Carson River, Nev., measurements of. Echo Mountain, Cal., location and elevation of .

rainfall at

Elberton, Ga., location and elevation of.... 158 rainfall at...................... 159, 161

Elkhorn River, Nebr., measurements of.... 55 , $264,266,296-297,299$

diagram showing discharge of......... 297

Elko, Nev., stream measurements at.. 59,437-438

Ellensburg, Wash., location and elevation

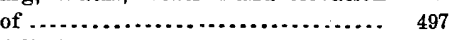
rainfall at....................... 498,500

Ellsworth, Kans., stream measurements at. 56 , $312,313,315$

El Paso, Tex., rainfall at. 58 stream measurements at...... 58, $358,359,372$

Elrod, M. J., aid by

EI Toro, Rio, Nicaragua. See Rio EI Toro.

Elwha River, Wash., measurements of. $63,520-521$ proposed dam on................ 519,520 diagram showing discharge of........ 521 plate showing bridges over.......... 516

Embudo, N. Mex., stream measurements at. rainfall at $58,358,359,364,366-369$

Tmery, R., aid by

Emery, S. M., work of cited on flow of Madison River, Mont.. cited on flow of Gallatin River, Mont.

Emmitsburg, Md., location and elevation of... rainfall at. 119,121

Endicott, M. T, work of ................ 591

Ericson, Nebr., location and elevation of... 257 rainfall at........................ 261, 265 tream measuremerits at.

Erie Canal, N. Y., plate showịng views of barges on .

Espinola, R., records kept by.

Escondido,

Escondido River, Nicaragua, course of.....

Etowah River, Ga., measurements of ......

plate showing view of................ 188 water powers on ................. 188-189

diagram showing discharge of. ........ 190

Eureka Canal, Idaho, measurements of.. 486, 487

Eureka ranch, Kans., rainfall at........ 310, 313

Evaporation, estimated, from Narraguinnet and Morton Lake reservoirs.......

Evaporation in Nicaragua................. Ewing, Nebr., stream measurements at....
Page.

Fairbanks, Nebr., stream measurements at. 301 Fairbury, Nebr., location and elevation of.. 306 rainfall at . Fall Creek, Colo., stream measurements at. 58 ,

plate showing viow of gaging station at 396 Fall River, S. Dak., plates showing views

of ......................... 252,254

Falls River, Idaho, measurements of...... 61

Farish, W. A., aid by .................. 2ృ, 405

Farmers' Union Canal, Idaho, measurements of ...................485,486,487

Fauna of Nicaragua .................. 584

Fayette, W. Va., rainfall at ..............

stream measurements at .......... 51, 202, 203

Fayetteville, N. C., stream measurements at ......................... 50,145

Fellows, A. L., work of........... 22, $383,404,410$ acknowledgments to ................ 409

Ferguson, J. D., mentioned ............... $\quad 86$

Finley, W. W., acknowledgments to........ 24

Fish ('reek Falls, Colo., plate showing road

to ............................ 386

Fisher, D., acknowled gments to.............

FitzGerald, D., work of...................

Flint, E., records kept by ................. $\quad 574$

Flint River, Ga., measurements of...... 51, 184 tributaries of .................... 176

Floods in the Lower Mississippi River, dis. cussion of .................. 347-352 Floyd, R.S., mentioned................. 528 Follows, B. M., aid by ................... $\quad 560$

Food products of Nicaragua ............. 583

Forbes, J. W., aid by ................... 560

Forks, Wash., stream measurements at.... 63, 522

Fort Collins, Colo., stream measurements at 55 location and elevation of ........... 257 rainfall at ..................... 258, 265

Fort Craig, N. Mex., location and elevation

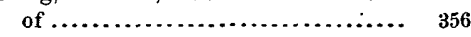
rainfall at......................... 357,359

Fort Crawford, Colo., stream neasurements at ................. 58, 378, 379, 391-392

Fort Duchesne, Utah, location and elevation of ............................ $\quad 375$ rainfall at............ 377,379

Fort Garland, Colo., location and elevation of ............................ 356 rainfall at. $\quad 359$

Fort Hall, Idaho, location and elevation of. $\quad 470$ rainfall at........................ 471,474 Fortier, S., work of ..................... 22 Fort Laramie, Wyo., location and elevation

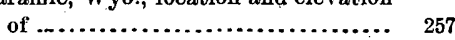
rainfall at.............................. 258,265

Fort Lewis, Colo., location and elevation of $\ldots \ldots \ldots \ldots \ldots \ldots \ldots \ldots \ldots \ldots \ldots \ldots \ldots \ldots \ldots+375$ rainfall at. ........................ 377,379

Fort Logan, Mont., location and elevation of 232 rainfall at...................... 233, 235 Fort Madison, N. C., plate showing meas. urement of Tugaloo River near.... 154

Fort MoRae, N. Mex., location and eleva. tion of........................ 356

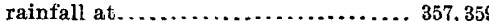


Fort Niobrara, Nebr., stream measurements at. 300,301

Fort Riley, Kans., location and elevation of. $\quad 306$ rainfall at....................... 311,313

Fort Robinson, Nebr., stream measurements at ..................... 254, 303

Fort San Carlos, Nicaragua, diagram show. ing rainfall at................... 578 rainfall at............................ temperature and relative humidity at.. gaging station at.

rainfall at...................... 498, 500

Fort Tejon, Cal., location and elevation of. 560 rainfall at.............................

Fort Wingate, N. Mex., diagram showing rainfall at..

Fowler Switch Canal, Cal., plate showing effect of high velocities on..........

Franklin, Pa., stream measurements at... 195

Frederick, Md., location and elevation of.. stream measurements at...... 49, 120, 129-130

Frederick, Pa., stream measurements at..

plate showing suspension bridge and nilumeter at.....................

Fremont, Nebr., stream measurements at.

Fremont, Ohio, references to stream measurements at..................... Railroad, acknowledgments to.....

French Broad River, N. C., measurements of .......................... 52,205 diagram showing discharge of........ 205

French Creek, Pa., measurements of . . .. 197-198 Frenchman River, Nebr., measurements of. 299

Frio River, Nicaragua, measurements of... 604

Fruits of Nicaragua.................... 583

Fteley. A., aid by ..................... 82,84

Fullerton, Nebr., stream measurements at. 298 ,

\section{G.}

Gafiney, S. C., stream measurements at.... Gaging stations, map showing location of. Gainesville, Ga., location and eleration of. rainfall at. Gallatin River, Mont., measurements of. $234,235,239-242,244$ method of farming in valley of ........ 239 diagrams showing discharge of...... 240,241

Garay, Don Jose de, work of .............. 586

Gardiner, Mo, rainfall at. stream measurements at

Gemmell, R. C., aid by .................... 469 Genesee River, N. X., measurements of, 52, 225-227 diagram showing discharge of ........ 227

Geneva, Nebr., location and elevation of.... 306 rainfall at......................... 308-313

Geneva, Utah, references to stream measure-

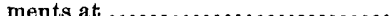

Genoa, Nebr., location and elevation of.....
Page. stream measurements at . 298 Georgetown, Colo., location and elevation of 257 rainfall at...................... 259,265 Georgetown, Nebr., stream measurements at 300 Georgia, stream measurements in ....... 50-51, $160,161,163,165,170-172,182-186,188-192$ rainfall in......................... 51 $159,160,161,177-181$ Gering, Nebr., stream measurements at ... 54 $263,267-268$ location and elevation of .............. 257 rainfall at. . . . . . . . . . . . . . Gibbon, Oreg., stream measurements at ... 63,515 Gila River, Ariz., measurements of........ 59

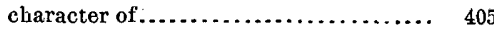
sediment carried by................. 634 Gilbert, G. K., mentioned...............44, 216 Gilchrist, Nebr., stream measurements at.. 303 Gillsville, Ga., location and elevation of.... 158 rainfall at...................... 159,161

Glasgow, Va., rainfall at ................ 49 stream measurements at ........ 49, 134, 135 Glenwood, Nebr., stream measurements at.. 303 Golconda, Nev., stream measurements at... $\quad 59$

Golconda Canal, Nev., estimated cost of .. 446-447 Gold mining along the Chattahoochee River,

Ga ........................ 172-174 Gorãon Creek, Nebr., measurements of. . ... 299 Gorman, Cal., location and elevation of..... 560

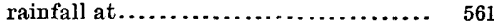
Gove City, Kans., location and elevation

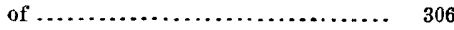
rainfall at.................... 310,313 Grainfield, Kans., location and elevation of. $\quad 306$ rainfall at...................... 310,313 Granada, Colo., description of gaging station at ......................... 325 Granada, Nicaragua, rainfall at .......... 577 Grand River, Colo., measurements of...... 58 $378,379,388-389$ diagram showing discharge of......... 389 Grande, Rio, Nicaragua. See Rio Grande.

Grand Island, Nebr., stream measurements at........................... 302 Grand Junction, Colo., stream measurements at........... 58,378,379,388-390 location and elevation of............ 375 rainfall at. ........... 377, 379, 397, 398, 399 Grand View, Idaho, stream measurements at. ................6 $62,473,474,481-482$ Granger, Wyo., stream measurements at.. 58 381-382 rainfall at.......... 50 stream measurements at........ 56, 329, 330 Grant, U.S., mentioned.................. 590 Graves, E. D , mentioned............ 77 cited on height of water in Connecticut River...................... 78

Great Falls, Md., rainfall at............ 49

Great Plains Water Company, irrigation

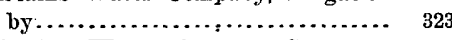
Great Plains Water Storage Compans acknowledgments to.............. 23 257 Great Salt Lake, rainfall in basin of...... 454-458 
Great Salt Lake, map showing location of stations in basin of .............. 455

Greele5, Colo., Iocation and eleration of... 257 rainfall at...................... 259,265 plate showing view of Cache la Poudre River near.................... 292

Green River, Wyo., stream measurements at............... $58,378,379,380-381$ plate sbowing views of Green River near....................... 380

Green River, measurements of... 58, 378, 379, 380$381,387-388$

plate showing views of............. 380 diagrams showing discharge of............381, 388 Greenbrier River, W. Va., measurements

of..................... 51, 202, 204 diagram showing discharge of......... 204 Greenville, Miss., plate showing view of levee at...................... $\quad 352$

Greenwood, S. C., location aud elevation of. 158 rainfall at...................... 159, 161

Grenola, Kans., location and elevation of.. 326 rainfall at...................... 327,330

Grey Bull River, Wyo., measurements of.. 53

Greytown, Nicaragua. See San Juan del Norte.

Griggs, J., cited on flow of Scioto River.... 214

Groveland, Cal., location and elevation of.. $\quad 560$ rainfall at......................... 561

Guadalupe River, Tex., reference to meas. urements of......................

Guiscoyal River, Nicaragua, measurements of............................ 609

Gunnison, Colo. location and elevation of.. $\quad 375$ rainfall at. . ........... 376, 379, 396, 398, 399

Gunnison River, Colo., measurements of'... 5 58, 378,390 diagram showing discharge of....... $\quad 390$

$$
\text { H. }
$$

Haigler, Nebr., stream measurements at. 298, 302 Hailey, Idaho, location and elevation of.... 470 rainfall at....................... 472,474

Hains, P. C., work of ................. 592

Hale, R. A., aid by ..................... 73

Hall, B. M., work of................. 22, 152 acknowledgments to.................. 23 cited ............................ 166, 175

Hall, M., acknowledgments to ........... 23

Hall, W. M., cited on irrigation in southern California ........................

Hamilton, Mont., capacity of ditches near. 493

Hammond, C. M., aid by................ 528

Hanus, G. C., work of . . ............... 60

Hardesty, W. P., cited.................. 280

Harney Creek, Nebr., measurements of.... 300

Harpers Ferry, W. Va., location and elevation of.......................... 117 rainfall at ....................... 119,121

Harrisburg, Pa., stream measurements at. . 48,

Harroun, P. E., work of . . 109-110

Hart, H. H., aid by ................... 395

Hartford, Conn., rainfall at............. 47 stream measurements at ............. 47

Harvard, Nebr., location and elevation of.. 306
Page. Harvard, Nebr., rainfall at............ 308,313 Hat Creek, Nebr., measurements of........ 299 Haupt, L. M., work of ................ 592 Havre, Mont., stream measurements at... 53

Haw River, N. C., references to measure ments of ..................... 146 Hayden, Colo., plate showing views of and near.......................... 384

Hayes, C. W., reference to............ 570, 573 cited on flood plain of Rio San Juan, Nicaragua .................... 617

Hays City, Kans., location and elevation of 306 rainfall at.................... 310,313 Heber, Utah, location and elevation of.... 454 rainfall at..................... 457,458

Hebron, Nebr., location and elevation of... 306 rainfall at...................... 309, 313

Heleva, Mont., location and elevation of... 232 rainfall at...................... 233, 235 Henrietta Cotton Mill, Rutherford County,

N. C., plate showing view of canal to 146

Henry, D. F., aid by .................. 217, 227

Henry Fork, Idaho, measurements of....... 61

Hering, R., work of . ...................... 88 eited on drainage area of Tohickou Creek $\quad 98$ Herman, B., ruling of................. 481 Herndon, Cal., stream measurements at.... 63

Hesperus, Colo., stream measurements at... 410 Hildts, Carl, mentioned .................. 463 Hinton, W. Va., location and elevation of... 199 rainfall at........................ 201, 202 Hitchcock, E. A., reference to........... 463 Hiwassee River, N. C., measurements of.... 52 208,209 diagram showing discharge of......... 209 Hiwassee River, Tenn., plate showing view of ............................ 208 Hodgson, J.H., acknowledgments to....... 208 aid by........................... 278 Holbrook, H. R:, aid by ................. 339 Holcomb Creek, Cal., elevation of........... 560 rainfall at .......................... 561

Holden, R. T., aid by .................... 324 Holdrege, Nebr., location and elevation of.. 306 rainfall at...................., 308,313

Hollaud, S. C., location and elevation of.... 158 rainfall at....................... 159, 161 Holloway, Nebr., stream measurements near 303 Hollingsworth, S., aid by ................ . 64 Holmes, J. A., work of . ............. 22, 137, 148 Holyoke, Mass., stream measurements at... 47 76,78

Home Supply dam, near Arkins, Colo., plate showing view of.................. 396 Hood, W., acknowledgments to............ 23 Hood River, Oreg., references to measurements of..................... 63,516

Hooper, Wash., rainfall at.................. 62 stream measurements at....... $62,489.490,513$ Horr, Mont., stream measurements at..... 53 Horse Creek, Nebr., measurements of....... 299 Horse Creek, Colo., plate showing view of.. 432 Horseshoe Creek, Wyo., plate showing view of gorge of..................... 270 
" Page. ( views of ranches on ........... 270,274 course of map showing location of ditches diverting water from .................. 270 reservoir sites on .................. 270-273 figure showing proposed reservoir on .. 271 figure showing gorge of ............. 272 figure showing small reservoir on ....... 272 plate showing view of dam site on ..... 274

Hnbbel, H., mentioned .................... 478

Hudson River, N. Y., measurements of .. 47, 78-81 diagram showing discharge of ......... 80

Hugo, Colo., location and elevation of...... 326 rainfall at ........................ 328,330 Humboldt County, map of proposed reservoir and supply canal in ........... 451

Humboldt River, Nev., measurements of... 59-61,

character of basin of $436-441$ map showing location of stations in basin of ..

diagrams showing discharge of . $\quad 437$ $438,439,440,441$

Humboldt Station, Nev., proposed reserroirs near........................ 448-452 proposed canals near ................ 452-454

Humboldt Valley, Nev., map of proposed reservoir, canals, and irrigable lands

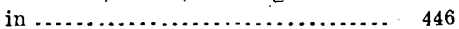

map of Lower ..................... 449

Humplrey, F., aid by ................. 391

Humphreys, A. A., reference to.......... 590

Humphreys, D. C., work of ............. 22, 132

Husted, Colo., location and elevation of.... 326 ruinfall at ....................... 327,330

Hutchinson, Kans., stream measurements at. 57 , $329,330,342-343$

location and elevation of ............ 326

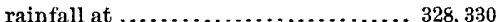

Hydrographic investigations, index map of special ..........................

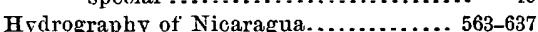

Hynes, 'I. F., aid by .................. 324 . I.

Idaho, stream measurements in ........... 60 , -459-460, 473, 474-477, 482-489 reservoir surveys in ................. 33 rainfall in .................... 471-472,474

Idaho Falls, Idaho, stream measurements at. $\quad 61$ location and elevation of ............ 470 rainfall at. $\ldots \ldots \ldots \ldots \ldots \ldots \ldots . . \ldots 71,474$

nlinois, stream measurements in......... 52 ,

Imperial, Nebr, location and elevation of $\begin{array}{r}218-223 \\ .306\end{array}$ rainfall at ....................... 307,313

Indian Creek, Nebr., measurements of ..... $\quad 300$ Ignacio, Colo., plate showing view on Los Pinos River near................ 392

Indianola, Nebr., location and elevation of. $\quad 306$ rainfall at ....................... 307,313

Iola, Kans., stream measurements at.. 57, 345-347 Irrigation in the Soutlern tote Indian Reservation, proposals for......... 418

Irrigation from Cherry Creek, Colo...... 280-284
Irrigation from Middle Creek Mont. Page. Irrigation from Tuolumne River, Cal..... 533 Isabella, Cal., location and elevation of.... 560 rainfall at........................ 561 Ives, Nebr., stream measurements near.... 302 $J$

Jackson, W. H., record kept by.......... 575 James, W., acknowledgments to..........

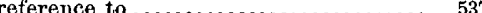
James River, Va., stream measurements in basin of .................49, 134-136 map showing location of stations in basin of ........................ 132 rainfall in basin of. . . . . . . . . . . 132-134 diagram showing discharge of......... 136 Jefferson River, Mont., neasurements of... 53, $237-238,244$

diagram showing discharge of......... 238 Jellys Ferry, Cal., stream measurements at $\ldots \ldots \ldots \ldots \ldots \ldots \ldots \ldots \ldots \ldots \ldots \ldots \ldots \ldots \ldots \ldots, 526,527$ Jicoral River, Nicaragua, measurements of. $\quad 609$ Jim Creek, Nebr., measurements of. ...... 300 Jones, H., reference to................... 383 Johnson, A., reference to............... 413 Johnson, C., aid by.................... 495 Johnston, C. T., work of ........... 22, 270, 277 Johnston, T. T., stream measurements bJ - 218 Judson, N. C., stream measurements at..... 52 , 207-208 Julesburg, Colo., stream measurements at. 302 Junction City, Kans., stream measurements a.t $\ldots \ldots \ldots \ldots \ldots \ldots \ldots \ldots \ldots, 55,312,313,318$

K.

Kanawha River Basin, rainfall in.... 51, 199-202 stream measurements in......... 51, 202-204 map showing stations in ............ 200 Kansas, stream measurements in ..... 55-56, 312 $313,314-316,318-322,342-347$ rainfall in ............ 309-311, 313, 328, 330 Kansas River, measurements of... $56,312,313,322$ diagram showing relation of gage height to solids carried by ................ $\quad 320$ analyses of water from.............. 321 diagram showing discharge of......... 322 plate showing views of.............. 304 map showing location of stations in basin of ....................... 305 rainfall in basin of ................. 305-313 Kaweah River, Cal., measurements of..... 526 Kearney, Nebr., location and elevation of... $\quad 257$ rainfall at...................... 260,265

Kelton, Utah, location and elevation of.... 454 rainfall at ...................... 456, 458

Kennebec River, Me., measurements of. . 46,64-65 diagram showing discharge of......... 65 Kennewick, Wash., location and elevation of .......................... 497 rainfall at......................... 498,500 Kenton, Ohio, stream measurements at. . . 214-215 Kern River, Cal., measurements of... 64,536-538 map showing point of measurement on. $\quad 537$ diagram showing discharge of........ 538 plate showing views of.............. 538 Kernville, Cal., location and elevation of.... 560 
Kernville, Cal., rainfall at ............. Page. Keya Paha River, Nebr, measurements of. 300 Kimball, Nebr., location and elevation of... ' 257 rainfall at ....................... 259,265 stream measurements at.............. 300

Kings River, Cal., measurements of.......663-64, $526,534-535$ diagram showing discharge of......... 535 plate showing gaging station on....... 534

Kingsburg, Cal.; reference to stream meas urements at. .................6. 64,534 plate showing view of gaging station at. $\quad 534$

Kiona, Wash., stream measurements at.... 62 , $499,500,502$

Kirwin, Kans., location and elevation of.... 306 rainfall at........................ 310,313

Knackstedt, L. A., acknowledgments to... 409 L.

Lafayette formation in the Lower Mississippi Valley..................... 352

Lagrange, Ga., location and elevation of.... 177 rainfall at....................... 180, 181 LaGrange, Cal., stream measurements at... 63 , $526,531-532$

Lagrange dam, Cal., plate showing views of. $\quad 532$ Laguna Canal, Colo., description of...... 339-340 Lake, Idaho, location and elevation of..... 470 rainfall at......................471,474

Lake Chelan, Wasb., description of........ 495 map of drainage basin of ............. 496

Lake Como, Mont., plate showing view of.. 496 Lake Managua, Nicaragua, location of.... 571 plate showing surveyors camp on...... 584 as a storage reservoir, discussion of. . 600-601

Lake Nicaragua, description of. ......... 570-571 evaporation from.................. 582 measurements of.................. 596-597 estimated monthly inflow into........ 605 daily elevation of, in $1898 \ldots \ldots \ldots \ldots \ldots .606$ elevation of, if all water had been held by a dam at siction

Lakeside, Wash., location and elevation of. 497 rainfall at. 498,500

Le Tenaya, Cal., plate showing view of.. $\quad \mathbf{5 3 0}$

La Liebre, Cal., location and elevation of... . 560 rainfall at.

Lamar, Colo., description of gaging station

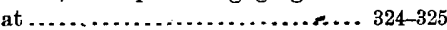
location and elevation of............. 326 rainfall at ................. 328, 330

La Maria, Rio, Nicaragua. See Rio LaMaria.

Lambertville, N. J., stream measurements at ......................... 48,84-86

Lander, Wyo., location and elevation of.... 257 rainfall at......................... 258, 265 La Plata River, Colo., measurements of..... 410 Laramie, Wyo., location and elevation of... 257 rainfall at........................ 258,265

Laramie River, measurements of ......... 54 , $262,265,274-276$ diagrams showing discharge of..... 274, 276 reservoir site on .................. 276-277 plate showing measurement and views

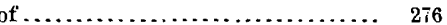

map showing proposed res rvoir oll.... 277
Laramie River, plate showing view of sky. line ditch diverting water from .... 292

Las Animas, Colo., location and elevation of $\mathbf{3 2 6}$ rainfall ai...................... 328,330 reference to stream measurements at.. 342

Las Cruces, N. Mex., location and elevation

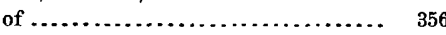

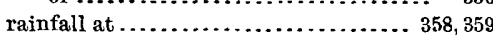

Las Lajas, Nicaragua, rainfall at .......... 578 temperature and relative humidity at.. $\quad 579$ Las Lajas, Rio, Nicaragua. See Rio Las Lajas.

Laurel, Md., stream measurements at . $48,113,116$ rainfall at.................... $49,113,114$ location and elevation of............. 112

Lavaca, Nebr., stream measurements at.... $\quad 301$ Lawrence, Kans., strean measurements at. 56 , $312,313,322$ plate showing view of Kansas Rirer at. $\quad 304$ location and elevation of ............ 306 rainfall at........................ 311,313

Lawrence, Mass., stream measurements at ....................... 46, 73-74 plate showing view of Merrimac River

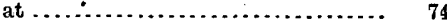

Leach, S. S., work of .................... 78 Leamington, Utah, stream measurements at. $\quad 61$ Lebec, Cal., location and elevation of ....... $\quad 560$

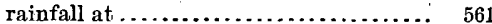
Lecompton, Kans,, plate sbowing gage on Kansas River at................ 30

Lehigh River, Pa., measurements of. ...... 86-88 Lehman, G. M., work of..... . ...... 195, 197, 198 Lemp Canal; Idaho, measurements of. . . 486, 487 Lesseps, M. de, reference to ............... 588 Levee, plate showing view of ............. $\quad 352$ Levee system, discussion of . . . ......... 350-352 map showing extent of .

Lewis, Tex., references to stream measurements at..................... 354 Lexington, Nebr., location and elevation of. $\quad 257$ rainfall at...................... 260, 265 Lexington, Va., geographic position of...... 132 rainfall at....................... 133, 134

Liberty, Kans., stream measurements at .. 57,344 Limpio River, Nicaragua, measurements of $\ldots \ldots \ldots \ldots \ldots \ldots \ldots \ldots \ldots \ldots .625-626$

Lincoln, A., reference to ............... 412 Lincoln, Nebr., location and elevation of ... 257 rainfall at..................... 261,265

Lippincott, J. B., work of. $22,524,534,543,552,555$ quoted on drought in southern Califor.

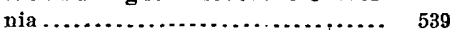
reference to.................. 543,550,558 Little River, Ga., water powers on ........ 168 Little Bear Valley, Cal., elevation of....... 560 rainfall at........................ 561

Little Cottonwood Creek, Nebr., measurements of....................... 298 Little Goose Creek, Wyo., measurements of. 53 Little Neshaminy Creek, Pa., plate showing high-water gage on............... 106 Little Rock Creek, Cal., measurements of. 64,540 Little Tennessee River, N. C., measurements of $\ldots \ldots \ldots \ldots \ldots \ldots \ldots \ldots \ldots \ldots \ldots \ldots \ldots \ldots \ldots+2,207-208$ diagram showing discharge of......... 208 
Little Thompson Creek, Colo., seepagemeas. urements on......................

Little Truckee River, Cal., measurements of

Tittlo Wood Rive

Livingston, Mont., stream measurements at $\ldots \ldots \ldots \ldots \ldots \ldots \ldots \ldots \ldots \ldots \ldots \ldots \ldots \ldots \ldots \ldots \ldots, 247-248$

Lodgepole Creek., Nebr., measurements of. 300 Lock ville, N. C., plate showing dam on Deep River near.

Ioess in the Lower Mississippi Valley .....

Logan, Mont., raiufall at.................. stream measurements at..... $53,234,235,240$

Logan, Utảh, stream measurements at... 60 462-463

location and elevation of 454

Logan River, Utab, measurements of.. . 60, 462-463 diagram showing discharge of......... 463 Lonergan Creek, Nebr., measurements of.. 300 Long Pine, Nebr., stream measurements at. 298,

Long Pine Creek, Nebr., measurements of. 300

Long tom Creek, Idaho, reservoir site on .. 477-481 maps of reservoir site on............ 479,480 land segregated for reservoir site on... 480 Looking Glass Creek, Nebr., measurements of ............................

Lord, H. S., acknowledgments to .......... 493 Los Angeles, Cal., stream measurements at. 542 Los Angeles River, Cal., measurements of 541-513 Los Lunas, N. Mex., Jocation and elevation of.....

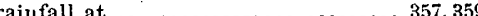

Los Pinos River, Colo., plates showing view

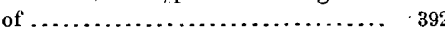

measurements of .

Lost River, Idaho, location and elevation

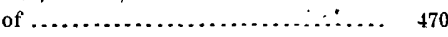

rainfall at...................... 471, 474

Loup City, Nebr., stream measurements at. 300 Loup River, Nebr., measurements of...... 55 , $263,264,266,294-295,300$

disgram showing lischarge of . Lovell, W yo., stream measurements at. ... 53, 249 Ludlow, W., work of ................. 591 Lull, E. P., work of ................... 590 Lyle, M. D., aid by................... 324

Lyle, Wash., location and elevation of..... 497 rainfall at..................... 498,500 Lyons, Colo., stream measurements at ...... 54, $264,285-286$

Lytle Creek, Cal., measurements of...... 555-557 $\mathrm{M}$

Machado River, Nicaragua, measurements of . .

Machuca, Nicaragua, rainfall at ......... 578 Machuca River, Nicaragua, measurements

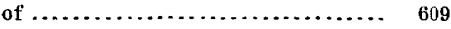

Macon, Ga., rainfall at.................. 51 stream measurements at ...... 51,161,171-172 plate showing view of Ocmulgee River

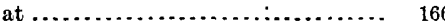

Madison, Nebr., stream measurements at.. 303

Madison, S. C., stream measurements at ... 162

Madison River, Mont., measurements of.. 53 $234,235-237,244$
Page.

Madison River, Mont., water power on.... 236 diagram showing discharge of......... 237

Malloning River, $\mathrm{Pa}$, measurements of.... 198

Maine, rainfall in ................... 46,72 stream measurements in ...........44,64-73

Malade River. Idaho, measurements of . 62, 473,477 diagram showing discharge of ....... 477 Malheur River, Oreg., measurements of.... 62 Mancos, Colo., stream measurements at.... 404 Mancos River, Colo., measurements of .... 404 character of ..................... 410

Manhattan, Kans., stream measurements at ..................... 56, 312, 313, 319 location and eleration of ............ 306 rainfall at....................... 311,313

Manzana, Cal., location and elevation of ... 560 rainfall at....................... 561

Managua, Lake. See Lake Managua.

Marbury, J. B., acknowledgments to ....... 23

Marietta, Ga., location and elevation of.... $\quad 177$ rainfall at...................... 179, 181

Marion, Ohio, stream measurements at... 214-215

Marion, Va., location and elevation of...... 199 rainfall at..................... 201, 202 Marlinton, W.Va., location and elevation of. 199 rainfall at...................... 201,202

Marquette. Nebr., location and elevation of. 257 rainfall at..................... 261, 265

Marshall, Colo., stream measurements at .. 54 ,

Marsland, Nebr., stream measurements at . $\quad 501$ Martinsburg, W. Va., location and elevation of ........................... 117 rainfall at ........................... 118,121 Martinsdale, Mont., location and eleration

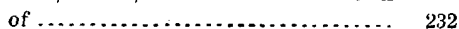

rainfall at......................... 233.235

Maryland, stream measurements in ..... 48-49, $110,116,120,121,122,129-131$ rainfall in .............. 112-114, 118, 119, 121 Masaya, Nicaragua, diagram showing com. parative rainfall at Rivas and..... 575 rainfall at....................... 577 Massachusetts, stream measurements in... 46 , 47,73-78 Mathews Creek, Nebr., measurements of.. 301 Maumee River, Ohio, references to measurements of ...................... 223 Maxwell, D. E, acknowledgments to ........ 24 McCalla, R. C., jr., acknowledgments to.... 24 McCarty Canal, Idaho, measurements of. 486,487 McCook, Nebr., stream measurements at... 302 . McCollum, J. L., acknowledgments to...... 24 McDonald, Wash., stream measurements at $\ldots \ldots \ldots \ldots \ldots \ldots \ldots \ldots \ldots \ldots, 63,521$ plate showing bridge over Elwha River at ............................. 516 McDowell, Ariz, stream measurements at.. $\quad 59$,

McGee, W $J$, quoted on geologic structure of the Lower Mississippi Valley. . 352-353 MeKinley, W., mentioned............... 592 McPherson, Kans., location and elevation of ........................... 326 rainfall at.................... 327,330 
Page.

McWilliams, J., acknowledgments to...... 24

Meadville, Pa., stream measurement at... 198

Mechanicsville, N. Y., stream measure. ments at ..................47,80,81

Meeker, Colo., location and elevation of... 375

rainfall at . 376,379

Meeteetse, Wyo., stream measurements at.

Mena River, Nicaragua, measurements of. 607

Menocal, A. G., work of............... 591

Menominee River, description of........ 217-218

Merrill, W. E., mentioned............. 196, 198

Merrimac River, measurements of..... 46,73-74

plate showing view of

diagram showing discharge of.........

Merriman, M., aid by..

Mesa Verde, Ariz, plates showing views of . . ....................... 410,41

Mexico, Ohio, references to stream measurements at...................

Middle Creek, Mont., measurements of.. 234, 243 irrigation from .................. 242-243 plate showing method of measuring... 244

Middleton Canal, Idaho, measurements of. 486,487

Middleton Mill slough, Idaho, measure ments of.......................

Milford, Nebr, stream measurements at .s 298

Mill Creek, Cal., measurements of....... 558

Mill Creek Canyon, Mont., plate showing view of.

Miltville, W. Va., rainfall at.............. stream measurements at.. 49, 120, 121, 127-128

Milk River, Colo., measurement of......... 383

Milk River, Mont., measurements of.. 53, 245-246 diagram showing discharge of ........ 246

Milstead, Ala., stream measurements at..... 51

plate showing view of Tallapoosa River at............................. 192

Minden, Nebr., location and elevation of... 306 rainfall at...................... 308, 313

Mineral resources of Nicaragua............ . 584

Minichaduza River, Nebr., measurements of 300

Minnesota, stream measurements in .. 52, 230-231

Mississippi River, consideration of floods along Lower.................. 347-352

map showing location of stations along. 348 plates showing views of crevasse and floods on ...................... 348, 352

map showing extent of levee system on Lower...................... 351 measurements of Upper.......... 52, 230-231 maps showing lakes and reservoirs at source of...................... 228

reservoirs on Upper.................. $928-230$

Mississippi Valley, Lower, geologic section of . ........................ 352-353

Missoula, Mont., stream measurements at. 62 , $63,490-491,49 \overline{5}$

plate showing view of Bitterroot River near......................... 492

Missoula River, Mont., measurements of. 63,

plate showing riew of 490-491.

Missouri River, Upper, stream measure.

ments in basin of . . . . ... 52-53,232-246

measurements of

$53,243-245$
Missouri Rirer, Upper, map showing location of stations in basin of......... 232 rainfall in basin of . ............... 232-235 diagram showing discharge of........ 245 Missouri, Kansas and Texas Railway Com. pany, acknowledgments to......... 24

Mixer, C. A., aid by ..................... $\quad 66$

Moab, Utah, location and elevation of..... 375 rainfall at..................... 377,379

Mohawk River, N. Y., map showing loca. tion of stations in basin of......... 79

Molina, Ga., stream measurements at.... 51, 184

Moncure, N. C., references to stream meas. urements at................... 146

Monero, N. Mex., location and elevation of 356 rainfall at......................... 359

Monocacy River, Md., measurements of. 49 , $120,121,129-130$

diagram showing discharge of........ 130

Monongahela River, Pa., measurements of 196-197 plate showing view of junction of Allegheny River and............... 196

Monroe Creek, Nebr., measurements of .. 300-301 Montana, reservoir surveys in............ 33-34 stream measurements in ............. 52-53, o $234,235-248,490,495$ rainfall in...................... 233-235 Montezuma Valley, Colo., plate showing view of flume in................ 414 map of canals and irrigated lands in ... 418

Montezuma Valley Canal, description of . 417-419 plates showing views of........... 420,424

Montgomery Ferry, Idaho, rainfaill at..... 61 stream measurements at...... 61, 473, 474-475

Montrose, Colo., location and elevation of. . 375 rainfall at................ 376, 379, 397,399 Monument, Kans., location and elevation of ........................... 306 rainfall at....................... 309, 313

Moore, W. L., acknowledgments to...... 46 Moraine, Colo., location and elevation of... $\quad 257$ rainfall at ........................ 259, 265

Morapos Creek, Colo., measurements of... 383

Morehead, J. T., aid by ................ 134

Moro, Oreg., references to stream measurements at ...................6.63,519

Morrill, P., cited on floods in Lower Mis. sissippi River.................... 349

Morillo River, Nicaragua, character of ..... 607 Morrison, Colo., stream measurements at... 54, $\begin{array}{r}263,284-285 \\ \hline\end{array}$ rrito, Nicaragua, rainfall at ............. 578 gaging station at. ................ 603-604 Morton Lake, Colo., reservoir site at .... 422-426 map of reservoir site at .............. 423 area and capacity of proposed reservoir at ........................... 424 plans for and cost of dam at. ........ 424-425 map of dam site at.................. $\quad 425$ Mount Breckenridge, Cal., location and elevation of...................... 560

Mount Carmel, S. C., location and elevation of ........................... 158 rainfall at. . . . . . . . . . . . . Mount Lowe, Cal., location and elevation of. $\quad 560$ rainfall at......................... 561 
Mount Morris, N. Y., stream measurements

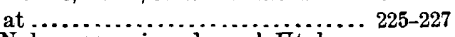
Nebo reservoir and canal, Utah, map showing relative location of.......

Mount Pleasant, Utah, location and elevation of .........................454

rainfall at. ......................... 457,458

Moxee Valley, Wash., artesian wells in .... 508

Moyales River, Nicaragua, character of .... 608

Mazanola, Colo., description of gaging station at

Mullen, Nebr, stream messurements at . 300

Murphy, E. C., work of............... 22,45,321

Murphy, N.C., stream measurements at .. 52, 209

Mutah Flat, Cal, location and elevation of... 560

rainfall at........................... 561

Myers, E. W., work of............... 22, 137, 148

$$
\text { N. - }
$$

Naches River, Wash., measurements of .... 62 , diagram showing discharge of ....... 503

Nampa, Idaho, location and elevation of.... 470 rainfall at ....... 472,474

Napipi-A trato canal route, discussion of... 587 Narraguinnep dam, map of site for....... $\quad 421$ cost of ........................... 422

Narraguinnep reservoir site, Colo., survey of 419-422 area and capacity of

figure showi plate showing views of ............... 428

National City, Cal., location and elevation

$$
\text { of . }
$$

rainfall at

Navajo Springs, Ariz., plate showing views

Neal, N. C., rainfall at.... stream measurements at........... 50, 139, 142

Nebraska, board of agriculture of, acknowledgments to......................

board of irrigation of, acknowledgments to ................................ stream measurements in .......... 253-255, $267-269,294-304,312,317$ rainfall in $257-265,308-309,313$

Neenach, Cal., location and elevation of.... 560 rainfall at........................ 561

Negro River, Nicaragua, character of.... 606-607

Neosho River, Kans., measurements of . 57, 345-347 comparison of Verdigris River with... 345 diagram showing discharge of ....... 346

Nepesta, Colo., stream measurements at.... 57,

$324,337-338$

Nephi, Utah, location of................ 454 rainfall at...................... 457, 458

Nesbaminy Creek, Pa., measurements of.. 48 , plate showing views on............. 104 diagram showing discharge of......... 108

Neuse River, N. C., measurements of .... 50, 144 diagram showing discharge of........ 144

Nevada, reservoir surveys in ............ 34 stream measurements in............ 59-60,
Now River, W. Va, measureme

measurements of. 51, 202-203 diagram showing discharge of........ 203 New Braunfels, Tex., references to stream measurements at

Newell, F. H., letter of transmittal by.... vi New Jersey, stream measurements in... 48, 84-80 Newmarket, Md., location and elevation of. 117 rainfall at......................... 119, 121

New Mexico, reservoir surveys in ....... 35 stream measurements in............ 57 , $58,358,359,364,366-371$ rainfall in...................... 357,359 Newnan, Ga., location and elevation of .... 177 rainfall at....................... 180,181 New Orleans, plate showing view of wharves during flood.................... 352 New York, stream measurements in ....... 47 $78-84,224-227$ rainfall at Boyds Corners .............. 82-83 Niagara River, measurements of.......... 224 Nicaragua, bydrography of............ 563-637 topographic features of............ $569-574$ boundaries of $\ldots \ldots \ldots \ldots \ldots \ldots \ldots \ldots .570$ harbors of .......................... 570 geologic history of .............. 572-573 boundary dispute between Costa Rica

and $\ldots \ldots \ldots \ldots \ldots \ldots \ldots \ldots \ldots \ldots .573-574$ rainfall in ........................ 574-578 temperature and relative humidity in . 579-581 evaporation in ..................... 582 resources and productions of......... 582-584 population of ................... 584-585 map of ............................. 569 map of portions of Costa Rica and, showing route of proposed canal ....... 592 Nicaragua Canal, routes for . . . . . . . . . . . . 589-592 Nicaragua Canal Company, records kept bJ. $\quad 575$ Nicholson Creek, Nicaragua, measurements

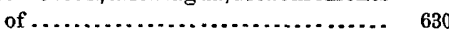

Niles, Kans., rainfall at . .................. 56 stream measurements at ...... 56, 312, 313, 314 Niobrara City, Nebr., stream measurements

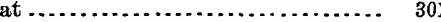

Niobrara River, Nebr., measurements of . 255, 301 Nita crevasse, Mississippi River, plate showing riews of.................... 348

Noble, A., work of . ..................... 591 Noble, T. A., aid by ................. 516,520 Noller, F., aid by ....................... 560 Norfolk, Nebr., rainfall at........... 55, 261, 265 stream measurements at ............. 55 , $264,266,296-297,299$

location and elevation of............. 257 Norfolk and Western Railway, acknowledgments to........................ 24 North River, Va., measurements of......... 49 , diagram showing discharge of 121, 122-124 North (of James) River, Va., measurements of .......................... 49,134,135 diagram showing discharge of ........ 135 North Carolina, stream measurements in.. 50 , $142-149,205-209$

North Loup, Nebr., location and eleration of * 257 rainfail at ........................ 261, 265 North Platte, Nebr., rainfall at........ 54,260, 265 
North Platte, Nebr, stream measurements

Page. at . . ............... .54, 263, 266, 269, 301, 302 location and elevation of.............. 257

North Platte River, measurements of ..... 5f, $262,263,266-269,301-302$ diagrams stowing discharge of .. 267, 268, 269 plate showing view of............... 296

North Yakima, Wash., stream measurements at .................. 62,499,503 location and elevation of ............. 497 rainfall at........................ 498,500

Norton, Kans., location and elevation of ... 306 rainfall at. ..................... 309,313

Norwood, N. C., stream measurements at... 50 ,

Nueva River, Nicaragua, measurements of. $\quad 599$ Nuttallburg, W. Va., location and elevation

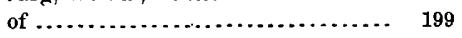
rainfall at ........................ 201,202

Nyssa, Oreg., stream measurements at .... 62 o.

Oakdale, Cal., stream measurements at.... 63, $526,530-531$

Oakdale, Ga., rainfall at................. 51 stream measurements at...... 51, 180, 181, 182 plate showing view of Proctors Creek near......................... 188

Oakdale, Nebr., location and elevation of .. $\quad 257$ rainfall at....................... 261, 265

Oakley, Idaho, location and eleration of.... 470 rainfall at. ....................471,474

-Oberlin, Kans., location and elevation of... 306 rainfall at ....................... 309,313

Ochoa, Nicaragua, rainfall at ........... 578 diagram showing rainfall at........... 578 temperature and relative humidity at .. 581 stream measurements at ........... 616-620

Ocmulgee River, Ga., measurements of.... 51, plate showing view of. water powers on ................... 167 diagram showing discharge of......... 172

Oconee River, Ga., measurements of....... 51 ,

$161,170-171$ plates showing views of............ 158, 166 water powers on .................. 167-168 diagram showing discharge of......... 170 Octoraru Creek, Md., measurements of. 48, 110-111 diagram showing discharge of........ 111

Ogden, Utah, rainfall at............ 60,456, 458 stream measurements at ..... $60,458,459,465$ location and elevation of ............ 454

Ogden River, Utah, measurements of ...... 60 , diagram showing discharge of........

Ohio, stream measurernents in ...... 212-216, 223

Ohio River, stream measurements in basin of ..................... 51-52,195-216 measurements of .................... 196

Olentangy River, Ohio, map showing location of stations in ................ 215 measurements of . . . . diagram showing discharge of....... 216

Olmstead, F. H., acknowledgments to..... 23 aid by............................ 540
Page.

metepe, Nicaragua, plate showing view of. $\quad 570$ O'Neill, Nebr., location and elevation of.... 257 rainfall at....................... 261, 265 stream measurements at . .......... 299 Oostanaula River, Ga., measurements of... 51, $181,190-191$ diagram showing discharge of........ 191 Orchard, Colo., stream measurements at.... 54, $264,266,293-294$

Oreana, Nev., stream measurementsat. $60,439-440$ Oregon, stream measurements in......... 63,515 Orin Junction, Wyo., rainfall at ........... 54 stream measurements at. . 54, 262, 265, 266-267 Oroci River, Nicaragua, measurements of.. $\quad 607$ Ottawa River, measurements of.......... 227 Ough, Nebr., location of................ 306 rainfall at........................ 307,313 Owyhee River, Oreg., measurements of.... 62 Oxford, Nebr., stream measurements at... 302 Oyate River, Nicaragua, character of..... 608

$$
\text { P. }
$$

Pagoda, Colo., location and elevation of... 375 rainfall at............................... 379

Palisade, Nebr., stream measurements at. 299, 303 Palmdale, Cal., stream measurements at.. 64,540 location and elevation of............. 560 rainfall at........................ 561

Palmer, Nebr., location and eleration of... 257 rainfall at....................... 261,265

Palouse River, Wash., measurements of... 62 $489-490$ diagram showing discharge of......... 490 Palouse and Wallawalla River basins, rain fall in .................... 512-514 map showing location of stations in... 513 Panama Canal, discussion of routes for.. 588-589 plate showing dredges on............ 590 Parachute, Colo., location and elevation of.. $\quad 375$ rainfall at ............. $376,379,397,398,399$ Paris, Idaho, location and elevation of .... 454 rainfall at..................... 456,458

Parkinson, H. F., acknowledgments to .... 23 aid by ......................... 550 Parrott, J.R., facknowledgments to....... 24 Pasadena, Cal., map showing location of artesian wells in vicinity of....... 545

Pasadena Mesa, Cal., description of .... 543-544 underground water from the bed of the

Arroso Seco and ................ 543-549 deseription of wells in the ......... 546-548 amount of water developed in the. ... 548-549 Paso Real, Nicaragua, stream measurements at ........................... 597-598

Patapsco River, Md., rainfall in basin of ... 48 ,

112-114

measurements of . . .......... 48,113,114,115 map showing location of rainfall sta-

tions in basin of .................. 114 diagram showing discharge of ....... 115 Patterson, C. P., reference to ........... $\quad 590$ Patuxent River, Md., rainfall in basin of.. 49 , $113-114$ measurements of. $. \ldots \ldots \ldots \ldots .49,113,114,110$ map showing location of stations in

basin of ....................... 114 
Patuxent River, Md., diagram showing discharge of.

Paul, E. G., work of .......... 109, 127

Pawnee Creek, Nebr., measurements of... 302 Payette, Idaho, stream measurements at ... 62 ,

location and elevation of $\quad 473,474$ rainfall at........................ 472,474

Payette River, Irlaho, measurements of .... 62,

Payne Canal, Idaho, measurements of. ... 485, 487

Pecos, Tex., stream measurements at..... 57,373

Pecos River, Tex., measurements of ...... 57, 373

Peko, Nev., stream measurements at.. 59, 436-437

Pennsylvania, stream measurements in .... $86-110,195-198$

Perault Canal, Idaho, measurements of .. 485, 487 Perkiomen Creek, Pa., measurements of . 48, 89-9i plate showing suspension bridge and nilometer on......................

diagram showing discharge of..........

Perry, T. O., work of ...................

Philadelphia, Pa., streanı measurements near..................... 48,97-98

Phillipsburg, Kans., location and elevation

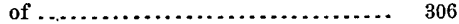

rainfall at......................... 310

Phyllis Canal, Idaho, measurements of .. 486, 487 Piedra River, Colo., measurements of...... 59,

diagram showing discharge of ........ 402 plate showing view of gaging station

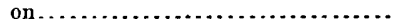

Piedras River, Nicaragua, character of ....... Pindell, L. M., acknowledgments to........ Pine Creek, Nebr., measurements of......... Piru River, Cal., measurements of........... Pisote River, Nicaragua, measurements of Pittsburg, Pa.,plate showing view of the junction of the Allegheny and Mo. nongahela Rivers at .............. stream measurements at ...............

Placerville, Idaho, location and elevation o rainfall at..................... 471,474

Platte Center, Nebr., stream measurements

at . ............................ 303

Platte River, measurements in basin of $\therefore$ 54-55,

measurements of $55,264,295-296,302$ map showing location of stations in basin of

rainfall in basin of : ............. 256-266

diagram showing discharge of ........ 296

plate showing view of head gates of canal of Farmers and Merchants' Irrigation Company on .............

Pleistocene deposits in the Lower Missis. sippi Valley....................

Plum Creek, Nebr., measurements of......

Plunge Creek, Cal., measurements of.......

Pocatello, Idaho, stream measurements at.. 61 ,

Pograen, P. M aid by

Point of Rocks, Md., rainfall at........... 49 stream measurements at ........ 49, 130-131

Point Peter, Ga., location and elevation of.. 158
Page.

.... 159, 161 Point Pleasant, Pa., stream measurements at ........................ 48,98-103 plate showing weir and nilometer on

Tohick on Creek at.............. 90 Pole Creek, Nebr., measurements of....... 302 Population of Nicaragua................. $\quad 584$ Porter, D., work of.................... 64

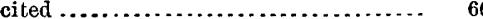
aid by............................ 560 Porter, J. M., work of ................... 88 Portneuf River, Idaho, measurements of... 61 ,

475-476

diagram showing discharge of......... 476

Port Republic, Va., rainfall at............ 49 stream measurements at...... 49,121, 122-120 Potomac River, measurements of......... 49 $120,121,130-131$ stream measurements in basin of...... 49 $120,121-132$ rainfall in basin of ................ 117-121 map showing location of stations in.

basin of ....................... 118 diagram showing discharge of ........ 131 Powell, C. F., work of ................... 195 mentioned ........................... 198 Powell, J. W., reservoir surveys by ........ 25 Precept, Nebr., location and elevation of... 306 rainfall at. ....................... 307, 313

Precipitation. See Rainfall.

Prestion, P.J., acknowledgments to........ 23

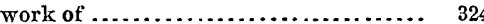
Presumpscot River, measurements of..... 46 Price, J. B., mentioned..................... $\quad 86$ Proctors Creek, Ga., plate showing view of. 188 Promontory, Utah, location and elevation of. $\quad 454$ rainfall at.................... 456, 458 Provo, Utah, stream measurements at .... 61 $458,459,468$ location and elevation of ............ 454 rainfall at........................ 457,458 Provo River, Utah, measurements of...... 61 $458,459,468$ diagram showing discharge of ........ 468 Püblo, Colo., stream measurements at ..... 56, $324,329,330,336-337$ plate showing view of Arkansas River

at ............................... 324 location and eleration of ............. 326 rainfall at....................... 327, 330 Pueblo River, Nicaragua, measurements of. $\quad 607$ Pumping water, investigations of......... 44 Purgatory River, Colo., measurements of .. 57 , $329,330,340-342$ diagram showing discharge of ........ 341

Q.

Quillayute, Wash., stream measurements at ........................... 63,523

Quintus, J.C., cited on measurements of Niagara River.................. 224, R.

Rafter, G. W., work of.................. 78

- cited on canals in New Iork.......... 80 reference to ........................ 225 


\begin{tabular}{|c|c|}
\hline & a. \\
\hline 2 & Ridenbaugh Canal, Idaho, measurements \\
\hline Gardiner, Me $\ldots \ldots \ldots \ldots \ldots \ldots \ldots$ & 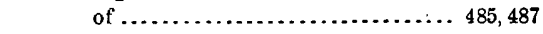 \\
\hline Hartford, Conn. ${ }^{\prime} \ldots \ldots \ldots \ldots \ldots \ldots \ldots \ldots$ & Riley, B., aid by ........ \\
\hline Boyds Corners, N. Y ................ 82-83 & incon, N. Mex., location and elevation of.. \\
\hline atuxent river basins.. $112-114$ & rainfall at. $\ldots \ldots \ldots \ldots \ldots \ldots \ldots \ldots \ldots \ldots \ldots \ldots$ \\
\hline $\sin \ldots \ldots \ldots \ldots \ldots \ldots \cdot 117-121$ & Rio El Toro, Nicaragua, measurements of.. \\
\hline$\nabla a \ldots \ldots \ldots \ldots \ldots$ 132-134 & Rio Grande, N. Mex., rainfall at......... \\
\hline .... 137-139 & stream neasurements at . .... $58,358,359,370$ \\
\hline iver basins $158-161$ & ements of ......... \\
\hline $\begin{array}{l}\text { iver hasins, } \\
\ldots \ldots \ldots \ldots \text { in }\end{array}$ & $\begin{array}{l}358,359,36 \\
\text { tations in ba- }\end{array}$ \\
\hline ...... 199-202 & per........................ \\
\hline $\sin \ldots \ldots \ldots: 232-235$ & of upper .......... $356-359$ \\
\hline$\ldots \ldots \ldots \ldots 256-266$ & ing discharge of $\ldots 365,369,371$ \\
\hline .... 305-313 & views on ............... 372 \\
\hline$\ldots \ldots \ldots \ldots .325-330$ & agua, course of ......... \\
\hline 1. $\quad \ldots \ldots \ldots .356-359$ & of $\ldots \ldots \ldots \ldots \ldots$ \\
\hline in ........ $374-379$ & ad, acknowl. \\
\hline$\ldots \ldots \ldots \ldots 396-400$ & (n.............. \\
\hline Wingate, $\mathrm{N}$. & aragua, character of..... \\
\hline City, Utah, & 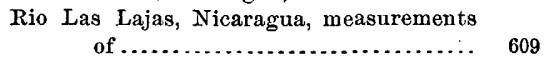 \\
\hline $\operatorname{tah} \ldots \ldots \ldots .454-458$ & Rio San Carlos, Nicaragua, rainfall at. \\
\hline$\ldots \ldots 469-474$ & ty at \\
\hline$\ldots \ldots .496-500$ & 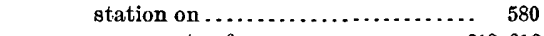 \\
\hline basins. $512-514$ & 8 of $\ldots \ldots \ldots \ldots \ldots \ldots \ldots, 613-616$ \\
\hline 5.52 & ng discharge of ......... 617 \\
\hline $539,560-561$ & ... $635-637$ \\
\hline .... 574-578 & Rio San \\
\hline 177 & .. $622-625$ \\
\hline ... 179,181 & char- \\
\hline $\begin{array}{l}\text { ation of.. } \quad 257 \\
\ldots \ldots . .260,265\end{array}$ & $\begin{array}{l}\ldots \ldots \ldots \ldots \ldots \ldots .571-572 \\
\text { on } \ldots \ldots \ldots \ldots 572,574,602\end{array}$ \\
\hline ........... 300 & fall on ............. \\
\hline levation of.... & $9-610,612,616-620$ \\
\hline 561 & 617 \\
\hline $\begin{array}{r}\text { If, Mont., stream measurements at .. } 53, \\
234,235,236-237\end{array}$ & $\begin{array}{l}\text { Rio } \\
\text { Riva }\end{array}$ \\
\hline ration of... 375 & $\mathrm{~d} . \therefore \ldots$ \\
\hline 306 & $\begin{array}{r}0,578 \\
584\end{array}$ \\
\hline ...... 308,313 & at.. 51,187 \\
\hline $63,526,534-535$ & view of dam \\
\hline $\begin{array}{lr}\text { gments to......... } & 23 \\
\ldots \ldots \ldots \ldots \ldots \ldots . & 324\end{array}$ & $\begin{array}{r}\text { Riverside, Ill., stream measurements at } 52 \text {, } \\
218-223\end{array}$ \\
\hline ............. & of 486,487 \\
\hline g view of $\mathrm{Hi}$. & 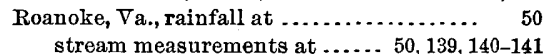 \\
\hline of...... 56 & ing location of \\
\hline$. .317,318$ & $\ldots 137-139$ \\
\hline 51 & $50,139,140-142$ \\
\hline $51,181,190-191$ & ... 141,142 \\
\hline s as to $\ldots \ldots \ldots 36-38$ & $\ldots \ldots \ldots \ldots \ldots \ldots 196,197,243$ \\
\hline .. $38-41$ & by ....... 196-197 \\
\hline on of depth & a, character of:... \\
\hline$\ldots \ldots \ldots 40,41$ & Rochester, N. Y., stream measurements at. $\begin{array}{r}52, \\
225-227\end{array}$ \\
\hline $25-27$ & 132 \\
\hline .. $27-29$ & f ....... \\
\hline . . . . . . . . . 29-36 & ription of reservoir \\
\hline position of .... 132 & $\ldots \ldots, \ldots \ldots \ldots \ldots, 441-4$ \\
\hline & \\
\hline 375 & 443 \\
\hline & \\
\hline
\end{tabular}


Page.

Rock Creek. Nev., canals on. ............ 445-447 Rockhill, S. C., wtream measurements at.. 50,150 Rocky Canyon, Mont., plate showing flume and restle across ................242 Rockyford, Colo., stream measurtments at. 57 , $324,329,330,338-339$

location and elevation of ............. 326 rainfall at.................... 328, 330

Rodenbabs, Nev., stream measurements

at .................................. 59

Rome, Ga., stream measurements at .. 51, 185-186 location and elevation of............ 177 rainfall at......................... 179, 181

Rosalia, Wash., location and elevation of.. 512 rainfall at..................... 512, 514

Rossi Canal, Idaho, measurements of ... 485,487

Ron landsville, Md., stream measurements

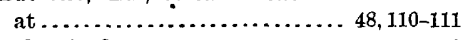

Ruddle, J., cited.

Rumford Falls, Me., stream measurements

$$
\text { at ......................... 46,66-72 }
$$

rainfall at ....................... 46,72 maps showing location of canals and dams at ......................... plate showing views at................

Russell, I. C., cited on Lake Lahontan.....

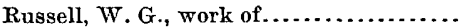

Ruthburg, Idaho, location of .......... 470 rainfall at....................... 472.474

Ryan flume, Idaho, measurements of......485, 487

$$
\text { S. }
$$

Sabalos, Nicaragua, rainfall at........... $\quad 578$ temperature and relative humidity at.. $\quad 580$ stream m€asurements at ............609-610

Sabalos River, Nicaragua, measurements of. $\quad 611$

Sacramento River, Cal., measurements o .. $63_{4}$ diagram showing discharge of . ....... 527

Saguache, Colo., location and elevation of.. $\quad \mathbf{3 5 6}$ rainfall at

St. Clair River, measurements of............

St. Cloud, Colo., location of............... 257 rainfall at...................... 258, 265

St. John, E., acknowledgments to ........

St. Michaels, Nebr., stream measurements

$$
\text { at........................... } 300
$$

St. Paul, Minn., rainfall at.............. 52 stream measurements at.... ...... 52, 230 -231

St. Vrain Creek, Colo., measurements of. 54, 264, diagram showing discharge. of . ........ $\quad 286$

Salem, Va., location and elevation of ...... 137 rainfall at ....................... 138, 139

Salesville, Mont., stream measurements at . $\quad 52$, plate showing view of gaging station near......................... 244

Salida, Colo., stream measurements at. $56,329,331$ Salina, Kans., stream measurements at .... 56

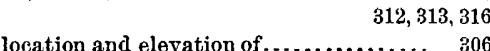
rainfall at ....................... 310,313

Saline River, Kans., measurements of ..... 56 , $312,313,316$
Salisbury N. C., stream measurements 146-147

Salt Lake City, Utah, diagram showing rainfall at ..................... 400

location and elevation of.............. 454 rainfall at..................... 457,458

Salt River, Ariz., measurements of . . 59, 405-406 diagram showing discharge of ........ 406 Saluda River, S. C., measurements of. . 50, 153-154 diagram showing discharge of

San Antonio, Tex., plate showing view of San Antonio River at ............ 354

San Antonjo Creek, Cal., measurements of. $\quad 552$

San Antonio River, Tex., plate showing view of........................ 354

San Bernardino, Cal., location and elevation of ............................. 560

rainfall at......................... 561 San Bernardino Valley, Cal., character of streams in ...................... 552-553

fruit culture in.................. 553

measurements of wells in............. 559

San Blas canal route, discussion of....... 588

Sanborn, K., acknowledgments to.........

San Carlos, Rio, Nicaragua. See Rio San Carlos.

Sanders, Lieut., measurement by ......... 196

San Diego, Cal., location and eleration of.. 560 rainfall at....................... 561

San Diego Flume Company, aid by ........ 560

Sandusky River, Ohio, references to meas urements of..................... 223

San Francisco, Nicaragua, rainfall at..... 578

San Francisco, Rio, Nicaragua. See Rio San Francisco.

San Gabriel River, Cal., measurements of. 64

Sanger, Cal., plate showing view of lumber flume at...................... 534

San Joaquin River, Cal., measurements of.. 63 $526,529-530$

diagram showing discharge of......... $\quad 530$ San Jose, Costa Rica, rainfall at............ 577 San Juan, Rio, Nicaragua. See Rio San Juan.

San Juan River, Colo., measurements of... 58 , $400-401,410,411$ diagram showing discharge of......... 401 plate showing view of gaging station on. 402 character of .

San Juan del Norte, Nicaragua, rainfall at 576,578 diagram showing rainfall at.......... $\quad 578$ temperature and relatire humidity at.. $\quad 581$ San Luis Rey River, Cal., measurements of. $\quad 64$ San Marcial, N. Mex., stream measurements at. ..............58, 358, 359, 371 San Miguel River, Colo., measurements of. 58 diagram showing discharge of. ........ 396 plate showing view of gaging station on. 395 San Miguelito, Rio. See Rio San Miguelito.

Santa Ana River, Cal., measurements of... 64 554-555 water power on .................. 553 diagram showing discharge of......... 555 
Santa Ana River, Cal., plate showing views of gaging station on and flume across. $\quad 554$ Santa Clara River, Cal., measurements of.. 54 Santa Fe, N. Mex., location and eleration of. $\quad 356$

rainfall at.

diagram showing rainfall at.......... 400

Santee River, S. C., measurements of tributaries of ................... 50,148-154

Sapoa River, Nicaragua, measurements of. 607 Sappington, Mont., stream measuremerts at ..................... 53, 234, 235, 238

Sarapiqui, Nicaragna, rainfall at......... 578 Sarapigui River, Nicaragua, measurements of ........................6.630-631

serliment carried by ................... 637 Savage, G. N., aill by .................... 560 Savalo River, Nicaragua, measurements of. $\quad 607$ Savannah River, measurements of ....... 50-51,

$160,164-165$

description of . ............. 154-155, 156-158 water powers on and in basin of...... 155-156 map showing location of stations in basin of ........................ 157 plate showing view of ................. 158 rainfall in basin of .................. 158-161 diugrams showing discharge of...... 164, 165 Schuyler, J. D., eited on watershed of Scioto

$$
\text { River. }
$$
212

reference to ................... 533, 539,540

Schuyler, Nebr., stream measurement at... 303 Schuylkill River, Pa., measurements of tributaries of . . . . . . . . . . . measurements of. ............... 48,96-98 map showing location of stations in basin of

diagram showing discharge of ......... oto River, Ohio, drainage basin of.... 212

proposed water storage on ...........212,214 measurements of .................. 212-215 map showing location of stations in basin of .....................

Scott, T. K., acknowledgments to......... 24

Seattle, Wash., stream measurements at.. 63,517

Sebago Lake, Me., rainfall at

stream measu

Sebree Canal, Idaho, measurements of ..... 488

Sedan, Kans., location and elevation of .... 326

rainfall at ....................... 327, 330

Seddon, J. A., mentioned ................ $\quad 349$

Sediment, method of determining the amount

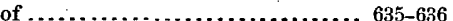

Sediment observations in Nicaragua .... 634-637

Sediment trap, figure showing ........... 635

Seepage measurements in Boise Valley, Idabo ....................... 484-488

Seepage measurements on Big and Little Thompson Creeks, Colo ............ 289

Seguin, Wash., stream measurements at... 63

518-519

Selah, Wash., stream measurements at... 62,499

Selma, N. C., rainfall at.................. 50 stream measurements at............ 50,144

Seneca, Nebr., stream measurements at.... 300

Sequoia, Cal., location and elevation of..... 560 rainfall at........................ 561

Sespe River, Cal., measurements of........ 541
Sevier River, Utah, measurements of Page. ts of....... 61 Seward, Nebr. stream measurements at... 298 Shadeville, Obio, stream measurements at. 214-215 Sharon Springs, Kans., location and eleva. tion of........................ 306 rainfall at.......................... 309,313 Sharpsburg, Md., rainfall at............ 49 stream measurements at......... 49, 120;122 Shaw, J., aid by ..................... 560 Shell Creek, Nebr., measurements of...... 303 Shonandoah River, stream measurements in

basin of ...............49,121, 123-128 measurements of........... 120,121,127-128 diagram showing discharge of........ 128 Sheridan, $W_{y o}$., stream measurements at... 53 Sherman, A. L., mentioned............... 505 Ship-railway projects in Central America. 586-587 Shirley, B. M., work of:................. 22 Shoshone River, Wyo., measurements of.. 53,249 diagram showing discharge of......... 249 Sickman, A. F., aid by. ................ 76 Sidney, Nebr., location and elevation of... 257 rainfall at.................... 260, 265 Silver, E. A., aid by ................... 560 Sisson, Cal., location and elevation of...... $\quad 560$ rainfall at...................... 561 Skunk Creek, Nebr., measurements of..... 303 Smith, E. A., acknowledgments to......... 23 Smith, F. D., work of . ................... 22 Smith, G. C., acknowledgments to......... 24 Smith, G. E., work of.................. 22, 255 Smith, J., acknowledgments to........... 409 Smith, M. D., aid by.................. 392 Smith, S.J., acknowledgments to......... 409 Smoky Hill mine, Colo., location and elevavation of...................... 257 rainfall at......................... 259, 265 Smoky Hill River, Kans., measurements of. $\quad 56$ $312,313,315$

diagram showing discharge of ........ 315 Snake River, measurements of .... 61, 473,474-475 course of ......................... 469 rainfall in basin of ............... 469-474 map showing location of stations in basin of ....................... 470 diagram showing discharge of ........ 475 Snake River, Nebr., measurements of ...... $\quad 303$ Snedden, B., aid by ..................... 560 Sneddens, Cal., location and elevation of ... 560 rainfall at......................... 561

Snowville, $\mathrm{ttah}$, location and elevation of .. $\quad \mathbf{4 5 4}$ rainfall at...................... 456, 458 Socorro, N. Mex., location and elevation of . $\quad 356$

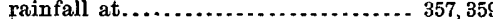

Soldier Creek, Nebr., measurements of ... 254, 303 Soldier Summit, Utah, location and elevation of ........................ 375 rainfall at. .................... 377,379 Solduck River, Wash., measurements of... 63,523 diagram showing discharge of......... 523

Solomon River, Kans., measurements of ...55-56, $312,313,314$ diagram showing discharge of........ 314 Sonora, Cal., location and elevation of ...... $\quad \mathbf{5 6 0}$ rainfall at...................... 561 South River, Ga., water powers on....... 166-167 
Page.

South River, Va., measurements of........ 49 4,

diagram showing discharge of ........ 126

South Boulder Creek, Colo., measurements of ...................... 54, 287-288

diagram showing discharge of ........ 288

South Carolina, stream measurements in... 50,

rainfall in. $151-154,160,162,164$

South Dakota, investigations in ........... 44

Southerland, Nebr., streanumeasurements at 298

Southern California Power Company, description of plant of.

$\begin{array}{ll}\text { Southern Pacific Railroad, aid by ........... } & 560\end{array}$ Southern Ute Indian Reservation,investiga-

tion of water supply of .......... 408-434

topography of ...................... 409

hydrography of ................... 409-411

geology of the...................... $\quad 412$

surveys of reservoir sites in ......... 419-426

proposals for irrigation in ............ 418

Southern Ute Indians, history of........ 412-417

food supplies purchased for distribution among......

South Platte River, measurements of ..... 410 $55,263,264,266,279-280,293-294,302$

course of........................ 277-278

diagrams showing discharge of...... 280, 294 Sowbelly Creek, Nebr., measurements of ... 303 Spalding, C. E., acknowledgments to ....... 24 Spanish Fork, Utah, measurements of...... 61 Spencer, A. C., work of ................. 412 Spokane, Wash., stream measurements at. 63,511 Spokane River, Wash., measurements of .. 63,511 figure showing profile of fall of........ 510 diagram showing discharge of......... 511

Spring Creek, Nebr., measurements of ..... 303 Squaw Creek, Nebr., measurements of ..... 303

Squirrel Inn, Cal., elevation of ............ 560 rainfall at.......................... 561

Stamford, Colo., location and elevation of.. $\quad 326$ rainfall at..................... 327,330 Stanislaus River, Cal., measurements of ... 63 , iugram ohowing discharge of.... 531 Starling, W., cited on floods in Lower Mississippi River.

Staunton Va, location and elevatio rainfall at

Staunton River, Va., measurements of .... 50,139 Steamboat Springs, Colo., geographic position of ..........................

rainfall at

description of

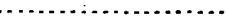

plate showing view of............... 38

Stewart, T., aid by ...................... 196

Stinking Water Creek, Nebr., measurements of ..........................

Stitt, J.G., aid by ...................... 560

Stont, O. V.P., work of. . ............... 22, 254

Strahorn Canal, Idaho, measurements of.. 486, 487

Stream measurements, report on progress of $\ldots \ldots \ldots \ldots \ldots \ldots \ldots \ldots \ldots \ldots \ldots . .17-561$

methods of ......................... 20-22

plates showing methods of ........... 90 , $106,154,244,276,380,458$
Stream measurements in Nicaragua, metb. Page ods of ......................... 593

Sudbury River, measurements of....... 46, 74-75 Sun River, Mont., measurements of......... 5 Superior, Nebr., stream measurements at 55 ,

311,317

Surface Creek, Colo., elevation of.......... 375 rainfall at............. 376, 379, 397, 398, 399 Susquehanua River, Pa., measurements of ....................... 48, 109-110 diagram showing discharge of ....... 110 Sweetwater dam, Cal., location and elevation of $\ldots . . . \ldots \ldots \ldots \ldots \ldots \ldots . .560$ rainfall at................................... 561 Swift, L., aid by ..................... 560 $\mathbf{T}$

Tallapoosa River, Ala., measurements of . . .........................51, 193-194 water power on .................. 192-193 diagram showing discharge of ....... 194 plate showing views of............... 192 Tallassee Falis, Ala., plate showing riew of .......................... 192

Tallassee Falls Manufacturing Company, Ala., power utilized by .......... 192-193 Tallulah River, Ga., water powers on ..... 155 Tar River, N. C., measurements of ....... 50,143 diagram showing discharge of.......... 143 Tarboro, N. C., stream measurements at. .. 50,143 Tauro River, Nicaragua, measurements of.. 632 Taylor, L. H., work of............. 22, 441, 448 Taylor, T. U., work of .................. 22 Temperature and relative humidity in Nicaragua .................... 579-581 Tenaya, Lake, Cal., plate showing view of'.. $\quad 530$ Tennessee River, measurements of tributaries of. . .................. 52, 205-211 measurements of............... 52,210-211 plate showing view of............... 208 diagram showing discharge of......... 211 Tepenaguasape Rirer, Nicaragua, character

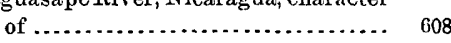
Terrace, Utah, location and elevation of.... 454 rainfall at........................ 456,458 Tertiary deposits in the Lower Mississippi valley ......................... 353 Tertiary history of Nicaragua . ........... $\quad 572$ Teton River, Idaho, measurements of ...... 61 Texas, stream measurements in......... 58, $358,359,372-373$ streams in ...................... 354-355 'Thedford, Nebr., location and elevation of.. 257 rainfall at........................ 260,265 stream measurements at ............. 300 Thompson, J. S. B., acknowledgments to ... 24 Threeforks, Mont., rainfall at ............. strearn measurements at......... 53, 234, 235

Timber in Nicaragua ................ 582-583 Tipitapa, Nicaragua, rainfall at........... 578 stream measurements at............ 601-603 Tipitapa River, Nicaragua, measurements of .......................... 601-603 plates showing riews of............. 574,602 Tiroli River, Nicaragua, measurements of.. 607 Toccoa, Ga., location and elevation of..... 158

20 GEOL, PT $4-42$ 
Page.

Toccoa, Ga., rainfall at ................ 159,161

Toccoa River, Ga., references to measure ments of..

Todd, J. E., work of ... (a) nilometer on... diagram showing discharge of........ 103

Tola, Nicaragua, rainfall at.............. $\quad 578$ diagram showing rainfall at.......... 578 stream measurements at ....... 594,595-596

Tola River, Nicaragua, measurements of. ... 594,

595-596

Tooele, Utah, location and elevation of ..... 45 rainfall at....................... 457,458

Topeka, Kans., location and elevation of ... 306 rainfall at ......................... 311,313 Toponis, Idaho, stream measurements at ... 62 473,477

Towers, W. M., acknowledgments to .......

Townsend, Mont., rainfall at ............. 53 stream measurements at... 53, 234, 235, 244-245

Towaliga River., Ga., water power on ...... 167

Transportation in Nicaragua............ 584

Trinidad, Colo., stream measurements at... 57, $329,330,340-342$

Trinity River, Tex., references to measurements of ........................

Truando-Atrato canal route, discussion of ........................ 587-588

Tuckasegee River, N. C., measurements of. 52,206 diagram showing discharge of......... 206

Tucker, Oreg., rainfall at ................. 63 references to stream measurements at. 63,516

Tugaloo River, N. C., plate showing measurement of water powers on galuo River, S. C., measurements of .... diagram showing discharge of Tule River, Cal., measurements of

Tule River, Nicaragua, character of

Tuolumne River, Cal., measurements of $526,531-532$

diagram showing discharge of ......... reservoir sites on .................... irrigation from......................

Tuolumne Meadows, Cal., plate sbowing view of . ....................... 530

Tuscaloosa, Ala., stream measurements at.. $\quad 51$ $194-195$

Twin Creek, Cal., measurements of........ 557

Twin Lakes, Colo., location and elevation of. 326 rainfall at..................... 327,330

U.

Uinta, Utah, stream measurements at...... 60 $61,458,459,466$ rainfall at. 61

Jmatilla River, Oreg., measurements of... 63,515 diagram showing discharge of ........ 515

Uncompahgre River, Colo., measurements of ........ 58,378,37y, 391-392

diagram showing discharge of . . . . . . $\quad 392$

Undergruund waters, investigations of..... 44-45

Underground water from the bed of the

Arroyo Seco and Pasadena Mesa. 543-549

Union Creek, Nebr., measurements of..... 303
Union Gap, Wash., stream measurements

at .......................62,499,500-501

Union Pacific Railroad, acknowledgments

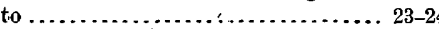

United States Weather Bureau, aid by. 60,560,575 Upper Holcomb, Cal., location and elevation of .......................... 560 rainfall at........................ 561

Utah, reservoir sites in .................. reservoir surveys in................ 36 stream measurements in ... 58,60-61, 378, 379, $387-388,458,459,460-463,464-469$ rainfall in................ $377,379,456-458$ Utah Lake, references to measurements of. $\quad 467$ Uva, Wyo, rainfall at................... stream measurements at. . 54, 262, 265, 275-276 plate showing views of Laramie River

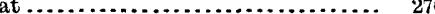

$\nabla$.

Vale, Oreg., stream measurements at ...... 62 Valentine, Nebr., stream measurements at. 255 diagram showing discharge of ........ 407 Verdigris River, measurements of ....... 57, 344 diagram showing discharge of........ 344 comparison of Neosho River with...... 345

Vernal, Utal, location and elevation of..... 375 rainfall at....................... 377,379

Victoria Creek, Nebr., measurements of.... 303

Viejo River, Nicaragua, rainfall at ........ 578 temperature and relative humidity at

station on ...................... 579

measurements of ................... 597-598

Vincent, H. P., reference to............. 543

Virginia, stream measurements in ....... 49-50, $121,122,123-126,134,135-136,139-142$ rainfall in ....................... 119

$121,132-134,137-139,201,202$

Virginia City, Mont., location and elevation of $\ldots \ldots \ldots \ldots \ldots \ldots \ldots \ldots \ldots \ldots \ldots . . .232$ rainfall at....................... 233, 235

W

Waco, Tex., references to stream measurements at...................... 354

Walker, J. G., work of . . . . . . . . . . . . . . . $\quad 592$ Wallace, Kans., location and elevation of... 306 rainfall at.................... 309,313

Wallace, Nebr., location and elevation of... 306 rainfall at. ..................... 307,313 Wallawalla, Wash., location and elevation of .......................... 512 rainfall at....................... 513,514 Wallawalla River, Wash., references to measurements of.................63,512

Wallawalla and Palouse River basins, rainfall in ....................... 512-514 maps showing location of stations in... 513 Wanks River, Nicaragua. See Coco River.

Warbonnet Creek, Nebr., measurement of.. $\quad 303$ Ware, W.J., work of............... 22, 518, 520 
Page.

Warm Creek, Cal, measurements of .... 558-559 Warm Springs, Cal., stream measurements at . ..................... 64,554-555 plate showing view of gaging station at. $\quad 554$ Warren, A.K., acknowledgments to....... 23 reference to....................... 537

Warren, Pa., stream measuroments at ..... 198

Washington, stream measurements in.... 62 $63,489-490,499,500,511,516-523$ rainfall in .............. 498-499, 500, 512-514

Washington, D. C., location and elevation of. $\quad 117$ rainfall at....................... 119, 121 Washington, Ga., location and elevation of.. 158 rainfall at...................... 160,161

Water, pumping, in vestigations of........ 44 analysis of, from White River, Nebr... 254 analyses of, from Kansas River....... 321 underground, from the bed of the Arroyo Seco aud Pasadena Mesa... 543-549

Waterloo, Nebr., stream measurements at.. 299

Waterloo, S. C., stream measurements at.. 50,

$153-154$

Waterrille, Me., stream measurements at... 46 ,

Waterville, Ohio, references to stream moas urements at ......................

Waterville, Wash. location and elevation of rainfall at.

Wauneta, Nebr., stream measurements at.: 299

Weber River, Utah, measurements of...... 60

$61,458,459,466$

diagram showing discharge of......... 466

Weems, W. S., acknowledgments to....... 24

Weiser, Idaho, rainfall at................ 62 stream measurements at .. $62,473,474,488-48$

Weiser River, Idaho, measurements of.... 62 $473,474,488-489$

diagram showing discharge of......... 489

Welles, A. M., reference to............... 281

Wells, artesian, investigations of.......... artesian, in Moxee Valley, Wash....... measurements of, in San Bernardino Valley, Cal .

Wenache, Wash, stream measurements at.

Wenache River, Wash., measurements of.

Wenas Creek, Wash., flow and estimated capacity of ditches receiving water from ....................... 504-505 reservoir site on................... 505-506 map of reservoir site on .............. 506

West Carson River, Nev., measurements of

West Gallatin Irrigation Company, plate showing head gate of the canal of

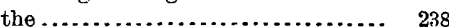

West Gallatin River, Mont., measurements of .................... 52, 234, 235, 241 diagram showing discharge of......... 241 plate showing gaging station on........ 244

West Middle Creek, Nebr., measurements

West Point, Ga, rainfall att. stream measurements at ...... 51, 180,181, 183 West Virginia, stream measurements in . ... 49 , $51,120,121,127-128,202-204$ rainfall in............51, 118, 119, 121, 201, 202
Page.

Wheatland, Wyo., location and elevation of. 257 rainfall at....................... 258, 265 Wheeler, E. S., work of................ 592 White River, Colo., reconnaissance in basins of Yampa River and........ 383-387 White River, Nebr., measurements of. . 54, 303-304 course of ......................... $\quad 253$ analysis of water from ................ 254 White River, S. Dak., plate showing views of ........................... 256

White Clay Creek, Nebr., measurements

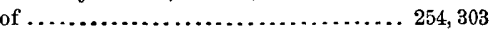
White Horse Creek, Nebr., measurements of ................ 303

White Sulphur Springs, W. Va., Jocation and elevation of................. 199 rainfall at..................... 201, 202

White Tail Creek, Nebr., measurements of. $\quad 303$ Whitewater River, Cal., measurements of ........................ 561-562

Whitman, Wash., rainfall at............. 63 references to stream measurements at. 63,512 Whitney, Nebr., stream measurements at.. 303 Wierman, T. T., aid by ................. 109 Wigglesworth, T. H., estimates by ....... 418 Wilford, Idaho, stream measurements at... 61 Wilkins, C., acknowledgments to.......... 24 Windmills, investigations of........... 44-45 Wisner, G. M., aid by .................. 218 Wissahickon Creek, Pa., measurements of. 48 , diagram showing discharge of......... 96 Wolaver, J. M., acknowledgments to ...... 23 Wood River, Nebr., measurements of...... 303 Woodford, Cal., stream measurements at.. $\quad 59$ Woods Landing, Wyo., rainfall at........ 54 tream measurements at ...... 54, 262, 265, 274

Woodstock, Md., rainfall at......... 48,113,114 stream measurements at........ 48, 113, 115 location and elevation of ............ 112

Woodstock, Va., location and elevation of. . $\quad 117$ rainfall at. . ................... 119, 121

Wright, J. G., mentioned ................ 418

Wright, J. T., acknowledgments to ........ 24

Wyoming, stream measurements in ...... 53, 58, 249-251, 262, 265, 266-267, 274-277, 378, 379, $380-382$.

rainfall in...................... 258, 265

Wyoming Development Company, map showing proposed reservoir of...... 277

Wytheville, Va., location and elevation of. 199 rainfall at....................... 201, 202 X.

Tadkin River, N. C., measurements of. 50, 146-148 diagrams showing discharge of ...... 147, 148 Yakima County, Wash., reservoir sites in 505 508 Yakima River, Wash., measurements of... 62 , 499,500-502 rainfall in basin of. ............... 496-500 map showing location of stations in basin of . ................... 497 diagrams showing discharge of..... 501, 502 Yampa River, Colo., reconnaissancein basins of White River and............. 383-387 
Yeates, W. S., acknowledgments to $\begin{array}{ll}\text { Yeates, W. S., acknowledgments to........ } & 23 \\ \text { Yellow River, Ga., measurements of....... } & 51\end{array}$ water powers on ................... 166

Yellowstone River, measurements of.. 53, 246-248 measurements of tributaries to... 53, 249-253 agricultural prospects in valley of...... 247 diagram showing discharge of......... 248 York, Nebr., location and elevation of...... 306

York, Nebr., rainfall at ................ 308,313
Yosemite, Cal., location and elevation of... 560 rainfall at......................... 561

Xoughiogheny River, $\mathbf{P a}$, references to measurements of .................. 199 Youngstown, Pa., stream measurements at. 198 Yuba River, Cal., measurements of ....... $\quad 526$ 